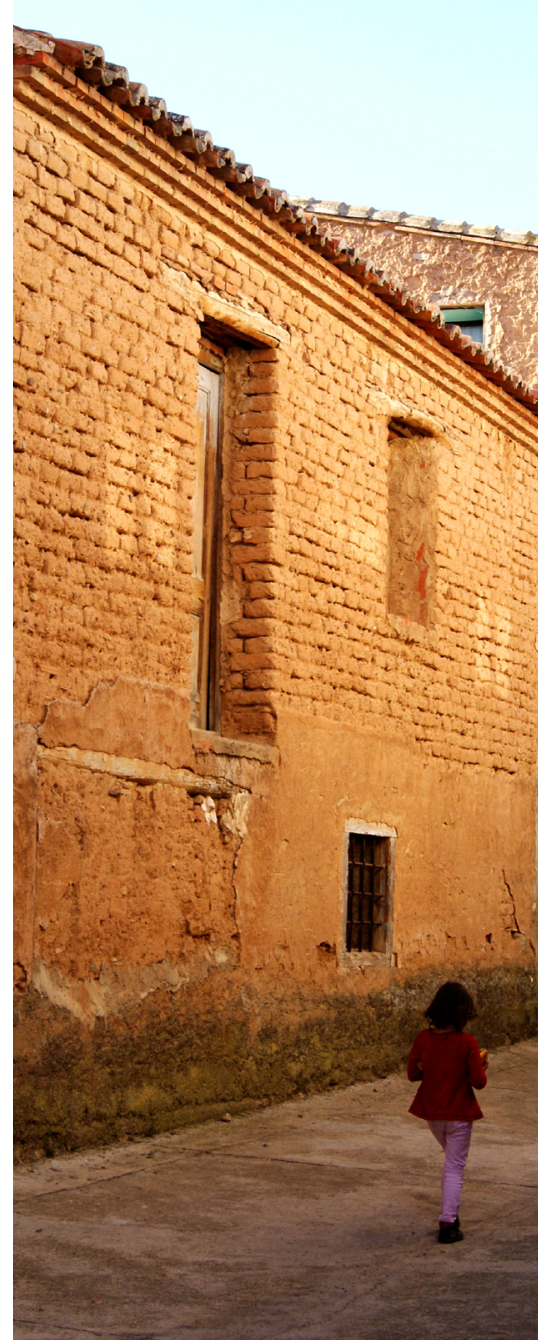

ANIVERSITAT

ENIII): POLITĖCNICA

Valencia, noviembre 2018
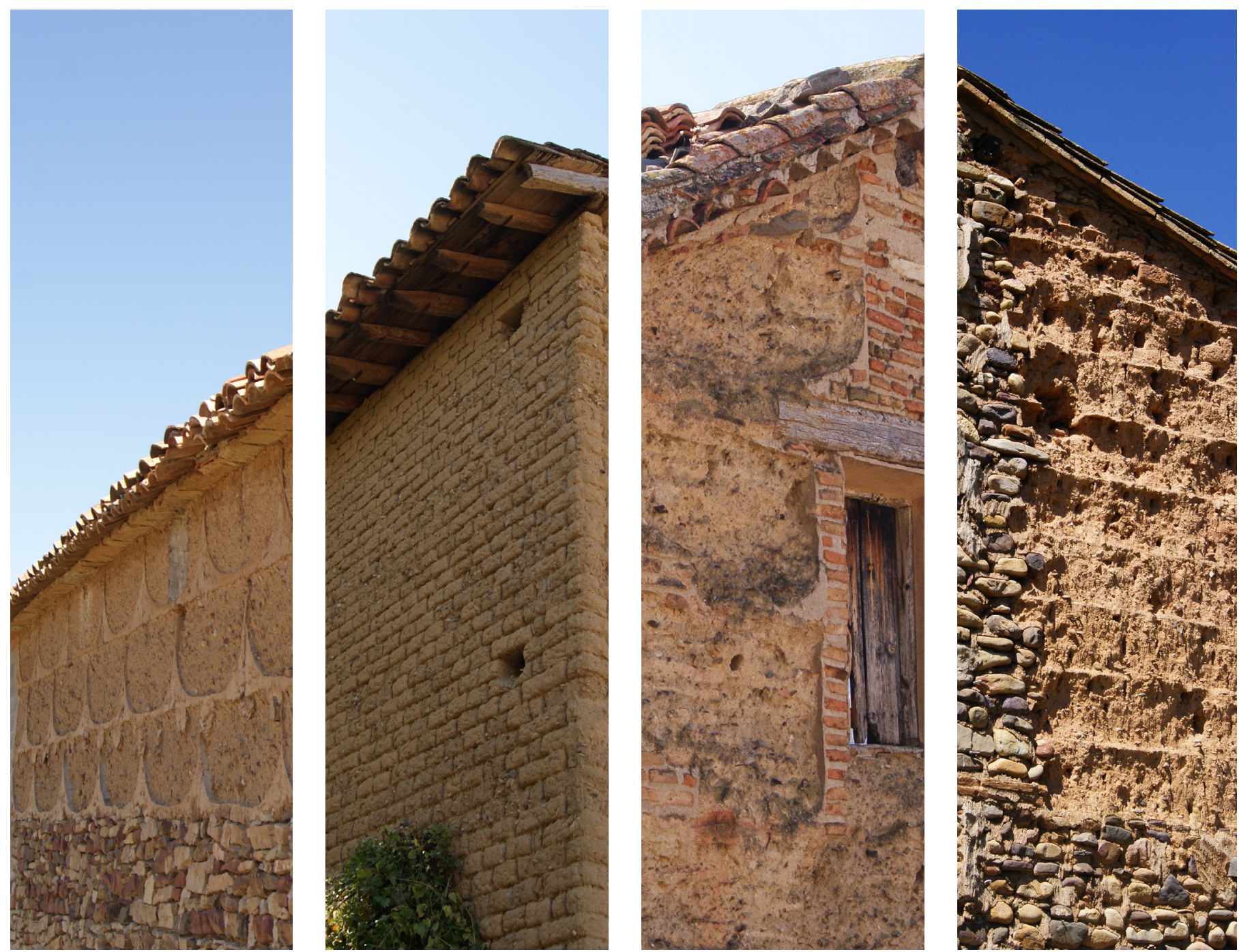

LA RESTAURACIÓN Y LA REHABILITACIÓN DE LA ARQUITECTURA TRADICIONAL DE TIERRA EL CASO DE ARAGÓN 



\title{
LA RESTAURACIÓN Y LA REHABILITACIÓN DE LA ARQUITECTURA TRADICIONAL DE TIERRA. \\ EL CASO DE ARAGÓN
}

\author{
Tesis doctoral Tomo I y Tomo II \\ Autora: Laura Villacampa Crespo \\ Directores: Dra. Camilla Mileto \\ Dr. Fernando Vegas López-Manzanares \\ Dra. Lidia García Soriano
}

Escuela Técnica Superior de Arquitectura, Universitat Politècnica de València

Programa de Doctorado en Arquitectura, Edificación, Urbanística y Paisaje.

Valencia, noviembre 2018 
* Todo el material pertenece a la autora a menos que se indique lo contrario en el pie de la figura correspondiente o dentro de la propia figura como las capturas de pantalla de Google.

* Los planos de localización han sido extraidos del visor Bing

Fotografías portada (de izq a dcha): Chodes, Zaragoza; Torre de las Arcas, Teruel; Graus, Huesca; Burbáguena, Teruel y Bulbuente, Zaragoza.

Fotografía contraportada: Embid de Ariza, Zaragoza. 
"Every people that has produced architecture has evolved its own favourite forms, as peculiar to that people as its language, its dress or its folklore. Until the collapse of cultural frontiers in the last century, there were all over the world distinctive local shapes and details in architecture, and the buildings of any locality were the beautiful children of a happy marriage between the imagination of the people and the demands of their countryside" 
RESUMEN

Los estudios en torno a la construcción con tierra se desarrollaron principalmente a partir de la crisis energética de los setenta, que dirigió la mirada a este tipo de arquitectura como una solución sostenible frente a la limitación de los recursos naturales. Desde entonces, los estudios han sido continuos lo cual ha generado una amplia red de conocimiento tanto a nivel nacional como internacional.

La arquitectura tradicional, y concretamente la de tierra, ha sido estudiada de forma creciente en las últimas décadas tanto por sus valores materiales, etnográficos, culturales y patrimoniales, como por el carácter sostenible y su relación directa con el entorno en el que establece, adaptándose a él y optimizando sus recursos, si bien algunos de estos estudios también derivan de la preocupación por el estado de conservación y la incesante pérdida de estas arquitecturas y su saber hacer intrínseco. El hecho de que la arquitectura tradicional ya no sea un fenómeno activo junto con la falta de su puesta en valor ha provocado que muchas de estas construcciones se hayan perdido o transformado notablemente sin ningún tipo de control y, con ello, la cultura constructiva asociada a las mismas. En el caso de la arquitectura tradicional de tierra es, si cabe, más alarmante ya que la falta de conocimiento de sus propiedades la ha llevado a ser injustamente estigmatizada y asociada a la pobreza.

Las investigaciones sobre la arquitectura tradicional de tierra se han desarrollado normalmente en relación con una técnica, en torno a las características generales de un territorio extenso o alrededor de un área de pequeñas dimensiones, localidad o edificio concreto. En el caso de Aragón es similar, si bien los estudios realizados en la comunidad se han centrado generalmente en toda la arquitectura tradicional o en una tipología concreta asociada a un área, y en muy pocos casos se han estudiado las intervenciones o las dinámicas de intervención actuales.
La arquitectura de tierra en Aragón es muy rica y variada en cuanto a técnicas constructivas, variantes y alcance territorial, lo cual muestra la gran tradición constructiva ligada a este material. Este hecho justifica la necesidad de ahondar en el conocimiento de estas técnicas constructivas y de sus características territoriales específicas. Además, es de gran importancia el estudio del estado de conservación de esta arquitectura, que ha permanecido desasistida durante décadas, provocando importantes transformaciones derivadas de la falta de conocimientos y de puesta en valor, tanto por parte de la población como de los organismos encargados de su protección.

Por ello, el objetivo principal de esta tesis ha sido el estudio y reconocimiento de la arquitectura de tierra en Aragón como parte de su cultura constructiva, así como el análisis de las dinámicas de transformación existentes con el objetivo de realizar una serie de propuestas de conservación e intervención.

Para llevar a cabo este objetivo, la tesis se ha estructurado en tres bloques. Un primer bloque introductorio sobrela situación y el contexto actual de esta arquitectura, así como la clasificación y descripción de las principales técnicas y variantes constructivas existentes. Un segundo bloque de análisis de la arquitectura tradicional de tierra de Aragón, sus variantes constructivas, su localización geográfica y la relación con las características del lugar donde se encuentran. Y, un tercer bloque de estudio y propuesta de intervenciones sobre esta arquitectura en la que se analiza el marco normativo y legislativo en el que se encuentra y las dinámicas de transformación y mecanismos de degradación generados por las intervenciones para, finalmente, realizar la propuesta de unas líneas guía y propuestas de intervención compatibles para la restauración, conservación, protección y difusión de esta arquitectura. 


\section{RESUM}

Els estudis entorn de la construcció amb terra es van desenvolupar principalment a partir de la crisi energètica dels setanta que va produir que aquest tipus d'arquitectura es vera com una solució sostenible enfront de la limitació dels recursos naturals. Des de llavors, els estudis han estat continus, la qual cosa ha generat una àmplia xarxa de coneixement tant a nivell nacional com a internacional.

L'arquitectura tradicional, i concretament la de terra, han estat estudiada de forma creixent en les últimes dècades tant pels seus valors materials, etnogràfics, culturals i patrimonials com pel caràcter sostenible i la seua relació directa amb l'entorn en el qual s'estableix, adaptant-se a ell i optimitzant els seus recursos. Si bé, alguns d'aquests estudis també deriven de la preocupació per l'estat de conservació i la incessant pèrdua d'aquestes arquitectures i el seu saber fer intrínsec El fet que l'arquitectura tradicional ja no siga un fenomen actiu juntament amb la manca de posada en valor ha provocat que moltes d'aquestes construccions s'hagen perdut o transformat notablement sense cap tipus de control i, amb açò, la cultura constructiva associada a les mateixes. En el cas de l'arquitectura tradicional de terra és, si cap, més alarmant ja que la falta de coneixement de les seues propietats I'ha portat a ser injustament estigmatitzada i associada a la pobresa.

Les recerques sobre l'arquitectura tradicional de terra s'han desenvolupat normalment en relació amb una tècnica, entorn de les característiques generals d'un territori extens o al voltant d'un àrea de xicotetes dimensions, localitat o edifici concret. En el cas d'Aragó és similar, si bé, els estudis realitzats en la comunitat se centren generalment en tota l'arquitectura tradicional o en una tipologia concreta associada a un àrea, i en molt pocs casos s'estudien les intervencions o les dinàmiques d'intervenció actuals.
L'arquitectura de terra a Aragó és molt rica i variada quant a tècniques constructives, variants i abast territorial, la qual cosa mostra la gran tradició constructiva lligada a aquest material. Aquest fet justifica la necessitat d'aprofundir en el coneixement d'aquestes tècniques constructives i de les seues característiques territorials específiques. A més, és de gran importància l'estudi de l'estat de conservació d'aquesta arquitectura que ha romàs desatesa durant dècades, provocant importants transformacions derivades de la seua manca de coneixements i de posada en valor, tant per part de la població com dels organismes encarregats de la seua protecció.

Per això, l'objectiu principal d'aquesta tesi ha estat l'estudi i reconeixement de l'arquitectura de terra a Aragó com a part de la seua cultura constructiva, així com l'anàlisi de les dinàmiques de transformació existents amb l'objectiu de realitzar una sèrie de propostes de conservació i intervenció.

Per a dur a terme aquest objectiu, la tesi ha estat estructurada en tres blocs: un primer bloc introductori sobre la situació i el context actual d'aquesta arquitectura, així com la classificació i descripció de les principals tècniques i variants constructives existents; un segon bloc d'anàlisi de l'arquitectura tradicional de terra d'Aragó, les seues variants constructives, la seua localització geogràfica i la relació amb les característiques del lloc on es troben; i un tercer bloc d'estudi i proposta d'intervencions sobre aquesta arquitectura en la qual s'analitza el marc normatiu i legislatiu en el qual es troba i les dinàmiques de transformació i mecanismes de degradació generats per les intervencions per a, finalment, realitzar la proposta d'unes línies guia i propostes d'intervenció compatibles per a la restauració, conservació, protecció i difusió d’aquesta arquitectura. 
ABSTRACT

The studies around earthen construction were developed mainly from the energy crisis of the seventies, which looked at this type of architecture as a sustainable solution against the limitation of natural resources. Since then, the studies have been continuous, which has generated an extensive network of knowledge at both the national and international levels.

The traditional architecture, and specifically the earthen one, has been studied in a growing way in the last decades both for its material, ethnographic, cultural and patrimonial values, as for the sustainable nature and its direct relation with the environment, adapting to it and optimizing its resources. Although some of these studies also derive from the concern for the state of conservation and the incessant loss of these architectures and their intrinsic know-how. The fact that traditional architecture is no longer an active phenomenon along with the lack of its value has caused that many of these constructions have been lost or transformed notably without any kind of control and, thus, the constructive culture linked to them. In the case of traditional earthen architecture is, if possible, more alarming because the lack of knowledge of their properties has led to being unjustly stigmatized and associated with poverty.

Research on traditional land architecture has been developed normally in relation to a technique, around the general characteristics of an extensive territory or around an area of small dimensions, village or concrete building. In the case of Aragón it is similar, although the studies carried out in the community have generally focused on the general traditional architecture or in a specific typology associated to an area, and in very few cases have studied the transformation and its dynamics.
Earthen architecture in Aragon is very rich and varied in terms of constructive techniques, variants and territorial scope, which shows the great constructive tradition linked to this material. This fact justifies the need to delve into the knowledge of these constructive techniques and their specific territorial characteristics. Moreover, it is of great importance the study of the state of conservation of this architecture, which has remained unattended for decades, causing important transformations derived from the lack of knowledge and value, both on the part of the Population as well as the responsible administration for their protection.

Therefore, the main objective of this thesis has been the study and recognition of the architecture of land in Aragon as part of its constructive culture, as well as the analysis of the transformation dynamics existing with the aim of carrying out a series of Conservation and intervention proposals.

To carry out this objective, the thesis has been structured in three blocks. A first introductory block on the situation and the current context of this architecture, as well as the classification and description of the main techniques and constructive variants existing. A second block of analysis of the traditional earthen architecture in Aragon, its constructive variants, its geographical location and the relation with the characteristics of the place where they are located. And, a third block of study and proposal of interventions on this architecture in which it analyses the legislative framework, and the dynamics of transformation and mechanisms of degradation generated by the interventions. Those data are the base to carry out the proposal of guidelines and intervention proposals compatible for the restoration, conservation, protection and dissemination of this architecture. 


\section{AGRADECIMIENTOS}

A mis tutores, Camilla Mileto, Fernando Vegas y Lidia García que me han acompañado durante todas las etapas del trabajo, cuyos consejos y recomendaciones fruto de su amplia experiencia han sido de gran ayuda.

Quisiera agradecer al Ministerio de Economía y Competitividad la financiación de mi contrato predoctoral en el Instituto de Restauración del Patrimonio de la UPV, el cual ha permitido la realización de esta tesis, así como por la financiación de una de las estancias internacionales en el extranjero.

También debo agradecer a mis tutores de las estancias en los centros receptores. A Hubert Guillaud por acogerme y aconsejarme durante mi estancia en CRAterre-ENSAG en Grenoble. A Hirohide Kobayashi (Kyoto University) por permitirme formar parte de su laboratorio durante tres meses y compartir las experiencias de investigaciones en torno a la arquitectura tradicional por todo el mundo.

A mis compañeros y amigos del IRP que han acompañado y apoyado durante estos tres años. Quiero agradecer especialmente a Sole, Javi y Lidia que han sido un gran soporte para la realización de este trabajo y que me han ayudado hasta el final.

A todas las personas anónimas con las que he tenido el placer de cruzarme durante los trabajos de campo cuyos conocimientos locales de la arquitectura tradicional han sido de gran interés para el desarrollo de la investigación.

A todos mis amigos, familiares y a Diego por mostrarme su apoyo durante todo el proceso y por acompañarme en los largos viajes a través de los cuales se ha recorrido el territorio aragonés. 


\section{TOMO I}

BLOQUE 1. MARCO DE LA INVESTIGACIÓN

1. INTRODUCCIÓN

1.1. Motivación del estudio

1.2. Marco de la investigación. Estado de la cuestión

2. OBJETIVOS Y ESTRUCTURA DEL ESTUDIO

2.1. Objetivos específicos

2.2. Límites de la investigación

2.3. Estructura de la tesis

3.1. Recopilación de la información

3.1.1. Fuentes indirectas. Bibliografía existente

3.1.3. Fuentes primarias. Testimonios de gente local 
3.3. Estancias de investigación en el marco del estudio

$$
\begin{aligned}
& \text { p.53 } \\
& \text { p.53 } \\
& \text { p.54 } \\
& \text { p.55 }
\end{aligned}
$$

3.3.1. Estancia en CRAterre- ENSAG (Grenoble, Francia) p.53 3.3.2. Estancia en la Universidad de Kioto, Japón p.54

3.4. Contribuciones previas

4. LA CONSTRUCCIÓN CON TIERRA

p.61

4.1. La tierra como material de construcción

p.64

4.2. Las técnicas constructivas de tierra

p.66

4.2.1. Muros monolíticos

p. 67

4.2.2. Muros de fábrica

4.2.3. Tierra en relleno de entramado

p.69

4.2.4. Tierra como acabados

p.71

p.71

BLOQUE 2. LA ARQUITECTURA TRADICIONAL DE TIERRA EN ARAGÓN

5. LA CONSTRUCCIÓN CON TIERRA EN ARAGÓN p.75

$\begin{array}{lr}\text { 5.1. Contexto histórico } & \text { p.79 }\end{array}$

$\begin{array}{lr}\text { 5.2. Situación actual } & \text { p.80 }\end{array}$

5.3. Descripción de la muestra $\quad$ p.82

6. APROXIMACIÓN A LAS TÉCNICAS Y VARIANTES CONSTRUCTIVAS DE TIERRA EN ARAGÓN p.87

6.1. La tapia

6.1.1. Variantes constructivas

6.1.2 Distribución geográfica p. 91

p.92

p.97 
6.2. El adobe

6.2.1. Variantes constructivas

6.2.2 Distribución geográfica

6.3. Los entramados con tierra

6.3.1. Variantes constructivas

6.3.2 Distribución geográfica

6.4. Otras técnicas existentes

\section{ARQUITECTURA DE TIERRA Y ENTORNO}

7.1. Factores morfológicos

7.1.1. Altimetría

7.1.2. Relación con los cauces fluviales

7.2. Factores climáticos

7.2.1. Temperatura media

7.2.2. Precipitaciones

7.2.3. Viento

7.2.4. Radiación solar

7.2.5. Climas

7.3. Factores geológicos

7.3.1. Litología

7.3.2. Sismicidad

7.4. Factores sociales

7.4.1. Densidad de población p.121

p.104

p.105

p.109

p.114

p.116

p.117

p.117

p. 125

p. 125

p.127

p. 128

p. 128

p.131

p.132

p.133

p.135

p.137

p.137

p.138

p.139

p.139 
8.1 Lesiones en la base del muro

BLOQUE 3. INTERVENCIONES EN LA ARQUITECTURA TRADICIONAL DE TIERRA. CRITERIOS Y TÉCNICAS.

\section{MARCO LEGISLATIVO DE LA ARQUITECTURA TRADICIONAL DE TIERRA}

9.1 Marco estatal

9.2 Marco autonómico

10. LAS INTERVENCIONES EN LA ARQUITECTURA DE TIERRA EN ARAGÓN

10.1. Análisis de los casos de estudio

10.2. Intervenciones generales en la arquitectura tradicional de tierra

10.3. Intervenciones por zona del edificio

10.3.1. Intervenciones en el zócalo o arranque del muro

10.3.2. Intervenciones en el cuerpo y coronación del muro

10.3.3. Intervenciones en la superficie o revestimiento del muro

10.3.4. Intervenciones en los vanos

10.3.5. Intervenciones en la cubierta

10.3.6. Intervenciones de mejora energética

10.4. Intervenciones en función de la técnica constructiva

10.2.1. Intervenciones en construcciones de tapia

10.2.2. Intervenciones en construcciones de adobe

10.2.3. Intervenciones en construcciones de entramado p.155

p.158

p,160

p.167

p.169

p.171

p.179

p.181

p.181

p.182

p.183

p.184

p.185

p. 187

p.187

p.192

p.195 
11. LÍNEAS GUÍA PARA UNA INTERVENCIÓN COMPATIBLE Y SOSTENIBLE

11.1. Criterios de intervención

11.1.1. Sostenibilidad

11.1.2. Compatibilidad

11.1.3. Expresión

p. 214

11.1.4. El respeto a las preexistencias

p. 215

11.2. Técnicas de intervención. Propuesta de soluciones

p.216

11.2.1. Intervenciones ligadas a la reparación de lesiones

11.2.2. Intervenciones ligadas a transformaciones

p. 218

11.2.3. Intervenciones de prevención y mejora.

p. 227

P. 228

11.3. Aplicación en el marco autonómico

\section{BLOQUE 4. CONCLUSIONES}

12. CONCLUSIONES

14. VERSIONES TRADUCIDAS DE LAS CONCLUSIONES

14.1. Versió en Valencià

p. 259

14.2. English versión

p. 273

15. BIBLIOGRAFÍA

p. 287 


\section{TOMO II}

BLOQUE 5. ANEXOS

16. BASE DE DATOS. FICHAS DE CATALOGACIÓN DE CASOS DE ESTUDIO

p.305

16.1. Casos de Teruel

p.307

16.2. Casos de Zaragoza

p.639

16.3. Casos de Huesca 


\section{BLOQUE I}

\section{MARCO DE LA INVESTIGACIÓN}

1. Introducción

2. Objetivos y estructura del estudio

3. Metodología del estudio

4. Introducción a la arquitectura de tierra 
1. INTRODUCCIÓN 


\section{INTRODUCCIÓN}

1. este documento se finaliza en 2015 y surge como respuesta a la preocupación ante la dificultad de conservación de este tipo de arquitectura, debido principalmente a su vulnerabilidad frente a la globalización.
La arquitectura tradicional es aquella realizada por el pueblo a través del uso óptimo de los recursos y de la adaptación al entorno donde se encuentra y que son el fruto de la evolución, de la tradición y de la experiencia de las comunidades para hacer frente a unas necesidades concretas.

Esta arquitectura forma parte del paisaje y se desarrolla de forma funcional y material a partir de este. Las construcciones tradicionales y sus conjuntos conforman un patrimonio cultural muy importante que está ligado a las tradiciones y a la forma de vida de sus habitantes. Este concepto no corresponde con el concepto que comúnmente tiene la gente del patrimonio que suele atribuirse a edificios o conjuntos monumentales o con unas características artísticas destacadas.

La preocupación por la pérdida de esta arquitectura y la importante transformación ha sufrido en las últimas décadas, sumado al hecho de que ya no existe como fenómeno activo, ha provocado un creciente interés y la proliferación de estudios entorno a la misma. Un importante avance a nivel nacional ha sido el desarrollo del Plan Nacional de Arquitectura Tradicional por parte del El Instituto de Patrimonio Cultural Español (IPCE) ${ }^{1}$.

Las técnicas tradicionales de construcción con tierra han formado una parte importante en la historia constructiva de la Península Ibérica hasta los años 50-60 del siglo pasado cuando la llegada de la industrialización produjo el abandono de estas técnicas. Pese a ello, el gran volumen y variedad técnicas construidas con este material en todo el territorio ha favorecido a que estas técnicas todavía sean identificables y que estén presentes en multitud de localidades (AA. VV 2011). La comunidad autónoma de Aragón constituye una de las áreas con mayor riqueza dentro de la península con construcciones de tierra presentes en prácticamente toda su extensión y en forma de distintas técnicas y variantes que conforman un patrimonio gran valor cultural, constructivo y material.

La arquitectura tradicional y concretamente la arquitectura tradicional de tierra ha sido objeto de estudio en las últimas décadas por su importancia e interés cultural y patrimonial, pero, también, por 
su carácter sostenible y de relación con el entorno, factor que incrementó notablemente su interés tras la crisis energética de los años setenta (Font e Hidalgo 2011). Los estudios sobre la arquitectura tradicional en Aragón se han centrado normalmente en zonas concretas de extensión limitada y suelen ser genéricas de toda arquitectura tradicional centrarse en las características de las construcciones de tierra. El incremento de estudios ha conllevado un aumento del conocimiento entorno a la arquitectura tradicional necesario para su puesta en valor y su consecuente conservación. Además, estos estudios también han permitido conocer y poner en valor algunas de las culturas constructivas y tradiciones ligadas a cada lugar antes de ser abandonadas por completo.

La arquitectura tradicional de tierra en Aragón está muy presente en gran cantidad de núcleos de población, sin embargo, muchas de las construcciones han sido transformadas e intervenidas duramente o se encuentran en un estado de deterioro avanzado derivado de la falta de mantenimiento y/o abandono. Este abandono ha sido favorecido por el éxodo rural importante sufrido en esta zona, por los cambios de uso y por la mala imagen que se tiene de este tipo de arquitectura, asociada tradicionalmente a la pobreza (Buzo 2014)

En el caso de Aragón, la despoblación ha sido uno de los factores que ha coadyuvado a que parte de los edificios se pierdan por su abandono, pero, al mismo tiempo, esto ha permitido que en la actualidad se puedan estudiar pueblos, o parte de los mismos, congelados en el tiempo que constituyen una gran fuente de información a nivel material y constructivo, pero también etnográfico y cultural.

Por otro lado, el carácter rural que tiene esta comunidad y llegada tardía de unas comunicaciones adecuadas a muchas localidades favoreció al retraso de la implementación de los materiales industrializados, pero, desde los años sesenta, su uso e inserción en la arquitectura tradicional de tierra ha sido continua. En esa época, el uso de los nuevos materiales estaba, en la mayoría de las ocasiones, asociado al progreso, a la modernización y al final del aislamiento las zonas rurales.

En la actualidad, la conservación o intervención sobre la arquitectura de tierra desde el respeto y el entendimiento de sus valores está apartado de la realidad, pero, no es sino a través de su conocimiento que esta situación se puede rectificarse.

La restauración de la arquitectura de tierra tiene cierto recorrido, si bien, mientras que en la arquitectura monumental existe una evolución de los métodos y técnicas empleadas ligada a la evolución de los criterios y el estudio de los resultados de otras intervenciones (García Soriano 2015), su aplicación en la arquitectura vernácula todavía no se ha desarrollado y es posible distinguir gran variedad de soluciones distintas, pero sin una evolución o mejora concreta de las mismas y sin un criterio aparente. 
Las intervenciones llevadas a cabo en esta arquitectura responden principalmente a la evolución y transformación ligadas al propio uso. Estas transformaciones han estado presentes siempre, si bien, la forma y el impacto de las mismas no son comparables, ya que tradicionalmente estaban integradas y los materiales eran compatibles y trabajan adecuadamente con el resto del edificio y, en la actualidad, los materiales utilizados son de origen industrial y las transformaciones mayores por los requisitos de confort actuales.

Los materiales industriales y los requisitos de habitabilidad actuales sumados a la falta de protección y de conocimiento de estos edificios hace que las intervenciones realizadas dependan directamente del interés y de los gustos de los propietarios que realizan las modificaciones que creen pertinentes sin ningún tipo de control o restricción. Por ello, es necesario destacar la importancia y el valor material y constructivo de estas técnicas de tierra que se encuentran por todo el territorio aragonés para poder promover su conservación. Si bien, como cita Guillermo Allanegui (Allanegui Burriel 1979):

"no se trata sólo de conservar una fachada «bonita», una casa "pintoresca», unas calles con "ambiente», unos tejados "curiosos», unas chimeneas "típicas», etc..., sino de aprovechar y mejorar (que para eso ha de servir el mayor conocimiento científico del arte de construir) unos edificios de indudable valor".

Uno de los objetivos de la tesis es el estudio de estas intervenciones y sus características (criterios seguidos, objetivos, trabajos realizados, zonas intervenidas, materiales y técnicas utilizadas, etc.) y para lo cual debe tenerse en cuenta que el criterio de intervención en estos casos no puede analizarse en base a los criterios de restauración tradicionales ya que generalmente no existe un criterio, sino que se actúa de forma espontánea.

Las intervenciones Ilevadas a cabo en la actualidad sobre las edificaciones en tierra son muy variadas y van desde su completa demolición, en base a premisas como la falta de resistencia de la tierra como material de construcción, hasta intervenciones más cuidadas, y también menos frecuentes, en las que premia la conservación material, constructivo y del carácter tradicional (original) del edificio

Por ello, es necesario plantear una serie de medidas de protección, revalorizar esta arquitectura de tierra y promover intervenciones compatibles y sostenibles en base a una serie de criterios establecidos. 


\subsection{Motivación del estudio}

La restauración arquitectónica y, concretamente, el estudio de la arquitectura tradicional es una materia que por la cual he sentido interés desde el comienzo de mis estudios de Arquitectura en la Escuela Técnica Superior de Arquitectura de la Universitat Politècnica de València, en parte, por la vinculación con este tipo de arquitectura desde mi temprana edad.

Durante mis estudios cursé distintas asignaturas optativas en relación con las técnicas constructivas tradicionales y la rehabilitación de edificios y participé en varios cursos y seminarios de especialización en la materia, sin embargo, el interés por la misma y la necesidad de seguir formándome en esta materia me llevó a cursar el Máster de Conservación del Patrimonio en la misma universidad durante el curso 2013-2014. En mi Trabajo Fin de Máster desarrollé una investigación en relación a las características y las dinámicas de transformación de la arquitectura tradicional de Montalbán y Peñarroyas (figura 1.1)), dos localidades de la provincia de Teruel, bajo la supervisión de los profesores Camilla Mileto y Fernando Vegas López-Manzanares. Este trabajo me permitió ampliar notablemente mis conocimientos y a reconocer las características de la arquitectura tradicional de una forma mucho más espontánea. La investigación de esta tesis no supone una continuación del Trabajo Fin de Máster, sin bien, ha sido una referencia en muchos aspectos ya que ambas investigaciones tienen como objetivo la puesta en valor para conservación de la arquitectura tradicional, aunque a escalas muy diferentes.

En 2016 comencé mi formación como investigadora predoctoral ${ }^{2}$ en colaboración en el grupo de investigación liderado por Camilla Mileto y Fernando Vegas López-Manzanares ${ }^{3}$ y fue entonces cuando comencé a desarrollar la investigación presentada en esta tesis. Este estudio nace de la ausencia de investigaciones en la que se estudie las características de la arquitectura de tierra de forma pormenorizada y las intervenciones de esta misma arquitectura en base a un amplio número de casos de estudio distribuidos en un territorio de dimensiones considerables. Si bien, es importante destacar que el objetivo de esta investigación no es poner en valor o proteger aquellos edificios que conforman la base de datos y que han sido elegidos con cierta aleatoriedad, sino reconocer el valor de la arquitectura tradicional de tierra en conjunto, denunciar su estado de conservación y/o intervención para proponer mejoras en las intervenciones y fomentar su conservación y difusión.

El interés de la investigación desarrollada radica en el propio enfoque del trabajo que se ha basado en el estudio de una gran cantidad de casos distribuidos por el territorio y de los cuales se han analizado tanto las técnicas constructivas como su relación con el entorno y la vinculación con los distintos tipos de intervención llevadas a cabo para finalmente realizar una propuesta de soluciones compatibles. La falta de protección y valoración de la arquitectura tradicional de tierra es una problemática que va más allá

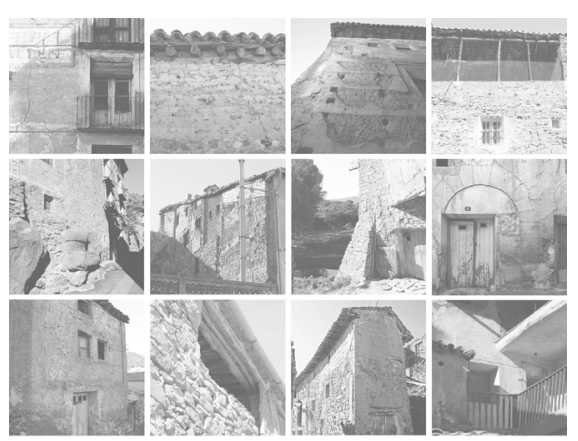

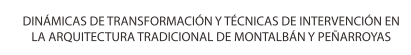

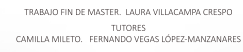

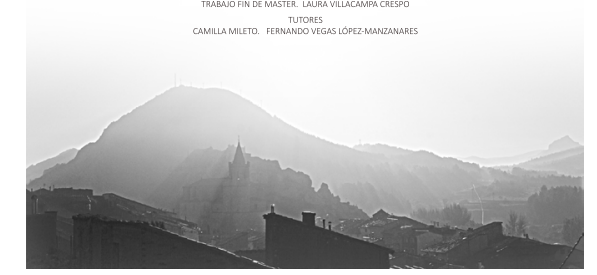

Figura 1.1. Portada del trabajo fin de máster de la autora.

2. Contrato predocatoral MINECO, en el marco del proyecto "La restauración y rehabilitación de arquitectura tradicional de tierra en la Península Ibérica. Líneas guía y herramientas para una intervención sostenible" SOStierra (ref. BIA 2014-55924-R, investigadores principales Camilla Mileto y Fernando Vegas) financiado por el Ministerio de Economía y Competitividad.

3. Grupo de investigación RES-Arquitectura: Investigación Restauración y Difusión de Patrimonio Arquitectónico, dentro del Instituto de Restauración del Patrimonio, Universitat Politècnica de València. 
de los límites de esta comunidad por lo que la metodología se podría extrapolar como referencia para otras áreas con características análogas.

\subsection{Marco de la investigación. Estado de la cuestión}

Los estudios entorno a la arquitectura tradicional y, concretamente, sobre las técnicas de construcción con tierra han ido aumentando paulatinamente a lo largo de las últimas décadas. Su valor histórico y material, así como su adaptabilidad y sostenibilidad han hecho que exista un creciente interés por estas técnicas por parte de profesionales, pero también por aquellas personas o grupos interesados en la etnografía o en la construcción sostenible y respetuosa con el medio ambiente.

La riqueza y adaptabilidad de estas técnicas y la preocupación por su conservación junto con la crisis del petróleo de los años 70 hizo que se advirtiera la limitación de los recursos naturales y potenció la creación de una red de conocimiento entorno a las mismas y sus aplicaciones en la arquitectura actual (García Soriano 2015). Al mismo tiempo, en las zonas rurales de Aragón donde la industrialización llegó de forma tardía, la arquitectura tradicional de tierra se encontraba todavía en sus primeros procesos de cambio tras el abandono de estas técnicas.

Esta red de conocimiento nace de la necesidad de estudiar y reaprender las técnicas constructivas de tierra tanto para conservarlas como para aplicarlas en arquitectura de nueva planta. Los estudios generalmente se han centrado en el análisis de una técnica constructiva de tierra, en sus características y su conservación desde el punto de vista técnico, o en el estudio de un edificio concreto, de una localidad o de una zona (generalmente de pequeña escala o gran escala). El presente estudio ha intentado cubrir el vacío intermedio a través del estudio detallado de las características de la arquitectura (técnicas, variantes y subvariantes) de un territorio lo suficientemente amplio.

La arquitectura de tierra se ha estudiado abundantemente lo cual ha conformado una red de conocimiento cada vez más amplia tanto a nivel nacional como internacional. Existen una serie de grupos de investigación y organizaciones cuyos trabajos están enfocados al estudio de la tierra como material, a las técnicas tradicionales y a sus aplicaciones en la arquitectura contemporánea, y desde estas se promueve notablemente su conocimiento y su difusión.

A nivel internacional existen diversos grupos de investigación entre los cuales es conveniente destacar la Red Iberoamericana PROTERRA, creada en 2006 y a la que pertenecen más de 100 expertos, que trabajan sobre integración y cooperación técnica y científica de la arquitectura de tierra en Iberoamérica. 
The Getty Conservation Institute- The earthen architecure iniciative, que busca mejorar y optimizar la conservación de los edificios de tierra, y The Auroville Earthen Institute, enfocado al aprendizaje de la construcción con tierra. Otro organismo importante a nivel internacional es la Catedra UNESCO de Arquitectura de Tierra, culturas constructivas y desarrollo sostenible fundada en 1998 y de la que forman parte más de 40 instituciones (Universidades, centro de investigación, ONGs, etc.) de África, América, Asia y Europa, y que promueve la difusión del patrimonio construido en tierra.

A nivel europeo destaca el laboratorio CRAterre en Grenoble, Francia, por ser pionero en la investigación de la tierra como material, de las construcciones existentes y de su conservación y de sus aplicaciones en la arquitectura de nueva planta. Este grupo ha generado una gran base de conocimiento que es referente en la investigación de este material y sus técnicas en todo el mundo. Otra organización destacable es el Dachverband Lehm e.V. en Alemania cuyos estudios se han centrado en el desarrollo de regulaciones técnicas para la construcción con tierra en edificios contemporáneos (Lehmbau Regeln), además de tener programas de aprendizaje de construcción con tierra.

A nivel nacional existen distintos grupos de investigación centrados en la construcción con tierra (Grupo Tierra y Fundación Navapalos, entre otros), si bien la principal base de conocimiento se ha generado a entorno a investigadores o grupos de investigación asociados a universidades y el desarrollo de proyectos cuyos objetivos es el estudio de la arquitectura de tierra.

En cuanto a las publicaciones, hay que destacar las realizadas por CRAterre, referentes a nivel internacional, y que han conformado la base del conocimiento tanto entorno a las técnicas tradicionales como la propia tierra como material de construcción (Houben y Guillaud. 1994; Doat et al. 1979). Si bien, existe un gran número de publicaciones y autores como John Warren (Warren 1999), Gernot Minke (Minke 1994), Graciela María Viñuales (Viñuales 1981), Bruno Pignal (Pignal 2005), Mariana Correia (Correia 2007), Paul Jaquin (Jaquin y Augarde 2012), José Luis Alonso Ponga (Alonso Ponga y Cid 1994), Jaime de Hoz Onrubia, Luis Maldonado Ramos y Fernando Vela Cossío (Hoz Onrubia, Maldonado Ramos y Vela Cossío2003), cuyas aportaciones son referentes en el estudio de la tierra.

En cuanto a publicaciones centradas en el estudio de técnicas constructivas de tierra cabe destacar autores como Francisco Javier castilla Pascual (Castilla Pascual y Nuñez Martí 2005), Fermín Font (Font e Hidalgo 2009), Fernando Vegas y Camilla Mileto (Vegas et al. 2014a), Valentina Cristini (Cristini 2012) y Lidia García Soriano (García Soriano 2015) y Amparo Graciani, Jacinto Canivell y José Manuel López Osorio (Canivell et al. 2014), Patrick Bardou (Bardou 1979), Juana Font (Font Arellano et al 2011).

En el caso de Aragón, las investigaciones en torno a la arquitectura de tierra son limitadas y se han 
desarrollado, generalmente ligadas a una zona determinada. Cabe destacar la labor de José María Sanz Zaragoza (Sanz Zaragoza y Sopensés 2009; Sanz Zaragoza 2014 ); María Figols (Figols González 2006); Félix A. Rivas y Àngels Castellarnau (Rivas González 2011; Castellarnau Visús y Rivas 2013), Abad Alegría (Abad Alegría 1997) y Guillermo Allanegui Burriel (Allanegui Burriel 1979).

A nivel autonómico, deben ser consideradas las aportaciones las personas anónimas que han estudiado la arquitectura de tierra de sus pueblos y que en ocasiones han analizado incluso las intervenciones llevadas a cabo. Esta se recoge frecuentemente en internet en los blogs de las localidades o de asociaciones que pretenden poner en valor la cultura local. Algunos ejemplos son: Amigos del Serrablo, Plenas, Centro de Estudios Borjanos. Este tipo referencias no conforman la base de conocimiento, sin embargo, se trata de información muy útil en el estudio de áreas concretas.

Por otro lado, en relación con la restauración y la rehabilitación de la arquitectura de tierra existen manuales o publicaciones con apartados de propuestas que han sido referentes directos en el desarrollo del bloque 3 de esta tesis (Terra incognita 2008; Warren 1999; Jaquin y Augarde 2012; Viñuales 1981; Naval Mas 1990; Pignal 2005, AA.VV. 2006; Morisset y Misse 2011). Las publicaciones sobre intervenciones suelen presentar soluciones a los problemas genéricos de las técnicas constructivas o a problemas concretos de un caso de estudio, pero no suelen hacer referencia al estudio de intervenciones preexistentes y las posibles problemáticas de estas. Además, las publicaciones o proyectos con estudios más específicos en la mayoría de los casos están centrados sobre la arquitectura monumental (Proyecto "Restapia: La restauración de la arquitectura de tapia en la Península Ibérica" BIA 2010-18921), cuyas características e incluso el tipo de variantes constructivas distan de las de la arquitectura tradicional.

De la preocupación por la falta de un estudio completo, así como por el estado de conservación y de intervención de la arquitectura tradicional de tierra nace el proyecto "La restauración y rehabilitación de arquitectura tradicional de tierra en la Península Ibérica. Líneas guía y herramientas para una intervención sostenible" SOStierra (ref. BIA 2014-55924-R, investigadores principales Camilla Mileto y Fernando Vegas) financiado por el Ministerio de Economía y Competitividad (2015-2018) y en el cual se enmarca esta tesis. Fruto de este proyecto se han realizado investigaciones específicas de las distintas áreas de la Península Ibérica, así como un reconocimiento global de las mismas. Además, derivada de este proyecto de investigación se ha realizado la publicación "Vernacular and Earthen Architecture: Conservation and Sustainability" (Balkema/ Taylor \& Francis 2018) que reúne las contribuciones del Congreso Internacional SOStierra 2017 (Valencia, septiembre 2017), organizado en el marco de este proyecto. 
2. OBJETIVOS Y ESTRUCTURA DEL ESTUDIO 


\section{OBJETIVOS Y ESTRUCTURA DEL ESTUDIO}

Este trabajo persigue el conocimiento y la puesta en valor de la arquitectura tradicional de tierra de Aragón ya que se trata de un importante patrimonio arquitectónico, constructivo, material, histórico y etnográfico (Taberner Pastor 2004 en La Spina 2014). La arquitectura tradicional en general y concretamente la de tierra no goza de especial prestigio ya que se considera precaria tanto por la sociedad como por la autonomía ya que no goza de ningún tipo de valor especial como el que sí tienen las casas tradicionales de piedra del Pirineo de la misma comunidad (ley 11/1992 de Ordenación del Territorio y Decreto 291/2005 del Gobierno de Aragón). Por ello, es necesario fomentar el conocimiento y la revalorización de esta arquitectura que permitirá abordar el objetivo principal de la investigación que es generar unas líneas guía para la conservación y restauración de esta arquitectura.

A través de conocimiento de la arquitectura tradicional de tierra se pretende realizar un análisis del estado de conservación y de los tipos intervención y las soluciones utilizadas comúnmente en las construcciones con el fin de establecer unas dinámicas de intervención generales.

Finalmente, partiendo de las dinámicas de intervención detectadas se propondrán unas líneas guía para la protección y la conservación de este patrimonio en las que se muestren soluciones compatibles para realizar reparaciones de forma adecuada y hacer frente a las nuevas necesidades.

\subsection{Objetivos específicos}

Con el fin de alcanzar el objetivo final de la tesis se han marcado los siguientes objetivos parciales:

- Conocer las técnicas constructivas de tierra y variantes en Aragón, así como su contexto dentro de la Península Ibérica. El conocimiento del abanico de técnicas constructivas y variantes, así como sus características y particularidades en cada zona se considera de especial interés ya que las distintas variantes responden a la optimización de los recursos de un lugar, en un momento y para hacer frente a unas necesidades concretas. 
- Estudiar geográficamente cada una de las técnicas y variantes con el fin de establecer relaciones entre ellas y con su entorno. La arquitectura tradicional es un tipo de construcción que está íntimamente ligada al lugar en el que se encuentra. Por ello es importante conocer la localización y la extensión del área donde se utiliza cada una de las técnicas y variantes, así como las posibles relaciones con las características geográficas de cada zona o lugar concreto.

- Analizar las lesiones y los factores de degradación más comunes, sus causas y efectos. Se estudiarán las distintas lesiones o mecanismos de degradación desde el punto de vista técnico, a la vez que se entablarán relaciones entre los tipos de lesión y las técnicas constructivas afectadas por cada una de ellas, así como su posible relación con el entorno en el que se encuentran.

- Estudiar el tipo de intervenciones realizadas de forma más recurrente con el fin de definir las dinámicas de intervención existentes. Es importante realizar un análisis de las intervenciones realizadas y valorar su adecuación respecto al edificio tradicional y a la técnica constructiva. El análisis del tipo de intervención tanto general como en cada una de las partes del edificio servirá para entender las dinámicas de transformación actuales. Además, se estudiará la compatibilidad material, estructural y estética de las distintas soluciones.

- Proponer unas posibles líneas guía y herramientas a utilizar para una restauración y conservación sostenible y adecuada a las técnicas constructivas. El conocimiento de las dinámicas de intervención y de las características de cada técnica constructiva y variantes junto el análisis de la bibliografía específica son el punto de partida para confeccionar unos criterios generales de protección y conservación de la arquitectura tradicional de tierra a aplicar en futuras intervenciones.

\subsection{Límites de la investigación}

El principal límite de esta investigación el es límite geográfico que viene acotado por el área de la comunidad autónoma de Aragón, que cuenta con 47.719 km2 (Huesca: 15.636 km², Zaragoza: 17.274 km² y Teruel: $14.809 \mathrm{~km}^{2}$ ) (www.aragon.es)

Aragón está dividido en 33 comarcas divididas en 731 municipios y un total de 1812 núcleos de población y una densidad de población media de 27,4 hab/km2. (Instituto Geográfico de Aragón)

El trabajo de investigación se ha centrado principalmente en los datos obtenidos a través de la toma de datos in situ. Por ello, además de la geografía, deben tenerse en cuenta otras limitaciones como 
la imposibilidad de visitar todas las localidades o núcleos de población existentes en Aragón. La gran superficie junto con el incontable número de poblaciones existentes hace que las tareas de campo se hayan limitado una muestra concreta que no corresponde ni con la totalidad de localidades ni con la totalidad de edificios dentro de las mismas. Por ello, con el fin de conocer la heterogeneidad de técnicas y variantes de esta arquitectura, una de las premisas en la toma de datos ha sido su distribución geográfica por todo el territorio.

Por otro lado, y debido a que la mayor parte de los datos provienen del análisis visual y la toma de fotografías, existe una limitación visual importante derivada de la inaccesibilidad a prácticamente la totalidad de los edificios analizados, ya que son de carácter privado. Esto limita el estudio entorno al conocimiento de algunas de las técnicas que en ocasiones se encuentran en el interior como puede ser los entramados tejidos o con adobe para conformar las particiones interiores.

Finalmente, las intervenciones o los elementos de protección de los edificios en ocasiones generan una imposibilidad de reconocimiento de las técnicas ya que impiden visualizar los materiales tras ellos.

En cuanto al estudio de las intervenciones, no existe un marco temporal, sino que se limita a las intervenciones de época reciente, desde el comienzo del uso de los materiales industrializados, a partir de los años 50-60 (en los edificios tradicionales de las zonas rurales) hasta la actualidad.

\subsection{Estructura de la tesis}

El trabajo de investigación se ha dividido en distintas fases que organizan las tareas a realizar en cada una de ellas con el fin de alcanzar los objetivos propuestos de forma eficiente. Además, todas las fases del estudio están orientadas al alcance del objetivo final que es la revalorización de la arquitectura de tierra en Aragón y la propuesta de líneas guía para la protección y la conservación de este patrimonio.

Las fases de trabajo seguidas para el desarrollo de la investigación han sido las siguientes:

1. Estudio de las técnicas constructivas de tierra, características generales y clasificación. La caracterización y reconocimiento y puesta en obra de las técnicas constructivas existentes se ha realizado partiendo de la bibliografía existente, así como de tratados de construcción. Esta parte tiene un carácter general, si bien es importante la extracción de datos referente a la Península Ibérica como contexto geográfico de Aragón. A continuación, se definirá la clasificación utilizada para definir las variantes para las técnicas constructivas más comunes en el caso de estudio (adobe, tapia y entramado). 
2. Análisis bibliográfico y normativo en el marco de Aragón. El estudio de los textos o publicaciones realizadas en materia de arquitectura de tierra o de arquitectura tradicional en Aragón es el punto de partida para el reconocimiento de las técnicas y variantes que afecta a las siguientes fases del trabajo. Por otro lado, el análisis de la normativa y los niveles de protección existentes es importante ya que puede condicionar las intervenciones existentes y por tanto las dinámicas de transformación estudiadas en las fases finales del trabajo.

3. Elaboración de la base de datos a la que se reunirán todos los casos de estudio. Esta base de datos se ha realizado a partir de una ficha de estudio que recoge datos de distintos tipos y que ha ido evolucionando con el fin de abarcar el máximo de datos posible de todos los casos. Esta ficha se compone de tres partes:

- Datos generales del edificio: localización, habitantes, altitud, tipo de propiedad, tipología edificatoria, uso, técnicas constructivas existentes, estado de intervención, entorno inmediato y estado del entorno, entorno paisajístico y presencia de turismo.

- Datos sobre las técnicas constructivas de tierra presentes (adobe, tapia o entramado): técnicas de tierra existentes y localización en el edifico y estudio detallado de cada una de las técnicas, sus características propias y la variante constructiva.

- Datos sobre la intervención: se ha definido la intervención general del edificio, la intencionalidad u objetivo de la misma y el tipo de intervención y las acciones llevadas a cabo en cada una de las partes del edificio.

4. Toma de datos por todo el territorio: esta tarea ha sido una de las más dilatadas debido a la extensión del territorio y al gran número de localidades. Durante las visitas técnicas se han intentado recoger el mayor número de datos del mayor número de ejemplos posible y no únicamente de los casos de estudio analizados en detalle con ayuda de la ficha. La toma de fotografías tanto generales como en detalle ha sido la herramienta más utilizada.

5. Clasificación de las técnicas y variantes más comunes en de territorio en base a todos los datos recogidos. La clasificación de las variantes generales se ha realizado en base a todos los datos recogidos y no únicamente a los de las fichas. Los datos recogidos en las fichas se han utilizado para profundizar en estas variantes y definir de forma más detallada sus características propias de cada zona como la localización exacta de los suplementos o su materialidad.

6. Análisis de las lesiones o fenómenos de degradación más comunes en cada técnica constructiva. Estas lesiones se han estudiado en referencia a su localización en los muros (base, cuerpo y superficie, y 
coronación), y se ha hecho alusión a las degradaciones particulares de cada técnica constructiva.

7. Estudio cruzado entre las técnicas constructivas y las propiedades del entorno en el que se encuentran. Este análisis permite reconocer aquellos factores que potencian o favorecen el desarrollo de las distintas técnicas constructivas con tierra y cuales lo dificultan.

8. Análisis de las intervenciones realizadas: a través de este análisis se han podido distinguir las intervenciones realizadas con mayor frecuencia y se han establecido unas dinámicas de intervención. También se han realizado análisis cruzando distintos parámetros de los recogidos en la ficha con el fin de buscar relaciones entre el tipo de intervención y otros factores como la población o la presencia de turismo.

9. Propuesta de líneas guía para intervenciones recurrentes de forma compatible y sostenible: partiendo de las intervenciones estudiadas se ha propuesto una serie de soluciones a las intervenciones recurrentes de forma compatible y sostenible con el edificio con el fin de potenciar el uso de estos edificios bajo la premisa de su capacidad para albergar los usos y necesidades actuales.

10. Extracción de conclusiones: en relación distintos los puntos estudiados se han extraído una serie de conclusiones que pretenden, por un lado, destacar la importancia de esta arquitectura de tierra con el fin de revalorizarla y, por otro lado, exponer las intervenciones más recurrentes y su estado con el fin de impulsar soluciones compatibles que permitan la conservación adecuada del elemento tradicional.

Las distintas fases de la investigación se han organizado en cinco bloques de trabajo que tratan aspectos relacionados de la investigación.

El primer bloque contiene la introducción a la investigación, el estado del arte, la introducción a las técnicas constructivas y variantes existentes, los objetivos de la investigación y la metodología desarrollada para la elaboración del trabajo.

El segundo bloque se centra en el estudio de la arquitectura tradicional de tierra en Aragón, sus características propias, distribución geográfica, los fenómenos de degradación y su relación con el entorno.

El tercer bloque comprende el estudio de las intervenciones realizadas, las dinámicas de transformación y la propuesta de líneas guía para su conservación, así como de la normativa existente y la aplicación de mejoras en el marco autonómico. 
El cuarto bloque está dedicado a las conclusiones del estudio y a las futuras líneas de investigación que pueden desarrollarse a partir del trabajo.

El quinto bloque contiene los anexos de la investigación que corresponden con las 410 fichas de estudio realizadas para el desarrollo del trabajo.

Así pues, la estructura general de los distintos bloques y fases de trabajo en forma de esquema es la siguiente: 
Bloque 1. Marco de la investigación

1. Introducción

2. Objetivos y estructura del estudio

3. Metodología de estudio

4. Introducción a la arquitectura de tierra

Bloque 2. La arquitectura tradicional de tierra en Aragón

5. La arquitectura tradicional de tierra en Aragón

6. Aproximación a las técnicas y variantes constructivas de tierra en Aragón

7. Arquitectura de tierra y entorno

8. Fenómenos de degradación de las construcciones con tierra

Bloque 3. Intervenciones en la arquitectura tradicional de tierra. Criterios y técnicas.

9. Marco legislativo de la arquitectura tradicional

10. Las intervenciones de la arquitectura de tierra en Aragón

11. Líneas guía para una intervención compatible y sostenible

Bloque 4. Conclusiones

12. Principales resultados

13. Futuras líneas de investigación

14. Versiones traducidas de las conclusiones

15. Bibliografía

\section{Bloques 5. Anexos}

16. Fichas de los casos de estudio 
3. METOdOLOGÍA DE ESTUdIO 


\section{METODOLOGÍA DE ESTUDIO}

La metodología utilizada en el estudio es compleja debido en parte a la escasa bibliografía específica, a la extensión del territorio y el gran número de ejemplos de construcciones en tierra.

Por ello, metodología desarrollada en este trabajo basa principalmente en el análisis de casos de estudios concretos distribuidos por toda la comunidad de Aragón a través de un método cuantitativo con el que obtener datos concretos de la información recopilada principalmente in situ, pero también de otras fuentes. Por ello, es muy importante el desarrollo del trabajo de forma científica, clara y objetiva que permita recoger, almacenar y gestionar los datos de forma fácil y ordenada'.

La investigación cuenta con diferentes fases a través de las cuales ha pretendido alcanzar cada uno de los objetivos definidos, desde el estudio de la arquitectura tradicional de tierra a la propuesta de las líneas guía de intervención.

\subsection{Recopilación de la información}

La información necesaria para la realización de la investigación se ha recopilado de distintas fuentes con el objetivo de obtener una información lo más contrastada posible. En este caso, la fuente principal de información ha sido las fuentes directas a través de un amplio trabajo de campo cuyos datos se han contrastado con las fuentes indirectas que constan de la bibliografía específica de la materia.

\subsubsection{Fuentes indirectas. Bibliografía existente.}

1. En el desarrollo de este trabajo se ha tomado de referencia parte de la metodología empleada por Lidia García Soriano en su tesis (García Soriano 2015)

La arquitectura tradicional en Aragón ha sido estudiada ampliamente, sin embargo, muy pocas de estas publicaciones están dedicadas a la arquitectura tradicional de tierra o hacen referencia a la materialidad de las construcciones estudiadas que en muchas ocasiones es de tierra. 
Por ello, se han consultado tanto textos específicos del área de estudio como bibliografía general sobre la arquitectura de tierra y las intervenciones en las mismas. Se ha utilizado esta bibliografía como punto de partida y la información de interés se ha extrapolado y comparado para poder aplicarla al caso concreto de Aragón (AA VV. 2011, AA VV. 2014 a).

También se ha utilizado como referencia bibliográfica publicaciones que, aunque con diferentes objetos y áreas de estudio, utilizan una metodología parecida (AA VV. 2014 a, García-Soriano 2015, Yuste Miguel 2010) y su finalidad es la propuesta de soluciones para la conservación de las construcciones tradicionales (AA.VV. 2014 b; AA.VV. 2014 c; AA VV. 2008; Vegas y Mileto 2014; Mileto, C y Vegas.F. 2016)

En cuanto a la bibliografía específica, Aragón es una de las comunidades que goza de mayor número de estudios sobre su arquitectura tradicional (AA.VV. 2015) y existen publicaciones muy completas y de gran interés (Allanegui Burriel 1979)(figura 3.1). También existen estudios específicos sobre la arquitectura tradicional de tierra, sin embargo, estos suelen estar limitados geográficamente (Abad Alegría 1997; Figols González 2006, Naval Mas 1990), pero no existen documentos en los que se estudie la arquitectura tradicional de tierra de forma global en todo el territorio. Por otro lado, existen publicaciones de carácter general de gran interés como es la "colección territorio" (Diputación General de Aragón) en las que se realiza una descripción genera de cada una de las comarcas de Aragón y, en algunos casos, se describe su arquitectura tradicional propia de la zona. También existe la plataforma on-line del SIPCA (http://www. sipca.es/) que funciona como buscador y que constituye una enorme base de datos entorno a edificios concretos donde se describen sus principales características, acompañado de un reportaje fotográfico.

Todo ello ha constituido las fuentes indirectas utilizadas para el desarrollo del trabajo permitiendo tener un conocimiento tanto global como específico del área concreta de Aragón.

\subsubsection{Fuentes directas. Trabajo de campo}

La toma de datos in situ ha sido la principal fuente de información para la realización del trabajo de investigación. Para ello se han realizado visitas técnicas por todo el territorio a la vez que se desarrollaba el trabajo de investigación.

Con el fin de abarcar la mayor parte del territorio y estudiar el mayor número de edificios se han establecido recorridos que se ha realizado a través de distintos viajes para los que no se ha dispuesto de una financiación específica. Estos recorridos se han determinado en relación con las propiedades del territorio, los límites comarcales y la bibliografía específica donde se reconocen áreas de abundante

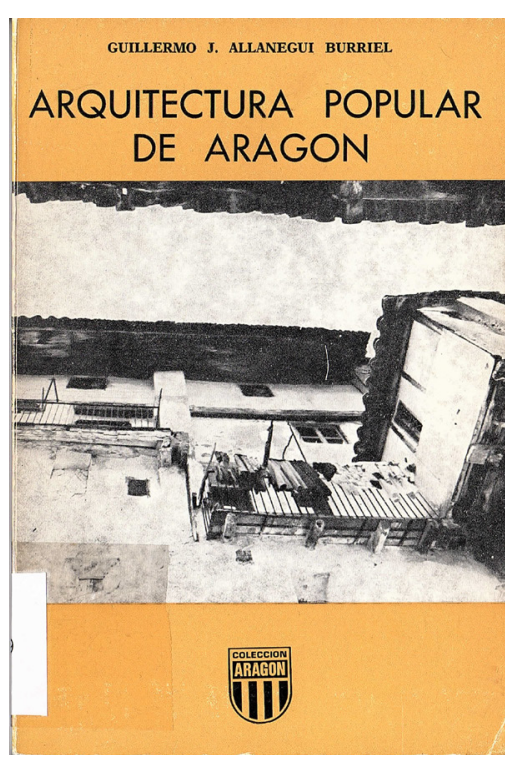

Figura 3.1. Portada del libro de Allanegui Burriel, 1979 


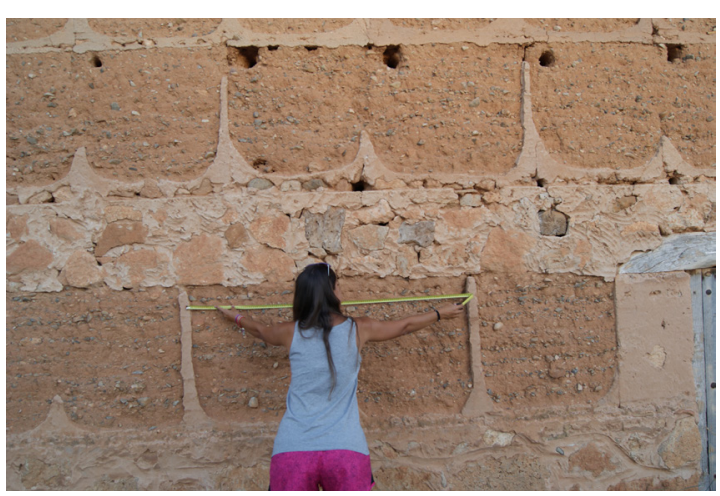

Figura 3.2. Toma de datos durante el trabajo de campo

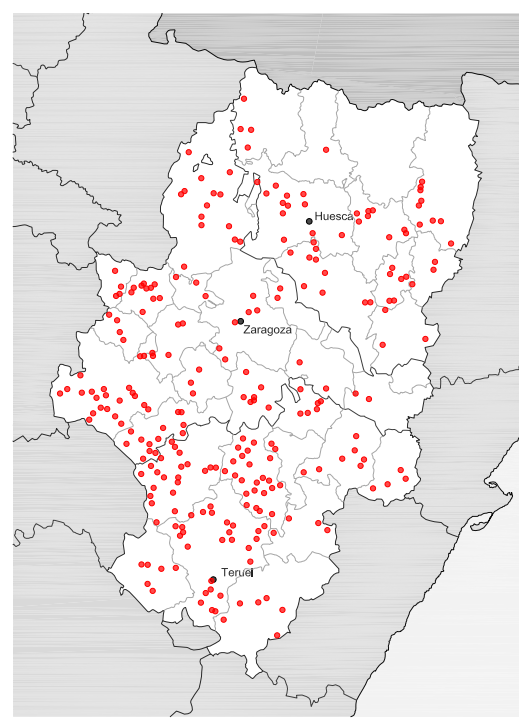

Figura 3.2. Localización de los núcleos de población donde se han tomado datos de construcciones en tierra. presencia de tierra (Allanegui Burriel 1979, Burillo Mozota 1985). El establecer zonas de trabajo ha permitido generar de forma cualitativa un conocimiento previo al procesamiento de los datos a través de la observación y las impresiones generadas en el lugar, como es la presencia relativa de la arquitectura de tierra en cada localidad.

El objetivo principal del trabajo de campo se ha sido conocer tanto las técnicas y variantes presentes en cada zona, así como sus peculiaridades concretas. Además, se ha analizado el estado actual de la arquitectura tradicional de tierra y el panorama de las intervenciones realizadas en las distintas partes del edificio.

Para recolectar toda la información posible por un lado se han realizado reportajes fotográficos exhaustivos de las localidades visitadas de forma general con el fin obtener unos datos lo más objetivos posible y reconocer la presencia de las distintas técnicas y variantes. Por otro lado, se han documentado de forma más detalla algunos casos con reportajes fotografías completos de las técnicas constructivas, las intervenciones existentes y de los mecanismos de degradación presentes. En los casos en los que ha sido posible, también se han tomado datos de las dimensiones de los muros construidos en tierra, de la dimensión de los módulos, de las piezas, etc.

El criterio de selección de casos ha sido principalmente geográfico, intentado abarcar la mayor parte del territorio con casos distribuidos de la forma más homogénea posible. Además, se ha intentado que los casos seleccionados estuvieran intervenidos o tuvieran un interés especial por sus características o estado de conservación.

\subsubsection{Fuentes primarias. Testimonios de gente local}

Los testimonios de la gente local ha sido una fuente de información limitada y, generalmente, de carácter local. Estos testimonios proceden generalmente la población más adulta que aún recuerdan haber utilizado o ver construir algunos de los edificios con las técnicas estudiadas (Castellarnau Visús y Rivas 2013)

La despoblación es uno de los factores que, sin duda, dificulta más esta tarea ya que, en ocasiones y dependiendo de la época del año en la que se realice la visita, uno puede recorrer todas las calles de la localidad sin ver a una persona.

En los casos en los que se ha conversado con la gente local, la información ha sido específica de la 
localidad generalmente en relación a edificios concretos construidos con las técnicas estudiadas en épocas que todavía alcanzaban a recordar. También se han tomado datos locales sobre las zonas de extracción de tierra, o las esplanadas o eras en las que se realizaban los adobes y se dejaban secar en una localidad determinada.

Esta fuente se considera de gran interés, aunque los datos recogidos no hayan podido aplicarse de forma directa en la metodología del trabajo por tener un carácter más general. Pese a no haberse centrado el trabajo esta fuente, es importante destacar la importancia de estas fuentes primarias cuyos conocimientos todavía existen pero que, desgraciadamente, cada vez es menor y tienen una duración finita.

\subsection{Gestión de la información}

La gestión y el análisis global de todos los datos recopilados ha sido una de las tareas más importantes para el desarrollo del trabajo de investigación. El hecho de tratarse de un estudio sobre la arquitectura tradicional ha hecho que en la mayoría de los casos no existan datos previos por lo que el propio elemento analizado ha sido la principal fuente de información.

Por ello, ha sido muy importante el desarrollo de una metodología que permita establecer un orden y dar sentido a los datos obtenidos del trabajo de campo. Con el fin de extraer el mayor número de resultados y utilizar toda la información recogida se ha generado una metodología mixta que engloba dos muestras diferenciadas que se complementan para el realizar un reconocimiento más profundo de las técnicas y variantes existentes en el territorio.

- Catalogación y clasificación de datos (muestra primera). En esta muestra se tienen en cuenta los datos de todas las construcciones de tierra localizadas durante las labores de campo. A partir de esta se han obtenido datos de la frecuencia o el número de localidades donde aparece cada técnica y variante respecto al total y la localización de las mismas.

- Base de datos de los casos de estudio (muestra segunda). En esta muestra se analizan únicamente los casos analizados con la ayuda de la ficha de estudio. Estos casos se encuentran repartidos por todo el territorio y complementa los datos de la muestra primera. 


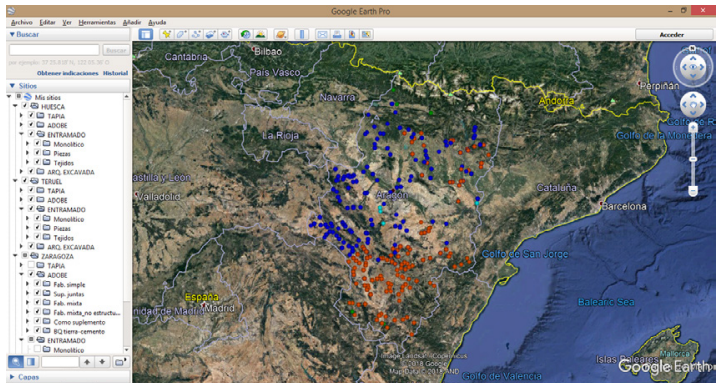

Figura 3.4. Herramienta Google Earth utilizada para localizar los núcleos de población donde se han recogido datos.

2. La base de datos fotográfica cuenta con alrededor de 10.000 imágenes.

\subsubsection{Catalogación y clasificación de datos.}

La catalogación y clasificación de datos para la configuración de la primera muestra se ha realizado a partir de toda la información recogida en las labores de campo. Esto quiere decir que se han tenido en cuenta las propiedades de todos los edificios de tierra localizados en el territorio aragonés y se han organizado según la clasificación establecida.

Para ello se ha trabajado sobre los propios datos tomados in situ, pero, principalmente sobre la base de datos fotográfica ${ }^{2}$ realizada de cada una de las localidades visitadas y sus edificios de tierra. Toda la información se ha transformado en datos geográficos con la ayuda del programa Google Earth que permite establecer marcas en puntos concretos y través del cual se han generado los mapeados de técnicas y variantes (figura 3.4). Se ha generado un plano distinto para cada una de las técnicas y variantes de tal modo que, si en una localidad concreta existe una variante, esa localidad se marca en el plano.

Debe tenerse en cuenta que en una localidad existen por lo general más de una técnica o una variante por lo que el mismo punto puede aparecer en mapeados sucesivos de tal manera que el sumatorio de técnicas y variantes no es el total de localidades.

Esta catalogación ha sido utilizada para conocer la frecuencia relativa o la incidencia de cada técnica y cada variante en el territorio, así como las zonas donde se han desarrollado cada una de ellas.

La complejidad de clasificar cada una de las técnicas y variantes, así como la extensión del territorio hace que la metodología de clasificación tenga limitaciones como la recurrencia de una técnica o variante dentro de un núcleo de población ya que la marca en el mapeado correspondiente no atiende al número de edificaciones localizadas con una técnica o variante determinada sino su mera existencia.

Por otro lado, también debe tenerse en cuenta que en estos planos aparece cada una de las variantes existentes de forma individual. Sin embargo, en muchos de los casos clasificados estas variantes aparecen combinadas dentro del mismo edificio. Por ello, la valoración cualitativa de las impresiones de cada área visitada ha sido importante con el fin de realizar un segundo análisis de la base de datos fotográfica para extraer datos sobre las tipologías constructivas combinadas y su área de influencia.

\subsubsection{Creación de la base de datos}

Con el fin de organizar la información recopilada sobre los distintos casos de estudio se ha creado una base de datos gestionada por soportes informáticos en la que se han analizado unos aspectos o 
parámetros determinados de cada caso con el fin de comparar, contrastar y obtener unos resultados de carácter general, así como los correspondientes datos estadísticos.

Para realizar el estudio de casos se ha utilizado el programa FileMaker Pro-13³ que permite la creación de fichas totalmente personalizadas y ordenadas, así como la inserción de los datos de forma fácil, científica y objetiva, además de datos fotográficos. La ficha diseñada está dividida en tres partes que contienen campos a rellanar con un amplio número de resultados posibles, lo cual le otorga una gran capacidad de adaptación para analizar y albergar los datos de diversidad de casos de estudio. Además, una vez la base de datos está completa, se pueden extraer los datos estadísticos directamente a través del programa o exportar los datos a formato Excel.

La ficha de estudio se ha estructurado en tres partes: datos generales del edificio, datos de las técnicas constructivas de tierra y datos de la intervención. La segunda parte se han rellenado en función de las técnicas constructivas existentes y la tercera dependiendo de si el edificio esta intervenido, por lo que pueden existir partes que queden sin completar dependiendo del caso (Villacampa et Al. 2016)

Parte 1. Datos generales del edificio (Figura 3.5)

En este punto se han analizado las características del edificio y su entorno de forma general, sin embargo, al ser datos obtenibles de toda la muestra, permite realizar comparaciones y cruzar datos con facilidad.

En esta primera parte se pueden distinguir tres grupos de datos: Localización, características generales del edificio y el entorno.

Los datos recogidos en el apartado de localización son los siguientes:

a) Aspectos geográficos: provincia, comarca, localidad, dirección. La recopilación de estos datos es importante ya permite filtrar los datos por zona geográfica y establecer relaciones con respecto a ella.

b) Número de habitantes de la localidad: este parámetro se ha introducido con el fin de estudiar las posibles relaciones entre densidad de población y la conservación o estado de intervención de la arquitectura tradicional ya que, en general, la zona rural de Aragón ha sufrido un gran éxodo rural y existe un gran número de edificios abandonados.

c) Altitud sobre el nivel del mar: este factor está relacionado con el tipo de clima y este último, a su vez, con el tipo de arquitectura. Por ello, se ha considerado interesante introducir este dato con el fin de realizar estudios cruzados.

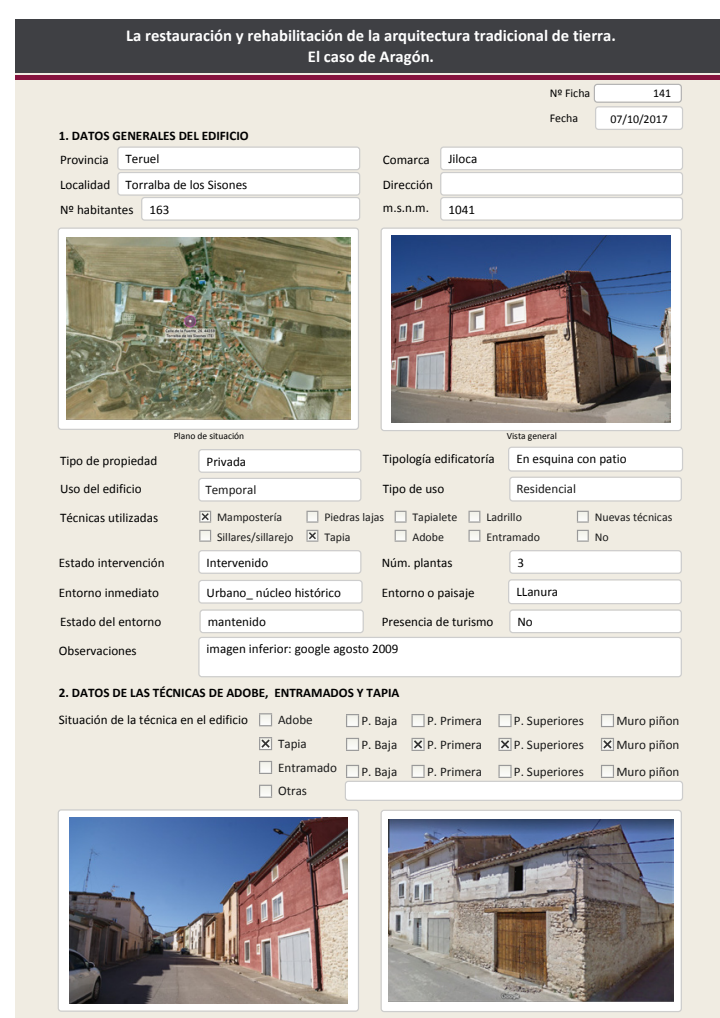

Figura 3.5. Parte 1 de la ficha de estudio, datos generales del edificio

3. Este programa permite la introducción de datos in situ ya que dispone de una aplicación para dispositivos móviles facilita la toma datos directa y de una forma rápida englobando parte de las herramientas utilizadas tradicionalmente en una única 
Las características generales del edificio se definen en los siguientes campos:

a) Tipo de propiedad: define la titularidad del edificio pudiendo ser público o privado. Este campo se ha introducido con el fin de obtener datos sobre la cantidad y calidad de las intervenciones realizadas en relación con la titularidad.

b) Tipología edificatoria y plantas: define las características físicas del edificio y su posición respecto al entorno.

c) Uso: se define por un lado el uso del edificio en el tiempo (continuado, temporal o sin uso) y el tipo de uso del edificio (residencial, productivo, agrícola u otros). Esta variable permite cruzar datos con el estado de conservación o intervención en el que se encuentra el edificio.

d) Técnicas constructivas: permite conocer las diferentes técnicas o materiales presentes en el edificio ya que, por lo general, son muy heterogéneos.

e) Estado de intervención: define si el edificio ha sido intervenido o no. Si el edificio no ha sido intervenido la tercera parte de la ficha no debe rellenarse.

Las características generales del entorno se han clasificado en base a los siguientes parámetros:

a) Entorno inmediato y estado del mismo: define la localización del edificio respecto del núcleo de población, así como el estado de conservación de ese entorno.

b) Entorno o paisaje: se refiere a la unidad del paisaje en la que se encuentra el edificio o el núcleo al que pertenece.

c) Presencia de turismo: este parámetro pretende comparar la presencia o no de turismo con las características de los edificios y de las intervenciones localizadas en los mismos.

Esta parte de la ficha va acompañada de un plano de situación una fotografía general y espacios para rellenar con la información gráfica que se crea pertinente.

Parte 2. Las técnicas constructivas de tierra. La segunda parte del análisis se centra en el análisis de las técnicas tradicionales de tierra. Esta parte se ha rellenado a tenor de las técnicas constructivas de tierra existentes en cada caso.

En primer lugar, se ha analizado en un cuadro resumen las técnicas existentes y la localización de cada una de ellas en el edificio con el fin de identificar pautas de uso de cada técnica en relación con la de 
funcionalidad, la optimización de materiales y los requerimientos estructurales. Posteriormente, se han analizado cada una de las técnicas constructivas de forma individual.

El análisis de las construcciones con adobe contempla los siguientes aspectos: estudio de la pieza de adobe, estudio de la fábrica de adobe y estudio de las patologías (figura 3.6).

Las piezas de adobe se han definido conforme a los siguientes parámetros:

a) Dimensión de las piezas: este dato viene dado por la dimensión de las adoberas y está relacionado con la tradición del lugar y el tipo de fábrica para el cual se realiza el adobe.

b) El color de las piezas depende del color de la tierra localizada en el entorno. Este dato no pretende aportar más información que la propia descripción de las piezas.

c) Composición del adobe y estabilizantes: este campo puede aportar información respecto a las propiedades de la tierra, en función de la cantidad de estabilizante utilizado, así como de los materiales disponibles para ello en cada lugar e incluso en cada época si se dispone de datos suficientes. Los áridos, las fibras vegetales, las fibras animales, el yeso o la cal son algunos de los materiales utilizados como estabilizantes.

Las características de la fábrica de adobe se han definido según los siguientes parámetros:

a) Dimensión del muro: Este dato es muy variable y por lo general depende directamente del aparejo del muro y de la dimensión de las piezas.

b) Aparejo del muro: Este dato está relacionado directamente con los requerimientos estructurales exigidos al muro en la configuración del edificio partiendo de que generalmente la arquitectura tradicional busca una optimización de los recursos disponibles.

c) Función estructural: este parámetro indica si el muro analizado tiene la función de muro de carga o trabaja como cerramiento. Este dato en ocasiones es difícil de distinguir sin embargo es interesante para establecer relaciones con el tipo de fábrica y la dimensión de las piezas.

d) Variante constructiva del muro: este parámetro se define en formato de cuadro resumen debido a la complejidad y la multitud de soluciones posibles. Siguiendo la clasificación definida previamente, se han establecido los tipos de suplementos, su localización en el muro y su materialidad, de modo que, si un muro contiene diferentes suplementos, todos ellos quedan definidos.

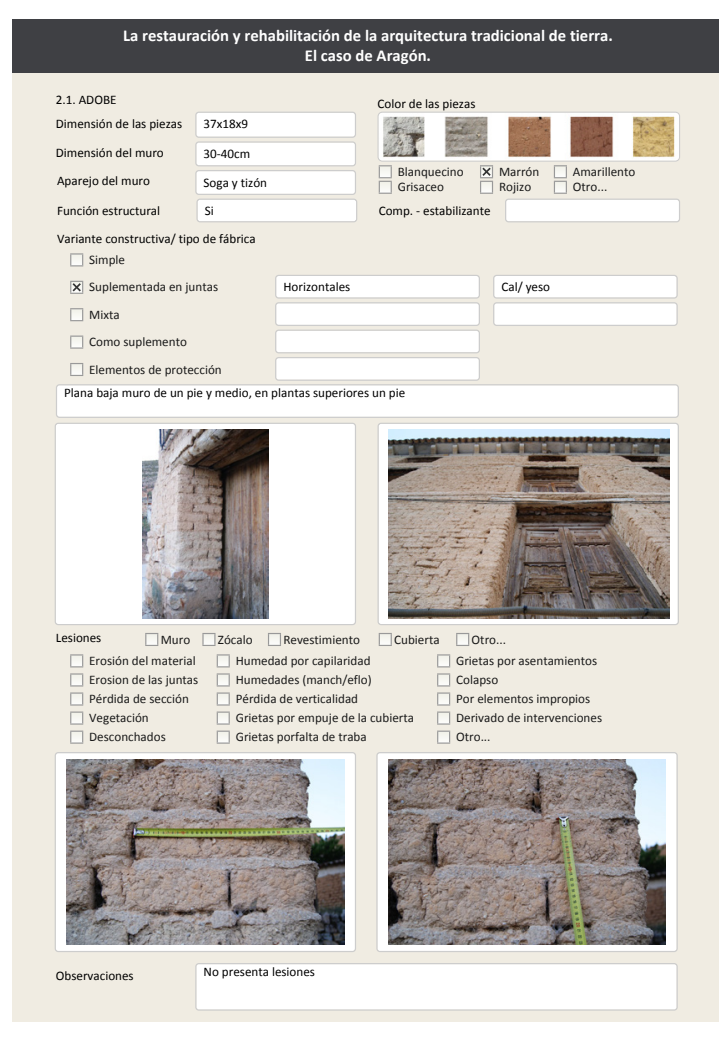

Figura 3.6. Parte 2 de la ficha de estudio, estudio de los muros de adobe. 


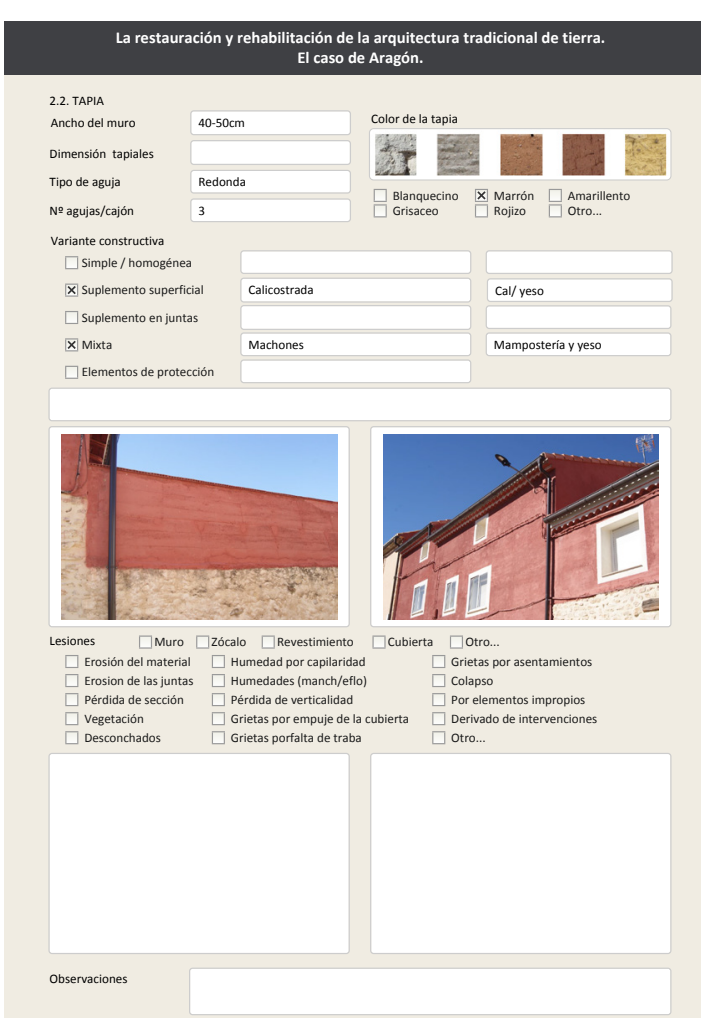

Figura 3.7. Parte 2 de la ficha de estudio, estudio de los muros de tapia.
Para definir las lesiones existentes en el edificio se ha definido en primer lugar las áreas afectadas (muro, zócalo, revestimiento, cubierta u otros) y posteriormente se determinan las lesiones concretas localizadas en un formato de selección con cruces que permite la selección múltiple y que define las lesiones localizadas más comúnmente, con opción a añadir otros nuevos.

Las construcciones de tapia se han definido a través de las propiedades físicas de la tapia dadas por las características de los cajones y de las características de la configuración del muro o variantes (figura 3.7).

Las características o la descripción física de los cajones se han definido a través de los siguientes parámetros:

a) Dimensión de los cajones (ancho del muros y dimensión del tapial): Los dos campos vienen definidos por las dimensiones del cajón utilizado.

b) Tipo de aguja: se trata de otro elemento más de los que configura el sistema del cajón de la tapia y principalmente son redondas o planas.

c) Número de agujas por cajón: determina el número de agujas en la dimensión horizontal del cajón y puede ir relacionado con la dimensión horizontal del mismo

b) El color de la tapia: esta información complementa la descripción física de la tierra utilizada en la tapia.

La definición de las variantes constructivas de la tapia sigue el mismo esquema que el descrito para el adobe. Se ha realizado un cuadro resumen con todos los tipos de suplemento definidos según la clasificación, su localización en el muro y su materialidad de manera que se puedan seleccionar los existente en cada caso

Por último, las lesiones se han definido del mismo modo y con la misma lógica que en el caso del adobe, en primer lugar, las áreas afectadas (muro, zócalo, revestimiento, cubierta u otros) y, a continuación, las lesiones existentes con un cuadro de selección adaptado al tipo de degradaciones más comunes en el caso de la tapia.

Por último, se han incluido la técnica de entramado de madera que se ha definido atendiendo a la configuración de los elementos de madera que lo componen y al relleno que configura el cerramiento de los paños entre estos elementos (figura 3.8).

Para definir por completo la configuración de la estructura del entramado de madera se ha atendido a las propiedades de la madera desde el punto de vista de la configuración o relación entre los distintos elementos y de las características de madera de cada uno de estos elementos. 
a) La configuración del entramado se ha definido a partir de los siguientes parámetros: distancia entre montantes, altura de los montantes, y presencia o no de elementos diagonales y horizontales intermedios. A través de estos parámetros se pretende realizar una descripción completa del entramado a través de la relación entre los distintos elementos.

b) Para definir las características de la madera se ha atendido en primer lugar al tipo de sección de los montantes y de las piezas horizontales (rollizos o escuadrada), información descriptiva pero que también puede estar relacionada con el tipo de edificio analizado debido al mayor coste que supone la inclusión de piezas escuadradas. Por otro lado, se ha estudiado la altura de los montantes y dimensión de la sección las piezas horizontales y verticales con el fin de establecer relaciones entre las secciones de los distintos elementos y en relación a la altura de los mismos.

Al igual que en los casos anteriores, el tipo de relleno del entramado se ha especificado según la clasificación descrita con anterioridad. De este modo, se han definido en primer lugar las propiedades o el tipo de relleno (monolítico, piezas o tejido) y finalmente la técnica de relleno, con distintas opciones predeterminadas para cada uno de los tipos de relleno.

Finalmente, las lesiones siguen el mismo esquema que en los dos casos anteriores con la diferencia de que en este caso se incluyen además una serie de lesiones, consideradas las más comunes, que se pueden localizar en los elementos de madera que componen este tipo de muros.

De forma adicional la parte de estudio de cada una de las técnicas contiene espacios para completar con información gráfica, así como un campo de observaciones para rellenar con información adicional en los casos que se estime necesario.

Parte 3. Datos de la intervención (figura 3.9). La tercera parte de la ficha está destinada al estudio de las intervenciones existentes. Este apartado se ha intentado realizar de tal forma que pudiera adaptarse e incluir el mayor tipo de intervenciones posibles. En este apartado se describen, por un lado, la intervención a nivel general y, por otro lado, las intervenciones llevadas a cabo en cada una de las partes del edificio.

La intervención a nivel general del edificio se ha reflejado con los siguientes campos:

a) El tipo de intervención en relación con el objetivo o los criterios generales de la intervención está en relación con el nivel de afección de la intervención sobre el edificio tradicional. Se han establecido los siguientes tipos de intervención con la finalidad de obtener unos resultados lo más objetivos posible:

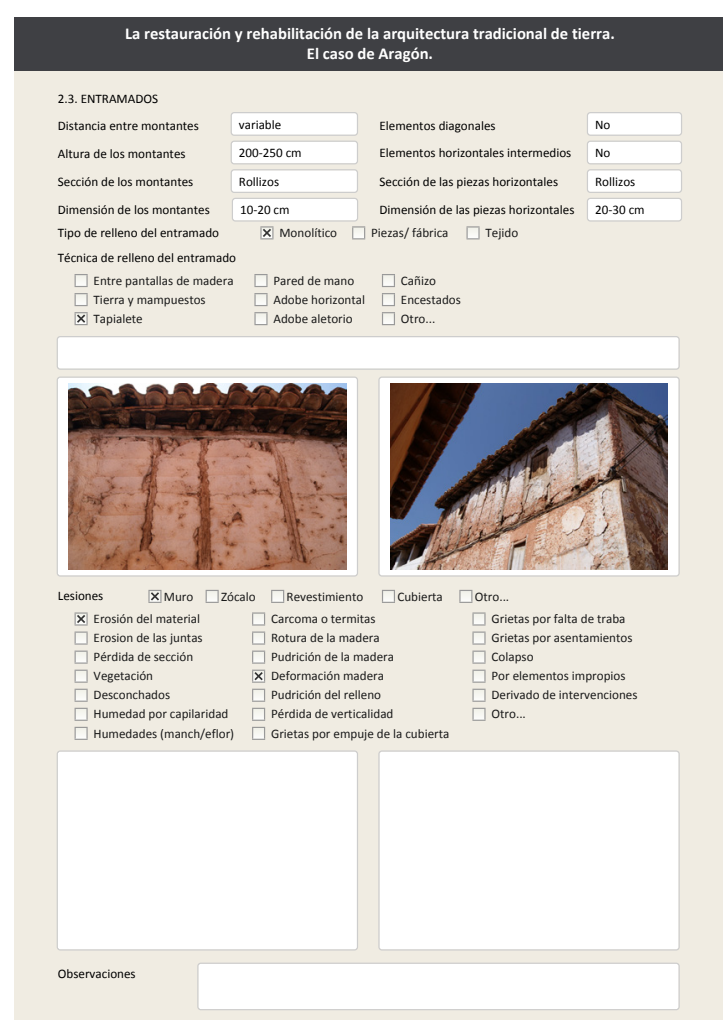

Figura 3.8. Parte 2 de la ficha de estudio, estudio de los muros de entramado. 


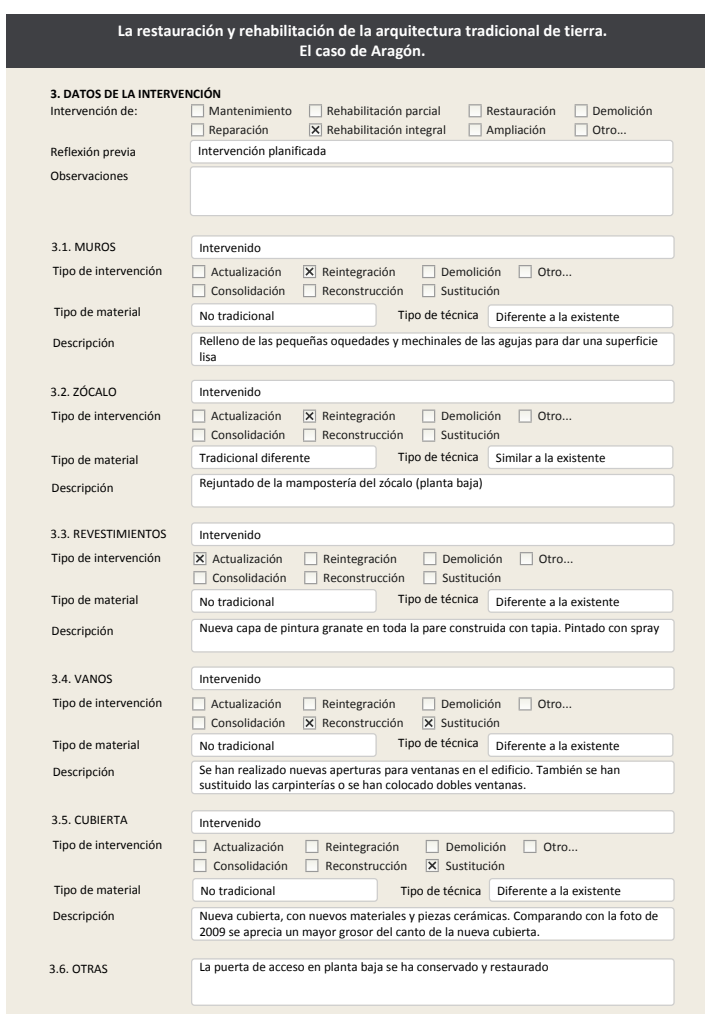

Figura 3.9. Parte 3 de la ficha de estudio, estudio de las intervenciones.
- Mantenimiento: responde a tareas de conservación de alguna de las partes de edificio antes de que se presenten daños a través de intervenciones mínimas y buscando la compatibilidad y la concordancia con el edificio tradicional. Suele tratarse de tareas que pueden ser desarrolladas por los propios dueños o inquilinos del edifico.

- Reparación: se trata de tareas realizadas sobre elementos que presentan alguna lesión o una falta de funcionalidad con el fin de frenar el deterioro y alargar su vida útil. Este tipo de trabajos suele ser parcial o puntual, limitándose generalmente a las zonas afectadas.

- Rehabilitación parcial: se trata de intervenciones parciales que buscan devolver o integrar una nueva función en el edificio sin importar las características de la misma

- Rehabilitación integral: suele implicar trabajos de gran envergadura en parte o en la totalidad del edificio con el fin de actualizarlo a los estándares actuales o dotarlo de un nuevo uso, aun modificando su naturaleza.

- Restauración: se trata intervenciones cuyo principal objetivo es la conservación del elemento preexistente sin alterarlo.

- Ampliación: este tipo de intervención supone el aumento volumétrico del edificio con el fin de incrementar la altura o la superficie útil.

- Demolición: tarea que implica la eliminación de alguna de las partes del edificio existente y cuyo objetivo suele ser desocupar total o parcialmente la parcela o eliminar de forma controlada algunas partes en muy mal estado de conservación.

b) La reflexión previa a la intervención se refiere al nivel de planificación previa o de espontaneidad que existe por parte de los propietarios que realizan o que solicitan los trabajos de intervención. Las intervenciones en la arquitectura tradicional se realizan en muchos casos de forma inmediata como respuesta a un problema o a una necesidad, sin una programación concreta ni estudios previos del elemento a intervenir. Por eso, en esta parte de la ficha no existe un campo propio sobre los criterios de intervención en la restauración, ya que, aun en los casos que la intervención está planificada, esta no suele seguir un criterio claro, sino que responde normalmente a las necesidades y gustos de los propietarios.

Para definir las intervenciones parciales en cada parte del edificio se han establecido en primer lugar las zonas a estudiar: muro, zócalo, revestimiento, vanos y cubierta. El análisis de todas las partes sigue el 
mismo esquema con el propósito de poder comparar y contabilizar los datos resultantes. Este análisis se ha estructurado en:

a) Tipo de intervención: define el tipo de trabajo que se han llevado a cabo en cada parte del edificio. Se han establecido los siguientes tipos de intervención:

- Actualización: se trata de actuaciones que buscan la modificación del decoro o la adaptación del edificio a los estándares del momento y que siguen generalmente unas tendencias o modas.

- Consolidación: implica la conservación y protección del elemento original aportando únicamente los materiales necesarios para garantizar su estabilidad. Este tipo de intervención está muy ligado a los trabajos de restauración.

- Reintegración: este tipo de intervención implica completar las partes faltantes sin tener en cuenta la naturaleza de los materiales utilizados. Este tipo de intervención está relacionada en muchos casos con labores de mantenimiento o de reparación.

- Reconstrucción: supone la incorporación de un nuevo elemento o la recuperación de uno que existía pero que se había perdido, sin atender al origen de los materiales utilizados.

- Demolición: supone la eliminación material de algún elemento o parte de este de forma intencionada.

- Sustitución: esta intervención conlleva la eliminación de un elemento preexistente y la construcción de otro nuevo. Este tipo de intervención esta relacionada con la reconstrucción.

b) Tipo de material: no se ha identificado el material concreto utilizado sino las propiedades de este y sus características de similitud o desigualdad respecto al tradicional (tradicional similar, tradicional diferente o industrial)

c) Tipo de técnica: para la técnica constructiva sucede igual que en los materiales, y se ha determinado si la técnica utilizada es similar o parecida a la existente o es diferente, sin tener en este caso el tipo de material con el que se realiza la técnica.

Estos campos se han definido con estos parámetros con el fin de obtener un número de resultados limitado y similar en todos los casos con el fin de poder compararlos ya que el abanico de soluciones es infinito. Además, permite observar la intencionalidad de la intervención a través de la búsqueda o no de la compatibilidad de los materiales y las técnicas con la construcción tradicional. 


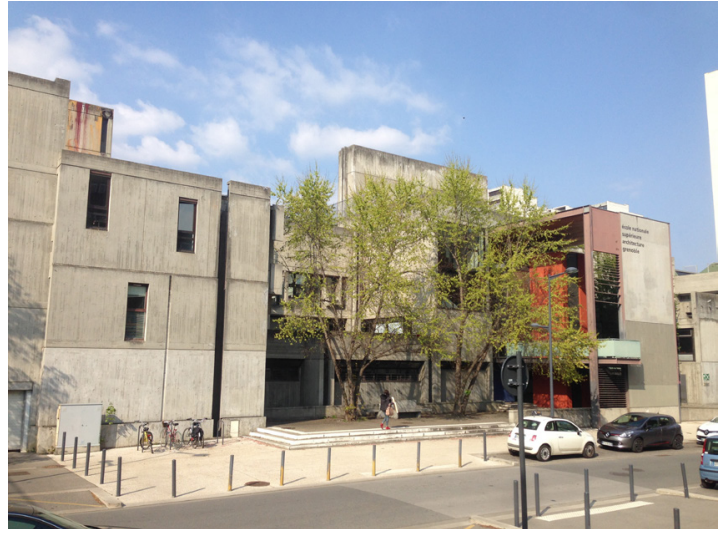

Figura 3.10. École Nationale Superieure d'Architecture de Grenoble. Grenoble, Francia. d) Descripción de la intervención: cada una de las partes contiene este aparado donde se definen las características concretas de la intervención: materiales, zonas afectadas, trabajos y técnicas utilizadas, etc.

En el último apartado de intervención se ha contemplado la existencia de rehabilitaciones energéticas indicando en este caso las partes afectadas por este tipo de intervenciones y una breve descripción de las acciones llevadas a cabo (incorporación de materiales, sustituciones...)

Por último, se ha dispuesto de una parte con espacios para complementar la información con fotografías y apoyar a la descripción de los casos de estudio.

\subsection{Estancias de investigación en el marco del estudio}

Las estancias de investigación han contribuido notablemente en el desarrollo, refuerzo y afianzamiento de conocimientos en la materia de investigación.

Se han realizado dos estancias internacionales de investigación durante los años 2017 y 2018 de tres meses cada una de ellas. Estas estancias han supuesto una gran oportunidad a través de la cual conocer distintos enfoques o puntos de vista a la hora de afrontar problemas semejantes.

Los centros receptores de las estancias han sido en primer lugar el grupo CRAterre en Grenoble (Francia) centro especialista en arquitectura de tierra y, en segundo lugar, el departamento de Global Environmental Architecture, GSGES de la Universidad de Kioto (Japón), donde se realizan estudios entorno a la arquitectura tradicional, su conservación y las culturas constructivas bajo el enfoque de la sostenibilidad. Ambos centros cuentan con una gran experiencia en materia de arquitectura de tierra, la arquitectura tradicional y la conservación, lo cual ha enriquecido notablemente al desarrollo de la tesis.

\subsubsection{Estancia en CRAterre- ENSAG (Grenoble, Francia)}

La estancia en centro de investigación CRAterre-ENSAG en la École Nationale Supérieure d'Architecture de Grenoble (Francia) se realizó en el año 2017 bajo la supervisión del profesor Hubert Guillaud (figura 3.10). Esta estancia ha sido de gran importancia ya quese trata de uno de los centros de investigación de arquitectura de tierra con más de 30 años de experiencia a sus espaldas. Durante está estancia se ha realizado un análisis exhaustivo de la literatura disponible tanto en la École Nationale Supérieure 
d'Architecture de Grenoble como en el centro de documentación de Villefontaine "Maison Levrant", donde están recogidas múltiples publicaciones en torno a la construcción tierra y su conservación, algunas de ellas muy exclusivas y difíciles de encontrar en otros lugares. Esto ha permitido desarrollar la investigación principalmente en torno las técnicas constructivas de tierra y sus principales características, así como sobre su restauración y conservación.

Durante la estancia también se ha participado en distintas actividades como los seminarios internos del grupo o la reunión "Bâti ancien en pisé en la Région Auvergne Rhône-Alpes" que tuvo lugar en Lyon el 24 de febrero de 2017 en la que se expuso la problemática en la protección del patrimonio tradicional construido en tierra de la región, así como las labores de puesta en valor y concienciación social que se están llevando a cabo. También se participó en los talleres "Terre" que tuvieron lugar el 12 de marzo 2017 como parte de la Biennale de Grenoble en la que, además, se inauguró el prototipo "Terra Nostra" de hábitat en tierra y madera (figura 3.11; figura 3.12). Todo ello ha contribuido al conocimiento de grupos e iniciativas existentes en la región que buscan la conservación del patrimonio en tierra y que son un referente para el trabajo que se está realizando.

Además, se han realizado reuniones informales con distintos integrantes del grupo CRAterre relacionados con la conservación del patrimonio arquitectónico y la investigación y su puesta en valor, con los que se han intercambiado experiencias e ideas que, sin duda han sido muy enriquecedoras.

Por último, se ha realizado una colaboración con la profesora Anne-Sophie Clemençon de la École Normale Supérieure de Lyon, Site Descartes, en el proyecto documental de fotografía "Récits fotographiques de la métropole de Lyon: les fonds de Anne-Sophie Clemençon" " que se centra en la arquitectura de tierra en Aragón y en el cual se ha colaborado como soporte técnico en la clasificación de las fotografías y en la redacción del texto introductorio de la colección de fotografías (figura 3.13).

\subsubsection{Estancia en la Universidad de Kioto, Japón}

La estancia se ha realizado en el departamento de Tecnología y Ecología donde se encuentra el equipo de "Global Environmental Architecture" de la Graduate School of Global Environmental Studies de la Universidad de Kioto bajo la supervisión del profesor Hirohide Kobayashi (figura 3.14).

Durante la estancia se han desarrollado labores de distintos tipos. Por un lado, se ha participado en actividades y se han estudiado algunos trabajos desarrollados por el grupo de investigación con el fin de ampliar los conocimientos y conocer la metodología de revalorización y uso de las culturas constructivas

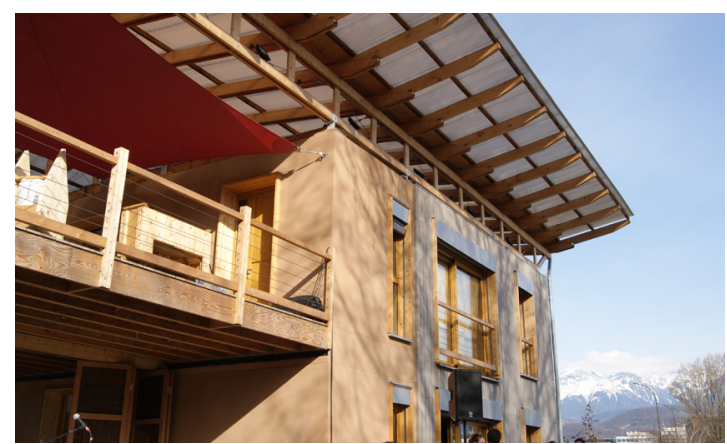

Figura 3.11. Prototipo "Terra" en Grenoble.

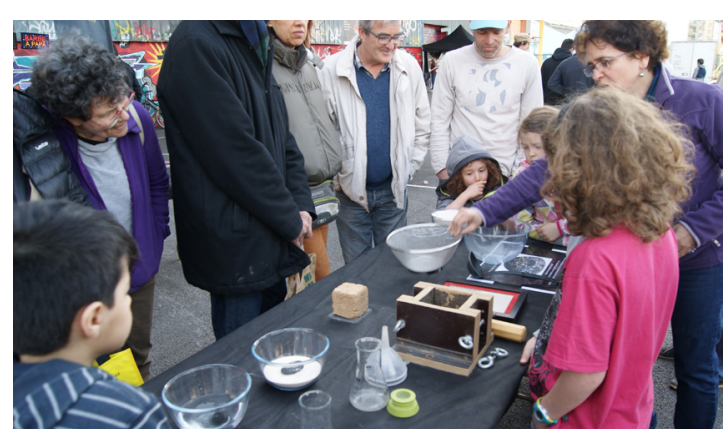

Figura 3.12. Presentación "Elementerre" durante la Biennale de Grenoble, marzo 2017.

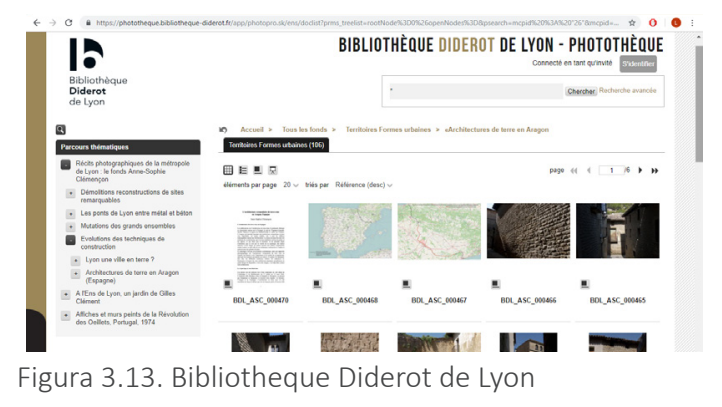

4. Bibliotheque Diderot de Lyon en el apartado Evolutions des techniques de construction, https:// phototheque.bibliotheque-diderot.fr/app/photopro.sk/ ens/?\#sessionhistory-ready 


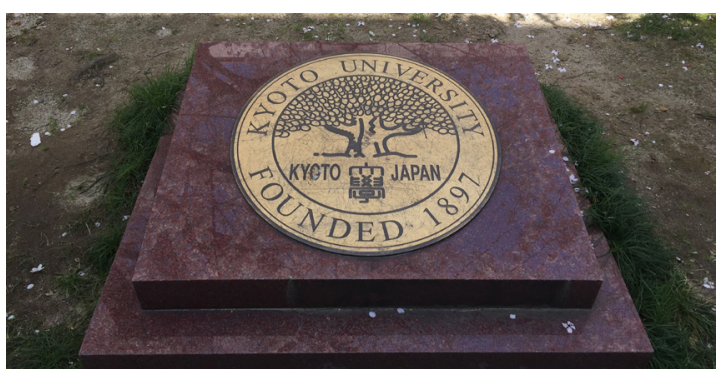

Figura 3.14. Universidad de kioto, placa en Yoshida Campus. Kioto, Japón.

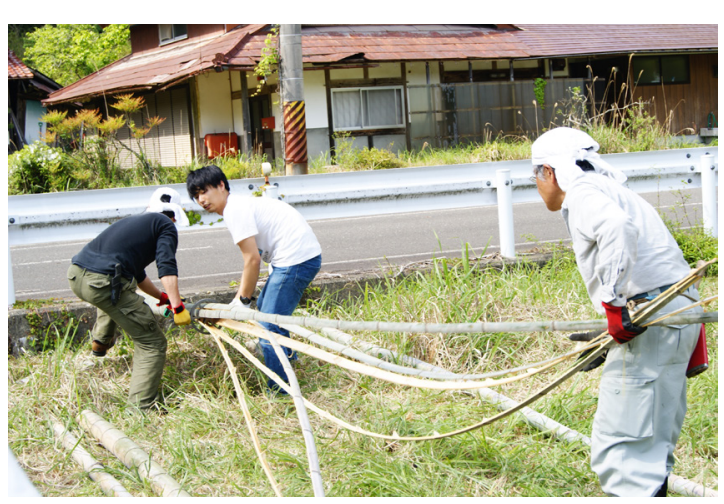

Figura 3.15. Trabajo con el bambú para la construcción del invernadero. Natasho, Japón

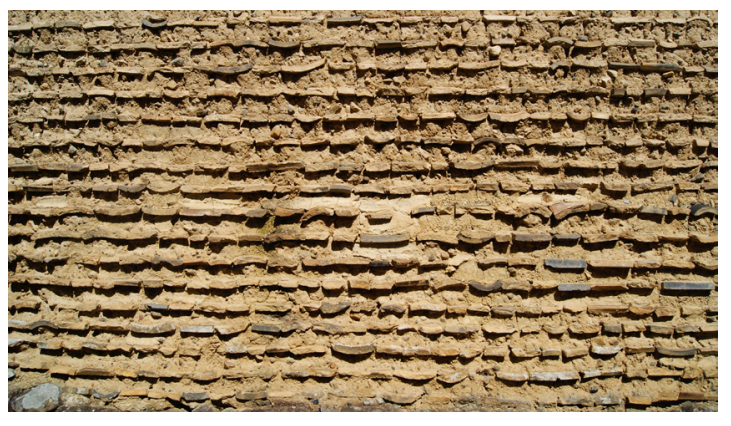

Figura 3.16. Reconocimiento de muros de tierra. Nara, Japón. en el país con el propósito de compararlos y aplicar algunos de ellos en este trabajo. Algunos de estos trabajos e investigaciones han sido el proyecto "Indigenous stone culture and living environment" desarrollado en un pueblo a las afueras de Kioto, junto al lago Biwa, la realización de un curso de revestimientos de tierra tradicionales o la construcción de un invernadero con bambú, material ligado a la cultura constructiva japonesa, para el cual se ha aplicado el saber hacer tradicional (figura 3.15).

Por otro lado, se han estudiado las técnicas constructivas de tierra existentes en Japón a través de una toma de datos directa sobre los edificios y el análisis de bibliografía donde se explican algunas de las intervenciones llevadas a cabo. Esa arquitectura está presente en todo el territorio, aunque en la mayoría de los casos no está estudiada en detalle por esta su cultura constructiva más ligada a la madera (figura 3.16). Se ha realizado una comparativa de las técnicas constructivas localizadas en Japón y las técnicas constructivas del área de estudio de la tesis, Aragón. Cabe destacar que el estudio bibliográfico no ha sido sencillo debido al lenguaje, sin embargo, se han revisado visualmente algunos libros de interés donde se todo el proceso de obras realizadas en edificios de tierra.

\subsection{Contribuciones previas.}

La investigación presentada comenzó a desarrollarse en el año 2016 a mismo tiempo que se comenzó la ayuda para contratos predoctorales para la formación de doctores del Ministerio de Economía y Competitividad (BES-2015-55924-R) asociada al proyecto La restauración y la rehabilitación de la arquitectura tradicional de tierra. Líneas guía y herramientas para una intervención sostenible (SOStierra).

\section{Colaboración en proyectos}

Título del proyecto: "SOSTIERRA: La restauración y rehabilitación de arquitectura tradicional de tierra en la Península Ibérica. Líneas guía y herramientas para una intervención sostenible (ref: BIA2014-55924-R)" Financiado por: Ministerio de Economía y Competitividad.

Investigadores principales: Fernando Vegas y Camilla Mileto.

Duración:2015-2018

Título del proyecto: TAP-TAP. Arquitectura de tierra para la sensibilización hacia el desarrollo sostenible. Financiado por: Centro de Cooperación al desarrollo-UPV Investigador principal: Camilla Mileto

Duración: 2016

Estos proyectos junto con otros previos desarrollados en el grupo de investigación donde se esta desarrollando la tesis has sido un marco y una referencia indiscutible en la investigación (figura 3.17). 
Además, se ha colaborado en la organización del congreso SOStierra 2017 que tuvo lugar en Valencia en septiembre de 2017 (figura 3.18)

\section{Publicaciones}

Las publicaciones realizadas durante los últimos tres años están ligadas tanto al desarrollo de la investigación de la tesis doctoral y al proyecto SOStierra. El progreso de ambas investigaciones de forma paralela ha permitido que se complementen y se asienten unas bases de conocimiento más firmes.

\section{5}

Antes de comenzar este contrato, ligado al trabo fin de máster se realizó una investigación sobre la conservación y la transformación de la arquitectura tradicional en el municipio de Montalbán (Teruel) bajo la supervisión de Camilla Mileto y Fernando Vegas:

Villacampa Crespo, L. 2015. Dinámicas de transformación y técnicas de intervención en la arquitectura tradicional de Montalbán y Peñarroyas.

\section{6}

Villacampa Crespo, L.; Gómez Patrocinio, F. J.; Balaguer Garzón, L.; Privitera, P. (2016). “Dinámicas de transformación de la arquitectura tradicional de Montalbán y Peñarroyas". Emerge 2016. Jornadas de Investigación Emergente en Conservación y Restauración del Patrimonio. Valencia, 26 de octubre de 2016.

Balaguer Garzón, L.; Villacampa Crespo, L.; Gómez Patrocinio. F. J.; García Soriano, L. (2016). “Patrimonio de tierra en el municipio de Alpuente (Valencia)". Emerge 2016. Jornadas de Investigación Emergente en Conservación y Restauración del Patrimonio. Valencia, 26 de octubre de 2016.

Gómez Patrocinio, F. J.; Balaguer Garzón, L.; Villacampa Crespo, L.; Diodato, M. (2016). “Mecanismos de degradación estructural en la tapia valenciana. El caso de la Alqueria del Pollastre de Xirivella, España". Emerge 2016. Jornadas de Investigación Emergente en Conservación y Restauración del Patrimonio. Valencia, 26 de octubre de 2016.

Villacampa Crespo, L.; Mileto, C.; Vegas López-Manzanares, F.; García Soriano, L. (2016). “El adobe en la arquitectura tradicional del Aragón (España). Metodología de estudio". 16ㅇ Seminario Iberoamericano de Arquitectura y Construcción con Tierra (SIACOT). Asunción, Paraguay, 24-28 de octubre de 2016.

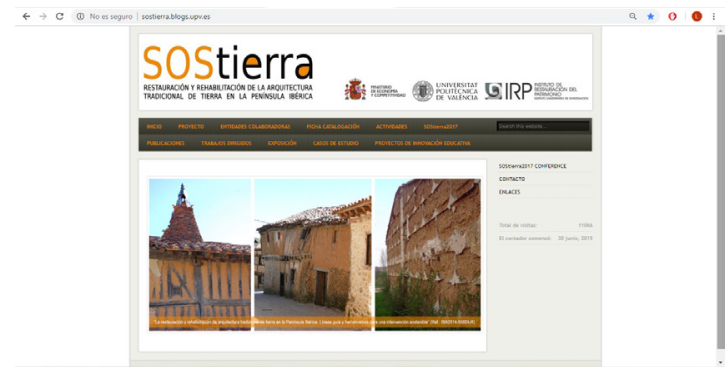

Figura 3.17. Página web del proyecto Sostierra

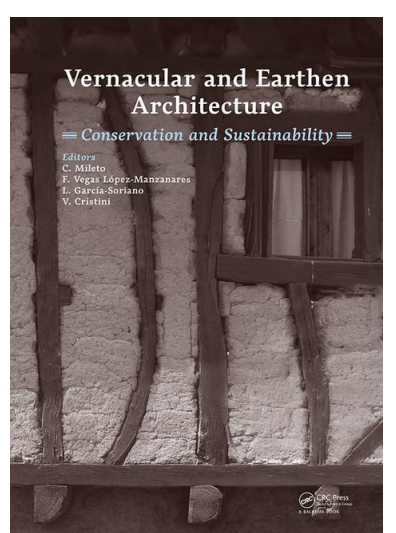

Figura 3.18. Publicación resultante del congreso internacional SoStierra 2017 celebrado en Valencia

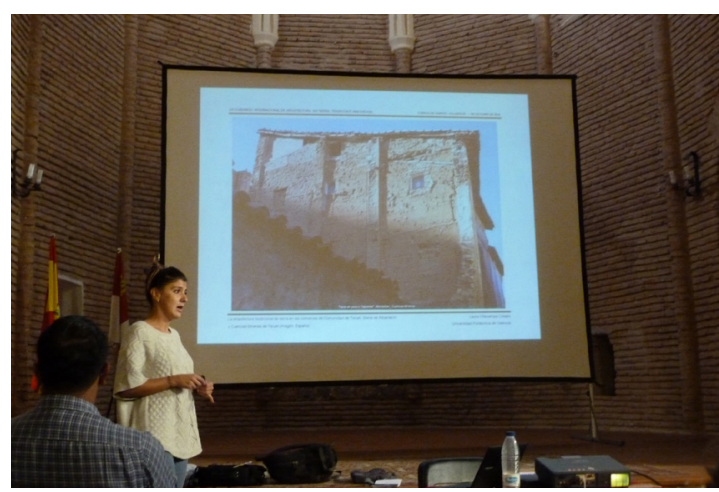

Figura 3.19. Presentación durante el congreso CIATTI 2016 en Cuenca de Campos, Valladolid 


\section{(6.}

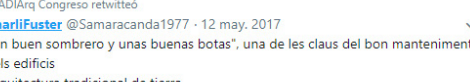
dels enificis
Arquitectura tradiciconal de teiera

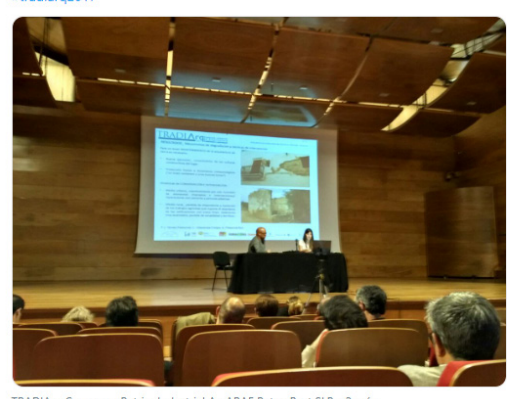

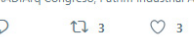

Figura 3.20. Presentación durante el congreso Tradiarq 2017 en Cullera. Publicación de Twitter

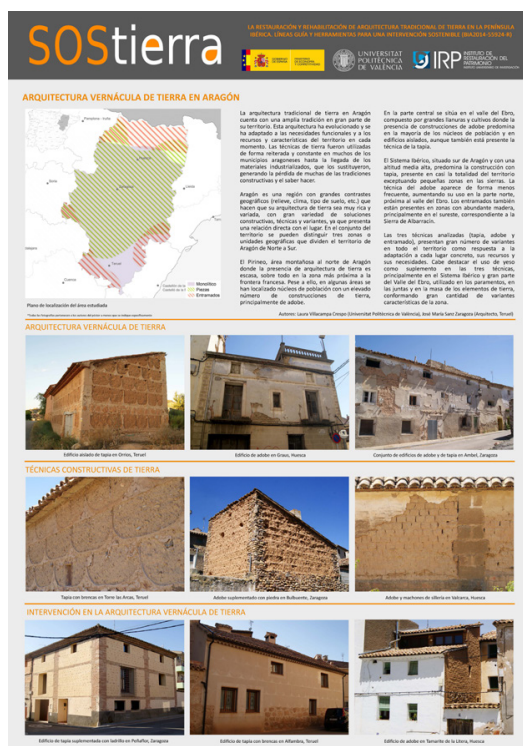

Figura 3.21. Póster realizado para la exposición "SOStierra" perteneciente a comunidad de Aragón
García Soriano, L.; Mileto, C.; Vegas, F.; Villacampa Crespo, L. (2016). “La arquitectura de tierra y su restauración en la comarca de La Mancha del Júcar". 16올 Seminario Iberoamericano de Arquitectura y Construcción con Tierra (SIACOT). Asunción, Paraguay, 24-28 de octubre de 2016.

Villacampa Crespo, L.; Mileto, C.; Vegas López-Manzanares, F.; García Soriano, L. (2016). “La arquitectura tradicional de tierra de las comarcas de Comunidad de Teruel, Sierra de Albarracín y Cuencas Mineras de Teruel (Aragón, España)". XIII Congreso Internacional de Arquitectura en Tierra. Tradición e Innovación (CIATTI 2016). Valladolid, España, 30-01-02 de octubre de 2016. p. 163-172.

2017

Gómez Patrocinio, F. J.; Villacampa Crespo, L.; Plasencia Bon, A. (2017). “Arquitectura tradicional de tierra en I'Alcudia, Valencia". II Congreso comarcal de arquitectura tradicional y patrimonio. TRADIARQ 2017. Rivera del Xuquer, Valencia, España. 11,12 y 13 de mayo de 2017. (figura 3.20)

Villacampa Crespo, L.; Mileto, C.; Vegas López-Manzanares, F.; García Soriano, L. (2017). “Características y transformación de la arquitectura tradicional de tierra en el este de Huesca (Aragón, España)". XIV Congreso internacional de arquitectura de tierra. Tradición e innovación. CIATTI 2017, Ciudad de México, México. 21,22 y 23 de septiembre de 2017.

Mileto, C.; Vegas López-Manzanares, F.; García Soriano, L.; Villacampa Crespo, L.; Gómez Patrocinio, F. J. (2017). "Primera aproximación a la variedad constructiva de la arquitectura vernácula de tierra en la Península Ibérica". X Congreso Nacional y II Congreso Internacional Hispanoamericano de Historia de la Construcción, Donostia, España. 03/07 de octubre de 2017. p. 1551-1561.

Mileto, C.; Vegas López-Manzanares, F.; Villacampa Crespo, L.; García Soriano, L.; Gómez Patrocinio, F. J. (2017). "Vernacular earthen architecture in the Iberian Peninsula. First phase of taxonomy and geographical distribution". Earth USA 2017. Ninth International Conference on Architecture and Construction with Earthen Materials, Santa Fe, New Mexico, EEUU. 29, 30 y 01 de octubre de 2017. p. 102-107.

Villacampa Crespo, L. y Sanz Zaragoza, J.M. 2017. Aragón. Póster de la exposición SOStierra (figura 3.21) 2018

Villacampa Crespo, L.; Sanz Zaragoza, J.M.; García Soriano, L. (2018). "Traditional earthen architecture in Aragón, Spain" en Vernacular and Earthen Architecture: Conservation and Sustainability. Balkema Taylor and Francis Group. p. 243-248 
García Soriano, L.; Villacampa Crespo, L.; Gómez Patrocinio, F. J. (2018). “Earthen elements in the Iberian Peninsula: cataloging and preliminary study" en Vernacular and Earthen Architecture: Conservation and Sustainability. Balkema Taylor and Francis Group. p. 119-122

Balaguer Garzón, L.; García Soriano, L.; Villacampa Crespo, L. (2018). "Supplemented rammed earth in the Northwestern regions of Valencia" en Vernacular and Earthen Architecture: Conservation and Sustainability. Balkema Taylor and Francis Group. p. 47-52

Villacampa Crespo, L.; García Soriano, L; Vegas, F.; Mileto, C. (2018). "Constructive techniques of the past for a sustainable future. The case of traditional earthen architecture in Aragon (Spain)" en International Journal of Latest Trends in Engineering and Technology, vol. II, Issue. 3, pp. 30-36.

Además, se ha colaborado en algunos capítulos de la publicación ligada al proyecto SOStierra: la restauración y la rehabilitación de la arquitectura tradicional de tierra en la Península lbérica. Líneas guía y herramientas para una intervención sostenible, que se encuentra actualmente en edición.

\section{Difusión}

También se ha colaborado en la realización de talleres prácticos con el principal objetivo de dar a conocer la construcción con tierra y poner en valor este tipo de construcciones entre públicos de características muy diferentes.

Organización taller: “Taller de barro” con niños en Escorihuela (Teruel), agosto 2017.

Organización y charla de apertura en: WORKSHOP ON TRADITIONAL ARCHITECTURE. EXPERIENCE INDIASPAIN. Taller práctico de construcción con tierra y bóvedas. Cátedra Unesco de Arquitectura de Tierra. Universidad Politécnica de Valencia (julio 2017)

Colaboración en el taller: Taller INFANTIL "Aprendiendo a jugar con barro". Cátedra Unesco de Arquitectura de Tierra. Guardería UPV. Universidad Politécnica de Valencia, junio 2017

Colaboración en el taller: Taller experimental de construcción con tierra con los alumnos de Restauración Arquitectónica de la ETSAV. "CON LAS MANOS" proyecto de innovación docente. Universidad Politécnica de Valencia, septiembre 2016

Colaboración en el taller: Taller Infantil "Jugando con barro". Cátedra Unesco de Arquitectura de Tierra. Guardería UPV. Universidad Politécnica de Valencia, mayo 2016

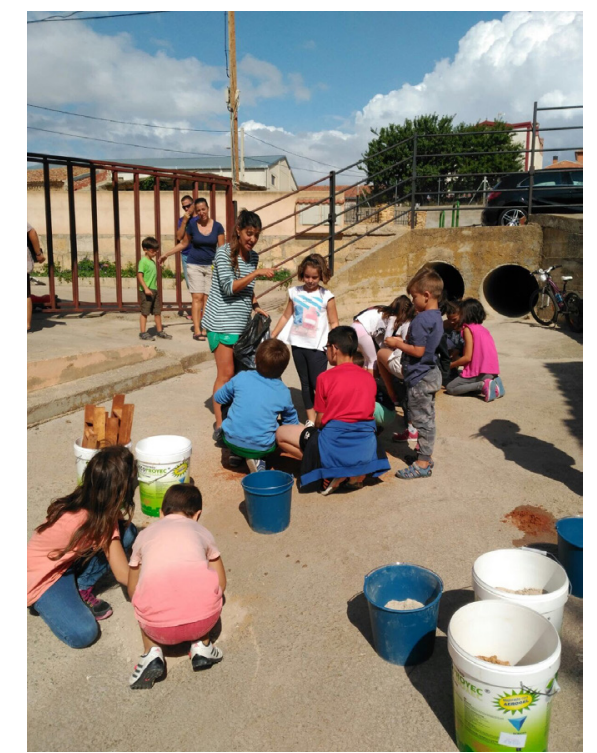

Figura 3.22. Realización del taller de barro en Escorihuela Teruel

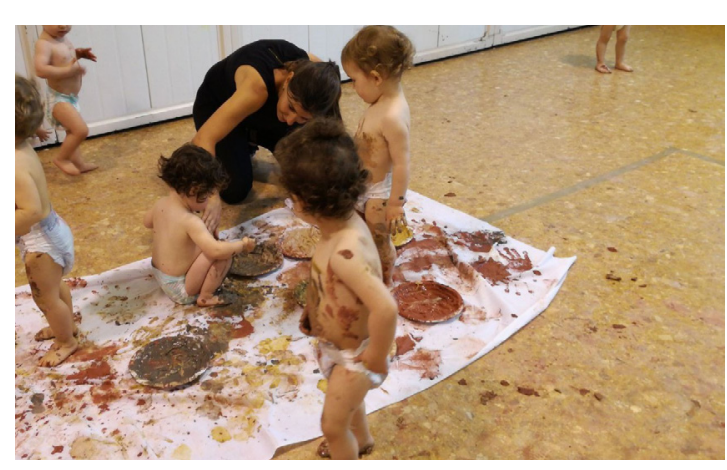

Figura 3.23. Colaboración en el taller infantil “Aprendiendo a jugar con barro" en la guarderia de la UPV en 2017 
Colaboración en la organización del taller: Taller de morteros de cal viva mezclada en caliente. Cátedra Unesco de Arquitectura de Tierra. Universidad Politécnica de Valencia, febrero 2016

\section{Cursos recibidos}

Las actividades de formación realizadas durante la realización de la tesis y, previamente, durante los estudios de arquitectura y máster, han sido de gran importancia ya que han favorecido a despertar del interés que llevó al desarrollo de este trabajo y que han ayudado a sentar las bases del conocimiento. Algunos de estas actividades o cursos han sido:

ISAlab workshop 2018- Interdisciplinary Sustainable Architecture (11-15 junio 2018)

Voluntariado para la participación social. Programa Incide. Centro de Cooperación al Desarrollo, UPV y CFP. Universidad Politécnica de Valencia, abril 2017

Cooperación internacional al desarrollo. Programa Incide. Centro de Cooperación al Desarrollo, UPV y CFP. Universidad Politécnica de Valencia, octubre-diciembre 2016

Taller: Restauració d'una barraca de pedra seca. Grup d'estudi i protecció dels ecosistemes catalans (GEPEC) y Ecologistes de Catalunya (EdC). Mony-roig del Camp, enero 2016.

4o Edición del workshop internacional: Construcción de la memoria. Universidad Politécnica de Valencia, mayo 2014

El patrimonio arquitectónico frente al riesgo sísmico. 2 edición. Universidad Politécnica de Valencia, abril 2014

La restauración a día de hoy: Italia y España. Universidad Politécnica de Valencia, noviembre 2013

XVII Taller de Arquitectura Tradicional en el Rincón de Ademuz (UPV). Rincón de Ademuz, septiembre 2013

Restaurar la Arquitectura Moderna: Criterios y ejemplos. Universidad Politécnica de Valencia, noviembre 2011

La restauración de los edificios en altura: de los criterios de proyecto a las técnicas de ejecución. Universidad Politécnica de Valencia, marzo 2009

Compatibilidad y Sostenibilidad: Conceptos para la práctica de la restauración arquitectónica. Universidad Politécnica de Valencia, noviembre 2008 
4. INTRODUCCIÓN A LA ARQUITECTURA DE TIERRA 


\section{INTRODUCCIÓN A LA ARQUITECTURA DE TIERRA}

1. Estudio realizado por el proyecto WHEAP (World Heritage Earthen Architecture Progremme). 2007- 2017

2. en 1980 Hugo Houben y Hubert Guillaud estimaron esa cifra, lo cual correspondía con 1500 millones de seres humanos
La construcción con tierra ha estado presente desde los comienzos de la evolución del ser humano, cuando este dejo de ser nómada y le surgió la necesidad de creación de espacios duraderos donde protegerse y refugiarse, lo cual tuvo como resultado la construcción de las primeras viviendas. Fruto del sedentarismo también se comenzaron a establecer relaciones con el entorno y el aprovechamiento de sus recursos, dando paso a los primeros rasgos culturales locales y a una arquitectura ligada a estos y a las condiciones de un lugar concreto. (Rocha y Jové 2015)

La tierra es un material de construcción que se ha utilizado en todos los continentes (a excepción de los polos) y en todos los climas, fomentado por su fácil disposición, su fácil manejo en la construcción y su bajo coste. La gran variedad de técnicas y variantes existentes muestra la gran adaptación al medio de este material, su heterogeneidad y riqueza de expresión y la habilidad y el ingenio ligados a las culturas constructivas (Guillaud 2017)

La arquitectura de tierra ha sido y es injustamente estigmatizada, asociándola a la escasez o la pobreza, no obstante, históricamente, la tierra ha formado parte tanto de la arquitectura tradicional como de la construcción de muchos monumentos que hoy forman parte del patrimonio mundial. En 2015 se determinó que de los 1.007 bienes culturales clasificados por la UNESCO 173 están construidos mayoritariamente en tierra ${ }^{1}$ en una gran variedad de tipologías (Guillaud 2017). La tierra, pese a ser ignorada por muchos, ha existido siempre como material de construcción y de ello queda constancia en estos monumentos y en el gran número de construcciones vernáculas existentes y en las que todavía habita aproximadamente un tercio de la población mundial (Houben y Guillaud 1989)².

Son diversos los tratados históricos de la construcción (San Nicolás 1796; Marcos y Bausá 1897; Ger y Lovez 1898; Barré 1899; Fontenay 1958) que han hecho alusión a la construcción con tierra. En estos textos se definen tanto las propiedades de las construcciones en tierra como sistema constructivo y los elementos que lo componen (en el caso de la tapia), así como las características que debe tener la tierra y los otros materiales que pueden formar parte de la técnica (ladrillos, piedra, yeso, cal, ...). 
El desarrollo de la arquitectura tradicional de tierra permaneció activo hasta aproximadamente la mitad del siglo XX, en los países desarrollados, época en la que irrumpieron los materiales de carácter industrial que provocó que estas técnicas dejaran de existir como sistema constructivo activo.

En este capítulo se han definido, por un lado, los elementos que componen el material de la tierra y, por otro lado, las técnicas constructivas de tierra existentes, haciendo especial mención a las técnicas constructivas localizadas en Aragón y que van a ser objeto de estudio en el desarrollo de esta tesis.

\subsection{La tierra como material de construcción}

La tierra ha formado parte de la cultura constructiva de los seres humanos desde los primeros asentamientos ligados al sedentarismo en todos los continentes habitados.

La tierra, está formada de granos o partículas sólidas de distintos tamaños (guijarros, gravas, arena, limos y arcillas) y de líquido (agua) y gas (aire y vapor de agua) que llenan los espacios intersticiales entre estas partículas. El conjunto de estos tres elementos sólido, líquido y gas conforman la estructura del suelo que permite obtener un material sólido para construir (Le Tiec y Paccoud 2006). Estas partículas proceden de la desintegración de las rocas derivada de la erosión de las mismas durante millones de años. Henri Van Damme cita en el prefacio de la publicación Grains de Bâtisseurs (Anger y Fontaine 2005)

"La Naturaleza, disgregando las rocas, transformándolas en fragmentos más finos o las cenizas volcánicas en arcilla, nos ha hecho de regalo un tesoro" 3

Los suelos utilizados para construcción son los que se encuentran por debajo de la capa superior, que generalmente contiene elementos orgánicos y de un estrato idealmente superior al nivel freático (Jaquin y Augarde 2012). Tradicionalmente, las zonas de extracción de tierra adecuada para la construcción eran conocidas a nivel local (figura 4.1).

Las partículas sólidas de origen mineral que componen la tierra se han clasificado tradicionalmente en función de su tamaño. Las partículas en orden de mayor a menor se denominan (Gómez Patrocinio 2017; Stulz, Mukerji y Klein 1997) (Figura 4.2):

Guijarros: son las partículas de mayor tamaño con un diámetro superior a $20 \mathrm{~mm}$. Este tipo de partículas no suele incluirse en la construcción con tierra, si bien, técnicas como la tapia pueden admitir este tamaño de partículas ya que quedan envueltas en el gran volumen de tierra, de hecho, en muchas ocasiones son apreciables cuando el muro se encuentra erosionado superficialmente (figura 4.3).

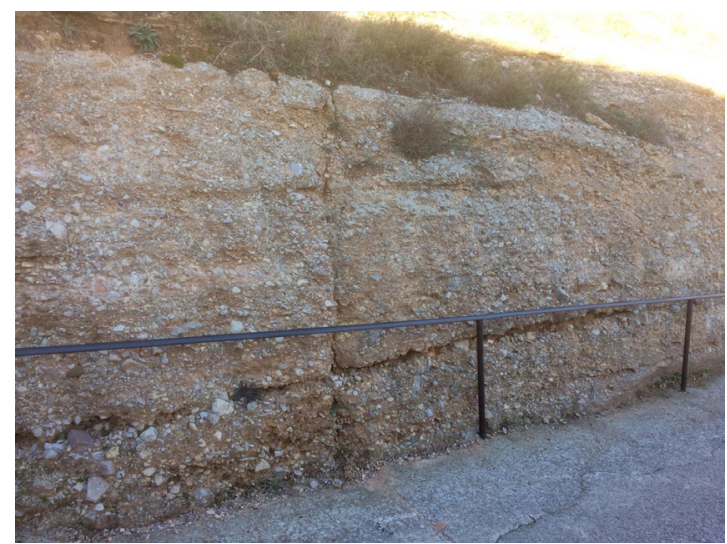

Figura 4.1. Corte del terreno cuya sección recuerda a un muro de tapia. Villastar, Teruel

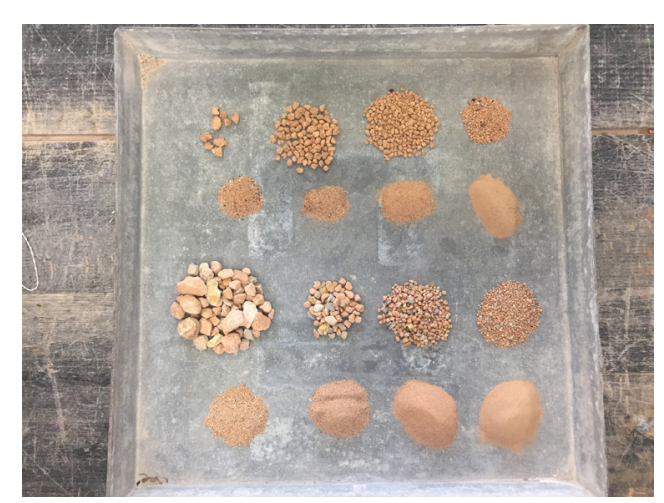

Figura 4.2. Análisis granulométrico de distintas muestras de tierra

3. Traducción del francés propia. Con este texto pretende poner en valor la posibilidad de disponer de este material para la construcción 


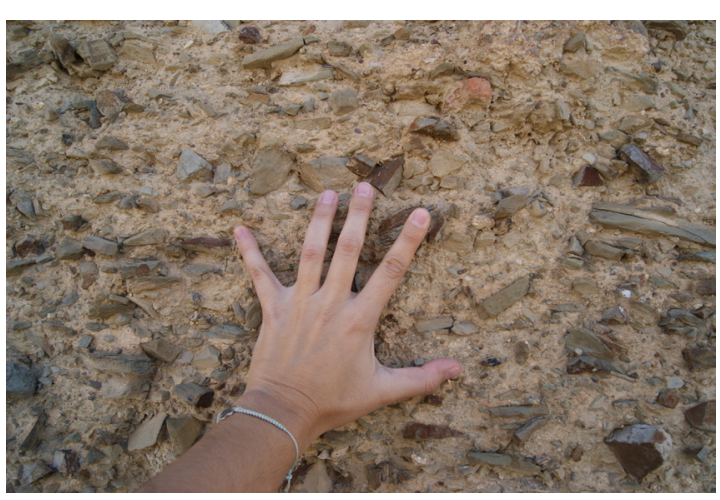

Figura 4.3. Muro de tapia erosionado en el que se aprecian guijarros. Burbáguena, Teruel

4. Esto ocurre cuando se realizan castillos o estructuras con la arena de playa que permanecen estables hasta que las capas exteriores se comienzan a secar y poco a poco se va erosionando
También son frecuentes en la construcción de muros que contienen conglomerantes, como algunas variantes de tapia, y que por lo tanto el endurecimiento se produce por fraguado, total o parcialmente en función del porcentaje en la mezcla.

Gravas: son partículas con diámetros entre 2 y 20 mm, Estas partículas constituyen el esqueleto de la tierra, no poseen cohesión entre ellas y ayudan a limitar la capilaridad y la retracción.

Arena: se trata de partículas de diámetro entre 2 y 0,06 mm principalmente de cuarzo o sílice. Estos granos no tienen cohesión en presencia de agua (si que presentan cierta atracción por capilaridad) y, al igual que las gravas, colaboran en la limitación de la retracción.

Limos: este grupo se compone por partículas de diámetros entre 0,06 y 0,002 mm. Estas partículas son muy parecidas a la arena, pero de menor tamaño. Estas partículas colaboran en la estabilidad del suelo a través de la fricción interna.

Arcilla: es la partícula más fina de la tierra y la que aporta la cohesión a la misma. Sus partículas son inferiores a 0,002 mm, si bien, su volumen varía notablemente en presencia de agua. La arcilla está sometida a fuerzas capilares mucho mayores que las otras partículas por su tamaño y por su forma plana que le confiere una superficie específica considerable con relación a su volumen. Las partículas de arcilla se unen entre ellas por su parte plana en presencia de agua, lo cual permite la adhesión de las otras partículas de mayor tamaño entre las cuales se colocan estas superficies laminares.

Partículas como las arenas y los limos tiene cierta cohesión en presencia de agua por las fuerzas capilares, si bien, cuando esta desaparece, las partículas vuelven a disgregarse ${ }^{4}$. En el caso de las arcillas es diferente ya que su estructura laminar le permite mantener parte de la humedad que une las partículas durante el proceso de secado, lo cual permite que las construcciones adquirieran su resistencia en estado seco. Además, el aumento de volumen y la plasticidad de la arcilla en presencia de agua permiten el amasado y el moldeado de la tierra para su uso en construcción. Si la proporción de agua no es excesiva, la forma concedida al material será la que permanezca después de seco.

La estructura granular del conjunto y la proporción entre las partículas varía en función de las características de las rocas y del suelo cada lugar. Por ello, para su uso en construcción, en ocasiones, es necesario realizar ciertas rectificaciones o mejoras del material que pueden consistir en la modificación de la granulometría o la adición de estabilizantes, en función de las necesidades (Houben y Guillaud 1985). No todas las técnicas requieren de una estructura terrosa similar (especialmente en relación con el porcentaje de fracción gruesa y de arcillas) ya que cada una se conforma de forma diferente. 
Por ejemplo, para conformar los muros de tapia la tierra debe estar en estado húmedo de forma que la mezcla no se deforme con el apisonado y el contenido en arcillas no tienen que ser muy alto ya que un exceso podría producir una variación de volumen importante y la aparición de fisuras por retracción, todo ello favorecido por el gran volumen de tierra que compone cada uno de los cajones. Por otro lado, los adobes se configuran en estado plástico para que la masa se pueda adaptar correctamente a la adobera o gradilla y no requieren de compactación (no es posible compactar en estado plástico) por lo que para mantener la cohesión del material la presencia de arcillas deberá ser mayor proporcionalmente. Además, el tamaño reducido de las piezas (respecto a un tapial) dificulta la aparición de grietas por la retracción del secado (figura 4.4).

Por otro lado, para el reconocimiento de la tierra y la comprobación de su adecuación para la construcción existen una serie de ensayos de campo que se pueden poner en práctica de forma fácil y que permiten estudiar aspectos como el contenido de arcilla (generalmente para el adobe) o la proporción adecuada de agua para la construcción (generalmente para la tapia). Las investigaciones de CRAterre fueron pioneras en este tipo de ensayos in situ y que han sido desarrollados y completados por otros investigadores (Doat et al. 1979; Stulz, Mukerji y Klein 1997; Minke 2006; Vick 1988) (figura 4.5).

\subsection{Las técnicas constructivas de tierra}

El empleo de la tierra desde el comienzo del desarrollo de la construcción ha producido que exista un amplio abanico de formas de uso, de colocación y de acabados.

Las amplias posibilidades de este material han generado además que en su construcción aparezca combinado frecuentemente con otros materiales, ampliando el abanico de soluciones posibles. Algunas técnicas constructivas son más propensas a este tipo de readaptaciones que otras, aunque el objetivo es común en todos los casos: mejorar el comportamiento y aumentar la durabilidad a través del uso de materiales locales.

El estudio de las técnicas se ha realizado en base a una clasificación existente y aceptada por la comunidad científica que fue desarrollada por CRAterre (Houben y Guillaud 1984) que establece las distintas técnicas constructivas, tanto tradicionales como nuevos sistemas ${ }^{5}$, dentro de grupos más amplios o familias de técnicas. Esta clasificación, junto con los reconocimientos in situ, han sido el punto de partida de la clasificación utilizada en este trabajo (figura 4.6). La clasificación definida a continuación se ha dividido en cuatro grupos principales: tierra en muros monolíticos, tierra en muros de fábrica, entramados con rellenos de tierra y tierra como acabado. En los dos primeros grupos la tierra es el material que conforma

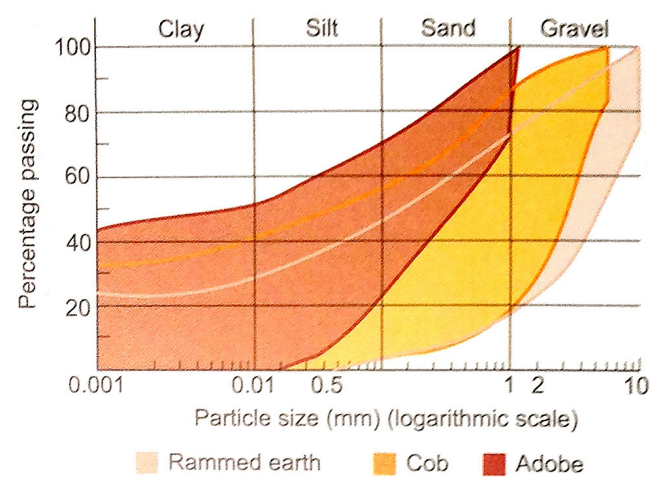

Figura 4.4. Grafica que muestra la proporción de partículas adecuadas en cada técnica constructiva. Extraido de: Jaquin y Augarde 2012

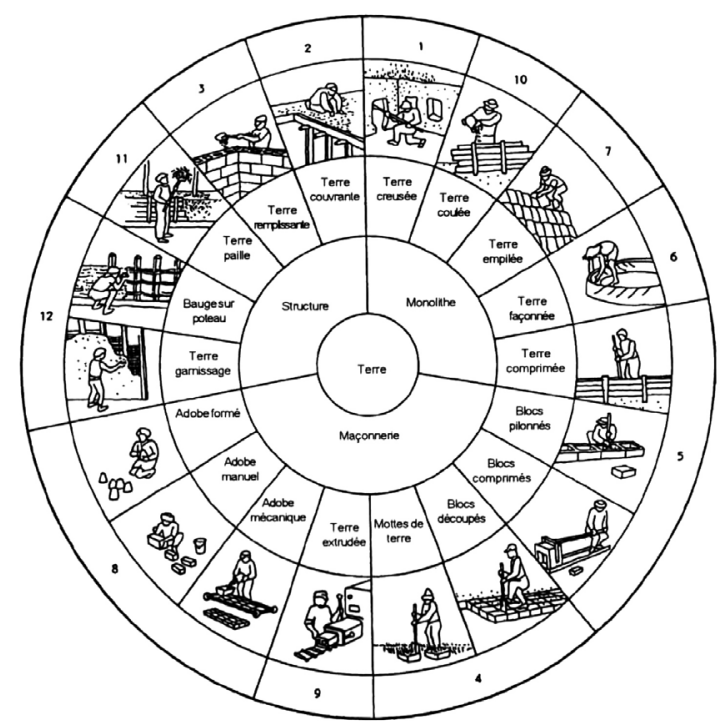

Figura 4.5. Rueda de las técnicas constructivas establecidas por CRAterre. Extraido de: Stulz, Mukerji y Klein 1997.

5. En este trabajo se van a estudiar únicamente las técnicas tradicionales 


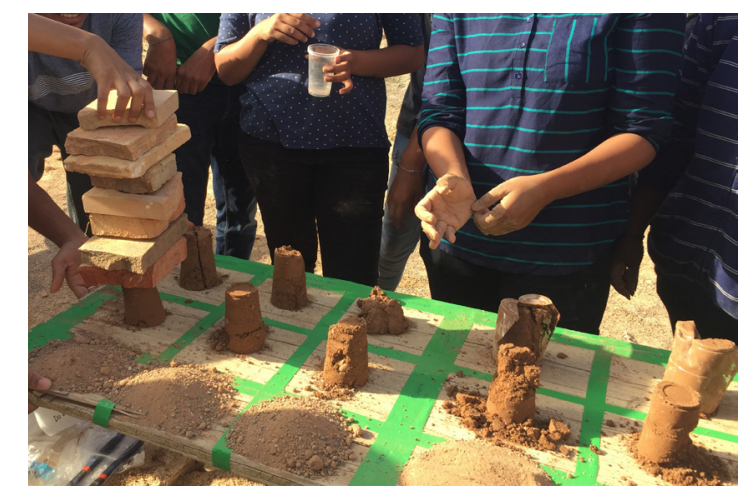

Figura 4.6. Ensayos de reconocimiento realizados durante los cursos de construcción con tierra realizados en la UPV

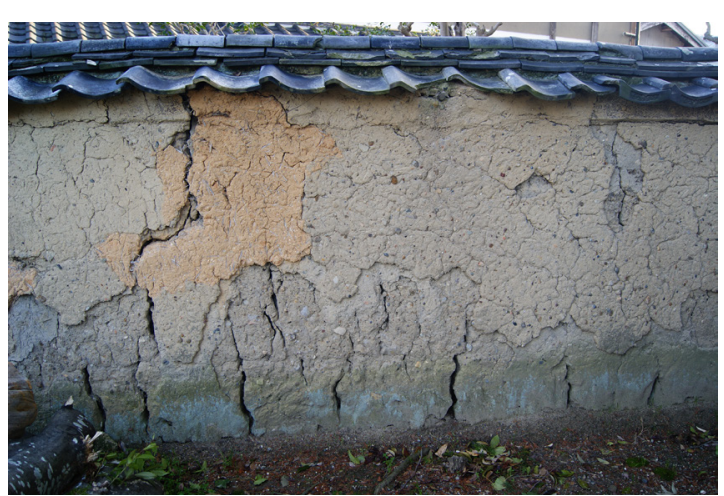

Figura 4.7. Muro de cob o pared de mano localizado durante la estancia de investigación en Kioto. Nara, Japón

6. El contexto este marcado por el proyecto SOStierra en el marco del cual se encuentra esta investigación principalmente los muros y su sustento, mientras que en los dos últimos casos se podría decir que tiene un papel secundario ya que funciona como relleno de un muro que tiene estabilidad en si mismo o como protección de distintas partes del edificio.

Dentro de cada uno de estos grupos se han definido las principales técnicas y han descrito con mayor detalle las localizadas en Aragón. Además, se ha hecho referencia a la situación en la península Ibérica como contexto del territorio de estudio ${ }^{6}$

En las técnicas presentes en Aragón (tapia, adobe y entramado) se ha mostrado la clasificación de las construcciones en tierra propuesta que está basada divisiones sucesivas de las características generales a las particulares: grupo o familia, técnica, variante, subvariante y materiales; con el fin de conseguir una definición completa de todas sus características.

\subsubsection{Tierra en muros monolíticos}

Este tipo de construcciones se caracterizan por estar conformadas in situ y tener unas propiedades masivas, compactas y homogéneas. Los muros monolíticos trabajan como una sola unidad, si bien, pueden estar conformados como tal o por unidades de grandes proporciones como los cajones de la tapia que producen un número reducido de juntas respecto al volumen total. Las principales técnicas que se recogen en la clasificación de CRAterre son la tierra excavada, conformada por sustracción, la tierra apilada y la pared de mano o cob, que se realizan a través de la colocación de capas sucesivas de tierra en estado plástico y sin la necesidad de elementos auxiliares o encofrados, y la tierra vertida y la tierra compactada o tapia, que necesitan de encofrados de madera para ser conformadas (figura 4.7).

En la Península Ibérica, y también de Aragón, predominan la arquitectura excavada y la tapia. La arquitectura excavada se genera por la extracción de material del terreno, a través de la cual se generan las distintas estancias en función de uso al que vaya a ser destinada (figura 4.8). Este tipo de construcción suele realizarse en laderas con una pendiente suficiente y con unas características del terreno adecuadas para realizar la excavación y garantizar su estabilidad. Desde el exterior solo son perceptibles los accesos a estas cuevas y, en la mayoría de los casos, también las chimeneas de ventilación de las mismas que garantizan la calidad del aire interior. En Aragón, estas construcciones suelen tener la función de bodegas asociadas al desarrollo de cultivos vinícolas.

La tapia se realiza a través de la compactación de capas sucesivas de tierra en estado húmedo dispuestas en el interior de un encofrado denominado tapial. Este tapial puede desmontarse en el momento 
que el módulo o cajón se ha completado lo cual permite su movimiento horizontal a lo largo del muro configurando las distintas hiladas. De esta forma, con un mismo tapial se puede construir un edificio completo (figura 4.9). Las características finales de estos muros dependerán del tipo de tierra, la compactación, el tipo de encofrado, los posibles estabilizantes en masa y/o suplementos y el acabado de la misma (López Martínez 1999). La tapia es la técnica más extendida en el territorio peninsular y ha sido utilizada tanto en la arquitectura tradicional como en un gran número de edificios de carácter monumental.

Las características intrínsecas a este tipo de construcción propician el uso de distintos tipos de suplementos que le proporcionan características muy heterogéneas y que tiene como resultado un número incontable de variantes y subvariantes diferentes. Los principales grupos o variantes son: tapia simple, tapia suplementada en paramentos, tapia suplementada en juntas y tapia mixta.

Tapia simple u homogénea, es aquella que no incorpora ningún tipo de suplemento en las caras exteriores de los cajones. No obstante, la propia masa de la tapia puede estar combinada con conglomerantes u otros materiales como la mampostería, difíciles de distinguir a menos que la tapia se encuentre deteriorada.

Las tapias suplementadas en los paramentos son aquellas que presentan elementos añadidos en su cara exterior con el objetivo de mejorar la durabilidad. Este tipo de suplementos consiste bien en la inclusión de un revestimiento en la propia construcción de la tapia (calicostrada) o en la colocación de piezas en su cara exterior (careada).

\begin{tabular}{|c|c|c|c|}
\hline TÉCNICA & VARIANTE & SUPLEMENTO & MATERIALES \\
\hline \multirow{13}{*}{ TAPIA } & \multirow{3}{*}{ Simple u homogénea } & Simple & Simple, real (con cal) \\
\hline & & Hormigones cal/yeso & Yeso/cal y mampuestos \\
\hline & & Mampostería encofrada & Mampuestos \\
\hline & \multirow{2}{*}{ Suplementada en paramentos } & Calicostrada & Cal, yeso \\
\hline & & Careada & Piedra, cerámica \\
\hline & \multirow{2}{*}{ Suplementada en juntas } & Con juntas & \multirow{2}{*}{$\begin{array}{l}\text { Cal, yeso, mampostería } \\
\text { y yeso, cerámica, piedra }\end{array}$} \\
\hline & & Con brencas & \\
\hline & \multirow{6}{*}{ Mixtas } & Verdugadas & \multirow{6}{*}{$\begin{array}{l}\text { Ladrillo, piedra, adobe, } \\
\text { mampostería y yeso, } \\
\text { mixtos }\end{array}$} \\
\hline & & Esquinas & \\
\hline & & Machones & \\
\hline & & Rafas & \\
\hline & & Esquinas y verdugadas & \\
\hline & & Machones y verdugadas & \\
\hline
\end{tabular}

Tabla 4.1. Clasificación de la tapia. Variantes, subvariantes y materiales de suplemento.

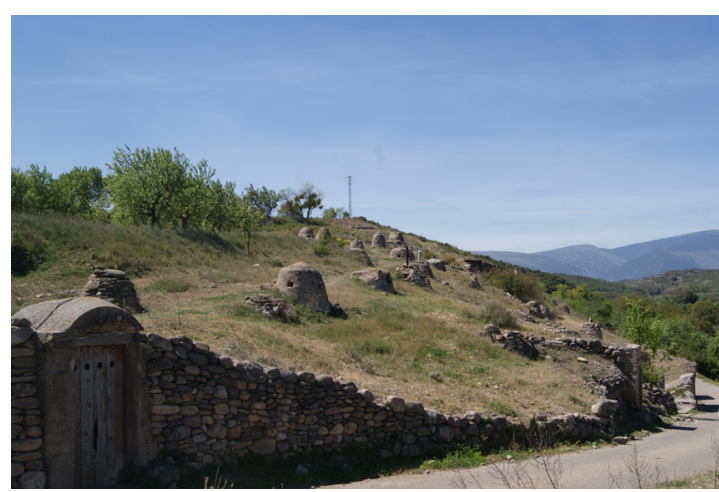

Figura 4.8. Arquitectura excavada en la ladera con chimeneas de ventilación. Ambel, Zaragoza

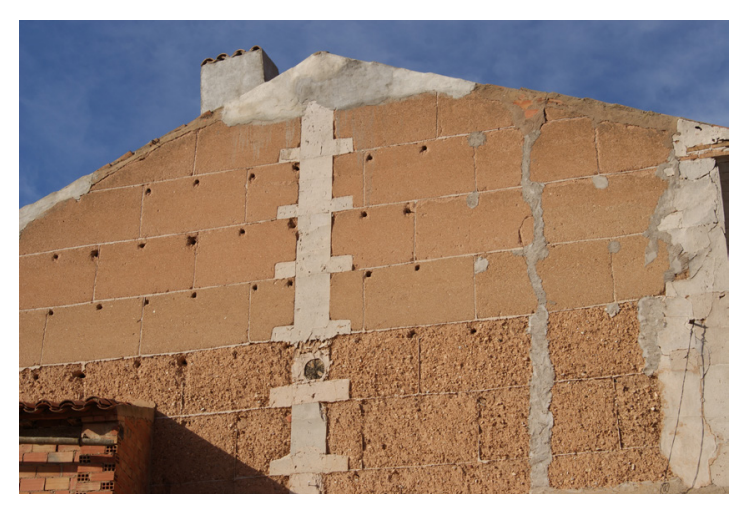

Figura 4.9. Edificio de tapia en el que se distingue claramente el módulo del cajón utilizado para su construcción. Monreal del Campo, Teruel 


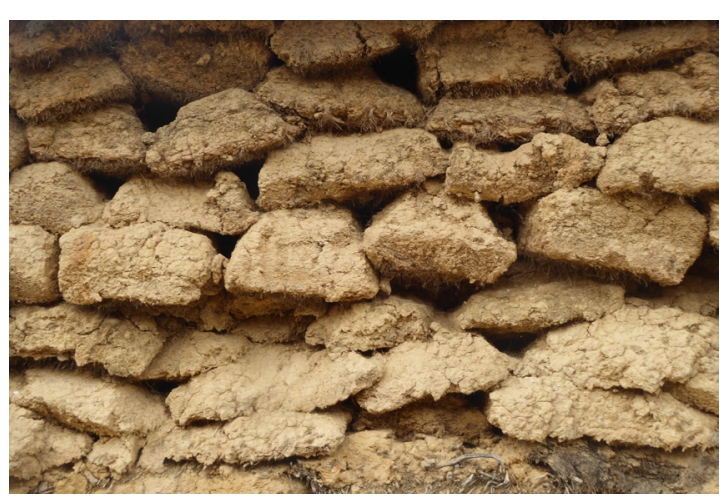

Figura 4.10. Muro construido con tepes. Mozuelas de la Carballeda, Zamora. Autores: Fernando Vegas y Camilla Mileto

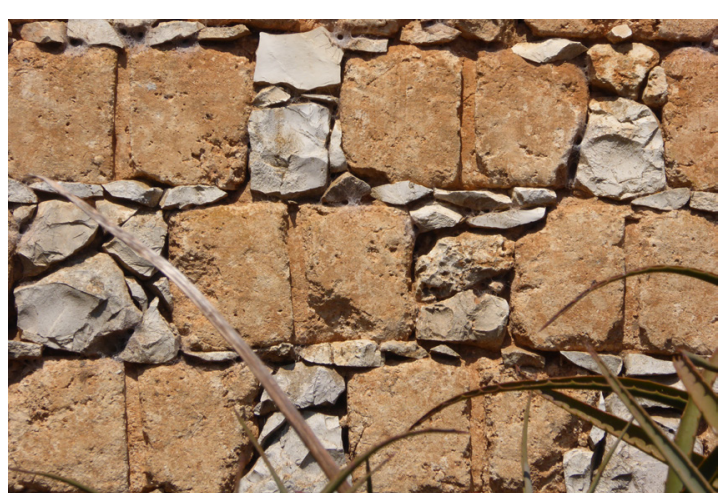

Figura 4.11. Muro construido con terrones. Châos, Santarem, Portugal. Autores: Fernando Vegas y Camilla Mileto
Las tapias suplementadas en juntas son aquellas que presentan elementos entre los cajones de tapia, generalmente conglomerantes, dispuestos en la cara exterior o en la totalidad de la sección del muro, y que se colocan durante la propia construcción, formando parte de la unidad constructiva o cajón de la tapia.

Las tapias mixtas son aquellas que se combinan con fábricas de otros materiales (ladrillo, piedra o adobe) construidos independientemente de los módulos de tapia. Los elementos verticales (esquinas y machones) ayudan a resolver más fácilmente las esquinas y los elementos horizontales (verdugadas) facilitan el asiento de las hiladas.

Debe tenerse en cuenta que en una misma construcción pueden aparecer distintos tipos de suplementos por el número de combinaciones hace que haya multitud de soluciones posibles.

\subsubsection{Tierra en muros de fábrica}

Las construcciones de tierra pertenecientes a este grupo se caracterizan por estar formadas por piezas o elementos independientes que se disponen en distintas posiciones, o con distintos aparejos, en función de las características de la técnica y de los requerimientos finales de los muros. Las técnicas tradicionales englobadas en esta familia son los tepes, los terrones, las glebas y los adobes. Las dos primeras técnicas se caracterizan por ser piezas extraídas directamente del suelo, en el primer caso, de tierras de pasto con contenido de sustrato vegetal y, en el segundo caso, de terrenos consistentes sin vegetación (figura 4.10; figura 4.11). Por otro lado, las glebas y adobes son piezas moldeadas, las primeras a mano y las segundas con ayuda de un molde denominado gradilla o adobera, respectivamente.

Los adobes son las piezas constructivas de tierra más utilizada y poseen características muy variadas en cuanto a composición, tamaño y aparejo de los muros (Fernandes 2005). Estas piezas son conformadas con la tierra en estado plástico para poder ser moldeadas, pero sin exceso de agua ya que deben permanecer estables tras retirar el molde inmediatamente después de haberle dado la forma. Estas piezas permanecen al aire libre en el sitio donde se han realizado durante varias semanas hasta se secan por completo y pueden acopiarse para su futura puesta en obra. La tierra utilizada para la fabricación de estas piezas suele ser más rica en arcilla que la de la tapia, por ello, es común el uso de paja para la prevención de fisuraciones (Bel 2016). Para la clasificación de las variantes constructivas de adobe no se han tenido en cuenta las características preestablecidas en la construcción de las piezas como la dimensión y la composición. Por ello la clasificación se ha realizado en base a la relación entre las piezas y los posibles y sin hacer distinción entre los aparejos ya que este corresponde con un nivel de 
clasificación más detallado (figura 4.12). El hecho de que muchos de los condicionantes o variables estén preestablecidos por la fabricación previa de las piezas, origina que el número de variantes sea menor que en el caso de la construcción con tapia.

La fábrica simple se ha determinado como aquella conformada únicamente por adobes colocados con mortero de barro, favoreciendo el comportamiento homogéneo de todo el muro.

Las fabricas suplementadas en juntas son aquellas que presentan materiales diferentes al mortero de barro en las juntas, otorgando una mayor resistencia o rigidez al espacio entre las piezas.

La fábrica mixta es aquella que se combina con otros elementos constructivos o fábricas con entidad propia y que ayudan a regular de la fábrica (verdugadas), a conformar las esquinas y a dar estabilidad al conjunto del muro.

Las fabricas mixtas de adobe y madera (entramados) no se ha clasificado como tal, sino que ha premiado la configuración estructural de estas y se han clasificado como entramado con relleno de adobe.

El adobe como suplemento funciona principalmente como suplementos en masa de muros monolíticos de tierra o como suplemento en muros mixtos de distintos materiales.

Por último, hay que hacer mención a los bloques de tierra- cemento, que son piezas moldeadas de tierra con cemento que siguen el mismo proceso de fabricación que los adobes tradicionales. Estas piezas aparecieron durante la primera mitad del siglo XX como la evolución del adobe en una época de transición entre el abandono de las técnicas tradicionales y la llegada de los materiales industrializados (Cazorla 2015) (Rivas 2002).

\begin{tabular}{|l|l|l|l|}
\hline TÉCNICA & VARIANTE & SUPLEMENTO & MATERIALES \\
\hline \multirow{4}{*}{ ADOBE } & Fábrica simple & & \\
\cline { 2 - 4 } & Fábrica suplementada en juntas & Horizontales, verticales, ambas & $\begin{array}{l}\text { Cal, yeso, cerámica, } \\
\text { piedra }\end{array}$ \\
\cline { 2 - 4 } & Fábrica mixta & Verdugadas & $\begin{array}{l}\text { Ladrillo, piedra, adobe, } \\
\text { mampostería y yeso, } \\
\text { madera, mixtos }\end{array}$ \\
\cline { 2 - 4 } & Adobe como suplemento & En fábricas mixtas & $/$ \\
\cline { 2 - 4 } & Bloque tierra- cemento & $/$ & $/$ \\
\hline
\end{tabular}

Tabla 4.2. Clasificación de las fábricas de adobe. Variantes, subvariantes y materiales de suplemento.

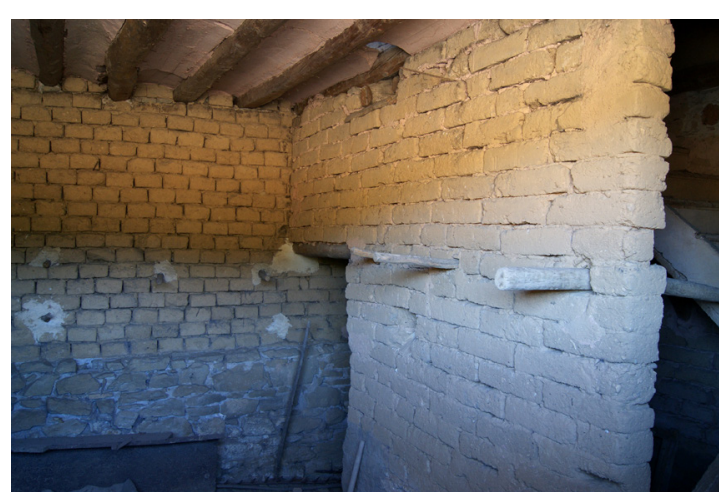

Figura 4.12. Fábricas de adobe que configuran tanto los cerramiento como la tabiquería. Graus, Huesca 


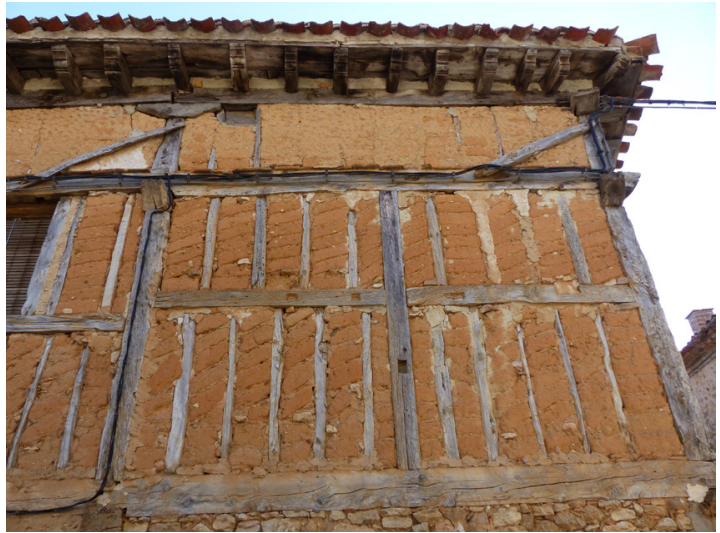

Figura 4.13. Entramado con relleno de adobes inclinados. Calatañazor, Soria. Autores: Fernando Vegas y Camilla Mileto

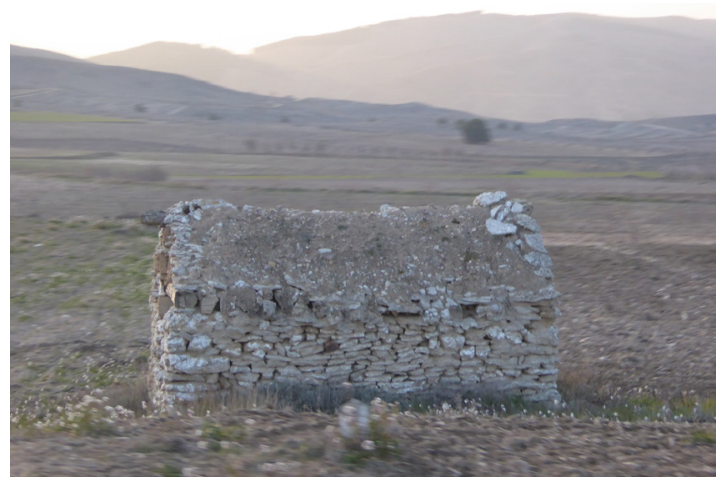

Figura 4.14. Construcción aislada con cubierta de tierra. Calatayud, Zaragoza. Autores: Fernando Vegas y Camilla Mileto

\subsubsection{Entramados con relleno de tierra}

Los entramados son estructuras configuradas con distintos elementos de madera que dejan espacios entre ellos para ser rellenados con materiales de distinto origen y configurar un muro que trabaje conjuntamente. Los entramados son muy diversos a tenor de las características de la madera, de su disposición o configuración y del relleno que conforma los cerramientos. Estos rellenos no tienen función estructural, no obstante, tienen la función de acodalar la estructura de madera colaborando con ella para evitar movimientos indeseados (figura 4.13). Los rellenos de tierra en los entramados pueden estar configurados únicamente por tierra (adobe o relleno monolítico) o estar compuesto por otros elementos que le otorgan estabilidad como los encestados, el cañizo, o las pantallas de madera o urdimbres.

Los rellenos monolíticos suelen estar realizados por tierra apilada, en ocasiones con encofrado a una cara, o por el vertido de tierra con conglomerante y cascotes en un encofrado de poco espesor.

Los rellenos de piezas suelen limitarse al uso de los adobes colocados generalmente a soga o a panderete ya que no tienen función estructural.

Los rellenos tejidos suelen presentar una urdimbre de cañizo o de encestados sobre los que se dispone una capa de tierra de diferentes grosores en función del propio tejido y de los requerimientos del edificio.

\subsubsection{Tierra como acabado}

La tierra como acabado tiene la función de proteger a otros elementos del edificio, para aumentar su durabilidad. Puede tener múltiples usos, si bien, los principales son como revestimientos y cubiertas. En el caso de Aragón no es frecuente el uso de la tierra como acabado, si bien en algunas zonas de la península su uso es muy reiterado y conforman algunas de las principales características de la arquitectura tradicional de esas áreas. Algunos ejemplos son los revestimientos de tierra en la zona de Tierra de Campos en Valladolid o las cubiertas de launa en la zona de la alpujarra de Almería y Granada (figura 4.14).

\begin{tabular}{|l|l|l|l|}
\hline TÉCNICA & VARIANTE & TIPO & MATERIALES \\
\hline \multirow{3}{*}{ ENTRAMADO } & Monolítico & $\begin{array}{l}\text { Pared de mano } \\
\text { Tapia con conglomerante } \\
\text { Entre pantallas de madera }\end{array}$ & $\begin{array}{l}\text { Yeso, cal, cascotes, } \\
\text { piedra }\end{array}$ \\
\cline { 2 - 4 } & Piezas & adobe & \\
\cline { 2 - 5 } & Tejido & $\begin{array}{l}\text { Cañizo } \\
\text { Encestado }\end{array}$ & \\
\hline
\end{tabular}

Tabla 4.3. Clasificación de los entramados con relleno de tierra. Variantes, subvariantes. 


\section{BLOQUE II}

\section{LA ARQUITECTURA TRADICIONAL DE TIERRA EN ARAGÓN}

5. La construcción con tierra en Aragón

6. Aproximación a las técnicas constructivas y variantes

7. Arquitectura de tierra y entorno

8. Fenómenos de degradación de las construcciones de tierra 
5. LA CONSTRUCCIÓN CON TIERRA EN ARAGÓN 


\section{La construcción con tierra en Aragón}

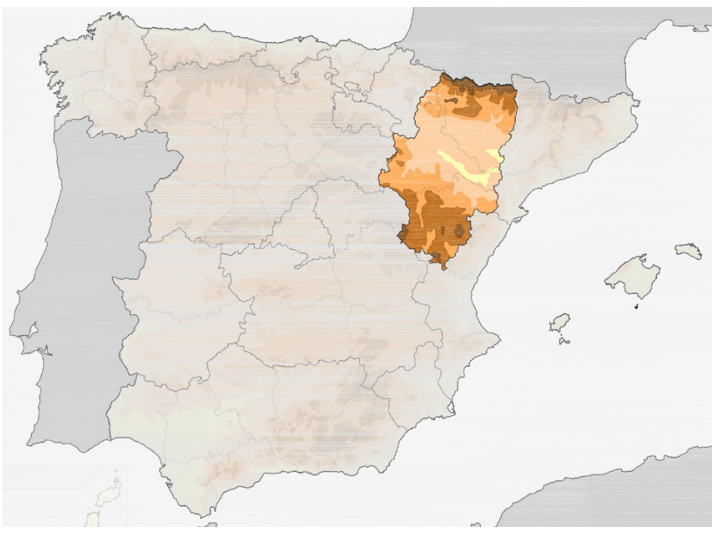

Figura 5.1. Localización de Aragón en la Península Ibérica. Fuente: Instituto Geográfico Nacional, edición propia.
Aragón está situado en la zona noreste de la Península Ibérica lindando con Francia en su cara norte, con Navarra y Castilla en el oeste y con Cataluña y la Comunidad Valenciana en el este. Se trata de la cuarta comunidad española en extensión con $47.719 \mathrm{~km}^{2}$, sin embargo, es una de las áreas europeas y nacionales con más baja densidad de población, situándose en el puesto número once en cuanto a población total por comunidades con una media de 27,4 hab/km2. Aragón está compuesto por tres provincias, Huesca $\left(15.636 \mathrm{~km}^{2}\right)$, Zaragoza $\left(17.274 \mathrm{~km}^{2}\right)$ y Teruel $\left(14.809 \mathrm{~km}^{2}\right)$, que dividen el territorio en franjas aproximadas de norte a sur respectivamente. Además, Aragón está dividido en 33 comarcas que delimitan el territorio en entidades con capacidad, autonomía y competencias propias (www.aragon. es). Cada comarca alberga, generalmente, áreas y localidades con características físicas, topográficas, culturales o históricas semejantes que le otorgan entidad propia.

El territorio aragonés se caracteriza por sus grandes contrastes geográficos y paisajísticos acentuados por el paso del río Ebro en su zona central. Estos contrastes permiten establecer tres áreas muy diferentes distribuidas de norte a sur, casi en correspondencia con las tres provincias. En el norte, en la provincia de Huesca, se sitúan los Pirineos, área montañosa con un relieve abrupto de grandes desniveles donde se encuentran algunas de las cumbres más altas de la Península Ibérica. La zona central coincide con la depresión y el valle del Ebro que se localiza principalmente en la provincia de Zaragoza, pero también en el sur de Huesca. Esta área se sitúa a una altitud media de $400 \mathrm{~m}$ y se compone por amplias llanuras destinadas principalmente al cultivo de regadío y por zonas de huerta en las proximidades al cauce del río. Al sur de la comunidad se localiza el Sistema Ibérico que ocupa la mayor parte de la superficie de Teruel y el suroeste de Zaragoza. Se trata de un territorio árido, con vegetación muy escasa en algunas zonas, compuesto por amplias llanuras a altitudes de unos $1.000 \mathrm{~m}$ aproximadamente en las zonas de depresión y por sierras o áreas montañosas con relieves más abruptos que alcanzan su punto más alto a $2.300 \mathrm{~m}$ en el Moncayo. 


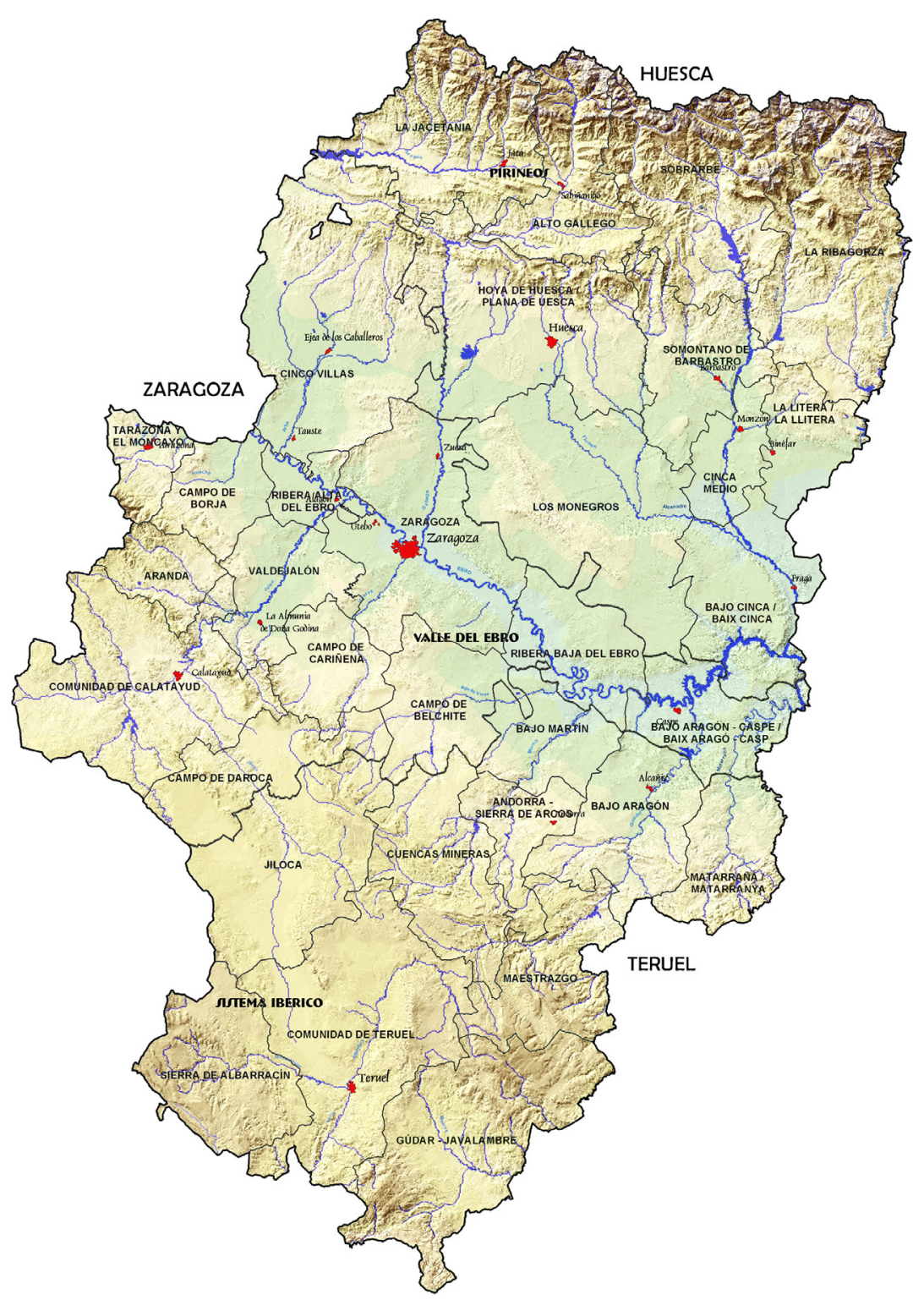

Figura 5.2. Plano de relieve y comarcas de Aragón. Fuente: comarcas.es, edición propia 


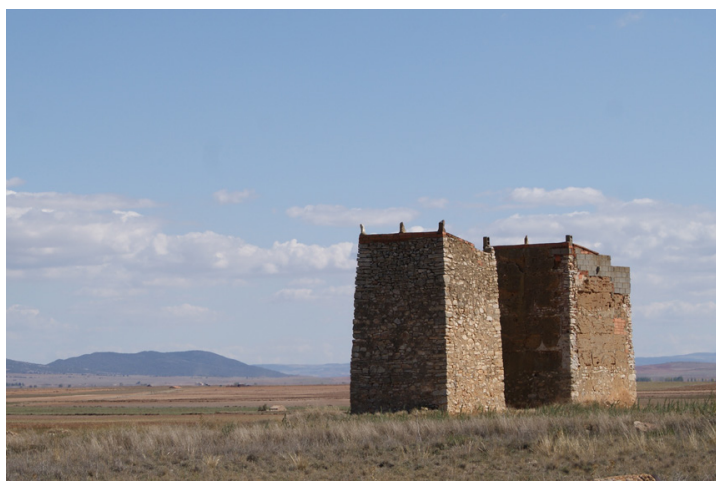

Figura 5.3. Palomares de tapia y de mampostería. Las Cuerlas, Zaragoza.

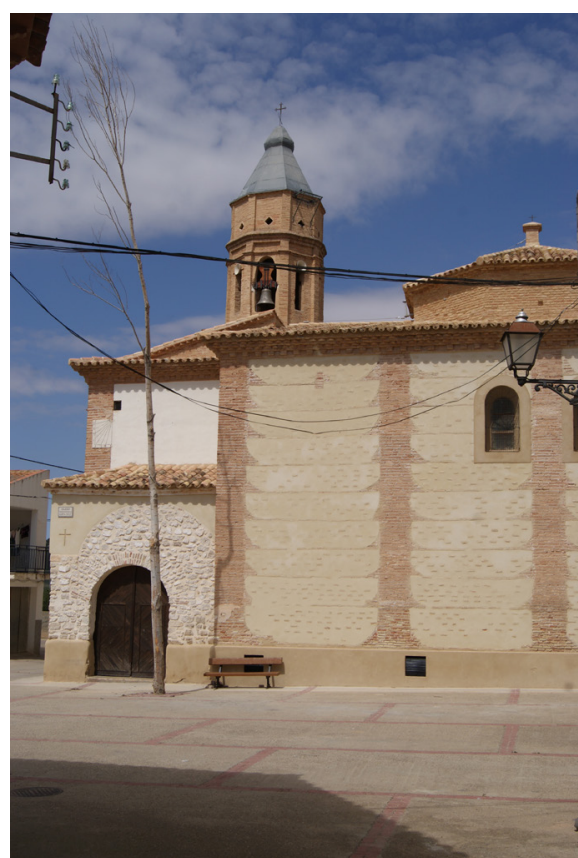

Figura 5.4. Iglesia construida con tapia valenciana intervenida recientemente (El cobijo arquitecturas 2014). Lagata, Zaragoza
Estas propiedades geográficas junto con la cultura y las tradiciones de cada lugar son factores determinantes en las características y la distribución de la arquitectura tradicional de tierra en la península.

\subsection{Contexto histórico}

El uso de la tierra como material de construcción es una solución habitual en la Península Ibérica donde se localiza la mayor concentración de Europa de este tipo de arquitectura (AA VV. 2011) En Aragón la arquitectura tradicional de tierra está muy presente en gran parte de su territorio donde multitud de edificios están construidos con técnicas de tierra.

La relación existente entre los materiales disponibles en el entorno próximo, el clima, la geografía del lugar y las técnicas constructivas utilizadas queda evidenciado en la arquitectura tradicional de tierra. En Aragón, la heterogeneidad del territorio ha propiciado la existencia de un elevado número de soluciones constructivas en forma de técnicas y variantes fruto de la evolución y la optimización de los recursos a lo largo de la historia que le ha otorgado una gran riqueza constructiva a la zona. Estas técnicas constructivas de tierra se han utilizado tanto en el medio rural como en el urbano y en todo tipo de edificios ya sean de carácter popular como viviendas, pajares, vallados, corrales, molinos, palomares, vallados, etc. o de carácter monumental como edificios nobles, militares y religiosos (Sanz Zaragoza 2014) (figura 5.3; figura 5.4).

La arquitectura de tierra en Aragón ha formado parte de su cultura constructiva durante siglos y en presencia de las distintas civilizaciones que han pasado por el territorio. El fácil acceso a los materiales, el bajo coste y las ventajosas propiedades térmicas frente al clima extremo que caracteriza muchas áreas de Aragón son algunos de los factores que han propiciado que estas técnicas hayan perdurado hasta la actualidad (Burillo Mozota 1985).

El origen de la arquitectura de tierra en Aragón se remonta a los poblados del Bronce Medio, época a la cual pertenecen los restos arqueológicos más antiguos de los cuales se tiene constancia. Estos restos datan del año 1520 a.C. y corresponden a un manteado de barro (entramado de madera con tejido vegetal y barro sobre el mismo) localizado en el Castillo de Frías de Albarracín, Teruel (Burillo Mozota 1985). Además, otros restos de esta misma técnica se han hallado distribuidos por todo el territorio, principalmente en la provincia de Teruel en localidades como Mora de Rubielos, Alcañiz o Formiche Bajo.

También se han localizado vestigios de adobes distintos poblados, principalmente alrededor del Bajo 
Aragón, cuyos orígenes datan del Bronce Final (Fatás Fernández y Catalán Gazarrán 2005). En época Ibérica el uso del adobe ya estaba extendido por prácticamente todo el territorio aragonés, al igual que el de la tapia. Los restos de la ciudad celtíbero-romana de Contrebia-Belaisca, actual localidad de Botorrita, Zaragoza, son especialmente interesantes ya que en ellos se encuentran los restos de la antigua muralla de la ciudad construida con un muro adobe de unos $3 \mathrm{~m}$ de espesor y $30 \mathrm{~m}$ de longitud que datan del siglo V-IV a.C. (Figols Gonzalez 2006; Burillo Mozota 1985).

Las distintas civilizaciones que han pasado por Aragón han hecho un uso más o menos recurrente de las técnicas de tierra en la construcción en función de la predilección de materiales de cada una de ella, y en ocasiones es posible localizar muros con una superposición de técnicas en forma de mural dispuesto de forma anárquica (Rábanos Faci y Gavín Moya 1991-1992). Los datos recogidos, así como los estudios existentes (Fatás Fernández y Catalán Gazarrán 2005) evidencian la larga tradición que tienen la Península Ibérica, y Aragón, en el uso de la tierra como material de construcción. Esta tradición constructiva ha proporcionado a lo largo de los siglos un saber hacer importante en base al conocimiento, la optimización y la mejora de las técnicas que ha pasado de forma oral de generación en generación.

\subsection{Situación actual}

La arquitectura tradicional y concretamente la de tierra se encuentran en la actualidad en un momento de cambio y reaprendizaje debido a la falta de interés por la misma y el abandono de las técnicas y el saber hacer durante décadas. Las construcciones tradicionales de tierra y la trasmisión de los conocimientos locales llegaron a su fin alrededor de los años 50 y 60 cuando los materiales de origen industrial irrumpieron en el mercado generando cambios económicos, laborales y sociales, y desvalorizaron las culturas locales fruto del aprendizaje durante siglos (Castellarnau Visús y Rivas 2013)

En España a partir de la década de los 80, época ligeramente más tardía que en el resto de Europa, se despierta un interés por las técnicas constructivas de tierra derivado de la preocupación por su pérdida y principalmente por escaso coste económico y energético que suponen. Tras la última crisis económica y a causa del calentamiento global y la contaminación, se ha incrementado el interés por la recuperación y actualización tanto de la arquitectura tradicional como nuevos edificios suscitado no solo por los materiales utilizados sino por los valores, la economía y la sostenibilidad ligadas a su utilización.

La arquitectura tradicional de tierra en Aragón está directamente ligada con el área rural, pese a localizarse también en los principales núcleos de población y capitales de provincia. La incesante emigración de la población a las ciudades ha producido el abandono de un amplio número de edificios

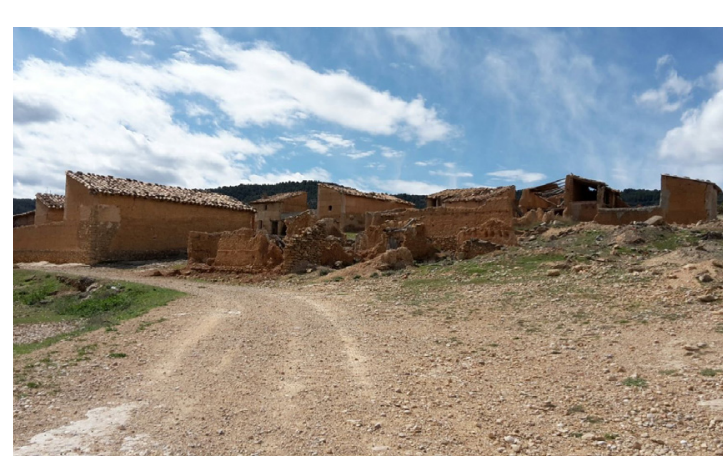

Figura 5.5. Conjunto de edificios de tierra abandonados. Torrevelilla, Teruel 


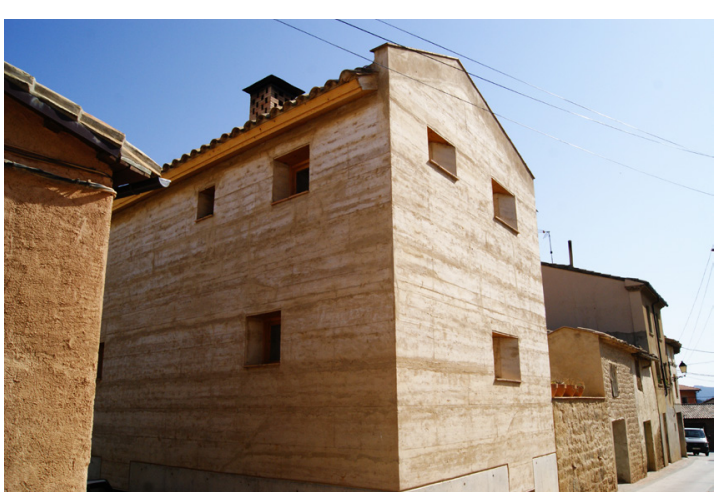

Figura 5.6. Arquitectura contemporánea de tierra en Aragón. Arquitecta: Angels Casellarnau. Ayerbe, Huesca e incluso localidades completas como es el caso de Villanueva de Jalón, entre otras (figura 5.5). Este abandono junto con las mutaciones y alteraciones producidas en gran cantidad de edificios a causa de intervenciones ajenas a la tradición y a la conservación del patrimonio han originado una preocupación por esta arquitectura tradicional que es la parte inmueble del patrimonio etnológico (Rivas 2013; Ley del Patrimonio Cultural 1999).

El creciente interés por la etnografía y las características de los entornos rurales, especialmente a pequeña escala, ha producido que las técnicas constructivas de tierra comiencen a ser reconocidas como parte de la tradición y la cultura de muchos lugares en los que su presencia y su tradición de uso había caído en el olvido. En general, y sobre todo entre las generaciones más jóvenes, la falta de conocimiento entorno a la cultura del lugar ha producido que las técnicas de tierra se obviaran por ser un material "pobre" y se entendiera que las casas tradicionales de "buena calidad" eran únicamente las construidas con piedra.

En gran parte de Aragón, el estudio de las tradiciones y de los saber haceres de cada lugar se encuentran en un momento generacional crítico y de gran interés en el que algunos de los últimos eslabones de la cadena de transmisión oral de estas técnicas tradicionales todavía están presentes y pueden aportar gran cantidad de conocimientos para el reaprendizaje de estas técnicas (Castellarnau Visús y Rivas 2013; documentalesetnograficos.es). La importancia de esos conocimientos queda patente en algunos de los estudios realizados en distintos puntos de la comunidad, sin embargo, están generalmente ligados a una localidad un entorno concreto. Por ejemplo, la composición o la mezcla a realizar para la construcción la conocen en función del punto de extracción de la tierra y tienen un razonamiento lógico del porqué de las cosas, pero no tienen datos científicos que sirvan de forma global. Conocen el terreno y los materiales disponibles y adecuados para la construcción de extracción cercana.

Por otro lado, existen un movimiento actual tanto por partes de expertos como gente interesada en este tipo de construcción que busca la recuperación de estas técnicas tradicionales con el fin de utilizarla en nuevos edificios por su baja emisión de $\mathrm{CO}_{2}$ y que generalmente se denomina arquitectura bioclimática o bioconstrucción. Se trata de uno de los tipos de construcción que más están potenciando el uso de la tierra como material de construcción tanto en la restauración de antiguos edificios como en edificios de nueva planta por sus propiedades beneficiosas como la fácil obtención y transformación, las propiedades térmicas y la localización en casi todos los ámbitos que hacen de la tierra un material muy adecuado para la construcción (figura 5.6). 


\subsection{Descripción de la muestra}

Para la realización del trabajo se han utilizado dos muestras distintas, procedentes de una misma toma de datos in situ por toda la comunidad de Aragón. La toma de datos se ha apoyado en la bibliografía, generalmente específica de pequeñas áreas o comarcas, donde se describe la arquitectura tradicional en general y en el caso de existir técnicas tradicionales de tierra solo se nombran al describir la materialidad de las construcciones. Por ello, la información de las construcciones de tierra recopilada de forma directa en las visitas de campo ha sido la principal fuente de datos sobre la que se ha trabajado.

Aragón cuenta con 731 municipios y un total de 1.812 núcleos de población, distribuidos en 33 comarcas, de los cuales más de la mitad pertenece a la provincia de Huesca (939) donde, especialmente en el Pirineo, los núcleos son de pequeñas dimensiones (poca población) y muy próximos entre sí. Zaragoza esta compuesta por 504 núcleos de población, si bien, la población que albergan es mucho mayor que en la mayoría de los núcleos oscenses. Por último, Teruel es la provincia con el menor número de núcleos población (369) y con la menor población total ya que, además de ser núcleos con un tamaño reducido, el éxodo rural ha afectado especialmente a esta zona (Instituto geográfico de Aragón 2018).

Para la realización del estudio se han visitado 303 núcleos de población, de los cuales en 258 se han localizado construcciones con tierra, lo cual supone un porcentaje muy elevado (figura 5.7). Cabe destacar que la presencia relativa dentro de cada localidad es muy cambiante ya que en algunos núcleos de población las técnicas de tierra están presentes casi en cada uno de los edificios, mientras que en otras pueden pasar casi desapercibidas a menos que se realice una búsqueda más profunda.

Una de las principales premisas en las que se ha basado la toma de datos ha sido la distribución geográfica de los núcleos de población con el objetivo de abarcar la mayor extensión de territorio posible y obtener una muestra heterogénea que exponga el panorama general existente en Aragón.

Además, deben tenerse en cuenta las limitaciones del estudio (definidas en el capítulo 2), especialmente la visual que, excepto en ocasiones excepcionales, presenta una imposibilidad a la hora de detectar cualquiera de las técnicas de construcción con tierra localizadas en el interior de los edificios. Este factor es especialmente relevante en la zona del Pirineo donde casi la totalidad de los muros exteriores están construidos con piedra, mientras que en el interior se tiene constancia del uso de entramado con adobe o "recha de buxo" con "buro" (entramados tejidos de boj y barro) para la realización de las particiones o tabiquería (Rábanos Faci y Gavín Moya 1991-1992).

La primera muestra (muestra 1) proviene de los datos tomados por todo el territorio con localidades

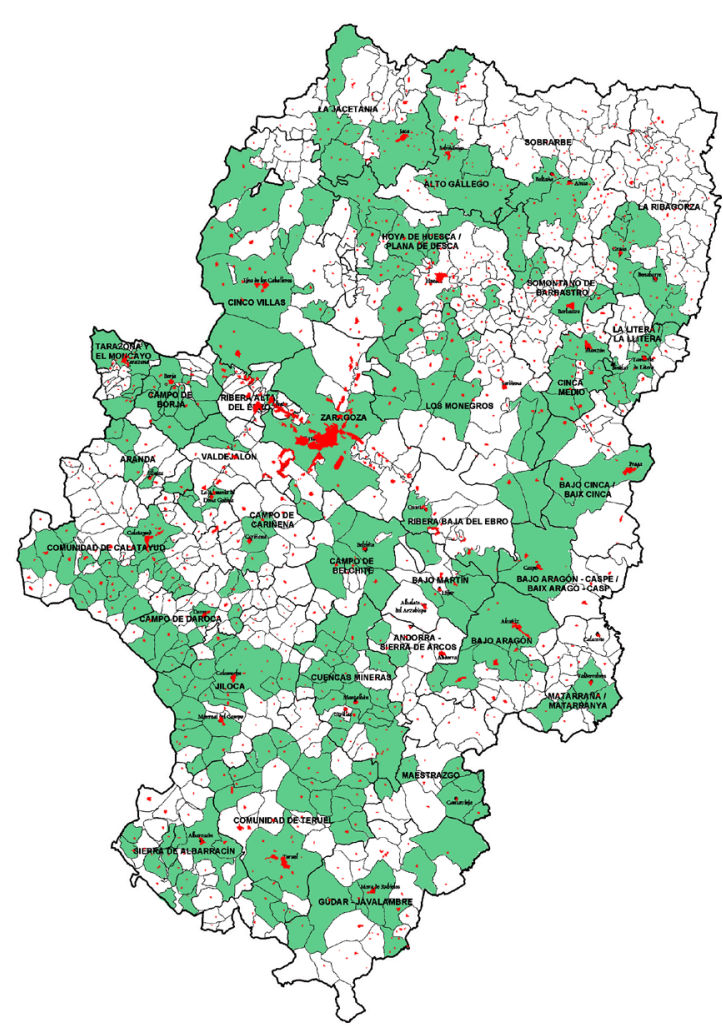

Figura 5.7. Plano de los municipios visitados durante la toma de datos 
muy heterogéneas y con una presencia de construcciones de tierra muy dispares. Sin embargo, estos factores no se han considerado determinantes en el estudio de las técnicas y las variantes constructivas, ya que el principal objetivo es estudiar la recurrencia de las distintas técnicas constructivas, variantes y subvariantes y su distribución geográfica en el territorio. Por lo tanto, la muestra 1 está compuesta por los 258 núcleos de población con construcciones en tierra y en cada uno de ellos pueden aparecer simultáneamente distintas técnicas, variantes y subvariantes, que deberán analizarse de forma aislada para no superponer y perder datos (por ejemplo: el sumatorio de los casos de tapia, 187 y los casos de adobe, 180, es superior a los 258 núcleos existentes en la muestra total por lo que si se analizan de forma conjunta se pierde parte de la información) (figura 5.8) (tabla 5.1)

Por otro lado, se ha trabajado de forma simultánea con una segunda muestra que consta de una selección de casos de estudio procedentes de la misma recopilación de datos que la muestra 1 pero con distinto tratamiento. En esta muestra se ha realizado un análisis más exhaustivo de los casos o edificios concretos para lo que se ha utilizado la ficha de estudio con el fin de conocer las técnicas constructivas con mayor detalle, así como las intervenciones realizadas en los edificios.

Se han analizado un total de 410 casos de estudio entre los cuales se ha buscado una distribución geográfica homogénea con el objetivo conocer las disparidades dentro del territorio (figura 5.9). Además, se ha procurado que la muestra albergara una gran variedad de tipologías constructivas, usos, técnicas y tipos de intervenciones de manera que la heterogeneidad de los datos iniciales quedara representada en esta segunda muestra. Para el estudio y la gestión de la información los 410 casos de estudio se han organizado en grupos parciales en función de la situación geográfica (por provincias), de la técnica constructiva y de la existencia o no de intervenciones en el edificio. Esta subdivisión ha permitido realizar análisis parciales y comparaciones entre los casos pertenecientes a las distintas provincias o técnicas constructivas (tabla 5.2).

Las características generales de los casos de estudio englobados en esta segunda muestra se han analizado a través de la primera parte de la ficha: datos generales del edificio. Los núcleos de población a los que pertenecen estos casos de estudio tienen características muy heterogéneas y, en general, tienen una población reducida (el 61\% de los pueblos tiene menos de 500 habitantes y el 85\% menos de 1500). La altitud de estos pueblos también es muy variada alentado por las propias características geográficas de la comunidad. Así, el rango en el que se sitúa la mayor parte de la muestra varía entre 200 y $1200 \mathrm{~m}$.

En relación al entorno paisajístico, existe un predominio de casos localizados en un entorno próximo a cauces fluviales (62\%), seguido a amplia distancia de los localizados en llanuras (15\%) y en zonas de monte de secano (14\%). 
La mayor parte de las construcciones estudiadas forman parte del núcleo de población, ya sea de la zona urbana (78\%) o de la periferia (20\%). Estos datos vienen dados, en parte, por la forma de implantación en el territorio que existe en Aragón donde predominan las construcciones concentradas. Pero, también, de la propia toma de datos donde han predominado las visitas sucesivas a poblaciones y no la búsqueda de edificaciones dispersas y aisladas en el territorio.

Por otro lado, de estos núcleos de población, apenas en un 12\% de los casos existe cierta presencia de turismo. El hecho de que la mayoría de los casos se localicen en el núcleo de población ha favorecido que la tipología más frecuente sea entre medianeras (48\%) o en esquina (32\%), y solo un 20\% de los casos sean edificios aislados. Además, los edificios son generalmente de 2 o 3 plantas (35\% y $42 \%$ respectivamente), si bien se han registrado casos puntuales con 5 y 6 plantas de altura.

Respecto a las características de la propiedad, la mayoría de los edificios son privados y de uso temporal (60\%), con carácter estacional o de fin de semana. Además, la mayoría de los casos tienen un uso residencial (58\%), hecho ligado al abandono de muchos de los edificios con otros usos y a que la tipología de vivienda tradicional era la más frecuente, ya que albergaba varias funciones en un mismo edificio (corral en planta baja, vivienda en primera plana y granero en la tercera planta) donde actualmente ha prevalecido el uso residencial.

Por último, desde el punto de vista estadístico se ha analizado el error muestral máximo en cada una de las muestras. Para ello la población (n) que se ha considerardo infinita en ambos casos por ser el numero de poblaciones y de edificios total con tierra números muy elevados. Se ha supuesto un nivel de confianza del 95\%, que es el estándar, por lo que $\alpha=5 \%$, y una variabilidad de las respuestas de $p=q=0,5$, que sería la opción más desfavorable. Siendo z una constante de valor 1,96, a partir de la siguiente fórmula $e=\sqrt{ }\left(\left(\left(z^{2} p q\right)\right) / N\right)$, se han obtenido los siguientes errores muestrales (tabla 5.3; tabla 5.4):

$$
e=\sqrt{\left(1,96^{2} \cdot 0.5 \cdot 0.5\right) / N}
$$




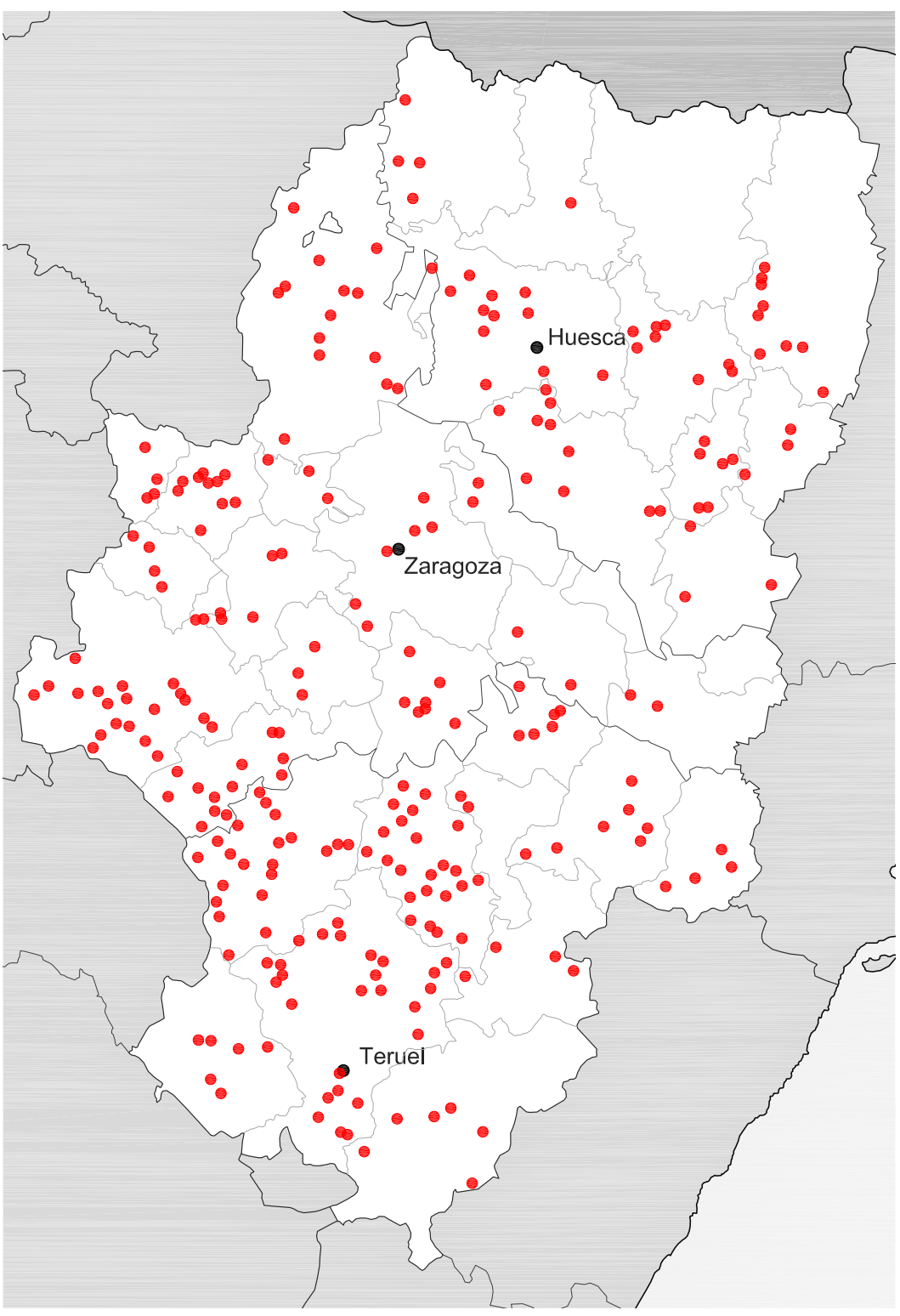

Figura 5.8. Muestra 1: Localización de los 258 núcleos de población.

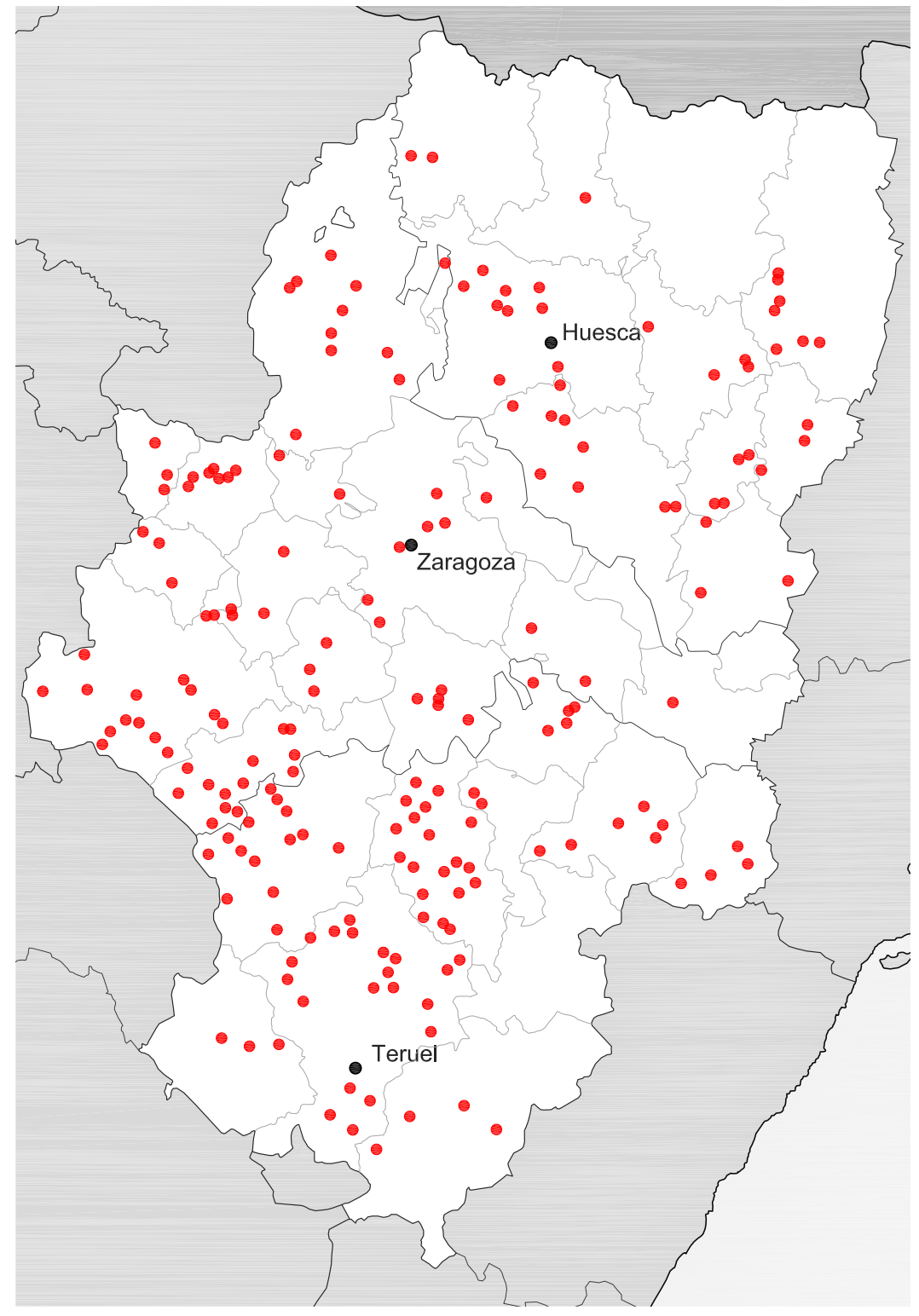

Figura 5.9. Muestra 2. Localidades con casos de estudio. 


\begin{tabular}{|l|l|l|l|l|}
\hline MUESTRA 1 & TOTAL & TAPIA & ADOBE & ENTRAMADO \\
\hline ARAGÓN & 258 & 187 & 180 & 45 \\
\hline TERUEL & 105 & 99 & 36 & 33 \\
\hline ZARAGOZA & 98 & 63 & 92 & 6 \\
\hline HUESCA & 55 & 25 & 52 & 5 \\
\hline
\end{tabular}

Tabla 5.1. Muestra 1. Número de de localidades con tierra en función del área y de la técnica

\begin{tabular}{|l|l|l|l|l|l|l|l|l|}
\hline MUESTRA 2 & \multicolumn{1}{|c|}{ Total } & \multicolumn{1}{|c|}{ Total } & \multicolumn{1}{|c|}{ Tapia } & $\begin{array}{c}\text { Tapia } \\
\text { intervenido }\end{array}$ & \multicolumn{1}{|c|}{ Adobe } & $\begin{array}{c}\text { Adobe } \\
\text { intervenido }\end{array}$ & Entramado & $\begin{array}{c}\text { Entramado } \\
\text { intervenido }\end{array}$ \\
\hline ARAGÓN & 410 & 345 & 213 & 190 & 237 & 188 & 22 & 13 \\
\hline TERUEL & 167 & 145 & 133 & 120 & 41 & 30 & 15 & 10 \\
\hline ZARAGOZA & 164 & 134 & 64 & 56 & 125 & 99 & 4 & 2 \\
\hline HUESCA & 79 & 66 & 15 & 14 & 71 & 59 & 3 & 1 \\
\hline
\end{tabular}

Tabla 5.2. Muestra 2. Número total de casos en función de la localización la técnica y el estado de intervención

\begin{tabular}{|c|c|c|}
\hline \multirow{2}{*}{$\begin{array}{c}\text { MUESTRA } 1 \\
\mathbf{e}\end{array}$} & \multicolumn{2}{|c|}{ TOTAL } \\
\hline & N & $\mathrm{e}$ \\
\hline ARAGÓN & 258 & $6,1 \%$ \\
\hline TERUEL & 105 & $9,6 \%$ \\
\hline ZARAGOZA & 98 & $9,9 \%$ \\
\hline HUESCA & 55 & $13,2 \%$ \\
\hline TAPIA & 187 & $7,2 \%$ \\
\hline ADOBE & 180 & $7,3 \%$ \\
\hline ENTRAMADO & 45 & $14,6 \%$ \\
\hline
\end{tabular}

Tabla 5.3. Error muestral, muestra 1.

\begin{tabular}{|c|c|c|}
\hline \multirow{2}{*}{$\begin{array}{c}\text { MUESTRA } 2 \\
\mathbf{e}\end{array}$} & \multicolumn{2}{|c|}{ TOTAL } \\
\hline & $\mathrm{N}$ & e \\
\hline ARAGÓN & 410 & $4,8 \%$ \\
\hline TERUEL & 167 & $7,6 \%$ \\
\hline ZARGOZA & 164 & $7,7 \%$ \\
\hline HUESCA & 79 & $11,0 \%$ \\
\hline TAPIA & 213 & $6,7 \%$ \\
\hline ADOBE & 237 & $6,4 \%$ \\
\hline ENTRAMADO & 22 & $20,9 \%$ \\
\hline
\end{tabular}

Tabla 5.4. Error muestral, muestra 2. 
6. APROXIMACIÓN A LAS TÉCNICAS Y VARIANTES CONSTRUCTIVAS 


\section{APROXIMACIÓN A LAS TÉCNICAS Y VARIANTES CONSTRUCTIVAS}

Las técnicas constructivas de tierra en Aragón son muy ricas y variadas, hecho suscitado por las grandes variaciones geográficas, pero también por el amplio número de culturas que se han asentado en este territorio a lo largo de la historia. La arquitectura tradicional ha evolucionado durante cientos de años en relación con las características de cada lugar, ha aprendido de las experiencias de épocas anteriores y ha optimizado los recursos naturales y materiales con el fin de hacer frente a las necesidades concretas de cada lugar en cada momento.

Las técnicas constructivas de tierra en Aragón están presentes en distintos tipos de entornos (aislados, rurales y urbanos), pero, también, en todo tipo de edificios desde los más humildes hasta palacios y fortificaciones, y se adapta a los requerimientos del lugar y del uso correspondientes. En muchas de las poblaciones las técnicas constructivas de tierra pueden localizase conformando algunos de los edificios más importantes o destacados como es el caso de Monterde y Alcolea del Cinca en Zaragoza, Graus en Huesca o Camarillas en Teruel (Villacampa Crespo, Sanz y García-Soriano 2018) (figura 6.1)
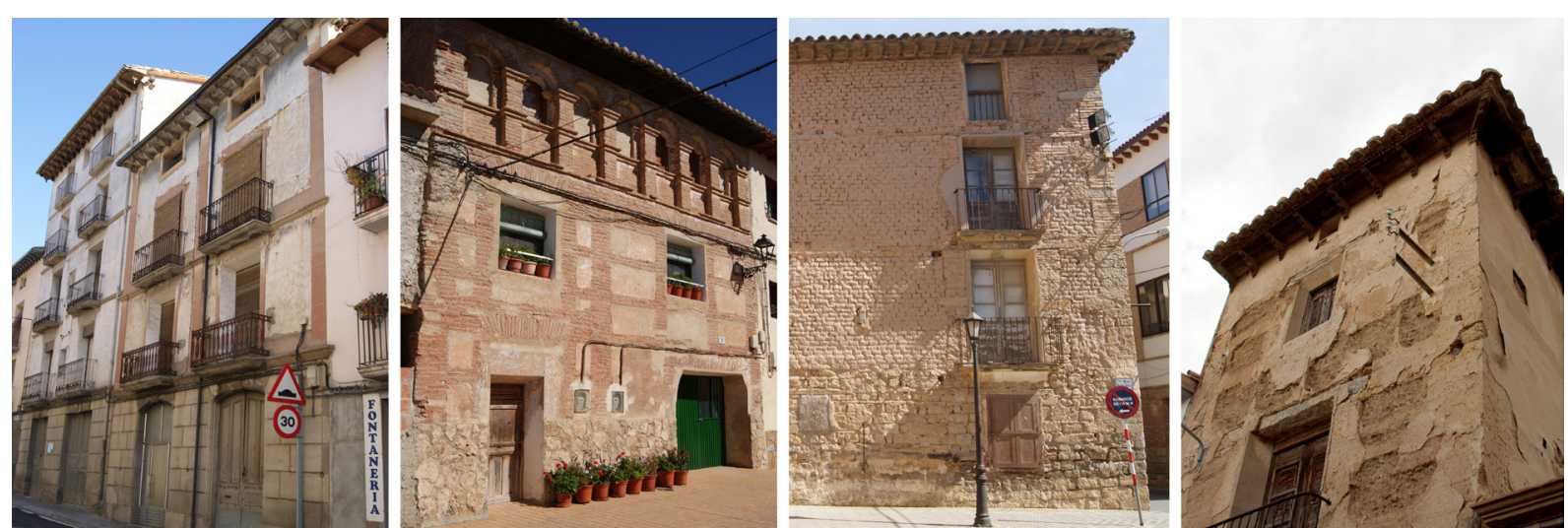

Figura 6.1. Edificios de tierra destacados en las localidades de (de izq. a dch.): Graus, Monterde, Alcolea del Cinca y Camarillas. 
En Aragón destacan las construcciones de adobe y de tapia, que se extienden en casi la totalidad del territorio, mientras que, los entramados de madera tienen una presencia menor y se encuentran principalmente en áreas donde la madera es abundante y posibilita su construcción.

Las técnicas constructivas de tierra están, en muchos casos, combinadas con otros materiales que las suplementan para mejorar las características constructivas y adaptarla a los requerimientos de cada lugar, utilizando los materiales del entorno y con la finalidad de aumentar su resistencia y durabilidad.

La heterogeneidad de materiales y técnicas hace que exista un número muy elevado de variantes y subvariantes constructivas. Por ello, para llevar clasificar cada construcción se han considerado todos los suplementos o características que definen la técnica en su globalidad, desde lo general a lo particular.

Para el reconocimiento de las técnicas y variantes se ha trabajado respecto a las dos muestras definidas. Por un lado, se ha trabajado con los datos recogidos en las visitas de campo transformados, a través de su revisión, en grupos de técnicas y variantes existentes por localidad o núcleo de población. Esto ha permitido establecer relaciones entre técnicas y variantes, su presencia relativa respecto al total de la muestra, así como las distintas áreas del territorio donde tienen mayor incidencia. Cada una de las variantes establecidas poseen elementos con características similares que hacen que se puedan relacionar entre ellas.

Por otro lado, se han analizado los casos de estudio recogidos en la base de datos a través de las fichas de estudio donde las técnicas y variantes se han definido con mayor detalle lo cual ha permitido la extracción de nuevos datos respecto a la primera muestra.

En ambos casos se ha trabajado en base a la misma clasificación de técnicas y variantes siguiendo criterios similares. La combinación del análisis de ambas muestras permite efectuar un estudio más completo de las técnicas y las variantes existentes en Aragón, sus características, su presencia relativa y su distribución geográfica.

Debe tenerse en cuenta que, al establecer la existencia de las técnica y variante en cada localidad se ha contabilizado la existencia o inexistencia de cada variante sin tener en cuenta su presencia relativa en el pueblo o si esta variante esta combinada con otras. Por lo tanto, la frecuencia con la que una técnica aparece en una localidad no queda reflejada en esta muestra y se tiene en cuenta tanto si es muy recurrente como si se trata de casos puntuales. Además, en las localidades donde la construcción de tierra es muy recurrente suelen aparecer multitud de soluciones diferentes en las que se utilizan combinaciones de suplementos con materiales muy variados 


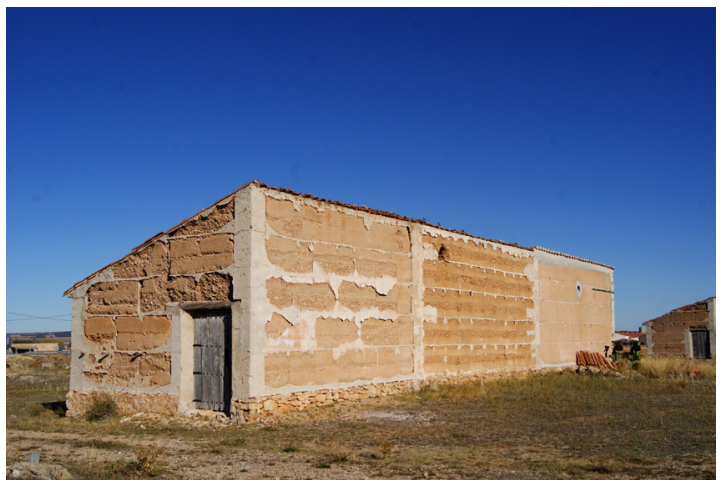

Figura 6.2. Conjunto de edificios de tapia. Caminreal, Teruel

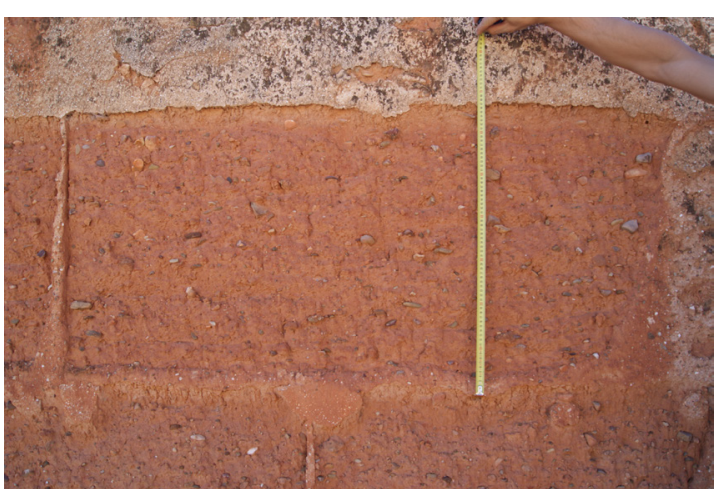

Figura 6.3. Toma de datos in situ sobre un muro de tapia. Ibdes, Zaragoza.

1. Debido a la imposibilidad de recoger el dato correspondiente al número de agujas en todos los casos estudiado el porcentaje se ha presentado respecto al total de casos de tapia (213) y respecto al número de casos en los que si que se ha podido recoger (102).
En este estudio se han analizado las técnicas y las variantes de forma aislada pero que en muchos casos se combinan entre ellas generando un número incontable de soluciones diferentes.

\subsection{La tapia}

La construcción con tapia constituye un ejemplo de gran interés y riqueza que se extiende en casi la totalidad del territorio aragonés y de la Península Ibérica, lo cual corrobora su importancia histórica (Mileto et al. 2011-2012, AA VV. 2014 a) (figura 6.2). La versatilidad de esta técnica y su capacidad de adaptación a los materiales y a los recursos disponibles en cada lugar propician la existencia de un gran número de soluciones o variantes constructivas distintas que también tienen una relación directa con el presupuesto de la construcción, la función del edificio y la proeza o imaginación del constructor (Vegas et al. 2014). La tapia se conforma a través del vertido de tierra en un molde, los tapiales, la cual se compacta a través de la acción mecánica ejercida con los pisones. Por lo tanto, la tapia resultante depende de las propiedades de los encofrados, de la fuerza ejercida en su compactación, del tipo de tierra, de los materiales utilizados como suplementos, de los acabados y de la propia conformación simple o mixta de los muros (López Martínez 1999)

Las dimensiones de la tapia también varían notablemente en función de las necesidades requeridas. El ancho de los muros de tapia en la arquitectura tradicional depende de muchos factores. Sin embargo, la mayoría de ellos se sitúan en el rango entre 40 y $60 \mathrm{~cm}$ (87\% de los casos en los que se ha recogido esta dimensión). Las medidas recopiladas del frente de cajón han sido muy dispares, entre 120 y 170 $\mathrm{cm}$ de ancho. Si bien, se han detectado muy pocos casos menores a $140 \mathrm{~cm}$ y una mayoría de casos de $160 \mathrm{~cm}$ y a $170 \mathrm{~cm}$. El intervalo de dimensión de la altura del cajón es más acotado y varía entre 60cm y $80 \mathrm{~cm}$, dentro del cual la altura de $70 \mathrm{~cm}$ a $75 \mathrm{~cm}$ es la más representativa. Las dimensiones descritas pertenecen principalmente a la provincia de Teruel ya que es el área donde más muestras de tapia se han localizado. Además, en la mayoría de los casos los tapiales están configurados con 3 agujas en el ancho de los cajones, dos laterales y una central (en un $42 \%$ del total de casos y un $88 \%$ de los casos donde se ha podido recoger este dato) ${ }^{1}$, mientras que, una proporción mucho menor están construidos con 2 agujas localizadas en los laterales del cajón (6\% del total, 12\% de los casos donde se ha podido recoger este dato) ${ }^{1}$ (figura 6.3). 


\subsubsection{Variantes constructivas}

La tapia posee unas propiedades constructivas que le permite modificar sus características con cierta facilidad en función de las necesidades (García-Soriano 2015). Esta disposición al cambio hace que las variantes y subvariantes sean muy dispares y numerosas por la posibilidad de combinarse también entre ellas. Por ello, para la clasificación de la muestra se ha diseñado una organización abierta que pueda albergar el mayor número de características y combinaciones analizando de los aspectos generales a las particularidades con el fin de generar una descripción lo más completa posible de cada ejemplo. Pese a ello, factores como la dimensión, tipo y número de agujas, grosor de cada vertido de tierra, tipo de apisonamiento etc. no se han tenido en cuenta en la clasificación por la dificultad de la toma de estos datos y por la dificultad que conllevaría localizar varios ejemplos con características comparables de los que extraer datos relevantes.

Por un lado, se han analizado los datos provenientes de la primera muestra que engloba todos los datos recogidos de los cuales se ha localizado tapia en 187 localidades, lo que supone un $73 \%$ del total. Se han analizado los resultados con el fin de determinar las variantes que predominan en el conjunto, y se ha mostrado la incidencia relativa de cada una de ellas respecto al total de lugares donde hay tapia (Tabla 6.1). La tapia simple es la variante más sencilla, sin embargo, no es la más común ( $27 \%$ de las localidades) debido, en parte, a la facilidad que presenta la inclusión de elementos o suplementos

\begin{tabular}{|c|c|c|c|c|c|c|c|c|c|}
\hline \multirow{2}{*}{\multicolumn{2}{|c|}{ TAPIA }} & \multirow{2}{*}{\multicolumn{2}{|c|}{ ARAGÓN }} & \multicolumn{2}{|c|}{ TERUEL } & \multicolumn{2}{|c|}{ ZARAGOZA } & \multicolumn{2}{|c|}{ HUESCA } \\
\hline & & & & \multicolumn{2}{|c|}{99} & \multicolumn{2}{|c|}{63} & \multicolumn{2}{|c|}{25} \\
\hline Familia / & variante & № loc & $\%$ loc & № loc & $\% \operatorname{loc}$ & № loc & $\%$ loc & № loc & $\%$ loc \\
\hline Simple u & homogénea & 50 & $27 \%$ & 23 & $23 \%$ & 22 & $35 \%$ & 5 & $20 \%$ \\
\hline & Tapialete & 42 & $22 \%$ & 32 & $32 \%$ & 4 & $6 \%$ & 6 & $24 \%$ \\
\hline Supleme & ntada en paramentos & 106 & $57 \%$ & 56 & $57 \%$ & 42 & $67 \%$ & 8 & $32 \%$ \\
\hline & Calicostrada & 100 & $53 \%$ & 56 & $57 \%$ & 37 & $59 \%$ & 7 & $28 \%$ \\
\hline & Careada & 23 & $12 \%$ & 6 & $6 \%$ & 14 & $22 \%$ & 3 & $12 \%$ \\
\hline Supleme & ntada en juntas & 104 & $56 \%$ & 62 & $63 \%$ & 38 & $60 \%$ & 4 & $16 \%$ \\
\hline & Con juntas & 77 & $41 \%$ & 45 & $45 \%$ & 29 & $46 \%$ & 3 & $12 \%$ \\
\hline & Con brencas & 61 & $33 \%$ & 38 & $38 \%$ & 22 & $35 \%$ & 1 & $4 \%$ \\
\hline Mixtas & & 139 & $74 \%$ & 70 & $71 \%$ & 50 & $79 \%$ & 19 & $76 \%$ \\
\hline
\end{tabular}

Tabla 6.1. Familias y variantes de tapia según la muestra de localidades. Porcentajes respecto al número de localidades con presencia de tapia ${ }^{2}$.

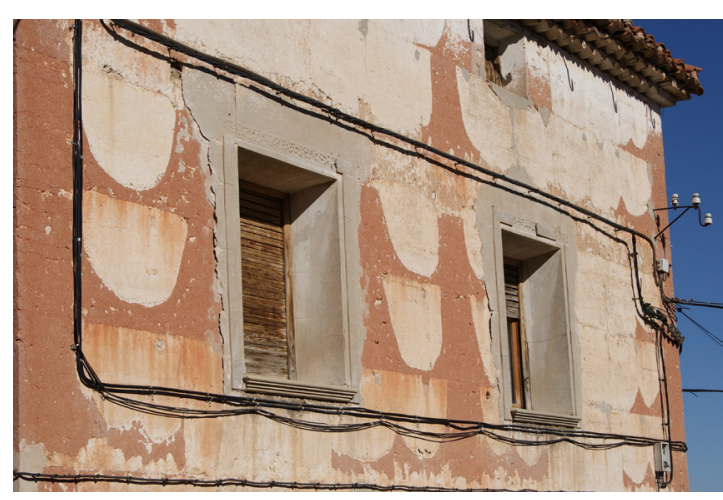

Figura 6.4. Tapia mixta con rafas, brencas y calicostrada. Torralba de los Sisones, Teruel

2. Dado que en un lugar pueden existir distintas variantes constructivas, la suma del número de familias/variantes es mayor que el número de lugares donde se ha localizado la técnica de la tapia. 


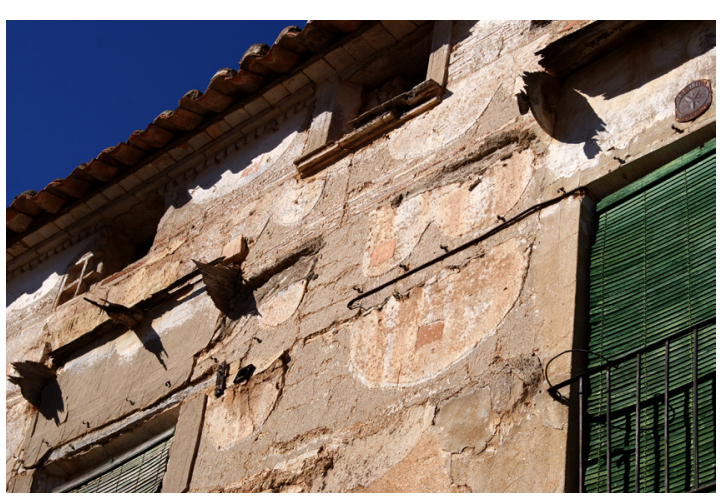

Figura 6.5. Tapia mixta con rafas, brencas, calicostrada y careada con una pieza cerámica central. Tornos, Teruel

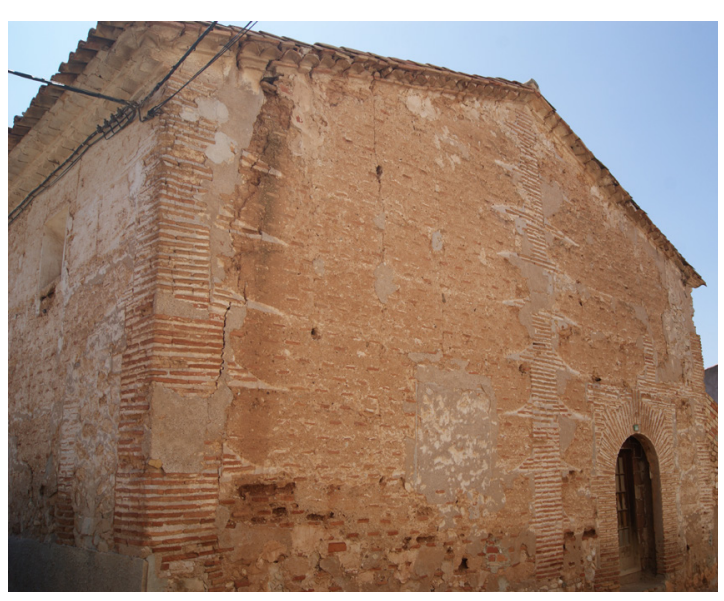

Figura 6.6. Tapia mixta con rafas de ladrillo, calicostrada y careada con ladrillo. Muniesa, Teruel. de distinta materialidad en ese sistema constructivo. En este grupo se han considerado también las tapias que contienen estabilizantes o suplementos en la masa como las tapias reales o la tapia con mampuestos debido a la dificultad de distinción o detección de estabilizantes en estas variantes. En Aragón, este tipo de construcciones se encuentran generalmente revestidas. Sin embargo, en gran parte los edificios secundarios destinados a funciones agrícolas o ganaderas se encuentra vista. Dentro de esta variante sí que se ha tenido en cuenta la tapia de yeso (22\%), ya que se distingue con facilidad de las anteriores y su construcción difiere ligeramente de la de la tapia tradicional ya que se vierte una mezcla de pequeños mampuestos y cascotes con la tierra y el yeso y se compacta ligeramente con el objetivo principal de evitar oquedades ya que la resistencia se adquiere esencialmente por el fraguado del yeso (Vegas et al. 2014; Font. 2013). Esta técnica es conocida con el nombre de tapialete en el área de Teruel (Villacampa Crespo, L. 2015) donde existe una gran tradición constructiva con yeso y donde esta técnica se ha desarrollado notablemente ya que el $76 \%$ del total de casos se localizan en esta provincia. Esta técnica ha sido utilizada históricamente en la zona y se pueden localizar ejemplos de edificios destacados como la torre del castillo de Villel (Sanz Zaragoza 2014) o el centro histórico de Albarracín.

La tapia suplementada en los paramentos es una técnica ampliamente utilizada en el territorio de Aragón y aparece en más de la mitad de las poblaciones de la muestra (57\%). Esta tapia incorpora un revestimiento desde du construcción (calicostrada) u otros materiales como piedra o ladrillos (careada) que ayudan a mejorar sus propiedades frente a la erosión por agentes externos, especialmente frente al agua que el elemento que más afecta a la durabilidad de las construcciones en tierra. En Aragón destaca la tapia calicostrada (53\%) frente a la careada (12\%). Además, en gran parte de las construcciones la costra está realizada con yeso, en lugar de cal, debido a la abundancia de este material y amplio conocimiento sobre su uso sin que presente mayores problemas de durabilidad frente a la acción del agua como se entiende en muchas ocasiones (La Spina 2014). Además, en función del tipo de edificio, su configuración y las variantes con las que se combine la costra tiene propiedades diferentes, como por ejemplo la tapia con brencas calicostrada. Esta variante es distinguible visualmente en muchos casos por la diferencia de tonalidad entre el conglomerante de la costra y el de la brenca así como por la habitual presencia de grietas en la junta entre la unión de la brenca y la tapia y de desconchados (figura 6.4). En cuanto a la tapia careada, existen tres tipos principales que, en la mayoría de los casos, se encuentran también calicostrados. La tapia careada con una única piedra o elemento cerámico colocado en el centro del cajón con la cara de mayor superficie al exterior (probablemente con fines decorativos, aunque también podrían estar colocados para facilitar el desencofrado evitando que la madera se adhiera al conglomerante de la costra en esta zona) (figura 6.5). La tapia careada con ladrillo, o tapia valenciana en ocasiones se combina con brencas realizadas con este mismo material (figura 6.6). 
La tapia suplementada en juntas, al igual que la anterior familia, es una solución frecuente que aparece en más de la mitad de las localidades que componen la muestra (56\%). Los suplementos consisten la colocación de conglomerantes u otros materiales en las juntas que se forman entre los cajones de tapia al mismo tiempo que se realiza la tapia por lo que forman parte de la propia unidad del cajón. Estos suplementos en ocasiones atraviesan toda la sección del muro, pero en el caso de las construcciones tradicionales suele encontrarse solo en el área más próxima a los paramentos permitiendo así el ahorro de material. Además, estas juntas normalmente también cubren los mechinales de las agujas protegiendo de esta forma al muro frente la erosión de estas zonas donde el agua se deposita con mayor facilidad. Esta variante de tapia es muy recurrente en Teruel y Zaragoza, sin embargo, en Huesca no se han localizado apenas casos. Existen dos subvariantes de esta familia, la tapia con juntas simples (41\%) que son suplementos que siguen la junta natural de los cajones de tapia y la tapia con brencas (33\%) que consiste en la creación de juntas con forma de "U" o media luna en la parte inferior del cajón (Vegas et al. 2009). Estas brencas se construyen generalmente con yeso y ayudan a evitar problemas derivados de la difícil compactación de las esquinas de la tapia. Ambas subvariantes se localizan principalmente en el área de Teruel y representan el 58\% y el 62\% respectivamente del total de localidades con suplementos en juntas en Aragón. En esta familia de variantes se incluye también la tapia trabada con rollizos en el interior de las juntas entre cajones, cuya función es el arriostramiento y no la protección de la propia junta. Esta solución se repite en el territorio aragonés pero su localización o reconocimiento es muy complejo, a menos que su presencia se haga evidente por el avanzado estado deterioro de los muros de tapia. Por ello se ha desestimado la incorporación de esta subvariante en el cómputo general, aunque sí que se han recogido algunos ejemplos (figura 6.7 y figura 6.8).

La tapia mixta es aquella que combina distintas técnicas constructivas con los cajones de tapia. Los suplementos se construyen generalmente con fábrica de piedra, ladrillo, mampostería encofrada o incluso adobe y conforman machones, esquinas y verdugadas que se combinan con los cajones de tapia. En el territorio aragonés es muy común el uso suplementos verticales o machones, sobre todo en las esquinas ya que facilitan su construcción e incrementan la durabilidad del muro. La gran adaptabilidad en cuanto a forma y materiales de este tipo de suplementos hace que sea la variante constructiva más común tanto en el conjunto de Aragón (78\%), como en cada una de sus provincias, ya que aparece en todos los casos entre el 70 y $79 \%$ del total de localidades donde se han localizado técnicas con tierra.

Con el fin de corroborar los datos existentes y definir sus características de forma más detallada, se han analizado los datos provenientes de las 410 fichas de estudio de las cuales 211 están construidas con tapia total o parcialmente. El análisis a través de las fichas ha permitido un estudio más exhaustivo de la técnica, en el que se han tenido en cuenta la localización y la materialidad de cada suplemento.

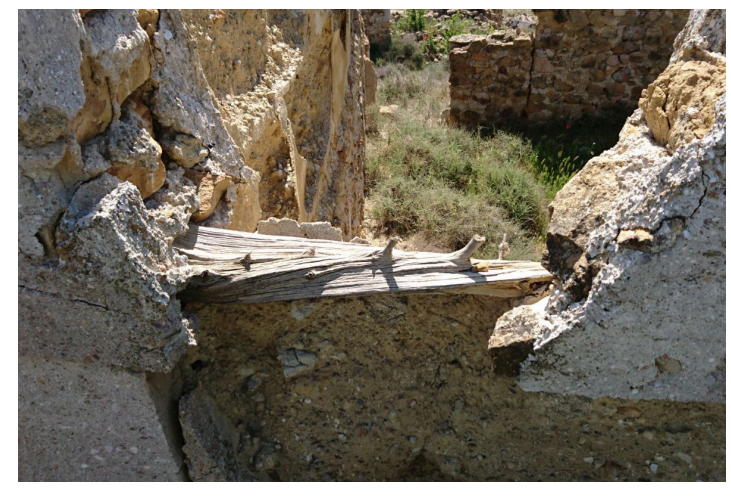

Figura 6.7. Tapia suplementada con madera de sabina en el interior del suplemento de juntas. Alcaine, Teruel

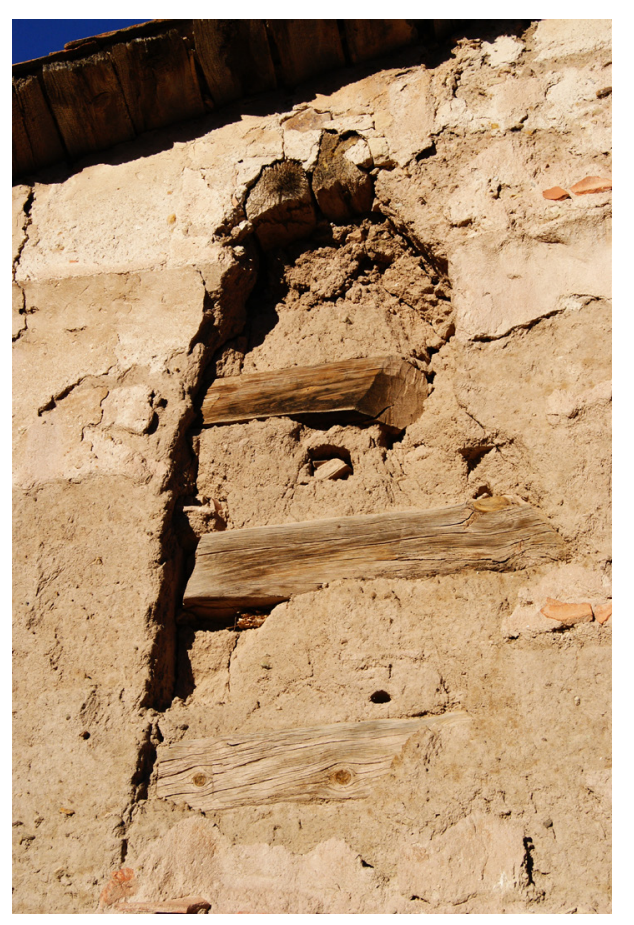

Figura 6.8. Tapia simple suplementada con madera en la masa. Mora de Rubielos, Teruel. 


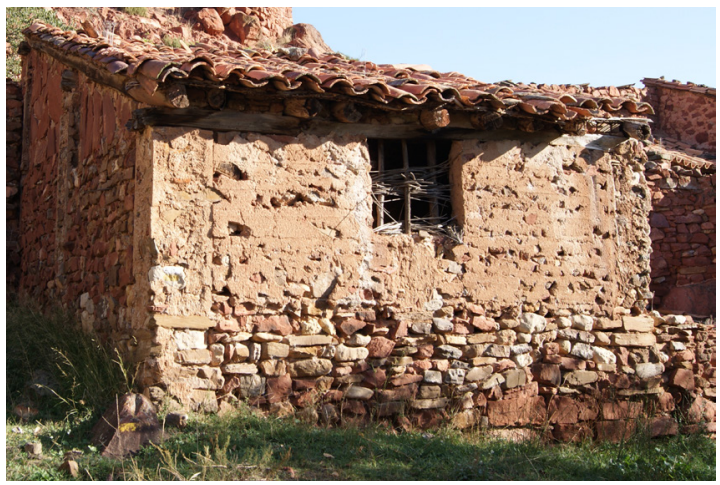

Figura 6.9. Tapia de yeso, tapialete, mixta con machones de mampostería y yeso. Peñarroyas, Teruel

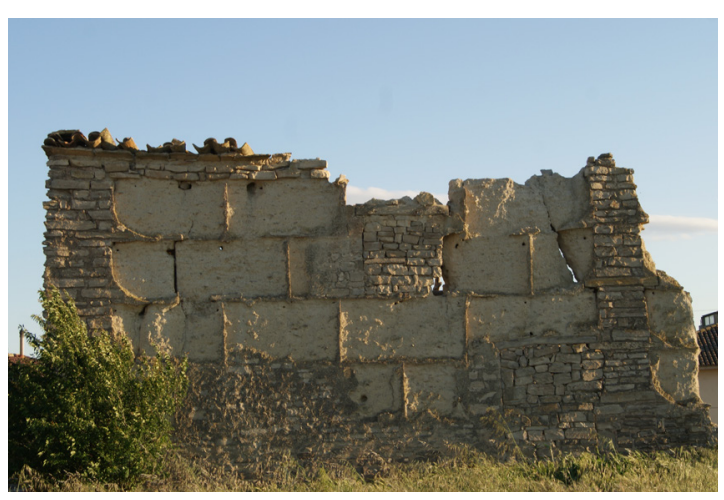

Figura 6.10. Tapia mixta con machones de piedra y juntas de conglomerante. Almudevar, Huesca
Los porcentajes de técnicas y variantes totales derivados de la base de datos de los casos de estudio muestran una relación directa con los procedentes de la muestra primera lo cual permite confirmar los resultados obtenidos (tabla 6.2.). Además, en la base de datos se han analizado los materiales utilizados en cada tipo de suplemento (tabla 6.3.)

Los casos de estudio analizados, en muchas ocasiones están construidos con distintas técnicas constructivas de tierra o con una misma técnica y distintas variantes por lo que el sumatorio de las variantes o subvariantes no tiene como resultado el total de casos de la técnica o la variante.

La tapia simple aparece en el $16 \%$ de los casos de estudio de la cual la mitad es tapia simple común y la otra mitad tapia de yeso o tapialete.

La tapia suplementada en paramentos o con suplementos en la superficie del muro aparece en el $48 \%$ de los casos y en este grupo destaca claramente la tapia calicostrada con el $45 \%$ de los casos frente a la tapia careada que aparece únicamente en el $5 \%$. La costra exterior se realiza con conglomerantes, cal o yeso, mientras que el material utilizado más frecuentemente para carear el muro es el ladrillo.

La tapia con suplementos en juntas se localiza en el $49 \%$ de los casos de estudio que están construidos en tapia. En cuanto a sus subvariantes, las tapias con juntas simples aparecen en el $26 \%$ de total de tapias y la tapia con brencas en el $23 \%$. Además, estos suplementos en juntas están realizadas con cal y principalmente con yeso en el $98 \%$ de los casos y en un número reducido de casos, $2 \%$ aproximadamente, con ladrillo.

La tapia mixta, en la muestra de las fichas, se ha analizado en detalle, añadiendo las subvariantes, que definen el tipo de suplementos y su localización en el muro. La combinación de muros de tapia con elementos verticales es la configuración de tapia mixta más común en Aragón con un 64\% de los casos. Estos suplementos verticales pueden localizarse únicamente en las esquinas del edificio (26\%), en forma de machones distribuidos en toda la longitud del muro (19\%) o estar configurados a partir del propio cajón de la tapia en forma de rafas (20\%). Los suplementos horizontales o combinación de horizontales con verticales (tapia encajonada) aparecen rara vez en la arquitectura tradicional aragonesa por ser más frecuentes en la arquitectura de carácter monumental. Los suplementos verticales están construidos en su mayoría con mampostería y yeso (64\%) en parte por ser la tapia más común en Teruel donde abunda el uso de estos materiales (figura 6.9). Los suplementos de piedra (14\%) (figura 6.10) y de ladrillo (15\%) también son comunes, especialmente en la provincia de Zaragoza y sur de Huesca. 


\begin{tabular}{|c|c|c|c|c|c|c|c|c|}
\hline \multirow{2}{*}{ TAPIA } & \multirow{2}{*}{\multicolumn{2}{|c|}{$\begin{array}{c}\text { ARAGÓN } \\
211\end{array}$}} & \multirow{2}{*}{\multicolumn{2}{|c|}{$\begin{array}{c}\text { TERUEL } \\
132\end{array}$}} & \multirow{2}{*}{\multicolumn{2}{|c|}{$\begin{array}{c}\text { ZARAGOZA } \\
64\end{array}$}} & \multirow{2}{*}{\multicolumn{2}{|c|}{$\begin{array}{c}\text { HUESCA } \\
15\end{array}$}} \\
\hline & & & & & & & & \\
\hline Familia /variante & casos & $\%$ & casos & $\%$ & casos & $\%$ & casos & $\%$ \\
\hline Simple u homogénea & 34 & $16 \%$ & 23 & $17 \%$ & 9 & $14 \%$ & 2 & $13 \%$ \\
\hline Simple & 16 & $8 \%$ & 11 & $8 \%$ & 5 & $8 \%$ & 0 & $0 \%$ \\
\hline Tapialete & 17 & $8 \%$ & 12 & $9 \%$ & 3 & $5 \%$ & 2 & $13 \%$ \\
\hline Mampostería encofrada & 1 & $0 \%$ & 0 & $0 \%$ & 1 & $2 \%$ & 0 & $0 \%$ \\
\hline Suplementada en paramentos & 105 & $50 \%$ & 62 & $47 \%$ & 34 & $53 \%$ & 9 & $60 \%$ \\
\hline Calicostrada & 94 & $45 \%$ & 61 & $46 \%$ & 27 & $42 \%$ & 6 & $40 \%$ \\
\hline Careada & 11 & $5 \%$ & 1 & $1 \%$ & 7 & $11 \%$ & 3 & $20 \%$ \\
\hline Suplementada en juntas & 104 & $49 \%$ & 75 & $57 \%$ & 28 & $44 \%$ & 1 & $7 \%$ \\
\hline Con juntas & 55 & $26 \%$ & 37 & $28 \%$ & 17 & $27 \%$ & 1 & $7 \%$ \\
\hline Con brencas & 49 & $23 \%$ & 38 & $29 \%$ & 11 & $17 \%$ & 0 & $0 \%$ \\
\hline Mixtas & 147 & $70 \%$ & 93 & $70 \%$ & 43 & $67 \%$ & 11 & $73 \%$ \\
\hline Verdugadas & 0 & $0 \%$ & 0 & $0 \%$ & 0 & $0 \%$ & 0 & $0 \%$ \\
\hline Esquinas & 55 & $26 \%$ & 35 & $27 \%$ & 16 & $25 \%$ & 4 & $27 \%$ \\
\hline Machones & 40 & $19 \%$ & 21 & $16 \%$ & 12 & $19 \%$ & 7 & $47 \%$ \\
\hline Rafas & 42 & $20 \%$ & 33 & $25 \%$ & 9 & $14 \%$ & 0 & $0 \%$ \\
\hline Esquinas y verdugadas & 1 & $0 \%$ & 0 & $0 \%$ & 1 & $2 \%$ & 0 & $0 \%$ \\
\hline Machones y verdugadas & 9 & $4 \%$ & 4 & $3 \%$ & 5 & $8 \%$ & 0 & $0 \%$ \\
\hline Con elementos de protección & 29 & $14 \%$ & 19 & $14 \%$ & 10 & $16 \%$ & 0 & $0 \%$ \\
\hline
\end{tabular}

Tabla 6.2. Tabla de variantes y subvariantes de tapia. Datos obtenidos de los casos analizados con la ficha de estudio.

\begin{tabular}{|c|c|c|c|c|c|c|c|c|c|}
\hline \multirow{3}{*}{\multicolumn{2}{|c|}{\begin{tabular}{|l} 
TAPIA \\
Materialidad suplementos \\
Familia /variante
\end{tabular}}} & \multirow{2}{*}{\multicolumn{2}{|c|}{$\begin{array}{c}\text { ARAGÓN } \\
211\end{array}$}} & \multirow{2}{*}{\multicolumn{2}{|c|}{$\begin{array}{c}\text { TERUEL } \\
132\end{array}$}} & \multirow{2}{*}{\multicolumn{2}{|c|}{$\begin{array}{c}\text { ZARAGOZA } \\
64\end{array}$}} & \multirow{2}{*}{\multicolumn{2}{|c|}{$\begin{array}{c}\text { HUESCA } \\
15\end{array}$}} \\
\hline & & & & & & & & & \\
\hline & & casos & $\%$ & casos & $\%$ & casos & $\%$ & casos & $\%$ \\
\hline \multicolumn{2}{|c|}{ Suplementada en paramentos } & 105 & & 62 & & 34 & & 9 & \\
\hline & Ladrillo & 10 & $10 \%$ & 1 & $2 \%$ & 6 & $18 \%$ & 3 & $33 \%$ \\
\hline & Piedra & 1 & $1 \%$ & 0 & $0 \%$ & 1 & $3 \%$ & 0 & $0 \%$ \\
\hline & Cal / Yeso & 94 & $90 \%$ & 61 & $98 \%$ & 27 & $79 \%$ & 6 & $67 \%$ \\
\hline \multicolumn{2}{|c|}{ Suplementada en juntas } & 104 & & 75 & & 28 & & 1 & \\
\hline & Ladrillo & 2 & $2 \%$ & 1 & $1 \%$ & 1 & $4 \%$ & 0 & $0 \%$ \\
\hline & Cal / Yeso & 102 & $98 \%$ & 74 & $99 \%$ & 27 & $96 \%$ & 1 & $100 \%$ \\
\hline \multicolumn{2}{|l|}{ Mixtas } & 147 & & 93 & & 43 & & 11 & \\
\hline & Ladrillo & 22 & $15 \%$ & 4 & $4 \%$ & 13 & $30 \%$ & 5 & $45 \%$ \\
\hline & Piedra & 21 & $14 \%$ & 10 & $11 \%$ & 7 & $16 \%$ & 4 & $36 \%$ \\
\hline & Adobe & 4 & $3 \%$ & 1 & $1 \%$ & 3 & $7 \%$ & 0 & $0 \%$ \\
\hline & Mampostería y yeso & 94 & $64 \%$ & 77 & $83 \%$ & 16 & $37 \%$ & 1 & $9 \%$ \\
\hline & Mixtos & 6 & $4 \%$ & 1 & $1 \%$ & 4 & $9 \%$ & 1 & $9 \%$ \\
\hline
\end{tabular}

Tabla 6.3. Tabla de los materiales utilizados como suplemento en cada una de las variantes. 


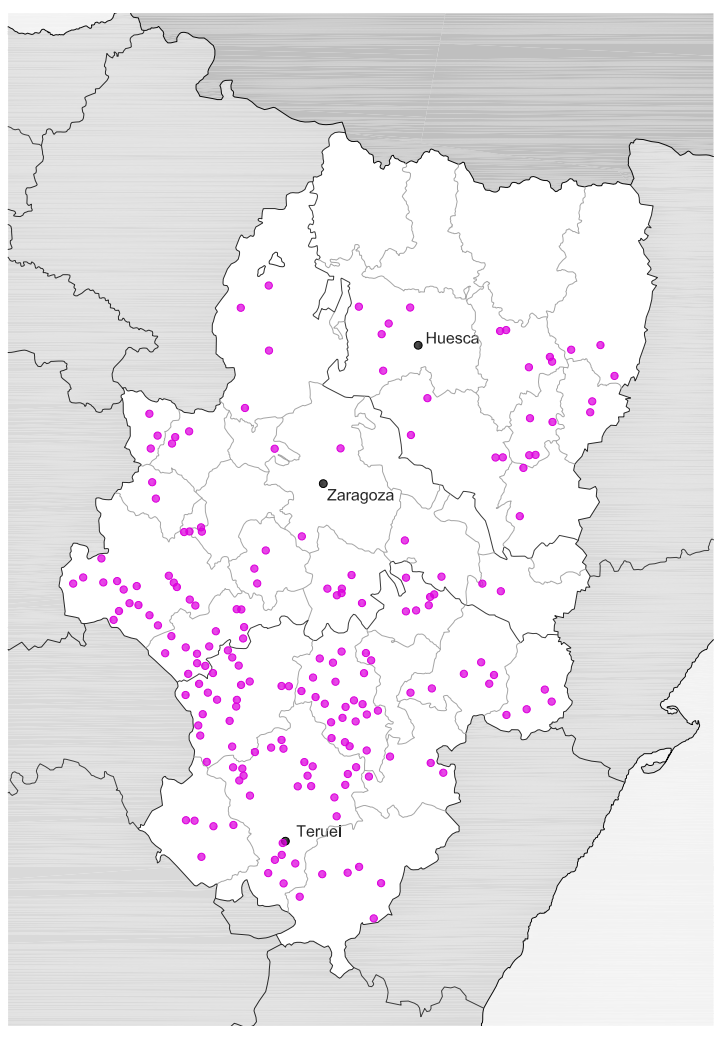

Figura 6.11. Localización construcciones de tapia

3. En esta misma zona (Sierra de Gúdar, Teruel), cuando se demuele algún edificio es posible observar como la mayoría de las medianeras están realizadas con tapia (Aguilar de Alfambra, Valvona, Rubielos de Mora...)

\subsubsection{Distribución geográfica}

La tapia se extiende por la mayor parte de la geografía aragonesa, sin embargo, su presencia es mayor en la zona sur, correspondiente con la provincia de Teruel y sureste de Zaragoza. Además, en esta zona la presencia dentro de los núcleos de población es mucho mayor que en otras áreas y su uso es predominante en gran parte de las localidades (figura 6.11).

Los Pirineos es la única área en la que no se han localizado ejemplos de tapia ni durante la toma de datos ni en la bibliografía existente. En el resto de territorio, pese a haber zonas en las que es menos frecuente por el predominio de otros materiales, se han localizado algunos ejemplos puntuales e indicios de que muros como los medianeros, no visibles en la mayoría de los casos, se realizaban con este material. Un ejemplo de este caso es la zona del Maestrazgo y sierra de Gúdar de Teruel donde, aunque muchos de los pueblos tienen un predominio de construcciones en piedra, algunos de los edificios secundarios y las medianeras entre los edificios de piedra están realizados con tapia (Mirambel, La Puebla de Valverde, etc. $)^{3}$

La tapia simple predomina en el norte de Teruel y sur de Zaragoza, mientras que la tapia de yeso tiene un predominio claro en toda la provincia de Teruel y con casos localizados puntualmente en el centro este de Huesca.

La tapia suplementada en paramentos o en la superficie se extiende por todo el territorio aragonés; sin embargo, su presencia es mucho mayor en la provincia de Teruel y en el oeste de Zaragoza donde, generalmente, el material utilizado para realizar esta costra es el yeso. La tapia careada aparece en su mayoría en la zona centro oeste de la comunidad mientras que la tapia calicostrada, mucho más común que la anterior, se encuentra más extendida destacando su presencia en la zona del valle del Jiloca que corresponde con el oeste de la provincia de Teruel y Zaragoza. Destaca en las comarcas de Campo de Belchite, Tarazona y EI Moncayo y norte de las Cuencas Mineras la presencia de tapia careada con ladrillo por el amplio desarrollo del uso del ladrillo principalmente en la provincia de Zaragoza.

En el caso de la tapia con juntas las áreas con mayor presencia son las mismas que en el caso anterior, tanto para juntas simples como con brencas, si bien las primeras están ligeramente más extendidas por todo el territorio. Destaca notablemente la presencia de la tapia con brencas en la zona central de las comarcas de las Cuencas Mineras y Andorra-Sierra de Arcos, además de la comarca del Jiloca.

Finalmente, la tapia mixta es la variante más común y se encuentra extendida por todo el territorio aragonés donde la tapia está presente, si bien en el plano se observa como en el área central 
correspondiente al valle del Ebro y la comarca de las Cinco Villas en Zaragoza su presencia es menor. En este tipo de tapia se pueden reconocer áreas donde los suplementos se realizan con unos materiales determinados como la comarca del Somontano de Barbastro donde la tapia aparece suplementada con sillares en sus esquinas y calicostrada y conforma una tipología conocida como como las casas de labranza (Naval Mas 1990). En la zona de Teruel, sin embargo, es común el uso de mampostería con yeso para la realización de pilares y machones para suplementar los cajones de tapia, donde, en gran número de ocasiones, están conformados dentro de los mismos cajones en forma de rafas. En la provincia de Zaragoza es común localizar tapias mixtas con fábrica de ladrillo por la amplia tradición y el abundante uso de este material.

Por otro lado, cabe destacar que es muy común la combinación de diferentes variantes o subvariantes. Por ejemplo, en el norte de la comarca de comunidad de Teruel y Jiloca es muy común la tapia mixta de machones con mampostería y yeso, suplementada en juntas (simples o brencas) y calicostrada con yeso (figura 6.12).

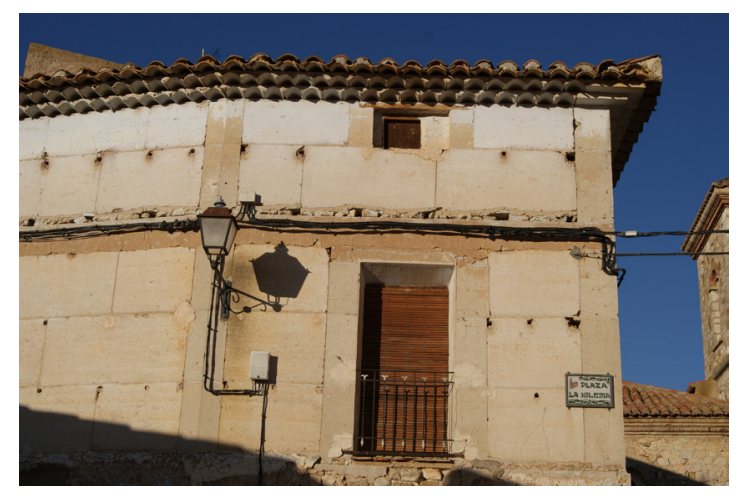

Figura 6.12. Tapia mixta con machones de mampostería y yeso, calicostrada y con suplemento de yeso en las juntas. Aguatón, Teruel 


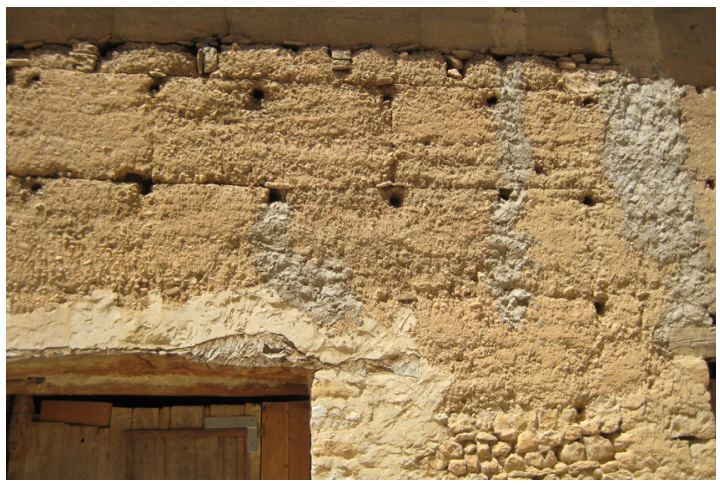

Figura 6.12. Tapia simple. Mirambel, Teruel

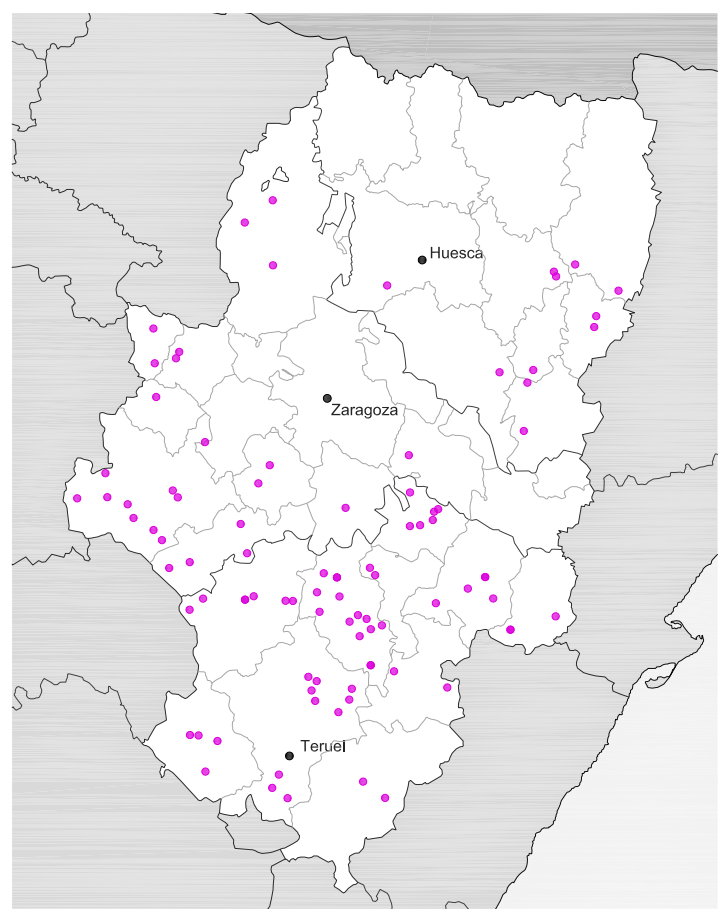

Figura 6.13. Localización tapia simple

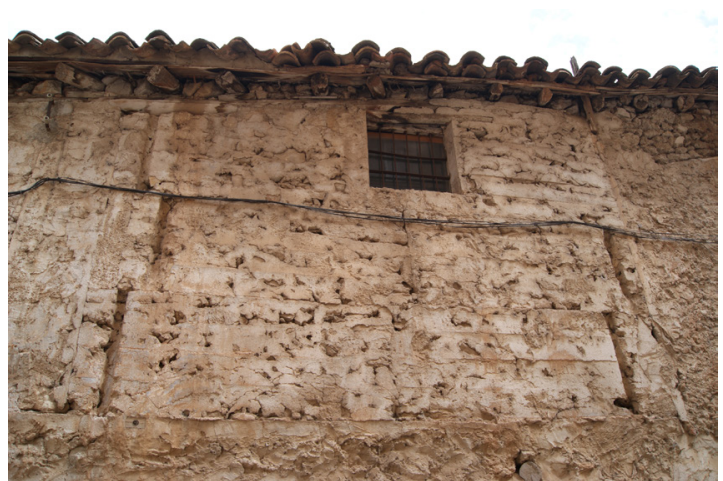

Figura 6. 14. Tapia de yeso, Tapialete. Montalbán, Teruel

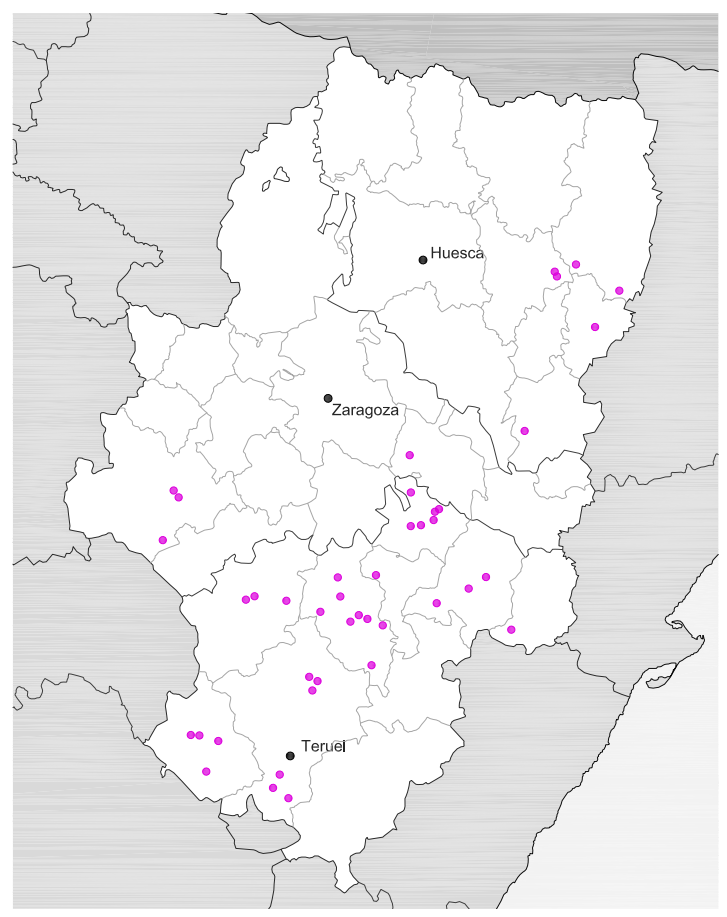

Figura 6.15. Localización tapia de yeso, tapialete

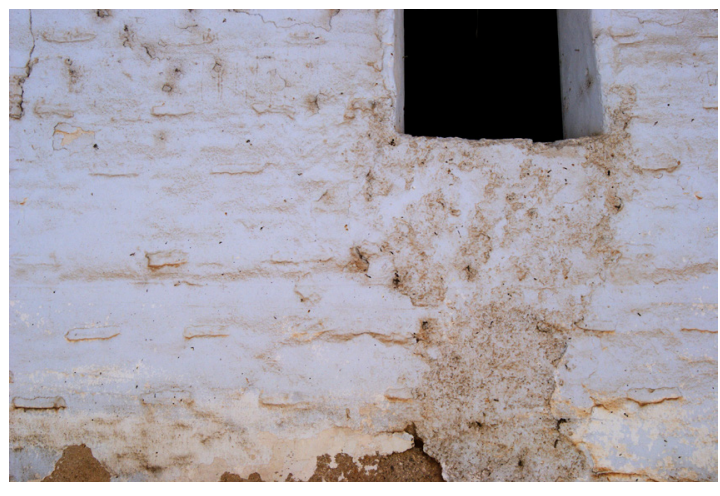

Figura 6.16. Tapia suplementada en paramentos y encalada. Cariñena, Zaragoza

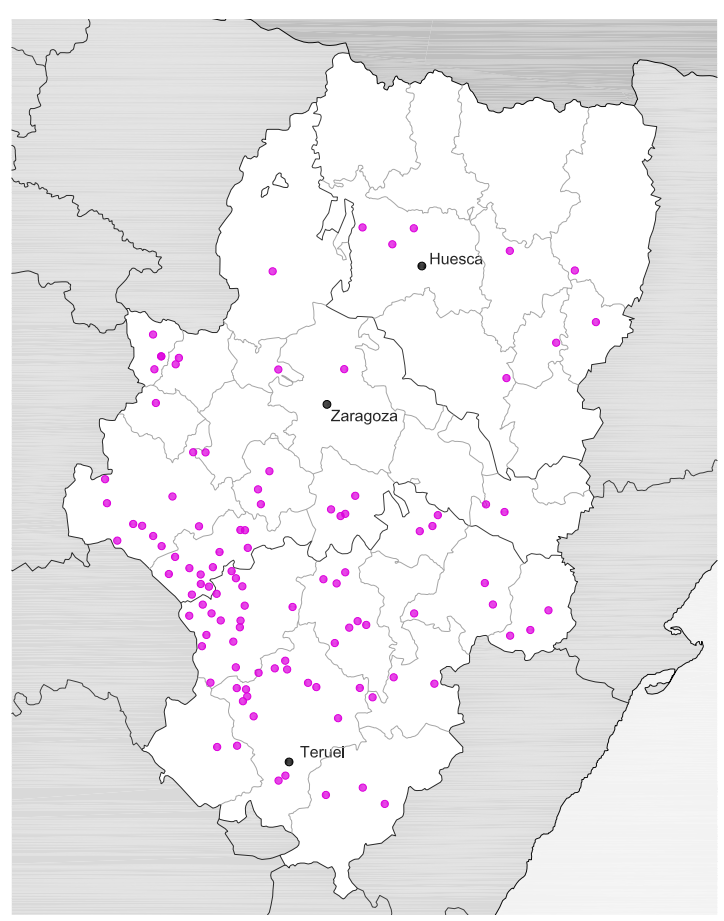

Figura 6.17. Localización tapia suplementada en paramentos 


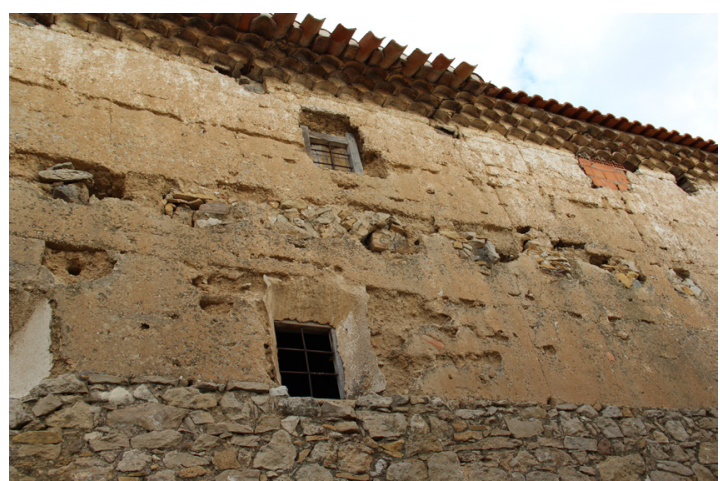

Figura 6.18. Tapia calicostrada. Camarillas, Teruel

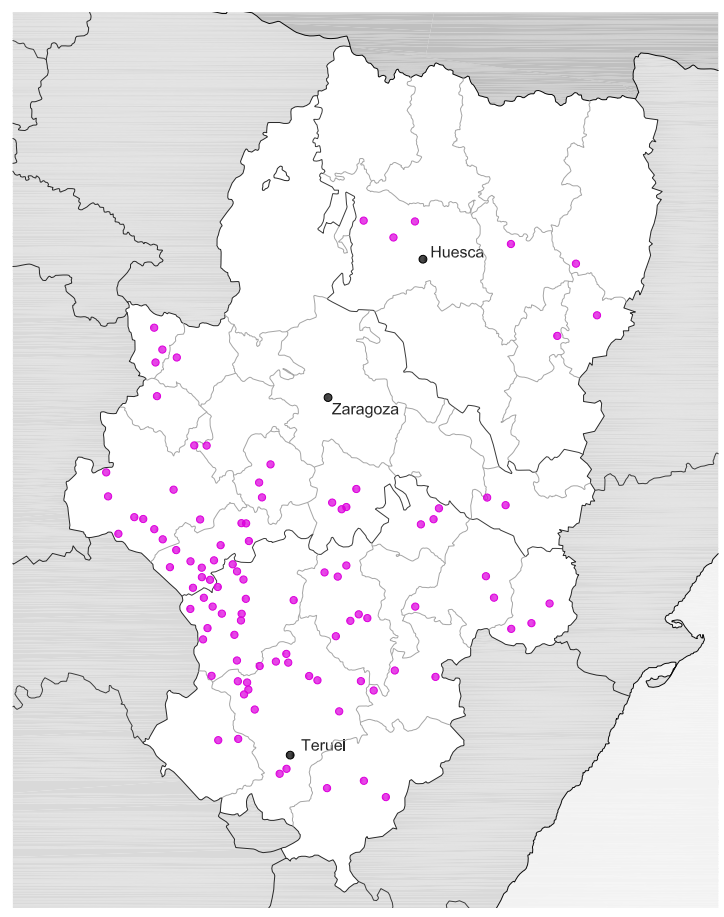

Figura 6.19. Localización tapia suplementada en paramentos calicostrada

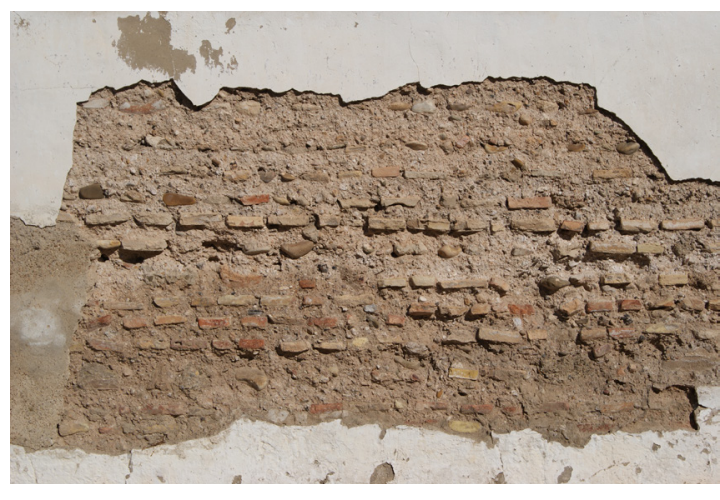

Figura 6.20. Tapia careada. Alagón, Zaragoza

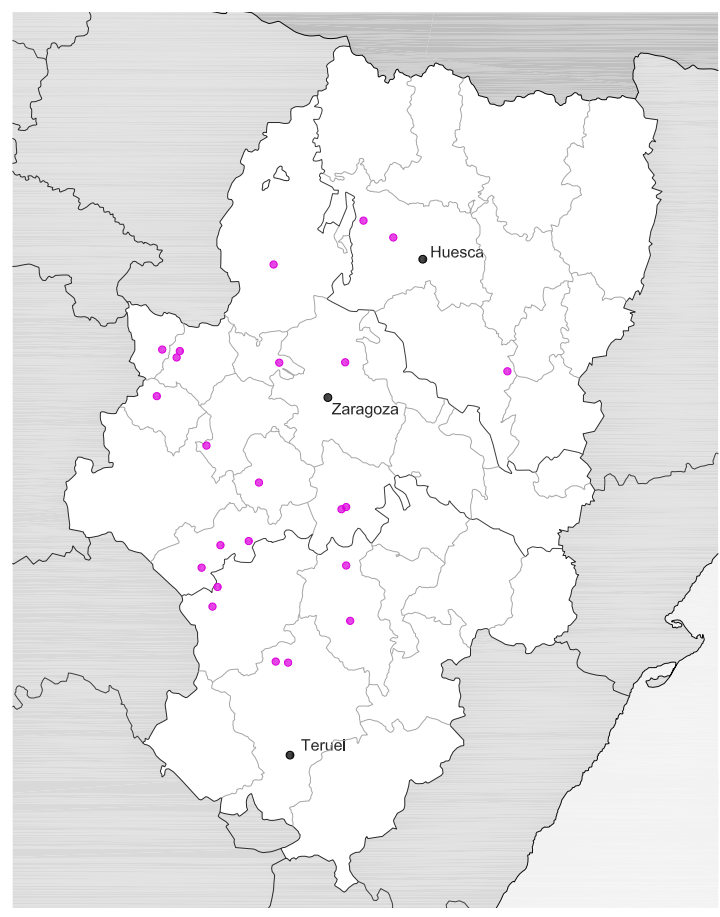

Figura 6.21. Localización tapia suplementada en paramentos_careada

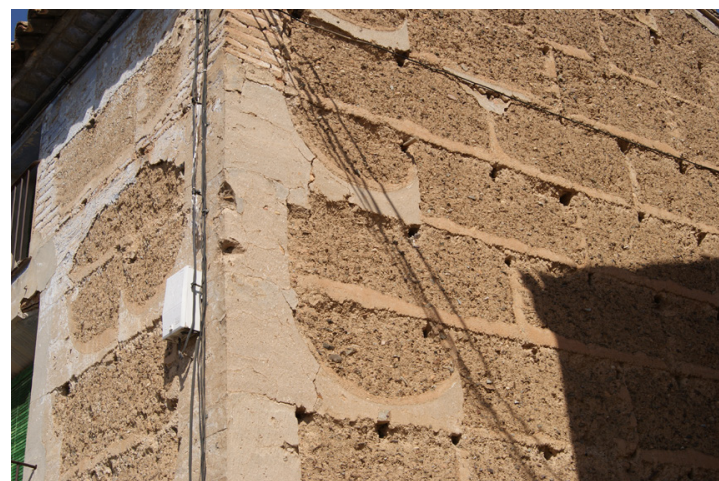

Figura 6.22. Tapia suplementada en juntas. Báguena, Teruel

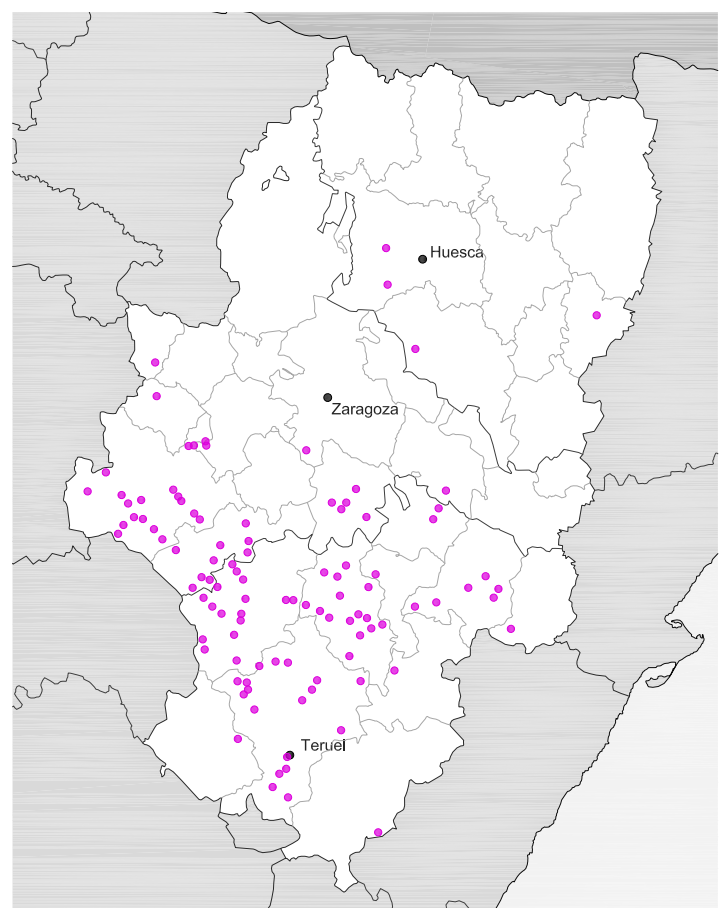

Figura 6.23. Localización tapia suplementada en las juntas 


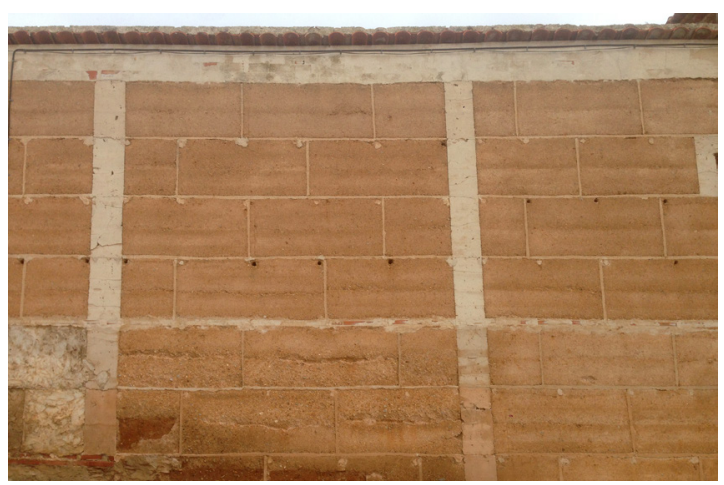

Figura 6.24. Tapia con suplemento en juntas. Villaspesa, Teruel

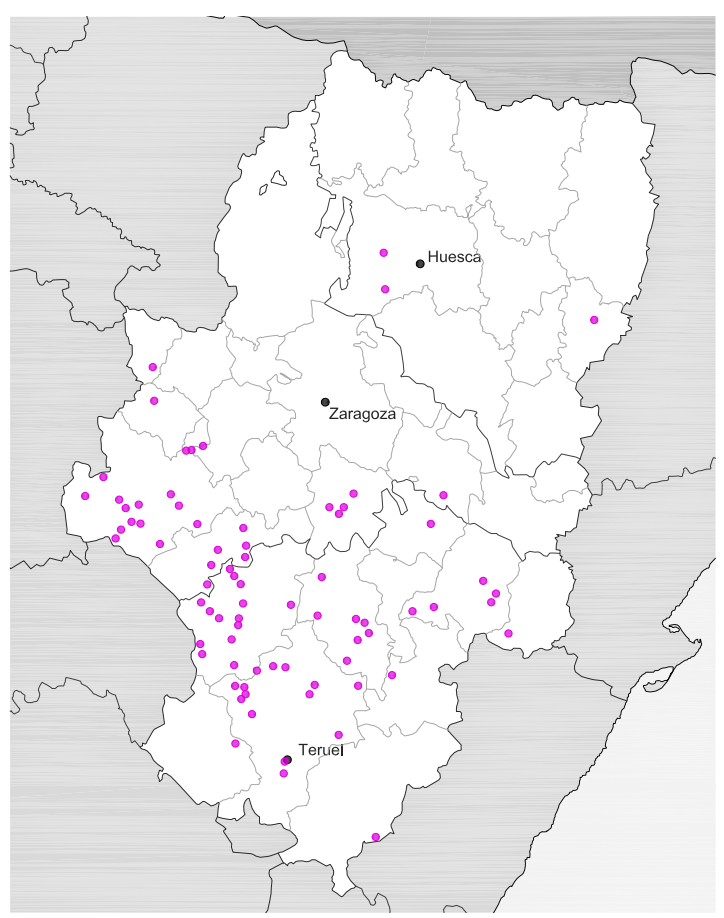

Figura 6.25. Localización tapia suplementada en juntas con juntas simples

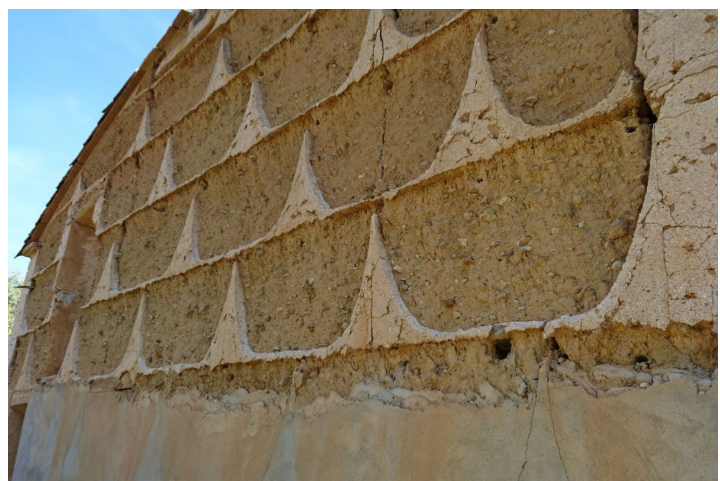

Figura 6.26. Tapia con brencas. Alcaine, Teruel

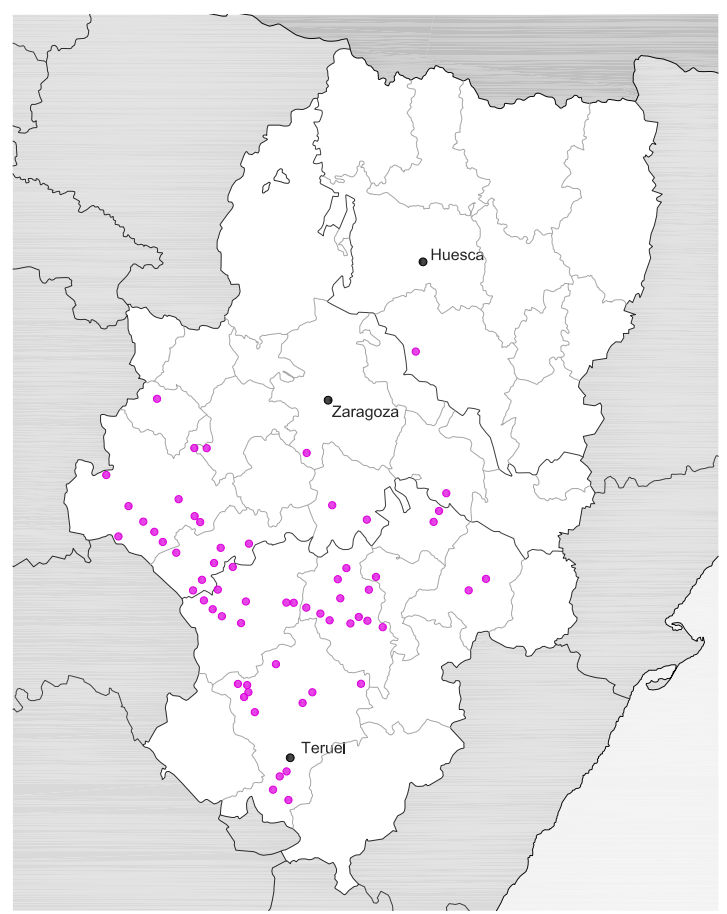

Figura 6.27. Localización tapia suplementada en juntas_ con brencas

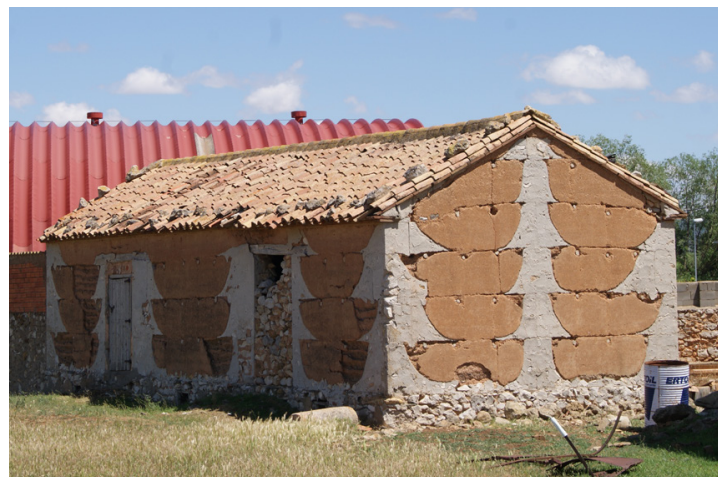

Figua 6.28. Tapia mixta. Romanos, Zaragoza

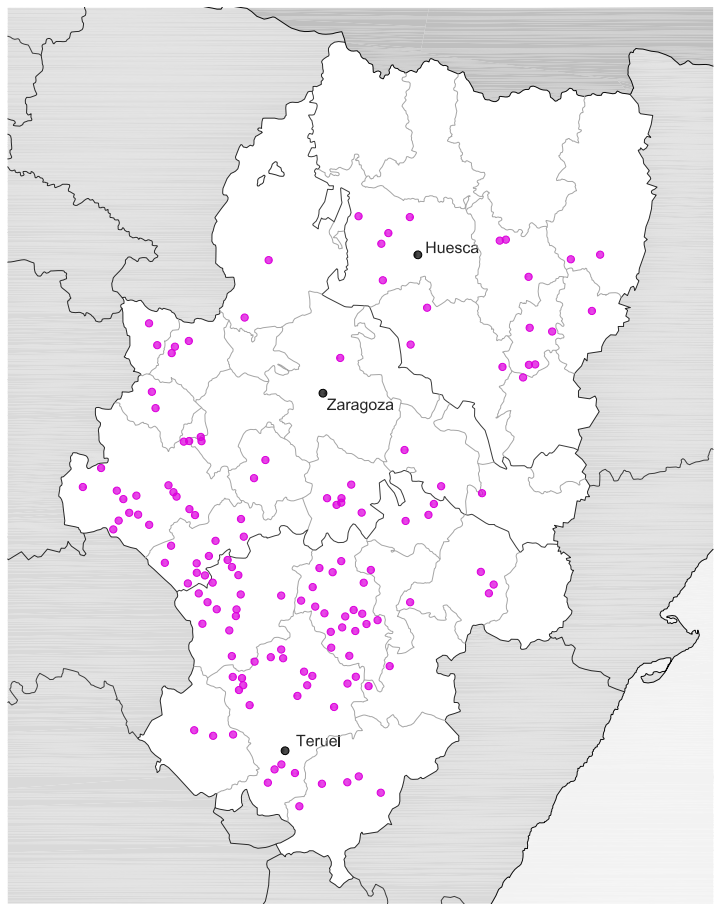

Figura 6.29. Localización tapia mixta 


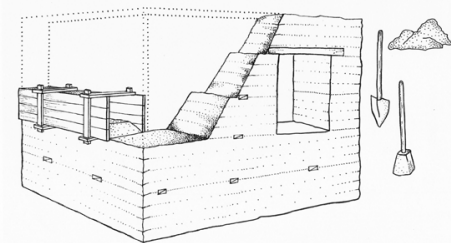

Tapia simple

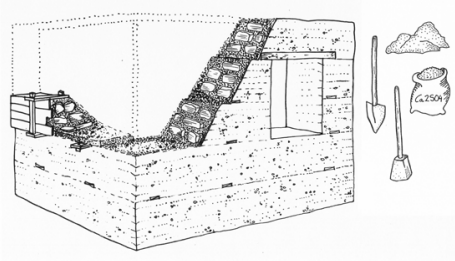

Tapia de yeso, tapialete

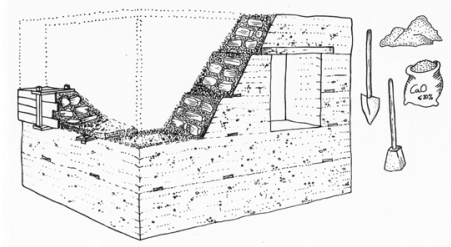

Tapia con relleno de mampostería y cal

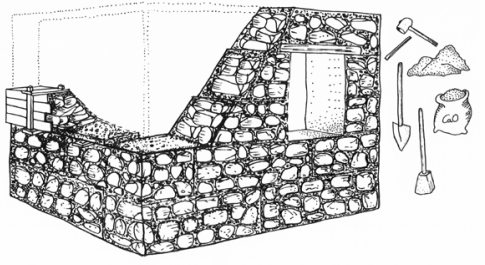

Mampostería encofrada

Principales variantes de tapia localizadas en

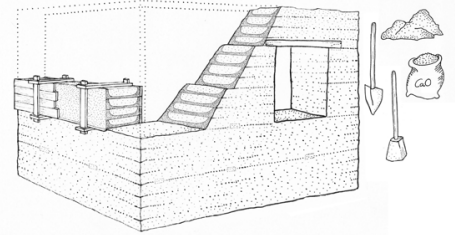

Tapia calicostrada con cuña y tongada interior

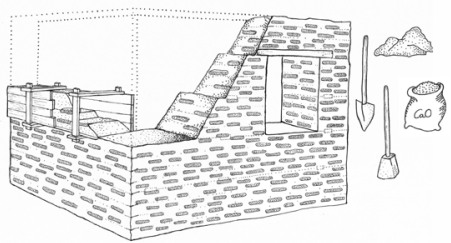

Tapia careada con ladrillo

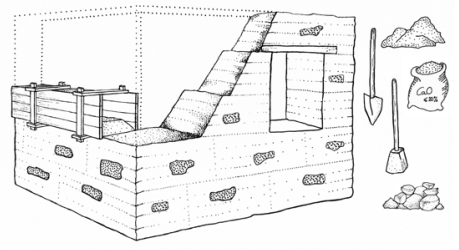

Tapia real careada con un mampuesto

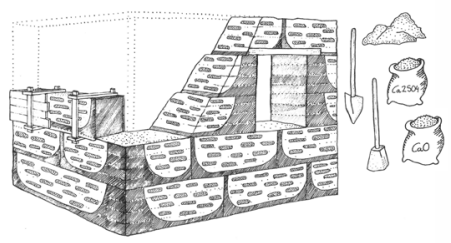

Tapia con brebcas careada con mampuestos

Tapia con brencas careada con ladrillos

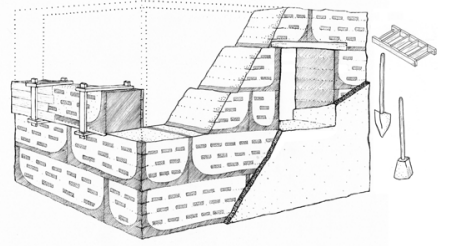

Tapias suplementadas en juntas

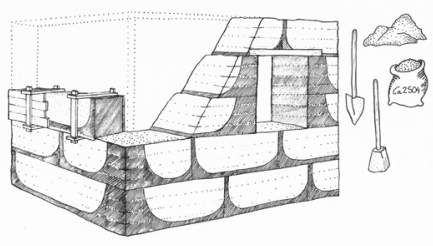

Tapia con brencas y refas

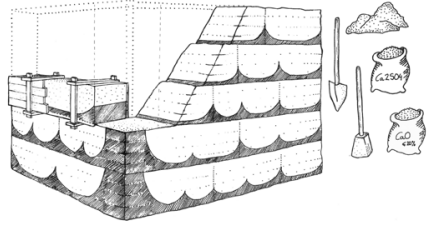

Tapia con medias brencas y rafas

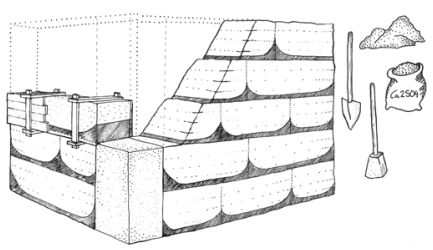

Tapia con brencas

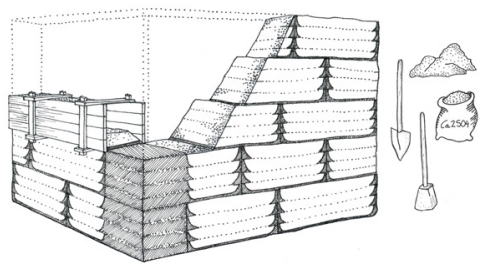

Tapia con brencas por tongadas 
Tapias suplementadas en juntas

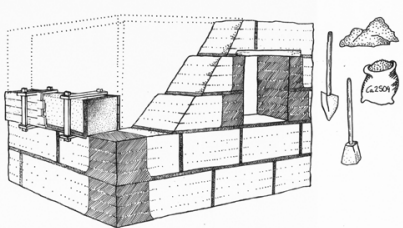

Tapia con juntas y rafas

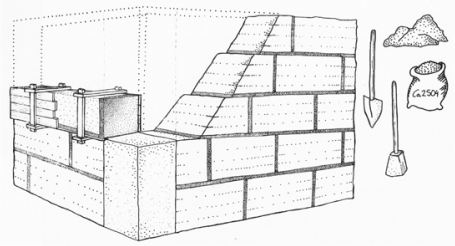

Tapia con juntas suplementadas

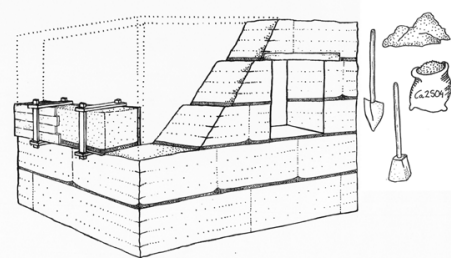

Tapia con juntas suplementadas

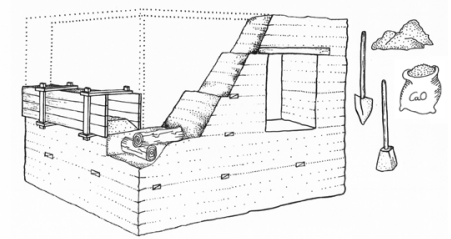

Tapia con armadura de troncos de madera

Principales variantes de tapia localizadas e
Tapias mixtas

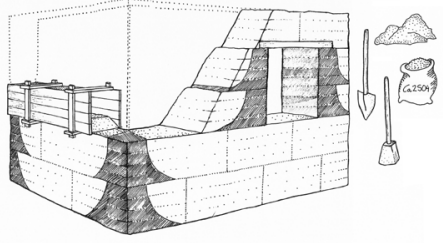

Tapia con rafas de yeso en las esquinas

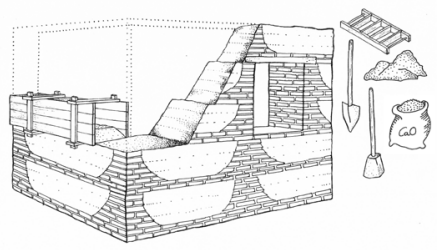

Tapia entre rafas y verdugadas de ladrillo

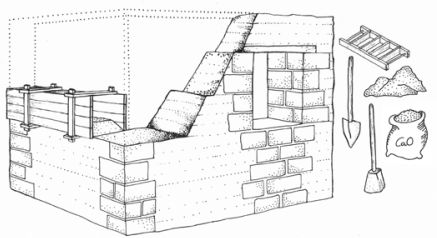

Tapia entre esquinas y machones de sillería

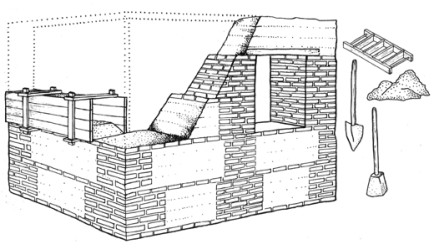

Tapias con revestimientos

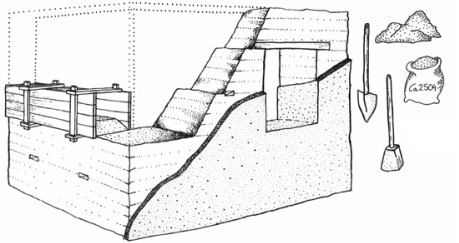

Tapia con enlucido de mortero de yeso

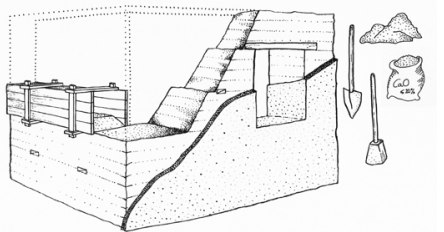

Tapia con enlucido de mortero de cal

Tapia con machones y verdugadas de ladrillo

ragón. Fuente: Proyecto Restapia (la restauración de la arquitectura de tapia en la Península Ibérica), autora: Lidia García Soriano 


\subsection{El adobe}

La construcción con adobes, o adobas como le denomina generalmente la gente local, constituye una de las principales técnicas constructivas de tierra en Aragón. Esta técnica, además de estar extendida por gran parte del territorio aragonés, en muchos casos constituye una de las principales técnicas de construcción dentro de los distintos núcleos de población.

Los adobes son piezas paralelepipédicas conformadas con la ayuda de moldes denominados adoberas o adoberos en las cuales se vierte la masa de tierra en estado plástico y se deja secar al aire libre (Fernandes y Tavares 2016). Las piezas varían de composición y dimensión dependiendo de distintos factores como la disposición en el muro, el tipo de suelo o el aparejo.

La composición de las piezas de adobe en Aragón es muy variada. El análisis visual de las piezas ha permitido obtener información de los estabilizantes utilizados en un número limitado de casos debido a la dificultad o imposibilidad de distinción por la presencia de revestimientos, el estado de las piezas o la distancia a estas; por ello debe entenderse como un estudio parcial. Los estabilizantes ayudan a controlar la capacidad de retracción y expansión, y en algunos casos las gravas también a aumentar su resistencia (Abad Alegría 1997). En el mayor número de casos el estabilizante utilizado son las fibras vegetales, con un 31\% de los casos y, en segundo lugar, los áridos, con un 15\%, si bien en ocasiones ambos aparecen combinados. La presencia de estabilizantes en la masa depende de muchos factores como los materiales disponibles en cada lugar, la calidad y cantidad de las cosechas de cada año o las propiedades de la tierra. Por ello, existen ejemplos en los que los adobes no presentan ningún estabilizante añadido. El color de las piezas está influenciado directamente por su composición que, en algunos casos, varía incluso dentro de una misma localidad o un edificio, lo que muestra la inmediatez y proximidad de los materiales utilizados para su conformación.

La dimensión de las piezas es muy variable y está en relación directa con el tipo de muro en el que se van a disponer. La dimensión y el aparejo de los muros varían principalmente entre los muros de cerramiento de adobe o tabiques en los que los adobes se disponen generalmente a soga o incluso a panderete, y los muros de carga de adobe que en su mayoría se disponen a tizón configurando muros de mínimo un pie. En ocasiones, en edificios de gran envergadura se realizan variaciones en la sección del muro modificando el aparejo y adaptándolo a los requerimientos (figura 6.30). Las dimensiones de los adobes en relación con los tipos de muro definidos también varían respondiendo a una optimización de uso de los materiales y de su puesta en obra (García-Soriano, Villacampa Crespo y Gómez-Patrocinio 2018). Por un lado, las dimensiones de los adobes utilizados en muros de cerramiento o tabiques varían entre 24 y $30 \mathrm{~cm}$ de largo, 10 y $13 \mathrm{~cm}$ de ancho y entre 4 y $10 \mathrm{~cm}$ de alto, siendo la dimensión más

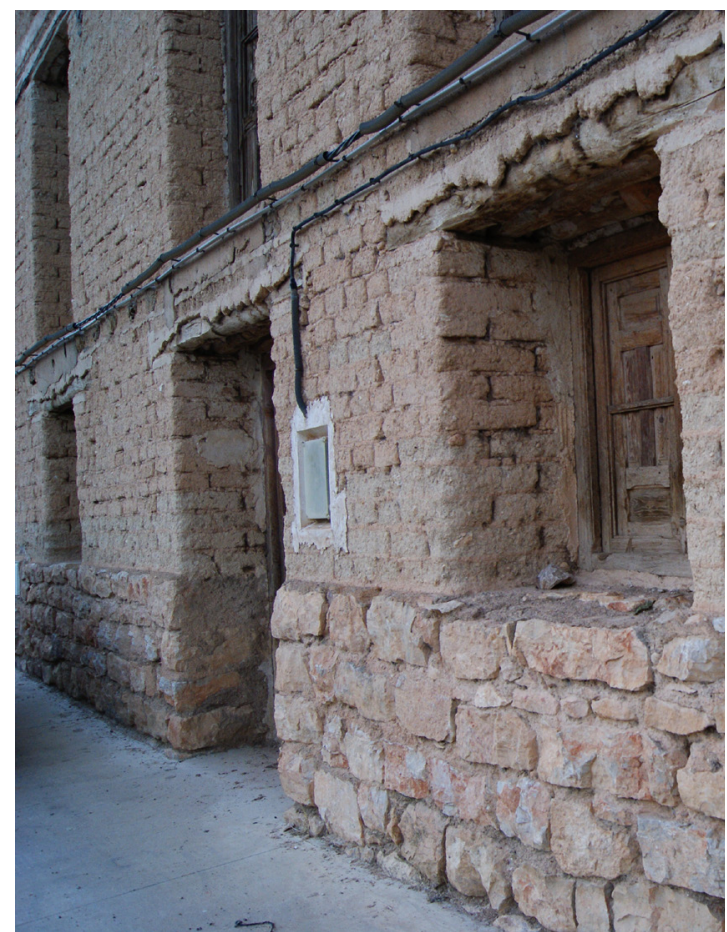

Figura 6.30. Cambio de la sección de un pie y medio en la planta baja a un pie en las plantas superiores. Embid de Ariza, Zaragoza. 
común de $28 \times 13 \times 9 \mathrm{~cm}$. Por otro lado, los adobes destinados a la construcción de muros de carga son ligeramente mayores y sus dimensiones normalmente están comprendidas entre 35 a $43 \mathrm{~cm}$ de largo, de 15 a $24 \mathrm{~cm}$ de ancho y de 9 a $16 \mathrm{~cm}$ de alto siendo la dimensión más común ${ }^{4}$ de $40 \times 18 \times 10 \mathrm{~cm}$, si bien, las dimensiones son muy variables entre piezas incluso dentro de una misma localidad (figura 6.31).

Existen diferentes tipos de muros de adobe en función de su disposición o aparejo. Sin embargo, las propias características constructivas de la técnica provocan que el número de variantes derivadas de incorporación de suplementos no sea tan extenso como sucede en el caso de la tapia.

\subsubsection{Variantes constructivas}

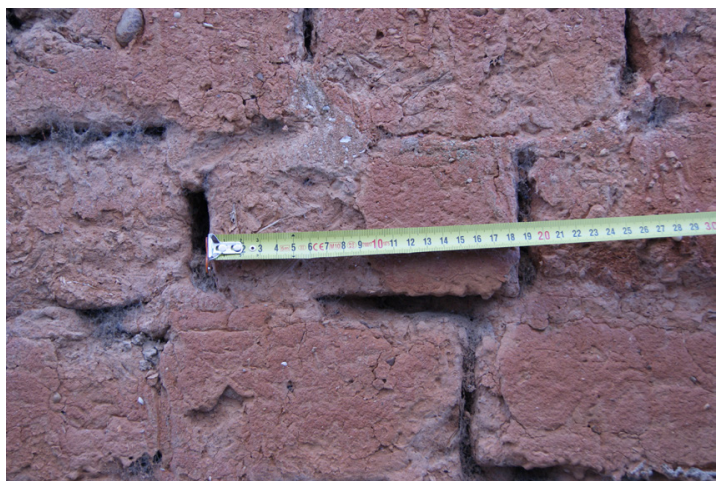

Figura 6.31. Medición de piezas de adobe. Jaraba, Zaragoza
4. Las dimensiones que comenta Abad Alegría en su publicación coincide con las recogidas en la toma de datos (Abad Alegría 1997)
La fábrica de adobe es un tipo de construcción que admite muchas variables tanto en la propia fabricación de la pieza como en su puesta en obra (Fernandes 2005). Aspectos como la composición de los adobes, los posibles estabilizantes utilizados o las dimensiones de las piezas son variables que hacen diferir unos muros de otros, pero están ligados a la propia fabricación del adobe y no a su puesta en obra. Por ello, en la clasificación de los muros se han desestimado estos aspectos derivados de esta fabricación previa de las piezas, así como su aparejo, y se ha atendido únicamente a las propiedades del muro en su conjunto y la combinación con otros elementos en su fábrica. Esto produce que el número de variantes y subvariantes se reduzca al quedar establecidas muchas variables antes de su construcción. Pese a ello, la propia configuración de los muros y los tipos de suplementos que se pueden incluir en la fábrica constituyen un amplio abanico de posibilidades.

Para el análisis de la primera muestra se han establecido cinco variantes o familias dentro de las cuales destacan la fábrica simple, la fábrica suplementada en juntas y la fábrica mixta. Sin embargo, también se han incluido por su interés el uso de los adobes como suplemento de otro tipo de fábricas y el uso de los bloques tierra-cemento.

En primer lugar, se han analizado los datos provenientes de la primera muestra que corresponde con el número de localidades donde se ha localizado la técnica constructiva de adobe y sus variantes. Se han localizado adobes en 180 localidades, lo que supone un $70 \%$ del total de localidades donde se hay presencia de construcciones en tierra (tabla 6.4)

Las fábricas simples de adobe es la fábrica más sencilla, ya que no tiene suplementos y es una de las variantes más comunes con un $59 \%$ de las localidades donde aparece el adobe. En la provincia de Zaragoza es donde esta variante tiene la mayor presencia tanto total (60 localidades) como relativa 
respecto a las otras variantes (65\%). Estas fábricas son, en general, fábricas de un pie que conforman la totalidad de los muros del edificio.

La fábrica suplementada en las juntas es una variante recurrente que se extiende en casi la mitad de los casos donde hay adobe. Esa variante aparece por todo el territorio, aunque su presencia relativa es menor en el caso de Huesca. La presencia de suplementos en las juntas (generalmente yeso o cal) es fácilmente distinguible ya que suele presentar otra coloración y cuando se produce una erosión o lavado del muro, las juntas permanecen en un plano saliente respecto al adobe. Además, existen ejemplos en los que el suplemento de conglomerante en las juntas se establece cada un cierto número de hiladas de adobe o unicamente en las esquinas del edificio (figura 6.32). En ocasiones puntuales, se han localizado casos en los que las juntas están suplementadas con piezas cerámicas o piedras de pequeña dimensión y proporciones planas (Figura 6.33).

La fábrica de adobe mixta es la variante predominante en todo el territorio y se localiza en el $79 \%$ de las localidades donde hay adobe. Esta variante contiene multitud de soluciones en función del material con el que se realizan los suplementos, que a su vez están íntimamente relacionados con los materiales disponibles de cada zona y las necesidades de las construcciones. En la clasificación de estos muros se ha creído pertinente distinguir entre los muros de adobe mixtos que conforman muros de carga y los muros mixtos donde la función principal del muro de adobe es la de cerramiento de la estructura porticada. Los muros de carga mixtos o fábricas mixtas con función estructural don muy frecuentes en la provincia de Huesca donde estos muros se conforman, en muchas ocasiones, con esquinas y machones de sillares. Sin embargo, en el caso los muros de cerramiento de adobe, fábricas mixtas no estructurales, su presencia es mucho mayor en la provincia de Teruel donde las piezas tienen generalmente dimensiones menores fruto de la optimización de los recursos materiales y del trabajo de puesta en obra, y se disponen con aparejo a soga o incluso a panderete (figura 6.34).

\begin{tabular}{|c|c|c|c|c|c|c|c|c|}
\hline \multirow{2}{*}{ ADOBE } & \multirow{2}{*}{\multicolumn{2}{|c|}{$\begin{array}{c}\text { ARAGÓN } \\
180\end{array}$}} & \multirow{2}{*}{\multicolumn{2}{|c|}{$\begin{array}{c}\text { TERUEL } \\
36\end{array}$}} & \multirow{2}{*}{\multicolumn{2}{|c|}{$\begin{array}{c}\text { ZARAGOZA } \\
92\end{array}$}} & \multirow{2}{*}{\multicolumn{2}{|c|}{$\frac{\text { HUESCA }}{52}$}} \\
\hline & & & & & & & & \\
\hline Familia /variante & № loc & \% loc & № $10 \mathrm{c}$ & $\%$ loc & № 100 & $\%$ loc & № loc & \% loc \\
\hline Fábrica simple & 106 & $59 \%$ & 17 & $47 \%$ & 60 & $65 \%$ & 29 & $56 \%$ \\
\hline Fábrica suplementada en juntas & 76 & $42 \%$ & 17 & $47 \%$ & 42 & $46 \%$ & 17 & $33 \%$ \\
\hline Fábrica mixta & 143 & $79 \%$ & 27 & $75 \%$ & 68 & $74 \%$ & 48 & $92 \%$ \\
\hline Mixta estructural & 114 & $63 \%$ & 8 & $22 \%$ & 59 & $64 \%$ & 47 & $90 \%$ \\
\hline Mixta no estructural & 55 & $31 \%$ & 23 & $64 \%$ & 23 & $25 \%$ & 9 & $17 \%$ \\
\hline Adobe como suplemento & 21 & $12 \%$ & 3 & $8 \%$ & 14 & $15 \%$ & 4 & $8 \%$ \\
\hline Bloques tierra-cemento & 36 & $20 \%$ & 6 & $17 \%$ & 16 & $17 \%$ & 14 & $27 \%$ \\
\hline
\end{tabular}

Tabla 6.4. Familias y variantes de adobe según la muestra de localidades. Porcentajes respecto al número de localidades con presencia de adobe

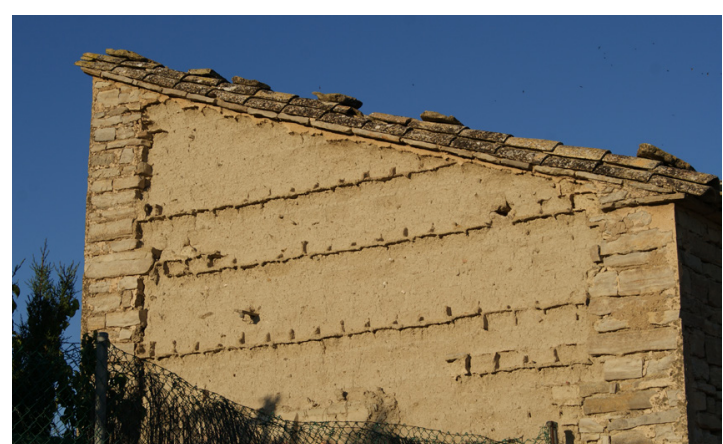

Figura 6.32. Adobe suplementado en hiladas alternas. Almudevar, Huesca

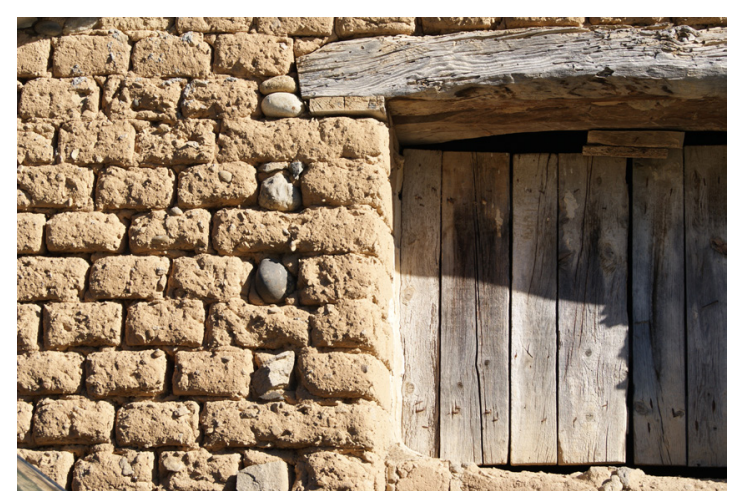

Figura 6.33. Piedras que forman parte del aparejo de los muros en las esquinas. Besians, Huesca. 


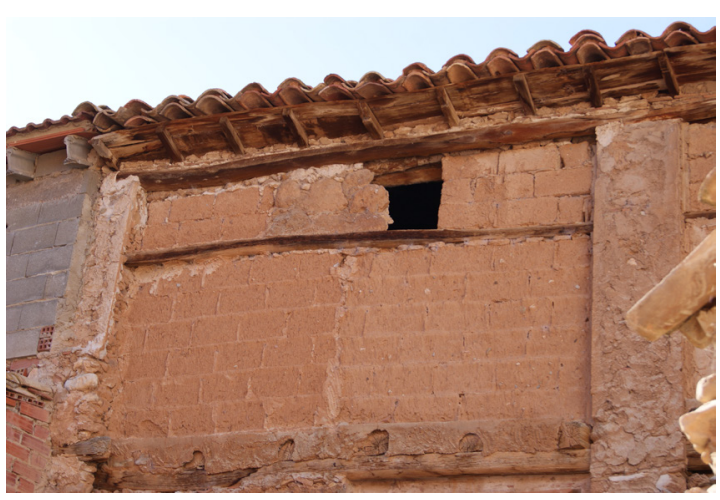

Figura 6.34. Fábrica mixta de adobe no estructural con aparejo a panderete. Martín del Río, Teruel.

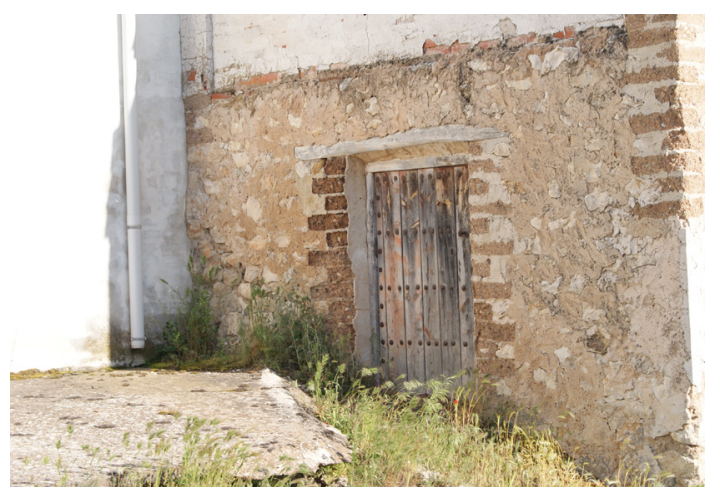

Figura 6.35. Adobe como suplemento de exquinas en muro de mampostería. Barrachina, teruel
Los adobes como suplemento y los bloques tierra-cemento son dos variables que en ocasiones están relacionadas, ya que son estos bloques tierra-cemento o nuevos adobes los que se utilizan para configurar las esquinas o machones que suplementan a los muros generalmente de mampostería, tapia o adobe (figura 6.35). Los adobes empleados como suplemento no están muy extendidos (12\%), aunque merecen especial mención por el uso de este tipo de material que comúnmente es considerado como poco duradero o débil para la conformación de las esquinas de algunos edificios.

Los bloques tierra-cemento son la evolución de los adobes tradicionales cuyo uso se extendió notablemente durante el periodo de industrialización como una readaptación de la construcción tradicional con adobe en la que se incluía el cemento como nuevo conglomerante. Este tipo de piezas se han localizado en un $20 \%$ de las localidades donde hay adobe.

Los porcentajes de técnicas y variantes de las dos muestras están relacionados, aunque algunas variantes como la fábrica mixta o la fábrica simple presentan mayor porcentaje en la muestra primera que es en la que se tienen en cuenta todas las localidades y sus construcciones. (tabla 6.5.). En la base de datos se ha completado la información referente a los materiales utilizados en los suplementos de las distintas variantes (tabla 6.6.).

La fábrica simple de adobe aparece en un 34\% de los 236 casos de estudio construidos con adobe que se concentran principalmente en las provincias de Zaragoza y Huesca.

\begin{tabular}{|c|c|c|c|c|c|c|c|c|}
\hline \multirow{2}{*}{ ADOBE } & \multirow{2}{*}{\multicolumn{2}{|c|}{$\frac{\text { ARAGÓN }}{236}$}} & \multirow{2}{*}{\multicolumn{2}{|c|}{$\begin{array}{l}\text { TERUEL } \\
41\end{array}$}} & \multirow{2}{*}{\multicolumn{2}{|c|}{$\begin{array}{c}\text { ZARAGOZA } \\
125 \\
\end{array}$}} & \multirow{2}{*}{\multicolumn{2}{|c|}{$\begin{array}{c}\text { HUESCA } \\
70\end{array}$}} \\
\hline & & & & & & & & \\
\hline Familia /variante & casos & $\%$ & casos & $\%$ & casos & $\%$ & casos & $\%$ \\
\hline Fábrica simple & 81 & $34 \%$ & 5 & $12 \%$ & 55 & $44 \%$ & 21 & $30 \%$ \\
\hline Fábrica suplementada en juntas & 56 & $24 \%$ & 23 & $56 \%$ & 23 & $18 \%$ & 10 & $14 \%$ \\
\hline Horizontales & 32 & $14 \%$ & 10 & $24 \%$ & 17 & $14 \%$ & 5 & $7 \%$ \\
\hline Verticales & 1 & $0 \%$ & 0 & $0 \%$ & 0 & $0 \%$ & 1 & $1 \%$ \\
\hline Horizontales y verticales & 23 & $10 \%$ & 13 & $32 \%$ & 6 & $5 \%$ & 4 & $6 \%$ \\
\hline Fábrica mixta & 128 & $54 \%$ & 24 & $59 \%$ & 58 & $46 \%$ & 46 & $66 \%$ \\
\hline Verdugadas & 0 & $0 \%$ & 0 & $0 \%$ & 0 & $0 \%$ & 0 & $0 \%$ \\
\hline Esquinas & 60 & $25 \%$ & 13 & $32 \%$ & 30 & $24 \%$ & 17 & $24 \%$ \\
\hline Machones & 62 & $26 \%$ & 11 & $27 \%$ & 24 & $19 \%$ & 27 & $39 \%$ \\
\hline Esquinas y verdugadas & 2 & $1 \%$ & 0 & $0 \%$ & 1 & $1 \%$ & 1 & $1 \%$ \\
\hline Machones y verdugadas & 4 & $2 \%$ & 0 & $0 \%$ & 3 & $2 \%$ & 1 & $1 \%$ \\
\hline Como suplemento & 16 & $7 \%$ & 3 & $7 \%$ & 8 & $6 \%$ & 5 & $7 \%$ \\
\hline Con elementos de protección & 60 & $25 \%$ & 10 & $24 \%$ & 29 & $23 \%$ & 21 & $30 \%$ \\
\hline
\end{tabular}

Tabla 6.5. Tabla de variantes y subvariantes de las fábricas de adobe. Datos obtenidos de los casos analizados con la ficha de estudio. 
La fábrica suplementada en juntas está presente en un $24 \%$ de los casos de los cuales la mayoría se encuentran en las provincias de Teruel y en la de Zaragoza. En todos los casos el principal suplemento es el yeso o la cal dependiendo de la disponibilidad de cada lugar que, en el caso de Teruel son comunes tanto en la junta horizontal como en horizontales y verticales, mientras que en Zaragoza y Huesca predominan los suplementos únicamente en la junta horizontal.

Las fábricas mixtas, al igual que en los resultados de la muestra primera, son la variante más común con un $54 \%$ de los casos. Existe un predominio claro de suplementos verticales en todo el territorio, ya sea únicamente en las esquinas (25\%), o también en puntos intermedios en forma de machones (26\%); y solo en un $3 \%$ de los casos estos van acompañados de suplementos horizontales en forma de verdugadas. En cuanto a los materiales utilizados como suplemento existe un predominio de la piedra y el ladrillo en las provincias de Zaragoza y Huesca, mientras que, en Teruel, por la abundancia y la gran tradición constructiva con yeso, las esquinas y machones se realizan en su mayoría con mampostería encofrada con yeso.

El adobe como suplemento se ha localizado en $7 \%$ de los casos y en todos ellos funcionan como suplemento de una fábrica mixta en esquinas y machones.

Por otro lado, a través de la ficha también se han analizado los elementos de protección de los muros de adobe con un predominio de los revestimientos de cal o yeso con un $25 \%$ de los casos.

\begin{tabular}{|c|c|c|c|c|c|c|c|c|c|}
\hline \multirow{3}{*}{\multicolumn{2}{|c|}{$\begin{array}{c}\text { ADOBE } \\
\text { Materialidad suplementos } \\
\text { Familia/variante }\end{array}$}} & \multirow{2}{*}{\multicolumn{2}{|c|}{$\begin{array}{c}\text { ARAGÓN } \\
236\end{array}$}} & \multirow{2}{*}{\multicolumn{2}{|c|}{$\begin{array}{c}\text { TERUEL } \\
41 \\
\end{array}$}} & \multirow{2}{*}{\multicolumn{2}{|c|}{$\begin{array}{c}\text { ZARAGOZA } \\
125\end{array}$}} & \multirow{2}{*}{\multicolumn{2}{|c|}{$\begin{array}{c}\text { HUESCA } \\
70\end{array}$}} \\
\hline & & & & & & & & & \\
\hline & & casos & $\%$ & casos & $\%$ & casos & $\%$ & casos & $\%$ \\
\hline \multicolumn{2}{|c|}{ Suplementada en juntas } & 56 & & 23 & & 23 & & 10 & \\
\hline & Tejas /cerámico & 1 & $0 \%$ & 0 & $0 \%$ & 0 & $0 \%$ & 1 & $1 \%$ \\
\hline & Cal / Yeso & 53 & $22 \%$ & 23 & $56 \%$ & 23 & $18 \%$ & 9 & $13 \%$ \\
\hline \multicolumn{2}{|l|}{ Mixtas } & 128 & & 24 & & 58 & & 46 & \\
\hline & Ladrillo & 40 & $17 \%$ & 2 & $5 \%$ & 19 & $15 \%$ & 19 & $27 \%$ \\
\hline & Piedra & 51 & $22 \%$ & 6 & $15 \%$ & 27 & $22 \%$ & 18 & $26 \%$ \\
\hline & Adobe & 7 & $3 \%$ & 0 & $0 \%$ & 4 & $3 \%$ & 3 & $4 \%$ \\
\hline & Mampostería y yeso & 21 & $9 \%$ & 15 & $37 \%$ & 5 & $4 \%$ & 1 & $1 \%$ \\
\hline & Mixtos & 7 & $3 \%$ & 0 & $0 \%$ & 2 & $2 \%$ & 5 & $7 \%$ \\
\hline & Madera & 2 & $1 \%$ & 1 & $2 \%$ & 1 & $1 \%$ & 0 & $0 \%$ \\
\hline \multicolumn{2}{|c|}{ Elementos de protección } & 60 & & 10 & & 29 & & 21 & \\
\hline & Revestimientos & 59 & $25 \%$ & 10 & $24 \%$ & 28 & $22 \%$ & 21 & $30 \%$ \\
\hline & Piedra & 1 & $0 \%$ & 0 & $0 \%$ & 1 & $1 \%$ & 0 & $0 \%$ \\
\hline
\end{tabular}

Tabla 6.6. Tabla de los materiales utilizados como suplemento en cada una de las variantes. 


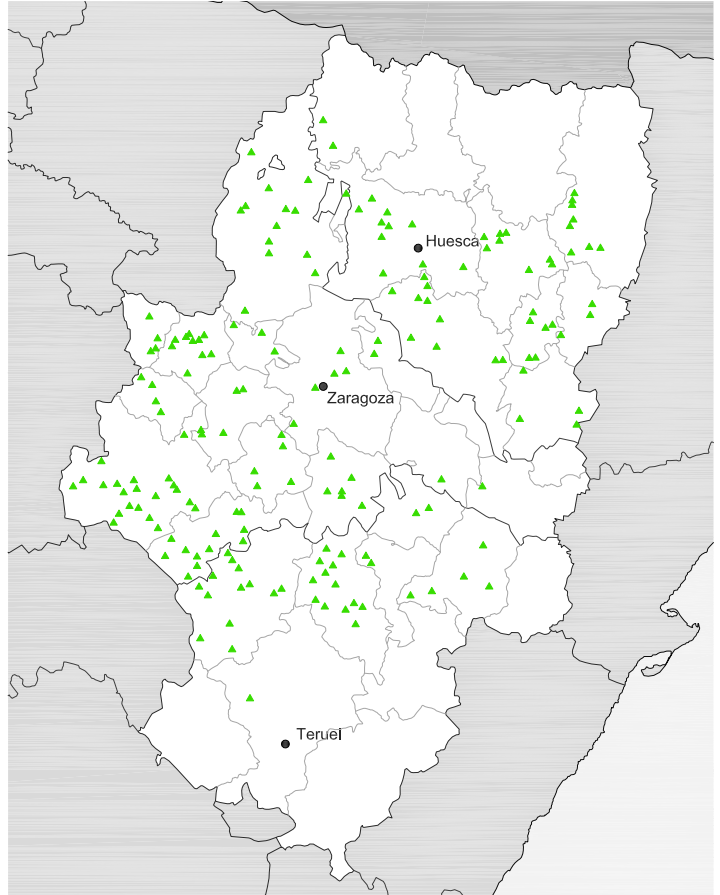

Figura 6.36. Localización construcciones de adobe

\subsubsection{Distribución geográfica}

Las variantes de muros de adobe están relacionadas directamente con la función o el tipo de cerramiento que conforma y los requerimientos y materiales disponibles del entorno o lugar en el que se encuentra. La técnica constructiva del adobe predomina en la zona central del territorio aragonés que engloba la parte norte de Teruel y la zona sur de Huesca, y que corresponde principalmente con la cuenca del Ebro y parte del sistema Ibérico en el sur (figura 6.36).

La extensión territorial de la fabrica de adobe simple es similar a la de la técnica del adobe en su conjunto. Esta variante, aunque localizada en menos puntos, se encuentra por todo el territorio debido a que es la forma más simple de muro de adobe y no tiene de ningún material como suplemento.

La fábrica de adobe suplementada en juntas aparece a lo largo del Sistema Ibérico en la parte sur del Ebro ligado a su amplia tradición del uso del yeso y en la parte norte, esta variante aparece principalmente en la provincia de Huesca, aunque con una frecuencia mucho menor.

La fábrica mixta, es la variante más común en todo el territorio y su presencia se extiende por todo el territorio donde hay adobe. Las fábricas mixtas con función de muro de carga se extienden principalmente en la provincia de Zaragoza y Huesca, a excepción del propio valle del Ebro donde la presencia es más reducida. Cabe destacar el uso de distintos materiales para la realización de estos suplementos. En Huesca los suplementos se construyen indistintamente con piedra, generalmente trabajada, y ladrillo, si bien, existen áreas o localidades con una amplia tradición constructiva en ladrillo como Alquézar, Barbastro o Sariñena, donde predomina el uso de este material. En la provincia de Zaragoza la situación es similar. En áreas como la de Tarazona, Calatayud, Cariñena o Daroca el uso del ladrillo está muy extendido por lo que predomina generalmente el uso de este material. Si bien, en la comarca de las Cinco Villas predomina el adobe con sillares en las esquinas. Cabe destacar por su peculiaridad el uso reiterado de cantos rodados para conformar las esquinas en la comarca de Campo de Borja (figura 6.37). Por otro lado, los casos en los que el adobe funciona como cerramiento, y pierde su función estructural, predominan en el norte de Teruel, concretamente en las comarcas de las Cuencas Mineras y el Jiloca, donde los pilares de esquinas y machones se realizan principalmente con mampostería y yeso encofrados. Este tipo de muros mixtos se extienden por todo el territorio, pero de forma más dispersa. Además, muchos de los casos anteriores aparecen también suplementados en las juntas con yeso.

El adobe como suplemento no se localiza en un área concreta, sino que los ejemplos se localizan dispersos por todo el territorio. Se puede distinguir una mayor presencia en el oeste de la comunidad y en la provincia de Zaragoza, pero sin una relación concreta entre ellos. 
Los bloques de tierra cemento también se extienden por todo el territorio, pero se distingue una presencia mayor en el noroeste de Zaragoza y en el sur de Huesca, donde en muchas ocasiones a su vez funcionan como suplementos en esquina y machones de otras fábricas (Figura 6.38).

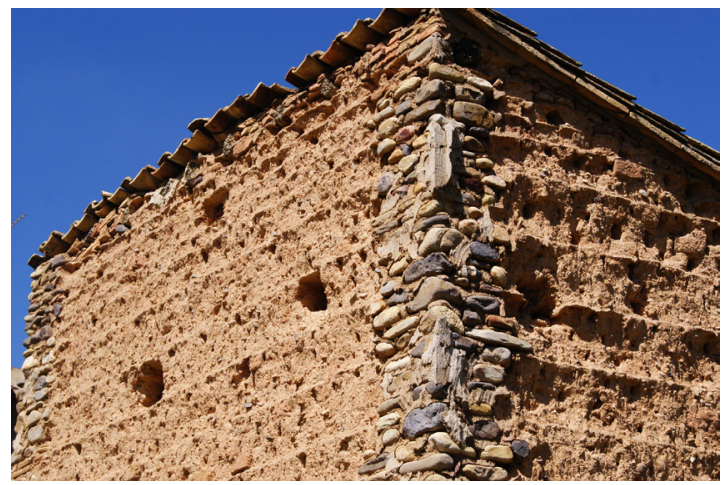

Figura 6.37. Esquina de cantos rodado en muro de adobe. Bulbuente, Zaragoza.

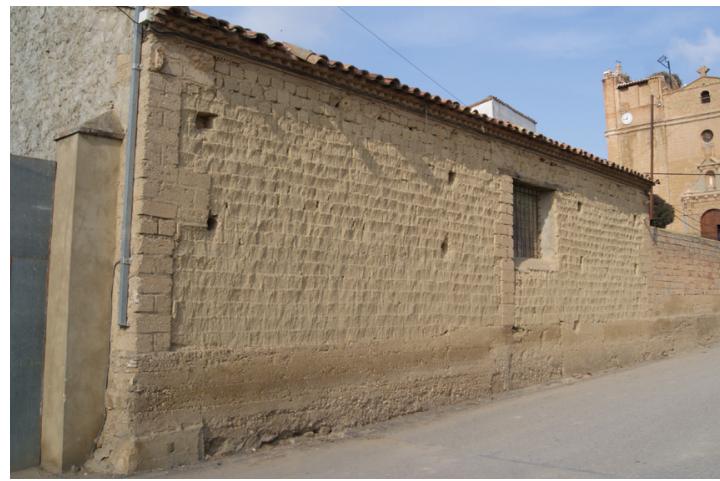

Figura 6.38. Bloque de tierra cemento como suplemento de una fábrica de adobe tradicional. Almuniente, Huesca.

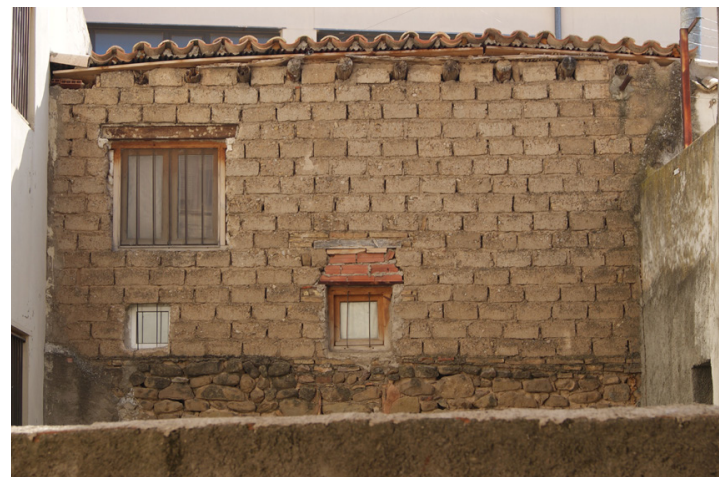

Figura 6.39. Construcción con bloque de tierra cemento. Loarre, Huesca

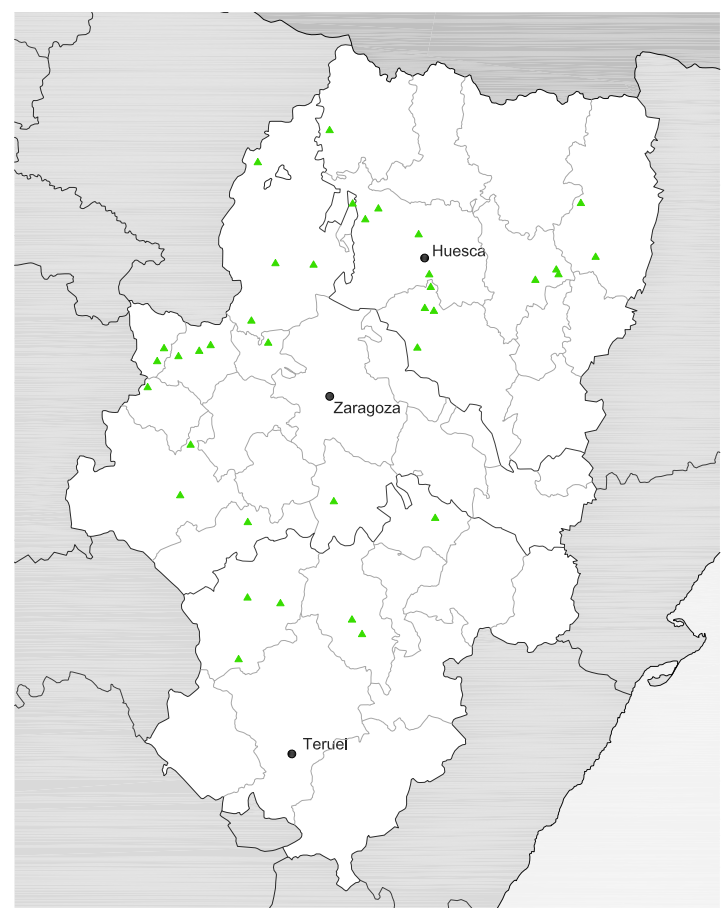

Figura 6.40. Localización fábricas con bloques tierracemento 


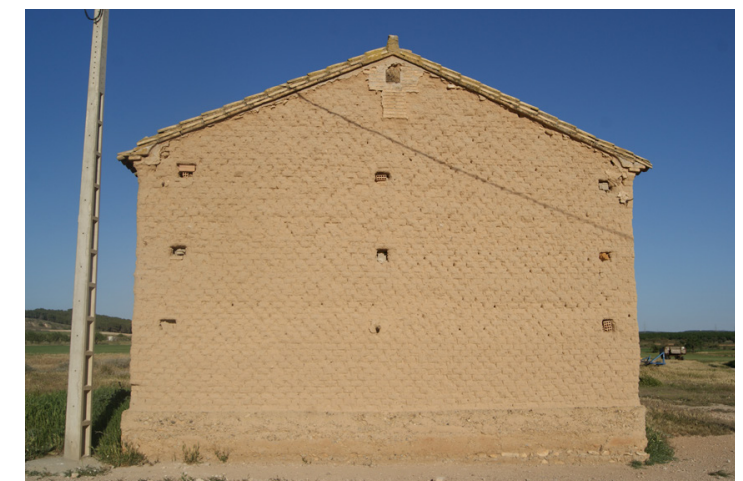

Figura 6.41. Fábrica de adobe simple. Peñaflor, Zaragoza

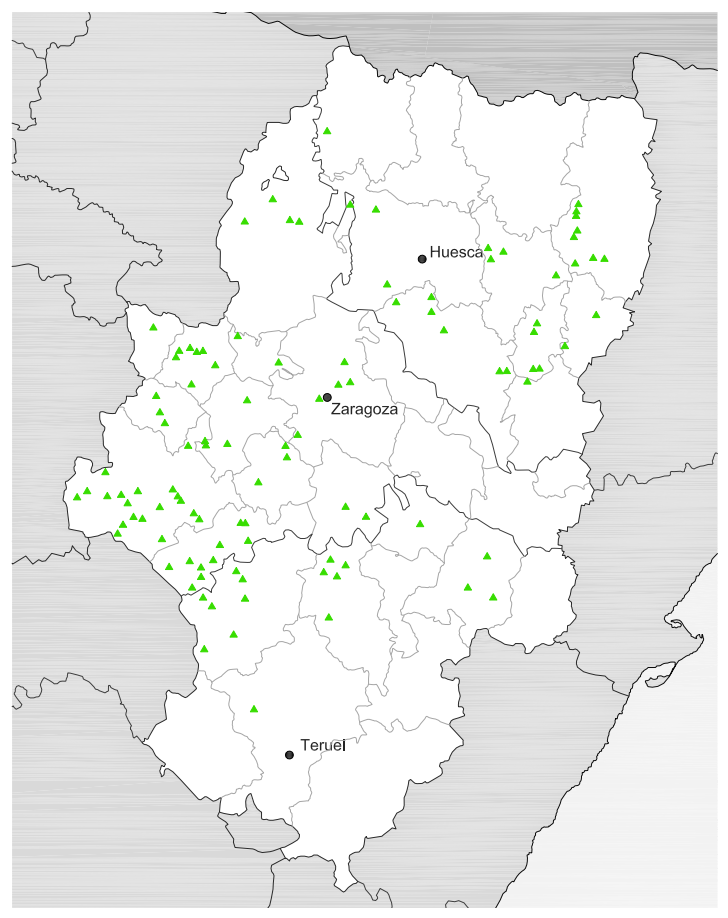

Figura 6.42. Localización fábrica de adobe simple

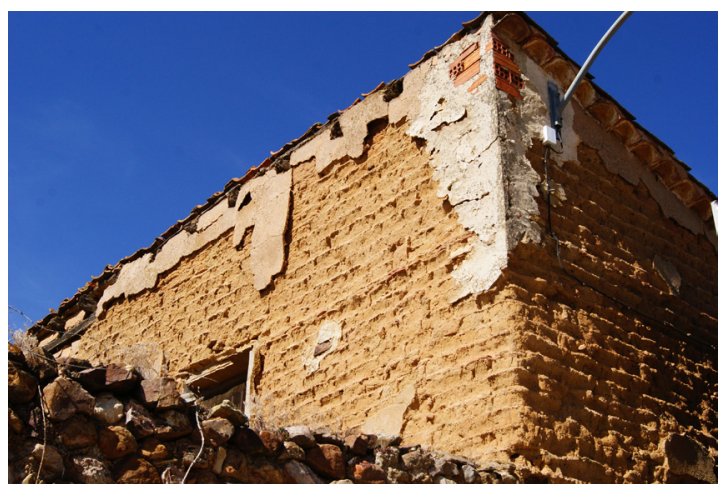

Figura 6.43. Fábrica suplementada en juntas. Used, Zaragoza

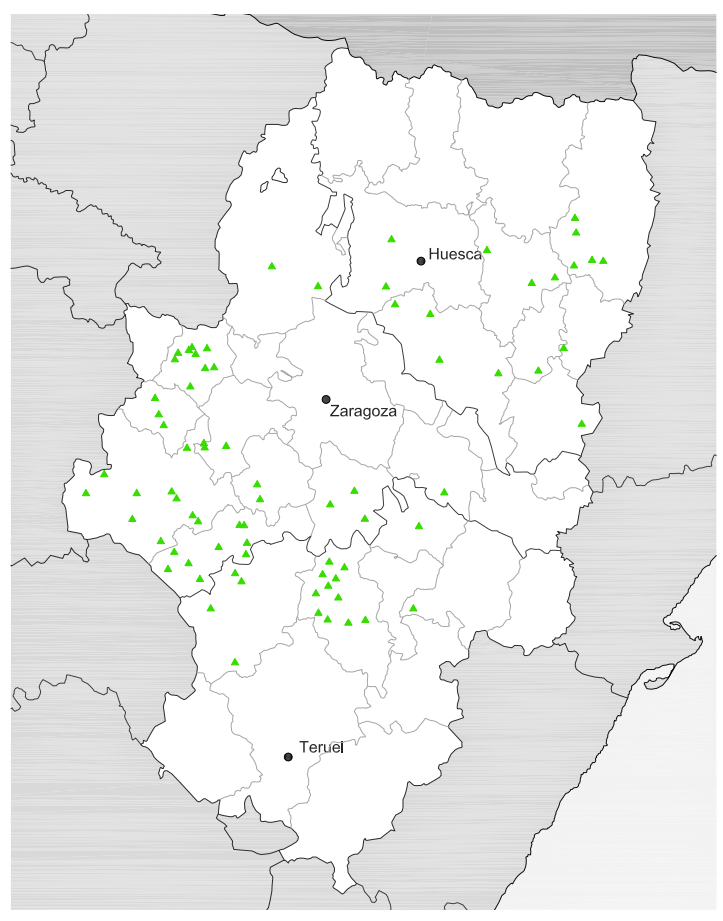

Figura 6.44. Localización fábrica de adobe suplementada en juntas

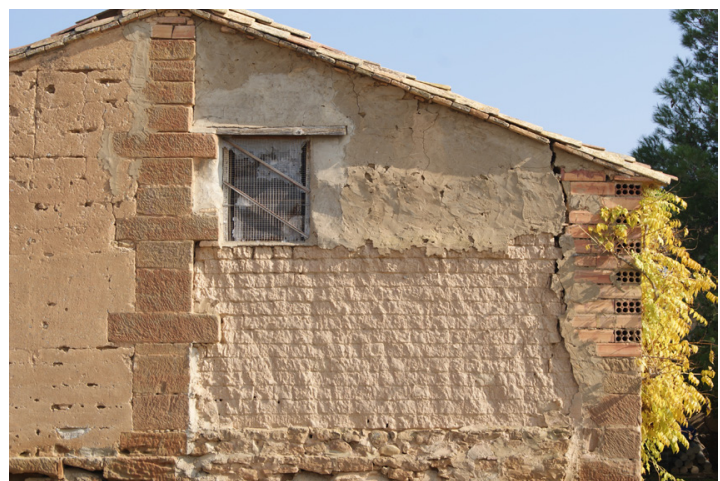

Figura 6.45. Fábrica mixta de adobe. Grañén, Huesca

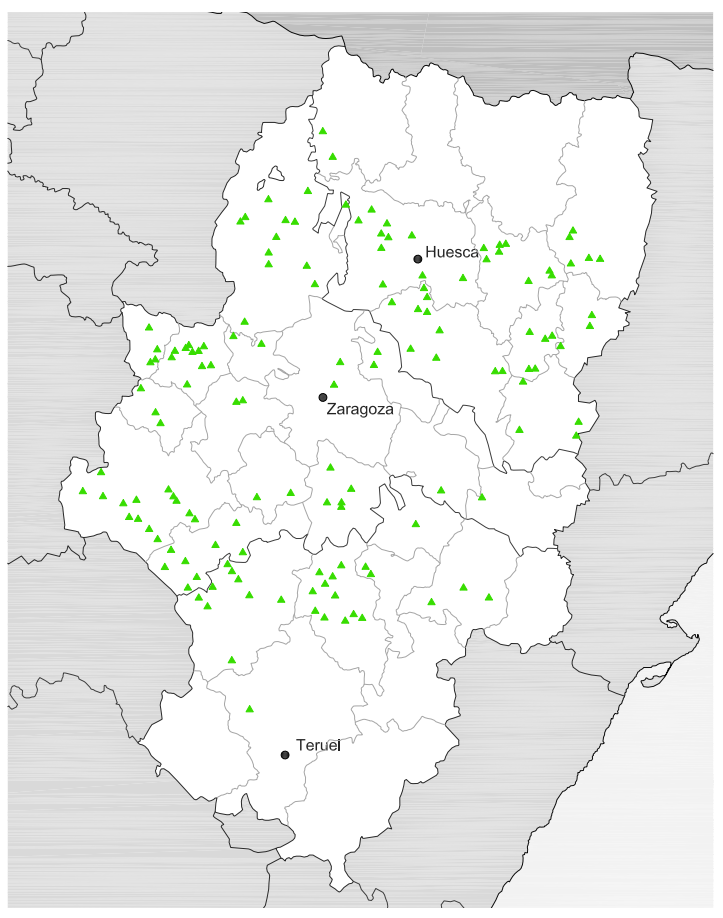

Figura 6.46. Localización fábrica mixta de adobe 


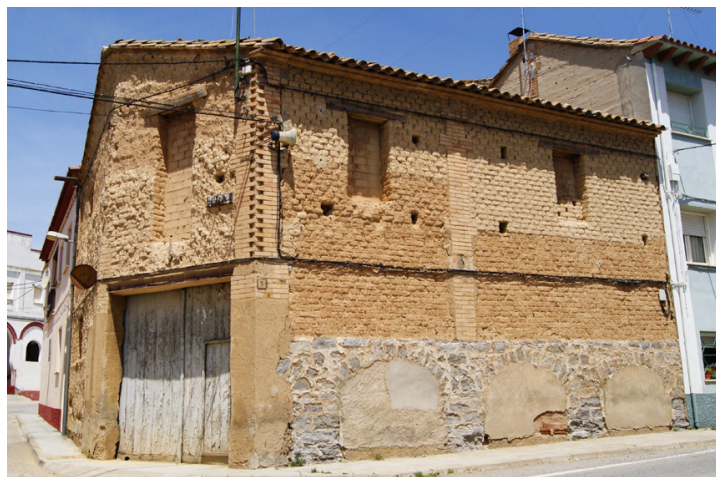

Figura 6.47. Fábrica mixta de adobe (estructural). Alcampell, Huesca

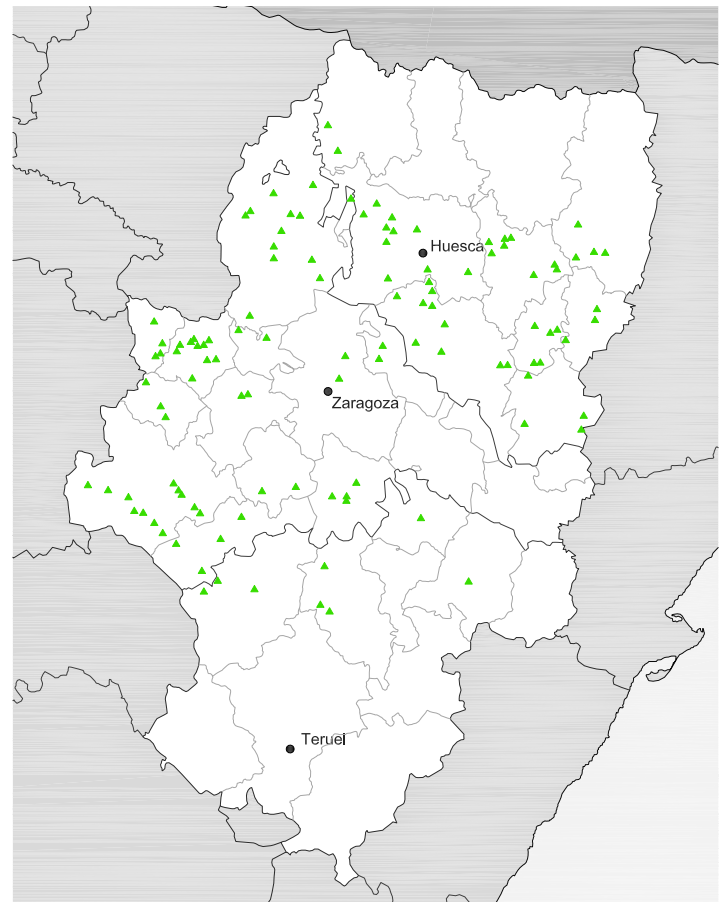

Figura 6.48. Localización fábrica mixta de adobe estructural

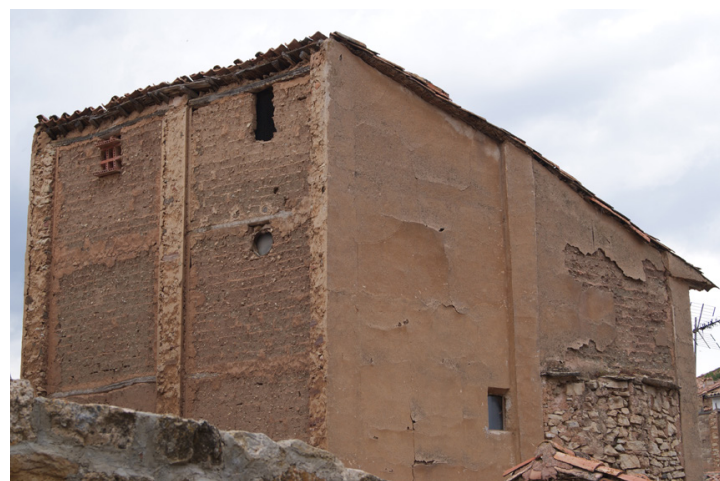

Figura 6.49. Fábrica de adobe mixta (no estructural). La Hoz de la Vieja, Teruel

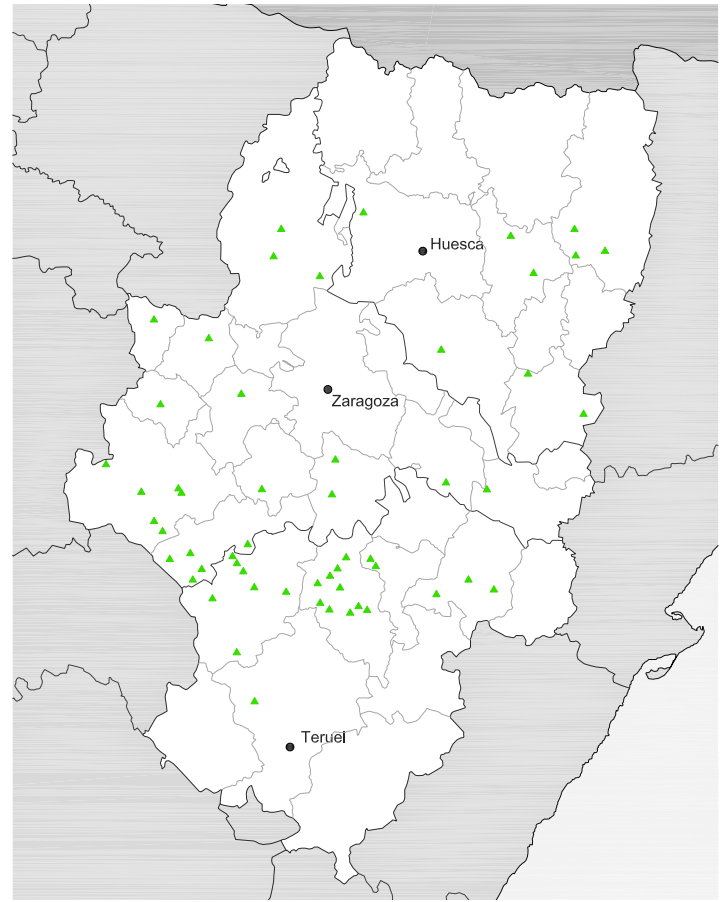

Figura 6.50. Localización fabrica mixta de adobe no estructural

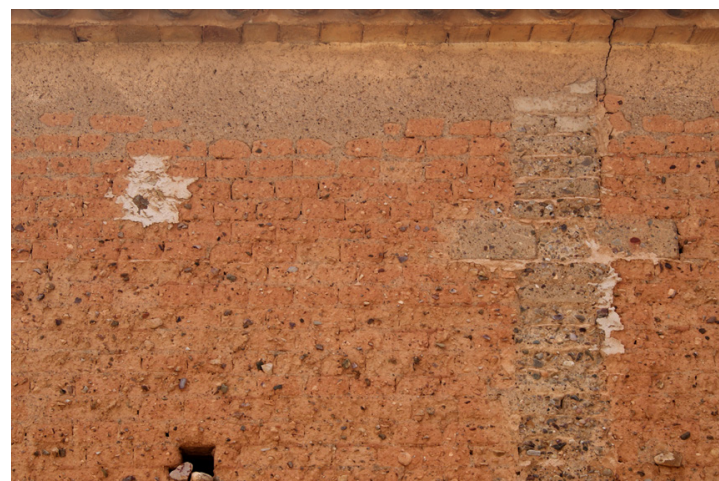

Figura 6.51. Adobe como suplemento. Azuara, Zaragoza

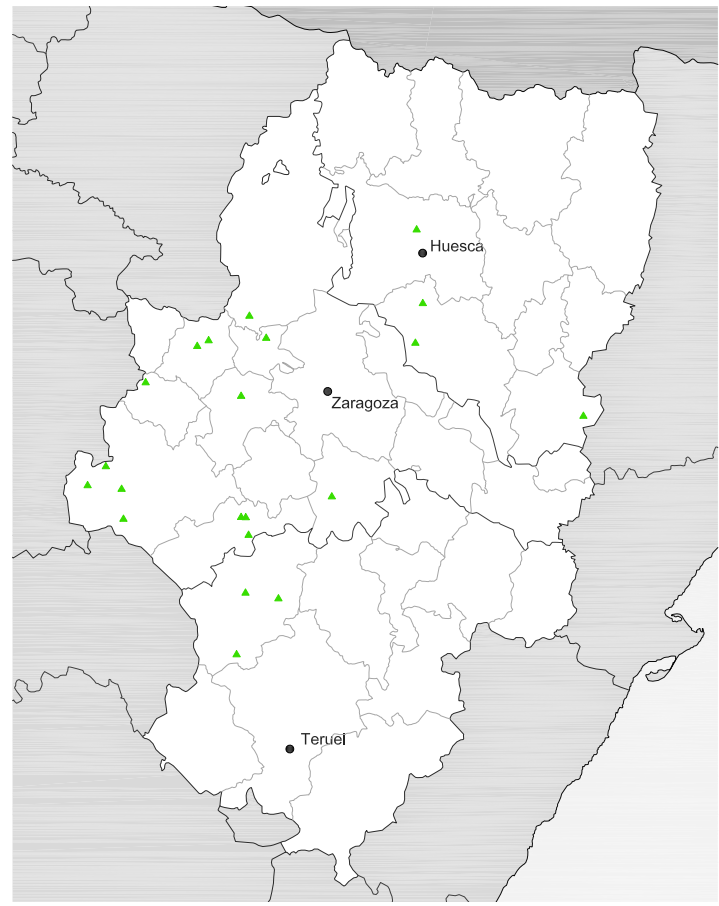

Figura 6.52. Localización adobe como suplemento 
Fábricas simples de adobe

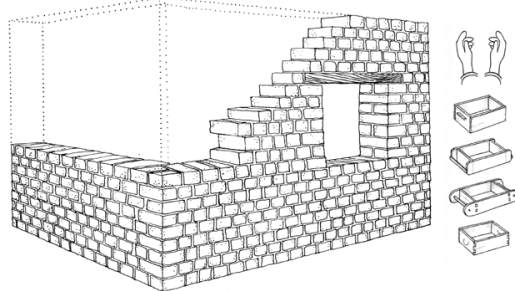

Fábrica simple a tizón

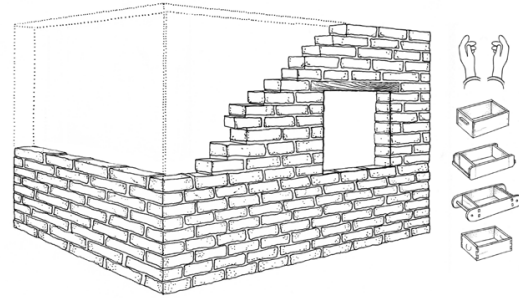

Fábrica simple a soga
Fábricas suplementadas en juntas

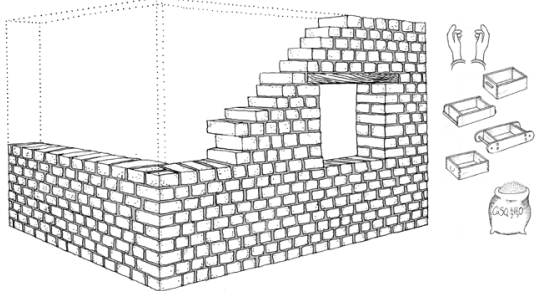

Fábrica de adobe con juntas de yeso

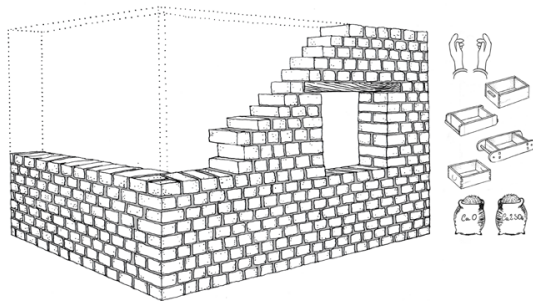

Fábrica de adobe con juntas de cal

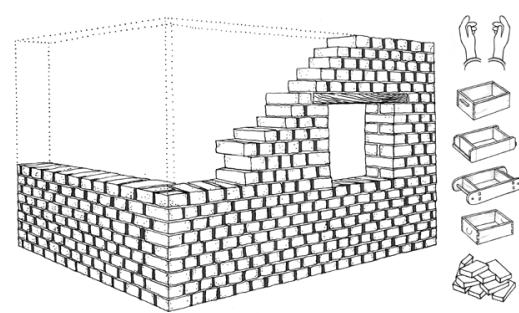

Fábrica de adobe con ladrillos en las juntas

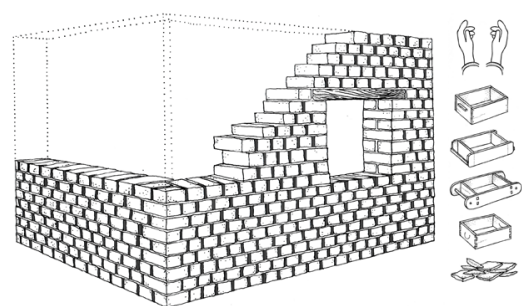

Fábrica de adobe con piedras en las juntas
Fábricas mixtas de adobe

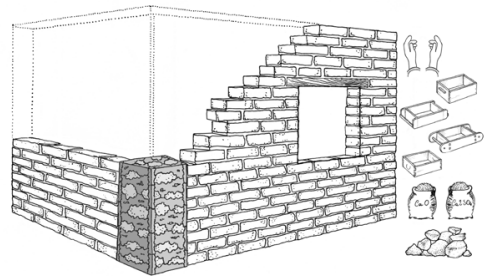

Adobe con machones de yeso y mampuestos

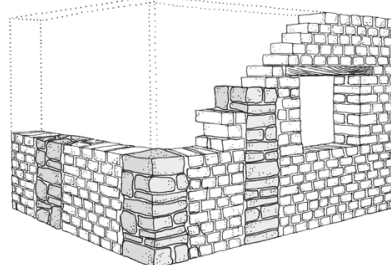

Adobe con machones de piedra

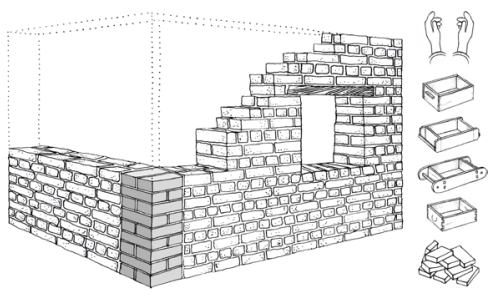

Adobe con machones de ladrillo

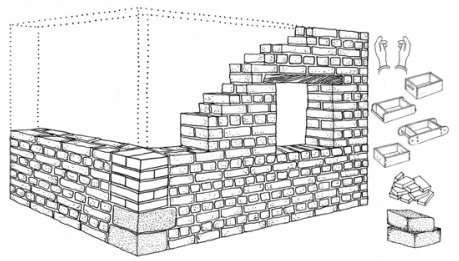

Adobe con machones mixtos
Fábricas mixtas de adobe / protección

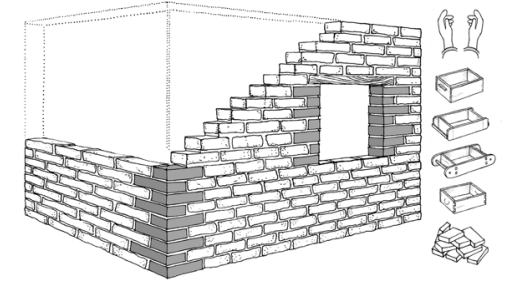

Adobe con canoneras de ladrillo en esquinas

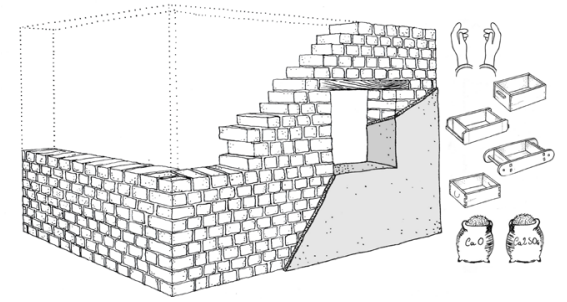

Adobe con revestimiento de yeso o cal

Principales variantes de adobe localizadas en Aragón. Fuente: proyecto SOStierra: la restauración y la rehabilitación de la arquitectura tradicional de tierra en la Península Ibérica. Líneas guía y herramientas para una intervención sostenible, autores: Lidia García Soriano, F. Javier Gómez Patrocinio, Marina Elia, Giorgia di Domenico y Giulia Ratti. 


\subsection{Los entramados con tierra}

Los entramados rellenos con tierra son una técnica mucho menos frecuente que la del adobe y la tapia, si bien en algunas zonas aparecen de forma reiterada y con unas características propias.

Los entramados en Aragón se localizan principalmente a partir de la primera planta, o en el interior de los edificios configurando la tabiquería, donde están protegidos de la humedad que afecta directamente a la degradación tanto del relleno como de la madera. El uso de este tipo de entramado en la configuración de las particiones interiores complica su identificación o la imposibilita en la mayoría de los casos debido a la incapacidad de acceso a los edificios.

Las estructuras de los entramados se componen únicamente con montantes verticales en la mayoría de los casos, aunque en algunos casos se suplementan con elementos horizontales intermedios y en contadas ocasiones presentan elementos diagonales. La distancia entre montantes verticales varía notablemente entre los distintos ejemplos desde menos de $40 \mathrm{~cm}$ a $120 \mathrm{~cm}$ aproximadamente y en algunas ocasiones esta dimensión varía incluso dentro del mismo edificio.

La altura de los montantes suele ser de una planta, aunque si este presenta elementos horizontales intermedios la altura total se ve reducida. En cuanto a las piezas de madera que configuran el entramado presentan tanto la sección escuadrada como la sección de los rollizos sin trabajar en proporciones similares y una dimensión entre 10 y $20 \mathrm{~cm}$ aproximadamente. La madera dispuesta de forma horizontal a la altura de los forjados también es escuadrada o en forma de rollizo indistintamente y su dimensión es ligeramente superior a la de los montantes, entre 20 y $30 \mathrm{~cm}$ generalmente.

Por otro lado, en Aragón la mayor parte de los entramados no constituyen la totalidad del edificio, sino que aparecen de forma parcial en alguno de sus cerramientos. Suele tratase de casos en los que la fachada principal está construida con un muro de carga y el entramado configura el cerramiento del muro piñón o casos en los que el edificio tiene una estructura porticada y las luces entre apoyos se subdividen con este sistema para conformar el cerramiento con distintos tipos de relleno.

\subsubsection{Variantes constructivas}

Las variantes constructivas de los entramadosse han establecido en relaciónal rellenoy noa la configuración y disposición de los elementos de madera, por ello el número de variantes es más reducido (tabla 6.7.).

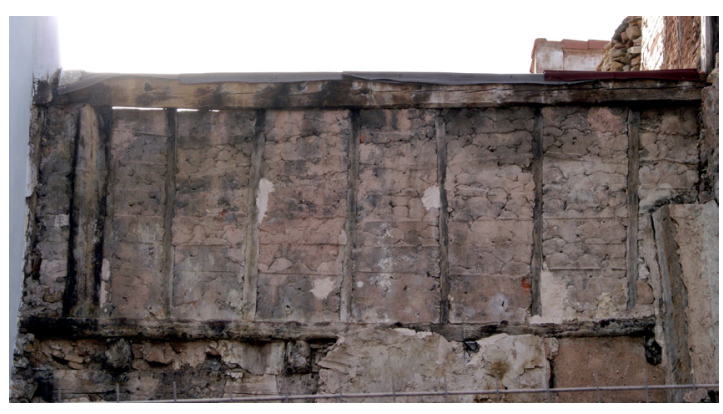

Figura 6.53. Entramado con pellas de tierra y yeso sobre un encofrado. Moscardon, Teruel. 


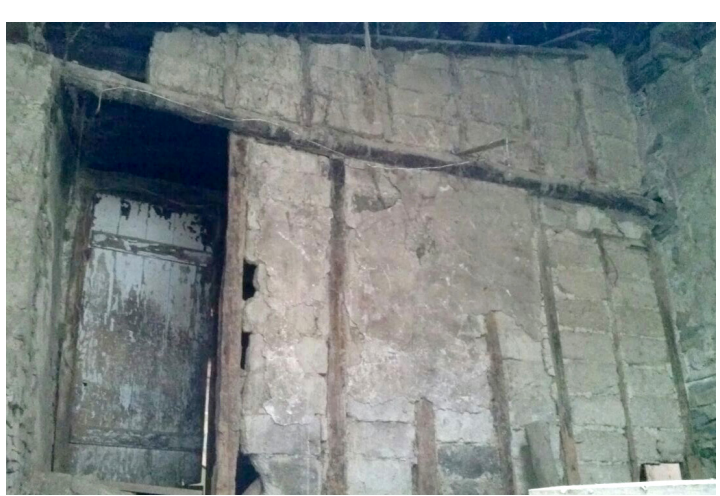

Figura 6.54. Entramado con adobe interior. Santa Engracia de Jaca, Huesca. Autor: Pedro Bel

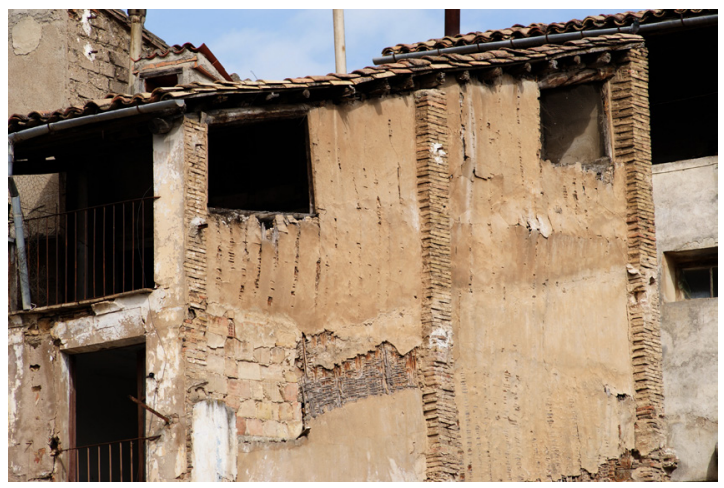

Figura 6.55. Cerramiento de entramado con cañizo en el muro piñon. Barbastro, Huesca
Los entramados con relleno monolítico se sitúan en más de la mitad de las localidades de la muestra total de entramados (56\%) de los cuales, casi la totalidad están en la provincia de Teruel donde representan el $73 \%$ de los ejemplos. Los rellenos monolíticos pueden estar configurados de distintas formas, aunque, en el caso de Aragón prácticamente la totalidad son relleno con tierra, yeso y mampuestos o tapialete. Este relleno se configura con la ayuda de un encofrado y gracias al fraguado del yeso que le permite adquirir la resistencia necesaria. También se ha localizado algún caso en el que el relleno se configura con una variante de pared de mano que contiene yeso en la mezcla, donde se pueden distinguir las trazas de las pellas de material colocadas unas sobre otras con la ayuda de un encofrado (figura 6.53). La dimensión entre montantes en estos casos es muy variable desde $40 \mathrm{~cm}$ a $120 \mathrm{~cm}$, si bien, es más común que esté alrededor de $100 \mathrm{~cm}$

Los entramados con relleno de piezas o adobes se localizan en el 36\% de los casos principalmente en la provincia de Teruel y Zaragoza. Estos entramados se sitúan en la mayor parte de los casos en muros piñón, medianeros o interiores. Las piezas de adobe, por lo general, tienen dimensiones menores que las que conforman los muros de carga y se disponen a soga o a panderete por lo que los muros tienen un espesor reducido. La distancia entre montantes de los entramados con este tipo de relleno es generalmente menor que en el caso de rellenos monolíticos. Las dimensiones varían de $40 \mathrm{~cm}$ hasta $100 \mathrm{~cm}$, si bien es común que para tabiquería interior este alrededor de $40-60 \mathrm{~cm}$ y en el exterior sea ligeramente superior, entre 60 y $80 \mathrm{~cm}$ (figura 6.54)

Los entramados con relleno tejido son la variante con el espesor de cerramiento más reducido. Este tipo de relleno se localiza tanto en muros de cerramiento exteriores como en tabiquería (figura 6.55). Es la variante de la que menos casos se han localizado, un $16 \%$, concentrados principalmente en la provincia de Teruel donde predominan los encañizados con yeso y tierra que son cerramientos de graneros o edificios secundarios destinados a la ganadería o la agricultura principalmente. Uno de los casos localizados en la provincia de Huesca corresponde con el único caso hallado de encestado con tierra y se trata de la

\begin{tabular}{|l|c|c|c|c|c|c|c|c|}
\hline \multirow{2}{*}{ ENTRAMADO } & \multicolumn{2}{|c|}{ ARAGÓN } & \multicolumn{2}{c|}{ TERUEL } & \multicolumn{2}{c|}{ ZARAGOZA } & \multicolumn{2}{c|}{ HUESCA } \\
\cline { 2 - 10 } & \multicolumn{2}{|c|}{45} & \multicolumn{2}{c|}{33} & \multicolumn{2}{c|}{6} & \multicolumn{2}{c|}{5} \\
\hline Familia /variante & № loc & $\%$ loc & № loc & $\%$ loc & № loc & $\%$ loc & № loc & $\%$ loc \\
\hline Monolítico & 25 & $56 \%$ & 24 & $73 \%$ & 0 & $0 \%$ & 1 & $20 \%$ \\
\hline Piezas (adobe) & 16 & $36 \%$ & 8 & $24 \%$ & 5 & $83 \%$ & 3 & $60 \%$ \\
\hline Tejido & 8 & $18 \%$ & 5 & $15 \%$ & 1 & $17 \%$ & 2 & $40 \%$ \\
\hline
\end{tabular}

Tabla 6.7. Familias y variantes de los entramados según la muestra de localidades. Porcentajes respecto al número de localidades con presencia de entramados 
tabiquería interior de una vivienda. Por otro lado, los entramados con relleno tejidos son los que tienen una distancia menor entre montantes, entre $40 \mathrm{~cm}$ y $60 \mathrm{~cm}$, en parte derivado por la mayor esbeltez de estos rellenos que hace que necesite mayor número de elementos que los fijen y rigidicen.

En la segunda muestra, correspondiente a los datos de las fichas de estudio, los resultados están directamente relacionados con los de la primera muestra y los entramados con relleno monolítico son los más comunes con un 55\% respecto al total de entramados (Tabla 6.8.). En este caso, debido en parte a la menor frecuencia y a las propias características de la técnica, el número de variantes y subvariantes es menor aún a través de la ficha de estudio. En este caso la distribución y proporción de cada variante respecto al conjunto muy parecida a la de la muestra primera.

\subsubsection{Distribución geográfica}

Se han localizado entramados en 45 localidades de las cuales 33 pertenecen a la provincia de Teruel. Los casos localizados en las provincias de Huesca y Zaragoza se sitúan al norte de estas, en las zonas montañosas donde la presencia de árboles que permiten su construcción es mayor.

Los entramados con relleno monolítico se sitúan casi en su totalidad en la provincia de Teruel y se distribuyen por toda su área a excepción de la parte norte de esta. Destaca la presencia de esta variante en la comarca de la Sierra de Albarracín donde la abundante presencia de madera de los bosques para la estructura y de yeso para el relleno favorece su uso. Esta variante también destaca en la parte central de la provincia correspondiente con las Cuencas Mineras y parte del Maestrazgo (figura 6.56).

\begin{tabular}{|c|c|c|c|c|c|c|c|c|c|}
\hline \multirow{2}{*}{\multicolumn{2}{|c|}{ ENTRAMADO }} & \multicolumn{2}{|c|}{ ARAGÓN } & \multicolumn{2}{|c|}{ TERUEL } & \multicolumn{2}{|c|}{ ZARAGOZA } & \multicolumn{2}{|c|}{ HUESCA } \\
\hline & & \multicolumn{2}{|c|}{22} & \multicolumn{2}{|c|}{15} & \multicolumn{2}{|c|}{4} & \multicolumn{2}{|c|}{3} \\
\hline \multicolumn{2}{|c|}{ Familia /variante } & casos & $\%$ & casos & $\%$ & casos & $\%$ & casos & $\%$ \\
\hline \multicolumn{2}{|c|}{ Monolítico } & 12 & $55 \%$ & 12 & $80 \%$ & 0 & $0 \%$ & 0 & $0 \%$ \\
\hline & Tapialete & 11 & $50 \%$ & 11 & $73 \%$ & 0 & $0 \%$ & 0 & $0 \%$ \\
\hline & Otros / no visible & 1 & $5 \%$ & 1 & $7 \%$ & 0 & $0 \%$ & 0 & $0 \%$ \\
\hline \multicolumn{2}{|c|}{ Piezas (adobe) } & 6 & $27 \%$ & 0 & $0 \%$ & 4 & $100 \%$ & 2 & $67 \%$ \\
\hline & Adobe & 6 & $27 \%$ & 0 & $0 \%$ & 4 & $100 \%$ & 2 & $67 \%$ \\
\hline \multicolumn{2}{|l|}{ Tejido } & 6 & $27 \%$ & 3 & $20 \%$ & 1 & $25 \%$ & 2 & $67 \%$ \\
\hline & Cañizo & 5 & $23 \%$ & 3 & $20 \%$ & 1 & $25 \%$ & 1 & $33 \%$ \\
\hline & Encestados & 1 & $5 \%$ & 0 & $0 \%$ & 0 & $0 \%$ & 1 & $33 \%$ \\
\hline
\end{tabular}

Tabla 6.8. Tabla de variantes y subvariantes de entramados. Datos obtenidos de los casos analizados con la ficha de estudio.

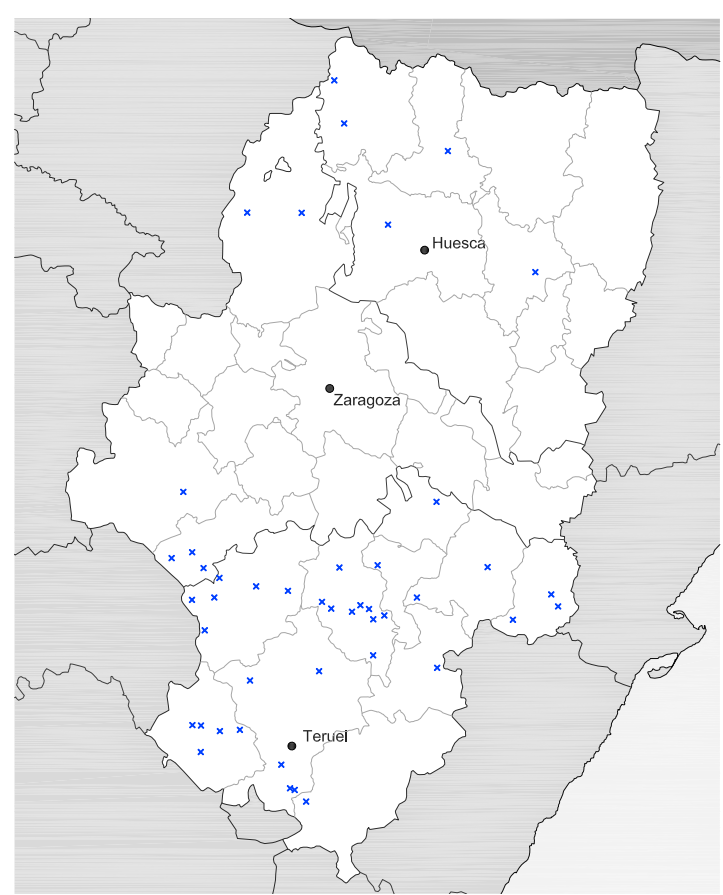

Figura 6.56. Localización construcciones con entramados 


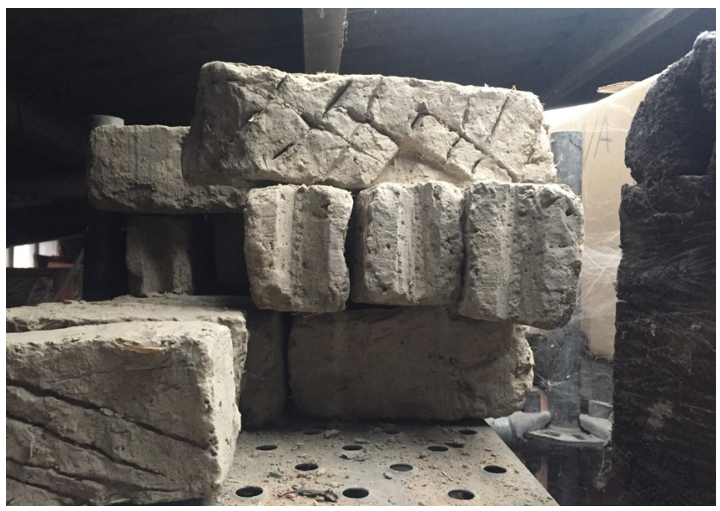

Figura 6.57. Adobillos extraidos de entramados interiores con hendiduras laterales para evitar movimientos. Yebra de Basa, Huesca.

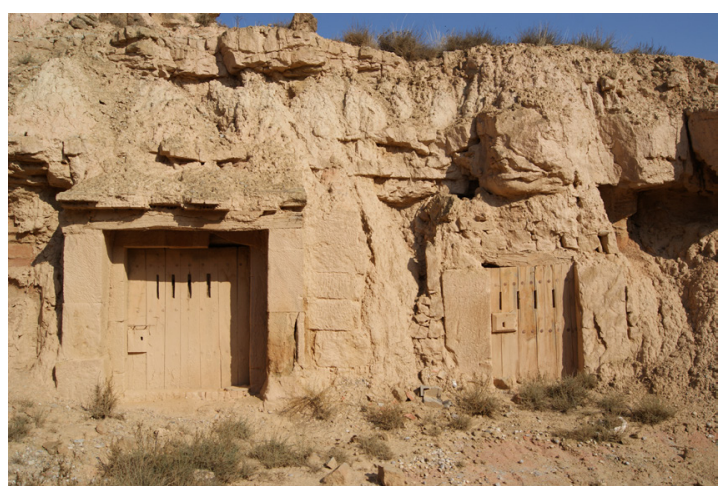

Figura 6.58. Arquitectura excavada en terreno arcilloso. Callén, Huesca.
Los entramados con adobe se localizan principalmente en dos áreas, la zona del Jiloca de Teruel y Campo de Daroca de Zaragoza (oeste de ambas provincias) y en el noroeste de Huesca (comarcas de la Jacetania y Alto Gállego) y Zaragoza (comarca de las Cinco Villas). El número de ejemplos de esa variante es reducido, sin embargo, los datos recogidos indican que posiblemente sea una técnica extendida por todo el pre-Pirineo para la configuración de la tabiquería interior. Los casos localizados en el Norte de Huesca son muros de tabiquería interior en los que se intercalan un montante de reducidas dimensiones y un adobe o "adobillo" que en ocasiones presenta hendiduras en sus laterales para evitar movimientos respecto al montante (Jorquera Silva y Cisternas Olguín 2017) (figura 6.57).

Los entramados con rellenos tejidos localizados son muy poco numerosos por lo que su presencia resulta dispersa por el territorio. Sin embargo, se puede distinguir de forma difusa una franja correspondiente con la zona norte de Teruel y suroeste de Zaragoza donde esta variante tiene mayor presencia. En la zona norte de Huesca y el somontano, los entramados con relleno tejido son frecuentes en el interior de las viviendas para configurar la tabiquería donde la urdimbre se revise con tierra o yeso. Estos tabiques están configurados generalmente con cañizo o con encestados de boj conocidos en la zona como "rechas de buxo" (Rábanos Faci y Gavín Moya 1991-1992).

\subsection{Otras técnicas existentes}

La variedad de técnicas constructivas de tierra en Aragón es limitada pese a ser uno de los materiales más utilizados. Además de las tres técnicas predominantes descritas con anterioridad, también existe un número considerable de casos de arquitectura excavada o cuevas. Este tipo de arquitectura aparece generalmente en las laderas próximas a los núcleos de población y en ocasiones componen amplios conjuntos de gran interés como es el caso de Ambel o Maleján. Este tipo cuevas suelen estar ligados a la producción vinícola por lo aparecen en áreas concretas donde este tipo de cultivos forman parte de la tradición (figura 6.58). Estas cuevas poseen un elemento fundamental que se denomina lumbrera y que es el que permite su ventilación. Las cubiertas de los accesos a estas cuevas suelen estar realizadas con arcos de piedra o con rollizos y bardas o barzas* (Abad Alegría 1997) sobre los que se coloca la tierra, presumiblemente extraída la propia excavación (cesbor.blogspot.com/). Se han localizado casos aislados alrededor de todo Aragón. Sin embargo, es destacable la presencia de conjuntos de cuevas de gran interés en la comarca de Campo de Borja.

También existen edificaciones o casetas en la comarca de Zaragoza destinadas a la agricultura o a refugio que pueden estar semi-enterradas, y que su cubierta, generalmente abovedada, puede, o no, estar revestida con tejas debido a la aridez del entorno y la falta de recursos. (Rivas González, F.A. 2011). 


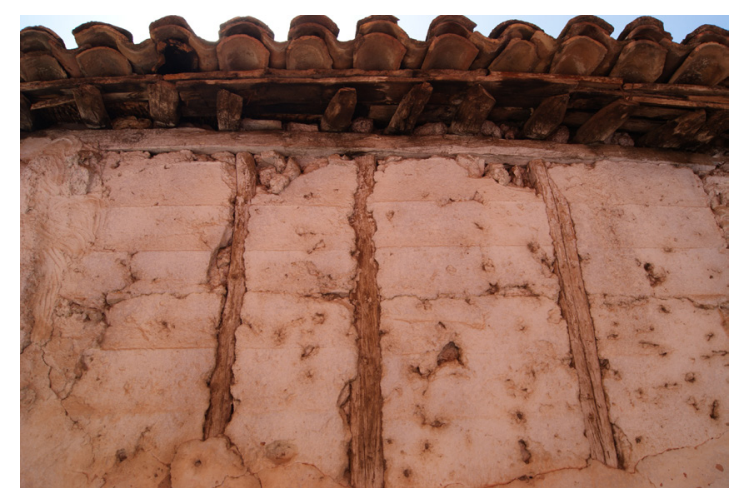

Figura 6.59. Entramado con relleno monolítico (tapialete) Gea de Albarracín, Teruel

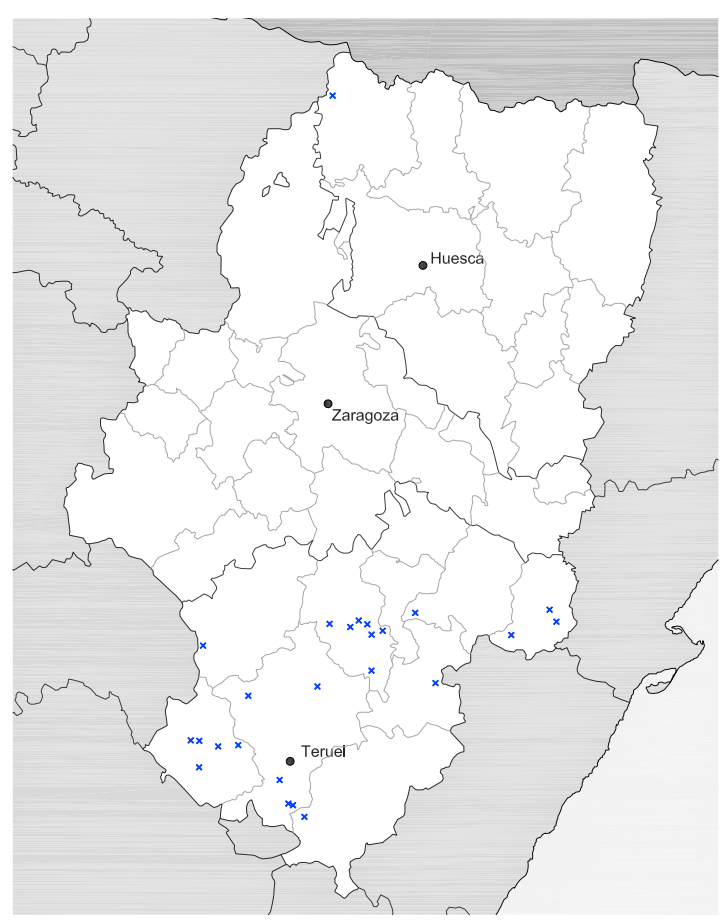

Figura 6.60. Localización entramado con relleno monolítico

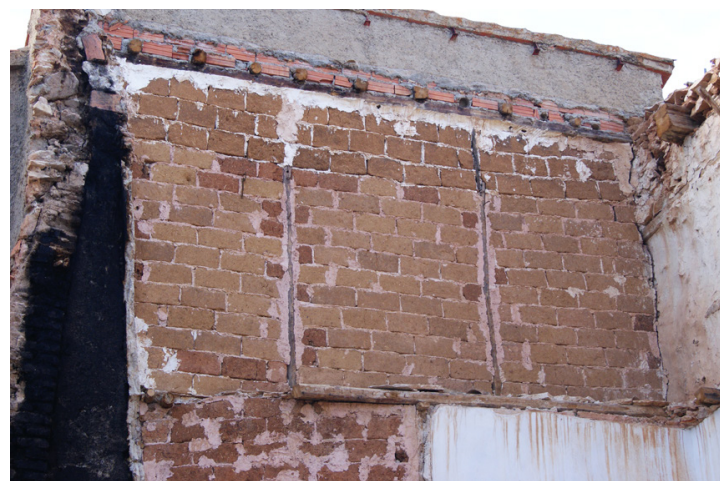

Figura 6.61. Entramado con relleno de adobe. Odón Teruel

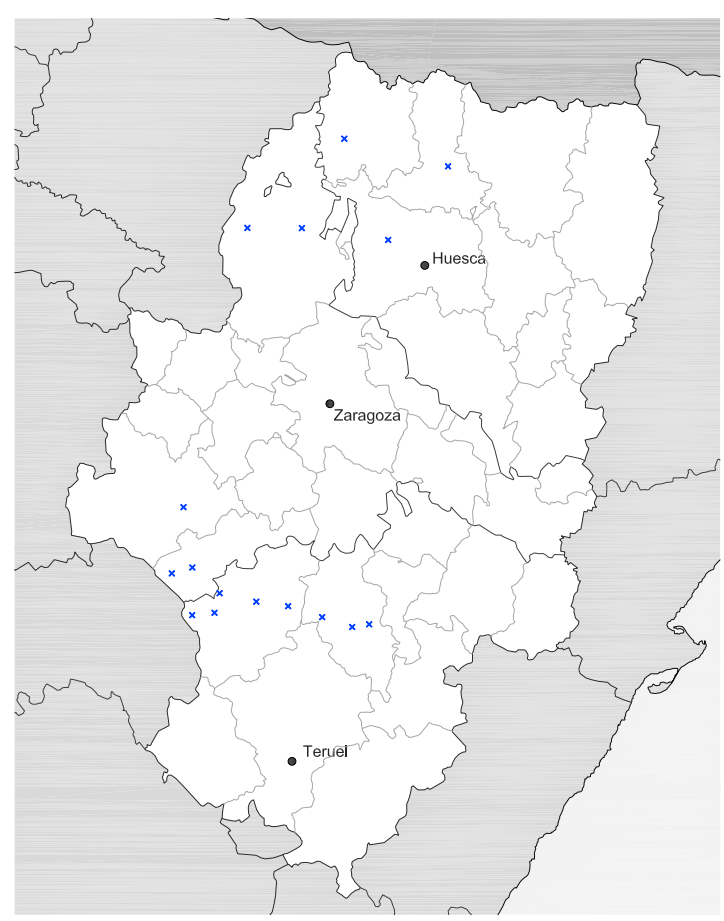

Figura 6.62. Localización entramado con relleno de adobe

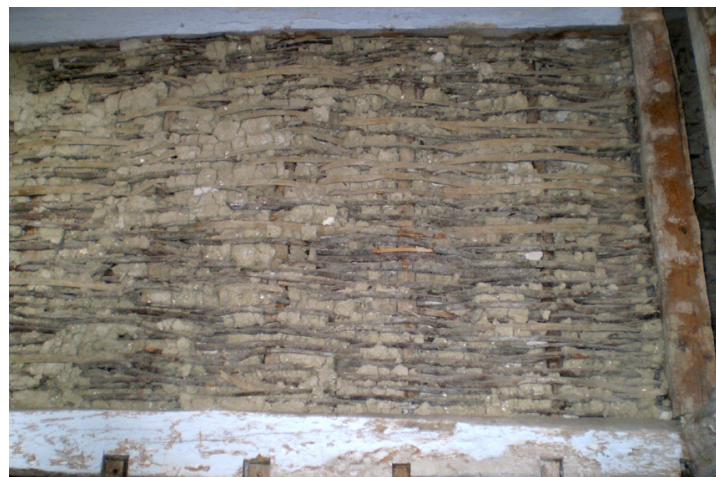

Figura 6.63. Entramado con relleno tejido (encestado). Yebra de Basa, Huesca. Autor: Jesús García Mainar.

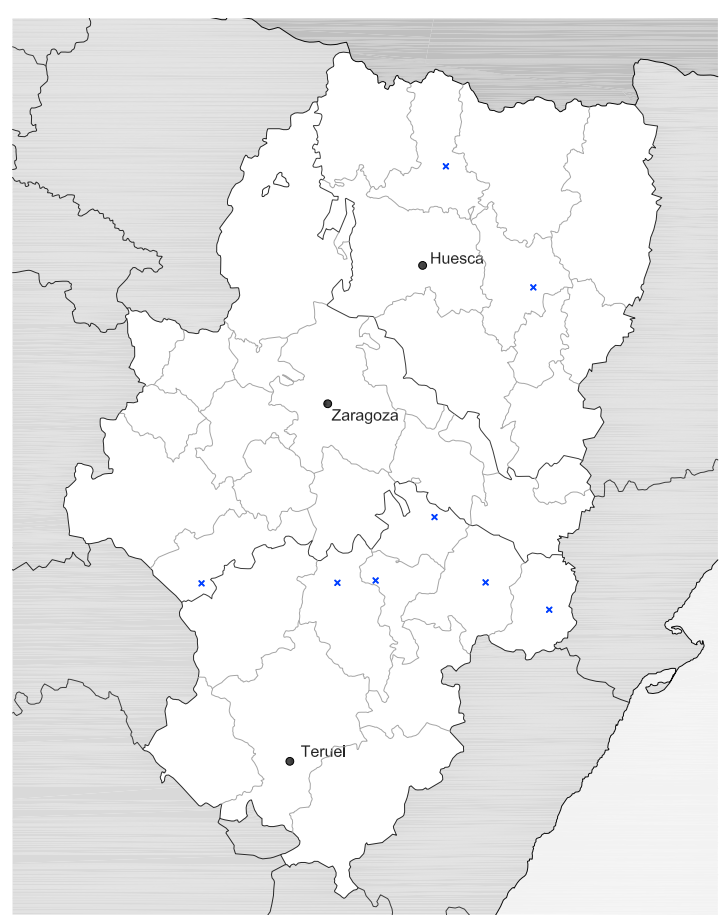

Figura 6.64. Localización entramado con relleno tejido 


\section{Entramado con relleno de piezas}

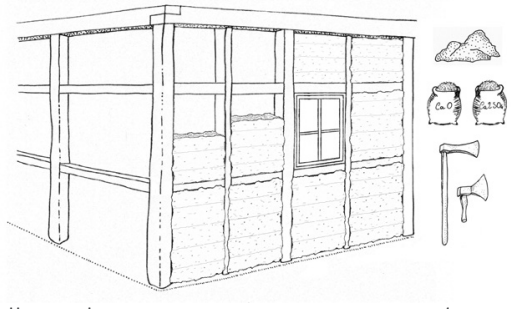

Relleno de yeso y mampuestos, tapialete

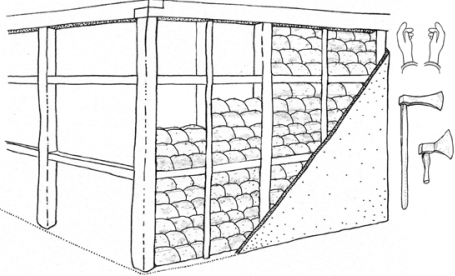

Relleno de glebas (encofrado a una cara)

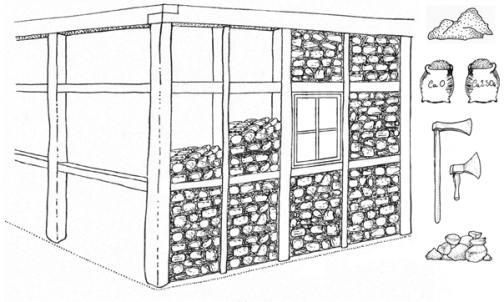

Relleno de tierra conglomerante mamposería abundante

\section{Entramado con relleno de piezas}

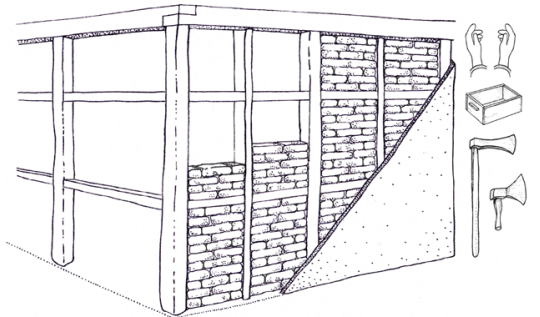

Relleno de adobe horizontal

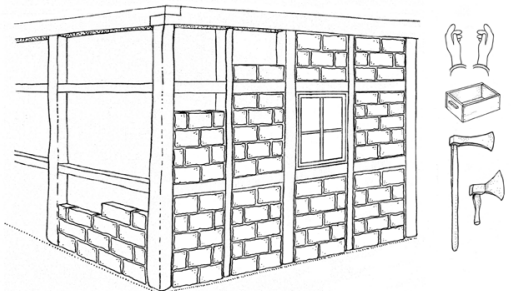

Relleno adobe a panderete

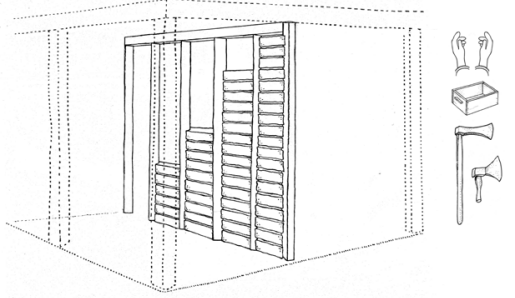

Relleno entramado interior con adobes machihembrados (adobillos)

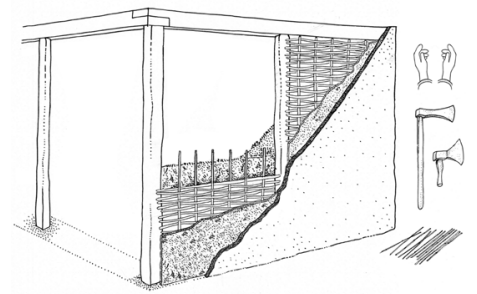

Relleno tejido de encestado

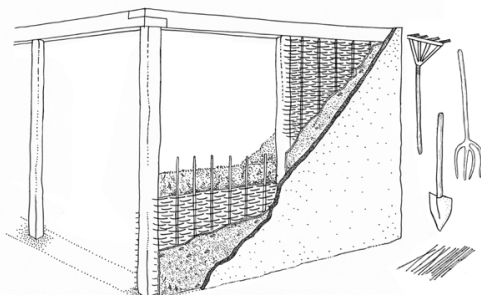

Relleno tejido de cañizos 


\section{Arquitectura y entorno}

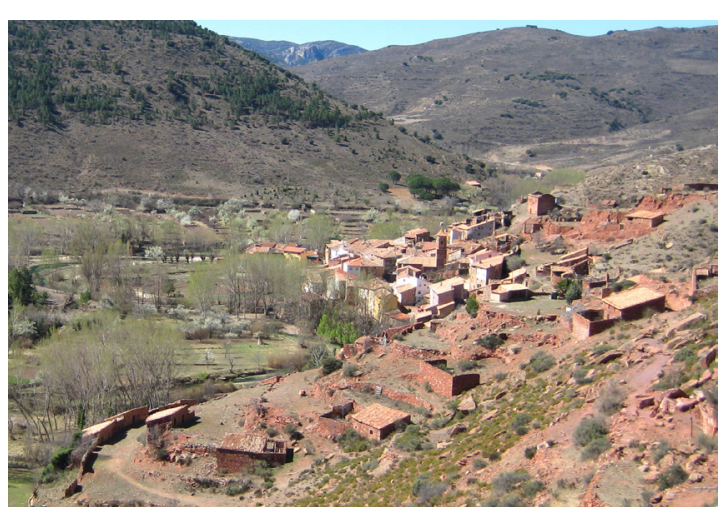

Figura 7.1. Arquitectura tracional en relación con su entorno. Peñarroyas, Teruel.
La arquitectura tradicional es muy rica y variada, en todo el mundo y presenta un número ilimitado de soluciones que se adaptan al lugar y a la sociedad de cada momento. Por ello como indica José Santibáñez: "La arquitectura vernácula del mundo es tan rica y variada como regiones hay en la tierra, porque nace con el sentido del lugar, en una metamorfosis del clima, geografía, sentimientos, costumbres y su sentir cotidiano".

La heterogeneidad de las características del territorio de Aragón en cuanto a clima, morfología, geología, cultura o materiales disponibles, entre otros, favorece la diversidad de soluciones tanto constructivas como compositivas en la arquitectura tradicional que se relaciona de forma directa con los factores externos de cada lugar.

El emplazamiento de los edificios, la posición respecto al sol, la forma, la distribución y las técnicas constructivas empleadas, en cada lugar constituyen la respuesta a la optimización de los recursos disponibles, fruto del aprendizaje y del desarrollo humano (figura 7.1). La arquitectura tradicional de tierra ha experimentado un proceso de adaptación a los distintos factores condicionantes, como los materiales disponibles, que permite distinguir multitud de soluciones constructivas (técnicas y variantes) incluso dentro de un territorio de extensión limitada como es Aragón.

Con el fin de estudiar la vinculación entre las técnicas constructivas de tierra y las características del lugar en el que se encuentran se ha partido del estudio de las técnicas constructivas de tierra existentes en el territorio aragonés y su localización a través de los mapeados de puntos mostrados en el capítulo previo. Este estudio permite conocer a nivel territorial que factores coadyuvan o coartan la construcción con tierra. La muestra utilizada corresponde a la muestra primera que se compone de 258 núcleos de población con tierra de los cuales en 187 se ha localizado tapia, en 180 adobe y en 45 entramado.

El estudio geográfico se ha realizado a través del solape de los mapeados de técnicas con mapas temáticos que muestran información territorial de tipo morfológicos, climáticos, geológicos y social, 
obtenido de fuentes oficiales como el IGN, AEmeT, INE, IGEAR, etc. ${ }^{1}$ Para ello se ha establecido una correspondencia entre los núcleos de población y las características del área del mapa temático en el que se encuentra con el fin de extraer datos relevantes sobre los factores que favorecen o limitan el desarrollo o la adopción de soluciones constructivas de tierra, así como determinar qué características de la arquitectura de tierra son propias de áreas con unas condiciones concretas.

A través del solape de los mapeados temáticos y los mapeados de técnicas se han contabilizado el número de núcleos de población localizados en cada uno de los intervalos o áreas establecidas en cada mapeado temático que corresponden con unas propiedades concretas. De esta forma se han obtenido unos resultados numéricos y porcentuales que permiten la comparación y la extracción de conclusiones.

Los mapeados temáticos estudiados se han agrupado en relación a las propiedades geográficas o naturales ${ }^{2}$ que describen: factores morfológicos, factores climáticos y factores geológicos; y en relación a los factores humanos o sociales en el cual se ha estudiado la densidad de población, pero englobaría otros factores como los económicos, históricos, culturales, etc.

Sin embargo, existen factores sociales o humanos como las costumbres, los usos, etc. que escapan de la pura funcionalidad y la relación de esta arquitectura con el medio en el que se encuentran. Esta contraposición fue analizada en detalle por Allanegui Burriel en su libro Arquitectura tradicional de Aragón, a través de citas de distintos autores como las siguientes ${ }^{3}$ :

Torres Balbás dice en referencia al análisis de las cubiertas:

"Este condicionamiento es muy relativo. En la edificación popular las formas no son nunca una resultante única del clima, ni de los materiales empleados, ni del cultivo, ni de los factores humanos. Todos estos elementos, como hemos dicho intervienen en la formación de la arquitectura popular, pero en proporciones muy diferentes, según los casos, y aun ocurre con frecuencia que se prescinda de uno o varios. Es pueril hacer depender de las condiciones naturales todas las manifestaciones distintivas de la actividad humana en un determinismo fatalista: el medio no lo es todo; hay tan sólo una cierta dependencia relativa y limitada del hombre con respecto a la naturaleza. Así, en las zonas más lluviosos de Galicia encontramos cubiertas de poca inclinación y el alero no tiene importancia, alcánzala mucho más en comarcas aragonesas de la España árida"

En torno a esta misma idea Albert Dauzaut comenta lo siguiente:

"La geografía no explica todo. El hombre cree gustoso que su casa, como su lenguaje, están sometidos a la lógica y no a la fantasía, pero aquella como esta obedecen sobre todo preocupaciones de otro orden:
1. IGN (Instituto Geográfico Nacional); AEmeT (Agencia Estatal de Metereología); INE (Instituto Nacional de Estadística); IGEAR (Instituto Geográfico de Aragón).

2. Esquema de A. Allanegui de las causas que determinan e influyen en la Casa Popular (Allaneui Burriel 1979, pp. 14) 3. Los siguentes fragmentos están extraidos del libro de G.J: Allanegui Burriel: Arquitectura popular de Aragón, pp. 14 
Tradiciones, ruinas, imitación y contagio mental.

Las emigraciones, las conquistas, la expansión de las civilizaciones han producido resultados que nada tienen que ver con la lógica. Donde la geografía es impotente, hay que recurrir a la historia: historia que, en muchos casos, tiene tan poca categoría que ni siquiera merece el nombre de historia"

Estas reflexiones permiten entender que, pese a buscar la racionalización de la arquitectura siempre hay aspectos que están fuera del alcance del conocimiento y que en ocasiones provienen de la pura aleatoriedad. Así mismo, los propios límites del área de estudio, Aragón, son principalmente aleatorios ya que no tienen ninguna lógica territorial ni una homogeneidad geográfica, sin embargo, se trata de un territorio con unos límites que se han mantenido prácticamente intactos durante siglos (Mairal Buil 2003).

\subsection{Factores morfológicos}

Los factores morfológicos son aquellos que definen las características físicas del territorio y que generalmente condicionan y se relacionan con los demás factores del territorio. En este apartado se ha analizado la altimetría, haciendo referencia al relieve en las distintas zonas y la relación con los principales cauces fluviales que articulan el territorio

\subsubsection{Altimetría}

La altitud en Aragón es muy heterogénea, desde las altas cumbres del Pirineo al Sistema Ibérico pasando por la depresión del río Ebro. En este territorio se localizan tanto zonas de montaña con relieves abruptos (zona pirenaica) como grandes llanuras tanto a altitudes bajas (valle del Ebro, alrededor de 400m) como elevadas (Sistema Ibérico, alrededor de 1.000m). Los grandes contrastes que la altitud genera en las propiedades del territorio, sobre todo en el clima, también produce que la arquitectura tradicional se adapte a las condiciones del entorno en el que se encuentra (tabla 7.1; figura 7.2).

\begin{tabular}{|r|c|c|c|c|c|c|c|c|}
\hline \multirow{2}{*}{ ALTIMETRÍA } & \multicolumn{2}{|c|}{ TAPIA } & \multicolumn{2}{c|}{ ADOBE } & \multicolumn{2}{c|}{ ENTRAMADO } & \multicolumn{2}{c|}{ TODO } \\
\cline { 2 - 9 } & 187 & $\%$ & 180 & $\%$ & 45 & $\%$ & 258 & $\%$ \\
\hline $0-200 \mathrm{~m}$ & 5 & $2,7 \%$ & 6 & $3,3 \%$ & 0 & $0,0 \%$ & 7 & $2,7 \%$ \\
\hline $201-600 \mathrm{~m}$ & 45 & $24,1 \%$ & 77 & $42,8 \%$ & 5 & $11,1 \%$ & 83 & $32,2 \%$ \\
\hline $601-1000 \mathrm{~m}$ & 77 & $41,2 \%$ & 79 & $43,9 \%$ & 18 & $40,0 \%$ & 102 & $39,5 \%$ \\
\hline $1.001-1.600 \mathrm{~m}$ & 60 & $32,1 \%$ & 18 & $10,0 \%$ & 22 & $48,9 \%$ & 64 & $24,8 \%$ \\
\hline$>1600 \mathrm{~m}$ & 2 & $1,1 \%$ & 0 & $0,0 \%$ & 0 & $0,0 \%$ & 2 & $0,8 \%$ \\
\hline
\end{tabular}

Tabla 7.1. Arquitectura de tierra y altimetría 


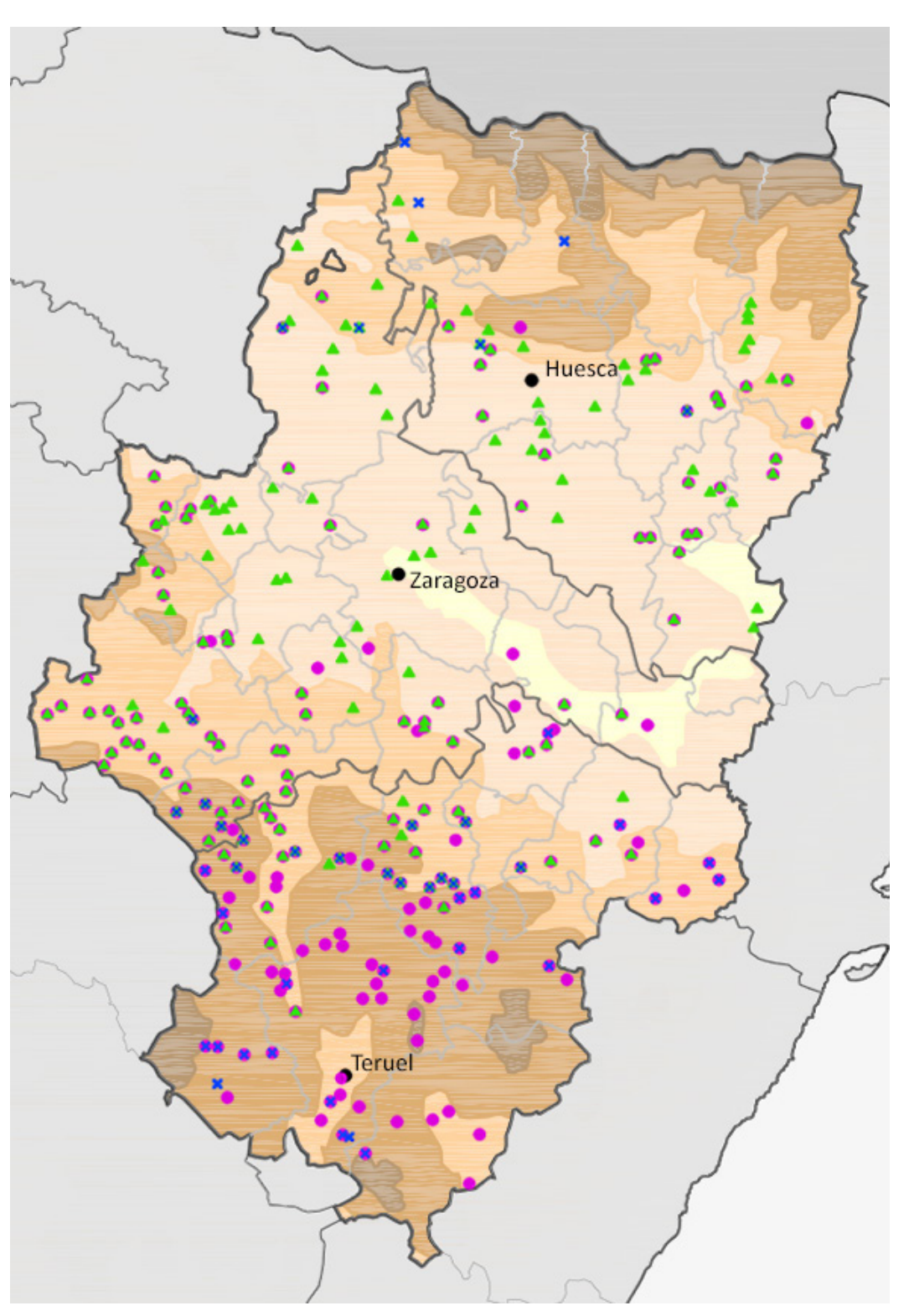

Figura 7.2. Altimetría. Fuente: Dirección General de Planificación Territorial 1994, edición propia.

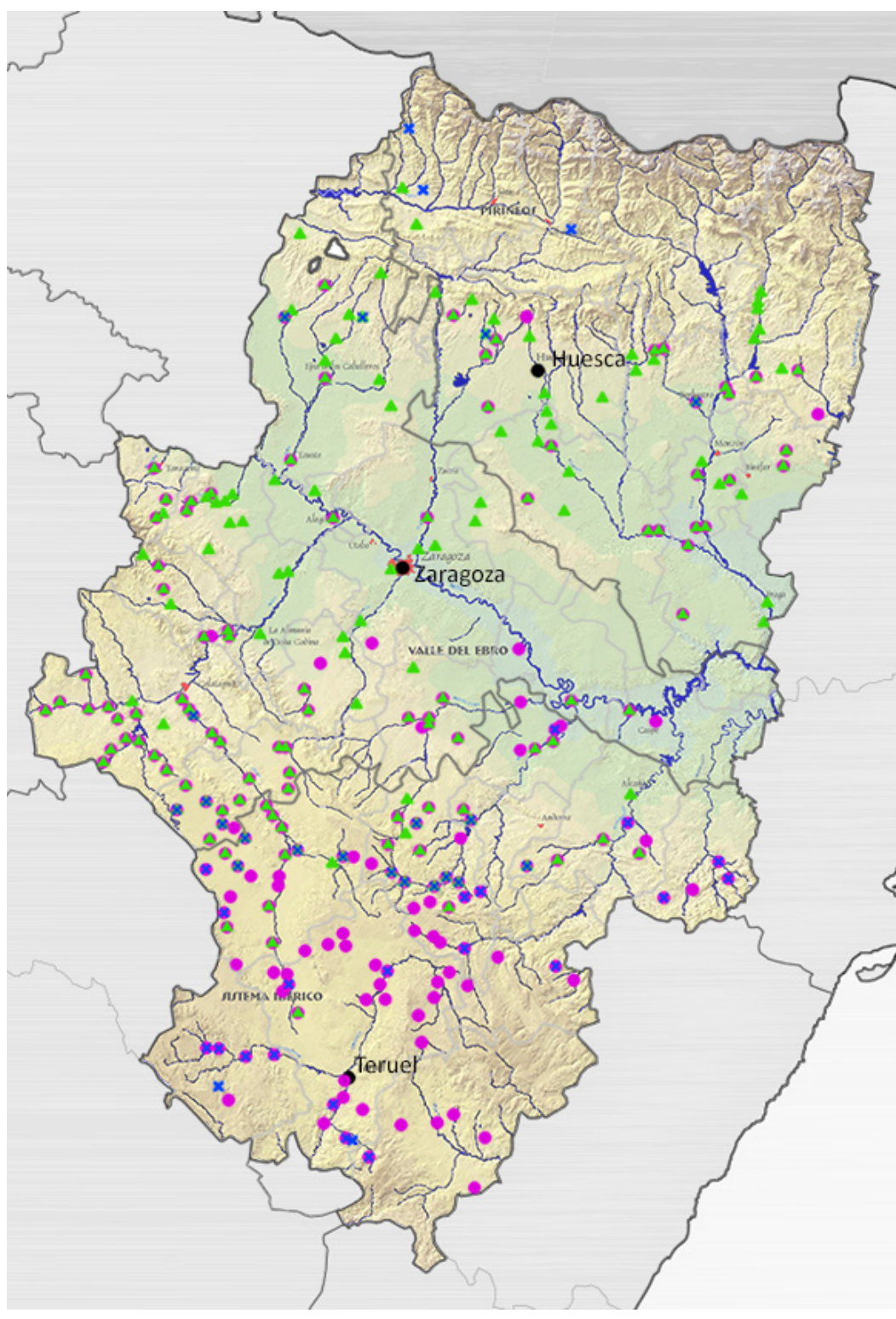

Figura 7.3. Cauces fluviales. Fuente: comarcas. es, edición propia.
Altimetría

0-200m $201-600 m$

$601-1000 m$

1.001-1.600m

- $>1600 \mathrm{~m}$ 
El mayor número de localidades en las que se han hallado construcciones con tierra se encuentran a una altitud media de 600 a 1.000m (40\%), y casi la totalidad de estas entre 200 y 1.600m (96,5\%). En cuanto a las técnicas constructivas analizadas de forma autónoma, los resultados son parecidos en todas ellas con alrededor del $40 \%$ en alturas de 600 a 100m. La tapia es la técnica que mayor presencia tiene en altitudes considerables $(73,3 \%$ entre 600 y $1.600 \mathrm{~m}$ ), ligada a su mayor presencia en el área del Sistema Ibérico donde el relieve es suave pero elevado. En cuanto al adobe predomina a altitudes menores ya que su construcción esta ligada principalmente al valle del Ebro (86,7\% entre 200 y 100m). Como se observa en el mapeado, ambas técnicas evitan las zonas de carácter montañoso como los Pirineos o las cumbres más altas del Sistema Ibérico. En cuanto a los entramados, casi la totalidad se localizan entre 600 y $1.600 m(88,9 \%)$ y es la técnica que más se aproxima a las zonas de montaña como los Pirineos o el sistema Ibérico, en parte a la relación de estas zonas con la presencia de bosques que permiten la obtención de madera para su construcción.

\subsubsection{Cauces fluviales}

El desarrollo tradicional siempre ha estado en relación con su entorno y se han adaptado a este haciendo uso de los recursos disponibles, especialmente del agua, ya que se trata del elemento fundamental para el desarrollo de la vida.

La localización y la forma de agrupación de los núcleos de población están íntimamente ligadas a los recursos hídricos de cada lugar, que suelen ser escasos en el clima mediterráneo, y más abundantes en el clima oceánico, lo cual permite una arquitectura más dispersa y disgregada. En el caso de Aragón, la mayor parte del territorio es de carácter árido, a excepción del área de los Pirineos donde las poblaciones son generalmente pequeñas, pero próximas entre ellas y dispersas por todo el territorio. Por ello, en el resto del territorio predominan los asentamientos núcleos de población compactos generalmente entorno a los recursos hídricos disponibles (tabla 7.2; figura 7.3).

Uno de los principales recursos son los ríos, que favorecen el desarrollo de la vida a su alrededor. De los núcleos de población pertenecientes a la muestra, alrededor de un $70 \%$ de estos se localizan en

\begin{tabular}{|r|c|c|c|c|c|c|c|c|}
\hline \multirow{2}{*}{ CAUCES FLUVIALES } & \multicolumn{2}{|c|}{ TAPIA } & \multicolumn{2}{c|}{ ADOBE } & \multicolumn{2}{c|}{ ENTRAMADO } & \multicolumn{2}{c|}{ TODO } \\
\cline { 2 - 9 } & 187 & $\%$ & 180 & $\%$ & 45 & $\%$ & 258 & $\%$ \\
\hline Próximo a cauces & 132 & $70,59 \%$ & 129 & $71,7 \%$ & 33 & $73,3 \%$ & 181 & $70,2 \%$ \\
\hline Alejado de cauces & 55 & $29,41 \%$ & 51 & $28,3 \%$ & 12 & $26,7 \%$ & 77 & $29,8 \%$ \\
\hline
\end{tabular}

Tabla 7.2. Arquitectura de tierra y cauces fluviales 
las proximidades de los cauces fluviales. Sin embargo, existen ostro recursos hídricos como las fuentes naturales, los barrancos, los arroyos, los pequeños ríos, las canalizaciones por acequias, etc. que son muy recurrentes en algunos entornos y que no se han tenido en cuenta en este estudio pero que permiten disponer de agua de una forma más o menos constante. En cuanto a la relación de cada una de las técnicas constructivas de forma aislada, el porcentaje es similar al de todos los casos analizados en conjunto (alrededor del 70\%)

\subsection{Factores climáticos}

La diferencia de latitud entre el extremo septentrional y meridional de la comunidad de Aragón y las influencias de los mares Cantábrico y Mediterráneo, así como las masas continentales Euroasiática y Africana, junto con la topografía cambiante del territorio hacen que los factores climáticos varíen notablemente de unos extremos a otros (IGEAR)

\subsubsection{Temperatura media}

La temperatura media anual está directamente influenciada por las diferencias de altitud existentes y su posición en el interior de la península con influencia de dos mares muy diferentes, que produce unos grandes contrastes entre los valores templados la depresión del Ebro y los valores más fríos asociados a las montañas. En el plano de temperaturas medias es posible observar la relación directa con el relieve ya que la distribución de las isotermas es casi paralela a las curvas de nivel (IGN, IGEAR) (tabla 7.3; figura 7.7).

La temperatura media influye directamente en el tipo de arquitectura, en su disposición y distribución, así como en la configuración de los muros, su espesor y los elementos de protección dispuestos para conseguir un confort térmico interior de forma pasiva. (Beckett y Ciancio 2012). La importante inercia térmica que posee la tierra junto con el amplio espesor que generalmente caracteriza a los muros construidos con este material provocan que su uso sea idóneo en todo tipo de temperaturas. La inercia térmica como propiedad aislante y de mejora del confort es especialmente favorable en áreas con soleamiento y oscilaciones de temperatura importantes entre el día y la noche (como ocurre en gran parte del territorio aragonés), ya que permite regular el intercambio de calor entre el interior y exterior, dilatándolo en el tiempo (Wilson et al. 2016).

Los ejemplos de la muestra se localizan en su mayoría (88,3\%) en el rango entre 10,0 y $15,0^{\circ} \mathrm{C}$, mientras que el total de la muestra se localiza entre 7,5 y $17,5^{\circ} \mathrm{C}$. La tapia, por su parte, es la técnica localizada

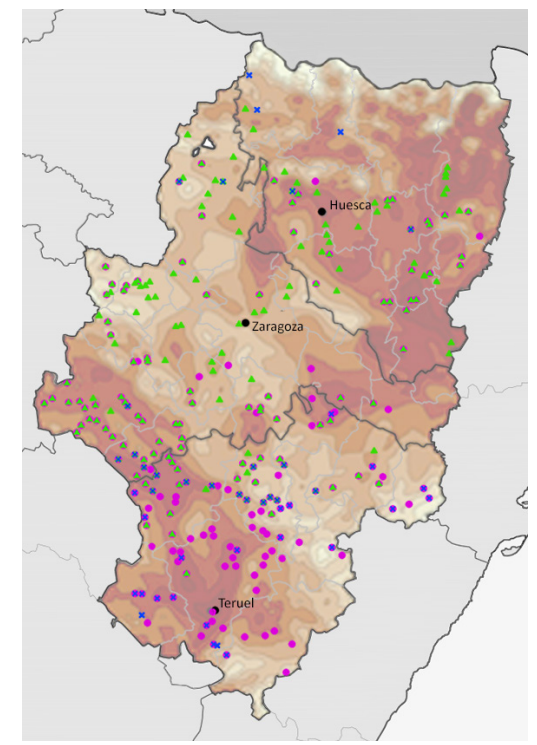

Figura 7.4. Amplitud térmica. Fuente: Atlas IGEAR 


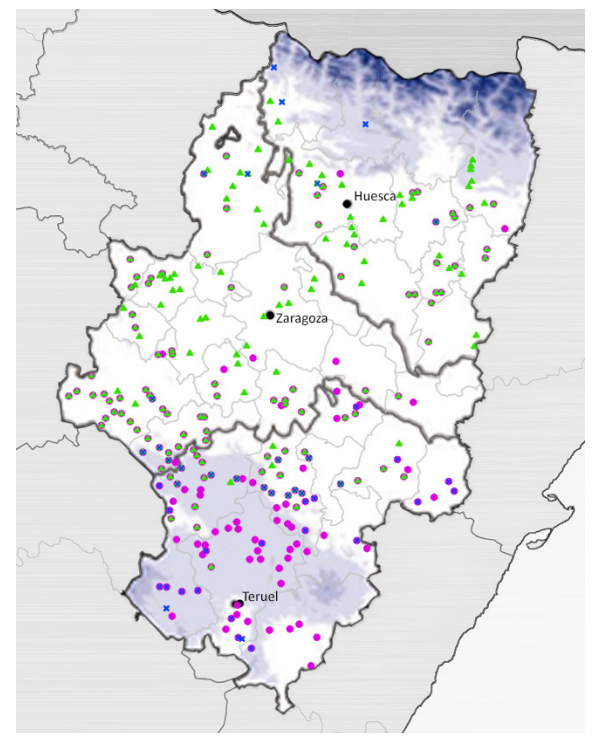

Figura 7.5. Nieve en enero. Fuente: Atlas IGEAR

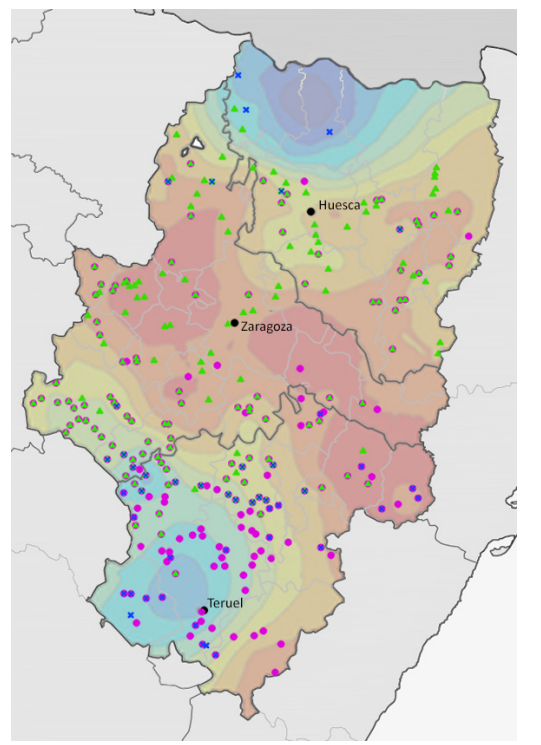

Figura 7.6. Días de helada. Fuente: Atlas IGEAR más comúnmente en el rango de menor temperatura con 19 casos entre 7,5 y $10^{\circ} \mathrm{C}$, hecho debido a su elevada presencia por todo el Sistema Ibérico donde se alcanzan temperaturas muy bajas en invierno. Los muros de tapia tienen carácter monolítico y un espesor considerable que le confiere unas propiedades adecuadas para adaptarse a un rango amplio de temperaturas, así como a las oscilaciones importantes entre el día y la noche.

Los casos de adobe están localizados en un 93,9\% de los casos entre 10,0 y $15,0^{\circ} \mathrm{C}$, y el resto de los casos en su mayoría, al contrario que en el caso de la tapia, se localizan en rangos de temperaturas superiores. La presencia de esta técnica en la franja central de la comunidad produce que al igual que la altitud media era menor las temperaturas sean mayores.

Por último, la presencia de entramados se limita a los rangos entre 7,5 y $15,0^{\circ} \mathrm{C}$ y no aparece en rangos superiores ya que no se ha localizado ningún caso en el área central del valle del Ebro.

Paralelamente se ha realizado un análisis visual comparativo con el plano de amplitud térmica que muestra la diferencia de temperatura entre el mes más cálido y el más frio. En el que se puede observar como la tierra parece reiteradamente en zonas donde se presentan las mayores amplitudes térmicas del territorio, superiores a $33^{\circ} \mathrm{C}$, que, en términos absolutos pueden llegar a superar los $50^{\circ} \mathrm{C}$ en muchos puntos habitados, sobre todo en el sistema Ibérico (AEmeT 2011). Este dato corrobora la adecuación de la tierra como material en zonas con temperaturas extremas y en áreas donde se producen grandes cambios de temperatura incluso entre día y noche gracias a la inercia térmica del material (Maldonado Ramos, Castilla Pascual y Vela Cossío 2001) (figura 7.4).

Por otro lado, la presencia de nieve y sobre todo las heladas (en algunas zonas se producen más de 90 días al año) son un factor importante en gran parte del territorio y pueden ser los causantes de mecanismos de degradación si los muros de tierra no se encuentran protegidos (figura 7.5; figura 7.6).

\begin{tabular}{|r|c|c|c|c|c|c|c|c|}
\hline \multirow{2}{*}{ TEMPERAURA MEDIA } & \multicolumn{2}{|c|}{ TAPIA } & \multicolumn{2}{c|}{ ADOBE } & \multicolumn{2}{c|}{ ENTRAMADO } & \multicolumn{2}{c|}{ TODO } \\
\cline { 2 - 9 } & 187 & $\%$ & 180 & $\%$ & 45 & $\%$ & 258 & $\%$ \\
\hline $0,0-2,5^{\circ} \mathrm{C}$ & 0 & $0,0 \%$ & 0 & $0,0 \%$ & 0 & $0,0 \%$ & 0 & $0,0 \%$ \\
\hline $2,5-5,0{ }^{\circ} \mathrm{C}$ & 0 & $0,0 \%$ & 0 & $0,0 \%$ & 0 & $0,0 \%$ & 0 & $0,0 \%$ \\
\hline $5,0-7,5^{\circ} \mathrm{C}$ & 0 & $0,0 \%$ & 0 & $0,0 \%$ & 0 & $0,0 \%$ & 0 & $0,0 \%$ \\
\hline $7,5-10,0{ }^{\circ} \mathrm{C}$ & 19 & $10,2 \%$ & 2 & $1,1 \%$ & 7 & $15,6 \%$ & 20 & $7,8 \%$ \\
\hline $10,0-12,5^{\circ} \mathrm{C}$ & 93 & $49,7 \%$ & 72 & $40,0 \%$ & 29 & $64,4 \%$ & 117 & $45,3 \%$ \\
\hline $12,5-15,0^{\circ} \mathrm{C}$ & 65 & $34,8 \%$ & 97 & $53,9 \%$ & 9 & $20,0 \%$ & 111 & $43,0 \%$ \\
\hline $15,0-17,5{ }^{\circ} \mathrm{C}$ & 10 & $5,3 \%$ & 9 & $5,0 \%$ & 0 & $0,0 \%$ & 10 & $3,9 \%$ \\
\hline
\end{tabular}

Tabla 7.3. Arquitectura de tierra y temperatura media 


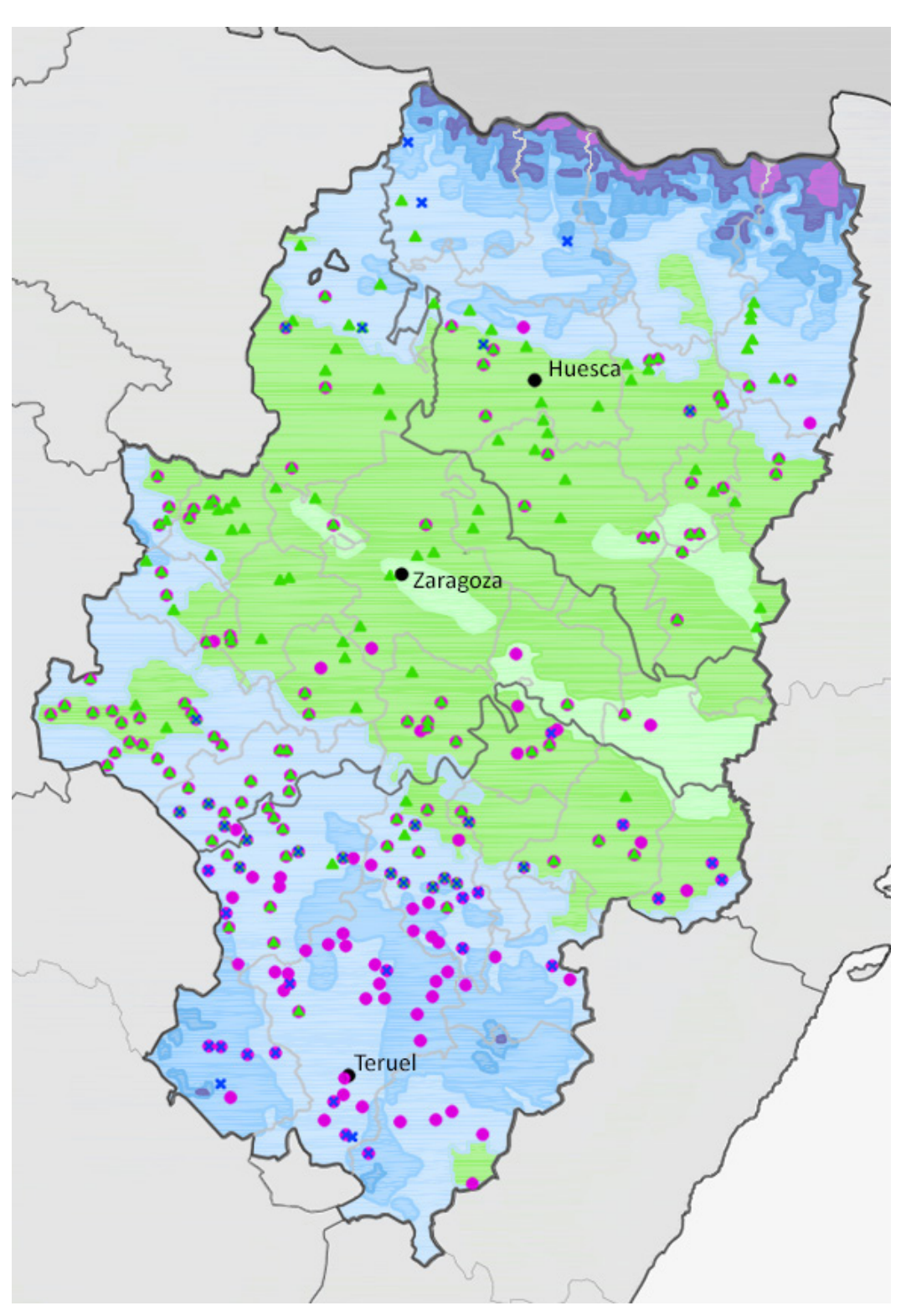

Figura 7.7. Temperatura media. Fuente: AEmeT 2011, edición propia.

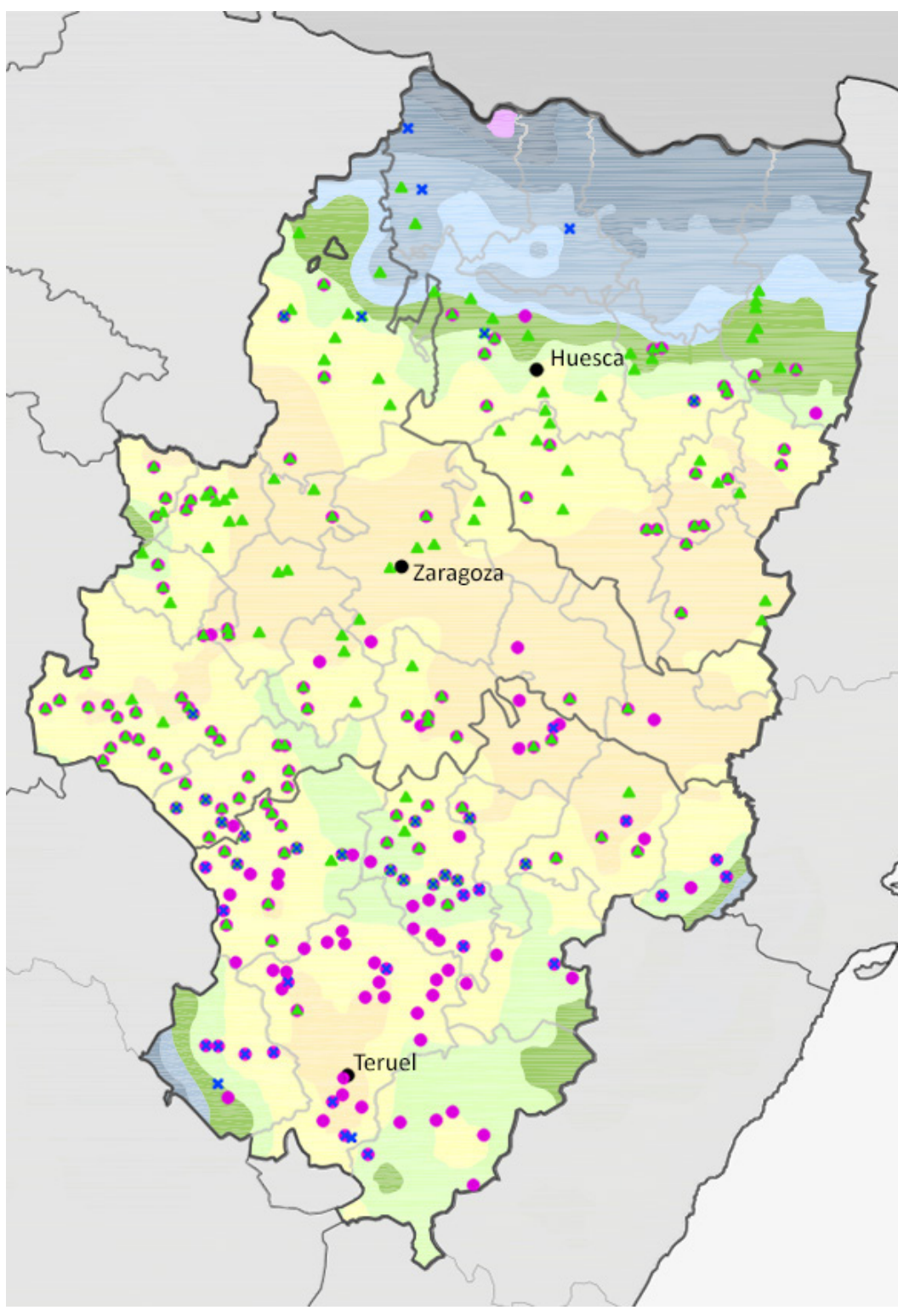

Figura 7.8. Precipitaciones medias. Fuente: AEmeT 2011, edición propia.
Temperatura media

$0,0-2,5^{\circ} \mathrm{C}$

$2,5-5,0^{\circ} \mathrm{C}$

$5,0-7,5^{\circ} \mathrm{C}$

$7,5-10,0^{\circ} \mathrm{C}$

$10,0-12,5^{\circ} \mathrm{C}$

$12,5-15,0^{\circ} \mathrm{C}$

$15,0-17,5^{\circ} \mathrm{C}$

Precipitaciones

301-400mm

$401-500 \mathrm{~mm}$

$501-600 \mathrm{~mm}$

$601-700 \mathrm{~mm}$

$701-800 \mathrm{~mm}$

$801-1.000 \mathrm{~mm}$

$1.001-1.400 \mathrm{~mm}$

$1.401-1.800 \mathrm{~mm}$

$1.801-2.200 \mathrm{~mm}$

- Tapia

$\triangle$ Adobe

$\times$ Entramado 


\subsubsection{Precipitaciones}

La precipitación en Aragón se sitúa en unos 550mm de media anual, precipitación algo menor que la media de España (AEmeT 2011) debido en parte a la dificultad de penetración de los frentes a causa de las cadenas montañosas de sus lindes. Además, al igual que en el caso de las temperaturas se puede observar la relación directa entre las precipitaciones y la topografía de la comunidad ya que se concentran principalmente en las zonas de montaña (tabla 7.4.; figura 7.8).

A nivel arquitectónico, el nivel de precipitaciones influye directamente en la configuración de los núcleos de población y su arquitectura, sobre todo en la configuración de las cubiertas, ya que son las encargadas de la evacuación de las aguas. Por ello en zonas con abundantes precipitaciones las cubiertas, deberán tener una inclinación suficiente y poseer aleros de un tamaño adecuado para alejar el agua de los muros y protegerlos de la humedad. Por ello, la adecuada conservación de las cubiertas junto con la presencia de materiales con mayor resistencia al agua en el zócalo es imprescindible para una adecuada conservación del edificio (Doat et Al. 1979). En Aragón, pese a que la precipitación anual no es muy alta, en verano suelen producirse tormentas de gran intensidad por lo que la mayor parte del territorio posee edificios con aleros considerables

El régimen pluviométrico es uno de los factores que suele determinar la presencia o ausencia de construcciones en tierra ya que el agua constituye uno de los principales factores de degradación y afecta notablemente a su durabilidad. Es posible observar en el mapeado como solo en ocasiones puntuales las construcciones de tierra se localizan en áreas con precipitaciones abundantes. Además, cabe destacar que los ejemplos localizados en el noroeste corresponden con entramados en el interior de los edificios o con casos puntuales de adobes en el interior o en la parte superior de edificios secundarios.

La mayor parte de las construcciones de tierra se localizan en el intervalo de 300 a $700 \mathrm{~mm}$, dentro del cual existe predominio de casos entre 400 y $500 \mathrm{~mm}$ con aproximadamente el $55 \%$ en todas las técnicas y entre 300 y $500 \mathrm{~mm}$ un $75 \%-80 \%$. Destaca el adobe con casi el $10 \%$ de los casos entre 600 y $700 \mathrm{~mm}$ debido a su alta presencia en el somontano pirenaico, sin embargo, los casos de tapia y entramado en este intervalo son mucho más escasos. 


\subsubsection{Viento}

El viento es un factor importante en amplias zonas de Aragón, especialmente en la depresión del Ebro, tanto por su frecuencia como su intensidad propiciados por la topografía que produce su canalización entre los Pirineos y la Cordillera Ibérica (Plan Territorial de Protección Civil de Aragón). El viento no suele ser un factor determinante en el uso de los materiales, pero si en la localización de los edificios y la disposición de los vanos evitando su exposición a los vientos predominantes, en el caso de Aragón al viento de noroeste conocido como Cierzo. Además, es un factor que puede favorecer la erosión o el desgaste de los muros de tierra si estos no están protegidos y especialmente si va acompañado de lluvia o contiene partículas de arena (figura 7.9).

Tanto la tapia como los entramados predominan en áreas donde la velocidad del viento es más suave, entre 1 y $3 \mathrm{~m} / \mathrm{s}$, con un $65 \%$ en el caso de la tapia y un $77,7 \%$ en el del entramado. Sin embargo, las construcciones de adobe, localizadas en gran parte en el valle del Ebro, predominan en áreas con vientos más fuertes con un $63,9 \%$ de los casos en el intervalo de 3 a $5 \mathrm{~m} / \mathrm{s}$. En construcciones aisladas, es posible observar la acción del viento sobre las construcciones que muestran los muros expuestos al Cierzo más erosionados que los otros, y como los huecos de entrada suelen localizarse generalmente al abrigo del cierzo (Rivas González 2011) (tabla 7.5.; figura 7.10).

\begin{tabular}{|r|c|c|c|c|c|c|c|c|}
\hline \multirow{2}{*}{ PRECIPITACIONES } & \multicolumn{2}{|c|}{ TAPIA } & \multicolumn{2}{c|}{ ADOBE } & \multicolumn{2}{c|}{ ENTRAMADO } & \multicolumn{2}{c|}{ TODO } \\
\cline { 2 - 9 } & 187 & $\%$ & 180 & $\%$ & 45 & $\%$ & 258 & $\%$ \\
\hline $301-400 \mathrm{~mm}$ & 43 & $23,0 \%$ & 44 & $24,4 \%$ & 5 & $11,1 \%$ & 58 & $22,5 \%$ \\
\hline $401-500 \mathrm{~mm}$ & 105 & $56,1 \%$ & 98 & $54,4 \%$ & 25 & $55,6 \%$ & 136 & $52,7 \%$ \\
\hline $501-600 \mathrm{~mm}$ & 31 & $16,6 \%$ & 17 & $9,4 \%$ & 10 & $22,2 \%$ & 36 & $14,0 \%$ \\
\hline $601-700 \mathrm{~mm}$ & 8 & $4,3 \%$ & 17 & $9,4 \%$ & 2 & $4,4 \%$ & 21 & $8,1 \%$ \\
\hline $701-800 \mathrm{~mm}$ & 0 & $0,0 \%$ & 1 & $0,6 \%$ & 0 & $0,0 \%$ & 1 & $0,4 \%$ \\
\hline $801-1.000 \mathrm{~mm}$ & 0 & $0,0 \%$ & 3 & $1,7 \%$ & 2 & $4,4 \%$ & 5 & $1,9 \%$ \\
\hline $1.001-1.400 \mathrm{~mm}$ & 0 & $0,0 \%$ & 0 & $0,0 \%$ & 1 & $2,2 \%$ & 1 & $0,4 \%$ \\
\hline $1.401-1.800 \mathrm{~mm}$ & 0 & $0,0 \%$ & 0 & $0,0 \%$ & 0 & $0,0 \%$ & 0 & $0,0 \%$ \\
\hline $1.801-2.200 \mathrm{~mm}$ & 0 & $0,0 \%$ & 0 & $0,0 \%$ & 0 & $0,0 \%$ & 0 & $0,0 \%$ \\
\hline
\end{tabular}

Tabla 7.4. Arquiectura de tierra y precipitación media

\begin{tabular}{|r|c|c|c|c|c|c|c|c|}
\hline \multirow{2}{*}{ VIENTO } & \multicolumn{2}{|c|}{ TAPIA } & \multicolumn{2}{c|}{ ADOBE } & \multicolumn{2}{c|}{ ENTRAMADO } & \multicolumn{2}{c|}{ TODO } \\
\cline { 2 - 9 } & 187 & $\%$ & 180 & $\%$ & 45 & $\%$ & 258 & $\%$ \\
\hline $1-2 \mathrm{~m} / \mathrm{s}$ & 81 & $43 \%$ & 31 & $17,2 \%$ & 20 & $44,4 \%$ & 85 & $32,9 \%$ \\
\hline $2-3 \mathrm{~m} / \mathrm{s}$ & 42 & $22 \%$ & 34 & $18,9 \%$ & 15 & $33,3 \%$ & 45 & $17,4 \%$ \\
\hline $3-4 \mathrm{~m} / \mathrm{s}$ & 32 & $17 \%$ & 61 & $33,9 \%$ & 8 & $17,8 \%$ & 67 & $26,0 \%$ \\
\hline $4-5 \mathrm{~m} / \mathrm{s}$ & 32 & $17 \%$ & 54 & $30,0 \%$ & 2 & $4,4 \%$ & 61 & $23,6 \%$ \\
\hline
\end{tabular}

Tabla 7.5. Arquitectura de tierra e intensidad del viento

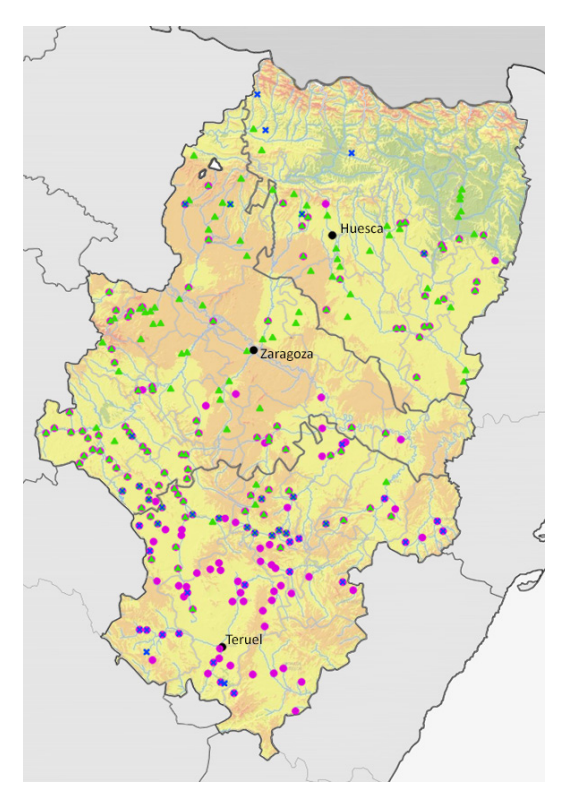

Figura 7.9. Riesgo de viento Fuente: Plan Territorial de Protección Civil de Aragón 


\subsubsection{Radiación solar}

La radiación solar en Aragón se encuentra en los niveles intermedios dentro de la Península Ibérica, entre 3,8 y $4,8 \mathrm{kWh} / \mathrm{m}^{2}$. día y los mayores rangos se localizan en el centro de la comunidad sobre la depresión del Ebro. La arquitectura tradicional siempre ha buscado el aprovechamiento solar como fuente de iluminación, pero también como fuente de calor en las épocas frías, y la protección frene al mismo en épocas calurosas en función de las condiciones de cada lugar (AA.VV. 2014 c). La incidencia solar en las construcciones con tierra puede suponer una ventaja gracias a la inercia térmica y a los amplios espesores que generalmente poseen los muros de forma que el calor es absorbido evitando su penetración al interior de los edificios de forma inmediata, dilatándolo hasta la noche cuando las temperaturas caen de nuevo (Dincyurek, Mallick y Numan 2003) (tabla 7.6.; figura 7.11).

Casi la totalidad de los núcleos de población se localizan en el rango de 4,0 a 4,8 kWh/m².día (98,4\%) ya que las zonas con radiación inferiores corresponden a la zona pirenaica. La tapia predomina en el intervalo de 4,2 a 4,4 kWh/m². día aunque, en el resto de los intervalos, se localiza un número de casos considerable. Por otro lado, el adobe predomina en áreas con radiaciones mayores, de 4,4 a 4,6 $\mathrm{kWh} / \mathrm{m}^{2}$. día y su presencia en áreas con radiación menor a $4,2 \mathrm{kWh} / \mathrm{m}^{2}$.día es muy reducida. Ambas técnicas poseen amplios grosores de muro, especialmente la tapia, que permiten la protección frente a la radiación solar en verano y el mantenimiento de temperaturas frescas. En cuanto a los entramados, su presencia en las proximidades a las zonas de montaña hace que una proporción elevada se localicen en áreas con radiaciones inferiores $\left(26,7 \%\right.$ en radiaciones menores a $4,2 \mathrm{kWh} / \mathrm{m}^{2}$.día). Los muros en entramados son generalmente de menor espesor, lo cual permite que el calor de la radiación solar incida con mayor facilidad al interior de los edificios, contribuyendo al aporte energético necesario para alcanzar el confort necesario en estas zonas (tradicionalmente el fuego), especialmente en invierno.

\begin{tabular}{|c|c|c|c|c|c|c|c|c|}
\hline \multirow{2}{*}{ RADIACIÓN SOLAR } & \multicolumn{2}{|c|}{ TAPIA } & \multicolumn{2}{c|}{ ADOBE } & \multicolumn{2}{c|}{ ENTRAMADO } & \multicolumn{2}{c|}{ TODO } \\
\cline { 2 - 9 } & 187 & $\%$ & 180 & $\%$ & 45 & $\%$ & 258 & $\%$ \\
\hline $3,8-4,0 \mathrm{kWh} / \mathrm{m}^{2}$ día & 0 & $0,0 \%$ & 1 & $0,6 \%$ & 3 & $6,7 \%$ & 4 & $1,6 \%$ \\
\hline $4,0-4,2 \mathrm{kWh} / \mathrm{m}^{2}$.día & 29 & $15,5 \%$ & 7 & $3,9 \%$ & 9 & $20,0 \%$ & 38 & $14,7 \%$ \\
\hline $4,2-4,4 \mathrm{kWh} / \mathrm{m}^{2}$.día & 85 & $45,5 \%$ & 72 & $40,0 \%$ & 27 & $60,0 \%$ & 105 & $40,7 \%$ \\
\hline $4,4-4,6 \mathrm{kWh} / \mathrm{m}^{2}$.día & 55 & $29,4 \%$ & 83 & $46,1 \%$ & 5 & $11,1 \%$ & 88 & $34,1 \%$ \\
\hline $4,6-4,8 \mathrm{kWh} / \mathrm{m}^{2}$. día & 18 & $9,6 \%$ & 17 & $9,4 \%$ & 1 & $2,2 \%$ & 23 & $8,9 \%$ \\
\hline
\end{tabular}

Tabla 7.6. Arquitectura de tierra y radiación solar 


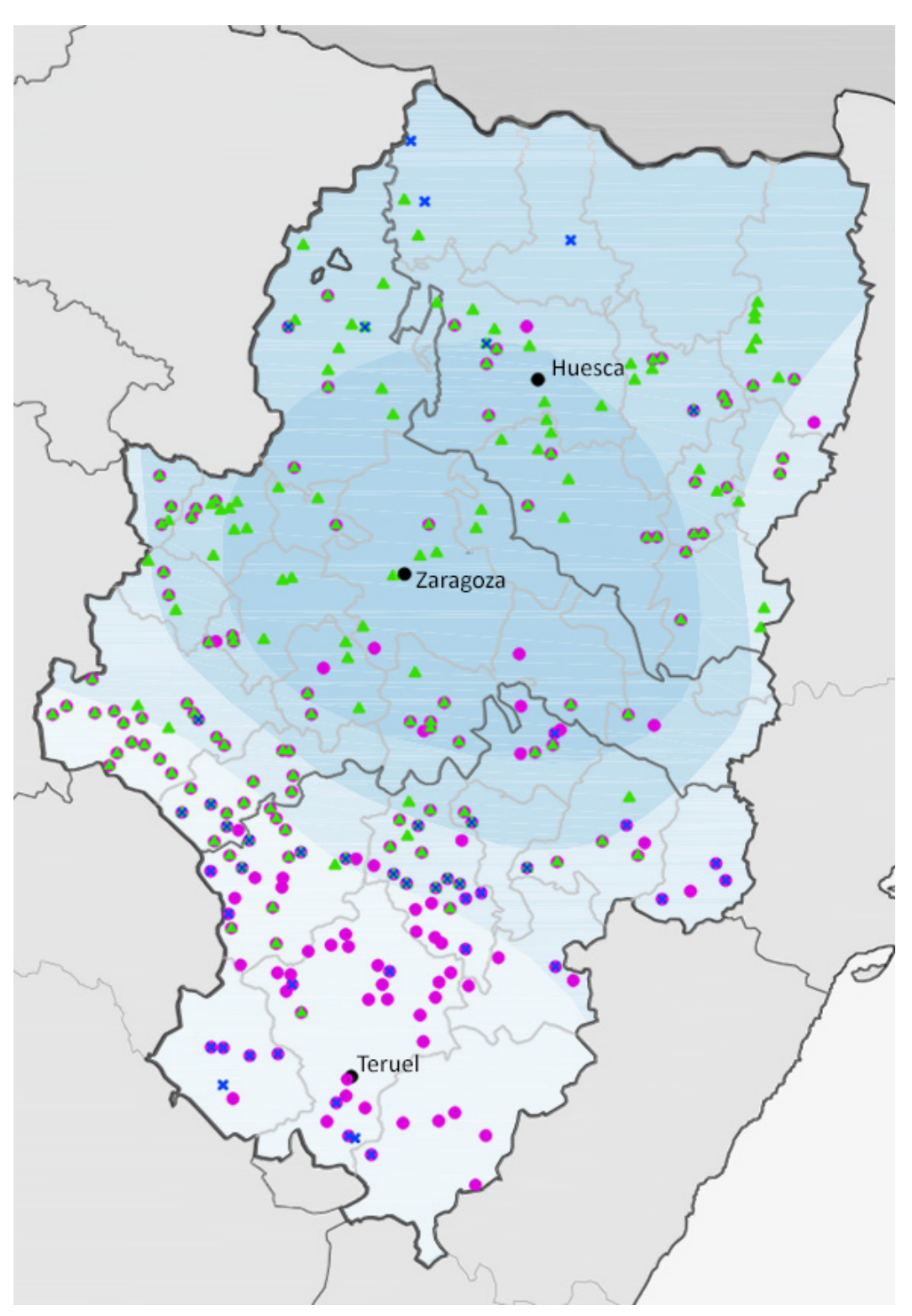

Figura 7. 10. Viento. Fuente: Atlas Nacional de España. IGN. Ministerio Español de Fomento

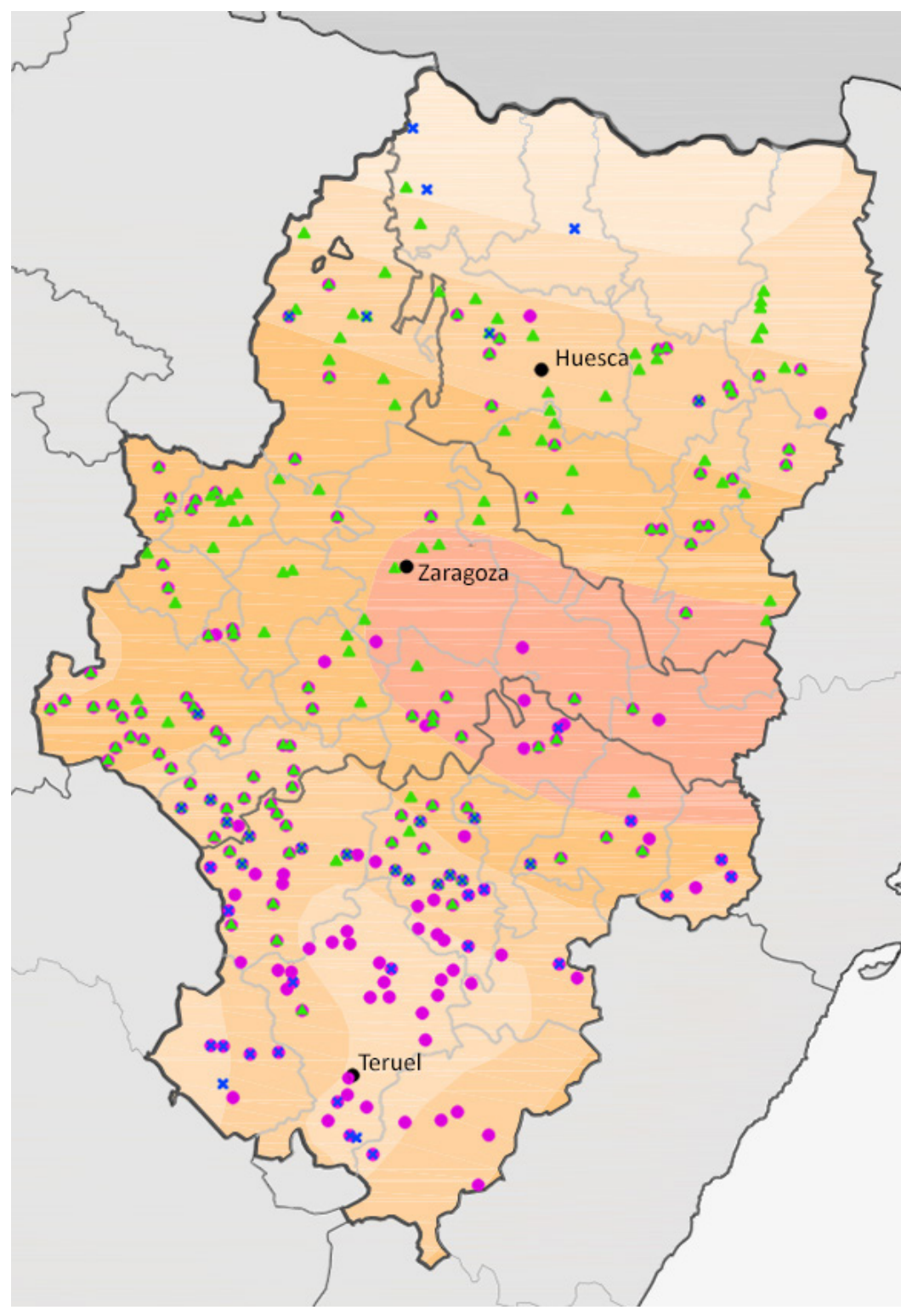

Figura 7.11. Radiación solar. Fuente: Cwhisphysics
Viento

$1-2 \mathrm{~m} / \mathrm{s}$

$2-3 \mathrm{~m} / \mathrm{s}$

$3-4 \mathrm{~m} / \mathrm{s}$

4-5 m/s

Radiación solar

$3,8-4,0 \mathrm{kWh} / \mathrm{m}^{2} \cdot \mathrm{dia}^{2}$

$4,0-4,2 \mathrm{kWh} / \mathrm{m}^{2} \cdot \mathrm{dí}^{\mathrm{a}}$

$4,2-4,4 \mathrm{kWh} / \mathrm{m}^{2} \cdot \mathrm{dia}$

$4,4-4,6 \mathrm{kWh} / \mathrm{m}^{2} \cdot \mathrm{dia}^{-}$

$4,6-4,8 \mathrm{kWh} / \mathrm{m}^{2} \cdot \mathrm{dia}^{-}$

Tapia

$\Delta$ Adobe

$\times$ Entramado 


\subsubsection{Climas}

El clima es la "síntesis de las condiciones meteorológicas" descrita de forma estadística a través de unos estudios de variabilidad de sus propiedades durante un periodo de tiempo determinado (AEmeT 2011). La clasificación de climas según Köppen- Geiger de 1936, utilizada para la realización de este análisis, se basa en los valores medios mensuales de precipitación y temperatura, y la influencia que tienen estos factores sobre la distribución de la vegetación y la actividad humana (Essenwanger y Landsberg 2001). Esta clasificación prevé distintos tipos de clima que son el resultado de la combinación de los climas principales con las características de precipitación y temperatura (tabla 7.7).

El clima en Aragón, como se ha viso en cada uno de los factores que lo componen, viene condicionado de forma directa por la topografía y las influencias de los dos mares y los dos continentes más próximos. Existe un predominio de los climas templados, sin embargo, la zona central del valle del Ebro se ha denominado como BSk que corresponde con clima estepario frio (tabla 7.8.; figura 7.12).

La construcción con tierra y las técnicas de forma individual, tienen un predominio en los climas Cfb que corresponden con climas cálidos y húmedos con veranos templados. Por otro lado, no se ha localizado ningún caso en los climas fríos correspondientes con el área de los pirineos.

La presencia de la tapia predomina en los climas templados cálidos de veranos templado ( $\mathrm{Cfb}$ ) con un 53,3\% de los casos, aunque también es común en los climas templados de veranos cálidos (Cfa, 19,8\%) y en la estepa fría (BSk, 22,5\%)

El adobe se encuentra distribuido de forma más homogénea entre los tres tipos de clima anteriores con aproximadamente un 30\% en cada uno de ellos, debido a su distribución en la franja central de Aragón.

Los entramados, por su parte, predominan en el clima cálido con veranos templado (Cfb, 71,1\%) por ser su presencia superior en el área sur de Aragón donde predomina este tipo de clima.

\begin{tabular}{|l|l|l|}
\hline Climas principales & Precipitaciones & \multicolumn{1}{|c|}{ Temperatura } \\
\hline A- ecuatorial & W- desierto & h- calor árido \\
\hline B- árido o secos & S- estepa & k- frío árido \\
\hline C- templado & f- húmedo & a- verano cálido \\
\hline D- frío (nieve) & s- verano seco & b- verano templado \\
\hline E- polar & w- invierno seco & c- verano frío \\
\hline & m- monzones & d- continentalizado \\
\hline & & F- polar muy frío \\
\hline & & T- polar tundra \\
\hline
\end{tabular}

Tabla 7.7. Clasificación de climas según Köppen-Geiger Fuente: Kottek et Al. 2006

\begin{tabular}{|r|c|c|c|c|c|c|c|c|}
\hline \multirow{2}{*}{ CLIMAS } & \multicolumn{2}{|c|}{ TAPIA } & \multicolumn{2}{|c|}{ ADOBE } & \multicolumn{2}{c|}{ ENTRAMADO } & \multicolumn{2}{c|}{ TODO } \\
\cline { 2 - 9 } & 187 & $\%$ & 180 & $\%$ & 45 & $\%$ & 258 & $\%$ \\
\hline Dfc & 0 & $0,0 \%$ & 0 & $0,0 \%$ & 0 & $0,0 \%$ & 0 & $0,0 \%$ \\
\hline Dfb & 0 & $0,0 \%$ & 0 & $0,0 \%$ & 0 & $0,0 \%$ & 0 & $0,0 \%$ \\
\hline Cfb & 100 & $53,5 \%$ & 62 & $34,4 \%$ & 32 & $71,1 \%$ & 122 & $47,3 \%$ \\
\hline Cfa & 37 & $19,8 \%$ & 57 & $31,7 \%$ & 5 & $11,1 \%$ & 60 & $23,3 \%$ \\
\hline Csb & 1 & $0,5 \%$ & 0 & $0,0 \%$ & 0 & $0,0 \%$ & 1 & $0,4 \%$ \\
\hline Csa & 7 & $3,7 \%$ & 8 & $4,4 \%$ & 4 & $8,9 \%$ & 11 & $4,3 \%$ \\
\hline BSk & 42 & $22,5 \%$ & 53 & $29,4 \%$ & 4 & $8,9 \%$ & 64 & $24,8 \%$ \\
\hline
\end{tabular}

Tabla 7.8. Arquitectura de tierra y climas 


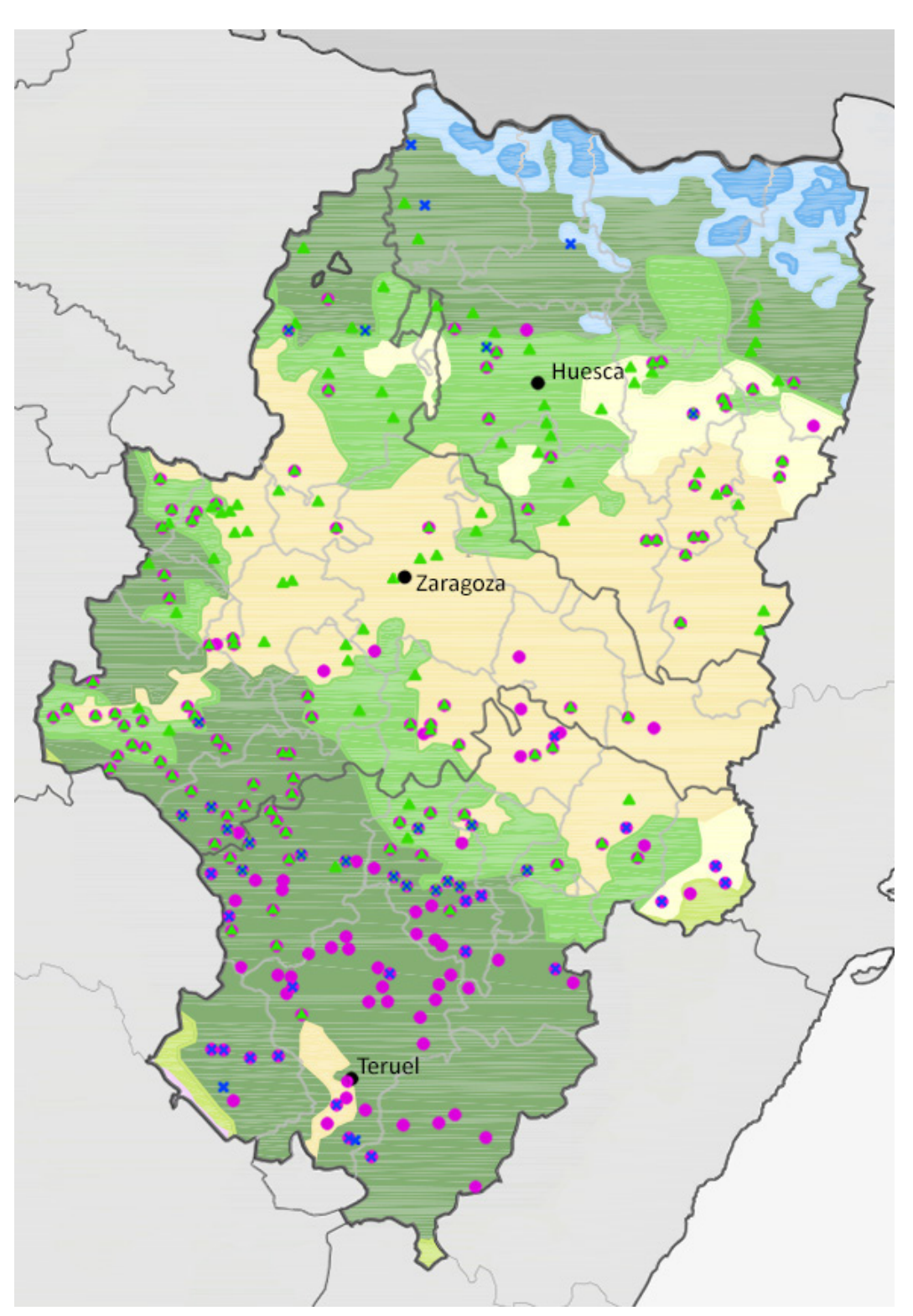

Figura 7.12. Climas (periodo de 1971 a 2001) Fuente: AEmeT 2011, edición propia.

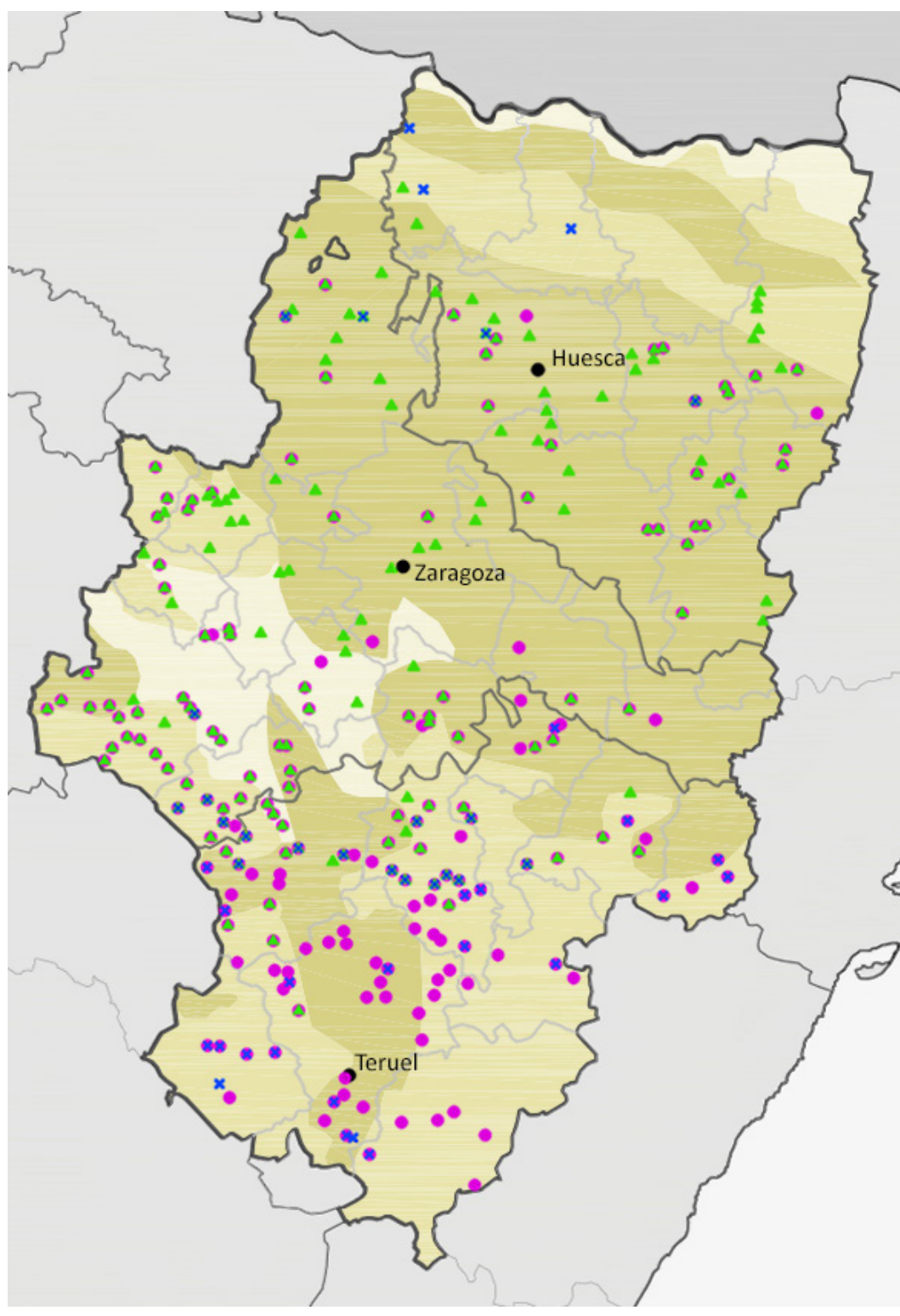

Figura 7.13. Litología. Fuente: Solé et al.1952, edición propia.
Climas

DfC

$\mathrm{Dfb}$

$\square \mathrm{Cfb}$

$\mathrm{cfa}$

Csb

Csa

BSk

Litología

Silícea

Calcárea

Arcillosa

- Tapia

$\Delta$ Adobe

$\times$ Entramado 


\subsection{Factores geológicos}

Los factores geológicos son aquellos que definen tanto los materiales que componen tanto el subsuelo como la corteza terrestre, así como su estructura. Estos factores afectan directamente a la disposición de materiales y, en el caso de tratarse de zonas sísmicas, en el diseño de los edificios. En este apartado se ha analizado la litología y la sismicidad del territorio aragonés.

\subsubsection{Litología}

La litología es la parte de la geología que estudia las características de las rocas localizadas en la parte superficial del terreno y, por tanto, las más accesibles. El tipo de roca o terreno existente en la superficie de una zona y los materiales utilizados para la construcción en ese mismo lugar están íntimamente relacionados, ya que la arquitectura tradicional hace el mejor uso posible de los recursos disponibles, evitando los transportes innecesarios y reduciendo el esfuerzo invertido en el proceso de construcción (AA.VV. 2014 c). En Aragón se pueden distinguir tres áreas litológicas: calcárea, arcillosa y silícea, esta última con una presencia mucho menor que las otras dos (tabla 7.9.; figura 7.13).

La arquitectura de tierra esta ligada a la existencia de arcilla ya que es el elemento que permite establecer las uniones entre las partículas que componen la tierra. En el caso de Aragón, el terreno arcilloso es predominante, factor que favorece el desarrollo y que pone de manifiesto una mayoría de localidades con construcciones de tierra (54\%), mientras que en el área silícea son mínimas (7\%).

En el caso de las localidades con tapia, existe una proporción semejante de casos en al área caliza (43,9\%) y en el área arcillosa (47,1\%). Por su parte, las construcciones con adobe predominan en el área arcillosa con un $56,7 \%$ de los casos, hecho que puede estar relacionado con su adecuación para la producción de adobes ya que se necesita una proporción de arcilla elevada (Fernandes 2005). La presencia de arcilla además está asociada a los valles de los ríos sonde se producen sedimentos de este material en forma de lodo o "buro", como se le conoce en Aragón, utilizados tradicionalmente en construcción

Los entramados, al estar condicionados a la existencia de madera y ser el tipo de relleno variable, no se ven afectados de forma directa por las características litológicas del terreno. Es la única técnica que predomina en el área calcárea, aunque en el caso de cerramiento de adobe el número total de casos localizados es casi similar a la del área calcárea (7 casos frente a 9 casos) 


\subsubsection{Sismo}

El riego sísmico en Aragón puede considerarse bajo en la mayor parte del territorio, dado que casi la totalidad del territorio se localiza en áreas con intensidades menores a VI con periodos de recurrencia de 500 años. En el norte de la comunidad, coincidiendo con la principal cadena montañosa, los Pirineos, existen áreas de alcance de intensidad VII, factor que debería ser considerado en los aspectos de diseño de su arquitectura. No obstante, esta área coincide con el área donde la arquitectura tradicional de tierra tiene menos presencia $(1,9 \%)$ por lo que no se ha detectado ningún aspecto característico relacionado con la presencia de sismos (tabla 7.10.; figura 7.14; figura 7.17).

El bajo grado sísmico y periodo de recurrencia en la mayor parte del territorio, dificulta la tarea establecer relaciones entre la técnica constructiva y la sismicidad. Aunque, en otras áreas sí que se han estudiado variantes específicas en los sistemas constructivos tradicionales y soluciones que mejoran las propiedades de los edificios frente a estos fenómenos y que controlan o limitan los movimientos y evitan grandes agrietamientos (Dipasquale, Sidik y Mecca 2014).

En Aragón algunas de soluciones de carácter sísmico como tirantes, contrafuertes o juntas de yeso (Correia y Carlos 2015), están presentes en algunos edificios, pero no se pueden establecer relaciones directas con el sismo por su poca frecuencia sino, más bien, con los movimientos puntuales del terreno o deficiencias estructurales del edificio (figura 7.15; figura 7.16).

\begin{tabular}{|r|c|c|c|c|c|c|c|c|}
\hline \multirow{2}{*}{ LITOLOGÍA } & \multicolumn{2}{|c|}{ TAPIA } & \multicolumn{2}{c|}{ ADOBE } & \multicolumn{2}{c|}{ ENTRAMADO } & \multicolumn{2}{c|}{ TODO } \\
\cline { 2 - 9 } & 187 & $\%$ & 180 & $\%$ & 45 & $\%$ & 258 & $\%$ \\
\hline Silícea & 17 & $9,1 \%$ & 18 & $10,0 \%$ & 1 & $2,2 \%$ & 18 & $7 \%$ \\
\hline Calcárea & 82 & $43,9 \%$ & 60 & $33,3 \%$ & 28 & $62,2 \%$ & 101 & $39 \%$ \\
\hline Arcillosa & 88 & $47,1 \%$ & 102 & $56,7 \%$ & 16 & $35,6 \%$ & 139 & $54 \%$ \\
\hline
\end{tabular}

Tabla 7.9. Arquitectura de tierra y litología

\begin{tabular}{|c|c|c|c|c|c|c|c|c|}
\hline \multirow{2}{*}{ SISMO } & \multicolumn{2}{|c|}{ TAPIA } & \multicolumn{2}{|c|}{ ADOBE } & \multicolumn{2}{|c|}{ ENTRAMADO } & \multicolumn{2}{|c|}{ TODO } \\
\hline & 187 & $\%$ & 180 & $\%$ & 45 & $\%$ & 258 & $\%$ \\
\hline$>\mathrm{VI}$ & 187 & $100,0 \%$ & 178 & $98,9 \%$ & 42 & $93,3 \%$ & 253 & $98,1 \%$ \\
\hline $\mathrm{VI}$ & 0 & $0,0 \%$ & 2 & $1,1 \%$ & 3 & $6,7 \%$ & 5 & $1,9 \%$ \\
\hline VII & 0 & $0,0 \%$ & 0 & $0,0 \%$ & 0 & $0,0 \%$ & 0 & $0,0 \%$ \\
\hline
\end{tabular}

Tabla 7.10. Arquitectura de tierra y sismo

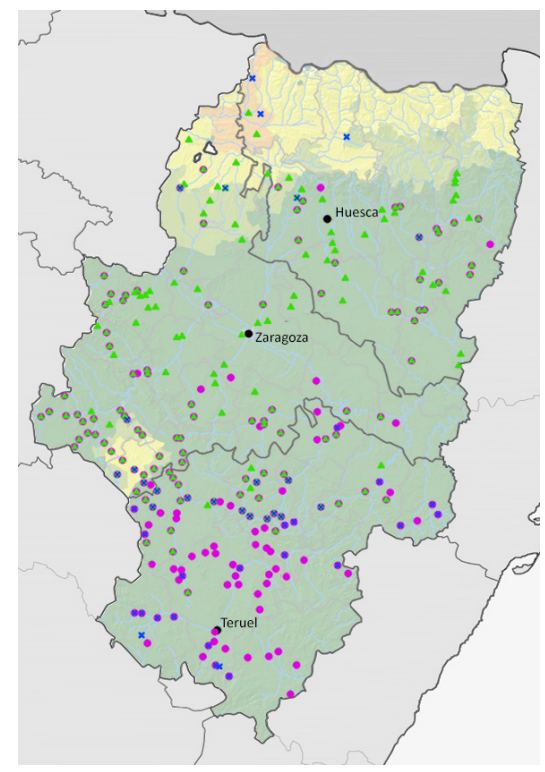

Figura 7.14. Riesgo de sismo Fuente: Plan Territorial de Protección Civil de Aragón, IGN 


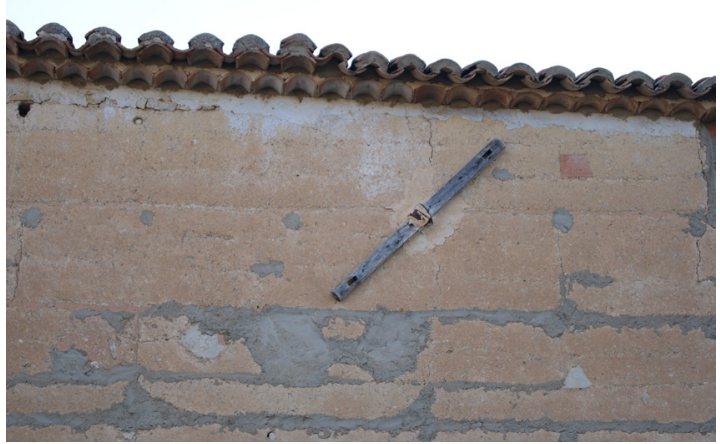

Figura 7.15. Tirante tradicional en un muro de tapia. Aguatón, Teruel

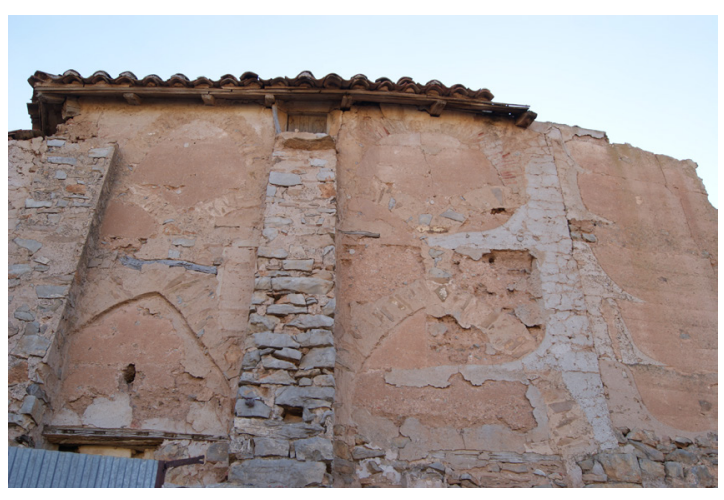

Figura 7.16. Contrafuertes de piedra sobre un muro de tapia. Argente, Teruel.

\subsection{Factores sociales}

Los factores sociales son aquellos que afectan a la sociedad y a los seres humanos, en el espacio o entorno concreto en el que se encuentran y que tienen un aspecto cultural. En este apartado se ha analizado la densidad de población en Aragón.

\subsubsection{Densidad de población}

La densidad de población no es un factor relacionado directamente con las técnicas constructivas sino mas bien con la conservación o el abandono de los edificios en áreas determinadas. Desde mitad del siglo XX Aragón ha sufrido una despoblación importante de los núcleos rurales en gran parte del territorio debido, en parte, a la llegada de la industrialización y al abandono de estas áreas por parte de los gobiernos correspondientes. Estos factores junto el difícil acceso a muchas de estas áreas produjo un aumento los niveles de pobreza, así como una desvinculación del progreso que se producía al mismo tiempo en las ciudades.

Algunas de estas áreas, especialmente en zonas de montaña, todavía disponen de vías de comunicación muy deficientes que dificultan su acceso y por tanto la posibilidad de habitar, de disponer de muchos de los requerimientos de confort actuales y de que su arquitectura se mantenga. Además, el clima severo, con inviernos fríos y secos y veranos calurosos, que caracteriza a gran parte territorio Aragonés junto con los nuevos estándares de confort y la inversión económica que supone adaptar las viviendas antiguas a estos han alentado a que parte de la población solo habite en estos pequeños núcleos los meses estivales y muchas de estas localidades pasen a ser el lugar de vacaciones.

Pese al abandono de la zona rural, gran parte de su arquitectura ha pervivido con más o menos deficiencias, en ocasiones dándoles un uso secundario y en otras con pequeñas reparaciones para utilizarla como segunda residencia. Por otro lado, las construcciones más afectadas son especialmente aquellas cuyo uso no tiene sentido actualmente y que en muchas ocasiones han sido abandonados y se encuentran en estado de ruina. Pese a su abandono, el estado actual de estos edificios ha permitido observar sus técnicas y secciones constructivas perfectamente, lo cual ha sido muy ventajoso para el desarrollo del trabajo, ya que gran parte del mismo se basa en la toma de datos de forma directa y visual.

La densidad de población en Aragón puede considerarse como baja o muy baja con una media de 27,4 hab/km2 (14,1 hab/km2 en Huesca, 55,2 hab/km2 en Zaragoza y 9,2 hab/km2 en Teruel) y cuanta con 15 comarcas y un $71,3 \%$ de los municipios con una densidad por debajo de $10 \mathrm{hab} / \mathrm{km} 2$. 


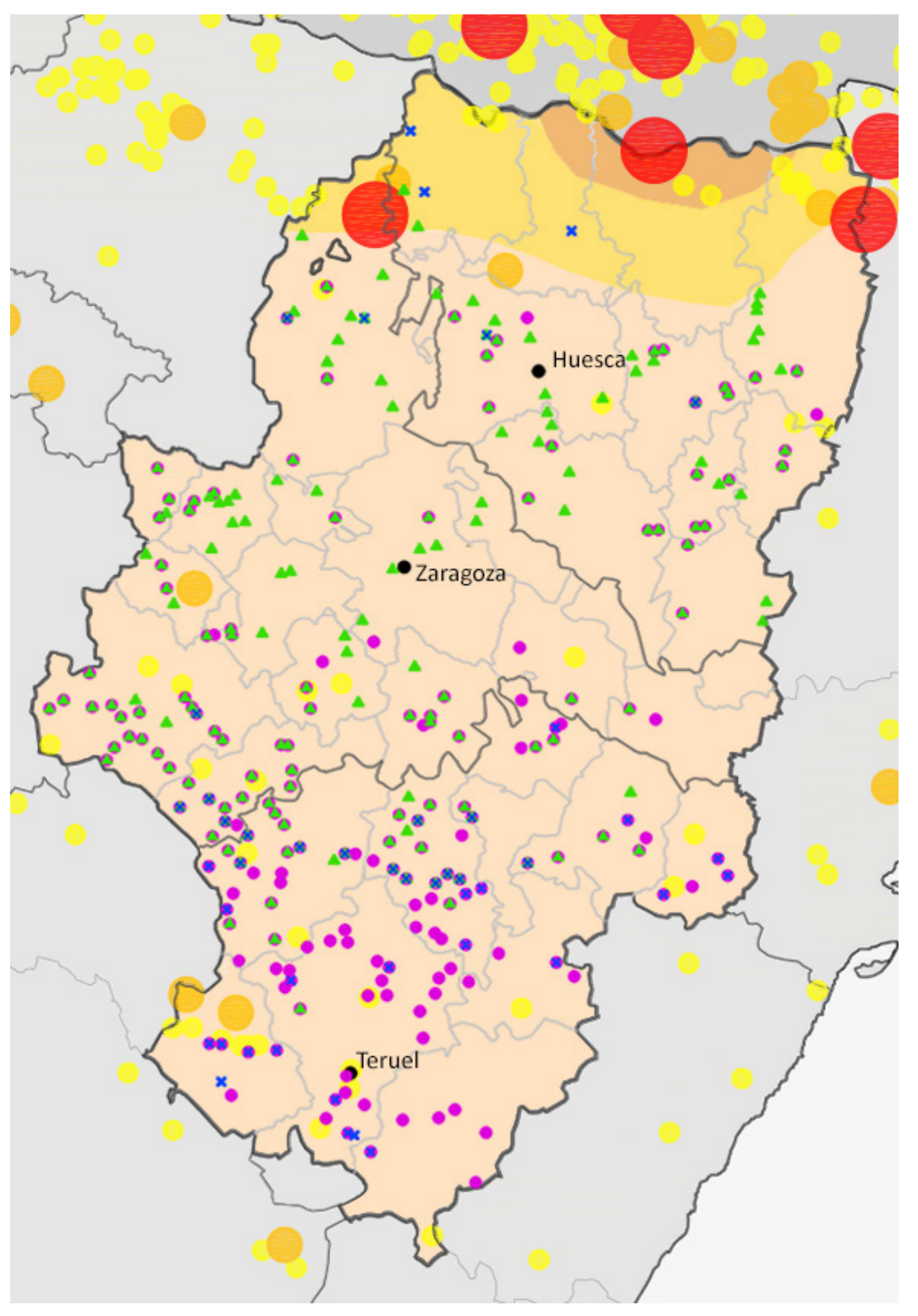

Figura 7.17. Sismicidad. IGN, Ministerio Español de Fomento 2002, edición propia.

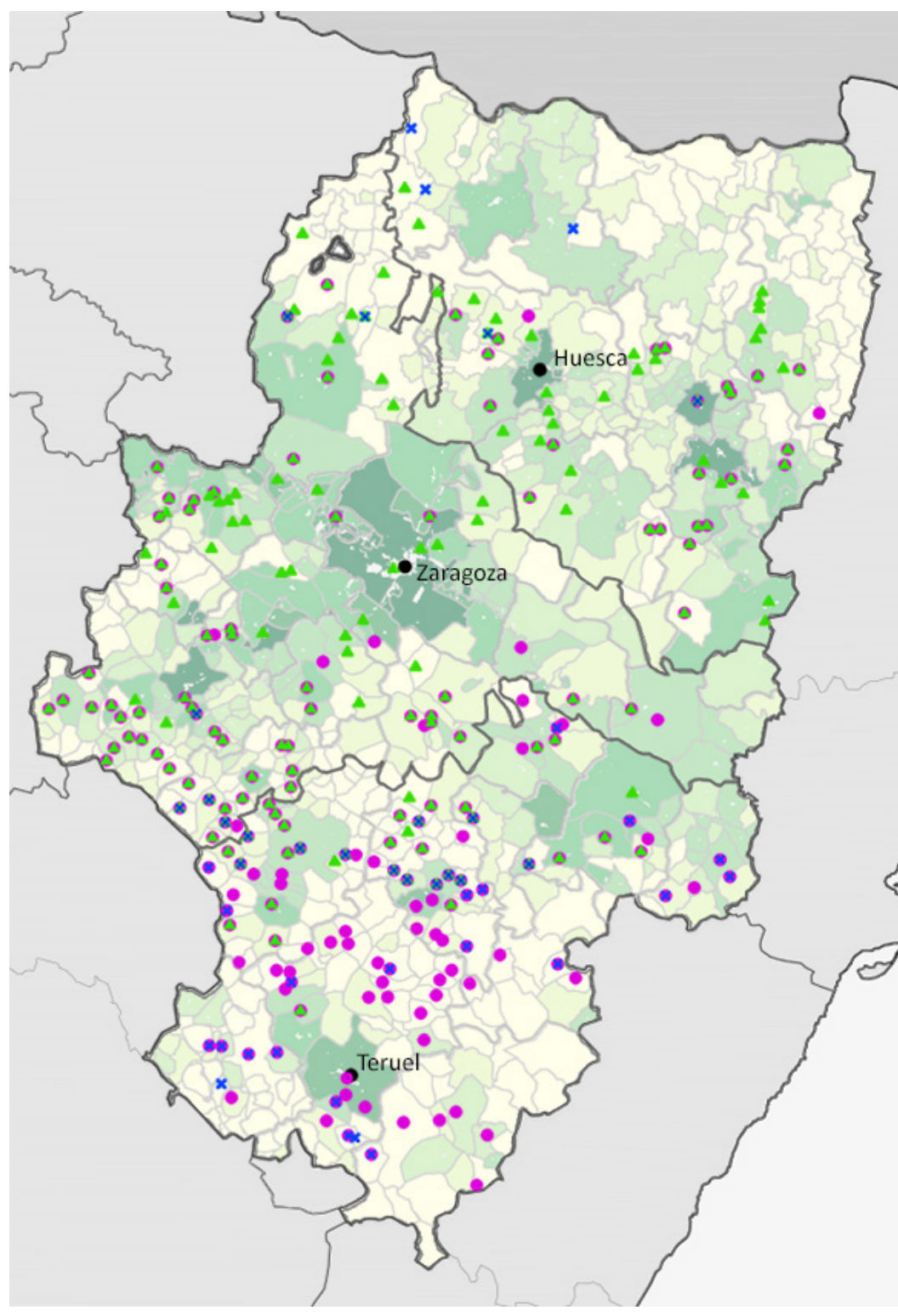

Figura 7.18. Densidad de población. Fuente: IGEAR, edición propia.
Sismicidad

- IV $\leq$ intensidad $\leq \mathrm{VI}$

VISintensidad $\leq \mathrm{VIII}$

VIII $\leq$ intensidad

$>\mathrm{VI}$

VI

VII

Densidad de población

\section{0-3 hab $/ \mathrm{km}^{2}$}

\section{4-6 hab $/ \mathrm{km}^{2}$}

7-10 hab/km²

11-20 hab/km²

20-50 hab/km²

50-100 hab/km²

101-4000 hab/km²

- Tapia

$\triangle$ Adobe

$\times$ Entramado 


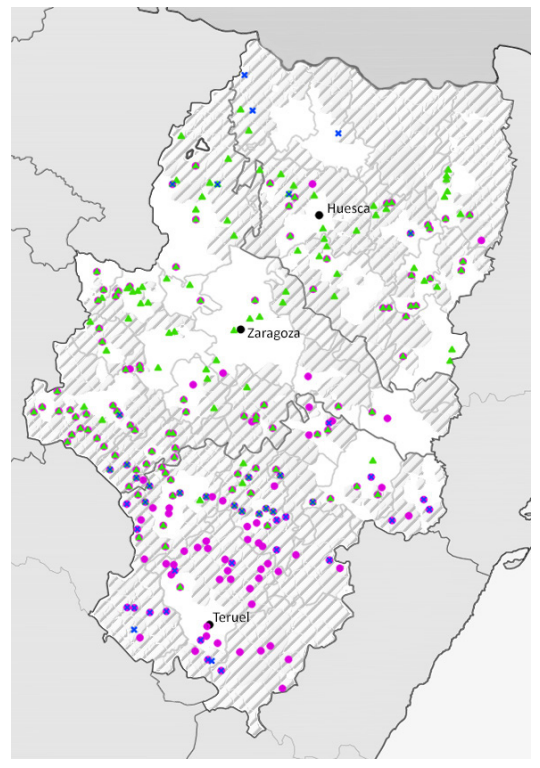

Figura 7.19. Áreas con densidad de población menor a 10hab/km2. Fuente: IGEAR
Los resultados al analizar el número de poblaciones con construcciones de tierra están en el mismo orden. Un $71,7 \%$ de las poblaciones se localizan en áreas con una densidad menor a $10 \mathrm{hab} / \mathrm{km} 2$ y dentro de las técnicas constructiva la localizada en zonas más pobladas es el adobe $(67,2 \%$ en áreas con $10 \mathrm{hab} / \mathrm{km} 2$ o menos) por su mayor presencia en el valle del Ebro donde se localiza la capital y núcleos de población de mayor tamaño (tabla 7.11.; figura 7.18; figura 7.19).

Existe una relación interesante entre la densidad de población y la altitud del terreno a través de la cual se puede detectar como las zonas de montaña, con mayor altitud y temperaturas más severas en invierno, son generalmente las menos pobladas.

\begin{tabular}{|c|c|c|c|c|c|c|c|c|}
\hline \multirow{2}{*}{$\begin{array}{c}\text { DENSIDAD DE } \\
\text { POBLACIÓN }\end{array}$} & \multicolumn{2}{|c|}{ TAPIA } & \multicolumn{2}{c|}{ ADOBE } & \multicolumn{2}{c|}{ ENTRAMADO } & \multicolumn{2}{c|}{ TODO } \\
\cline { 2 - 9 } & 187 & $\%$ & 180 & $\%$ & 45 & $\%$ & 258 & $\%$ \\
\hline$<10 \mathrm{hab} / \mathrm{km}^{2}$ & 139 & $74,3 \%$ & 121 & $67,2 \%$ & 37 & $82,2 \%$ & 185 & $71,7 \%$ \\
\hline$>10 \mathrm{hab} / \mathrm{km}^{2}$ & 48 & $25,7 \%$ & 59 & $32,8 \%$ & 8 & $17,8 \%$ & 73 & $28,3 \%$ \\
\hline
\end{tabular}

Tabla 7.11. Arquitectura de tierra y densidad de población

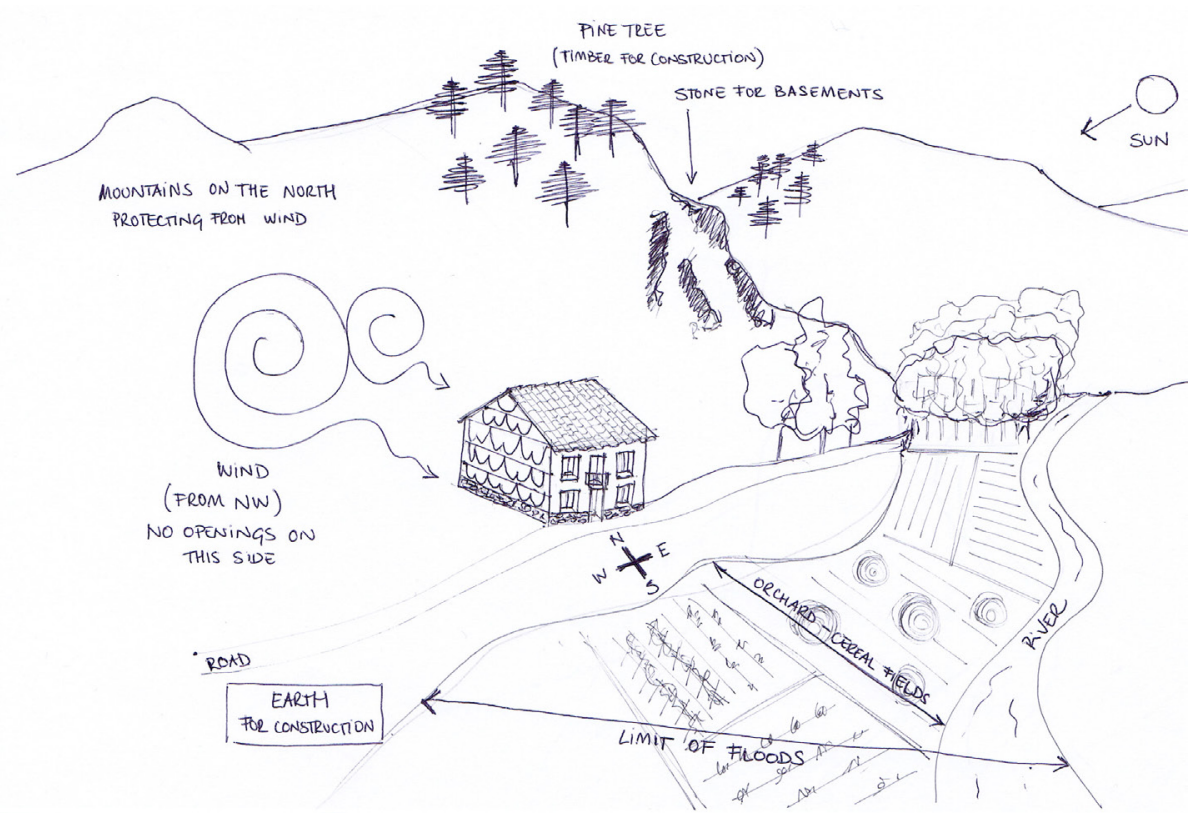

Figura 7.20. Esquema de relación de la arquitectura con el entorno en el que se encuentra 
8. FENÓMENOS DE DEGRADACIÓN DE LAS CONSTRUCCIONES DE TIERRA 


\section{FENÓMENOS DE DEGRADACIÓN DE LAS CONSTRUCCIONES DE}

TIERRA

1. Este tipo de degradaciones se estudiarán en el tercer bloque de intervención en relación a los casos de estudio y sus intervenciones
La arquitectura tradicional de tierra en Aragón es abundante y variada en la mayor parte del territorio. Sin embargo, desde los años 50-60, derivado del importante éxodo rural, se ha ido produciendo un abandono y deterioro progresivo en gran cantidad de edificios, sobre todo en aquellos que en el proceso de industrialización perdieron su función y con ello su razón de ser. Además, la disminución de la población también a producido que, debido al uso reducido de muchos edificios, estos se reparen de forma inadecuada y se generen nuevos problemas.

La arquitectura de tierra puede ser muy duradera en el tiempo si se realiza un buen mantenimiento de la construcción y se encuentra bien protegida frente al agua, especialmente en su base y su coronación como indica el proverbio inglés "Give him a good hat and a good pair of boots and he will take care of himself" (Dale un buen sombrero y unas buenas botas y se cuidará solo) (Mileto et al. 2017 b). Otras citas hacen referencia a la susceptibilidad de la tierra frente a la acción del agua como el de un oficial francés que defendía uno de los castillos de tapia de Marruecos en 1956- "No son sus armas lo que me asusta, pero que Dios nos ayude si utilizan pistolas de agua"- (Maxwell 2000).

En este tipo de arquitectura, si las construcciones de tierra quedan desprotegidas, los daños pueden manifesarse en un periodo de tiempo relativamente corto (Viñuales 1981). Además, es importante tener en cuenta que las lesiones percibidas visualmente son la manifestación de otros mecanismos de degradación más complejos en un momento concreto, y que, si no se actúa en el origen o en la causa, evolucionarán modificando las características de las lesiones perceptibles. (Mileto, García-Soriano y Vegas 2014).

Los fenómenos de degradación pueden estar generados por distintos factores, sin embargo, las causas más comunes derivan generalmente de la climatología (agua, viento, heladas, cambios de temperatura, etc.), del origen del edificio (concepción o diseño, construcción, calidad de los materiales, etc.) y causas antropológicas ya sea por la falta de mantenimiento o por las modificaciones o intervenciones posteriores ${ }^{1}$ (cambio de distribución de cargas, incompatibilidad material, etc.). Además, por la naturaleza de las construcciones en tierra, los mecanismos de degradación pueden combinarse de forma que la presencia 
de agua puede generar problemas estructurales y los problemas estructurales pueden favorecer la entrada de agua y generar de esta forma problemas distintos a los del origen (Jaquin et al. 2013)

Los estudios referentes a los fenómenos de degradación de las construcciones de tierra, habitualmente, se han realizado de forma genérica o en referencia a las técnicas de construcción (Pignal 2005, Viñuales 1981) y, en pocas ocasiones, en referencia a las variantes constructivas (Mileto, García-Soriano y Vegas 2014; Mileto el al. 2017 b).

Los fenómenos de degradación más comunes en Aragón se han estudiado de forma cualitativa a partir del conjunto de datos recopilados de los distintos edificios de tierra en todos los núcleos de población visitados durante las labores de campo, esto es, los edificios de los 258 núcleos de población. Entorno a esta muestra se ha realizado un estudio general de los principales fenómenos de degradación en cada una de las partes del muro y la relación de las distintas degradaciones con las características propias del territorio estudiado. Además, se ha analizado la degradación y lesiones que presentan algunas de las variantes y subvariantes más presentes en las distintas zonas.

\subsection{Lesiones en la base del muro}

La base del muro es un área que generalmente presenta lesiones derivadas principalmente de la presencia de agua proveniente de distintos focos. Uno de los factores principales que genera la presencia de humedad en la base del muro es la ascensión por capilaridad. Este mecanismo de degradación se manifiesta en primera instancia en forma de manchas, sin embargo, si la humedad persiste en el tiempo puede producir la disgregación del material y el problema puede evolucionar hasta generar una perdida volumétrica o de sección importante que derive en la inestabilidad del muro y en su el colapso por falta de apoyo. Existen factores como la lluvia (y las salpicaduras derivadas), el viento, o las heladas que pueden favorecer notablemente el desarrollo de este mecanismo.

Las temperaturas bajas suponen un problema importante en algunas zonas de Aragón donde se producen heladas de forma casi continua durante largos periodos de tiempo ya que provocan el aumento de las partículas de agua y con ello una disgregación de la tierra más rápida que pueden producir una pérdida de material importante.

Además, existen otros factores como incorrecta concepción del edificio que favorecen la ascensión de humedad por capilaridad como puede ser la inexistencia de un zócalo que proteja y evite el contacto directo del muro de tierra con el terreno (figura 8.1)

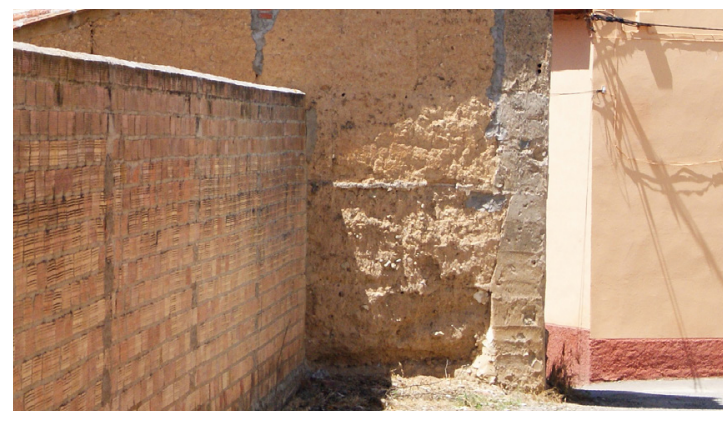

Figura 8.1. Edificio sin zócalo. Alcampell, Huesca

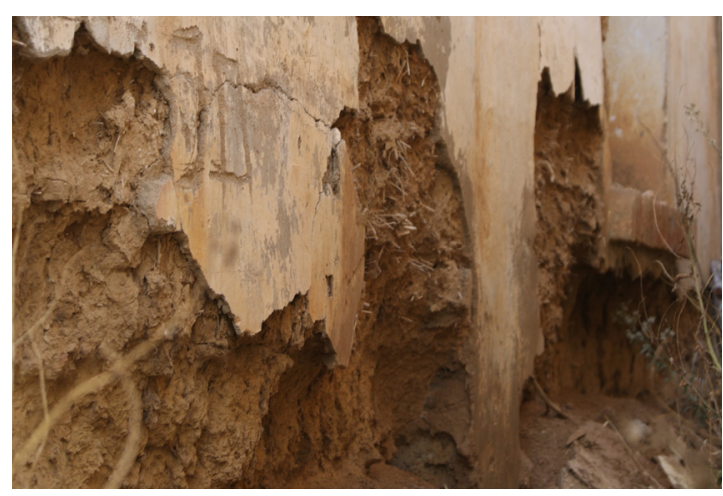

Figura 8.2. Fibras vegetales visibles por la erosión de muro. Grañén, Huesca.

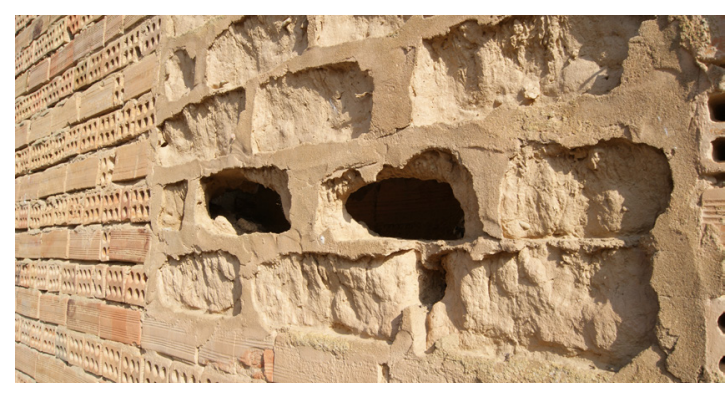

Figura 8.3. Completa desaparición de los adobes a causa de la humedad. Albero bBajo, Huesca. 


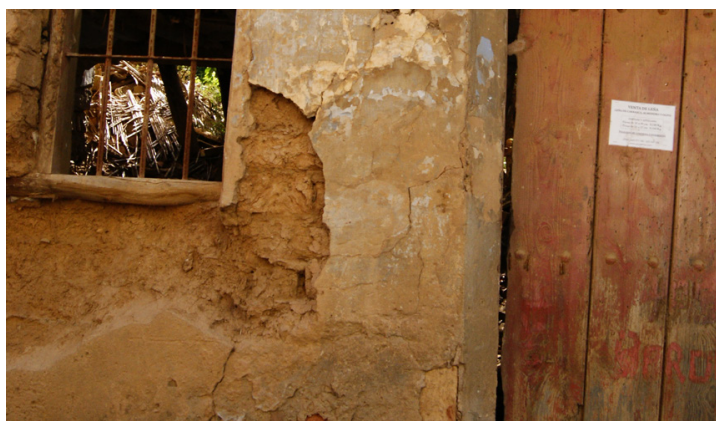

Figura 8.4. Grave perdida de sección derivada de la humedad por capilaidad. Alcolea del Cinca, Huesca.

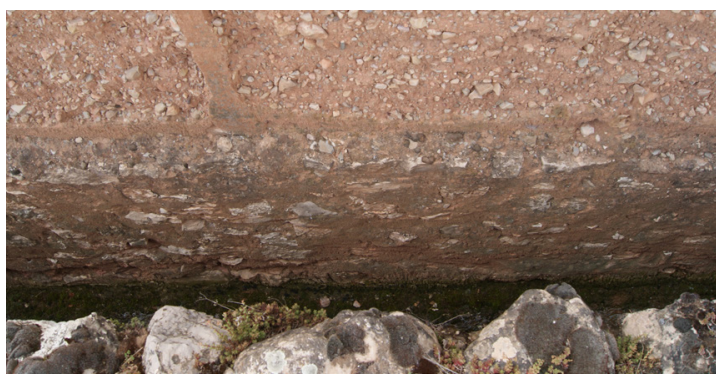

Figura 8.5. Construcción de tapia pegada a una acequia en su cara norte. Montalbán, Teruel.

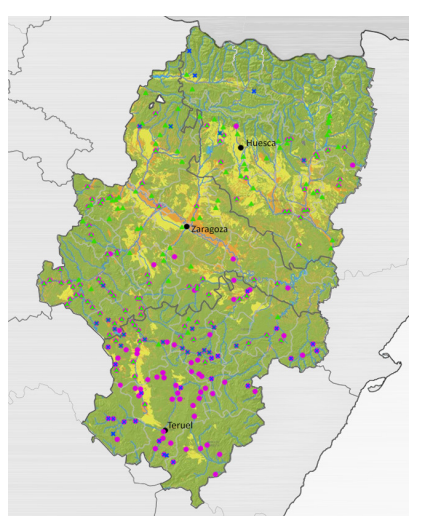

Figura 8.6. Plano de riego de inundaciones (naranja). Fuente: IGEAR, edición propia.
La humedad por capilaridad produce lesiones de características semejantes en las distintas técnicas de tierra, y en las áreas afectadas por el deterioro, en ocasiones y en función del grado de afección, es posible distinguir parte de los componentes de la mezcla como gravas de mayor tamaño, o cantos rodados en la tapia, o la presencia de fibras vegetales en los muros de adobe (figura 8.2).

La presencia de humedades en la parte inferior de los muros es un mecanismo extendido por todo el territorio aragonés, pero no suele generar lesiones graves debido a que gran parte del territorio tiene un clima seco con precipitaciones escasas. Sin embargo, existen varias localidades que presentan lesiones graves derivadas de este factor (Alcolea del Cinca, Grañén, Albero Bajo...) (figura 8.3; figura 8.4). Los casos concretos localizados se sitúan en el sureste de la provincia de Huesca, ligadas al río Cinca y sus afluentes (río Flúmen) donde se generan amplias áreas de cultivos en regadío lo confirma una mayor presencia de humedad en el terreno.

La presencia de líquenes o el enmohecimiento de la superficie, no es una lesión muy frecuente debido a la aridez de la mayor parte del territorio, sin embargo, en ocasiones aparecen de forma puntual en edificios con umbrías permanentes con una presencia de humedad continua (figura 8.5)

Por último, existen otros tipos de fenómenos de degradación generados por situaciones puntuales en algunas áreas concretas como puede ser las inundaciones. En Aragón las inundaciones se producen generalmente por las avenidas o desbordamientos de los ríos por grandes lluvias o por el deshielo acelerado junto con lluvias y afecta principalmente al valle del río Ebro que recoge el agua de los Pirineos y de gran parte del sistema Ibérico. (figura 8.6). Estas crecidas de los ríos pueden alcanzar a edificios secundarios próximos a los cauces e incluso a las poblaciones y generar daños importantes en los muros de tierra debido a la acción del agua acentuada por la erosión que produce al estar en movimiento.

\subsection{Lesiones en el cuerpo y la superficie del muro}

El abanico de lesiones presentes en el cuerpo y la superficie del muro es muy amplio y puede estar generadas por multitud de factores, incluso pueden derivar de los mecanismos de degradación presentes en la base o la coronación del muro.

En el caso de Aragón, las constantes heladas, el viento de noroeste, Cierzo, y la presencia de las lluvias, comúnmente en forma de tormenta, son los principales factores que originan la degradación del cuerpo de los muros de tierra. 
Por un lado, es muy común la presencia de desconchados en los revestimientos que protegen los muros de tierra. La condensación de la humedad (Pignal 2005) entre el muro y el revestimiento, tradicional o no, se ve acentuada por las grandes variaciones de temperatura que existen en entre estaciones y entre el día la noche en gran parte del territorio (figura 7.4). Este tipo de lesión afecta también a la tapia calicostrada y especialmente a la tapia con brencas y calicostrada con yeso, muy frecuente en la zona oeste del sistema Ibérico aragonés, donde es común observar grietas en la junta o la perdida completa de la costra entre la parte que contiene la tierra y la parte de yeso que conforma la brenca (figura 8.7)

En los casos donde no existe revestimiento o este se ha perdido total o parcialmente, la tierra está expuesta a los distintos fenómenos atmosféricos nombrados que producen una erosión del material que puede evolucionar de una erosión superficial a perdidas importantes de sección. En el caso concreto de los muros de adobe, las lesiones superficiales del muro permiten establecer una distinción clara entre el muro de adobe con junta de mortero de barro, cuya erosión y lavado produce una erosión uniforme que en muchos casos hace casi desaparecer las juntas. En los muros de adobe con juntas suplementadas la erosión superficial de las piezas hace que estas juntas permanezcan en un plano saliente respecto a los adobes (figura 8.8). Además, estas juntas horizontales salientes favorecen que el agua se deposite en ellas acelerando de esta forma el proceso de erosión y degradación de las piezas. Este tipo de degradación es común especialmente en la zona de Teruel, donde predomina la técnica, y donde muchos de los muros de adobe funcionan como cerramiento, con el aparejo a soga, y, por lo tanto, poseen un grosor reducido que favorece a que en ocasiones se produzca la pérdida o erosión completa de la sección del adobe (figura 8.9). Algo similar ocurre en el caso de la tapia con suplementos en paramento o suplementos en juntas donde estos materiales suelen quedar en un plano saliente que favoreciendo los depósitos de agua o nieve y acentuado de esa forma la erosión en ese punto (figura 8.10).

En los muros de adobe se pude producir una lesión de características similares a las anteriores pero con origen opuesto ya que consiste en la presencia de oquedades o concretamente juntas vacías. En ocasiones las juntas verticales se dejan sin mortero o con mortero insuficiente para alcanzar el plano exterior del muro presentando pequeñas ranuras en el muro de fábrica. Estas oquedades al igual que las de las agujas de la tapia, favorecen la entrada y depósito de agua, de aire e incluso de pequeños animales que intensifican la erosión de la tierra en ese punto aumentando el tamaño las mismas (figura 8.11). En otras ocasiones se produce una erosión la erosión de las juntas y de las piezas produce un relieve abrupto de pequeños bultos que son la parte central de los adobes (figura 8.12).

En el caso de los entramados, las lesiones derivan generalmente de los agentes meteorológicos, que afectan tanto a la estructura como al relleno, y de la propia construcción y la conexión entre los distintos

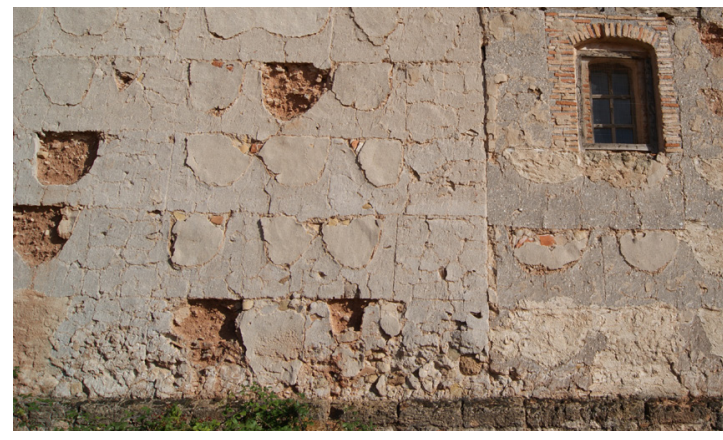

Figura 8.7. Pérdida de la costra entre brencas. Martín del Río, Teruel.

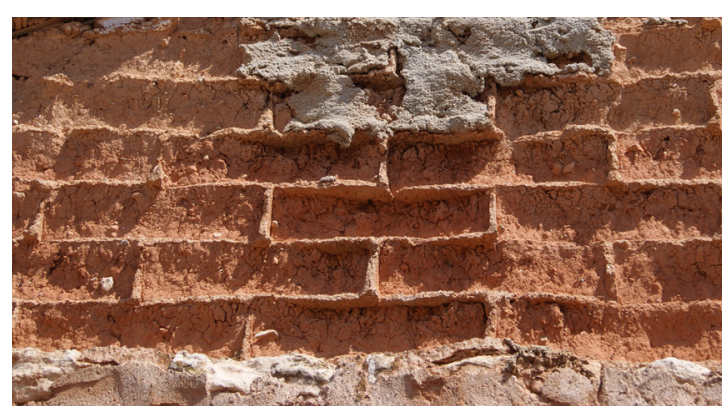

Figura 8.8. Erosión muro de adobe con juntas de yeso. Muniesa, Teruel.

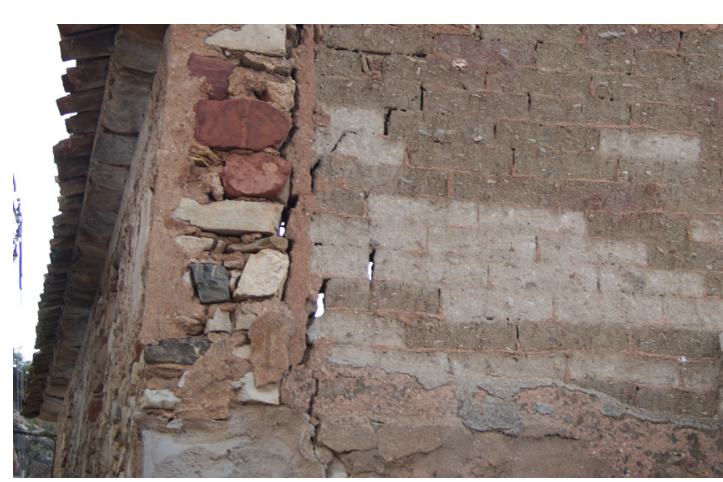

Figura 8.9. Grieta en la sección completa en la fábrica de adobe mixta. La Hoz de la Vieja, Teruel 


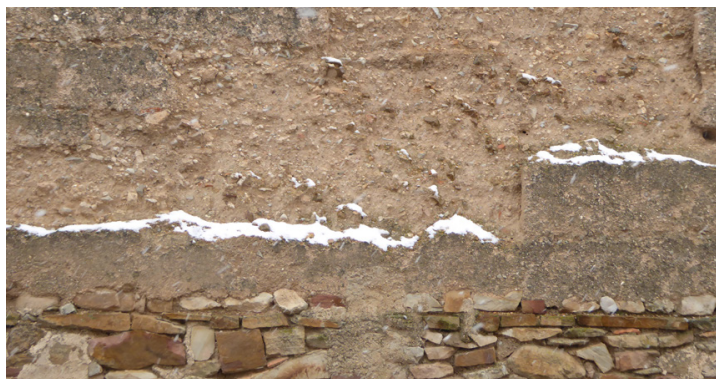

Figura 8.10. Depósitos de nieve en una tapia que ha perdido la costra. Alba de Campo, Teruel. Autores: Fernando Vegas y Camilla Mileto

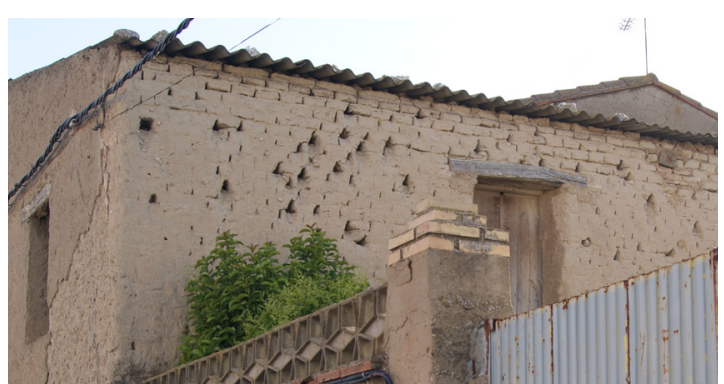

Figura 8.11. Oquedades realizadas por animales en las juntas del adobe. Villamayor de Gállego, Zaragoza.

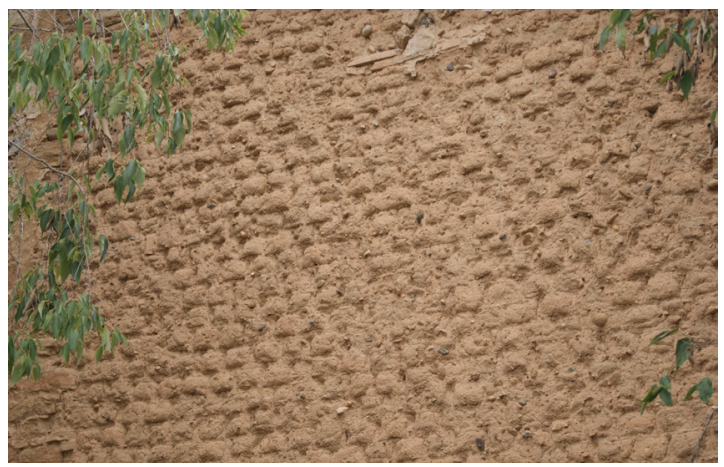

Figura 8.12. Relieve abrupto del muro de adobe por la erosión de las juntas. Estadilla, Huesca.

elementos (Pignal 2005). En el primer caso la acumulación de agua puede producir la pudrición de las cabezas de los montantes y el movimiento derivado de los mismo. En el caso del relleno, al tratarse generalmente de muros de poco espesor es común la pérdida total o parcial de ese material. Por otro lado, en el caso de los entramados tejidos es común la pudrición de las fibras vegetales y su rotura. En el caso de Aragón, esta ultima técnica aparece reiteradamente en la provincia de Teruel donde la tierra se combina con yeso y se puede apreciar la huella o impronta del cañizo desaparecido en la parte de muro restante (figura 8.13).

El viento en gran parte de Aragón es un factor importante, especialmente en los casos de edificios aislados donde, debido a la frecuencia, a la intensidad, a las partículas que transporta, así como la influencia sobre la dirección del agua de lluvia, se genera una erosión mayor en los muros localizados a noroeste que se puede apreciar visualmente (figura 8.14). El viento en Aragón es frecuente especialmente en todo el valle del Ebro, sin embargo, las zonas de mayor altitud también son puntos de riesgo ya que están más expuestas y, por tanto, también su arquitectura (figura 7.9).

Por otro lado, las tormentas, especialmente en verano, pueden desencadenar distintos fenómenos de degradación ya sea por la propia acción del agua con el viento o por ocasionar desperfectos en distintas partes de los edificios. Los desperfectos suelen originar por la presencia de vientos fuertes acompañando la tormenta, por las tormentas eléctricas o a causa de el granizo (sobre todo en parte de la provincia de Teruel y en el Pirineo oscense).

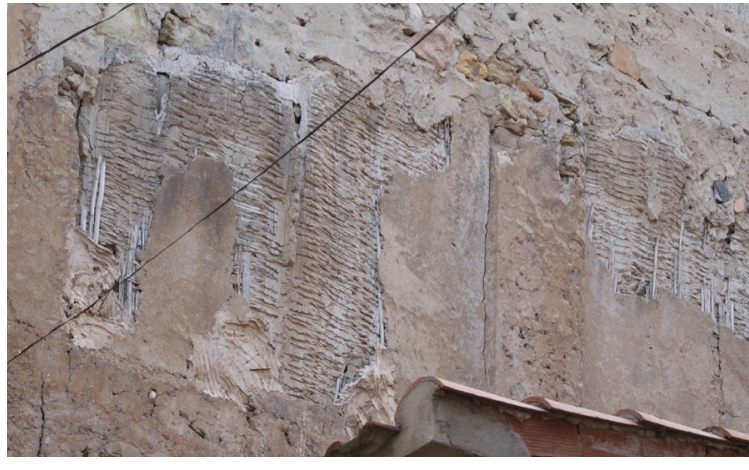

Figura 8.13. Pérdida de la tierra con yeso sobre el cañizo Oliete, Teruel.

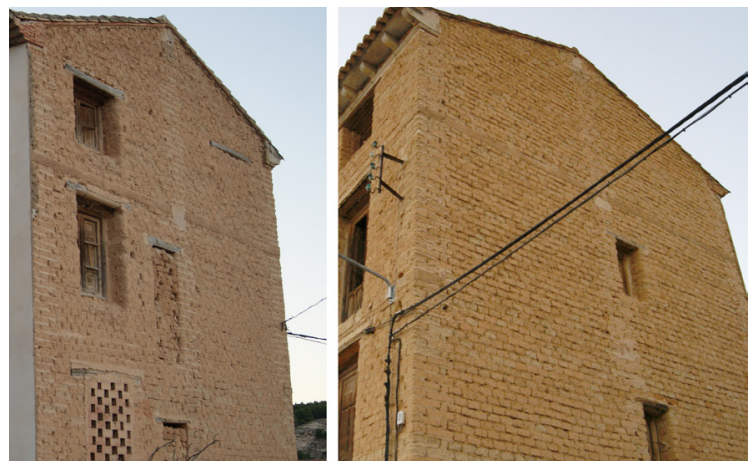

Figura 8.14. Comparación de la erosión de la fachada Oeste (dch.) y la este (izq.). Embid de Ariza, Zaragoza 
Las lesiones debidas a la presencia de insectos no son tan evidentes (arañas o pequeños insectos en juntas $u$ oquedades), sin embargo, aparecen en gran cantidad de edificios y en ocasiones generan lesiones muy características como las oquedades (Figura 8.15).

Un mismo mecanismo puede generar lesiones de distintas características o niveles en función de la configuración del edificio, la composición y compactación de los materiales, los estabilizantes utilizados etc., ya que estos factores son determinantes en la durabilidad del conjunto. Por ello, existen casos en los que, bajo unas mismas condiciones, unos muros se ven más afectados que otros o incluso en un mismo muro piezas o tongadas se degradan de forma desigual (figura 8.16)

Los mecanismos de degradación derivados de un diseño deficiente o de carácter estructural se presentan generalmente en forma de grietas u oquedades. Las lesiones detectadas no presentan particularidades en este territorio sin embargo algunas de ellas se ven afectadas por la técnica o la variante constructiva. En el caso de los muros mixtos, un pequeño movimiento puede generar la apertura y aparición de grietas entre los distintos materiales ya que estos no suelen presentar conexiones entre ellos y no pueden afrontar los esfuerzo a tracción (Jaquin et Al. 2013) (figura 8.17). Esta discontinuidad material afecta a los muros mixtos tanto de tapia y adobe como a los entramados donde las deformaciones excesivas de la estructura de madera pueden generar la inestabilidad del relleno, generalmente de poco espesor, y la perdida parcial o total del mismo. Además, como se ha comentado, la doble naturaleza que poseen los mecanismos de degradación en la arquitectura de tierra suscita a que las grietas de origen estructural pasen a ser un punto frágil frente a los agentes atmosféricos y pequeños animales.

Por último, se han considerado los daños en las construcciones derivados de acontecimientos históricos como la Guerra Civil (1936-1939) ya que fue un episodio muy notorio en la mayor parte de Aragón. En este periodo algunos pueblos fueron completamente destruidos como Belchite o Roden de los que hoy en día es posible visitar sus imponentes ruinas en las que es posible detectar que gran parte de los edificios estaban construidos con técnicas de tierra y como estas se han ido deteriorando posteriormente por la acción del agua, el viento, etc. En algunas construcciones es posible localizar fracturas producidas por la guerra, sin embargo, en la mayoría de los casos el mecanismo de degradación ha evolucionado y se ha perdido la claridad de sus huellas o los edificios se han intervenido o reconstruido parcialmente, borrando las trazas de este evento. No obstante, se ha detectado alguna construcción en las que es posible distinguir incisiones en el muro de los que pudieron ser los impactos de las balas (figura 8.18).

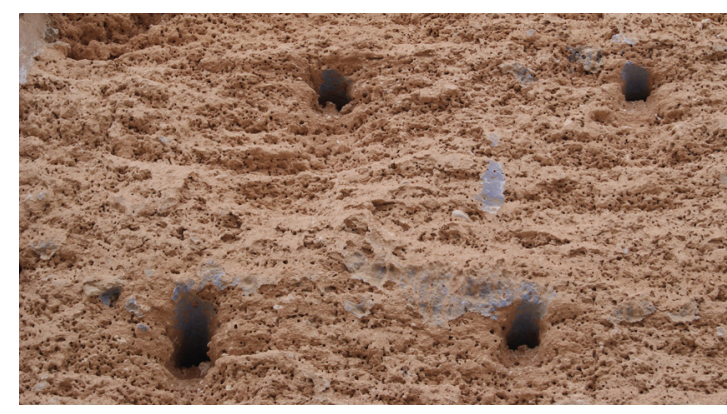

Figura 8.15. Muro de tapia atacado por insectos Castelserás, Teruel.

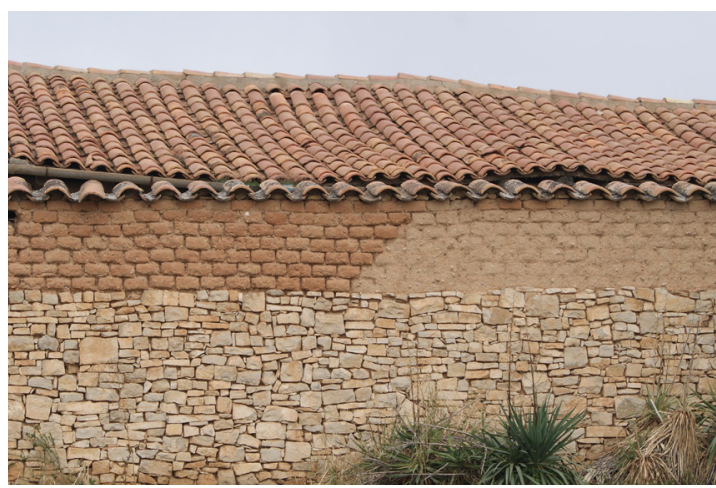

Figura 8.16. Muro con dos tipos de adobe con erosión desigual. Estadilla, Huesca.

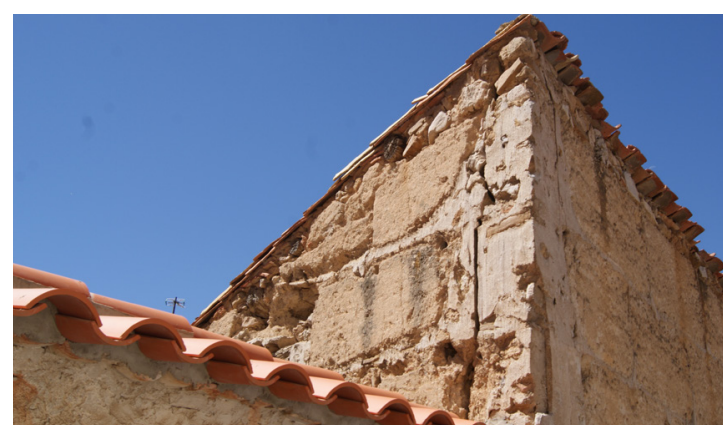

Figura 8.17. Grieta entre la tapia y el machón de mampostería y yeso. Palomar de Arroyos, Teruel 


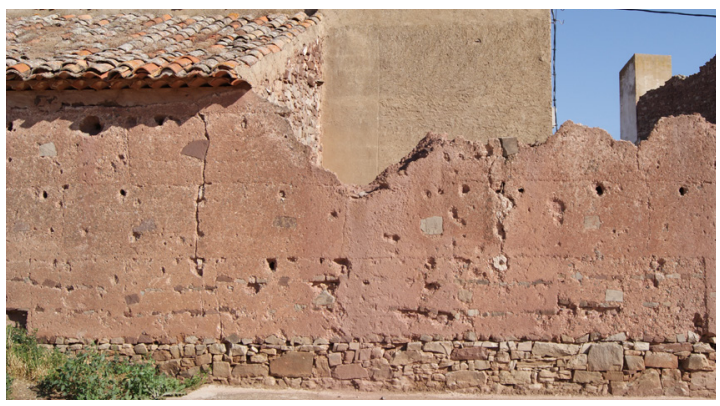

Figura 8.18. Muro de tapia con incisiones de forma aleatoria presumiblemente derivadas de los impactos de las balas en la bat donde se vio envuelta esta localidad. Visiedo, Teruel.

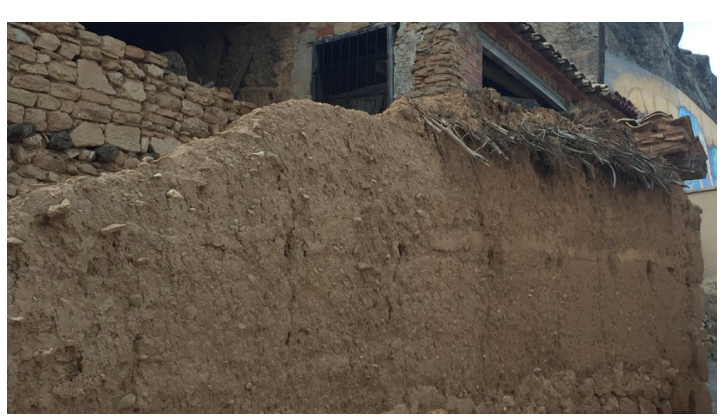

Figura 8.19. Muro que ha perdido gran parte de volumen en la zona desprotegida. Monroyo, Teruel.

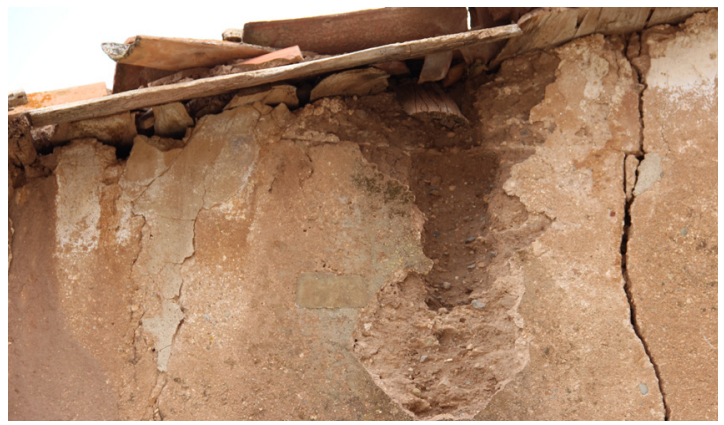

Figura 8.20. Escorrentía de agua por desperfectos en la cubierta. El Pobo, Teruel.

\subsection{Lesiones la coronación del muro}

Las lesiones en la coronación de los muros suelen originarse por la fala de protección o por la presencia de daños en la cubierta generalmente debidos a la falta de mantenimiento. Se trata de un punto es especialmente susceptible a la presencia de agua ya que su afección puede verse extendida a otras partes del muro por acción de la gravedad (figura 8.19).

En el caso de la arquitectura tradicional, la mayoría de las construcciones se encuentran protegidas por la cubierta, en al caso de edificios cerrados y, en el caso de muros de cerca, por distintos materiales como tejas cerámicas, piedras o ramajes, barzas, con barro sobre las mismas. Sin embargo, la falta de mantenimiento en muchas de las construcciones derivada del abandono y el descenso de la población, o el mal diseño y configuración de edificio producen que los elementos de protección se deterioren o fallen, generando lesiones que se manifiestan con cierta rapidez y que son fácilmente reconocibles en los muros (figura 8.20).

La exposición continuada de los muros a la acción del agua provoca el arrastre de partículas de tierra y la consecuente pérdida de material. Si se trata de muros que han perdido por completo o que no disponían de protección, suelen presentar lesiones avanzadas con una pérdida de material importante en la coronación y el paramento lavado. En función de la técnica y la variante constructiva, los muros presentan características distintas frente a la acción del agua. La tapia simple, presenta una erosión más o menos homogénea en su parte superior, sin embargo, la tapia calicostrada en ocasiones presenta la costra exterior menos erosionada concentrándose el agua en el centro o en uno se los lados del muro en función de si la costra es simple o doble. Las lesiones en la tapia con brencas con brencas, muy característica en Aragón, presenta un perfil muy característico ya que en ocasiones la tierra ha desaparecido por completo pero las brencas persisten como pequeños pináculos sobresalientes del muro (figura 8.21). Por otro lado, los muros de adobe presentan características diferentes en función de la variante constructiva y las características de la construcción. Se han detectado casos en los que los muros se han erosionado de forma homogénea, sin embargo, en otras construcciones debido que las juntas favorecen la entrada de agua en ese punto se encuentran más erosionadas que las piezas y los muros presentan un perfil desigual con pequeños "montículos", que corresponden con las piezas de adobe (figura 8.22).

Además de perdida de material en la coronación y el lavado, el muro puede presentar otra serie de problemas favorecidos por la presencia de grietas o la calidad de los materiales y su puesta en obra. 
En los casos en los que los muros están protegidos y existen problemas en la cubierta o esta se ha perdido parcialmente las lesiones son ligeramente diferentes. En el caso de roturas en la cubierta, las lesiones producidas suelen ser puntuales, pero en general se manifiestan de forma rápida favorecidas por la canalización y aumento de la velocidad del agua en ese punto que hacen que la erosión y la cantidad de partículas arrastradas sea mayor. Este tipo de mecanismos de degradación puede generar oquedades de grandes dimensiones y canalizaciones de agua a través del propio muro hasta el suelo (figura 8.23).

Los problemas derivados del diseño o de carácter estructural en la coronación del muro suelen derivar de la acción del agua, del empuje de la cubierta o de la sobrecarga producida por el apoyo directo de los pares de la cubierta sobre el muro de tierra. Además, estos problemas se pueden ver acentuados si la cubierta se encuentra deteriorada y se producen filtraciones de agua próximas a las fisuras o grietas ya que estas serán el punto de evacuación y canalización más inmediato, acelerando notablemente el deterioro.

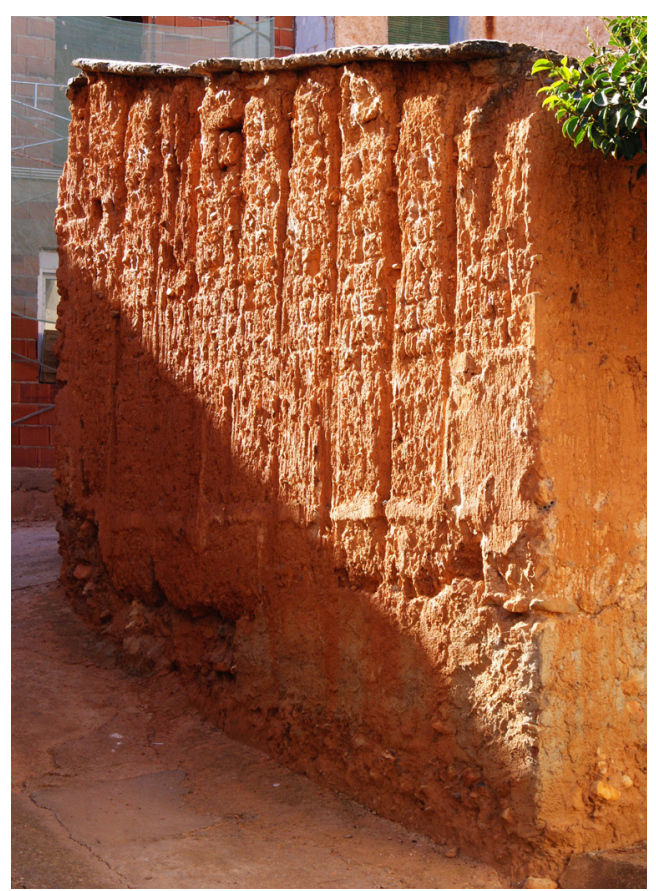

Figura 8.23. Escorrentías en el muro por una protección ineficiente. Ibdes, Zaragoza

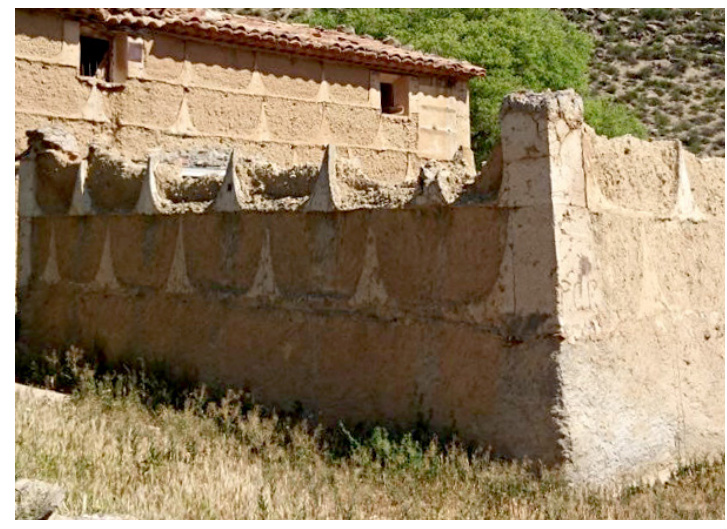

Figura 8.20. Erosión de la tierra y permanencia de las brencas. Alcaine, Teruel.

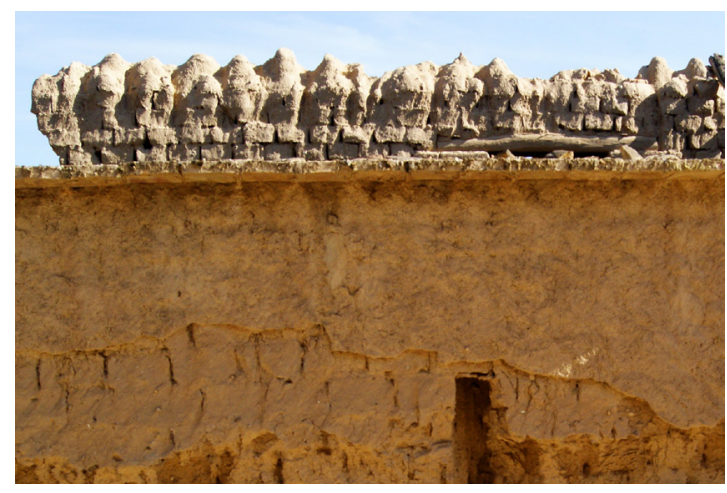

Figura 8.21. Pequeños montículos generados por la erosión de las piezas de adobe y escorrentía por el interior del muro situado al frente en la fotografía. Sena, Huesca. 


\section{BLOQUE III}

\section{INTERVENCIONES EN LA ARQUITECTURA TRADICIONAL DE TIERRA DE ARAGÓN. CRITERIOS Y TÉCNICAS}

9. Marco legislativo de la arquitectura tradicional

10. Las intervenciones en la arquitectura tradicional de tierra en Aragón

11. Líneas guía para una intervención compatible y sostenible 


\section{MARCO LEGISLATIVO DE LA ARQUITECTURA} TRADICIONAL 


\section{MARCO LEGISLATIVO DE LA AQUITECTURA TRADICIONAL}

La legislación en torno al patrimonio vernáculo ha ido evolucionando en las últimas décadas, si embargo, la mayor parte de la arquitectura tradicional no se encuentra al abrigo de ningún marco o legislación específica que la proteja o que acote las formas de actuar sobre la misma.

La arquitectura tradicional ha dejado de ser un fenómeno activo en la mayor parte del mundo por la evolución de la construcción hacia sistemas y técnicas estandarizadas con materiales industriales. El uso de estas técnicas, también en los edificios tradicionales, ha generado el abandono de las técnicas, los materiales y los oficios locales ligados a la tradición local dando paso a una homogeneización y globalización de soluciones cada vez mayor. Esta situación ha levantado una preocupación generalizada por el estado de conservación y la futura evolución, aunque, en general, no ha visto plasmada en las normativas.

El estudio del marco legislativo de la arquitectura tradicional, dentro de la que se engloba la arquitectura tradicional de tierra, busca reconocer los aspectos valorados por los organismos del a la hora de proteger estos edificios o sus conjuntos.

Desde que se desarrolló el concepto de arquitectura tradicional este ha evolucionado y a pasado de tratarse de algo únicamente "pintoresco" o "rustico" con un valor principalmente estético ligado al fachad ismo a tener un valor propio como parte del patrimonio cultural de un lugar.

A continuación, se presentan las principales normativas o marcos legislativos a nivel estatal y autonómico, así como las características de las ayudas o subvenciones ligadas con la rehabilitación de estos edificios. 


\subsection{Marco estatal}

La principal ley de protección del patrimonio a nivel estatal es la ley 16/1985 del Patrimonio Histórico Español, en la que quedan comprendidos los bienes muebles e inmuebles referentes al Patrimonio Arqueológico y Etnográfico, los Museos, Archivos y Bibliotecas de titularidad estatal y el Patrimonio Documental y Bibliográfico, que tengan valor artístico, histórico o antropológico.

Esta ley establece que las competencias de protección quedan distribuidas entre el Estado y las Comunidades Autónomas, de las cuales emana la Constitución y los Estatutos de Autonomía.

Entre los bienes inmuebles, en este documento se muestran las obligaciones y deberes de protección de los Bienes de Interés Cultural y de los inmuebles declarados como Monumento, Jardín Histórico, Conjunto Histórico, Sitio Histórico o Zona Arqueológica. Cada unos de estos inmuebles o grupos deberá disponer de un Plan Especial de Protección para el área correspondiente y al formar parte del Patrimonio Histórico Español deberán ser conservados y mantenidos.

Además, en el artículo treinta y cinco perteneciente al Título IV sobre la protección de los bienes muebles e inmuebles se cita:

"Para la protección de los bienes integrantes del Patrimonio Histórico Español y al objeto de facilitar el acceso de los ciudadanos a los mismos, fomentar la comunicación entre los diferentes servicios y promover la información necesaria para el desarrollo de la investigación científica y técnica se formularán periódicamente Planes Nacionales de Información sobre el Patrimonio Histórico Español."

Los Planes Nacionales de Patrimonio Cultural son instrumentos de gestión compartidos por las distintas administraciones y otras entidades públicas o privadas cuyas competencias de elaboración y aprobación se atribuyen al Consejo de Patrimonio Histórico Español. En estos planes se desarrollan actuaciones de protección, conservación y restauración, investigación, documentación, formación y difusión del patrimonio y constituyen una base informativa para tomar de decisiones, establecer metodologías de actuación y fijar prioridades en función de las necesidades concretas.

En este marco nace el Plan Nacional de Arquitectura Tradicional en el año 2015 como respuesta a la falta de protección jurídica y administrativa específica hacia este tipo de arquitectura, así como a la disparidad de soluciones, criterios y metodologías de actuación existentes y la falta de adaptación de la normativa actual a las características sistemas constructivos históricos.

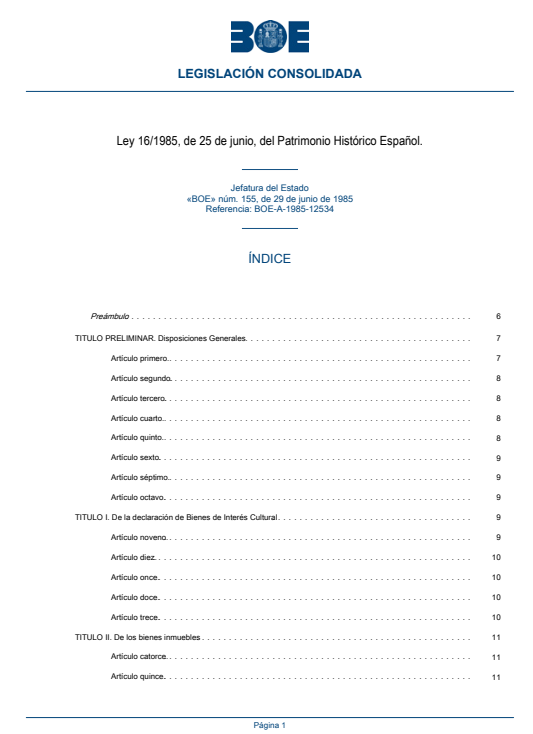

Figura 9.1. Publicación de la ley 16/1985 del Patrimonio Histórico Español en el BOE 


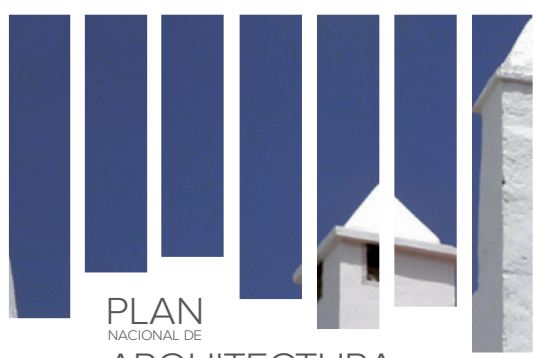

ARQUITECTURA

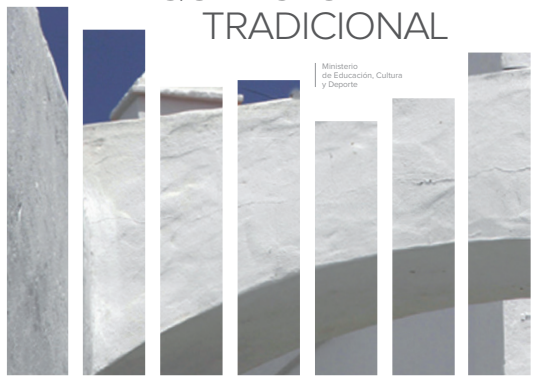

Figura 9.2. Portada del Plan Nacional de Arquitectura Tradicional.

1. Este factor es uno de los que afecta negativamente a la tierra como material de construcción por su estigmatización.
En este documento se presenta un estudio profundo de la situación actual de la arquitectura tradicional, de sus valores y de las necesidades que esta requiere para poder ser conservada de forma adecuada. Algunos de los aspectos más destacados son: la relación de las legislaciones con lo "típico" o lo "pintoresco" como una imagen y el peligro de la protección ambiental de conjuntos históricos; la necesidad de revisión de los planes generales y de protección; los grandes vacíos en los inventarios y la fragmentación de la información por la focalización en determinadas tipologías y el olvido de otras ${ }^{1}$; y la falta de formación, valoración y sensibilización en torno a esta arquitectura.

Derivado de estos factores, el Plan Nacional nombra la necesidad de medidas legislativas de protección con los correspondientes planes económicos para hacerlas factibles. Además, la carencia de estudios, de medidas protectoras, de difusión y de normativa específica dificultan la protección y el uso de las técnicas tradicionales en la actualidad. Por ello, en base a su objetivo principal que es la salvaguarda de este patrimonio, se proponen algunas medidas de protección como: la necesidad de Planes específicos de cada municipio, comarca o mancomunidad adaptados a las características concretas de su arquitectura y la revisión de los existentes; el conocimiento profundo de esta arquitectura; la educación, información y sensibilización ciudadana siendo partícipes de las intervenciones llevadas a cabo; la valoración para que su protección jurídica y protección general básica sean efectivas; la correcta aplicación de la protección por parte de los organismos pertinentes; la difusión de metodologías y ejemplos de buenas prácticas.

Se trata de un documento muy completo en el que quedan definidos los valores, los riesgos, las características, los objetivos del plan, los criterios seguidos y las medidas a llevar a cabo como la investigación y documentación, la protección, la intervención y recuperación de sistemas tradicionales y la difusión y transmisión de los conocimientos. Si bien, como se ha plasmado en el documento, la aplicación de estas medidas, los planes específicos, los inventarios y la protección concreta de un conjunto o edificio depende de las autonomías, las diputaciones provinciales, las comarcas o los propios ayuntamientos. Por ello, el documento tiene un carácter general que sirve de marco para las propuestas a menor escala, pero no tiene valor legislativo.

Por otro lado, este texto presenta un recorrido por los principales estudios de arquitectura tradicional a nivel nacional, así como un resumen de los tipos de protección y elementos protegidos en cada comunidad en base a su normativa y los inventarios realizados, información que resulta de gran interés.

Además de la norma nacional, Aragón también se encuentra al amparo de los reglamentos europeos y en el marco de las disposiciones dictadas por ICOMOS Y la UNESCO, entidades encargadas de salvaguardar el patrimonio mundial. 


\subsection{Marco autonómico}

La principal ley de protección de la arquitectura tradicional en Aragón es la ley 3/1999, de 10 de marzo, del Patrimonio Cultural Aragonés cuyo objetivo es "Ia creación de un marco legal específico de Aragón para proteger, conservar, investigar, incrementar y proyectar al exterior los bienes culturales de nuestra comunidad". En esta misma ley se define el Patrimonio Cultural como: "conjunto de elementos naturales, o culturales, materiales e inmateriales, tanto heredados de nuestros antepasados como creados en el presente, en el cual los aragoneses reconocen sus señas de identidad, y que ha de ser conservado, conocido y transmitido a las generaciones venideras, acrecentándolo." Además, en su artículo 2 cita que este patrimonio está integrado por "por todos los bienes materiales e inmateriales relacionados con la historia y la cultura de Aragón que presenten interés antropológico, antrópico, histórico, artístico, arquitectónico, mobiliario arqueológico, paleontológico, etnológico, científico, lingüístico, documental, cinematográfico, bibliográfico o técnico, hayan sido o no descubiertos y tanto si se encuentran en la superficie como en el subsuelo o bajo la superficie de las aguas."

Por tanto, la arquitectura tradicional de tierra, común en gran parte del territorio aragonés, y su saber hacer debe formar parte de este patrimonio como parte material e inmaterial. Sin embargo, en términos de arquitectura tradicional la ley solo afecta a los bienes que clasifica como: bienes de interés cultural $(\mathrm{BIC})$, bienes catalogados $(\mathrm{BC})$ y bienes inventariados (BI). Dentro del primer grupo se encuentran los Conjuntos de Interés Cultural que engloba distintos tipos de conjuntos de los cuales la arquitectura tradicional puede englobarse en: los Conjuntos Históricos (CH), los Sitios Históricos (SH) y los Lugares de Interés Etnográfico (LIE). Por otro lado, dentro de los bienes catalogados se pueden declarar como Monumentos de Interés Local (art.25) los inmuebles que merezcan especial consideración a los cuales se les aplicará el régimen de protección de los Bienes Catalogados y cuya tutela corresponde al ayuntamiento. Además, los Conjuntos Históricos deberán disponer de un plan especial de protección acompañado de un Catálogo del Patrimonio Arquitectónico que deberán ser incluidos en el Plan General de Ordenación Urbana según la ley 3/2009, de 17 junio, de Urbanismo de Aragón.

El sistema de información del Patrimonio Cultural Aragonés (SIPCA), engloba más de 15000 obras de arquitectura e ingeniería entre Bienes de Interés Cultural, Catalogados e Inventariados. Si bien, esto implica que la gran mayoría de los edificios, al no estar recogidos en ese Censo General no gozan de ningún tipo de protección especial, a menos que localicen en alguno de los conjuntos protegidos y esté recogido en los ayuntamientos de cada localidad.

En segundo lugar, se han analizado el régimen general de protección y conservación del Patrimonio Cultural Aragonés (Título II de la ley). En esta se definen algunos aspectos condicionantes de las

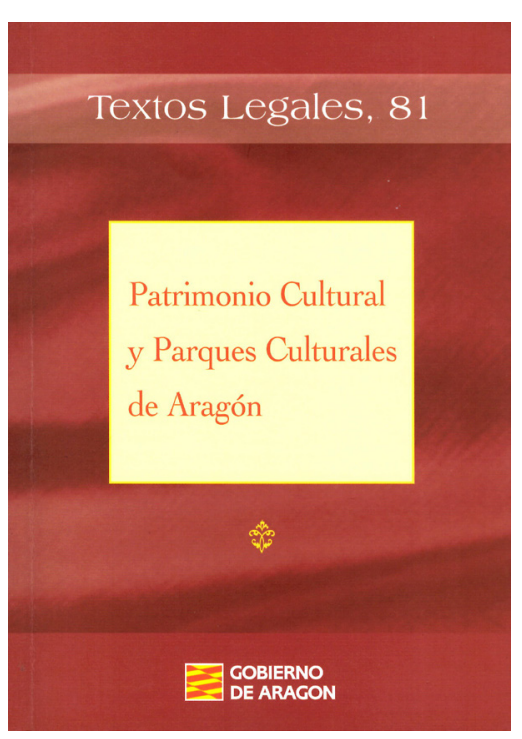

Figura 9.X. Publicación con las principales leyes de Patrimonio en Aragón. 
2. La disposición adicional quinta de esta ley habla de la actualización profesional y formación de los funcionarios encargados de la administración y custodia del Patrimonio intervenciones a realizar en los bienes inmuebles con algún tipo de protección. Los Bienes de interés Cultural inmuebles están, en todo momento bajo la tutela del consejero responsable de Patrimonio Cultural. Los correspondientes a Conjuntos de Interés Cultural necesitan de Planes Especiales de protección del área en los que se definirán entre otras cosas las áreas de protección preferentes, los criterios relativos a la conservación de fachadas y cubiertas y las instalaciones sobre las mismas (art. 43) y, se creará un catálogo de los elementos unitarios donde a excepción de los BIC que disponen de una protección integral, se fijará el nivel de protección correspondiente a los bienes catalogados o inventariados (de nivel ambiental) (art.44). Como se nombra en el Plan Nacional, la norma se centra principalmente en los aspectos estéticos exteriores y en la protección a nivel ambiental sin hacer referencia en ningún caso al valor constructivo o etnográfico de los bienes inmuebles.

El régimen de protección de los Bienes catalogados e Inventariados no hace referencia directa a las intervenciones o las características de los mismos, sino que únicamente nombra la obligatoriedad de la compatibilidad de los usos con la correcta conservación y la protección de los mismos con fines de investigación, consulta y difusión. Por tanto, las normas, si las hay, para llevar a cabo la adecuada conservación de estos bienes quedan a cargo de los ayuntamientos donde se localizan.

El concepto de "fachadismo" o "pintoresquismo" que se ha seguido en la redacción de muchas de las normas y en la declaración de muchos de los bienes ha dejado de lado la protección de muchos edificios que no están ligados a conjuntos protegidos y que poseen un gran valor etnográfico y constructivo que ligados directamente con las costumbres de un área o una localidad. Por otra parte, la dificultad de conocer el interior de los edificios privados también ha influido en que la normativa se haya centrado comúnmente en el aspecto exterior de esta arquitectura tradicional. Por ello, la investigación, el reconocimiento y estudio de los edificios históricos deberían tratarse a nivel local antes de la realización de cualquier obra, para lo cual, los técnicos deberían tener los conocimientos pertinentes ${ }^{2}$ para evaluar y valorar esta arquitectura desde el punto de vista constructivo, material, estructural, etnográfico y de paisaje tanto rural como urbano.

Por otro lado, se considera de interés el análisis de la tercera disposición general de esta ley (3/1999) que habla de los Pueblos deshabitados y cita:

"Los pueblos deshabitados constituyen parte de nuestras raíces culturales y de nuestros modos de vida tradicionales. En los mismos se prohíbe la retirada de materiales y la realización de obras sin autorización de la Comisión Provincial del Patrimonio Cultural. Se impulsará el inventario de sus bienes y la recuperación paulatina de los mismos" 
Esta disposición contiene un aspecto de gran interés que es el valor de los asentamientos tradicionales y de sus construcciones por formar parte de los modos de vida tradicionales. Si bien, todos los cascos históricos de los pueblos de Aragón ${ }^{3}$, y en muchos casos la localidad completa por tener un tamaño y una población reducidos, son representantes de unas raíces culturales, todavía vivas en estos casos, y de los modos de vida tradicionales. Como se ha dicho, la arquitectura tradicional, y la de tierra, ya no existe como fenómeno activo, sin embargo, su puesta en valor puede generar la apropiación de la misma y de su saber hacer por parte de la población. Sin embargo, si la población es inexistente, solo se conservan las ruinas o el aspecto de unos edificios que han perdido su razón de ser y que se exhiben a modo de ruina romántica de lo que fue en su día.

Por otro lado, la ley 12/1997 de 3 de diciembre, de Parques Culturales de Aragón, está, en algunos aspectos, más ligada a los valores de la arquitectura tradicional. Se define el Parque Cultural como "un territorio que contiene elementos relevantes del patrimonio cultural, integrados en un marco físico de valor paisajístico y/o ecológico singular, que gozará de promoción y protección global en su conjunto, con especiales medidas de protección para dichos elementos relevantes". Además, las políticas integradas de estos parques están orientadas a la protección y la restauración del patrimonio, la acción cultural, el desarrollo rural sostenible y el equilibrio territorial (art. 2.2). Y, entre sus objetivos está la protección, conservación y difusión del patrimonio cultural; estimular el conocimiento a través de la difusión cultural y turística y fomentar el desarrollo rural con especial atención a los usos y aprovechamientos tradicionales (art. 3). Esta figura de protección se ha considerado de interés en el marco de esta investigación por la relación atribuida al patrimonio arquitectónico con su marco territorial poniendo de manifiestos algunos de los valores de esta arquitectura que no se contemplan en la ley del Patrimonio. Si bien, debe tenerse en cuenta que esta ley afecta a los seis Parques Culturales declarados en la Actualidad: Parque Cultural del Maestrazgo, Parque Cultural del Río Martín, Parque Cultural del Chopo Cabecero del Alto Alfambra, Parque Cultural de Albarracín, Parque Cultural de San Juan de la Peña, Parque Cultural de Río Vero.

A continuación, se han revisado otras normas que afectan a la arquitectura tradicional y que ya ha sido comentadas en el apartado de ordenamiento jurídico de las comunidades autónomas del Plan Nacional de Arquitectura Tradicional.

Estas normas, en su mayoría están ligadas a la puesta en valor de elementos singulares, como los vinculados a las vías pecuarias (ley 20/2005, de 11 de noviembre, de vías pecuarias de Aragón) y, sobre todo, a la protección de elementos con interés turístico. Las principales normas o leyes referentes al turismo son las siguientes: el Decreto 69/1997, de 27 mayo, del Gobierno de Aragón; la Ley 6/2003, de 27 de febrero, de Turismo de Aragón; la Ley 3/2010, de 7 de junio (modificación de la anterior); el
3. A excepción de los pueblos de concentración o colonización ligados a las zonas de regadío creados en los años 60-70. En total 30 nuevas localidades en Aragón. 
Decreto 295/2006, de 13 de diciembre, del Gobierno de Aragón. En ellas se habla de la arquitectura tradicional desde un punto de vista principalmente estético haciendo alusión a la posibilidad de construcción de viviendas de turismo rural con las "características arquitectónicas de la zona donde se encuentre situada", a la renovación o cambio de uso de algunos edificios si se desina al turismo o a hostelería y se refiere directamente a la arquitectura tradicional únicamente cuando supone un espacio de interés turístico como "el lugar que, debido a su extraordinaria singularidad y valor, potencie el atractivo turístico de la zona".

Esta normativa no comenta la originalidad de los edificios que conforman el espacio de interés turístico ni la conservación de los mismos y hace únicamente alusión a sus propiedades estéticas. De hecho, para la puesta en valor de este entorno y la construcción de viviendas de turismo rural no indica que deben ser únicamente edificios tradicionales existentes, sino que si son nuevos es suficiente con que se "adecúe" a las características arquitectónicas del lugar. Estas normativas llevan implícitas un peligro importante ya que se centran únicamente en la estética de los edificios buscando el máximo pintoresquismo del lugar y que acaban por distorsionar el entorno y crear "parques temáticos rurales" cuyos edificios poco tienen que ver con los tradicionales.

Por otro lado, el organismo competente encargado de la gestión de la arquitectura tradicional es el Área de Etnología de la Dirección General de Patrimonio Cultural del Gobierno de Aragón cuyas funciones son la prevención, la protección jurídica, la catalogación, la investigación y la difusión de este patrimonio. Además, existe otra base legislativa que son las normas de Comarcalización de Aragón (Decreto 1/2006, de 27 de diciembre, del Gobierno de Aragón) a través de las cuales las comarcas tienen ciertas competencias en lo relativo a su patrimonio cultural y traiciones populares (art. 9). Estas competencias y obligaciones se recogen en el artículo 19 del Decreto 1/2006, entre las que se encuentran: "la promoción, planificación, coordinación y fomento de las actuaciones que garanticen la protección, conservación, acrecentamiento y difusión del Patrimonio Cultural Aragonés", "la colaboración con los municipios en la redacción de planes especiales de protección" y "La promoción de las labores de estudio, documentación, investigación y recogida de información sobre los bienes, costumbres y tradiciones que integran el patrimonio etnográfico, con atención especial a la recogida exhaustiva de los bienes etnográficos inmateriales en soportes que garanticen su transmisión a generaciones futuras". El hecho de que las comarcas posean estas competencias es de gran interés ya que son entidades más cercanas a la realidad de cada zona por lo que presumiblemente pueden asumir el control y el estudio del área con más facilidad. Además, algunos de los procedimientos como labores de difusión y transmisión de algunos de los valores culturales de la arquitectura tradicional son mucho más efectivas cuando la población se siente partícipe o responsable de conservarlos y mantenerlos. 
Por último, se han analizado las convocatorias de ayudas y subvenciones para la rehabilitación de edificios de los dos últimos años (2017 y 2018) con la finalidad de ver las condiciones de las mismas y la influencia que tiene que el edificio se tradicional o parte del Patrimonio Cultural de la comunidad.

En primer lugar, se ha revisado la convocatoria de ayudas en Aragón 2017 del Programa de Fomento de Rehabilitación Edificatoria. Esta convocatoria aplica únicamente a edificios de vivienda colectiva de antes de 1981 con mínimo 8 viviendas, para rehabilitaciones energéticas o de accesibilidad y 2 viviendas si además se van a llevar a cabo trabajos de conservación. Este aspecto favorece la posibilidad de acceder a la ayuda a edificios de menores dimensiones características más ligadas a la arquitectura estudiada en este trabajo, pese a ello la mayoría de los edificios estudiados son unifamiliares. Los trabajos de conservación definidos en este caso están relacionados con las deficiencias de cimentación, estructura o instalaciones, deficiencias asociadas a edificios BIC, catalogados o protegidos que además se rehabiliten energéticamente (cubiertas y azoteas, fachadas y medianeras y oros elementos comunes), que dispondrán de un 10\% más de subvención, e intervenciones para la adaptación del edificio a la normativa vigente. Entre otros factores, a la hora de evaluar los edificios beneficiarios de la ayuda se evalúa el nivel de protección del edificio y la antigüedad del mismo. Estas ayudas presentan un apartado de conservación si bien, su conservación no se refiera a la entendida desde el punto de vista de la restauración. Además, en ningún caso se definen o se limitan el tipo de intervenciones llevadas a cabo sobre los mismos.

Las subvenciones de rehabilitación de edificios y viviendas, correspondientes al Plan Estatal de vivienda 2018-2021, para el año 2018, por su parte, están destinadas tanto a viviendas unifamiliares como edificios de vivienda colectiva. El objetivo de estas ayudas es por un lado la rehabilitación energética y la sostenibilidad en viviendas, y el fomento de la conservación, de la mejora de la seguridad de utilización y de la accesibilidad a las viviendas. Se han analizado los criterios de evaluación para la asignación de beneficiarios de primer grupo correspondiente a las viviendas unifamiliares (artículo 13, de la orden VMV/1290/2018 publicada en el BOA el 3 de agosto de 2018) que son el tipo de edificios entre los que se engloba comúnmente la arquitectura de tierra de la comunidad. Los criterios que afectan a las condiciones del edificio y su entorno son: la clasificación del municipio (municipios dependientes mayor puntuación), la antigüedad del edificio (más antiguo, mayor puntuación), el tipo de intervención (solo conservación no tiene puntos, debe ir combinada con accesibilidad o eficiencia energética para obtenerlos), actuaciones en cubierta (su sustitución completa otorga puntos) y la protección patrimonial del edificio (BIC o protección integral). Algunos de estos criterios de evaluación están en discrepancia con la conservación y la restauración del edificio y el valor patrimonial de sus elementos constructivos. Por un lado, el criterio del tipo de intervención premia a las intervenciones de rehabilitación energética o accesibilidad frente 
a las de conservación que solo suman puntos si se realizan otras intervenciones simultáneamente. Por otro lado, la intervención en cubierta deja clara la intencionalidad de las intervenciones premiadas ya que la sustitución completa de los tableros de cubierta puntúa frente adaptación de la tradicional a estándares actuales o su conservación. Además, se valoran favorablemente a los edificios protegidos de forma integral (BIC), mientras que otros edificios que forman parte del Patrimonio Cultural no reciben mayor puntuación por el hecho de tener esta categoría (catalogados o inventariados).

Para concluir, cabe destacar el carácter genérico de las normas o leyes en las que no se especifica las características concretas que tienen que tener las intervenciones en términos de de compatibilidad material, compatibilidad visual, etc. y utiliza de forma continua conceptos como de interés o característicos sin especificar que se entiende como tal en la ley.

Por otro lado, se puede apreciar una falta de coordinación entre las subvenciones destinadas a la rehabilitación de edificios y el organismo de gestión del patrimonio que podría premiar a las intervenciones realizadas de forma compatible, poniendo en valor el valor del edificio, frente a otras intervenciones. 
10. INTERVENCIONES EN LA ARQUITECTURA TRADICIONAL DE TIERRA EN ARAGÓN 


\section{INTERVENCIONES EN LA ARQUITECURA TRADICIONAL DE TIERRA} EN ARAGÓN

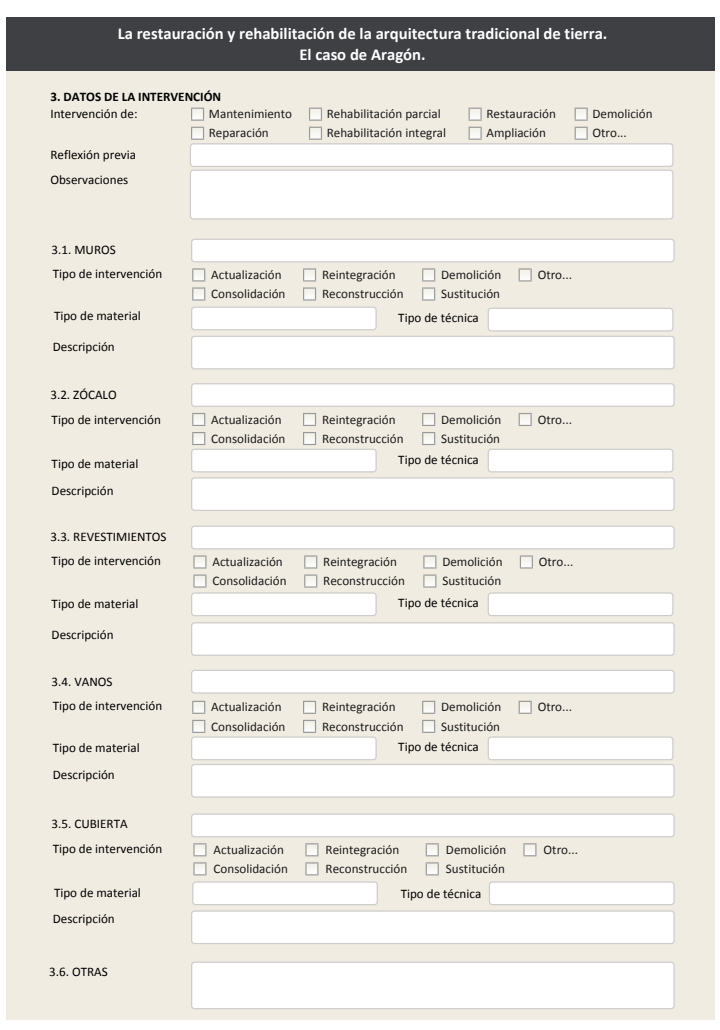

Figura 10.1. Parte III de la ficha correspondiente al análisis de la intervención.
La falta de una legislación específica que regule las intervenciones en los edificios tradicionales y concretamente los de tierra en la mayoría de los núcleos de población ha provocado que exista un abanico de soluciones muy heterogéneo que depende principalmente de las necesidades o la voluntad de los propietarios.

Las intervenciones sobre la arquitectura tradicional en Aragón están muy ligadas a la realidad social en la que se encuentra, con gran número de núcleos de población completamente abandonados y un éxodo rural que sigue aumentando ante la falta de salidas laborales en muchas de las localidades.

A pesar de ello, existe generalmente un arraigo profundo de la población emigrada a sus pueblos de origen y a las "casas viejas" pertenecientes a generaciones anteriores de la familia, factores que han influido directamente en las intervenciones realizadas sobre la arquitectura tradicional. Estos factores junto a las nuevas necesidades y los cambios de uso, realizados generalmente por parte de la población que habita de forma continuada en estos núcleos de población, y la necesidad de reparar los daños existentes son las circunstancias que generalmente propician la mayor parte de las intervenciones.

\subsection{Análisis de los casos de estudio}

El análisis de las intervenciones tiene la finalidad de conocer el tipo de actuaciones llevadas a cabo con mayor frecuencia en Aragón y en relación con el tipo de técnica constructiva, con la finalidad de establecer unas dinámicas de transformación.

El estudio de las intervenciones se ha centrado principalmente en la información recogida en la parte 3 de la ficha de estudio (figura 10.1), de cuyos datos se ha extraído la información de forma numérica y porcentual en relación al tipo de intervención general y por partes del edificio. Estos datos se han cruzado con la información de otros parámetros de la ficha como el tipo y la frecuencia de uso con el 
fin de conocer la relación que pueden tener estos factores con el número o el tipo de intervenciones realizadas en las distintas construcciones

Estas intervenciones se han analizado a partir de los datos recogidos en la muestra segunda, correspondiente a las fichas de estudio. Esta muestra consta de 410 casos de estudio de los cuales el 84\%, 345 casos, son construcciones intervenidas y conformarán, por lo tanto, la muestra general utilizada en este apartado del trabajo. Dentro de los 345 casos que componen la muestra se ha realizado una distinción en función del área geográfica, por provincias, y en función de la técnica constructiva (tabla 10.1). Teruel es la provincia con mayor número de casos intervenidos con un total de 145 seguida de Zaragoza con 134 y Huesca con 66. En cuanto a las técnicas constructivas, la tapia y el adobe cuenta con un número de casos muy parecido (190 y 188 respectivamente). Por su parte, los entramados tienen una representatividad mucho menor en la muestra con únicamente 13 casos, derivado de la menor frecuencia de esta técnica en el territorio aragonés.

En la muestra general se ha observado que todos los casos con un uso continuado, 50 casos, han sido intervenidos, mientras que las construcciones de uso temporal solo 226 de 247 y de los casos sin uso 69 de 111, por lo que son los edificios sin uso los que conforman la mayoría de los casos de la muestra inicial no intervenidos (tabla 10.2). Además, es posible detectar como el porcentaje de casos de edificios productivos y agrícolas sin intervenir es mucho más alto que en el caso de los edificios residenciales ya que muchos de ellos han perdido su funcionalidad y se han abandonado (tabla 10.3).

El estudio de las intervenciones y de los criterios específicos de intervención tal y como se realiza en el caso de la arquitectura monumental es una tarea ardua en el caso de la arquitectura tradicional ${ }^{1}$. Las intervenciones realizadas nacen, en la mayoría de los casos, de la necesidad inmediata de reparar el edificio para evitar deterioros mayores, de su cambio de uso o del mero cambio estético en el que no suelen existir unos criterios establecidos, sino que más bien premia la inmediatez de la realización y de la obtención de los materiales utilizados.

También es complicado el análisis en función de la tipología ya que en muchas ocasiones las intervenciones se realizan precisamente para cambiar el uso o readaptarlo, lo que dificulta la distinción de la tipología original.

Otro aspecto que tradicionalmente se tiene en cuenta en este tipo de análisis son las intervenciones en función de las lesiones existentes. En este caso no se conoce el estado previo de la mayoría de los edificios por lo que las lesiones previas solo es posible localizarlas cuando se ha actuado de forma puntual sobre la misma o cuando a pesar de las intervenciones los mecanismos de degradación iniciales

\begin{tabular}{|c|c|c|c|c|}
\hline $\begin{array}{c}\text { Muestra de los } \\
\text { casos intervenidos }\end{array}$ & $\begin{array}{c}\text { TOTAL } \\
\text { intervenido }\end{array}$ & $\begin{array}{c}\text { TAPIA } \\
\text { intervenido }\end{array}$ & $\begin{array}{c}\text { ADOBE } \\
\text { intervenido }\end{array}$ & $\begin{array}{c}\text { ENTRAMADO } \\
\text { intervenido }\end{array}$ \\
\hline ARAGÓN & 345 & 190 & 188 & 13 \\
\hline TERUEL & 145 & 120 & 30 & 10 \\
\hline ZARAGOZA & 134 & 56 & 99 & 2 \\
\hline HUESCA & 66 & 14 & 59 & 1 \\
\hline
\end{tabular}

Tabla 10.1. Muestra de los casos intervenidos

\begin{tabular}{|c|c|c|c|c|}
\hline & Continuado & Temporal & Sin uso & Total \\
\hline Intervenido & 50 & 226 & 69 & 345 \\
\hline No intervenido & 0 & 21 & 44 & 65 \\
\hline Total & 50 & 247 & 11 & 410 \\
\hline
\end{tabular}

Tabla 10.2. Frencuencia de uso de los cosas de estudio

\begin{tabular}{|c|c|c|c|c|c|}
\hline & Residencial & Productivo & Agrícola & Otros usos & Total \\
\hline Intervenido & 210 & 70 & 34 & 31 & 345 \\
\hline No intervenido & 27 & 18 & 14 & 6 & 65 \\
\hline Total & 237 & 88 & 48 & 37 & 410 \\
\hline
\end{tabular}

Tabla 10.3. Tipo de uso de los casos de estudio analizados

1. Pese a que en algunos casos se puede conocer la fecha de realización de las intervenciones o intuirla de forma aproximada por el tipo de materiales utilizados ligados a las modas o tendencias del momento, este tipo de intervenciones son difíciles de datar, así como de conocer el estado previo a las mismas. Por ello no se han hecho distinciones temporales y se han analizado por igual todos los casos en los que se han detectado intervenciones que suelen datar de los años 60-70 en adelante. 


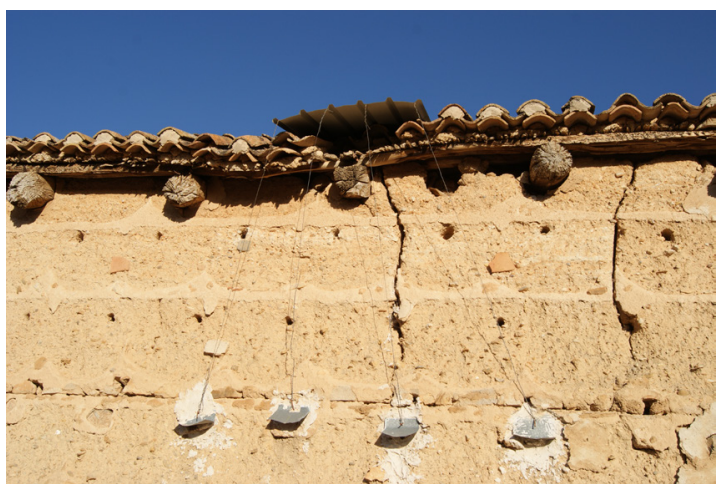

Figura 10.2. Reparación espontánea de la cubierta de un edificio de tapia con chapa y tirandes cuyo anclaje dispone de una canaleta de protección del muro frente al agua de lluvia. Orrios, Teruel persisten. Por ello los criterios de intervención se han tenido que simplificar y ligarlos a la intencionalidad o a la reflexión previa definidas como: intervención espontánea o intervención planificada.

En general, no existe un criterio de intervención o un razonamiento teórico de restauración en las intervenciones sobre la arquitectura tradicional. Las actuaciones suelen tratar de eliminar los problemas o lesiones de la forma más inmediata, sin buscar soluciones reversibles, compatibles, distinguibles, etc. Por ello el criterio de análisis se ha centrado en estudiar la analogía de la intervención en referencia a la técnica utilizada y al tipo de material.

La complejidad de la muestra ha permitido realizar estudios parciales en torno a distintos grupos de casos con características comparables como la técnica utilizada (tapia, adobe o entramado) o el área geográfica o provincias (Teruel, Zaragoza o Huesca). Estos análisis parciales han facilitado el reconocimiento las peculiaridades de cada grupo y realizar comparaciones entre ellos.

Por otro lado, también se han realizado análisis parciales comparativos ligados al nivel de intervención general de los distintos casos aislando por un lado los casos con intervenciones de mantenimiento y reparación (grupo 1), y por otro lado los casos con mayor nivel de intervención: restauración, rehabilitación parcial, rehabilitación integral, ampliación y demolición (grupo 2).

En todos los casos se ha realizado en primer lugar el análisis del tipo de intervención a nivel general sobre el edificio y posteriormente se han estudiado las intervenciones parciales en cada una de las zonas del edificio especificadas en la ficha: muros, zócalo, revestimiento, vanos y cubierta.

\subsection{Intervenciones generales en la arquitectura tradicional de tierra}

Para llevar a cabo el análisis de las intervenciones recogidas en la base de datos se ha realizado un análisis sistemático de lo general (la muestra completa) a lo particular (las distintas subdivisiones geográficas y por técnicas) de forma que los análisis parciales queden enmarcados en los resultados del conjunto de la muestra.

En primer lugar, se ha analizado el criterio general o la reflexión previa a la intervención. Un total de 240 casos se han intervenido de forma espontánea frente a los 105 casos en los que la intervención ha sido planificada (tabla 10.4; figura 10.2). Esto supone que casi un $70 \%$ de total de los casos intervenidos corresponden con intervenciones sin apenas reflexión previa y en la mayoría de los casos sin atender a las propiedades de las técnicas constructivas tradicionales sobre las que se está interviniendo ni 
al tipo de materiales y técnicas utilizadas para ello. En el caso de las intervenciones planificadas los materiales y técnicas utilizados no son necesariamente adecuados o compatibles respecto a las técnicas existentes, pero existe un trabajo de reflexión previa en la que el elemento tradicional se tiene en cuenta otorgándole un cierto valor.

Los resultados de la reflexión previa en cada una de las provincias siguen el mismo orden de magnitud que en el caso de Aragón. Teruel es la provincia en la cual la proporción de intervenciones planificadas es mayor con un 33,8\% de los casos (49 casos de 145) mientras que Huesca es la que tiene una proporción menor de intervenciones planificadas con un $25,8 \%$ (17 casos de 66).

Las intervenciones llevadas a cabo en este tipo de arquitectura son muy dispares y en ocasiones su definición ha sido una tarea compleja ya que suele no existir un único patrón de intervención. Por ello, en muchos casos, se ha identificado la existencia de varios tipos de intervención de forma simultánea.

Las reparaciones son las intervenciones más frecuentes con un total de 201 casos (58,3\% respecto al total de casos) seguido por las rehabilitaciones parciales con 93 casos (27\%) (figura 10.3). Este tipo de intervenciones tienen un carácter de mínima intervención en las que únicamente se reparan o se rehabilitan las zonas necesarias para dotarlas con nuevos usos o adecuar alguna de las partes del edificio a los estándares actuales.

Por otro lado, las rehabilitaciones integrales, con 53 casos (15,4\% de los casos), y las ampliaciones de edificios, con 17 casos (4,9\% de los casos), son intervenciones presentes en muchos de los núcleos de población y que suelen afectar a casi la totalidad de los elementos constructivos (figura 10.4). Este tipo de intervenciones no son tan comunes como las dos anteriores, especialmente las reparaciones, que aparecen casi en cualquier edificio a menos que se encuentran abandonados.

Por último, las intervenciones de mantenimiento, restauración y demolición son las menos frecuentes. El mantenimiento y la restauración, como se ha definido previamente, implican una voluntad de conservación del elemento preexistente y de su carácter sin producir grandes alteraciones. Por ello, el

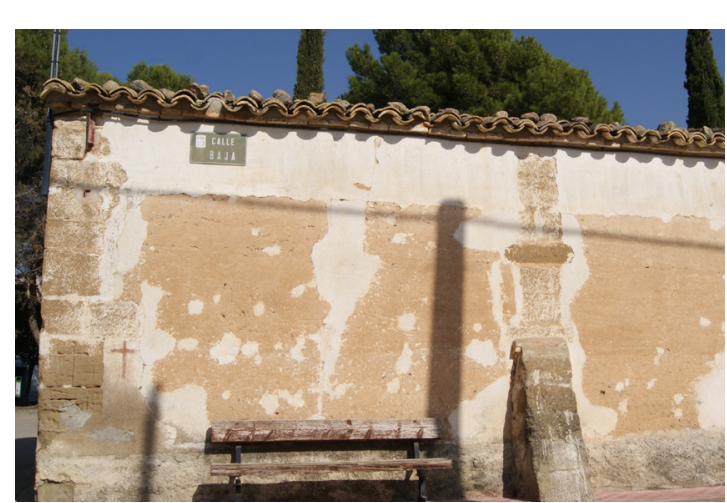

Figura 10.3. Reintegración espontánea sobre muro de tapia. Esquedas, Huesca

\begin{tabular}{|c|c|c|c|c|c|c|c|c|c|c|c|}
\hline & Intervenido & No intervenido & Interv. espontánea & Interv. Planificada & Mantenimiento & Reparación & Restauración & Rehab. Parcial & Rehab. Integral & Ampliación & Demolición \\
\hline ARAGÓN & 345 & 65 & 240 & 105 & 8 & 201 & 6 & 93 & 53 & 17 & 4 \\
\hline TERUEL & 145 & 22 & 96 & 49 & 4 & 83 & 3 & 37 & 26 & 6 & 0 \\
\hline ZARAGOZA & 134 & 30 & 95 & 39 & 0 & 79 & 2 & 36 & 21 & 6 & 1 \\
\hline HUESCA & 66 & 13 & 49 & 17 & 4 & 39 & 1 & 20 & 6 & 5 & 3 \\
\hline
\end{tabular}

Tabla 10.4. Critero o reflexión previa de intervención y tipo de intervención 


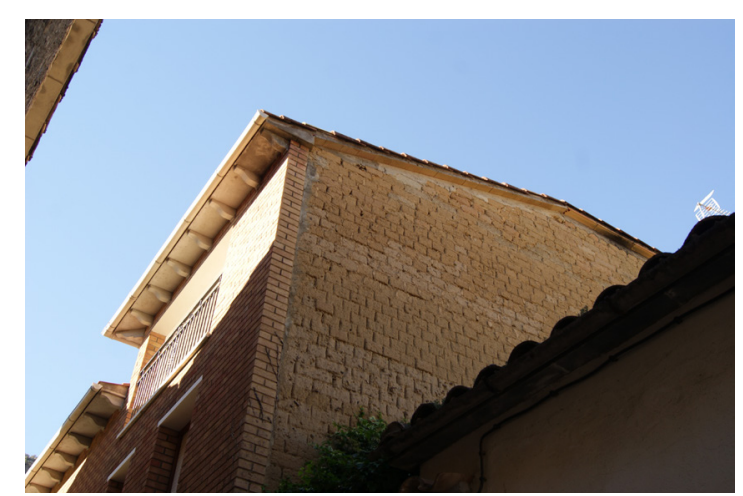

Figura 10.4. Rehabilitación integral de un edificio de adobe con nueva fachada de ladrillo adosada. Besians, Huesca uso generalizado de los materiales industrializados sin ningún tipo control ha generado que este tipo de intervenciones sean poco frecuentes o difíciles de localizar. La demolición de grandes partes del edificio en la arquitectura tradicional no es común, sino que generalmente se trata de eliminaciones puntuales de partes que afectan únicamente a alguno de los elementos por ello no se han tenido en cuenta a nivel de intervención general. Si bien, podrían existir casos en los que el nivel de protección de la normativa obliga a conservar la fachada u otros elementos del edificio, mientras que el resto se demuele. Si bien, no se ha detectado ninguno de estos casos durante la toma de datos.

Si se analizan los datos correspondientes a cada una de las tres provincias de forma aislada, los resultados se encuentran en el mismo orden de magnitud que los generales. En los tres casos las intervenciones más comunes siguen siendo las reparaciones, seguidas de las rehabilitaciones parciales y de las rehabilitaciones integrales. Sin embargo, en al caso de la provincia de Huesca, la proporción de rehabilitaciones parciales es mayor que en el resto (30,3\% frente a 25,5\% en Teruel y 26,9\% en Zaragoza) y la de rehabilitaciones integrales menor (9,1\% frente a 17,9\% en Teruel y 15,7\% en Zaragoza).

Para realizar un análisis más completo de la muestra, se han cruzado los datos de las intervenciones con la frecuencia de uso de los edificios (continuado, temporal o sin uso) y el tipo de uso (residencial, productivo, agrícola u otro) con la finalidad de obtener la relación entre ellos (tabla 10.5).

En primer lugar, se ha analizado la relación entre la reflexión previa (intervención espontánea o planificada) y la frecuencia de uso, a través la cual se ha determinado que las intervenciones planificadas solo predominan frente a las espontáneas en los casos en los que el uso del edificio es continuo con 30 casos frente a 20. En los casos de uso temporal y sin uso predominan las intervenciones espontáneas con un $78 \%$ y un $81 \%$ de los casos respectivamente, aunque en valores absolutos el número total de casos con uso temporal es mucho más elevado.

\begin{tabular}{|c|c|c|c|c|c|c|c|c|c|c|c|}
\hline \multirow{2}{*}{ TODO } & Intervenido & \begin{tabular}{|l|} 
No intervenido \\
\end{tabular} & Interv. espontánea & Interv. Planificada & Mantenimiento & Reparación & Restauración & Rehab. Parcial & Rehab. Integral & Ampliación & Demolición \\
\hline & 345 & 65 & 240 & 105 & 8 & 201 & 6 & 93 & 53 & 17 & 4 \\
\hline \multicolumn{12}{|c|}{ FRECUENCIA DE USO } \\
\hline Continuado & 50 & 0 & 20 & 30 & 0 & 13 & 1 & 22 & 17 & 4 & 0 \\
\hline Temporal & 226 & 21 & 164 & 62 & 7 & 132 & 5 & 67 & 29 & 7 & 2 \\
\hline Sin uso & 69 & 44 & 56 & 13 & 1 & 56 & 0 & 4 & 7 & 6 & 2 \\
\hline \multicolumn{12}{|l|}{ USO } \\
\hline Residencial & 210 & 27 & 112 & 98 & 5 & 95 & 4 & 67 & 49 & 14 & 3 \\
\hline Productivo & 70 & 18 & 69 & 1 & 3 & 55 & 0 & 16 & 0 & 1 & 0 \\
\hline Agrícola & 34 & 14 & 33 & 1 & 0 & 33 & 0 & 1 & 1 & 1 & 1 \\
\hline Otro & 31 & 6 & 26 & 5 & 0 & 18 & 2 & 9 & 3 & 1 & 0 \\
\hline
\end{tabular}

Tabla 10.5. Datos cruzados de toda la muestra con la frecuencia de uso y el tipo de uso de los casos analizados. 
En cuanto a los tipos de uso, en todos ellos predominan las intervenciones espontáneas, pero, en el caso de uso residencial, la proporción muchos más igualada con 112 casos frente a 98 (59\% frente a 41\% del total). Cabe destacar como en los edificios con otros tipos de uso, las intervenciones planificadas son casi nulas con 1 caso en edificios productivos y otro en agrícolas y 5 en edificios con otros usos distintos que corresponden en su mayoría a edificios públicos, algunos de ellos con cierto carácter monumental como la ermita de Calcena y Lagata (Zaragoza) o el ayuntamiento de Bello (Teruel) (figura 10.5).

En el análisis de los casos por provincias (tablas 10.6;10.7;10.8) los resultados varían ligeramente respecto al cómputo general. Los casos con uso continuo en la provincia de Teruel presentan una mayor proporción de intervenciones planificadas, 75\%, mientras que en el caso de Huesca y Zaragoza existen el mismo número de casos con intervención planificada que espontánea figura 10.6). Los casos con uso temporal siguen un criterio mayoritariamente espontáneo entre el 67\% de los casos, en Teruel, y el 78\%, en Zaragoza. Finalmente, entre los casos que no presentan usos en la actualidad existe una presencia casi nula de intervenciones planificadas en Huesca y Teruel, pero en Zaragoza representan el 31\% de sus casos. Estos resultados parecen estar fuera de la lógica, pero en su mayoría corresponden con edificios en los cuales se comenzaron unas obras importantes que no se han finalizado o con edificios que estaban en obras en el momento de la toma de datos.

En segundo lugar, se ha atendido a la correspondencia entre los tipos de intervención y la información referente a los usos, como en el caso anterior. Las intervenciones de mantenimiento tienen una frecuencia de uso principalmente temporal (7 casos) y solo un caso sin uso. En las intervenciones de reparación también existe un predominio de uso temporal y sin uso, y solo el 6\% (13 casos) corresponde con edificios de uso continuado. Las intervenciones de restauración, rehabilitación parcial y rehabilitación integral predominan en edificios con uso temporal, aunque su presencia en edificios de uso continuado es notable, sobre todo, en las rehabilitaciones ya que en muchos casos suponen una adecuación del edificio a los estándares de vida actuales necesarios para habitarlos de forma continua, especialmente en invierno cuando el clima es más severo. Las intervenciones de ampliación se localizan casi por igual en los tres tipos de uso y las intervenciones de demolición en edificios con uso temporal y sin uso en igual proporción. Cabe destacar que los casos que no tienen uso y se han realizado intervenciones integrales (7 casos) o ampliaciones (6 casos) corresponden con los mismos casos nombrados previamente en los que las obras permanecen inacabadas o están en ejecución (figura 10.7).

Los resultados de los tipos de uso en relación con las intervenciones son muy variados, aunque existe un predominio claro de uso residencial en todas ellas, entre otros factores, por ser la tipología más común dentro de la muestra. Las intervenciones de reparación, pese a predominar en edificios residenciales,

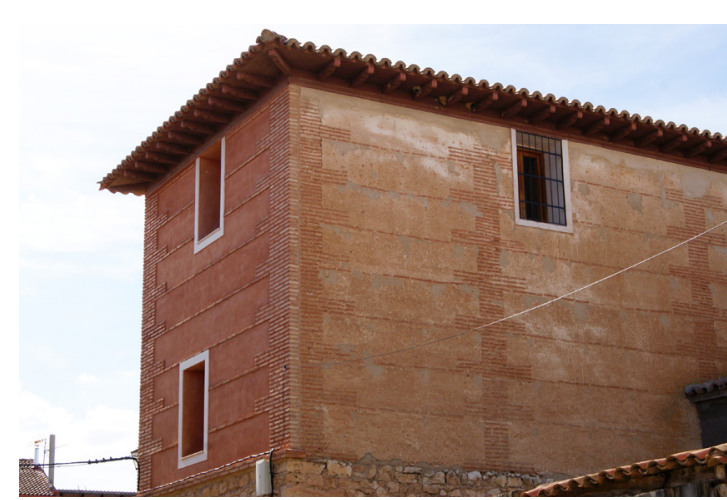

Figura 10.5. Rehabilitación integral del Ayuntamiento de Bello, Teruel. Actuación en las fachadas principales.

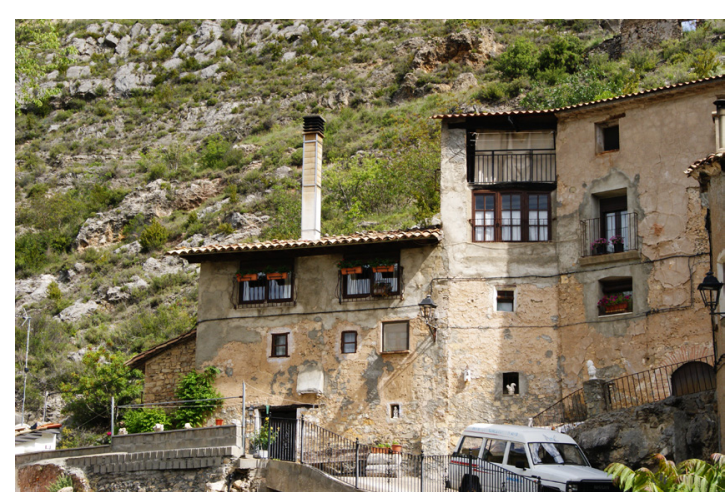

Figura 10.6. Edificios de tapia de yeso en uso rehabilitados de forma integral. Aguinaliú, Huesca 


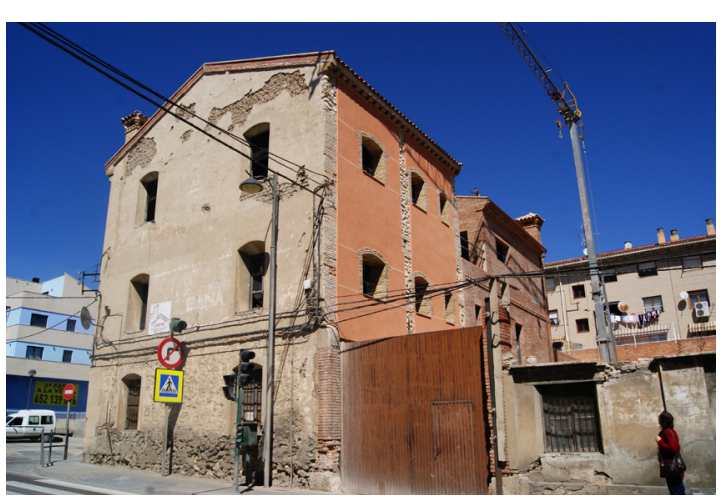

Figura 10.7. Obras de rehabilitación integral de un edificio de adobe. Borja, Zaragoza

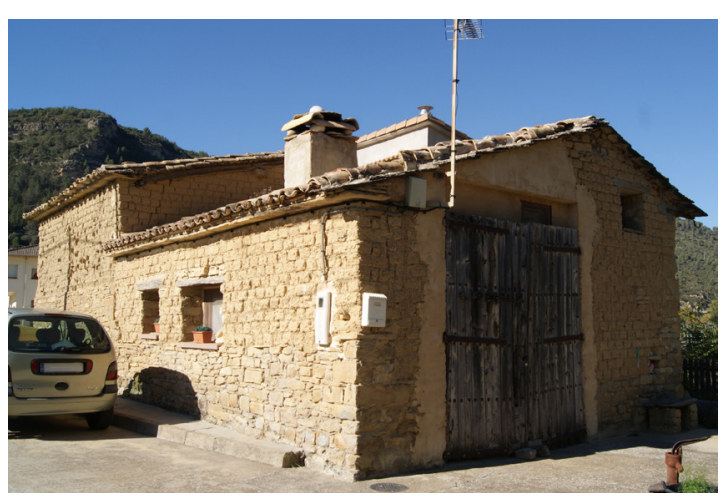

Figura 10.8. Rehabilitación parcial y cambio de uso de un edificio de uso originariamente agrícola. Perarrúa, Huesca tienen una presencia notable en todo tipo de edificios con 95 casos de tipo residencial (47\%), 55 casos de tipo productivo (27\%), 33 casos de tipo agrícola (17\%) y 18 casos con otros usos $(9 \%)$. La rehabilitación parcial es el otro tipo de intervención con mayor presencia en edificios con usos distintos a los anteriores con 16 casos en edificios de uso productivo (17\%), un único caso en agrícola (1\%) y 9 casos con otros usos (10\%), a parte de los 67 de tipo residencial (72\%). Este tipo de intervención es recurrente y en muchos casos se utiliza para cambiar el uso de pequeños edificios que han perdido su uso tradicional por otro actual con los mínimos cambios como es el caso de corrales transformados en garajes. Los otros tipos de intervención, mantenimiento, restauración, rehabilitación integral, ampliación y demolición tienen una presencia casi nula en los edificios que no son de uso residencial.

En las tres provincias los resultados son parecidos, no obstante, los cambios en los tipos de intervención hacen que algunos de los resultados varíen respecto de los generales. En Teruel la frecuencia de uso presenta unos porcentajes similares a excepción las rehabilitaciones parciales, donde la proporción de casos sin uso es mayor, y las intervenciones de demolición, ya que no se ha recogido ningún caso en esta provincia. En Zaragoza la situación es parecida, las intervenciones rehabilitación integral presentan el mismo número de casos en las 3 frecuencias de uso analizadas (7 casos), por lo que es en esta provincia donde mayor número de casos con obras inacabadas o en construcción se localizan y por ello, no tienen ningún uso. En Huesca, al ser la provincia con la muestra más reducida al cruzar los datos existen muchos resultados en los que la representatividad es muy baja o nula. Estos resultados están, aproximadamente, en el mismo orden de magnitud que los resultados de la muestra general, aunque, cabe destacar la mayor frecuencia relativa en las intervenciones de reparación con uso continuo ( $10 \%$ respecto al $6 \%$ de los resultados generales) así como la nula presencia de casos de rehabilitación tanto parcial como integral sin uso.

Los resultados de los tipos de uso en referencia al tipo de intervención en cada una de las provincias siguen la relación que los resultados en la muestra general. En Teruel, por ejemplo, la proporción de edificios residenciales es mayor que en las otras provincias por lo que su porcentaje es mayor y repercute especialmente en las rehabilitaciones parciales (84\% frente a $72 \%$ en la muestra general). En la provincia de Zaragoza no existe tanta diferencia entre el uso residencial y el resto de los usos. Los resultados en esta provincia muestran como casi la totalidad de edificios productivos, agrícolas y con otros usos han sido intervenidos mediante reparaciones. En el caso de Huesca, casi la totalidad de los edificios analizados son residenciales o productivos con el 52\% (34 casos) y el $41 \%$ ( 27 casos) respectivamente. Los casos de estudio han sido intervenidos en su mayoría a través de reparaciones (18 casos residenciales y 19 productivos) y de rehabilitaciones parciales (11 casos residenciales y 7 productivos) (figura 10.8). Además, existen 5 casos de rehabilitaciones integrales, 3 de ampliaciones y 2 demoliciones en edificios de uso residencial. 


\begin{tabular}{|c|c|c|c|c|c|c|c|c|c|c|c|}
\hline \multirow{2}{*}{ TERUEL } & Intervenido & No intervenido & Interv. espontánea & Interv. Planificada & \begin{tabular}{|l|} 
Mantenimiento \\
\end{tabular} & Reparación & Restauración & Rehab. Parcial & Rehab. Integral & \begin{tabular}{|l|} 
Ampliación \\
\end{tabular} & Demolición \\
\hline & 145 & 22 & 96 & 49 & 4 & 83 & 3 & 37 & 26 & 6 & 0 \\
\hline \multicolumn{12}{|c|}{ FRECUENCIA DE USO } \\
\hline Continuado & 20 & 0 & 5 & 15 & 0 & 4 & 1 & 9 & 8 & 1 & 0 \\
\hline Temporal & 95 & 7 & 63 & 32 & 3 & 53 & 2 & 25 & 18 & 2 & 0 \\
\hline Sin uso & 30 & 15 & 28 & 2 & 1 & 26 & 0 & 3 & 0 & 3 & 0 \\
\hline \multicolumn{12}{|l|}{ USO } \\
\hline Residencial & 96 & 11 & 50 & 46 & 4 & 41 & 2 & 31 & 24 & 5 & 0 \\
\hline Productivo & 17 & 5 & 16 & 1 & 0 & 15 & 0 & 3 & 0 & 0 & 0 \\
\hline Agrícola & 20 & 5 & 20 & 0 & 0 & 20 & 0 & 0 & 0 & 0 & 0 \\
\hline Otro & 12 & 1 & 10 & 2 & 0 & 7 & 1 & 3 & 2 & 1 & 0 \\
\hline
\end{tabular}

Tabla 10.6. Datos cruzados de los casos de estudio localizados en Teruel con la frecuencia de uso y el tipo de uso de los casos analizados.

\begin{tabular}{|c|c|c|c|c|c|c|c|c|c|c|c|}
\hline \multirow{2}{*}{ ZARAGOZA } & Intervenido & No intervenido & Interv. espontánea & Interv. Planificada & Mantenimiento & Reparación & Restauración & Rehab. Parcial & Rehab. Integral & \begin{tabular}{|l|} 
Ampliación \\
\end{tabular} & Demolición \\
\hline & 134 & 30 & 95 & 39 & 0 & 79 & 2 & 36 & 21 & 6 & 1 \\
\hline \multicolumn{12}{|l|}{ FRECUENCIA DE USO } \\
\hline Continuado & 22 & 0 & 11 & 11 & 0 & 5 & 0 & 10 & 7 & 1 & 0 \\
\hline Temporal & 81 & 10 & 63 & 18 & 0 & 51 & 2 & 25 & 7 & 3 & 0 \\
\hline Sin uso & 31 & 20 & 21 & 10 & 0 & 23 & 0 & 1 & 7 & 2 & 1 \\
\hline \multicolumn{12}{|l|}{ USO } \\
\hline Residencial & 80 & 12 & 44 & 36 & 0 & 36 & 1 & 25 & 20 & 6 & 1 \\
\hline Productivo & 26 & 8 & 26 & 0 & 0 & 21 & 0 & 6 & 0 & 0 & 0 \\
\hline Agrícola & 12 & 6 & 12 & 0 & 0 & 12 & 0 & 1 & 0 & 0 & 0 \\
\hline Otro & 16 & 4 & 13 & 3 & 0 & 10 & 1 & 4 & 1 & 0 & 0 \\
\hline
\end{tabular}

Tabla 10.7. Datos cruzados de los casos de estudio localizados en Zaragoza con la frecuencia de uso y el tipo de uso de los casos analizados.

\begin{tabular}{|c|c|c|c|c|c|c|c|c|c|c|c|}
\hline \multirow{2}{*}{ HUESCA } & Intervenido & No intervenido & Interv. espontánea & Interv. Planificada & Mantenimiento & Reparación & Restauración & Rehab. Parcial & Rehab. Integral & Ampliación & Demolición \\
\hline & 66 & 13 & 49 & 17 & 4 & 39 & 1 & 20 & 6 & 5 & 3 \\
\hline \multicolumn{12}{|c|}{ FRECUENCIA DE USO } \\
\hline Continuado & 8 & 0 & 4 & 4 & 0 & 4 & 0 & 3 & 2 & 2 & 0 \\
\hline Temporal & 50 & 4 & 38 & 12 & 4 & 28 & 1 & 17 & 4 & 2 & 2 \\
\hline Sin uso & 8 & 9 & 7 & 1 & 0 & 7 & 0 & 0 & 0 & 1 & 1 \\
\hline \multicolumn{12}{|l|}{ USO } \\
\hline Residencial & 34 & 4 & 18 & 16 & 1 & 18 & 1 & 11 & 5 & 3 & 2 \\
\hline Productivo & 27 & 5 & 27 & 0 & 3 & 19 & 0 & 7 & 0 & 1 & 0 \\
\hline Agrícola & 2 & 3 & 1 & 1 & 0 & 1 & 0 & 0 & 1 & 1 & 1 \\
\hline Otro & 3 & 1 & 3 & 0 & 0 & 1 & 0 & 2 & 0 & 0 & 0 \\
\hline
\end{tabular}

Tabla 10.8. Datos cruzados de los casos de estudio localizados en Huesca con la frecuencia de uso y el tipo de uso de los casos analizados. 
Por último, se ha realizado un estudio específico en función del nivel de intervención que presentan los distintos casos, reorganizándolos en dos grupos. En el primer grupo se han englobado los casos con intervenciones de mantenimiento o reparación, con 186 casos (tabla 10.9) y, en el segundo grupo, el resto de los casos con intervenciones de restauración, rehabilitación parcial, rehabilitación integral, ampliación y demolición, con 159 casos (tabla 10.10). A través de este análisis se ha observado que el 95\% (177 casos) de las intervenciones de mantenimiento y reparación siguen un criterio de intervención espontánea, mientras que, en el segundo grupo, correspondiente a los otros tipos de intervención, predominan las intervenciones planificadas con un 60\% (96 casos). El bajo nivel de intervención que suponen las reparaciones favorece a que el número de trabajos planificados sea muy bajo, mientras que, el segundo grupo el porcentaje de casos con intervenciones planificadas es mucho mayor y supera, en este caso, al número de intervenciones espontáneas (96 intervenciones planificadas frente a 63 espontáneas).

En cuanto a la frecuencia de uso de los casos de cada grupo, en el grupo 1 las intervenciones de mantenimiento y reparación recaen en su mayoría sobre construcciones con uso temporal con 126 casos, seguido de los edificios sin uso con 51 casos y por último los de uso continuado con únicamente 9 casos. En el caso del segundo grupo, al igual que en el primero, predominan las construcciones con uso temporal con 102 ejemplos, no obstante, el orden de los casos con uso continuado y sin uso esta invertido, con 41 y 16 casos respectivamente. Esta aproximación permite reconocer como las intervenciones de mayor envergadura predominan en los casos en los que los edificios presentan un uso temporal o continuo, mientras que, las pequeñas intervenciones aparecen en muchos casos (51 casos) en edificios que han perdido su uso pero que se intentan conservar, generalmente con la mínima inversión, para evitar problemas mayores o su pérdida.

El tipo de uso de las construcciones analizadas también está en relación con el nivel de intervención de las mismas. Por un lado, los casos englobados en el primer grupo presentan usos muy heterogéneos con 79 casos de uso residencial (47\%), 52 casos de uso productivo (28\%), 31 casos de uso agrícola (17\%) y 15 casos con otros usos (8\%). Además, de los casos con intervención planificada 8 de los 9 casos son de uso residencial. Por otro lado, en el segundo grupo las construcciones son mayoritariamente de uso residencial con 125 casos (79\%) y solo 16 casos son de uso productivo (10\%), 3 casos de uso agrícola (2\%) y 15 casos con otros usos (9\%). Al mismo tiempo, de los 96 casos con intervenciones planificadas 89 son edificios residenciales y solo 7 corresponden con otros usos distintos. La comparación de estos datos ha permitido detectar como los casos con intervenciones planificadas corresponden mayoritariamente a construcciones de uso residencial y uso continuado o temporal. Además, la mayoría de los edificios con intervenciones de mayor envergadura son de uso residencial mientras que las reparaciones aparecen indistintamente en todo tipo de edificios. 


\begin{tabular}{|c|c|c|c|c|c|}
\hline \multirow{2}{*}{ GRUPO 1} & Intervenido & Interv. espontánea & Interv. Planificada & Mantenimiento & Reparación \\
\hline & 186 & 177 & 9 & 8 & 180 \\
\hline \multicolumn{6}{|c|}{ FRECUENCIA DE USO } \\
\hline Continuado & 9 & 9 & 0 & 0 & 9 \\
\hline Temporal & 126 & 119 & 7 & 7 & 121 \\
\hline Sin uso & 51 & 49 & 2 & 1 & 50 \\
\hline \multicolumn{6}{|l|}{ USO } \\
\hline Residencial & 87 & 79 & 8 & 5 & 83 \\
\hline \begin{tabular}{|l|} 
Productivo \\
\end{tabular} & 52 & 52 & 0 & 3 & 50 \\
\hline Agrícola & 31 & 31 & 0 & 0 & 31 \\
\hline Otro & 16 & 15 & 1 & 0 & 16 \\
\hline
\end{tabular}

Tabla 10.9. Datos cruzados de los casos de estudio correspondientes al grupo 1 de intervenciones con la frecuencia de uso y el tipo de uso de los casos analizados.

\begin{tabular}{|c|c|c|c|c|c|c|c|c|c|}
\hline \multirow{2}{*}{ GRUPO 2} & Intervenido & Interv. espontánea & Interv. Planificada & Reparación & Restauración & Rehab. Parcial & Rehab. Integral & Ampliación & Demolición \\
\hline & 159 & 63 & 96 & 21 & 6 & 93 & 53 & 17 & 4 \\
\hline \multicolumn{10}{|c|}{ FRECUENCIA DE USO } \\
\hline Continuado & 31 & 12 & 29 & 5 & 1 & 21 & 17 & 4 & 0 \\
\hline \begin{tabular}{|l|} 
Temporal \\
\end{tabular} & 102 & 46 & 56 & 12 & 5 & 68 & 29 & 7 & 2 \\
\hline \begin{tabular}{|l|} 
Sin uso \\
\end{tabular} & 16 & 5 & 11 & 4 & 0 & 4 & 7 & 6 & 2 \\
\hline \multicolumn{10}{|l|}{ USO } \\
\hline Residencial & 125 & 36 & 89 & 15 & 4 & 66 & 49 & 14 & 3 \\
\hline Productivo & 16 & 15 & 1 & 3 & 0 & 16 & 0 & 1 & 0 \\
\hline Agrícola & 3 & 1 & 2 & 1 & 0 & 2 & 1 & 1 & 1 \\
\hline Otro & 15 & 11 & 4 & 2 & 2 & 9 & 3 & 1 & 0 \\
\hline
\end{tabular}

Tabla 10.10. Datos cruzados de los casos de estudio correspondientes al grupo 2 de intervenciones con la frecuencia de uso y el tipo de uso de los casos analizados. 


\subsection{Intervenciones por zona del edificio}

El análisis de las intervenciones por zona se ha estructurado en torno a cinco partes o zonas: zócalo o arranque, muro, superficie o revestimiento, vanos y cubierta. A través del análisis específico por partes se prevé establecer el tipo de trabajos desarrollados de forma más común en cada una de ellas. Para ello se ha establecido tres parámetros que contienen respuestas predeterminadas, lo cual ha permitido comparar los datos resultantes de forma sencilla. Estos parámetros han sido: tipo de intervención o trabajos Ilevados a cabo, tipo de material y tipo de técnica. Además de estos campos, se ha realizado una descripción específica en cada caso para completar la descripción de la intervención realizada.

Existen otros elementos como la cimentación o los forjados que pueden afectar a los muros de tierra, sin embargo, se ha decidido no estudiarlos debido a la escasa o nula información que es posible obtener de los mismos a través de una toma de datos in situ y principalmente visual. Los escasos datos, además, habrían producido un sesgo o vacío en la muestra por su poca representatividad por lo que, en el caso de haber obtenido información sobre los mismo se ha añadido en las observaciones.

Intervenciones como la actualización podrían haber tenido cabida en el grupo de intervenciones generales estudiadas previamente ya que no se trata de un tipo o una forma de intervención específica. Sin embargo, se ha considerado de mayor interés incluirla en al análisis por partes con la finalidad de conocer que áreas o elementos son los más afectados por este tipo de intervención.

En primer lugar, se ha realizado una comparación relativa entre las partes con el fin de conocer cuáles son las más afectadas o las se han intervenido en mayor número de casos (tabla 10.11). El elemento más intervenido de la muestra ha sido el zócalo con un 78\% de los casos (270 casos), probablemente derivado de la presencia habitual de humedad y de su fácil acceso. En segundo elemento más intervenido ha sido la cubierta con intervenciones en un $67 \%$ de los casos de estudio (232 casos). La importancia del mantenimiento de la cubierta para evitar el acceso del agua en la arquitectura de tierra ha sido, probablemente, uno de los factores que ha favorecido que esta zona sea una de las más intervenidas. Los muros y los vanos han sido intervenidos casi en la misma proporción, en el 60\% (208 casos) y 59\% (202 casos) del total de casos respectivamente. Finalmente, el revestimiento es el elemento con una proporción menor de intervenciones, un 48\% del total (166 casos), sin embargo, debe tenerse en cuenta que en muchos casos los edificios no tienen revestimiento por lo que no puede estar intervenido. El total de casos en los que no existe revestimiento, y por tanto no plica, es de 123 por lo que, en realidad, este elemento se ha intervenido en un 75\% de los casos aplicables (166 casos de 222).

Los resultados de las intervenciones por zonas en las distintas provincias son muy parecidos ${ }^{2}{ }^{3}$. En el
2. En las intervenciones por zonas no se han definido el orden de magnitud de los tipos de intervención es aproximado al general y se ha considerado mas interesante centrarse en otros aspectos. Sin bien, es posible ver los resultados las tres provincias en las tablas cada una de las zonas del edificio estudiadas.

3. Al estar algunas de las intervenciones ligadas a la técnica constructiva se desarrollarán en profundidad en el siguiente apartado 
caso de Teruel, el orden de las zonas en cuanto a número de intervenciones es el mismo. En la provincia de Zaragoza solo se invierte el orden entre los muros y los vanos, que en este caso han sido los segundos más intervenidos. Y, finalmente, en la provincia de Huesca el orden varía ligeramente y siguen, de mayor a menor número de intervenciones, el siguiente orden: zócalo, vanos, cubierta, muros y revestimiento. Si bien, es la provincia en los que la proporción de intervenciones en las distintas zonas es más equiparada.

Por otro lado, la proporción de elementos intervenidos en función del nivel de intervención general (mantenimiento y reparación, por un lado, y el resto de las intervenciones por otro lado) varía especialmente en el caso de las intervenciones de mayor envergadura. El grupo de casos con intervenciones de mantenimiento y reparaciones el elemento más intervenido ha sido el zócalo (139 casos, $75 \%$ ) seguido de los muros (120 casos, 65\%). Estos elementos son muy susceptibles de pequeñas reparaciones, en su mayoría, realizadas con mortero de cemento. A los zócalos y muros les siguen las cubiertas (97 casos, 52\%), los vanos y los revestimientos con un total de casos muy parecido (66 casos, $35 \%$ y 63 casos, 34\%, respectivamente). Los pertenecientes al segundo grupo presentan el mayor número de intervenciones en los vanos (136 casos, $86 \%$ ) y en las cubiertas (135 casos, 85\%). Estos elementos son algunos de los que primero se intervienen cuando se quiere acondicionar o adaptar las antiguas viviendas de tierra a los estándares actuales. A estos elementos les siguen los zócalos (131 casos, 82\%), los revestimientos (103 casos, 65\%) y por último los propios muros (88 casos, 55\%). Este tipo de intervenciones al tener una mayor proporción de revestimientos intervenidos provoca que las intervenciones de los muros, en el caso de que las haya, no se puedan apreciar a través del análisis visual.

\begin{tabular}{|l|c|c|c|c|c|c|c|}
\hline & TOTAL INTERV. & MUROS & ZÓCALO & REVESTIMIENTO & VANOS & CUBIERTA & $\begin{array}{c}\text { Rehab. } \\
\text { ENERGÉTICA }\end{array}$ \\
\hline ARAGÓN & 345 & 208 & 270 & 166 & 202 & 232 & 55 \\
\hline TERUEL & 145 & 102 & 111 & 65 & 80 & 104 & 28 \\
\hline ZARAGOZA & 134 & 71 & 102 & 69 & 83 & 92 & 20 \\
\hline HUESCA & 66 & 35 & 57 & 32 & 39 & 36 & 6 \\
\hline \hline GRUPO 1 & 186 & 120 & 139 & 63 & 66 & 97 & 3 \\
\hline GRUPO 2 & 159 & 88 & 131 & 103 & 136 & 135 & 52 \\
\hline
\end{tabular}

Tabla 10.11. Comparación relativa entre las partes del edificio y los grupos de estudio establecidos.w 


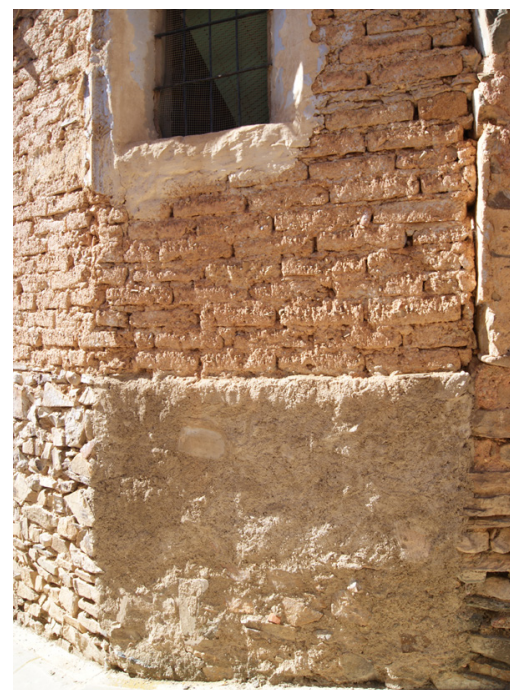

Figura 10.9. Reconstrucción del zócalo con cemento. Val de San Martín, Zaragoza

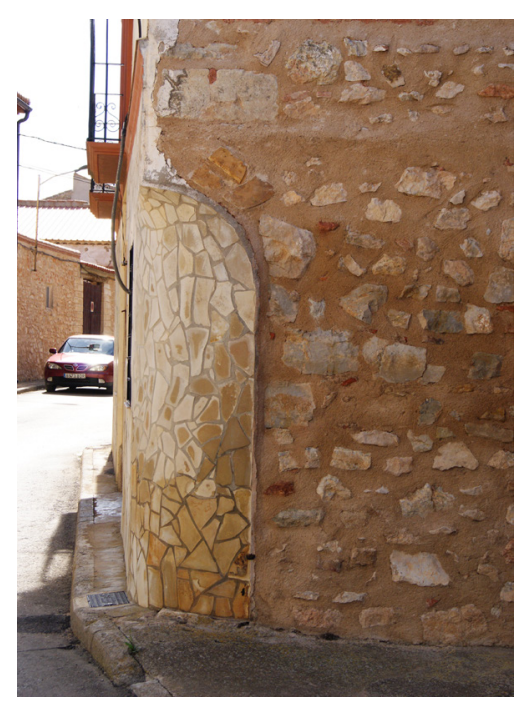

Figura 10.10. Actualización del zócalo con un aplacado de lajas de piedra sobre mampostería. Bello, Teruel

\subsubsection{Intervenciones en el zócalo o arranque del muro}

El zócalo de las construcciones ha sido intervenido en la mayoría de los casos (78\%) (tabla 10.12). Entre las intervenciones llevadas a cabo predominan la reconstrucción con 148 casos (55\% del total de casos intervenidos), la reintegración con 112 casos (41\%) y la actualización con 59 casos (22\%). Además, existen 10 casos en los que se ha sustituido el zócalo y un único caso en el que se ha consolidado. Los materiales utilizados son en casi todos los casos (190 casos) de carácter industrial, en su mayoría cemento y con técnicas diferentes a la existente. La reconstrucción consiste generalmente en la colocación de una capa gruesa de mortero de cemento, de aproximadamente $2 \mathrm{~cm}$ o superior, cuyo acabado final varía en función del objetivo general de la intervención (figura 10.9). Las reintegraciones suelen tratarse de actuaciones de carácter puntual o parcial como el rejuntado de la piedra que suele conformar los zócalos o de intervenciones de relleno de las partes faltantes en los zócalos revestidos, utilizando generalmente cemento en ambos casos. La constante necesidad de mantenimiento derivada de la humedad del terreno, así como la accesibilidad de esta zona del edificio, favorece el desarrollo de todo tipo de intervenciones como las actualizaciones cuya finalidad es el cambio del aspecto del edifico ligado a las modas o a los gustos de los propietarios. Estas consisten normalmente en la modificación del zócalo original revistiéndolo con materiales como los aplacados o las lajas de piedra, o cambiándole el color (figura 10.10).

En relación con el tipo de intervención general, los casos pertenecientes a intervenciones de mantenimiento o reparación presentan un número muy reducido de casos con actualización (13 casos). También cabe destacar que, en este grupo, todos los casos el material utilizado ha sido no tradicional, en parte por la espontaneidad que caracteriza a la mayoría de las reparaciones, que recurren a los materiales más comunes y de fácil acceso en la actualidad. Por otro lado, en el caso de las intervenciones de mayor relevancia el número de casos actualizados es mayor (46 casos) pero el número de reintegraciones menor ya que en muchas ocasiones se pretende renovar el edificio por completo dándole un nuevo aspecto.

\subsubsection{Intervenciones en el cuerpo y coronación del muro}

Las intervenciones en los muros son muy heterogéneas y varían notablemente en función de la técnica constructiva sobre las que se realizan (tabla 10.13). El tipo de intervención presente en mayor número ejemplos es la reintegración con 130 casos (63\%), seguida de la reconstrucción con 57 casos (27\%) y de la sustitución con 50 casos (24\%) (figura 10.11). Otras intervenciones minoritarias han sido las 
demoliciones, totales o parciales, con 10 casos, las actualizaciones con 2 casos y un único caso de consolidación. En cuanto a los materiales utilizados, la mayoría son de origen industrial (190 casos, 91\%) y en una minoría de casos se han utilizado materiales tradicionales pero diferentes a los que conforman el muro. Por otro lado, las técnicas utilizadas para la intervención en muros suelen ser diferente a la original (178 casos, $86 \%$ ) y, en los pocos casos en los que la técnica es similar a la tradicional, el material no suele serlo.

El estudio en relación con el tipo intervención general muestra que el número de casos reintegrados en el primer grupo de intervenciones (mantenimiento y reparación) es mucho mayor que en el segundo grupo con 81 casos (68\%) frente a 49 (56\%). Asimismo, en el primer grupo de intervenciones las sustituciones parciales en los muros es una práctica común (38 casos, 32\%), seguido de las reconstrucciones (20 casos, $17 \%)$. Mientras que, en el segundo grupo de intervenciones generales predominan las reconstrucciones (37 casos, 42\%), en muchos casos asociadas a recrecidos en los muros, sobre los 12 casos de sustitución, y los 10 casos de demolición.

\subsubsection{Intervenciones en la superficie o revestimiento del muro}

Como se ha analizado, las intervenciones sobre los revestimientos son las menos comunes, en parte por la inexistencia de este elemento en el 35\% de los casos de estudio.

El revestimiento es el elemento que se localiza en la superficie exterior del muro y el que por lo tanto le otorga su aspecto final. La frecuente renovación del aspecto de los edificios por parte de los propietarios favorece a que los principales tipos de intervención que presente sean: reconstrucción en 129 casos (77,8\%), actualización en 58 casos (35\%) y reintegración en 20 casos (12\%) (tabla10.14). Además, se han determinado 8 casos de sustitución, 2 de consolidación y 2 de demolición. Las actualizaciones al responder a una finalidad estética más que a la forma de actuar normalmente va acompañada del tipo de intervención a través de la cual se ha llevado a cabo (figura 10.12). En muchas ocasiones se ha ligado a la reconstrucción del revestimiento, sin embargo, en los casos en los que la intervención ha consistido en pintar el revestimiento se ha considerado de forma aislada. Por otro lado, debido a la imposibilidad de conocer el estado previo del edificio por la falta de documentación la intervención de construcción de un revestimiento nuevo se ha definido como reconstrucción tanto si no existía como si existía, pero no se tiene constancia del mismo. Los materiales utilizados son mayoritariamente industriales (158 casos, $95 \%)$, y solo en 8 casos tienen propiedades tradicionales. Las técnicas constructivas tienen un carácter diferente a la preexistente en la mayor parte de los casos (137 casos, 83\%), debido principalmente a las

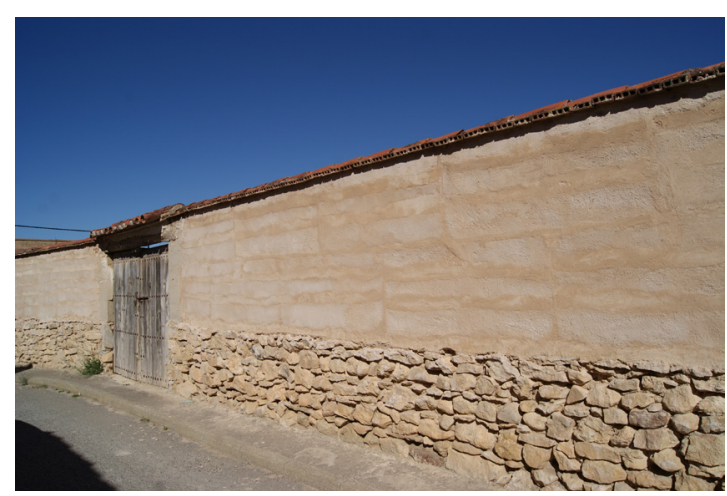

Figura 10.11. Reintegración de un muro de tapia. Torralba de los Sisones, Teruel

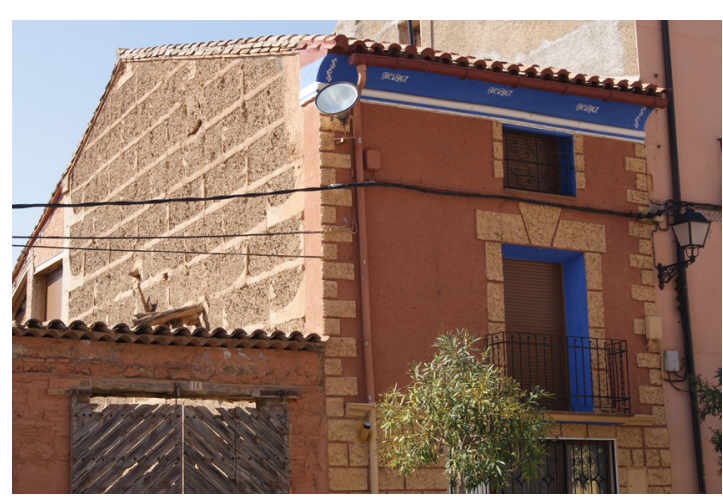

Figura 10.12. Reconstrucción y actualización del resvestimiento. Báguena, Teruel 


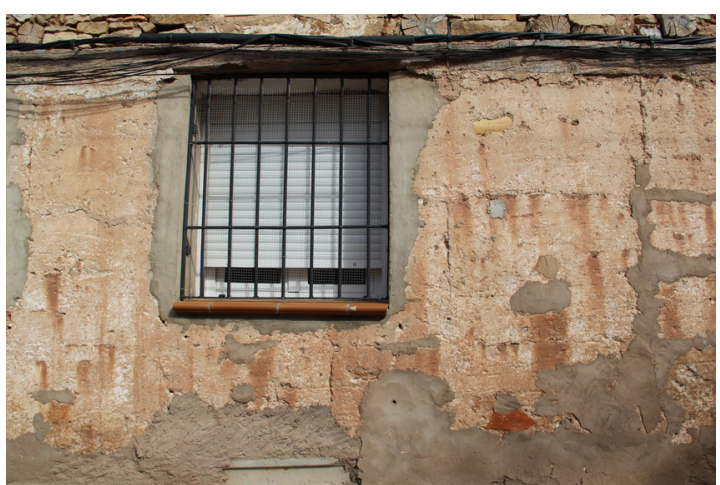

Figura 10.13. Reintegración del hueco con nuevas carpinterías en fachada. El Pobo, Terue

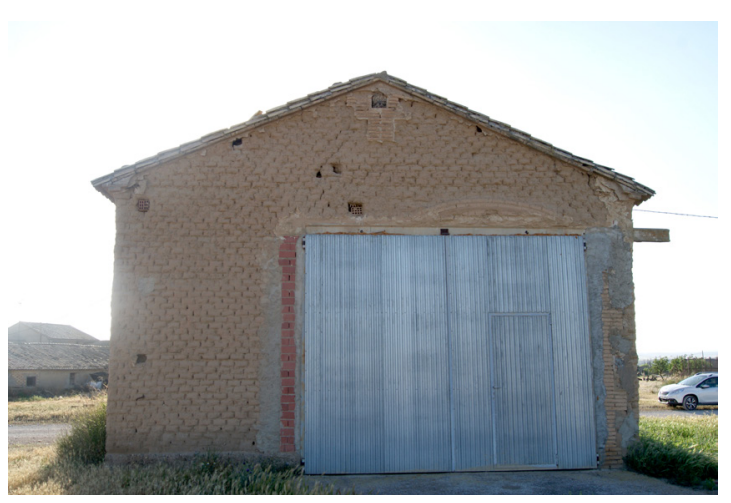

Figura 10.14. Ampliacción del vano de acceso. Peñaflor, Zaragoza características del revestimiento final que suele presentar paramentos y esquinas perfectas que hacen que el edificio pierda en muchas ocasiones su esencia tradicional.

En referencia al tipo de intervención general, la proporción de casos con revestimiento intervenido es mayor en el segundo grupo correspondiente a las intervenciones de mayor alcance. Además, ese grupo presenta un gran número de casos en los que el revestimiento se ha reconstruido (83 casos), 45 casos en los que se ha actualizado y de los 8 casos de sustitución, 7 pertenecen a este grupo. Los casos asociados a intervenciones generales de mantenimiento y reparación presentan una mayoría de casos reconstruidos (46 casos) y la mayor parte de los casos de reintegración (14 casos de los 20 totales). En ambos casos los resultados en torno al tipo de material y al tipo de técnica utilizada se encuentran en los mismos rangos que los resultados de la muestra inicial.

\subsubsection{Intervenciones en los vanos.}

Los datos relativos a las intervenciones en los vanos engloban tanto los casos en los que se han intervenido las carpinterías como casos en los que se ha intervenido en el contorno de los vanos o modificado sus dimensiones. La intervención más común es la sustitución con 154 casos (76\%) seguida de la reintegración (61 casos, 30\%) y la reconstrucción (46 casos, 23\%) (tabla 10.15). Las intervenciones en vanos conllevan, normalmente, la sustitución de las carpinterías que en gran número de ocasiones aparece combinada con reintegraciones o con reconstrucciones por la adaptación de las carpinterías o la modificación de las dimensiones del hueco (figura 10.13). Un ejemplo muy común es la ampliación de huecos en planta baja para el acceso de vehículos (figura 10.14). Aparte de estas intervenciones existen otras menos frecuentes como los trabajos de actualización con 13 casos, de consolidación con 4 casos o de demolición con un único caso. La determinación del origen de los materiales, así como la técnica constructiva ha sido una tarea complicada ya que se ha hecho referencia a dos elementos diferentes, el contorno del vano y la carpintería. Por ello, en el caso de estar los dos elementos intervenidos se ha optado por la opción más desfavorable que es el uso de materiales industriales y técnicas diferentes a la original. En base a este criterio se ha determinado que en 186 ejemplos se han utilizado materiales de origen industrial y en 16 casos de origen tradicional. Estos últimos corresponden en muchas ocasiones con el uso de carpinterías de madera nuevas con características distintas a las originales. En cuanto a las técnicas, en general son distintas a la original, 180 casos, y solo en 22 ejemplos se han utilizado técnicas similares a la existente.

Por otro lado, existe una gran diferencia entre el número de casos ligados a intervenciones de 
mantenimiento o reparación (66 casos) y el número de casos ligados a intervenciones mayor magnitud (136 casos). Esto indica una mayor relación de las intervenciones en vanos con actuaciones de mayor envergadura, especialmente con las rehabilitaciones (127 casos de los 136). Dentro del primer grupo de intervenciones generales (mantenimiento y reparación) predomina la sustitución con 41 casos (62\%) seguido de la reintegración con 26 casos (32\%) y la reconstrucción con 14 casos (21\%). Al segundo grupo de intervenciones pertenecen la mayor parte de los trabajos de sustitución (113 casos, 83\%) y casi la totalidad de actualizaciones (12 casos de 13 totales) mientras que en las intervenciones de reintegración (34 casos, 25\%) y reconstrucción (35 casos, 26\%) el total de casos está repartido de forma más equitativa con el primer grupo. En relación con las técnicas y materiales, en los dos grupos se mantiene una distribución de casos muy parecida a la del cómputo general.

\subsubsection{Intervenciones en la cubierta}

Las intervenciones en la cubierta son unas de las más reiteradas en el conjunto de casos por la importancia que tiene su adecuada conservación de cara a la durabilidad y conservación del edificio (tabla 10.16).

Los tipos de intervención más destacados son la reintegración con 95 casos (41\%), la sustitución, total o parcial, con 92 casos (40\%) y la reconstrucción con 62 casos (26\%). Estas intervenciones incluyen trabajos como la recolocación de tejas o la sustitución de algunas piezas, de partes de la cubierta o de la totalidad de la misma. Las otras intervenciones contempladas aparecen de forma anecdótica con 4 casos de demolición, 2 casos de actualización. En cuanto a los materiales, en la mayoría de los casos se reutilizan las tejas antiguas sustituyendo solo los elementos necesarios pero la recolocación de estas piezas cerámicas se realiza casi en la totalizada de los casos con mortero de cemento (223 casos, 96\%). Por otro lado, las intervenciones en cubierta son las únicas que mantienen, en su mayoría, la técnica constructiva tradicional (121 casos, 52\%), aunque algunos materiales cambien como por ejemplo el mortero de asiento.

Los casos asociados a intervenciones generales de mantenimiento o reparación presentan una mayoría de casos de reintegración (50 casos, 52\%) en los que principalmente se han recolocado las tejas para evitar filtraciones de agua (figura 10.15). En este grupo también son comunes las sustituciones (33 casos, $34 \%$ ) y las reconstrucciones (19 casos, 20\%), sin embargo, estos presentan una proporción menor que en grupo correspondiente a intervenciones de mayor envergadura. En este segundo grupo predominan las intervenciones de sustitución con 59 casos (44\%) seguidas por las reintegraciones y las reconstrucciones con 45 (33\%) y 42 (31\%) casos respectivamente (figura 10.16). En cuanto a los materiales y las técnicas

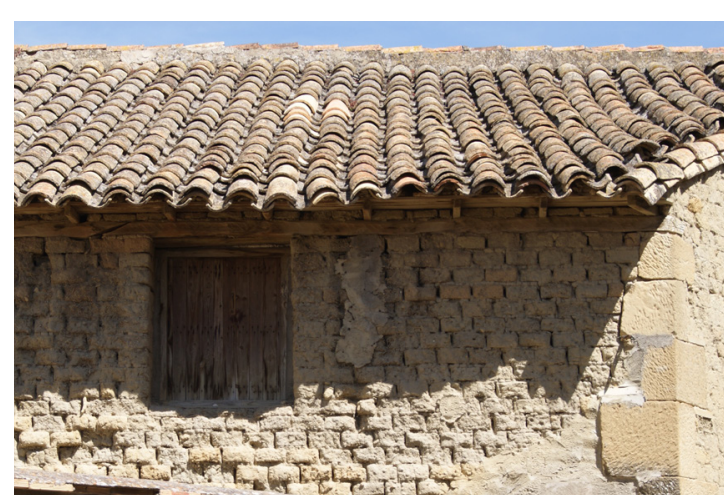

Figura 10.15. Recolocación de las tejas de cumbrera con motero de cemento. Uncastillo, Zaragoza

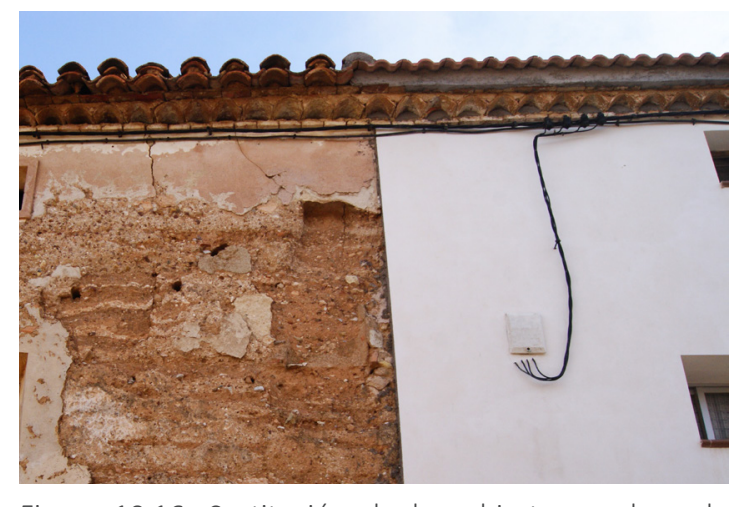

Figura 10.16. Sustitución de la cubierta por losa de hormigón. Odón, Teruel 


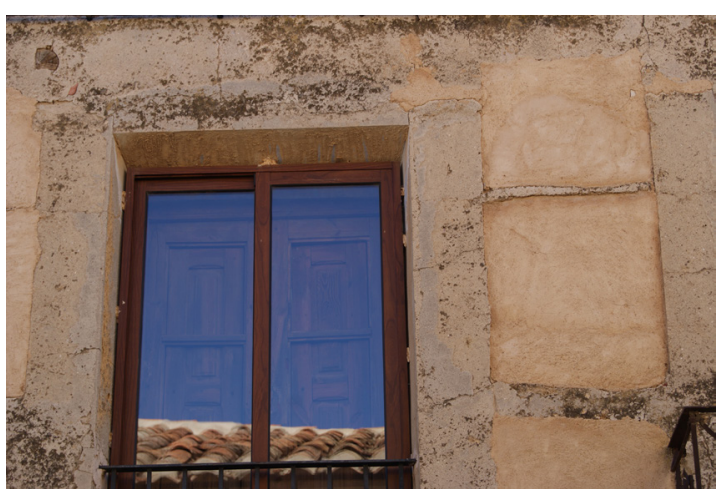

Figura 10.17. Doble carpintería. Villalba de los Morales, Teruel

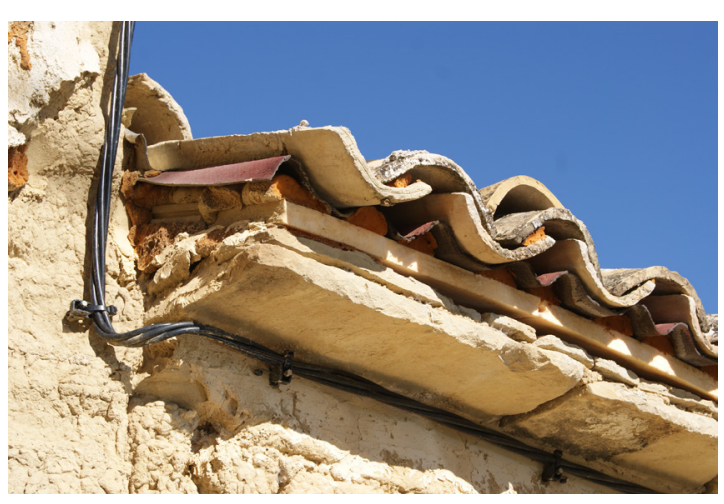

Figura 10.18. Inserción de aislantes en la cubierta. Perarrúa, Huesca en relación a estos grupos, la relación es muy parecida a la de la muestra general. Si bien, en el caso del tipo de técnicas el primer grupo tiene un porcentaje de casos con técnicas similares ligeramente superior que el cómputo general (57\% frente a $52 \%$ ) y que los casos del segundo grupo (49\%), aunque en valores absolutos el número de casos es menor.

\subsubsection{Intervenciones de mejora energética}

Las intervenciones de mejora energética consisten generalmente en la incorporación de materiales o en los cambios de disposición y arreglo de los existentes. La mejora del funcionamiento energético de los edificios y el ahorro en el consumo de las aportaciones necesarias para alcanzar una temperatura de confort son objetivos importantes para alcanzar la sostenibilidad.

Se han detectado intervenciones de mejora energética en 55 casos (16\%) del total, si bien no siempre es posible determinar su existencia a través de la toma de datos in situ y el análisis visual (tabla 10.17). Por ello, el número de intervenciones de mejora energética podría ser mayor en el total de la muestra. Cabe destacar que, dentro de los casos intervenidos energéticamente casi la totalidad pertenecen al segundo grupo de intervenciones ( 52 casos) de las cuales 49 casos ( $89 \%$ del total) son intervenciones de rehabilitación, 29 de ellas integrales y 20 parciales.

Por otro lado, se han analizado las partes del edificio con posibles intervenciones: fachada, vanos, forjado y cubierta. Entre ellos, el elemento con mayor número de casos intervenidos son los vanos con un total de 51 casos (25\% de los casos en los que los vanos están intervenidos) de los que casi la totalidad han consistido en la sustitución de las carpinterías (figura 10.17). El otro elemento con mayor número de intervenciones ha sido la cubierta con 27 casos de mejora energética (figura 10.18). Estas intervenciones se han llevado a cabo en las ocasiones en las que el desmontaje de la cubierta ha permitido la colocación de aislantes para mejorar sus características, principalmente a través de reconstrucciones y sustituciones.

Además, se han recogido datos de 5 edificios rehabilitados en los que se ha aumentado la sección de los muros en fachada para mejorar sus propiedades energéticas. Los ejemplos han consistido en el doblado de los muros con ladrillo, tanto por el interior como el exterior, y en la incorporación de aislante térmico en el interior. 


\begin{tabular}{|c|c|c|c|c|c|c|c|c|c|c|c|c|c|c|c|}
\hline ZÓCALO & \begin{tabular}{|c|} 
total \\
int \\
\end{tabular} & Intervenido & $\begin{array}{c}\text { No } \\
\text { intervenido }\end{array}$ & Actualización & Consolidación & Reintegración & Reconstrucción & Demolición & Sustitución & Otros & $\begin{array}{c}\text { Trad. } \\
\text { similar }\end{array}$ & $\begin{array}{c}\text { Trad. } \\
\text { diferente }\end{array}$ & $\begin{array}{c}\text { No } \\
\text { tradicional }\end{array}$ & \begin{tabular}{|c|} 
Téc. \\
Similar \\
\end{tabular} & \begin{tabular}{|c|} 
Téc. \\
diferente
\end{tabular} \\
\hline ARAGÓN & 345 & 270 & 75 & 59 & 1 & 112 & 148 & 0 & 10 & 0 & 2 & 7 & 261 & 27 & 243 \\
\hline TERUEL & 145 & 111 & 34 & 22 & 1 & 55 & 47 & 0 & 9 & 0 & 2 & 4 & 105 & 15 & 96 \\
\hline ZARAGOZA & 134 & 102 & 32 & 28 & 0 & 32 & 68 & 0 & 1 & 0 & 0 & 2 & 100 & 7 & 95 \\
\hline HUESCA & 66 & 57 & 9 & 9 & 0 & 25 & 33 & 0 & 0 & 0 & 0 & 1 & 56 & 5 & 52 \\
\hline GRUPO 1 & 186 & 139 & 47 & 13 & 0 & 67 & 70 & 0 & 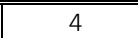 & 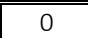 & 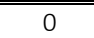 & 0 & 139 & $\overline{99}$ & 130 \\
\hline GRUPO 2 & 159 & 131 & 28 & 46 & 1 & 45 & 78 & 0 & 6 & 0 & 2 & 7 & 122 & 18 & 113 \\
\hline
\end{tabular}

Tabla 10.12. Intervenciones en el zócalo o arranque del muro

\begin{tabular}{|c|c|c|c|c|c|c|c|c|c|c|c|c|c|c|c|}
\hline MUROS & \begin{tabular}{|c|} 
total \\
int
\end{tabular} & Intervenido & $\begin{array}{c}\text { No } \\
\text { intervenido }\end{array}$ & Actualización & Consolidación & Reintegración & Reconstrucción & Demolición & Sustitución & Otros & $\begin{array}{l}\text { Trad. } \\
\text { similar }\end{array}$ & $\begin{array}{c}\text { Trad. } \\
\text { diferente }\end{array}$ & $\begin{array}{c}\text { No } \\
\text { tradicional } \\
\end{array}$ & $\begin{array}{c}\text { Téc. } \\
\text { Similar }\end{array}$ & $\begin{array}{c}\text { Téc. } \\
\text { diferente }\end{array}$ \\
\hline ARAGÓN & 345 & 208 & 137 & 0 & 1 & 130 & 57 & 10 & 50 & 0 & 1 & 17 & 190 & 30 & 178 \\
\hline TERUEL & 145 & 102 & 43 & 0 & 1 & 61 & 28 & 3 & 28 & 0 & 1 & 15 & 86 & 10 & 92 \\
\hline ZARAGOZA & 134 & 71 & 63 & 0 & 0 & 46 & 24 & 3 & 12 & 0 & 0 & 1 & 70 & 13 & 58 \\
\hline HUESCA & 66 & 35 & 31 & 0 & 0 & 23 & 5 & 4 & 10 & 0 & 0 & 1 & 34 & 7 & 28 \\
\hline GRUPO 1 & 186 & 120 & 104 & 0 & 0 & 81 & 20 & 0 & 38 & 0 & 0 & 6 & 114 & 16 & 104 \\
\hline GRUPO 2 & 159 & 88 & 71 & 0 & 1 & 49 & 37 & 10 & 12 & 0 & 1 & 11 & 76 & 14 & 74 \\
\hline
\end{tabular}

Tabla 10.13. Intervenciones en el cuerpo y coronación del muro

\begin{tabular}{|c|c|c|c|c|c|c|c|c|c|c|c|c|c|c|c|}
\hline REVESTIMIENTO & $\begin{array}{c}\text { total } \\
\text { int }\end{array}$ & Intervenido & \begin{tabular}{|c|} 
No \\
intervenido
\end{tabular} & Actualización & Consolidación & Reintegración & Reconstrucción & Demolición & Sustitución & Otros & \begin{tabular}{|c|} 
Trad. \\
similar
\end{tabular} & $\begin{array}{c}\text { Trad. } \\
\text { diferente }\end{array}$ & $\begin{array}{c}\text { No } \\
\text { tradicional }\end{array}$ & \begin{tabular}{|c|} 
Téc. \\
Similar \\
\end{tabular} & $\begin{array}{c}\text { Téc. } \\
\text { diferente }\end{array}$ \\
\hline ARAGÓN & 345 & 166 & 179 & 58 & 2 & 20 & 129 & 2 & 8 & 0 & 2 & 6 & 158 & 29 & 137 \\
\hline TERUEL & 145 & 65 & 80 & 19 & 2 & 6 & 46 & 1 & 7 & 0 & 2 & 5 & 58 & 13 & 52 \\
\hline ZARAGOZA & 134 & 69 & 65 & 32 & 0 & 7 & 54 & 1 & 1 & 0 & 0 & 0 & 69 & 8 & 61 \\
\hline HUESCA & 66 & 32 & 34 & 7 & 0 & 7 & 29 & 0 & 0 & 0 & 0 & 1 & 31 & 8 & 24 \\
\hline GRUPO 1 & 186 & 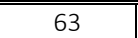 & 1123 & 13 & 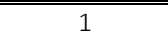 & 114 & 46 & 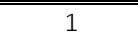 & 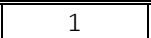 & 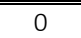 & $\overline{11}$ & $\overline{11}$ & $\bar{~} 61$ & 15 & 48 \\
\hline GRUPO 2 & 159 & 103 & 56 & 45 & 1 & 6 & 83 & 1 & 7 & 0 & 1 & 5 & 97 & 14 & 89 \\
\hline
\end{tabular}

Tabla 10.14. Intervenciones en la superficie o revestimiento del muro

\begin{tabular}{|c|c|c|c|c|c|c|c|c|c|c|c|c|c|c|c|}
\hline VANOS & \begin{tabular}{|c|} 
total \\
int \\
\end{tabular} & Intervenido & $\begin{array}{c}\text { No } \\
\text { intervenido }\end{array}$ & Actualización & Consolidación & Reintegración & Reconstrucción & Demolición & Sustitución & Otros & $\begin{array}{l}\text { Trad. } \\
\text { similar }\end{array}$ & $\begin{array}{c}\text { Trad. } \\
\text { diferente }\end{array}$ & $\begin{array}{c}\text { No } \\
\text { tradicional }\end{array}$ & $\begin{array}{c}\text { Téc. } \\
\text { Similar }\end{array}$ & $\begin{array}{c}\text { Téc. } \\
\text { diferente }\end{array}$ \\
\hline ARAGÓN & 345 & 202 & 143 & 13 & 4 & 61 & 46 & 1 & 154 & 0 & 1 & 15 & 186 & 22 & 180 \\
\hline TERUEL & 145 & 80 & 65 & 6 & 2 & 22 & 15 & 0 & 63 & 0 & 0 & 7 & 73 & 12 & 68 \\
\hline ZARAGOZA & 134 & 83 & 51 & 6 & 0 & 32 & 27 & 1 & 60 & 0 & 1 & 3 & 79 & 6 & 77 \\
\hline HUESCA & 66 & 39 & 27 & 1 & 2 & 7 & 4 & 0 & 31 & 0 & 0 & 5 & 34 & 4 & 35 \\
\hline GRUPO 1 & 186 & 66 & 120 & 1 & 1 & 26 & 14 & 0 & 41 & 0 & 0 & 3 & 63 & 7 & 59 \\
\hline GRUPO 2 & 159 & 136 & 23 & 12 & 3 & 35 & 32 & 1 & 113 & 0 & 1 & 12 & 123 & 15 & 121 \\
\hline
\end{tabular}

Tabla 10.15. Intervenciones en los vanos 


\begin{tabular}{|c|c|c|c|c|c|c|c|c|c|c|c|c|c|c|c|}
\hline CUBIERTA & $\begin{array}{c}\text { total } \\
\text { int }\end{array}$ & Intervenido & \begin{tabular}{c|} 
No \\
intervenido
\end{tabular} & Actualización & Consolidación & Reintegración & Reconstrucción & Demolición & Sustitución & Otros & $\begin{array}{l}\text { Trad. } \\
\text { similar }\end{array}$ & \begin{tabular}{c|} 
Trad. \\
diferente
\end{tabular} & $\begin{array}{c}\text { No } \\
\text { tradicional }\end{array}$ & \begin{tabular}{|c|} 
Téc. \\
Similar
\end{tabular} & $\begin{array}{c}\text { Téc. } \\
\text { diferente }\end{array}$ \\
\hline ARAGÓN & 345 & 232 & 113 & 2 & 0 & 95 & 62 & 4 & 92 & 0 & 5 & 4 & 223 & 121 & 111 \\
\hline TERUEL & 145 & 104 & 41 & 1 & 0 & 45 & 25 & 3 & 44 & 0 & 3 & 4 & 97 & 54 & 50 \\
\hline ZARAGOZA & 134 & 92 & 42 & 1 & 0 & 39 & 26 & 1 & 33 & 0 & 0 & 0 & 92 & 46 & 46 \\
\hline HUESCA & 66 & 36 & 30 & 0 & 0 & 11 & 11 & 0 & 15 & 0 & 2 & 0 & 34 & 21 & 15 \\
\hline GRUPO 1 & 186 & 97 & 89 & 0 & 0 & 50 & 19 & 1 & 33 & 0 & 1 & 1 & 95 & 55 & 42 \\
\hline GRUPO 2 & 159 & 135 & 24 & 2 & 0 & 45 & 43 & 3 & 59 & 0 & 4 & 3 & 128 & 66 & 69 \\
\hline
\end{tabular}

Tabla 10.16. Intervenciones en la cubierta

\begin{tabular}{|l|c|c|c|c|c|c|c|}
\hline $\begin{array}{c}\text { REHAB. } \\
\text { ENERGÉTICA }\end{array}$ & $\begin{array}{c}\text { total } \\
\text { int }\end{array}$ & Intervenido & & Fachada & Vanos & Forjado & Cubierta \\
\hline ARAGÓN & 345 & 55 & & 5 & 51 & 1 & 27 \\
\hline TERUEL & 145 & 28 & & 3 & 29 & 1 & 10 \\
\hline ZARAGOZA & 134 & 20 & & 2 & 18 & 0 & 12 \\
\hline HUESCA & 66 & 6 & & 0 & 4 & 0 & 5 \\
\hline \hline GRUPO 1 & 186 & 3 & 0 & 3 & 0 & 1 \\
\hline GRUPO 2 & 159 & 52 & 5 & 48 & 1 & 26 \\
\hline
\end{tabular}

Tabla 10.17. Intervenciones de mejora energética

\subsection{Intervenciones en función de la técnica constructiva}

A continuación, se han analizado las intervenciones realizadas en función de la técnica constructiva presente en el edifico con la finalidad de conocer los tipos de intervención y las soluciones más comunes en cada una de ellas. Este análisis ha seguido el mismo esquema que el realizado de toda la muestra, pero con el objetivo de exponer de forma detallada soluciones ligadas las técnicas de construcción estudiadas.

\subsubsection{Intervenciones en construcciones de tapia}

Las construcciones de tapia representan el 55\% del total de la muestra con 190 casos intervenidos (tabla 10.18). En esta muestra la gran mayoría de los edificios tiene una frecuencia de uso temporal ( 120 casos), seguida por las construcciones $\sin$ uso (42 casos) y las edificaciones utilizadas de forma continuada con solo 28 casos. En cuanto a los tipos de uso, existe un predominio claro del uso residencial con 124 casos (65\%), mientras que los ejemplos destinados a los otros usos son mucho menores: 28 construcciones de uso productivo, 23 de uso agrícola y 15 destinadas a otros usos. 
La mayor parte de las intervenciones realizadas en las construcciones de tapia se han realizado de forma espontánea y estas presentan casi el doble de casos que las intervenciones planificadas (125 casos frente a 65). En cuanto a la relación de los usos con el tipo de intervención, las intervenciones espontáneas aparecen ligadas principalmente a construcciones con usos temporales o sin uso (80 y 36 casos respectivamente), mientras que, las intervenciones planificadas predominan entre los ejemplos con uso temporal y uso continuo (40 y 19 casos respectivamente). Con relación a los usos de los distintos edificios, se ha detectado una vinculación directa entre los edificios destinados a usos residenciales y las intervenciones planificadas ya que 59 de los 65 casos responden a este uso. Las intervenciones espontáneas, por su parte, se han realizado por igual en construcciones con todo tipo de usos.

En cuanto a las intervenciones las más comunes son las reparaciones con 109 casos (57\%) que corresponden con todo tipo de edificios de uso temporal o nulo. Las rehabilitaciones con 80 casos (42\%, con 46 casos parciales y 34 integrales) generalmente están llevadas a cabo en edificios de carácter residencial y uso temporal o continuado. Además de estás, se han localizado 5 casos con intervenciones de mantenimiento, 6 con restauraciones, 8 con ampliaciones y un caso de demolición.

Los trabajos llevados a cabo en cada parte del edificio se han estudiado buscando la relación concreta entre la técnica estudiada y las soluciones constructivas aplicadas en cada caso. (materiales y técnicas) (tabla 10.19).

Las intervenciones en los zócalos de los edificios de tapia son muy recurrentes. El tipo de intervención con mayor número de casos ha sido la reconstrucción (72 casos) que generalmente consiste en la disposición de una capa de mortero de cemento. El otro tipo de intervención más recurrente es la reintegración con un total de 65 casos seguida de la actualización con 32 casos de estudio (figura 10.19).

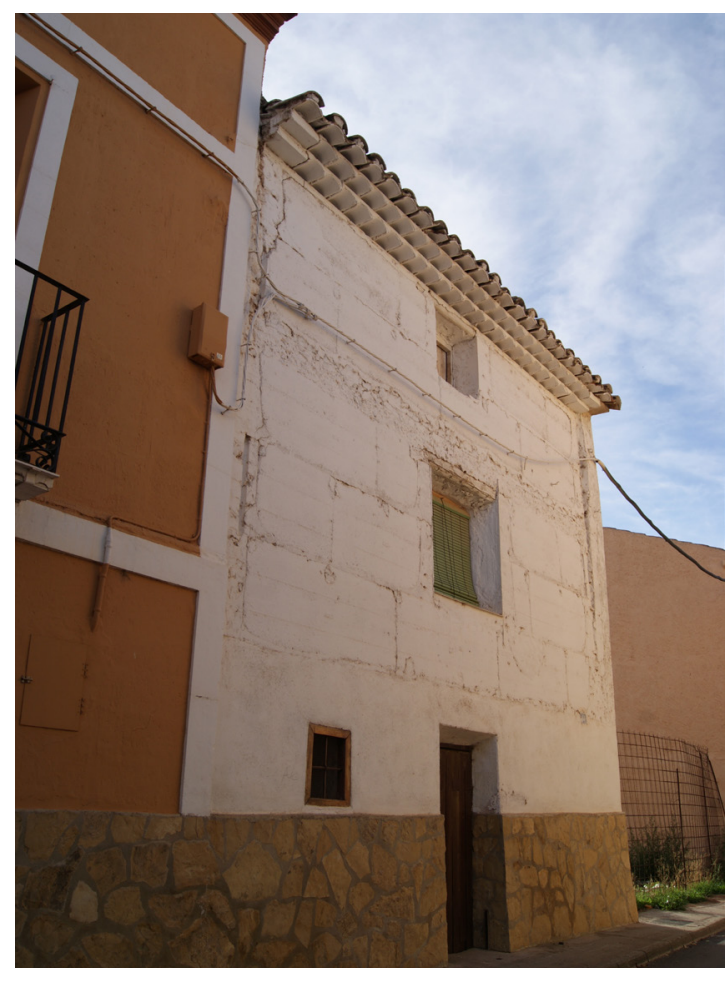

Figura 10.19. Edificios de tapia actualizado según las tendencias del momento. Villafranca del Campo, Teruel

\begin{tabular}{|c|c|c|c|c|c|c|c|c|c|c|}
\hline \multirow{2}{*}{ TAPIA } & Intervenido & Interv. espontánea & Interv. Planificada & Mantenimiento & Reparación & Restauración & Rehab. Parcial & Rehab. Integral & Ampliación & Demolición \\
\hline & 190 & 125 & 65 & 5 & 109 & 6 & 46 & 34 & 8 & 1 \\
\hline \multicolumn{11}{|c|}{ FRECUENCIA DE USO } \\
\hline Continuado & 28 & 9 & 19 & 0 & 7 & 1 & 13 & 9 & 2 & 0 \\
\hline Temporal & 120 & 80 & 40 & 4 & 68 & 5 & 30 & 22 & 2 & 0 \\
\hline Sin uso & 42 & 36 & 6 & 1 & 34 & 0 & 3 & 3 & 4 & 1 \\
\hline \multicolumn{11}{|l|}{ USO } \\
\hline Residencial & 124 & 65 & 59 & 4 & 53 & 4 & 40 & 31 & 7 & 1 \\
\hline Productivo & 28 & 27 & 1 & 1 & 24 & 0 & 4 & 0 & 0 & 0 \\
\hline Agrícola & 23 & 23 & 0 & 0 & 23 & 0 & 0 & 0 & 0 & 0 \\
\hline Otro & 15 & 10 & 5 & 0 & 9 & 2 & 2 & 3 & 1 & 0 \\
\hline
\end{tabular}

Tabla 10.18. Datos cruzados de los casos construidos con tapia con la frecuencia de uso y el tipo de uso de los casos analizados. 


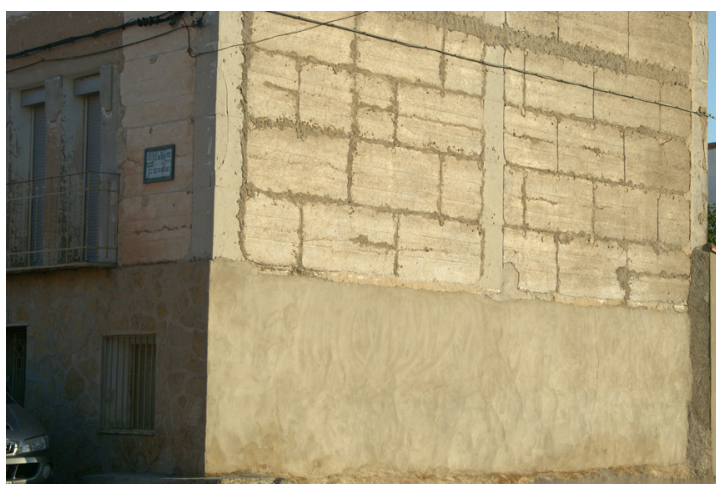

Figura 10.20. Reintegración de juntas entre cajones con cemento. Torrelacarcel, Teruel.

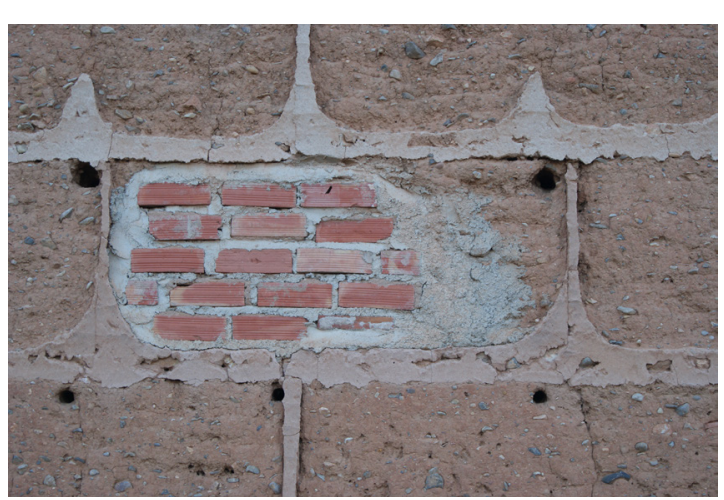

Figura 10.21. Reintegración de un muro de tapia con ladrillo hueco y cemento. Orrios, Teruel.
No se han detectado en las intervenciones sobre las construcciones de tapia características propias ligadas a la técnica constructiva.

Las intervenciones en los muros son recurrentes en el caso de la tapia con un 67,9\% de los casos intervenidos (129 casos). Estas intervenciones se han realizado directamente sobre los muros de tierra estudiados y, por ello, las soluciones planteadas guardan una relación más directa con la técnica constructiva sobre la que se trabaja. El tipo de intervención más común es la reintegración con un total de 87 casos (67\%), en parte, favorecido por las características monolíticas de la tapia que generan que las oquedades o pequeños faltantes sean unas de las lesiones más comunes. Por otro lado, también son comunes las intervenciones de reconstrucción (36 casos) y de sustitución (30 casos), que consisten principalmente en el doblado de los muros y la sustitución de algunas partes debido a la pérdida de sección importante en paños de muro o partes completas.

Las reintegraciones están ligadas generalmente a trabajos de reparación de oquedades. En función de la afección o la gravedad de los problemas, las soluciones empleadas son distintas. Si la erosión del muro es poco profunda se dispone generalmente mortero de cemento hasta quedar enrasado con la superficie exterior del muro. Esta solución también es común en las construcciones que presentan grietas o fisuras como las producidas por la discontinuidad material (normalmente muros mixtos), las juntas entre cajones o las derivadas de daños estructurales (figura 10.20). En la mayoría de los casos en los que la pérdida de sección más importante, las reintegraciones se han llevado a cabo con ladrillo cerámico cogido con mortero de cemento que permite evitar de esta forma gruesas capas de mortero. Si la degradación del muro está muy avanzada y la sección del mismo afectada, el muro de tapia se ha doblado por el exterior con ladrillo con distintos aparejos en función de la dimensión de la sección a recuperar (figura 10.21).

Las sustituciones realizadas en los muros de tapia son generalmente puntuales en alguna zona del muro o paños en las que suelen incluirse las esquinas por ser uno de los puntos más expuestos y de mayor dificultad de construcción. Estas sustituciones se han realizado principalmente con dos materiales:

\begin{tabular}{|c|c|c|c|c|c|c|c|c|c|c|c|c|c|c|}
\hline TAPIA_ 190 & Intervenido & \begin{tabular}{|c|} 
No \\
intervenido
\end{tabular} & Actualización & Consolidación & Reintegración & Reconstrucción & Demolición & Sustitución & Otros & $\begin{array}{l}\text { Trad. } \\
\text { similar }\end{array}$ & $\begin{array}{c}\text { Trad. } \\
\text { diferente }\end{array}$ & \begin{tabular}{|c|} 
No \\
tradicional
\end{tabular} & $\begin{array}{c}\text { Téc. } \\
\text { Similar }\end{array}$ & \begin{tabular}{|c|} 
Téc. \\
diferente
\end{tabular} \\
\hline ZÓCALO & 144 & 46 & 32 & 1 & 65 & 72 & 0 & 6 & 0 & 2 & 5 & 137 & 17 & 127 \\
\hline MURO & 129 & 61 & 0 & 1 & 87 & 36 & 4 & 30 & 0 & 1 & 15 & 113 & 12 & 117 \\
\hline REVESTIMIENTO & 85 & 105 & 29 & 2 & 10 & 64 & 2 & 4 & 0 & 1 & 3 & 81 & 12 & 73 \\
\hline VANOS & 111 & 79 & 5 & 2 & 32 & 22 & 0 & 88 & 0 & 0 & 12 & 99 & 11 & 100 \\
\hline CUBIERTA & 134 & 56 & 1 & 0 & 57 & 37 & 1 & 52 & 0 & 4 & 1 & 129 & 68 & 66 \\
\hline
\end{tabular}

Tabla 10.19. Intervenciones en las distintas zonas del edificio en el caso de las construcciones con tapia. 
ladrillos y bloques de hormigón prefabricados. En los casos en los que el área perdida es mayor o se ha demolido parte para mejorar la superficie de apoyo y reconstruirlo se han utilizado también bloques de termoarcilla. En el caso de los recrecidos de muros de tapia se han detectado dos tipos predominantes. En el caso de los muros de cerca, predomina el recrecido con bloque de hormigón prefabricado mientras que en el caso de edificios cerrados el material predominante ha sido el ladrillo hueco sobre el cual apoya la nueva cubierta.

Además, las intervenciones en los muros de tapia están estrechamente relacionadas con la variante constructiva en la que se efectúan. La tapia con brencas presenta un abanico de soluciones muy heterogéneas que tienen como objetivo cubrir las zonas de tierra entre las "medias lunas" de yeso (figura 10.22). Estas intervenciones en ocasiones se realizan sobre muros originalmente desprotegidos, pero es mucho más común la presencia de intervenciones en tapias con brencas que además estaban calicostradas y han perdido esta costra. Por ello, no siempre se presenta en la totalidad del muro, sino que se interviene solo en las "medias lunas" donde se ha perdido este elemento de protección. Algunas soluciones y materiales utilizados comúnmente son la piedra, el ladrillo hueco, mortero con pequeñas piedras, el mortero de cemento y, tradicionalmente, yeso con cascotes de elementos cerámicos como las tejas. Estas soluciones rellenan la perdida de sección o de la costra y queda enrasados con las brencas de yeso que permanecen visibles.

Las reintegraciones en los muros de tapia calicostrada es una práctica muy habitual debido a las pérdidas parciales de la costra (figura 10.23). Esta pérdida suele producir oquedades, generalmente en franjas horizontales, que corresponden con las tongadas de tierra y que pueden derivar en daños mayores con cierta rapidez. Por ello la reparación más común de estas oquedades se realiza con mortero de cemento lo cual genera una apariencia estética muy característica con franjas horizontales de tierra y cemento.

Los revestimientos son el elemento menos intervenido con 85 casos (44,7\%), influenciado, en parte, por la existencia de las tapias calicostradas que incluyen la protección en la propia técnica pero que no se ha contabilizado en este grupo.

El tipo de intervención más recurrente en el caso de los revestimientos es la reconstrucción (64 casos, 75\%). Este tipo de intervención en ocasiones afecta únicamente a la fachada principal y se encuentra ligada en su mayoría a trabajos de actualización (29 casos, 34\%).

Otras intervenciones menos frecuentes en la tapia son las reintegraciones con 10 casos, las sustituciones con 4 casos y las consolidaciones y demoliciones cuya representación es muy baja con únicamente 2 casos cada una.

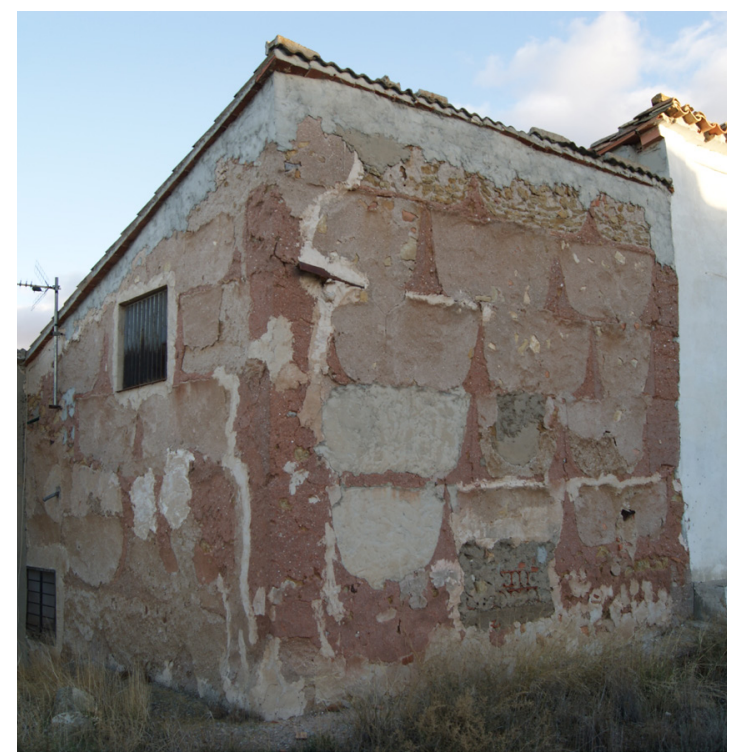

Figura 10.22. Reintegración de espacio entre brencas con distintos materiales (Piedra en la parte superior, mortero de yeso y cascotes cerámicos). Oliete, Teruel

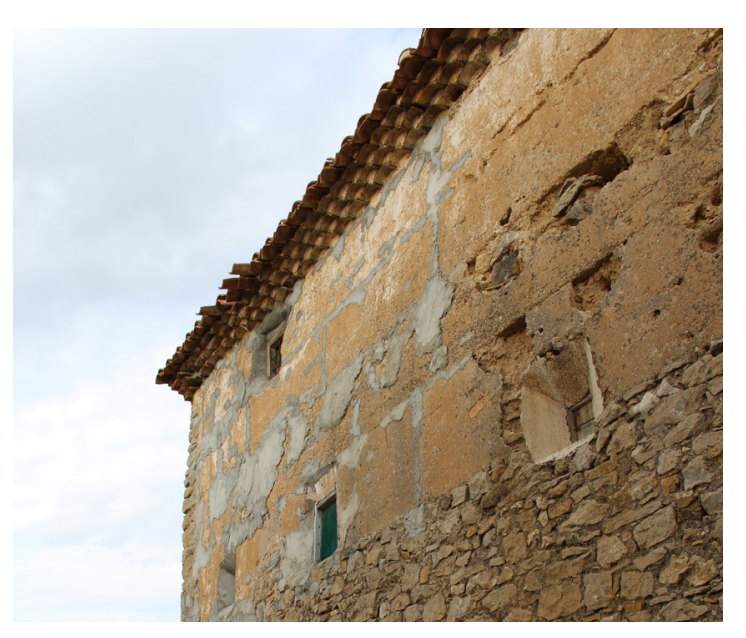

Figura 10.23. Reintegración de oquedades con cemento en la tapia calicostrada. Camarillas, Teruel 


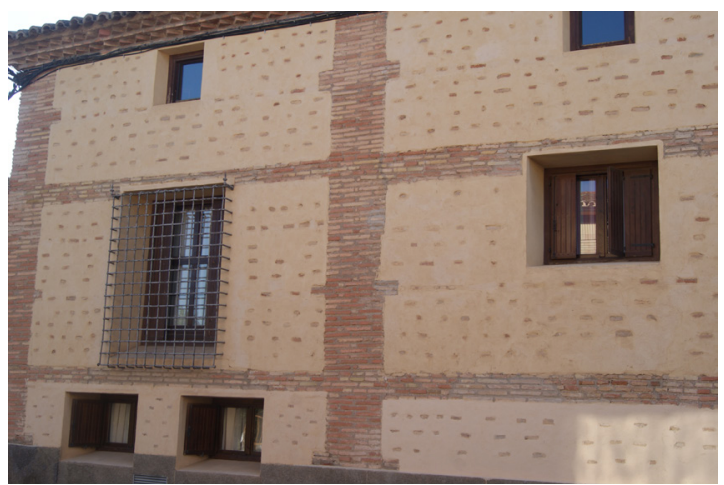

Figura 10.24. Revestimiento de tapia careada con ladrillo dejando los ladrillos vistos. Peñaflor, Zaragoza

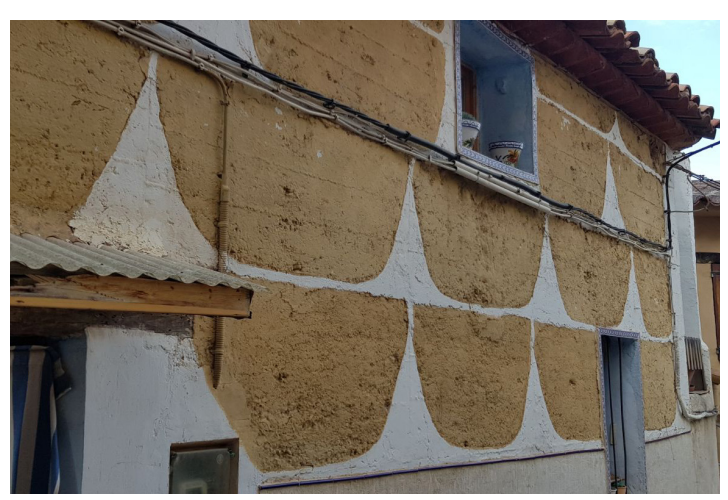

Figura 10.25. Tapia con brencas resaltadas con pintura. Alcaine, Teruel
Al igual que en el caso de los muros, algunas intervenciones en los revestimientos están ligadas a una variante constructiva concreta. En el caso de las tapias mixtas es común que los cajones de tapia se revistan con un nuevo mortero dejando vistos los machones y las verdugadas (estas últimas presentes en un número muy reducido), resaltando de esta forma la tipología mixta del muro. Este tipo de intervención se ha detectado especialmente en los casos en los que los machones son de piedra o ladrillo, sin embargo, en los casos en los que son de mampostería y yeso suelen cubrirse con el mismo revestimiento continuo.

Otra solución que generalmente aparece combinada con la anterior es la aplicada en las construcciones de tapia suplementada en paramentos, concretamente en la tapia careada con ladrillos (figura 10.24). Este tipo de muros se ha localizado en varios casos revestido con una capa gruesa de mortero de cemento que deja vistas las piezas de ladrillo que permanecen en un plano retranqueado respecto al del revestimiento.

Además, se ha detectado otro grupo de intervenciones en relación con la tapia con brencas que consiste en fingir o resaltar estos elementos característicos de la tapia en Aragón en el nuevo revestimiento. Además, en estos casos, ambos elementos, brencas y tierra, suelen pintarse con colores o tonalidades distintas que hace que resalten más estas formas tradicionales de "media luna" (figura 10.25). Este tipo de intervenciones no es muy común, sin embargo, se ha entendido que merece una mención especial ya que está directamente relacionado con el reconocimiento de estas técnicas como las tradicionales de un lugar y se pretende ponerlas en valor, aunque sea a través de fingidos o pintura sobre el propio muro que contiene la técnica original. Los cuatro casos localizados pertenecen a la provincia de Teruel

Los vanos se encuentran intervenidos en 111 casos, el 58,4\% del total de casos intervenidos de tapia. En 88 casos las intervenciones han incorporado sustituciones bien de las carpinterías o de estas y el propio hueco. Además, en 32 casos se han realizado trabajo de reintegración en los vanos ya sea con mortero en el contorno de los huecos o con rasillas principalmente en las jambas de los huecos. En el caso de las reconstrucciones generalmente se ha intervenido insertando nuevos elementos como los ladrillos en las jambas o las viguetas prefabricadas de hormigón o perfiles metálicos para el dintel ya sea en vanos preexistentes o en la creación de nuevos vanos, generalmente de dimensiones mayores.

Las intervenciones en este elemento no guardan relación directa con la técnica constructiva por lo que las soluciones detectadas aparecen indistintamente de la técnica constructiva.

Las intervenciones en cubiertas es una de las más recurrentes en los edificios de tapia. Los tipos de intervención predominantes se pueden englobar en dos grupos. Por un lado, las intervenciones de 
reintegración aparecen en el 43\% de las intervenciones (57 casos) y consisten principalmente en la recolocación de tejas con abundante mortero de cemento para asegurar la estanqueidad de la cubierta. Y, por otro lado, las intervenciones de reconstrucción y de sustitución ya sean totales o parciales con el 27\% (37 casos) y el 39\% (52 casos) respectivamente. En los casos en los que se ha reconstruido la cubierta por completo se ha detectado que frecuentemente se establece un zuncho de hormigón armado sobre el muro de tapia y sobre este la cubierta. Una solución constructiva utilizada tradicionalmente era la colocación de rollizos de madera para distribuir estas cargas con el objetivo de evitar problemas derivados de las cargas puntuales de los pares de cubierta y arriostrar los muros.

\subsubsection{Intervenciones en construcciones de adobe}

Las construcciones de adobe intervenidas están presentes en el 55\% de la muestra total de casos intervenidos (188 casos de 345) (tabla 10.20). La mayor parte de las construcciones englobadas en esos 188 ejemplos tienen un uso temporal (125 casos) y con una representación mucho menor están los casos sin uso (36 casos) y los de uso continuado (27 casos). Con relación a los usos de los edificios, la mayoría responden a un uso residencial con 104 casos seguido por las construcciones de uso productivo con aproximadamente la mitad de los ejemplos, 51 casos. Por último, las construcciones de uso agrícola y con otros usos tienen una presencia mucho menor en esta muestra con 17 y 16 casos respectivamente.

Las intervenciones realizadas de forma espontánea son las más frecuentes con 145 casos (77\%) con más de tres veces el número de casos de las intervenciones planificadas (43 casos, 23\%). La relación entre la reflexión previa y los usos sigue la misma lógica que en los casos anteriores, si bien, la distribución de los ejemplos en este caso hace que los resultaos no sean tan claros o diferenciados entre ellos. Las

\begin{tabular}{|c|c|c|c|c|c|c|c|c|c|c|}
\hline \multirow{2}{*}{ ADOBE } & Intervenido & Interv. espontánea & Interv. Planificada & Mantenimiento & Reparación & Restauración & Rehab. Parcial & Rehab. Integral & Ampliación & Demolición \\
\hline & 188 & 145 & 43 & 4 & 114 & 0 & 54 & 21 & 11 & 3 \\
\hline \multicolumn{11}{|c|}{ FRECUENCIA DE USO } \\
\hline Continuado & 27 & 15 & 12 & 0 & 8 & 0 & 12 & 8 & 3 & 0 \\
\hline \begin{tabular}{|l|} 
Temporal \\
\end{tabular} & 125 & 102 & 23 & 4 & 77 & 0 & 40 & 9 & 5 & 2 \\
\hline Sin uso & 36 & 28 & 8 & 0 & 29 & 0 & 2 & 4 & 3 & 1 \\
\hline \multicolumn{11}{|l|}{ USO } \\
\hline Residencial & 104 & 62 & 42 & 1 & 52 & 0 & 32 & 20 & 9 & 2 \\
\hline Productivo & 51 & 51 & 0 & 3 & 38 & 0 & 13 & 0 & 1 & 0 \\
\hline Agrícola & 17 & 16 & 1 & 0 & 16 & 0 & 1 & 1 & 1 & 1 \\
\hline Otro & 16 & 16 & 0 & 0 & 8 & 0 & 8 & 0 & 0 & 0 \\
\hline
\end{tabular}

Tabla 10.20. Datos cruzados de los casos construidos con adobe con la frecuencia de uso y el tipo de uso de los casos analizados.

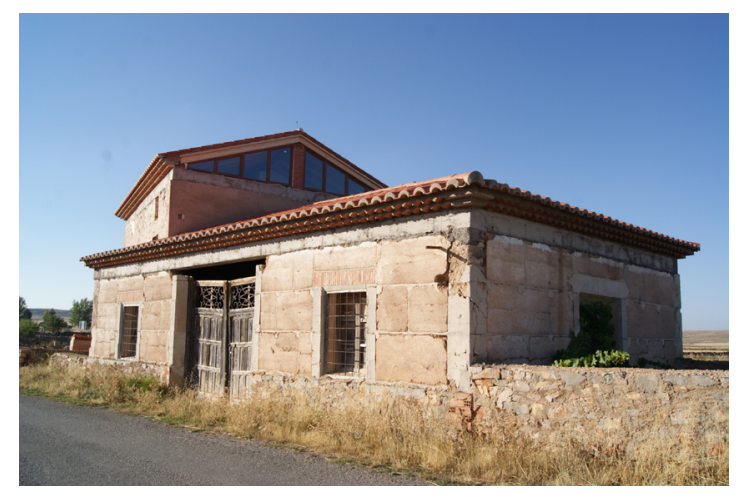

Figura 10.26. Zuncho de hormigón sobre muro de tapia. Argente, Teruel

\footnotetext{
The 10.20. Datos cruz dos delos casos construidos con adobecon la frecuencia de usoyelipo deuso de los casos analizados.
} 


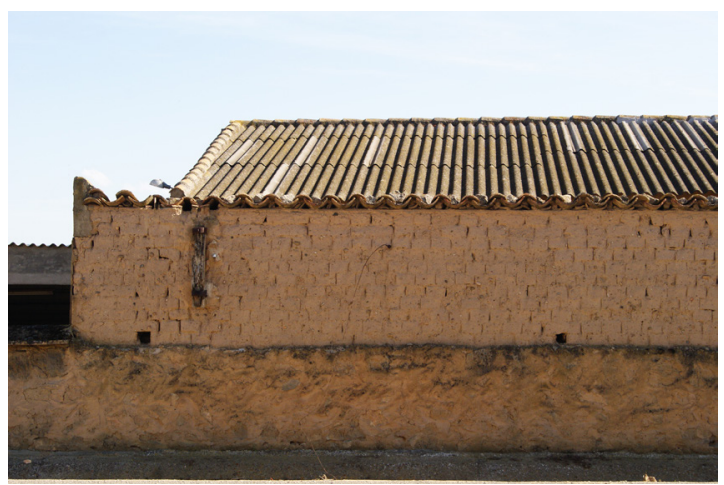

Figura 10.27. Reconstrucción del zócalo con mortero de cemento sobre el muro de adobe. Villanueva de Sigena, Huesca. intervenciones espontáneas predominan entre las construcciones de uso temporal y sin uso (102 y 28 casos respectivamente) y, en este caso, también en las construcciones con uso continuado con 15 casos frente a 12 en intervenciones planificadas. Las intervenciones planificadas predominan los edificios con uso temporal con 23 casos, aunque la diferencia con los casos de uso continuado (12 casos) y los ejemplos sin uso (8 casos) es reducida. En cuanto a la relación con los usos, existe una distribución clara ya que todos menos un caso de los pertenecientes a intervenciones planificas tienen uso residencial. Por lo tanto, las intervenciones realizadas en el resto de las construcciones con sus distintos usos (62 residenciales, 51 productivos, 16 agrícolas y 16 con otros usos) han sido de forma espontánea.

El tipo de intervención más común en las construcciones de adobe son las reparaciones con 114 casos (60\%) presentes en edificios con todo tipo de uso y una frecuencia de uso, generalmente, temporal o sin uso. El segundo tipo de intervención más común es la rehabilitación con 75 casos (40\%) de los cuales 54 casos son rehabilitaciones parciales y 21 integrales. Las rehabilitaciones parciales predominan en edificios residenciales o productivos de uso continuado o temporal, mientras que, las rehabilitaciones integrales afectan casi únicamente a edificios residenciales con uso continuado y temporal. Los casos rehabilitados y sin uso son los correspondientes a edificios en construcción o con obras paralizadas. También se han detectado intervenciones de ampliación en 11 casos, de demolición en 3 casos y de mantenimiento en 4 casos.

Las intervenciones realizadas en algunas de las partes o elementos de los edificios presentan en la mayoría de los casos soluciones semejantes independientemente de la técnica constructiva. Por ello, se han estudiado de forma aislada construcciones con adobe con el objetivo de reconocer soluciones ligadas directamente con esta técnica (tabla 10.21).

Las intervenciones en el zócalo de las construcciones en adobe son muy recurrentes ya que 150 de los 188 casos intervenidos presentan modificaciones en esta zona. Estas intervenciones son en la mayoría de los casos reconstrucciones (89 casos) seguidas por las reintegraciones (58 casos) y algunas de ellas con carácter de actualización (31 casos) (figura 10.27). Las soluciones constructivas y los materiales

\begin{tabular}{|c|c|c|c|c|c|c|c|c|c|c|c|c|c|c|}
\hline ADOBE_188 & Intervenido & $\begin{array}{c}\text { No } \\
\text { intervenido }\end{array}$ & Actualización & Consolidación & Reintegración & Reconstrucción & Demolición & Sustitución & Otros & $\begin{array}{l}\text { Trad. } \\
\text { similar }\end{array}$ & $\begin{array}{c}\text { Trad. } \\
\text { diferente }\end{array}$ & $\begin{array}{c}\text { No } \\
\text { tradicional }\end{array}$ & $\begin{array}{l}\text { Téc. } \\
\text { Similar }\end{array}$ & $\begin{array}{c}\text { Téc. } \\
\text { diferente }\end{array}$ \\
\hline ZÓCALO & 150 & 38 & 31 & 0 & 58 & 89 & 0 & 4 & 0 & 0 & 2 & 148 & 14 & 136 \\
\hline MURO & 101 & 87 & 0 & 0 & 56 & 29 & 6 & 29 & 0 & 0 & 1 & 100 & 21 & 80 \\
\hline REVESTIMIENTO & 94 & 94 & 33 & 0 & 11 & 78 & 0 & 3 & 0 & 0 & 2 & 92 & 15 & 79 \\
\hline VANOS & 111 & 77 & 9 & 2 & 31 & 31 & 1 & 83 & 0 & 1 & 6 & 104 & 10 & 101 \\
\hline CUBIERTA & 112 & 76 & 2 & 0 & 46 & 25 & 3 & 47 & 0 & 1 & 1 & 110 & 58 & 54 \\
\hline
\end{tabular}

Tabla 10.21. Intervenciones en las distintas zonas del edificio en el caso de las construcciones con adobe. 
utilizados en las intervenciones de esta zona del muro no presentan características propias en las construcciones realizadas con adobe.

Los muros de adobe aparecen intervenidos aproximadamente en la mitad de los casos (101 casos, 53,7\%). Estas intervenciones han sido realizadas directamente sobre la fábrica de adobe por lo que, en general, mantienen una relación estrecha con las características de los muros. El tipo de intervención más común es la reintegración con 56 casos, seguida por la reconstrucción y la sustitución con 29 casos cada una (figura 10.28).

Las sustitución total o parcial en los muros de adobe suele producirse especialmente en las variantes mixtas con muros sin función estructural. La mayor esbeltez de estos muros favorece a que, ante los distintos mecanismos de degradación, la estabilidad de los muros se vea comprometida con más facilidad. Por ello, son comunes los ejemplos en los que estos muros, localizados en muchas ocasiones en el muro piñón, han sido sustituidos por una fábrica de ladrillo hueco (figura 10.29). En estos mismos casos, existe otra solución recurrente que es el doblado del muro de adobe con una fábrica de ladrillo hueco en el interior (figura 10.30). Esta solución se ha utilizado tanto con el objetivo de reparar y reforzar el muro existente como para mejorar sus características térmicas y acústicas.

Una de las reparaciones más comunes en los muros de adobe son las reintegraciones de esquinas de algunas de las fábricas con ladrillo hueco o bien con bloques de tierra-cemento. En estos casos los ladrillos sustituyen a algunas de las piezas de adobe y se traban con el muro existente como parte de la fábrica. Otro ejemplo de reintegración en las esquinas es la reparación con mortero de cemento con el fin de evitar el desprendimiento o la perdida de alguno de los elementos que la componen. Esta solución aparece en los muros mixtos de adobe con esquinas y machones de cantos rodados, característicos de oeste de Zaragoza, ya que las características propias de estos elementos de piedra facilitan su posible deslizamiento y consecuente desprendimiento

Las reintegraciones en el cuerpo del muro con mortero de cemento son una solución muy recurrente, al igual que ocurre en las construcciones de tapia. Estas reintegraciones suelen producirse en áreas del muro limitadas donde, por distintas causas, se ha producido una erosión mayor de las piezas o una pérdida de sección mayor. Esta solución es utilizada en las fábricas de adobe con suplementos en las juntas que se encuentran muy erosionadas ya que la junta sobresale respecto al cuerpo de las piezas y permite un mejor agarre del mortero, generalmente de cemento.

Los revestimientos aparecen intervenidos en el 50\% de los casos (94 casos). Entre los tipos de intervención destacan las reconstrucciones con 78 casos, las actualizaciones con 33 casos y las reintegraciones con 11 casos. Los materiales y las técnicas de intervención llevadas a cabo en los revestimientos tienen

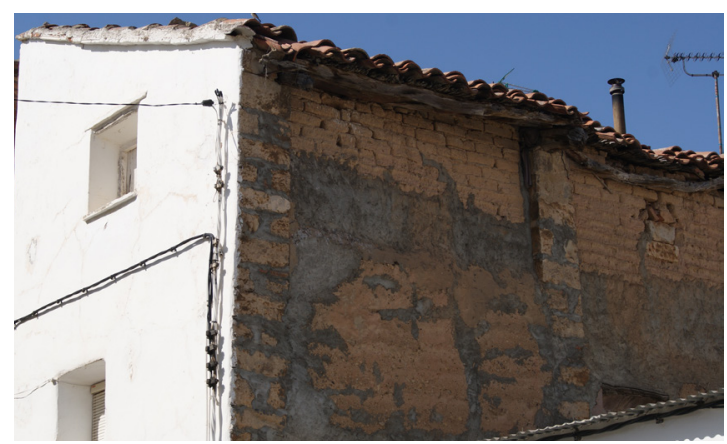

Figura 10.28. Reintegración muro de adobe. Ontiñena, Huesca

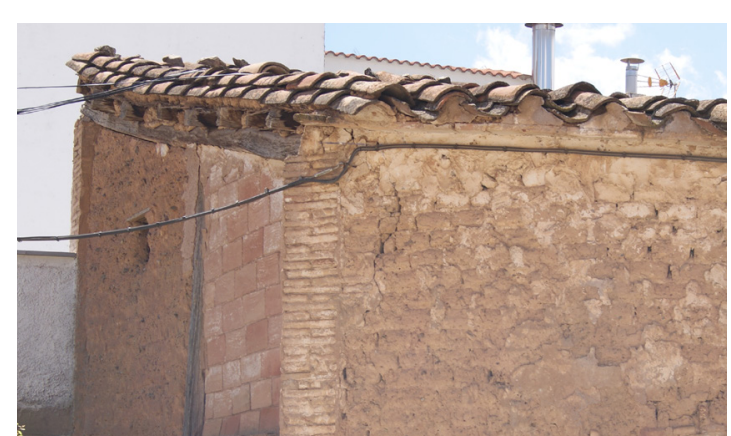

Figura 10.29. Sustitución parcial del muro piñón de adobe. Paniza, Zaragoza

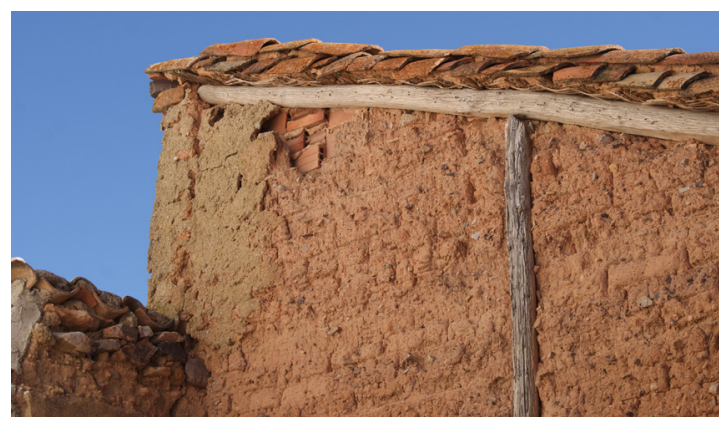

Figura 10.30. Muro de adobe sin función estructura doblado por el interior con ladrillo hueco. Tornos, Teruel 


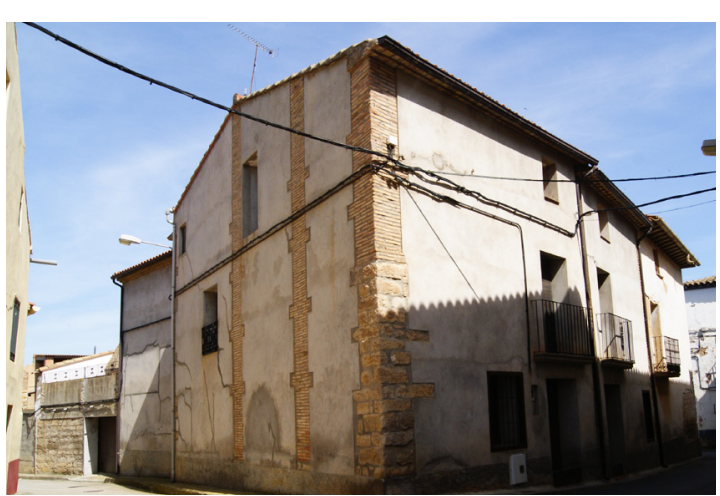

Figura 10.31. Edificio intevenido dejando vistas los machones realizados con piedra y ladrillo. Alcolea del Cinca, Huesca

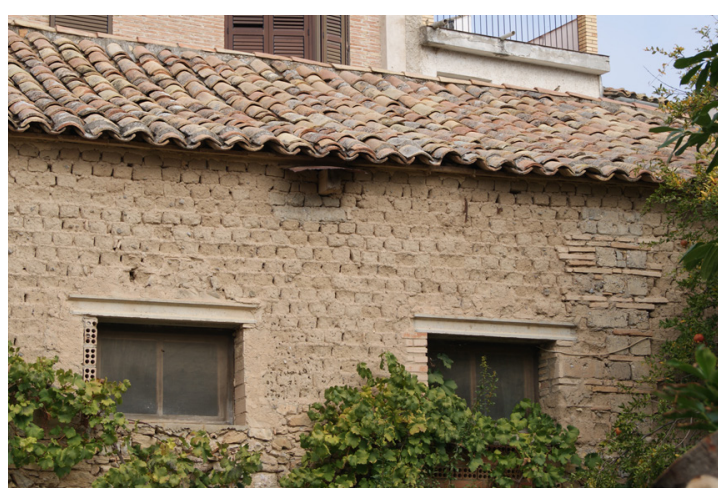

Figura 10.32. Huecos en muro de adobe con dintel prefabricado de hormigón y jambas de ladrillo hueco. Estada, Huesca unas características parecidas a los de la muestra general. Cabe destacar la reconstrucción de los revestimientos en las fábricas mixtas con machones de piedra o ladrillo, localizadas en su mayoría en la mitad norte de Aragón que se caracteriza por dejar vistos estos machones que le otorgan una imagen propia a zonas como el valle del Cinca o las Cinco Villas (figura 10.31).

Las intervenciones en vanos son muy recurrentes en las construcciones de adobe con 111 casos (59\%). Entre las intervenciones llevadas a cabo destaca la sustitución en vanos con 83 casos (generalmente ligadas a la sustitución de las carpinterías) y la reintegración y la reconstrucción con 31 casos cada una.

Una de las intervenciones más recurrentes es la ampliación en los huecos de acceso de planta baja, generalmente ligadas a permitir el acceso a vehículos. Esta solución es especialmente común en los muros de adobe donde las jambas se han conformado con ladrillo que suele trabarse con la propia fábrica de adobe (figura 10.32).

Las intervenciones en cubierta en los edificios de adobe presentan un porcentaje de casos menor que la muestra general (59,6\% frente a 67,2\%, y 112 casos en total). Los tipos de intervención más comunes coinciden con los de los anteriores análisis: 47 casos de sustitución, 46 casos de reintegración y 25 casos de reconstrucción. En este elemento no se ha detectado ningún tipo de intervención que esté relacionado con la técnica o que se produzca reiteradamente en este tipo de construcciones.

\subsubsection{Intervenciones en construcciones de entramado}

Tanto el número de casos de estudio intervenidos (13 casos) como los englobados en la muestra general (22 casos) son muy reducidos, derivado presencia localizada o puntual de las construcciones con entramado. El escaso número de ejemplos condiciona al estudio cuyos resultados no pueden considerarse determinantes. Los resultados del estudio de datos cruzados son todavía más circunstanciales, ya que muchos de los casos de estudio aparecen como único representante de unas características concretas, lo cual no permiten extraer datos concluyentes de carácter general.

La mayor parte de las construcciones de entramado son usadas de forma temporal (8 casos) y responden al uso de viviendas (9 casos) (tabla 10.22). En relación con el criterio o reflexión previa seguida en las intervenciones, 7 de los casos se han intervenido de forma espontánea y 6 de forma planificada. Además, al igual que en las otras técnicas los casos intervenidos de forma espontánea son generalmente casos con una frecuencia de uso temporal o nula ligados a todo tipo de usos y los casos intervenidos de forma planificada son únicamente de construcciones residenciales de uso temporal o continuado. 
En cuanto a los tipos de intervenciones llevadas a cabo, las reparaciones son las más frecuentes (8 casos) seguidas por las rehabilitaciones ( 5 casos, 3 rehabilitaciones parciales y 2 rehabilitaciones integrales).

El estudio de las intervenciones por partes en el caso de los entramados se ha realizado como una aproximación ya que a través de una muestra tan reducida no se pueden extraer datos concluyentes entorno a la técnica (tabla 10.23).

Las intervenciones en los zócalos son muy frecuentes con 10 casos intervenidos. Estas intervenciones responden casi en su totalidad a trabajos de reconstrucción ( 6 casos) y de reintegración (4 casos). Las intervenciones realizadas en estos casos siguen el mismo patrón que las realizadas en las construcciones de tapia y adobe.

Los muros han sido intervenidos en 10 de los casos de estudio. El tipo de intervención más frecuente son las sustituciones con 6 casos, seguido por la reintegración con 4 casos y la reconstrucción con 2 casos. La intervención más destacada es la sustitución derivada de la propia configuración de los entramados en paños de muro independientes. Este factor favorece la posibilidad de realizar sustituciones y reconstrucciones parciales sin necesidad de intervenir el conjunto del muro. Estas sustituciones han sido realizadas, en la mayoría de los casos, con fábrica de ladrillo hueco favorecido por la fácil colocación y la ligereza de las piezas (figura 10.33). Este tipo de intervención responde al mismo esquema descrito en el caso de los adobes localizados en fábricas mixtas sin función estructural.

Las intervenciones en el revestimiento de las construcciones de entramado no son muy habituales ( 5 casos) en parte porque muchos de los casos localizados en Aragón tienen relleno de tapialete que tradicionalmente no se ha revestido por contener yeso en su propia composición. Los casos intervenidos corresponden con 3 reconstrucciones, una sustitución y una actualización. Pese al reducido número de casos se ha detectado que las reconstrucciones del revestimiento, realizadas con mortero de cemento, suelen tener un grosor importante lo cual produce que queden generalmente en un plano saliente respecto a los montantes de madera (figura 10.34).

Los vanos presentan intervenciones únicamente en 5 casos, todas ellas con sustituciones. Las sustituciones en planta baja tienen las mismas características que en las otras técnicas ya que en el caso de Aragón los entramados se localizan generalmente a partir de la primera planta. Por otro lado, las sustituciones de lo vanos localizados sobre el entramado se han limitado a la sustitución de las carpinterías en todos los casos ya que las modificaciones de las dimensiones de los vanos, ampliaciones, pueden requerir modificaciones en la estructura original del entramado.

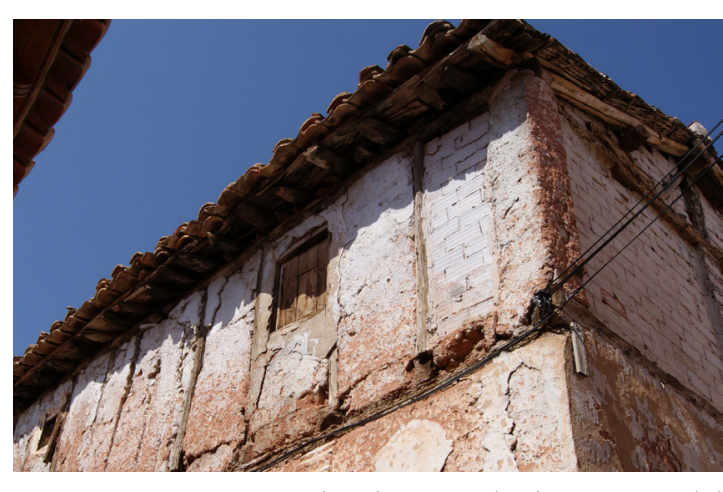

Figura 10.33. Sustitución de uno de los paños del entramado con ladrillo hueco. Gea de Albarracín, Teruel

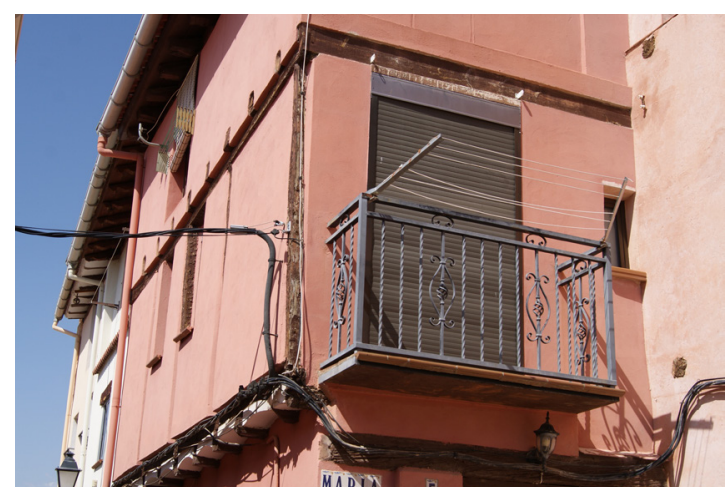

Figura 10.34. Nuevo revestimiento de gran grosor que hace que los montantes permanezcan retranqueados sustitución de carpinterias. Gea de Albarracín, Teruel 
Por últimos, las intervenciones en cubiertas afectan a 8 casos de estudio de los cuales 4 son intervenciones de reconstrucción, 2 de reintegración y 2 de sustitución. En este caso no se ha detectado ninguna dinámica ligada al tipo de construcción con entramados.

Por otro lado, cabe destacar dentro del estudio de esta técnica constructiva la localidad de Albarracín, en Teruel, cuyo núcleo histórico está construido en gran parte con edificios de entramado relleno con tapialete. Se han incluido algunos ejemplos de esta localidad en la base de datos, sin embargo, estos no pueden considerarse representativos de la dinámica general ya que las construcciones del núcleo histórico están sujetas a una legislación y niveles de protección muy altos que no corresponden con la realidad en otras localidades.

\begin{tabular}{|c|c|c|c|c|c|c|c|c|c|c|}
\hline \multirow{2}{*}{ ENTRAMADO } & Intervenido & Interv. espontánea & Interv. Planificada & Mantenimiento & Reparación & Restauración & Rehab. Parcial & Rehab. Integral & Ampliación & Demolición \\
\hline & 13 & 7 & 6 & 0 & 8 & 0 & 3 & 2 & 0 & 1 \\
\hline \multicolumn{11}{|c|}{\begin{tabular}{|l|l} 
FRECUENCIA DE USO \\
\end{tabular}} \\
\hline Continuado & 2 & 1 & 1 & 0 & 0 & 0 & 1 & 1 & 0 & 0 \\
\hline Temporal & 8 & 3 & 5 & 0 & 5 & 0 & 2 & 1 & 0 & 1 \\
\hline Sin uso & 3 & 3 & 0 & 0 & 3 & 0 & 0 & 0 & 0 & 0 \\
\hline \multicolumn{11}{|l|}{ USO } \\
\hline Residencial & 9 & 3 & 6 & 0 & 4 & 0 & 3 & 2 & 0 & 1 \\
\hline Productivo & 1 & 1 & 0 & 0 & 1 & 0 & 0 & 0 & 0 & 0 \\
\hline Agrícola & 2 & 2 & 0 & 0 & 2 & 0 & 0 & 0 & 0 & 0 \\
\hline Otro & 1 & 1 & 0 & 0 & 1 & 0 & 0 & 0 & 0 & 0 \\
\hline
\end{tabular}

Tabla 10.22. Datos cruzados de los casos construidos de entramado con la frecuencia de uso y el tipo de uso de los casos analizados.

\begin{tabular}{|c|c|c|c|c|c|c|c|c|c|c|c|c|c|c|}
\hline ENTRAMADO_13 & Intervenido & $\begin{array}{c}\text { No } \\
\text { intervenido }\end{array}$ & Actualización & Consolidación & Reintegración & Reconstrucción & Demolición & Sustitución & Otros & $\begin{array}{l}\text { Trad. } \\
\text { similar }\end{array}$ & $\begin{array}{c}\text { Trad. } \\
\text { diferente }\end{array}$ & $\begin{array}{c}\text { No } \\
\text { tradicional }\end{array}$ & $\begin{array}{l}\text { Téc. } \\
\text { Similar }\end{array}$ & $\begin{array}{c}\text { Téc. } \\
\text { diferente }\end{array}$ \\
\hline ZÓCALO & 10 & 3 & 1 & 0 & 4 & 6 & 0 & 1 & 0 & 0 & 0 & 10 & 0 & 10 \\
\hline MURO & 10 & 3 & 0 & 0 & 4 & 2 & 1 & 6 & 0 & 0 & 2 & 8 & 2 & 8 \\
\hline \begin{tabular}{|l|} 
REVESTIMIENTO \\
\end{tabular} & 5 & 8 & 1 & 0 & 0 & 3 & 0 & 1 & 0 & 1 & 2 & 2 & 2 & 3 \\
\hline VANOS & 5 & 8 & 0 & 0 & 1 & 0 & 0 & 5 & 0 & 0 & 1 & 4 & 2 & 3 \\
\hline \begin{tabular}{|l|} 
CUBIERTA \\
\end{tabular} & 8 & 5 & 0 & 0 & 2 & 4 & 0 & 2 & 0 & 1 & 2 & 5 & 6 & 2 \\
\hline
\end{tabular}

Tabla 10.23. Intervenciones en las distintas zonas del edificio en el caso de las construcciones de entramado 


\subsection{Dinámicas de transformación}

Las dinámicas de transformación de la arquitectura tradicional de tierra están ligadas a la evolución y la adaptación de los edificios a las necesidades y a la realidad social de cada momento.

Estas dinámicas están representadas a través de los cambios más recurrentes de la arquitectura en el territorio, así como los materiales y las técnicas utilizadas para ellos. Se trata de un estudio de la evolución de la arquitectura tradicional y hacia dónde se dirige, con el fin de poder establecer mejoras.

La transformación de la arquitectura es un proceso natural que, en la mayoría de los casos, debe seguir para garantizar su conservación. Sin embargo, no es lo mismo la transformación de un edificio de forma que este permanezca reconocible que su transformación sustituyendo casi la totalidad de lo mismo y cubriendo sus paramentos con nuevos revestimientos (figura 10.35). Los modelos económicos y sociales en la actualidad tienden hacia una homogeneización que conlleva la perdida de la cultura local y las tradiciones asociadas a un lugar concreto. A nivel arquitectónico, esta homogeneización supone la pérdida de los saber haceres locales y de las técnicas tradicionales asociadas al lugar que van desapareciendo de forma continuada por la inserción de elementos que pueden localizarse casi en cualquier lugar del mundo y que carecen de identidad.

Las dinámicas predominantes, en el caso de Aragón, están ligadas a las intervenciones descritas previamente y los objetivos o finalidades de las mismas son principalmente estéticas, funcionales o de reparación.

Los cambios estéticos pueden aparecer de forma aislada o ligados a intervenciones con otras finalidades. Estas transformaciones suelen localizarse en la fachada de los edificios y suelen presentar soluciones muy heterogéneas en cuanto a materialidad, texturas y colores. Este tipo de intervención suele ir ligada a los criterios y a la sensibilidad de los propietarios ya que, excepto en ocasiones excepcionales, no existe una normativa que determine la estética o los materiales a utilizar y en otras, esta normativa no se aplica de la forma adecuada (Villacampa Crespo 2015). Este tipo de dinámicas están directamente relacionadas con las intervenciones de actualización y comprenden intervenciones como nuevos revestimientos y pinturas, zócalos pintados o con lajas de piedra, contornos decorativos en los vanos, etc. Además, en gran número de ocasiones estas intervenciones afectan únicamente a la fachada principal o a la planta baja de la misma.

Las transformaciones funcionales suelen afectar principalmente al interior de las viviendas $y$, en ocasiones, se ven expresadas en fachada a través de sus vanos. En el caso de las construcciones de uso residencial las intervenciones suelen afectar a la distribución ya que los edificios tradicionales no

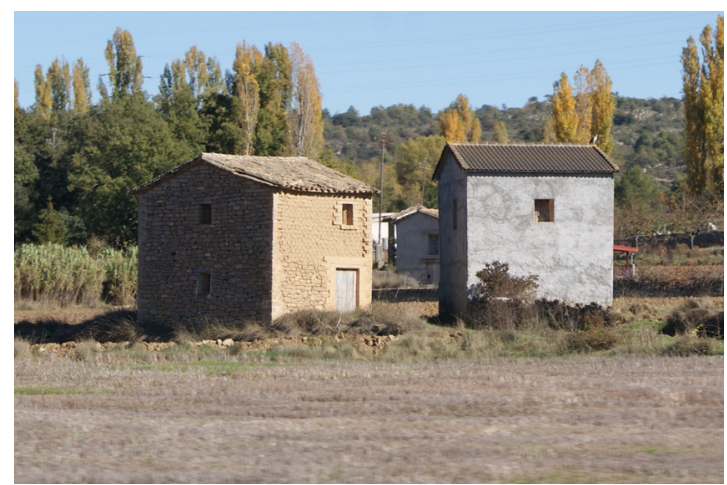

Figura 10.35. Edificios agrícolas de características similares, uno conservado y el otro intervenido. Torre de Ésera, Huesca

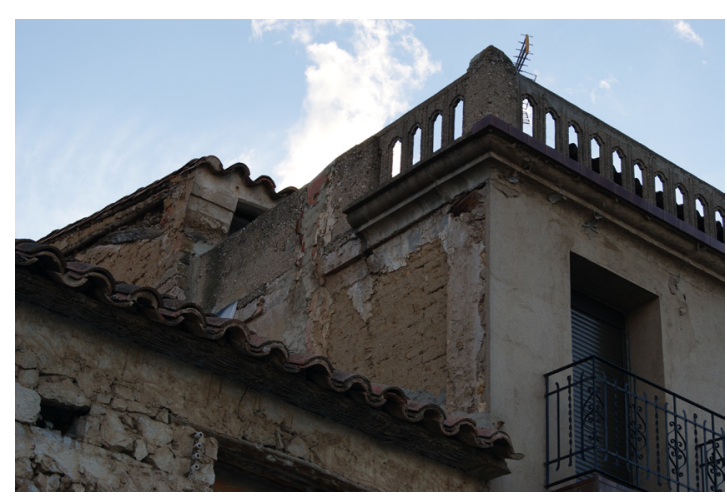

Figura 10.36. Sustitución parcial de la cubierta por una cubierta plana. Oliete, Teruel. 


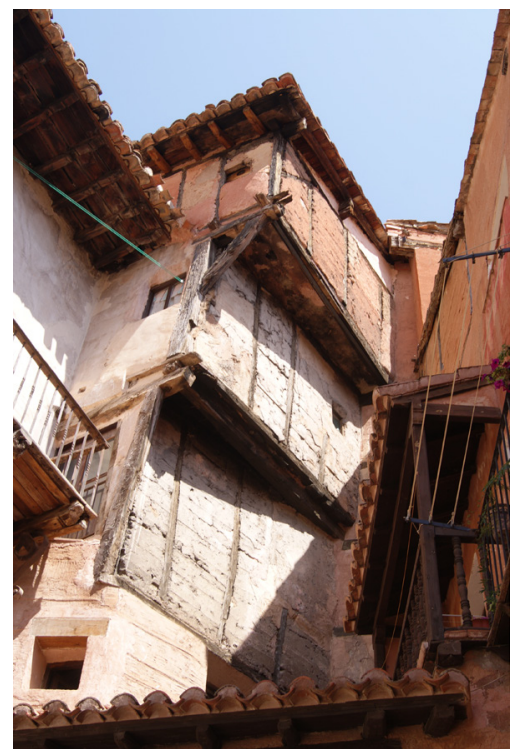

Figura 10.37. Arquitectura de entramado con tapialete conservada en el la localidad de Albarracín, Terue

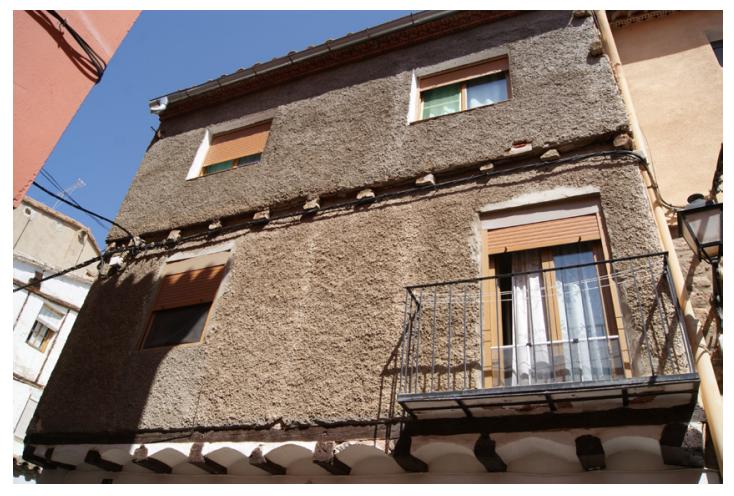

Figura 10.38. Edificio de entramado cubierto con cemento y con todas las carpinterías nuevas. Gea de Albarracín, Teruel (localidad vecina a Albarracín y con una arquitectura muy parecida, pero, en este caso, sin protección) disponían de aseos en el interior ni de cocinas con los equipamientos actual. La inserción de estos elementos requiere necesariamente de cambios como el paso de instalaciones de agua, de electricidad, telecomunicaciones, extracción de humos, etc. Existen otros tipos de intervenciones funcionales que afectan tanto al interior como al exterior o a la conexión entre ambos. Un ejemplo muy recurrente es la transformación de planta baja en garajes para los cuales se abren huecos de mayores dimensiones y se insertan materiales industrializados, como el metal, en las carpinterías y el dintel. Otros cambios destacables, aunque menos frecuentes, son los realizados en las cubiertas donde pate de la misma se sustituye por una cubierta plana con función de terraza (figura 10.36).

Las transformaciones producidas por las reparaciones suelen ir ligadas a la presencia de lesiones sobre las que se interviene con materiales industrializados que las cubren pero que en la mayor parte de los casos no resuelven el problema de origen. Estas intervenciones además suelen producir incompatibilidades materiales y estéticas que afectan tanto al propio edificio como al entorno en el que se encuentra.

Las construcciones tradicionales de las localidades visitadas presentan un amplio abanico de soluciones o transformaciones que generalmente desvirtúan el carácter tradicional de los edificios y de su entorno, salvo en casos excepcionales de núcleos de población con un alto nivel de protección en los centros históricos como pueden ser Albarracín o Alquézar (Almagro Gorbea 2005). Pese a que las intervenciones incompatibles representan la gran mayoría, también existen algunos casos cuyas intervenciones buscan el respeto y la máxima conservación del elemento tradicional y de su carácter, así como la integración y la armonía con el entorno (figura 10.37).

Finalmente cabe destacar que las continuas transformaciones y la utilización de materiales industrializados en las construcciones tradicionales producen una completa desvirtuarían de estas. La homogeneización y globalización de soluciones por todo el territorio ha producido también el abandono de muchas de las técnicas y soluciones locales ligadas a la arquitectura tradicional (figura 10.38). En el caso de la arquitectura de tierra la falta de conservación o la necesidad de ocultarla es incluso mayor debido al desprestigio que poseen estas técnicas de tierra que por su desconocimiento se asocian comúnmente a la pobreza o a la construcción de mala calidad.

\subsection{Lesiones derivadas de intervenciones previas}

Los mecanismos de degradación derivados de la acción humana son muy heterogéneos ya que pueden tener su origen en la falta de acción o en las acciones llevadas a cabo, ya sean de eliminación o de incorporación de elementos. 
La degradación de la arquitectura tradicional de tierra derivada de la falta de mantenimiento puede considerarse como una degradación de origen antrópico indirecto (Gómez Patrocinio 2017) aunque no se deban a una acción concreta sino a la ausencia de las mismas. La arquitectura tradicional de tierra por sus propias características necesita de un mantenimiento que garantice su conservación y su buen comportamiento. Sin embargo, en las últimas décadas muchos de estos edificios han dejado de recibir el mantenimiento adecuado derivado del abandono de las técnicas, pero también de los cambios en la sociedad y las costumbres.

La falta de mantenimiento es un problema importante en todo el territorio aragonés, especialmente para aquellos edificios que han perdido el uso para el que fueron construidos y han quedado abandonados. Este es el caso de muchas de las edificaciones auxiliares localizados en áreas rurales de difícil acceso. Por otro lado, debido a la emigración de la población, muchas de las viviendas han sido abandonadas en los núcleos históricos de las poblaciones, aunque gran parte se conservan pese a que están vacías de forma continua. Este abandono está íntimamente relacionado con los movimientos migratorios y el descenso de la población del que se ha hablado en el estudio de los factores sociales con relación a la arquitectura tradicional (punto 6.4.1). La falta de mantenimiento suele generar problemas en las cubiertas ya que están muy expuestas y esto las hace especialmente sensibles a los efectos de los agentes meteorológicos como el aire que puede producir el movimiento de las tejas. Además, estos problemas en la cubierta suelen desencadenar problemas en otras partes del edificio o acelerar los mecanismos existentes debido principalmente a la acción del agua (figura 10.39).

En cuanto a los mecanismos de degradación antrópicos directos, una de las principales causas son las intervenciones en las construcciones tradicionales. Estas intervenciones pueden generar lesiones o incompatibilidades de distintos tipos entre las que destacan la incompatibilidad material, la estructural y la estética o visual. Estas lesiones no son necesariamente independientes, sino que suelen aparecer combinadas entre ellas fruto de una misma acción. Las intervenciones que generan este tipo de lesiones o incompatibilidades suelen modificar las características iniciales de la construcción y pueden derivar tanto de la adición de materiales o elemento como de la sustracción de los mismos.

En el caso de Aragón, el tipo de degradaciones más frecuentes son las estéticas o visuales que están presentes en todos los núcleos de población y que se caracterizan por la falta de armonía con el edificio y su entorno. Estas degradaciones están ligadas, generalmente, a intervenciones de carácter espontáneo en las que no se tiene en cuenta la estética del resultado final, sino que el principal objetivo es solucionar un problema o darle nuevo uso a alguna parte del edificio, sin importar ni los materiales ni la técnica utilizados (figura 10.40; figura 10.41). Por otro lado, existe otro tipo de intervención que, pese a que su

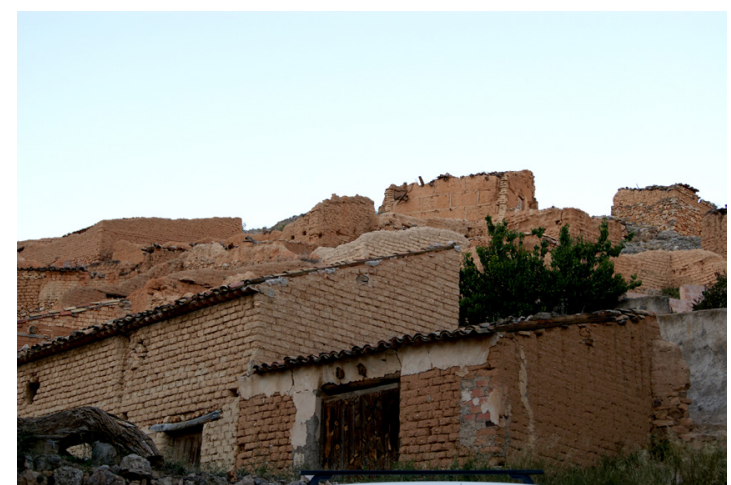

Figura 10.39. Conjunto de edificios en los que se aprecia la diferencia entre los muros con protección y los que la han perdido. Embid de Ariza, Zaragoza.

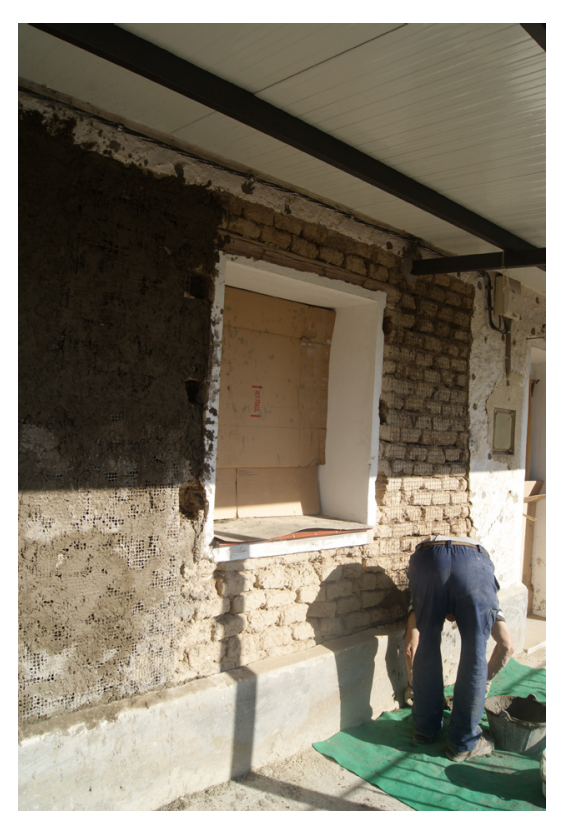

Figura 10.40. Reparación del revestimiento para evitar la erosión de las adobas con tela de gallinero y cemento. Peñaflor, Zaragoza. 


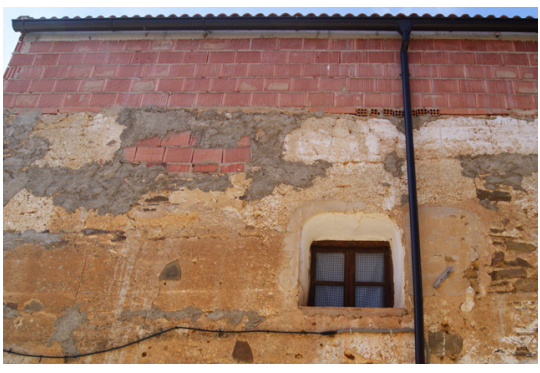

Figura 10.41. Recrecido del muro y sustitución de la cubierta con ladrillo hueco. Santed, Zaragoza.

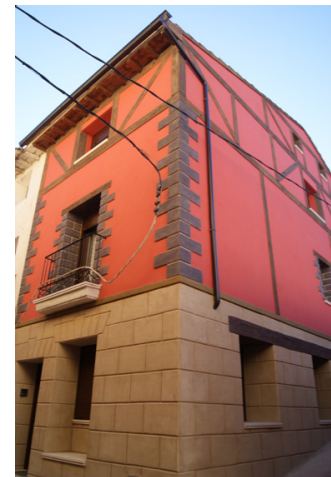

Figura 10.42. En ocasiones el "pintoresquismo" se lleva a extremos. En este caso es, además, completamente ajeno a la tradición ya que no existen edificios de entramado en la localidad donde se encuentra. Por contra, sí que existe un gran patrimonio de tierra. Ibdes, Zaragoza.

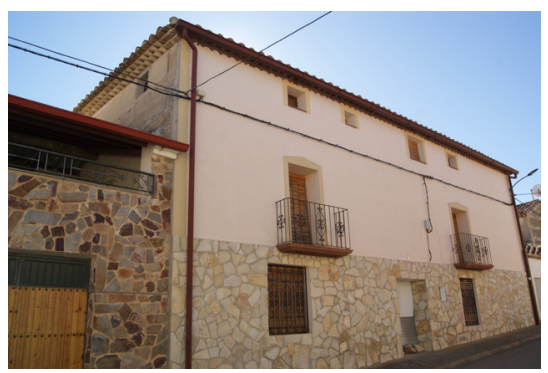

Figura 10.43. Edificio con intervenciones tradicionales de actualiación. Torralba de los Sisones, Teruel. finalidad es principalmente estética (actualizaciones) están ligadas al fachadismo y al concepto de lo "rústico" y cuyos resultados finales poco tienen que ver con la estética tradicional (figura 10.42) (Vegas y Mileto 2007).

Las degradaciones estéticas suelen estar ligadas causas diversas: inserción de nuevos elementos, reparaciones y sustitución de elementos que ya existían por otros con un carácter distinto. En el primer grupo se encuentran elementos como las cajas de luz y los contadores, normalmente de plástico, los cableados por fachada y el uso de canaletas para su paso, las cajas de persianas, las rejas de materiales, formas y colores ajenos a la tradición del lugar. La inserción de elementos en el espacio público de los núcleos históricos como pavimentos continuos de hormigón o asfalto también afectan al conjunto. La mayoría de estos elementos son necesarios y por tanto su inserción es inevitable, si bien, deben tenerse en cuenta sus características para que no sean especialmente llamativos y tengan cierta armonía con el entorno. Por otro lado, las reparaciones con materiales industriales como el cemento, los ladrillos huecos o los bloques prefabricados de hormigón son muy frecuentes y suelen producir efectos muy negativos en el aspecto del propio edificio y en el entorno. Además, existe un gran contraste de forma, color y textura entre estos materiales y las construcciones de tierra, así como con el entorno en el que se encuentran Finalmente, el último grupo de intervenciones están relacionadas con el cambio de carácter de algunos elementos derivado de su sustitución. El cambio de las carpinterías tradicionales por elementos metálicos, de aluminio, de PVC o incluso de madera con tonalidades diferentes; la reconstrucción de revestimientos con materiales como el monocapa que elimina cualquier traza o imperfección del edificio tradicional; la sustitución de los aleros y cubiertas por elementos prefabricados; etc. (figura 10.43).

Las degradaciones por incompatibilidad material o estructural suelen estar relacionadas, y en muchas ocasiones originadas por intervenciones aisladas que no tienen en cuenta las propiedades del edificio ni el origen de la lesión que intentan subsanar (figura 10.44).

Las degradaciones derivadas de intervenciones en la zona del zócalo son unas de las más frecuentes. La presencia de materiales que no permiten la transpiración natural de los muros como el cemento, solo o combinado con otros materiales produce un efecto negativo frente a la presencia de humedad que generalmente intentan frenar. Las reconstrucciones del zócalo con mortero de cemento, o cemento junto con piedra u otros materiales, generan una barrera impermeable en la parte inferior de muro que impide la ventilación del muro y evacuación del agua sobrante produciendo que esta ascienda hasta el nivel superior a ese zócalo para su evaporación. Este efecto produce que el área de muro afectada sea mucho mayor y que el muro permanezca constantemente húmedo hasta una altura superior con la perdida de resistencia que eso conlleva. Este mismo problema se ha dado en los casos de reparaciones 
por la perdida de sección de la parte inferior de los muros de tierra que se han reparado con estos materiales cementosos y que han producido el agravamiento de la lesión existente (figura 10. 45).

Algo parecido ocurre en las intervenciones de sustitución de los revestimientos por otros de cemento o en la disposición de pinturas plásticas ya que las propiedades impermeables no permiten la ventilación natural de los muros y el intercambio de humedad con el exterior. La incapacidad de relación con el ambiente exterior produce el aumento del contenido de humedad del muro que puede mermar su resistencia y favorecer el desarrollo de otros mecanismos de degradación. Estos mismos problemas pueden darse en las intervenciones de cubiertas que insertan capas de impermeabilizantes no transpirables ya que pueden generar condensaciones en el interior. Por otro lado, en el caso de los revestimientos pueden darse también problemas a largo plazo por la eliminación de los revestimientos tradicionales cuya función es la de proteger al muro de tierra.

Las intervenciones generalizadas con cemento y otros materiales industrializados en los muros pueden generar nuevos daños en lugar de reparar las lesiones por las que generalmente son dispuestos en primera instancia. Las reintegraciones con cemento es una práctica común, pero a la larga suelen presentar problemas derivados de las características del cemento, como la rigidez o la falta de traspiración, que producen incompatibilidades como los movimientos diferenciales o la falta de adherencia y que producen que estos revestimientos se acaben perdiendo. Además, los desprendimientos de las reintegraciones de cemento producen el arrastre de parte del muro de tierra por lo que acrecienta el problema inicial (figura 10.46).

Las intervenciones más importantes en vanos suelen producirse en planta baja y están relacionadas con el aumento de dimensión. Estas intervenciones en ocasiones presentan problemas de traba entre el muro preexistente y las nuevas jambas sobre las que apoya el dintel. Por ello, en el punto de unión se dispone generalmente una gran cantidad de mortero de cemento con la finalidad de conectarlos.

Las intervenciones en cubierta pueden causar incompatibilidades de distintos tipos. Una de las lesiones más comunes es la perdida o rotura de tejas tradicionales reintegradas o recolocadas con cemento debido a la rigidez de este junto con las grandes variaciones térmicas presentes en la mayor parte del territorio.

A parte de las intervenciones en el propio edificio, existen otras capaces de generar daños en los edificios como la pavimentación de las calles que impiden la transpiración del terreno por lo que parte de la humedad se redirige a los muros para ser evacuada. La inserción de elementos o instalaciones por parte de los ayuntamientos en las fachadas como cables o farolas también pueden generar desperfectos (figura 10.47).

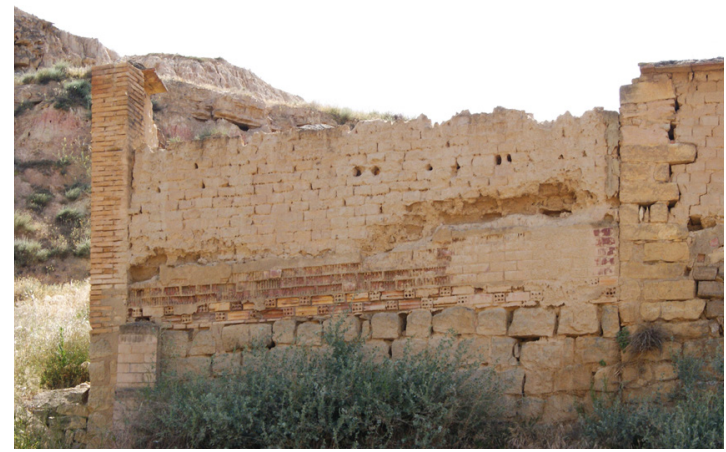

Figura 10.44. Reparación ineficiente del muro de adobe. Alcolea del Cinca, Huesca.

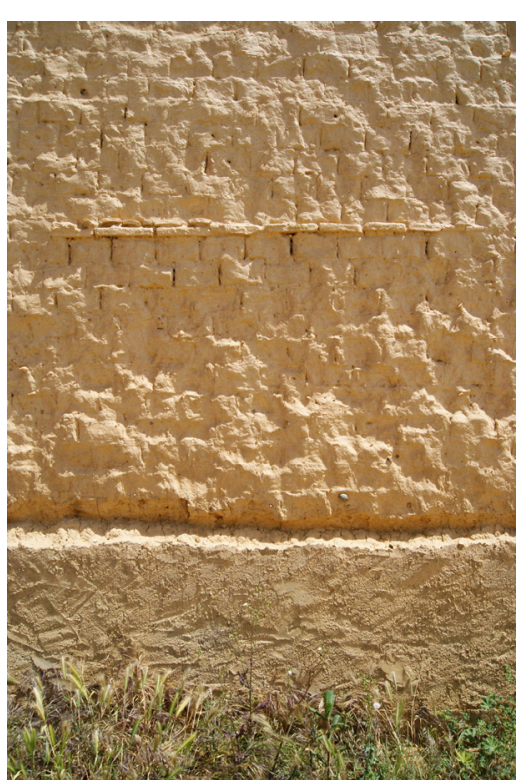

Figura 10.45. Reparación en la que se aprecia como al cubrir el zócalo con cemento la humedad ha ascendido hasta el punto superior. Valcarca, Huesca. 


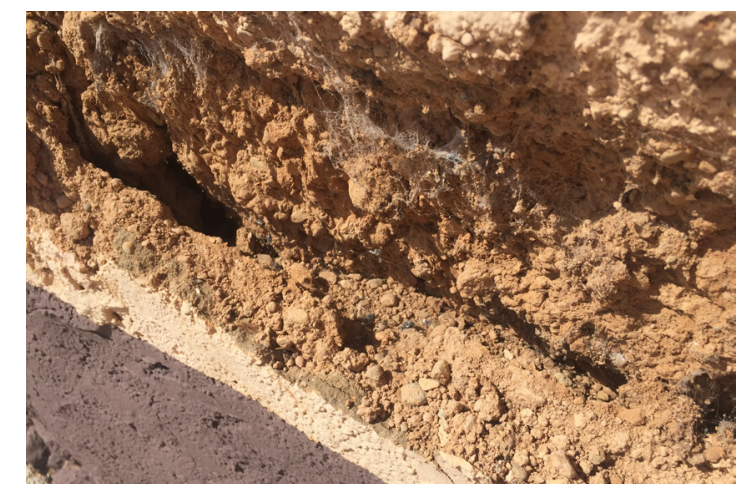

Figura 10.46. Perdida del revestimiento de cemento arrastrando una amplia sección de tierra. Villastar, teruel.

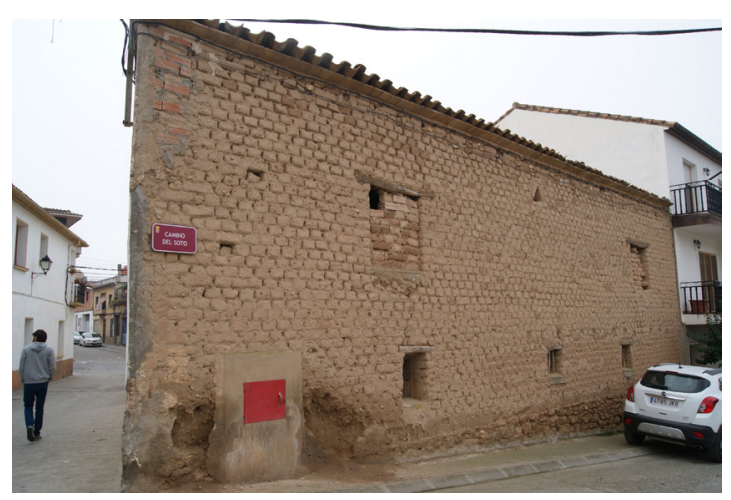

Figura 10.47. Instalación inadecuada del suministro de agua que esta arruinando el muro. Estadilla, Huesca.
Por otro lado, las incompatibilidades estructurales suelen estar generadas por el comportamiento dispar entre los materiales tradicionales los industriales, generalmente de origen cementoso o metálico. La falta de traba en las intervenciones o el exceso de solicitaciones de la estructura original son algunos de los problemas comunes. Además de estas causas, los problemas estructurales también pueden tener su origen en la eliminación de algún elemento importante, lo cual puede comprometer la estabilidad del edificio. 
11. LÍNEAS GUÍA PARA UNA INTERVENCIÓN COMPATIBLE Y SOSTENIBLE 
La restauración y la rehabilitación de la arquitectura tradicional de tierra. El caso de Aragón 


\section{LIINEAS GUIIA PARA UNA INTERVENCIÓN COMPATIBLE Y SOSTENIBLE}

La arquitectura tradicional en general y la de tierra en particular, es muy vulnerable a la globalización y a la adaptación a los usos actuales, en parte debido a su desconocimiento. Por ello es muy importante estudiar y reconocer los valores de esta arquitectura ligada a la cultura constructiva de un lugar o una zona concreta que ha optimizado el uso de los recursos disponibles y sus técnicas constructivas durante siglos para hacer frente a unas necesidades.

La puesta en valor de esta arquitectura es imprescindible para poder conservar no solo los propios edificios sino el patrimonio que supone y el saber hacer implícito en ella. En Aragón, el estudio de las técnicas constructivas y la toma de datos in situ han permitido reconocer algunos de estos valores, así como su conexión con las propiedades del territorio y los materiales disponibles en cada área.

El valor de la arquitectura tradicional puede estar ligado a un conjunto (características de la arquitectura en un área concreta, de una localidad, o en unos elementos comunes destacados) y al propio edificio como parte del patrimonio constructivo, etnográfico, paisajístico y arquitectónico. El valor de conjunto y el valor individual de cada construcción están directamente relacionados ya que en muchas ocasiones dependen el uno del otro. En la actualidad, el sistema de puesta en valor esta basado la protección de edificios concretos, o de alguna de sus partes por lo que el contexto en los que se encuentras en la mayoría de los casos carece de protección; y, solo en unos pocos casos, cuando el núcleo histórico es muy singular, existe una protección del conjunto con una normativa específica.

La arquitectura tradicional tiene un valor intrínseco por estar ligado al paisaje y sus los materiales usados de forma eficiente en forma de técnicas constructivas para dar respuesta a las necesidades en el marco de una cultura concreta. El uso indiscriminado de materiales de origen industrial ha producido que esta arquitectura y el uso de las técnicas constructivas de tierra hayan dejado de existir de forma activa en la actualidad. Por ello es esencial divulgar todos los valores de esta arquitectura: etnográficos, históricos, de autenticidad, de antigüedad, artísticos, funcionales, económicos y estéticos; que están ligados a un estilo de vida ya no existe y que es importantes conservar y estudiar (Vegas y Mileto 2014). 
En el caso de la arquitectura de tierra, las propias características del material y de las técnicas permiten la combinación con otros materiales o elementos de las que resultan un gran abanico de soluciones constructivas y variantes distintas (AA VV. 2014 a.). Estas variantes han ido surgiendo a lo largo de la historia como respuesta a las necesidades y como mejora de las técnicas constructivas con las que se pretendía facilitar la construcción o aumentar su durabilidad. En la actualidad, estos conocimientos se encuentran en grave peligro de desaparición a causa la globalización, el uso indiscriminado de materiales y técnicas ajenas al lugar y el desprestigio que posee injustificadamente la tierra como material de construcción

A nivel internacional, las Cartas Internacionales de la Restauración han sido los documentos encargados de velar por la protección del patrimonio a nivel mundial desde 1931. Estos documentos son redactados por expertos de distintas entidades como ICOMOS, UNESCO e ICCROM ${ }^{1}$. La primera carta en la que se nombra específicamente el valor del patrimonio vernáculo fue 1964 con la Carta de Venecia:

"...representan en la vida actual el testimonio vivo de sus tradiciones seculares. La humanidad, que cada día toma conciencia de los valores humanos, las considera patrimonio común reconociéndose responsable de su salvaguardia frente a las generaciones futuras. Estima que es su deber transmitirlas en su completa autenticidad."

Posteriormente, en otras cartas se ha mostrado la preocupación por el reconocimiento de esta arquitectura. La Carta de París de 1972 cuya reunión se celebró en el marco de la 17ạ reunión de la Conferencia General de la Organización de las Naciones Unidas para la Educación, la Ciencia y la Cultura, define los conceptos de "patrimonio natural" y "patrimonio cultural". La Carta de Amsterdam de 1975 reconoce el gran valor de esta arquitectura y sus conjuntos y le otorga una importancia comparable a la de los grandes monumentos.

"El patrimonio arquitectónico europeo está formado no sólo por nuestros monumentos más importantes, sino también por los conjuntos que constituyen nuestras ciudades y nuestros pueblos tradicionales en su entorno natural o construido."

La Carta de Nairobi de 1976 alude a los conjuntos tradicionales desde el punto de vista etnográfico y pone en valor la vida desarrollada en estos como valor patrimonial. Con el fin de recoger y reconocer los valores de la arquitectura tradicional, en 1999, ICOMOS desarrolla la Carta del Patrimonio Vernáculo Construido donde definie este tipo de arquitectura como "una expresión fundamental de la identidad de una comunidad, de sus relaciones con el territorio y al mismo tiempo, la expresión de la diversidad cultural del mundo".

\footnotetext{
1. ICOMOS: Consejo internacional de Monumentos y Sitios.

UNESCO: Organización de las Naciones Unidas para la Educación, la Ciencia y la Cultura.

ICCROM: Centro Internacional de Estudios para la Conservación y la Restauración de los Bienes Culturales
} 
Por otro lado, en el año 1998 se crea la Cátedra UNESCO "Arquitectura de tierra, Culturas Constructivas y Desarrollo Sostenible" que tiene como objetivo principal la difusión de conocimiento científicos y técnico de la arquitectura de tierra y que pone en manifiesto la importancia y el valor de esta arquitectura a nivel mundial ${ }^{2}$.

A nivel nacional, en el año 2015 se finalizó el Plan Nacional de Arquitectura Tradicional por el Instituto del Patrimonio Cultural Español, IPCE, que cuenta con un estudio de los valores de esta arquitectura y facilita información para la coordinación entre administraciones. Además, este Plan Nacional va acompañado de otros documentos complementarios (publicaciones, libros, manuales, inventarios, etc.) para promover la conservación de la arquitectura tradicional.

Con unos objetivos similares se ha desarrollado el Proyecto Coremans por el Ministerio de Educación, Cultura y Deporte, que en el año 2017 publicó su cuarto documento- guía de intervención en torno a las técnicas constructivas de tierra, Criterios de intervención en la arquitectura de tierra (AA.VV. 2017).

Pese a que el valor de la arquitectura tradicional ha sido apuntado en algunos de los documentos más importantes en materia de restauración, la falta de reconocimiento de estos valores en la sociedad, así como la falta de protección u orientación por parte de los ayuntamientos hacen que su correcta conservación sea una tarea ardua. Además, existe un cierto escepticismo en cuanto a la calidad de estas construcciones, así como su posibilidad de readaptación que hace que mucha gente no quiera invertir el dinero en la reparación de las mismas. Por ello, es muy importante estos valores se difundan entre la población que, en el caso de la arquitectura tradicional, es la encargada de salvaguardar estas construcciones a falta de una normativa. Para ello, es imprescindible establecer una serie de criterios y ejemplos de soluciones adecuadas basadas en el conocimiento que sirvan de referencia, y hacer hincapié en las en las soluciones impropias para evitar su propagación.

Antes analizar o establecer los criterios generales debe tenerse en cuenta que no existe una norma general que sirva para todos los edificios tradicionales o históricos, sino que cuando se va a intervenir en un edificio es necesario realizar una toma de datos exhaustiva que proporcione un conocimiento completo del mismo (estudio histórico, levantamiento, estudio de técnicas, estudio de daños, reportajes fotográficos, estratigrafía, etc.). Cuantos más datos y mejor se conozca el edificio, más se podrán ajustar y detallar los trabajos a llevar a cabo en la intervención (AA VV. 2008). Si bien, la restauración no es

2. Fundación en la École Nationale Supérieure d'Architecture de Grenoble (Francia) por el laboratorio CRAterre que reunió 41 miembros institucionales y entidades profesionales de 21 paises (AA.VV. 2017) una ciencia exacta por lo que, para garantizar el éxito de la intervención, los trabajos deben planearse en base a unos criterios establecidos y con la máxima precaución y sensibilidad hacia los elementos preexistentes (Vegas y Mileto 2014). 


\subsection{Criterios de intervención}

Los criterios de intervención son los principios generales que deben seguirse para controlar las características de las intervenciones en los edificios. Por ello, deben establecerse unos objetivos o pautas generales que deben cumplirse para la realización de una intervención adecuada y que deben complementarse con una serie de decisiones concretas ligadas a los estudios previos del edificio concreto.

Existen unos criterios generales que se han seguido tradicionalmente en materia de restauración: conservación autenticidad, mínima intervención, reversibilidad, compatibilidad, actualidad expresiva y durabilidad (Carbonara 1997). Si bien, estos criterios están enfocados a la arquitectura monumental que generalmente requieren de intervenciones para preservarla en su estado primitivo, pero no para readaptarla a nuevos usos.

En el caso de la arquitectura tradicional pese a que estos criterios están siempre presentes, existen una serie de consideraciones que deben tenerse en cuenta. El principal aspecto a tener en cuenta es que los edificios tradicionales deben tener uso y responder adecuadamente al funcionamiento y los estándares actuales para garantizar su pervivencia. La incorporación de nuevos usos o la actualización de los mismos va a suponer necesariamente una serie de modificaciones o transformaciones que dificultan el cumplimiento de los principios de restauración y conservación. Si bien, estas intervenciones deben realizarse de la forma más cuidadosa posible y requieren un compromiso entre la preexistencia y los requerimientos de la normativa a través de su reinterpretación (Vegas y Mileto 2007). Por otro lado, los edificios tradicionales han evolucionado y se han transformado de forma continua durante su existencia. Estas intervenciones eran realizadas de forma espontánea con los materiales del lugar por lo que suponía una evolución o readaptación ligada a los usos o la cultura del lugar que, en la mayoría de los casos son difíciles de distinguir (figura 11. 1). Sin embargo, el uso indiscriminado de técnicas y materiales ajenos al lugar de las últimas décadas ha producido una alteración importante en los edificios y los cascos urbanos de las distintas poblaciones en cuanto a técnicas, materiales, volumenes, colores y texturas (figura 11. 2)

Estos factores junto con otros aspectos como la relación directa con el lugar, la cultura y la espontaneidad de estas construcciones, deben tenerse en cuenta a la hora de plantear los criterios o principios de intervención en la arquitectura tradicional. En el proyecto europeo Versus, Vernacular Heritage, Sustainable Architecture ${ }^{3}$ se han estudiado estos aspectos de forma detallada y se han enunciado una serie de principios o lecciones que proporciona el patrimonio vernáculo en relación con la sostenibilidad. Además, este proyecto presenta una metodología de análisis muy interesante en la que los principios se engloban en una rueda que los engloba en tres tipos de sostenibilidad: medioambiental, sociocultural

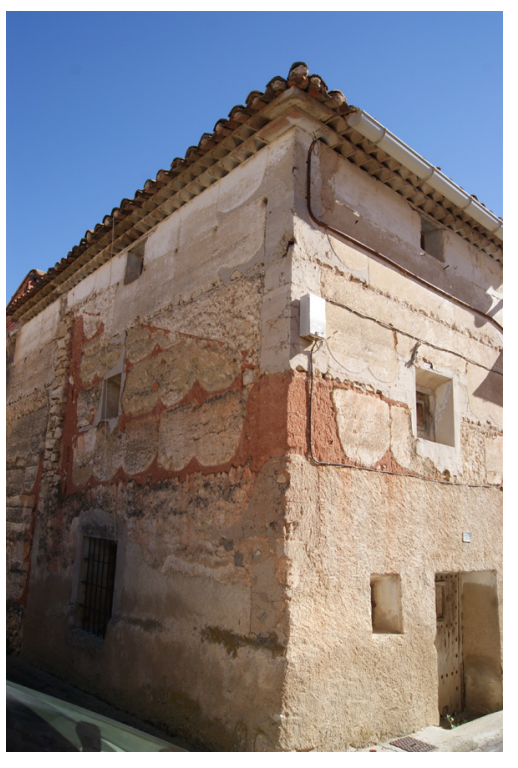

Figura 11.1. Evolución (ampliación) de una construcción de forma tradicional. Torralba de los Sisones, Teruel.

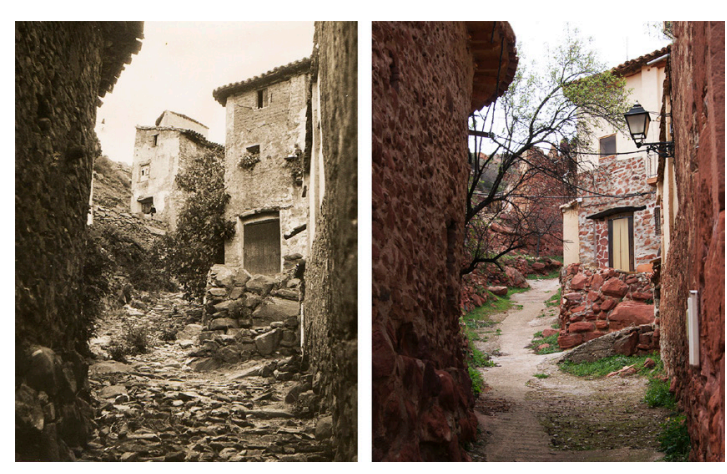

Figura 11.2. Transformación de Peñarroyas, Teruel. (Fuente: Villacampa Crespo 2015)

3. Proyecto Versus Vernacular Heritage Sustainable Architecture. Principales publicaciones ligadas. Etc AA.VV. 2014 b; AA.VV. 2014 c 


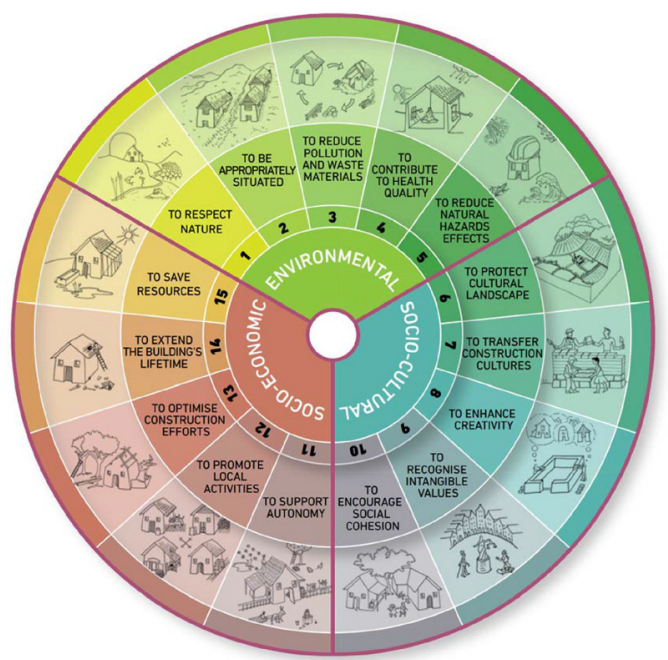

Figura 11.3. Rueda del Poyecto Versus. Fuente: AA.VV. 2014 b.

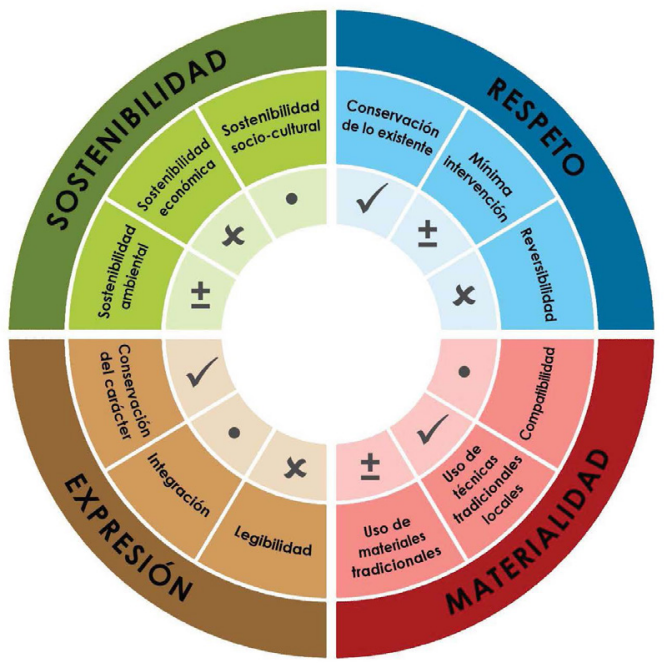

Figura 11.4. Rueda de criterios. Fuente: Estudio de buenas prácticas en las intervenciones de la arquitectura tradicional española, 2016 y socioeconónmica (figura 11.3). Los principios de sostenibilidad de esta arquitectura deben de ser, por lo tanto, aspectos a tener en cuenta en la propuesta de intervenciones tanto sobre los edificios tradicionales como en la arquitectura de nueva planta.

Basado en la metodología del proyecto Versus se ha desarrollado la parte de intervención del "Estudio de buenas prácticas en las intervenciones de la arquitectura tradicional española" (Mileto y Vegas 2016), publicación ligada al Plan Nacional de Arquitectura Tradicional. Este estudio tiene formato de manual y en él se han propuesto un gran número intervenciones ligadas a distintas técnicas constructivas y partes del edificio. El nivel de adecuación de las intervenciones propuestas se ha evaluado a través de una ruleta que sigue el modelo de la del proyecto Verus, donde se han sintetizado los criterios que deben tenerse en cuenta en las intervenciones sobre la arquitectura tradicional. Los criterios establecidos son los siguientes: sostenibilidad, respeto, materialidad y expresión, y dentro de cada uno existen tres principios a tener en cuenta en la propuesta de actuaciones (figura 11.4).

La arquitectura de tierra de Aragón presenta unas características muy heterogéneas debido, por un lado, al abandono de los núcleos rurales de población y, por otro lado, a las dinámicas de transformación actuales modificado el carácter de la mayor parte de los núcleos de población. El estudio de estos edificios en desuso en base a su validez para albergar nuevos usos y alcanzar los niveles de confort actuales es muy importante para promover la conservación y la reutilización de esta arquitectura tradicional que, de otra forma, estaría destinada a desaparecer.

Además, la arquitectura tradicional de tierra en la Península Ibérica, y concretamente en Aragón, conforma un patrimonio inmueble muy importante e irremplazable que constituye una base documental muy extensa de la que todavía queda mucha información por extraer y muchos oficios y técnicas que aprender. Por tanto, la conservación de estos edificios conlleva, por un lado, la preservación de un documento histórico y, por otro lado, la reutilización y el reciclaje de un espacio y unos materiales que de otra forma desaparecerían. Este tipo de intervenciones ofrece una ocasión importante para favorecer el desarrollo local a través de los principios de la sostenibilidad ambiental, sociocultural y socioeconómica (Vegas et al. 2014 b).

Debe tenerse en cuenta que cada caso de estudio es único y debe analizarse de forma detallada ya que, pese a que en muchas ocasiones es imposible el cumplimiento de todos los criterios, un conocimiento profundo permite un mejor razonamiento entorno a las posibilidades. (AA VV. 2008).

Los criterios enunciados se han mantenido, adaptado y desarrollado con algunos ejemplos para el caso concreto de la arquitectura de tierra de Aragón. 


\subsubsection{Sostenibilidad}

Las técnicas de construcción tradicionales son el fruto su propia evolución y desarrollo a través de las mejoras y la optimización de los recursos existentes que le otorgan una perfecta adaptación y adecuación al medio en que se encuentran para hacer frente a las necesidades y a las condiciones adversas.

La arquitectura tradicional de tierra lleva implícita en sus propiedades el carácter sostenible. Por ello es importante conocer la relación que establece esta arquitectura con el entorno en el que se encuentra ya que sigue una serie de conceptos o lecciones fruto de la observación y el aprendizaje durante cientos de años que deben tenerse en cuenta tanto en las intervenciones llevadas a cabo como en la arquitectura de nueva planta (Minke 2006).

La propia evolución de las técnicas constructivas de tierra está ligada a la sostenibilidad ya que en cada lugar se ha desarrollado de forma diferente y donde los suplementos son realizados con los materiales disponibles en cada área con el fin de mejorar las propiedades y la durabilidad de la construcción (Mileto et al. 2017 a). Un ejemplo muy claro en el caso de Aragón es la localización de los materiales utilizados en la configuración de los muros mixtos, algunos de ellos en áreas muy localizadas.

La sostenibilidad ambiental está relacionada con las propiedades de los materiales utilizados y el coste energético de la construcción que es un indicador ecológico que contabiliza el consumo y emisiones de $\mathrm{CO} 2$ en todos los procesos de la obra (Maldonado Ramos, Castilla Pascual y Vela Cossío 2001). El consumo de CO2 de la producción, la procedencia y la necesidad de transporte, la vida útil de los materiales o la contaminación que suponen sus residuos en el caso de ser eliminados son algunos de los aspectos a tener en cuenta. En el caso de la arquitectura de tierra el material está disponible en casi la totalidad de la superficie terrestres por lo que procede del entorno próximo, no se consume CO2 para su transformación (González y García Navarro 2006) y, si se elimina, vuelve al terreno del que proviene, por lo que es un material sostenible ambientalmente cuyo uso es muy aconsejable tanto en restauración como en la arquitectura de nueva planta. Además, si la tierra es de extracción local la compatibilidad con el edificio preexistente será presumiblemente mayor por poseer propiedades análogas y se reducirá tanto el impacto ambiental como el coste económico material. Puede considerarse que la propia conservación de la arquitectura tradicional constituye ejemplo importante de sostenibilidad, ya que supone el "reciclaje" de unos materiales existentes, incrementando su vida útil.

Además, el propio diseño de la arquitectura tradicional está íntimamente con el concepto de eficiencia energética y de sostenibilidad, ya que generalmente aspectos como la posición respecto al entorno, la orientación, las dimensiones de los vanos de fachada, los usos de las distintas estancias, la ventilación 
y los materiales utilizados eran estudiados para mejorar el confort interior ya que los únicos aportes energéticos eran los del fuego en invierno (Achenza, M. y Giovagnorio, I. 2014; Vegas et al. 2014 b).

La sostenibilidad económica está relacionada con la producción de los materiales y su puesta en obra. Si los materiales son de origen local, o próximos, y los trabajos son realizados por mano de obra del municipio. La mayor parte del coste de la obra se mantiene en la localidad, potenciando su economía y desarrollo (Castellarnau Visús 2012). En muchas de las localidades de Aragón la extracción de tierra y la producción de adobes era local, como algunas personas mayores han indicado durante la toma de datos, y suponían el jornal de muchas familias que se dedicaban a ello pasando de generación en generación (Bel 2016).

La sostenibilidad cultural está ligada con el mantenimiento de la cultura y las tradiciones locales, en el caso de la arquitectura, de los oficios y el saber hacer. En el caso de la tierra en Aragón todavía existen ciudadanos que recuerdan haber utilizado estas técnicas, los lugares de extracción local del material - las áreas donde se realizaban los adobes y se dejaban secar (Castellarnau Visús y Rivas 2013). Sin embargo, estos casos son cada vez menores por lo que debe potenciarse el todavía posible traspase de conocimientos locales entre generaciones. La amplia variedad de técnicas y soluciones concretas está ligada, no solo a los materiales, sino también a los usos y a las tradiciones de cada zona o localidad. Los oficios locales suponen una gran riqueza cultural y material que, lamentablemente, cada día están más cerca de su extinción.

\subsubsection{Compatibilidad}

La intervención de edificio tradicional supone necesariamente una serie de cambios que permitan adaptarlo a los estándares contemporáneos, en su mayoría, a través de la inserción de instalaciones. Si bien, es importante conocer las características técnicas y espaciales del edificio en el que se va a intervenir, de forma que, si se plantea cambiar el uso, se pueda comprobar la compatibilidad funcional con la preexistencia. Como se ha visto en el capítulo anterior, un ejemplo reiterado es la apertura de vanos en planta baja para el acceso de vehículos. Esta intervención en edificios de pequeñas dimensiones como los antiguos corrales o pajares ha generado que, en muchas ocasiones, se necesiten refuerzos estructurales y que se pierda totalmente su carácter tradicional.

Por otro lado, es importante hacer una buena elección de los materiales a utilizar, ya que deben trabajar de forma solidaria con el elemento preexistente, sin generarle daños futuros. La intervención en tierra supone en este aspecto un trabajo complicado debido a factores como sus propiedades higrotérmicas o 
su fácil erosión que, además, dificulta la adherencia de otros materiales. El uso de materiales industriales como el cemento, suele generar daños perceptibles en un periodo corto de tiempo. Por ello, es aconsejable el uso de materiales tradicionales, idealmente tierra, especialmente en reintegraciones. Por otro lado, el uso de materiales y técnicas tradicionales locales, además de potenciar la sostenibilidad cultural, presenta una solución más compatible que las técnicas actuales con materiales industriales que generalmente poseen una rigidez mucho mayor y que pueden generar problemas de distintos tipos. En este caso debe tenerse una especial precaución con el uso indiscriminado del cemento en todo tipo de intervenciones y que en la actualidad se utiliza para cualquier edificio o parte del mismo y puede generar problemas importantes por su rigidez, falta de transpiración y alto contenido en sales. Idealmente se deberían utilizar los materiales extraídos del mismo lugar que se hacía tradicionalmente. Un problema actual es el uso generalizado del cemento y el ladrillo hueco que elimina toda riqueza material de la arquitectura tradicional y su conexión con el lugar homogeneizando las soluciones constructivas.

Otro aspecto muy importante es la compatibilidad estructural, ya que una intervención inadecuada puede generar problemas muy graves Ilegando a comprometer la estabilidad del edificio. Los materiales industriales poseen unas propiedades muy diferentes a la de los muros de tierra, como la rigidez o la transpirabilidad que pueden coaccionar los movimientos producidos de forma natural en los edificios tradicionales o producir daños por los movimientos diferenciales. Por otro lado, la eliminación de algunas de las partes por una falta de conocimiento del edificio también puede ser la causante de daños graves. Por ello es vital conocer el comportamiento estructural del edifico a intervenir y utilizar materiales con características análogas como la madera que trabaja solidariamente con la tierra. Materiales como el cemento colocados en forma de revestimientos puede generar indirectamente problemas estructurales en los muros de tierra por el aumento de la humedad relativa y la consecuente pérdida de resistencia. En Aragón la mayoría de las intervenciones estructurales detectadas se han realizado con viguetas de hormigón prefabricadas, perfiles metálicos u hormigón armado, materiales con un comportamiento mucho más rígido que el de los tradicionales.

\subsubsection{Expresión}

La expresión en las intervenciones está ligada a las características estéticas y a la relación de las mismas con los acabados tradicionales y entorno en el que se encuentra finales de la intervención y como esta ser relaciona con los acabados tradicionales. 
Un aspecto importante es la legibilidad de la intervención, que debe permitir la distinción entre los elementos añadidos y los originales. La legibilidad o distinción de las intervenciones se puede llevar a cabo a través de la materialidad, la textura, los colores, etc. En el caso de la arquitectura de tierra, si las técnicas son vistas, la propia erosión superficial del material preexistente permite distinguir fácilmente la existencia de reintegraciones o de sustitución de piezas. Si bien, la distinción no debe ser excesiva ya que podría desvirtuar el elemento tradicional e impedir la integración en el edificio o conjunto tradicional. Para que los trabajos realizados queden integrados en la construcción deben tener unos colores o una textura que estén en armonía con el edificio y con su entorno. En el caso de la arquitectura tradicional es aconsejable el uso de elementos sencillos y funcionales, que no alteren el carácter tradicional de las construcciones. Hay que considerar la importancia del edificio como parte de un paisaje construido y como construcción en la que cada una de sus partes es importante e influye en el carácter del edificio donde y no únicamente la fachada es importante. No debe confundirse la conservación del carácter tradicional con la creación de un museo al aire libre sino que se trata de mantener la relación entre los elementos del edificio, las texturas, los materiales, etc. con el lugar en el que se encuentra. En el caso de Aragón estos criterios no se suelen tener en cuenta. Existen, principalmente dos tipos e intervenciones al respecto, las reintegraciones ligadas a reparaciones en las que se deja visto el mortero de cemento utilizado o las intervenciones de actualización ligadas a rehabilitaciones donde el muro se cubre totalmente y es imposible detectar si bajo este revestimiento se ha realizado alguna otra intervención.

En el caso de Aragón, la arquitectura de tierra es, sin duda, la que conforma el carácter de muchos de los pueblos. Por ello, cuando se interviene, se debe tener en cuenta y utilizar materiales que se integren con la misma, idealmente la propia tierra, y evitar su cobertura con cemento como ocurre en muchos casos en la actualidad. Pese a su elevada frecuencia, en pocos lugares la población reconoce la arquitectura de tierra como característica o pintoresca de un lugar y solo se atiende y se valoran aquellos edificios que contienen elementos de piedra o ladrillo. Por otro lado, en los últimos años, principalmente en la zona de Teruel y sur de Zaragoza, se ha incrementado el uso desafortunado de cemento con tono rosáceo como imitación del yeso de Albarracín, localidad referente por su conservación que supone un exponente de lo "pintoresco" y lo "rústico" en Aragón. Este cemento se ha utilizado como revestimiento en numerosos edificios principalmente de tapia tanto tradicionales como monumentales de los que se ha borrado toda huella de sus propiedades matérico-constructivas y pasando a tener un valor meramente estético (Galarza Tortajada 1996; Plenas 2013 c) 


\subsubsection{El respeto a las preexistencias}

El respeto y la conservación del elemento tradicional es la premisa más importante a la hora de intervenir en un edificio histórico y bajo la cual deben aplicarse todos los demás criterios expuestos. Debe considerarse el valor del edificio en su conjunto y el de todos los elementos que lo componen de forma que no se pierdan sus valores constructivos, funcionales, de carácter y de singularidad. Por ello es adecuado llevar a cabo intervenciones mínimas que permitan mantener legibles estos valores y su carácter ya que cualquier intervención no cuidadosa puede alterarlos. Por ello el edificio y los trabajos realizar deben estudiarse detalladamente antes de la intervención con la finalidad de aprovechar al máximo los elementos preexistentes y actuar únicamente en las zonas que es necesario. La intervención mínima es uno de los criterios más difíciles de cumplir en el caso de la arquitectura tradicional, si bien este puede reinterpretarse y considerar como mínimas las intervenciones necesarias para el alcance de los estándares básicos de habitabilidad actuales.

Otro aspecto importante es la reversibilidad que está relacionada con el respeto a la preexistencia. Es importante poder revertir las intervenciones sin daños o un mínimo de daños ya que la intervención realizada puede no ser compatible o la función para la que se realizó ya no existe, por lo que deberían poder eliminarse. Por otro lado, las intervenciones pueden llevarse a cabo tanto a través de la incorporación como la eliminación de elementos o partes, con la diferencia de que una intervención en la que se ha retirado una parte nunca será reversible. Las intervenciones con conglomerantes en el caso de las construcciones con tierra hacen imposible su completa reversibilidad ya que si este se eliminara posteriormente siempre arrastraría parte de la tierra sobre la que se encontraba adherido.

En el caso de la arquitectura tradicional, en la mayoría de los casos con uso residencial, es inevitable realizar cambios o modificaciones que permitan al edificio tener un uso que garantice su pervivencia y que difícilmente no dejarán huella en el mismo. Si bien, la forma de intervenir y la voluntad del que planifica la intervención son muy importantes y se deberán buscar las opciones menos destructivas y agresivas para que, pese a ellas, los valores y el carácter de la arquitectura tradicional prevalezca sobre los nuevos elementos.

\subsection{Técnicas de intervención. Propuesta de soluciones}

Las intervenciones propuestas a continuación son ejemplos de referencia que pretenden mostrar soluciones concretas para las que se han intentado aplicar los criterios definidos. Estas propuestas se han centrado en el muro de tierra y en la relación o conexión con otros elementos que pueden afectarle 
de forma directa, por lo que algunos de los criterios no son aplicables. Sin embargo, los trabajos que afectan únicamente a otros elementos constructivos del edificio no se han analizado, al quedar fuera del objetivo de esta investigación. Debe tenerse en cuenta que las características de las intervenciones en las construcciones de tierra dependen de la técnica constructiva y la variante concreta, así como de las lesiones presentes en cada caso.

A la hora de intervenir existen una serie de trabajos previos o premisas a seguir en todos los casos:

- Estudio y diagnóstico previo del edificio. Los estudios previos deben realizarse desde el punto de vista formal, material, estructural, funcional y estético. Además, debe existir un conocimiento profundo de los mecanismos de degradación existentes y las lesiones ligadas a estos para que las reparaciones efectuadas sean efectivas.

- Estudio del entorno en el que se encuentra el edificio. Deben conocerse las características estéticas y el carácter del entorno en el que se encuentra, así como las características climáticas locales, las transformaciones previas y las pendientes del terreno para la evacuación de aguas del entorno.

-Cumplimiento de los criterios enunciados con anterioridad. El cumplimiento de todos los criterios enunciados no es una tarea fácil, si bien, estos se deben tener siempre presentes a la hora de proponer soluciones para poder satisfacerlos al máximo. En el caso de que un criterio no se pueda cumplir, pueden establecerse rangos intermedios de cumplimiento e intentar que la intervención sea lo menos perjudicial posible y que, sobre todo, no genere daños en la preexistencia.

-Eliminación de los añadidos impropios que generan daños. A la hora de intervenir es aconsejable eliminar aquellos materiales ajenos al edificio tradicional siempre que esta no provoque daños mayores en el edificio. Esto permitirá realizar las intervenciones necesarias de forma adecuada.

- Preparación de la superficie intervenida. Previamente a la intervención debe realizarse una limpieza y preparación de las superficies o las zonas que van a ser intervenidas que consiste en la eliminación del material en mal estado o disgregado para mejorar la superficie de adherencia. Debe tenerse precaución y eliminar solo el material necesario. Si bien, en función de las características de la degradación puede ser necesaria la eliminación de parte del material en buen estado para generar una geometría que favorezca la colocación y el apoyo del material de reparación y evitar así su desprendimiento a corto plazo, principalmente en reintegraciones.

- Selección del material. Los materiales utilizados deben cumplir con la compatibilidad estética, material, fisicoquímica y estructural, pero, además debe existir una compatibilidad entre material utilizado 
y su puesta en obra (Mileto y Vegas 2016). La composición de la tierra o de los morteros utilizados debe variar en función de los requisitos, del tipo de intervención y de las características del muro preexistente. Por ello deben realizarse dosificaciones de forma manual para garantizar su compatibilidad y asegurar un envejecimiento de los materiales lo más homogéneo posible. Antes de la colocación de estos materiales deberá humedecerse ligeramente la superficie del muro para mejorar la adherencia de los mismo. Por otro lado, la selección de los materiales también variará en función de la técnica y la variante constructiva sobre la que se intervenga. En todos los casos se debe buscar un acabado lo más integrado posible por lo que en la elección del material también deben tenerse en cuenta características como el color o el tono la tierra a utilizar. Se debe evitar el uso de materiales como el cemento ya que su elevada rigidez respecto a los materiales tradicionales, su falta de transpirabilidad y su elevado contenido en sales pueden generar problemas. Lo mismo ocurre con los metales que además pueden producir otros daños derivados de su oxidación.

- Mantenimiento y/o revisión de las intervenciones realizadas para comprobar que las reparaciones siguen siendo efectivas y que las intervenciones no han generado ningún daño. Las experiencias de intervención en tierra indican que se trata de intervenciones complicadas ya que en ocasiones los trabajos realizados no responden como cabría esperar por lo que las revisiones periódicas tienen un papel muy importante.

Las soluciones propuestas en este apartado pueden agruparse en 3 bloques en función de las características y el objetivo de las mismas: intervenciones ligadas a la reparación de lesiones, intervenciones ligadas a transformaciones e intervenciones de prevención o mejora.

En todos los casos las soluciones descritas hacen referencia en primera instancia a la variante simple de las técnicas $y$, para las variantes que se crea pertinente, se presentarán soluciones o factores a tener en cuenta en la intervención sobre las mismas.

El tipo de intervención y las soluciones propuestas en estudios anteriores han ido evolucionando conforme se ven los efectos de las distintas intervenciones ${ }^{4}$ por ello pese a realizar un estudio completo de la bibliografía ha sino necesario un proceso de análisis crítico de la bibliografía para la propuesta de las siguientes soluciones ${ }^{5}$. (*nota: las intervenciones en el caso de Aragón no son distintas a las que se deben realizar en edificios de otros lugares, por ello en el texto se hacen alusiones a algunas de las variantes o características de estas técnicas en el territorio)

\footnotetext{
4. Las propuestas de intervención han ido evolucionando y puede observarse como algunas de las soluciones que aparecen en publicaciones antiguas hoy en día han sido desestimadas)

5. Las intervenciones en el caso de Aragón no son distintas a las que se deben realizar en edificios de otros lugares, por ello debe nutrirse de todas las fuentes posibles para aplicarlas a las características de las técnicas estudiadas
} 


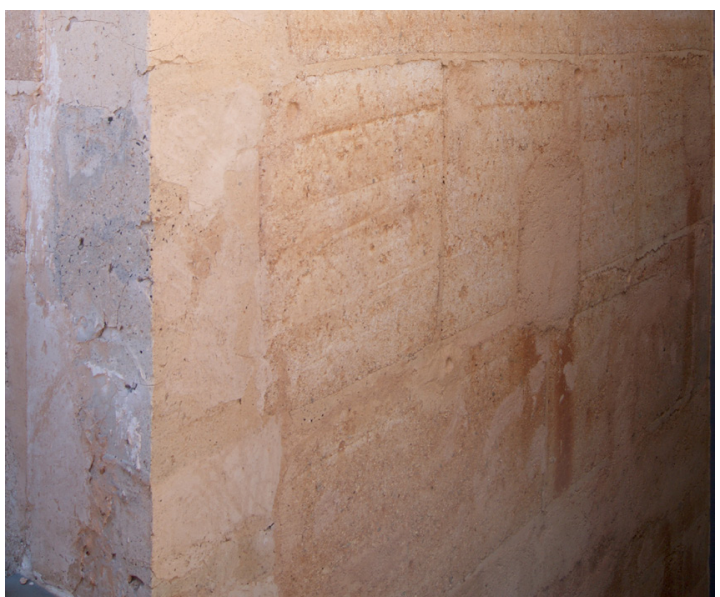

Figura 11.5. Tapia con reintegraciones. En este caso, según explicó el propietario, la tapia ha sido reintegrada utilizando arena de la misma rambla donde se extrajo el material original de construcción y añadiéndole cal para realizar la costra. Villaspesa, Teruel

\subsubsection{Intervenciones ligadas a la reparación de lesiones}

Las intervenciones derivadas de la existencia de lesiones tienen como objetivo principal reparar el elemento y detener su deterioro para que pueda cumplir su función y evitar la eventual aparición de nuevas lesiones. Para ello, existen distintos tipos de trabajos que están ligados directamente con el nivel de afección de las lesiones existentes.

En función de las características de las lesiones y del objetivo de los trabajos llevados a cabo se han determinado los siguientes tipos de intervención: consolidación, reintegración, reconstrucción y reparaciones y refuerzos estructurales.

Las reintegraciones son intervenciones realizadas sobre elementos que han sufrido una pérdida volumétrica. El tipo de reintegración varía en función de la profundidad de los daños, de la localización de los mismo y de la técnica y las variantes constructivas. En base a los casos de estudio se han determinado cinco tipos de reintegraciones en los muros: superficiales, en juntas, de sección, en esquinas y en coronación.

Las lesiones superficiales en los muros suponen una degradación principalmente visual ya que no afectan a la integridad a o la estabilidad del muro, aunque, si no se frena su deterioro, la lesión puede agravarse. Estas lesiones pueden resolverse rellenando las pequeñas oquedades con tierra de propiedades similares o con tierra con un porcentaje muy bajo de conglomerante ya que si el material es mucho más rígido que el existente no trabajaran solidariamente (figura 11.5). Se recomienda que la reintegración esté en el mismo nivel del paramento o retranqueada ligeramente para evitar que el agua penetre por la junta entre el material antiguo y el nuevo. Al tratarse de daños superficiales no tiene cabida el uso de conectores debido a la poca sección de esta. Siguiendo el criterio de mínima intervención la consolidación es preferible a las intervenciones superficiales que es fácil que caigan arrastrando parte de la materia.

Sobre la tapia simple se debe intervenir con tierra, aunque, si está calicostrada, debe reponerse la costra de la misma de forma que trabajen solidariamente y tengan un envejecimiento lo más parecido posible. Si el grosor de la afección lo permite es aconsejable establecer dos capas con dosificaciones distintas para mejorar la adhesión, la primera de ellas con una proporción de cal o yeso muy pequeña y una segunda capa con una proporción de conglomerante mayor que variará en función de las características de la costra existente. En el caso de darse pérdidas parciales en el revestimiento el procedimiento a seguir será similar al descrito para la tapia calicostrada, para el cual se debe buscar una textura y una coloración lo más parecida posible. 
En el caso del muro de adobe, este tipo de lesión varía ligeramente ya que el muro se compone de piezas fabricadas previamente. Si la lesión afecta a una serie de piezas concretas puede realizarse una reintegración de las mismas, si bien, se recomiendan otro tipo de soluciones como la consolidación por su dificultad de integración dentro del ritmo de la fábrica. En el caso de las fábricas con juntas de yeso, la erosión superficial produce que el yeso quede en un plano saliente por lo que puede rellenarse con tierra o tierra con una baja proporción de conglomerante la retícula formada por las juntas.

El tipo reintegración que debe llevarse a cabo en las juntas o en las oquedades de los propios elementos constructivos es similar a la descrita. Las juntas abiertas de las fabricas de adobe o las producidas entre materiales de distinto origen (en muros mixtos o con inserciones de otros materiales) así como los mechinales de las agujas de la tapia son puntos frágiles donde se pueden desarrollar otro tipo de lesiones derivadas de la acción del agua, del viento o de pequeños animales. Por ello es importante cegar estas fisuras y evitar futuros daños. Una vez más se recomienda la utilización de materiales lo más parecidos posible a los existentes, por ello en el caso de que las juntas de la fabrica sean de yeso, las nuevas también lo serán (figura 11.6). Lo mismo ocurrirá en el caso en el que se hayan perdido parte de los suplementos de yeso entre tapiales, variante muy común en Aragón.

Las reintegraciones en muros que presentan lesiones profundas en las que la sección del muro se ve afectada varían notablemente de las descritas con anterioridad. En este caso, las lesiones pueden llegar a afectar a la integridad y la estabilidad del muro por lo que la sección reintegrada debe ser resistente y colaborar solidariamente con el muro preexistente. Por eso, las soluciones propuestas deben estar íntimamente relacionadas con la variante concreta del muro que se esté interviniendo.

Este tipo de intervención requiere una preparación de la superficie que en general debe ir más allá de la limpieza del área afectada. La pérdida de sección de un muro de tierra presenta generalmente un perfil curvo lo cual impide el buen asiento o el apoyo de los materiales añadidos para recuperar el volumen. Por ello se, debe trabajar en la sección del material perdido para obtener una superficie más o menos planas con perfil en $\mathrm{C}$ y ángulos rectos en los muros o entramados de adobe y con un perfil apuntado en $V$ en los extremos superior e inferior para los muros de tapia o rellenos con entramados monolíticos (AA VV. 2008; AA.VV. 2010; Jaquin y Augarde 2012). La preparación de los muros de esta forma es la que permite que los materiales se apoyen correctamente y el material añadido permanezca estable (figura 11.7).

Existen distintas soluciones y materiales para reintegrar volumétricamente las partes faltantes, por lo que, en cada caso deberá estudiarse su adecuación y llevar a cabo aquella que sea más compatible con el edificio existente.

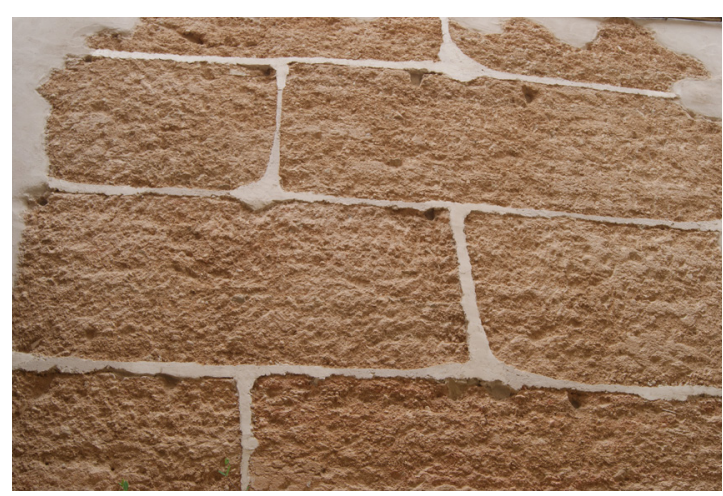

Figura 11.6. Reintegración de juntas con yeso. La Codoñera, Teruel

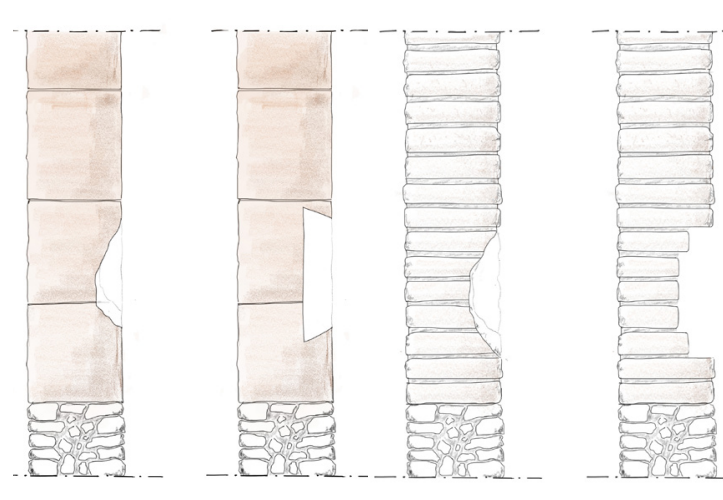

Figura 11.7. Perfil generado para garantizar el apoyo adecuado de los materiales utilizados en la reintegración. 


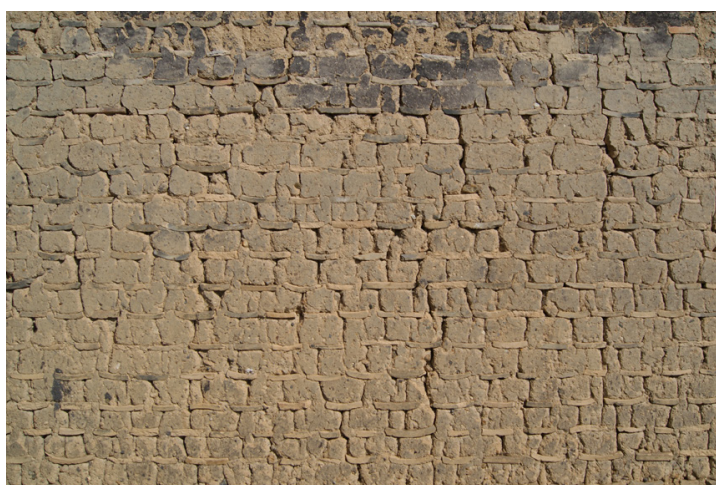

Figura 11.8. Muro tierra en Nara, Japón.

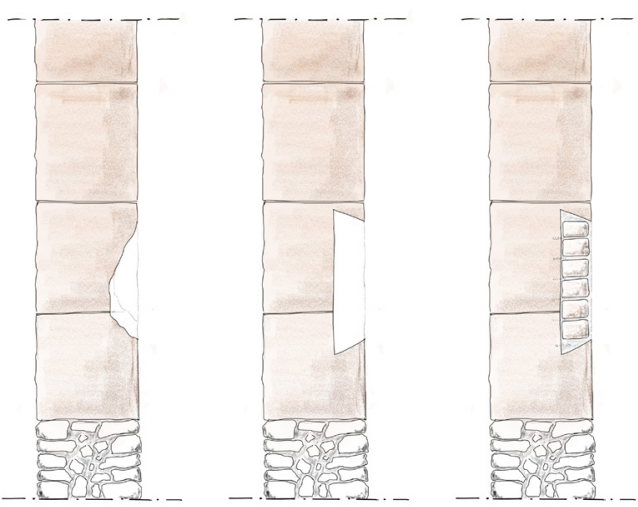

Figura 11.9. Reintegración de un muro de tapia

6. El estado de la mezcla, los componentes y la cantidad de agua también son determinantes a la hora de realizar intervenciones (Le Tiec y Paccoud 2006)

7. Una de las técnicas de tierra tradicionales estudiadas durante la estancia de doctorado en Japón consiste en la colocación de pequeñas bolas de tierra entre hiladas de ladrillos sobre las que se golpeaba de forma lateral antes de su secado para obtener una superficie lisa y sin poros.
Por un lado, la tapia se puede restituir volumétricamente utilizando la propia tierra como material de relleno. Para su realización deberán disponerse conectores, para asegurar que ambas partes del muro trabajan conjuntamente ${ }^{6}$. Los conectores serán idealmente de madera, material utilizado tradicionalmente como suplemento en el interior de los muros, y se unirán entre ellos con cuerda natural de esparto, creando una red que favorezca el agarre de la tierra. Esta solución requiere de encofrados a una cara para que se pueda compactar correctamente la tierra dispuesta. No obstante, esto conlleva una gran dificultad de ejecución y si no se compacta correctamente el material añadido puede disgregarse con facilidad. Por ello, se aconseja esta solución cuando deba reintegrarse la sección completa de muro lo cual permite su apisonado desde la parte superior (muros de cerca), aunque estos casos son más comunes en construcciones de carácter militar, como las murallas, que en edificios tradicionales. Otra opción es la compactación lateral de capas estrechas, aunque se debe tener especial precaución en el apisonado y en el contenido en arcillas del material añadido ya que un exceso de estas puede producir retracciones importantes. La compactación puede realizarse con pequeños pisones manuales de cabeza estrecha y acabarlo con una herramienta de mayor superficie que ayude a cerrar los poros del material añadido para mejorar su durabilidad. En este tipo de intervención sería necesario el uso de conectores para asegurar su estabilidad ${ }^{7}$ (figura 11.8).

Debido a la dificultad o la imposibilidad de compactación de la tierra y a los posibles problemas de retracción de la masa de tierra colmatando el muro original, las siguientes soluciones contemplan la inclusión de otros elementos en la masa de la tapia para completar la parte faltante. Los elementos añadidos serán idealmente de tierra, adobes o bloques de tierra comprimidos (BTC), si bien, materiales como los ladrillos tradicionales o la piedra también trabajan solidariamente con los muros de tierra (figura 11.9). La elección del material dependerá, entre otras cosas, de la variante constructiva y de las propiedades de la masa de tierra del muro concreto. Para asegurar la unión de ambas partes se dispondrán conectores entre estos materiales y el muro de tapia. Una vez colocado el relleno principal se dispondrá un revestimiento con un tono y textura parecidos al existente para garantizar la integración de la intervención y la conservación del carácter de la construcción.

Con el fin de adecuar el material utilizado a la técnica, variantes como la tapia con mampuestos debe ser reintegrada con este material, a poder ser extraído de las proximidades. Lo mismo ocurre con la tapia careada con ladrillo para la cual se debe utilizar ladrillo tradicional y en su cara exterior se colocarán los ladrillos de forma que sigan el mismo patrón y distribución que en el resto de muro. En el caso de los muros mixtos, si se ha perdido tanto parte de la tapia como de los machones o verdugadas, cada parte se repondrá siguiendo los criterios anteriores. Lo mismo ocurre en el caso de suplementos como las brencas. 
Además, en las tapias que dispongan de costra deberá reponerse para evitar que el área reintegrada se erosione más rápidamente garantizando de esta forma su durabilidad, integración, y un envejecimiento parecido al del muro tradicional.

Por otro lado, los muros de entramado con relleno monolítico seguirán las mismas premisas que para los muros de tapia. En el caso de Aragón los más frecuentes son los rellenos de tapialete (tierra y yeso con pequeños mampuestos o cascotes) por lo que las reparaciones en este caso deben ser de yeso con pequeños mampuestos. Además, en este caso, la superficie del muro desprendido es generalmente dura y rugosa lo cual favorece su adherencia por lo que, generalmente, no es necesaria una preparación previa de la misma, a parte de la limpieza.

La configuración en aparejo de los muros de adobe favorece a su integración a través de la sustitución total o parcial de las piezas de adobe deterioradas. En Aragón la mayor parte de los muros de adobe están aparejados a tizón y configuran fábricas de un pie por lo que una sola pieza abarca toda la sección del muro de alrededor de $40 \mathrm{~cm}$. Por ello, en las ocasiones en las que la lesión sea muy severa será necesario la sustitución completa de la sección. Sin embargo, en las lesiones menos profundas se aconseja eliminar únicamente la parte dañada de las piezas reconfigurando su forma paralelepipédica de manera que las partes faltantes se repongan con adobes de las medidas pertinentes. Esta reparación debe garantizarse la traba de la fábrica tradicional y las nuevas piezas. Si esto no fuera posible se deben utilizar conectores en las juntas que faciliten el trabajo conjunto de ambas partes (figura 11.10). Este tipo de intervención supone una conservación de las técnicas y el saber hacer tradicional ya que los adobes de repuesto deben fabricarse siguiendo el modelo tradicional. Si bien, la mano de obra debe ser especializada para que la calidad de los mismos esté garantizada y no se produzcan problemas de durabilidad por parte de las piezas del área reintegrada. También pueden utilizarse para su reintegración bloques de tierra comprimida (BTC), aunque, estos suelen tener un tamaño y una dosificación predeterminados de fábrica por lo que dificulta la traba con la fábrica preexistente.

En el caso de los muros de adobe el número de variantes es más reducido, pero deben tenerse en cuenta componentes como el mortero de agarre ya que debe tener unas características similares al preexistente, generalmente de tierra, yeso o cal. Además, pese a que en el caso de Aragón no es muy frecuente, si el aparejo tradicional tiene inserciones en el aparejo, la zona reparada deberá tenerlas para integrarse en el conjunto. Por otro lado, al igual que en la tapia, si la parte faltante afecta a machones o verdugadas de muros mixtos estos deberán reponerse con los materiales pertinentes, generalmente yeso y mampuestos, piedra o ladrillo.

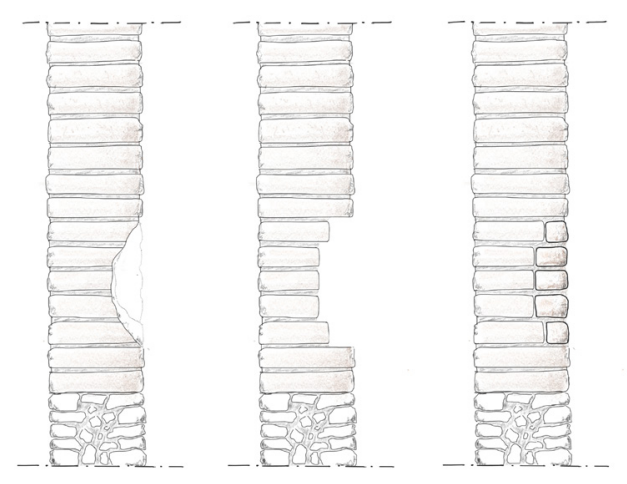

Figura 11.10. Reintegración de un muro de adobe 
8. En el directorio de la Red de Maestros se ha localizado una persona que realiza tejidos de cañizo: el Cañicero del Matarraña (https://redmaestros.com/)
Los entramados con relleno de adobe suelen ser tener aparejos a soga o panderete por lo que si alguna zona se encuentra muy deteriorada, probablemente sea necesaria una restitución parcial del muro con nuevas piezas ya que toda la sección se ve afectada.

Por último, los entramados con relleno de tejido suelen tener una sección de escasos centímetros por lo que cuando se encuentra deteriorado afecta generalmente a toda ella. Si bien, si hay pequeñas perdidas del material que reviste la urdimbre, estas deberán reponerse con un material de características similares. Este tipo de técnica no se utiliza de forma generalizada en Aragón, si bien, suele aparecer en pequeñas zonas de las partes altas de los edificios o graneros. La fragilidad de esta técnica junto con la ausencia de tejedores que fabriquen los cañizos ${ }^{8}$ ha producido que cada vez existan menos los casos ya que se sustituyen por materiales como el ladrillo hueco.

Las esquinas son unos de los puntos más frágiles de las construcciones de tierra debido a la fácil erosión por su alta exposición. Si la erosión o la parte faltante de la esquina es importante puede generar daños estructurales importantes por ser un punto importante en la distribución de cargas al terreno. En función del problema existente debe estudiarse la posibilidad de recomponer la esquina con tierra o recomponer esta zona con otro tipo de material más resistente a la abrasión generada por el viento, la Iluvia y las cargas excesivas y que garantice una durabilidad mayor.

La reintegración de la tapia idealmente se debe realizar con su misma técnica, pero debido a la dificultad que supone su correcta compactación en las esquinas, el espacio reducido y, en ocasiones, la imposibilidad de compactación, se aconseja realizarla a través del uso de otras técnicas, como el adobe o el BTC de forma que exista una continuidad material. Las esquinas son un punto delicado por lo que la ejecución de la reparación tiene que ser cuidadosa para que sea efectiva. Por otro lado, en función de las características climáticas del entorno y de las variantes constructivas existentes en el lugar de la construcción reparada también pueden ser aconsejable el uso de otros materiales como la piedra o el ladrillo, materiales utilizados tradicionalmente en la configuración de machones, y que pueden dotar de una mayor resistencia y durabilidad a la reparación por la elevada exposición de esta zona del muro. Estas soluciones también son aplicables en el caso de las jambas de los vanos que se encuentran deterioradas. Finalmente, si en la reparación se han utilizado materiales locales y utilizados frecuentemente en la localidad no sería necesaria su revestimiento para integrarlo en el edificio. En el caso de ser un muro es revestido, la reparación se debe reintegrar con el mismo.

Los muros de tapia requieren una preparación previa de la superficie antes de la reintegración para que ambos materiales estén trabados y permanezcan estables. Para ello se aconseja la creación de perfiles dentados que permita la colocación de las nuevas piezas por lo que, probablemente, sea 
necesario eliminar una pequeña parte de material en buen estado, que hace irreversible este tipo de intervenciones. Durante la colocación de las nuevas piezas que van a configurar la esquina es importante incluir conectores, preferiblemente de madera, entre el muro de tapia y la fábrica.

En el caso de los muros de adobe, la reintegración de esquinas debe seguir las premisas descritas para la reintegración del paño del muro. Se eliminarán las piezas en mal estado, total o parcialmente en función del caso, y se repondrán con piezas nuevas del mismo material. La configuración de las piezas de espera del muro tradicional debe asegurar la traba con los nuevos adobes y, si esto no es posible por la necesidad de eliminar partes o piezas en buen estado, se deben utilizar conectores que aseguren su unión.

En Aragón, un gran número de edificios tanto de tapia como de adobe tienen una configuración mixta por lo que, en estos casos, se repondrán las esquinas con el material que estén configuradas, generalmente, mampostería y yeso, piedra o ladrillo. El caso de los entramados es similar y deberán conservarse las esquinas de madera a través de prótesis o sustituciones parciales.

Los muros que se encuentran desprotegidos en su coronación suelen deteriorarse rápidamente, por ello es importante que el muro se encuentre protegido. Cuando los muros se encuentran desprotegidos durante un periodo de tiempo es común que pierdan parte de su volumen, especialmente en la parte superior. El perfil superior irregular que suele caracterizar a esta lesión dificulta la disposición de elementos de protección por lo que, generalmente, es necesario reintegrar o reconstruir parcialmente el muro para que la protección sea efectiva. Existen múltiples opciones a la hora de intervenir en este tipo de lesión que varían en función del criterio seguido y del objetivo de la intervención (figura 11.11) (Mileto et al. 2012; García-Soriano 2015). La mínima intervención en este caso conlleva la eliminación única del material disgregado para disponer directamente sobre el muro la protección. Debido a las irregularidades remanentes los elementos de protección tienen que poder adaptarse, por lo que las soluciones suelen limitarse al uso de mortero de cal o mortero de barro o cal con ramas. Otra solución es la preparación previa de la coronación del muro aplanando la superficie superior del muro sin realizar ninguna reintegración. Esta intervención supondría una eliminación material mínima y sobre la superficie lisa se pueden disponer distintos elementos de protección. La tercera opción es restituir el volumen perdido hasta el punto más alto existente en el muro (tras los trabajos de limpieza y preparación de superficies). Esta intervención nivela el muro y restituye la apariencia de un muro finalizado. Este tipo de reintegración debe realizarse utilizando la técnica tradicional del muro. En este caso es posible disponer encofrados a ambos lados lo cual permite reintegrar los muros de tapia con su misma técnica y realizar la compactación correctamente. Tanto en la tapia como en el adobe debe estudiarse las características
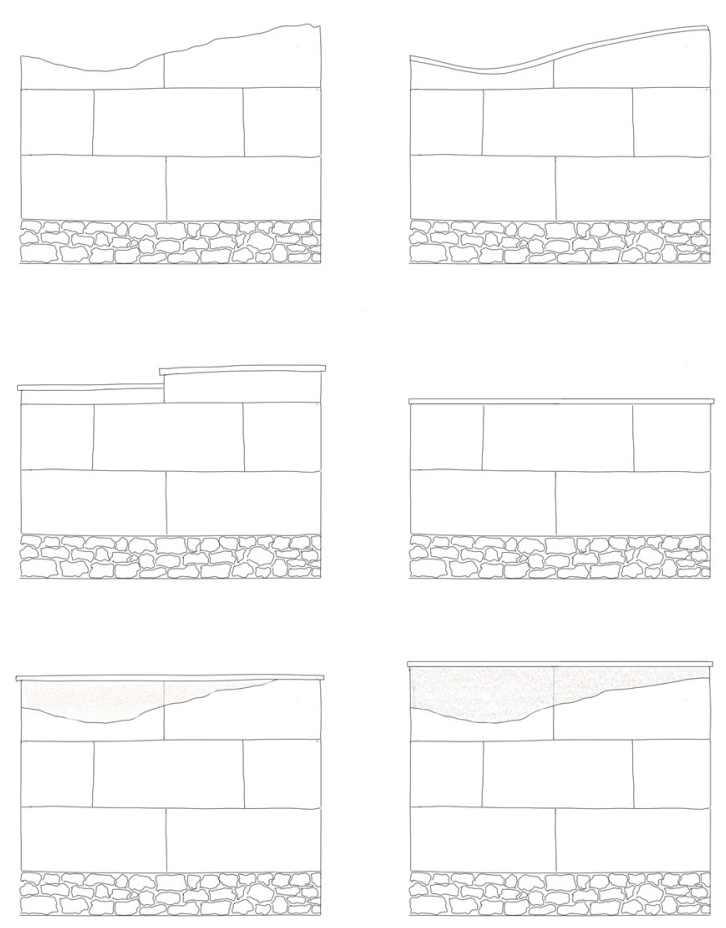

Figura 11. 11. Tipos de criterios seguidos en las intervenciones sobre la coronación 


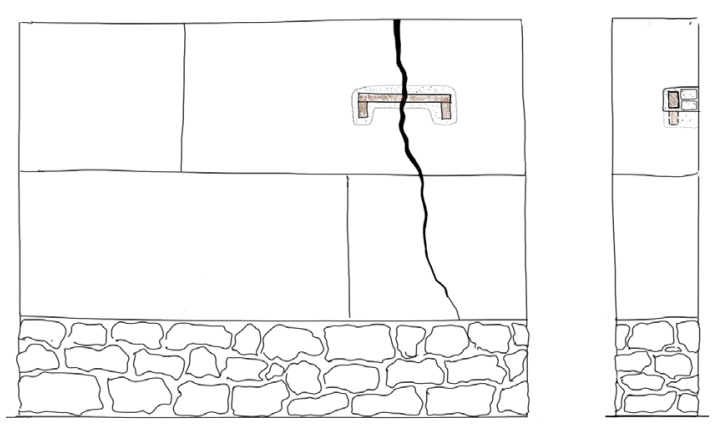

Figura 11.12. Cosido de grietas en muro de tapia
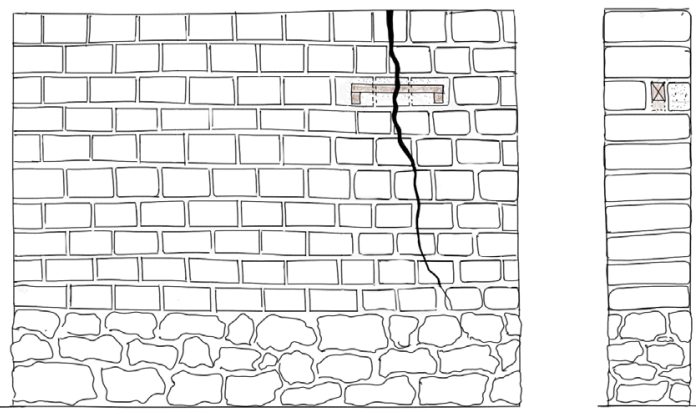

Figura 11.13. Cosido de grietas en muros de adobe

9. La solución utilizada actualmente en Aragón es doblar el muro con ladrillo hueco en el interior. de la variante constructiva y las dimensiones de los tapiales y de las piezas para que la nueva parte del muro quede integrada en la tradicional. Por último, si es objetivo el aumentar la altitud del muro, generalmente de cerca, o reconstruirlo hasta su altura original, el procedimiento a seguir será el mismo que en el caso anterior. En todos los ejemplos tras la intervención en el propio muro se debe disponer un elemento de protección que garantice la durabilidad del muro y de la reparación. Esta coronación puede ser de distintos materiales, aunque es aconsejable disponer materiales ligados a la tradición de cada lugar (lajas de piedra, cerámica, ramajes...) colocados con morteros compatibles.

Las intervenciones ligadas a lesiones estructurales suelen estar ligadas a la aparición de grietas, si bien, en función del desarrollo del mecanismo de degradación, estas lesiones también pueden requerir de reintegraciones. Antes de intervenir es especialmente importante realizar un estudio estructural completo del edificio que permita detectar el origen de las grietas y comprobar si el mecanismo sigue activo para, en tal caso, actuar en el origen de este para detenerlo, y no únicamente en las grietas ya que son su manifestación, pero no su origen. En este apartado se han definido los trabajos que se deben llevar a cabo para reparar las grietas ya que el comportamiento estructural de cada caso de estudio puede ser completamente diferente en función de su construcción y sus componentes externos. Por ello, un mismo edificio puede requerir más de una reparación o refuerzo como es el caso de reparación de grietas en esquina y la colocación de tirantes o contrafuertes que ayuden a conservar la estabilidad, y el de los refuerzos en la cimentación para mejorar el apoyo y evitar movimientos (Jaquin y Augarde. 2012).

La reparación de grietas puede tener múltiples soluciones en función de sus características y las de la técnica constructiva. El cosido de grietas es una de las soluciones más comunes y consiste en la disposición de grapas o llaves que unen las dos partes del muro. Es aconsejable que estas llaves sean de materiales compatibles, idealmente de origen vegetal como la madera (Vegas, Mileto y López Osorio 2017), de forma que trabajen solidariamente con el muro existente. En el caso de los muros de tapia es necesaria la realización de rozas para su colocación y su posterior reintegración a través de alguna de las soluciones expuestas con anterioridad (figura 11.12). En el caso de los muros de adobe, si es posible, se extraerán las piezas necesarias y se recolocarán cosiendo la grieta y sin alterar el ritmo de la fábrica (figura 11.13). En el caso de los entramados las grietas en los cuarterones suelen ir ligada a los movimientos o deformaciones de la madera que configura su estructura. Por ello además de la reparación y reintegración de la grieta serán necesarias algunas intervenciones para reforzar estos muros.

En el caso de los entramados o de las fábricas mixtas de adobe sin función estructural pueden producirse problemas de estabilidad debido a la esbeltez de los muros de cerramiento. En estos casos una solución es doblar el muro por el interior con otra hoja de adobe conectada a la primera mediante llaves ${ }^{9}$. Si 
el relleno es monolítico, mampuestos con tierra y yeso generalmente en Aragón, puede disponerse una red de fibras por el interior conectadas al propio muro y a los montantes laterales sobre la que se dispondrá una capa gruesa de mortero de yeso de forma que esta coarte los movimientos del muro. En el caso de los entramados con muros tejidos la solución más adecuada es la creación de una segunda capa de tejido por el interior anclada a los montantes y que se conecte con el tejido existente. De esta forma, el espacio entre ambas capas se puede rellenar con tierra lo cual le otorga una mayor estabilidad. En todos los casos se pueden llevar a cabo otras soluciones, sin embargo, estas se han considerado las más adecuada por la analogía con las técnicas preexistentes en cada caso. Además, estas soluciones pueden realizarse en los casos de transformación o adaptación a los estándares de confort actuales y a la normativa vigente con la finalidad de aumentar su capacidad aislante o pasar instalaciones.

Otras lesiones son las generadas por las cargas puntuales de las vigas de forjado o cubierta. En el primer caso, además de la reparación de la grieta generada, debe disponerse una superficie de reparto de cargas. Esta intervención consiste en la colocación de una plancha horizontal, preferiblemente de madera, bajo la viga de madera que ha generado los daños (figura 11.14 y figura 11.15). Para ello se debe apuntalar la viga y realizar una roza en el muro sobre la que se coloca la tabla asegurando su horizontalidad y la correcta transmisión de cargas. Una vez colocado debe reintegrarse la roza realizada para la inserción de la tabla. En el caso de la tapia la roza consiste en la eliminación de material a través del corte de la misma mientras que en los muros de adobe se puede eliminar algunas piezas de una misma hilada, como en el cosido de grietas. En el caso de las cargas puntuales por los pares de cubierta es aconsejable realizar una superficie de reparto en la coronación del muro que requerirá del desmontaje de la cubierta pero que también servirá de prevención y atado del perímetro.

Las grietas derivadas del empuje de la cubierta o por problemas de estabilidad del propio muro afectan generalmente a edificios asilados o en esquina y requieren, de intervenciones de mayor envergadura. Existen distintas soluciones para corregir este tipo de problemas y se utilizarán en función de las características del mecanismo, del objetivo general de la intervención y de las condiciones del entorno. Una solución utilizada frecuentemente en los edificios tradicionales es la colocación de contrafuertes, generalmente de piedra, en la parte exterior del muro para contrarrestar los empujes de muro (figura 11.16) (Pignal 2005, AA.VV. 2014. d). Esta solución es factible si se puede invadir del espacio alrededor del edificio por lo que su disposición en edificios situados en los cascos históricos es complicada. Para que la acción del contrafuerte sea más efectiva debe trabajarse con la fábrica de adobe o con la masa de tapia de forma que no se produzcan movimientos relativos entre ellos. Una de las soluciones más frecuente es la colocación de un zuncho de atado en la coronación del muro, para lo cual, hace falta desmontar la cubierta original. Se recomienda el uso de madera anclada con conectores compatibles

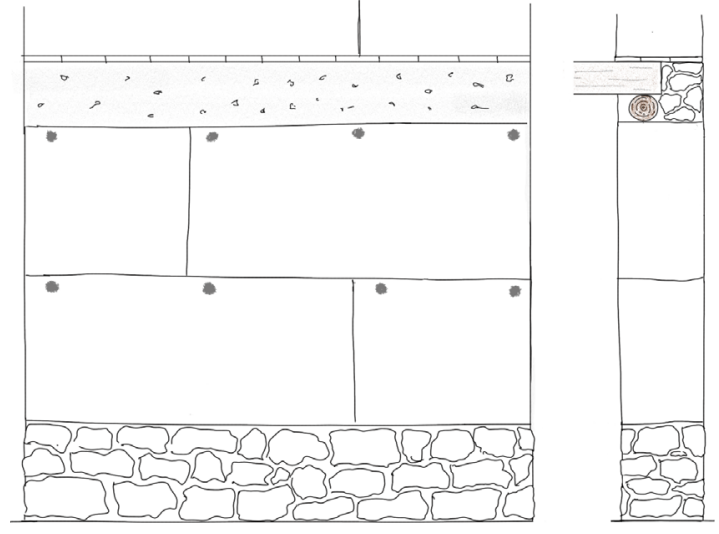

Figura 11.14. Tipo de apoyo de forjado tradicional existente en algunos de los edificios para mejorar el reparto de cargas del forjado. Rollizo logitudinal de apoyo con revestimiento de mampostería y yeso al exterior y capa de ladrillo en la parte superior para regularizar la superficie

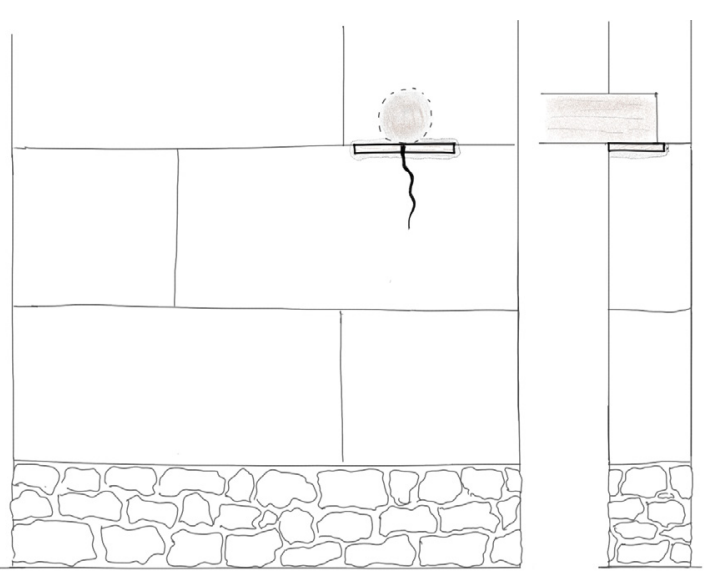

Figura 11.15. Apoyo común en los muros de tierra. Colocación de superficies de reparto para solventar los problemas generados por cargas puntuales 
o para la realización de este refuerzo, ya que otro material como el hormigón pueden generar daños debido a su elevada rigidez (AA.VV. 2014. D; Mileto y Vegas 2016) (figura 11.17). Esta solución ha sido utilizada tradicionalmente en muchos edificios desde su concepción para evitar problemas estructurales.

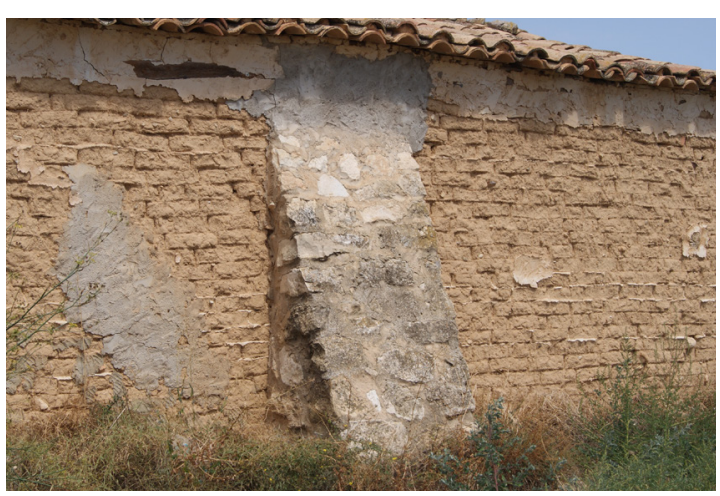

Figura 11.16. Contrafuerte de piedra sobre muro de dobe. Lagata, Zaragoza

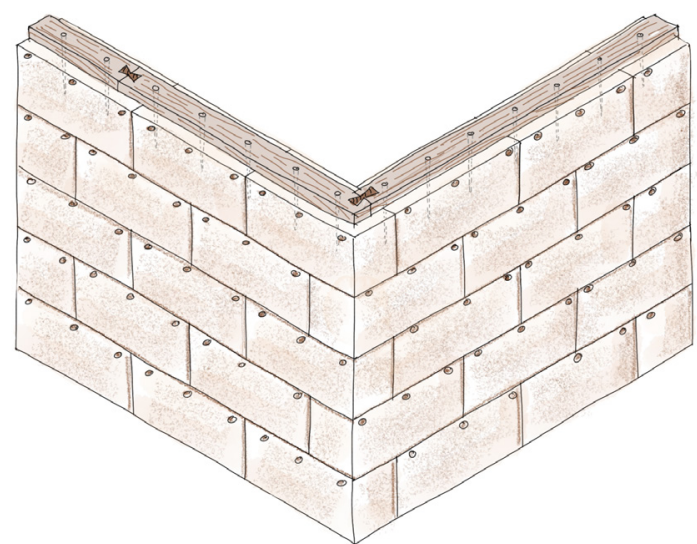

Figura 11.17. Zuncho superior de madera en muro de tapia

\subsubsection{Intervenciones ligadas a transformaciones}

Las transformaciones en los edificios tradicionales son, en la mayoría de los casos, necesarias para garantizar su pervivencia ya que, si estos carecen de uso, son abandonados y transformados en ruinas hasta su desaparición. Estas intervenciones, por lo general, no siguen muchos de los principios de la restauración ya que su objetivo, además de la conservación, es la dotación de uso. Si bien, a través del conocimiento profundo del edificio y del seguimiento de los principios anunciados, se pueden realizar intervenciones en las que las modificaciones sean mínimas. Para ello, debe existir una gran voluntad por parte de todos los actores involucrados (técnicos, constructores y propietarios) y trabajar con un objetivo común.

En intervenciones de rehabilitación es común la necesidad de refuerzos estructurales por el aumento de solicitaciones, así como la rehabilitación energética y el paso de instalaciones por necesidades de uso y cumplimiento de la normativa. Por ello las intervenciones deben pensarse desde el conjunto para optimizar los trabajos realizados e incluir todos los elementos necesarios (aislantes e instalaciones), sin necesidad de generar daños a la construcción original. Por ello si se realizan refuerzos en el forjado esta intervención se aprovechará para el paso de instalaciones al igual que si se levanta la cubierta para atar la coronación del muro o recolocar las tejas se debe incluir el aislante necesario. Estos aspectos varían notablemente en función de cada caso, por ello en cada caso deben plantearse previamente todas las intervenciones y así optimizar los trabajos y plantear soluciones mínimas y respetuosas la construcción tradicional.

Por otro lado, existen actuaciones que, desde el punto de vista de la conservación del edificio, no se consideran compatibles, si bien, estas intervenciones son muy comunes y debido a que, bajo la falta de una normativa que contemple estos aspectos, la última palabra la tienen los propietarios. Por ello, pese a que se desaconseja su realización, si finalmente se decide llevarlas a cabo sea de la forma más compatible posible y sin generar daños en la construcción.

La apertura de vanos en planta baja es una transformación muy común ya que en muchas ocasiones solo existe el propio acceso, lo que produce que esta parte del edificio este en constante penumbra. Por ello para poder utilizar esta parte del edificio muchos propietarios recurren a la apertura de vanos 
con técnicas completamente ajenas a la tradición. Si es posible, es aconsejable realizar las ampliaciones los huecos en altura ya que de esta forma no se modifica el esquema estructural del edificio. En el caso la ampliación de vanos, intervención muy frecuente y difícil de evitar, es aconsejable que, al menos, la intervención sea compatible material, estructural y visualmente. Por ello es imprescindible realizar un estudio estructural que compruebe su adecuación, así como un estudio de la fachada a intervenir y de las de su entorno para que estén en concordancia. De esta forma, el dintel del nuevo vano deberá ser de madera y las jambas del hueco estas deben conformarse al igual que en el caso de reintegración de esquinas, si no se han podido conformar ortogonales durante su apertura o ampliación. Para la realización del hueco es necesaria, en primer lugar, la colocación del dintel en el lugar que va a permanecer para luego vaciar el espacio determinado bajo este (Moriset y Misse 2011).

Otra intervención común es la actualización, generalmente en fachada, en la que los propietarios buscan un cambio en la imagen del edificio ligado a las modas del momento y que, además de realizarse con materiales generalmente no adecuados como el cemento y las pinturas plásticas, cambian radicalmente el aspecto de los edificios y por tanto el del entorno en el que se encuentran. Este tipo de intervención busca la eliminación del aspecto deteriorado de los edificios, si bien, lo adecuado en estas ocasiones es la limpieza del paramento, su consolidación y, si se estima pertinente, el uso de pinturas transpirables. Estas intervenciones también son comunes en el zócalo que se suele cubrir con nuevos materiales en lugar de rejuntar el material, normalmente de piedra, con materiales compatibles y dejarlo visto para que ventile correctamente y pueda evacuar la humedad fácilmente. De esta forma se sigue percibiendo estéticamente la antigüedad y originalidad del edificio, pero adquiere el aspecto renovado y limpio que la mayoría de los usuarios desean cuando intervienen sobre sus edificios tradicionales.

\subsubsection{Intervenciones de prevención y mejora}

Las intervenciones de prevención o mejora en los muros de tierra están relacionadas con el aumento de su durabilidad y su conservación en buen estado, sin estar ligadas necesariamente a lesiones previas. En primer lugar, cabe resaltar que, para garantizar la durabilidad y el adecuado estado de conservación de un edificio lo más importante es llevar a cabo el adecuado mantenimiento de todas sus partes.

Existe una gran variedad de trabajos y materiales o productos a utilizar para mejorar las características de los muros de tierra. Algunas de las intervenciones más adecuadas y adaptadas a la realidad social de hoy en día son la protección a través de revestimientos, la utilización de consolidantes e hidrofugantes, la prevención de humedades y los refuerzos estructurales. 
El revestimiento es un elemento que se ha utilizado tradicionalmente en Aragón para la protección de las construcciones de tierra, especialmente del adobe. Muchas de las intervenciones llevadas a cabo hoy en día tienden a despojar de esta capa protectora a los edificios para dejar vistas unas técnicas que quizás no fueron concebidas para ello. También existe el caso contrario, edificios que originalmente no tenían revestimiento, por ser estar dedicados en muchos casos a funciones secundarias y que, hoy en día, se revisten para protegerlos, pero utilizando en la mayoría de los casos mortero de cemento en lugar de otros materiales más compatibles como la tierra, la cal o el yeso. En el caso de la tierra por sus características intrínsecas la desprotección de los muros favorece a su erosión y a la perdida volumétrica, por lo que es aconsejable su protección a excepción de variantes como la tapia calicostrada que integra su propia costra de protección. Uno de los materiales utilizados tradicionalmente es el encalado o pinturas a la cal que se disponían de forma periódica para higienizar, proteger y decorar los edificios. Este material es adecuado dado que permite la transpiración del muro, al igual que las pinturas al silicato que tienen propiedades muy parecidas y son más duraderas, mientras que el uso de pinturas de origen plástico se desaconseja.

Una alternativa al revestimiento es la consolidación de los paramentos y su protección frente al agua a través del uso de hidrofugantes que impiden que esta penetre, pero que permiten la transpiración natural de los muros de tierra. La aplicación de productos consolidantes ayuda a proteger de la intemperie a los materiales sin cohesión o resistencia, como es el caso de los muros de tierra erosionados superficialmente. Los consolidantes deben ser fluidos y aplicarse sobre el muro de forma que penetren en los poros para dar resistencia a una sección de muro suficiente. El material utilizado tradicionalmente es el agua de cal, si bien su aplicación es muy costosa ya que requiere de muchas manos para que sea efectiva. Se aconseja el uso de silicato de etilo, aunque se debe tener precaución ya que si se dispone en exceso puede generar brillos en la superficie. Por otro lado, la hidrofugación consiste la disposición de una capa de protección frente al agua. Existen materiales con orígenes muy diversos, si bien, en el caso de la tierra se aconseja el uso de compuestos de la familia de los organosilícicos y los halogenados ya que permiten la perfecta transpiración natural del muro de tierra (Martín Peinado 2017)

Por otro lado, la prevención de humedades en la base del muro o su eliminación es muy importante para asegurar la conservación del muro y su adecuado comportamiento estructural, especialmente en las áreas donde se han detectado problemas graves de este tipo como la comarca de los Monegros y valle del Cinca. Existen diferentes sistemas de prevención de humedades que deberán utilizarse en función de las características del edificio, del entorno en el que se encuentre y de la existencia o no de problemas preexistentes de este tipo. El conocimiento de los factores externos, de los cambios producidos, la pendiente del terreno, la vegetación y la creación de drenajes que recojan el agua alrededor de los 
edificios para impedir el acceso directo a los mismo son algunos de los principales trabajos a realizar para evitar la presencia de humedad (AA VV. 2008).

Los refuerzos estructurales no tienen porque ir ligados a lesiones previas por lo que pueden funcionar como medidas preventivas. Este tipo de intervenciones están ligadas a las nombradas previamente en las transformaciones del edificio ya que suelen ir ligadas a la rehabilitación del mismo.

\subsection{Aplicación en el marco autonómico.}

El conocimiento de la arquitectura tradicional, la relación con su entorno, el estado de conservación e intervención actuales y unos criterios establecidos son básicos para la adecuada conservación y pervivencia de esta arquitectura.

La escasa difusión de los valores de esta arquitectura entre la población y falta de especialistas en la construcción tradicional de tierra, tanto técnicos como constructores, ha producido que las dinámicas de intervención en la actualidad no tengan ningún tipo de control y que el abanico de soluciones recogidas sea muy heterogéneo y, en general, no adecuadas o compatibles con el edificio existente.

Para difundir el valor y la importancia de la conservación de la arquitectura tradicional de tierra, así como sus características concretas en Aragón se ha realizado un estudio de los centros educativos de la comunidad donde se desarrollan estudios en temas relacionados con la construcción, tanto para constructores como técnicos, y las posibilidades de mejora de los mismos en temas de patrimonio vernáculo.

Se han analizado el temario estudiado en los cursos de formación profesional, en los estudios universitarios y en los talleres de empleo para conocer el nivel de implicación de estos con los temas de restauración y reconocimiento de las culturas constructivas de la comunidad. Ya que la mano de obra ni los técnicos requiere de un certificado de especialidad en construcciones tradicional para realizar trabajos sobre los edificios históricos es importante que, por lo menos, se disponga de unos conocimientos básicos o unos criterios para intervenir en esas construcciones.

En el caso de la formación profesional, existen cinco módulos de especialización en distintos aspectos de la construcción, algunos de ellos ligados a la Fundación Laboral de la Construcción de Aragón (http://aragon.fundacionlaboral.org/). La formación profesional básica cuenta con el curso "Reforma y mantenimiento de edificios" destinado principalmente a trabajos auxiliares en el interior de edificios. 
La formación profesional media cuenta dos módulos: “Construcción", en el que se estudian los distintos tipos de construcción, pero no se indica en ningún punto las técnicas tradicionales, y "Obras de interior, decoración y rehabilitación", enfocado a labores de acabado de interiores. La formación profesional superior oferta dos cursos: "Proyectos de edificación", destinado a labores de delineación principalmente y "Organización y control de obras de construcción", que es el único curso en el que uno de sus objetivos o materias es la rehabilitación y la conservación de obras de construcción. La falta de especialización de los oficiales de obra en temas de restauración, así como el escaso conocimiento de las técnicas constructivas tradicionales es un problema actual que podría resolverse incluyendo materias en los que se las que se aprendiera a trabajar las técnicas tradicionales de construcción y el comportamiento de las mismas respecto a los materiales industrializados. En el caso de la arquitectura tradicional de tierra es especialmente importante que los oficiales de obra conozcan las técnicas constructivas y sus características ya que generalmente son consideradas de mala calidad. Este desconocimiento lleva a su sustitución y cobertura generalizada por cemento u hormigón ya que son los materiales conocidos y con los que se aprende a trabajar hoy en día. Muchas de las obras realizadas en los edificios de tierra son llevadas a cabo de forma espontánea por encargo de los propietarios a los constructores locales sin técnicos supervisores por lo que es importante que estos oficios tengan conocimientos sobre el valor de estas construcciones y su conservación.

Por otro lado, Aragón cuenta con dos escuelas de arquitectura (Escuela de Ingeniería y Arquitectura, Universidad de Zaragoza y ETSA Universidad San Jorge) y una escuela de arquitectura técnica (Escuela Universitaria Politécnica- La Almunia, Universidad de Zaragoza). Se ha revisado el temario de las tres titulaciones y solo en arquitectura técnica existen dos asignaturas obligatorias en relación con la historia de la construcción y la intervención en edificios, aunque en el temario no se especifica el estudio de las técnicas constructivas tradicionales. Si bien, sí que se nombra el mantenimiento y rehabilitación sobre materiales como la madera o el hormigón. Por otro lado, solo se ha localizado una asignatura optativa en esta misma escuela y otra en la ETSA Universidad San Jorge que tratan temas de restauración o rehabilitación de edificios; mientras que en la Escuela de arquitectura de la Universidad de Zaragoza no se ha hallado ninguna asignatura cuyo objetivo sea el estudio de la construcción tradicional o su conservación. La falta de reconocimiento de esta arquitectura incluso dentro de las universidades es un problema serio que requiere de la inclusión de materias de estudio que sensibilicen y permitan a los futuros técnicos reconocer los valores constructivos, etnográficos y patrimoniales, no solo de la construcción tradicional de tierra, sino de la arquitectura tradicional en general. Además, los arquitectos y arquitectos técnicos tienen que ser capaces de valorar las construcciones históricas o tradicionales, los problemas que presentan y su adecuada reparación ya que las reparaciones inadecuadas pueden generar daños de gran envergadura. 
Por otro lado, en Aragón existen las escuelas taller que son programas de formación en alternancia con el empleo subvencionados por el INAEM ${ }^{10}$. Estos cursos combinan el aprendizaje con trabajos prácticos in situ sobre edificios de valor patrimonial, histórico o cultural, además de otros trabajos fuera del campo de estudio de esta investigación. En estas escuelas se lleva a cabo un aprendizaje de las técnicas constructivas tradicionales para su aplicación sobre el edificio histórico. Sin embargo, en ocasiones los criterios o la forma de llevar a cabo las intervenciones no son las más adecuadas desde el punto de vista de la conservación y la restauración. Estos talleres de empleo se realizan de forma alternativa en distintas localidades por lo que el temario varía en cada caso. En la localidad de Daroca (Zaragoza) entre los años 2007 y 2011 se realizaron distintos talleres de empleo con formación específica en arquitectura de tierra (albañilería de tapia y adobe) en los que se llevaron a cabo trabajos de restauración y reconstrucción de distintos lienzos de las murallas históricas de la localidad. Tanto las iniciativas como los trabajos llevados a cabo en estos talleres son de gran interés y son de gran interés y constituyen un buen ejemplo para extrapolar a otras zonas. En estos talleres se llevaron a cabo trabajos prácticos de aprendizaje de las técnicas, tanto la construcción como la reparación con materiales tradicionales (construcción con tapia, adobe, apagado de cal, etc.), antes de la intervención en el monumento. Además, se realizaron charlas y seminarios de concienciación y difusión sobre la importancia de la conservación del patrimonio cultural de la zona del que forman parte las técnicas tradicionales estudiadas. En las memorias también se describe la colaboración con los especialistas y el director de las obras y la participación de distintas instituciones y organismos para controlar los estudios previos y los trabajos de restauración. Algunos de los trabajos llevados a cabo ha sido la experimentación con distintos tipos de suplementos en las tapias construidas para ensayos. En estas se han probado reparaciones con mallazo de acero inoxidables, fibra de vidrio, madera y esparto, si bien, según lo descrito en la obra de restauración de la muralla se utilizaron varillas de fibra de vidrio y en algunos casos armaduras de acero inoxidable (figura 11.18; figura 11.19) (patrimonioculturaldearagon.es; Sanz Zaragoza y Sopensés 2009). Este tipo de iniciativa son de gran interés a nivel de difusión y formación en las técnicas tradicionales de tierra y en su restauración, pese a que hoy en día algunas de las soluciones propuestas han quedado obsoletas por producir incompatibilidades materiales (AA VV. 2014 a; García Soriano 2015).

A nivel nacional existen iniciativas como la red de maestros cuyo objetivo es localizar y dar visibilidad a empresas o particulares que desarrollan trabajos artesanos y buenas prácticas en el ámbito de la construcción tradicional y su restauración. En el caso de Aragón se han localizado cinco especialistas en la construcción con técnicas de tierra (adobe y tapia), dos en Teruel y Zaragoza y una en Huesca que supone un porcentaje alto respecto al total de maestros localizados en todo el país. La puesta en valor y la difusión de los conocimientos de esos artesanos es de gran importancia para mantener el saber hacer tradicional que en muchas áreas se ha perdido. Por ello sería interesante contar con ellos para

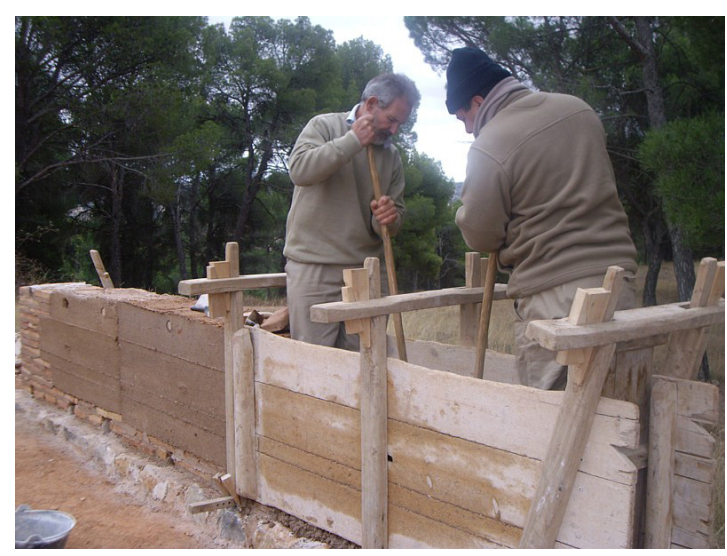

Figura 11.18. Taller de empleo Daroca II. Prácticas de realización de tapias. Fuente: Patrimonio Cultural de Aragón (sitio web)

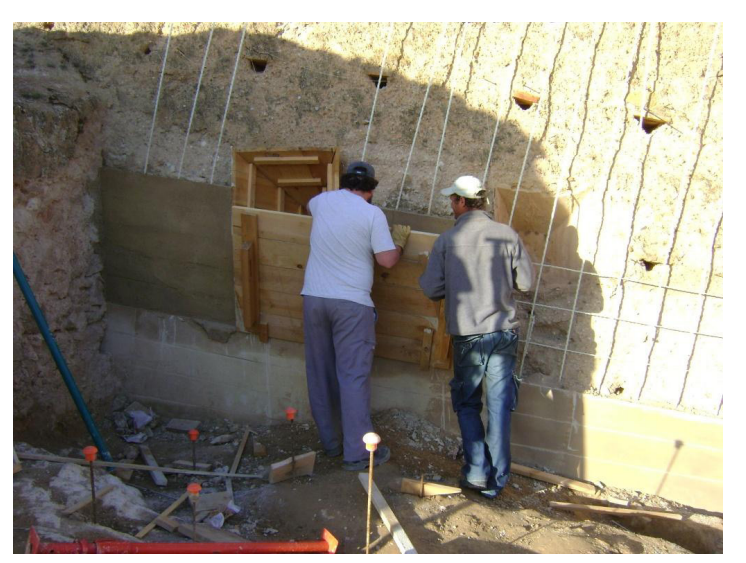

Figura 11.19. Taller de empleo Daroca IV. Colocación de fibra de vidrio y de los tapiales. Fuente: Patrimonio Cultural de Aragón (sitio web)

10. INAEM. Instituto Aragonés de Empleo 
impartir cursos o talleres en la formación profesional, en los talleres de empleo e incluso en las escuelas de arquitectura y arquitectura técnica.

La difusión entre la población y los propietarios de edificios construidos con tierra es un factor muy importante que, en ocasiones, se deja de lado por la dificultad de alcance que supone. La concienciación del valor de esas técnicas y el reconocimiento de las mismas como parte de la identidad cultural del lugar por parte de la población es básico para analizar su conservación ya que bajo la ausencia de normativa específica los propietarios son los que tienen la última palabra sobre los trabajos a llevar a cabo y la estética de los edificios intervenidos. Una forma de difusión con un alcance considerable puede ser la contribución con charlas o talleres en las semanas culturales que se realizan en múltiples localidades de todo Aragón, especialmente en los meses estivales cuando los "hijos" de los pueblos regresan a estos para pasar las vacaciones, asistir a los festejos locales y reunirse con familiares y amigos.

Es importante el desarrollo de este tipo de actividades en las que la población toma consciencia de su papel como protagonistas y responsables de la conservación de este patrimonio. En general, esta arquitectura tiene un valor sentimental para sus propietarios y desean conservarlos. Sin embargo, la forma de llevar a cabo no suele ser trascendental y, por ello, las intervenciones llevadas a cabo se suelen hacer de forma espontánea, con el mínimo coste y sin pensar en su valor cultural.

Por otro lado, a nivel normativo, una posible medida a llevar a cabo es ligar las subvenciones existentes destinadas a la rehabilitación de edificios con el tipo de intervención realizada. Esto permitiría premiar a las intervenciones adecuadas o buenas prácticas que, además de mantener el parque inmobiliario actual, contribuyen a la conservación de patrimonio tradicional y etnográfico de la comunidad. 


\section{BLOQUE IV}

\section{CONCLUSIONES}

12. Conclusiones

13. Futuras líneas de investigación

14. Versiones traducidas de las conclusiones

15. Bibliografía 
12. CONCLUSIONES 


\section{CONCLUSIONES}

La investigación realizada ha permitido conocer la arquitectura tradicional de tierra y su estado de conservación e intervención en 258 núcleos de población distribuidos por todo Aragón. El desarrollo del trabajo a través de la metodología mixta con dos muestras diferentes, (la muestra primera de carácter geográfico con 258 localidades y la muestra segunda basada 410 casos concretos analizados a través de la ficha de estudio), ha permitido conocer de forma detallada la arquitectura de tierra de la comunidad y sus principales características en relación con la zona geográfica. Además, con ayuda de las fichas de estudio se ha realizado un estudio de las intervenciones presentes en esta arquitectura y una valoración de las mismas que ha sido el punto de partida de la propuesta de las líneas guía de intervención que pretenden ser una herramienta útil para intervenciones futuras.

\section{LA ARQUITECTURA TRADICIONAL DE TIERRA EN ARAGÓN}

En primer lugar, se han estudiado de forma detallada todos los datos recogidos durante las tareas de campo, los cuales han mostrado la gran riqueza y la variedad de esta arquitectura en casi la totalidad del territorio aragonés. Además, estos datos han mostrado la relación de las técnicas y las variantes constructivas con el lugar en el que se encuentran, con los materiales locales y con la cultura constructiva de las distintas zonas.

La tapia, por sus características constructivas, ha sido la técnica con mayor número de variantes constructivas y su uso es el más extendido abarcando casi en la totalidad del territorio, si bien, su presencia es mucho más recurrente en el sur. Las principales variantes de tapia detectadas y sus principales áreas de desarrollo son las siguientes:

La tapia simple, pese a ser la variante más sencilla no es la más común en el caso de Aragón. Las subvariantes más recurrentes son la tapia simple de tierra y el tapialete (tapia de tierra, yeso y mampuestos), esta última muy característica de la zona de estudio por la amplia tradición constructiva con yeso existente. Estas 
variantes se localizan por todo el territorio, aunque predominan en el norte de Teruel y Sur de Zaragoza.

La tapia suplementada en paramentos es una variante muy frecuente en el territorio que se presenta en forma de tapia calicostrada, con yeso o con cal, y tapia careada con ladrillo generalmente pero también con piedra. La primera es más común en el suroeste de Aragón mientras que la segunda es más frecuente en la zona centro.

La tapia suplementada en juntas tiene dos subvariantes principales, la tapia con conglomerante en las juntas y la tapia con brencas de yeso o de yeso y mampuestos, aunque también las hay de ladrillo. Estas variantes tienen un predominio claro en la zona de Teruel y suroeste de Zaragoza.

La tapia mixta, es muy frecuente en todo el territorio y presenta mayoritariamente suplementos verticales en forma de machones y rafas, conformados generalmente con mampostería y yeso, pero también, con piedra y con ladrillo.

La construcción con adobe también es muy frecuente en el territorio, si bien, los ejemplos se localizan en un área más acotada que corresponde con la parte central de Aragón. Las variantes más frecuentes en este caso son:

La fábrica de adobe simple recibida con tierra es la variante más sencilla en la que la fábrica se compone únicamente de las piezas de adobe y el mortero de tierra. El principal aparejo en este tipo de muros es a tizón y la presencia de esta variante se extiende por todo el territorio donde hay adobe, si bien, se concentra especialmente en la provincia de Zaragoza.

La fábrica de adobe con suplementos en juntas aparece en un amplio número de casos y en ella se utiliza mortero, generalmente de yeso, para aparejar el muro. Esta variante se sitúa principalmente a lo largo del Sistema Ibérico y en la provincia de Huesca.

La fabrica mixta de adobe es la variante más común en todo el territorio y los suplementos son mayoritariamente verticales. Una subvariante es el uso del adobe como cerramiento con aparejo a soga, solución muy recurrente en la zona norte de Teruel.

Otra variante, menos frecuente en el caso de Aragón, es el uso de los adobes como suplemento. En esta comunidad se han localizado principalmente como suplemento en las esquinas de fábricas mixtas.

La construcción con entramados es la técnica menos frecuente de las tres estudiadas. Esta técnica se localiza en la zona norte y en la Sur, existiendo un vacío en la parte central correspondiente al valle del Ebro. La 
variante más común es el relleno monolítico en forma de tapialete localizado en la zona de Teruel. El relleno con piezas de adobe se sitúa principalmente en la parte oeste tanto del norte y del sur de la comunidad, y el relleno con tejidos, normalmente con cañizo, y predomina en la parte norte y este de Teruel.

Cabe destacar que el conjunto de variantes definidas responde al esquema de los posibles suplementos existentes en cada técnica. Sin embargo, estos suplementos han aparecido frecuentemente combinados entre ellos en una misma construcción conformando variantes más complejas. Por ello, cabe destacar que el número de variantes real es mucho mayor debido a las múltiples combinaciones posibles entre técnicas, variantes, suplementos y materialidad de los mismos.

Este estudio ha permitido en primer lugar determinar a las técnicas constructivas como un sistema recurrente en gran parte del territorio y que, en el caso de la tapia y el adobe, además, suponen las principales técnicas de construcción en muchos de los municipios. El análisis de las técnicas y variantes ha permitido conocer la gran versatilidad de estas técnicas que se adaptan a las necesidades y a los recursos de cada zona concreta y que queda patente en la materialidad y la forma de los distintos suplementos.

La adaptación de las técnicas al entorno, que generalmente tiene el objetivo de garantizar el confort interior y mejorar la durabilidad de la construcción, se ha estudiado a través de la comparación entre la localización de las distintas técnicas y una serie de planos temáticos del territorio en los que se definen sus características morfológicas, climáticas, geológicas y sociales. Algunos de los factores climáticos como la temperatura media, la amplitud térmica (tanto diaria como anual) o el soleamiento son importantes a la hora del diseño, la disposición, la distribución de los edificios, así como en la configuración del espesor y la protección de los muros.

De las técnicas presentes en el territorio, la tapia es la que se ha localizado con mayor frecuencia en las construcciones de las zonas con las temperaturas más bajas, mayor número de días de heladas y presencia de nieve, que corresponde con las áreas de mayor altitud del Sistema Ibérico. Este hecho ha podido ser favorecido, en parte, por el gran espesor que suelen poseer los muros de estas construcciones, cuyo comportamiento es muy adecuado por la inercia térmica del material que regula el intercambio de calor y frío con el exterior. Algunas variantes como la tapia con suplementos en las juntas y/o en los paramentos, frecuentes en esta misma zona, favorecen la protección de la tierra de estos fenómenos meteorológicos adversos. Aunque la tapia sea la técnica de tierra localizada en las áreas de Aragón con las temperaturas más bajas, la construcción con tierra, en general, tiene un buen funcionamiento en un rango muy amplio de temperaturas. Del mismo modo, en la zona central de Aragón, que corresponde con el valle del Ebro y los Monegros y se caracteriza por tener unos veranos 
muy cálidos cuyas temperaturas superan los 40ㄷ $\mathrm{C}$ reiteradamente, muchas de las construcciones son de adobe y sus propiedades térmicas le permiten garantizan un cierto frescor en el interior de los edificios.

El viento es otro factor a tener en cuenta en amplias zonas de Aragón tanto por su frecuencia como por su intensidad, especialmente en la depresión del Ebro donde, propiciado por su topografía, se genera una canalización del aire procedente de noroeste entre los Pirineos y el Sistema Ibérico. Tradicionalmente este fenómeno no ha sido determinante en la elección de materiales a utilizar en los edificios, pero si en su localización paisajística y en la disposición de los vanos y elementos de protección como la costra de las tapias o los revestimientos. Por otro lado, el régimen pluviométrico es uno de los factores que influyen de forma directa en el desarrollo de la arquitectura de tierra. Aragón no se caracteriza por las precipitaciones abundantes, si bien la arquitectura de tierra ha aparecido dispersa por todo el territorio a excepción de las áreas donde la pluviometría es mayor. Pese a que la precipitación anual media no es muy alta, las tormentas en verano son frecuentes e intensas lo que, junto con la alta presencia de edificios de tierra, contribuye a que los aleros de los edificios hayan adquirido una presencia considerable.

Los factores geográficos definen las propiedades del terreno y la disposición de materiales que condicionan la presencia de unas determinadas técnicas y variantes en cada lugar, ya que esta arquitectura ha buscado siempre la optimización de los recursos evitando transportes y esfuerzos innecesarios. Dentro de los factores geográficos se ha definido la importancia de litología del suelo y de la disposición de arcilla, ya que es el material encargado de generar las uniones entre las partículas que componen la tierra. La presencia de un terreno mayoritariamente arcilloso en la comunidad ha favorecido el desarrollo de estas técnicas y principalmente del adobe en la zona central de la comunidad, donde se concentran estas construcciones que generalmente requieren de una proporción elevada de arcilla en la mezcla, superior a la de la tapia, donde un exceso podría producir su agrietamiento derivado de la retracción. A nivel de extracción de la tierra, los valles de los ríos han favorecido la presencia de arcillas por los depósitos producidos en los valles. A su vez, los cauces de los ríos han sido siempre un entorno ligado al desarrollo de vida y por ello, ambas propiedades han provocado que, de los pueblos que componen la muestra, la gran mayoría sitúen en las proximidades de estos cauces.

Los conocimientos ligados a la relación de la arquitectura y su entorno son parte de la cultura constructiva del lugar y deberían ser tenidos en cuenta tanto en las intervenciones de edificios preexistentes como en las nuevas construcciones. Por ello, previa a una intervención deben estudiarse la arquitectura tradicional del lugar, sus condicionantes externos y su comportamiento como parte del propio proyecto de restauración o construcción.

Por otro lado, se han estudiado los fenómenos de degradación y las lesiones más frecuentes (erosión, 
presencia de humedad, desconchados, perdida material, oquedades, etc.), así como su afección en las distintas partes de los muros (base, cuerpo, superficie o coronación) del conjunto de construcciones estudiadas. Las lesiones han sido causadas en la mayoría de los casos por la acción de los agentes atmosféricos, especialmente el agua, y por los agentes antrópicos tanto por las acciones llevadas a cabo como por la total ausencia de las mismas. Además, las características concretas de las lesiones están relacionadas con la técnica y la variante constructiva del muro donde se producen y las propiedades del entorno en el que se encuentra, ya que pueden acelerar los procesos de degradación considerablemente.

\section{INTERVENCIONES EXISTENTES Y PROPUESTAS EN BASE A LA CONSERVACIÓN}

El análisis de las intervenciones realizadas hasta el momento sobre las construcciones de tierra en el territorio ha sido el punto de partida para conocer las dinámicas de transformación generales. En el estudio de estas intervenciones se ha analizado, en primer lugar, el criterio o reflexión previa (intervención espontánea o intervención planificada) y el tipo de intervención general (mantenimiento, reparación, rehabilitación parcial, rehabilitación integral, restauración, ampliación o demolición) y, a continuación, en cada una de las partes del edificio (zócalo, muros, revestimiento, vanos y cubierta), el tipo de intervención sobre estas (actualización, consolidación, reintegración, reconstrucción, demolición y sustitución), el tipo de técnicas (similar o diferente) y las características de los materiales empleados (industriales, tradicional similar o tradicional diferente).

Para la realización de este trabajo se han analizado todos los casos de estudio en conjunto, pero también de forma parcial en función del tipo de intervención general (de reparación o mantenimiento, por un lado, y el resto de las intervenciones, por otro) y en función de la técnica constructiva (tapia, adobe o entramado) con el fin de detectar las posibles intervenciones o dinámicas asociadas a estos subgrupos.

La reflexión previa o los criterios seguidos en la mayor parte de las intervenciones han sido nulos ya que estas se han realizado desde la espontaneidad. Esta ausencia de reflexión está vinculada en la mayor parte de los casos a reparaciones, pero también a intervenciones de mayor envergadura como rehabilitaciones. La realización de intervenciones de carácter espontáneo por parte del propietario o el constructor local es una característica ligada a la propia arquitectura tradicional. Esta espontaneidad hasta los años 50 estaba ligada al uso de los materiales tradicionales, que eran los disponibles en ese momento, y al saber hacer de las técnicas constructivas del lugar. Sin embargo, hoy en día los materiales más fácilmente accesibles son los industriales y, además, se ha perdido el saber hacer y el entendimiento de la lógica constructiva tradicional, lo cual general una serie de incompatibilidades e incluso eventuales lesiones en la obra original. Por otro lado, las intervenciones planificadas son mucho menores en número 
y responden generalmente a intervenciones donde, debido a la envergadura de la obra, existe un cierto orden en los trabajos realizados, aunque los materiales y técnicas empleados suelen ser similares a los del caso anterior. Este tipo criterio o reflexión previa aparece ligada principalmente a edificios residenciales con un uso continuado o temporal que han sido rehabilitados.

En cuanto a las intervenciones llevadas a cabo, las más comunes son las reparaciones y las rehabilitaciones, tanto en el análisis de conjunto como en cada uno de los grupos establecidos. Estas intervenciones presentan una relación directa con el objetivo final de la intervención que generalmente está ligado a la frecuencia o el tipo de uso, entre las que destacan dos grupos. Las reparaciones están ligadas, generalmente, a edificios sin uso actual o uso temporal sobre los cuales los propietarios realizan reparaciones sucesivas de forma espontánea para evitar su pérdida o daños mayores con los medios y el coste económico mínimos. Y, las rehabilitaciones, generalmente están ligadas a edificios de uso temporal o continuado que transforman el edificio para albergar nuevos usos o el mismo, pero con los requisitos de confort y necesidades actuales, para lo cual se modifican gran parte de sus elementos constructivos (carpinterías, cubiertas, interiores, etc.).

Intervenciones por zona. En el total de casos analizados, las zonas con mayor número de intervenciones han sido el zócalo y la cubierta, hecho probablemente derivado de la necesidad de mantenimiento que estos requieren para asegurar la durabilidad y la conservación del edificio, especialmente en las construcciones con tierra'. Si bien, cabe destacar que en las intervenciones de reparación predominan las intervenciones en zócalos y muros, ya que son las zonas más accesibles a la hora de realizar intervenciones sin ningún tipo de planeamiento. Y, en las intervenciones de mayor envergadura ligadas a la rehabilitación, predominan las intervenciones en vanos y en cubiertas, con el objetivo principal mejorar el aislamiento, asegurar la impermeabilidad y alcanzar los estándares de confort actuales.

Las intervenciones en el zócalo han consistido, en su mayoría, en reconstrucciones y reintegraciones con mortero de cemento hasta una altura determinada con el fin de proteger de la humedad y también actualizar su aspecto, sobre todo en los edificios rehabilitados. Por lo general, se han utilizado materiales y técnicas con propiedades diferentes a las existentes.

El tipo de intervención más frecuente en los muros ha sido la reintegración, basada en el relleno de oquedades o partes faltantes del mismo. Este tipo de intervención predomina en todos los subgrupos de casos (tipo de intervención general y técnicas), pero están especialmente asociadas a las intervenciones generales de reparación y a los muros de tapia cuyas características monolíticas favorecen este tipo de soluciones, derivadas a su vez de las características de sus lesiones. En general, las intervenciones en los muros han sido las que han presentado mayor variedad de soluciones, ya que dependen directamente del nivel de afección

1. Proverbio inglés: "Dale un buen sombrero y unas buenas botas y se cuidará solo" 
de la sección y de la técnica constructiva y la variante concretas. Para la realización de las intervenciones se han utilizado, en la mayoría de los casos materiales de carácter industrial y técnicas distintas a las existentes.

El tipo de intervención predominante en el caso de los revestimientos ha sido la reconstrucción, ya que engloba tanto los casos en los que el revestimiento existía con anterioridad como los casos en los que se ha realizado nuevo. Esta solución es más recurrente en las intervenciones generales de rehabilitación, y que, en muchas ocasiones, va asociada a la actualización de la imagen del edificio. Los nuevos revestimientos, al igual que se hacía tradicionalmente, se han realizado principalmente con los siguientes objetivos: la protección del muro, la cobertura de una construcción que no fue concebida para ser vista o no se considera adecuada para ello, o la renovación de la imagen del edificio.

Los vanos de los casos de estudio han sido intervenidos principalmente a través de la sustitución de las carpinterías antiguas por otras nuevas adaptadas al vano existente o a través del cambio de dimensiones de los huecos y el consecuente cambio de carpinterías adaptadas al mismo. Este tipo de intervenciones están directamente asociadas a las rehabilitaciones que buscan unas carpinterías que garanticen un cierre más hermético y un mejor aislamiento. Tanto en las intervenciones de ampliación y reintegración de huecos como en las nuevas carpinterías se han utilizado mayoritariamente materiales de carácter industrial.

El tipo de intervenciones Ilevadas a cabo en las cubiertas han sido más heterogéneas que en las otras zonas. La intervención más frecuente ha sido la reintegración que generalmente responde a tareas de reparación parcial de la cubierta, ya sea de una zona o de unas piezas concretas. También ha sido frecuente la sustitución completa de la cubierta que responde, bien a rehabilitaciones o a casos en los que su mal estado ha llevado a sustituirla con materiales industriales y de la forma más económica posible. Por último, otra de las intervenciones frecuentes ha sido la reconstrucción parcial, localizada en áreas en mal estado, o integral, generalmente debidas a la inserción de nuevos elementos como aislantes e impermeabilizantes.

Las intervenciones de rehabilitación energética en la arquitectura tradicional de tierra se han producido en los casos de rehabilitación de los edificios ya que, por un lado, ayudan a alcanzar los niveles de confort actuales y, por otro lado, son necesarias, en ocasiones, para cumplir con la normativa actual. La mayoría de los casos de rehabilitación energética han afectado a los vanos, si bien la cubierta es un elemento que generalmente se ha rehabilitado energéticamente si sobre la misma se han realizado trabajos de reconstrucción importantes. Estas zonas, vanos y cubierta, son en las que generalmente se producen mayores pérdidas energéticas por lo que es un factor a tener en cuenta, sobre todo si el edificio va a permanecer en uso durante los meses de invierno. 
Dinámicas de intervención. El amplio panorama de intervenciones analizadas alerta sobre el estado de transformación avanzada en el que se encuentra la arquitectura tradicional de tierra. Estas transformaciones están ligadas a la propia evolución del edificio y a su necesidad de readaptarse para seguir siendo útil y funcional y no caer en el abandono. El estudio de las dinámicas de transformación ha permitido reconocer los cambios recurrentes y la evolución de esta arquitectura y, a partir de estos, se han buscado posibles mejoras para reconducirlas hacia una arquitectura compatible y sostenible con las preexistencias y con el medio ambiente.

En las transformaciones de la arquitectura tradicional de Aragón se han detectado tres dinámicas predominantes cuyos fines son estéticos, funcionales o de reparación. Estas dinámicas pueden aparecer de forma aislada, aunque es común que se encuentren combinadas entre ellas. Las transformaciones ligadas a la estética de los edificios suelen afectar a los elementos de la fachada como el zócalo o los revestimientos y están directamente ligadas a las intervenciones de actualización. Las transformaciones funcionales afectan principalmente al interior de los edificios, si bien, en ocasiones, estas pueden ser perceptibles en la fachada, especialmente a través de las intervenciones en los vanos. Por último, las dinámicas ligadas a reparaciones varían en función de las lesiones sobre las que se actúa, si bien existe un criterio generalizado que es cubrir o rellenar con cemento cualquier tipo de desperfecto, desconchado u oquedad.

Las distintas intervenciones han sido analizadas través de la ficha de estudio lo cual ha permitido advertir una gran variedad de intervenciones llevadas a cabo. Esta heterogeneidad va ligada directamente al objetivo de la intervención y a las características concretas del edificio y de las lesiones; y no a los materiales y técnicas utilizados en las soluciones, ya que estos están sufriendo un proceso importante de homogeneización fruto de la industrialización y la globalización.

Las transformaciones actuales ligadas al uso de materiales y técnicas industrializados junto a la homogeneización de soluciones en todo el territorio han producido una desvirtuación de la arquitectura tradicional y el abandono de muchas técnicas ligadas a la tradición local de años de experiencia. Pese a esta globalización, y favorecido por el hecho de que la mayoría de las intervenciones son reparaciones puntuales, la riqueza y variedad de la arquitectura de tierra en el territorio aragonés sigue presente y es perceptible en la mayoría de los núcleos de población, lo cual debería alentar a los ayuntamientos sobre su pronta protección para no perderla en un futuro próximo.

Las dinámicas de transformación actuales han derivado principalmente de la falta de valoración de esta arquitectura que durante décadas se ha considerado pobre o de mala calidad tanto por la población como por constructores, técnicos y políticos. Por otro lado, la ausencia de una normativa específica que 
vele por su protección a permitido realizar casi cualquier trabajo. La normativa de protección, en el caso de Aragón, está ligada a edificios considerados patrimonio cultural y, para que esta normativa les aplique, deben estar declarados BIC, estar catalogados o estar inventariados. Además, la normativa, tanto a nivel estatal como autonómico, tiene un carácter muy genérico y de libre interpretación en la mayoría de los casos. El reciente Plan Nacional de Arquitectura Tradicional (2015) supone una importante puesta en valor de toda la arquitectura tradicional pero, aun así, el documento tiene un carácter genérico que es conveniente detallar en cada área específica. La especificidad de las normas en áreas relativamente pequeñas permite llegar a la población de forma más directa de manera que ésta se siente aludida por formar parte del grupo de actores responsables del proceso de conservación de sus pueblos.

Por otro lado, en las normativas existe una valoración general de lo "pintoresco", ya que se nombra en distintos documentos el deber de valoración y/o protección de los casos en los que la arquitectura tenga un valor cultural y represente los modos de vida o una relación con el entorno. Si bien, por definición, toda arquitectura tradicional tiene estas características, pero los casos o conjuntos protegidos, generalmente por su "pintoresquismo", han conservado parte de estas propiedades mientras que otras localidades han sufrido cambios severos derivados de intervenciones, pero también del crecimiento, que han provocado que las vayan perdiendo poco a poco. También se da la situación en la que, pese a existir una norma local (Plan General de Ordenación Urbana) en la que se especifica una cierta protección del área limitada normalmente por el casco histórico (colores a utilizar, proporción de las ventanas, características de los aleros, etc.), su cumplimiento no siempre se ve implementado.

En Aragón, el único área que goza de cierta protección a nivel de ordenación territorial y urbanismo es el Pirineo (ley 11/1992 de Ordenación del Territorio y Decreto 291/2005 del Gobierno de Aragón), donde están aprobadas las Directrices Parciales de Ordenación Territorial del Pirineo Aragonés en las que se pone de manifiesto el valor de paisaje, conjunto urbano y arquitectura tradicional como parte del patrimonio, por ser un factor fundamental del atractivo de la zona y de su desarrollo turístico. La arquitectura tradicional de esta zona es de piedra al exterior, material que tradicionalmente ha gozado de mayor prestigio que la tierra, y, además, se encuentra en un área paisajística muy privilegiada. Por ello, es importante mantenerla, aunque, como queda plasmado en la ley, uno de los principales objetivos es la protección estética del territorio para su desarrollo turístico y no tanto el valor de las construcciones en sí mismas. Pese a ello, es un ejemplo que debería extenderse a otras áreas del territorio.

Entre las construcciones tradicionales protegidas en Aragón se encuentran, generalmente, construcciones con una tipología concreta o con un uso concreto como pueden ser los molinos, las bordas o las salinas. El único caso en el que se ha protegido a un conjunto por la técnica constructiva ha sido el conjunto de 
arquitecturas de piedra en seco de la Iglesuela del Cid, declarado conjunto etnográfico. Una vez más, en este caso, la puesta en valor va ligada al uso de la piedra como material de construcción.

El carácter genérico de la normativa y la protección y puesta en valor aislada de conjuntos o construcciones consideradas como patrimonio no ofrece al conjunto de la arquitectura tradicional y de los núcleos históricos una protección real. Por ello, la existencia de subvenciones ligadas a la conservación adecuada de los edificios tradicionales podría ser un aliciente para fomentar la restauración o rehabilitación de los mismos. Sin embargo, las subvenciones existentes dirigidas a la rehabilitación y la conservación no están adaptadas a las características de los edificios tradicionales y, en algunas de las convocatorias, se premia incluso la sustitución completa de algunos elementos. La actual falta de entendimiento de las características de los edificios tradicionales en aspectos materiales, estructurales o térmicos genera que propiedades como la inercia térmica de los muros no se contemple en la normativa. Por ello en estas subvenciones se premia a intervenciones que quizás no son primordiales y que pueden generar un gran impacto en la construcción tradicional, ya que se evalúan por igual bloques de edificios de hormigón y ladrillo de los años 70 con serias deficiencias energéticas, que una construcción de tapia con muros de $60 \mathrm{~cm}$ de grosor.

Fruto de las dinámicas de transformación actuales se han detectado una serie de lesiones y que pueden tener su origen en el abandono y la falta de mantenimiento de las construcciones o en las intervenciones llevadas a cabo. La falta de mantenimiento está ligada entre otros factores al descenso de población y a la pérdida de los usos tradicionales de muchos de los edificios que han perdido su razón de ser. Por otro lado, las degradaciones o lesiones generadas por intervenciones son principalmente de los siguientes tipos: estéticas, materiales o estructurales. La degradación estética de los edificios tradicionales y de su entorno es una de las más frecuentes y deriva del uso indiscriminado de materiales industriales sin tener en cuenta su aspecto o características. Las degradaciones materiales están relacionadas principalmente con el uso generalizado de materiales industriales, especialmente el cemento, cuya rigidez, contenido en sales y mínima transpiración genera una serie de incompatibilidades con el edificio tradicional que derivan en lesiones comúnmente perceptibles a simple vista. Las lesiones estructurales están también están generadas normalmente por el uso de estos materiales y la falta de entendimiento del comportamiento estructural de estos edificios, lo cual genera comportamientos diferenciales entre los materiales, además de la habitual falta de traba entre los mismos

Criterios y propuestas de intervención. Las dinámicas actuales junto con la falta de una normativa específica han motivado la necesidad de establecer unos criterios intervención adaptados a la arquitectura tradicional de tierra para reconducir las intervenciones hacia la conservación y el respeto 
de las preexistencias. Estos criterios han partido del valor de esta arquitectura (cultural, etnográfico, arquitectónico, artístico, constructivo, paisajístico, etc.) y de su capacidad para albergar los usos actuales de forma adecuada.

La aplicación de unos criterios adecuados suele ser garantía de una intervención exitosa ya que un conocimiento profundo del edificio sin unos criterios adecuados puede generar intervenciones igual de dañinas que aquellas que se realizan de forma espontánea.

Los criterios establecidos se han basado en los propuestos en otros estudios anteriores y se han agrupado en cuatro bloques: la sostenibilidad, la compatibilidad, la expresión y el respeto a las preexistencias. Cada uno de estos cuatro bloques incluye tres subobjetivos. La sostenibilidad ambiental, económica y cultural olvidada en la actualidad, está ligada directamente con las propiedades de la arquitectura tradicional. La compatibilidad material, constructiva y estructural implica que la intervención pasa a formar parte del edificio, por lo que esta debe trabajar solidariamente con la preexistencia para ser lo más duradera posible. La expresión, traducida en la legibilidad, la integración y la conservación del carácter significa que la intervención debe estar en sintonía con la construcción preexistente y no generar alteraciones en la misma. Por último, el respeto a las preexistencias, esto es, la conservación, la intervención mínima y la reversibilidad, supone que en toda intervención debe tenerse en cuenta que el valor principal es el elemento preexistente y, por tanto, es importante preservarlo. El objetivo de estos criterios ha sido, por tanto, conservar las construcciones tradicionales, el saber hacer ligado a los usos y a la cultura constructivo y los valores de conjunto, paisajístico o de antigüedad.

Las propuestas de intervención realizadas son soluciones concretas que han pretendido mostrar la aplicabilidad de estos criterios. Estas propuestas se han centrado en el elemento constructivo de tierra y, a partir de ellas, se ha elaborado un inventario de soluciones a aplicar en función de las lesiones existentes, las características de la técnica y el objetivo de la intervención. Para ello se han establecido tres grupos de intervenciones: intervenciones ligadas a reparaciones (aquellos casos en los que existe una lesión en el muro ya sea por su erosión o derivado de problemas estructurales); intervenciones ligadas a transformaciones (relacionadas con la rehabilitación del edificio y las nuevas necesidades); intervenciones de prevención y mejora (cuyo objetivo es aumentar la durabilidad del edificio y la adecuada conservación del mismo).

En cada uno de los grupos se ha definido una serie de intervenciones concretas cuyo objetivo es mostrar un abanico de posibilidades compatibles y sostenibles que sirvan de referencia y que sean extrapolables a construcciones de tierra con características diversas, para lo cual deberán readaptarse. En estos casos no se ha considerado importante únicamente la solución en sí, que cambiará en cada 
caso, sino los conceptos y los criterios que hay tras ellas y que son los que pueden garantizar el éxito de las intervenciones.

Por otro lado, el incumplimiento de algunos de los criterios establecidos no supone que la intervención sea inadecuada. Intervenir en la arquitectura tradicional, y concretamente en la arquitectura de tierra, no es tarea fácil, por lo que en ocasiones es necesario el incumplimiento de alguno de los criterios para garantizar que otros se cumplan y que la intervención trabaje de forma compatible con el edificio y sea duradera. En el caso de la arquitectura tradicional, criterios como la mínima intervención o la reversibilidad son difíciles de cumplir para garantizar su uso, no obstante, deben de ser mínimos dentro de sus posibilidades. Por tanto, la intervención debe pensarse desde el conjunto y hacer un balance entre los criterios y las distintas posibilidades con el fin de encontrar la mejor solución.

En cuanto a la puesta en valor de la arquitectura tradicional de tierra, a nivel autonómico, por lo general, existe una difusión escasa entorno a los valores de esta arquitectura y la importancia de su conservación. En los centros de estudios específicos relativos a la construcción en Aragón (formación profesional y universitarios), se ha detectado una falta de materias específicas en las que se enseñen las características de las construcciones tradicionales. La formación en oficios en los que solo se aprenden las técnicas constructivas actuales supone un problema importante ya que, en la comunidad autónoma la arquitectura tradicional, y concretamente la de tierra, conforma gran parte del parque inmobiliario. Por ello, aunque una persona no quiera especializarse en cuestiones de patrimonio, es básico tener unas nociones mínimas de las características de estas construcciones para poder realizar propuestas adecuadas y llevarlas a cabo de forma correcta.

Por último, otro aspecto muy importante es la difusión entre la población de la importancia de la arquitectura de tierra y del amplio patrimonio construido que supone concretamente en Aragón. Los ciudadanos y propietarios deben conocer los valores de la arquitectura de tierra, tradicionalmente asociada a la pobreza, para poder promover su conservación ya que, ante la falta de una normativa, son ellos los que tienen la última palabra y los que deben velar por su conservación y mantenimiento. Además, de esta forma, la población es partícipe de la revalorización de su propia cultura y de los procesos que afectan al patrimonio de todos.

\section{CONSIDERACIONES FINALES}

La arquitectura tradicional es el documento material que muestra la forma de vida de un lugar concreto, el diálogo perfecto entre el hombre y el paisaje. Esta arquitectura ha dejado de existir como elemento 
activo, por lo que los edificios existentes en la actualidad son los últimos de su tipo y por tanto su puesta en valor y su conservación es de vital importancia.

La difusión de las técnicas tradicionales de tierra locales ha formado parte de la tradición oral cuyo saber hacer pasaba de generación en generación (lugar de extracción de tierras, forma de apisonado, estabilizantes usados, áreas y tiempo de secado de los adobes, etc.). Sin embargo, hoy en día las nuevas generaciones han crecido ajenas a estas técnicas constructivas y ya muy poca gente es conocedora de este saber hacer que generalmente estaba ligado a las características locales del entorno y la disposición de material.

La arquitectura tradicional de tierra esta ligada íntimamente al concepto de sostenibilidad que tanto se busca en las construcciones de hoy en día, ya que nace de la tierra y vuelve a ella sin contaminar. Por ello, en las últimas décadas ha aumentado el interés en estas construcciones por parte de técnicos, constructores y gente que busca unas soluciones más sostenibles para sus viviendas. Pese a ello, muchos edificios tradicionales siguen derribándose en la actualidad para la erección de otros nuevos que en ocasiones presumen tener un comportamiento energético mejor y ser más sostenible y en los que muchas veces no se tienen en cuenta las características del lugar concreto.

A lo largo de los años, las intervenciones han estado ligadas a las reparaciones con los medios mínimos o a las rehabilitaciones bajo el concepto de lo "rural", lo "rústico" o lo "pintoresco", en las que se han llevado a cabo intervenciones desvinculadas del lugar en base a una imagen que nunca existió y que poco tienen que ver con la tradición local. Estas intervenciones, pese a realizarse en muchas ocasiones sobre edificios de tierra, suelen revestirse e incluir elementos de piedra o ladrillo para darle un acabado de "calidad". Si bien, se han detectado intervenciones realizadas en los últimos años en las que la propia técnica de tierra se pone en valor resaltando su estética y sus elementos y que, pese a realizarse con materiales industriales, es un primer reconocimiento de las mismas como características y propias del lugar.

Como se ha estudiado, esta arquitectura necesita revisar y reconducir el tipo intervenciones realizadas para poder conservarla, tanto de forma aislada como la relación que posee con el entorno. Las soluciones propuestas han buscado la simplicidad de conceptos para que puedan ser comprendidos tanto por especialistas como por los usuarios que realizan intervenciones de forma espontánea. Además, es importante que se comprenda la necesidad de conservación de las imperfecciones de esta arquitectura ligadas a la espontaneidad, donde una brenca es más alta o más ancha que otras o las piezas de adobe de un mismo muro tienen colores diferentes, y que el objetivo de estas intervenciones no es dotar de un aspecto perfecto del edificio. 
Estas propuestas pueden parecer utópicas, pero todas las personas que participan en las intervenciones deben entender que se trata de una labor de mantenimiento, restauración o rehabilitación de construcciones muy valiosas cuyas propiedades han permitido la adecuada adaptación a casi todos los entornos de la comunidad. Además, estas lecciones de uso de los materiales y de adaptación al medio deberían ser reestudiadas y aplicadas tanto en estas intervenciones como en las propuestas contemporáneas de arquitectura de nueva planta. 


\section{FUTURAS LÍNEAS DE INVESTIGACIÓN}

1. Colaboración de Pedro Bel Anzué y de Jesús García Mainarque ha permitido la localización de los casos de estudio y en la documentación fotográfica

2. En Aragón destaca la labor de APUDEPA: Acción Pública para la Defensa del Patrimonio Aragonés
Este trabajo de tesis ha permitido reconocer la abundancia y la riqueza constructiva de tierra existente en la comunidad de Aragón. Pese a ello, los límites de la investigación ligados a la gran extensión del territorio y a la imposibilidad de acceso a los edificios invita a pensar que esta riqueza es incluso mayor. El estudio podría completarse a través de más visitas de campo específicas a algunas zonas y del estudio de los interiores de las viviendas.

Derivada de esta reflexión se considera de especial interés el estudio de la zona del Pirineo que ha sido el área con menos presencia de construcciones de tierra, por ser los exteriores, generalmente, de piedra. No obstante, en esta zona se han podido obtener datos ${ }^{1}$ de algunas edificaciones cuya distribución interior estaba realizada por completo con entramado de madera con relleno adobe y encestado, y el cuerpo de las chimeneas con adobe. El reconocimiento de la tierra como material ligado a la tradición constructiva de las viviendas del pirineo sería de gran importancia debido al valor que se deposita en estas edificaciones, derivado, en parte, de la consideración que gozan las construcciones en piedra frente al desprestigio de las construcciones con tierra. Este tipo de trabajos podrían ser extrapolable a otras zonas donde no se han detectado apenas construcciones con tierra con el fin de corroborar y ampliar los datos.

Este trabajo se ha centrado en el estudio de las técnicas constructivas de tierra, sus características y las intervenciones en el edificio, especialmente, sobre los muros. Si embargo, con el fin de complementar el proyecto y profundizar en las características de esta arquitectura, sería interesante analizar las tipologías edificatorias en relación con las técnicas constructivas y con la zona concreta donde se localizan. Este estudio además permitiría detallar las líneas guía y ampliar las soluciones propuestas al edificio en su conjunto y no únicamente al muro y a los elementos que afectan directamente a este.

Por otro lado, la difusión del trabajo realizado es uno de los objetivos más importantes. El estudio tiene un objetivo claro que es la conservación y puesta en valor de la arquitectura tradicional de tierra. Si bien, esta es una tarea difícil si no se da a conocer la importancia cultural, etnográfica y constructiva de esta arquitectura entre la población, los propietarios, las asociaciones de protección del patrimonio ${ }^{2}$ y las administraciones, que son las encargadas de promocionar su conservación o establecer las normativas 
pertinentes. Por ello, está previsto dar a conocer el trabajo a la Dirección General de Cultura y Patrimonio de Aragón con el fin de poder convertirlo en un documento oficial con mayor alcance y divulgación y sirva, de esta forma, como marco a las futuras intervenciones.

Además, existen otras posibilidades abiertas ligadas al desarrollo de proyectos en los que la investigación presentada puede nutrirse desde otros puntos de vista como es el de la prevención de riesgos. En la actualidad, el grupo de investigación del cual forma parte la doctoranda ha realizado la solicitud de dos proyectos de investigación que se centran en el estudio de los riegos asociados a áreas con construcciones de tierra. El primer proyecto se titula Risk Terra, "La arquitectura de tierra en la Península Ibérica: estudio de los riesgos naturales, sociales y antrópicos y estrategias de intervención e incremento de la resiliencia" (Ministerio de Ciencia, Innovación y Universidades), que tiene como objetivo el estudio científico de las distintas amenazas que afectan actualmente a esta arquitectura como los desastres naturales, los factores sociales y los factores antrópicos, para proponer una serie de estrategias de conservación, intervención y rehabilitación compatibles y que además ayuden a prevenir y mitigar los posibles daños e incrementar la resiliencia. El segundo proyecto se titula "Tierra en peligro. Amenazas, riesgos, prevención e intervención en la arquitectura de tierra en la Comunidad Valenciana" (Conselleria de Educación, Investigación, Cultura y Deporte. Dirección General de Universidad, Investigación y Ciencia. Generalitat Valenciana), el cual tiene unos objetivos parecidos al anterior, si bien este se centra en el territorio de la Comunitat Valenciana. Además, en el caso de la Comunitat Valenciana sus características geográficas hacen que el territorio sea especialmente vulnerable a amenazas naturales como el sismo o las inundaciones, y a amenazas sociales como el desarrollo del turismo en la costa que, durante años, ha acabado con todo lo preexistente.

Por último, es importante hacer especial mención a la importancia de la difusión de los valores de esta arquitectura tradicional de tierra, que ha sido injustamente desprestigiada durante décadas. Sin embargo, sus características beneficiosas para el confort interior y su sostenibilidad han sido estudiadas ampliamente. Es importante destacar que cada una de las construcciones tradicionales es un objeto irremplazable, ya que ya no existen como fenómeno activo, y que, las intervenciones realizadas sobre las mismas afectan y pasan a integrar parte de los edificios, por lo que deben ser lo más respetuosas y compatibles posible. Dado que en la actualidad la conservación de estos edificios depende, casi por completo, de los habitantes, es de especial interés hacerlos partícipe y conocedores de los valores y de las formas adecuadas de intervención. Para ello sería interesante realizar estudios parciales por zonas más acotadas en base a los datos recogidos, o con una ampliación de los mismos si fuera necesario. De esta forma, la población se sentiría más aludida o afectada por tratarse de ejemplos conocidos y el trabajo podría llegar de forma más directa y la difusión ser más efectiva. 



\subsection{VERSIÓ EN VALENCIÀ_CONCLUSIONS}

La recerca realitzada ha permès conèixer l'arquitectura tradicional de terra i el seu estat de conservació i intervenció en 258 nuclis de població distribuïts per tot Aragó. El desenvolupament del treball, a través de la metodologia mixta amb dues mostres diferents (la mostra primera de caràcter geogràfic amb 258 localitats i la mostra segona basada en 410 casos concrets analitzats a través de la fitxa d'estudi), ha permès conèixer de forma detallada l'arquitectura de terra de la comunitat i les seues principals característiques en relació amb la zona geogràfica. A més, amb ajuda de les fitxes d'estudi, s'ha realitzat un estudi de les intervencions presents en aquesta arquitectura i una valoració de les mateixes que ha estat el punt de partida de la proposta de les línies guia d’intervenció que pretenen ser una eina útil per a intervencions futures.

\section{L'ARQUITECTURA TRADICIONAL DE TERRA A ARAGÓ}

En primer Iloc, s'han estudiat de forma detallada totes les dades recollides durant les tasques de camp, les quals han mostrat la gran riquesa i la varietat d'aquesta arquitectura en gairebé la totalitat del territori aragonès. A més, aquestes dades han mostrat la relació de les tècniques i les variants constructives amb el lloc en el qual es troben, els materials locals i la cultura constructiva de les diferents zones.

La tàpia, per les seues característiques constructives, ha estat la tècnica amb major nombre de variants constructives i el seu ús és el més estès abastant, gairebé, la totalitat del territori, si bé, la seva presència és molt més recurrent en el sud.

Les principals variants de tàpia detectades i les seues principals àrees de desenvolupament són les següents:

La tàpia simple, malgrat ser la variant més senzilla no és la més comuna en el cas d’Aragó. Les subvariants més recurrents són la tàpia simple de terra i el tapialete (tàpia de terra, guix i maçoneria) aquesta última 
molt característica a la zona d'estudi per l'àmplia tradició constructiva amb guix existent. Aquestes variants es localitzen per tot el territori, encara que predominen en el nord de Terol i sud de Saragossa.

La tàpia suplementada en paraments és una variant molt freqüent en el territori que es presenta en forma de tàpia calicostrada, amb guix o amb calç, i tàpia carejada, amb rajola generalment però també amb pedra. La primera és més comuna en el sud-oest d'Aragó mentre que la segona és més freqüent en la zona centre.

La tàpia suplementada en juntes té dues subvariants principals: la tàpia amb conglomerant a les juntes i la tàpia amb brenques de guix o de guix i maçoneria, encara que també les hi ha de rajola. Aquestes variants tenen un predomini clar en la zona de Terol i sud-oest de Saragossa.

La tàpia mixta, és molt freqüent en tot el territori i presenta majoritàriament suplements verticals en forma de matxons i rafes, conformats generalment amb maçoneria i guix però, també, amb pedra i amb rajola.

La construcció amb tova també és molt freqüent en el territori, si bé, els exemples es localitzen en un àrea més fitada que correspon amb la part central d’Aragó.

Les variants més freqüents en aquest cas són:

La fàbrica de tova simple rebuda amb terra és la variant més senzilla en la qual la fàbrica es compon únicament de les peces de tova i el morter de terra. El principal aparell en aquest tipus de murs és d'apar Il al través i la presència d'aquesta variant s'estén per tot el territori on hi ha tova, si bé, es concentra especialment en la província de Saragossa.

La fàbrica de tova amb suplements en juntes apareix en un ampli nombre de casos i en ella s'utilitza morter, generalment de guix, per a aparellar el mur. Aquesta variant es situa principalment al Ilarg del Sistema Ibèric i en la província d'Osca.

La fàbrica mixta de tova és la variant més comuna en tot el territori i els suplements són majoritàriament verticals. Una subvariant és l'ús de la tova com a tancament amb aparell al llarg, solució molt recurrent en la zona nord de Terol.

Una altra variant, menys freqüent en el cas d'Aragó, és l'ús de les toves com a suplement. En aquesta comunitat s'han localitzat principalment com a suplement en les cantonades de fàbriques mixtes.

La construcció amb entramats és la tècnica menys freqüent de les tres estudiades. Aquesta tècnica 
es localitza a les zones nord i sud, existint un buit en la part central corresponent a la vall de l'Ebre. La variant més comuna és el farciment monolític en forma de tapialete, localitzat en la zona de Terol. El farciment amb peces de tova es situa principalment a la part oest, tant del nord com del sud de la comunitat, i el farciment amb teixits, normalment amb canyís, predomina en la part nord i est de Terol.

Cal destacar que el conjunt de variants definides respon a l'esquema dels possibles suplements existents en cada tècnica. No obstant açò, aquests suplements han aparegut freqüentment combinats entre ells en una mateixa construcció conformant variants més complexes. Per açò, cal destacar que el nombre de variants real és molt major a causa de les múltiples combinacions possibles entre tècniques, variants, suplements i materialitat dels mateixos.

Aquest estudi ha permès en primer lloc determinar les tècniques constructives com un sistema recurrent en gran part del territori i que, en el cas de la tàpia i la tova, a més, suposen les principals tècniques de construcció en molts dels municipis. L'anàlisi de les tècniques i variants ha permès conèixer la gran versatilitat d'aquestes tècniques que s'adapten a les necessitats i als recursos de cada zona concreta i que queda patent en la materialitat i la forma dels diferents suplements.

L'adaptació de les tècniques a l'entorn, que generalment té l'objectiu de garantir el confort interior i millorar la durabilitat de la construcció, s’ha estudiat a través de la comparació entre la localització de les diferents tècniques i una sèrie de plànols temàtics del territori en els quals es defineixen les seues característiques morfològiques, climàtiques, geològiques i socials. Alguns dels factors climàtics, com la temperatura mitjana, l'amplitud tèrmica (tant diària com anual) o l'assolellament són importants a l'hora del disseny, la disposició, la distribució dels edificis, així com en la configuració de l’espessor i la protecció dels murs.

De les tècniques presents en el territori, la tàpia és la que s'ha localitzat amb major freqüència en les construccions de les zones amb les temperatures més baixes, major nombre de dies de gelades i presència de neu, que correspon amb les àrees de major altitud del Sistema Ibèric. Aquest fet ha pogut ser afavorit, en part, pel gran espessor que solen posseir els murs d'aquestes construccions, el comportament de les quals és molt adequat per la inèrcia tèrmica del material que regula l'intercanvi de calor i fred amb l'exterior. Algunes variants com la tàpia amb suplements en les juntes i/o en els paraments, freqüents en aquesta mateixa zona, afavoreixen la protecció de la terra d'aquests fenòmens meteorològics adversos. Encara que la tàpia siga la tècnica de terra localitzada a les àrees d'Aragó amb les temperatures més baixes, la construcció amb terra, en general, té un bon funcionament en un rang molt ampli de temperatures. De la mateixa manera, en la zona central d’Aragó, que correspon amb la vall de l'Ebre i els Monegros i es caracteritza per tindre uns estius molt càlids (les temperatures dels 
quals superen els 40 ㄷ $\mathrm{C}$ reiteradament), moltes de les construccions són de tova i les seues propietats tèrmiques li permeten garantir una certa frescor a l'interior dels edificis.

El vent és un altre factor a tindre en compte en àmplies zones d’Aragó, tant per la seua freqüència com per la seua intensitat, especialment en la depressió de l'Ebre on, propiciat per la seua topografia, es genera una canalització de l'aire procedent de nord-oest entre els Pirineus i el Sistema Ibèric. Tradicionalment aquest fenomen no ha sigut determinant en l'elecció de materials a utilitzar en els edificis, però sí en la seua localització paisatgística i en la disposició de les obertures i elements de protecció com la crosta de les tàpies o els revestiments. D'altra banda, el règim pluviomètric és un dels factors que influeixen de forma directa en el desenvolupament de l'arquitectura de terra. Aragó no es caracteritza per les precipitacions abundants, si bé l'arquitectura de terra ha aparegut dispersa per tot el territori a excepció de les àrees on la pluviometria és major. Malgrat que la precipitació anual mitjana no és molt alta, les tempestes a l'estiu són freqüents i intenses, fet que, juntament amb l'alta presència d'edificis de terra, contribueix a que els ràfecs dels edificis hagen adquirit una presència considerable.

Els factors geogràfics defineixen les propietats del terreny i la disposició de materials que condicionen la presència d'unes determinades tècniques i variants en cada Iloc, ja que aquesta arquitectura ha cercat sempre l'optimització dels recursos evitant transports i esforços innecessaris. Dins dels factors geogràfics s’ha definit la importància de la litologia del sòl i de la disposició d'argila, ja que és el material encarregat de generar les unions entre les partícules que componen la terra. La presència d'un terreny majoritàriament argilenc en la comunitat ha afavorit el desenvolupament d'aquestes tècniques i principalment de la tova en la zona central de la comunitat, on es concentren aquestes construccions que generalment requereixen d'una proporció elevada d'argila en la mescla, superior a la de la tàpia, on un excés podria produir la seua esquerda deguda a la retracció. A nivell d'extracció de la terra, les valls dels rius han afavorit la presència d'argiles pels dipòsits produïts en les valls. Al seu torn, els llits dels rius han sigut sempre un entorn Iligat al desenvolupament de vida i per açò, ambdues propietats han provocat que, dels pobles que componen la mostra, la gran majoria situen en les proximitats d'aquests llits.

Els coneixements lligats a la relació de l'arquitectura i el seu entorn són part de la cultura constructiva del lloc i haurien de considerar-se tant en les intervencions d'edificis preexistents com en les noves construccions. Per açò, prèviament a una intervenció han d'estudiar-se l'arquitectura tradicional del Iloc, els seus condicionants externs i el seu comportament com a part del propi projecte de restauració o construcció.

D’altra banda, s'han estudiat els fenòmens de degradació i les lesions més freqüents (erosió, presència 
d’humitat, escantells, perduda material, cavitats, etc.), així com la seua afecció en les diferents parts dels murs (base, cos, superfície o coronació) del conjunt de les construccions estudiades. Les lesions han sigut causades en la majoria dels casos per l'acció dels agents atmosfèrics, especialment l'aigua, i pels agents antròpics tant per les accions dutes a terme com per la total absència de les mateixes. A més, les característiques concretes de les lesions estan relacionades amb la tècnica i la variant constructiva del mur on es produeixen i les propietats de l'entorn en el qual es troba, ja que poden accelerar els processos de degradació considerablement.

\section{INTERVENCIONS EXISTENTS I PROPOSTES SOBRE LA BASE DE LA CONSERVACIÓ}

L'anàlisi de les intervencions realitzades fins al moment sobre les construccions de terra en el territori ha estat el punt de partida per a conèixer les dinàmiques de transformació generals. En l'estudi d'aquestes intervencions s'ha analitzat, en primer lloc, el criteri o reflexió prèvia (intervenció espontània o intervenció planificada) i el tipus d'intervenció general (manteniment, reparació, rehabilitació parcial, rehabilitació integral, restauració, ampliació o demolició) i, a continuació, en cadascuna de les parts de l'edifici (sòcol, murs, revestiment, obertures i coberta), el tipus d'intervenció sobre aquestes (actualització, consolidació, reintegració, reconstrucció, demolició i substitució), el tipus de tècniques (similar o diferent) i les característiques dels materials emprats (industrials, tradicional similar o tradicional diferent).

Per a la realització d'aquest estudi s'han analitzat tots els casos d'estudi en conjunt però també de forma parcial en funció del tipus d’intervenció general (de reparació o manteniment, d'una banda, i la resta de les intervencions, per altra) i en funció de la tècnica constructiva (tàpia, tova o entramat) amb la finalitat de detectar les possibles intervencions o dinàmiques associades a aquests subgrups.

La reflexió prèvia o els criteris seguits en la major part de les intervencions han estat nuls, ja que aquestes s'han realitzat des de l'espontaneïtat. Aquesta absència de reflexió està vinculada en la major part dels casos a reparacions, però també a intervencions de major envergadura com a rehabilitacions. La realització d'intervencions de caràcter espontani per part del propietari o el constructor local és una característica lligada a la pròpia arquitectura tradicional. Aquesta espontaneïtat fins als anys 50 estava Iligada a l'ús dels materials tradicionals, que eren els disponibles en aqueix moment, i al coneixement de les tècniques constructives del lloc. No obstant això, actualment els materials més fàcilment accessibles són els industrials i, a més, s'ha perdut el saber fer i l'enteniment de la lògica constructiva tradicional, la qual cosa general una sèrie d'incompatibilitats i fins i tot eventuals lesions en l'obra original. D'altra banda, les intervencions planificades són molt menors en nombre i responen generalment a intervencions on, a causa de l'envergadura de l'obra, existeix un cert ordre en els treballs realitzats, encara que els materials i 
tècniques empleats solen ser similars als del cas anterior. Aquest tipus de criteri o reflexió prèvia apareix Iligada principalment a edificis residencials amb un ús continuat o temporal que han sigut rehabilitats.

Quant a les intervencions dutes a terme, les més comunes són les reparacions i les rehabilitacions, tant en l'anàlisi de conjunt com en cadascun dels grups establits. Aquestes intervencions presenten una relació directa amb l'objectiu final de la intervenció que generalment està lligat a la freqüència o el tipus d'ús, entre les quals destaquen dos grups: les reparacions i les rehabilitacions. Les reparacions estan lligades, generalment, a edificis sense ús actual o ús temporal sobre els quals els propietaris realitzen reparacions successives de forma espontània per a evitar la seua pèrdua o danys majors amb els mitjans i el cost econòmic mínims. Les rehabilitacions, generalment estan Iligades a edificis d'ús temporal o continuat que transformen l'edifici per a acollir nous usos o el mateix, però amb els requisits de confort i necessitats actuals, per a això es modifiquen gran part dels seus elements constructius (fusteries, cobertes, interiors, etc.).

Intervencions per zona. En el total de casos analitzats, les zones amb major nombre d'intervencions han estat el sòcol i la coberta, fet probablement derivat de la necessitat de manteniment que aquests requereixen per a garantir la durabilitat i la conservació de l'edifici, especialment en les construccions amb terra'. Si bé, cal destacar que en les intervencions de reparació predominen les intervencions en sòcols i murs, ja que són les zones més accessibles a l'hora de realitzar intervencions sense cap tipus de planejament. I, en les intervencions de major envergadura lligades a la rehabilitació, predominen les intervencions en obertures i en cobertes, amb l'objectiu principal millorar l'aïllament, assegurar la impermeabilitat i aconseguir els estàndards de confort actuals.

Les intervencions en el sòcol han consistit, en la seua majoria, en reconstruccions i reintegracions amb morter de ciment fins a una altura determinada amb la finalitat de protegir de la humitat i també actualitzar el seu aspecte, sobretot en els edificis rehabilitats. En general, s'han utilitzat materials i tècniques amb propietats diferents a les existents.

El tipus d'intervenció més freqüent en els murs ha estat la reintegració, basada en el farciment de cavitats o parts mancants del mateix. Aquest tipus d'intervenció predomina en tots els subgrups de casos (tipus d'intervenció general i tècniques) però està especialment associada a les intervencions generals de reparació i als murs de tàpia on que les seues característiques monolítiques afavoreixen aquest tipus de solucions, derivades de les característiques de les seues lesions. En general, les intervencions en els murs han estat les que han presentat major varietat de solucions, ja que depenen directament del nivell d'afecció de la secció i de la tècnica constructiva i la variant concretes. Per a la realització de les intervencions s'han utilitzat en la majoria dels casos materials de caràcter industrial i tècniques diferents a les existents.

1. Proverbi anglés: "Dona-li un bon barret $i$ unes bones botes es cuidarà sol" 
El tipus d'intervenció predominant en el cas dels revestiments ha estat la reconstrucció, ja que engloba tant els casos en els quals el revestiment existia amb anterioritat com els casos en els quals s'ha realitzat nou. Aquesta solució és més recurrent en les intervencions generals de rehabilitació que, en moltes ocasions, va associada a l'actualització de la imatge de l'edifici. Els nous revestiments, igual que es feia tradicionalment, s'han realitzat principalment amb els següents objectius: la protecció del mur, la cobertura d'una construcció que no va ser concebuda per a ser vista o no es considera adequada per a açò, o la renovació de la imatge de l'edifici.

Les obertures dels casos d'estudi han estat intervinguts principalment a través de la substitució de les fusteries antigues per altres noves adaptades a l'obertura existent o a través del canvi de dimensions dels buits i el conseqüent canvi de fusteries adaptades al mateix. Aquest tipus d'intervencions estan directament associades a les rehabilitacions que cerquen unes fusteries que garantisquen un tancament més hermètic i un millor aïllament. Tant en les intervencions d’ampliació i reintegració de buits com en les noves fusteries s'han utilitzat majoritàriament materials de caràcter industrial.

Els tipus d'intervencions dutes a terme en les cobertes han estat més heterogènies que en les altres zones. La intervenció més freqüent ha estat la reintegració que generalment respon a tasques de reparació parcial de la coberta, ja siga d'una zona o d'unes peces concretes. També ha estat freqüent la substitució completa de la coberta que respon, bé a rehabilitacions o a casos en els quals el seu mal estat ha portat a substituir-la amb materials industrials i de la forma més econòmica possible. Finalment, una altra de les intervencions freqüents ha estat la reconstrucció parcial, localitzada en àrees en mal estat, o integral, generalment degudes a la inserció de nous elements com a aïllants i impermeabilitzants.

Les intervencions de rehabilitació energètica en l'arquitectura tradicional de terra s'han produït en els casos de rehabilitació dels edificis ja que, d'una banda, ajuden a aconseguir els nivells de confort actuals i, d'altra banda, són necessàries, en ocasions, per a complir amb la normativa actual. La majoria dels casos de rehabilitació energètica han afectat a les obertures, si bé la coberta és un element que generalment s'ha rehabilitat energèticament si sobre la mateixa s'han realitzat treballs de reconstrucció importants. Aquestes zones, obertures i coberta, són en les quals generalment es produeixen majors pèrdues energètiques, pel que és un factor a tenir en compte, sobretot si l'edifici va a romandre en ús durant els mesos d'hivern.

Dinàmiques d'intervenció. L'ampli panorama d'intervencions analitzades adverteix sobre l'estat de transformació avançada en el qual es troba l'arquitectura tradicional de terra. Aquestes transformacions estan Iligades a la pròpia evolució de l'edifici i a la seua necessitat de readaptar-se per a seguir sent útil i funcional i no caure en l'abandó. L'estudi de les dinàmiques de transformació ha permès reconèixer els 
canvis recurrents i l'evolució d'aquesta arquitectura i, a partir d'aquests, s'han cercat possibles millores per a reconduir-les cap a una arquitectura compatible i sostenible amb les preexistències i amb el medi ambient.

En les transformacions de l'arquitectura tradicional d'Aragó s'han detectat tres dinàmiques predominants, les finalitats de les quals són estètiques, funcionals o de reparació. Aquestes dinàmiques poden aparèixer de forma aïllada, encara que és comú que es troben combinades entre elles. Les transformacions Iligades a l'estètica dels edificis solen afectar als elements de la façana com el sòcol o els revestiments i estan directament Iligades a les intervencions d'actualització. Les transformacions funcionals afecten principalment a l'interior dels edificis, si bé, en ocasions, aquestes poden ser perceptibles en la façana, especialment a través de les intervencions en les obertures. Finalment, les dinàmiques Iligades a reparacions varien en funció de les lesions sobre les quals s'actua, si bé existeix un criteri generalitzat que és cobrir o farcir amb ciment qualsevol tipus de desperfecte, escantell o cavitat.

Les diferents intervencions han estat analitzades a través de la fitxa d'estudi, la qual cosa ha permès advertir una gran varietat d'intervencions dutes a terme. Aquesta heterogeneïtat va Iligada directament a l'objectiu de la intervenció i a les característiques concretes de l'edifici i de les lesions i no als materials i tècniques utilitzats en les solucions, ja que aquests estan patint un procés important d'homogeneïtzació fruit de la industrialització i la globalització.

Les transformacions actuals, lligades a l'ús de materials i tècniques industrialitzats al costat de l'homogeneïtzació de solucions en tot el territori, han produït una adulteració de l'arquitectura tradicional i l'abandó de moltes tècniques lligades a la tradició local d’anys d'experiència. Malgrat aquesta globalització, i afavorit pel fet que la majoria de les intervencions són reparacions puntuals, la riquesa i varietat de l'arquitectura de terra en el territori aragonés segueix present i és perceptible en la majoria dels nuclis de població, la qual cosa hauria d'encoratjar als ajuntaments sobre la seua ràpida protecció per a no perdre-la en un futur pròxim.

Les dinàmiques de transformació actuals han derivat principalment de la falta de valoraciò d'aquesta arquitectura que durant dècades s'ha considerat pobra o de mala qualitat tant per la població com per constructors, tècnics i polítics. D’altra banda, l’absència d’una normativa específica que vetle per la seua protecció ha permès realitzar quasi qualsevol treball. La normativa de protecció, en el cas d’Aragó, està Iligada a edificis considerats patrimoni cultural i, perquè aquesta normativa els hi puga se aplicada, han d'estar declarats BIC, estar catalogats o estar inventariats. A més, la normativa, tant a nivell estatal com a autonòmic, té un caràcter molt genèric i de lliure interpretació en la majoria dels casos. El recent Pla Nacional d'Arquitectura Tradicional (2015) suposa una important posada en valor de tota l'arquitectura 
tradicional, però, així i tot, el document té un caràcter genèric que és convenient detallar en cada àrea específica. L'especificitat de les normes en àrees relativament xicotetes permet arribar a la població de forma més directa en la qual la població se sent al·ludida per formar part del grup d’actors responsables del procés de conservació dels seus pobles.

D’altra banda, en les normatives existeix una valoració general de tot allò "pintoresc", ja que es nomena en diferents documents el deure de valoració i/o protecció dels casos en els quals l'arquitectura tinga un valor cultural i represente les maneres de vida o una relació amb l'entorn. Si bé, per definició, tota arquitectura tradicional té aquestes característiques, els casos o conjunts protegits, generalment pel seu caràcter "pintoresc", han conservat part d'aquestes propietats mentre que altres localitats han patit canvis severs derivats d'intervencions, però també del creixement, que han provocat que les vagen perdent a poc a poc. També es dóna la situació en la qual, malgrat existir una norma local (Pla General d’Ordenació Urbana) en la qual s'especifica una certa protecció de l'àrea limitada normalment pel casc històric (colors a utilitzar, proporció de les finestres, característiques dels ràfecs, etc), el seu compliment no sempre es veu implementat.

A Aragó, l'únic àrea que gaudeix de certa protecció a nivell d'ordenació territorial i urbanisme és el Pirineu (Ilei 11/1992 d'Ordenació del Territori i Decret 291/2005 del Govern d'Aragó), on estan aprovades les Directrius Parcials d'Ordenació Territorial del Pirineu Aragonés, en les quals es posa en manifest el valor de paisatge, conjunt urbà i arquitectura tradicional com a part del patrimoni, per ser un factor fonamental de l'atractiu de la zona y del seu desenvolupament turístic. L'arquitectura tradicional d'aquesta zona és de pedra a l'exterior, material que tradicionalment ha gaudit de major prestigi que la terra i, a més, es troba en un àrea paisatgística molt privilegiada. Per açò és important mantenir-la, encara que, com queda plasmat en la llei, un dels principals objectius és la protecció estètica del territori per al seu desenvolupament turístic i no tant el valor de les construccions en si mateixes. Malgrat açò, és un exemple que hauria d'estendre's a altres àrees del territori.

Entre les construccions tradicionals protegides a Aragó es troben, generalment, construccions amb una tipologia concreta o amb un ús concret com poden ser els molins, les brodes o les salines. L'únic cas en el qual s'ha protegit un conjunt per la tècnica constructiva ha estat el conjunt d'arquitectures de pedra en sec de la Iglesuela del Cid, declarat conjunt etnogràfic. Una vegada més, en aquest cas, la posada en valor va lligada a l'ús de la pedra com a material de construcció.

El caràcter genèric de la normativa i la protecció i posada en valor aïllada de conjunts o construccions considerades com a patrimoni no ofereix al conjunt de l'arquitectura tradicional i dels nuclis històrics una protecció real. Per açò, l'existència de subvencions lligades a la conservació adequada dels edificis 
tradicionals podria ser un al-licient per a fomentar la restauració o rehabilitació dels mateixos. No obstant açò, les subvencions existents dirigides a la rehabilitació i la conservació no estan adaptades a les característiques dels edificis tradicionals i, en algunes de les convocatòries, es premia fins i tot la substitució completa d'alguns elements. L'actual manca d'enteniment de les característiques dels edificis tradicionals en aspectes materials, estructurals o tèrmics genera que propietats com la inèrcia tèrmica dels murs no es contemple en la normativa. Per això en aquestes subvencions es premia a intervencions que potser no són primordials i que poden generar un gran impacte en la construcció tradicional, ja que s'avaluen per igual blocs d'edificis de formigó i rajola dels anys 70 amb serioses deficiències energètiques, que una construcció de tàpia amb murs de $60 \mathrm{~cm}$ de grossor.

Fruit de les dinàmiques de transformació actuals s'han detectat una sèrie de lesions i que poden tindre el seu origen en l'abandó i la falta de manteniment de les construccions o en les intervencions dutes a terme. La falta de manteniment està lligada, entre altres factors, al descens de població i a la pèrdua dels usos tradicionals de molts dels edificis que han perdut la seua raó de ser. D’altra banda, les degradacions o lesions generades per intervencions són principalment dels següents tipus: estètiques, materials o estructurals. La degradació estètica dels edificis tradicionals i del seu entorn és una de les més freqüents i deriva de l'ús indiscriminat de materials industrials sense tenir en compte el seu aspecte o característiques. Les degradacions materials estan relacionades principalment amb l'ús generalitzat de materials industrials, especialment el ciment, la rigidesa del qual, contingut en sals i falta de transpiració genera una sèrie d'incompatibilitats amb l'edifici tradicional que deriven en lesions comunament perceptibles a simple vista. Les lesions estructurals estan també generades normalment per l'ús d'aquests materials i la falta d'enteniment del comportament estructural d'aquests edificis, la qual cosa genera comportaments diferencials entre els materials, a més de l'habitual falta de trava entre els mateixos.

Criteris i propostes d'intervenció. Les dinàmiques actuals, juntament amb la manca d'una normativa específica, han motivat la necessitat d'establir uns criteris intervenció adaptats a l'arquitectura tradicional de terra per a reconduir les intervencions cap a la conservació i el respecte de les preexistències. Aquests criteris han partit del valor de l'arquitectura (cultural, etnogràfic, arquitectònic, artístic, constructiu, paisatgístic, etc.) i de la seua capacitat per a albergar els usos actuals de forma adequada.

L'aplicació d'uns criteris adequats sol ser garantia d'una intervenció exitosa, ja que un coneixement profund de l'edifici sense uns criteris adequats pot generar intervencions igual de nocives que aquelles que es realitzen de forma espontània.

Els criteris establits s'han basat en els proposats en altres estudis anteriors i s'han agrupat en quatre 
blocs: la sostenibilitat, la compatibilitat, l'expressió i el respecte a les preexistències. Cadascun d'aquests quatre blocs inclou tres subobjectius; la sostenibilitat ambiental, econòmica i cultural oblidada en l'actualitat, està Iligada directament amb les propietats de l'arquitectura tradicional ; la compatibilitat material, constructiva i estructural implica que la intervenció passa a formar part de l'edifici, per la qual cosa aquesta ha de treballar solidàriament amb la preexistència per a ser el més duradora possible; l'expressió, traduïda en la llegibilitat, la integració i la conservació del caràcter significa que la intervenció ha d'estar en sintonia amb la construcció preexistent i no generar alteracions en la mateixa; finalment, el respecte a les preexistències, açò és, la conservació, la intervenció mínima i la reversibilitat, suposa que en tota intervenció s'ha de tindre en compte que el valor principal és l'element preexistent i, per tant, és important preservar-ho. L'objectiu d'aquests criteris ha estat, per tant, conservar les construccions tradicionals, el saber fer lligat als usos i a la cultura constructiu i els valors de conjunt, paisatgístic o d'antiguitat.

Les propostes d'intervenció realitzades són solucions concretes que han pretès mostrar l'aplicabilitat d'aquests criteris. Aquestes propostes s'han centrat en l'element constructiu de terra i, a partir d'elles, s'ha elaborat un inventari de solucions a aplicar en funció de les lesions existents, les característiques de la tècnica i l'objectiu de la intervenció. Per a això s'han establit tres grups d'intervencions: intervencions lligades a reparacions (aquells casos en els quals existeix una lesió en el mur ja siga per la seua erosió o derivat de problemes estructurals); intervencions Iligades a transformacions (relacionades amb la rehabilitació de l'edifici i les noves necessitats) i intervencions de prevenció i millora (que el seu objectiu és augmentar la durabilitat de l'edifici i l’adequada conservació del mateix).

En cadascun dels grups s'ha definit una sèrie d'intervencions concretes de les quals el seu objectiu és mostrar un ventall de possibilitats compatibles i sostenibles que servisquen de referència i que es puguen extrapolar a construccions de terra amb característiques diverses, fet pe al qual hauran de readaptar-se. En aquests casos no s'ha considerat important únicament la solució en si, que canviarà en cada cas, sinó els conceptes i els criteris que hi ha després d'elles i que són els que poden garantir l'èxit de les intervencions.

D’altra banda, l'incompliment d'alguns dels criteris establits no suposa que la intervenció siga inadequada. Intervenir en l'arquitectura tradicional, i concretament en l'arquitectura de terra, no és tasca fàcil, per la qual cosa en ocasions és necessari l'incompliment d'algun dels criteris per a garantir que uns altres es complisquen i que la intervenció treballe de forma compatible amb l'edifici i siga duradora. En el cas de l'arquitectura tradicional, criteris com la mínima intervenció o la reversibilitat són difícils de complir per a garantir el seu ús, no obstant açò, deuen ser mínims dins de les seues possibilitats. Per tant, la 
intervenció ha de pensar-se des del conjunt i fer un balanç entre els criteris i les diferents possibilitats amb la finalitat de trobar la millor solució.

Quant a la posada en valor de l'arquitectura tradicional de terra, a nivell autonòmic, en general, existeix una difusió escassa entorn als valors d'aquesta arquitectura i la importància de la seua conservació. En els centres d'estudis específics relatius a la construcció a Aragó (formació professional i universitaris) s'ha detectat una falta de matèries específiques en les quals s'ensenyen les característiques de les construccions tradicionals. La formació en oficis en els quals solament s'aprenen les tècniques constructives actuals suposa un problema important ja que, en la comunitat autònoma l'arquitectura tradicional, i concretament la de terra, conforma gran part del parc immobiliari. Per això, encara que una persona no vulga especialitzar-se en qüestions de patrimoni, és bàsic tenir unes nocions mínimes de les característiques d'aquestes construccions per a poder realitzar propostes adequades i dur-les a terme de forma correcta.

Finalment, un altre aspecte molt important és la difusió entre la població de la importància de l'arquitectura de terra i de l'ampli patrimoni construït que suposa concretament a Aragó. Els ciutadans i propietaris han de conèixer els valors de l'arquitectura de terra, tradicionalment associada a la pobresa, per a poder promoure la seua conservació ja que, davant la falta d'una normativa, són ells els que tenen I'última paraula i els que han de vetlar per la seua conservació i manteniment. A més, d'aquesta forma, la població és partícip de la revaloració de la seua pròpia cultura i dels processos que afecten al patrimoni de tots.

\section{CONSIDERACIONS FINALS}

L'arquitectura tradicional és el document material que mostra la forma de vida d'un lloc concret, el diàleg perfecte entre l'home i el paisatge. Aquesta arquitectura ha deixat d'existir com a element actiu, per la qual cosa els edificis existents en l'actualitat són els últims del seu tipus pel que la seua posada en valor i la seua conservació és de vital importància.

La difusió de les tècniques tradicionals de terra locals ha format part de la tradició oral que el seu saber fer passava de generació en generació (lloc d'extracció de terres, forma de piconat, estabilitzants usats, àrees i temps d'assecat de les toves, etc). No obstant açò, avui dia les noves generacions han crescut alienes a aquestes tècniques constructives i ja molt poca gent és coneixedora d'aquest saber fer que generalment estava lligat a les característiques locals de l'entorn i la disposició de material. 
L'arquitectura tradicional de terra està lligada íntimament al concepte de sostenibilitat que tant es cerca en les construccions d'avui dia, ja que naix de la terra i torna a ella sense contaminar. Per això, en les últimes dècades ha augmentat l'interès en aquestes construccions per part de tècnics, constructors i gent que cerca unes solucions més sostenibles per als seus habitatges. Malgrat això, molts edificis tradicionals segueixen derrocant-se en l'actualitat per a l'erecció d'altres nous que en ocasions presumeixen de tindre un comportament energètic millor i ser més sostenible i en els quals moltes vegades no es tenen en compte les característiques del lloc concret.

Al Ilarg dels anys, les intervencions han estat lligades a les reparacions amb els mitjans mínims o a les rehabilitacions sota el concepte de "rural", "rústic" o "pintoresc", en les quals s'han dut a terme intervencions desvinculades del lloc sobre la base d'una imatge que mai va existir i que poc tenen a veure amb la tradició local. Aquestes intervencions, malgrat realitzar-se en moltes ocasions sobre edificis de terra, solen revestir-se i incloure elements de pedra o rajola per a donar-li un acabat de "qualitat". Si bé, s'han detectat intervencions realitzades en els últims anys en les quals la pròpia tècnica de terra es posa en valor ressaltant la seua estètica i els seus elements i que, malgrat realitzar-se amb materials industrials, és un primer reconeixement de les mateixes com a característiques i pròpies del lloc.

Com s'ha estudiat, aquesta arquitectura necessita revisar i reconduir el tipus d'intervencions realitzades per a poder conservar-la, tant de forma aïllada com la relació que posseeix amb l'entorn. Les solucions proposades han cercat la simplicitat de conceptes perquè puguen ser compresos tant per especialistes com pels usuaris que realitzen intervencions de forma espontània. A més, és important que es comprenga la necessitat de conservació de les imperfeccions d'aquesta arquitectura lligades a l'espontaneïtat, on una brenca és més alta o més ampla que unes altres o les peces de tova d'un mateix mur tenen colors diferents, i que l'objectiu d'aquestes intervencions no és dotar d'un aspecte perfecte de l'edifici.

Aquestes propostes poden semblar utòpiques, però totes les persones que participen en les intervencions han d'entendre que es tracta d'una labor de manteniment, restauració o rehabilitació de construccions molt valuoses les propietats de les quals han permès l'adequada adaptació a quasi tots els entorns de la comunitat. A més, aquestes lliçons d'ús dels materials i d’adaptació al mitjà haurien de ser estudiadas i aplicades tant en aquestes intervencions com en la propostes d'arquitectura de nova planta. 


\subsection{ENGLISH VERSION_CONCLUSIONS}

The undertaken research has allowed for a better knowledge of traditional earthen architecture, its state of conservation and the interventions carried out in 258 towns and villages distributed throughout Aragon. This work has been developed using a mixed methodology supported on two different samples: the former has a geographic nature and includes the study of 258 settlements, and the latter analyses in detail 410 construction study cases with the aid of a specific worksheet. This method has led to detailed knowledge of earthen architecture in the region and allowed the identification of its main characteristics in connection with the geographical area. Moreover, the interventions on this architecture have been studied and assessed using datasheets, which has allowed for the proposal of intervention guidelines that intend to be a useful tool for future works.

\section{TRADITIONAL EARTHEN ARCHITECTURE IN ARAGON}

First, data gathered in field work has been studied, showing the remarkable wealth and variety of this architecture in most of the Aragonese territory. Furthermore, these data have shown the close connection between the different techniques and the place where they can be found, available materials and local constructive culture.

Due to its constructive features, rammed earth is the building technique with a highest number of variations. It is the most widespread construction system and covers most of the territory. However, its presence is far more frequent in the south of the region. Most common variations and the main areas where they can be found are described below.

In spite of being the most basic variation, simple rammed earth is not the most common technique in Aragon. The most frequent subtypes of simple rammed earth are earthen rammed earth and tapialete (a variety of rammed earth made from earth, gypsum and rubble). The latter is very representative of the studied region, which has ample tradition on the use of gypsum for construction purposes. These 
variations can be found through most of the territory but are particularly common in the north of Teruel and the south of Zaragoza.

Rammed earth with supplemented surfaces is very common in this territory, being found in different forms such as lime-crusted rammed earth (sometimes using gypsum instead of lime), rammed earth with brick facing or rammed earth with stone facing, the latter scarcer than the others. Lime-crusted rammed earth is more common in the southwestern region of Aragon, while the other techniques are more frequent in the centre of the territory.

Rammed earth with supplemented joints is divided in two main sub-variants: rammed earth with binder materials in its joints and rammed earth with brencas, that can be made of gypsum, gypsumand-rubble or ceramic bricks. These techniques are clearly predominant in the province of Teruel and the southwest of Zaragoza.

Mixed rammed earth is very frequent in the whole territory and usually presents vertical supplements like pillars and rafas. These supplements are generally built using gypsum and rubble but can also be found in stone or brick.

Adobe construction is very frequent in this territory as well. However, examples are located mainly in the central area of Aragon. The most frequent variations using adobe are:

Simple adobe masonry using mud as layering mortar is the simplest variation, using just earth in the composition blocks and mixtures. This walls usually show a header bond. This variation is extended throughout all the regions featuring adobe construction but is particularly common in the province of Zaragoza.

Adobe masonry with supplemented joints has been identified in a wide range of study cases that usually employ gypsum to bond the adobe blocks. This variation can be found wherever there is adobe, but mainly in the Iberian System and in the province of Huesca.

Mixed adobe masonry is the most frequent variation in the whole territory, having usually vertical supplements. An outstanding example of this variation is the use of adobe in stretcher bond for walling in buildings sustained by pillars. This solution is very common in the north of Teruel.

Another variation, less frequent in the case of Aragon, is the use of adobe as a supplement in other construction techniques. In this region, this practice has been identified mainly as supplements in the corners of mixed masonries. 
Half-timber is the least common of the three constructive groups included in this study. This technique can be found in the northern and southern areas in the territory, with a gap in the river valley of the Ebro. The most common variation of half-timber shows a monolithic infilling of tapialete and can be found in Teruel. Half-timber with adobe masonry infilling is mostly located in the northern and southern areas of Aragon and wattle-and-daub, usually made using reeds, has only been found in the northeast of Teruel.

It must be remarked that the variations defined in this work respond to the different supplements that can be found in each technique. However, sometimes more complex variations can be found from the combination of different supplements. Therefore, multiple combinations of techniques, varieties, supplements and materials give rise to an amount of variations far higher than represented in this research.

This study has made possible to recognise earth construction techniques as a recurring system in most of the territory. As a matter of fact, rammed earth and adobe have been identified as the main construction techniques in many of the settlements. The analysis of the techniques and variations has shown their versatility and their adaptability to the needs and resources present in each particular area, feature that is clearly stated by the different materials and shapes of the different supplements.

Adaptation of the techniques to their context, generally aiming to maximize the conditions of comfort and durability of the constructions, has been studied through the comparation of the location of the different techniques and a series of thematic cartographies of the territory, showing their morphologic, climatic, geologic and social features. Some of the climatic features, namely average temperature, temperature variation or solar irradiance, are important factors in the design and arrangement of the buildings and influence constructive aspects, such as the thickness and protection of the walls.

Among the techniques identified in the territory, rammed earth is the most common in colder regions, like the higher lands of the Iberian System, where frost and snow are more frequent. This may have been enhanced by the thickness of rammed earth walls and their high thermal inertia, that eases the heating of interior spaces. Some variations, like rammed earth with supplements in joints or surfaces, also common in this region, work out well for the protection of earthen walls from these climatic phenomena. Although rammed earth is the technique that most commonly appears in cooler regions, all earthen architecture tends to work well in a wide range of temperatures. The central area of Aragon, namely the Ebro Valley and the Monegros, is characterised by hot summers with temperatures raising above 40 으. In this region, the use of adobe constructions guarantees a certain level of coolness in the interior of dwellings even in the hotter days of summer. 
Wind is another important factor in vast regions of Aragon because of both its frequency and its intensity. This is particularly relevant in the Ebro valley, where topography channels north-western winds coming from the Pyrenees and the Iberian System. This phenomenon has not been decisive in the materials used in vernacular construction, but it has been highly relevant in their location and in the layout of hollows and coatings. Furthermore, rainfall climatology directly affects the development of earthen architecture. Aragon is not characterised by strong rainfall, but it is in its rainier areas where this architecture is scarcer. Despite annual average rainfall is not too high, summer storms are frequent and strong, propelling the widespread use of big eaves.

Geographic factors determine soil properties and material availability, which conditions the appearance of different techniques and variations in each region, as vernacular architecture is generally based on the optimization of local resources. Among the geographic factors, soil lithology and presence of clay outstand as the most important features, as they will determine the cohesive capacity of earth and its suitability for construction. The predominance of clay soils in the region has enhanced the development of these techniques, specially adobe, as it demands a higher amount of clay in the mixture. On the contrary, excessive clay content in rammed earth may increment its drying shrinkage and trigger cracking phenomena. River valleys are usually environments with strong human activity and present soils with important clay deposits. As a result, most of the settlements where earthen architecture has been identified are located in the surroundings of river beds.

Knowledge linked to the connection between architecture and its environment is an integral part of local constructive culture and must be considered both in interventions of existing buildings and in construction of new ones. Therefore, every intervention must be preceded by the study and comprehension of local traditional architecture, the external agents that affect it and its constructive behaviour.

Additionally, most common lesions and decay phenomena have been studied (for example: erosion, rising damp, degradation of coatings, material losses, etc.) and their influence in different parts of the walls (basis, body, surface or crowning) has been assessed for the whole study sample. Most of the lesions have been produced by atmospheric causes, primarily water, and by anthropic agents through harmful actions or neglection. Furthermore, specific characteristics of the lesions are linked to the particular technique and variation of the wall where they appear and to the features of the environment where it is located, as they can propel or hinder the decay processes. 


\section{EXISTING INTERVENTIONS AND PROPOSALS REGARDING PRESERVATION}

The analysis of interventions carried out so far on earthen constructions in the considered territory has been the starting point for the identification of general transformation trends. The study of these interventions has considered two factors. Firstly, the existence of a certain degree of planning (spontaneous or planned intervention) and the general kind of intervention (maintenance, repair, partial restoration, total restoration, preservation, extension or demolition). Secondly, each part of the building (plinth, walls, coating, hollows and roof) has been studied to determine the type of intervention (update, consolidation, reintegration, reconstruction, demolition and substitution), the type of techniques employed (similar or different to the originals) and the characteristics of the employed materials (industrial materials, similar traditional materials or different traditional materials).

To carry out this study, all the study cases have been analysed both as an ensemble and as separated groups depending on the general type of intervention (repair and maintenance in one group and the rest of interventions in another one) and on the constructive technique (rammed earth, adobe or halftimber). The latter partial analysis aimed to detect eventual interventions or dynamics linked to these subgroups.

Most of the intervened study cases lacked planning, as the works had been carried spontaneously. This lack of planning is mainly linked to repair tasks, but it is also obvious in some bigger restoration works. Interventions undertaken spontaneously by the owner or a local builder are inherent to traditional architecture. Until the 1950s, this spontaneity was connected to the use of traditional materials, as they were the most available ones, and to the local constructive culture. However, at present industrialised materials are the easiest to get and most of this traditional savoir-faire has been forgotten. As a consequence, many of these interventions result in material incompatibilities with the original fabrics. On the other hand, planned interventions are scarcer and appear in bigger works that require a certain degree of organisation in the tasks. Even though, materials and techniques employed are usually the same as in the spontaneous interventions. Planning mostly appears in restoration works carried out in residential buildings with permanent or seasonal use.

As the results of the study have shown, repair and rehabilitation works are the most common in the intervention of both the whole sample and each of the different subgroups. These tasks are directly linked to the final objective of the intervention which is usually linked to the frequency or the type of use. Among them, two groups stand out: repairs and restorations. Repairs are usually linked to buildings that have no use or are used only temporally and where owners make successive repairs in a spontaneous way to avoid their loss or major damage at a minimum economic cost. Restorations are usually linked 
to buildings with temporary or continuous use and consist on the transformation of the building to accommodate new uses or to adapt the original function to the current comfort requirements, for which many of its elements are modified (carpentry, roofs, interiors, etc.).

Interventions by area. In the whole sample, the areas with higher number of interventions have been the plinth and the roof, probably derived from the need of good maintenance that these require to ensure the durability and conservation of the building, especially in earthen constructions ${ }^{1}$. However, it should be noted that, among the repair interventions, the intervention in renderings and walls predominates, since these are the most accessible areas. In larger interventions, usually linked to restoration, openings and roofs are frequently transformed, aiming to improve the isolation, to guarantee waterproofing and to reach the current comfort standards.

The interventions in the plinth have usually been related to reconstructions and reintegration with cement mortar up to a certain height, in order to protect from rising damp and also to update its aspect, especially in renovated buildings. The materials and techniques used generally have different properties from the existing ones.

The most frequent intervention in walls has been reintegration based on the filling of cavities or missing parts thereof. This type of work predominates in all the analysed subgroups of cases (type of general intervention and techniques), but they are especially linked to the general repairs and to rammed earth walls whose monolithic characteristics favour this type of solutions. The interventions on the walls have generally been the ones that have presented a greater variety of solutions, because they depend directly on the level of affection of the section, the constructive technique and the specific variant. To carry out the interventions mainly industrial materials and techniques different of the existing ones have been used.

The prevailing type of intervention on renderings has been their reconstruction, since it covers both the cases in which the coating has been substituted and the cases in which it is has been built for the first time. This solution is recurrent in restorations and is frequently associated with the updating of the image of the building. New renderings have been carried out mainly with the following objectives: to protect the wall, to cover a construction that was not conceived to be seen, or to renovate the building's image.

The interventions on openings have mainly consisted on replacements of the old carpentry and the change of the dimensions of the gaps and the consequent installation of new carpentries. This type of interventions are directly associated with restorations that look for a carpentry that guarantees a

1. English proverb: "Give him a good hat and a good pair of boots and he will take care of himself" 
hermetic closure and better insulation. Both on the enlargement and reintegration of openings and on the new carpentry, the materials used have been mostly industrial.

Interventions carried out on roofs have been more heterogeneous than in other areas. The most frequent intervention has been reintegration, usually partial reparation of the roof, either of an area or of specific pieces. The replacement of the whole roof is also frequent, and it is usually linked to the restoration of the building or to cases where it was badly preserved, which has led to its replacement with cheap industrial materials. Finally, another common intervention has been partial or integral reconstruction, including the insertion of new elements such as insulation and waterproof.

Energy rehabilitation interventions in traditional earthen architecture have occurred in case of refurbishment since, on the one hand, they help to reach the contemporary comfort levels, and, on the other hand, they are necessary to comply with the current regulations. Most of the energy rehabilitation cases include actions on the openings (carpentry), but also the roof has generally been energetically restored if reconstruction works have been carried out on it. Openings and roofs are the parts where most energy losses concentrate so it is a factor to be considered, especially if the building is going to be used during the winter.

Intervention Dynamics. The wide range of interventions analysed warns about the advanced level of transformation in which traditional earthen architecture is nowadays. These transformations are linked to the very evolution of the building and its need to readapt to remain useful and functional not to fall into abandonment. The study of transformation dynamics has allowed to recognize recurring changes and evolution of this architecture. Based on this knowledge, improvements have been proposed to achieve a more compatible and sustainable architecture, both with the pre-existence and with the environment.

Among the transformations of traditional earthen architecture in Aragon, three predominant dynamics have been detected with aesthetic, functional or repair purposes. These types of dynamics can be found isolated, although it is common for them to appear combined. Transformations linked to the aesthetics of the buildings usually affect the elements of the facade as the plinth or the rendering, and are directly linked to updating interventions. Functional transformations mainly affect the interior of the buildings, although sometimes they can be affect the facade, especially in interventions on the openings. Finally, dynamics linked to repairs vary depending on the existing damage, although the generalized criterion is to cover or to fill with cement any type of damage, chipping or hollow.

The different interventions have been analysed by means of datasheets, which has allowed the detection 
of a wide variety of interventions. This heterogeneity is directly linked to the aim of the intervention and to the specific characteristics of the building and its lesions, but not to the materials and techniques used, since there is an important homogenization process going on due to industrialization and globalization.

Transformations linked to the use of industrialized materials and techniques, together with the homogenization of solutions throughout the territory have distorted traditional architecture and caused the abandonment of many local traditional techniques developed by years of experience. Despite globalization, the richness and variety of earthen architecture in the Aragonese territory remains present and is perceptible in most population centres. This fact should encourage city councils to protect this architecture to avoid its lost in the near future.

Current transformation dynamics mainly derive from the lack of valuation of this architecture that for decades has been considered of poor quality by both general population and constructors, technicians and politicians. On the other hand, the absence of specific regulations to ensure its protection has led to the authorisation of almost any kind of work. In the case of Aragon, protection regulations are linked to buildings considered part of the Cultural Heritage and, for this regulation to apply, the building must be declared BIC (building with special cultural interest) or be included in a catalogue on in an inventory. In addition, current regulations, both at state and regional levels, have a very generic character and allow free interpretation in most cases. The recent National Plan of Traditional Architecture (2015) is an important enhancement of the value of all traditional architecture but, still, the document has a generic character and a greater detail for each specific area would be convenient. The specificity of the regulations in relatively small areas makes it possible to reach the population in a more direct way. This way, the general population feels included as part of the group of actors responsible for the process of conservation of their own villages.

On the other hand, regulations include a general valuation of what's "picturesque", since different documents refer to the duty of valuation and/or protection of the cases in which architecture has a cultural value and represents the ways of life or a relation with the environment. By definition, all traditional architecture has these characteristics, but the protected cases or sets (generally protected because of their "picturesqueness") have preserved part of these properties while other sites have undergone severe changes derived from interventions, but also from their growth, which have caused their loss little by little. Sometimes, despite the existence of a local standard (General Urban Development Plan), which usually includes a protection area normally limited to the historic centre (colours to be used, proportion of the openings, characteristics of the eave, etc), their fulfilment is not always implemented.

In Aragon, the only area that has some urban planning protection is the Pyrenees (law 11/1992 of 
Territory Planning and Decree 291/2005 of the Government of Aragon). There, the Partial Guidelines of Territorial Planning of the Aragonese Pyrenees Norms have been approved and include the valuation of landscape, urban complex and traditional architecture as part of its heritage, as it is a fundamental factor of the attractiveness of the zone and its touristic development. Traditional architecture in the area is built with stone for the exterior walls, material traditionally better considered than earth, and, in addition, it is located in a very privileged landscape area. Therefore, it is important to preserve it, although, as it is reflected in the law, one of the main objectives is the aesthetic protection of the territory for its touristic development and not because of the value of the constructions themselves. Despite this, it is an example that should be extended to other areas of the territory.

Traditional architecture protected in Aragon generally includes constructions with a specific typology or use such as mills, barns or the salt pans. The only case in which a group has been protected because of its constructive technique has been the set of dry-stone architectures in Iglesuela del Cid, declared ethnographic heritage. Once again, in this case, the value is linked to the use of stone as a building material.

The generic nature of the regulations and the isolated protection and enhancement of settlements or constructions considered heritage do not offer a real protection for traditional architecture and historical centres. Therefore, the existence of subventions linked to the proper conservation of traditional buildings could be an incentive to encourage their restoration or rehabilitation. However, existing subventions aimed at restoration and conservation are not adapted to the characteristics of traditional buildings and, in some of the calls, even the complete substitution of some elements is rewarded. The current lack of understanding of the characteristics of traditional buildings regarding material, structural or thermal aspects generates that properties such as thermal inertia of the walls are not considered on the regulations. For this reason, these subventions reward interventions that may not be essential and that can generate a great impact on the traditional construction, since the evaluation of the proposals is similar for housing blocks built with concrete and brick wall on the 70's that usually have serious energetic deficiencies, and for a $60 \mathrm{~cm}$ rammed earth wall.

As a result of the current transformation dynamics, some damages have been detected that may have been originated by the abandonment and lack of maintenance of the constructions or by the interventions carried out. Among other factors, lack of maintenance is linked to population decline and to the loss of traditional activities and uses of many of the buildings. On the other hand, the degradations or damages caused by interventions usually follow one of these types: aesthetic, material or structural. Aesthetic degradation of traditional buildings and their surroundings is one of the most frequent. It usually 
derives from the indiscriminate use of industrial materials without taking into account their aspect or characteristics. Material degradations are mainly related to the widespread use of industrial materials, especially cement, whose rigidity, salt content and minimal transpiration generate incompatibilities with the traditional construction that causes damages perceptible with the naked eye. Structural damages are also normally generated by the use of these materials and the misunderstanding of the structural behaviour of these buildings, which generates differential behaviours between the materials. In addition, those materials are usually not properly linked between them.

Criteria and intervention proposals. The current dynamics, together with the lack of specific regulations, have motivated the need to establish some intervention criteria adapted to traditional earthen architecture to redirect interventions towards conservation and respect for those constructions. These criteria have started from the value of this architecture (cultural, ethnographic, architectural, artistic, constructive, scenic, etc.) and its capacity to accommodate current uses in an appropriate way.

The implementation of appropriate criteria is usually a guarantee of a successful intervention. A thorough knowledge of the building without adequate criteria can generate interventions as harmful as those that are performed spontaneously.

The established criteria have been based on those proposed in previous studies and have been grouped into four blocks: sustainability, compatibility, expression and respect for pre-existences. Each of these four blocks includes three sub-targets. Environmental, economic and cultural sustainability, currently forgotten, is directly linked to the properties of traditional architecture. Material, constructive and structural compatibility implies that the intervention becomes part of the building, so it must work jointly with the pre-existence to be as durable as possible. Expression is reflected into the legibility, integration and conservation of the character, which means that the intervention must be in harmony with the pre-existing construction and not generate alterations in it. Finally, respect for pre-existence is linked to conservation, minimal intervention and reversibility, and it assumes that all intervention should consider that the main value is the pre-existing element and therefore it is important to preserve it. The objective of these criteria has been, therefore, to preserve traditional constructions, the know-how linked to the uses and constructive culture, and the ensemble, landscape or antiquity values.

The intervention proposals are particular solutions that have tried to show the applicability of these criteria. These proposals have focused on the constructive earth elements and, from them, an inventory of solutions has been developed to be applied according to the existing damages, the characteristics of the technique and the objective of the intervention. Three groups of interventions have been established for this purpose: repair-related interventions (those cases where there is damage on the wall either 
by erosion or from structural problems); interventions linked to transformations (related to building restoration and new needs); prevention and improvement interventions (which aim to increase the durability of the building and its proper conservation).

On each of the groups, a series of specific interventions has been defined, aimed at showing a range of compatible and sustainable possibilities that can be used as reference and which can be extrapolated to earth constructions with different characteristics, for which the solution must be readjusted. It is not just important the solution itself, that will change in each case, but the concepts and the criteria behind them that are the ones that can guarantee the success of the interventions.

On the other hand, failure to comply with some of the established criteria does not imply that the intervention is inadequate. To act on traditional architecture, and specifically on earthen architecture, is not an easy task, so sometimes it is necessary the fail to keep some of the criteria to ensure that others are fulfilled and that the intervention works in a compatible way with the building and is durable. For traditional architecture, criteria such as minimal intervention or reversibility are difficult to fulfil in order to guarantee their use; however, they should be looked after within the possibilities. Therefore, the intervention should be thought from the whole and take a balance between the criteria and the different possibilities in order to find the best solution.

Regarding enhancement of traditional earthen architecture, at the regional level there is generally little dissemination about the values of this architecture and the importance of its conservation. In specific study centres related to construction in Aragon (professional and university training), there is a lack of specific subjects in which the characteristics of traditional constructions are taught. The crafts training in which only current constructive techniques are taught is a major problem because, in this region, traditional architecture, and specifically earthen architecture, constitutes a large part of the real estate park. Therefore, although a person does not want to specialize in heritage matters, it is important to have a basic knowledge of the characteristics of these constructions to be able to make suitable proposals and to carry them out in a correct way.

To conclude, a significant aspect is the dissemination among the population of the importance of earthen architecture and of the ample built heritage that it implies, concretely in Aragon. Citizens and owners must know the values of earthen architecture, usually linked with poverty, in order to promote its conservation, because, in absence of a proper regulation, they are the ones who ultimately decide and the ones who must watch over their conservation and maintenance. In this way, people participate in the revaluation of their own culture and in the processes that affect everybody's heritage. 


\section{FINAL CONSIDERATIONS}

Traditional architecture is a material document that shows the way of life of a particular place, the perfect dialogue between man and landscape. This architecture does not longer exist as an active element, so currently existing buildings are the last ones and therefore their value and conservation are very important.

The dissemination of local traditional earthen techniques has been part of the oral tradition, a knowhow passed from one generation to the next (place of earth extraction, the way of tamping, stabilizers used, areas and time for drying of the adobes, etc). However, nowadays the new generations have grown oblivious to these constructive techniques and very few people are aware of this know-how that was generally linked to the local characteristics of the environment and the material disposition.

Traditional earthen architecture is closely linked to the concept of sustainability that is sought in today's constructions, since it is born from the earth and returns to it without polluting. For this reason, over the last decades the interest in these constructions has increased from technicians, builders and people who are looking for more sustainable solutions for their homes. In spite of this, many traditional buildings are demolished every day to allow the erection of new ones that sometimes claim to have better energy behaviour and to be more sustainable without taking into account the characteristics of the particular place.

Over the years, interventions have been linked to repairs with minimal means or restorations under the concept of "rural" and "rustic", delinked from the site and based on an image that never existed and that has little to do with local tradition. Despite being carried out on earthen buildings, these interventions are usually covered and they include materials such a stone or brick to give an appearance of "quality". Even though, there are some recent interventions where the earthen technique itself is valued, highlighting its aesthetics and its particular elements and, despite being made with industrial materials, this constitutes a first recognition of them as characteristic of the place.

As it has been studied, this architecture needs to revise and redirect the type of interventions made in order to preserve it, both as isolated element and as part of the cultural landscape. The solutions proposed have looked for the simplicity of concepts so that they can be understood by both specialists and users who carry out interventions in a spontaneous way. Furthermore, it is important to understand that buildings must not be perfect and value the need to preserve the imperfections of this architecture linked to spontaneity, where elements as joints are not regular or adobe pieces can have different colours in the same wall. 
These proposals may seem utopian, but people involved in those interventions must understand that this is a work of maintenance, restoration or rehabilitation in very valuable constructions whose properties have allowed the proper adaptation to almost every environment in the region. In addition, the lessons of the materials use and adaptation to the environment should be restudied and applied both in these interventions and in the contemporary architecture proposals. 
15. BIBLIOGRAFÍA 


\section{BIBLIOGRAFÍA}

AA.VV. 1981. Las arquitecturas de tierra o el porvenir de una tradición milenaria. [exposición] Paris: CNAC Centre Georges Pompidou, $\mathrm{CCl}$.

AA.VV. 2007. "Arquitectura en Tierra" en Apuntes, núm. 20, vol. 2. Bogotá: Pontificia Universidad Javeriana.

AA.VV. 2008. Terra Incognita: Discovering \& Preserving European Earthen Archtiecture. Lisboa: Argumentum Ediçóes. | Tervuren: Culture Lab Éditions.

AA.VV. 2010. Restaurer son bâti en terre. Parc natural régional des marais du Cotentin et du Bessin.

AA VV. 2011. Terra Europae. Earthen Architecture in the European Union. M. Correia, L. Dipasquale \& S. Mecca (eds.). Pisa. Edizioni ETS. | Tervuren: Culture Lab Éditions.

AA VV. 2014 a. La restauración de la tapia en la Península Ibérica. Criterios, técnicas, resultados y perspectivas. C. Mileto \& F. Vegas (eds.). Lisboa: Argumentum Ediçóes | Valencia: TC Cuadernos.

AA.VV. 2014 b. Versus. Heritage for tomorrow. Vernacular knowledge for sustainable architecture. M. Correia, L. Dipasquale y S. Mecca (eds.). Florencia: Firenze University Press.

AA.VV. 2014 c. Versus. Lessons from vernacular heritage to sustainable architecture. CRAterre/ ESG/ UNICA/ UNIFI/ UPV

AA.VV. 2014 d. Antalogías. Reutilización del patrimonio edificado en adobe. L.F. Guerrero Baca (ed.). México D.F.: Universidad Autónoma Metropolitana.

AA.VV. 2015. Plan Nacional de Arquitectura Tradicional. Ministerio de Educación, Cultura y Deporte.

AA.VV. 2017. Criterios de intervención en la arquitectura de tierra. Proyecto Coremans. Madrid: Ministerio de Economía Cultura y Deporte. 
Abad Alegría, F. 1997. Construcciones de barro en Aragón. Huesca: La Val de Onsera.

Achenza, M. y Giovagnorio, I. 2014. “Environmental sustainability in vernacular architecture.”, en Versus, heritage for tomorrow, pp.41-47. Firenze: Firenze University Press

Agencia Estatal de Meteorología, AEmeT 2011. "Atlas Climático Ibérico". Ministerio de Medio Ambiente y Medio Rural y Marino.

Almagro Gorbea, A. 2005. Albarracín: EL proceso de restauración de su patrimonio histórico. Albarracín: Fundación Santa María de Albarracín.

Alonso Ponga, J.L. y Cid, S. 1994. La arquitectura del barro. Valladolid: Junta de Castilla y León, Consejería de Cultura y Turismo.

Allanegui Burriel, G. J. 1979. Arquitectura popular de Aragón. Zaragoza: Librería General.

Allánegui Félez, A. 1965. "La vivienda popular aragonesa”

Anger, R. y Fontaina, L. 2005. Grains de Bâtisseurs: La matière en grains, de la géologie à l'architecture. Villefontaine: CRAterre Edition

Arciniega García, L. 2006. "Prejuicios historiográficos sobre la técnica del tapial de tierra en la España de Edad Moderna" en Houses and Cities built with earth: conservation, significance and urban quality. Lisboa: Argumentum.

Carlos, G.D. et al. 2014. "Research method and operative approach" en Versus- Heritage for tomorrow, pp 23-31. Firenze: Firenze University Press

Benito Moliner, M. 1995. Cuestionario básico para investigación etnográfica en Aragón. Estudios Altoaragoneses (Diputación de Huesca).Huesca: La Val de Onsera.

Balaguer Garzón, L.; García-Soriano, L. y Villacampa Crespo. 2018. "Supplemented rammed earth in the northwestern regions of Valencia" en Vernacular and earthen architecture. Conservation and Sustainability, pp. 47 - 52. C. Mileto, F. Vegas, L. García-Soriano y V. Cristini (Eds.). Londres: Taylor and Francis Group.

Bardou, P. 1979. Arquitecturas de Adobe. Barcelona: Gustavo Gil 
Barré, L. A. 1899. "Carpintería de Armar", en Pequeña enciclopedia práctica de construcción, traducido y anotado por L. Gaztelu. Madrid: Librería Editorial de Bailly-Bailliere e Hijos.

Beckett, C. y Ciancio, D. 2012. "A review of the contribution of thermal mass to thermal comfort in rammed earth structures" En actas de 2nd International Conference on Sustainable Built Environment, ICSBE. Kandy (Sri Lanka).

Brusq, S. y Paccoud, G. 2006. La restauration du bâti en pisé en Dauphiné. Memoire du Diplôme de Spécialisation et d'Approfondissemente- Architecture de Terre. (DSA). Grenoble: École Nationale Superieure d'Architecture de Grenoble.

Burillo Mozota, F. 1985. "Inroducción a los orígenes de la arquitectura de tierra en Aragón" en Turia, núm. 1, pp. 112-117. Teruel: Instituto de Estudios Turolenses

Buzo, A. 2014. Bâtir en terre en Estrémadure. Memoire du Diplôme de Spécialisation et d'Approfondissemente- Architecture de Terre. Mention Patrimoine (DSA). Grenoble: École Nationale Superieure d'Architecture de Grenoble.

Canivell, J., Rodríguez García, R., González Serrano, A.M. y Romero Girón, A. 2014. “Vernacular rammed earth builng typologies in the ancient reign of Seville, Spain" en Vernacular heritage and earthen architecture, CIAV 2013, pp. 117-122 London: Balkema

Carbonara, G. 1997. Avvicinamento al restauro. Napoles: Liguori

Castellarnau Visús, A. 2012. "Construcción de una vivienda con muros de tapial en Ayerbe, Huesca. Fase 1: Estructura y cerramientos", en Construcción con tierra. Pasado, presente y Futuro. Actas del IX Congraso de arquitectura de tierra en Cuenca de Campos, pp. 259-268. Valladolid: Universidad de Valladolid.

Castellarnau Visús, A. y Rivas, F.A. 2013. "Las dos caras de una misma técnica constructiva. Registro y trasmisión de la construcción en tapia", en Construcción con tierra: Patrimonio y vivienda. Actas de X CIATTI 2013 congreso de arquitectura de tierra en Cuenca de Campos, pp:97-108. Valladolid: Universidad de Valladolid.

Castilla Pascual, F. J. y Núñez Martí, P. 2005. "Estudio para la recuperación de la técnica del tapial en la construcción tradicional de la provincia de Albacete" en Actas del cuarto congreso nacional de historia de la construcción: Cádiz, 27-29 de enero de 2005 (1st ed.). Instituto Juan de Herrera. pp. 259-276. 
Cazorla, C. 2015. Arquitectura de tierra. Construcciones tradicionales en la huerta norte de Valencia. Trabajo Fin de Máster. Valencia: Universitat Politècnica de València.

Childs, K.W.; Courville, G.E. y Bates, E.L. .1983. Thermal mass assessment. Oak Ridge (Tennessee): Oak Ridge National Laboratory.

Cornerstones Community. 2006. Adobe conservation. A preservation handbook. Santa Fe, Nuevo México: Sunstone Press.

Correia, M. 2007. Tapia no Alentejo: Rammed earth in Alentejo. Lisboa: Argumentum Ediçóes

Correia, M. y Carlos, G.D. 2015. "Cultura sísmica local em Portugal." Lisboa: Argumentum.

Cristini, V. 2012. Muros intra muros: el ladrillo en las fábricas del centro histórico de Valencia. Análisis cronotipológico y propuesta de conservación. Tesis Doctoral. Valencia: Universitat Politècnica de València.

De Cárdenas y Chávarri, J.; Maldonado Ramos, L.; Barbero Barrera, M.M. y Gil Crespo, I.J.. 2008. "Sostenibilidad y mecanismos bioclimáticos de la arquitectura vernácula española: el caso de las construcciones subterráneas". en actas de la 14 Convención científica de ingeniería y arquitectura. La Habana: Cujae.

De Oteiza, I. 2002. "Inrroducción a la construcción con tierra” en Arquitectura y construcción con tierra: Tradición e innovación. pp. 99-116. L. Maldonado Ramos, D. Rivera Gámez y F. Vela Cossío (eds.). Madrid: Mairea

Del Río Muñoz, M. y Jové, F. 2015. "From refined to popular architecture. Mixed rammed earth walls with adobe reinforcements" in Earthen architecture: past, present and future, pp. 115-120. C. Mileto, F. Vegas, L. García-Soriano y V. Cristini (eds.) London: Taylor and Francis Group

Dincyurek, O, Mallick, F.H.y Numan, I. 2003. "Cultural and environmental values in arcaded Mesaorian houses of Cyprus", en Building and Environment, núm. 38, pp. 1463-1473, Amsterdam: Elsevier.

Dipasquale, L. Sidik D.O. y Mecca, S. 2014. "Earthquake resistant structures." In Versus- Heritage for tomorrow, 232-243. Firenze: Firenze University Press

Doat, P., Hays, A., Houben, H., Matuk, S. y Vitoux, F. 1979. Construir en terre. CRATerre. Paris: Éditions Alternative et parallèles. 
Essenwanger, O. M. y Landsberg, H.E. 2001. "General Climatology 1C: Classification of Climates". Amsterdam; London: Elsevier science.

Facey, W. 1997. Back to Earth: Adobe building in Saudi Arabia. Londres: Al- Turath con the London Centre of Arab Studies.

Fatás Fernández, L. y Catalán Gazarrán, S. 2005. “La construcción con tierra en la protohistoria del Bajo Aragón: el caso de San Cristóbal de Mazaleón" en Salduie, núm. 5, pp.131-141. Zaragoza: Universidad de Zaragoza.

Fernandes, M. 2005. "Mouled Adobe", en Earthen Architecture in Portugal. M.Fernandes y M. Correia (eds), pp. 45-49. Lisboa: Argumentum.

Fernandes, M. y Tavares, A. 2016. O Adobe. Lisboa: Argumentum Ediçóes.

Fernandes, M. y Conceição Lopes, M. 2011 "L'adobe au Portugal" en Les culturas constructives de la brique crue. pp. 205-212. C.A. de Chazelles, A. Klein \& N. Pousthomis (eds.), Montpellier: Éditions de l’Espérou

Fernández Palicio. A. 2016. "Impossible, comme construire en terre en Galice" Memoire du Diplôme de Spécialisation et d’Approfondissemente- Architecture de Terre. (DSA). Grenoble: École Nationale Superieure d'Architecture de Grenoble.

Figols González, M. 2006. Arquitectura de tierra en Valdejalón. Zaragoza: Institución Fernando el Católico.

Font Arellano, J. 2005. "Earth construction in Spain and Portugal" en Earthen Architecture in Portugal. pp. 119-123. M.Fernandes \& M. Correia (eds.) Lisboa: Argumentum.

Font Arellano, J. 2007. "La tapia dans les textes hispaniques", en Les constructions en terre massive, pisé et bauge, pp. 53 - 69. H. Guillaud, C. A. de Chazelles y A. Klein (eds.). Montpellier: Éditions de l'Esperou.

Font Arellano, J. et al. 2011. "La présence de l'adobe en Espagne", en Les cultures constructives de la brique crue, p. 205 - 212. C. A. de Chazelles, A. Klein y N. Pousthomis (coord.). Montpellier: Éditions de l’Esperou.

Font Arellano, J.; Vegas, F. y Mileto, C. 2017. "Técnicas y puesta en obra en España", en Proyecto Coremans. Criterios de intervención en la arquitectura de tierra. Madrid: Ministerio de Educación, Cultura y Deporte. 
Font Mezquita, F. y Hidalgo, P. 2009. Arquitecturas de tapia. Castellón: Colegio Oficial de Aparejadores y Arquitectos Técnicos de Castellón.

Font Mezquita, F. y Hidalgo, P. 2011. "La tapia en España. Técnicas actuales y ejemplos", en Informes de la Construcción, vol. 63, núm. 523, pp. 21 - 34. Madrid: Instituto Eduardo Torroja de la Construcción y del Cemento.

Fontenay, M. 1858. Manual de Construcciones Rústicas. Madrid: Calleja, López y Rivadeneyra Editores.

Galarza Tortajada, M. 1996. "La tapia valenciana: una técnica constructiva poco conocida" en actas del Primer Congreso Nacional de Historia de la Construcción, pp. 211-215. Madrid: Instituto Juan de Herrera, CEHOPU.

Garcés Romeo, J.; Gavín Moya, J. y Satué Olivan, E. 1988. “Arquitectura popular de Serrablo” en Colección de estudios Altoaragoneses, num. 26. Huesca: Instituto de estudios Altoaragoneses.

García-Soriano, L. 2015. La restauración de la arquitectura de tapia de 1980 a la actualidad a través de los fondos del Ministerio de Cultura y del Ministerio de Fomento del Gobierno de España. Criterios, técnicas y resultados. Tesis doctoral. Valencia: Universitat Politècnica de València.

García-Soriano, L.; Villacampa, L. y Gómez-Patrocinio, F. J. 2018. "Earthen elements in the Iberian Peninsula: Cataloging and preliminary study", en Venacular and Earthen Architecture. Conservation and sustainability, pp. 119 - 122. C. Mileto, F. Vegas, L. García-Soriano y V. Cristini (eds.). Londres: Taylor and Francis Group.

Ger y Lóbez, F. 1898. Tratado de construcción civil. Badajoz: La Minerva Extremeña.

Gil Crespo, I.J. 2014. "Geographical cataloguing of earthen architecture in Soria, Spain" en. Vernacular heritage and earthen architecture, CIAV 2013. pp. 123-128. London: Balkema

González, M.J. y García Navarro, J. 2006. "Assessment of the decrease of $\mathrm{CO} 2$ emissions in the construction field through the selection of materials.", en Building and Environment, núm.41, pp.902909. Amsterdam: Elsevier.

Gómez Patrocinio, F.J. 2017. Arquitectura tradicional de tierra en España: Estudio, caracterización constructiva y mecanismos de degradación. Trabajo Final de Máster. Valencia: Universitat Politècnica de València. 
Guillaud, H. 2017. "Conservar la arquitectura de tierra, condición de futuro de una modernidad recreada" en Proyecto Coremans: Criterios de intervención en la arquitectura de tierra, pp. 15-21. Madrid: Ministerio de Educación, Cultura y Deporte.

Houben, H. y Guillaud, H. 1985. Manuel de construction en terre. Belguique: CRAterre-EAG

Houben, H. \& Guillaud, H. 1989, 1995. Traité de construction en terre. CRAterre-EAG. Marseille: Parenthèses.

Houben, H. y Guillaud, H. 1994. Earth construction: A comprehensive guide. Londres: Intermediate Technology.

Hoz Onrubia, J.; Maldonado Ramos, L. y Vela Cossío, F. 2003. Diccionario de la construcción tradicional: tierra. Hondarribia:Nerea

Harrison, R. 1999. Earth. The conservation and repair of Bowhill, Exeter: Working with cob. London: James \& James.

Instituto Geográfico de Aragón 2018. Atlas de Aragón, Gobierno de Aragón

Jaquin, P. y Augarde, C. 2012. Earth building: History, science and conservation. U.K: C.E. BRE Press

Jaquin, P., Gerrard, C., Augarde, C. y Canivell, J. 2013 "Damage in historic rammed earth structures: a case study in Ambel, Zaragoza, Spain", en Revista digital de arqueología, arquitectura e artes., núm 1, pp. 32-41. Coimbra: Impactum, Coimbra University Press.

Jorquera Silva, N. y Cisternas Olguín, R. 2017. "El tabique-adobillo, una técnica sismorresistente de Valparaíso" en actas de Terra Lyon 2016, pp. 47-51. Villefontaine: Éditions CRAterre

Kottek, M., Grieser, J.; Beck, C., Rudolf, B. y Rubel, F. 2006. "World Mapo f Köppen-Geiger climate clasification updated", en Meteorologische Zeitschrift, vol. 15, núm. 3, pp. 259-263. Stuttgart: Gebrüder Borntraeger

La Spina, V. 2014. Vestigios de yeso. Los revestimientos constinuos históricos en las fachadas de la valencia intramuros: estudio histórico, caracterización y propuesta de conservación. Tesis doctoral. Valencia: Universitat Politècnica de València. 
La Spina, V. 2016. Estudio del Yeso Tradicional en España: Yacimientos, canteras, hornos y la arquitectura tradicional, su estado de conservación y propuestas de itinerarios visitables para su revalorización y difusión. Fase I y II. Madrid: Ministerio de Cultura y Deporte

La Spina, V. 2018 "Earth and gypsum: From the theory to practice in Spanish vernacular architecture" en Vernacular and earthen architecture. Conservation and Sustainability, pp. 153 - 158. C. Mileto, F. Vegas, L. García-Soriano y V. Cristini (Eds.). Londres: Taylor and Francis Group.

Le Tiec, J.M. y Paccoud, G. 2006. Pisé H2O: De l'eau et des grains pour un renouveau du pisé en RhôneAlpes. Villefontaine: CRAterre editions.

López Casado C. y Peláez Montilla, J.A. 2002. "Peligrosidad sísmica en la Península Ibérica." En Revista Española de Física, núm.4, vol.16, pp. 29-32

López Gómez, J.M. 2006. "La arquitectura de la vivienda tradicional en La Ribagorza" en Colección territorio, Comarca de la Ribagorza. pp. 231-236. Zaragoza: Diputación General de Aragón. Departamento de Presidencia y Relaciones Institucionales.

López Martínez, F. J. 1999. “Tapias y tapiales”, en Loggia Arquitectura \& Restauración, núm. 8, pp. 74 89. Valencia: Servicio de Publicaciones de la Universitat Politècnica de València.

Mairal Buil, G. 2003. "La comarca como paisaje cultural” en Las comarcas de Aragón: territorio y futuro. Colección territorio, núm.5, pp. 157-167, J. Infante Díaz (ed), Zaragoza: Diputación General de Aragón.

Maldonado Ramos, L., Castilla Pascual, F. y Vela Cossío, F. 2001. "Rendimiento y coste energético en la construcción de cerramientos de fábrica de adobe y bloque de tierra comprimida.", en Informes de la construcción, vol. 53, núm. 473, pp. 27-37. Madrid: Instituto Eduardo Torroja de la Construcción y del Cemento.

Marcos y Bausá, R. 1879. Manual del Albañil. Madrid: Dirección y Administración.

Correia, M.; Merten, J.; Vegas, F.; Mileto, C. y Cristini, V. 2011. "Earthen architecure in Southwastern Europe: Portugal, Spain and Southern France." en Terra Europae. pp. 71-75. Pisa: Edizioni ETS

Martín Peinado, B. 2017. "Conservación y consolidación" en Criterios de intervención en la arquitectura de tierra. Proyecto Coremans. Madrid: Ministerio de Economía Cultura y Deporte.

Maxwell, G. 2000. Lords of the Atlas. Morocco:The Rise and Fall of the House of Glaoua. (text written 1996). London: Cassel \& Co. 
Mileto, C.; García-Soriano, L. y Vegas, F. 2014. "Los fenómenos de degradación más comunes en fábricas de tapia", en La restauración de la tapia en la Península Ibérica. Criterios, técnicas, resultados y perspectivas, pp. 52-59. C. Mileto y F. Vegas (eds.). Lisboa: Argumentum Ediçóes. Valencia: TC Cuadernos.

Mileto, Cy Vegas.F. 2016. "Estudio de buenas prácticas en las intervenciones de la arquitectura tradicional española”. IPC- Plan Nacional de Arquitectura Tradicional. Ministerio de Educación, Cultura y Deporte.

Mileto, C., Vegas, F., García-Soriano, L. y Cristini, V. 2011-2012. "La restauración de la arquitectura de tapia en la Península Ibérica. Metodología de catalogación y análisis de casos" en Arché, núms. 6 y 7, pp. 309-314. Valencia: Universitat Politècnica de València.

Mileto, C., Vegas, F., Cristini, V. y García-Soriano, L. 2012. "Restoration of rammed earth architecure in the Iberian Peninsula: Ongoing research" en Rammed Earth Conservation, pp. 381-386. C. Mileto, F. Vegas, y V. Cristini (eds.). Londres: Taylor and Francis Group.

Mileto, C., Vegas, F., García-Soriano, L., Villacampa Crespo, L. y Gómez Patrocinio, F.J. 2017 a. “Primera aproximación a la variedad constructiva de la arquitectura vernácula de tierra en la Península Ibérica", en actas del X Congreso Nacional y II Congreso Internacional Hispanoamericano de Historia de la Construcción, pp. 1051-1061, Madrid: Instituto Juan de Herrera.

Mileto, C.; Vegas, F.; Vendrell, M. y García-Soriano, L. 2017 b. “Mecanismos de degradación: fenómenos y causas", en Proyecto Coremans: Criterios de intervención en la arquitectura de tierra, pp. 78-88. Madrid: Ministerio de Educación, Cultura y Deporte.

Minke, G. 1994 (2001). Manual de construcción en tierra: la tierra como material de construcción y sus aplicaciones como material actual. Montevideo: Fin de Siglo

Minke, G. 2006. Building with Earth: Design and Technology of a Sustainable Architecture. Basel-BerlinBasel-Berlin-Boston: Birkhäuser

Moriset, S. y Misse, A. 2011. Construire et renover en pisé dans le Parc naturel regional Livradois-Forez. Parc natural regional Livradois-Forez.

Muñoz Monaserio, M. 1931. "Arquitectura popular altoaragonesa” en Revista Arquitectura, núm. 152, pp. 397-405, Madrid.

MVCS. 2014. Fichas para la reparación de viviendas de adobe. Lima: Ministerio de Vivienda, Construcción y Saneamiento de la República del Perú 
Naval Mas, A. 1990. Restauración y Mantenimiento de las casas de Labranza del Somontano en el Alto Aragón. Zaragoza: Diputación General de Aragón.

Noriega, G.F. y Vauzelle, D. 2014. Jeux d’adobes: une pédagogie autor de la brique de terre crue. Memoire du Diplôme de Spécialisation et d'Approfondissemente- Architecture de Terre. Mention Patrimoine (DSA). Grenoble: École Nationale Superieure d’Architecture de Grenoble.

Office of Archeology ans Historic Preservation/ Heritage Conservation and Recreation Service. 1978. "Preservation of Historic Adobe Buildings" in Preservation briefs, num 5. Washington: Technical Preservation Services Division, Department of the Interior.

Parra-Saldivar, M.S. y Batty, W. 2006. "Thermal behaviour of adobe constructions." En Building and Environment, núm. 41, pp. 1982-1904. Amsterdam: Elsevier.

Pasquet, L. 1986. La restauration des constructions en pans de bois: Remplissage terre. Paris: Agence Nationale pour l'Amélioration de l'Habitat.

Peiró Labarta, E.A. 2010. Repensar la arquitectura tradicional para el habitar actual. Estudio de caso: Zaragoza, Cuarto espacio. Tesis Doctoral. Zaragoza: Universidad de Zaragoza

Pignal, B. 2005. "Terre Crue. Techniques de construction et restauration”. Paris: Eyrolles

Rábanos Faci, C. y Gavín Moya, J. 1991-1992. "La arquitectura doméstica en las comarcas del somontano oscense. La casa rural”, en Artigrama, núms. 8-9, pp. 475-525, Zaragoza: Universidad de Zaragoza.

Rivas González, F.A. 2011. "Arquitectura popular y paisaje cultural”, Delimitación Comarcal de Zargoza, Colección territorio núm 36, pp. 275-286. Zaragoza: Departamento de Política Territorial, Justicia e Interior.

Rivas, F.A. 2012. "Introduction to traditional rammed-earth building in the Aragonian Valley of Jiloca (Spain)", en Rammed Earth Conservation, pp.193-198. C. Mileto, F. Vegas y V. Cristini (eds.). London: Taylor and Francis Group.

Rivas, F.A. 2013. "Arquitectura popular en Aragón, hoy", en Crisis. Revista de crítica cultural, núm. 2, pp. 76-77. Zaragoza: Erial Ediciones

Rocha, M. y Jové, F. 2015. Técnicas de construcción con tierra. Introducción. Lisboa: Argumentum Ediçóes. 
San Nicolás, Fray L. 1796. Arte y uso de arquitectura. Madrid: Imprenta de D. Plácido Barco López.

Sanz Zaragoza, J.M. y Sopensés, J. 2009. "Talleres de empleo y rehabilitación del patrimonio: el caso de las murallas de Daroca", en Kausis núm. 6, pp. 87-94.

Sanz Zaragoza, J.M. 2014. "Aragón", en La restauración de la tapia en la Península Ibérica. Criterios, técnicas, resultados y perspectivas, pp.90-97. C. Mileto y F. Vegas (eds.). Lisboa: Argumentum Ediçóes | Valencia: TC Cuadernos.

Sevillano Gutiérrez, E y Camarasaltas Pérez, E. 2018. "Campiña Segoviana's earthen heritage and conservation dlues from Isère" en Vernacular and earthen architecture. Conservation and Sustainability, pp. 335-341. C. Mileto, F. Vegas, L. García-Soriano y V. Cristini (Eds.). Londres: Taylor and Francis Group.

Souto Silva, M. 2004. Palomares en el sur de Aragón. Las tierras del Jiloca. Calamocha: Centro de estudios del Jiloca

Stulz, R.; Mukerji, K. y Klein, M. 1997. Materiaux de construction appropriés. Un catalogue de solutions potentielles. Saint Gallen: SKAT Publications.

Taberner Pastor, F. 2004. La evolución de los criterios del patrimonio arquitectónico: Del monumento histórico artístico al valor cultural. Valencia: Universitat Politècnica de València.

Vegas, F. y Mileto, C. 2007. Renovar conservando: manual para la restauración de la arquitectura rural del Rincón de Ademuz. Mancomunidad de Municipios del Rincón de Ademuz.

Vegas, F. y Mileto, C. 2014. Aprendiendo a restaurar. Un manual de restauración de la arquitectura tradicional de la Comunidad Valenciana. Valencia: Generalitat Valenciana.

Vegas, F., Mileto, C. y Cristini, V. 2009. "Reinforcement of rammed earth constructions with gypsum in Aragon area, Spain", en Mediterra, 1St Mediterranean Conference on Earth Architecture, Gagliari. pp. 99-108. Cagliari: Udime

Vegas, F.; Mileto, C.; Cristini, V. y García-Soriano, L. 2014 a. "La tapia en la Península Ibérica”, en La restauración de la tapia en la Península Ibérica. Criterios, técnicas, resultados y perspectivas, pp. 32 - 51. C. Mileto y F. Vegas (eds.). Lisboa: Argumentum Ediçóes. Valencia: TC Cuadernos.

Vegas, F.; Mileto, C.; Guimaraens, G. y Navalón, V. 2014 b. “Defining sustainable architecture." In Versus, heritage for tomorrow, 35-39. Firenze: Firenze University Press 
Vegas, F., Milecto, C. y López Osorio, J.M. 2017. "La consolidación estructural y el completamiento" en Criterios de intervención en la arquitectura de tierra. Proyecto Coremans. Madrid: Ministerio de Economía Cultura y Deporte.

Vick, C. B. 1988. "Adobe Construction" en Encyclopedia of architecture: design, engineering and construction. Nueva York: John Wiley \& Sons.

Villacampa Crespo, L.; Mileto, C.; Vegas, F. y García-Soriano, L. 2016. “El adobe en la arquitectura tradicional del Aragón (España). Metodología de estudio", en Actas del 16 Seminario Iberoamericano de Arquitectura y Construcción con Tierra (SIACOT). Asunción: Facultad de Arquitectura, Diseño y Arte/ Red Proterra.

Villacampa Crespo, L.; Sanz, J. M. y García-Soriano, L. 2018. "Traditional earthen architecture in Aragon, Spain", en Vernacular and earthen architecture. Conservation and Sustainability, pp. $243-248$. C. Mileto, F. Vegas, L. García-Soriano y V. Cristini (Eds.). Londres: Taylor and Francis Group.

Villacampa Crespo, L. 2015. Dinámicas de transformación y técnicas de intervención en la arquitectura tradicional de Montalbán y Peñarroyas. Trabajo fin de máster. Valencia: Universitat Politècnica de València.

Viñuales, G.M. 1981 "Restauración de arquitecturas de Tierra", Tucumán: Universidad Nacional de Tucumán. (Buenos aires: reedición digital abril 2009)

Yuste Miguel, B. 2010. Arquitectura de tierra. Caracterización de los tipos edificatorios. Trabajo fin de máster. Barcelona. Universitat Politècnica de Catalunya.

Warren, J. 1999. Conservation of earth structures. Oxford: Butterworth Heinemann.

Wilson, Q., Hibee-Barzola, K., Stickney, B. y Friedman, G. 2016. "When thermal mass becomes resistance”, en LEHM 2016. Tagungsbeitrage der 7 Internationalen Fachtagung fur Lahmbau. Weimar (Alemania). Dachverband Lehm

\section{Documentos web / Sitios web}

Asomo, Acebo, Larraz, J. M. y Roc, Chema. Santa Cruz de Moncayo. La Cultura del Barro: (http://etno. patrimoniocultural.aragon.es/culturabarro/anexo1.htm)

Bel, P. 2016. Viviendas de adobes. Secretos de su elaboración: https://www.youtube.com/ watch?v=4buOvmGdGSo 
Rivas, F.A. 2002. Las adobas, los ladrillos y las tejas, en Ana Maorad y Félix A. Rivas. Técnicas tradicionales de construcción de Aragón. Monegros: 21-56. En línea: (http://etno.patrimoniocultural.aragon.es/ tecnicas/adobaindice.htm)

Centro de estudios del Jiloca 2011. Elaboración de adobes. Burbáguena. (http://www.xiloca.org/ filmoteca/?p=8935)

Plenas. 2012. Plenas, 28 abr. 2012. "El tapial en Plenas, 1a parte" http://plenaszaragoza.blogspot. com/2012/04/el-tapial-en-plenas-1-parte.html

Plenas. 2013 a. Plenas, 19 de junio de 2013. “El tapial en Plenas (2) La tapia valenciana” https://www. documentalesetnograficos.eshttp://plenas-zaragoza.blogspot.com/2013/06/el-tapial-en-plenas-2-latapia.html

Plenas. 2013 b. Plenas, 20 de junio de 2013. "El tapial en Plenas (3). Tapial ordinario y tapial mejorado" http://plenas-zaragoza.blogspot.com/2013/06/el-tapial-en-plenas-3-tapial-sencillo.html

Plenas. 2013 c. Plenas, 23 de junio de 2013. “El tapial en Plenas (4) Tapial reforzado con brencas" http:// plenas-zaragoza.blogspot.com/2013/06/el-tapial-en-plenas-4-tapial-reforzado_23.html

Atlas de Aragón: http://idearagon.aragon.es/atlas/\#

Instituto Geográfico de Aragón: http://www.aragon.es/igear

Parimonio etnográfico de Aragón: http://etno.patrimoniocultural.aragon.es

Sistema de información del Patrimonio Cultural Aragonés: http://www.sipca.es/

Centro de estudios borjanos: http://cesbor.blogspot.com/

Portal del centro de estudios del Jiloca: http://www.xiloca.org

\section{Legislación/ Normas}

Decreto 69/1997, de 27 mayo, del Gobierno de Aragón

Decreto 1/2006, de 27 de diciembre, del Gobierno de Aragón, Ley de Comarcalización de Aragón

Dirección General de Arquitectura, Vivienda y Suelo. 2015. "DA DB-HE / 1 Cálculo de parámetros característicos de la envolvente."en Código Técnico de la Edificación. Ministerio de Fomento. 


\section{Ley 16/1985 del Patrimonio Histórico Español}

Ley 12/1997 de 3 de diciembre, de Parques Culturales de Aragón

Ley 3/1999, de 10 de marzo, del Patrimonio Cultural Aragonés

Ley 6/2003, de 27 de febrero, de Turismo de Aragón

Ley 20/2005, de 11 de noviembre, de vías pecuarias de Aragón

Ley 3/2009, de 17 junio, de Urbanismo de Aragón 


\section{BLOQUE V}

\section{ANEXOS}

16. Base de datos. Fichas de catalogación de casos 
La restauración y la rehabilitación de la arquitectura tradicional de tierra. El caso de Aragón 
La restauración y la rehabilitación de la arquitectura tradicional de tierra. El caso de Aragón 


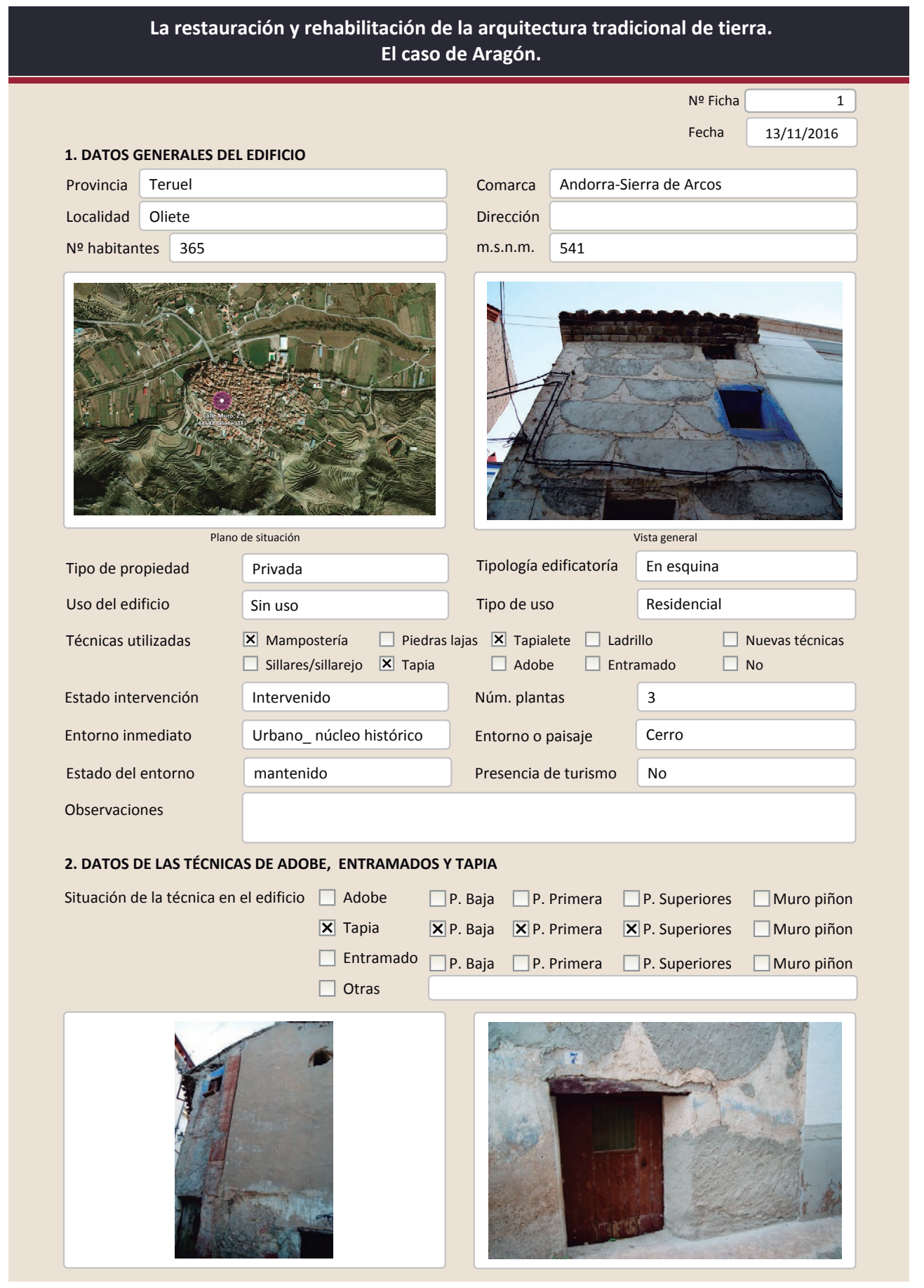

La restauración y rehabilitación de la arquitectura tradicional de tierra.

El caso de Aragón.

2.2. TAPIA

Ancho del muro

Dimensión tapiales

Tipo de aguja

№ agujas/cajón

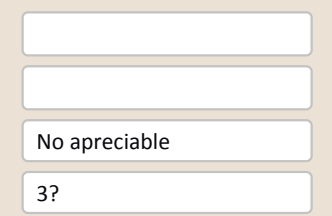

Color de la tapia

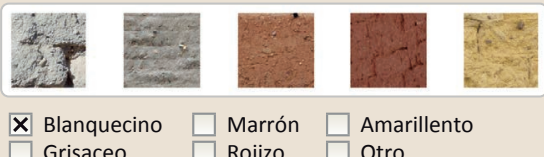

$\mathbf{X}$ Blanquecino
$\square$ Grisaceo Marrón $\square$ Amarillento

Variante constructiva

$\square$ Simple / homogénea

$\square$ suplemento superficial

$\boldsymbol{X}$ Suplemento en juntas

X Mixta
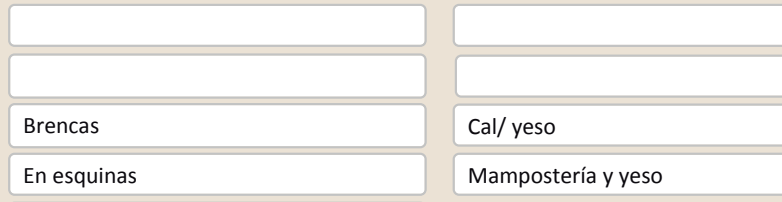

$\square$ Elementos de protección

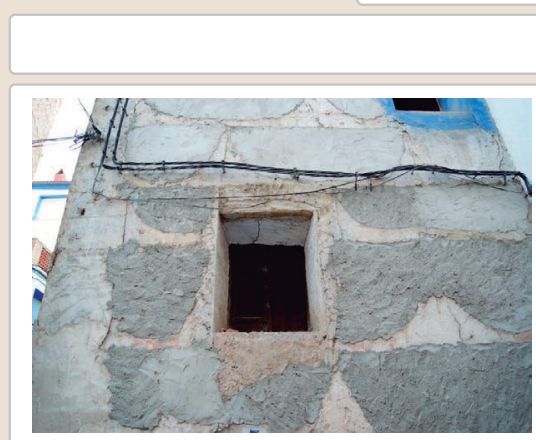

Lesiones $\quad \square$ Muro $\square$ Zócalo $\square$ Revestimiento $\square$ Erosión del material $\quad \square$ Humedad por capilaridad $\square$ Erosion de las juntas $\square$ Humedades (manch/eflo) $\square$ Pérdida de sección $\quad \square$ Pérdida de verticalidad

$\square$ Vegetación

X Desconchados

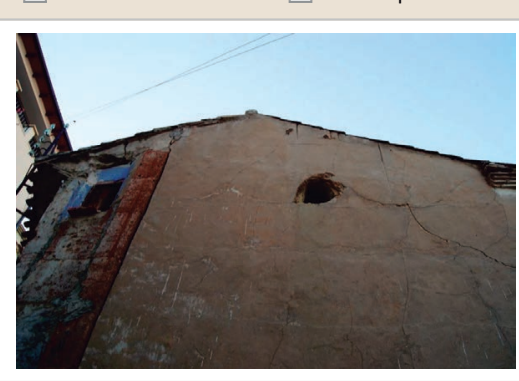

Observaciones
Desconchados y perdida de la costra de la tapia. Esta intervenido

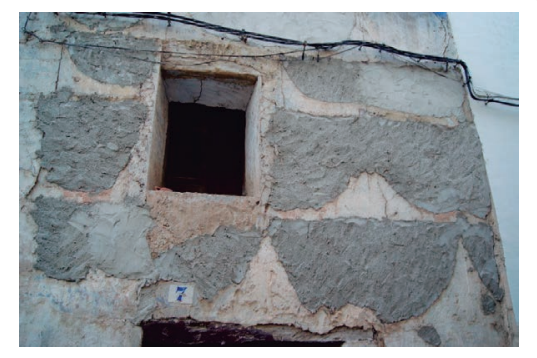

$\square$ Cubierta $\square$ otro...

$\square$ Grietas por asentamientos $\square$ Colapso

$\square$ Por elementos impropios

$\square$ Derivado de intervenciones $\square$ otro...

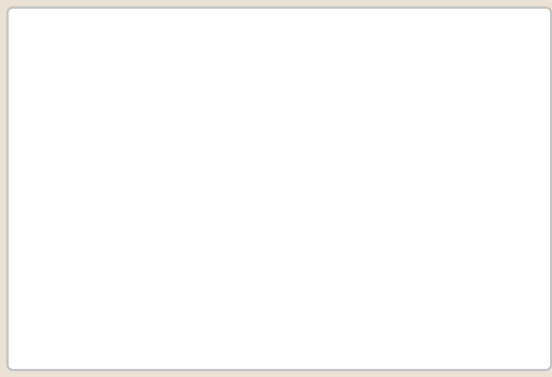




\section{La restauración y rehabilitación de la arquitectura tradicional de tierra.}

\section{El caso de Aragón.}

3. DATOS DE LA INTERVENCIÓN

X Mantenimiento $\square$ Rehabilitación parcial

$\square$ Restauración $\square$ Demolición

Reflexión previa Intervención espontanea

Observaciones Se han tapado las oquedades existentes.

3.1. MUROS

Tipo de intervención

Tipo de material

Descripción

3.2. ZÓCALO

Tipo de intervención

Tipo de material

Descripción

3.3. REVESTIMIENTOS

Tipo de intervención

Tipo de material

Descripción

3.4. VANOS

Tipo de intervención

Tipo de material

Descripción

3.5. CUBIERTA

Tipo de intervención

Tipo de material

Descripción

3.6. OTRAS

Intervenido

$\square$ Actualización $\square$ Reintegración $\square$ Demolición $\square$ Otro...

$\square$ Consolidación $\square$ Reconstrucción $\quad$ X Sustitución

No tradicional Tipo de técnica Diferente a la existente

Nuevo zócalo de cemento en parte del edificio

No aplica

$\square$ Actualización $\square$ Reintegración $\square$ Demolición $\square$ Otro...

$\square$ Consolidación $\square$ Reconstrucción $\square$ sustitución

Tipo de técnica

\section{No intervenido}

$\square$ Actualización $\quad \square$ Reintegración $\quad \square$ Demolición $\square$ Otro...

$\square$ Consolidación $\square$ Reconstrucción $\square$ Sustitución

$$
\text { Tipo de técnica }
$$

No visible

$\square$ Actualización $\square$ Reintegración $\square$ Demolición $\square$ Otro.

$\square$ Consolidación $\square$ Reconstrucción $\square$ Sustitución Tipo de técnica

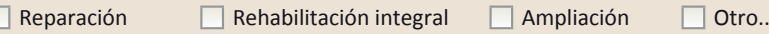

La restauración y rehabilitación de la arquitectura tradicional de tierra.

El caso de Aragón.

3.7. REHABILITACIÓN ENERGÉTICA $\quad \square$ Fachada $\square$ Vanos $\square$ Forjados $\square$ Cubierta

Observaciones

FOTOGRAFÍAS DE LA INTERVENCIÓN

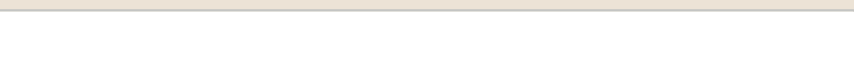
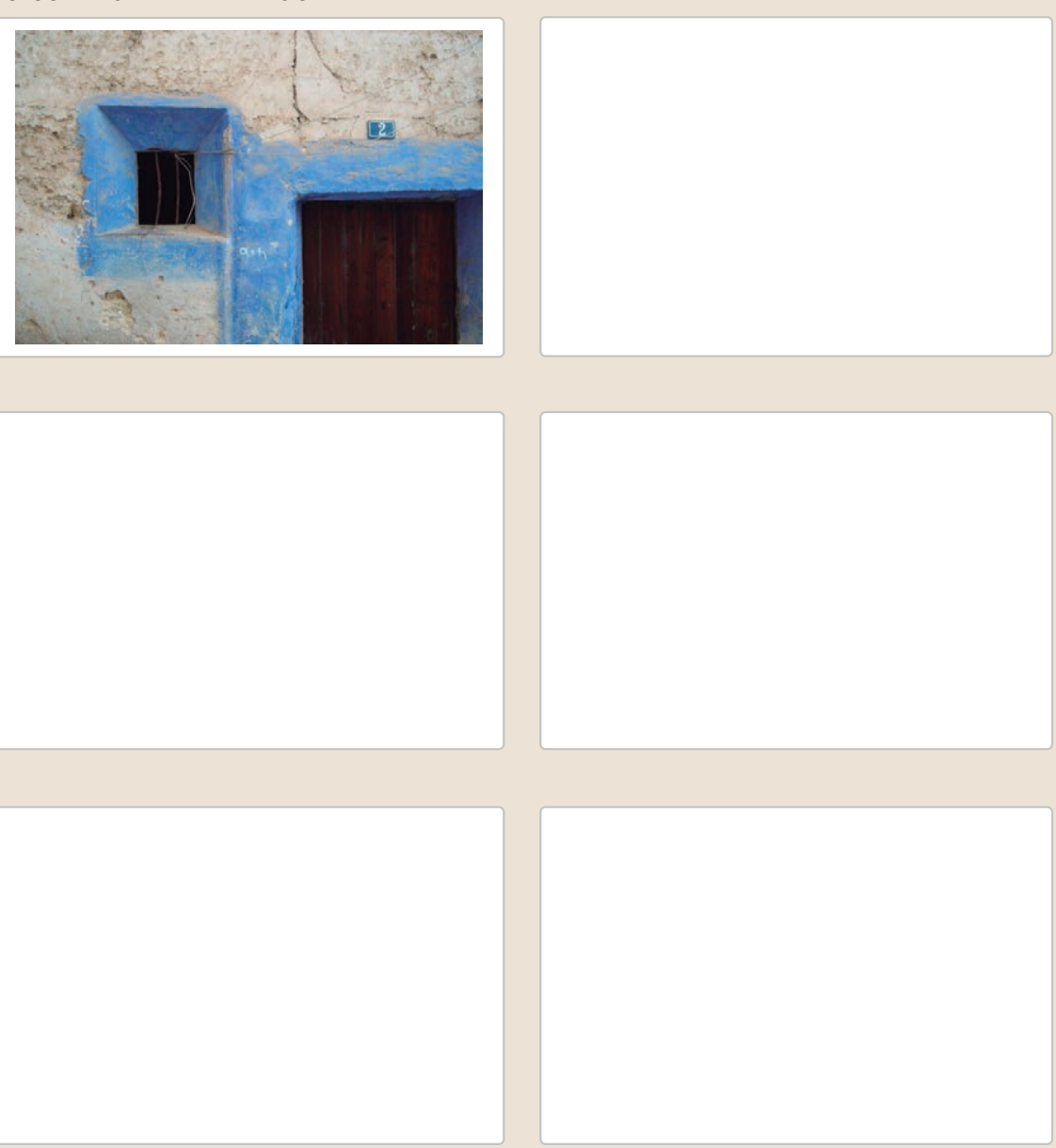


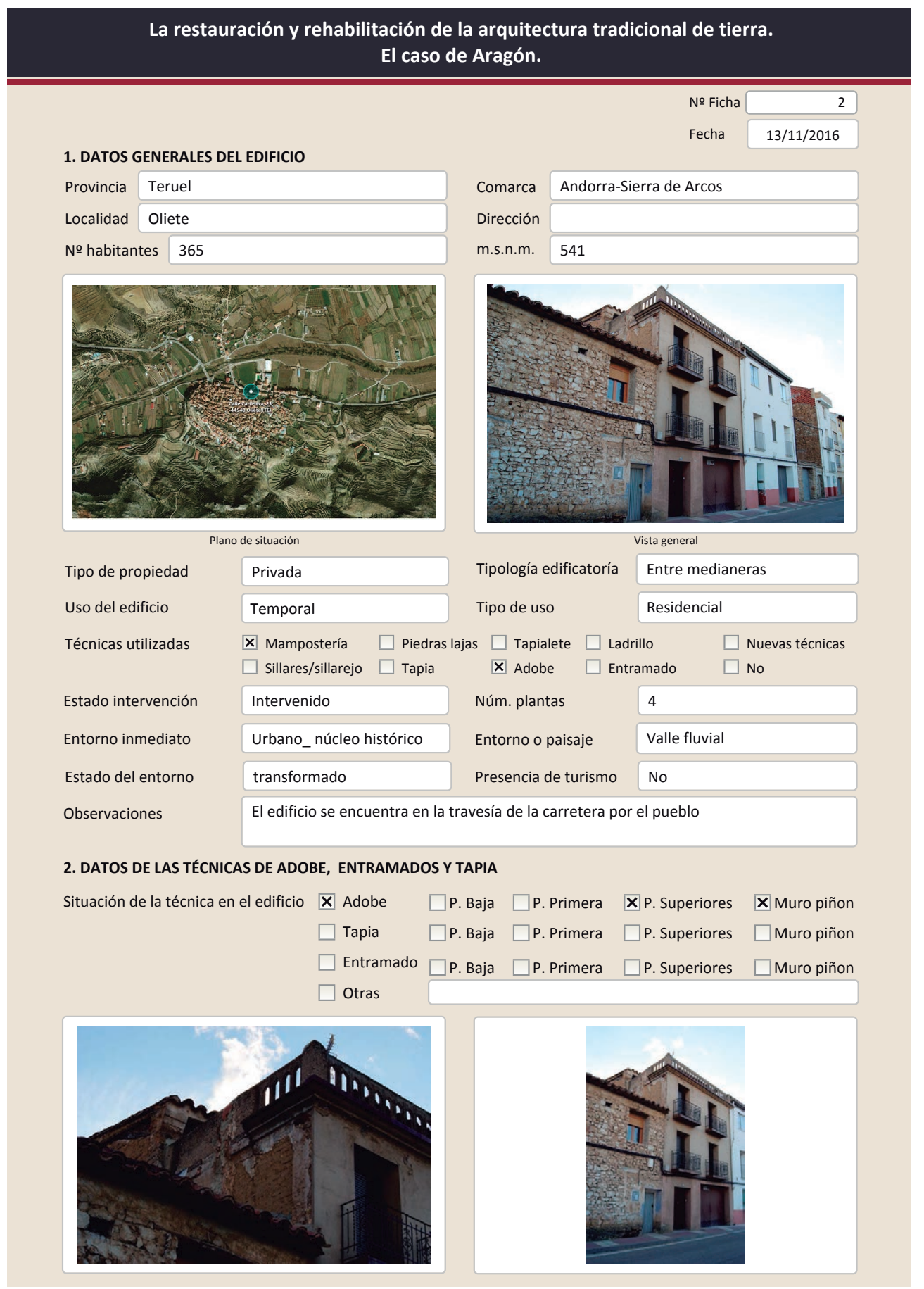

La restauración y rehabilitación de la arquitectura tradicional de tierra.

El caso de Aragón.

2.1. ADOBE

Dimensión de las piezas Dimensión del muro Aparejo del muro Función estructural
Color de las piezas

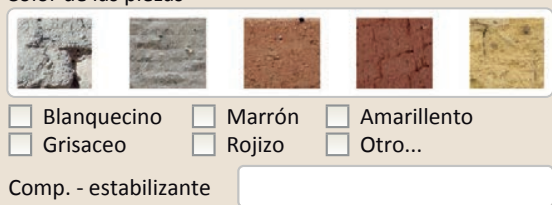

$\square$ Blanquecino $\square$ Marrón $\square$ Amarillento

Comp. - estabilizante

Variante constructiva/ tipo de fábrica

$\square$ simple

$\square$ Suplementada en juntas

X Mixta

$\square$ Como suplemento

$\square$ Elementos de protección

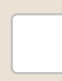

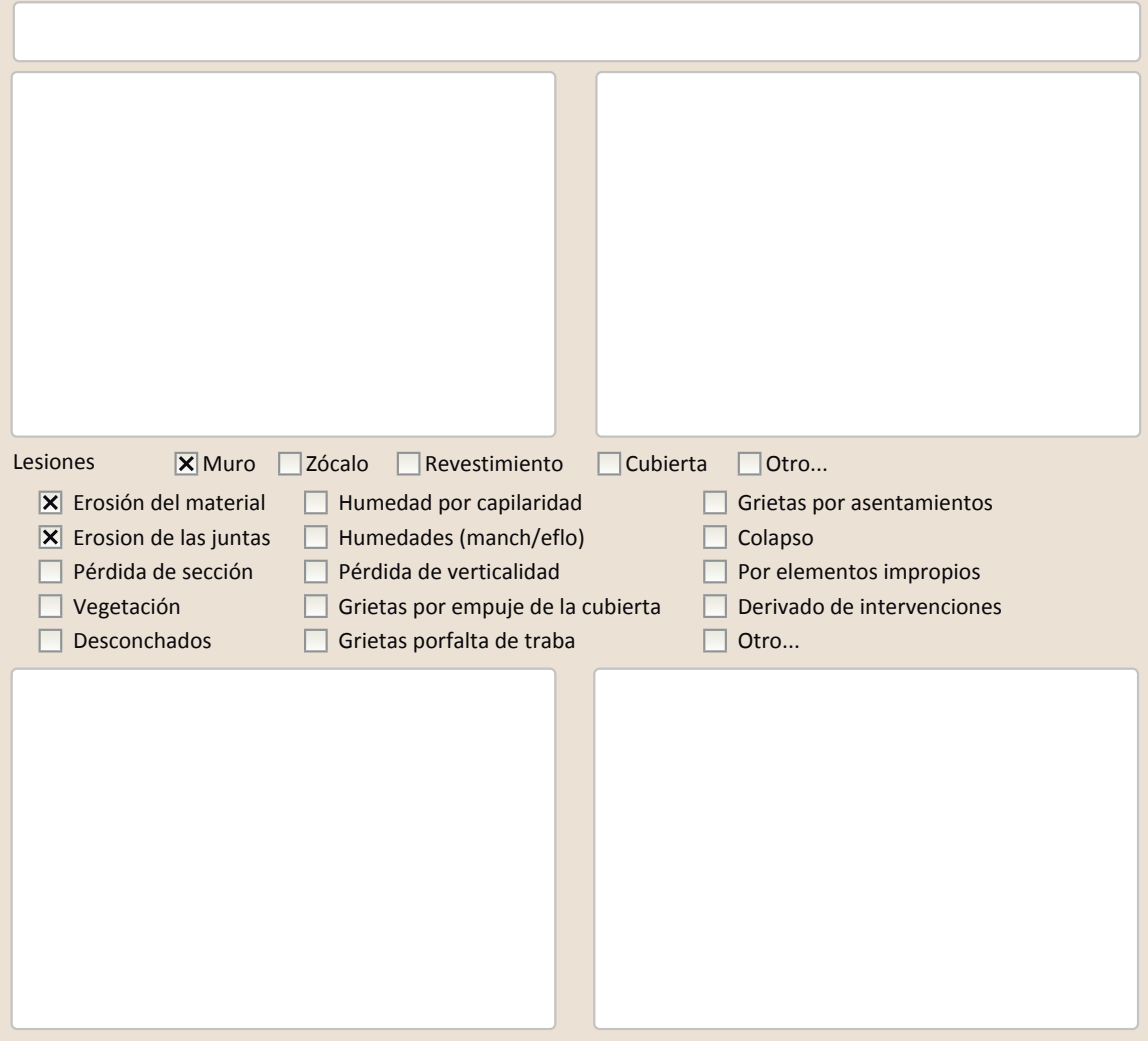

Observaciones

Pérdida del revestimiento que hace que los adobes estén visibles 


\section{La restauración y rehabilitación de la arquitectura tradicional de tierra.}

\section{El caso de Aragón.}

3. DATOS DE LA INTERVENCIÓN

Intervención de:

Mantenimiento $\quad X$ Rehabilitación parcial

$\square$ Restauración $\square$ Demolición

Reflexión previa

Intervención planificada

Observaciones

3.1. MUROS

Tipo de intervención

Intervenido

Tipo de material

$\square$ Actualización

$\square$ Consolidación

X Reintegración

$\begin{array}{lll}\text { No tradicional } & \text { Tipo de técnica } & \text { Diferente a la existente }\end{array}$

Descripción

La parte superior del muro ha sido afectada por la sustitución de la cubierta y creación
de una terraza. Uso de hormigón en este elemento / adobes de cemento

3.2. ZÓCALO

Intervenido

Tipo de intervención

$\square$ Actualización

$\square$ Consolidación

$\square$ Reintegración $\quad \square$ Demolición

$\square$ Otro...

No tradicional

Tipo de material

Zocalo planta baja de cemento

3.3. REVESTIMIENTOS

Tipo de intervención

\section{Intervenido}

$\square$ Actualización $\square$ Reintegración $\square$ Demolición $\square$ Otro...

$\square$ Consolidación $\square$ Reconstrucción $\mathbf{X}$ Sustitución

Tipo de material

No tradicional

Tipo de técnica Similar a la existente

Descripción

3.4. VANOS

Tipo de intervención

Intervenido

Tipo de material

$\square$ Actualización

$\square$ Consolidación

$\square$ Reintegración

$\square$ Demolición $\square$ Otro...

$\square$ Reconstrucción $\boldsymbol{X}$ Sustitución

Descripción

Nuevo acceso $p$

Tipo de técnica Diferente a la existente

3.5. CUBIERTA

Tipo de intervención

Intervenido

X Actualización $\square$ Reintegración $\quad \mathbf{X}$ Demolición $\square$ Otro.

$\square$ Consolidación $\quad \mathbb{X}$ Reconstrucción $\quad \square$ Sustitución

\begin{tabular}{l|lll} 
Tipo de material No tradicional Tipo de técnica Diferente a la existente &
\end{tabular}

Descripción Sustitución parcial de la cubierta y construcción de una cubierta plana con terraza en fachada. Actualización con a la tendencia del momento.
La restauración y rehabilitación de la arquitectura tradicional de tierra.

El caso de Aragón.

3.7. REHABILITACIÓN ENERGÉTICA $\square$ Fachada $\quad$ V Vanos $\square$ Forjados $\square$ Cubierta

Observaciones

Nuevas carpinterías y persianas en los huecos de ventanas

FOTOGRAFíAS DE LA INTERVENCIÓN
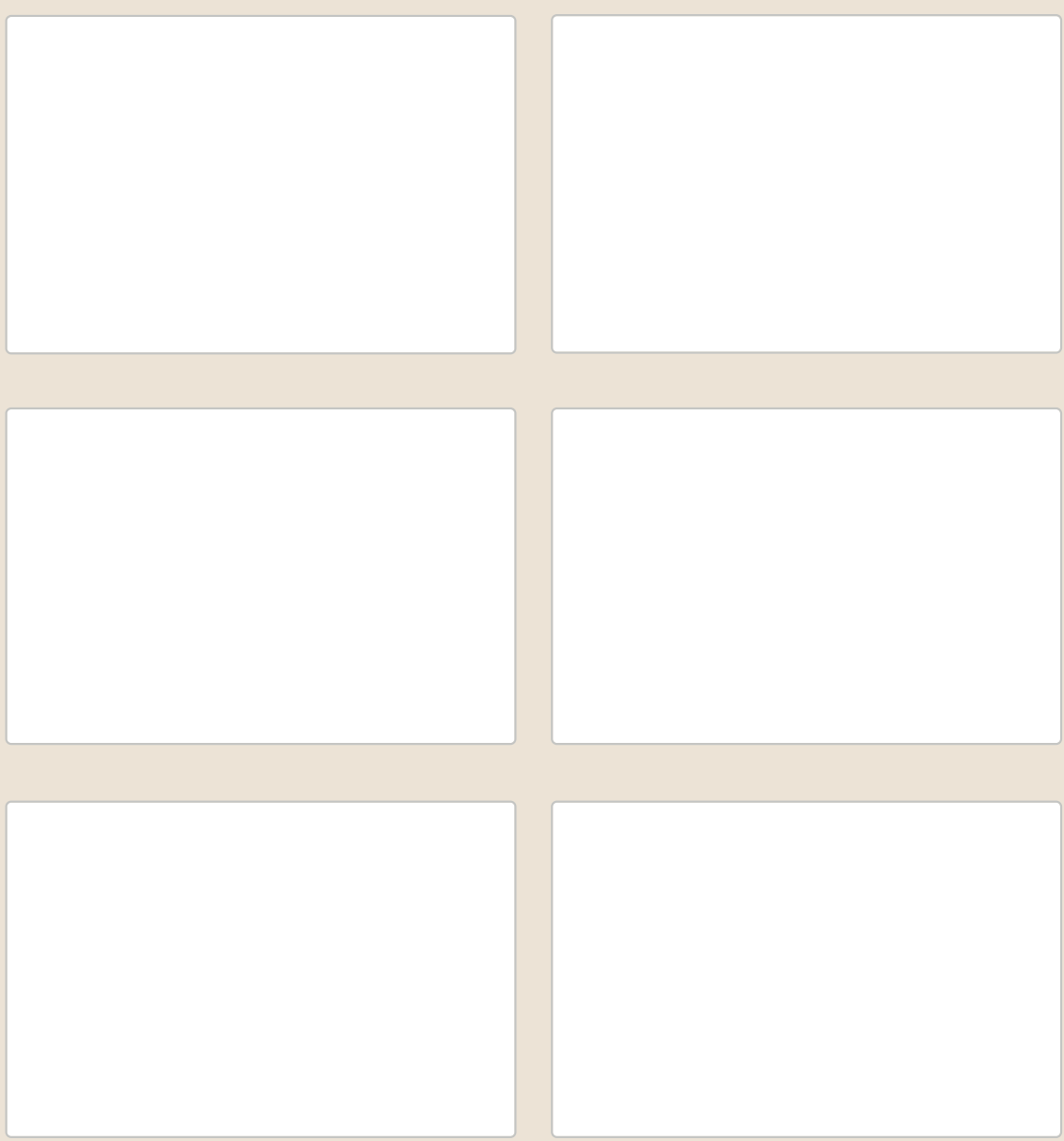

3.6. OTRAS 


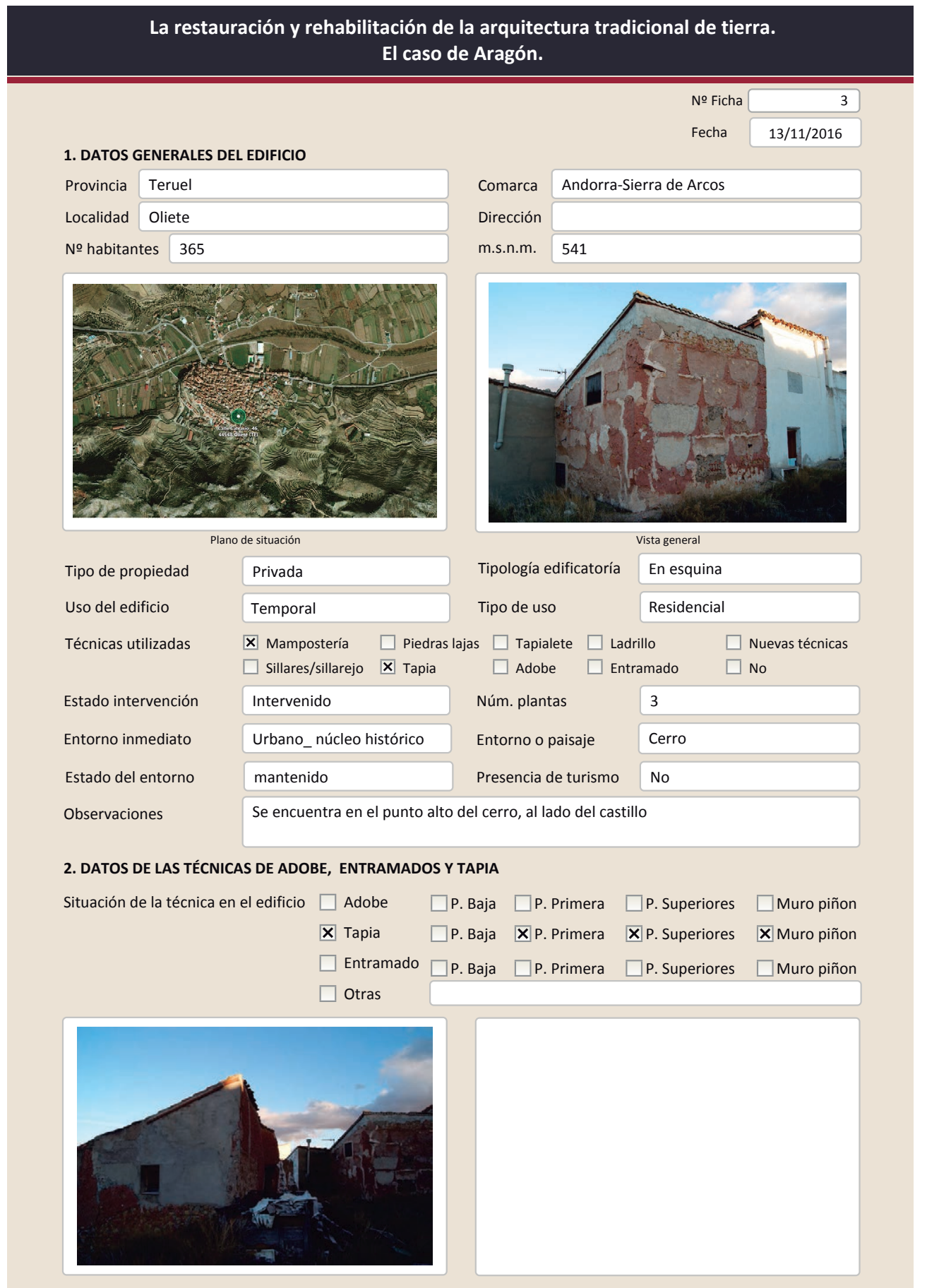

La restauración y rehabilitación de la arquitectura tradicional de tierra.

El caso de Aragón.

2.2. TAPIA

Ancho del muro

Dimensión tapiales

Tipo de aguja

№ agujas/cajón

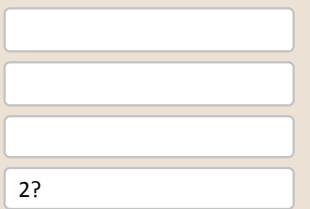

Color de la tapia

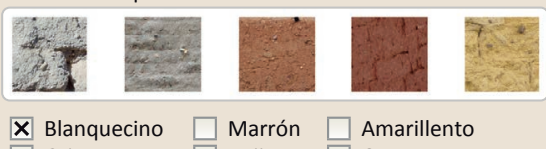

X Blanquecino $\square$ Marrón $\square$ Amarillento

Variante constructiva

$\square$ simple / homogénea

$\square$ suplemento superficial

$\boldsymbol{X}$ Suplemento en juntas

$\mathbf{X}$ Mixta
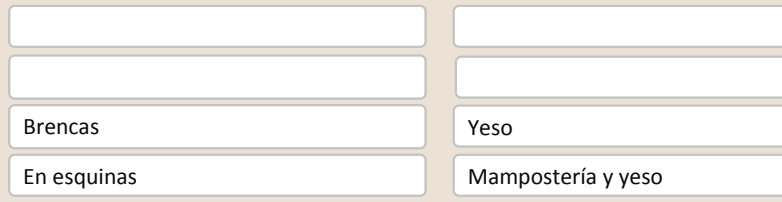

$\square$ Elementos de protección

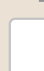

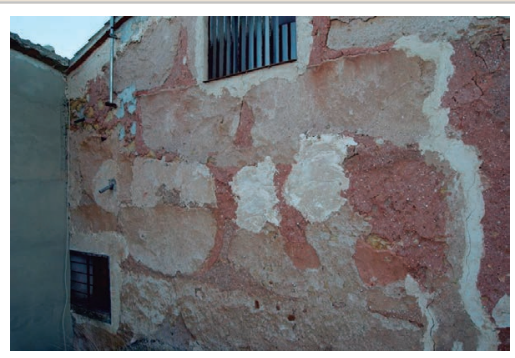

Lesiones $\square$ Muro $\square$ Zócalo $\square$ Revestimiento $\square$ Cubierta $\square$ otro...

$\square$ Erosión del material $\quad$ X Humedad por capilaridad $\quad \square$ Grietas por asentamiento $\square$ Erosion de las juntas $\square$ Humedades (manch/eflo)

$\square$ Pérdida de sección $\quad \square$ Pérdida de verticalidad

$\square$ Vegetación $\square$ Grietas por empuje de la cubieta

$\mathbf{X}$ Desconchados

$\square$ Grietas porfalta de traba

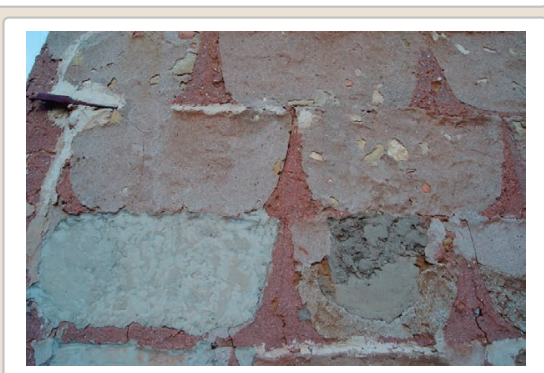

$\square$ Colapso

$\square$ Por elementos impropios

$\square$ Derivado de intervenciones $\square$ Otro...

Observaciones 


\section{La restauración y rehabilitación de la arquitectura tradicional de tierra.}

\section{El caso de Aragón.}

3. DATOS DE LA INTERVENCIÓN

Mantenimiento $\square$ Rehabilitación parcial $\square$ Restauración $\square$ Demolición X Reparación $\quad \square$ Rehabilitación integral $\square$ Ampliación $\quad \square$ Otro...

Reflexión previa Intervención espontanea

Observaciones En algunos de los huecos entre brencas se ha sustituido la tierra por relleno de piedras $y$ en la mayoría de los casos por cemento

\subsection{MUROS Intervenido \\ Tipo de intervención $\square$ Actualización $\quad \mathbf{X}$ Reintegración $\square$ Demolición $\square$ Otro... \\ $\square$ Consolidación $\quad \mathbf{X}$ Reconstrucción $\quad \square$ Sustitución}

$\begin{array}{llll}\text { Tipo de material } & \text { No tradicional } & \text { Tipo de técnica } & \text { Diferente a la existente }\end{array}$

$\begin{array}{lll}\text { Descripción } & \text { Reintegración de lagunas en el muro con cemento y relleno de cascotes cerámicos }\end{array}$ recontrucción de la parte superior por la sustitución de la cubierta

3.2. ZÓCALO No aplica

Tipo de intervención

$\square$ Actualización $\square$ Reintegración $\square$ Demolición $\square$ Otro..

$\square$ Consolidación $\square$ Reconstrucción $\square$ Sustitución

Tipo de material

Descripción

3.3. REVESTIMIENTOS

Tipo de intervención

Tipo de material

Descripción

3.4. VANOS

Tipo de intervención

Tipo de material

Descripción

3.5. CUBIERTA

Tipo de intervención

Tipo de material

Descripción Tipo de técnica

\section{No aplica}

$\square$ Actualización $\square$ Reintegración $\square$ Demolición $\square$ Otro...

Consolidación $\square$ Reconstrucción $\square$ Sustitución

Tipo de técnica

Intervenido

$\square$ Actualización $\quad \mathbf{X}$ Reintegración $\square$ Demolición $\square$ Otro..

$\square$ Consolidación $\square$ Reconstrucción $\square$ Sustitución

Tradicional diferente Tipo de técnica Diferente a la existente

Ampliación de huecos e incorporación de rejerías. Todo el contorno está intervenido

Intervenido

$\square$ Actualización $\square$ Reintegración $\quad \square$ Demolición $\square$ Otro.

$\square$ Consolidación $\square$ Reconstrucción $\mathbf{X}$ Sustitución

No tradicional Tipo de técnica Diferente a la existente

Sustitución por bardos y teja curva
La restauración y rehabilitación de la arquitectura tradicional de tierra.

El caso de Aragón.

Observaciones

FOTOGRAFíAS DE LA INTERVENCIÓN
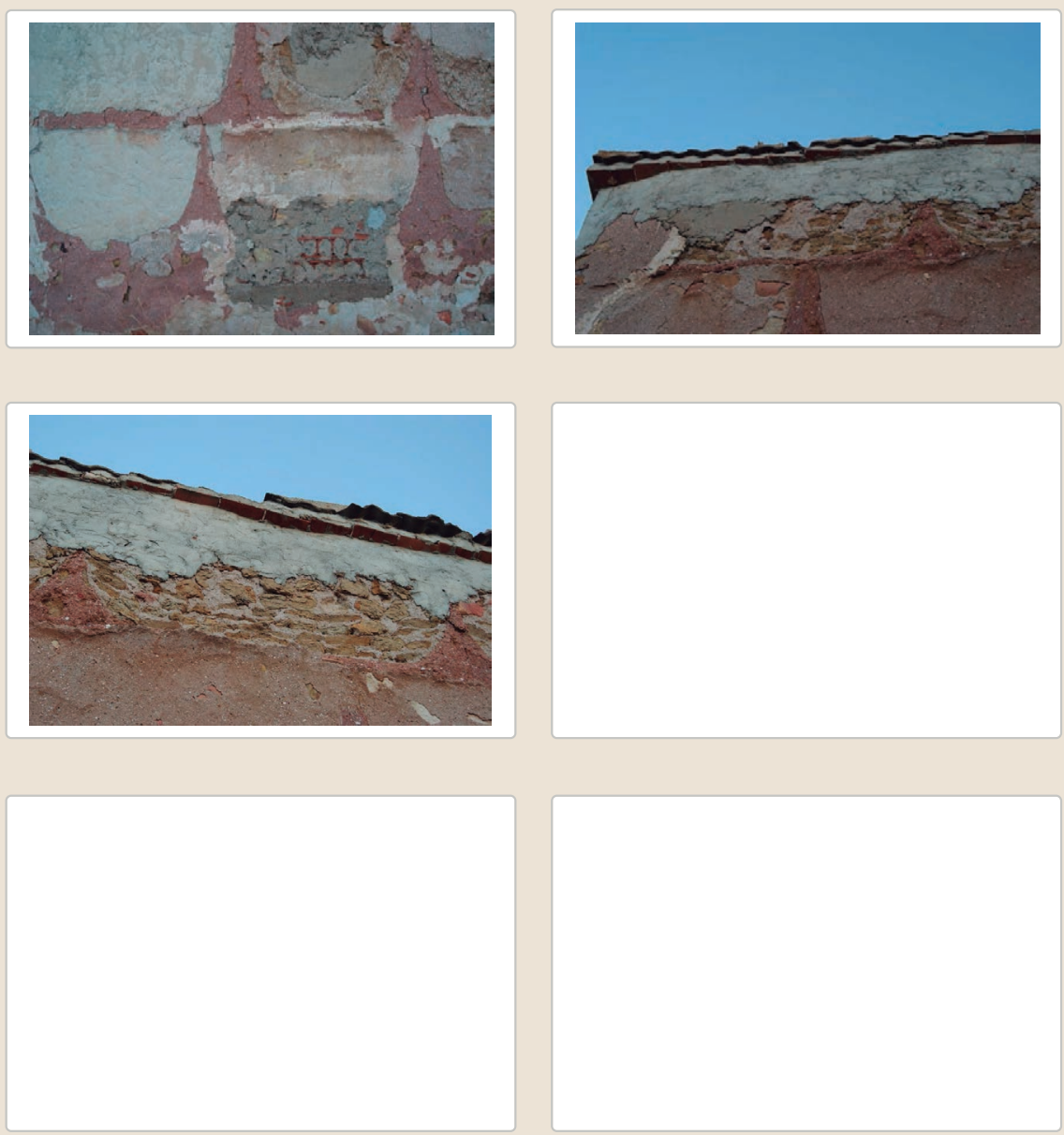

3.6. OTRAS 


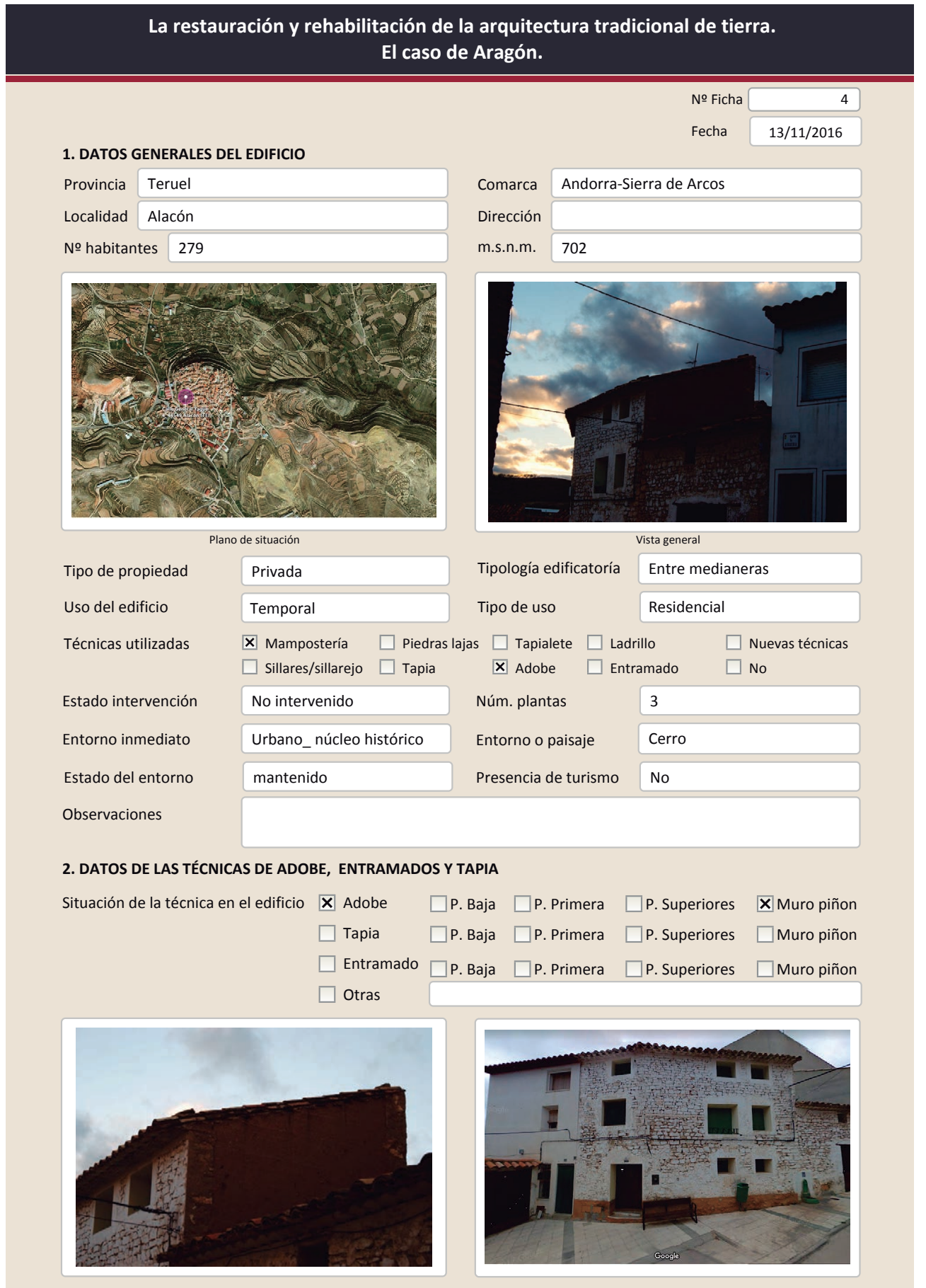

La restauración y rehabilitación de la arquitectura tradicional de tierra.

El caso de Aragón.

2.1. ADOBE

Dimensión de las piezas

Dimensión del muro

Aparejo del muro

Función estructural

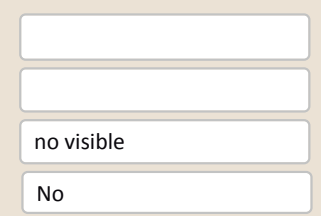

Color de las piezas

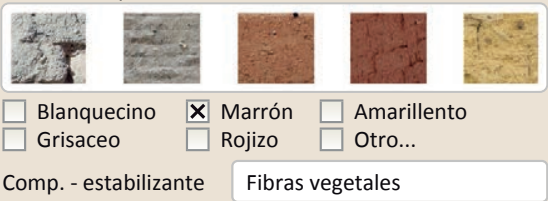

Variante constructiva/ tipo de fábrica

$\square$ simple
X Suplementada en juntas
Horizontales
Cal/ yeso
X Mixta
En esquinas
Piedra

$\square$ Como suplemento

$\square$ Elementos de protección

Se aprecia una junta horizontal suplementada cada 304 hiladas

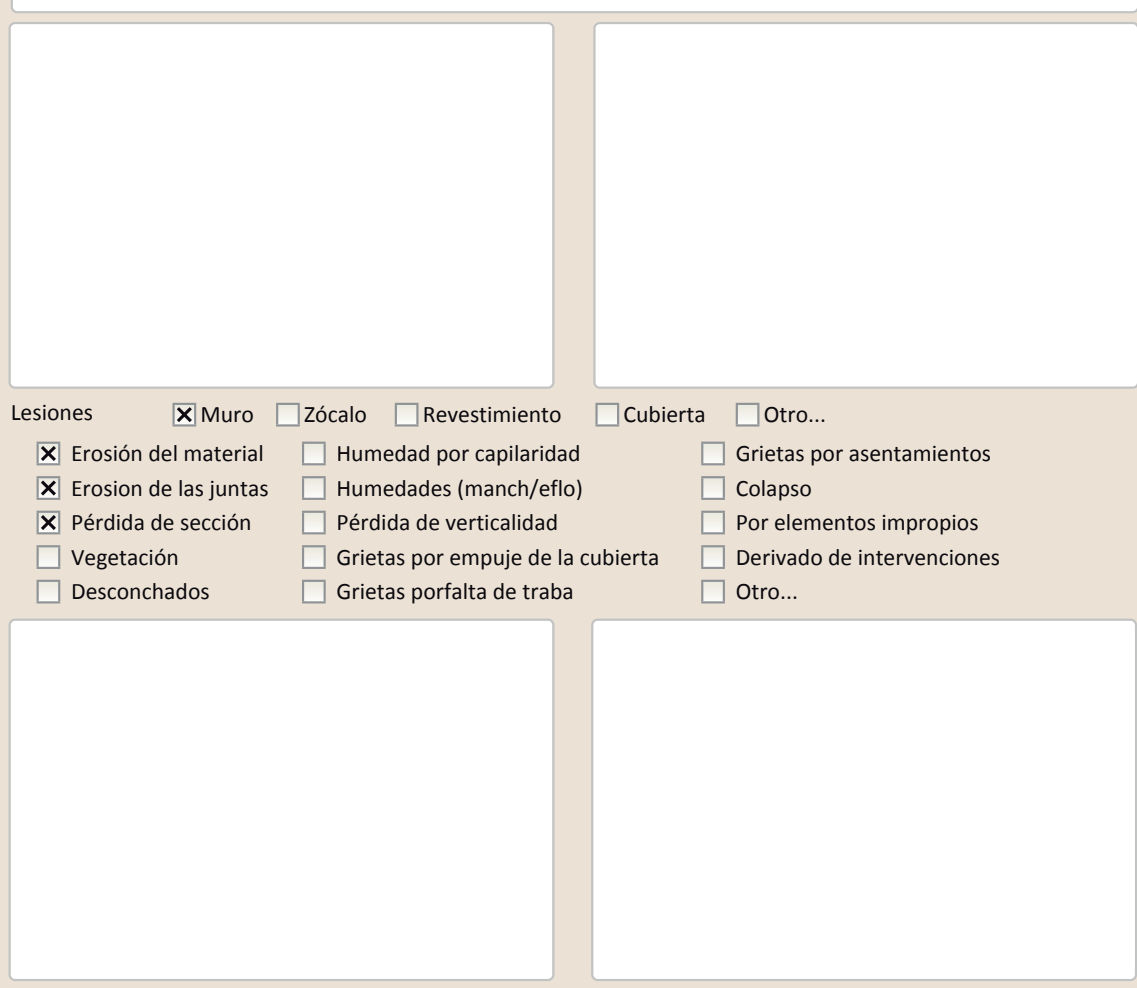

Observaciones

El suplemento entre juntas aparece cada un cierto número de hiladas (5) 
La restauración y rehabilitación de la arquitectura tradicional de tierra. El caso de Aragón

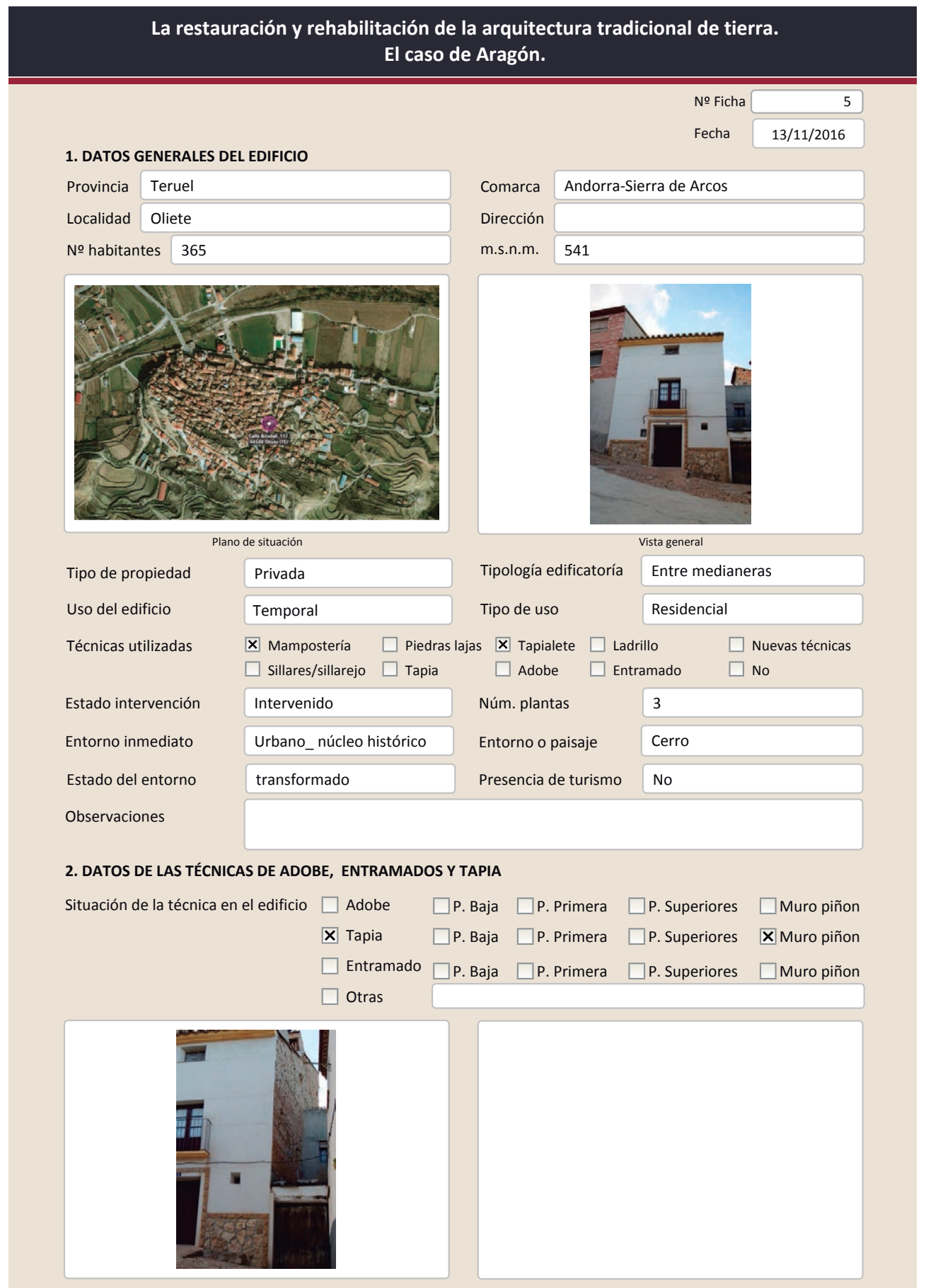

La restauración y rehabilitación de la arquitectura tradicional de tierra.

El caso de Aragón.

2.2. TAPIA

Ancho del muro

Dimensión tapiales

Tipo de aguja

No apreciable

№ agujas/cajón

Variante constructiva

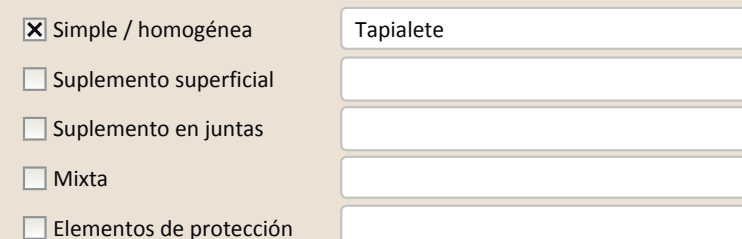

Solo se aprecia en el muro piñón pero quizás la técnica se extienda a todo el edificio.

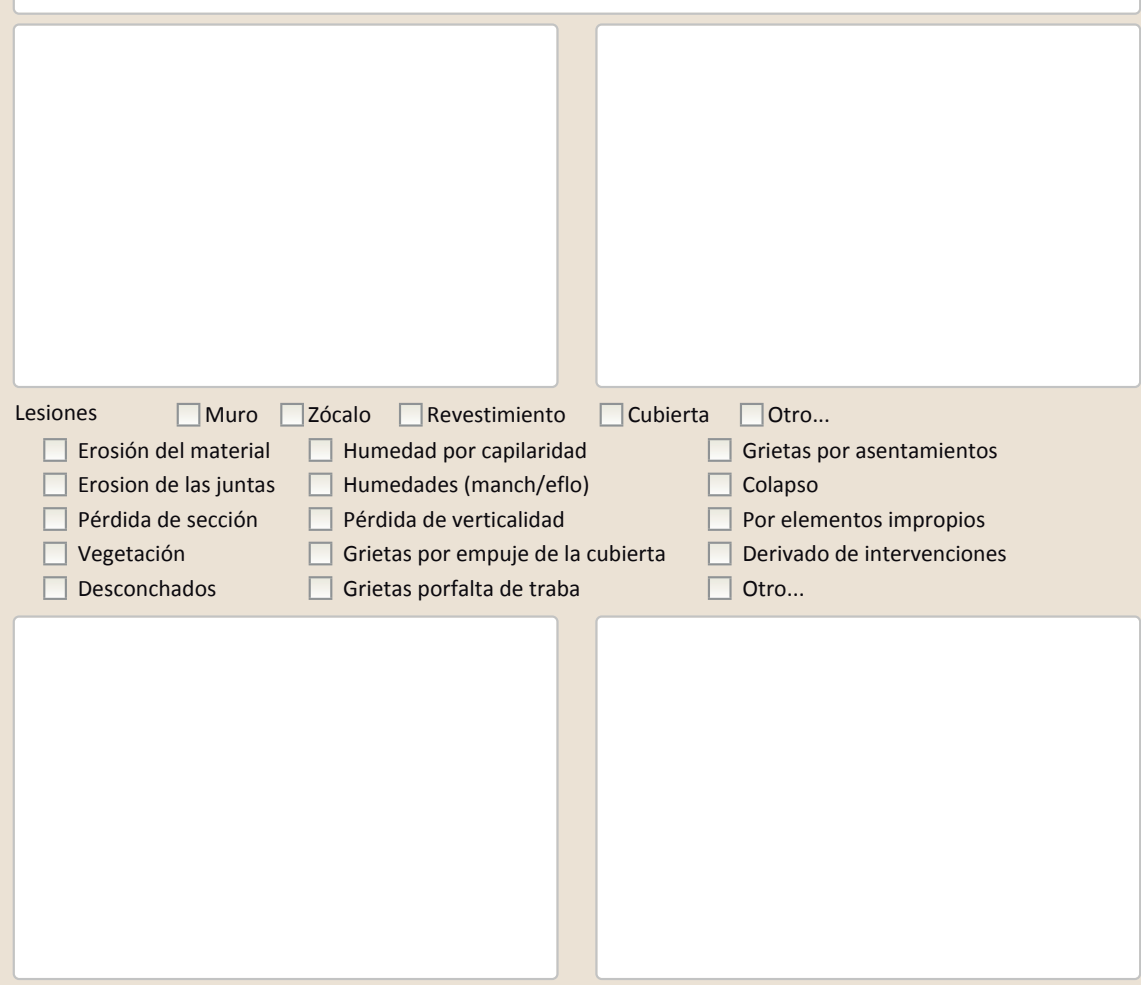

Observaciones 
La restauración y rehabilitación de la arquitectura tradicional de tierra.

\section{El caso de Aragón.}

3. DATOS DE LA INTERVENCIÓN

$\begin{array}{llll}\text { Intervención de: } & \square \text { Mantenimiento } \quad \square \text { Rehabilitación parcial } & \square \text { Restauración } & \square \text { Demolición } \\ & \square \text { Reparación } \quad \boldsymbol{X} \text { Rehabilitación integral } & \square \text { Ampliación } \quad \square \text { Otro... } \\ \text { Reflexión previa } & \text { Intervención planificada } & \\ \text { Observaciones } & & \\ & & \end{array}$

\subsection{MUROS}

Tipo de intervención

No visible

Tipo de material

$\square$ Actualización $\square$ Reintegración $\square$ Demolición $\square$ Otro... $\square$ Consolidación $\square$ Reconstrucción $\square$ sustitución

Descripción

3.2. ZÓCALO

Tipo de intervención

Intervenido

$\square$ Actualización

$\square$ Reintegración $\square$ Demolición $\square$ Otro..

Tipo de material

Descripción

3.3. REVESTIMIENTOS
Tipo de intervención

Lajas de piedra cogidas con cemento

Intervenido

Tipo ingental

Tipo de material

Descripción

No tradicional

$\square$ Reintegración $\square$ Demolición $\square$ Otro...

X Reconstrucción $\square$ Sustitución

Tipo de técnica Diferente a la existente

3.4. VANOS

Intervenido

Tipo de intervención

$\square$ Actualización $\quad \mathbf{X}$ Reintegración $\square$ Demolición $\square$ Otro...

Tipo de material

$\square$ Consolidación $\quad \square$ Reconstrucción $\square$ Sustitución

Descripción

No tradicional

Tipo de técnica Diferente a la existente

3.5. CUBIERTA

Tipo de intervención

Se conservan las carpinerías

Tipo de material

Intervenido

$\square$ Actualización $\quad \mathbf{X}$ Reintegración $\square$ Demolición $\square$ Otro.

$\square$ Consolidación $\quad \square$ Reconstrucción $\square$ Sustitución

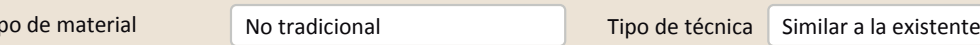

Descripción

Reintegración de tejas y nueva conformación del alero

3.6. OTRAS 
La restauración y rehabilitación de la arquitectura tradicional de tierra. El caso de Aragón

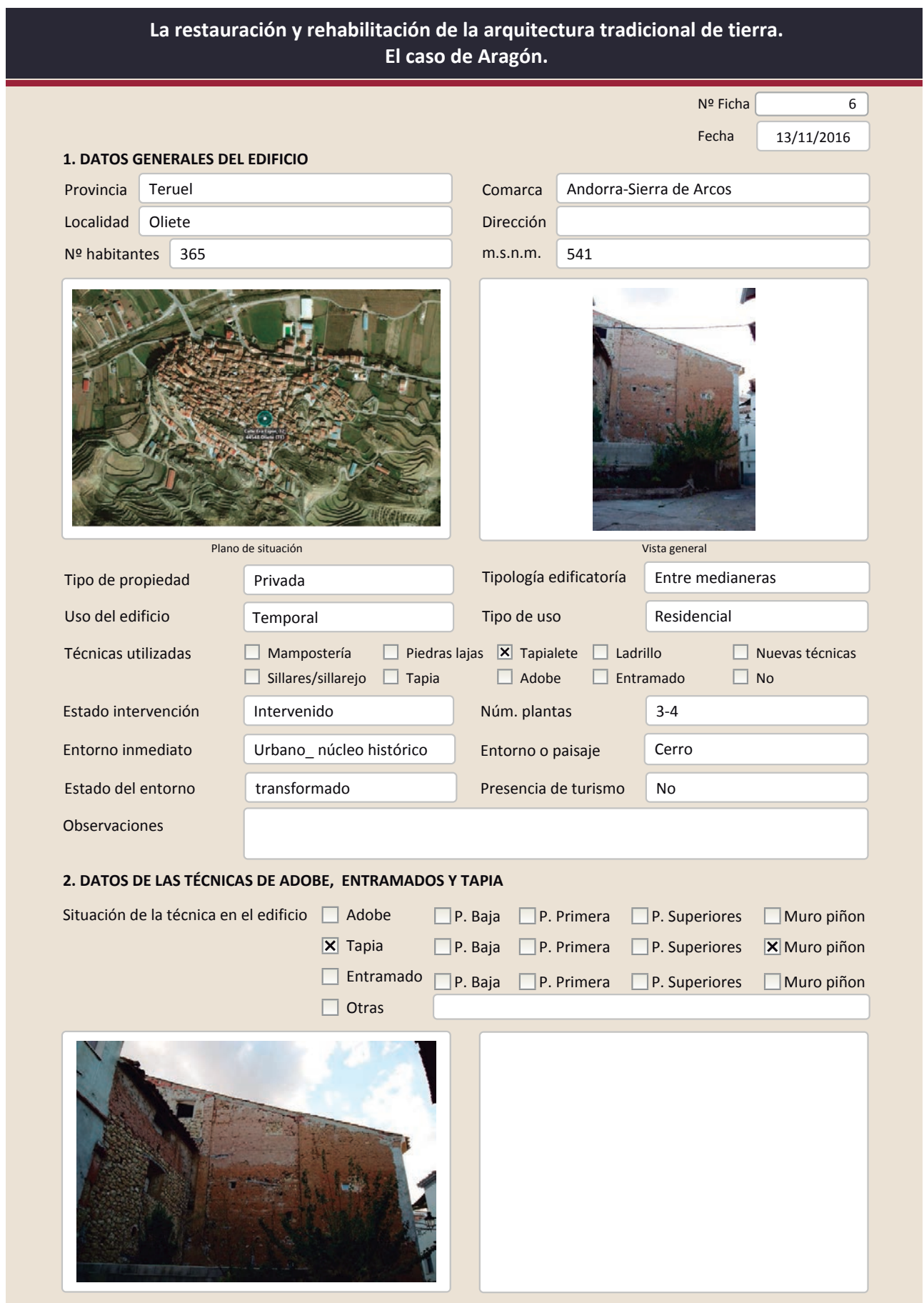

2.2. TAPIA

Ancho del muro

Dimensión tapiales

Tipo de aguja

№ agujas/cajón

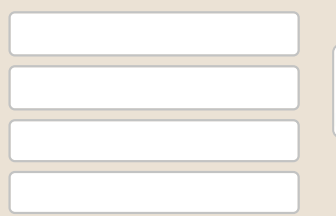

Color de la tapia

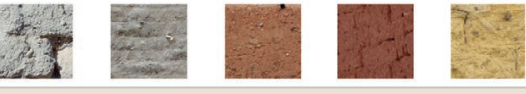

$\square$ Blanquecino $\quad \mathbf{X}$ Marrón $\square$ Amarillento

$\square$ Grisaceo

$\begin{array}{ll}\boldsymbol{x} \text { Marrón } & \square \text { Amarillento } \\ \square \text { Rojizo } & \square \text { Otro... }\end{array}$

Variante constructiva
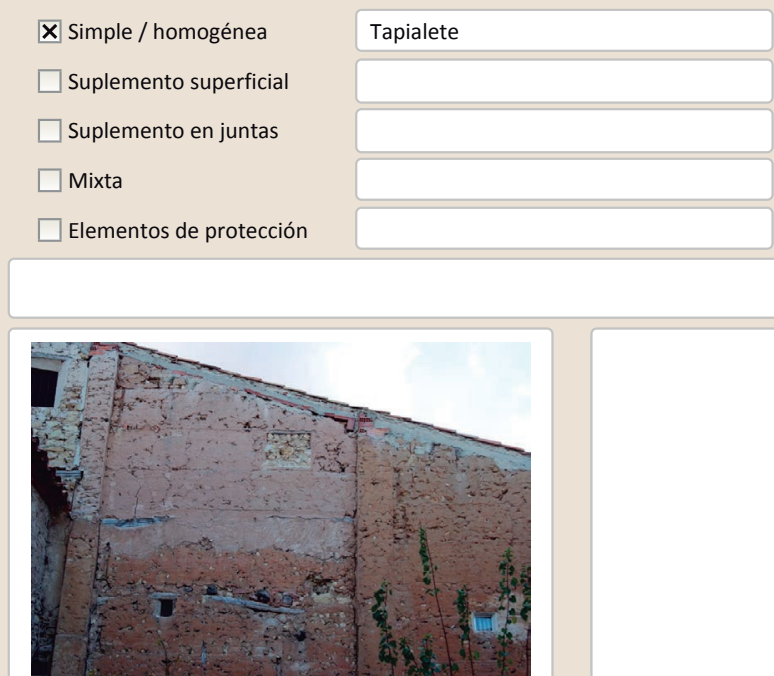

Lesiones $\quad \mathbf{X}$ Muro $\square$ Zócalo $\square$ Revestimiento $\square$ Cubierta $\square$ otro...

X Erosión del material $\quad \square$ Humedad por capilaridad $\quad \square$ Grietas por asentamientos $\square$ Erosion de las juntas $\square$ Humedades (manch/eflo) $\quad \square$ Colapso

$\square$ Pérdida de sección $\quad \square$ Pérdida de verticalidad $\quad \square$ Por elementos impropios

$\square$ Vegetación $\quad \square$ Grietas por empuje de la cubierta $\quad \square$ Derivado de intervenciones

$\square$ Desconchados $\quad \square$ Grietas porfalta de traba $\quad \square$ Otro...

Observaciones 


\section{La restauración y rehabilitación de la arquitectura tradicional de tierra.}

\section{El caso de Aragón.}

3. DATOS DE LA INTERVENCIÓN

Intervención de:

$\square$ Mantenimiento $\quad$ X Rehabilitación parcial

$\square$ Restauración $\square$ Demolición

Reflexión previa

$\square$ Reparación

$\square$ Rehabilitación integra

$\square$ Ampliación

$\square$ Otro...

Observaciones

Intervención planificada

3.1. MUROS
Tipo de intervención

No intervenido

Tipo de material

Descripción

3.2. ZÓCALO

Tipo de intervención

Tipo de material

Descripción

3.3. REVESTIMIENTOS

Tipo de intervención

Tipo de material

Descripción

3.4. VANOS

Tipo de intervención

Tipo de material

Descripción

3.5. CUBIERTA

Tipo de intervención

Tipo de material

Descripción

$\square$ Actualización $\square$ Reintegración $\square$ Demolición $\square$ Otro...

$\square$ Consolidación $\square$ Reconstrucción $\square$ sustitución

Tipo de técnica

Intervenido

\ Actualización $\square$ Reintegración $\quad \square$ Demolición $\square$ Otro...

$\square$ Consolidación $\quad \mathbf{X}$ Reconstrucción $\square$ Sustitución

No tradicional Tipo de técnica Similar a la existente

Piedras lajas

\section{Intervenido}

X Actualización $\square$ Reintegración $\square$ Demolición $\square$ Otro...

$\square$ Consolidación $\mathbf{X}$ Reconstrucción $\square$ sustitución

No tradicional Tipo de técnica Diferente a la existente

Nuevo revestimiento

Intervenido

邓 Actualización $\square$ Reintegración $\square$ Demolición $\square$ Otro...

$\square$ Consolidación $\square$ Reconstrucción $\mathbf{X}$ Sustitución

No tradicional Tipo de técnica Diferente a la existente

Reconstrucción del contorno de los huecos y sustitución de las carpinterías

Intervenido

$\square$ Actualización $\square$ Reintegración $\square$ Demolición $\square$ Otro.

$\square$ Consolidación $\quad \mathbf{X}$ Reconstrucción $\square$ Sustitución

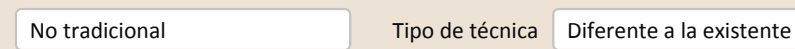

Reconstrucción de la cubierta sobe un zuncho de hormigón
La restauración y rehabilitación de la arquitectura tradicional de tierra.

El caso de Aragón.

3.7. REHABILITACIÓN ENERGÉTICA $\quad \square$ Fachada $\square$ Vanos $\square$ Forjados $\square$ Cubierta

Observaciones

FOTOGRAFÍAS DE LA INTERVENCIÓN
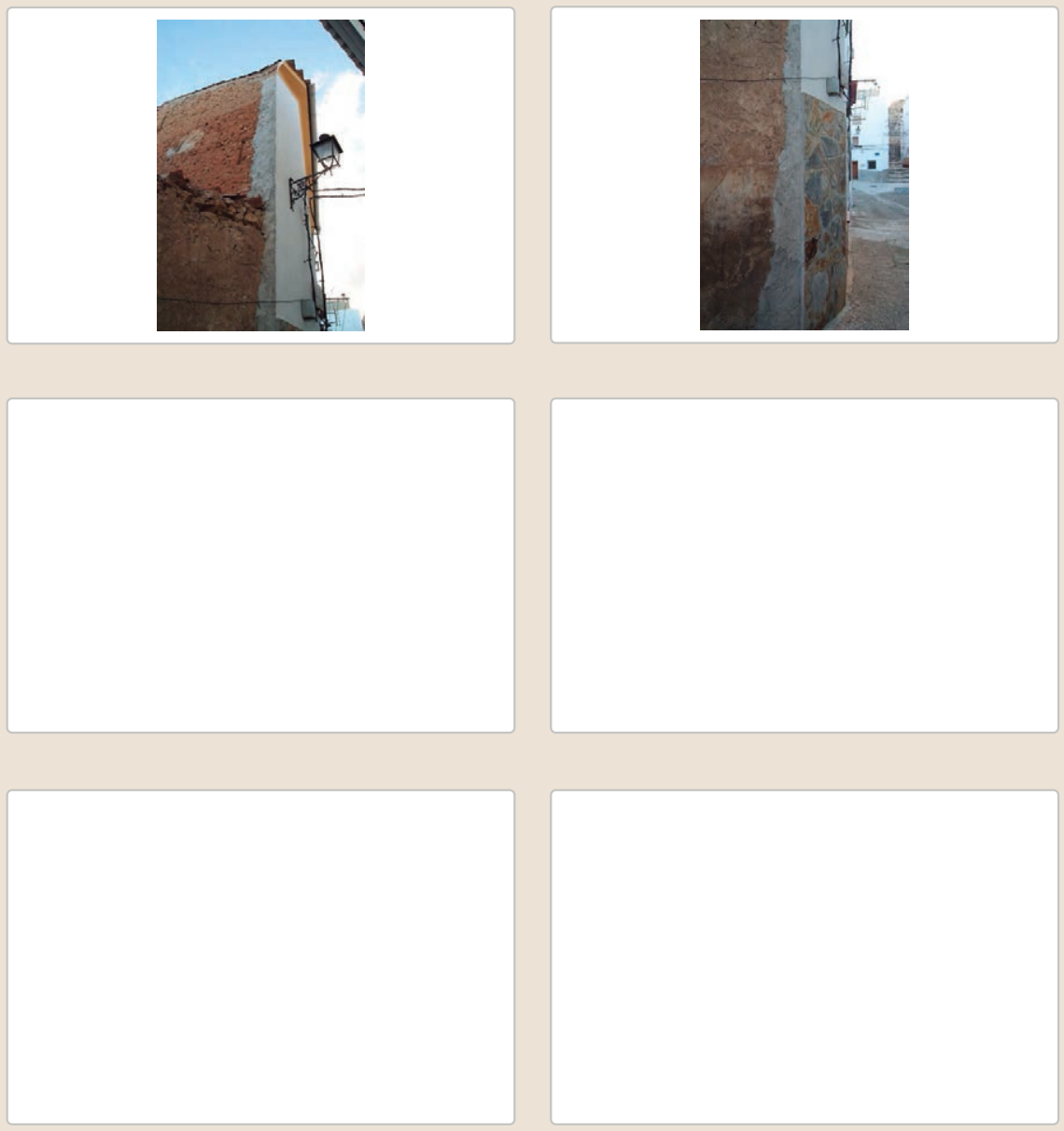

3.6. OTRAS 
La restauración y rehabilitación de la arquitectura tradicional de tierra. El caso de Aragón

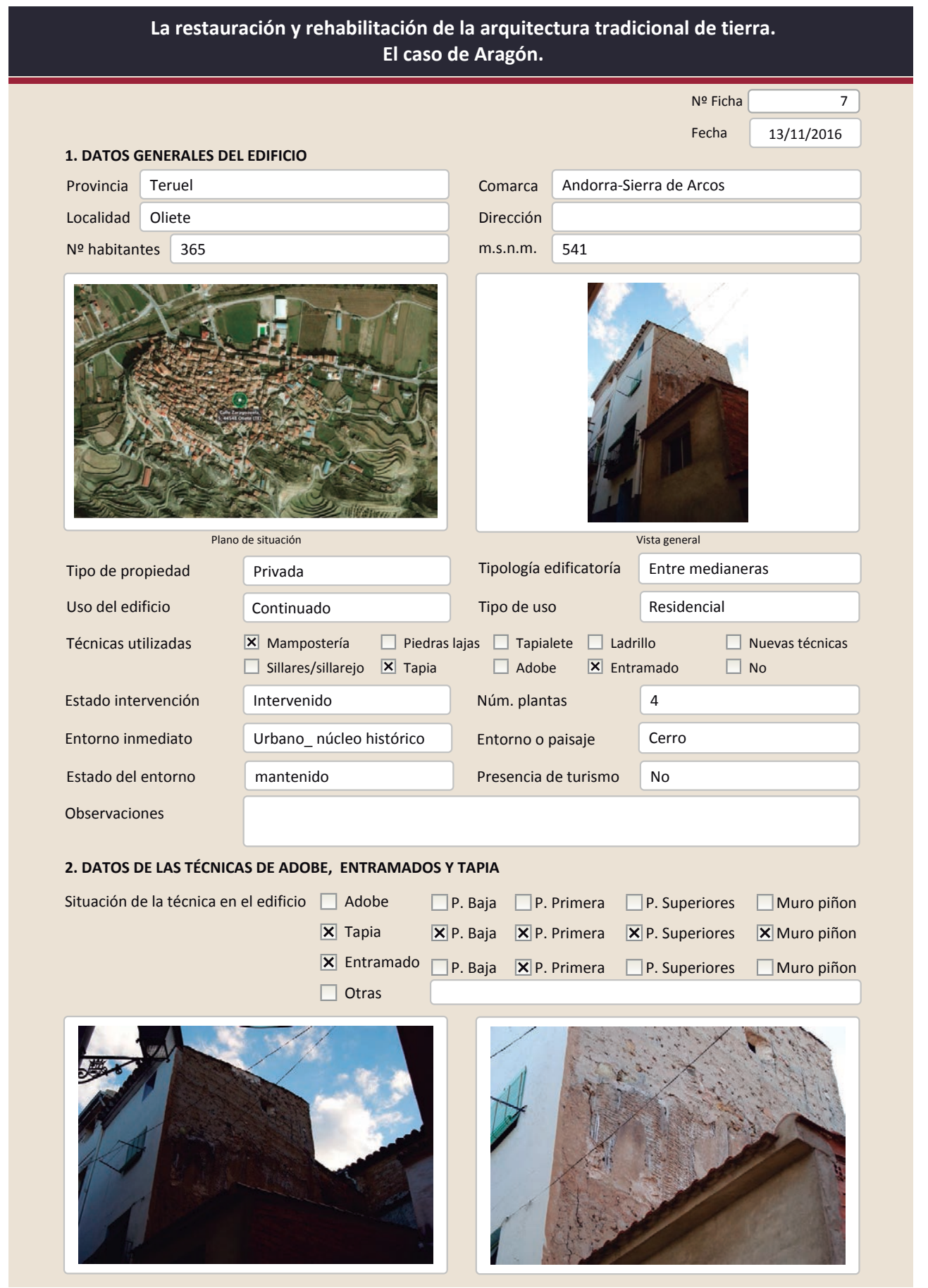

2.2. TAPIA

Ancho del muro

Dimensión tapiales

Tipo de aguja

№ agujas/cajón

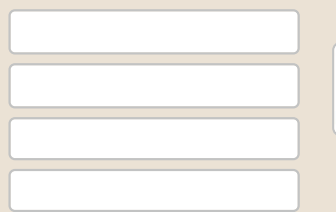

Color de la tapia

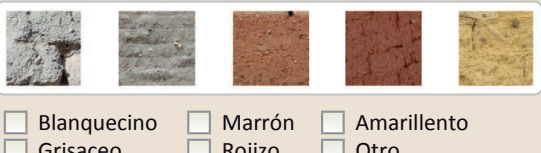

$\square$ Blanquecino $\square$ Marrón $\square$ Amarillento

X Simple / homogéne

$\square$ Suplemento superficial

$\square$ suplemento en juntas

$\square$ Mixta

$\square$ Elementos de protección
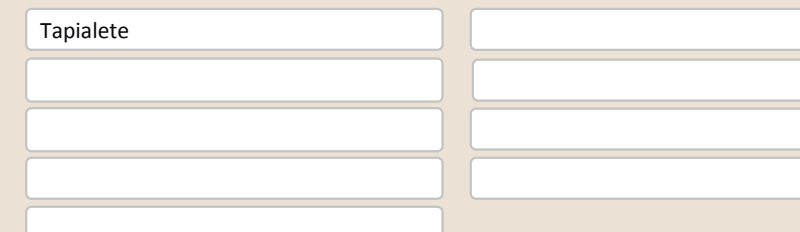

Todo el edificio esta construido con tapialete (mampuestos tierra y yeso principalmente)

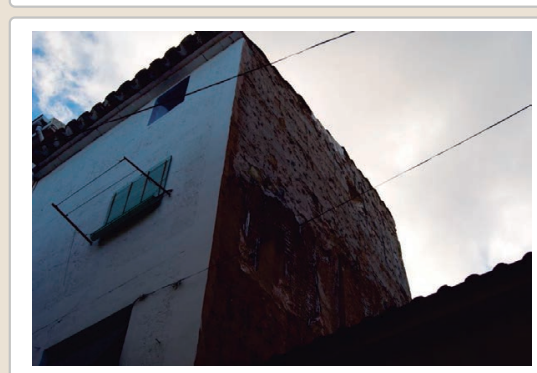

Lesiones $\quad \mathbf{X}$ Muro $\square$ Zócalo $\square$ Revestimiento $\square$ Cubierta $\square$ Otro...

X Erosión del material $\quad \square$ Humedad por capilaridad $\quad \square$ Grietas por asentamiento $\square$ Erosion de las juntas $\square$ Humedades (manch/eflo)

$\square$ Pérdida de sección $\square$ Pérdida de verticalidad

$\square$ Vegetación

$\square$ Colapso

X Desconchado

$\square$ Grietas porfalta de traba

Por elementos impropios

$\square$ Derivado de intervenciones

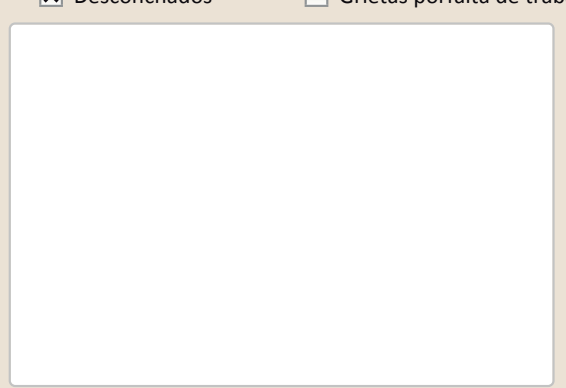

Observaciones 


\section{La restauración y rehabilitación de la arquitectura tradicional de tierra.}

\section{El caso de Aragón.}

\subsection{ENTRAMADOS}

Distancia entre montantes

Altura de los montantes

Sección de los montantes

Dimensión de los montantes

Tipo de relleno del entramado

Técnica de relleno del entramado
$\square$ Entre pantallas de madera
$\square$ Tierra y mampuestos
$\square$ Tapialete
$\square$ Pared de mano $\quad \mathbf{X}$ Cañizo
$\square$ Adobe horizontal $\square$ Encestados
$\square$ Adobe aletorio $\square$ Otro...

Cañizo con yeso. No se aprecian piezas de madera pero si el tejido de cañizo

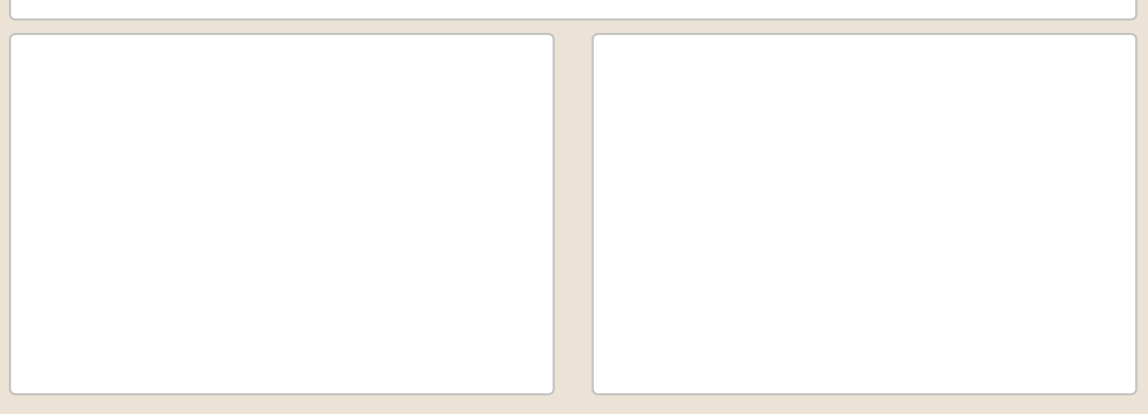

Lesiones $\quad$ XMuro $\square$ Zócalo $\square$ Revestimiento $\square$ Cubierta $\square$ Otro...
$\square$ Erosión del material
$\square$ Carcoma o termitas
$\square$ Grietas por falta de traba
$\square$ Erosion de las juntas
Rotura de la madera
$\square$ Pérdida de secir
$\square$ Pudrición de la madera
$\square$ Grietas por asentamiento
$\mathbf{X}$ Desconchados
$\square$ Deformación madera
$\square$ Colapso
$\square$ Humedad por capilaridad $\square$ Pérdida de verticalidad
Por elementos impropios
$\square$ Otro...
$\square$ Humedades (manch/eflor) $\quad \square$ Grietas por empuje de la cubierta

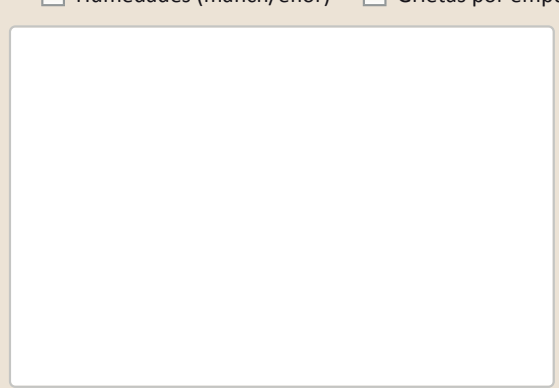

Observaciones
La restauración y rehabilitación de la arquitectura tradicional de tierra.

El caso de Aragón.

DATOS DE LA INTERVENCIÓN

Intervención de: $\quad \square$ Mantenimiento $\quad \mathbf{X}$ Rehabilitación parcial $\square$ Restauración

$\square$ Reparación $\quad \square$ Rehabilitación integral $\square$ Ampliación $\quad \square$ Otro...

\begin{tabular}{l|l} 
Intervención espontanea \\
\hline
\end{tabular}

Observaciones

Intervención espontanea

3.1. MUROS

Tipo de intervención

No intervenido
$\square$ Actualización $\quad \square$ Reintegración $\quad \square$ Demolición $\quad \square$ Otro...
$\square$ Consolidación $\quad \square$ Reconstrucción $\quad \square$ Sustitución

Tipo de material

Descripción

3.2. ZÓCALO

Tipo de intervención

Tipo de material

Intervenido

X Actualización $\square$ Reintegración $\square$ Demolición $\square$ Otro..

$\square$ Consolidación $\quad \mathbf{X}$ Reconstrucción $\square$ Sustitución

Descripción

No tradicional Tipo de técnica Diferente a la existente

3.3. REVESTIMIENTOS

Cemento con pintura plástica azul

Tipo de intervención $\quad$ X Actualización $\square$ Reintegración $\square$ Demolición $\square$ Otro...

$\square$ Consolidación $\quad \square$ Reconstrucción $\square$ Sustitución

$\begin{array}{llll}\text { Tipo de material } & \text { No tradicional Tipo de técnica Diferente a la existente }\end{array}$

$\begin{array}{lll}\text { Descripción } & \text { Pintura plástica con relieve en el contorno }\end{array}$

3.4. VANOS

Tipo de intervención

No intervenido

Tipo de material

$\square$ Actualización $\square$ Reintegración $\square$ Demolición $\square$ Otro...

$\square$ Consolidación $\square$ Reconstrucción $\square$ Sustitución

Descripción

3.5. CUBIERTA

Tipo de intervención

Intervenido

$\square$ Actualización $\square$ Reintegración $\square$ Demolición $\square$ Otro

$\square$ Consolidación $\quad \mathbf{X}$ Reconstrucción $\square$ Sustitución

Tipo de material

No tradicional Tipo de técnica Similar a la existente

Descripción

Reconstrucción con teja curva

3.6. OTRAS 


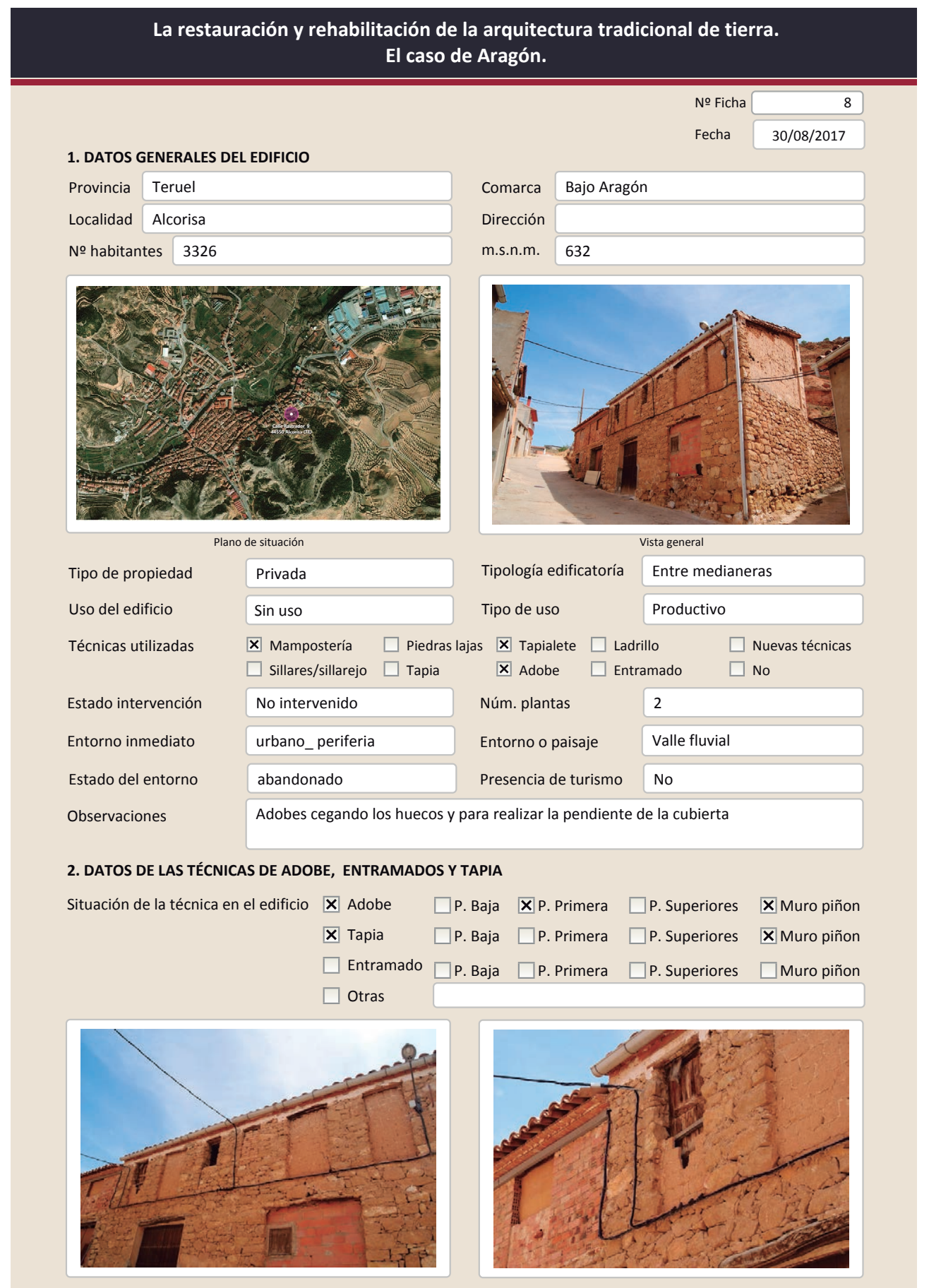

2.1. ADOBE

Dimensión de las piezas $27 \times 13$

Dimensión del muro

Aparejo del muro

$27 \times 13 \times 4$

Función estructural

panderete

No

Variante constructiva/tipo de fábric

X simple

$\square$ Mixta

$\square$ Como suplemento

$\square$ Elementos de protección

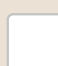

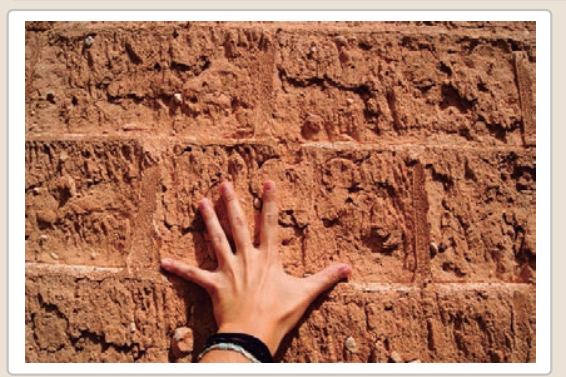

Lesiones $\quad \mathbf{X}$ Muro $\square$ Zócalo $\square$ Revestimiento

$\mathbf{X}$ Erosión del material $\quad \square$ Humedad por capilaridad $\square$ Erosion de las juntas $\square$ Humedades (manch/eflo)

$\square$ Pérdida de sección $\square$ Pérdida de verticalidad

$\square$ Vegetación $\quad \square$ Grietas por empuje de la c

$\square$ Desconchados

$\square$ Grietas porfalta de traba

Color de las piezas

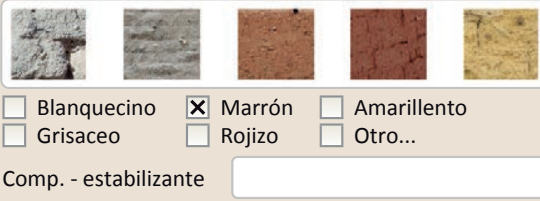

Comp. - estabilizante

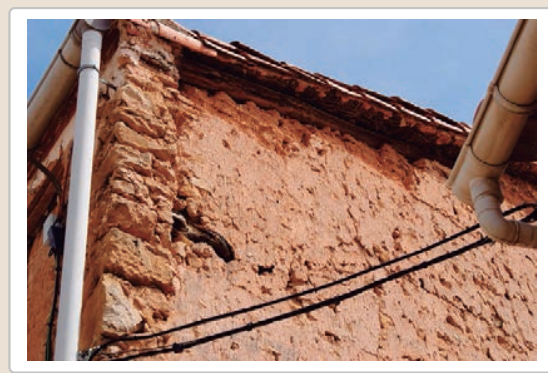

X Cubierta $\square$ Otro...

$\square$ Grietas por asentamiento

$\square$ Colapso

$\square$ Por elementos impropios

$\square$ Derivado de intervenciones

$\square$ otro...

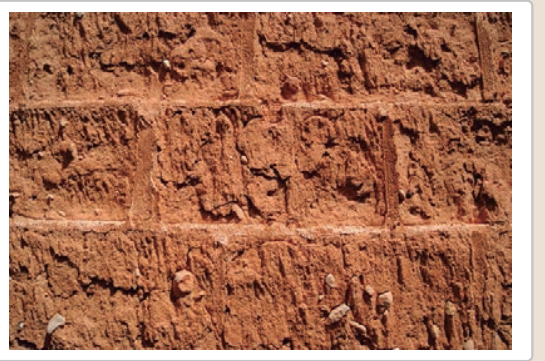

Observacione

El adobe se está deshaciendo por capas. Problemas en cubierta por movimiento de

tejas y rotura de viga.

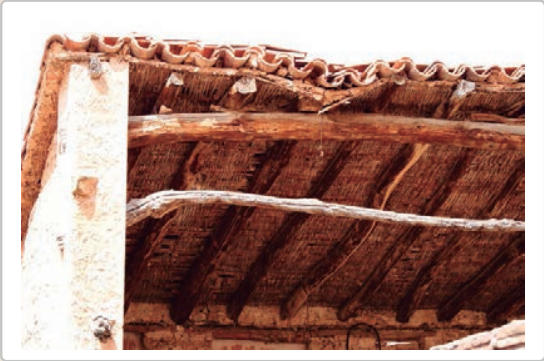


La restauración y rehabilitación de la arquitectura tradicional de tierra.

El caso de Aragón.

\subsection{TAPIA \\ Ancho del muro}

Dimensión tapiales

Tipo de aguja

№ agujas/cajón

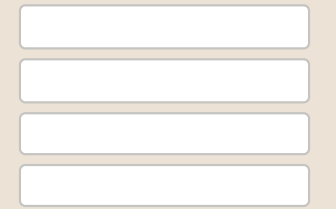

Color de la tapia

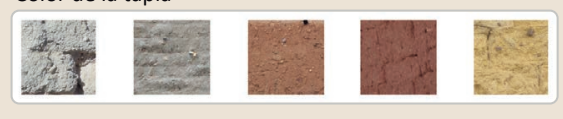

$\square$ Blanquecino $\quad \mathbf{X}$ Marrón $\square$ Amarillento

$\square$ Grisaceo

$\times$ Marrón
Rojizo Otro...

X Simple / homogénea

$\square$ Suplemento superficial

$\square$ suplemento en juntas

X Mixta

Tapialete

$\square$ Elementos de protección

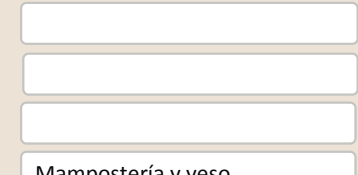

Mampostería y yeso

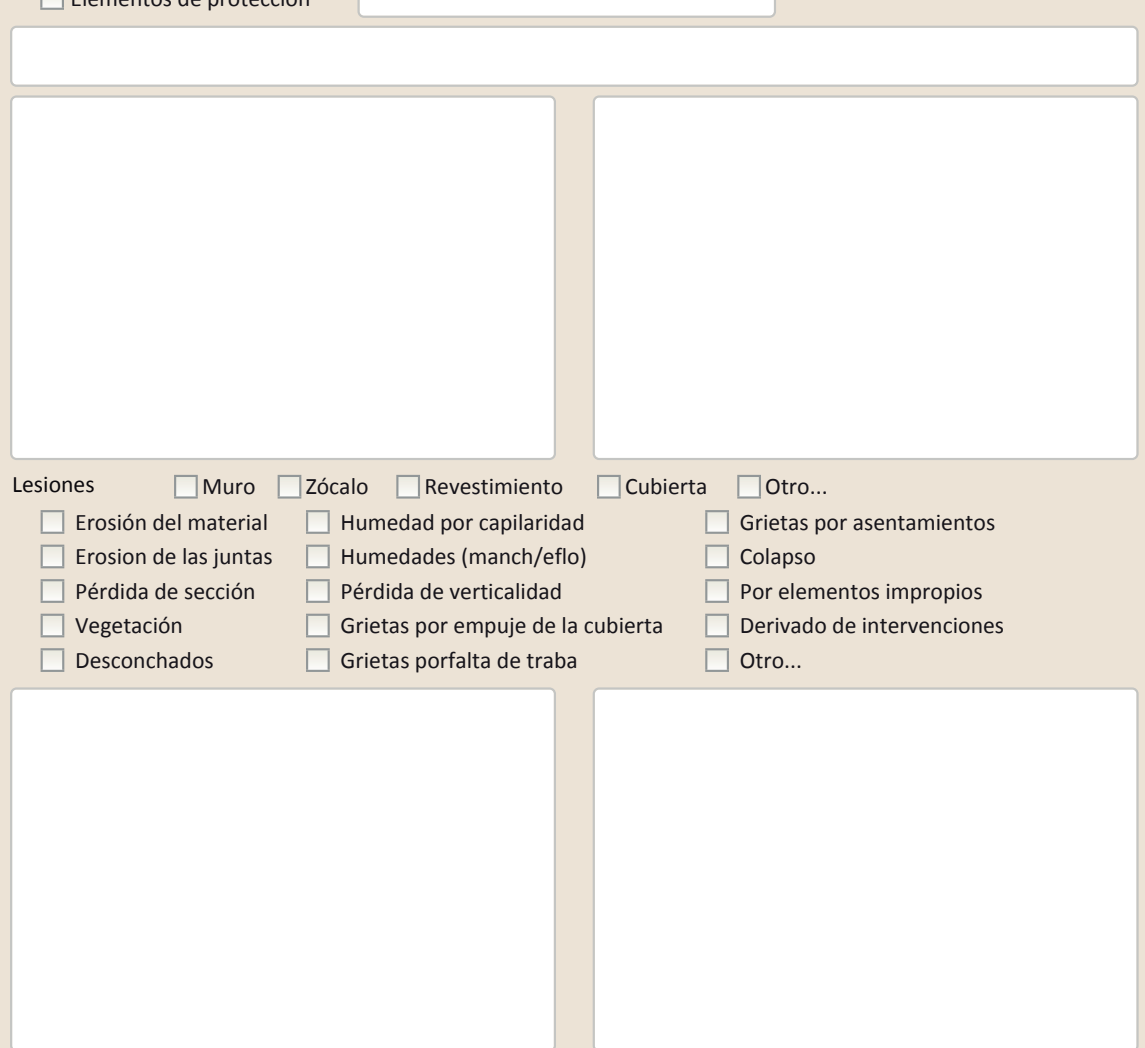

Observaciones

La restauración y rehabilitación de la arquitectura tradicional de tierra.

El caso de Aragón.

Observaciones

FOTOGRAFÍAS DE LA INTERVENCIÓN
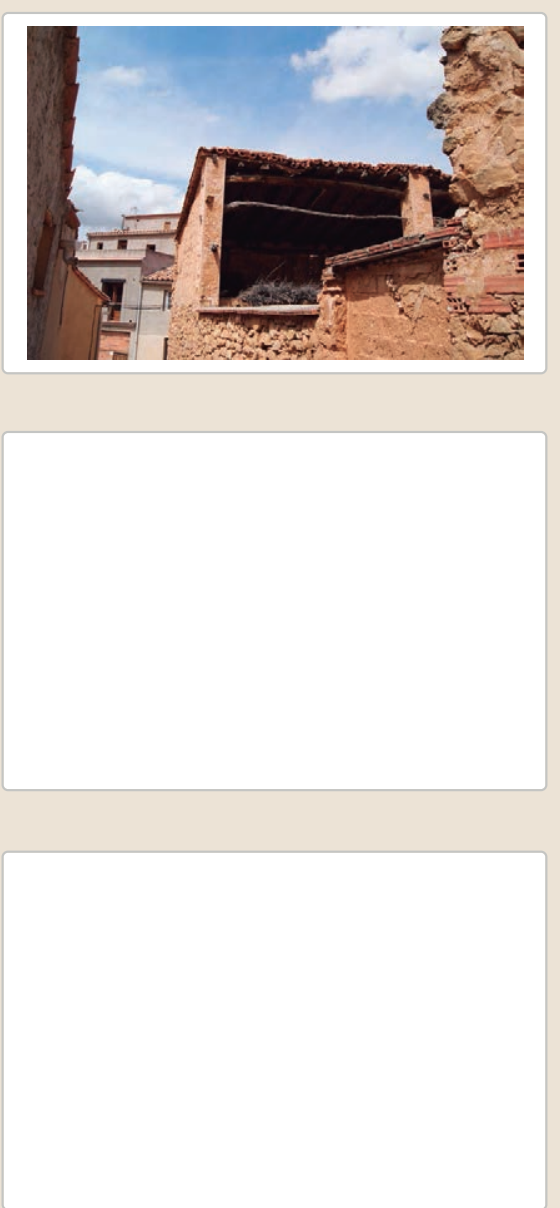
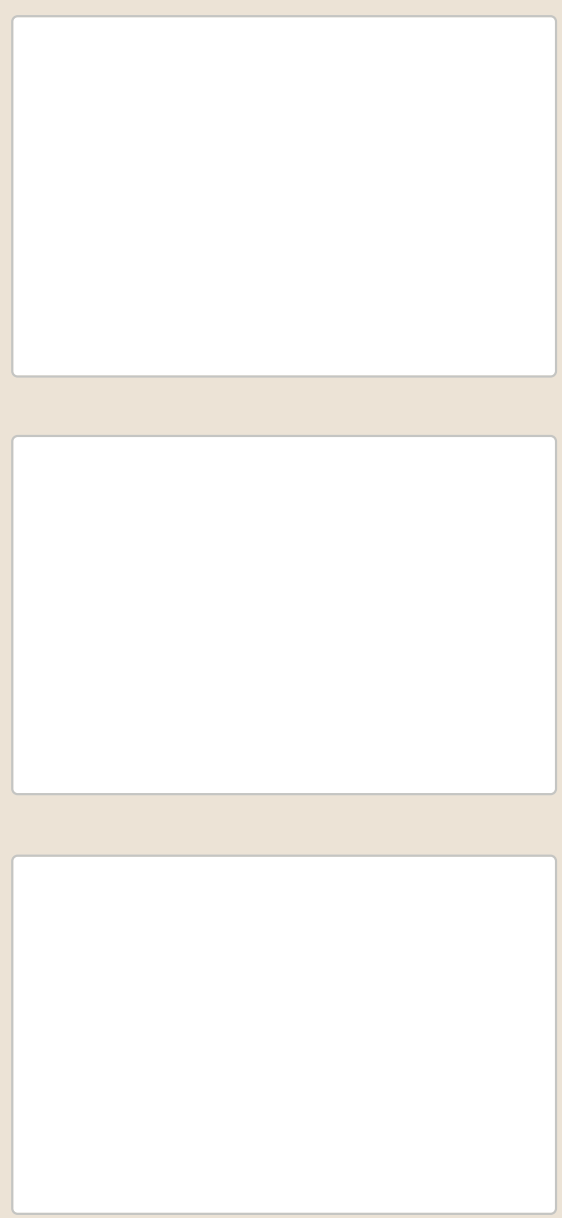
La restauración y rehabilitación de la arquitectura tradicional de tierra. El caso de Aragón

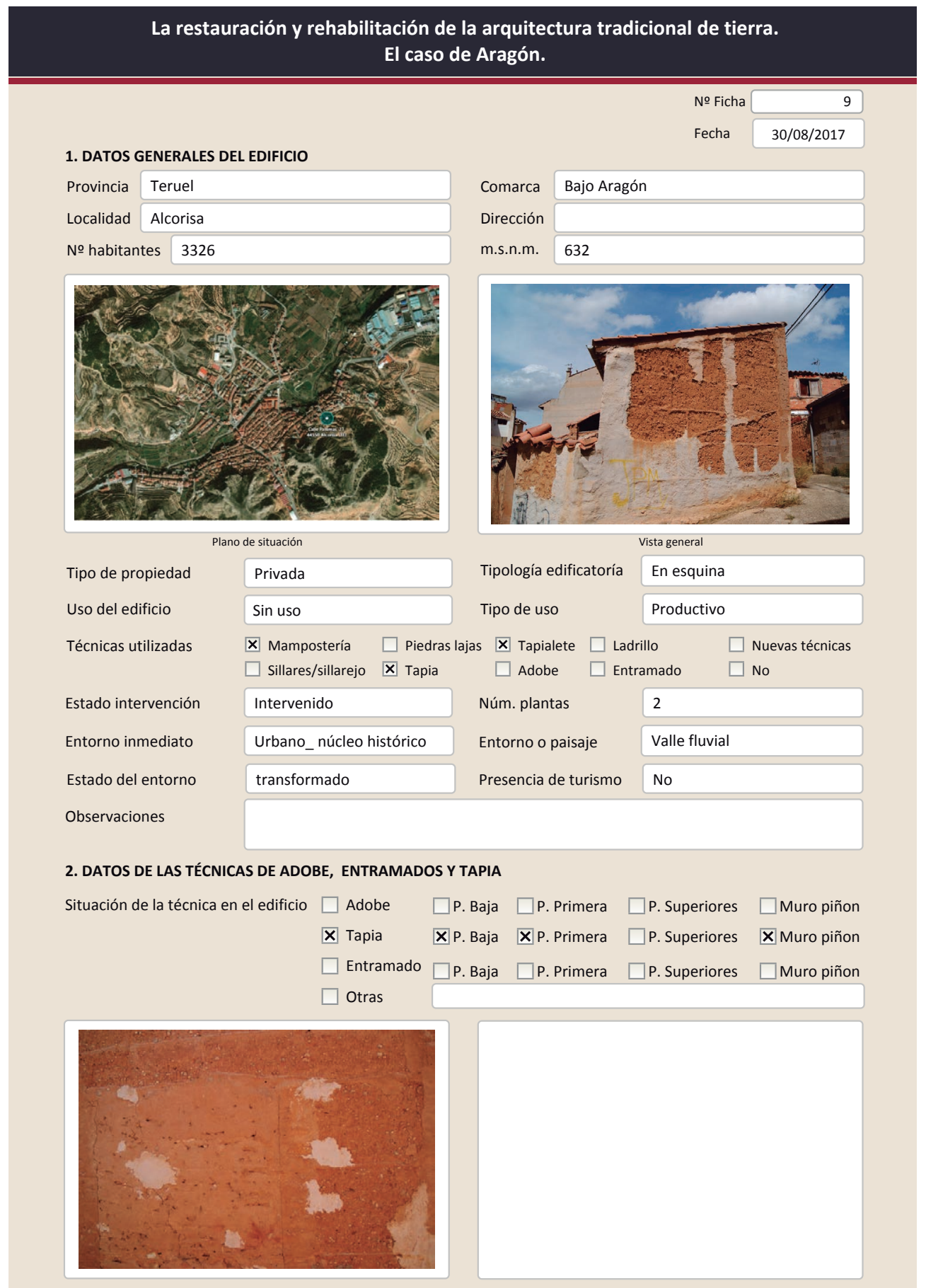

La restauración y rehabilitación de la arquitectura tradicional de tierra.

El caso de Aragón.

2.2. TAPIA

Ancho del muro

Dimensión tapiales

Tipo de aguja

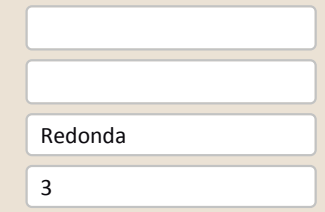

Color de la tapia

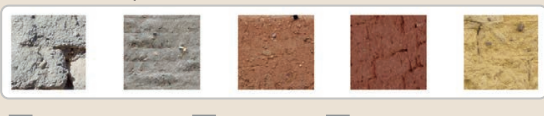

$\square$ Blanquecino $\quad \mathbf{X}$ Marrón $\square$ Amarillento

$\begin{array}{ll}\square \text { Blanquecino } & \mathbf{x} \text { Marrón } \\ \square \text { Grisaceo } & \square \text { Rojizo } \quad \square \text { Otro... }\end{array}$

№ agujas/cajón

Variante constructiva

X Simple / homogénea
$\square$ Suplemento superficial
$\mathbb{X}$ Suplemento en juntas
$\mathbf{X}$ Mixta

Tapialete

$\mathbf{X}$ Mixt

\section{Juntas}

En esquinas

$\mathrm{Cal} /$ yeso

entos de protección

Solo existe tapialete en un punto que parece un hueco cegado

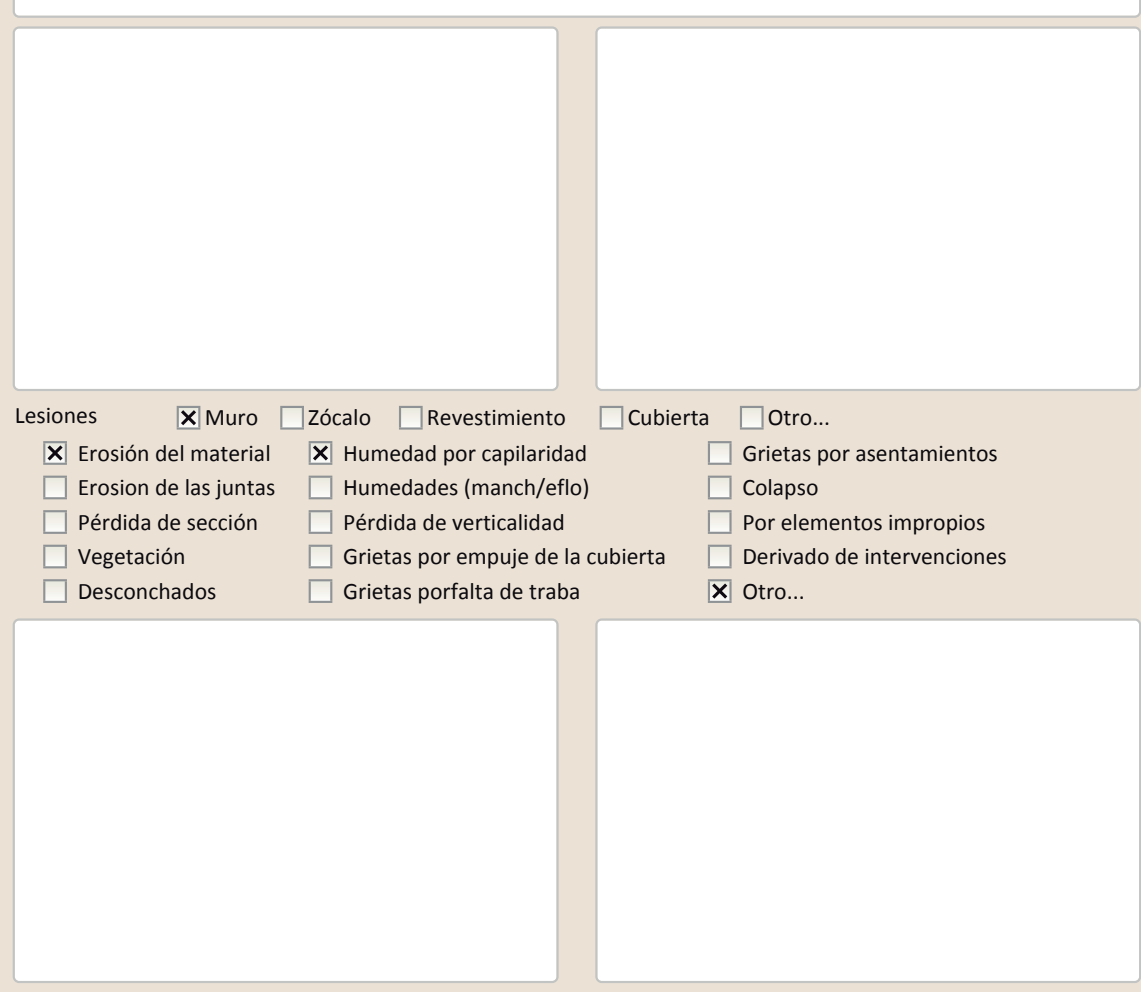

Observaciones 


\section{La restauración y rehabilitación de la arquitectura tradicional de tierra.}

\section{El caso de Aragón.}

3. DATOS DE LA INTERVENCIÓN

\begin{tabular}{l|lll|} 
Intervención de: & $\square$ Mantenimiento & $\square$ Rehabilitación parcial & $\square$ Restauración \\
& $\mathbf{X}$ Reparación & $\square$ Demolición \\
Reflexión previa & Intervención espontanea & \\
Observaciones & & \\
& & \\
& &
\end{tabular}

\subsection{MUROS}

Tipo de intervención

Intervenido

Tipo de material

$\square$ Actualización $\quad$ X Reintegración $\square$ Demolición $\square$ Otro...

$\square$ Consolidación $\square$ Reconstrucción $\square$ sustitución

Descripción

No tradicional Tipo de técnica Diferente a la existente

3.2. ZóCALO

Tipo de intervención

Se han rellenado oquedades existentes en el muro con yeso.

Tipo de material

Intervenido

$\square$ Actualización $\square$ Reintegración $\square$ Demolición $\square$ Otro...

$\square$ Actualización
$\square$ Consolidación $\quad \boldsymbol{X}$ Reintegracionstrucción $\quad \square$ Sustitución

Descripción
No tradicional
Tipo de técnica Diferente a la existente

3.3. REVESTIMIENTOS

nuevo zócalo de yeso sobre la mampostería

Tipo de intervención

\section{No aplica}

Tipo de material

Descripción

$\square$ Reintegración $\square$ Demolición $\square$ Otro...

$\square$ Consolidación $\square$ Reconstrucción $\square$ Sustitución

3.4. VANOS

No intervenido

Tipo de intervención

$\square$ Actualización $\square$ Reintegración $\square$ Demolición $\square$ Otro...

Tipo de material

Descripción

$\square$ Consolidación $\square$ Reconstrucción $\square$ sustitución

3.5. CUBIERTA

Tipo de intervención

Intervenido

$\square$ Actualización $\square$ Reintegración $\square$ Demolición $\square$ Otro.

Tipo de material

$\square$ Consolidación $\square$ Reconstrucción $\quad \mathbf{X}$ Sustitución

Descripción

No tradicional Tipo de técnica Diferente a la existente

Cubierta con bardos y cemento que coge la teja curva

3.6. OTRAS 


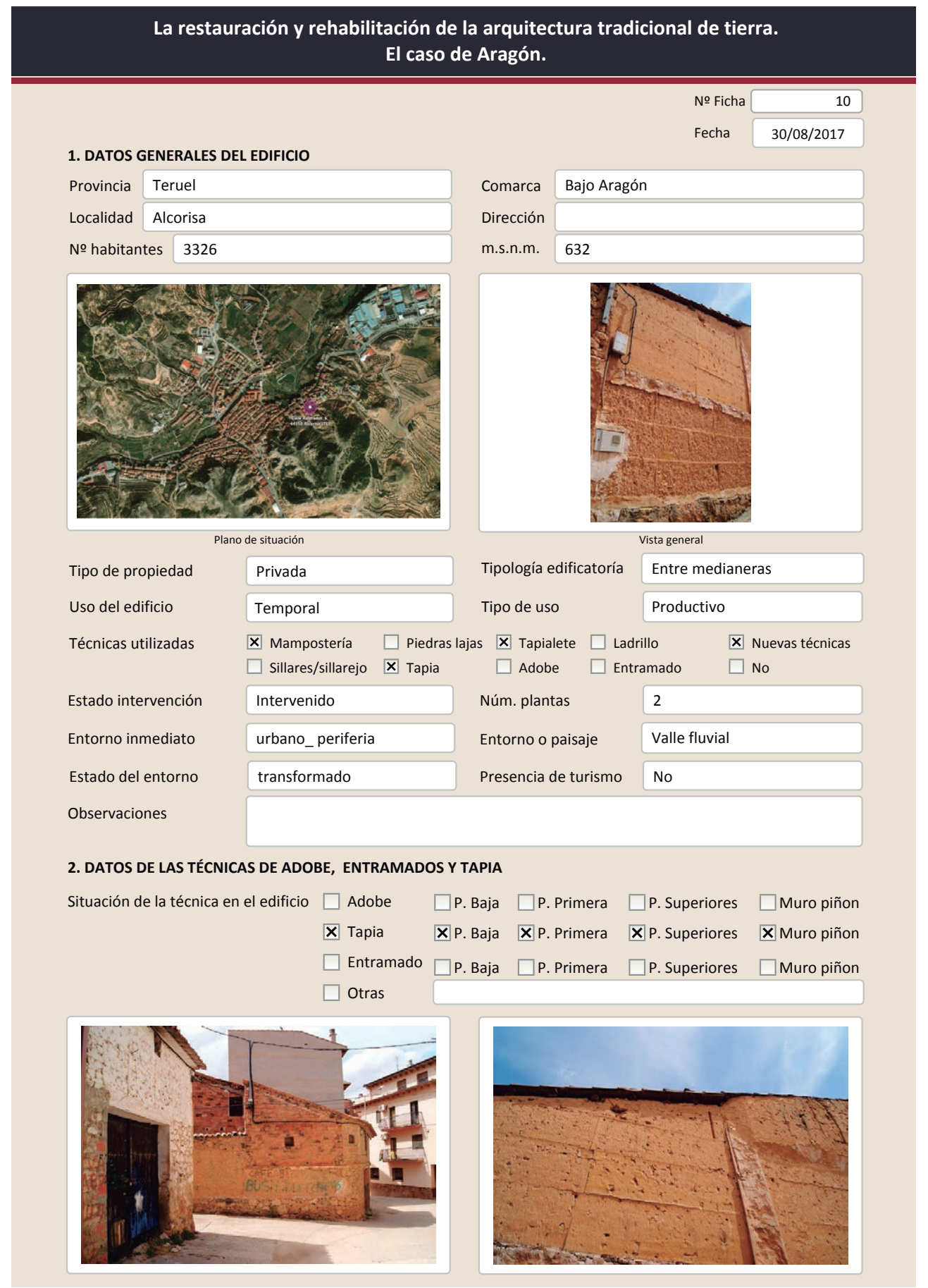

2.2. TAPIA

Ancho del muro

Dimensión tapiales

Tipo de aguja

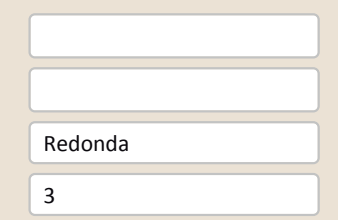

Color de la tapia

№ agujas/cajón

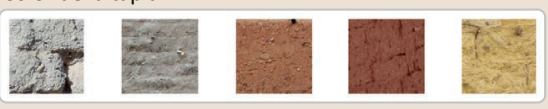

$\square$ Blanquecino $\mathbf{X}$ Marrón $\square$ Amarillento

$\begin{array}{lll}\square \text { Blanquecino } & \mathbf{X} \text { Marrón } \\ \square \text { Grisaceo } & \square \text { Amarillen } \\ & \text { Rojizo } & \end{array}$

Variante constructiva

X Simple / homogénea
$\square$ Suplemento superficial
X Suplemento en juntas
$\mathbf{X}$ Mixta

$\mathbf{x}$ Mixta
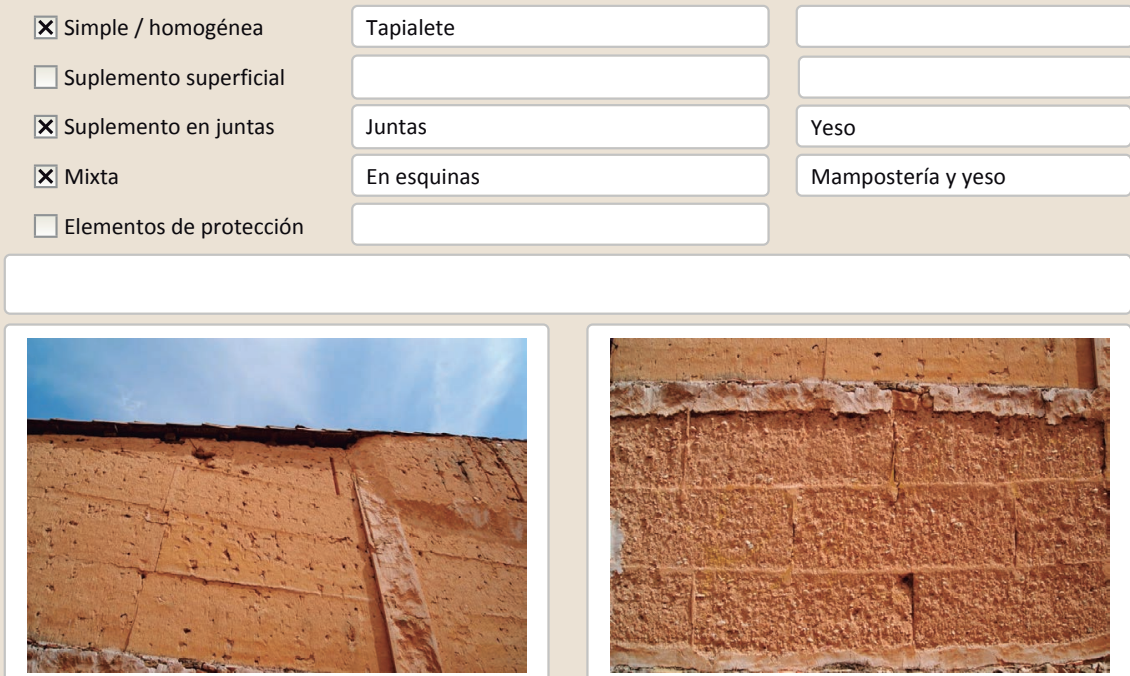

Lesiones $\mathbf{X}$ Muro $\square$ Zócalo $\square$ Revestimiento $\mathbf{X}$ Cubierta $\square$ Otro...

X Erosión del material $\quad \square$ Humedad por capilaridad $\quad \square$ Grietas por asentamiento

$\square$ Erosion de las juntas $\mathbf{X}$ Humedades (manch/eflo)

$\square$ Pérdida de sección $\quad \square$ Pérdida de verticalidad

$\square$ Vegetación

$\square$ Desconchados

$\square$ Grietas porfalta de trab
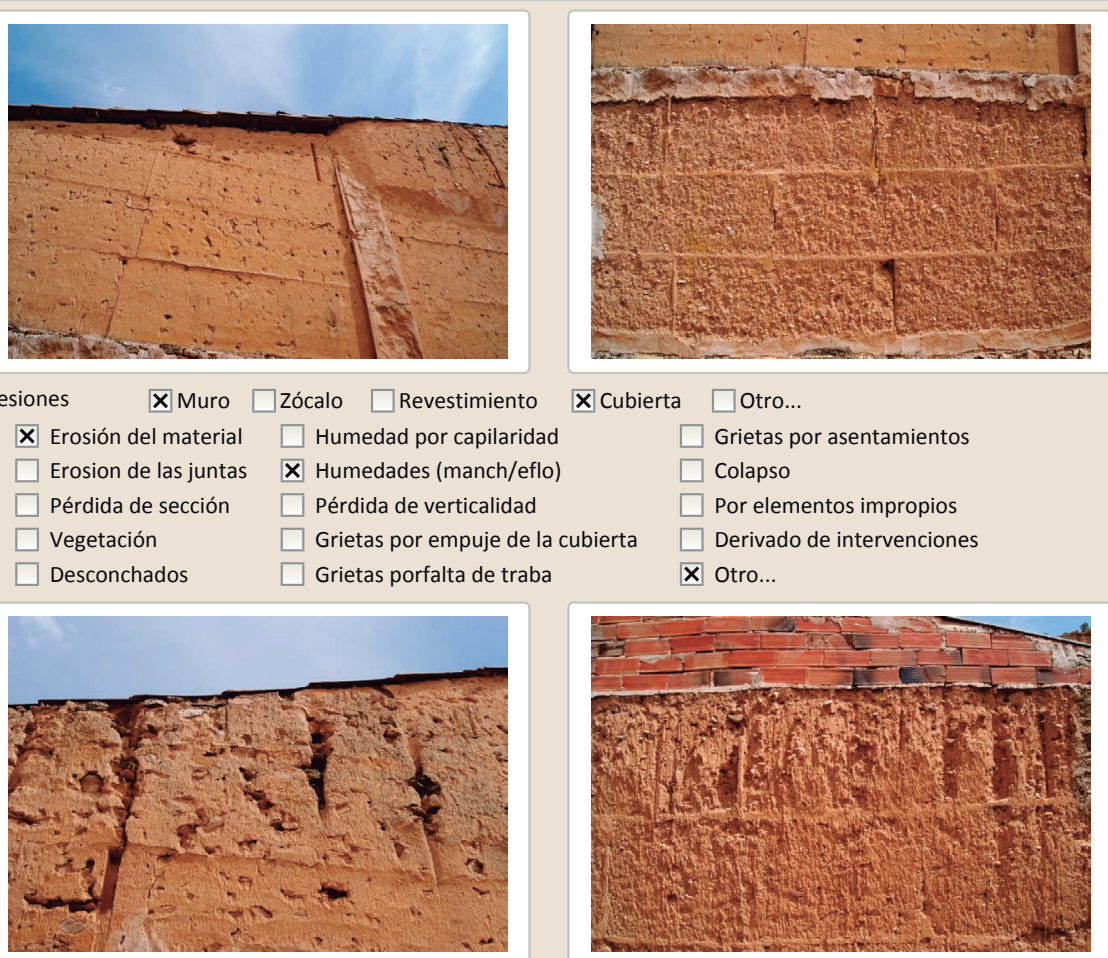

$\square$ Derivado de in

$\mathbf{X}$ Otro...

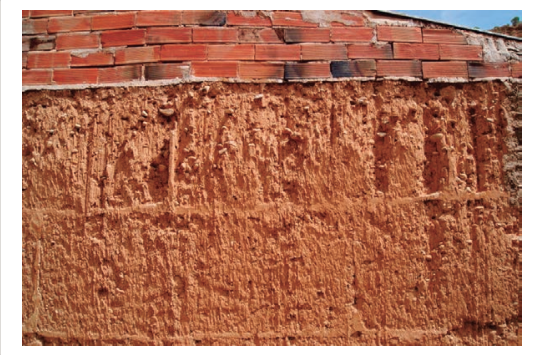

Observaciones

El muro se ha lavado en algunos punto por la evacuación del agua de las tejas de cubierta. 


\section{La restauración y rehabilitación de la arquitectura tradicional de tierra.} El caso de Aragón.

3. DATOS DE LA INTERVENCIÓN

Intervención de:

$\square$ Mantenimiento $\quad \mathbf{X}$ Rehabilitación parcia

$\square$ Restauración $\square$ Demolición

Reflexión previa X Reparación Rehabilitación integra $\square$ Ampliación $\square$ otro...

Reflexión previa
Observaciones

Intervención espontanea

\subsection{MUROS}

Tipo de intervención

Tipo de material

Descripción

3.2. ZÓCALO

Tipo de intervención

Tipo de material

Descripción

3.3. REVESTIMIENTOS

Tipo de intervención

Tipo de material

Descripción

3.4. VANOS
Tipo de intervención

Tipo de material

Descripción

3.5. CUBIERTA

Tipo de intervención

Tipo de material

Descripción

\section{Intervenido}

$\square$ Actualización $\square$ Reintegración $\square$ Demolición $\square$ Otro...

$\square$ Consolidación $\square$ Reconstrucción $\quad \boldsymbol{X}$ Sustitución

No tradicional Tipo de técnica Similar a la existente

Probablemente la zona que se ha sustituido fuera de adobe - no estructural -, poniendo ladrillos en su lugar.

Intervenido

$\square$ Actualización $\quad \square$ Reintegración $\square$ Demolición $\square$ Otro...

X Consolidación $\square$ Reconstrucción $\square$ Sustitución

No tradicional Tipo de técnica Diferente a la existente

Rejuntado de la mampostería del zócalo con gran cantidad de cemento

\section{No aplica}

$\square$ Actualización $\quad \square$ Reintegración $\quad \square$ Demolición $\square$ Otro...

$\square$ Consolidación $\quad \square$ Reconstrucción $\quad \square$ sustitución

Tipo de técnica

(1) de

Intervenido

$\square$ Actualización $\quad \square$ Reintegración $\quad \square$ Demolición $\square$ Otro...

$\square$ Consolidación $\square$ Reconstrucción $\mathbf{X}$ Sustitución
No tradicional
Tipo de técnica Diferente a la existente

Nuevo hueco de acceso en planta baja

\section{Intervenido}

$\square$ Actualización $\square$ Reintegración $\square$ Demolición $\square$ Otro..

$\square$ Consolidación $\mathbf{X}$ Reconstrucción $\mathbf{X}$ Sustitución

La restauración y rehabilitación de la arquitectura tradicional de tierra.

El caso de Aragón.

3.7. REHABILITACIÓN ENERGÉTICA $\quad \square$ Fachada $\square$ Vanos $\square$ Forjados $\square$ Cubierta

Observaciones

FOTOGRAFíAS DE LA INTERVENCIÓN
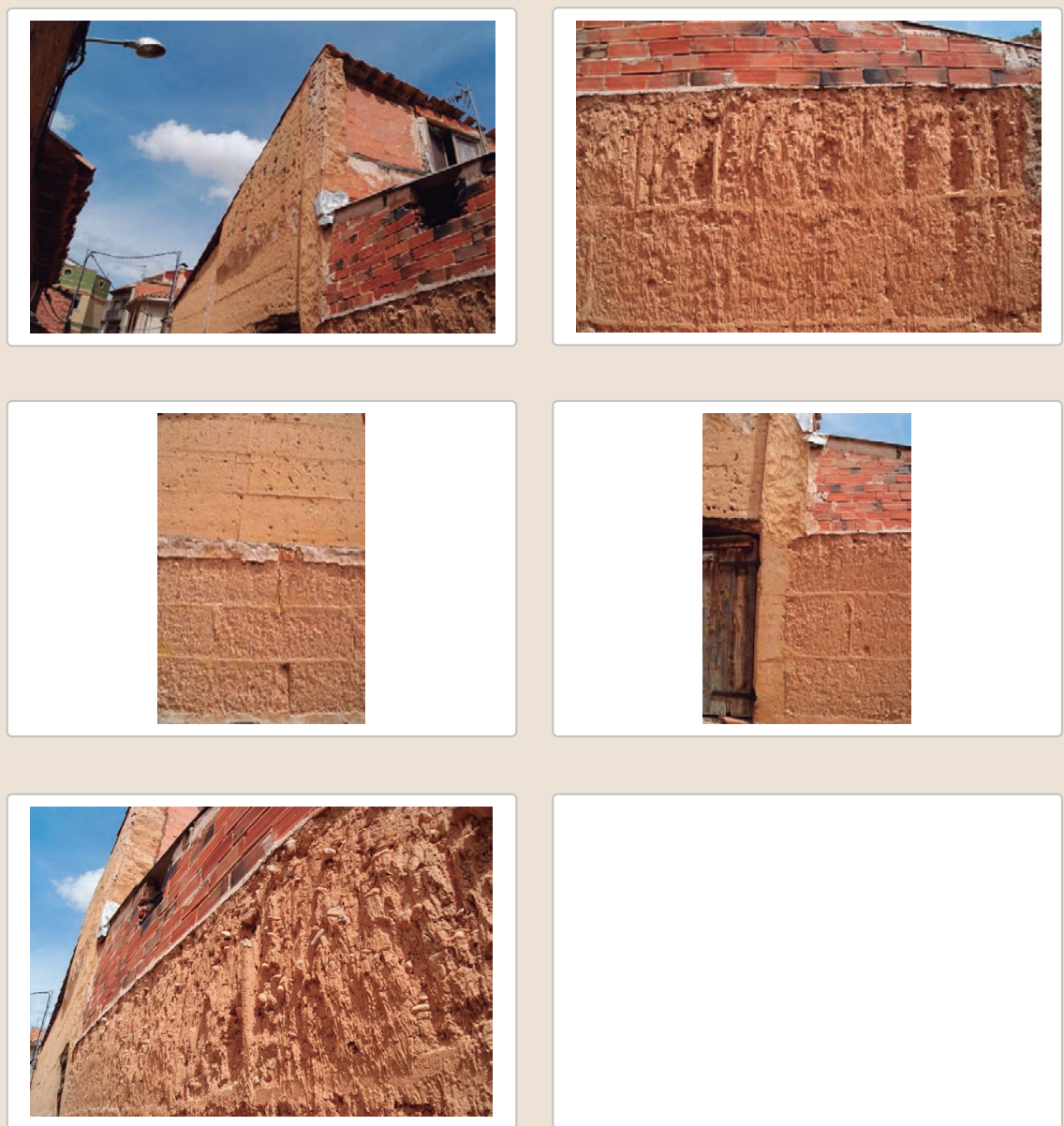

Parte de la cubierta ha sido sustituida y otra se ha sustituido parcialmente los

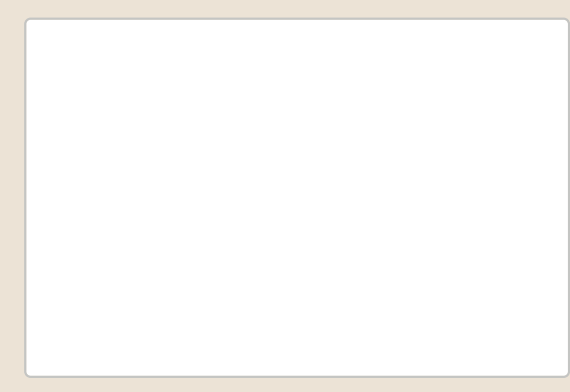

3.6. OTRAS elementos cerámicos. 


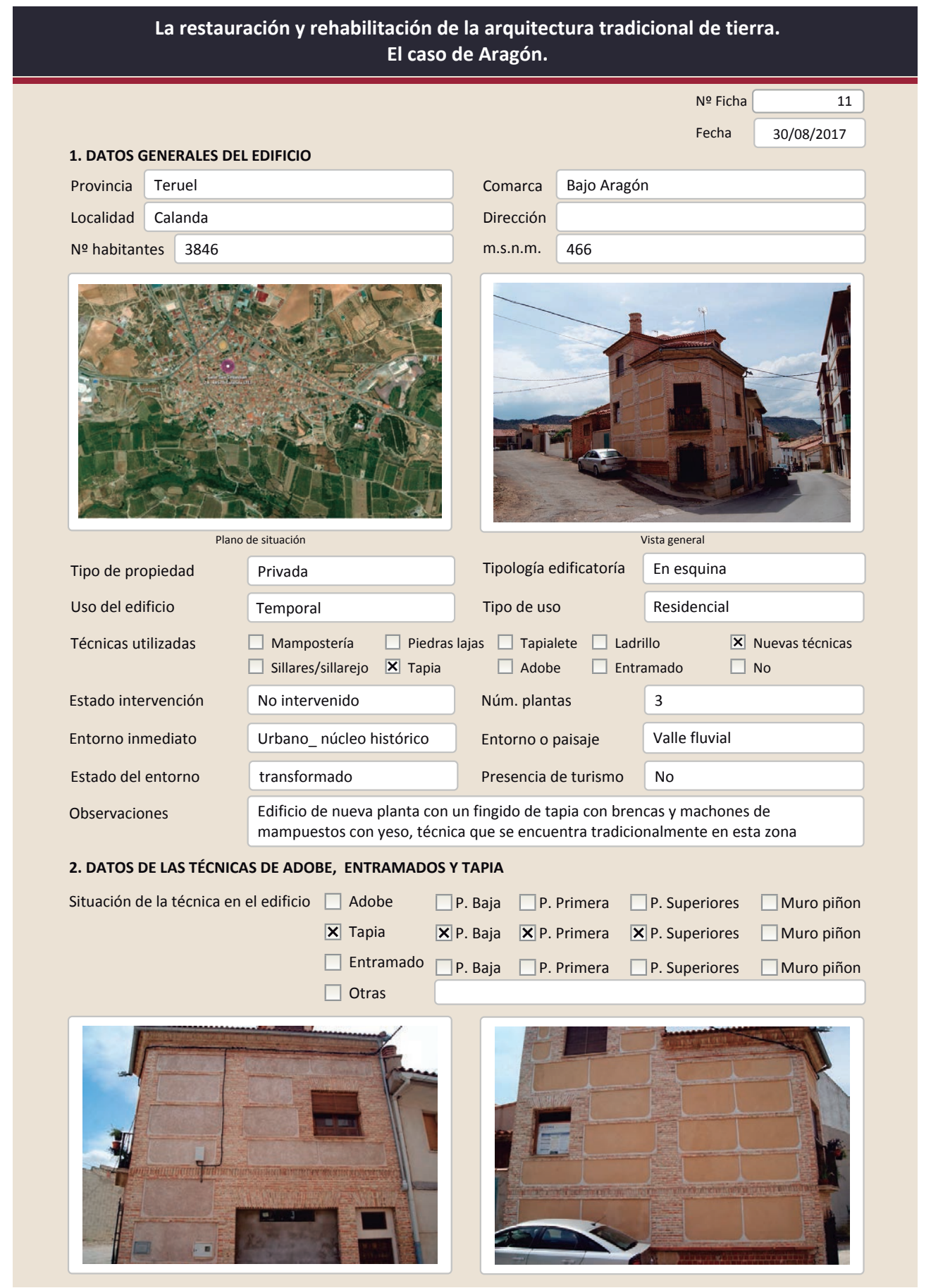

2.2. TAPIA

Ancho del muro

Dimensión tapiales

Tipo de aguja

№ agujas/cajón

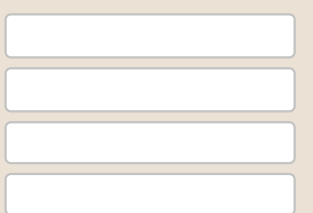

Color de la tapia

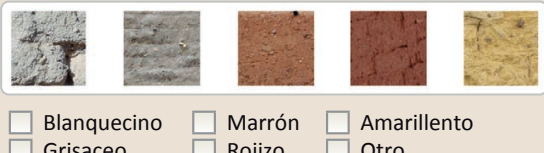

$\square$ Blanquecino $\square$ Marrón $\square$ Amarillento

$\square$ Simple / homogénea

$\square$ suplemento superficial

$\boldsymbol{X}$ Suplemento en juntas

$\mathbf{X}$ Mixta
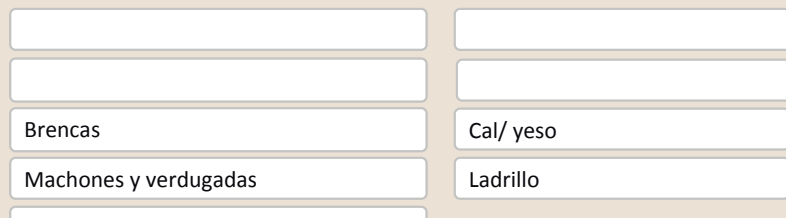

Ladrillo

El nuevo edificio ha tomado elementos de la arquitectura tradicional para su diseño

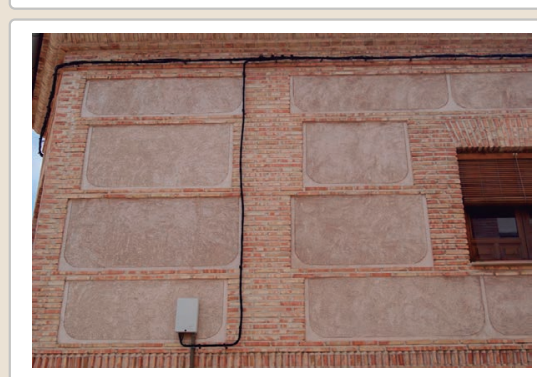

Lesiones $\square$ Muro $\square$ Zócalo $\square$ Revestimiento $\square$ Cubierta $\square$ otro...

$\square$ Erosión del material $\quad \square$ Humedad por capilaridad $\quad \square$ Grietas por asentamientos $\square$ Erosion de las juntas $\square$ Humedades (manch/eflo)

$\square$ Pérdida de sección $\quad \square$ Pérdida de verticalidad

$\square$ Vegetación $\square$ Grietas por empuje de la cubierta

$\square$ Desconchado

$\square$ Grietas porfalta de traba
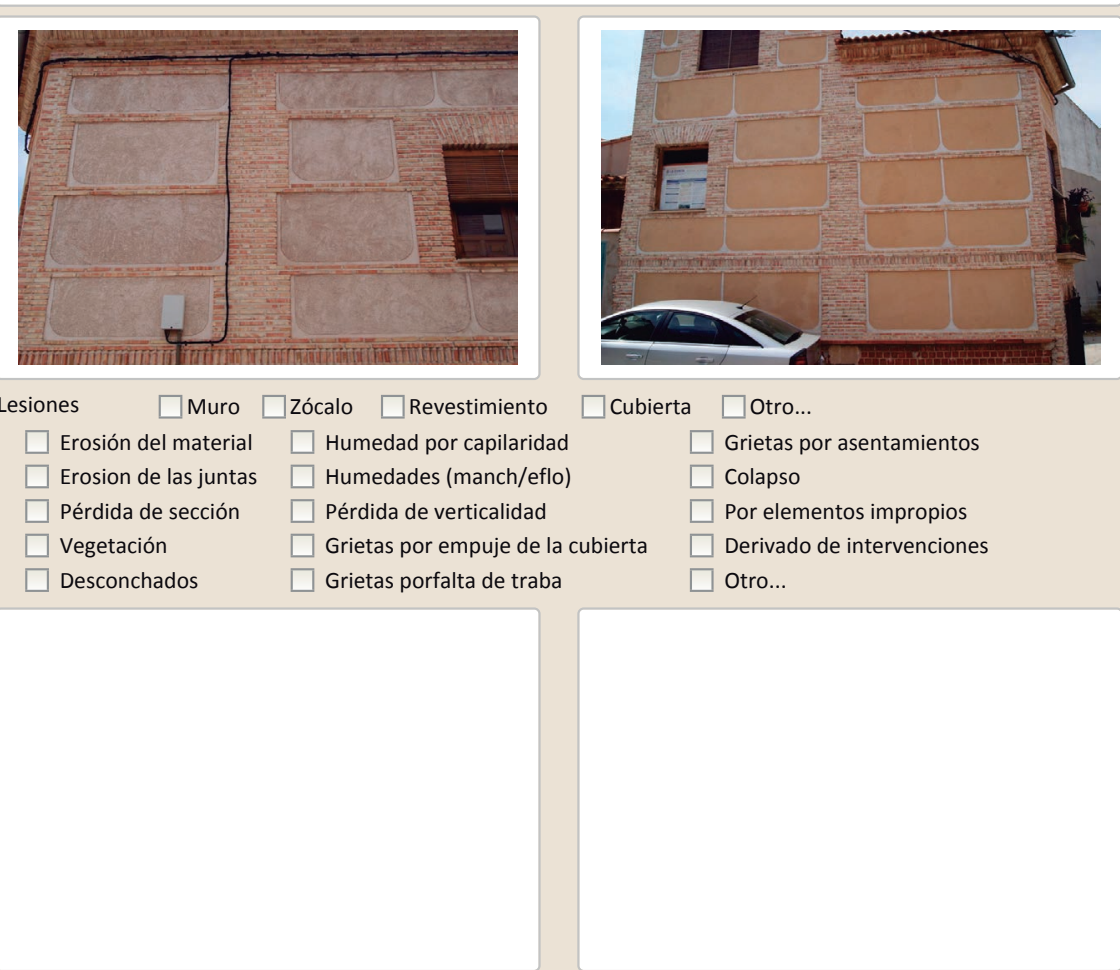

Observaciones 


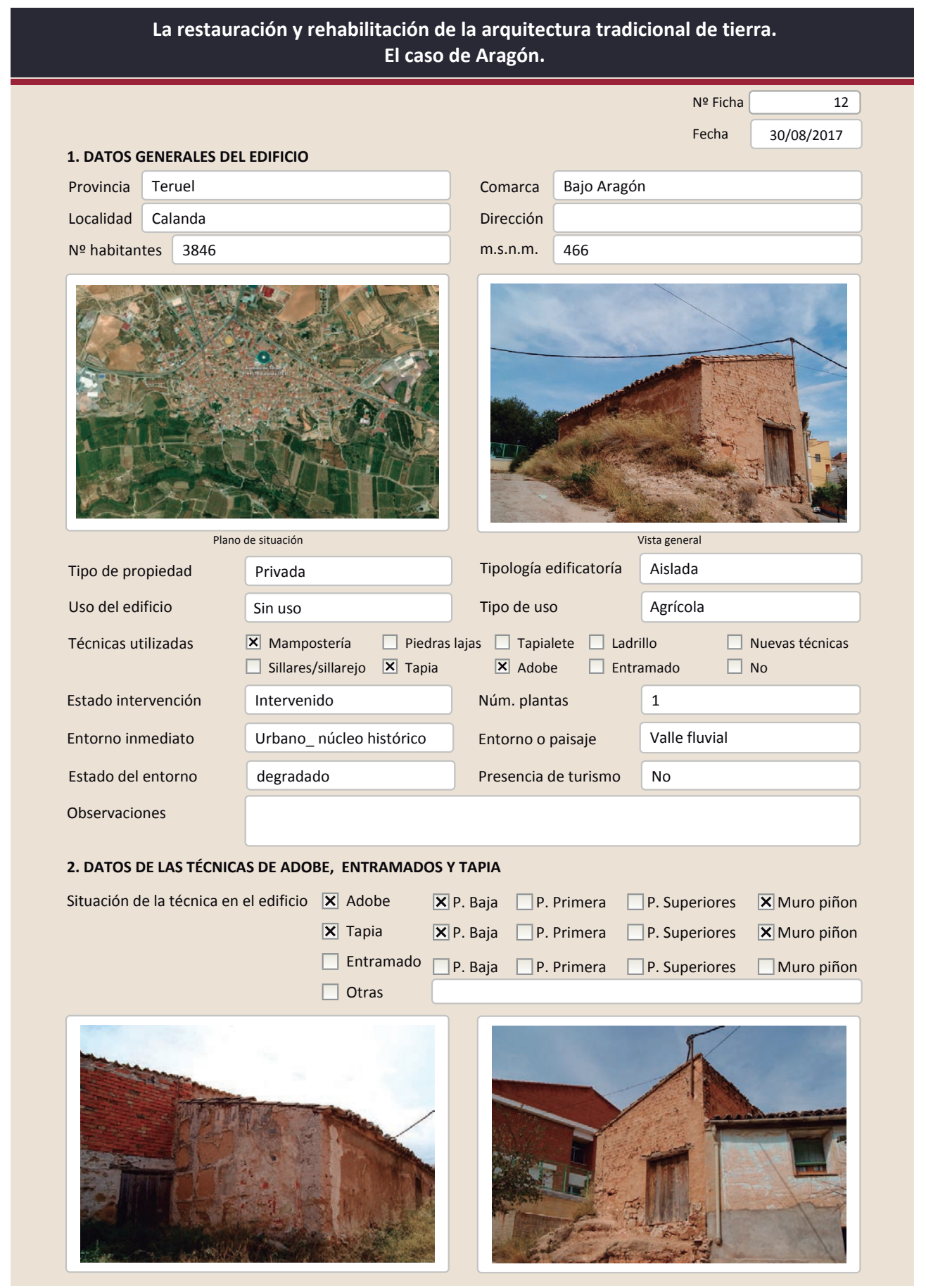

La restauración y rehabilitación de la arquitectura tradicional de tierra.

2.1. ADOBE

Dimensión de las piezas

Dimensión del muro

Aparejo del muro

Función estructural

\section{El caso de Aragón.}

Color de las piezas

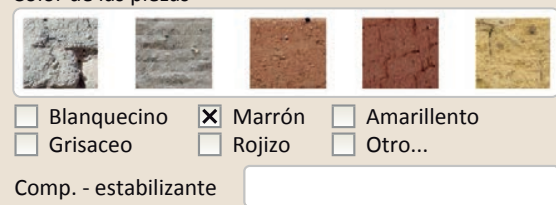

Variante constructiva/ tipo de fábrica

$\square$ Simple

$\square$ Suplementada en juntas

X Mixta

En esquinas

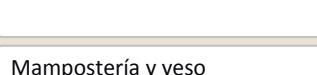

$\square$ Como suplemento

$\mathbf{X}$ Elementos de protección

Revestimiento

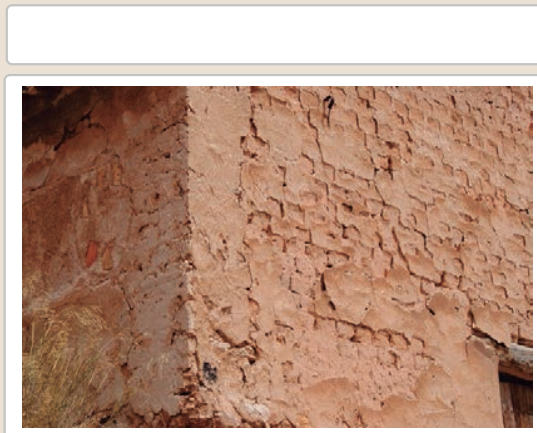

Lesiones $\quad \mathbf{X}$ Muro $\mathbf{X}$ Zócalo $\square$ Revestimiento

\ Erosión del material $\mathbf{X}$ Humedad por capilaridad

$\square$ Erosion de las juntas $\square$ Humedades (manch/eflo)

$\square$ Pérdida de sección $\square$ Pérdida de verticalidad

$\square$ Vegetación $\quad \square$ Grietas por empuje de la cubiet $\square$ Grietas porfalta de traba

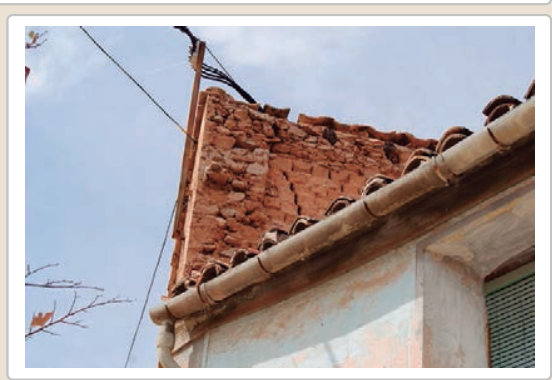

$\square$ Cubierta $\square$ otro...

$\square$ Grietas por asentamientos

$\square$ Colapso

X Desconchado

$\square$ Por elementos impropios

$\square$ Derivado de intervenciones

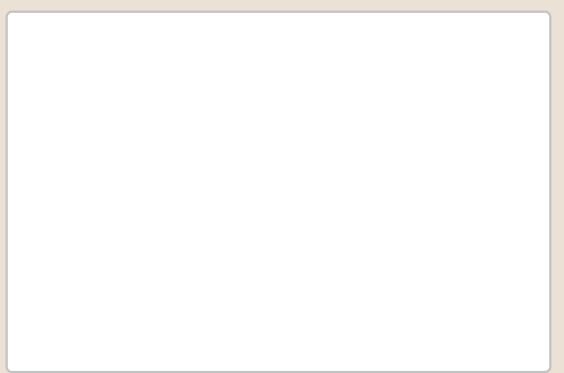

Observaciones

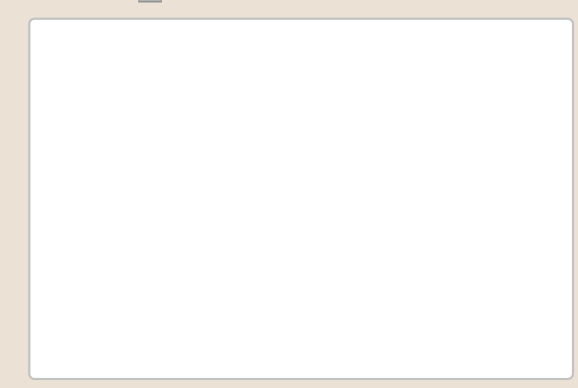




\section{La restauración y rehabilitación de la arquitectura tradicional de tierra.} El caso de Aragón.

\subsection{TAPIA}

Ancho del muro

Dimensión tapiales

Tipo de aguja

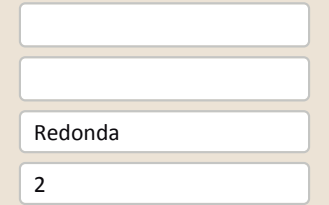

Color de la tapia

№ agujas/cajón

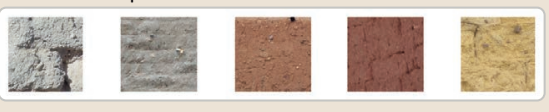

$\square$ Blanquecino $\quad \mathbf{X}$ Marrón $\square$ Amarillento

$\square$ Grisaceo $\square$ Rojizo $\square$ Otro...

$\square$ Simple / homogénea

X Suplemento superficial

$\mathbb{X}$ Suplemento en juntas

$\mathbf{X}$ Mixta

\begin{tabular}{|l|}
\hline \\
\hline Calicostrada \\
\hline Brencas \\
\hline En esquinas \\
\hline
\end{tabular}

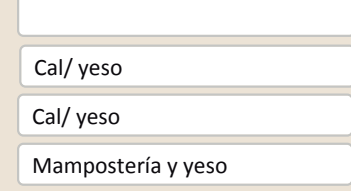

$\square$ Elementos de protecció

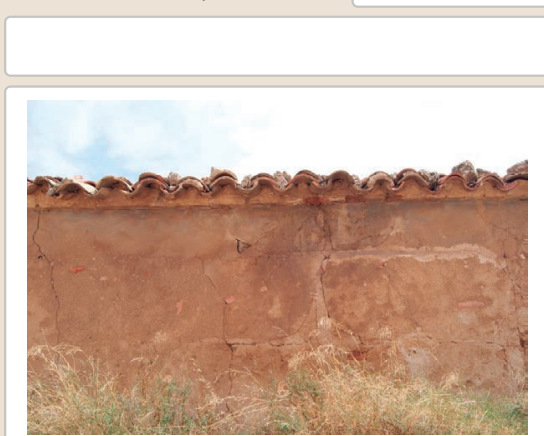

Lesiones $\quad$ Muro $\square$ Zócalo $\square$ Revestimiento

$\mathbf{X}$ Erosión del material $\square$ Humedad por capilaridad

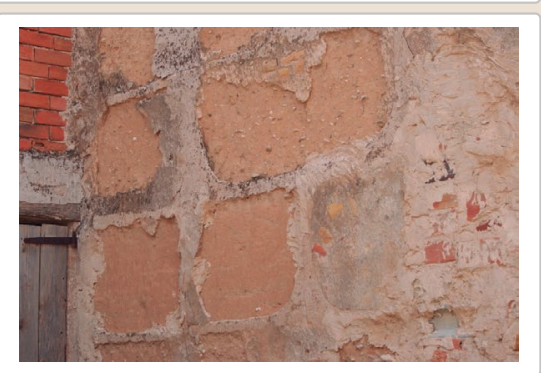

$\square$ Erosion de las juntas

$\square$ Pérdida de sección

$\square$ Humedades (manch/eflo)

Cubierta $\square$ otro...

$\square$ Pérdida de verticalidad

$\square$ Vegetación

$\square$ Grietas por empuje de la cub

$\square$ Grietas por asentamientos

$\square$ Colapso

Х Desconchados

$\square$ Grietas porfalta de traba

$\square$ Por elementos impropios

$\square$ Derivado de interven

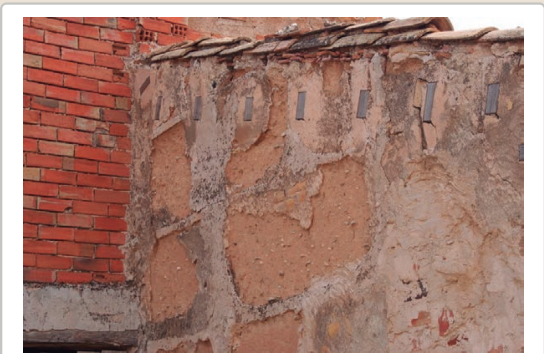

$\square$ Otro...

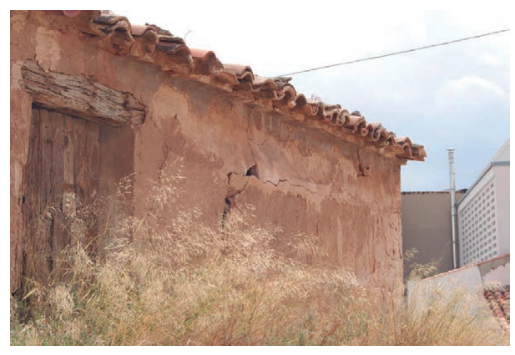

Observaciones
La restauración y rehabilitación de la arquitectura tradicional de tierra.

El caso de Aragón.

3. DATOS DE LA INTERVENCIÓN

Intervención de: $\quad \square$ Mantenimiento $\quad \square$ Rehabilitación parcial $\quad \square$ Restauración $\square$ Demolición

Reflexión previa Intervención espontanea

Observaciones

3.1. MUROS

Tipo de intervención

Intervenido

$\square$ Consolidación $\quad \square$ Reconstrucción $\quad \square$ Sustitución

\begin{tabular}{l|l|l|l|l|l|l|l|l|l} 
Tipo de material & No tradicional de técnica & Diferente a la existente
\end{tabular}

Descripción

Reintegración de perdida de material con cemento y trozos de material cerámico

3.2. ZÓCALO

No intervenido

Tipo de intervención

$\square$ Actualización $\square$ Reintegración $\square$ Demolición $\square$ Otro.

$\square$ Consolidación $\square$ Reconstrucción $\square$ Sustitución

Tipo de material

Descripción

3.3. REVESTIMIENTOS

Tipo de intervención

Intervenido

$\square$ Actualización $\quad \square$ Reintegración $\quad \square$ Demolición $\square$ Otro.

Tipo de material

Consolidación $\mathbf{X}$ Reconstrucción $\square$ Sustitución

Descripción En el área de la tapia donde existía costra se ha reconstruido parcialmente con un

revestimiento

3.4. VANOS

Tipo de intervención

No intervenido

$\square$ Actualización $\square$ Reintegración $\square$ Demolición $\square$ Otro..

$\square$ Consolidación $\quad \square$ Reconstrucción $\square$ Sustitución

Tipo de material

Descripción

3.5. CUBIERTA

No intervenido

Tipo de intervención

$\square$ Actualización

$\square$ Consolidació

$\square$ Reintegración $\quad \square$ Demolición $\square$ Otro...

Tipo de material

Descripción

3.6. OTRAS

\section{Tipo de técnica}




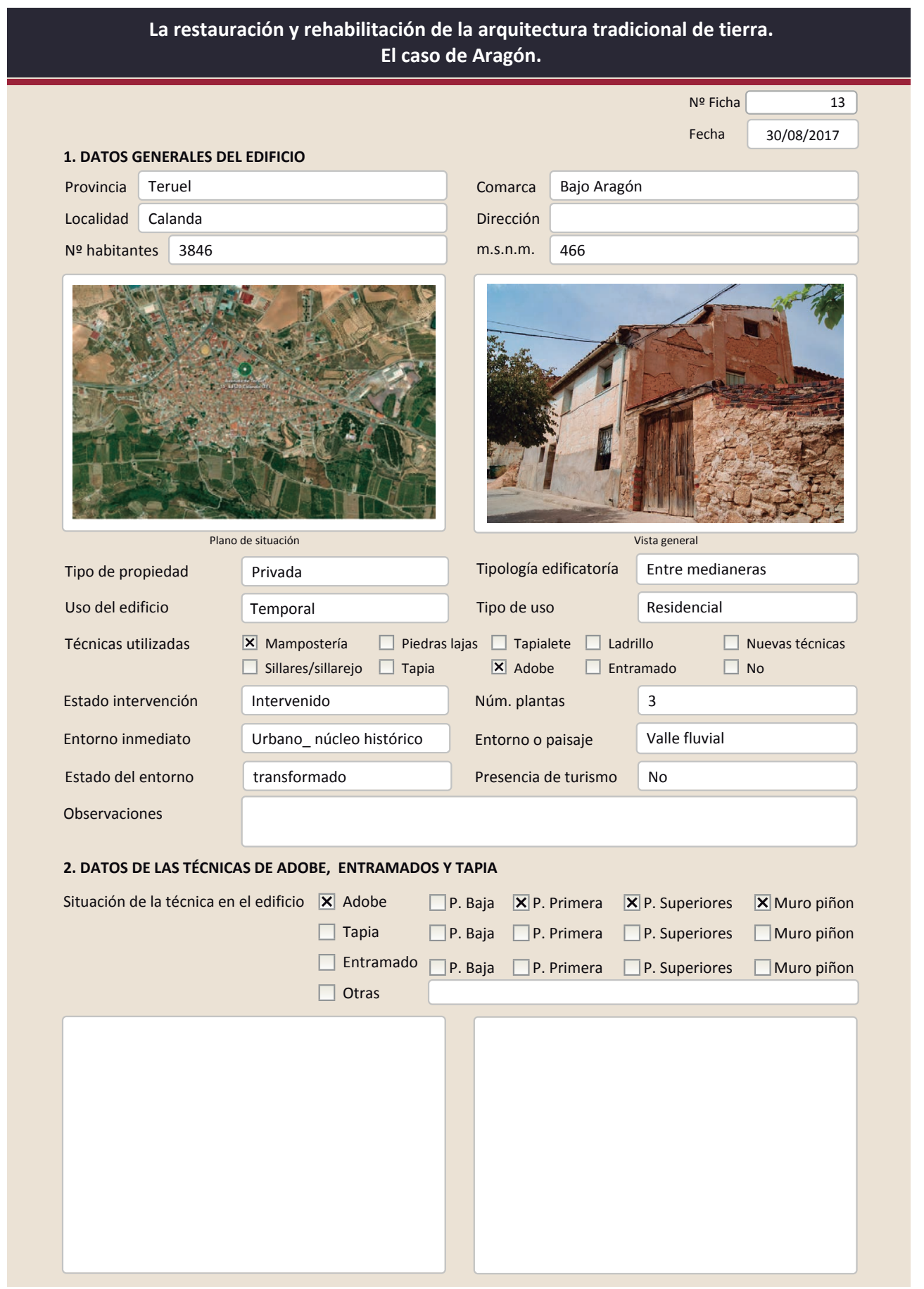

La restauración y rehabilitación de la arquitectura tradicional de tierra.

El caso de Aragón.

2.1. ADOBE

Dimensión de las piezas

Dimensión del muro

Aparejo del muro

Función estructural
Color de las piezas

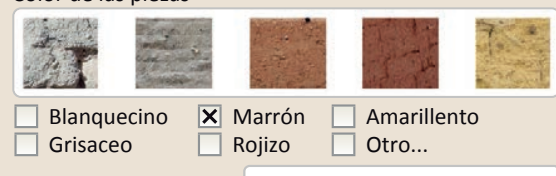

Comp. - estabilizante

Variante constructiva/ tipo de fábrica

$\square$ Simple
$\mathbf{X}$ Suplementada en juntas
Verticales y horizontales
$\mathrm{Cal} /$ yeso
X Mixta

\section{En esquinas}
Mampostería y yeso
$\square$ Como suplemento
$\square$ Elementos de protección

Se aprecia como la madera o montante se colocó antes que los muros de adobe ya que existen adobes cortados para rellenar el hueco.
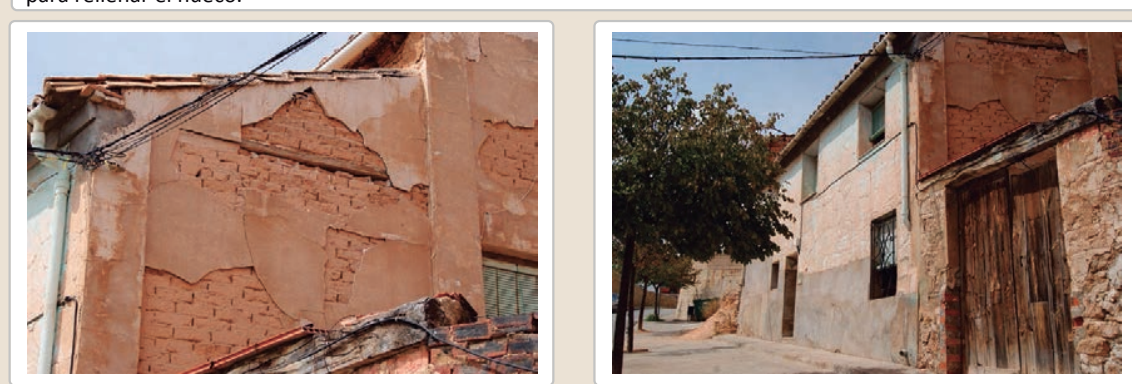

Lesiones $\mathbf{X}$ Muro $\square$ Zócalo $\mathbf{X}$ Revestimiento $\mathbb{X}$ Erosión del material $\square$ Humedad por capilaridad $\mathbf{X}$ Erosion de las juntas $\square$ Humedades (manch/eflo) $\square$ Pérdida de sección $\quad \square$ Pérdida de verticalidad $\square$ Cubierta $\square$ otro...

$\square$ Vegetación $\quad \square$ Grietas por empuje de la cubierta $\square$ Derivado de intervenciones $\mathbf{X}$ Desconchados $\quad \square$ Grietas porfalta de traba $\square$ Derivad
$\square$ Otro...

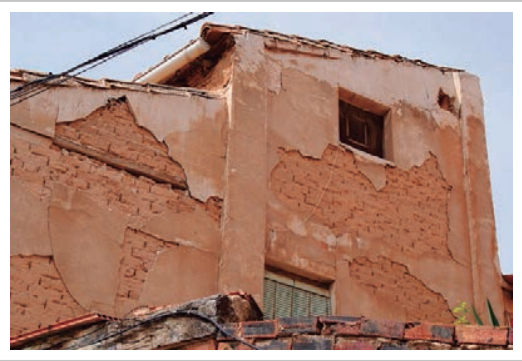

Observaciones 
La restauración y rehabilitación de la arquitectura tradicional de tierra. El caso de Aragón

\section{La restauración y rehabilitación de la arquitectura tradicional de tierra.}

\section{El caso de Aragón.}

3. DATOS DE LA INTERVENCIÓN

Intervención de:

$\square$ Mantenimiento $\square$ Rehabilitación parcia

$\square$ Restauración $\square$ Demolición

Reflexión previa

X Reparación

Rehabilitación integra

Ampliación

$\square$ Otro..

Reflexión previa

Intervención espontanea

(20)

3.1. MUROS

No intervenido

Tipo de intervención

$\square$ Actualización $\square$ Reintegración $\square$ Demolición $\square$ Otro...

$\square$ Consolidación $\square$ Reconstrucción $\square$ Sustitución

Tipo de material

Descripción

3.2. ZÓCALO

Tipo de intervención

Intervenido

Tipo de intervención

Actualización $\square$ Reintegración $\square$ Demolición $\square$ Otro...

Tipo de material

$\square$ Consolidación $\quad \mathbf{X}$ Reconstrucción $\square$ Sustitución

Descripción

Similar a la existente

3.3. REVESTIMIENTOS

Se ha rehecho el zócalo con cemento en la fachada principal

Tipo de intervención

No intervenido

Tho de interion

$\square$ Actualización $\quad \square$ Reintegración $\quad \square$ Demolición
$\square$ Consolidación $\quad \square$ Reconstrucción $\quad \square$ Sustitución

$\square$ Reintegración $\square$ Demolición $\square$ Otro...

Descripción

3.4. VANOS

No intervenido

Tipo de intervención

$\square$ Actualización $\square$ Reintegración $\square$ Demolición $\square$ Otro...

Tipo de material

Descripción

$\square$ Consolidación $\square$ Reconstrucción $\square$ sustitución

3.5. CUBIERTA

Tipo de intervención

Intervenido

$\square$ Actualización $\quad \boldsymbol{X}$ Reintegración $\square$ Demolición $\square$ Otro.

Tipo de material

$\square$ Consolidación $\quad \square$ Reconstrucción $\square$ Sustitución

Descripción

No tradicional Tipo de técnica Diferente a la existente

3.6. OTRAS

En la esquina derecha de la fachada se aprecia una intervención en la zona del alero y cubierta. Probablemente por la pérdida de algún elemento en este punto 


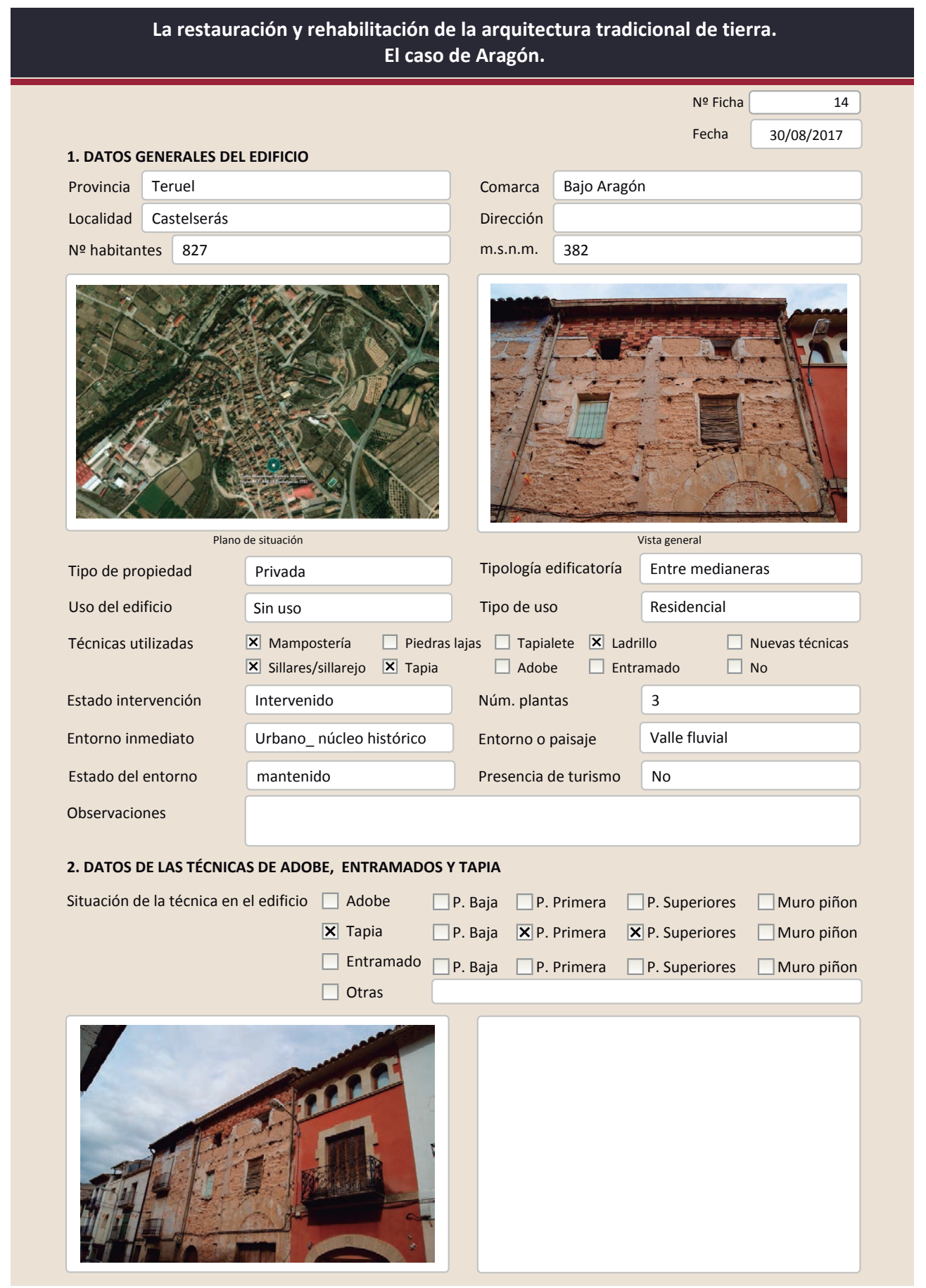

La restauración y rehabilitación de la arquitectura tradicional de tierra. El caso de Aragón.

$\begin{aligned} & \text { 2.2. TAPIA } \\ & \text { Ancho del muro }\end{aligned}$
Dimensión tapiales
Tipo de aguja
No agujas/cajón
Variante constructiva
$\begin{aligned} & \square \text { Simple / homogénea } \\ & \text { X Suplemento superficial }\end{aligned}$
$\begin{aligned} & \text { X Suplemento en juntas } \\ & \text { X Mixta }\end{aligned}$
$\square$ Elementos de protección

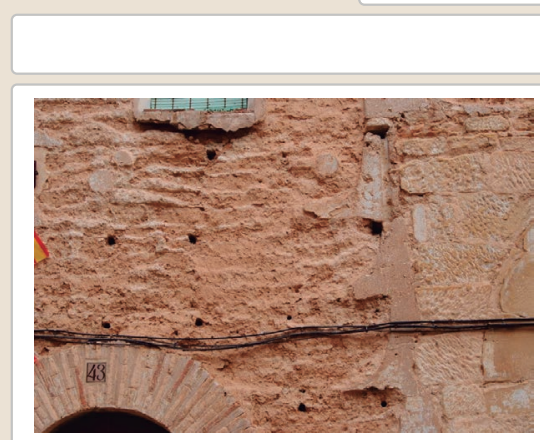

Lesiones $\quad \mathbf{X}$ Muro $\square$ Zócalo $\square$ Revestimiento $\square$ Cubierta $\square$ otro...

X Erosión del material $\quad \square$ Humedad por capilaridad $\quad \square$ Grietas por asentamientos $\square$ Erosion de las juntas $\square$ Humedades (manch/eflo) $\quad \square$ Colapso

$\square$ Pérdida de sección $\square$ Pérdida de verticalidad $\quad \square$ Por elementos impropios

$\square$ Vegetación $\square$ Grietas por empuje de la cubierta $\square$ Derivado de intervenciones Х Desconchados $\square$ Grietas porfalta de traba $\quad \square$ Otro...
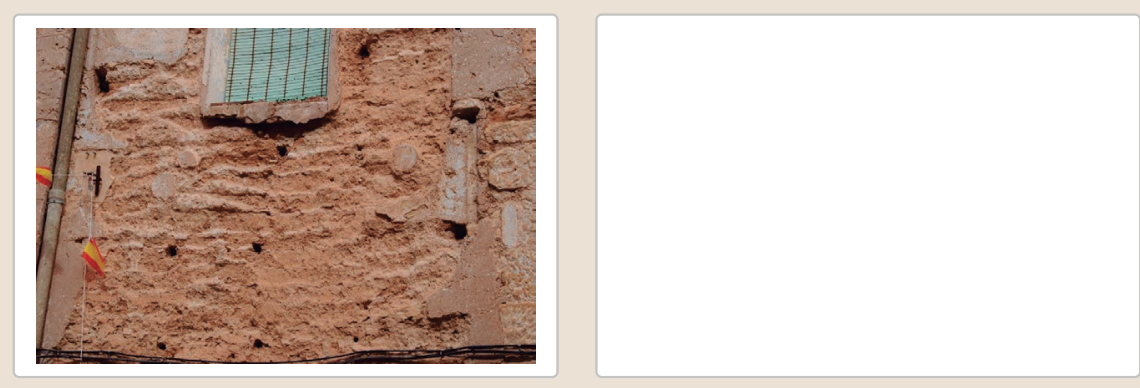

Observaciones 


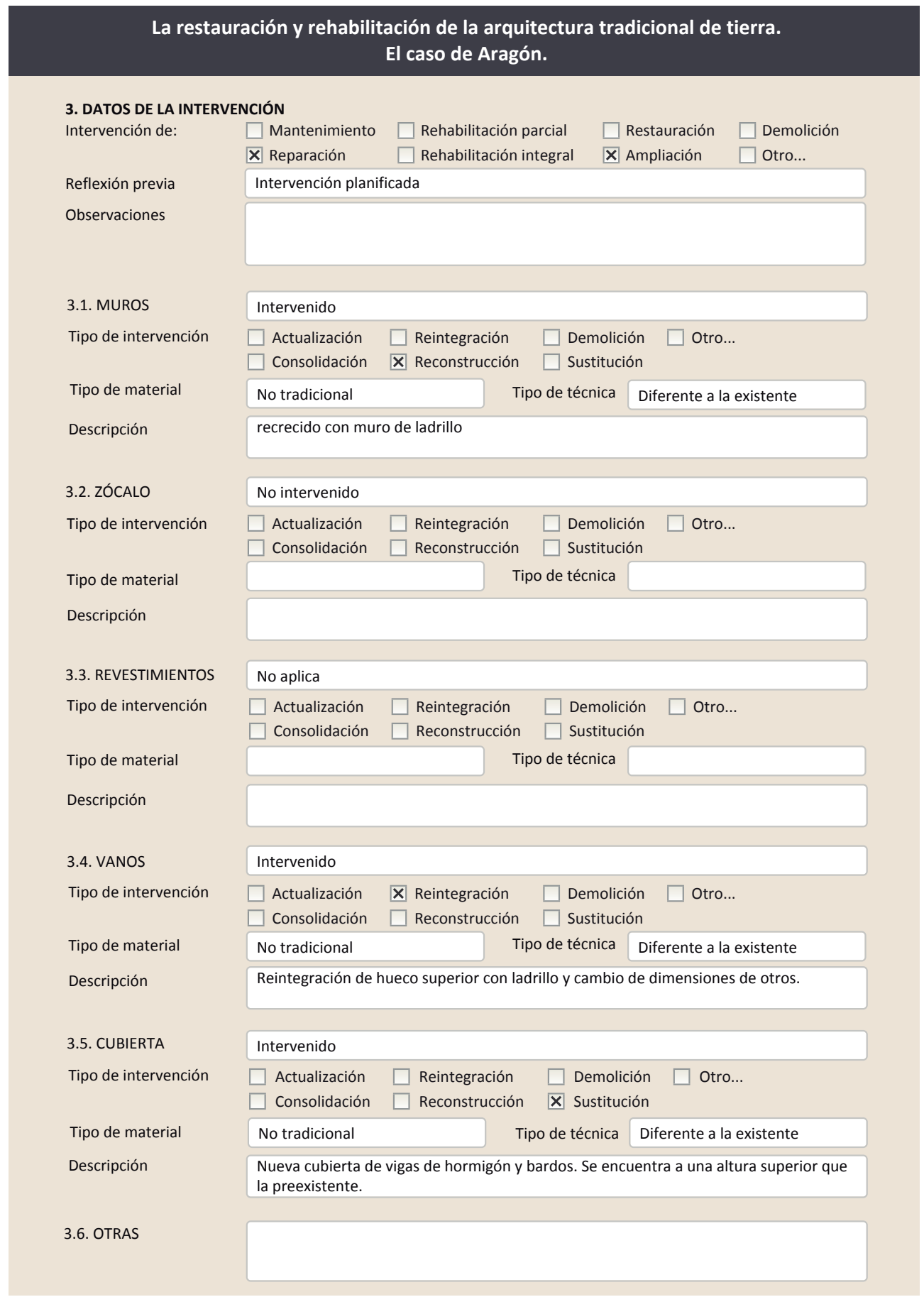

\subsection{REHABILITACIÓN ENERGÉTICA $\quad \square$ Fachada $\square$ Vanos $\square$ Forjados $\square$ Cubierta}

Observaciones

FOTOGRAFíAS DE LA INTERVENCIÓN
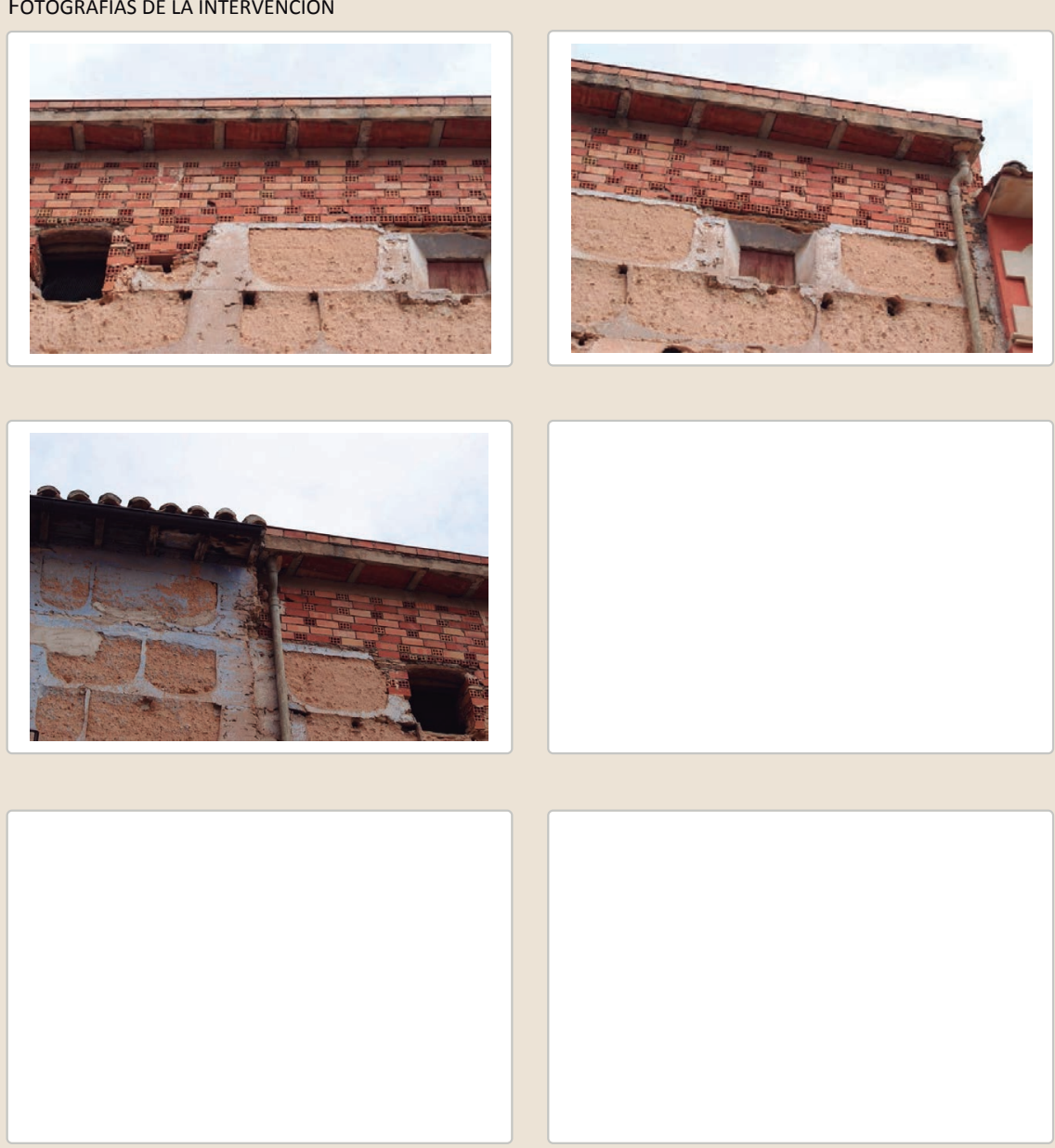


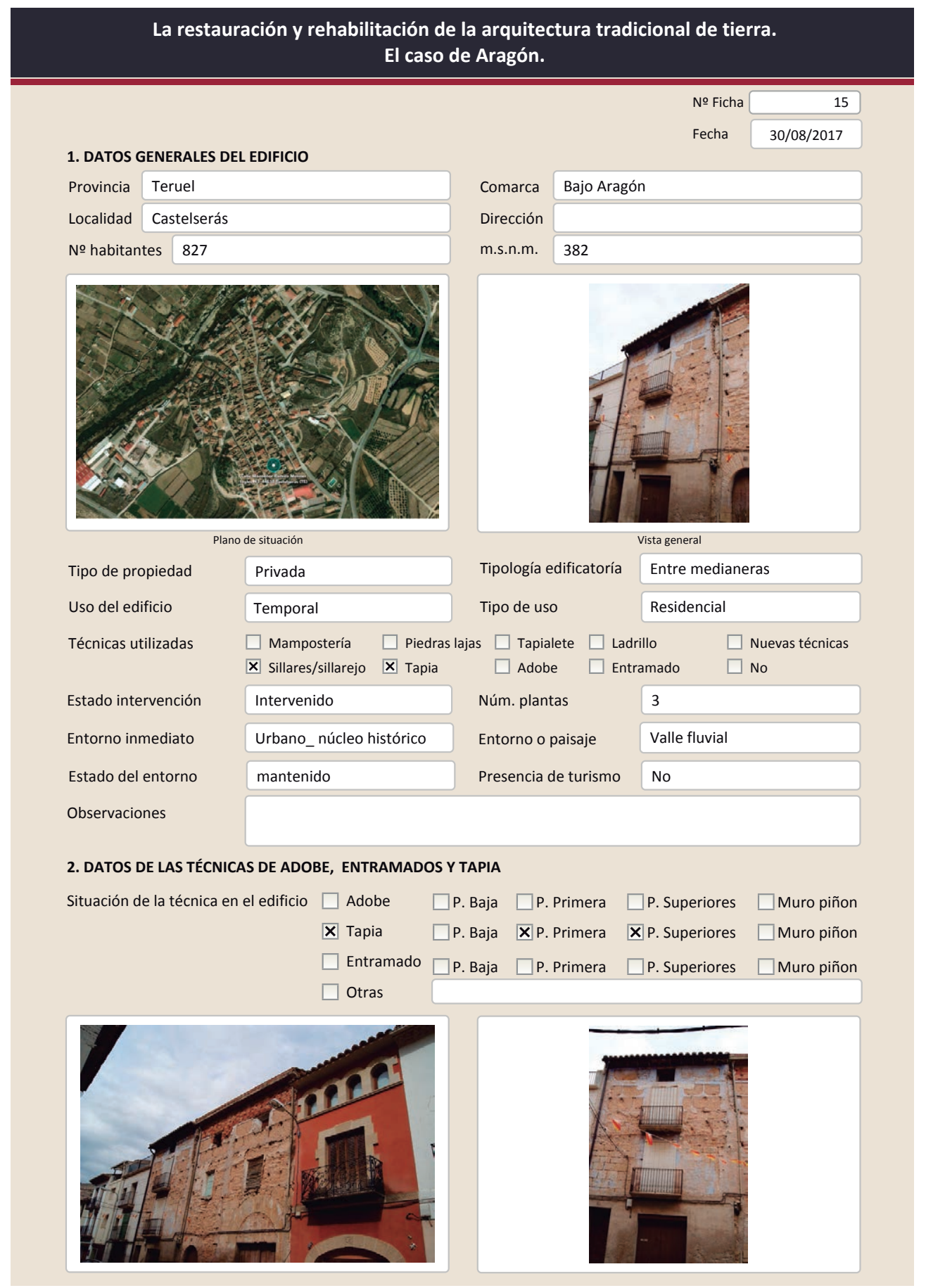

La restauración y rehabilitación de la arquitectura tradicional de tierra. El caso de Aragón.

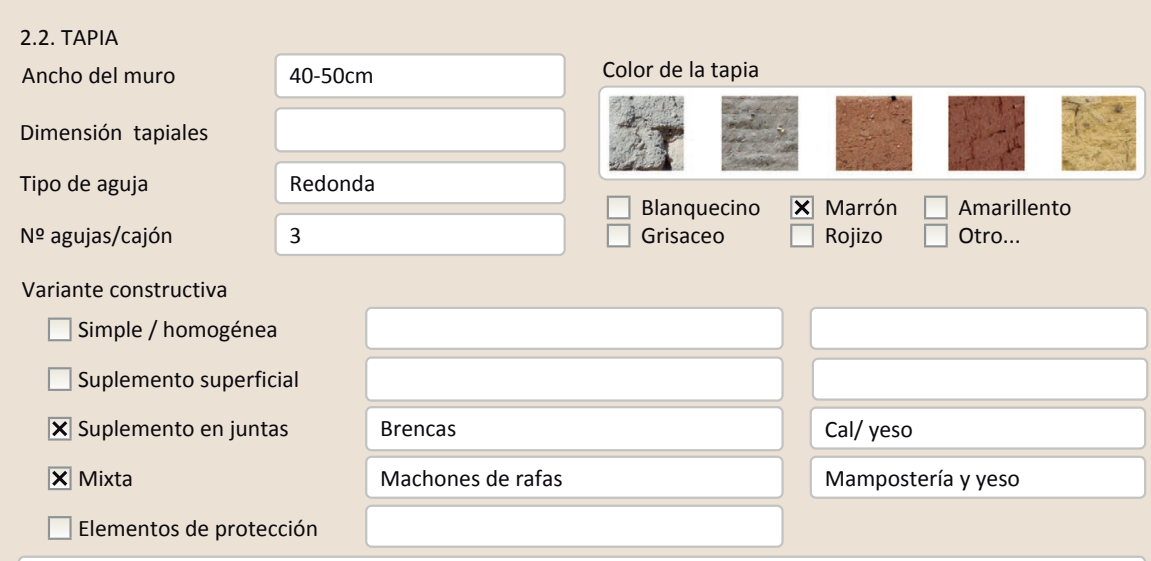

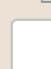

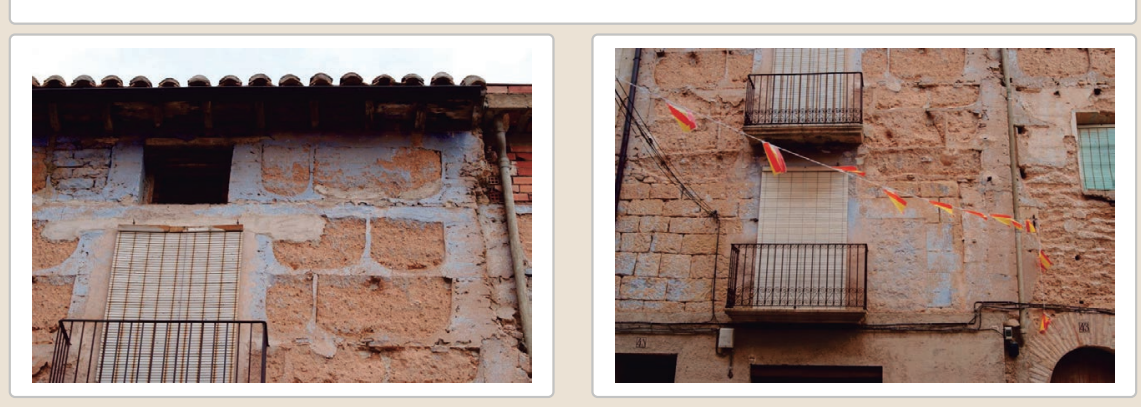
Lesiones \Muro $\square$ Zócalo $\square$ Revestimiento $\square$ Cubierta $\square$ Otro...
X Erosión del material $\quad \square$ Humedad por capilaridad $\quad \square$ Grietas por asentamientos $\square$ Erosion de las juntas $\quad \square$ Humedades (manch/eflo) $\quad \square$ Colapso
$\square$ Pérdida de sección $\square$ Pérdida de verticalidad $\quad \square$ Por elementos impropios
$\square$ Vegetación $\quad \square$ Grietas por empuje de
$\square$ Derivado de intervenciones

$\square$ Desconchados $\quad \square$ Grietas porfalta de traba

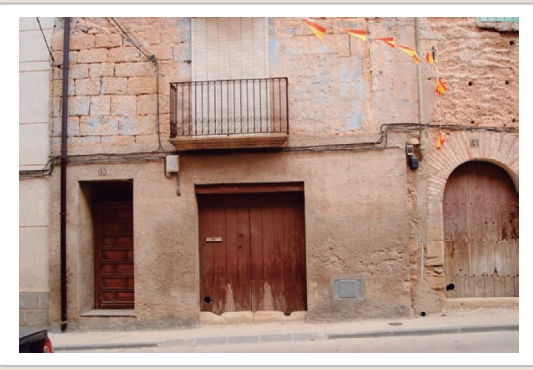

$\square$ otro...

Observaciones

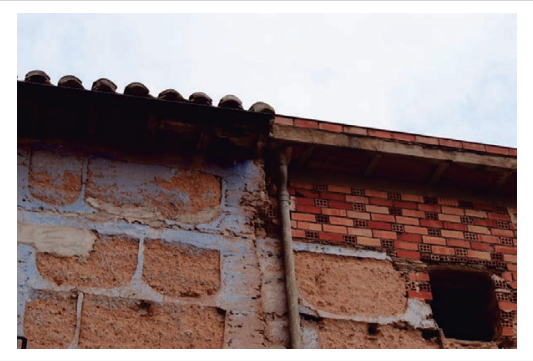


La restauración y rehabilitación de la arquitectura tradicional de tierra. El caso de Aragón

\section{La restauración y rehabilitación de la arquitectura tradicional de tierra.}

\section{El caso de Aragón.}

3. DATOS DE LA INTERVENCIÓN

Intervención de:

$\square$ Mantenimiento $\quad \mathbf{X}$ Rehabilitación parcial

$\square$ Restauración $\square$ Demolición

Reflexión previa

$\square$ Reparación

$\square$ Rehabilitación integral $\square$ Ampliació

$\square$ Otro..

Observaciones

Intervención espontanea

\subsection{MUROS}

Tipo de intervención

Intervenido

Tipo de material

$\square$ Actualización $\quad$ X Reintegración $\square$ Demolición $\square$ Otro...

$\square$ Consolidación $\quad \square$ Reconstrucción $\square$ Sustitución

Descripción

No tradicional Tipo de técnica Diferente a la existente

3.2. ZóCALO

Reintegración de oquedades con mortero

Tipo de intervención

Intervenido

Tipo de material

Actualización $\quad$ Reintegración $\square$ Demolición $\square$ Otro..

Descripción

No tradicional Tipo de técnica Diferente a la existente

3.3. REVESTIMIENTOS

cemento

Tipo de intervención

\section{No aplica}

Tipo de material

$\square$ Actualización

$\square$ Reintegración $\square$ Demolición $\square$ Otro...

$\square$ Consolidación $\square$ Reconstrucción $\square$ Sustitución

Descripción

3.4. VANOS

Tipo de intervención

Intervenido

Tipo de material

$\square$ Actualización $\quad \mathbf{X}$ Reintegración $\square$ Demolición $\square$ Otro...

$\square$ Consolidación $\quad \square$ Reconstrucción $\quad \boldsymbol{X}$ Sustitución

Descripción

No tradicional Tipo de técnica Diferente a la existente

Nuevo hueco en planta baja. Cierre y apertura de nuevos huecos. Cambio de carpinterías e introducción de persianas

3.5. CUBIERTA

Tipo de intervención

Intervenido

Tipo de intervención

$\square$ Actualización $\quad \boldsymbol{X}$ Reintegración $\quad \square$ Demolición $\square$ Otro..

Tipo de material

$\square$ Consolidación $\quad \square$ Reconstrucción $\square$ Sustitución

Descripción

No tradicional

Tipo de técnica Diferente a la existente

3.6. OTRAS

Reintegración de tejas con mortero de cemento 


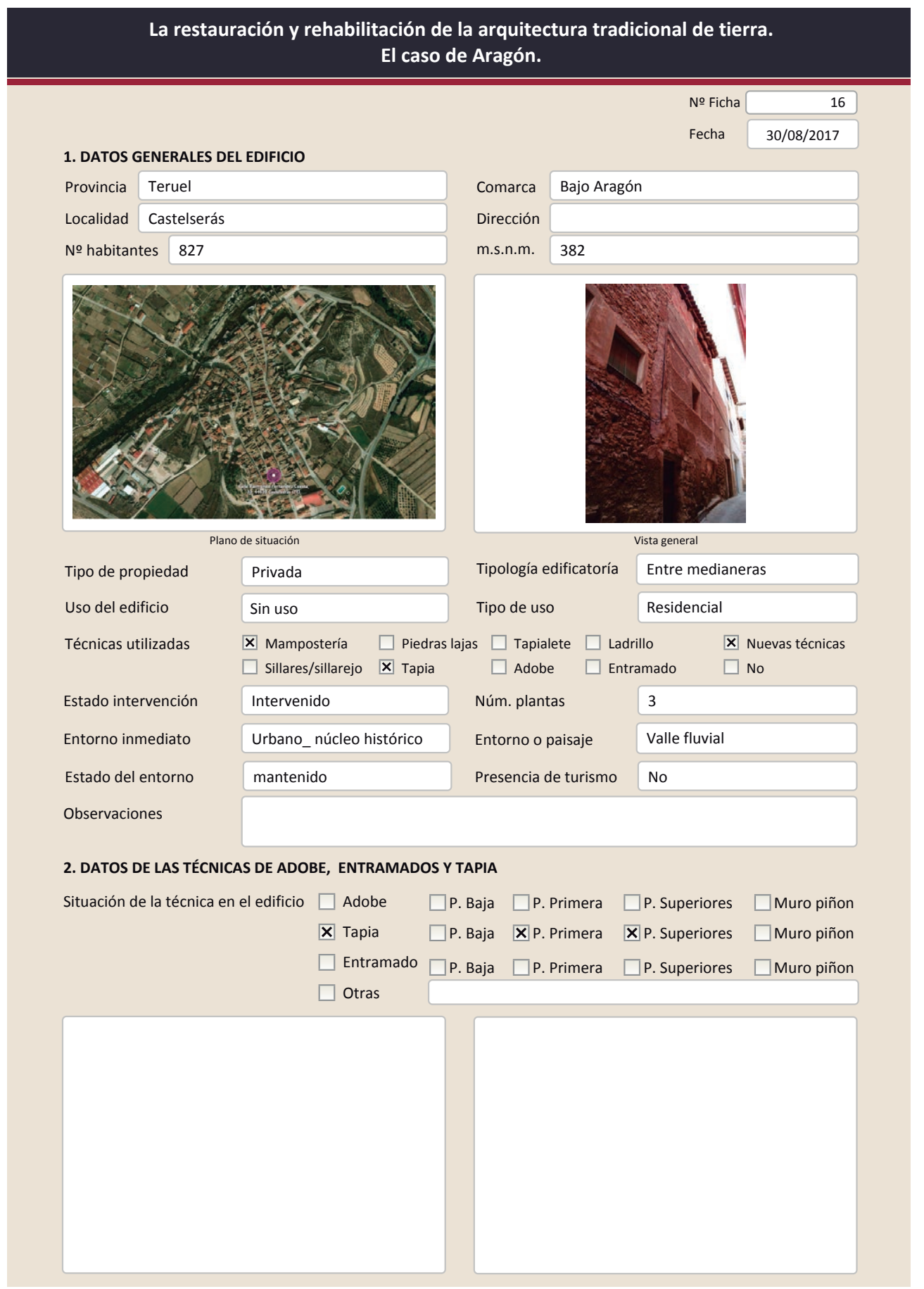

La restauración y rehabilitación de la arquitectura tradicional de tierra.

El caso de Aragón.

\subsection{TAPIA}

Ancho del muro

Dimensión tapiales

Tipo de aguja

\begin{tabular}{|l|}
\hline $50-60 \mathrm{~cm}$ \\
\hline \\
\hline
\end{tabular}

Color de la tapia

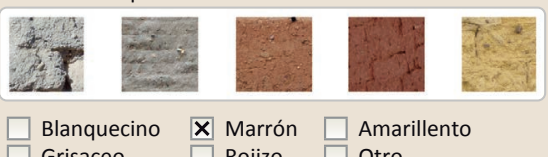

№ agujas/cajón

Variante constructiva

$\square$ Simple / homogénea

$\mathbf{X}$ Suplemento superficial

$\mathbf{X}$ Suplemento en juntas

X Mixta

\begin{tabular}{|l|}
\hline \\
\hline Calicostrada \\
\hline Brencas \\
\hline Machones de rafas \\
\hline
\end{tabular}

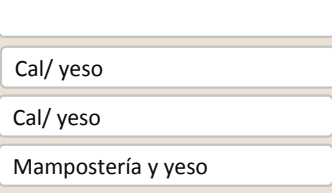

$\square$ Elementos de protección

La costra se ha perdido y se ha repuesto con cemento

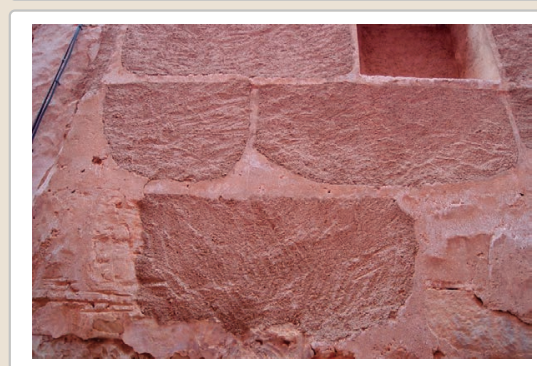

Lesiones \Muro $\square$ Zócalo $\square$ Revestimiento $\square$ Cubierta $\square$ otro...

X Erosión del material $\quad \square$ Humedad por capilaridad $\quad \square$ Grietas por asentamiento $\square$ Erosion de las juntas $\square$ Humedades (manch/eflo)

$\square$ Pérdida de sección $\square$ Pérdida de verticalidad

$\square$ Vegetación $\square$ Grietas por empuje de la cubierta

$\mathbf{X}$ Desconchado

$\square$ Por elementos impropios

$\square$ Grietas porfalta de traba

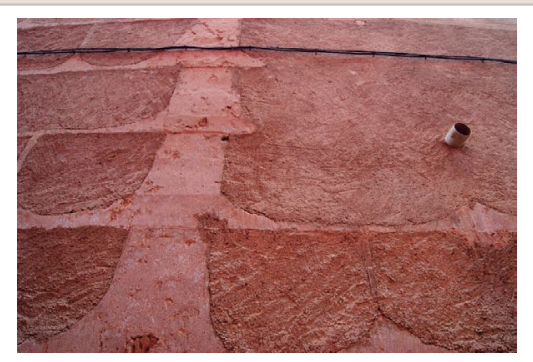

$\square$ Derivado de intervenciones

$\square$ Otro...

Observaciones 


\section{La restauración y rehabilitación de la arquitectura tradicional de tierra.} El caso de Aragón.

3. DATOS DE LA INTERVENCIÓN

Mehabilitación parcial X Reparación Rehabilitación integra

$\square$ Restauración $\quad \square$ Demolición

Intervención espontanea

Reflexión previa Irion

Observaciones

Intervenido

3.1. MUROS Tipo de intervención

Tipo de material

$\square$ Actualización

$\square$ Consolidación

$\square$ Reintegración

$\square$ Demolición

No tradicional Tipo de técnica Diferente a la existente

Descripción Recrecido del muro en la parte superior con ladrillo hueco o se ha cubierto por
completo el muro existente. La cubierta e tradicional de rollizos con cañizo

3.2. ZÓCALO

Tipo de intervención

Intervenido

$\square$ Actualización $\quad \square$ Reintegración $\quad \square$ Demolición $\quad \square$ Otro...

$\square$ Consolidación $\quad \mathbf{X}$ Reconstrucción $\square$ Sustitución

\begin{tabular}{llll} 
Tipo de material No tradicional Tipo de técnica Diferente a la existente & \\
\hline
\end{tabular}

Descripción

3.3. REVESTIMIENTOS

Tipo de intervención

Reconstrucción parcial con cemento en la parte inferior

\section{Intervenido}

$\square$ Actualización $\square$ Reintegración $\square$ Demolición $\square$ Otro...

$\square$ Consolidación $\quad \mathbf{X}$ Reconstrucción $\square$ Sustitución

Tipo de material

Descripción

No tradicional

Tipo de técnica Diferente a la existente

Relleno de las zonas entre brencas en todos los cajones de tapia. Indica que

probablemente el revestimiento en esta zona se hubiera perdido o no existiera

3.4. VANOS

Tipo de intervención

Intervenido

Tipo de material

$\square$ Actualización $\square$ Reintegración $\square$ Demolición $\square$ Otro...

Descripción

3.5. CUBIERTA

Tipo de intervención

Consolidación $\mathbf{X}$ Reconstrucción $\square$ Sustitución

\begin{tabular}{|l|l|l}
\hline No tradicional & Tipo de técnica Diferente a la existente \\
\hline Nuta
\end{tabular}

Nuevo hueco en planta baja para permitir el acceso de vehículos

Intervenido

$\square$ Actualización $\quad \square$ Reintegración $\square$ Demolición $\square$ Otro.

$\square$ Consolidación $\square$ Reconstrucción $\mathbf{X}$ Sustitución

Tipo de material

No tradicional

Tipo de técnica Diferente a la existente

Descripción

Nueva cubierta sobre el recrecido de ladrillo con base de cañizo y teja cerámica curva nueva

3.6. OTRAS
La restauración y rehabilitación de la arquitectura tradicional de tierra.

El caso de Aragón.

3.7. REHABILITACIÓN ENERGÉTICA $\quad \square$ Fachada $\square$ Vanos $\square$ Forjados $\square$ Cubierta

Observaciones

FOTOGRAFíAS DE LA INTERVENCIÓN
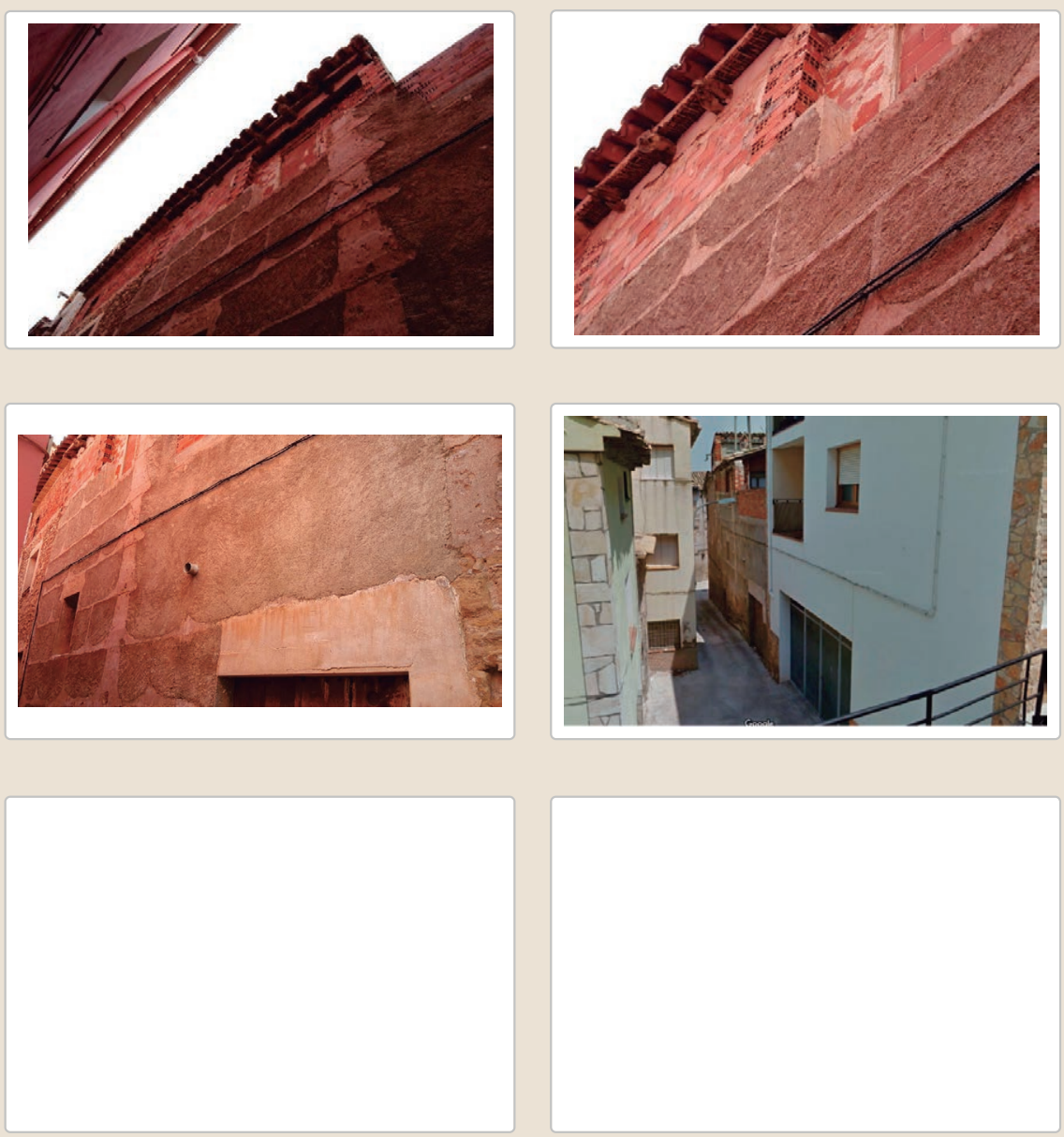


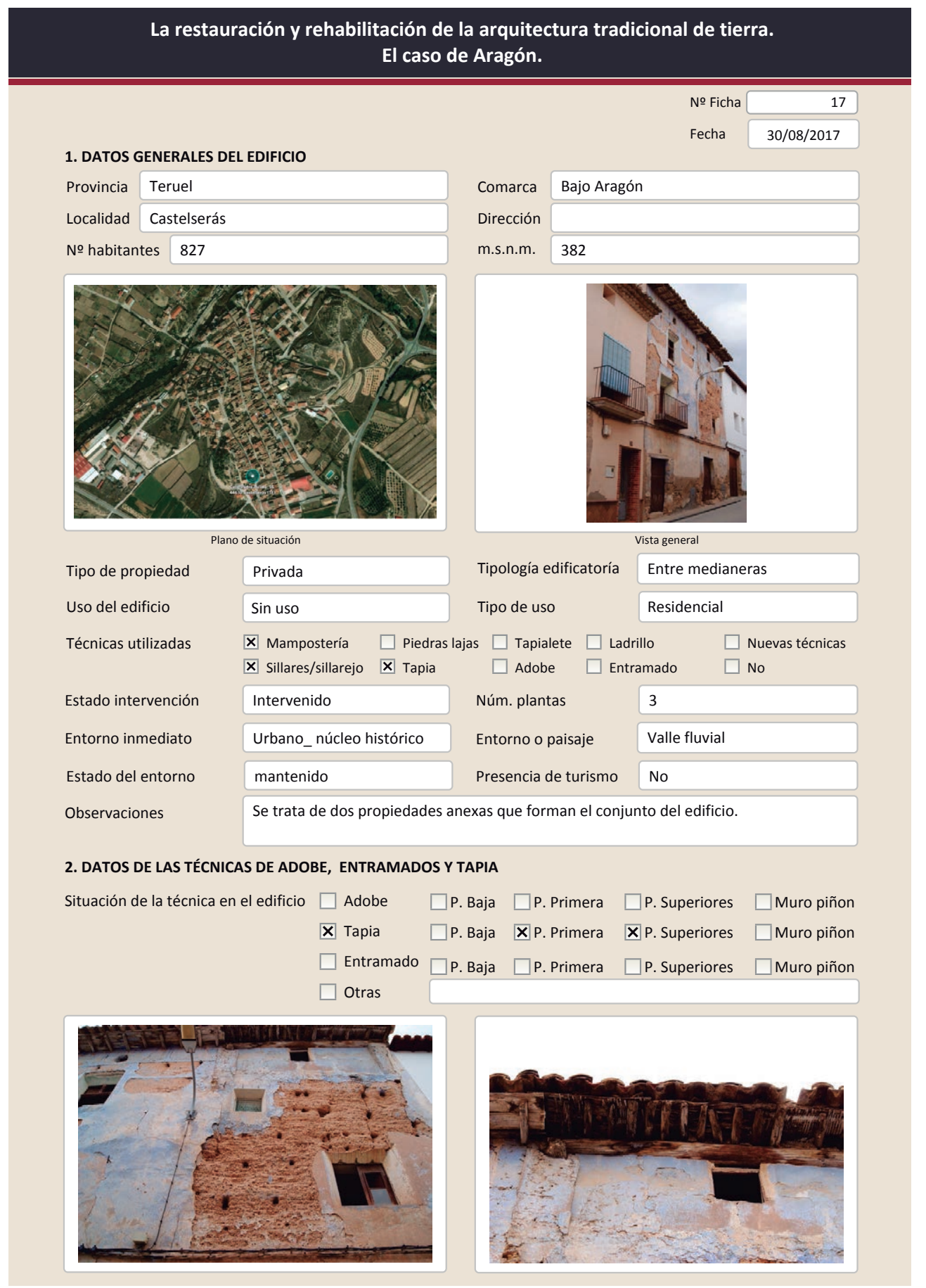

La restauración y rehabilitación de la arquitectura tradicional de tierra. El caso de Aragón.

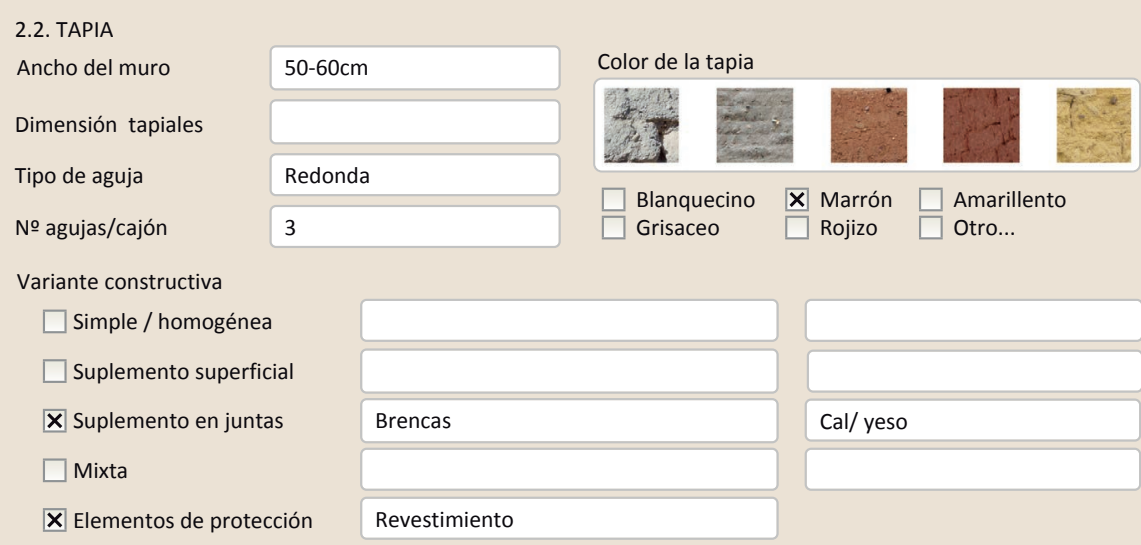

El revestimiento se ha perdido. Existe un machón de rafas en la zona central del edificio.

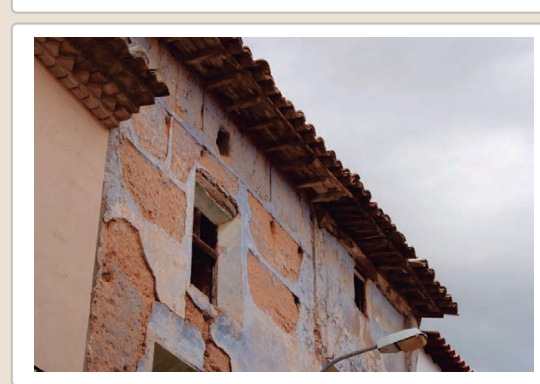

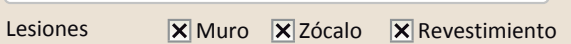
$\mathbf{X}$ Erosión del material $\mathbf{X}$ Humedad por capilaridad $\square$ Erosion de las juntas $\square$ Humedades (manch/eflo) $\square$ Pérdida de sección $\quad \square$ Pérdida de verticalidad

$\square$ Vegetación $\square$ Desconchados
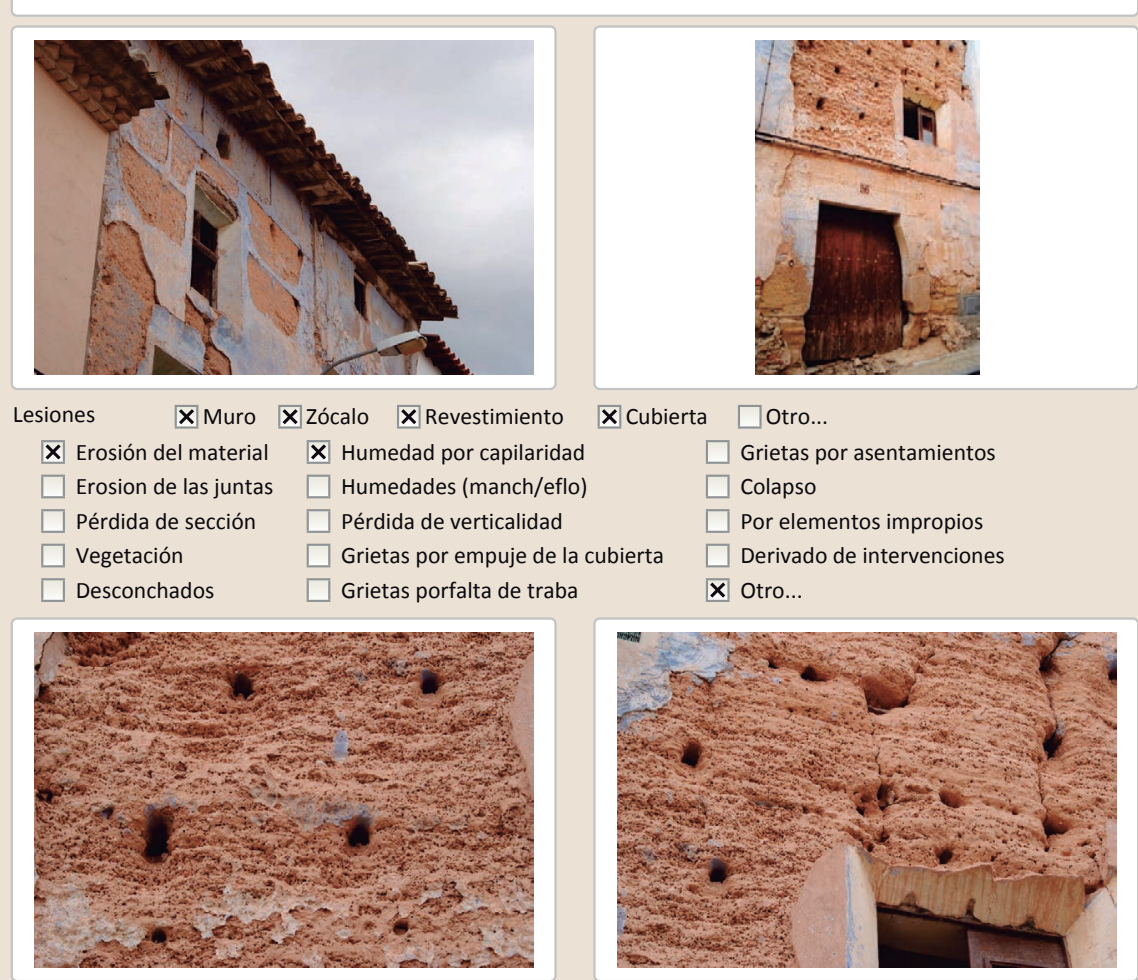

X Cubierta $\square$ otro...

$$
\square \text { Grietas por asentamientos }
$$
$\square$ Colapso

$\square$ Por elementos impropios $\square$ Derivado de intervenciones $\mathbf{X}$ Otro...

Observaciones

La tapia se encuentra llena de pequeñas oquedades que parecen generadas por algún insecto 
La restauración y rehabilitación de la arquitectura tradicional de tierra. El caso de Aragón

\section{La restauración y rehabilitación de la arquitectura tradicional de tierra.}

\section{El caso de Aragón.}

3. DATOS DE LA INTERVENCIÓN

Intervención de:

$\square$ Mantenimiento $\square$ Rehabilitación parcia

$\square$ Restauración $\square$ Demolición X Reparación $\quad \square$ Rehabilitación integral $\quad \square$ Ampliación $\quad \square$ Otro...

Reflexión previa Intervención espontanea

Observaciones Solo pequeño rejuntado de cemento en el zócalo

\subsection{MUROS}

Tipo de intervención

Tipo de material

Descripción

3.2. ZÓCALO

Tipo de intervención

Tipo de material

Descripción

3.3. REVESTIMIENTOS

Tipo de intervención

Tipo de material

Descripción

3.4. VANOS

Tipo de intervención

Tipo de material

Descripción

3.5. CUBIERTA

Tipo de intervención

Tipo de material

Descripción

3.6. OTRAS

\section{No intervenido \\ $\square$ Actualización $\quad \square$ Reintegración $\quad \square$ Demolición $\square$ Otro.. \\ $\square$ Consolidación $\quad \square$ Reconstrucción $\quad \square$ Sustitución}

Tipo de técnica

Intervenido

$\square$ Actualización $\quad \mathbf{X}$ Reintegración $\square$ Demolición $\square$ Otro..

$\square$ Consolidación $\quad \square$ Reconstrucción $\quad \square$ Sustitución
No tradicional
Tipo de técnica Diferente a la existente

Reintegración del zócalo de piedra con cemento

\section{No intervenido}

$\square$ Actualización $\square$ Reintegración $\square$ Demolición $\square$ Otro...

$\square$ Consolidación $\square$ Reconstrucción $\square$ Sustitución

Tipo de técnica

No intervenido

$\square$ Actualización $\square$ Reintegración $\square$ Demolición $\square$ Otro...

$\square$ Consolidación $\square$ Reconstrucción $\square$ Sustitución

Tipo de técnica

No intervenido

$\square$ Actualización $\square$ Reintegración $\quad \square$ Demolición $\square$ Otro.

$\square$ Consolidación $\square$ Reconstrucción $\square$ Sustitución

Tipo de técnica 


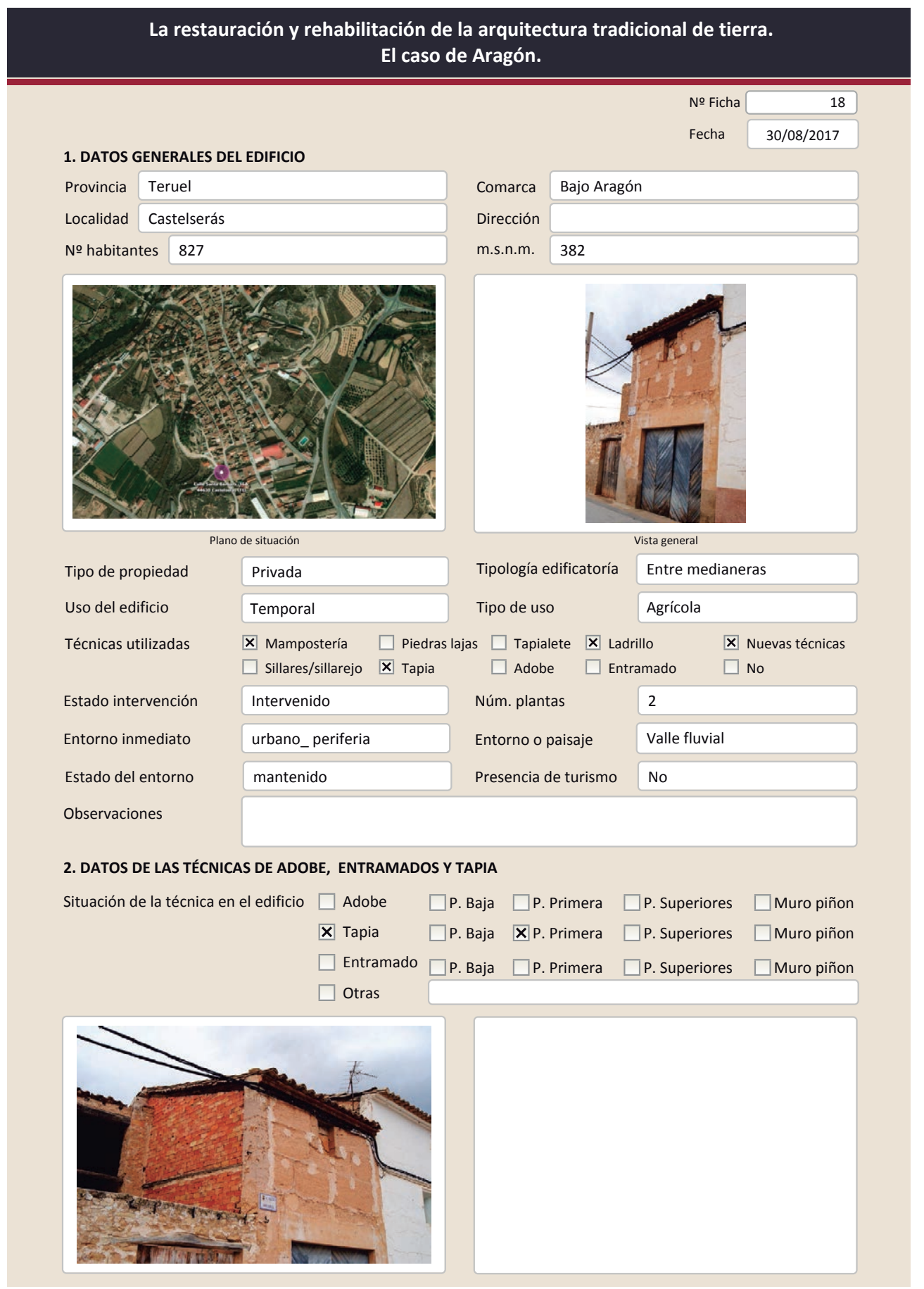

La restauración y rehabilitación de la arquitectura tradicional de tierra.

El caso de Aragón.

\subsection{TAPIA}

Ancho del muro

Dimensión tapiales

Tipo de aguja

№ agujas/cajón

\begin{tabular}{|l|}
\hline $40-50 \mathrm{~cm}$ \\
\hline \\
\hline Redonda \\
\hline 3 \\
\hline
\end{tabular}

Color de la tapia

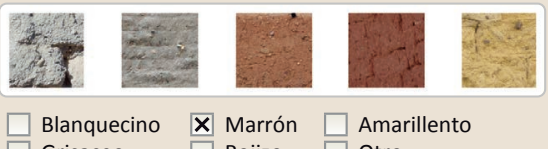

$\square$ Blanquecino $\quad \mathbf{X}$ Marrón $\square$ Amarillento

Variante constructiva

$\square$ Simple / homogénea
$\square$ Suplemento superficial
X Suplemento en juntas
X Mixta

$\square$ Elementos de protección

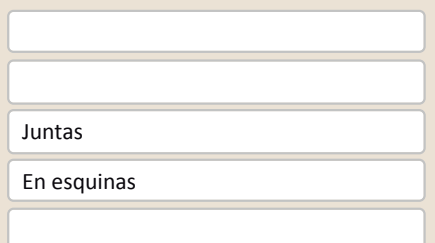

\section{Cal/ yeso}

Mampostería y yeso

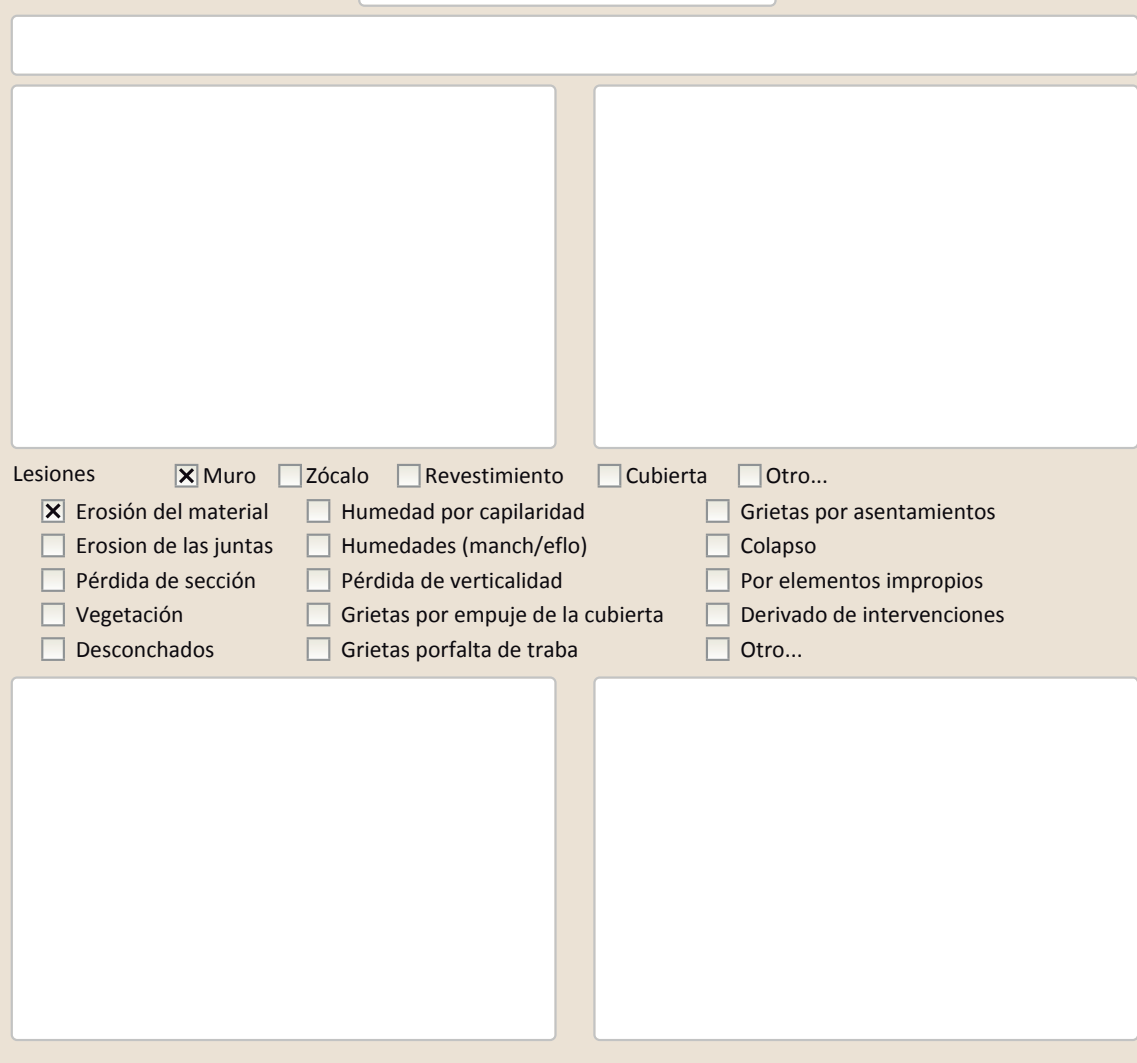

Observaciones 
La restauración y rehabilitación de la arquitectura tradicional de tierra. El caso de Aragón

\section{La restauración y rehabilitación de la arquitectura tradicional de tierra.}

\section{El caso de Aragón.}

3. DATOS DE LA INTERVENCIÓN

Intervención de:

$\square$ Mantenimiento $\square$ Rehabilitación parcia

$\square$ Restauración $\square$ Demolición

Reflexión previa

X Reparación

Rehabilitación integra

Ampliación

$\square$ Otro..

Observaciones

Intervención espontanea

3.1. MUROS

Intervenido

Tipo de intervención

$\square$ Actualización $\square$ Reintegración $\square$ Demolición $\square$ Otro..

$\square$ Consolidación $\mathbf{X}$ Reconstrucción $\mathbf{X}$ Sustitución

Tipo de material

\begin{tabular}{l|l|l} 
No tradicional & Tipo de técnica Diferente a la existente
\end{tabular}

Descripción

Sustitución del muro piñón por ladrillo. Sustitución del alero por piezas cerámicas. Relleno de los huecos de las agujas con yeso y otras zonas con yeso.

3.2. ZÓCALO No intervenido

Tipo de intervención

$\square$ Actualización

$\square$ Consolidación $\square$ Reconstrucción $\square$ Sustitución

Tipo de material

Descripción

3.3. REVESTIMIENTOS

Tipo de intervención

\section{No aplica}

Tipo de material

$\square$ Actualización

Descripción

3.4. VANOS

Tipo de intervención

Intervenido

Tipo de material

$\square$ Actualización $\quad \boldsymbol{X}$ Reintegración $\square$ Demolición $\square$ Otro...

$\square$ Consolidación $\square$ Reconstrucción $\quad \boldsymbol{X}$ Sustitución

Descripción

Tradicional diferente Tipo de técnica Diferente a la existente

3.5. CUBIERTA

$\begin{array}{ll}\text { Tipo de intervención } & \square \text { Actualización } \quad \boldsymbol{X} \text { Reintegración } \quad \square \text { Demolición } \quad \square \text { Otro... } \\ & \square \text { Consolidación } \quad \square \text { Reconstrucción } \quad \square \text { Sustitución }\end{array}$

Ampliación del hueco de planta baja
hueco de planta superior con piedra

\begin{tabular}{lll} 
Tipo de material No tradicional Tipo de técnica Diferente a la existente \\
\hline
\end{tabular}

Descripción

Nuevo alero de ladrillo hueco

3.6. OTRAS 


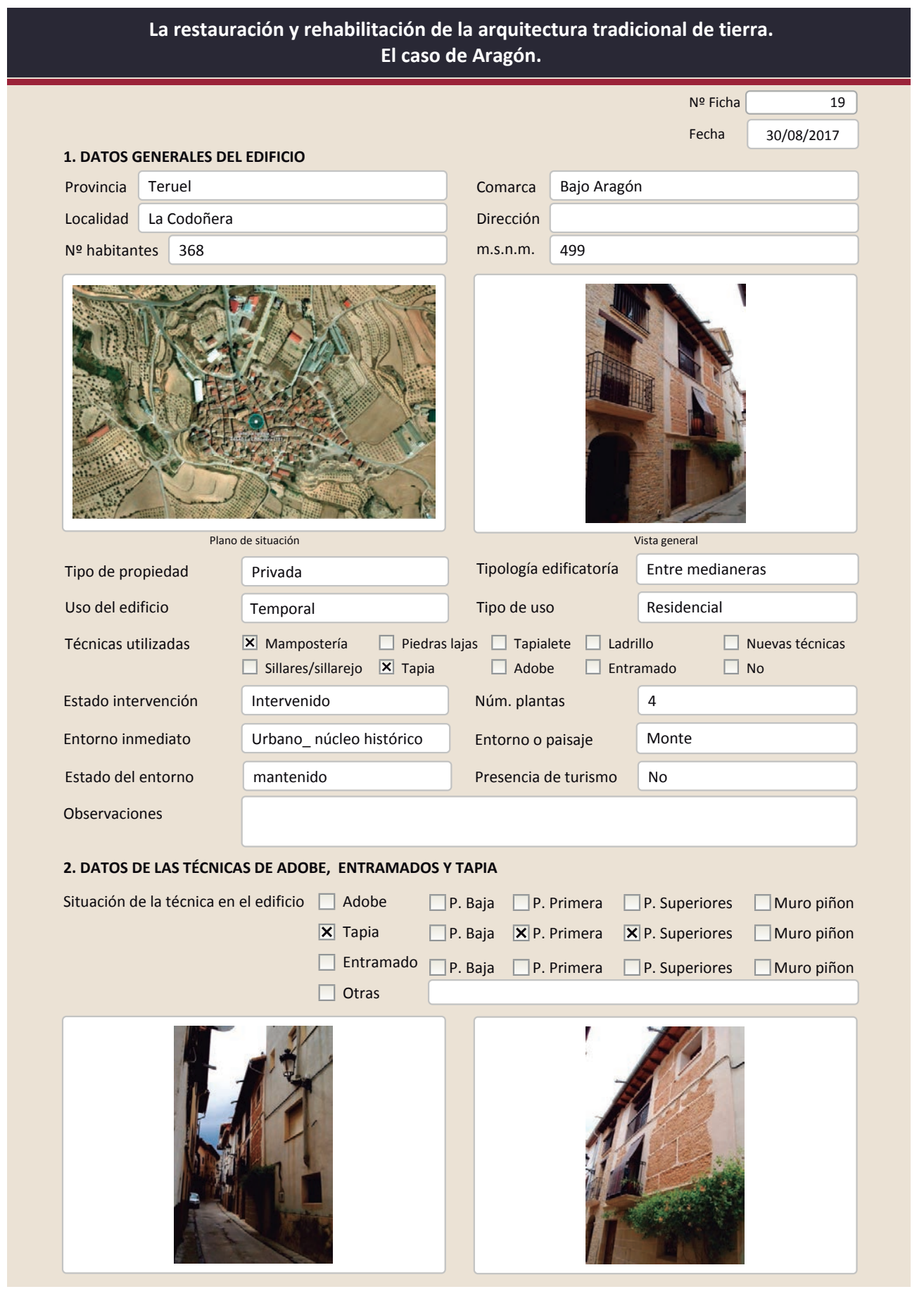

La restauración y rehabilitación de la arquitectura tradicional de tierra.

El caso de Aragón.
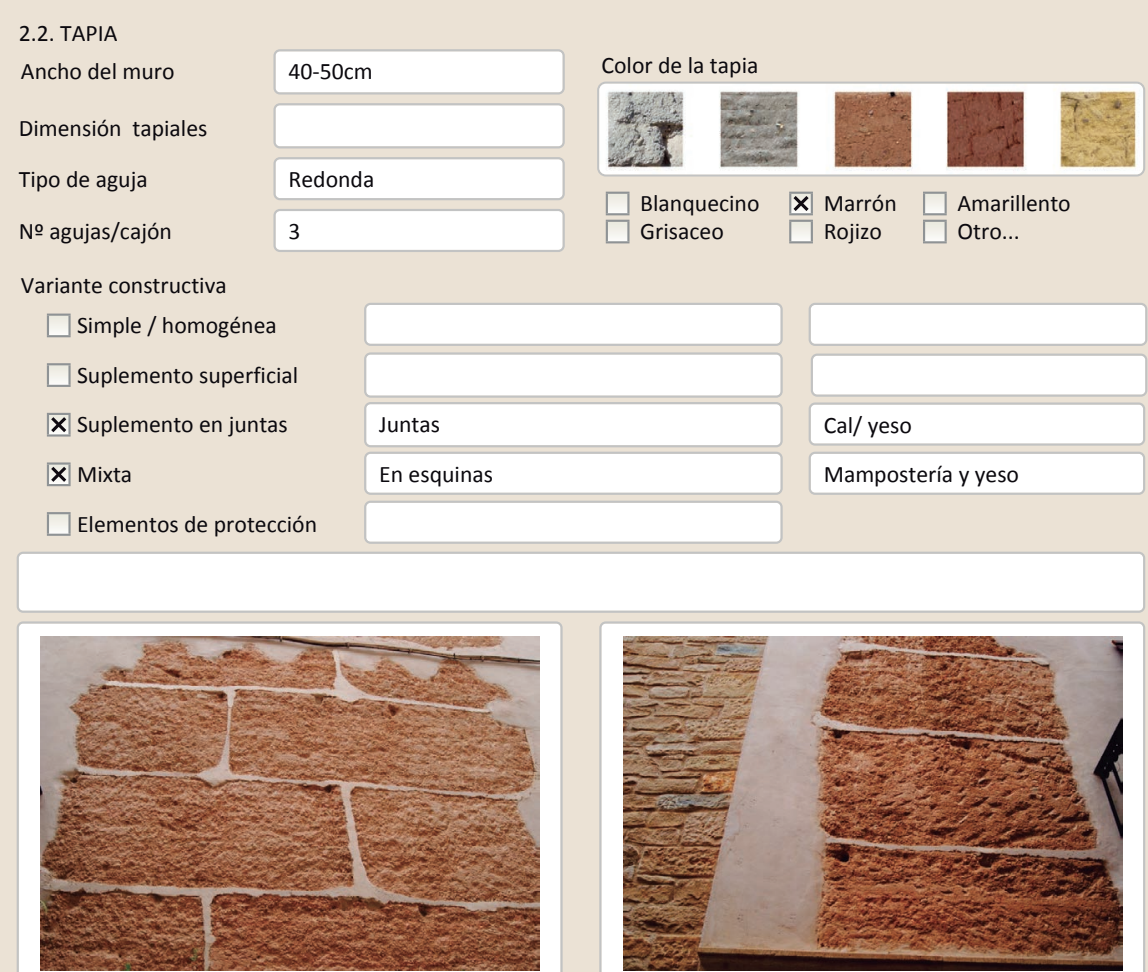

Lesiones $\square$ Muro $\square$ Zócalo $\square$ Revestimiento $\square$ Cubierta $\square$ otro...

\begin{tabular}{|c|c|c|}
\hline$\square$ Erosión del material & & \\
\hline Erosion de las juntas & $\square$ Humedades (manch/eflo) & $\square$ Colapso \\
\hline Pérdida de sección & $\square$ Pérdida de verticalidad & $\square$ Por elementos impropios \\
\hline Vegetación & $\square$ Grietas por empuje de la cubierta & $\square$ Derivado de intervenciones \\
\hline
\end{tabular}

$\square$ Vegetación $\square$ Grietas por empuje de la cubierta $\square$ Derivado de intervenciones $\square$ Desconchados $\quad \square$ Grietas porfalta de traba $\quad \square$ Otro...

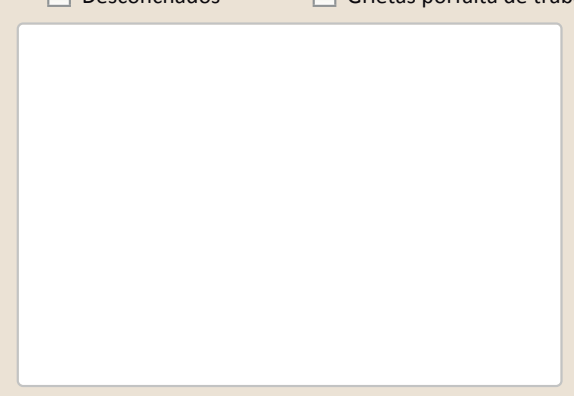

Observaciones no presenta patologías 


\section{La restauración y rehabilitación de la arquitectura tradicional de tierra.} El caso de Aragón.

3. DATOS DE LA INTERVENCIÓN

Reflexión previa Intervención planificada

Observaciones La vivienda fue restaurada alrededor del año 2000. Se han conservado todos sus elementos tanto interiores como exteriores.

\subsection{MUROS Intervenido \\ Tipo de intervención $\quad \square$ Actualización $\quad \square$ Reintegración $\quad \square$ Demolición $\quad \square$ Otro... \\ X Consolidación $\square$ Reconstrucción $\square$ Sustitución}

\begin{tabular}{llll} 
Tipo de material & Tradicional diferente & Tipo de técnica & Diferente a la existente \\
\hline
\end{tabular}

Descripción Se ha rejuntado con yeso las juntas de la tapia y los pilares de las esquinas y jambas que probablemente sean de mampostería encofrada con yeso.

3.2. ZÓCALO

Tipo de intervención

Intervenido

$\square$ Actualización $\square$ Reintegración $\square$ Demolición $\square$ Otro.

$\square$ Consolidación $\square$ Reconstrucción $\mathbf{X}$ Sustitución

Tipo de material No tradicional Tipo de técnica Diferente a la existente

Descripción

3.3. REVESTIMIENTOS

Tipo de intervención

Se ha forrado el zócalo con piedra natural. Este anteriormente estaba intervenido con cemento que se eliminó.

Intervenido

$\square$ Actualización $\square$ Reintegración $\quad$ \ Demolición $\square$ Otro...

$\square$ Consolidación $\quad \square$ Reconstrucción $\square$ Sustitución

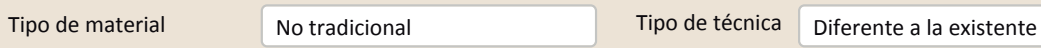

Descripción

3.4. VANOS Se ha eliminado el revestimiento que existía anteriormente sobre la tapia

Tipo de intervención

\begin{tabular}{l|l|l|l|l} 
Tipo de material & Tradicional diferente & Tipo de técnica & Diferente a la existente
\end{tabular}

Intervenido

$\square$ Actualización $\quad \mathbf{X}$ Reintegración $\square$ Demolición $\square$ Otro...

X Consolidación $\square$ Reconstrucción $\square$ Sustitución

Descripción Se han tratado las carpinterías y se ha consolidado las jambas de los huecos. Se ha cerrado el solanar de la planta superior.

3.5. CUBIERTA

Tipo de intervención

Intervenido

$\square$ Actualización $\square$ Reintegración $\square$ Demolición $\square$ Otro...

$\square$ Consolidación $\quad$ X Reconstrucción $\square$ Sustitución

$\begin{array}{llll}\text { Tipo de material } & \text { Tradicional similar } & \text { Tipo de técnica } & \text { Similar a la existente }\end{array}$

Descripción

Reconstrucción de la cubierta incluyendo los elementos actuales necesarios
La restauración y rehabilitación de la arquitectura tradicional de tierra.

El caso de Aragón.

3.7. REHABILITACIÓN ENERGÉTICA $\square$ Fachada $\quad$ \ Vanos $\square$ Forjados $\square$ Cubierta

Observaciones

FOTOGRAFÍAS DE LA INTERVENCIÓN
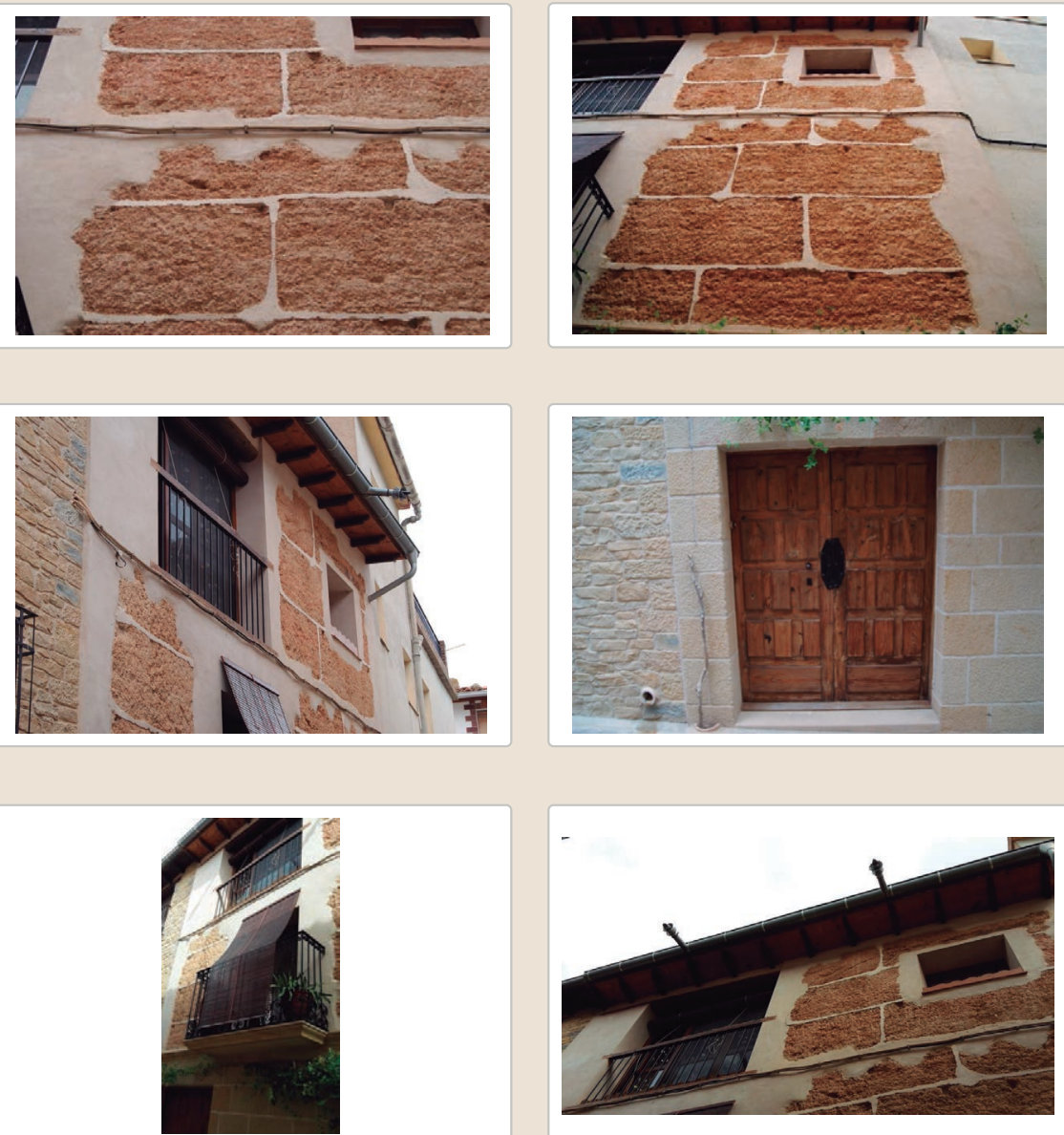

3.6. OTRAS 


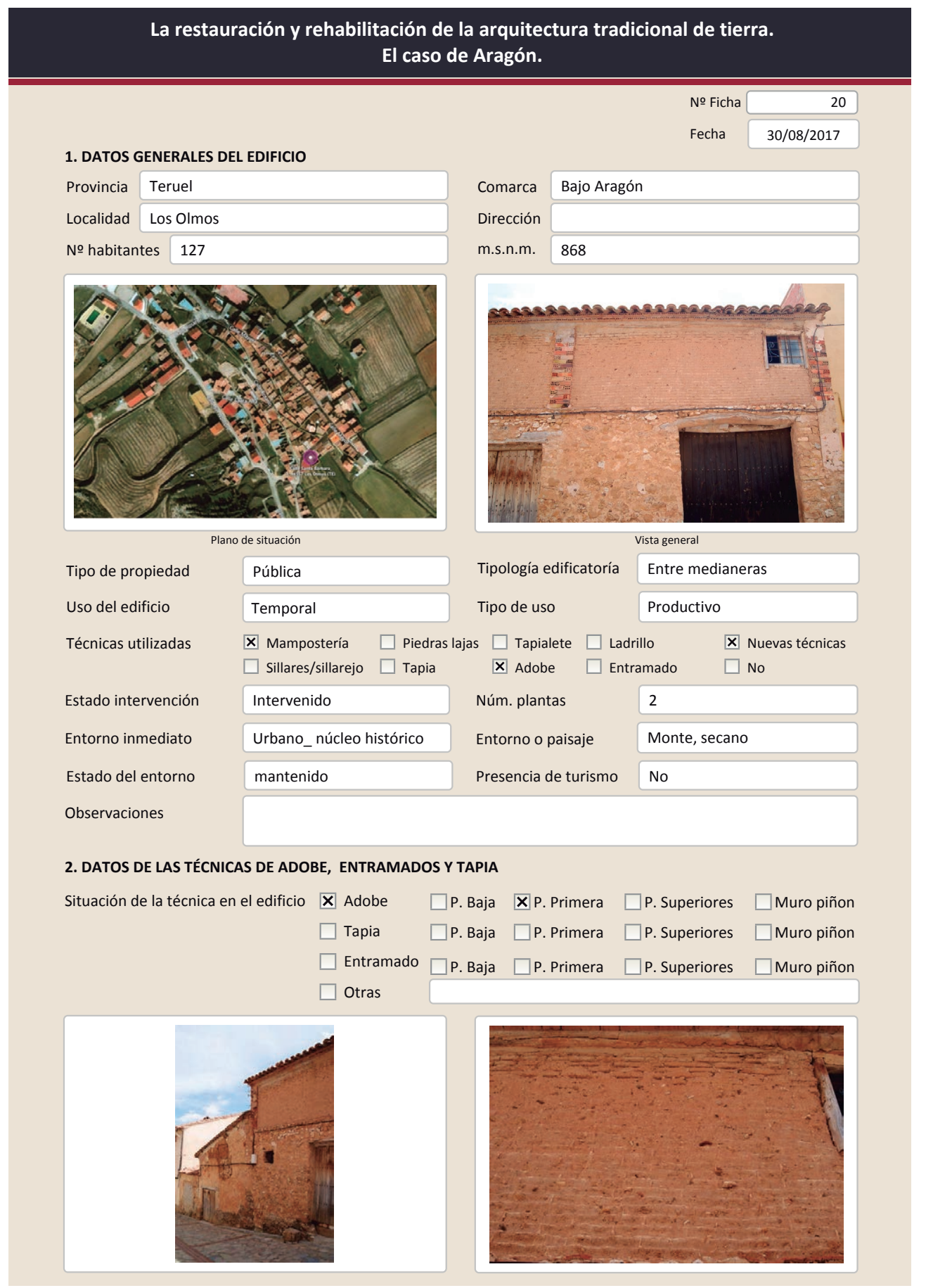

La restauración y rehabilitación de la arquitectura tradicional de tierra.

El caso de Aragón.

2.1. ADOBE

Dimensión de las piezas

Dimensión del muro

Aparejo del muro

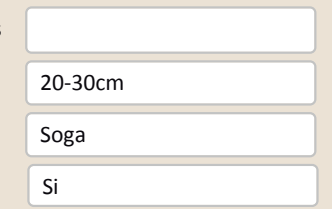

Color de las piezas

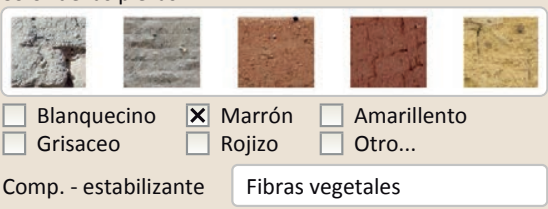

Función estructural

Variante constructiva/ tipo de fábrica

$\square$ simple
X Suplementada en juntas
Verticales $\mathrm{y}$ horizontales
区 Mixta

\section{Machones}
$\mathrm{Cal} /$ yeso
$\square$ Como suplemento

$\square$ Elementos de protección

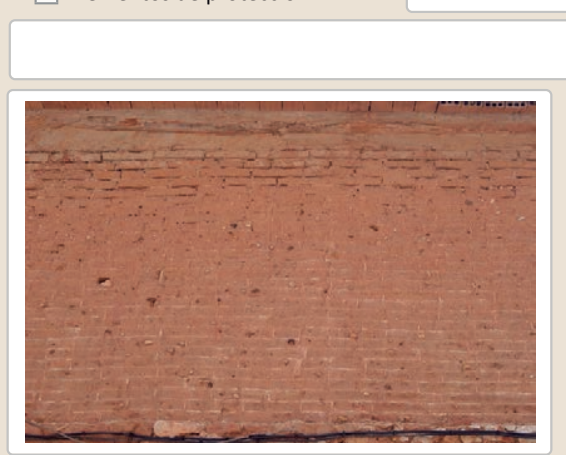

Lesiones $\quad$ Muro $\square$ Zócalo $\square$ Revestimiento

X Erosión del material $\square$ Humedad por capilaridad

$\mathbf{X}$ Erosion de las juntas $\square$ Humedades (manch/eflo)

$\square$ Pérdida de sección $\square$ Pérdida de verticalidad

$\square$ Vesetación

$\begin{array}{ll}\square \text { Vegetación } & \square \text { Grietas por empuje de la cube } \\ \square \text { Desconchados } & \square \text { Grietas porfalta de traba }\end{array}$
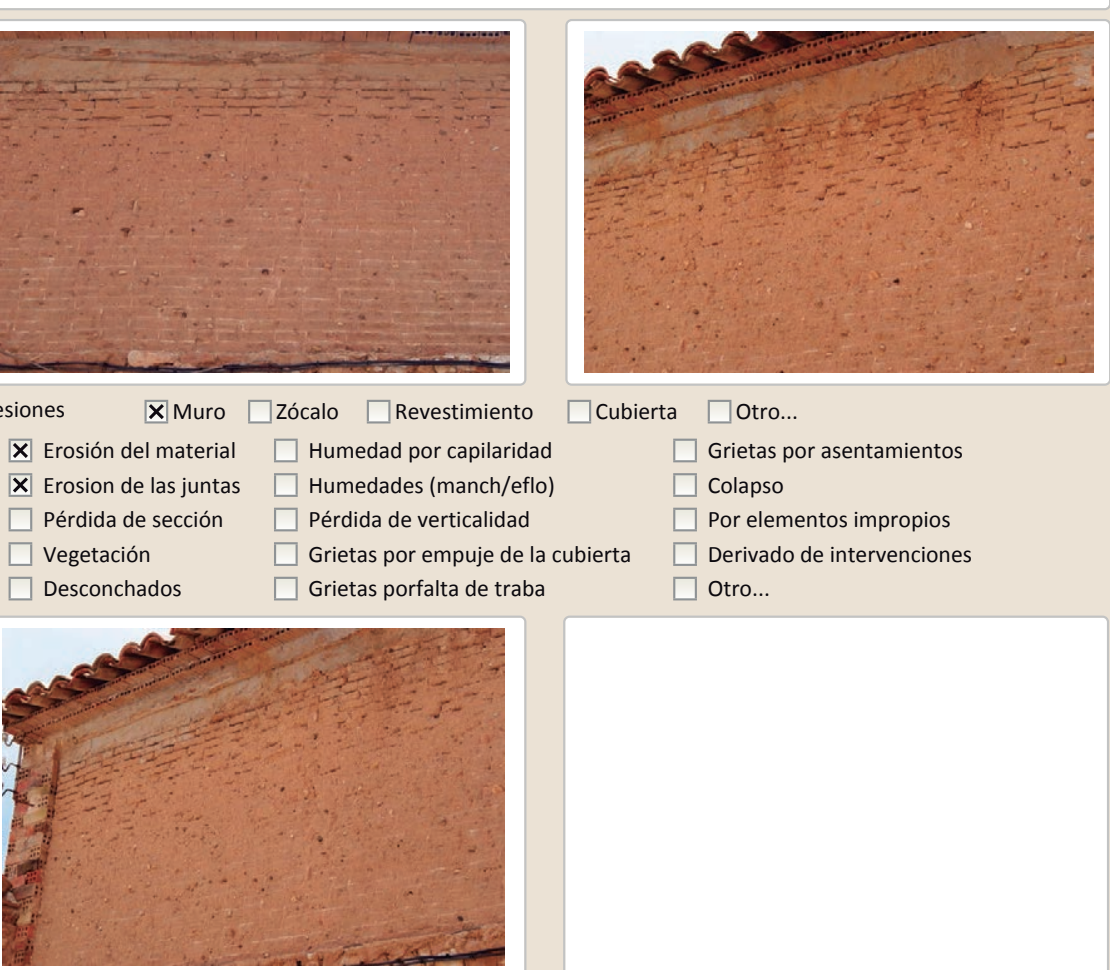

Observacione

El muro de adobe esta construido a soga. Se trata de una estructura porticada de ladrillo en la planta superior pero la amplia luz entre pilares hace pensar en una un 
La restauración y rehabilitación de la arquitectura tradicional de tierra. El caso de Aragón

\section{La restauración y rehabilitación de la arquitectura tradicional de tierra.}

\section{El caso de Aragón.}

3. DATOS DE LA INTERVENCIÓN

Intervención de:

$\square$ Mantenimiento $\square$ Rehabilitación parcia

$\square$ Restauración $\square$ Demolición X Reparación $\quad \square$ Rehabilitación integral $\quad \square$ Ampliación $\quad \square$ Otro...

Reflexión previa

Intervención espontanea

Observaciones

(n)

3.1. MUROS

Tipo de intervención

Intervenido

$\square$ Actualización $\quad \boldsymbol{X}$ Reintegración $\square$ Demolición $\square$ Otro...

$\square$ Consolidación $\square$ Reconstrucción $\square$ Sustitución

Descripción

No tradicional Tipo de técnica Diferente a la existente

3.2. ZóCALO

Mortero de cemento bajo cubierta

Tipo de intervención

No intervenido

$\square$ Actualización

Tipo de material

Descripción

3.3. REVESTIMIENTOS

Tipo de intervención

\section{No aplica}

Tipo de material

$\square$ Actualización

$\square$ Reintegración $\square$ Demolición

$\square$ Otro...

Tipo de técnica

Descripción

3.4. VANOS

Tipo de intervención

No intervenido

Tipo de material

Descripción

3.5. CUBIERTA

Tipo de intervención

No intervenido

Tipo de intervención

$\square$ Actualización $\quad \square$ Reintegración $\quad \square$ Demolición $\square$ Otro..

$\square$ Consolidación $\square$ Reconstrucción $\square$ Sustitución

Descripción

$$
\text { Tipo de técnica }
$$

Al ser lo machones de ladrillo es posible que el muro de adobe, machones y cubierta sean contemporáneos.

3.6. OTRAS 


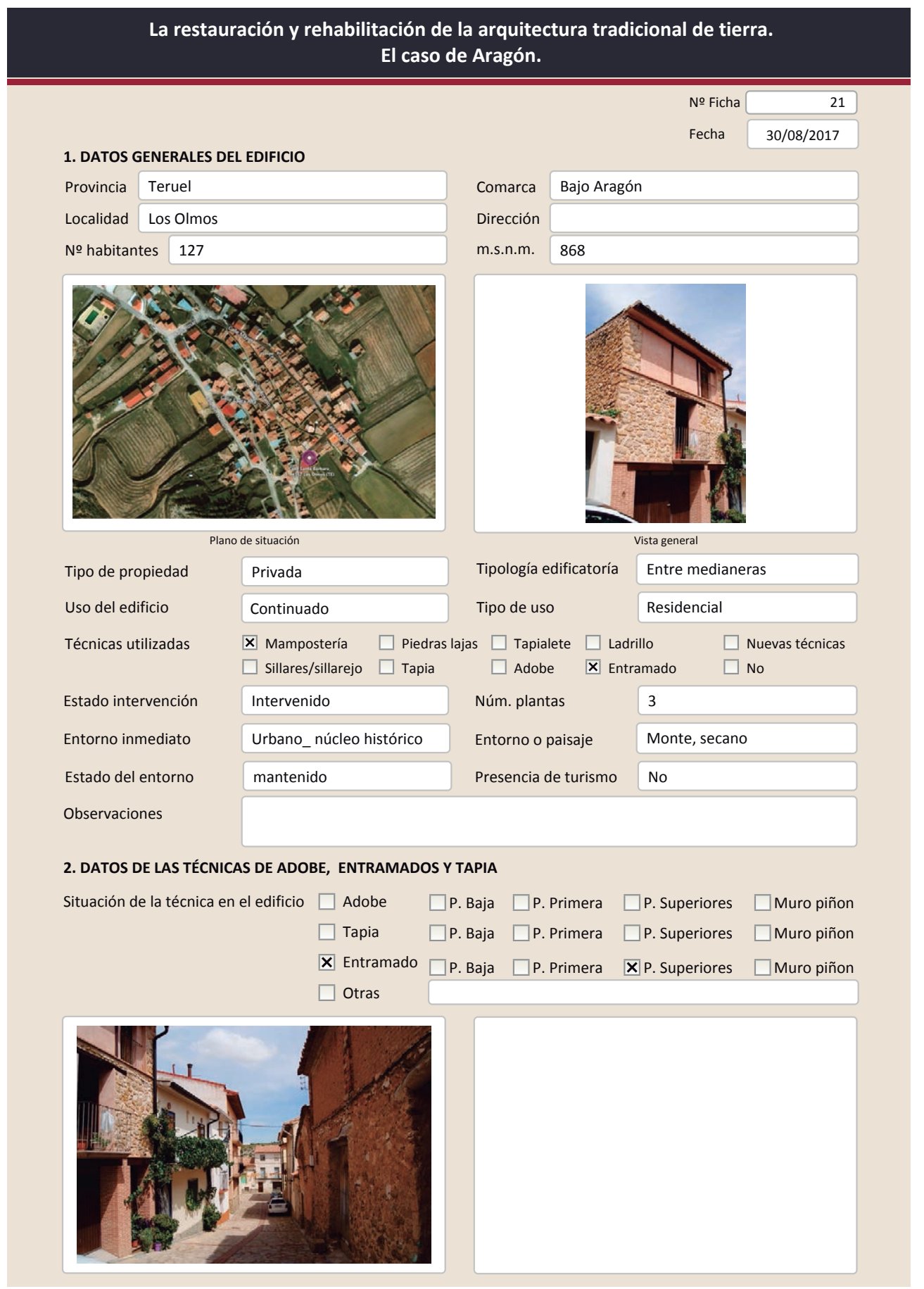

La restauración y rehabilitación de la arquitectura tradicional de tierra.

El caso de Aragón.

2.3. ENTRAMADOS

Distancia entre montantes

Altura de los montantes

Sección de los montantes

Dimensión de los montantes

Tipo de relleno del entramado

Técnica de relleno del entramado
$\square$ Entre pantallas de made
$\square$ Tapialete
$\square$ Pared de mano $\square$ Cañizo
$\square$ Pared de mano
$\square$ Adobe horizontal $\quad \square$ Encestados

\begin{tabular}{|l|}
\hline $150-200 \mathrm{~cm}$ \\
\hline Escuadrada \\
\hline $10-20 \mathrm{~cm}$ \\
\hline
\end{tabular}

Elementos diagonales

Elementos horizontales intermedios

Sección de las piezas horizontales

Dimensión de las piezas horizontales

No

No se aprecia el relleno o si a sido sustituido ya que hay un nuevo revestimiento. Probablemente tapialete (técnicas más comunes en la zona)

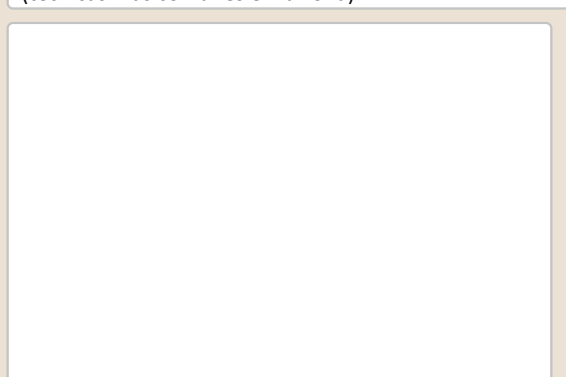
Lesiones
$\square$ Muro
$\square$ Carcoma o termitas
$\square$ Cubierta $\square$ otro...
$\square$ Erosión del material
$\square$ Erosion de las juntas
Rotura de la madera
$\square$ Pérdida de sección
$\square$ Pudrición de la madera
$\square$ Grietas por falta de traba
$\square$ Desconchados
$\square$ Deformación madera
$\square$ Grietas por asentamiento
Pudrición del relleno
$\square$ Colapso
capilaridad
$\square$ Grietas por empuje de la cubierta
$\square$ Por elementos impropios
$\square$ Humedades (manch/eflor)
$\square$ Derivado de intervenciones
$\square$ Otro...

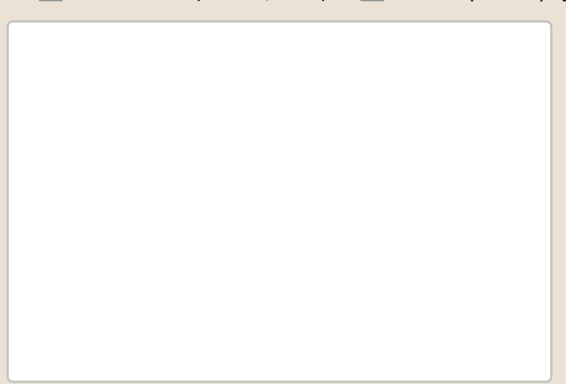

Observaciones 


\section{La restauración y rehabilitación de la arquitectura tradicional de tierra.}

\section{El caso de Aragón.}

3. DATOS DE LA INTERVENCIÓN

Intervención de:

$\square$ Mantenim

$\square$ Rehabilitación parcial

$\square$ Restauración $\square$ Demolición

$\square$ Reparación $\$ Rehabilitación integral $\square$ Ampliación $\square$ Otro...

Reflexión previa

Intervención planificada

Observaciones

(n)

3.1. MUROS

Tipo de intervención

Intervenido

Tipo de material

$\square$ Actualización $\quad \boldsymbol{X}$ Reintegración $\quad \square$ Demolición $\square$ Otro...

$\square$ Consolidación $\square$ Reconstrucción $\square$ sustitución

Descripción

Tradicional diferente Tipo de técnica Similar a la existente

3.2. ZÓCALO

Tipo de intervención

Intervenido

Actuación $\square$ Reintegración $\square$ Demolición $\square$ Otro...

Tipo de material

Descripción

Tipo de técnica Diferente a la existente

3.3. REVESTIMIENTOS

Nuevo zócalo de ladrillo

Tipo de intervención

Intervenido

Actualización $\square$ Reintegración $\square$ Demolición $\square$ Otro...

Tipo de material

$\square$ Consolidación $\square$ Reconstrucción $\mathbf{X}$ Sustitución

Descripción

3.4. VANOS

Tipo de intervención

Intervenido

Tipo de material

$\square$ Actualización $\quad \boldsymbol{X}$ Reintegración $\quad \square$ Demolición $\square$ Otro...

$\square$ Consolidación $\quad \square$ Reconstrucción $\quad \boldsymbol{X}$ Sustitución

Descripción

\begin{tabular}{l|l} 
No tradicional & Tipo de técnica Diferente a la existente \\
\hline
\end{tabular}

3.5. CUBIERTA

Ampliación de los huecos en planta baja. En las p
dimensiones pero se han regularizado las jambas

Tipo de intervención

Intervenido

Tipo de intervención

$\square$ Actualización $\square$ Reintegración $\square$ Demolición $\square$ Otro..

$\square$ Consolidación $\quad$ Reconstrucción $\square$ Sustitución

\begin{tabular}{l|l|l|l|l|l|l|l} 
Tipo de material & Tradicional diferente de técnica & Similar a la existente \\
\hline
\end{tabular}

Descripción Reconstrucción de la cubierta posiblemente reutilizando los materiales preexistentes

3.6. OTRAS 


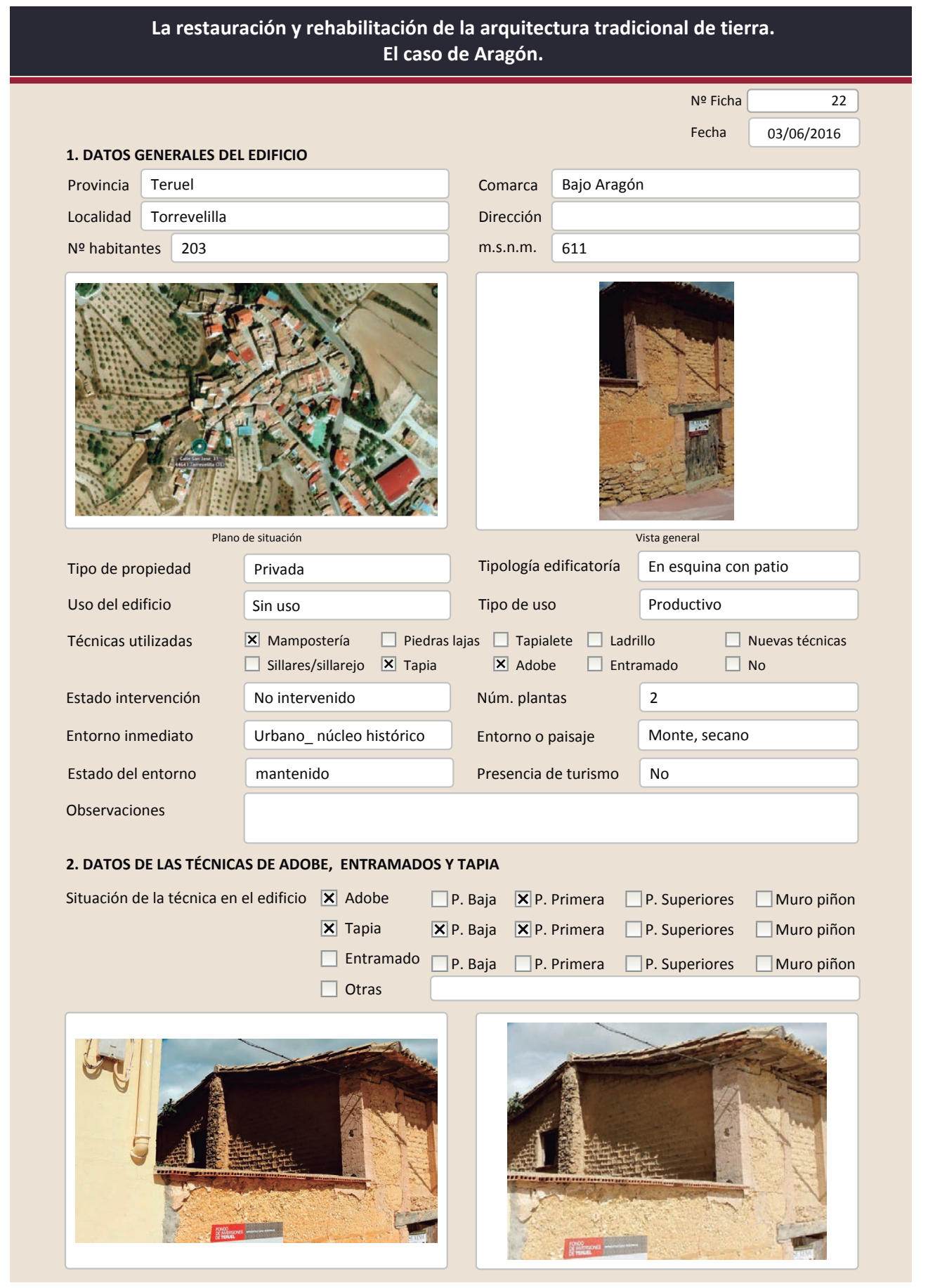

La restauración y rehabilitación de la arquitectura tradicional de tierra.

El caso de Aragón.

2.1. ADOBE

Dimensión de las piezas Dimensión del muro

Aparejo del muro

Función estructural

\begin{tabular}{|l|}
\hline \\
\hline $10-20 \mathrm{~cm}$ \\
\hline Tizón \\
\hline No \\
\hline
\end{tabular}

Color de las piezas

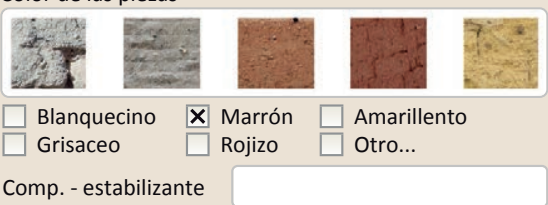

Variante constructiva/ tipo de fábrica

$\square$ simple

$\square$ Suplementada en juntas

X Mixta

Machones

Mampostería y yeso

$\square$ Como suplemento

$\square$ Elementos de protección

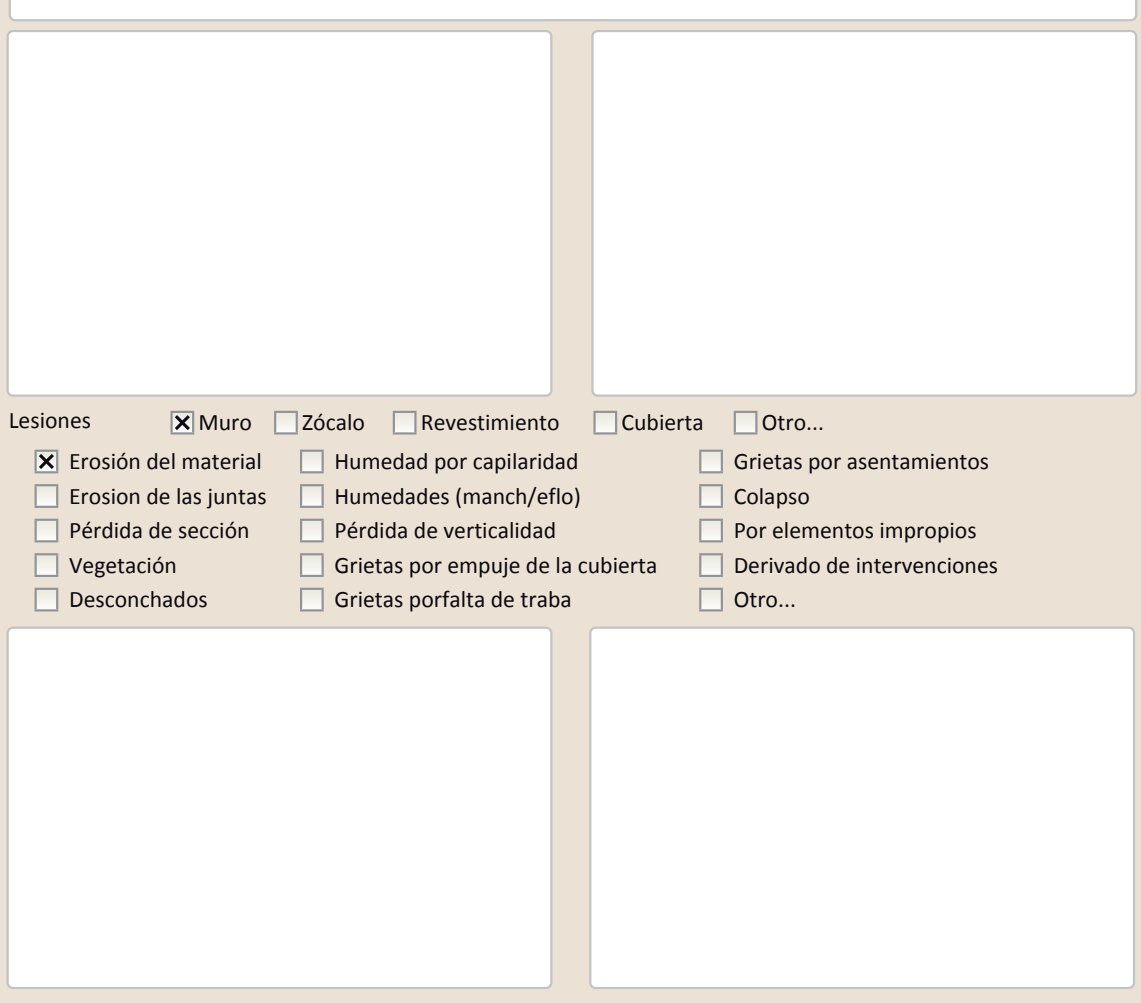

Observaciones 
La restauración y rehabilitación de la arquitectura tradicional de tierra. El caso de Aragón

\section{La restauración y rehabilitación de la arquitectura tradicional de tierra.}

\section{El caso de Aragón.}

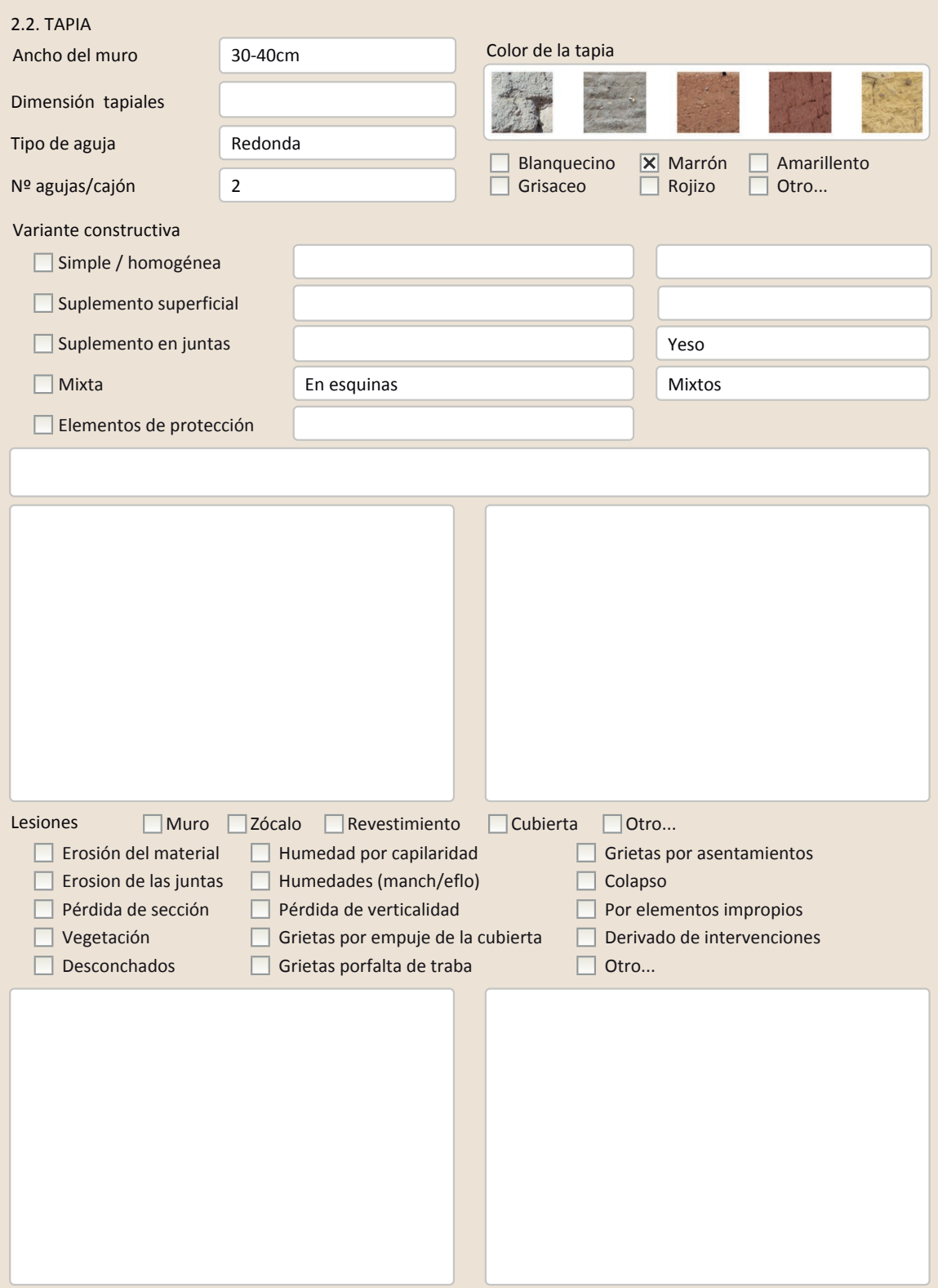

Observaciones 


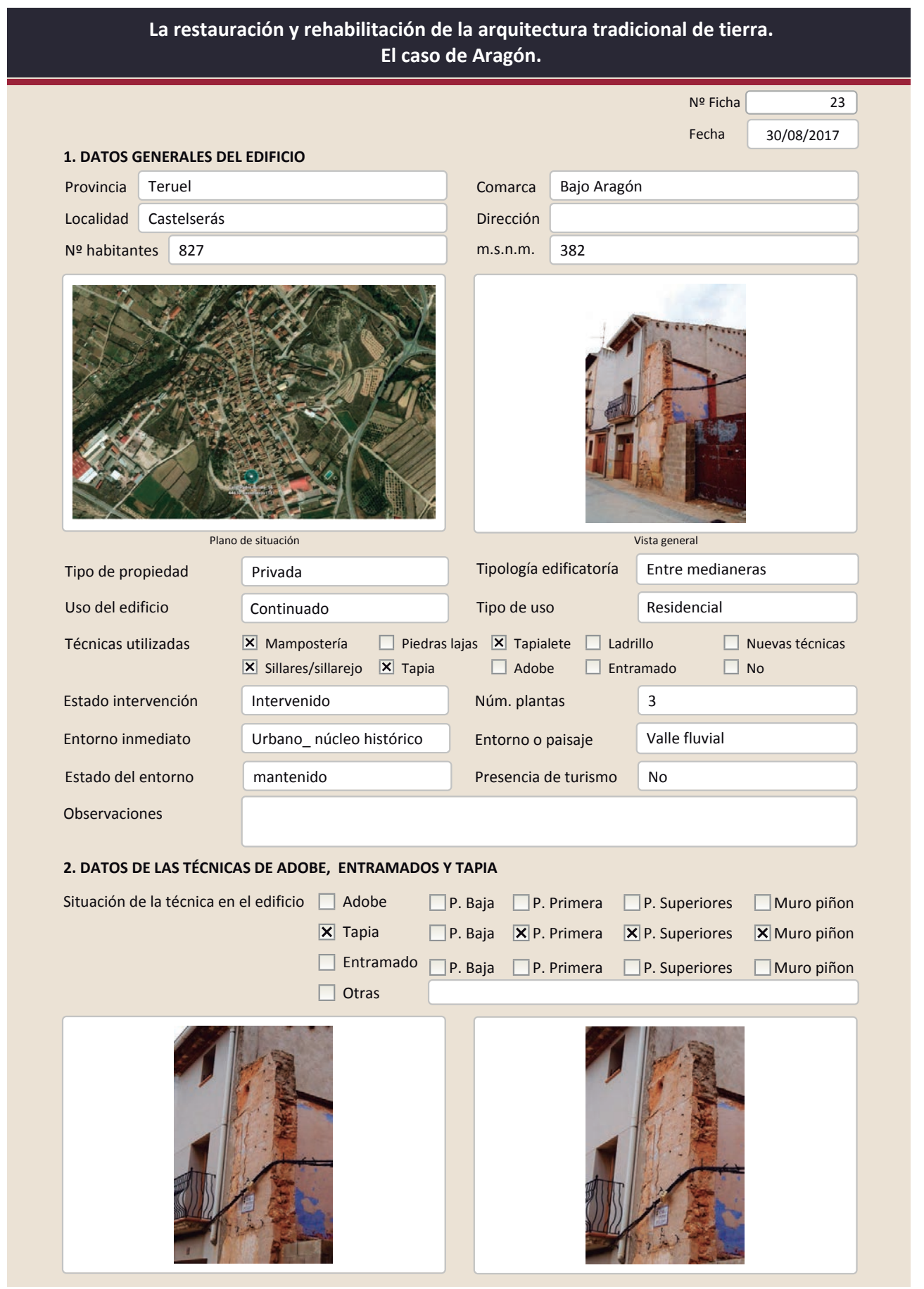

La restauración y rehabilitación de la arquitectura tradicional de tierra.

El caso de Aragón.

2.2. TAPIA

Ancho del muro

Dimensión tapiales

Tipo de aguja

№ agujas/cajón

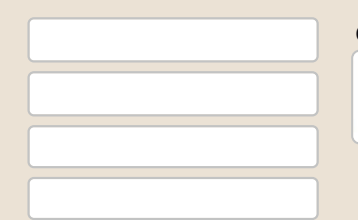

Color de la tapia

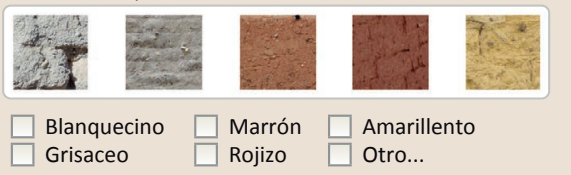

$\square$ simple / homogénea

$\square$ Suplemento superficial

$\mathbf{X}$ Suplemento en juntas

X Mixta

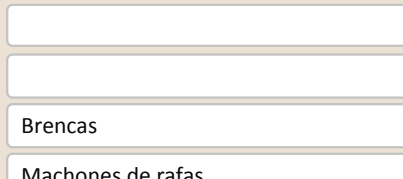

Machones de rafas

\section{Cal/ yeso}

Mampostería y yeso

No se aprecia el muro del propio edificio pero si el que esta a continuación

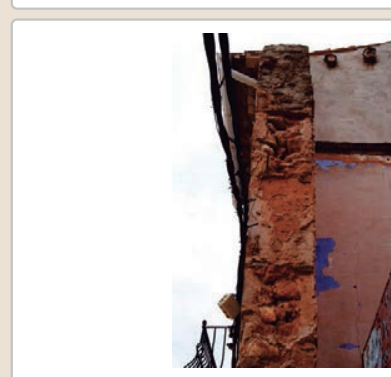

Lesiones $\square$ Muro $\square$ Zócalo $\square$ Revestimiento $\square$ Cubierta $\square$ Otro..

$\square$ Erosión del material $\quad \square$ Humedad por capilaridad $\quad \square$ Grietas por asentamiento

$\square$ Erosion de las juntas $\square$ Humedades (manch/eflo) $\quad \square$ Colapso

$\square$ Pérdida de sección $\quad \square$ Pérdida de verticalidad $\square$ Por elementos impropios

$\square$ Vegetación $\quad \square$ Grietas por empuje de la cubierta $\quad \square$ Derivado de intervenciones

$\square$ Desconchados $\quad \square$ Grietas porfalta de traba $\quad \square$ Otro...

Observaciones 
La restauración y rehabilitación de la arquitectura tradicional de tierra. El caso de Aragón

\section{La restauración y rehabilitación de la arquitectura tradicional de tierra.}

\section{El caso de Aragón.}

3. DATOS DE LA INTERVENCIÓN

Intervención de:

$\square$ Mantenimiento $\square$ Rehabilitación parcial

$\square$ Restauración $\square$ Demolición

Reflexión previa

$\square$ Reparación

X Rehabilitación integra

Ampliación

$\square$ Otro...

Observaciones

Intervención planificada

(n)

3.1. MUROS

Tipo de intervención

No visible

Tipo de material

$\square$ Actualización $\square$ Reintegración $\square$ Demolición $\square$ Otro...

$\square$ Consolidación $\square$ Reconstrucción $\square$ sustitución

Descripción

3.2. ZÓCALO

Tipo de intervención

Intervenido

Tipo de intervención

X Actualización $\square$ Reintegración $\square$ Demolición $\square$ Otro...

Tipo de material

Descripción

No tradicional Tipo de técnica

Tipo de técnica

3.3. REVESTIMIENTOS

Reintegración del zócalo con baldosas y cemento

Tipo de intervención

Intervenido

Tipo de material

$\square$ Reintegración $\square$ Demolición $\square$ Otro...

Tipo de material

Descripción

No tradicional Tipo de técnica D

resto

3.4. VANOS

Intervenido

Tipo de intervención

X Actualización $\square$ Reintegración $\square$ Demolición $\square$ Otro...

Tipo de material

$\square$ Consolidación $\square$ Reconstrucción $\quad \boldsymbol{x}$ Sustitución

Descripción

No tradicional

Tipo de técnica Diferente a la existente

Ampliación de los huecos y sustitución de carpinterías y balcones ligados a estos

3.5. CUBIERTA

Intervenido

Tipo de intervención

$\square$ Actualización $\quad \boldsymbol{X}$ Reintegración $\square$ Demolición $\square$ Otro.

$\square$ Consolidación $\square$ Reconstrucción $\square$ Sustitución

Tipo de material

No tradicional

Tipo de técnica Diferente a la existente

Descripción

Reintegración de la cubierta con cemento. Ladrillos sustituidos en ele alero

3.6. OTRAS 


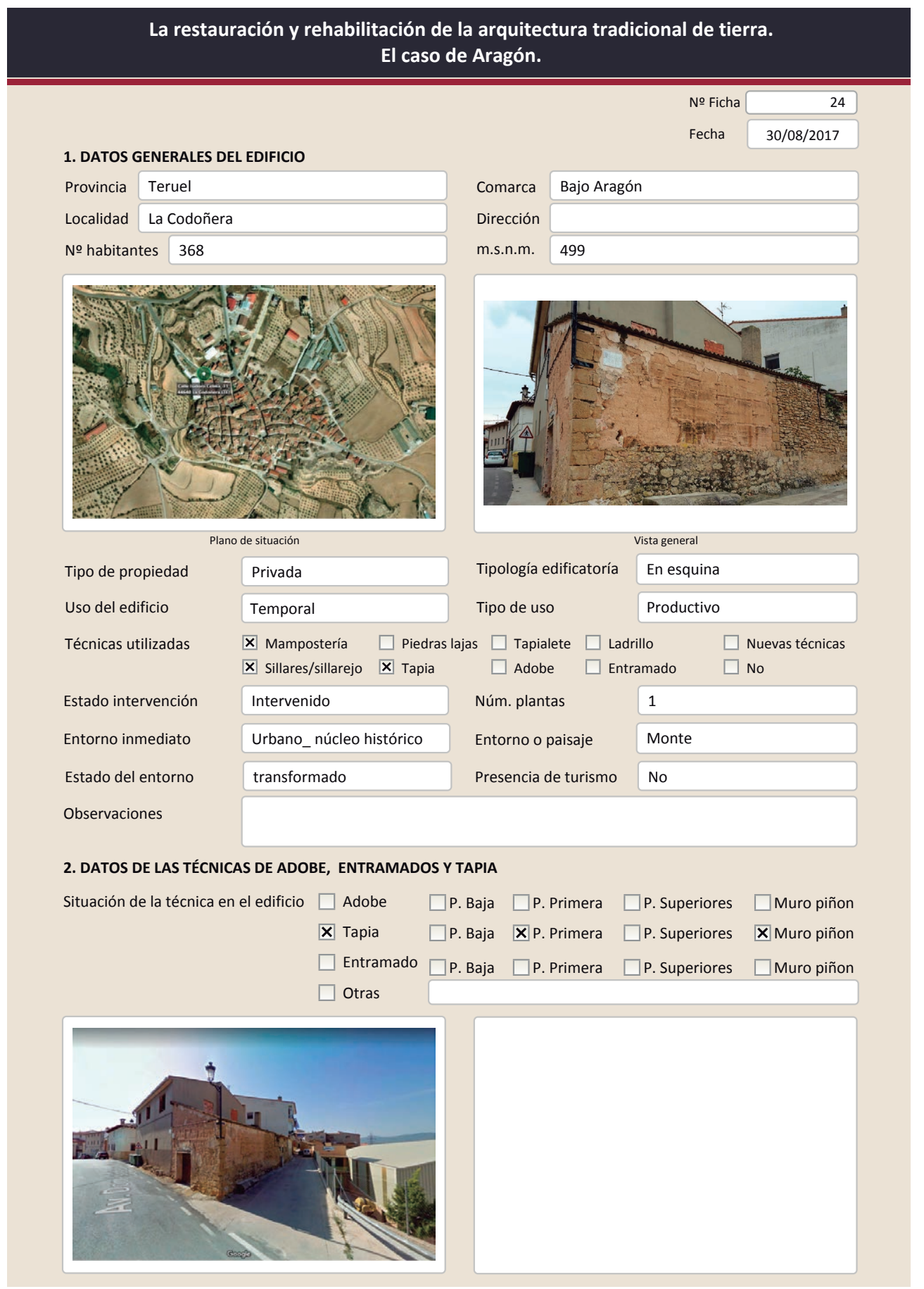

La restauración y rehabilitación de la arquitectura tradicional de tierra.

El caso de Aragón.

2.2. TAPIA

Ancho del muro

Dimensión tapiales

Tipo de aguja

№ agujas/cajón

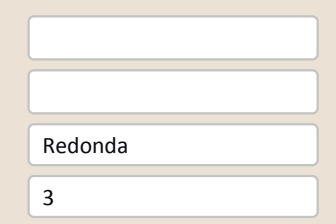

Color de la tapia

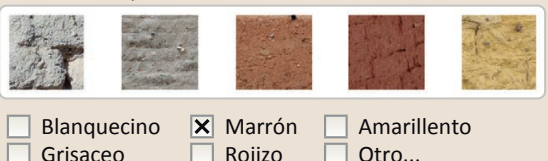

$\begin{array}{ll}\square \text { Blanquecino } & \mathbf{X} \text { Marrón } \\ \square \text { Grisaceo } & \square \text { Amarillento } \\ & \square \text { Rojizo } \quad \square \text { Otro... }\end{array}$

$\square$ Simple / homogénea

X Suplemento superficial

$\mathbf{X}$ Suplemento en juntas

X Mixta
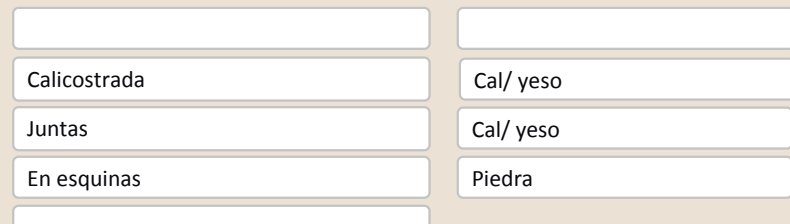

$\square$ Elementos de protección

En cada fachada hay un tipo de tapia, en un lado con juntas de yeso y en el otro calicosrada.

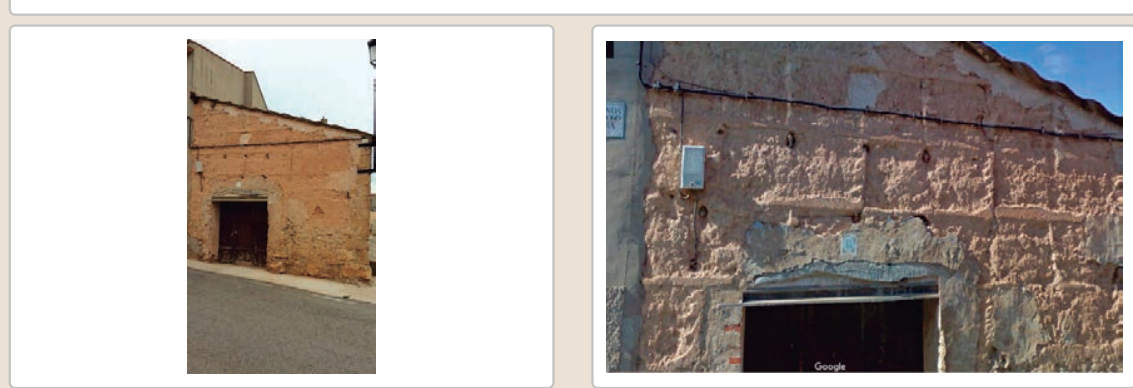

Lesiones $\quad \mathbf{X}$ Muro $\square$ Zócalo $\square$ Revestimiento $\square$ Cubierta $\square$ otro..

X Erosión del material $\quad \mathbf{X}$ Humedad por capilaridad $\quad \square$ Grietas por asentamientos $\square$ Erosion de las juntas $\quad \square$ Humedades (manch/eflo) $\quad \square$ Colapso

X Pérdida de sección $\square$ Pérdida de verticalidad $\quad \square$ Por elementos impropios

$\square$ Vegetación $\quad \square$ Grietas por empuje de la cubierta $\quad \square$ Derivado de intervenciones

$\square$ Desconchados $\quad \square$ Grietas porfalta de traba

$\square$ Otro...

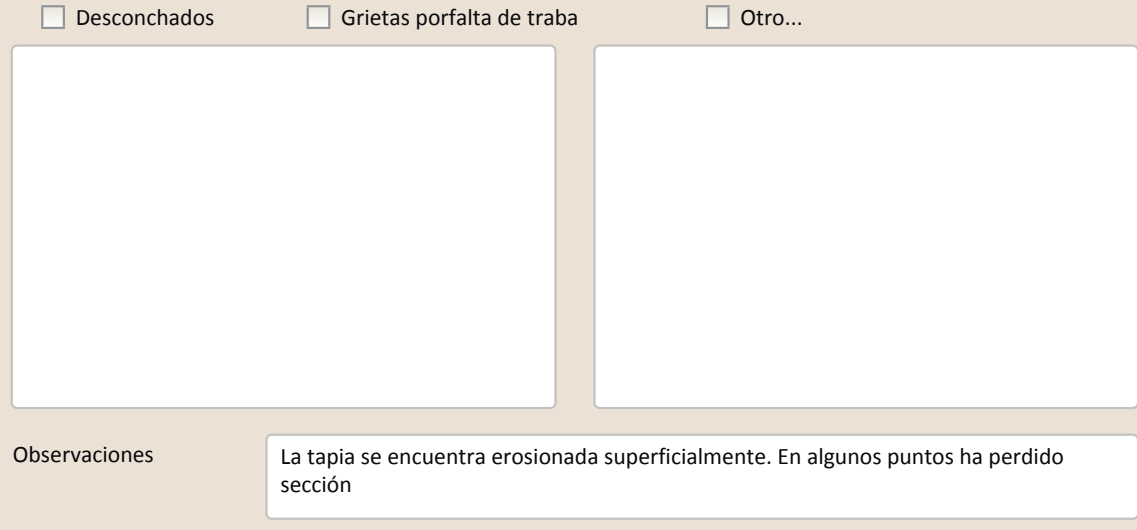


La restauración y rehabilitación de la arquitectura tradicional de tierra. El caso de Aragón

\section{La restauración y rehabilitación de la arquitectura tradicional de tierra.}

\section{El caso de Aragón.}

3. DATOS DE LA INTERVENCIÓN

Intervención de:

$\square$ Mantenimiento $\square$ Rehabilitación parcia

$\square$ Restauración $\square$ Demolición

Х Reparación $\square$ Rehabilitación integral $\square$ Ampliación $\quad \square$ Otro...

Reflexión previa

Intervención espontanea

Observaciones

(a)

3.1. MUROS

No intervenido

Tipo de intervención

$\square$ Actualización $\quad \square$ Reintegración $\quad \square$ Demolición
$\square$ Consolidación $\quad \square$ Reconstrucción $\quad \square$ Sustitución

Tipo de material

Descripción

3.2. ZÓCALO

Tipo de intervención

Intervenido

Tipo de intervención

$\square$ Actualización

X Reintegración $\square$ Demolición $\square$ Otro..

Tipo de material

No tradicional

$\mathbf{X}$ Reintegración
$\square$ Reconstrucción
$\square$ Sustitución

Descripción

Reintegración de oquedades con cemento

3.3. REVESTIMIENTOS

\section{No aplica}

Tipo de intervención

$\square$ Actualización

$\square$ Reintegración $\square$ Demolición $\square$ Otro...

$\square$ Consolidación $\square$ Reconstrucción $\square$ Sustitución

Tipo de material

Descripción

3.4. VANOS

Tipo de intervención

Intervenido

Tipo de material

$\square$ Actualización $\quad \mathbf{X}$ Reintegración $\square$ Demolición $\square$ Otro...

$\square$ Consolidación $\quad \square$ Reconstrucción $\square$ sustitución

\begin{tabular}{|l|l|l|l} 
No tradicional & Tipo de técnica & Diferente a la existente
\end{tabular}

Descripción Se ha colocado una vigueta de madera debajo del dintel de madera original

probablemente por problemas en el mismo

3.5. CUBIERTA

Tipo de intervención

Intervenido

Tipo de material

$\square$ Actualización $\square$ Reintegración $\square$ Demolición $\square$ Otro..

$\square$ Consolidación $\square$ Reconstrucción $\quad$ S Sustitución

\begin{tabular}{|l|l|l|l|l|l}
\hline & No tradicional & Tipo de técnica & Diferente a la existente \\
\hline
\end{tabular}

Descripción

Sustitución de la cubierta tradicional por fibrocemento

3.6. OTRAS 


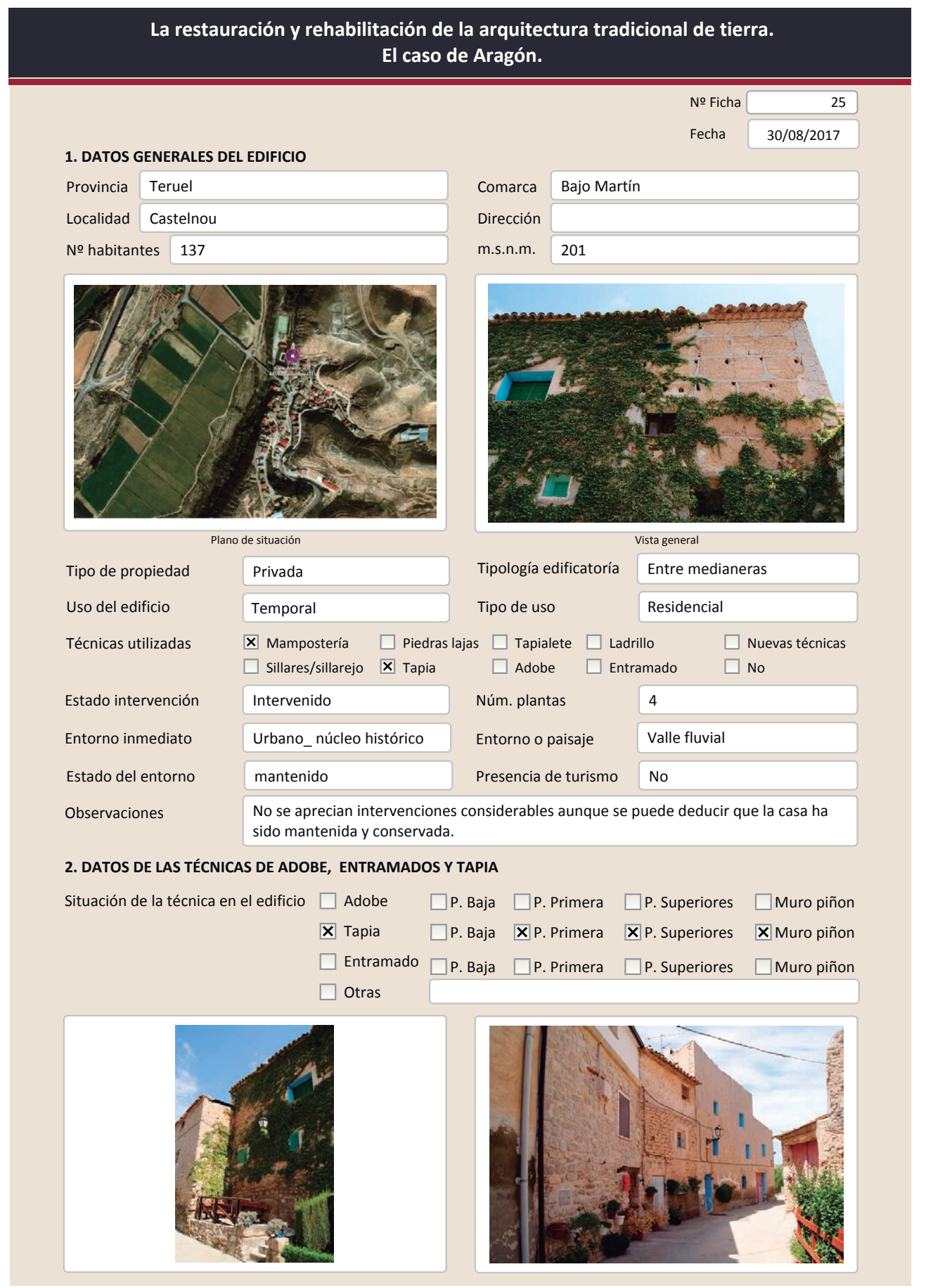

La restauración y rehabilitación de la arquitectura tradicional de tierra. El caso de Aragón.
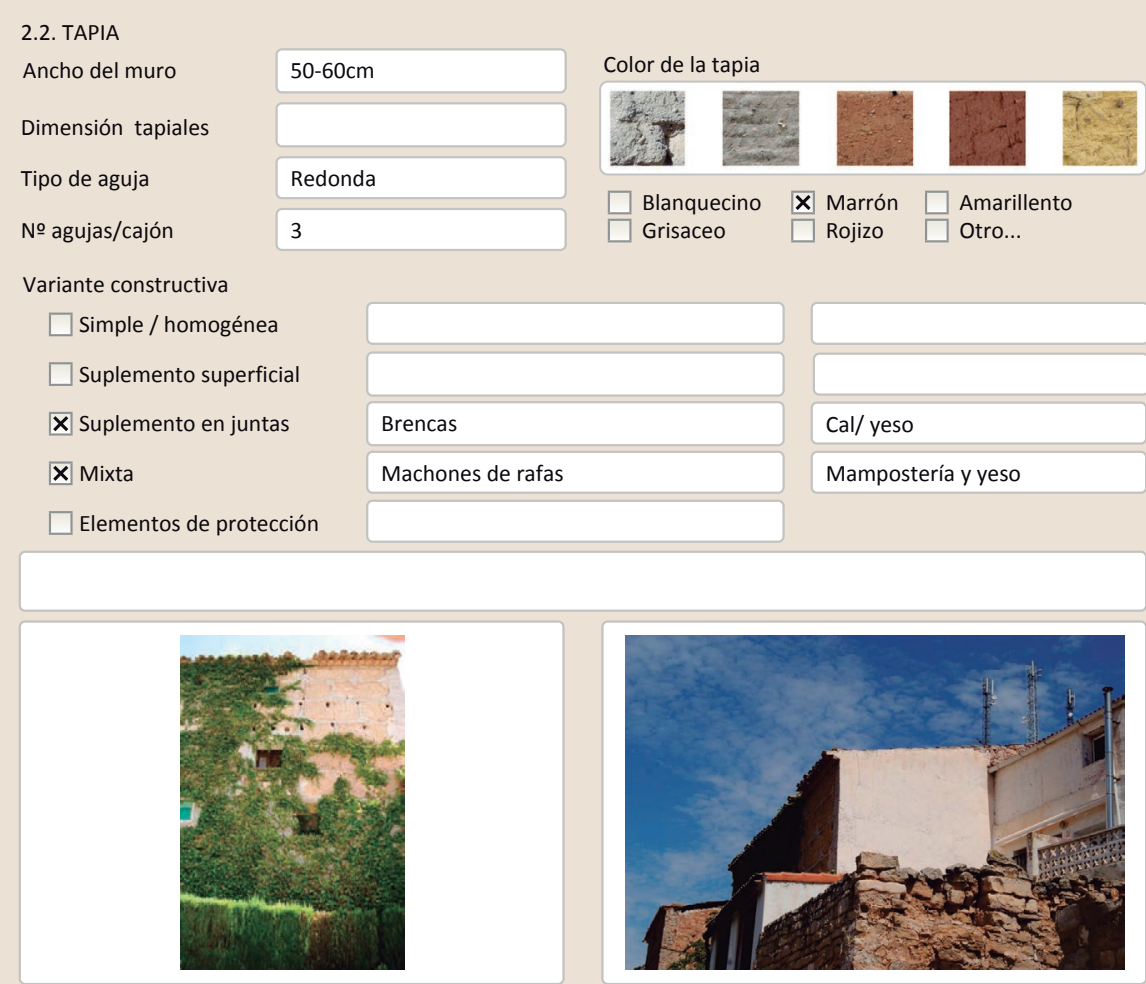

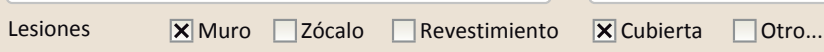
X Erosión del material $\quad \square$ Humedad por capilaridad $\quad \square$ Grietas por asentamientos $\mathbf{X}$ Erosion de las juntas $\square$ Humedades (manch/eflo) $\quad \square$ Colapso
$\square$ Pérdida de sección $\square$ Pérdida de verticalidad $\quad \square$ Por elementos impropios
$\square$ Vegetación
$\square$ vegetaci
$\square$ Grietas por empuje de
$\square$ Derivado de in X Otro...

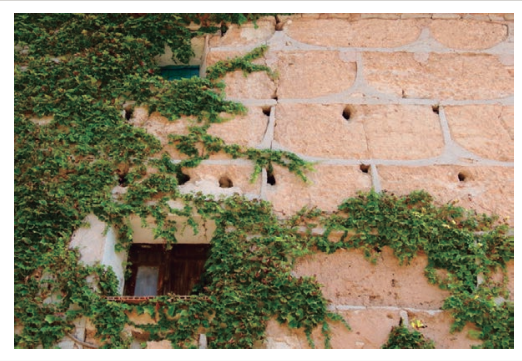




\section{La restauración y rehabilitación de la arquitectura tradicional de tierra.} El caso de Aragón.

3. DATOS DE LA INTERVENCIÓN

Mantenimiento $\square$ Rehabilitación parcial $\square$ Restauración $\square$ Demolición X Reparación $\square$ Rehabilitación integral $\square$ Ampliación $\quad \square$ Otro...

Reflexión previa Intervención espontanea

Observaciones pequeñas intervenciones para intentar conservar el edificio

3.1. MUROS
Tipo de intervención

Intervenido

Tipo de material

$\square$ Actualización $\quad \mathbf{X}$ Reintegración $\quad \square$ Demolición $\quad \square$ Otro...

Descripción

$\square$ Reconstrucción $\square$ sustitucic

(2.)

Tipo de intervención

Tradicional diferente

Tipo de técnica Diferente a la existente

Intervenido

$\square$ Actualización $\quad \mathbf{x}$ Reintegración $\square$ Demolición $\square$ Otro...

$\square$ Consolidación $\quad \square$ Reconstrucción $\square$ Sustitución

Tipo de material

No tradicional

Tipo de técnica Diferente a la existente

Descripción

3.3. REVESTIMIENTOS

Tipo de intervención

Tipo de material

Descripción

3.4. VANOS

Tipo de intervención

Tipo de material

Rejuntado del zócalo de mampostería con gran cantidad de mortero de cemento

\section{No intervenido}

$\square$ Actualización $\square$ Reintegración $\square$ Demolición $\square$ Otro...

$\square$ Consolidación $\square$ Reconstrucción $\square$ sustitución

Tipo de técnica

Descripción

3.5. CUBIERTA

Tipo de intervención

Tipo de material

Descripción

3.6. OTRAS

Intervenido

$\square$ Actualización $\quad \mathbf{X}$ Reintegración $\quad \square$ Demolición $\square$ Otro...

$\square$ Consolidación $\quad \square$ Reconstrucción $\square$ Sustitución

\begin{tabular}{|l|l|l|l|l} 
No tradicional Tipo de técnica Diferente a la existente &
\end{tabular} de los laterales del hueco con cemento en otro caso.

No intervenido

$\square$ Actualización $\square$ Reintegración $\square$ Demolición $\square$ Otro.. $\square$ Consolidación $\square$ Reconstrucción $\square$ Sustitución Tipo de técnica
La restauración y rehabilitación de la arquitectura tradicional de tierra.

El caso de Aragón.

3.7. REHABILITACIÓN ENERGÉTICA $\square$ Fachada $\square$ Vanos $\square$ Forjados $\square$ Cubierta

Observaciones

FOTOGRAFÍAS DE LA INTERVENCIÓN

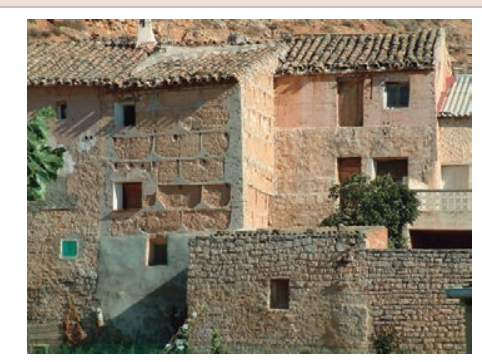

Fotografia previa a la intervención y sin vegetación.Autor: José Ángel Guimerá.

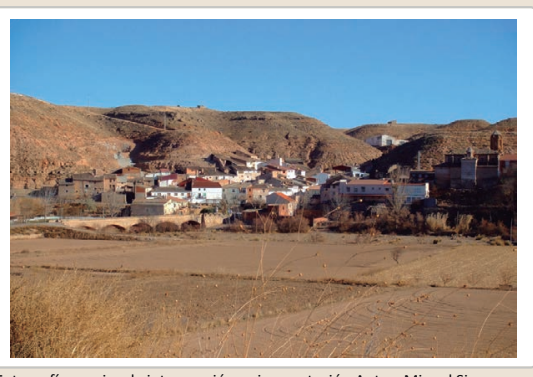

Fotografia previa a
(httpsmapio.net)

(attsmapionet)

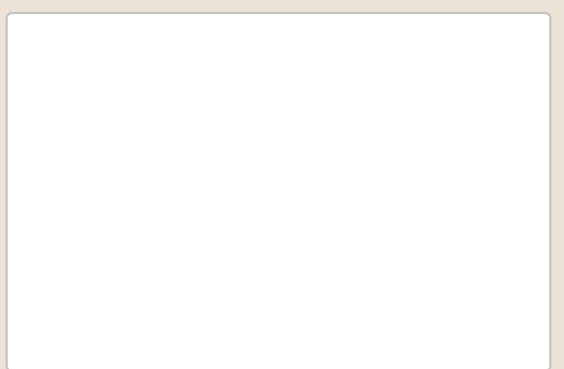

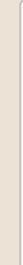

Diferentes intervenciones. Nuevo alfeizar con ladrillo hueco en un caso y reintegración
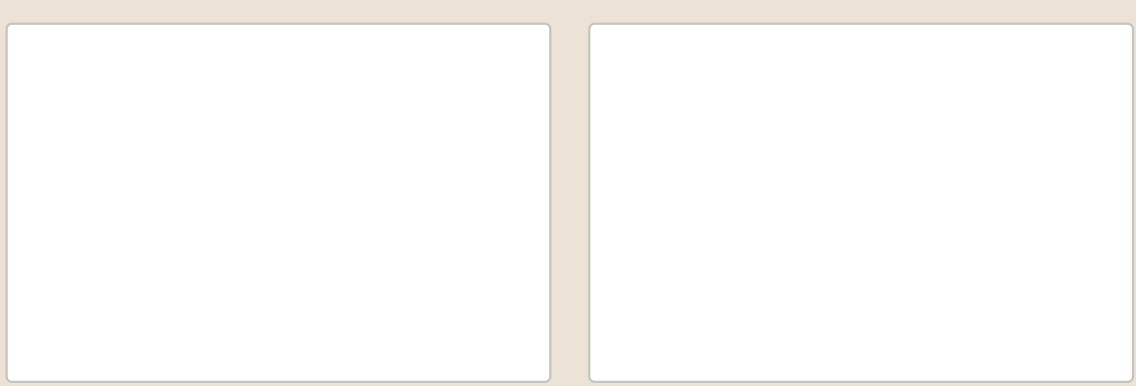


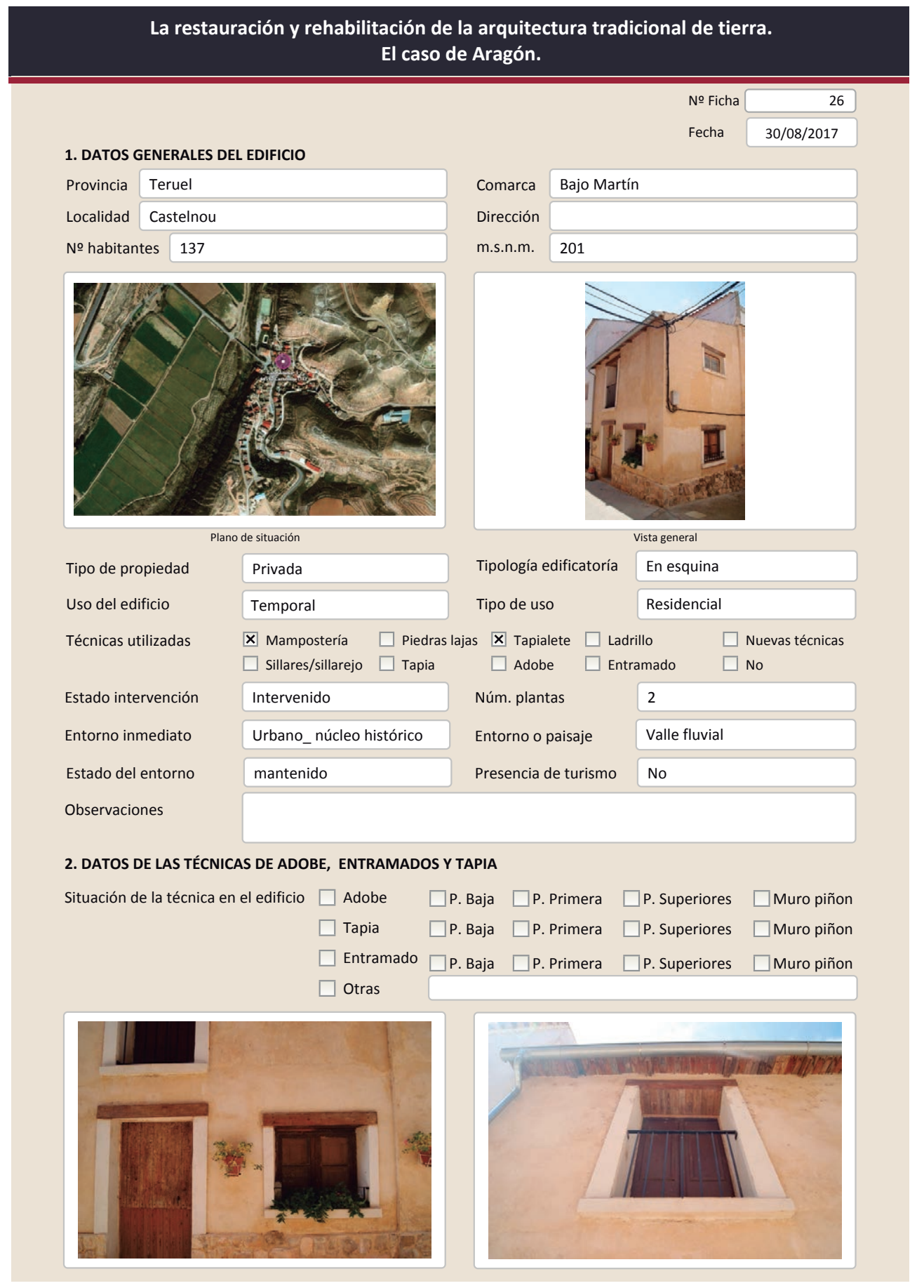

La restauración y rehabilitación de la arquitectura tradicional de tierra.

El caso de Aragón.

\subsection{TAPIA}

Ancho del muro

Dimensión tapiales

Tipo de aguja

№ agujas/cajón

Variante constructiva

$\square$ simple/h

$\square$ Suplemento superficial

$\square$ suplemento en juntas

$\square$ Mixta

$\square$ Elementos de protección
Color de la tapia

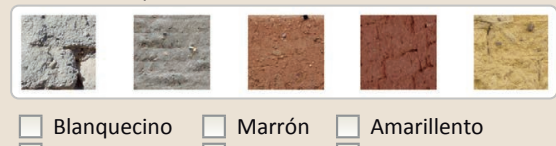

$\square$ Blanquecino $\square$ Marrón $\square$ Amarillento

$\square$ Grisaceo $\square$ Rojizo $\square$ Otro

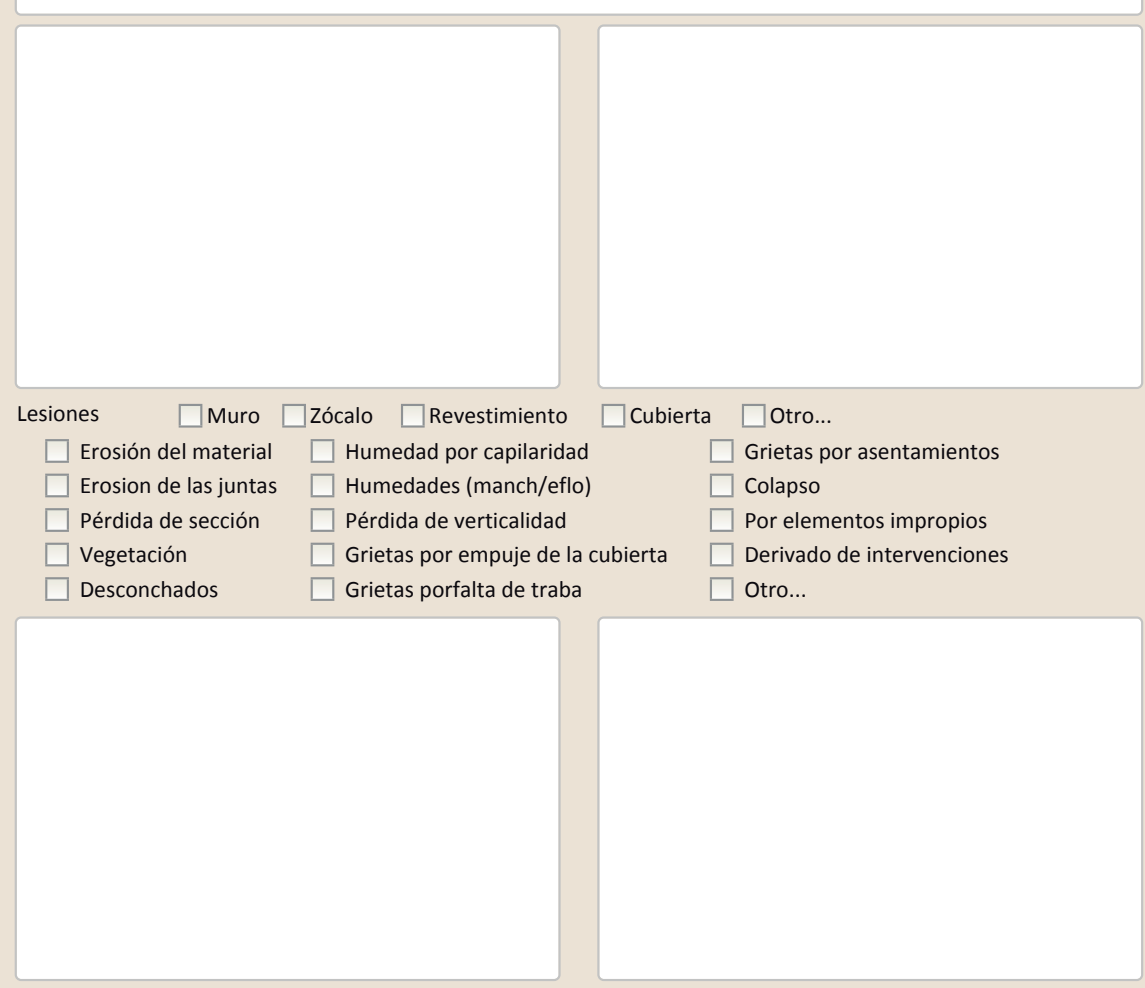

Observaciones 


\section{La restauración y rehabilitación de la arquitectura tradicional de tierra.}

\section{El caso de Aragón.}

3. DATOS DE LA INTERVENCIÓN

$\square$ Mantenimien

Intervención de:

$\square$ Reparación

$\square$ Rehabilitación parcial

$\square$ Restauración $\square$ Demolición

Intervención planificada

Reflexion previa

Inter

\subsection{MUROS \\ Tipo de intervención}

Tipo de material

Descripción

3.2. ZÓCALO

Tipo de intervención

Tipo de material

Descripción

3.3. REVESTIMIENTOS

Tipo de intervención

Tipo de material

Descripción

3.4. VANOS

Tipo de intervención

Tipo de material

Descripción

3.5. CUBIERTA

Tipo de intervención

Tipo de material

Descripción

\section{No visible}

$\square$ Actualización $\square$ Reintegración $\square$ Demolición $\square$ Otro...

$\square$ Consolidación $\square$ Reconstrucción $\square$ Sustitución

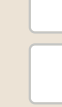

\section{Intervenido}

$\square$ Actualización $\quad$ X Reintegración $\square$ Demolición $\square$ Otro...

$\square$ Consolidación $\square$ Reconstrucción $\square$ Sustitución
No tradicional
Tipo de técnica Diferente a la existente

Rejuntado de la mampostería del zócalo con cemento

\section{Intervenido}

$\square$ Actualización $\quad \square$ Reintegración $\quad \square$ Demolición $\square$ Otro...

$\square$ Consolidación $\square$ Reconstrucción $\quad$ \ Sustitución

No tradicional Tipo de técnica Diferente a la existente

Nuevo revestimiento de cemento coloreado. Se pueden apreciar las humedades por capilaridad en la parte inferior.

$$
\text { Intervenido }
$$

$\square$ Actualización $\square$ Reintegración $\square$ Demolición $\square$ Otro...

X Consolidación $\square$ Reconstrucción $\mathbf{X}$ Sustitución

\begin{tabular}{ll} 
No tradicional Tipo de técnica Diferente a la existente \\
\hline
\end{tabular}

Consolidación de los huecos (jambas). Sustitución del dintel del hueco de planta primera donde se observan pequeñas tablas. Carpinterías conservadas.

\section{Intervenido}

$\square$ Actualización $\quad \square$ Reintegración $\quad \square$ Demolición $\square$ Otro.. $\square$ Consolidación $\mathbf{x}$ Reconstrucción $\mathbf{x}$ Sustitución
No tradicional
Tipo de técnica Similar a la existente

3.6. OTRAS
La restauración y rehabilitación de la arquitectura tradicional de tierra.

El caso de Aragón.

3.7. REHABILITACIÓN ENERGÉTICA $\quad \square$ Fachada $\square$ Vanos $\square$ Forjados $\square$ Cubierta

Observaciones

FOTOGRAFÍAS DE LA INTERVENCIÓN
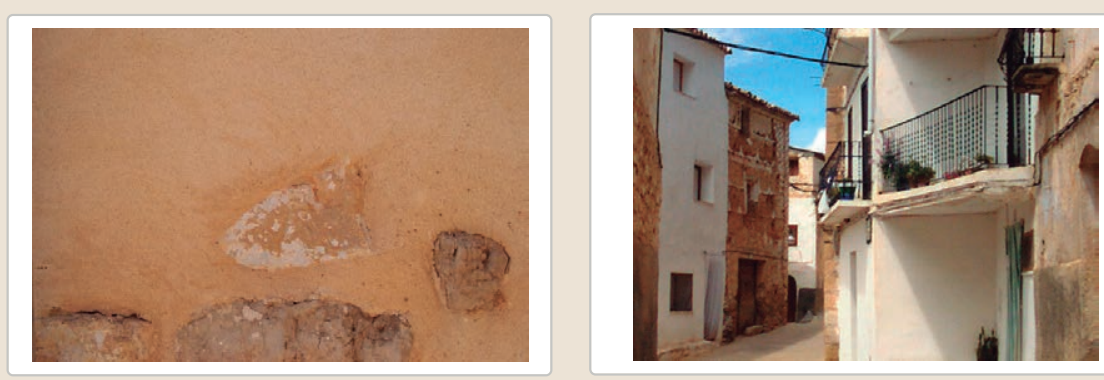

El edificio antes de la intervención. Autor: José Ángel G Gimerá (httpssmapion.n
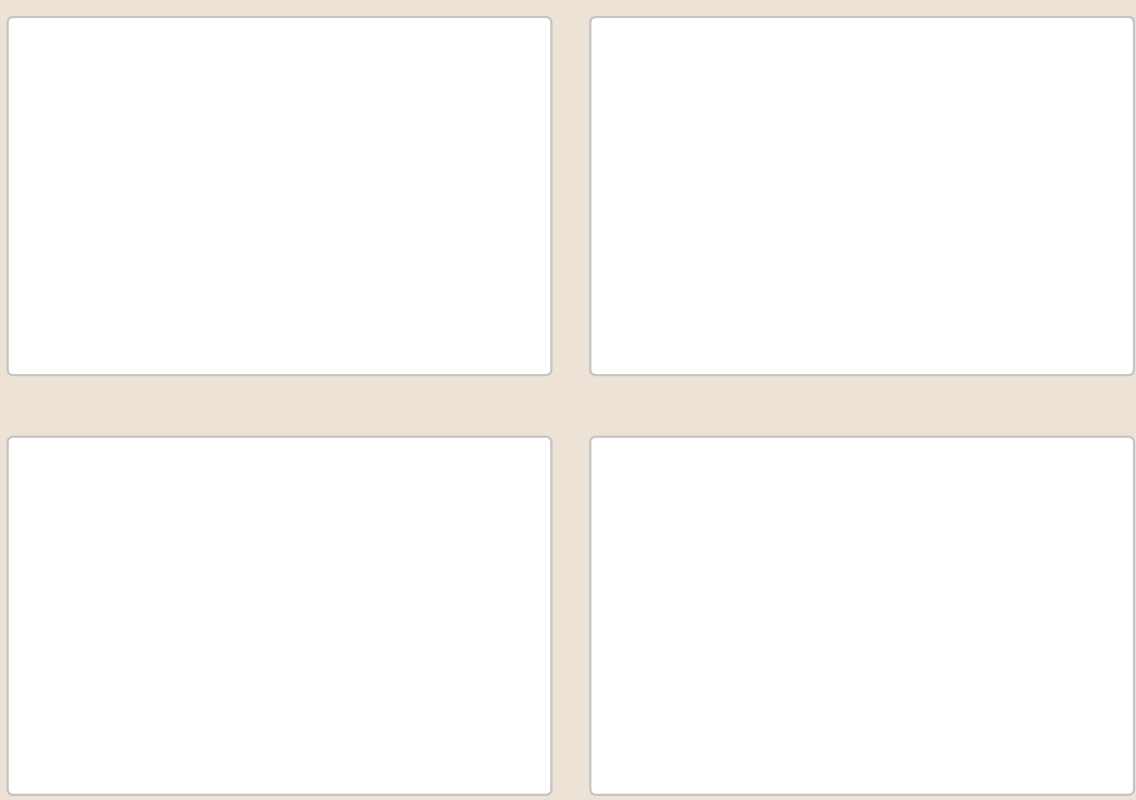


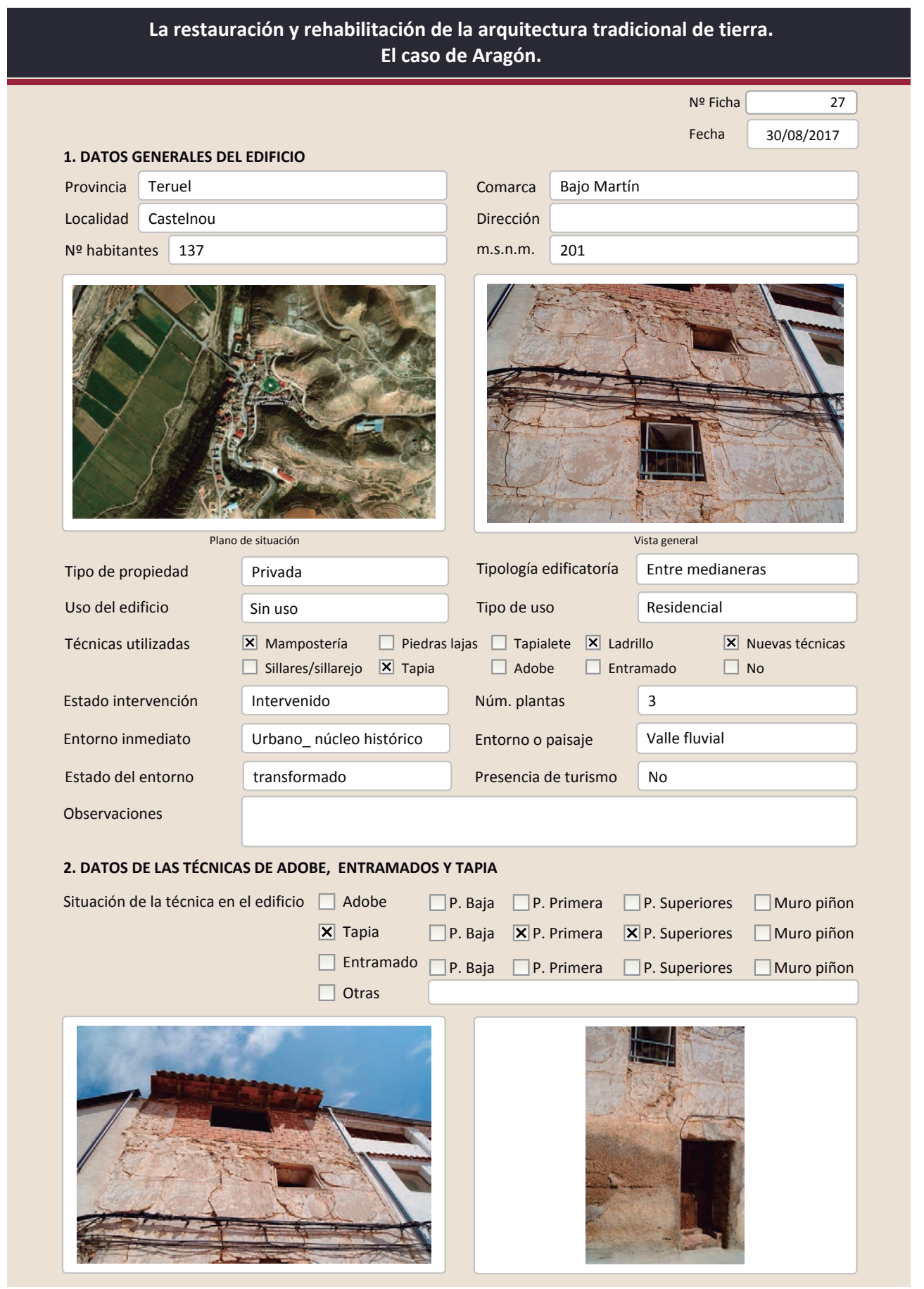

La restauración y rehabilitación de la arquitectura tradicional de tierra. El caso de Aragón.

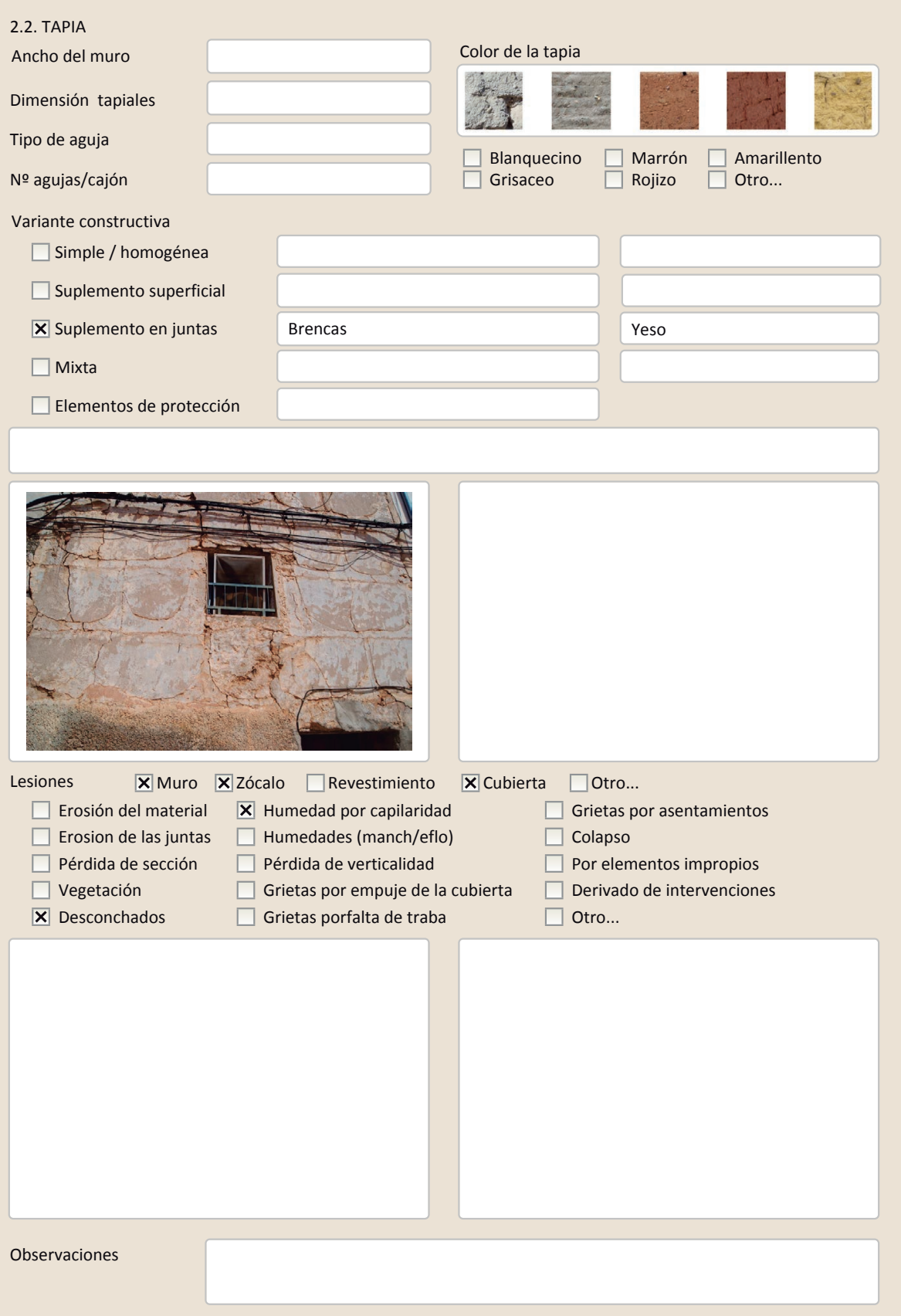




\section{La restauración y rehabilitación de la arquitectura tradicional de tierra.}

\section{El caso de Aragón.}

3. DATOS DE LA INTERVENCIÓN

Intervención de:

Mantenimiento $\mathbf{X}$ Rehabilitación parcia

$\square$ Restauración $\square$ Demolición

Reflexión previa

$\square$ Reparación

Rehabilitación integra

Ampliación

$\square$ Otro...

Observaciones

Intervención espontanea

\subsection{MUROS}

Tipo de intervención

Tipo de material

Descripción

3.2. ZÓCALO

Tipo de intervención

Tipo de material

Descripción

3.3. REVESTIMIENTOS

Tipo de intervención

Tipo de material

Descripción

3.4. VANOS

Tipo de intervención

Tipo de material

Descripción

3.5. CUBIERTA

Tipo de intervención

Tipo de material

Descripción

3.6. OTRAS
Intervenido

$\square$ Actualización $\square$ Reintegración $\square$ Demolición $\square$ Otro...

$\square$ Consolidación $\quad$ Xeconstrucción $\square$ sustitución

No tradicional Tipo de técnica Diferente a la existente

Se ha cerrado el solanar superior y se ha realizado un recrecido de unos $20 \mathrm{~cm}$ donde apoya la nueva cubierta.

Intervenido

$\square$ Actualización $\square$ Reintegración $\quad \square$ Demolición $\square$ Otro..

$\square$ Consolidación $\square$ Reconstrucción $\quad$ X Sustitución

No tradicional Tipo de técnica Diferente a la existente

Sustitución del zócalo por cemento en forma de gotelé. La intervención no es reciene y

se encuentra bastante degradado (humedades, desconchados, etc)

No intervenido

$\square$ Actualización $\square$ Reintegración $\square$ Demolición $\square$ Otro...

$\square$ Consolidación $\square$ Reconstrucción $\square$ Sustitución

Tipo de técnica

No intervenido

$\square$ Actualización $\square$ Reintegración $\square$ Demolición $\square$ Otro...

$\square$ Consolidación $\square$ Reconstrucción $\square$ Sustitución

Tipo de técnica

Intervenido

$\square$ Actualización $\square$ Reintegración $\square$ Demolición $\square$ Otro.

$\square$ Consolidación $\square$ Reconstrucción $\quad \mathbf{x}$ Sustitución
No tradicional
Tipo de técnica Diferente a la existente

Sustitución completa de la cubierta (nivel superior, muro recrecido muy poquito) 


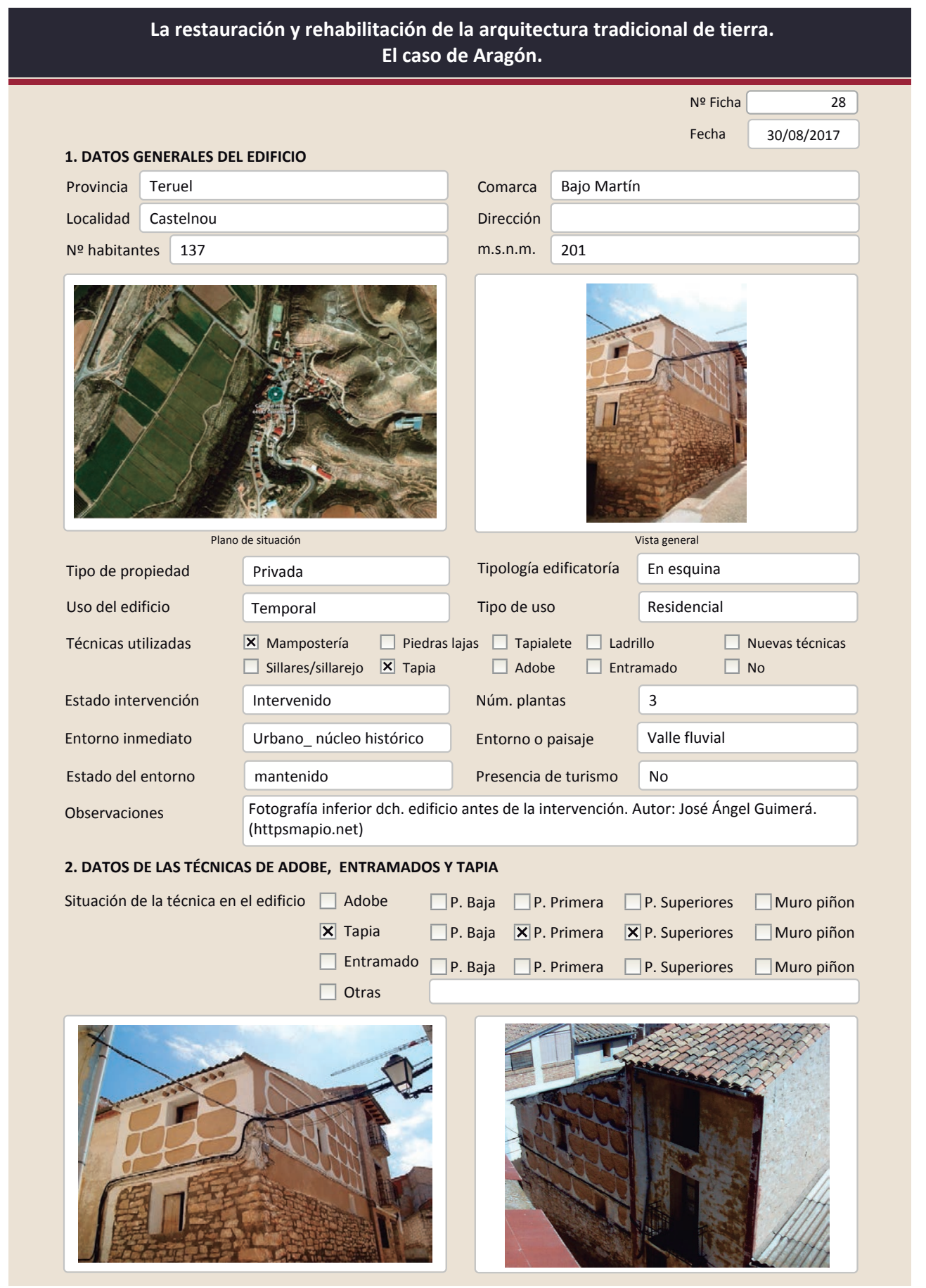

La restauración y rehabilitación de la arquitectura tradicional de tierra. El caso de Aragón.

\subsection{TAPIA}

Ancho del muro

Dimensión tapiales

Tipo de aguja

\begin{tabular}{|l|}
\hline $40-50 \mathrm{~cm}$ \\
\hline \\
\hline No apreciable \\
\hline
\end{tabular}

Color de la tapia

№ agujas/cajón

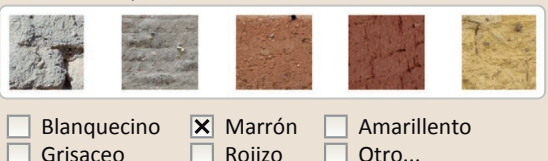

Variante constructiva

$\square$ simple / homogénea

$\square$ suplemento superficial

$\mathbf{X}$ Suplemento en juntas

X Mixta
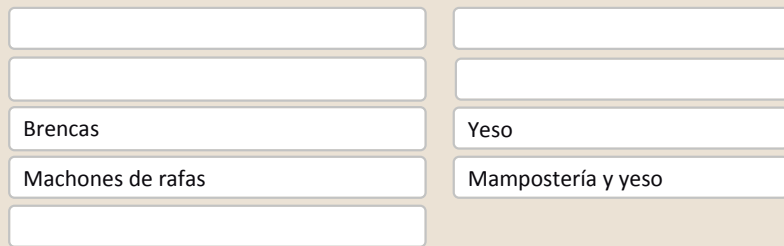

$\square$ Elementos de protección

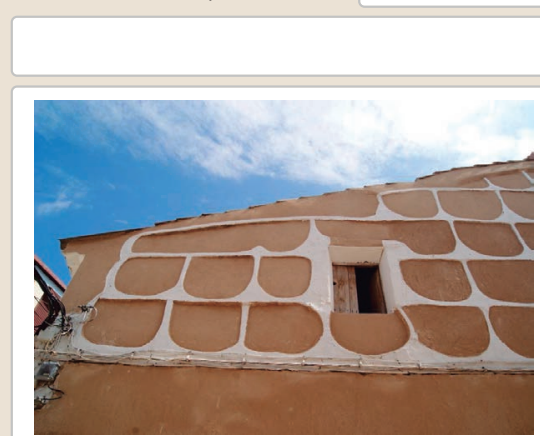

Lesiones $\square$ Muro $\square$ Zócalo $\square$ Revestimiento $\square$ Cubierta $\square$ otro...

$\square$ Erosión del material $\quad \square$ Humedad por capilaridad $\quad \square$ Grietas por asentamientos $\square$ Erosion de las juntas $\square$ Humedades (manch/eflo)

$\square$ Pérdida de sección $\quad \square$ Pérdida de verticalidad

$\square$ Vegetación

Perrida de verticalidad

$\square$ Desconchados

$\square$ Grietas porfalta de traba
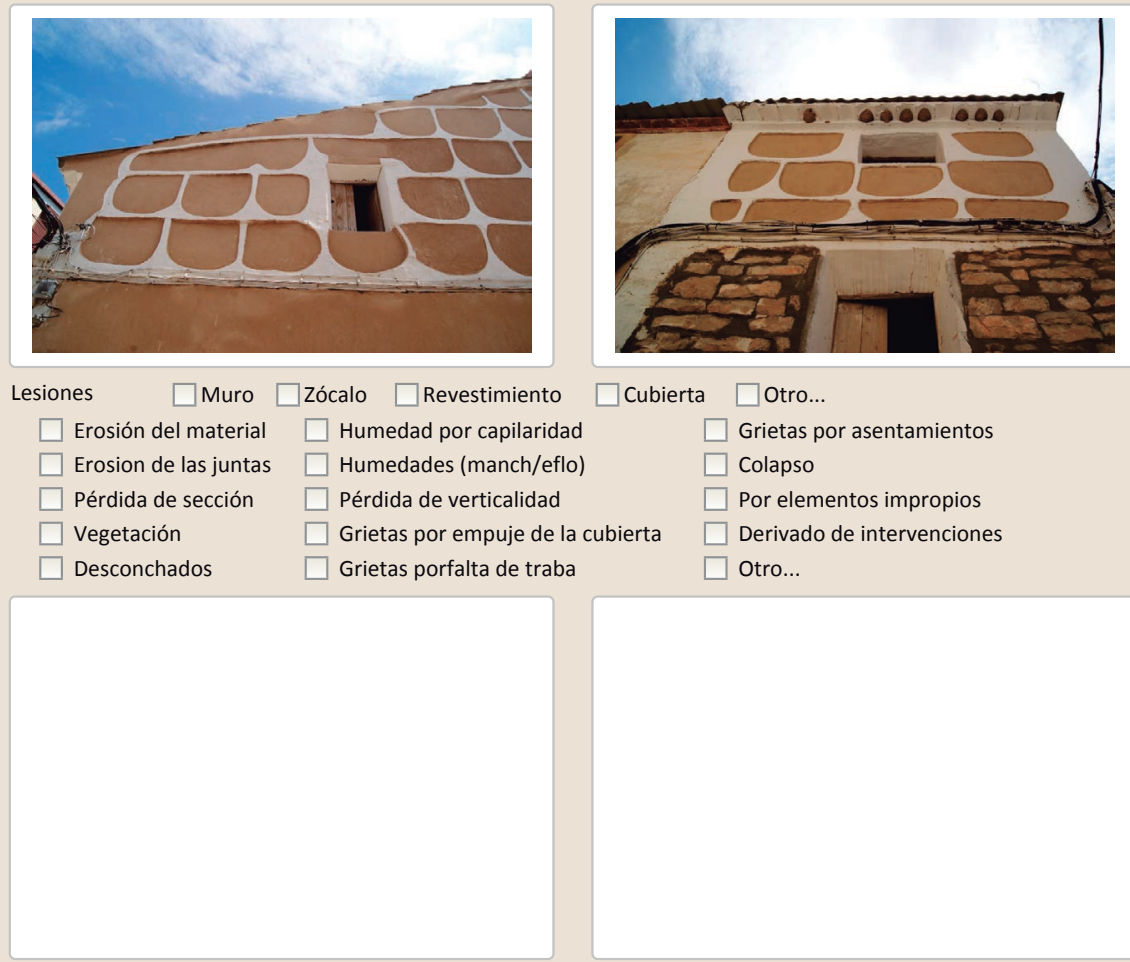

Observaciones

El edificio esta muy intervenido y no es apreciable el elemento de tapia original 


\section{La restauración y rehabilitación de la arquitectura tradicional de tierra.}

\section{El caso de Aragón.}

3. DATOS DE LA INTERVENCIÓN

Intervención de:

$\square$ Mantenim

$\square$ Rehabilitación parcial

$\square$ Restauración $\square$ Demolición

$\square$ Reparación $\quad$ X Rehabilitación integral $\square$ Ampliación $\square$ Otro...

Reflexión previa Intervención planificada

Observaciones Se ha intervenido el edificio cubriéndolo por completo pero remarcando un elemento característico de la zona que son las brencas de las tapias

3.1. MUROS

No visible

Tipo de intervención

$\square$ Actualización $\quad \square$ Reintegración $\quad \square$ Demolición $\square$ Otro...

$\square$ Consolidación $\square$ Reconstrucción $\square$ sustitución

Tipo de material

Descripción

3.2. ZÓCALO

Tipo de intervención

Intervenido

$\square$ Actualización

区 Reintegración $\square$ Demolición $\square$ Otro...

Tipo de material

No tradicional

Tipo de técnica

Descripción

3.3. REVESTIMIENTOS

\section{Intervenido}

Tipo de intervención

$\square$ Actualización $\square$ Reintegración $\quad \square$ Demolición $\square$ Otro...

$\square$ Consolidación $\mathbf{X}$ Reconstrucción $\square$ Sustitución

Tipo de material

Descripción
No tradicional
Tipo de técnica Diferente a la existente

Nuevo revestimiento que deja notables las brencas que sobres
tierra probablemente más erosionada antes de la actuación.

3.4. VANOS

No intervenido

Tipo de intervención

$\square$ Actualización $\square$ Reintegración $\square$ Demolición $\square$ Otro...

$\square$ Consolidación $\square$ Reconstrucción $\square$ sustitución

Tipo de material

Tipo de técnica

Descripción

No se observa ninguna intervención especial en esta zona aparte del revestimiento que afecta a todo el edificio.

3.5. CUBIERTA

Tipo de intervención

Intervenido

Tipo de material

$\square$ Actualización $\quad$ X Reintegración $\quad \square$ Demolición $\square$ Otro..

$\square$ Consolidación $\square$ Reconstrucción $\quad$ X Sustitución

\begin{tabular}{l|l|l|l} 
No tradicional & Tipo de técnica & Diferente a la existente
\end{tabular}

Descripción Sustitución parcial de la cubierta, tejas eliminadas sobre el alero y sustitución por placa de fibrocemento

3.6. OTRAS 


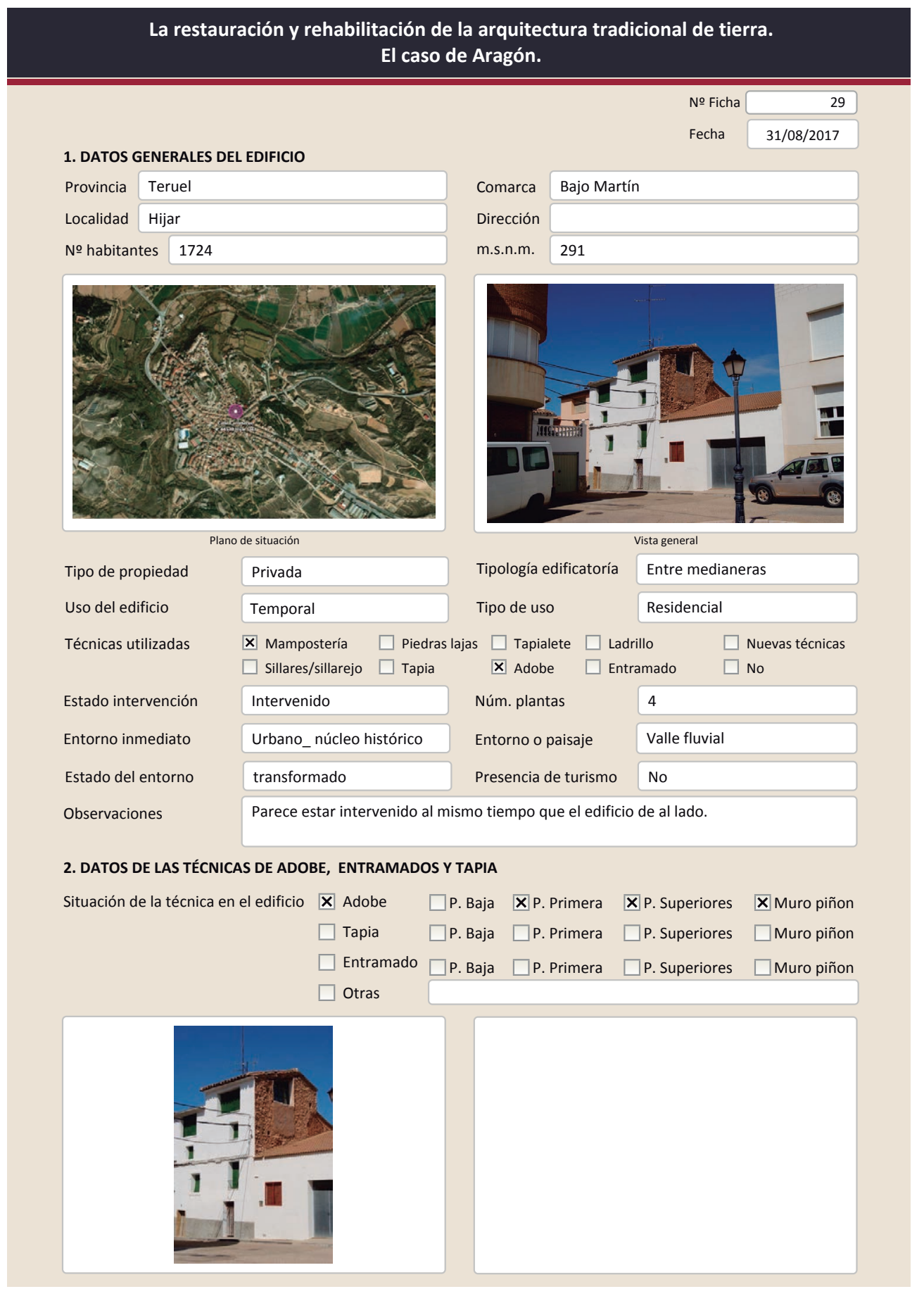

La restauración y rehabilitación de la arquitectura tradicional de tierra.

El caso de Aragón.

\begin{tabular}{ll} 
2.1. ADOBE \\
Dimensión de las piezas \\
Dimensión del muro \\
Aparejo del muro & \\
Función estructural & Tizón \\
\hline
\end{tabular}

Color de las piezas

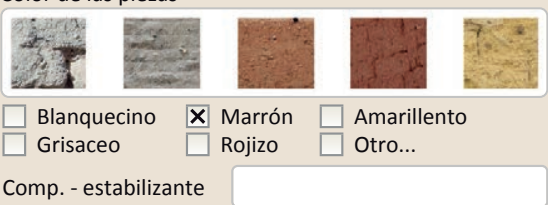

Variante constructiva/ tipo de fábrica
$\square$ Simple
X Suplementada en juntas
$\square$ Mixta
$\square$ Como suplemento
$\square$ Elementos de protección
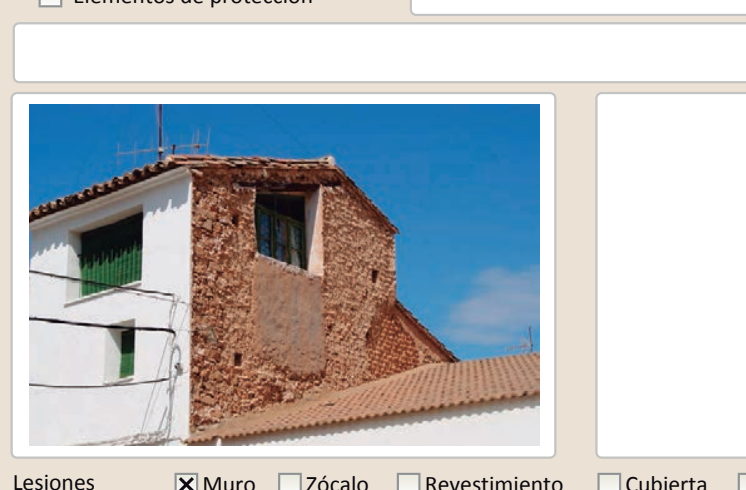

Lesiones $\quad \mathbf{X}$ Muro $\square$ Zócalo $\square$ Revestimiento

X Erosión del material $\square$ Humedad por capilaridad $\mathbf{X}$ Erosion de las juntas $\square$ Humedades (manch/eflo)

$\square$ Pérdida de sección $\square$ Pérdida de verticalidad

$\square$ Vegetación $\quad \square$ Grietas por empuje de la cube $\square$ Grietas porfalta de traba

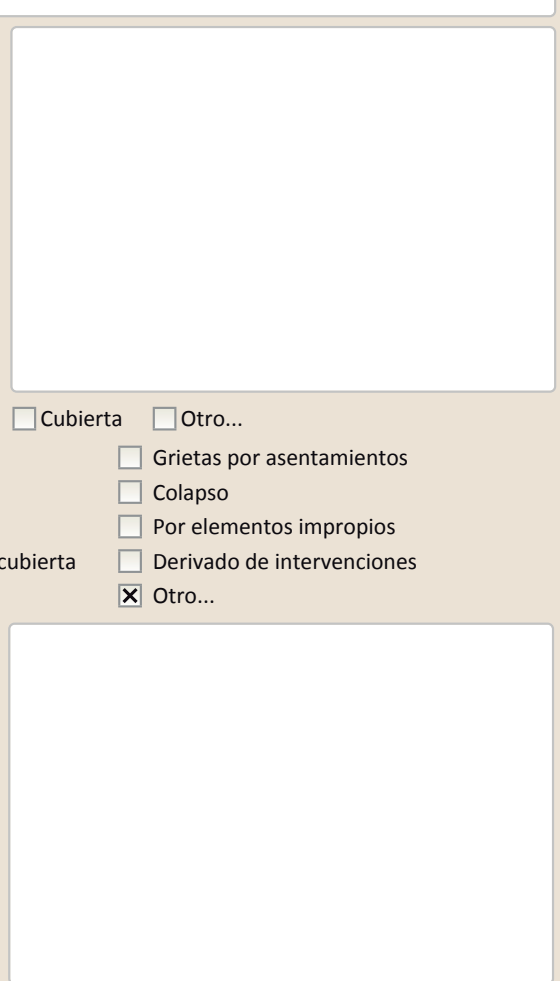

Observacione La fachada es de piedra mientras que toda la parte trasera del edificio esta construida con adobe 


\section{La restauración y rehabilitación de la arquitectura tradicional de tierra.}

\section{El caso de Aragón.}

3. DATOS DE LA INTERVENCIÓN

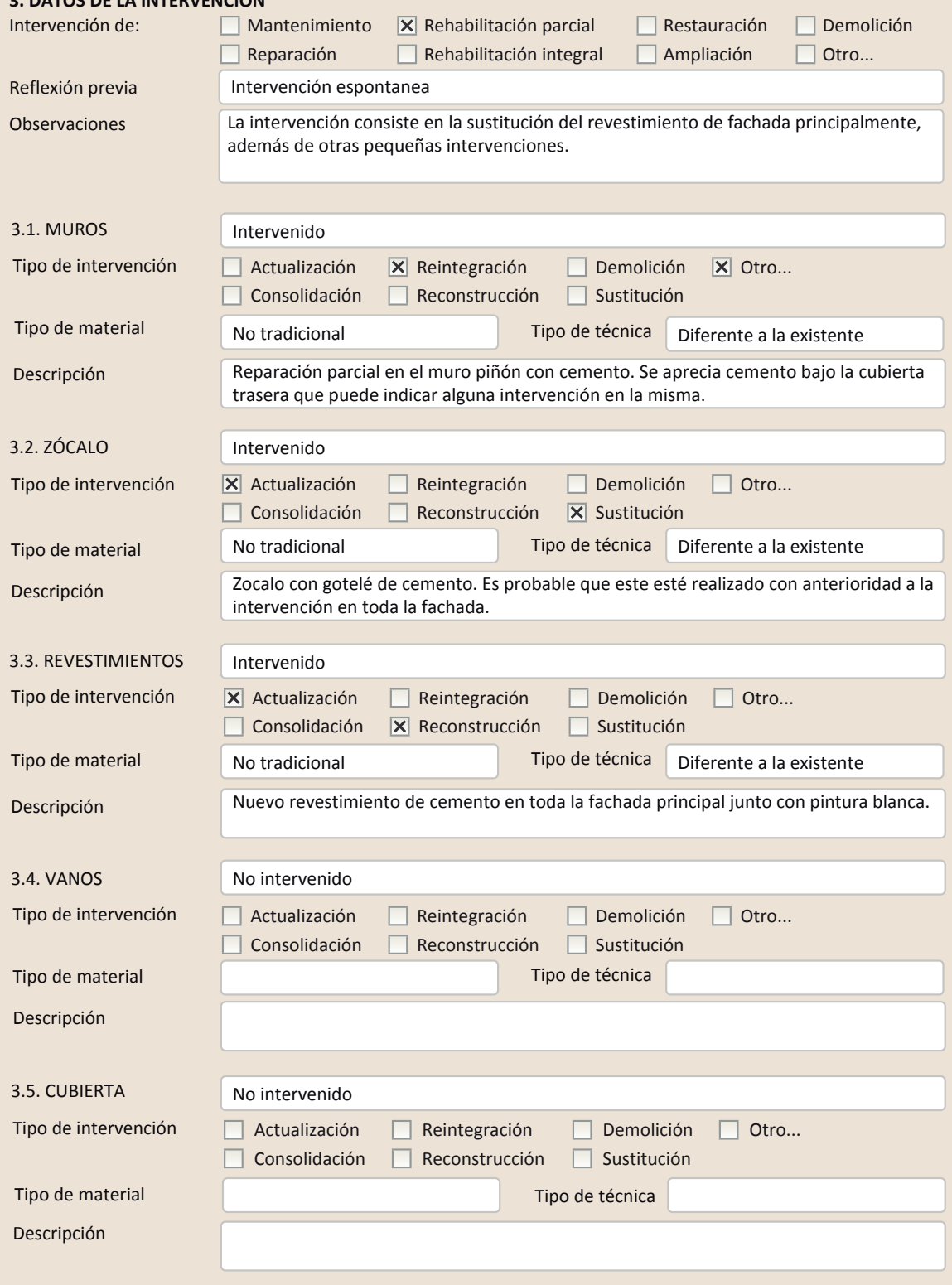

3.6. OTRAS 


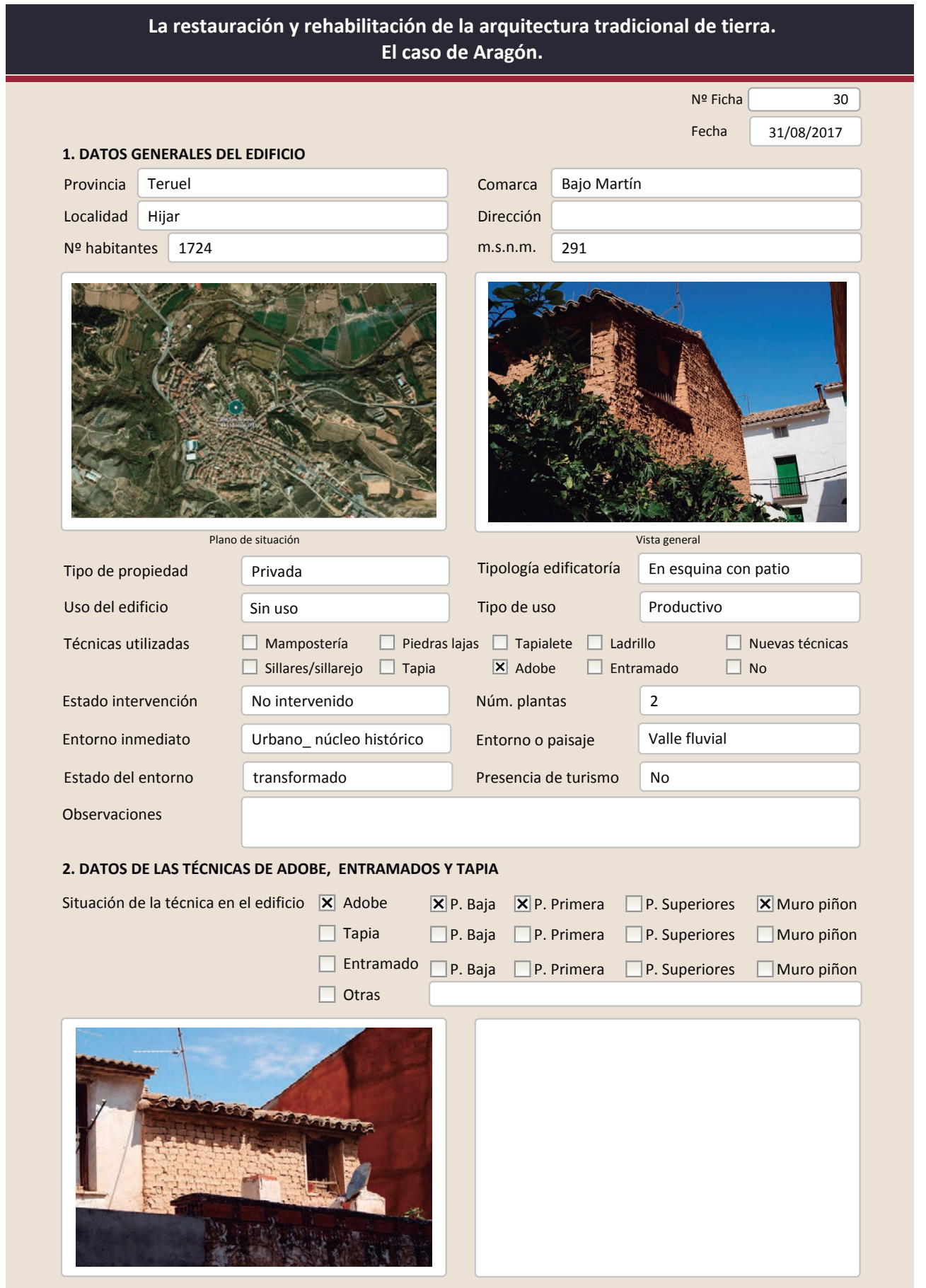

La restauración y rehabilitación de la arquitectura tradicional de tierra.

El caso de Aragón.

2.1. ADOBE

Dimensión de las piezas

Dimensión del muro

Aparejo del muro

Función estructural

\begin{tabular}{|l|}
\hline \\
\hline $30-40 \mathrm{~cm}$ \\
\hline Tizón \\
\hline $\mathrm{Si}$ \\
\hline
\end{tabular}

Color de las piezas

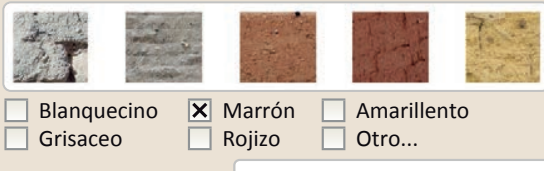

Comp. - estabilizante

Variante constructiva/ tipo de fábrica

$\square$ simple
$\mathbf{X}$ Suplementada en juntas
$\square$ Mixta
$\square$ Como suplemento
$\square$ Elementos de protección

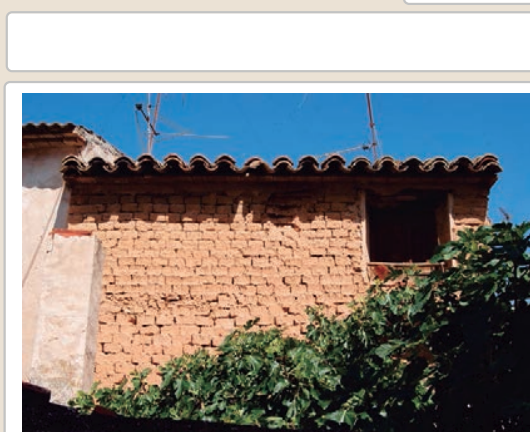

Lesiones $\mathbf{X}$ Muro $\square$ Zócalo $\square$ Revestimiento $\mathbf{X}$ Cubierta $\square$ Otro...

$\mathbf{X}$ Erosión del material $\quad \square$ Humedad por capilaridad $\quad \square$ Grietas por asentamientos $\square$ Erosion de las juntas $\square$ Humedades (manch/eflo) $\quad \square$ Colapso

X Pérdida de sección $\square$ Pérdida de verticalidad

$\square$ Vegetación $\quad \square$ Grietas por empuje de la cubierta

$\square$ Desconchados

$\square$ Grietas por empuje de la cu
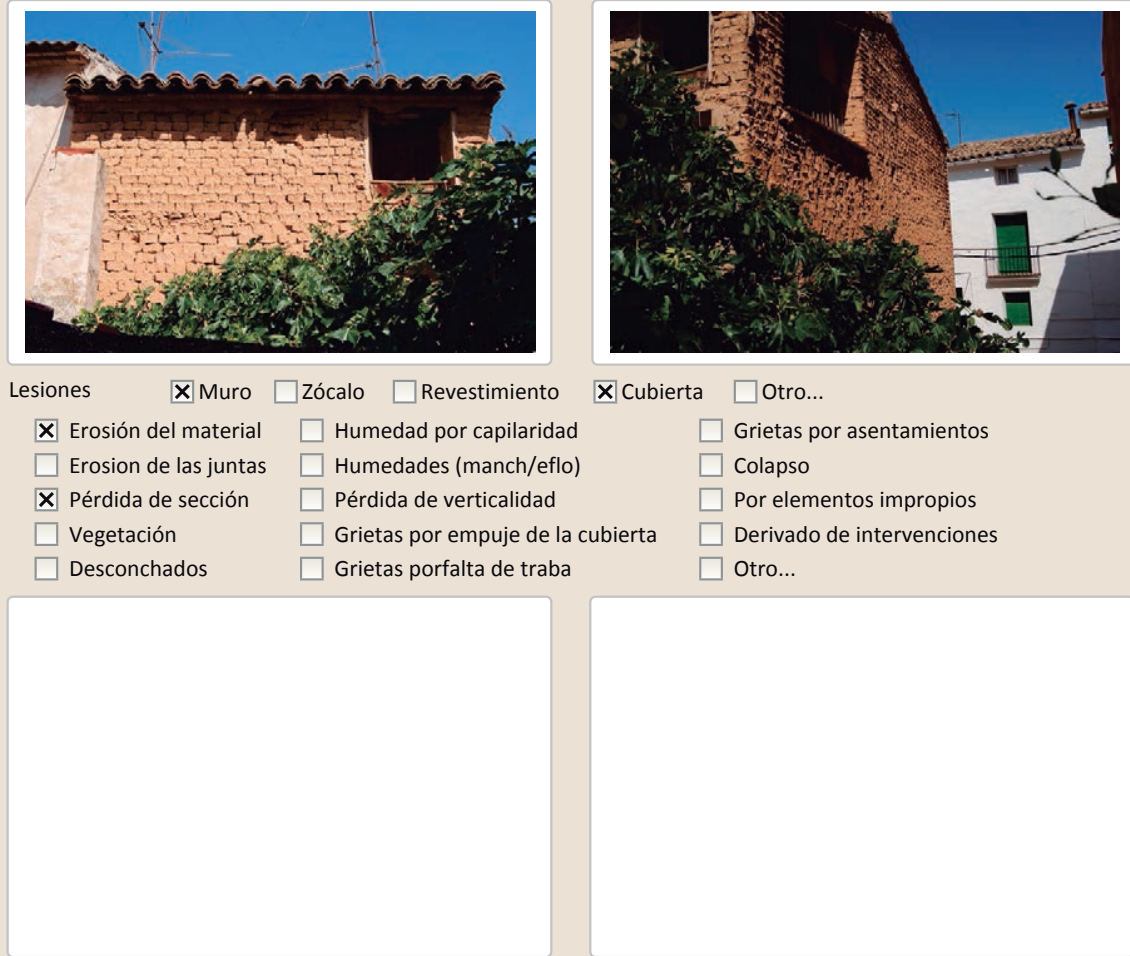

Observaciones edificio no presenta ninguna patología grave. Perdida volumétrica mayor en algunas de las piezas. 


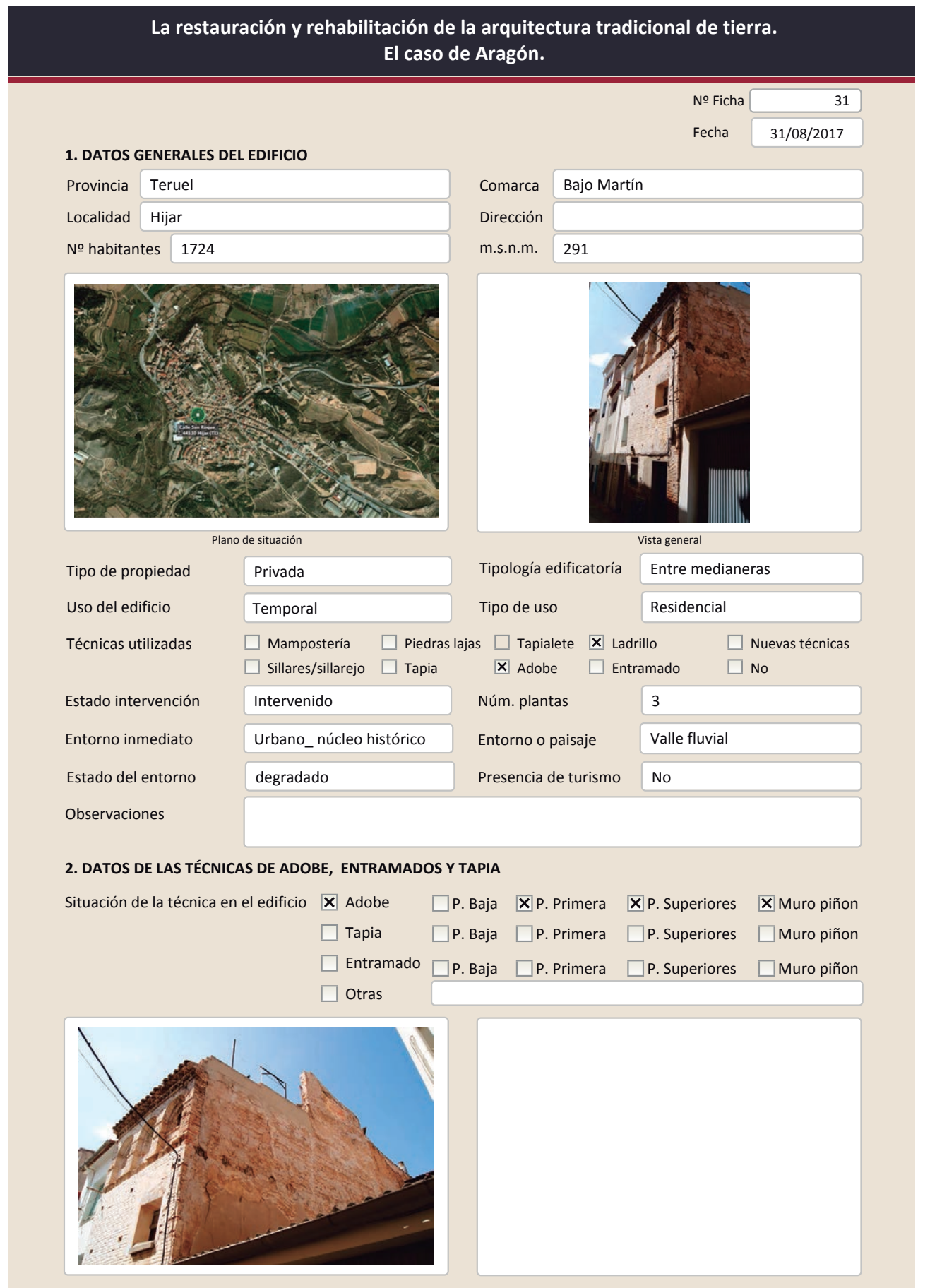

La restauración y rehabilitación de la arquitectura tradicional de tierra.

El caso de Aragón.
2.1. ADOBE

Dimensión de las piezas

Dimensión del muro

Aparejo del muro

Función estructural

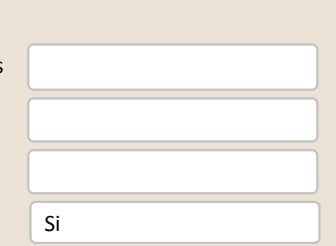

Color de las piezas

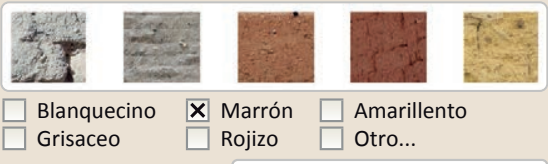

Grisaceo $\square$ Rojizo $\square$ Otro..

Comp. - estabilizante
Variante constructiva/ tipo de fábrica
$\square$ Simple
X Suplementada en juntas
$\square$ Mixta
$\square$ Como suplemento
$\square$ Elementos de protección

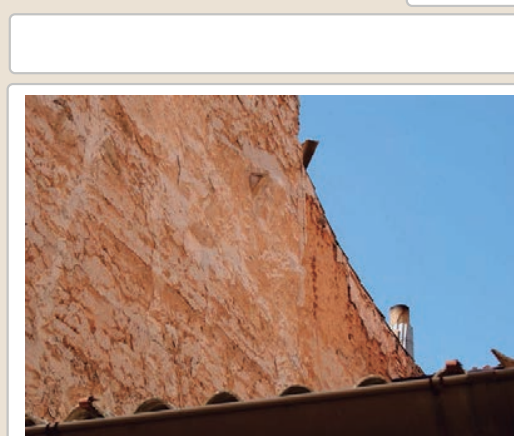

Lesiones $\quad \mathbf{X}$ Muro $\square$ Zócalo $\square$ Revestimiento

Х Erosión del material $\square$ Humedad por capilaridad $\square$ Erosion de las juntas $\square$ Humedades (manch/eflo)

X Pérdida de sección $\square$ Pérdida de verticalidad

$\square$ Vegetación $\quad \square$ Grietas por empuje de la cubie

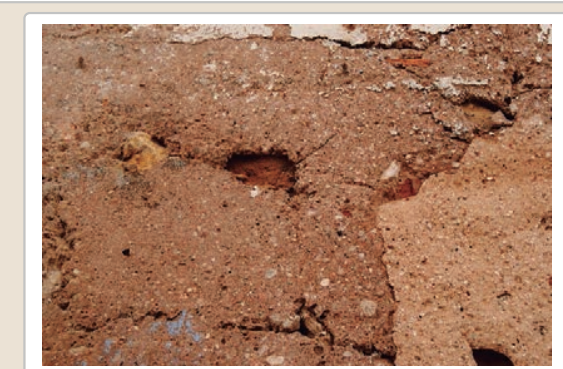

$\square$ Grietas por empuje de las porfalta de traba

$\square$ Cubierta $\square$ Otro...

$\square$ Grietas por asentamiento

$\square$ Colapso

$\square$ Por elementos impropios

$\square$ Desconchados

$\square$ Derivado de intervenciones
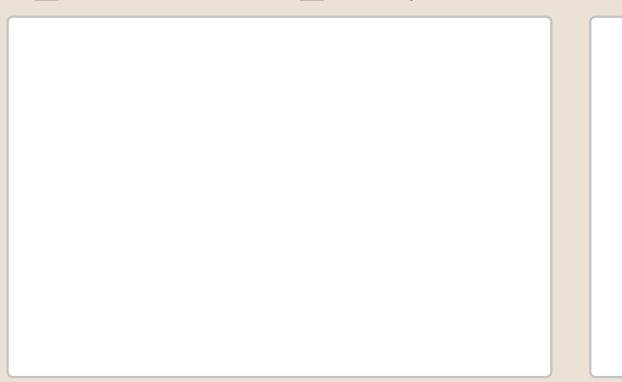

Observaciones

Perdidas volumétricas importantes 


\section{La restauración y rehabilitación de la arquitectura tradicional de tierra.}

\section{El caso de Aragón.}

3. DATOS DE LA INTERVENCIÓN

$\square$ Mantenimiento $\quad$ X Rehabilitación parcial $\square$ Restauración $\square$ Demolición $\square$ Reparación $\square$ Rehabilitación integral $\square$ Ampliación $\square$ Otro...

Reflexión previa Intervención espontanea

Observaciones Las intervenciones en el edificio no siguen una lógica ni parecen estar ligadas en el tiempo entre ellas.

3.1. MUROS
Tipo de intervención

Intervenido

Tipo de material

$\square$ Actualización $\square$ Reintegración $\quad \square$ Demolición $\square$ Otro...

$\square$ Consolidación $\quad \mathbf{X}$ Reconstrucción $\square$ Sustitución

Descripción

3.2. ZÓCALO

Tipo de intervención

No tradicional

Tipo de técnica Diferente a la existente

\begin{tabular}{l}
$\begin{array}{l}\text { recrecido } \\
\text { cubierta }\end{array}$ \\
\hline
\end{tabular}

Intervenido

$\square$ Actualización $\quad \square$ Reintegración $\quad \square$ Demolición $\square$ Otro...

$\square$ Consolidación $\quad \mathbf{X}$ Reconstrucción $\square$ Sustitución

Tipo de material

No tradicional Tipo de técnica Diferente a la existente

Descripción

3.3. REVESTIMIENTOS

Tipo de intervención

nuevo zócalo de cemento

\section{No intervenido}

$\square$ Actualización $\square$ Reintegración $\square$ Demolición $\square$ Otro...

$\square$ Consolidación $\square$ Reconstrucción $\square$ sustitución

Tipo de material

Descripción

3.4. VANOS

Tipo de intervención

Intervenido

Tipo de material

$\square$ Actualización $\square$ Reintegración $\quad \square$ Demolición $\square$ Otro...

Tipo de materia
Descripción

Consolidación $\square$ Reconstrucción $\mathbf{X}$ Sustitución

3.5. CUBIERTA

Tipo de intervención

Tipo de técnica Diferente a la existente

puerta de acceso sustituida. cierre del arco de ladrillo

\section{Intervenido}

$\square$ Actualización $\square$ Reintegración $\square$ Demolición $\square$ Otro..

$\square$ Consolidación $\square$ Reconstrucción $\quad$ Sustitución

Tipo de material

No tradicional

Tipo de técnica Diferente a la existente

Descripción

Se ha eliminado la cubierta tradicional para realizar una cubierta plana en su lugar
La restauración y rehabilitación de la arquitectura tradicional de tierra.

El caso de Aragón.

3.7. REHABILITACIÓN ENERGÉTICA $\quad \square$ Fachada $\square$ Vanos $\square$ Forjados $\square$ Cubierta

Observaciones

FOTOGRAFÍAS DE LA INTERVENCIÓN
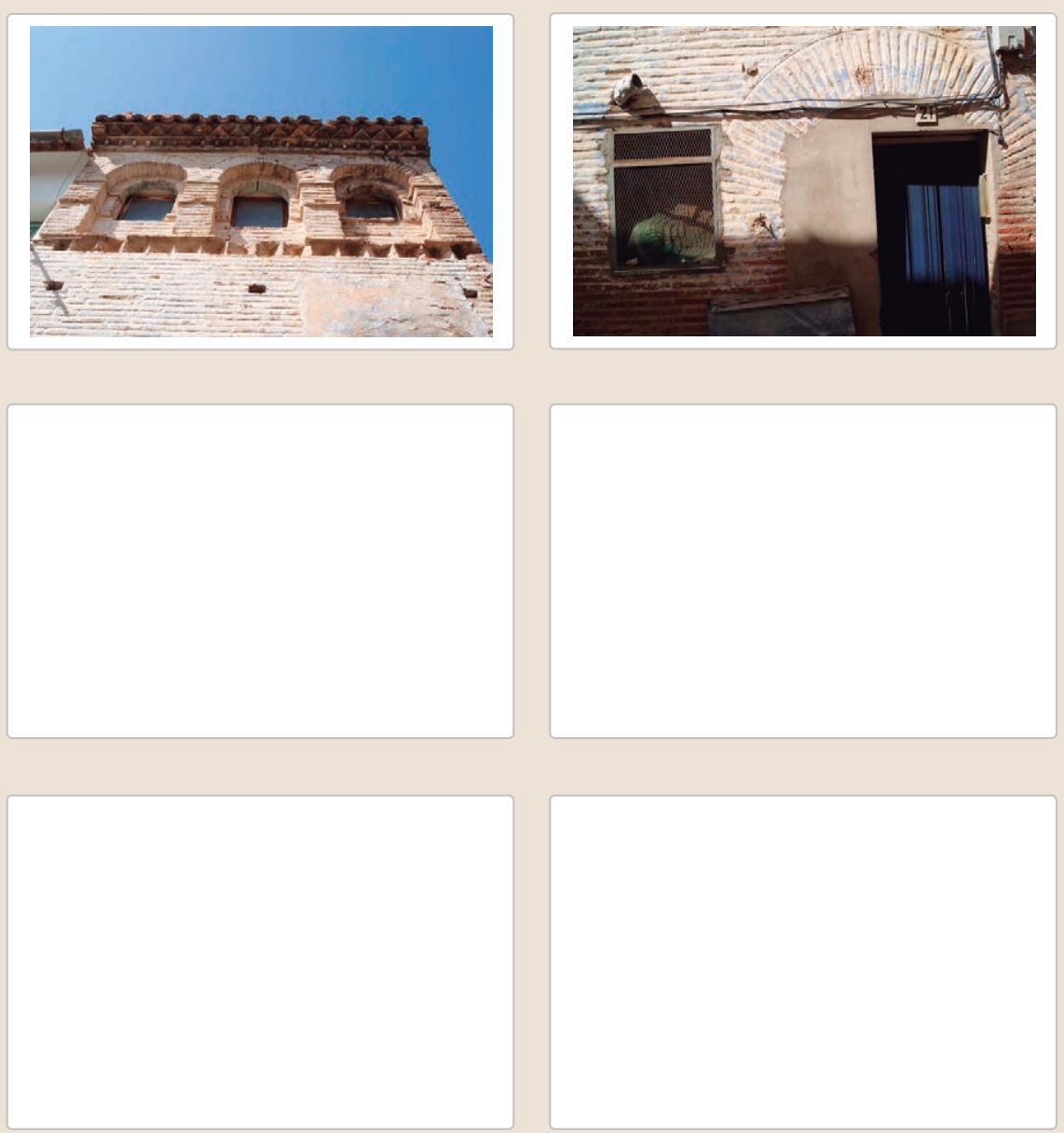

3.6. OTRAS 


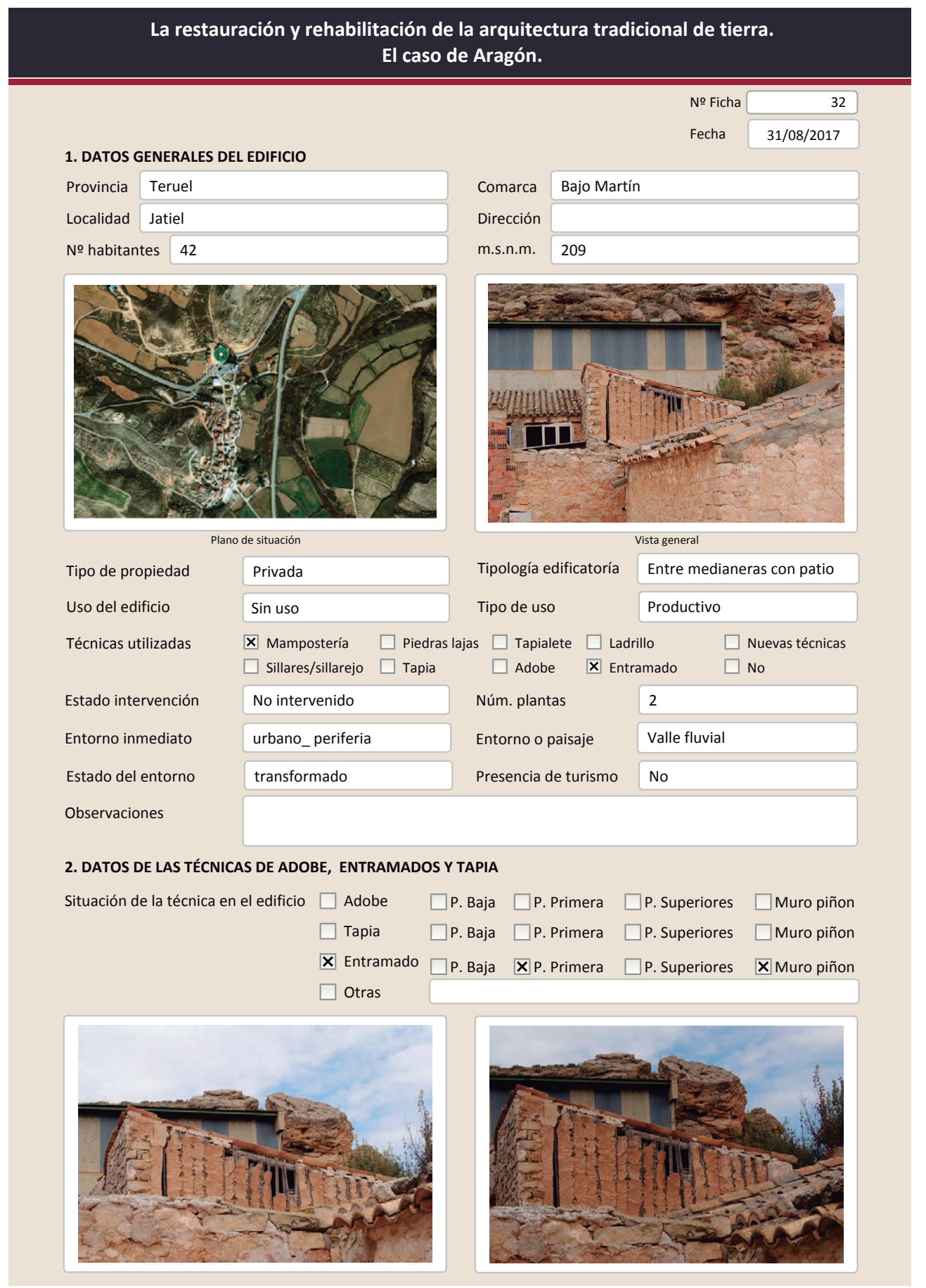

2.3. ENTRAMADOS

Distancia entre montantes

Altura de los montantes

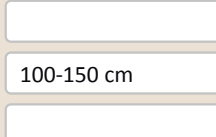

Elementos diagonales

No

Sección de los montantes

Dimensión de los montantes Tipo de relleno del entramado

Técnica de relleno del entramado

$\square$ Entre pantallas de madera $\square$ Pared de mano $\quad \mathbf{X}$ Cañizo

$\square$ Tierra y mampuestos $\quad \square$ Adobe horizontal $\quad \square$ Encestados

$\square$ Tapialete

$\square$ Adobe aletorio $\quad \square$ Otro.

\section{Entramado de cañizo con tierra y yeso. El resto de la estructura es de piedra}

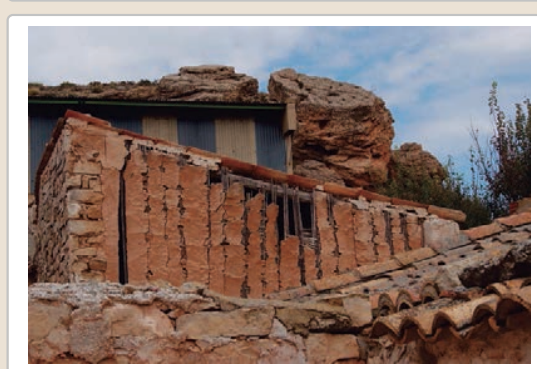

Lesiones $\quad$ XMuro $\square$ Zócalo $\square$ Revestimiento $\square$ Cubierta $\square$ Otro...

$\square$ Erosión del material $\quad \square$ Carcoma o termitas $\quad \square$ Grietas por falta de traba

$\square$ Erosion de las juntas $\quad \square$ Rotura de la madera $\quad \square$ Grietas por asentamientos

X Pérdida de sección

$\square$ Pudrición de la made

X Colapso

$\square$ Vegetación $\quad \square$ Deformación madera $\quad \square$ Por elementos impropios

$\square$ Desconchados

$\square$ Pudrición del relleno

$\square$ Derivado de intervenciones

$\square$ Humedad por capilaridad

Pérdida de verticalidad

$\square$ Otro...

$\square$ Humedades (manch/eflor) $\square$ Grietas por empuje de la cubierta

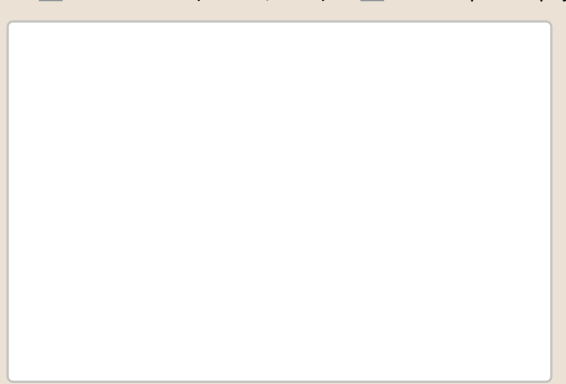

Observaciones

Rotura del cañizo. Muro de cañizo muy degradado. 


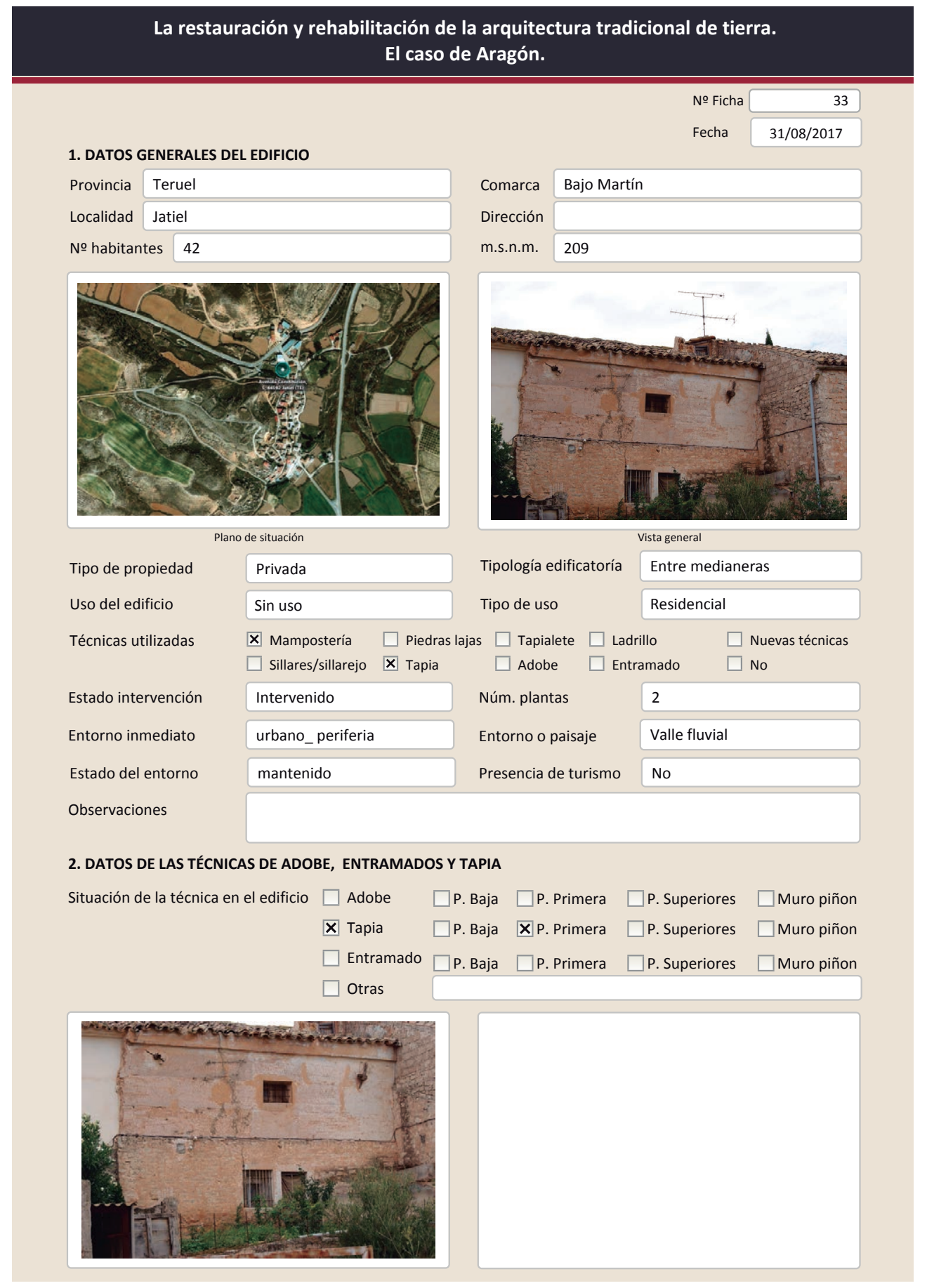

La restauración y rehabilitación de la arquitectura tradicional de tierra.

El caso de Aragón.

\subsection{TAPIA \\ Ancho del muro \\ Dimensión tapiales \\ Tipo de aguja

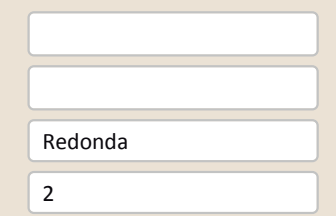 \\ Color de la tapia \\ № agujas/cajón \\ $\square$ Grisaceo \\ Variante constructiva \\ $\square$ Simple / homogénea \\ X Suplemento superficial \\ $\square$ suplemento en juntas \\ $\square$ Mixta \\ $\square$ Elementos de protección

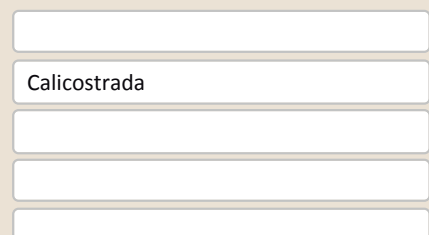 \\ En un caso similar se aprecian las agujas redondas de tamaño muy pequeño}

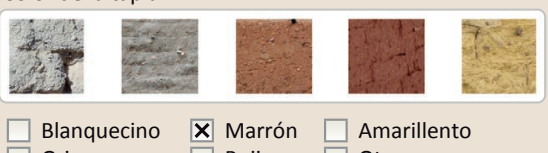

X Marrón $\square$ Amarillen

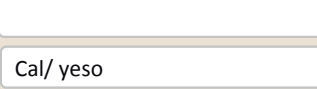

Cal/yeso

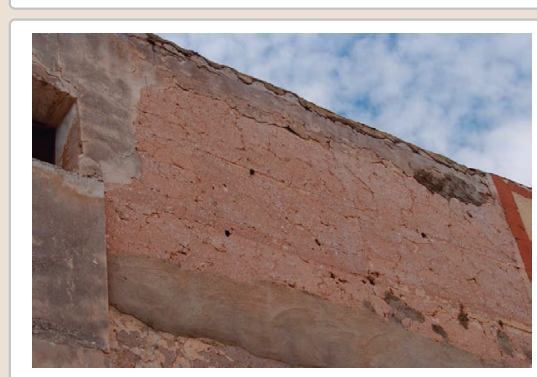

Lesiones $\quad$ Muro $\square$ Zócalo $\square$ Revestimiento $\square$ Cubierta $\square$ otro...

$\square$ Erosión del material $\quad \mathbf{X}$ Humedad por capilaridad $\quad \mathbf{X}$ Grietas por asentamientos

$\square$ Erosion de las juntas $\square$ Humedades (manch/eflo)

$\square$ Pérdida de sección $\square$ Pérdida de verticalidad

$\square$ Vegetación

$\square$ Colapso

$\square$ Desconchados

$\square$ Grietas porfalta de traba

Por elementos impropios

$\square$ Derivado de intervenciones
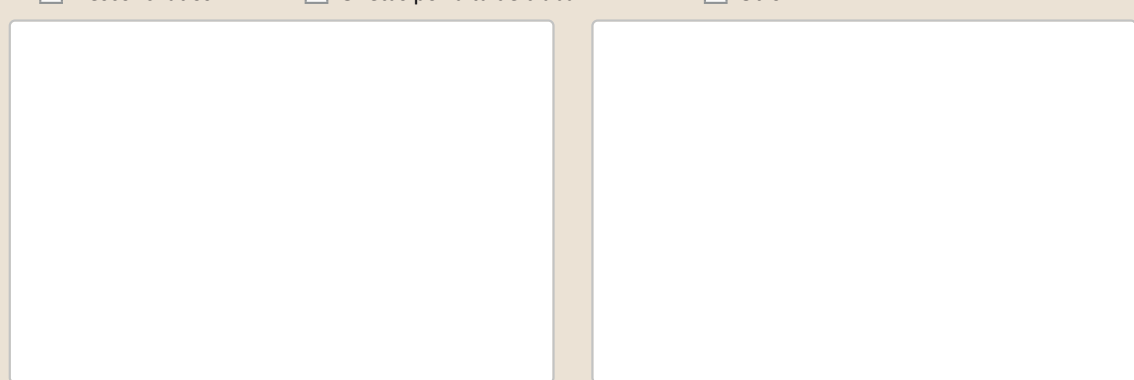

Observaciones

Existe una grieta en la fachada intervenida. EL muro se conserva bastante bien 
La restauración y rehabilitación de la arquitectura tradicional de tierra. El caso de Aragón

\section{La restauración y rehabilitación de la arquitectura tradicional de tierra.}

\section{El caso de Aragón.}

3. DATOS DE LA INTERVENCIÓN

Intervención de:

$\square$ Mantenimiento $\square$ Rehabilitación parcia

$\square$ Restauración $\square$ Demolición

Reflexión previa

X Reparación

$\square$ Rehabilitación integral $\square$ Ampliació

$\square$ Otro..

Reflexión previa

Intervención espontanea

(n)

3.1. MUROS

Tipo de intervención

Intervenido

Tipo de material

$\square$ Actualización $\quad$ X Reintegración $\square$ Demolición $\square$ Otro...

$\square$ Consolidación $\square$ Reconstrucción $\square$ sustitución

Descripción

\begin{tabular}{|l|l|l}
\hline Tradicional diferente & Tipo de técnica & Diferente a la existente
\end{tabular}

3.2. ZOCALO

Intervenciones antiguas rellenando oquedades del muro. Existe un cosido de la grieta con elementos metálicos

3.2. ZÓCALO No intervenido

Tipo de intervención

$\square$ Actualización

Tipo de material

$\square$ Consolidación $\square$ Reconstrucción $\square$ sustitución

Descripción

3.3. REVESTIMIENTOS

Tipo de intervención

\section{No aplica}

Tipo de material

$\square$ Actualización

Tipo de técnica

Descripción

3.4. VANOS

Tipo de intervención

No intervenido

Tipo de material

$\square$ Actualización $\quad \square$ Reintegración $\quad \square$ Demolición $\quad \square$ Otro...
$\square$ Consolidación $\quad \square$ Reconstrucción $\quad \square$ sustitución

Tipo de materia

3.5. CUBIERTA

Tipo de intervención

No intervenido

$\square$ Actualización $\square$ Reintegración $\square$ Demolición $\square$ Otro.

Tipo de material

$\square$ Consolidación $\square$ Reconstrucción $\square$ Sustitución

Descripción

Tipo de técnica

3.6. OTRAS 


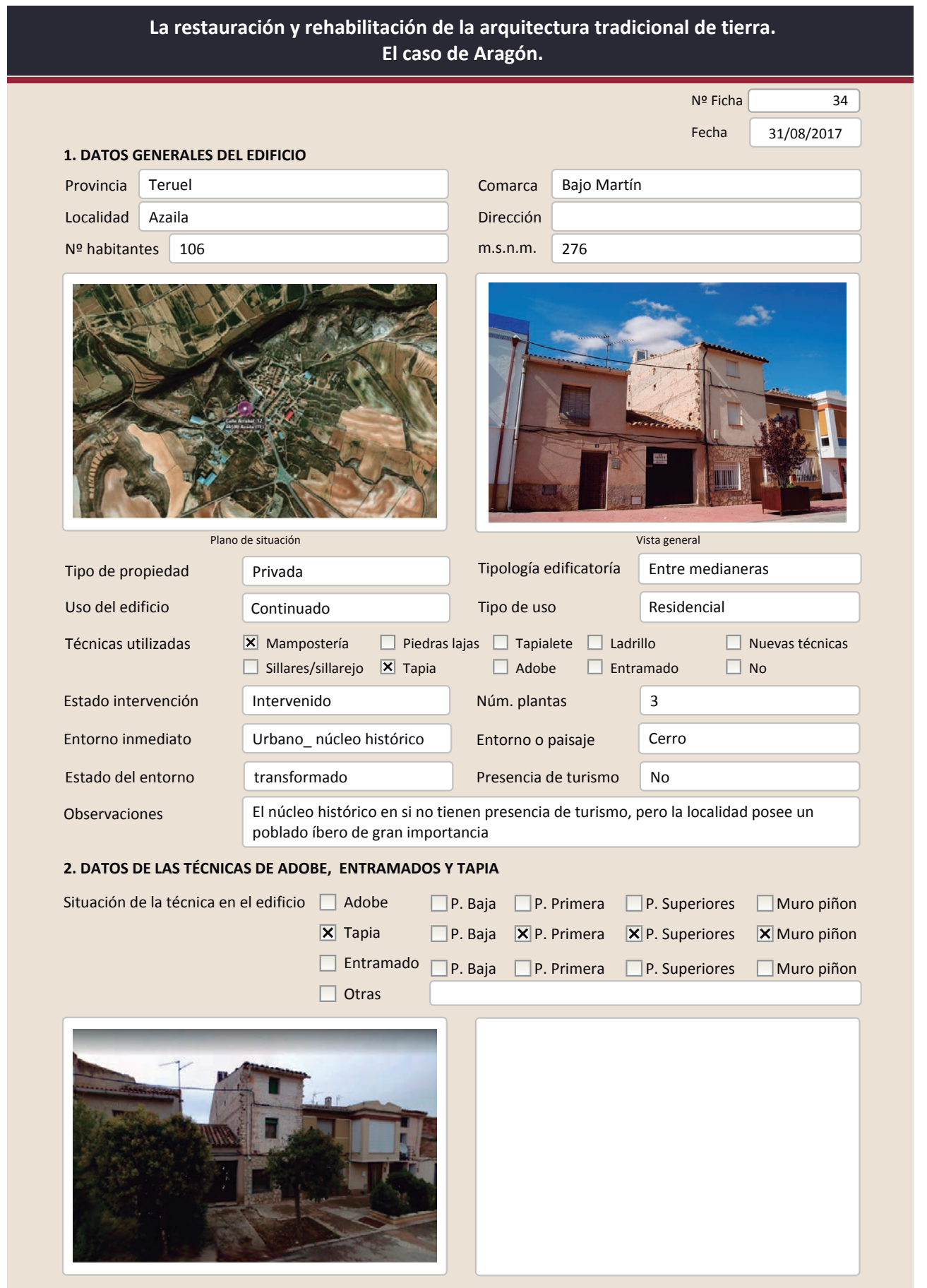

La restauración y rehabilitación de la arquitectura tradicional de tierra. El caso de Aragón.

2.2. TAPIA

Ancho del muro

Dimensión tapiales

Tipo de aguja

№ agujas/cajón

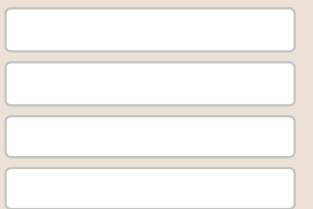

Color de la tapia

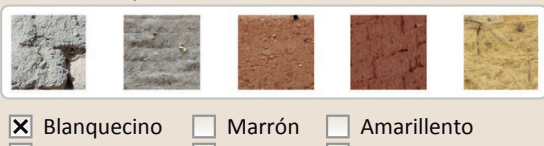

X Blanquecino $\square$ Marrón $\square$ Amarillento

Variante constructiva

X Simple / homogénea

$\square$ Suplemento superficial

$\square$ suplemento en juntas

$\mathbf{X}$ Mixta

Tapialete

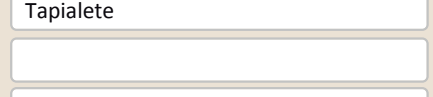

En esquinas

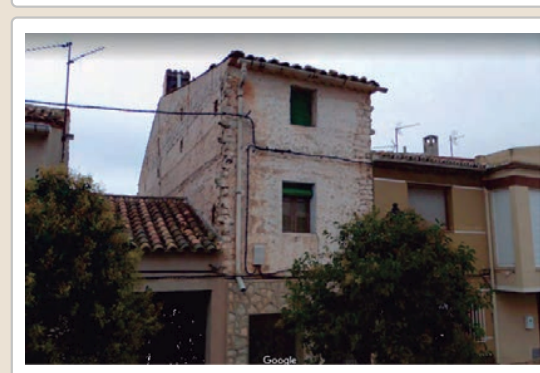

Lesiones $\quad \mathbf{X}$ Muro $\square$ Zócalo $\square$ Revestimiento $\square$ Cubierta $\square$ otro...

X Erosión del material $\quad \square$ Humedad por capilaridad $\quad \square$ Grietas por asentamientos $\square$ Erosion de las juntas $\square$ Humedades (manch/eflo)

$\square$ Pérdida de sección $\square$ Pérdida de verticalidad

$\square$ Vegetación $\quad \square$ Grietas por empuje de la cubie

$\mathbf{X}$ Desconchados

$\square$ Grietas porfalta de traba
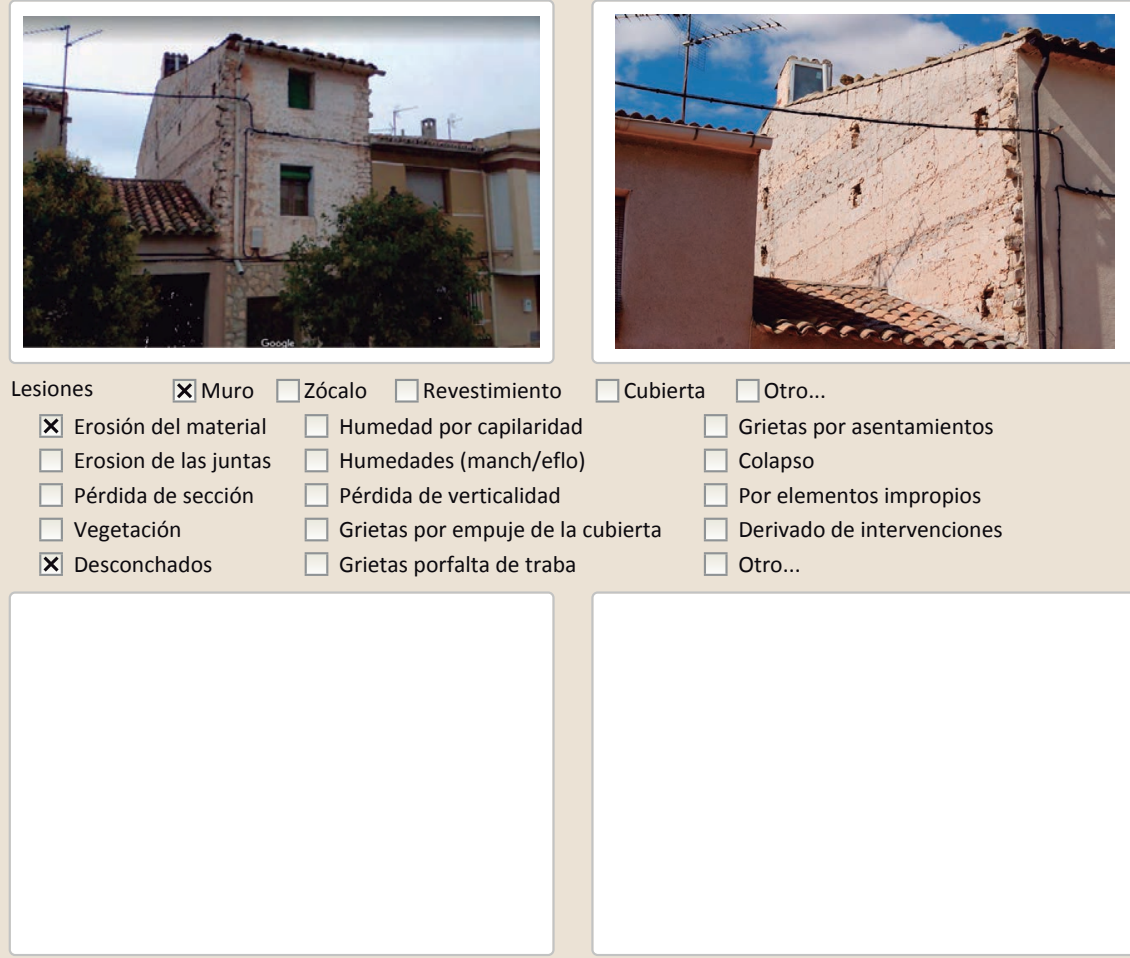

Observaciones

Pequeños desconchado de la costra en el muro piñón 


\section{La restauración y rehabilitación de la arquitectura tradicional de tierra.}

\section{El caso de Aragón.}

3. DATOS DE LA INTERVENCIÓN

$\square$ Mantenimiento $\quad$ X Rehabilitación parcial $\square$ Restauración $\square$ Demolición $\square$ Reparación $\quad \square$ Rehabilitación integral $\quad \square$ Ampliación $\quad \square$ Otro...

Reflexión previa Intervención planificada

Observaciones Existen dos intervenciones diferentes. En las fotos de google de 2008 se aprecia que el zócalo ya está intervenido, sin embargo el revestimiento y la ventana de cubierta y su reintegración todavía no

3.1. MUROS

No intervenido

Tipo de intervención

$\square$ Actualización

$\square$ Consolidació

$\square$ Reintegracion

$\square$ Demolición $\square$ Otro...

Tipo de material

Descripción

3.2. ZÓCALO

Tipo de intervención

Intervenido

$\mathbf{X}$ Actualización $\quad \boldsymbol{X}$ Reintegración $\square$ Demolición $\square$ Otro...

$\square$ Consolidación $\square$ Reconstrucción $\square$ Sustitución

$\begin{array}{llll}\text { Tipo de material Tradicional diferente Tipo de técnica Diferente a la existente } & \end{array}$

Descripción

3.3. REVESTIMIENTOS

Tipo de intervención

Zócalo con lajas de piedra y junta saliente entre ellas.

\section{Intervenido}

X Actualización $\quad \square$ Reintegración $\quad \square$ Demolición $\quad \square$ Otro...

$\square$ Consolidación $\mathbf{X}$ Reconstrucción $\square$ Sustitución

Tipo de material

Descripción

3.4. VANOS

Tipo de intervención

No tradicional

Tipo de técnica Diferente a la existente

Antes no había revestimiento era la propia costra de la tapia. Cemento (entre 2008 y

Intervenido

Tipo de material

$\square$ Actualización $\quad \mathbf{X}$ Reintegración $\square$ Demolición $\square$ Otro...

$\square$ Consolidación $\square$ Reconstrucción $\quad \mathbb{X}$ Sustitución

Descripción

3.5. CUBIERTA

No tradicional

Tipo de técnica Diferente a la existente

Sustitución de carpinterías (entre 2008 y 2017) y reintegración de los contornos

Tipo de intervención

Intervenido

$\square$ Actualización $\quad \boldsymbol{X}$ Reintegración $\square$ Demolición $\square$ Otro.

$\square$ Consolidación $\quad \square$ Reconstrucción $\quad \square$ Sustitución

\begin{tabular}{lll} 
Tipo de material No tradicional Tipo de técnica Diferente a la existente \\
\hline
\end{tabular}

Descripción

Reintegración de cubierta con cemento
La restauración y rehabilitación de la arquitectura tradicional de tierra.

El caso de Aragón.

3.7. REHABILITACIÓN ENERGÉTICA $\square$ Fachada $\quad$ \ Vanos $\square$ Forjados $\square$ Cubierta

Observaciones

Sustitución de carpinterías.

FOTOGRAFíAS DE LA INTERVENCIÓN
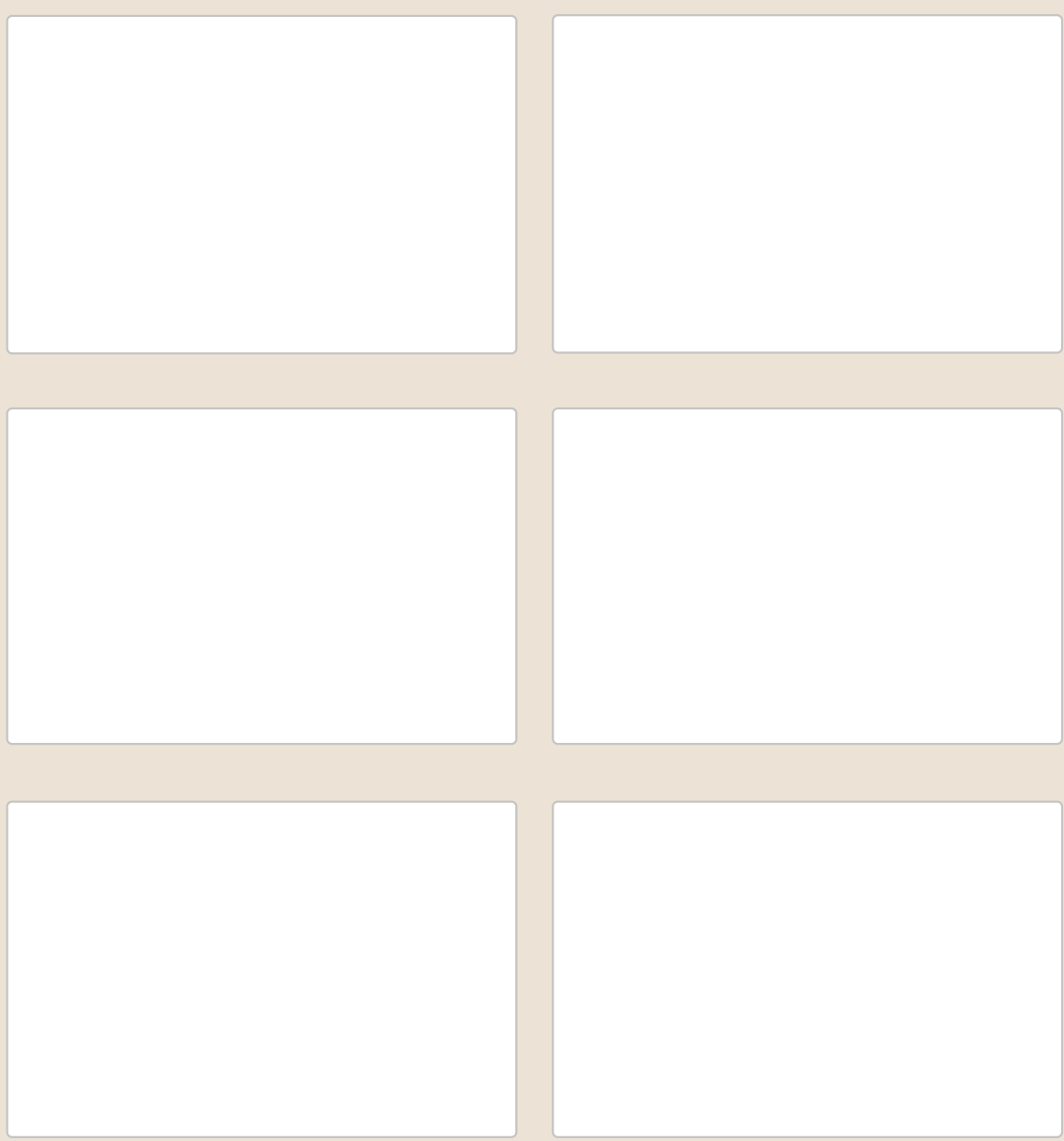

3.6. OTRAS 


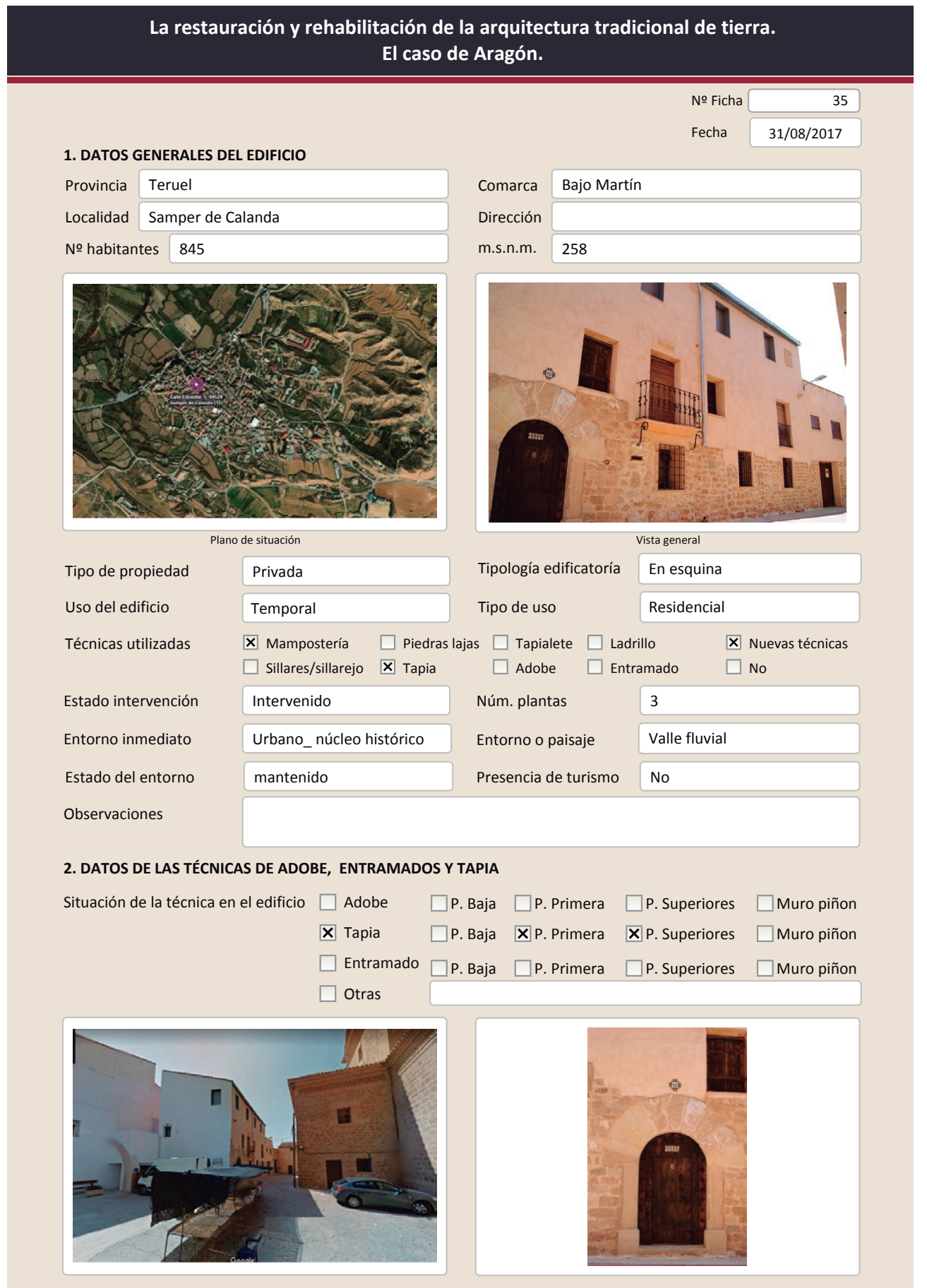

La restauración y rehabilitación de la arquitectura tradicional de tierra.

El caso de Aragón.

2.2. TAPIA

Ancho del muro

Dimensión tapiales

Tipo de aguja

№ agujas/cajón

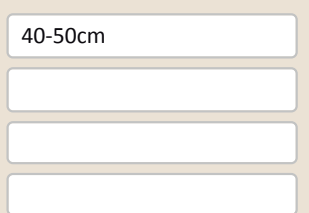

Color de la tapia

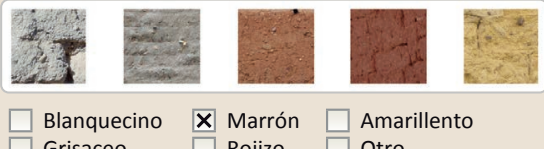

$\square$ Blanquecino $\quad \mathbf{X}$ Marrón $\square$ Amarillento

Variante constructiva

$\square$ Simple / homogénea

$\square$ suplemento superficial

$\mathbf{X}$ Suplemento en juntas

$\square$ Mixta

$\square$ Elementos de protección
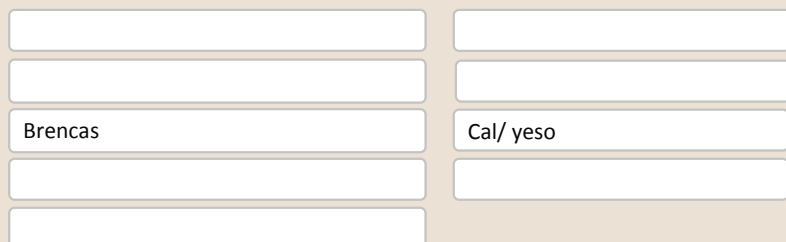

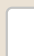

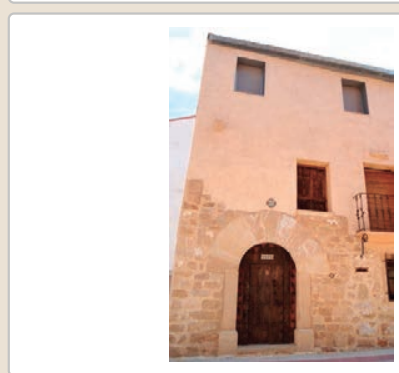

Lesiones

X Muro $\square$ Zócalo $\square$ Revestimiento

\ Erosión del material $\square$ Humedad por capilaridad $\square$ Erosion de las juntas $\square$ Humedades (manch/eflo)

$\square$ Pérdida de sección $\quad \square$ Pérdida de verticalidad

$\square$ Vegetación $\square$ Grietas por empuie de la cubierta

$\square$ Desconchados $\quad \square$ Grietas porfalta de traba $\quad \square$ Otro

$\square$ Desconchados $\square$ Grietas porfalta de traba $\quad \square$ Otro

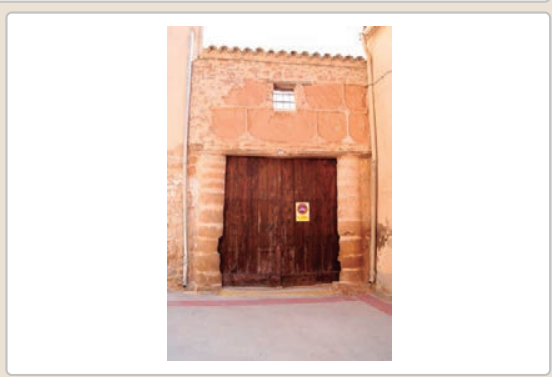

$\square$ Cubierta $\square$ otro...

$\square$ Grietas por asentamiento $\square$ Colapso

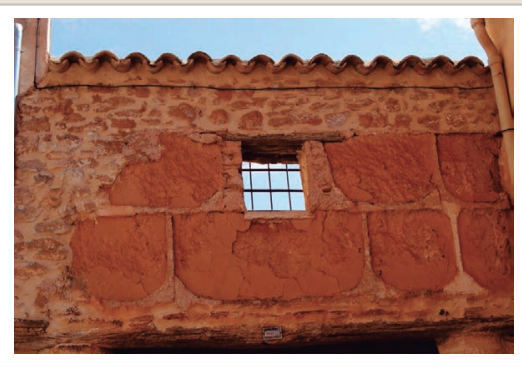

Observaciones 


\section{La restauración y rehabilitación de la arquitectura tradicional de tierra.}

\section{El caso de Aragón.}

3. DATOS DE LA INTERVENCIÓN

Intervención de:

$\square$ Mantenimien

Intervención de.

$\square$ Reparación

$\square$ Rehabilitación parcial

$\square$ Restauración $\square$ Demolición

Reflexión previa

Intervención planificada

Observaciones

(n)

3.1. MUROS
Tipo de intervención

Intervenido

Tipo de material

$\square$ Actualización $\square$ Reintegración $\square$ Demolición $\square$ Otro...

$\square$ Consolidación $\quad$ Reconstrucción $\square$ sustitución

Descripción

No tradicional

Tipo de técnica Diferente a la existente

3.2. ZóCALO

Tipo de intervención

Parece que el

\section{Intervenido}

$\square$ Actualización $\quad \mathbf{X}$ Reintegración $\square$ Demolición $\square$ Otro...

$\square$ Consolidación $\quad \square$ Reconstrucción $\square$ Sustitución

Tipo de material

Tradicional diferente

Tipo de técnica Similar a la existente

Descripción

3.3. REVESTIMIENTOS

Tipo de intervención

Reintegración de las juntas de mampostería

\section{Intervenido}

$\square$ Actualización $\square$ Reintegración $\quad \square$ Demolición $\square$ Otro...

$\square$ Consolidación $\quad \boldsymbol{X}$ Reconstrucción $\square$ sustitución

Tipo de material

Descripción

No tradicional

Tipo de técnica Diferente a la existente

3.4. VANOS

Tipo de intervención

Nuevo revestimiento en todo el edificio

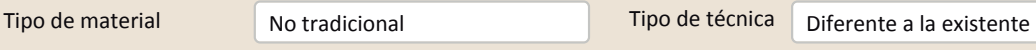

Intervenido

$\square$ Actualización $\quad \mathbf{X}$ Reintegración $\square$ Demolición $\square$ Otro...

$\square$ Consolidación $\mathbf{x}$ Reconstrucción $\mathbf{x}$ Sustitución

Descripción Construcción de nuevos vanos en la planta superior. Reintegración del contorno y de las carpinterías de los vanos preexistentes

3.5. CUBIERTA

Tipo de intervención

Intervenido

$\square$ Actualización $\quad \square$ Reintegración $\square$ Demolición $\square$ Otro...

$\square$ Consolidación $\mathbf{X}$ Reconstrucción $\mathbf{X}$ Sustitución

\begin{tabular}{lll} 
Tipo de material & No tradicional \\
\hline & Tipo de técnica Diferente a la existente
\end{tabular}

Descripción Nueva cubierta. Sustitución o reconstrucción, no se conoce como estaba antes de la intervención
La restauración y rehabilitación de la arquitectura tradicional de tierra.

El caso de Aragón.

3.7. REHABILITACIÓN ENERGÉTICA \ Fachada $\bigotimes$ Vanos $\square$ Forjados $\mathbf{X}$ Cubierta Observaciones

Nuevas carpinterías en planta superior. Probablemente tb en cubierta y muros

FOTOGRAFíAS DE LA INTERVENCIÓN
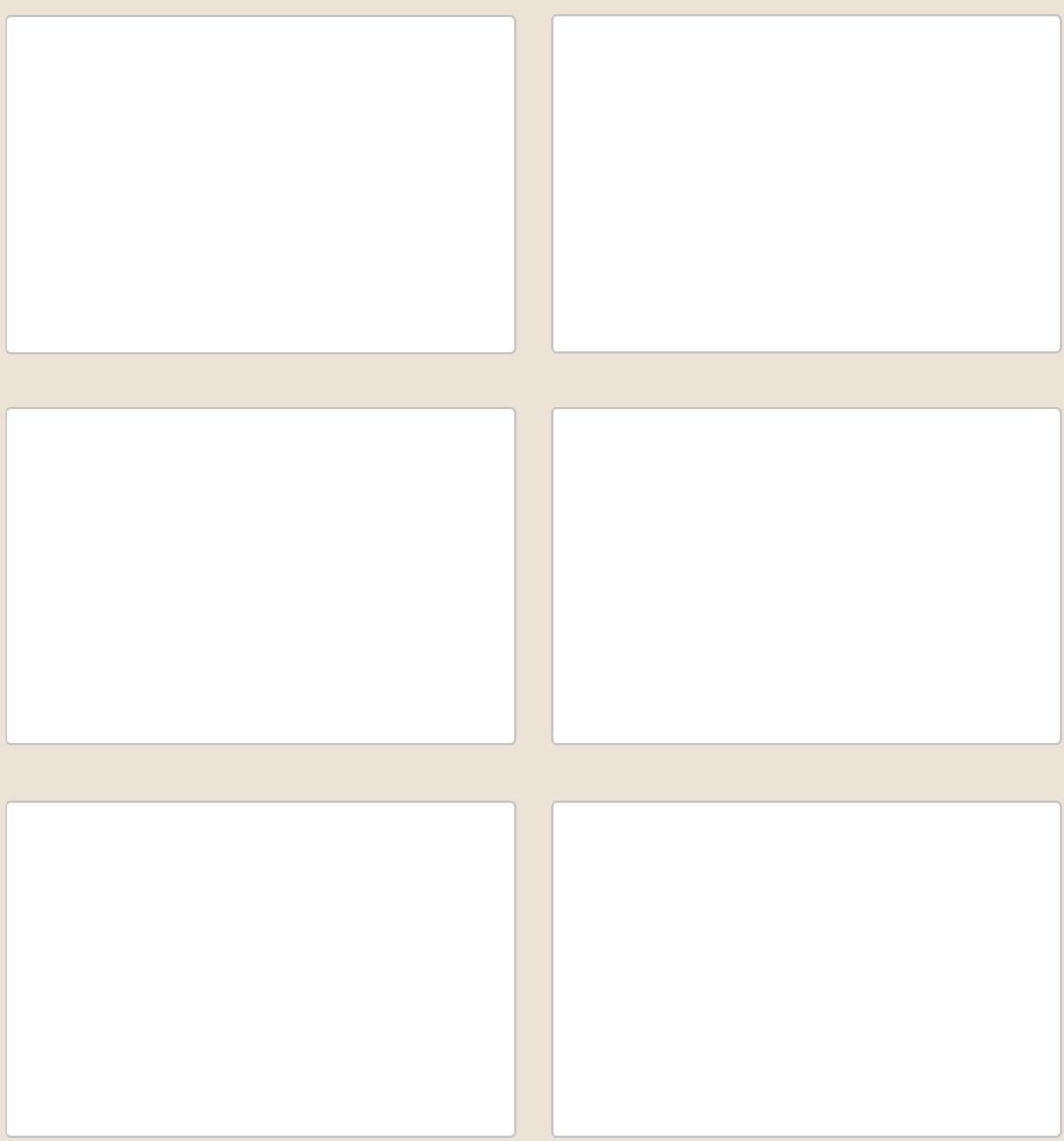

3.6. OTRAS 


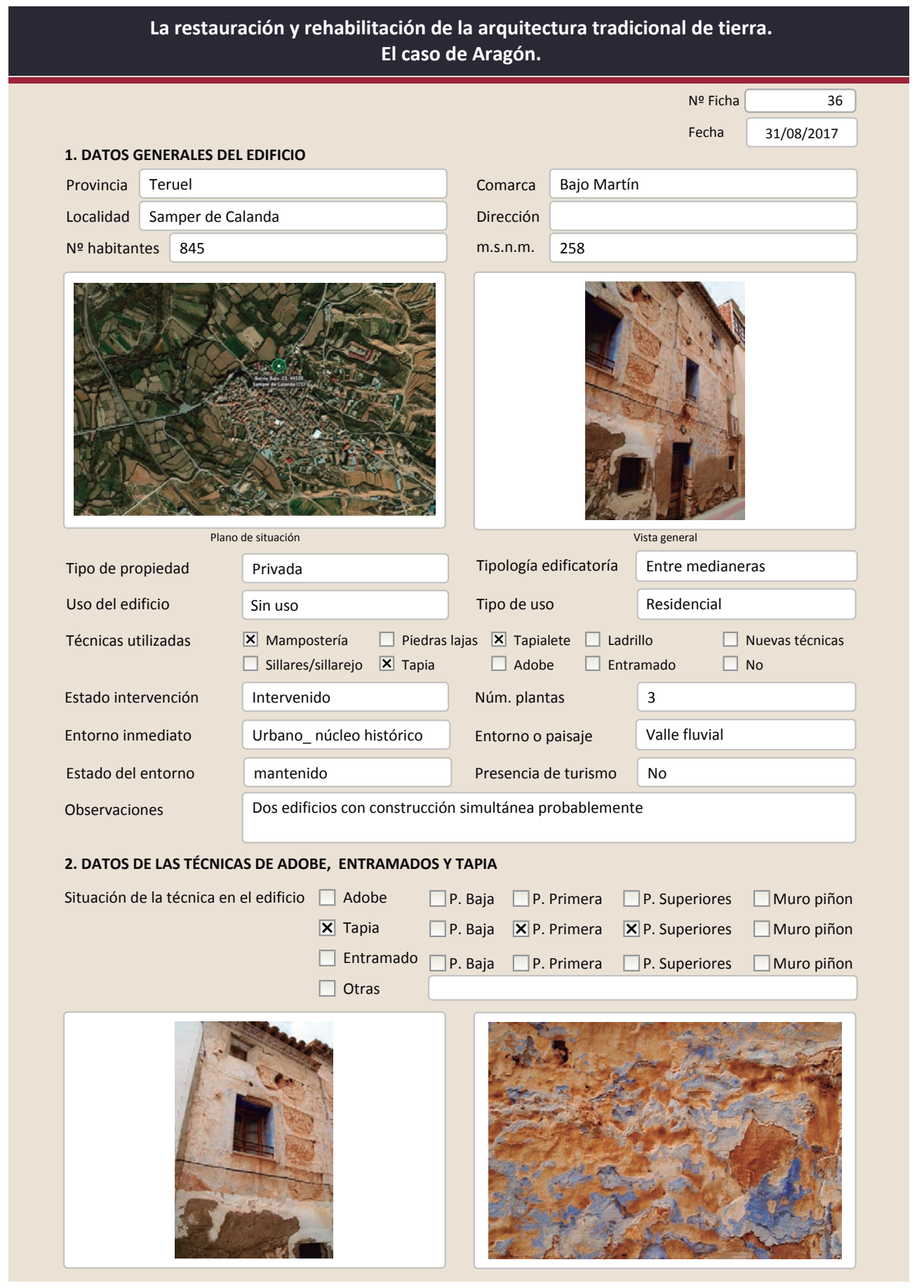

La restauración y rehabilitación de la arquitectura tradicional de tierra. El caso de Aragón.

2.2. TAPIA

Ancho del muro

Dimensión tapiales

Tipo de aguja

№ agujas/cajón

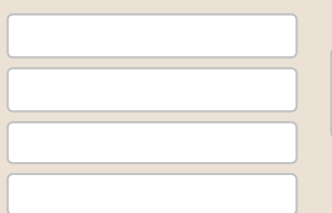

Color de la tapia

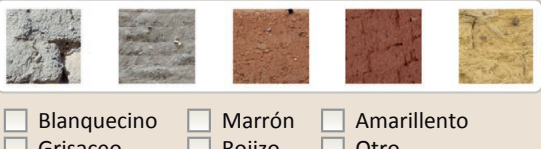

$\square$ Blanquecino $\square$ Marrón $\square$ Amarillento

Variante constructiva

$\square$ simple / homogénea

$\square$ suplemento superficial

$\boldsymbol{X}$ Suplemento en juntas

$\mathbf{X}$ Mixta
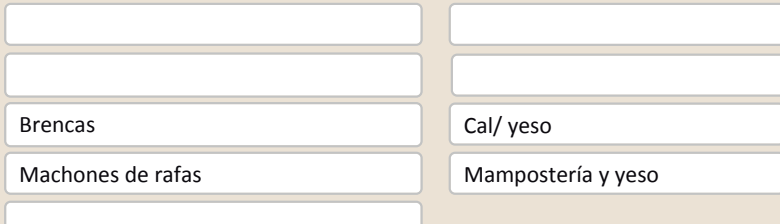

$\square$ Elementos de protección$$
\text { areng }
$$

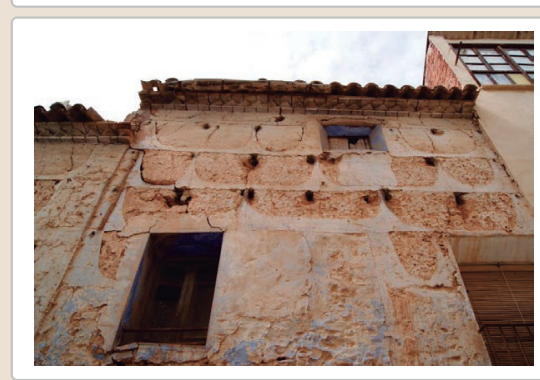

Lesiones $\mathbf{X}$ Muro $\mathbf{X}$ Zócalo $\mathbf{X}$ Revestimiento \ Erosión del material $\mathbf{X}$ Humedad por capilaridad $\square$ Erosion de las juntas $\square$ Humedades (manch/eflo) $X$ Pérdida de sección $\square$ Pérdida de verticalidad

$\square$ Vegetación $\quad \square$ Grietas por empuje de la cubierta

$\mathbf{X}$ Desconchados $\mathbf{X}$ Grietas porfalta de traba

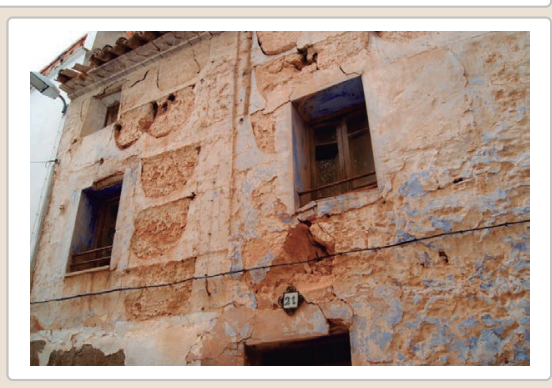

X Cubierta $\square$ otro...

$\boldsymbol{X}$ Grietas por asentamientos $\square$ Colapso

Por elementos impropios

X Derivado de intervenciones

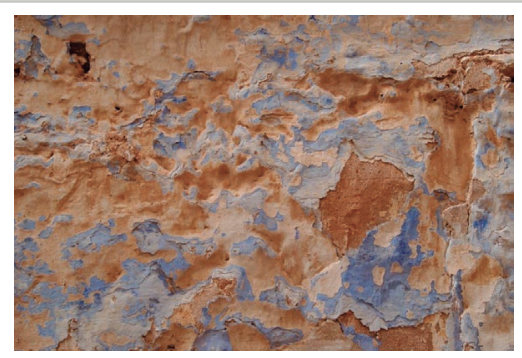

Observaciones

El edificio se encuentra bastante deteriorado. Grietas entre la masa de tierra de la tapia y las brencas. Ascenso de la humedad por uso de cemento en el zócalo 
La restauración y rehabilitación de la arquitectura tradicional de tierra. El caso de Aragón

\section{La restauración y rehabilitación de la arquitectura tradicional de tierra.}

\section{El caso de Aragón.}

3. DATOS DE LA INTERVENCIÓN

Intervención de:

$\square$ Mantenimiento $\square$ Rehabilitación parcia

$\square$ Restauración $\square$ Demolición

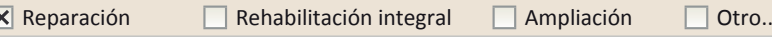

Reflexión previa Intervención espontanea

Observaciones Intervenciones con cemento en planta baja

3.1. MUROS

No intervenido

Tipo de intervención

$\square$ Actualización $\square$ Reintegración $\square$ Demolición $\square$ Otro...

$\square$ Consolidación $\square$ Reconstrucción $\square$ Sustitución

Tipo de material

Descripción

3.2. ZÓCALO

Tipo de intervención

Intervenido

$\square$ Actualización $\quad \mathbf{X}$ Reintegración $\square$ Demolición $\square$ Otro...

Tipo de material

$\square$ Consolidación $\square$ Reconstrucción $\square$ Sustitución

Descripción

Tipo de técnica Diferente a la existente

3.3. REVESTIMIENTOS

Cemento

Tipo de intervención

Intervenido

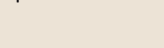

X Consolidación

$\square$ Reintegración $\square$ Demolición $\square$ Otro...

Reconstrucción $\square$ sustitución

Tipo de material

Tradicional similar Tipo de técnica Similar a la existente

Descripción

muro

3.4. VANOS

No intervenido

Tipo de intervención $\square$ Actualización $\square$ Reintegración $\quad \square$ Demolición $\quad \square$ Otro...

Tipo de material $\quad \square$ Consolidación $\square$ Reconstrucción $\square$ Sustitución

Descripción

3.5. CUBIERTA

Tipo de intervención

No intervenido

Tipo de material

$\square$ Actualización

$\square$ Consolidación $\quad \square$ Reconstrucción $\quad \square$ Sustitución

Tipo de técnica

Descripción

Tipo de técnica

3.6. OTRAS 


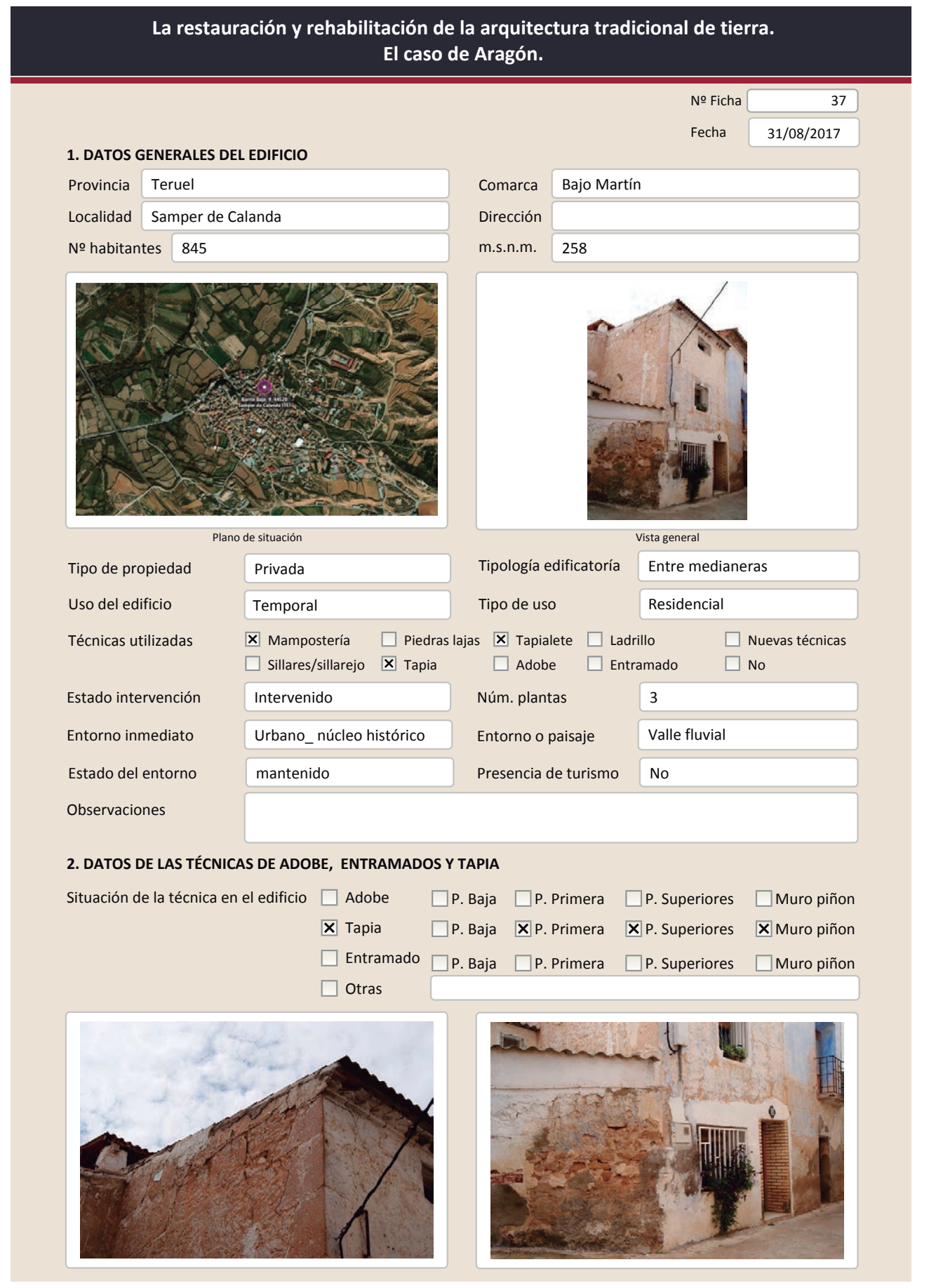

La restauración y rehabilitación de la arquitectura tradicional de tierra.

El caso de Aragón.

\subsection{TAPIA \\ Ancho del muro \\ Dimensión tapiales \\ Tipo de aguja \\ № agujas/cajón \\ Variante constructiva \\ $\square$ simple / homogénea \\ $\square$ suplemento superficial \\ $\square$ suplemento en juntas \\ X Mixta}

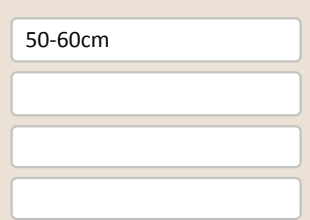

Color de la tapia
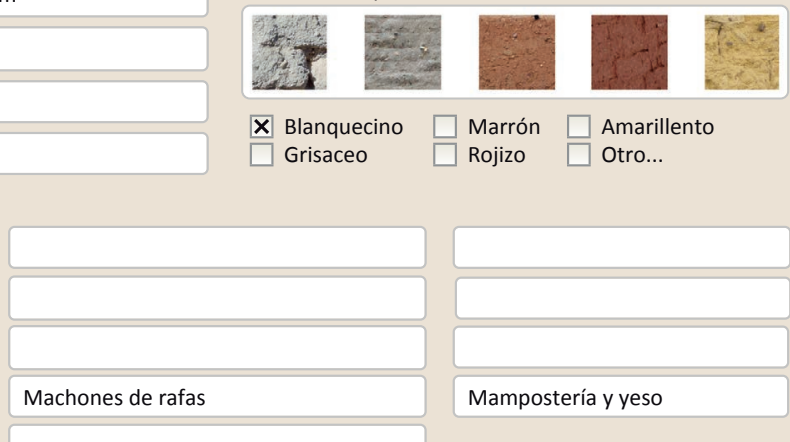

Mampostería y yeso

$\square$ Elementos de protección

No se aprecia bien ya que hay un revestimiento. Si que se aprecia el macho en la esquina

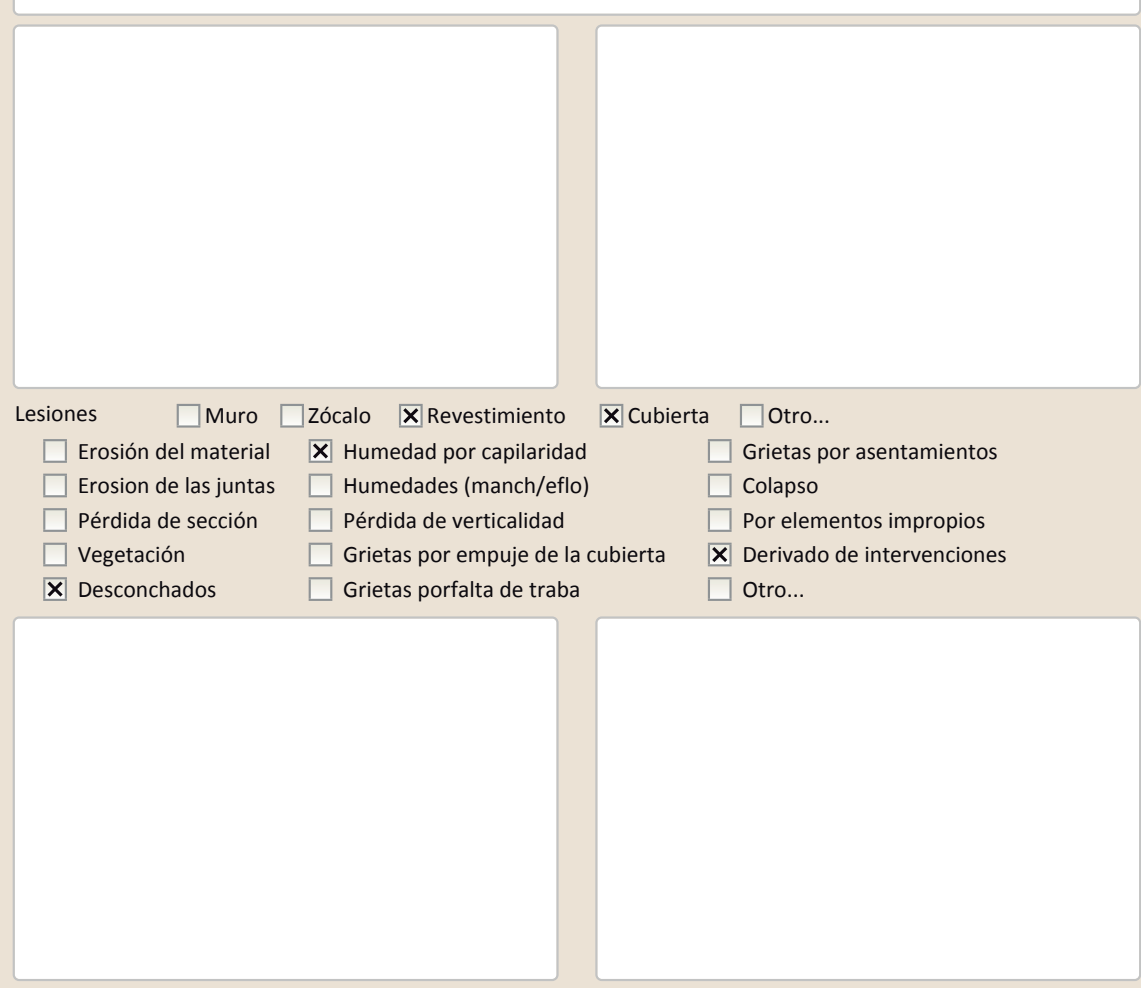

Observaciones

Ascensión de la humedad por la presencia de cemento en el zócalo 
La restauración y rehabilitación de la arquitectura tradicional de tierra. El caso de Aragón

\section{La restauración y rehabilitación de la arquitectura tradicional de tierra.}

\section{El caso de Aragón.}

3. DATOS DE LA INTERVENCIÓN

Intervención de:

$\square$ Mantenimiento $\quad \boldsymbol{X}$ Rehabilitación parcial $\square$ Restauración $\quad \square$ Demolición

X Reparación $\square$ Rehabilitación integral $\quad \square$ Ampliación $\quad \square$ Otro...

Reflexión previa Intervención espontanea

Observaciones Intervención únicamente en planta baja y reparación en cubierta

3.1. MUROS

No intervenido

Tipo de intervención

$\square$ Actualización $\square$ Reintegración $\square$ Demolición $\square$ Otro...

$\square$ Consolidación $\quad \square$ Reconstrucción $\quad \square$ Sustitución

Tipo de material

Descripción

3.2. ZÓCALO

Tipo de intervención

Intervenido

Tipo de intervención

$\square$ Actualización $\quad \mathbf{X}$ Reintegración $\square$ Demolición $\square$ Otro...

Tipo de material

$\square$ Consolidación $\square$ Reconstrucción $\quad \square$ Sustitución

Descripción

Tipo de técnica Diferente a la existente

3.3. REVESTIMIENTOS

Cemento

Tipo de intervención

Intervenido

Tipo de material

Actualización $\square$ Reintegración $\quad \square$ Demolición $\quad \square$ Otro...

Consolidación X Reconstrucción $\square$ Sustitución

Descripción

$\begin{array}{lll}\text { Tradicional diferente Tipo de técnica } & \text { Diferente a la existente }\end{array}$

Recomposición del revestimiento en el muro piñón. Se entiende que esta intervención

3.4. VANOS

Tipo de intervención

Intervenido

$\square$ Actualización $\quad \boldsymbol{X}$ Reintegración $\square$ Demolición
Consolidación Reconstrucción $\quad \square$ Sustitución

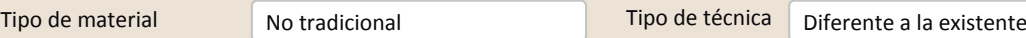

Descripción Nueva composición de los huecos en planta baja añadiendo jambas de ladrillo y rejería

3.5. CUBIERTA

Tipo de intervención

Intervenido

Tipo de material

$\square$ Actualización $\quad$ Reintegración $\square$ Demolición $\square$ Otro.

$\square$ Consolidación $\quad \square$ Reconstrucción $\square$ Sustitución

No tradicional $\quad$ Tipo de técnica Diferente a la existente

Descripción

Reintegración de tejas con cemento

3.6. OTRAS 


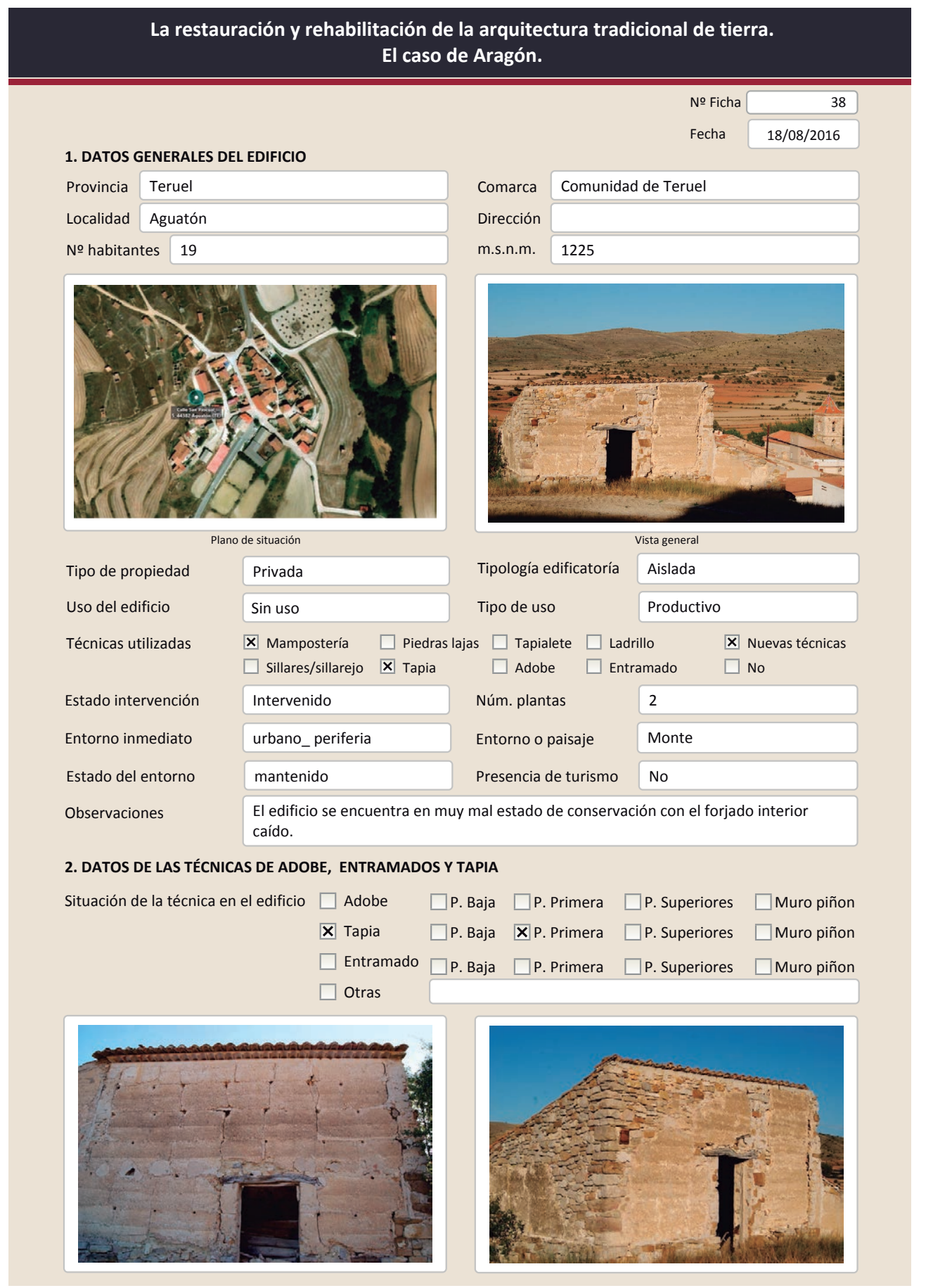

La restauración y rehabilitación de la arquitectura tradicional de tierra. El caso de Aragón.
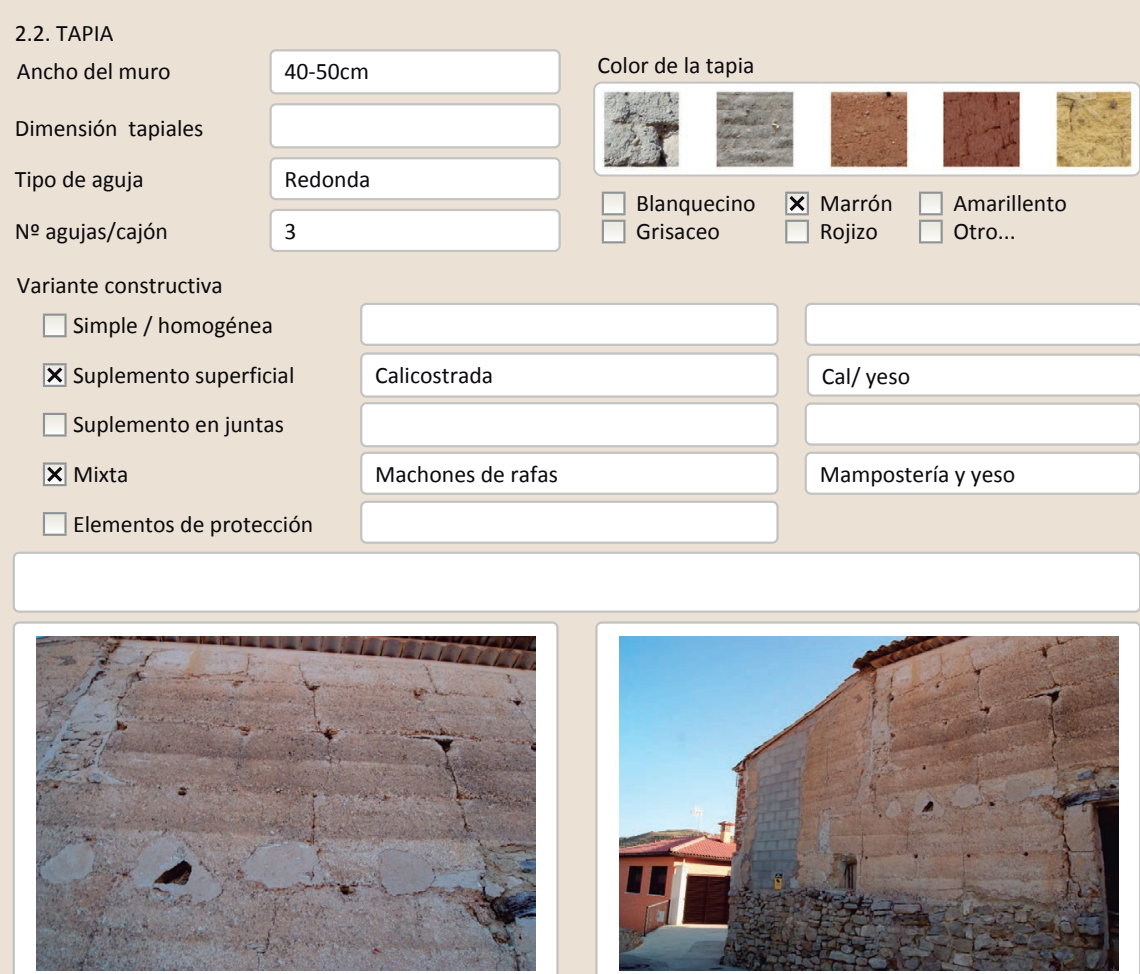

Lesiones \Muro $\square$ Zócalo $\square$ Revestimiento $\quad \mathbf{X}$ Cubierta $\square$ Otro...

$\mathbf{X}$ Erosión del material $\square$ Humedad por capilaridad $\quad \mathbf{X}$ Grietas por asentamientos

$X$ Colapso

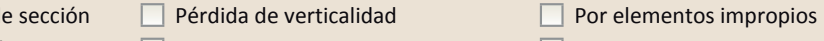

$\square$ Vegetación $\quad \square$ Grietas por empuje de la cubierta $\square$ Derivado de intervenciones

$\square$ Desconchados $\square$ Grietas porfalta de traba $\quad$ X Otro...

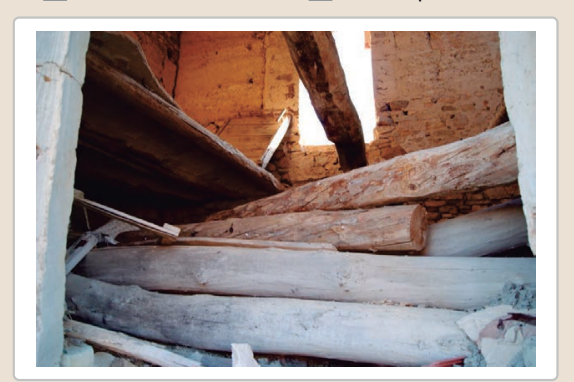

Observaciones

La tapia se encuentra ennegrecida por la presencia de líquenes. El interior ha colapsado o se ha derribado 


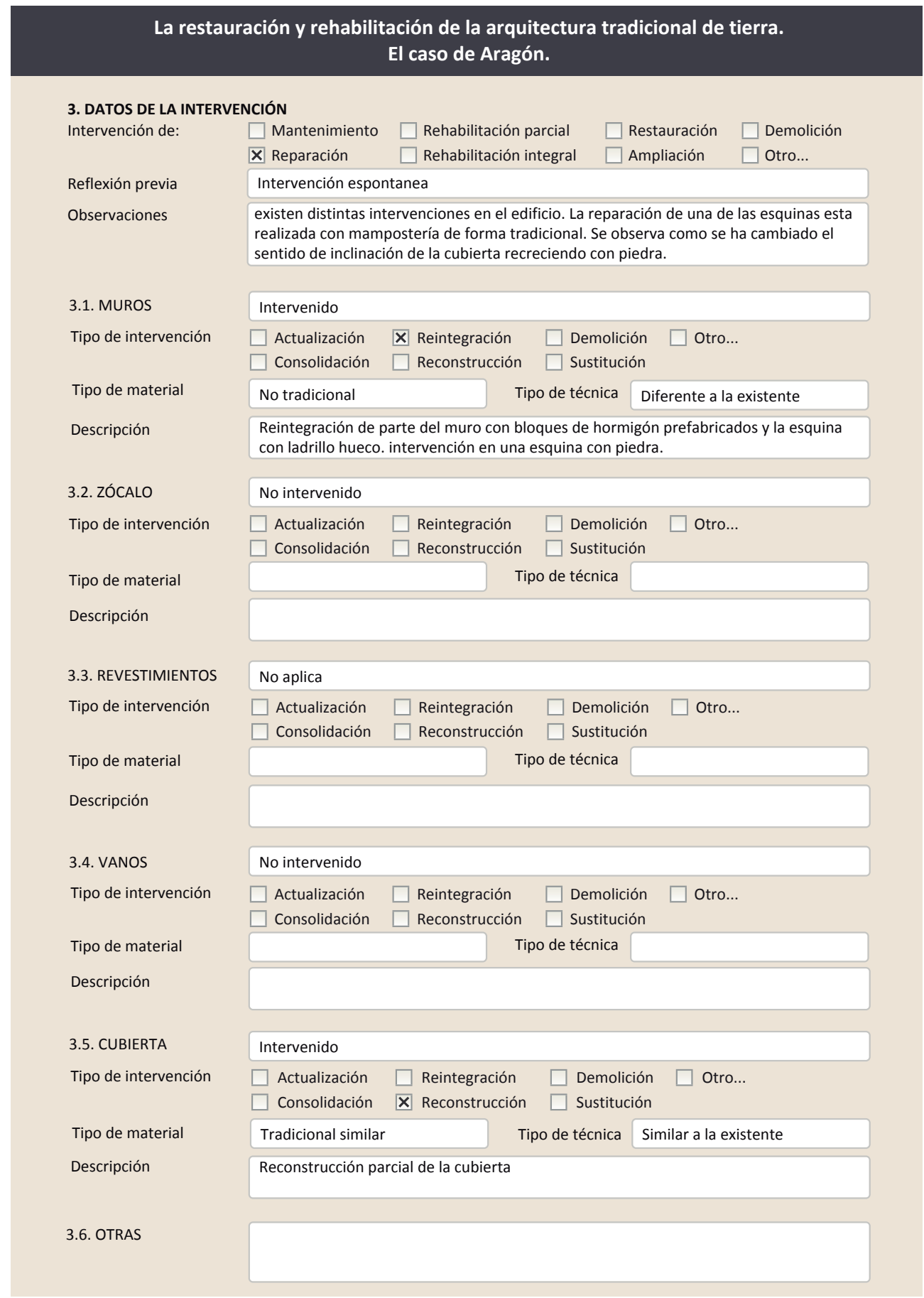

3.7. REHABILITACIÓN ENERGÉTICA $\quad \square$ Fachada $\square$ Vanos $\square$ Forjados $\square$ Cubierta Observaciones

FOTOGRAFíAS DE LA INTERVENCIÓN

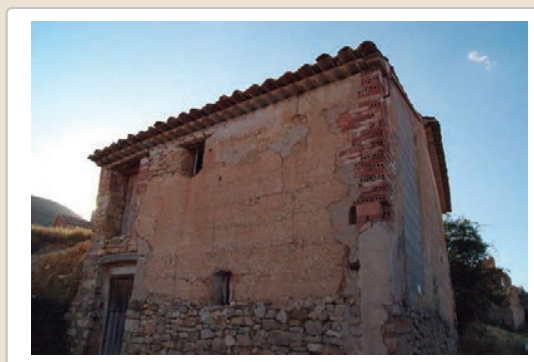

Vista general. Intervención esquina con ladrillo

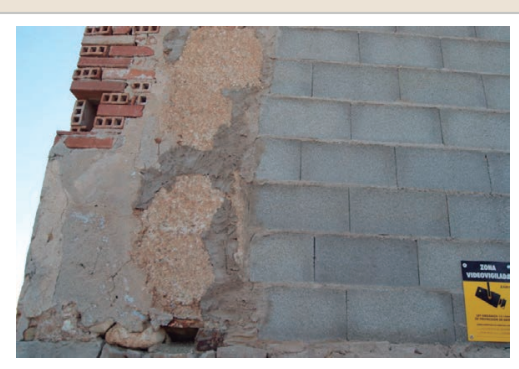

Zona con mayor intervención

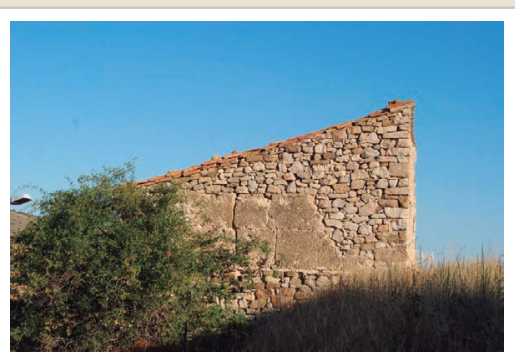

esquina intervenida con piedra. Exterior

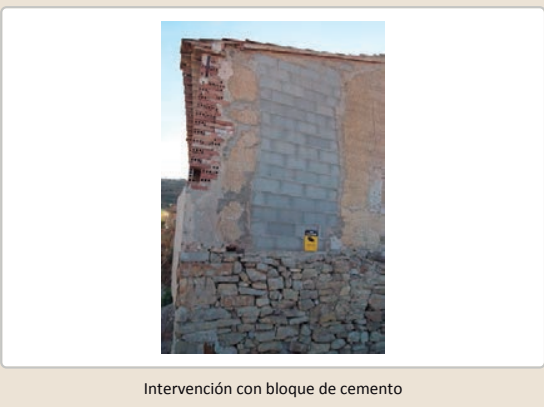

Intervención con bloque de cemento

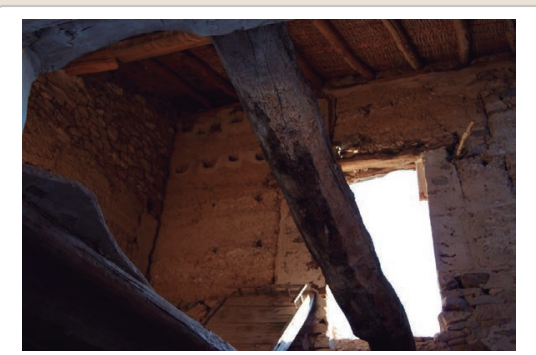

interior de edificio en muy mal estado

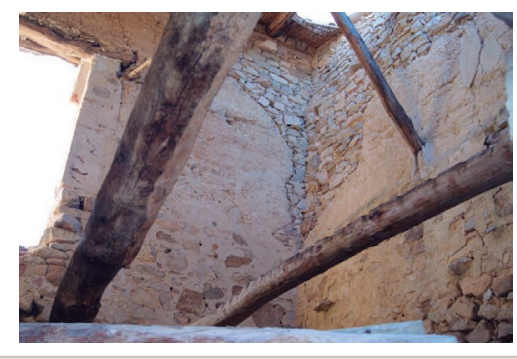

Esquina intervenida con piedra. Interior. 


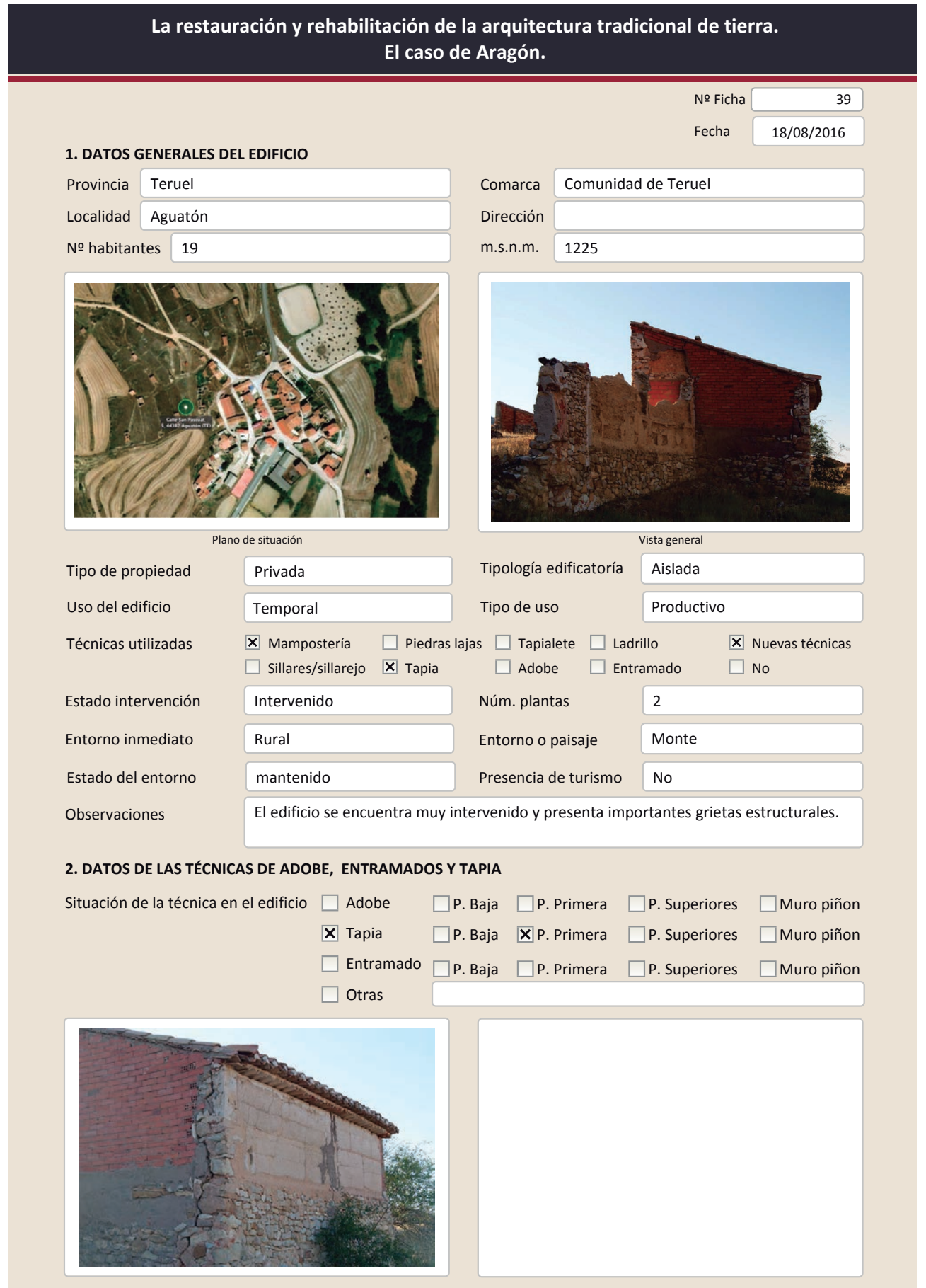

La restauración y rehabilitación de la arquitectura tradicional de tierra.

El caso de Aragón.

2.2. TAPIA

Ancho del muro

Dimensión tapiales

Tipo de aguja

\begin{tabular}{|l|}
\hline $40-50 \mathrm{~cm}$ \\
\hline \\
\hline Redonda \\
\hline 2 \\
\hline
\end{tabular}

Color de la tapia

№ agujas/cajón

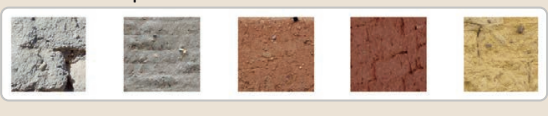

$\square$ Blanquecino $\quad \mathbf{X}$ Marrón $\square$ Amarillento

$\square$ Blanquecino $\quad \mathbf{X}$ Marrón $\square$ Amarill
$\square$ Grisaceo
$\square$ Rojizo $\quad \square$ Otro...

Variante constructiva

$\square$ simple / homogénea

$\square$ suplemento superficial

$\square$ suplemento en juntas

X Mixta
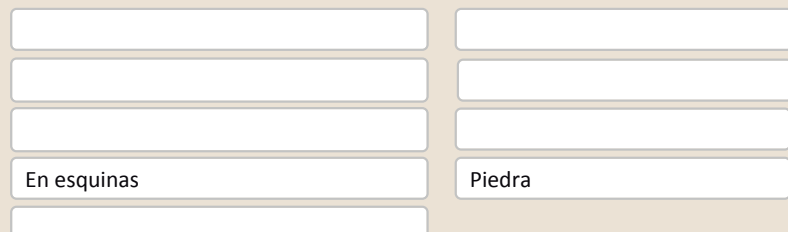

$\square$ Elementos de protección

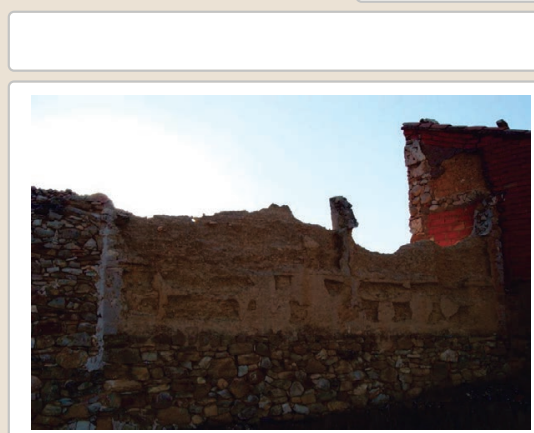

Lesiones $\mathbf{X M u r o ~} \square$ Zócalo $\square$ Revestimiento $\mathbf{X}$ Cubierta $\square$ otro...

X Erosión del material $\quad \square$ Humedad por capilaridad $\quad \square$ Grietas por asentamiento

$\square$ Erosion de las juntas $\square$ Humedades (manch/eflo)

$\square$ Pérdida de sección $\quad \square$ Pérdida de verticalidad

$\square$ Vegetación

$\square$ Por elementos impropios

$\square$ Desconchados

$\square$ Grietas porfalta de trab
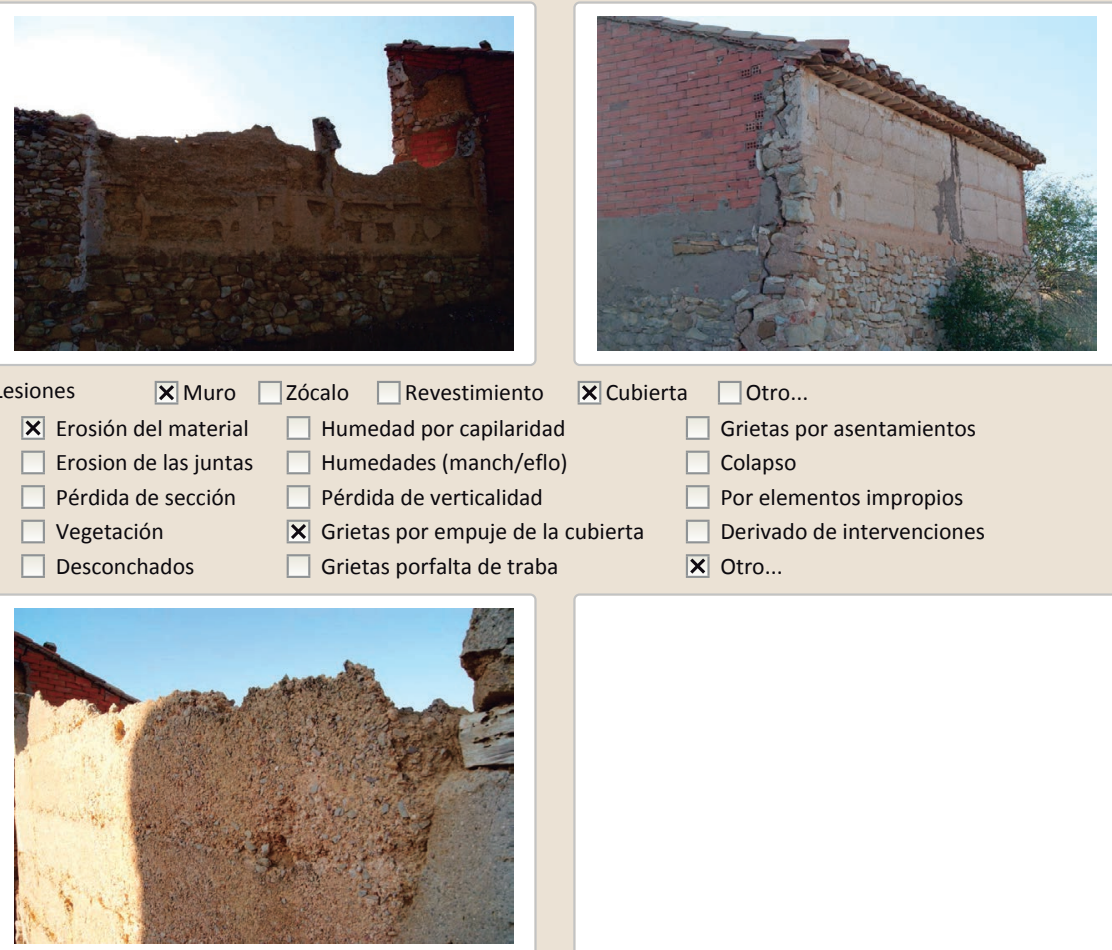

Observaciones

El edificio se encuentra en un estado de deterioro avanzado 


\section{La restauración y rehabilitación de la arquitectura tradicional de tierra.} El caso de Aragón.

3. DATOS DE LA INTERVENCIÓN

$\square$ Mantenimiento $\square$ Rehabilitación parcial $\square$ Restauración $\square$ Demolición X Reparación $\quad \square$ Rehabilitación integral $\quad \square$ Ampliación $\quad \square$ Otro...

Reflexión previa Intervención espontanea

Observaciones intervención de los muros laterales sustituyendo la tapia

3.1. MUROS
Tipo de intervención

Intervenido

Tipo de material

$\square$ Actualización $\square$ Reintegración $\quad \square$ Demolición $\square$ Otro...

$\square$ Consolidación $\quad \mathbf{X}$ Reconstrucción $\square$ Sustitución

Descripción

No tradicional

Tipo de técnica Diferente a la existente

3.2. ZÓCALO

Tipo de intervención

reconstrucción

Intervenido

$\square$ Actualización $\mathbf{X}$ Reintegración $\square$ Demolición $\square$ Otro...

$\square$ Consolidación $\square$ Reconstrucción $\square$ sustitución

Tipo de material

No tradicional

Tipo de técnica Diferente a la existente

Descripción

Rejuntado de la mampostería con mortero de cemento

3.3. REVESTIMIENTOS

Tipo de intervención

Tipo de material

Descripción

3.4. VANOS

Tipo de intervención

Tipo de material

Descripción

3.5. CUBIERTA

Tipo de intervención

Tipo de material

Descripción

\section{No aplica}

$\square$ Actualización $\square$ Reintegración $\square$ Demolición $\square$ Otro...

$\square$ Consolidación $\square$ Reconstrucción $\square$ sustitución

Tipo de técnica

(a)

\section{No intervenido}

$\square$ Actualización $\square$ Reintegración $\square$ Demolición $\square$ Otro...

$\square$ Consolidación $\square$ Reconstrucción $\square$ Sustitución

$$
\text { Tipo de técnica }
$$

\section{Intervenido}

$\square$ Actualización $\quad \mathbf{X}$ Reintegración $\square$ Demolición $\square$ Otro.. $\square$ Consolidación $\square$ Reconstrucción $\square$ Sustitución
No tradicional
Tipo de técnica Similar a la existente

3.6. OTRAS

Reintegración de tejas con cemento. En el lateral de la cubierta se aprecia esta intervención
La restauración y rehabilitación de la arquitectura tradicional de tierra.

El caso de Aragón.

3.7. REHABILITACIÓN ENERGÉTICA $\square$ Fachada $\square$ Vanos $\square$ Forjados $\square$ Cubierta

Observaciones

FOTOGRAFíAS DE LA INTERVENCIÓN
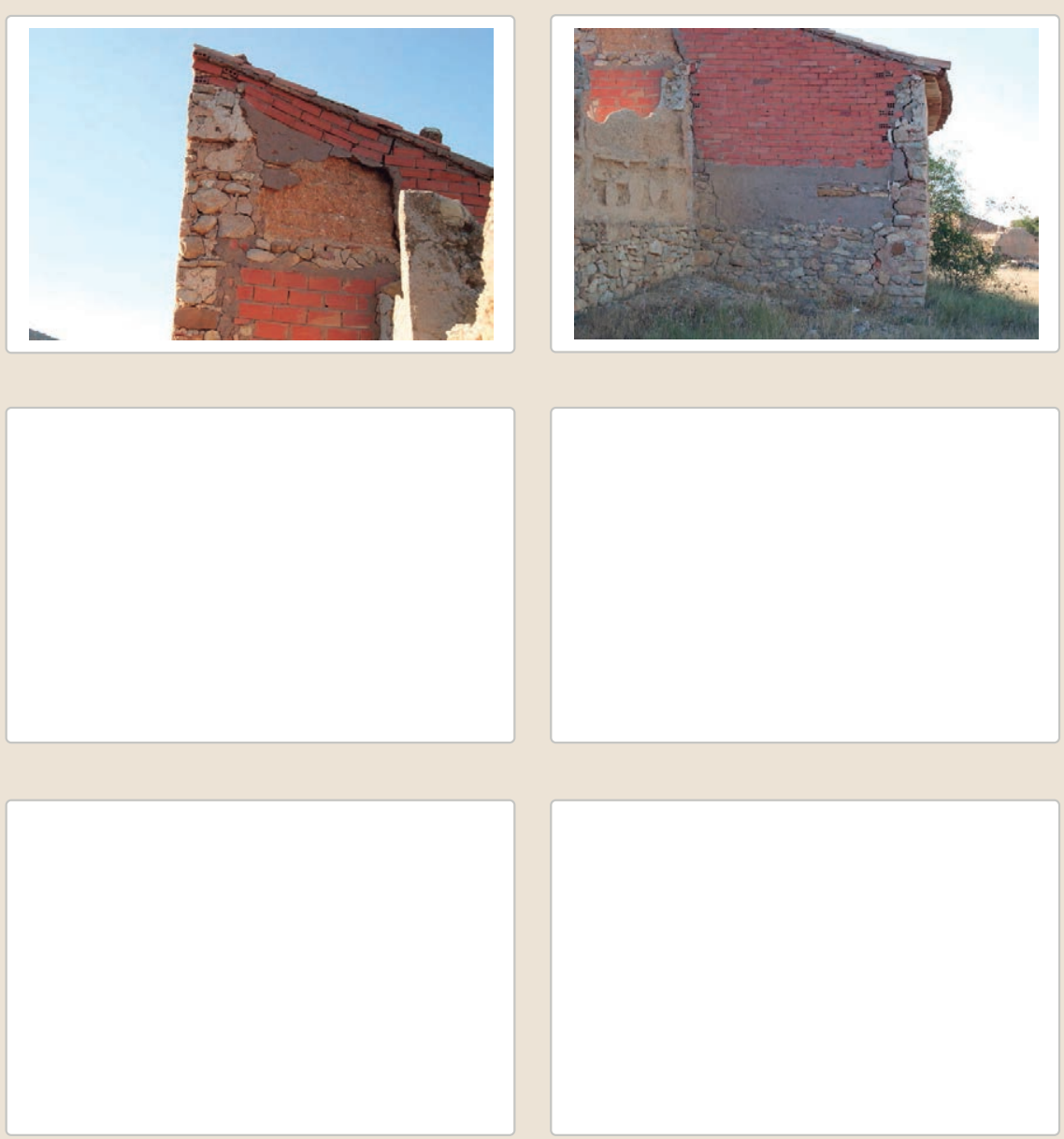


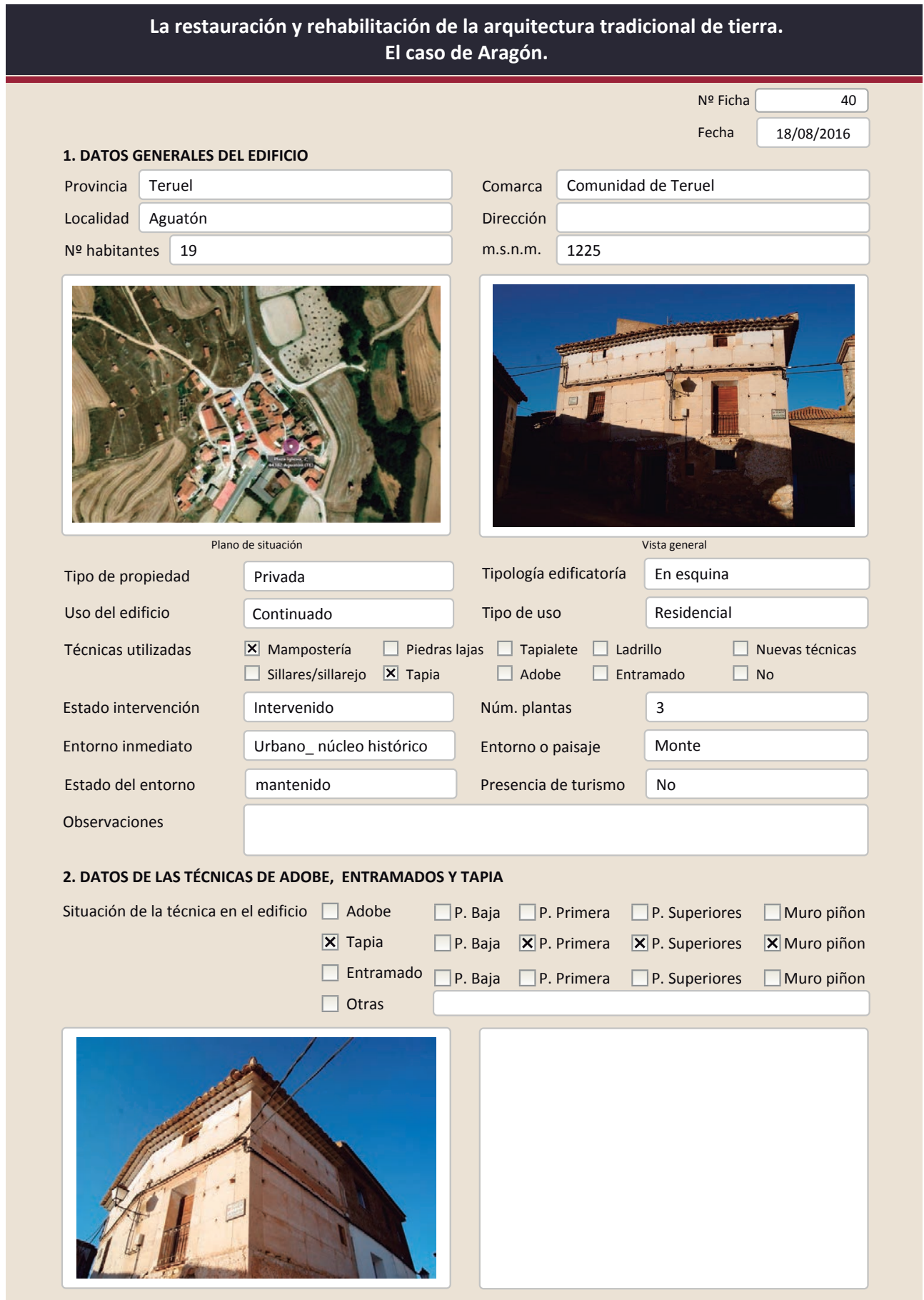

La restauración y rehabilitación de la arquitectura tradicional de tierra.

El caso de Aragón.

\subsection{TAPIA}

Ancho del muro

Dimensión tapiales

Tipo de aguja

\begin{tabular}{|l|}
\hline $40-50 \mathrm{~cm}$ \\
\hline \\
\hline Redonda \\
\hline 3 \\
\hline
\end{tabular}

Color de la tapia

№ agujas/cajón

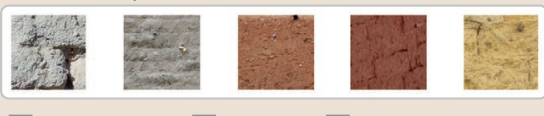

X Blanquecino $\square$ Marrón $\square$ Amarillento

$\mathbf{X}$ Blanquecino
$\square$ Grisaceo Marrón $\square$ Rojizo $\square$ Otro..

Variante constructiva

$\square$ Simple / homogénea

X Suplemento superficial

$\square$ Suplemento en juntas

X Mixta

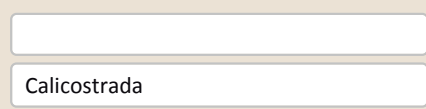

Machones

Cal/yeso

$\square$ Elementos de protección

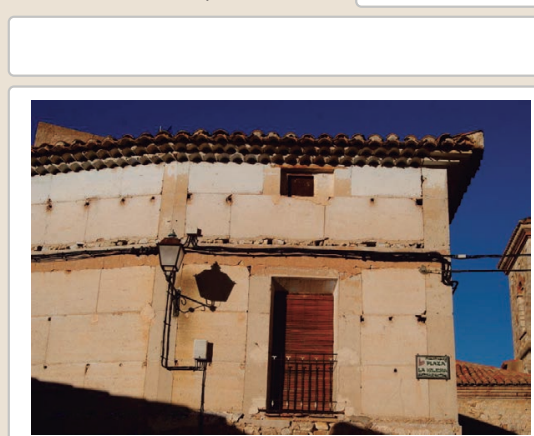

Lesiones $\square$ Muro $\mathbf{X}$ Zócalo $\square$ Revestimiento $\square$ Cubierta $\square$ otro...

$\square$ Erosión del material $\quad \square$ Humedad por capilaridad $\quad \square$ Grietas por asentamientos

$\square$ Erosion de las juntas $\square$ Humedades (manch/eflo)

$\square$ Pérdida de sección $\square$ Pérdida de verticalidad

$\square$ Vegetación

$\square$ Por elementos impropios

X Desconchado

$\square$ Grietas porfalta de traba

$\square$ Derivado

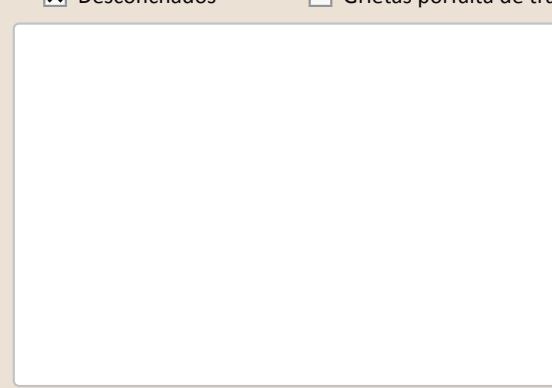

Observaciones 


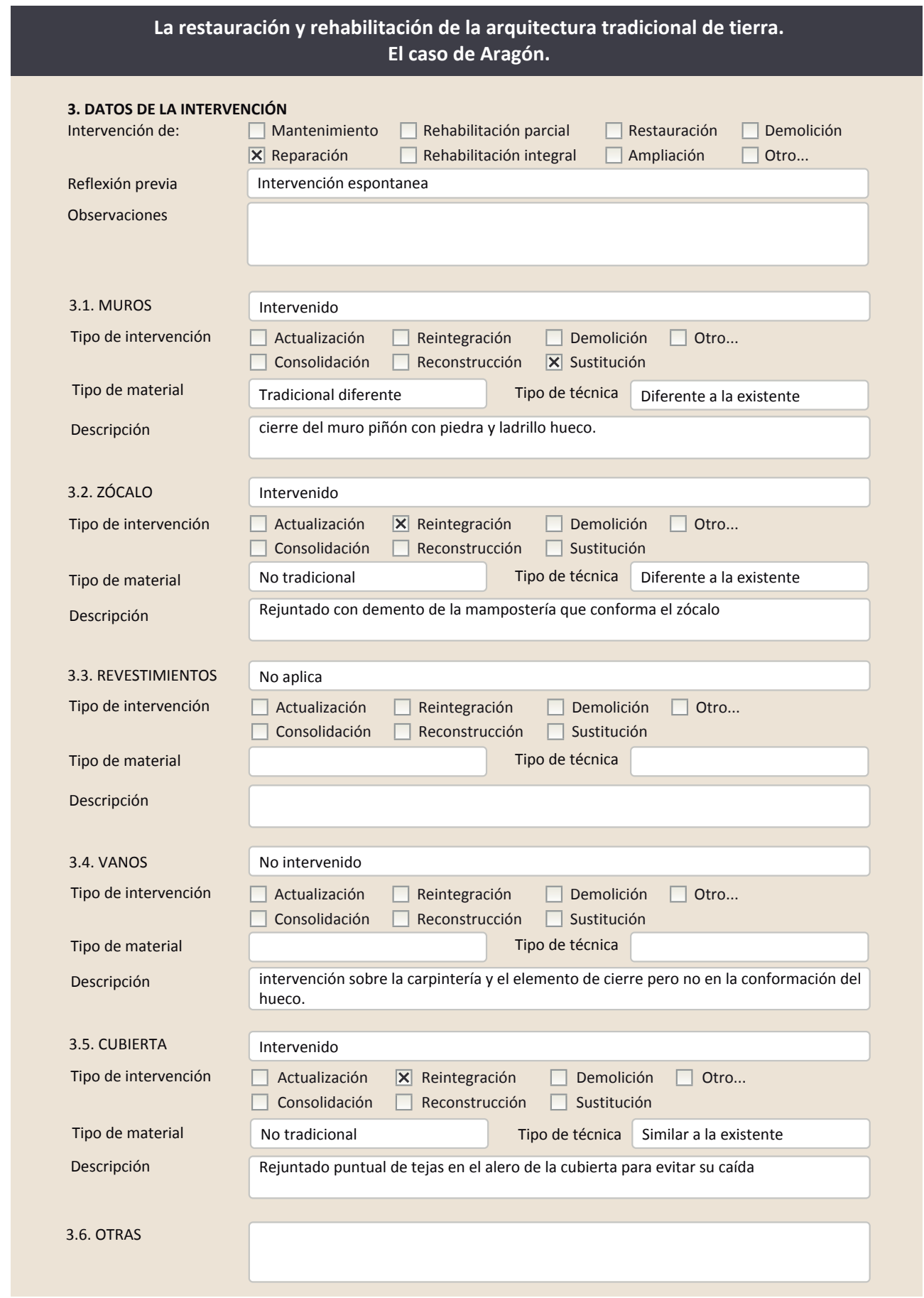

3.7. REHABILITACIÓN ENERGÉTICA $\quad \square$ Fachada $\square$ Vanos $\square$ Forjados $\square$ Cubierta Observaciones

FOTOGRAFÍAS DE LA INTERVENCIÓN
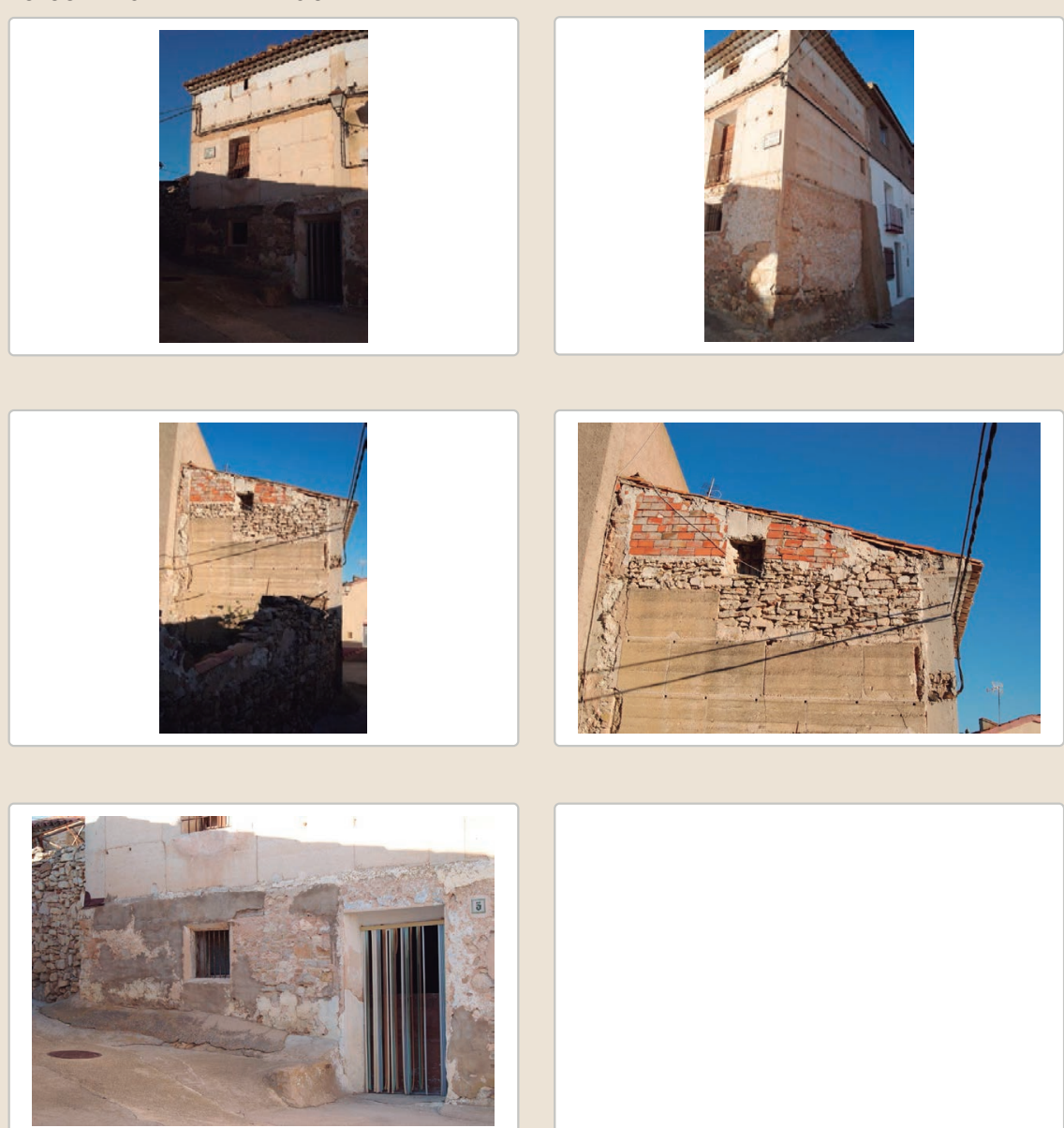


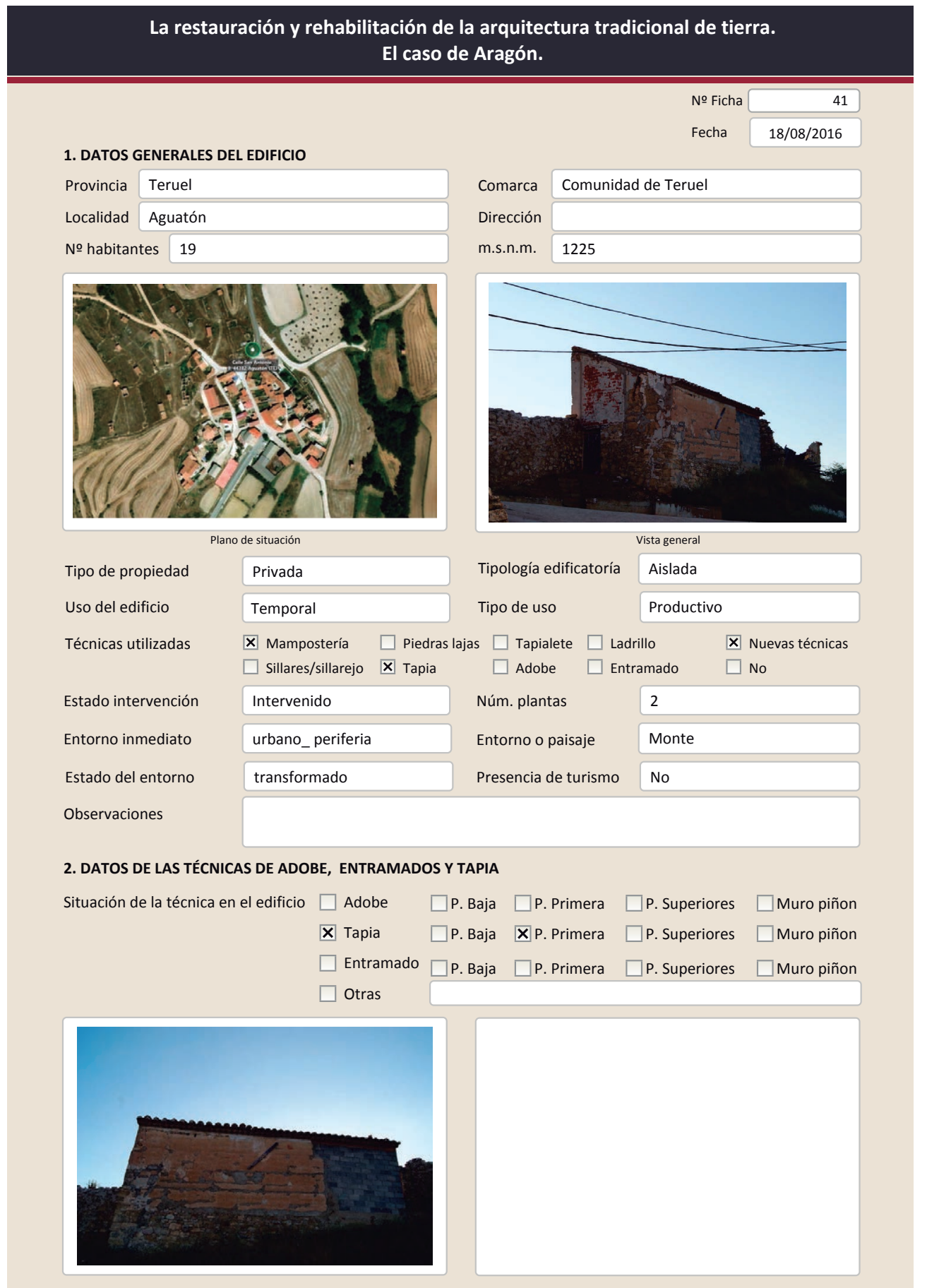

La restauración y rehabilitación de la arquitectura tradicional de tierra.

El caso de Aragón.

2.2. TAPIA

Ancho del muro

Dimensión tapiales

Tipo de aguja

\begin{tabular}{|l|}
\hline $40-50 \mathrm{~cm}$ \\
\hline \\
\hline Redonda \\
\hline 3 \\
\hline
\end{tabular}

Color de la tapia

№ agujas/cajón

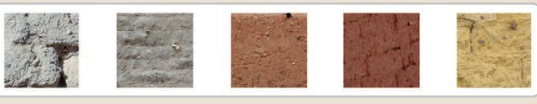

$\square$ Blanquecino $\quad \mathbf{X}$ Marrón $\square$ Amarillento

$\square$ Blanquecino $\quad \mathbf{X}$ Marrón
$\square$ Grisaceo
$\square$ Rojizo $\quad \square$ Amarill

Variante constructiva

$\square$ simple / homogénea

$\mathbf{X}$ Suplemento superficial

$\square$ suplemento en juntas

X Mixta

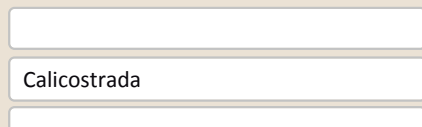

Cal/yeso

Machones de rafas

Mampostería y yeso

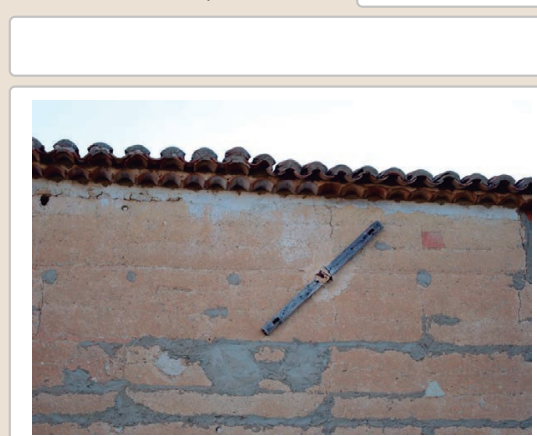

Lesiones $\quad$ M Muro $\square$ Zócalo $\square$ Revestimiento $\quad \mathbf{X}$ Cubierta $\square$ Otro...

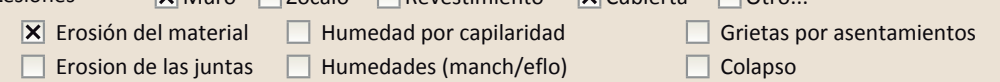

$\square$ Pérdida de sección $\square$ Pérdida de verticalidad $\square$ Por elementos impropios

$\square$ Vegetación $\quad \mathbf{X}$ Grietas por empuje de la cubierta $\square$ Derivado de intervenciones

Х Desconchados $\quad \square$ Grietas porfalta de traba $\quad \square$ Otro...

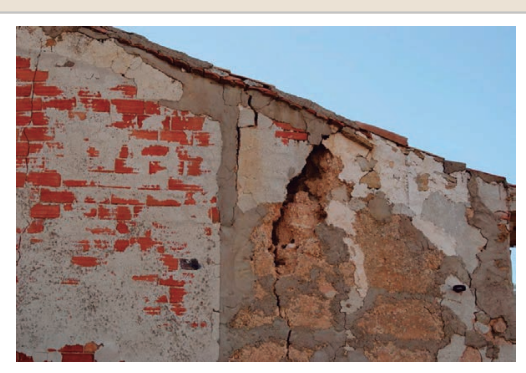

Observaciones 


\section{La restauración y rehabilitación de la arquitectura tradicional de tierra.}

\section{El caso de Aragón.}

3. DATOS DE LA INTERVENCIÓN

$\square$ Mantenimiento $\quad \square$ Rehabilitación parcial $\quad \square$ Restauración $\quad \square$ Demolición X Reparación $\quad \square$ Rehabilitación integral $\square$ Ampliación $\quad \square$ Otro...

Reflexión previa Intervención espontanea

Observaciones la intervención busca mantener el uso del edificio sin importar la compatibilidad de los materiales o la estética de estos. Atirantamiento del muro utilizando un costal del cajón de la tap

\subsection{MUROS}

Tipo de intervención

Intervenido

Tipo de material

$\square$ Actualización $\mathbf{X}$ Reintegración $\square$ Demolición $\square$ Otro...

$\square$ Consolidación $\square$ Reconstrucción $\quad$ X Sustitución

Descripción

No tradicional Tipo de técnica Diferente a la existente

3.2. ZóCALO

Tipo de intervención

Sustitcion de parte del muro por un muro de ladrillo hueco y reintegración de huecos

Intervenido

$\square$ Actualización

$\square$ Consolidación $\square$ Reconstrucción $\square$ Sustitución

$\begin{array}{llll}\text { Tipo de material No tradicional Tipo de técnica Diferente a la existente } & \end{array}$

Descripción

3.3. REVESTIMIENTOS

Tipo de intervención

Tipo de material

Descripción

3.4. VANOS

Tipo de intervención

Tipo de material

Descripción

3.5. CUBIERTA

Tipo de intervención

Reintegración de las juntas de mampostería con mortero de cemento.

No aplica

$\square$ Actualización $\quad \square$ Reintegración $\quad \square$ Demolición $\square$ Otro...

$\square$ Consolidación $\square$ Reconstrucción $\square$ sustitución

Tipo de técnica

No intervenido

$\square$ Actualización $\quad \square$ Reintegración $\quad \square$ Demolición $\square$ Otro...

$\square$ Consolidación $\square$ Reconstrucción $\square$ Sustitución

$$
\text { Tipo de técnica }
$$

\section{Intervenido}

$\square$ Actualización $\quad \boldsymbol{X}$ Reintegración $\square$ Demolición $\square$ Otro.. $\square$ Consolidación $\quad \square$ Reconstrucción $\square$ Sustitución

\begin{tabular}{l|l|l|l|l|l|l} 
Tipo de material To tradicional técnica & Similar a la existente \\
\hline
\end{tabular}

Descripción

Reintegración de tejas con cemento en la zona del alero
La restauración y rehabilitación de la arquitectura tradicional de tierra.

El caso de Aragón.

3.7. REHABILITACIÓN ENERGÉTICA $\quad \square$ Fachada $\square$ Vanos $\square$ Forjados $\square$ Cubierta

Observaciones

FOTOGRAFÍAS DE LA INTERVENCIÓN
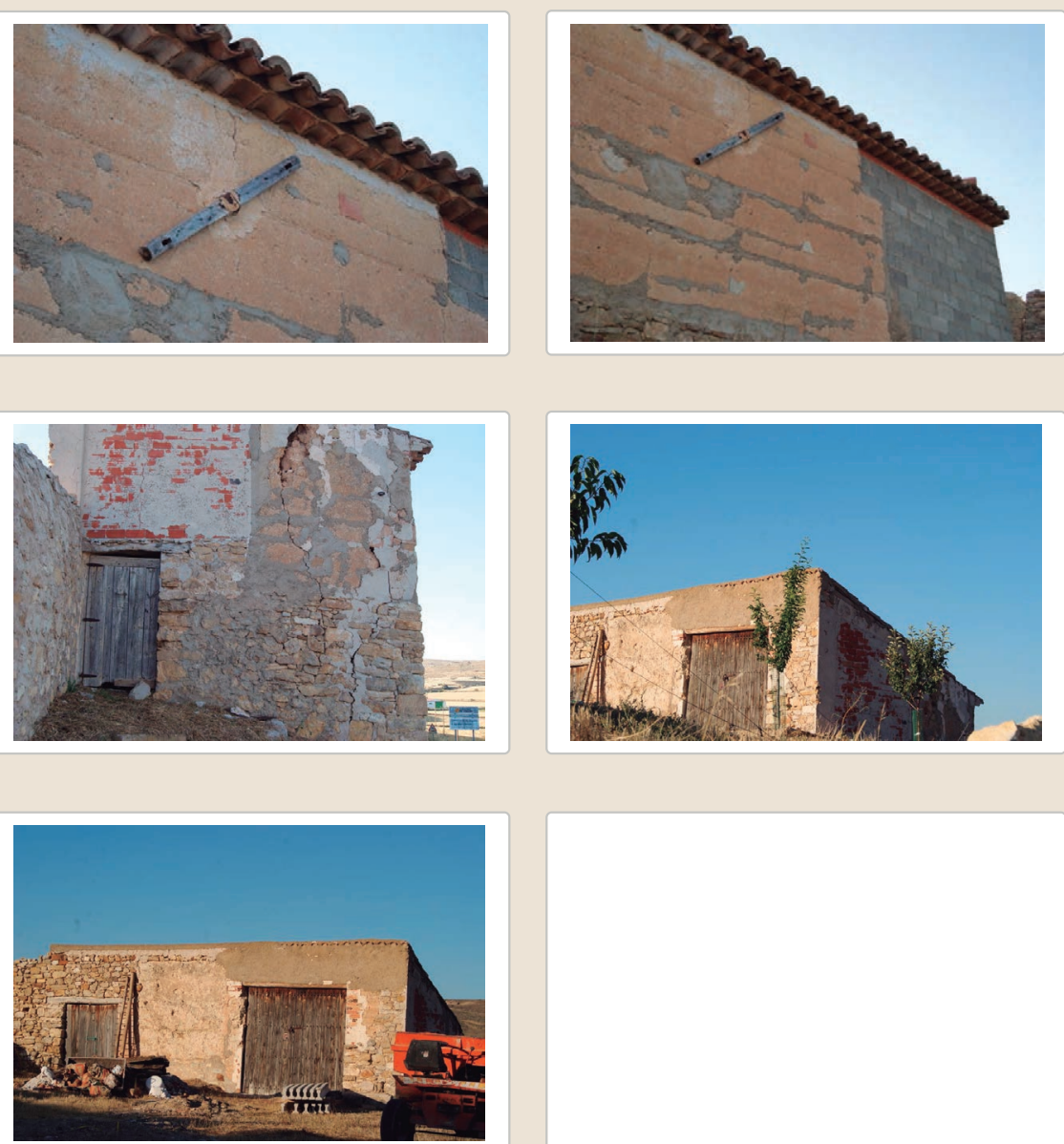

3.6. OTRAS 


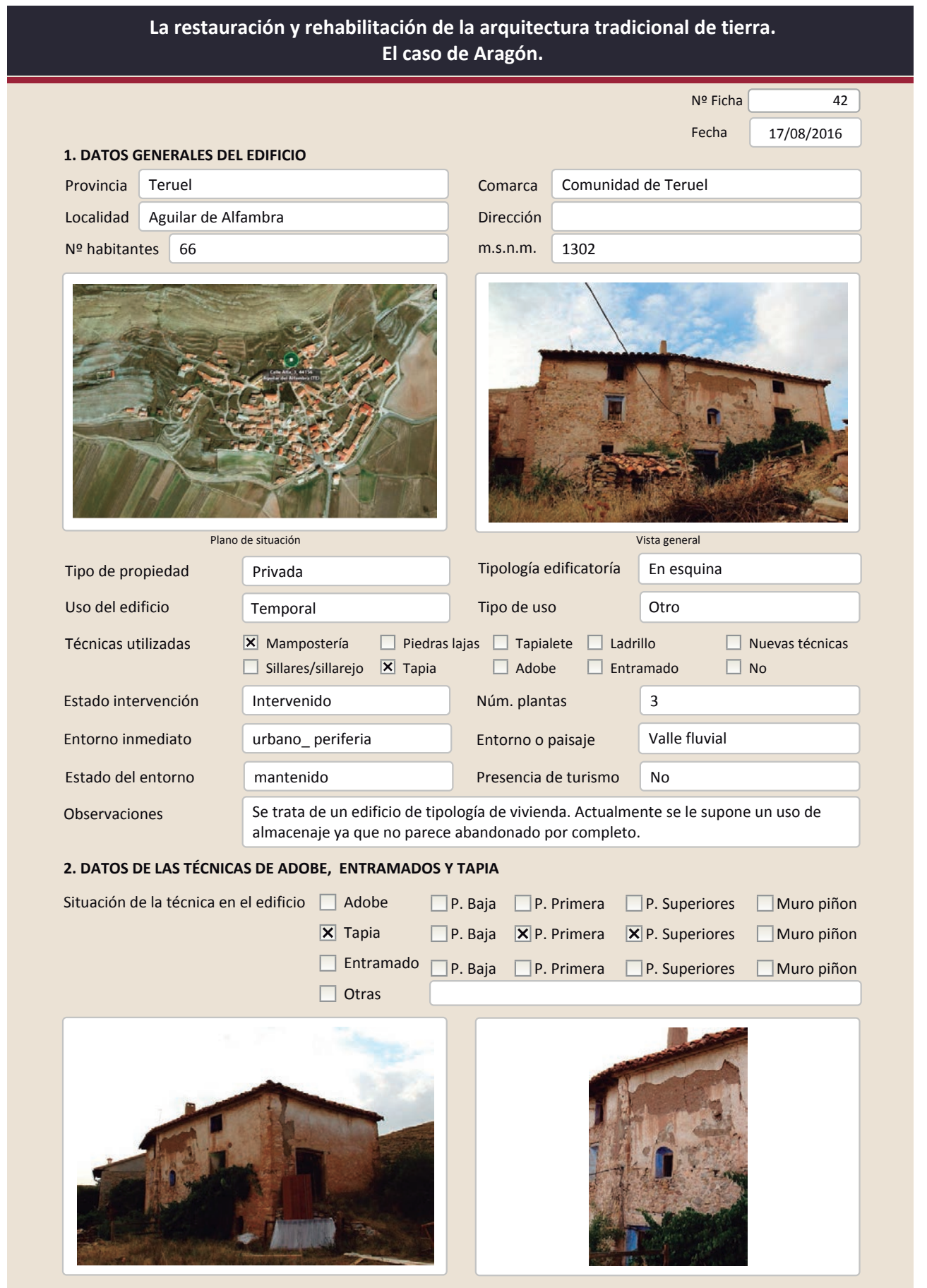

La restauración y rehabilitación de la arquitectura tradicional de tierra. El caso de Aragón.

2.2. TAPIA

Ancho del muro

Dimensión tapiales

Tipo de aguja

№ agujas/cajón

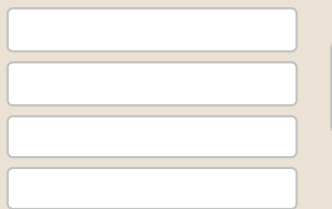

Color de la tapia

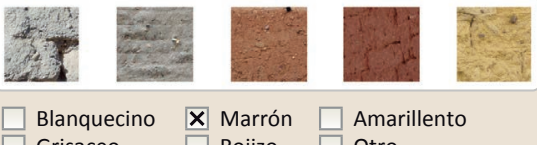

Variante constructiva

$\square$ simple / homogénea

$\square$ suplemento superficial

$\square$ suplemento en juntas

$\mathbf{X}$ Mixta

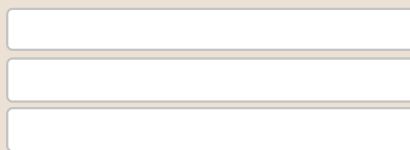

X Elementos de protección

En esquinas

$\square$ Rojizo $\square$ Otro...

Revestimiento

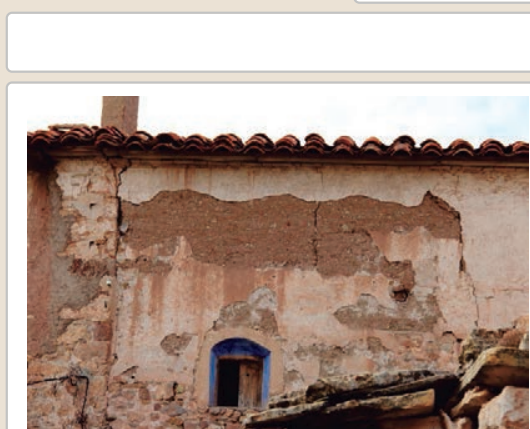

Lesiones $\mathbf{X}$ Muro $\square$ Zócalo $\mathbf{X}$ Revestimiento $\mathbf{X}$ Cubierta $\square$ Otro...

$\square$ Erosión del material $\quad \square$ Humedad por capilaridad $\quad \square$ Grietas por asentamientos

$\square$ Erosion de las juntas $\square$ Humedades (manch/eflo)

$\square$ Pérdida de sección $\quad \mathbf{X}$ Pérdida de verticalidad

$\square$ Vegetación $\quad \mathbf{X}$ Grietas por empuje de la cubic

X Desconchados

$\square$ Grietas porfalta de trab

Colapso

$\square$ Por elementos impropios

Derivado de intervenciones
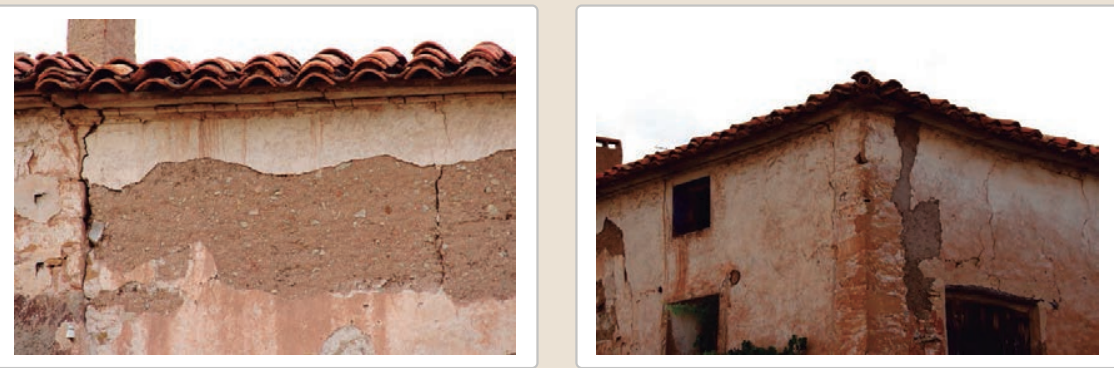

movimiento de tejas en cubierta 
La restauración y rehabilitación de la arquitectura tradicional de tierra. El caso de Aragón

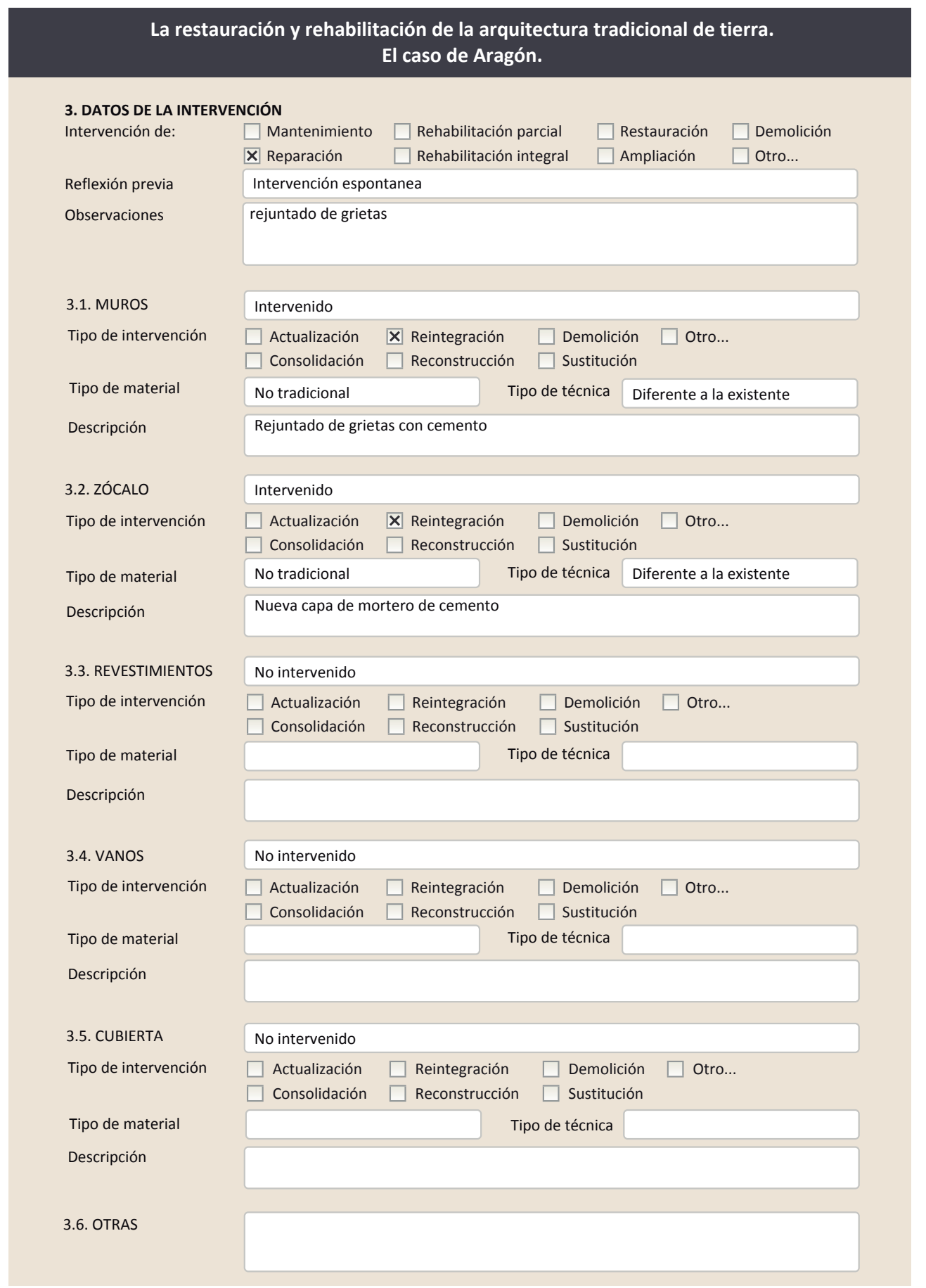

\subsection{REHABILITACIÓN ENERGÉTICA $\quad \square$ Fachada $\square$ Vanos $\square$ Forjados $\square$ Cubierta}

Observaciones

FOTOGRAFíAS DE LA INTERVENCIÓN
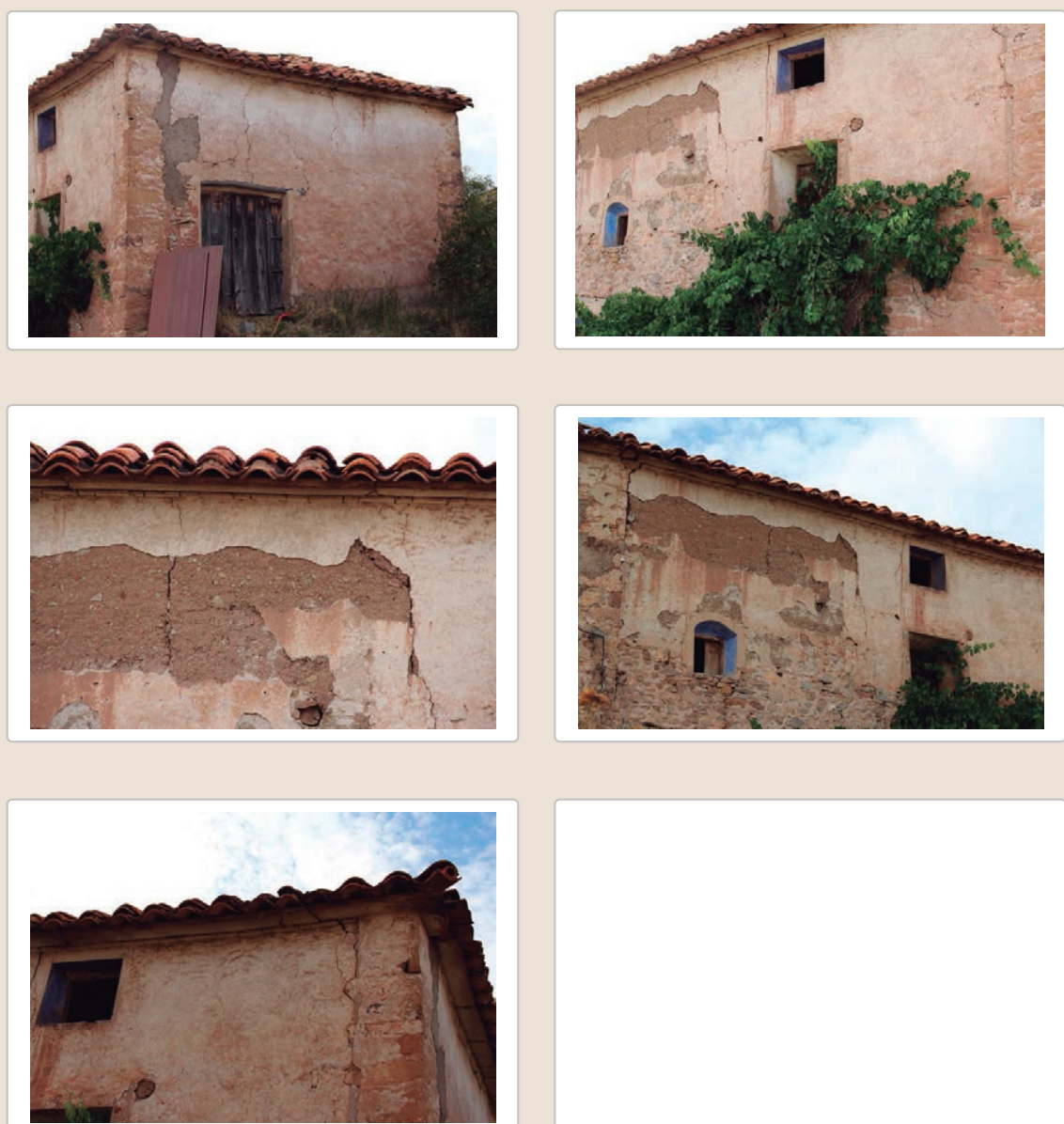


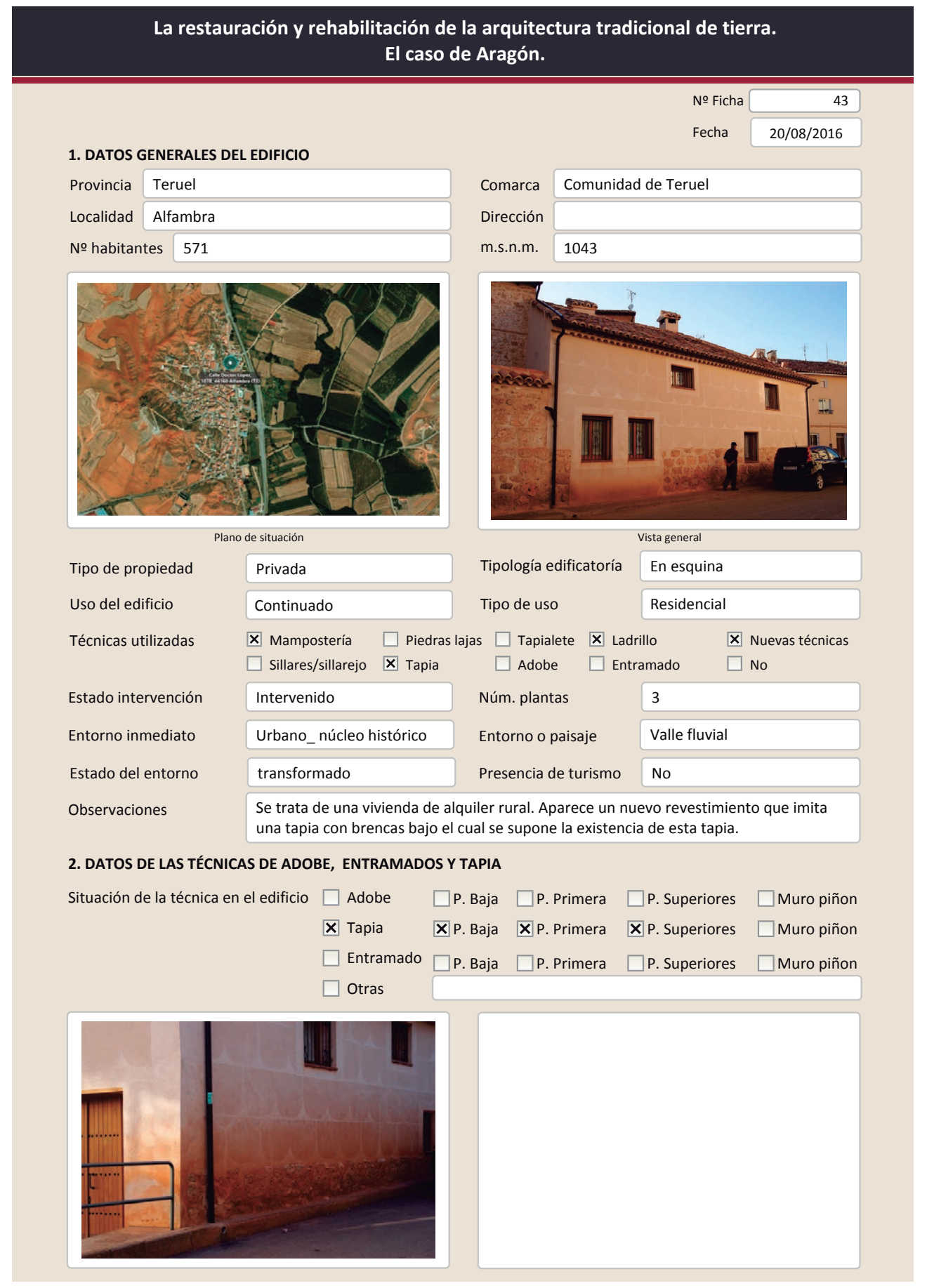

La restauración y rehabilitación de la arquitectura tradicional de tierra.

El caso de Aragón.
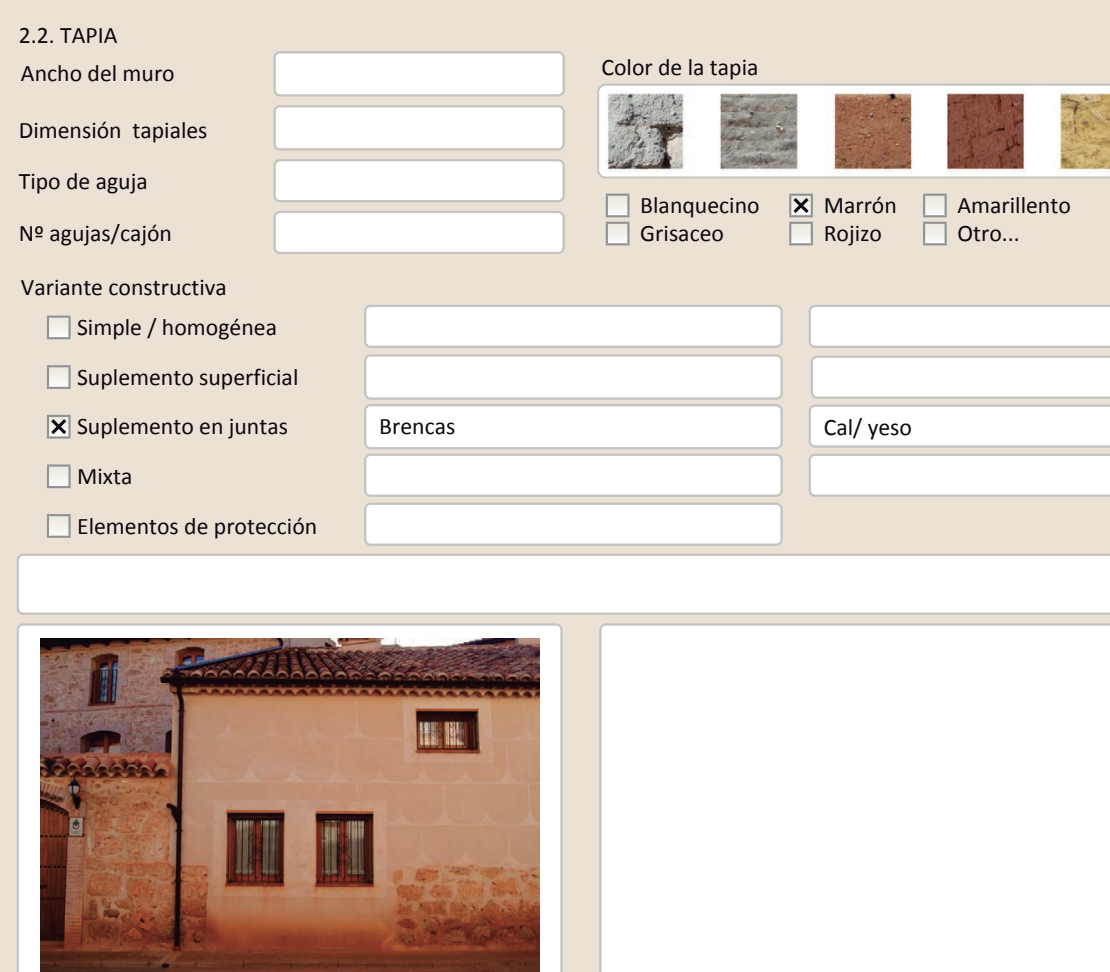

Lesiones $\square$ Muro $\boldsymbol{X}$ Zócalo $\square$ Revestimiento $\square$ Cubierta $\square$ otro...

$\square$ Erosión del material $\quad \mathbf{X}$ Humedad por capilaridad $\quad \square$ Grietas por asentamientos

$\square$ Erosion de las juntas $\square$ Humedades (manch/eflo)

$\square$ Pérdida de sección $\square$ Pérdida de verticalidad

$\begin{array}{ll}\square \text { Pérdida de verticalidad } & \square \text { Por elementos impropios } \\ \square \text { Grietas por empuje de la cubierta } \quad \square \text { Derivado de intervenciones }\end{array}$

$\square$ Desconchados

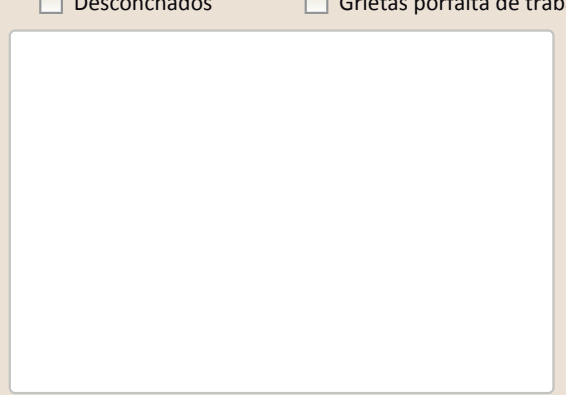

$\square$ Otro...

Observaciones 


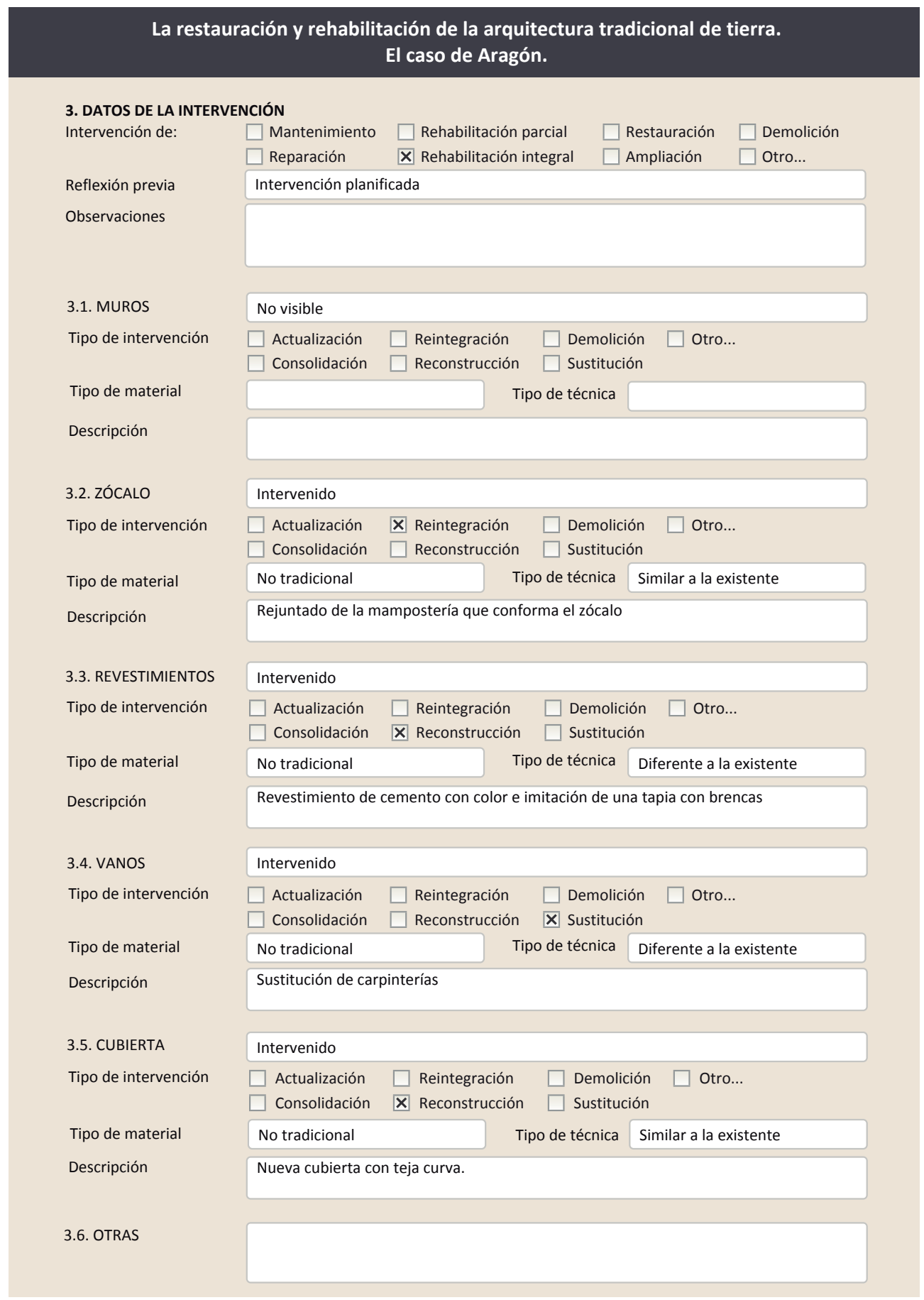

3.7. REHABILITACIÓN ENERGÉTICA \ Fachada $\mathbf{\bigotimes}$ Vanos $\square$ Forjados $\mathbf{X}$ Cubierta

Observaciones Al tener un uso público probablemente por normativa se hayan incorporado mejoras energéticas

FOTOGRAFÍAS DE LA INTERVENCIÓN
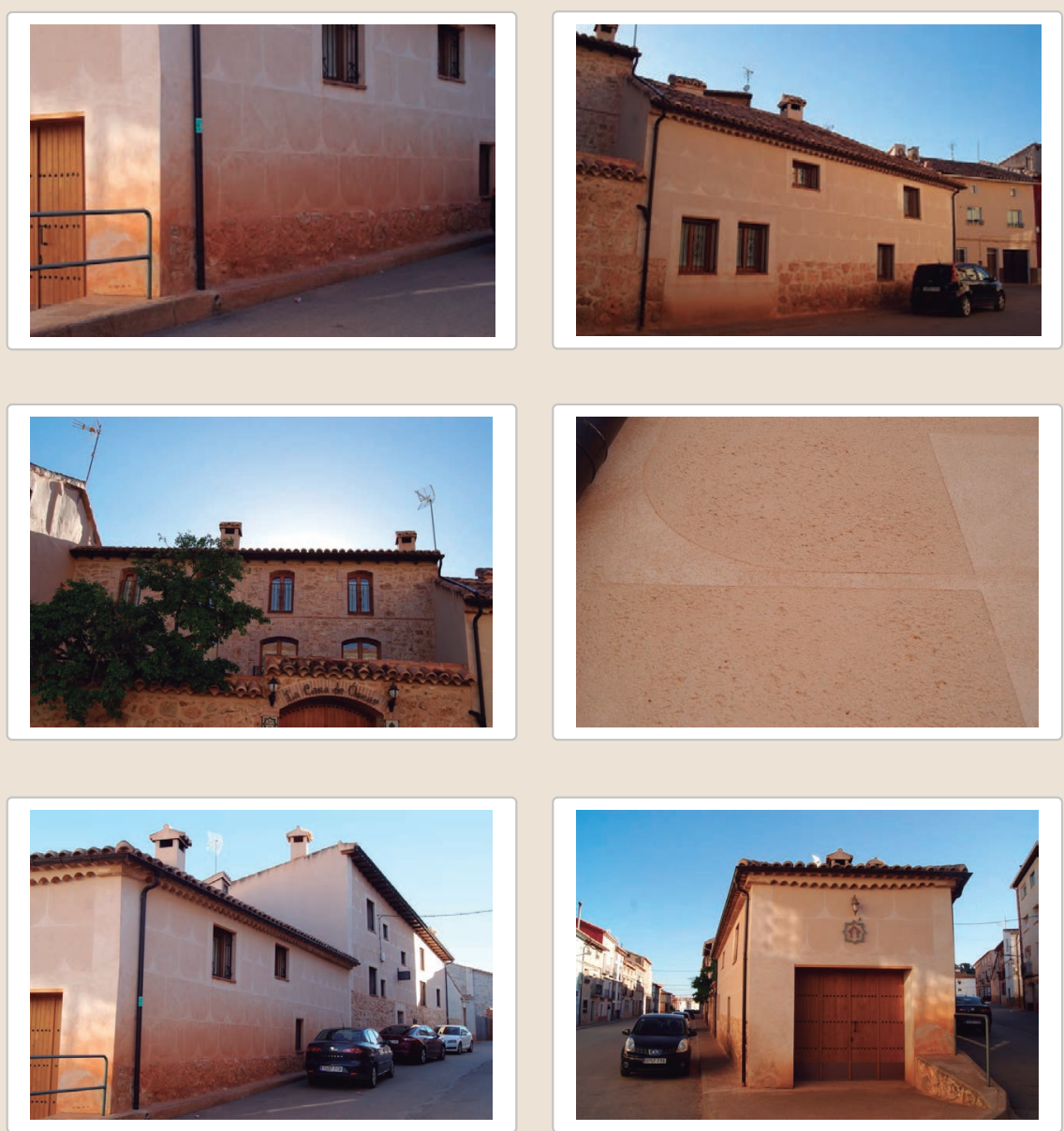


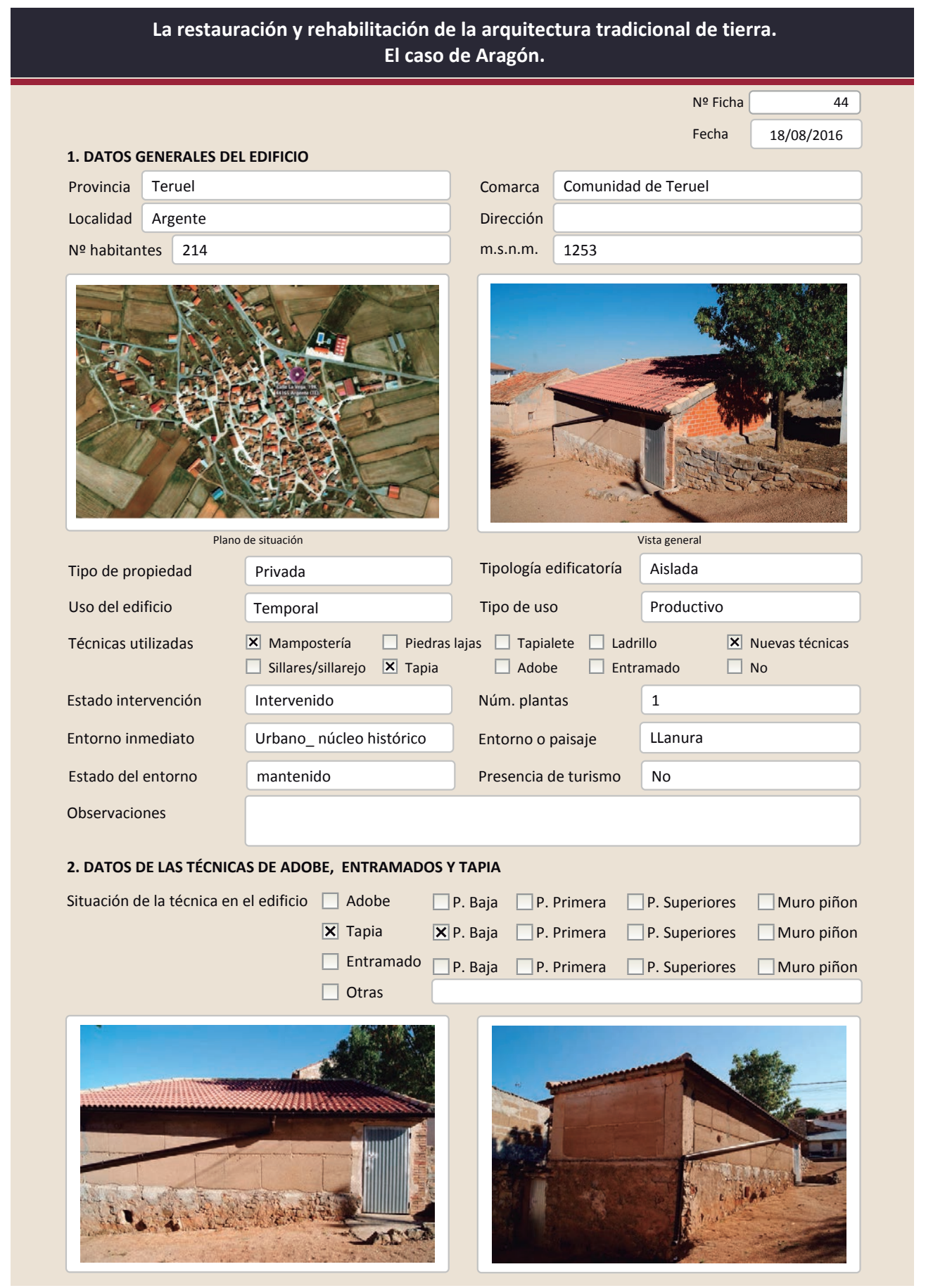

La restauración y rehabilitación de la arquitectura tradicional de tierra. El caso de Aragón.

2.2. TAPIA

Ancho del muro

Dimensión tapiales

Tipo de aguja

\begin{tabular}{|l|}
\hline $40-50 \mathrm{~cm}$ \\
\hline $140 \times 73$ \\
\hline Redonda \\
\hline 3 \\
\hline
\end{tabular}

Color de la tapia

№ agujas/cajón

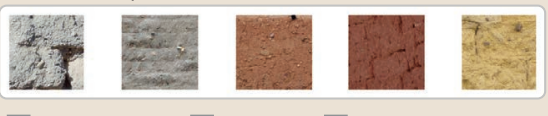

$\square$ Blanquecino $\quad \mathbf{X}$ Marrón $\square$ Amarillento $\overline{\mathbf{X}}$ Grisaceo $\square$ Rojizo $\square$ Otro.

Variante constructiva

$\square$ Simple / homogénea

X Suplemento superficial

$\mathbf{X}$ Suplemento en juntas

$\mathbf{X}$ Mixta
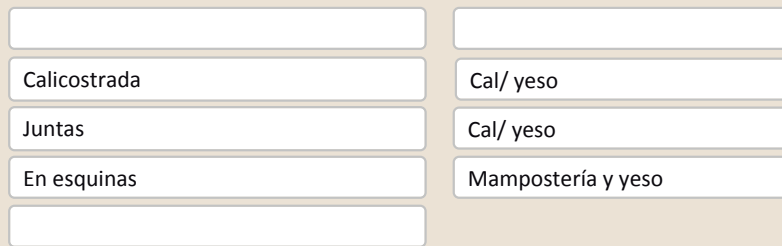

$\square$ Elementos de protección

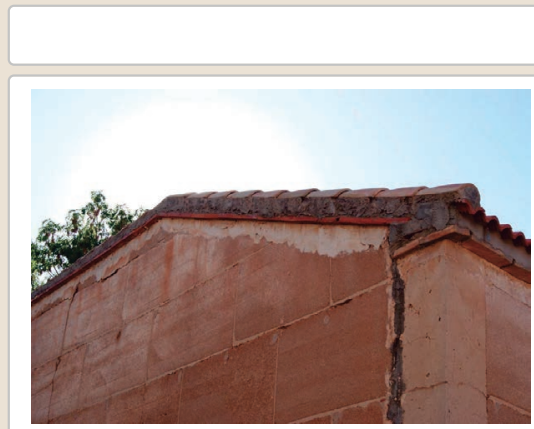

Lesiones $\quad \mathbf{M}$ Mro $\square$ Zócalo $\square$ Revestimiento $\square$ Cubierta $\square$ otro...

$\square$ Erosión del material $\square$ Humedad por capilaridad $\quad \mathbf{X}$ Grietas por asentamientos $\square$ Erosion de las juntas $\square$ Humedades (manch/eflo) $\square$ Pérdida de sección $\square$ Pérdida de verticalidad

$\square$ Vegetación

$\square$ Por elementos impropios

$\square$ Desconchados

$\square$ Grietas porfalta de traba
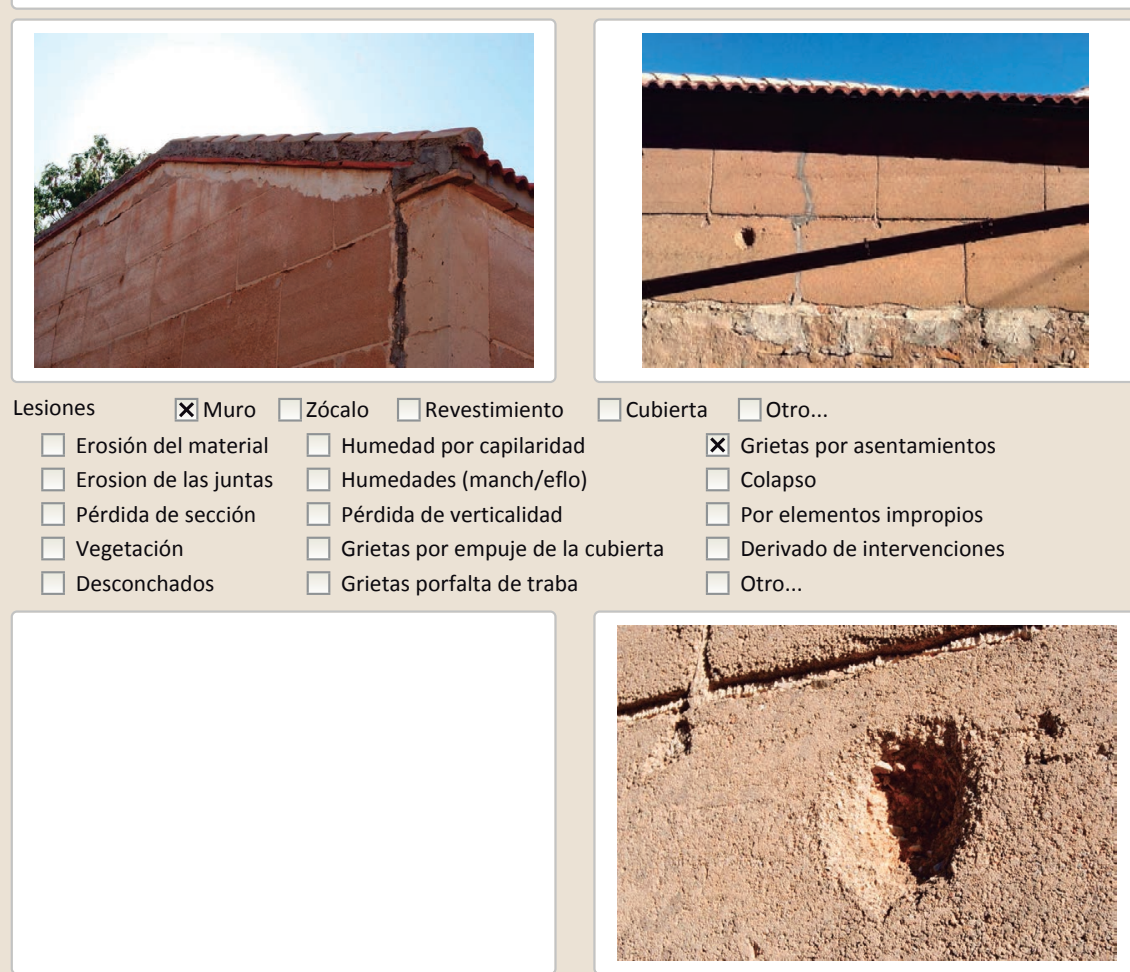
$\square$ Otro...

Observaciones

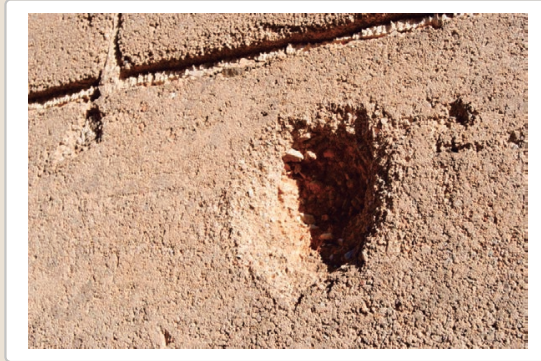




\section{La restauración y rehabilitación de la arquitectura tradicional de tierra.}

\section{El caso de Aragón.}

3. DATOS DE LA INTERVENCIÓN

$\square$ Mantenimiento $\quad \mathbf{X}$ Rehabilitación parcial

$\square$ Restauración $\square$ Demolición

(a)

$\square$ Reparación

$\square$ Rehabilitación integra

$\square$ Ampliación

$\square$ Otro...

Observaciones

Intervención planificada

3.1. MUROS
Tipo de intervención

Intervenido

Tipo de material

$\square$ Actualización $\quad$ Reintegración $\quad$ X Demolición $\square$ Otro...

$\square$ Consolidación $\quad \square$ Reconstrucción $\quad \square$ Sustitución

Descripción

Tipo de técnica

Descripción

3.2. ZÓCALO

Tipo de intervención

El muro ha sido derribado parcialmente para la realiza
cubierta. Se aprecia en la parte superior de estos.

Intervenido

$\square$ Actualización $\quad \mathbf{X}$ Reintegración $\square$ Demolición $\square$ Otro...

$\square$ Consolidación $\square$ Reconstrucción $\square$ sustitución

Descripción

3.3. REVESTIMIENTOS

Tipo de intervención

Tipo de material

Descripción

3.4. VANOS

Tipo de intervención

No tradicional

Tipo de técnica Similar a la existente

Reintegración parcial del zócalo que estaba cubierto con yeso, en ese caso utilizando cemento.

No aplica

$\square$ Actualización $\quad \square$ Reintegración $\quad \square$ Demolición $\square$ Otro...

$\square$ Consolidación $\square$ Reconstrucción $\square$ Sustitución

Tipo de técnica

$\square$ Consolidación $\square$ Reconstrucción $\times$ Sustitución $\square$ dro...

\begin{tabular}{l|l|l|l|l|l|l} 
Tipo de material & No tradicional de técnica & Similar a la existente \\
\hline
\end{tabular}

Descripción ampliación del hueco de acceso. Se aprecia en el muro la presencia de nuevo mortero blanco en las jambas y el dintel del mismo.

3.5. CUBIERTA

Tipo de intervención

Intervenido

$\square$ Actualización $\quad \square$ Reintegración $\quad \square$ Demolición $\square$ Otro..

$\square$ Consolidación $\square$ Reconstrucción $\mathbf{x}$ Sustitución

\begin{tabular}{l|l|l|l|l|l|l} 
Tipo de material Tipo de técnica Diferente a la existente \\
\hline
\end{tabular}

Descripción

Nueva cubierta construida con tejas curvas y losa de hormigón
La restauración y rehabilitación de la arquitectura tradicional de tierra.

El caso de Aragón.

3.7. REHABILITACIÓN ENERGÉTICA $\square$ Fachada $\square$ Vanos $\square$ Forjados $\square$ Cubierta

Observaciones

FOTOGRAFÍAS DE LA INTERVENCIÓN
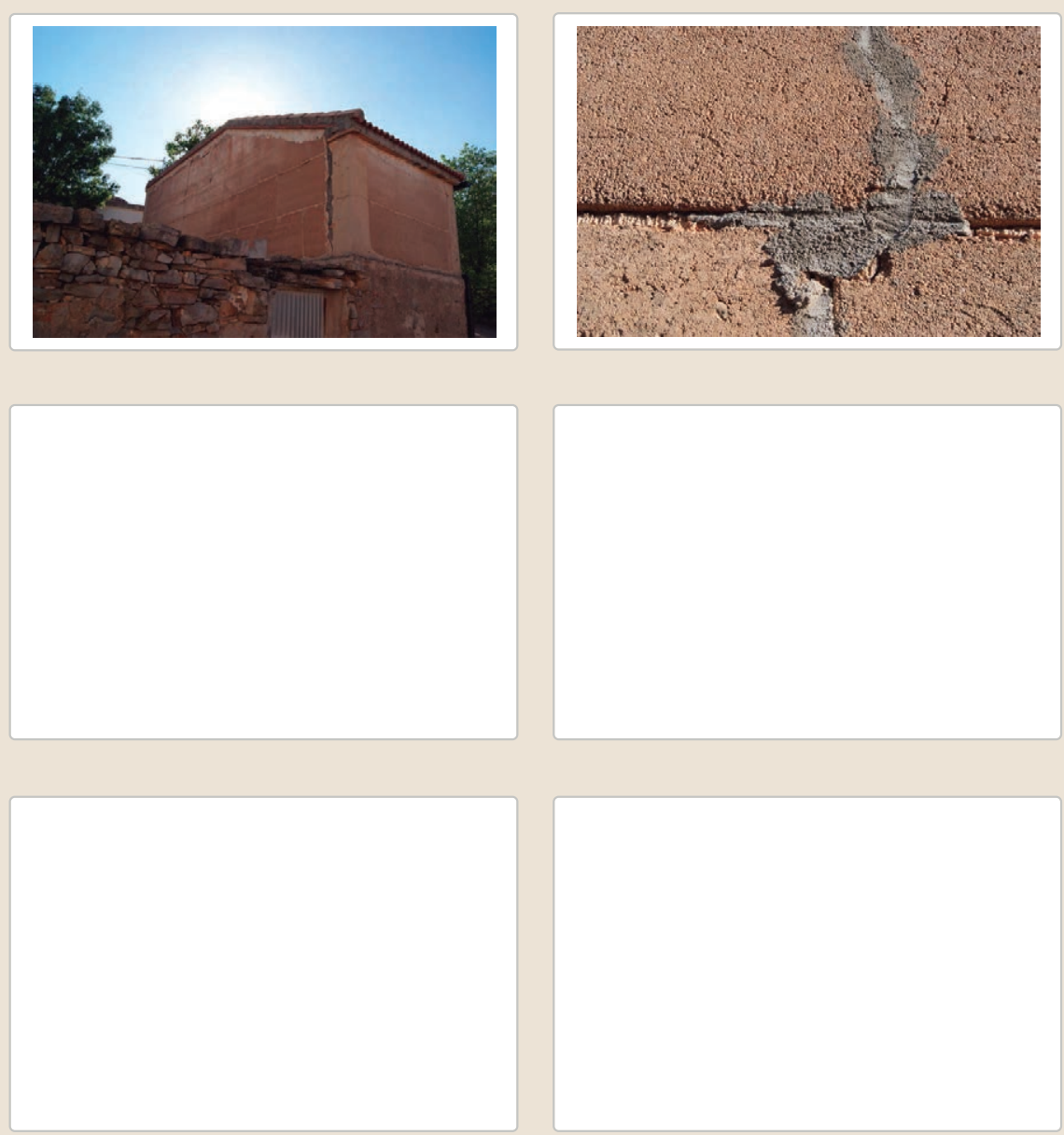

3.6. OTRAS 


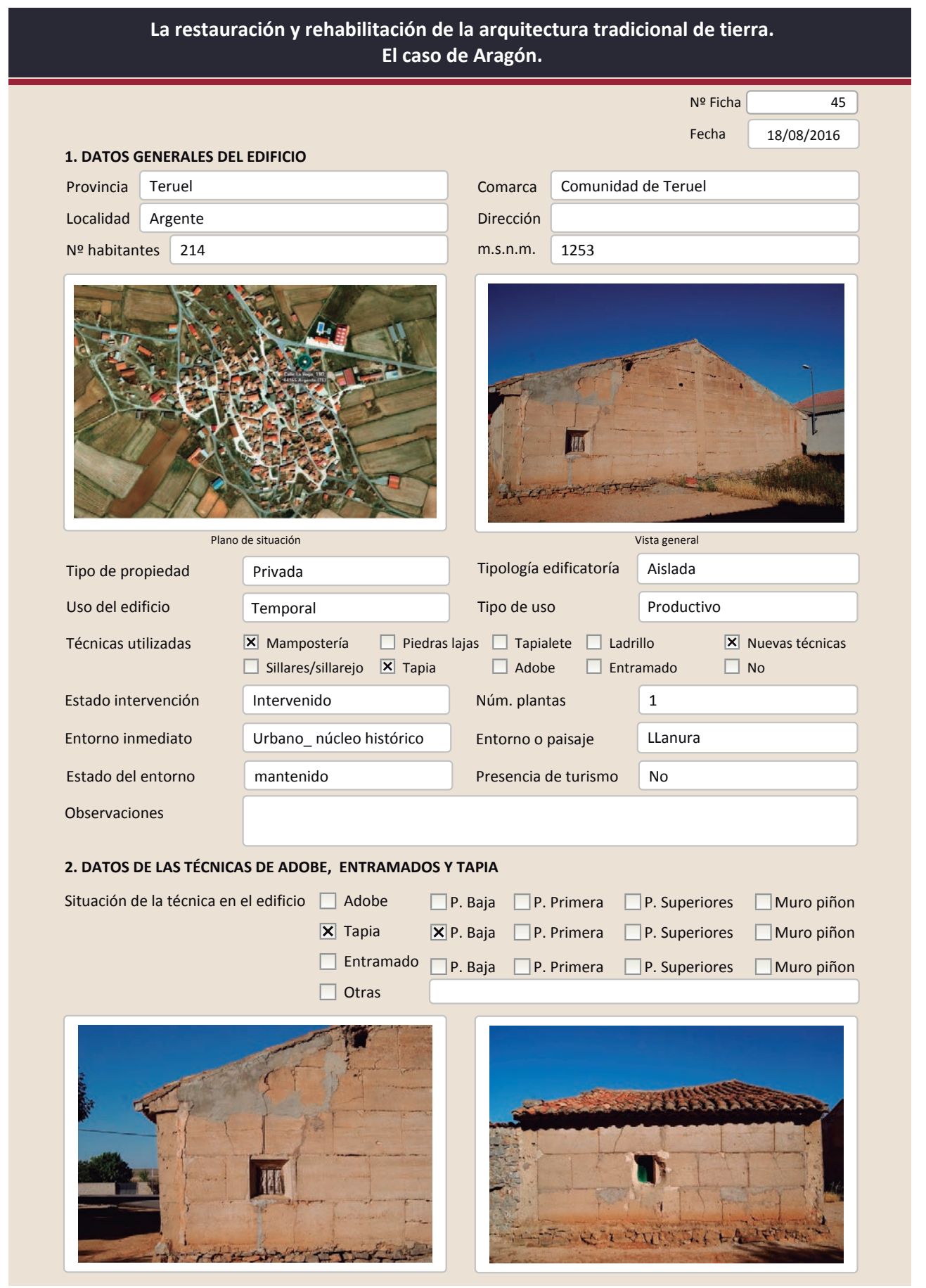

La restauración y rehabilitación de la arquitectura tradicional de tierra. El caso de Aragón.

2.2. TAPIA

Ancho del muro

Dimensión tapiales

Tipo de aguja

\begin{tabular}{|l|}
\hline $40-50 \mathrm{~cm}$ \\
\hline $118 \times 73$ \\
\hline Redonda \\
\hline
\end{tabular}

Color de la tapia

№ agujas/cajón

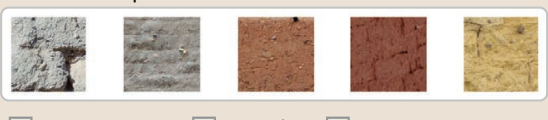

X Blanquecino $\square$ Marrón $\square$ Amarillento

$\mathbf{x}$ Blanquecino $\square$ Marrón $\square$ Amari.
$\square$ Grisaceo

Variante constructiva

$\square$ Simple / homogénea

X Suplemento superficial

$\mathbf{X}$ Suplemento en juntas

X Mixta

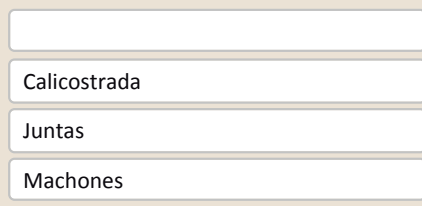

Cal/yeso

Mampostería y yeso

$\square$ Elementos de protección

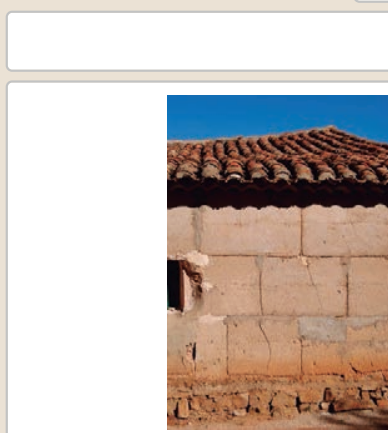

Lesiones

× Muro $\square$ Zócalo $\square$ Revestimiento

$\square$ Erosión del material $\square$ Humedad por capilaridad

$\square$ Erosion de las juntas $\square$ Humedades (manch/eflo)

$\square$ Pérdida de sección $\quad$ X Pérdida de verticalidad

$\square$ Vegetación $\quad \square$ Grietas por empuje de la cubierta

X Desconchados

$\square$ Grietas porfalta de traba

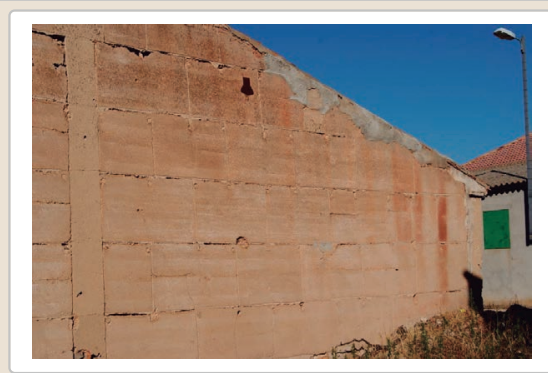

X Cubierta $\square$ Otro...

$\boldsymbol{X}$ Grietas por asentamientos

$\square$ Colapso

$\square$ Por elementos impropios

$\square$ Derivado de intervenciones
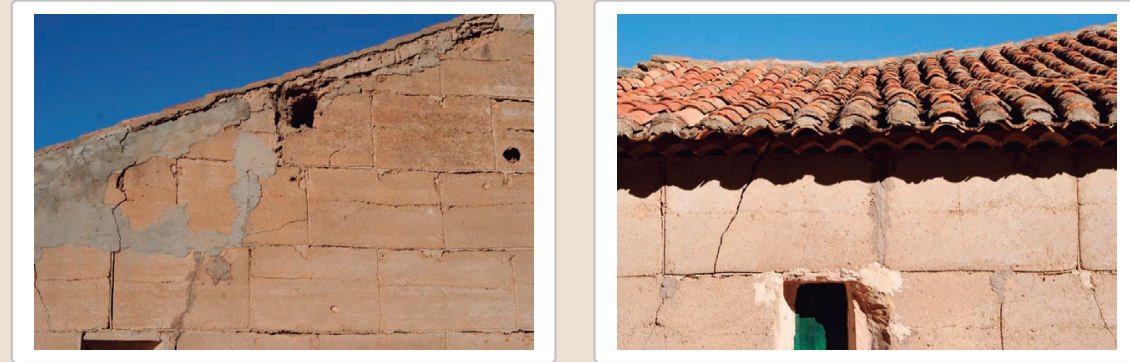

Observaciones

Se aprecian oquedades producidas por la pérdida de la costra de la tapia así como grietas producidas por el asentamiento en el terreno y que ademas producen una 


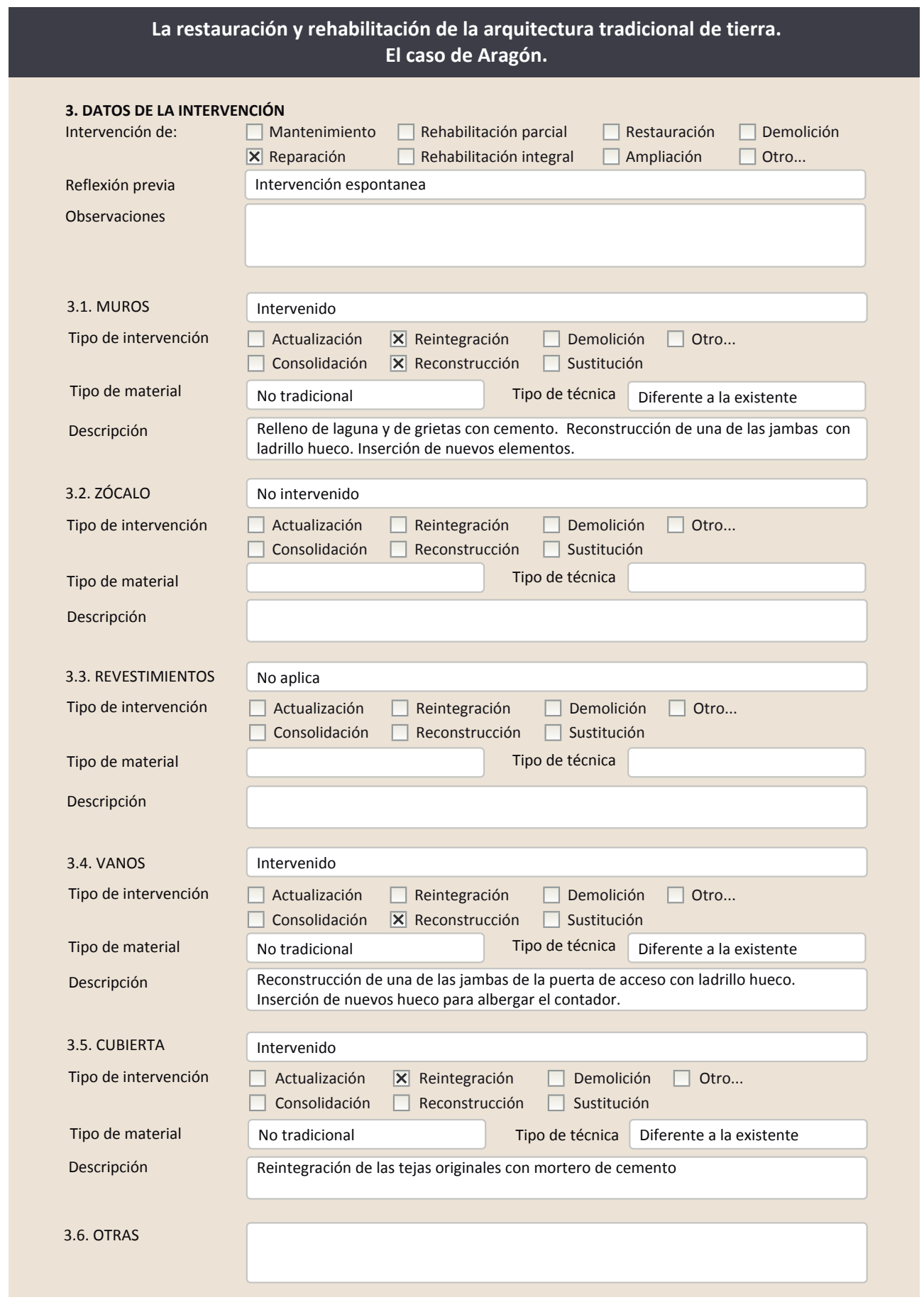

\subsection{REHABILITACIÓN ENERGÉTICA $\quad \square$ Fachada $\square$ Vanos $\square$ Forjados $\square$ Cubierta}

Observaciones

FOTOGRAFÍAS DE LA INTERVENCIÓN
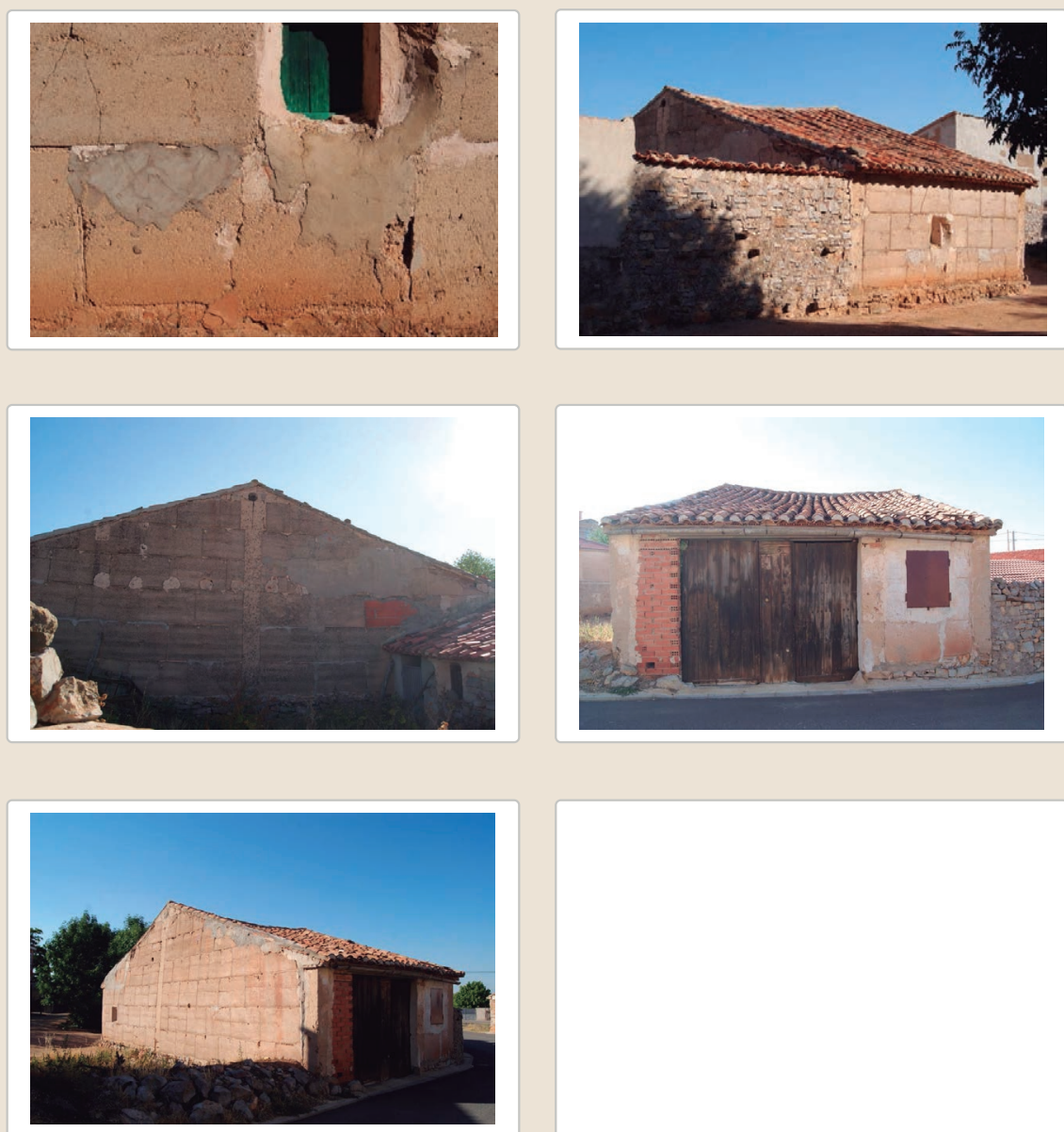


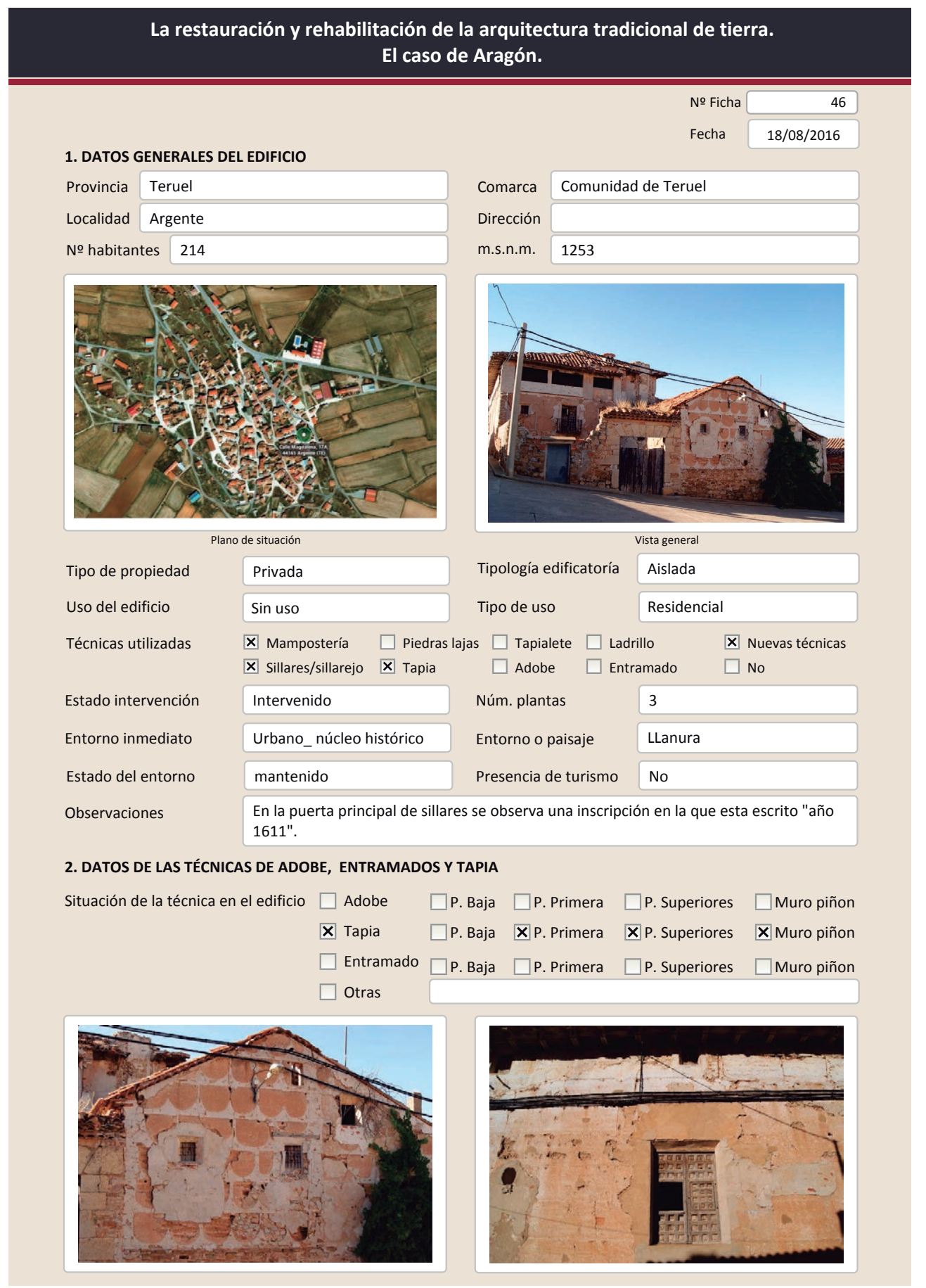

La restauración y rehabilitación de la arquitectura tradicional de tierra. El caso de Aragón.

2.2. TAPIA

Ancho del muro

Dimensión tapiales

Tipo de aguja

\begin{tabular}{|l|}
\hline $40-50 \mathrm{~cm}$ \\
\hline \\
\hline Redonda \\
\hline 3 \\
\hline
\end{tabular}

Color de la tapia

№ agujas/cajón

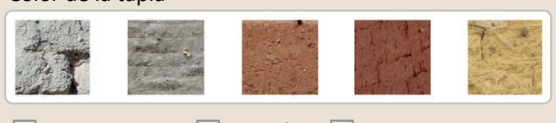

$\square$ Blanquecino $\quad$ X Marrón $\square$ Amarillento

Variante constructiva

$\square$ Simple / homogénea

X Suplemento superficial

$\mathbf{X}$ Suplemento en juntas

X Mixta
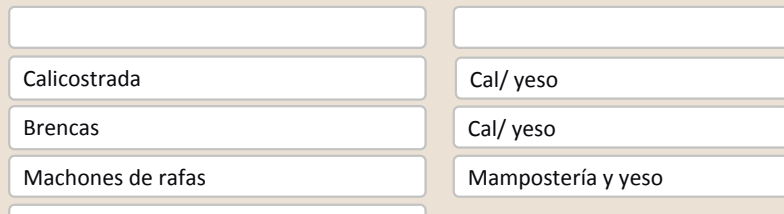

$\square$ Elementos de protección

El edificio es muy grande por lo que aparecen distintas variantes en todo el conjunto

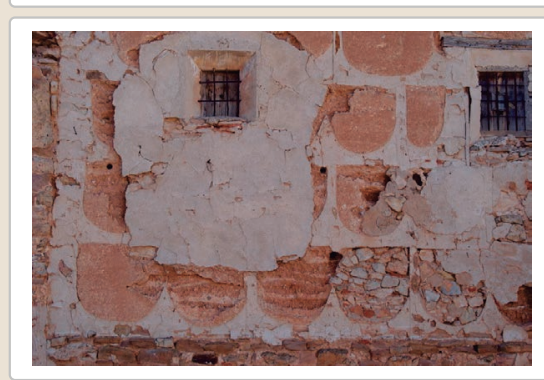

Lesiones $\quad \mathbf{X}$ Muro $\square$ Zócalo $\mathbf{X}$ Revestimiento $\mathbf{X}$ Erosión del material $\quad \square$ Humedad por capilaridad $\square$ Erosion de las juntas $\square$ Humedades (manch/eflo) X Pérdida de sección $\quad \square$ Pérdida de verticalidad

$\square$ Vegetación X Desconchados
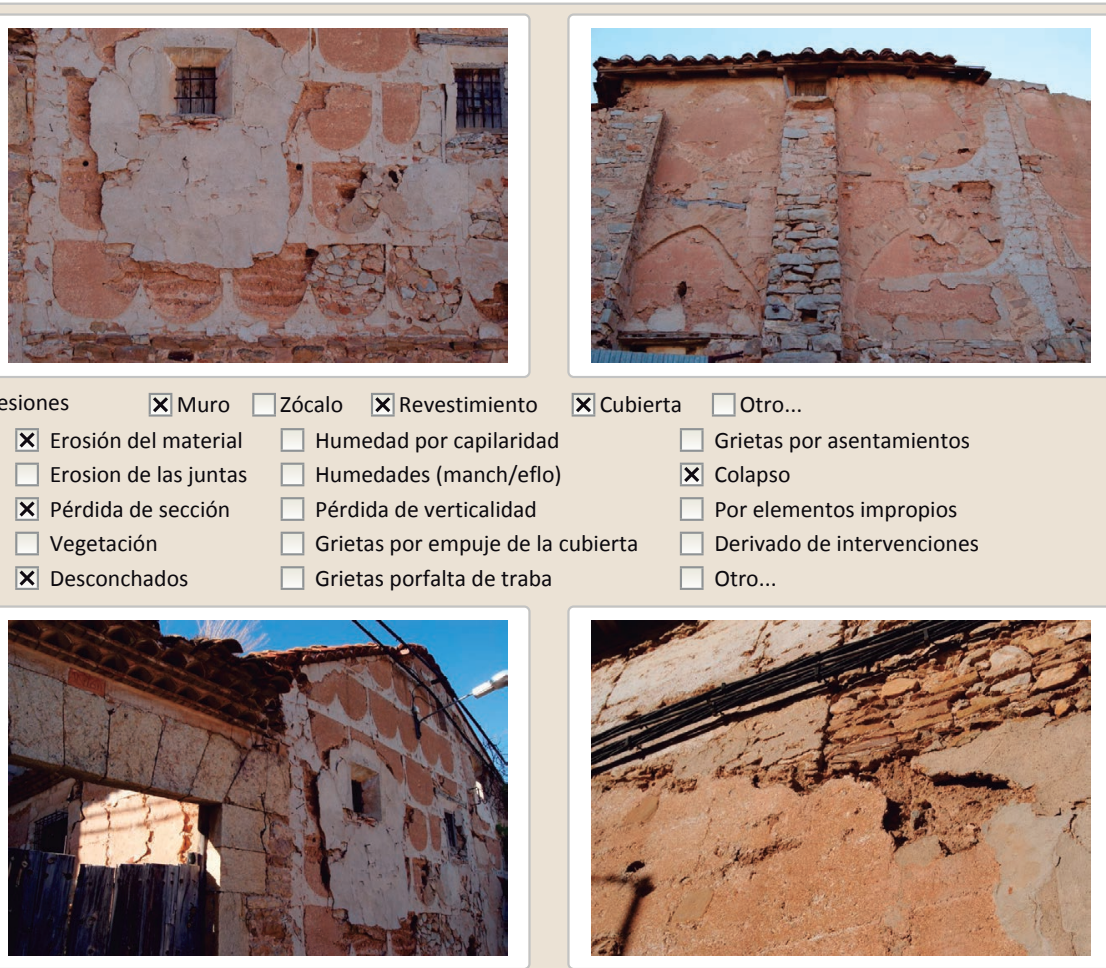

X Cubierta $\square$ Otro...

$\square$ Grietas por asentamientos X Colapso

$\square$ Por elementos impropios

$\square$ Derivado de intervenciones $\square$ Otro...

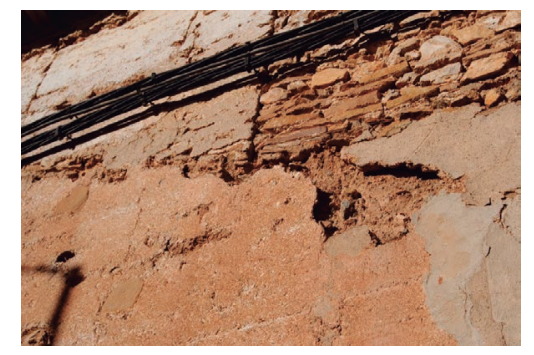

Observaciones desencadenan degradaciones mayores. 


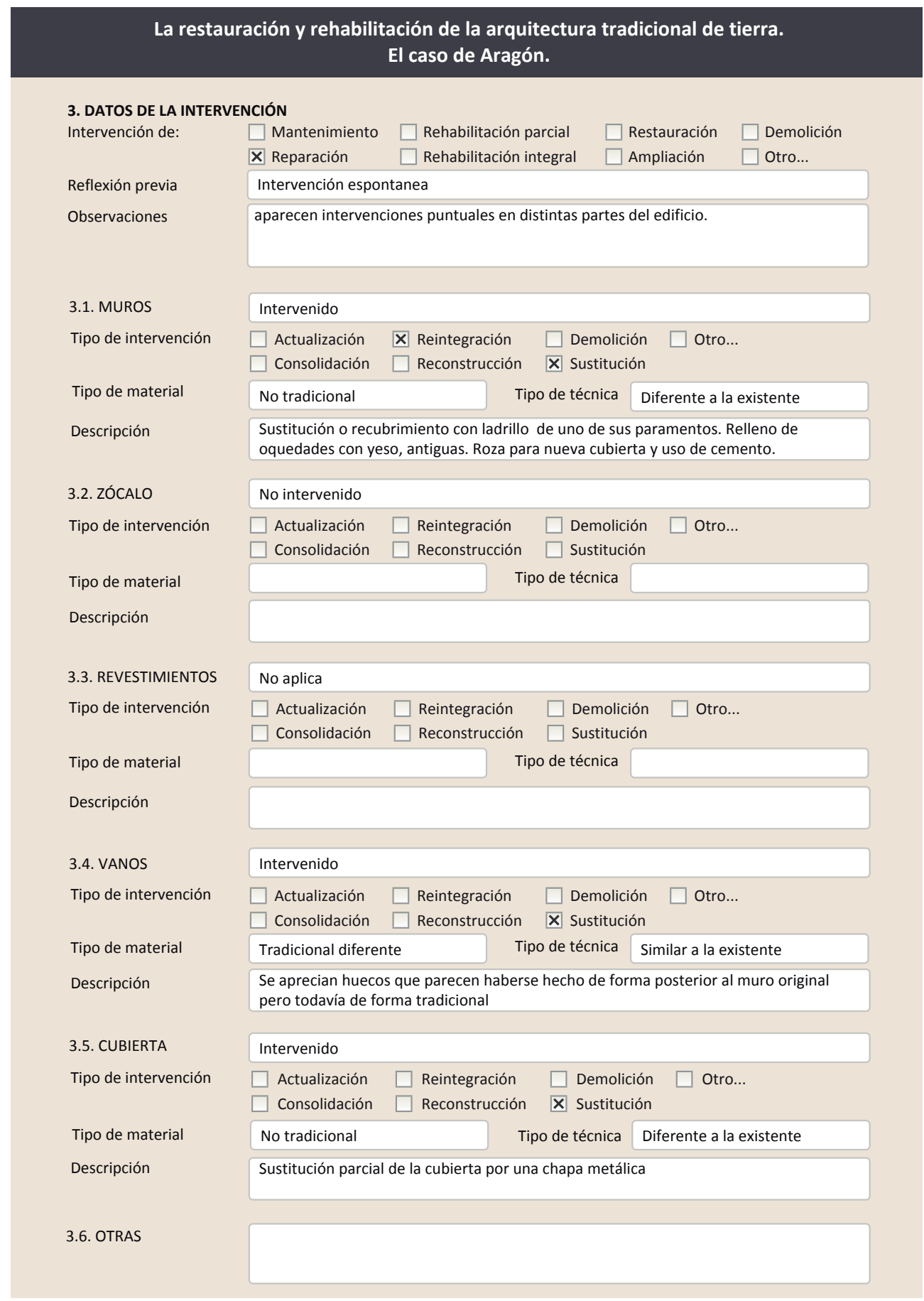

3.7. REHABILITACIÓN ENERGÉTICA $\quad \square$ Fachada $\square$ Vanos $\square$ Forjados $\square$ Cubierta Observaciones

FOTOGRAFíAS DE LA INTERVENCIÓN
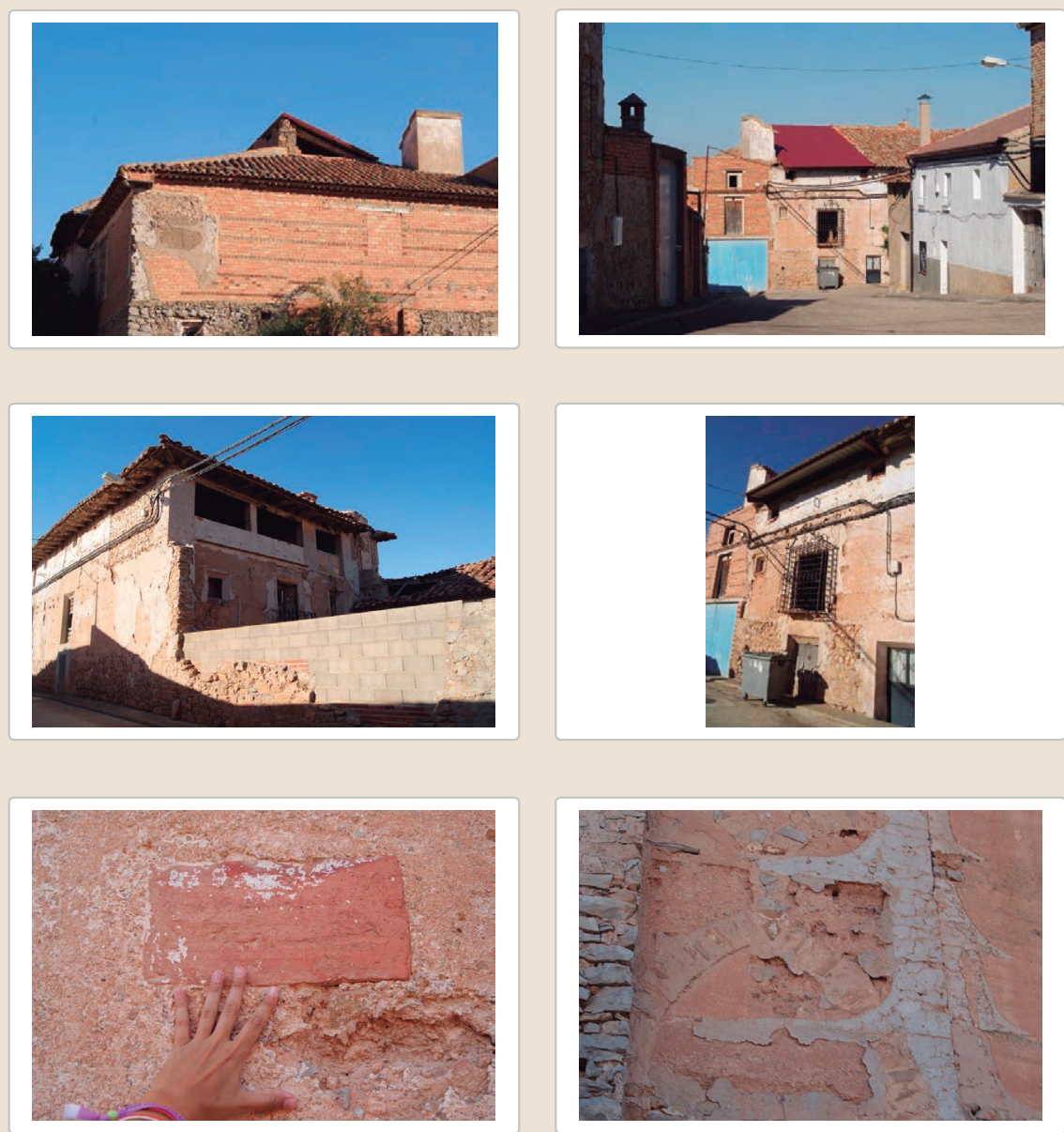


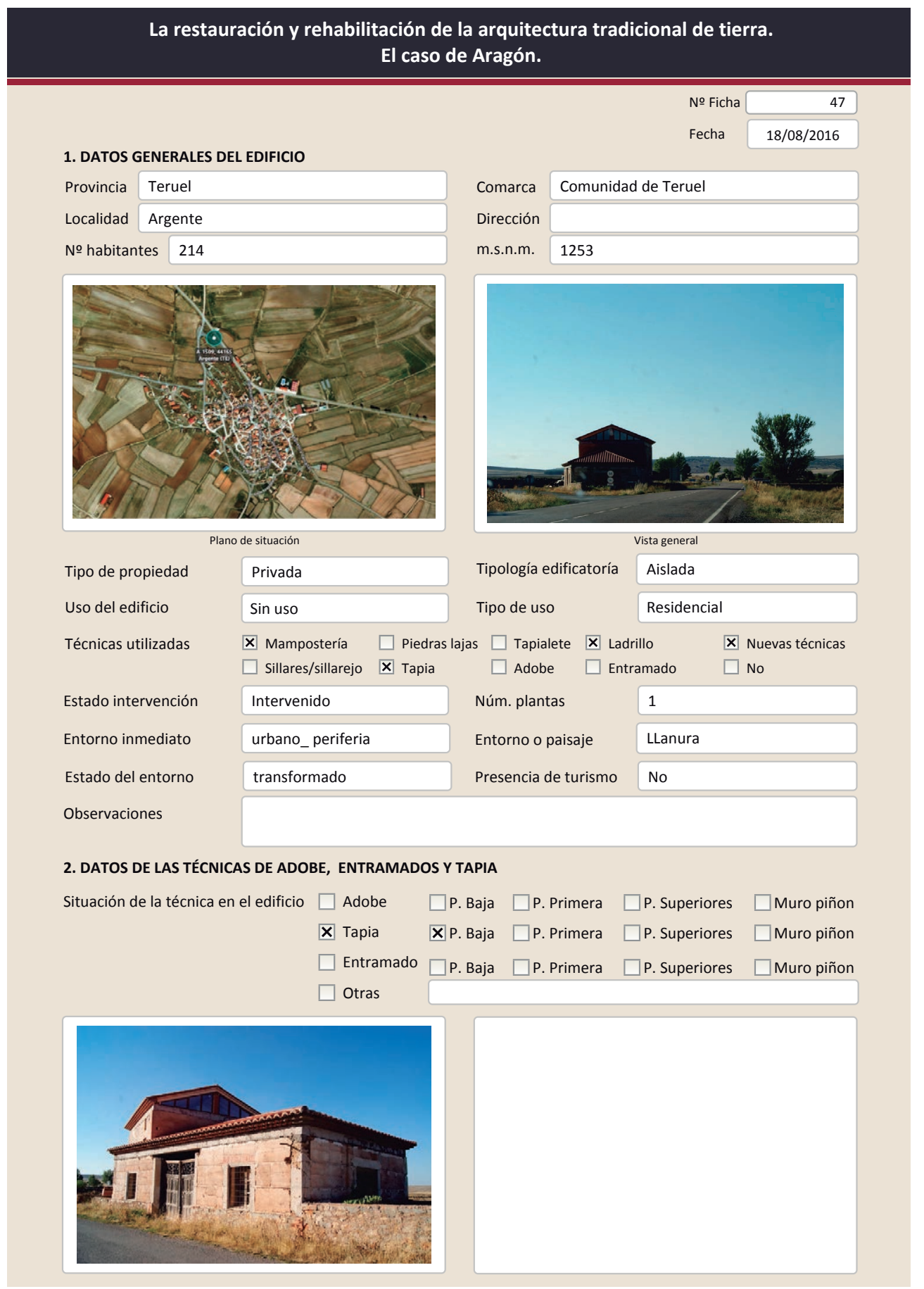

La restauración y rehabilitación de la arquitectura tradicional de tierra. El caso de Aragón.

2.2. TAPIA

Ancho del muro

Dimensión tapiales

Tipo de aguja

\begin{tabular}{|l|}
\hline $40-50 \mathrm{~cm}$ \\
\hline \\
\hline Redonda \\
\hline 3 \\
\hline
\end{tabular}

Color de la tapia

№ agujas/cajón

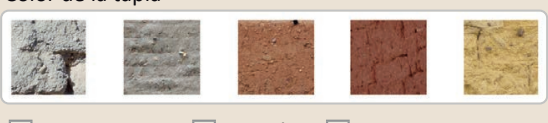

X Blanquecino $\square$ Marrón $\square$ Amarillento

$\mathbf{x}$ Blanquecino $\square$ Marrón
$\square$ Grisaceo

Variante constructiva

$\square$ Simple / homogénea

$\mathbf{X}$ Suplemento superficial

$\boldsymbol{X}$ Suplemento en juntas

X Mixta

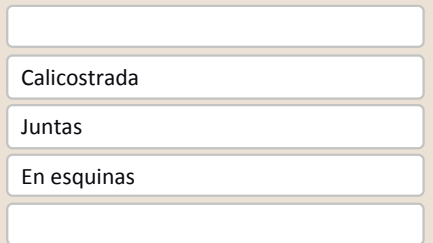

\section{Cal/ yeso}

$\mathrm{Cal} /$ yeso

$\square$ Elementos de protección

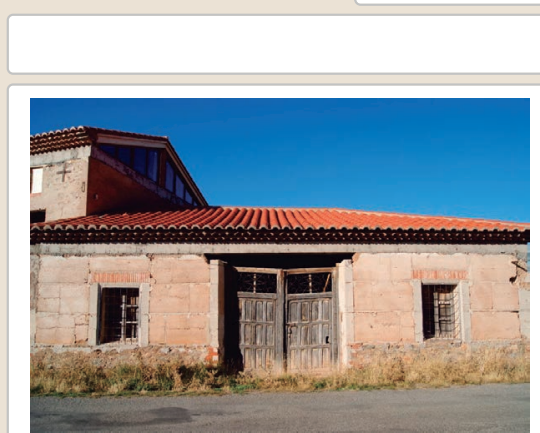

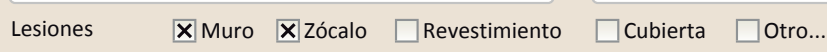

$\square$ Erosión del material $\quad \square$ Humedad por capilaridad $\quad \square$ Grietas por asentamientos

$\square$ Erosion de las juntas $\square$ Humedades (manch/eflo)

$\square$ Pérdida de sección $\square$ Pérdida de verticalidad

$\square$ Vegetación

$\square$ Por elementos impropios

X Desconchado

$\square$ Grietas porfalta de traba

$\square$ Derivado

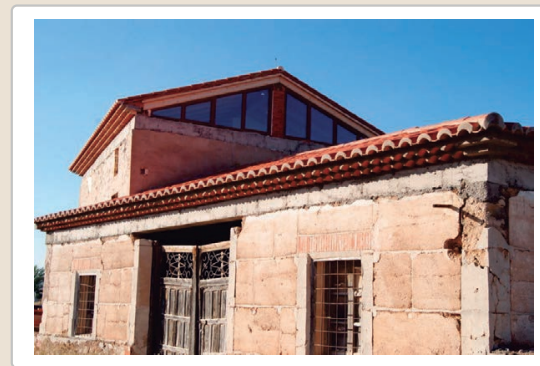

Observaciones 


\section{La restauración y rehabilitación de la arquitectura tradicional de tierra.} El caso de Aragón.

3. DATOS DE LA INTERVENCIÓN

$\square$ Manteni

$\square$ Restauración $\square$ Demolición

Reflexión previa Intervención planificada

Observaciones Nueva cubierta sobre zuncho de hormigó

3.1. MUROS
Tipo de intervención

\section{Intervenido}

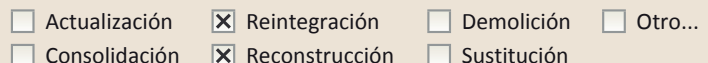

Tipo de material

Descripción

No tradicional

Tipo de técnica Diferente a la existente

3.2. ZÓCALO

Tipo de intervención Reconstrucción

Tipo de material

Intervenido

$\square$ Actualización $\quad \mathbf{X}$ Reintegración $\square$ Demolición $\square$ Otro...

$\square$ Consolidación $\square$ Reconstrucción $\square$ Sustitución

Descripción

3.3. REVESTIMIENTOS

Tipo de intervención

Tipo de técnica Diferente a la existente

Reparación de oquedades utilizando mortero de cemento o ladrillo hueco en zonas puntuales.

Tipo de material

Descripción

3.4. VANOS

Tipo de intervención

Tipo de material

Descripción

3.5. CUBIERTA

Tipo de intervención

Intervenido

$\square$ Actualización $\quad \square$ Reintegración $\quad \square$ Demolición $\square$ Otro...

$\square$ Consolidación $\square$ Reconstrucción $\square$ Sustitución

\section{No intervenido}

$\square$ Actualización $\square$ Reintegración $\square$ Demolición $\square$ Otro...

$\square$ Consolidación $\square$ Reconstrucción $\square$ Sustitución

\section{Tipo de material}

$\square$ Actualización

$\square$ Consolidación

$\square$ Reintegració

Descripción

Tipo de técnica Diferente a la existente

Nueva cubierta sobre zuncho de hormigón de unos $30 \mathrm{~cm}$ de alto. La cubierta se ha realizado con alero de tejas curvas.
La restauración y rehabilitación de la arquitectura tradicional de tierra.

El caso de Aragón.

3.7. REHABILITACIÓN ENERGÉTICA $\quad \square$ Fachada $\square$ Vanos $\square$ Forjados $\square$ Cubierta

Observaciones

FOTOGRAFÍAS DE LA INTERVENCIÓN
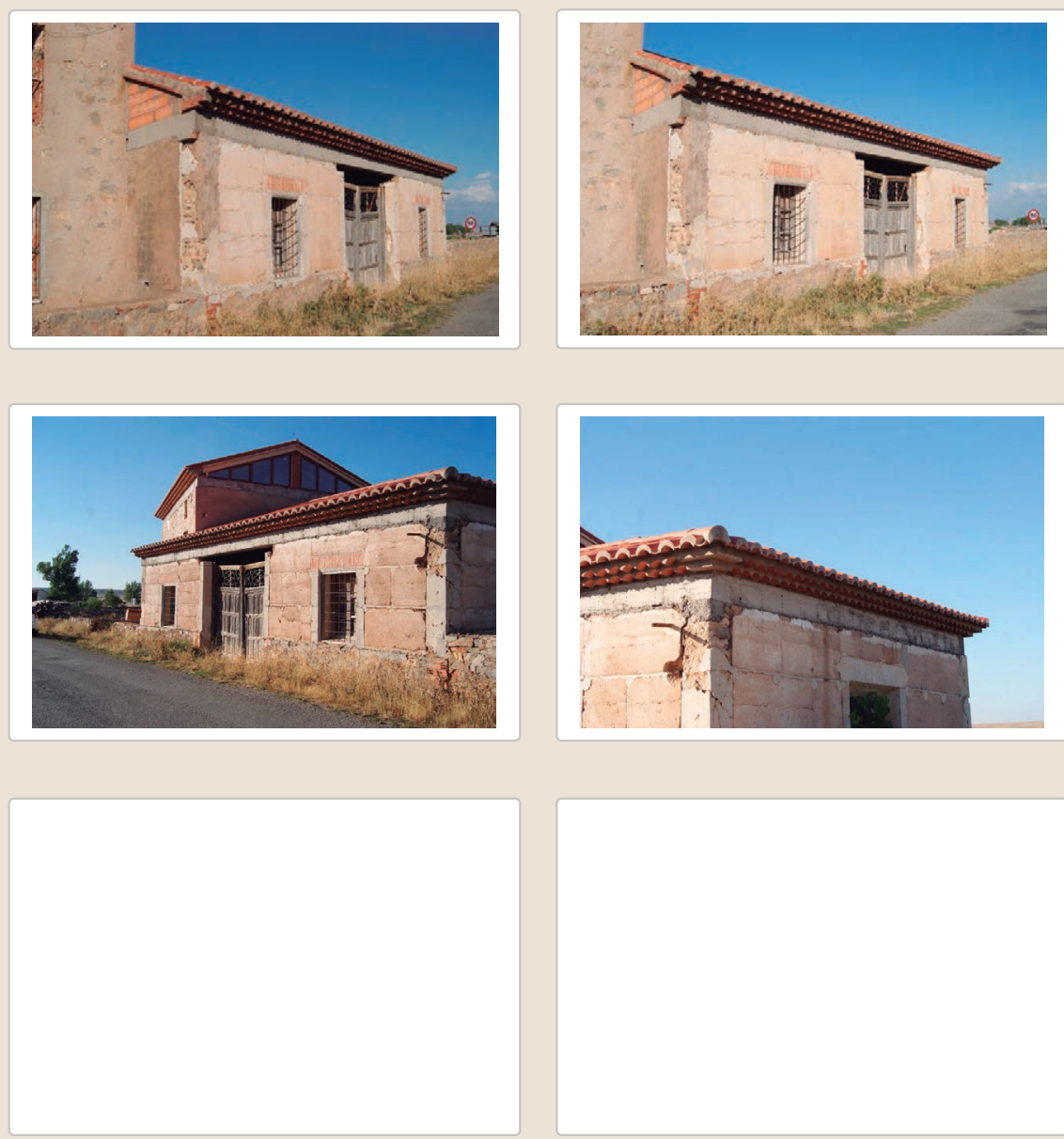

3.6. OTRAS 


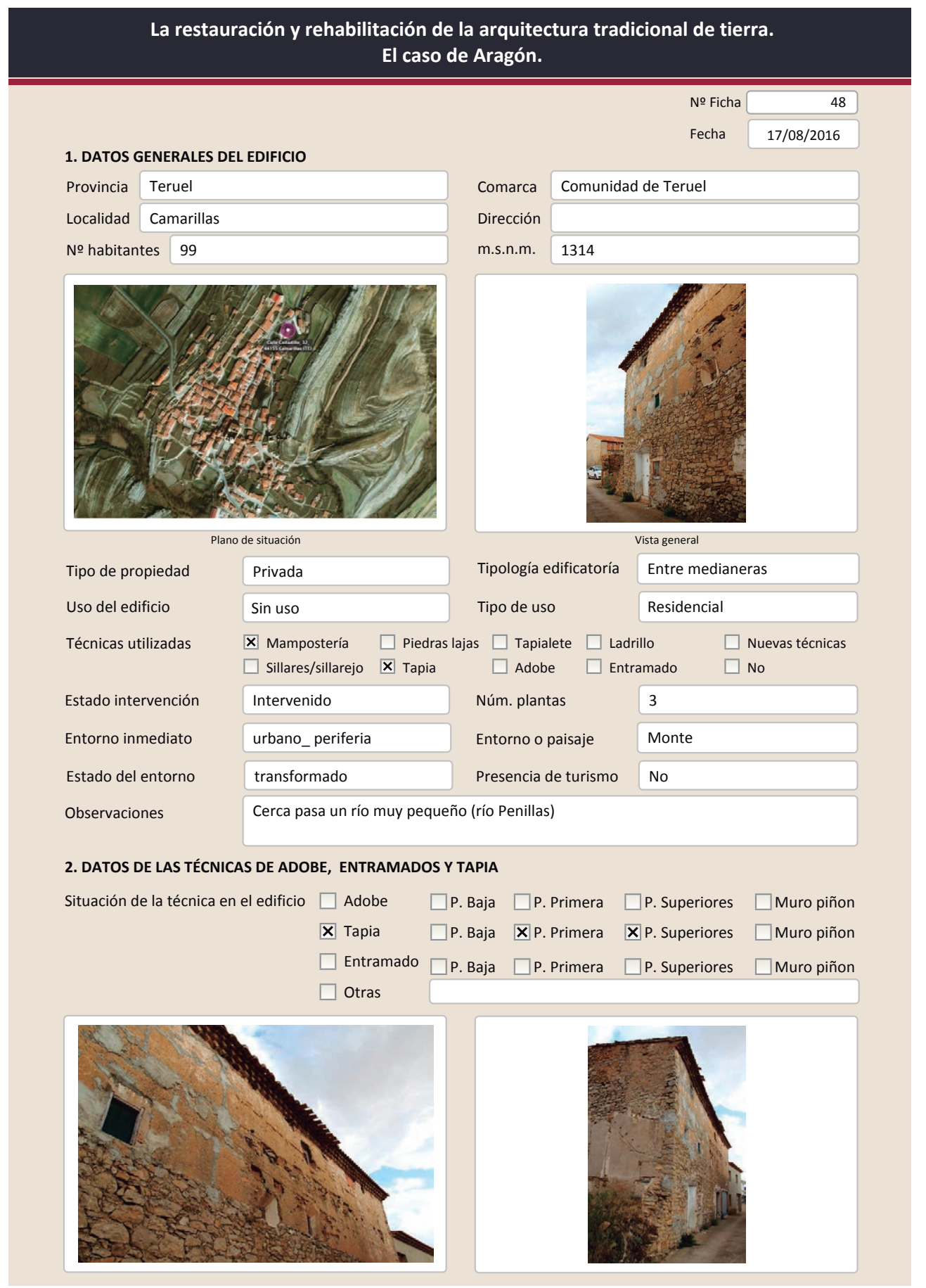

La restauración y rehabilitación de la arquitectura tradicional de tierra. El caso de Aragón.

2.2. TAPIA

Ancho del muro

Dimensión tapiales

Tipo de aguja

№ agujas/cajón

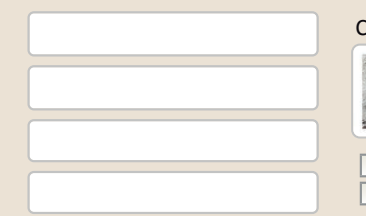

Color de la tapia

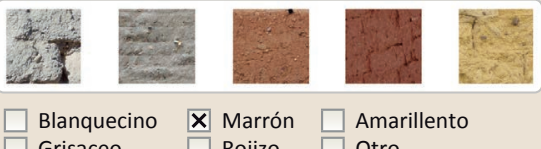

Variante constructiva

$\square$ Simple / homogénea

X Suplemento superficial

$\square$ suplemento en juntas

$\square$ Mixta

$\square$ Elementos de protección

EL muro piñón es de piedra

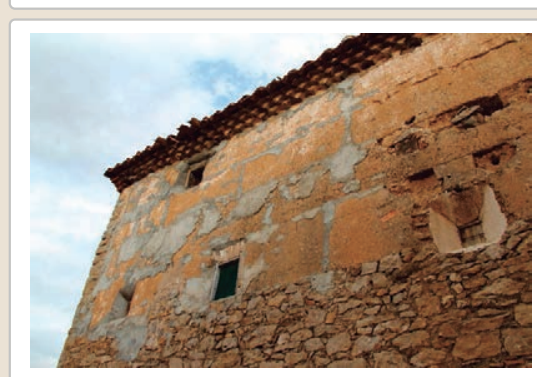

Lesiones $\quad$ M Muro $\square$ Zócalo $\square$ Revestimiento $\square$ Cubierta $\square$ otro...

X Erosión del material $\quad \square$ Humedad por capilaridad $\quad \square$ Grietas por asentamiento $\mathbf{X}$ Erosion de las juntas $\square$ Humedades (manch/eflo)

$\square$ Pérdida de sección $\quad \square$ Pérdida de verticalidad

$\square$ Vegetación

X Desconchados

$\square$ Grietas porfalta de traba
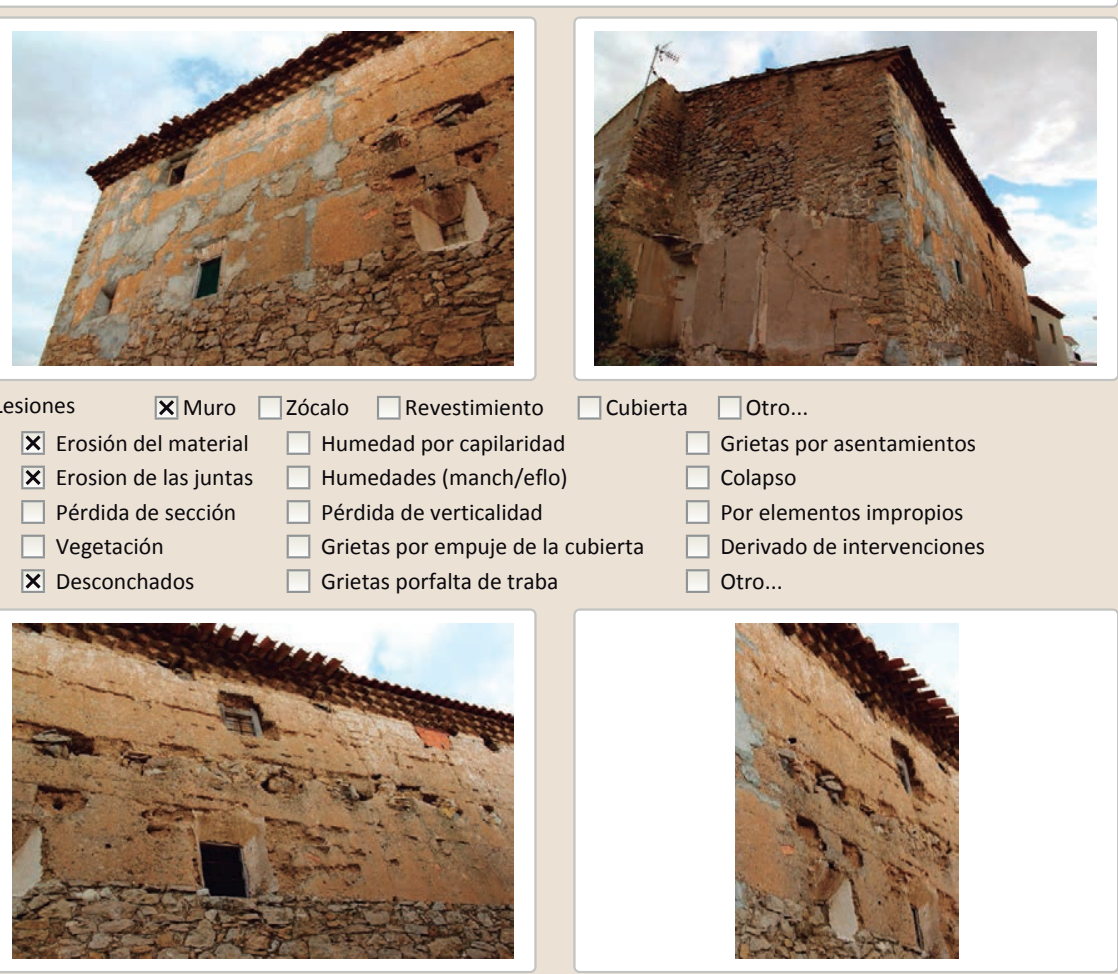

$\square$ Por elementos impropios

$\square$ Derivado de intervenciones $\square$ Otro...

Observaciones 


\section{La restauración y rehabilitación de la arquitectura tradicional de tierra.}

\section{El caso de Aragón.}

3. DATOS DE LA INTERVENCIÓN

Mantenimiento $\square$ Rehabilitación parcial

$\square$ Restauración $\square$ Demolición

Reflexión previa

X Reparación

Rehabilitación integr

$\square$ Ampliación

$\square$ Otro...

Reflexion previa
Observaciones

Intervención espontanea

Observaciones

3.1. MUROS

Tipo de intervención

Tipo de material

Descripción

3.2. ZÓCALO

Tipo de intervención

Tipo de material

Descripción

3.3. REVESTIMIENTOS

Tipo de intervención

Tipo de material

Descripción

3.4. VANOS

Tipo de intervención

Tipo de material

Descripción

3.5. CUBIERTA

Tipo de intervención

Tipo de material

Descripción

Intervenido

$\square$ Actualización $\quad$ Reintegración $\square$ Demolición $\square$ Otro...

$\square$ Consolidación $\quad \square$ Reconstrucción $\quad \square$ Sustitución

\begin{tabular}{|l|l|l|l} 
No tradicional Tipo de técnica Diferente a la existente \\
\hline Ren
\end{tabular}

Relleno de las oquedades presentes con mortero de cemento. Existen otras intervenciones más antiguas con relleno de piedras.

No intervenido

$\square$ Actualización $\square$ Reintegración $\square$ Demolición $\square$ Otro..

$\square$ Consolidación $\quad \square$ Reconstrucción $\quad \square$ Sustitución

Tipo de técnica

\section{No aplica}

$\square$ Actualización $\square$ Reintegración $\quad \square$ Demolición $\square$ Otro...

$\square$ Consolidación $\square$ Reconstrucción $\square$ Sustitución

Tipo de técnica

Intervenido

$\square$ Actualización $\quad \boldsymbol{X}$ Reintegración $\square$ Demolición $\square$ Otro...

$\square$ Consolidación $\square$ Reconstrucción $\quad \mathbf{x}$ Sustitución

No tradicional Tipo de técnica Diferente a la existente

Relleno de las oquedades presentes alrededor de las vanos con mortero de cemento.

Ampliación del hueco de acceso en planta baja. Cambio carpinterías

Intervenido

$\square$ Actualización $\quad \boldsymbol{X}$ Reintegración $\square$ Demolición $\square$ Otro.

$\square$ Consolidación $\mathbf{X}$ Reconstrucción $\square$ Sustitución

\begin{tabular}{|l|l|l|l}
\hline No tradicional Tipo de técnica Similar a la existente \\
\hline
\end{tabular}

Retejado en algunas zonas y reintegración de tejas con mortero de cemento en ambos casos
La restauración y rehabilitación de la arquitectura tradicional de tierra.

El caso de Aragón.

3.7. REHABILITACIÓN ENERGÉTICA $\square$ Fachada $\square$ Vanos $\square$ Forjados $\square$ Cubierta

Observaciones

FOTOGRAFÍAS DE LA INTERVENCIÓN
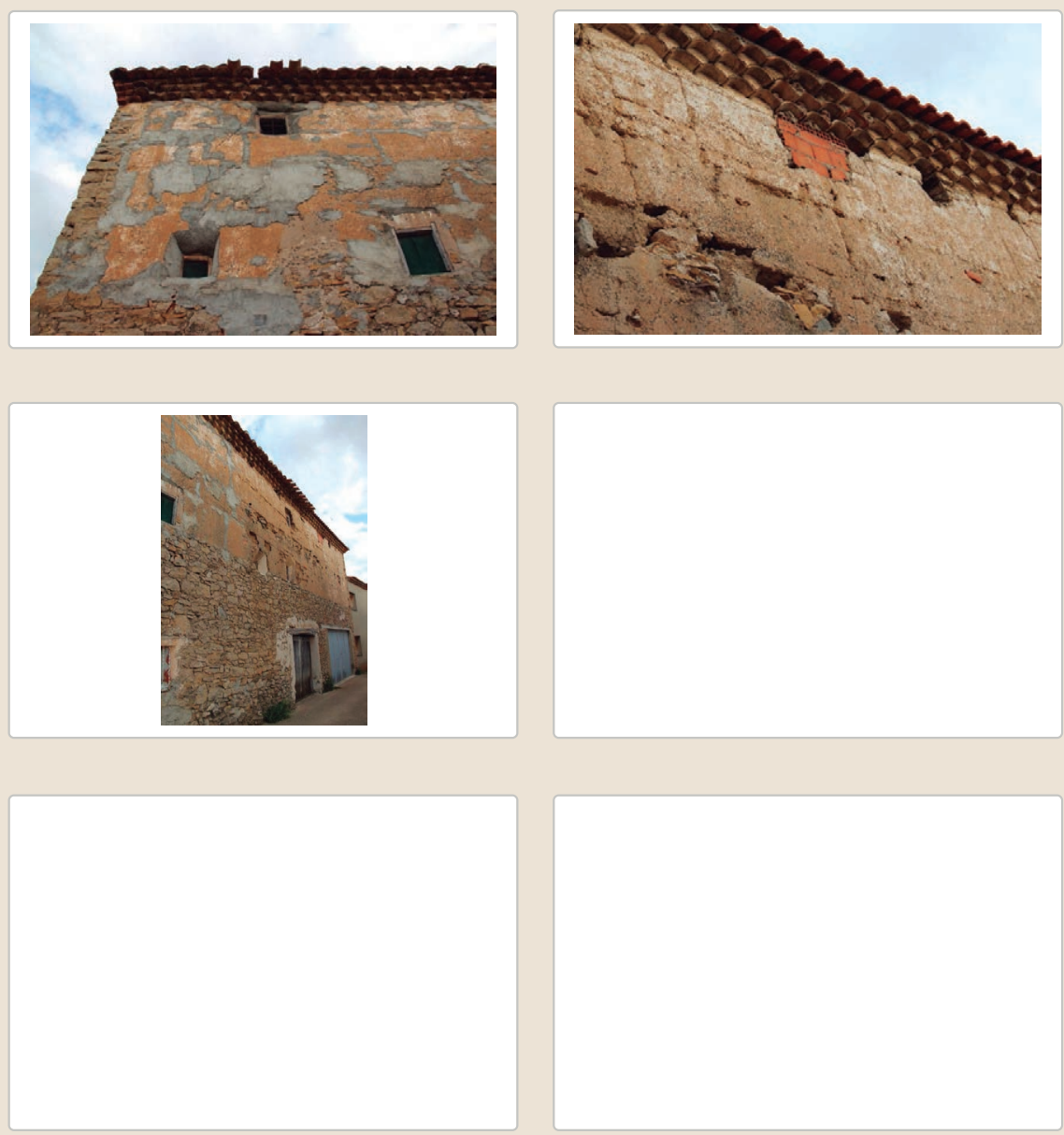

3.6. OTRAS 


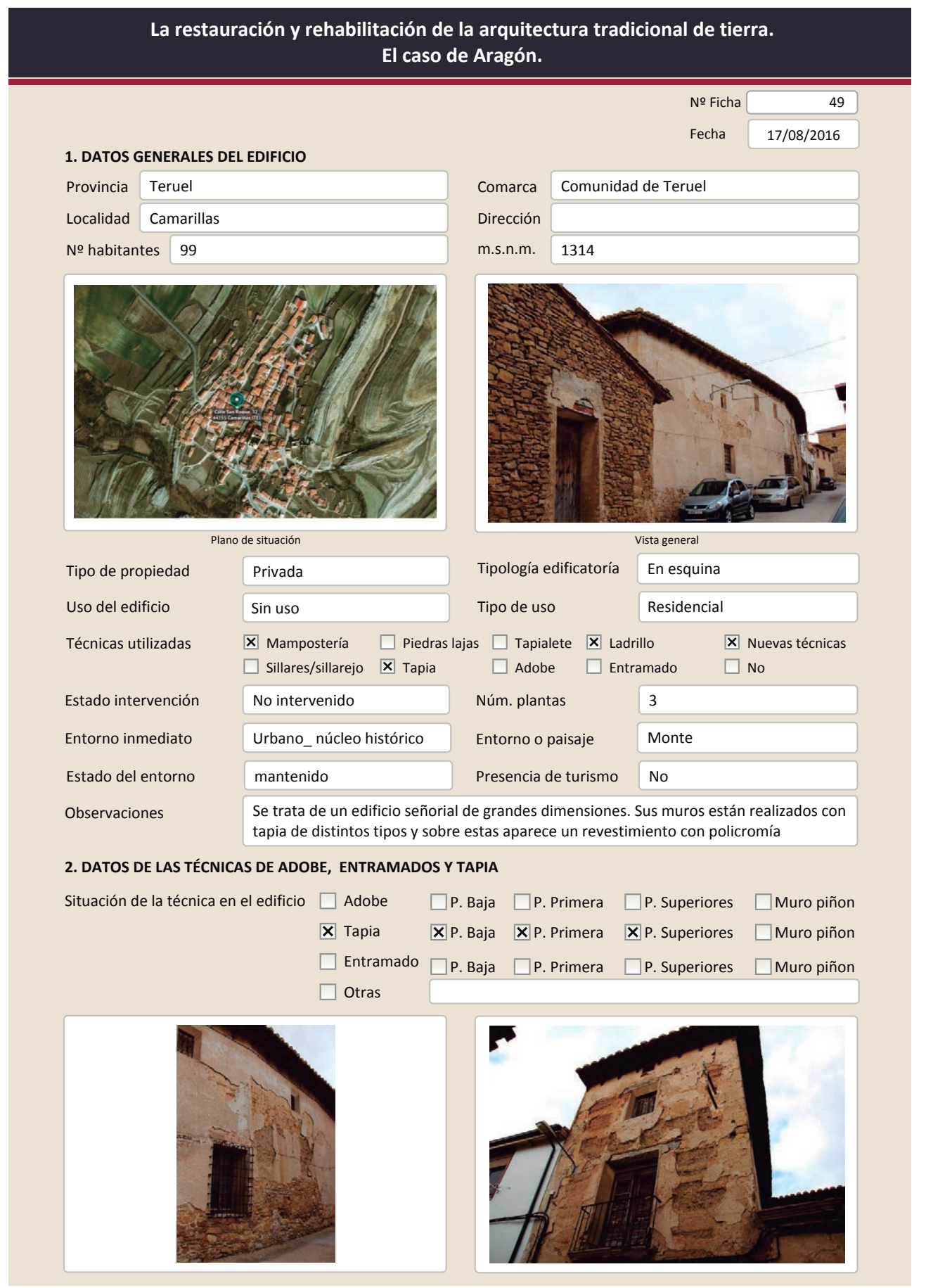

La restauración y rehabilitación de la arquitectura tradicional de tierra. El caso de Aragón.
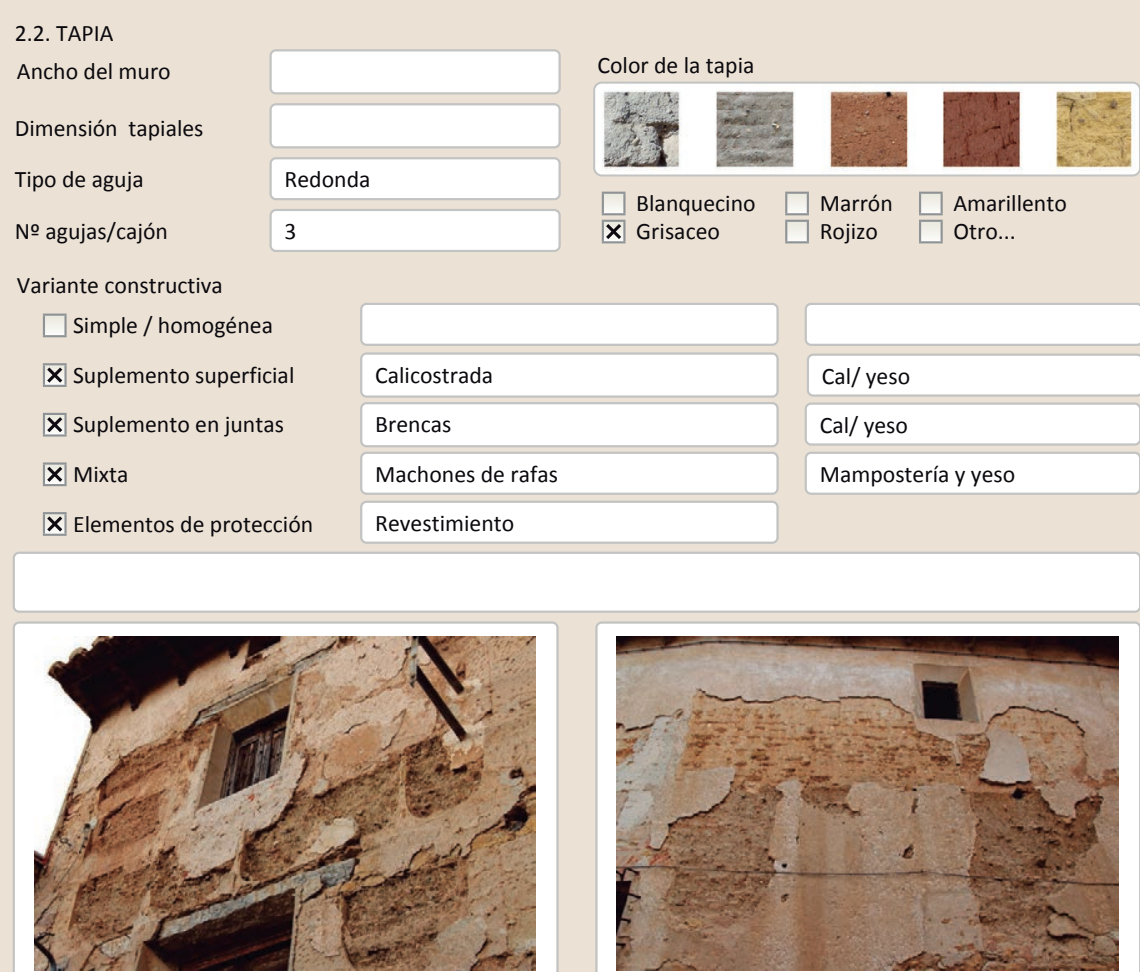

Lesiones $\quad$ M Muro $\square$ Zócalo $\quad$ Xevestimiento $\square$ Cubierta $\square$ otro...

X Erosión del material $\quad \square$ Humedad por capilaridad $\quad \square$ Grietas por asentamiento $\mathbf{X}$ Erosion de las juntas $\square$ Humedades (manch/eflo) $\quad \square$ Colapso

$\square$ Pérdida de sección $\square$ Pérdida de verticalidad

$\square$ Vegetación

Por elementos impropios

X Desconchados $\square$ Grietas porfalta de traba

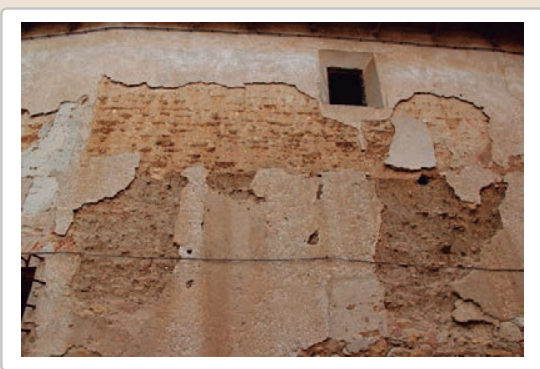

$\square$ Derivado de intervenciones
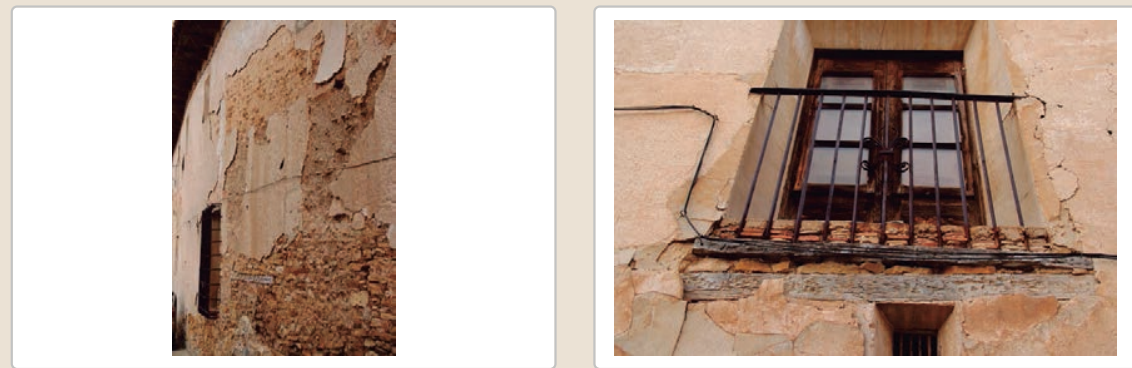

Observaciones

Perdida del revestimiento exterior que posee pinturas y fingidos 
La restauración y rehabilitación de la arquitectura tradicional de tierra. El caso de Aragón

\section{La restauración y rehabilitación de la arquitectura tradicional de tierra.}

$$
\text { El caso de Aragón. }
$$
3.7. REHABILITACIÓN ENERGÉTICA
$\square$ Fachada $\square$ Vanos $\square$ Forjados $\square$ Cubierta

Observaciones

FOTOGRAFÍAS DE LA INTERVENCIÓN
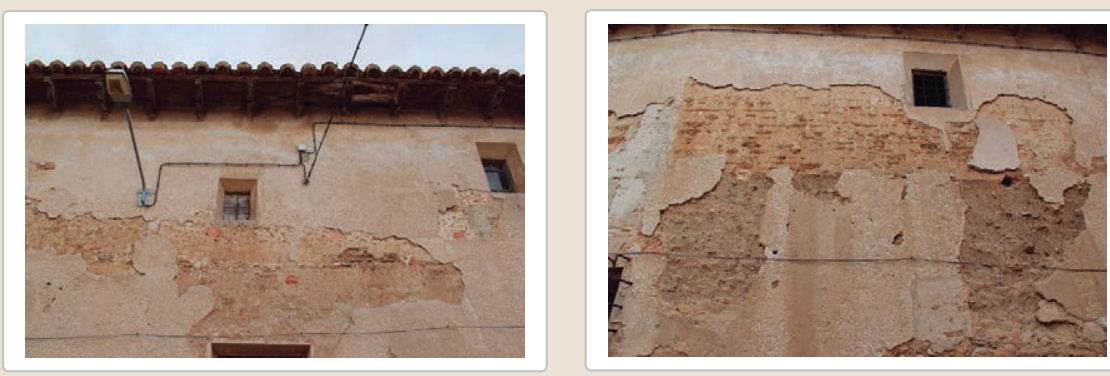

Dos tipos diferentes de tapia. Tonalidad diferente

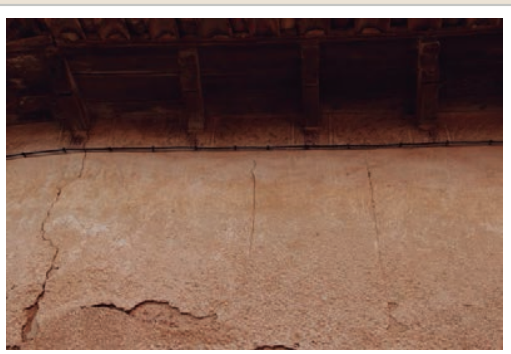

Dealle policromia bajo el alero

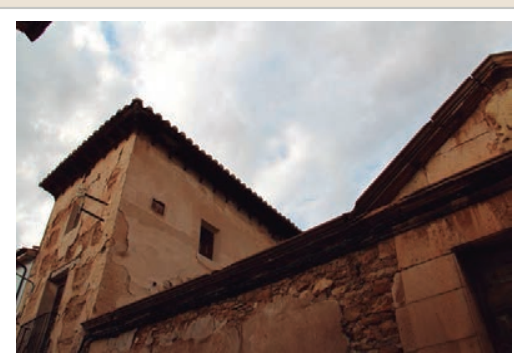

Lateral con tapia con brencas de yeso
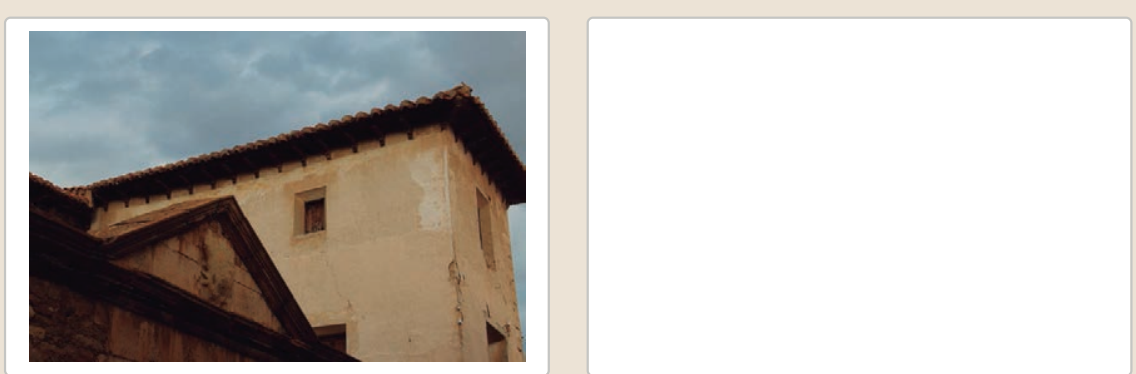


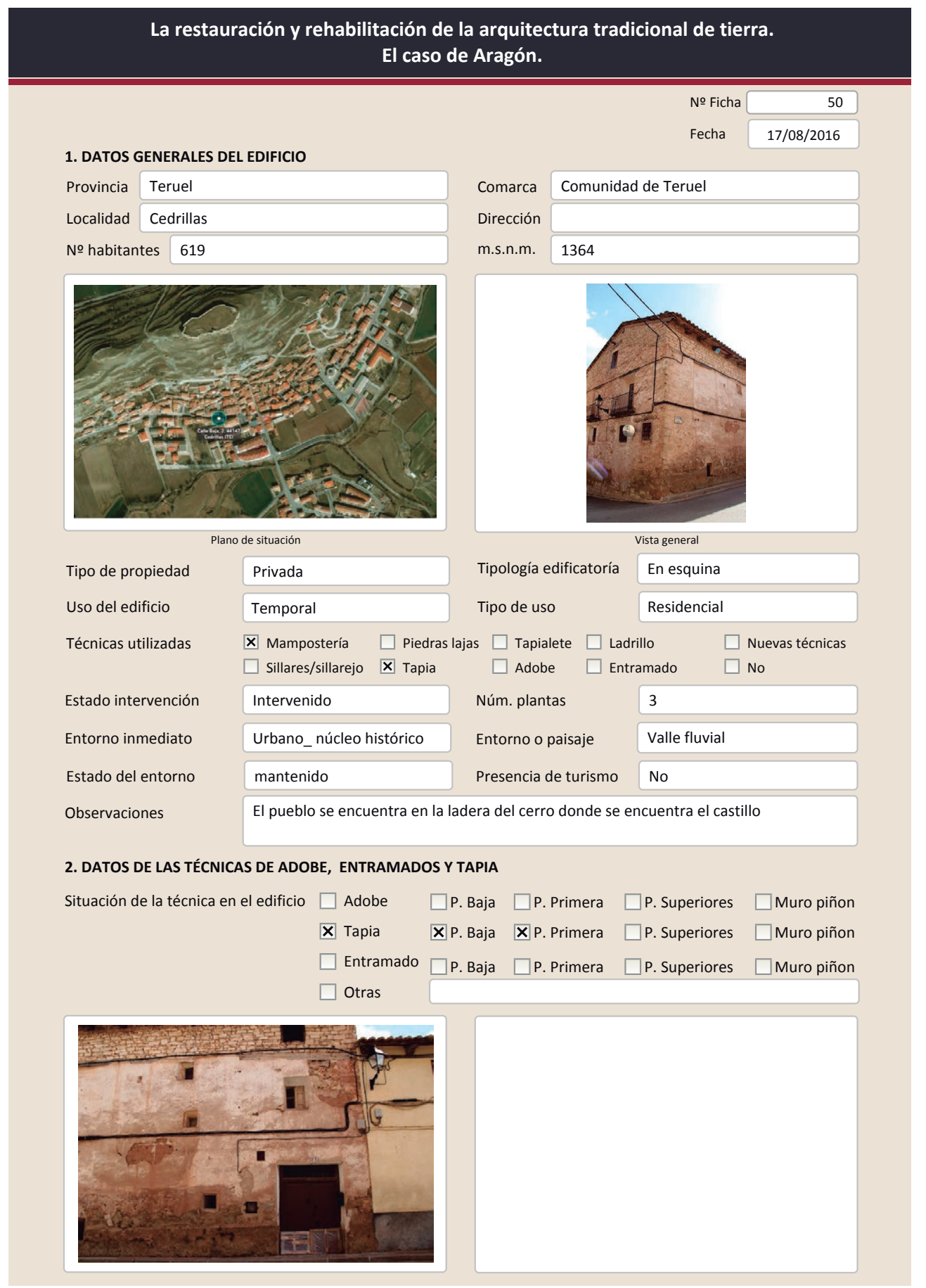

La restauración y rehabilitación de la arquitectura tradicional de tierra. El caso de Aragón.

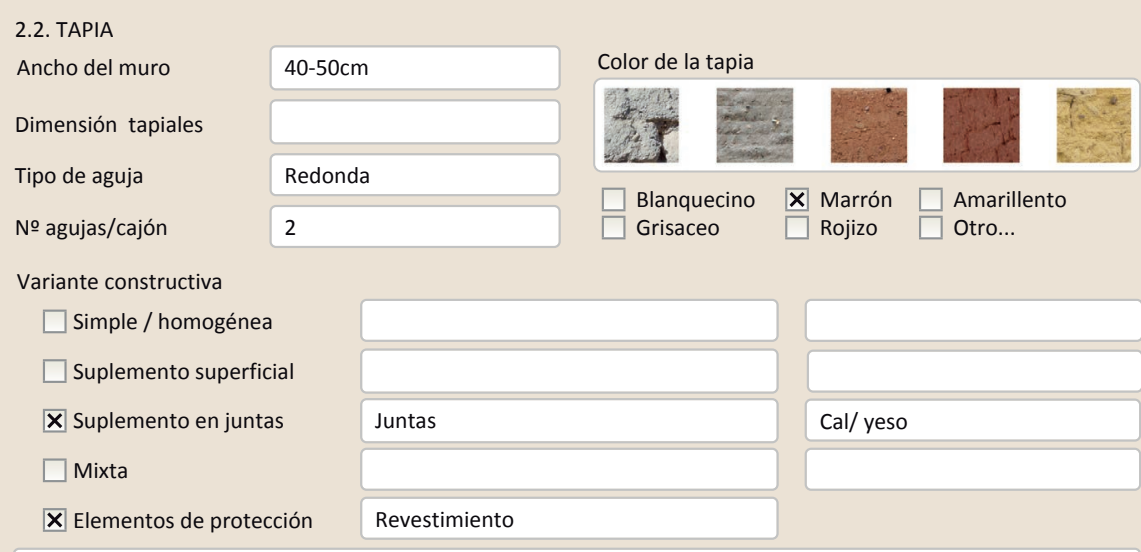

$$
x
$$

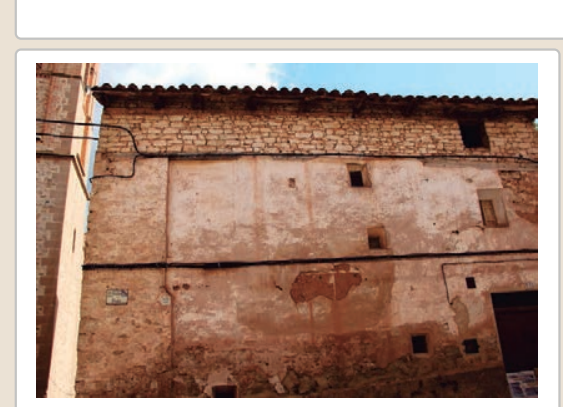

Lesiones $\square$ Muro $\square$ Zócalo $\mathbf{X}$ Revestimiento $\square$ Erosión del material $\square$ Humedad por capilaridad $\square$ Erosion de las juntas $\square$ Humedades (manch/eflo) $\square$ Pérdida de sección $\square$ Pérdida de verticalidad

$\square$ Vegetación X Desconchados

$\square$ Grietas por empuje de la cubir
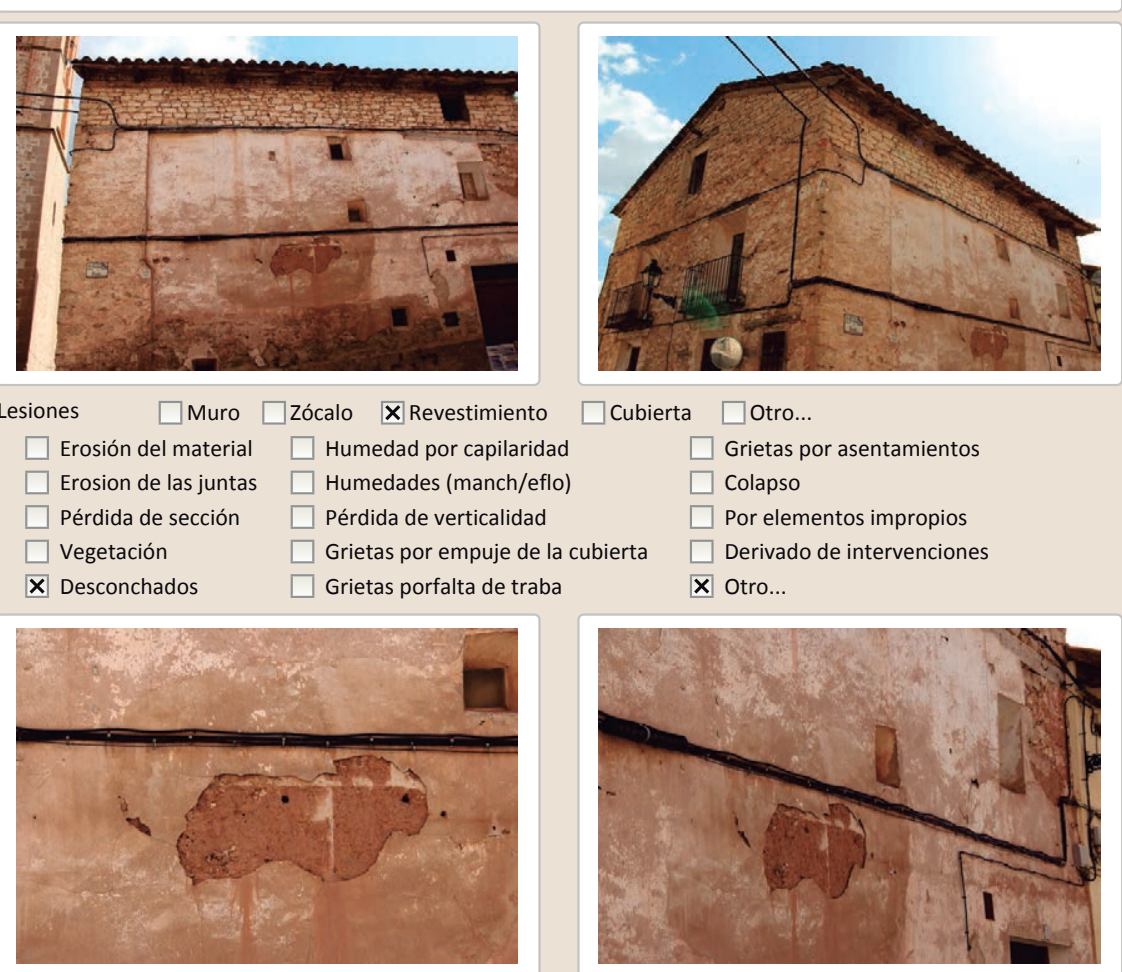

$\square$ Cubierta $\square$ otro..

$$
\begin{aligned}
& \square \text { Grietas por asentamientos } \\
& \square \text { Colapso } \\
& \square \text { Por elementos impropios } \\
& \square \text { Derivado de intervenciones }
\end{aligned}
$$

$$
\text { \ Otro... }
$$

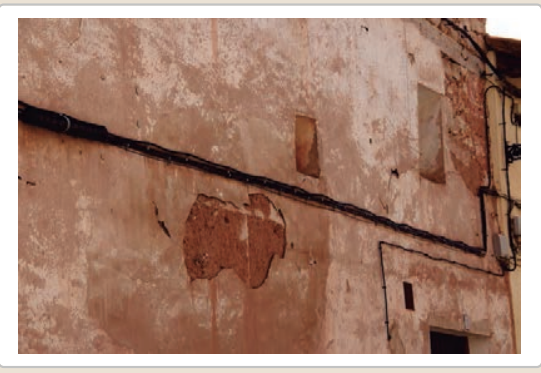

Observaciones 


\section{La restauración y rehabilitación de la arquitectura tradicional de tierra.} El caso de Aragón.

3. DATOS DE LA INTERVENCIÓN

$\boldsymbol{X}$ Mantenimiento $\quad \square$ Rehabilitación parcial $\quad \square$ Restauración $\quad \square$ Demolición $\square$ Reparación $\square$ Rehabilitación integral $\square$ Ampliación $\square$ otro...

Reflexión previa Intervención espontanea

Observaciones Intervención tradicional de ampliación del edificio en altura y anchura. No hay intervenciones recientes.

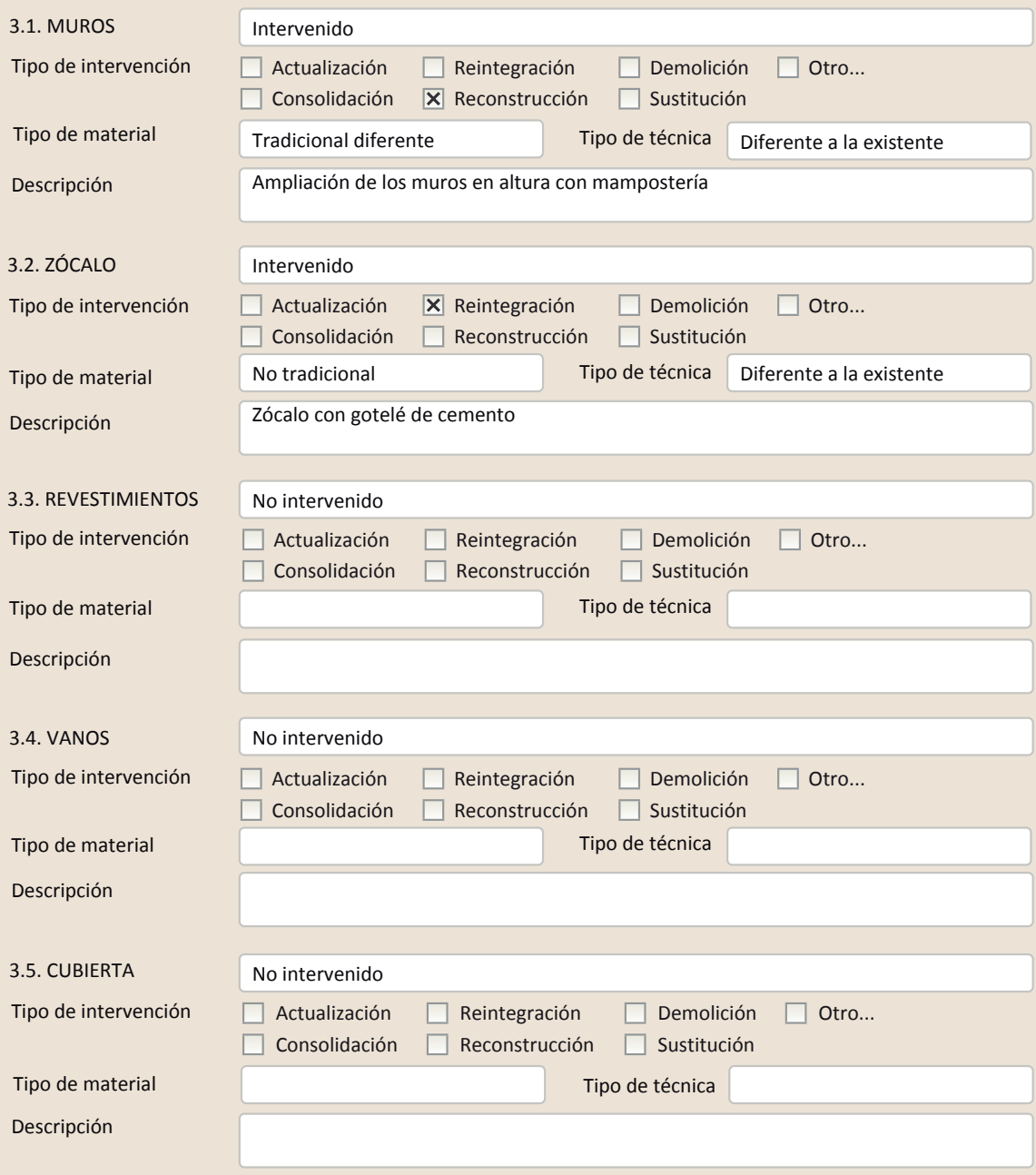

3.6. OTRAS
La restauración y rehabilitación de la arquitectura tradicional de tierra.

El caso de Aragón.

3.7. REHABILITACIÓN ENERGÉTICA $\square$ Fachada $\square$ Vanos $\square$ Forjados $\square$ Cubierta

Observaciones

FOTOGRAFÍAS DE LA INTERVENCIÓN
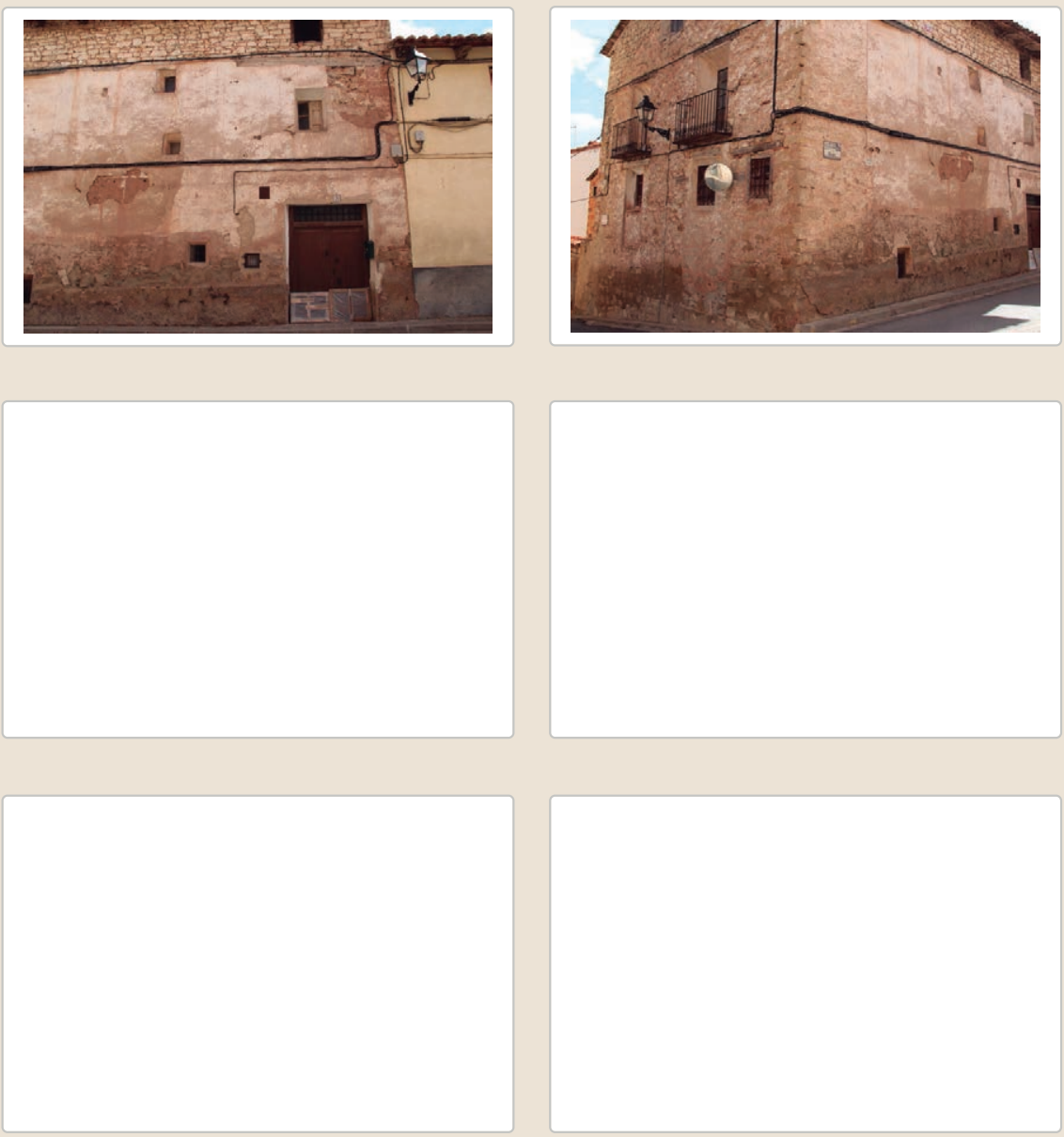


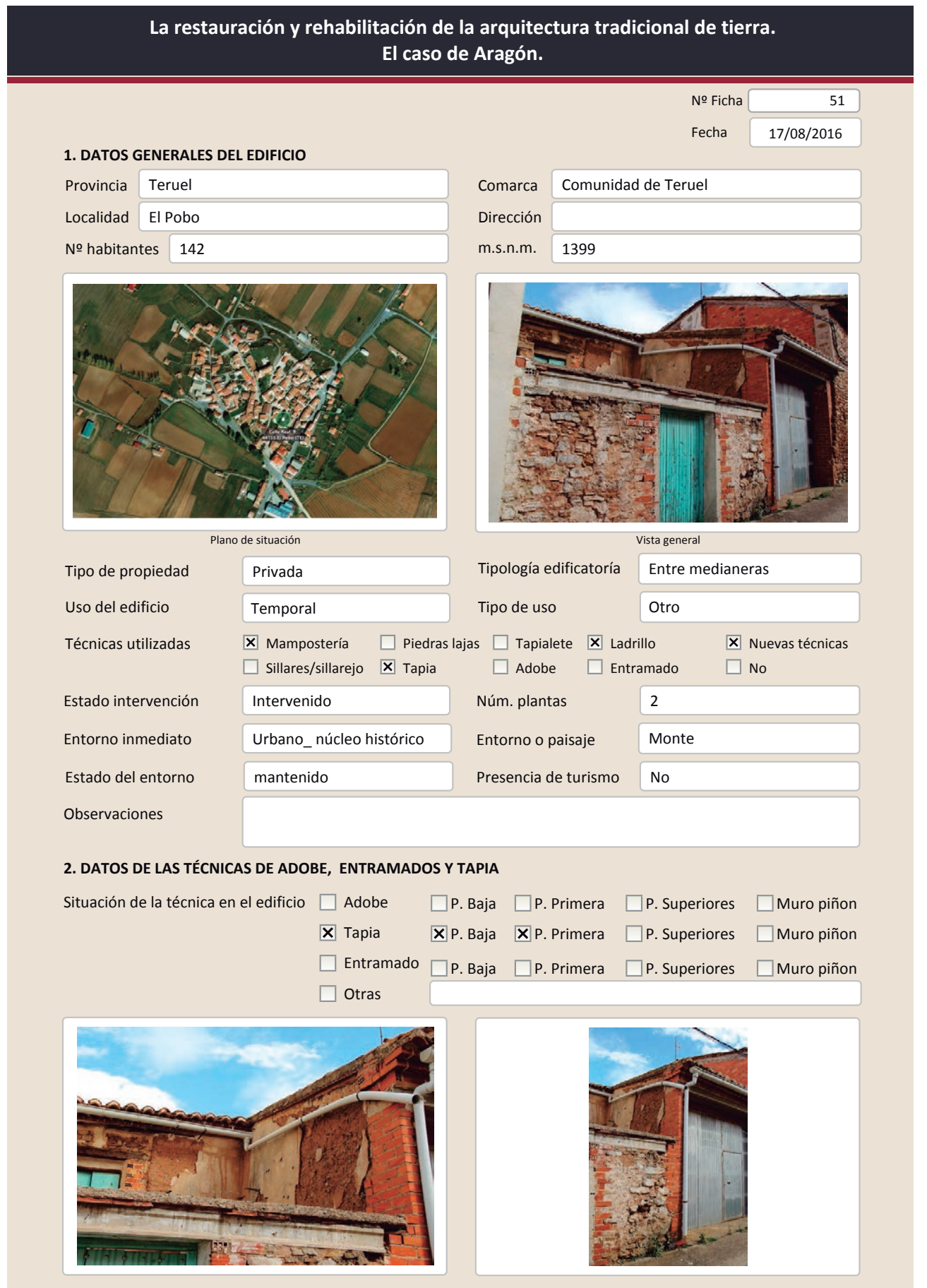

La restauración y rehabilitación de la arquitectura tradicional de tierra.

El caso de Aragón.

2.2. TAPIA

Ancho del muro

Dimensión tapiales

Tipo de aguja

№ agujas/cajón

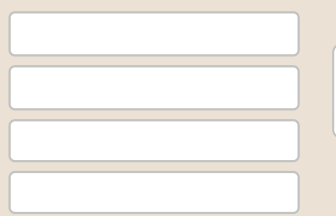

Color de la tapia

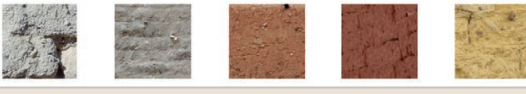

$\square$ Blanquecino $\mathbf{X}$ Marrón $\square$ Amarillento

$\square$ Grisaceo $\square$ Rojizo $\square$ Otro.

Variante constructiva

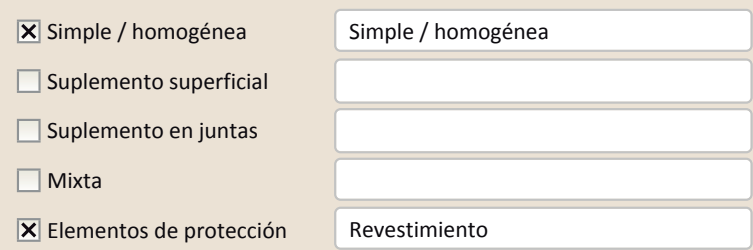

$\mathbf{X}$ Elementos de protección

Revestimiento

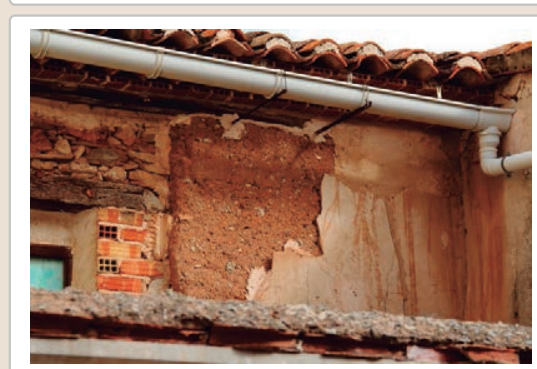

Lesiones $\mathbf{X}$ Muro $\square$ Zócalo $\mathbf{X}$ Revestimiento $\square$ Cubierta $\square$ Otro...

Х Erosión del material $\quad \square$ Humedad por capilaridad $\quad \square$ Grietas por asentamientos $\square$ Erosion de las juntas $\square$ Humedades (manch/eflo) $\quad \square$ Colapso

$\square$ Pérdida de sección $\quad \square$ Pérdida de verticalidad $\quad \square$ Por elementos impropios

$\square$ Vegetación $\quad \square$ Grietas por empuje de la cubierta $\quad \square$ Derivado de intervenciones X Desconchados $\square$ Grietas porfalta de traba $\quad \square$ Otro... 


\section{La restauración y rehabilitación de la arquitectura tradicional de tierra.}

\section{El caso de Aragón.}

3. DATOS DE LA INTERVENCIÓN

Intervención de:

$\square$ Mantenimie

$\square$ Rehabilitación parcial

$\square$ Restauración $\square$ Demolición

$\square$ Reparación $\quad$ Rehabilitación integral $\square$ Ampliación $\square$ Otro...

Reflexión previa Intervención espontanea

Observaciones Nuevo uso del edificio como garaje. Se ha insertado un nuevo hueco de grandes dimensiones.

\subsection{MUROS}

Tipo de intervención

Intervenido

Tipo de material

$\square$ Actualización $\square$ Reintegración $\square$ Demolición $\square$ Otro...

$\square$ Consolidación $\square$ Reconstrucción $\mathbf{X}$ Sustitución

Descripción

\begin{tabular}{ll|l} 
No tradicional & Tipo de técnica Diferente a la existente \\
\hline
\end{tabular}

3.2. ZÓCALO

Demolición para la construcción del nuevo hueco y sustitución de esta zona por ladrillo

Tipo de intervención

No intervenido

Tipo de material

$\square$ Actualización $\square$ Reintegración $\square$ Demolición $\square$ Otro...

$\square$ Consolidación $\square$ Reconstrucción $\square$ Sustitución

Descripción

3.3. REVESTIMIENTOS

Tipo de intervención

No intervenido

Actualización

Reintegración $\square$ Demolición

$\square$ Otro...

Tipo de material

Descripción

3.4. VANOS

Tipo de intervención

\section{Intervenido}

Tipo de material

$\square$ Actualización $\square$ Reintegración $\square$ Demolición $\square$ Otro...

$\square$ Consolidación $\square$ Reconstrucción $\quad \boldsymbol{X}$ Sustitución

Descripción
No tradicional
Tipo de técnica Diferente a la existente

Nuevas jambas y refuerzos en huecos con ladrillo hueco. Ampliación del hueco y cambio de carpintería

3.5. CUBIERTA

Tipo de intervención

Intervenido

Tipo de material

$\square$ Actualización $\square$ Reintegración $\square$ Demolición $\square$ Otro..

$\square$ Consolidación $\square$ Reconstrucción $\quad \mathbf{X}$ Sustitución

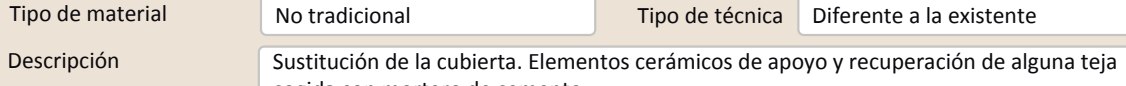
cogida con mortero de cemento

3.6. OTRAS 


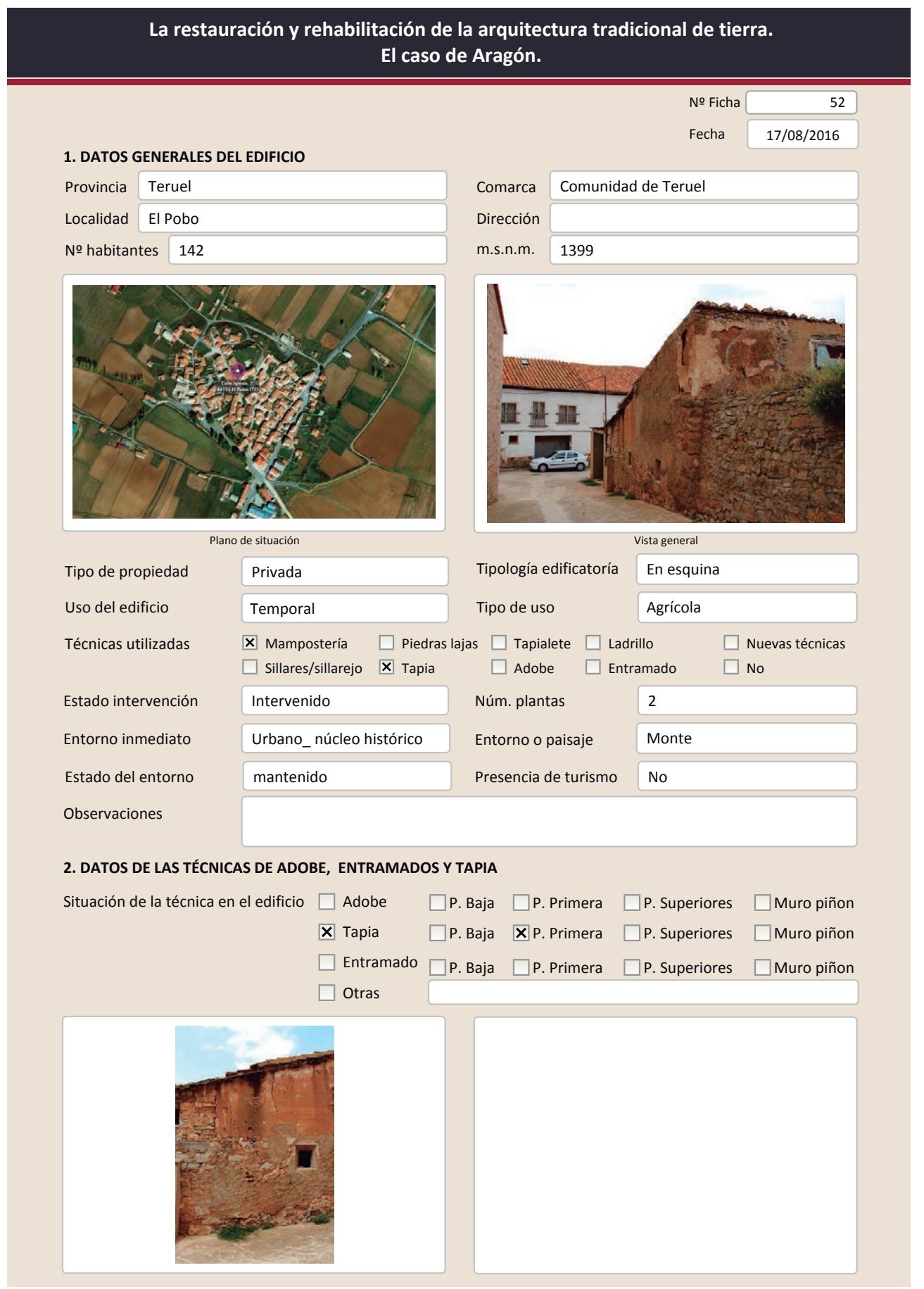

La restauración y rehabilitación de la arquitectura tradicional de tierra. El caso de Aragón.

2.2. TAPIA

Ancho del muro

Dimensión tapiales

Tipo de aguja

№ agujas/cajón

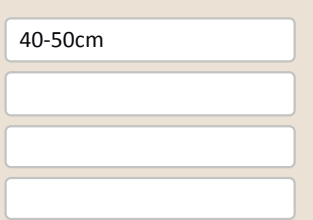

Color de la tapia

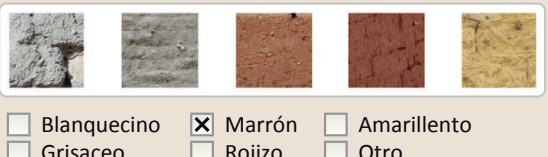

$\square$ Blanquecino $\quad \mathbf{X}$ Marrón $\square$ Amarillento

Variante constructiva

$\square$ Simple / homogénea

X Suplemento superficial

$\square$ suplemento en juntas

X Mixta
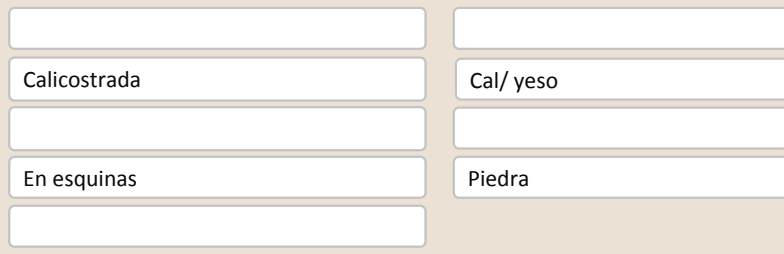

$\square$ Elementos de protección

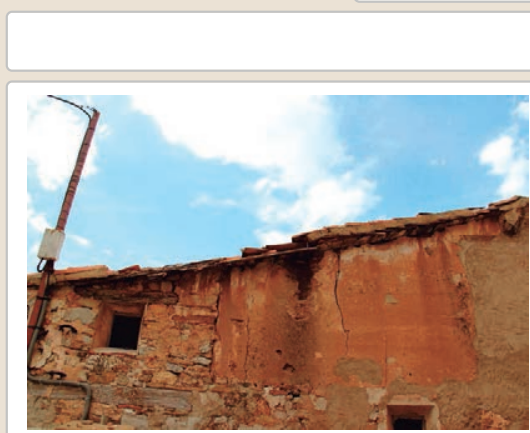

Lesiones $\mathbf{X}$ Muro $\mathbf{X}$ Zócalo $\mathbf{X}$ Revestimiento $\mathbf{X}$ Cubierta $\square$ otro...

$\mathbf{X}$ Erosión del material $\square$ Humedad por capilaridad $\quad \mathbf{X}$ Grietas por asentamientos

$\square$ Erosion de las juntas $\square$ Humedades (manch/eflo)

$\square$ Pérdida de sección $\quad \square$ Pérdida de verticalidad

$\square$ Vegetación

X Por elementos impropios

$\mathbf{X}$ Desconchados

$\square$ Grietas porfalta de trab

X Otro...
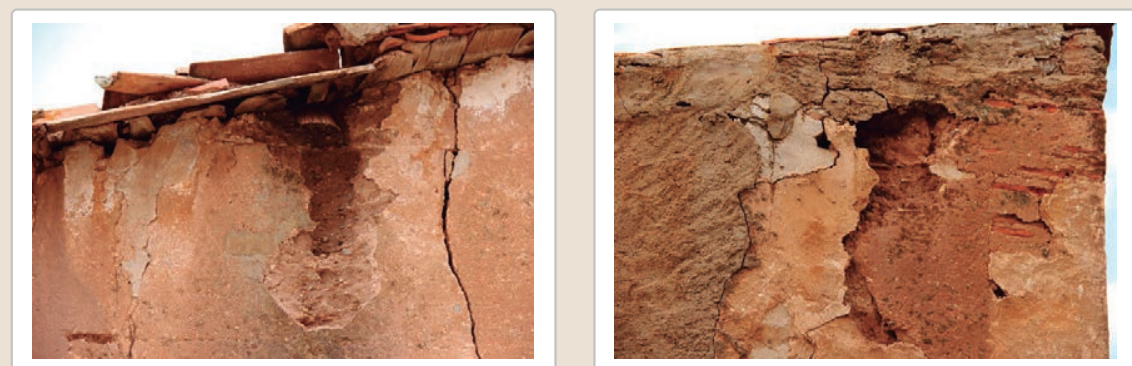

Observaciones

Patologías por desperfectos en la cubierta, nuevas intervenciones con cemento y yeso. Aparecen grietas entre el muro de piedra y tapia y otra en el muro de tapia por 


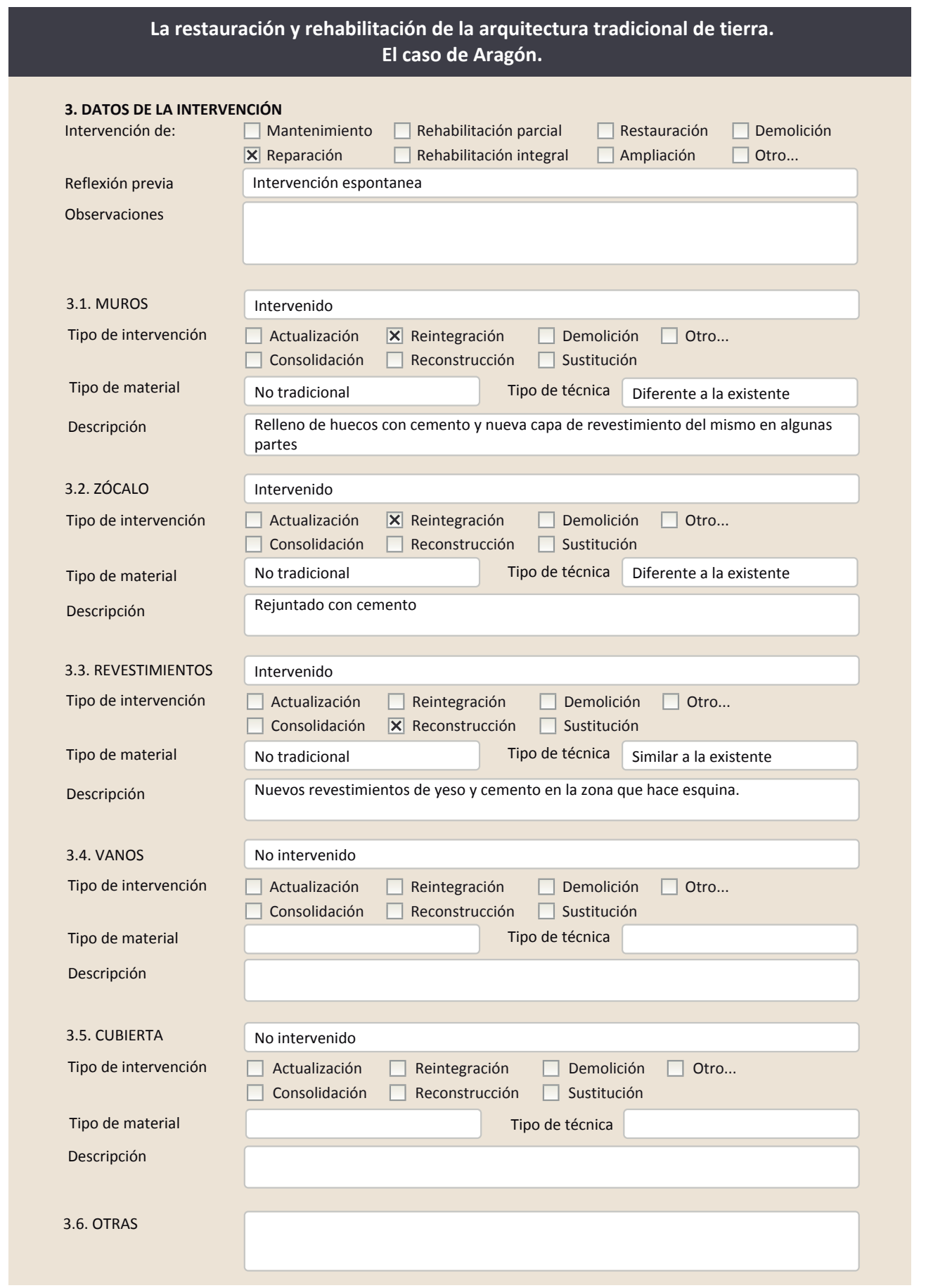

3.7. REHABILITACIÓN ENERGÉTICA $\quad \square$ Fachada $\square$ Vanos $\square$ Forjados $\square$ Cubierta Observaciones

FOTOGRAFíAS DE LA INTERVENCIÓN
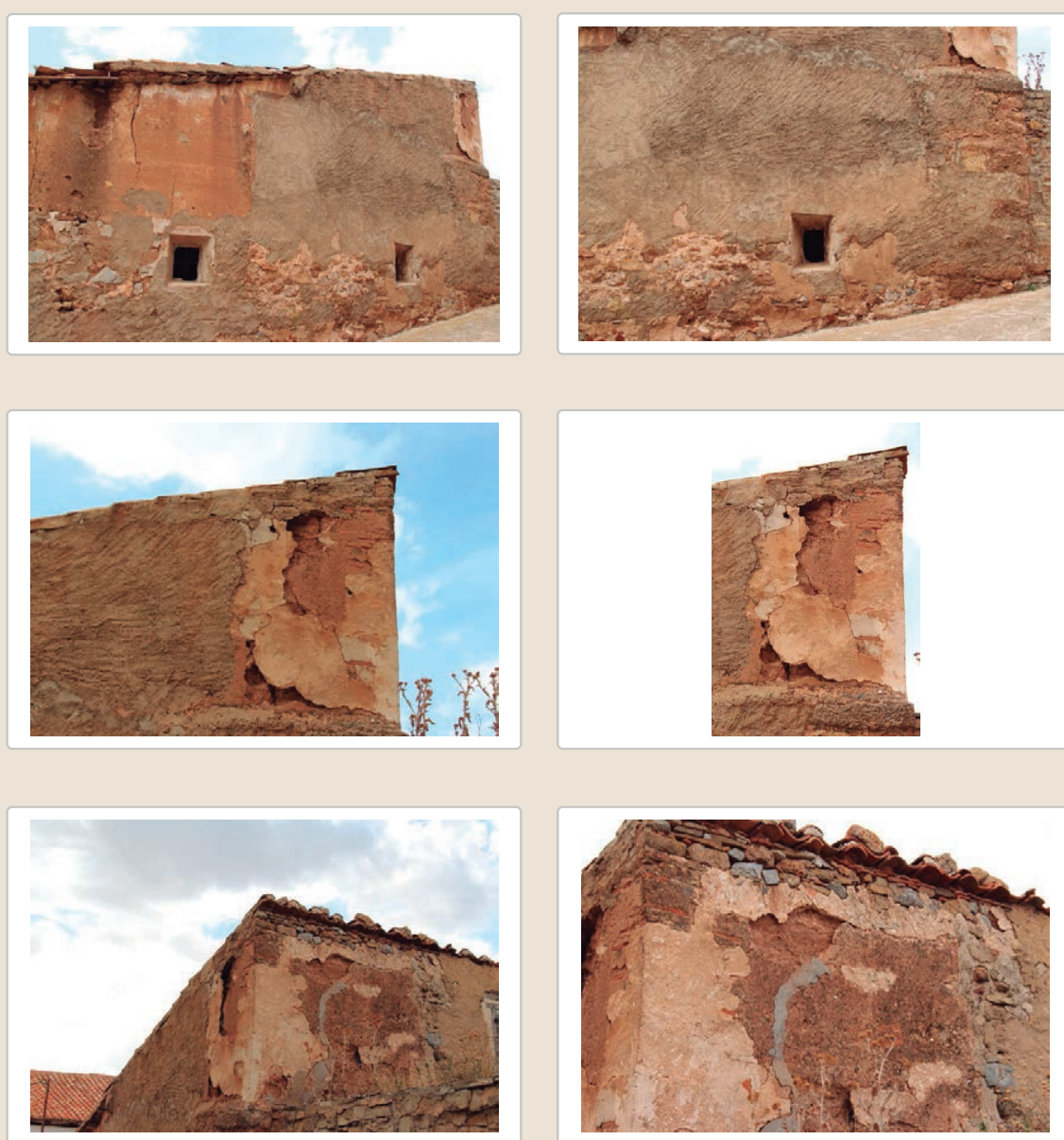


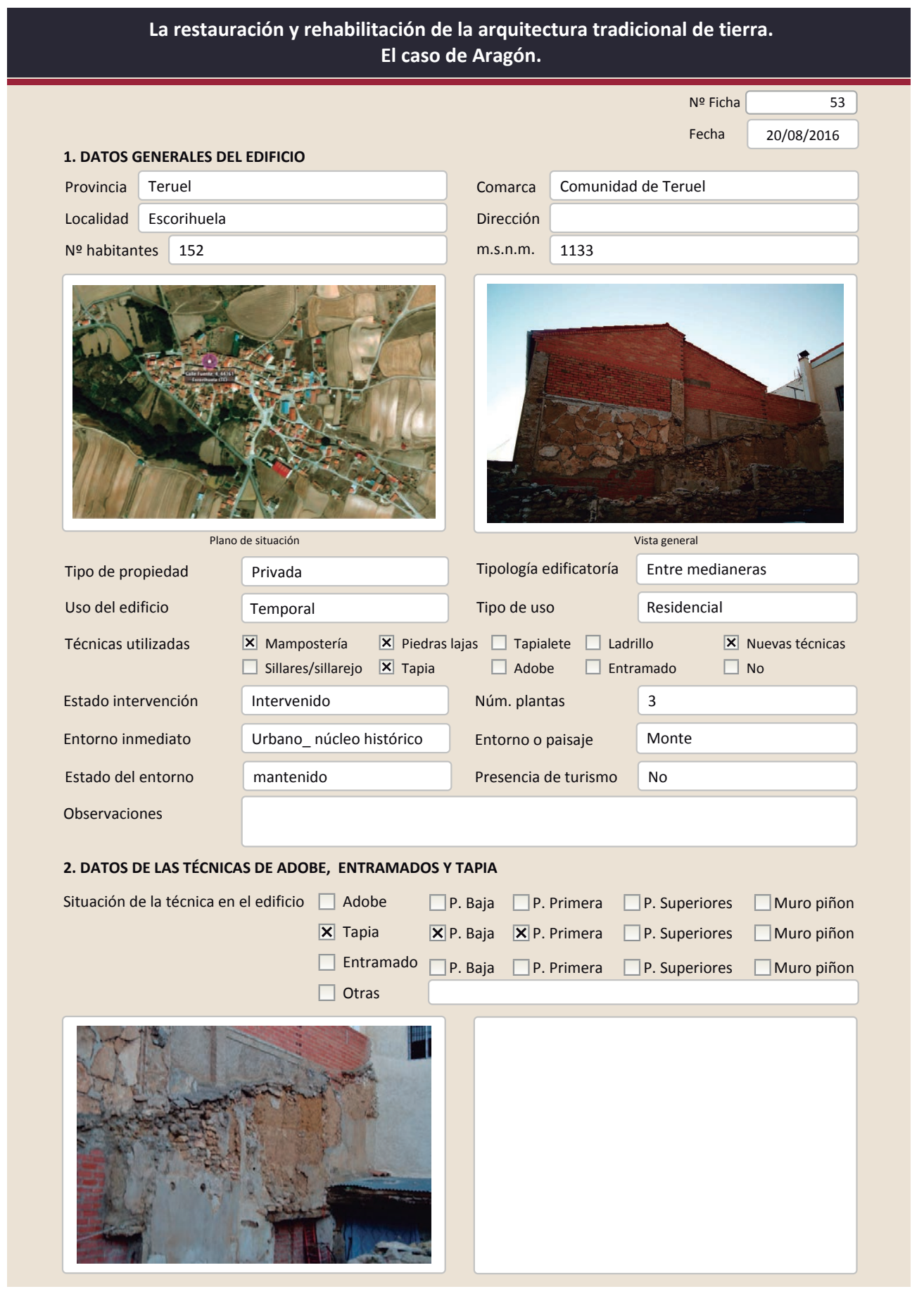

La restauración y rehabilitación de la arquitectura tradicional de tierra.

El caso de Aragón.

2.2. TAPIA

Ancho del muro

Dimensión tapiales

Tipo de aguja

№ agujas/cajón

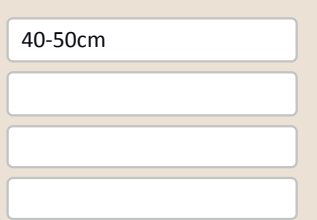

Color de la tapia

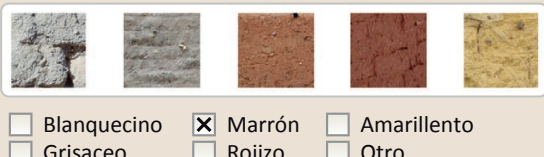

$\begin{array}{ll}\square \text { Blanquecino } & \boldsymbol{X} \text { Marrón } \\ \square \text { Grisaceo } & \square \text { Amarillento } \\ & \square \text { Rojizo } \quad \square \text { Otro... }\end{array}$

Variante constructiva
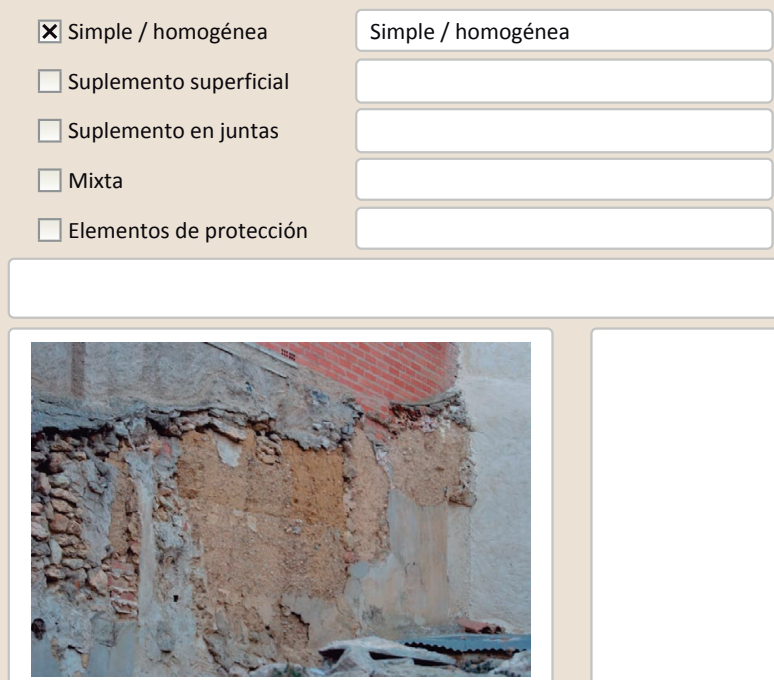

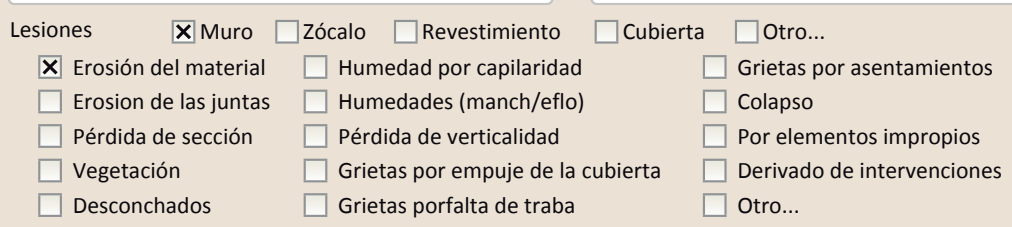

Observaciones 


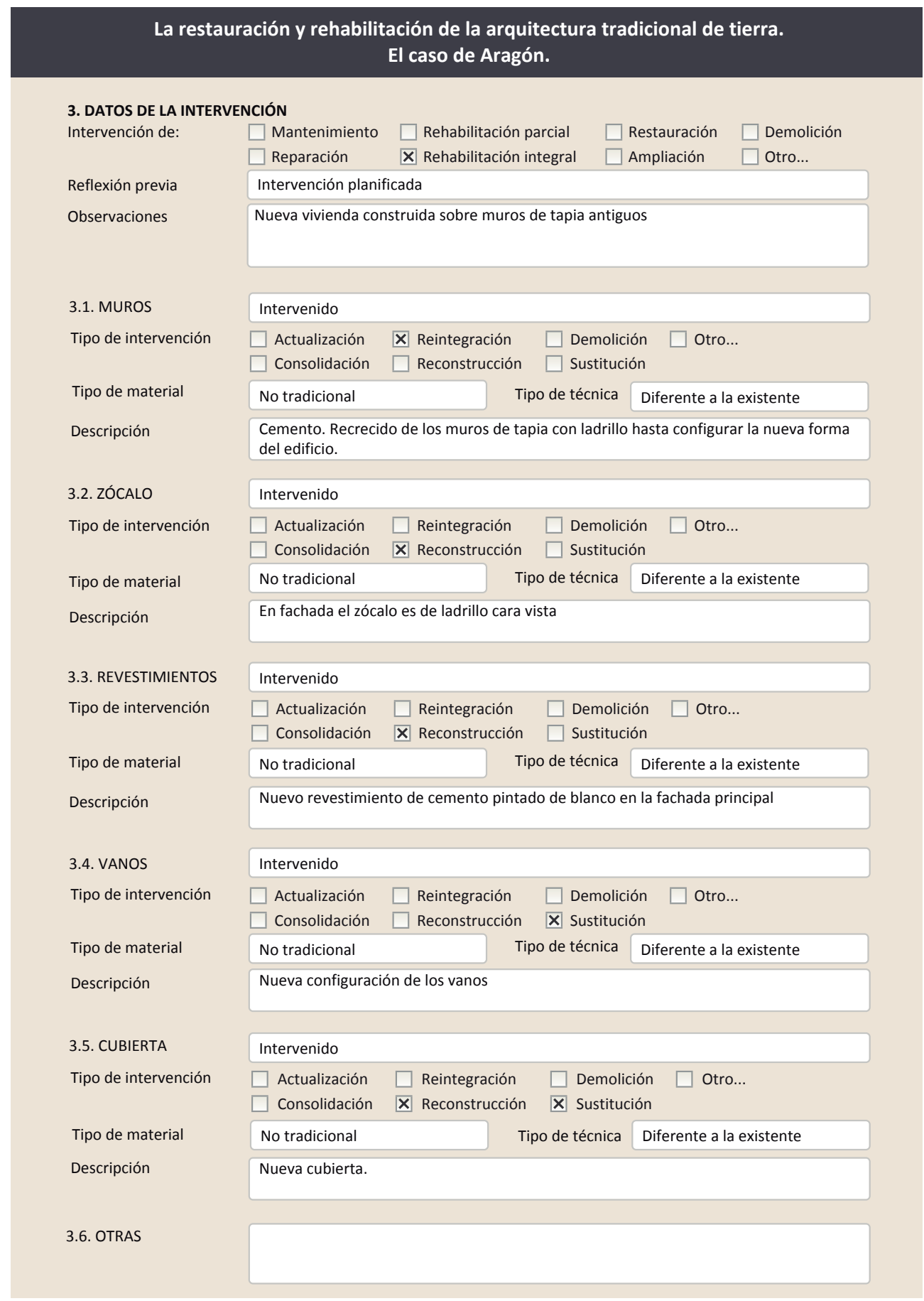

3.7. REHABILITACIÓN ENERGÉTICA $\square$ Fachada $\square$ Vanos $\square$ Forjados $\square$ Cubierta

Observaciones

FOTOGRAFíAS DE LA INTERVENCIÓN
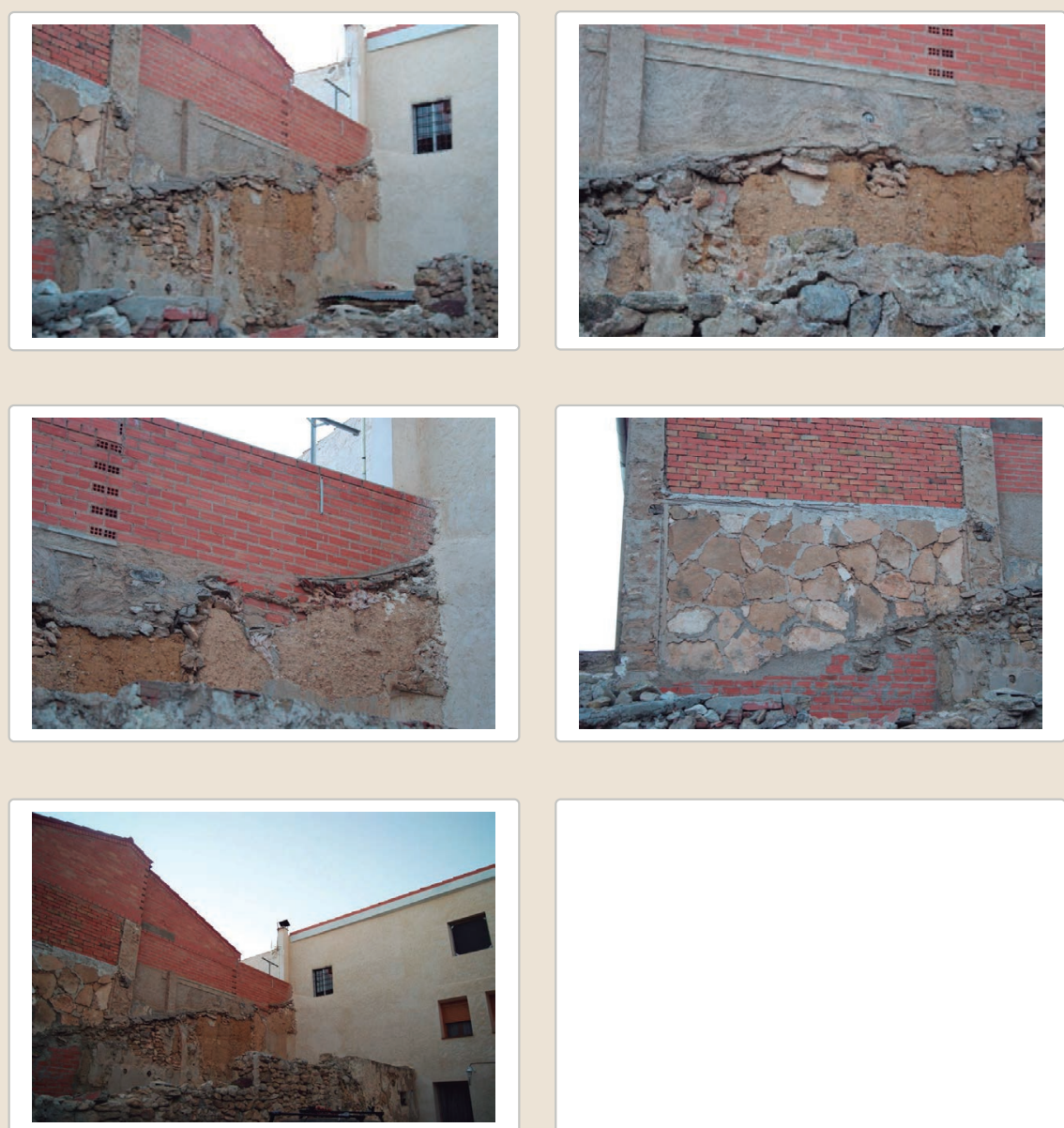


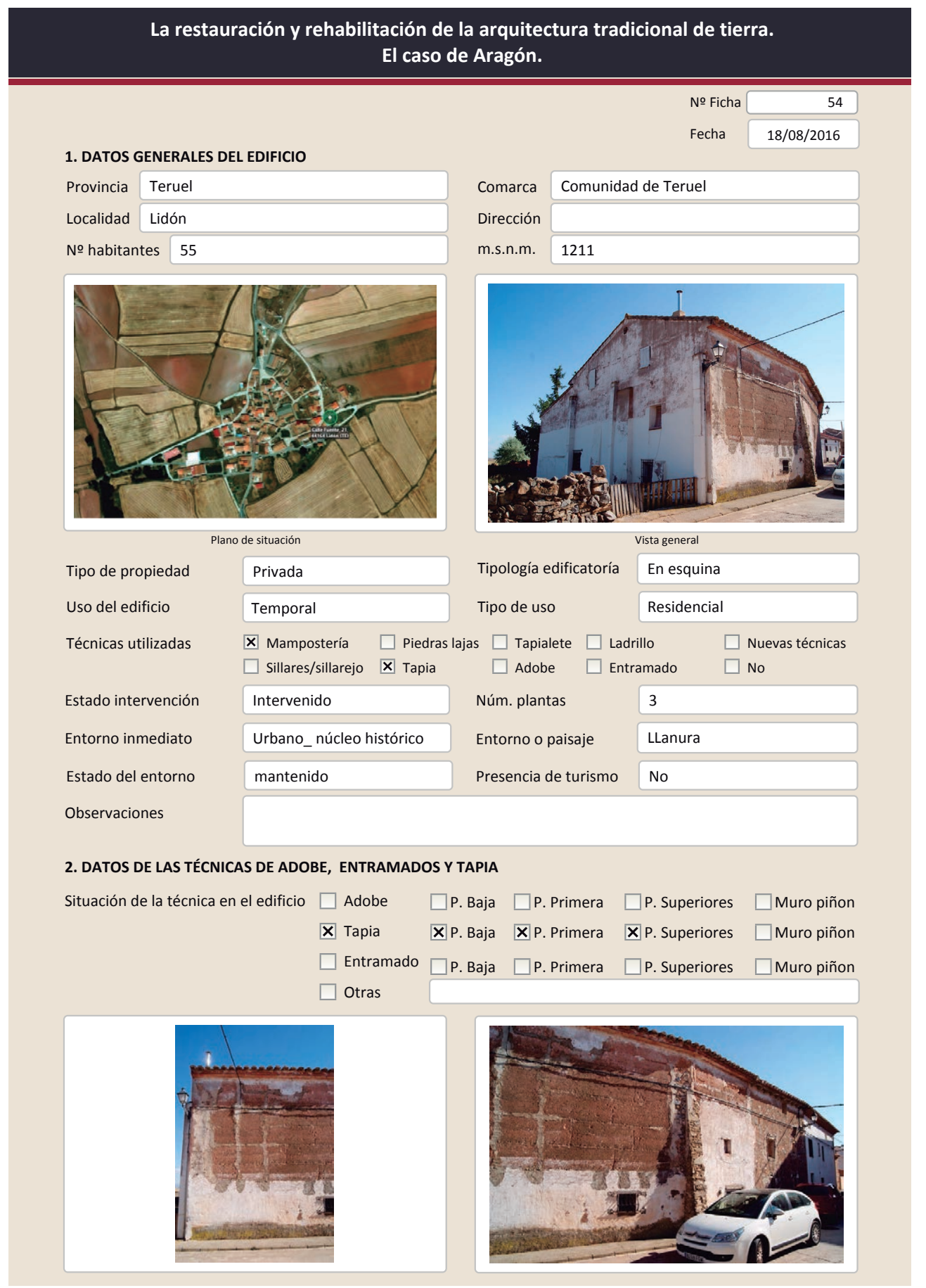

La restauración y rehabilitación de la arquitectura tradicional de tierra. El caso de Aragón.

2.2. TAPIA

Ancho del muro

Dimensión tapiales

Tipo de aguja

№ agujas/cajón

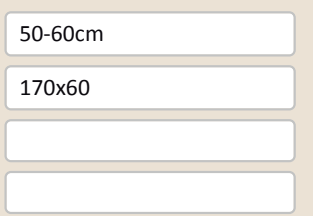

Color de la tapia

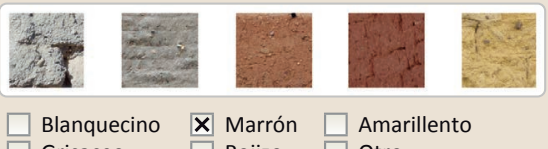

$\begin{array}{ll}\square \text { Blanquecino } & \boldsymbol{X} \text { Marrón } \\ \square \text { Grisaceo } & \square \text { Rojizo } \quad \square \text { Otro.... }\end{array}$

Variante constructiva

$\square$ Simple / homogénea

$\mathbf{X}$ Suplemento superficial

$\square$ suplemento en juntas

$\square$ Mixta

$\square$ Elementos de protección
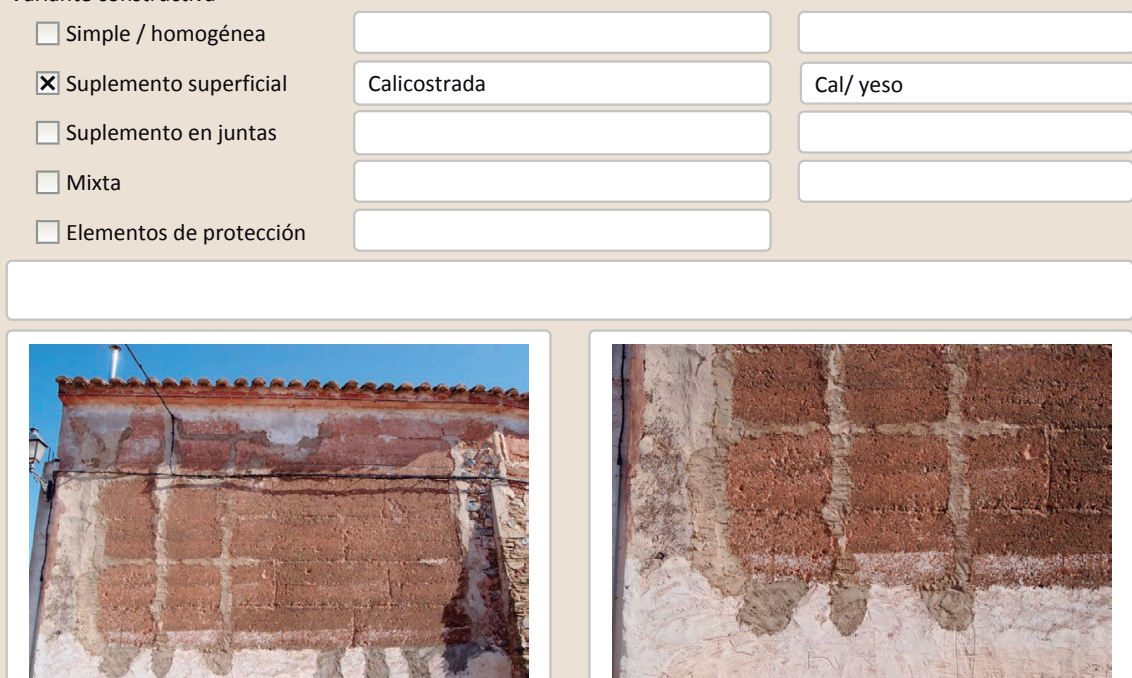

Lesiones $\quad \mathbf{X}$ Muro $\mathbf{X}$ Zócalo $\square$ Revestimiento $\square$ Cubierta $\square$ Otro...

$\mathbf{X}$ Erosión del material $\quad \mathbf{X}$ Humedad por capilaridad $\quad \square$ Grietas por asentamientos $\mathbf{X}$ Erosion de las juntas $\square$ Humedades (manch/eflo) $\quad \square$ Colapso

$\square$ Pérdida de sección $\square$ Pérdida de verticalidad $\square$ Por elementos impropios

$\square$ Grietas por empuje de la cubierta $\square$ Derivado de intervenciones

$\square$ Desconchados $\quad \square$ Grietas porfalta de traba

$\square$ Otro...
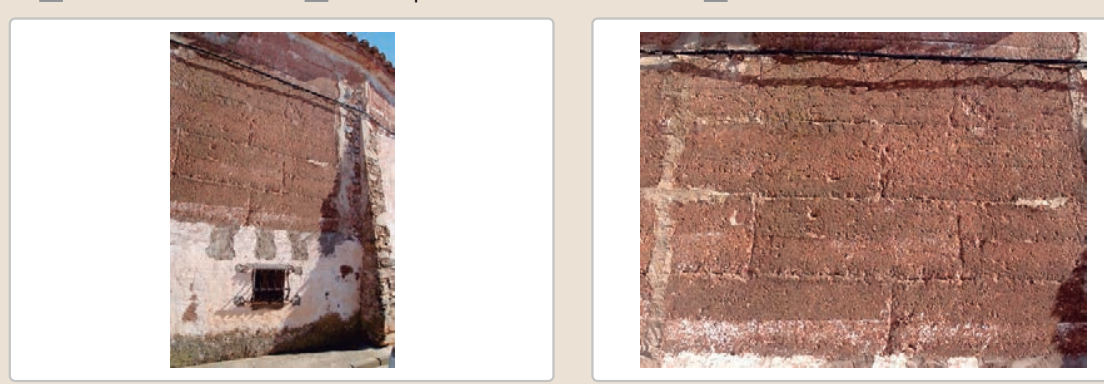

Observaciones 


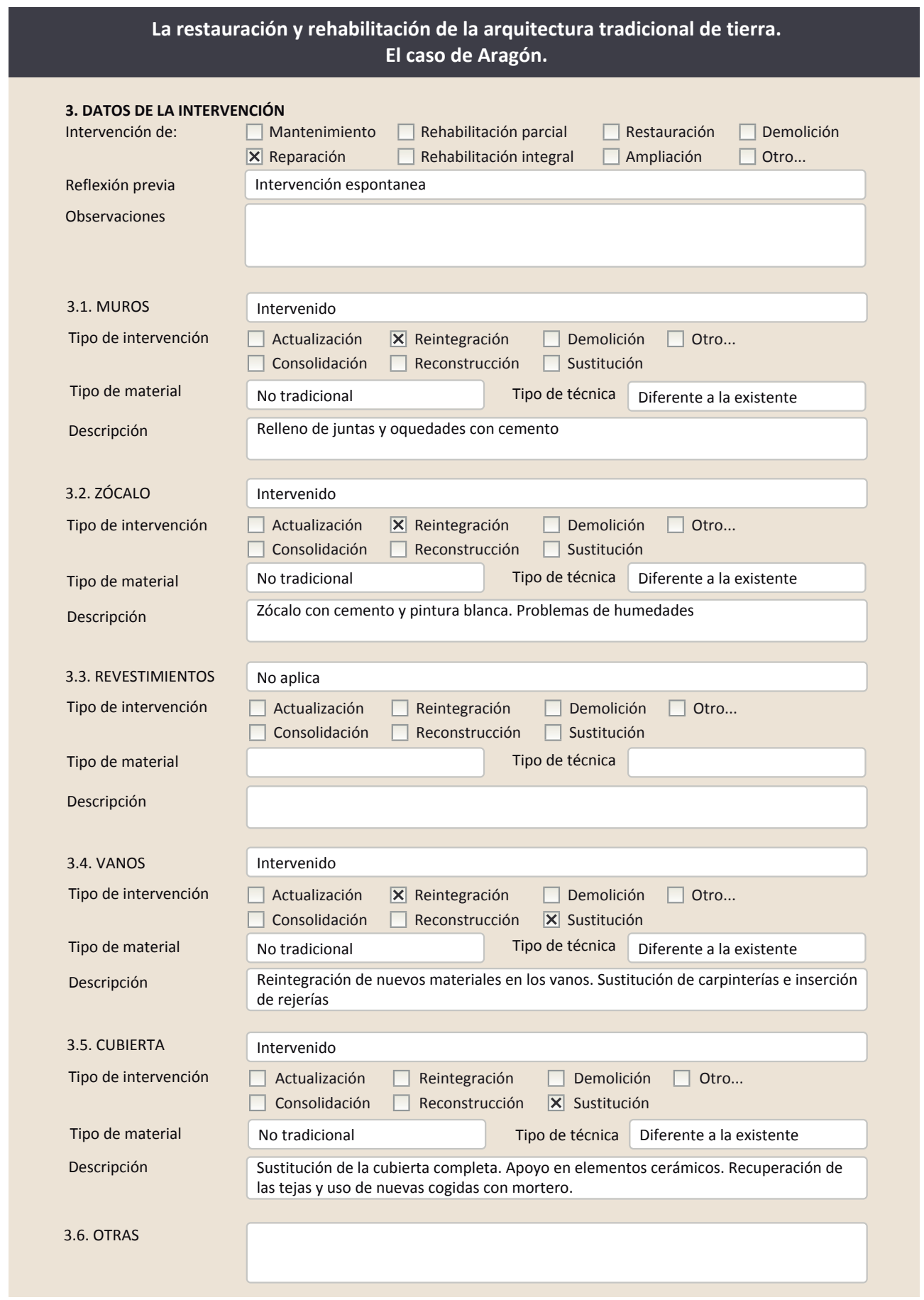

3.7. REHABILITACIÓN ENERGÉTICA $\square$ Fachada $\quad$ \ Vanos $\square$ Forjados $\square$ Cubierta Observaciones Los vanos visibles tienen nuevas carpinterías

FOTOGRAFÍAS DE LA INTERVENCIÓN
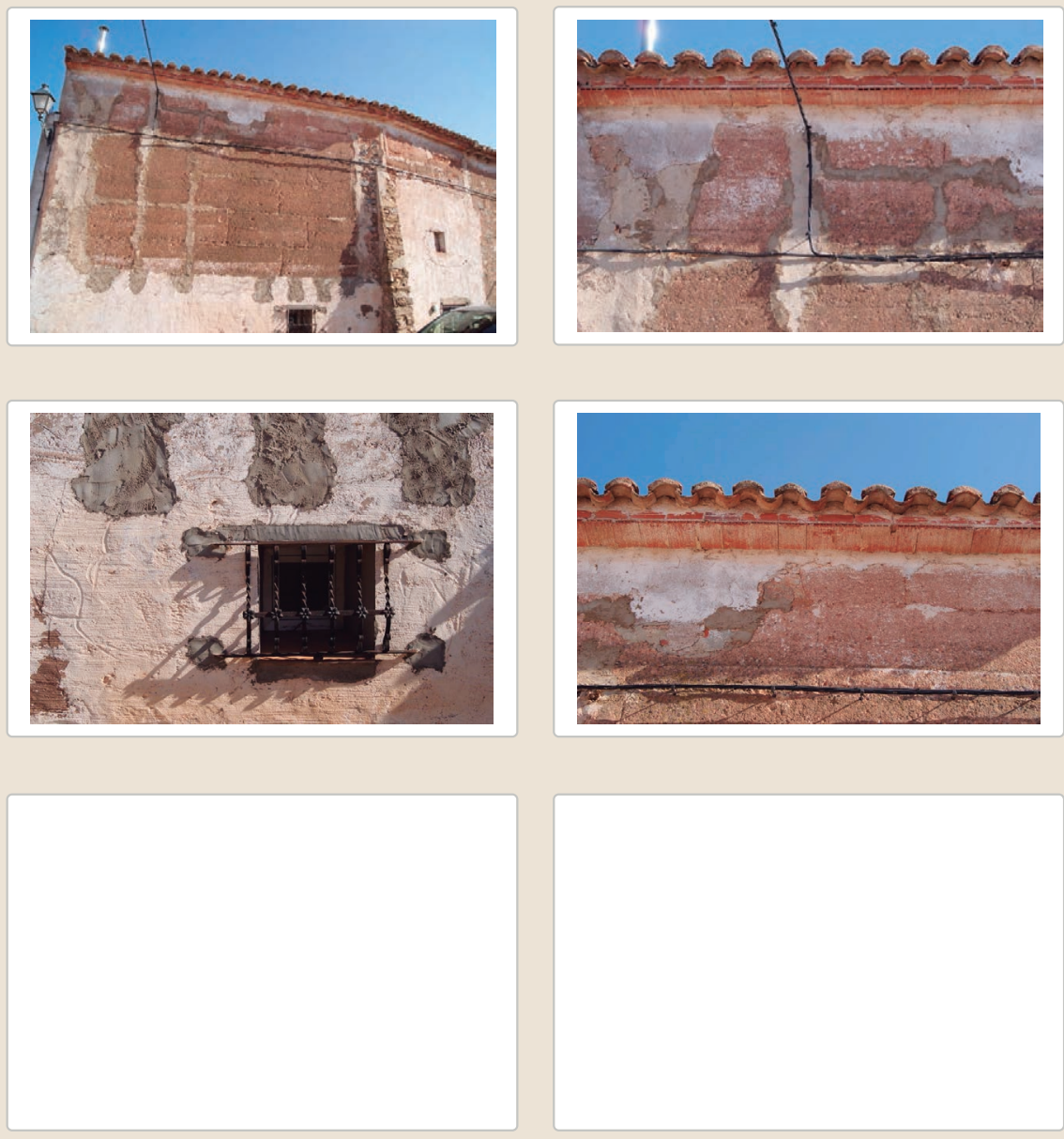


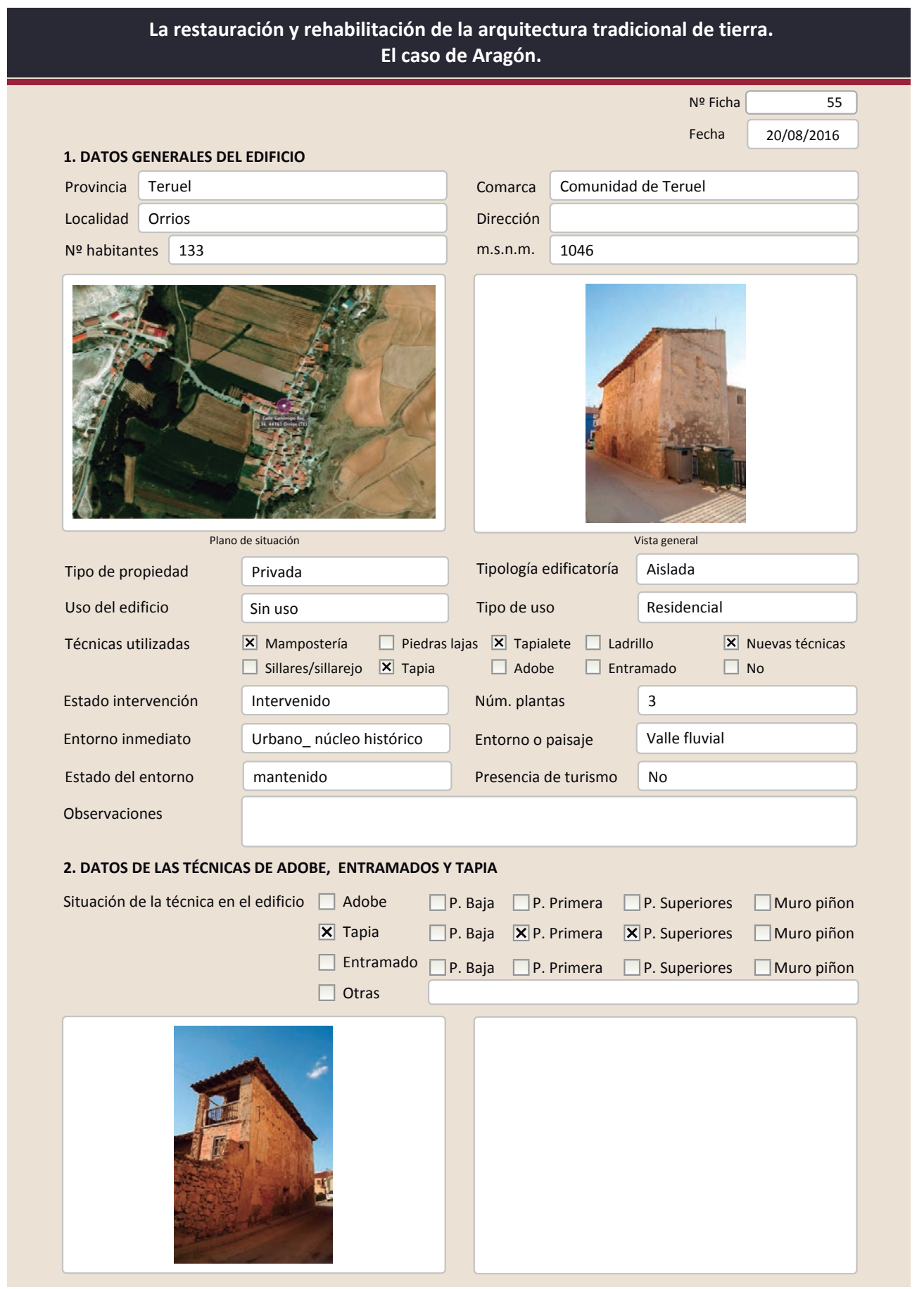

La restauración y rehabilitación de la arquitectura tradicional de tierra.

El caso de Aragón.

2.2. TAPIA

Ancho del muro

Dimensión tapiales

Tipo de aguja

\begin{tabular}{|l|}
\hline $50-60 \mathrm{~cm}$ \\
\hline $170 \times 78$ \\
\hline Redonda \\
\hline 3 \\
\hline
\end{tabular}

Color de la tapia

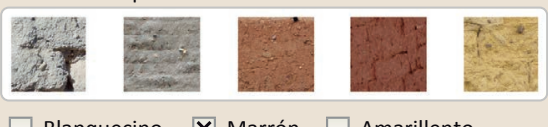

$\square$ Blanquecino $\quad \mathbf{X}$ Marrón $\square$ Amarillento

№ agujas/cajón

Grisaceo

Variante constructiva

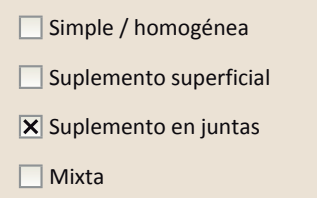

$\square$ Mixta

$\square$ Elementos de protección
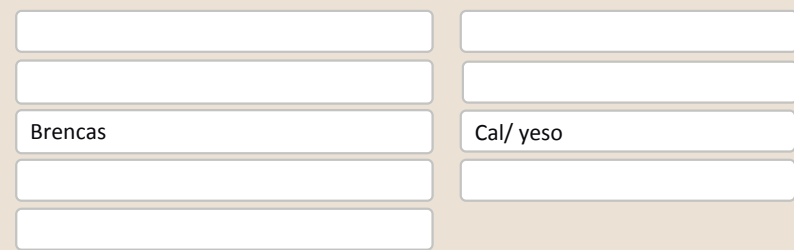

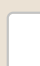

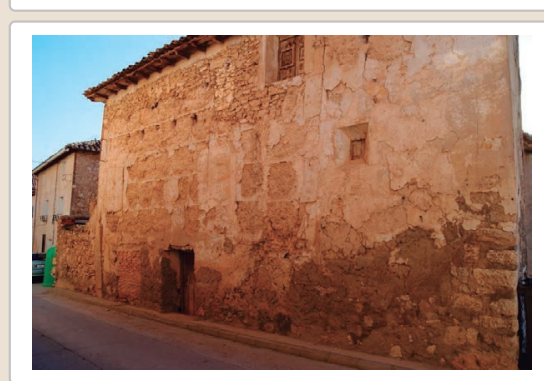

Lesiones $\quad \mathbf{X}$ Muro $\square$ Zócalo $\square$ Revestimiento $\quad \mathbf{X}$ Cubierta $\square$ otro...

X Erosión del material $\mathbf{X}$ Humedad por capilaridad $\quad \square$ Grietas por asentamientos $\square$ Erosion de las juntas $\square$ Humedades (manch/eflo)

$\square$ Pérdida de sección $\square$ Pérdida de verticalidad

$\square$ Vegetación $\square$ Grietas por empuje de la cubie

$\square$ Desconchados $\quad \square$ Grietas porfalta de traba

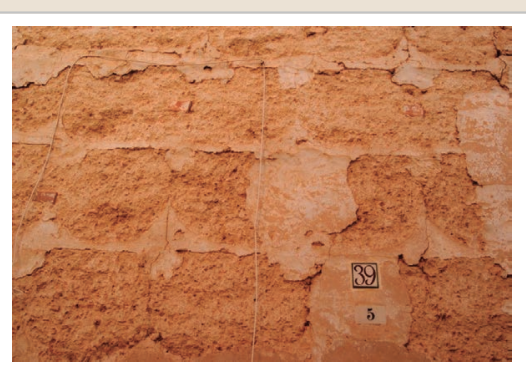

Observaciones

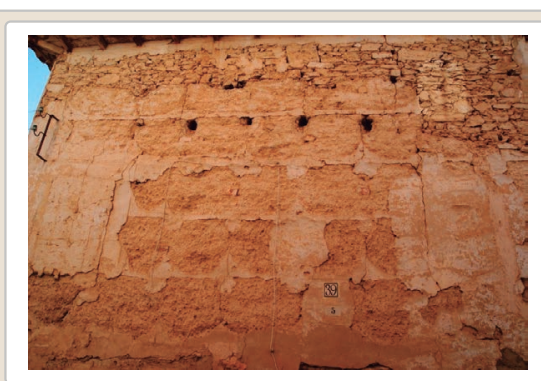

$\square$ Colapso

Por elementos impropios

$\square$ Derivado de intervenciones $\square$ Otro... 


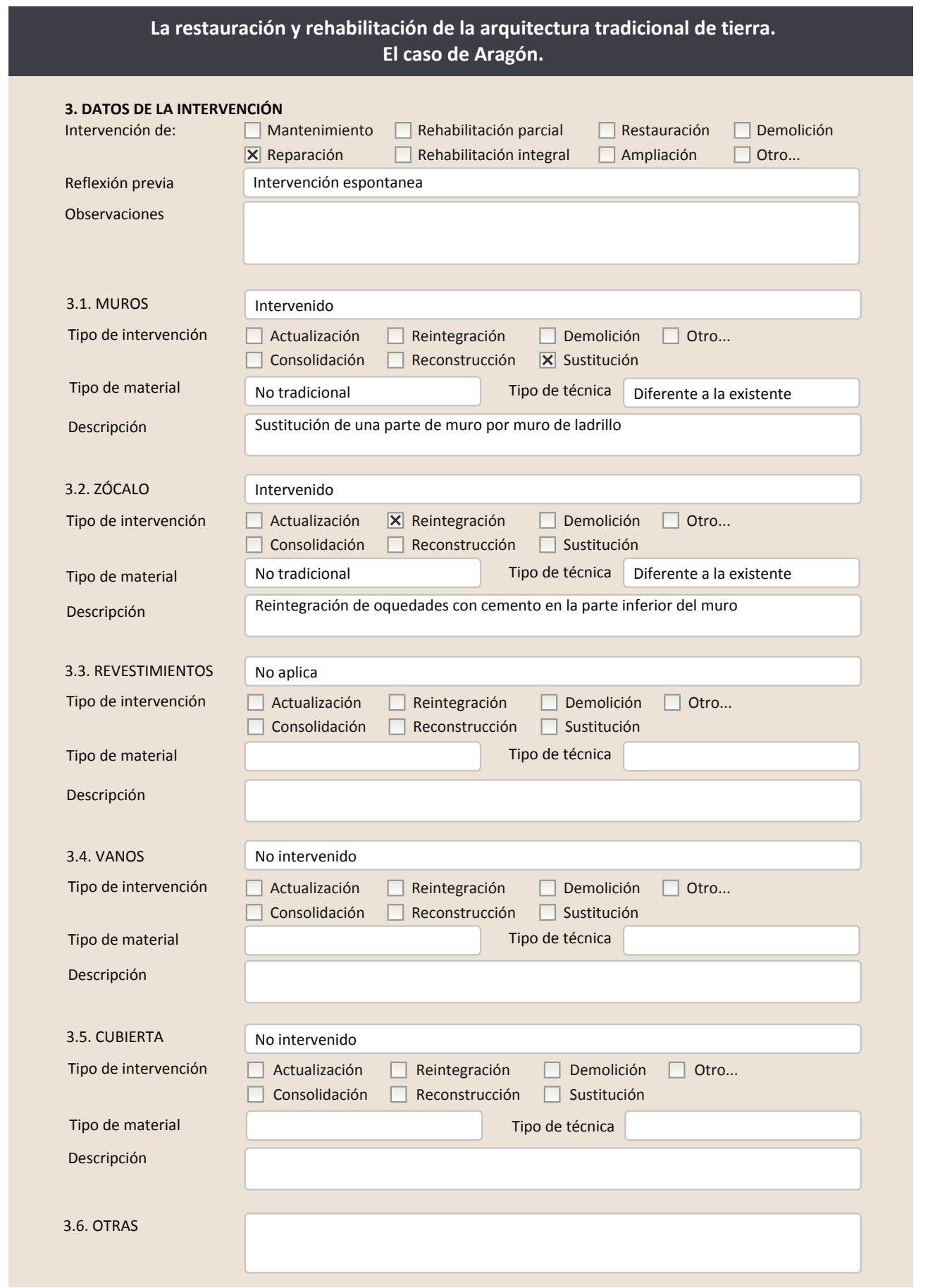

\subsection{REHABILITACIÓN ENERGÉTICA $\quad \square$ Fachada $\square$ Vanos $\square$ Forjados $\square$ Cubierta}

Observaciones

FOTOGRAFíAS DE LA INTERVENCIÓN
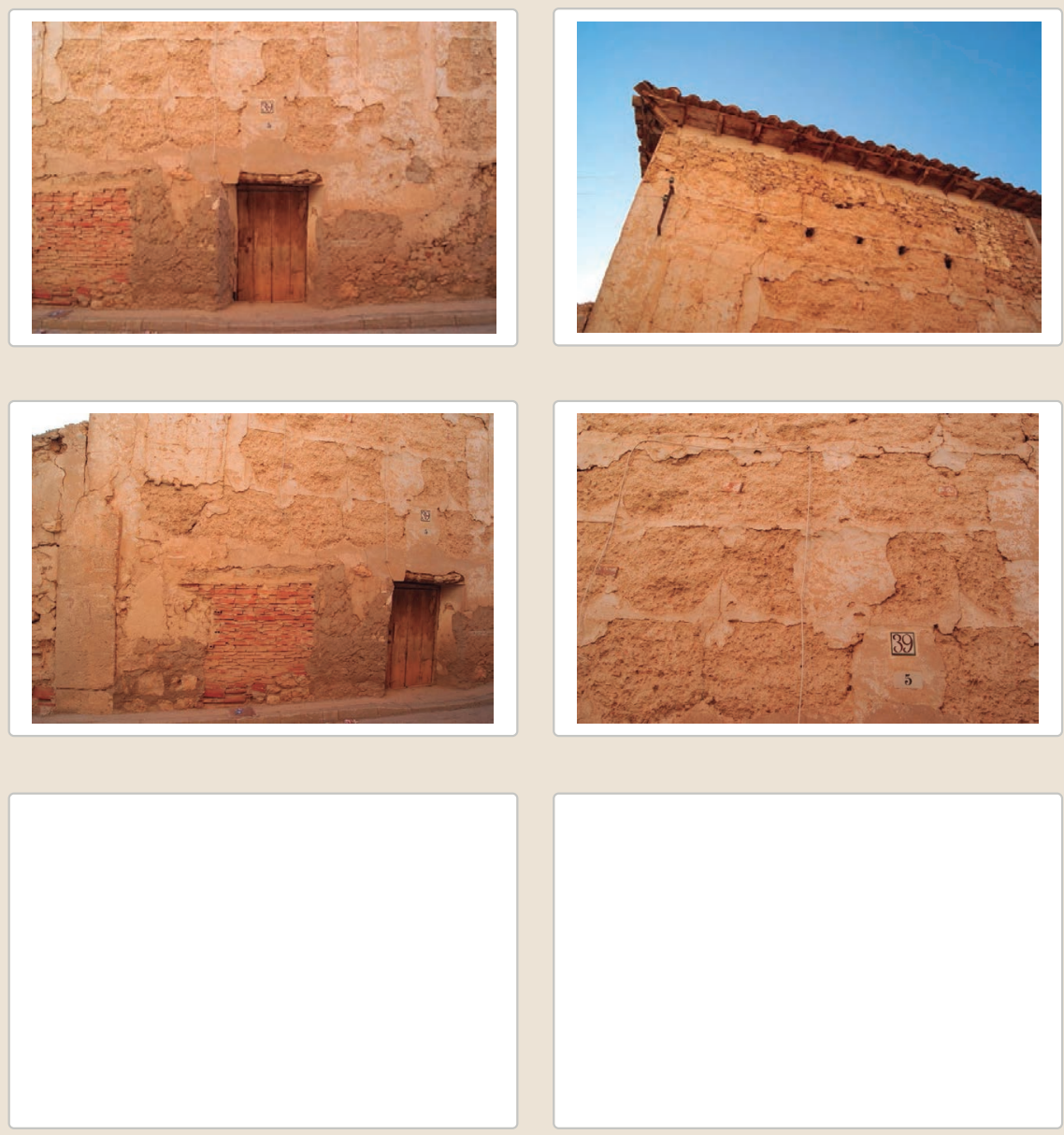


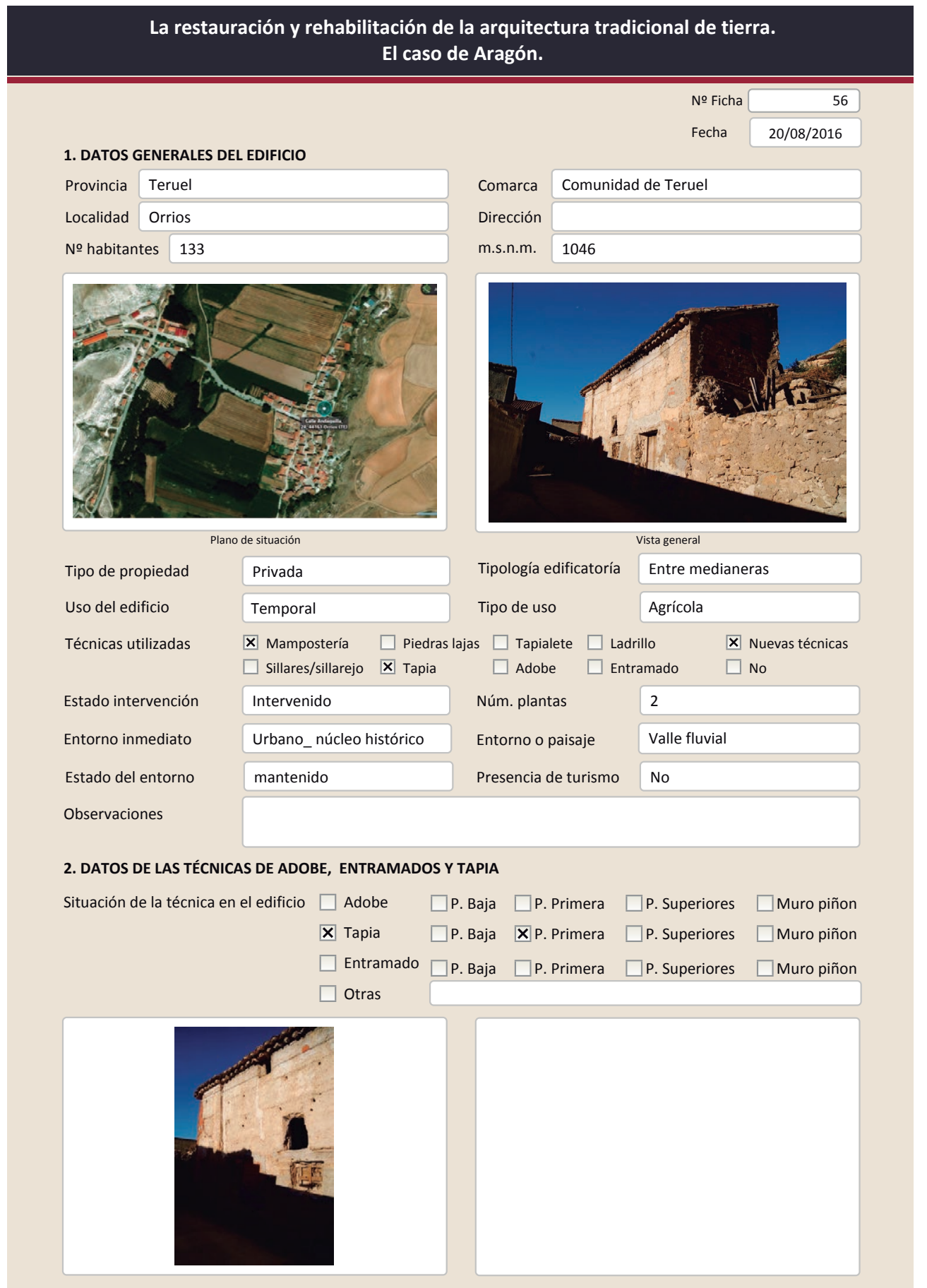

La restauración y rehabilitación de la arquitectura tradicional de tierra.

El caso de Aragón.

\subsection{TAPIA}

Ancho del muro

Dimensión tapiales

Tipo de aguja

\begin{tabular}{|l|}
\hline $40-50 \mathrm{~cm}$ \\
\hline \\
\hline Redonda \\
\hline 3 \\
\hline
\end{tabular}

Color de la tapia

№ agujas/cajón

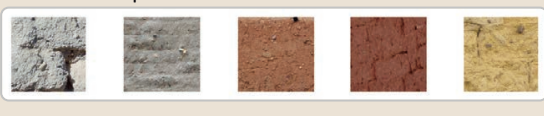

X Blanquecino $\square$ Marrón $\square$ Amarillento

$x$ Blanquecino $\square$ Marrón $\square$ Amaril
$\square$ Grisaceo

Variante constructiva

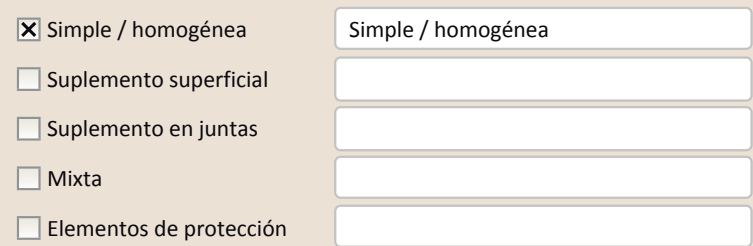

$\square$ Elementos de protección

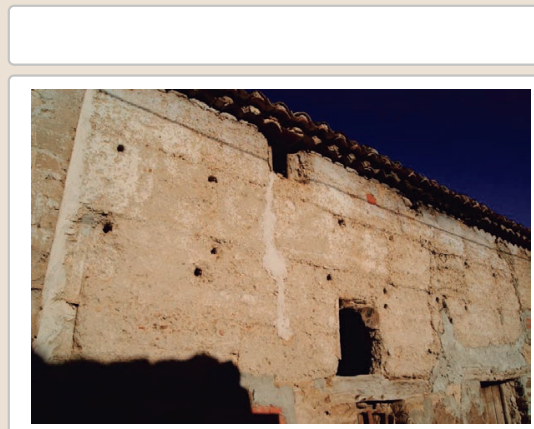

Lesiones $\mathbf{X}$ Muro $\mathbf{X}$ Zócalo $\square$ Revestimiento $\square$ Cubierta $\square$ Otro..

$\mathbf{X}$ Erosión del material $\quad \square$ Humedad por capilaridad $\quad \square$ Grietas por asentamientos $\mathbf{X}$ Erosion de las juntas $\square$ Humedades (manch/eflo) $\quad \square$ Colapso

$\mathbf{X}$ Pérdida de sección $\quad \square$ Pérdida de verticalidad $\quad \square$ Por elementos impropios

$\square$ Vegetación $\quad \square$ Grietas por empuje de la cubierta $\quad \square$ Derivado de intervenciones $\square$ Desconchados $\quad \mathbf{X}$ Grietas porfalta de traba $\quad \square$ Otro... 


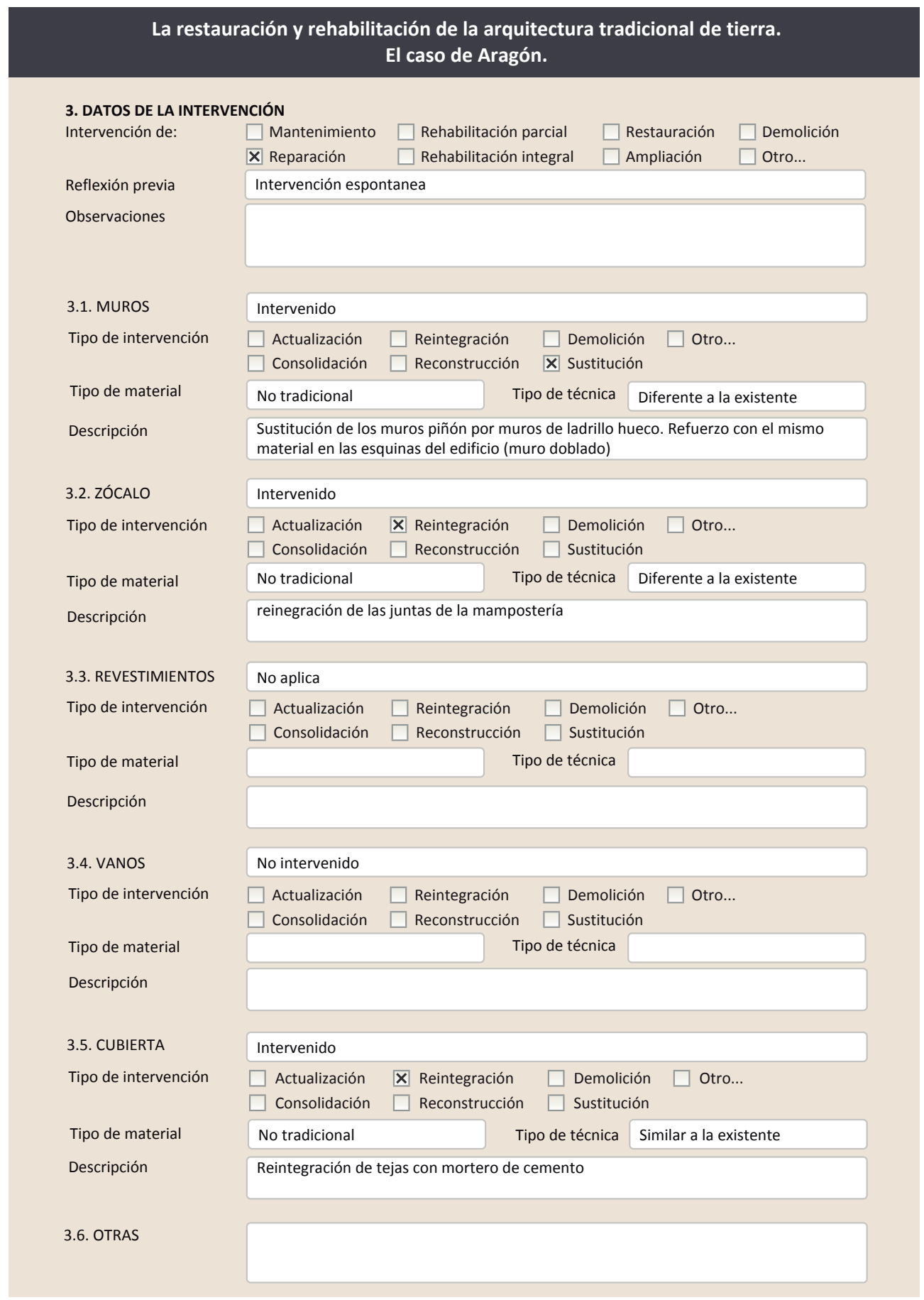

3.7. REHABILITACIÓN ENERGÉTICA $\quad \square$ Fachada $\square$ Vanos $\square$ Forjados $\square$ Cubierta

Observaciones

FOTOGRAFíAS DE LA INTERVENCIÓN
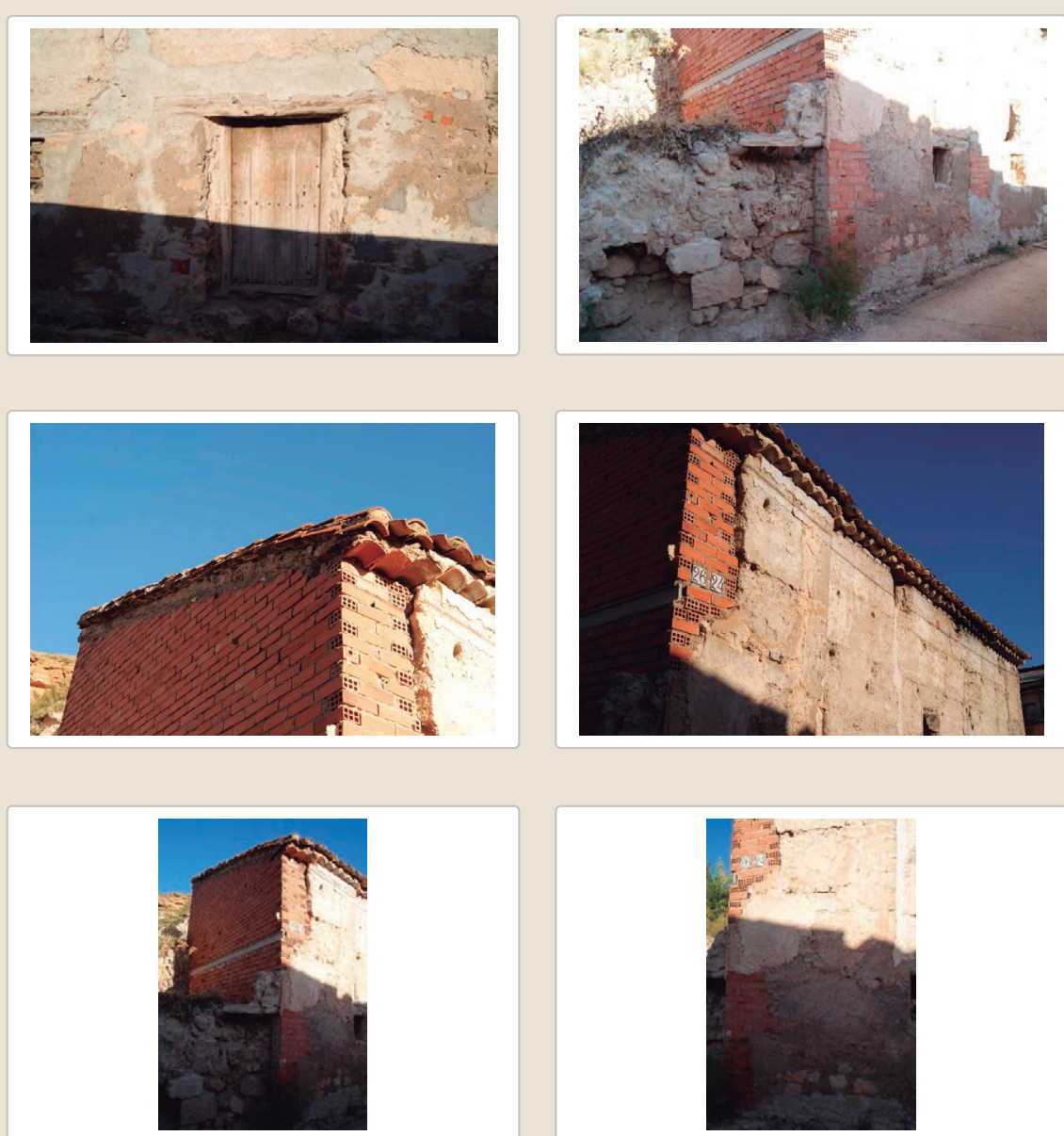


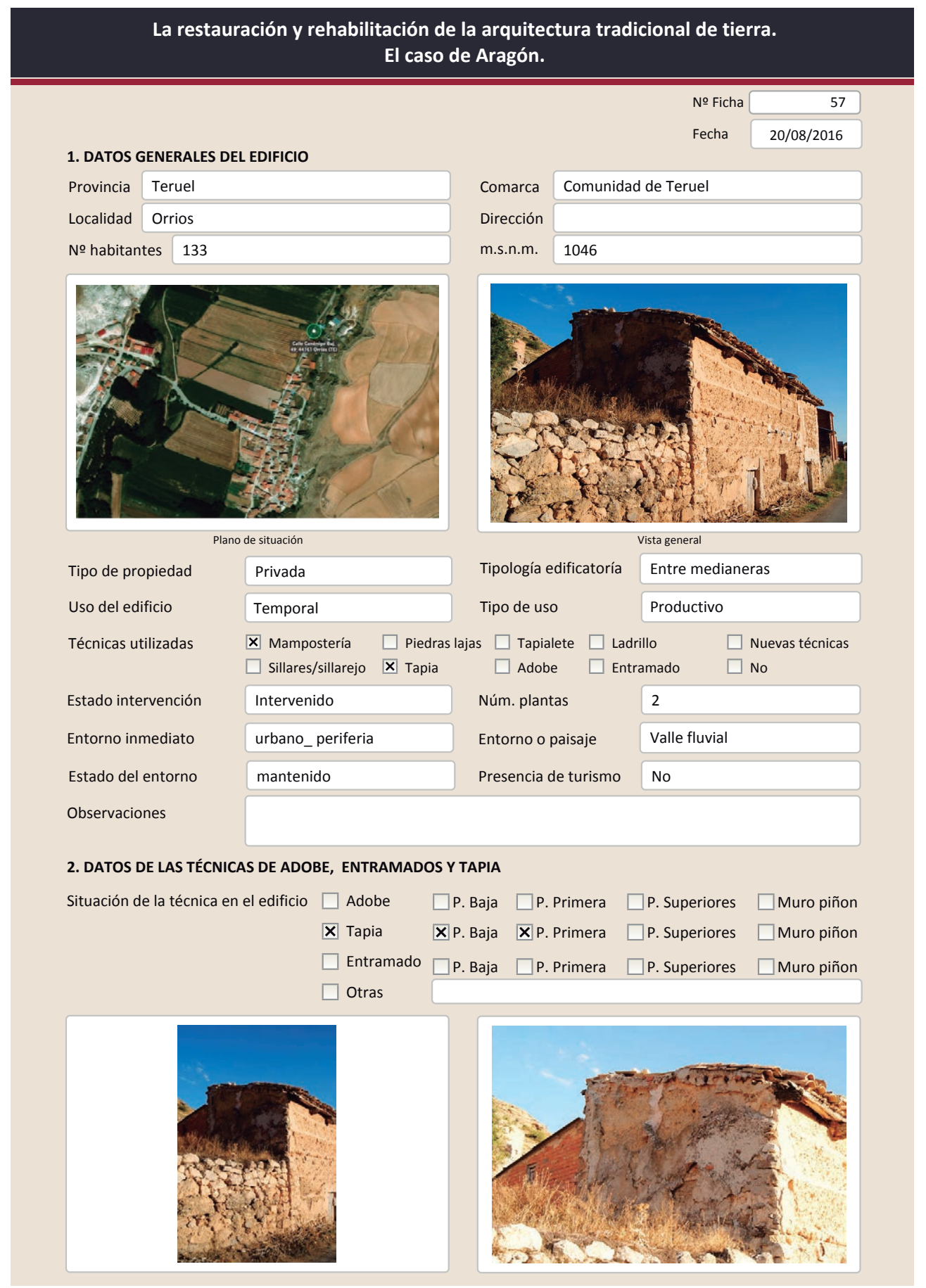

La restauración y rehabilitación de la arquitectura tradicional de tierra. El caso de Aragón.

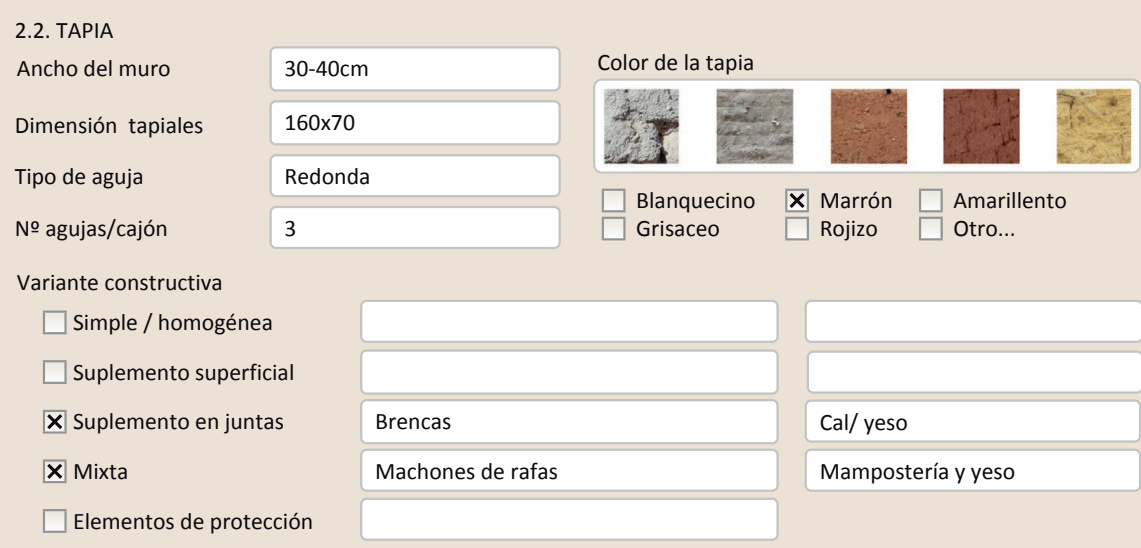

$\square$ Elemento

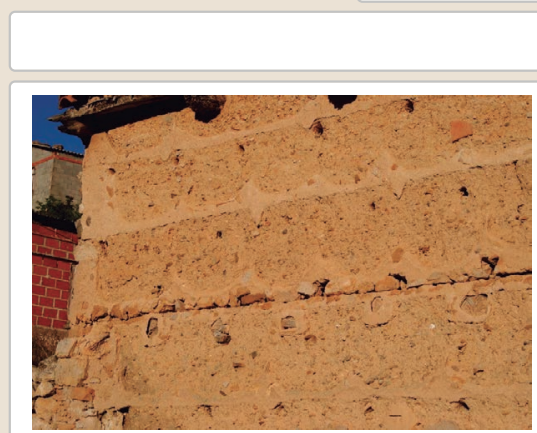

Lesiones ХMuro XZŹcalo $\square$ Revestimiento \X Cubierta $\square$ Otro...

$\mathbf{X}$ Erosión del material $\square$ Humedad por capilaridad $\quad \mathbf{X}$ Grietas por asentamientos $\square$ Erosion de las juntas $\square$ Humedades (manch/eflo) $\quad \square$ Colapso

X Pérdida de sección $\square$ Pérdida de verticalidad $\square$ Por elementos impropios

$\square$ Vegetación $\quad \square$ Grietas por empuje de la cubierta $\square$ Derivado de intervenciones $\square$ Desconchados $\quad \square$ Grietas porfalta de traba

$\square$ Otro...
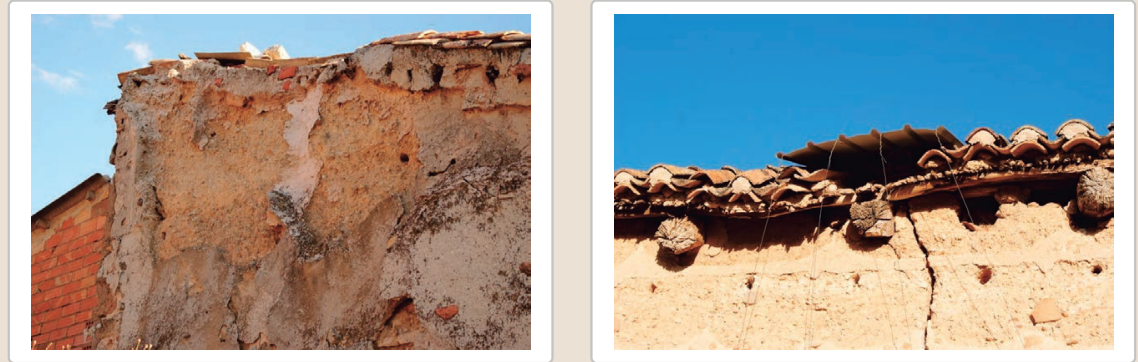

Observaciones

Perdida de sección principalmente en la cara norte del edificio 


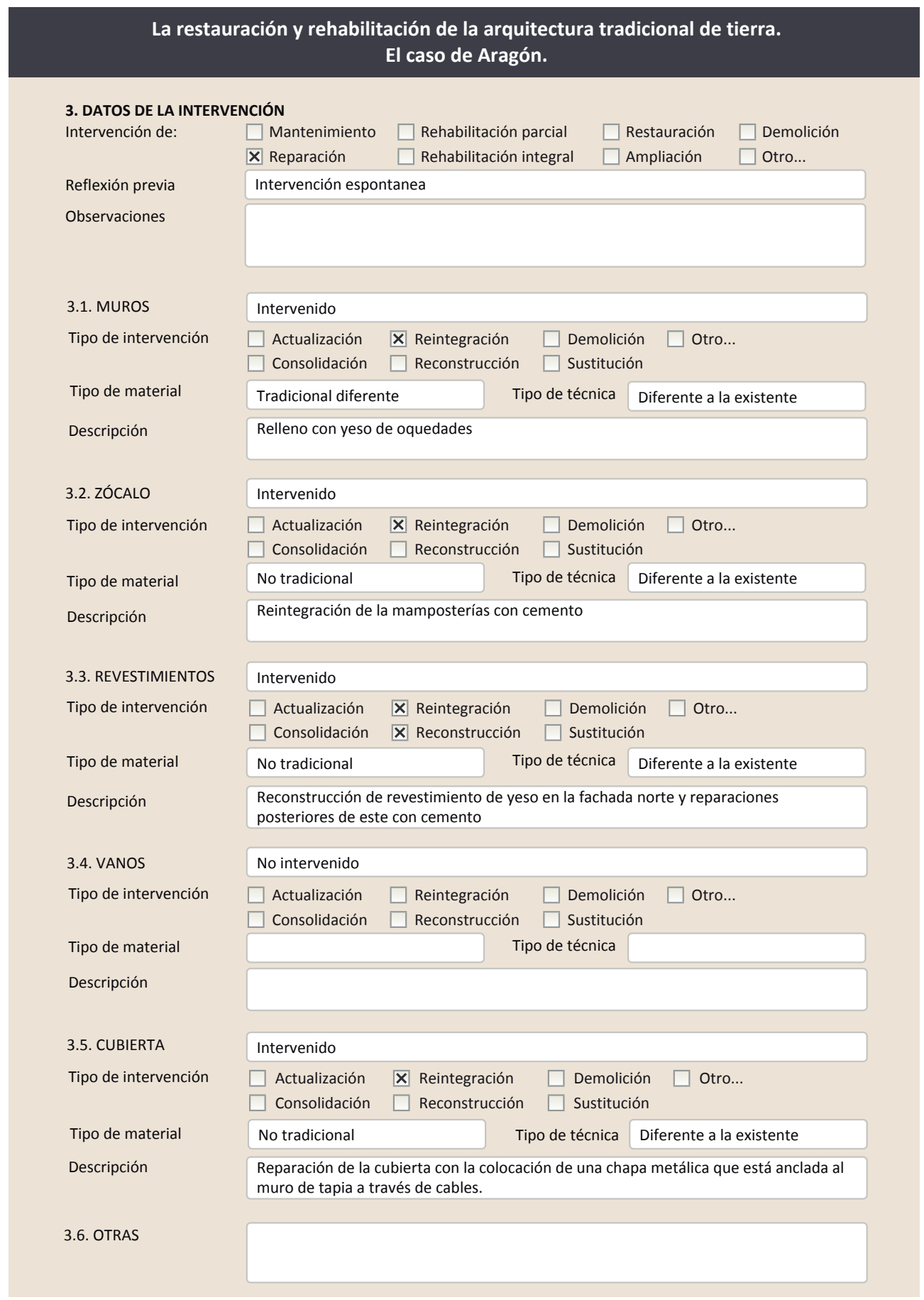

3.7. REHABILITACIÓN ENERGÉTICA $\quad \square$ Fachada $\square$ Vanos $\square$ Forjados $\square$ Cubierta Observaciones

FOTOGRAFÍAS DE LA INTERVENCIÓN
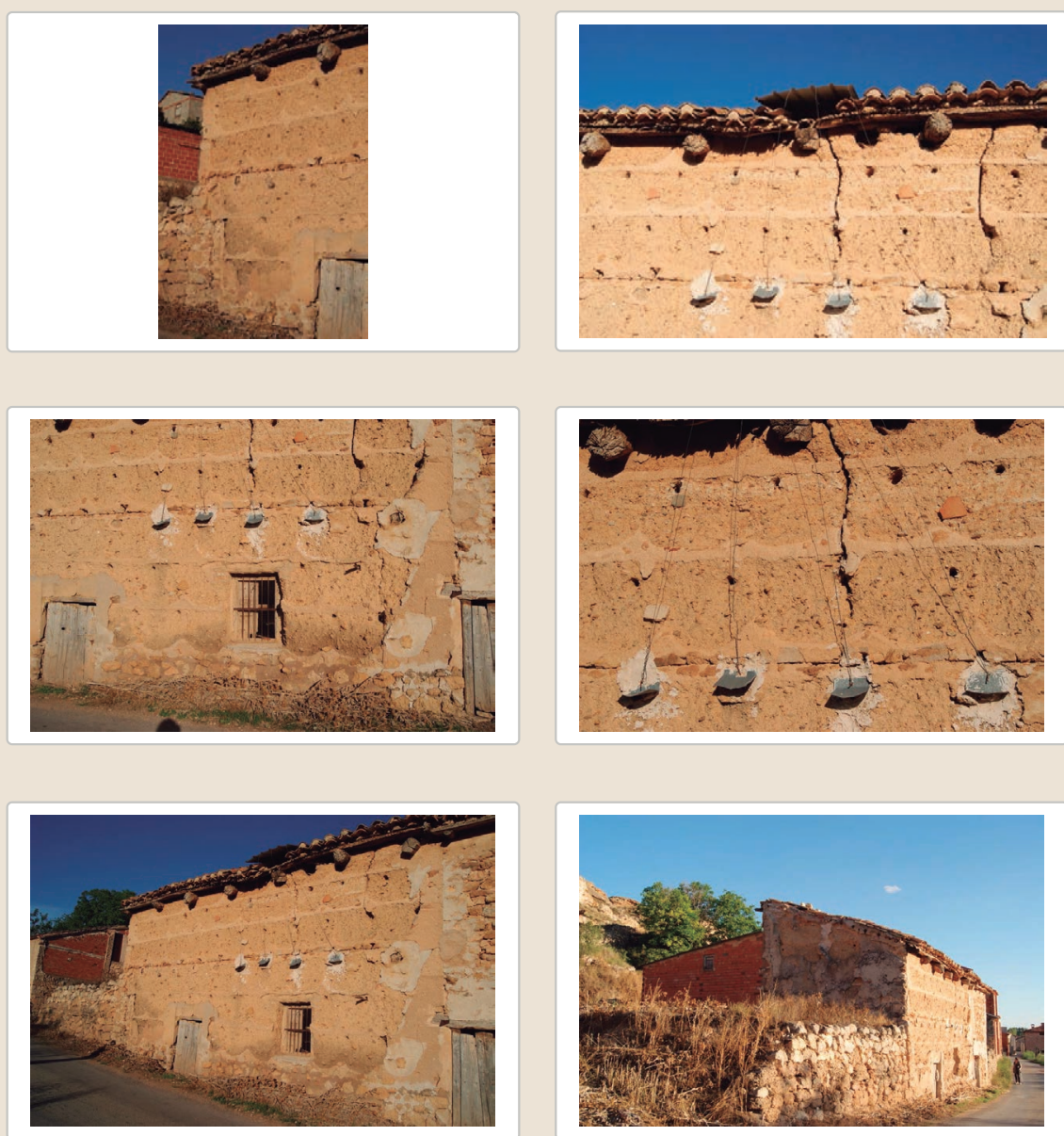


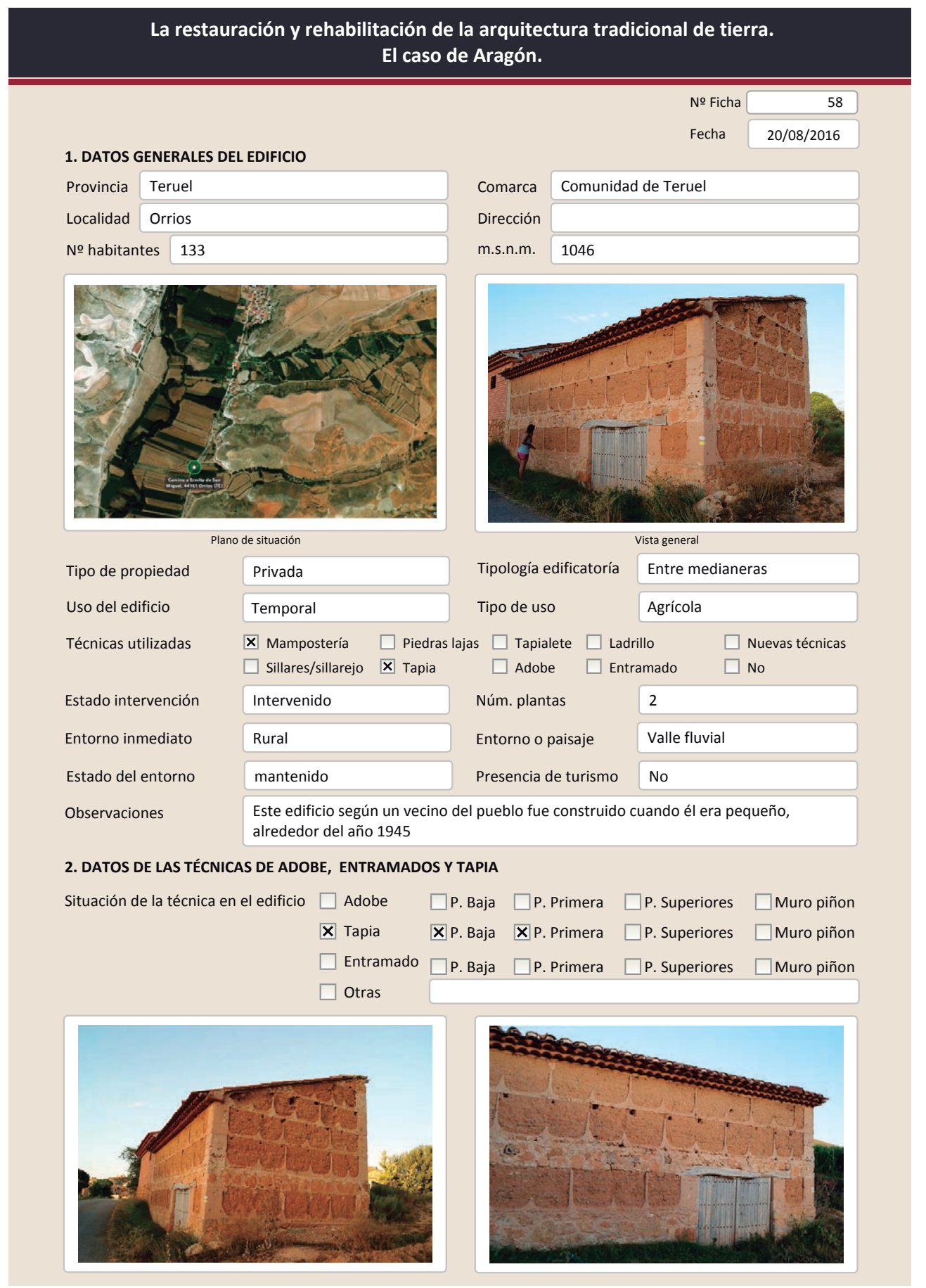

La restauración y rehabilitación de la arquitectura tradicional de tierra. El caso de Aragón.
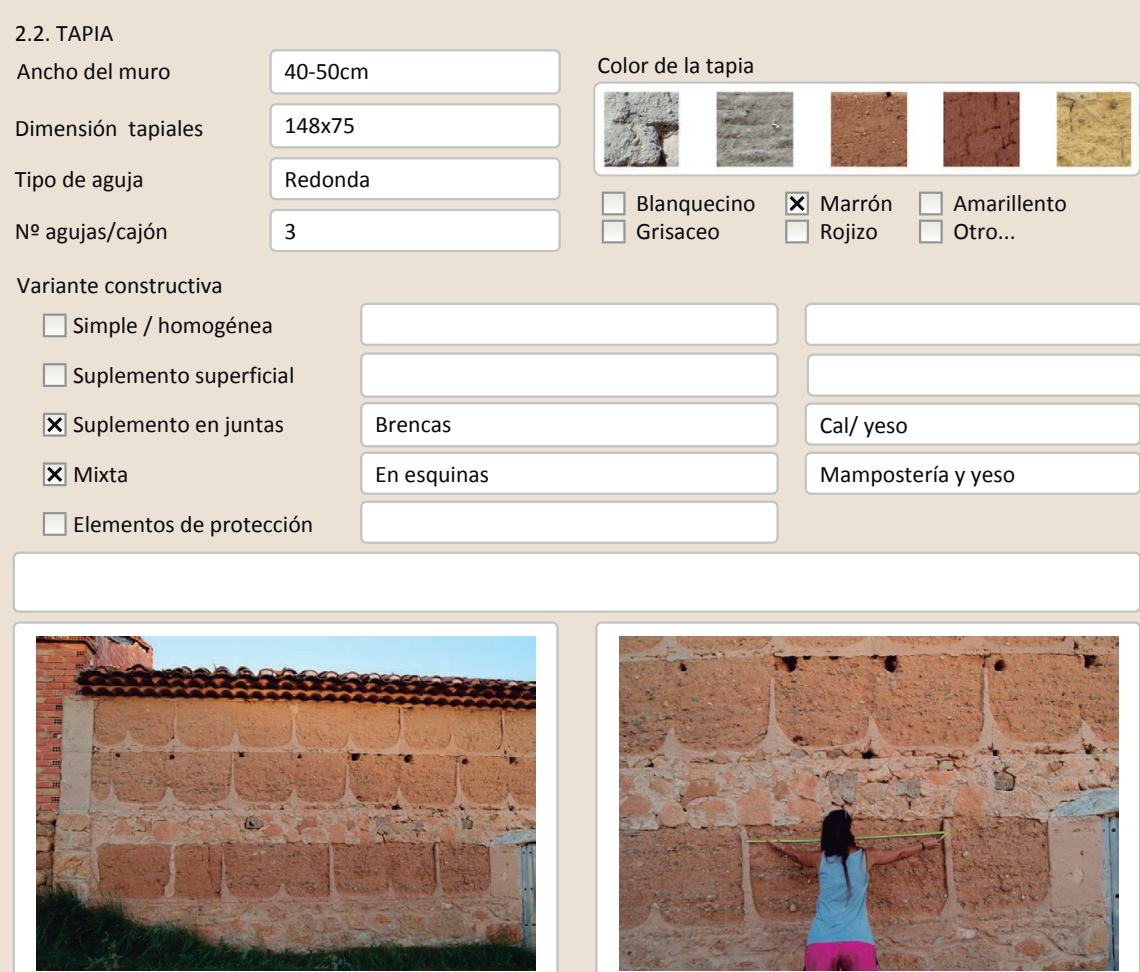

Lesiones $\quad \mathbf{X}$ Muro $\square$ Zócalo $\square$ Revestimiento $\square$ Cubierta $\square$ otro...

X Erosión del material $\quad \square$ Humedad por capilaridad $\quad \square$ Grietas por asentamientos $\square$ Erosion de las juntas $\square$ Humedades (manch/eflo) $\quad \square$ Colapso

$\mathbf{X}$ Pérdida de sección $\square$ Pérdida de verticalidad

$\square$ Vegetación

$\square$ Por elementos impropios

$\square$ Desconchados
$\square$ Grietas por empuje de la cubierta
$\square$ Perivado de

$\square$ Desconchados $\quad \square$ Grietas porfalta de traba

$\square$ Otro...
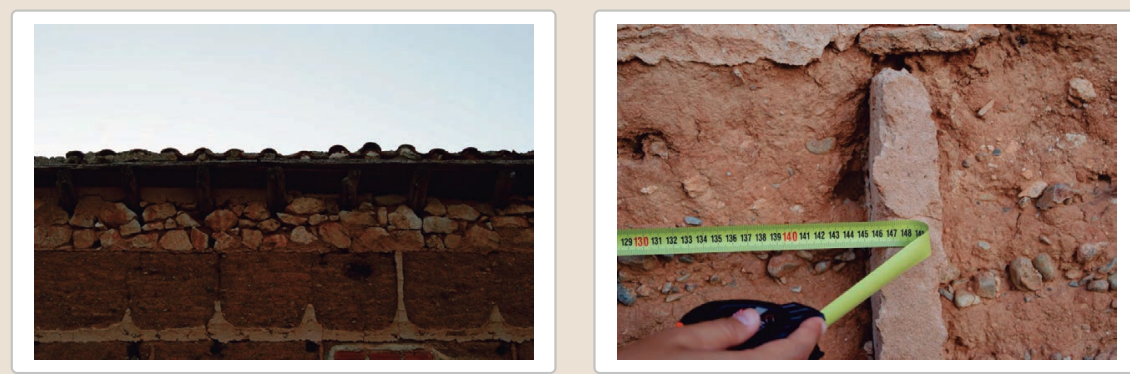

Observaciones

hay zonas donde el muro ha perdido una sección importante y se ve como algunas juntas de yeso no tienen elemento de sujeción 


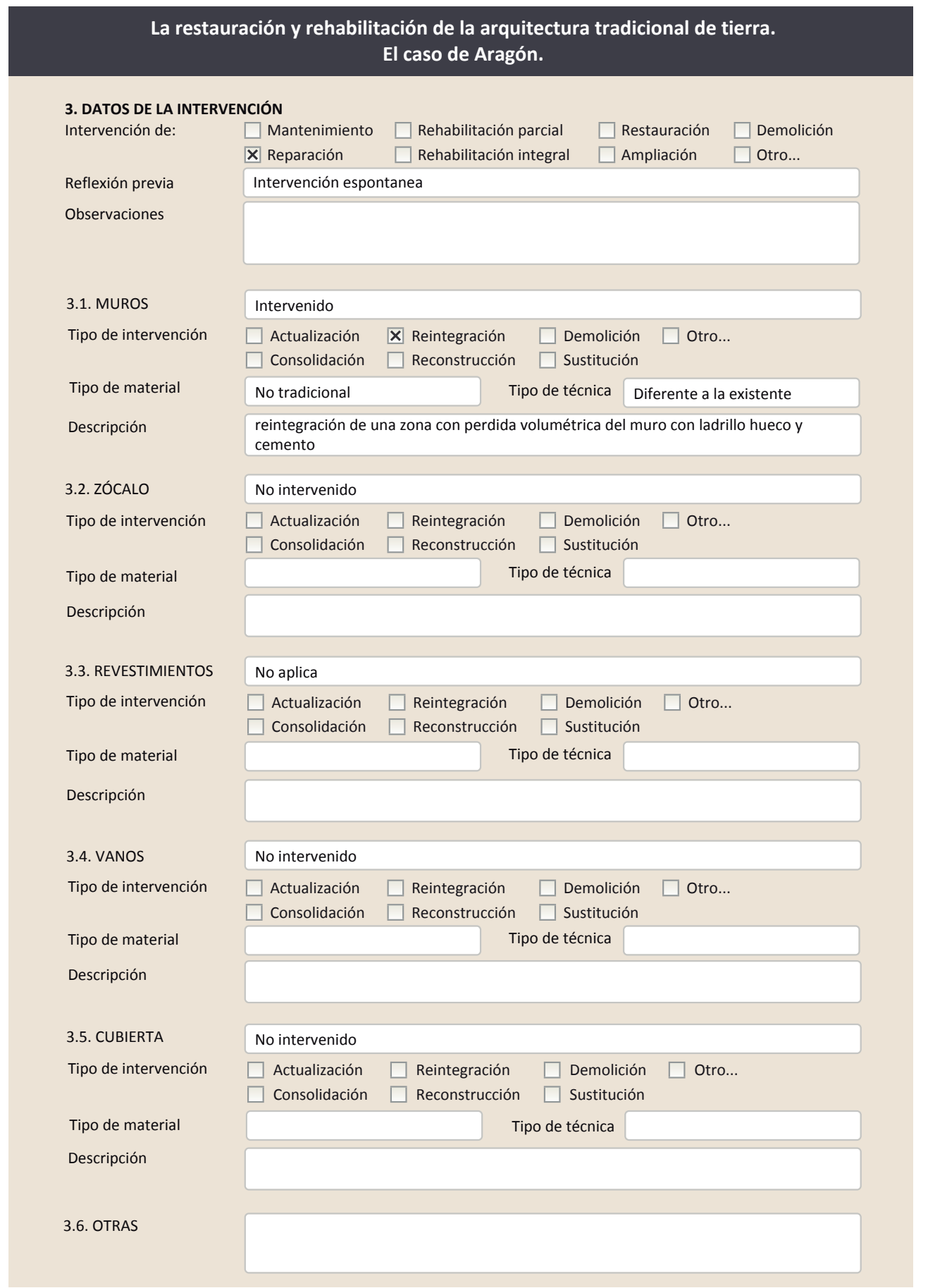

\subsection{REHABILITACIÓN ENERGÉTICA $\quad \square$ Fachada $\square$ Vanos $\square$ Forjados $\square$ Cubierta}

Observaciones

FOTOGRAFíAS DE LA INTERVENCIÓN
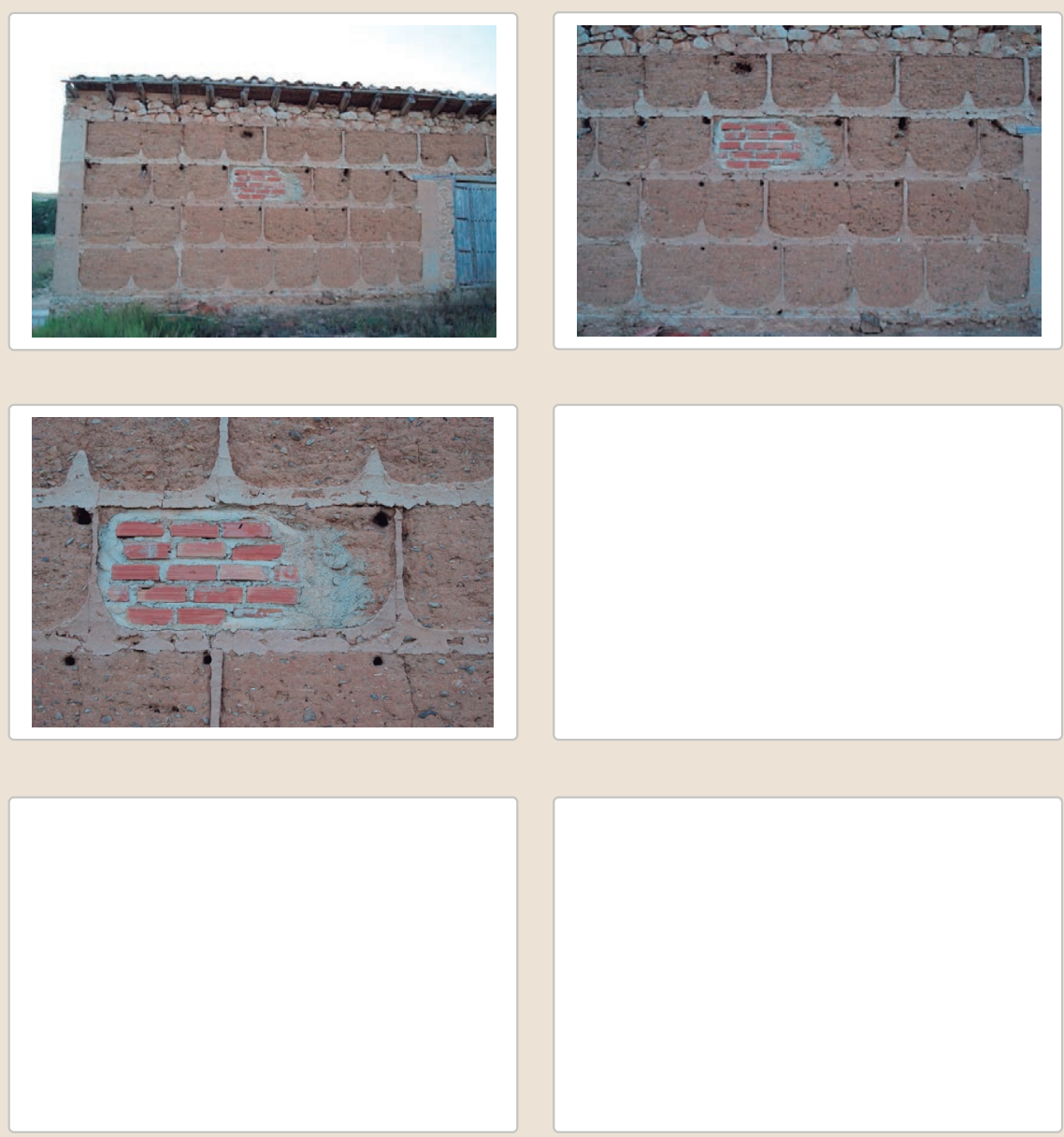


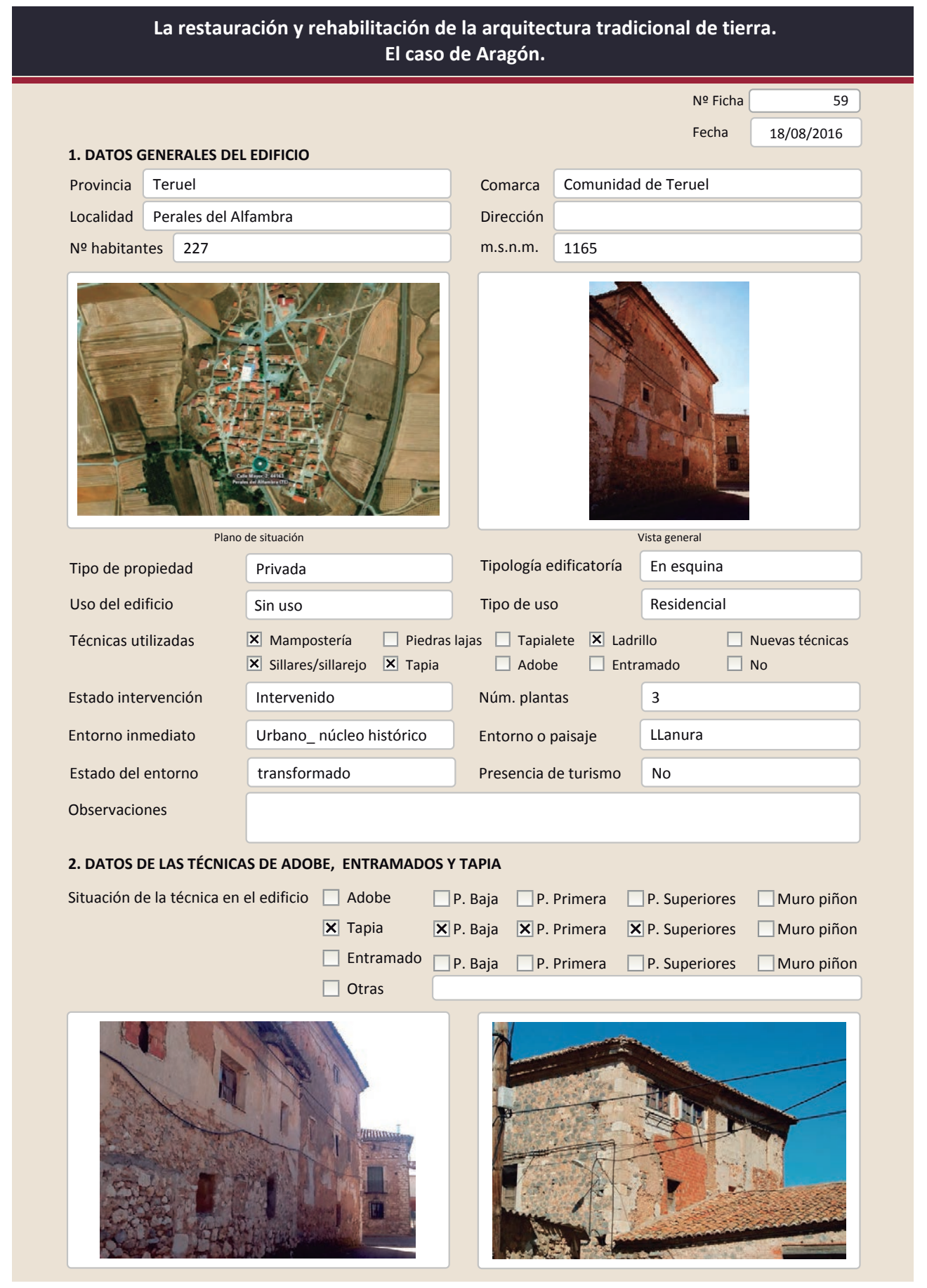

La restauración y rehabilitación de la arquitectura tradicional de tierra. El caso de Aragón.
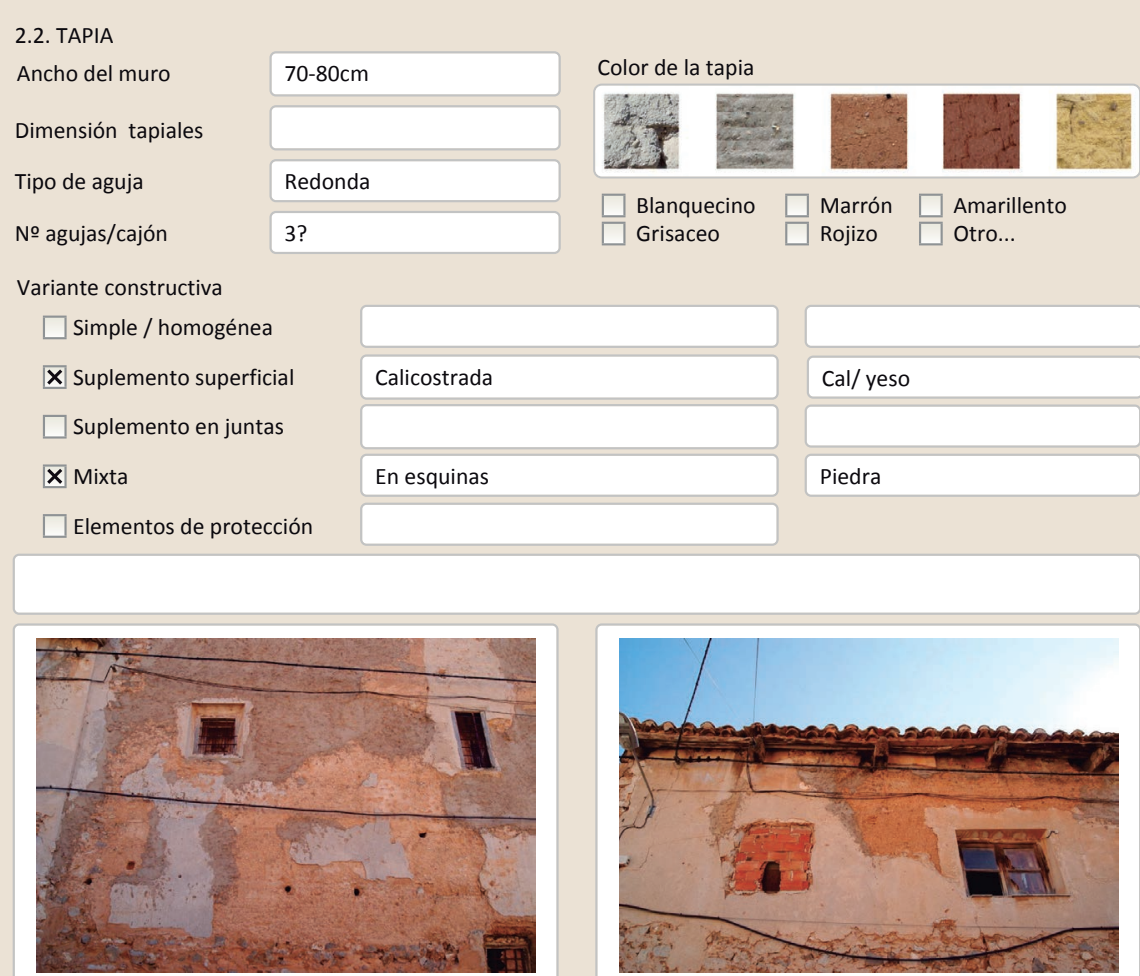

Lesiones $\mathbf{X}$ Muro $\mathbf{X}$ Zócalo $\mathbf{X}$ Revestimiento $\mathbf{X}$ Cubierta $\square$ Otro...

$\mathbb{X}$ Erosión del material $\quad \square$ Humedad por capilaridad $\quad \square$ Grietas por asentamientos $\square$ Erosion de las juntas $\square$ Humedades (manch/eflo) X Pérdida de sección $\square$ Pérdida de verticalidad

$\square$ Vegetación $\quad \square$ Grietas por empuje de la cubierta $\mathbf{X}$ Desconchados $\square$ Grietas porfalta de traba

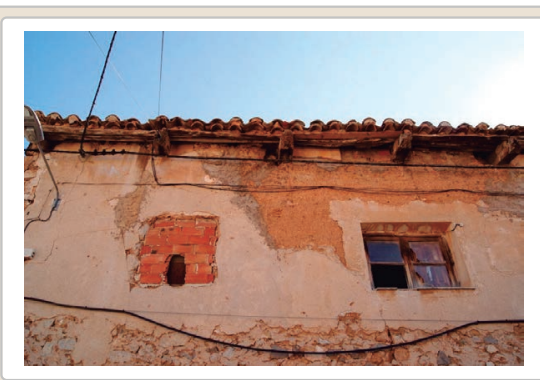

$\square$ Por elem

$\square$ Derivadontos impropios $\square$ Otro...
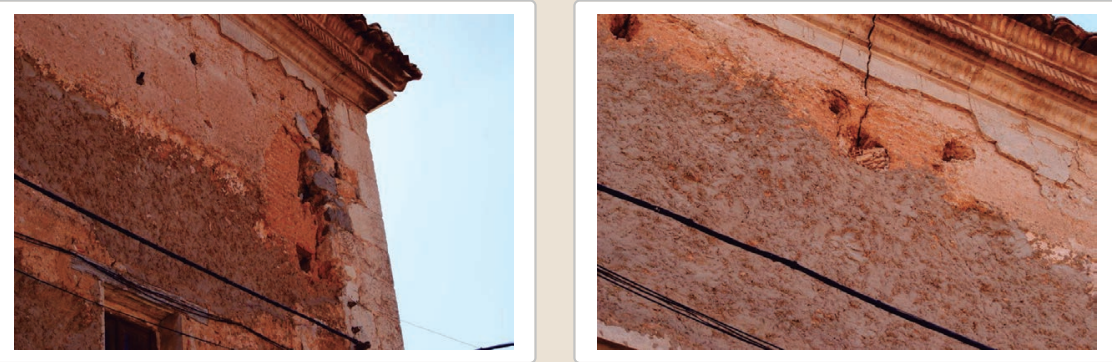

Observaciones Grietas en los apoyos de las vigas de cubierta. Presenta problemas estructurales serios en el muro piñón 


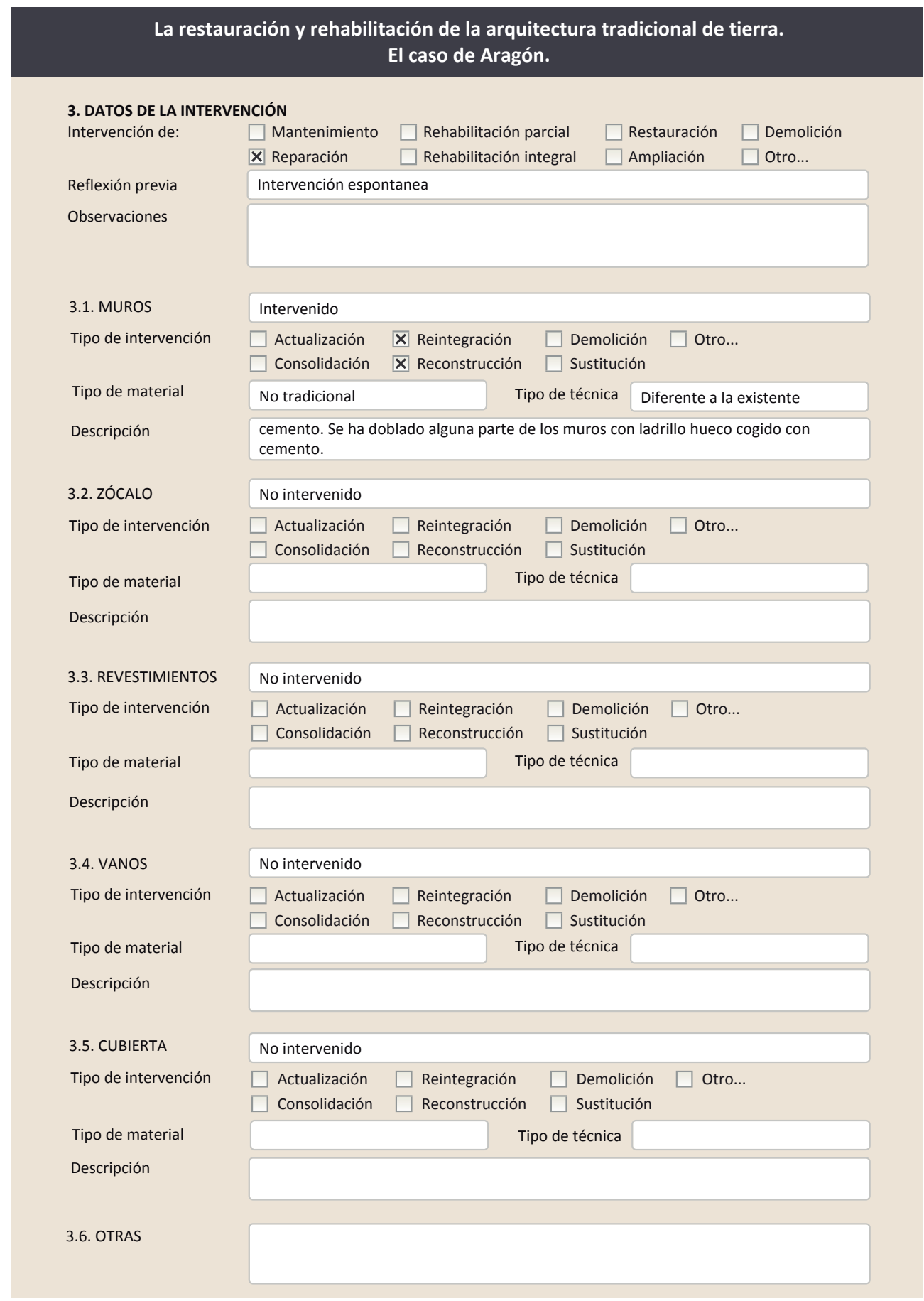

3.7. REHABILITACIÓN ENERGÉTICA $\quad \square$ Fachada $\square$ Vanos $\square$ Forjados $\square$ Cubierta Observaciones

FOTOGRAFíAS DE LA INTERVENCIÓN
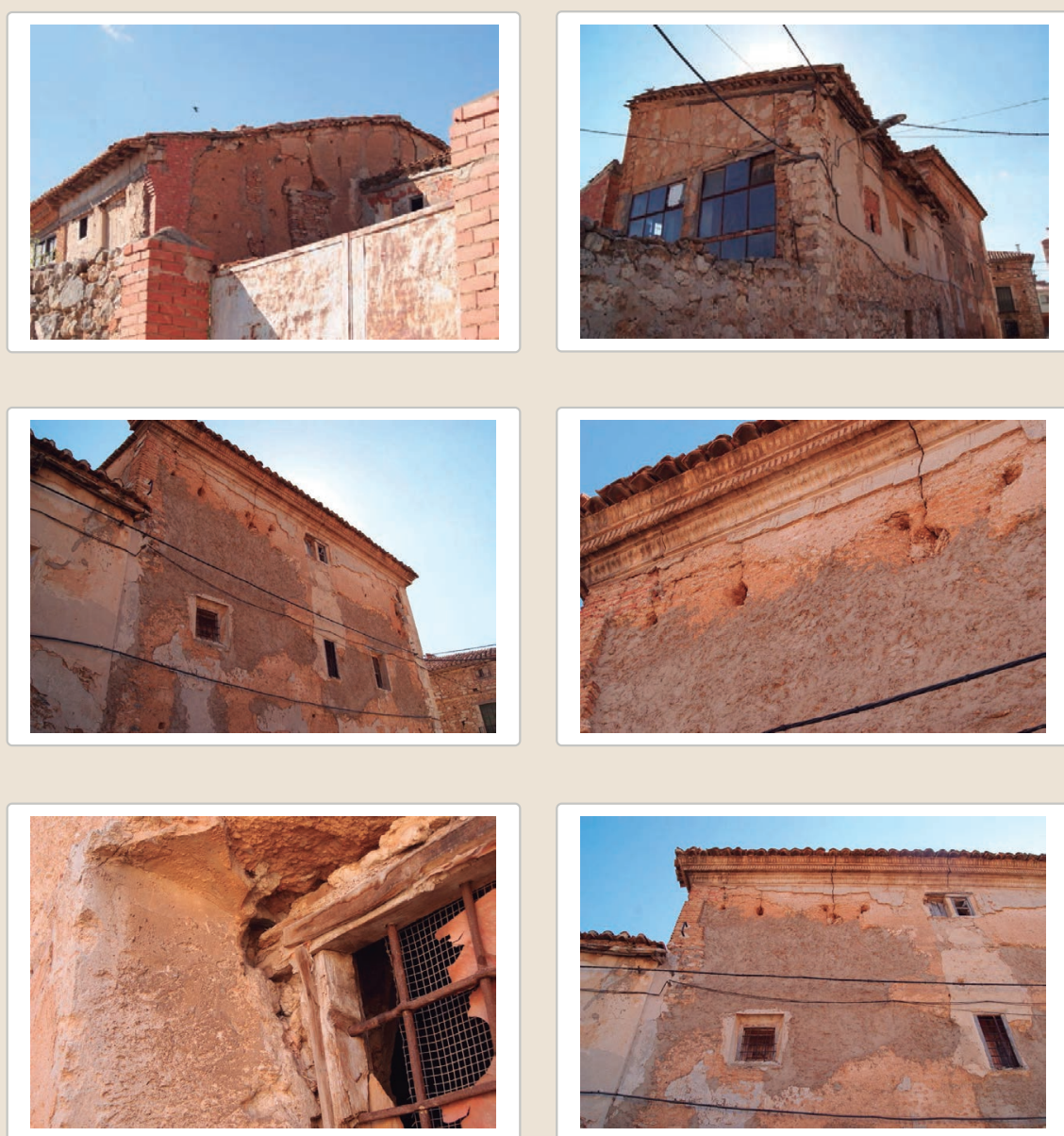


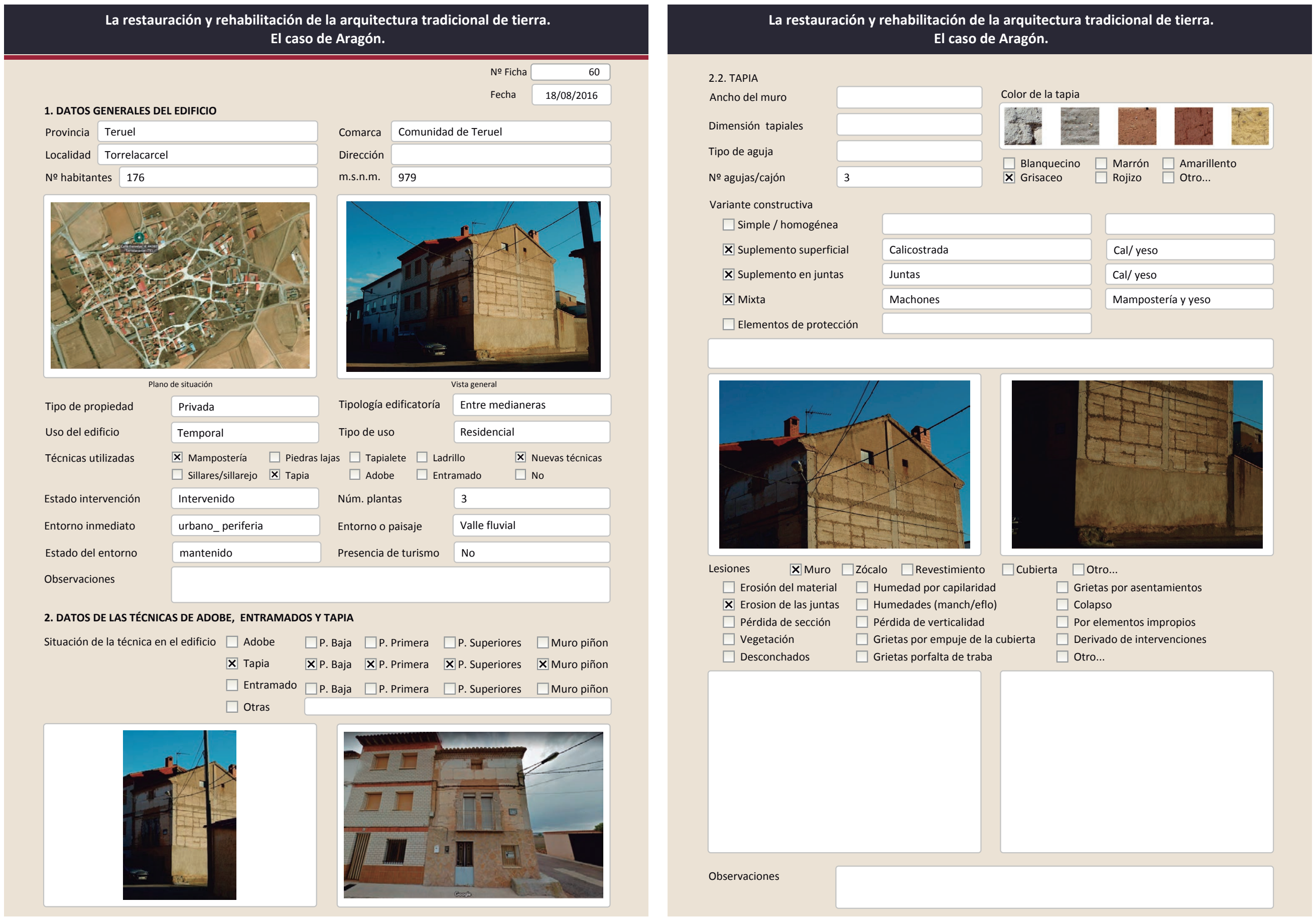




\section{La restauración y rehabilitación de la arquitectura tradicional de tierra.}

\section{El caso de Aragón.}

3. DATOS DE LA INTERVENCIÓN

Mantenimiento $\times$ Rehabilitación parcial

$\square$ Restauración $\square$ Demolición

Reflexión previa

X Reparación

Rehabilitación integr

$\square$ Ampliación

$\square$ Otro...

Reflexion previa
Observaciones

Intervención espontanea

Observacion

3.1. MUROS

Tipo de intervención

Tipo de material

Descripción

3.2. ZÓCALO

Tipo de intervención

Tipo de material

Descripción

3.3. REVESTIMIENTOS

Tipo de intervención

Tipo de material

Descripción

3.4. VANOS

Tipo de intervención

Tipo de material

Descripción

3.5. CUBIERTA

Tipo de intervención

Tipo de material

Descripción

Intervenido

$\square$ Actualización $\quad \boldsymbol{X}$ Reintegración $\square$ Demolición $\square$ Otro...

$\square$ Consolidación $\quad \square$ Reconstrucción $\quad \mathbb{X}$ Sustitución

\begin{tabular}{|lll}
\hline No tradicional Tipo de técnica Diferente a la existente \\
\hline
\end{tabular}

Reintegración de las juntas entre tapiales con cemento. La parte superior del muro Reintegración de las juntas entre tapiales con cemento. La
piñon ha sido sustituida por ladrillo revestido de cemento.

Intervenido

X Actualización $\square$ Reintegración $\square$ Demolición $\square$ Otro...

$\square$ Consolidación $\quad \square$ Reconstrucción $\quad \square$ Sustitución

No tradicional Tipo de técnica Diferente a la existente

Zócalo de planta baja con lajas de piedra cogidas con cemento. EN la fachada lateral solo revestimiento de cemento

No aplica

$\square$ Actualización $\square$ Reintegración $\square$ Demolición $\square$ Otro...

$\square$ Consolidación $\square$ Reconstrucción $\square$ sustitución

Tipo de técnica

rang

Intervenido

$\square$ Actualización $\square$ Reintegración $\square$ Demolición $\square$ Otro...

$\square$ Consolidación $\square$ Reconstrucción $\quad \boldsymbol{X}$ Sustitución

\begin{tabular}{|l|l|l|l|l} 
No tradicional Tipo de técnica Diferente a la existente &
\end{tabular}

Sustitución de carpinterías por elementos de aluminio

\section{Intervenido}

$\square$ Actualización $\quad \mathbf{X}$ Reintegración $\square$ Demolición $\square$ Otro.

$\square$ Consolidación $\square$ Reconstrucción $\square$ Sustitución
No tradicional
Tipo de técnica Similar a la existente

Reintegración de la cubierta con mortero de cemento. Se ha cogido las tejas y rehecho la zona del alero y lateral de la misma
La restauración y rehabilitación de la arquitectura tradicional de tierra.

El caso de Aragón.

3.7. REHABILITACIÓN ENERGÉTICA $\quad \square$ Fachada $\square$ Vanos $\square$ Forjados $\square$ Cubierta

Observaciones

FOTOGRAFÍAS DE LA INTERVENCIÓN
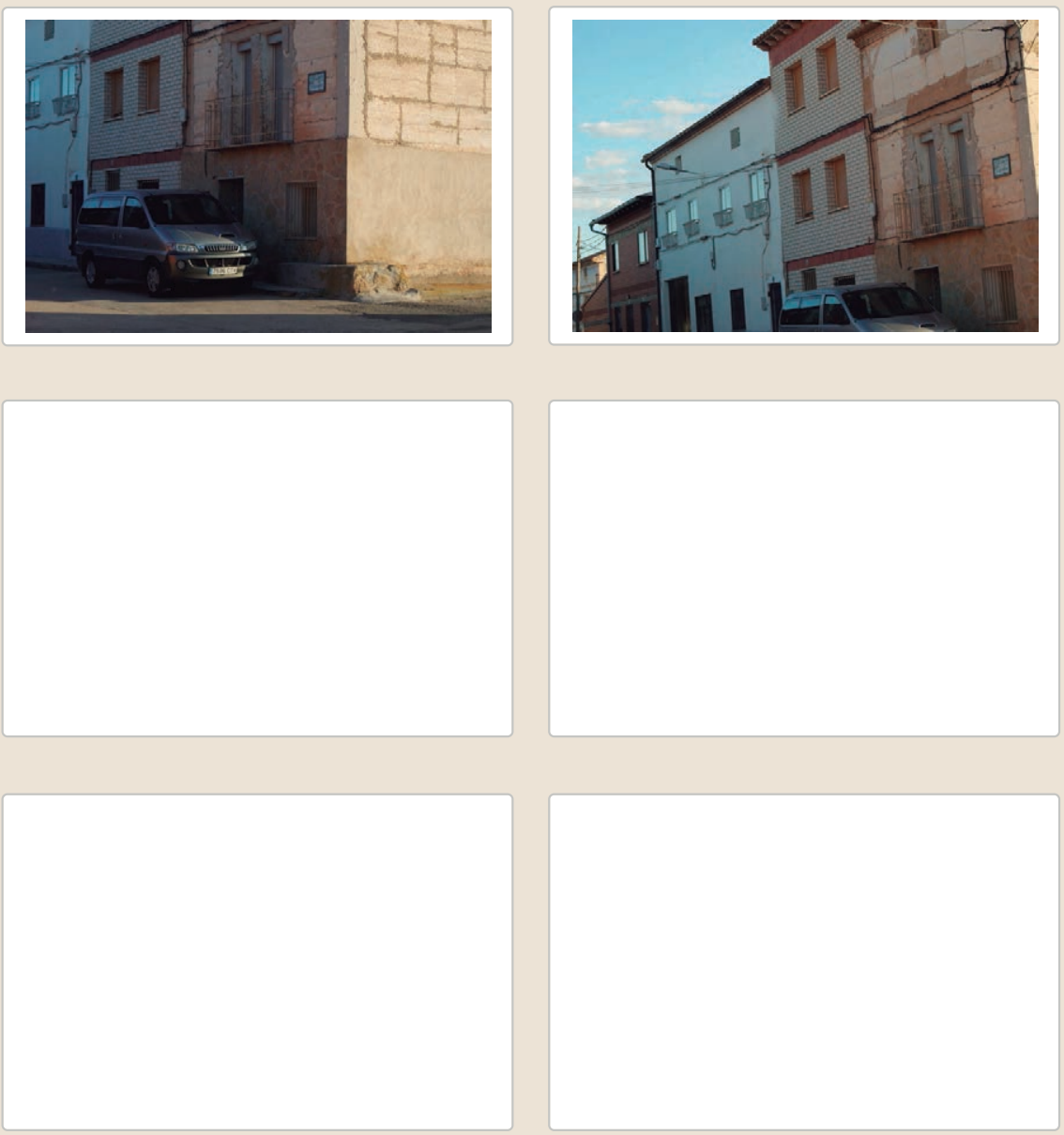

3.6. OTRAS 


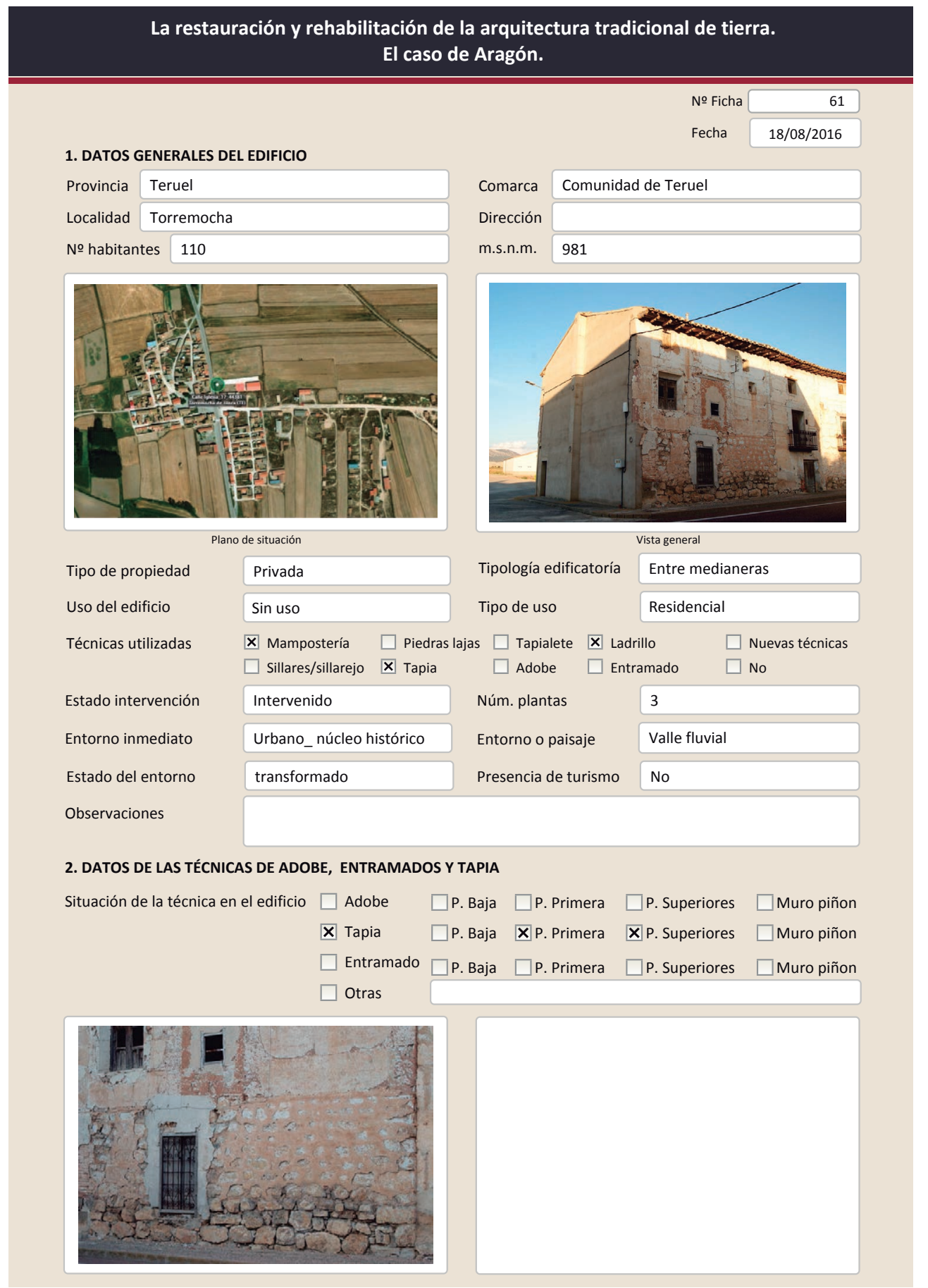

La restauración y rehabilitación de la arquitectura tradicional de tierra.

El caso de Aragón.

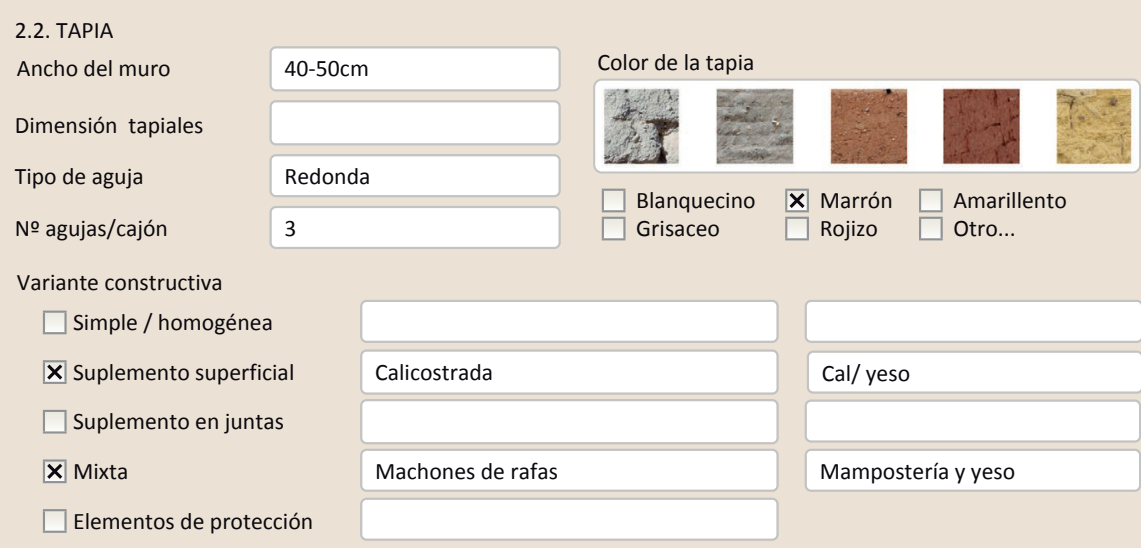

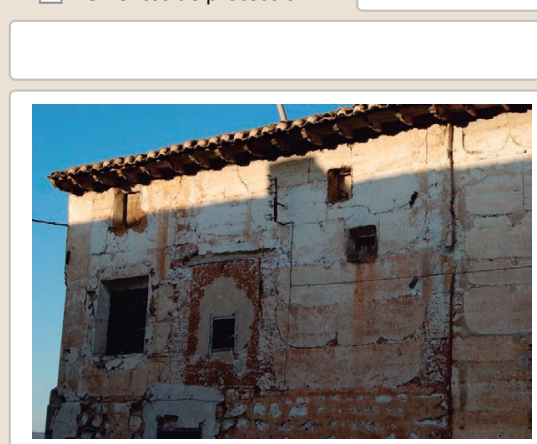

Lesiones $\quad \mathbf{X}$ Muro $\mathbf{X}$ Zócalo $\square$ Revestimiento $\square$ Cubierta $\square$ otro...

X Erosión del material $\quad \mathbf{X}$ Humedad por capilaridad $\quad \square$ Grietas por asentamientos $\square$ Erosion de las juntas $\square$ Humedades (manch/eflo)

$\square$ Pérdida de sección $\square$ Pérdida de verticalidad

$\square$ Vegetación

$\square$ Desconchados

$\square$ Grietas por empuje de la

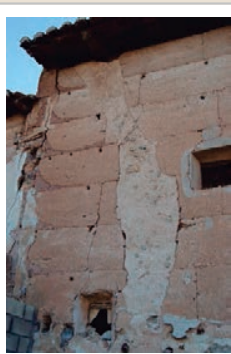

Observaciones problemas en el zócalo, en parte por intervenciones previas con cemento

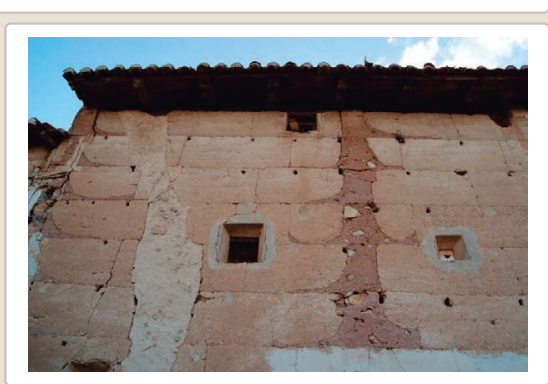

$\square$ Colapso

$\square$ Por elementos impropios

$\mathbf{X}$ Derivado de intervenciones $\square$ Otro...

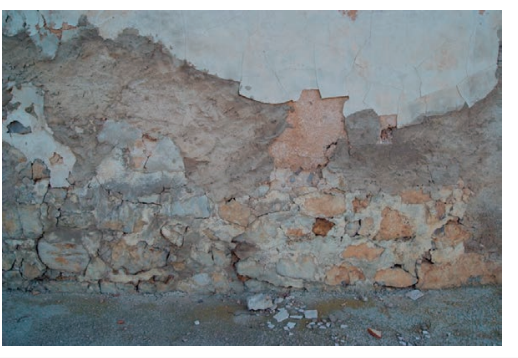




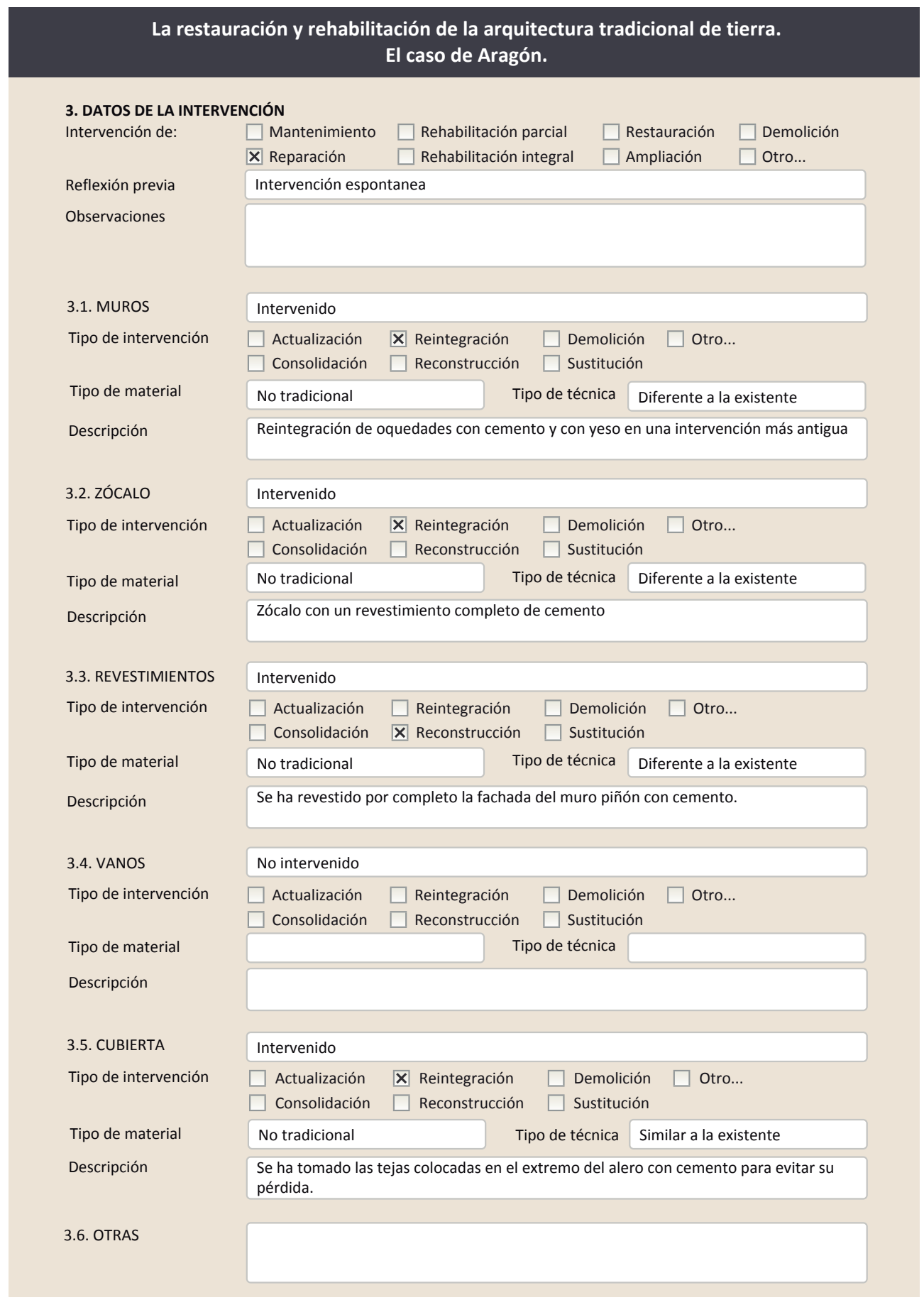

3.7. REHABILITACIÓN ENERGÉTICA $\quad \square$ Fachada $\square$ Vanos $\square$ Forjados $\square$ Cubierta Observaciones

FOTOGRAFÍAS DE LA INTERVENCIÓN
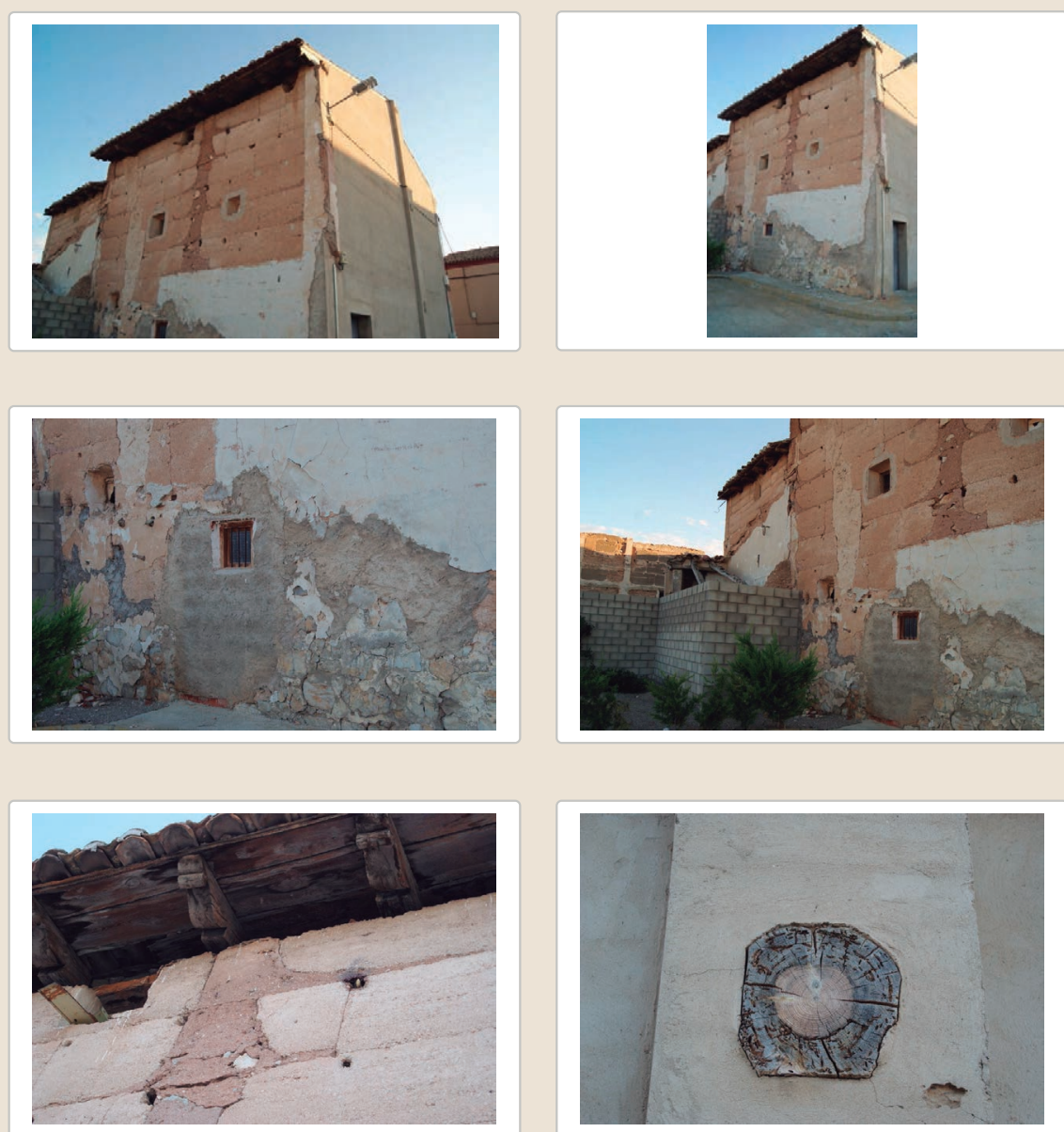


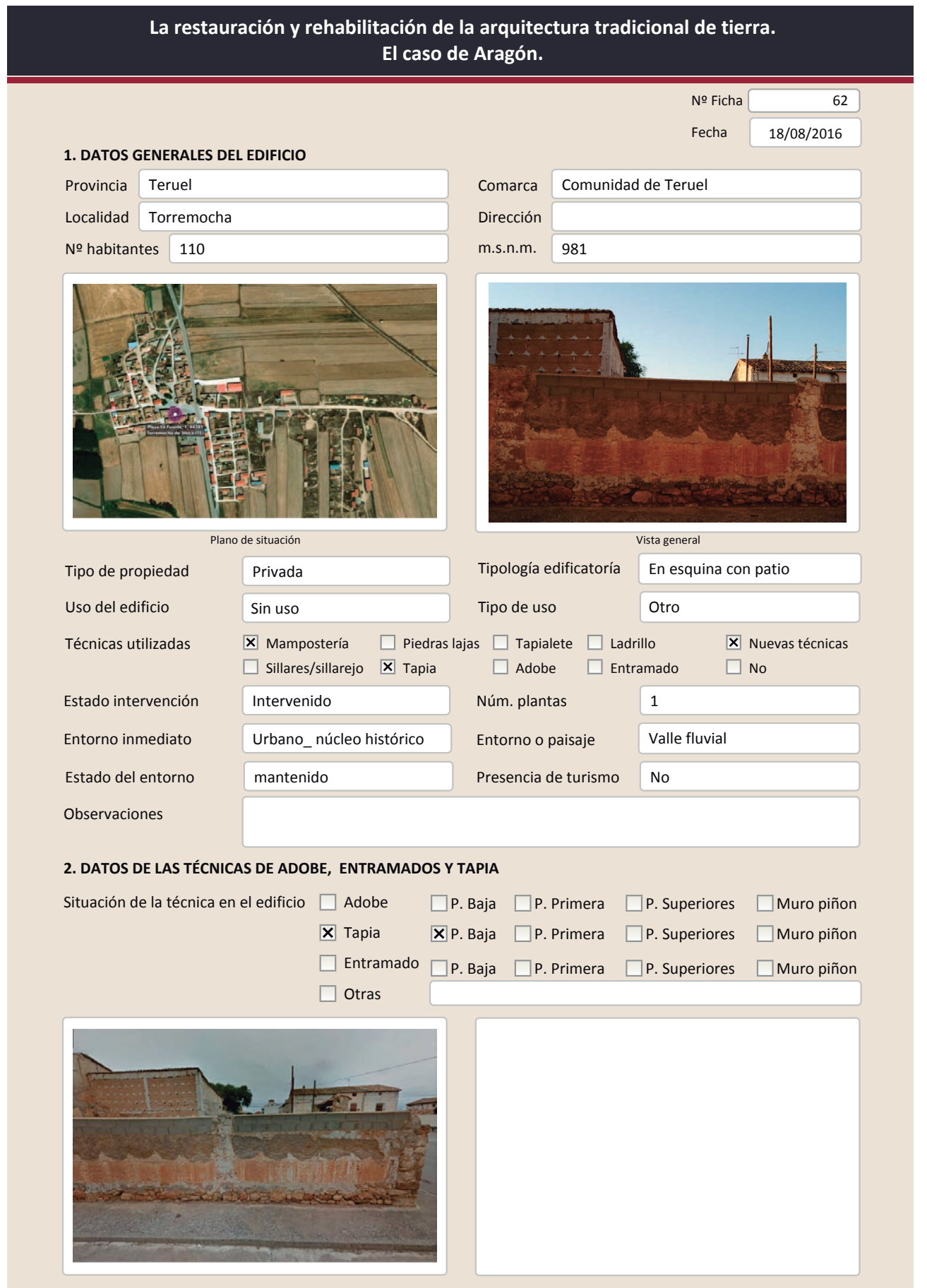

La restauración y rehabilitación de la arquitectura tradicional de tierra.

El caso de Aragón.

2.2. TAPIA

Ancho del muro

Dimensión tapiales

Tipo de aguja

\begin{tabular}{|l|}
\hline $30-40 \mathrm{~cm}$ \\
\hline \\
\hline Redonda \\
\hline 3 \\
\hline
\end{tabular}

Color de la tapia

№ agujas/cajón

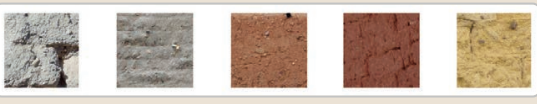

$\square$ Blanquecino $\quad \mathbf{X}$ Marrón $\square$ Amarillento

$\square$ Blanquecino $\quad \mathbf{x}$ Marrón
$\square$ Grisaceo $\quad \square$ Rojizo $\quad \square$ Otro...

Variante constructiva

$\square$ simple / homogénea

X Suplemento superficial

$\mathbf{X}$ Suplemento en juntas

X Mixta
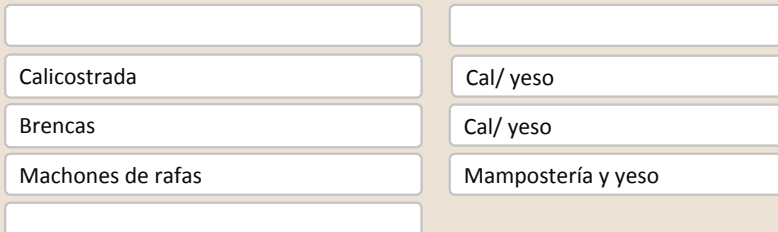

$\square$ Elementos de protección

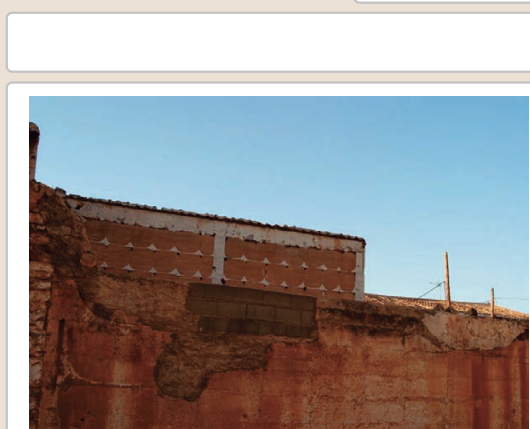

Lesiones $\quad$ Muro $\square$ Zócalo $\square$ Revestimiento $\square$ Cubierta $\square$ otro..

X Erosión del material $\quad \square$ Humedad por capilaridad $\quad \square$ Grietas por asentamientos $\square$ Erosion de las juntas $\square$ Humedades (manch/eflo) $\quad \square$ Colapso

X Pérdida de sección $\square$ Pérdida de verticalidad $\quad \square$ Por elementos impropios

$\square$ Vegetación $\quad \square$ Grietas por empuje de la cubierta $\quad \square$ Derivado de intervenciones X Desconchados

$\square$ Grietas porfalta de traba

$\square$ Otro...

Observaciones 
La restauración y rehabilitación de la arquitectura tradicional de tierra. El caso de Aragón

\section{La restauración y rehabilitación de la arquitectura tradicional de tierra.}

\section{El caso de Aragón.}

3. DATOS DE LA INTERVENCIÓN

Intervención de:

$\square$ Mantenimiento $\square$ Rehabilitación parcia

$\square$ Restauración $\square$ Demolición

Reflexión previa

X Reparación

$\square$ Rehabilitación integral $\square$ Ampliació

$\square$ Otro..

Observaciones

Intervención espontanea

(n)

3.1. MUROS

Tipo de intervención

Intervenido

Tipo de material

$\square$ Actualización $\quad \boldsymbol{X}$ Reintegración $\square$ Demolición $\square$ Otro...

$\square$ Consolidación $\quad \mathbf{X}$ Reconstrucción $\square$ Sustitución

Descripción

No tradicional Tipo de técnica Diferente a la existente

3.2. ZOCALO Reintegración del muro en las partes
bloques de hormigón prefabricado

3.2. ZÓCALO

Tipo de intervención

No intervenido

Tipo de material

$\square$ Actualización

Descripción

3.3. REVESTIMIENTOS

Tipo de intervención

\section{No aplica}

Tipo de material

$\square$ Actualización

$\square$ Reintegración $\square$ Demolición Tipo de técnica

Descripción

3.4. VANOS

Tipo de intervención

$\square$ Actualización $\square$ Reintegración $\square$ Demolición $\square$ Otro...

Tipo de material

Descripción

3.5. CUBIERTA

Tipo de intervención

No aplica

Tipo de material

$\square$ Actualización $\quad \square$ Reintegración $\quad \square$ Demolición $\quad \square$ Otro...
$\square$ Consolidación $\quad \square$ Reconstrucción $\quad \square$ Sustitución

Descripción

$$
\text { Tipo de técnica }
$$

3.6. OTRAS 


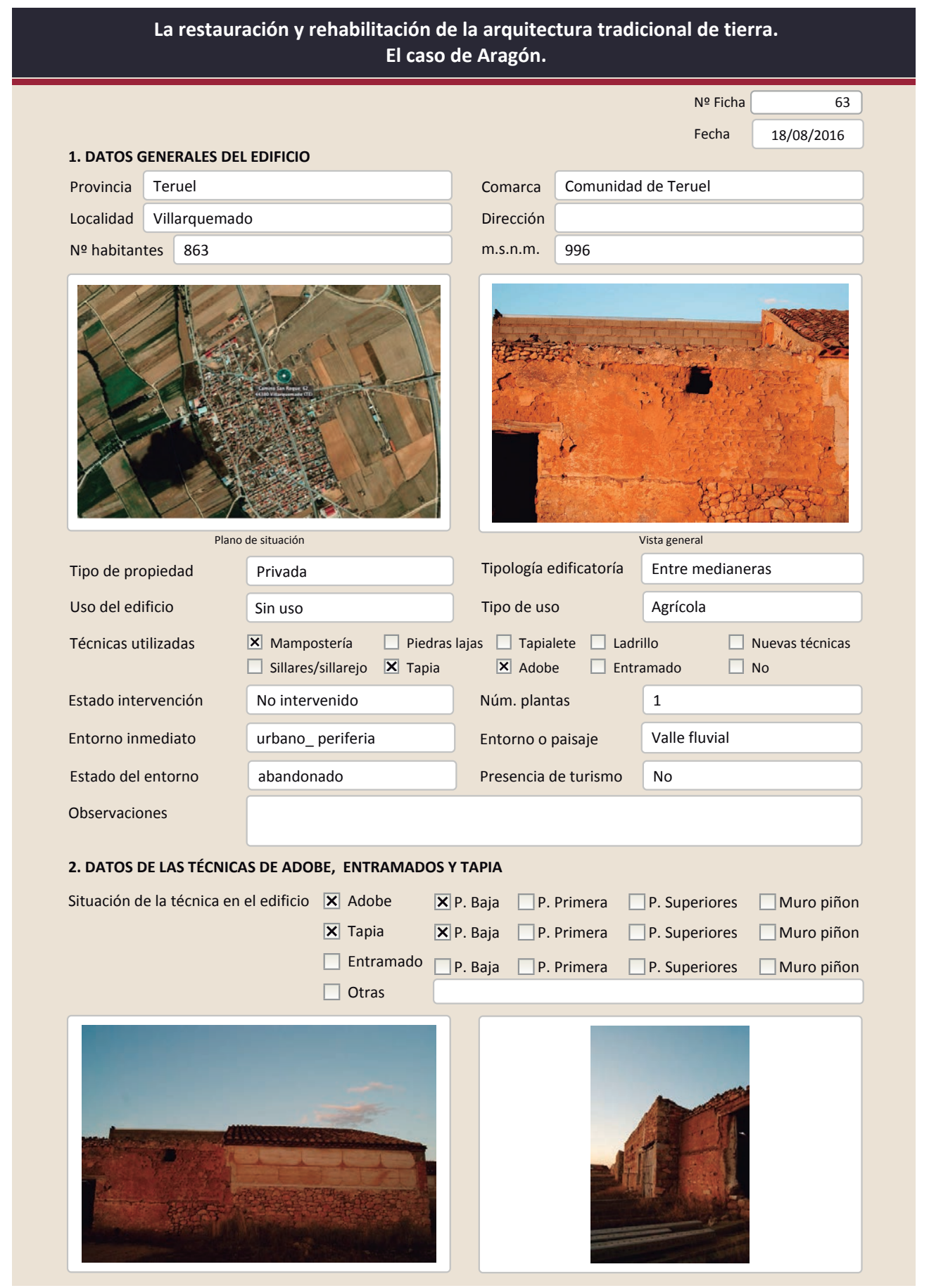

La restauración y rehabilitación de la arquitectura tradicional de tierra.

2.1. ADOBE

Dimensión de las piezas

Dimensión del muro

Aparejo del muro

Función estructural

\section{El caso de Aragón.}

Color de las piezas

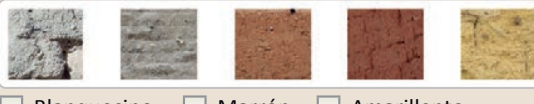

$\square$ Blanquecino $\square$ Marrón $\square$ Amarillento $\square$ Grisaceo $\square$ Rojizo $\square$ Otro...

Comp. - estabilizante Fibras vegetales

Variante constructiva/ tipo de fábrica

$\square$ simple

$\begin{array}{lll}\text { X Suplementada en juntas } & \text { Verticales } y \text { horo } \text { yorizontales }\end{array}$

$\square$ Mixta

$\square$ Como suplemento

$\square$ Elementos de protección

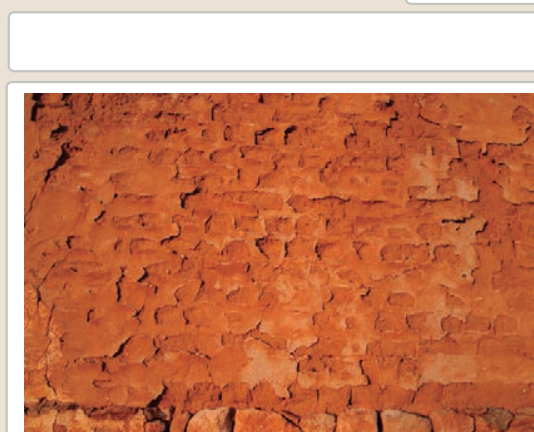

Lesiones $\quad \mathbf{X}$ Muro $\square$ Zócalo $\square$ Revestimiento

$\mathbf{X}$ Erosión del material $\quad \square$ Humedad por capilaridad

$\square$ Erosion de las juntas $\square$ Humedades (manch/eflo)

$\square$ Pérdida de sección $\square$ Pérdida de verticalidad

$\square$ Vegetación $\quad \square$ Grietas por empuje de la cubierta

$\square$ Desconchados $\quad \square$ Grietas porfalta de traba
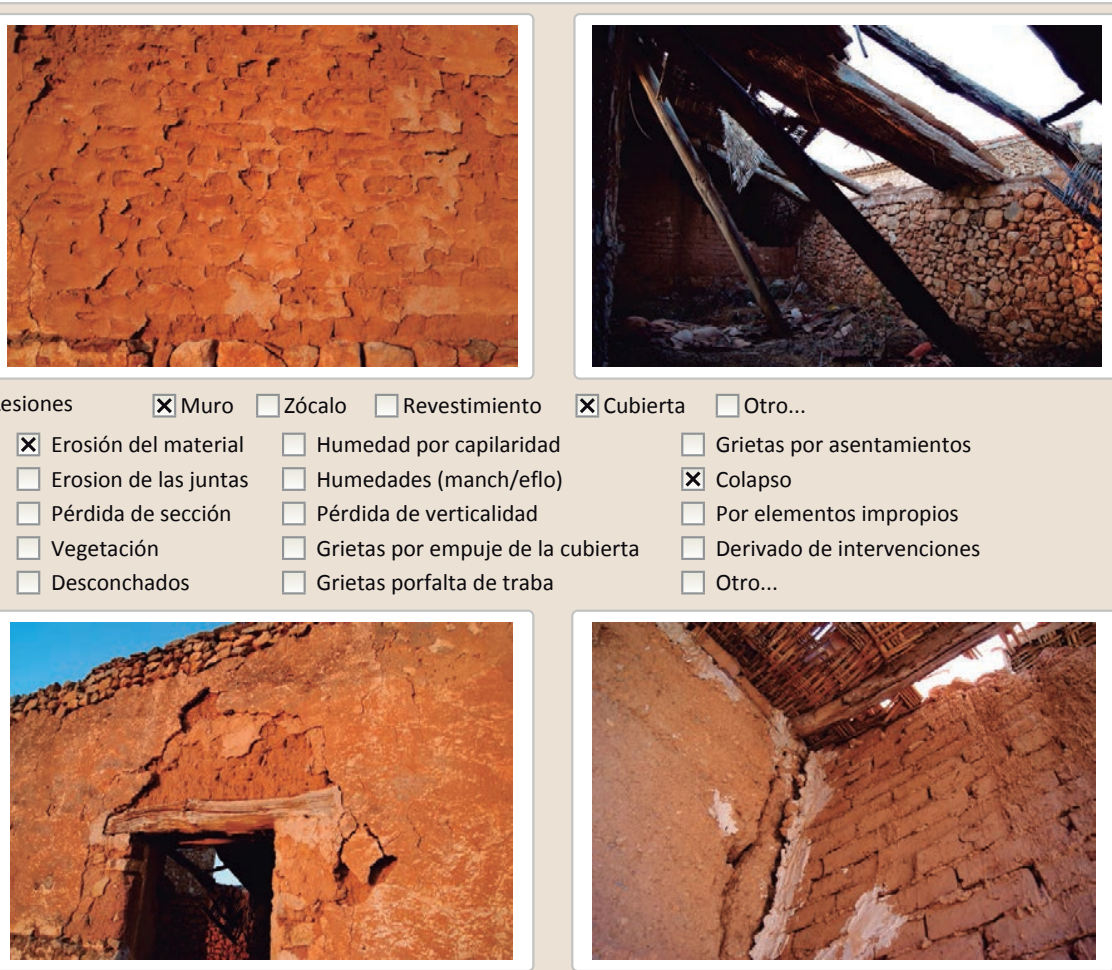

Cubierta $\square$ Otro...

$\square$ Grietas por asentamientos

X Colapso

$\square$ Por elementos impropios

$\square$ Derivado de intervenciones $\square$ Otro...

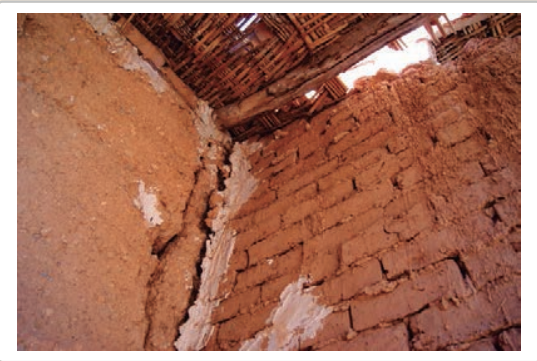

Observaciones 


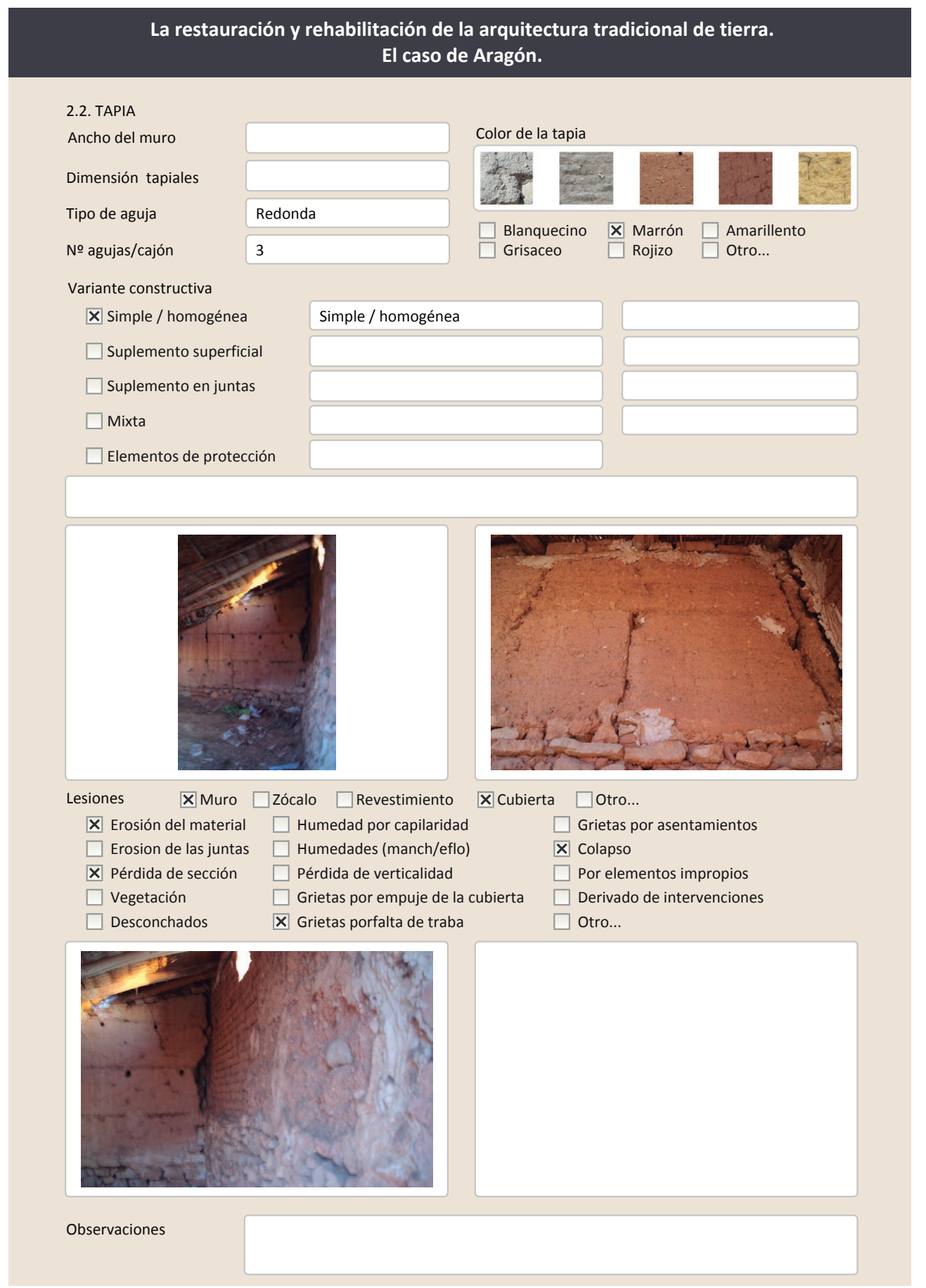

3.7. REHABILITACIÓN ENERGÉTICA $\quad \square$ Fachada $\square$ Vanos $\square$ Forjados $\square$ Cubierta Observaciones

FOTOGRAFÍAS DE LA INTERVENCIÓN
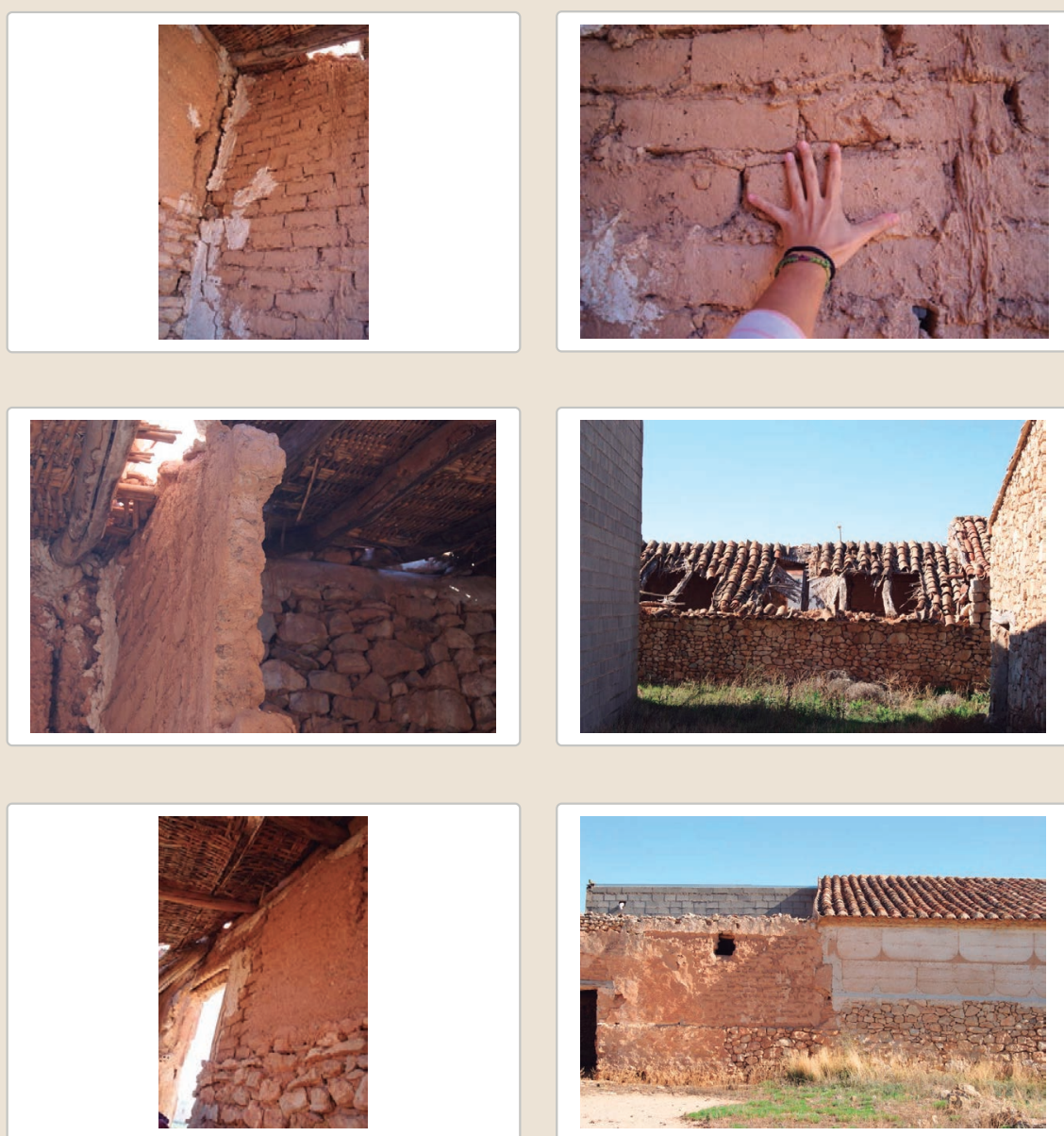


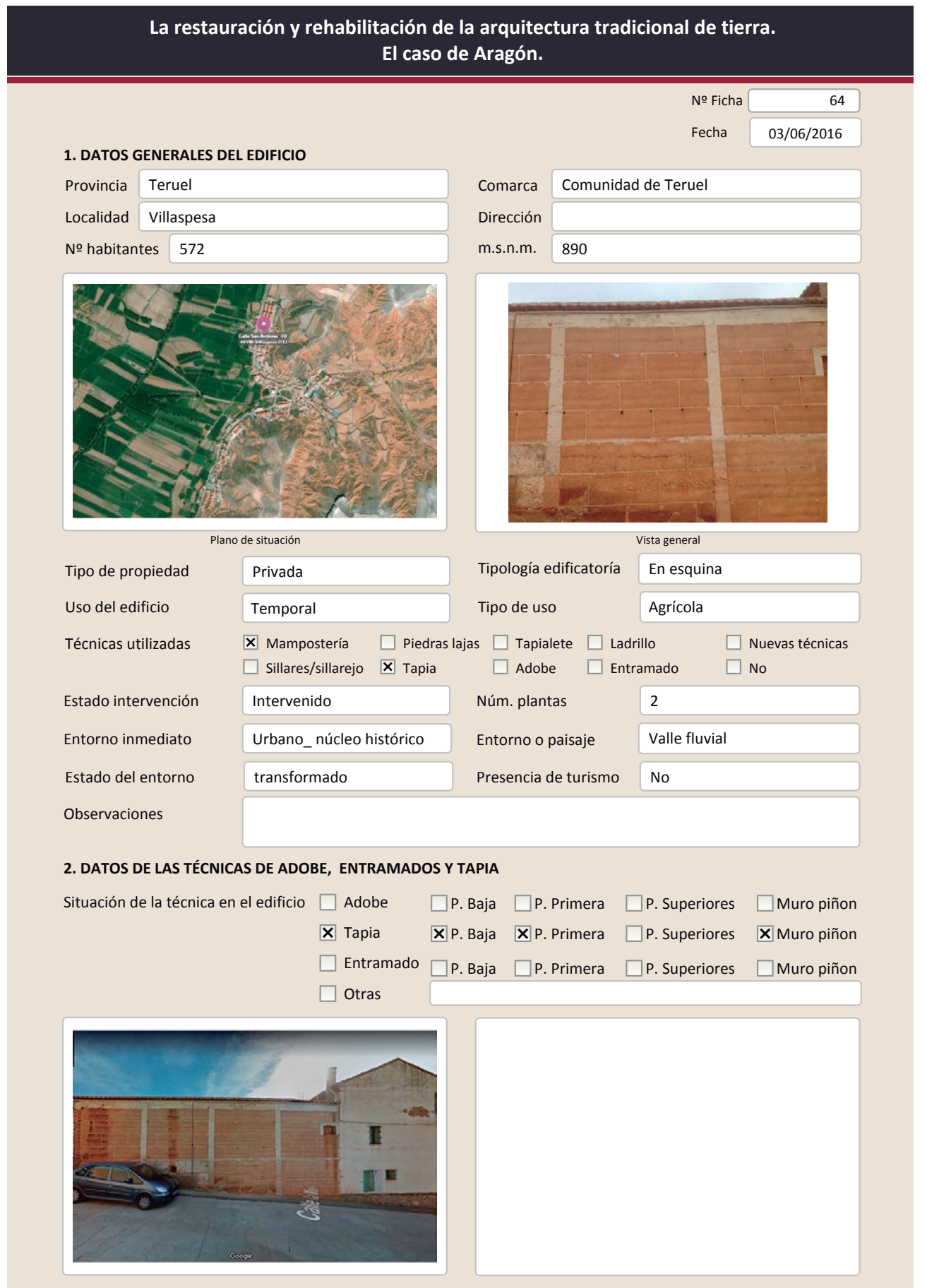

La restauración y rehabilitación de la arquitectura tradicional de tierra.

El caso de Aragón.

2.2. TAPIA

Ancho del muro

Dimensión tapiales

Tipo de aguja

№ agujas/cajón

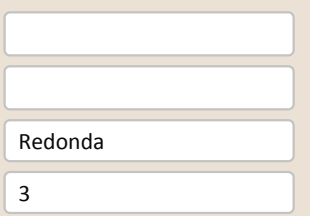

Color de la tapia

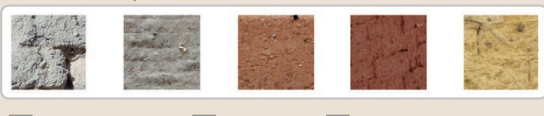

$\square$ Blanquecino $\square$ Marrón $\square$ Amarillento

Blanquecino $\square$ Marron
$\square$ Grisaceo Rojizo $\square$ Otro..

Variante constructiva

$\square$ Simple / homogénea

X Suplemento superficial

$\boldsymbol{X}$ Suplemento en juntas

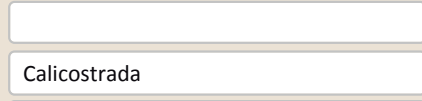

$\mathrm{Cal} /$ yeso

$\mathbf{X}$ Mixta

Juntas

Machones

$\mathrm{Cal} /$ yeso

$\square$ Elementos de protección

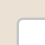

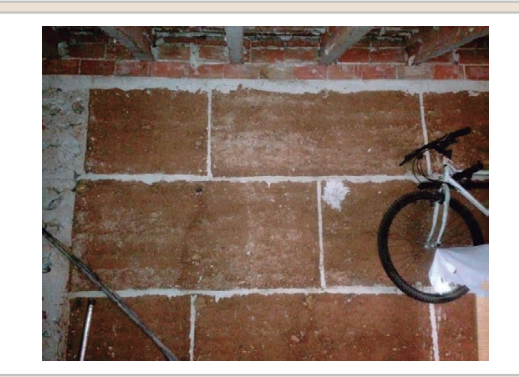

Lesiones $\square$ Muro $\square$ Zócalo $\square$ Revestimiento $\square$ Cubierta $\square$ otro...

\ Erosión del material $\quad \mathbf{X}$ Humedad por capilaridad $\quad \square$ Grietas por asentamiento

$\square$ Erosion de las juntas $\quad \mathbf{X}$ Humedades (manch/eflo)

X Pérdida de sección $\quad \square$ Pérdida de verticalidad

$\square$ Vegetación $\square$ Grietas por empuje de la cubierta

X Desconchados $\quad \square$ Grietas porfalta de traba

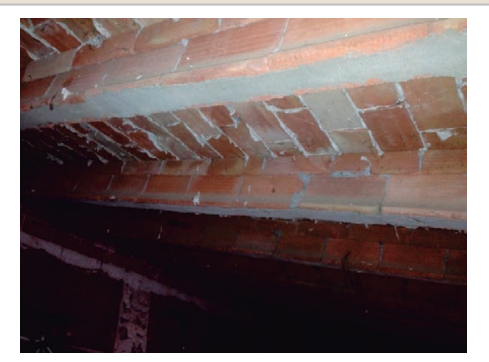

$\square$ Por elementos impropios

Derivado de intervenciones

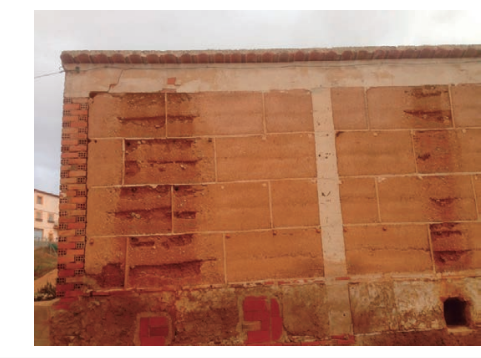

Observaciones

Lavado del paramento en dos zonas puntuales aunque no se aprecia ninguna lesión en la cubierta que produzca este fenómeno. 
La restauración y rehabilitación de la arquitectura tradicional de tierra. El caso de Aragón

\section{La restauración y rehabilitación de la arquitectura tradicional de tierra.}

\section{El caso de Aragón.}

3. DATOS DE LA INTERVENCIÓN

Intervención de:

$\square$ Mantenimiento $\square$ Rehabilitación parcia

$\square$ Restauración $\square$ Demolición

Reflexión previa

X Reparación

Rehabilitación integra

Ampliación

$\square$ Otro..

Observaciones

Intervención espontanea

3.1. MUROS

No intervenido

Tipo de intervención

$\square$ Actualización

$\square$ Consolidación $\square$ Reconstrucción $\square$ Sustitución

Tipo de material

Descripción

3.2. ZÓCALO

Tipo de intervención

Intervenido

Tipo de intervención

$\square$ Actualizació

Tipo de material

Descripción

Tipo de técnica Diferente a la existente

3.3. REVESTIMIENTOS

Nuevo revestimiento en la zona del zócalo del muro con cemento. Posiblemente se debe a la presencia de humedad en esta zona

Tipo de intervención

No aplica

Tipo de material

Descripción

$\square$ Consolidación $\square$ Reconstrucción $\square$ Sustitución

3.4. VANOS

Tipo de intervención

Intervenido

Tipo de material

$\square$ Actualización $\square$ Reintegración $\square$ Demolición $\quad$ O Otro...

$\square$ Consolidación $\square$ Reconstrucción $\square$ Sustitución

Descripción

No tradicional

Tipo de técnica Diferente a la existente

se han cegado algunos huecos situados en la parte baja del muro con ladrillo hueco.

3.5. CUBIERTA

Tipo de intervención

No intervenido

Tipo de material

$\square$ Actualización $\square$ Reintegración $\square$ Demolición $\square$ Otro..

$\square$ Consolidación $\square$ Reconstrucción $\square$ sustitución

Descripción

Tipo de técnica

3.6. OTRAS 


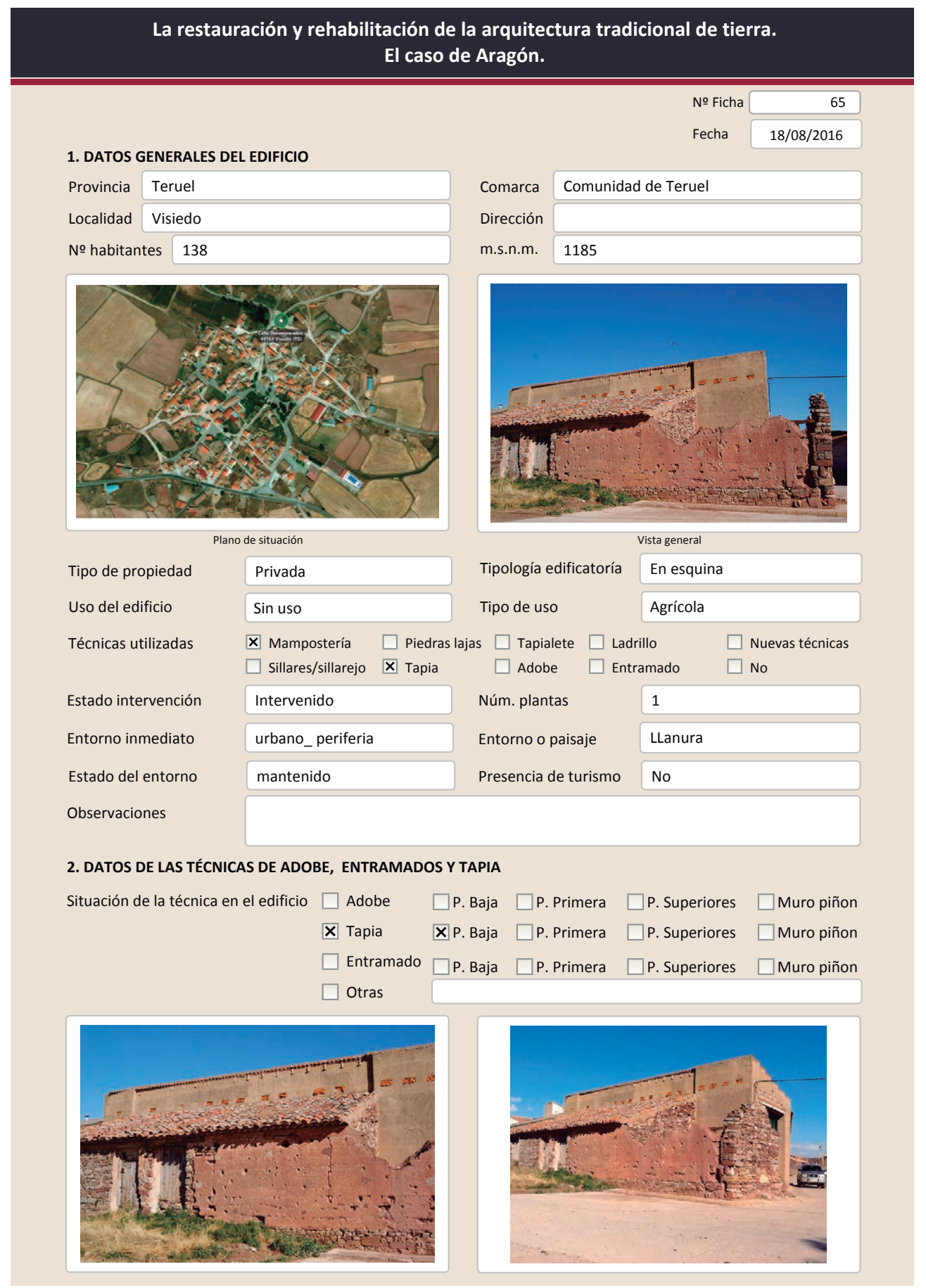

La restauración y rehabilitación de la arquitectura tradicional de tierra. El caso de Aragón.

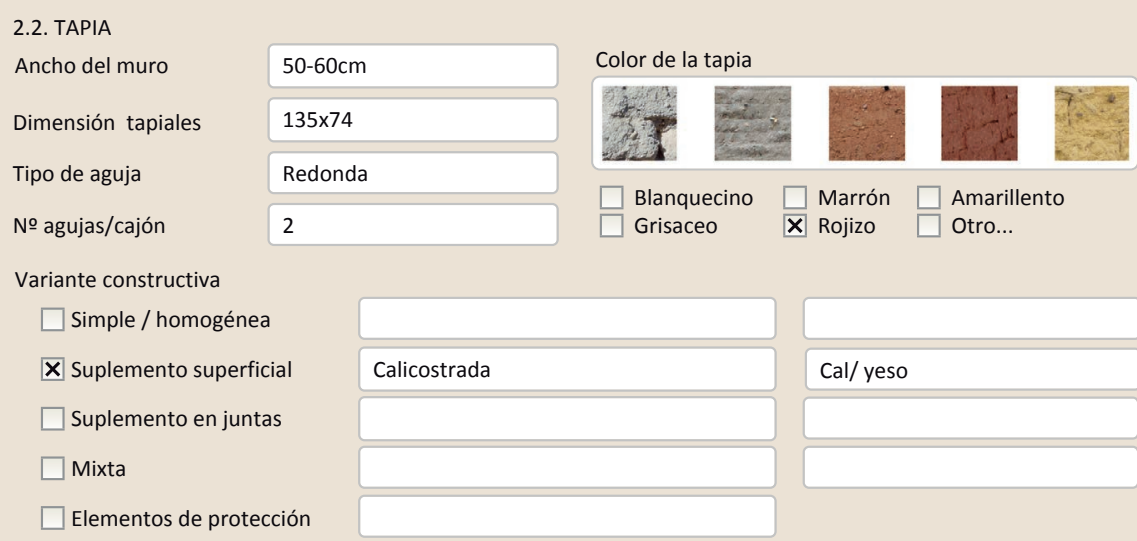

Además de la costra en la mayoría de los módulos tienen una piedra con la cara plana hacia la superficie del tapial (careada con piedra)

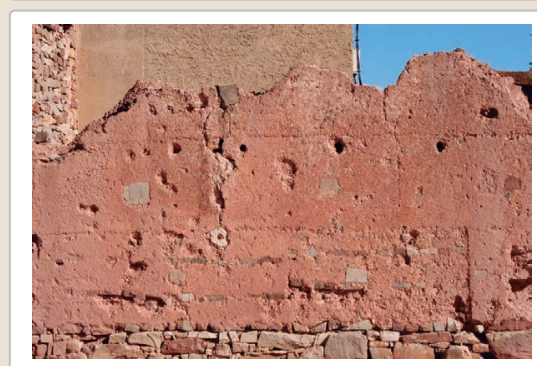

Lesiones \Muro $\square$ Zócalo $\square$ Revestimiento $\square$ Cubierta $\square$ Otro...

X Erosión del material $\quad \square$ Humedad por capilaridad $\quad \square$ Grietas por asentamientos $\square$ Erosion de las juntas $\square$ Humedades (manch/eflo) $\quad \mathbf{X}$ Colapso

X Pérdida de sección $\quad \square$ Pérdida de verticalidad $\quad \square$ Por elementos impropios

$\square$ Vegetación $\quad \square$ Grietas por empuje de la cubierta $\quad \square$ Derivado de intervenciones

$\square$ Desconchados $\quad \square$ Grietas porfalta de traba $\quad \square$ Otro...
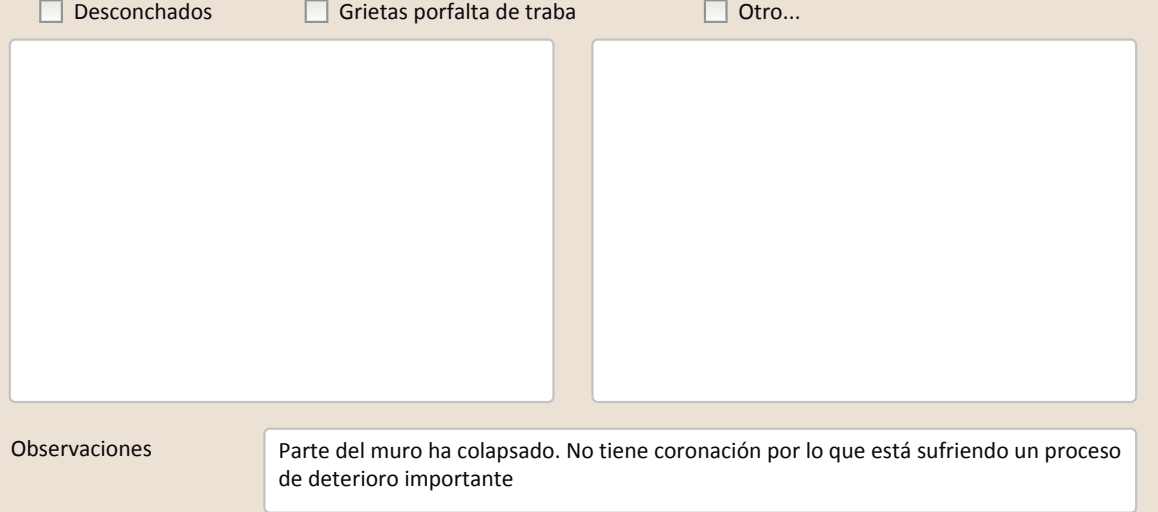
La restauración y rehabilitación de la arquitectura tradicional de tierra. El caso de Aragón

\section{La restauración y rehabilitación de la arquitectura tradicional de tierra.}

\section{El caso de Aragón.}

3. DATOS DE LA INTERVENCIÓN

Intervención de:

$\square$ Mantenimiento $\square$ Rehabilitación parcia

$\square$ Restauración $\square$ Demolición

Reflexión previa

X Reparación

$\square$ Rehabilitación integral $\square$ Ampliació

$\square$ Otro..

Observaciones

Intervención espontanea

3.1. MUROS

No intervenido

Tipo de intervención

$\square$ Actualización $\square$ Reintegración $\square$ Demolición $\square$ Otro...

$\square$ Consolidación $\square$ Reconstrucción $\square$ sustitución

Tipo de material

Descripción

3.2. ZÓCALO

No intervenido

Tipo de intervención

$\square$ Actualización

Tipo de material

Descripción

3.3. REVESTIMIENTOS

Tipo de intervención

\section{No aplica}

Tipo de material

$\square$ Actualización

Tipo de técnica

Descripción

3.4. VANOS

Tipo de intervención

No intervenido

Tipo de material

Descripción

3.5. CUBIERTA

Tipo de intervención

Intervenido

Tipo de intervención

$\square$ Actualización $\quad \mathbf{X}$ Reintegración $\square$ Demolición $\square$ Otro..

Tipo de material

$\square$ Consolidación $\square$ Reconstrucción $\quad \square$ Sustitución

Descripción

No tradicional Tipo de técnica Similar a la existente

Reintegración de piezas de cubierta nuevas cogidas con mortero. Algunas de las tejas nuevas también se han recolocado con mortero de cemento.

3.6. OTRAS 


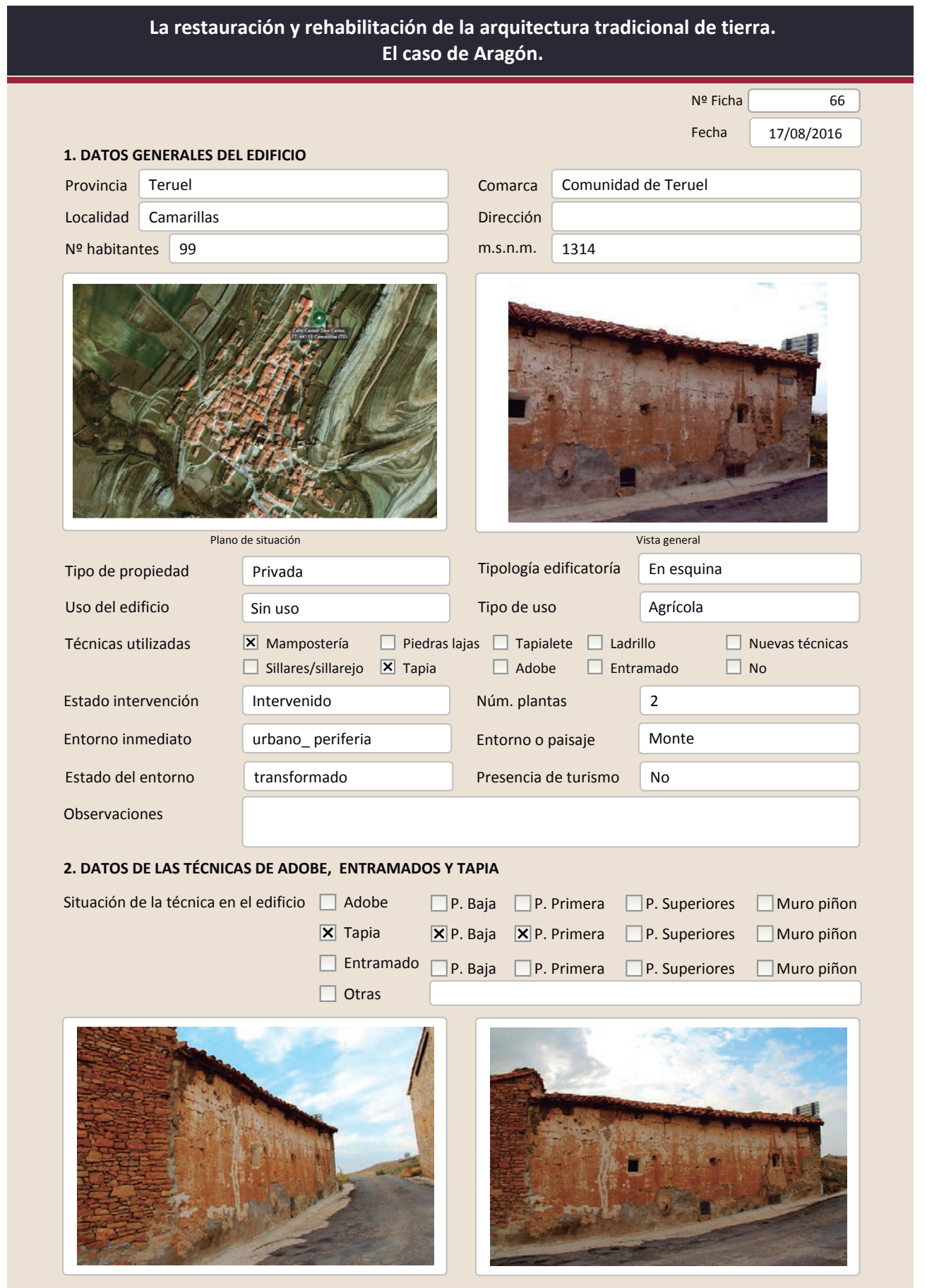

La restauración y rehabilitación de la arquitectura tradicional de tierra.

El caso de Aragón.

\subsection{TAPIA}

Ancho del muro

Dimensión tapiales

Tipo de aguja

\begin{tabular}{|l|}
\hline $50-60 \mathrm{~cm}$ \\
\hline $130 \times 75$ \\
\hline Redonda \\
\hline
\end{tabular}

№ agujas/cajón

Variante constructiva

$\square$ Simple / homogénea

$\mathbf{X}$ Suplemento superficial

$\square$ suplemento en juntas

$\square$ Mixta

$\square$ Elementos de protección

\section{Color de la tapia}

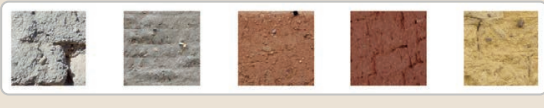

$\begin{array}{ll}\square \text { Blanquecino } & \mathbf{X} \text { Marrón } \\ \square \text { Grisaceo } & \square \text { Amarillento } \\ \text { Rojizo } & \square \text { Otro... }\end{array}$

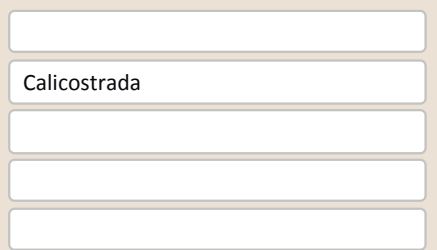

Cal/ yeso

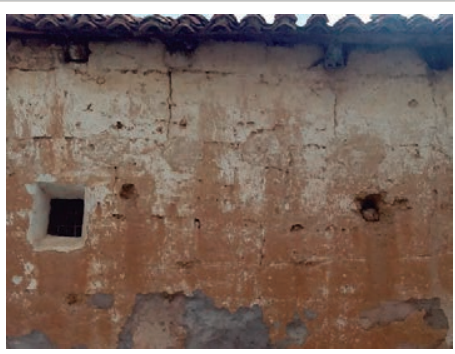

Lesiones $\mathbf{X}$ Muro $\mathbf{X}$ Zócalo $\square$ Revestimiento $\square$ Cubierta $\square$ Otro...

X Erosión del material $\quad \square$ Humedad por capilaridad $\quad \square$ Grietas por asentamiento

$\mathbf{X}$ Erosion de las juntas $\square$ Humedades (manch/eflo) $\square$ Colapso

$\square$ Pérdida de sección $\square$ Pérdida de verticalidad $\quad \square$ Por elementos impropios

$\square$ Vegetación $\quad \square$ Grietas por empuje de la cubierta $\quad \square$ Derivado de intervenciones

X Desconchados $\quad \square$ Grietas porfalta de traba $\quad \square$ Otro...

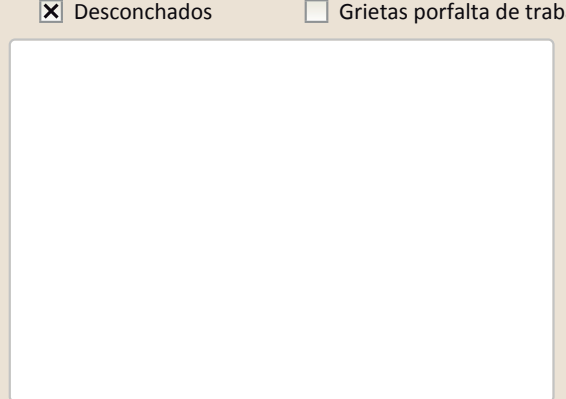

Observaciones 


\section{La restauración y rehabilitación de la arquitectura tradicional de tierra.}

\section{El caso de Aragón.}

3. DATOS DE LA INTERVENCIÓN

Mantenimiento $\square$ Rehabilitación parcial

$\square$ Restauración $\square$ Demolición

Reflexión previa

X Reparación

Rehabilitación integra

$\square$ Ampliación

$\square$ otro...

Reflexión previa
Observaciones

Intervención espontanea

3.1. MUROS

Tipo de intervención

Intervenido

Tipo de material

$\square$ Actualización $\quad \boldsymbol{X}$ Reintegración $\quad \square$ Demolición $\quad \square$ Otro...
Consolidación

Descripción

3.2. ZÓCALO

Tipo de intervención

Tipo de técnica Diferente a la existente

Reintegración de oquedades en la tapia con
la esquina con gran cantidad de cemento.

Tipo de intervención

Intervenido

$\square$ Actualización $\mathbf{X}$ Reintegración $\square$ Demolición $\square$ Otro...

$\square$ Consolidación $\quad \square$ Reconstrucción $\quad \square$ Sustitución

Descripción

No tradicional

Tipo de técnica Diferente a la existente

Reintegración de toda la zona del zócalo con cemento que sigue la forma de las partes faltantes de costra de la tapia

3.3. REVESTIMIENTOS

Tipo de intervención

No aplica

$\square$ Actualización $\square$ Reintegración $\quad \square$ Demolición $\square$ Otro...

$\square$ Consolidación $\square$ Reconstrucción $\square$ Sustitución

Tipo de técnica

Tipo de material

Descripción

3.4. VANOS

Tipo de intervención

Intervenido

$\begin{array}{lll} & \square \text { Consolidación } & \boldsymbol{X} \text { Reconstrucción } \square \text { Sustitución } \\ \text { Tipo de material } & \text { No tradicional } & \text { Tipo de técnica }\end{array}$

$\square$ Actualización $\square$ Reintegración $\square$ Demolición $\square$ Otro...

Descripción Se han abierto o modificado dos huecos en la zona inferior del muro y se ha colocada una rejilla. Probablemente con fines de ventilación del edificio.

3.5. CUBIERTA

Tipo de intervención

Intervenido

$\square$ Actualización \ Reintegración $\square$ Demolición $\square$ Otro..

$\square$ Consolidación $\quad \square$ Reconstrucción $\square$ Sustitución

Tipo de material

No tradicional

Tipo de técnica Similar a la existente

Descripción

se han integrado gran número de piezas cerámicas nuevas combinadas con las antiguas
La restauración y rehabilitación de la arquitectura tradicional de tierra.

El caso de Aragón.

3.7. REHABILITACIÓN ENERGÉTICA $\quad \square$ Fachada $\square$ Vanos $\square$ Forjados $\square$ Cubierta

Observaciones

FOTOGRAFÍAS DE LA INTERVENCIÓN
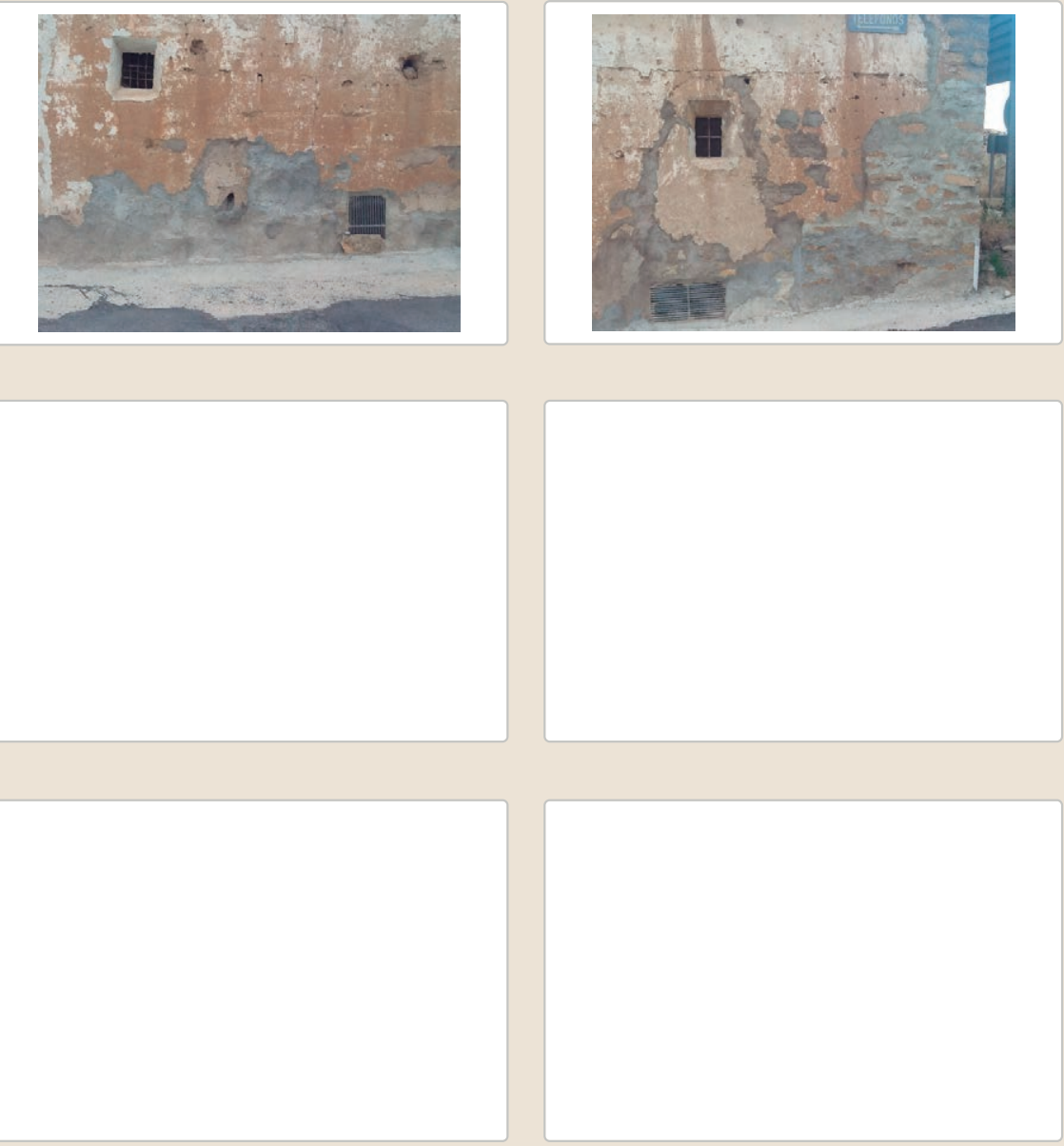

3.6. OTRAS 


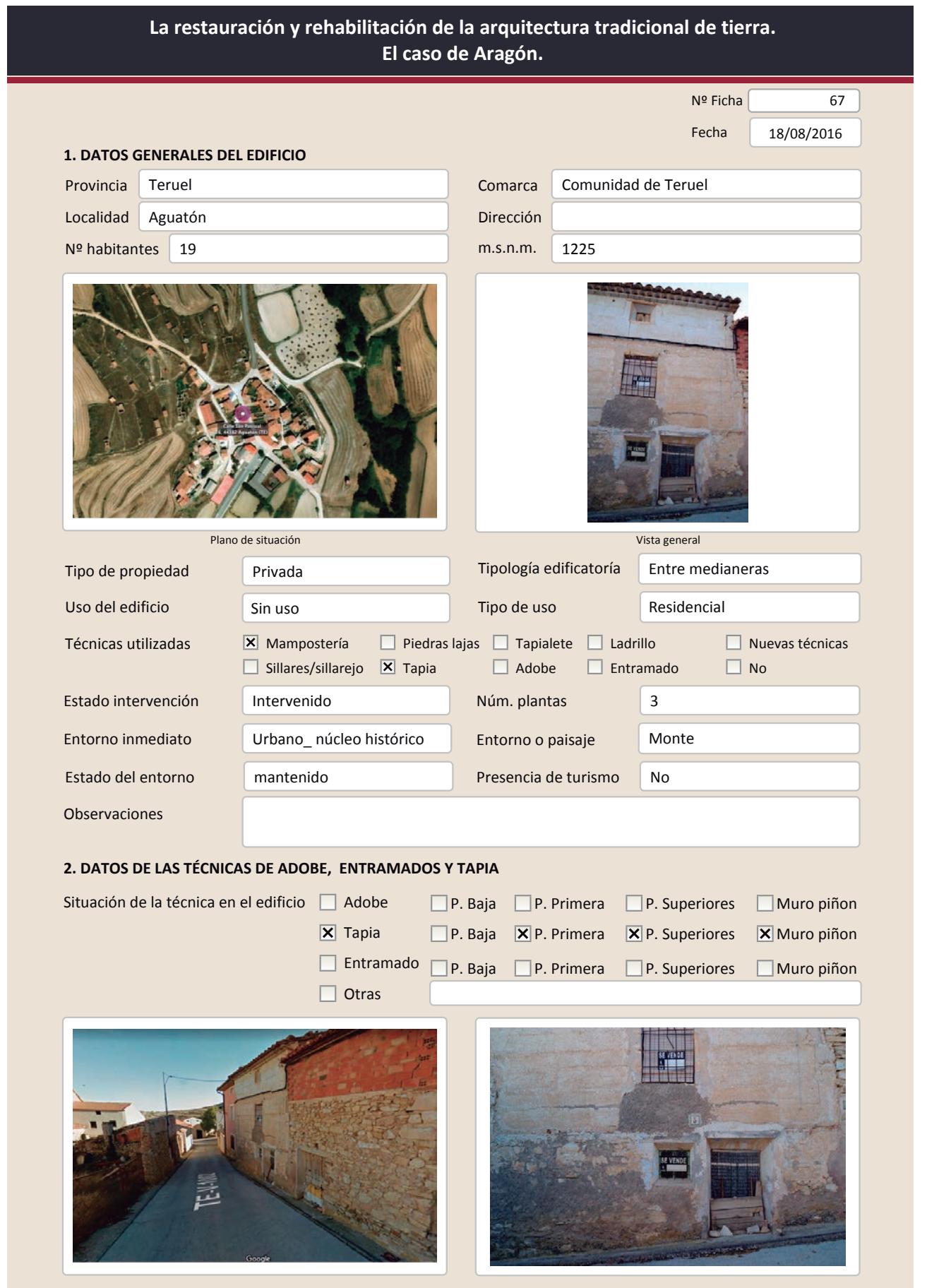

La restauración y rehabilitación de la arquitectura tradicional de tierra.

El caso de Aragón.

2.2. TAPIA

Ancho del muro

Dimensión tapiales

Tipo de aguja

№ agujas/cajón

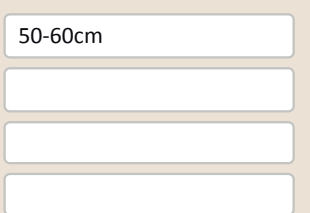

Color de la tapia

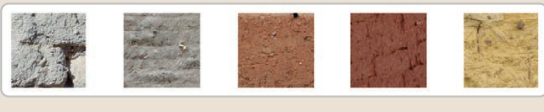

$\mathbf{X}$ Blanquecino $\square$ Marrón $\square$ Amarillento

\begin{tabular}{ll}
$\boldsymbol{X}$ Blanquecino & \multicolumn{1}{c}{ Marrón } \\
$\square$ Grisaceo & $\square$ Rojizo
\end{tabular} Omarill

Variante constructiv

$\square$ simple / homogénea

X Suplemento superficial

$\square$ suplemento en juntas

X Mixta

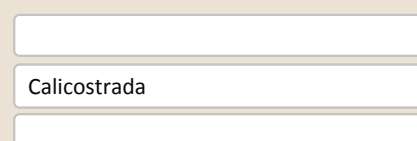

$\mathrm{Cal} / \mathrm{Ves}$

\section{Cal/yeso}

Machones de rafas

Mampostería y yeso

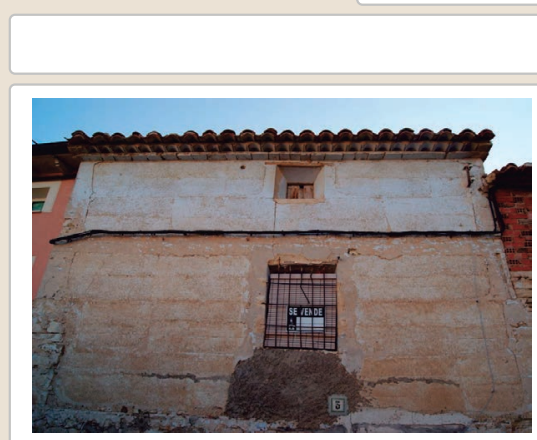

Lesiones $\quad \mathbf{X}$ Muro $\boldsymbol{X}$ Zócalo $\square$ Revestimiento $\square$ Cubierta $\square$ otro...

$\square$ Erosión del material $\quad \mathbf{X}$ Humedad por capilaridad $\quad \square$ Grietas por asentamientos $\square$ Erosion de las juntas $\square$ Humedades (manch/eflo) $\square$ Pérdida de sección $\square$ Pérdida de verticalidad

$\square$ Vegetación $\quad \square$ Grietas por empuje de la cubieta

X Desconchados $\quad \square$ Grietas porfalta de traba 


\section{La restauración y rehabilitación de la arquitectura tradicional de tierra.}

\section{El caso de Aragón.}

3. DATOS DE LA INTERVENCIÓN

$\square$ Mantenimiento $\square$ Rehabilitación parcial

$\square$ Restauración $\square$ Demolición

(a)

X Reparación

$\square$ Rehabilitación integra

Ampliación

$\square$ otro...

Observaciones

Observaciones

3.1. MUROS

Tipo de intervención

Intervenido

Tipo de material

$\square$ Actualizacion

$\square$ Consolidación

X Reintegración

$\square$ Demolición

No tradicional Tipo de técnica Diferente a la existente

Descripción

Reintegración de oquedades con mortero de cemento

3.2. ZÓCALO

Tipo de intervención

Intervenido

Tipo de intervención

$\square$ Actualización

$\square$ Consolidació

X Reintegración $\quad \square$ Demolición $\square$ Otro...

Descripción

Tipo de técnica Diferente a la existente

3.3. REVESTIMIENTOS

Tipo de intervención

Tipo de material

Descripción

3.4. VANOS

Tipo de intervención

Tipo de material

Descripción

3.5. CUBIERTA

Tipo de intervención

Tipo de material

Descripción

3.6. OTRAS

\section{No aplica}

$\square$ Actualización $\square$ Reintegración $\square$ Demolición $\square$ Otro...

$\square$ Consolidación $\quad \square$ Reconstrucción $\quad \square$ sustitución

Tipo de técnica

\section{No intervenido}

$\square$ Actualización $\square$ Reintegración $\square$ Demolición $\square$ Otro...

$\square$ Consolidación $\square$ Reconstrucción $\square$ Sustitución

Tipo de técnica

\section{No intervenido}

$\square$ Actualización $\square$ Reintegración $\square$ Demolición $\square$ Otro..

$\square$ Consolidación $\square$ Reconstrucción $\square$ Sustitución Tipo de técnica
Intervención espontanea

La restauración y rehabilitación de la arquitectura tradicional de tierra.

El caso de Aragón.

3.7. REHABILITACIÓN ENERGÉTICA $\square$ Fachada $\square$ Vanos $\square$ Forjados $\square$ Cubierta

Observaciones

FOTOGRAFíAS DE LA INTERVENCIÓN
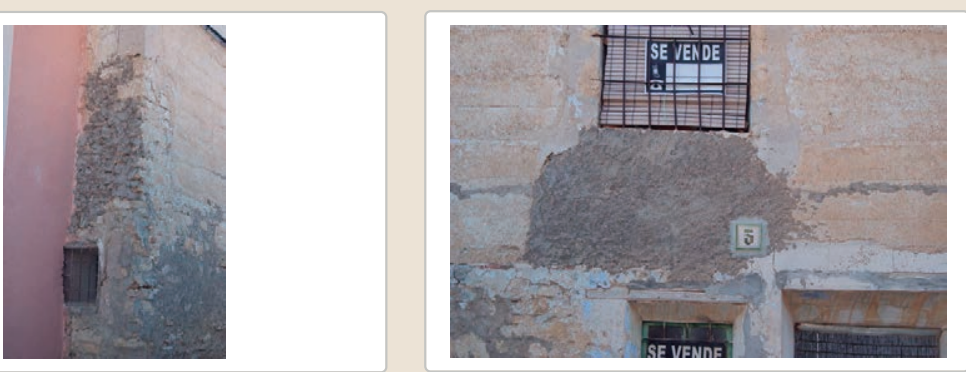

(2)
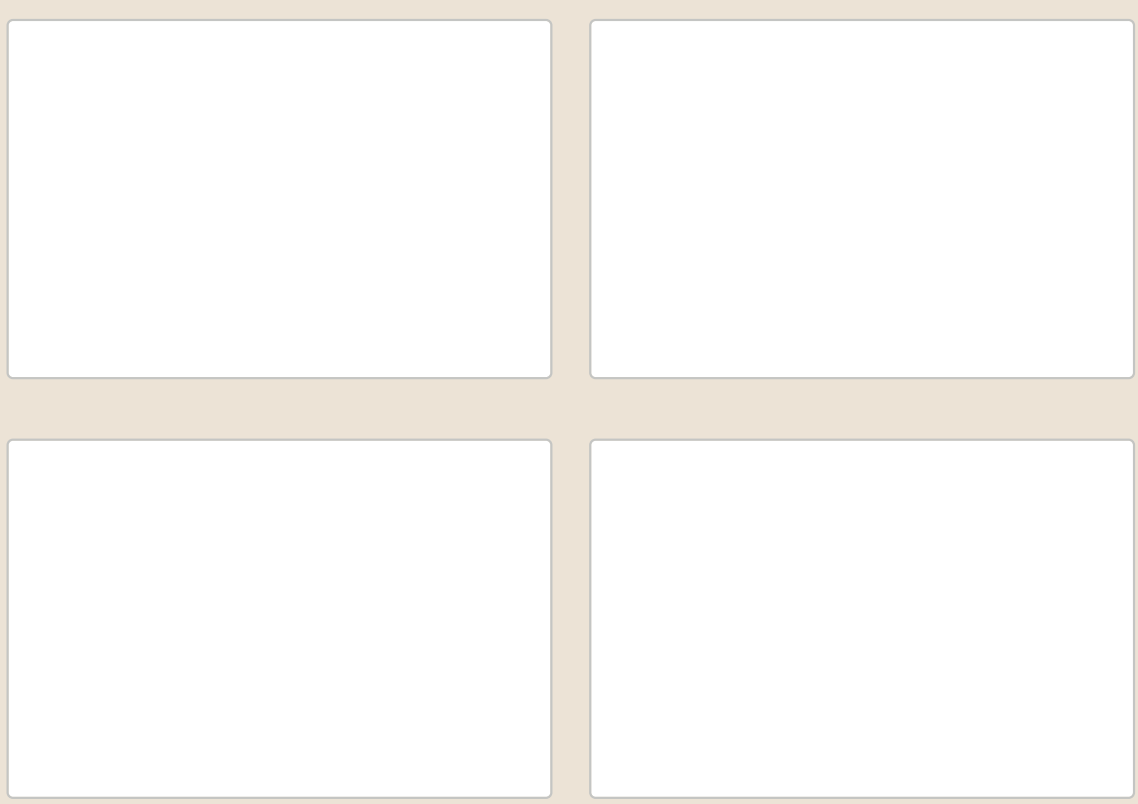
La restauración y rehabilitación de la arquitectura tradicional de tierra. El caso de Aragón.

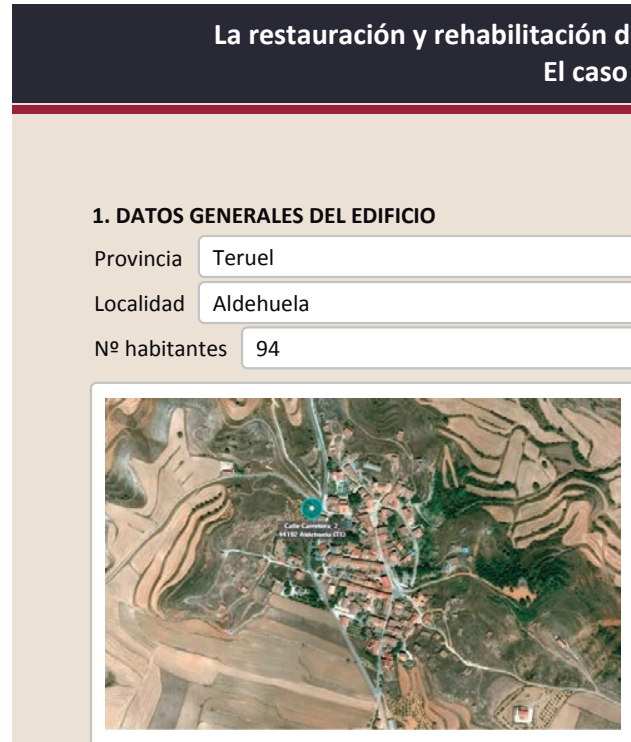

Plano de situación

Tipo de propiedad

Uso del edificio

Técnicas utilizadas

\section{$\left\{\begin{array}{l}\mathrm{m} \\ \mathrm{m}\end{array}\right.$}

68

№ Ficha

Fecha $17 / 09 / 2017$

Comarca Comunidad de Teruel

Dirección

m.s.n.m. 1081

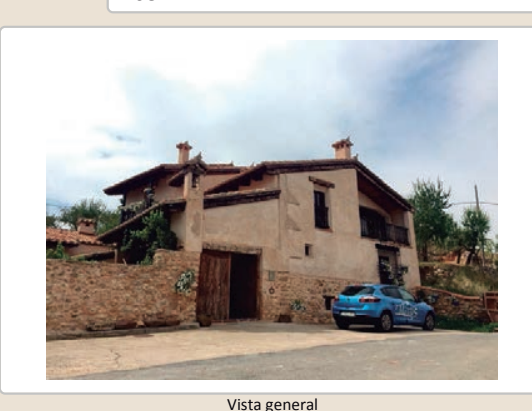

Tipología edificatoría Aislada

Tipo de uso Residencial

Continuado Tipo de uso

Х Mampostería $\square$ Piedras lajas $\square$ Tapialete $\square$ Ladrillo $\quad \square$ Nuevas técnicas $\square$ sillares/sillarejo $\mathbf{X}$ Tapia $\quad \square$ Adobe $\square$ Entramado $\square$ No

Estado intervención Intervenido Núm. plantas 3

Entorno inmediato urbano_periferia Entorno o paisaje Monte

Estado del entorno transformado Presencia de turismo No

Observaciones

\section{DATOS DE LAS TÉCNICAS DE ADOBE, ENTRAMADOS Y TAPIA}

Situación de la técnica en el edificio $\square$ Adobe $\quad \square$ P. Baja $\quad \square$ P. Primera $\quad \square$ P. Superiores $\square$ Muro piñon Х Tapia $\square$ P. Baja $\quad \mathbf{X}$ P. Primera $\quad$ XP. Superiores $\square$ Muro piñon $\square$ Entramado $\square$ P. Baja $\square$ P. Primera $\square$ P. Superiores $\square$ Muro piñon $\square$ Otras $\square$. Baja $\square$ P. Primera $\square$ P. Superiores $\square$ Muropinon

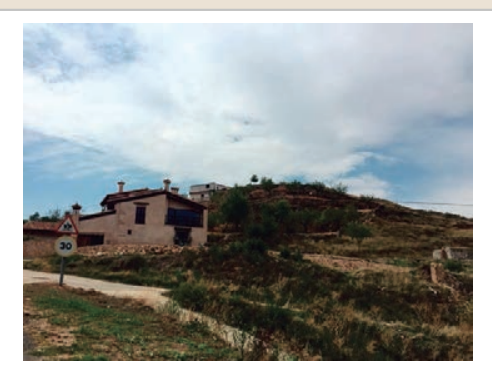

La restauración y rehabilitación de la arquitectura tradicional de tierra. El caso de Aragón.

\subsection{TAPIA}

Ancho del muro

Dimensión tapiales

Tipo de aguja

№ agujas/cajón

Variante constructiva

$\square$ Simple / homogénea

$\mathbf{X}$ Suplemento superficial

$\square$ suplemento en juntas

X Mixta

$\square$ Elementos de protección

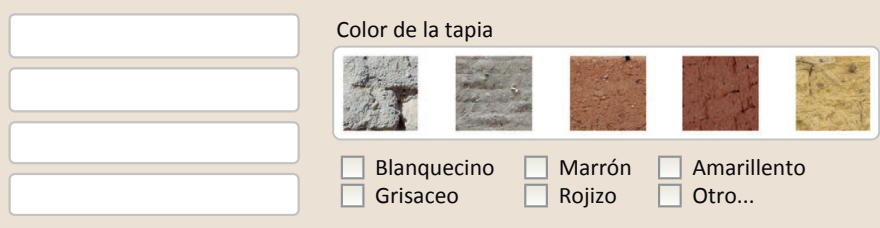

No se aprecia el tipo de tapia original pero los fingidos que aparecen en la fachada puede hacerse una aproximación a la variante original.

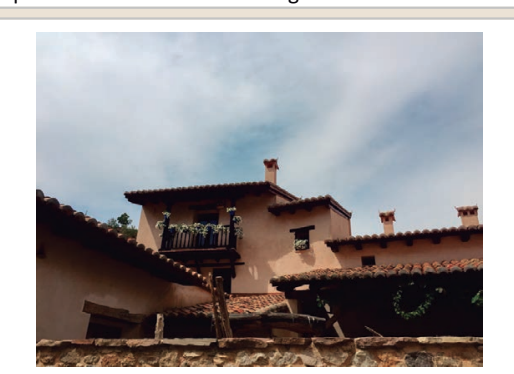

Lesiones $\square$ Muro $\square$ Zócalo $\quad$ X Revestimiento $\square$ Cubierta $\square$ otro...

$\square$ Erosión del material $\quad \square$ Humedad por capilaridad $\quad \square$ Grietas por asentamientos

$\square$ Erosion de las juntas $\square$ Humedades (manch/eflo)

$\square$ Pérdida de sección $\square$ Pérdida de verticalidad

$\square$ Vegetación $\quad \square$ Grietas por empuje de la cubierta

$\square$ Desconchados

$\square$ Grietas porfalta de trab$$
\square
$$

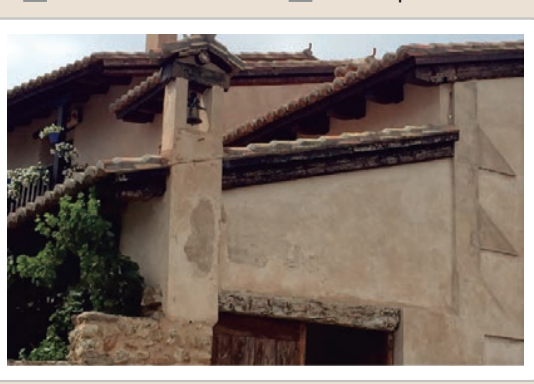

Observaciones

Humedades y perdida de la pintura y nuevo revestimiento por la incompatibilidad con los nuevos materiales 


\section{La restauración y rehabilitación de la arquitectura tradicional de tierra.}

\section{El caso de Aragón.}

3. DATOS DE LA INTERVENCIÓN

Intervención de:

$\square$ Mantenimien

Rehabilitación parcial $\square$ Restauración $\square$ Demolición

Reflexión previa Intervención planificada

Observaciones Todo el edificio se encuentra muy intervenid

3.1. MUROS

No visible

Tipo de intervención

$\square$ Actualización

$\square$ Consolidació

$\square$ Reintegración

$\square$ Reconstrucción $\square$ Demolición

Tipo de material

Descripción

3.2. ZÓCALO

Tipo de intervención

Intervenido

Tipo de intervención

$\square$ Actualización

$\square$ Consolidació

X Reintegración $\square$ Demolición $\square$ Otro...

$\square$ Reconstrucción $\square$ Sustitución

Tipo de materia

Tipo de técnica Similar a la existente

Descripción

3.3. REVESTIMIENTOS

Tipo de intervención

Intervenido

Tipo de material

$\square$ Actualización

$\square$ Consolidación

$\square$ Demolición

$\square$ Sustitución

Descripción

Todo el edificio ha sido revestido de nuevo con mortero de cemento coloreado.

3.4. VANOS

Tipo de intervención

Intervenido

Tipo de material

$\square$ Actualización $\quad \square$ Reintegración $\quad \square$ Demolición $\square$ Otro...

$\square$ Consolidación $\square$ Reconstrucción $\mathbf{x}$ Sustitución

\begin{tabular}{l|l|l|l|} 
Tipo de material & Tradicional diferente & Tipo décnica & Diferente a la existente
\end{tabular}

Descripción En alguno de los huecos se ha sustituido el dintel colocando una pieza de madera que sobresale del plano de fachada

3.5. CUBIERTA

Tipo de intervención

Intervenido

$\square$ Actualización $\quad \square$ Reintegración $\quad \square$ Demolición $\square$ Otro...

$\square$ Consolidación $\square$ Reconstrucción $\quad$ Sustitución

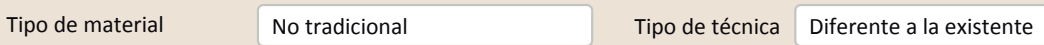

Descripción La cubierta se ha sustituido por completo aunque se ha conservado la tipología de teja curva.
La restauración y rehabilitación de la arquitectura tradicional de tierra.

El caso de Aragón.

3.7. REHABILITACIÓN ENERGÉTICA $\square$ Fachada $\quad$ X Vanos $\square$ Forjados $\quad$ C Cubierta

observaciones Se aprecia el cambio de carpinterías y la remodelación completa de la cubierta por lo que probablemente se haya mejorado térmicamente.

FOTOGRAFÍAS DE LA INTERVENCIÓN
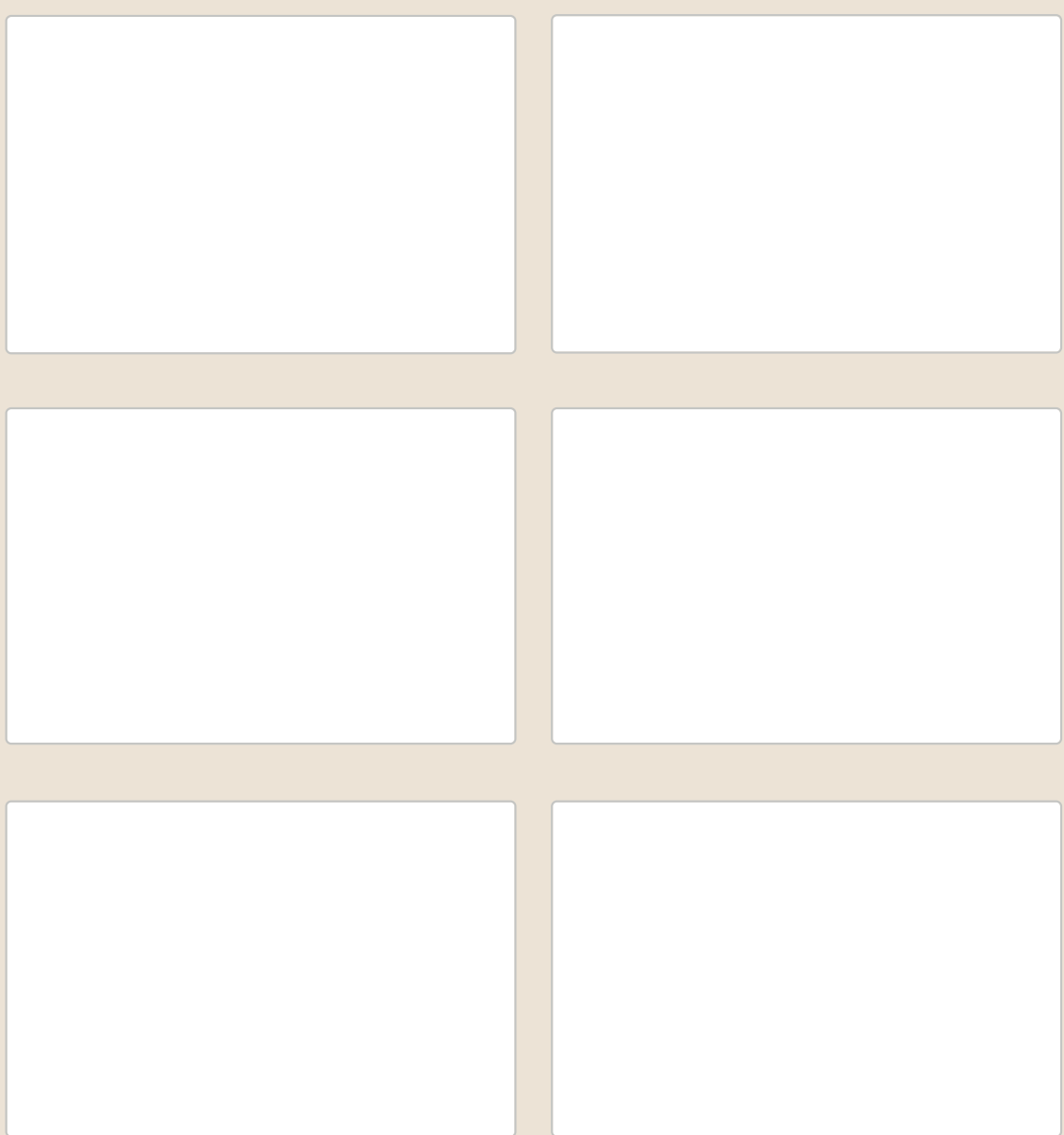

3.6. OTRAS 


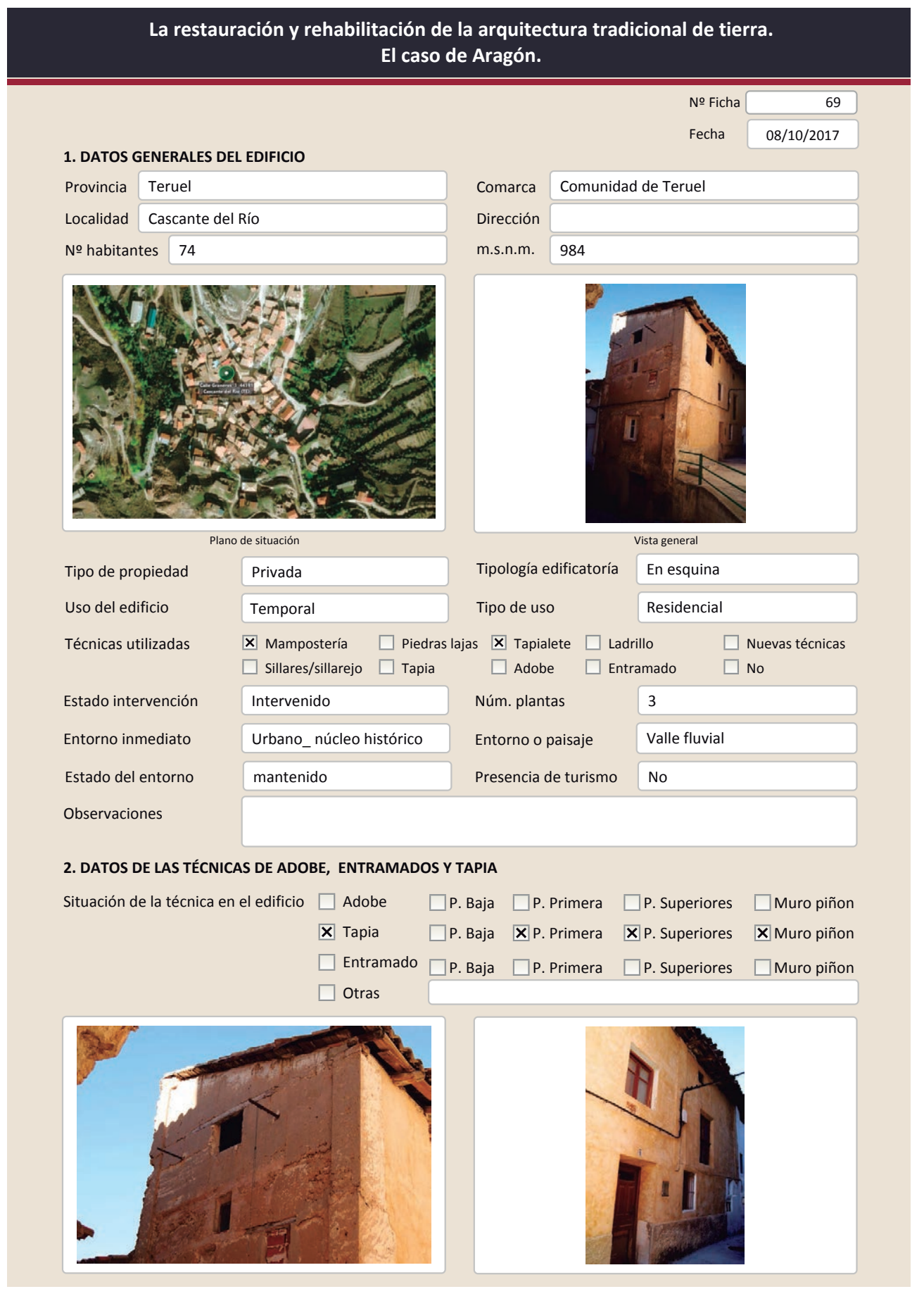

La restauración y rehabilitación de la arquitectura tradicional de tierra.

El caso de Aragón.

\subsection{TAPIA}

Ancho del muro

Dimensión tapiales

Tipo de aguja

№ agujas/cajón

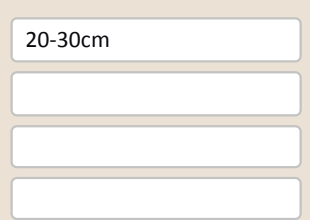

Color de la tapia

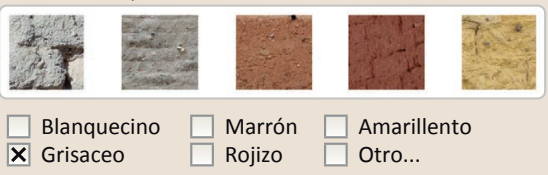

Variante constructiva

$\boldsymbol{X}$ Simple / homogénea
$\square$ Suplemento superficial
$\square$ suplemento en juntas
$\mathbb{X}$ Mixta

$\square$ Elementos de protección
Tapialete

En esquinas

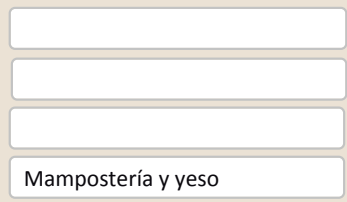

El edificio está configurado como una estructura porticada. Los cerramientos apoyan sobre durmientes que son las viguetas que conforman los forjados.

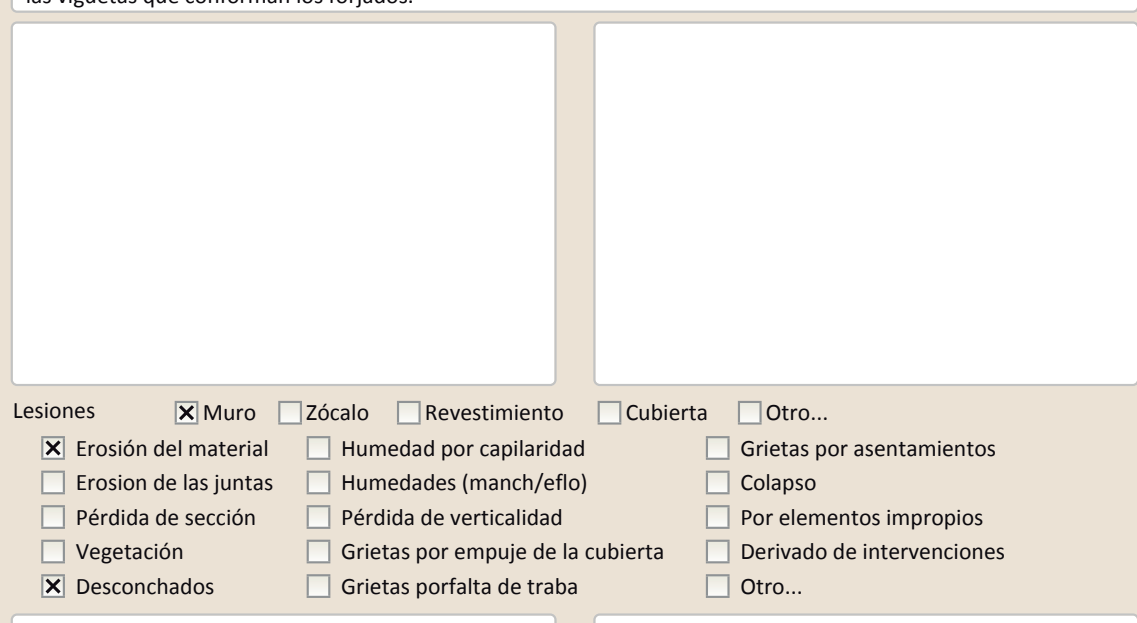

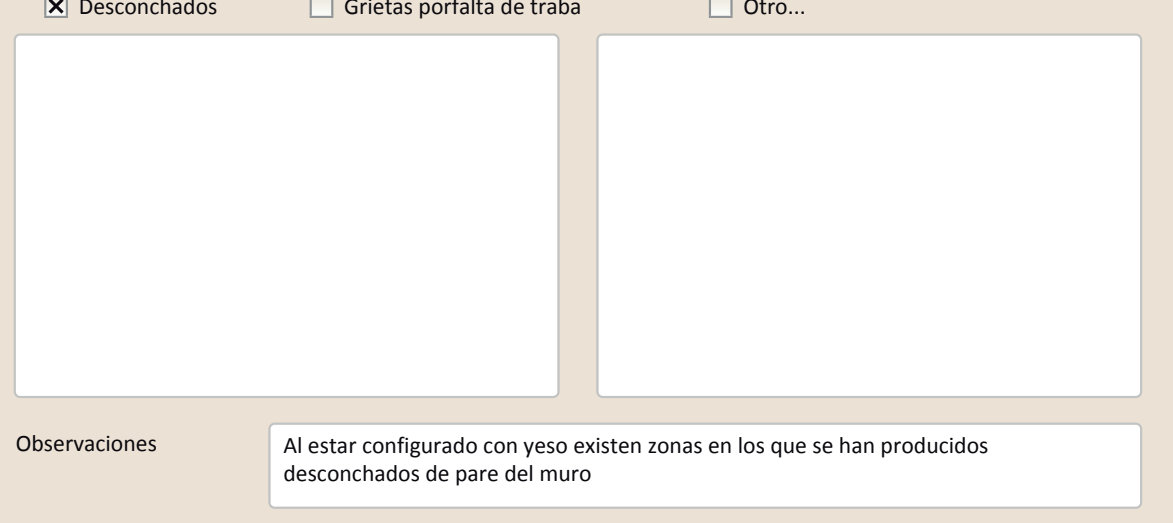




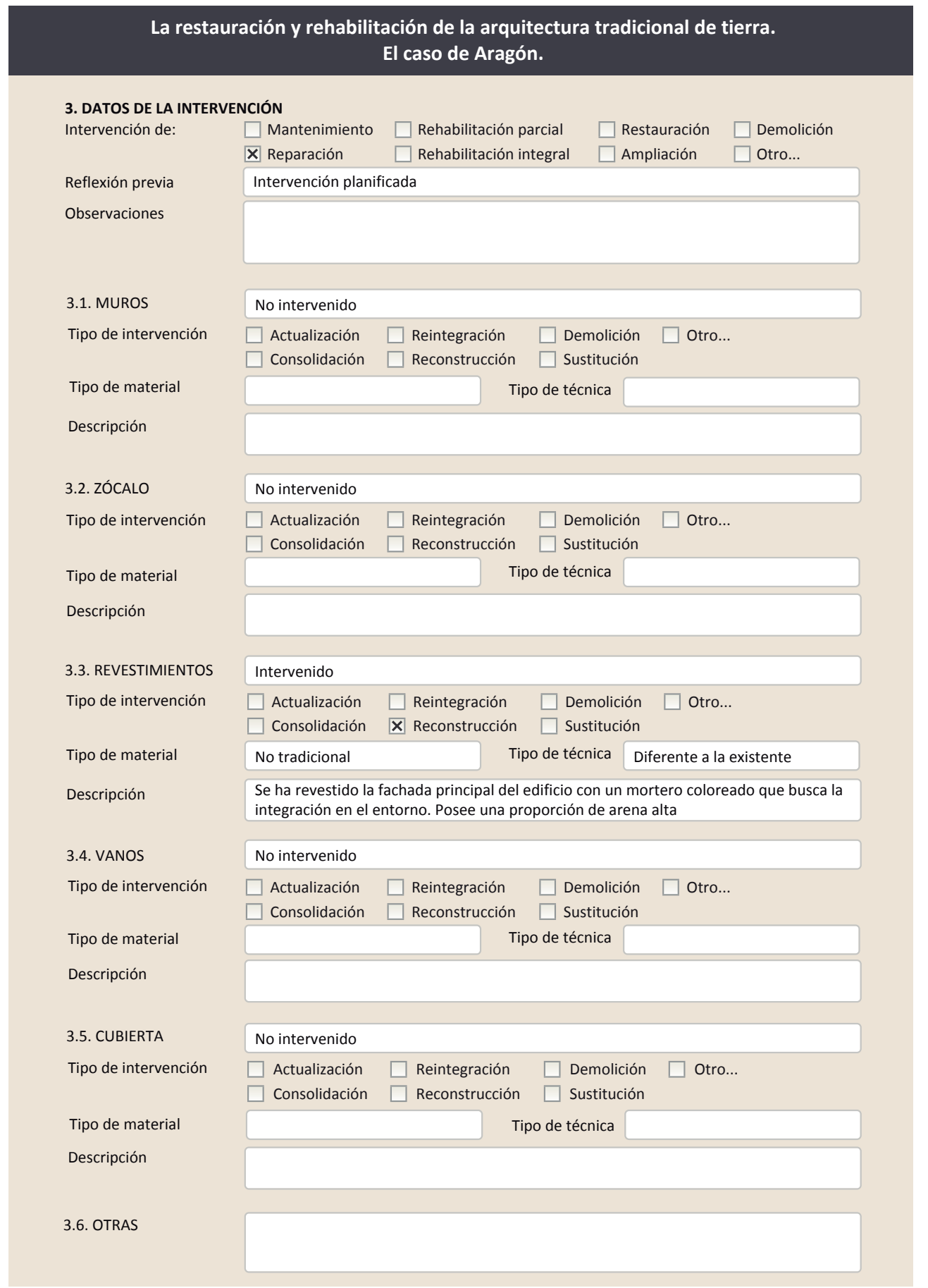

\subsection{REHABILITACIÓN ENERGÉTICA $\quad \square$ Fachada $\square$ Vanos $\square$ Forjados $\square$ Cubierta}

Observaciones

FOTOGRAFÍAS DE LA INTERVENCIÓN
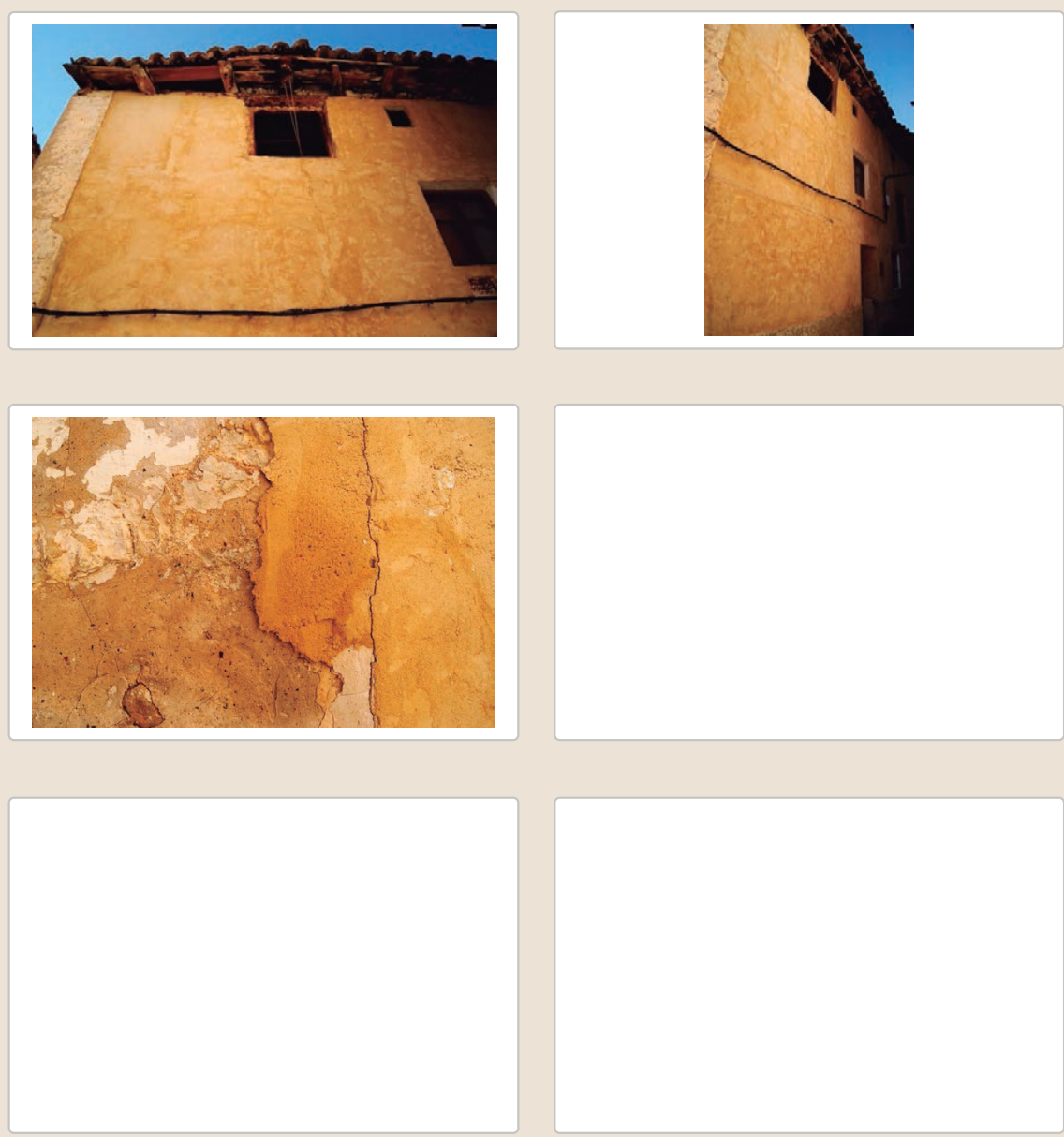
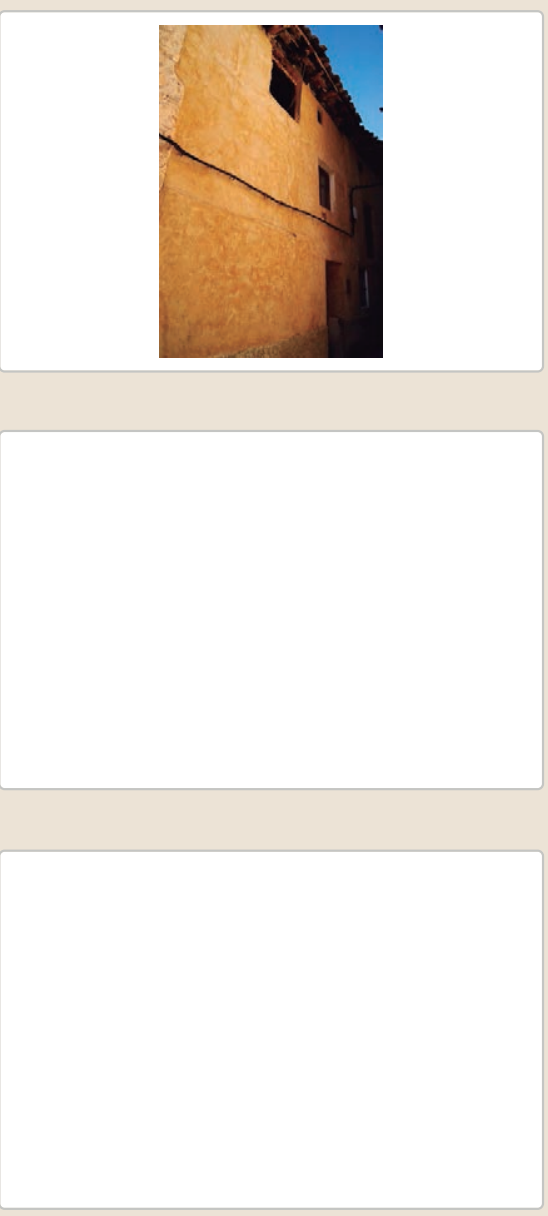


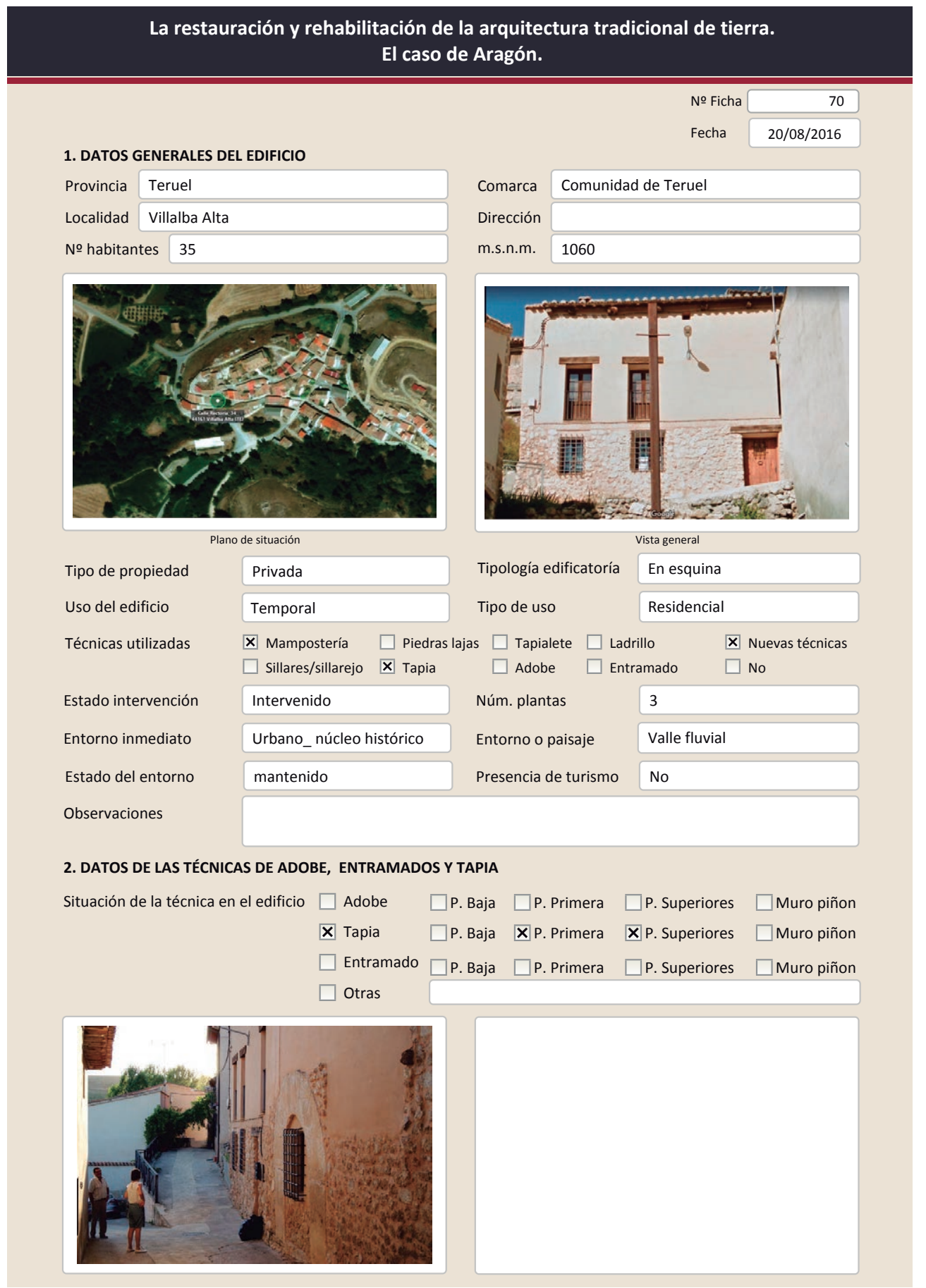

La restauración y rehabilitación de la arquitectura tradicional de tierra. El caso de Aragón.

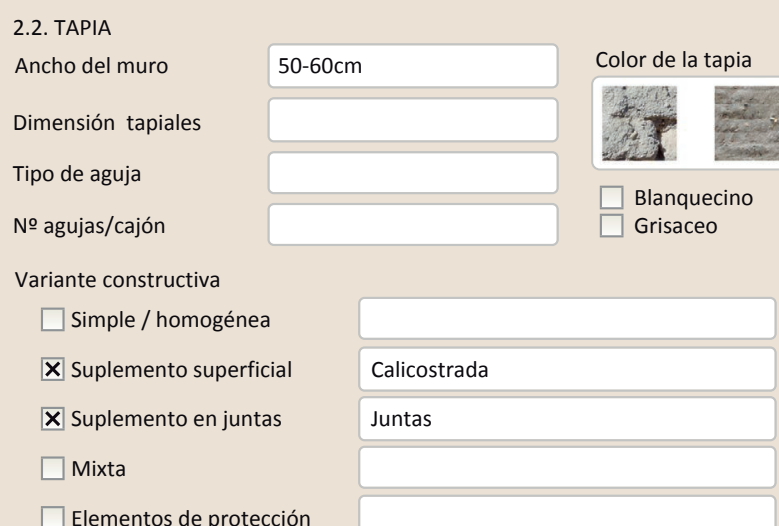

Probablemente tapia con juntas de yeso y colicostrada con yeso como son la mayoría de los casos en esta localidad. Probablemente tapia con juntas de yeso y calicostrada con yeso como son la may
tapia probablemente que solo se ha dejado vista la piedra en la planta baja.

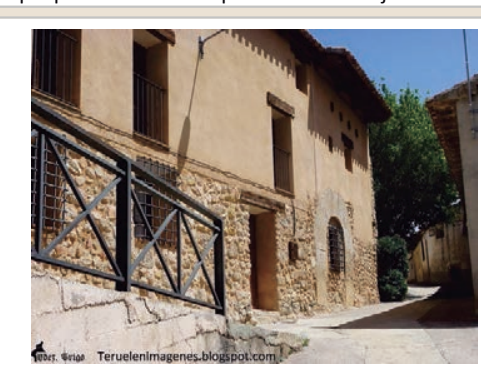

Lesiones $\square$ Muro $\square$ Zócalo $\square$ Revestimiento $\square$ Cubierta $\square$ Otro...

$\square$ Erosión del material $\quad \square$ Humedad por capilaridad $\quad \square$ Grietas por asentamientos $\square$ Erosion de las juntas $\square$ Humedades (manch/eflo) $\quad \square$ Colapso

$\square$ Pérdida de sección $\square$ Pérdida de verticalidad $\square$ Por elementos impropios

$\square$ Vegetación $\quad \square$ Grietas por empuje de la cubierta $\quad \square$ Derivado de intervenciones

$\square$ Desconchados $\quad \square$ Grietas porfalta de traba $\quad \square$ Otro..

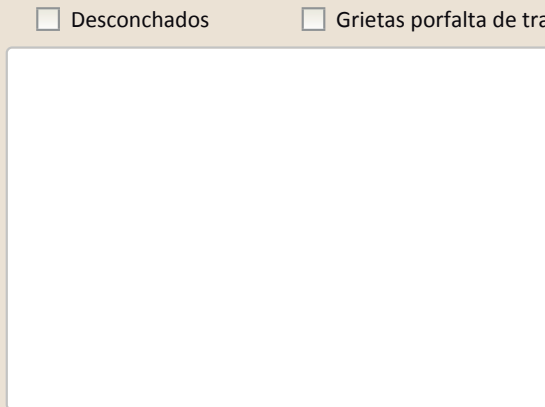

Observaciones 


\section{La restauración y rehabilitación de la arquitectura tradicional de tierra.}

\section{El caso de Aragón.}

3. DATOS DE LA INTERVENCIÓN

$\square$ Mantenimien

Intervención de:

$\square$ Reparación

$\square$ Rehabilitación parcial

$\square$ Restauración $\square$ Demolición

Reflexión previa

Intervención planificada

Observaciones

(1)

3.1. MUROS
Tipo de intervención

Intervenido

Tipo de material

$\square$ Actualización $\square$ Reintegración $\square$ Demolición $\square$ Otro...

$\square$ Consolidación $\square$ Reconstrucción $\quad$ Sustitución

Descripción

No tradicional

Tipo de técnica Diferente a la existente

3.2. ZÓCALO

Tipo de intervención

El muro lateral se ha rehecho por completo

\section{Intervenido}

$\square$ Actualización $\quad$ X Reintegración $\square$ Demolición $\square$ Otro...

$\square$ Consolidación $\quad \square$ Reconstrucción $\square$ Sustitución

Tipo de material

No tradicional

Tipo de técnica Diferente a la existente

Descripción

3.3. REVESTIMIENTOS

Tipo de intervención

Rejuntado de la mampostería con cemento

\section{Intervenido}

$\square$ Actualización $\quad \square$ Reintegración $\quad \square$ Demolición $\square$ Otro...

Tipo de material

Descripción

$\square$ Consolidación $\square$ Reconstrucción $\quad \mathbf{X}$ Sustitución
No tradicional
Tipo de técnica

3.4. VANOS

Tipo de intervención

Tipo de técnica Diferente a la existente

Nuevo revestimiento de cemento coloreado por todo el edificio

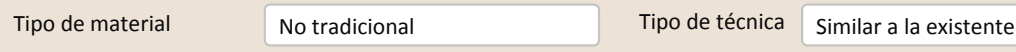

Intervenido

$\square$ Actualización $\quad \mathbf{X}$ Reintegración $\square$ Demolición $\square$ Otro...

$\square$ Consolidación $\square$ Reconstrucción $\quad \boldsymbol{x}$ Sustitución

Descripción Se ha intervenido en los laterales de los huecos para regularizarlos y se han sustituido las carpinterías de planta baja

3.5. CUBIERTA

Tipo de intervención

Intervenido

$\square$ Actualización $\square$ Reintegración $\square$ Demolición $\square$ Otro...

$\square$ Consolidación $\square$ Reconstrucción $\quad \mathbf{X}$ Sustitución

Tipo de material No tradicional Tipo de técnica Diferente a la existente

Descripción Se ha sustituido la cubierta por completo. Se ha realizado una losa de hormigón para la realización de la cubierta.
La restauración y rehabilitación de la arquitectura tradicional de tierra.

El caso de Aragón.

3.7. REHABILITACIÓN ENERGÉTICA $\square$ Fachada $\quad \mathbf{X}$ Vanos $\square$ Forjados $\mathbf{X}$ Cubierta

Observaciones

FOTOGRAFÍAS DE LA INTERVENCIÓN
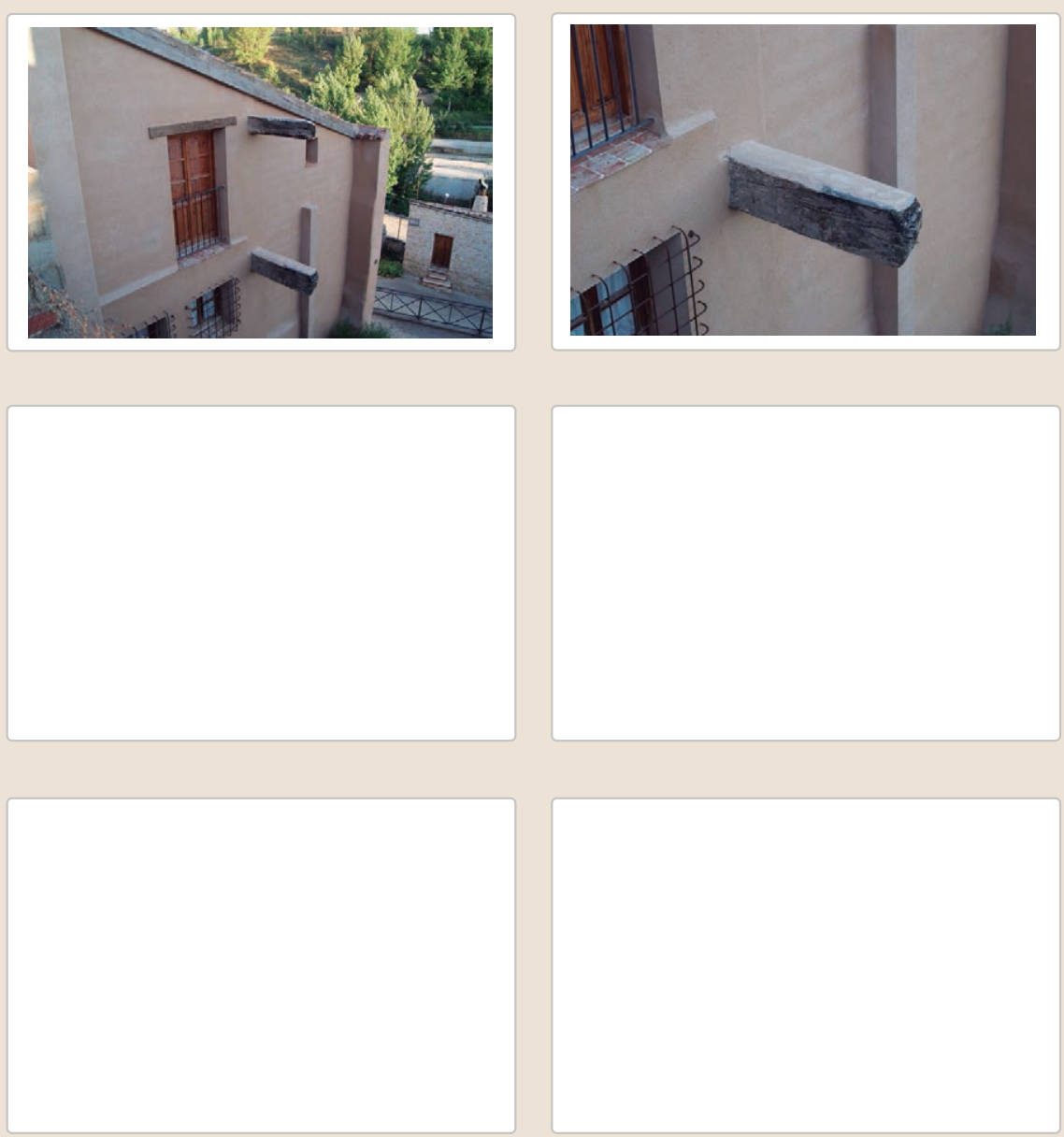

3.6. OTRAS 


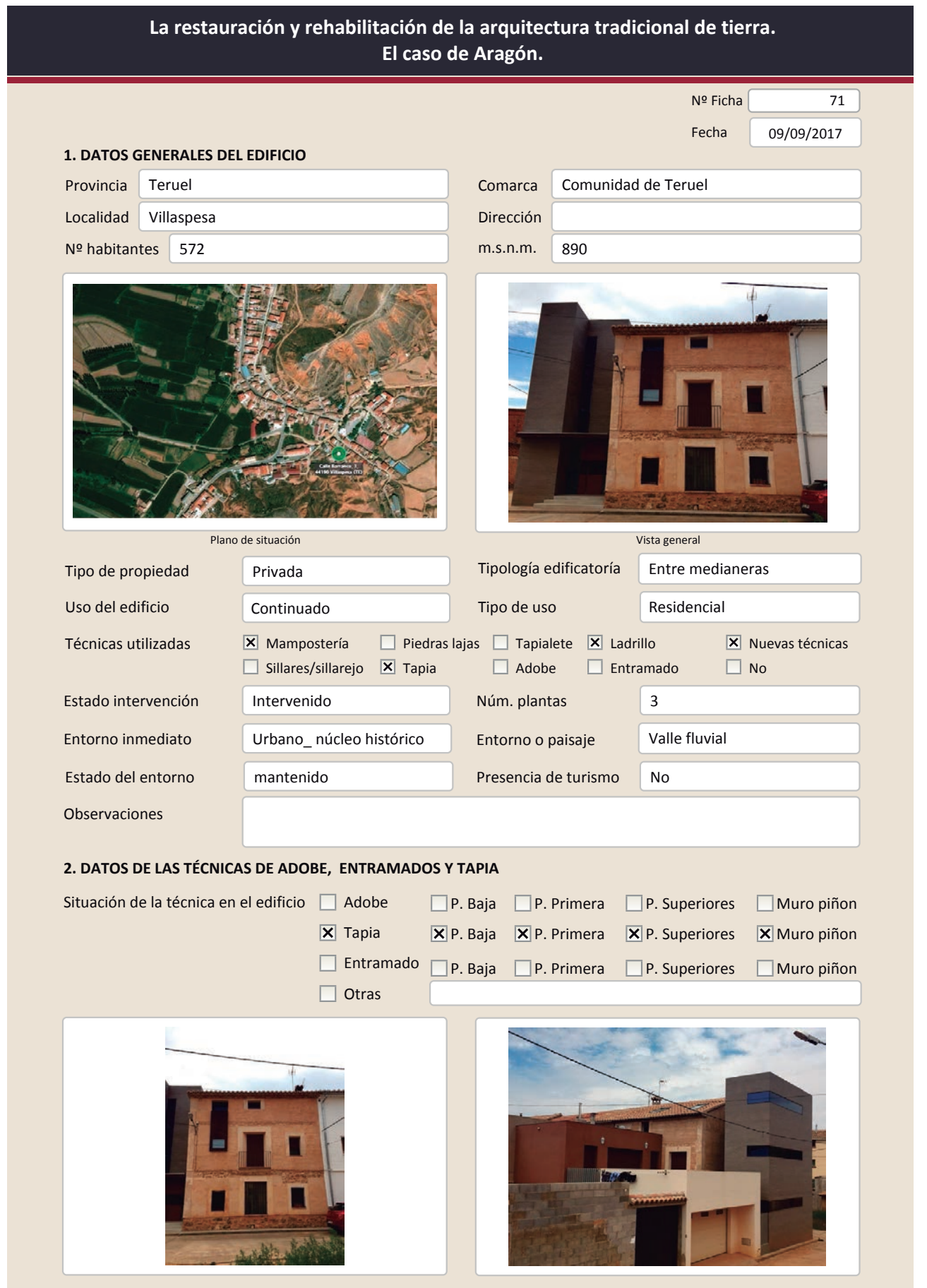

La restauración y rehabilitación de la arquitectura tradicional de tierra.

El caso de Aragón.

2.2. TAPIA

Ancho del muro

Dimensión tapiales

Tipo de aguja

\begin{tabular}{|l|}
\hline $50-60 \mathrm{~cm}$ \\
\hline \\
\hline Redonda \\
\hline 3 \\
\hline
\end{tabular}

Color de la tapia

№ agujas/cajón

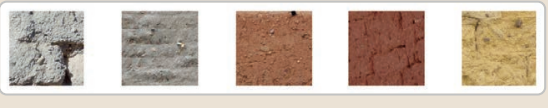

$\square$ Blanquecino $\quad \mathbf{X}$ Marrón $\square$ Amarillento

$\square$ Blanquecino $\quad \boldsymbol{X}$ Marrón
$\square$ Grisaceo
$\square$ Rojizo $\quad \square$ Amarill

Variante constructiva

$\square$ simple / homogénea

$\mathbf{X}$ Suplemento superficial

$\boldsymbol{X}$ Suplemento en juntas

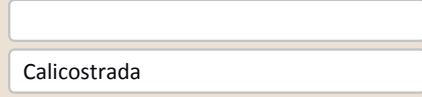

Cal/yeso

$\mathbf{X}$ Mixta

Juntas

$\mathrm{Cal} /$ yeso

En esquinas

Mampostería y yeso

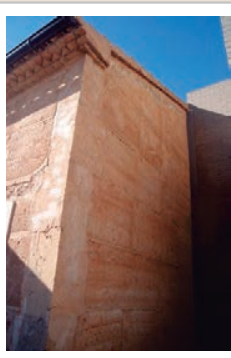

Lesiones $\square$ Muro $\square$ Zócalo $\square$ Revestimiento $\square$ Cubierta $\square$ otro..

$\square$ Erosión del material $\quad \square$ Humedad por capilaridad $\quad \square$ Grietas por asentamientos $\square$ Erosion de las juntas $\square$ Humedades (manch/eflo)

$\square$ Pérdida de sección $\quad \square$ Pérdida de verticalidad

$\square$ Vegetación

$\square$ Por elementos impropios

$\square$ Desconchados

$\square$ Grietas porfalta de traba
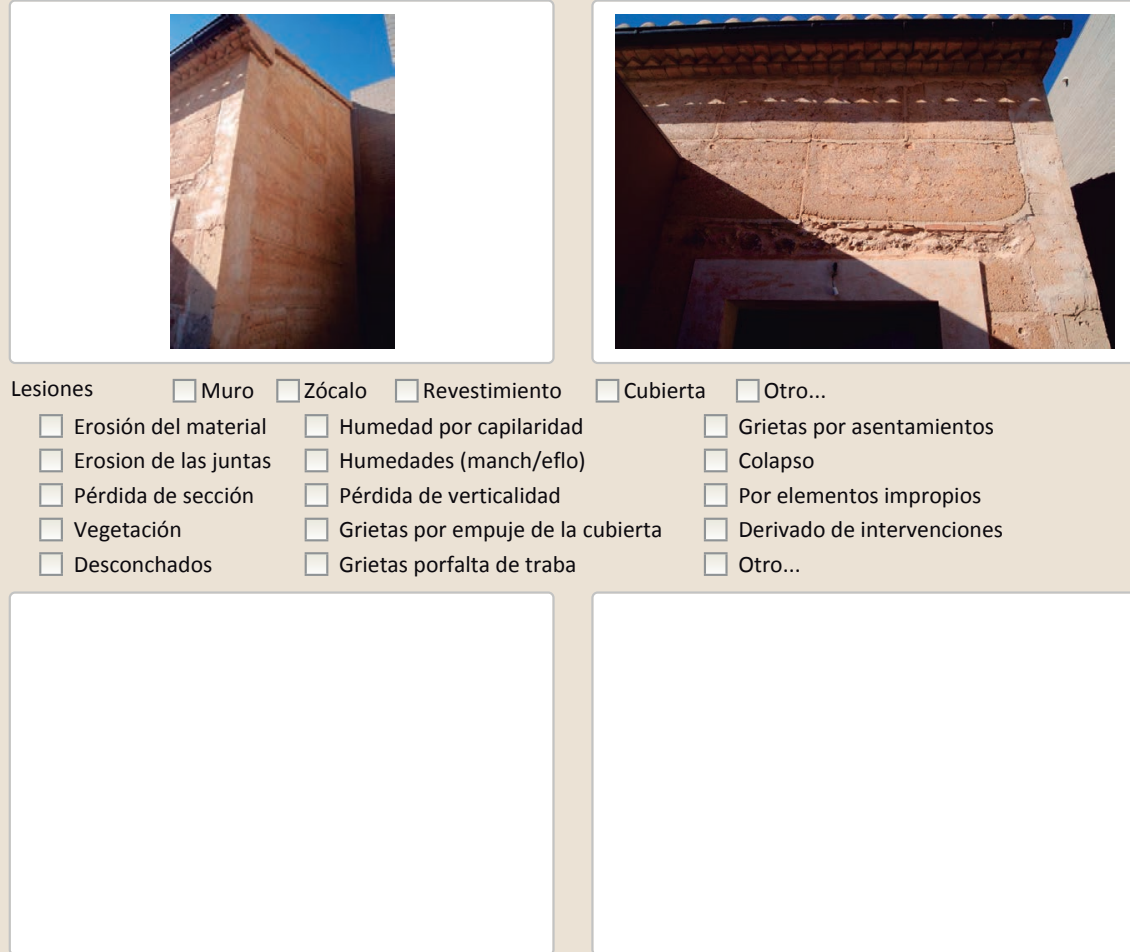

Observaciones 


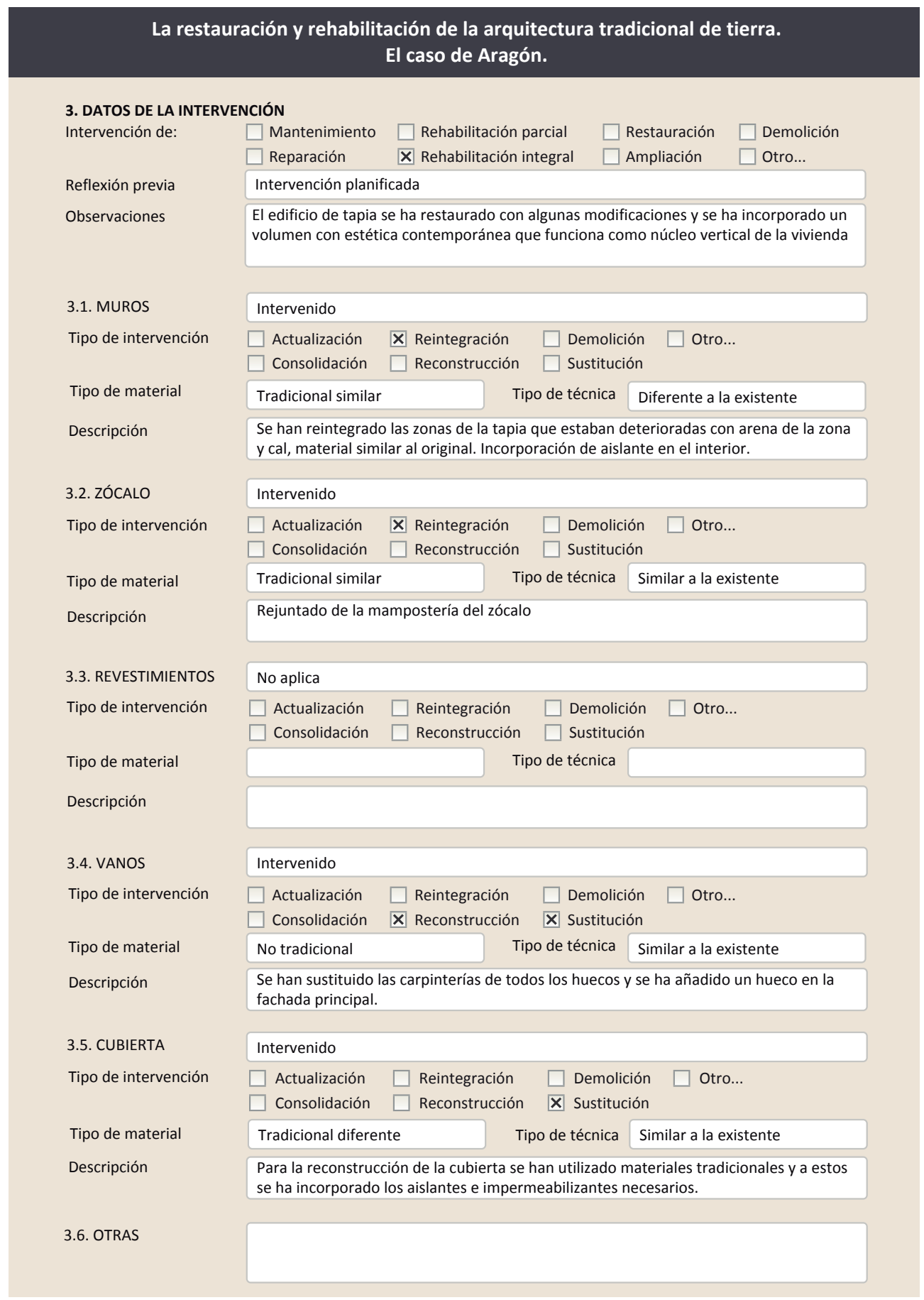

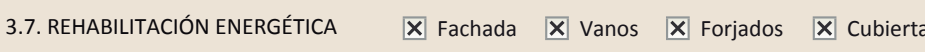

Observaciones $\quad$ Al muro se le ha incorporado aislante por en interior

FOTOGRAFÍAS DE LA INTERVENCIÓN
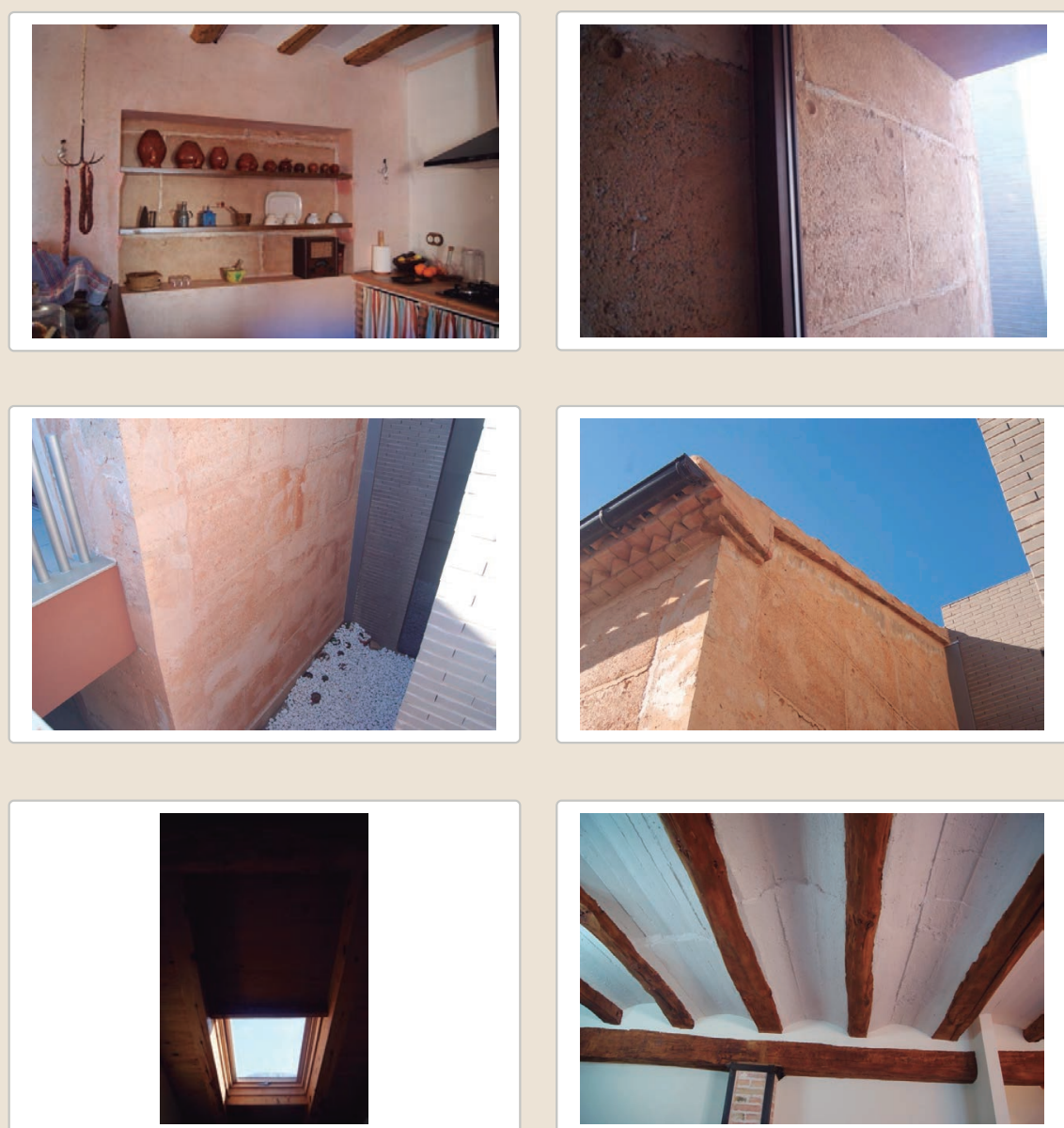


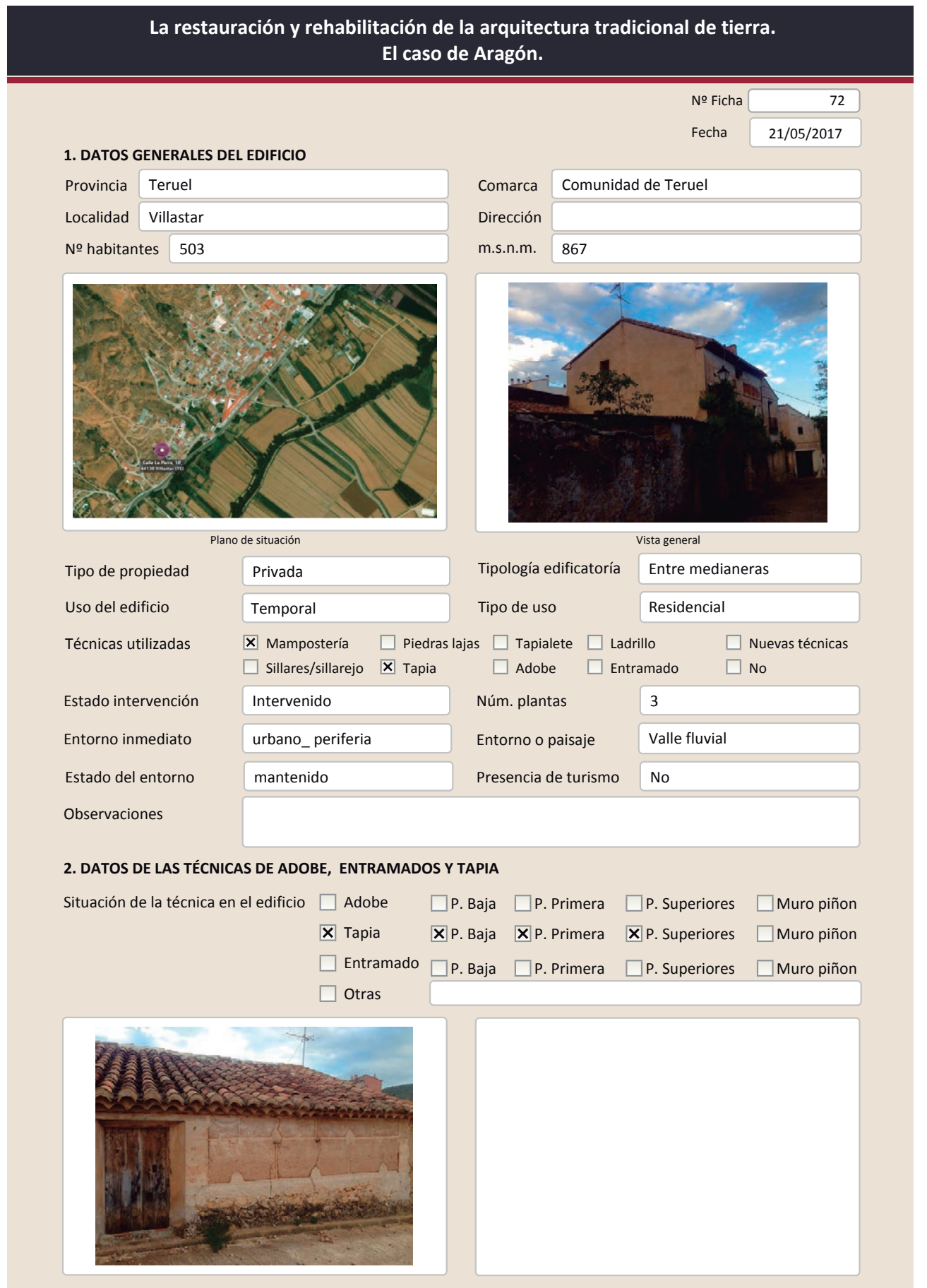

La restauración y rehabilitación de la arquitectura tradicional de tierra.

El caso de Aragón.

2.2. TAPIA

Ancho del muro

Dimensión tapiales

Tipo de aguja

\begin{tabular}{|l|}
\hline $50-60 \mathrm{~cm}$ \\
\hline \\
\hline Redonda \\
\hline 3 \\
\hline
\end{tabular}

Color de la tapia

№ agujas/cajón

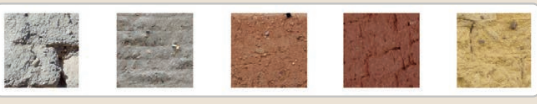

$\square$ Blanquecino $\square$ Marrón $\square$ Amarillento

$\square$ Blanquecino $\square$ Marrón $\square$ Amari.
$\square$ Grisaceo

Variante constructiva

$\square$ Simple / homogénea

X Suplemento superficial

X Suplemento en juntas
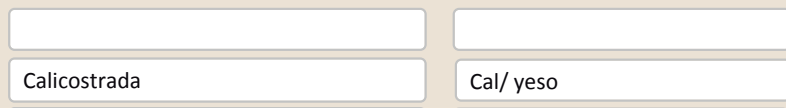

Х Mixta

Juntas

Cal/yeso

En esquinas

$\mathrm{Cal} /$ yeso

Mampostería y yeso

La tapia tiene una forma de campana en la parte central de cajón

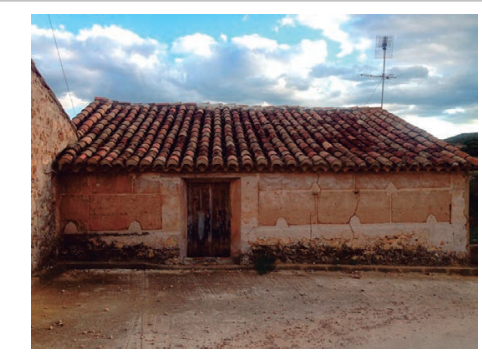

Lesiones $\quad \mathbf{X M u r o} \square$ Zócalo $\square$ Revestimiento

$\mathbf{X}$ Erosión del material $\mathbf{X}$ Humedad por capilaridad

$\square$ Erosion de las juntas $\mathbf{X}$ Humedades (manch/eflo)

$\square$ Pérdida de sección $\square$ Pérdida de verticalidad

$\square$ Vegetación $\quad \mathbf{X}$ Grietas por empuje de la cubierta

$\mathbf{X}$ Desconchados $\quad \square$ Grietas porfalta de traba

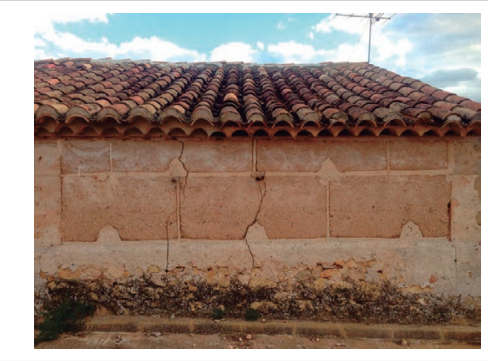

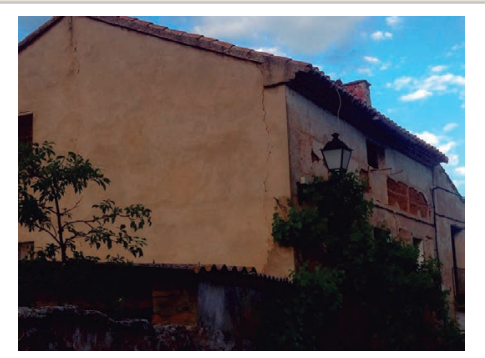

$\square$ Cubierta $\square$ Otro...

$\mathbf{X}$ Grietas por asentamiento

$\square$ Colapso

$\square$ Por elementos impropios

$\square$ Derivado de intervenciones

$\square$ Otro...

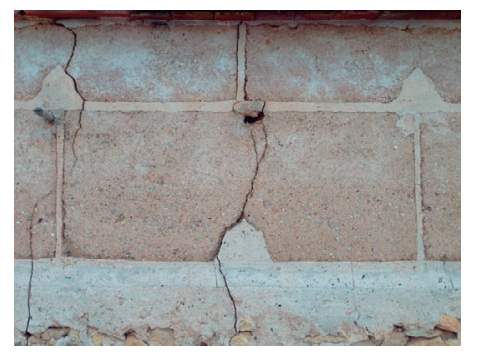

Observaciones 
La restauración y rehabilitación de la arquitectura tradicional de tierra. El caso de Aragón

\section{La restauración y rehabilitación de la arquitectura tradicional de tierra.}

\section{El caso de Aragón.}

3. DATOS DE LA INTERVENCIÓN

Intervención de:

$\square$ Mantenimiento $\square$ Rehabilitación parcia

$\square$ Restauración $\square$ Demolición

Reflexión previa

X Reparación

$\square$ Rehabilitación integral $\square$ Ampliación

$\square$ Otro..

Observaciones

Intervención espontanea

3.1. MUROS

No intervenido

Tipo de intervención

$\square$ Actualización $\square$ Reintegración $\square$ Demolición $\square$ Otro...

$\square$ Consolidación $\square$ Reconstrucción $\square$ sustitución

Tipo de material

Descripción

3.2. ZóCALO

Tipo de intervención

Intervenido

Tipo de intervención

$\square$ Actualización

X Reintegración $\square$ Demolición $\square$ Otro..

Tipo de material

$\square$ Consolidación $\quad \square$ Reconstrucción $\square$ Sustitución

Descripción

Tipo de técnica Similar a la existente

3.3. REVESTIMIENTOS

Tipo de intervención

Intervenido

Reintegración $\square$ Demolición $\square$ Otro...

Tipo de material

No tradicional

X Reconstrucción $\square$ Sustitución

Descripción

3.4. VANOS

Revestimiento de todo el muro piñón con cemento

Tipo de intervención

No intervenido

Tipo de material

$\square$ Actualización $\square$ Reintegración $\square$ Demolición $\square$ Otro...

Descripción

$\square$ Consolidación $\quad \square$ Reconstrucción $\square$ Sustitución

3.5. CUBIERTA

Tipo de intervención

Intervenido

$\square$ Actualización $\quad \mathbf{X}$ Reintegración $\square$ Demolición $\square$ Otro

Tipo de material

$\square$ Consolidación $\square$ Reconstrucción $\square$ Sustitución

Descripción

No tradicional Tipo de técnica Similar a la existente

3.6. OTRAS

Reintegración de tejas con mortero de cemento principalmente en la cumbrera y el alero

$$
\text { Tipo de técnica }
$$




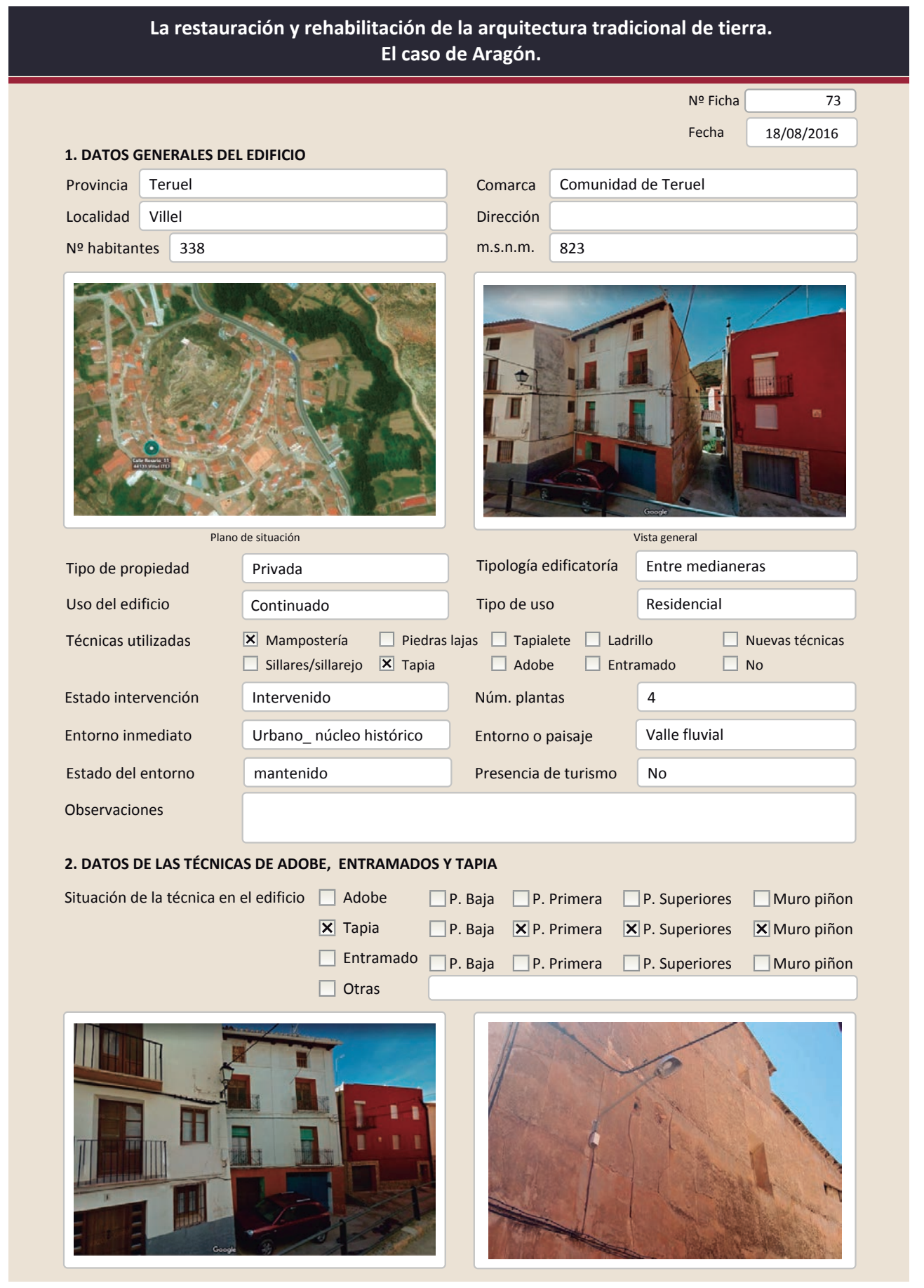

La restauración y rehabilitación de la arquitectura tradicional de tierra. El caso de Aragón.

\subsection{TAPIA}

Ancho del muro

Dimensión tapiales

Tipo de aguja

№ agujas/cajón

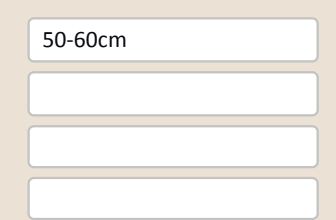

Color de la tapia

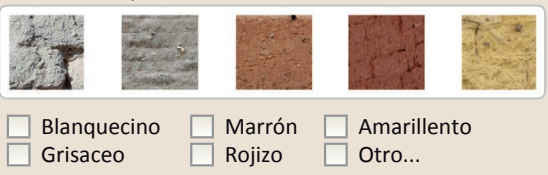

Variante constructiva

$\square$ simple / homogénea

$\square$ suplemento superficial

$\mathbf{X}$ Suplemento en juntas

$\square$ Mixta

$\mathbf{X}$ Elementos de protección
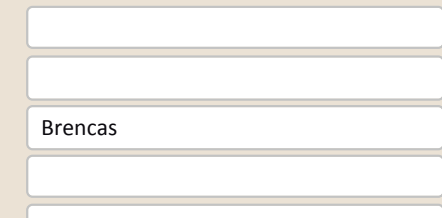

Revestimiento

En uno de los desconchados del muro se puede apreciar la tapia con brencas que hay detrás

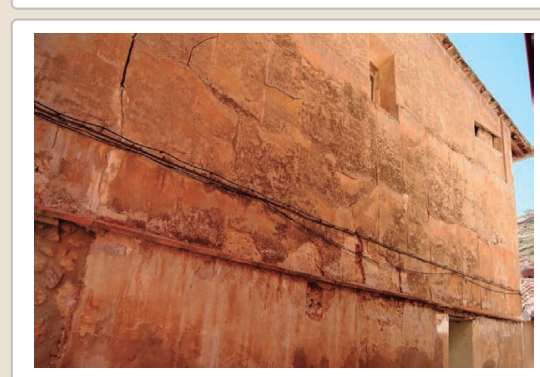

Lesiones $\quad \mathbf{X}$ Muro $\square$ Zócalo $\quad \mathbf{X}$ Revestimiento $\square$ Cubierta $\square$ otro...

$\square$ Erosión del material $\quad \square$ Humedad por capilaridad $\quad \square$ Grietas por asentamientos

$\square$ Erosion de las juntas $\square$ Humedades (manch/eflo)

$\square$ Pérdida de sección $\square$ Pérdida de verticalidad

$\square$ Vegetación

$\square$ Por elementos impropios

$\mathbf{X}$ Desconchados

$\mathbf{X}$ Grietas porfalta de trab

$\square$ Derivado

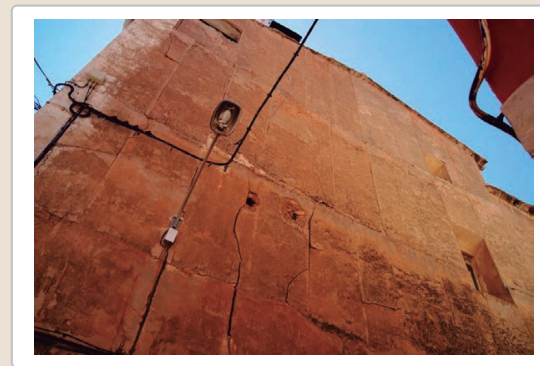

Observaciones

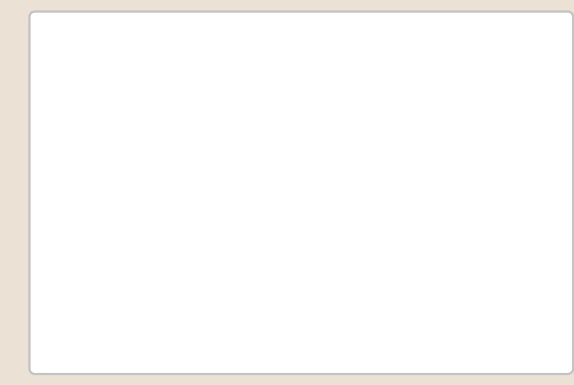

Grietas en el revestimiento 


\section{La restauración y rehabilitación de la arquitectura tradicional de tierra.}

\section{El caso de Aragón.}

3. DATOS DE LA INTERVENCIÓN

$\square$ Mantenimien

Rehabitacion parcial

Reflexión previa

$\square$ Reparación

Rehabilitación incia

$\square$ Restauración $\square$ Demolición

Intervención espontanea

Observaciones

(n)

3.1. MUROS

No intervenido

Tipo de intervención

$\square$ Actualización

$\square$ Consolidación $\square$ Reconstrucción $\square$ sustitución

Tipo de material

Descripción

3.2. ZÓCALO

Tipo de intervención

\section{Intervenido}

$\mathbf{X}$ Actualización $\mathbf{x}$ Reintegración $\square$ Demolición $\square$ Otro...

$\square$ Consolidación $\quad \square$ Reconstrucción $\quad \square$ Sustitución

Tipo de material

Descripción

3.3. REVESTIMIENTOS

Tipo de intervención

Tipo de técnica Diferente a la existente

Rejuntado de la mampostería con gran cantidad de mortero y pintura plástica en todo el zócalo de planta baja

\section{Intervenido}

X Actualización $\square$ Reintegración $\square$ Demolición $\square$ Otro...

$\square$ Consolidación $\square$ Reconstrucción $\square$ Sustitución

Tipo de material

Descripción

3.4. VANOS

Tipo de intervención

No tradicional

Tipo de técnica Diferente a la existente

Pintura plástica blanca en la fachada principal

Tipo de material

Intervenido

$\square$ Actualización $\square$ Reintegración $\square$ Demolición $\square$ Otro...

$\square$ Consolidación $\square$ Reconstrucción $\quad$ X Sustitución

Descripción

3.5. CUBIERTA

Tipo de intervención

No tradicional

Tipo de técnica Diferente a la existente

Nuevo hueco de acceso para vehículos en planta baja

\section{Intervenido}

$\square$ Actualización $\quad \mathbf{X}$ Reintegración $\square$ Demolición $\square$ Otro.

$\square$ Consolidación $\quad \square$ Reconstrucción $\square$ Sustitución

Tipo de material

No tradicional

Tipo de técnica Similar a la existente

Descripción

Reintegración de tejas con mortero de cemento y pintura blanca
La restauración y rehabilitación de la arquitectura tradicional de tierra.

El caso de Aragón.

3.7. REHABILITACIÓN ENERGÉTICA $\quad \square$ Fachada $\square$ Vanos $\square$ Forjados $\square$ Cubierta

Observaciones

FOTOGRAFíAS DE LA INTERVENCIÓN
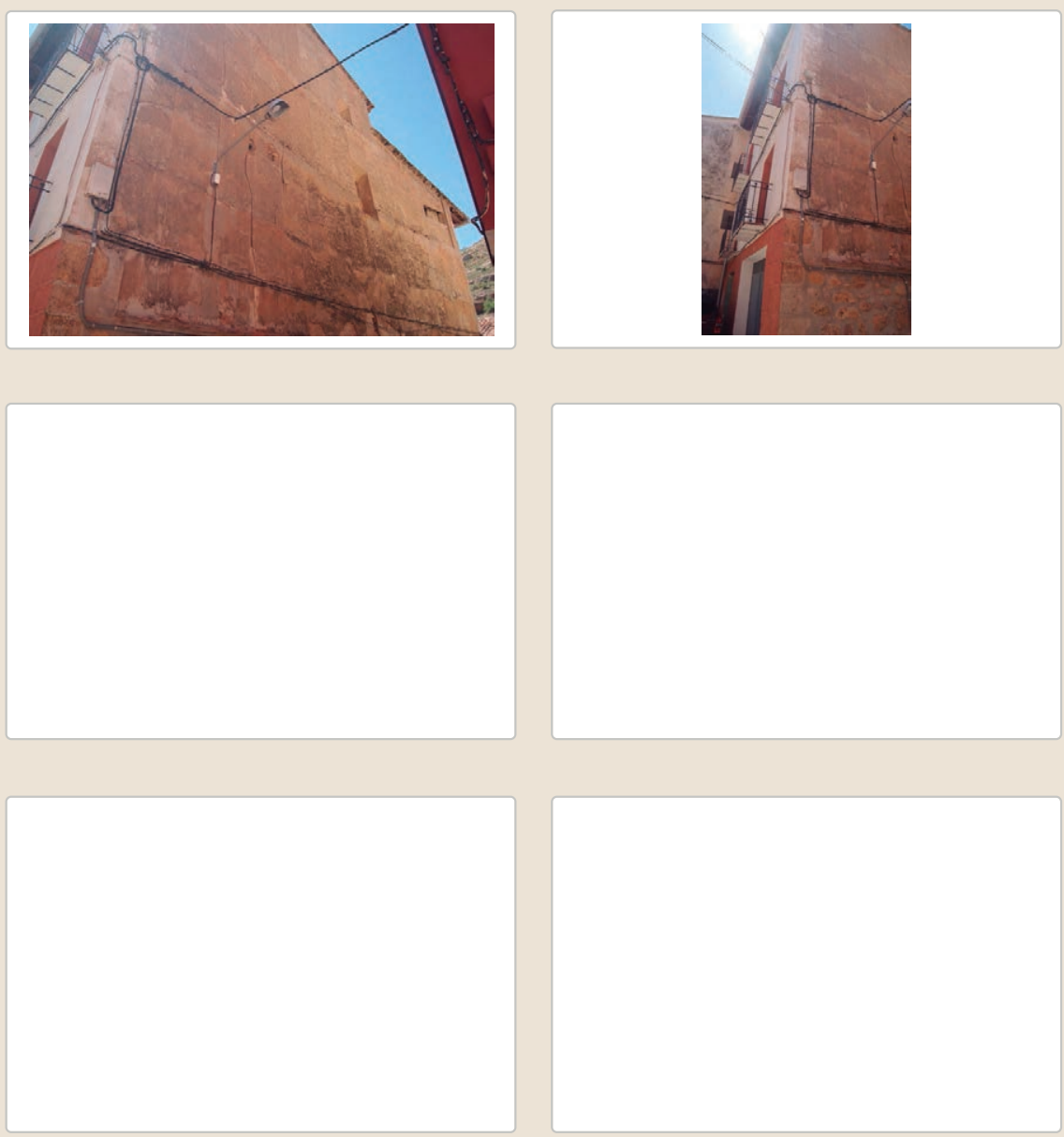

3.6. OTRAS 


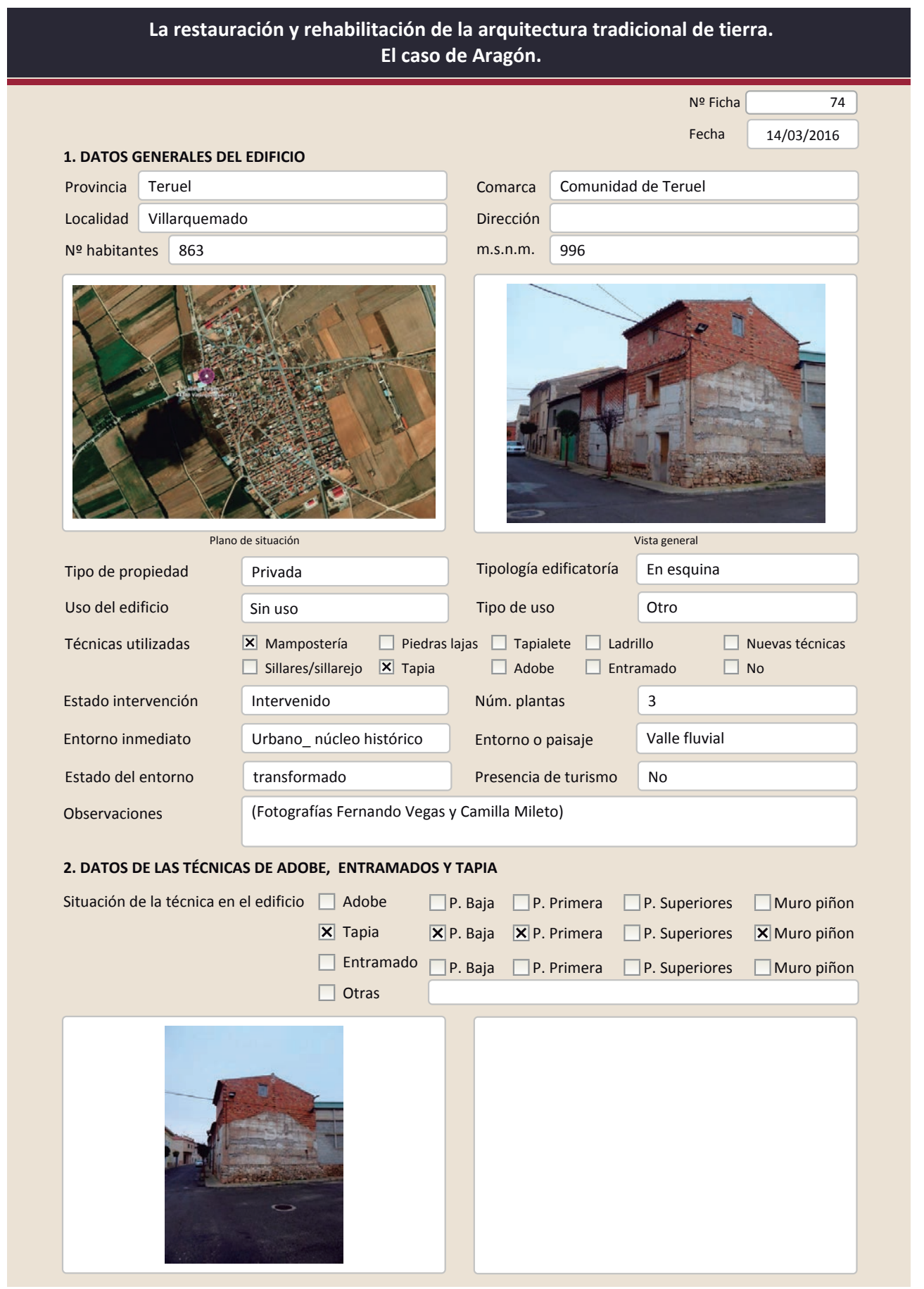

La restauración y rehabilitación de la arquitectura tradicional de tierra.

El caso de Aragón.

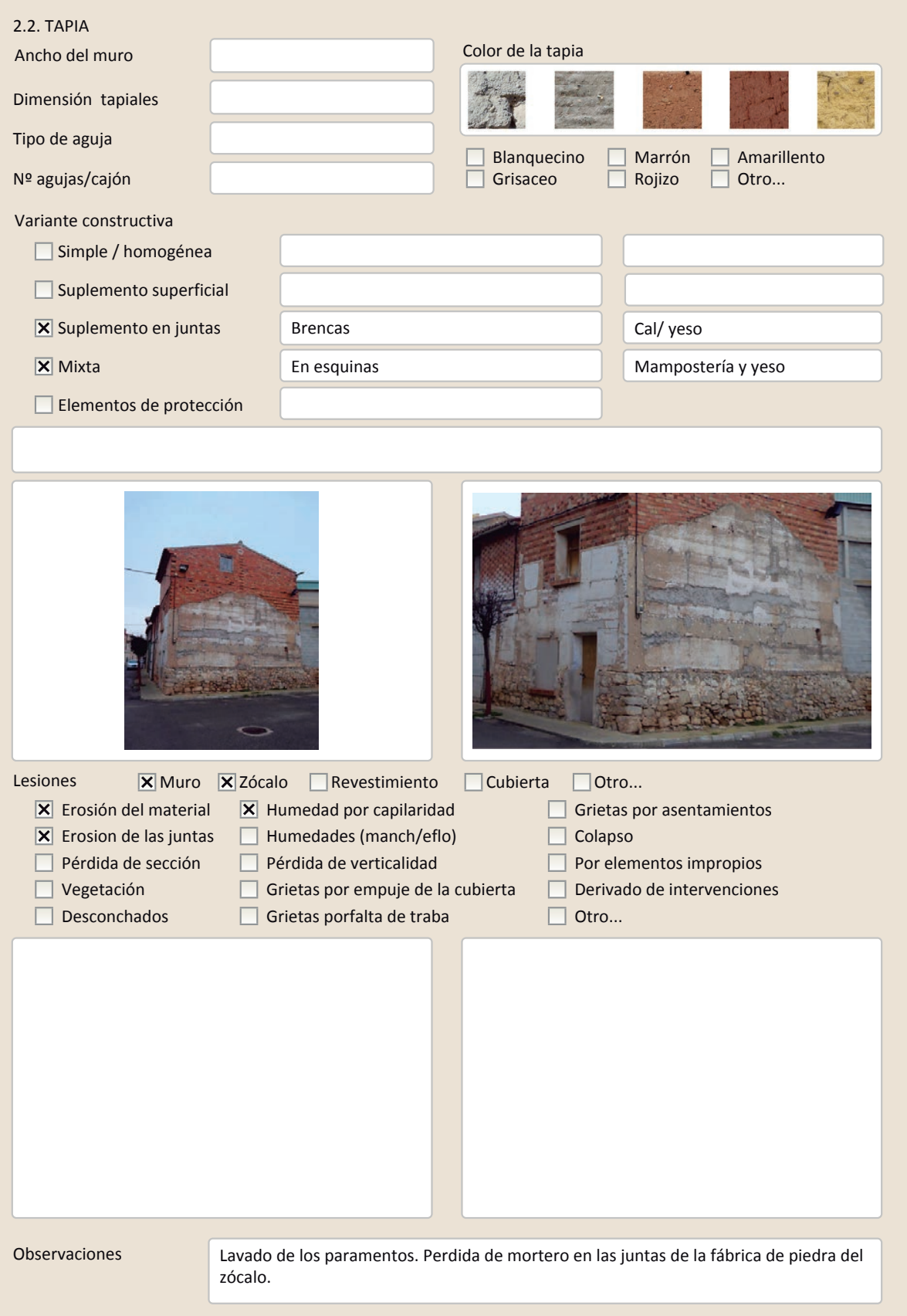




\section{La restauración y rehabilitación de la arquitectura tradicional de tierra.} El caso de Aragón.

3. DATOS DE LA INTERVENCIÓN

Mantenimiento $\square$ Rehabilitación parcial X Reparación $\square$ Rehabilitación integral $\mathbf{X}$ Ampliación $\square$ Otro...

Reflexión previa Intervención espontanea

Observaciones Intervención importante probablemente realizada de forma espontánea por el constructor de la zona.

\subsection{MUROS Intervenido \\ Tipo de intervención $\quad \square$ Actualización $\quad \mathbf{X}$ Reintegración $\quad \square$ Demolición $\square$ Otro... \\ $\square$ ctualización
$\square$ Consolidación $\quad \boldsymbol{X}$ Reintegración}

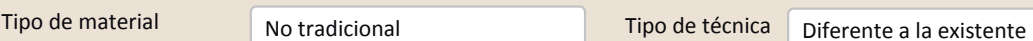

Descripción Sobrelevación del muro original con ladrillo hueco. Inserción de elementos añadidos en estructuras históricas. Recrecido de los muros con fábrica de ladrillo hueco. Relleno de

3.2. ZÓCALO

Tipo de intervención

No intervenido

Tipo de intervención

$\square$ Actualizació

Tipo de material

Descripción

3.3. REVESTIMIENTOS

Tipo de intervención

Tipo de material

Descripción

3.4. VANOS
Tipo de intervención

Intervenido

Tipo de intervención $\square$ Actualización $\square$ Reintegración $\square$ Demolición $\square$ Otro...

Tipo de material No tradicional Tipo de técnica Diferente a la existente

Descripción En la fachada se puede apreciar el desplazamiento del hueco realizado con ladrillo y vigueta de hormigón en la unión de ambos tipos de muro.

3.5. CUBIERTA

Tipo de intervención

Intervenido

$\square$ Actualización $\quad \square$ Reintegración $\quad \square$ Demolición $\square$ Otro.

$\square$ Consolidación $\square$ Reconstrucción $\quad$ X Sustitución

\begin{tabular}{llll} 
Tipo de material Tipo de técnica & Diferente a la existente \\
\hline
\end{tabular} $\begin{array}{ll}\text { Descripción } & \begin{array}{l}\text { Nueva cubierta sobre el recrecido de una planta realizado sobre el muro de tapia. } \\ \text { Materiales industriales (ladrillo, viguetas hormigón...) }\end{array}\end{array}$
La restauración y rehabilitación de la arquitectura tradicional de tierra.

El caso de Aragón.

3.7. REHABILITACIÓN ENERGÉTICA $\quad \square$ Fachada $\square$ Vanos $\square$ Forjados $\square$ Cubierta

Observaciones

FOTOGRAFÍAS DE LA INTERVENCIÓN
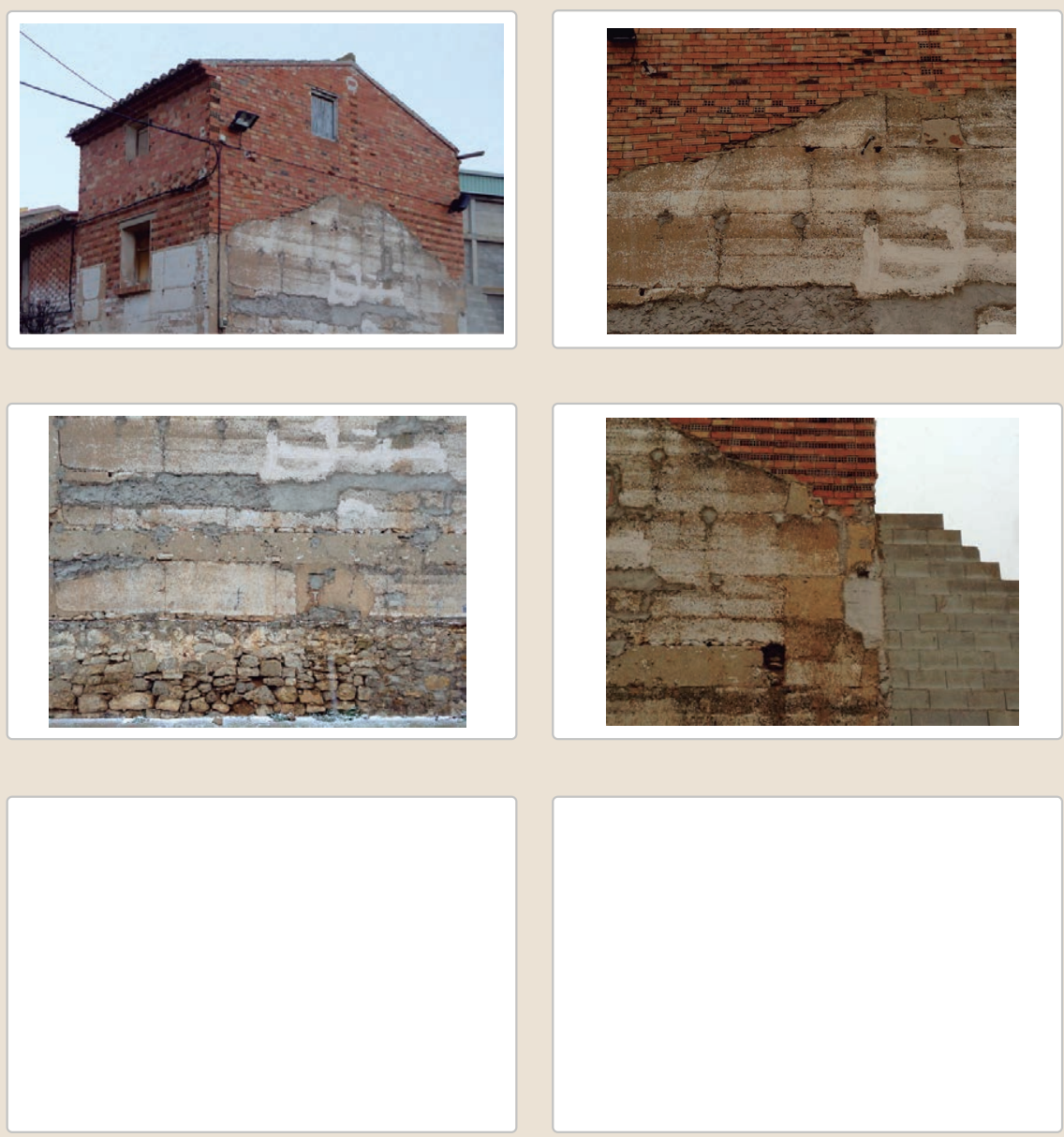

3.6. OTRAS 


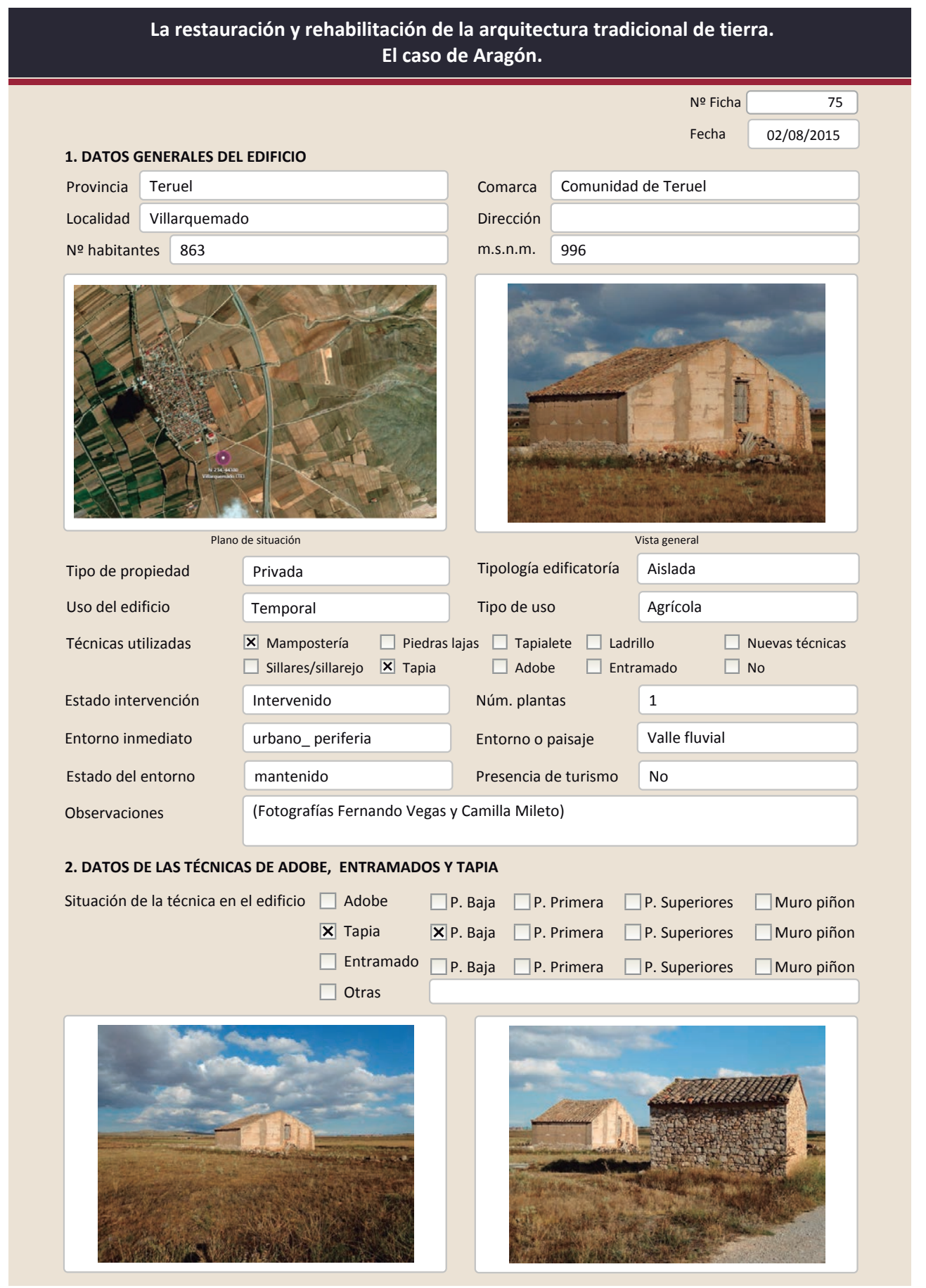

La restauración y rehabilitación de la arquitectura tradicional de tierra.

El caso de Aragón.

2.2. TAPIA

Ancho del muro

Dimensión tapiales

Tipo de aguja

№ agujas/cajón

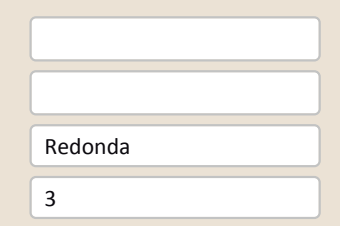

Color de la tapia

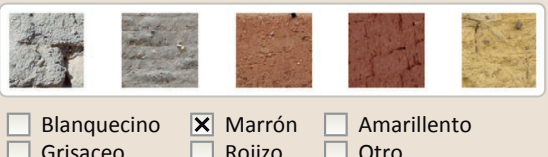

$\square$ Blanquecino $\quad \boldsymbol{x}$ Marrón $\square$ Amarillento
$\square$ Grisaceo

Variante constructiva

$\square$ Simple / homogénea

$\mathbf{X}$ Suplemento superficial

$\mathbf{X}$ Suplemento en juntas

$\mathbf{X}$ Mixta
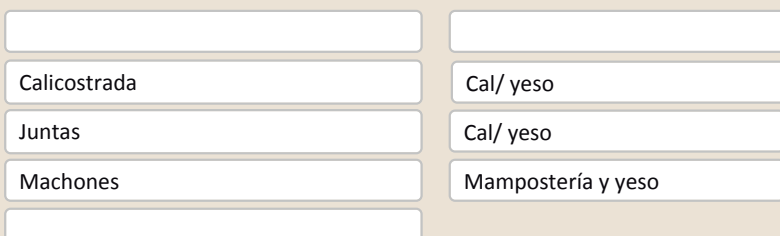

$\square$ Elementos de protección

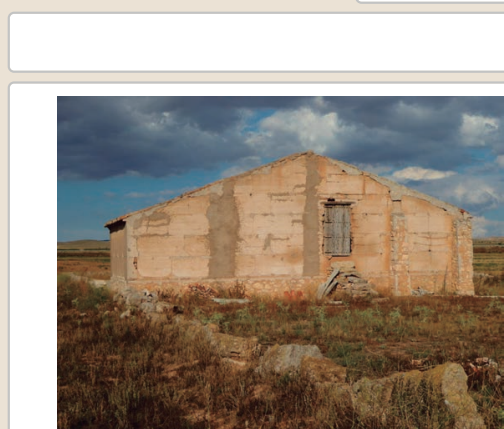

Lesiones $\quad \mathbf{X}$ Muro $\square$ Zócalo $\square$ Revestimiento $\square$ Cubierta $\square$ otro..

X Erosión del material $\quad \square$ Humedad por capilaridad $\quad \square$ Grietas por asentamientos $\mathbf{X}$ Erosion de las juntas $\square$ Humedades (manch/eflo)

$\square$ Pérdida de sección $\square$ Pérdida de verticalidad

$\square$ Vegetación $\square$ Grietas por empuje de la cubierta

$\square$ Vesconchado $\square$ Grietas por empuje de la cubir
$\square$ Grietas porfalta de traba

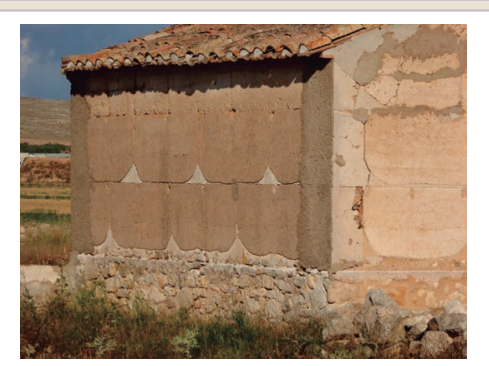

$\square$ Desconchados

$\square$ Por elementos impropios

$\square$ Derivado de intervenciones
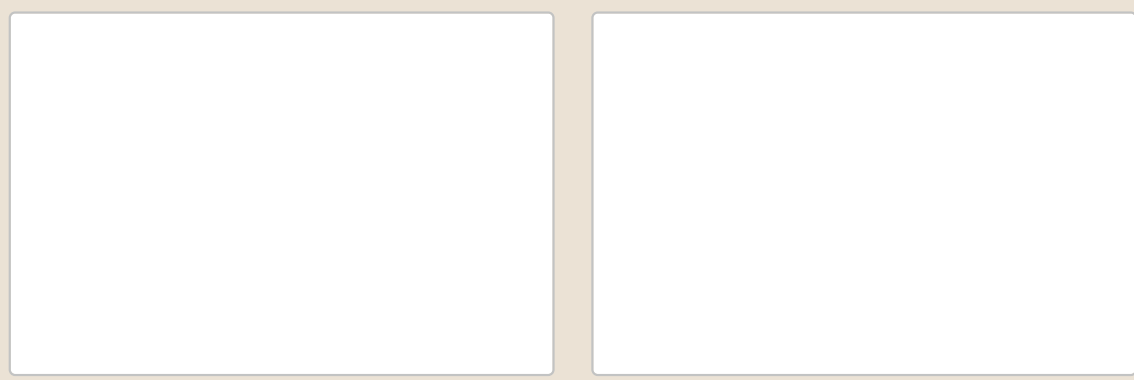

Observaciones

Erosión y pérdida de material sobre todo en esquinas. 


\section{La restauración y rehabilitación de la arquitectura tradicional de tierra.}

\section{El caso de Aragón.}

3. DATOS DE LA INTERVENCIÓN

Mantenimiento $\square$ Rehabilitación parcial $\square$ Restauración $\square$ Demolición X Reparación $\quad \square$ Rehabilitación integral $\square$ Ampliación $\quad \square$ Otro...

Reflexión previa Intervención espontanea

Observaciones Se han tapado las oquedades $\mathrm{y}$ los faltantes de yeso de pilares $\mathrm{y}$ rafas con cemento

3.1. MUROS
Tipo de intervención

Intervenido

Tipo de material

$\square$ Actualización

$\square$ Consolidación

X Reintegració

$\square$ Demolición

\begin{tabular}{lll} 
No tradicional Tipo de técnica Diferente a la existente \\
\hline centan
\end{tabular}

Descripción

cemento en faltantes

3.2. ZÓCALO

Tipo de intervención

No intervenido

Tipo de intervención

$\square$ Actualización

$\square$ Reintegración $\square$ Demolición $\square$ Otro...

$\square$ Consolidación $\quad \square$ Reconstrucción $\square$ Sustitución

Tipo de material

Descripción

3.3. REVESTIMIENTOS

Tipo de intervención

Tipo de material

Descripción

3.4. VANOS

Tipo de intervención

Tipo de material

Descripción

3.5. CUBIERTA

Tipo de intervención

Tipo de material

Descripción

\section{Intervenido}

$\square$ Actualización $\quad \mathbf{X}$ Reintegración $\square$ Demolición $\square$ Otro.

$\square$ Consolidación $\quad \square$ Reconstrucción $\square$ Sustitución

No tradicional Tipo de técnica Similar a la existente

reintegración de la unión cubierta muro con cemento. En el alero se han recolocado y recibido las tejas con cemento
La restauración y rehabilitación de la arquitectura tradicional de tierra.

El caso de Aragón.

3.7. REHABILITACIÓN ENERGÉTICA $\quad \square$ Fachada $\square$ Vanos $\square$ Forjados $\square$ Cubierta

Observaciones

FOTOGRAFÍAS DE LA INTERVENCIÓN
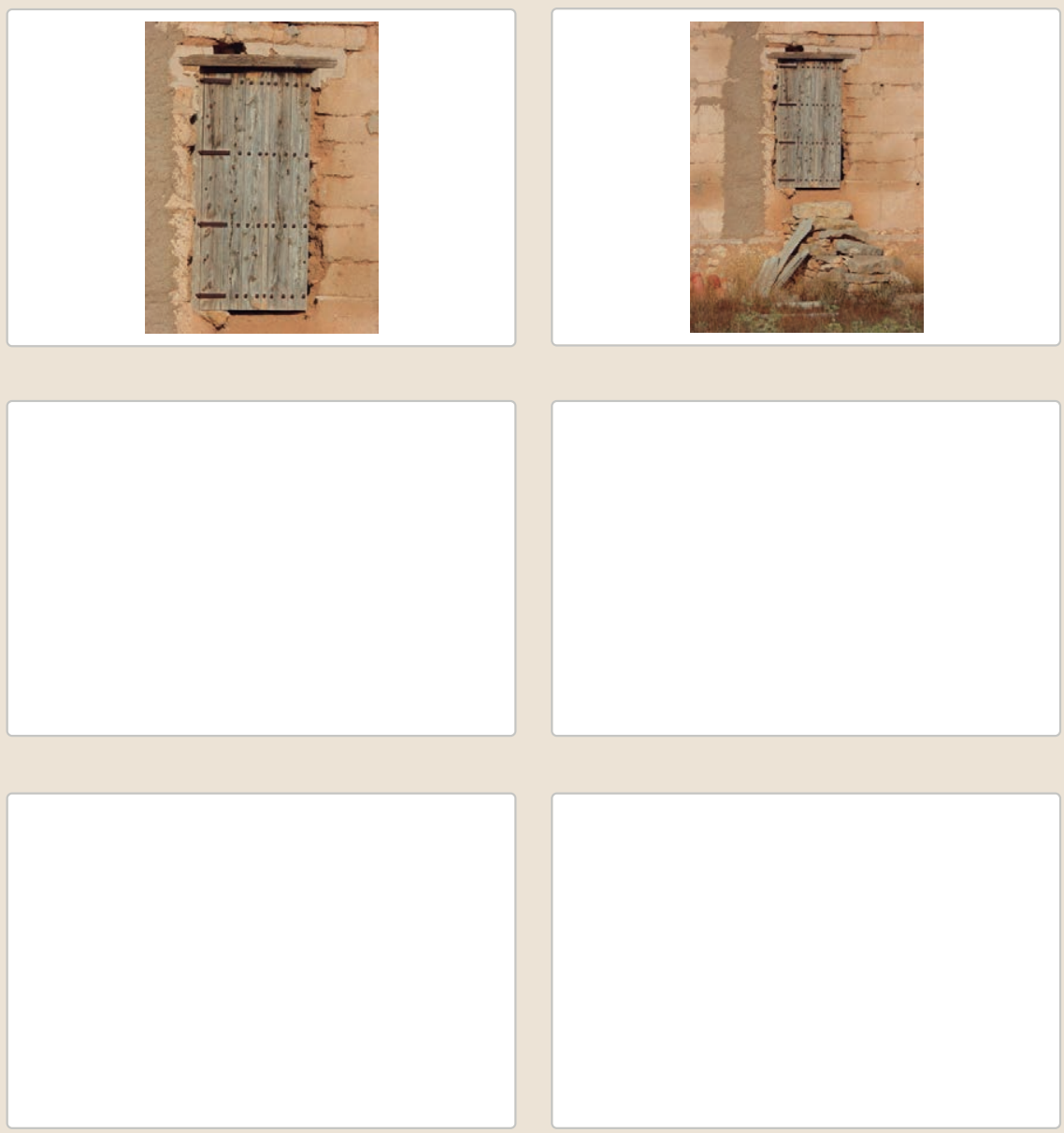

3.6. OTRAS 


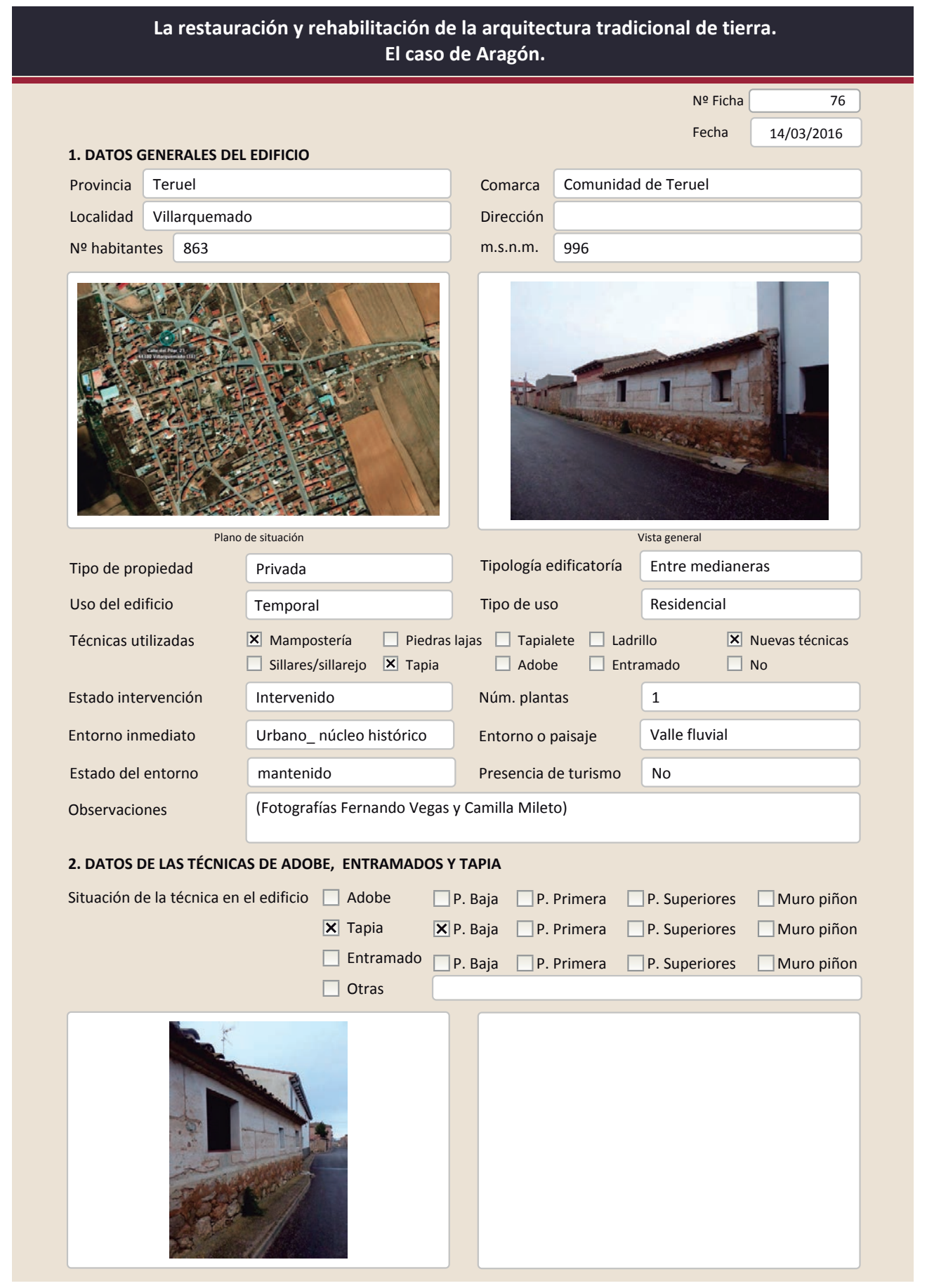

La restauración y rehabilitación de la arquitectura tradicional de tierra.

El caso de Aragón.

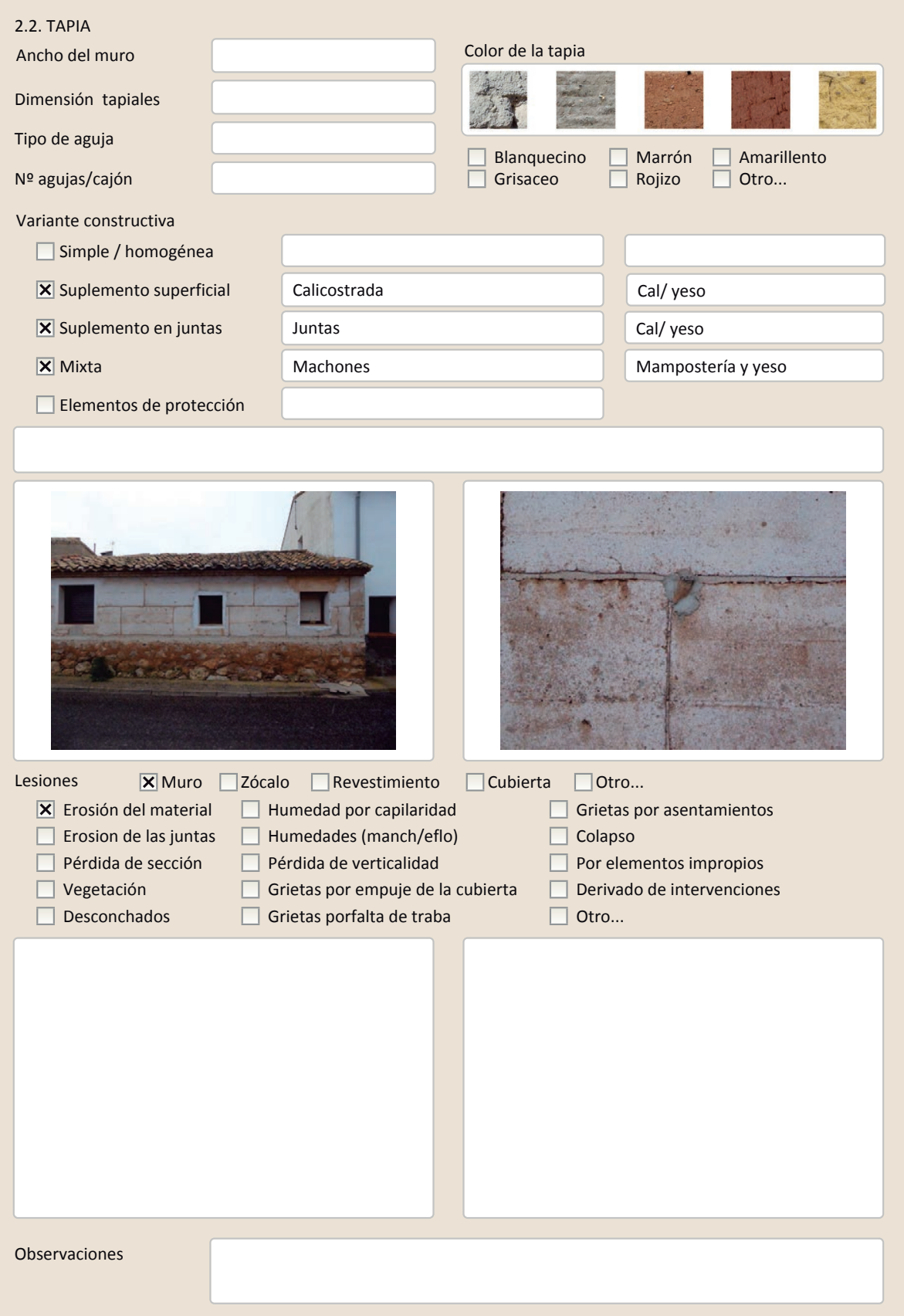




\section{La restauración y rehabilitación de la arquitectura tradicional de tierra.}

\section{El caso de Aragón.}

3. DATOS DE LA INTERVENCIÓN

$\mathbf{X}$ Rehabilitación parcial

$\square$ Restauración $\square$ Demolición

alexión previa

$\square$ Reparación

$\square$ Rehabilitación integra

Ampliación

$\square$ Otro...

Reflexión previa Intervención planificada

Observaciones El edificio se ha rehabilitado para ser una vivienda. Los huecos parecen haberse abierto posteriormente

3.1. MUROS
Tipo de intervención

Intervenido

Tipo de material

$\square$ Actualización $\quad \boldsymbol{X}$ Reintegración $\square$ Demolición $\square$ Otro...

$\square$ Consolidación $\quad \mathbf{X}$ Reconstrucción $\square$ Sustitución

Descripción

No tradicional

Tipo de técnica Diferente a la existente

Recrecido de parte del mu
tapia en otra de las partes.

3.2. ZÓCALO

No intervenido

Tipo de intervención

$\square$ Actualizació

Tipo de material

Descripción

3.3. REVESTIMIENTOS

Tipo de intervención

Tipo de material

Descripción

3.4. VANOS

Tipo de intervención

Tipo de material

Descripción

3.5. CUBIERTA

Tipo de intervención

Tipo de material

Descripción

\section{No aplica}

$\square$ Actualización $\square$ Reintegración $\quad \square$ Demolición $\square$ Otro...

$\square$ Consolidación $\square$ Reconstrucción $\square$ Sustitución

Tipo de técnica

the

Intervenido

$\square$ Actualización $\square$ Reintegración $\square$ Demolición $\square$ Otro...

$\square$ Consolidación $\square$ Reconstrucción $\mathbf{X}$ Sustitución

No tradicional Tipo de técnica Diferente a la existente

Huecos nuevos abiertos en el muro de tapia a posteriori. Dintel de material industrial (presuntamente)

Intervenido

$\square$ Actualización $\quad \square$ Reintegración $\quad \square$ Demolición $\square$ Otro.

$\square$ Consolidación $\square$ Reconstrucción $\quad \mathbf{x}$ Sustitución

No tradicional Tipo de técnica Diferente a la existente

Sustitución parcial de la cubierta en la zona en la que se ha recrecido el muro. En el resto de cubierta se han cogido las tejas del alero con mortero de cemento
La restauración y rehabilitación de la arquitectura tradicional de tierra.

El caso de Aragón.

3.7. REHABILITACIÓN ENERGÉTICA $\quad \square$ Fachada $\square$ Vanos $\square$ Forjados $\square$ Cubierta

Observaciones

FOTOGRAFÍAS DE LA INTERVENCIÓN
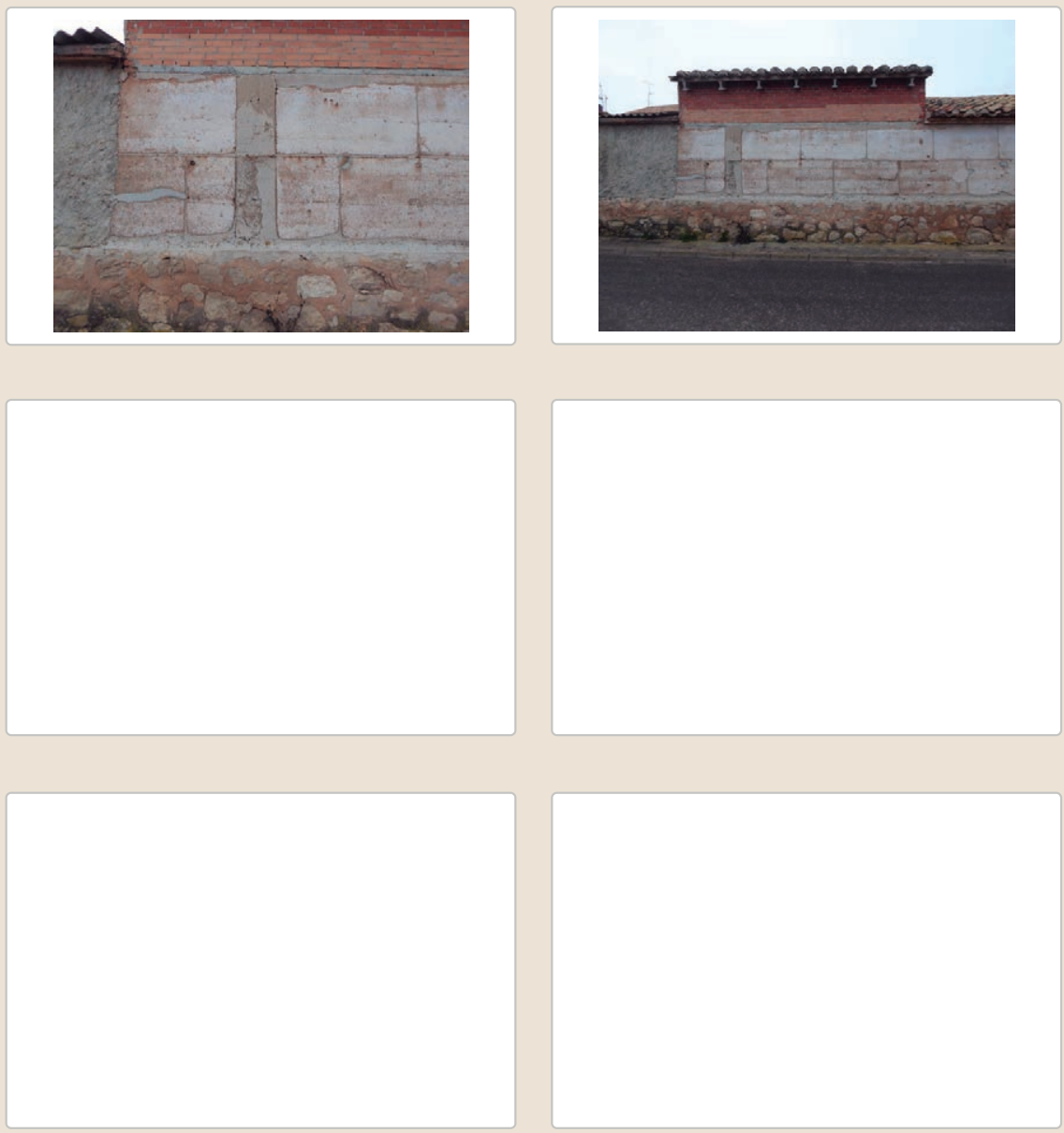

3.6. OTRAS 


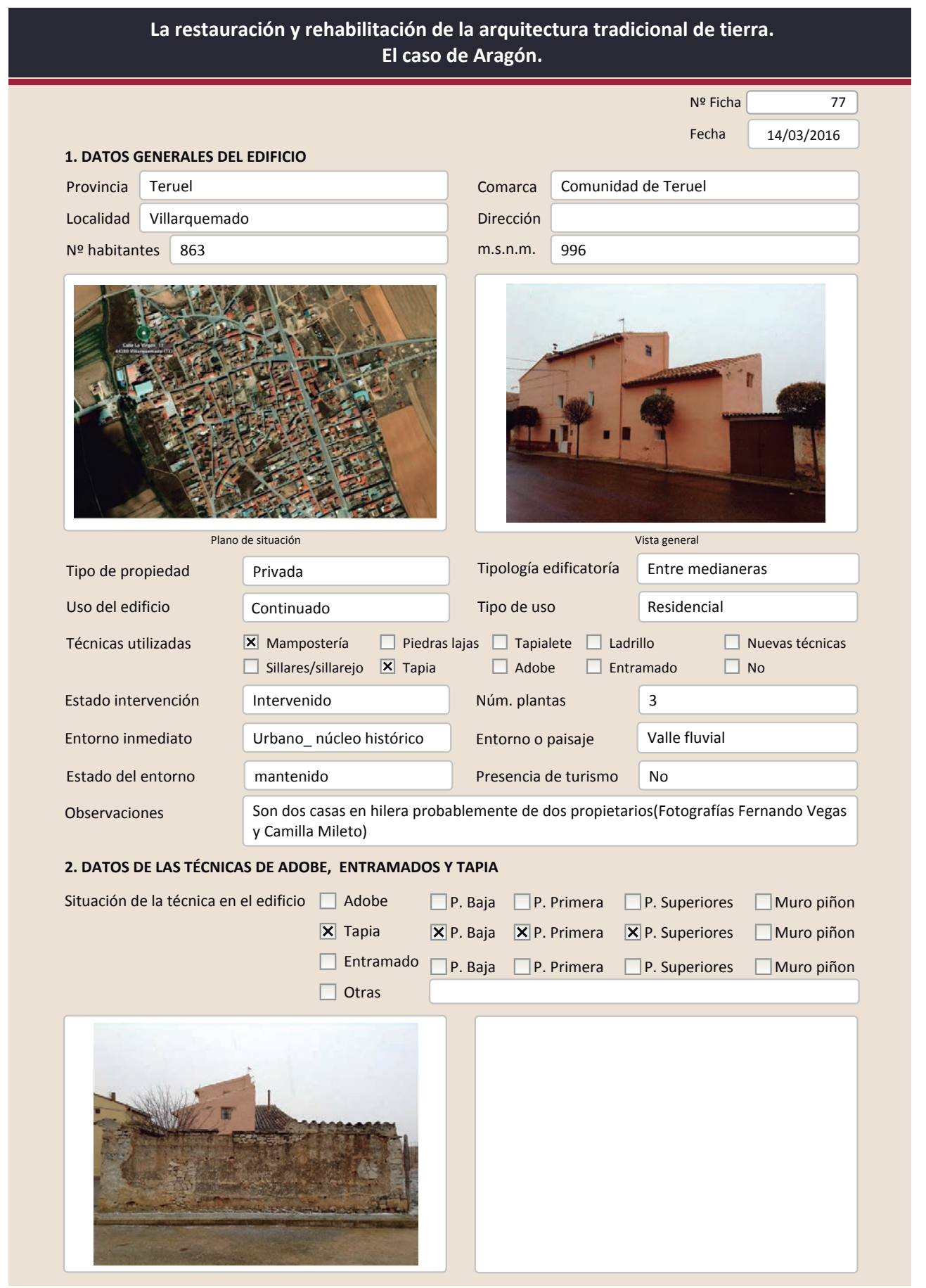

La restauración y rehabilitación de la arquitectura tradicional de tierra.

El caso de Aragón.

2.2. TAPIA

Ancho del muro

Dimensión tapiales

Tipo de aguja

№ agujas/cajón

Variante constructiva

$\square$ Simple / homogénea

X Suplemento superficial

$\square$ Suplemento en juntas

$\square$ Mixta

$\square$ Elementos de protección

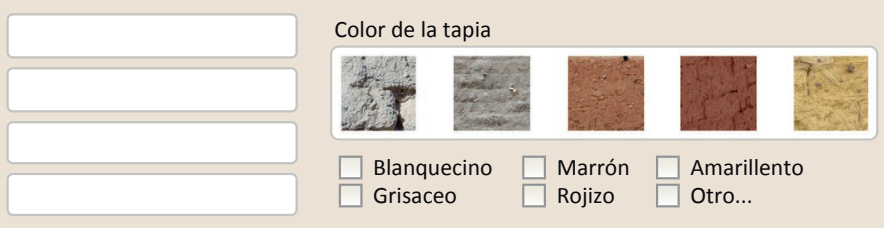

$\square$ Banquecino $\square$ Marrón $\square$ Amarillento
Grisaceo
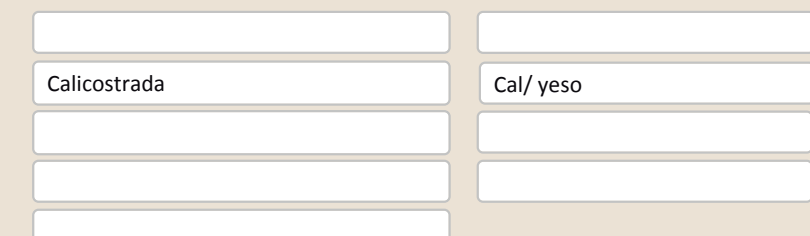

parece ser calicostrada con yeso. Visible en el muro de cerca exterior que está sin revestir

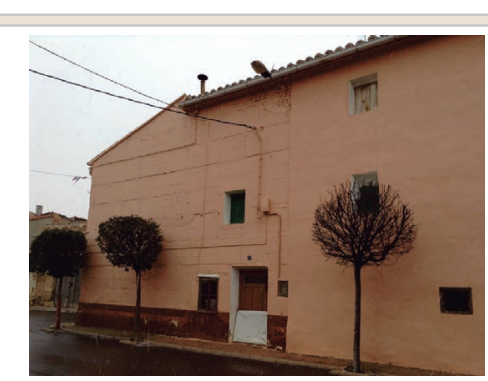

Lesiones $\square$ Muro $\square$ Zócalo $\square$ Revestimiento $\square$ Cubierta $\square$ otro...

$\square$ Erosión del material $\quad \square$ Humedad por capilaridad $\quad \square$ Grietas por asentamientos

$\square$ Erosion de las juntas $\square$ Humedades (manch/eflo)

$\square$ Pérdida de sección $\square$ Pérdida de verticalidad

$\square$ Colapso

$\square$ Desconchados

$\square$ Derivado de intervenciones

$\square$ Desconchados $\quad \square$ Grietas porfalta de traba

$\square$ Otro...

Observaciones 
La restauración y rehabilitación de la arquitectura tradicional de tierra. El caso de Aragón

\section{La restauración y rehabilitación de la arquitectura tradicional de tierra.}

\section{El caso de Aragón.}

3. DATOS DE LA INTERVENCIÓN

Intervención de:

Mantenimiento $\mathbf{X}$ Rehabilitación parcial

$\square$ Restauración $\square$ Demolición

Reflexión previa

X Reparación

Rehabilitación integra

Ampliación

$\square$ Otro...

Observaciones

Intervención planificada

3.1. MUROS

No visible

Tipo de intervención

$\square$ Actualización $\quad \square$ Reintegración $\quad \square$ Demolición $\square$ Otro...

$\square$ Consolidación $\square$ Reconstrucción $\square$ Sustitución

Tipo de material

Descripción

3.2. ZÓCALO

Tipo de intervención

\section{Intervenido}

X Actualización $\square$ Reintegración $\quad \square$ Demolición $\square$ Otro..

$\square$ Consolidación $\quad \mathbf{X}$ Reconstrucción $\square$ Sustitución

Tipo de material

No tradicional Tipo de técnica Diferente a la existente

Descripción

3.3. REVESTIMIENTOS

Tipo de intervención

Intervenido

Tipo dematenta

X Actualización $\square$ Reintegración $\square$ Demolición $\square$ Otro...

$\square$ Consolidación $\quad \mathbf{X}$ Reconstrucción $\square$ Sustitución

\section{Descripción}

No tradicional

Tipo de técnica Diferente a la existente

Nuevo revestimiento de cemento sobre la tapia. Antes no

3.4. VANOS

No intervenido

Tipo de intervención

$\square$ Actualización $\square$ Reintegración $\square$ Demolición $\square$ Otro...

Tipo de material

Descripción

$\square$ Consolidación $\square$ Reconstrucción $\square$ sustitución

3.5. CUBIERTA

Tipo de intervención

Intervenido

$\square$ Actualización $\quad \boldsymbol{X}$ Reintegración $\quad \square$ Demolición $\quad \square$ Otro...
$\square$ Consolidación $\quad \square$ Reconstrucción $\quad \square$ Sustitución

Tipo de material

No tradicional

Tipo de técnica Similar a la existente

Descripción

Se ha reintegrado parte de la techumbre con nuevas piezas cerámicas nuevas de

características parecidas a las preexistentes. Se puede apreciar que en la zona izq las

3.6. OTRAS 


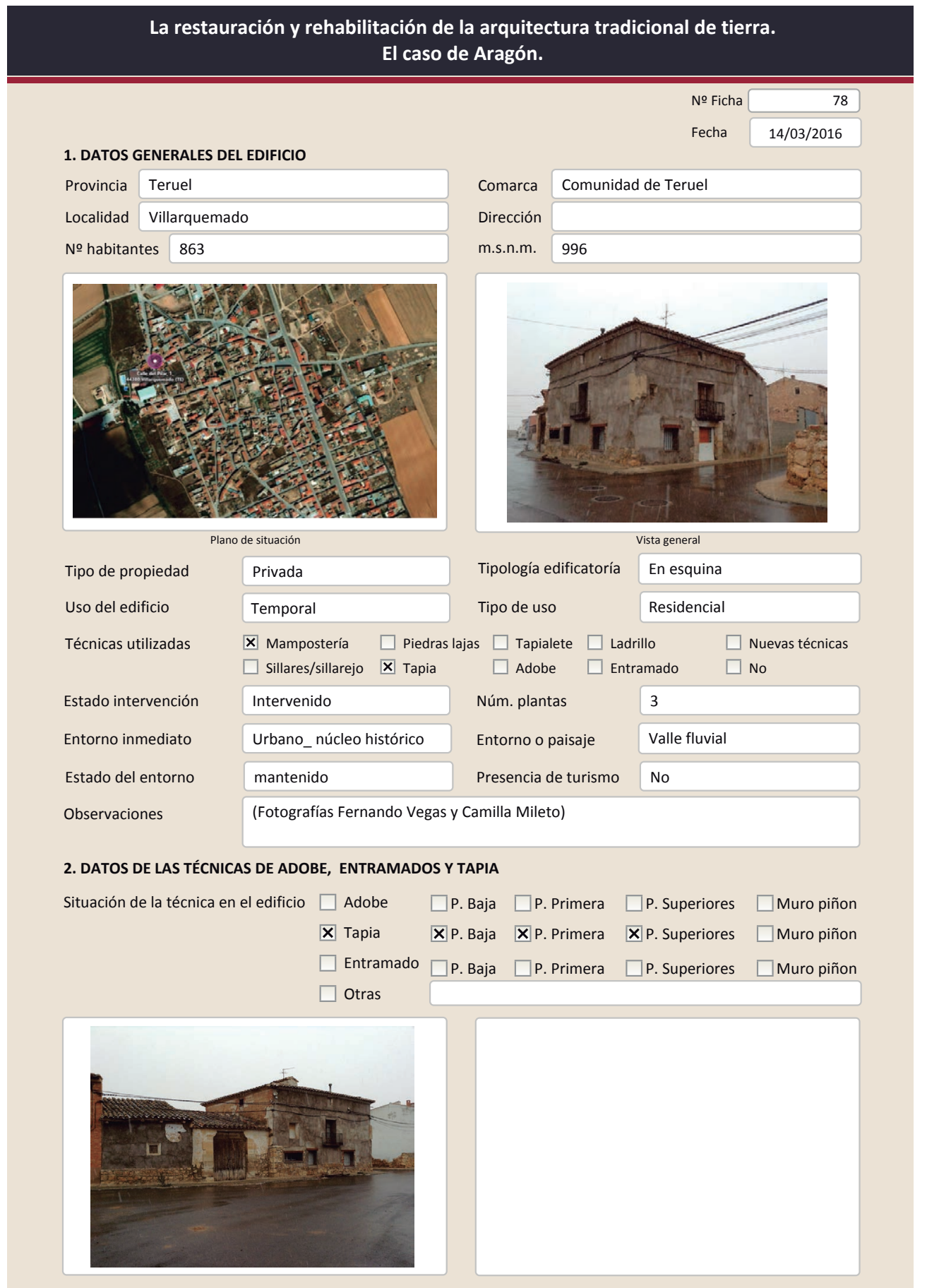

La restauración y rehabilitación de la arquitectura tradicional de tierra.

El caso de Aragón.

2.2. TAPIA

Ancho del muro

Dimensión tapiales

Tipo de aguja

№ agujas/cajón

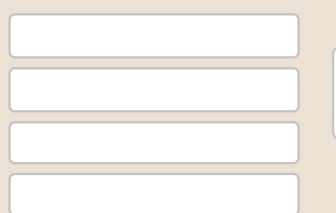

Color de la tapia

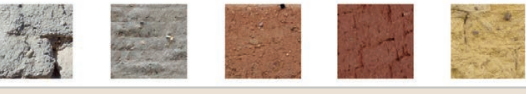

$\square$ Blanquecino $\square$ Marrón $\square$ Amarillento

$\square$ Blanquecino
$\square$ Grisaceo Marrón $\square$ Rojizo $\quad \square$ Otro...

Variante constructiva

$\square$ simple / homogénea

$\square$ suplemento superficial

$\square$ suplemento en juntas

X Mixta

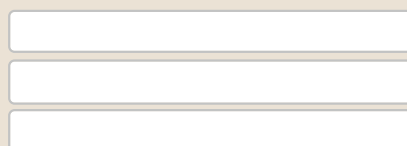

$\square$ Elementos de protección

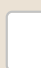

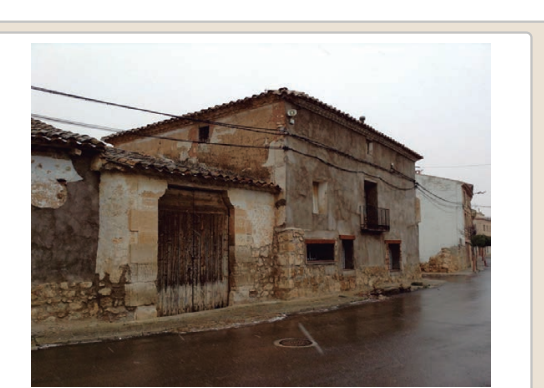

Lesiones \Muro $\square$ Zócalo $\square$ Revestimiento $\square$ Cubierta $\square$ otro...

Х Erosión del material $\quad \square$ Humedad por capilaridad $\quad \square$ Grietas por asentamientos $\square$ Erosion de las juntas $\square$ Humedades (manch/eflo)

$\square$ Pérdida de sección $\quad \square$ Pérdida de verticalidad

$\square$ Vegetación $\square$ Grietas por empuje de la cubierta

$\square$ Desconchados $\quad \square$ Grietas porfalta de traba

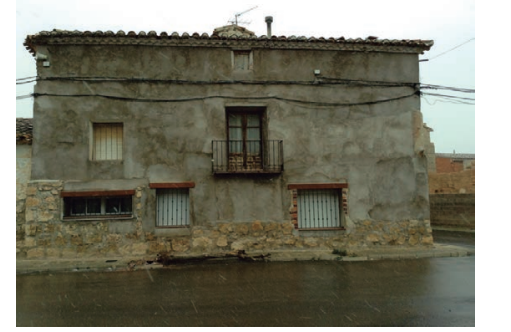




\section{La restauración y rehabilitación de la arquitectura tradicional de tierra.}

\section{El caso de Aragón.}

3. DATOS DE LA INTERVENCIÓN

Intervención de:

Mantenimiento $\mathbf{X}$ Rehabilitación parcial

$\square$ Restauración $\square$ Demolición

Reflexión previa

$\square$ Reparación

Rehabilitación integra

Ampliación

$\square$ Otro...

Observaciones

Intervención espontanea

3.1. MUROS

Tipo de intervención

Intervenido

$\square$ Actualización $\quad \boldsymbol{X}$ Reintegración $\square$ Demolición $\square$ Otro...

$\square$ Consolidación $\square$ Reconstrucción $\square$ Sustitución

Descripción

No tradicional Tipo de técnica Diferente a la existente

3.2. ZóCALO

Tipo de intervención

Intervenido

$\square$ Actualización $\quad \mathbf{X}$ Reintegración $\quad \square$ Demolición $\square$ Otro...

$\square$ Consolidación $\quad \square$ Reconstrucción $\square$ Sustitución

Tipo de material

No tradicional Tipo de técnica Similar a la existente

Descripción

Rejuntado con cemento

3.3. REVESTIMIENTOS

\section{Intervenido}

Tipo de intervención

$\square$ Actualización $\square$ Reintegración $\square$ Demolición $\square$ Otro...

Tipo de material

$\square$ Consolidación $\mathbf{X}$ Reconstrucción $\mathbf{X}$ Sustitución

Descripción
No tradicional
Tipo de técnica Similar a la existente

3.4. VANOS

Nuevo revestimiento de cemento en las fachadas principales.

Tipo de intervención

Intervenido

Tipo de material

$\square$ Actualización $\quad \square$ Reintegración $\quad \square$ Demolición $\square$ Otro...

$\square$ Consolidación $\square$ Reconstrucción $\quad \boldsymbol{X}$ Sustitución

Descripción

No tradicional

$$
\text { Tipo de técnica Similar a la existente }
$$

3.5. CUBIERTA

Tipo de intervención

Intervenido

$\square$ Actualización $\quad$ X Reintegración $\square$ Demolición $\square$ Otro.

Tipo de material

$\square$ Consolidación $\quad \boldsymbol{x}$ Reconstrucción $\square$ Sustitución

Descripción
No tradicional
Tipo de técnica Diferente a la existente

Reintegración de tejas con cemento. No se aprecia si se han sustituido. El alero de teja y ladrillo se ha revestido por completo con cemento

3.6. OTRAS 


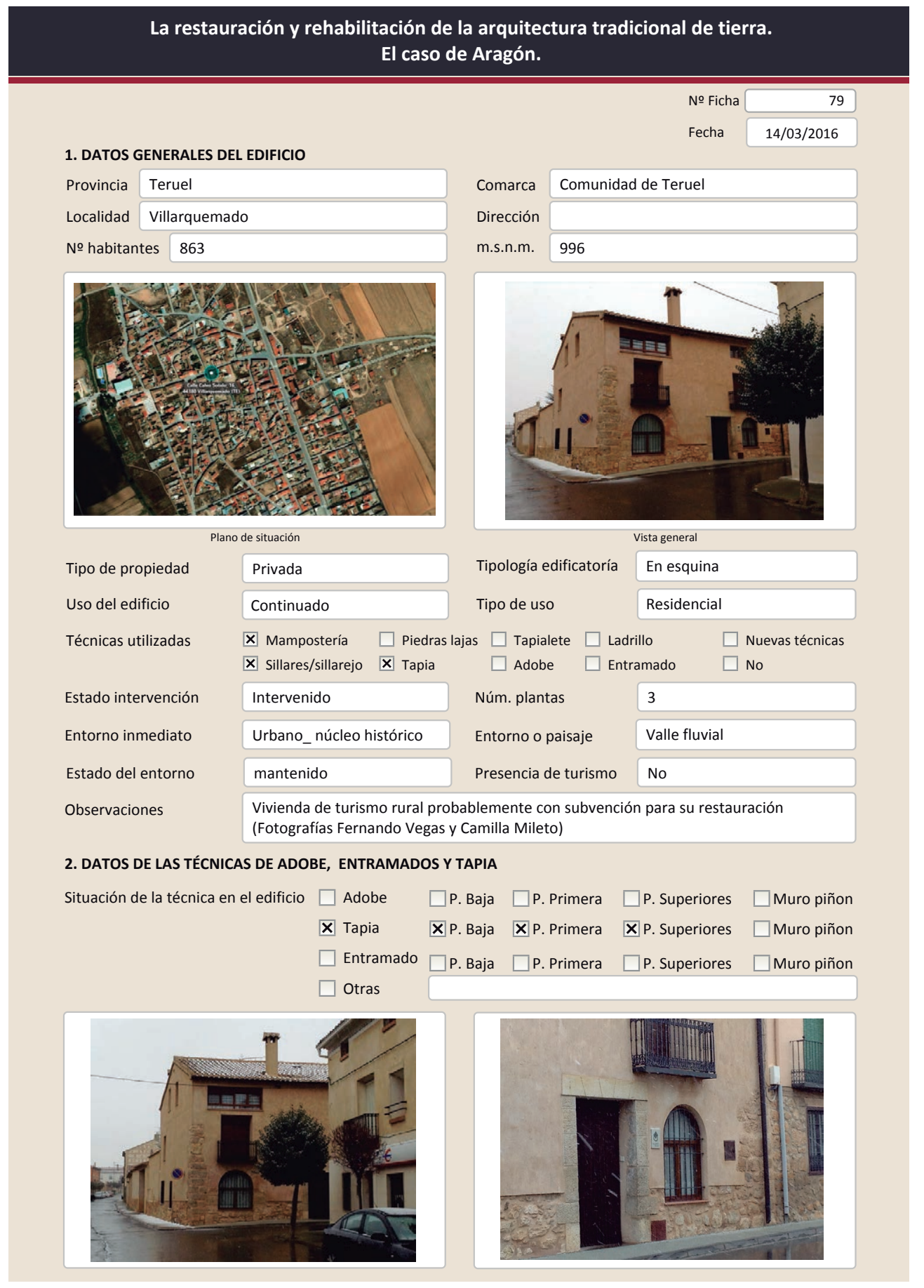

La restauración y rehabilitación de la arquitectura tradicional de tierra.

El caso de Aragón.

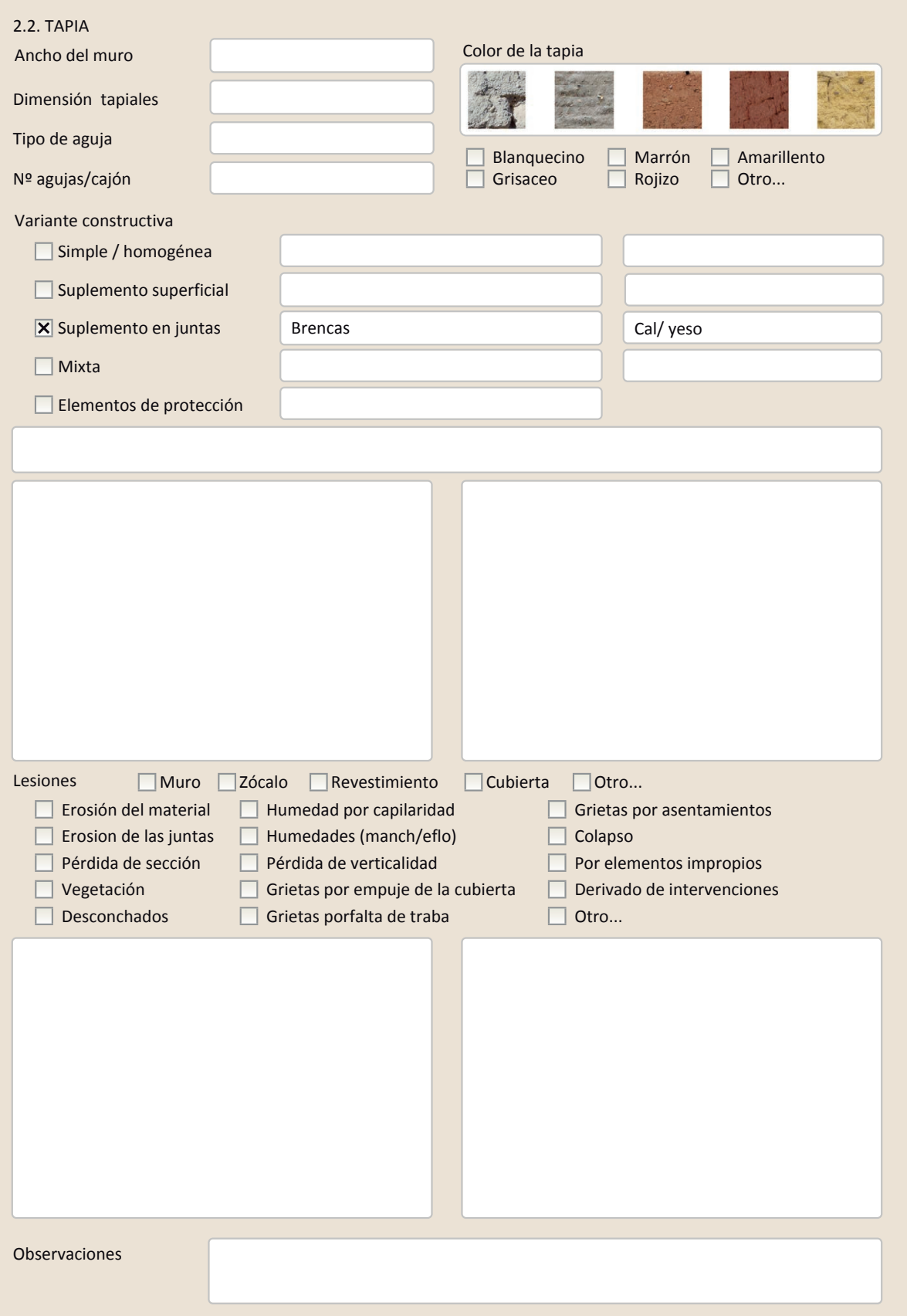




\section{La restauración y rehabilitación de la arquitectura tradicional de tierra.} El caso de Aragón.

3. DATOS DE LA INTERVENCIÓN

Mantenimie

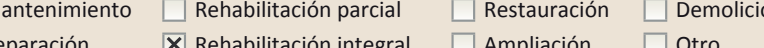

Reflexión previa $\quad$ Intervención planificada

Observaciones Eliminación o transformación de la materia histórica con inserción de elementos añadidos en estructuras históricas.

Se deja la piedra vista, "ruralización" del aspecto del edificio.

\subsection{MUROS \\ Tipo de intervención \\ No visible \\ $\square$ Actualización $\square$ Reintegración $\square$ Demolición $\square$ Otro... \\ $\square$ Consolidación $\quad \square$ Reconstrucción $\square$ Sustitución}

Tipo de material

Descripción

No es visible una intervención clara sobre el muro debido al revestimiento, pero el nivel de intervención del edificio indica que probablemente exista.

3.2. ZóCALO
Tipo de intervención

Intervenido

$\mathbf{x}$ Actualización $\mathbf{x}$ Reintegración $\square$ Demolición $\square$ Otro...

$x$ Actualización
$\square$ consolidación $\quad \square$ Reconstrucción $\quad \square$ Sustitución

Tipo de material

\section{No tradicional}

\section{Tipo de técnica Similar a la existente}

Descripción

3.3. REVESTIMIENTOS

Tipo de intervención

\section{Intervenido}

$\mathbf{X}$ Actualización $\quad \square$ Reintegración $\quad \square$ Demolición $\square$ Otro...

$\square$ Consolidación $\quad \mathbf{X}$ Reconstrucción $\square$ Sustitución

Tipo de material

Descripción

3.4. VANOS

Tipo de intervención

No tradicional

Tipo de técnica Similar a la existente

Cemento coloreado color tierra

Intervenido

Tipo de material

$\square$ Actualización $\square$ Reintegración $\square$ Demolición $\square$ Otro...

$\square$ Consolidación $\square$ Reconstrucción $\mathbf{X}$ Sustitución

\begin{tabular}{l|l|l|l} 
No tradicional & Tipo de técnica Diferente a la existente
\end{tabular} Descripción $\quad \begin{aligned} & \text { Sustitución por carpinterías de madera. Huecos de planta superior modificados (son } \\ & \text { muy horizontales) }\end{aligned}$

3.5. CUBIERTA

Tipo de intervención

Intervenido

$\square$ Actualización $\square$ Reintegración $\square$ Demolición $\square$ Otro..

$\square$ Consolidación $\square$ Reconstrucción $\quad \boldsymbol{X}$ Sustitución

Tipo de material

No tradicional

Tipo de técnica Similar a la existente

Descripción

Sustitución de toda la cubierta (la estructura no visible). Se han incorporado elementos aislantes e impermeablizantes.
La restauración y rehabilitación de la arquitectura tradicional de tierra.

El caso de Aragón.

3.7. REHABILITACIÓN ENERGÉTICA \ Fachada $\quad$ \ Vanos $\square$ Forjados $\mathbf{X}$ Cubierta

Observaciones

FOTOGRAFÍAS DE LA INTERVENCIÓN
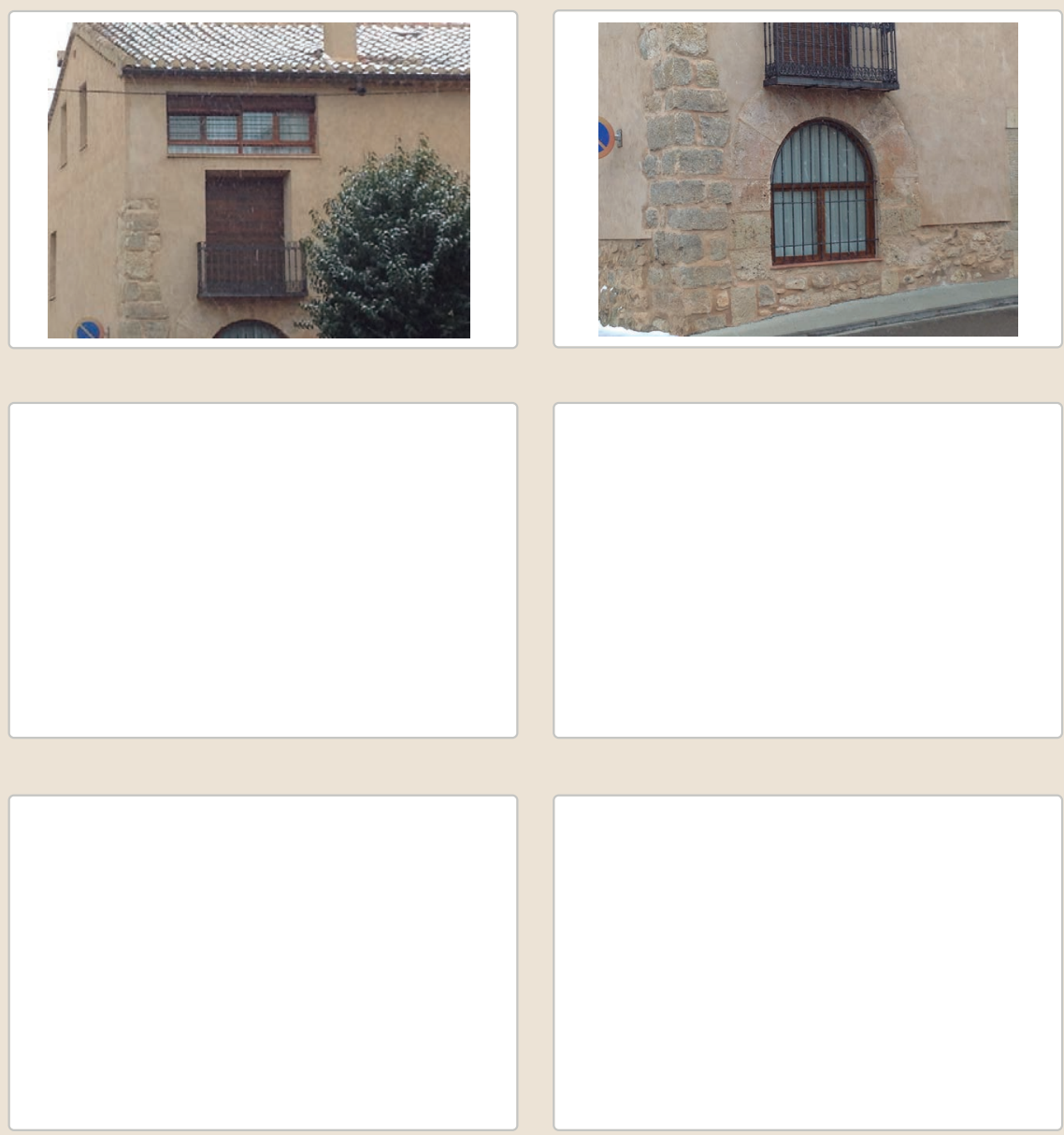

3.6. OTRAS 


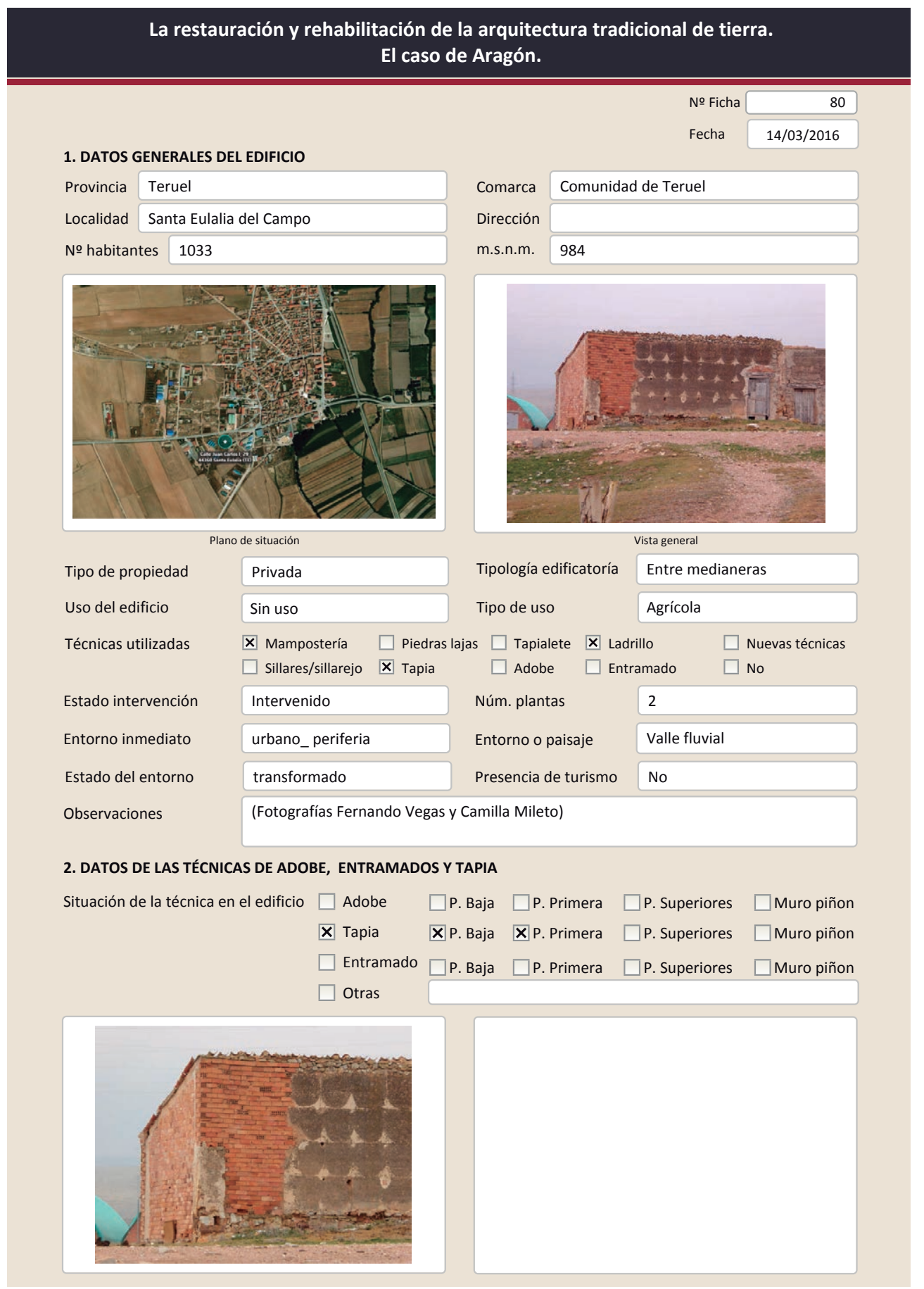

La restauración y rehabilitación de la arquitectura tradicional de tierra.

El caso de Aragón.

2.2. TAPIA

Ancho del muro

Dimensión tapiales

Tipo de aguja

№ agujas/cajón

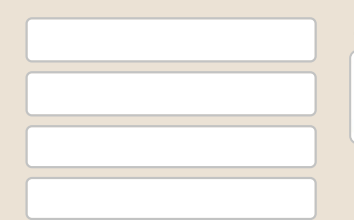

Color de la tapia

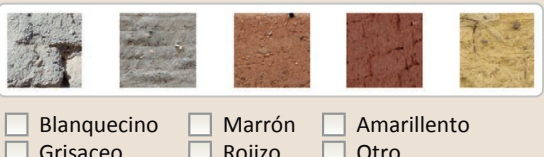

$\square$ Blanquecino $\quad \square$ Marrón $\quad \square$ Amarillento
$\square$ Grisaceo

$\square$ Simple / homogénea

X Suplemento superficial

$\mathbf{X}$ Suplemento en juntas

$\square$ Mixta

$\square$ Elementos de protección
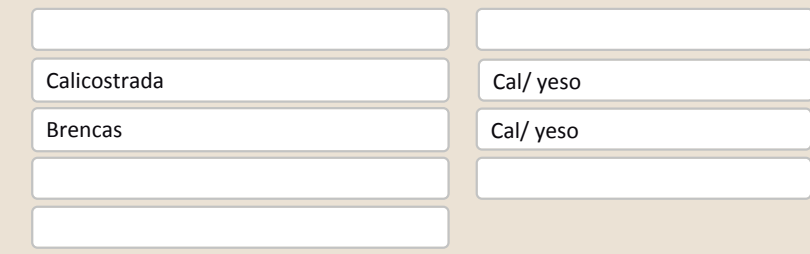

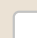

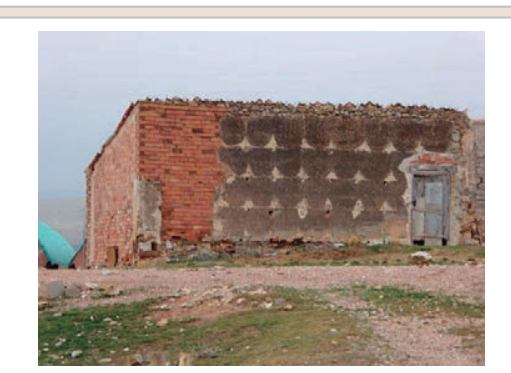

Lesiones $\quad$ Muro $\square$ Zócalo $\square$ Revestimiento $\square$ Cubierta $\square$ otro...

$\square$ Erosión del material $\quad \square$ Humedad por capilaridad $\quad \square$ Grietas por asentamientos

$\square$ Erosion de las juntas $\mathbf{X}$ Humedades (manch/eflo)

$\square$ Pérdida de sección $\quad \square$ Pérdida de verticalidad

$\square$ Vegetación $\square$ Grietas por empuje de la cubieta

$\square$ Desconchados $\quad \square$ Grietas porfalta de traba

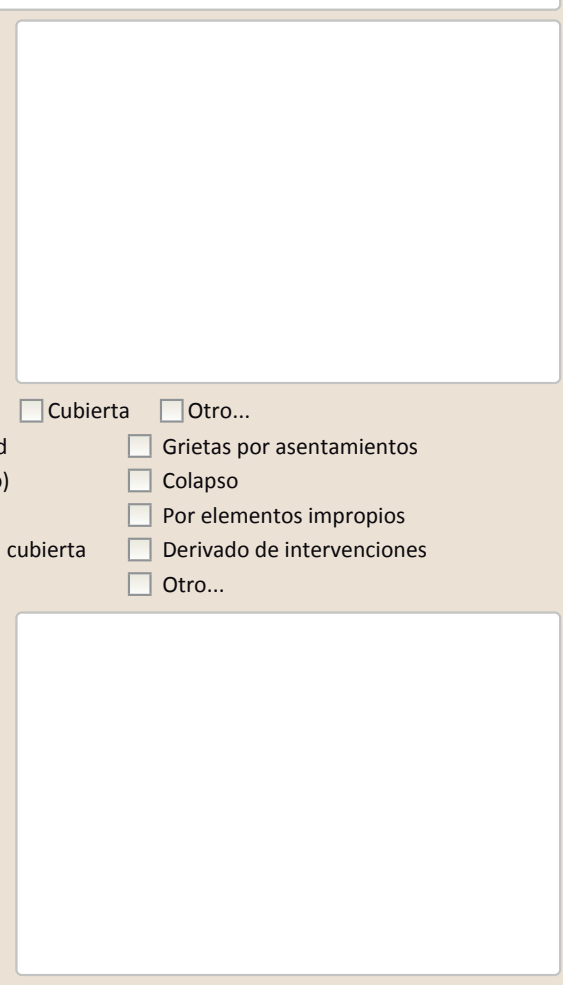

Observaciones

Costra negra en el revestimiento de yeso que pertenece a la misma tapia 
La restauración y rehabilitación de la arquitectura tradicional de tierra. El caso de Aragón

\section{La restauración y rehabilitación de la arquitectura tradicional de tierra.}

\section{El caso de Aragón.}

3. DATOS DE LA INTERVENCIÓN

Intervención de:

$\square$ Mantenimiento $\square$ Rehabilitación parcia

$\square$ Restauración $\square$ Demolición X Reparación $\quad \square$ Rehabilitación integral $\quad \square$ Ampliación $\quad \square$ Otro...

Reflexión previa Intervención espontanea

Observaciones Sustitución de una de las esquinas dl edificio

3.1. MUROS

Tipo de intervención

Intervenido

Tipo de material

$\square$ Actualización $\square$ Reintegración $\square$ Demolición $\square$ Otro...

$\square$ Consolidación $\mathbf{X}$ Reconstrucción $\mathbf{X}$ Sustitución

Descripción

\begin{tabular}{l|l|l|} 
No tradicional & Tipo de técnica Diferente a la existente \\
\hline
\end{tabular}

D.2.

Sustitución o reconstrucción parcial del muro de tapia por fabrica de ladrillo hueco

3.2. ZÓCALO

No intervenido

Tipo de intervención

$\square$ Actualización

$\square$ Reintegración $\square$ Demolición $\square$ Otro...

Tipo de material

raration

Descripción

3.3. REVESTIMIENTOS

Tipo de intervención

\section{No aplica}

Tipo de material

$\square$ Actualización $\square$ Reintegración $\square$ Demolición $\square$ Otro...

Reconstrucción Tipo de técnica

Descripción

3.4. VANOS

Tipo de intervención

No intervenido

Tipo de material

Descripción

Consolidación $\quad \square$ Reconstrucción $\quad \square$ Sustitución

3.5. CUBIERTA

Tipo de intervención

No intervenido

Tipo de intervención

$\square$ Actualización

$\square$ Consolidación $\square$ Reconstrucción $\square$ Sustitución

Tipo de material

Descripción

Tipo de técnica

3.6. OTRAS 


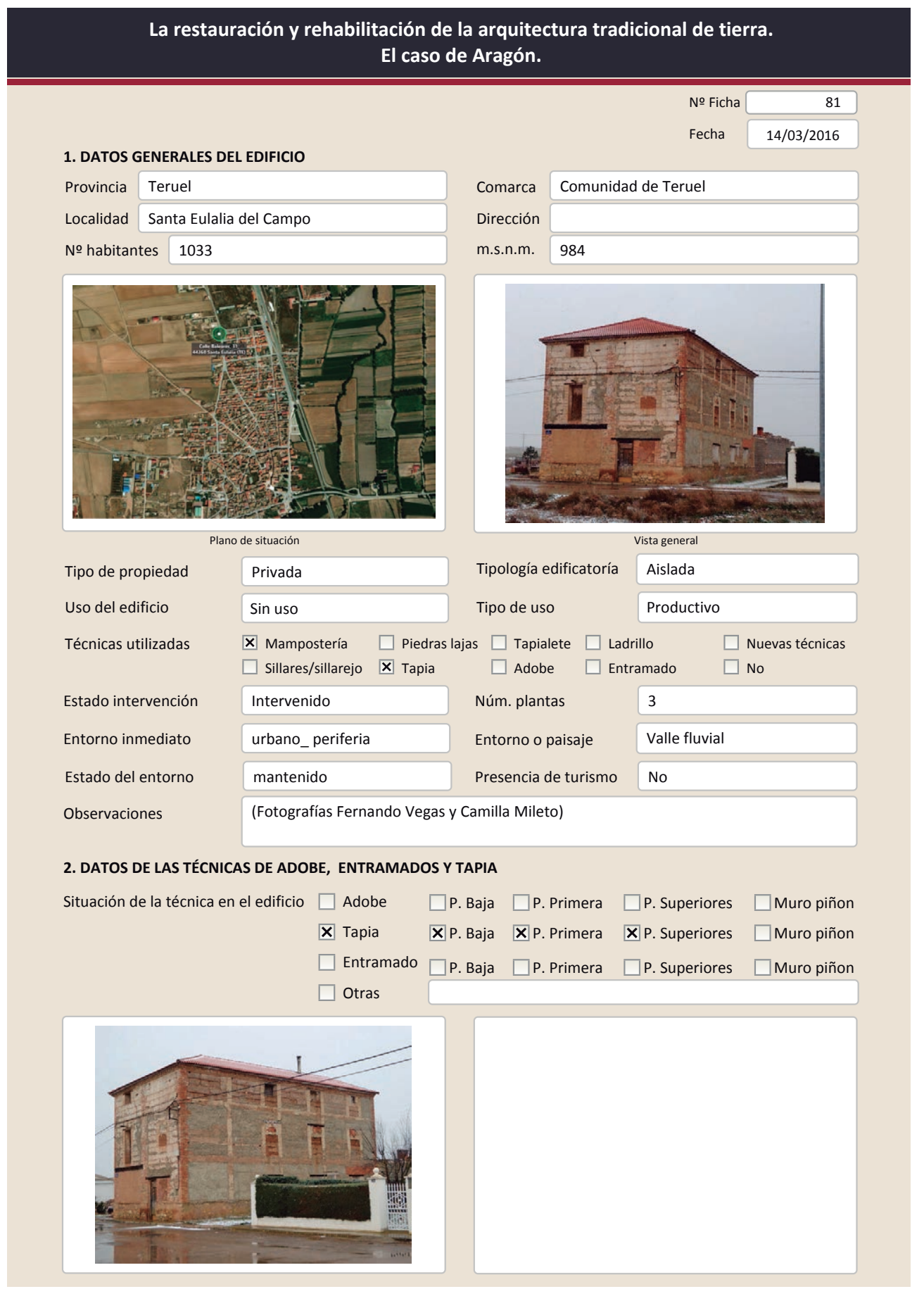

La restauración y rehabilitación de la arquitectura tradicional de tierra.

El caso de Aragón.

2.2. TAPIA

Ancho del muro

Dimensión tapiales

Tipo de aguja

№ agujas/cajón

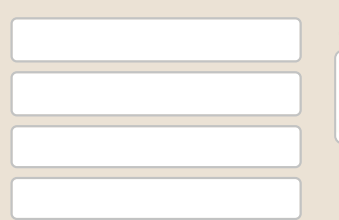

Color de la tapia

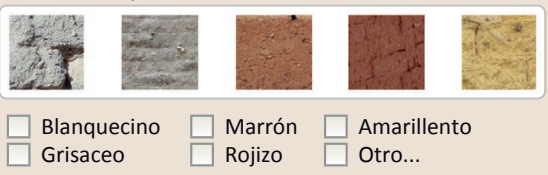

Variante constructiva

$\square$ Simple / homogénea

X Suplemento superficial

$\square$ suplemento en juntas

X Mixta
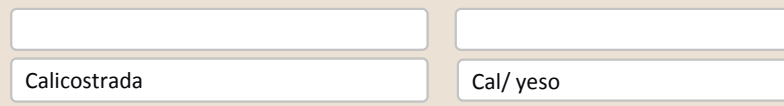

$\square$ Elementos de protección
Cal/yeso
Mampostería y yeso

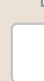

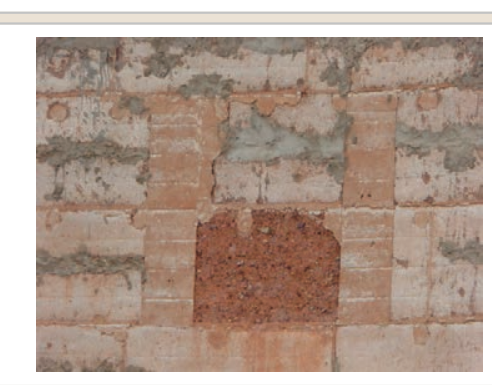

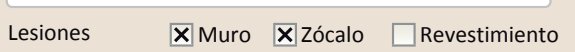

$\square$ Erosión del material $\quad \boldsymbol{X}$ Humedad por capilaridad

$\square$ Erosion de las juntas $\square$ Humedades (manch/eflo)

$\square$ Pérdida de sección $\square$ Pérdida de verticalidad

$\square$ Vegetación $\square$ Grietas por empuje de la cubierta

$\mathbf{X}$ Desconchados

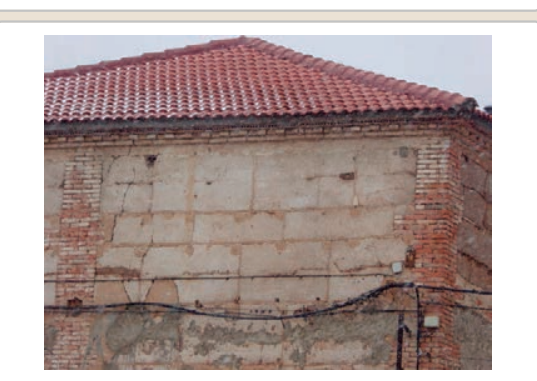

$\square$ Cubierta $\square$ Otro...

$\square$ Grietas por asentamientos

$\square$ Colapso

$\square$ Por elementos impropios

$\square$ Derivado de intervenciones $\square$ Otro...

Observaciones 


\section{La restauración y rehabilitación de la arquitectura tradicional de tierra.} El caso de Aragón.

3. DATOS DE LA INTERVENCIÓN

$\square$ Mantenimiento $\square$ Rehabilitación parcial

$\square$ Restauración $\square$ Demolición

Reflexión previa

X Reparación

Rehabilitación integra

$\square$ Ampliación

$\square$ Otro...

Observaciones

Intervención espontanea

3.1. MUROS
Tipo de intervención

Intervenido

Tipo de material

$\square$ Actualización

$\square$ Consolidación

X Reintegración

$\square$ Demolición

No tradicional Tipo de técnica Diferente a la existente

Descripción

Relleno de huecos con cemento,

3.2. ZÓCALO

Tipo de intervención

Intervenido

Tipo de intervención

$\square$ Actualización

$\square$ Consolidació

$\mathbf{x}$ Reintegración $\square$ Demolición $\square$ Otro...

Descripción

3.3. REVESTIMIENTOS

Tipo de intervención

Tipo de técnica Diferente a la existente

Rejuntado y revestimiento del zócalo con cemento

\section{Intervenido}

$\square$ Actualización $\square$ Reintegración $\square$ Demolición $\square$ Otro...

$\square$ Consolidación $\mathbf{X}$ Reconstrucción $\square$ Sustitución

Tipo de material

Descripción

3.4. VANOS

Tipo de intervención

No tradicional

Tipo de técnica Diferente a la existente

Reparaciones puntuales $\mathrm{y}$ superficies completas con cemento

Intervenido

Tipo de material

$\square$ Actualización $\square$ Reintegración $\square$ Demolición $\square$ Otro...

$\square$ Consolidación $\square$ Reconstrucción $\quad \mathbf{X}$ Sustitución

Descripción

No tradicional

Tipo de técnica Similar a la existente

Sustituciones varias en planta baja. Se han añadido nuevas carpinterías y cajas de

persiana. Los dinteles aparentemente son similares pero con la madera tratada

3.5. CUBIERTA

Intervenido

Tipo de intervención

$\square$ Actualización

$\square$ Consolidación

$\square$ Reintegración

$\square$ Otro...

No tradicional Tipo de técnica Similar a la existente

Tipo de material

Tejas nuevas. Prob

Descripción

Tesabs sustituido parte de la estructura.
La restauración y rehabilitación de la arquitectura tradicional de tierra.

El caso de Aragón.

3.7. REHABILITACIÓN ENERGÉTICA $\quad \square$ Fachada $\square$ Vanos $\square$ Forjados $\square$ Cubierta

Observaciones

FOTOGRAFÍAS DE LA INTERVENCIÓN
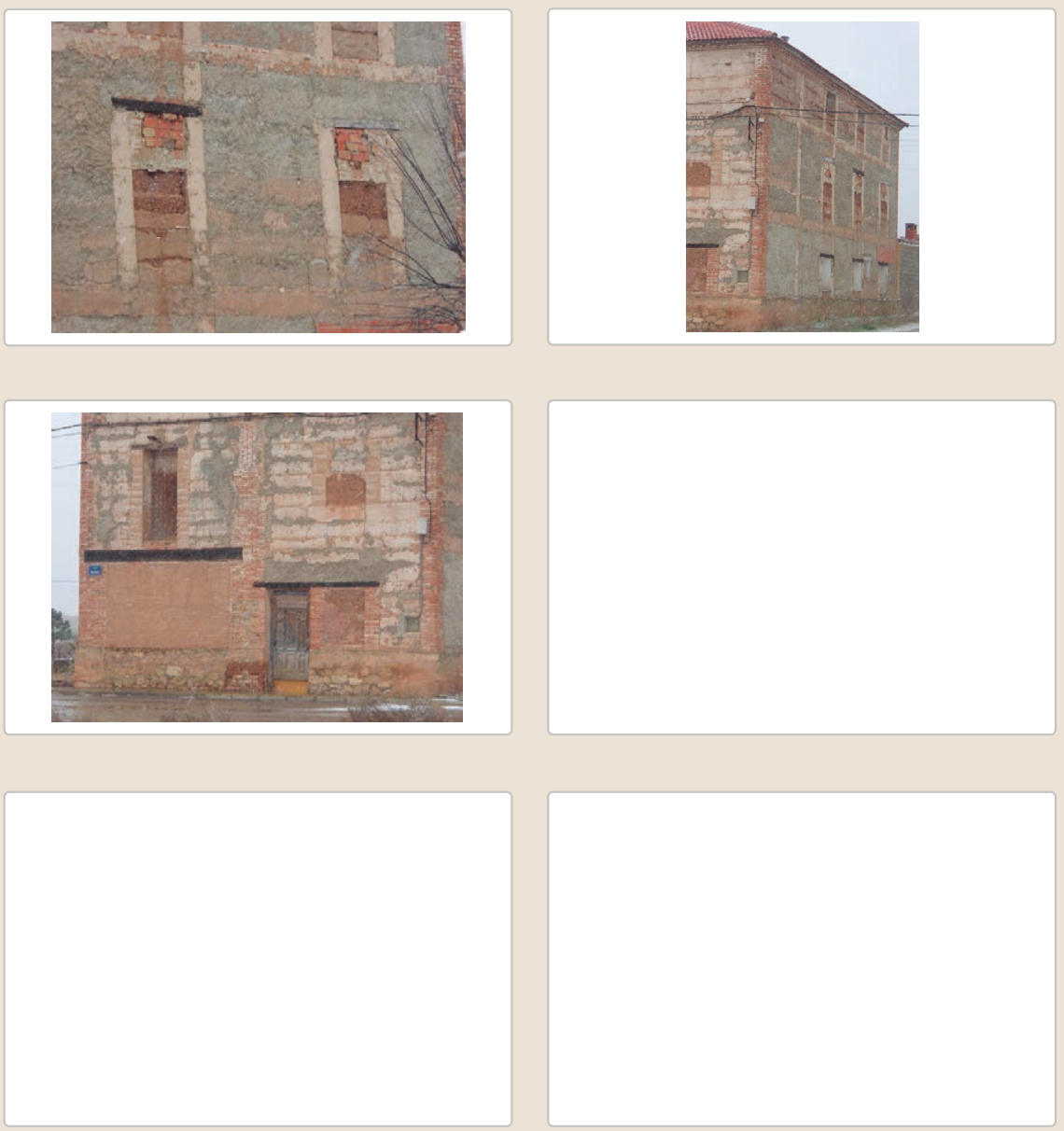

3.6. OTRAS 
La restauración y rehabilitación de la arquitectura tradicional de tierra. El caso de Aragón.

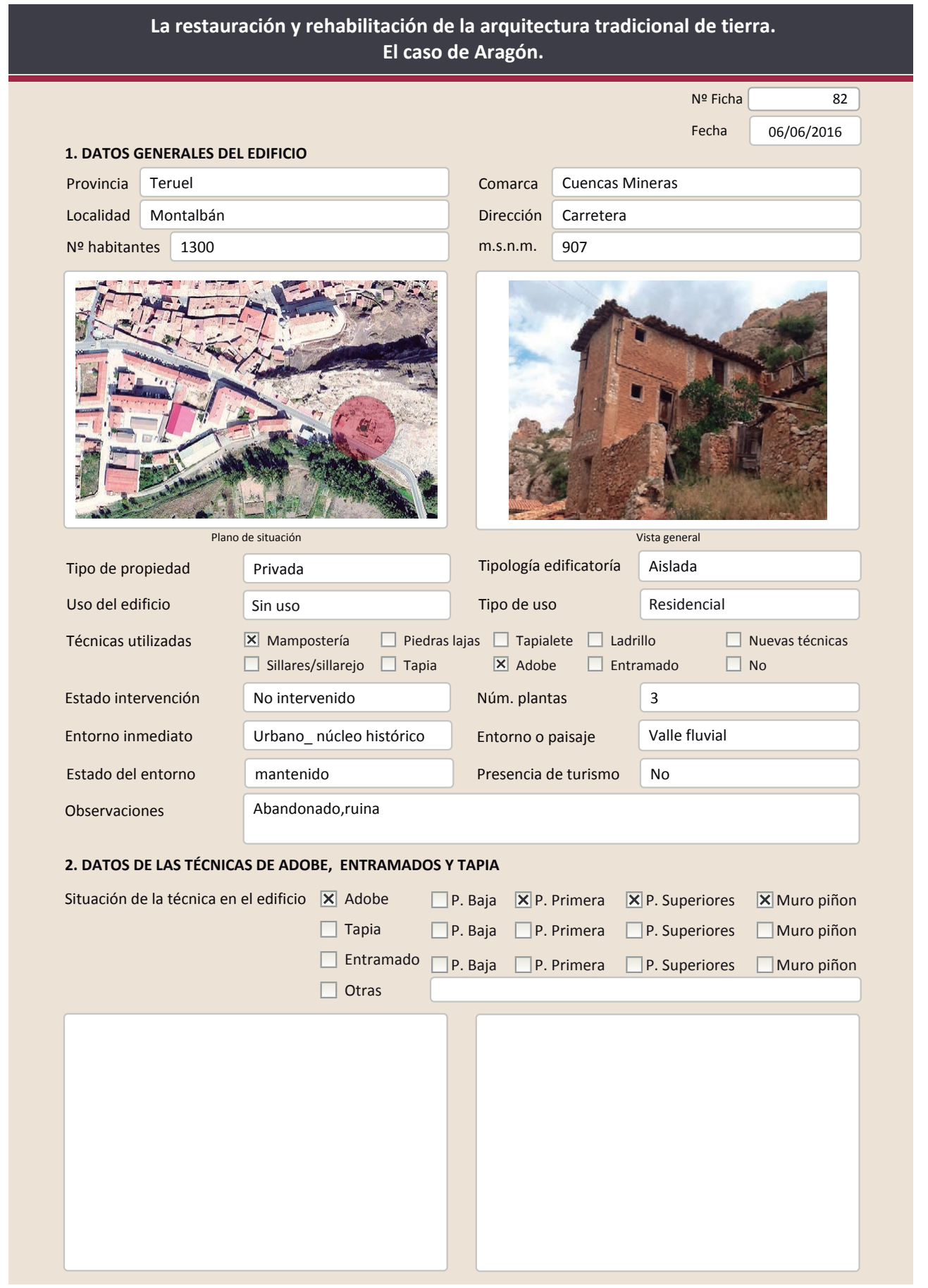

La restauración y rehabilitación de la arquitectura tradicional de tierra. El caso de Aragón.
2.1. ADOBE

Dimensión de las piezas $30 \times 10 \mathrm{~cm}$

Dimensión del muro $10-20 \mathrm{~cm}$

Aparejo del muro Soga

Función estructural
Color de las piezas

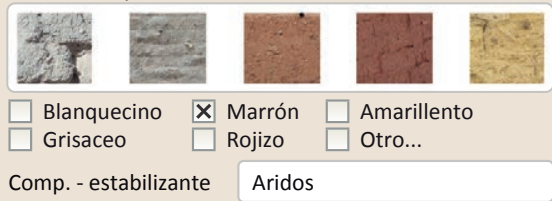

Variante constructiva/ tipo de fábrica

$\square$ simple
Х Suplementada en juntas
Verticales y horizontales
$\mathrm{Cal} /$ yeso
区 Mixta

\section{Machones}
Mampostería y yeso
$\square$ Como suplemento
$\square$ Elementos de protección

Se trata de muros muy delgados que no tienen una función estructural directa ya que principalmente recae sobre la estructura porticada de yeso y mampostería.

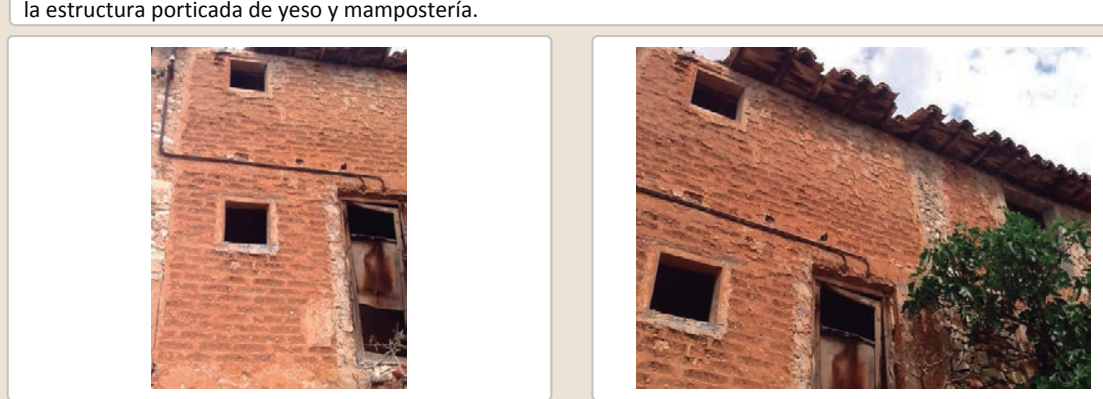

Lesiones $\mathbf{X}$ Muro $\square$ Zócalo $\square$ Revestimiento $\mathbf{X}$ Cubierta $\square$ Otro...

区 Erosión del material $\quad \square$ Humedad por capilaridad $\quad \square$ Grietas por asentamientos $\square$ Erosion de las juntas $\square$ Humedades (manch/eflo) $\quad \mathbf{X}$ Colapso

$\square$ Pérdida de sección $\square$ Pérdida de verticalidad $\square$ Por elementos impropios

$\square$ Vegetación $\quad \square$ Grietas por empuje de la cubierta $\square$ Derivado de intervenciones

$\square$ Desconchados $\square$ Grietas porfalta de traba $\quad \square$ Otro...

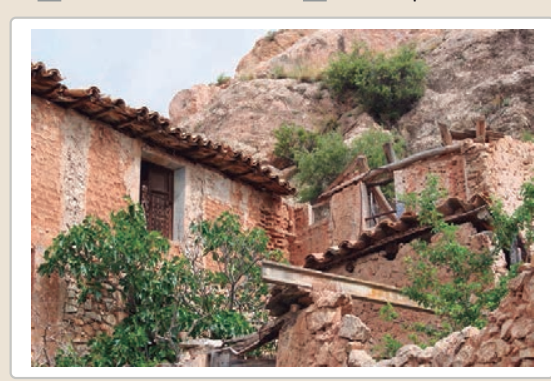

Observaciones 


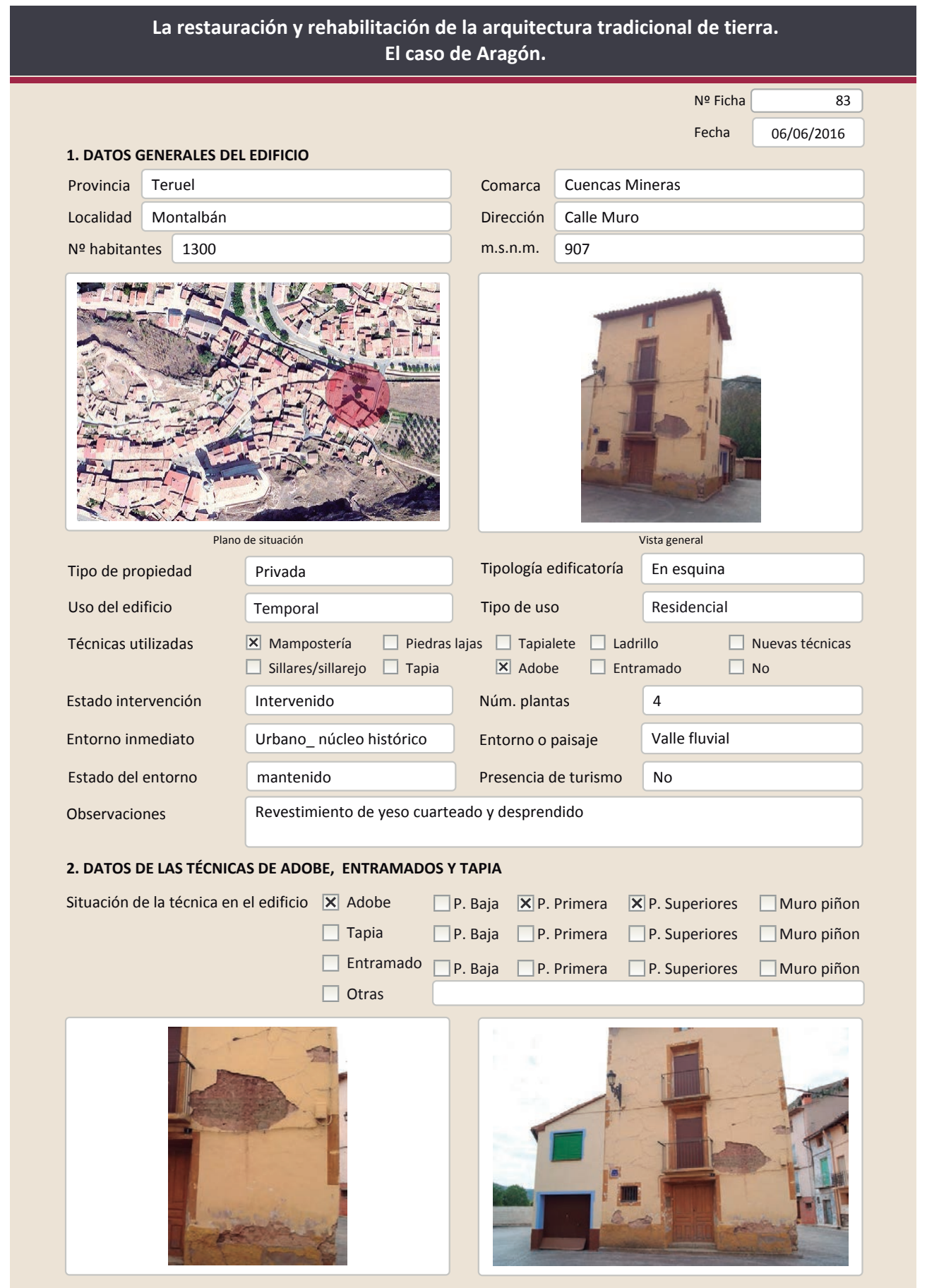

\subsection{ADOBE \\ Dimensión de las piezas $30 \times 10$ \\ Dimensión del muro 20-30cm \\ Aparejo del muro Soga y tizón \\ Función estructural

Soga y tizon \\ Color de las piezas

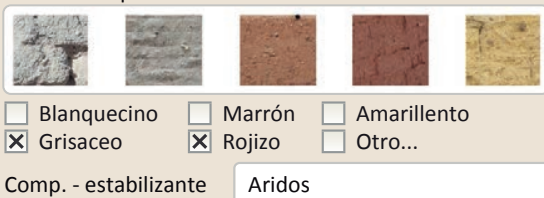

Variante constructiva/ tipo de fábrica
$\square$ Simple
Х Suplementada en juntas
Verticales $\mathrm{y}$ horizontales
区 Mixta
En esquinas
$\square$ Como suplemento
X Elementos de protección
Revestimiento

$\mathrm{Cal} /$ yeso

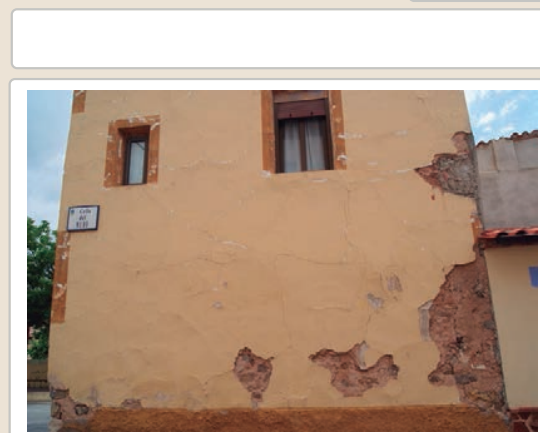

Lesiones $\quad \mathbf{X}$ Muro $\square$ Zócalo $\mathbf{X}$ Revestimiento $\square$ Cubierta $\square$ otro...

Х Erosión del material $\quad \square$ Humedad por capilaridad $\quad \square$ Grietas por asentamientos $\square$ Erosion de las juntas $\square$ Humedades (manch/eflo) $\quad \square$ Colapso

$\square$ Pérdida de sección $\square$ Pérdida de verticalidad

$\square$ Por elementos impropios

$\square$ Vegetación $\quad \square$ Grietas por empuje de la cub

X Desconchados $\quad \square$ Grietas porfalta de traba

Derivado de intervenciones

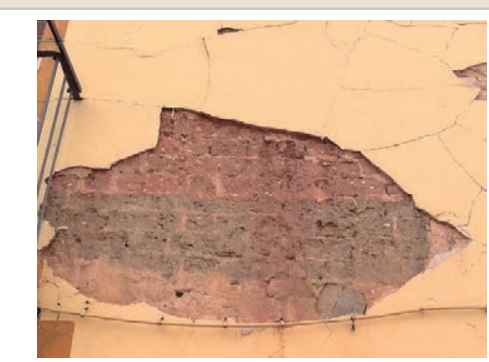

Observaciones 


\section{La restauración y rehabilitación de la arquitectura tradicional de tierra.}

\section{El caso de Aragón.}

3. DATOS DE LA INTERVENCIÓN

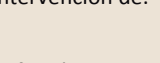

Reparación $\square$ Rehabilitación parcial $\square$ Restauración $\square$ Demolición

Observaciones

3.1. MUROS

Tipo de intervención

Tipo de material

Descripción

3.2. ZÓCALO

Tipo de intervención

Tipo de material

Descripción

3.3. REVESTIMIENTOS

Tipo de intervención

Tipo de material

Descripción

3.4. VANOS

Tipo de intervención

Tipo de material

Descripción

3.5. CUBIERTA

Tipo de intervención

Tipo de material

Descripción

\section{No intervenido}

$\square$ Actualización $\square$ Reintegración $\square$ Demolición $\square$ Otro...

$\square$ Consolidación $\quad \square$ Reconstrucción $\quad \square$ Sustitución

$$
\text { Tipo de técnica }
$$

\section{Intervenido}

邓 Actualización $\square$ Reintegración $\square$ Demolición $\square$ Otro...

$\square$ Consolidación $\quad$ X Reconstrucción $\square$ Sustitución

Reconstrucción del zócalo por completo con cemento y gotelé sobre el mismo

$$
\text { coloreadao }
$$

\section{Intervenido}

$\mathbf{X}$ Actualización $\square$ Reintegración $\square$ Demolición $\square$ Otro...

$\square$ Consolidación $\square$ Reconstrucción $\square$ sustitución

No tradicional Tipo de técnica Diferente a la existente

Pintura plástica sobre el revestimiento

\section{Intervenido}

$\square$ Actualización $\quad \square$ Reintegración $\square$ Demolición $\square$ Otro...

$\square$ Consolidación $\square$ Reconstrucción $\quad$ X Sustitución

No tradicional Tipo de técnica Similar a la existente

Sustitución de carpinterías e incorporación de nuevas persianas

\section{Intervenido}

$\square$ Actualización $\square$ Reintegración $\square$ Demolición $\quad \square$ Otro. $\square$ Consolidación $\quad \mathbf{x}$ Reconstrucción $\square$ Sustitución
No tradicional
Tipo de técnica Diferente a la existente

3.6. OTRAS

Retejado de toda la cubierta con teja curva nueva cogida con una capa de espesor notable de cemento (se aprecia en el alero)
Intervención espontanea

No tradicional Tipo de técnica Diferente a la existente

La restauración y rehabilitación de la arquitectura tradicional de tierra.

El caso de Aragón.

3.7. REHABILITACIÓN ENERGÉTICA $\square$ Fachada $\quad \boldsymbol{X}$ Vanos $\square$ Forjados $\square$ Cubierta

Observaciones

FOTOGRAFíAS DE LA INTERVENCIÓN 


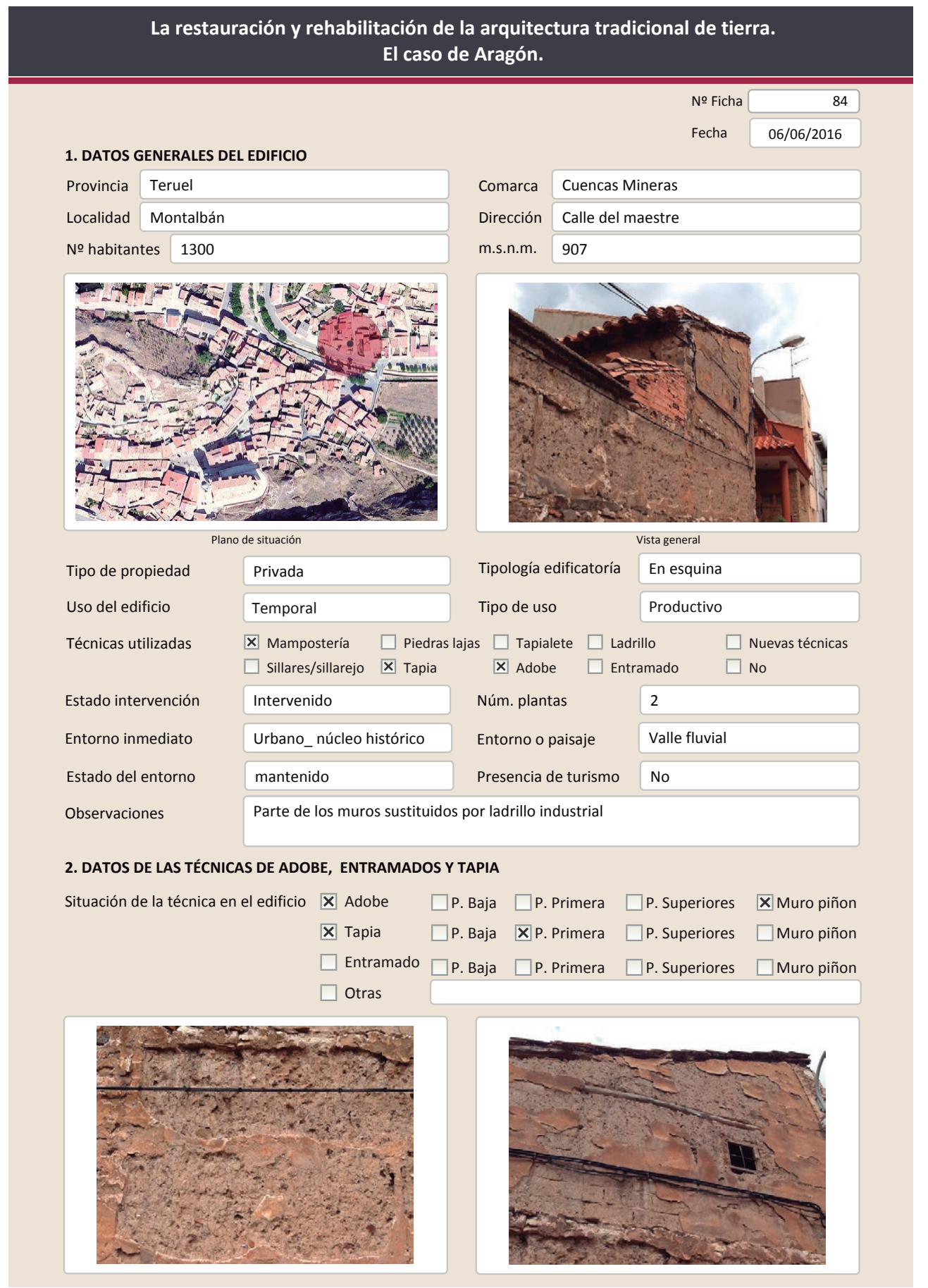

\begin{tabular}{|c|c|c|c|c|}
\hline \multicolumn{2}{|l|}{ 2.1. $A D O B E$} & \multicolumn{3}{|l|}{ Color de las piezas } \\
\hline Dimensión de las piezas & $35 \times 15$ & & & \\
\hline Dimensión del muro & $10-20 \mathrm{~cm}$ & 2 & & \\
\hline Aparejo del muro & Soga & $\begin{array}{l}\square \text { Blanquecino } \\
\square \text { Grisaceo }\end{array}$ & $\begin{array}{l}\mathbf{X} \text { Marrón } \\
\square \text { Rojizo }\end{array}$ & $\begin{array}{l}\square \text { Amarillento } \\
\square \text { Otro... }\end{array}$ \\
\hline Función estructural & No & Comp. - estabilizar & Fibras & vegetales \\
\hline
\end{tabular}

Función estructural No

Comp. - estabilizante Fibras vegetales
$\square$ Simple
$\square$ Suplementada en juntas

X Mixta

Enesqunas

$\square$ Como suplemento

X Elementos de protección
En esquinas

\section{Mampostería y yeso}

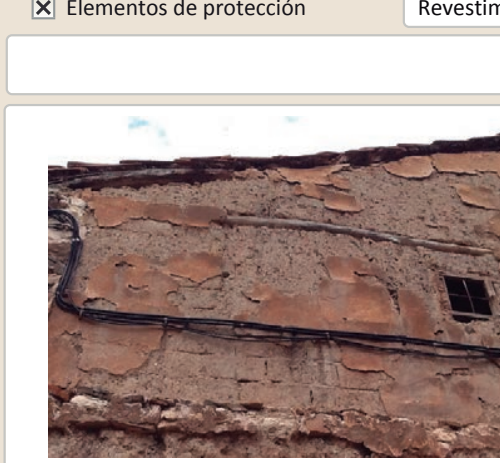

Lesiones $\mathbf{X}$ Muro $\mathbf{X}$ Zócalo $\mathbf{X}$ Revestimiento

$\mathbf{X}$ Erosión del material $\mathbf{X}$ Humedad por capilarida $\square$ Erosion de las juntas $\square$ Humedades (manch/eflo) $\square$ Pérdida de sección $\square$ Pérdida de verticalidad

$\square$ Vegetación $\quad \square$ Grietas por empuje de la c $\times$ Desconchados

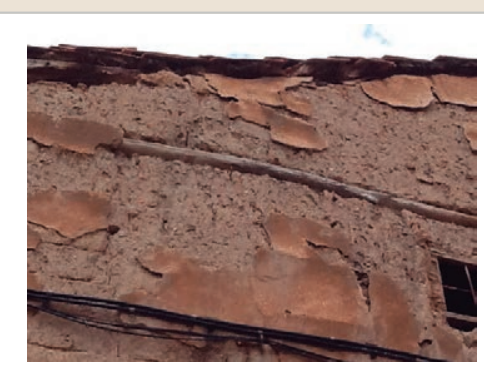

Observaciones $\square$ Cubierta $\square$ otro...

$\square$ Grietas por asentamiento $\square$ Colapso

$\square$ Por elementos impropios

$\square$ Derivado de intervenciones X Otro... 


\section{La restauración y rehabilitación de la arquitectura tradicional de tierra.}

El caso de Aragón.
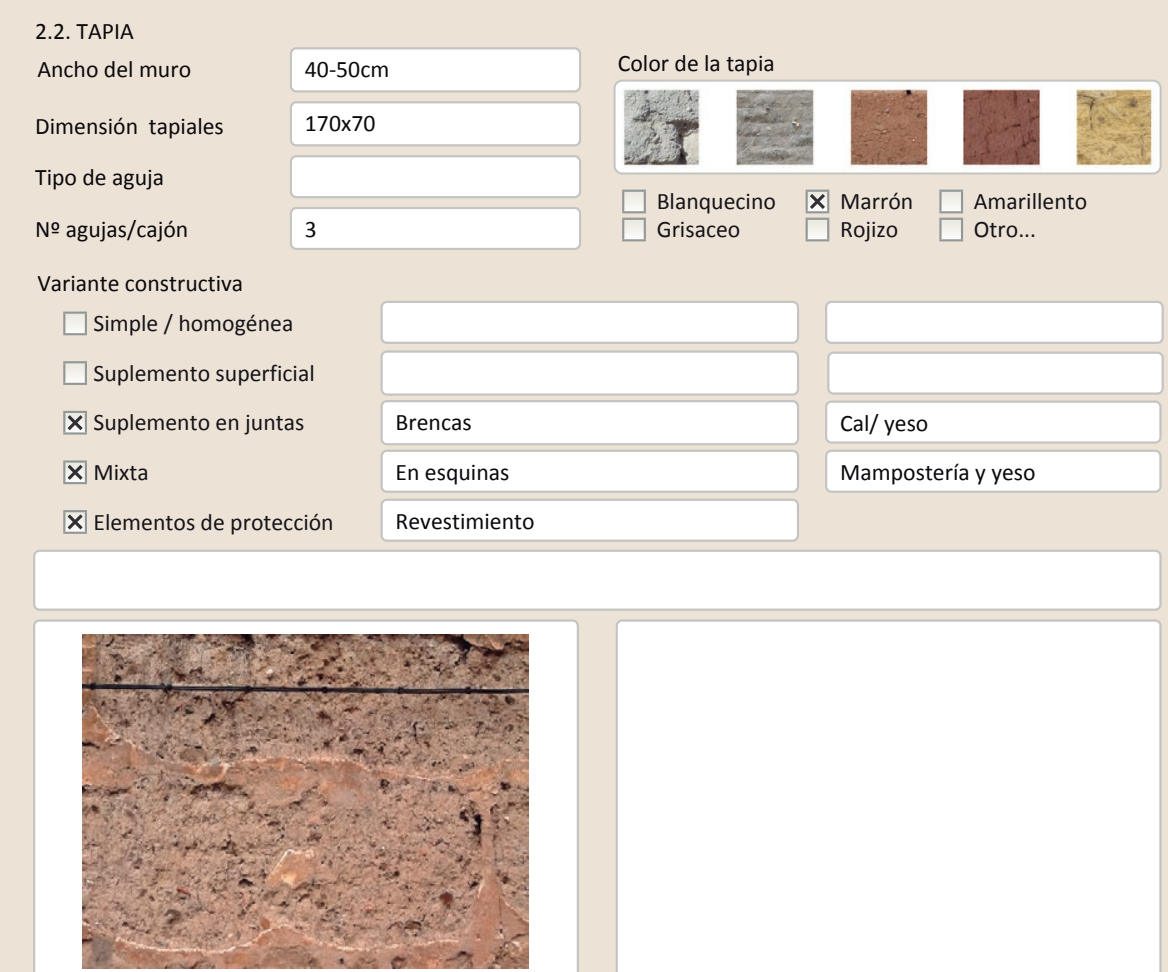

Lesiones ХMuro $\mathbf{X}$ Zócalo $\mathbf{X}$ Revestimiento $\square$ Cubierta $\square$ Otro...

$\begin{array}{lll}\mathbf{X} \text { Erosión del material } & \square \text { Humedad por capilaridad } & \square \text { Grietas por asentamientos } \\ \square \text { Erosion de las juntas } & \square \text { Humedades (manch/eflo) } & \square \text { Colapso } \\ \square \text { Pérdida de sección } & \square \text { Pérdida de verticalidad } & \square \text { Por elementos impropios } \\ \square \text { Vegetación } & \square \text { Grietas por empuje de la cubierta } & \square \text { Derivado de intervenciones }\end{array}$

Vegetación

$\square$ Grietas por empuje de la

$\mathbf{X}$ Otro...
La restauración y rehabilitación de la arquitectura tradicional de tierra.

El caso de Aragón.
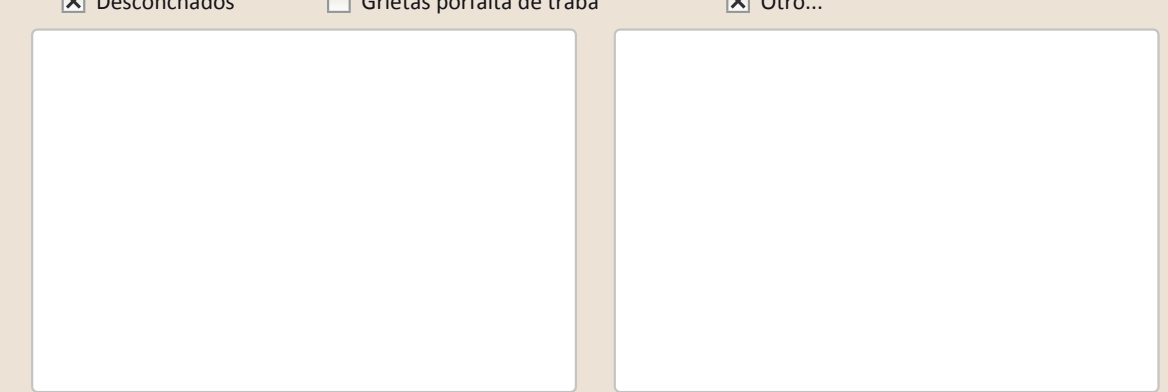

Observaciones

3. DATOS DE LA INTERVENCIÓN

Intervención de:

Reflexión previa

Observaciones

X Reparación $\quad \square$ Rehabilitación integral $\square$ Ampliación $\quad \square$ Otro...

3.1. MUROS

Tipo de intervención

Tipo de material

Intervenido

$\square$ Actualización $\square$ Reintegración $\square$ Demolición $\square$ Otro...

$\square$ Consolidación $\square$ Reconstrucción $\quad \mathbf{X}$ Sustitución

Descripción

No tradicional Tipo de técnica Similar a la existente

3.2. ZÓCALO

Sustitución de parte del muro piñón por ladrillo hueco

Tipo de intervención

Tipo de material

Descripción

3.3. REVESTIMIENTOS

Tipo de intervención

\section{No intervenido}

No intervenido

$\square$ Actualización $\quad \square$ Reintegración $\quad \square$ Demolición $\square$ Otro..

$\square$ Consolidación $\square$ Reconstrucción $\square$ sustitución

$$
\text { Tipo de técnica }
$$

Tipo de material

Descripción

3.4. VANOS

Tipo de intervención

Actualización $\square$ Reintegración $\quad \square$ Demolición $\quad \square$ Otro...

$\square$ Consolidación $\square$ Reconstrucción $\square$ Sustitución

Tipo de material

Descripción

3.5. CUBIERTA

Tipo de intervención

Tipo de material

Descripción

$$
\text { Tipo de técnica }
$$

No intervenido

$\square$ Actualización $\square$ Reintegración $\square$ Demolición $\square$ Otro..

$\square$ Consolidación $\square$ Reconstrucción $\square$ Sustitución

Tipo de técnica

3.6. OTRAS

\section{Intervenido}

$\square$ Actualización $\quad \mathbf{X}$ Reintegración $\square$ Demolición $\square$ Otro

$\square$ Consolidación $\square$ Reconstrucción $\square$ Sustitución

Reintegración de tejas con cemento y sustitución de alguna de ellas por otras nuevas
No tradicional
Tipo de técnica Similar a la existente 


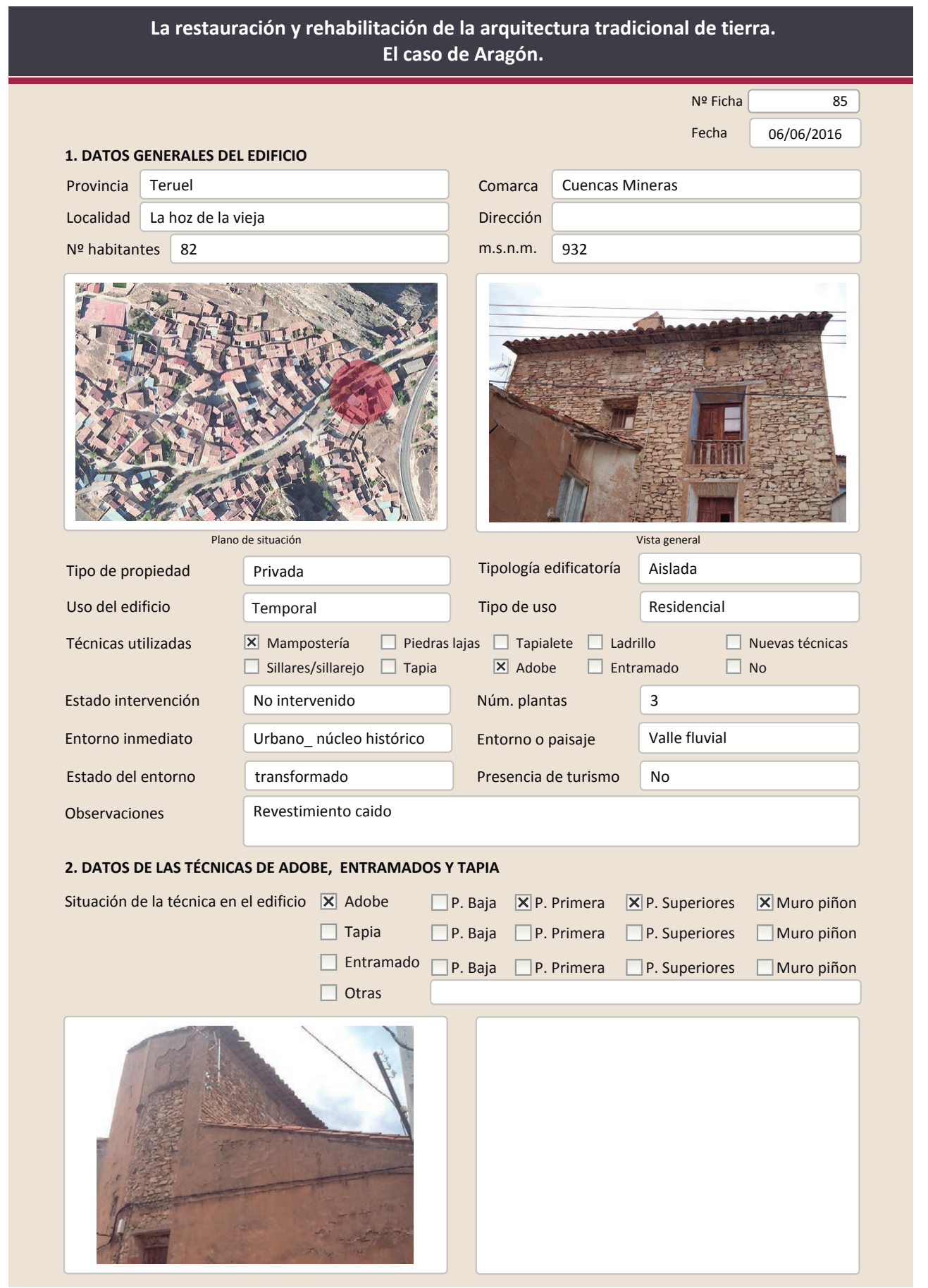

2.1. ADOBE

Dimensión de las piezas 15 altura Dimensión del muro

Aparejo del muro Función estructural Soga Variante constructiva/ tipo de fábrica

$\square$ Simple

$\square$ Suplementada en juntas

メ Mixta

Color de las piezas

$\square$ Como suplemento

$\mathbf{X}$ Elementos de protección

Revestimiento

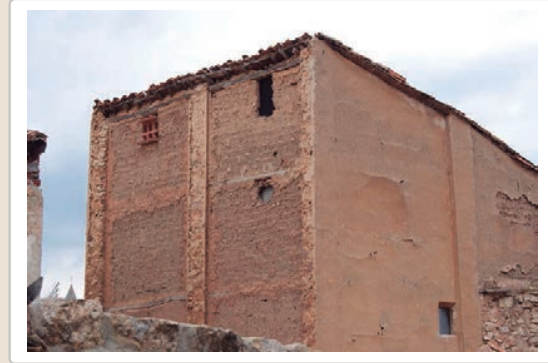

Lesiones ХMuro $\square$ Zócalo Х Revestimiento \ Erosión del material $\square$ Humedad por capilaridad $\square$ Erosion de las juntas $\square$ Humedades (manch/eflo) \ Pérdida de sección $\square$ Pérdida de verticalidad

$\square$ Vegetación $\quad \square$ Grietas por empuje de la c X Desconchados $\quad \square$ Grietas porfalta de traba

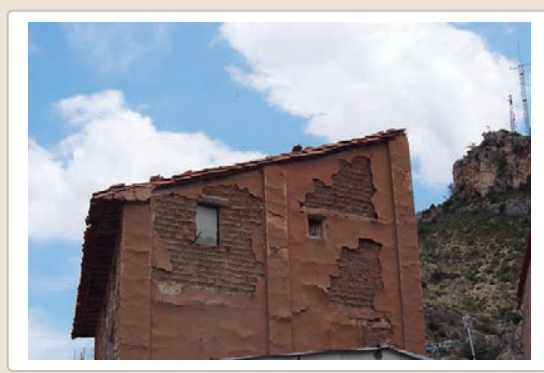

Observaciones

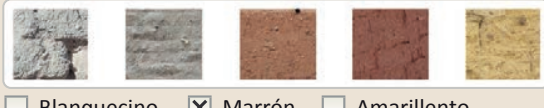

$\square$ Blanquecino $\mathbf{X}$ Marrón $\square$ Amarillento $\square$ Grisaceo $\square$ Rojizo $\square$ Otro.. Comp. - estabilizante Fibras vegetales 
La restauración y rehabilitación de la arquitectura tradicional de tierra.

El caso de Aragón.

3.7. REHABILITACIÓN ENERGÉTICA

$\square$ Fachada $\square$ Vanos $\square$ Forjados $\square$ Cubierta

Observaciones

FOTOGRAFÍAS DE LA INTERVENCIÓN
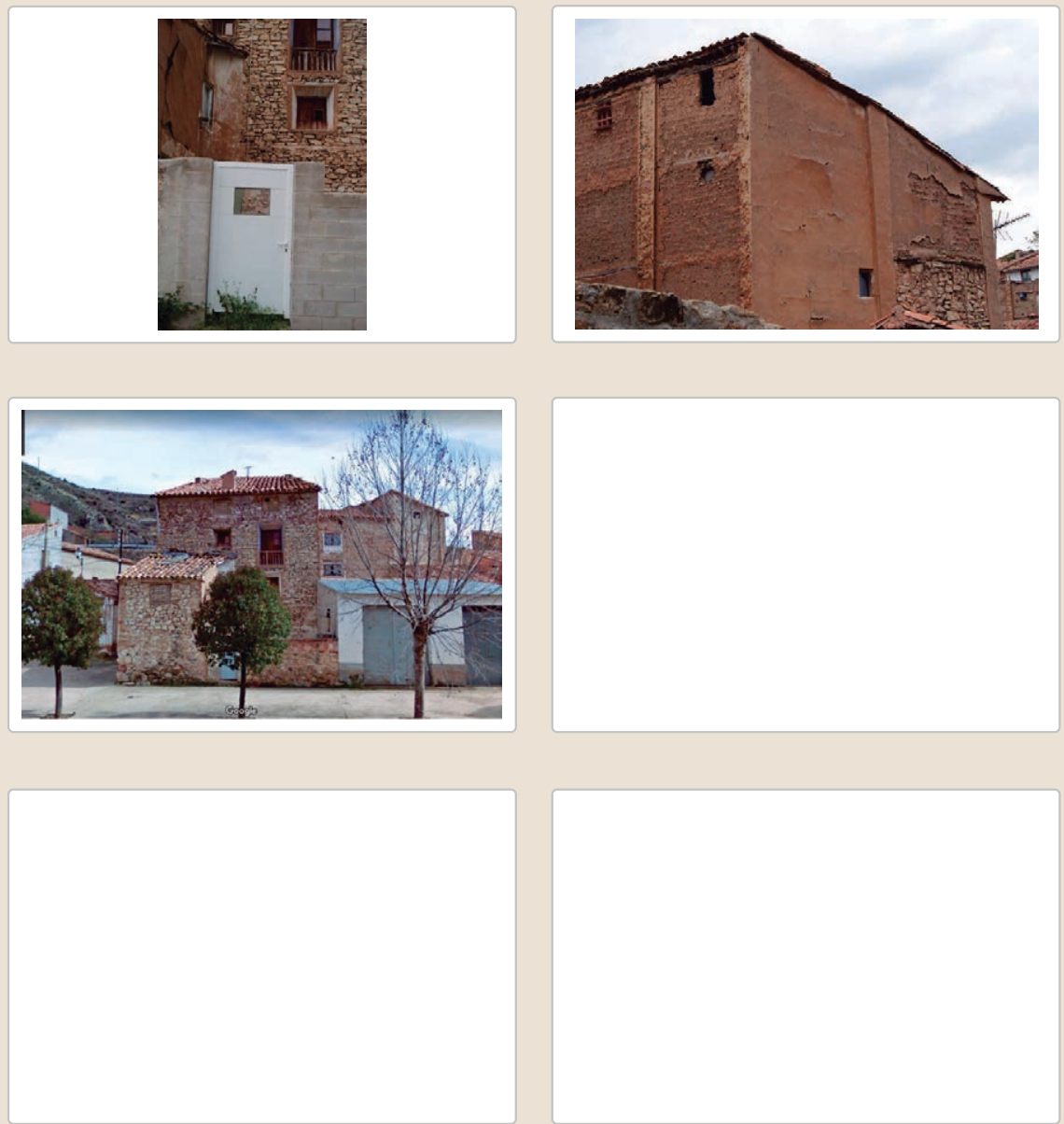

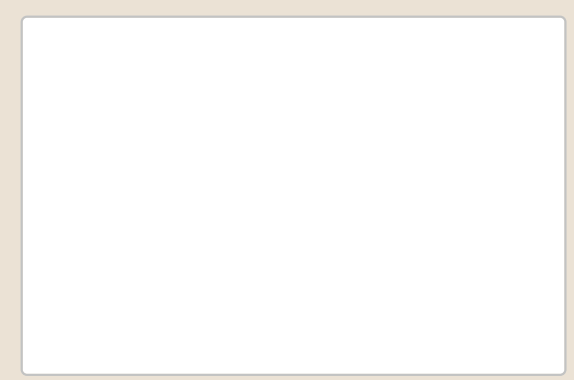




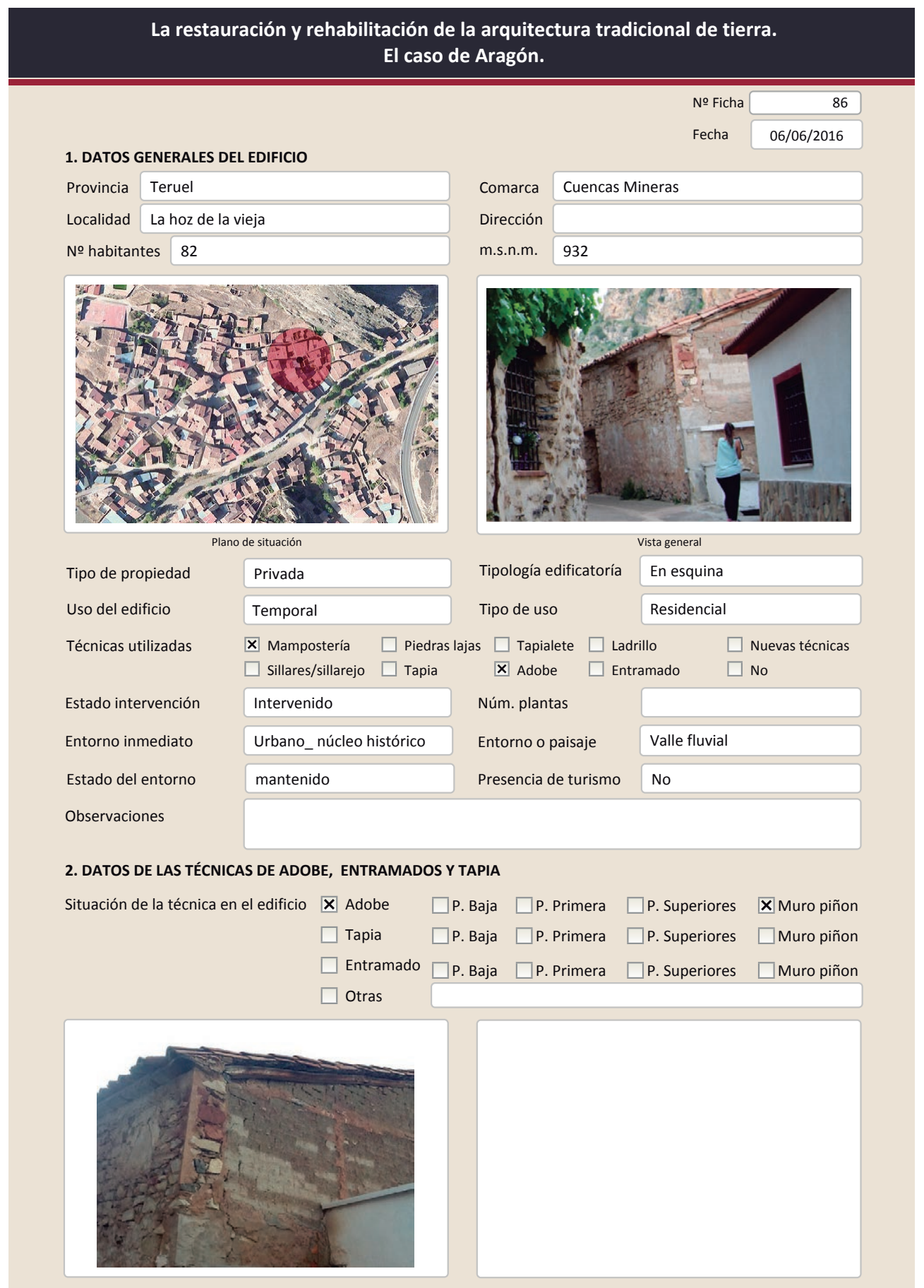

2.1. ADOBE

Dimensión de las piezas $40 \times 12$

Dimensión del muro 14

Aparejo del muro Soga

Función estructural

No
Color de las piezas

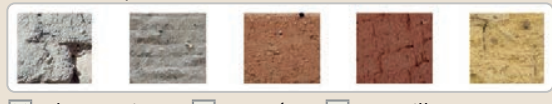

$\mathbf{X}$ Blanquecino $\square$ Marrón $\square$ Amarillento $\mathbf{X}$ Grisaceo $\square$ Rojizo $\square$ Otro..

Comp. - estabilizante Fibras vegetales

Variante constructiva/ tipo de fábrica
$\square$ Simple
Х Suplementada en juntas
Verticales y horizontales
X Mixta
En esquinas
$\mathrm{Cal} /$ yeso
$\square$ Como suplemento
$\square$ Elementos de protección

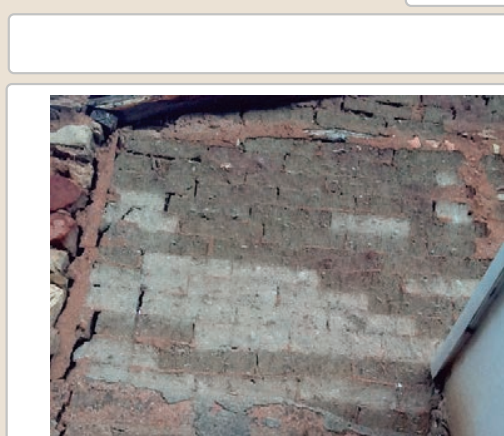

Lesiones $\square$ Muro $\square$ Zócalo $\square$ Revestimiento

$\mathbf{X}$ Erosión del material $\square$ Humedad por capilaridad $\square$ Erosion de las juntas $\square$ Humedades (manch/eflo)

$\square$ Pérdida de sección $\square$ Pérdida de verticalidad

$\square$ Vegetación $\quad \square$ Grietas por empuje de la cub

$\square$ Desconchados

$\square$ Grietas porfalta de traba

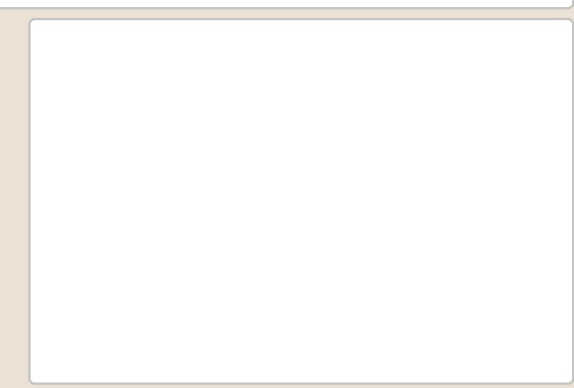

$\square$ Cubierta $\square$ otro...

$\square$ Grietas por asentamiento

$\square$ Colapso

$\square$ Por elementos impropios

$\square$ Derivado de intervenciones

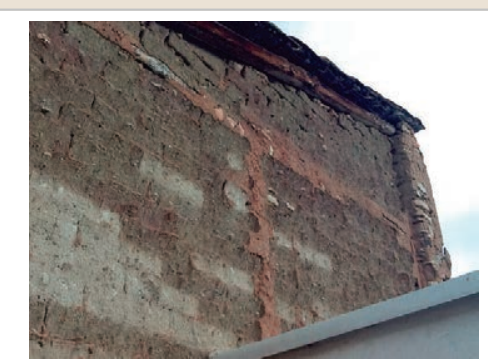

Observaciones 


\section{La restauración y rehabilitación de la arquitectura tradicional de tierra.}

\section{El caso de Aragón.}

3. DATOS DE LA INTERVENCIÓN

tervención de:

$\square$ Mantenimiento $\square$ Rehabilitación parcial

$\square$ Restauración $\square$ Demolición X Reparación $\square$ Rehabilitación integral $\square$ Ampliación $\square$ Otro...

Reflexión previa

Intervención espontanea

Observaciones

3.1. MUROS
Tipo de intervención

No intervenido

Tipo de intervencion

Tipo de material

Descripción

3.2. ZÓCALO

Tipo de intervención

Tipo de material

Descripción

3.3. REVESTIMIENTOS

Tipo de intervención

Tipo de material

Descripción

3.4. VANOS

Tipo de intervención

Tipo de material

Descripción

3.5. CUBIERTA

Tipo de intervención

Tipo de material

Descripción

3.6. OTRAS

Intervenido

$\square$ Actualización $\mathbf{x}$ Reintegración $\square$ Demolición $\square$ Otro...

$\square$ Consolidación $\square$ Reconstrucción $\square$ Sustitución

No tradicional Tipo de técnica Diferente a la existente

Reintegración de la mampostería en la esquina con cemento. Se ha insertado en esta zona un elemento de protección del hueco que hay en un nivel inferior.

\section{No intervenido}

$\square$ Actualización $\square$ Reintegración $\square$ Demolición $\square$ Otro...

$\square$ Consolidación $\square$ Reconstrucción $\square$ sustitución

Tipo de técnica

\section{No intervenido}

$\square$ Actualización $\square$ Reintegración $\square$ Demolición $\square$ Otro...

$\square$ Consolidación $\square$ Reconstrucción $\square$ Sustitución

Tipo de técnica

\section{No intervenido}

$\square$ Actualización $\square$ Reintegración $\square$ Demolición $\square$ Otro.

$\square$ Consolidación $\square$ Reconstrucción $\square$ Sustitución Tipo de técnica
La restauración y rehabilitación de la arquitectura tradicional de tierra.

El caso de Aragón.

3.7. REHABILITACIÓN ENERGÉTICA $\quad \square$ Fachada $\square$ Vanos $\square$ Forjados $\square$ Cubierta

Observaciones

FOTOGRAFÍAS DE LA INTERVENCIÓN
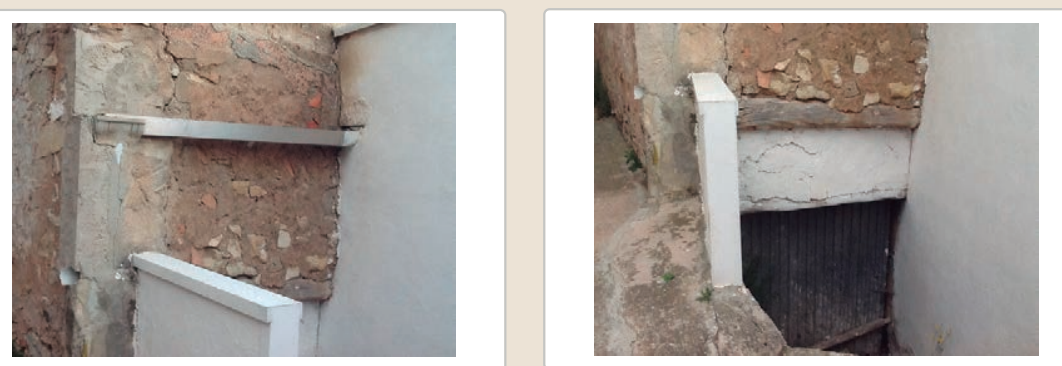

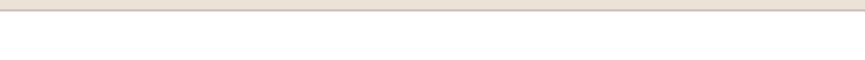
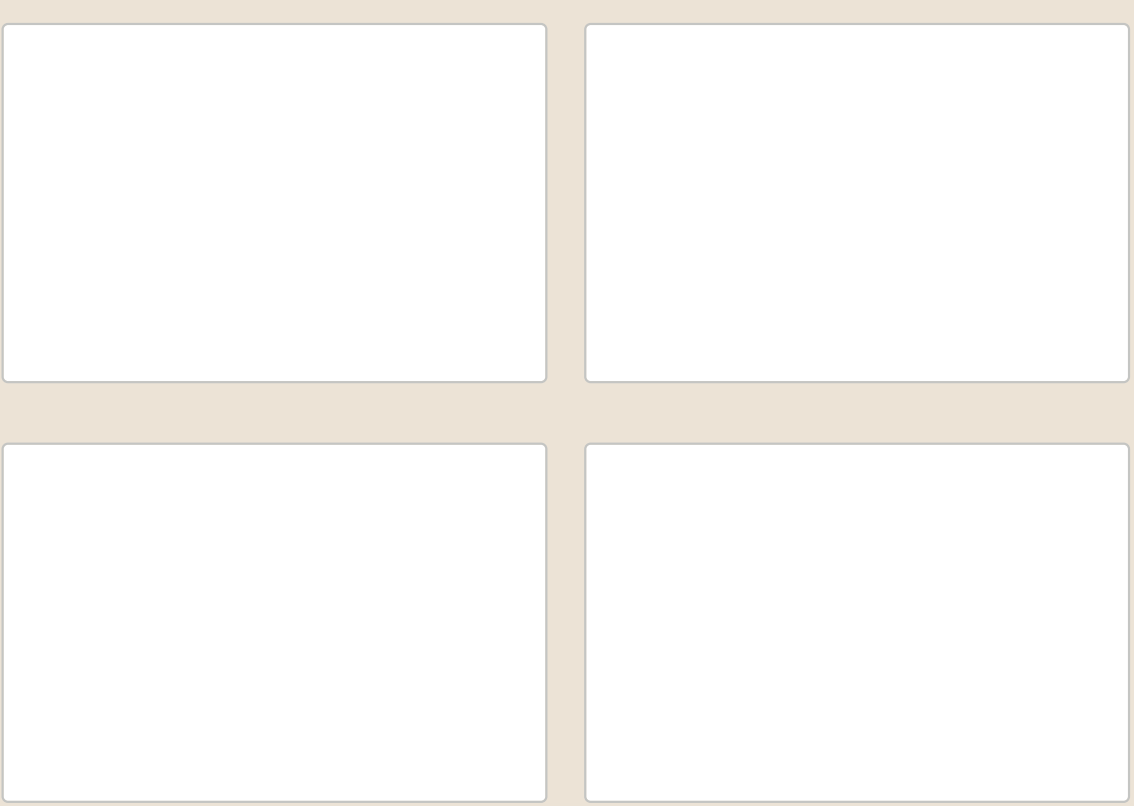


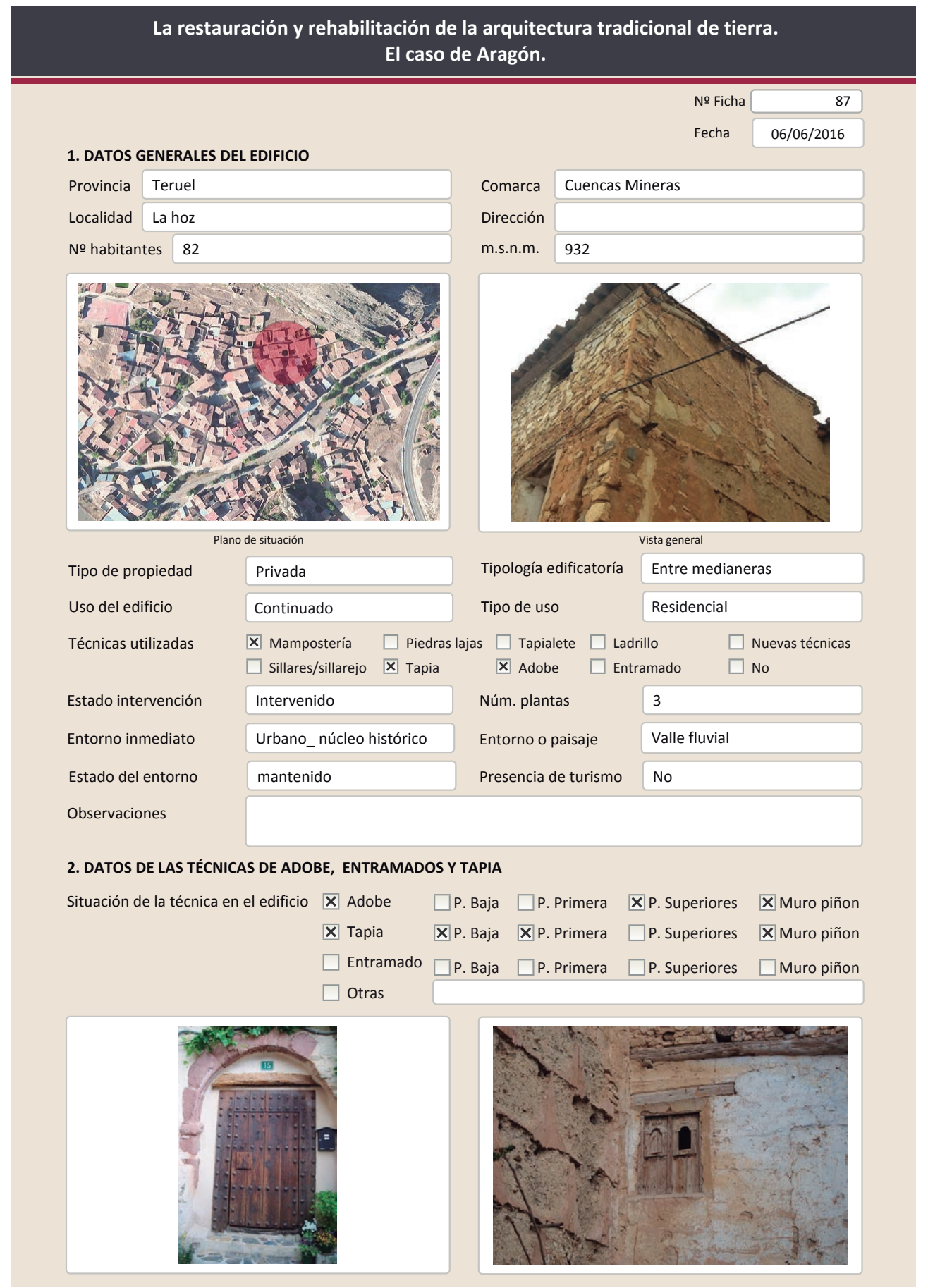

2.1. ADOBE

Dimensión de las piezas Dimensión del muro

Aparejo del muro

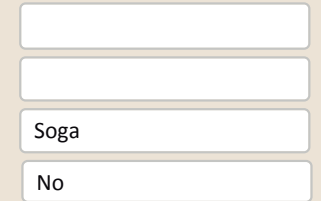

Color de las piezas

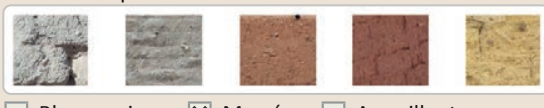

$\square$ Blanquecino $\mathbf{X}$ Marrón $\square$ Amarillento

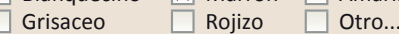

$\begin{array}{lll}\text { Función estructural No Comp. - estabilizante } & \end{array}$

Variante constructiva/ tipo de fábrica

$\square$ Simple

$\square$ Suplementada en juntas

X Mixt

\section{Machones}

$\square$ Como suplemento

$\square$ Elementos de protección

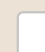

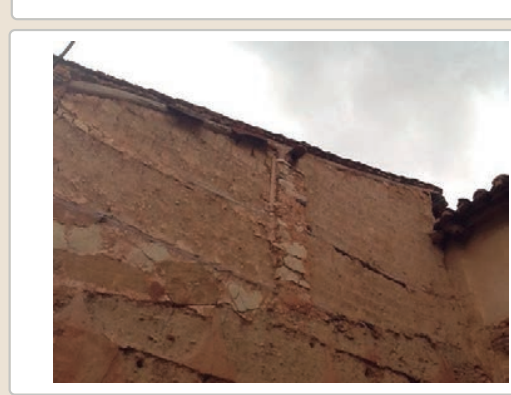

Lesiones $\quad \mathbf{X}$ Muro $\square$ Zócalo $\square$ Revestimiento

X Erosión del material $\square$ Humedad por capilaridad $\square$ Erosion de las juntas $\square$ Humedades (manch/eflo)

$\square$ Vegetación

$\square$ Grietas por empuje de $\square$ Grietas porfalta de traba $\square$ Pérdida de sección $\square$ Pérdida de verticalidad $\square$ Cubierta $\square$ Otro...

$\square$ Grietas por asentamiento

$\square$ Colapso

$\square$ Por elementos impropios

$\square$ Derivado de intervenciones $\square$ Otro... $\square$ Desconchados

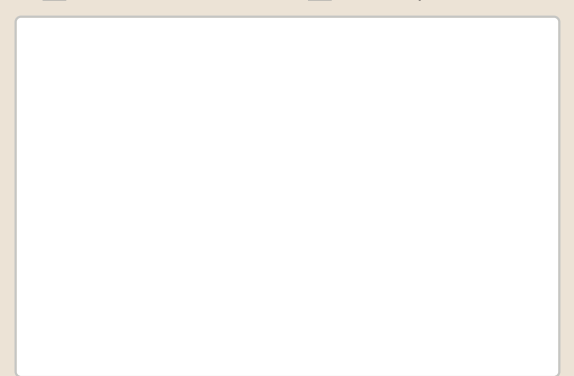

Observaciones 


\section{La restauración y rehabilitación de la arquitectura tradicional de tierra.}

\section{El caso de Aragón.}

\subsection{TAPIA}

Ancho del muro

Dimensión tapiales

Tipo de aguja

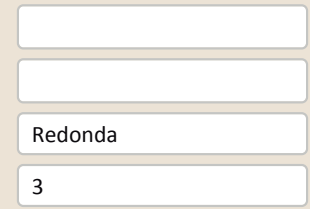

Color de la tapia

№ agujas/cajón

3

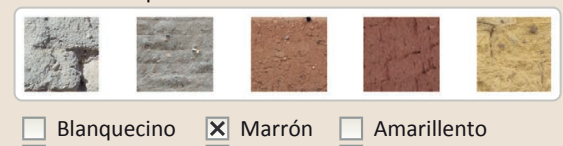

$\square$ Blanquecino $\quad$ X Marrón $\square$ Amarillento $\square$ Grisaceo

$\square$ Rojizo $\square$ Otro...

Variante constructiva

$\square$ Simple / homogénea

$\mathbf{X}$ Suplemento superficial

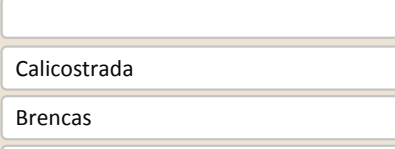

\section{Calveso}

$\mathbb{X}$ Suplemento en juntas

$\square$ Mixta

$\square$ Elementos de protección

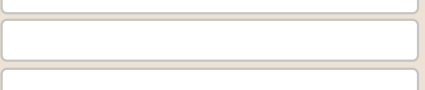

$\mathrm{Cal} /$ yeso

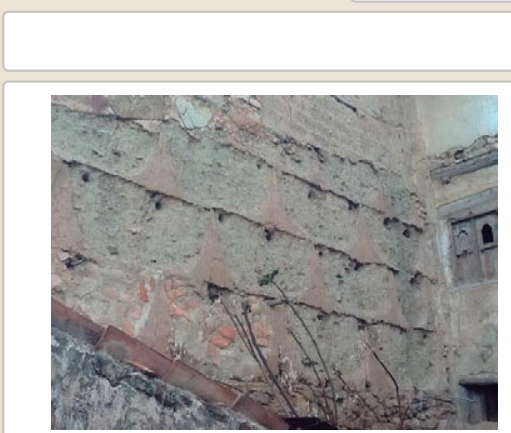

Lesiones $\quad$ M Muro $\square$ Zócalo $\square$ Revestimiento $\square$ Cubierta $\square$ otro...

X Erosión del material $\quad \square$ Humedad por capilaridad $\quad \square$ Grietas por asentamientos

$\square$ Erosion de las juntas $\square$ Humedades (manch/eflo) $\quad \square$ Colapso

$\square$ Pérdida de sección $\quad \square$ Pérdida de verticalidad

$\square$ Por elementos impropios

$\square$ Vegetación

$\mathbf{X}$ Desconchados

$\square$ Grietas porfalta de traba

$\square$ Otro...
La restauración y rehabilitación de la arquitectura tradicional de tierra.

El caso de Aragón.
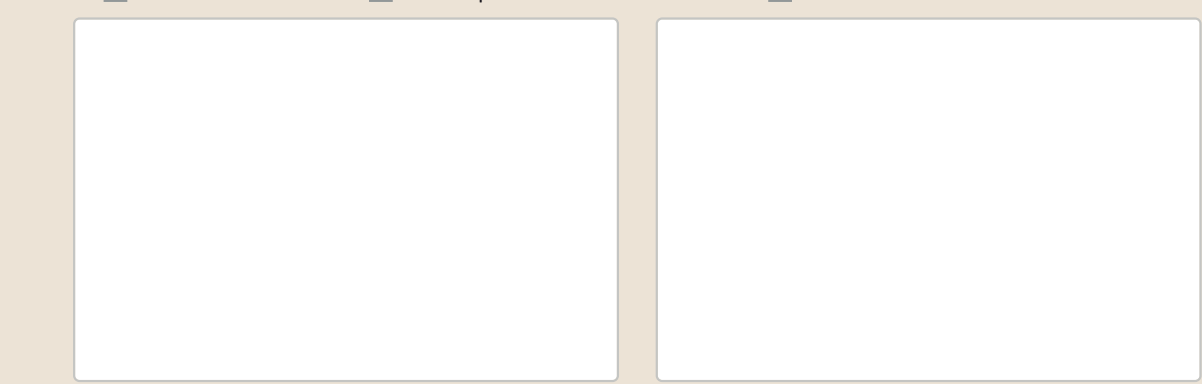

Observaciones

Perdida de la costra de la tapia

3. DATOS DE LA INTERVENCIÓN

Intervención de: $\quad \square$ Mantenimiento $\quad \mathbf{X}$ Rehabilitación parcial $\quad \square$ Restauración $\square$ Demolición

$\square$ Reparación $\quad \square$ Rehabilitación integral $\square$ Ampliación $\square$ Otro..

Reflexión previa Intervención planificada

Observaciones

Intervención planificada

3.1. MUROS

Tipo de intervención

Tipo de material

Descripción

3.2. ZÓCALO

Tipo de intervención

Tipo de material

Descripción

3.3. REVESTIMIENTOS

Tipo de intervención

Tipo de material

Descripción

3.4. VANOS

Tipo de intervención

Tipo de material

Descripción

3.5. CUBIERTA

Tipo de intervención

Tipo de material

Descripción

3.6. OTRAS

\section{No intervenido \\ $\square$ Actualización $\square$ Reintegración $\square$ Demolición $\square$ Otro.. \\ $\square$ Consolidación $\square$ Reconstrucción $\square$ sustitución}

Tipo de técnica

Intervenido

$\square$ Actualización $\quad \mathbf{x}$ Reintegración $\square$ Demolición $\square$ Otro.

$\square$ Consolidación $\square$ Reconstrucción $\square$ Sustitución

No tradicional Tipo de técnica Similar a la existente

Reintegración de la mampostería con cemento

\section{No aplica}

$\square$ Actualización $\quad \square$ Reintegración $\quad \square$ Demolición $\quad \square$ Otro...

$\square$ Consolidación $\square$ Reconstrucción $\square$ sustitución

$$
\text { Tipo de técnica }
$$

Intervenido

$\square$ Actualización $\square$ Reintegración $\square$ Demolición $\square$ Otro...

$\square$ Consolidación $\mathbf{X}$ Reconstrucción $\square$ Sustitución

\begin{tabular}{l|l|l} 
Tradicional diferente & Tipo de técnica & Diferente a la existente
\end{tabular}

Incorporación de nuevos elementos de rejería en los huecos de planta baja

\section{No visible}

$\square$ Actualización $\square$ Reintegración $\quad \square$ Demolición $\square$ Otro

$\square$ Consolidación $\square$ Reconstrucción $\square$ sustitución

Tipo de técnica 
La restauración y rehabilitación de la arquitectura tradicional de tierra. El caso de Aragón

\section{La restauración y rehabilitación de la arquitectura tradicional de tierra.} El caso de Aragón.

3.7. REHABILITACIÓN ENERGÉTICA $\square$ Fachada $\square$ Vanos $\square$ Forjados $\square$ Cubierta

Observaciones

FOTOGRAFÍAS DE LA INTERVENCIÓN
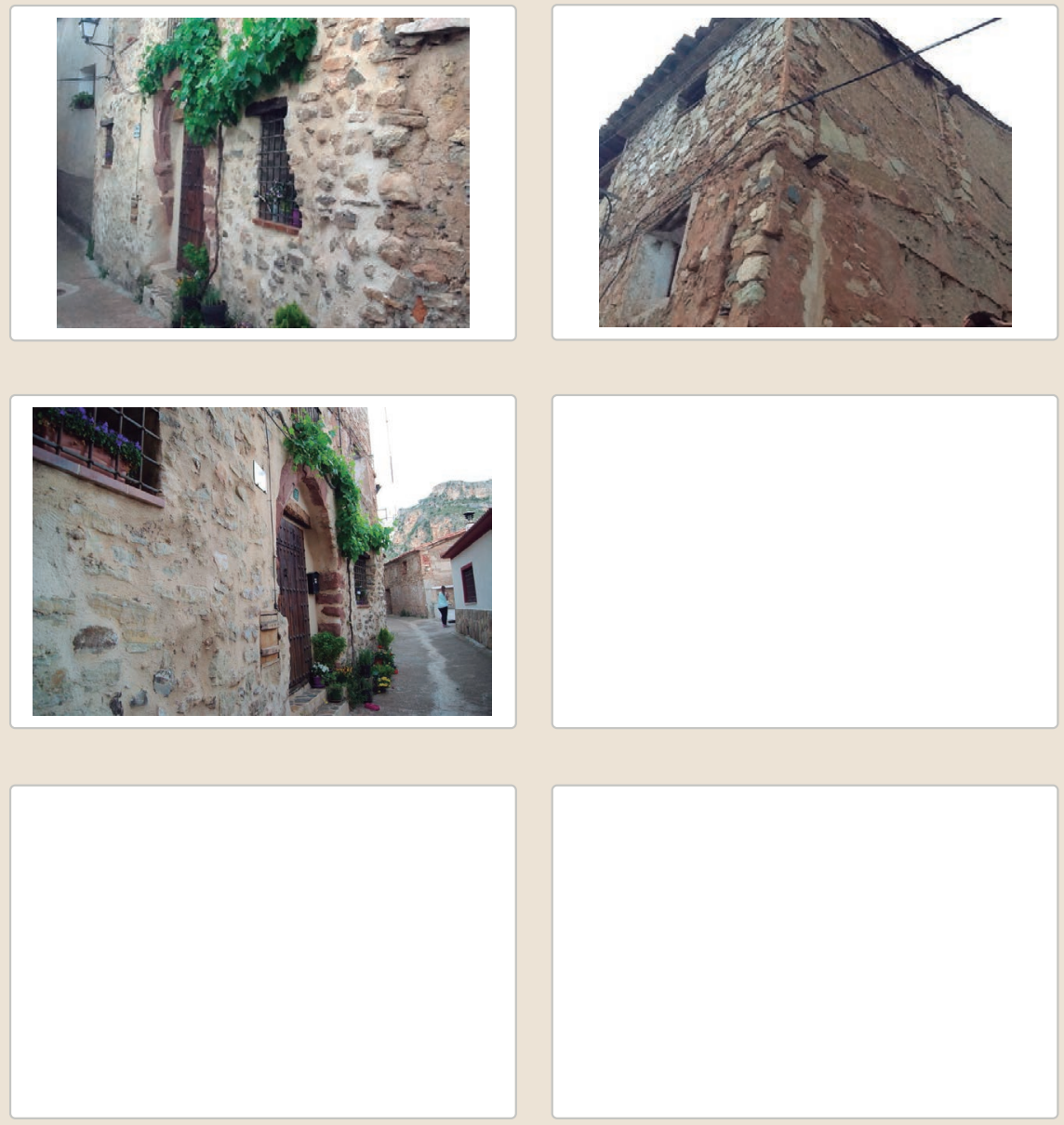
La restauración y rehabilitación de la arquitectura tradicional de tierra. El caso de Aragón.

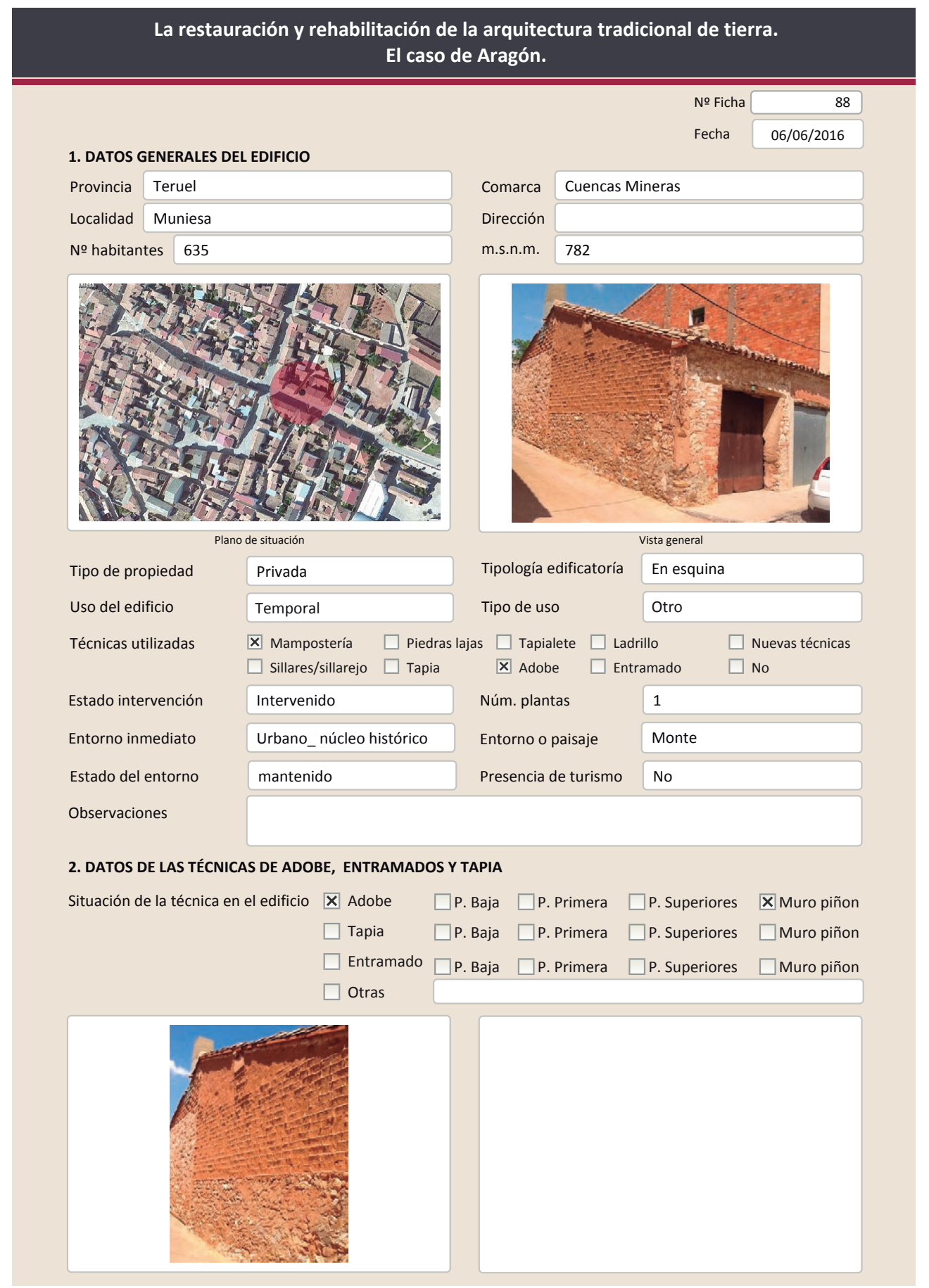

La restauración y rehabilitación de la arquitectura tradicional de tierra. El caso de Aragón.
2.1. ADOBE

Dimensión de las piezas $40 \times 10$

Dimensión del muro

Aparejo del muro

Función estructural
Variante constructiva/ tipo de fábrica

$\square$ simple
$\mathbf{X}$ Suplementada en juntas
$\square$ Mixta
$\square$ Como suplemento
$\square$ Elementos de protección

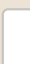

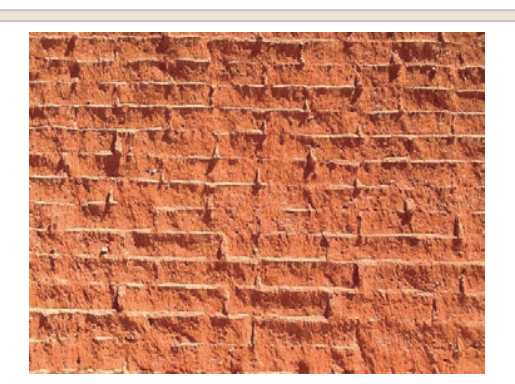

Lesiones $\quad \mathbf{X}$ Muro $\square$ Zócalo $\square$ Revestimiento $\mathbf{X}$ Erosión del material $\square$ Humedad por capilaridad $\mathbf{X}$ Erosion de las juntas $\square$ Humedades (manch/eflo) X Pérdida de sección $\square$ Pérdida de verticalidad

$\square$ Vegetación $\quad \square$ Grietas por empuje de la cubie

$\square$ Desconchados

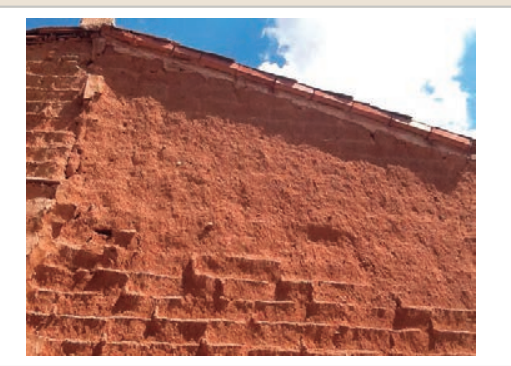

Color de las piezas

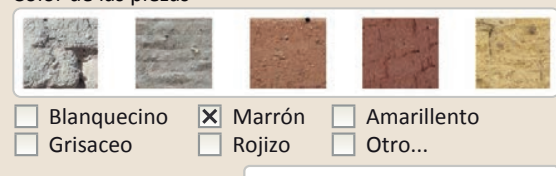

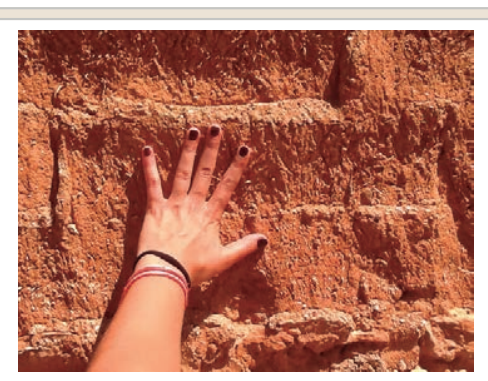

$\square$ Cubierta $\square$ Otro...

$\square$ Grietas por asentamiento $\square$ Colapso

$\square$ Por elementos impropios

$\square$ Derivado de intervenciones Х Otro...

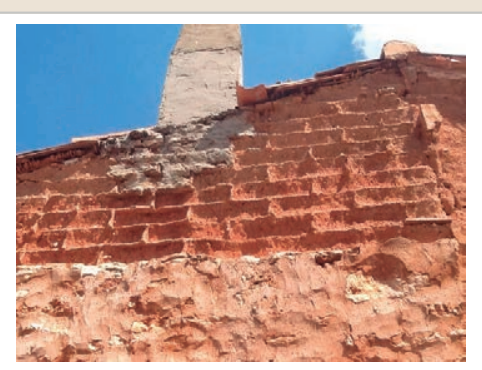

Observaciones 


\section{La restauración y rehabilitación de la arquitectura tradicional de tierra.} El caso de Aragón.

3. DATOS DE LA INTERVENCIÓN

$\square$ Mantenimiento $\square$ Rehabilitación parcial

$\square$ Restauración $\square$ Demolición

Rexionprevia

X Reparación

Rehabilitación integra

Ampliación

$\square$ Otro...

Reflexión previa
Observaciones

Intervención espontanea

Observaciones

3.1. MUROS

Tipo de intervención

Tipo de material

Descripción

3.2. ZÓCALO

Tipo de intervención

Tipo de material

Descripción

3.3. REVESTIMIENTOS

Tipo de intervención

Tipo de material

Descripción

3.4. VANOS

Tipo de intervención

Tipo de material

Descripción

3.5. CUBIERTA

Tipo de intervención

Tipo de material

Descripción

\section{Intervenido}

$\square$ Actualización $\quad \boldsymbol{X}$ Reintegración $\square$ Demolición $\square$ Otro...

$\square$ Consolidación $\quad \square$ Reconstrucción $\square$ Sustitución

\begin{tabular}{|l|l|l|l|l} 
No tradicional & Tipo de técnica Diferente a la existente
\end{tabular}

Cemento en zonas donde se ha perdido una sección importante del adobe

\section{Intervenido}

$\square$ Actualización $\mathbf{x}$ Reintegración $\square$ Demolición $\square$ Otro..

$\square$ Consolidación $\square$ Reconstrucción $\square$ sustitución
No tradicional
Tipo de técnica Diferente a la existente

Reintegración de la mampostería con una cantidad importante de cemento

\section{No aplica}

$\square$ Actualización $\square$ Reintegración $\square$ Demolición $\square$ Otro...

$\square$ Consolidación $\square$ Reconstrucción $\square$ sustitución

Tipo de técnica

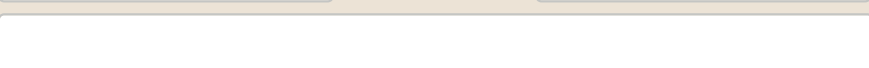

\section{No intervenido}

$\square$ Actualización $\square$ Reintegración $\square$ Demolición $\square$ Otro...

$\square$ Consolidación $\quad \square$ Reconstrucción $\quad \square$ Sustitución

Tipo de técnica

\section{Intervenido}

$\square$ Actualización $\square$ Reintegración $\square$ Demolición $\square$ Otro. $\square$ Consolidación $\square$ Reconstrucción $\mathbf{X}$ Sustitución

No tradicional Tipo de técnica Diferente a la existente

Sustitución parcial de la cubierta en una de las aguas. Se ha eliminado el cañizo y se han colocado elementos cerámicos de base
La restauración y rehabilitación de la arquitectura tradicional de tierra.

El caso de Aragón.

3.7. REHABILITACIÓN ENERGÉTICA $\square$ Fachada $\square$ Vanos $\square$ Forjados $\square$ Cubierta

Observaciones

FOTOGRAFíAS DE LA INTERVENCIÓN
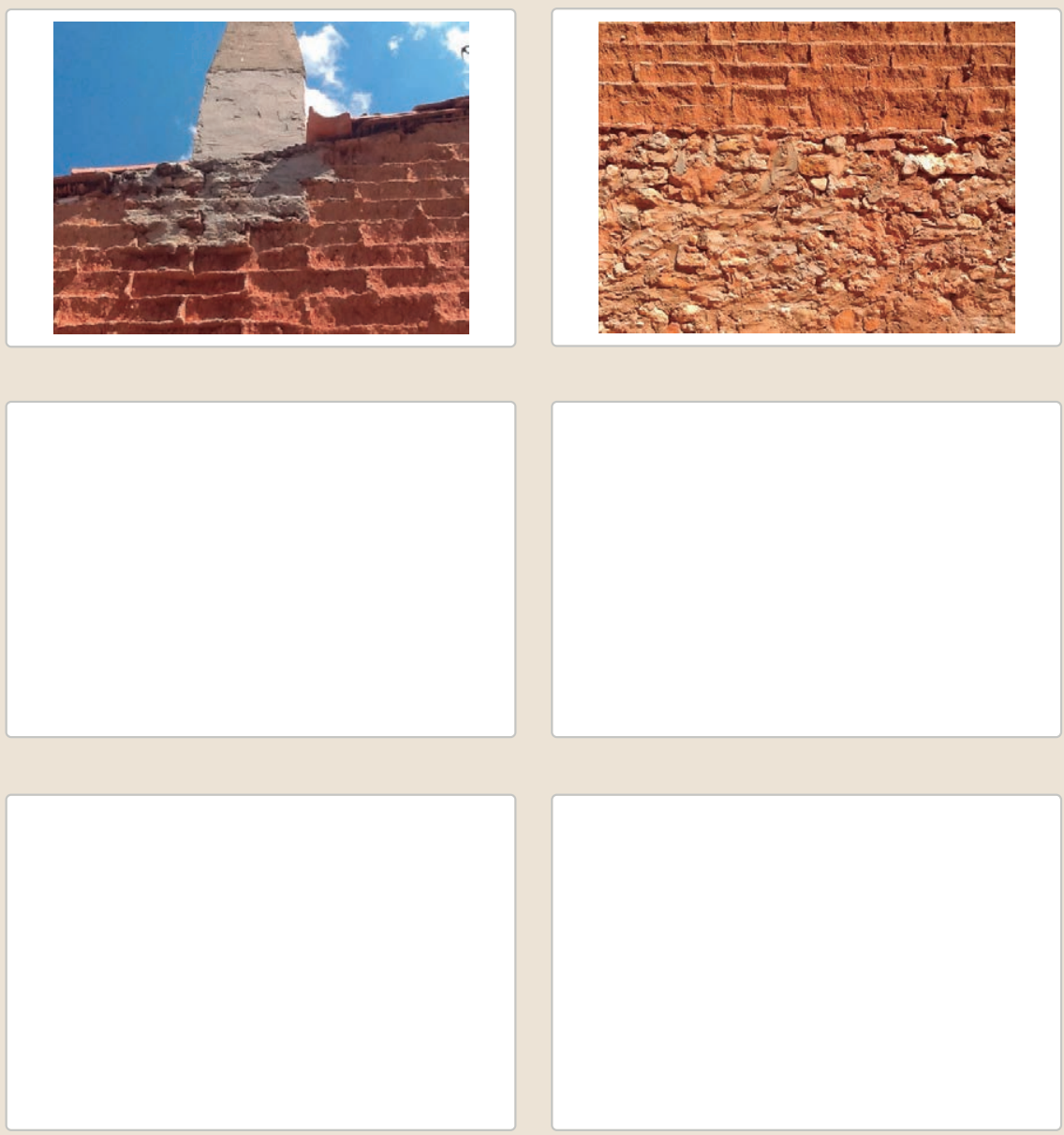

3.6. OTRAS 


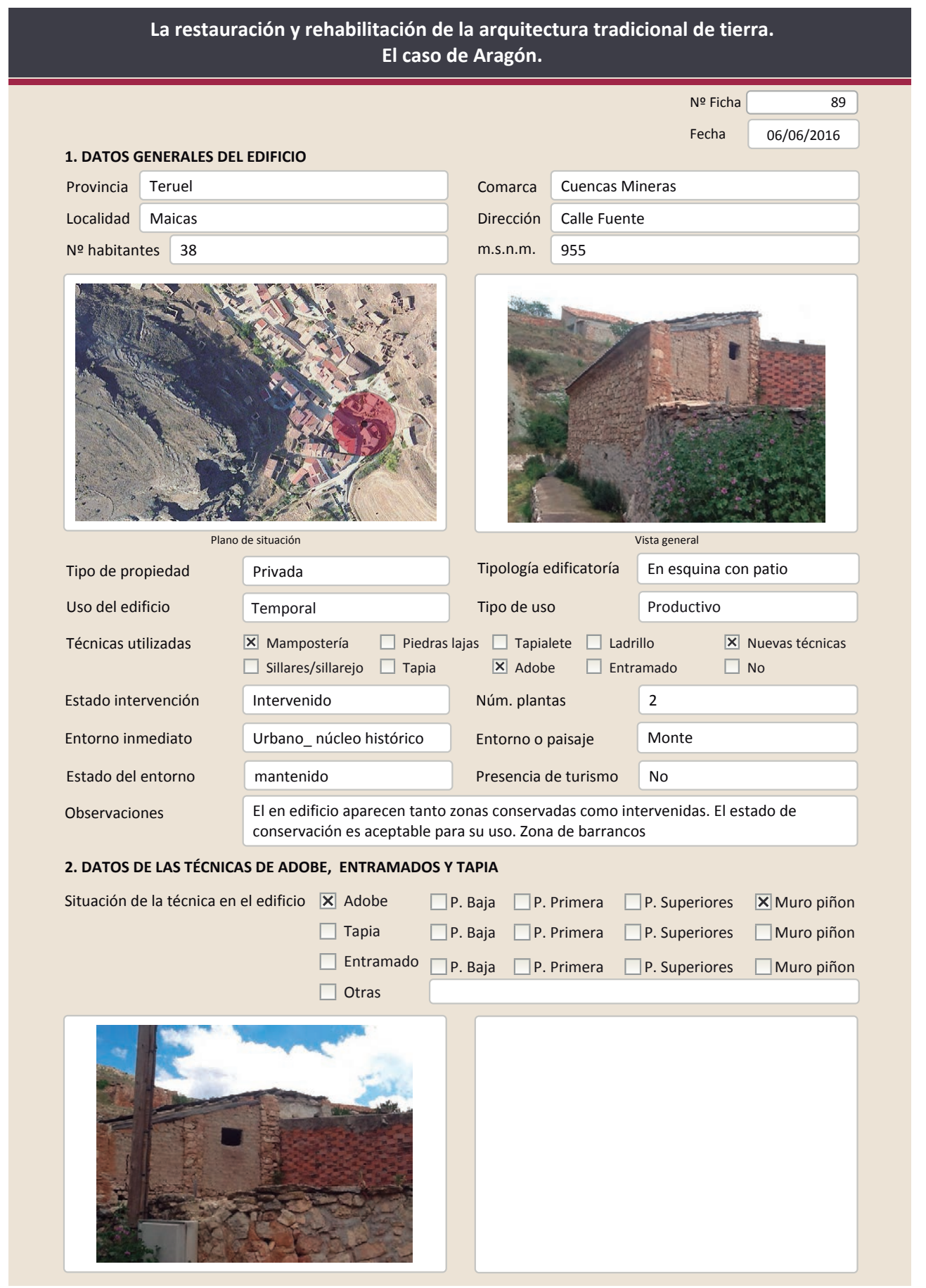

La restauración y rehabilitación de la arquitectura tradicional de tierra. El caso de Aragón.

\begin{tabular}{ll} 
2.1. ADOBE \\
Dimensión de las piezas & $40 \times 10$ aprox \\
Dimensión del muro & $10-20 \mathrm{~cm}$ \\
Aparejo del muro & Soga \\
\hline
\end{tabular}

Función estructural

Variante constructiva/ tipo de fábrica
$\square$ simple
Х Suplementada en juntas
Horizontales
X Mixta
Machones
$\square$ Como suplemento
$\square$ Elementos de protección Cal/ yeso
Piedra

Color de las piezas

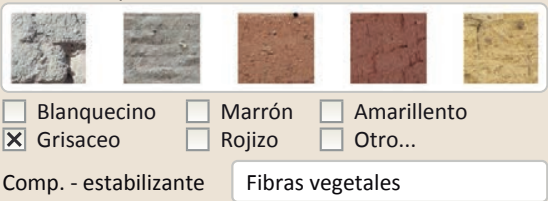

X

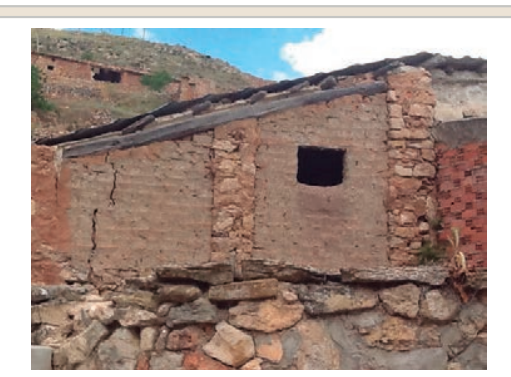

Lesiones $\mathbf{X}$ Muro $\square$ Zócalo $\square$ Revestimiento

X Erosión del material $\square$ Humedad por capilaridad $\square$ Erosion de las juntas $\square$ Humedades (manch/eflo)

$\square$ Pérdida de sección $\square$ Pérdida de verticalidad

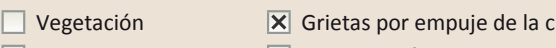

$\square$ Desconchados

$\square$ Grietas porfalta de trab

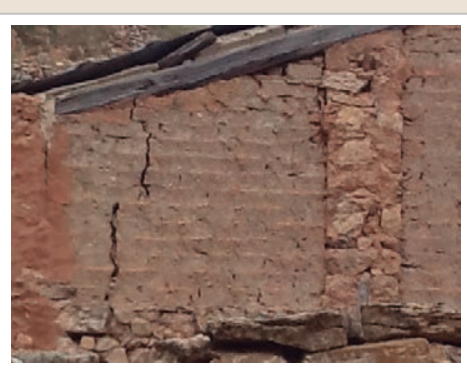

Observaciones

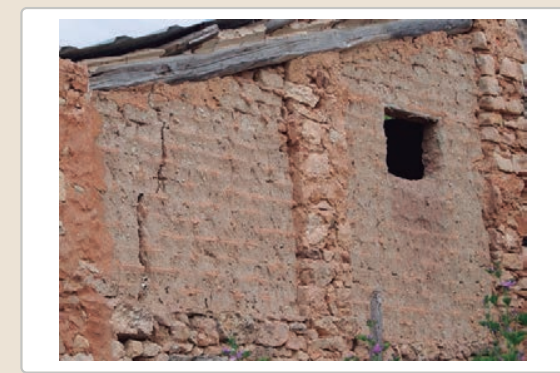

XCubierta $\square$ Otro...
$\square$ Grietas por a
$\square$ Por elementos impropios

$\mathbf{X}$ Otro...

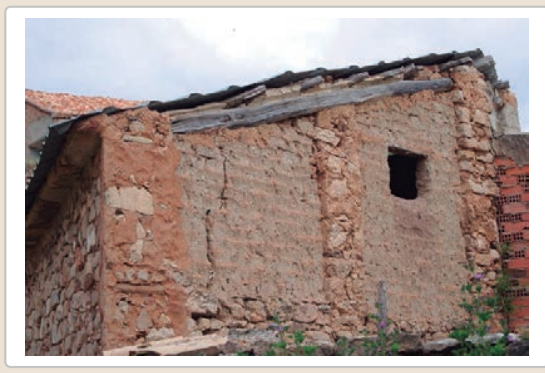




\section{La restauración y rehabilitación de la arquitectura tradicional de tierra.} El caso de Aragón.

3. DATOS DE LA INTERVENCIÓN

$\square$ Mantenimiento $\square$ Rehabilitación parcial $\quad \square$ Restauración $\quad \square$ Demolición X Reparación $\quad \square$ Rehabilitación integral $\square$ Ampliación $\square$ Otro...

Reflexión previa Intervención espontanea

Observaciones Se trata de intervenciones que responden a los problemas de una forma inmediata sin pensar previamente en su adecuación.

\subsection{MUROS Intervenido \\ Tipo de intervención $\quad \square$ Actualización $\quad \square$ Reintegración $\quad \square$ Demolición $\quad \square$ Otro... \\ $\square$ Actualización $\square$ Reintegración $\quad \square$ Demolición}

\begin{tabular}{l|l|l|l|l} 
Tipo de material Tipo de técnica & No tradicional a la existent
\end{tabular}

Descripción

Sustitución muro de adobe por muro de bloques de hormigón en la parte trasera.

3.2. ZÓCALO

Tipo de intervención

Intervenido

$\square$ Actualizació

$\square$ Consolidación $\square$ Reconstrucción $\square$ Sustitución

Descripción

Tipo de técnica Diferente a la existente

3.3. REVESTIMIENTOS

Tipo de intervención

Tipo de material

Descripción

3.4. VANOS

Tipo de intervención

Tipo de material

Descripción

3.5. CUBIERTA

Tipo de intervención

Tipo de material

Descripción

Se ha añadido mortero de cemento en la parte inferior del muro insertando esta parte del muro inexistente previamente.

No aplica

$\square$ Actualización $\quad \square$ Reintegración $\quad \square$ Demolición $\square$ Otro...

$\square$ Consolidación $\square$ Reconstrucción $\square$ Sustitución Tipo de técnica

Intervenido

$\square$ Actualización $\square$ Reintegración $\square$ Demolición $\square$ Otro...

$\square$ Consolidación $\mathbf{X}$ Reconstrucción $\square$ Sustitución

No tradicional Tipo de técnica Diferente a la existente

Creación de un nuevo vano en el muro reconstruido manteniendo la antigua carpintería. Dintel con piezas cerámicas.

Intervenido

$\square$ Actualización $\quad \square$ Reintegración $\quad \square$ Demolición $\square$ Otro.

$\square$ Consolidación $\square$ Reconstrucción $\quad \mathbf{x}$ Sustitución

No tradicional Tipo de técnica Diferente a la existente

Sustitución de la cubierta tradicional por una chapa metálica
La restauración y rehabilitación de la arquitectura tradicional de tierra.

El caso de Aragón.

3.7. REHABILITACIÓN ENERGÉTICA $\quad \square$ Fachada $\square$ Vanos $\square$ Forjados $\square$ Cubierta

Observaciones

FOTOGRAFÍAS DE LA INTERVENCIÓN

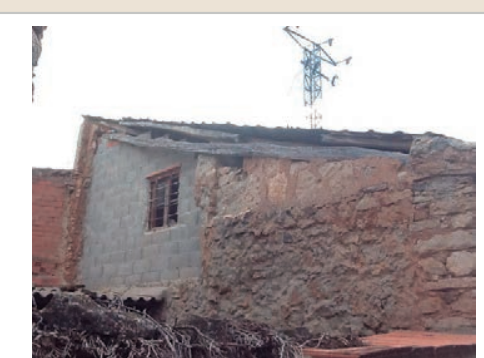

Nuevo muro de bloques de hormigón

Nueva cubierta de chapa prefabricada

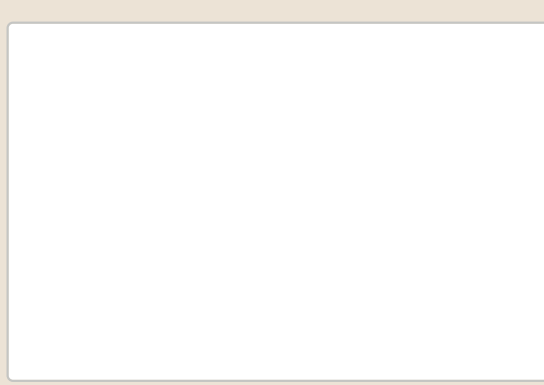

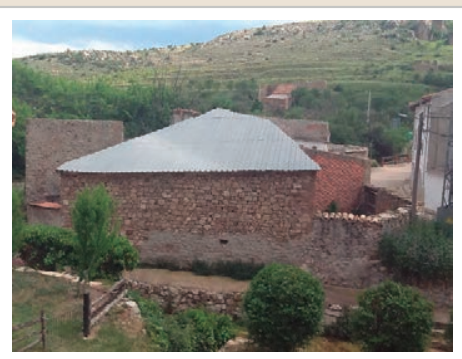

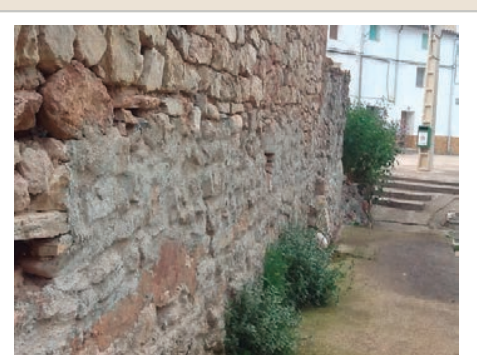

Mortero de cemento en la pare inferior del muro

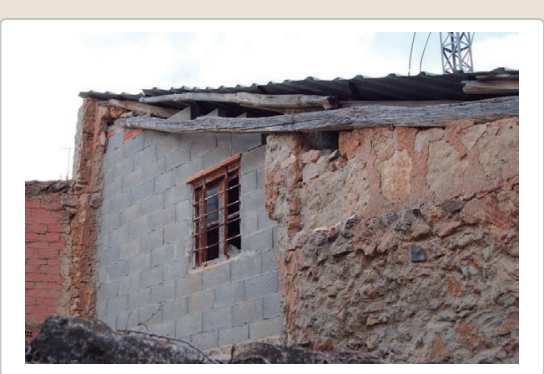

Nuevo hueco con la carpintería preexistente.

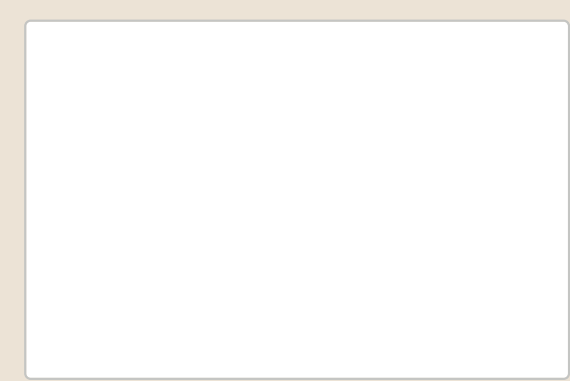

3.6. OTRAS 
La restauración y rehabilitación de la arquitectura tradicional de tierra. El caso de Aragón.

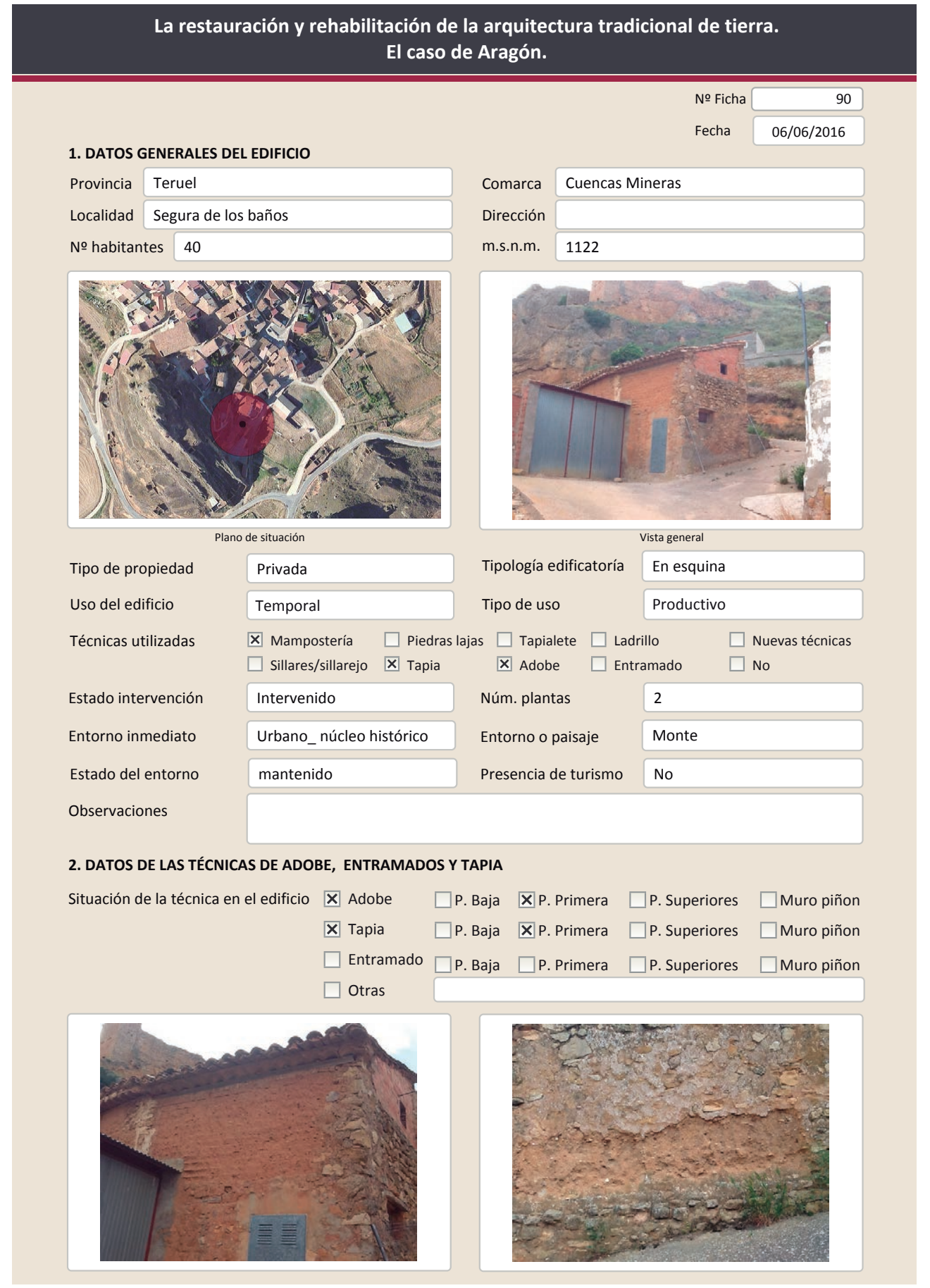

La restauración y rehabilitación de la arquitectura tradicional de tierra.

El caso de Aragón.
2.1. ADOBE

Dimensión de las piezas

Dimensión del muro

Aparejo del muro

Función estructural

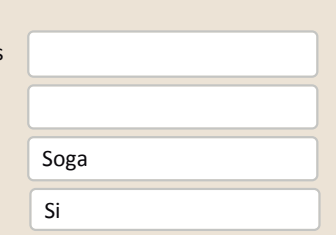

Color de las piezas

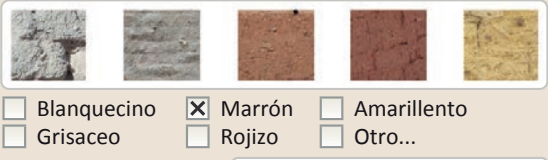

$\square$ Rojizo $\square$ Otro..

Comp. - estabilizante Fibras vegetales
Variante constructiva/ tipo de fábrica
$\square$ simple
区 Suplementada en juntas
Horizontales
$\mathrm{Cal} /$ yeso
X Mixta

\section{En esquinas} Piedra
$\square$ Como suplemento
$\square$ Elementos de protección

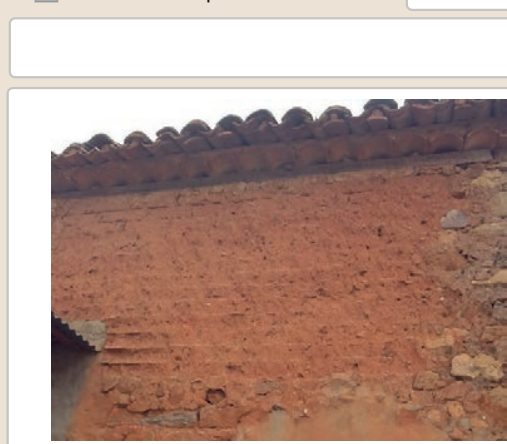

Lesiones \Muro $\square$ Zócalo $\square$ Revestimiento

X Erosión del material $\square$ Humedad por capilaridad

$\square$ Erosion de las juntas $\square$ Humedades (manch/eflo)

$\square$ Pérdida de sección $\square$ Pérdida de verticalidad

$\begin{array}{ll}\square \text { Vegetación } & \square \text { Grietas por empuje de la c } \\ \square \text { Desconchados } & \square \text { Grietas porfalta de traba }\end{array}$

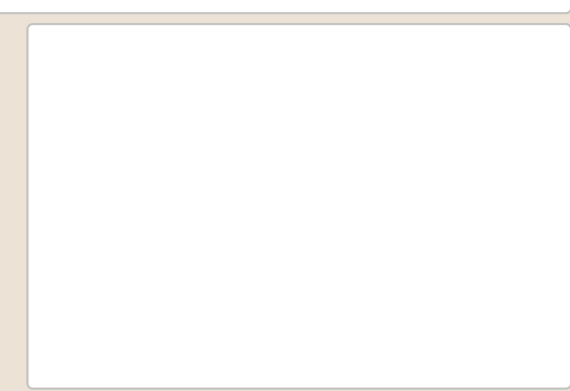

$\square$ Grietas por asentamientos

$\square$ Colapso

$\square$ Por elementos impropios

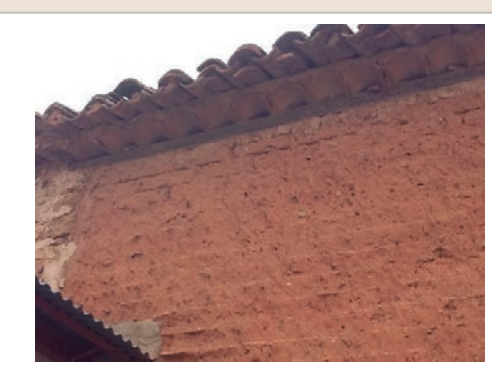

$\square$ Derivado
$\boldsymbol{X}$ Otro...

Observaciones 


\section{La restauración y rehabilitación de la arquitectura tradicional de tierra.} El caso de Aragón.

\subsection{TAPIA}

Ancho del muro

Dimensión tapiales

\begin{tabular}{|l|}
\hline $40-50 \mathrm{~cm}$ \\
\hline $120 \times 60$ \\
\hline Redonda \\
\hline 3 \\
\hline
\end{tabular}

Color de la tapia

Tipo de aguja

3

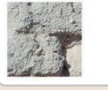

$\square$ Blanquecin
$\square$ Grisaceo

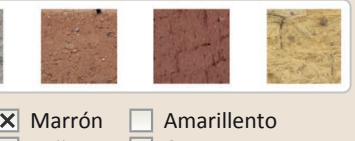

№ agujas/cajón

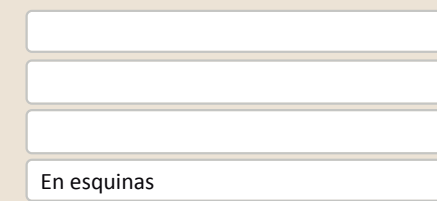

\section{En esquinas}

X Mixta

$\square$ Elementos de protección

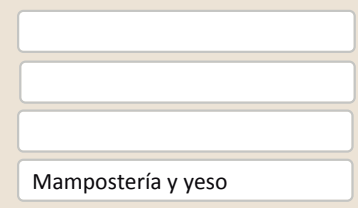

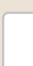

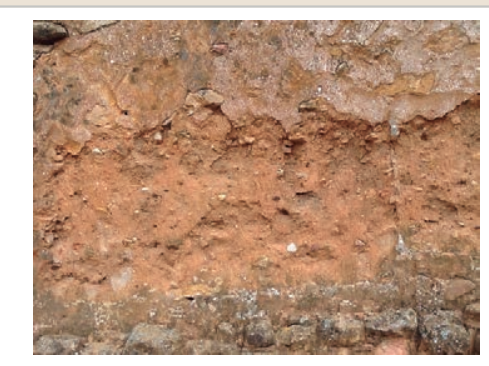

Lesiones $\quad \mathbf{M}$ Muro $\square$ Zócalo $\square$ Revestimiento $\square$ Cubierta $\square$ Otro...

$\begin{array}{lll}\mathbf{X} \text { Erosión del material } & \square \text { Humedad por capilaridad } & \square \text { Grietas por asentamientos } \\ \square \text { Erosion de las juntas } & \square \text { Humedades (manch/eflo) } & \square \text { Colapso } \\ \square \text { Pérdida de sección } & \square \text { Pérdida de verticalidad } & \square \text { Por elementos impropios } \\ \square \text { Vegetación } & \square \text { Grietas por empuje de la cubierta } & \square \text { Derivado de intervenciones }\end{array}$

$\square$ Pérdida de sección $\square$ Pérdida de verticalidad $\quad \square$ Por elementos impropios

$\square$ Desconchados $\square$ Grietas porfalta de traba $\quad$ X Otro...
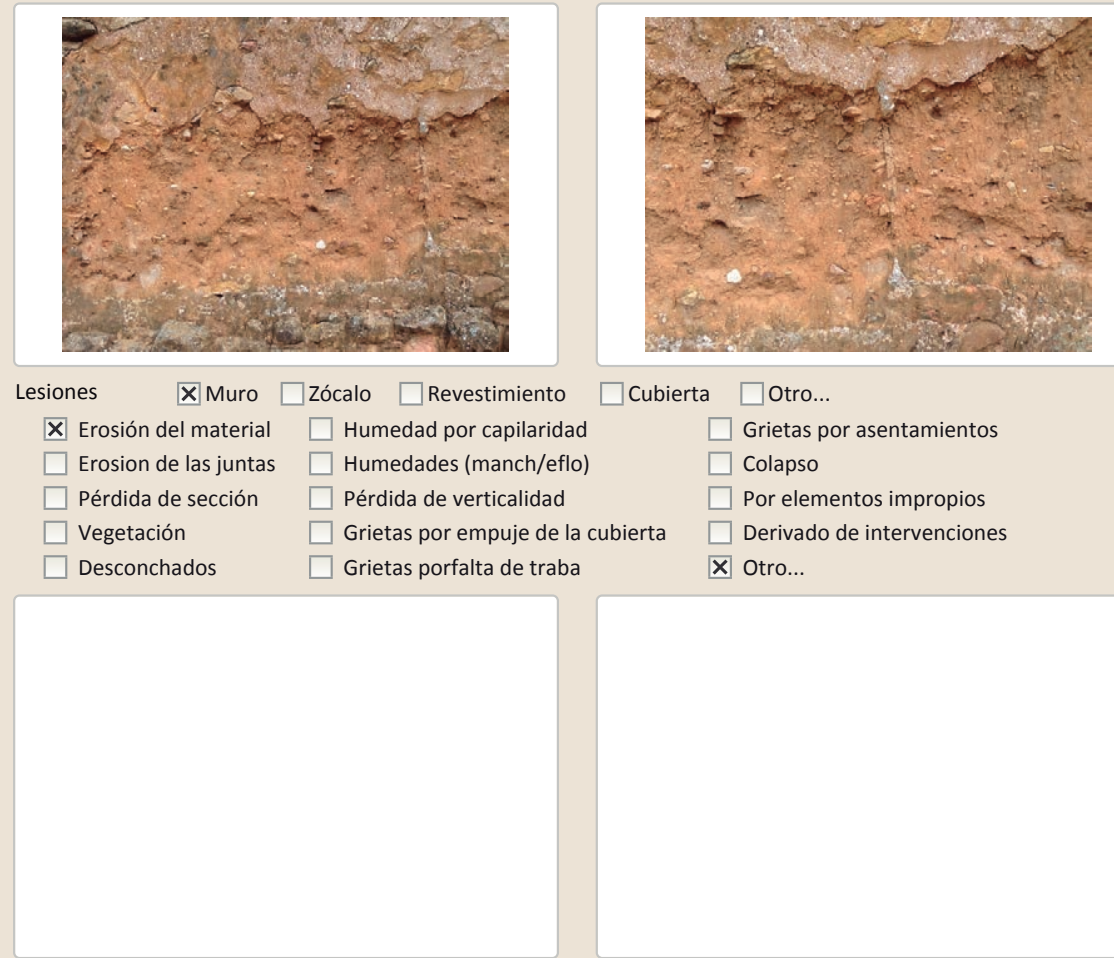

Observaciones
La restauración y rehabilitación de la arquitectura tradicional de tierra.

El caso de Aragón.

3. DATOS DE LA INTERVENCIÓN

Intervención de: $\quad \square$ Mantenimiento $\quad \square$ Rehabilitación parcial $\quad \square$ Restauración $\square$ Demolición

Reflexión previa Intervención espontanea

Observaciones

3.1. MUROS

Tipo de intervención

Tipo de material

Intervenido

$\square$ Actualización $\square$ Reintegración $\quad \square$ Demolición $\square$ Otro.

$\square$ Consolidación $\square$ Reconstrucción $\quad \mathbf{X}$ Sustitución

Descripción

Tipo de técnica Similar a la existente

3.2. ZÓCALO

Sustitución parcial del muro de adobe en el muro piñón por muro de ladrillo hueco

Tipo de intervención $\square$ Actualización $\square$ Reintegración $\square$ Demolición $\quad \square$ Otro...

Tipo de material

Actualización $\square$ Reintegración $\square$ Demolición
Consolidación $\square$ Reconstrucción $\square$ Sustitución

Descripción

3.3. REVESTIMIENTOS

Tipo de intervención

No aplica

Tipo de material

Descripción

3.4. VANOS

Tipo de intervención

Intervenido

$\square$ Actualización $\square$ Reintegración $\square$ Demolición $\square$ Otro..

$\square$ Consolidación $\square$ Reconstrucción $\mathbf{X}$ Sustitución

\begin{tabular}{l|l|l|l|l|l|l|l|l} 
Tipo de material & No tradicional de técnica & Diferente a la existente
\end{tabular}

Descripción

Sustitución de la puerta de acceso. La dimensión del hueco parece la misma

3.5. CUBIERTA

No intervenido

Tipo de intervención

$\square$ Actualización

$\square$ Consolidación

$\square$ Reintegración $\square$ Demolición $\square$ Otro...

Tipo de material

Descripción

3.6. OTRAS 
La restauración y rehabilitación de la arquitectura tradicional de tierra.

El caso de Aragón.

3.7. REHABILITACIÓN ENERGÉTICA

$\square$ Fachada $\quad \square$ Vanos $\square$ Forjados $\square$ Cubierta

Observaciones

FOTOGRAFÍAS DE LA INTERVENCIÓN
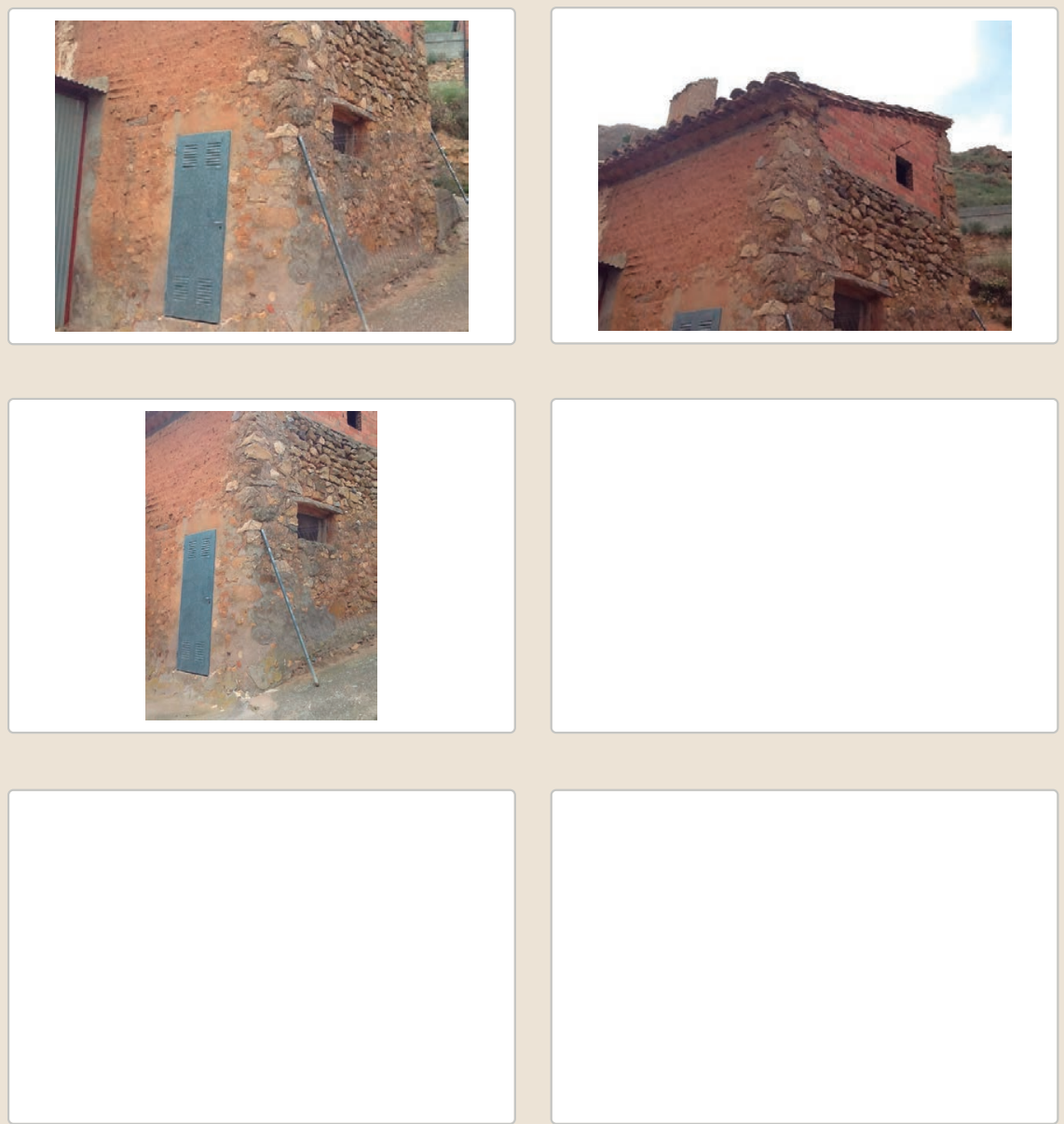

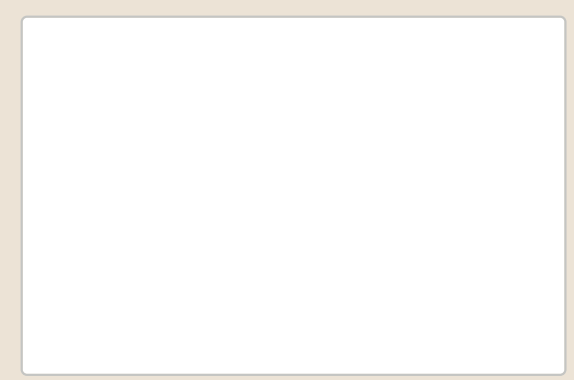




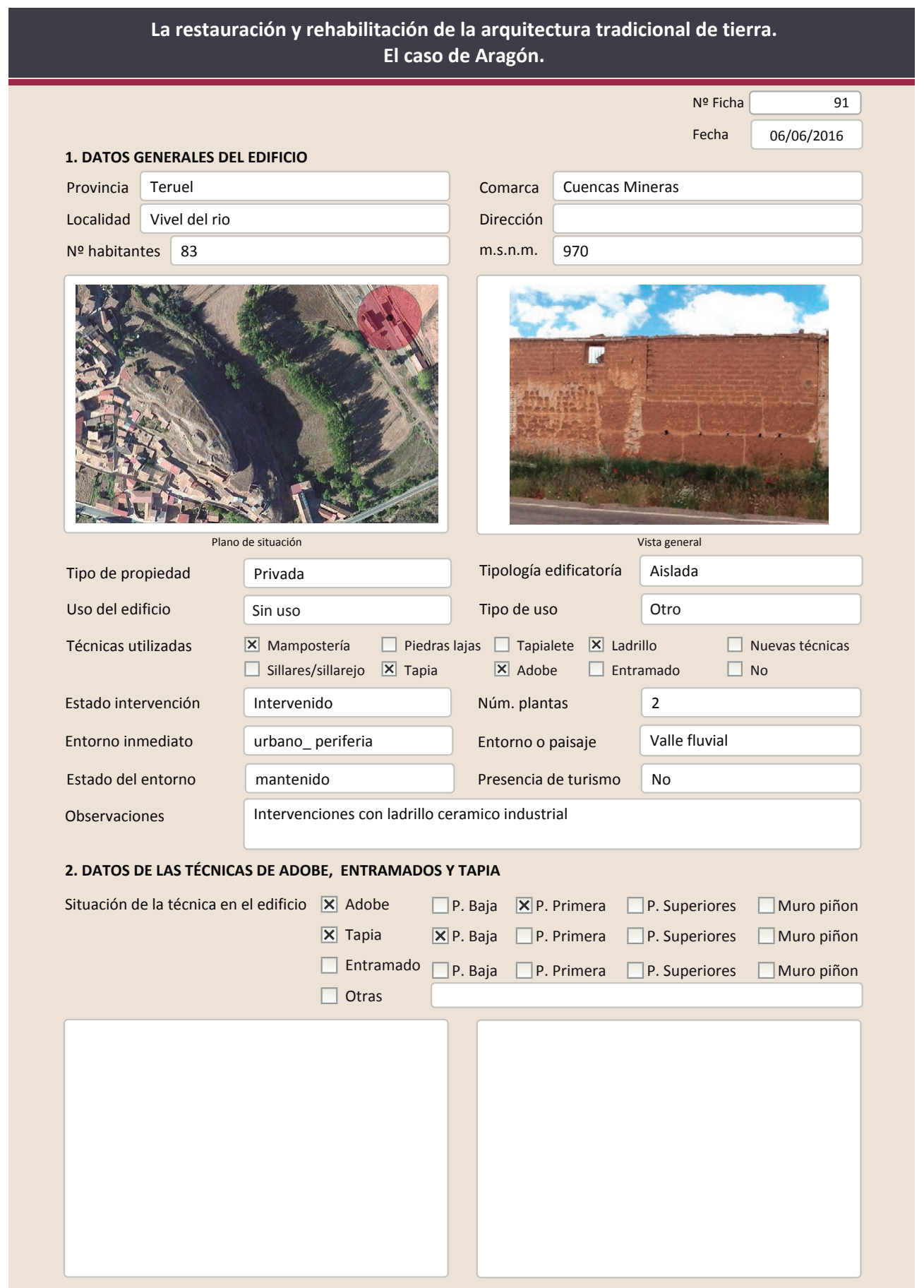

2.1. ADOBE

Dimensión de las piezas $40 \times 12$

Dimensión del muro

Aparejo del muro

$10-20 \mathrm{~cm}$

Función estructural

Soga

Variante constructiva/ tipo de fábrica

$\square$ Simple

区 Suplementada en juntas

Verticales y horizontales

区 Mixta

\section{Machones}

Color de las piezas

$\square$ Como suplemento

$\square$ Elementos de protección

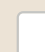

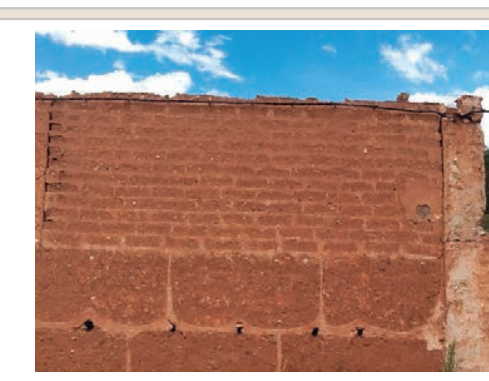

Lesiones $\quad$ Muro $\square$ Zócalo $\square$ Revestimiento $\square$ Cubierta $\square$ Otro...

\ Erosión del material $\square$ Humedad por capilaridad $\quad \square$ Grietas por asentamientos

$\square$ Erosion de las juntas $\square$ Humedades (manch/eflo) $\quad \square$ Colapso

$\square$ Pérdida de sección $\square$ Pérdida de verticalidad

$\square$ Por elementos impropios

$\square$ Vegetación

$\square$ Grietas por empuje de la

$\square$ Desconchados

$\square$ Grietas porfalta de traba

$\square$ Derivado
$\square$ Otro... 


\section{La restauración y rehabilitación de la arquitectura tradicional de tierra.}

\section{El caso de Aragón.}

\subsection{TAPIA}

Ancho del muro

Dimensión tapiales

Tipo de aguja

$170 \times 83$

Color de la tapia

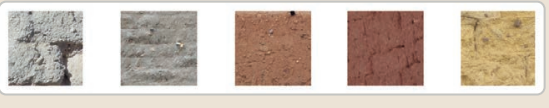

$\square$ Blanquecino $\quad \mathbf{X}$ Marrón $\square$ Amarillento

$\square$ Grisaceo $\square$ Rojizo $\square$ Otro...

3

Variante constructiva

$\square$ Simple / homogénea

$\square$ Suplemento superficial

$X$ Suplemento en juntas

X Mixta
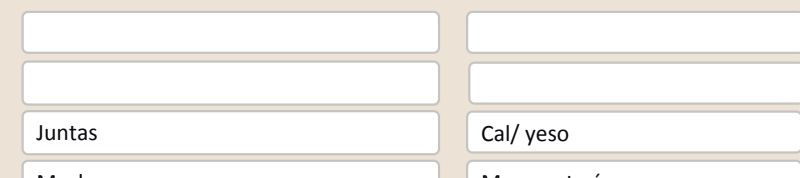

Cal/ yeso

$\square$ Elementos de protección

Mampostería y yeso

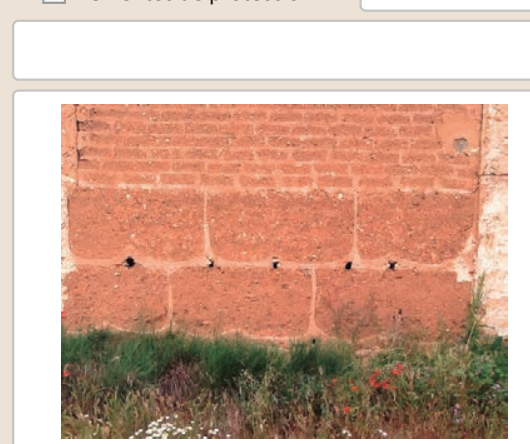

Lesiones ХMuro $\square$ Zócalo $\square$ Revestimiento $\square$ Cubierta $\square$ Otro...

X Erosión del material $\quad \square$ Humedad por capilaridad $\quad \square$ Grietas por asentamientos

$\square$ Erosion de las juntas $\square$ Humedades (manch/eflo) $\quad \square$ Colapso

$\square$ Pérdida de sección $\square$ Pérdida de verticalidad $\square$ Por elementos impropios

$\square$ Vegetación $\square$ Grietas por empuje de la cubierta $\square$ Derivado de intervenciones

$\square$ Desconchados $\square$ Grietas porfalta de traba $\quad \square$ Otro...
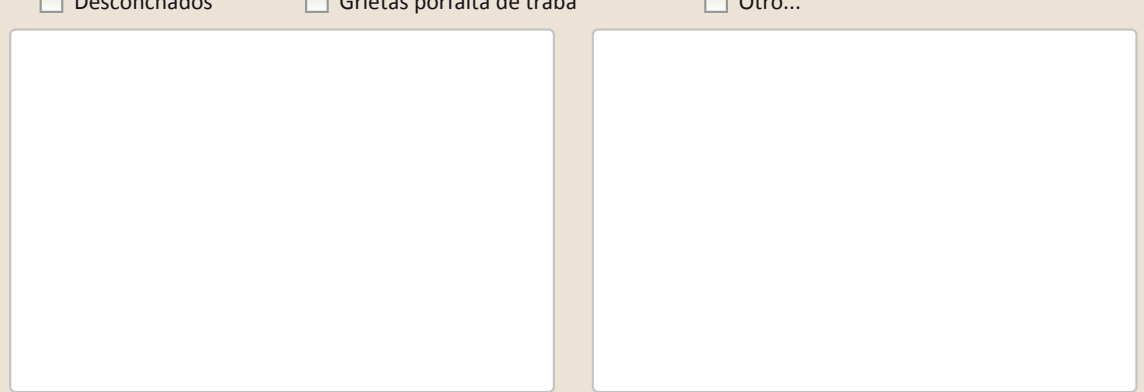

Observaciones

La restauración y rehabilitación de la arquitectura tradicional de tierra.

El caso de Aragón.

3. DATOS DE LA INTERVENCIÓN

Intervención de: $\quad \square$ Mantenimiento $\quad \mathbf{X}$ Rehabilitación parcial $\quad \square$ Restauración $\square$ Demolición

$\square$ Reparación $\quad \square$ Rehabilitación integral $\square$ Ampliación $\square$ Otro..

Reflexión previa Intervención espontanea

Observaciones

Intervención espontanea

3.1. MUROS

Tipo de intervención

Tipo de material

Descripción

3.2. ZÓCALO

Tipo de intervención

Tipo de material

Descripción

3.3. REVESTIMIENTOS

Tipo de intervención

\section{No aplica}

$\square$ Actualización $\square$ Reintegración $\square$ Demolición $\square$ Otro...

$\square$ Consolidación $\square$ Reconstrucción $\square$ sustitución

Tipo de material

Descripción

3.4. VANOS

Tipo de intervención

Intervenido

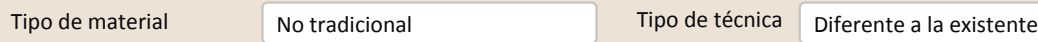

$\square$ Actualización $\square$ Reintegración $\square$ Demolición $\square$ Otro...

$\square$ Consolidación $\square$ Reconstrucción $\quad \boldsymbol{x}$ Sustitución

Descripción Se aprecia la ampliación del hueco de acceso y se han rehecho las jambas y dintel con ladrillo cerámico hueco

3.5. CUBIERTA

Tipo de intervención

No aplica

$\square$ Actualización $\square$ Reintegración $\quad \square$ Demolición $\quad \square$ Otro...

$\square$ Consolidación $\square$ Reconstrucción $\square$ Sustitución

Tipo de material

Descripción

$$
\text { Tipo de técnica }
$$

3.6. OTRAS 


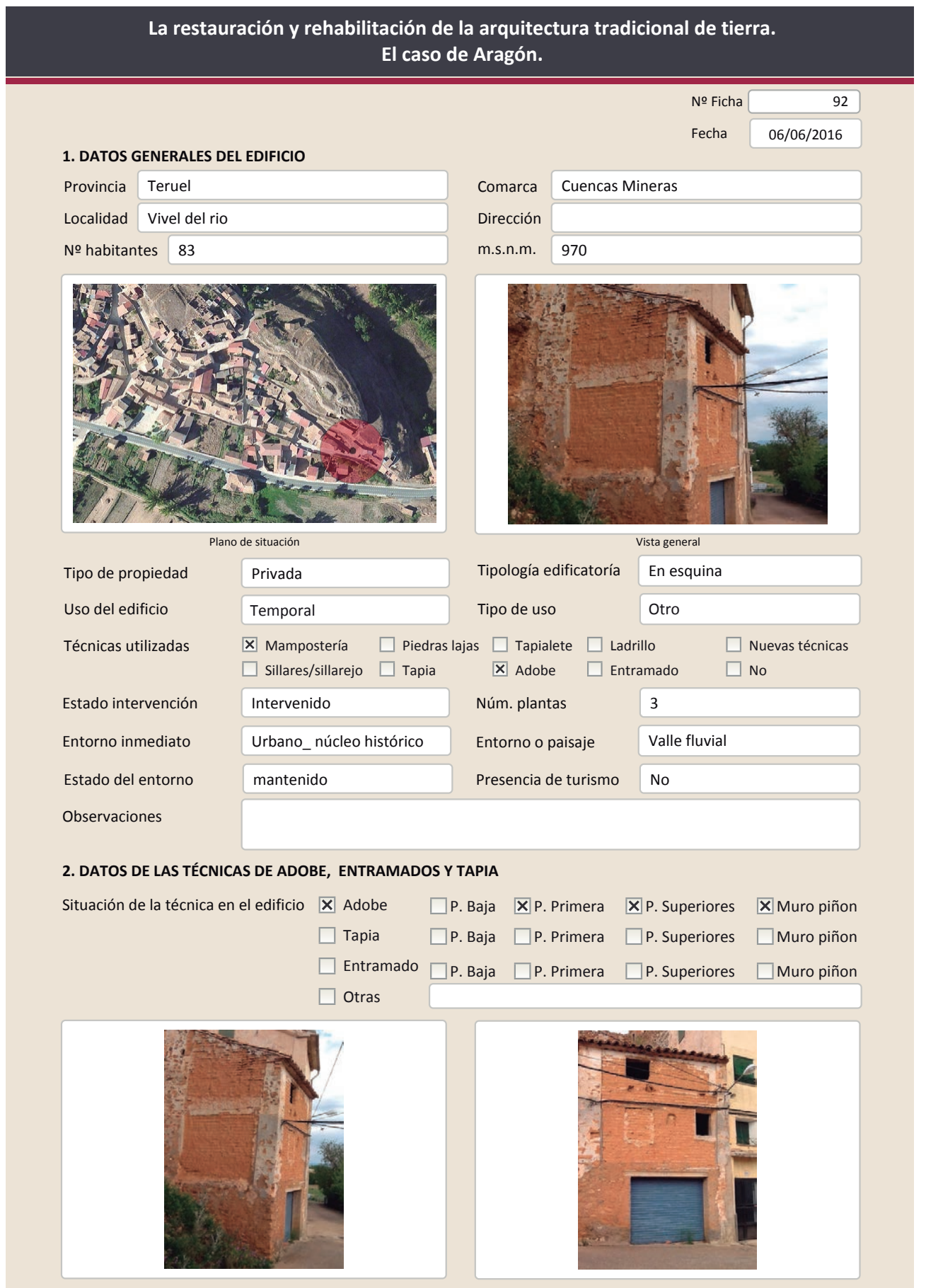

2.1. ADOBE

Dimensión de las piezas $10 \times 40$

Dimensión del muro

Aparejo del muro

$10-20 \mathrm{~cm}$

Función estructural

Variante constructiva/ tipo de fábrica

Color de las piezas

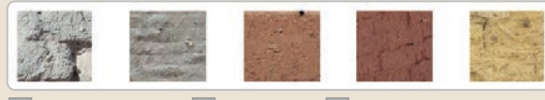

Blanquecino Х Marrón $\square$ Amarillento $\square$ Grisaceo $\square$ Rojizo $\square$ Otro..

Comp. - estabilizante Fibras vegetales

\section{$\square$ Simple}

区 Mixta

Horizontales

Cal/ yeso

$\square$ Como suplemento

Х Elementos de protección En esquinas Mampostería y yeso

Revestimiento

El revestimiento se ha perdido casi por completo

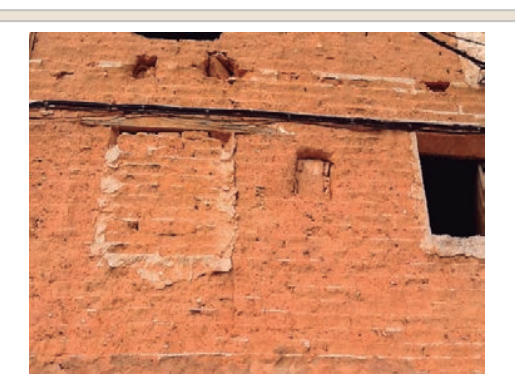

Lesiones $\mathbf{X}$ Muro $\mathbf{X}$ Zócalo $\mathbf{X}$ Revestimiento X Erosión del material $\square$ Humedad por capilaridad $\mathbf{X}$ Erosion de las juntas $\mathbf{X}$ Humedades (manch/eflo) \ Pérdida de sección $\quad \square$ Pérdida de verticalidad

$\square$ Vegetación $\quad \square$ Grietas por empuje de la cub $\square$ Desconchados $\square$ Grietas porfalta de traba

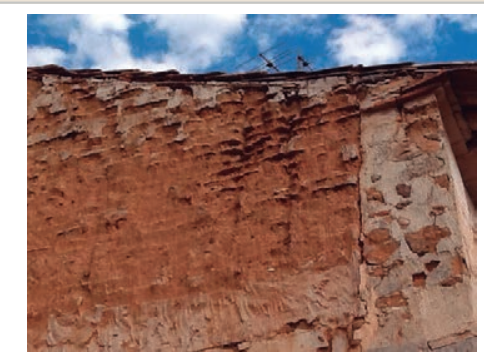

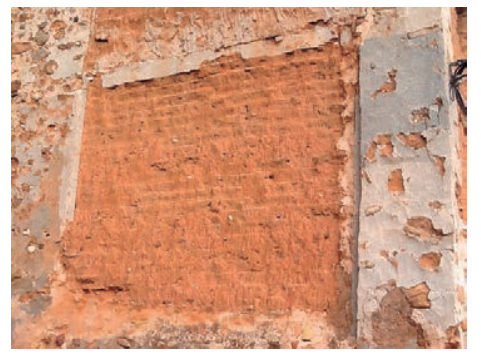

$\square$ Cubierta $\square$ Otro...

$\square$ Grietas por asentamientos $\square$ Colapso

$\square$ Por elementos impropios

$\square$ Derivado de intervenciones $\square$ Otro...

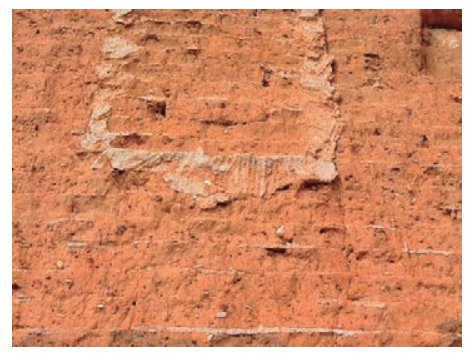

Observaciones 


\section{La restauración y rehabilitación de la arquitectura tradicional de tierra.}

\section{El caso de Aragón.}

3. DATOS DE LA INTERVENCIÓN

Intervención de:

$\square$ Mantenimie

X Rehabilitacion parcial Reparación $\square$ Rehabilitación parcial $\square$ Restauración $\square$ Demolición

Reflexión previa Intervención espontanea

Observaciones Nuevo hueco en planta baja. Puerta de garaje

\begin{tabular}{|c|c|c|c|c|}
\hline 3.1. MUROS & No intervenido & & & \\
\hline Tipo de intervención & $\begin{array}{l}\square \text { Actualización } \\
\square \text { Consolidación }\end{array}$ & $\begin{array}{l}\square \text { Reintegración } \\
\square \text { Reconstrucción }\end{array}$ & $\begin{array}{l}\square \text { Demolición } \\
\square \text { Sustitución }\end{array}$ & n $\square$ Otro... \\
\hline Tipo de material & \multicolumn{4}{|c|}{ Tipo de técnica } \\
\hline \multicolumn{5}{|l|}{ Descripción } \\
\hline 3.2. ZÓCALO & \multicolumn{4}{|l|}{ Intervenido } \\
\hline Tipo de intervención & $\begin{array}{l}\square \text { Actualización } \\
\square \text { Consolidación }\end{array}$ & \multicolumn{3}{|c|}{$\begin{array}{ll}\mathbf{X} \text { Reintegración } & \square \text { Demolición } \quad \square \text { Otro... } \\
\square \text { Reconstrucción } & \square \text { Sustitución }\end{array}$} \\
\hline Tipo de material & No tradicional & & oo de técnica $D$ & Diferente a la existente \\
\hline Descripción & \multicolumn{4}{|c|}{ Se ha rejuntado el zócalo con cemento en toda la planta baja } \\
\hline 3.3. REVESTIMIENTOS & \multicolumn{4}{|l|}{ No intervenido } \\
\hline Tipo de intervención & $\begin{array}{l}\square \text { Actualización } \\
\square \text { Consolidación }\end{array}$ & $\begin{array}{l}\square \text { Reintegración } \\
\square \text { Reconstrucción }\end{array}$ & $\begin{array}{l}\square \text { Demolición } \\
\square \text { Sustitución }\end{array}$ & n $\square$ Otro... \\
\hline Tipo de material & \multicolumn{4}{|c|}{ Tipo de técnica } \\
\hline \multicolumn{5}{|l|}{ Descripción } \\
\hline 3.4. VANOS & \multicolumn{4}{|l|}{ Intervenido } \\
\hline Tipo de intervención & $\begin{array}{l}\square \text { Actualización } \\
\square \text { Consolidación }\end{array}$ & \multicolumn{3}{|c|}{$\begin{array}{l}\square \text { Reintegración } \quad \square \text { Demolición } \quad \square \text { Otro... } \\
\square \text { Reconstrucción } \quad \text { X Sustitución }\end{array}$} \\
\hline Tipo de material & No tradicional & & oo de técnica $D$ & Diferente a la existente \\
\hline Descripción & \multicolumn{4}{|c|}{$\begin{array}{l}\text { Nuevo hueco en planta baja para permitir el acceso de vehículos. Nueva carpintería } \\
\text { metálica }\end{array}$} \\
\hline 3.5. CUBIERTA & \multicolumn{4}{|l|}{ No intervenido } \\
\hline Tipo de intervención & $\begin{array}{l}\square \text { Actualización } \\
\square \text { Consolidación }\end{array}$ & $\begin{array}{l}\square \text { Reintegración } \\
\square \text { Reconstrucción }\end{array}$ & $\begin{array}{l}\square \text { Demoliciór } \\
\square \text { Sustituciór }\end{array}$ & ón $\square$ Otro... \\
\hline Tipo de material & \multicolumn{4}{|c|}{ Tipo de técnica } \\
\hline Descripción & & & & \\
\hline
\end{tabular}

3.6. OTRAS
La restauración y rehabilitación de la arquitectura tradicional de tierra.

El caso de Aragón.

3.7. REHABILITACIÓN ENERGÉTICA $\quad \square$ Fachada $\square$ Vanos $\square$ Forjados $\square$ Cubierta

Observaciones

FOTOGRAFíAS DE LA INTERVENCIÓN
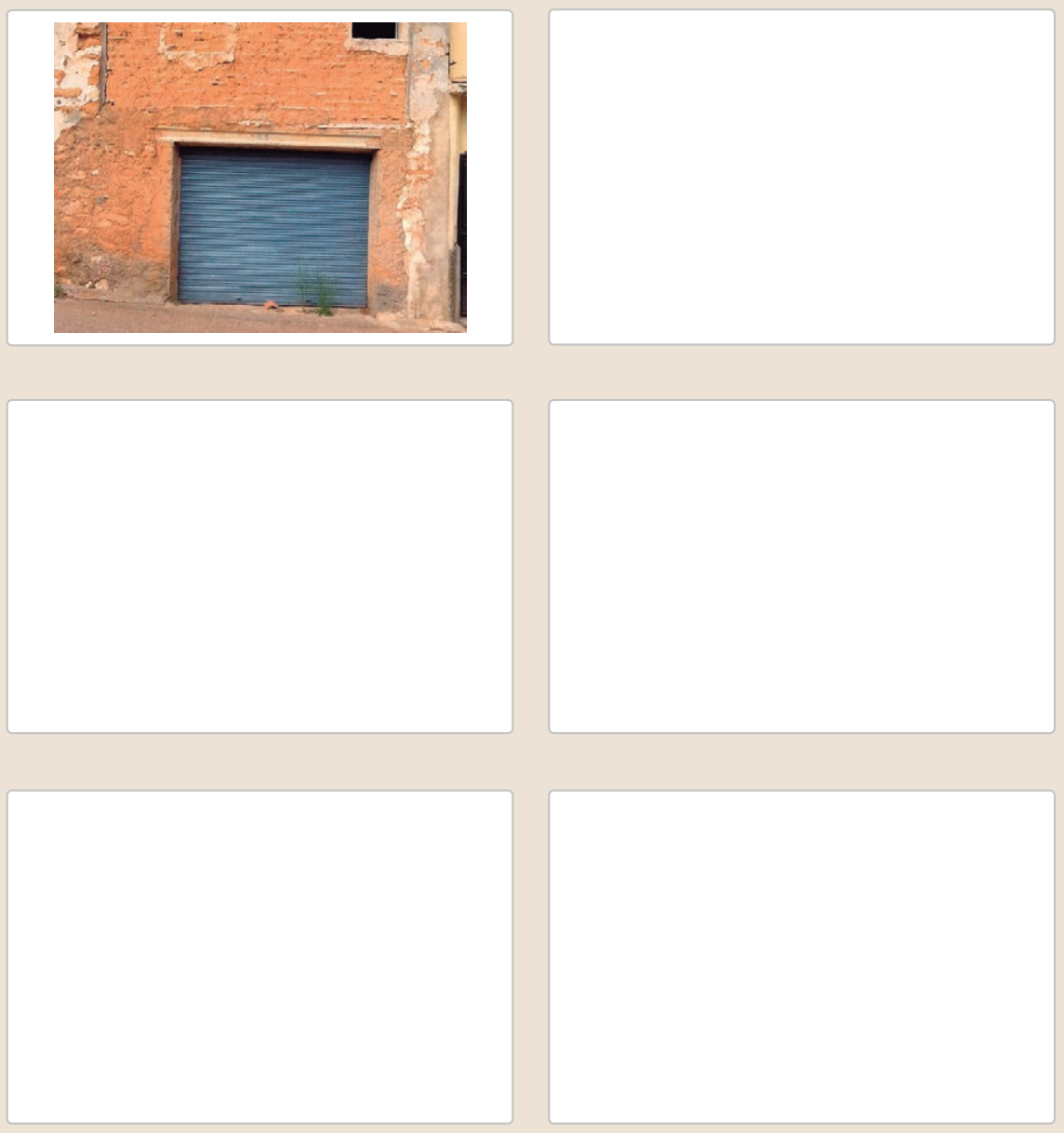


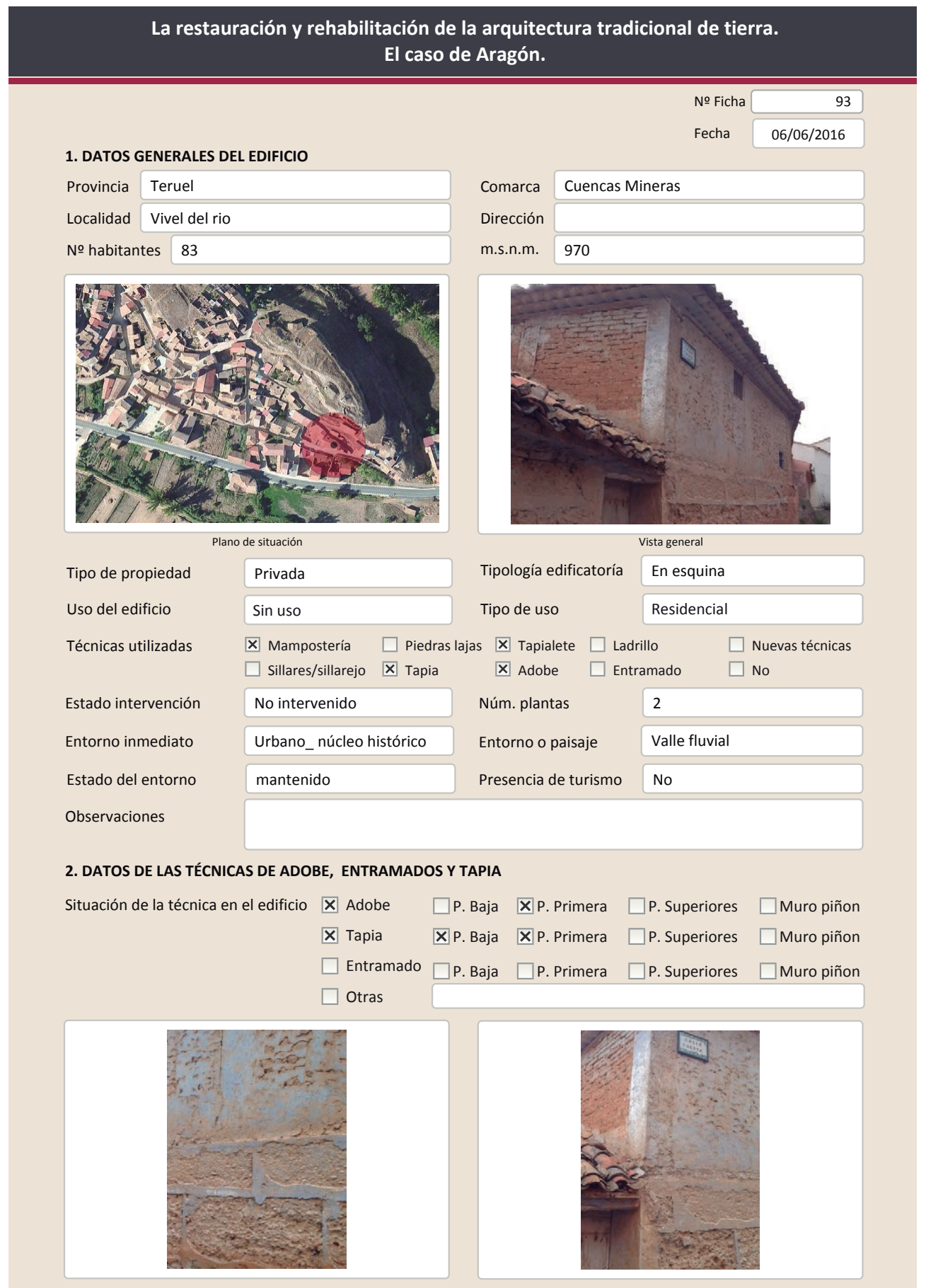

2.1. ADOBE

Dimensión de las piezas Dimensión del muro

Aparejo del muro

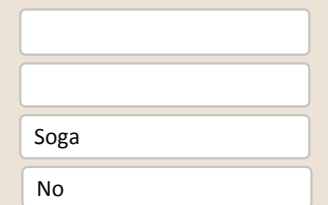

Color de las piezas

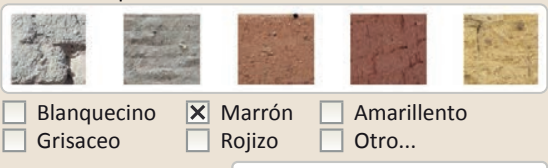

Función estructural

Rojizo -

Variante constructiva/ tipo de fábrica

$\square$ simple

$\square$ Suplementada en juntas

区 Mixta

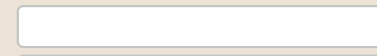

$\square$ Como suplemento

$\square$ Elementos de protección

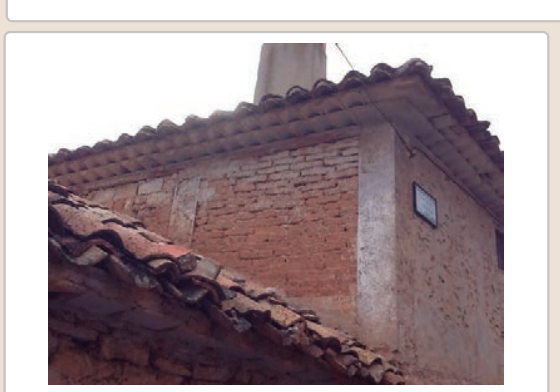

Lesiones $\quad \mathbf{X}$ Muro $\square$ Zócalo $\square$ Revestimiento

Х Erosión del material $\square$ Humedad por capilaridad

$\square$ Erosion de las juntas $\square$ Humedades (manch/eflo)

$\square$ Pérdida de sección

$\square$ Pérdida de verticalidad

$\square$ Vegetación

$\square$ Grietas por empuje de la cub

$\square$ Grietas porfalta de traba

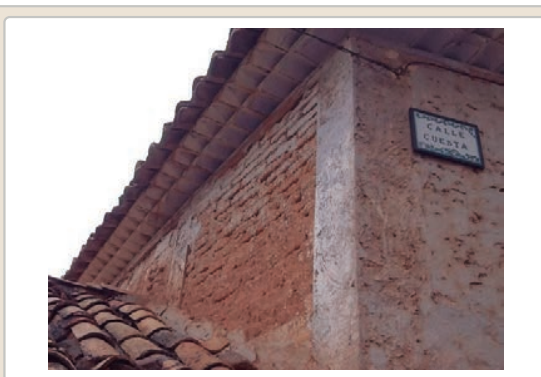

$\square$ Desconchados

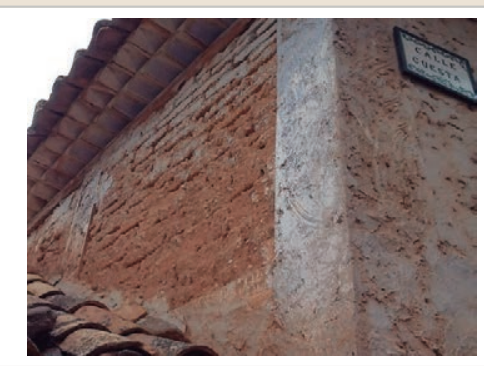

Observaciones 
La restauración y rehabilitación de la arquitectura tradicional de tierra.

El caso de Aragón.

\subsection{TAPIA \\ Ancho del muro}

Dimensión tapiales

Tipo de aguja

№ agujas/cajón

Variante constructiva

X Simple / homogénea

$\square$ suplemento superficial

$\mathbf{X}$ Suplemento en juntas

X Mixta

Machones de rafas

Color de la tapia

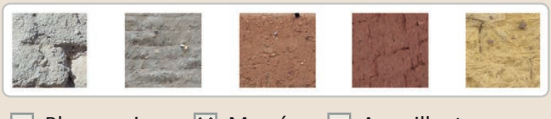

$\square$ Blanquecino $\mathbf{X}$ Marrón $\square$ Amarillento $\square$ Grisaceo

Cal/ yeso

Mampostería y yeso

Dos tipos diferentes en el mismo muro

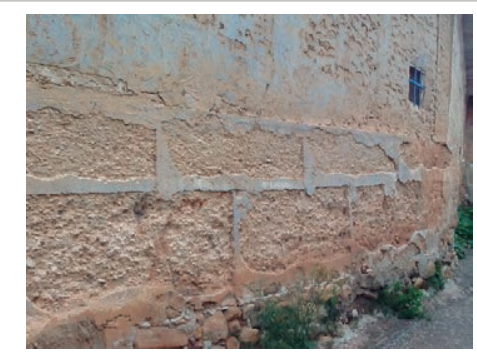

Lesiones \Muro $\square$ Zócalo $\square$ Revestimiento $\square$ Cubierta $\square$ Otro...

X Erosión del material $\quad \square$ Humedad por capilaridad $\quad \square$ Grietas por asentamientos

$\square$ Erosion de las juntas $\square$ Humedades (manch/eflo)

$\square$ Pérdida de sección $\square$ Pérdida de verticalidad

$\square$ Colapso

$\square$ Vegetación $\quad \square$ Grietas por empuje de la

Por elementos impropios

$\square$ Desconch

$\square$ Grietas porfalta de trab

$\square$ Otro...
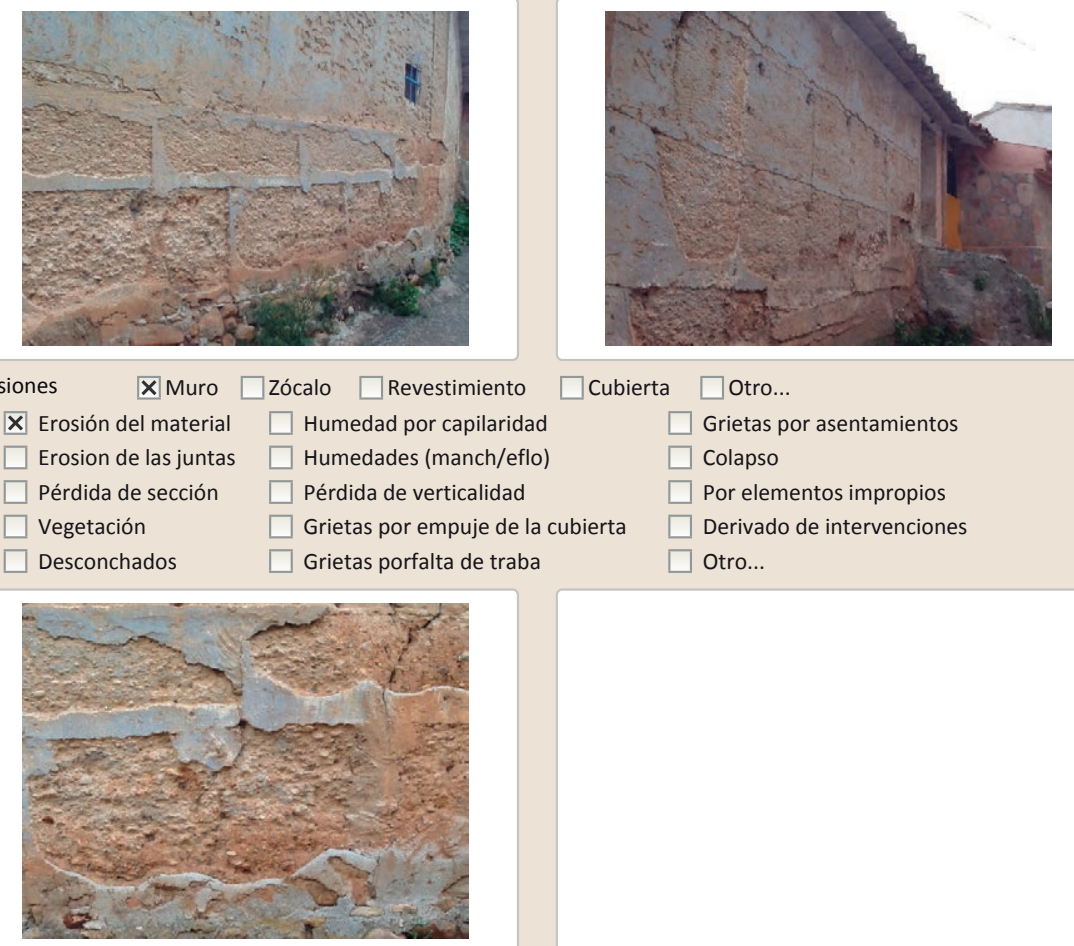

observaciones 


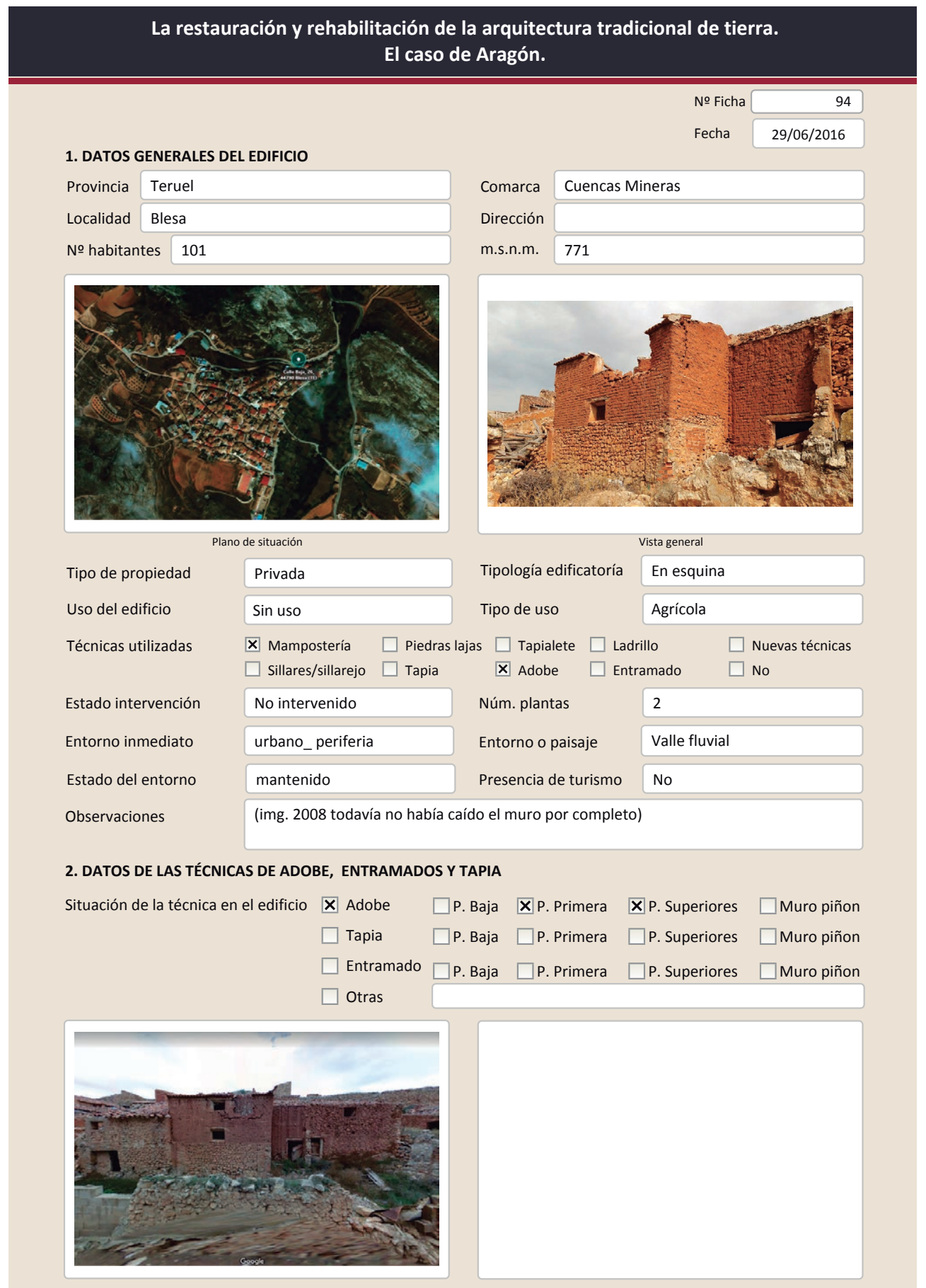

2.1. ADOBE

Dimensión de las piezas Dimensión del muro

Aparejo del muro

Función estructural

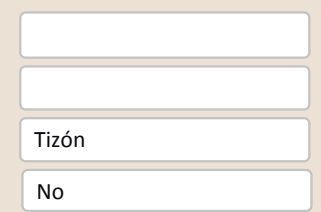

Color de las piezas

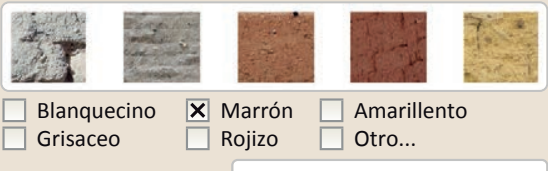

Variante constructiva/ tipo de fábrica

$\square$ Simple
Horizontales

Fibras vegetales
X Suplementada en juntas
$\square$ Mixta
$\square$ Como suplemento

$\square$ Elementos de protección

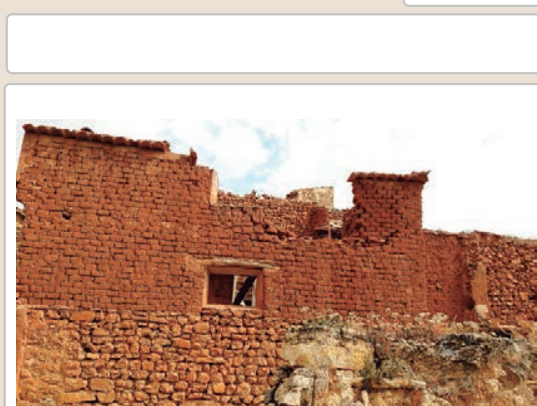
Lesiones $\quad \mathbf{X}$ Muro $\square$ Zócalo $\square$ Revestimiento $\quad \mathbf{X}$ Cubierta $\square$ Otro...
$\mathbf{X}$ Erosión del material $\quad \square$ Humedad por capilaridad $\quad \square$ Grietas por asentamiento $\square$ Erosion de las juntas $\square$ Humedades (manch/eflo) $\quad$ X Colapso
$\square$ Pérdida de sección $\square$ Pérdida de verticalidad
$\square$ Vegetación $\quad \square$ Grietas por empuje de la cube
$\square$ Por elementos impropios
$\square$ Desconchados
$\square$ Grietas porfalta de traba
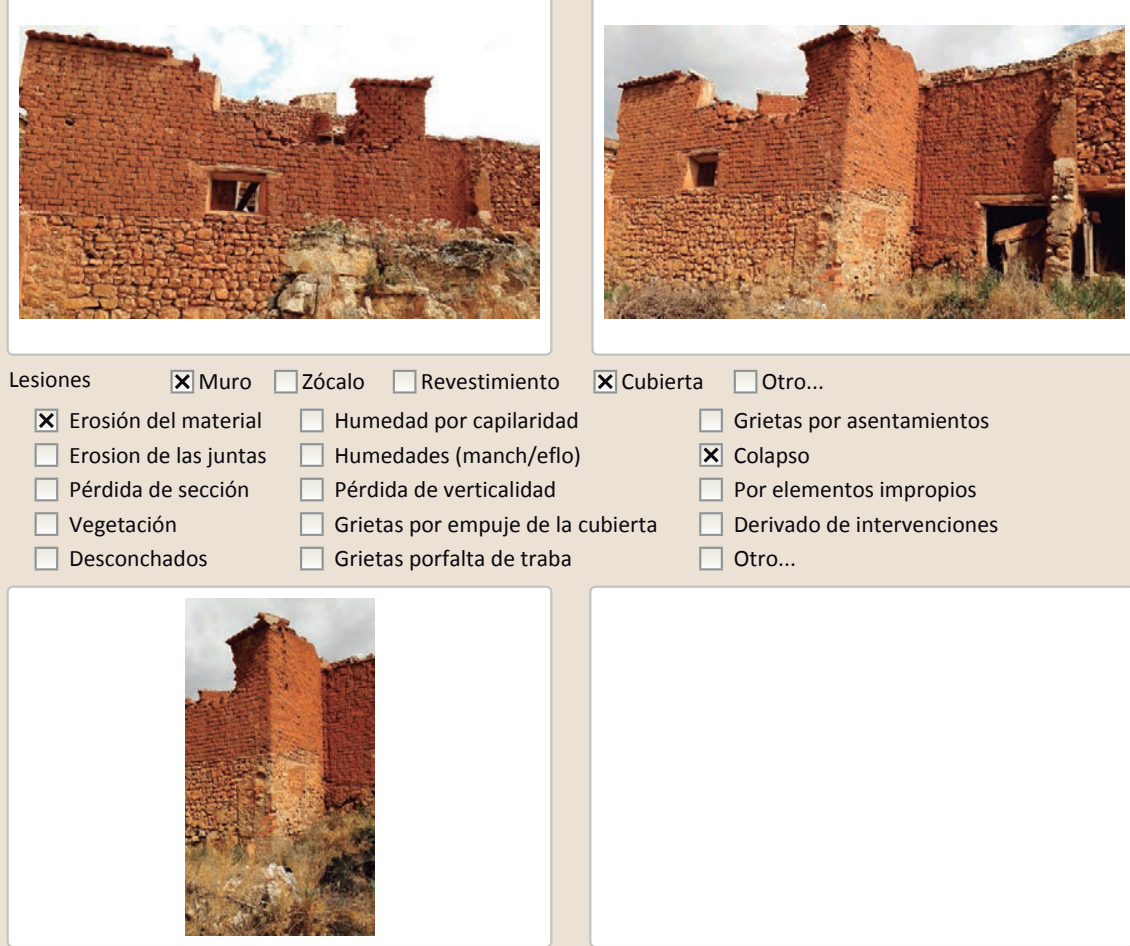

Observaciones

Edificio abandonado muy degradado y parcialmente derrumbado 


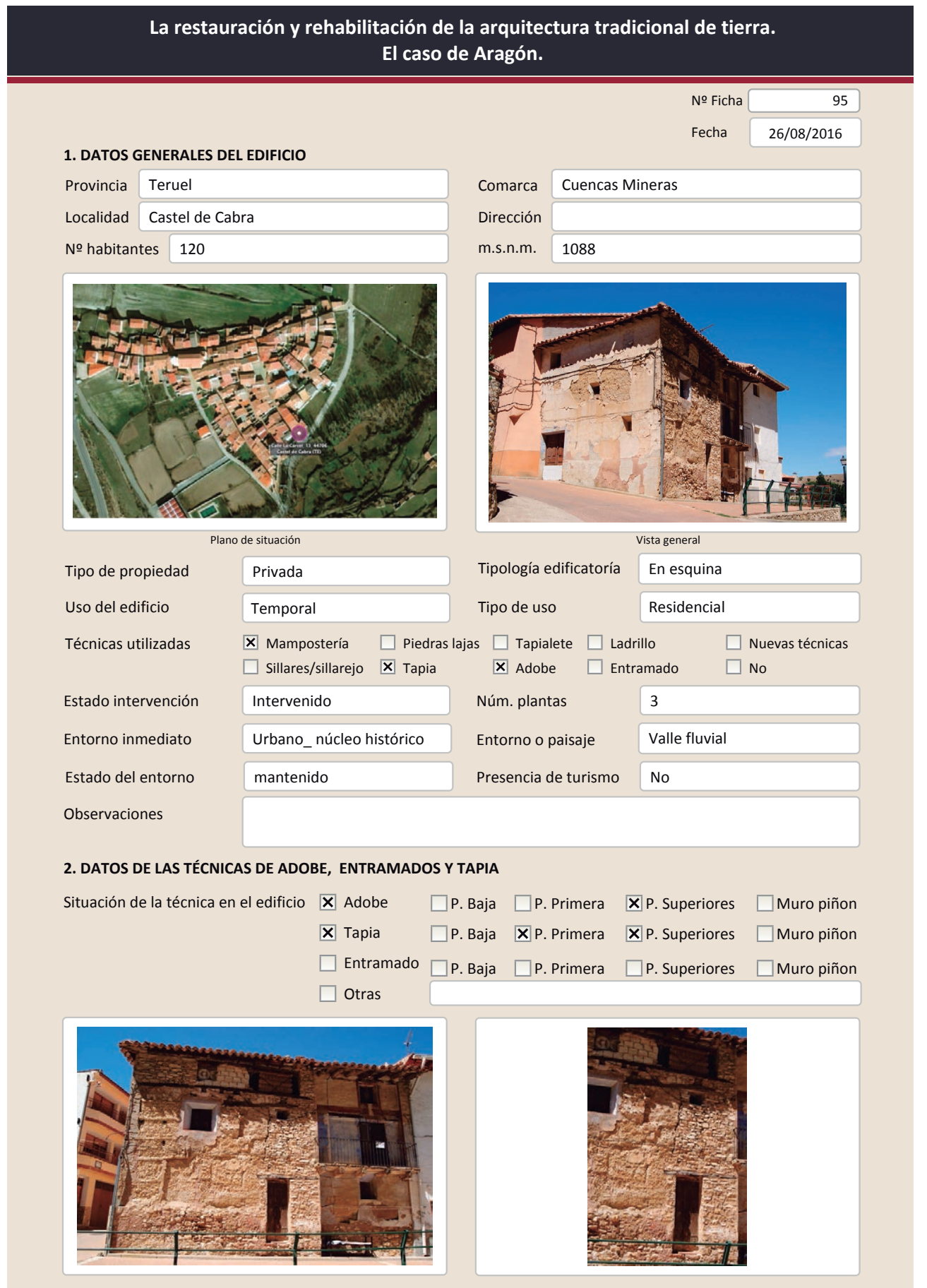

La restauración y rehabilitación de la arquitectura tradicional de tierra.

El caso de Aragón.

2.1. ADOBE

Dimensión de las piezas

Dimensión del muro

Aparejo del muro

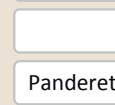

Función estructural

No

Variante constructiva/tipo de fábrica

X simple

$\square$ suplementada en juntas

$\square$ Mixta

$\square$ Como suplemento

$\square$ Elementos de protección

Solo en una pequeña zona bajo cubierta.

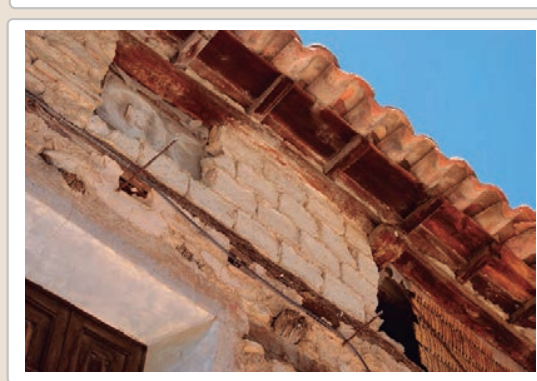

Lesiones

$\square$ Muro $\square$ Zócalo $\square$ Revestimiento

$\square$ Erosión del material $\quad \square$ Humedad por capilaridad

$\square$ Erosion de las juntas $\square$ Humedades (manch/eflo)

$\square$ Pérdida de sección $\square$ Pérdida de verticalidad

$\square$ Vegetación

$\square$ Grietas por empuje de la $\square$ Grietas porfalta de traba
Color de las piezas

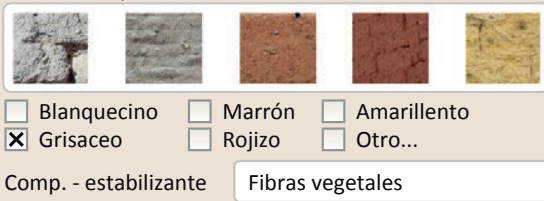

Comp. - estabilizante Fibras vegetales

cubierta $\quad \square$ Derivado de intervenciones
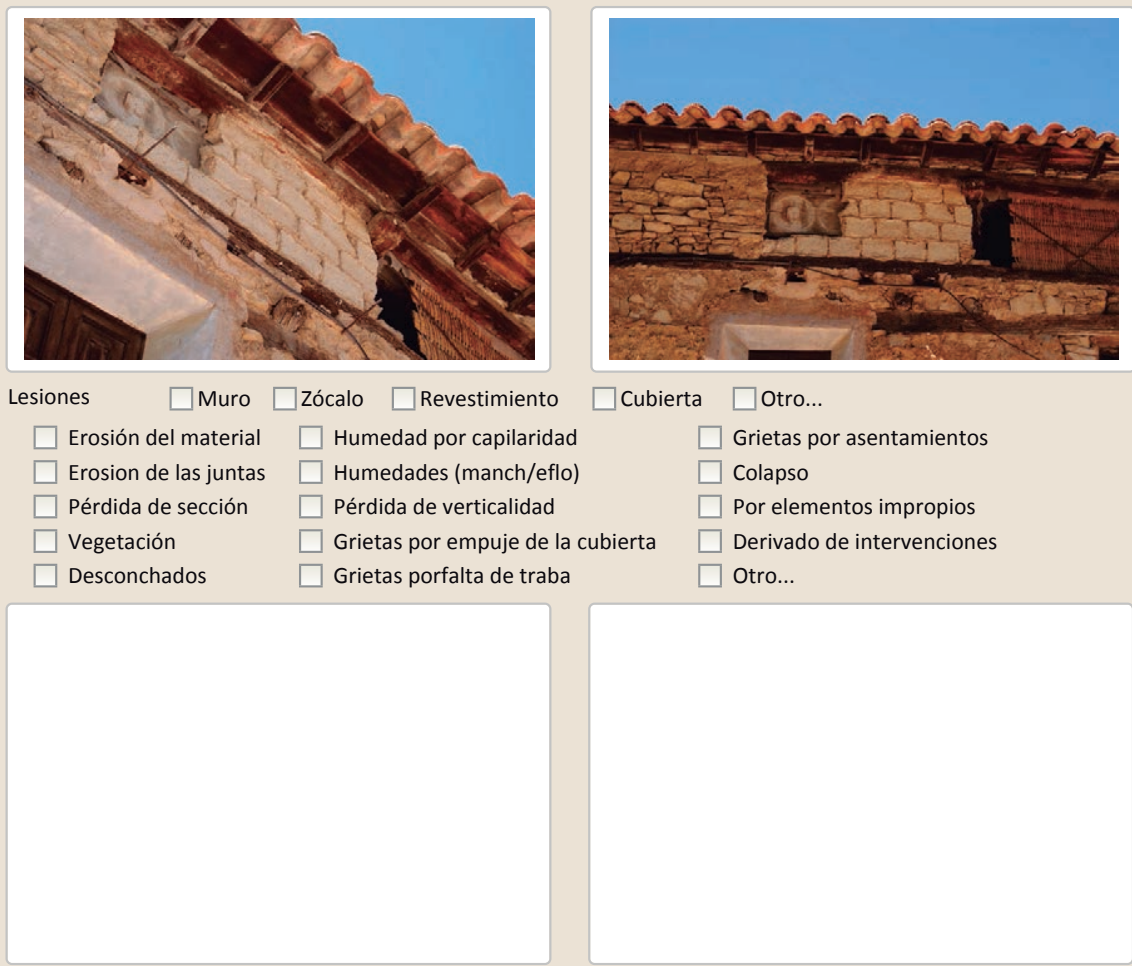

Observaciones

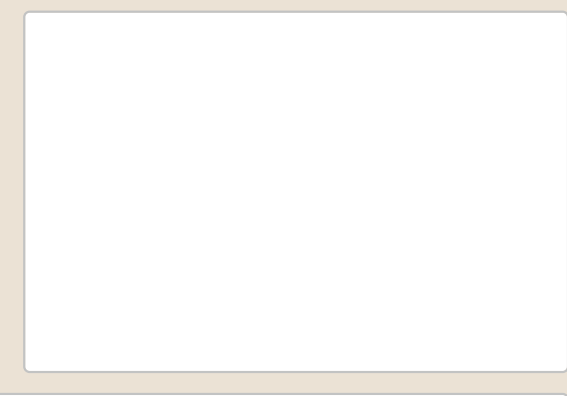




\section{La restauración y rehabilitación de la arquitectura tradicional de tierra.} El caso de Aragón.

\subsection{TAPIA}

Ancho del muro

Dimensión tapiales

Tipo de aguja

\begin{tabular}{|l|}
\hline $50-60 \mathrm{~cm}$ \\
\hline \\
\hline \\
\hline
\end{tabular}

\section{Color de la tapia}

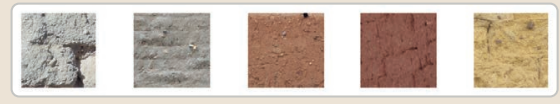

$\square$ Blanquecino $\quad \mathbf{X}$ Marrón $\square$ Amarillento

$\square$ Grisaceo $\square$ Rojizo $\square$ Otro...

Variante constructiva

X Simple / homogénea

$\square$ Suplemento superficial

$X$ Suplemento en juntas

$\square$ Mixta

X Elementos de protección
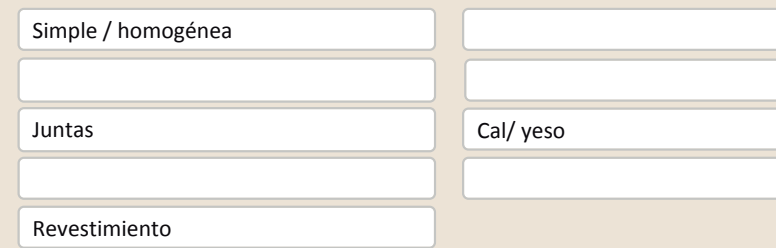

Existen dos tipos de tapia distintas en el edificio.

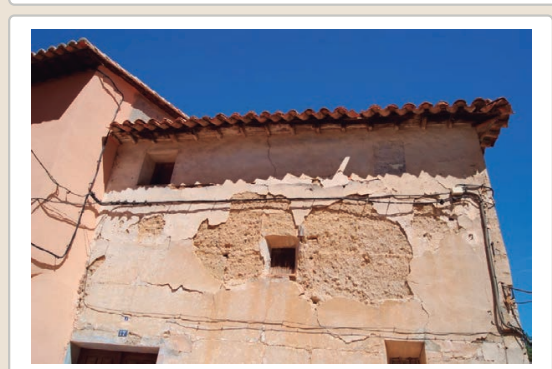

Lesiones

XMuro ХZócalo ХRevestimiento

$\mathbf{X}$ Erosión del material $\square$ Humedad por capilaridad

$\square$ Cubierta $\square$ otro

$\square$ Erosion de las juntas $\square$ Humedades (manch/eflo)

$\square$ Pérdida de sección $\square$ Pérdida de verticalidad

$\begin{array}{ll}\square \text { Vegetación } & \square \text { Grietas por empuje de la } \\ \mathbf{X} \text { Desconchados } & \mathbf{X} \text { Grietas porfalta de traba }\end{array}$

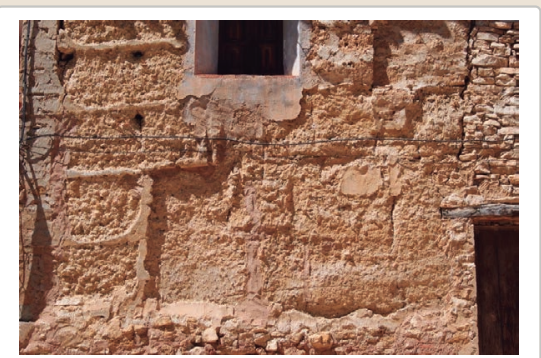

$\square$ Grietas por asentamiento

$\square$ Colapso

$\square$ Por elementos impropios

$\square$ Derivado de intervenciones

$\square$ Otro...
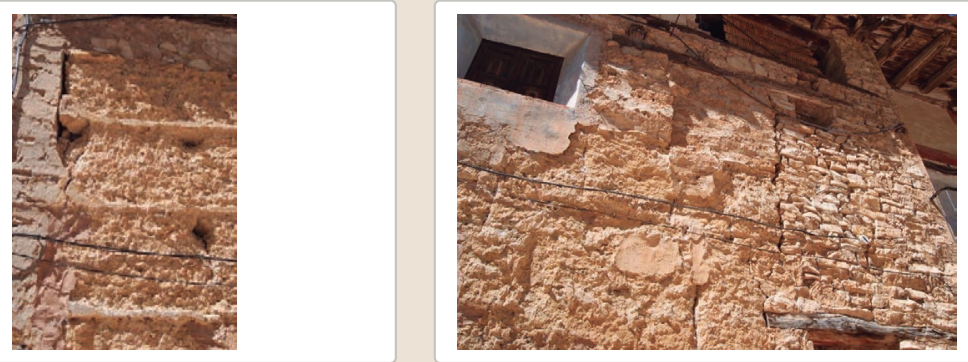

La restauración y rehabilitación de la arquitectura tradicional de tierra. El caso de Aragón.

3. DATOS DE LA INTERVENCIÓN

Intervención de: $\quad \square$ Mantenimiento $\quad \square$ Rehabilitación parcial $\quad \square$ Restauración $\square$ Demolición

Reflexión previa Intervención espontanea

Observaciones

3.1. MUROS

Tipo de intervención

No intervenido

Tipo de material

Descripción

3.2. ZÓCALO

Tipo de intervención

Tipo de material

Descripción

3.3. REVESTIMIENTOS

Tipo de intervención

Tipo de material

Descripción

3.4. VANOS

Tipo de intervención

No intervenido

$\square$ Actualización $\square$ Reintegración $\square$ Demolición $\square$ Otro.

$\square$ Consolidación $\quad \square$ Reconstrucción $\square$ Sustitución

Tipo de material

Descripción

3.5. CUBIERTA

Tipo de intervención

Tipo de material

Descripción

No intervenido

$\square$ Actualización $\square$ Reintegración $\square$ Demolición $\square$ Otro

$\square$ Consolidación $\square$ Reconstrucción $\square$ Sustitución Tipo de técnica

\section{Tipo de técnica}

Observaciones

3.6. OTRAS 
La restauración y rehabilitación de la arquitectura tradicional de tierra. El caso de Aragón.

3.7. REHABILITACIÓN ENERGÉTICA

$\square$ Fachada $\square$ Vanos $\square$ Forjados $\square$ Cubierta

Observaciones

FOTOGRAFÍAS DE LA INTERVENCIÓN
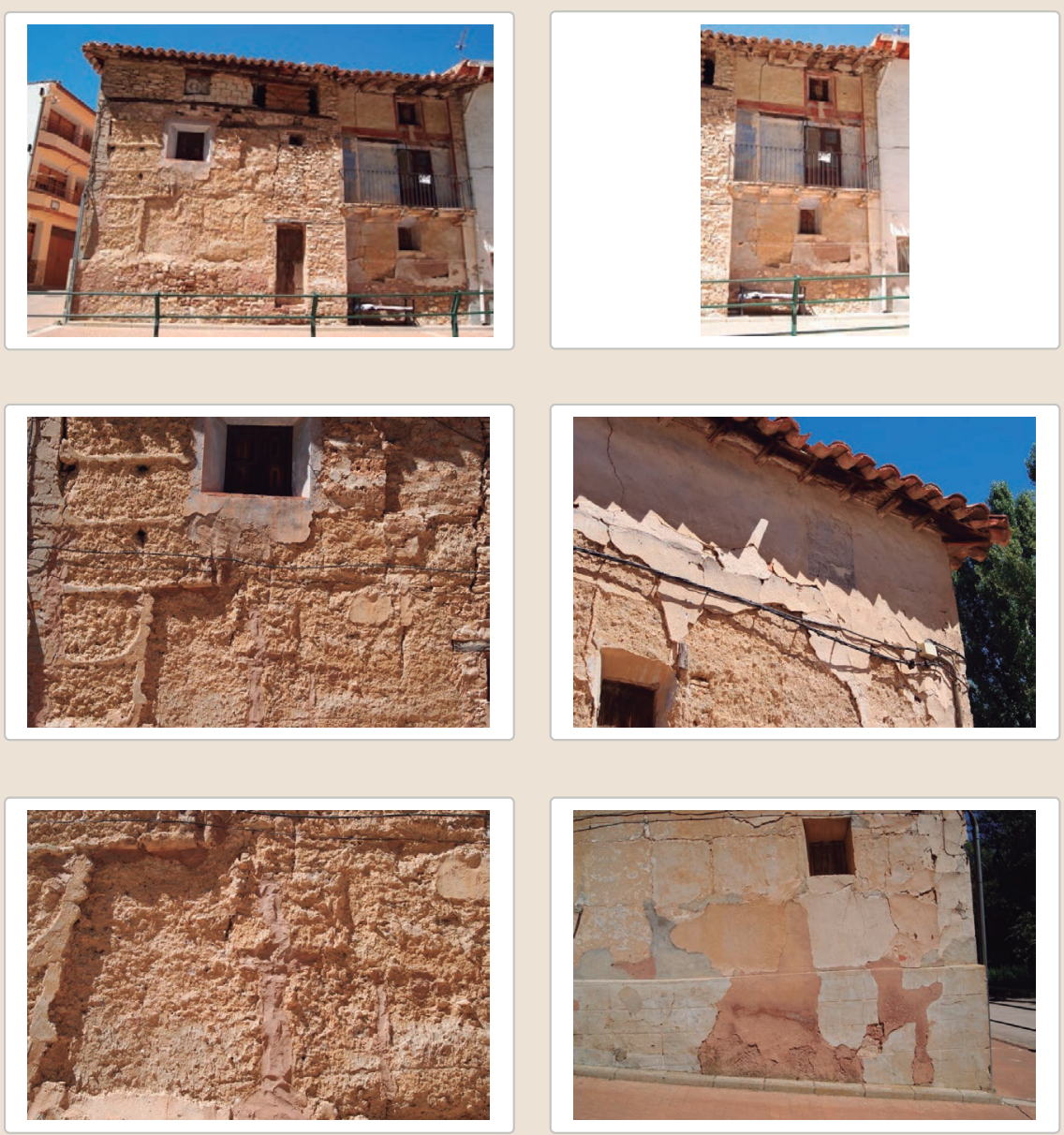
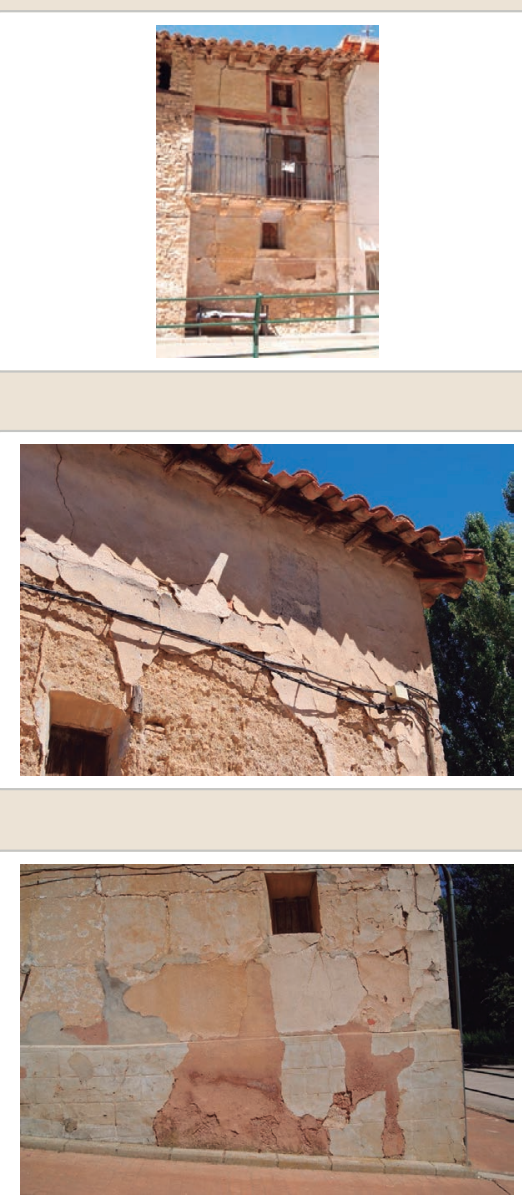


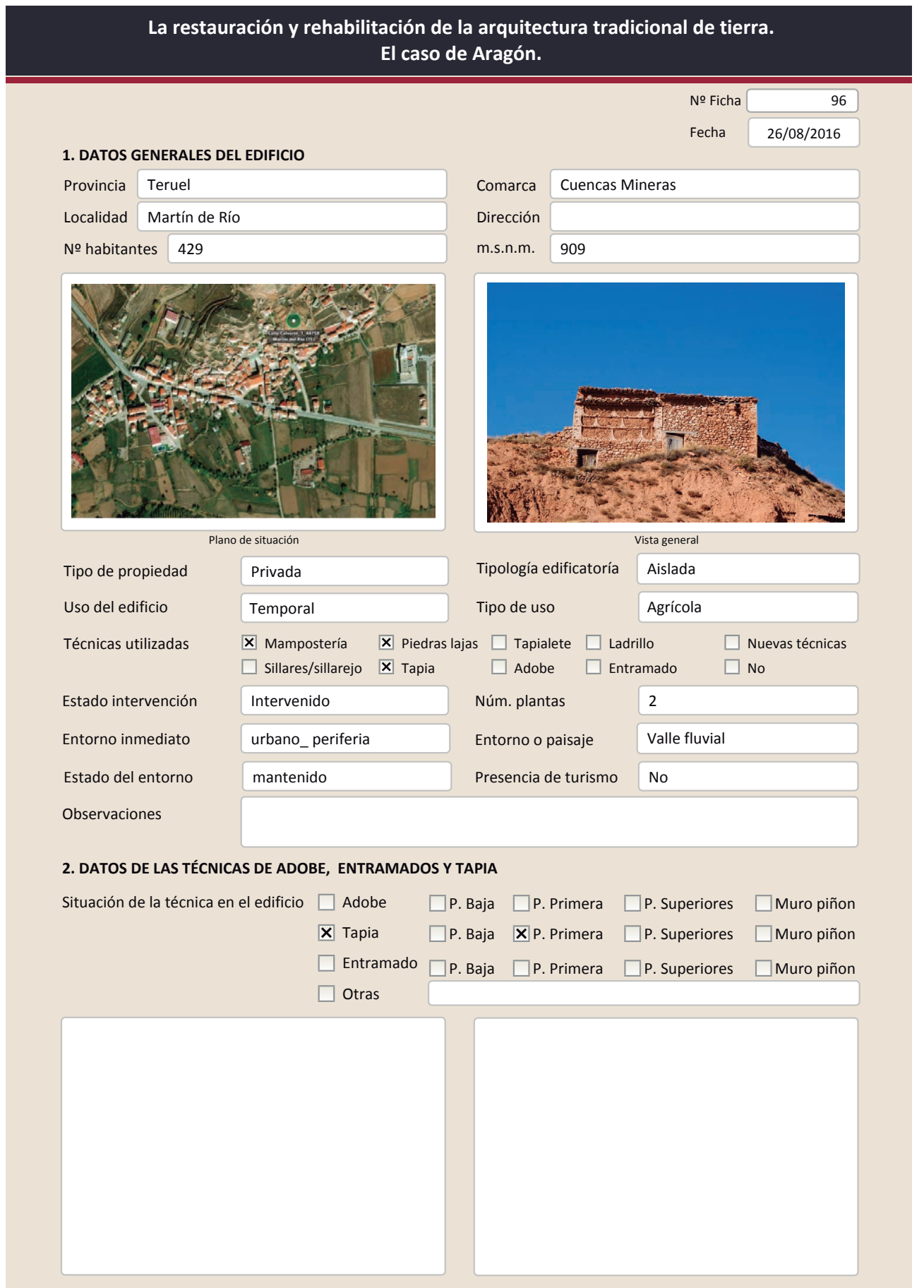

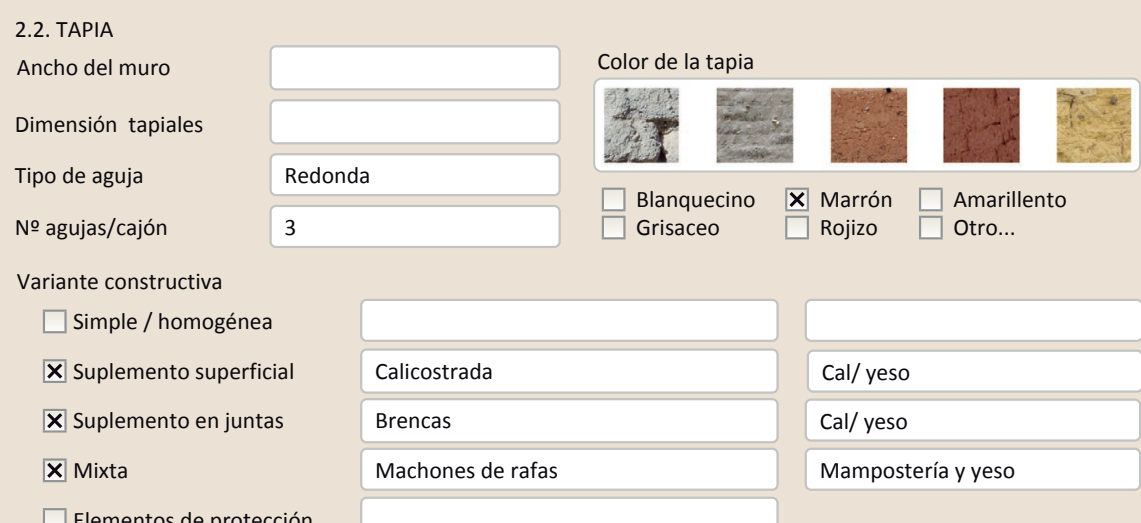

de protección

En el lateral izquierdo parece estar calicostrada con yeso y cascotes, el mismo material que las brencas en este

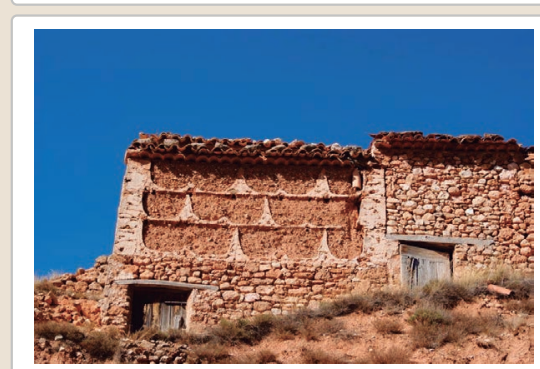

Lesiones $\mathrm{XMuro} \square$ Zócalo $\square$ Revestimiento

X Erosión del material $\quad \square$ Humedad por capilaridad $\quad \square$ Grietas por asentamientos $\square$ Erosion de las juntas $\square$ Humedades (manch/eflo) $\quad \square$ Colapso

X Pérdida de sección $\quad \square$ Pérdida de verticalidad $\quad \square$ Por elementos impropios

Vegetación

$\square$ Desconchados

$\square$ Grietas porfalta de traba

$\square$ Otro...

Observaciones 
La restauración y rehabilitación de la arquitectura tradicional de tierra.

El caso de Aragón.

3. DATOS DE LA INTERVENCIÓN

\begin{tabular}{llll|} 
Intervención de: & $\square$ Mantenimiento $\quad \square$ Rehabilitación parcial & $\square$ Restauración $\quad \square$ Demolición \\
Reflexión previa & $\mathbf{X}$ Reparación $\quad \square$ Rehabilitación integral $\quad \square$ Ampliación $\quad \square$ Otro... \\
\hline Observaciones & Intervención espontanea & \\
& & \\
& & \\
\end{tabular}

\subsection{MUROS}

Tipo de intervención

Intervenido

Tipo de material

$\square$ Actualización $\square$ Reintegración $\square$ Demolición $\square$ Otro...

$\square$ Consolidación $\square$ Reconstrucción $\bigotimes$ Sustitución

Descripción

No tradicional Tipo de técnica Diferente a la existente

Descripción Sustitución del muro piñón por muro de lad
la fachada principal que está retranqueada

\subsection{ZÓCALO}

Tipo de intervención

No intervenido

Tipo de material

$\square$ Actualización

Descripción

3.3. REVESTIMIENTOS

Tipo de intervención

\section{No aplica}

Tipo de material

$\square$ Actualización $\square$ Reintegración $\square$ Demolición $\square$ Otro...

$\square$ Reintegración $\quad \square$ Demolición

Descripción

3.4. VANOS

Tipo de intervención

No intervenido

Tipo de material

$\square$ Actualización $\quad \square$ Reintegración $\quad \square$ Demolición $\quad \square$ Otro...
$\square$ Consolidación $\quad \square$ Reconstrucción $\quad \square$ Sustitución

Descripción

3.5. CUBIERTA

Tipo de intervención

No intervenido

$\square$ Actualización $\square$ Reintegración $\square$ Demolición $\square$ Otro...

Tipo de material

$\square$ Reconstrucción $\square$ Sustitución

Descripción

Tipo de técnica

3.6. OTRAS 


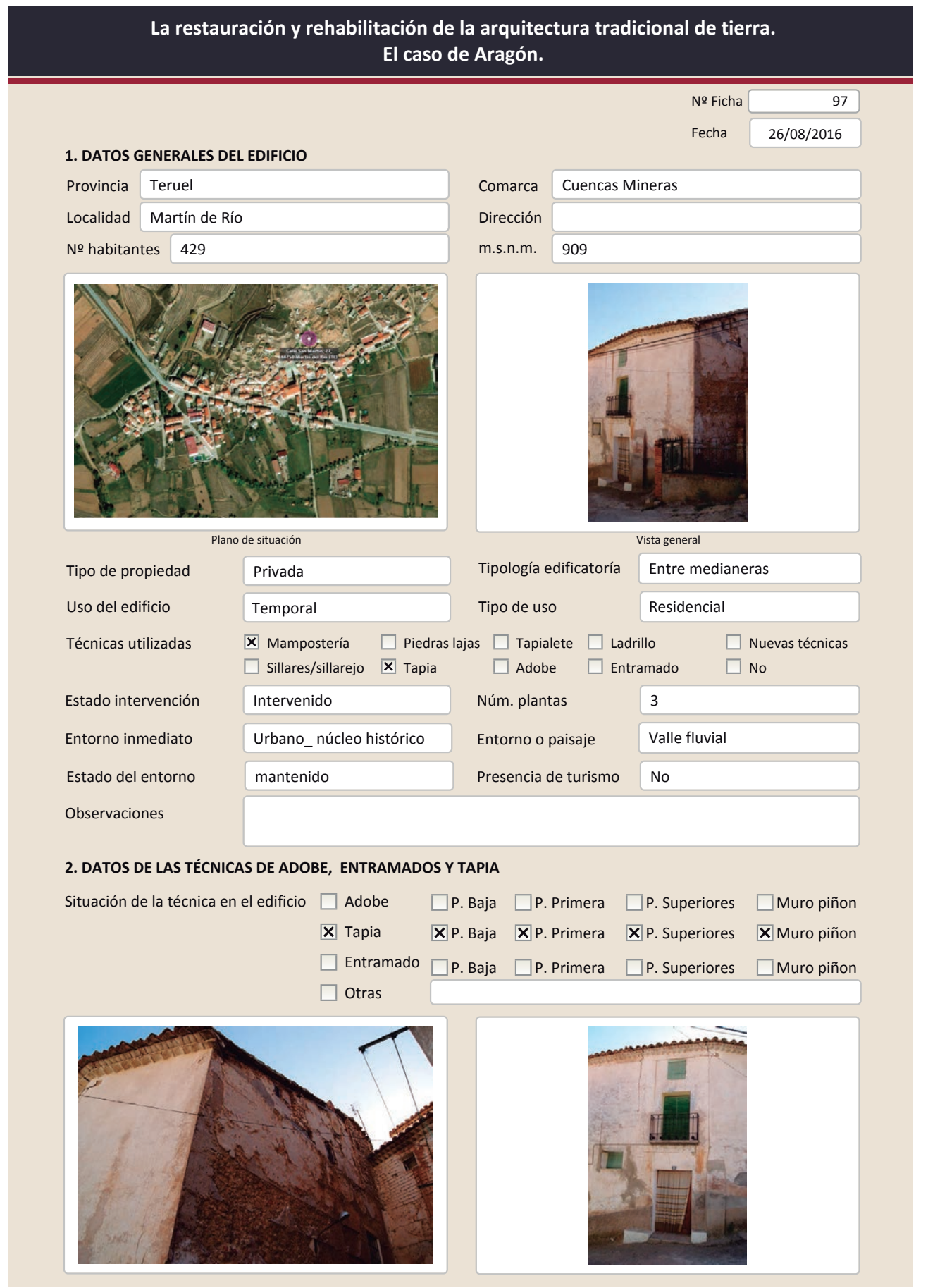

2.2. TAPIA

Ancho del muro

Dimensión tapiales

Tipo de aguja

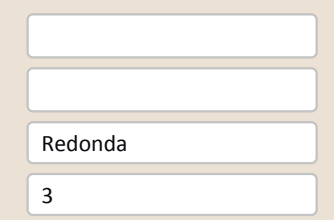

Color de la tapia

№ agujas/cajón

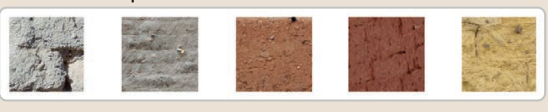

$\square$ Blanquecino $\mathbf{X}$ Marrón $\square$ Amarillento

$\begin{array}{ll}\square \text { Blanquecino } & \mathbf{x} \text { Marrón } \\ \square \text { Grisaceo } & \square \text { Amajizo } \quad \square \text { Otro... }\end{array}$

Variante constructiva

$\square$ Simple / homogénea

X Suplemento superficial

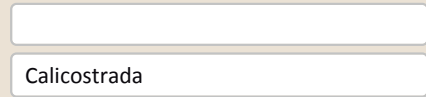

$\mathbf{X}$ Suplemento en juntas

$\mathbf{X}$ Mixta

Calicostrada

Machones de rafas

Cal/ yeso

Revestimiento

Revestimiento solo en la fachada principal

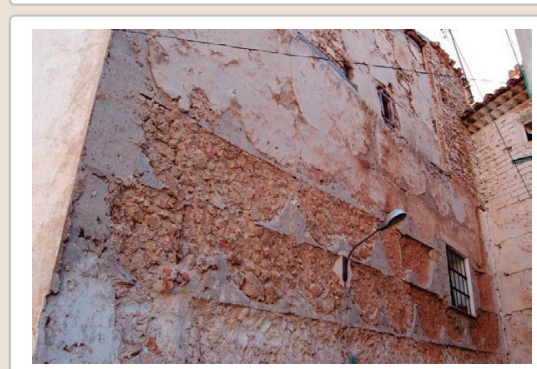

Lesiones $\quad$ Muro $\square$ Zócalo $\square$ Revestimiento $\square$ Cubierta $\square$ otro...

X Erosión del material $\square$ Humedad por capilaridad $\quad \mathbf{X}$ Grietas por asentamiento $\square$ Erosion de las juntas $\square$ Humedades (manch/eflo)

X Pérdida de sección $\quad \square$ Pérdida de verticalidad

$\square$ Vegetación $\quad \square$ Grietas por empuje de la cubierta

$\mathbf{X}$ Desconchados

$\square$ Grietas porfalta de traba
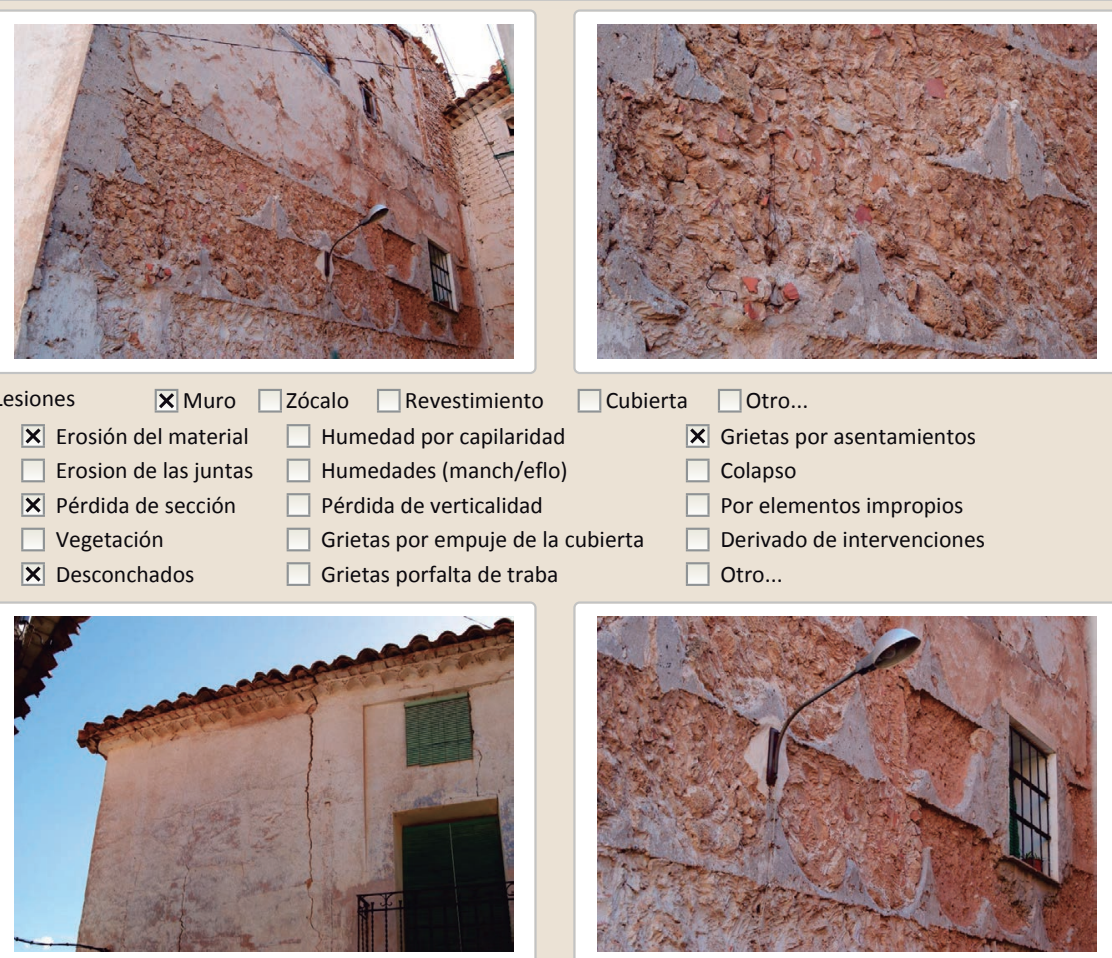

$\square$ Por elementos impropios

$\square$ Derivado de intervenciones

$\square$ otro...

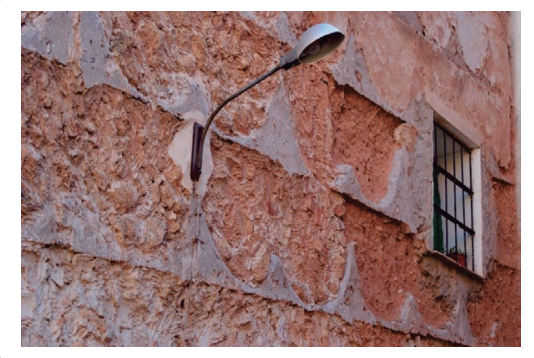

Observaciones 


\section{La restauración y rehabilitación de la arquitectura tradicional de tierra.}

\section{El caso de Aragón.}

3. DATOS DE LA INTERVENCIÓN

Mantenimiento $\square$ Rehabilitación parcial

Reflexión previa X Reparación $\square$ Rehabilitación integra Ampliación $\square$ otro..

Observaciones

Intervención espontanea

Observaciones

\subsection{MUROS} Tipo de intervención Tipo de material

Descripción

3.2. ZÓCALO Tipo de intervención Tipo de material

Descripción

3.3. REVESTIMIENTOS Tipo de intervención Tipo de material

Descripción

3.4. VANOS

Tipo de intervención

Tipo de material Descripción

3.5. CUBIERTA Tipo de intervención Tipo de material Descripción

3.6. OTRAS
Actualización $\quad \mathbf{X}$ Reintegración $\square$ Demolición $\square$ Otro. $\square$ Consolidación $\square$ Reconstrucción $\square$ Sustitución No tradicional Tipo de técnica Similar a la existente Recolocación de las tejas del lateral con mortero de cemento \begin{tabular}{l} 
ración \\
rucción \\
\hline Demolición
\end{tabular}

$$
\text { Tipo de técnica }
$$

$\square$ Actualización $\square$ Reintegración $\square$ Demolición $\square$ Otro...

Recocaion delas tejas del hatera con motero decemento $\square$ Consolidación $\quad \square$ Reconstrucción $\square$ Sustitución
Tipo de técnica
La restauración y rehabilitación de la arquitectura tradicional de tierra. El caso de Aragón.

3.7. REHABILITACIÓN ENERGÉTICA $\square$ Fachada $\square$ Vanos $\square$ Forjados $\square$ Cubierta

Observaciones

FOTOGRAFÍAS DE LA INTERVENCIÓN
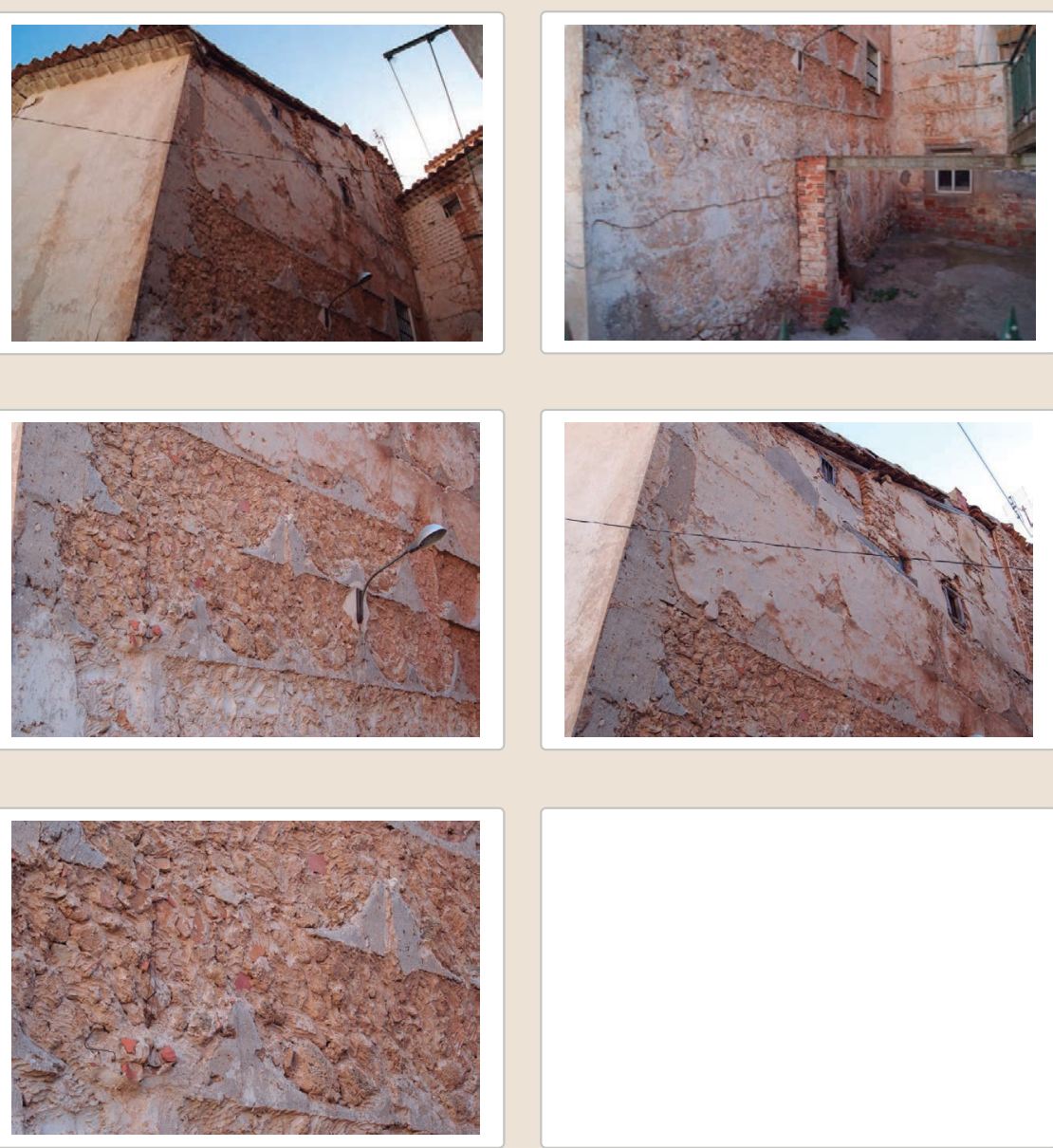


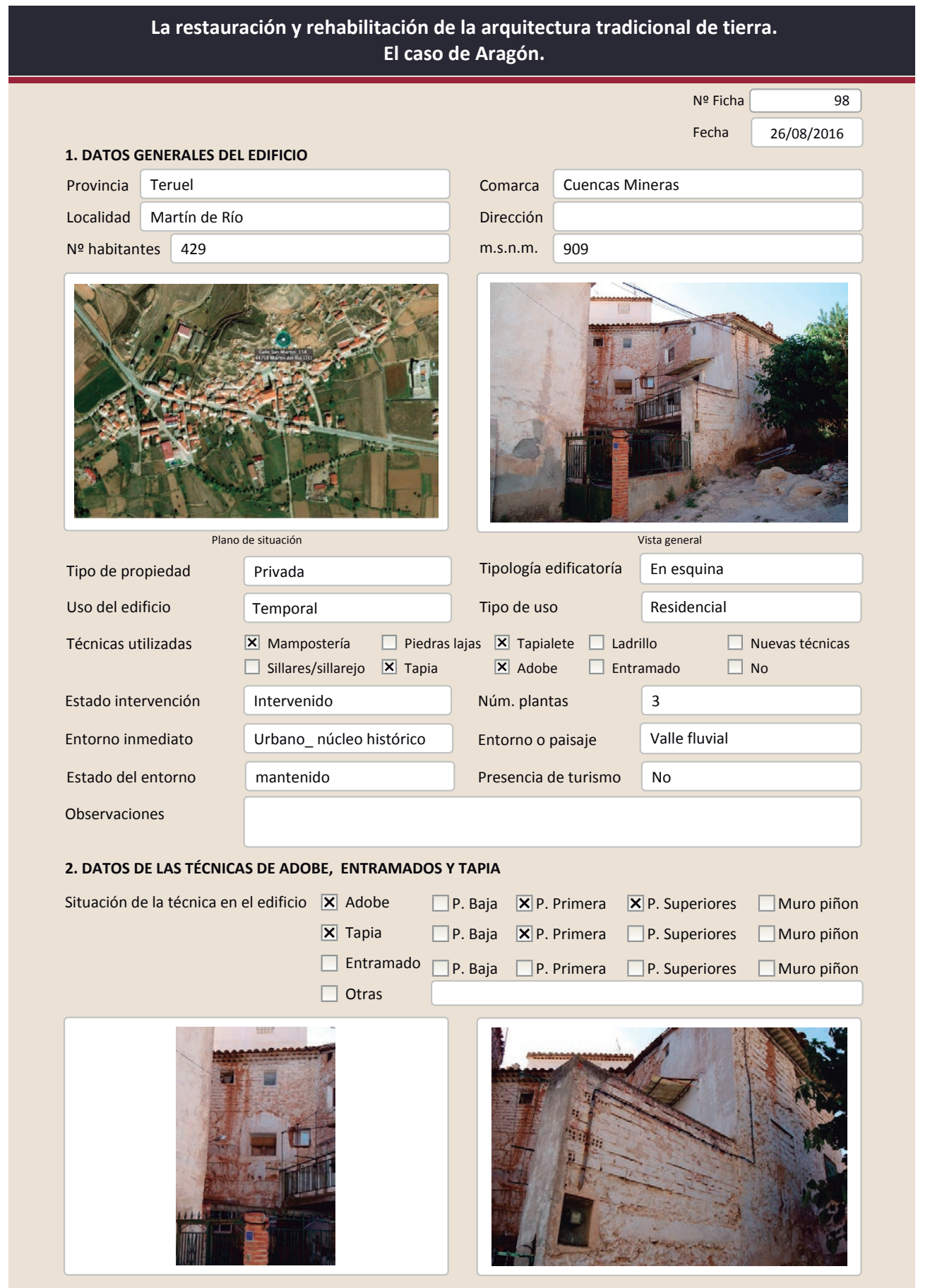

2.1. ADOBE

Dimensión de las piezas

Dimensión del muro

Aparejo del muro

Función estructural

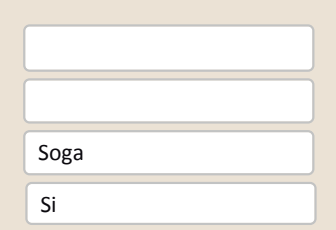

Color de las piezas

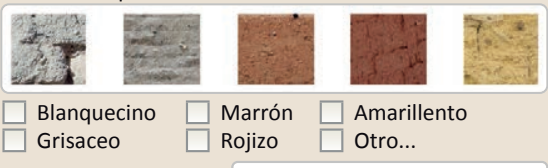

$\square$ Rojizo $\square$ Otro..

Variante constructiva/ tipo de fábrica

X Simple

$\square$ suplementada en juntas

$\square$ Mixta

$\square$ Como suplemento

$\mathbf{X}$ Elementos de protección
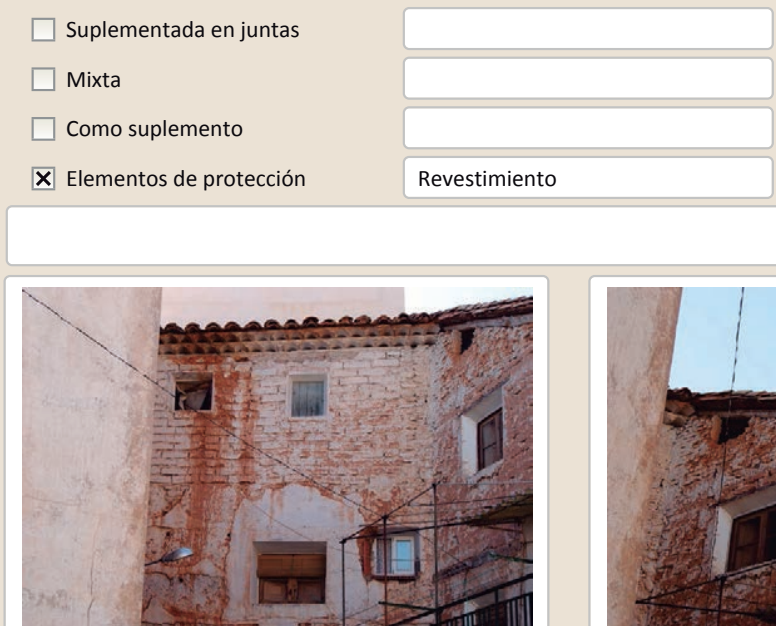

Lesiones $\quad \mathbf{X}$ Muro $\square$ Zócalo $\square$ Revestimiento

X Muro $\square$ Zócalo $\square$ Revestimiento

X Erosión del material $\square$ Humedad por capilaridad

$\square$ Pérdida de sección $\square$ Pérdida de verticalidad

$\square$ Vegetacion

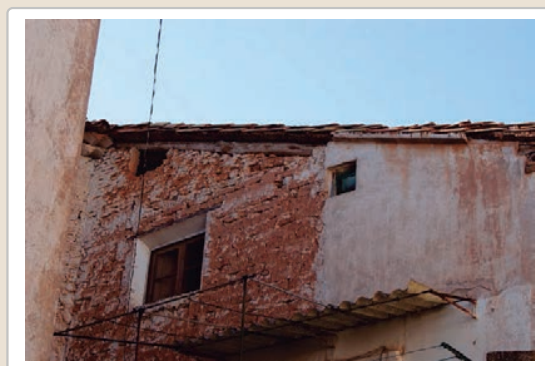

$\square$ Desconchados
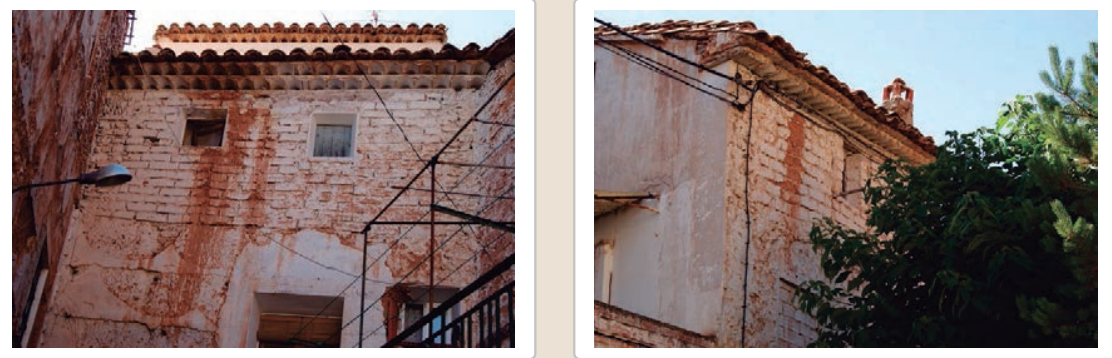

Observaciones $\square$ Grietas por empuje de la

$\square$ Grietas porfalta de traba

\begin{tabular}{l} 
puntos concretos \\
\hline
\end{tabular}

$\square$ Grietas por asentamientos

$\square$ Colapso

$\square$ Por elementos impropios

$\square$ Derivado de intervenciones 


\section{La restauración y rehabilitación de la arquitectura tradicional de tierra.}

\section{El caso de Aragón.}

\subsection{TAPIA}

Ancho del muro

Dimensión tapiales

Tipo de aguja

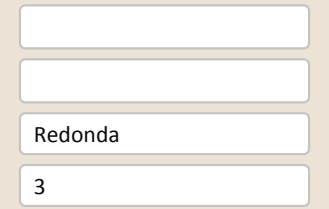

Color de la tapia

№ agujas/cajón

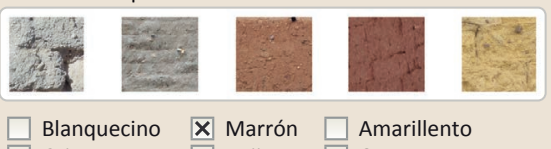

$\square$ Blanquecino $\quad \mathbf{X}$ Marrón $\square$ Amarillento $\square$ Grisaceo

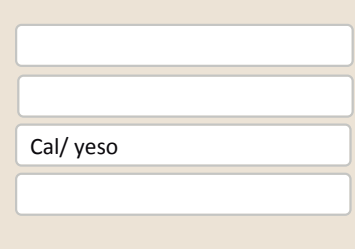

Variante constructiva

$\square$ Simple / homogénea

$\square$ Suplemento superficial

$X$ Suplemento en juntas

$\square$ Mixta

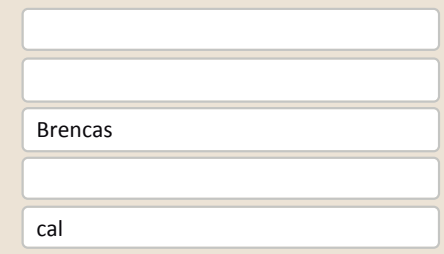

$\mathbf{X}$ Elementos de protección

cal

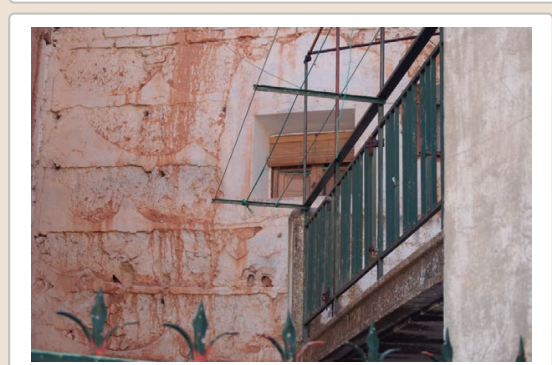

Lesiones $\quad$ XMuro $\mathbf{X}$ Zócalo $\square$ Revestimiento $\square$ Cubierta $\square$ otro...

\ Erosión del material $\quad \mathbf{X}$ Humedad por capilaridad $\quad \square$ Grietas por asentamientos

$\square$ Erosion de las juntas $\square$ Humedades (manch/eflo)

X Pérdida de sección $\square$ Pérdida de verticalidad

$\square$ Colapso

Xérdida de seccin

Pérdida de verticalidad

$\square$ Desconchados

$\square$ Grietas porfalta de traba
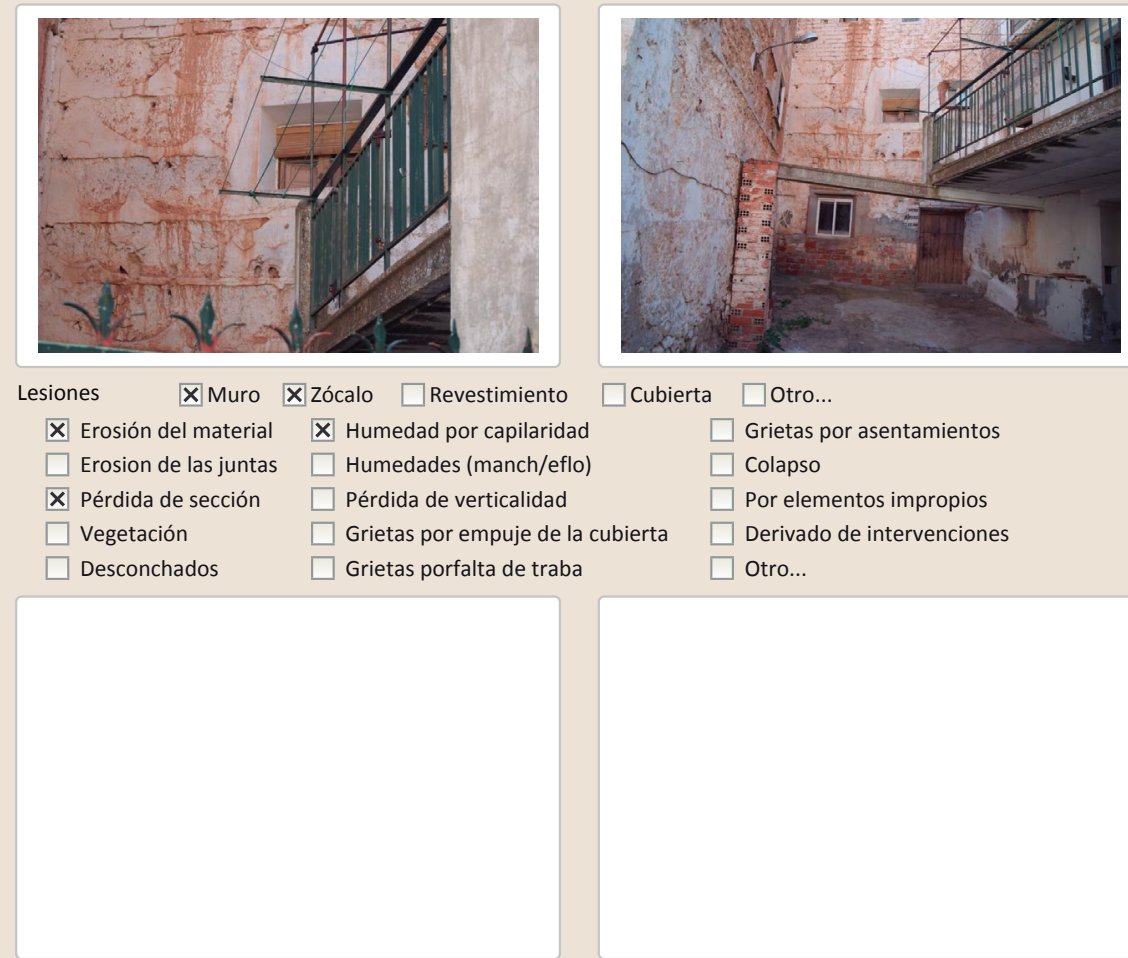

Por elementos impropios

$\square$ Derivado de intervenciones

$\square$ Otro...

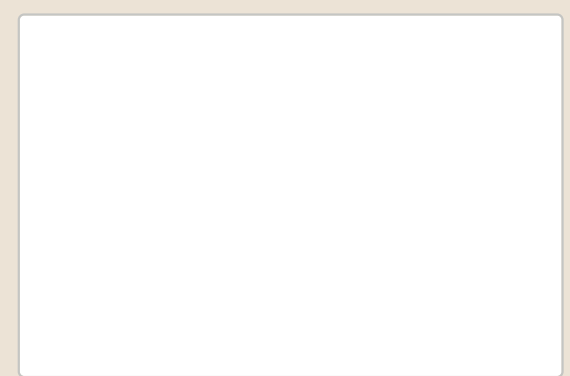

Observaciones

La restauración y rehabilitación de la arquitectura tradicional de tierra.

El caso de Aragón.

3. DATOS DE LA INTERVENCIÓN

Intervención de: $\square$ Mantenimiento $\square$ Rehabilitación parcial $\square$ Restauración $\square$ Demolicón

\Reparación $\quad \square$ Rehabilitación integral $\square$ Ampliación $\quad \square$ Otro...

Reflexión previa Intervención espontanea

Observaciones

3.1. MUROS

Tipo de intervención

Tipo de material

Intervenido

$\square$ Actualización $\square$ Reintegración $\square$ Demolición $\square$ Otro..

$\square$ Consolidación $\square$ Reconstrucción $\quad \mathbf{X}$ Sustitución

Descripción

No tradicional Tipo de técnica Diferente a la existente

3.2. ZóCALO

Sustitución parcial de pares de muro por muro de ladrillo hueco

Tipo de intervención $\square$ Actualización $\square$ Reintegración $\quad \square$ Demolición $\square$ Otro..

$\square$ Actualización $\square$ Reintegración $\square$ Demolición
$\square$ Consolidación $\quad \boldsymbol{X}$ Reconstrucción $\square$ Sustitución

Tipo de material

No tradicional

Tipo de técnica Diferente a la existente

Descripción

Zócalo con un nuevo revestimiento de ladrillo hueco colocado con cemento

3.3. REVESTIMIENTOS

Tipo de intervención

No aplica

Tipo de material

Descripción

3.4. VANOS

Tipo de intervención

Intervenido

Tipo de material

$\square$ Actualización $\square$ Reintegración $\square$ Demolición $\square$ Otro...

$\square$ Consolidación $\square$ Reconstrucción $\mathbf{X}$ Sustitución

Descripción

No tradicional

Tipo de técnica Diferente a la existente

Sustitución de la carpintería del hueco de planta baja

3.5. CUBIERTA

No intervenido

Tipo de intervención

$\square$ Actualización

$\square$ Consolidación

$\square$ Reintegración $\square$ Demolición $\square$ Otro...

Tipo de material

Descripción

3.6. OTRAS

Se ha incorporado un cuerpo saliente que hace de porche en planta baja y terraza en primera planta construido con viguetas de hormigón prefabricado. Apoya en la fachada de la vivienda estudiada y en la colindante 
La restauración y rehabilitación de la arquitectura tradicional de tierra. El caso de Aragón

\section{La restauración y rehabilitación de la arquitectura tradicional de tierra.} El caso de Aragón.
3.7. REHABILITACIÓN ENERGÉTICA

Observaciones

FOTOGRAFíAS DE LA INTERVENCIÓN
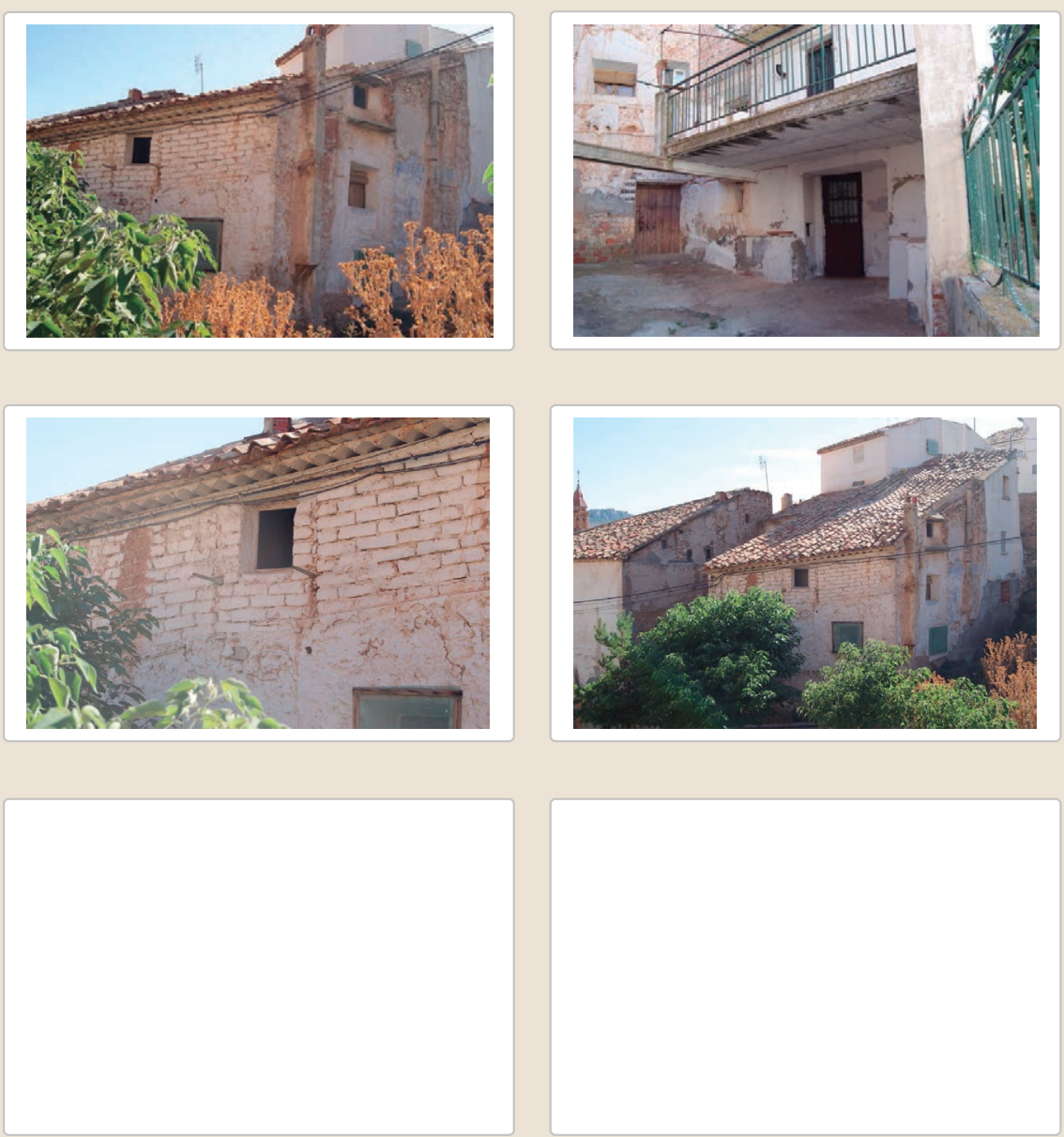


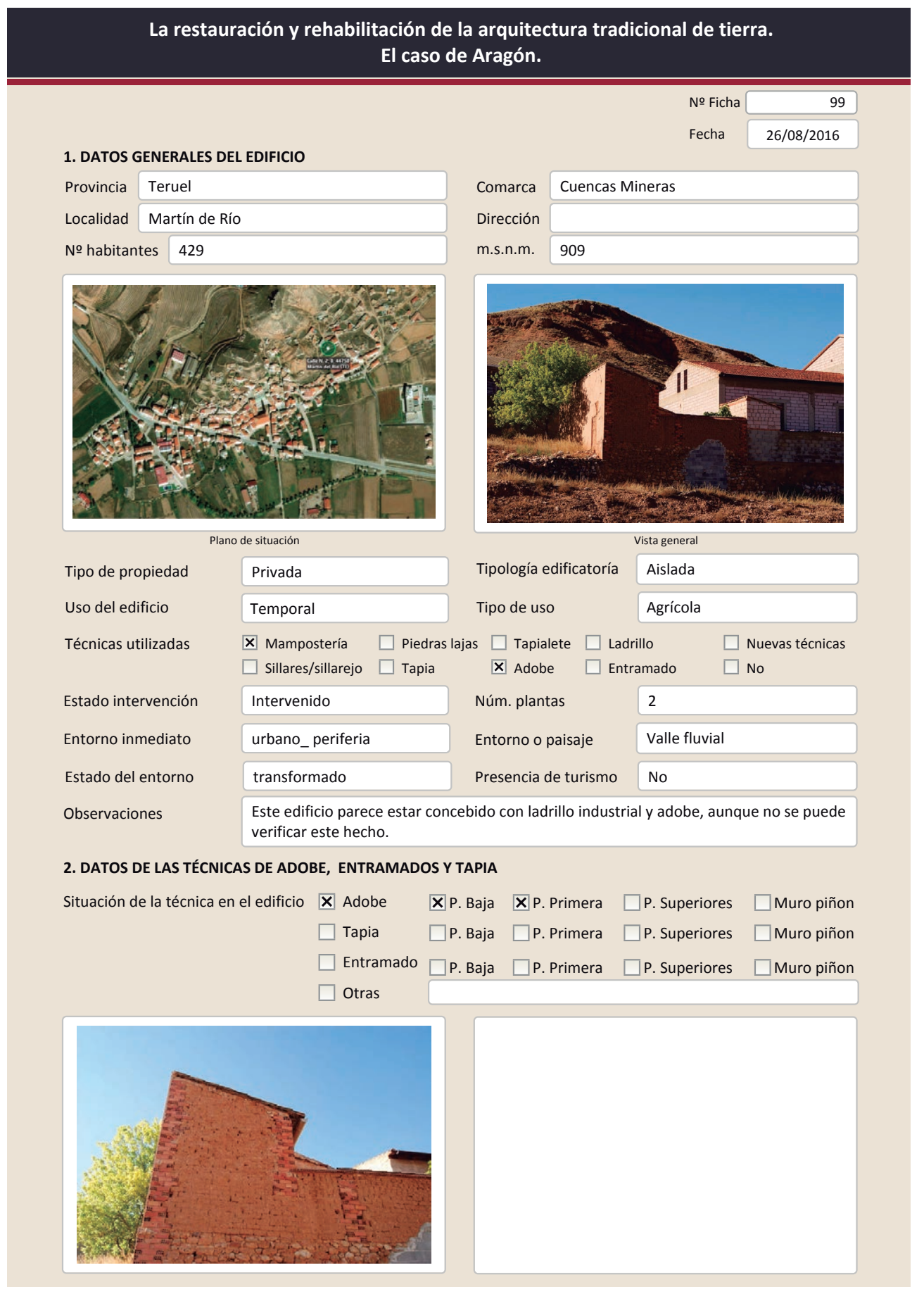

La restauración y rehabilitación de la arquitectura tradicional de tierra.

El caso de Aragón.

2.1. ADOBE

Dimensión de las piezas Dimensión del muro Aparejo del muro Función estructural
Color de las piezas

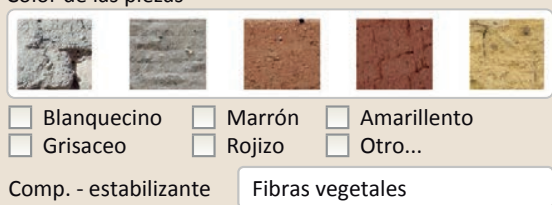

Variante constructiva/ tipo de fábrica

$\square$ Simple

$\square$ Suplementada en juntas

X Mixta
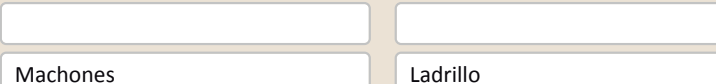

$\square$ Como suplemento

X Elementos de protección Revestimiento solo en una fachada

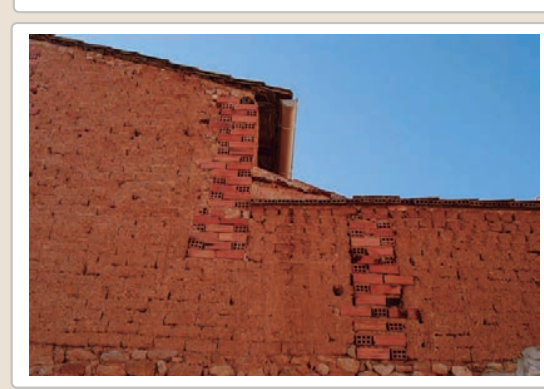

Lesiones $\mathbf{X}$ Muro $\mathbf{X}$ Zócalo $\mathbf{X}$ Revestimiento X Erosión del material $\square$ Humedad por capilaridad $\square$ Erosion de las juntas $\square$ Humedades (manch/eflo) X Pérdida de sección $\square$ Pérdida de verticalidad $\square$ Vegetación $\quad \square$ Grietas por empuje de la cubie $\boldsymbol{X}$ Desconchados $\quad \square$ Grietas porfalta de traba

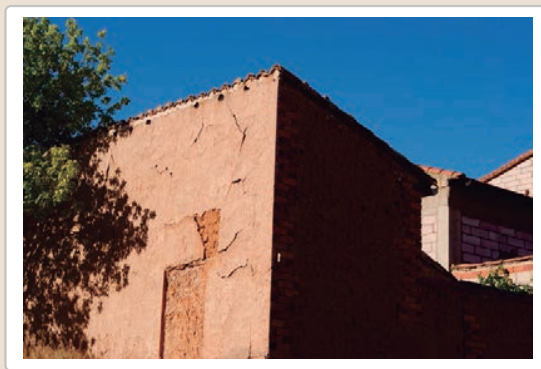

$\square$ Cubierta $\square$ Otro...

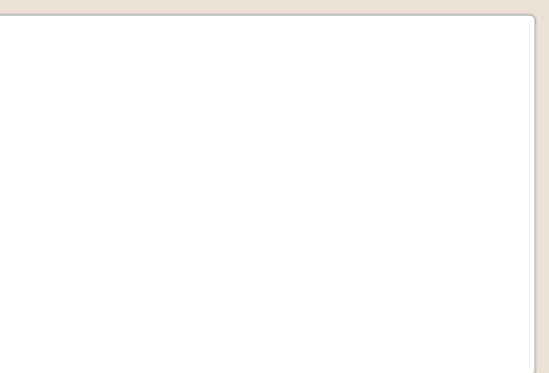

$\square$ Grietas por asentamiento $\square$ Colapso

$\square$ Por elementos impropios

$\square$ Derivado de intervenciones $\square$ Otro...

Observaciones 


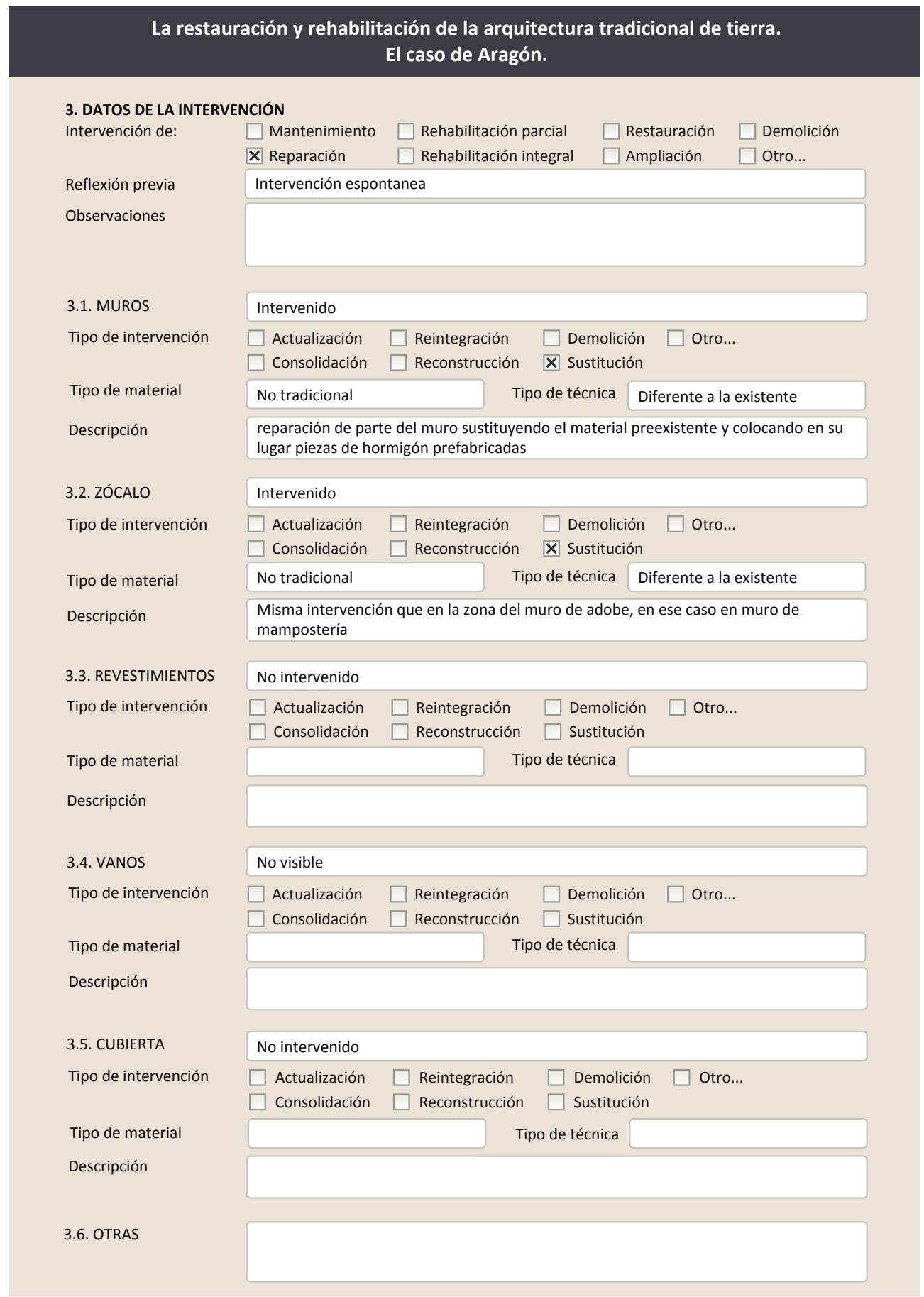

\subsection{REHABILITACIÓN ENERGÉTICA $\quad \square$ Fachada $\square$ Vanos $\square$ Forjados $\square$ Cubierta}

Observaciones

FOTOGRAFíAS DE LA INTERVENCIÓN
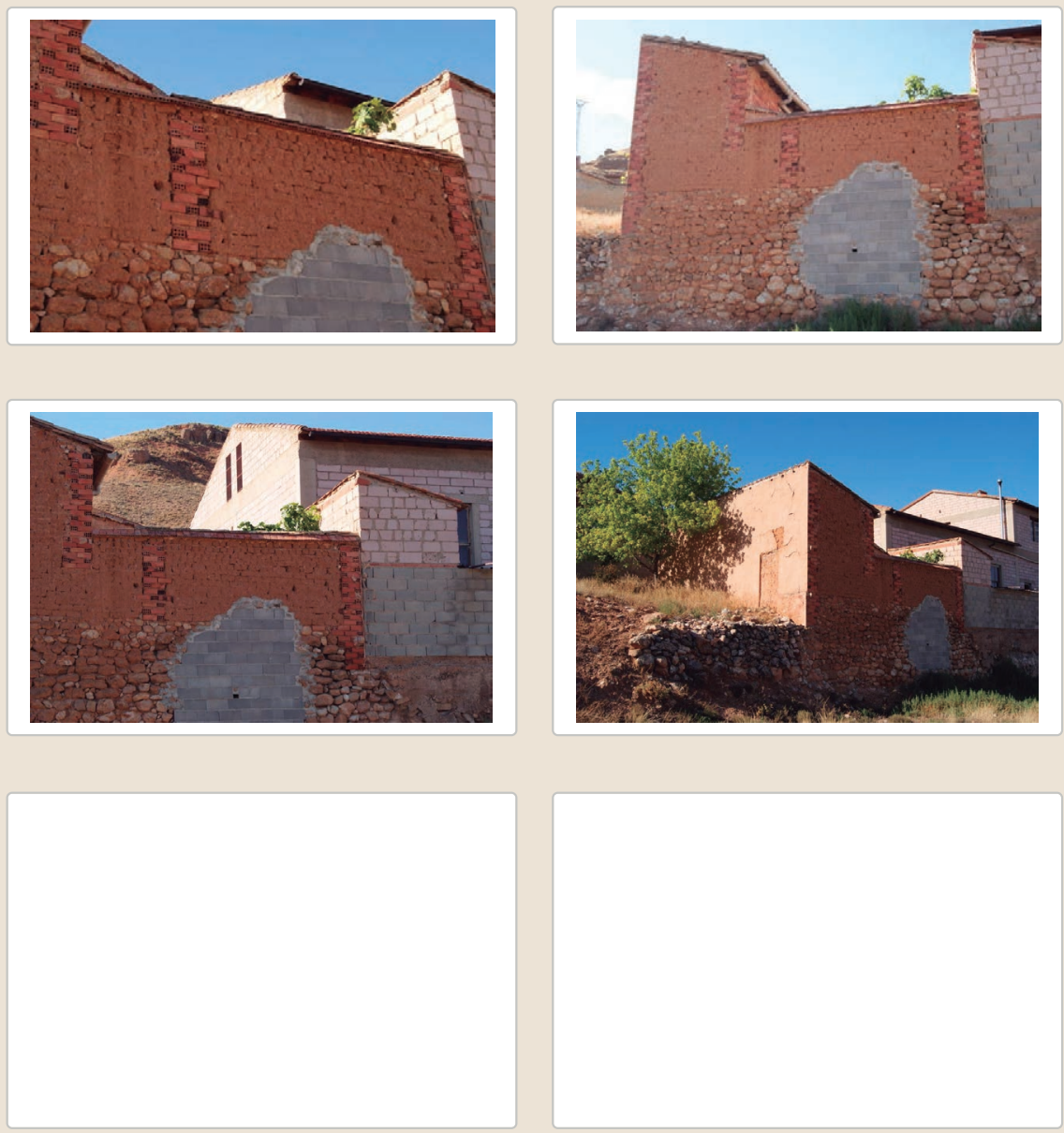


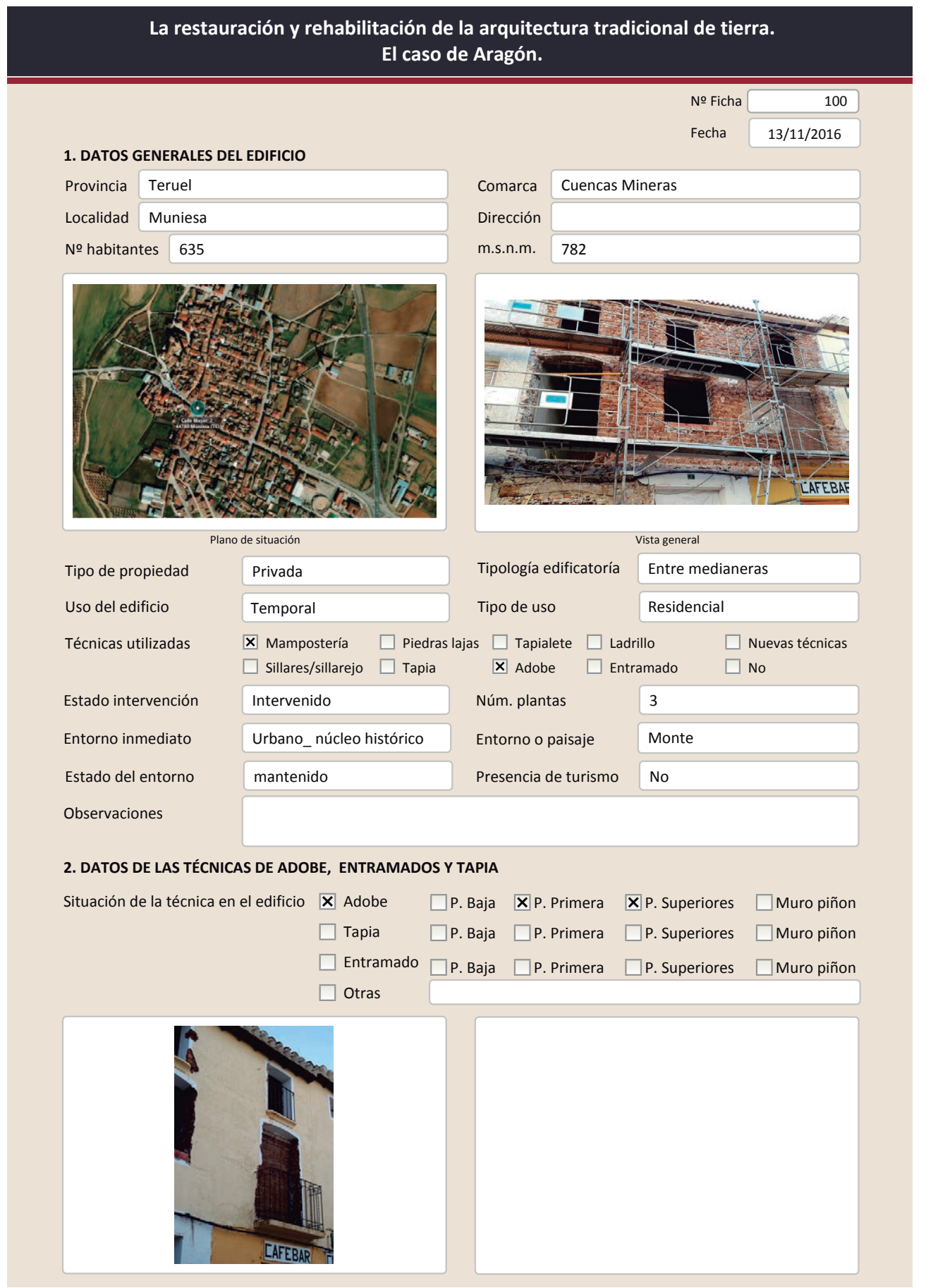

La restauración y rehabilitación de la arquitectura tradicional de tierra.

El caso de Aragón.

2.1. ADOBE

Dimensión de las piezas

Dimensión del muro

Aparejo del muro

Función estructural

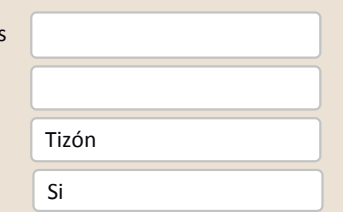

Color de las piezas

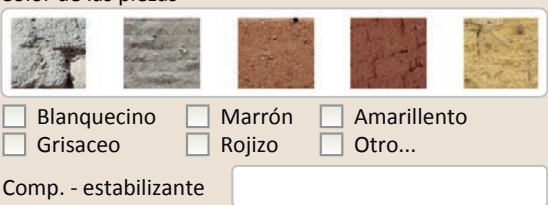

Variante constructiva/ tipo de fábrica

$\square$ simple
X Suplementada en juntas
Verticales y horizontales
Cal/ yeso
$\square$ Mixta
$\square$ Como suplemento
$\mathbf{X}$ Elementos de protección
Revestimiento

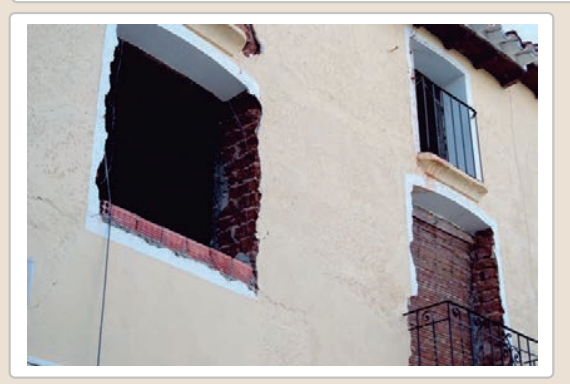

Lesiones $\square$ Muro $\square$ Zócalo $\square$ Revestimiento

$\square$ Erosión del material $\quad \square$ Humedad por capilaridad

$\square$ Erosion de las juntas $\square$ Humedades (manch/eflo)

$\square$ Pérdida de sección $\square$ Pérdida de verticalidad

$\square$ Vegetación $\quad \square$ Grietas por empuje de la cubic

$\square$ Desconchados

$\square$ Grietas por empuje de la cu
$\square$ Grietas porfalta de traba

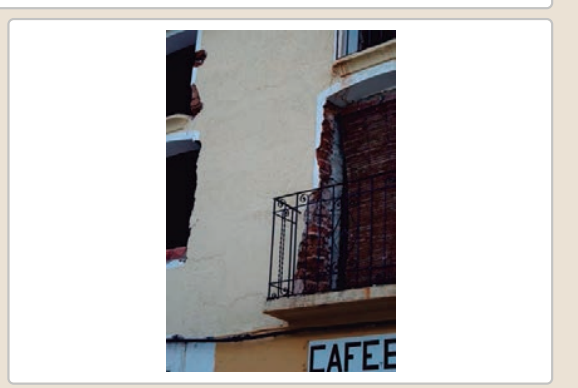

$\square$ Cubierta $\square$ otro...

$\square$ Grietas por asentamientos

$\square$ Colapso

$\square$ Por elementos impropios

Dos

Observaciones 


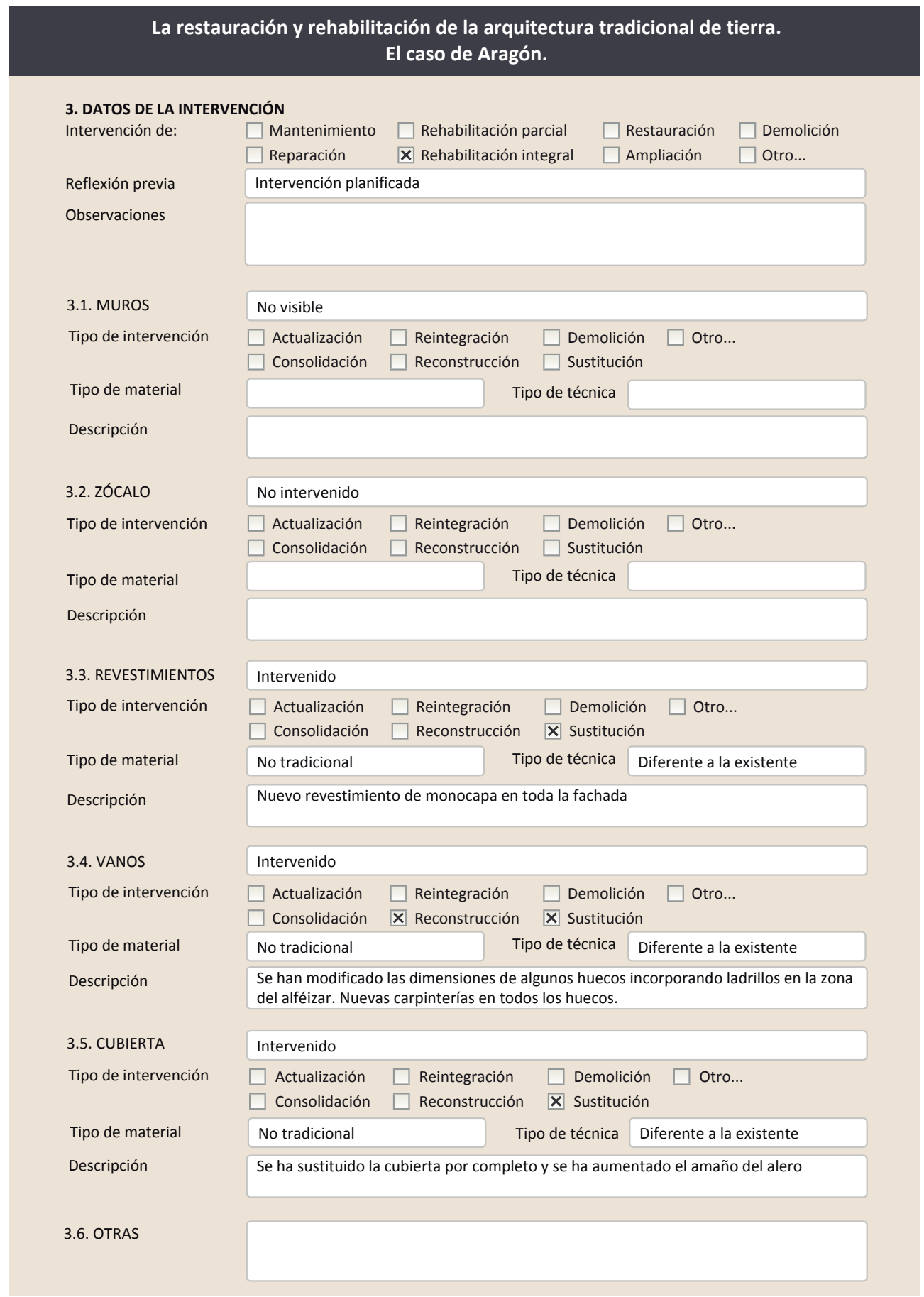

3.7. REHABILITACIÓN ENERGÉTICA $\square$ Fachada $\quad$ V Vanos $\square$ Forjados $\bigotimes$ Cubierta Observaciones

Tal vez también la fachada por el interior

FOTOGRAFíAS DE LA INTERVENCIÓN
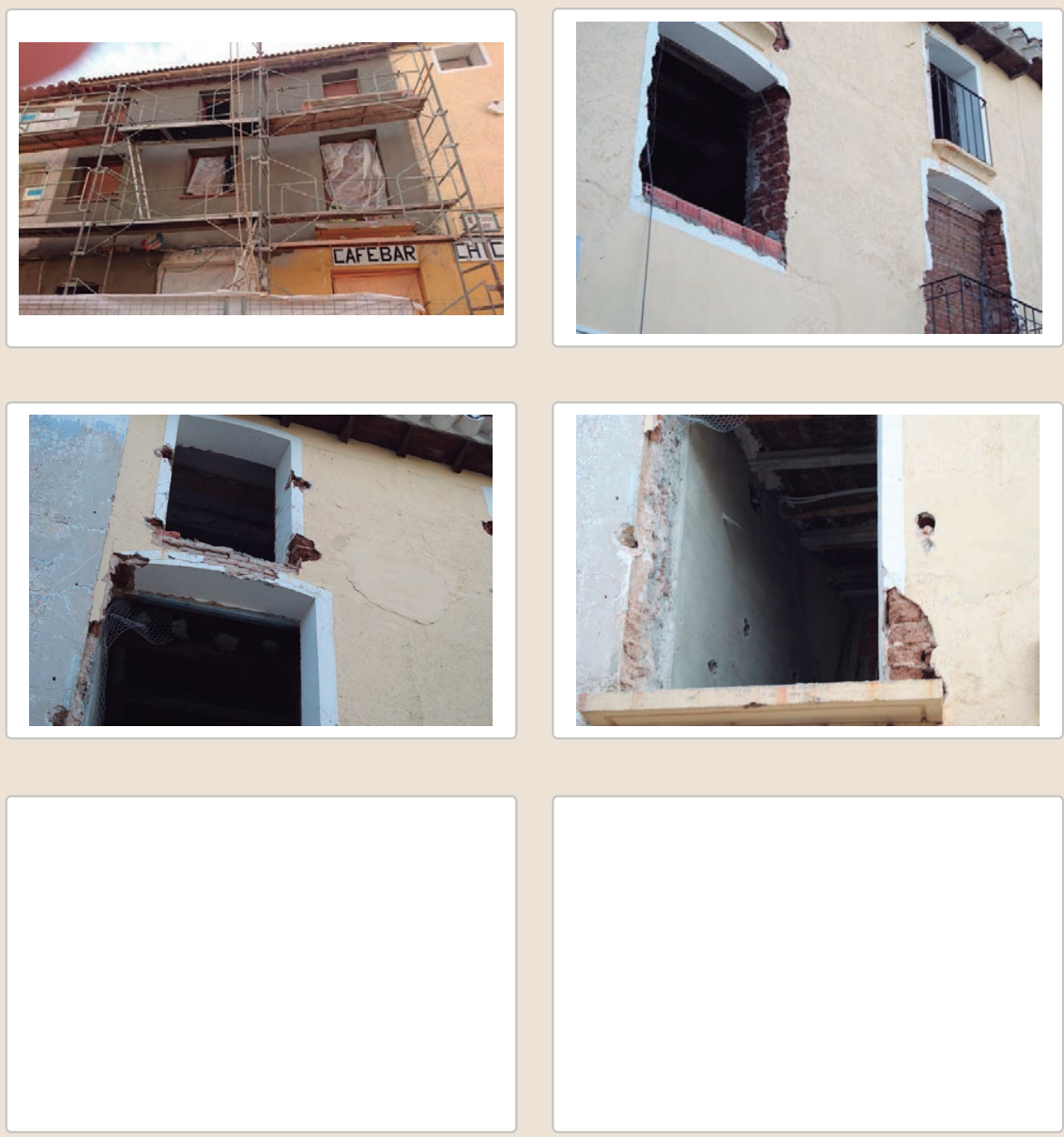


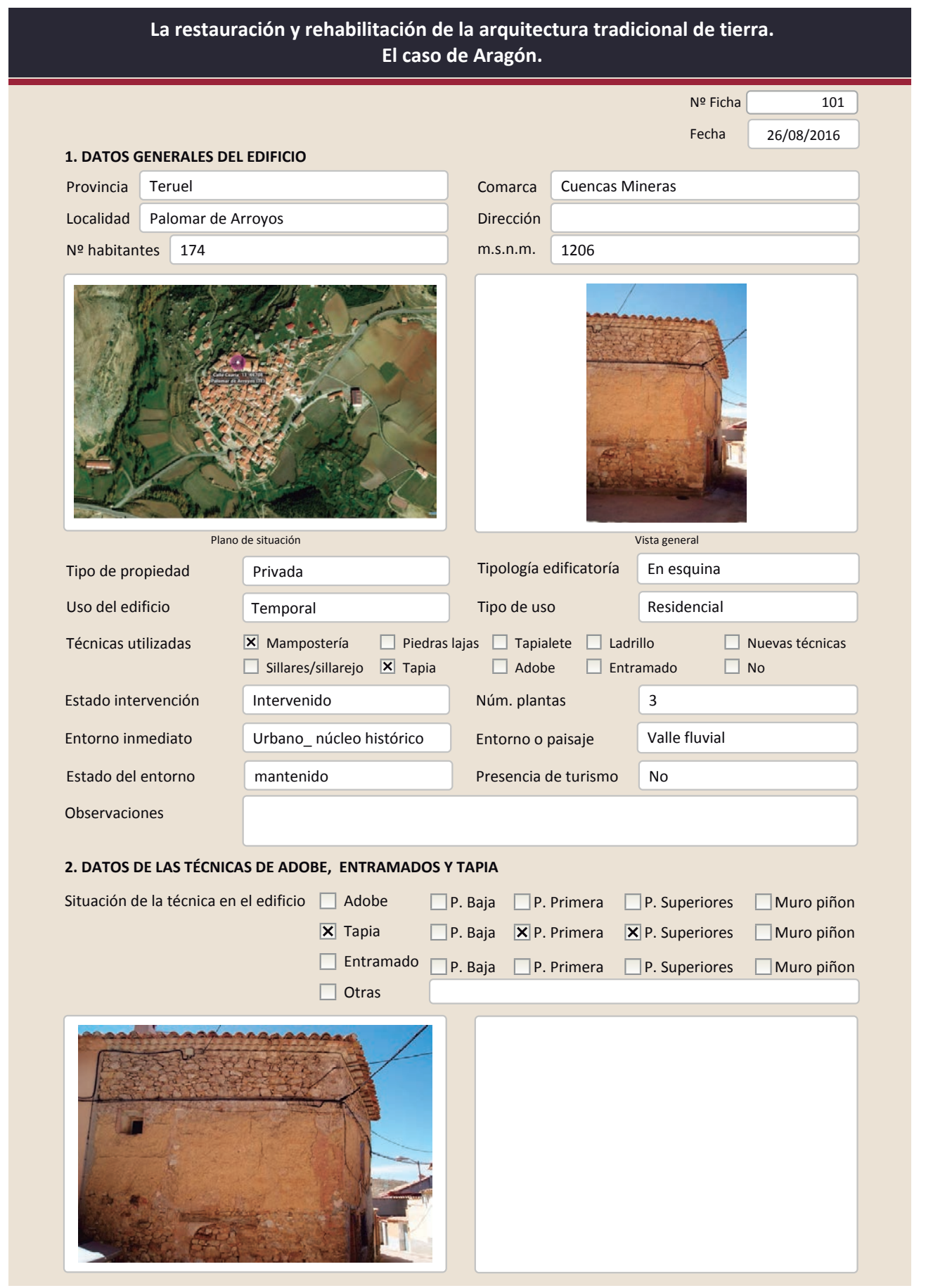

La restauración y rehabilitación de la arquitectura tradicional de tierra.

El caso de Aragón.
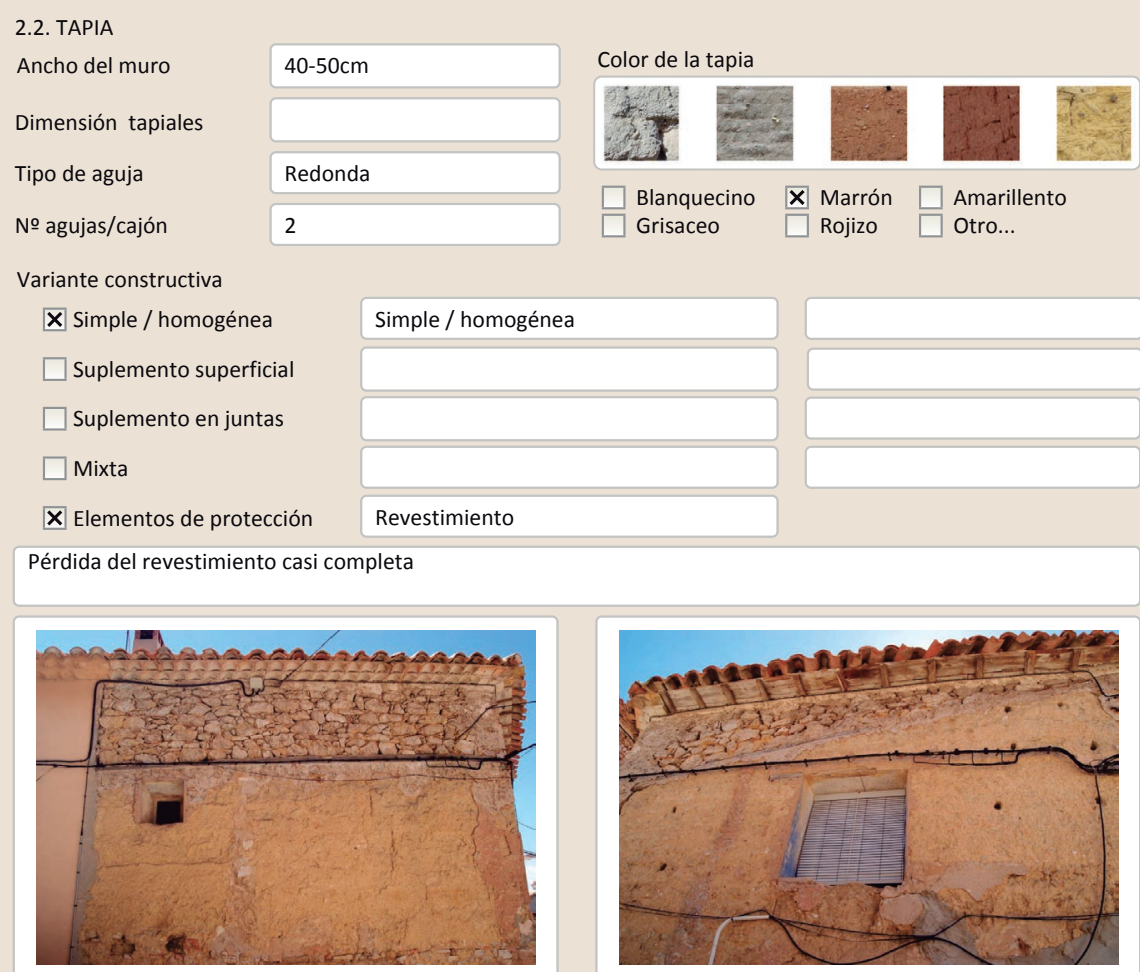

Lesiones $\quad$ MMuro $\square$ Zócalo $\square$ Revestimiento $\square$ Cubierta $\square$ otro...

$\begin{array}{lll}\boldsymbol{X} \text { Erosión del material } & \square \text { Humedad por capilaridad } & \square \text { Grietas por asentamientos } \\ \square \text { Erosion de las juntas } & \square \text { Humedades (manch/eflo) } & \square \text { Colapso } \\ \square \text { Pérdida de sección } & \square \text { Pérdida de verticalidad } & \square \text { Por elementos impropios } \\ \square \text { vegetación } & \square \text { Grietas por empuje de la cubierta } & \square \text { Derivado de intervenciones }\end{array}$ $\boldsymbol{X}$ Desconchados $\square$ Grietas porfalta de traba $\quad \square$ Otro...
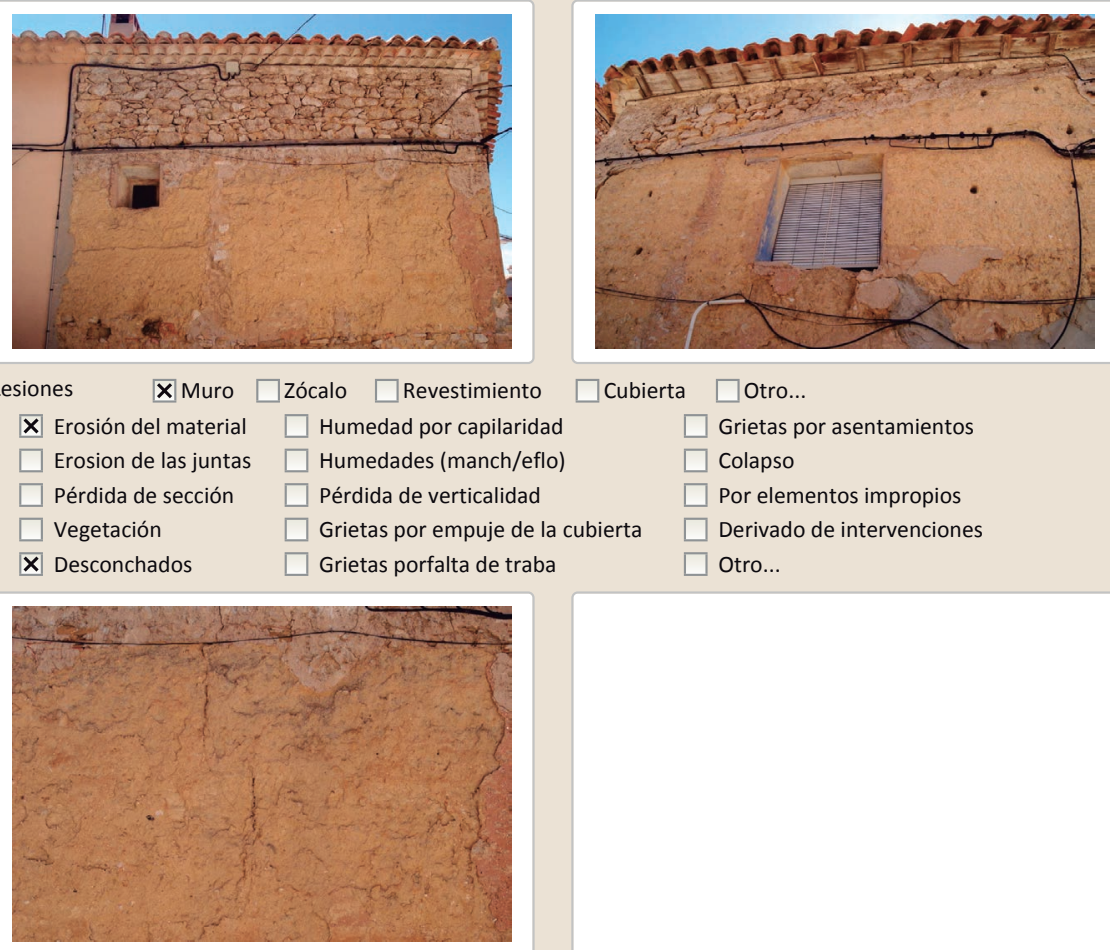

Observaciones 


\section{La restauración y rehabilitación de la arquitectura tradicional de tierra.}

\section{El caso de Aragón.}

3. DATOS DE LA INTERVENCIÓN

Mantenimiento $\square$ Rehabilitación parcial $\square$ Restauración $\square$ Demolición X Reparación $\quad \mathbf{X}$ Rehabilitación integral $\square$ Ampliación $\quad \square$ Otro...

Reflexión previa Intervención planificada

Observaciones Existen dos intervenciones. una más antigua en la que se recrece el muro y se cambian las pendientes de la cubierta (tradicional) y otra más actual en la que se ha intervenido

3.1. MUROS Intervenido

Tipo de intervención

$\square$ Actualización $\square$ Reintegración $\square$ Demolición $\square$ Otro..

$\square$ Consolidación $\quad$ Reconstrucción $\square$ Sustitución

Tipo de material

\begin{tabular}{l|l|l|}
\hline Tradicional diferente & Tipo de técnica & Diferente a la existente \\
\hline
\end{tabular}

Descripción

3.2. ZÓCALO

Tipo de intervención

Recrecido del muro con mampostería (intervención antigua)

\section{No intervenido}

Actualización $\square$ Reintegración $\square$ Demolición $\square$ Otro.

$\square$ Consolidación $\square$ Reconstrucción $\square$ sustitución

Tipo de material

Descripción

3.3. REVESTIMIENTOS

Tipo de intervención

Tipo de material

Descripción

3.4. VANOS

Tipo de intervención

Tipo de material

Descripción

3.5. CUBIERTA

Tipo de intervención

Tipo de material

Descripción

3.6. OTRAS
La restauración y rehabilitación de la arquitectura tradicional de tierra.

El caso de Aragón.
3.7. REHABILITACIÓN ENERGÉTICA $\square$ Fachada $\square$ Vanos $\square$ Forjados $\square$ Cubierta

Observaciones

FOTOGRAFÍAS DE LA INTERVENCIÓN
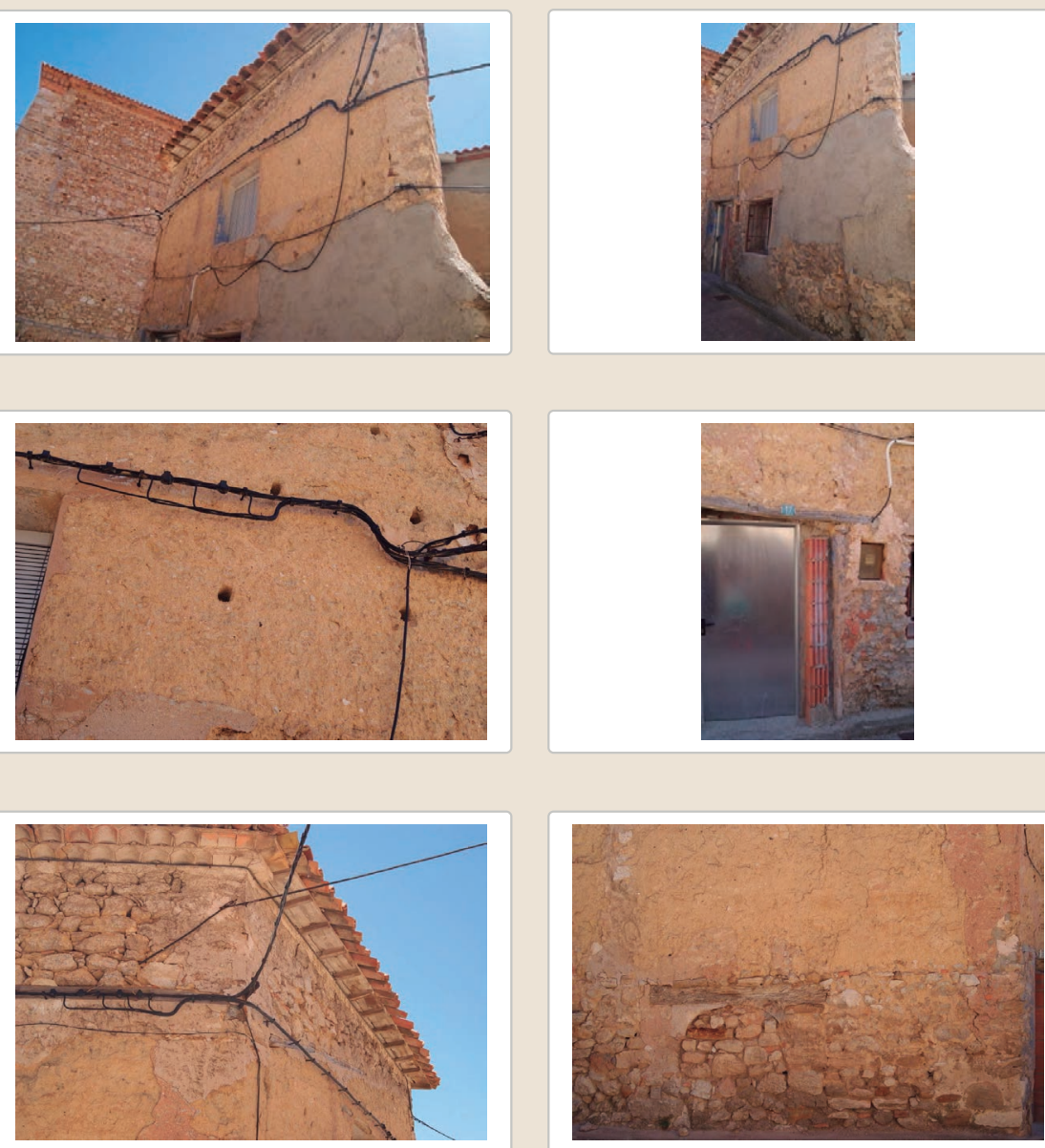


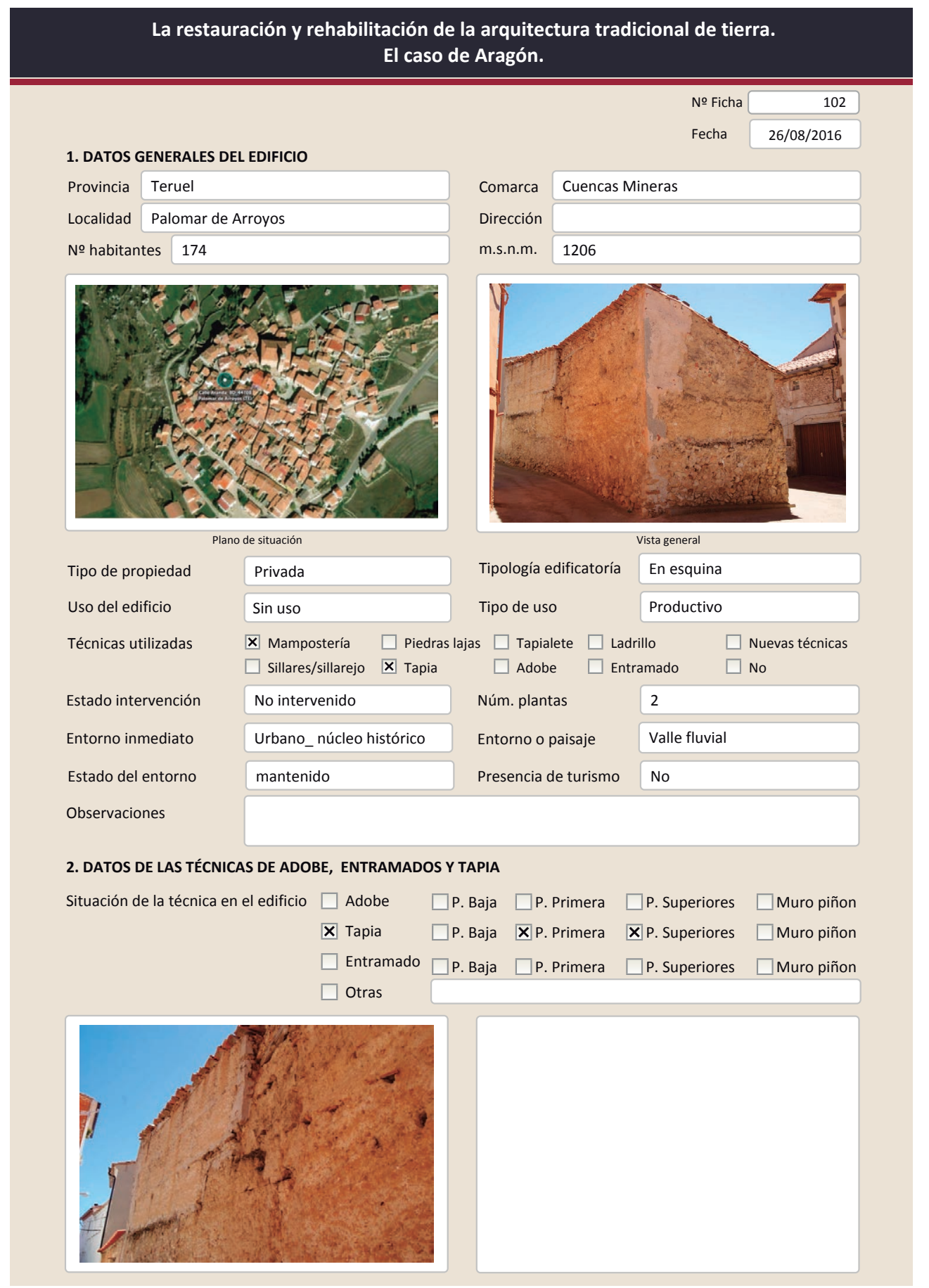

La restauración y rehabilitación de la arquitectura tradicional de tierra. El caso de Aragón.

2.2. TAPIA

Ancho del muro

Dimensión tapiales

Tipo de aguja

№ agujas/cajón

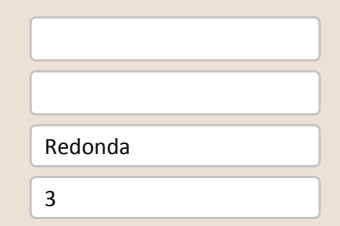

Color de la tapia

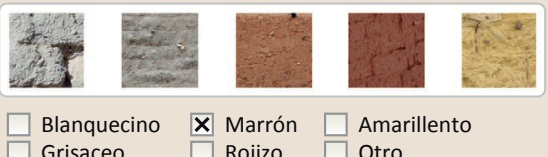

$\square$ Blanquecino $\quad \mathbf{X}$ Marrón $\square$ Amarillento

Variante constructiva

$\square$ Simple / homogénea

$\square$ suplemento superficial

X Suplemento en juntas

$\square$ Mixta

$\square$ Elementos de protección
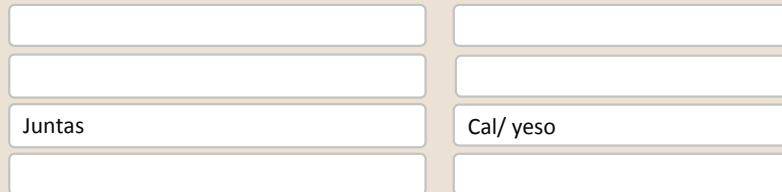

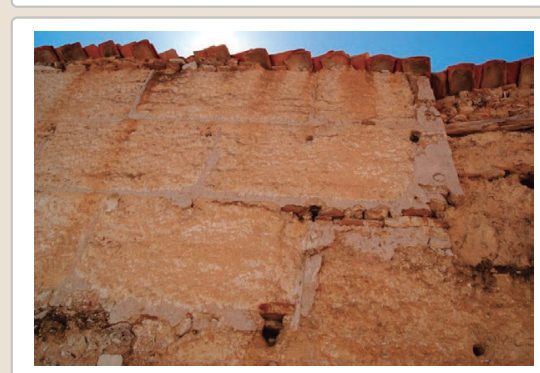

Lesiones

$\square$ Muro $\square$ Zócalo $\square$ Revestimiento $\square$ Erosion de las juntas $\square$ Humedades (manch/eflo) X Pérdida de sección $\square$ Pérdida de verticalidad

$\square$ Vegetación

$\square$ Desconchados

$\square$ Grietas por empuje de la cubierta

$\square$ Grietas porfalta de traba
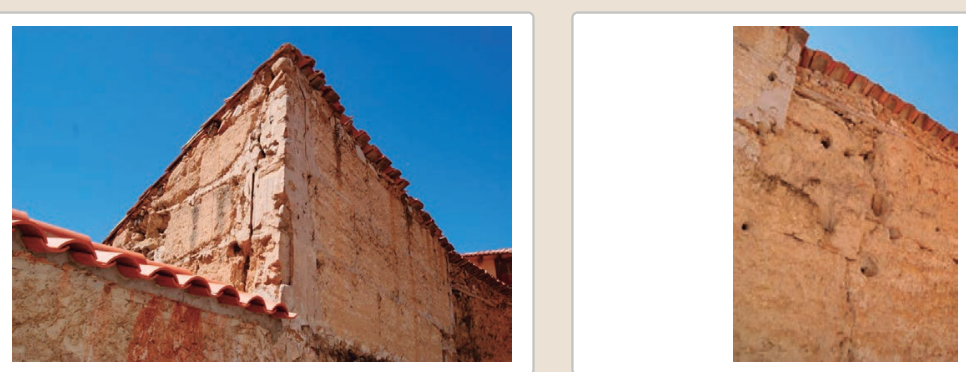

Observaciones

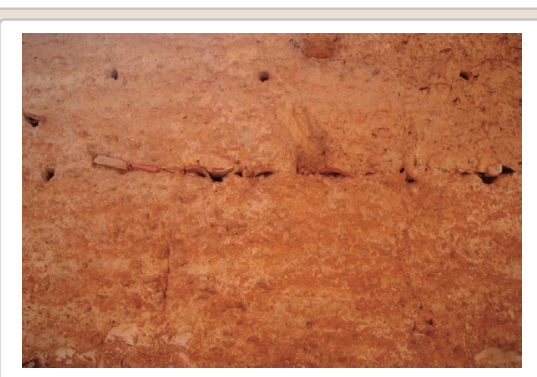

Cubierta $\square$ Otro..

$\square$ Grietas por asentamientos

$\square$ Colapso

Por elementos impropios $\square$ Otro... 
La restauración y rehabilitación de la arquitectura tradicional de tierra. El caso de Aragón

\section{La restauración y rehabilitación de la arquitectura tradicional de tierra.}

El caso de Aragón.
3.7. REHABILITACIÓN ENERGÉTICA
$\square$ Fachada
$\square$ Vanos
$\square$ Forjados $\square$ Cubierta

Observaciones

FOTOGRAFÍAS DE LA INTERVENCIÓN
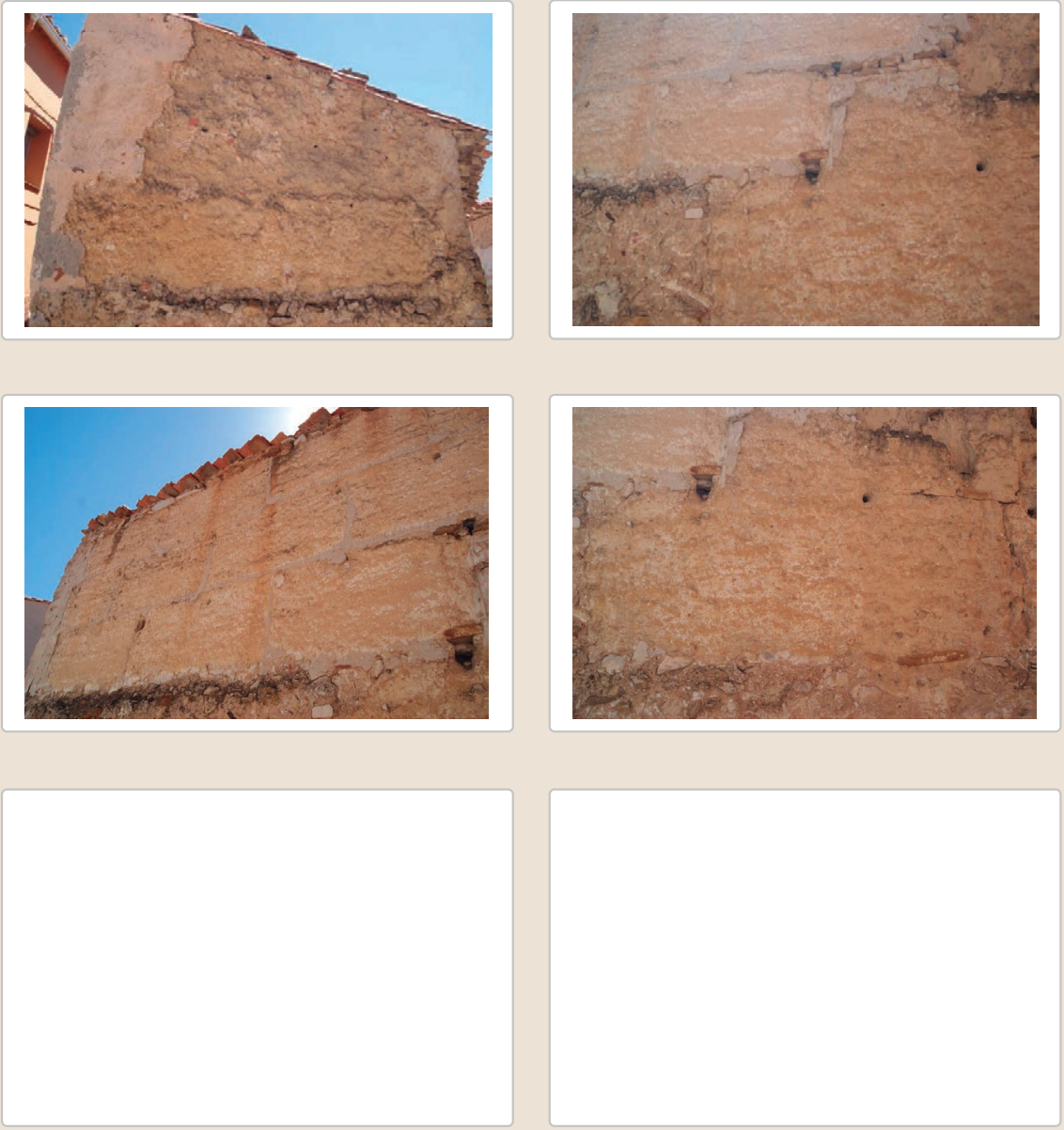
La restauración y rehabilitación de la arquitectura tradicional de tierra. El caso de Aragón.

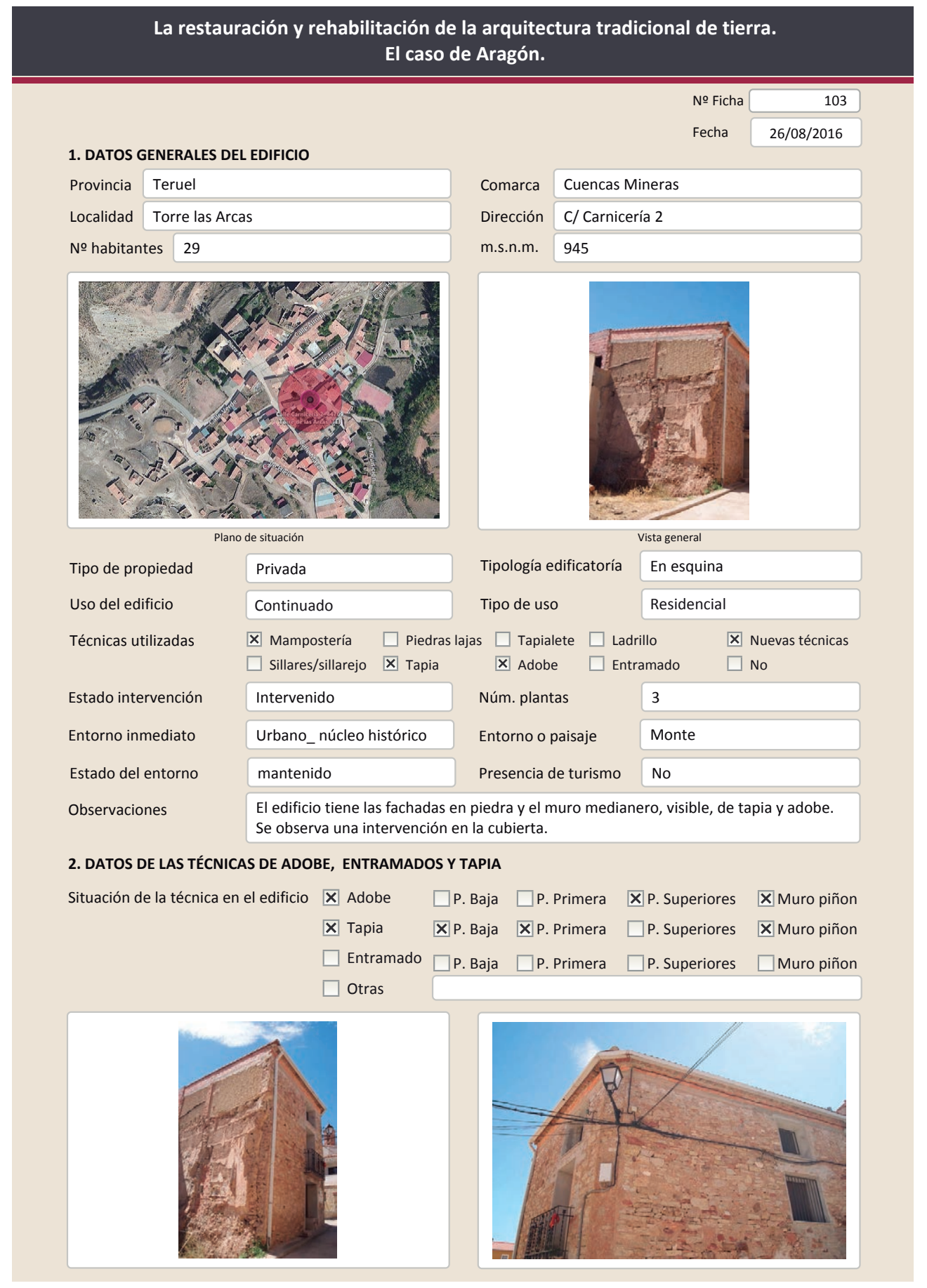

La restauración y rehabilitación de la arquitectura tradicional de tierra. El caso de Aragón.
2.1. ADOBE

Dimensión de las piezas $13 \times 28 \times 9$ aprox

Dimensión del muro $10-20 \mathrm{~cm}$

Aparejo del muro Soga

Función estructural iva/ tipo de fábrica $\square$ Simple
$\square$ Suplementada en juntas

$\square$ suplem

X Mixta

$\square$ Como suplemento

$\square$ Elementos de protección

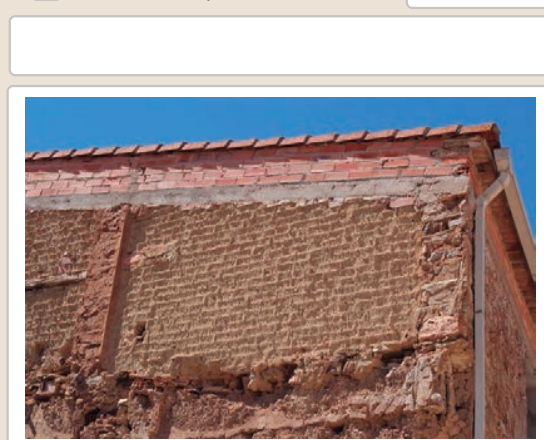

Lesiones $\quad \mathbf{X}$ Muro $\square$ Zócalo $\square$ Revestimiento

X Erosión del material $\square$ Humedad por capilaridad

$\square$ Erosion de las juntas $\square$ Humedades (manch/eflo)

$\square$ Pérdida de sección $\square$ Pérdida de verticalidad

$\square$ Vegetación $\quad \square$ Grietas por empuje de la cu

$\square$ Desconchados

$\square$ Grietas por empuje de la cubie
Color de las piezas

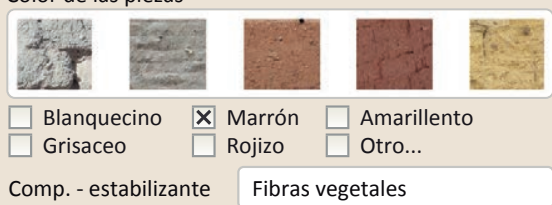

$\square$ Blanquecino $\mathbf{X}$ Marrón $\square$ Amarillento

Comp. - estabilizante Fibras vegetales

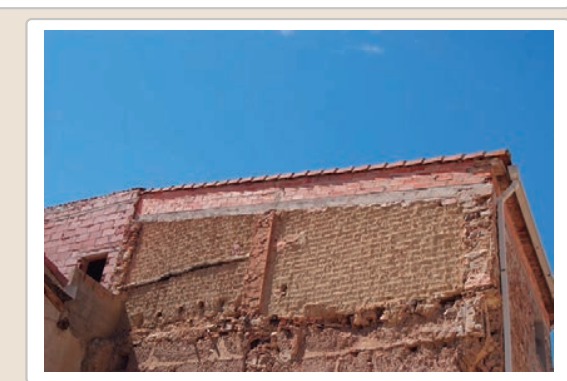

Cubierta $\square$ Otro...

$\square$ Grietas por asentamientos

$\square$ Colapso

$\square$ Por elementos impropios

$\square$ Derivado de intervenciones

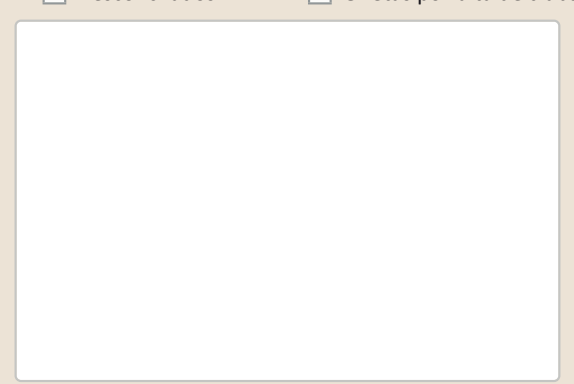

Observaciones

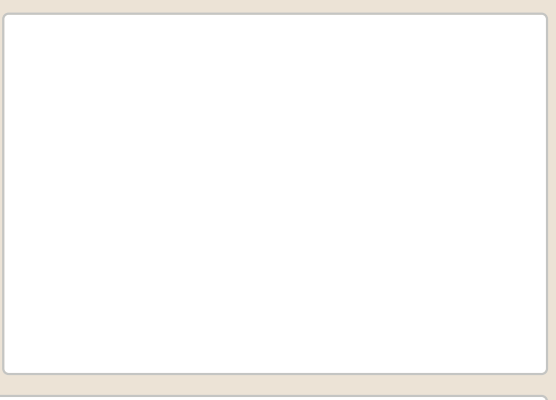




\section{La restauración y rehabilitación de la arquitectura tradicional de tierra.} El caso de Aragón.

\subsection{TAPIA} Ancho del muro Dimensión tapiales

40-50 cm $160 \times 70$ aprox Tipo de aguja Redonda

№ agujas/cajón 3 $\square$ Simple / homogénea $\square$ suplemento superficial $\mathbb{X}$ Suplemento en juntas $\mathbf{X}$ Mixta

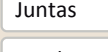
Machones

\section{Color de la tapia}

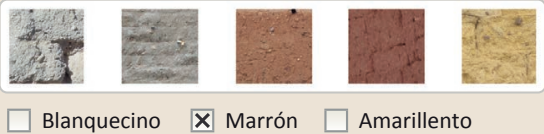

$\square$ Blanquecino $\mathbf{X}$ Marrón $\square$ Amarillento $\square$ Grisaceo

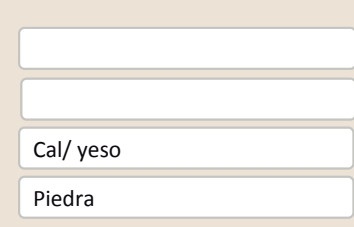

$\square$ Elementos de protección
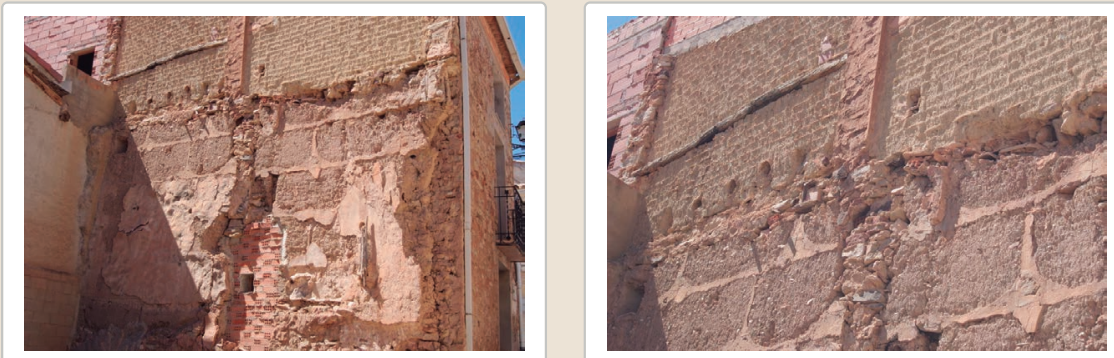

Lesiones \Muro $\square$ Zócalo $\square$ Revestimiento $\square$ Cubierta $\square$ Otro...
X Erosión del material $\square$ Humedad por capilaridad
$\square$ Grietas por asentamiento
$\square$ Erosion de las juntas
$\square$ Humedades (manch/eflo)
$\square$ Colapso
$\square$ Pérdida de sección $\square$ Pérdida de verticalidad
$\mathbf{X}$ Por elementos impropios
$\square$ Vegetación
$\square$ Grietas por empuje de la cubierta $\square$ Derivado de intervenion

$\square$ Desconchados

$\mathbf{X}$ Grietas porfalta de traba

$\square$ Otro..
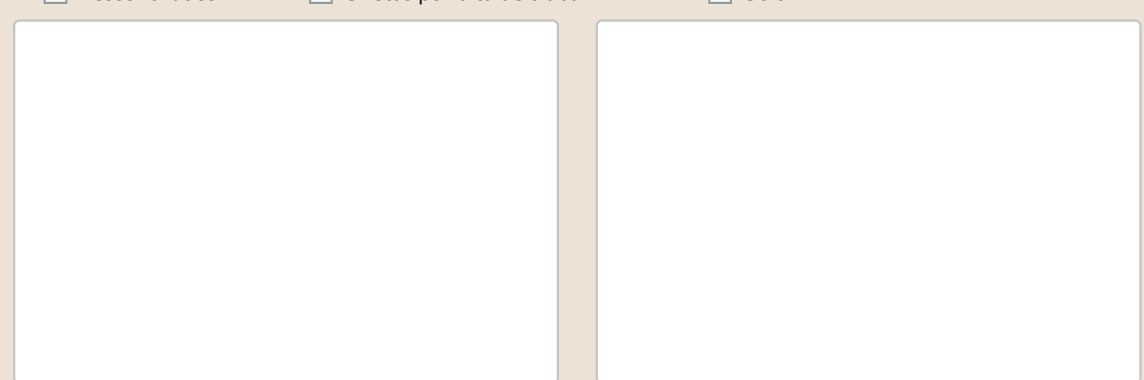

Observaciones

EL muro de tapia fue probablemente anterior y sobre ese se construyo el muro de adobe. Existen grietas por la discontinuidad material y problemas generados por
La restauración y rehabilitación de la arquitectura tradicional de tierra.

El caso de Aragón.

3. DATOS DE LA INTERVENCIÓN

Intervención de: $\quad \square$ Mantenimiento $\quad \square$ Rehabilitación parcial $\quad \square$ Restauración $\square$ Demolición

Reflexión previa Intervención espontanea

Observaciones Se ha sustituido la cubierta por otra nueva de mayor altitud, presumiblemente para aumentar la altura en la buhardilla.

3.1. MUROS

Tipo de intervención

Intervenido

Tipo de material

$\square$ Actualización $\quad$ X Reintegración $\quad \square$ Demolición $\square$ Otro..

$\square$ Consolidación $\quad \mathbf{X}$ Reconstrucción $\square$ Sustitución

Descripción

No tradicional Tipo de técnica Diferente a la existente

Sustitución de la cubierta que apoya sobre el muro de adobes. Se recrece el muro utilizando ladrillo hueco y cemento. Oquedades para inclusión de chimeneas...

3.2. ZÓCALO No aplica

Tipo de intervención

$\square$ Actualización $\square$ Reintegración $\quad \square$ Demolición $\square$ Otro.

$\square$ Consolidación $\square$ Reconstrucción $\square$ sustitución

Tipo de material

Descripción

3.3. REVESTIMIENTOS

Tipo de intervención

No aplica

Tipo de material

Descripción

3.4. VANOS

Tipo de intervención

Intervenido

Tipo de material

$\square$ Actualización $\quad \mathbf{X}$ Reintegración $\square$ Demolición $\square$ Otro...

$\square$ Consolidación $\square$ Reconstrucción $\square$ Sustitución

\begin{tabular}{l|l|l|l} 
Tipo de material & No tradicional & Tipo de técnica & Diferente a la existente
\end{tabular}

Descripción Reintegración contorno de los vanos y sustitución de las carpinterías (no cambia la dimensión) e inserción de rejas.

3.5. CUBIERTA

Intervenido

Tipo de intervención

$\square$ Actualización $\square$ Reintegración $\square$ Demolición $\square$ Otro

$\square$ Consolidación $\square$ Reconstrucción $\mathbb{X}$ Sustitución

\begin{tabular}{l|l|l|l|l} 
Tipo de material Tipo de técnica & No tradicional & Diferente a la existente \\
\hline
\end{tabular}

Descripción

nueva cubierta

3.6. OTRAS 
La restauración y rehabilitación de la arquitectura tradicional de tierra.

El caso de Aragón.

3.7. REHABILITACIÓN ENERGÉTICA $\square$ Fachada $\quad$ Х Vanos $\square$ Forjados $\square$ Cubierta

Observaciones

\author{
Sustitución de las carpinterías.
}

FOTOGRAFÍAS DE LA INTERVENCIÓN
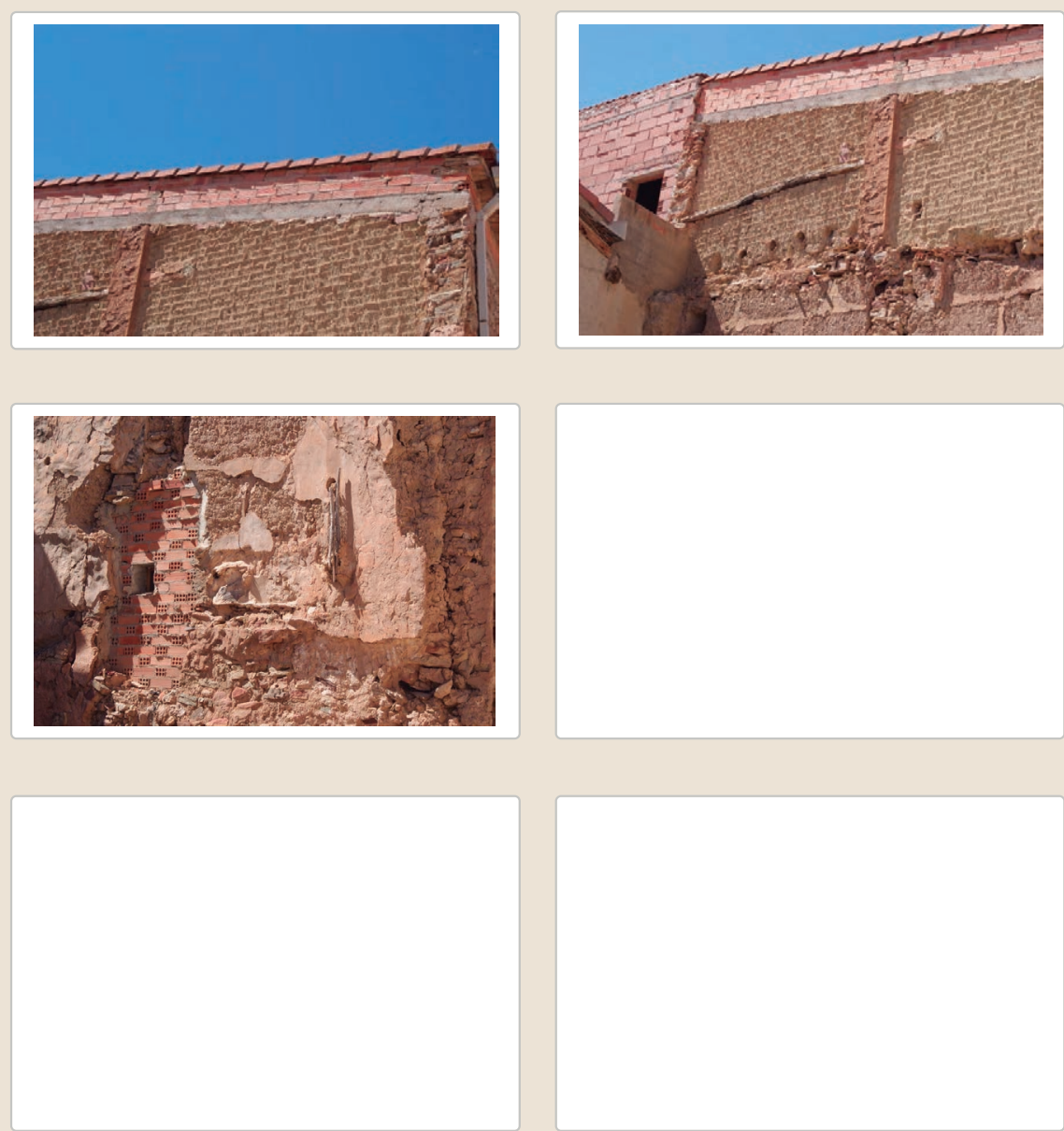

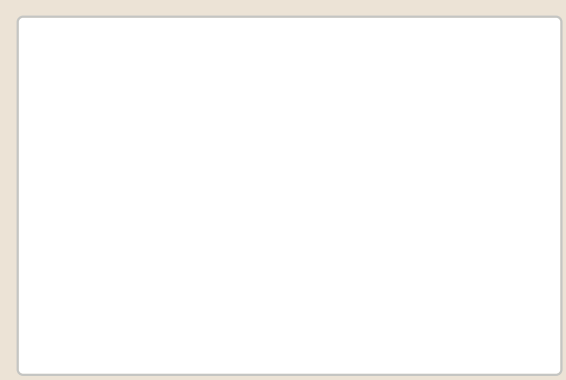




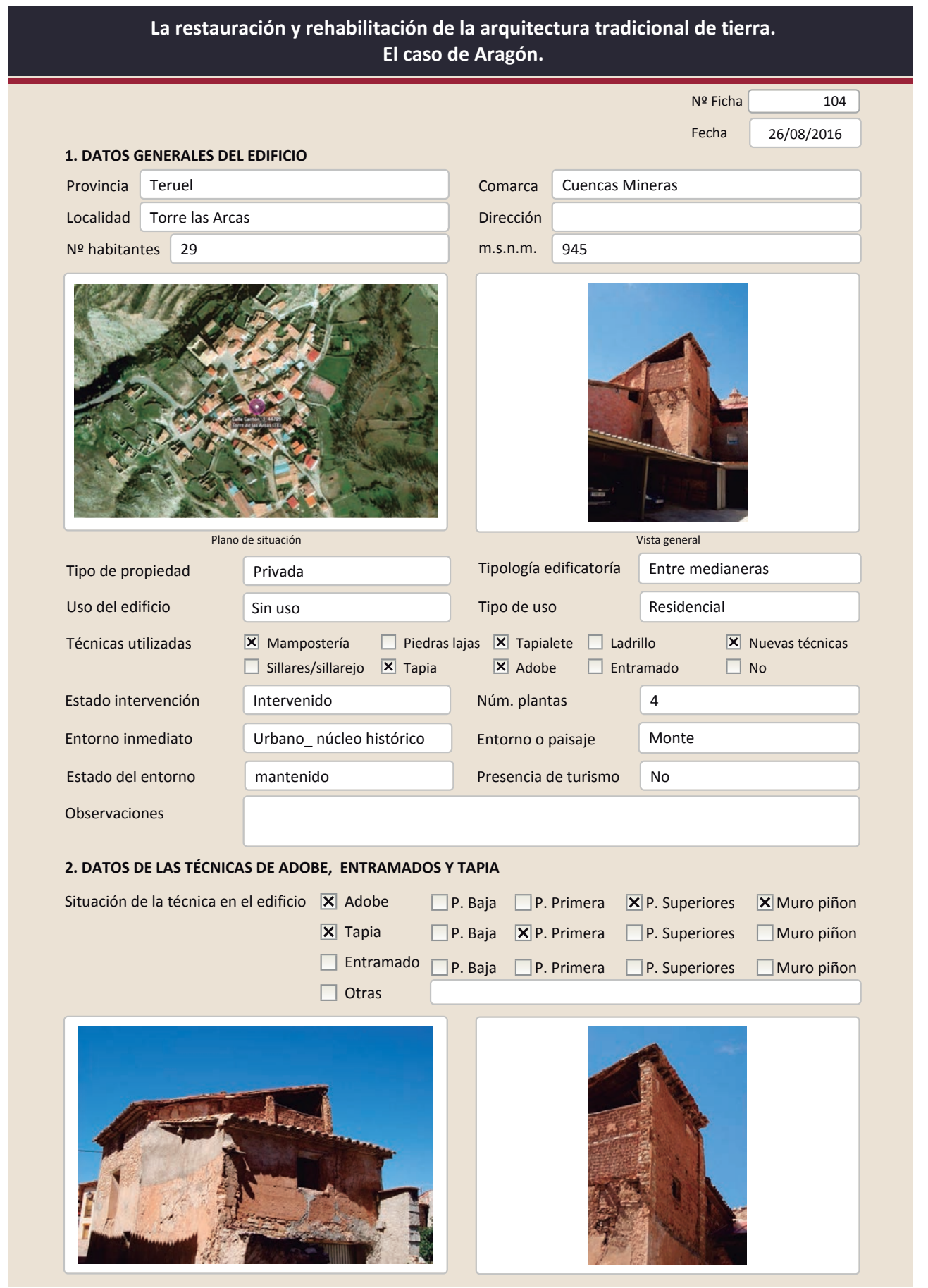

2.1. ADOBE

Dimensión de las piezas Dimensión del muro

Aparejo del muro

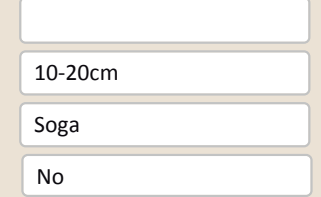

Color de las piezas

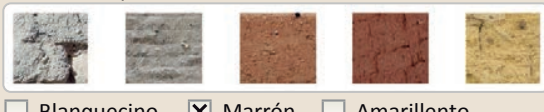

Blanquecino $\mathbf{X}$ Marrón $\square$ Amarillento $\square$ Grisaceo $\square$ Rojizo $\square$ Otro...

Función estructural

Comp. - estabilizante

Variante constructiva/ tipo de fábrica

$\square$ Simple
$\mathbf{X}$ Suplementada en juntas
Verticales y horizontales
$\square$ Mixta
$\square$ Como suplemento
$\square$ Elementos de protección

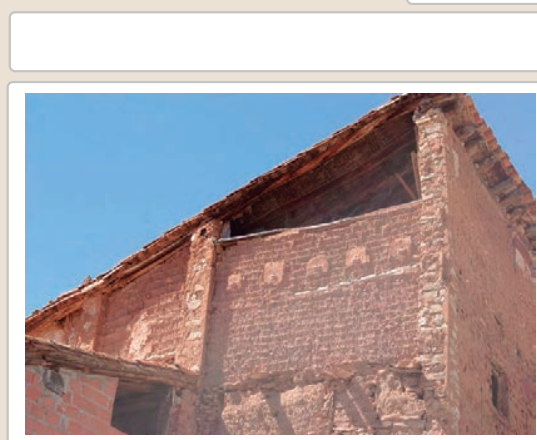

Lesiones $\quad \mathbf{X}$ Muro $\square$ Zócalo $\square$ Revestimiento

X Erosión del material $\square$ Humedad por capilaridad $\square$ Erosion de las juntas $\square$ Humedades (manch/eflo)

X Pérdida de sección $\square$ Pérdida de verticalidad

$\square$ Vegetación

$\square$ Grietas por empuje de la cubir $\square$ Grietas porfalta de traba

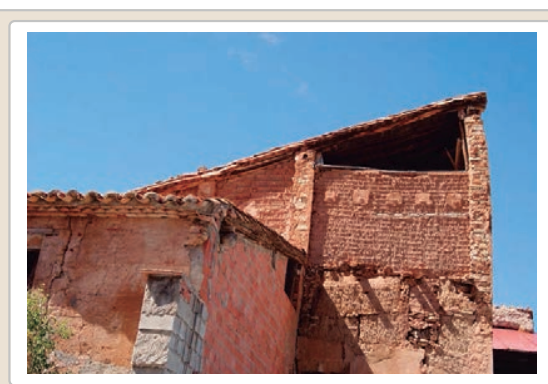

$\square$ Cubierta $\square$ Otro...

$$
\begin{aligned}
& \square \text { Grietas por asentamientos } \\
& \square \text { Colapso } \\
& \square \text { Por elementos impropios } \\
& \square \text { Derivado de intervenciones }
\end{aligned}
$$

$\square$ Desconchados $\square$ Otro...

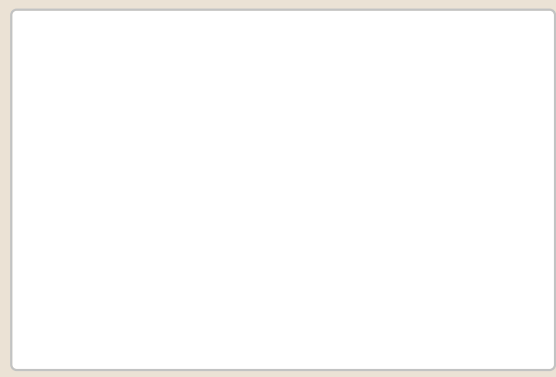

Observacione 


\section{La restauración y rehabilitación de la arquitectura tradicional de tierra.} El caso de Aragón.

\subsection{TAPIA}

Ancho del muro

Dimensión tapiales

Tipo de aguja

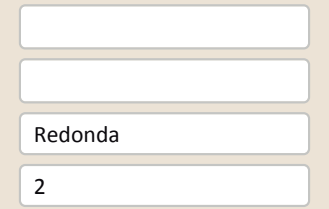

Color de la tapia

№ agujas/cajón

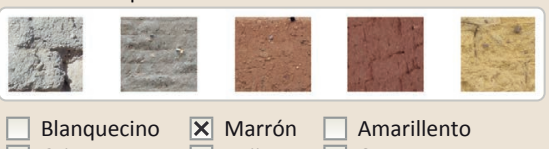

$\square$ Blanquecino $\quad \mathbf{X}$ Marrón $\square$ Amarillento $\square$ Grisaceo

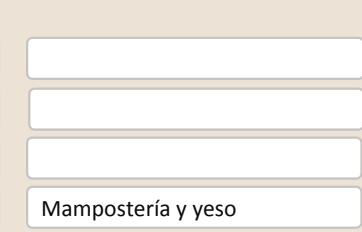

Variante constructiva

$\mathbb{X}$ Simple / homogénea
$\square$ Suplemento superficial
$\square$ Suplemento en juntas
$\mathbb{X}$ Mixta

$\mathbf{X}$ Elementos de protección

\section{Tapialete}

Machones

Revestimiento

Lo módulos de tapia aparecen de forma puntual entre otras técnicas por lo que no tiene una clasificación clara. Tapia y tapialete en distintas fachadas
Tán

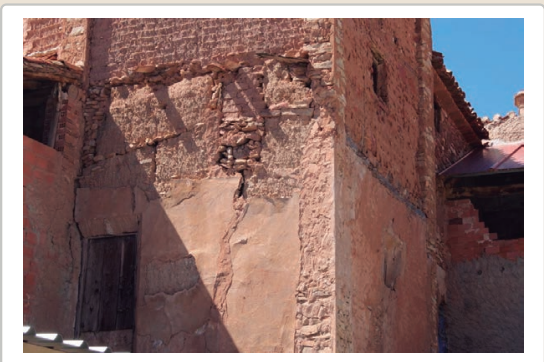

Lesiones

ХMuro $\square$ Zócalo ХRevestimiento

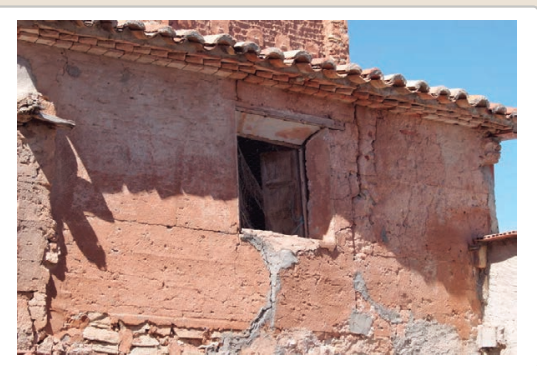

X Erosión del material $\quad \square$ Humedad por capilaridad $\quad \square$ Grietas por asentamientos

$\square$ Erosion de las juntas $\square$ Humedades (manch/eflo)

$\mathbb{X}$ Pérdida de sección $\square$ Pérdida de verticalidad

$\square$ Colapso

$\square$ Por elementos impropios

X Desconchados

$\mathbf{X}$ Grietas porfalta de traba

Por elementos impropios

$\square$ Otro...
La restauración y rehabilitación de la arquitectura tradicional de tierra.

El caso de Aragón.
3. DATOS DE LA INTERVENCIÓN

Intervención de: $\quad \square$ Mantenimiento $\square$ Rehabilitación parcial $\square$ Restauración $\square$ Demolición

Reflexión previa Intervención espontanea

Observaciones En el conjunto del edificio aparecen distintos tipo de intervenciones de forma puntual.

3.1. MUROS

Tipo de intervención

Tipo de material

Intervenido

$\square$ Actualización $\quad \square$ Reintegración $\quad \square$ Demolición $\quad \square$ Otro...

$\square$ Consolidación $\square$ Reconstrucción $\quad \mathbf{X}$ Sustitución

Descripción

Tipo de técnica Diferente a la existente

Sustitución parcial de pare del muro por muro de ladrillo hueco

3.2. ZÓCALO

Intervenido

Tipo de intervención

Tipo de material

$\square$ Actualización $\square$ Reintegración $\square$ Demolición $\square$ Otro.

$\square$ Consolidación $\quad \mathbf{X}$ Reconstrucción $\square$ Sustitución

Descripción

No tradicional

Tipo de técnica Diferente a la existente

3.3. REVESTIMIENTOS

Tipo de intervención

Nuevo revestimiento de cemento en la zona del zócalo

Tipo de material

Descripción

3.4. VANOS

Tipo de intervención

Tipo de material

Descripción

3.5. CUBIERTA

Tipo de intervención

Tipo de material

Descripción

Intervenido

$\square$ Actualización $\square$ Reintegración $\square$ Demolición $\square$ Otro...

$\square$ Consolidación $\quad \mathbf{X}$ Reconstrucción $\square$ Sustitución

No tradicional Tipo de técnica Diferente a la existente

No intervenido

$\square$ Actualización $\square$ Reintegración $\square$ Demolición $\square$ Otro..

$\square$ Consolidación $\square$ Reconstrucción $\square$ Sustitución

Intervenido

$\square$ Actualización $\quad \mathbf{X}$ Reintegración $\square$ Demolición $\square$ Otro

$\square$ Consolidación $\square$ Reconstrucción $\square$ Sustitución
No tradicional
Tipo de técnica Similar a la existente

Reintegración de tejas con mortero de cemento y sustitución de algunas piezas po otras de características parecidas.

Observaciones

3.6. OTRAS 


\section{La restauración y rehabilitación de la arquitectura tradicional de tierra.} El caso de Aragón.
3.7. REHABILITACIÓN ENERGÉTICA
$\square$ Fachada $\square$ Vanos $\square$ Forjados $\square$ Cubierta

Observaciones

FOTOGRAFÍAS DE LA INTERVENCIÓN
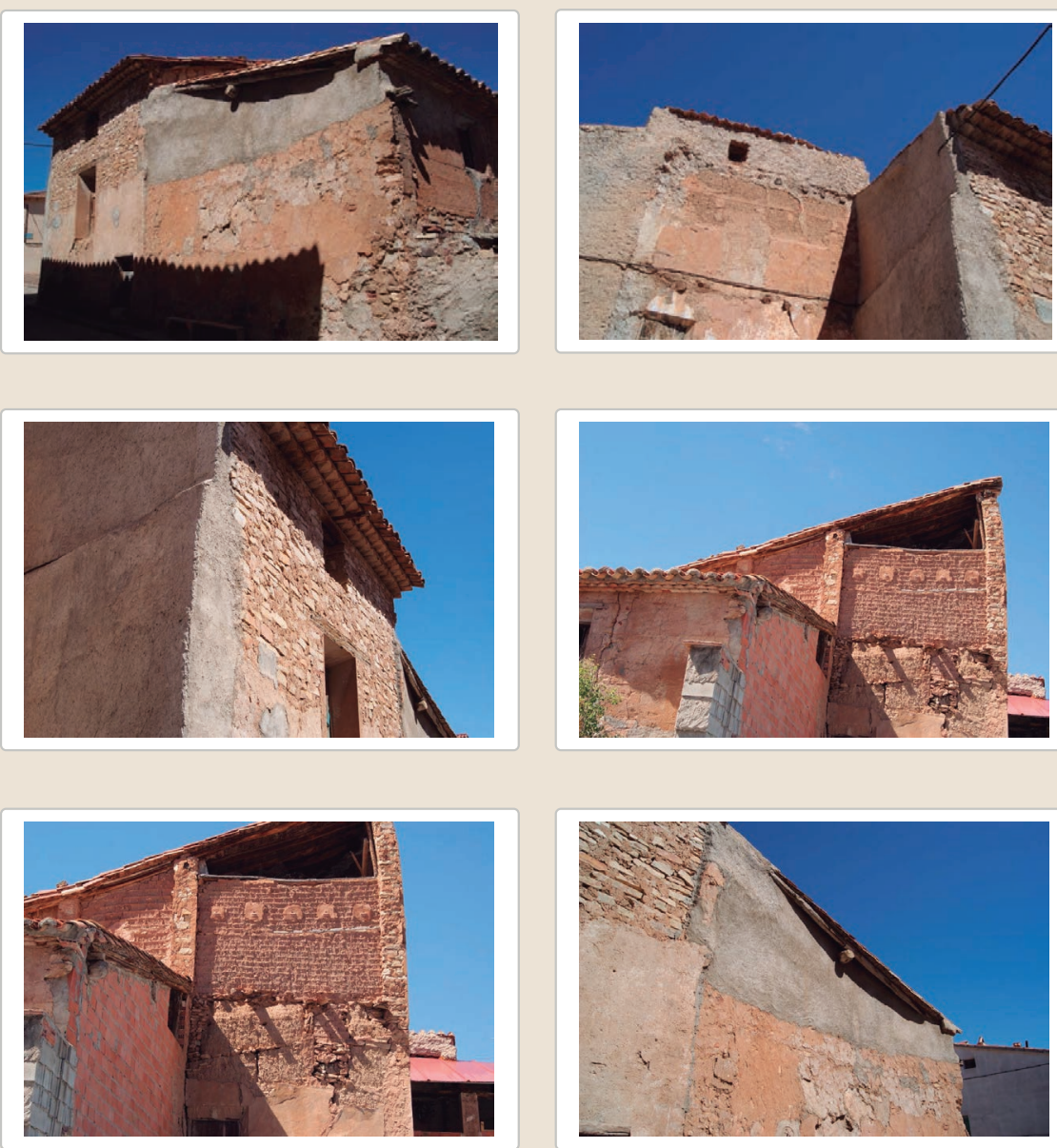


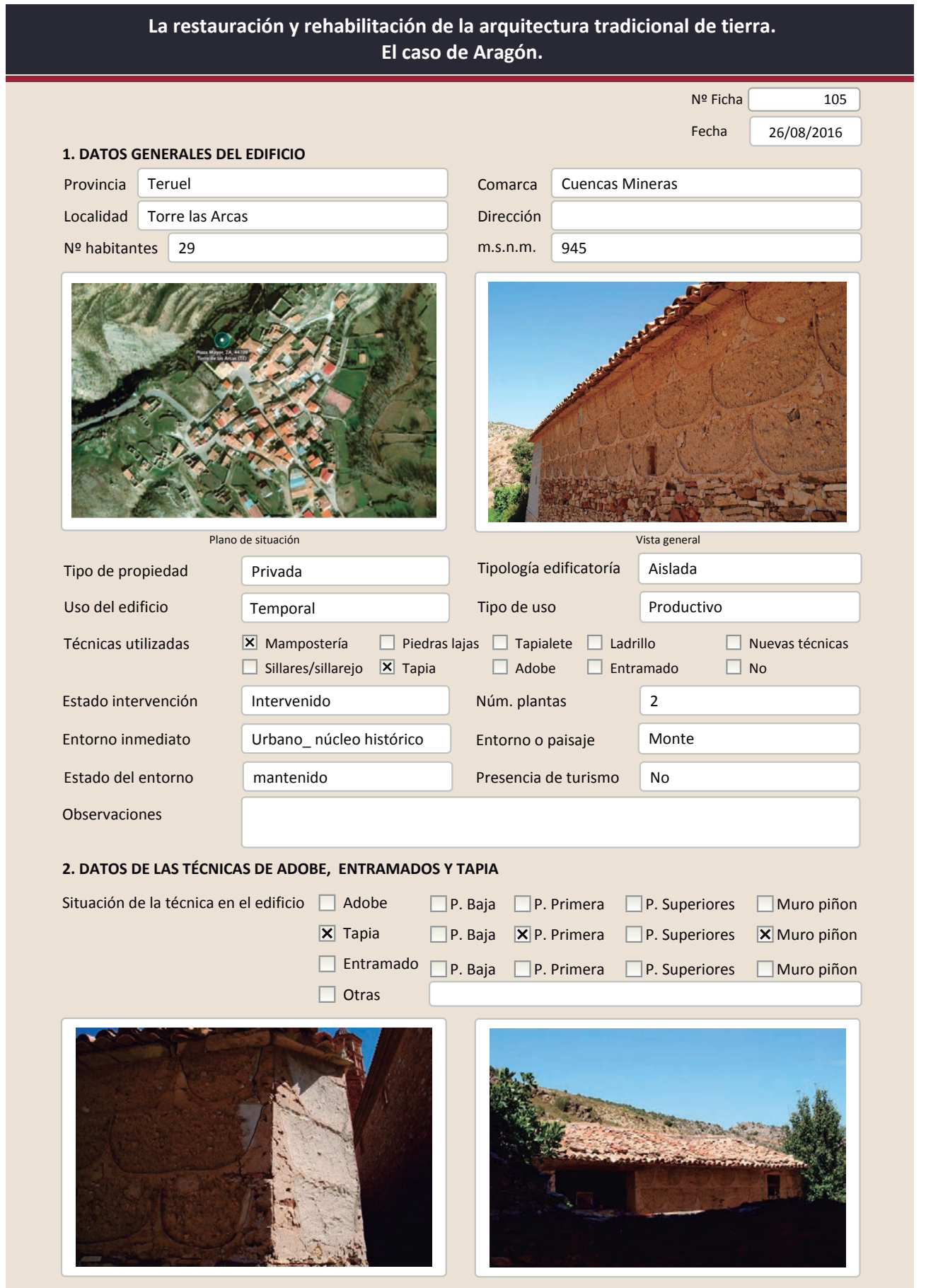

La restauración y rehabilitación de la arquitectura tradicional de tierra. El caso de Aragón.

2.2. TAPIA

Ancho del muro

Dimensión tapiales

Tipo de aguja

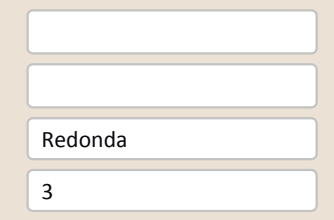

Color de la tapi

№ agujas/cajón

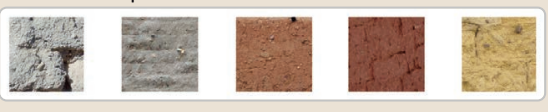

$\square$ Blanquecino $\mathbf{X}$ Marrón $\square$ Amarillento

$\begin{array}{ll}\square \text { Blanquecino } & \mathbf{X} \text { Marrón } \quad \square \text { Amarill } \\ \square \text { Grisaceo } & \square \text { Rojizo } \quad \square \text { Otro... }\end{array}$

Variante constructiva

$\square$ simple / homogénea

$\square$ suplemento superficial

X Suplemento en juntas

$\square$ Mixta

$\square$ Elementos de protección
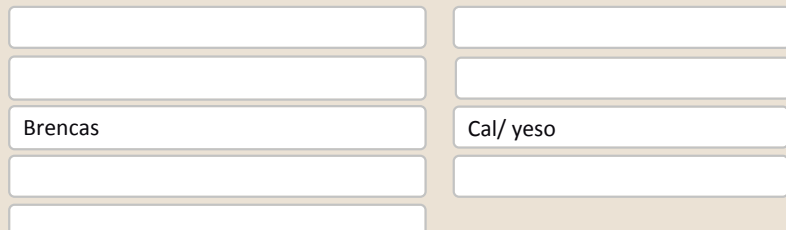

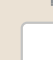

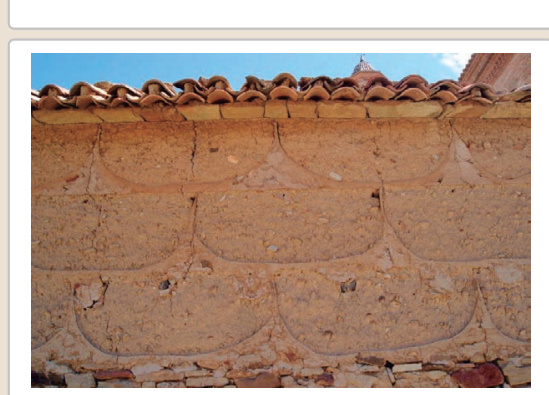

Lesiones $\quad \mathbf{M}$ Muro $\square$ Zócalo $\square$ Revestimiento $\square$ Cubierta $\square$ otro...

X Erosión del material $\quad \square$ Humedad por capilaridad $\quad \square$ Grietas por asentamientos $\square$ Erosion de las juntas $\square$ Humedades (manch/eflo)

X Pérdida de sección $\square$ Pérdida de verticalidad

$\square$ Vegetación $\quad \square$ Grietas por empuje de la cubierta

$\square$ Desconchados

$\square$ Grietas porfalta de traba

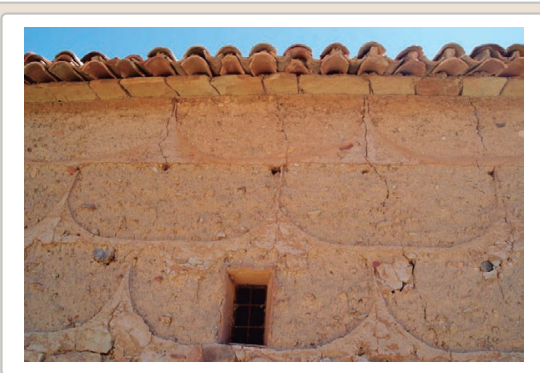

$\square$ Por elem

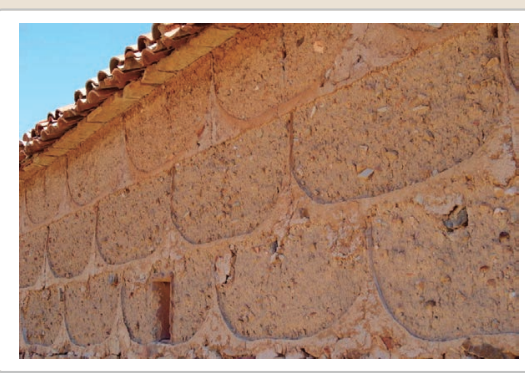

$\square$ Derivado de in

$\square$ Otro... 


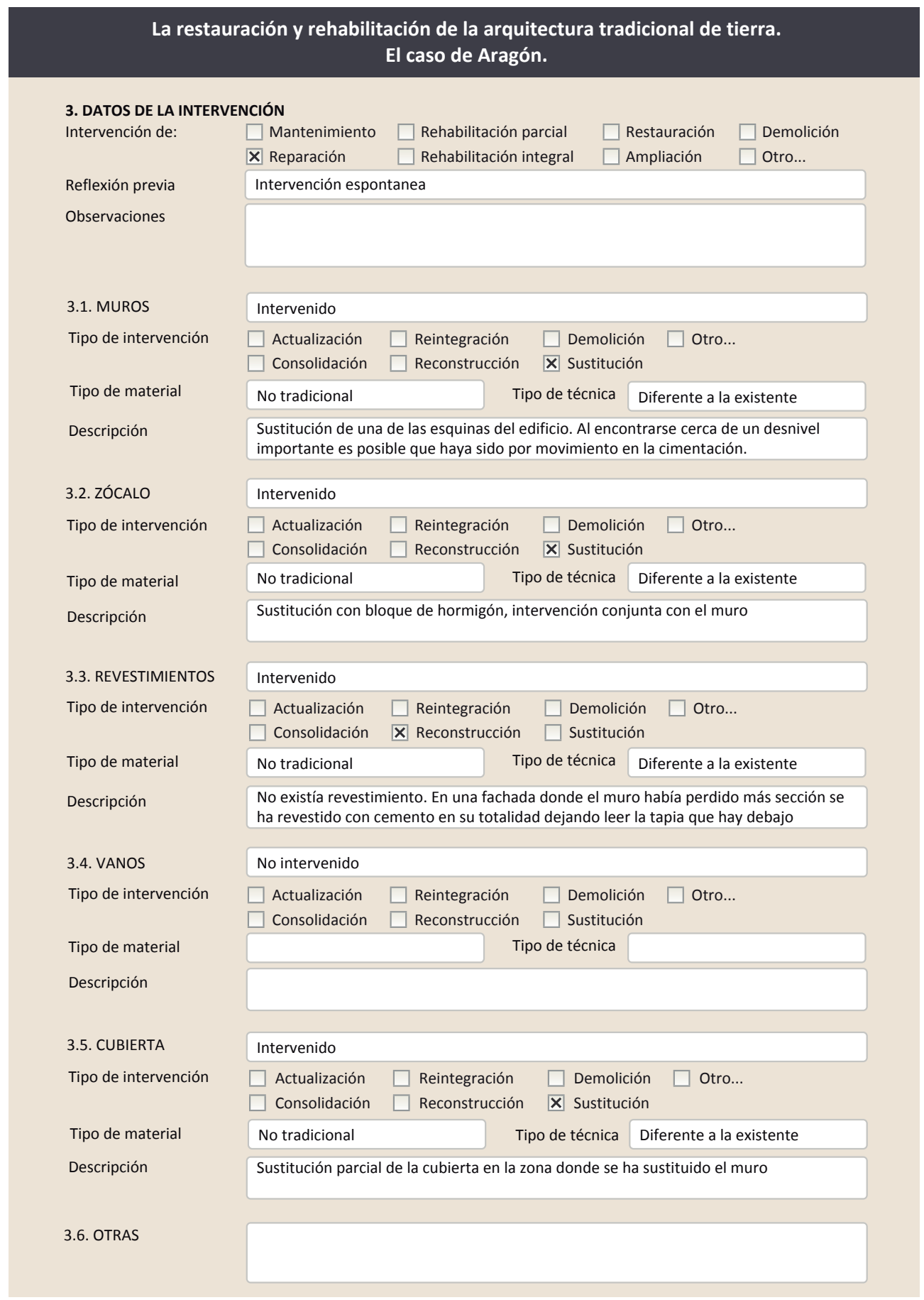

3.7. REHABILITACIÓN ENERGÉTICA $\quad \square$ Fachada $\square$ Vanos $\square$ Forjados $\square$ Cubierta Observaciones

FOTOGRAFÍAS DE LA INTERVENCIÓN
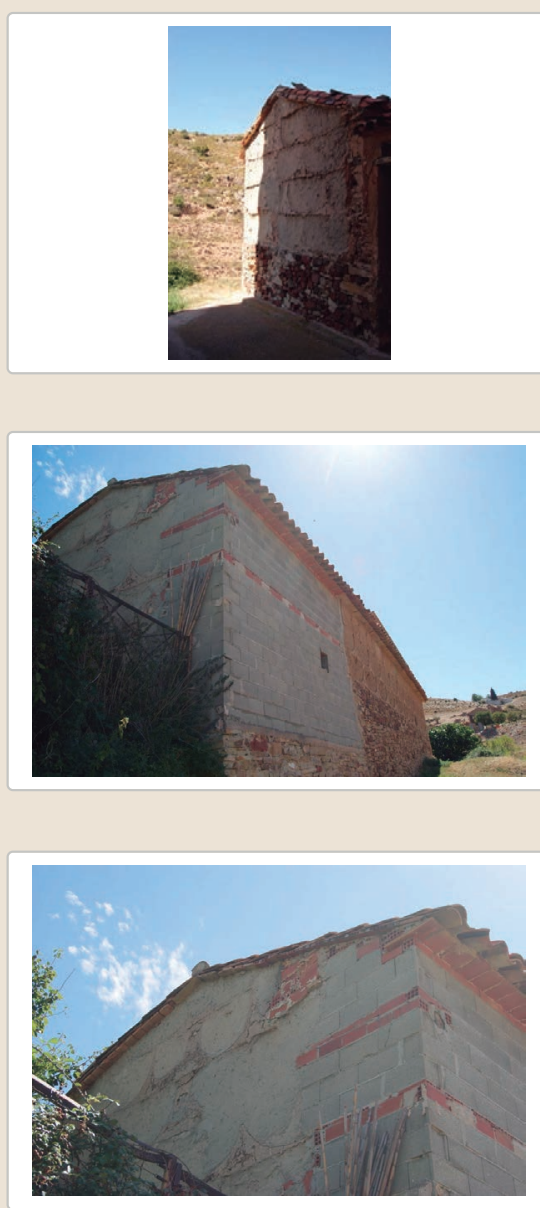
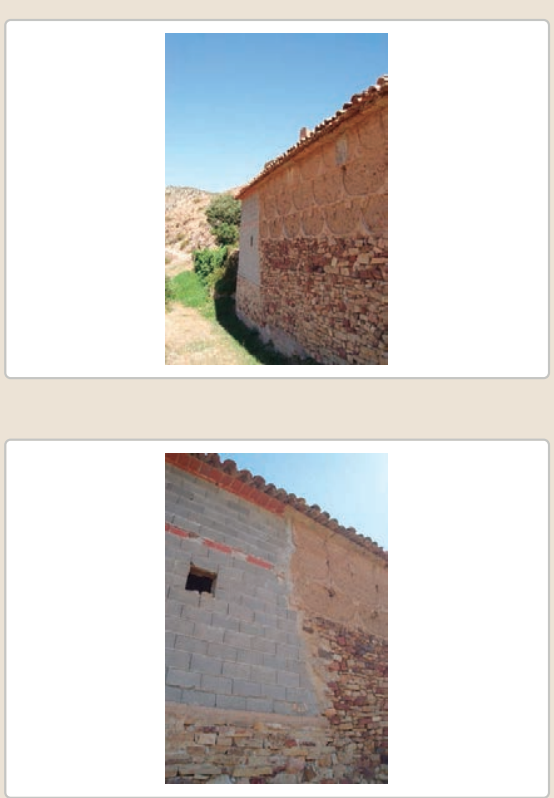


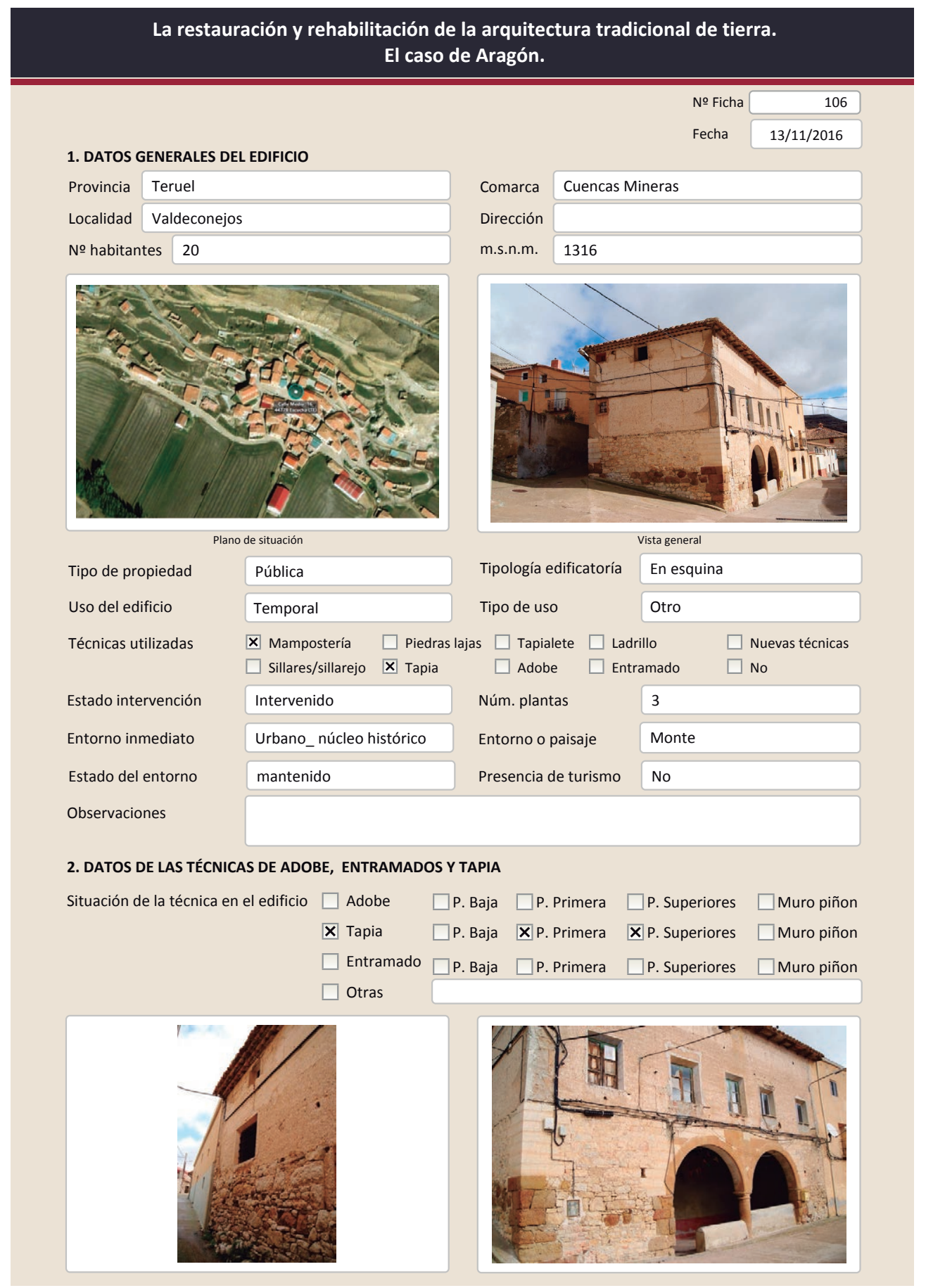

La restauración y rehabilitación de la arquitectura tradicional de tierra. El caso de Aragón.

2.2. TAPIA

Ancho del muro

Dimensión tapiales

Tipo de aguja

№ agujas/cajón

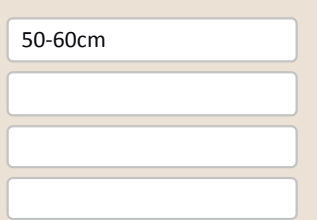

Color de la tapia

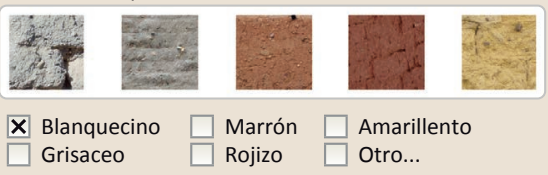

Variante constructiva

$\square$ Simple / homogénea

\ Suplemento superficial

$\square$ suplemento en juntas

X Mixta
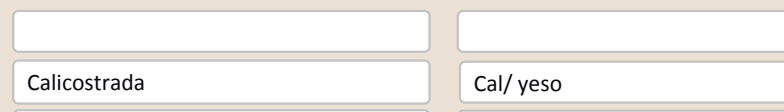

Machones de rafas

$\square$ Elementos de protección

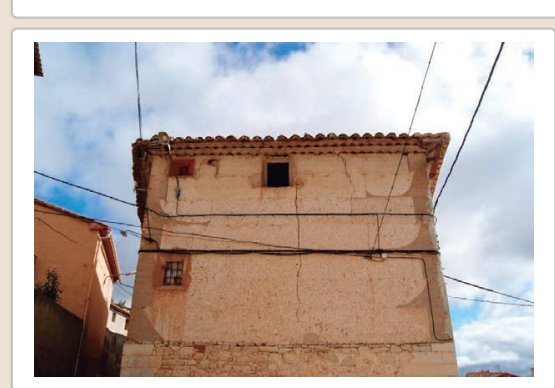

Lesiones $\quad$ XMuro $\square$ Zócalo $\square$ Revestimiento X Erosión del material $\quad \square$ Humedad por capilaridad $\square$ Erosion de las juntas $\square$ Humedades (manch/eflo) $\square$ Pérdida de sección $\square$ Pérdida de verticalidad
$\square$ Vegetación
$\square$ Grietas por empuje de la cubic

$\square$ Grietas porfalta de traba

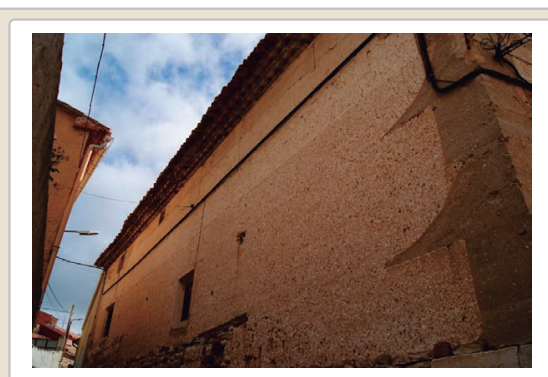

$\square$ Cubierta $\square$ Otro...

$$
\begin{aligned}
& \square \text { Grietas por asentamientos } \\
& \square \text { Colapso } \\
& \square \text { Por elementos impropios } \\
& \square \text { Derivado de intervenciones }
\end{aligned}
$$

X Desconchados
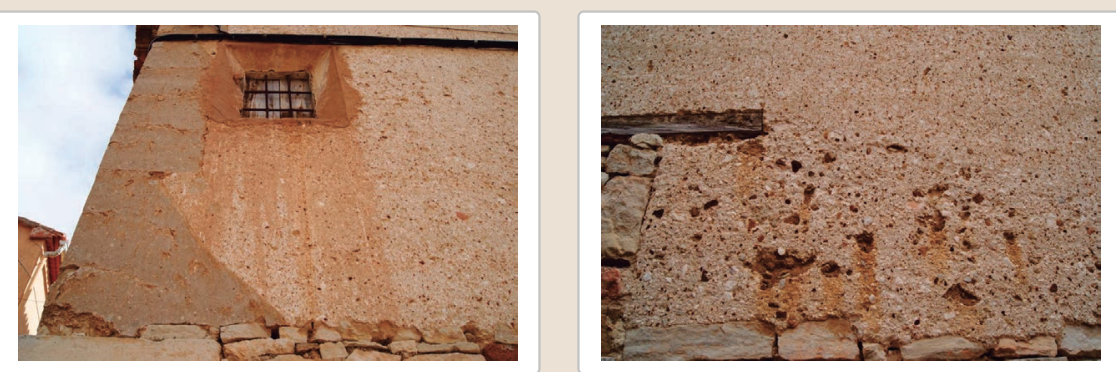

Observaciones 


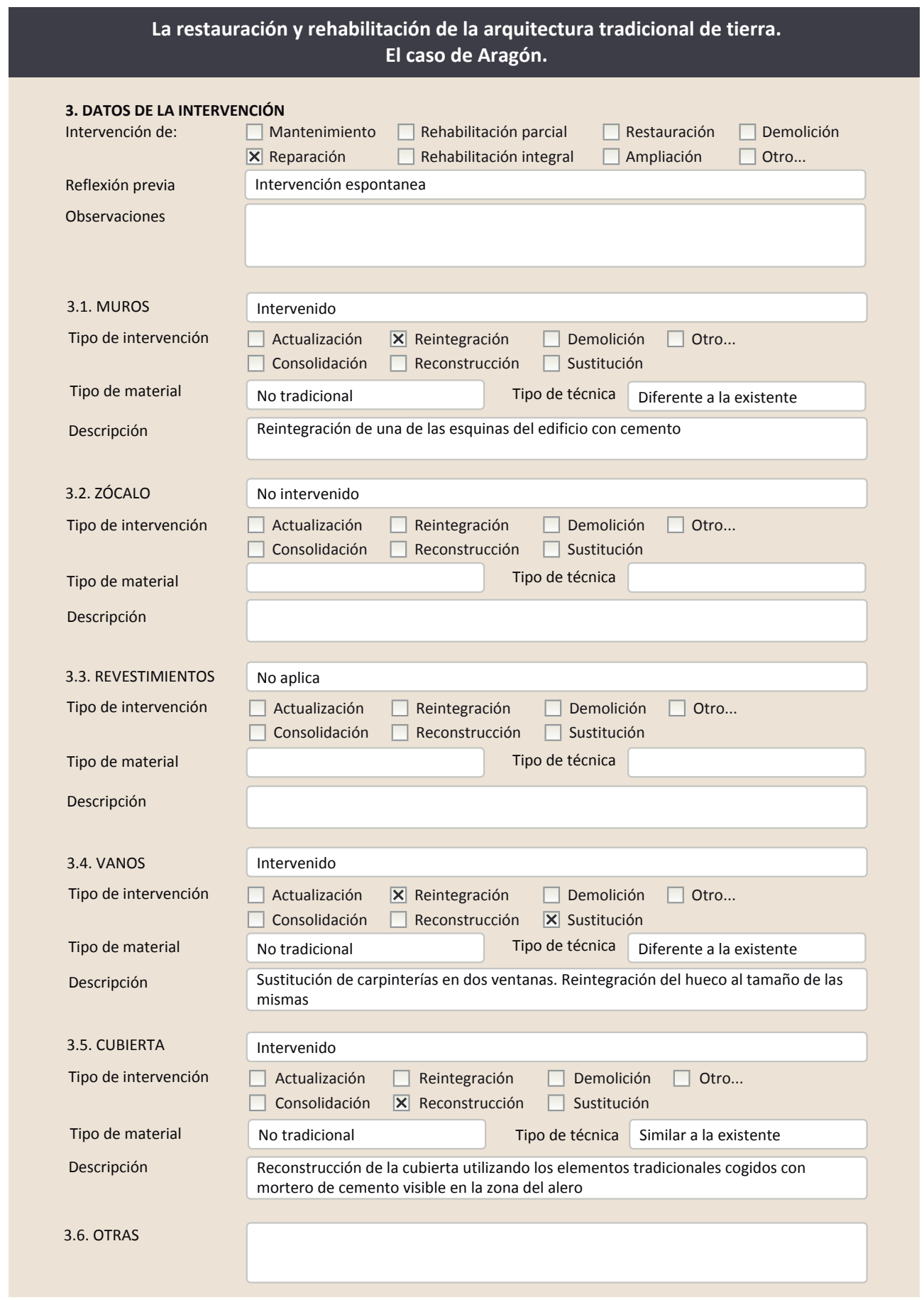

3.7. REHABILITACIÓN ENERGÉTICA $\square$ Fachada $\square$ Vanos $\square$ Forjados $\square$ Cubierta

Observaciones

FOTOGRAFÍAS DE LA INTERVENCIÓN
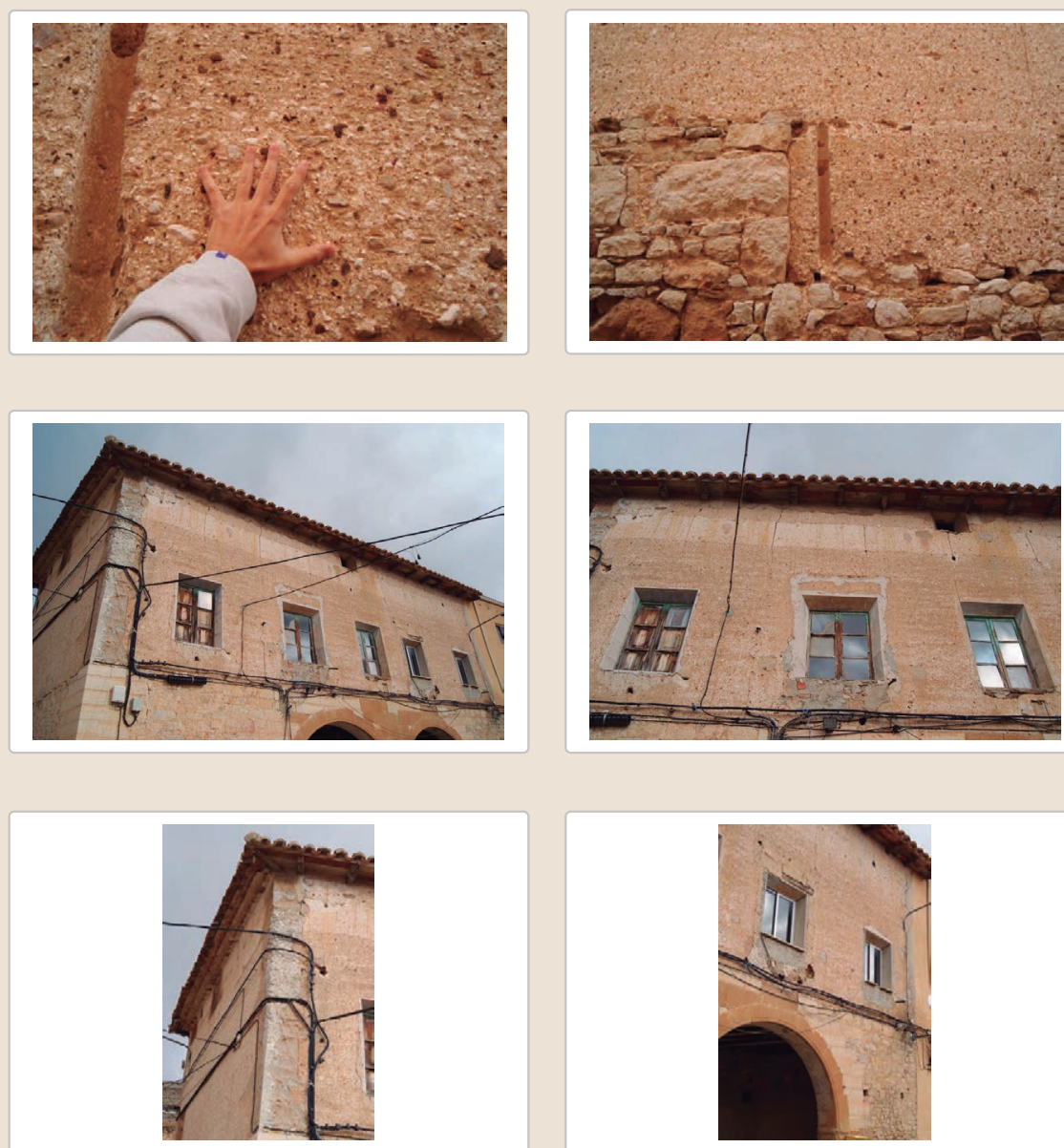


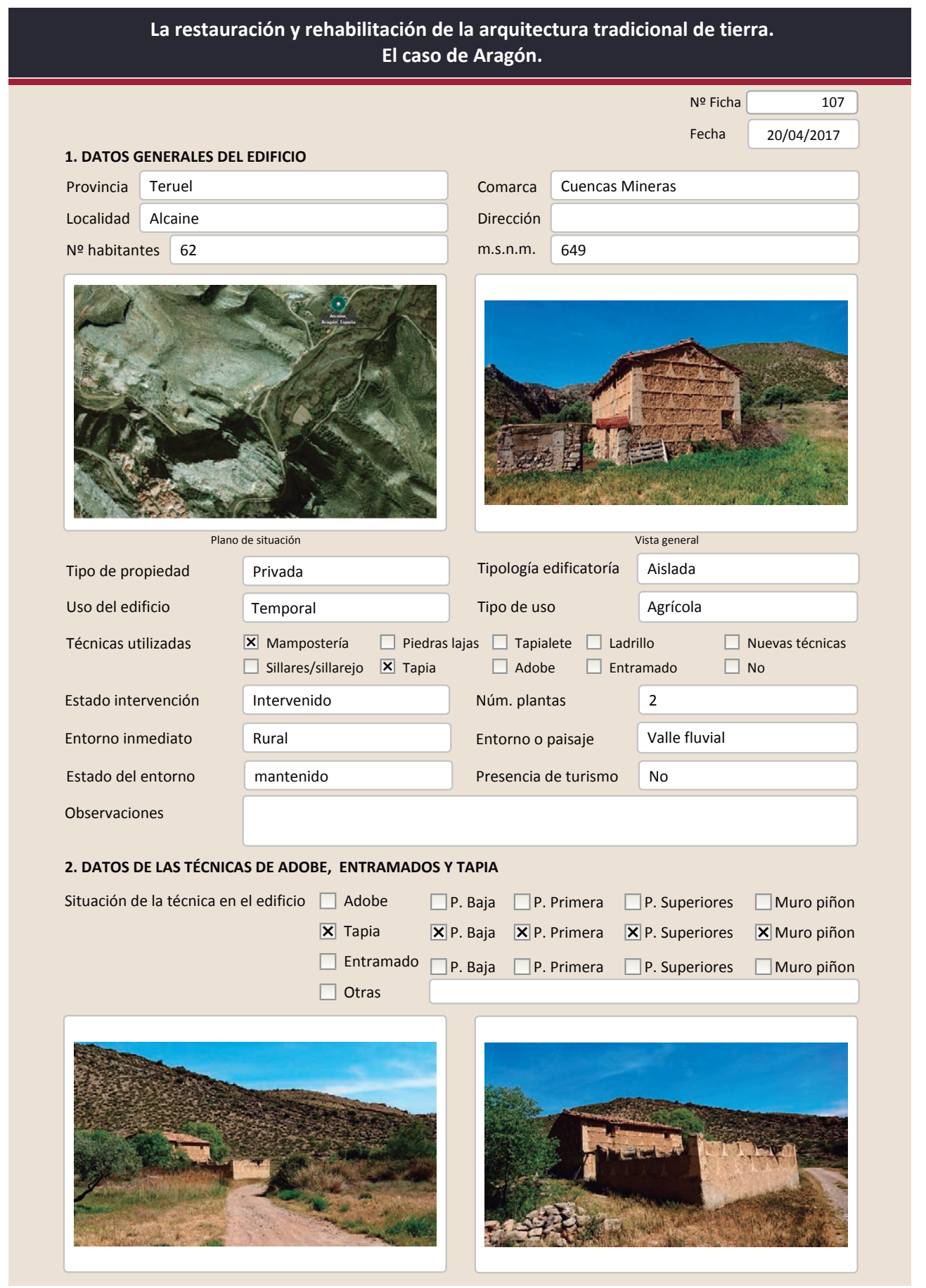

La restauración y rehabilitación de la arquitectura tradicional de tierra. El caso de Aragón.

2.2. TAPIA

Ancho del muro

Dimensión tapiales

Tipo de aguja

№ agujas/cajón

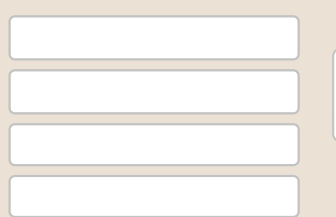

Color de la tapia

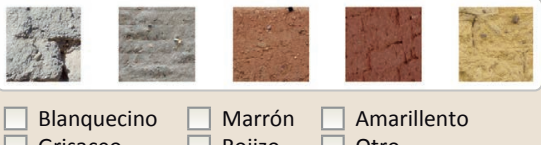

$\square$ Blanquecino $\square$ Marrón $\square$ Amarillento

$\square$ Simple / homogénea

$\square$ suplemento superficial

$\boldsymbol{X}$ Suplemento en juntas

$\mathbf{X}$ Mixta
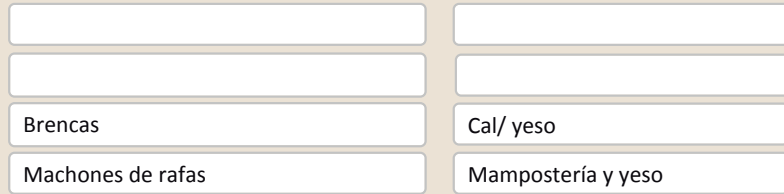

Mampostería y yeso

$\square$ Elementos de protección

Esta tapia debido a su deterioro muestra suplementos con madera de sabina en su interior de forma longitudinal al muro

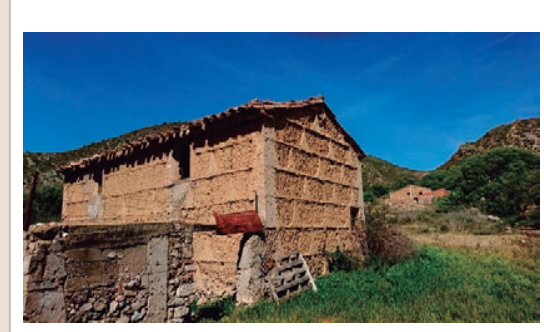

Lesiones $\quad \mathbf{X}$ Muro $\square$ Zócalo $\square$ Revestimiento

X Erosión del material $\quad \square$ Zócalo $\square$ Revestimiento
$\square$ Humedad por capilaridad $\mathbf{X}$ Erosion de las juntas $\square$ Humedades (manch/eflo)

X Pérdida de sección $\quad \square$ Pérdida de verticalidad

$\square$ Vegetación

$\square$ Desconchados $\quad \mathbf{X}$ Grietas porfalta de traba

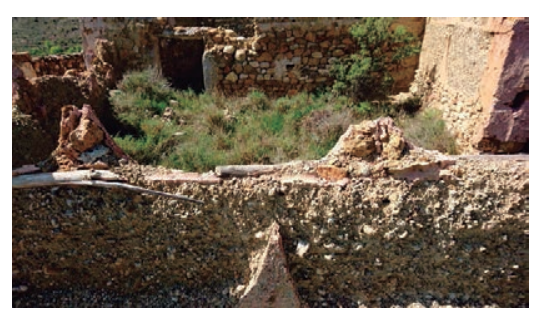

X Cubierta $\square$ otro...

$\square$ Grietas por asentamiento X Colapso

$\square$ Por elementos impropios

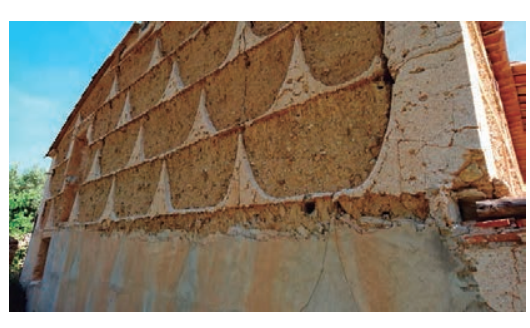

$\square$ Otro...

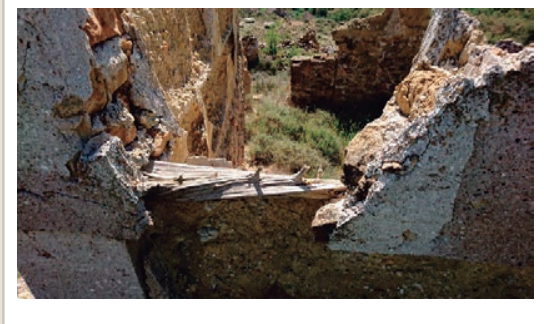

Observaciones En la zona intervenida con cemento se ve como se ha agrietado este en el punto entre la brenca y la tierra por ser este muy rígidos y los otros materiales moverse de forma
Nifaranto 
La restauración y rehabilitación de la arquitectura tradicional de tierra. El caso de Aragón

\section{La restauración y rehabilitación de la arquitectura tradicional de tierra.}

\section{El caso de Aragón.}

3. DATOS DE LA INTERVENCIÓN

Intervención de:

$\square$ Mantenimiento $\square$ Rehabilitación parcia

$\square$ Restauración $\square$ Demolición

Reflexión previa

X Reparación

$\square$ Rehabilitación integral $\square$ Ampliación

$\square$ Otro..

Observaciones

Intervención espontanea

(n)

3.1. MUROS

Tipo de intervención

Intervenido

Tipo de material

$\square$ Actualización $\square$ Reintegración $\square$ Demolición $\square$ Otro...

$\square$ Consolidación $\quad$ Reconstrucción $\square$ Sustitución

Descripción

No tradicional Tipo de técnica Diferente a la existente

3.2. ZÓCALO

Tipo de intervención

Reconstrucción parcial del muro en la entrada al patio con hormigón

Tipo de material

Intervenido

$\square$ Actualización $\square$ Reintegración $\square$ Demolición $\square$ Otro...

$\square$ Consolidación $\quad \mathbf{X}$ Reconstrucción $\square$ Sustitución

Descripción
No tradicional
Tipo de técnica Diferente a la existente

3.3. REVESTIMIENTOS

Se ha realizado un zócalo con revestimiento de cemento en una de las fachadas

Tipo de intervención

\section{No aplica}

Tipo de material

$\square$ Actualización

$\square$ Reintegración $\square$ Demolición $\square$ Otro...

$\square$ Consolidación $\square$ Reconstrucción $\square$ Sustitución

Descripción

3.4. VANOS

Tipo de intervención

No intervenido

Tipo de material

$\square$ Actualización $\quad \square$ Reintegración $\quad \square$ Demolición $\quad \square$ Otro...
$\square$ Consolidación $\quad \square$ Reconstrucción $\quad \square$ sustitución

Descripción

(3.5. CUBERTA

3.5. CUBIERTA

Tipo de intervención

No intervenido

Tipo de material

$\square$ Actualización $\quad \square$ Reintegración $\quad \square$ Demolición $\quad \square$ Otro...
$\square$ Consolidación $\quad \square$ Reconstrucción $\quad \square$ Sustitución

Descripción

Tipo de técnica

3.6. OTRAS 


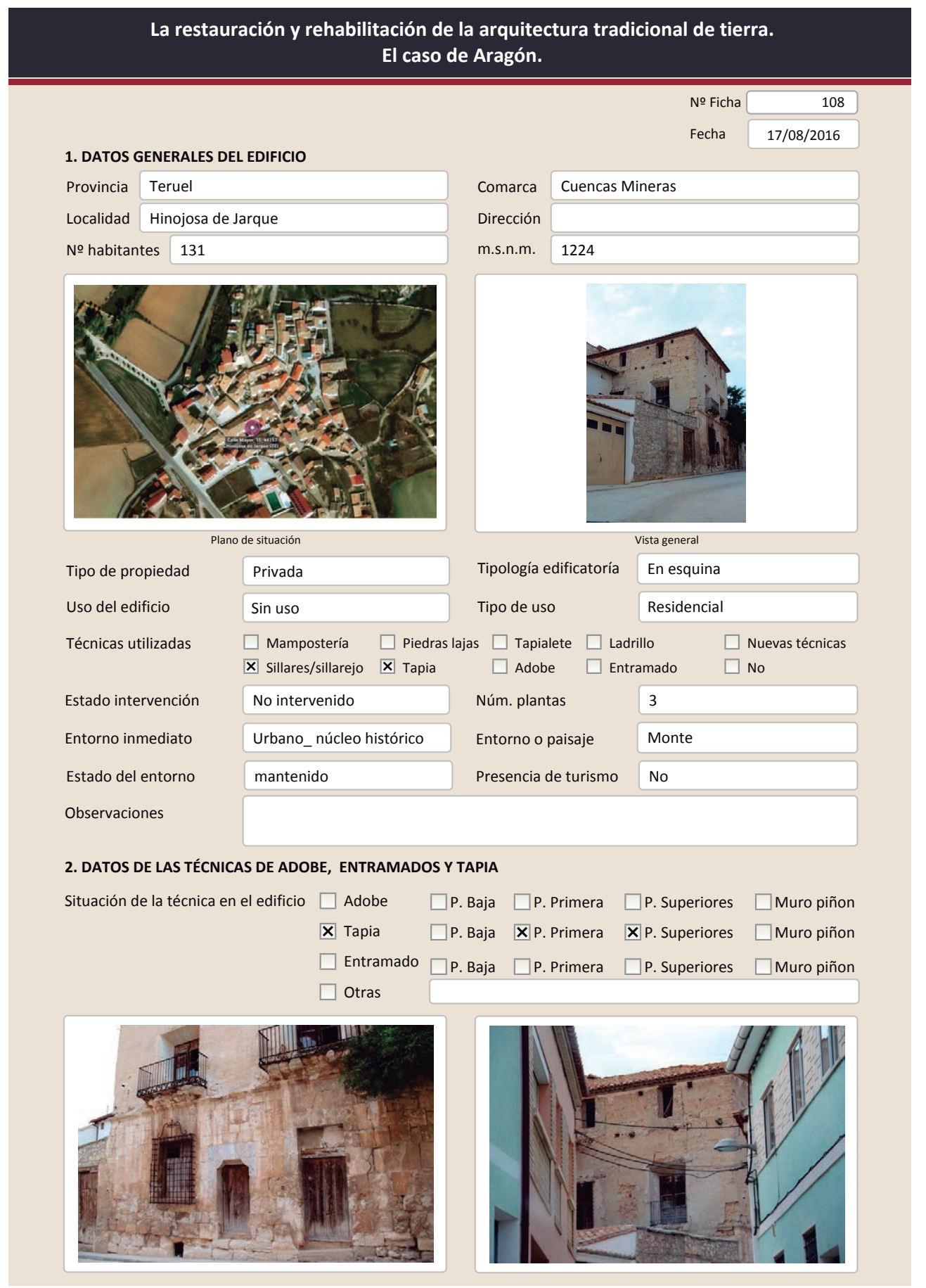

La restauración y rehabilitación de la arquitectura tradicional de tierra. El caso de Aragón.

2.2. TAPIA

Ancho del muro

Dimensión tapiales

Tipo de aguja

Redonda

№ agujas/cajón

Variante constructiva

$\square$ simple / homogénea

$\square$ suplemento superficial

$\boldsymbol{X}$ Suplemento en juntas

X Mixta

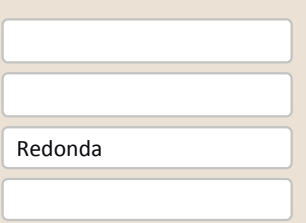

Color de la tapia

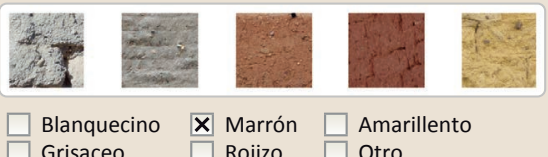

$\begin{array}{ll}\square \text { Blanquecino } & \boldsymbol{x} \text { Marrón } \\ \square \text { Grisaceo } & \square \text { Amarillento } \\ & \text { Rojizo } \\ \end{array}$

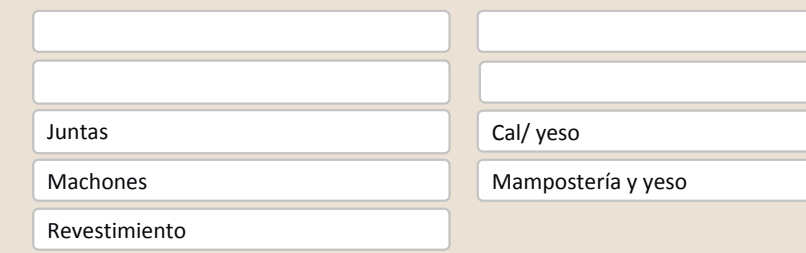

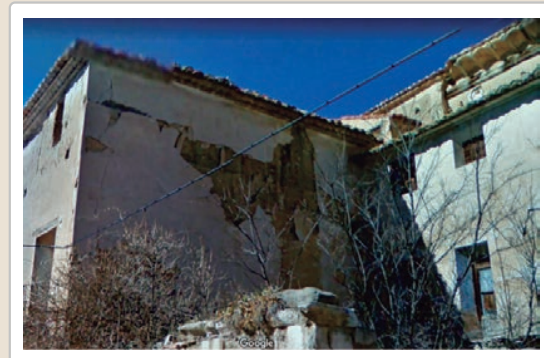

Lesiones $\mathbf{X}$ Muro $\mathbf{X}$ Zócalo $\mathbf{X}$ Revestimiento $\mathbf{X}$ Erosión del material $\mathbf{X}$ Humedad por capilaridad $\square$ Erosion de las juntas $\square$ Humedades (manch/eflo) $\square$ Pérdida de sección $\quad \square$ Pérdida de verticalidad
$\square$ Vegetación
X Grietas por empuje de la cubic

X Desconchados

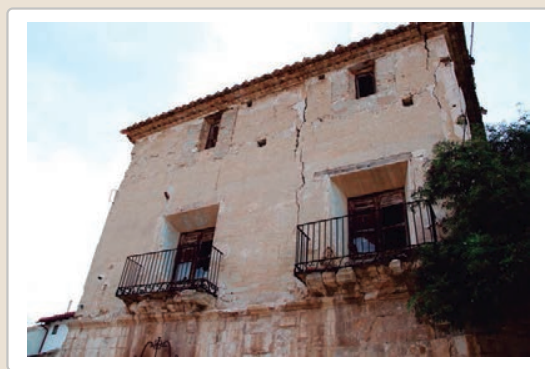

X Cubierta $\square$ Otro...

$\square$ Grietas por asentamiento $\square$ Colapso

$\square$ Por elementos impropios

$\square$ Derivado de intervenciones

$\square$ Otro...
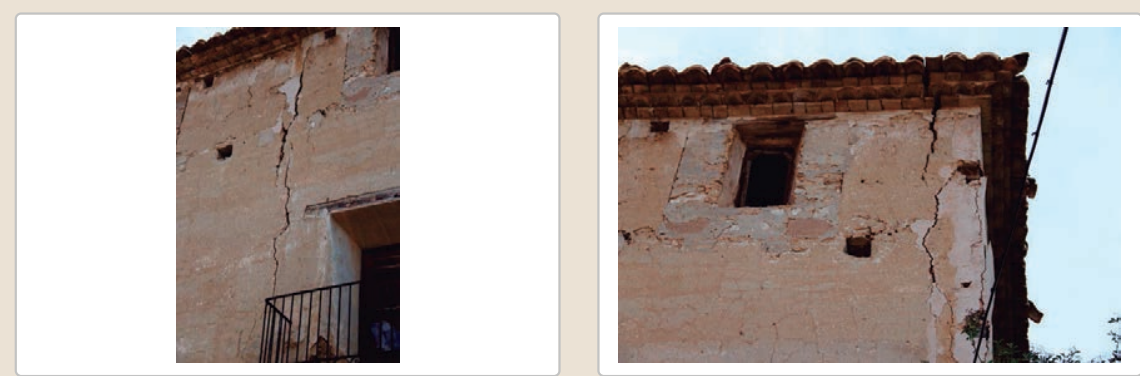


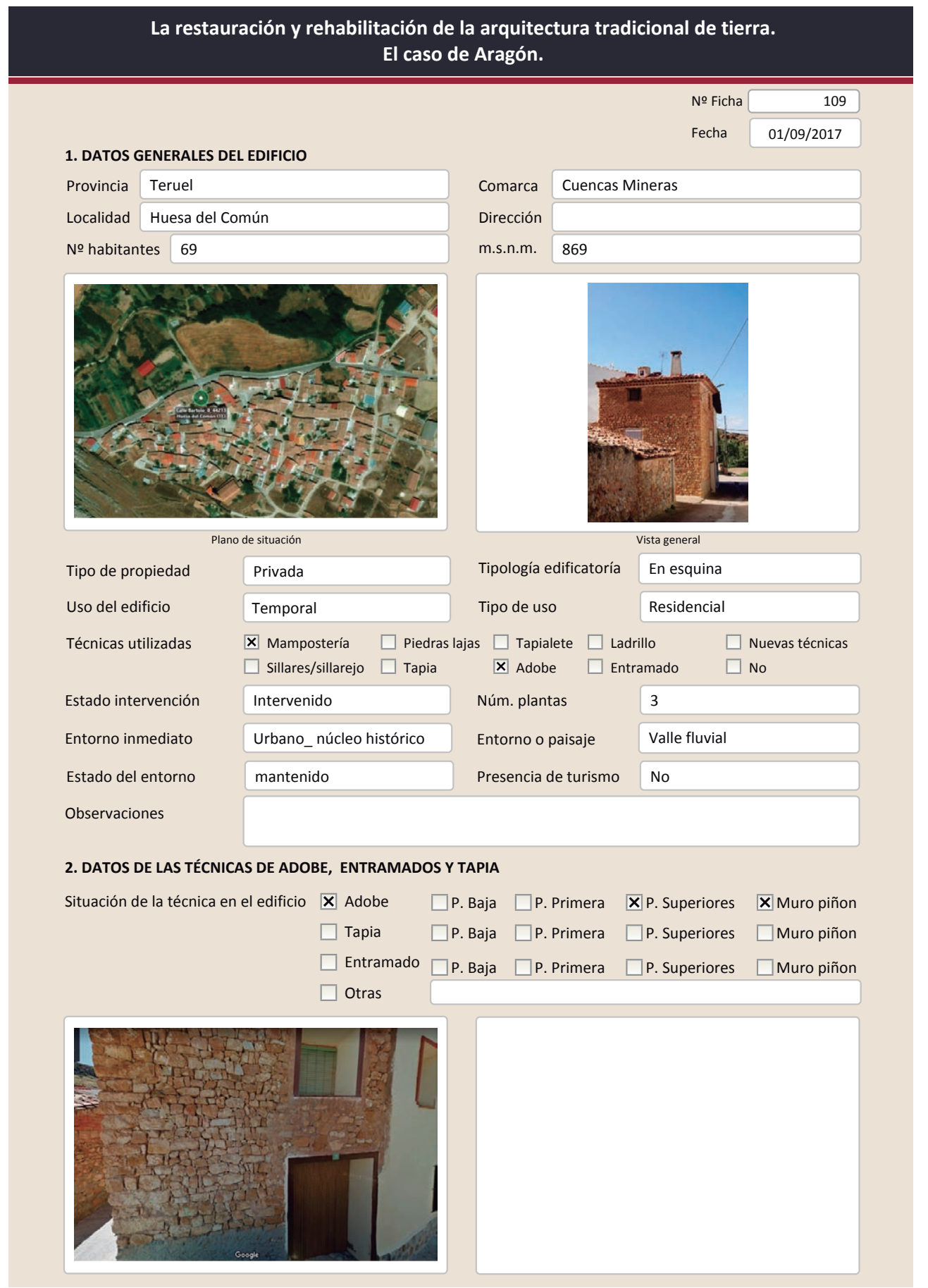

2.1. ADOBE

Dimensión de las piezas Dimensión del muro

Aparejo del muro

Función estructural

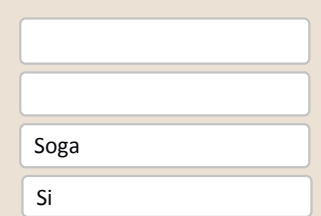

Color de las piezas

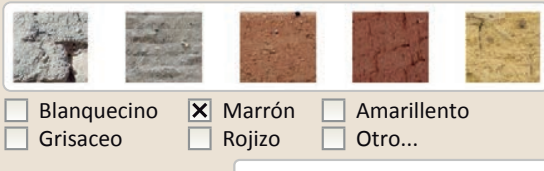

Comp. - estabilizante

Variante constructiva/ tipo de fábrica

$\square$ Simple

$\square$ suplementada en juntas

区 Mixta

En esquinas

Piedra

$\square$ Como suplemento

$\square$ Elementos de protección

Se trata de un único paño de fábrica de adobe

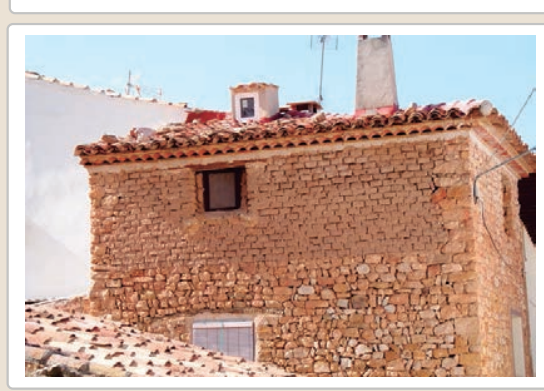

Lesiones $\quad \mathbf{X}$ Muro $\square$ Zócalo $\square$ Revestimiento

X Erosión del material $\square$ Humedad por capilaridad $\square$ Erosion de las juntas $\square$ Humedades (manch/eflo)

$\square$ Pérdida de sección $\square$ Pérdida de verticalidad

$\square$ Vegetación

$\square$ Grietas por empuje de la $\square$ Grietas porfalta de traba

$\square$ Cubierta $\square$ otro...

$\square$ Grietas por asentamiento

$\square$ Colapso

$\square$ Desconchados

$\square$ Por elementos impropios

$\square$ Derivado de intervenciones

$\square$ otro..

Observaciones 


\section{La restauración y rehabilitación de la arquitectura tradicional de tierra.}

\section{El caso de Aragón.}

\section{DATOS DE LA INTERVENCIÓN}

Intervención de:

$\square$ Mantenimiento $\mathbf{X}$ Rehabilitación parcial

$\square$ Restauración $\square$ Demolición

Reflexión previa

$\square$ Reparación

Rehabilitación integra

Ampliación

$\square$ Otro...

Observaciones

Intervención espontanea

(2)

3.1. MUROS

No intervenido

Tipo de intervención

$\square$ Actualización

$\square$ Consolidación $\square$ Reconstrucción $\square$ Sustitución

Tipo de material

Descripción

3.2. ZÓCALO

Tipo de intervención

Intervenido

$\square$ Actualizació

Reintegración $\square$ Demolición $\square$ Otro..

Tipo de material

$\square$ Consolidación $\quad \mathbf{X}$ Reconstrucción $\square$ Sustitución

Descripción

Tipo de técnica Diferente a la existente

3.3. REVESTIMIENTOS

Zócalo de revestimiento de cemento en la fachada principal

Tipo de intervención

\section{No aplica}

Tipo de material

$\square$ Actualización

$\square$ Reintegración $\square$ Demolición $\square$ Otro..

Consolidación $\square$ Reconstrucción $\square$ Sustitución

Descripción

3.4. VANOS

Tipo de intervención

Intervenido

Tipo de material

$\mathbf{X}$ Actualización $\square$ Reintegración $\square$ Demolición $\square$ Otro...

\begin{tabular}{llll} 
No tradicional Tipo de técnica Diferente a la existente \\
\hline
\end{tabular}

Descripción Nuevo contorno de los huecos con cemento como elemento decorativo. Se han sustituido algunas carpinterías

3.5. CUBIERTA

$\begin{array}{ll}\text { Tipo de intervención } & \square \text { Actualización } \quad \square \text { Reintegración } \quad \square \text { Demolición } \quad \square \text { Otro... } \\ & \square \text { consolidación } \quad \boldsymbol{X} \text { Reconstrucción } \quad \boldsymbol{X} \text { Sustitución }\end{array}$

Intervenido

$\begin{array}{llll}\text { Tipo de material Tradicional diferente Tipo de técnica Similar a la existente } & \end{array}$

Descripción Se ha reconstruido la cubierta por completo utilizando materiales tradicionales y recuperando las tejas antiguas.

3.6. OTRAS 


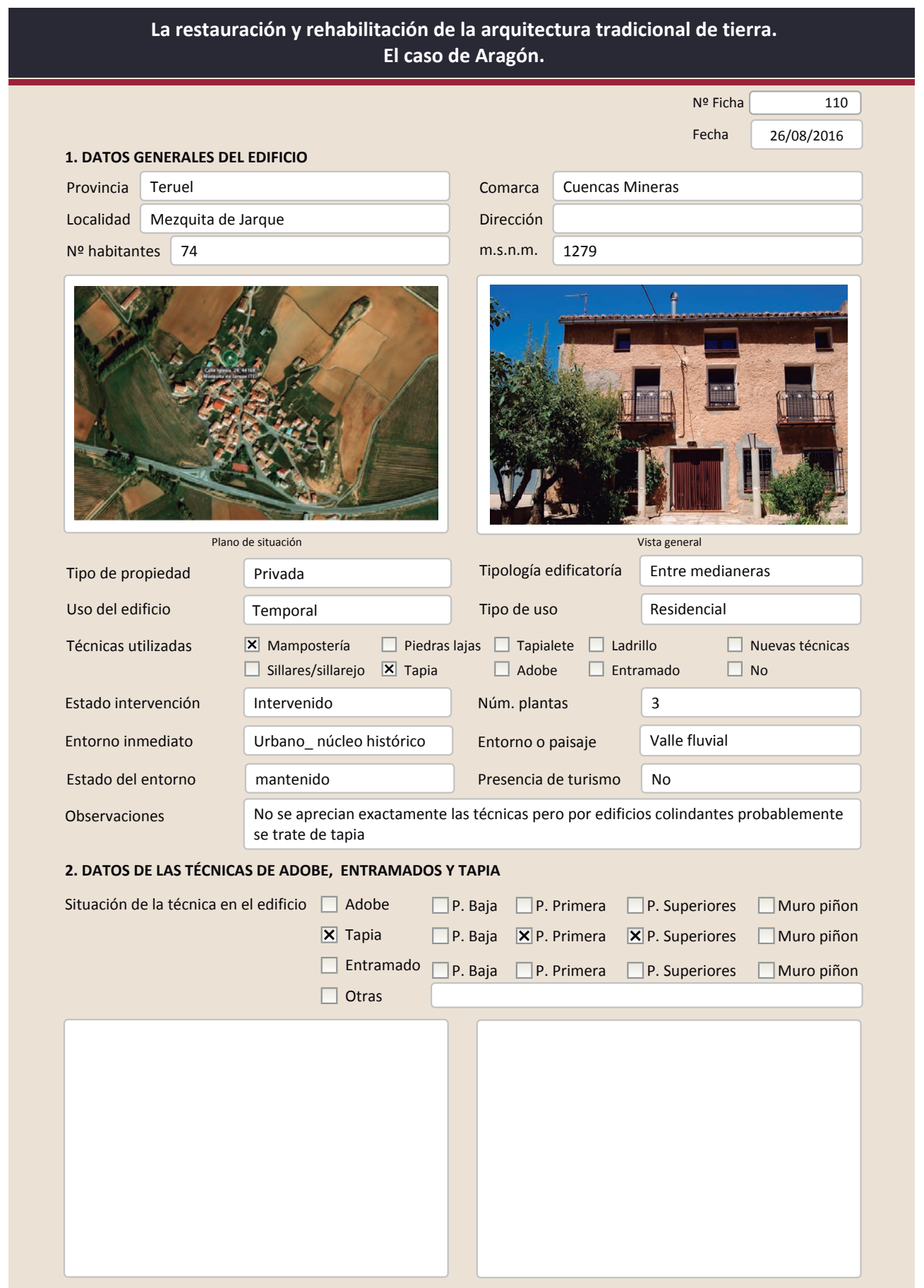

2.2. TAPIA

Ancho del muro

Dimensión tapiales

Tipo de aguja

№ agujas/cajón

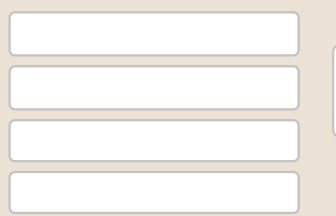

Color de la tapia

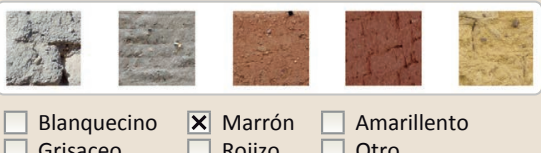

$\square$ Blanquecino $\quad \mathbf{X}$ Marrón $\square$ Amarillento

Variante constructiva

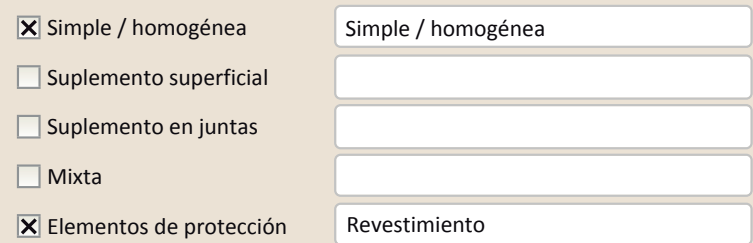

$\mathbf{X}$ Elementos de protección

Revestimiento

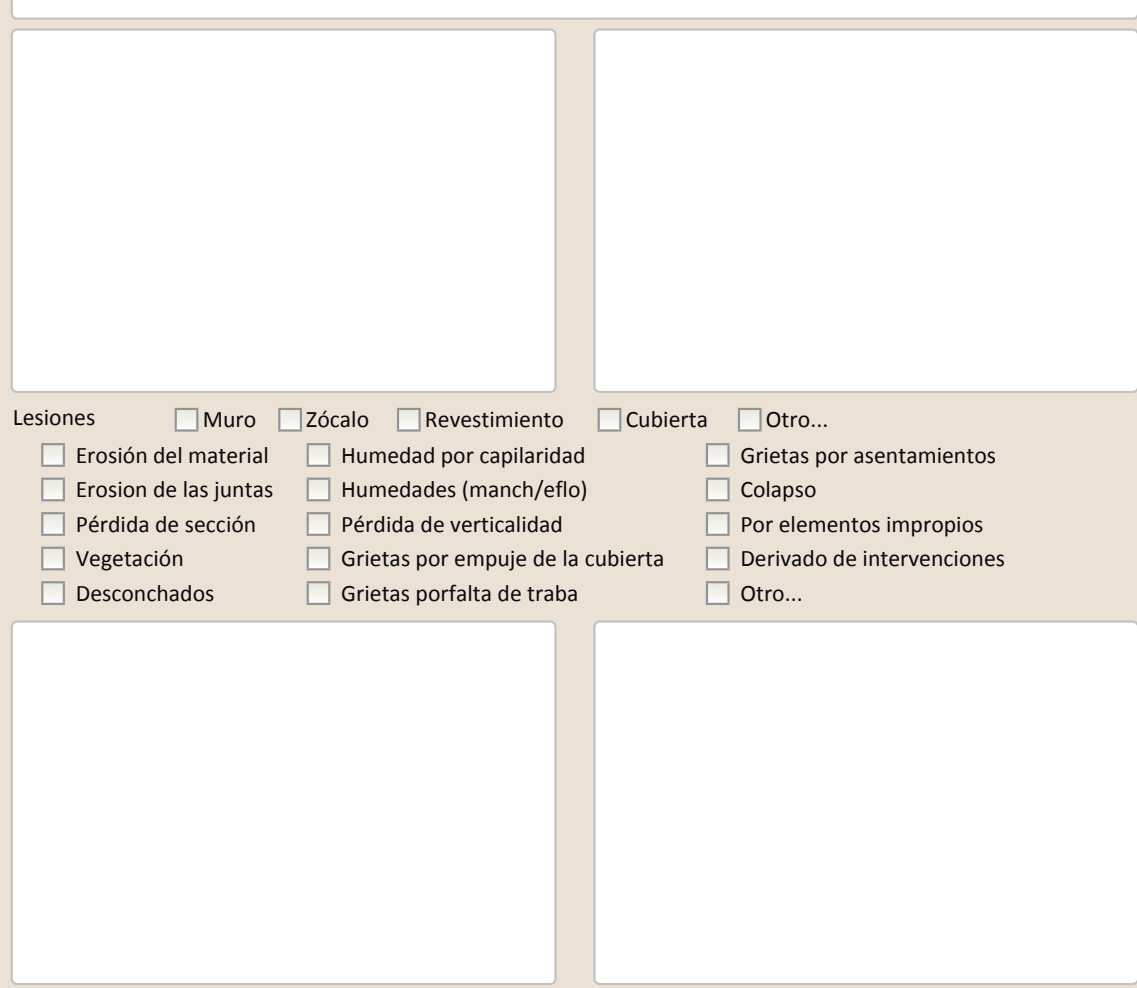

Observaciones 
La restauración y rehabilitación de la arquitectura tradicional de tierra. El caso de Aragón.

3. DATOS DE LA INTERVENCIÓN

$\square$ Mantenimiento $\square$ Rehabilitación parcial $\quad \square$ Restauración $\quad \square$ Demolición $\square$ Reparación $\quad \mathbf{X}$ Rehabilitación integral $\square$ Ampliación $\square$ Otro...

Reflexión previa Intervención planificada

Observaciones Las intervenciones no se han realizado todas al mismo tiempo. Primero la cubierta y la reintegración del revestimiento y luego cambio de carpinterías y edificio colindante fotos google

\begin{tabular}{|c|c|c|c|c|}
\hline 3.1. MUROS & Intervenido & & & \\
\hline Tipo de intervención & $\begin{array}{l}\square \text { Actualización } \\
\square \text { Consolidación }\end{array}$ & $\begin{array}{l}\square \text { Reintegración } \\
\square \text { Reconstrucción }\end{array}$ & $\begin{array}{l}\mathbf{X} \text { Demolició } \\
\mathbf{X} \text { Sustituciór }\end{array}$ & $\begin{array}{l}\text { in } \\
\text { n }\end{array}$ \\
\hline Tipo de material & No tradicional & Tip & ipo de técnica & Diferente a la existente \\
\hline Descripción & $\begin{array}{l}\text { Se ha tirado gran } p \\
\text { muros laterales de }\end{array}$ & $\begin{array}{l}\text { barte del edificio anexc } \\
\text { la misma afectados } p\end{array}$ & $\begin{array}{l}\text { xo al de vivienda } \\
\text { por la demoliciór }\end{array}$ & $\begin{array}{l}\text { y se ha intervenido en los } \\
\text { n. Muro exterior sustituido. }\end{array}$ \\
\hline 3.2. ZÓCALO & No intervenido & & & \\
\hline Tipo de intervención & $\begin{array}{l}\square \text { Actualización } \\
\square \text { Consolidación }\end{array}$ & $\begin{array}{l}\square \text { Reintegración } \\
\square \text { Reconstrucción }\end{array}$ & $\begin{array}{l}\square \text { Demolició } \\
\square \text { Sustituciór }\end{array}$ & n $\square$ Otro... \\
\hline Tipo de material & & & po de técnica & \\
\hline Descripción & & & & \\
\hline 3.3. REVESTIMIENTOS & Intervenido & & & \\
\hline Tipo de intervención & $\begin{array}{l}\square \text { Actualización } \\
\square \text { Consolidación }\end{array}$ & $\begin{array}{l}\mathbf{X} \text { Reintegración } \\
\square \text { Reconstrucción }\end{array}$ & $\begin{array}{l}\square \text { Demolició } \\
\square \text { Sustitució }\end{array}$ & in \\
\hline Tipo de material & No tradicional & & po de técnica & Diferente a la existente \\
\hline Descripción & Reintegración del & revestimiento con cen & mento & \\
\hline 3.4. VANOS & Intervenido & & & \\
\hline Tipo de intervención & $\begin{array}{l}\square \text { Actualización } \\
\square \text { Consolidación }\end{array}$ & $\begin{array}{l}\mathbf{X} \text { Reintegración } \\
\square \text { Reconstrucción }\end{array}$ & $\begin{array}{l}\square \text { Demolició } \\
\text { Х Sustituciór }\end{array}$ & $\begin{array}{l}\text { in } \\
\text { n }\end{array}$ \\
\hline Tipo de material & No tradicional & & ipo de técnica & Similar a la existente \\
\hline Descripción & $\begin{array}{l}\text { Se han sustituido } t \\
\text { dimensiones de lo: }\end{array}$ & $\begin{array}{l}\text { odas las carpinterías. } \\
\text { s huecos pero en la ma }\end{array}$ & $\begin{array}{l}\text { En algunos caso } \\
\text { nayoría solo se } h\end{array}$ & $\begin{array}{l}\text { s se han modificado las } \\
\text { a intervenido en el alfeizar }\end{array}$ \\
\hline 3.5. CUBIERTA & Intervenido & & & \\
\hline Tipo de intervención & $\begin{array}{l}\square \text { Actualización } \\
\square \text { Consolidación }\end{array}$ & $\begin{array}{l}\mathbf{X} \text { Reintegración } \\
\square \text { Reconstrucción }\end{array}$ & $\begin{array}{l}\square \text { Demolicic } \\
\square \text { Sustitució }\end{array}$ & ón $\quad \square$ otro... \\
\hline Tipo de material & No tradicional & & ipo de técnica & Similar a la existente \\
\hline Descripción & Reintę & idas $\mathrm{cc}$ & nento. Visible en & el alero del edificio. \\
\hline
\end{tabular}

3.6. OTRAS
La restauración y rehabilitación de la arquitectura tradicional de tierra.

El caso de Aragón.

3.7. REHABILITACIÓN ENERGÉTICA $\square$ Fachada $\quad \mathbf{X}$ Vanos $\square$ Forjados $\square$ Cubierta

Observaciones

FOTOGRAFÍAS DE LA INTERVENCIÓN

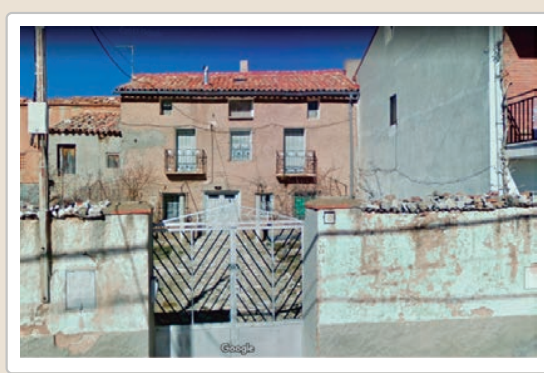

feb 2009 (google)

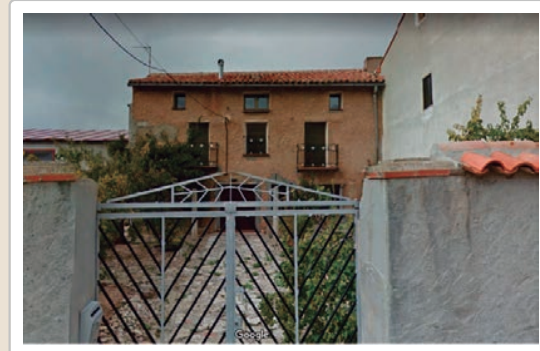

oct. 2015 (google)

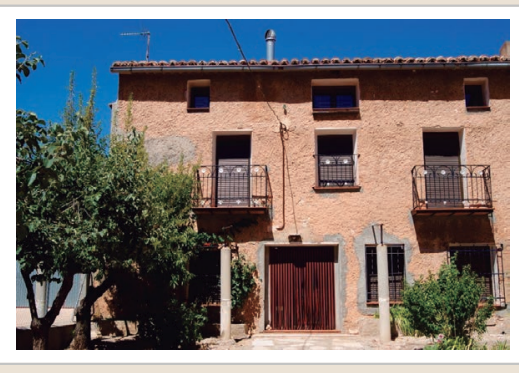

3asto 2016

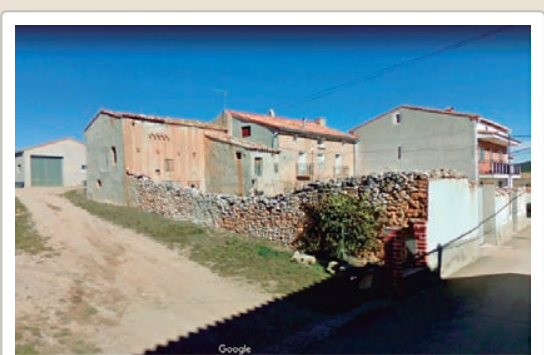

feb 2009 (google)

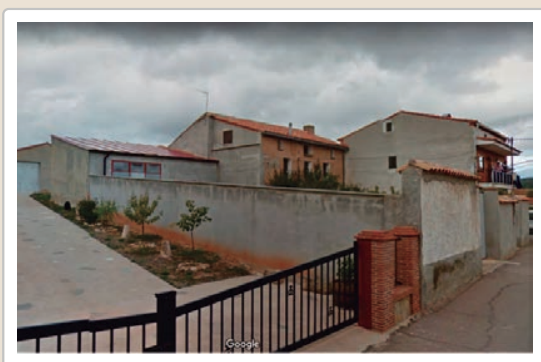

oct 2015 (google)

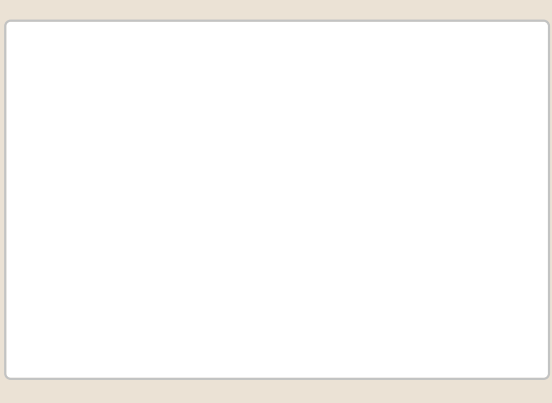


La restauración y rehabilitación de la arquitectura tradicional de tierra. El caso de Aragón

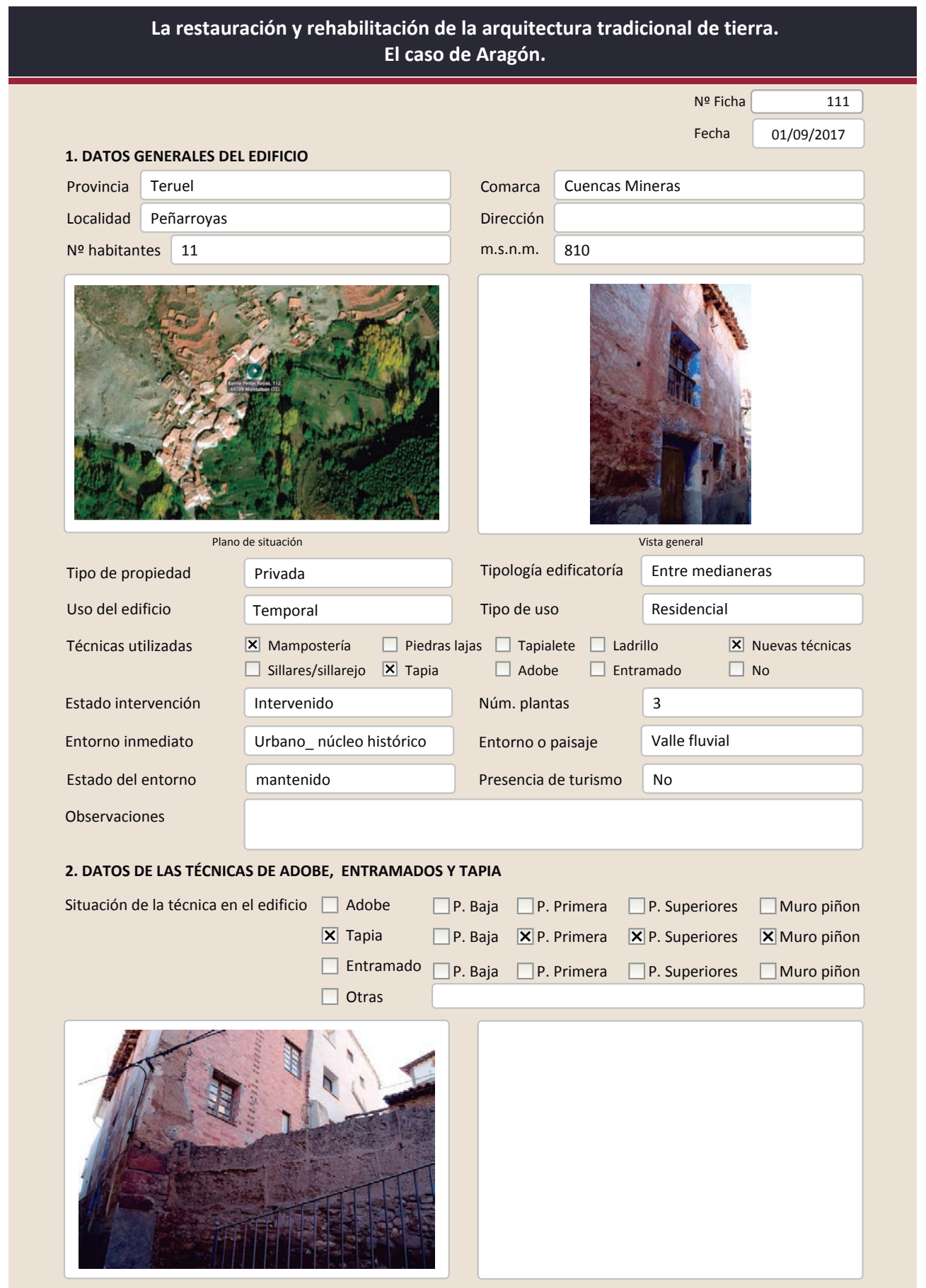

2.2. TAPIA

Ancho del muro

Dimensión tapiales

Tipo de aguja

\begin{tabular}{|l|}
\hline $50-60 \mathrm{~cm}$ \\
\hline \\
\hline Redonda \\
\hline
\end{tabular}

Color de la tapia

№ agujas/cajón

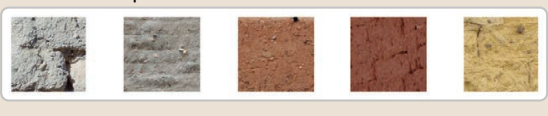

$\square$ Blanquecino $\square$ Marrón $\square$ Amarillento

$\square$ Banquecino $\square$ Marró
$\square$ Grisaceo Rojizo

Variante constructiva

$\square$ simple / homogéne

$\mathbf{X}$ Suplemento superficial

$\mathbf{X}$ Suplemento en juntas

X Mixta
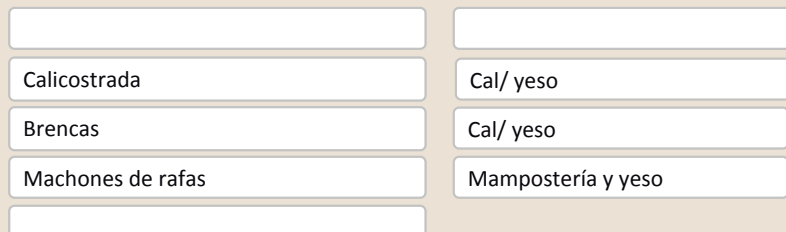

$\square$ Elementos de protección

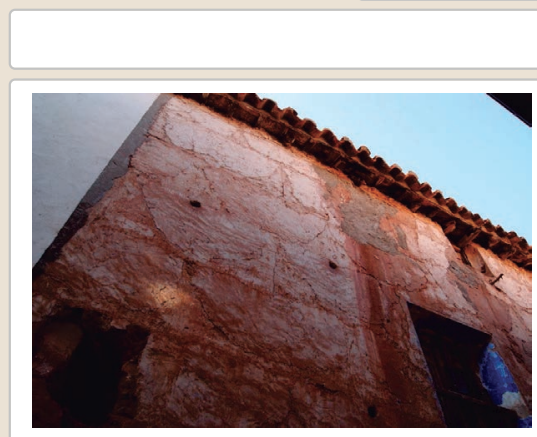

Lesiones $\quad \mathbf{X}$ Muro $\square$ Zócalo $\square$ Revestimiento Х Erosión del material $\square$ Humedad por capilaridad $\square$ Erosion de las juntas $\square$ Humedades (manch/eflo) X Pérdida de sección $\square$ Pérdida de verticalidad

$\square$ Vegetación

X Desconchados

$\square$ Grietas por empuje de la cub

$\square$ Grietas porfalta de traba

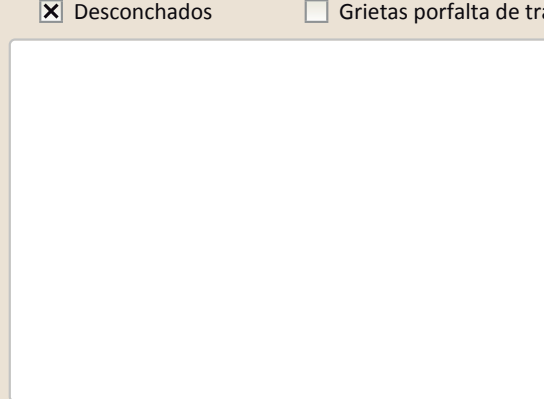

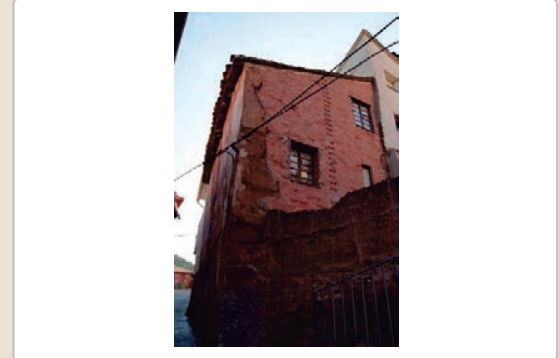

$\square$ Cubierta $\square$ Otro...

$\square$ Grietas por asentamientos $\square$ Colapso

$\square$ Por elementos impropios

$\square$ Derivado de intervenciones $\square$ Otro... 


\section{La restauración y rehabilitación de la arquitectura tradicional de tierra.}

\section{El caso de Aragón.}

3. DATOS DE LA INTERVENCIÓN

\begin{tabular}{|c|c|c|c|c|}
\hline Intervención de: & $\begin{array}{l}\square \text { Mantenimiento } \\
\mathbf{X} \text { Reparación }\end{array}$ & $\begin{array}{l}\square \text { Rehabilitación parcial } \\
\square \text { Rehabilitación integral }\end{array}$ & $\begin{array}{l}\square \text { Restauración } \\
\square \text { Ampliación }\end{array}$ & $\begin{array}{l}\square \text { Demolición } \\
\square \text { Otro... }\end{array}$ \\
\hline Reflexión previa & \multicolumn{4}{|c|}{ Intervención espontanea } \\
\hline tou & & & & \\
\hline
\end{tabular}

\subsection{MUROS}

Tipo de intervención

Intervenido

Tipo de material

$\square$ Actualización $\quad \square$ Reintegración $\quad \square$ Demolición $\square$ Otro...

$\square$ Consolidación $\square$ Reconstrucción $\mathbf{X}$ Sustitución

Descripción

No tradicional Tipo de técnica Diferente a la existente

3.2. ZÓCALO

Muro piñón sustituido por un muro de ladrillo hueco.

Tipo de intervención

Intervenido

$\square$ Actualización $\square$ Reintegración $\quad \square$ Demolición $\square$ Otro...

Tipo de material

$\square$ Consolidación $\quad \boldsymbol{X}$ Reconstrucción $\square$ Sustitución

Descripción

Tipo de técnica Diferente a la existente

3.3. REVESTIMIENTOS

Zócalo de cemento

Tipo de intervención

\section{No aplica}

Tipo de material

$\square$ Actualización

Tipo de materia

Descripción

3.4. VANOS

Tipo de intervención

No intervenido

Tipo de material

$\square$ Actualización $\quad \square$ Reintegración $\quad \square$ Demolición $\quad \square$ Otro...
$\square$ Consolidación $\quad \square$ Reconstrucción $\quad \square$ Sustitución

Descripción

3.5. CUBIERTA

Tipo de intervención

Intervenido

Tipo de intervención

$\square$ Actualizació

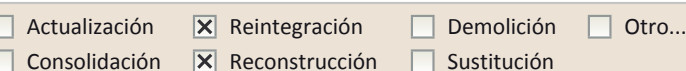

Tipo de material

Descripción
No tradicional
Tipo de técnica Diferente a la existente

Reintegración de parte de la cubierta y parte reconstruida con gran cantidad de mortero de agarre en las tejas

3.6. OTRAS 
La restauración y rehabilitación de la arquitectura tradicional de tierra. El caso de Aragón

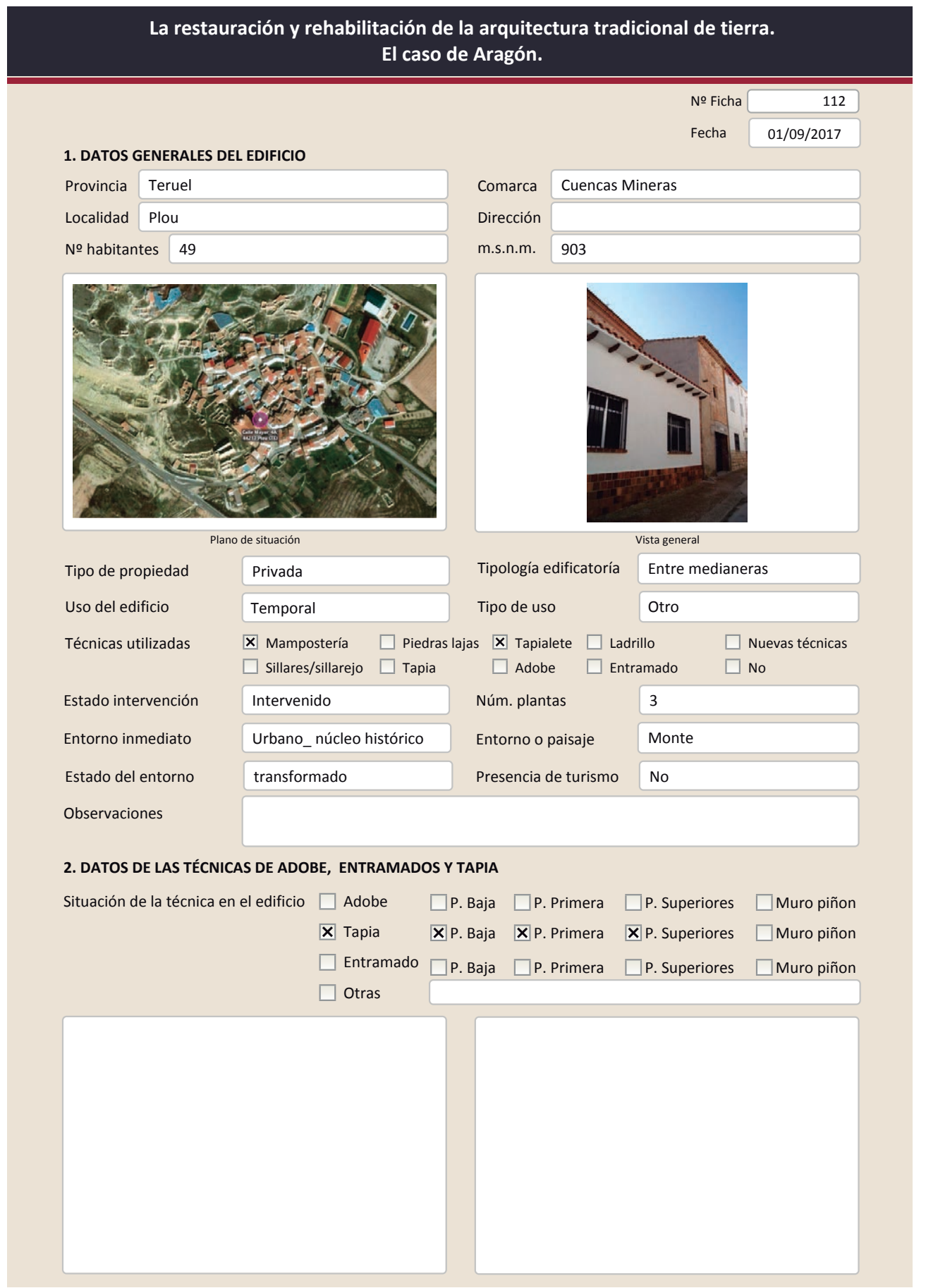

La restauración y rehabilitación de la arquitectura tradicional de tierra.

El caso de Aragón.

\subsection{TAPIA}

Ancho del muro

Dimensión tapiales

Tipo de aguja

№ agujas/cajón

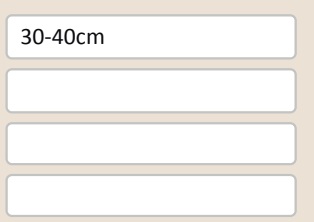

Color de la tapia

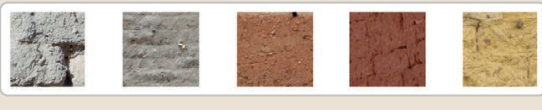

$\square$ Blanquecino $\square$ Marrón $\square$ Amarillento

$\square$ Grisaceo

$\square$ Marrón $\square$ Amari
$\square$ Rojizo

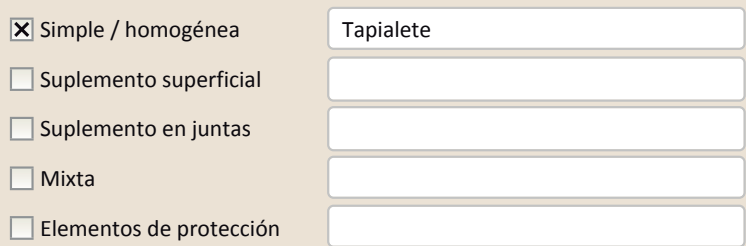

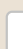

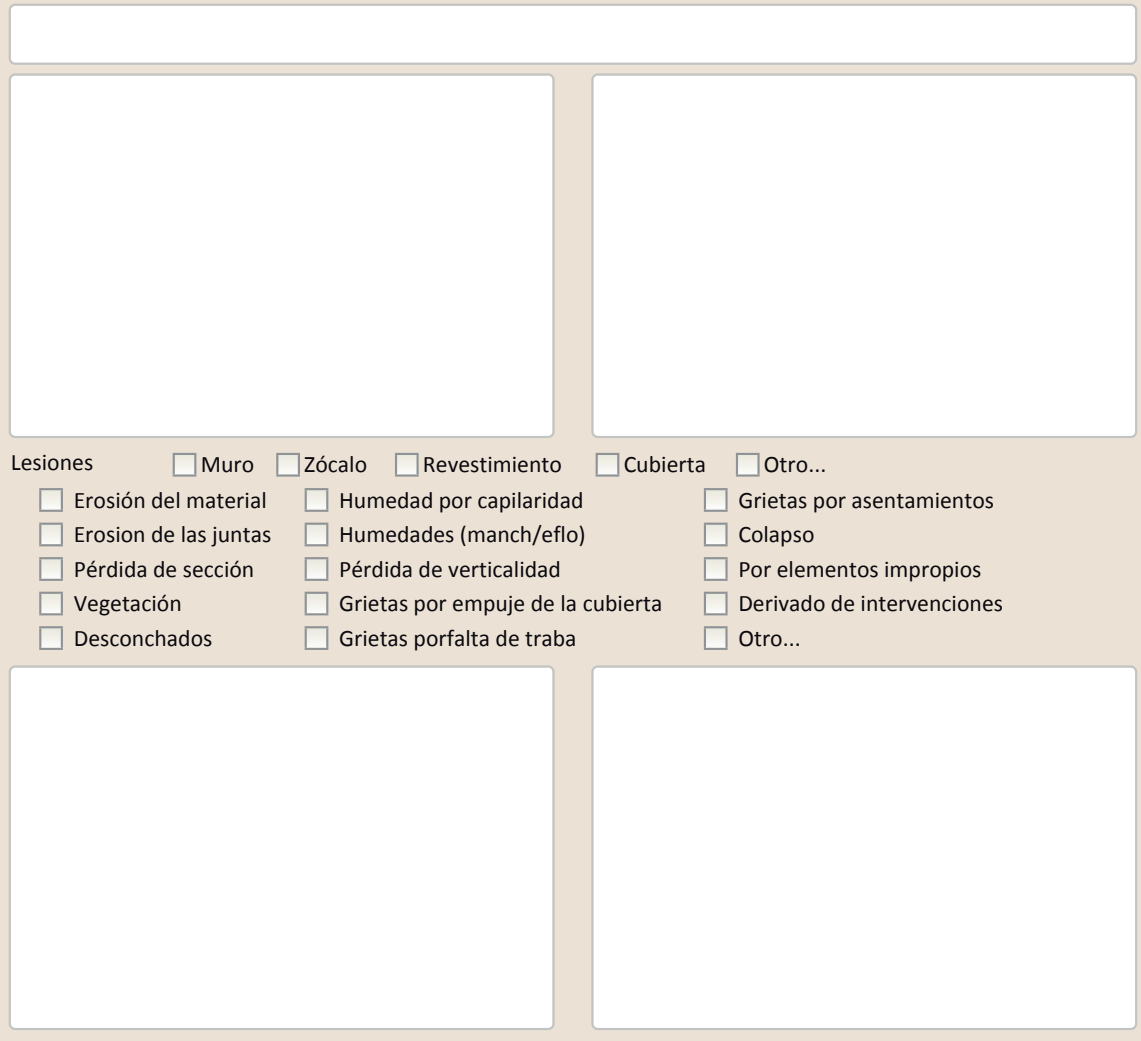

Observaciones 
La restauración y rehabilitación de la arquitectura tradicional de tierra.

\section{El caso de Aragón.}

3. DATOS DE LA INTERVENCIÓN

\begin{tabular}{lllll|} 
Intervención de: & $\square$ Mantenimiento $\quad \boldsymbol{X}$ Rehabilitación parcial & $\square$ Restauración & $\square$ Demolición \\
& $\square$ Reparación & $\square$ Rehabilitación integral & $\square$ Ampliación $\quad \square$ Otro... \\
Reflexión previa & Intervención espontanea & \\
Observaciones & & & \\
& & & \\
& &
\end{tabular}

\subsection{MUROS}

Tipo de intervención

No intervenido

Tipo de material

$\square$ Actualización $\square$ Reintegración $\square$ Demolición $\square$ Otro... $\square$ Consolidación $\square$ Reconstrucción $\square$ sustitución

Descripción

3.2. ZÓCALO

Tipo de intervención

Intervenido

$\square$ Actualizació

Tipo de material

Descripción

Tipo de técnica Diferente a la existente

3.3. REVESTIMIENTOS

Tipo de intervención

\section{No aplica}

Tipo de material

$\square$ Actualización

Tipo de técnica

Descripción

3.4. VANOS

Tipo de intervención

$\square$ Consolidación

$\square$ Demolición $\square$ Otro...

Tipo de técnica

Tipo de material

Intervenido

$\square$ Actualización $\quad \square$ Reintegración $\quad \square$ Demolición $\square$ Otro...

$\square$ Consolidación $\square$ Reconstrucción $\quad$ \ Sustitución

Descripción

No tradicional

Tipo de técnica Diferente a la existente

Nueva puerta de acceso para vehículos en planta baja. Se han ampliado las

dimensiones. Dintel de hormigón y pavés para iluminar.

3.5. CUBIERTA

Tipo de intervención

Intervenido

$\square$ Actualización $\square$ Reintegración $\square$ Demolición $\square$ Otro.

$\square$ Consolidación $\quad \boldsymbol{X}$ Reconstrucción $\quad \square$ Sustitución

Tipo de material

Tipo de técnica Similar a la existente

Descripción

Reconstrucción de la cubierta con la técnica tradicional de teja curva pero utilizando mortero de cemento para el agarre de las tejas en el soporte.

3.6. OTRAS 


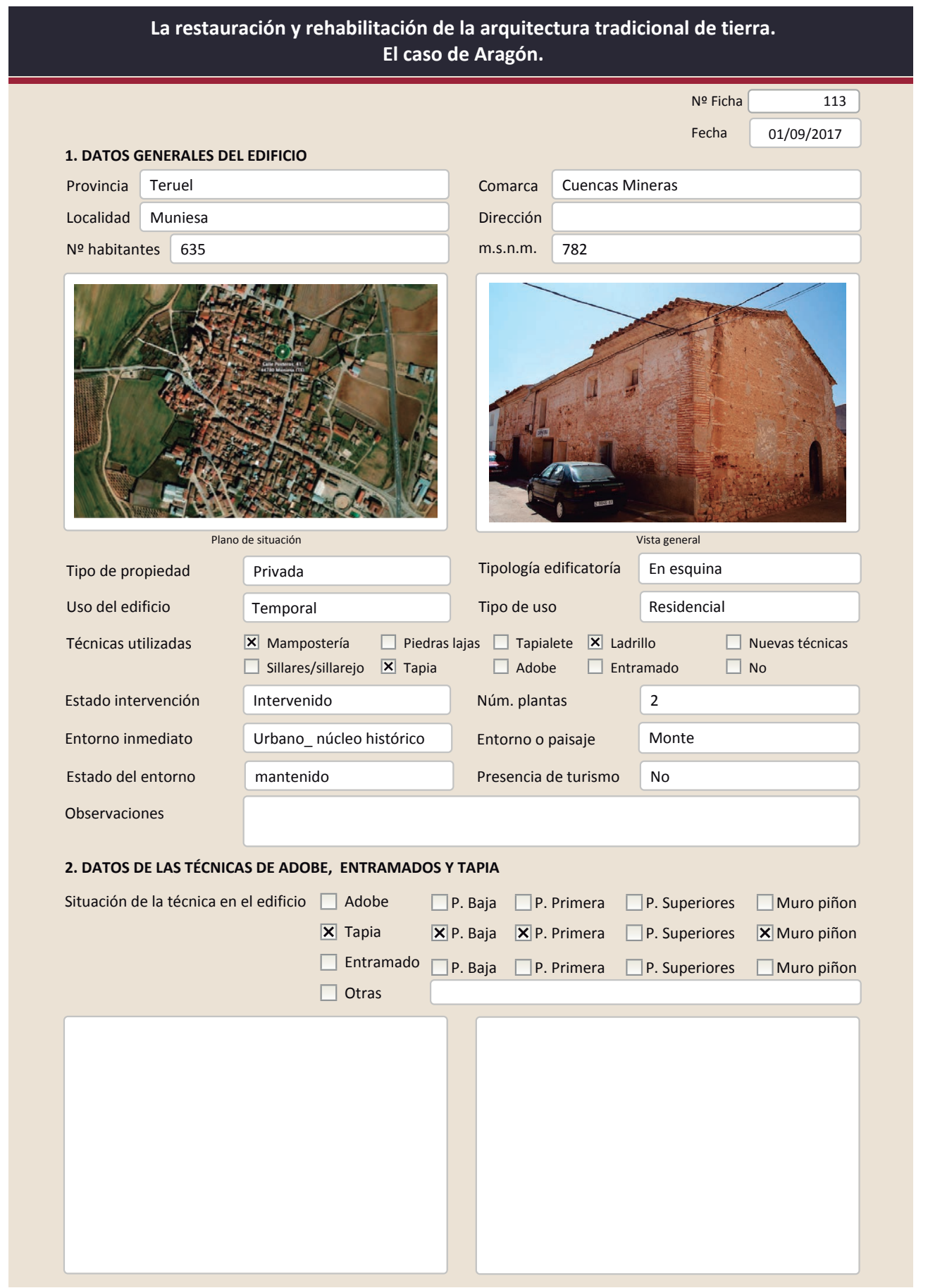

2.2. TAPIA

Ancho del muro

Dimensión tapiales

Tipo de aguja

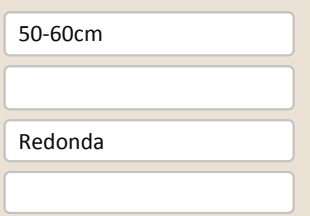

Color de la tapia

№ agujas/cajón

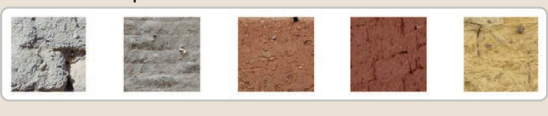

$\square$ Blanquecino $\mathbf{X}$ Marrón $\square$ Amarillento

$\begin{array}{ll}\square \text { Blanquecino } & \mathbf{x} \text { Marrón } \\ \square \text { Grisaceo } & \square \text { Rojizo } \quad \square \text { Otro... }\end{array}$

Variante constructiva

$\square$ Simple / homogénea

X Suplemento superficial

$\square$ suplemento en juntas

X Mixta

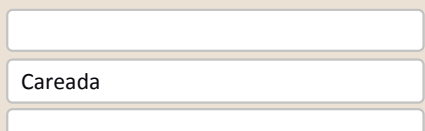

Machones de rafas
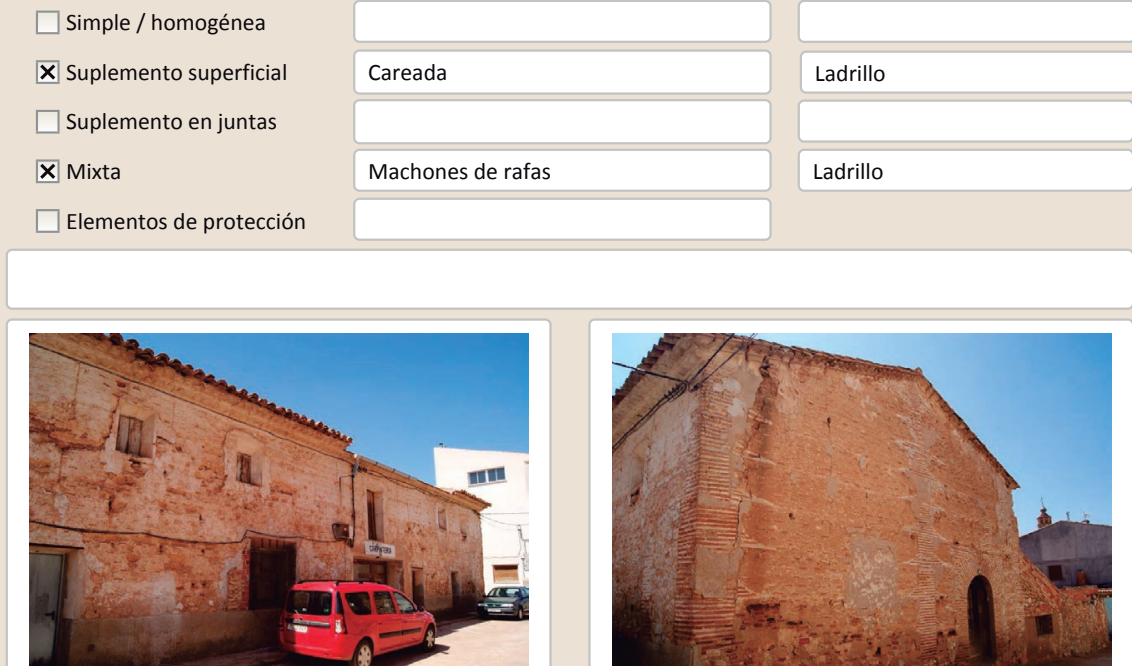

Lesiones $\quad \mathbf{X}$ Muro $\mathbf{X}$ Zócalo $\square$ Revestimiento $\mathbf{X}$ Cubierta $\square$ otro..

X Erosión del material $\mathbf{X}$ Humedad por capilaridad $\quad \square$ Grietas por asentamientos $\mathbf{X}$ Erosion de las juntas $\square$ Humedades (manch/eflo)

X Pérdida de sección $\square$ Pérdida de verticalidad

$\square$ Vegetación

$\square$ Por elementos impropios

Desconch

$\square$ Grietas porfalta de trab
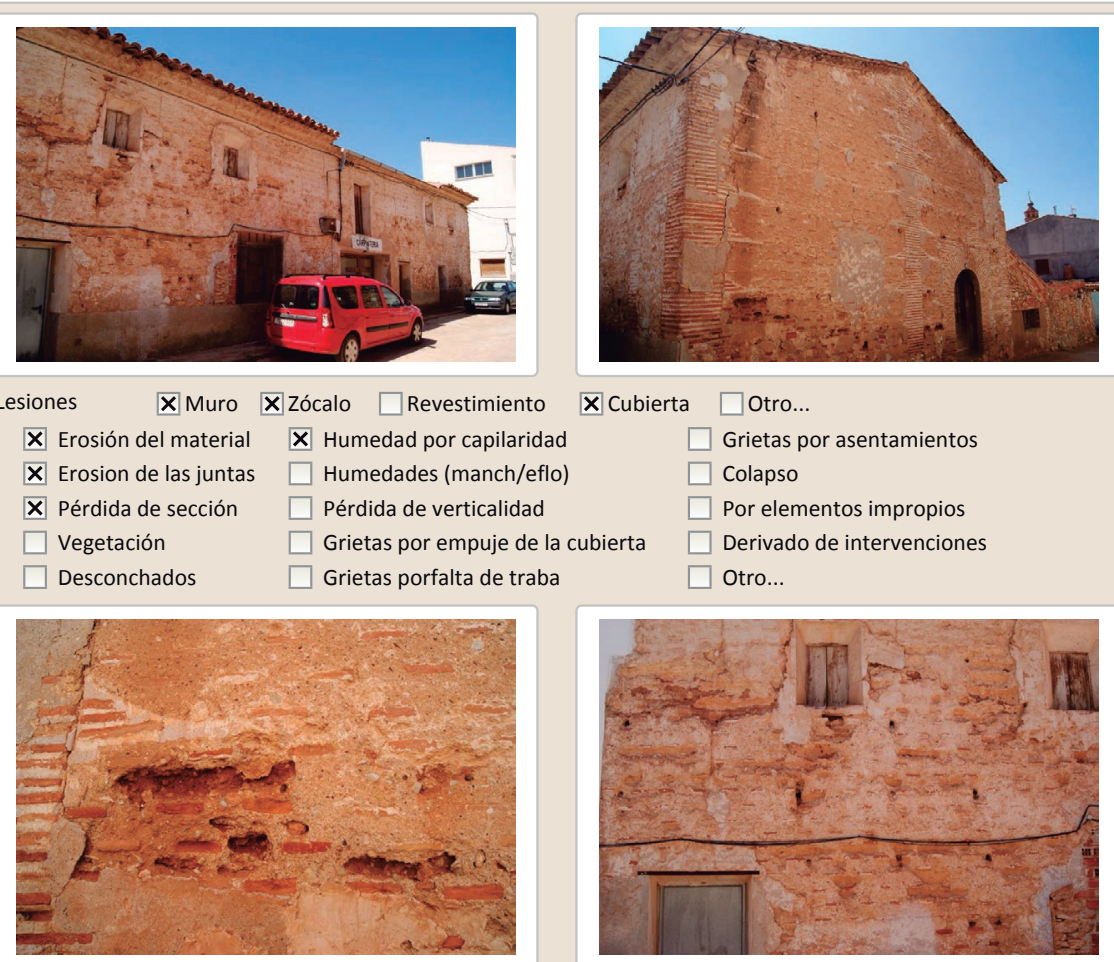
$\square$ Otro...

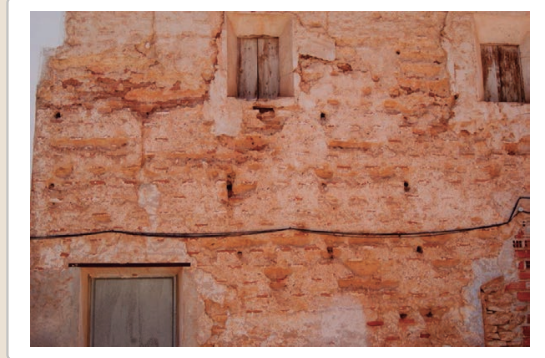

Observaciones 


\section{La restauración y rehabilitación de la arquitectura tradicional de tierra.}

\section{El caso de Aragón.}

3. DATOS DE LA INTERVENCIÓN

Intervención de:

$\square$ Mantenimiento $\square$ Rehabilitación parcial

$\square$ Restauración $\square$ Demolición

Reflexión previa

X Reparación

$\square$ Rehabilitación integra

$\square$ Ampliación

$\square$ otro...

Reflexión previ

Intervención espontanea

3.1. MUROS

Tipo de intervención

Tipo de material

Descripción

3.2. ZÓCALO

Tipo de intervención

Tipo de material

Descripción

3.3. REVESTIMIENTOS

Tipo de intervención

Tipo de material

Descripción

3.4. VANOS

Tipo de intervención

Tipo de material

Descripción

3.5. CUBIERTA

Tipo de intervención

Tipo de material

Descripción

Intervenido

$\square$ Actualización $\quad$ X Reintegración $\square$ Demolición $\square$ Otro...

$\square$ Consolidación $\square$ Reconstrucción $\square$ Sustitución

\begin{tabular}{|l|l|l|l|l} 
No tradicional & Tipo de técnica Diferente a la existente
\end{tabular}

Reintegraciones puntuales con cemento

Intervenido

$\square$ Actualización $\square$ Reintegración $\square$ Demolición $\square$ Otro...

$\square$ Consolidación \ Reconstrucción $\square$ Sustitución

No tradicional Tipo de técnica Diferente a la existente

Zocalo de revestimiento de cemento en una de las fachadas

\section{No aplica}

$\square$ Actualización $\quad \square$ Reintegración $\quad \square$ Demolición $\square$ Otro...

$\square$ Consolidación $\square$ Reconstrucción $\square$ sustitución

Tipo de técnica

Intervenido

$\square$ Actualización $\square$ Reintegración $\square$ Demolición $\square$ Otro...

$\square$ Consolidación $\square$ Reconstrucción $\mathbf{X}$ Sustitución

No tradicional Tipo de técnica Diferente a la existente

Sustitución de la carpintería del acceso principal que tiene forma de arco. Se ha acoplado al hueco existente con ladrillo hueco

Intervenido

$\square$ Actualización $\quad \boldsymbol{X}$ Reintegración $\square$ Demolición $\square$ Otro..

$\square$ Consolidación $\square$ Reconstrucción $\quad \mathbf{x}$ Sustitución

No tradicional Tipo de técnica Diferente a la existente

Reintegración de la cumbrera con cemento y sustitución parcial de la cubierta en uno de los tramos por chapa grecada (posible derrumbe anteriormente)
La restauración y rehabilitación de la arquitectura tradicional de tierra.

El caso de Aragón.

3.7. REHABILITACIÓN ENERGÉTICA $\quad \square$ Fachada $\square$ Vanos $\square$ Forjados $\square$ Cubierta

Observaciones

FOTOGRAFÍAS DE LA INTERVENCIÓN
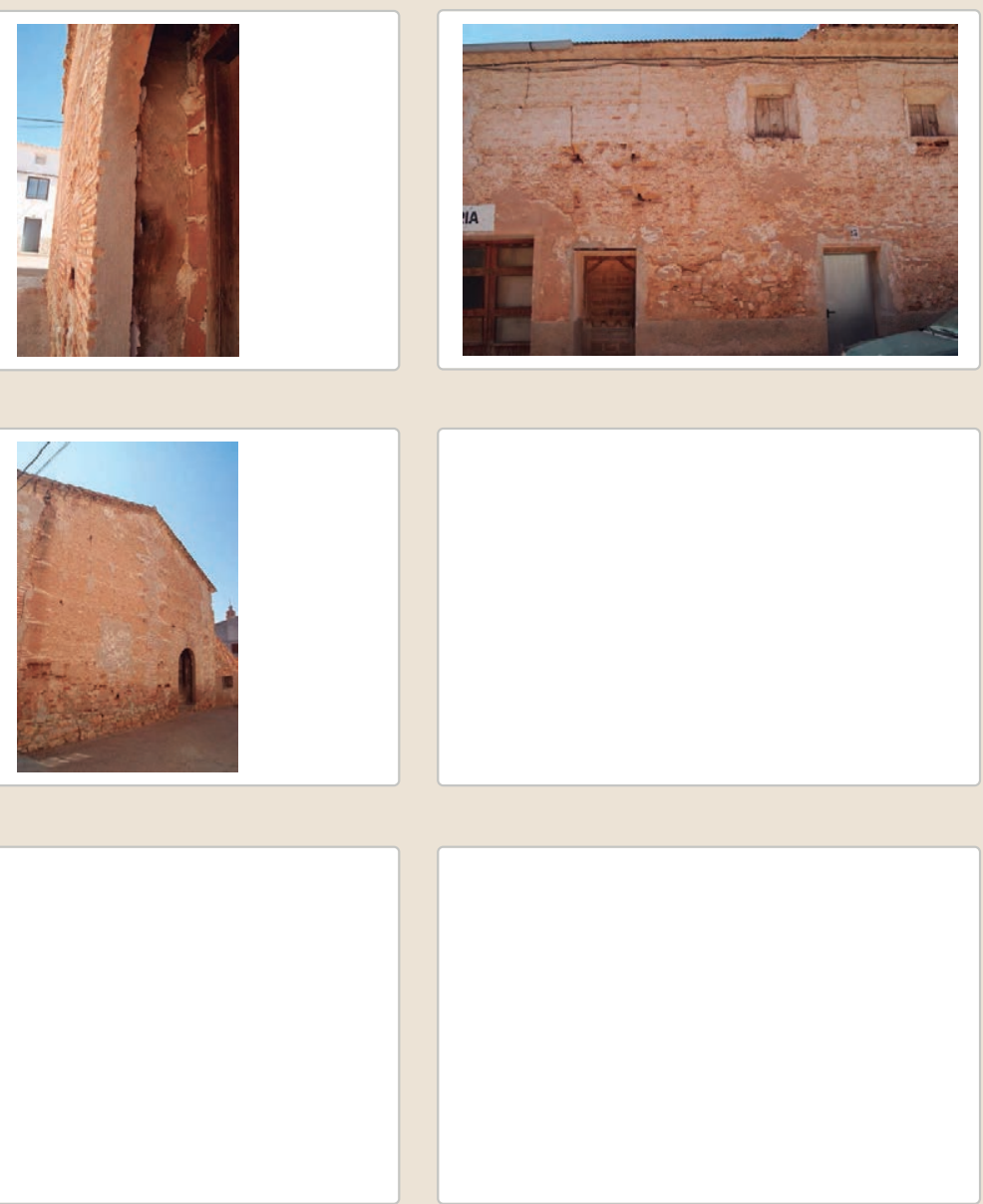

3.6. OTRAS 
La restauración y rehabilitación de la arquitectura tradicional de tierra. El caso de Aragón

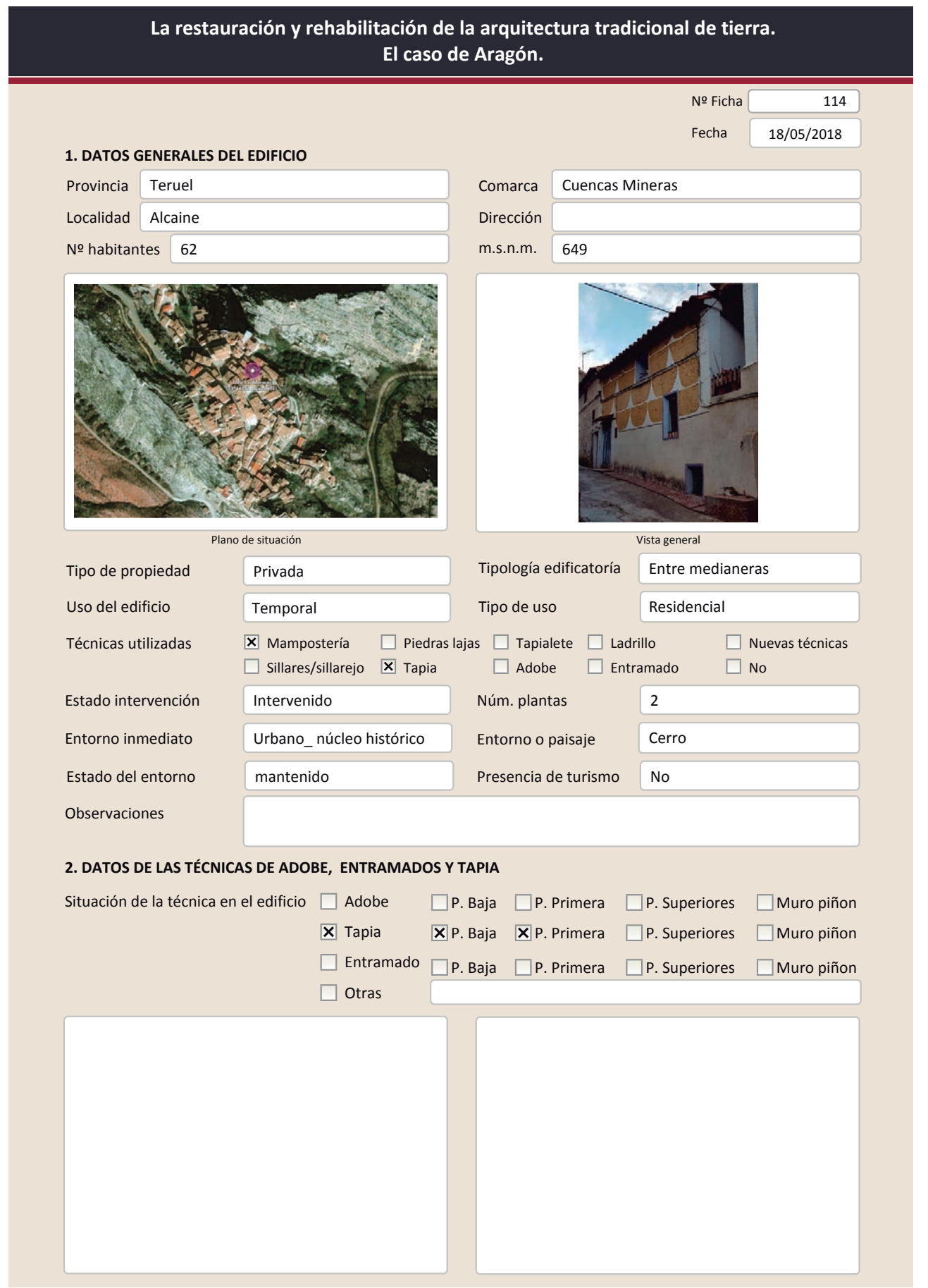

2.2. TAPIA

Ancho del muro

Dimensión tapiales

Tipo de aguja

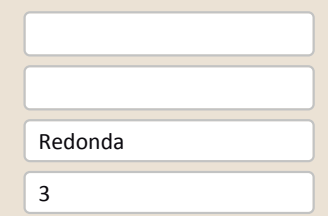

Color de la tapia

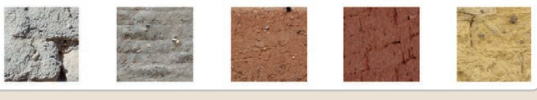

$\square$ Blanquecino $\square$ Marrón $\square$ Amarillento

№ agujas/cajón

$\square$ Grisaceo

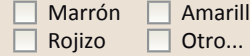

Variante constructiva

$\square$ Simple / homogénea

X Suplemento superficial

$\mathbf{X}$ Suplemento en juntas

$\mathbf{X}$ Mixta
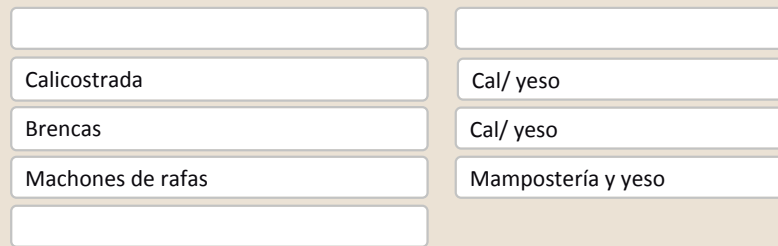

$\square$ Elementos de protección

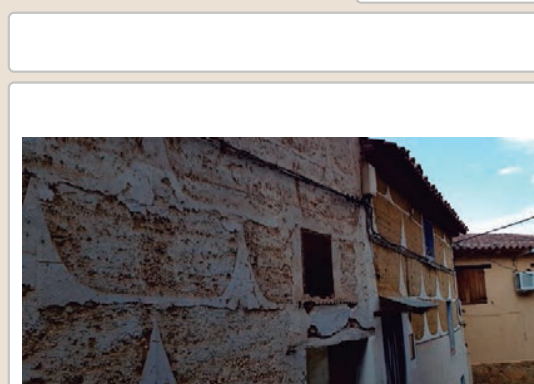

$$
\begin{array}{lll}
\text { Lesiones } \quad \square \text { Muro } \quad \boldsymbol{X} \text { Zócalo } \square \text { Revestimiento } & \square \text { Cubierta } & \square \text { Otro... } \\
\square \text { Erosión del material } \quad \boldsymbol{X} \text { Humedad por capilaridad } & \square \text { Grietas por asentamientos } \\
\square \text { Erosion de las juntas } & \boldsymbol{X} \text { Humedades (manch/eflo) } & \square \text { Colapso } \\
\square \text { Pérdida de sección } & \square \text { Pérdida de verticalidad } & \square \text { Por elementos impropios } \\
\square \text { Vegetación } & \square \text { Grietas por empuje de la cubierta } & \square \text { Derivado de intervenciones } \\
\square \text { Desconchados } & \square \text { Grietas porfalta de traba } & \square \text { Otro... }
\end{array}
$$
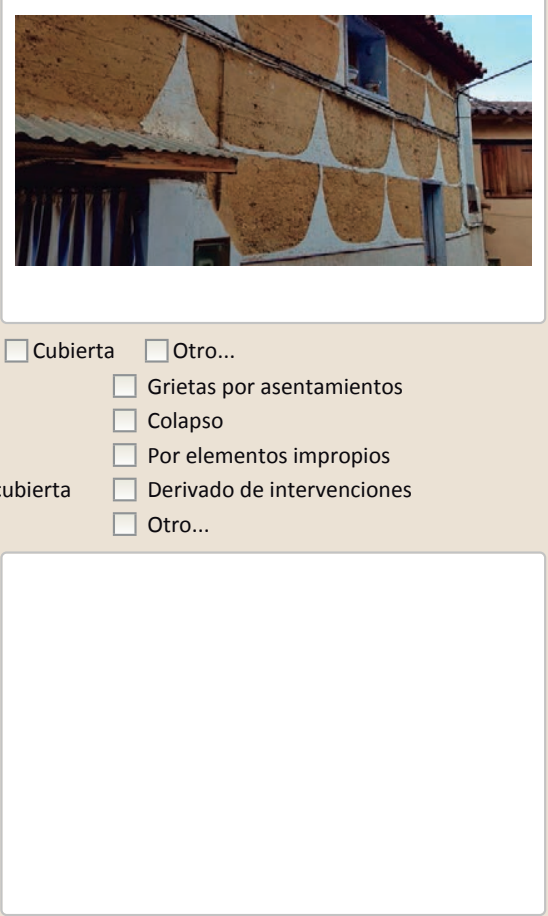


\section{La restauración y rehabilitación de la arquitectura tradicional de tierra.}

\section{El caso de Aragón.}

3. DATOS DE LA INTERVENCIÓN

\begin{tabular}{|c|c|c|c|c|}
\hline Intervención de: & $\begin{array}{l}\square \text { Mantenimiento } \\
\square \text { Reparación }\end{array}$ & $\begin{array}{l}\text { X Rehabilitación parcial } \\
\square \text { Rehabilitación integral }\end{array}$ & $\begin{array}{l}\square \text { Restauración } \\
\square \text { Ampliación }\end{array}$ & $\begin{array}{l}\square \text { Demolición } \\
\square \text { Otro... }\end{array}$ \\
\hline Reflexión previa & \multicolumn{4}{|c|}{ Intervención espontanea } \\
\hline Observaciones & \multicolumn{4}{|c|}{ Actualización general de la imagen del edificio } \\
\hline
\end{tabular}

\subsection{MUROS}

Tipo de intervención

No intervenido

Tipo de material

$\square$ Actualización $\square$ Reintegración $\square$ Demolición $\square$ Otro... $\square$ Consolidación $\square$ Reconstrucción $\square$ sustitución

Descripción

3.2. ZÓCALO

Tipo de intervención

Intervenido

Tipo de intervención

メ Actualizació

Descripción

3.3. REVESTIMIENTOS

Revestimiento de cemento

Tipo de intervención

Intervenido

Tipo de material

X Actualización $\quad \mathbf{X}$ Reintegración $\square$ Demolición $\square$ Otro...

$\square$ Consolidación $\quad \square$ Reconstrucción $\square$ Sustitución

Descripción

3.4. VANOS

Tipo de intervención

Pintura / colores evidenciando la existencia de las brencas

Tipo de material

Intervenido

Tipo de material
Descripción

$\mathbf{X}$ Actualización $\quad \square$ Reintegración $\quad \square$ Demolición $\square$ Otro...

$\square$ Consolidación $\quad \mathbf{X}$ Reconstrucción $\square$ sustitución

3.5. CUBIERTA

No tradicional

Tipo de técnica Diferente a la existente

Nuevos huecos y reconstrucción de jambas con decoración de baldosas cerámicas.

Nuevos huecos y reconstruccion de jambas con decorlo en la puerta de acceso con fibrocemento
Tejad

Tipo de intervención

Intervenido

Tipo de material

$\square$ Actualización $\square$ Reintegración $\square$ Demolición $\square$ Otro..

Descripción

No tradicional Tipo de técnica Similar a la existente

3.6. OTRAS 
La restauración y rehabilitación de la arquitectura tradicional de tierra. El caso de Aragón

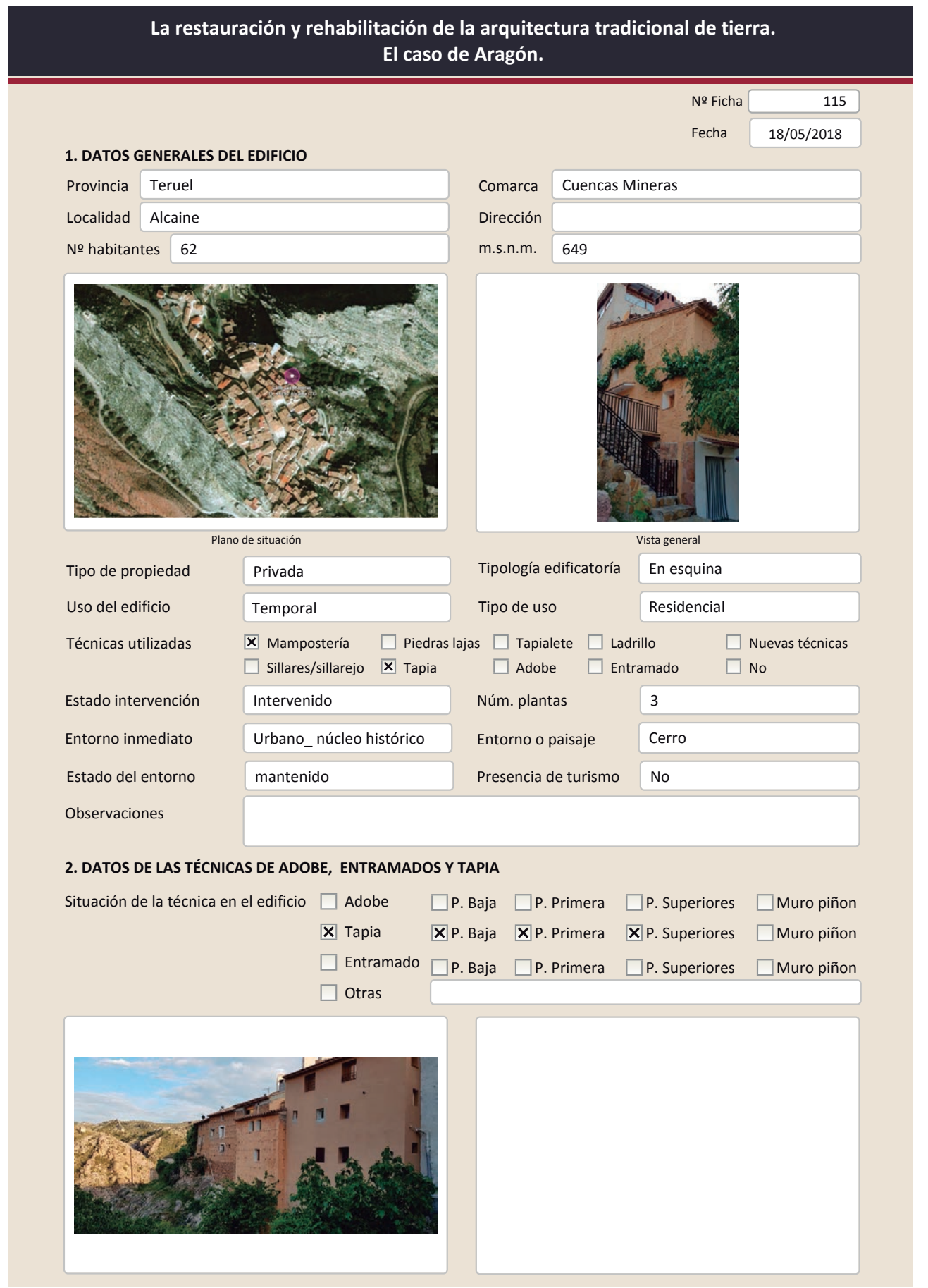

2.2. TAPIA

Ancho del muro

Dimensión tapiales

Tipo de aguja

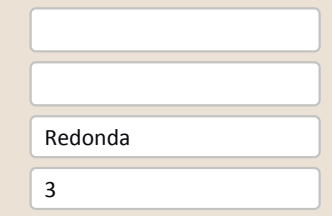

Color de la tapia

№ agujas/cajón

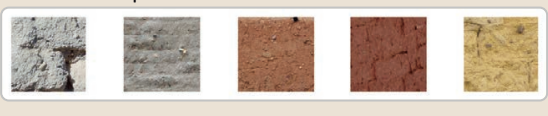

$\square$ Blanquecino $\square$ Marrón $\square$ Amarillento

$\square$ Blanquecino $\square$ Marrón $\square$ Amarill
$\square$ Grisaceo

Variante constructiva

$\square$ Simple / homogénea
$\square$ Suplemento superficial
X Suplemento en juntas
X Mixta
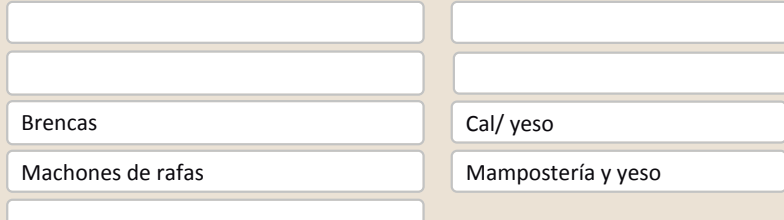

$\square$ Elementos de protección

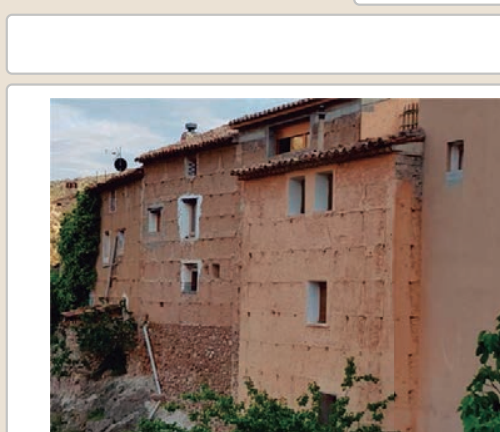

Lesiones $\square$ Muro $\square$ Zócalo $\square$ Revestimiento $\square$ Cubierta $\square$ Otro..

$\square$ Erosión del material $\quad \square$ Humedad por capilaridad $\quad \square$ Grietas por asentamiento $\square$ Erosion de las juntas $\square$ Humedades (manch/eflo)

$\square$ Pérdida de sección $\quad \square$ Pérdida de verticalidad

$\square$ Vegetación $\square$ Grietas por empuje de la cubierta

$\square$ Desconchados $\quad \square$ Grietas porfalta de trab

$\square$ Por elementos impropios

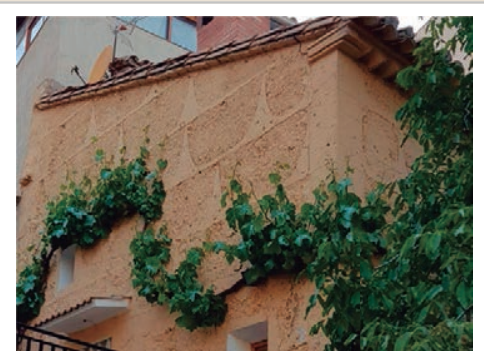

$\square$ Derivado de intervenciones

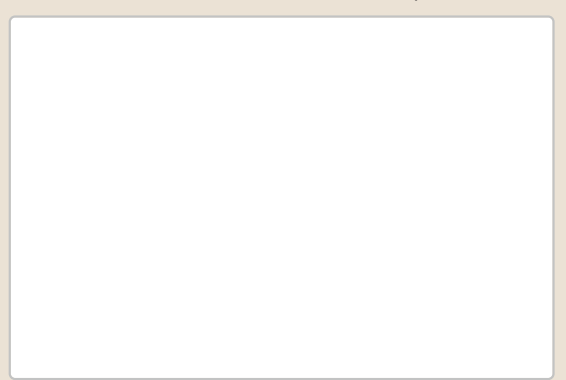

Observaciones 


\section{La restauración y rehabilitación de la arquitectura tradicional de tierra.}

\section{El caso de Aragón.}

3. DATOS DE LA INTERVENCIÓN

\begin{tabular}{|c|c|c|c|c|}
\hline Intervención de: & $\begin{array}{l}\square \text { Mantenimiento } \\
\square \text { Reparación }\end{array}$ & $\begin{array}{l}\text { X Rehabilitación parcial } \\
\square \text { Rehabilitación integral }\end{array}$ & $\begin{array}{l}\square \text { Restauración } \\
\square \text { Ampliación }\end{array}$ & $\begin{array}{l}\square \text { Demolición } \\
\square \text { Otro... }\end{array}$ \\
\hline Reflexión previa & \multicolumn{4}{|c|}{ Intervención planificada } \\
\hline Observaciones & \multicolumn{4}{|c|}{ actualización general del edificio especialmente de los elementos exteriores } \\
\hline
\end{tabular}

\subsection{MUROS}

Tipo de intervención

No intervenido

Tipo de material

$\square$ Actualización $\square$ Reintegración $\square$ Demolición $\square$ Otro... $\square$ Consolidación $\square$ Reconstrucción $\square$ sustitución

Descripción

3.2. ZÓCALO

Tipo de intervención

Intervenido

Tipo de intervención

$\mathbf{X}$ Actualización

Reintegración $\quad \square$ Demolición $\quad \square$ Otro...

Tipo de material

No tradicional

Tipo de técnica

Descripción

Tipo de técnica Diferente a la existente

3.3. REVESTIMIENTOS

Reconstrucción del zócalo con lajas de piedra cogidas con cemento

\section{Tipo de intervención}

Intervenido

Trog materal

X Actualización $\square$ Reintegración $\square$ Demolición $\square$ Otro...

Tipo de material

$\square$ Consolidación $\quad \mathbf{X}$ Reconstrucción $\square$ sustitución

Descripción

No tradicional

Tipo de técnica Diferente a la existente

3.4. VANOS

Tipo de intervención

Pintura salmón sobre toda la superficie del muro de tapia

Tipo de material

Intervenido

Descripción

X Actualización $\square$ Reintegración $\square$ Demolición $\square$ Otro...

$\square$ Consolidación $\quad \boldsymbol{X}$ Reconstrucción $\square$ Sustitución

3.5. CUBIERTA

Tipo de intervención

No tradicional Tipo de técnica Diferente a la existente

Inserción de tejadillos de
contornos de los huecos.

Intervenido

Tipo de material

$\square$ Actualización $\square$ Reintegración $\square$ Demolición $\square$ Otro.

Descripción
No tradicional
Tipo de técnica Similar a la existente

X Reconstrucción $\square$ Sustitución

3.6. OTRAS

Reconstrucción de la cubierta con tejas cogidas con cemento. 


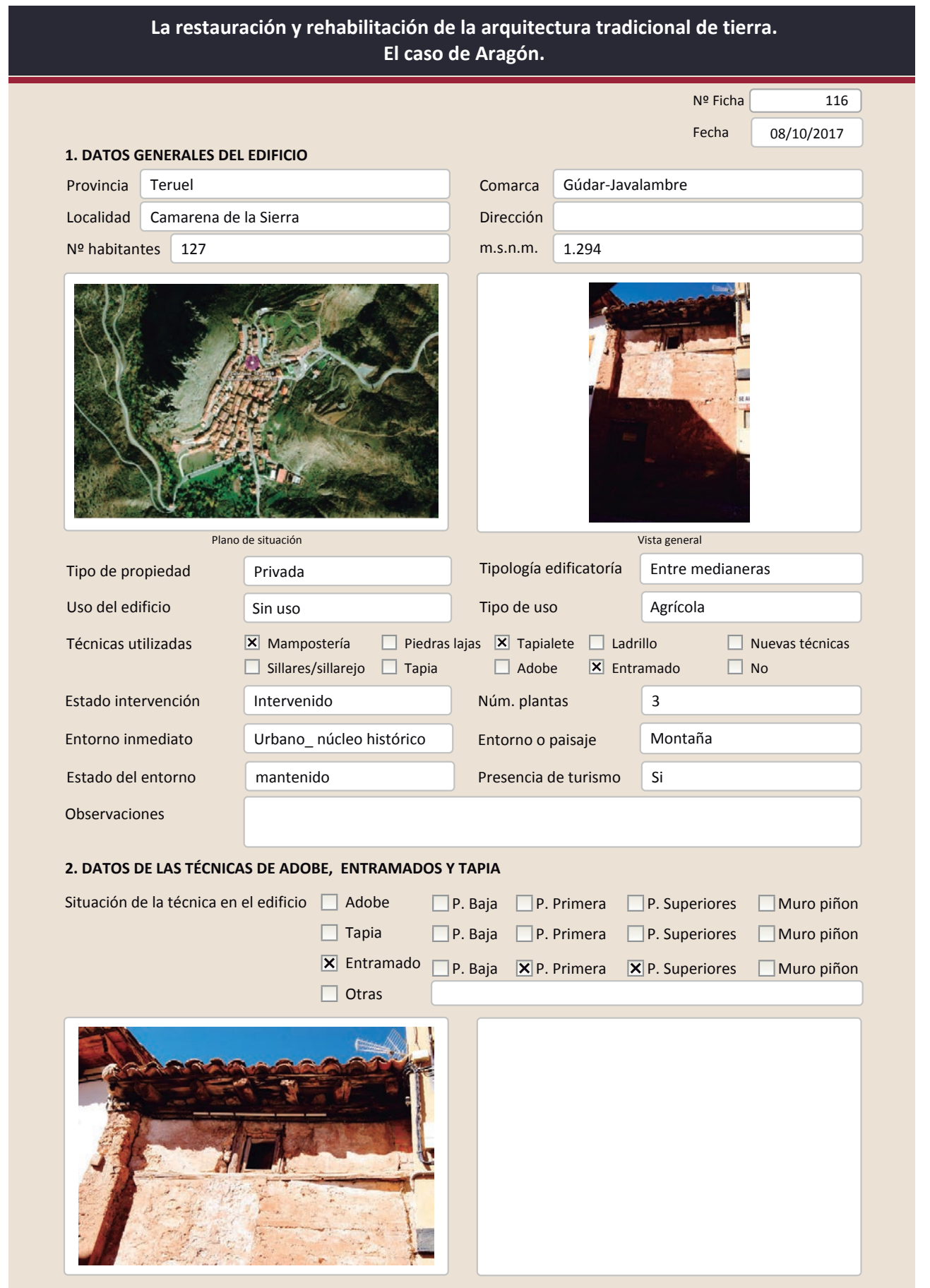

La restauración y rehabilitación de la arquitectura tradicional de tierra.

El caso de Aragón.

2.3. ENTRAMADOS

Distancia entre montantes

Altura de los montantes

Sección de los montantes

Dimensión de los montantes

Tipo de relleno del entramado

Técnica de relleno del entramado

$\begin{array}{ll}\square \text { Entre pantallas de madera } & \square \text { Pared de mano } \\ \square \text { Tierra y mampuestos } & \square \text { Adobe horizontal } \quad \square \text { Encestados }\end{array}$

$\mathbf{x}$ Tapialete 


\section{El caso de Aragón.}

3. DATOS DE LA INTERVENCIÓN

\begin{tabular}{l|ll|}
$\begin{array}{l}\text { Intervención de: } \\
\text { Reflexión previa }\end{array}$ & $\square$ Mantenimiento $\quad \square$ Rehabilitación parcial $\quad \square$ Restauración $\quad \square$ Demolición \\
Observaciones & Reparación $\quad \square$ Rehabilitación integral $\quad \square$ Ampliación $\quad \square$ Otro... \\
\hline & $\begin{array}{l}\text { Existe una reparación en la zona derecha de la fachada probablemente causa por la } \\
\text { intervención en el edificio anexo }\end{array}$ \\
\hline
\end{tabular}

\subsection{MUROS}

Tipo de intervención

Intervenido

Tipo de material

$\square$ Actualización $\square$ Reintegración $\square$ Demolición $\square$ Otro...

$\square$ Consolidación $\quad$ Reconstrucción $\square$ Sustitución

Descripción

No tradicional Tipo de técnica Diferente a la existente

3.2. ZÓCALO

Reconstrucción parcial del muro con ladrillo hueco

Tipo de intervención

Intervenido

$\square$ Actualización

$\mathbf{x}$ Reintegración $\square$ Demolición $\square$ Otro..

Tipo de material

$\square$ Consolidación $\square$ Reconstrucción $\square$ Sustitución

Descripción

Tipo de técnica Diferente a la existente

3.3. REVESTIMIENTOS

Mortero de cemento en las zonas donde se había perdido parte del material

Tipo de intervención

\section{No aplica}

Tipo de material

$\square$ Actualización

$\square$ Reintegración $\square$ Demolición $\square$ Otro...

$\square$ Consolidación $\square$ Reconstrucción $\square$ Sustitución

Descripción

3.4. VANOS

No intervenido

Tipo de intervención

$\square$ Actualización $\square$ Reintegración $\square$ Demolición $\square$ Otro...

Tipo de material

Descripción

$\square$ Consolidación $\square$ Reconstrucción $\square$ sustitución

3.5. CUBIERTA

Tipo de intervención

Intervenido

$\square$ Actualización $\quad \boldsymbol{X}$ Reintegración $\quad \square$ Demolición $\quad \square$ Otro...
$\square$ Consolidación $\quad \square$ Reconstrucción $\quad \square$ Sustitución

Tipo de material

No tradicional Tipo de técnica Diferente a la existente

Descripción

Las tejas del lateral de la cubierta e han cogido con abundante cemento para evitar su pérdida

3.6. OTRAS 
La restauración y rehabilitación de la arquitectura tradicional de tierra. El caso de Aragón

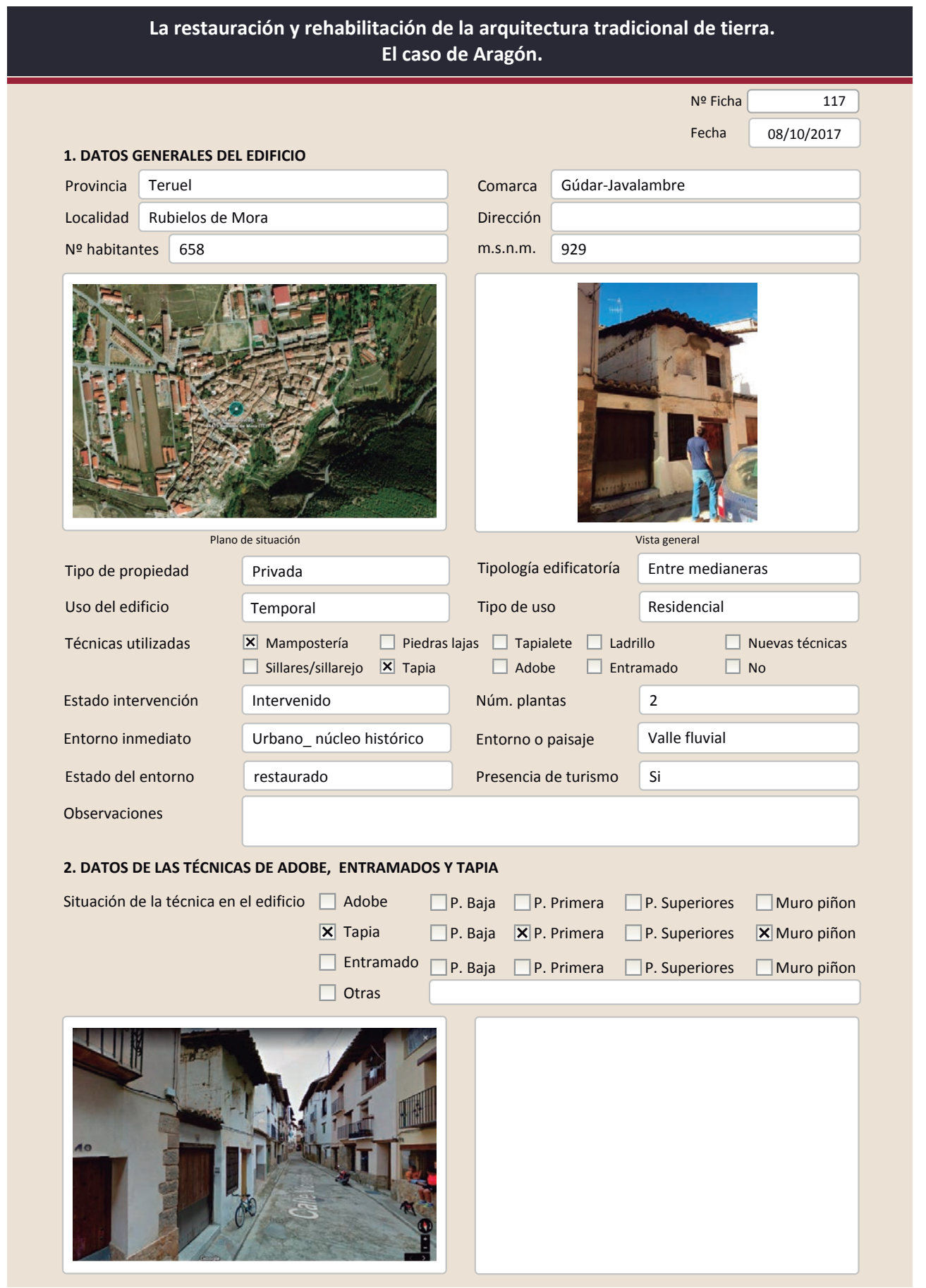

La restauración y rehabilitación de la arquitectura tradicional de tierra.

El caso de Aragón.

2.2. TAPIA

Ancho del muro

Dimensión tapiales

Tipo de aguja

\begin{tabular}{|l|}
\hline $30-40 \mathrm{~cm}$ \\
\hline \\
\hline Redonda \\
\hline
\end{tabular}

Color de la tapia

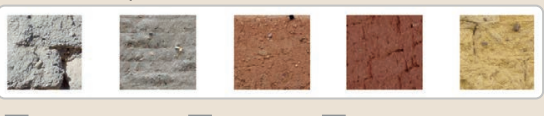

$\square$ Blanquecino $\square$ Marrón $\square$ Amarillento

№ agujas/cajón

Variante constructiva

$\square$ simple / homogénea

X Suplemento superficial

$\square$ Suplemento en juntas

X Mixta
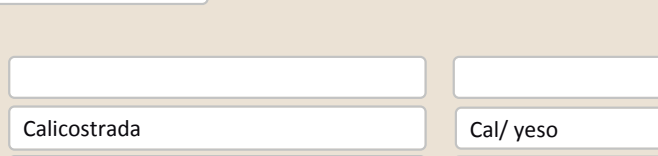

Cal/y

$\mathrm{Cal} /$ yeso

Mampostería y yeso
En esquinas

Revestimiento

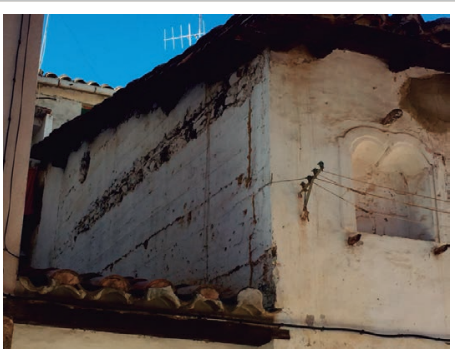

Lesiones $\quad \mathbf{X}$ Muro $\square$ Zócalo $\square$ Revestimiento $\square$ Cubierta $\square$ Otro...

X Erosión del material $\quad \square$ Humedad por capilaridad $\quad \square$ Grietas por asentamientos $\mathbf{X}$ Erosion de las juntas $\square$ Humedades (manch/eflo) $\square$ Colapso

$\square$ Pérdida de sección $\square$ Pérdida de verticalidad $\quad \square$ Por elementos impropios

$\square$ Vegetación $\quad \square$ Grietas por empuje de la cubierta $\square$ Derivado de intervenciones

$\square$ Desconchados $\quad \square$ Grietas porfalta de traba $\quad \square$ Otro... 


\section{La restauración y rehabilitación de la arquitectura tradicional de tierra.}

\section{El caso de Aragón.}

3. DATOS DE LA INTERVENCIÓN

\begin{tabular}{|c|c|c|c|c|}
\hline Intervención de: & $\begin{array}{l}\mathbf{X} \text { Mantenimiento } \\
\square \text { Reparación }\end{array}$ & $\begin{array}{l}\square \text { Rehabilitación parcial } \\
\square \text { Rehabilitación integral }\end{array}$ & $\begin{array}{l}\square \text { Restauración } \\
\square \text { Ampliación }\end{array}$ & $\begin{array}{l}\square \text { Demolición } \\
\square \text { Otro... }\end{array}$ \\
\hline Reflexión previa & \multicolumn{4}{|c|}{ Intervención espontanea } \\
\hline Observaciones & & & & \\
\hline
\end{tabular}

\subsection{MUROS}

Tipo de intervención

Intervenido

Tipo de material

$\square$ Actualización $\quad \mathbf{X}$ Reintegración $\square$ Demolición $\square$ Otro...

$\square$ Consolidación $\square$ Reconstrucción $\square$ Sustitución

Descripción

No tradicional Tipo de técnica Diferente a la existente

3.2. ZócALO

Tipo de intervención

Relleno con poliestireno de huecos y juntas en el muro piñón

Tipo de material

Intervenido

$\square$ Actualización $\quad \square$ Reintegración $\quad \square$ Demolición $\square$ Otro...

$\square$ Actualización $\square$ Reintegración
$\square$ Consolidación $\quad \square$ Reconstrucción $\quad \square$ Sustitución

Descripción
No tradicional
Tipo de técnica Diferente a la existente

3.3. REVESTIMIENTOS

Nuevo revestimiento de cemento y pintura blanca en la planta primera

Tipo de intervención

No intervenido

Tipo de material

$\square$ Actualización $\square$ Reintegración $\square$ Demolición $\square$ Otro...

Tipo de materia

$\square$ Consolidación $\square$ Reconstrucción $\square$ Sustitución

Descripción

3.4. VANOS

No intervenido

Tipo de intervención

$\square$ Actualización $\square$ Reintegración $\square$ Demolición $\square$ Otro...

Tipo de material

$\square$ Consolidación $\square$ Reconstrucción $\square$ sustitución

Descripción

$$
\text { Tipo de técnica }
$$

No se han intervenido los vanos, sin embargo si que se ha trabajado en la conservación de las carpinterías.

3.5. CUBIERTA

$\begin{array}{ll}\text { Tipo de intervención } & \square \text { Actualización } \quad \boldsymbol{X} \text { Reintegración } \quad \square \text { Demolición } \quad \square \text { Otro... } \\ & \square \text { Consolidación } \quad \square \text { Reconstrucción } \quad \square \text { Sustitución }\end{array}$

Intervenido

Tipo de material No tradicional Tipo de técnica Similar a la existente

Descripción Reintegración de la cubierta colocando de nuevo las tejas con mortero de cemento

3.6. OTRAS 


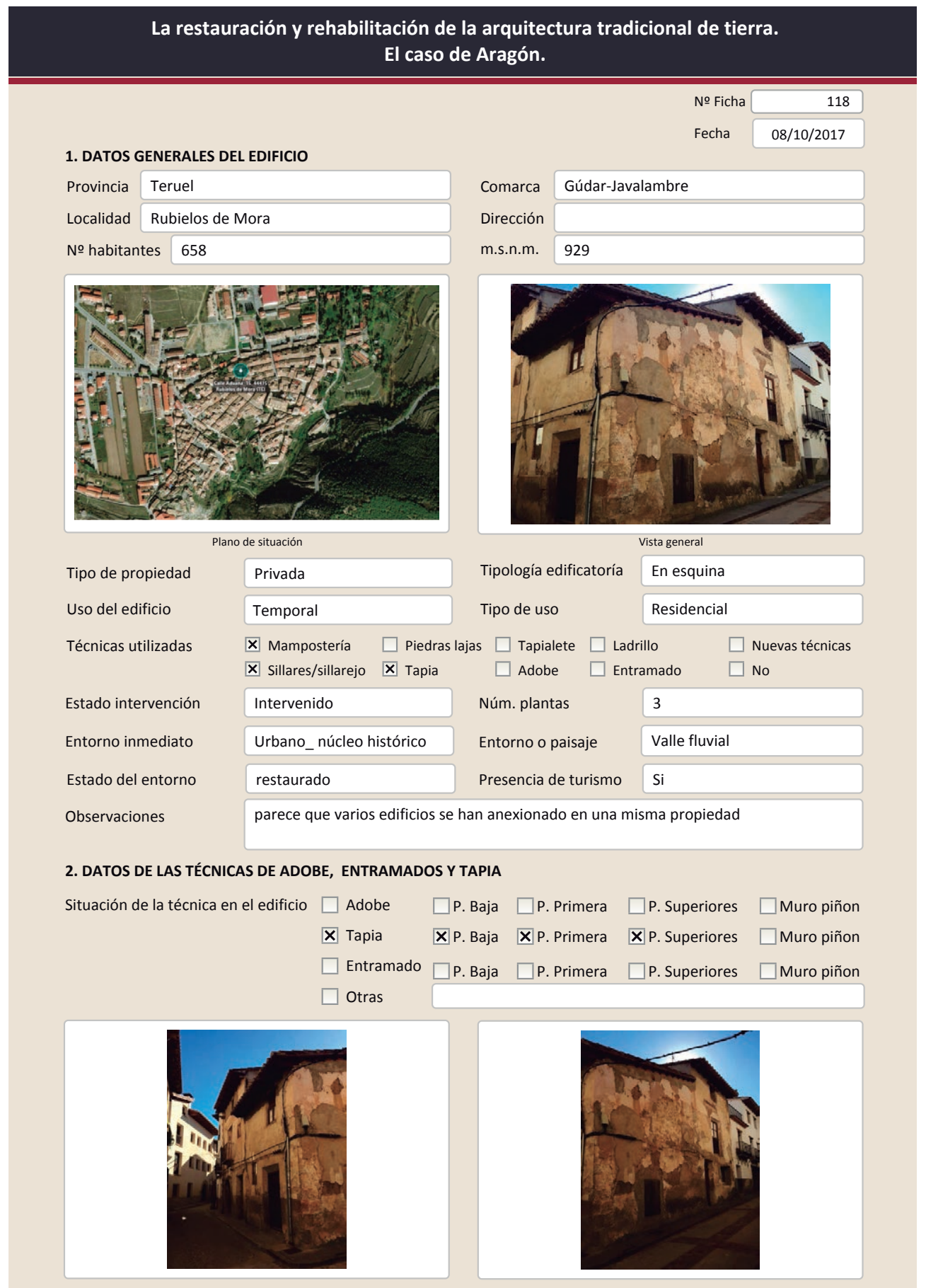

2.2. TAPIA

Ancho del muro

Dimensión tapiales

Tipo de aguja

№ agujas/cajón

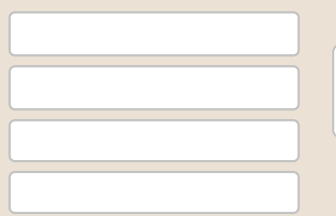

Color de la tapia

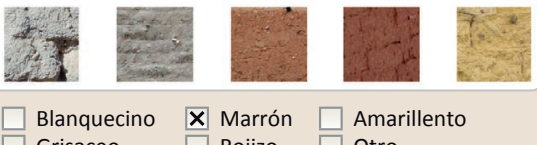

$\square$ Blanquecino $\quad \boldsymbol{X}$ Marrón $\square$ Amarillento

Variante constructiv

$\square$ Simple / homogéne

$\square$ Suplemento superficial

$\square$ suplemento en juntas

$\mathbf{X}$ Mixta

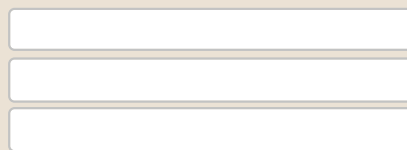

X Elementos de protección

En esquinas

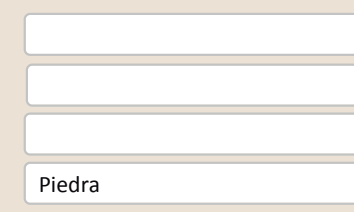

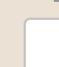

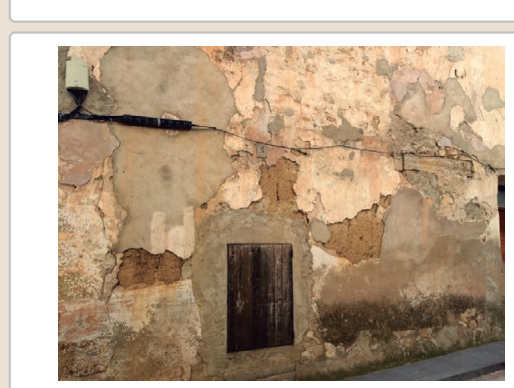

Lesiones $\mathbf{X}$ Muro $\mathbf{X}$ Zócalo $\mathbf{X}$ Revestimiento

$\mathbf{X}$ Erosión del material $\mathbf{X}$ Humedad por capilaridad $\square$ Erosion de las juntas $\mathbf{X}$ Humedades (manch/eflo)

$\square$ Pérdida de sección $\quad \square$ Pérdida de verticalidad

$\square$ Vegetación $\square$ Grietas por empuje de la cubierta

X Desconchados $\square$ Grietas porfalta de traba

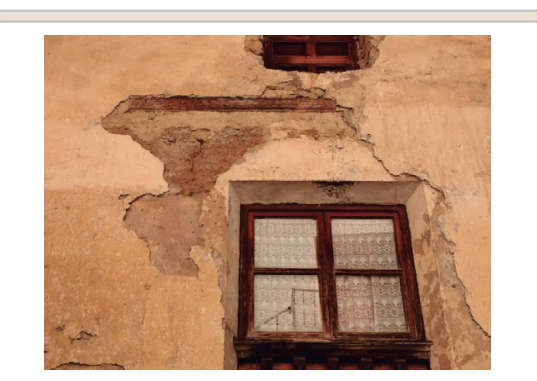

$\square$ Cubierta $\square$ Otro...

$\square$ Grietas por asentamiento $\square$ Colapso

$\square$ Por elementos impropios

$\mathbf{X}$ Derivado de intervenciones $\square$ Otro... 


\section{La restauración y rehabilitación de la arquitectura tradicional de tierra.}

\section{El caso de Aragón.}

3. DATOS DE LA INTERVENCIÓN

Mantenimiento $\mathbf{X}$ Rehabilitación parcial

$\square$ Restauración $\square$ Demolición

Reflexión previ

$\square$ Reparación

Rehabilitación integra

$\square$ Ampliación

$\square$ Otro...

Observaciones

Intervención planificada

3.1. MUROS
Tipo de intervención

Intervenido

$\square$ Actualización $\quad \mathbf{X}$ Reintegración $\square$ Demolición $\square$ Otro...

$\square$ Consolidación $\quad \mathbf{X}$ Reconstrucción $\square$ Sustitución

Tipo de material

Descripción

3.2. ZÓCALO

Tipo de intervención

No tradiciona

Tipo de técnica Diferente a la existente

nueva

Intervenido

$\square$ Actualización $\mathbf{X}$ Reintegración $\square$ Demolición $\square$ Otro.

$\square$ Consolidación $\square$ Reconstrucción $\square$ Sustitución

Tipo de material No tradicional Tipo de técnica Diferente a la existente

Descripción

3.3. REVESTIMIENTOS

Tipo de intervención

Toda la zona inferior del muro tiene un pqueño revestimiento de cemento que actualmente se encuentra enmohecido

\section{Intervenido}

$\square$ Actualización $\quad \mathbf{X}$ Reintegración $\square$ Demolición $\square$ Otro...

$\square$ Consolidación $\square$ Reconstrucción $\square$ Sustitución

Tipo de material

No tradicional

Tipo de técnica Similar a la existente

Descripción

Reintegración de pare del revestimiento con mortero de cemento. NO está en todo el edificio por lo que puede ser que sea únicamente derivado de la interv. en muro

\begin{tabular}{|c|c|c|c|c|}
\hline 3.4. VANOS & No intervenido & & & \\
\hline Tipo de intervención & $\begin{array}{l}\square \text { Actualización } \\
\square \text { Consolidación }\end{array}$ & $\begin{array}{l}\square \text { Reintegración } \\
\square \text { Reconstrucción }\end{array}$ & $\begin{array}{l}\square \text { Demolición } \\
\square \text { Sustitución }\end{array}$ & $\square$ Otro... \\
\hline Tipo de material & \multicolumn{4}{|c|}{ Tipo de técnica } \\
\hline Descripción & & & & \\
\hline 3.5. CUBIERTA & \multicolumn{4}{|l|}{ Intervenido } \\
\hline Tipo de intervención & $\begin{array}{l}\square \text { Actualización } \\
\square \text { Consolidación }\end{array}$ & $\begin{array}{l}\square \text { Reintegración } \\
\square \text { Reconstrucción }\end{array}$ & $\begin{array}{l}\square \text { Demolición } \\
\boldsymbol{X} \text { Sustitución }\end{array}$ & $\square$ Otro... \\
\hline
\end{tabular}

\begin{tabular}{l|l|l|l|l|l} 
Tipo de material & No tradicional de técnica & Diferente a la existente
\end{tabular}

Descripción

Sustitución completa de la cubierta
La restauración y rehabilitación de la arquitectura tradicional de tierra.

El caso de Aragón.

3.7. REHABILITACIÓN ENERGÉTICA $\quad \square$ Fachada $\square$ Vanos $\square$ Forjados $\square$ Cubierta

Observaciones

FOTOGRAFíAS DE LA INTERVENCIÓN
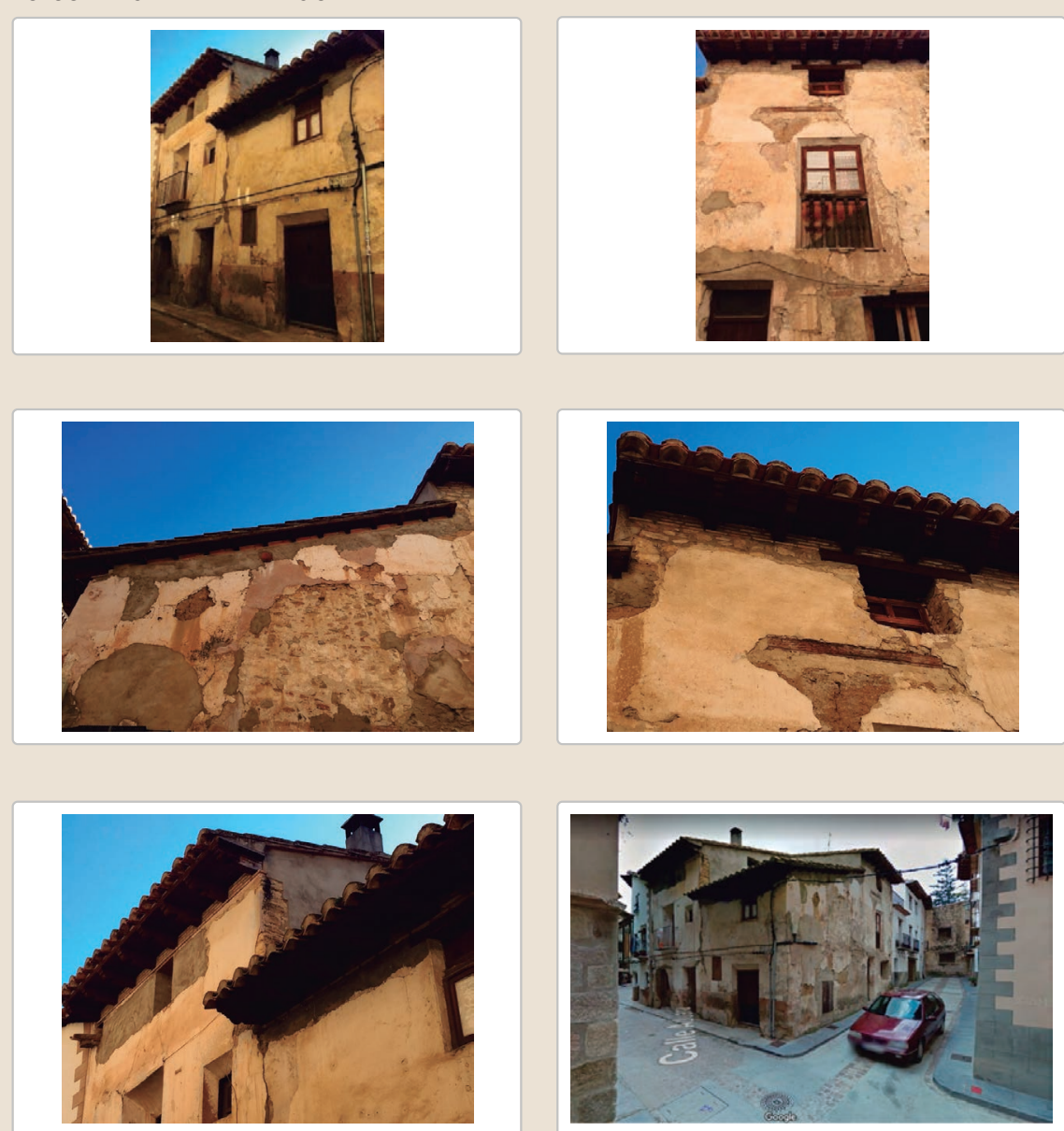

3.6. OTRAS 


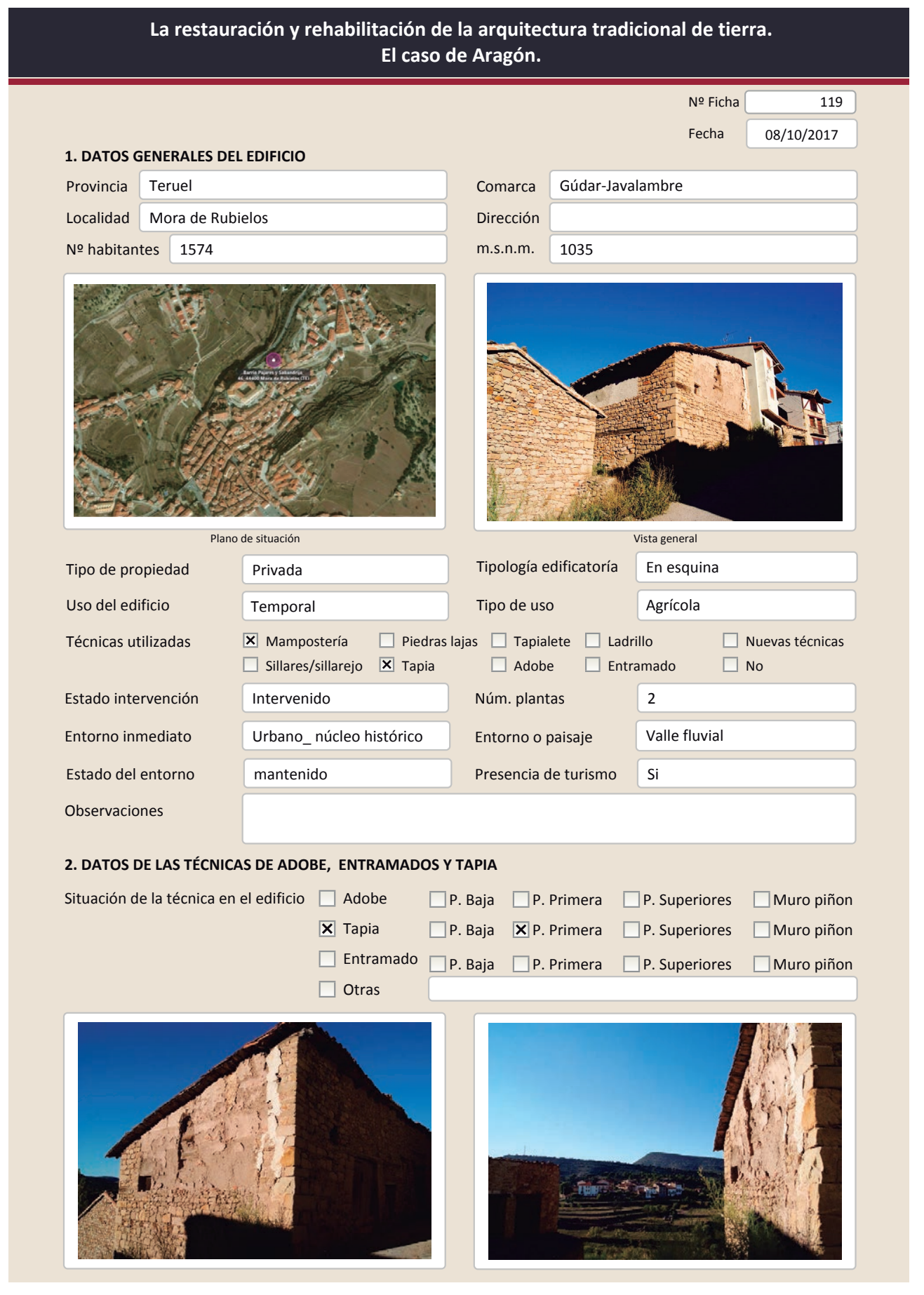

2.2. TAPIA

Ancho del muro

Dimensión tapiales

Tipo de aguja

№ agujas/cajón

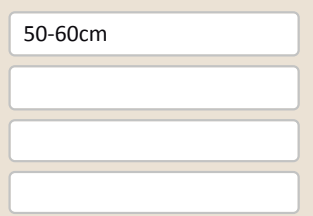

Color de la tapia

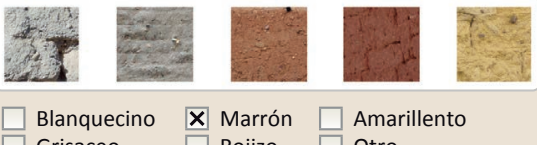

$\square$ Blanquecino $\quad \mathbf{X}$ Marrón $\square$ Amarillento

Variante constructiva

X Simple / homogénea

$\square$ suplemento superficial

$\square$ suplemento en juntas

$\mathbf{X}$ Mixta

Simple / homogénea

Madera

$\square$ Elementos de protección

El muro tiene rollizos en su interior que se cruzan. Probablemente como atado de los muros laterales
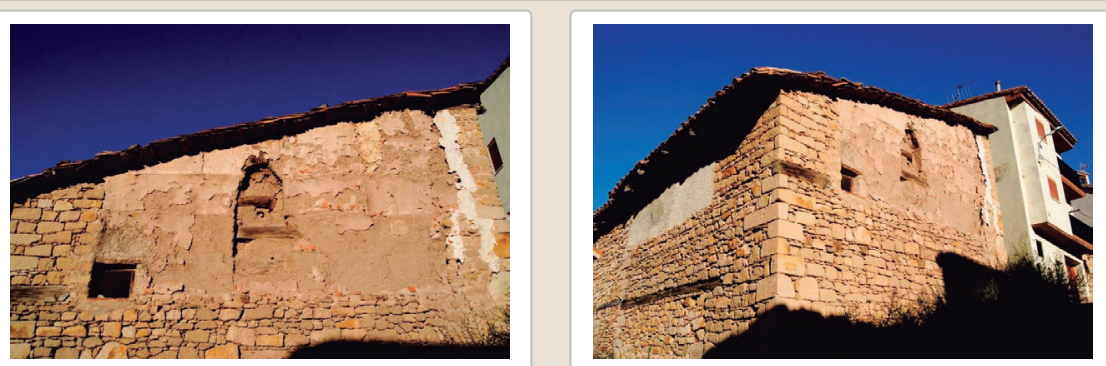

Lesiones \Muro $\square$ Zócalo $\square$ Revestimiento $\square$ Cubierta $\square$ Otro...

X Erosión del material $\quad \square$ Humedad por capilaridad $\quad \square$ Grietas por asentamiento $\square$ Erosion de las juntas $\square$ Humedades (manch/eflo)

X Pérdida de sección $\square$ Pérdida de verticalidad

$\square$ Vegetación

$\square$ Colapso

X Desconchados

Grietas por empuje de la cubierta

$\square$ Por elementos impropios

$\square$ Derivado de intervenciones
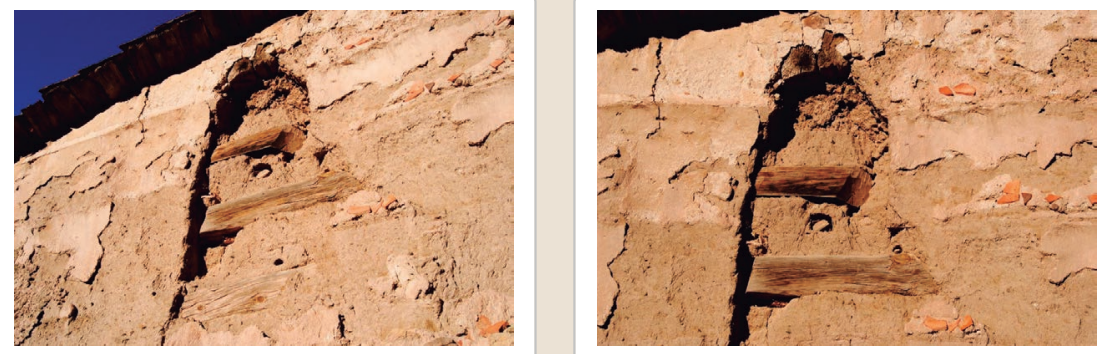

Observaciones

Perdida volumétrica importante en el área central. Parece causada a partir del agrietamiento del muro por los rollizos centrales que apoyan justo en el punto superior del desconchado. 


\section{La restauración y rehabilitación de la arquitectura tradicional de tierra.}

\section{El caso de Aragón.}

3. DATOS DE LA INTERVENCIÓN

\begin{tabular}{|c|c|c|c|c|}
\hline Intervención de: & $\begin{array}{l}\square \text { Mantenimiento } \\
\text { Х Reparación }\end{array}$ & $\begin{array}{l}\square \text { Rehabilitación parcial } \\
\square \text { Rehabilitación integral }\end{array}$ & $\begin{array}{l}\square \text { Restauración } \\
\square \text { Ampliación }\end{array}$ & $\begin{array}{l}\square \text { Demolición } \\
\square \text { Otro... }\end{array}$ \\
\hline Reflexión previa & \multicolumn{4}{|c|}{ Intervención espontanea } \\
\hline erva & & & & \\
\hline
\end{tabular}

\subsection{MUROS}

Tipo de intervención

Intervenido

Tipo de material

$\square$ Actualización $\quad$ X Reintegración $\square$ Demolición $\square$ Otro...

$\square$ Consolidación $\square$ Reconstrucción $\square$ sustitución

Descripción

No tradicional Tipo de técnica Similar a la existente

3.2. ZÓCALO

Tipo de intervención

Se ha tapado con yeso una grieta en la zona derecha de la fachada.

Tipo de material

Intervenido

$\square$ Actualización $\quad \mathbf{X}$ Reintegración $\square$ Demolición $\square$ Otro...

$\square$ Consolidación $\quad \square$ Reconstrucción $\square$ Sustitución

Descripción
No tradicional
Tipo de técnica Diferente a la existente

3.3. REVESTIMIENTOS

Se ha rejuntado la parte inferior del muro con mortero aunque en el edificio este no es muy visible en ningún punto.

3.3. REVESTIMIENTOS
Tipo de intervención

Intervenido

Tipo de material

$\square$ Actualización $\square$ Reintegración $\quad \square$ Demolición $\square$ Otro...

$\square$ Consolidación $\quad \mathbf{X}$ Reconstrucción $\square$ Sustitución

Descripción
No tradicional
Tipo de técnica Diferente a la existente

3.4. VANOS

Existe una zona en la que se ha realizado un revestimiento de cemento pero se

3.4. VANOS
Tipo de intervención

desconoce si está cubriendo tapia o mampostería

Tipo de material
Descripción

No intervenido

$\square$ Actualización $\square$ Reintegración $\square$ Demolición $\square$ Otro...

Descripción

3.5. CUBIERTA

Tipo de intervención

No intervenido

Tipo de material

$\square$ Actualización $\quad \square$ Reintegración $\quad \square$ Demolición
$\square$ Consolidación $\quad \square$ Reconstrucción $\quad \square$ Sustitución

Descripción

Tipo de técnica

3.6. OTRAS 


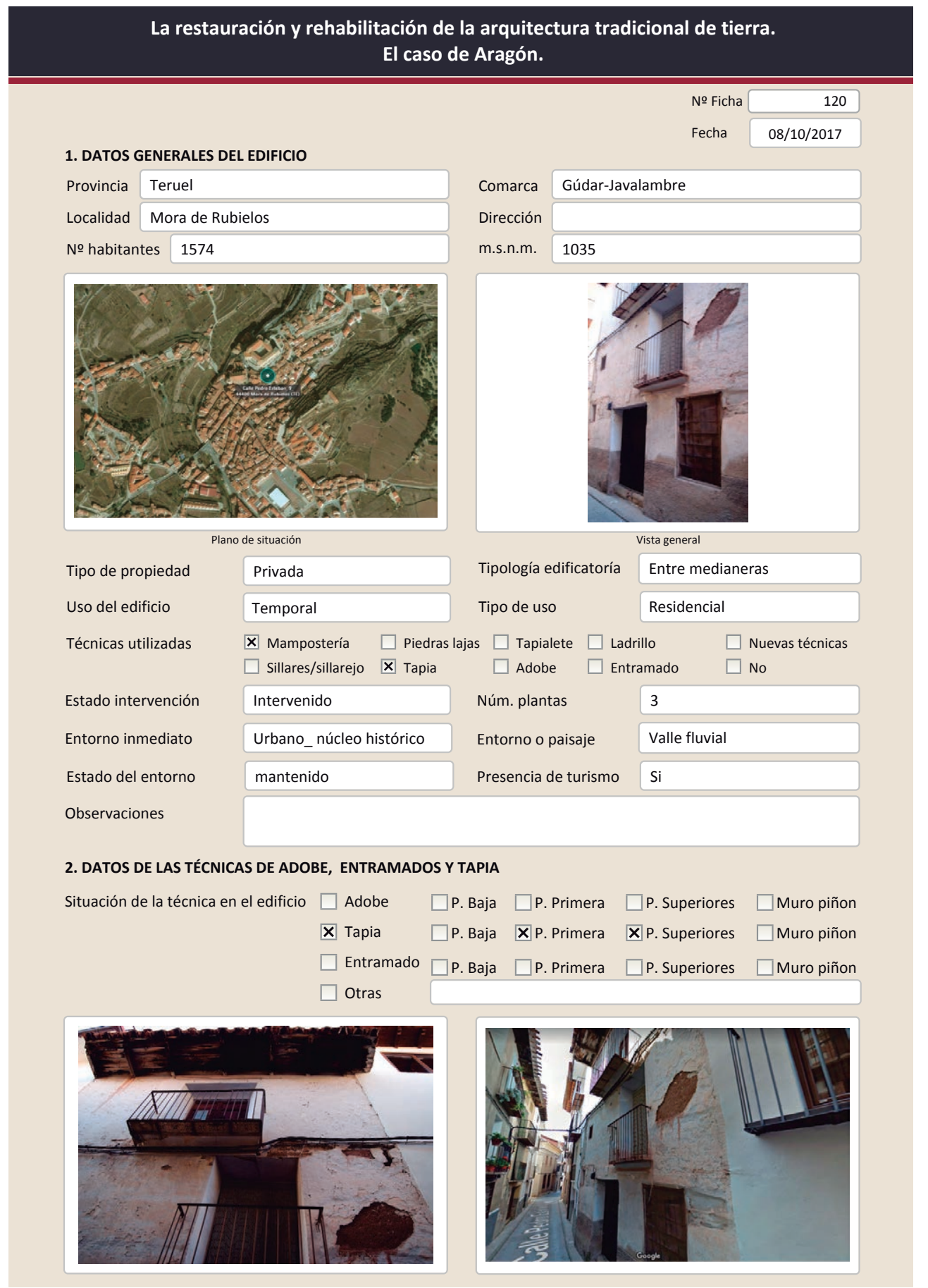

2.2. TAPIA

Ancho del muro

Dimensión tapiales

Tipo de aguja

№ agujas/cajón

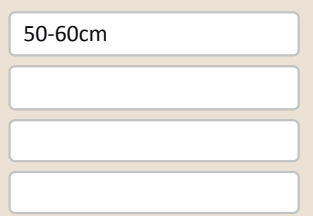

Color de la tapia

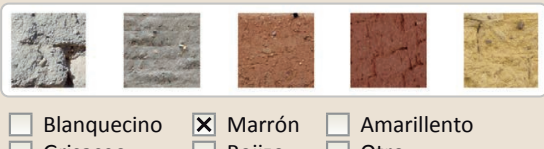

$\begin{array}{ll}\square \text { Blanquecino } & \boldsymbol{X} \text { Marrón } \quad \square \text { Amarillento } \\ \text { Grisaceo } & \square \text { Rojizo } \quad \square \text { Otro... }\end{array}$

Variante constructiv

X Simple / homogéne

$\square$ Suplemento superficial

$\square$ suplemento en juntas

$\square$ Mixta

$\mathbf{X}$ Elementos de protección

Simple / homogénea
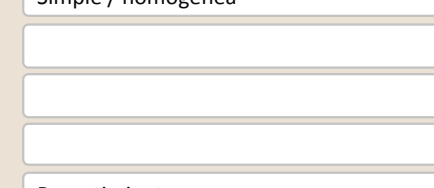

Revestimiento

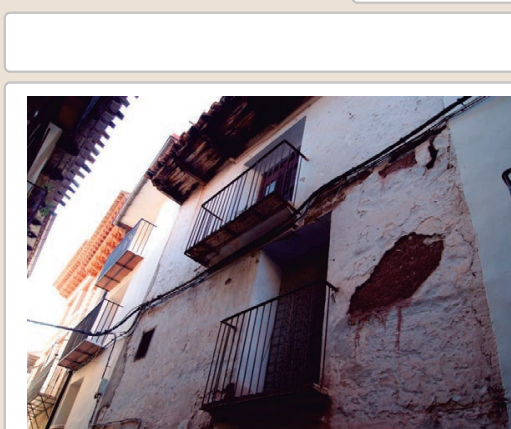

Lesiones $\mathbf{X}$ Muro $\square$ Zócalo $\mathbf{X}$ Revestimiento $\square$ Cubierta $\square$ Otro...

X Erosión del material $\quad \square$ Humedad por capilaridad $\quad \square$ Grietas por asentamiento $\square$ Erosion de las juntas $\square$ Humedades (manch/eflo) $\quad \square$ Colapso

$\square$ Pérdida de sección $\quad \square$ Pérdida de verticalidad $\quad \square$ Por elementos impropios

$\square$ Vegetación $\quad \square$ Grietas por empuje de la cubierta $\square$ Derivado de intervenciones $\mathbf{X}$ Desconchados

$\square$ Grietas porfalta de traba

$\square$ otro...

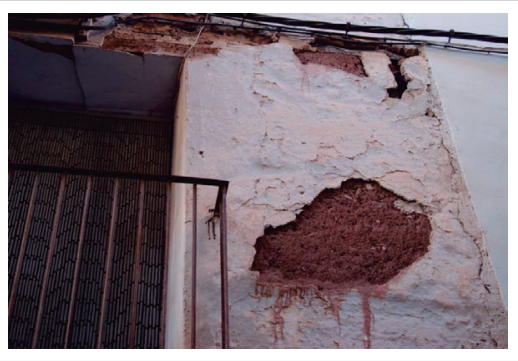

Observaciones 
La restauración y rehabilitación de la arquitectura tradicional de tierra.

El caso de Aragón.

3. DATOS DE LA INTERVENCIÓN

\begin{tabular}{|c|c|c|c|c|}
\hline Intervención de: & $\begin{array}{l}\square \text { Mantenimiento } \\
\mathbf{X} \text { Reparación }\end{array}$ & $\begin{array}{l}\square \text { Rehabilitación parcial } \\
\square \text { Rehabilitación integral }\end{array}$ & $\begin{array}{l}\square \text { Restauración } \\
\square \text { Ampliación }\end{array}$ & $\begin{array}{l}\square \text { Demolición } \\
\square \text { Otro... }\end{array}$ \\
\hline Reflexión previa & \multicolumn{4}{|c|}{ Intervención espontanea } \\
\hline Observacione & & & & \\
\hline
\end{tabular}

\subsection{MUROS}

Tipo de intervención

No intervenido

Tipo de material

$\square$ Actualización $\square$ Reintegración $\square$ Demolición $\square$ Otro...

$\square$ Consolidación $\square$ Reconstrucción $\square$ Sustitución

Descripción

3.2. ZÓCALO

Tipo de intervención

Intervenido

Tipo de material

X Actualización

Reintegración $\quad \square$ Demolición $\square$ Otro...

Descripción

No tradicional

Tipo de técnica

3.3. REVESTIMIENTOS

Tipo de técnica Diferente a la existente

intervención

Tipo de intervención

Intervenido

Tipo de material

Actualización $\square$ Reintegración $\square$ Demolición $\square$ Otro...

Tipo de material

$\square$ Consolidación $\mathbf{X}$ Reconstrucción $\square$ sustitución

Descripción

Tradicional diferente Tipo de técnica Similar a la existente

3.4. VANOS

Se aprecian capas sucesivas de encalado sobre el muro de tapia

Tipo de intervención

No intervenido

Tipo de material

$\square$ Actualización $\quad \square$ Reintegración $\quad \square$ Demolición $\quad \square$ Otro...
$\square$ Consolidación $\quad \square$ Reconstrucción $\quad \square$ Sustitución

Descripción

Descripción

3.5. CUBIERTA

Tipo de intervención

No visible

Tipo de material

$\square$ Actualización $\quad \square$ Reintegración $\quad \square$ Demolición $\quad \square$ Otro...
$\square$ Consolidación $\quad \square$ Reconstrucción $\quad \square$ Sustitución

Descripción

$$
\text { Tipo de técnica }
$$

3.6. OTRAS 


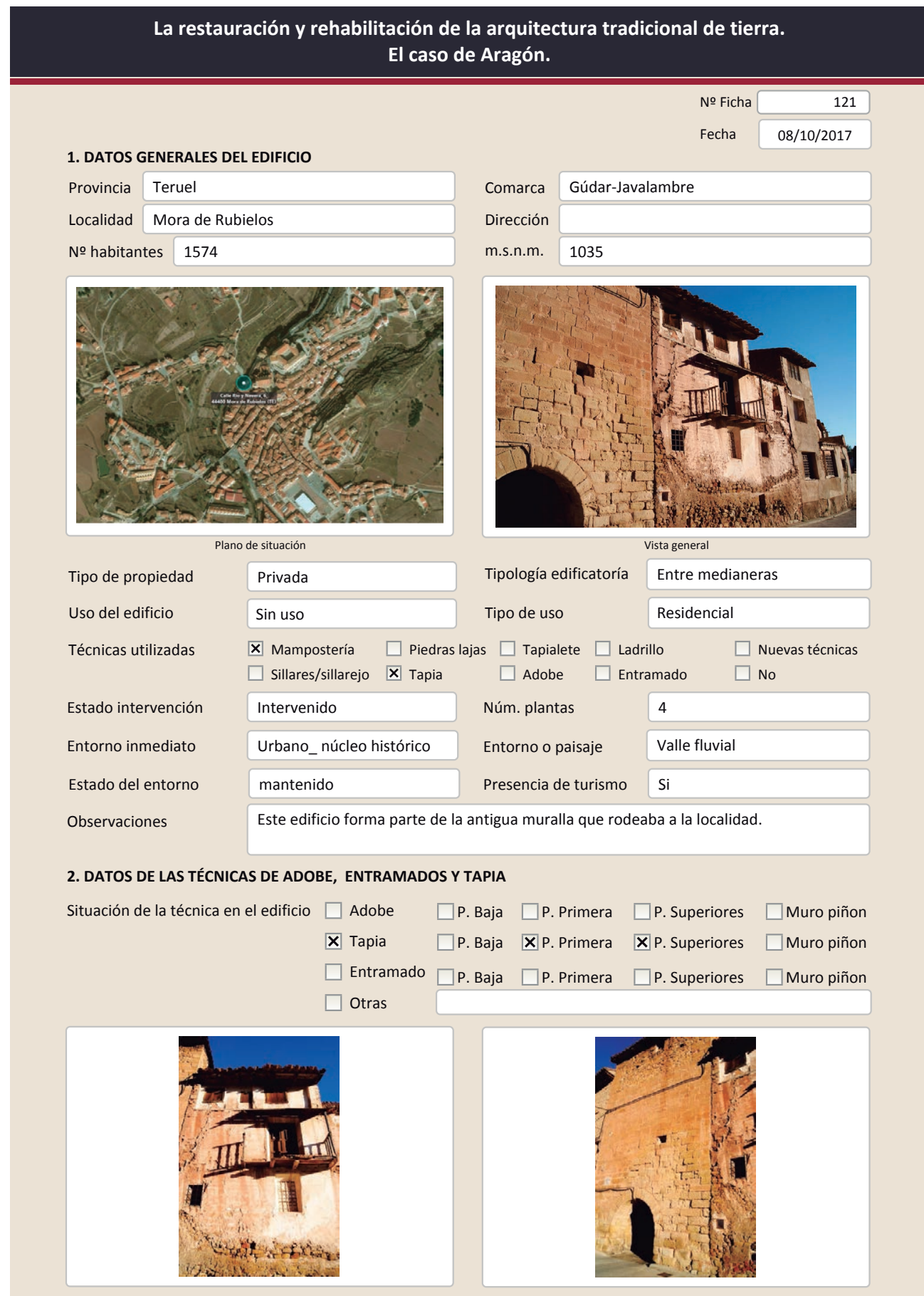

2.2. TAPIA

Ancho del muro

Dimensión tapiales

Tipo de aguja

№ agujas/cajón

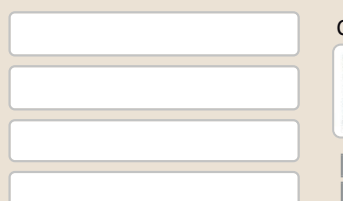

Color de la tapia

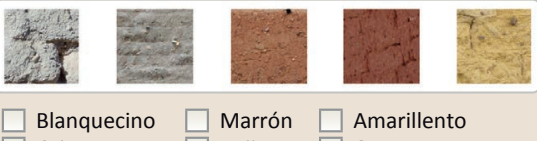

$\square$ Blanquecino $\square$ Marrón $\square$ Amarillento

Variante constructiva

$\square$ Simple / homogénea

$\mathbf{X}$ Suplemento superficial

$\square$ suplemento en juntas

$\square$ Mixta

$\square$ Elementos de protección

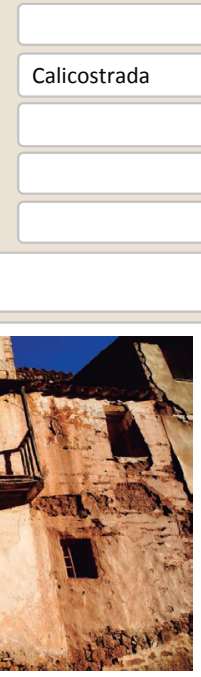

Lesiones ХMuro ХZŹcalo $\square$ Revestimiento $\square$ Cubierta $\square$ Otro...

X Erosión del material $\quad \mathbf{X}$ Humedad por capilaridad $\quad \square$ Grietas por asentamientos $\square$ Erosion de las juntas $\square$ Humedades (manch/eflo)

X Pérdida de sección $\square$ Pérdida de verticalidad

$\square$ Vegetación $\quad \square$ Grietas por empuje de la cubierta

X Desconchados $\square$ Grietas porfalta de traba $\quad \square$ Otro.

Х Desconchados $\quad \square$ Grietas porfalta de traba $\quad \square$ Otro...

Colapso

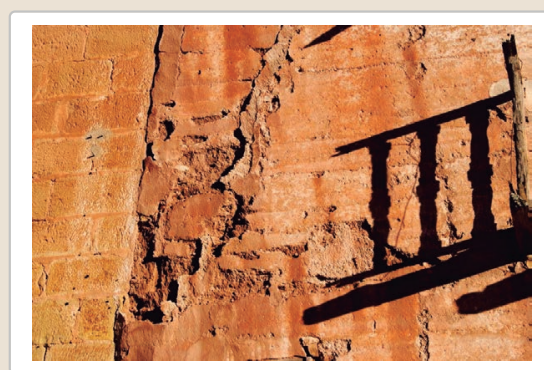

Observaciones 
La restauración y rehabilitación de la arquitectura tradicional de tierra.

El caso de Aragón.

3. DATOS DE LA INTERVENCIÓN

\begin{tabular}{|c|c|c|c|c|}
\hline Intervención de: & $\begin{array}{l}\square \text { Mantenimiento } \\
\mathbf{X} \text { Reparación }\end{array}$ & $\begin{array}{l}\square \text { Rehabilitación parcial } \\
\square \text { Rehabilitación integral }\end{array}$ & $\begin{array}{l}\square \text { Restauración } \\
\square \text { Ampliación }\end{array}$ & $\begin{array}{l}\square \text { Demolición } \\
\square \text { Otro... }\end{array}$ \\
\hline Reflexión previa & \multicolumn{4}{|c|}{ Intervención espontanea } \\
\hline Observacione & & & & \\
\hline
\end{tabular}

\subsection{MUROS}

Tipo de intervención

No intervenido

Tipo de material

$\square$ Actualización $\square$ Reintegración $\square$ Demolición $\square$ Otro...

$\square$ Consolidación $\square$ Reconstrucción $\square$ sustitución

Descripción

3.2. ZÓCALO

Tipo de intervención

Intervenido

Tipo de intervención

$\square$ Actualización $\mathbf{X}$ Reintegración $\square$ Demolición $\square$ Otro...

$\begin{array}{ll}\square \text { Actualización } & \boldsymbol{X} \text { Reintegración } \\ \square \text { Consolidación } \quad \square \text { Reconstrucción } \quad \square \text { Sustitución }\end{array}$

Descripción
No tradicional
Tipo de técnica Diferente a la existente

3.3. REVESTIMIENTOS

Rejuntado de la mampostería del zócalo con gran cantidad de mortero

Tipo de intervención

\section{No aplica}

Tipo de material

Descripción

$\square$ Actualización

Tipo de técnica

3.4. VANOS

Reintegración $\square$ Demolición $\square$ Otro...

Consolidación $\square$ Reconstrucción $\quad \square$ Sustitución

Tipo de técnica

Tipo de intervención

No intervenido

Tipo de material

$\square$ Actualización $\quad \square$ Reintegración $\quad \square$ Demolición $\quad \square$ Otro...
$\square$ Consolidación $\quad \square$ Reconstrucción $\quad \square$ Sustitución

Descripción

3.5. CUBIERTA

Tipo de intervención

Intervenido

$\square$ Actualización $\quad \boldsymbol{X}$ Reintegración $\square$ Demolición $\square$ Otro.

Tipo de material

$\square$ Consolidación $\square$ Reconstrucción $\quad \boldsymbol{X}$ Sustitución

Descripción

No tradicional Tipo de técnica Similar a la existente

Reintegración y sustitución parcial de tejas

3.6. OTRAS 


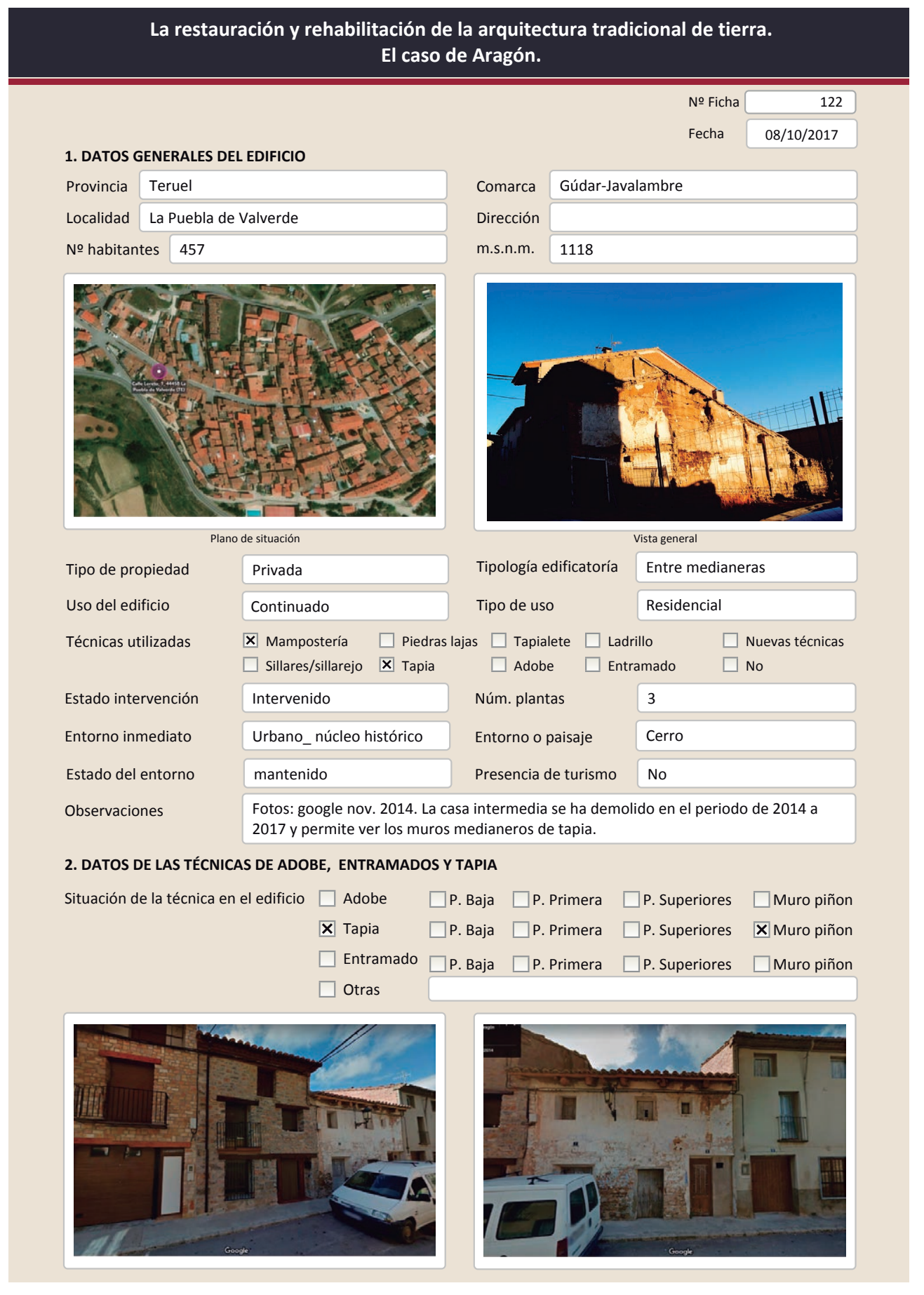

2.2. TAPIA

Ancho del muro

Dimensión tapiales

Tipo de aguja

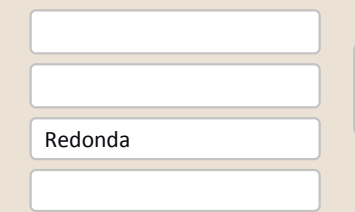

Color de la tapia

№ agujas/cajón

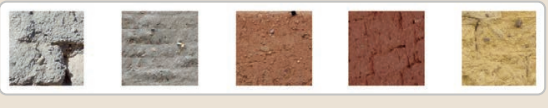

$\square$ Blanquecino $\quad \mathbf{X}$ Marrón $\square$ Amarillento

$\square$ Blanquecino $\quad \boldsymbol{x}$ Marrón $\square$ Amaril
$\square$ Grisaceo
$\square$ Rojizo $\quad \square$ Otro...

Variante constructiva

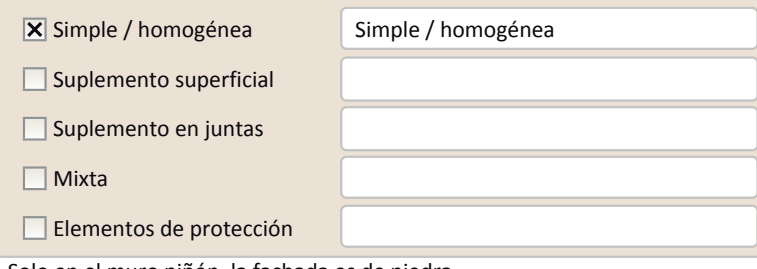

Solo en el muro piñón, la fachada es de piedra

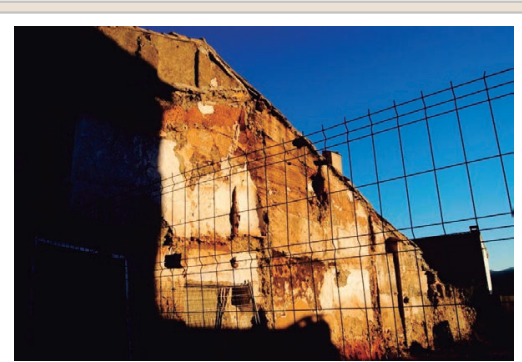

Lesiones $\square$ Muro $\square$ Zócalo $\square$ Revestimiento $\square$ Cubierta $\square$ otro...

$\square$ Erosión del material $\quad \square$ Humedad por capilaridad $\quad \square$ Grietas por asentamientos $\square$ Erosion de las juntas $\square$ Humedades (manch/eflo)

$\square$ Pérdida de sección $\quad \square$ Pérdida de verticalidad

$\square$ Vegetación $\square$ Grietas por empuje de la cubierta

$\square$ Desconch

$\square$ Grietas porfalta de traba
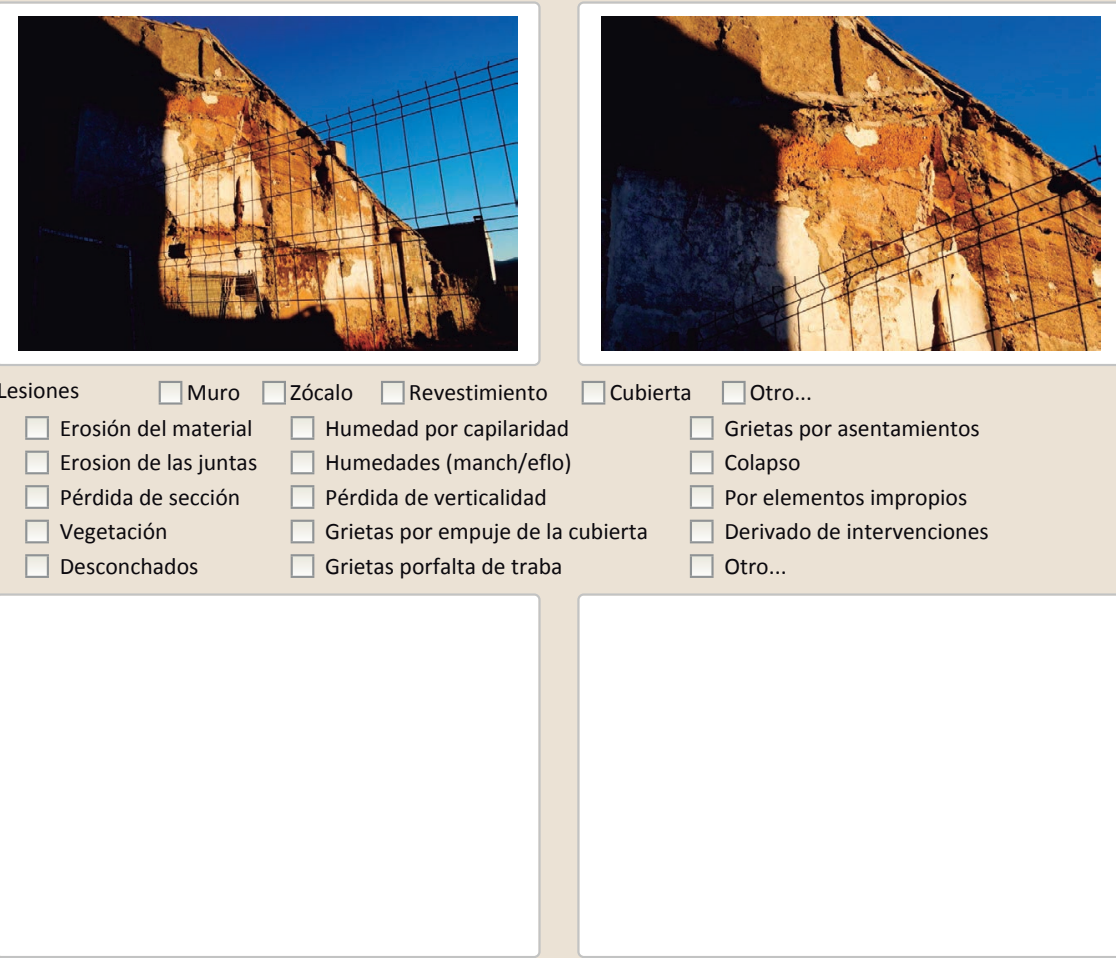

Observaciones 


\section{La restauración y rehabilitación de la arquitectura tradicional de tierra.}

\section{El caso de Aragón.}

3. DATOS DE LA INTERVENCIÓN

Intervencín LA:

(a)

$\square$ Restauración $\square$ Demolición

Reflexión previa

Intervención planificada

Observaciones

3.1. MUROS
Tipo de intervención

Intervenido

Tipo de material

$\square$ Actualización

$\square$ Consolidación

X Reintegración $\square$ Demolición

Descripción

Tipo de técnica Similar a la existente

\begin{tabular}{l}
$\begin{array}{l}\text { Rejuntado } \\
\text { cemento. }\end{array}$ \\
\hline
\end{tabular}

3.2. ZÓCALO

Tipo de intervención

No aplica

$\square$ Actualización $\square$ Reintegración $\square$ Demolición $\square$ Otro...

$\square$ Consolidación $\quad \square$ Reconstrucción $\quad \square$ Sustitución

Tipo de material

Descripción

3.3. REVESTIMIENTOS

Tipo de intervención

Tipo de material

Descripción

3.4. VANOS

Tipo de intervención

Tipo de material

Descripción

3.5. CUBIERTA

Tipo de intervención

Tipo de material

Descripción

3.6. OTRAS

\section{No aplica}

$\square$ Actualización $\quad \square$ Reintegración $\quad \square$ Demolición $\square$ Otro...

$\square$ Consolidación $\square$ Reconstrucción $\square$ sustitución

Tipo de técnica

Intervenido

$\square$ Actualización $\quad \square$ Reintegración $\square$ Demolición $\square$ Otro...

$\square$ Consolidación $\square$ Reconstrucción $\mathbf{X}$ Sustitución

No tradicional Tipo de técnica Diferente a la existente

Sustitución de dinteles y carpinterías de los huecos. Se han añadido persianas

\section{Intervenido}

$\square$ Actualización $\quad$ Xeintegración $\square$ Demolición $\square$ Otro..

$\square$ Consolidación $\quad \square$ Reconstrucción $\square$ Sustitución

No tradicional Tipo de técnica Diferente a la existente

Se ha retejado utiliando las piezas antiguas junto con algunas nuevas y mortero de cemento. $\square$ Mantenimiento $\mathbf{X}$ Rehabilitación parcial

La restauración y rehabilitación de la arquitectura tradicional de tierra.

El caso de Aragón.

3.7. REHABILITACIÓN ENERGÉTICA $\square$ Fachada $\quad$ V Vanos $\square$ Forjados $\square$ Cubierta

Observaciones Nuevas carpinterías y persianas

FOTOGRAFíAS DE LA INTERVENCIÓN

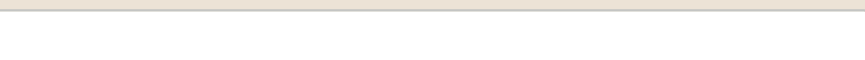
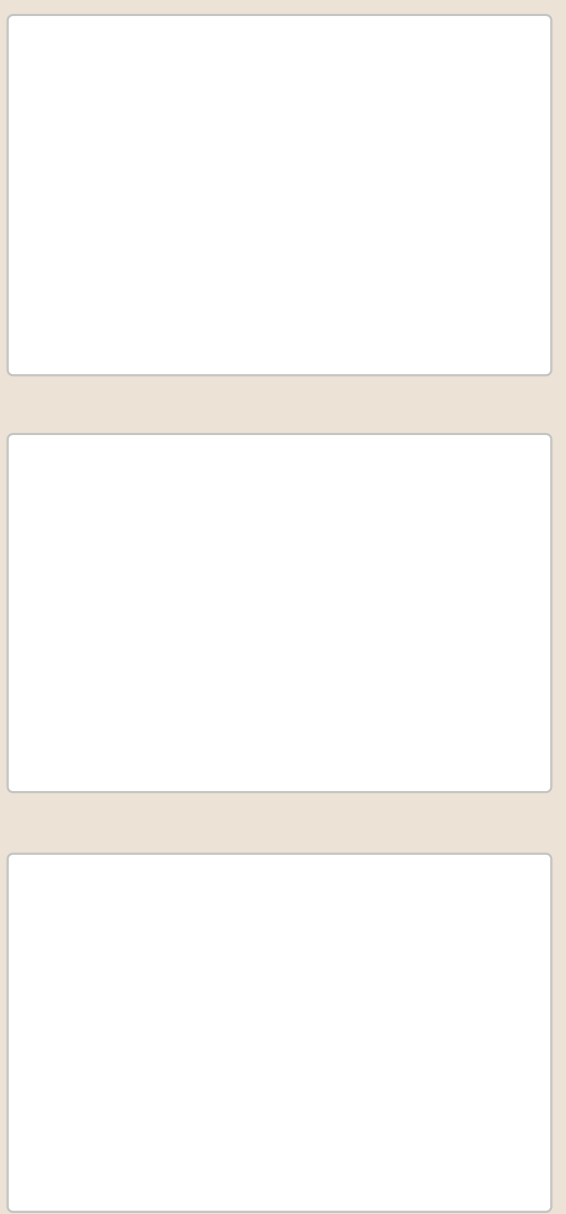
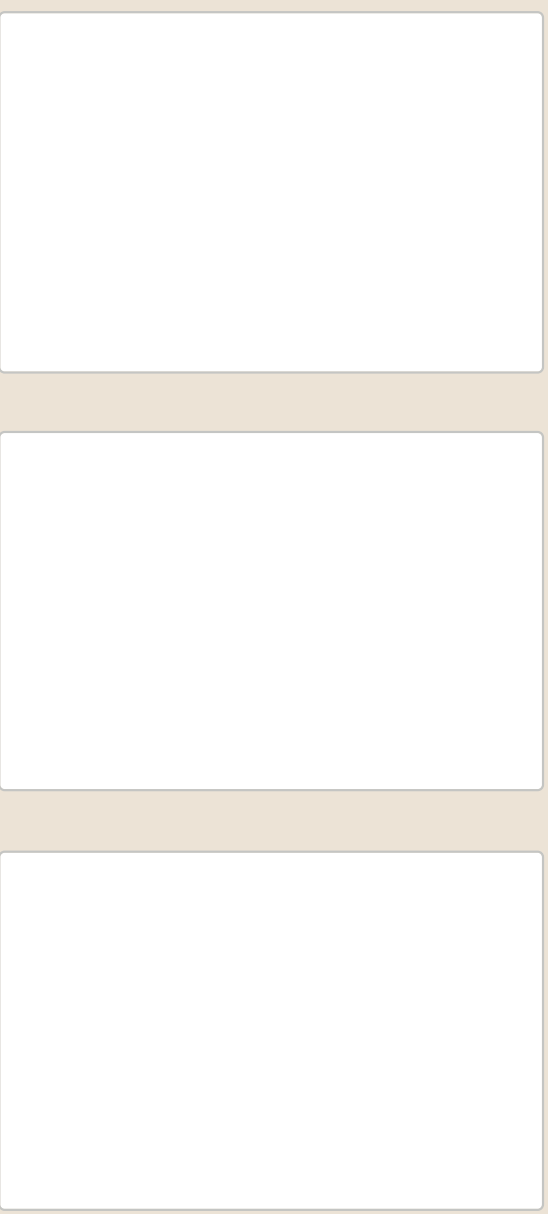


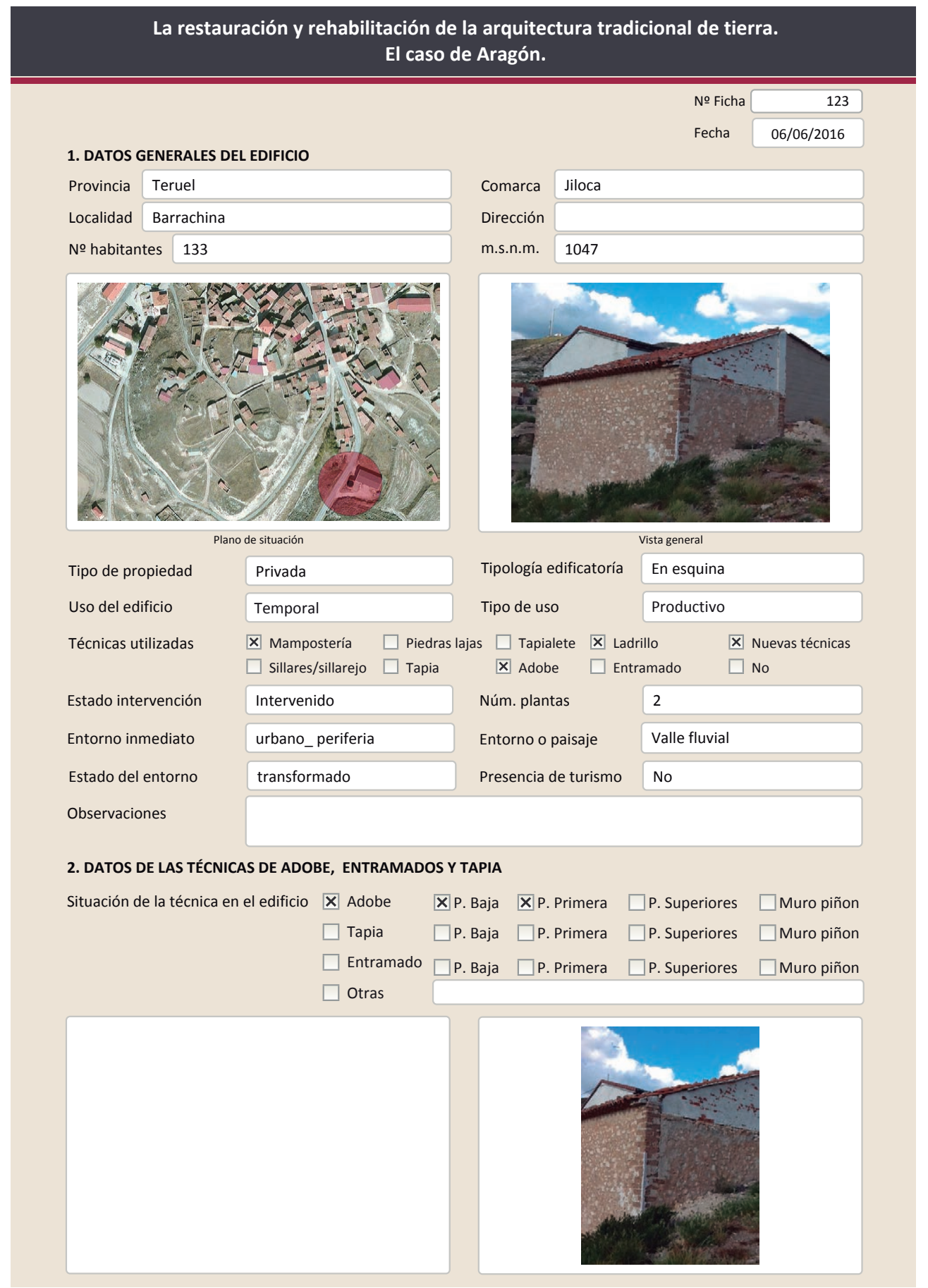

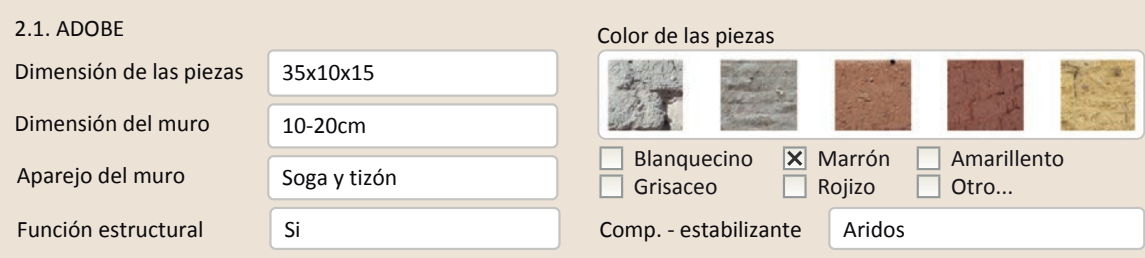

Función estructural $\mathrm{Si}$

Variante constructiva/ tipo de fábrica
$\square$ simple
$\square$ Suplementada en juntas
$\square$ Mixta
X Como suplemento Mixto- En esquinas
$\square$ Elementos de protección

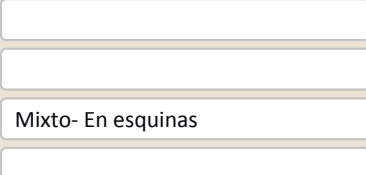

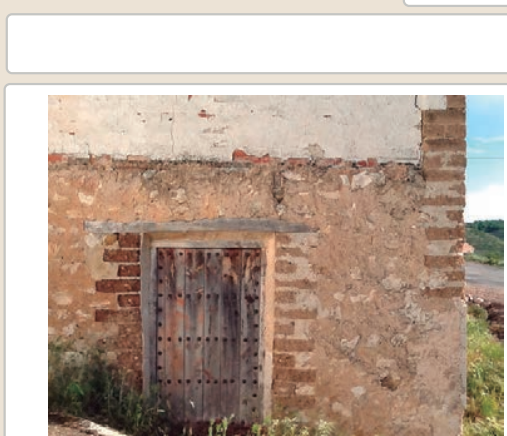

Lesiones $\quad \mathbf{X}$ Muro $\square$ Zócalo $\mathbf{X}$ Revestimiento

$\mathbf{X}$ Erosión del material $\square$ Humedad por capilaridad $\square$ Erosion de las juntas $\square$ Humedades (manch/eflo) X Pérdida de sección $\square$ Pérdida de verticalidad

$\square$ Pérdida de sección $\square$ Pérdida de verticalidad $\square$ Grietas porfalta de traba

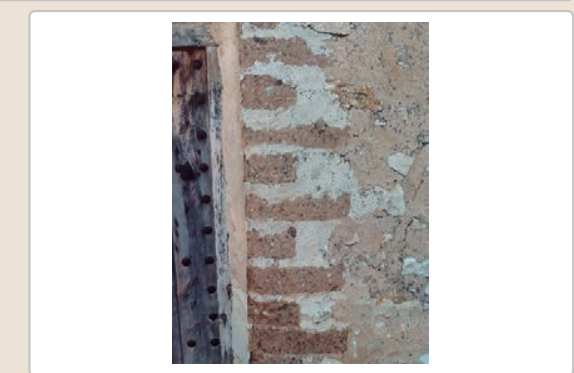

$\mathbf{X}$ Desconchados

Cubierta $\square$ Otro...

cubierta $\square$ Por elementos impropios

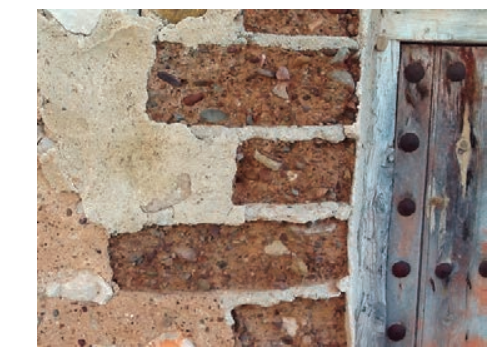

Observaciones 


\section{La restauración y rehabilitación de la arquitectura tradicional de tierra.} El caso de Aragón.

3. DATOS DE LA INTERVENCIÓN

Intervención de:

$\square$ Mantenimiento $\quad$ Xehabilitación parcial

$\square$ Restauración $\square$ Demolición

Reflexión previa

$\square$ Reparación

$\square$ Rehabilitación integra

$\square$ Ampliación

$\square$ Otro...

Observaciones

Intervención espontanea

Observaciones

\subsection{MUROS}

Tipo de intervención

Tipo de material

Descripción

3.2. ZÓCALO

Tipo de intervención

Tipo de material

Descripción

3.3. REVESTIMIENTOS

Tipo de intervención

Tipo de material

Descripción

3.4. VANOS

Tipo de intervención

Tipo de material

Descripción

3.5. CUBIERTA

Tipo de intervención

Tipo de material

Descripción

\section{Intervenido}

$\square$ Actualización $\square$ Reintegración $\square$ Demolición $\square$ Otro...

$\square$ Consolidación $\square$ Reconstrucción $\quad \boldsymbol{X}$ Sustitución

\begin{tabular}{|l|l|l} 
No tradicional & Tipo de técnica & Diferente a la existente
\end{tabular}

Sustitución parcial de los muros piñón en la zona superior

No intervenido

$\square$ Actualización $\square$ Reintegración $\quad \square$ Demolición $\square$ Otro...

$\square$ Consolidación $\quad \square$ Reconstrucción $\square$ Sustitución

\section{Intervenido}

$\square$ Actualización $\square$ Reintegración $\quad \square$ Demolición $\square$ Otro...

$\square$ Consolidación $\quad \mathbf{X}$ Reconstrucción $\quad \square$ Sustitución

Tradicional diferente Tipo de técnica Diferente a la existente

Revestimiento sobre las zonas nuevas de los muros

No intervenido

$\square$ Actualización $\square$ Reintegración $\square$ Demolición $\square$ Otro...

$\square$ Consolidación $\square$ Reconstrucción $\square$ Sustitución

Intervenido

$\square$ Actualización $\square$ Reintegración $\square$ Demolición $\square$ Otro.

$\square$ Consolidación $\square$ Reconstrucción $\quad$ x Sustitución
No tradicional
Tipo de técnica Similar a la existente

Retejado completo de la cubierta cogida con yeso?
La restauración y rehabilitación de la arquitectura tradicional de tierra.

El caso de Aragón.

3.7. REHABILITACIÓN ENERGÉTICA $\quad \square$ Fachada $\square$ Vanos $\square$ Forjados $\square$ Cubierta

Observaciones

FOTOGRAFíAS DE LA INTERVENCIÓN
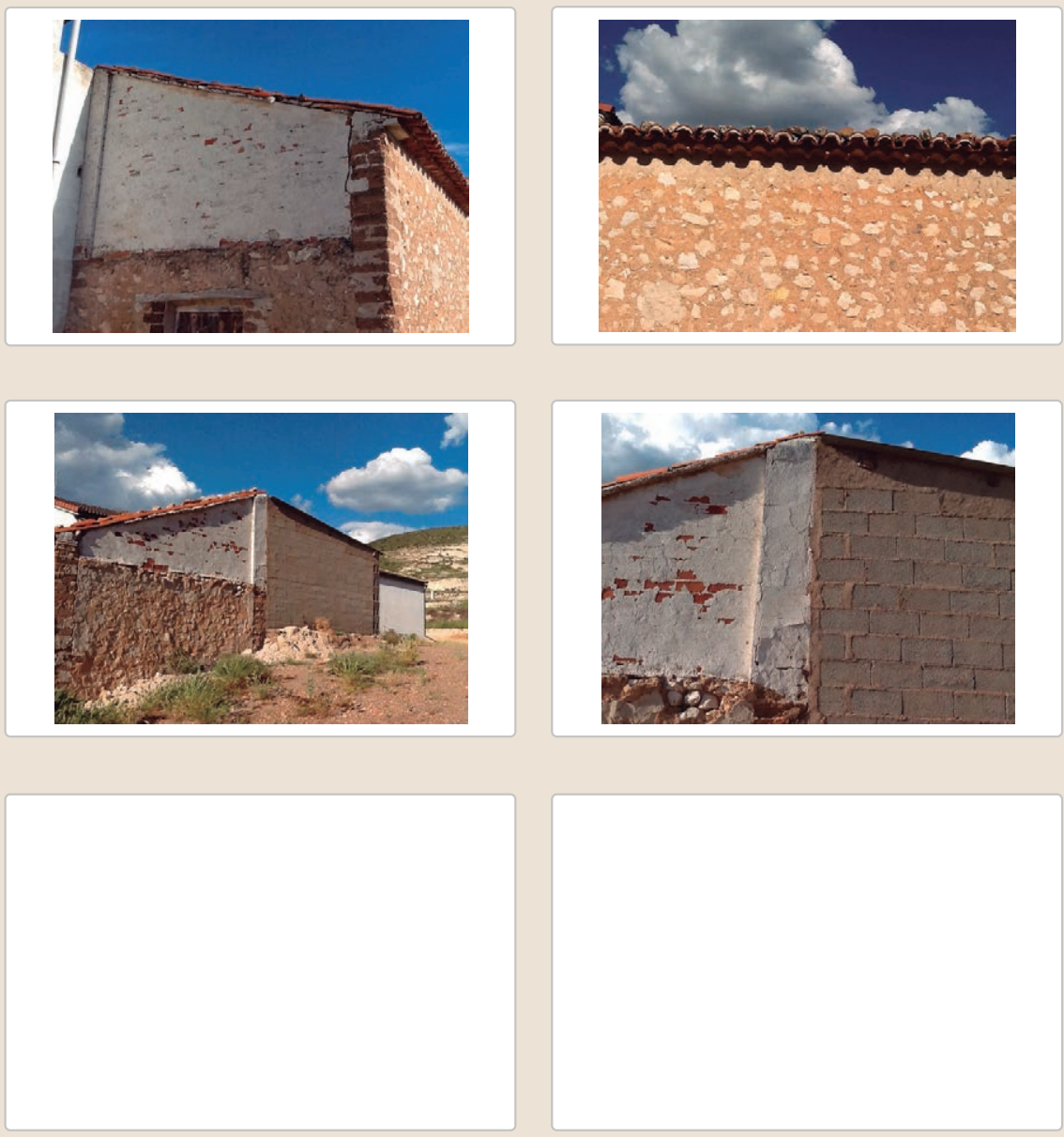

3.6. OTRAS 


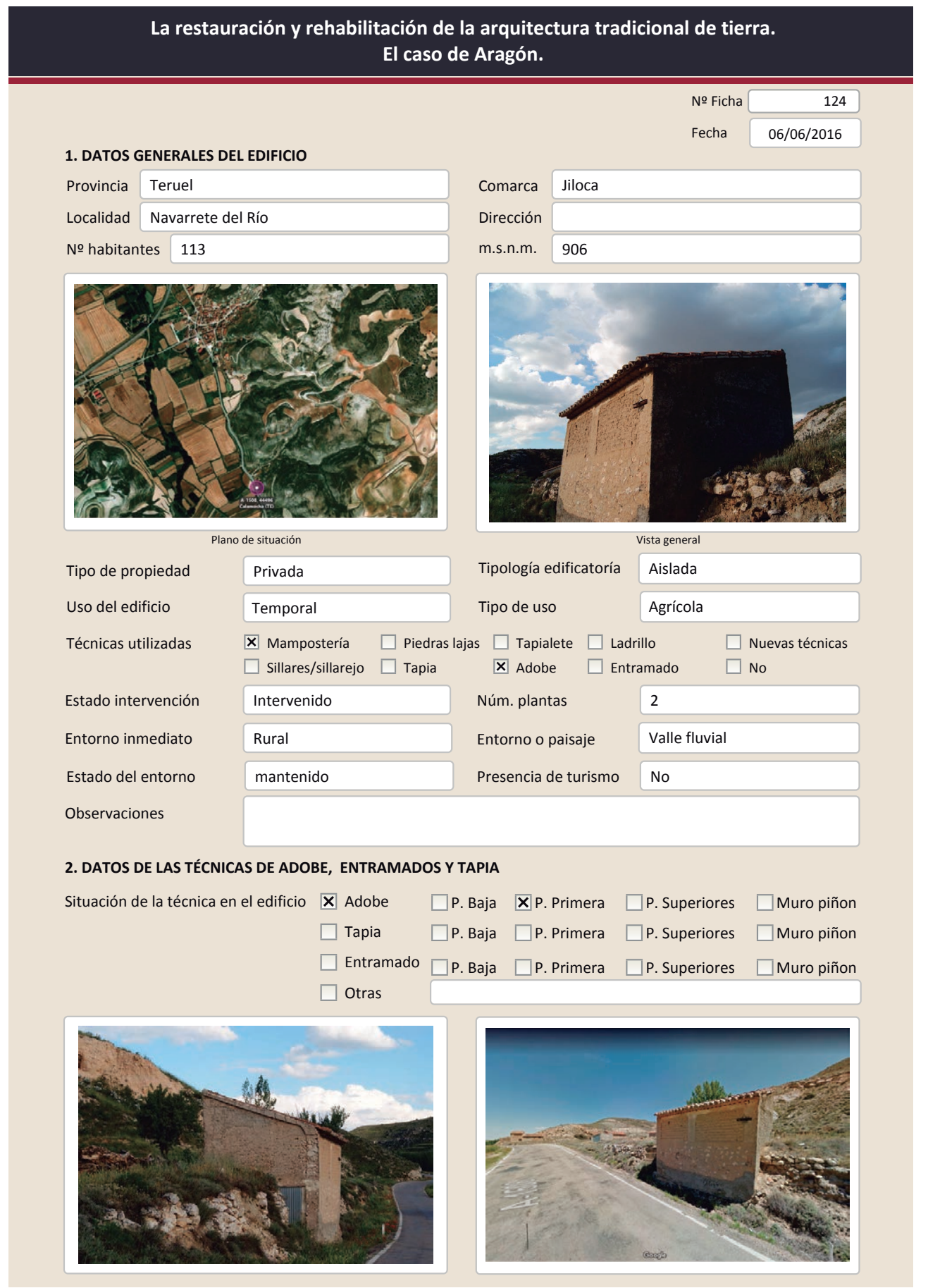

2.1. ADOBE

Dimensión de las piezas Dimensión del muro

Aparejo del muro

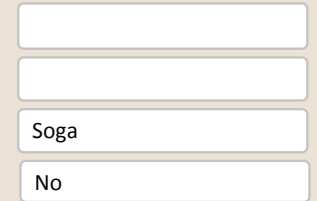

Color de las piezas

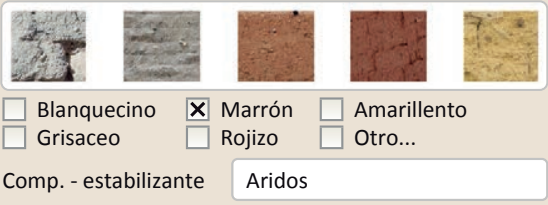

Función estructural

Comp. - estabilizante Aridos

Variante constructiva/ tipo de fábrica

$\square$ simple

$\square$ Suplementada en juntas

X Mixta

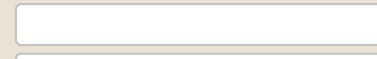

$\square$ Como suplemento

$\square$ Elementos de protección

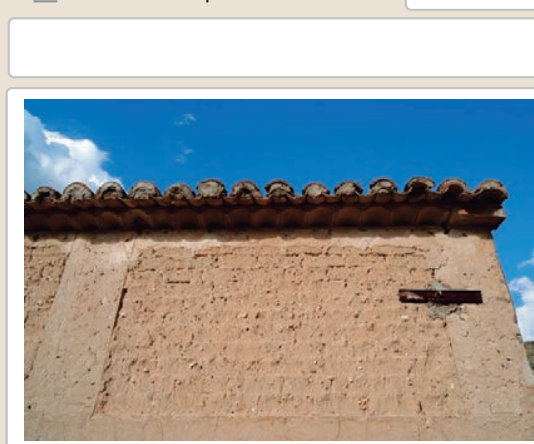

Lesiones $\quad \mathbf{X}$ Muro $\square$ Zócalo $\square$ Revestimiento

$\mathbf{X}$ Erosión del material $\mathbf{X}$ Humedad por capilaridad $\square$ Erosion de las juntas $\square$ Humedades (manch/eflo)

$\square$ Pérdida de sección $\quad \square$ Pérdida de verticalidad

$\square$ Vegetación

$\square$ Grietas por empuje de la cubir $\square$ Grietas porfalta de traba

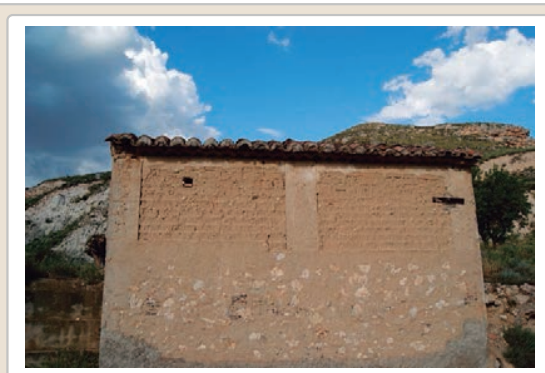

$\square$ Cubierta $\square$ otro...

$\square$ Grietas por asentamiento

$\square$ Colapso

$\square$ Desconchado

$\square$ Por elementos impropios

$\square$ Derivado de intervenciones

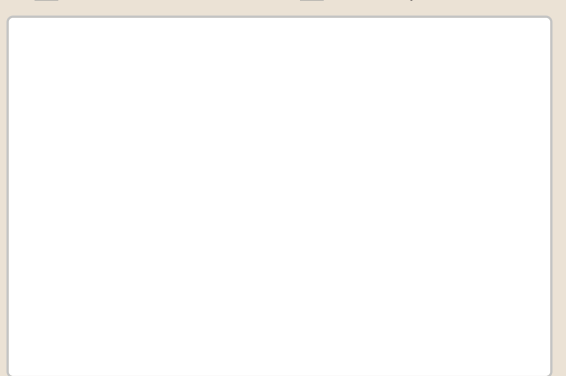

Observaciones

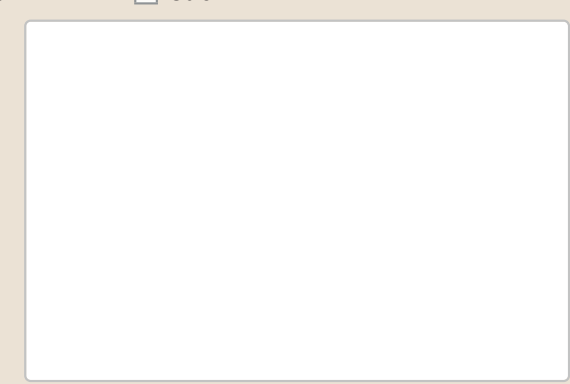




\section{La restauración y rehabilitación de la arquitectura tradicional de tierra.} El caso de Aragón.

3. DATOS DE LA INTERVENCIÓN

Mantenimiento $\square$ Rehabilitación parcial

Reflexín previa X Reparación Rehabilitación integra Ampliación $\square$ Otro...

Reflexion previa
Observaciones

Intervención espontanea

Observaciones

\subsection{MUROS}

Tipo de intervención

Tipo de material

Descripción

3.2. ZÓCALO

Tipo de intervención

Tipo de material

Descripción

3.3. REVESTIMIENTOS

Tipo de intervención

Tipo de material

Descripción

3.4. VANOS

Tipo de intervención

Tipo de material

Descripción

3.5. CUBIERTA

Tipo de intervención

Tipo de material

Descripción

3.6. OTRAS

Intervenido

$\square$ Actualización $\square$ Reintegración $\square$ Demolición $\square$ Otro...

$\square$ Consolidación $\quad \mathbf{X}$ Reconstrucción $\square$ Sustitución

No tradicional Tipo de técnica Diferente a la existente

Revestimiento de cemento en toda la zona del zócalo

No tradicional Tipo de técnica Similar a la existente
Actualización $\mathbf{x}$ Reintegración $\square$ Demolición $\square$ Otro.

$\square$ Consolidación $\quad \square$ Reconstrucción $\square$ Sustitución

Reintegración de las tejas de cubierta con mortero de cemento

$\square$ Actualización $\square$ Reintegración $\square$ Demolición $\square$ Otro...

$\square$ Consolidación $\quad \square$ Reconstrucción $\quad \square$ Sustitución

$$
\text { Tipo de técnica }
$$

Rentegracion de las tejas de cubeta con motero de cemento
La restauración y rehabilitación de la arquitectura tradicional de tierra.

El caso de Aragón.

Observaciones

FOTOGRAFÍAS DE LA INTERVENCIÓN
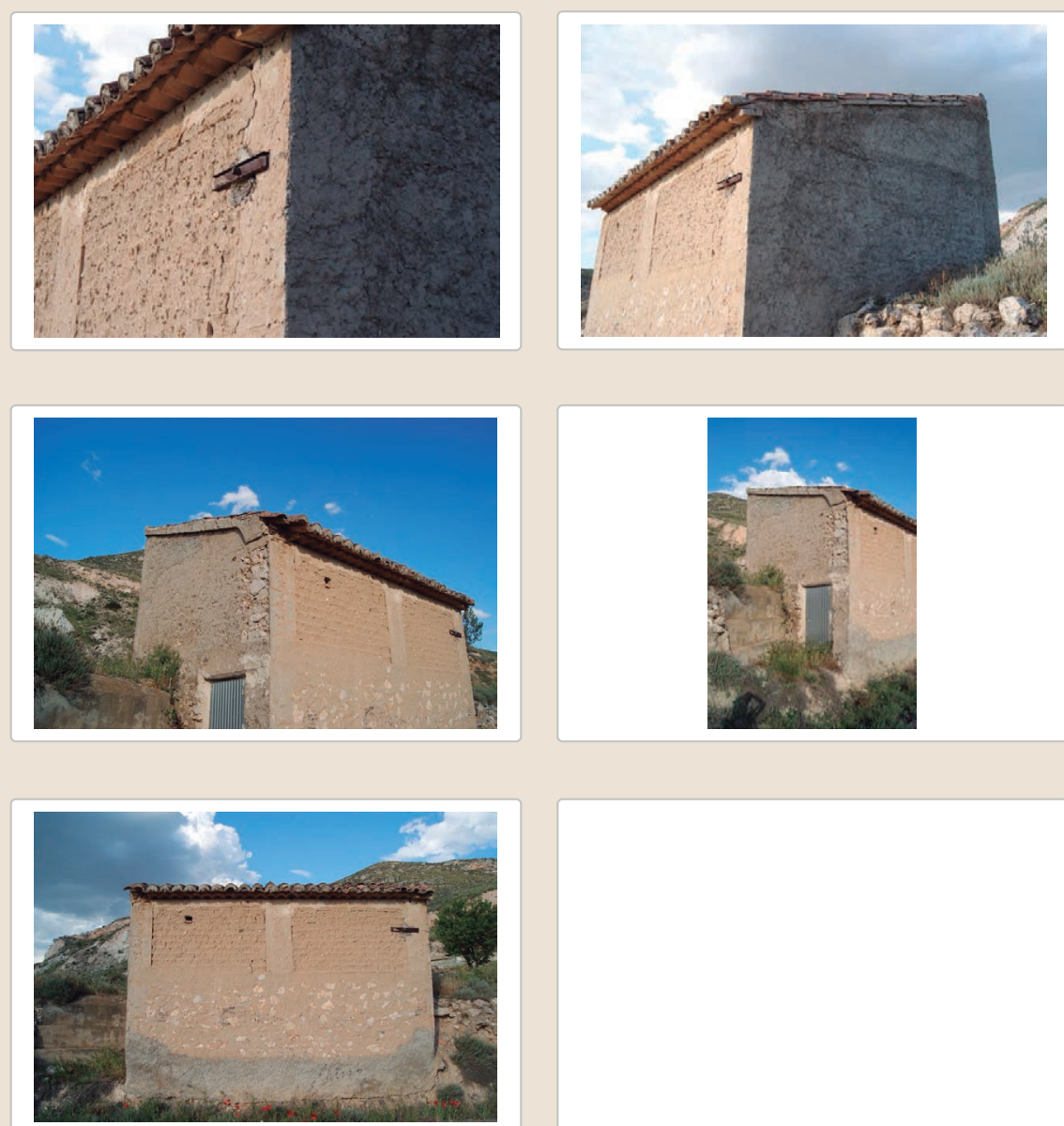
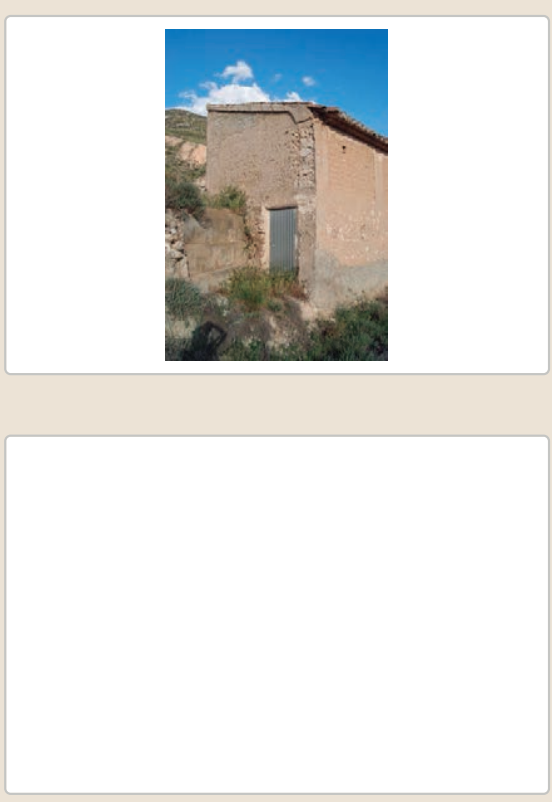


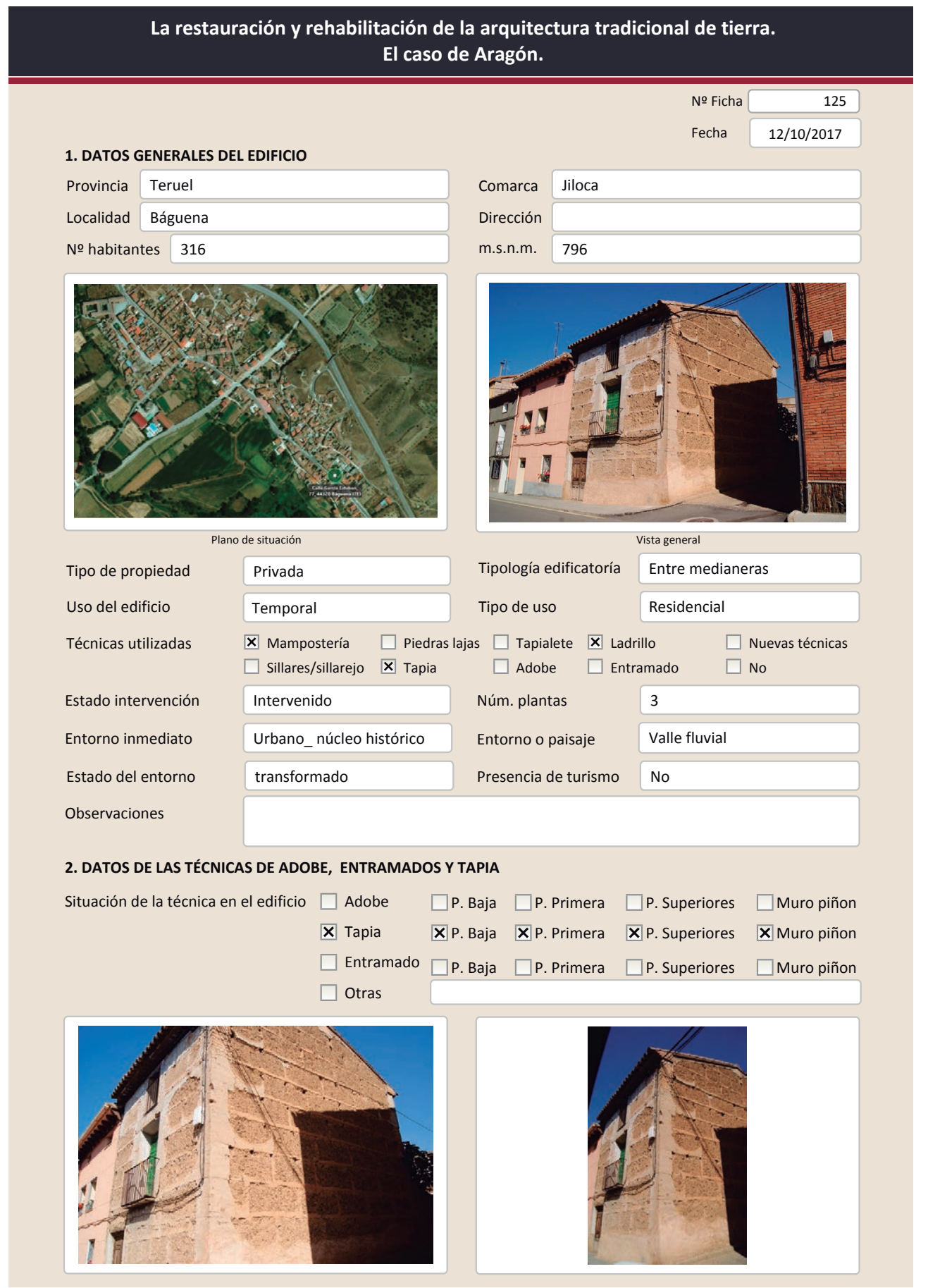

2.2. TAPIA

Ancho del muro

Dimensión tapiales

Tipo de aguja

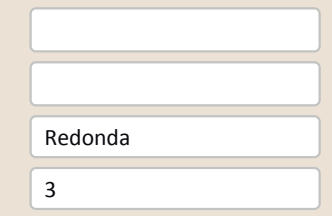

Color de la tapia

№ agujas/cajón

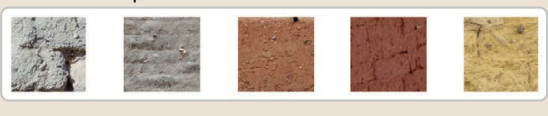

$\square$ Blanquecino $\quad \mathbf{X}$ Marrón $\square$ Amarillento

$\begin{array}{ll}\square \text { Blanquecino } & \mathbf{X} \text { Marrón } \square \text { Amarill } \\ \square \text { Grisaceo } & \square \text { Rojizo } \quad \square \text { Otro... }\end{array}$

Variante constructiva

$\square$ Simple / homogénea

$\square$ suplemento superficial

$\boldsymbol{X}$ Suplemento en juntas

$\mathbf{X}$ Mixta
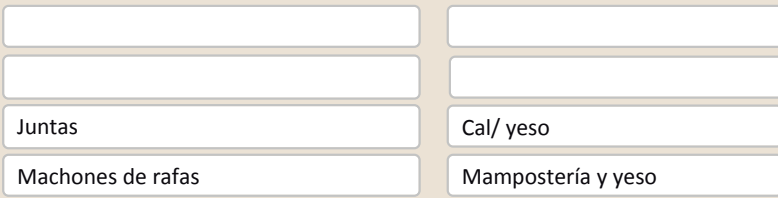

Mampostería y yeso

$\square$ Elementos de protección

Suplementos pegado al machón con forma de media luna completa

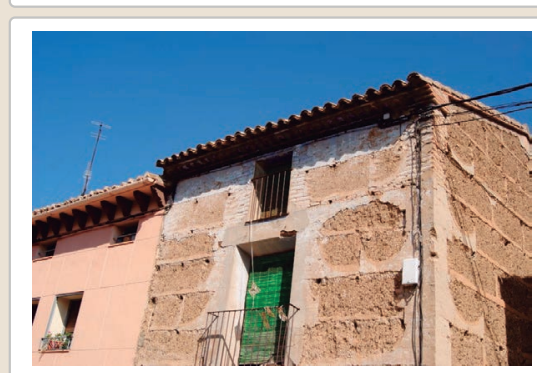

Lesiones $\quad$ XMuro $\square$ Zócalo $\square$ Revestimiento $\square$ Cubierta $\square$ otro...

区 Erosión del material $\quad \square$ Humedad por capilaridad $\quad \square$ Grietas por asentamiento $\square$ Erosion de las juntas $\square$ Humedades (manch/eflo)

$\square$ Pérdida de sección $\quad \square$ Pérdida de verticalidad

$\square$ Vegetación

X Desconchados

$\square$ Grietas porfalta de traba
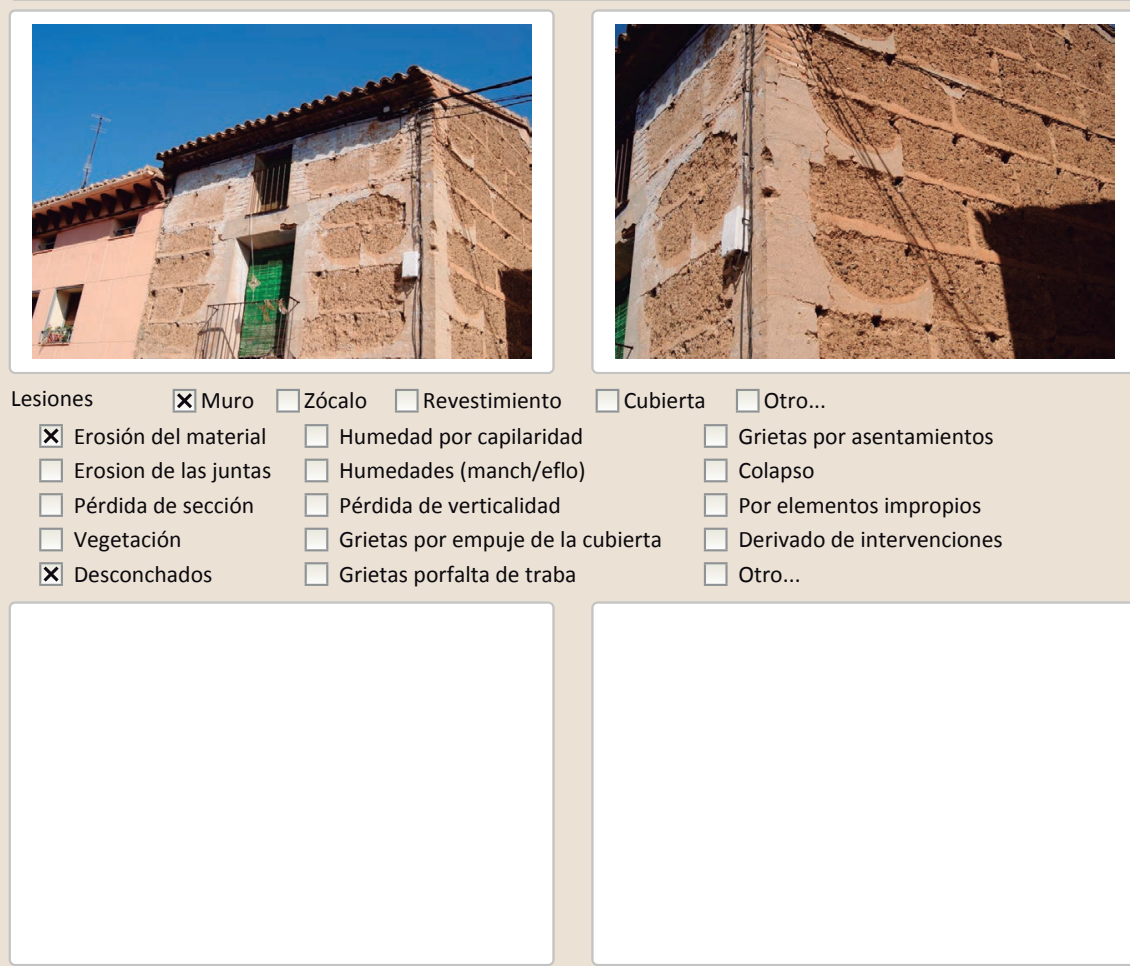

Observaciones 


\section{La restauración y rehabilitación de la arquitectura tradicional de tierra.}

\section{El caso de Aragón.}

3. DATOS DE LA INTERVENCIÓN

Intervención de:

$\square$ Mantenimiento $\square$ Rehabilitación parcial

$\square$ Restauración $\square$ Demolición

Reflexión previa X Reparación $\square$ Rehabilitación integra

$\square$ Ampliación $\square$ Otro...

Observaciones

Intervención espontanea

(n)

3.1. MUROS

Tipo de intervención

Tipo de material

Descripción

3.2. ZÓCALO

Tipo de intervención

Tipo de material

Descripción

3.3. REVESTIMIENTOS

Tipo de intervención

Tipo de material

Descripción

3.4. VANOS

Tipo de intervención

Tipo de material

Descripción

3.5. CUBIERTA

Tipo de intervención

Tipo de material

Descripción

\section{No intervenido}

$\square$ Actualización $\quad \square$ Reintegración $\quad \square$ Demolición $\quad \square$ Otro...
$\square$ Consolidación $\quad \square$ Reconstrucción $\quad \square$ Sustitución

Tipo de técnica

Intervenido

$\square$ Actualización $\square$ Reintegración $\square$ Demolición $\square$ Otro...

$\square$ Consolidación \ Reconstrucción $\square$ Sustitución

No tradicional Tipo de técnica Diferente a la existente

Zócalo con una capa gruesa de cemento

\section{No aplica}

$\square$ Actualización $\square$ Reintegración $\square$ Demolición $\square$ Otro...

$\square$ Consolidación $\square$ Reconstrucción $\square$ sustitución

Tipo de técnica

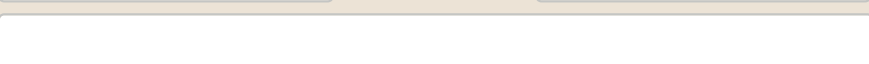

\section{No intervenido}

$\square$ Actualización $\square$ Reintegración $\square$ Demolición $\square$ Otro...

$\square$ Consolidación $\quad \square$ Reconstrucción $\square$ sustitución

Tipo de técnica

\section{Intervenido}

$\square$ Actualización $\quad \mathbf{X}$ Reintegración $\square$ Demolición $\square$ Otro...

$\square$ Consolidación $\quad \square$ Reconstrucción $\quad \square$ Sustitución
No tradicional
Tipo de técnica Similar a la existente

Reintegración de las tejas del lateral de la cubierta para evitar posibles

desprendimientos.
La restauración y rehabilitación de la arquitectura tradicional de tierra.

El caso de Aragón.

3.7. REHABILITACIÓN ENERGÉTICA $\quad \square$ Fachada $\square$ Vanos $\square$ Forjados $\square$ Cubierta

Observaciones

FOTOGRAFÍAS DE LA INTERVENCIÓN
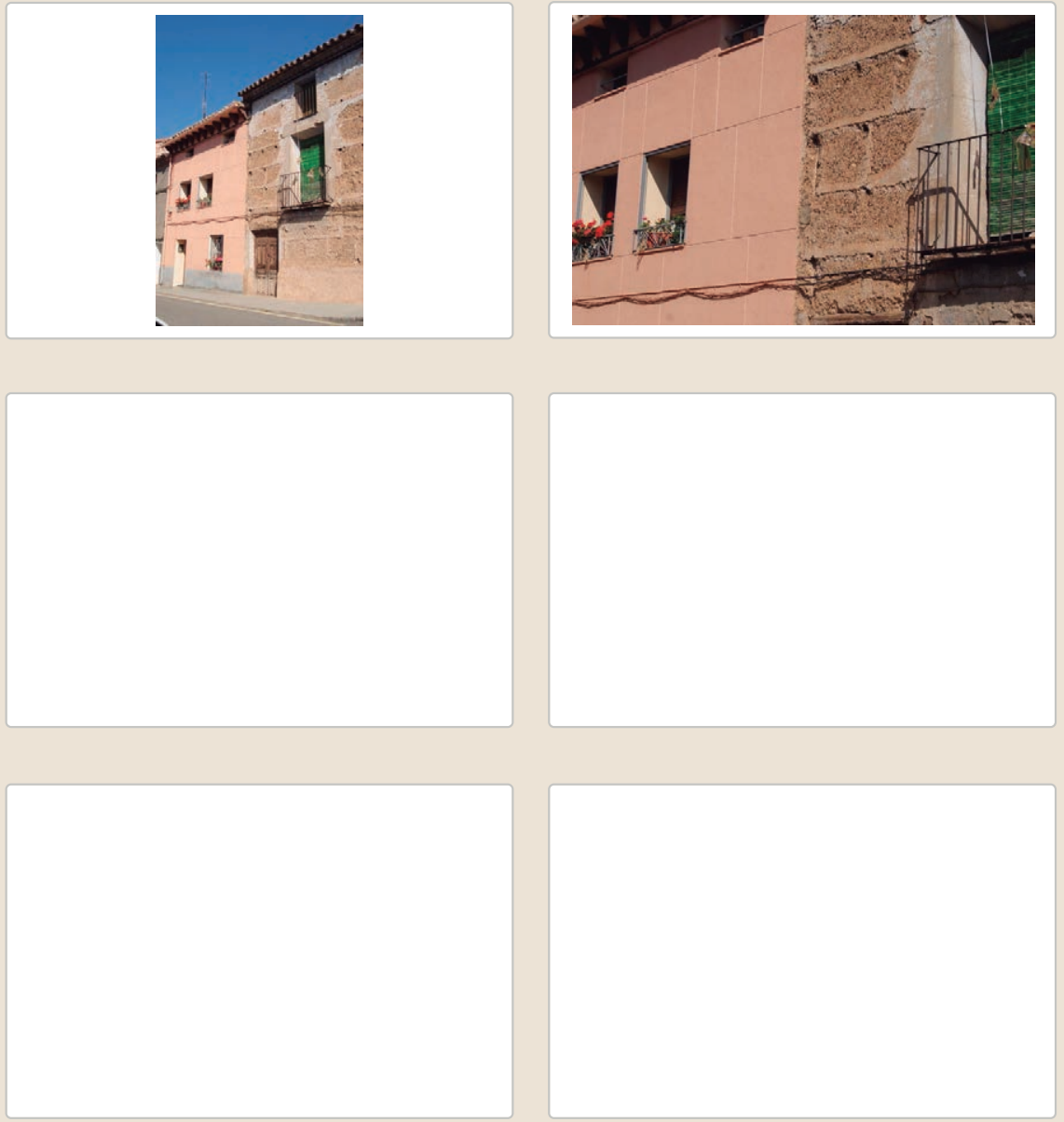

3.6. OTRAS 


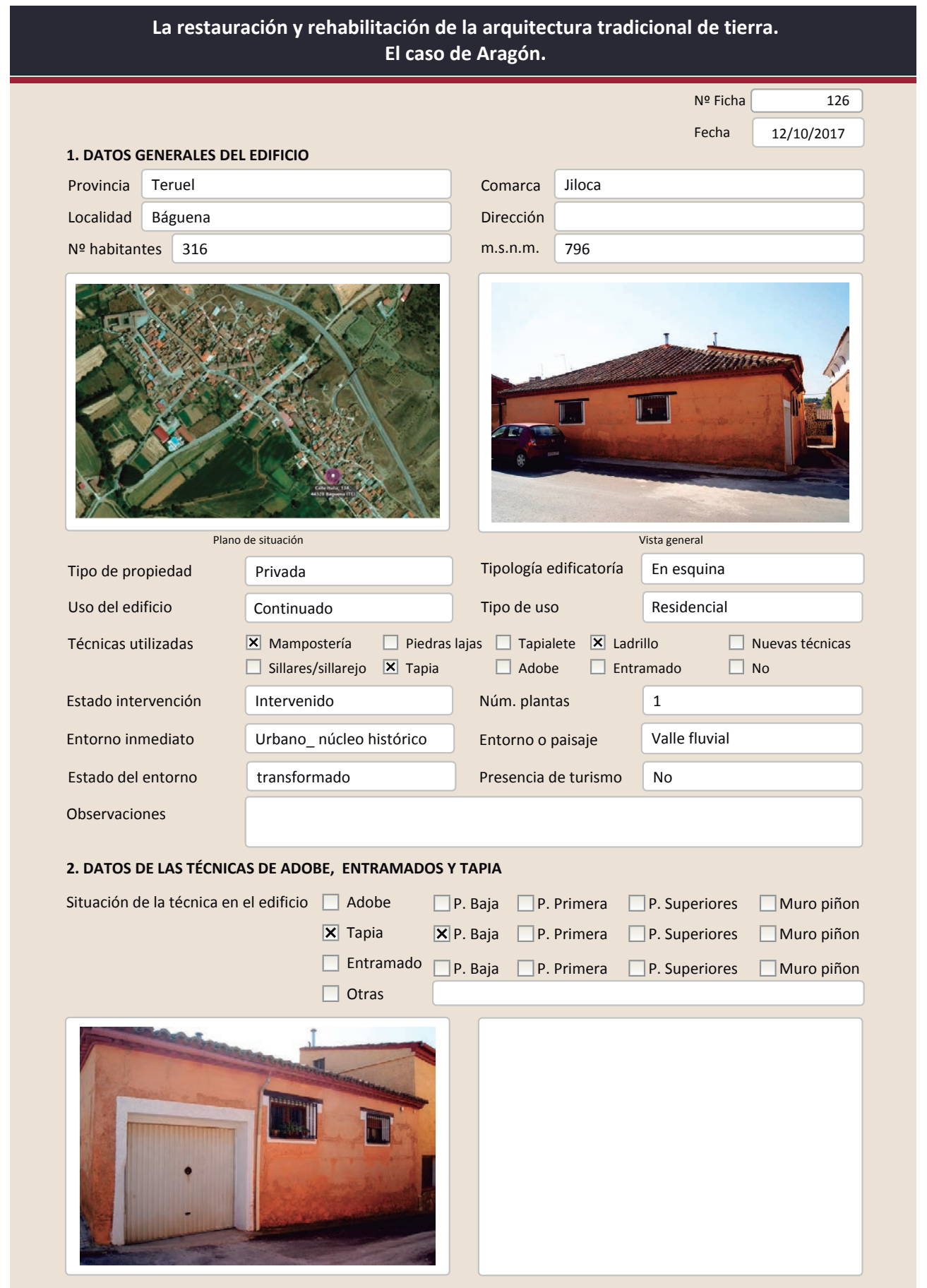

2.2. TAPIA

Ancho del muro

Dimensión tapiales

Tipo de aguja

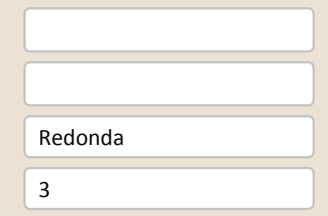

Color de la tapia

№ agujas/cajón

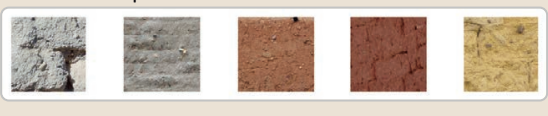

$\square$ Blanquecino $\square$ Marrón $\square$ Amarillento

$\square$ Blanquecino $\square$ Marrón $\square$ Amarill
$\square$ Grisaceo

Variante constructiva

$\square$ Simple / homogénea

$\square$ suplemento superficial

$\boldsymbol{X}$ Suplemento en juntas

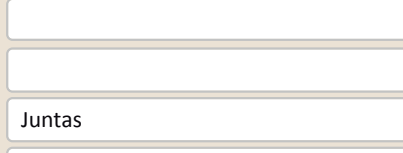

$\mathbf{X}$ Mixta

Machones

Ladrillo

Elementos de protección

Tiene junta de ladrillo horizontal y brencas muy pequeñas solo al lado de los huecos

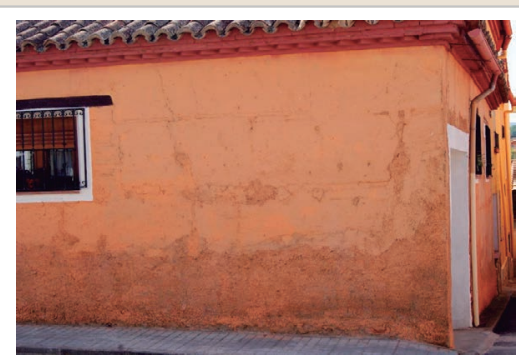

Lesiones \Muro $\square$ Zócalo $\square$ Revestimiento $\square$ Cubierta $\square$ Otro...

$\square$ Erosión del material $\quad$ X Humedad por capilaridad $\quad \square$ Grietas por asentamiento $\square$ Erosion de las juntas $\square$ Humedades (manch/eflo)

$\square$ Pérdida de sección $\square$ Pérdida de verticalidad

$\square$ Vegetación

$\square$ Desconchados

$\square$ Grietas porfalta de traba
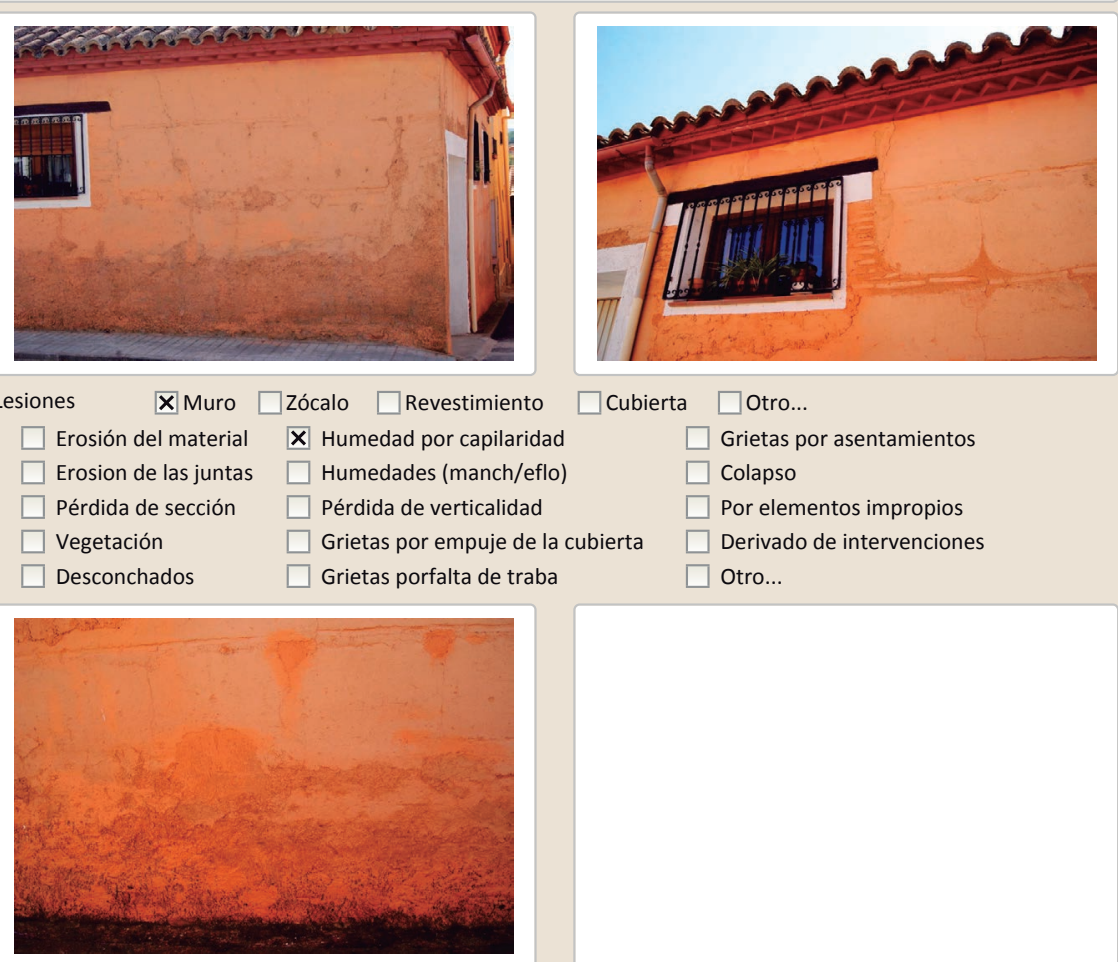

$\square$ Por elementos impropios

$\square$ Derivado de intervenciones

$\square$ Otro... 


\section{La restauración y rehabilitación de la arquitectura tradicional de tierra.}

\section{El caso de Aragón.}

3. DATOS DE LA INTERVENCIÓN

Intervencín LA:

NCIÓN

\begin{tabular}{lll|} 
Intervención de: & $\square$ Mantenimiento & $X$ Rehabilitación parcial \\
Reflexión previa & Reparación $\quad \square$ Rehabilitación integral $\quad \square$ Ampliación $\quad \square$ Otro... \\
Observaciones & Intervención planificada \\
\hline & $\begin{array}{l}\text { El edificio parece adaptado a las necesidades de vida actuales, sin embargo el muro no } \\
\text { parece haber sido intervenido severamente }\end{array}$ \\
\hline
\end{tabular}

\subsection{MUROS}

Tipo de intervención

Tipo de material

Descripción

3.2. ZÓCALO

Tipo de intervención

Tipo de material

Descripción

3.3. REVESTIMIENTOS

Tipo de intervención

Tipo de material

Descripción

3.4. VANOS

Tipo de intervención

Tipo de material

Descripción

3.5. CUBIERTA

Tipo de intervención

Tipo de material

Descripción

\section{No intervenido}

$\square$ Actualización $\square$ Reintegración $\quad \square$ Demolición $\square$ Otro...

$\square$ Consolidación $\quad \square$ Reconstrucción $\quad \square$ Sustitución

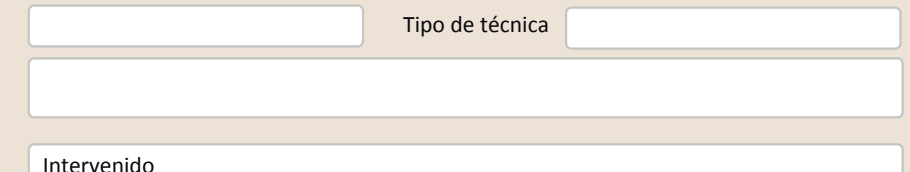

Intervenido

$\square$ Actualización $\square$ Reintegración $\quad \square$ Demolición $\square$ Otro...

$\square$ Consolidación $\quad$ X Reconstrucción $\square$ Sustitución

No tradicional Tipo de técnica Diferente a la existente

Revestimiento con gotelé de cemento

\section{Intervenido}

$\square$ Actualización $\square$ Reintegración $\quad \square$ Demolición $\square$ Otro...

$\square$ Consolidación $\quad \boldsymbol{X}$ Reconstrucción $\square$ sustitución

No tradicional Tipo de técnica Diferente a la existente

Pintura plástica coloreada en todo el edificio

\section{Intervenido}

$\square$ Actualización $\square$ Reintegración $\square$ Demolición $\square$ Otro...

$\square$ Consolidación $\square$ Reconstrucción $\quad \boldsymbol{X}$ Sustitución
No tradicional
Tipo de técnica Diferente a la existente

Sustitución de carpinterías y colocación de persianas

\section{Intervenido}

$\square$ Actualización $\quad \boldsymbol{X}$ Reintegración $\square$ Demolición $\square$ Otro..

$\square$ Consolidación $\quad \square$ Reconstrucción $\square$ Sustitución
No tradicional
Tipo de técnica Similar a la existente

3.6. OTRAS
La restauración y rehabilitación de la arquitectura tradicional de tierra.

El caso de Aragón.

3.7. REHABILITACIÓN ENERGÉTICA $\square$ Fachada $\quad \boldsymbol{X}$ Vanos $\square$ Forjados $\square$ Cubierta

Observaciones

FOTOGRAFíAS DE LA INTERVENCIÓN
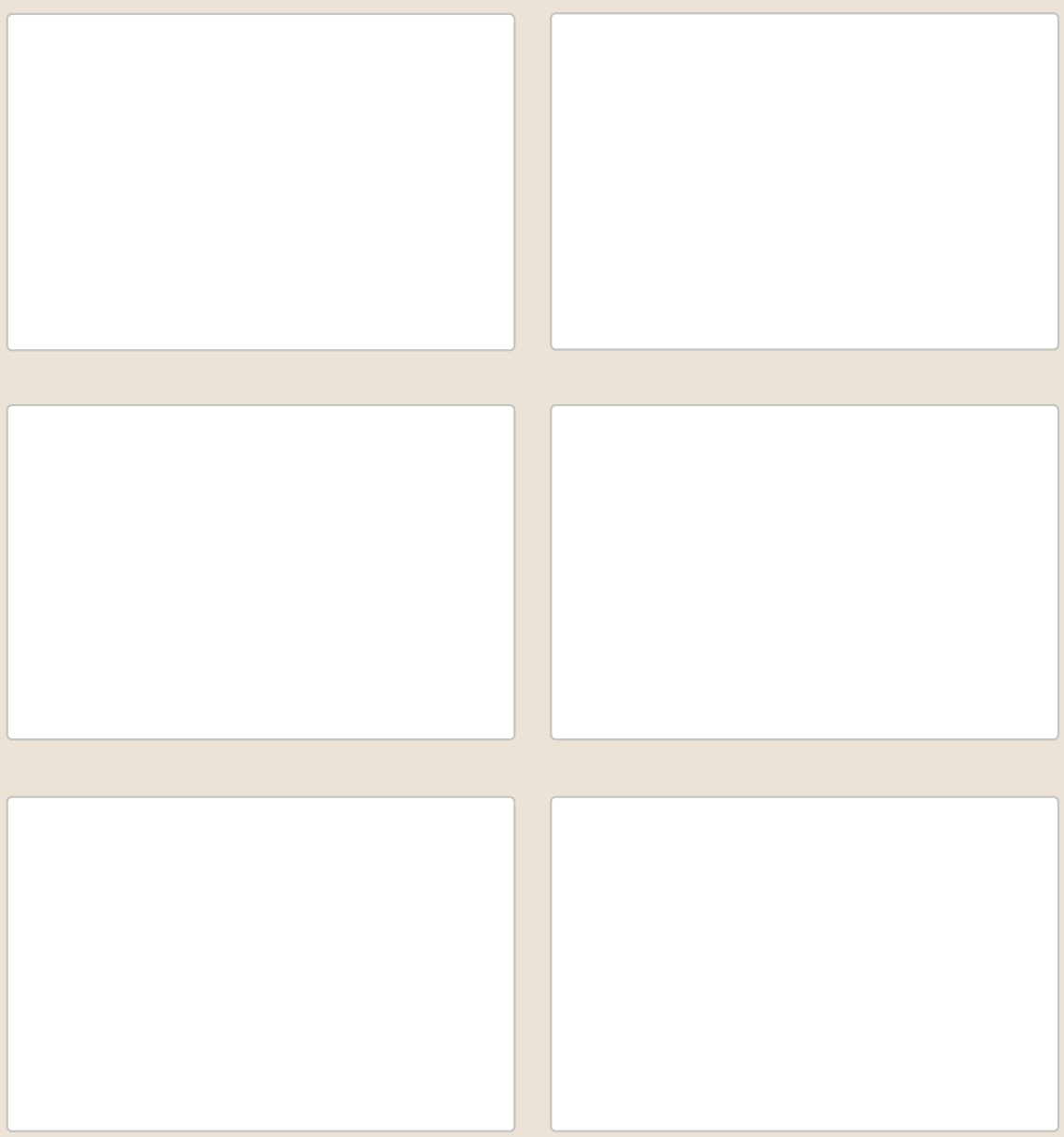


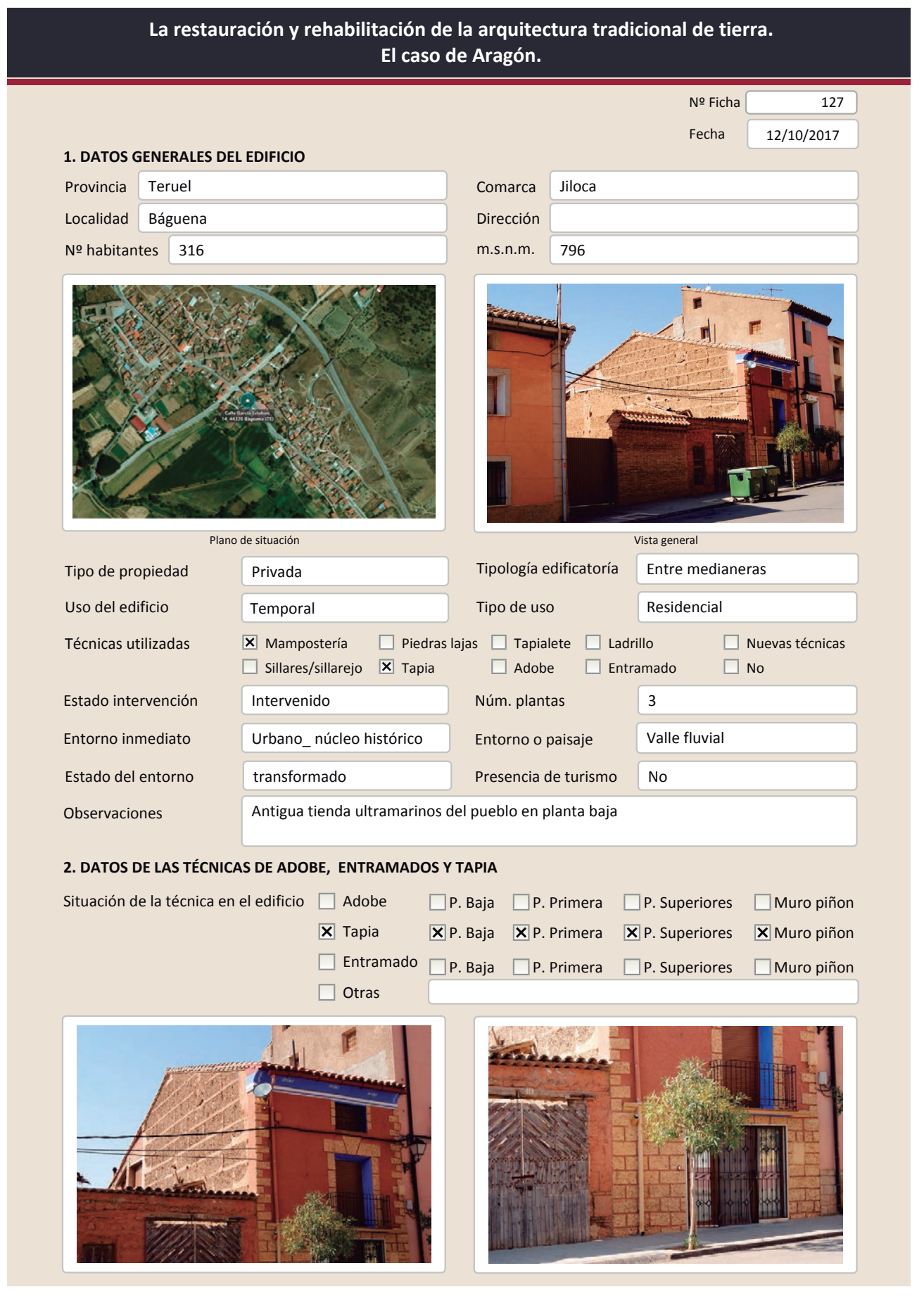

2.2. TAPIA

Ancho del muro

Dimensión tapiales

Tipo de aguja

№ agujas/cajón

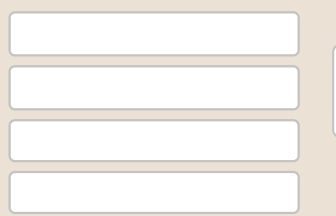

Color de la tapia

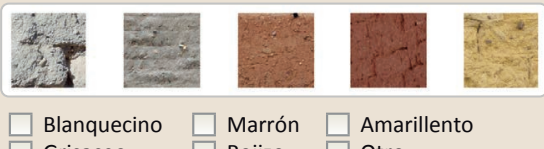

$\square$ Blanquecino $\quad \square$ Marrón $\square$ Amarillento
$\square$ Grisaceo
Rojizo $\quad \square$ Otro...

Variante constructiva

$\square$ Simple / homogénea

$\square$ suplemento superficial

$\boldsymbol{X}$ Suplemento en juntas

$\mathbf{X}$ Mixta
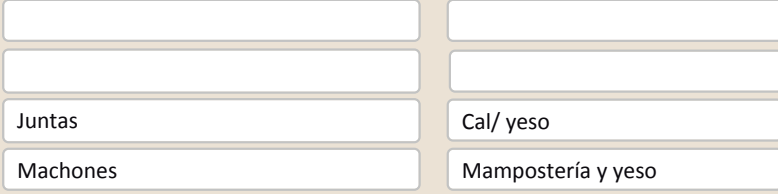

$\square$ Elementos de protección

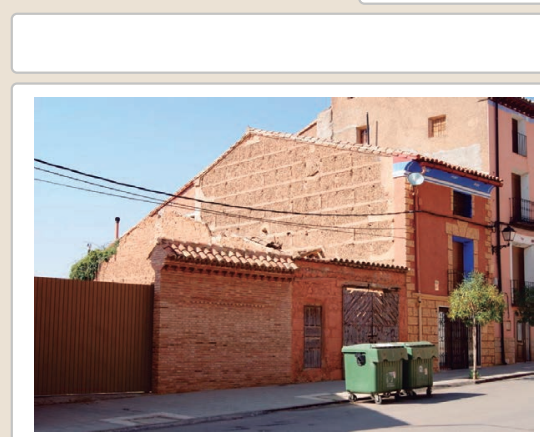

Lesiones $\quad \mathbf{X}$ Muro $\square$ Zócalo $\square$ Revestimiento X Erosión del material $\quad \square$ Humedad por capilaridad $\square$ Erosion de las juntas $\square$ Humedades (manch/eflo) $\square$ Pérdida de sección $\quad \square$ Pérdida de verticalidad

$\square$ Vegetación

$\square$ Desconchados

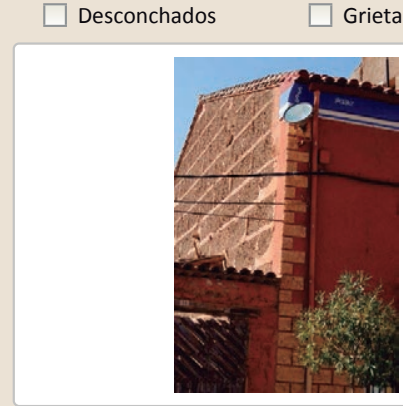

\section{Mampostería y yeso}

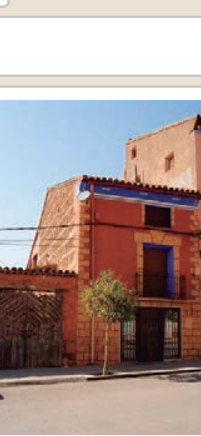

$\square$ Cubierta $\square$ otro...

$\square$ Grietas por asentamientos

$\square$ Colapso

$\square$ Por elementos impropios

$\square$ Derivado de intervenciones $\square$ Otro...

Observaciones 


\section{La restauración y rehabilitación de la arquitectura tradicional de tierra.}

\section{El caso de Aragón.}

3. DATOS DE LA INTERVENCIÓN

Intervención de:

$\square$ Mantenimiento

\begin{abstract}
Reflexión previa
\end{abstract}
$\square$ Reparación

$\square$ Rehabilitación parcial

$\square$ Restauración $\square$ Demolición

Intervención planificada

Observaciones

(2)

3.1. MUROS
Tipo de intervención

Intervenido

Tipo de material

$\square$ Actualización $\square$ Reintegración $\square$ Demolición $\square$ Otro...

$\square$ Consolidación $\quad \mathbb{\text { Reconstrucción }} \square$ Sustitución

Descripción

No tradicional Tipo de técnica Diferente a la existente

3.2. ZOCALO

Tipo de intervención

$$
\begin{aligned}
& \begin{array}{l}
\text { Reconst } \\
\text { mismo }
\end{array} \\
& \hline
\end{aligned}
$$

Intervenido

\ Actualización $\square$ Reintegración $\square$ Demolición $\square$ Otro...

$\square$ Consolidación $\mathbf{X}$ Reconstrucción $\square$ Sustitución

Tipo de material

No tradicional

Tipo de técnica Diferente a la existente

Descripción

3.3. REVESTIMIENTOS

Tipo de intervención

\section{Intervenido}

X Actualización $\square$ Reintegración $\square$ Demolición $\square$ Otro...

$\square$ Consolidación $\quad \mathbf{X}$ Reconstrucción $\square$ Sustitución

Tipo de material

Descripción

No tradicional

Tipo de técnica Diferente a la existente

Nuevo revestimiento en toda la fachada principal con piedra fingida en las esquinas con cemento y pintura de distintos colores

3.4. VANOS

Intervenido

Tipo de intervención

$\square$ Actualización

$\square$ Reintegración $\quad \square$ Demolición $\square$ Otro...

Tipo de material

Consolidación $\square$ Reconstrucción $\mathbb{X}$ Sustitución

Descripción

\begin{tabular}{l|l} 
No tradicional & Tipo de técnica Diferente a la existente
\end{tabular}

Ampliación del hueco de acceso en planta baja y sustitución de las carpinterías en todo el edificio

3.5. CUBIERTA

Tipo de intervención

Intervenido

$\square$ Actualización $\square$ Reintegración $\square$ Demolición $\quad \mathbf{X}$ Otro...

$\square$ Consolidación $\quad \boldsymbol{x}$ Reconstrucción $\square$ Sustitución

Tipo de material

No tradicional

Tipo de técnica Similar a la existente

Descripción

La cubierta se ha reconstruido utilizando los materiales antiguos y ampliándola para dar cobertura al nuevo espacio interior. Uso de cemento para colocación
La restauración y rehabilitación de la arquitectura tradicional de tierra.

El caso de Aragón.

3.7. REHABILITACIÓN ENERGÉTICA $\square$ Fachada $\quad$ V Vanos $\square$ Forjados $\square$ Cubierta

Observaciones

FOTOGRAFíAS DE LA INTERVENCIÓN
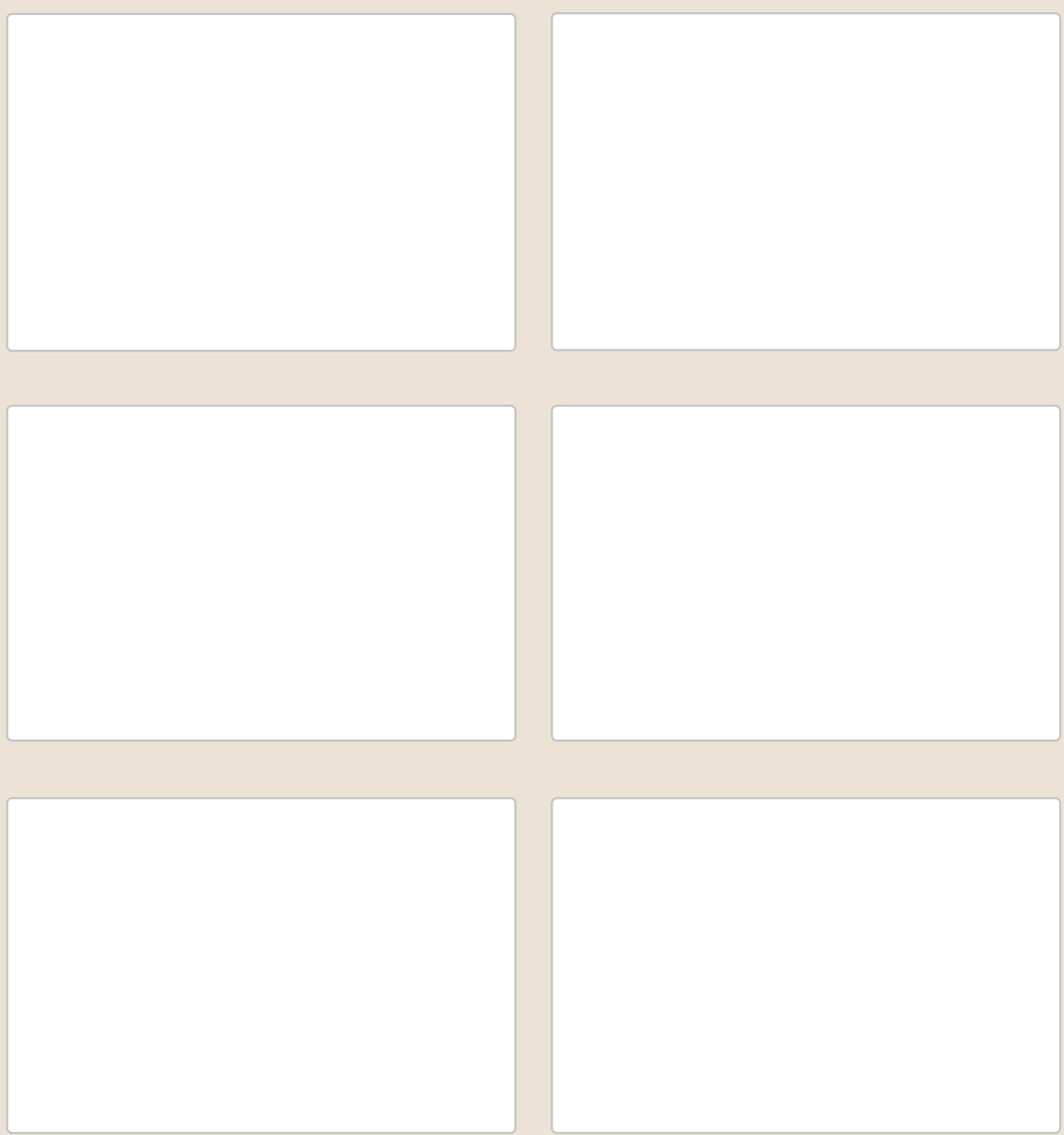

3.6. OTRAS 


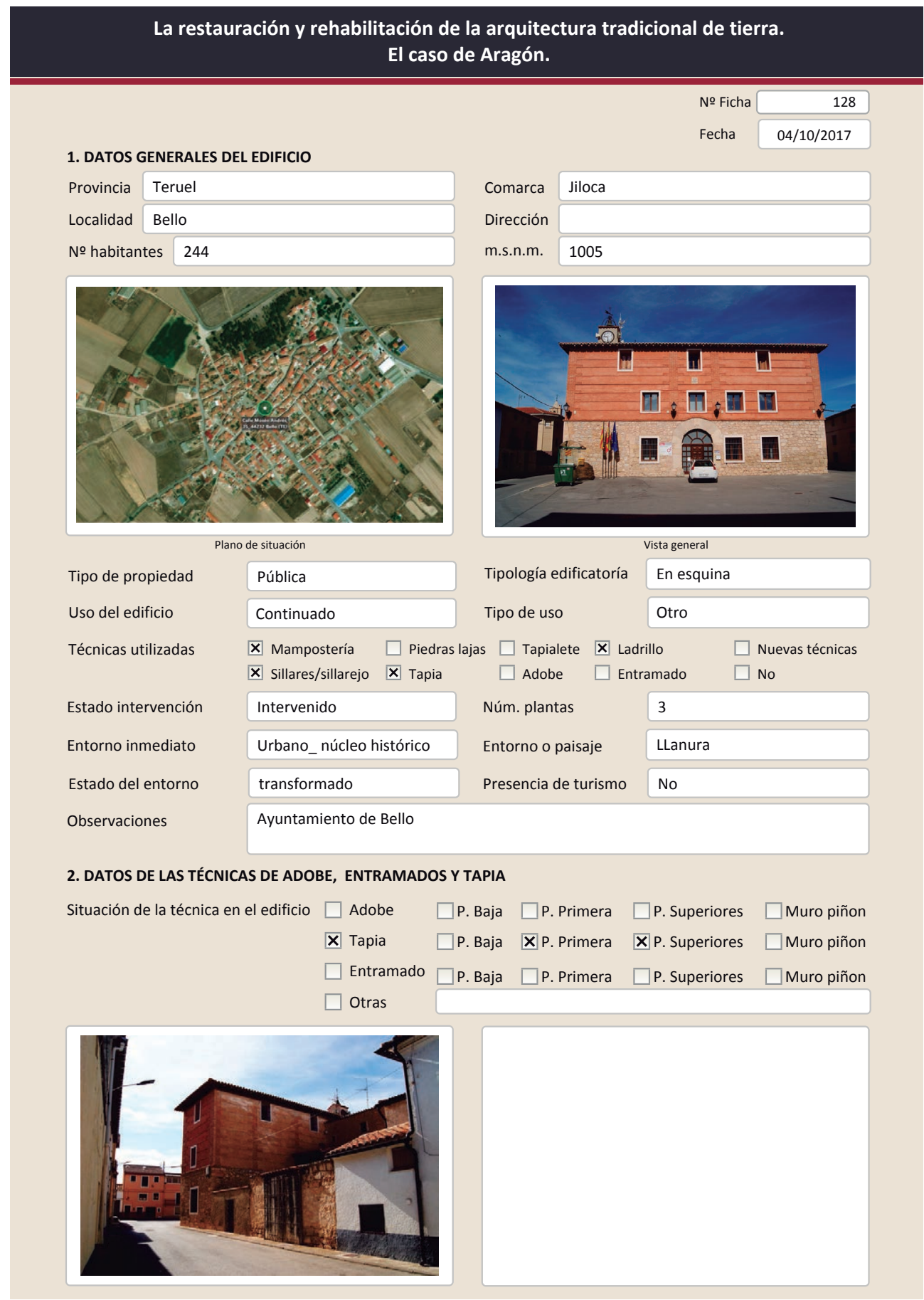

2.2. TAPIA

Ancho del muro

Dimensión tapiales

Tipo de aguja

№ agujas/cajón

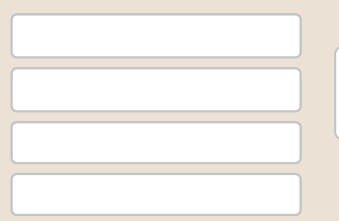

Color de la tapia

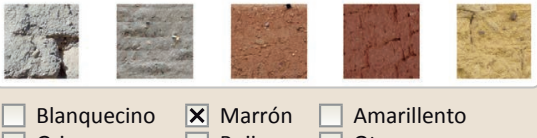

$\begin{array}{ll}\square \text { Blanquecino } & \boldsymbol{X} \text { Marrón } \\ \square \text { Grisaceo } & \square \text { Amarillento } \\ \text { Rojizo } \quad \square \text { Otro... }\end{array}$

Variante constructiva

$\square$ Simple / homogénea

$\mathbf{X}$ Suplemento superficial

$\square$ suplemento en juntas

X Mixta
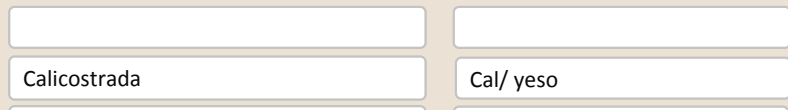

Machones y verdugadas

Cal/ yeso

$\square$ Elementos de protección

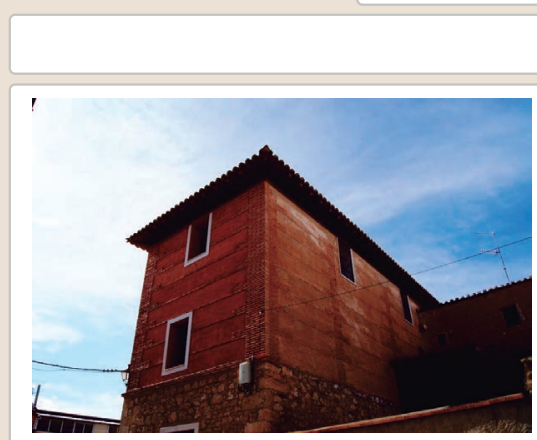

Lesiones $\quad \square$ Muro $\square$ Zócalo $\square$ Revestimiento $\square$ Erosion de las juntas $\square$ Humedades (manch/eflo) $\square$ Pérdida de sección $\quad \square$ Pérdida de verticalidad

$\square$ Vegetación

$\square$ Desconchados $\square$ Erosión del material $\square$ Humedad por capilaridad

$\square$ Grietas por empuje de la cubierta $\square$ Derivado de intervenciones

$\square$ Otro...

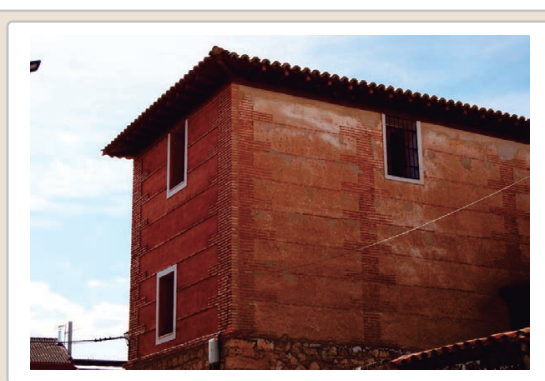

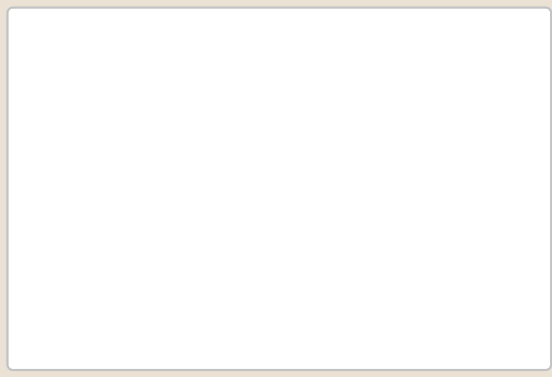

Observaciones 


\section{La restauración y rehabilitación de la arquitectura tradicional de tierra.}

\section{El caso de Aragón.}

3. DATOS DE LA INTERVENCIÓN

Intervencionde:

\section{NCIÓN}

$\square$ Mantenimiento $\square$ Rehabilitación parcial $\square$ Restauración $\square$ Demolición

Reflexión previa Intervención planificada

Observaciones Se ha intervenido fachada principal y laterales, sin embargo en la trasera se aprecia el muro de tapia original.

3.1. MUROS
Tipo de intervención

\section{Intervenido}

Tipo de material

$\square$ Actualización $\quad$ Reintegración $\square$ Demolición $\square$ Otro...

$\square$ Consolidación $\mathbf{X}$ Reconstrucción $\square$ Sustitución

Descripción

Tradicional diferente Tipo de técnica Similar a la existente

3.2. ZóCALO

Tipo de intervención En el lateral del muro parece que se
quizás para incorporar aislamiento.

Tipo de intervención

Intervenido

$\square$ Actualización $\quad \mathbf{X}$ Reintegración $\square$ Demolición $\square$ Otro...

$\square$ Consolidación $\quad \square$ Reconstrucción $\square$ Sustitución

Tipo de material Tradicional similar Tipo de técnica Similar a la existente

Descripción

3.3. REVESTIMIENTOS

Tipo de intervención

Se ha reintegrado el zócalo de mampostería de planta baja

\section{Intervenido}

$\square$ Actualización $\square$ Reintegración $\square$ Demolición $\square$ Otro...

$\square$ Consolidación $\quad \mathbf{X}$ Reconstrucción $\quad \square$ Sustitución

Tipo de material

Descripción

3.4. VANOS

Tipo de intervención

No tradicional

Tipo de técnica Similar a la existente

Se ha reconstruido un revestimiento sobre los cajones de tapia.

Tipo de material

Intervenido

Descripción

$\square$ Consolidación $\square$ Reconstrucción $\mathbf{X}$ Sustitución

3.5. CUBIERTA

Tipo de intervención

No tradicional

Tipo de técnica Similar a la existente

Se han sustituido la mayor parte de las carpinterías por elementos con dimensiones y configuración parecidas.

Intervenido

$\square$ Actualización $\quad \square$ Reintegración $\quad \square$ Demolición $\quad \square$ Otro...

$\square$ Consolidación $\square$ Reconstrucción $\mathbf{X}$ Sustitución

Tipo de material

No tradicional

Tipo de técnica Similar a la existente

Descripción

Se ha sustituido o intervenido la cubierta por completo con elementos tradicionale cogidos con cemento
La restauración y rehabilitación de la arquitectura tradicional de tierra.

El caso de Aragón.

3.7. REHABILITACIÓN ENERGÉTICA \ Fachada \ Vanos $\square$ Forjados $\mathbf{X}$ Cubierta

Observaciones

FOTOGRAFíAS DE LA INTERVENCIÓN
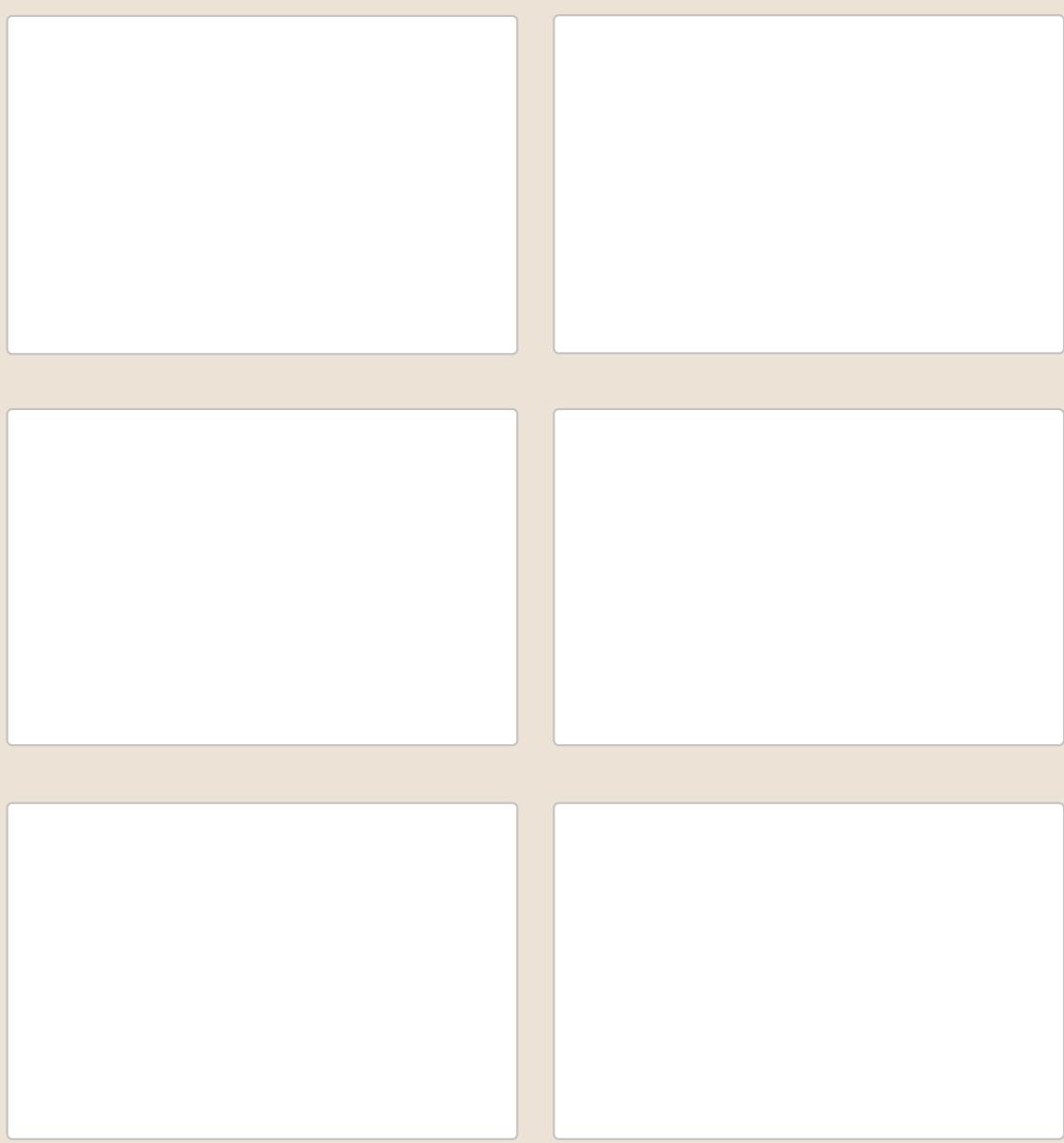

3.6. OTRAS 


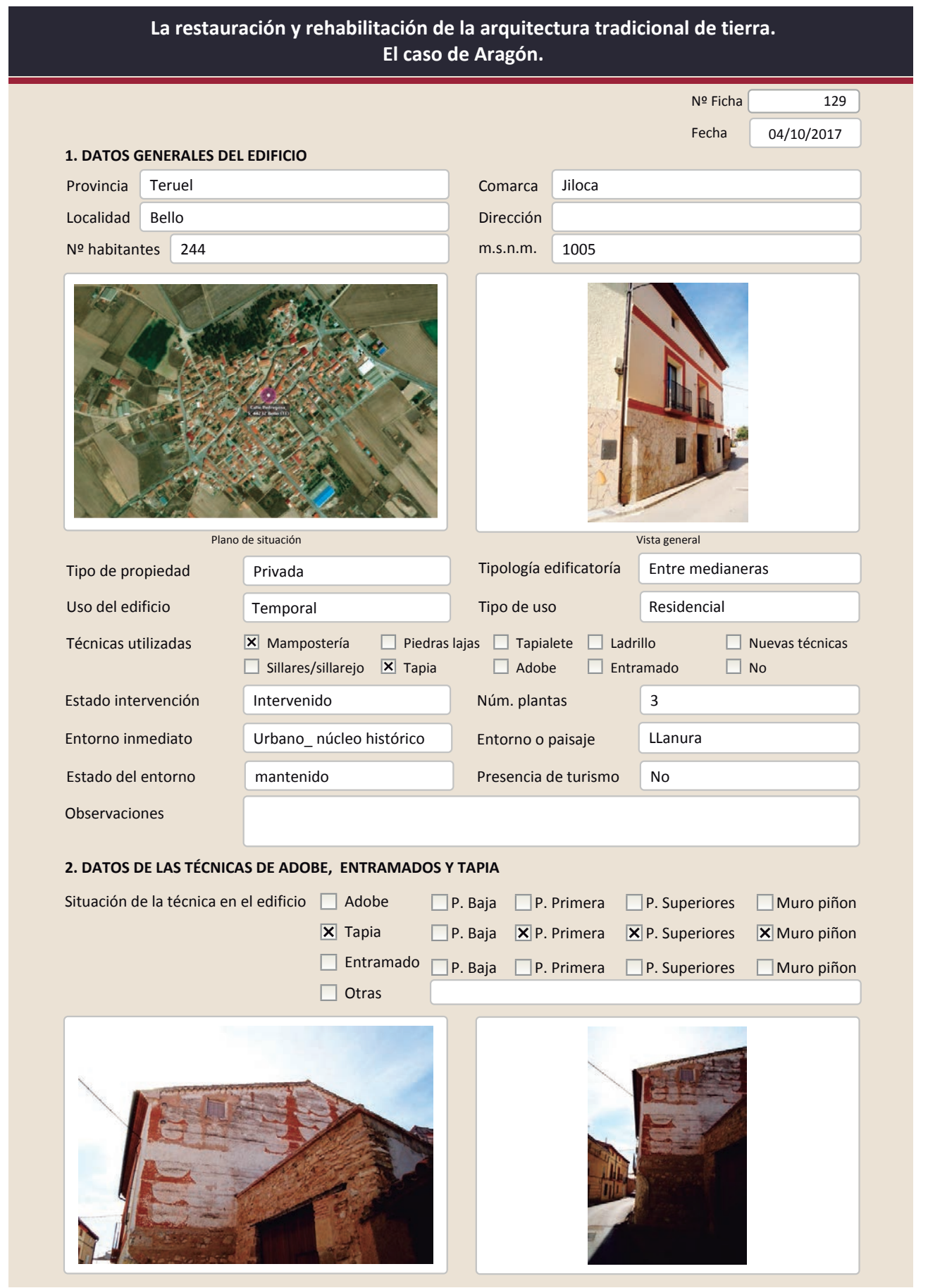

2.2. TAPIA

Ancho del muro

Dimensión tapiales

Tipo de aguja

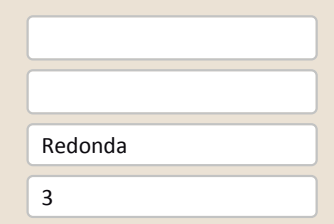

Color de la tapia

№ agujas/cajón

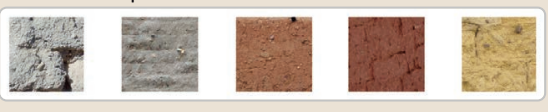

$\square$ Blanquecino $\square$ Marrón $\square$ Amarillento $\overline{\mathbf{x}}$ Grisaceo $\overline{\mathbf{x}}$ Rojizo $\square$ Otro...

Variante constructiva

$\square$ Simple / homogénea

X Suplemento superficial

$\mathbf{X}$ Suplemento en juntas

$\mathbf{X}$ Mixta
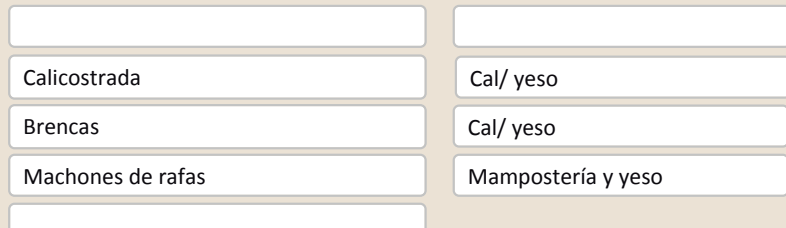

$\square$ Elementos de protección

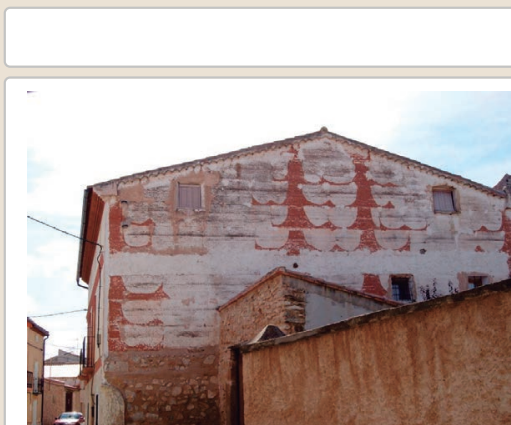

Lesiones

X Muro XZćcalo $\square$ Revestimiento

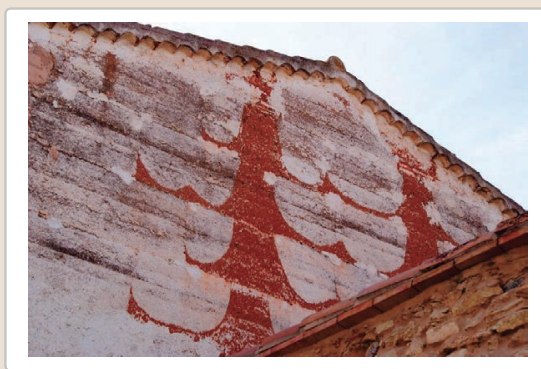

$\square$ Erosion de las juntas $\mathbf{X}$ Humedades (manch/eflo)

Pérdida de sección $\square$ Pérdida de verticalidad

$\square$ Vegetación

$\square$ Por elementos impropios

$\square$ Desconchados

$x$ Gretas por enpuje de la

$\square$ Otro... 


\section{La restauración y rehabilitación de la arquitectura tradicional de tierra.} El caso de Aragón.

3. DATOS DE LA INTERVENCIÓN

Intervención de:

$\square$ Mantenimiento $\quad$ Rehabilitación parcial

$\square$ Restauración $\square$ Demolición

Reflexión previa

$\square$ Reparación

$\square$ Rehabilitación integra

$\square$ Ampliación

$\square$ otro...

Reflexión previ
Observaciones

tervención planificada

Se ha intervenido principalmente la fachada principal y sus elementos

3.1. MUROS
Tipo de intervención

Intervenido

Tipo de material

$\square$ Actualización $\quad$ Reintegración $\square$ Demolición $\square$ Otro...

$\square$ Consolidación $\square$ Reconstrucción $\square$ Sustitución

Descripción

No tradicional

Tipo de técnica Diferente a la existente

3.2. ZÓCALO

Tipo de intervención

Reintegración de oquedades o pequeñas grietas del muro con mortero de cemento

Intervenido

X Actualización $\square$ Reintegración $\square$ Demolición $\square$ Otro...

$\square$ Consolidación $\quad \mathbf{X}$ Reconstrucción $\square$ Sustitución

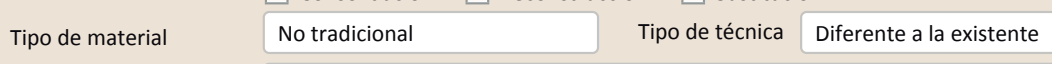

Descripción

3.3. REVESTIMIENTOS

Tipo de intervención

Nuevo zócalo con lajas de piedra en toda la fachada de planta baja

\section{Intervenido}

$\square$ Actualización $\quad \square$ Reintegración $\quad \square$ Demolición $\quad \square$ Otro...

$\square$ Consolidación $\quad \mathbf{X}$ Reconstrucción $\square$ sustitución

Tipo de material

Descripción

No tradicional

Tipo de técnica Similar a la existente

Nuevo revestimiento, probablemente siguiendo la forma del anterior, y nueva pintura con distintos colores para molduras $\mathrm{y}$ fondo

3.4. VANOS

Tipo de intervención

Intervenido

Tipo de material

$\square$ Actualización $\square$ Reintegración $\square$ Demolición $\square$ Otro...

$\square$ Consolidación $\square$ Reconstrucción $\quad \boldsymbol{x}$ Sustitución

Descripción

3.5. CUBIERTA

No tradicional

Tipo de técnica Diferente a la existente

Sustitución de las carpinterías por otras correderas

Tipo de intervención

\section{Intervenido}

$\square$ Actualización $\quad$ Xeintegración $\square$ Demolición $\square$ Otro..

$\square$ Consolidación $\square$ Reconstrucción $\square$ Sustitución

Tipo de material

No tradicional

Tipo de técnica Similar a la existente

Descripción

La zona del alero se ha intervenido reintegrando las tejas con mortero de cemento coloreado para evitar su desprendimiento. EL resto no es visible
La restauración y rehabilitación de la arquitectura tradicional de tierra.

El caso de Aragón.

3.7. REHABILITACIÓN ENERGÉTICA $\square$ Fachada $\quad$ \ Vanos $\square$ Forjados $\square$ Cubierta

Observaciones

FOTOGRAFÍAS DE LA INTERVENCIÓN
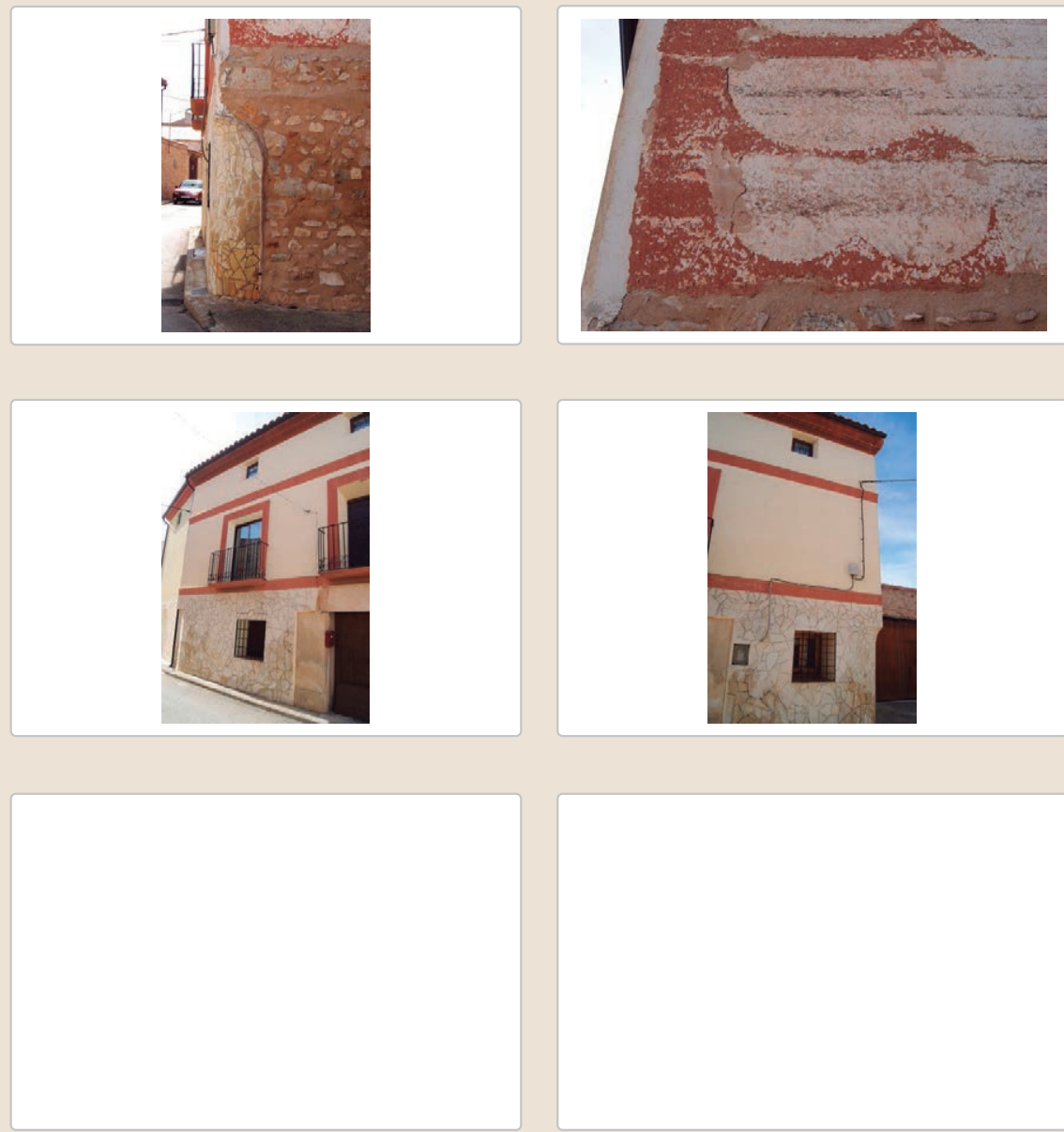

3.6. OTRAS 


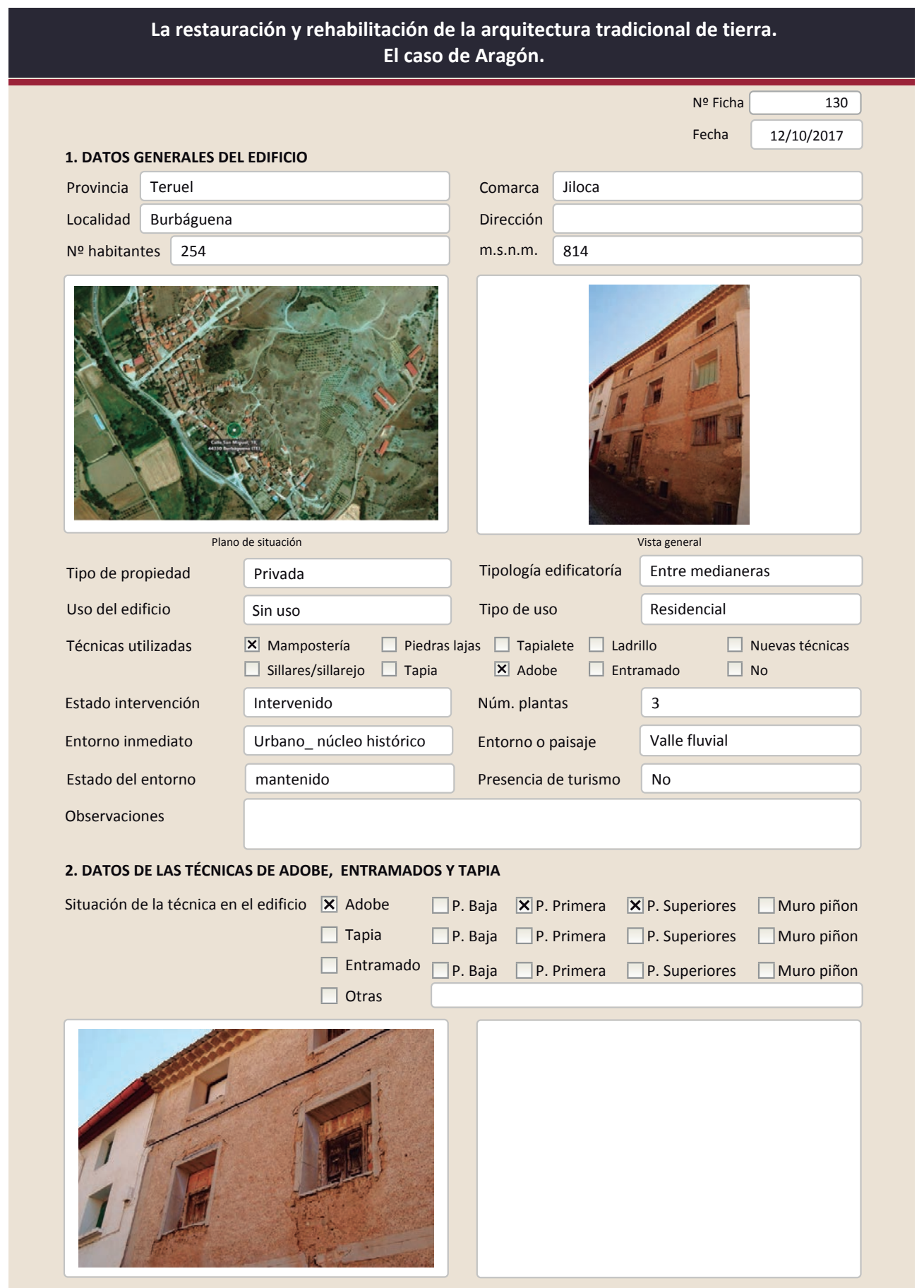

2.1. ADOBE

Dimensión de las piezas Dimensión del muro

Aparejo del muro

\begin{tabular}{|l|}
\hline $30-40 \mathrm{~cm}$ \\
\hline Tizón \\
\hline $\mathrm{Si}$ \\
\hline
\end{tabular}

Color de las piezas

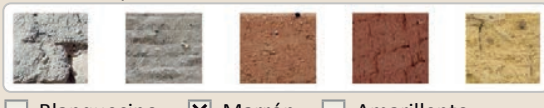

$\square$ Blanquecino $\mathbf{X}$ Marrón $\square$ Amarillento $\square$ Grisaceo $\square$ Rojizo $\square$ Otro...

Función estructural

Comp. - estabilizante Aridos

Variante constructiva/ tipo de fábrica
$\square$ Simple
$\mathbf{X}$ Suplementada en juntas
Verticales $\mathrm{y}$ horizontales
$\square$ Mixta
$\square$ Como suplemento
$\mathbf{X}$ Elementos de protección
Revestimiento

$\mathrm{Cal} /$ yeso

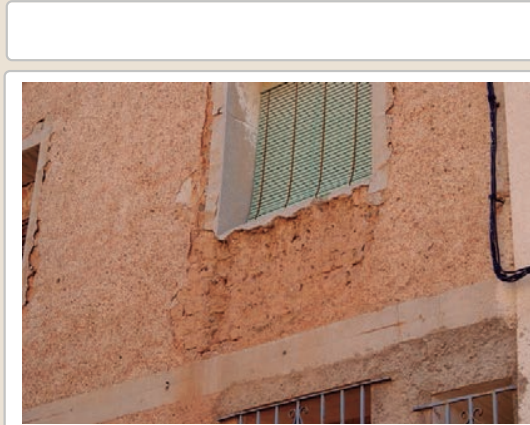

Lesiones XMuro XZócalo X Xevestimiento

$\mathbf{X}$ Erosión del material $\mathbf{X}$ Humedad por capilaridad

$\square$ Erosion de las juntas $\mathbf{X}$ Humedades (manch/eflo)

$\mathbf{X}$ Pérdida de sección $\square$ Pérdida de verticalidad

$\square$ Vegetación $\quad \square$ Grietas por empuje de la cubierta

X Desconchados

$\square$ Grietas por empuje de la

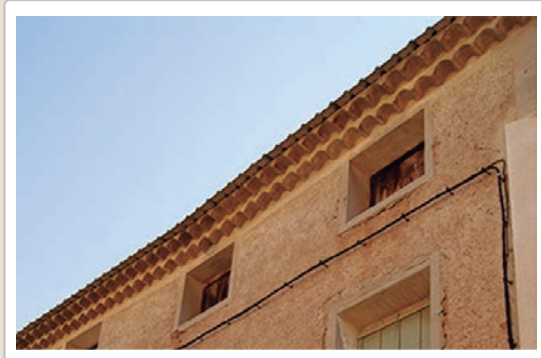

$\square$ Cubierta $\square$ Otro...

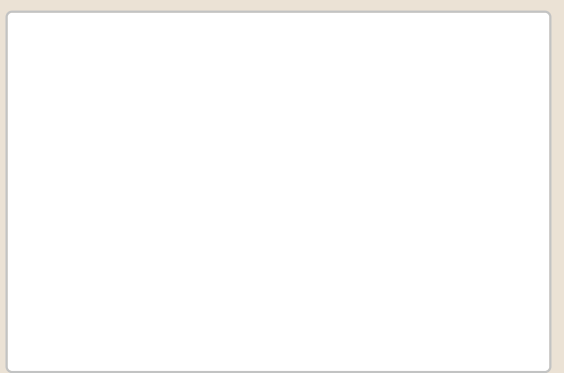

$\square$ Grietas por asentamiento

$\square$ Colapso

$\square$ Por elementos impropios

$\square$ Derivado de intervenciones

$\square$ Otro...

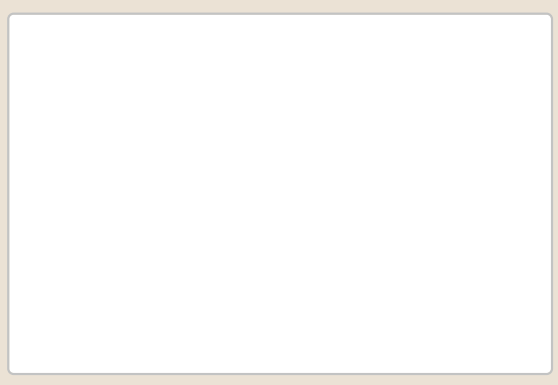

Observacione 


\section{La restauración y rehabilitación de la arquitectura tradicional de tierra.}

\section{El caso de Aragón.}

3. DATOS DE LA INTERVENCIÓN

\begin{tabular}{|c|c|c|c|c|}
\hline Intervención de: & $\begin{array}{l}\square \text { Mantenimiento } \\
\mathbf{X} \text { Reparación }\end{array}$ & $\begin{array}{l}\square \text { Rehabilitación parcial } \\
\square \text { Rehabilitación integral }\end{array}$ & $\begin{array}{l}\square \text { Restauración } \\
\square \text { Ampliación }\end{array}$ & $\begin{array}{l}\square \text { Demolición } \\
\square \text { Otro... }\end{array}$ \\
\hline Reflexión previa & \multicolumn{4}{|c|}{ Intervención espontanea } \\
\hline erva & & & & \\
\hline
\end{tabular}

\subsection{MUROS}

Tipo de intervención

No intervenido

Tipo de material

$\square$ Actualización $\square$ Reintegración $\square$ Demolición $\square$ Otro... $\square$ Consolidación $\square$ Reconstrucción $\square$ sustitución

Descripción

3.2. ZÓCALO

Tipo de intervención

Intervenido

$\square$ Actualizació

Tipo de material

Descripción

Zócalo con cemento que actualmente se encuentra en un estado de deterioro avanzado

3.3. REVESTIMIENTOS

\section{Intervenido}

Tipo de intervención

$\square$ Actualización $\quad \boldsymbol{X}$ Reintegración $\square$ Demolición $\square$ Otro...

$\square$ Consolidación $\square$ Reconstrucción $\square$ Sustitución

Tipo de material

Descripción
No tradicional
Tipo de técnica Similar a la existente

3.4. VANOS

Reintegración de pequeñas zonas con nuevo revestimiento de cemento.

Tipo de intervención

Intervenido

Tipo de material

$\square$ Actualización $\quad \mathbf{X}$ Reintegración $\quad \square$ Demolición $\square$ Otro...

$\square$ Consolidación $\quad \square$ Reconstrucción $\quad$ \ Sustitución

Descripción

\begin{tabular}{|l|l|l} 
No tradicional & Tipo de técnica & Diferente a la existente \\
\hline
\end{tabular}

3.5. CUBIERTA

Tipo de intervención

Algunos hueco se han cegado parcialmente. En los huecos de PB se han sustituido las carpinterías y se han incluido nuevas rejas.

Intervenido

Tipo de material

$\square$ Actualización $\square$ Reintegración $\quad \boldsymbol{X}$ Demolición $\square$ Otro..

Descripción
No tradicional
Tipo de técnica Diferente a la existente

3.6. OTRAS 


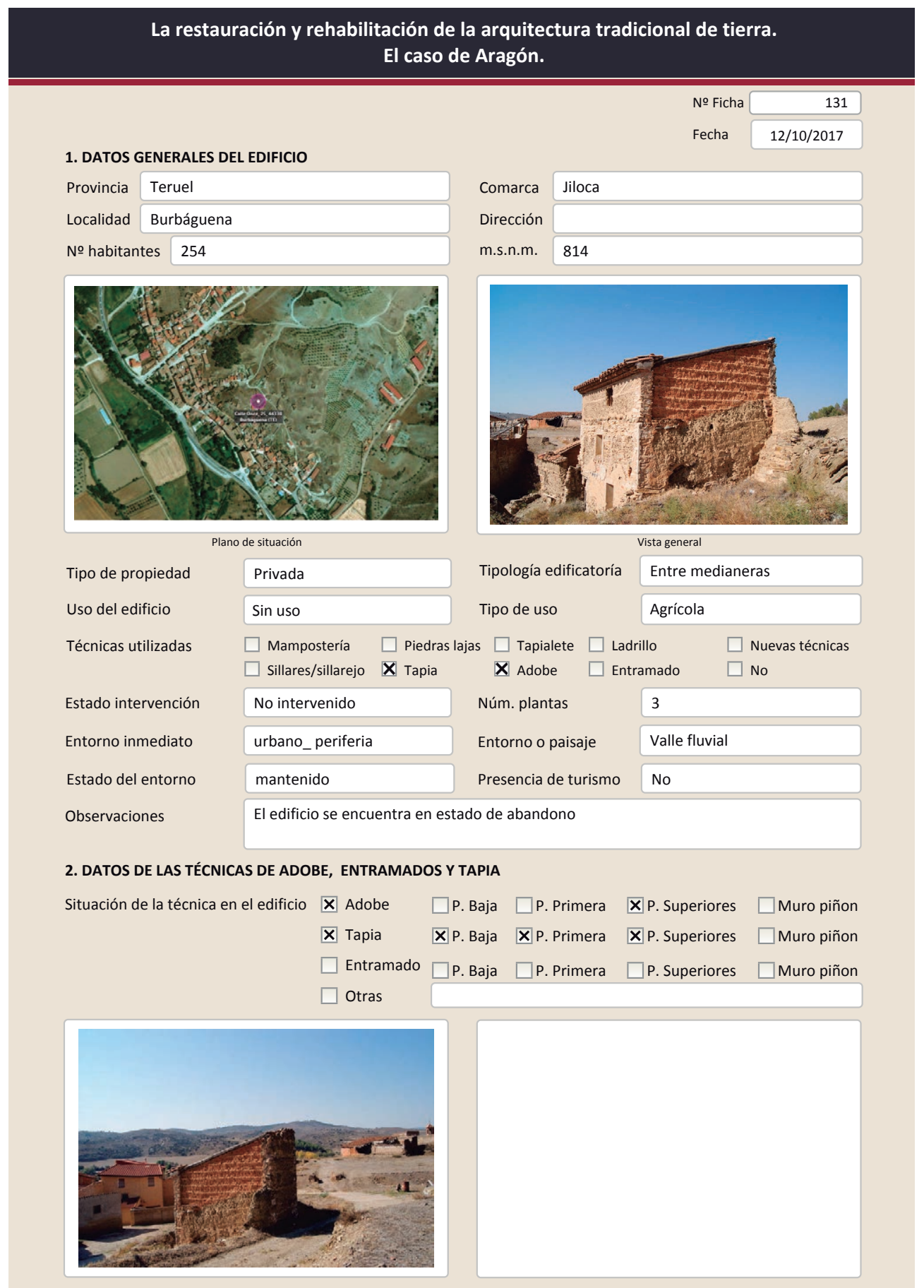

2.1. ADOBE

Dimensión de las piezas $35 \times 17 \times 9,5$

Dimensión del muro $10-20 \mathrm{~cm}$

Aparejo del muro Soga

Función estructural

No

Variante constructiva/ tipo de fábrica

$\square$ Simple
$\mathbf{X}$ Suplementada en juntas
Horizontales
区 Mixta
En esquinas
$\mathrm{Cal} /$ yeso

Color de las piezas

$\square$ Como suplemento

$\square$ Elementos de protección

Junta suplementada cada tres hiladas

(la foto de dimensión es del edificio que está situado a su lado)

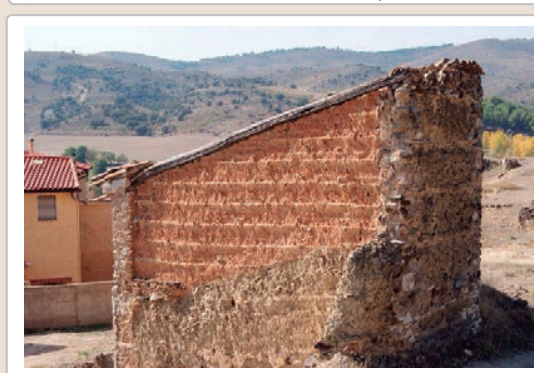

Lesiones $\quad \mathbf{X}$ Muro $\square$ Zócalo $\square$ Revestimiento

$\mathbf{X}$ Erosión del material $\quad \square$ Humedad por capilarida $\square$ Erosion de las juntas $\square$ Humedades (manch/eflo)

X Pérdida de sección $\square$ Pérdida de verticalidad

$\square$ Vegetación $\quad \square$ Grietas por empuje de la cubie $\square$ Grietas porfalta de traba

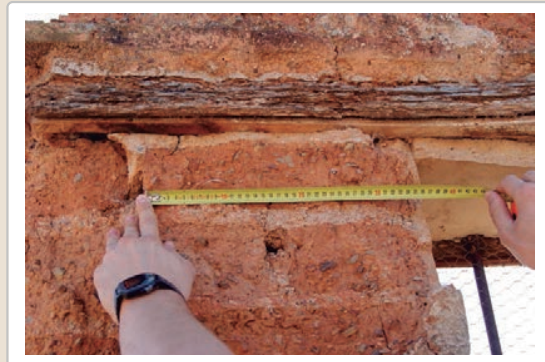

X Cubierta $\square$ Otro...

$\square$ Desconchados

$\square$ Grietas por asentamiento X Colapso

$\square$ Por elementos impropios

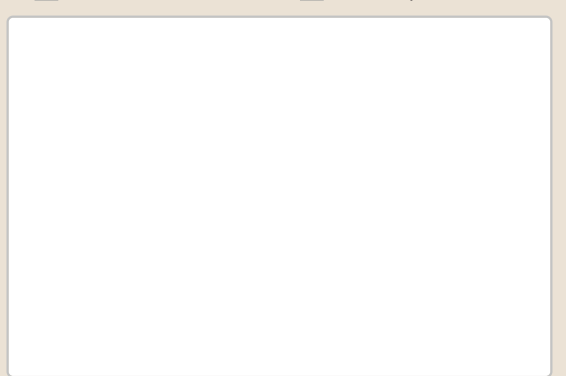

$\square$ Derivad
$\square$ Otro...

Observaciones 
La restauración y rehabilitación de la arquitectura tradicional de tierra.

El caso de Aragón.

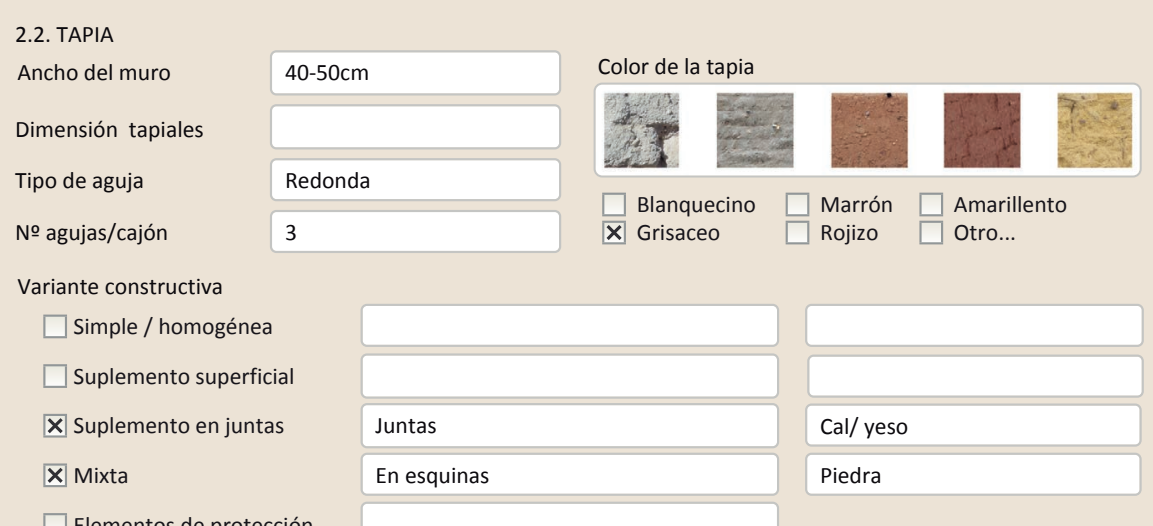

$\square$ Elementos de protecció

La tapia tienen un alto contenido de esquistos ya que el terreno tiene esta composición (foto incluida)

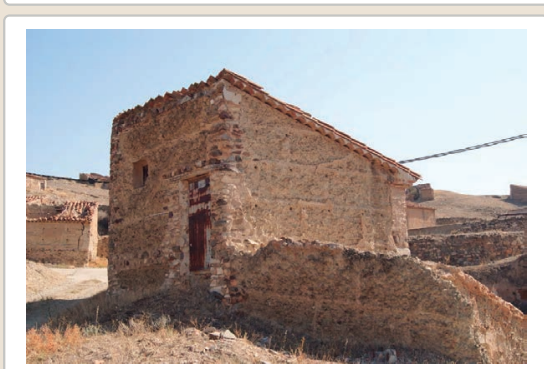

Lesiones $\quad$ XMuro $\square$ Zócalo $\square$ Revestimiento $\mathbf{X}$ Cubierta $\square$ Otro...

$\boldsymbol{X}$ Erosión del material $\quad \square$ Humedad por capilaridad $\quad \square$ Grietas por asentamientos

$\square$ Erosion de las juntas $\square$ Humedades (manch/eflo)

X Pérdida de sección $\square$ Pérdida de verticalidad

$\mathbf{X}$ Colapso

$\square$ Vegetación $\quad \square$ Grietas por empuje de la

$\square$ Por elementos impropios

$\square$ Desconchados

$\square$ Grietas porfalta de traba
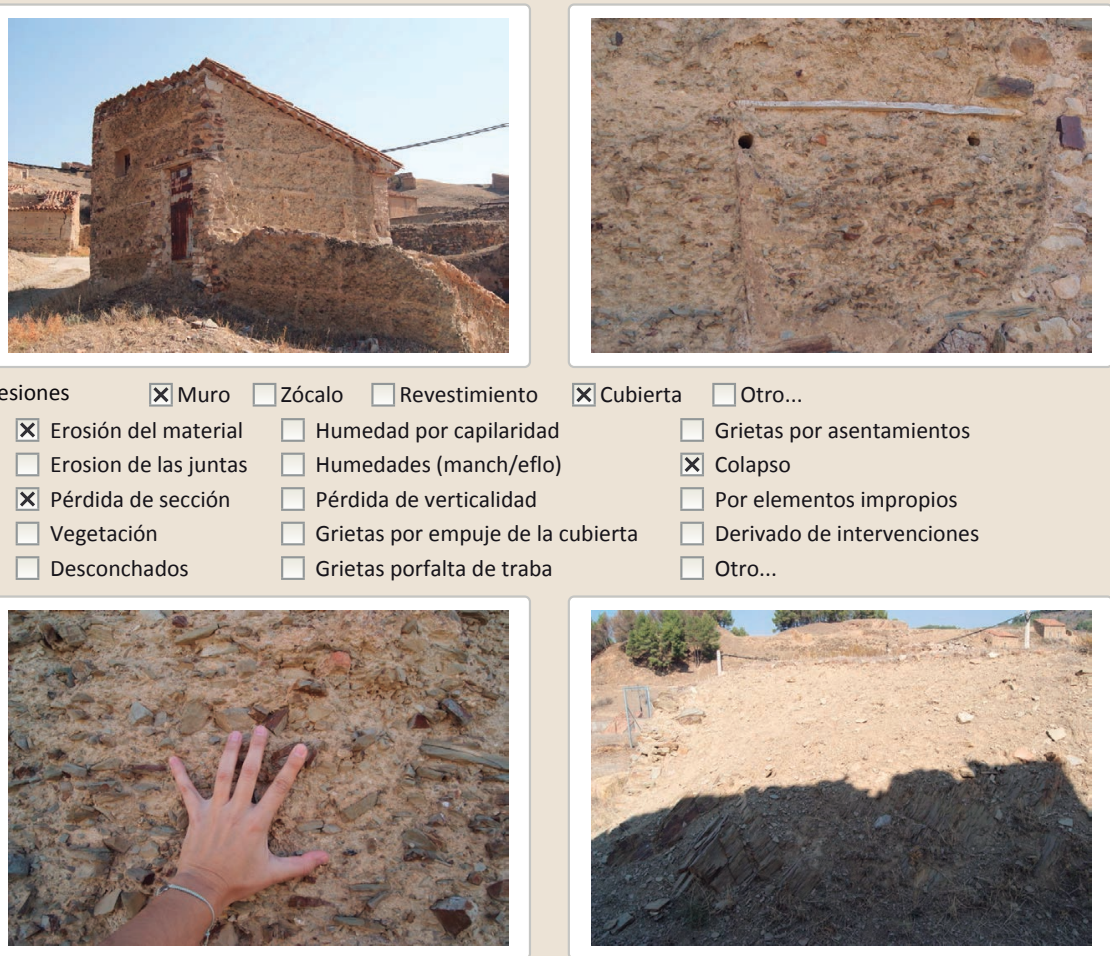

$\square$ Otro...

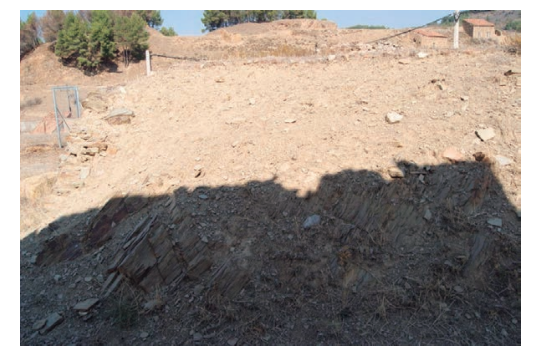

Observaciones 


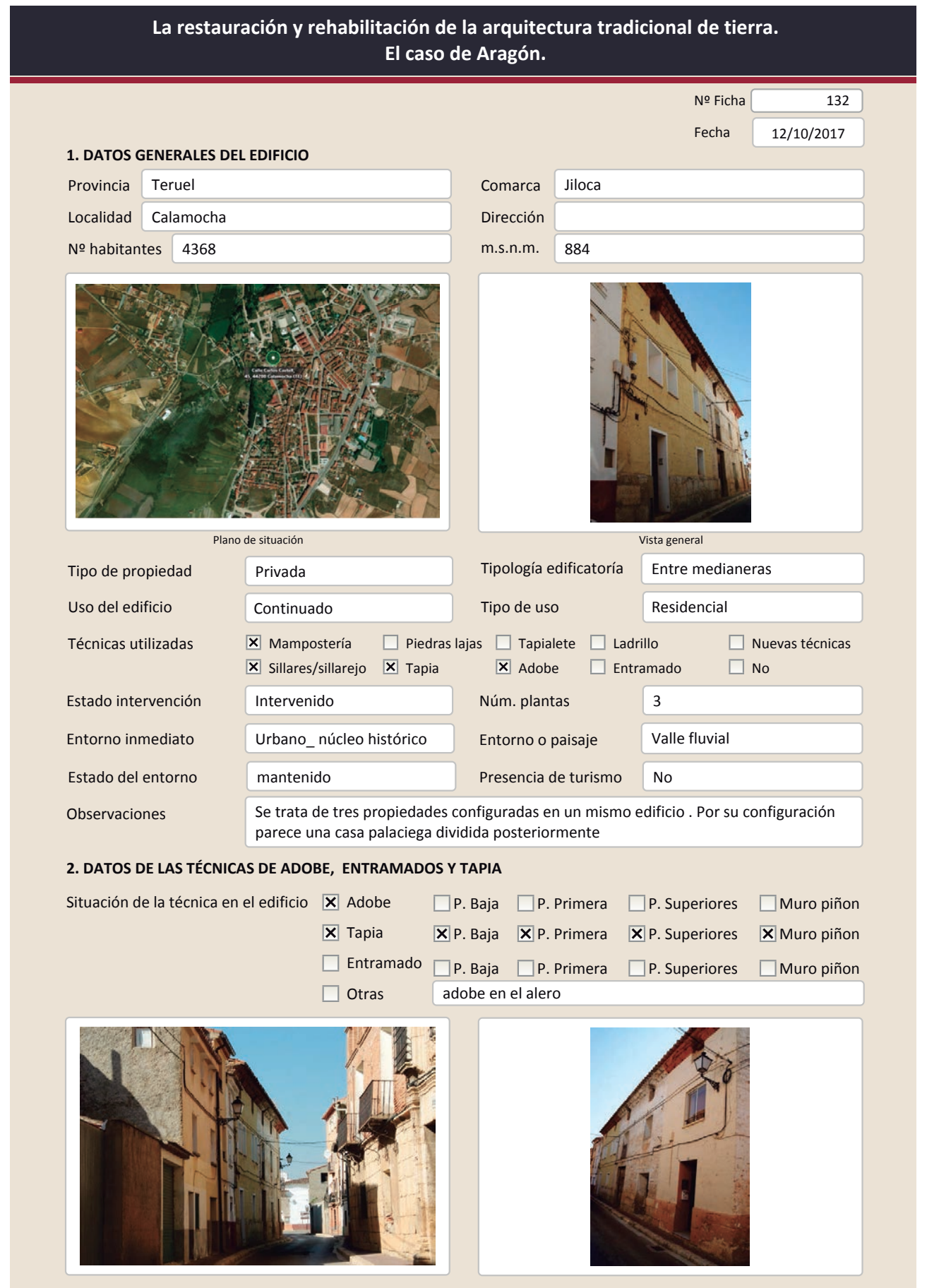

2.1. ADOBE

Dimensión de las piezas

Dimensión del muro

Aparejo del muro

Función estructural

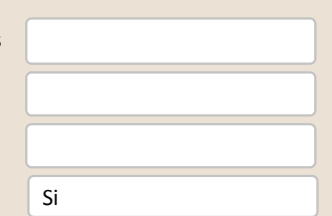

Color de las piezas

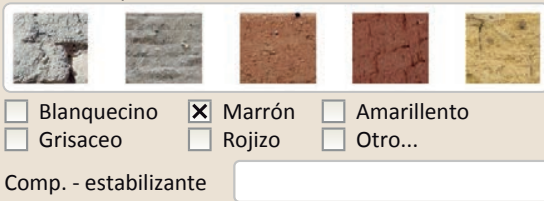

Variante constructiva/ tipo de fábrica

X simple

$\square$ suplementada en juntas

$\square$ Mixta

$\square$ Como suplemento

$\square$ Elementos de protección

Los adobes están conformando el alero. Tienen una forma trapezoidal de forma que sobresalen los unos sobre los otros
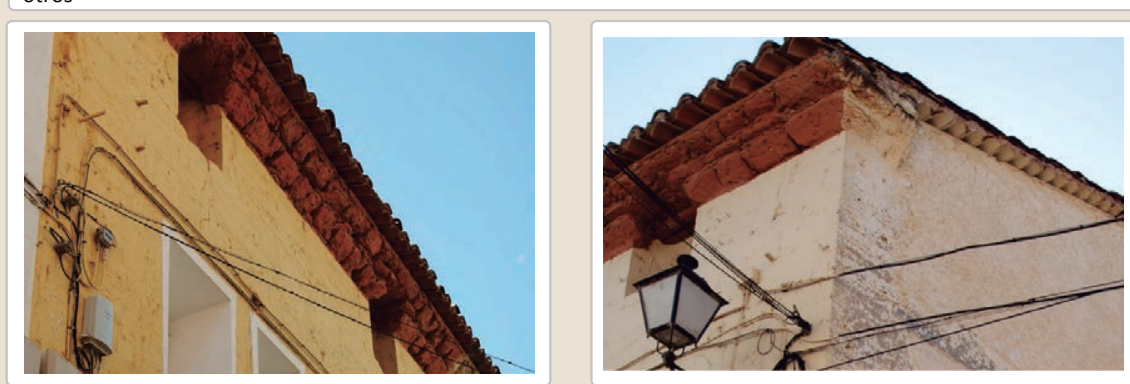

Lesiones \Muro $\square$ Zócalo $\square$ Revestimiento $\square$ Cubierta $\square$ Otro...

$\square$ Erosión del material $\quad \square$ Humedad por capilaridad $\quad \square$ Grietas por asentamientos $\square$ Erosion de las juntas $\square$ Humedades (manch/eflo) $\quad \mathbf{X}$ Colapso

$\square$ Pérdida de sección $\square$ Pérdida de verticalidad

$\square$ Vegetación $\quad \square$ Grietas por empuje de la cubierta

$\square$ Desconchados

$\square$ Grietas porfalta de traba

$\square$ Por elementos impropios

$\square$ Derivado de intervenciones

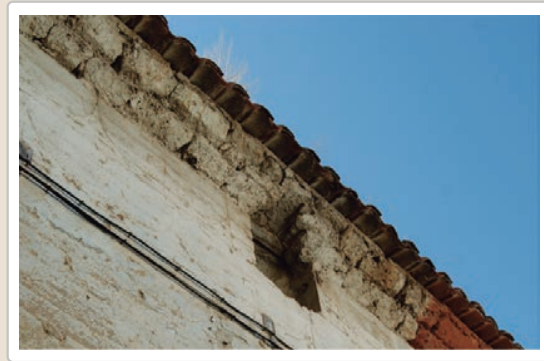

Observaciones
Se ha perdido alguna pieza cuando se encuentra volando sobre un hueco 


\section{La restauración y rehabilitación de la arquitectura tradicional de tierra.} El caso de Aragón.

\subsection{TAPIA}

Ancho del muro

Dimensión tapiales

Tipo de aguja

$60-70 \mathrm{~cm}$

Redonda

№ agujas/cajón

3

Variante constructiva

$\square$ Simple / homogénea

$\mathbf{X}$ Suplemento superficial

$\boldsymbol{X}$ Suplemento en juntas

X Mixta

\begin{tabular}{|l|}
\hline Calicostrada \\
\hline Brencas \\
\hline Machones de rafas \\
\hline
\end{tabular}

Cal/ yeso

Cal/ yeso

$\square$ Elementos de protección

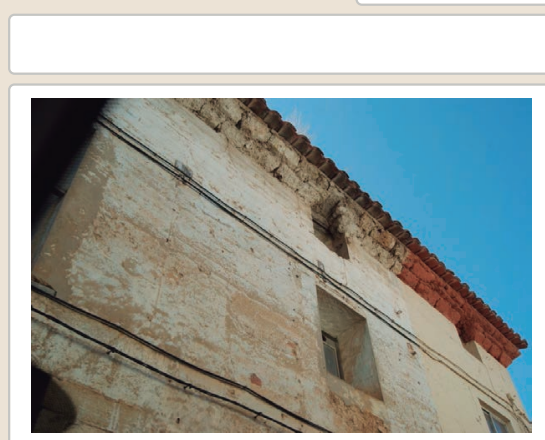

Lesiones

$\square$ Muro $\square$ Zócalo $\square$ Revestimiento $\square$ Cubierta $\square$ Otro..

$\square$ Erosión del material $\quad \square$ Humedad por capilaridad $\quad \square$ Grietas por asentamientos

$\square$ Colapso

$\square$ Pérdida de sección $\square$ Pérdida de verticalidad

$\square$ Pérdida de verticalidad $\quad \square$ Por elementos impropios

$\square$ Vegetación

$\square$ Desconchados

$\square$ Grietas porfalta de traba

$\square$ Otro...
La restauración y rehabilitación de la arquitectura tradicional de tierra.

El caso de Aragón.
3. DATOS DE LA INTERVENCIÓN

Intervención de: $\quad \square$ Mantenimiento $\quad \mathbf{X}$ Rehabilitación parcial $\quad \square$ Restauración $\square$ Demolición

Reflexión previa Intervención espontanea

Observaciones Las dos vivienda anexas han sido intervenidas de forma muy parecida.

3.1. MUROS

Tipo de intervención

Tipo de material

Descripción

3.2. ZÓCALO

Tipo de intervención

Tipo de material

Descripción

3.3. REVESTIMIENTOS

Tipo de intervención

Tipo de material

Descripción

3.4. VANOS

Tipo de intervención

Tipo de material

Descripción

3.5. CUBIERTA

Tipo de intervención

Tipo de material

Descripción

3.6. OTRAS

\section{No visible \\ $\square$ Actualización $\square$ Reintegración $\square$ Demolición $\square$ Otro... $\square$ Consolidación $\square$ Reconstrucción $\square$ sustitución} Tipo de técnica

Intervenido

$\square$ Actualización $\quad \mathbf{X}$ Reintegración $\square$ Demolición $\square$ Otro..

$\square$ Consolidación $\square$ Reconstrucción $\square$ Sustitución

No tradicional Tipo de técnica Diferente a la existente

Reintegración parcial del zócalo de sillares con mortero de cemento en las juntas

Intervenido

X Actualización $\square$ Reintegración $\quad \square$ Demolición $\quad \square$ Otro..

$\square$ Consolidación $\quad \square$ Reconstrucción $\square$ Sustitución

No tradicional Tipo de técnica Diferente a la existente

Capas de pintura sucesivas sobre el muro de tapia

Intervenido

$\square$ Actualización $\square$ Reintegración $\square$ Demolición $\square$ Otro.

$\square$ Consolidación $\mathbf{X}$ Reconstrucción $\mathbf{X}$ Sustitución

No tradicional Tipo de técnica Diferente a la existente

Apertura de nuevos huecos en planta baja para el acceso de las viviendas laterales. Apertura de nuevos huecos en planta baja para el
Sustitución de las carpinterías y doble acristalado.

No visible

$\square$ Actualización $\square$ Reintegración $\square$ Demolición $\square$ Otro...

$\square$ Consolidación $\square$ Reconstrucción $\square$ Sustitución
Observaciones Lavado del muro, deterioro por el tiempo pero no se aprecia ningún problema puntua o grave 
La restauración y rehabilitación de la arquitectura tradicional de tierra. El caso de Aragón

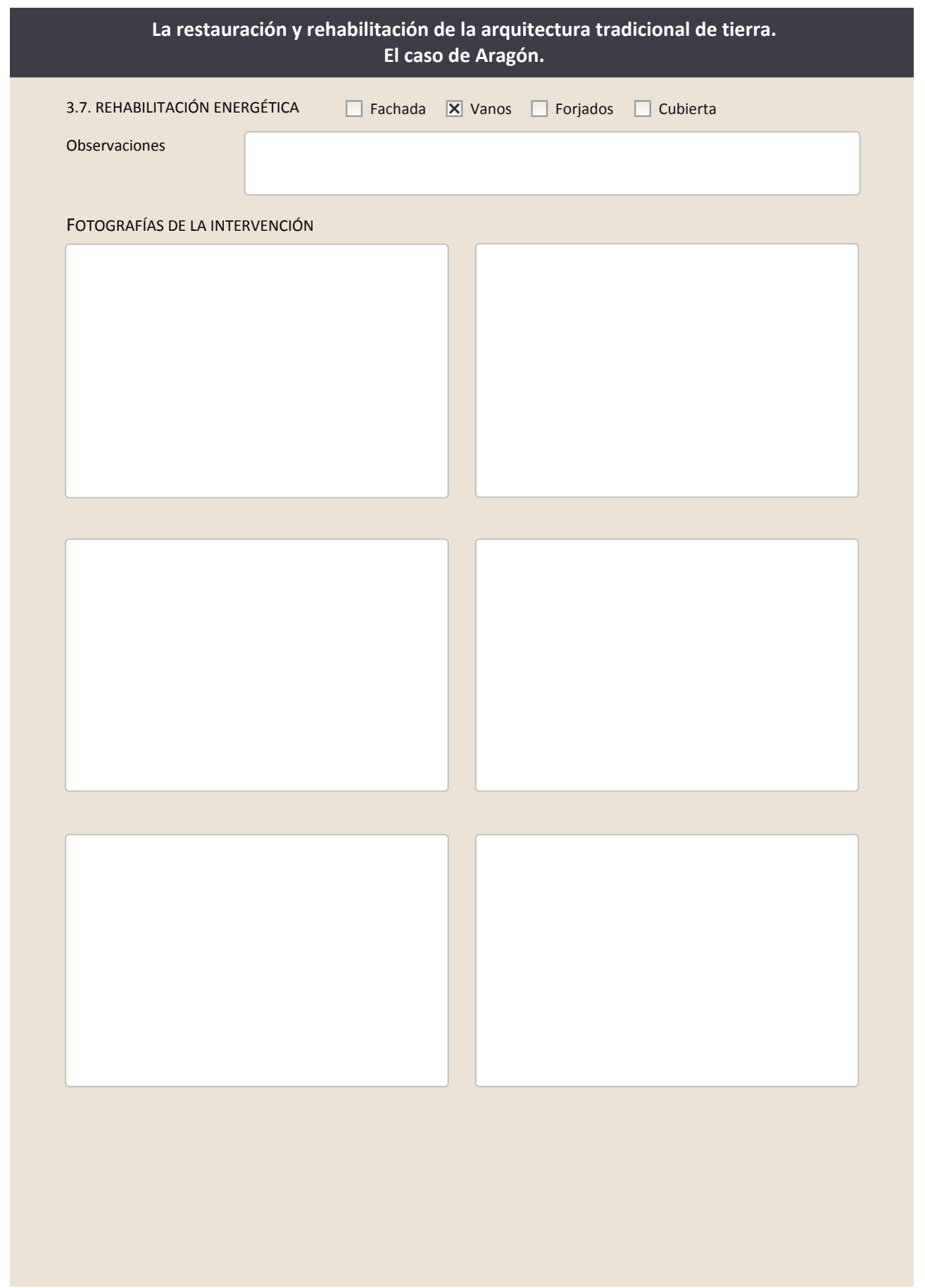

La restauración y rehabilitación de la arquitectura tradicional de tierra.

El caso de Aragón.

3.7. REHABILITACIÓN ENERGÉTICA $\square$ Fachada $\quad \boldsymbol{X}$ Vanos $\square$ Forjados $\square$ Cubierta

Observaciones

FOTOGRAFÍAS DE LA INTERVENCIÓN 


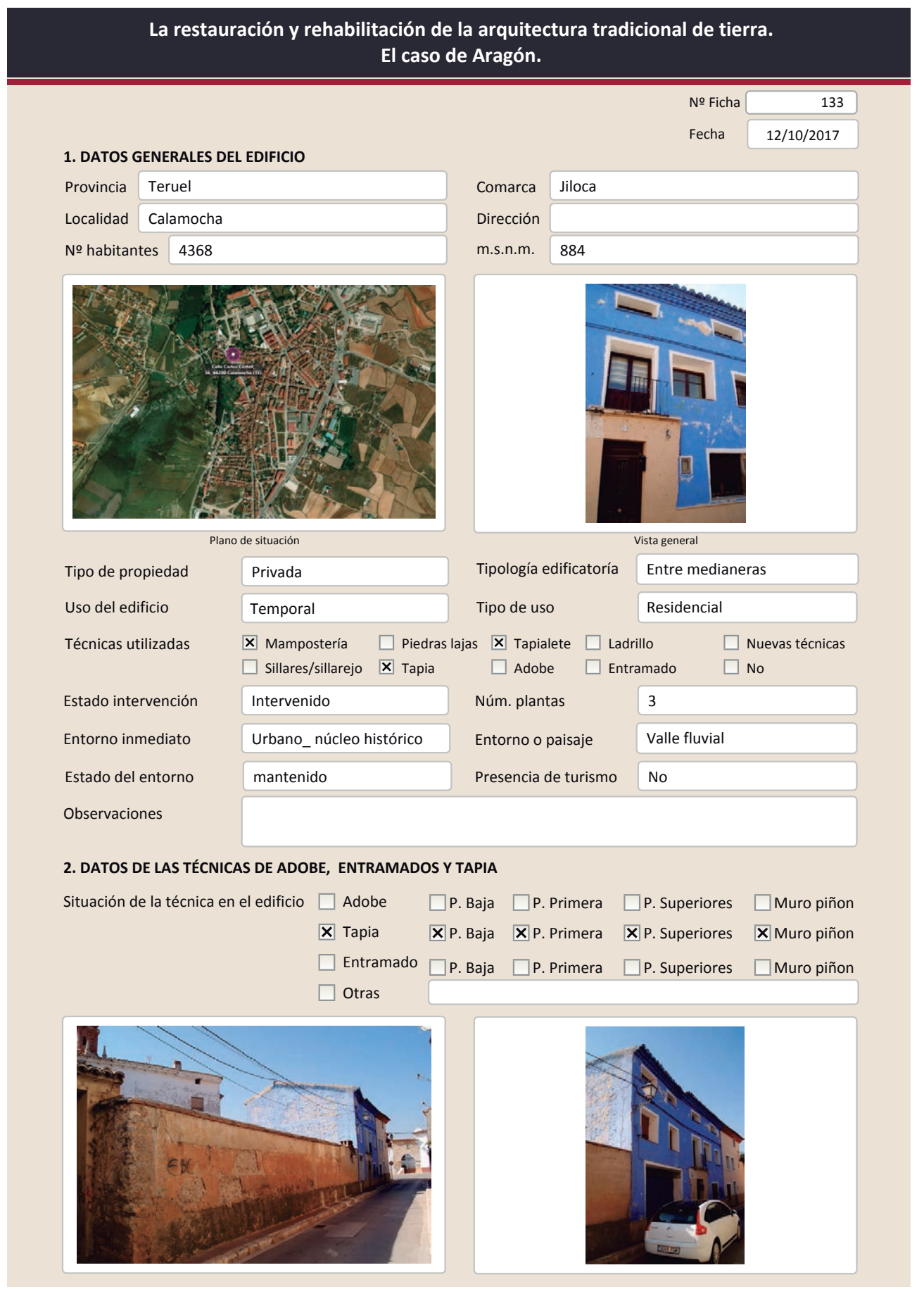

La restauración y rehabilitación de la arquitectura tradicional de tierra. El caso de Aragón.

2.2. TAPIA

Ancho del muro

Dimensión tapiales

Tipo de aguja

№ agujas/cajón

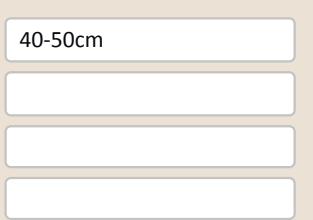

Color de la tapia

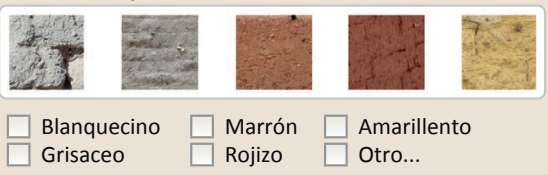

Variante constructiva

X Simple / homogénea
$\square$ Suplemento superficial
$\square$ suplemento en juntas
$\mathbb{X}$ Mixta

X Mixta

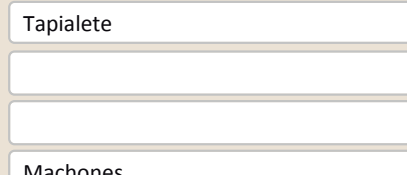

Machones

Mampostería y yeso

La fachada principal probablemente sea de tapia siguiendo la tipología de los otros edificios de la calle

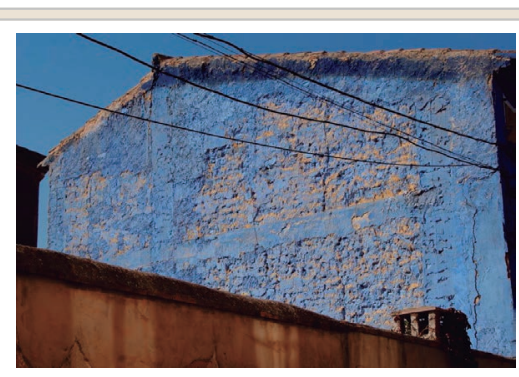

Lesiones $\quad \mathbf{X}$ Muro $\square$ Zócalo $\mathbf{X}$ Revestimiento $\square$ Cubierta $\square$ Otro...

X Erosión del material $\quad \square$ Humedad por capilaridad $\quad \square$ Grietas por asentamientos $\square$ Erosion de las juntas $\square$ Humedades (manch/eflo)

$\square$ Pérdida de sección $\square$ Pérdida de verticalidad

$\square$ Vegetación $\quad \mathbf{X}$ Grietas por empuje de la cubierta

$\mathbf{X}$ Desconchados

$\square$ Grietas porfalta de traba

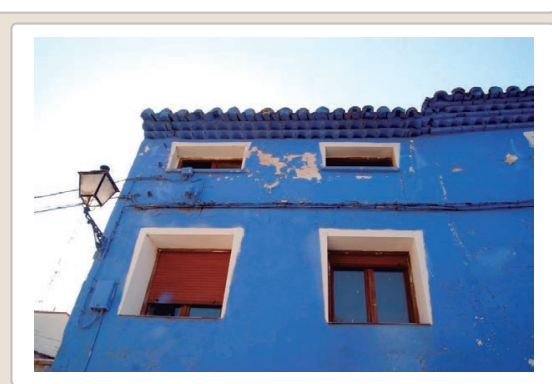

$\square$ Colapso

$\square$ Por elementos impropios

$\mathbf{X}$ Derivado de intervenciones

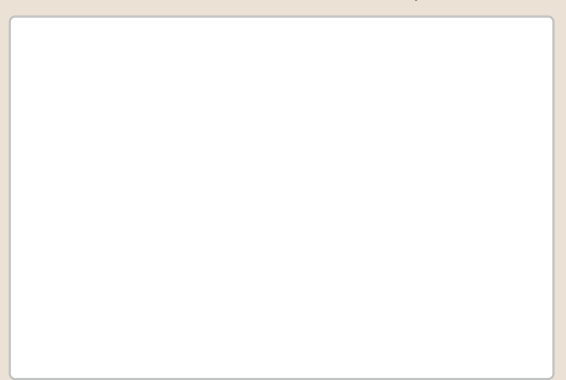

Observaciones 
La restauración y rehabilitación de la arquitectura tradicional de tierra. El caso de Aragón

\section{La restauración y rehabilitación de la arquitectura tradicional de tierra.}

\section{El caso de Aragón.}

3. DATOS DE LA INTERVENCIÓN

Intervención de:

$\square$ Mantenimiento $\square$ Rehabilitación parcial

$\square$ Restauración $\square$ Demolición

Reflexión previa

$\square$ Reparación

X Rehabilitación integra

Ampliación

$\square$ Otro...

Observaciones

Intervención planificada

(n)

3.1. MUROS

Tipo de intervención

No visible

Tipo de material

$\square$ Actualización $\square$ Reintegración $\square$ Demolición $\square$ Otro...

$\square$ Consolidación $\square$ Reconstrucción $\square$ Sustitución

Descripción

3.2. ZÓCALO

Tipo de intervención

Intervenido

Tipo de intervención

X Actualizació

$\square$ Reintegración $\square$ Demolición $\square$ Otro...

Tipo de material

\begin{tabular}{|l|l|}
\hline No tradicional Tipo de técnica & Diferente a la existente \\
\hline Nuevo zócalo con contrachapado de piedra &
\end{tabular}

Tipo de técnica

Descripción

3.3. REVESTIMIENTOS

Tipo de intervención

Intervenido

Tipo de material

$\square$ Actualización $\square$ Reintegración $\quad \square$ Demolición $\square$ Otro...

$\square$ Consolidación $\quad \mathbf{X}$ Reconstrucción $\square$ Sustitución

Tipo de materia

No tradicional Tipo de técnica Diferente a la existente

Descripción

Nueva capa de pintura plástica azul sobe el reves
desprendimiento debido a su incompatibilidad

3.4. VANOS

Intervenido

Tipo de intervención $\square$ Actualización $\square$ Reintegración $\quad \square$ Demolición $\square$ Otro...

\begin{tabular}{l|l|l|l|l} 
Tipo de material & No tradicional & Tipo de técnica & Diferente a la existente
\end{tabular}

Descripción Apertura de nuevo hueco para el acceso de vehículos. Sustitución de carpinterías en la planta primera.

3.5. CUBIERTA

Tipo de intervención

No visible

Tipo de material

$\square$ Actualización $\square$ Reintegración $\square$ Demolición $\square$ Otro..

$\square$ Consolidación $\square$ Reconstrucción $\square$ Sustitución

Descripción

Tipo de técnica

3.6. OTRAS 


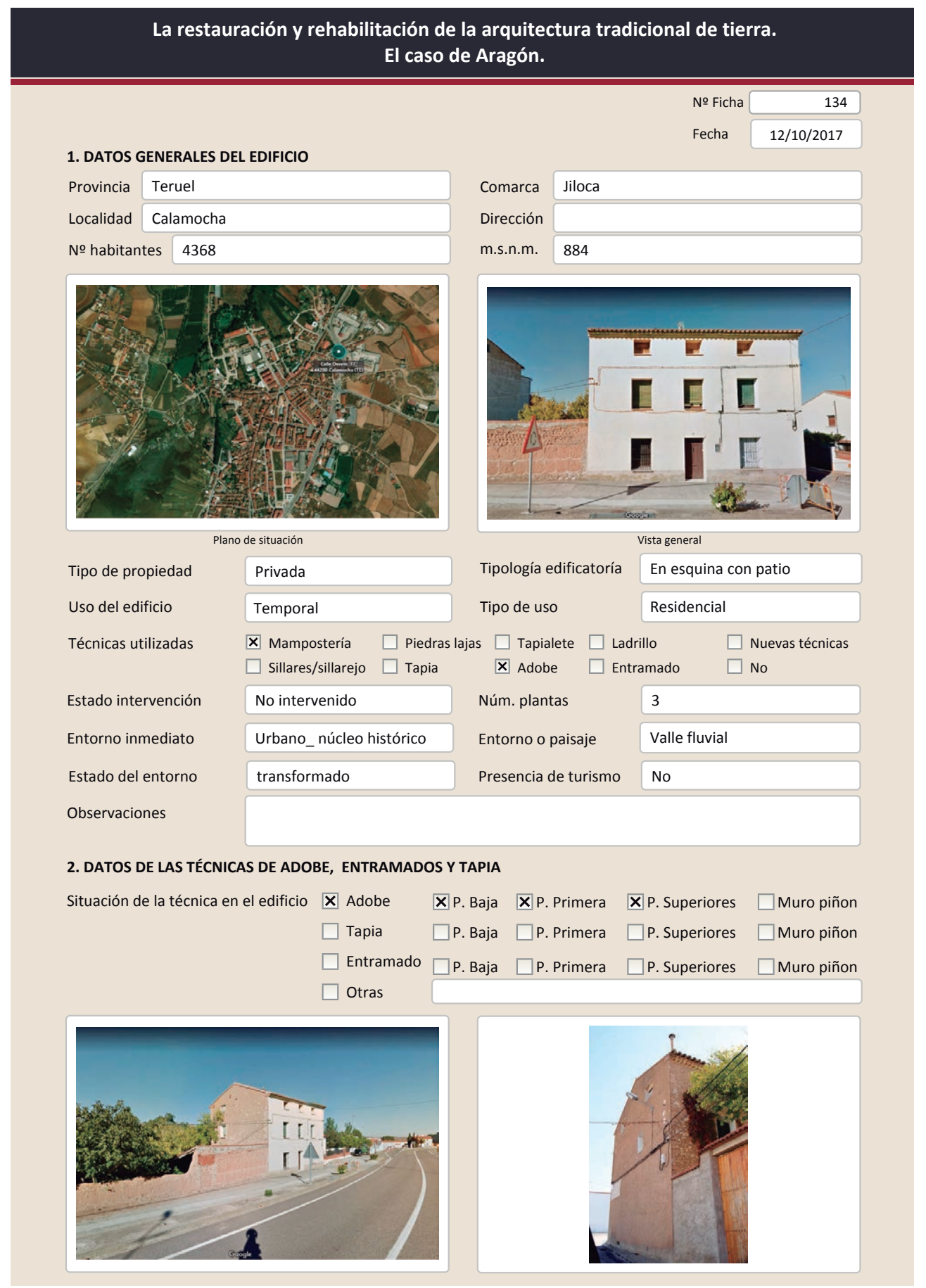

La restauración y rehabilitación de la arquitectura tradicional de tierra.

El caso de Aragón.

2.1. ADOBE

Dimensión de las piezas

Dimensión del muro

Aparejo del muro

Función estructural

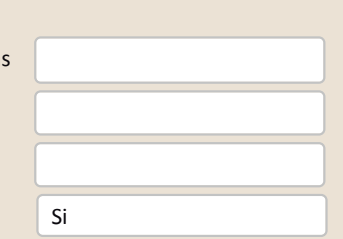

Color de las piezas

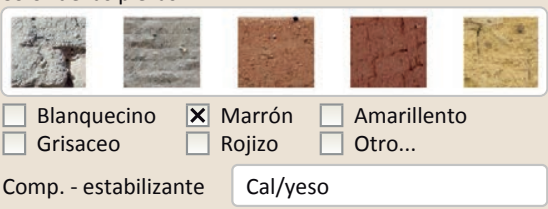

constructiva/tipo de fábrica

$\square$ simple

$\square$ Suplementada en juntas

$\square$ Mixta

$\mathbf{X}$ Como suplemento

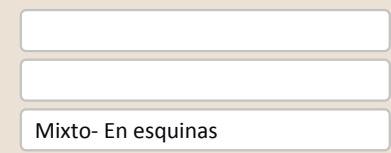

$\square$ Elementos de protección

la zona visible del edificio deja ver el muro de mampostería y las esquinas realizadas con adobe.
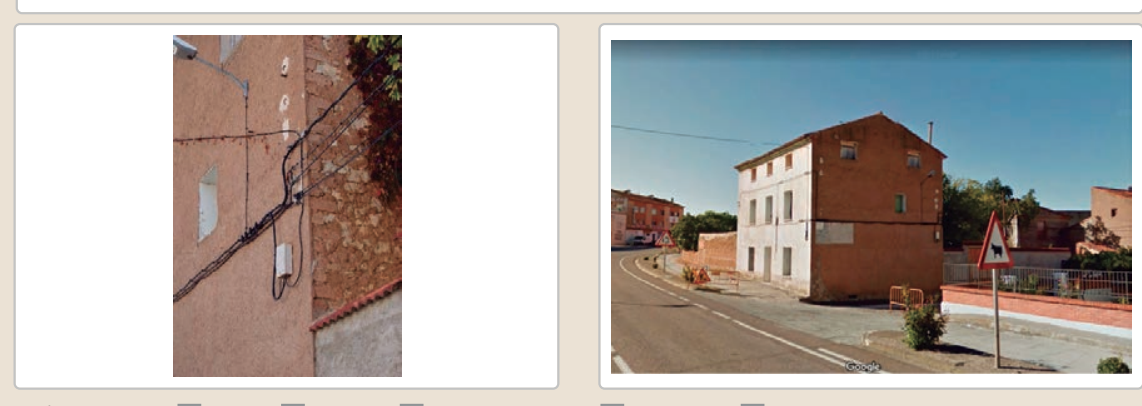

Lesiones $\quad \square$ Muro $\square$ Zócalo $\quad \square$ Revestimiento

$\square$ Erosión del material $\square$ Humedad por capilaridad

$\square$ Pérdida de sección $\square$ Pérdida de verticalidad

$\square$ Vegetación

$\square$ Grietas por empuje de la
$\square$ Grietas porfalta de traba

$\square$ Grietas por asentamientos

$\square$ Colapso

$\square$ Desconchados

$\square$ Por elementos impropios

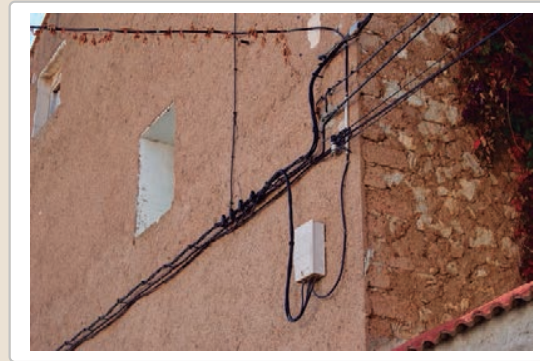

$\square$ Derivado
$\square$ Otro...

Observaciones 


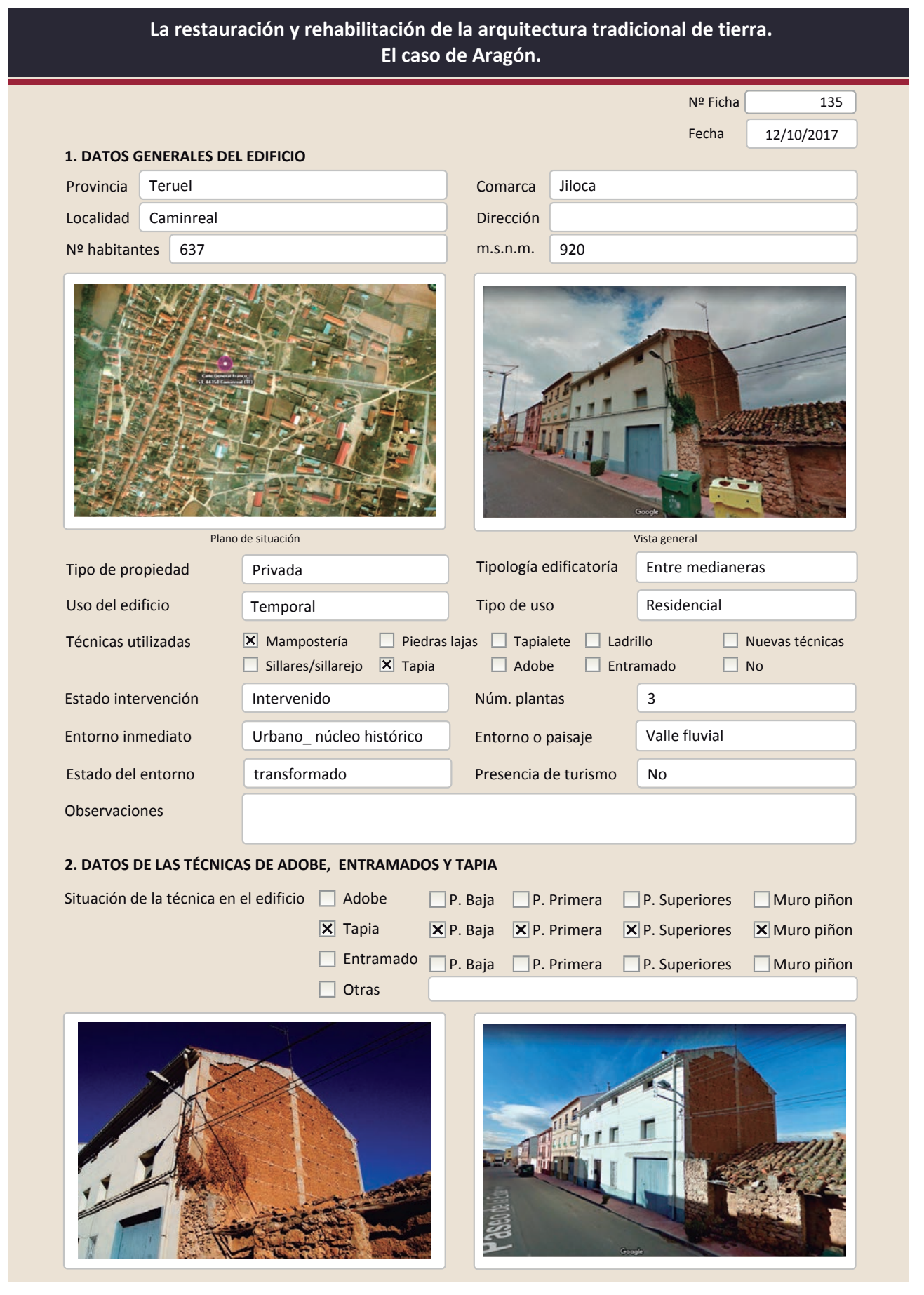

2.2. TAPIA

Ancho del muro

Dimensión tapiales

Tipo de aguja

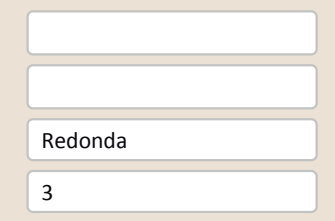

Color de la tapi

№ agujas/cajón

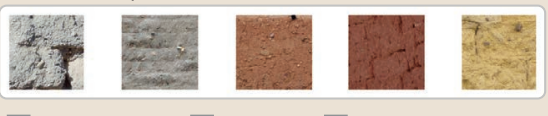

$\square$ Blanquecino $\mathbf{X}$ Marrón $\square$ Amarillento

$\square$ Blanquecino $\quad \mathbf{X}$ Marrón $\square$ Amarill
$\square$ Grisaceo
$\square$ Rojizo $\quad \square$ Otro...

Variante constructiva

$\square$ Simple / homogénea

$\square$ suplemento superficial

$\boldsymbol{X}$ Suplemento en juntas

X Mixta
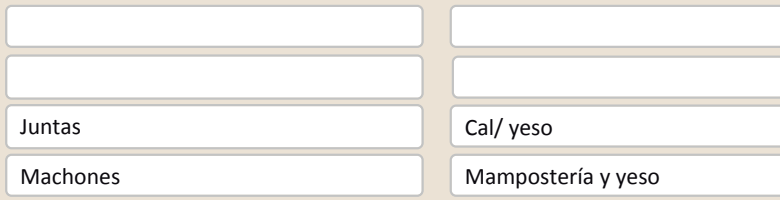

$\square$ Elementos de protección

(foto 1. Dic.2009, google)
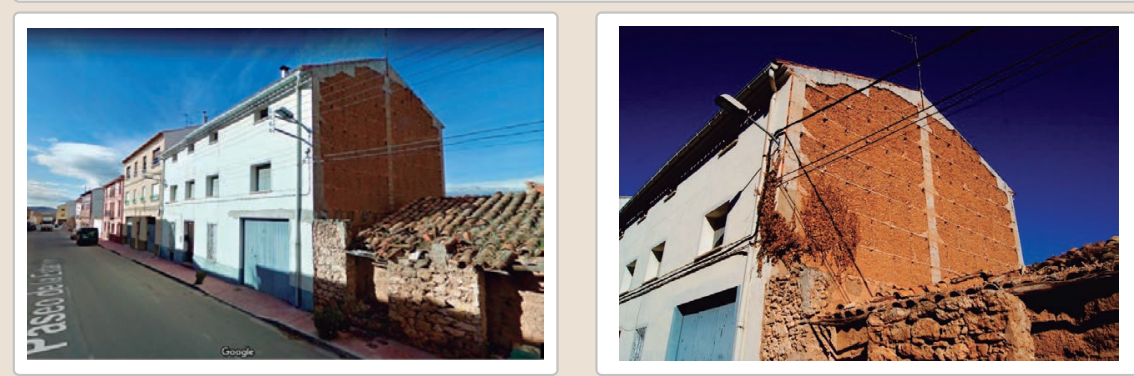

Lesiones $\square$ Muro $\square$ Zócalo $\square$ Revestimiento $\square$ Cubierta $\square$ otro...

$\square$ Erosión del material $\quad \square$ Humedad por capilaridad $\quad \square$ Grietas por asentamientos $\square$ Erosion de las juntas $\square$ Humedades (manch/eflo)

$\square$ Pérdida de sección $\quad \square$ Pérdida de verticalidad

$\square$ Vegetación $\square$ Grietas por empuje de la cubieta

$\square$ Desconchados

$\square$ Grietas porfalta de traba

$\square$ Colapso

$\square$ Por elementos impropios

$\square$ Derivado de intervenciones

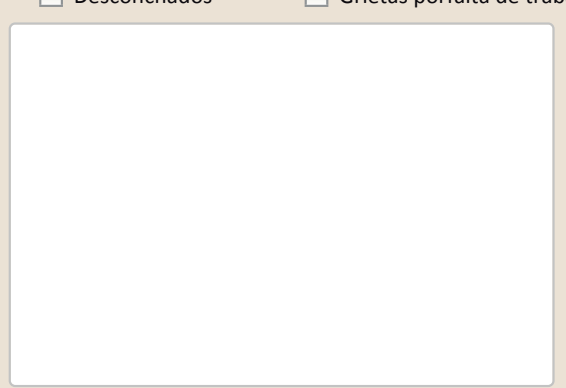

$\square$ Otro... 


\section{La restauración y rehabilitación de la arquitectura tradicional de tierra.}

\section{El caso de Aragón.}

3. DATOS DE LA INTERVENCIÓN

Intervención de:

$\square$ Mantenimiento

Reflexión previa

$\square$ Reparació

$\square$ Rehabilitación parcial

$\square$ Restauración $\square$ Demolición

Intervención planificada

Observaciones

(2)

3.1. MUROS
Tipo de intervención

Intervenido

Tipo de material

$\square$ Actualización $\square$ Reintegración $\square$ Demolición $\square$ Otro...

$\square$ Consolidación $\quad \mathbb{\text { Reconstrucción }} \square$ Sustitución

Descripción

No tradicional Tipo de técnica Diferente a la existente

3.2. ZOCALO

Tipo de intervención Doblado del $\mathrm{m}$.
revestimiento.

Tipo de material

Intervenido

\ Actualización $\square$ Reintegración $\square$ Demolición $\square$ Otro...

$\square$ Consolidación $\quad \mathbf{X}$ Reconstrucción $\square$ Sustitución

Descripción

3.3. REVESTIMIENTOS

Tipo de intervención

No tradicional Tipo de técnica Diferente a la existente

Capa gruesa de cemento en con pintura azul

\section{Intervenido}

区 Actualización $\square$ Reintegración $\quad \square$ Demolición $\square$ Otro...

$\square$ Consolidación $\quad \mathbf{X}$ Reconstrucción $\square$ Sustitución

Tipo de material

Descripción

3.4. VANOS

Tipo de intervención

No tradicional

Tipo de técnica Diferente a la existente

Nuevo revestimiento sobre el doblado del muro con ladrillo

Tipo de material
Descripción

Intervenido

$\square$ Actualización $\square$ Reintegración $\square$ Demolición $\square$ Otro...

$\square$ Consolidación $\mathbf{X}$ Reconstrucción $\mathbf{X}$ Sustitución

3.5. CUBIERTA

Tipo de intervención

No tradicional

Tipo de técnica Diferente a la existente

Ampliación de huecos
nuevas persianas

Tipo de material

\section{Intervenido}

$\square$ Actualización $\quad \square$ Reintegración $\square$ Demolición $\quad \square$ Otro...

$\square$ Consolidación $\square$ Reconstrucción $\quad \mathbb{X}$ Sustitución

Descripción

\begin{tabular}{l|l|l|l} 
No tradicional & Tipo de técnica Similar a la existente \\
\hline
\end{tabular}

Sustitución de la cubierta utilizando teja cerámica nueva. Nuevo alero de ladrillo cerámico
La restauración y rehabilitación de la arquitectura tradicional de tierra.

El caso de Aragón.

3.6. OTRAS

3.7. REHABILITACIÓN ENERGÉTICA $\quad$ F Fachada $\quad$ \ Vanos $\square$ Forjados $\square$ Cubierta

Observaciones

FOTOGRAFíAS DE LA INTERVENCIÓN
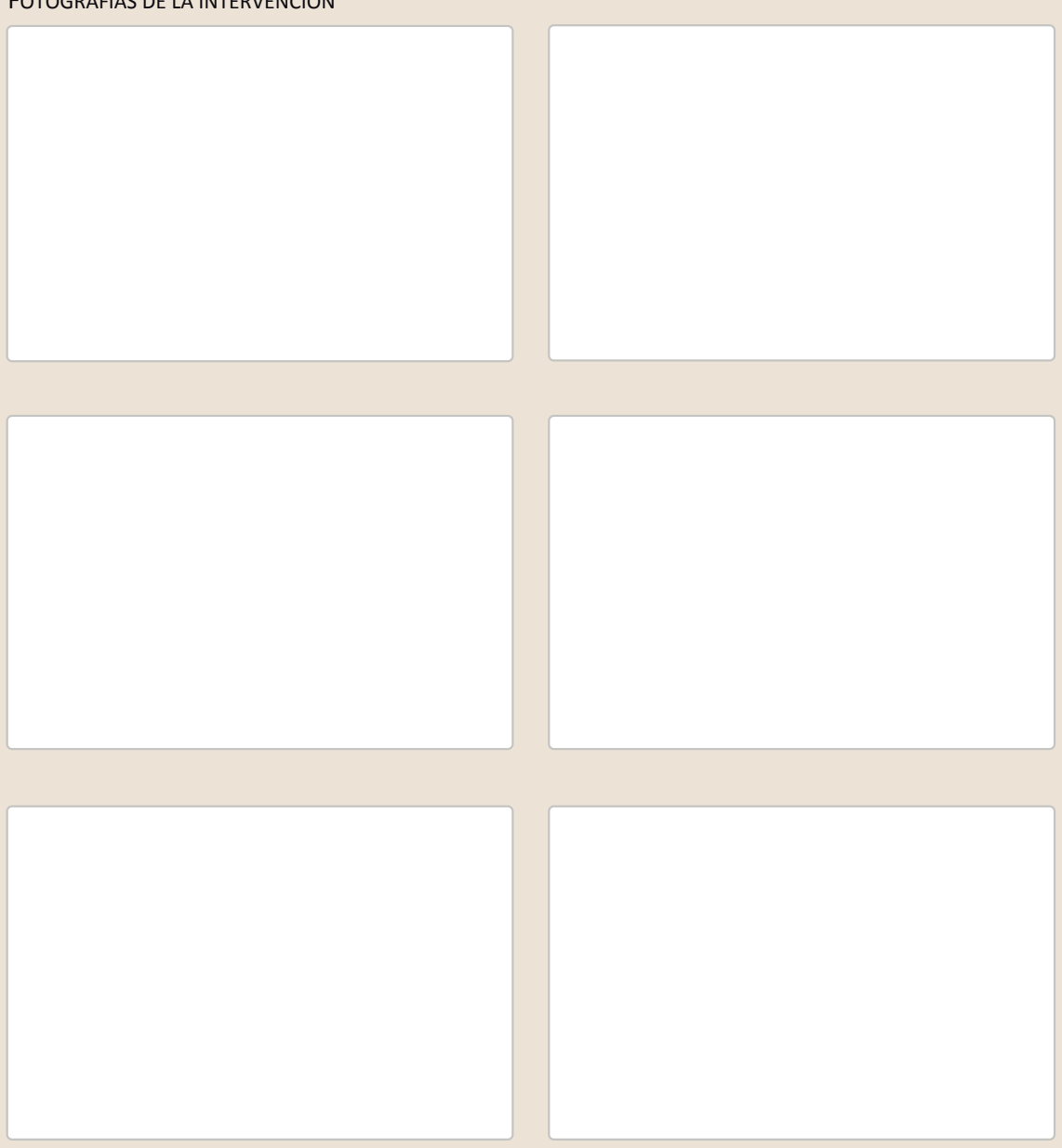


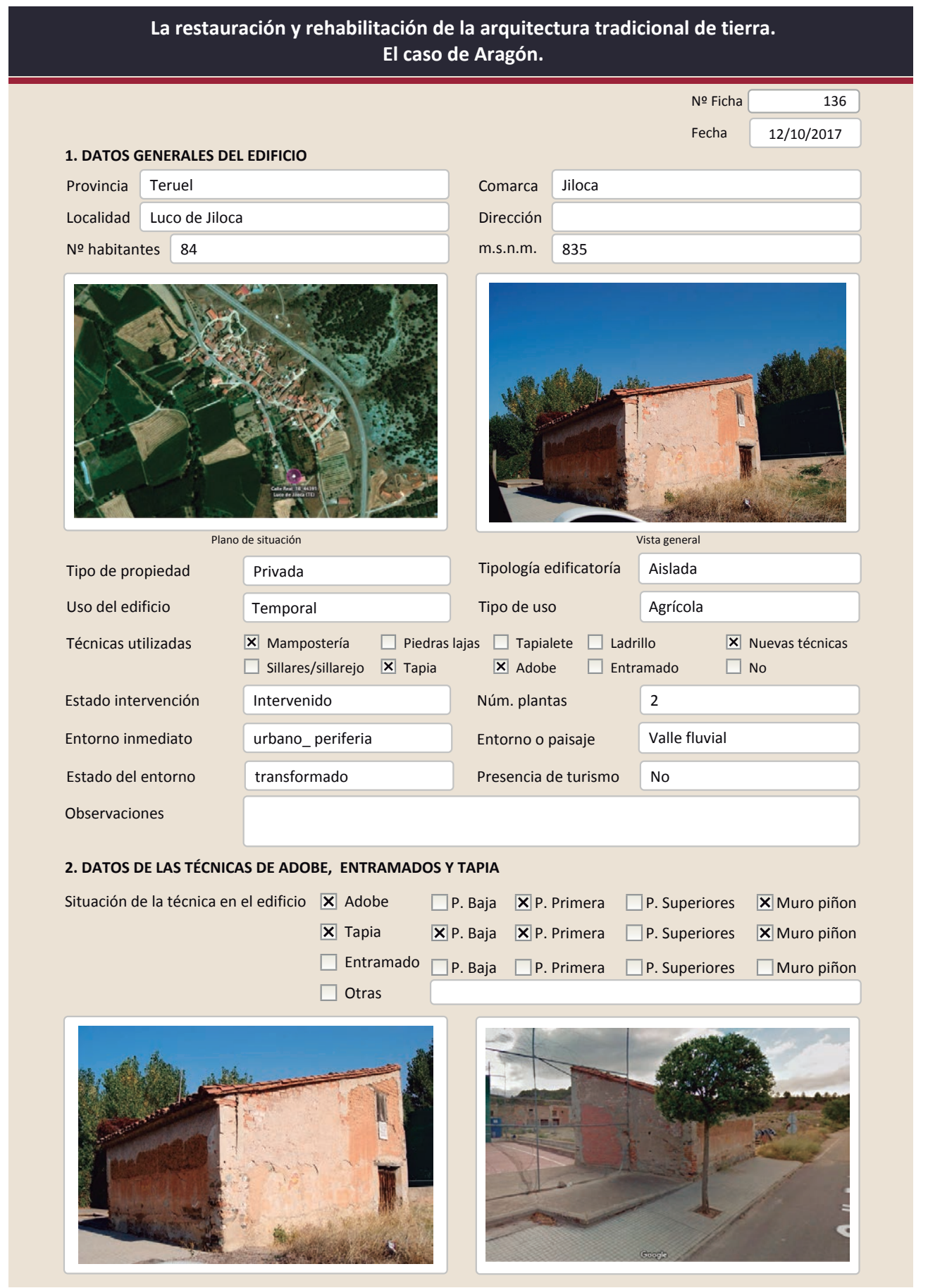

2.1. ADOBE

Dimensión de las piezas Dimensión del muro

Aparejo del muro

Función estructural

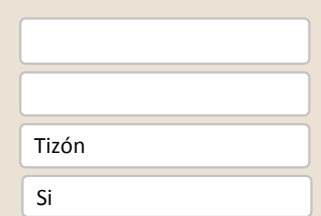

Color de las piezas

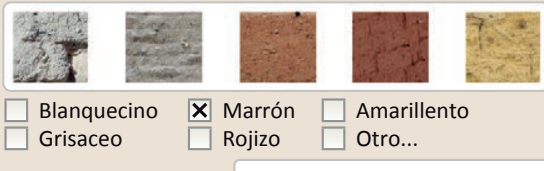

Comp. - estabilizante

Variante constructiva/ tipo de fábrica

$\square$ Simple

\begin{tabular}{l|l}
$\mathbf{X}$ Suplementada en juntas & Horizontales \\
$\mathbf{X}$ Mixta & En esquinas \\
$\square$ Como suplemento &
\end{tabular}

$\mathrm{Cal} /$ yeso

$\square$ Como suplemento

$\mathbf{X}$ Elementos de protección

Revestimiento

Revestimiento perdido casi en la totalidad

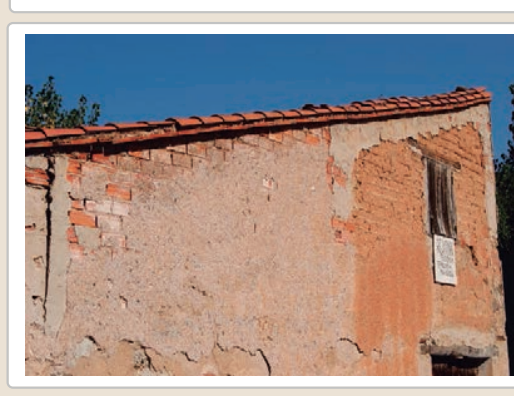

Lesiones $\quad \mathbf{X}$ Muro $\square$ Zócalo $\mathbf{X}$ Revestimiento $\square$ Cubierta $\square$ otro...

X Erosión del material $\quad \square$ Humedad por capilaridad $\quad \square$ Grietas por asentamientos

$\square$ Erosion de las juntas $\square$ Humedades (manch/eflo) $\quad \square$ Colapso

$\square$ Pérdida de sección $\square$ Pérdida de verticalidad

$\square$ Por elementos impropios

$\square$ Vegetación

X Grietas por empuje de la

$\square$ Derivado de intervenciones

$\mathbf{X}$ Desconchados $\square$ Grietas porfalta de traba $\square$ Otro... 


\section{La restauración y rehabilitación de la arquitectura tradicional de tierra.}

\section{El caso de Aragón.}

\subsection{TAPIA}

Ancho del muro

Dimensión tapiales

Tipo de aguja

№ agujas/cajón

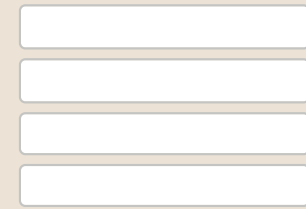

\section{Color de la tapia}

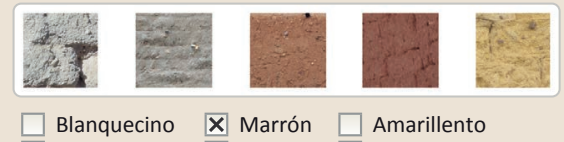
$\begin{array}{ll}\square \text { Blanquecino } & \mathbf{X} \text { Marrón } \\ \square \text { Grisaceo } & \square \text { Amarillento } \\ \text { Rojizo } & \square \text { Otro... }\end{array}$

$$
\checkmark \text { Rojizo } \square \text { Otro... }
$$

Variante constructiva

$\square$ Simple / homogénea

$\square$ suplemento superficial

$X$ Suplemento en juntas

X Mixta

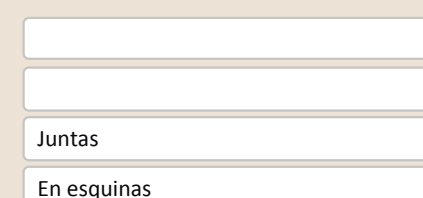

En esquinas

Cal/ yeso

$\square$ Elementos de protección

Mampostería y yeso

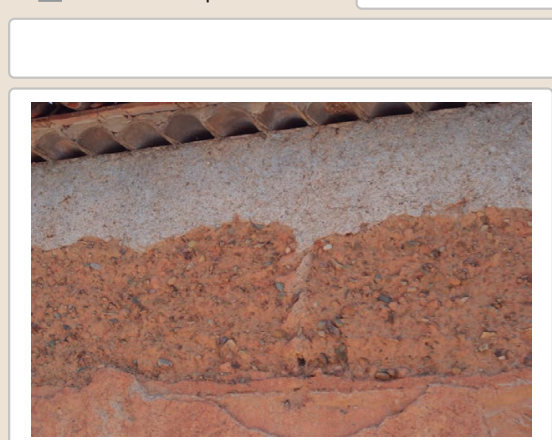

Lesiones ХMuro $\square$ Zócalo $\quad$ X Revestimiento $\square$ Cubierta $\square$ Otro...

X Erosión del material $\square$ Humedad por capilaridad $\quad \square$ Grietas por asentamientos

$\square$ Grietas

$\square$ Pérdida de sección

$\square$ Humedades (manch/eflo)

$\square$ Por elementos impropios

$\square$ Vegetación

Por elementos impropios

$\mathbf{X}$ Desconchados

$\mathbf{X}$ Grietas por empuje de la
$\square$ Grietas porfalta de traba

$\square$ Otro...
La restauración y rehabilitación de la arquitectura tradicional de tierra.

El caso de Aragón.

DATOS DE LA INTERVENCIÓN

reflén

$\square$ Mantenimiento $\quad \square$ Rehabilitación parcial

Inehabilitación integral $\square$ Ampliación $\square$ Otro...

Reflexión previa $\quad$ Intervención espontanea

Observaciones

3.1. MUROS

Tipo de intervención

Tipo de material

Intervenido

Descripción

$\square$ Consolidación $\square$ Reconstrucción $\quad \mathbf{X}$ Sustitución

Descripción

Tipo de técnica Diferente a la existente

3.2. ZÓCALO

Sustitución parcial de los muros de adobe y tapia por muro de ladrillo

Tipo de intervención

Tipo de material

Intervenido

$\square$ Actualización $\quad \mathbf{x}$ Reintegración $\square$ Demolición $\square$ Otro..

$\square$ Consolidación $\square$ Reconstrucción $\square$ Sustitución

Descripción

\section{No tradicional}

Tipo de técnica Diferente a la existente

3.3. REVESTIMIENTOS

Tipo de intervención

reparaciones con cemento en la zona inferior de los muros

Tipo de material

Descripción

3.4. VANOS

Tipo de intervención

Tipo de material

Descripción

3.5. CUBIERTA

Tipo de intervención

Tipo de material

Descripción

\section{Intervenido}

$\square$ Actualización $\square$ Reintegración $\square$ Demolición $\square$ Otro...

$\square$ Consolidación $\mathbf{X}$ Reconstrucción $\square$ Sustitución

No tradicional Tipo de técnica Diferente a la existente

Revestimiento realizado sobre el muro de ladrillo. Actualmente se encuentra en muy mal estado de conservación

No intervenido

$\square$ Actualización $\square$ Reintegración $\square$ Demolición $\square$ Otro...

$\square$ Consolidación $\square$ Reconstrucción $\square$ Sustitución

Intervenido

$\square$ Actualización $\square$ Reintegración $\quad \square$ Demolición $\square$ Otro.

$\square$ Consolidación $\square$ Reconstrucción $\mathbb{X}$ Sustitución

No tradicional Tipo de técnica Diferente a la existente

La cubierta parece sustituida ya que la base es ladrillo aunque puede ser que se construyera en una época tardía y ese sea el material original

Observaciones

3.6. OTRAS 


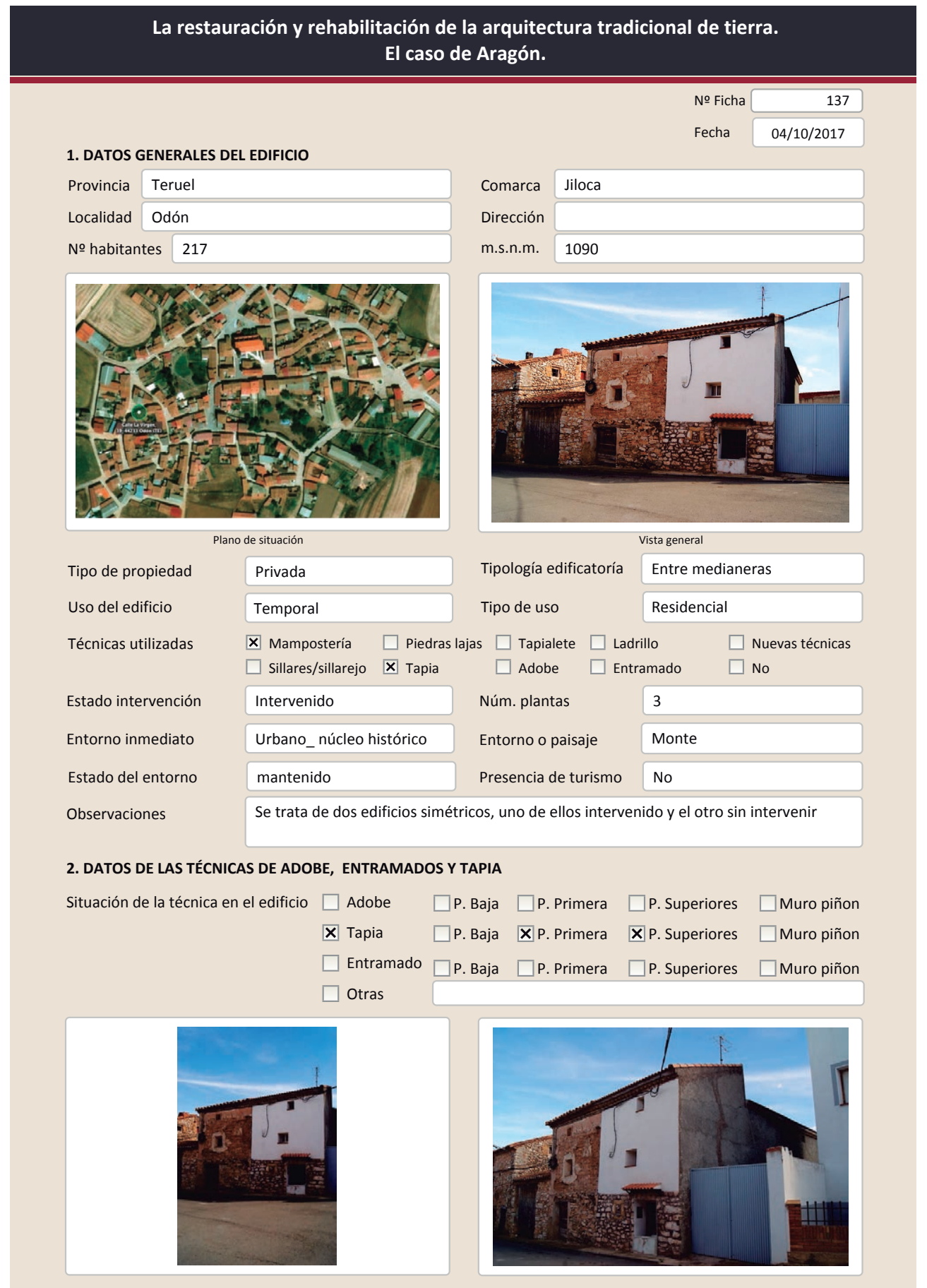

2.2. TAPIA

Ancho del muro

Dimensión tapiales

Tipo de aguja

№ agujas/cajón

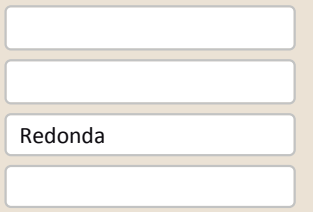

Color de la tapi

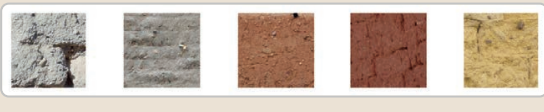

$\square$ Blanquecino $\quad \mathbf{X}$ Marrón $\square$ Amarillento

$\begin{array}{ll}\square \text { Blanquecino } & \mathbf{X} \text { Marrón } \square \text { Amarill } \\ \square \text { Grisaceo } & \square \text { Rojizo } \quad \square \text { Otro... }\end{array}$

Variante constructiva

$\square$ Simple / homogénea

X Suplemento superficial

$\square$ suplemento en juntas

X Mixta
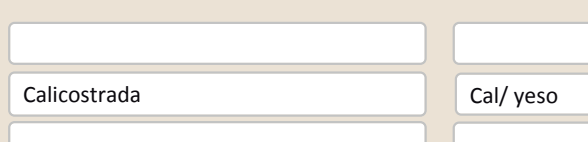

Cal/ yeso

$\mathrm{Cal} /$ yeso

Mampostería y yeso

En esquinas

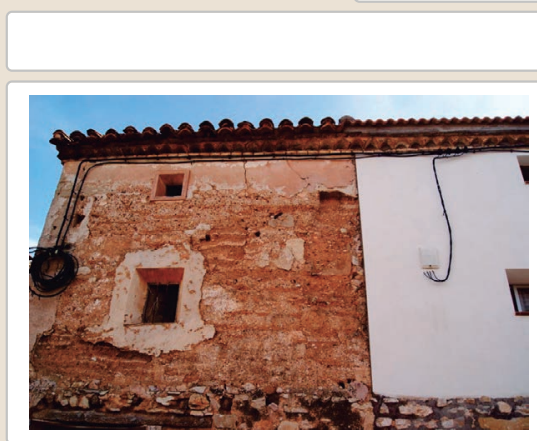

Lesiones \Muro $\square$ Zócalo $\mathbf{X}$ Revestimiento $\square$ Cubierta $\square$ otro...

Х Erosión del material $\mathbf{X}$ Humedad por capilaridad $\quad \square$ Grietas por asentamientos $\mathbf{X}$ Erosion de las juntas $\mathbf{X}$ Humedades (manch/eflo)

$\square$ Pérdida de sección $\square$ Pérdida de verticalidad

$\square$ Vegetación $\square$ Grietas por empuje de la cubierta

X Desconchados $\quad \square$ Grietas porfalta de traba
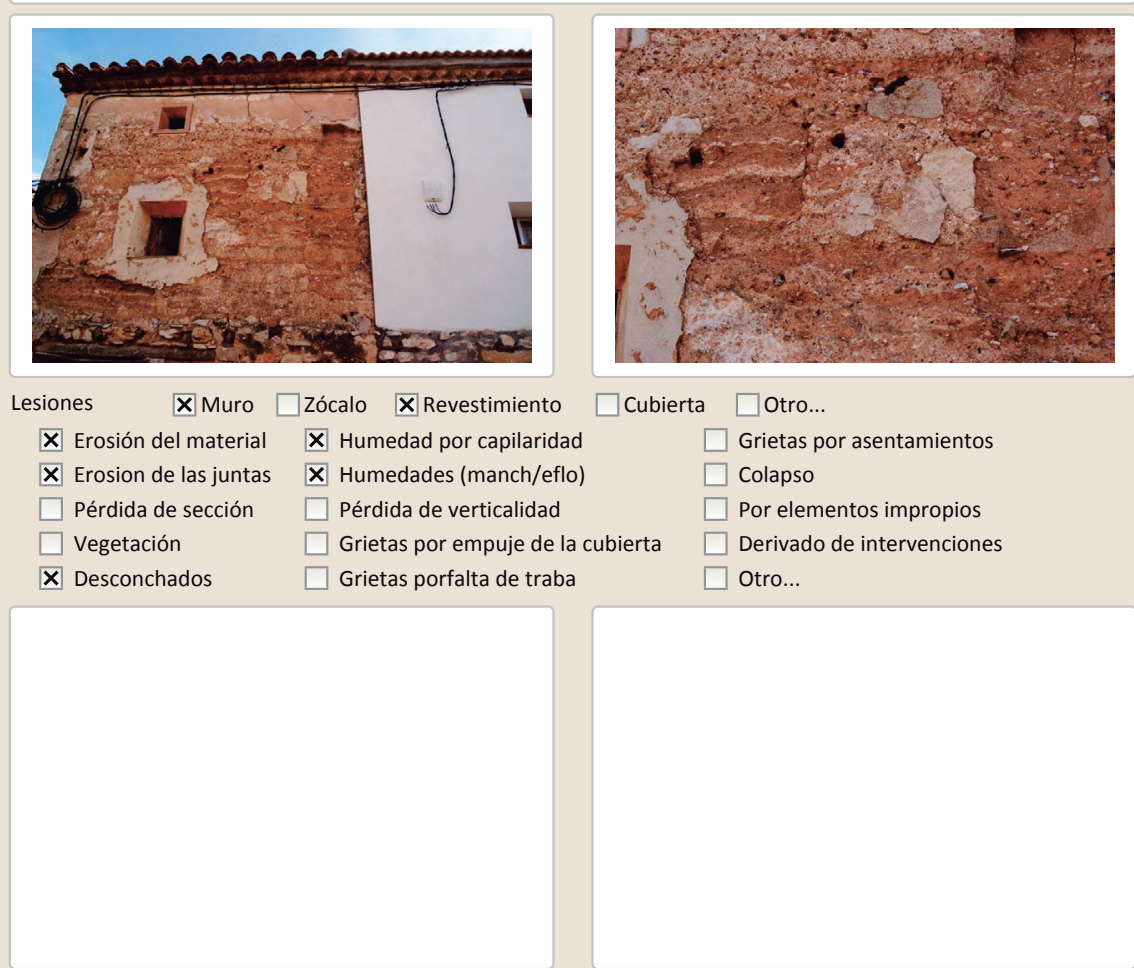

Colapso

$\square$ Por elementos impropios

$\square$ Derivado de intervenciones

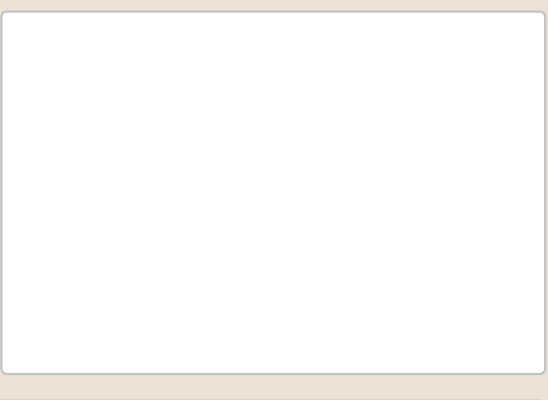




\section{La restauración y rehabilitación de la arquitectura tradicional de tierra.} El caso de Aragón.

3. DATOS DE LA INTERVENCIÓN

Intervención de:

$\square$ Mantenim

Reflexión previa Intervención planificada

Observaciones Se observa perfectamente lo elementos intervenidos gracias a que el edificio anexo es similar.

\subsection{MUROS \\ Tipo de intervención}

\section{No visible}

$\square$ Actualización $\square$ Reintegración $\square$ Demolición $\square$ Otro...

$\square$ Consolidación $\square$ Reconstrucción $\square$ sustitución

Tipo de material

Descripción

\subsection{ZÓCALO}

Tipo de intervención

Tipo de material

Descripción

3.3. REVESTIMIENTOS

Tipo de intervención

Tipo de material

Descripción

3.4. VANOS

Tipo de intervención

Tipo de material

Descripción

3.5. CUBIERTA

Tipo de intervención

Tipo de material

Descripción

3.6. OTRAS

Nuevo revestimiento de cemento pintado de blanco en la fachada principal y solo mortero en la lateral

Intervenido

$\square$ Actualización $\square$ Reintegración $\square$ Demolición $\square$ Otro...

$\square$ Consolidación $\square$ Reconstrucción $\quad \boldsymbol{x}$ Sustitución

No tradicional Tipo de técnica Diferente a la existente

Sustitución de carpinterías. Baldosas en el alfeizar

\section{Intervenido}

$\square$ Actualización $\quad \square$ Reintegración $\quad \square$ Demolición $\quad \square$ Otro...

$\square$ Consolidación $\square$ Reconstrucción $\quad$ Sustitución

No tradicional Tipo de técnica Diferente a la existente

Nueva cubierta realizada con una losa de hormigón y tejas curvas prefabricadas y machihembradas para su colocación.
La restauración y rehabilitación de la arquitectura tradicional de tierra.

El caso de Aragón.

3.7. REHABILITACIÓN ENERGÉTICA $\square$ Fachada $\quad$ V Vanos $\square$ Forjados $\quad$ C Cubierta

Observaciones

FOTOGRAFÍAS DE LA INTERVENCIÓN
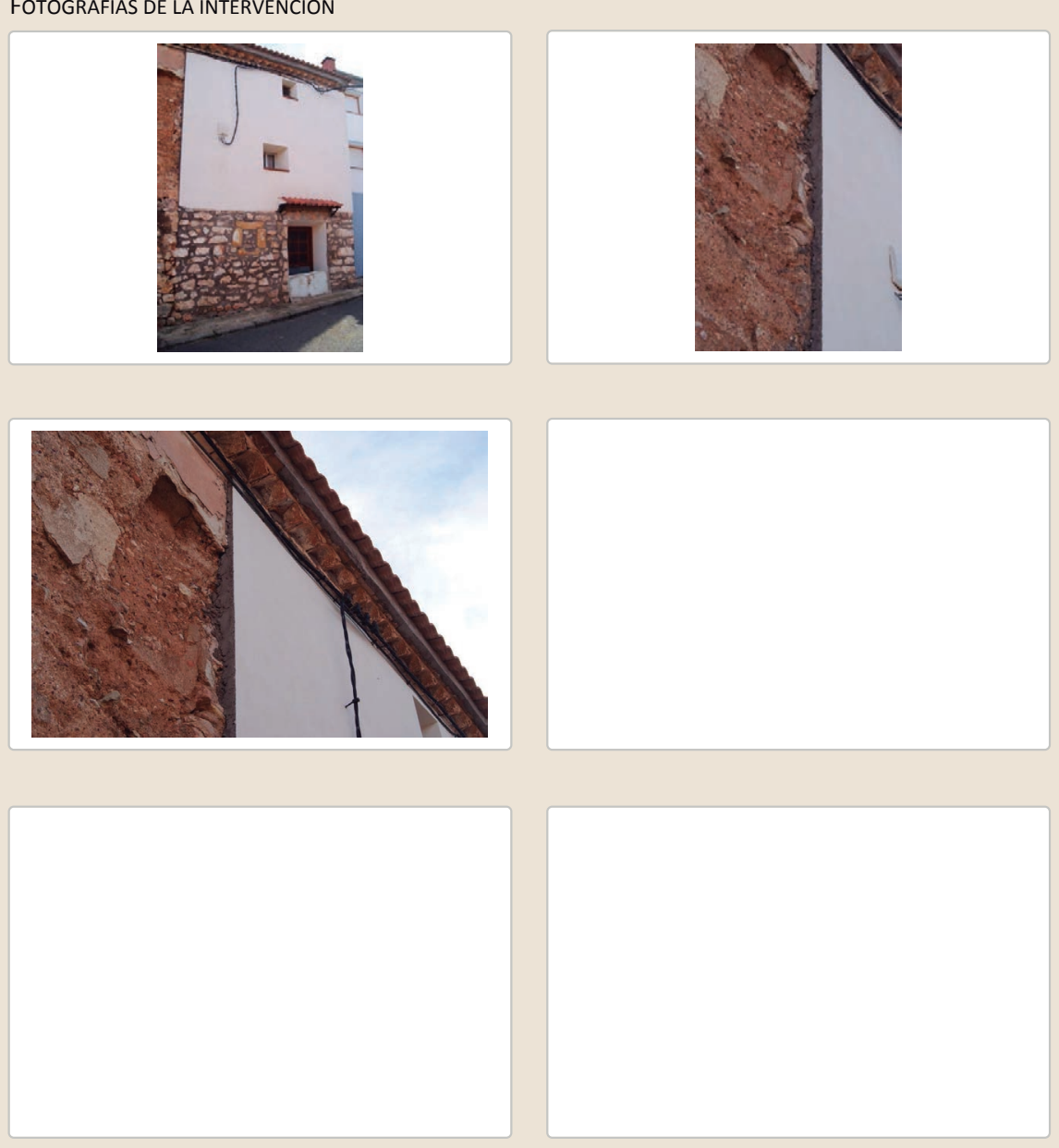


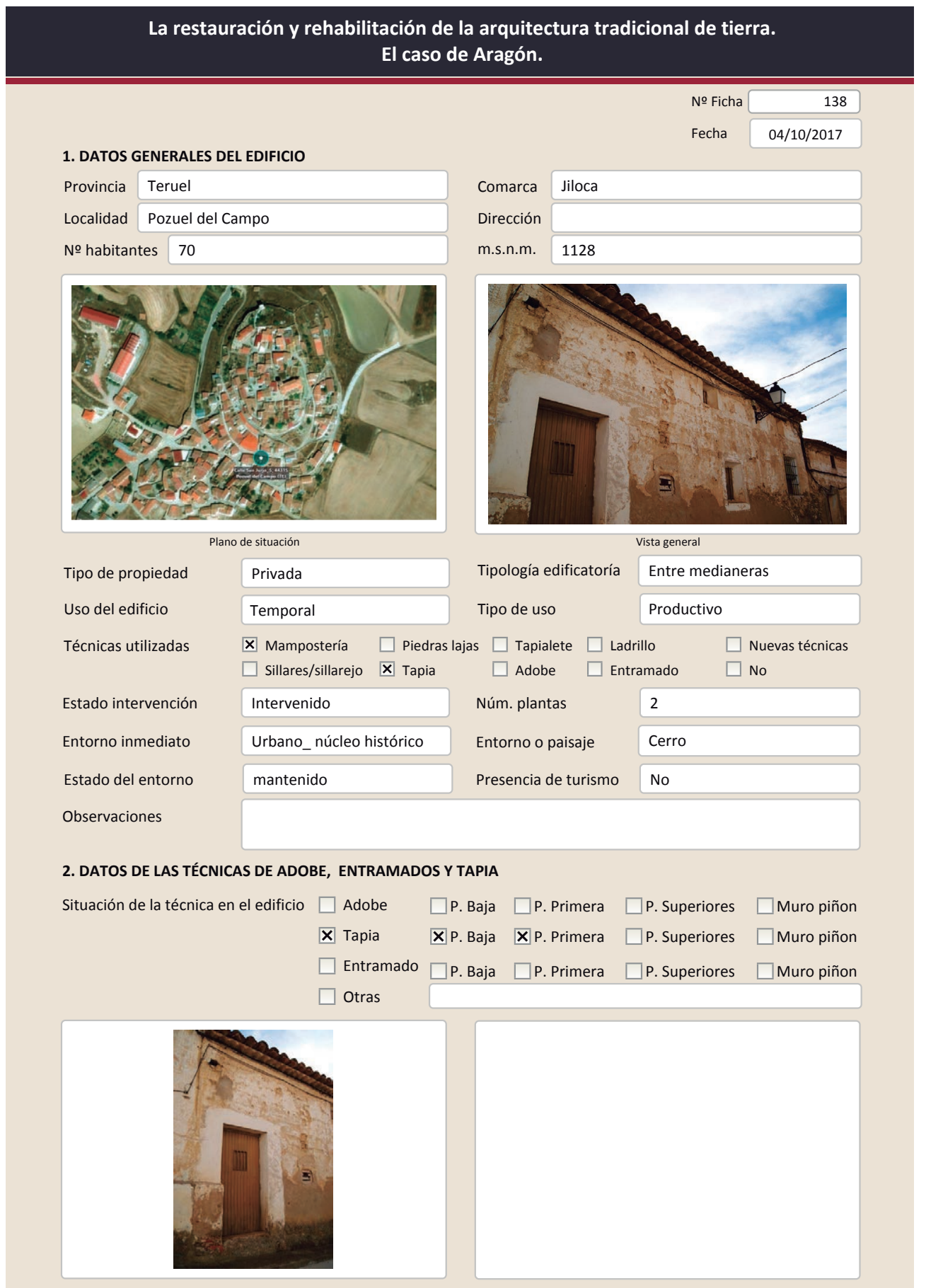

2.2. TAPIA

Ancho del muro

Dimensión tapiales

Tipo de aguja

№ agujas/cajón

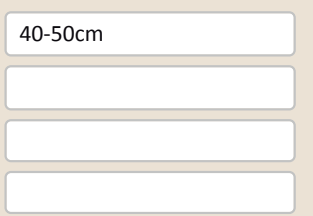

Color de la tapia

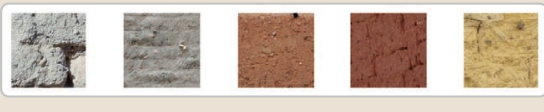

$\square$ Blanquecino $\square$ Marrón $\square$ Amarillento

$\square$ Blanquecino $\square$ Marrón $\square$ Amarill
$\square$ Grisaceo

Variante constructiva

$\square$ Simple / homogénea

X Suplemento superficial

$\square$ suplemento en juntas

$\square$ Mixta

$\square$ Elementos de protección
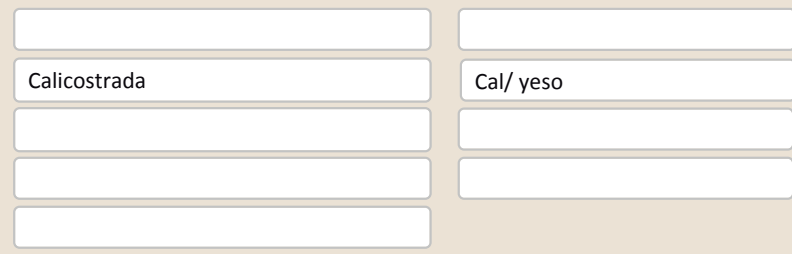

(1)

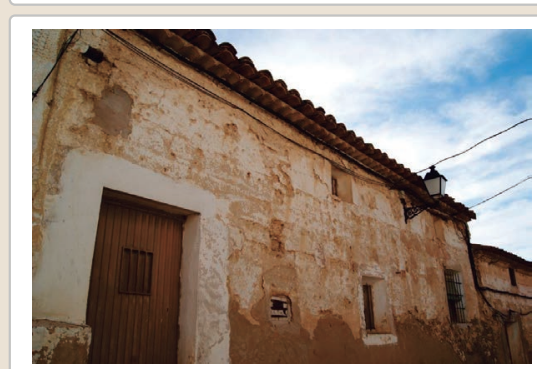

Lesiones \Muro $\square$ Zócalo $\square$ Revestimiento $\square$ Cubierta $\square$ otro...

X Erosión del material $\quad \square$ Humedad por capilaridad $\quad \square$ Grietas por asentamiento $\square$ Erosion de las juntas $\square$ Humedades (manch/eflo)

$\square$ Pérdida de sección $\square$ Pérdida de verticalidad

$\square$ Vegetación

$\square$ Por elementos impropios

X Desconchados

$\square$ Grietas porfalta de traba
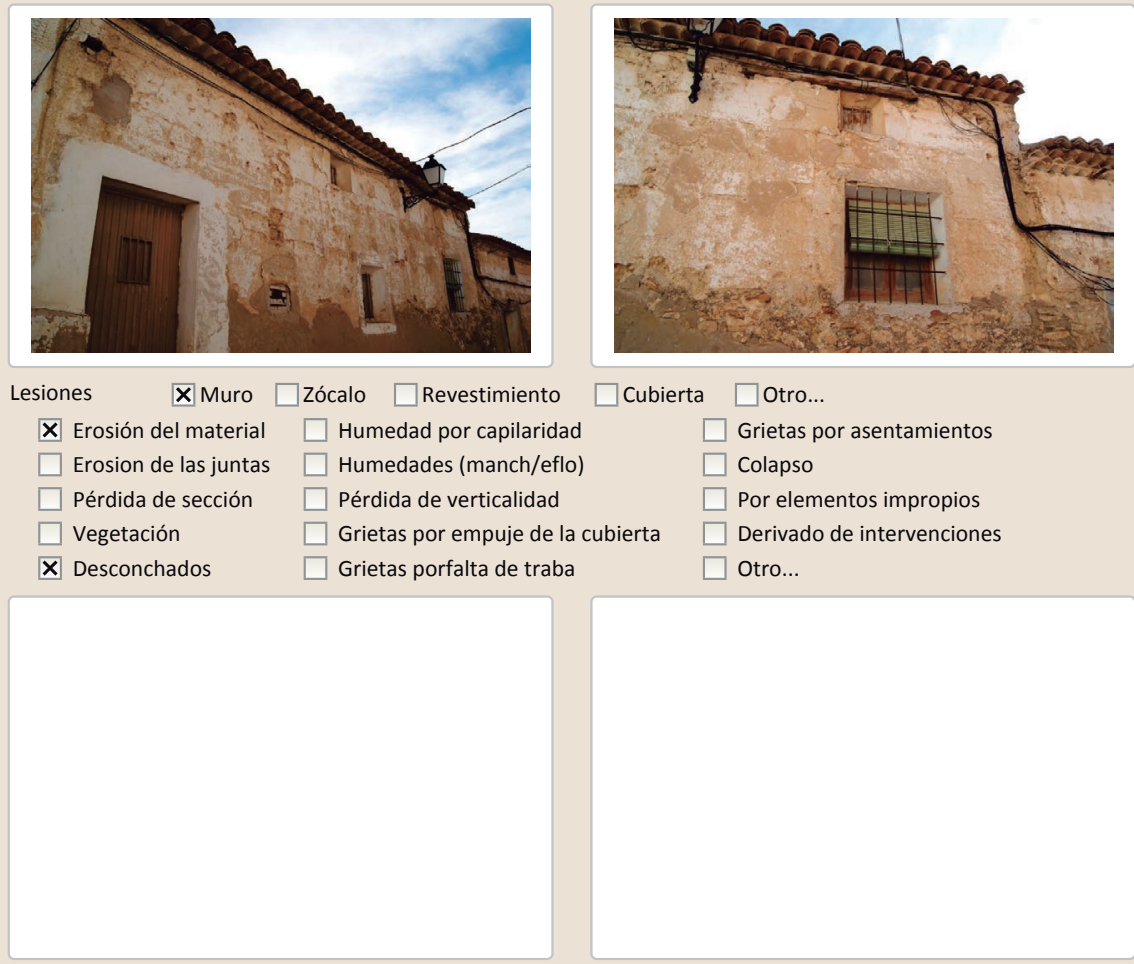

Observaciones

En la zona superior, bajo cubierta, se aprecia que el durmiente de madera sobresale de fachada y lo han atado con una cuerda a modo de tirante 
La restauración y rehabilitación de la arquitectura tradicional de tierra.

El caso de Aragón.

3. DATOS DE LA INTERVENCIÓN

\begin{tabular}{|c|c|c|c|c|}
\hline Intervención de: & $\begin{array}{l}\square \text { Mantenimiento } \\
\mathbf{X} \text { Reparación }\end{array}$ & $\begin{array}{l}\square \text { Rehabilitación parcial } \\
\square \text { Rehabilitación integral }\end{array}$ & $\begin{array}{l}\square \text { Restauración } \\
\square \text { Ampliación }\end{array}$ & $\begin{array}{l}\square \text { Demolición } \\
\square \text { Otro... }\end{array}$ \\
\hline Reflexión previa & \multicolumn{4}{|c|}{ Intervención espontanea } \\
\hline Observacione & & & & \\
\hline
\end{tabular}

\subsection{MUROS}

Tipo de intervención

Intervenido

Tipo de material

$\square$ Actualización $\quad \mathbf{X}$ Reintegración $\quad \square$ Demolición $\square$ Otro...

$\square$ Consolidación $\square$ Reconstrucción $\square$ Sustitución

Descripción

\begin{tabular}{l|l|l|l|l} 
No tradicional & Tipo de técnica Diferente a la existente
\end{tabular}

3.2. ZÓCALO

relleno de oquedades con cemento

Tipo de intervención

Intervenido

Actualización $\square$ Reintegración $\square$ Demolición $\square$ Otro..

$\square$ Consolidación $\quad$ X Reconstrucción $\quad \square$ Sustitución

Tipo de material

No tradicional

Descripción

Tipo de técnica Diferente a la existente

3.3. REVESTIMIENTOS

\section{No intervenido}

Tipo de intervención

$\square$ Actualización $\square$ Reintegración $\square$ Demolición $\square$ Otro...

Tipo de material

Descripción

$\square$ Consolidación $\square$ Reconstrucción $\square$ Sustitución

Tipo de técnica

3.4. VANOS

No intervenido

Tipo de intervención

$\square$ Actualización $\square$ Reintegración $\square$ Demolición $\square$ Otro...

Tipo de material

Descripción

$\square$ Consolidación $\square$ Reconstrucción $\square$ Sustitución

3.5. CUBIERTA

Tipo de intervención

No visible

Tipo de material

$\square$ Actualización

Tipo de técnica

Descripción

$\square$ Consolidación $\quad \square$ Reconstrucción $\quad \square$ Demolición
$\square$ Sustitución

Tipo de técnica

3.6. OTRAS 


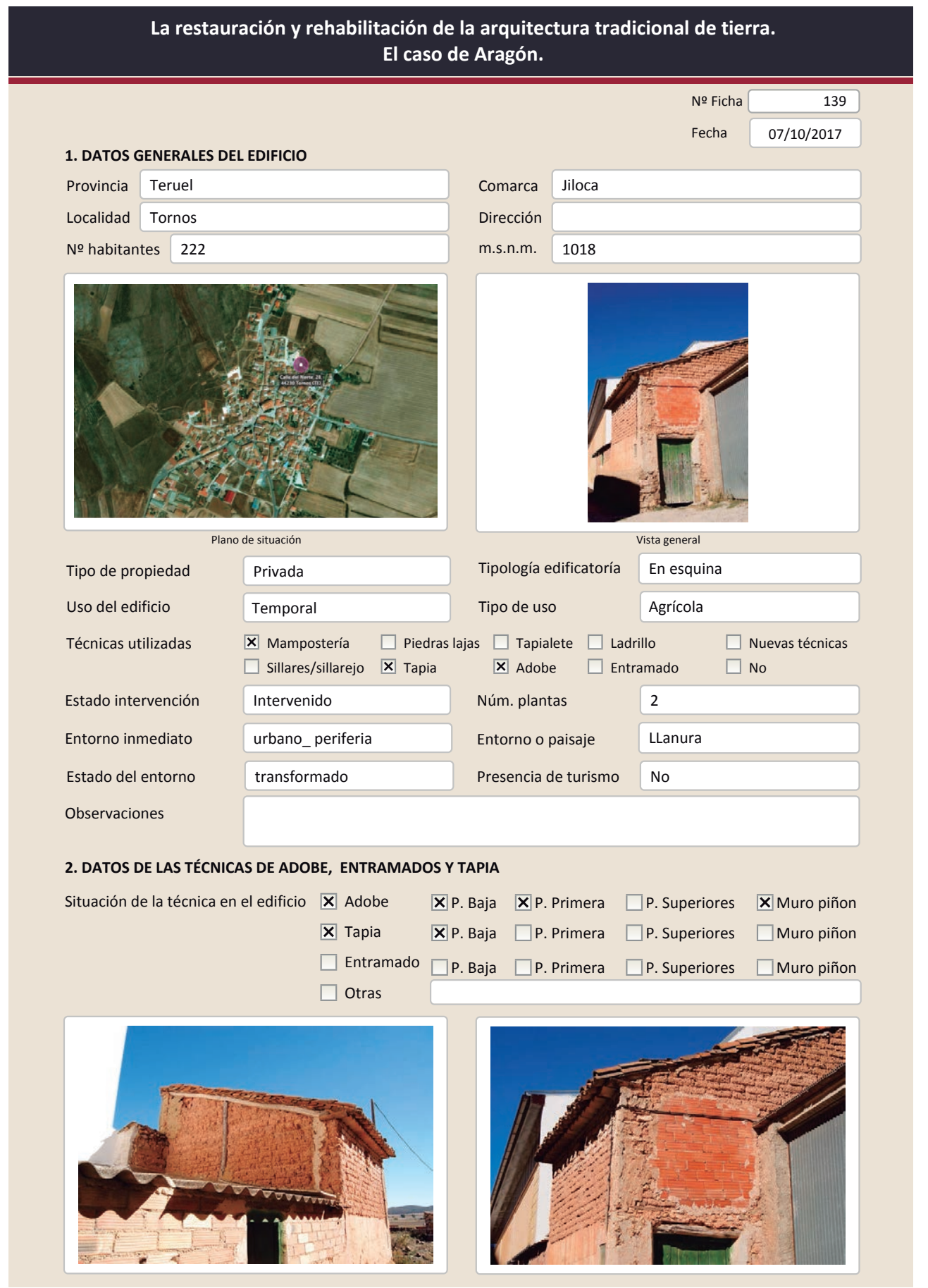

2.1. ADOBE

Dimensión de las piezas

Dimensión del muro

Aparejo del muro

Función estructural

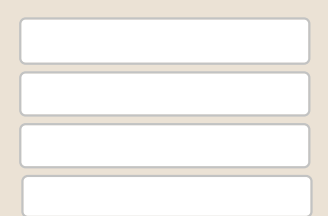

Color de las piezas

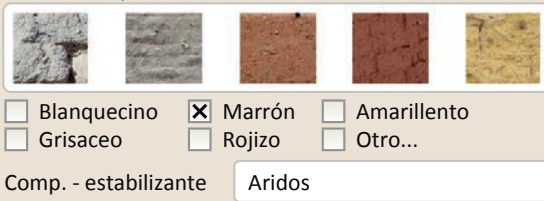

Variante constructiva/ tipo de fábrica

X Simple

$\square$ Suplementada en juntas

区 Mixta

\section{Machones}

Madera

$\square$ Como suplemento

$\square$ Elementos de protección

Dos tipos de muro diferentes. Fachada: muro estructural a tizón. Muro piñón: muro de cerramiento mixto, suplementado con madera para darle mayor rigidez y con las piezas a soga.

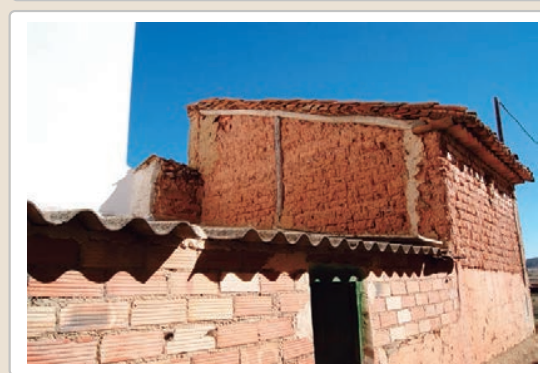

Lesiones $\quad \mathbf{X}$ Muro $\square$ Zócalo $\mathbf{X}$ Revestimiento

$\mathbf{X}$ Erosión del material $\square$ Humedad por capilaridad $\square$ Erosion de las juntas $\square$ Humedades (manch/eflo)

X Pérdida de sección $\square$ Pérdida de verticalidad

$\square$ Vegetación

$\square$ Grietas por empuje de la $\square$ Grietas porfalta de traba

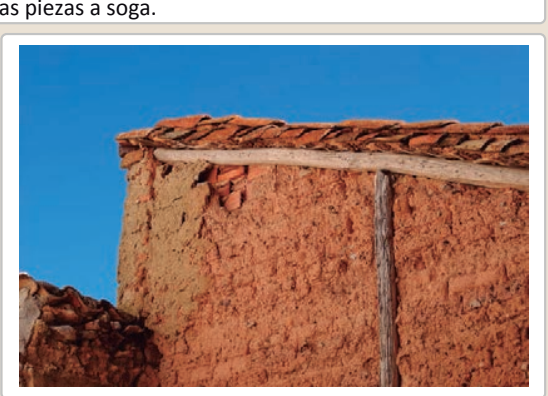

$\square$ Cubierta $\square$ otro...

$\square$ Grietas por asentamiento

$\square$ Desconchados

$\square$ Por elementos impropios

$\square$ Derivado de intervenciones $\square$ Otro...

Observacione 


\section{La restauración y rehabilitación de la arquitectura tradicional de tierra.}

\section{El caso de Aragón.}

\subsection{TAPIA}

Ancho del muro

\section{0-50cm}

Dimensión tapiales

Tipo de aguja

№ agujas/cajón

Variante constructiva

$\square$ Simple / homogénea

X Suplemento superficial

$\square$ suplemento en juntas

X Mixta

$\square$ Elementos de protección

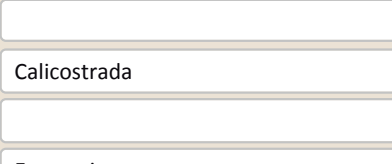

En esquinas

\section{Color de la tapia}

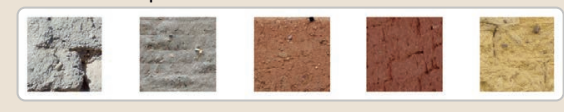

$\square$ Blanquecino $\quad \mathbf{X}$ Marrón $\square$ Amarillento

$\begin{array}{ll}\square \text { Blanquecino } & \mathbf{X} \text { Marrón } \square \text { Amarillento } \\ \square \text { Grisaceo } & \square \text { Rojizo } \quad \square \text { Otro... }\end{array}$

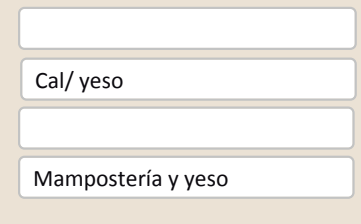

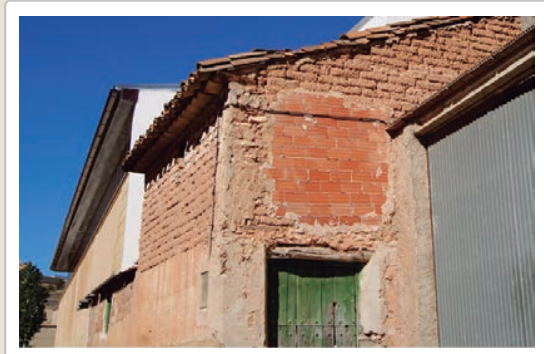

Lesiones

XMuro $\square$ Zócalo $\square$ Revestimiento $\square$ Cubierta $\square$ Otro...

X Erosión del material $\square$ Humedad por capilaridad $\quad \square$ Grietas por asentamientos

$\square$ Colapso

$\square$ Erosion de las juntas $\square$ Humedades (manch/eflo)

$\square$ Pérdida de verticalidad $\quad \square$ Por elementos impropios

$\square$ Vegetación

$\square$ Desconchados

$\square$ Grietas porfalta de traba

$\square$ Otro...
La restauración y rehabilitación de la arquitectura tradicional de tierra.

El caso de Aragón.
3. DATOS DE LA INTERVENCIÓN

Intervención de:

Reflexión previa

Observaciones

3.1. MUROS

Tipo de intervención

Tipo de material

Descripción

3.2. ZÓCALO

Tipo de intervención

Tipo de material

Descripción

3.3. REVESTIMIENTOS

Tipo de intervención

Tipo de material

Descripción

3.4. VANOS

Tipo de intervención

Tipo de material

Descripción

3.5. CUBIERTA

Tipo de intervención

Tipo de material

Descripción

3.6. OTRAS $\square$ Mantenimiento $\square$ Rehabilitación parcial $\square$ Restauración $\square$ Demolición X Reparación $\square$ Rehabilitación integral $\square$ Ampliación $\square$ Otro...

Intervención espontanea

\section{Intervenido}

$\square$ Actualización $\quad \square$ Reintegración $\quad \square$ Demolición $\quad \square$ Otro.

$\square$ Consolidación $\mathbf{X}$ Reconstrucción $\mathbf{X}$ sustitución

No tradicional Tipo de técnica Diferente a la existente

Existen áreas en las que se ha sustituido por completo el muro de adobe y otras en las que este se ha doblado para asegurar su estabilidad.

Intervenido

$\square$ Actualización $\square$ Reintegración $\square$ Demolición $\square$ Otro.

$\square$ Consolidación $\quad \mathbf{X}$ Reconstrucción $\square$ Sustitución

No tradicional Tipo de técnica Diferente a la existente

Revestimiento grueso de cento

\section{No aplica}

$\square$ Actualización $\square$ Reintegración $\square$ Demolición $\square$ Otro...

$\square$ Consolidación $\square$ Reconstrucción $\square$ sustitución

Tipo de técnica

No intervenido

$\square$ Actualización $\square$ Reintegración $\square$ Demolición $\square$ Otro...

$\square$ Consolidación $\square$ Reconstrucción $\quad \square$ Sustitución

Tipo de técnica

No intervenido

$\square$ Actualización $\square$ Reintegración $\square$ Demolición $\square$ Otro

$\square$ Consolidación $\square$ Reconstrucción $\square$ Sustitución Tipo de técnica 


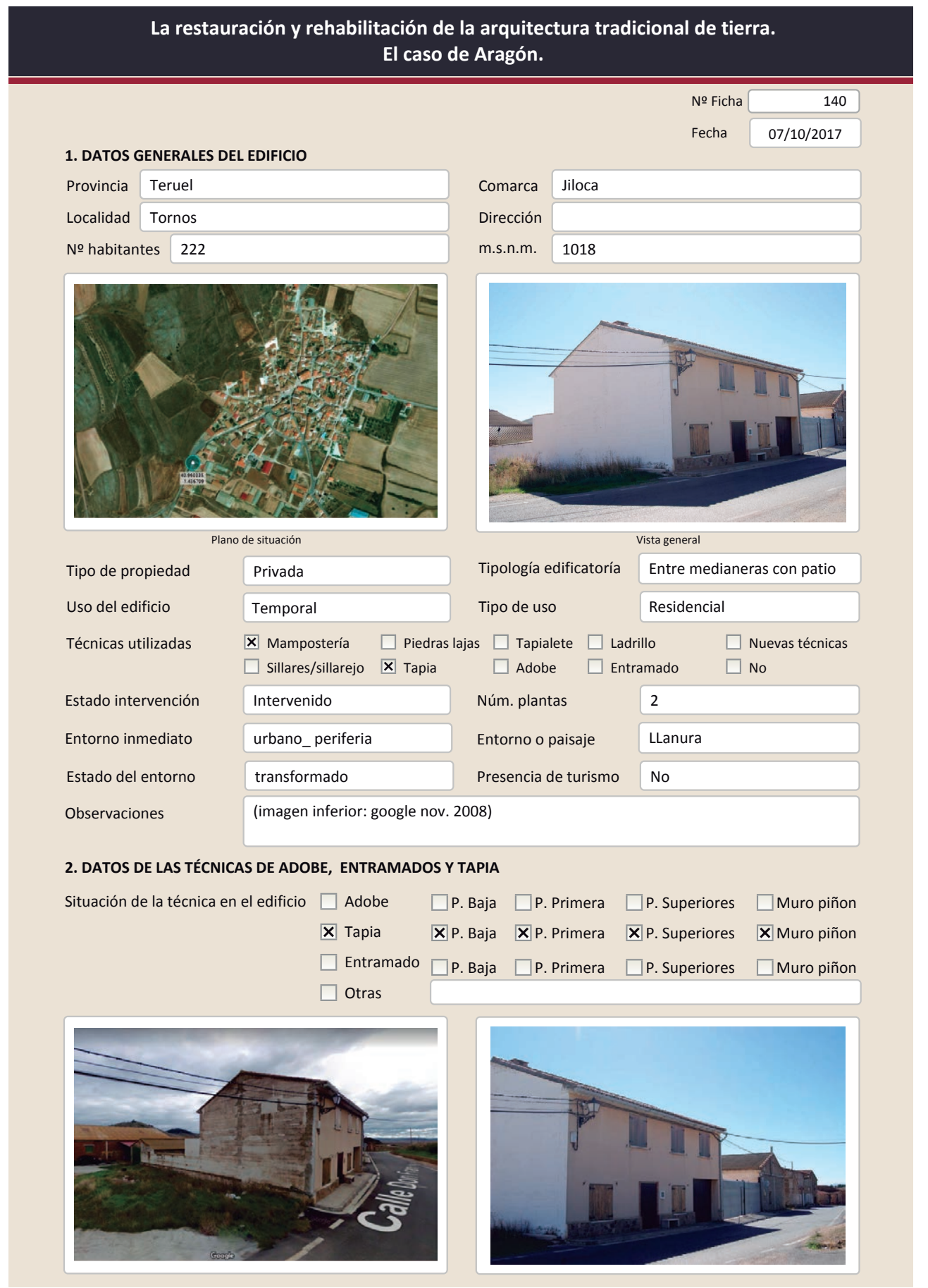

2.2. TAPIA

Ancho del muro

Dimensión tapiales

Tipo de aguja

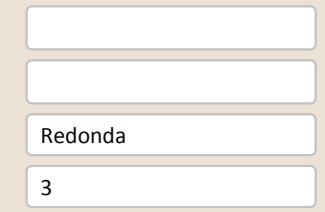

Color de la tapi

№ agujas/cajón

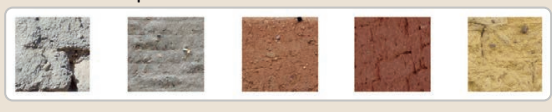

$\square$ Blanquecino $\square$ Marrón $\square$ Amarillento

$\square$ Blanquecino $\square$ Marrón $\square$ Amarill
$\square$ Grisaceo

Variante constructiva

$\square$ Simple / homogénea

X Suplemento superficial

$\square$ suplemento en juntas

X Mixta

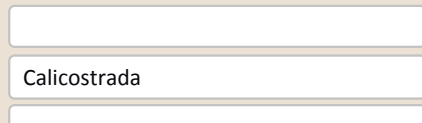

Machones

Cal/yeso

Elementos de protección

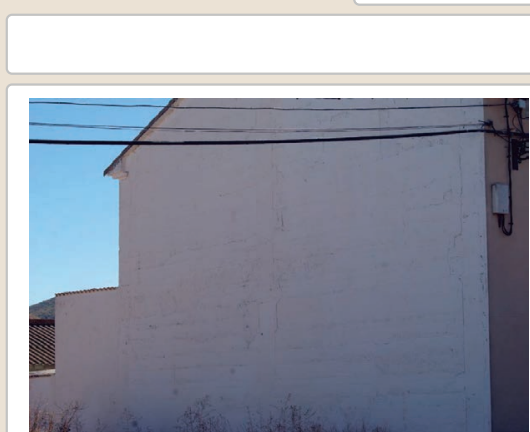

Lesiones $\square$ Muro $\square$ Zócalo $\square$ Revestimiento $\square$ Cubierta $\square$ otro...

$\square$ Erosión del material $\quad \square$ Humedad por capilaridad $\quad \square$ Grietas por asentamientos $\square$ Erosion de las juntas $\square$ Humedades (manch/eflo)

$\square$ Pérdida de sección $\square$ Pérdida de verticalidad

$\square$ Vegetación

$\square$ Desconchados

$\square$ Grietas porfalta de trab
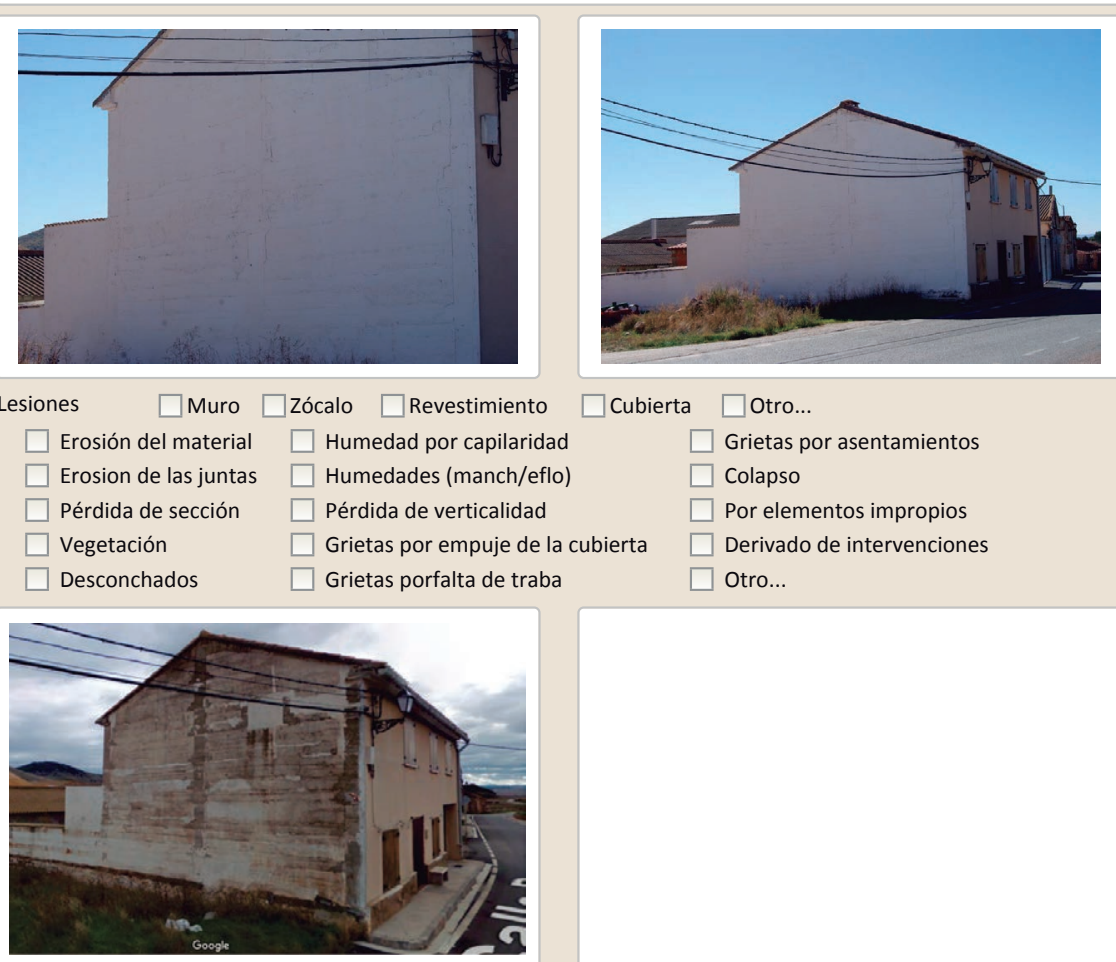

Observaciones 


\section{La restauración y rehabilitación de la arquitectura tradicional de tierra.}

\section{El caso de Aragón.}

3. DATOS DE LA INTERVENCIÓN

Intervencionde:

\section{NCIÓN}

$\square$ Mantenimiento $\square$ Rehabilitación parcial $\square$ Restauración $\square$ Demolición

Reflexión previa $\quad$ Intervención planificada

Observaciones El propietario explico ligeramente las intervenciones que habían realizado sobre los muros

3.1. MUROS
Tipo de intervención

Intervenido

Tipo de material

$\square$ Actualización $\quad$ Reintegración $\square$ Demolición $\square$ Otro...

$\square$ Consolidación $\square$ Reconstrucción $\square$ Sustitución

Descripción

Tipo de técnica Diferente a la existente

3.2. ZóCALO

Tipo de intervención

Renteción de oquedades con cal

Intervenido

X Actualización $\square$ Reintegración $\square$ Demolición $\square$ Otro...

$\square$ Consolidación $\quad \boldsymbol{X}$ Reconstrucción $\square$ Sustitución

Tipo de material

No tradicional

Tipo de técnica Diferente a la existente

Descripción

3.3. REVESTIMIENTOS

Tipo de intervención

\section{Intervenido}

$\square$ Actualización $\square$ Reintegración $\quad \square$ Demolición $\square$ Otro...

$\mathbf{X}$ Consolidación $\mathbf{X}$ Reconstrucción $\square$ Sustitución

Tipo de material

Descripción

No tradicional

Tipo de técnica Diferente a la existente

Dos intervenciones diferentes. Fachada principal: revestimiento con monocapa.

Fachada lateral: pintura o encalado

3.4. VANOS

Tipo de intervención

Intervenido

Tipo de material

$\square$ Actualización $\square$ Reintegración $\square$ Demolición $\square$ Otro...

$\square$ Consolidación $\square$ Reconstrucción $\quad \boldsymbol{X}$ Sustitución

Descripción

3.5. CUBIERTA

Tipo de intervención

No tradicional

Tipo de técnica Diferente a la existente

Se han modificado las dimensiones de los huecos, nuevas carpinterías y contraventanas de madera.

Intervenido

$\square$ Actualización $\square$ Reintegración $\square$ Demolición $\square$ Otro..

$\square$ Consolidación $\square$ Reconstrucción $\quad$ Sustitución

Tipo de material No tradicional Tipo de técnica Diferente a la existente

Descripción

Cubierta con base de ladrillo hueco o bardos y tejas curvas cogidas con cemento.
La restauración y rehabilitación de la arquitectura tradicional de tierra.

El caso de Aragón.

3.7. REHABILITACIÓN ENERGÉTICA $\square$ Fachada $\quad$ V Vanos $\square$ Forjados $\square$ Cubierta

Observaciones

FOTOGRAFíAS DE LA INTERVENCIÓN
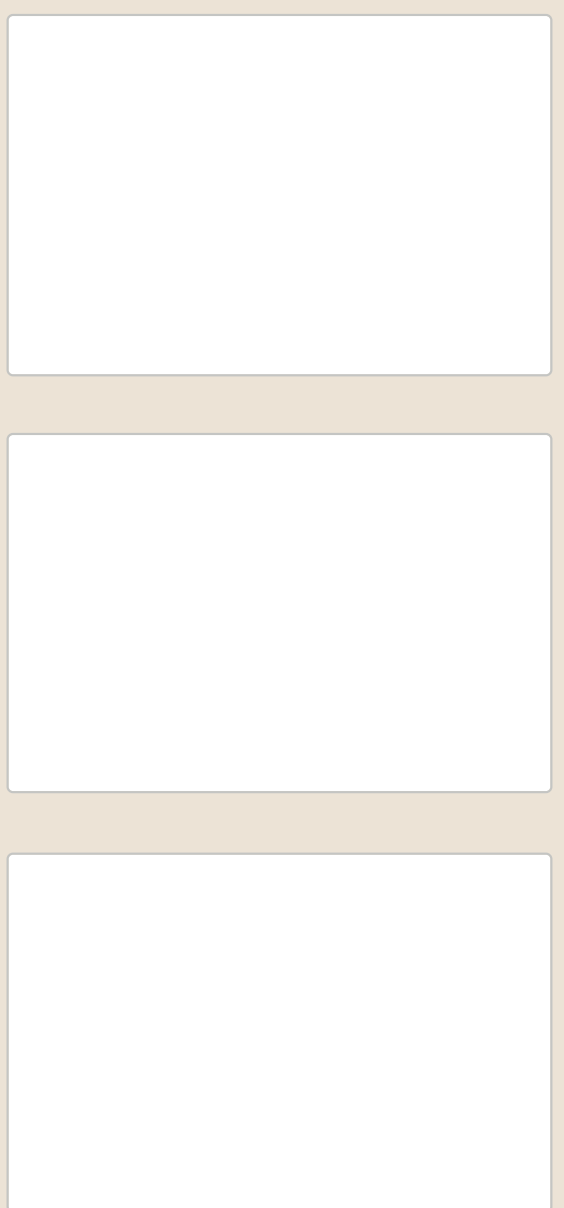
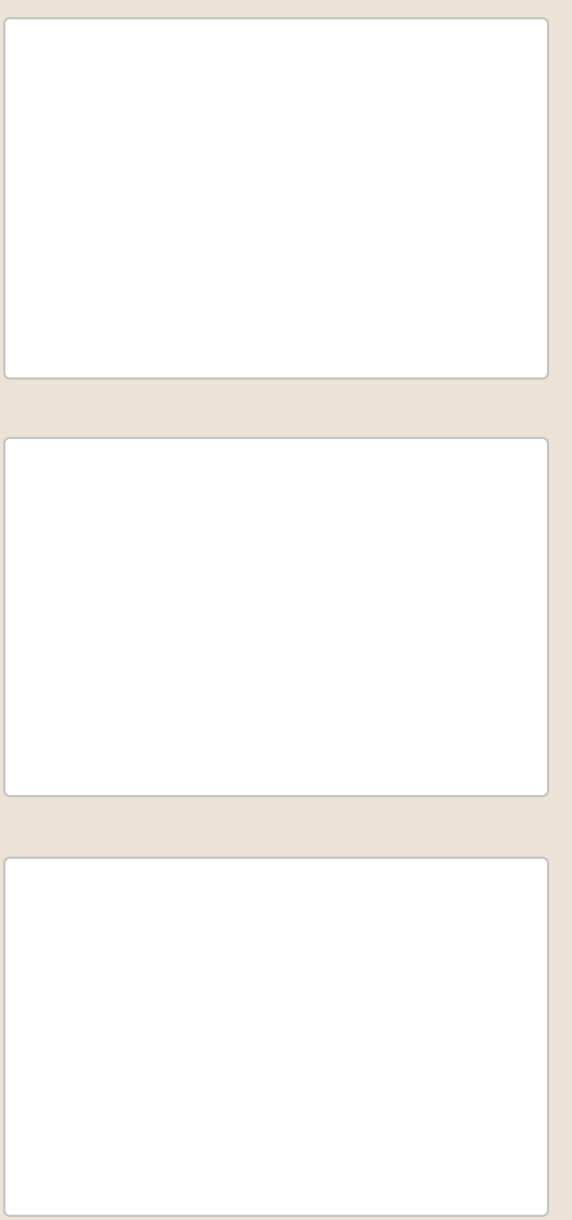

3.6. OTRAS 


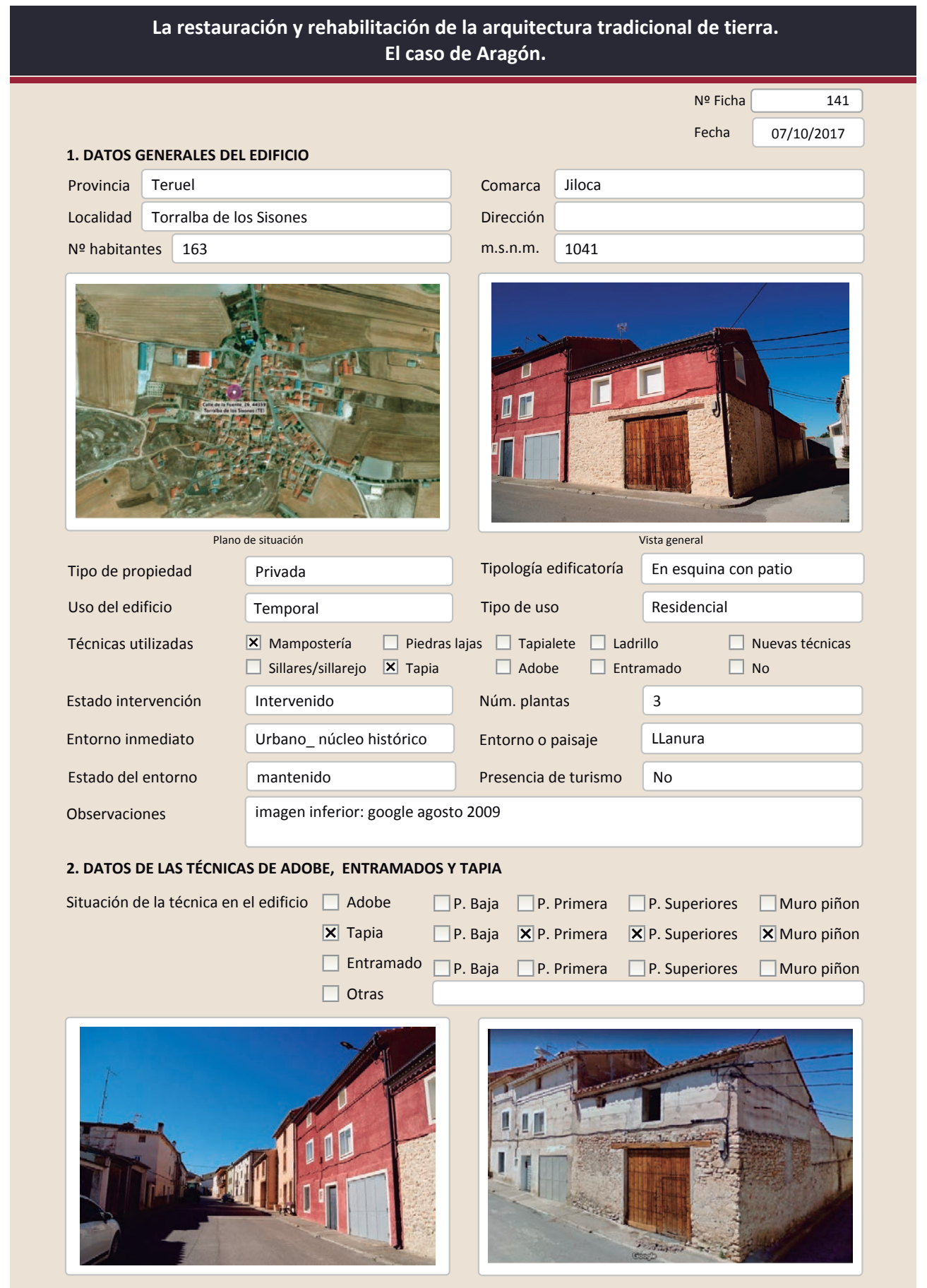

2.2. TAPIA

Ancho del muro

Dimensión tapiales

Tipo de aguja

\begin{tabular}{|l|}
\hline $40-50 \mathrm{~cm}$ \\
\hline \\
\hline Redonda \\
\hline 3 \\
\hline
\end{tabular}

Color de la tapia

№ agujas/cajón

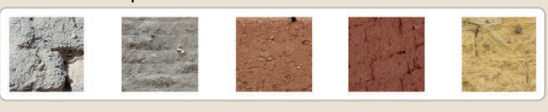

$\square$ Blanquecino $\quad \mathbf{X}$ Marrón $\square$ Amarillento

$\begin{array}{ll}\square \text { Blanquecino } & \mathbf{x} \text { Marrón } \\ \square \text { Grisaceo } & \square \text { Rojizo } \quad \square \text { Otro... }\end{array}$

Variante constructiva

$\square$ simple / homogénea

X Suplemento superficial

$\square$ suplemento en juntas

X Mixta

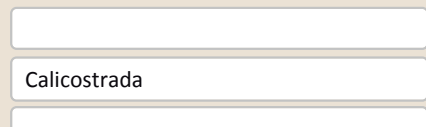

Machones

Cal/yeso

Elementos de protección

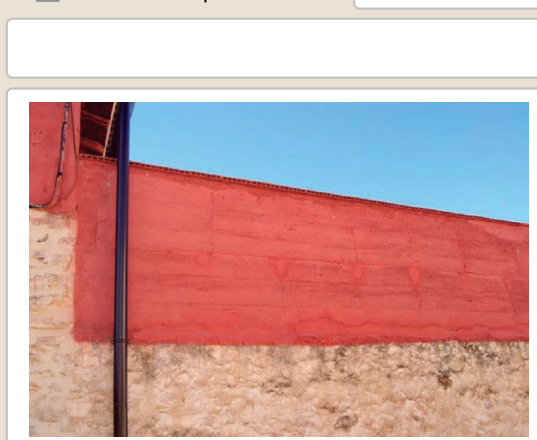

Lesiones $\square$ Muro $\square$ Zócalo $\square$ Revestimiento

$\square$ Erosión del material $\square$ Humedad por capilaridad $\square$ Erosion de las juntas $\square$ Humedades (manch/eflo)

$\square$ Pérdida de sección $\square$ Pérdida de verticalidad

$\square$ Vegetación

$\square$ Desconchados

$\square$ Grietas porfalta de traba

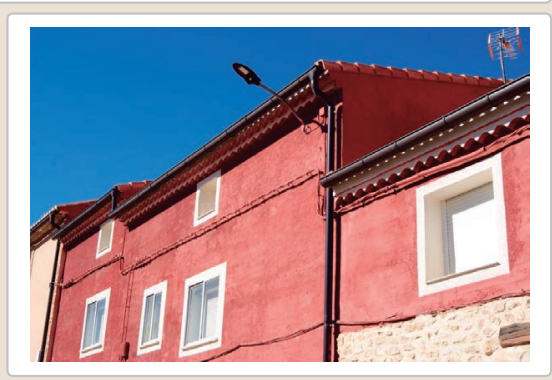

$\square$ Cubierta $\square$ otro..

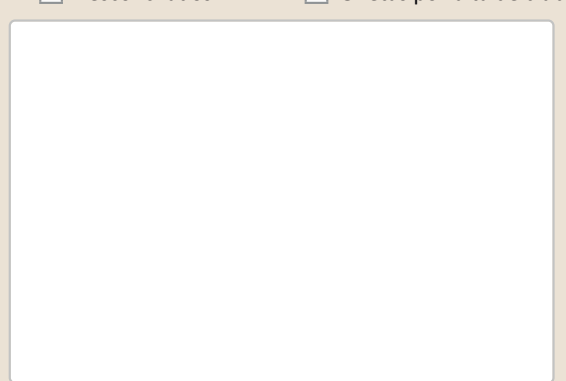

$\square$ Grietas por asentamientos $\square$ Colapso

$\square$ Por elementos impropios

$\square$ Derivado de intervenciones $\square$ Otro... 


\section{La restauración y rehabilitación de la arquitectura tradicional de tierra.}

\section{El caso de Aragón.}

3. DATOS DE LA INTERVENCIÓN

Intervención de:

Mantenimie

Reflexión previa

$\square$ Reparación

$\square$ Rehabilitación parcial

$\square$ Restauración $\square$ Demolición

Intervención planificada

Observaciones

(n)

3.1. MUROS
Tipo de intervención

Intervenido

Tipo de material

$\square$ Actualización $\quad \mathbf{X}$ Reintegración $\square$ Demolición $\square$ Otro...

$\square$ Consolidación $\quad \square$ Reconstrucción $\square$ Sustitución

Descripción

3.2. ZÓCALO

Tipo de intervención

Tipo de material

Descripción

3.3. REVESTIMIENTOS

Tipo de intervención

No tradicional

Tipo de técnica Diferente a la existente

Relleno
lisa

Intervenido

$\square$ Actualización $\quad \boldsymbol{X}$ Reintegración $\quad \square$ Demolición $\square$ Otro...

$\square$ Consolidación $\quad \square$ Reconstrucción $\square$ Sustitución

Tradicional diferente Tipo de técnica Similar a la existente

Rejuntado de la mampostería del zócalo (planta baja)

\section{Intervenido}

X Actualización $\square$ Reintegración $\quad \square$ Demolición $\square$ Otro...

$\square$ Consolidación $\quad \square$ Reconstrucción $\quad \square$ sustitución

Tipo de material

Descripción

3.4. VANOS

Tipo de intervención

No tradicional

Tipo de técnica Diferente a la existente

Nueva capa de pintura granate en toda la pare construida con tapia. Pintado con spray

Tipo de material No tradicional Tipo de técnica Diferente a la existente

Intervenido

$\square$ Actualización $\square$ Reintegración $\square$ Demolición $\square$ Otro...

$\square$ Consolidación $\mathbf{X}$ Reconstrucción $\mathbf{X}$ Sustitución

Descripción Se han realizado nuevas aperturas para ventanas en el edificio. También se han sustituido las carpinterías o se han colocado dobles ventanas.

3.5. CUBIERTA

Tipo de intervención

Intervenido

$\square$ Actualización $\square$ Reintegración $\square$ Demolición $\square$ Otro..

$\square$ Consolidación $\square$ Reconstrucción $\quad \boldsymbol{X}$ Sustitución

Tipo de material

No tradicional

Tipo de técnica Diferente a la existente

Descripción

Nueva cubierta, con nuevos materiales y piezas cerámicas. Comparando con la foto de 2009 se aprecia un mayor grosor del canto de la nueva cubierta.

3.6. OTRAS
La restauración y rehabilitación de la arquitectura tradicional de tierra.

El caso de Aragón.

3.7. REHABILITACIÓN ENERGÉTICA $\square$ Fachada $\quad \boldsymbol{X}$ Vanos $\square$ Forjados $\quad \mathbf{X}$ Cubierta

Observaciones

FOTOGRAFÍAS DE LA INTERVENCIÓN

FOTOGRAFIAS DE LA INTERVENCIÓN
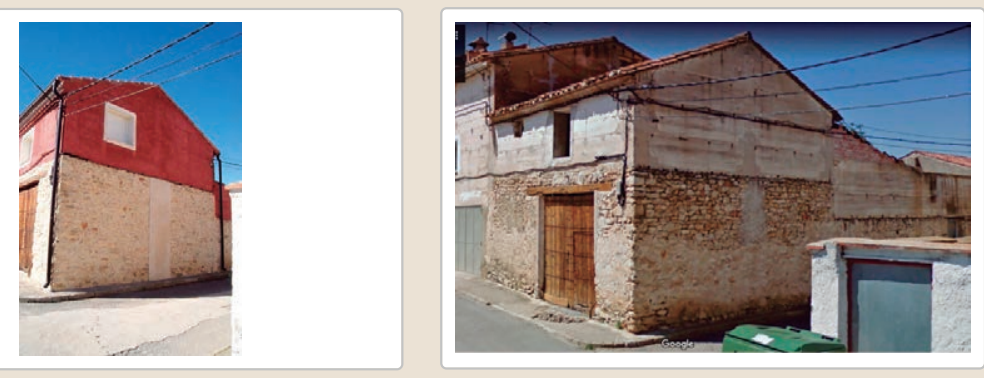

img. google agosto 2009
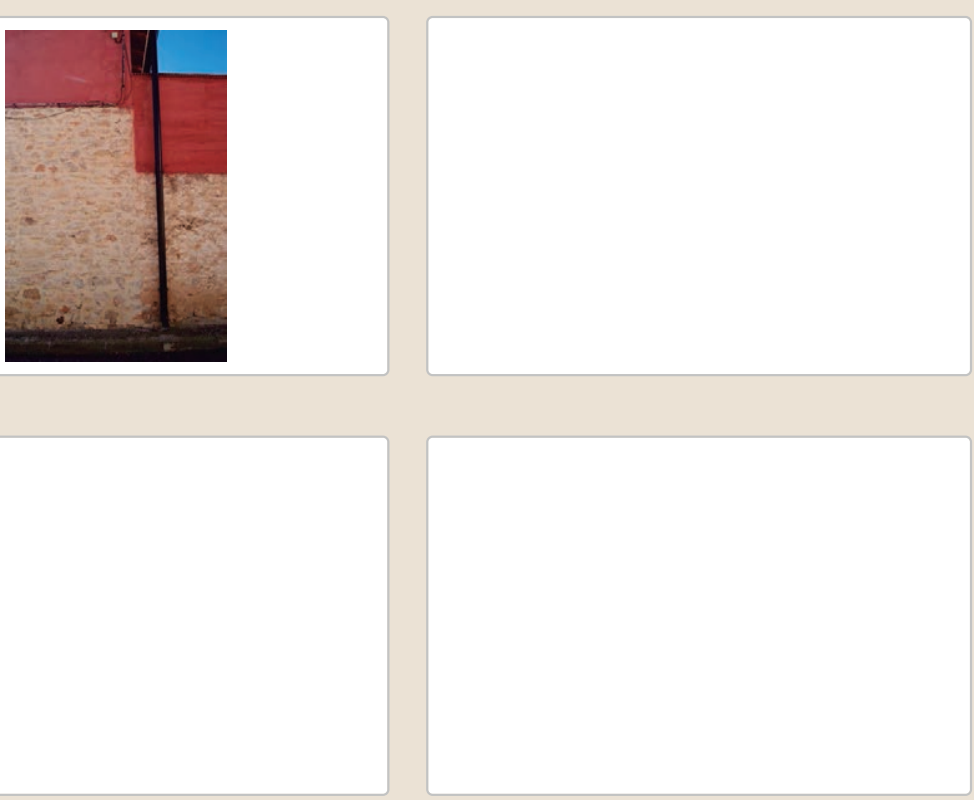


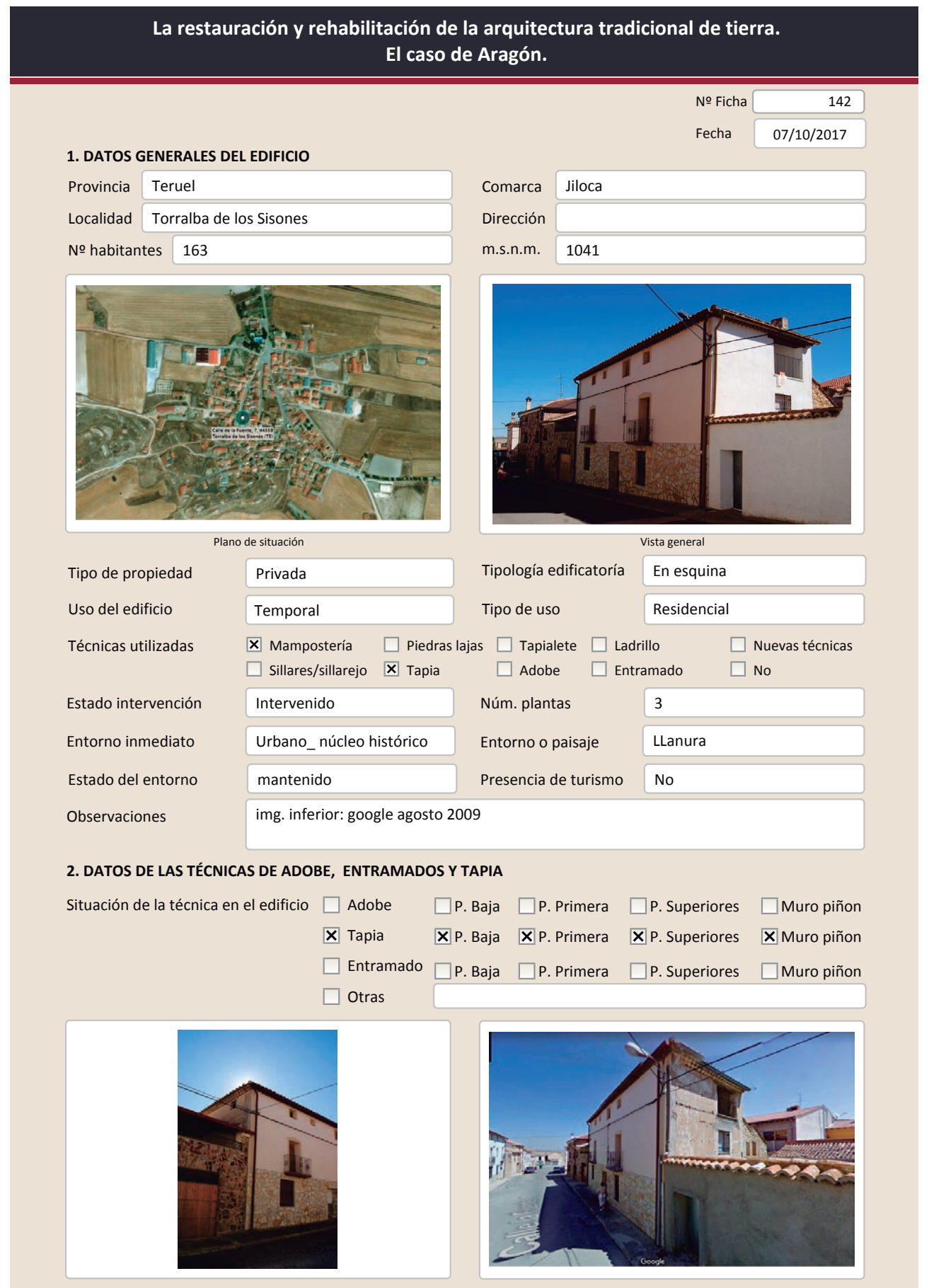

2.2. TAPIA

Ancho del muro

Dimensión tapiales

Tipo de aguja

\begin{tabular}{|l|}
\hline $50-60 \mathrm{~cm}$ \\
\hline \\
\hline Redonda \\
\hline 3 \\
\hline
\end{tabular}

Color de la tapia

№ agujas/cajón

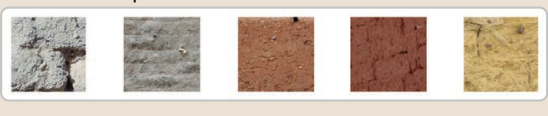

X Blanquecino $\square$ Marrón $\square$ Amarillento

$\mathbf{X}$ Blanquecino $\square$ Marrón $\square$ Amari..
$\square$ Grisaceo

Variante constructiva

$\square$ Simple / homogénea

\ Suplemento superficial

$\square$ suplemento en juntas

X Mixta

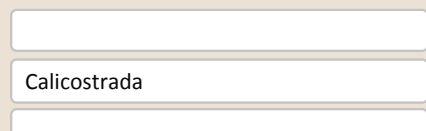

En esquinas

Cal/yeso

$\square$ Elementos de protección

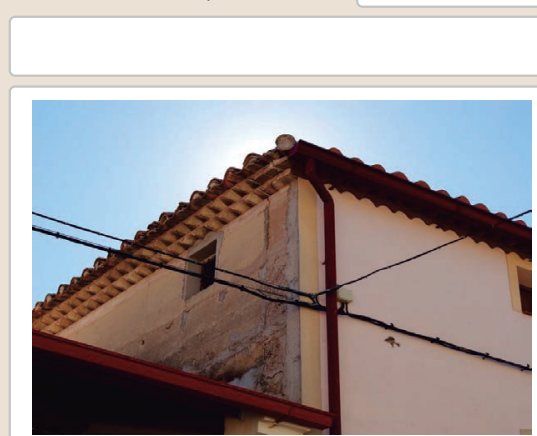

Lesiones $\square$ Muro $\square$ Zócalo $\square$ Revestimiento $\square$ Cubierta $\square$ otro...

$\square$ Erosión del material $\quad \square$ Humedad por capilaridad

$\square$ Erosion de las juntas $\square$ Humedades (manch/eflo)

$\square$ Pérdida de sección $\quad \square$ Pérdida de verticalidad

$\square$ Vegetación

$\square$ Desconchados

$\square$ Grietas por empuje de la $\square$ Grietas porfalta de traba

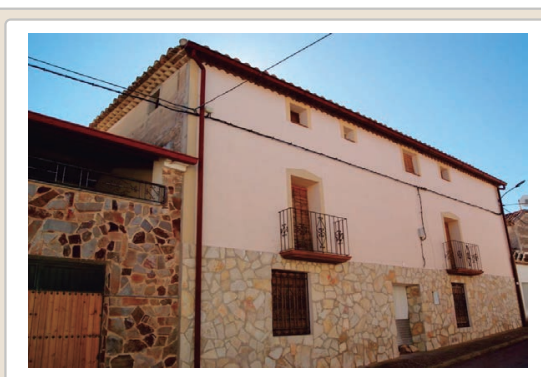

$\square$ Grietas por

Por elementos impropios

$\square$ Derivado de intervenciones $\square$ Otro... 
La restauración y rehabilitación de la arquitectura tradicional de tierra.

\section{El caso de Aragón.}

3. DATOS DE LA INTERVENCIÓN

\begin{tabular}{|c|c|c|c|c|}
\hline Intervención de: & $\begin{array}{l}\square \text { Mantenimiento } \\
\square \text { Reparación }\end{array}$ & $\begin{array}{l}\square \text { Rehabilitación parcial } \\
\boldsymbol{X} \text { Rehabilitación integral }\end{array}$ & $\begin{array}{l}\square \text { Restauración } \\
\square \text { Ampliación }\end{array}$ & $\begin{array}{l}\square \text { Demolición } \\
\square \text { Otro... }\end{array}$ \\
\hline Reflexión previa & \multicolumn{4}{|c|}{ Intervención planificada } \\
\hline Observaciones & & & & \\
\hline
\end{tabular}

\subsection{MUROS}

Tipo de intervención

Intervenido

Tipo de material

$\square$ Actualización $\quad$ Reintegración $\square$ Demolición $\square$ Otro...

$\square$ Consolidación $\square$ Reconstrucción $\square$ sustitución

Descripción

\begin{tabular}{|l|l|l|l} 
No tradicional Tipo de técnica Diferente a la existente &
\end{tabular}

3.2. ZóCALO

Tipo de intervención

Relleno de oquedades con cemento

Tipo de intervención

Intervenido

$\square$ Actualización $\quad \square$ Reintegración $\quad \square$ Demolición $\square$ Otro...

$\square$ Actualización
$\square$ Consolidación $\quad \boldsymbol{X}$ Reintegracionstrucción $\quad \square$ Sustitución

Descripción
No tradicional
Tipo de técnica Diferente a la existente

3.3. REVESTIMIENTOS

Zócalo de toda planta baja con lajas de piedra

Tipo de intervención

Intervenido

Tipo de material

$\square$ Reintegración $\square$ Demolición $\square$ Otro...

Tipo de materia

No tradicional

X Reconstrucción $\square$ Sustitución

Descripción

Diferente a la existente

3.4. VANOS

Intervenido

Tipo de intervención $\quad \square$ Actualización $\square$ Reintegración $\quad \square$ Demolición $\square$ Otro...

\begin{tabular}{l|l|l|l|l|l|l} 
Tipo de material & No tradicional de técnica & Diferente a la existente
\end{tabular}

Descripción

Sustitución de las carpinterías. Se han incorporado nuevas rejas.

3.5. CUBIERTA

Intervenido

Tipo de intervención

$\square$ Actualización $\quad$ Reintegración $\square$ Demolición $\square$ Otro.

Tipo de material

$\square$ Consolidación $\square$ Reconstrucción $\square$ Sustitución

Descripción

$\begin{array}{lll}\text { No tradicional Tipo de técnica Similar a la existente } & \end{array}$

Reintegración de las tejas antiguas cogidas con cemento

3.6. OTRAS 


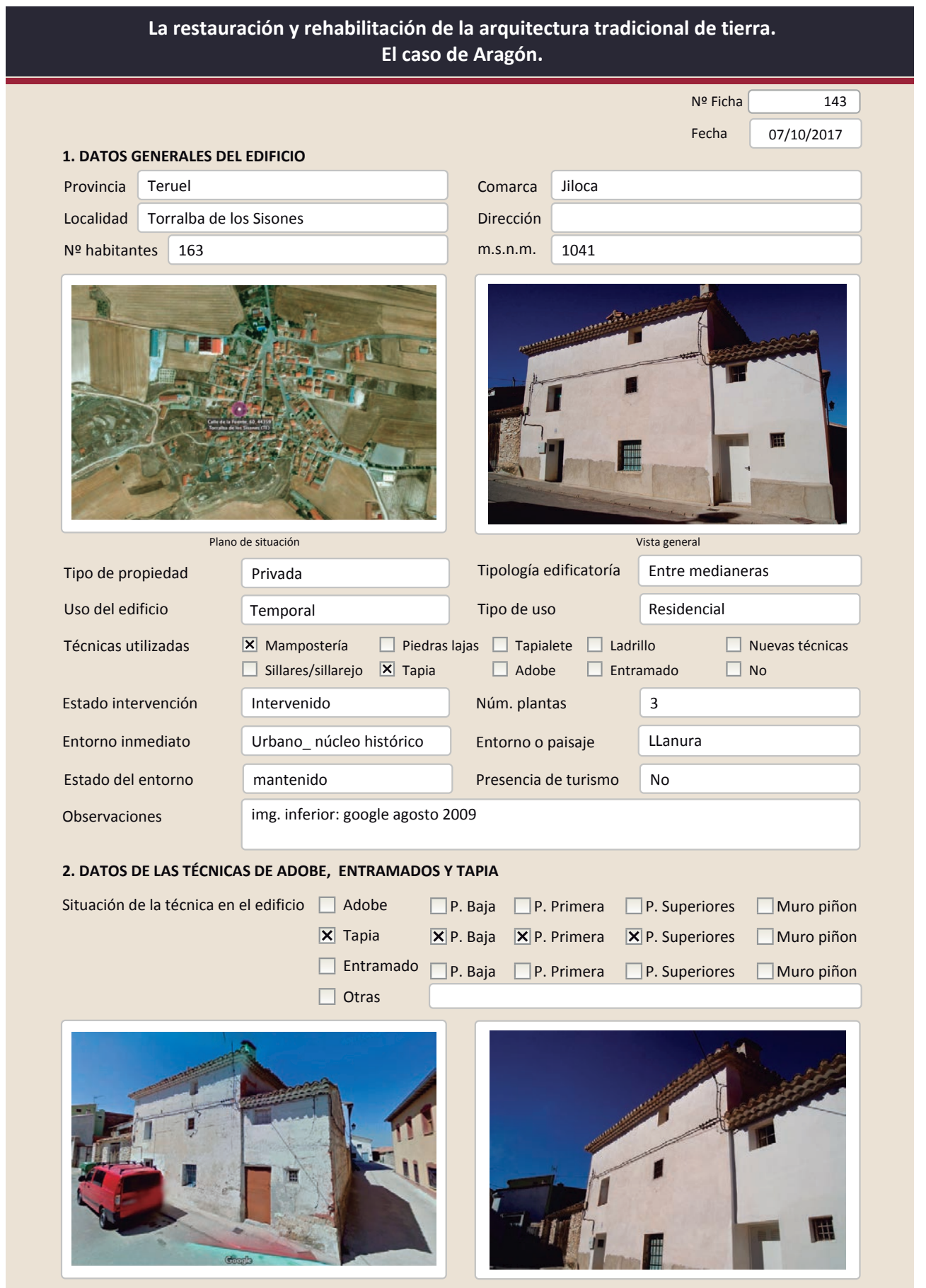

2.2. TAPIA

Ancho del muro

Dimensión tapiales

Tipo de aguja

\begin{tabular}{|l|}
\hline $40-50 \mathrm{~cm}$ \\
\hline \\
\hline Redonda \\
\hline 3 \\
\hline
\end{tabular}

Color de la tapia

№ agujas/cajón

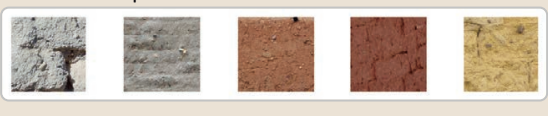

X Blanquecino $\square$ Marrón $\square$ Amarillento

$\mathbf{x}$ Blanquecino $\square$ Marrón $\square$ Amari..
$\square$ Grisaceo

Variante constructiva

$\square$ Simple / homogénea

X Suplemento superficial

$\square$ suplemento en juntas

X Mixta
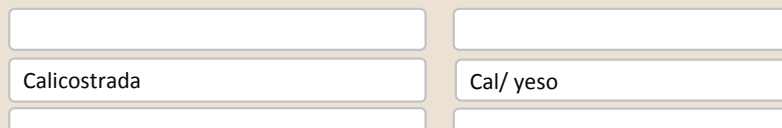

Machones

$\mathrm{Cal} /$ yeso

$\square$ Elementos de protección

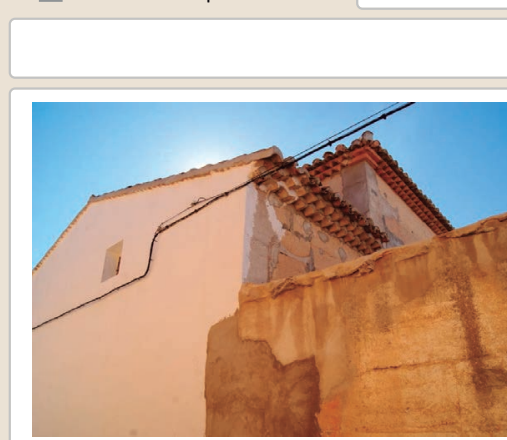

Lesiones $\quad$ XMuro $\square$ Zócalo $\square$ Revestimiento

X Muro $\square$ Zócalo $\square$ Revestimiento
material $\quad \square$ Humedad por capilaridad

$\mathbf{X}$ Erosión del material $\quad \square$ Humedad por capilaridad
$\square$ Erosion de las juntas $\quad \square$ Humedades (manch/eflo)

$\square$ Pérdida de sección $\square$ Pérdida de verticalidad

$\square$ Vegetación $\square$ Grietas por empuje de la cubieta

$\square$ Desconchados

$\square$ Grietas porfalta de traba

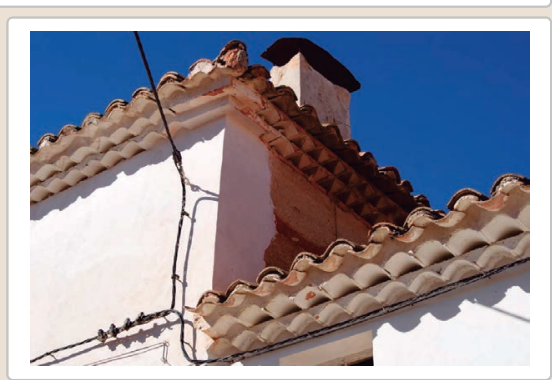

Cubierta $\square$ Otro..

$\square$ Grietas por asentamientos

$\square$ Colapso

$\square$ Por elementos impropios

$\square$ Derivado de intervenciones

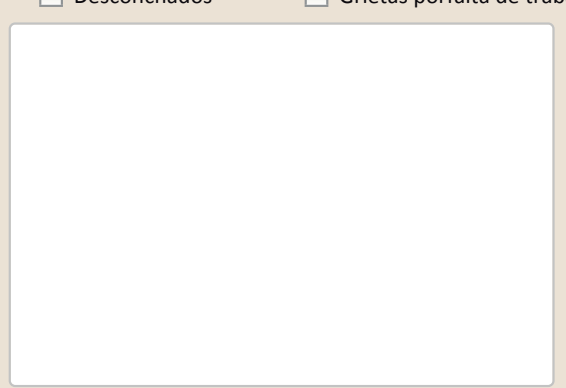

Observaciones 


\section{La restauración y rehabilitación de la arquitectura tradicional de tierra.}

\section{El caso de Aragón.}

3. DATOS DE LA INTERVENCIÓN

Intervención de:

$\square$ Mantenimiento $\quad$ Xehabilitación parcial

$\square$ Restauración $\square$ Demolición

Reflexión previa

$\square$ Reparación

$\square$ Rehabilitación integra

$\square$ Ampliación

$\square$ Otro...

Observaciones

Intervención planificada

3.1. MUROS
Tipo de intervención

Intervenido

$\square$ Actualización $\quad \boldsymbol{X}$ Reintegración $\quad \square$ Demolición $\square$ Otro...

$\square$ Consolidación $\quad \square$ Reconstrucción $\quad \square$ Sustitución

Tipo de material

Descripción

3.2. ZÓCALO

Tipo de intervención

Tipo de técnica Diferente a la existente

Reintegración de las zonas que presentaban oquedades con cemento.

Intervenido

Tipo de intervención

$\square$ Actualización

$\square$ Consolidación $\quad \mathbf{X}$ Reconstrucción $\square$ Sustitución

Tipo de material
Descripción

3.3. REVESTIMIENTOS

Tipo de intervención

$$
\text { Tipo de técnica Diferente a la existente }
$$

Capa de gran grosor de cemento

\section{Intervenido}

$\square$ Actualización $\square$ Reintegración $\square$ Demolición $\square$ Otro...

$\square$ Consolidación $\quad \mathbf{X}$ Reconstrucción $\square$ Sustitución

Tipo de material

Descripción

3.4. VANOS

Tipo de intervención

Tradicional diferente

Tipo de técnica Diferente a la existente

Nuevo revestimiento de yeso en toda la fachada principal y parte de la secundaría

Intervenido

Tipo de material

$\square$ Actualización $\square$ Reintegración $\square$ Demolición $\square$ Otro...

Descripción

Consolidación $\square$ Reconstrucción $\mathbf{X}$ Sustitución

3.5. CUBIERTA

No tradicional

Tipo de técnica Diferente a la existente

Sustitución de las dos puertas de acceso del edifico.

Tipo de intervención

Intervenido

$\square$ Actualización $\quad \mathbf{X}$ Reintegración $\square$ Demolición $\square$ Otro.

$\square$ Consolidación $\quad \square$ Reconstrucción $\square$ Sustitución

Tipo de material

No tradicional

Tipo de técnica Similar a la existente

Descripción

Reintegración de tejas en laterales y alero con cemento
La restauración y rehabilitación de la arquitectura tradicional de tierra.

El caso de Aragón.

3.7. REHABILITACIÓN ENERGÉTICA $\quad \square$ Fachada $\square$ Vanos $\square$ Forjados $\square$ Cubierta

Observaciones

FOTOGRAFÍAS DE LA INTERVENCIÓN

\section{FOTOGRAFIAS DELAINTERVENCON}
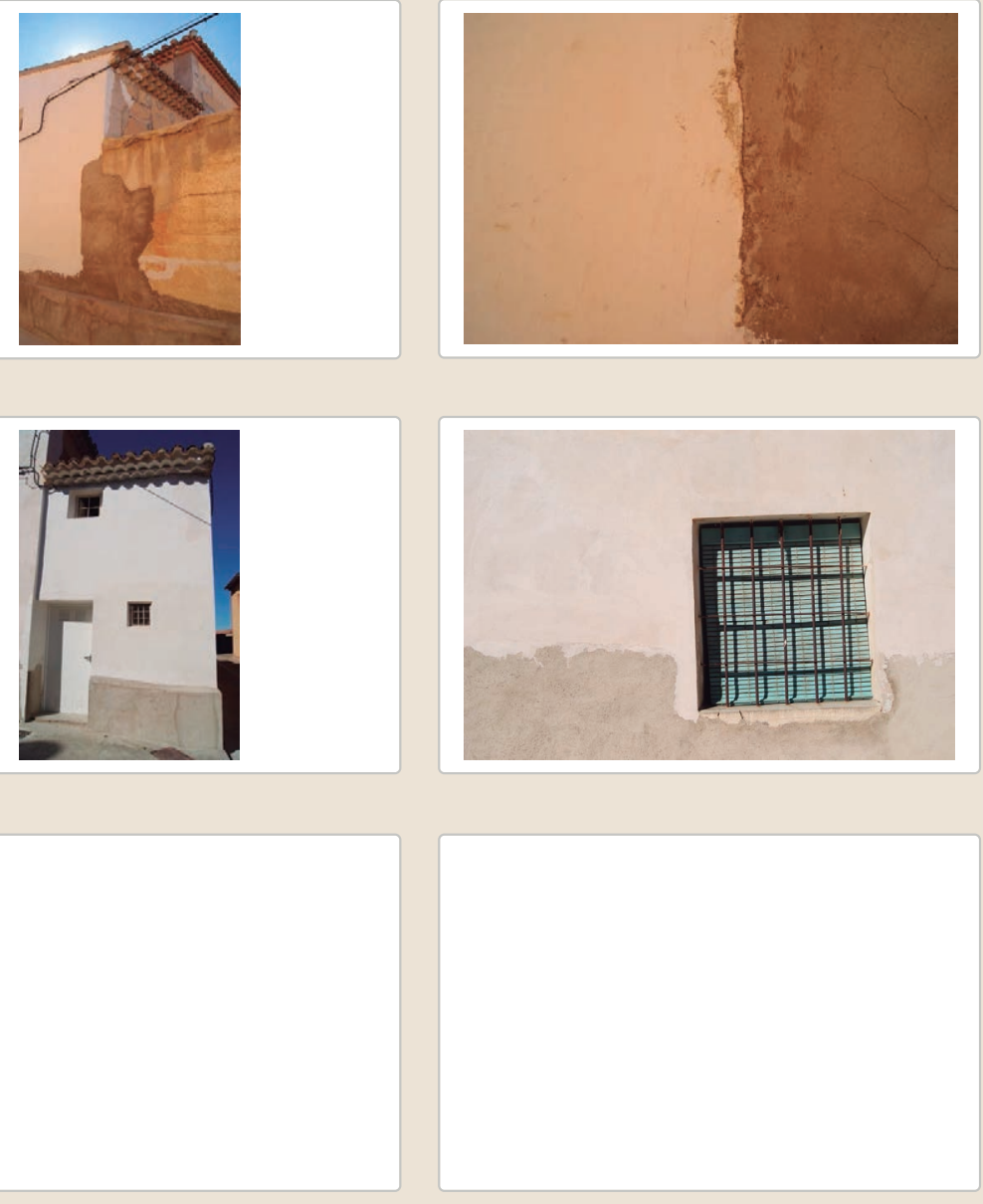

3.6. OTRAS 

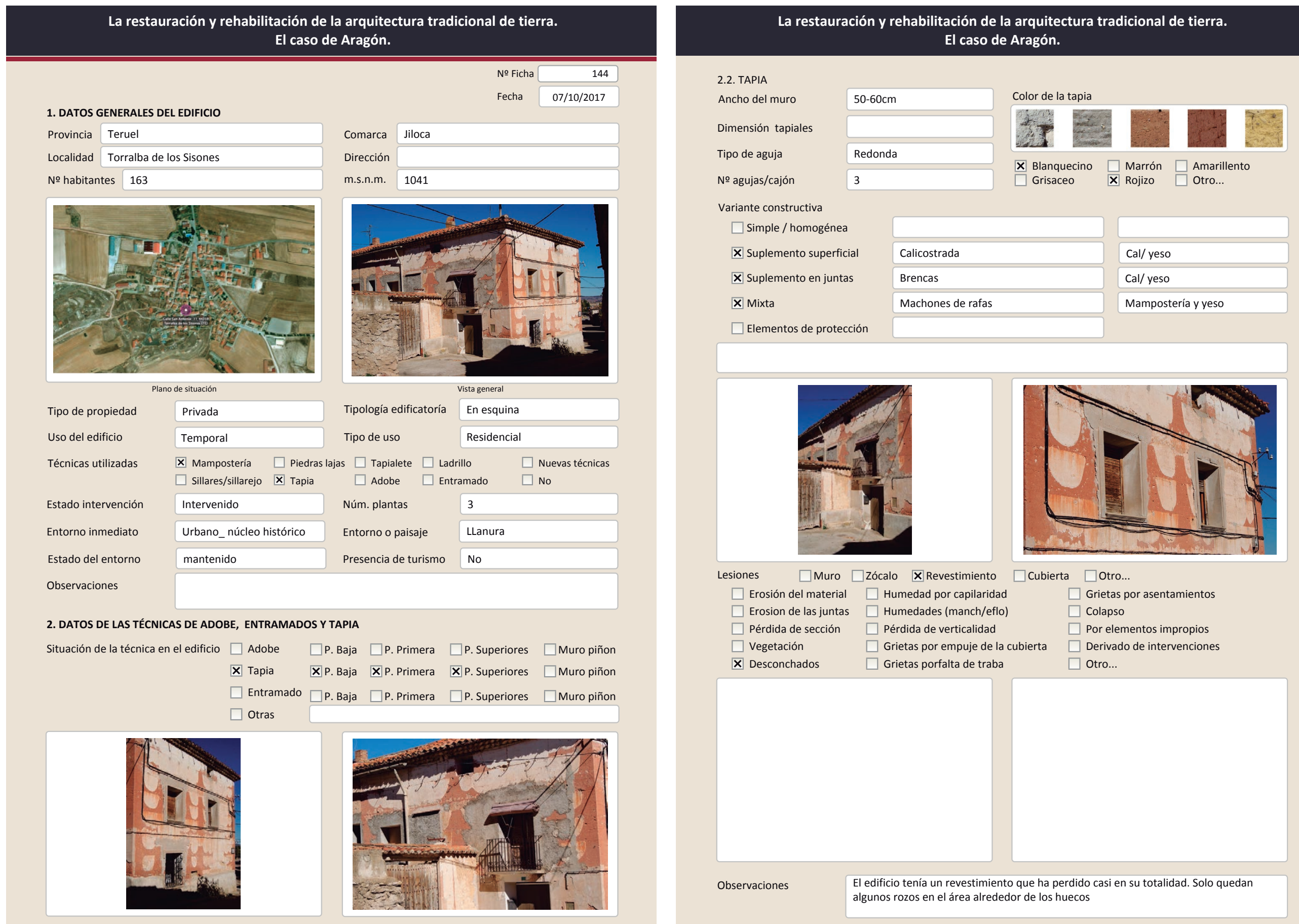


\section{La restauración y rehabilitación de la arquitectura tradicional de tierra.}

\section{El caso de Aragón.}

3. DATOS DE LA INTERVENCIÓN

NCIÓN

Reflexión previa

\Rehabilitación parcial

$\square$ Restauración $\square$ Demolición

Intervención espontanea

Observaciones

3.1. MUROS
Tipo de intervención

Intervenido

Tipo de material

$\square$ Actualización $\quad \boldsymbol{X}$ Reintegración $\quad \square$ Demolición $\quad \square$ Otro...
$\square$ Consolidación $\quad \square$ Reconstrucción $\quad \square$ Sustitución

Descripción

3.2. ZÓCALO

Tipo de intervención

No tradicional

Tipo de técnica Diferente a la existente

Se a reinegrado el área alrededor de los huecos principalmente

Intervenido

$\square$ Actualización $\quad \square$ Reintegración $\quad \square$ Demolición $\square$ Otro...

$\square$ Consolidación $\quad \boldsymbol{X}$ Reconstrucción $\square$ Sustitución

Tipo de material

No tradicional

Tipo de técnica Diferente a la existente

Descripción

3.3. REVESTIMIENTOS

Tipo de intervención

Tipo de material

Descripción

3.4. VANOS

Tipo de intervención

Zócalo con espesor notable realizado con ladrillo hueco del 4 y cemento.

\section{No aplica}

$\square$ Actualización $\square$ Reintegración $\quad \square$ Demolición $\square$ Otro...

$\square$ Consolidación $\quad \square$ Reconstrucción $\square$ sustitución

Tipo de técnica

Tipo de técnica $\square$

Intervenido

$\square$ Actualización $\quad \boldsymbol{X}$ Reintegración $\square$ Demolición $\square$ Otro...

$\square$ Consolidación $\square$ Reconstrucción $\quad \boldsymbol{X}$ Sustitución

\begin{tabular}{lll} 
Tipo de material No tradicional Tipo de técnica Diferente a la existente \\
\hline
\end{tabular}

Descripción Sustitución de gran parte de las carpinterías y reintegración del contorno de los huecos

3.5. CUBIERTA

Intervenido

Tipo de intervención

$\square$ Actualización

\begin{tabular}{l}
$\square$ Consolidación $\square$ Reconstrucción $\square$ Sustitución \\
\hline No tradicional Tipo de técnica Diferente a la existente
\end{tabular}

Reintegración $\quad \boldsymbol{X}$ Demolición $\square$ Otro...

Tipo de material

Eliminación del la ventana abuhardillada que había en cubierta
La restauración y rehabilitación de la arquitectura tradicional de tierra.

El caso de Aragón.

3.7. REHABILITACIÓN ENERGÉTICA $\quad \square$ Fachada $\square$ Vanos $\square$ Forjados $\square$ Cubierta

Observaciones

FOTOGRAFÍAS DE LA INTERVENCIÓN

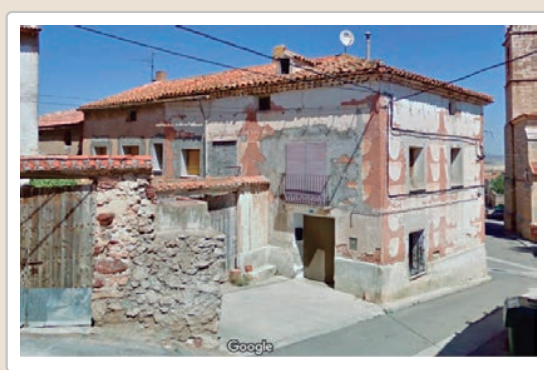

google: agosto 2009
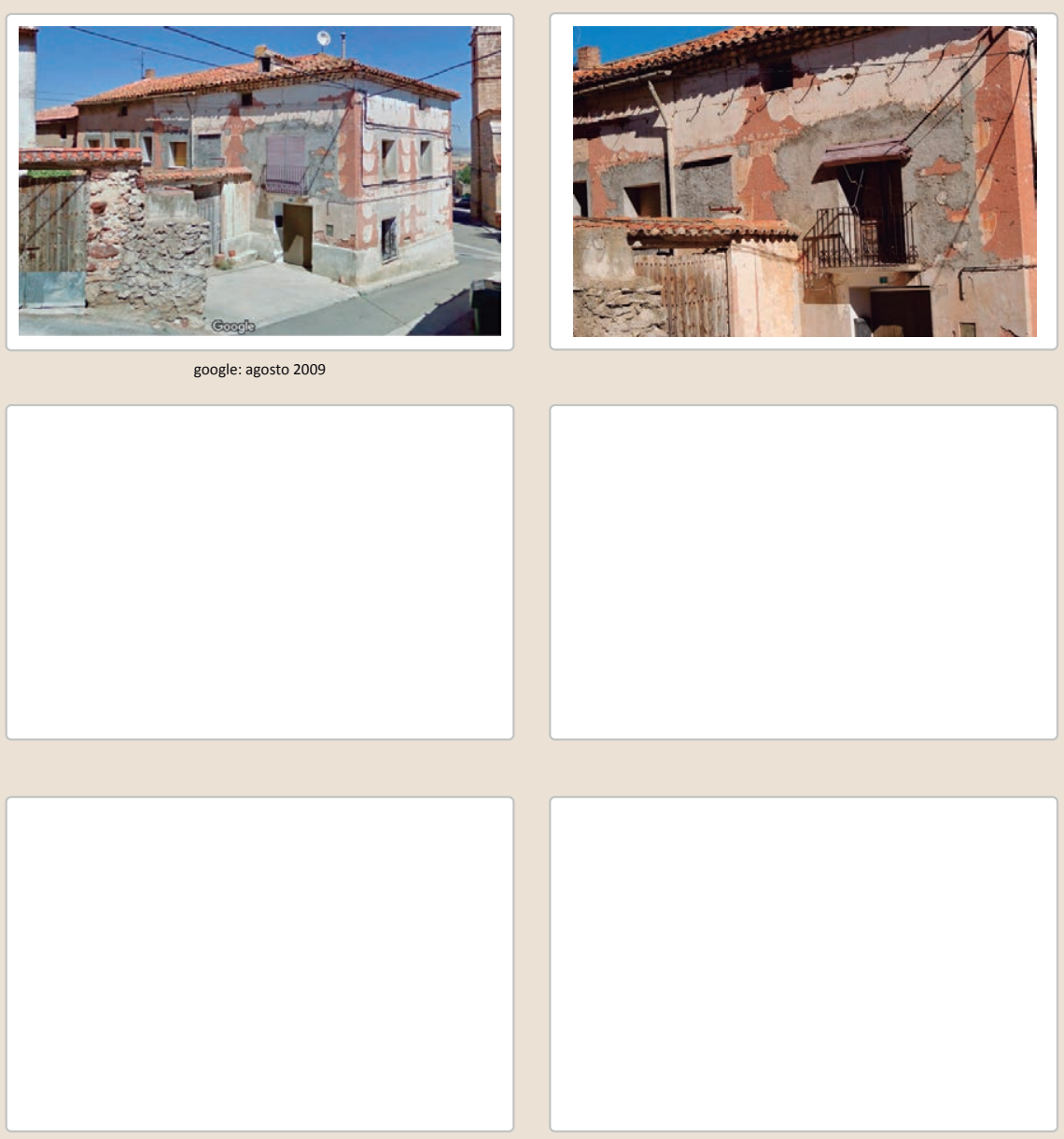

3.6. OTRAS 


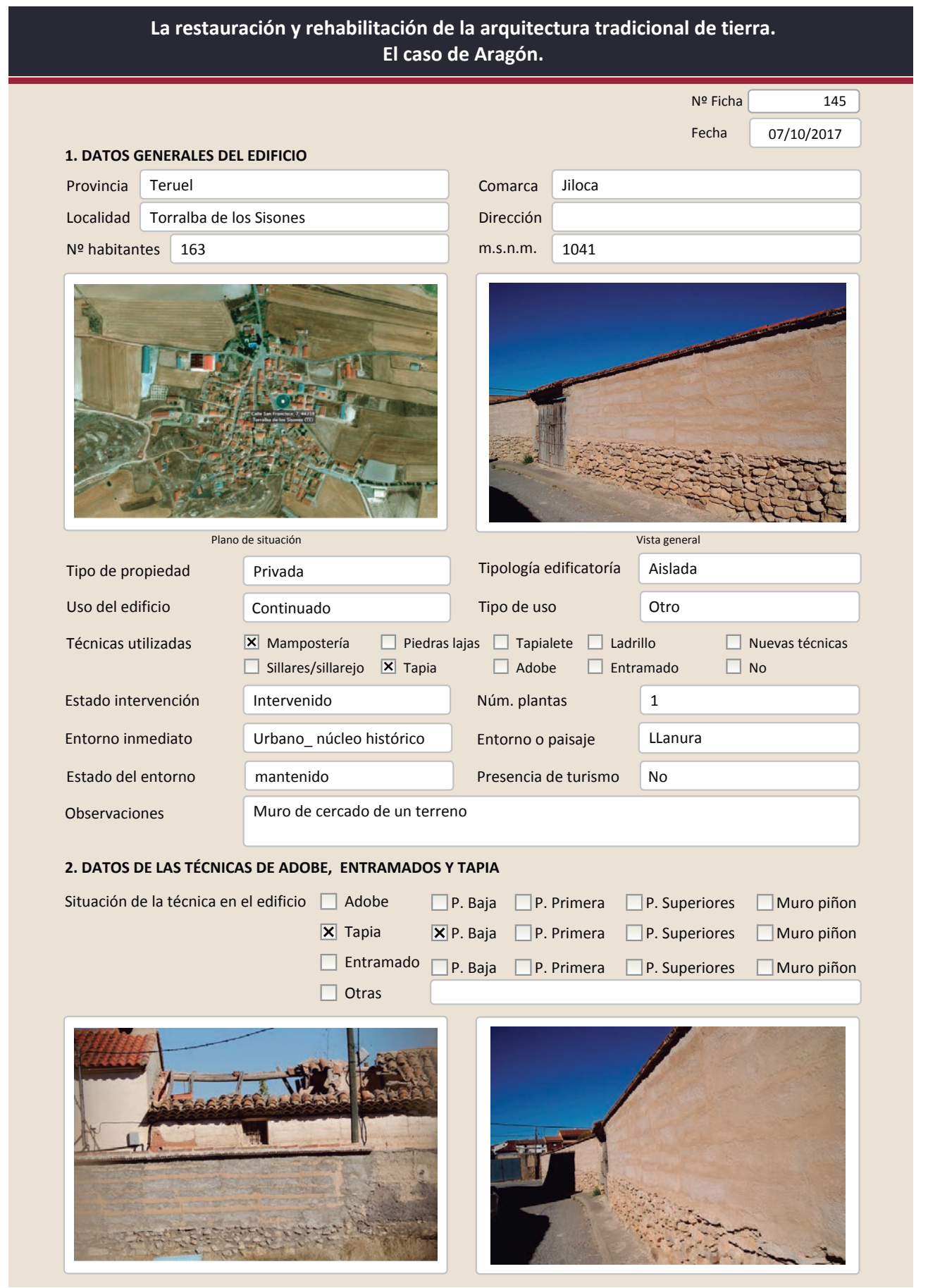

2.2. TAPIA

Ancho del muro

Dimensión tapiales

Tipo de aguja

№ agujas/cajón

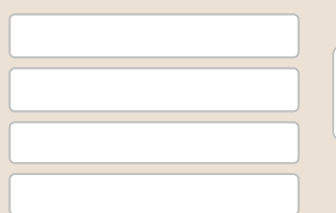

Color de la tapia

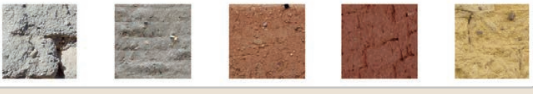

$\square$ Blanquecino $\mathbf{X}$ Marrón $\square$ Amarillento

$\begin{array}{lll}\square \text { Blanquecino } & \mathbf{X} \text { Marrón } \quad \square \text { Amarillen } \\ \square \text { Grisaceo } & \square \text { Rojizo } \quad \square \text { Otro... }\end{array}$

$\square$ Simple / homogénea

X Suplemento superficial

$\square$ suplemento en juntas

$\square$ Mixta

$\square$ Elementos de protección
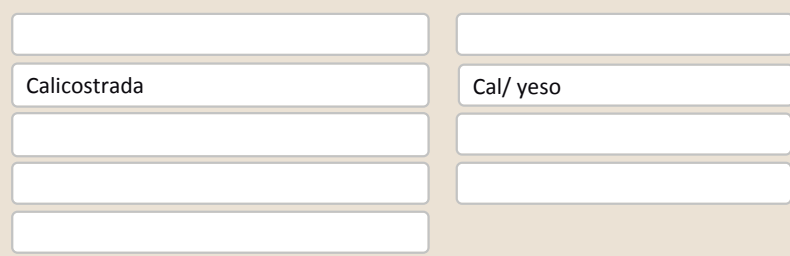

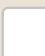
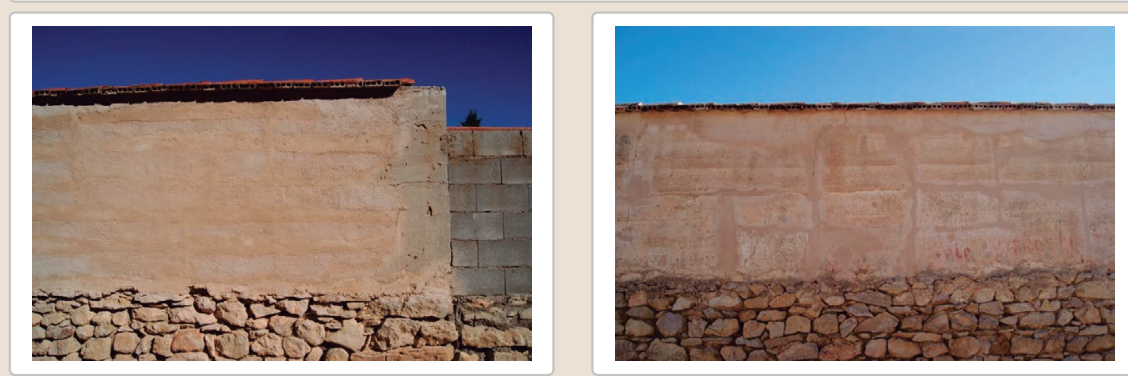

Lesiones $\square$ Muro $\square$ Zócalo $\square$ Revestimiento $\square$ Cubierta $\square$ otro...

$\square$ Erosión del material $\quad \square$ Humedad por capilaridad $\quad \square$ Grietas por asentamientos $\square$ Erosion de las juntas $\square$ Humedades (manch/eflo)

$\square$ Pérdida de sección $\quad \square$ Pérdida de verticalidad

$\square$ Vegetación $\square$ Grietas por empuje de la cubierta

$\square$ Desconchado $\square$ Grietas porfalta de traba

$\square$ Colapso

$\square$ Por elementos impropios

$\square$ Otro...

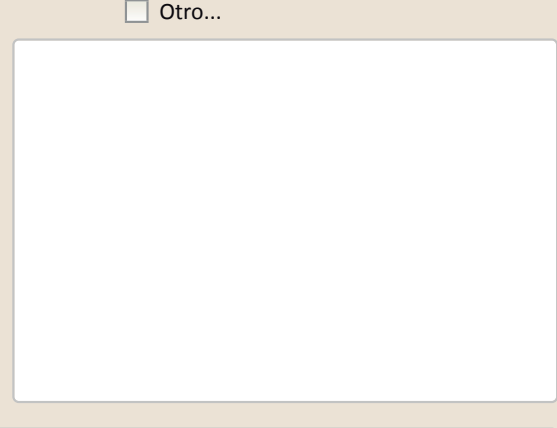

Observaciones 


\section{La restauración y rehabilitación de la arquitectura tradicional de tierra.}

\section{El caso de Aragón.}

3. DATOS DE LA INTERVENCIÓN

Intervención de:

$\square$ Mantenimiento $\quad \square$ Rehabilitación parcial

X Restauración $\square$ Demolición

Reflexión previa

X Reparación

$\square$ Rehabilitación integr

$\square$ Ampliación

$\square$ Otro...

Observaciones

Intervención planificada

3.1. MUROS
Tipo de intervención

Intervenido

$\square$ Actualización $\quad$ X Reintegración $\square$ Demolición $\square$ Otro...

$\square$ Consolidación $\square$ Reconstrucción $\square$ Sustitución

$\begin{array}{llll}\text { Tipo de material Tradicional diferente } & \text { Tipo de técnica } \\ & \text { Diferente a la existente }\end{array}$

Descripción

Se han rellenado los huecos faltanes de la tapia con mortero (generalmente bandas horizontales donde la costra se ha perdido. Coronación con ladrillo

3.2. ZÓCALO

Tipo de intervención

No intervenido

Tipo de intervención

$\square$ Actualización

$\square$ Reintegración $\quad \square$ Demolición $\quad \square$ Otro..

Tipo de material

Descripción

3.3. REVESTIMIENTOS

Tipo de intervención

Tipo de material

Descripción

3.4. VANOS

Tipo de intervención

Tipo de material

Descripción

3.5. CUBIERTA

Tipo de intervención

Tipo de material

Descripción

Intervenido

$\square$ Actualización $\quad \square$ Reintegración $\quad \square$ Demolición $\quad \square$ Otro..

$\square$ Consolidación $\quad \mathbf{X}$ Reconstrucción $\square$ Sustitución

$\square$ Actualización $\square$ Reintegración $\quad \square$ Demolición $\square$ Otro...

$\square$ Consolidación $\square$ Reconstrucción $\square$ sustitución

Tipo de técnica

No aplica

$\square$ Actualización $\square$ Reintegración $\square$ Demolición $\square$ Otro...

$\square$ Consolidación $\square$ Reconstrucción $\square$ Sustitución

No tradicional Tipo de técnica Diferente a la existente

Coronación del muro con ladrillo cerámico y tejas. No cubierta coronación
La restauración y rehabilitación de la arquitectura tradicional de tierra.

El caso de Aragón.

3.7. REHABILITACIÓN ENERGÉTICA $\quad \square$ Fachada $\square$ Vanos $\square$ Forjados $\square$ Cubierta

Observaciones

FOTOGRAFÍAS DE LA INTERVENCIÓN
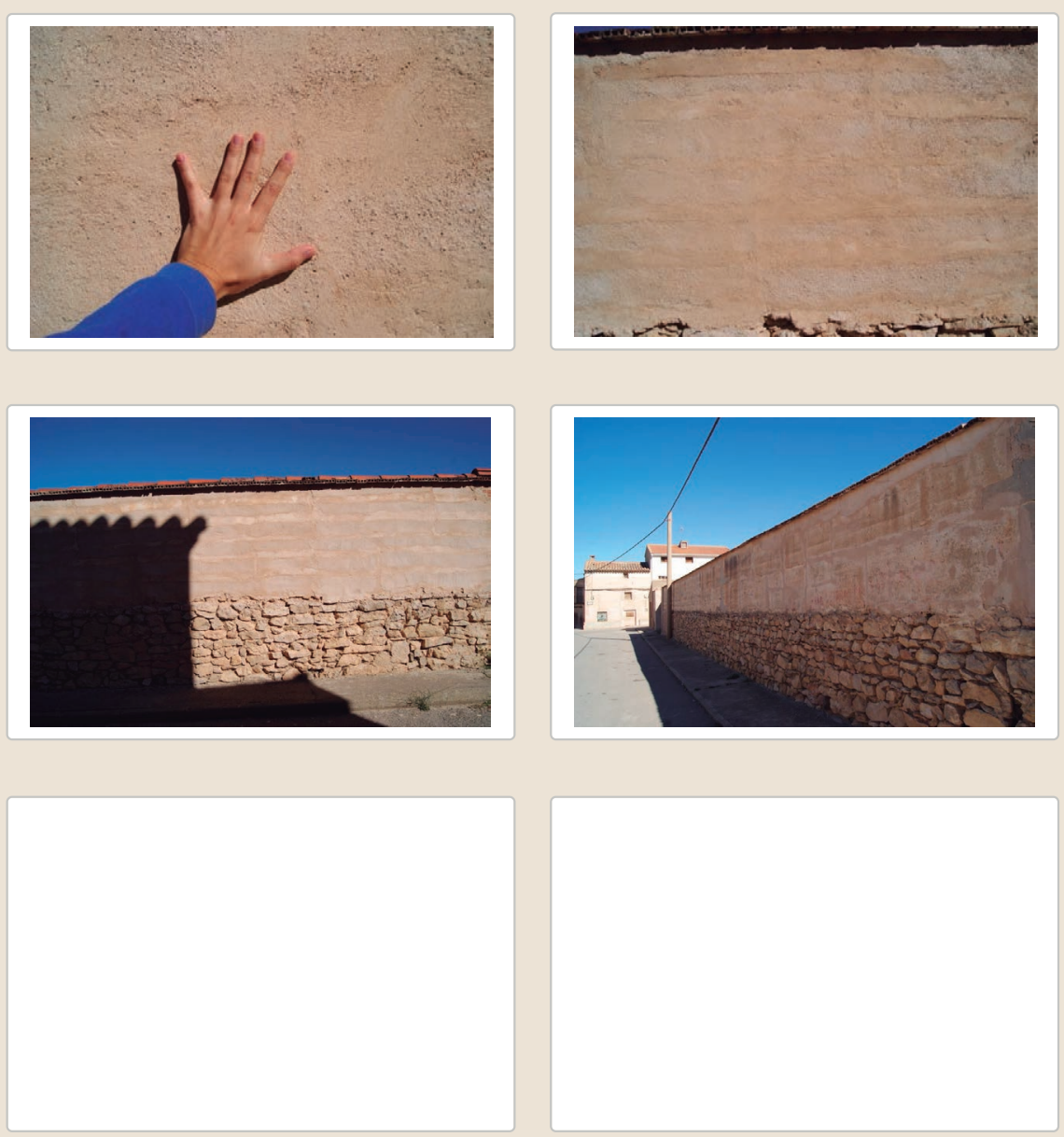

3.6. OTRAS 


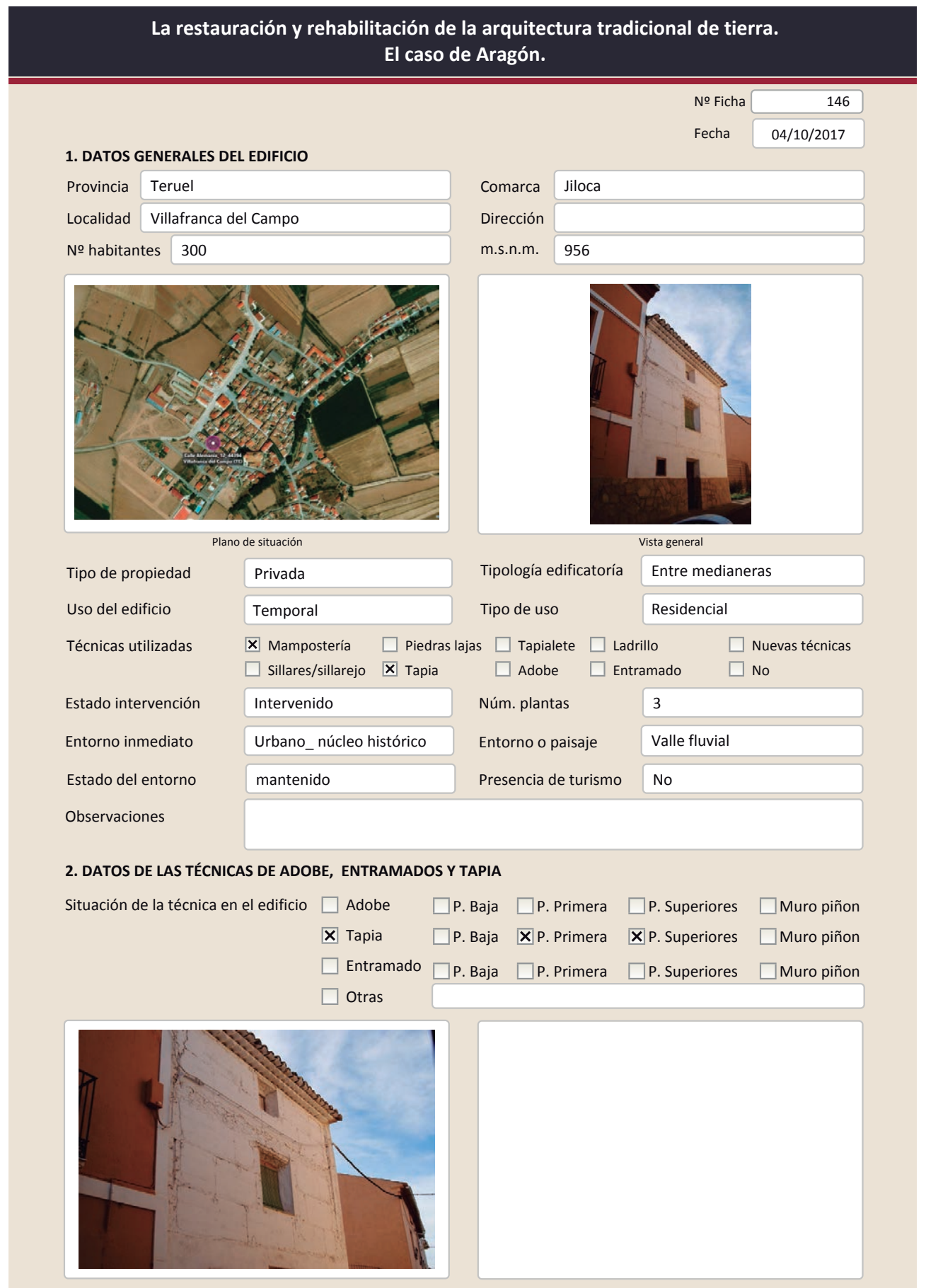

2.2. TAPIA

Ancho del muro

Dimensión tapiales

Tipo de aguja

\begin{tabular}{|l|}
\hline $40-50 \mathrm{~cm}$ \\
\hline \\
\hline Redonda \\
\hline 3 \\
\hline
\end{tabular}

Color de la tapia

№ agujas/cajón

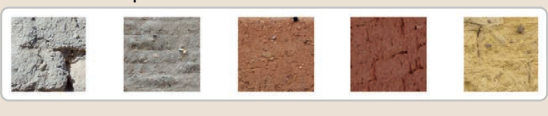

$\square$ Blanquecino $\mathbf{X}$ Marrón $\square$ Amarillento

$\begin{array}{ll}\square \text { Blanquecino } & \mathbf{x} \text { Marrón } \\ \square \text { Grisaceo } & \square \text { Amajizo } \quad \square \text { Otro... }\end{array}$

Variante constructiva

$\square$ Simple / homogénea

X Suplemento superficial

$\mathbf{X}$ Suplemento en juntas

$\mathbf{X}$ Mixta
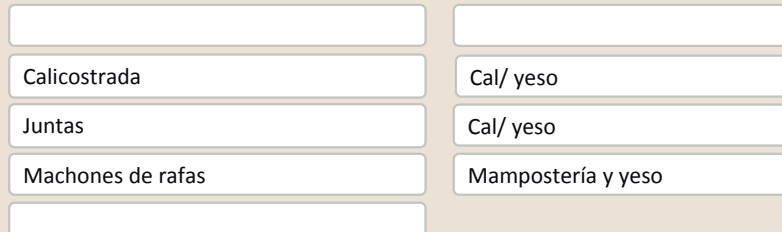

$\square$ Elementos de protección
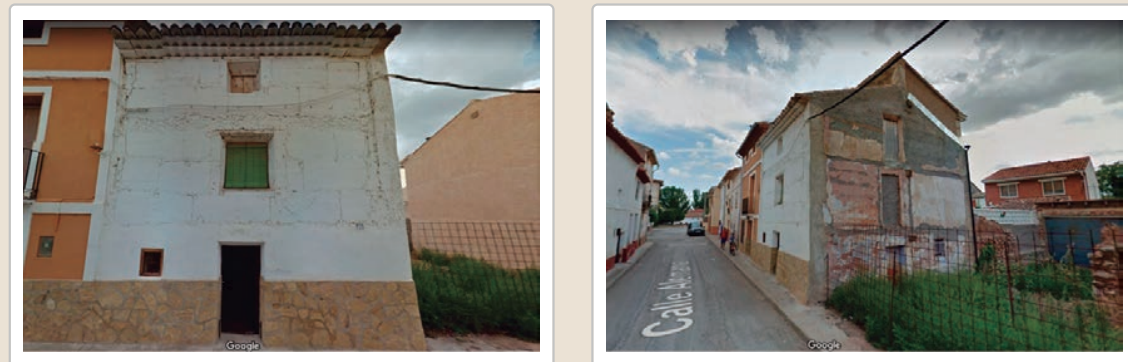

Lesiones $\square$ Muro $\square$ Zócalo $\square$ Revestimiento $\square$ Cubierta $\square$ otro..

$\square$ Erosión del material $\quad \square$ Humedad por capilaridad $\quad \square$ Grietas por asentamientos $\square$ Erosion de las juntas $\square$ Humedades (manch/eflo)

$\square$ Pérdida de sección $\quad \square$ Pérdida de verticalidad

$\square$ Vegetación $\square$ Grietas por empuje de la cubierta

$\square$ Desconchados $\square$ Grietas porfalta de traba

Colapso

Dor elementos impropios

$\square$ Derivado de intervenciones

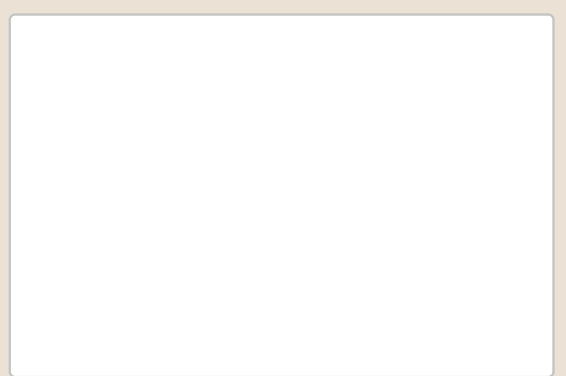

Observaciones 


\section{La restauración y rehabilitación de la arquitectura tradicional de tierra.}

\section{El caso de Aragón.}

3. DATOS DE LA INTERVENCIÓN

\begin{tabular}{|c|c|c|c|c|}
\hline Intervención de: & $\begin{array}{l}\square \text { Mantenimiento } \\
\mathbf{X} \text { Reparación }\end{array}$ & $\begin{array}{l}\square \text { Rehabilitación parcial } \\
\square \text { Rehabilitación integral }\end{array}$ & $\begin{array}{l}\square \text { Restauración } \\
\square \text { Ampliación }\end{array}$ & $\begin{array}{l}\square \text { Demolición } \\
\square \text { Otro... }\end{array}$ \\
\hline Reflexión previa & \multicolumn{4}{|c|}{ Intervención planificada } \\
\hline Observaciones & & & & \\
\hline
\end{tabular}

\subsection{MUROS}

Tipo de intervención

Intervenido

Tipo de material

$\square$ Actualización $\quad$ X Reintegración $\square$ Demolición $\square$ Otro...

$\square$ Consolidación $\square$ Reconstrucción $\square$ sustitución

Descripción

\begin{tabular}{l|l|l|l|l} 
No tradicional Tipo de técnica Diferente a la existente &
\end{tabular}

3.2. ZÓCALO

Tipo de intervención

Intervenido

$\square$ Actualización

$\square$ Reintegración $\square$ Demolición $\square$ Otro..

Tipo de material

Descripción

\begin{tabular}{lll} 
Tipo de técnica Diferente a la existente \\
\hline
\end{tabular}

Construcción de un zócalo con lajas de piedra y cemento. Además el revestimiento de cemento se extiende en toda la altura de planta baja

3.3. REVESTIMIENTOS

Intervenido

Tipo de intervención

X Actualización $\square$ Reintegración $\square$ Demolición $\square$ Otro...

Tipo de material

$\square$ Consolidación $\square$ Reconstrucción $\square$ Sustitución

Descripción
No tradicional
Tipo de técnica Diferente a la existente

3.4. VANOS

Toda la fachada esta pintada de blanco

Tipo de intervención

No intervenido

Tipo de material

$\square$ Actualización $\square$ Reintegración $\square$ Demolición $\square$ Otro...

Descripción

$\square$ Consolidación $\square$ Reconstrucción $\square$ sustitución

3.5. CUBIERTA

Tipo de intervención

No visible

$\square$ Actualización

Tipo de técnica

Tipo de material

$\square$ Consolidación $\quad \square$ Reconstrucción $\quad \square$ Sustitución

Descripción

$$
\text { Tipo de técnica }
$$

3.6. OTRAS 


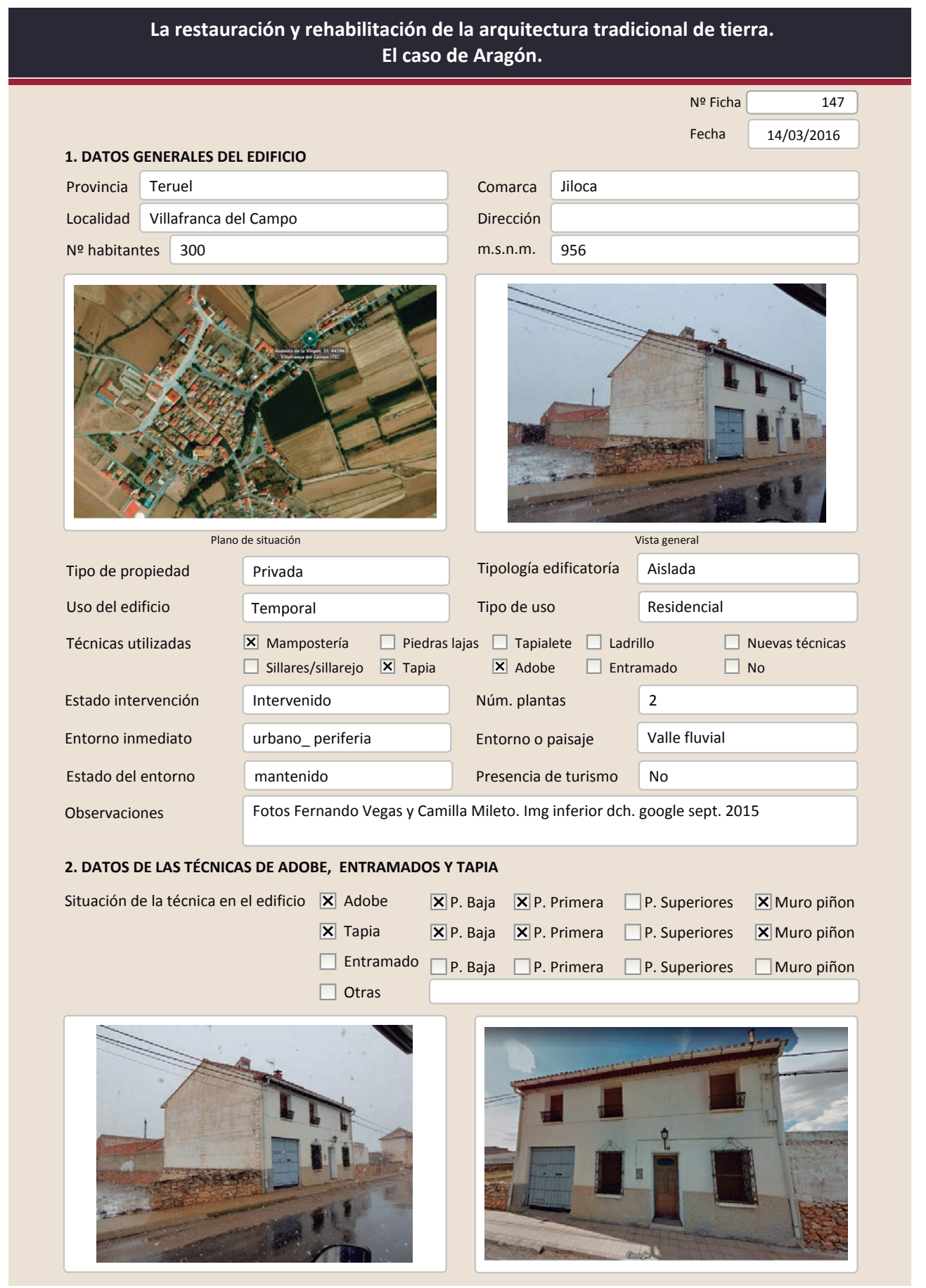

2.1. ADOBE

Dimensión de las piezas

Dimensión del muro

Aparejo del muro

Función estructural

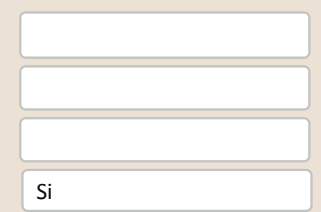

Color de las piezas

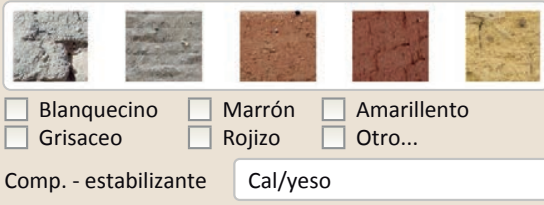

Variante constructiva/ tipo de fábrica

$\square$ Simple

$\square$ Suplementada en juntas

$\square$ Mixta

$\mathbf{X}$ Como suplemento

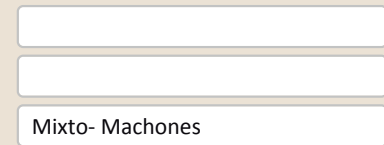

$\square$ Elementos de protección Parecen bloques de tierra - cemento

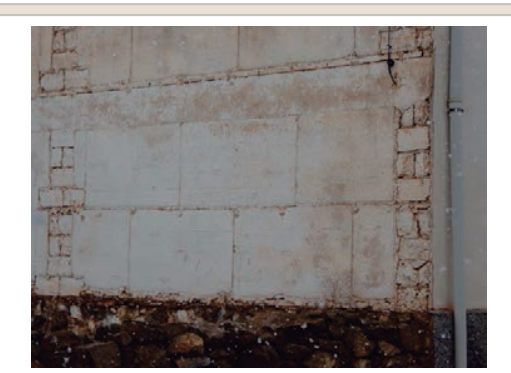

Lesiones $\quad \square$ Muro $\square$ Zócalo $\square$ Revestimiento

$\square$ Erosión del material $\square$ Humedad por capilaridad $\square$ Erosion de las juntas $\square$ Humedades (manch/eflo)

$\square$ Pérdida de sección $\square$ Pérdida de verticalidad

$\square$ Vegetación $\quad \square$ Grietas por empuje de la c $\square$ Grietas porfalta de traba

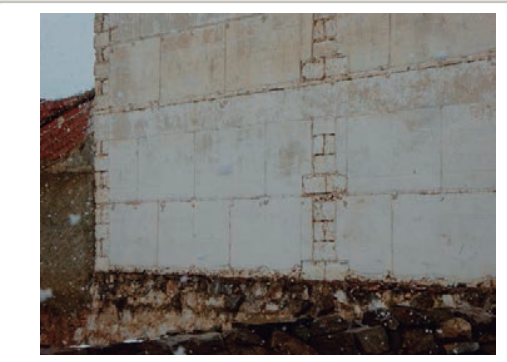

$\square$ Desconchados

Cubierta $\square$ Otro...

$\square$ Grietas por asentamiento

$\square$ Colapso

$\square$ Por elementos impropios

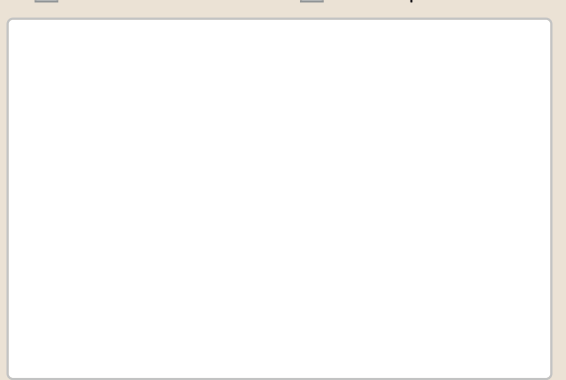

$\square$ Derivado de intervenciones

$\square$ Otro... 


\section{La restauración y rehabilitación de la arquitectura tradicional de tierra.}

\section{El caso de Aragón.}

\subsection{TAPIA}

Ancho del muro

Dimensión tapiales

Tipo de aguja

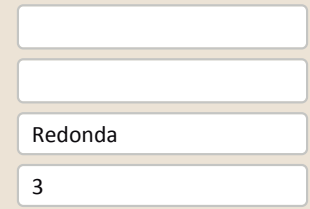

Color de la tapia

№ agujas/cajón

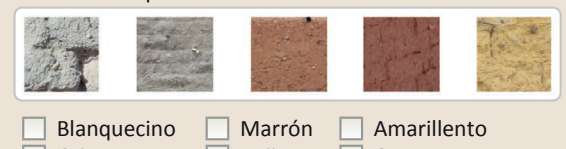
$\square$ Blanquecino $\quad \square$ Marrón $\quad \square$ Amarillento
$\square$ Grisaceo $\quad \square$ Rojizo $\quad \square$ Otro...

\begin{tabular}{|l|}
\hline Cal/yeso \\
\hline Cal/yeso \\
\hline Adobe \\
\hline
\end{tabular}

Variante constructiva

$\square$ simple / homogénea

X Suplemento superficial

$\mathbf{X}$ Suplemento en juntas

X Mixta

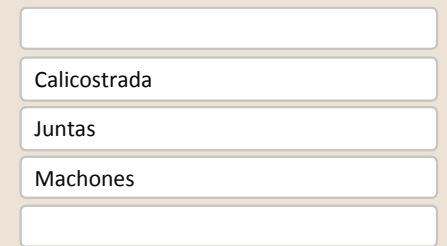

$\square$ Elementos de protección

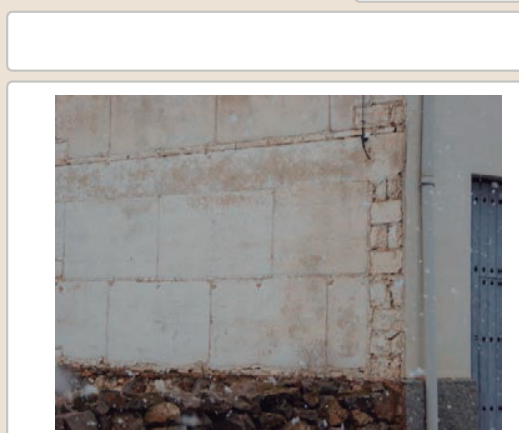

Lesiones $\square$ Muro $\square$ Zócalo $\square$ Revestimiento $\square$ Cubierta $\square$ otro...

$\square$ Erosión del material $\quad \square$ Humedad por capilaridad $\quad \square$ Grietas por asentamientos

$\square$ Erosion de las juntas $\square$ Humedad por

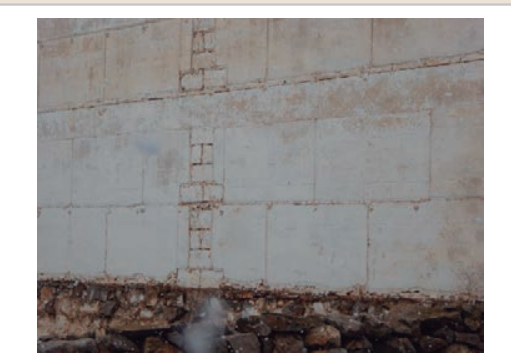

Pérdida de sección

$\square$ Humedades (manch/eflo)

$\square$ Colapso

$\square$ Vegetación

$\square$ Pérdida de verticalidad

$\square$ Por elementos impropios

$\square$ Desconchados

$\square$ Grietas porfalta de traba

$\square$ Derivadod

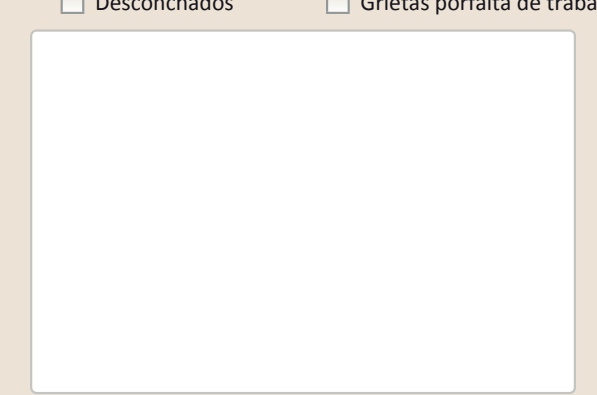

$\square$ Otro..

Observaciones

La restauración y rehabilitación de la arquitectura tradicional de tierra.

El caso de Aragón.

3. DATOS DE LA INTERVENCIÓN

Intervención de: $\quad \square$ Mantenimiento $\quad \mathbf{X}$ Rehabilitación parcial $\square$ Restauración $\square$ Demolición

Reflexión previa Intervención planificada

Observaciones Las intervenciones de han producido principalmente en la fachada principal. Responden a una actualización del aspecto de la vivienda

3.1. MUROS

\section{No intervenido}

Tipo de intervención

$\square$ Actualización $\quad \square$ Reintegración $\quad \square$ Demolición $\quad \square$ otro..

$\square$ Consolidación $\square$ Reconstrucción $\square$ sustitución

Tipo de material

Descripción

3.2. ZÓCALO

Intervenido

Tipo de intervención

Tipo de material

X Actualización

$\square$ Consolidación

$\square$ Reintegración $\square$ Demolición $\square$ Otro..

Descripción

Zócalo de cemento -gotelé- en la fachada principal

3.3. REVESTIMIENTOS

Tipo de intervención

Intervenido

\ Actualización $\square$ Reintegración $\square$ Demolición $\square$ Otro...

$\square$ Consolidación $\mathbf{X}$ Reconstrucción $\square$ sustitución

$\begin{array}{lll}\text { Tipo de material } & \text { No tradicional Tipo de técnica Diferente a la existente }\end{array}$

Descripción

Revesimiento de cemento en toda la fachada principal. Todo el edificio se ha pintado de blando

3.4. VANOS

Tipo de intervención

Intervenido

\begin{tabular}{llll} 
Tipo de material & No tradicional & Tipo de técnical Diferente a la existente \\
\cline { 2 - 3 }
\end{tabular}

\ Actualización $\square$ Reintegración $\square$ Demolición $\square$ Otro...

$\square$ Consolidación $\square$ Reconstrucción $\quad \mathbf{X}$ Sustitución

Descripción Sustitución de carpinterías con persianas y nuevas rejas. Ampliación de hueco en planta baja.

3.5. CUBIERTA

Tipo de intervención

Intervenido

$\square$ Actualización $\square$ Reintegración $\square$ Demolición $\square$ Otro

$\square$ Consolidación $\quad \boldsymbol{X}$ Reconstrucción $\square$ Sustitución

Tipo de material

No tradicional Tipo de técnica $\quad$ Similar a la existente

Descripción

Reconstrucción de la cubierta con tejas viejas y nuevas utilizando cemento como elemento de agarre.

3.6. OTRAS 
La restauración y rehabilitación de la arquitectura tradicional de tierra. El caso de Aragón

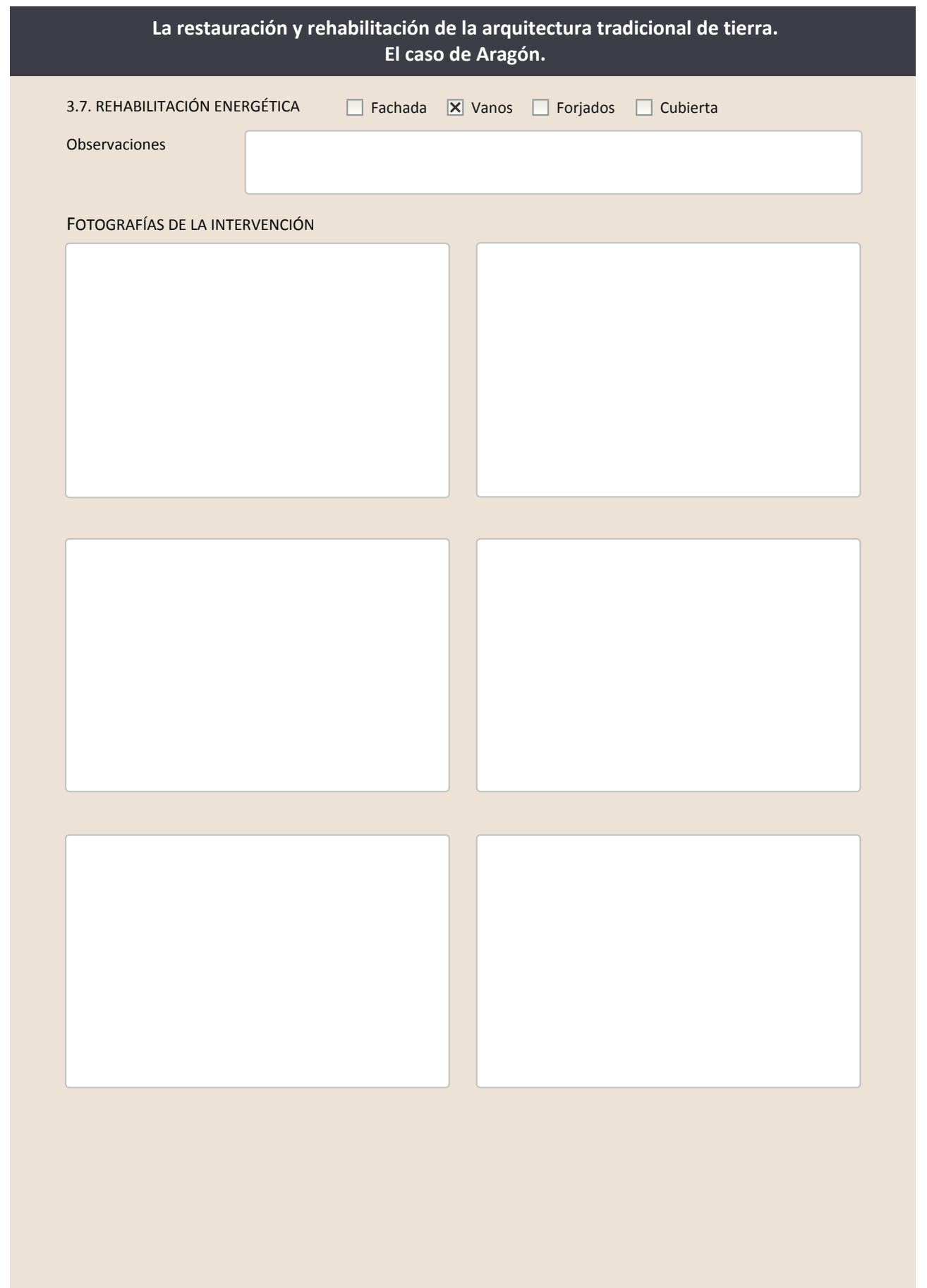

La restauración y rehabilitación de la arquitectura tradicional de tierra.

El caso de Aragón.

3.7. REHABILITACIÓN ENERGÉTICA $\square$ Fachada $\quad \boldsymbol{X}$ Vanos $\square$ Forjados $\square$ Cubierta

Observaciones

FOTOGRAFÍAS DE LA INTERVENCIÓN 


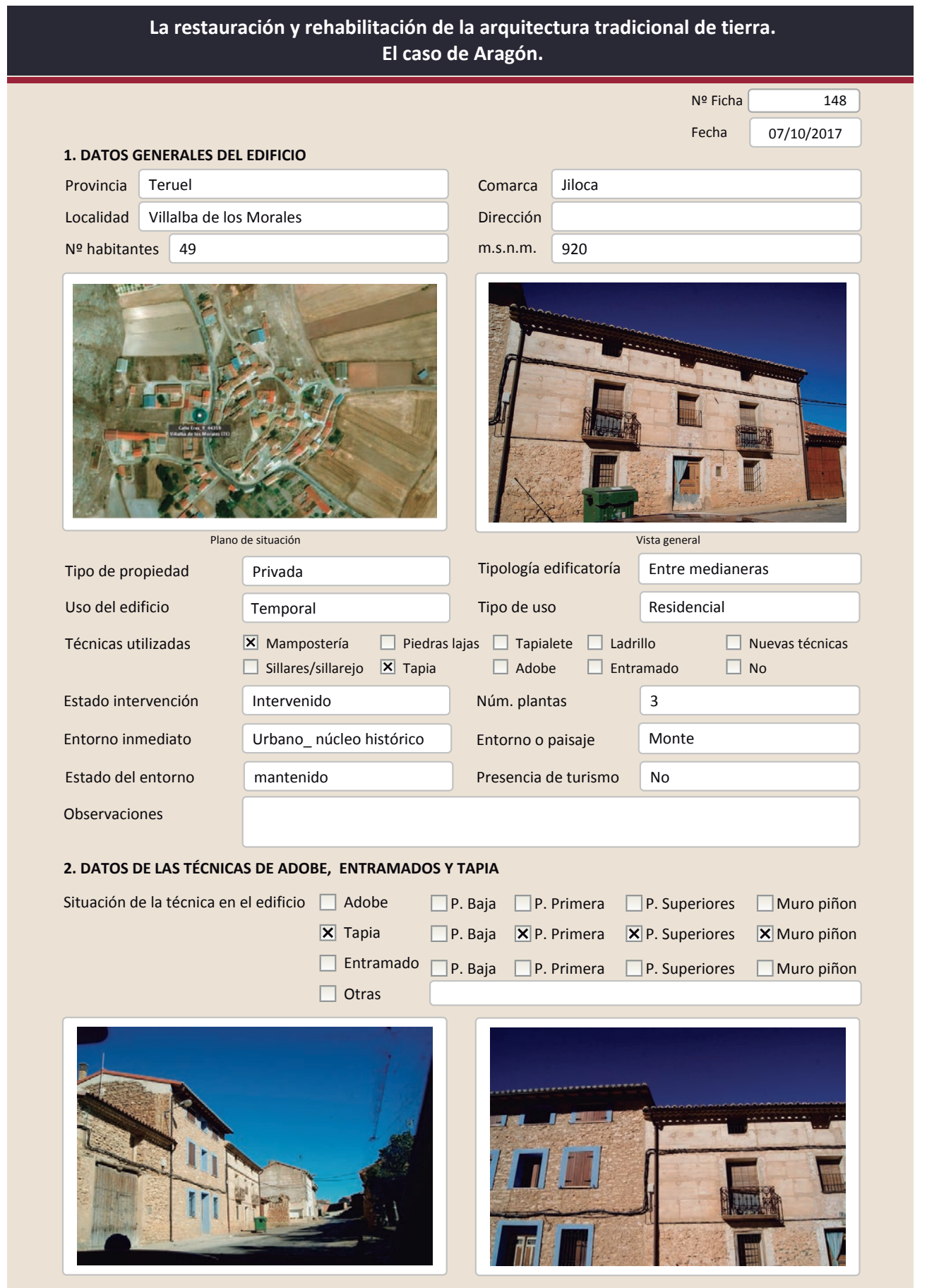

La restauración y rehabilitación de la arquitectura tradicional de tierra.

El caso de Aragón.

\subsection{TAPIA}

Ancho del muro

Dimensión tapiales

Tipo de aguja

№ agujas/cajón

\begin{tabular}{|l|}
\hline $40-50 \mathrm{~cm}$ \\
\hline \\
\hline Redonda \\
\hline 3 \\
\hline
\end{tabular}

Color de la tapia

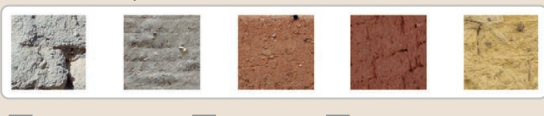

X Blanquecino $\square$ Marrón $\square$ Amarillento

$\begin{array}{ll}\mathbf{X} \text { Blanquecino } & \text { Marrón } \\ \square \text { Grisaceo } & \square \text { Rojizo }\end{array}$ Otro..

Variante constructiva

$\square$ Simple / homogénea

X Suplemento superficial

X Suplemento en juntas

$\mathbf{x}$ Mixta

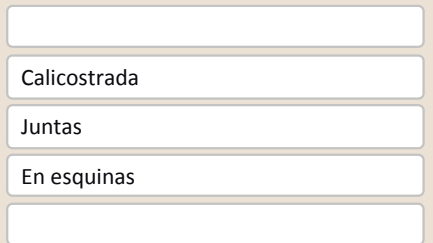

Cal/yeso

$\mathrm{Cal} /$ yeso

Mampostería y yeso

$\square$ Elementos de protección

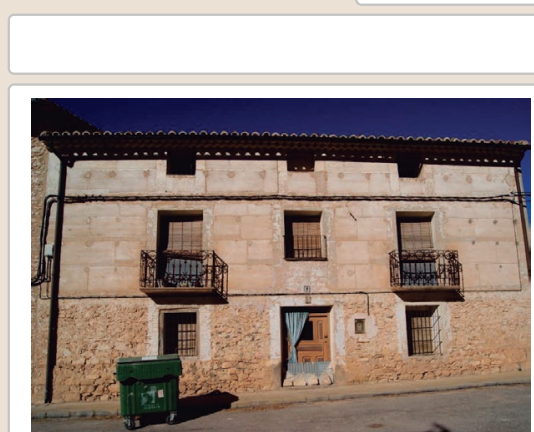

Lesiones $\square$ Muro XZócalo $\square$ Revestimiento $\square$ Cubierta $\square$ otro...

$\square$ Erosión del material $\quad \mathbf{X}$ Humedad por capilaridad $\quad \square$ Grietas por asentamientos

$\square$ Erosion de las juntas $\square$ Humedades (manch/eflo)

$\square$ Pérdida de sección $\quad \square$ Pérdida de verticalidad

$\square$ Vegetación $\square$ Grietas por empuje de la cubierta

$\square$ Desconchan

$\square$ Grietas porfalta de traba

Colapso

$\square$ Por elementos impropios

$\square$ Derivado de intervenciones

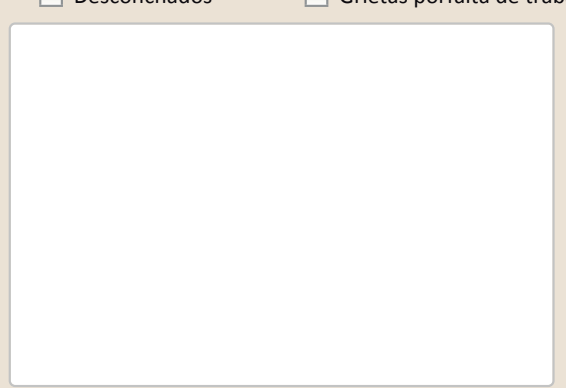

Observaciones 
La restauración y rehabilitación de la arquitectura tradicional de tierra. El caso de Aragón

\section{La restauración y rehabilitación de la arquitectura tradicional de tierra.}

\section{El caso de Aragón.}

3. DATOS DE LA INTERVENCIÓN

Intervención de:

X Mantenimiento $\square$ Rehabilitación parcia

$\square$ Restauración $\square$ Demolición

Reparación $\square$ Rehabilitación integral $\square$ Ampliación $\quad \square$ Otro...

Reflexión previa Intervención espontanea

Observaciones

(n)

3.1. MUROS

Intervenido

Tipo de intervención

$\square$ Actualización $\quad \boldsymbol{X}$ Reintegración $\square$ Demolición $\square$ Otro..

$\square$ Consolidación $\square$ Reconstrucción $\square$ sustitución

Tipo de material

\begin{tabular}{|l|l|l|l|l} 
No tradicional & Tipo de técnica Diferente a la existente \\
\hline
\end{tabular}

Descripción

Pequeños parches con cemento o cal en las zonas donde había alguna pequeña pérdida de material

3.2. ZÓCALO

No intervenido

Tipo de intervención

$\square$ Actualización

$\square$ Consolidación $\square$ Reconstrucción $\square$ Sustitución

Tipo de material

Descripción

3.3. REVESTIMIENTOS

Tipo de intervención

\section{No aplica}

Tipo de material

$\square$ Actualización

Tipo de técnica

Descripción

3.4. VANOS

Tipo de intervención

Intervenido

$\square$ Reintegración $\square$ Demolición -

$\square$ Consolidación $\quad$ X Reconstrucción $\square$ Sustitución

Descripción $\quad \begin{aligned} & \text { Reducción del tamaño de uno de los huecos cegándolo con ladrillo (hueco central plana } \\ & \text { primera) }\end{aligned}$ primera)

3.5. CUBIERTA

Tipo de intervención

Intervenido

Tipo de material

$\square$ Actualización $\quad \boldsymbol{X}$ Reintegración $\square$ Demolición $\square$ Otro..

$\square$ Consolidación $\quad \square$ Reconstrucción $\square$ Sustitución

Descripción

No tradicional Tipo de técnica Similar a la existente

Reintegración de las tejas con mortero de cemento

3.6. OTRAS 


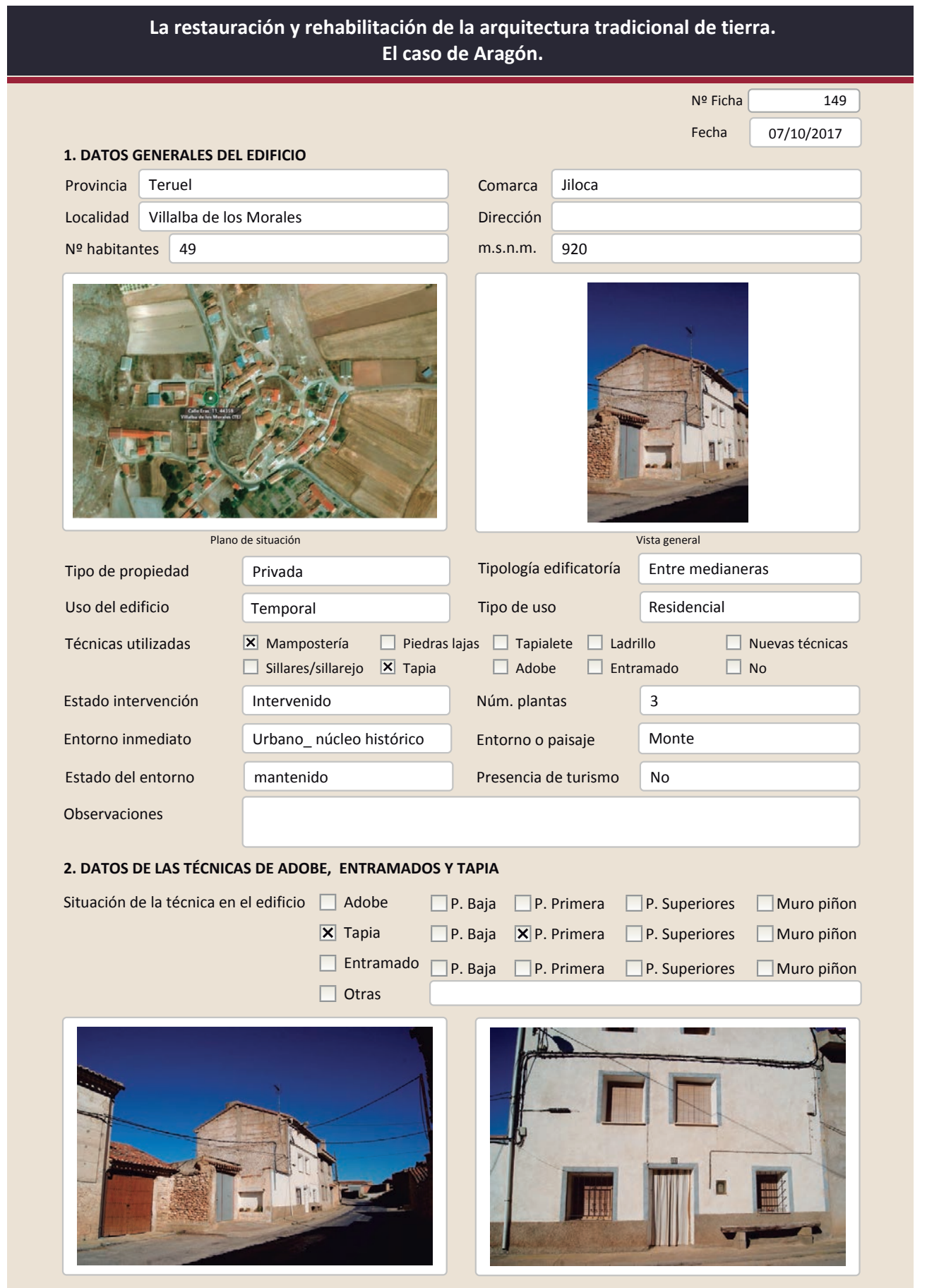

La restauración y rehabilitación de la arquitectura tradicional de tierra.

El caso de Aragón.

2.2. TAPIA

Ancho del muro

Dimensión tapiales

Tipo de aguja

№ agujas/cajón

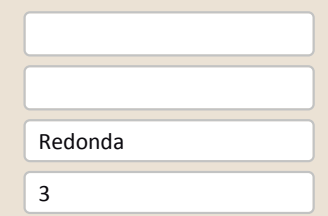

Color de la tapia

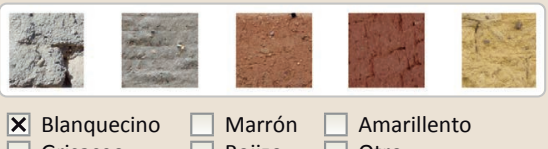

X Blanquecino $\square$ Marrón $\square$ Amarillento

Variante constructiva

$\square$ Simple / homogénea

X Suplemento superficial

$\mathbf{X}$ Suplemento en juntas

$\mathbf{X}$ Mixta
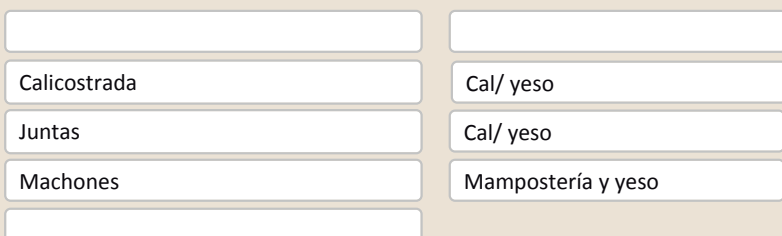

$\square$ Elementos de protección

\section{पines}
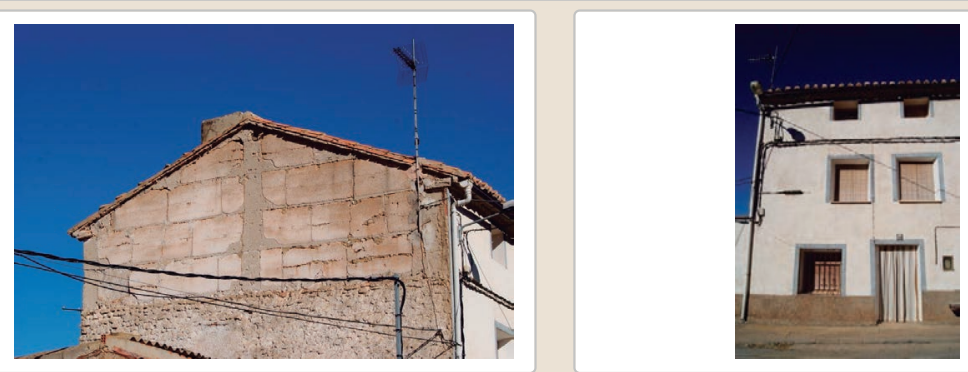

Lesiones $\quad \mathbf{M}$ Mro $\square$ Zócalo $\square$ Revestimiento $\square$ Cubierta $\square$ otro...

X Erosión del material $\quad \square$ Humedad por capilaridad $\quad \square$ Grietas por asentamientos $\square$ Erosion de las juntas $\square$ Humedades (manch/eflo)

$\square$ Pérdida de sección $\quad \square$ Pérdida de verticalidad

$\square$ Vegetación $\square$ Grietas por empuje de la cubie

$\mathbf{X}$ Desconchados $\square$ Grietas porfalta de traba

$\square$ Colapso

Por elementos impropios $\square$ Otro... 
La restauración y rehabilitación de la arquitectura tradicional de tierra. El caso de Aragón

\section{La restauración y rehabilitación de la arquitectura tradicional de tierra.}

\section{El caso de Aragón.}

3. DATOS DE LA INTERVENCIÓN

Intervención de:

Mantenimiento $\quad \mathbf{x}$ Rehabilitación parcia

$\square$ Restauración $\square$ Demolición

Reflexión previa

$\square$ Reparación

Rehabilitación integra

Ampliación

$\square$ Otro..

Observaciones

Intervención espontanea

3.1. MUROS

Tipo de intervención

Intervenido

Tipo de material

$\square$ Actualización $\quad$ Reintegración $\square$ Demolición $\square$ Otro...

$\square$ Consolidación $\square$ Reconstrucción $\square$ Sustitución

Descripción

No tradicional Tipo de técnica Diferente a la existente

3.2. ZÓCALO

Tipo de intervención

Reintegración de algunas zonas donde se ha perdido la costra de la tapia

Tipo de material

Intervenido

X Actualización $\square$ Reintegración $\quad \square$ Demolición $\square$ Otro...

$\square$ Consolidación $\quad \mathbf{X}$ Reconstrucción $\square$ Sustitución

Descripción

No tradicional Tipo de técnica Diferente a la existente

3.3. REVESTIMIENTOS

gruesa capa de cemento con gotelé

Tipo de intervención

Intervenido

Tipo de material

X Actualización $\square$ Reintegración $\square$ Demolición $\square$ Otro...

Tipo de materia

Consolidación $\mathbf{X}$ Reconstrucción $\square$ Sustitución

Descripción

Nuevo revestimiento en la fachada principal del edificio

3.4. VANOS

No intervenido

Tipo de intervención

$\square$ Actualización $\square$ Reintegración $\square$ Demolición $\square$ Otro...

Tipo de material

Descripción

$\square$ Consolidación $\square$ Reconstrucción $\square$ sustitución

3.5. CUBIERTA

Tipo de intervención

Intervenido

$\square$ Actualización $\quad \boldsymbol{X}$ Reintegración $\square$ Demolición $\square$ Otro.

Tipo de material

$\square$ Consolidación $\quad \square$ Reconstrucción $\quad \square$ Sustitución

Descripción

No tradicional Tipo de técnica Similar a la existente

3.6. OTRAS

Reintegración de tejas con mortero de cemento. Lateral y alero (es donde es visible) 


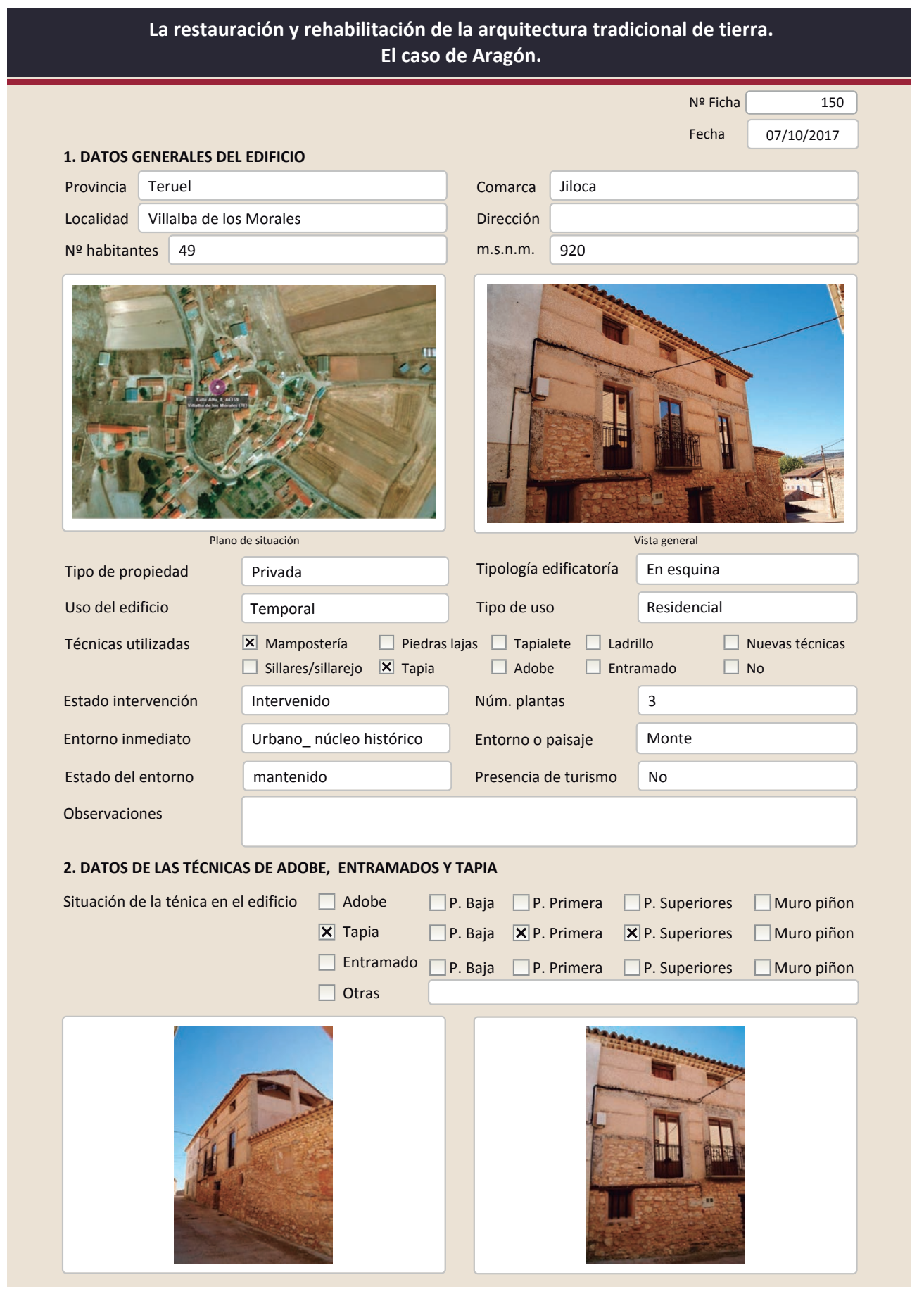

La restauración y rehabilitación de la arquitectura tradicional de tierra.

El caso de Aragón.

2.2. TAPIA

Ancho del muro

Dimensión tapiales

Tipo de aguja

№ agujas/cajón

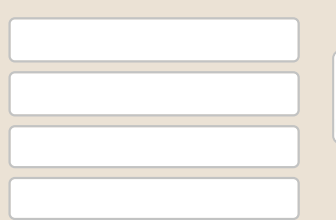

Color de la tapia

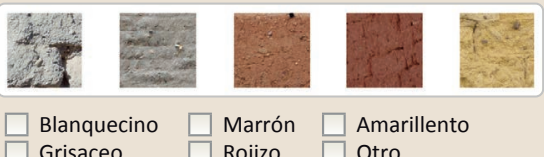

$\square$ Blanquecino $\square$ Marrón $\square$ Amarillento

Variante constructiva

$\square$ simple / homogénea

$\mathbf{X}$ Suplemento superficial

$\mathbf{X}$ Suplemento en juntas

X Mixta
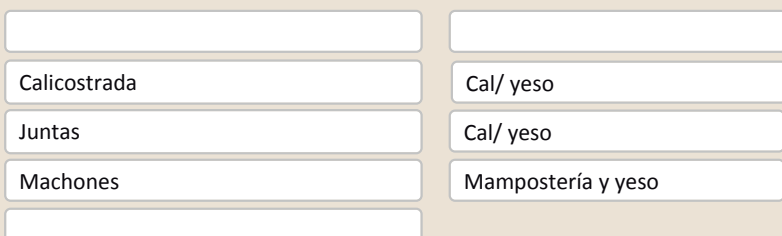

$\square$ Elementos de protección

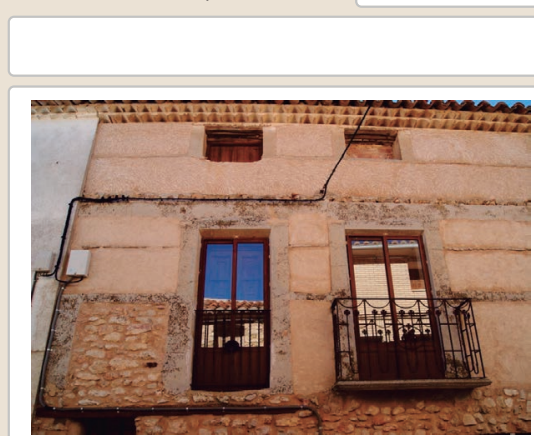

Lesiones $\square$ Muro $\square$ Zócalo $\square$ Revestimiento $\square$ Cubierta $\square$ otro..

$\square$ Erosión del material $\quad \square$ Humedad por capilaridad $\quad \square$ Grietas por asentamientos $\square$ Erosion de las juntas $\square$ Humedades (manch/eflo)

$\square$ Pérdida de sección $\square$ Pérdida de verticalidad

$\square$ Vegetación $\square$ Grietas por empuje de la cubierta

$\square$ Desconcha

$\square$ Grietas porfalta de traba
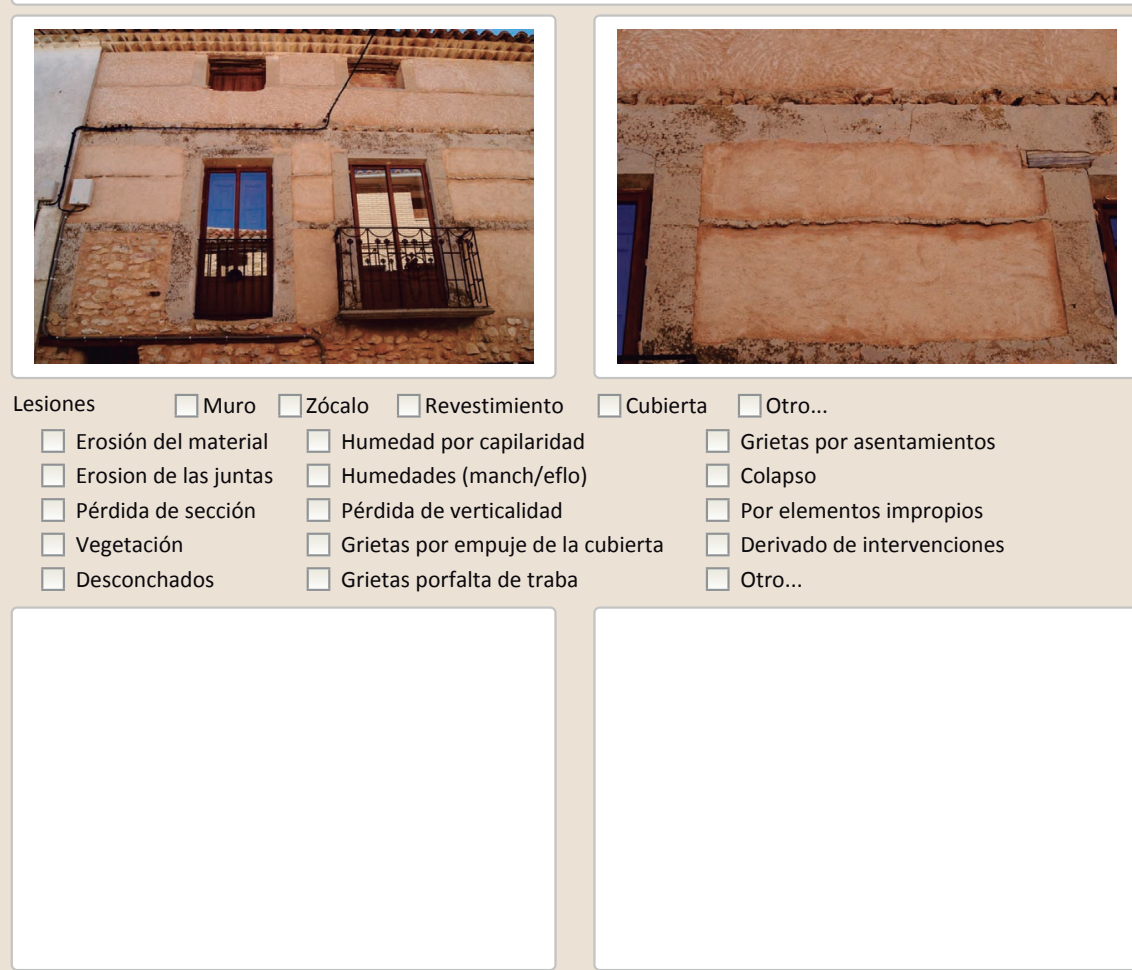

Observaciones

No presenta lesiones 


\section{La restauración y rehabilitación de la arquitectura tradicional de tierra.} El caso de Aragón.

3. DATOS DE LA INTERVENCIÓN

$\square$ Mantenimien

Reflexión previa

$\square$ Reparación

$\square$ Rehabilitación parcial

\ Restauración $\square$ Demolición

Intervención planificada

Observaciones

El edificio ha sido rehabillado tradicionales y su estética

3.1. MUROS Tipo de intervención

Tipo de material

\section{Intervenido}

$\square$ Actualización $\square$ Reintegración $\square$ Demolición $\square$ Otro...

$\square$ Consolidación $\mathbf{X}$ Reconstrucción $\square$ Sustitución

Descripción

Tradicional diferente

Tipo de técnica Diferente a la existente

Se ha vuelto ha realizar la costra del cada uno de los tapiales conservando la junta Se ha vuelto ha realizar la costra del cada uno de los tapiales conservando la ju
intermedia entre unos y otros. Muro piñón superior pueden que sean nuevos

3.2. ZÓCALO

Tipo de intervención

Intervenido

$\square$ Actualización $\quad \mathbf{X}$ Reintegración $\quad \square$ Demolición $\square$ Otro..

$\square$ consolidación $\quad \square$ Reconstrucción $\square$ Sustitución

Tipo de material

Tradicional diferente

Tipo de técnica Similar a la existente

Descripción

3.3. REVESTIMIENTOS

Tipo de intervención

Rejuntado de la mampostería de planta baja

\section{No aplica}

$\square$ Actualización $\square$ Reintegración $\square$ Demolición $\square$ Otro...

$\square$ Consolidación $\square$ Reconstrucción $\square$ sustitución

Tipo de material

Descripción

3.4. VANOS

Tipo de intervención

Intervenido

Tipo de material

$\square$ Actualización $\quad \boldsymbol{X}$ Reintegración $\square$ Demolición $\square$ Otro...

$\square$ Consolidación $\square$ Reconstrucción $\quad \boldsymbol{X}$ Sustitución

\begin{tabular}{l|l|l|l|l|l} 
Tipo de material & No tradicional de técnica & Diferente a la existente
\end{tabular}

Descripción Doble carpintería en los huecos. Se han insertado carpinterías correderas en el exterior y las antiguas son visibles en el interior. Puerta acceso sustituida

3.5. CUBIERTA Intervenido

Tipo de intervención

$\square$ Actualización

X Reintegración $\square$ Demolición $\square$ Otro...

$\square$ Consolidación $\square$ Reconstrucción $\square$ Sustitución

Tipo de material

No tradicional

Tipo de técnica Similar a la existente

Descripción

Reintegración de la tejas de cubierta con mortero de cemento
La restauración y rehabilitación de la arquitectura tradicional de tierra.

El caso de Aragón.

3.7. REHABILITACIÓN ENERGÉTICA $\quad \square$ Fachada $\square$ Vanos $\square$ Forjados $\square$ Cubierta

Observaciones

FOTOGRAFÍAS DE LA INTERVENCIÓN
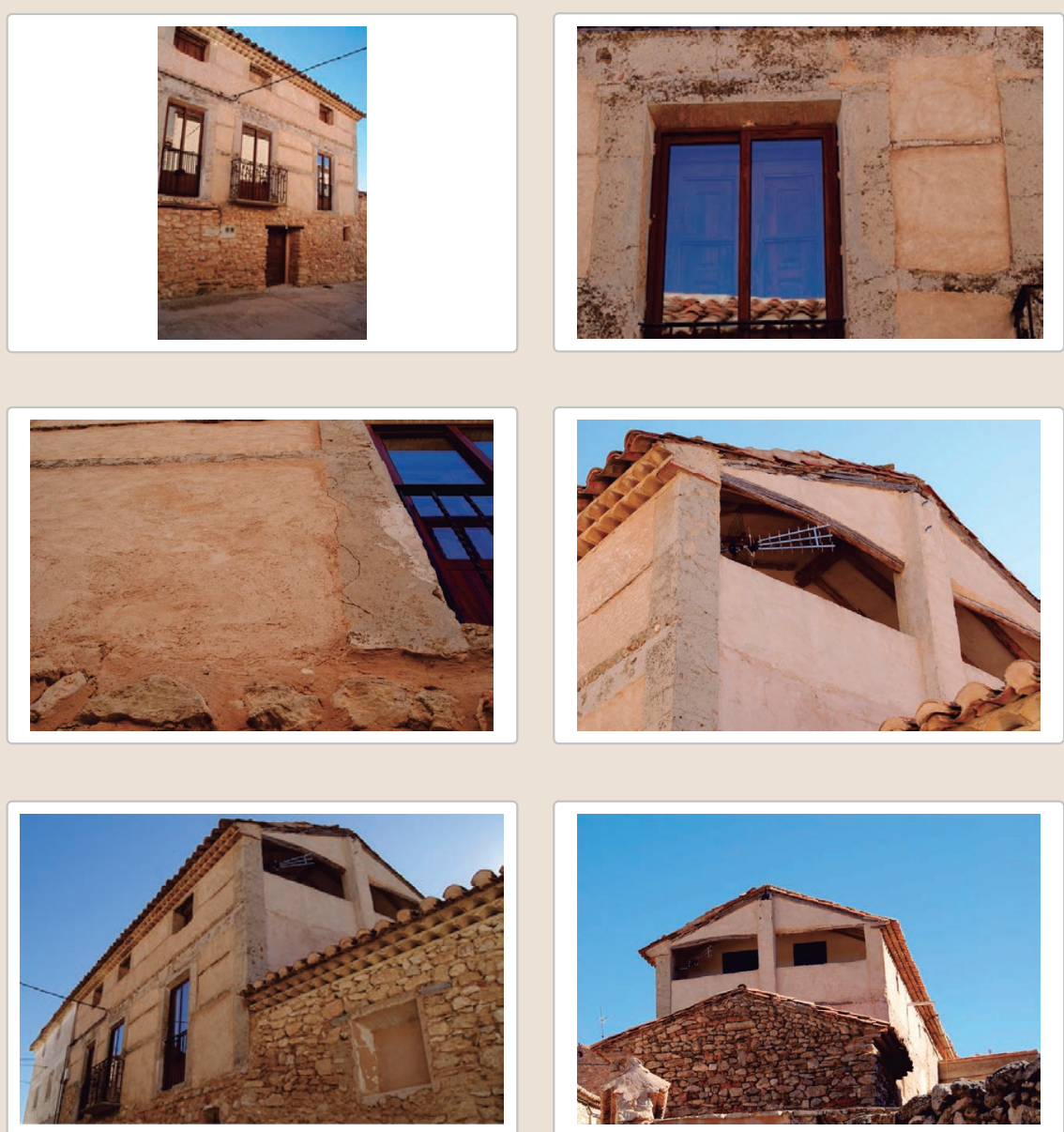

3.6. OTRAS 


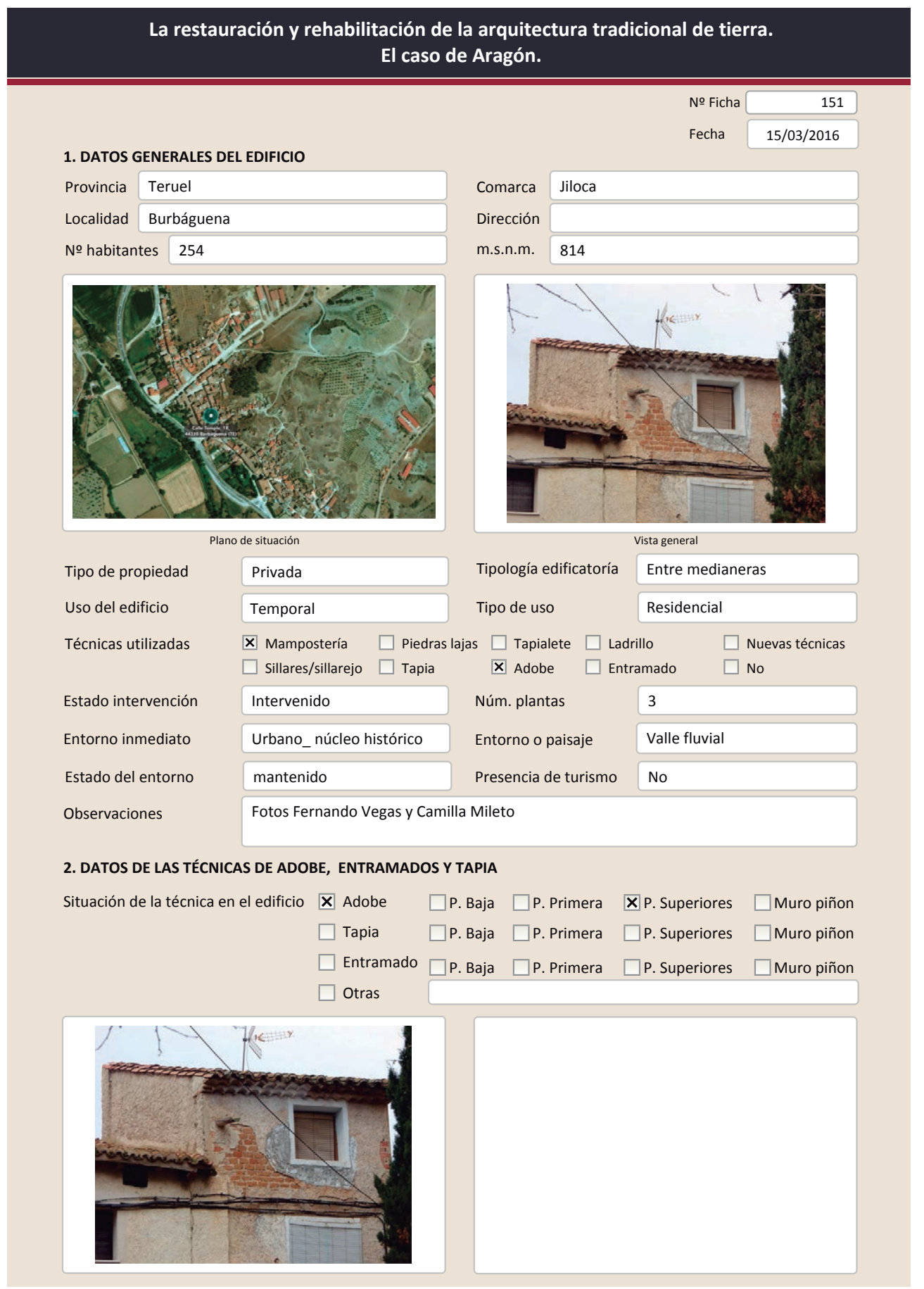

La restauración y rehabilitación de la arquitectura tradicional de tierra.

El caso de Aragón.

2.1. ADOBE

Dimensión de las piezas

Dimensión del muro

Aparejo del muro

Función estructural

Variante constructiva/ tipo de fábrica

$\square$ Simple

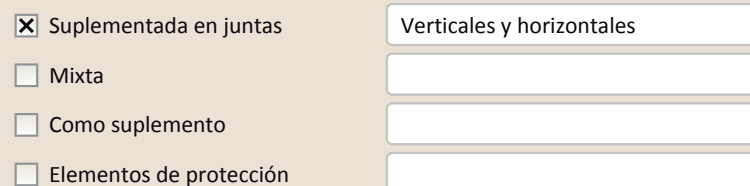

$\square$ Elementos de protección

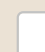

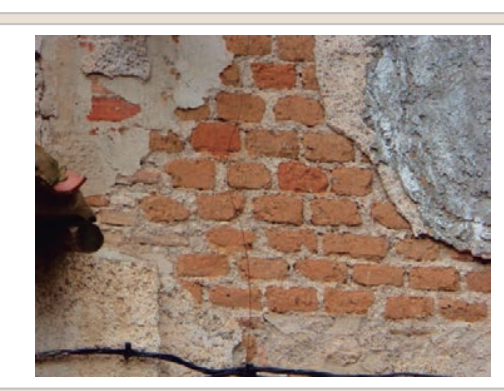

Lesiones $\quad \mathbf{X}$ Muro $\square$ Zócalo $\mathbf{X}$ Revestimiento

$\mathbf{X}$ Erosión del material $\square$ Humedad por capilaridad $\square$ Erosion de las juntas $\square$ Humedades (manch/eflo)

$\square$ Pérdida de sección $\square$ Pérdida de verticalidad

$\square$ Vegetación

X Desconchados

$\square$ Grietas por empuje de la cubie
$\square$ Grietas porfalta de traba

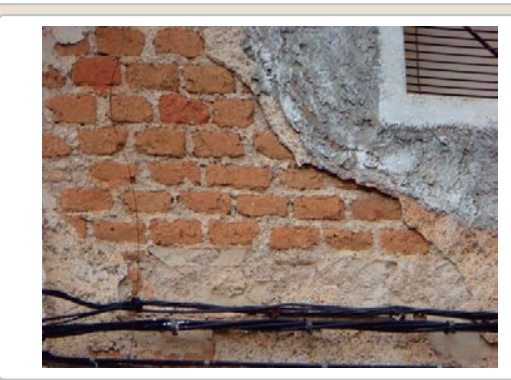

Color de las piezas

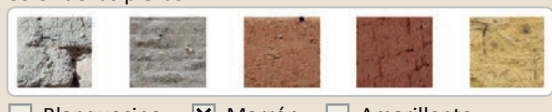

$\square$ Blanquecino $\quad \mathbf{X}$ Marrón $\square$ Amarillento

Grisaceo $\square$ Rojizo $\square$ Otro...

Comp. - estabilizante $\square$ Cubierta $\square$ otro...
$\square$ Grietas por asentamiento
$\square$ Colapso
$\square$ Por elementos impropios
$\square$ Derivado de intervenciones $\square$ Otro...

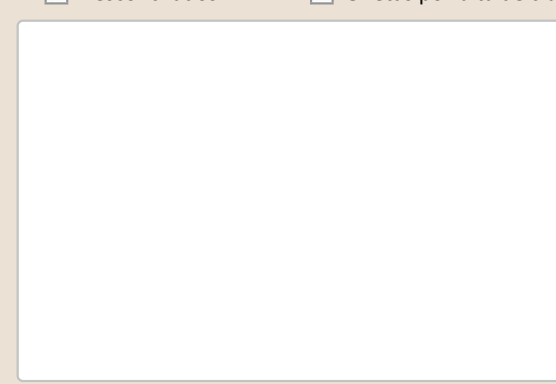

Observacione 
La restauración y rehabilitación de la arquitectura tradicional de tierra. El caso de Aragón

\section{La restauración y rehabilitación de la arquitectura tradicional de tierra.}

\section{El caso de Aragón.}

3. DATOS DE LA INTERVENCIÓN

Intervención de:

$\square$ Mantenimiento $\square$ Rehabilitación parcia

$\square$ Restauración $\square$ Demolición X Reparación $\quad \square$ Rehabilitación integral $\quad \square$ Ampliación $\quad \square$ Otro...

Reflexión previa Intervención espontanea

Observaciones

3.1. MUROS

Intervenido

Tipo de intervención

$\square$ Actualización $\square$ Reintegración $\square$ Demolición $\square$ Otro...

$\square$ Consolidación $\square$ Reconstrucción $\quad \boldsymbol{X}$ Sustitución

Tipo de material

\begin{tabular}{l|l|l|l} 
No tradicional & Tipo de técnica & Similar a la existente
\end{tabular}

Descripción

Sustitución de las piezas de las esquinas por ladrillos huecos.

3.2. ZÓCALO

Intervenido

Tipo de intervención

Actualización $\square$ Reintegración $\square$ Demolición $\square$ Otro..

$\square$ Actualización
$\square$ Consolidación $\quad \boldsymbol{X}$ Reintegracionstrucción $\quad \square$ Sustitución

Tipo de material

No tradicional Tipo de técnica Diferente a la existente

Descripción

3.3. REVESTIMIENTOS

Tipo de intervención

Intervenido

Tipo dematenta

$\square$ Actualización $\square$ Reintegración $\square$ Demolición $\square$ Otro...

$\square$ Consolidación $\quad \mathbf{X}$ Reconstrucción $\square$ Sustitución

Tipo de materia

No tradicional

Tipo de técnica Diferente a la existente

Descripción

3.4. VANOS

Nuevo revestimiento de cemento en todo el edificio

Tipo de intervención

No visible

Tipo de material

Descripción

3.5. CUBIERTA

Tipo de intervención

Intervenido

Tipo de intervención

$\square$ Actualización $\quad \boldsymbol{X}$ Reintegración $\quad \square$ Demolición $\quad \square$ Otro...
$\square$ Consolidación $\quad \square$ Reconstrucción $\quad \square$ Sustitución

Tipo de material

No tradicional

Tipo de técnica Similar a la existente

Descripción

Reintegración de tejas en la zona del alero con mortero de cemento

3.6. OTRAS 


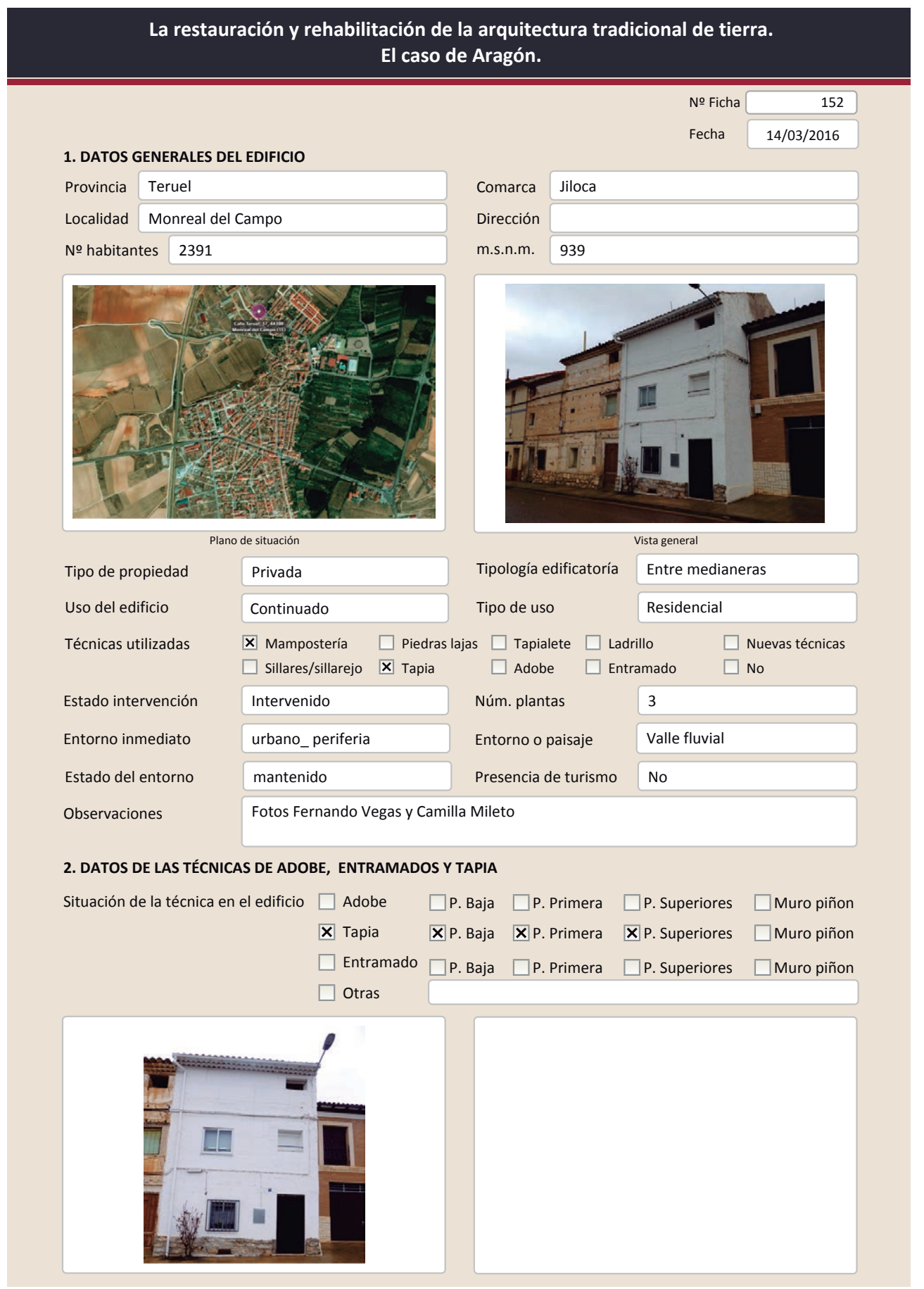

La restauración y rehabilitación de la arquitectura tradicional de tierra.

El caso de Aragón.

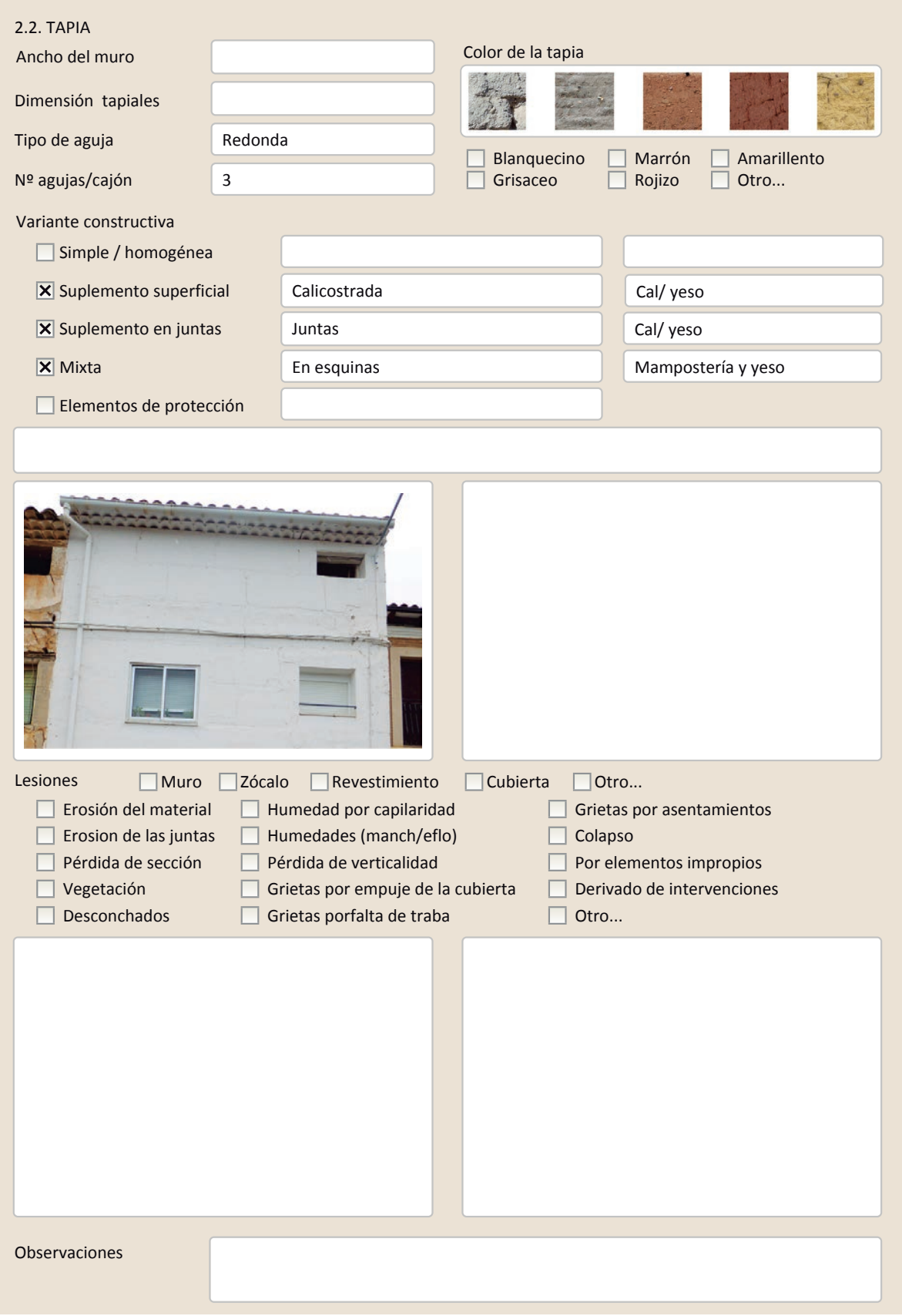




\section{La restauración y rehabilitación de la arquitectura tradicional de tierra.}

\section{El caso de Aragón.}

3. DATOS DE LA INTERVENCIÓN

$\square$ Mantenimiento $\quad \mathbf{X}$ Rehabilitación parcia

$\square$ Restauración $\square$ Demolición

Reflexión previa

X Reparación

Rehabilitación integra

$\square$ Ampliación

$\square$ otro...

Reflexion previa

Intervención planificada

Observaciones

\subsection{MUROS}

Tipo de intervención

Tipo de material

Intervenido

$\square$ Actualización $\quad \mathbf{x}$ Reintegración $\square$ Demolición $\square$ Otro...

$\square$ Consolidación $\quad \square$ Reconstrucción $\square$ Sustitución

Descripción

No tradicional

Tipo de técnica Diferente a la existente

3.2. ZÓCALO

Tipo de intervención

Se aprecian parches sobre el muro de tapia.

Intervenido

X Actualización $\mathbf{x}$ Reintegración $\square$ Demolición $\square$ Otro...

$\square$ Consolidación $\quad \square$ Reconstrucción $\square$ Sustitución

Tipo de material

Descripción

3.3. REVESTIMIENTOS

Tipo de intervención

Tipo de material

Descripción

3.4. VANOS

Tipo de intervención

Tipo de material

Descripción

3.5. CUBIERTA

Tipo de intervención

Tipo de material

Descripción

3.6. OTRAS

Tipo de técnica Similar a la existente

Intervenido

X Actualización $\square$ Reintegración $\square$ Demolición $\square$ Otro...

$\square$ Consolidación $\mathbf{X}$ Reconstrucción $\square$ Sustitución

No tradicional Tipo de técnica Diferente a la existente

revestimiento de cemento en la fachada lateral. Pintura plástica blanca en todo el

edificio

Intervenido

$\square$ Actualización $\quad \square$ Reintegración $\square$ Demolición $\square$ Otro...

$\square$ Consolidación $\square$ Reconstrucción $\mathbf{X}$ Sustitución

No tradicional Tipo de técnica Diferente a la existente

Sustitución parcial por carpinterías. Doble carpintería de aluminio en algunos de los huecos

\section{No visible}

$\square$ Actualización $\quad \square$ Reintegración $\quad \square$ Demolición $\square$ Otro.

$\square$ Consolidación $\square$ Reconstrucción $\square$ Sustitución Tipo de técnica
La restauración y rehabilitación de la arquitectura tradicional de tierra.

El caso de Aragón.

3.7. REHABILITACIÓN ENERGÉTICA $\square$ Fachada $\quad$ V Vanos $\square$ Forjados $\square$ Cubierta

Observaciones

FOTOGRAFíAS DE LA INTERVENCIÓN 


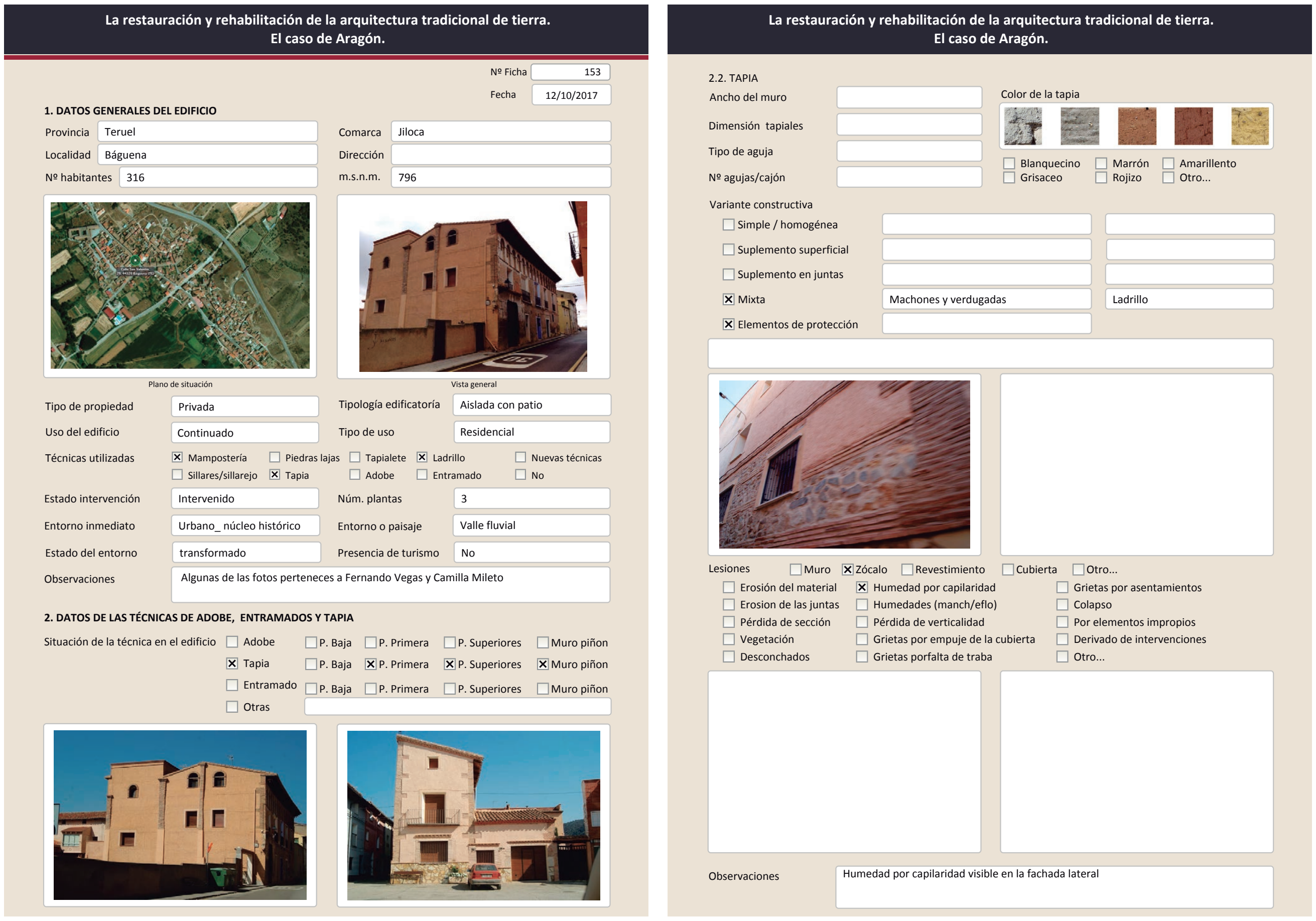




\section{La restauración y rehabilitación de la arquitectura tradicional de tierra.} El caso de Aragón.

3. DATOS DE LA INTERVENCIÓN

Intervención de:

$\checkmark$ Mantenimiento

Reflexión previa Intervención planificada

Observaciones El edificio parece haber sido ampliado por la parte trasera. Los huecos en el muro lateral son nuevos (arcos de ladrillo nuevos)

3.1. MUROS
Tipo de intervención

\section{Intervenido}

$\square$ Actualización $\quad$ X Reintegración $\square$ Demolición $\square$ Otro...

$\square$ Consolidación $\square$ Reconstrucción $\square$ Sustitución

$\begin{array}{lll}\text { Tipo de material Tradicional diferente } & \text { Tipo de técnica Similar a la existente }\end{array}$

Descripción

3.2. ZÓCALO

Tipo de intervención

Intervenido

邓 Actualización $\square$ Reintegración $\quad \square$ Demolición $\square$ Otro...

$\square$ Consolidación $\quad \mathbf{X}$ Reconstrucción $\square$ Sustitución

Tipo de material
Descripción

3.3. REVESTIMIENTOS

Tipo de intervención

Tipo de material

Descripción

3.4. VANOS

Tipo de intervención

Tipo de material

Descripción

3.5. CUBIERTA

Tipo de intervención

Tipo de material

Descripción

\section{Tipo de técnica Diferente a la existente}

\section{Intervenido}

X Actualización $\square$ Reintegración $\square$ Demolición $\square$ Otro...

$\square$ Consolidación $\square$ Reconstrucción $\mathbf{X}$ Sustitución

No tradicional Tipo de técnica Diferente a la existente

Enlucido de cemento con pintura plástica en un lateral y momocapa coloreado en el

otro

\section{Intervenido}

$\square$ Actualización $\quad \square$ Reintegración $\square$ Demolición $\square$ Otro...

$\square$ Consolidación $\square$ Reconstrucción $\mathbf{X}$ Sustitución

Tradicional diferente Tipo de técnica Similar a la existente

Sustitución carpinterías de madera

\section{Intervenido}

$\square$ Actualización $\square$ Reintegración $\square$ Demolición $\square$ Otro..

$\square$ Consolidación $\quad \boldsymbol{x}$ Reconstrucción $\square$ Sustitución
No tradicional
Tipo de técnica Similar a la existente

La cubierta parece reconstruida desde el exterior. Se aprecian las tejas tradicionales pero se desconoce el sistema estructural utilizado
La restauración y rehabilitación de la arquitectura tradicional de tierra.

El caso de Aragón.

3.6. OTRAS

3.7. REHABILITACIÓN ENERGÉTICA $\square$ Fachada $\quad \boldsymbol{X}$ Vanos $\square$ Forjados $\square$ Cubierta

Observaciones Intervención en la fachada lateral, cambio de carpinterías.

FOTOGRAFíAS DE LA INTERVENCIÓN
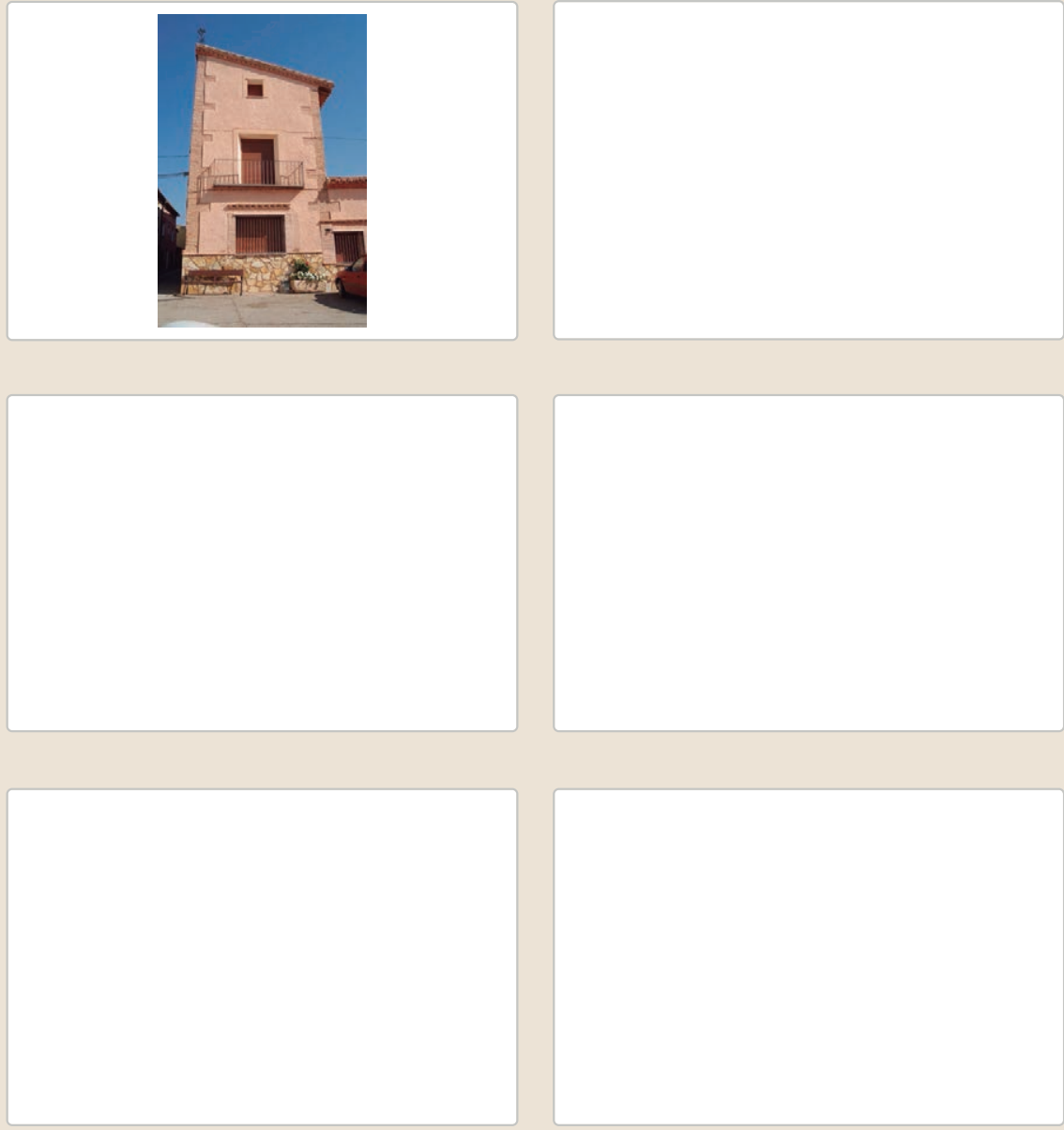


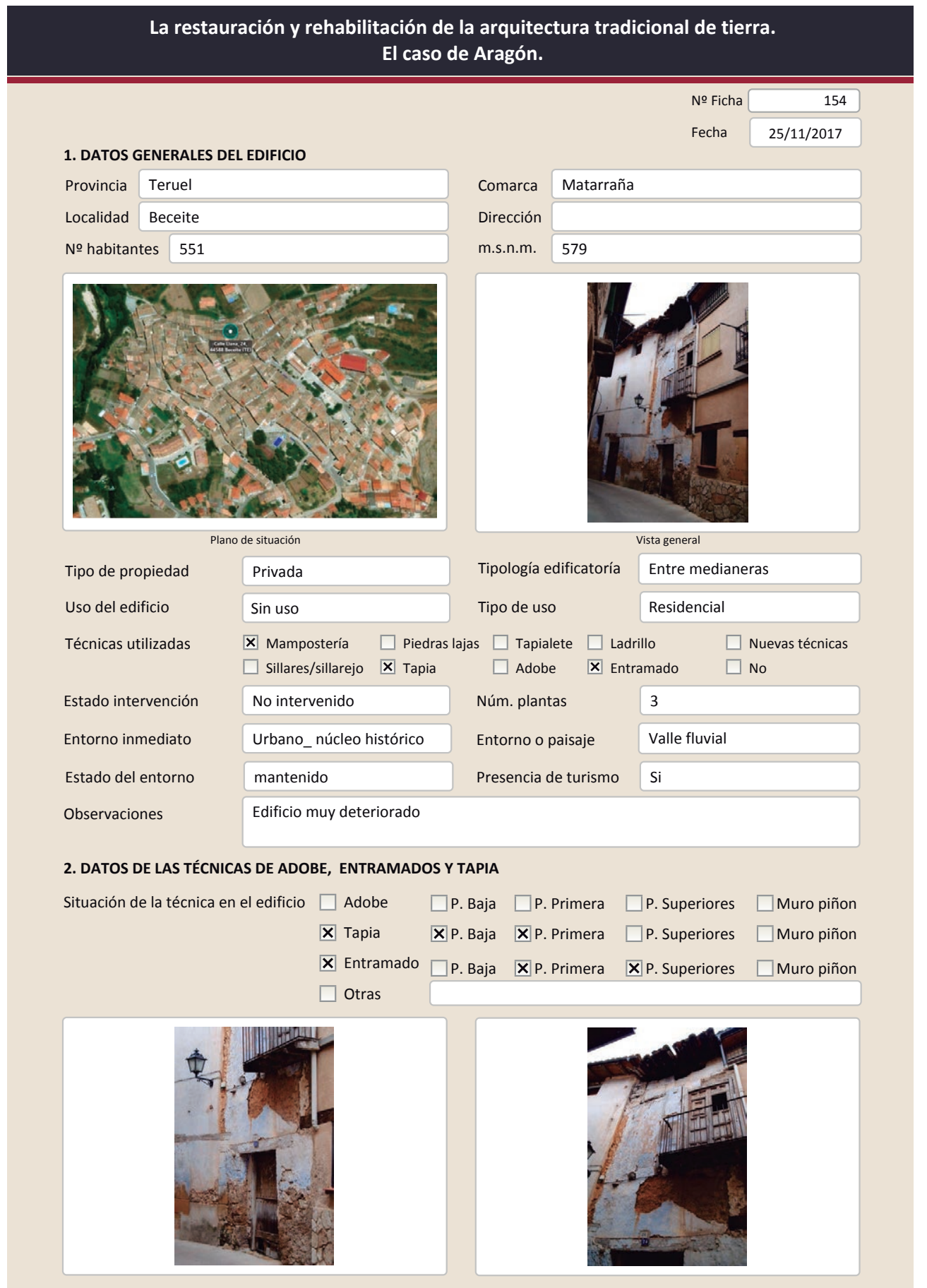

La restauración y rehabilitación de la arquitectura tradicional de tierra.

El caso de Aragón.

2.2. TAPIA

Ancho del muro

Dimensión tapiales

Tipo de aguja

№ agujas/cajón

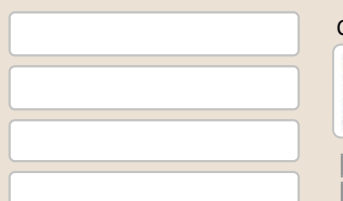

Color de la tapia

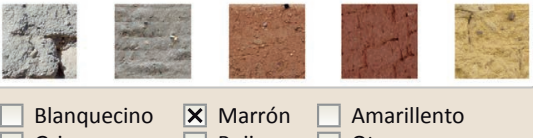

$\square$ Blanquecino $\quad \mathbf{X}$ Marrón $\square$ Amarillento

X Simple / homogén

$\square$ Suplemento superficial

$\square$ Suplemento en juntas

$\square$ Mixta

$\mathbf{X}$ Elementos de protección

Simple / homogénea

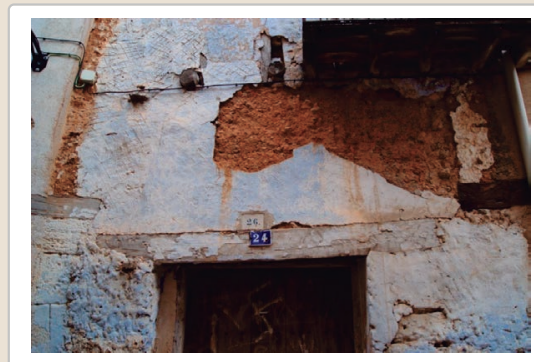

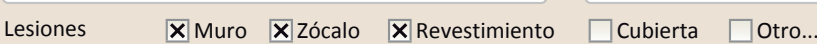

X Erosión del material $\quad \mathbf{X}$ Humedad por capilaridad $\quad \square$ Grietas por asentamiento $\square$ Erosion de las juntas $\quad \square$ Humedades (manch/eflo)

$\square$ Pérdida de sección $\quad \square$ Pérdida de verticalidad

$\square$ Vegetación

$\square$ Por elementos impropios

$\mathbf{X}$ Desconchado

$\square$ Grietas porfalta de traba
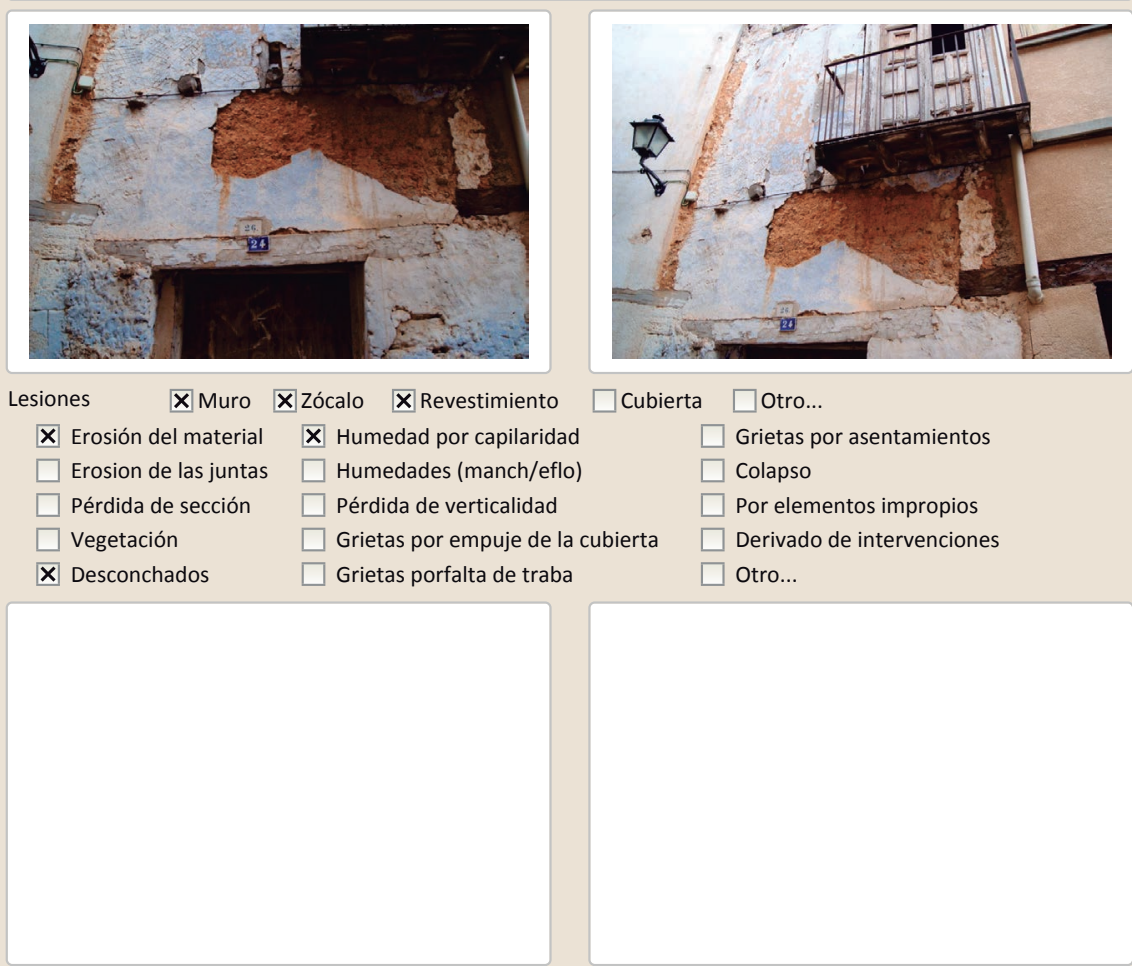

Observaciones 
La restauración y rehabilitación de la arquitectura tradicional de tierra. El caso de Aragón

\section{La restauración y rehabilitación de la arquitectura tradicional de tierra.}

\section{El caso de Aragón.}

2.3. ENTRAMADOS

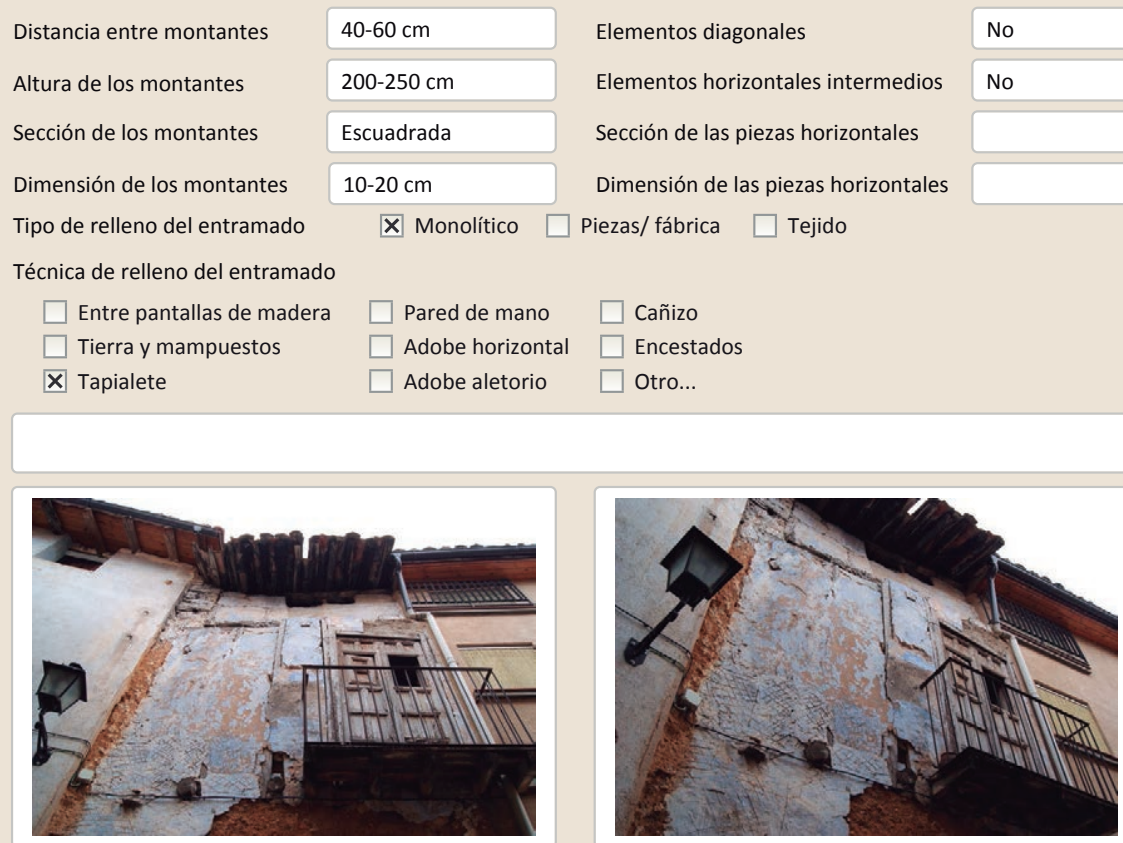

Lesiones $\quad \mathbf{X}$ Muro $\square$ Zócalo $\mathbf{X}$ Revestimiento $\square$ Cubierta $\square$ Otro...
$\mathbf{X}$ Erosión del material
$\mathbf{X}$ Carcoma o termitas
$\square$ Grietas por falta de traba
$\square$ Erosion de las juntas
$\square$ Rotura de la madera
$\square$ Pérdida de sección
$\square$ Pudrición de la madera
$\square$ Grietas por asentamientos
$\square$ Vegetación
X Deformación madera
$\square$ Colapso
$\square$ Humedad por capilaridad $\quad \mathbf{X}$ Pérdida de verticalidad
Derivado de intervenciones
$\square$ Humedades (manch/eflor) $\quad \square$ Grietas por empuje de la cubierta
$\square$ Otro...

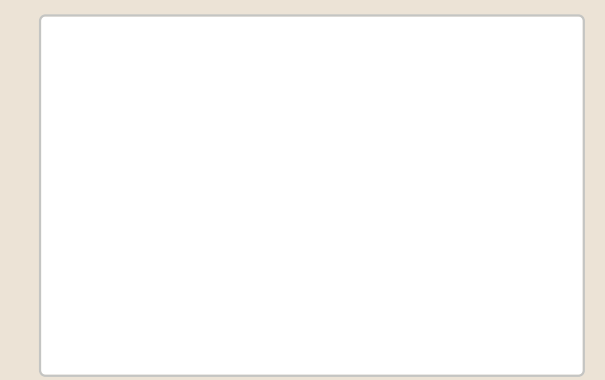




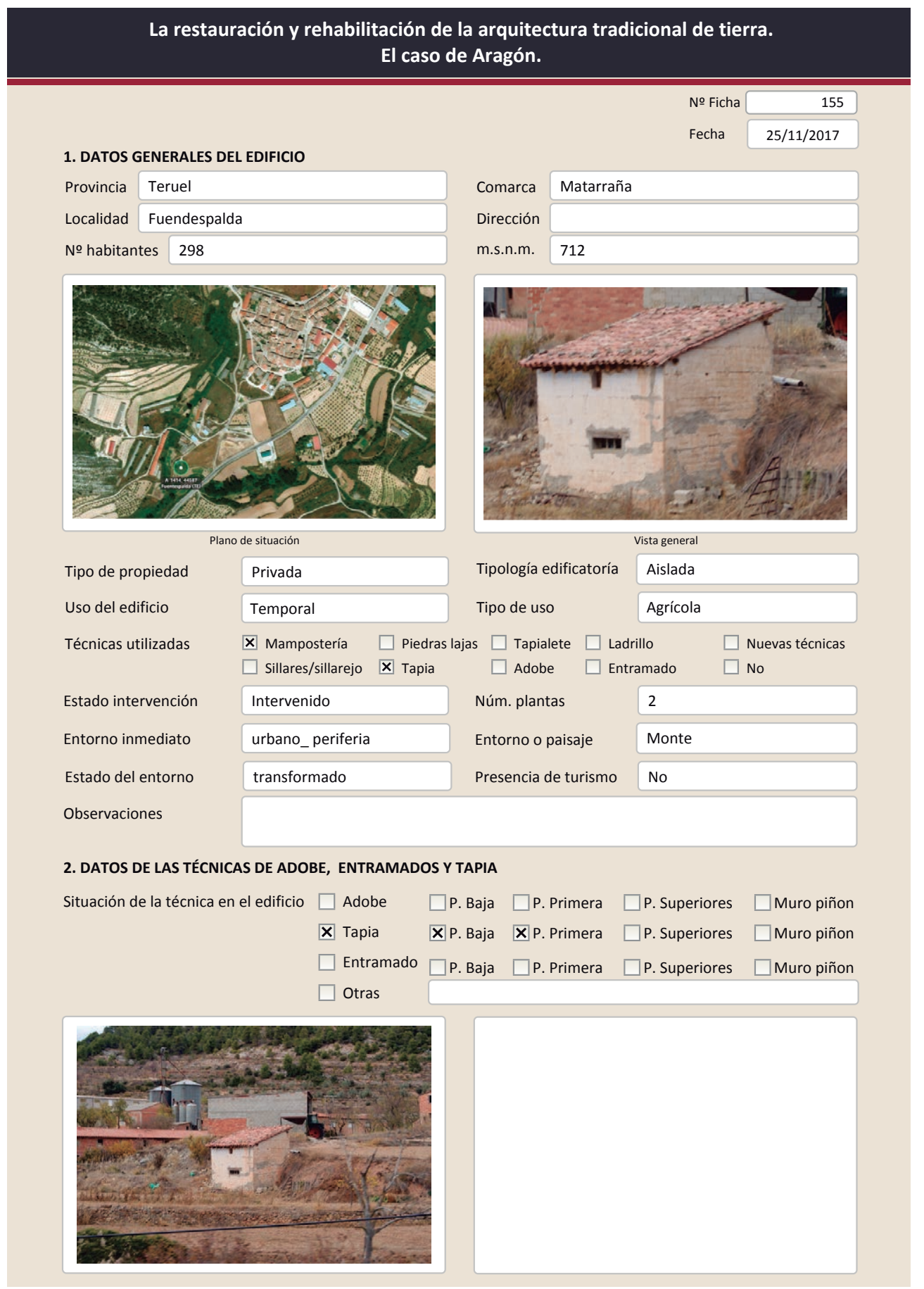

La restauración y rehabilitación de la arquitectura tradicional de tierra. El caso de Aragón.

2.2. TAPIA

Ancho del muro

Dimensión tapiales

Tipo de aguja

№ agujas/cajón

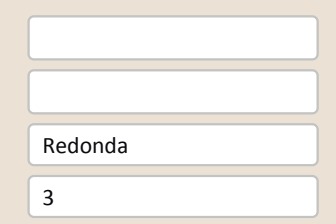

Color de la tapia

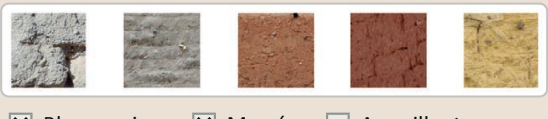

$\mathbf{X}$ Blanquecino $\mathbf{X}$ Marrón $\square$ Amarillento

$\begin{array}{ll}x \text { Blanquecino } & \mathbf{x} \text { Marrón } \\ \square \text { Grisaceo } & \square \text { Rojizo } \quad \square \text { Otro.. }\end{array}$

Variante constructiva

$\square$ Simple / homogénea

X Suplemento superficial

$\square$ suplemento en juntas

$\square$ Mixta

$\square$ Elementos de protección
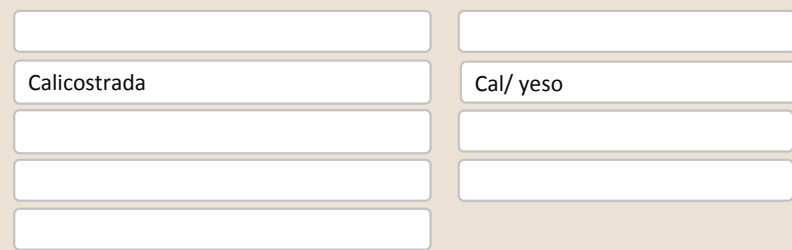

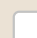

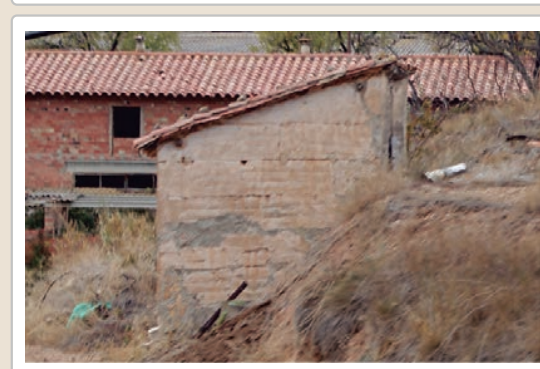

Lesiones $\mathbf{X M u r o ~} \mathbf{X}$ Zócalo $\square$ Revestimiento $\square$ Cubierta $\square$ otro...

X Erosión del material $\quad \mathbf{X}$ Humedad por capilaridad $\quad \square$ Grietas por asentamiento

$\square$ Erosion de las juntas $\square$ Humedades (manch/eflo) $\quad \square$ Colapso

$\square$ Pérdida de sección $\square$ Pérdida de verticalidad $\quad \square$ Por elementos impropios

$\square$ Vegetación $\quad \square$ Grietas por empuje de la cubierta $\square$ Derivado de intervenciones X Desconchados $\square$ Grietas porfalta de traba $\quad \square$ Otro...

Observaciones 
La restauración y rehabilitación de la arquitectura tradicional de tierra. El caso de Aragón

\section{La restauración y rehabilitación de la arquitectura tradicional de tierra.}

\section{El caso de Aragón.}

3. DATOS DE LA INTERVENCIÓN

Intervención de:

$\square$ Mantenimiento $\square$ Rehabilitación parcia

$\square$ Restauración $\square$ Demolición

Reflexión previa

X Reparación

$\square$ Rehabilitación integral $\square$ Ampliación

$\square$ Otro..

Reflexión previa
Observaciones

Intervención espontanea

3.1. MUROS

Tipo de intervención

Intervenido

Tipo de material

$\square$ Actualización $\quad$ X Reintegración $\square$ Demolición $\square$ Otro..

$\square$ Consolidación $\square$ Reconstrucción $\square$ Sustitución

Descripción

\begin{tabular}{ll|l} 
No tradicional & Tipo de técnica Diferente a la existente
\end{tabular}

3.2. ZÓCALO

Reintegración de oquedades o partes faltantes

Tipo de intervención

No intervenido

Tipo de material

$\square$ Actualización $\square$ Reintegración $\square$ Demolición $\square$ Otro...

$\square$ Consolidación $\square$ Reconstrucción $\square$ Sustitución

Descripción

3.3. REVESTIMIENTOS

Tipo de intervención

\section{No aplica}

Tipo de material

$\square$ Actualización

Tipo de técnica

Descripción

3.4. VANOS

Tipo de intervención

Intervenido

$\begin{array}{lll} & \square \text { Consolidación } \square \text { Reconstrucción } \square \text { Sustitución } \\ \text { Tipo de material } & \text { No tradicional } & \text { Tipo de técnica Similar a la existente }\end{array}$

$\square$ Actualización $\quad \mathbf{X}$ Reintegración $\square$ Demolición $\square$ Otro...

Descripción Reintegración de uno de los huecos de planta baja con cemento

3.5. CUBIERTA

Tipo de intervención

No intervenido

Tipo de material

$\square$ Actualización $\square$ Reintegración $\square$ Demolición $\square$ Otro..

$\square$ Consolidación $\square$ Reconstrucción $\square$ Sustitución

Descripción

$$
\text { Tipo de técnica }
$$

3.6. OTRAS 


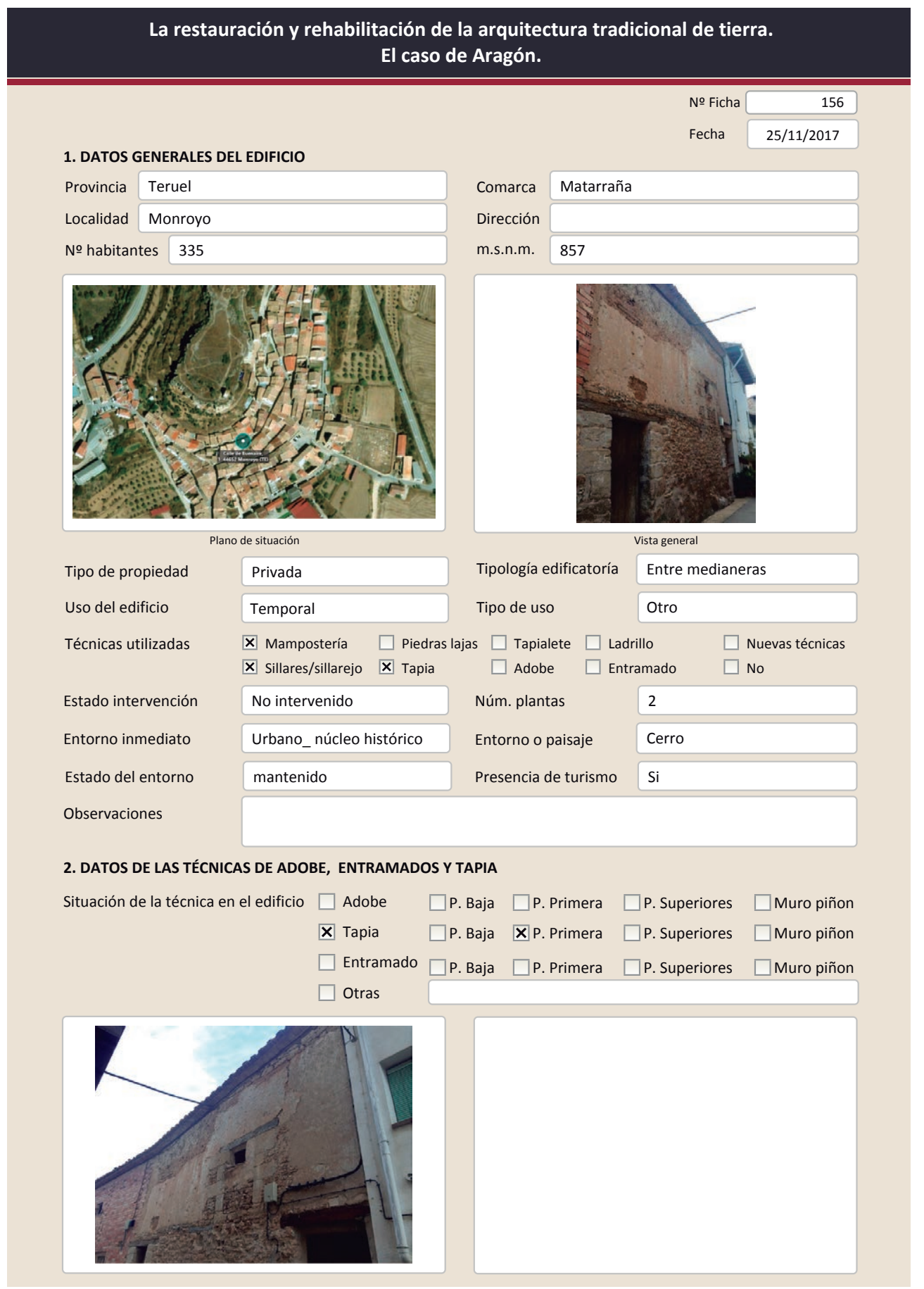

La restauración y rehabilitación de la arquitectura tradicional de tierra.

El caso de Aragón.
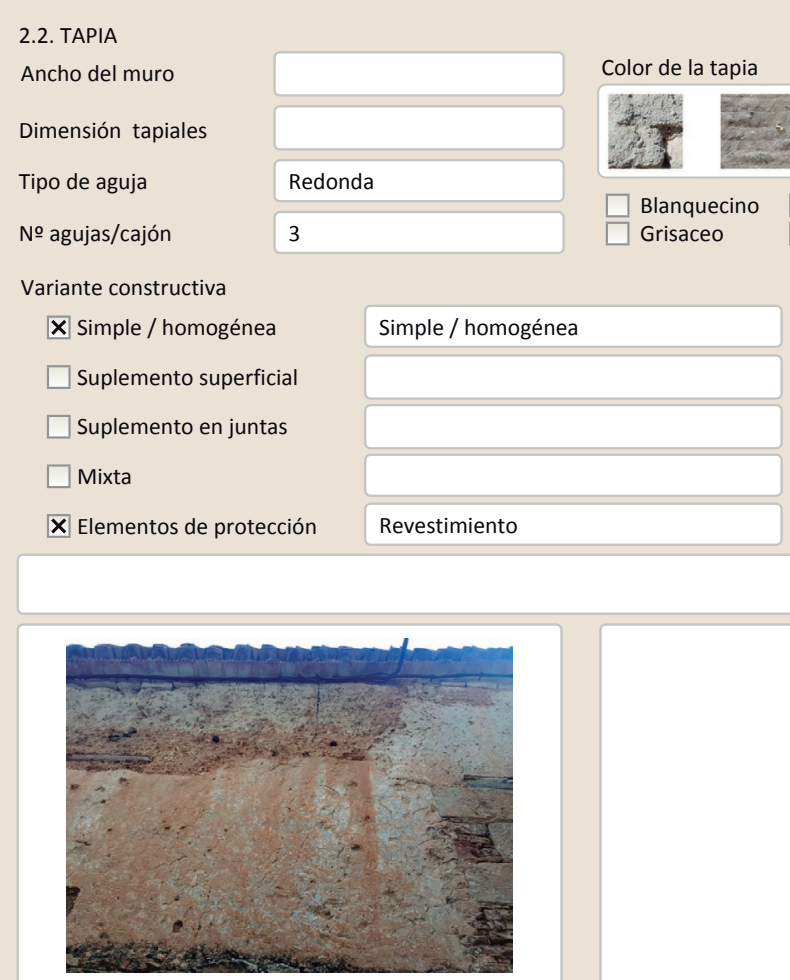

Lesiones $\mathbf{X}$ Muro $\mathbf{X}$ Zócalo $\mathbf{X}$ Revestimiento $\square$ Cubierta $\square$ otro...

X Erosión del material $\mathbf{X}$ Humedad por capilaridad $\quad \square$ Grietas por asentamientos $\square$ Erosion de las juntas $\square$ Humedades (manch/eflo) $\quad \square$ Colapso

$\square$ Pérdida de sección $\square$ Pérdida de verticalidad $\quad \square$ Por elementos impropios

$\square$ Vegetación $\quad \square$ Grietas por empuje de la cubierta $\square$ Derivado de intervenciones 区 Desconchados $\quad \square$ Grietas porfalta de traba $\quad \square$ Otro...

Observaciones 


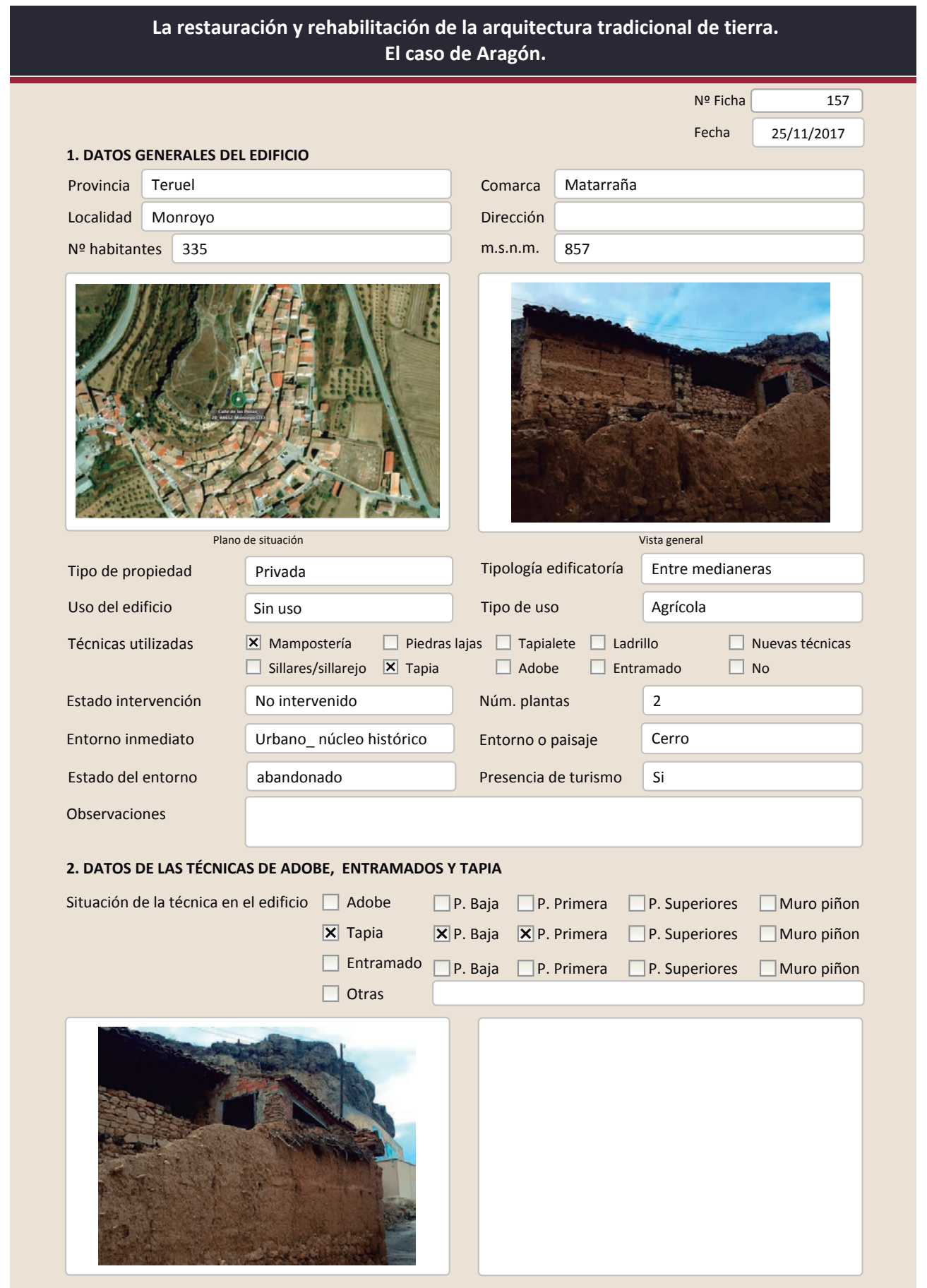

2.2. TAPIA

Ancho del muro

Dimensión tapiales

Tipo de aguja

\begin{tabular}{|l|}
\hline $40-50 \mathrm{~cm}$ \\
\hline \\
\hline Redonda \\
\hline 3 \\
\hline
\end{tabular}

Color de la tapia

№ agujas/cajón

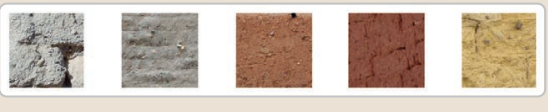

$\square$ Blanquecino $\quad \mathbf{X}$ Marrón $\square$ Amarillento

$\begin{array}{ll}\square \text { Blanquecino } & \mathbf{X} \text { Marrón } \quad \square \text { Amarillento } \\ \square \text { Grisaceo } & \square \text { Rojizo } \quad \square \text { Otro... }\end{array}$

Variante constructiva

$\square$ simple / homogénea

$\square$ suplemento superficial

$\mathbf{X}$ Suplemento en juntas

$\mathbf{X}$ Mixta
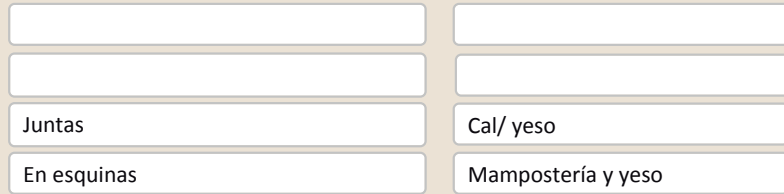

Mampostería y yeso

$\square$ Elementos de protección

Tapia en el edificio y en el muro de cerca con una coronación de ramas con barro que protege al muro

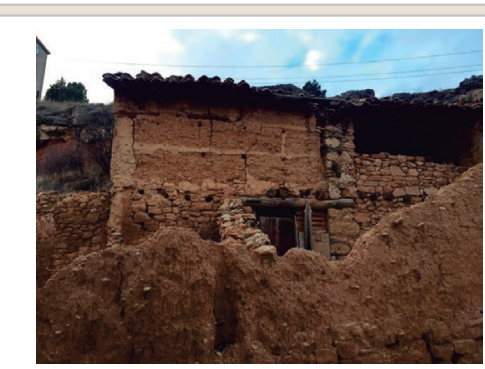

Lesiones \Muro $\square$ Zócalo $\square$ Revestimiento $\square$ Cubierta $\square$ otro...

X Erosión del material $\quad \square$ Humedad por capilaridad $\quad \square$ Grietas por asentamientos $\square$ Erosion de las juntas $\square$ Humedades (manch/eflo)

X Pérdida de sección $\square$ Pérdida de verticalidad

$\square$ Vegetación $\square$ Grietas por empuje de la cubierta

X Colapso

$\square$ Desconchados $\quad \square$ Grietas porfalta de traba

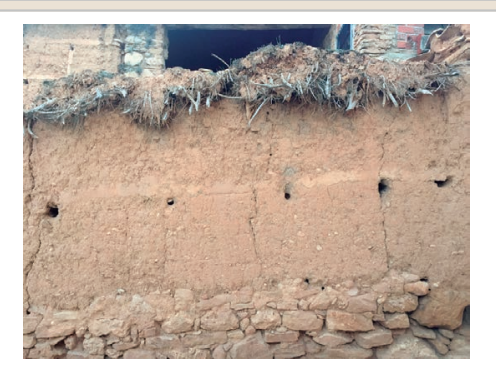

Por elementos impropios

$\square$ Derivado de intervenciones

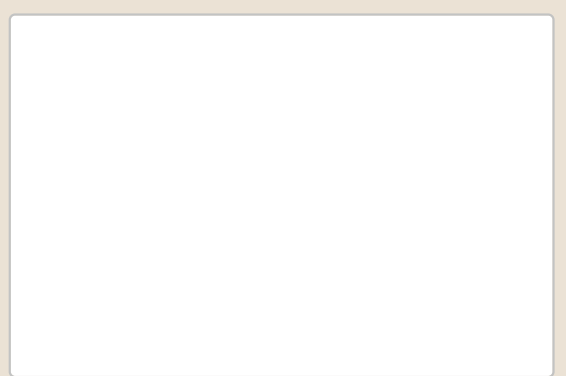
elementos de protección de la coronación 


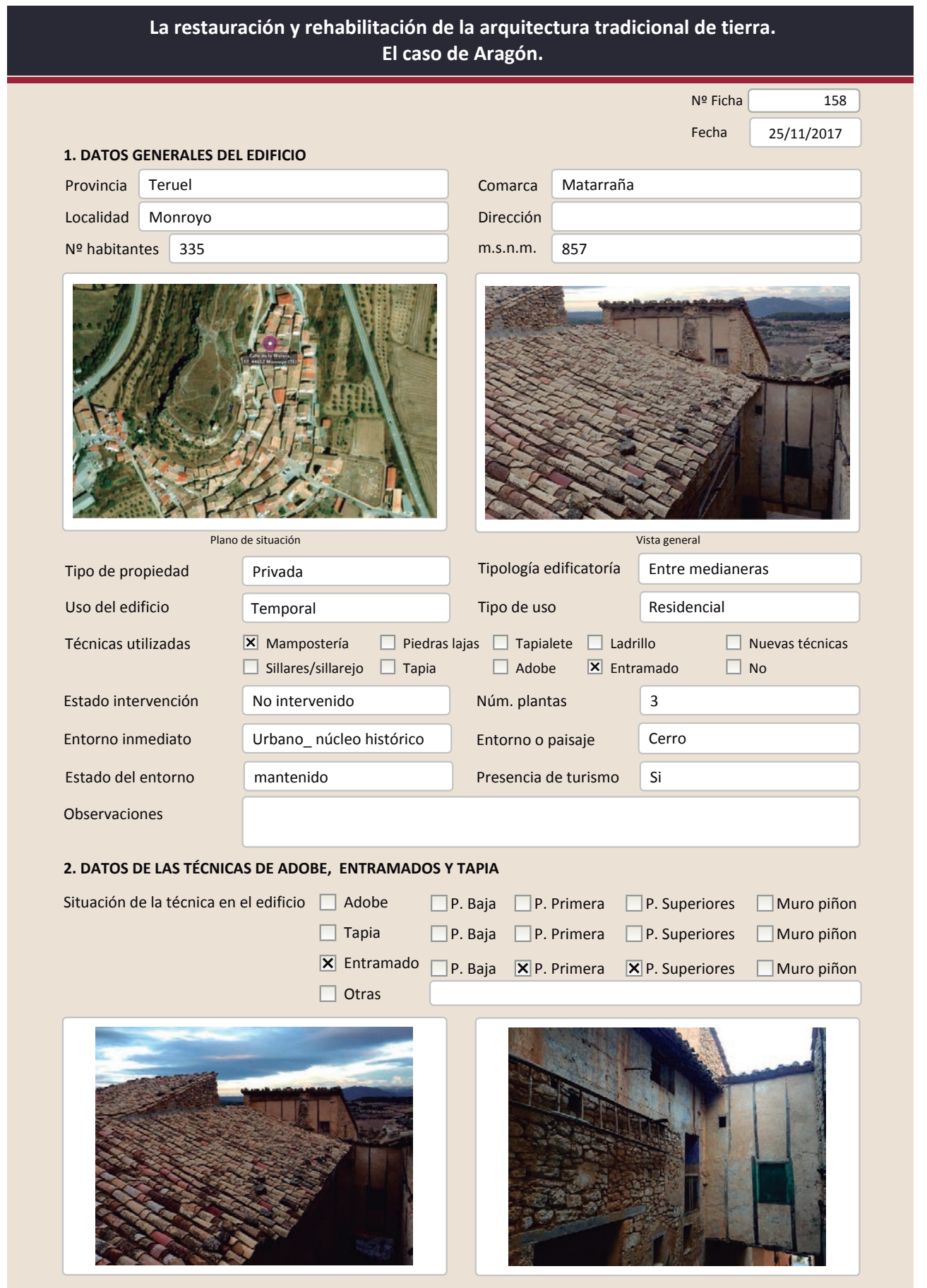

La restauración y rehabilitación de la arquitectura tradicional de tierra.

El caso de Aragón.

2.3. ENTRAMADOS

\begin{tabular}{|c|c|c|c|}
\hline Distancia entre montantes & $60-80 \mathrm{~cm}$ & Elementos diagonales & No \\
\hline Altura de los montantes & $150-200 \mathrm{~cm}$ & Elementos horizontales intermedios & No \\
\hline Sección de los montantes & Escuadrada & Sección de las piezas horizontales & \\
\hline Dimensión de los montantes & $10-20 \mathrm{~cm}$ & Dimensión de las piezas horizontales & \\
\hline
\end{tabular}

Dimensión de los montantes Dimensión de las piezas horizontales

Tipo de relleno del entramado $\quad \mathbf{X}$ Monolítico $\square$ Piezas/fábrica $\quad \square$ Tejido

Técnica de relleno del entramado

$\square$ Entre pantallas de madera $\quad \square$ Pared de mano $\quad \square$ Cañizo

$\square$ Tierra y mampuestos $\square$ Adobe horizontal $\square$ Encestados

X Tapialete $\square$ Adobe aletorio $\square$ Otro..

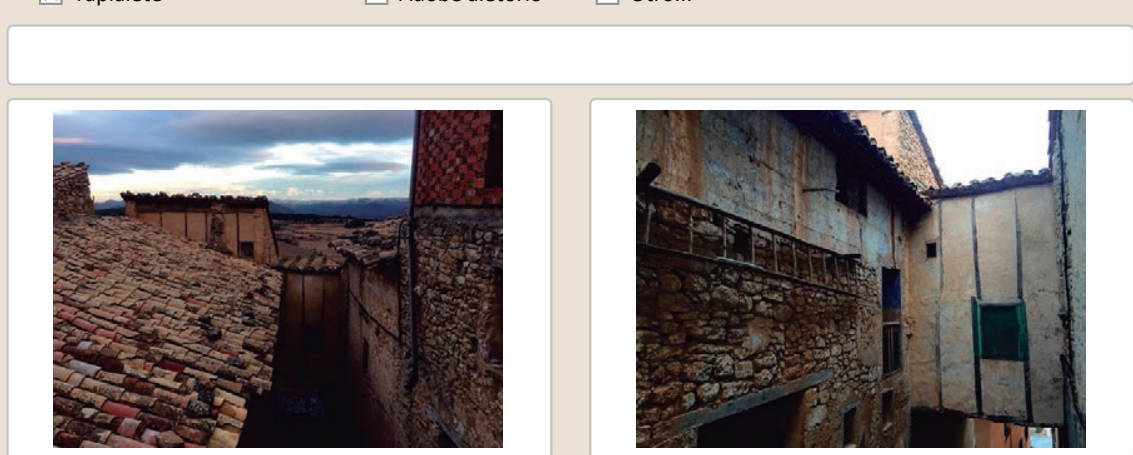

Lesiones $\square$ Muro $\square$ Zócalo $\square$ Revestimiento $\square$ Cubierta $\square$ otro...

$\square$ Erosión del material $\quad \square$ Carcoma o termitas $\quad \square$ Grietas por falta de traba

$\square$ Erosion de las juntas $\quad \square$ Rotura de la madera $\quad \square$ Grietas por asentamientos

$\square$ Pérdida de sección $\square$ Pudrición de la madera $\quad \square$ Colapso

$\square$ Vegetación $\quad \square$ Deformación madera $\quad \square$ Por elementos impropios

$\square$ Desconchados $\quad \square$ Pudrición del relleno $\quad \square$ Derivado de intervenciones

$\square$ Humedad por capilaridad $\square$ Pérdida de verticalidad $\quad \square$ Otro...

$\square$ Humedades (manch/eflor) $\square$ Grietas por empuje de la cubierta

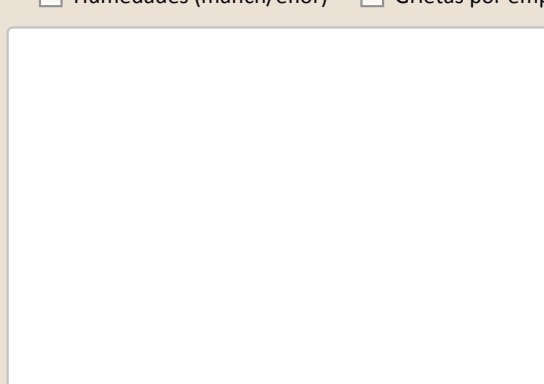

Observaciones 


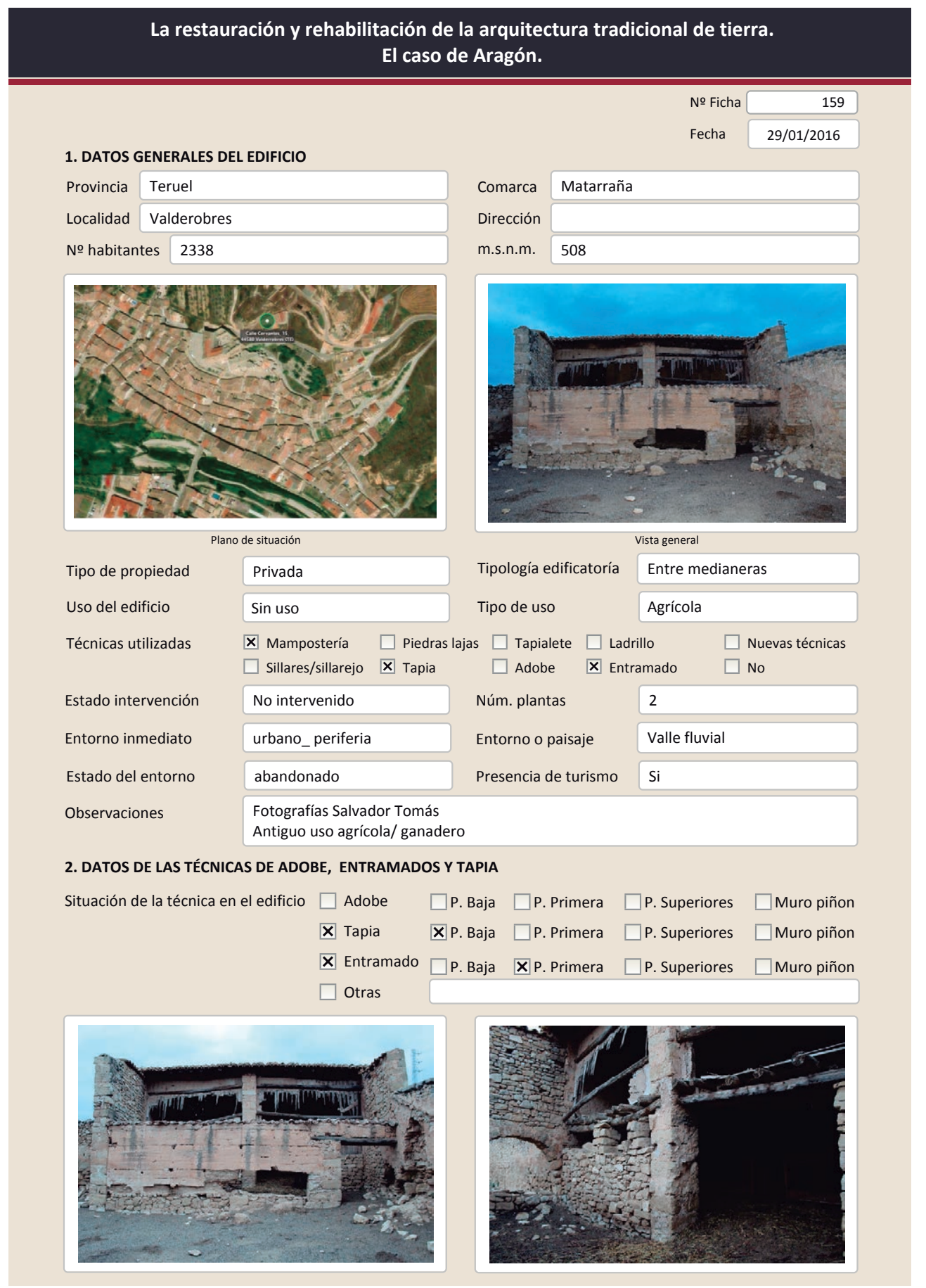

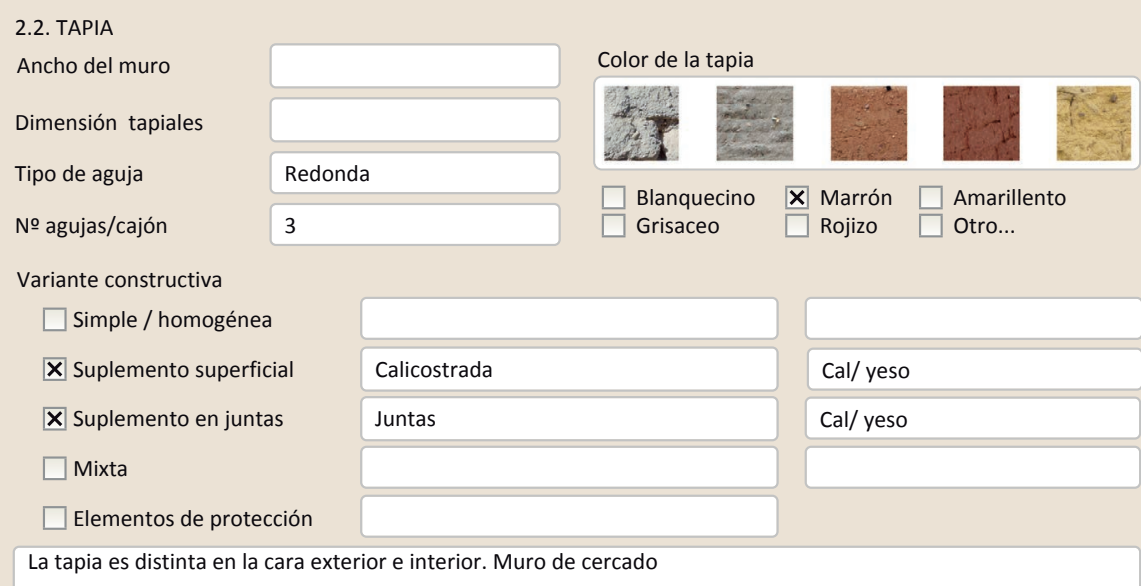

La tapia es distinta en la cara exterior e interior. Muro de cercado

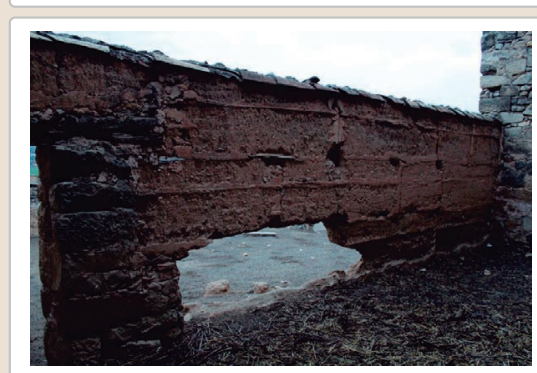

Lesiones $\quad \mathbf{X}$ Muro $\square$ Zócalo $\square$ Revestimiento $\square$ Cubierta $\square$ Otro...

X Erosión del material $\quad \square$ Humedad por capilaridad $\quad \square$ Grietas por asentamientos $\square$ Erosion de las juntas $\square$ Humedades (manch/eflo) X Pérdida de sección $\quad \square$ Pérdida de verticalidad

$\square$ Vegetación $\square$ Grietas por empuje de la cubierta

$\mathbf{X}$ Desconchados

$\square$ Grietas porfalta de traba
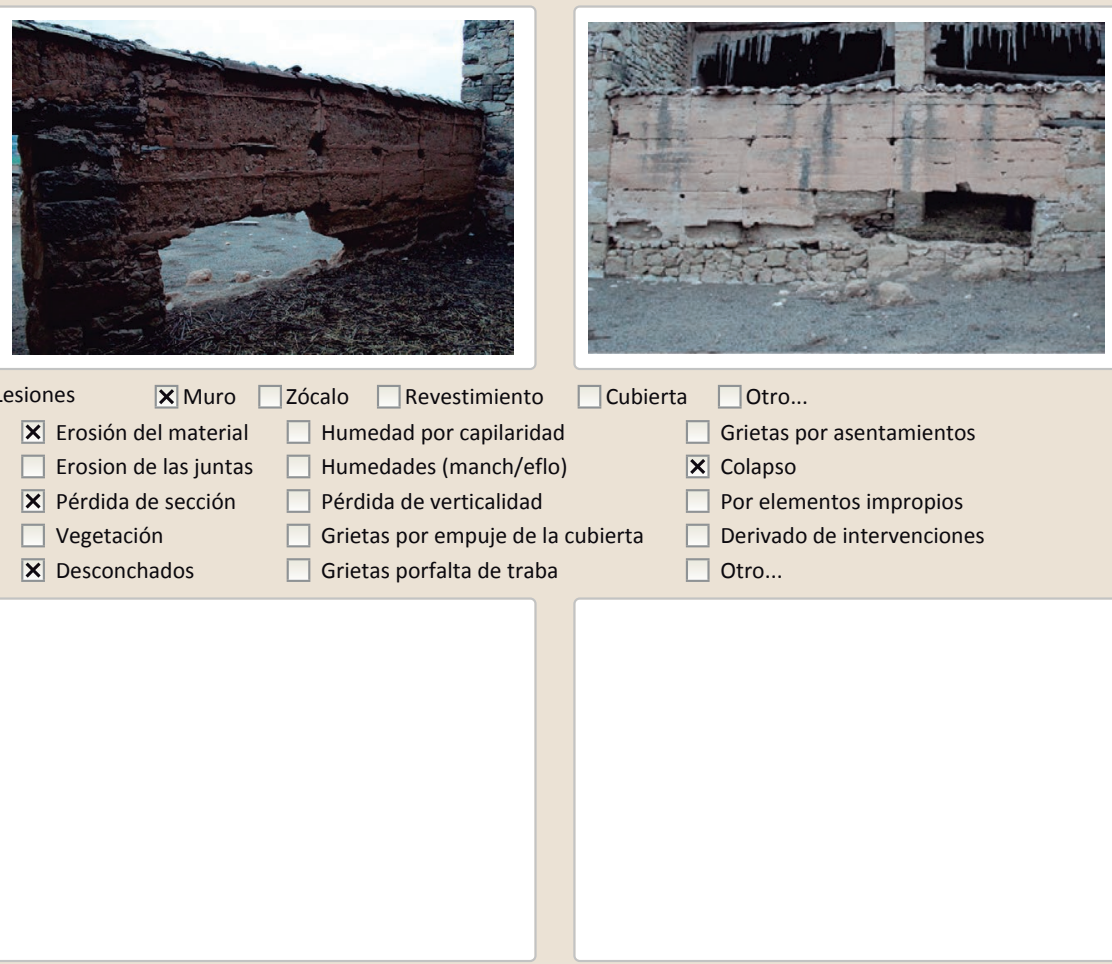

$\square$ Por elementos impropios

$\square$ Derivado de intervenciones

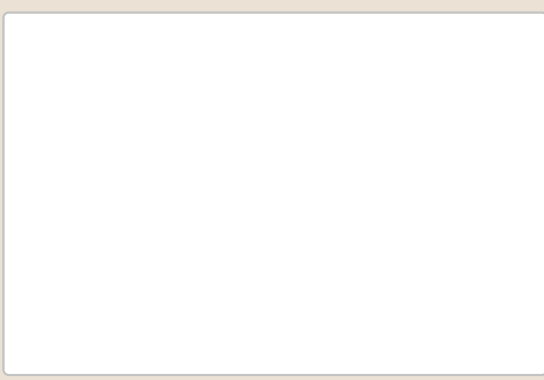

Observaciones

Gran hueco en la pare baja del muro. Pese a ello el muro se mantiene en pie. 
La restauración y rehabilitación de la arquitectura tradicional de tierra.

\section{El caso de Aragón.}

2.3. ENTRAMADOS

Distancia entre montantes

Altura de los montantes

Sección de los montantes

Dimensión de los montantes

Tipo de relleno del entramado

Técnica de relleno del entramado

$\square$ Entre pantallas de madera
$\square$ Tierra y mampuestos

$\square$ Tapialete

$\square$ Pared de mano $\quad \mathbf{X}$ Cañizo

$\square$ Adobe horizontal $\square$ Encestados

Adobe

$\square$ Otro...

No hay montantes verticales sino un elemento horizontal intermedio que hace de rigidizador del muro de cañizo con tierra y yeso.
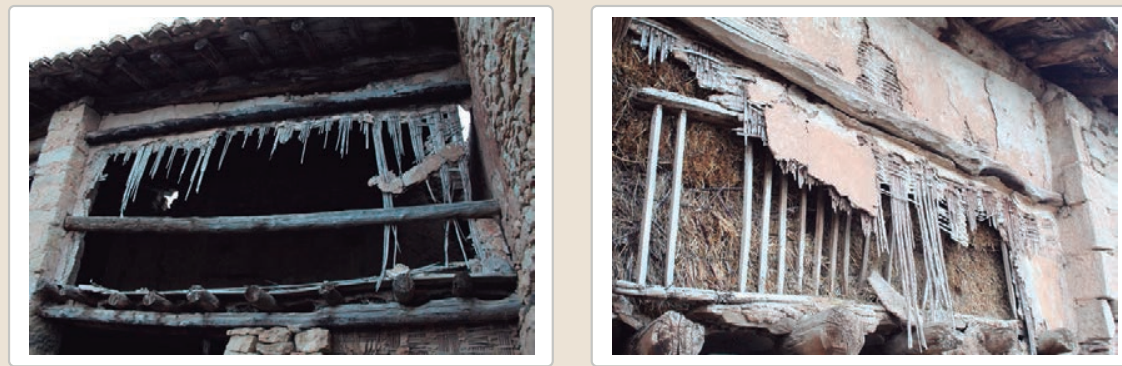

Lesiones

$\square$ Muro $\square$ Zócalo $\square$ Revestimien

$\square$ Cubierta $\square$ Otro...
$\square$ Erosión del material
$\square$ Carcoma o termitas
$\square$ Grietas por falta de traba
$\square$ Erosion de las juntas
$\square$ Rotura de la madera
$\square$ Pudrición de la madera
$\square$ Grietas por asentamientos
$\square$ Pérdida de secci
$\square$ Pudrición de la madera
$\square$ Colapso
$\square$ Vegetación
$\square$ Desconchados
$\square$ Pudrición del relleno
Por elementos impropios
$\square$ Humedad por capilaridad
$\square$ Pérdida de verticalidad
$\square$ Otro...
$\square$ Humedades (manch/eflor) $\square$ Grietas por empuje de la cubierta

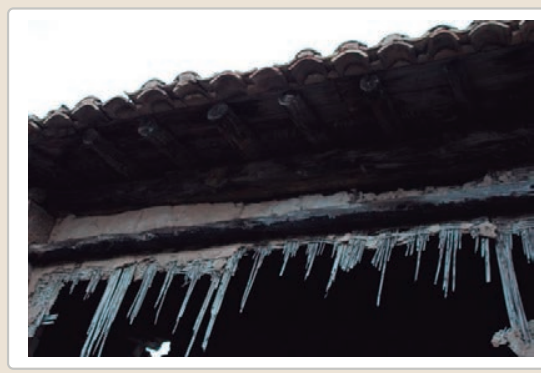

No

Rolizos

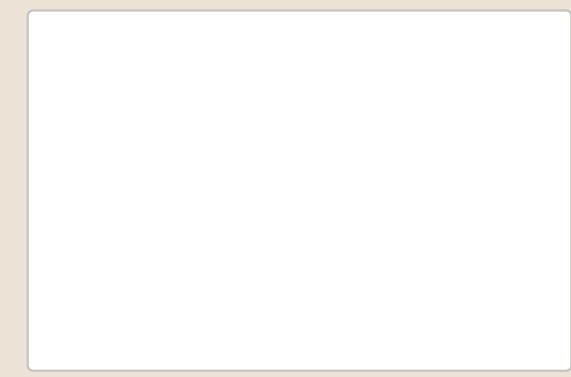

Observaciones 


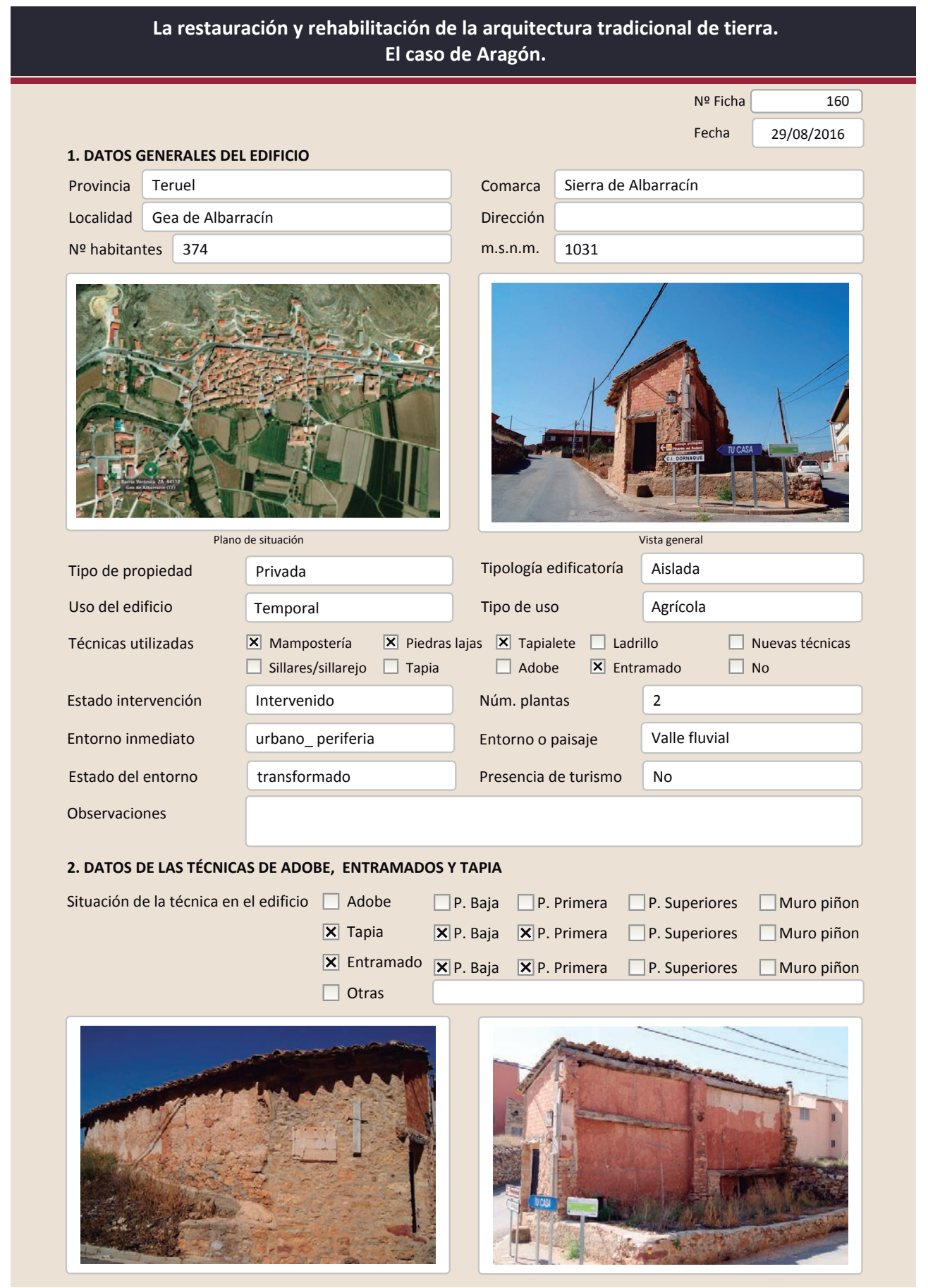

2.2. TAPIA

Ancho del muro

Dimensión tapiales

Tipo de aguja

\begin{tabular}{|l|}
\hline \\
\hline $140 \times 70$ \\
\hline Redonda \\
\hline 3 \\
\hline
\end{tabular}

Color de la tapia

№ agujas/cajón

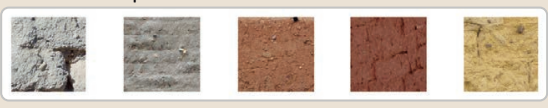

$\square$ Blanquecino $\mathbf{X}$ Marrón $\square$ Amarillento

$\begin{array}{ll}\square \text { Blanquecino } & \mathbf{x} \text { Marrón } \\ \square \text { Grisaceo } & \square \text { Rojizo } \quad \square \text { Otro... }\end{array}$

Variante constructiva

$\square$ Simple / homogénea

$\mathbf{X}$ Suplemento superficial

$\square$ suplemento en juntas

X Mixta

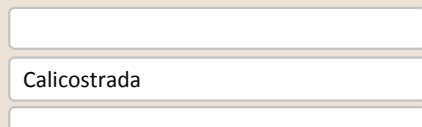

Machones de rafas

Cal/yeso

Elementos de protección

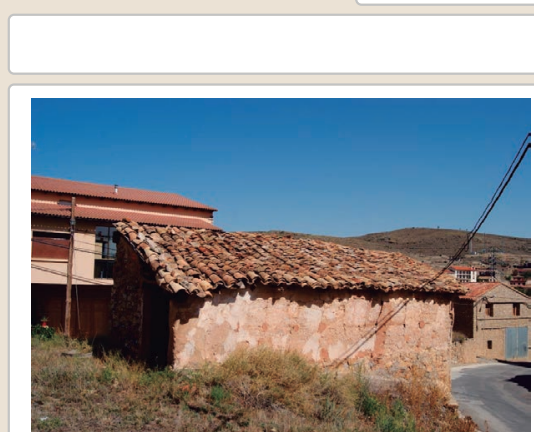

Lesiones $\quad \mathbf{M}$ Mro $\square$ Zócalo $\square$ Revestimiento $\square$ Cubierta $\square$ Otro...

X Erosión del material $\quad \square$ Humedad por capilaridad $\quad \square$ Grietas por asentamientos $\square$ Erosion de las juntas $\square$ Humedades (manch/eflo)

$\square$ Pérdida de sección $\quad \square$ Pérdida de verticalidad

$\square$ Vegetación

X Desconchados

$\square$ Grietas porfalta de traba
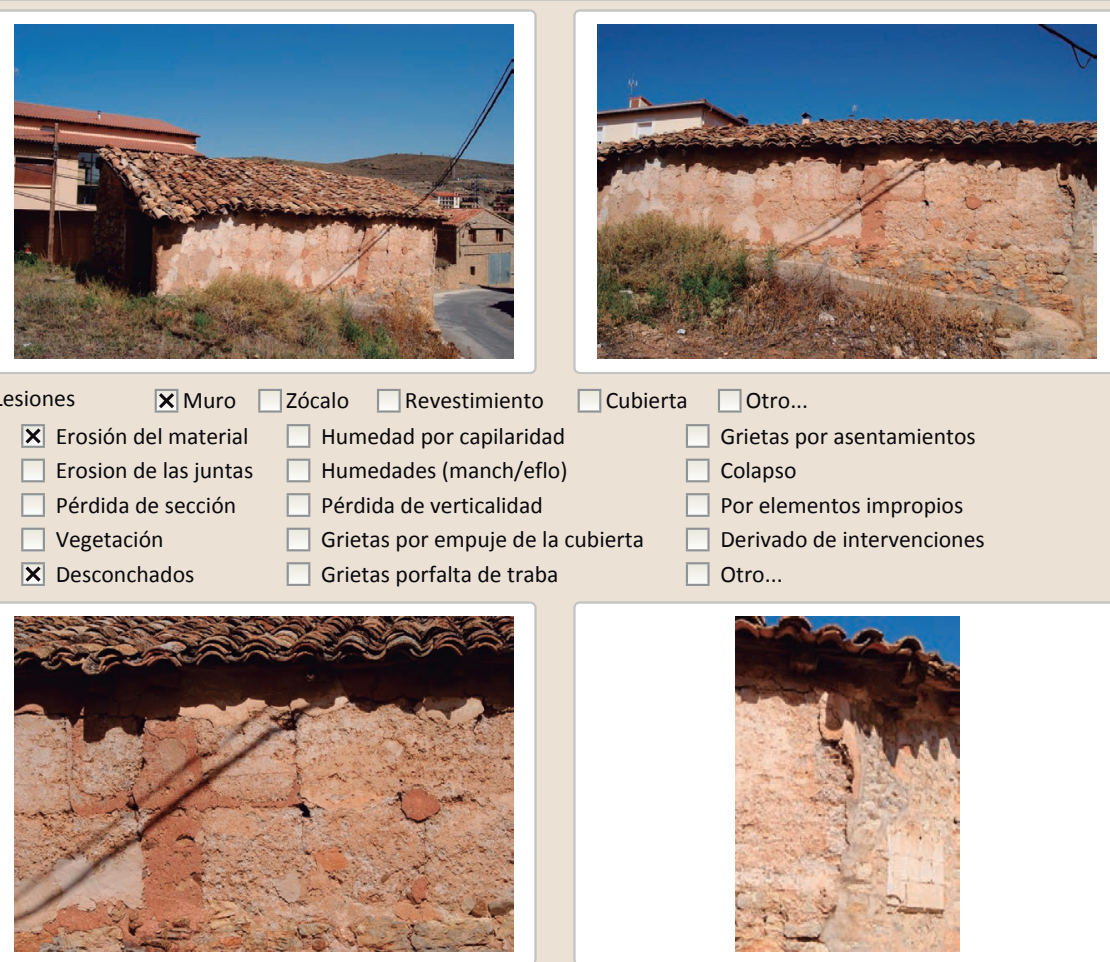

$\square$ Por elementos impropios

$\square$ Derivado de intervenciones

$\square$ Otro...

Observaciones 


\section{La restauración y rehabilitación de la arquitectura tradicional de tierra.} El caso de Aragón.

2.3. ENTRAMADOS

\begin{tabular}{|c|c|c|c|}
\hline Distancia entre montantes & $100-120 \mathrm{~cm}$ & Elementos diagonales & No \\
\hline Altura de los montantes & $250-300 \mathrm{~cm}$ & Elementos horizontales intermedios & $\mathrm{Si}$ \\
\hline Sección de los montantes & Rollizos & Sección de las piezas horizontales & Rollizos \\
\hline Dimensión de los montantes & $10-20 \mathrm{~cm}$ & Dimensión de las piezas horizontales & $30-40 \mathrm{~cm}$ \\
\hline Tipo de relleno del entramado & X Monolítico $\square$ & Piezas/fábrica $\quad \square$ Tejido & \\
\hline \multicolumn{4}{|l|}{ Técnica de relleno del entramado } \\
\hline $\begin{array}{l}\square \text { Entre pantallas de madera } \\
\square \text { Tierra y mampuestos } \\
\text { X Tapialete }\end{array}$ & $\begin{array}{l}\square \text { Pared de mano } \\
\square \text { Adobe horizontal } \\
\square \text { Adobe aletorio }\end{array}$ & $\begin{array}{l}\square \text { Cañizo } \\
\square \text { Encestados } \\
\square \text { Otro... }\end{array}$ & \\
\hline
\end{tabular}
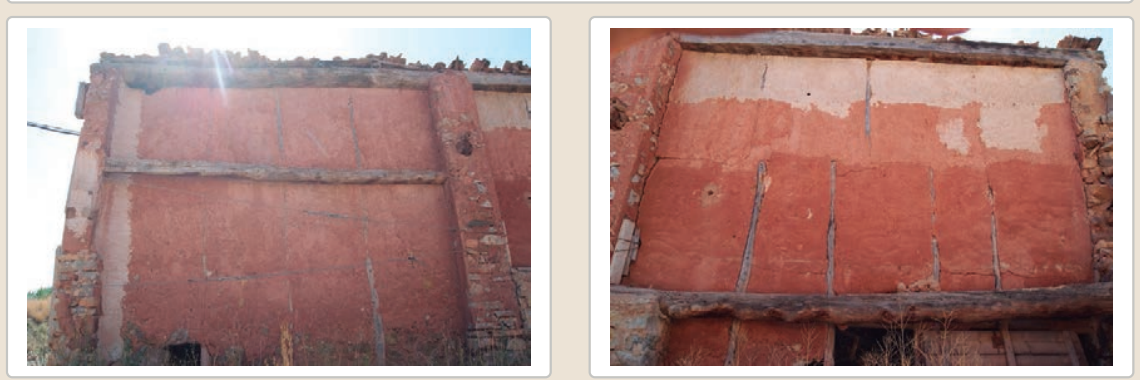

Lesiones $\quad \mathbf{X}$ Muro $\square$ Zócalo $\square$ Revestimiento $\square$ Cubierta $\square$ otro..
$\mathbf{X}$ Erosión del material
$\square$ Carcoma o termitas
$\mathbf{X}$ Grietas por falta de traba
$\square$ Grietas por asentamientos
$\square$ Erosion de las juntas
$\square$ Rotura de la madera
$\square$ Pérdida de sección
$\square$ Pudrición de la madera
$\square$ Vegetación
$\square$ Deformación madera
X Colapso
$\square$ Desconchados
$\checkmark$ Pudrición del relleno
$\square$ Por elementos impropios
$\square$ Humedad por capilaridad
$\square$ Grietas por empuje de la cubierta
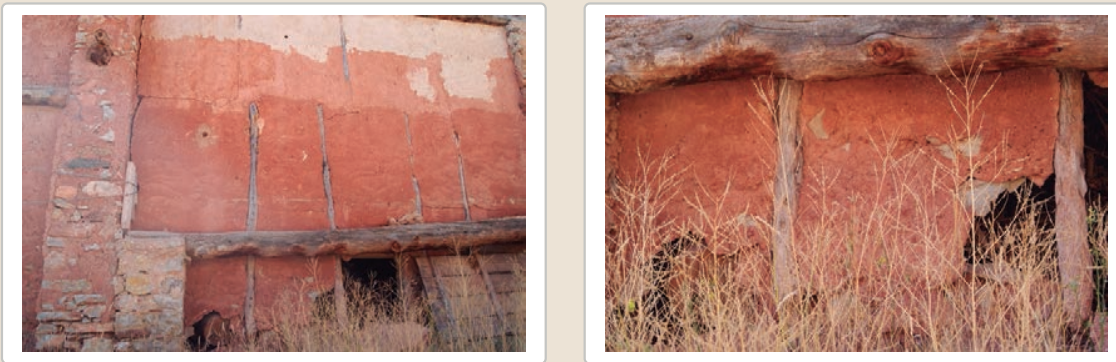

La restauración y rehabilitación de la arquitectura tradicional de tierra.

El caso de Aragón.

3. DATOS DE LA INTERVENCIÓN

Intervención de: $\quad \square$ Mantenimiento $\quad \square$ Rehabilitación parcial $\quad \square$ Restauración $\square$ Demolición

Reflexión previa Intervención espontanea

Observaciones El edificio es muy heterogéneo por lo que las intervenciones también lo son en función de la técnica en la que se esté actuando

3.1. MUROS

Tipo de intervención

Intervenido

Tipo de material

$\square$ Actualización $\quad \boldsymbol{X}$ Reintegración $\quad \square$ Demolición $\square$ Otro...

$\square$ Consolidación $\square$ Reconstrucción $\quad \mathbf{X}$ Sustitución

Descripción

No tradicional Tipo de técnica Diferente a la existente

3.2. zOCALO

Diferentes intervenciones. Sustitución parcial por ladrillo. Rejuntado de mampostería y reintegración de oquedades en la tapia. Tirantes exterior metal.

3.2. ZÓCALO Intervenido

Tipo de intervención

$\square$ Actualización $\mathbf{X}$ Reintegración $\square$ Demolición $\square$ Otro.

$\square$ Actualización $\quad \mathbf{X}$ Reintegración
$\square$ Consolidación $\quad \mathbf{X}$ Reconstrucción $\quad \square$ Sustitución

Tipo de material

Descripción

Rejuntado de la mampostería. También se ha realizado una nueva capa gruesa de cemento en la parte más baja

3.3. REVESTIMIENTOS

Tipo de intervención

No aplica

$\square$ Actualización $\square$ Reintegración $\square$ Demolición $\square$ Otro...

$\square$ Consolidación $\square$ Reconstrucción $\square$ sustitución

Tipo de material

Descripción

3.4. VANOS

Tipo de intervención

No intervenido

Tipo de material

$\square$ Actualización $\square$ Reintegración $\square$ Demolición $\square$ Otro...

$\square$ Consolidación $\square$ Reconstrucción $\square$ Sustitución

Descripción

3.5. CUBIERTA

Tipo de intervención

Tipo de material

Descripción

$\square$ Actualización $\square$ Reintegración $\square$ Demolición $\square$ Otro

$\square$ Consolidación $\square$ Reconstrucción $\square$ Sustitución Tipo de técnica

3.6. OTRAS

Observaciones 
La restauración y rehabilitación de la arquitectura tradicional de tierra. El caso de Aragón

\section{La restauración y rehabilitación de la arquitectura tradicional de tierra.}

El caso de Aragón.
3.7. REHABILITACIÓN ENERGÉTICA
$\square$ Fachada
$\square$ Vanos
$\square$ Forjados $\square$ Cubierta

Observaciones

FOTOGRAFÍAS DE LA INTERVENCIÓN
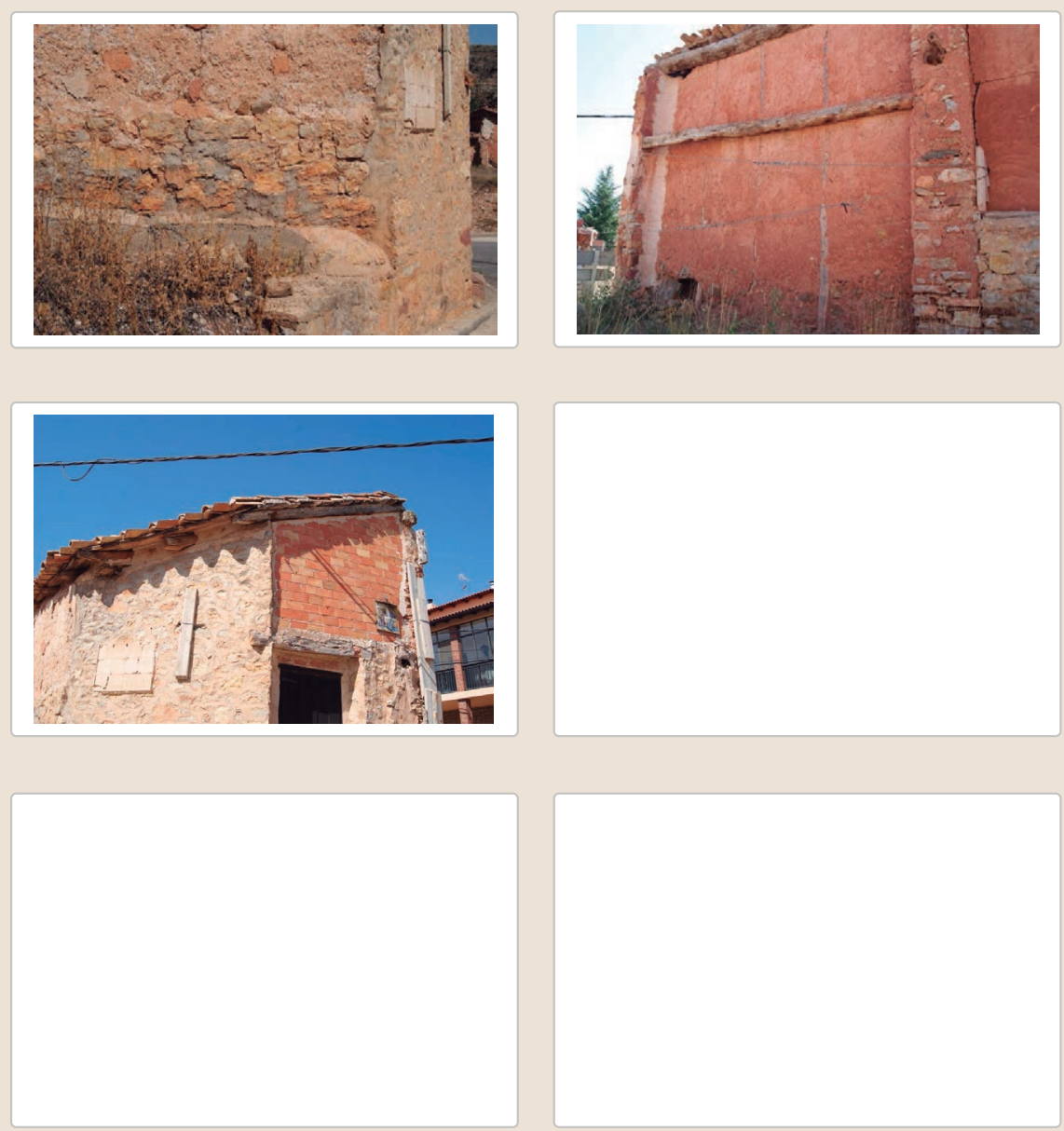


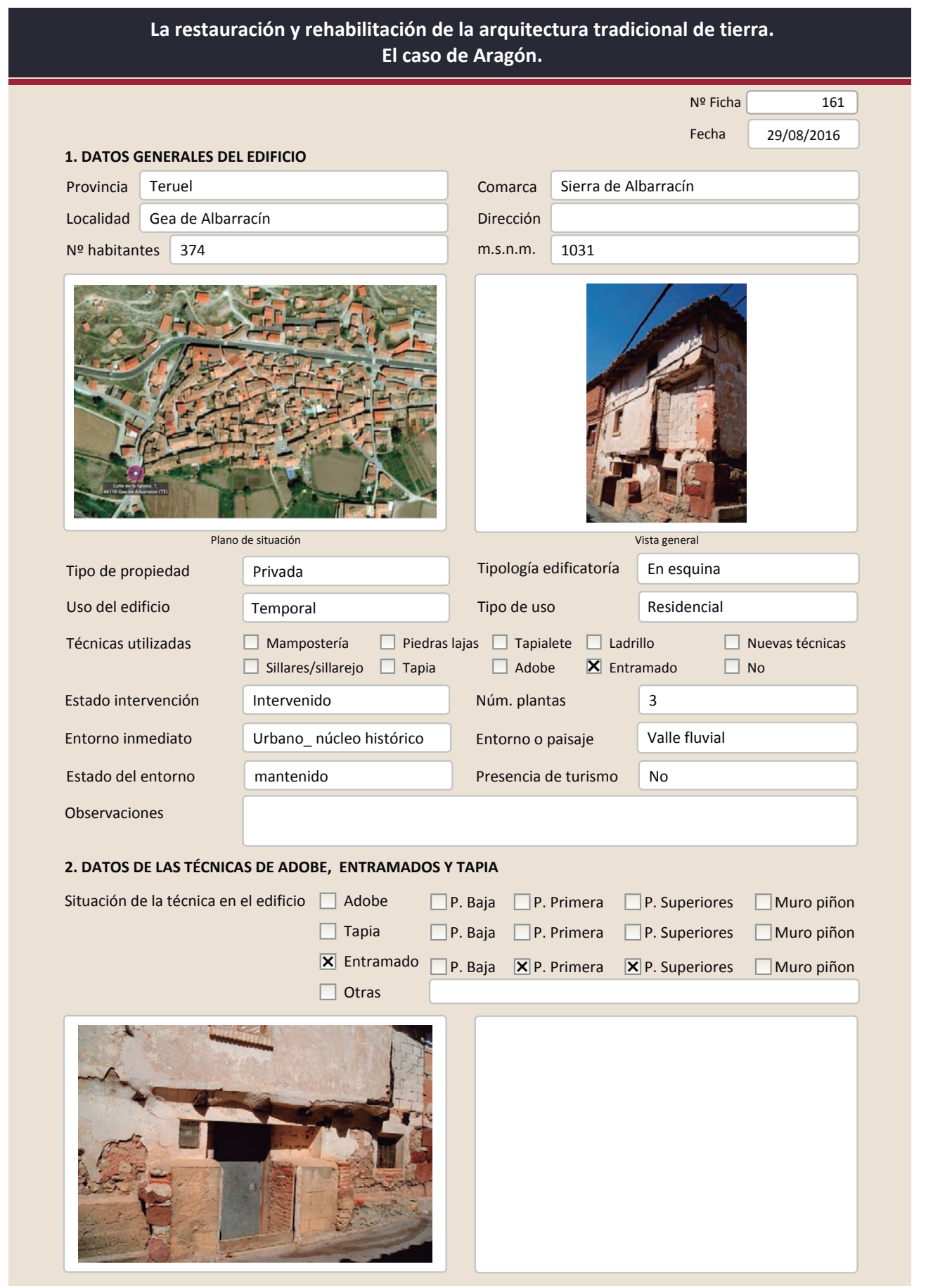

La restauración y rehabilitación de la arquitectura tradicional de tierra.

El caso de Aragón.

2.3. ENTRAMADOS

\begin{tabular}{|c|c|c|c|}
\hline & & & \\
\hline Distancia entre montantes & $100-120 \mathrm{~cm}$ & Elementos diagonales & No \\
\hline Altura de los montantes & $250-300 \mathrm{~cm}$ & Elementos horizontales intermedios & No \\
\hline Sección de los montantes & Escuadrada & Sección de las piezas horizontales & Escuadrada \\
\hline Dimensión de los montantes & $10-20 \mathrm{~cm}$ & Dimensión de las piezas horizontales & $20-30 \mathrm{~cm}$ \\
\hline Tipo de relleno del entramado & X Monolítico $\square$ & Piezas/fábrica $\quad \square$ Tejido & \\
\hline Técnica de relleno del entramado & & & \\
\hline$\square$ Entre pantallas de madera & $\square$ Pared de mano & $\square$ Cañizo & \\
\hline$\square$ Tierra y mampuestos & $\square$ Adobe horizontal & I $\square$ Encestados & \\
\hline $\mathbf{X}$ Tapialete & $\square$ Adobe aletorio & $\square$ Otro... & \\
\hline
\end{tabular}
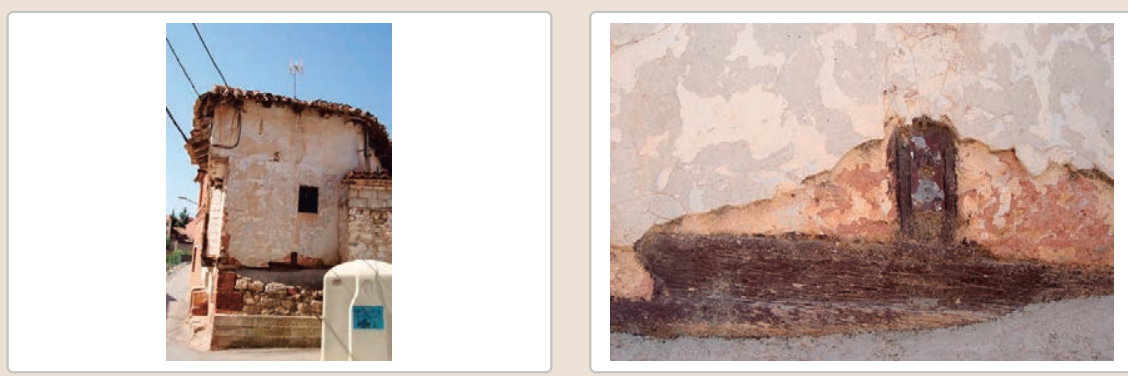

Lesiones

ХMuro ХZócalo ХRevestimiento $\square$ Cubierta $\square$ Otro...

$\mathbf{X}$ Erosión del materia

$\square$ Carcoma o termitas

X Grietas por falta de traba

$\square$ Erosion de las juntas

$\square$ Carcoma o termitas
$\square$ Rotura de la madera

$\square$ Pérdida de sección

X Pudrición de la madera

$\square$ Grietas por asentamientos

$\square$ Vegetación

$\square$ Deformación madera

$\square$ Colapso

X Humedad por capilaridad $\square$ Pérdida de verticalidad

$\square$ Derivado de intervenciones

$\square$ Otro...
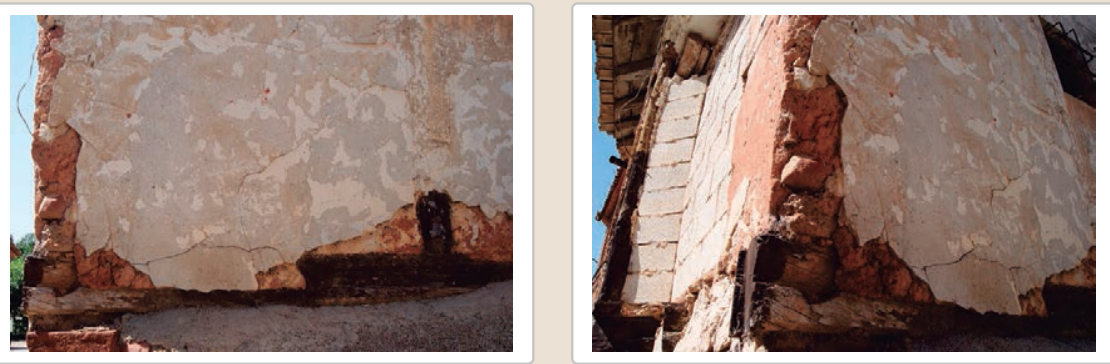

Observaciones 


\section{La restauración y rehabilitación de la arquitectura tradicional de tierra.} El caso de Aragón.

3. DATOS DE LA INTERVENCIÓN

Reflexión previa Intervención espontanea

Observaciones Intervenciones de sustitución de paños y en la zona del zócalo

\subsection{MUROS} Tipo de intervención Tipo de material

Descripción

3.2. ZóCALO Tipo de intervención Tipo de material

Descripción

3.3. REVESTIMIENTOS Tipo de intervención

Tipo de material

Descripción

\subsection{VANOS}

Tipo de intervención

Tipo de material

Descripción

3.5. CUBIERTA

Tipo de intervención

Tipo de material

Descripción

3.6. OTRAS

Intervenido

$\square$ Actualización $\square$ Reintegración $\square$ Demolición $\square$ Otro..

$\square$ Consolidación $\quad \mathbf{X}$ Reconstrucción $\square$ Sustitución se han realizado dos muretes al los lados de la puerta de acceso.

\section{No intervenido}

$\square$ Actualización $\square$ Reintegración $\square$ Demolición $\square$ Otro...

$\square$ Consolidación $\quad \square$ Reconstrucción $\quad \square$ Sustitución Tipo de técnica
La restauración y rehabilitación de la arquitectura tradicional de tierra. El caso de Aragón.

3.7. REHABILITACIÓN ENERGÉTICA $\quad \square$ Fachada $\square$ Vanos $\square$ Forjados $\square$ Cubierta

Observaciones

FOTOGRAFíAS DE LA INTERVENCIÓN
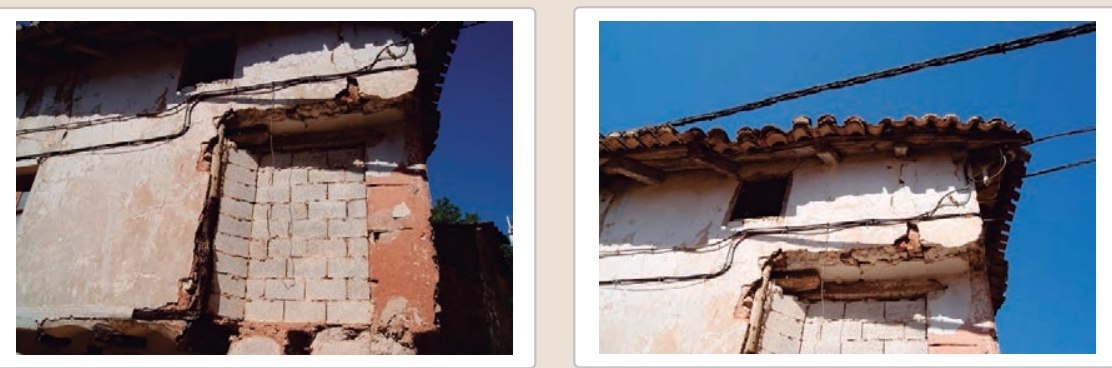

No tradicional Tipo de técnica Diferente a la existente

En la zona del zócalo se ha insertado una gruesa capa de hormigón encofrado. También
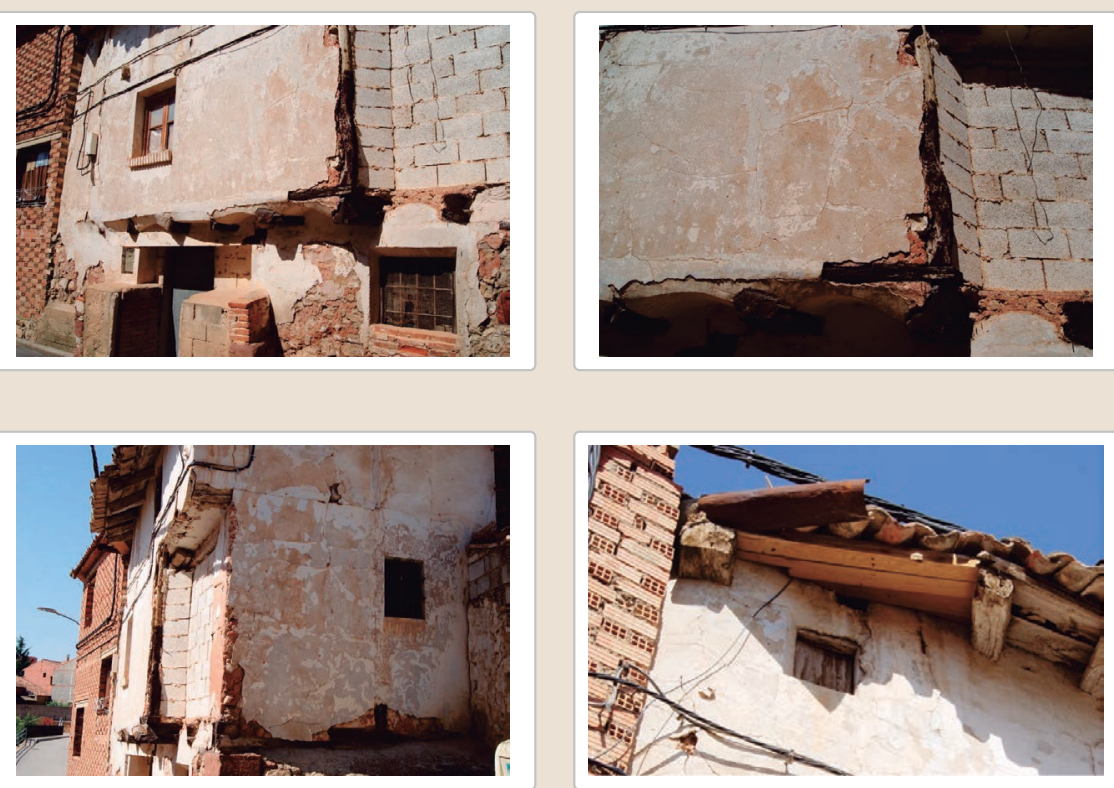


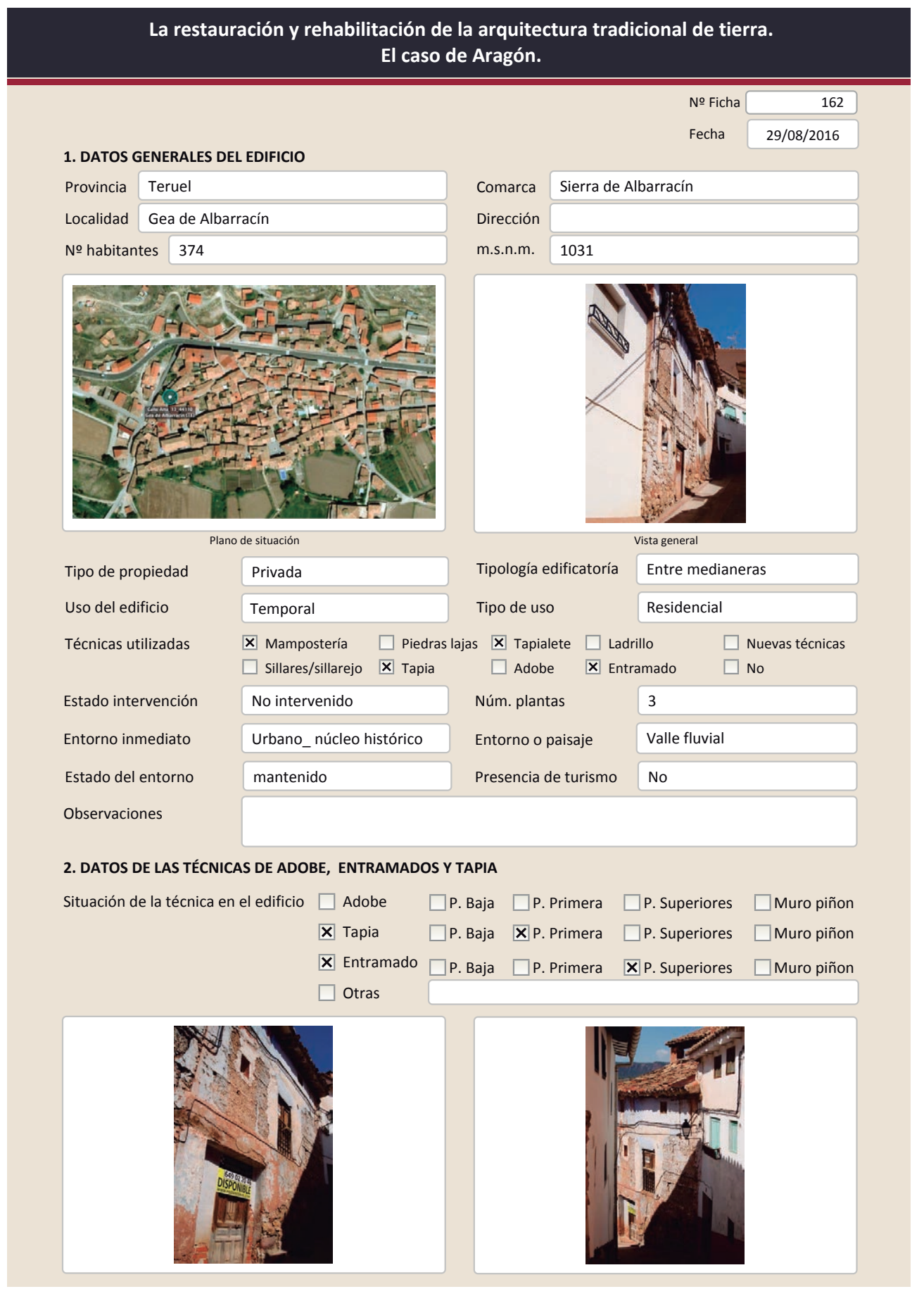

La restauración y rehabilitación de la arquitectura tradicional de tierra. El caso de Aragón.

2.2. TAPIA

Ancho del muro

Dimensión tapiales

Tipo de aguja

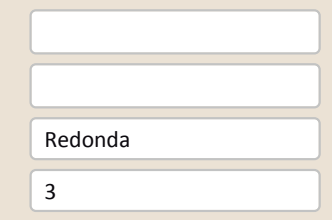

Color de la tapia

№ agujas/cajón

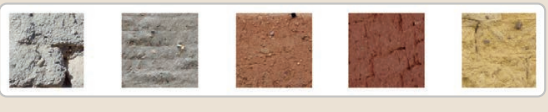

$\square$ Blanquecino $\quad \mathbf{X}$ Marrón $\square$ Amarillento

$\begin{array}{ll}\square \text { Blanquecino } & \mathbf{x} \text { Marrón } \\ \square \text { Grisaceo } & \square \text { Rojizo } \quad \square \text { Otro... }\end{array}$

$\square$ Simple / homogénea

$\square$ suplemento superficial

X Suplemento en juntas

X Mixta

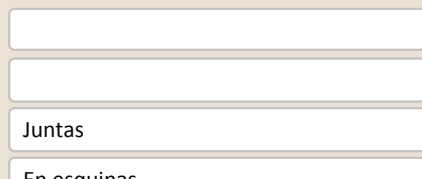

En esquinas

\section{Cal/ yeso}

Mampostería y yeso

$\square$ Elementos de protección

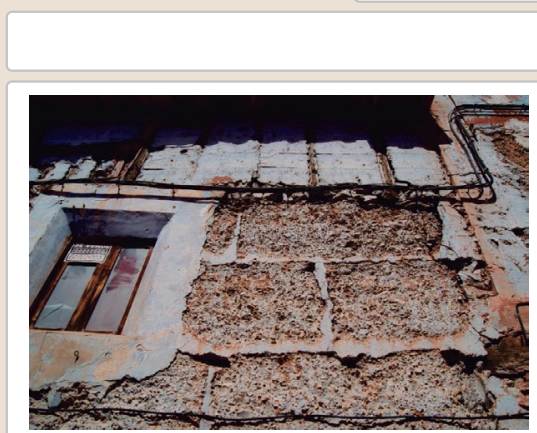

Lesiones \Muro $\square$ Zócalo $\square$ Revestimiento $\square$ Cubierta $\square$ Otro...

Х Erosión del material $\square$ Humedad por capilaridad $\quad \square$ Grietas por asentamiento $\square$ Erosion de las juntas $\square$ Humedades (manch/eflo)

X Pérdida de sección $\square$ Pérdida de verticalidad

$\square$ Vegetación $\square$ Grietas por empuie de la cubierta

$\square$ Desconchados

$\square$ Grietas porfalta de traba
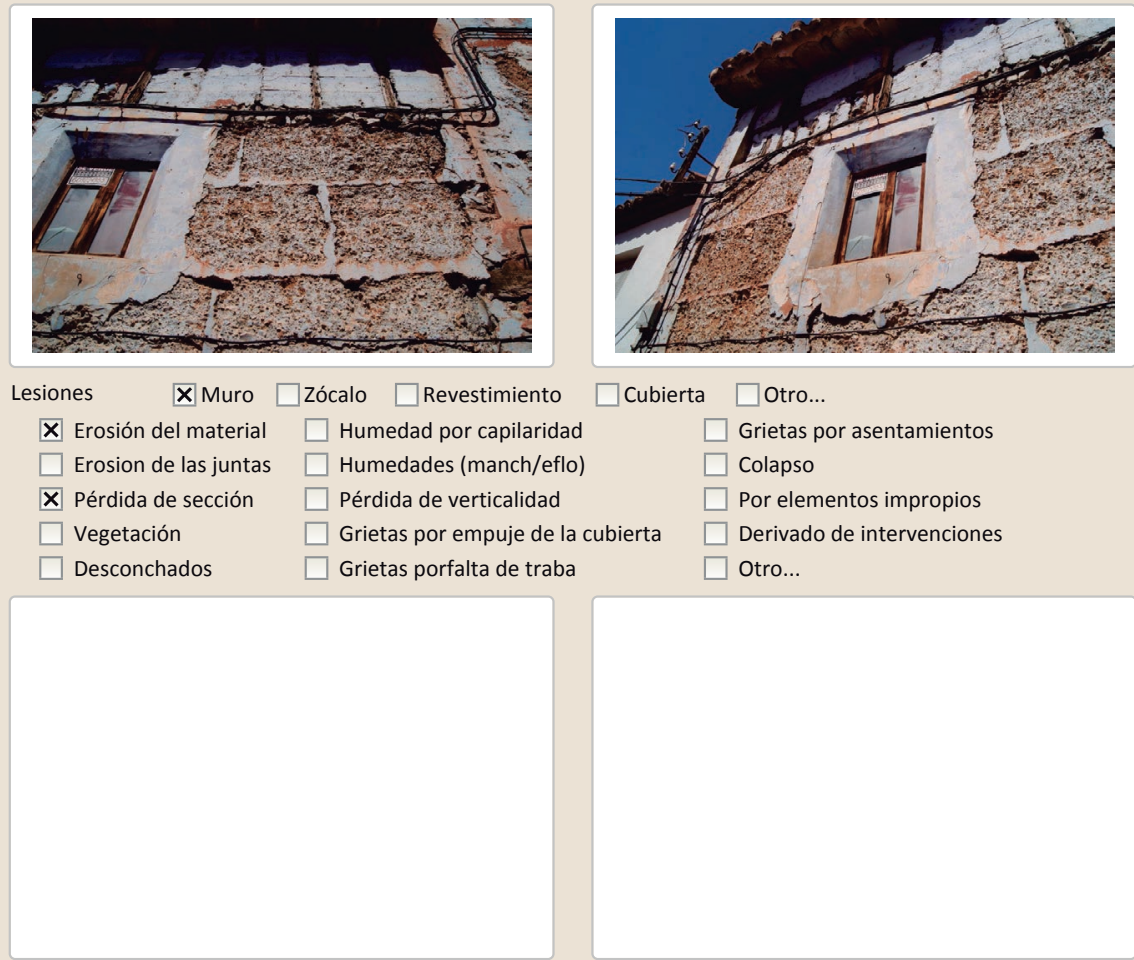

Observaciones 
La restauración y rehabilitación de la arquitectura tradicional de tierra. El caso de Aragón

\section{La restauración y rehabilitación de la arquitectura tradicional de tierra.}

\section{El caso de Aragón.}

2.3. ENTRAMADOS

$\begin{array}{lll}\text { Distancia entre montantes } & 40-60 \mathrm{~cm} & \text { Elementos diagon } \\ \text { Altura de los montantes } & 150-200 \mathrm{~cm} & \text { Elementos horizo } \\ \text { Sección de los montantes } & \text { Rollizos } & \text { Sección de las piezs } \\ \text { Dimensión de los montantes } & 10-20 \mathrm{~cm} & \text { Dimensión de las } \\ \text { Tipo de relleno del entramado } & \boldsymbol{X} \text { Monolítico } & \text { Piezas/ fábrica } \\ \text { Técnica de relleno del entramado } & & \\ \square \text { Entre pantallas de madera } & \square \text { Pared de mano } & \square \text { Cañizo } \\ \square \text { Tierra y mampuestos } & \square \text { Adobe horizontal } & \square \text { Encestados } \\ \text { X Tapialete } & \square \text { Adobe aletorio } & \square \text { Otro... }\end{array}$

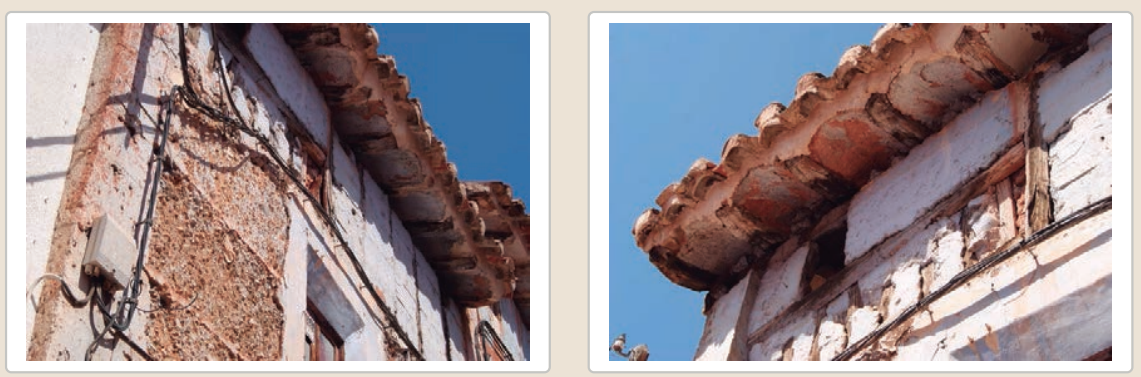

\section{Lesiones $\quad \mathbf{X}$ Muro $\square$ Zócalo $\square$ Revestimiento $\square$ Cubierta $\square$ Otro...}
$\mathbf{X}$ Erosión del material
$\square$ Carcoma o termitas
$\square$ Grietas por falta de traba
$\square$ Erosion de las juntas
$\square$ Rotura de la madera
$\square$ Grietas por asentamiento
$\square$ Pérdida de seci
$\square$ Vegetación
$\square$ Pudrición de la madera
$\square$ Colapso
$\square$ Desconchados
Deformación madera
$\square$ Por elementos impropios
$\square$ Humedad por capilaridad
$\square$ Pérdida de verticalidad
$\square$ Derivado de intervenciones
$\square$ Humedades (manch/eflor) $\quad \square$ Grietas por empuje de la cubierta
$\square$ Otro...
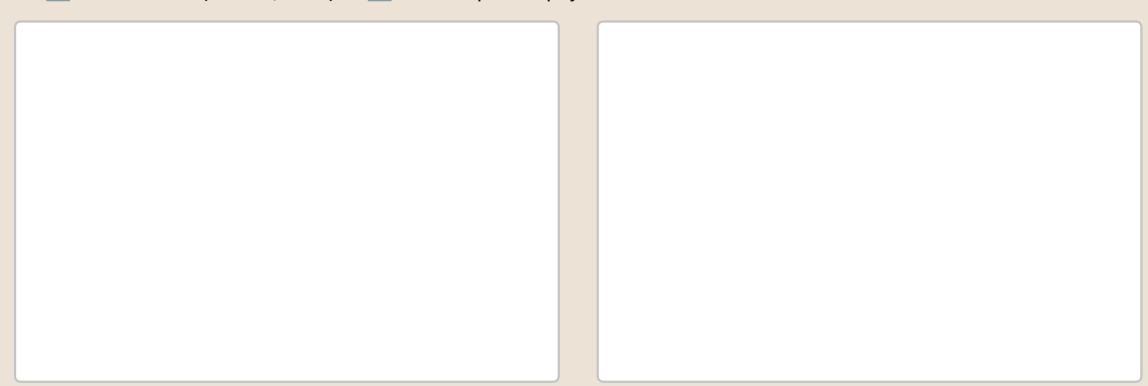

Observaciones 
La restauración y rehabilitación de la arquitectura tradicional de tierra. El caso de Aragón.

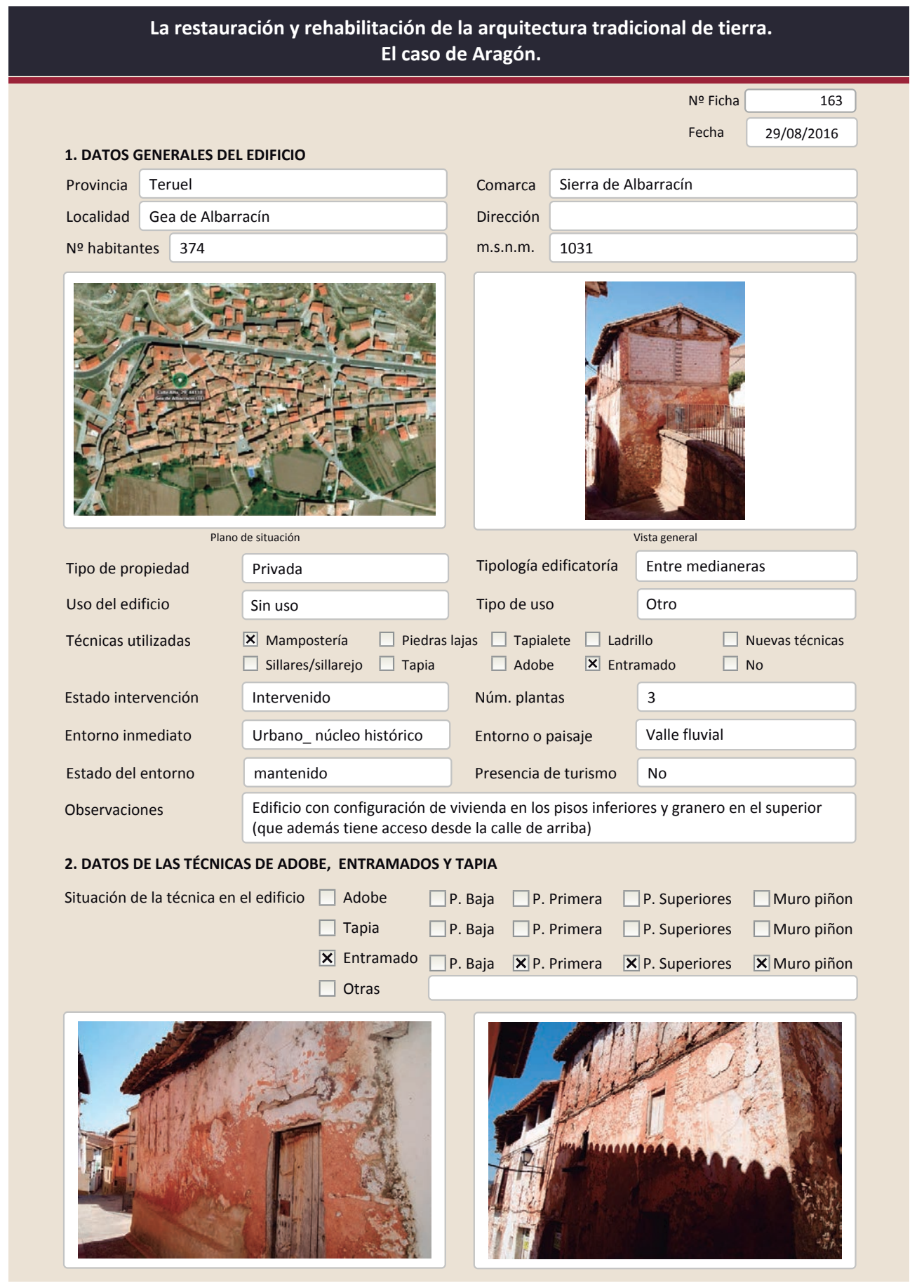

La restauración y rehabilitación de la arquitectura tradicional de tierra.

El caso de Aragón.

\subsection{ENTRAMADOS}

\begin{tabular}{|c|c|c|c|}
\hline & & & \\
\hline Distancia entre montantes & variable & Elementos diagonales & No \\
\hline Altura de los montantes & $200-250 \mathrm{~cm}$ & Elementos horizontales intermedios & No \\
\hline Sección de los montantes & Rollizos & Sección de las piezas horizontales & Rollizos \\
\hline Dimensión de los montantes & $10-20 \mathrm{~cm}$ & Dimensión de las piezas horizontales & $20-30 \mathrm{~cm}$ \\
\hline Tipo de relleno del entramado & \ Monolítico $\square$ & $\square$ Piezas/fábrica $\quad \square$ Tejido & \\
\hline Técnica de relleno del entramado & & & \\
\hline $\begin{array}{l}\square \text { Entre pantallas de madera } \\
\square \text { Tierra y mampuestos } \\
\mathbf{x} \text { Tapialete }\end{array}$ & $\begin{array}{l}\square \text { Pared de mano } \\
\square \text { Adobe horizontal } \\
\square \text { Adobe aletorio }\end{array}$ & $\begin{array}{l}\square \text { Cañizo } \\
\square \text { Encestados } \\
\square \text { Otro... }\end{array}$ & \\
\hline
\end{tabular}
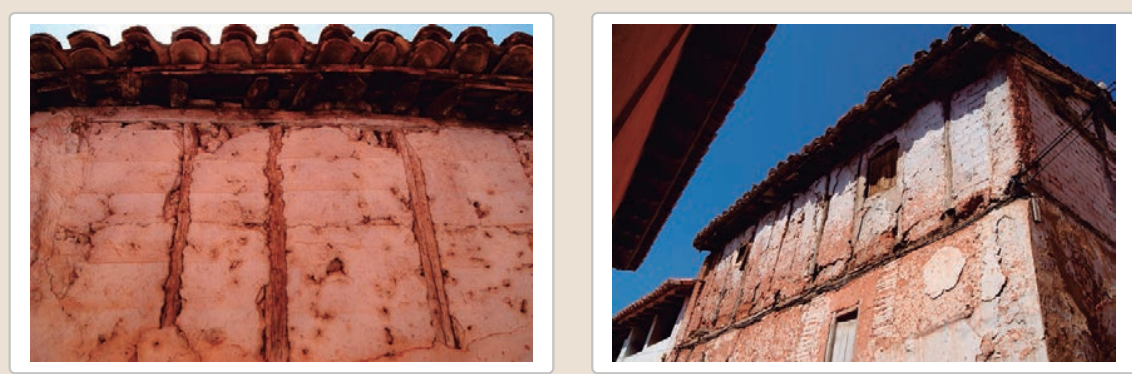

$$
\begin{array}{lll}
\text { Lesiones } \quad \text { M Muro } \square \text { Zócalo } & \square \text { Revestimiento } \quad \square \text { Cubierta } & \square \text { Otro... } \\
\mathbf{X} \text { Erosión del material } & \square \text { Carcoma o termitas } & \square \text { Grietas por falta de traba } \\
\square \text { Erosion de las juntas } & \square \text { Rotura de la madera } & \square \text { Grietas por asentamientos } \\
\square \text { Pérdida de sección } & \square \text { Pudrición de la madera } & \square \text { Colapso } \\
\square \text { Vegetación } & \boldsymbol{X} \text { Deformación madera } & \square \text { Por elementos impropios } \\
\square \text { Desconchados } & \square \text { Pudrición del relleno } & \square \text { Derivado de intervenciones } \\
\square \text { Humedad por capilaridad } & \square \text { Pérdida de verticalidad } & \square \text { Otro... } \\
\square \text { Humedades (manch/eflor) } & \square \text { Grietas por empuje de la cubierta } &
\end{array}
$$

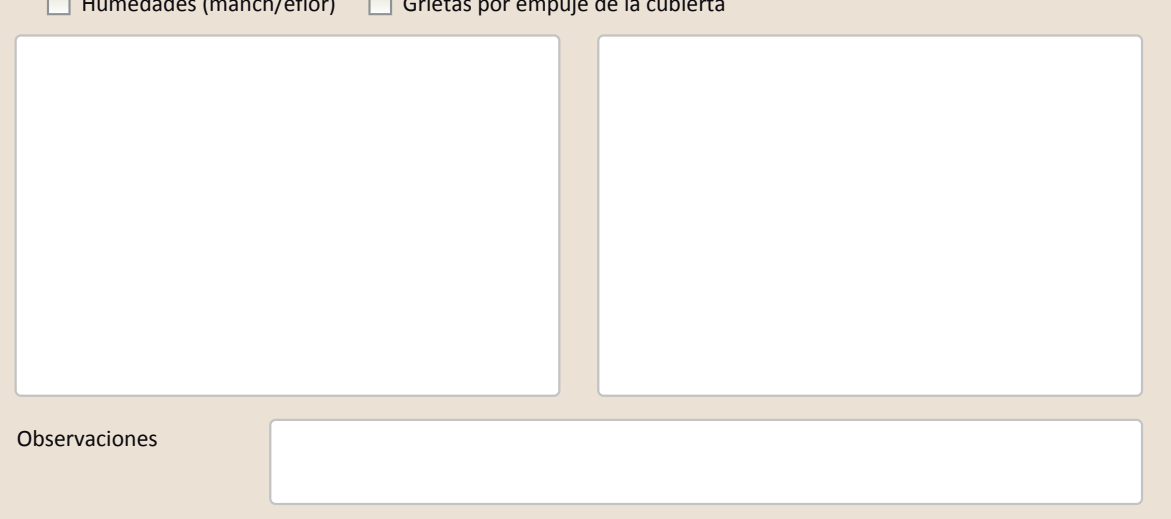




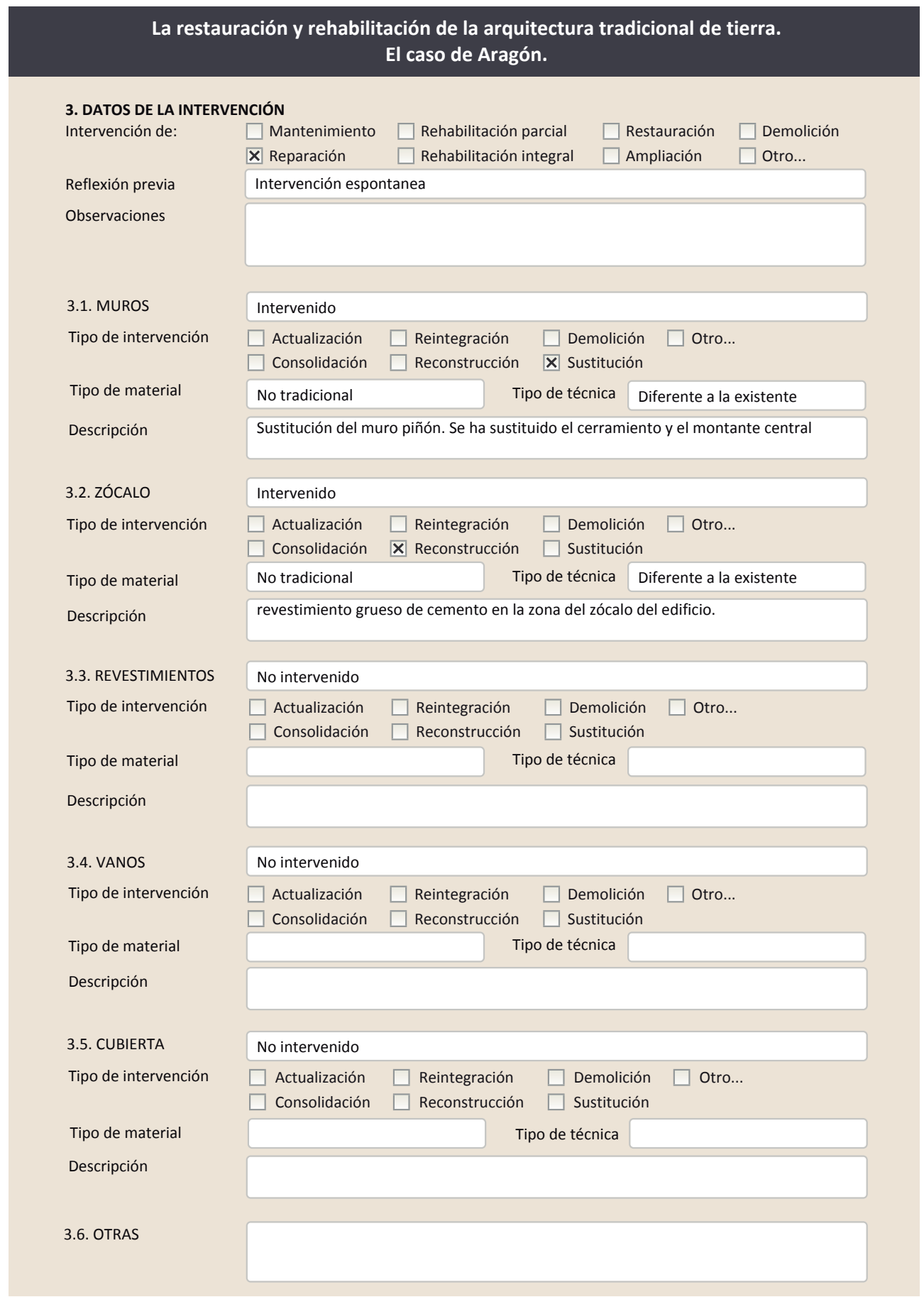

3.7. REHABILITACIÓN ENERGÉTICA $\square$ Fachada $\square$ Vanos $\square$ Forjados $\square$ Cubierta

Observaciones

FOTOGRAFÍAS DE LA INTERVENCIÓN
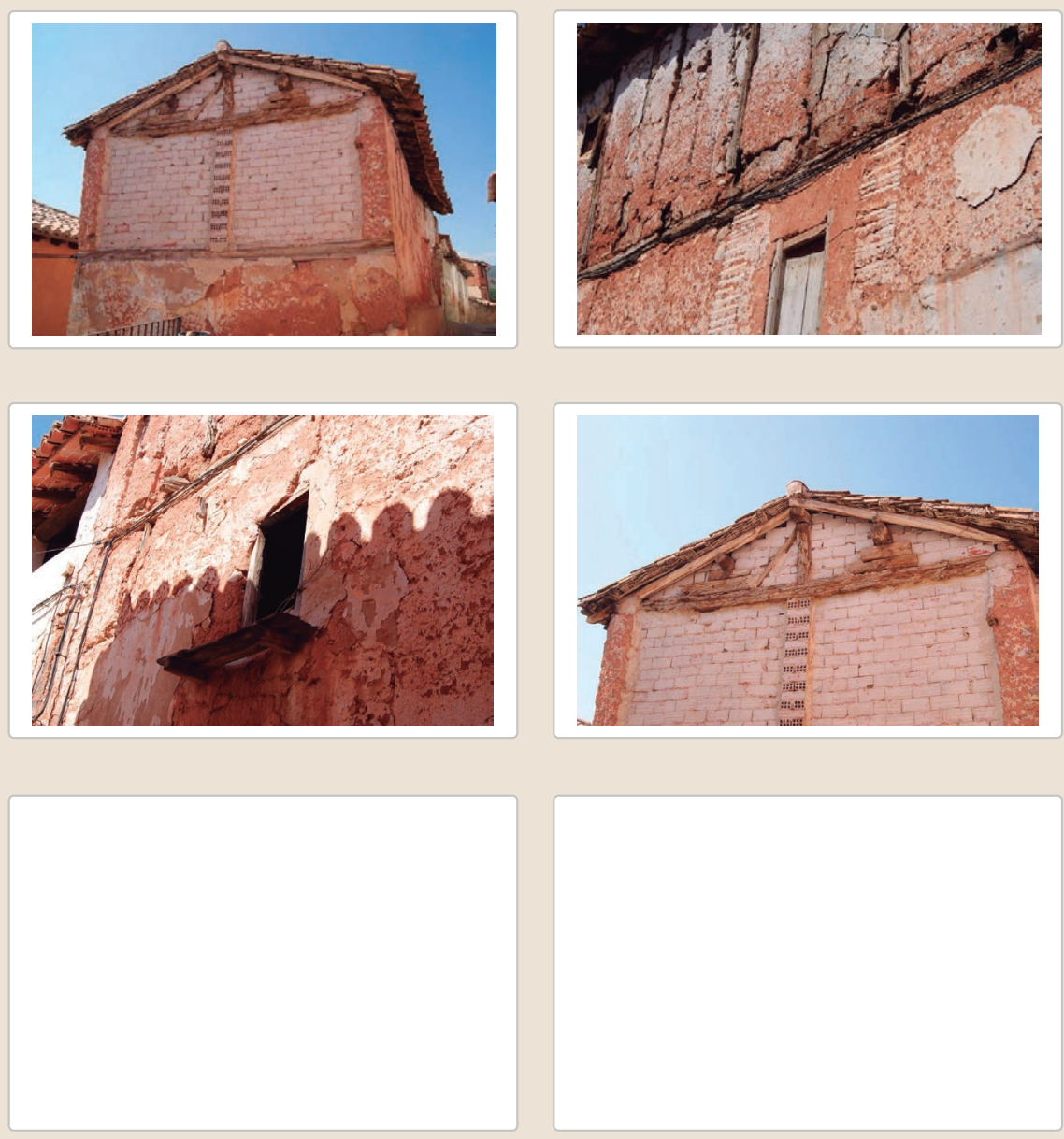
La restauración y rehabilitación de la arquitectura tradicional de tierra. El caso de Aragón.

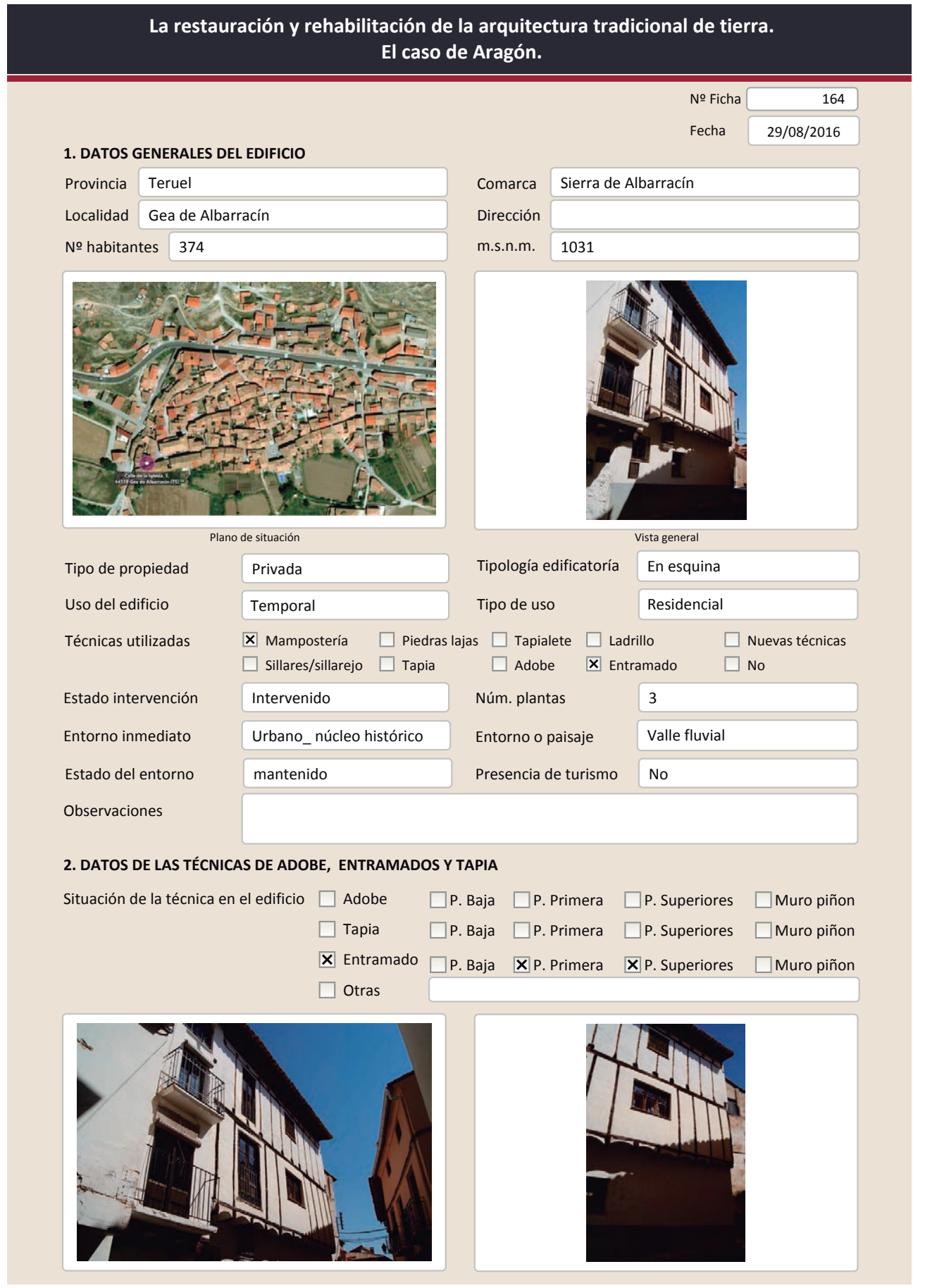

La restauración y rehabilitación de la arquitectura tradicional de tierra. El caso de Aragón.

2.3. ENTRAMADOS

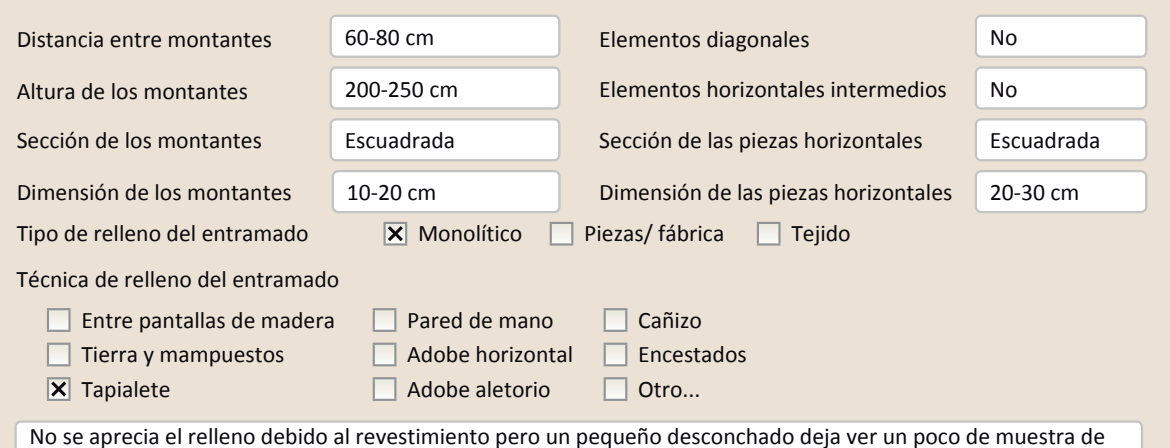

No se aprecia el relleno debido al revestimiento pero un pequeño desconchado deja ver un poco de muestra de
tapialete

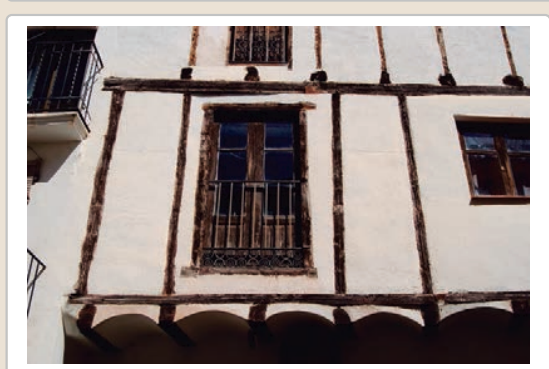

Lesiones $\square$ Muro $\mathbf{X}$ Zócalo $\mathbf{X}$ Revestimiento $\square$ Cubierta $\square$ Otro...

$\begin{array}{lll}\square \text { Erosión del material } & \square \text { Carcoma o termitas } & \square \text { Grietas por falta de traba } \\ \square \text { Erosion de las juntas } & \square \text { Rotura de la madera } & \square \text { Grietas por asentamientos } \\ \square \text { Pérdida de sección } & \square \text { Pudrición de la madera } & \square \text { Colapso } \\ \square \text { Vegetación } & \square \text { Deformación madera } & \square \text { Por elementos impropios } \\ \mathbf{X} \text { Desconchados } & \square \text { Pudrición del relleno } & \square \text { Derivado de intervenciones } \\ \mathbf{X} \text { Humedad por capilaridad } & \square \text { Pérdida de verticalidad } & \square \text { Otro... } \\ \square \text { Humedades (manch/eflor) } & \square \text { Grietas por empuje de la cubierta } & \end{array}$

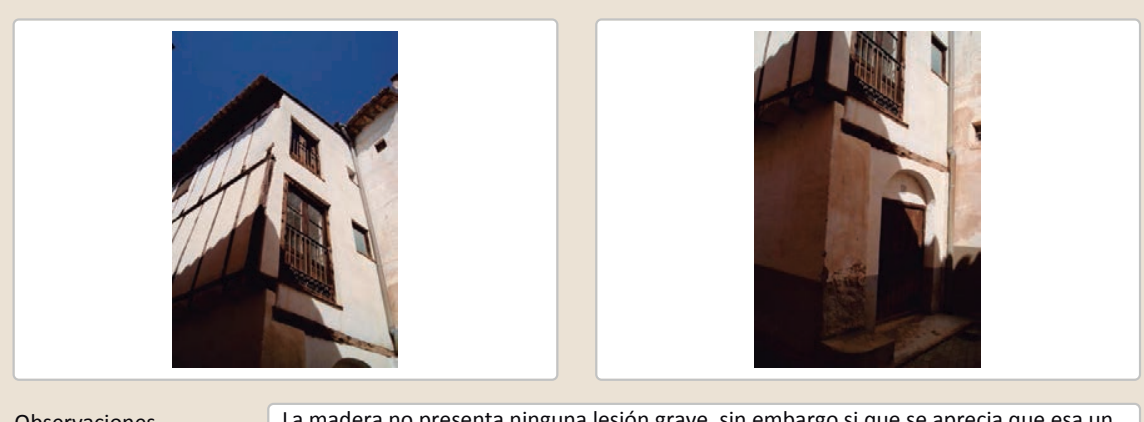

Observaciones La madera no presenta ninguna lesión grave, sin embargo si que se aprecia que esa un

poco deteriorada por el paso del tiempo

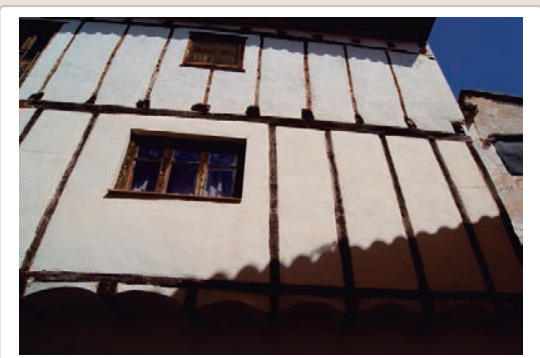




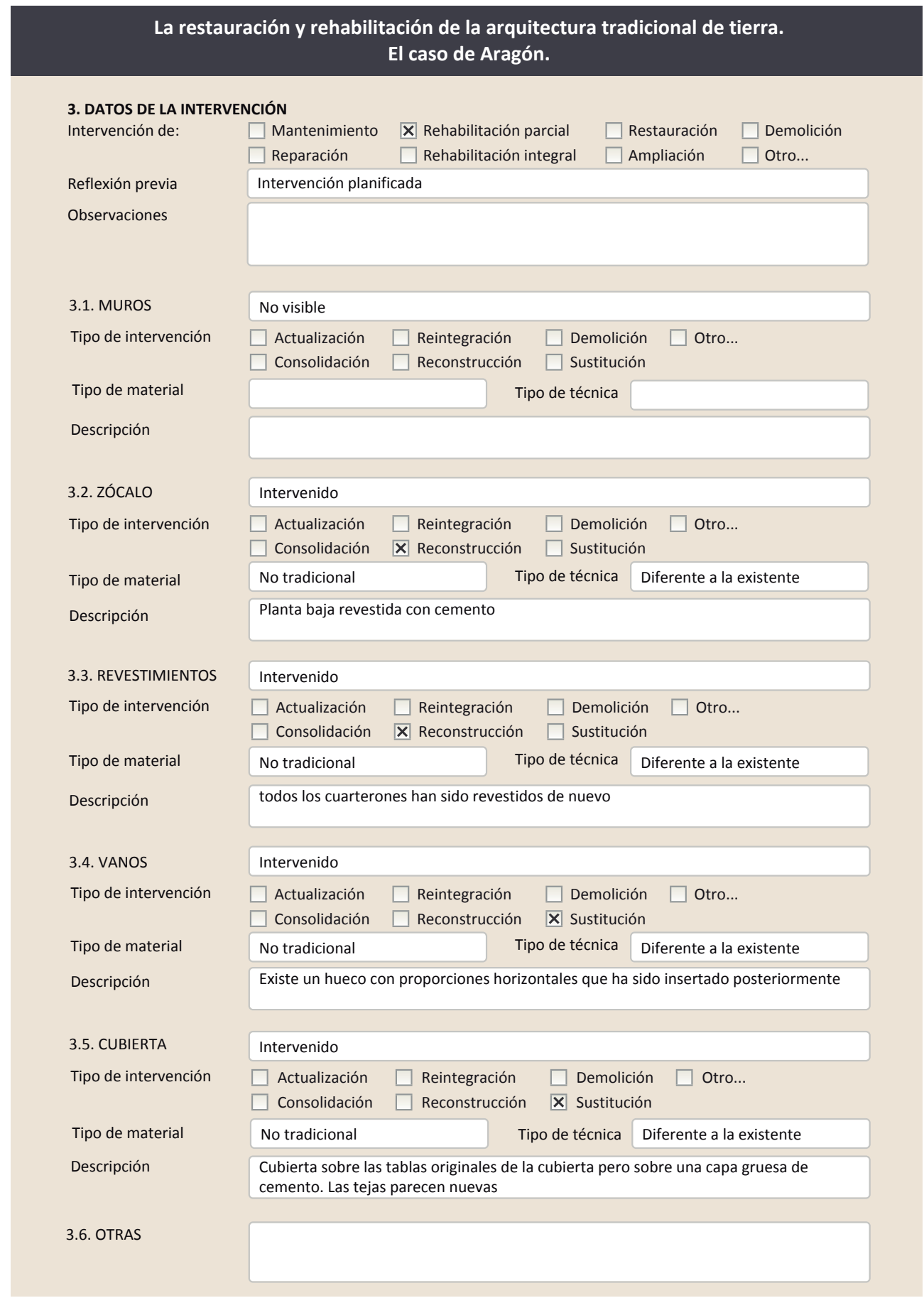

3.7. REHABILITACIÓN ENERGÉTICA $\quad \square$ Fachada $\square$ Vanos $\square$ Forjados $\square$ Cubierta Observaciones

FOTOGRAFíAS DE LA INTERVENCIÓN
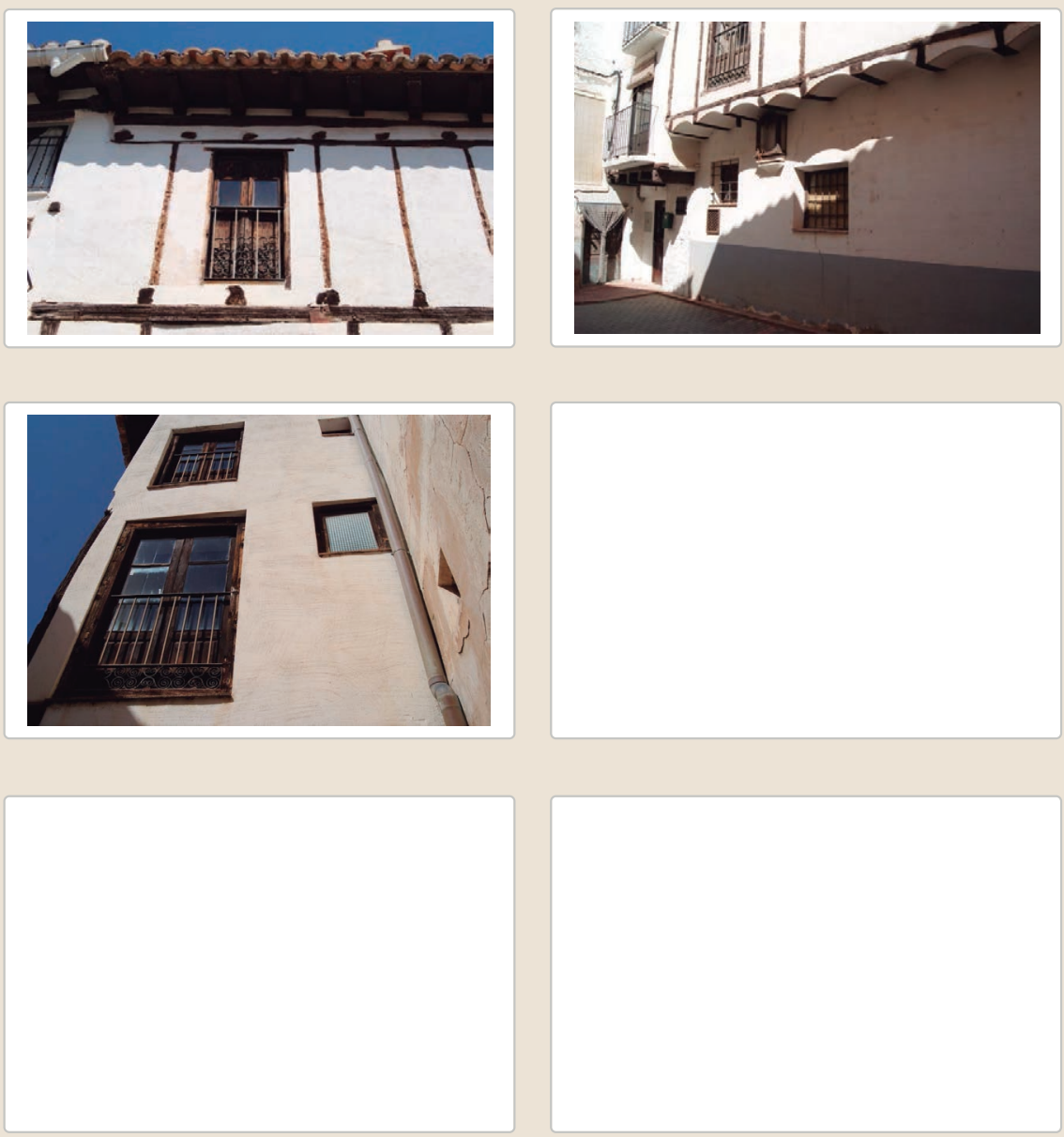


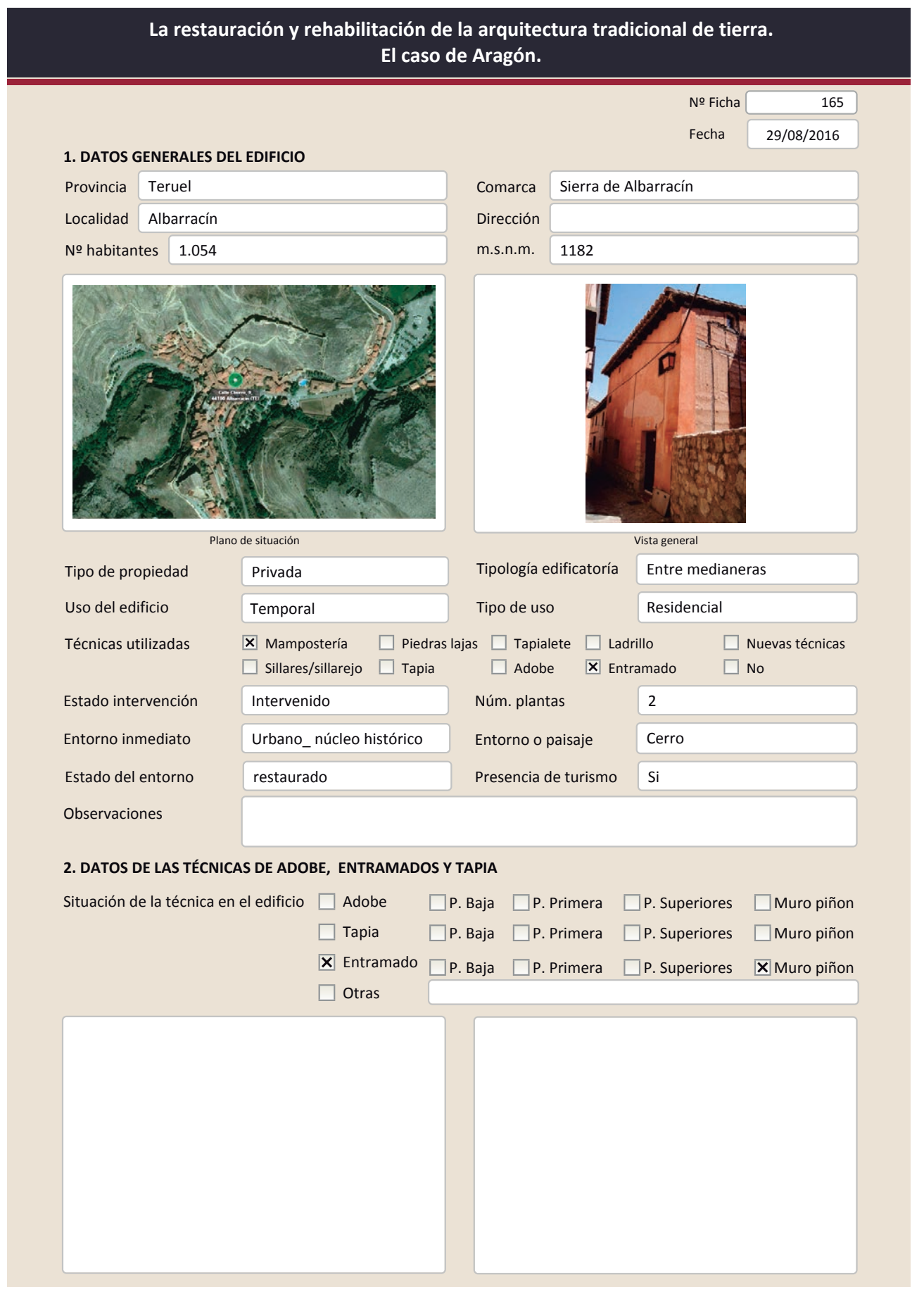

La restauración y rehabilitación de la arquitectura tradicional de tierra.

El caso de Aragón.

2.3. ENTRAMADOS

\begin{tabular}{|c|c|c|c|}
\hline Distancia entre montantes & $80-100 \mathrm{~cm}$ & Elementos diagonales & No \\
\hline Altura de los montantes & $200-250 \mathrm{~cm}$ & Elementos horizontales intermedios & No \\
\hline Sección de los montantes & Escuadrada & Sección de las piezas horizontales & Escuadrada \\
\hline Dimensión de los montantes & $10-20 \mathrm{~cm}$ & Dimensión de las piezas horizontales & $20-30 \mathrm{~cm}$ \\
\hline Tipo de relleno del entramado & $x$ Mo & lezas/fábrica $\quad \square$ Tejido & \\
\hline
\end{tabular}

Técnica de relleno del entramado

\begin{tabular}{ll}
$\square$ Entre pantallas de madera & $\square$ Pared de mano \\
$\square$ Tierra y mampuestos & $\square$ Cañizo \\
$\mathbf{X}$ Tapialete & $\square$ Adobe horizontal \\
\hline
\end{tabular}

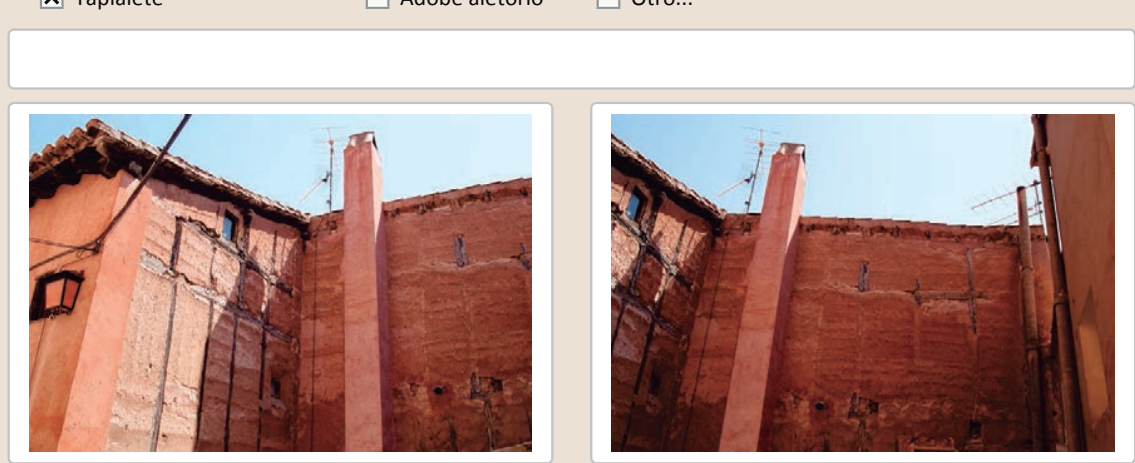

Lesiones $\quad$ Muro $\square$ Zócalo $\square$ Revestimiento $\square$ Cubierta $\square$ Otro...

$\begin{array}{lll}\square \text { Erosión del material } & \square \text { Carcoma o termitas } & \square \text { Grietas por falta de traba } \\ \square \text { Erosion de las juntas } & \square \text { Rotura de la madera } & \square \text { Grietas por asentamientos } \\ \square \text { Pérdida de sección } & \square \text { Pudrición de la madera } & \square \text { Colapso } \\ \square \text { Vegetación } & \square \text { Deformación madera } & \square \text { Por elementos impropios } \\ \boldsymbol{X} \text { Desconchados } & \square \text { Pudrición del relleno } & \square \text { Derivado de intervenciones } \\ \square \text { Humedad por capilaridad } & \square \text { Pérdida de verticalidad } & \square \text { Otro... } \\ \square \text { Humedades (manch/eflor) } & \square \text { Grietas por empuje de la cubierta } & \end{array}$

$\square$ Humedades (manch/eflor) $\square$ Grietas por empuje de la cubierta

Observaciones 


\section{La restauración y rehabilitación de la arquitectura tradicional de tierra.}

\section{El caso de Aragón.}

3. DATOS DE LA INTERVENCIÓN

$\square$ Mantenimien

Intervención de:

X Rehabilitación parcial

$\square$ Restauración $\square$ Demolición

Reflexión previa

Intervención planificada

Observaciones

(2)

3.1. MUROS
Tipo de intervención

\section{No visible}

$\square$ Actualización $\square$ Reintegración $\quad \square$ Demolición $\square$ Otro...

$\square$ Consolidación $\square$ Reconstrucción $\square$ Sustitución

Tipo de material

Descripción

\subsection{ZÓCALO}

Tipo de intervención

Tipo de material

Descripción

3.3. REVESTIMIENTOS

Tipo de intervención

Tipo de material

Descripción

3.4. VANOS
Tipo de intervención

Tipo de material

Descripción

3.5. CUBIERTA

Tipo de intervención

Tipo de material

Descripción

\section{Intervenido}

$\square$ Actualización $\quad$ X Reintegración $\square$ Demolición $\square$ Otro...

$\square$ Consolidación $\quad \square$ Reconstrucción $\square$ Sustitución

No tradicional Tipo de técnica Diferente a la existente

Rejuntado de la mampostería con cemento

\section{Intervenido}

$\square$ Actualización $\square$ Reintegración $\quad \square$ Demolición $\square$ Otro...

$\square$ Consolidación $\quad \mathbf{X}$ Reconstrucción $\square$ sustitución

Tradicional similar Tipo de técnica Similar a la existente

Revestimiento con yeso

Intervenido

$\square$ Actualización $\quad \square$ Reintegración $\quad \square$ Demolición $\square$ Otro...

$\square$ Consolidación $\square$ Reconstrucción $\mathbf{X}$ Sustitución

No tradicional Tipo de técnica Similar a la existente

Sustitución de las carpinterías

\section{Intervenido}

$\square$ Actualización $\quad \boldsymbol{X}$ Reintegración $\square$ Demolición $\square$ Otro..

$\square$ Consolidación $\square$ Reconstrucción $\square$ Sustitución
No tradicional
Tipo de técnica Similar a la existente

3.6. OTRAS
La restauración y rehabilitación de la arquitectura tradicional de tierra.

El caso de Aragón.

3.7. REHABILITACIÓN ENERGÉTICA $\square$ Fachada $\quad \boldsymbol{X}$ Vanos $\square$ Forjados $\square$ Cubierta

Observaciones

FOTOGRAFÍAS DE LA INTERVENCIÓN
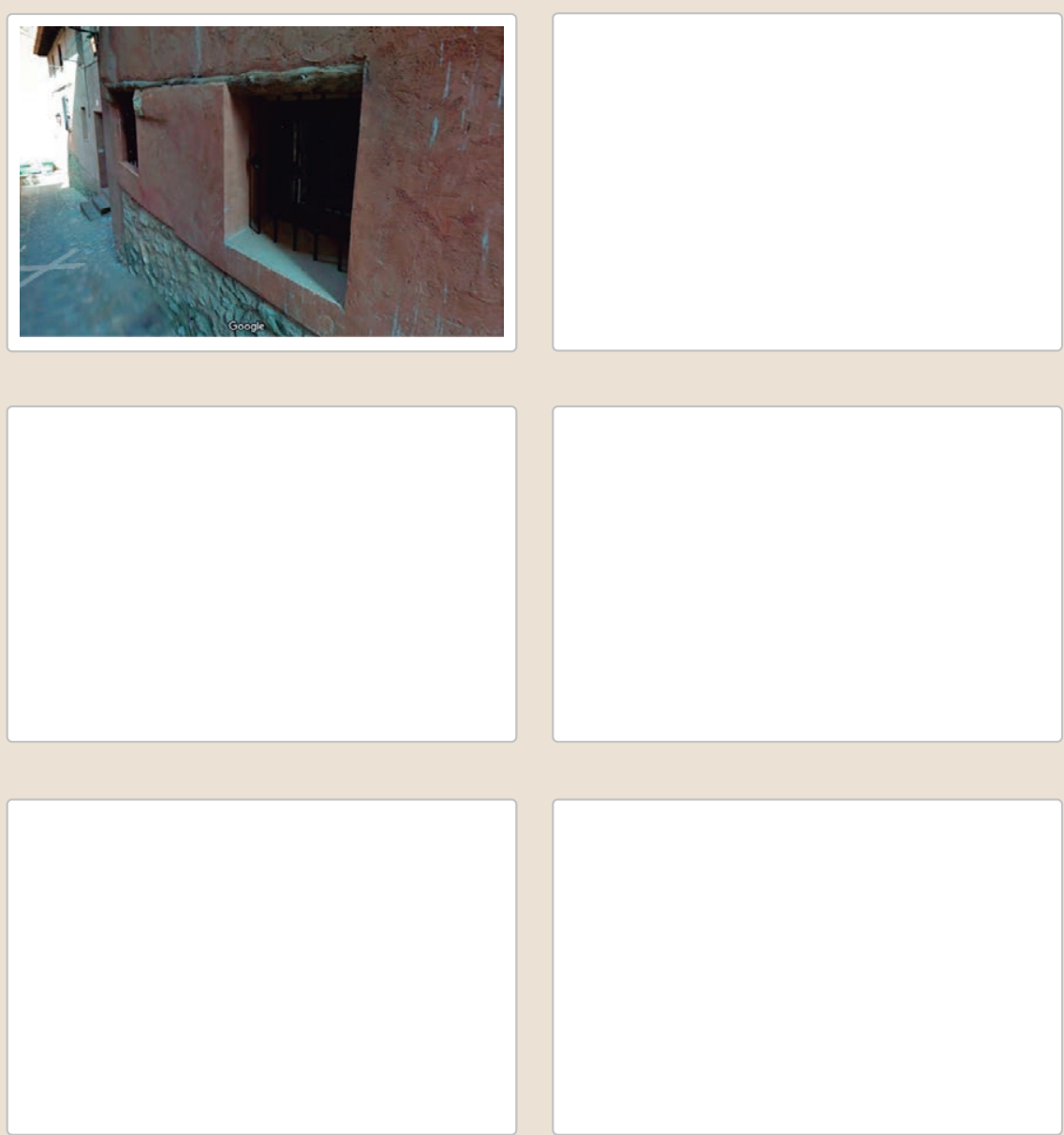


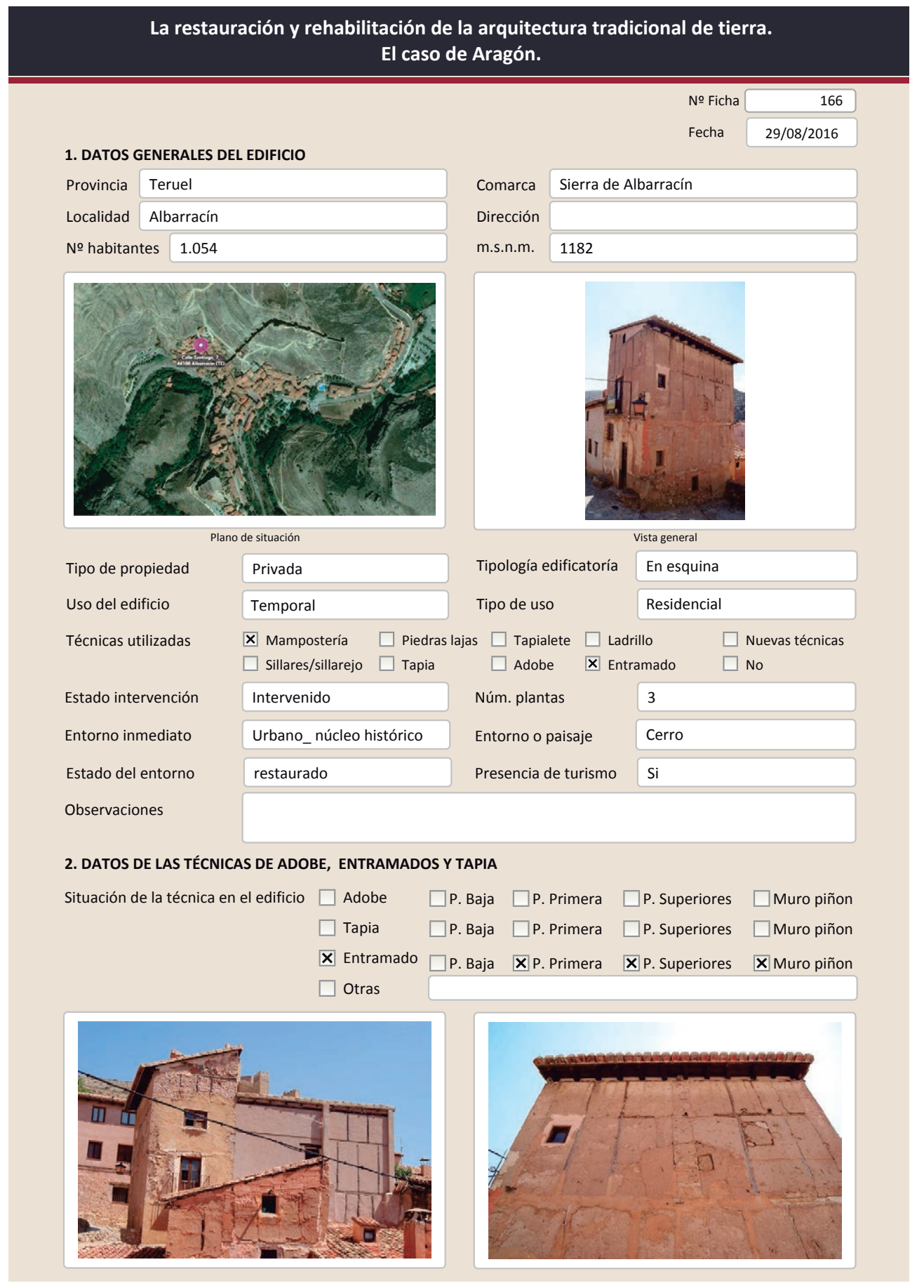

La restauración y rehabilitación de la arquitectura tradicional de tierra.

El caso de Aragón.

2.3. ENTRAMADOS

\begin{tabular}{|c|c|c|c|}
\hline Distancia entre montantes & $80-100 \mathrm{~cm}$ & Elementos diagonales & No \\
\hline Altura de los montantes & $200-250 \mathrm{~cm}$ & Elementos horizontales intermedios & No \\
\hline Sección de los montantes & Escuadrada & Sección de las piezas horizontales & Escuadrada \\
\hline Dimensión de los montantes & $10-20 \mathrm{~cm}$ & Dimensión de las piezas horizontales & $10-20 \mathrm{~cm}$ \\
\hline
\end{tabular}

Tipo de relleno del entramado $\quad$ X Monolítico $\square$ Piezas/fábrica $\square$ Tejido

Técnica de relleno del entramado
$\square$ Entre pantallas de madera
$\square$ Pared de mano $\square$ Cañizo
$\square$ Adobe horizontal $\square$ Encestados

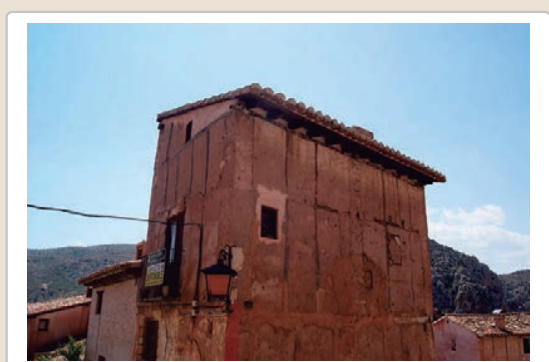

Lesiones

XMuro XZócalo $\square$ Revestimiento

$\mathbf{X}$ Erosión del material

$\square$ Erosion de las juntas

$\square$ Pérdida de sección

$\square$ Vegetación

$\square$ Carcoma o termitas

$\square$ Rotura de la madera

$\square$ Pudrición de la madera

$\square$ Deformación madera

$\square$ Pudrición del relleno

X Humedad por capilaridad $\square$ Pérdida de verticalidad

$\square$ Humedades (manch/eflor) $\square$ Grietas por empuje de la cubierta

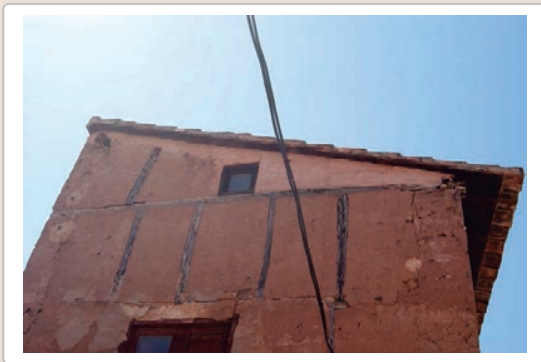

$\square$ Cubierta $\square$ otro...

$\mathbf{X}$ Grietas por falta de traba

$\mathbf{X}$ Grietas por asentamientos

$\square$ Colapso

$\square$ Por elementos impropios

$\square$ Derivado de intervenciones

$\square$ Otro...

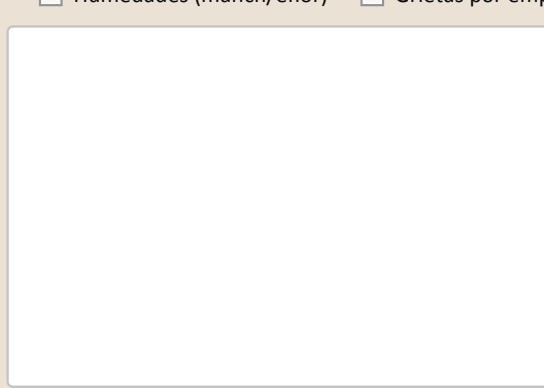

Observaciones 
La restauración y rehabilitación de la arquitectura tradicional de tierra. El caso de Aragón

\section{La restauración y rehabilitación de la arquitectura tradicional de tierra.}

\section{El caso de Aragón.}

3. DATOS DE LA INTERVENCIÓN

Intervención de:

$\square$ Mantenimiento $\square$ Rehabilitación parcia

$\square$ Restauración $\square$ Demolición

Reflexión previa

X Reparación

$\square$ Rehabilitación integral

Ampliación

$\square$ Otro..

Observaciones

Intervención planificada

3.1. MUROS

Tipo de intervención

Intervenido

Tipo de intervención

$\square$ Actualización $\quad$ Reintegración $\square$ Demolición $\square$ Otro...

$\square$ Consolidación $\square$ Reconstrucción $\square$ Sustitución

Descripción

No tradicional

Tipo de técnica Diferente a la existente

3.2. ZóCALO

Relleno de oquedades

Tipo de intervención

Intervenido

Tipo de intervención

$\square$ Actualización $\quad \mathbf{X}$ Reintegración $\quad \square$ Demolición $\square$ Otro...

$\square$ Consolidación $\square$ Reconstrucción $\square$ sustitución

Descripción

3.3. REVESTIMIENTOS

Rejuntado de la mampostería en la parte baja del edificio

Tipo de intervención

\section{No aplica}

Tipo de material

$\square$ Actualización

$\square$ Reintegración $\square$ Demolición $\square$ Otro...

$\square$ Consolidación $\square$ Reconstrucción $\square$ Sustitución

Descripción

3.4. VANOS

No intervenido

Tipo de intervención

$\square$ Actualización $\square$ Reintegración $\square$ Demolición $\square$ Otro...

Tipo de material

Descripción

$\square$ Consolidación $\square$ Reconstrucción $\square$ sustitución

3.5. CUBIERTA

Tipo de intervención

Intervenido

$\square$ Actualización $\square$ Reintegración $\square$ Demolición $\square$ Otro..

Tipo de material

$\square$ Consolidación $\quad \mathbf{X}$ Reconstrucción $\square$ Sustitución

Descripción

No tradicional Tipo de técnica Similar a la existente

3.6. OTRAS

Reconstrucción de la cubierta utilizando los materiales tradicionales y colocándolos con mortero de cemento (no seguro) 


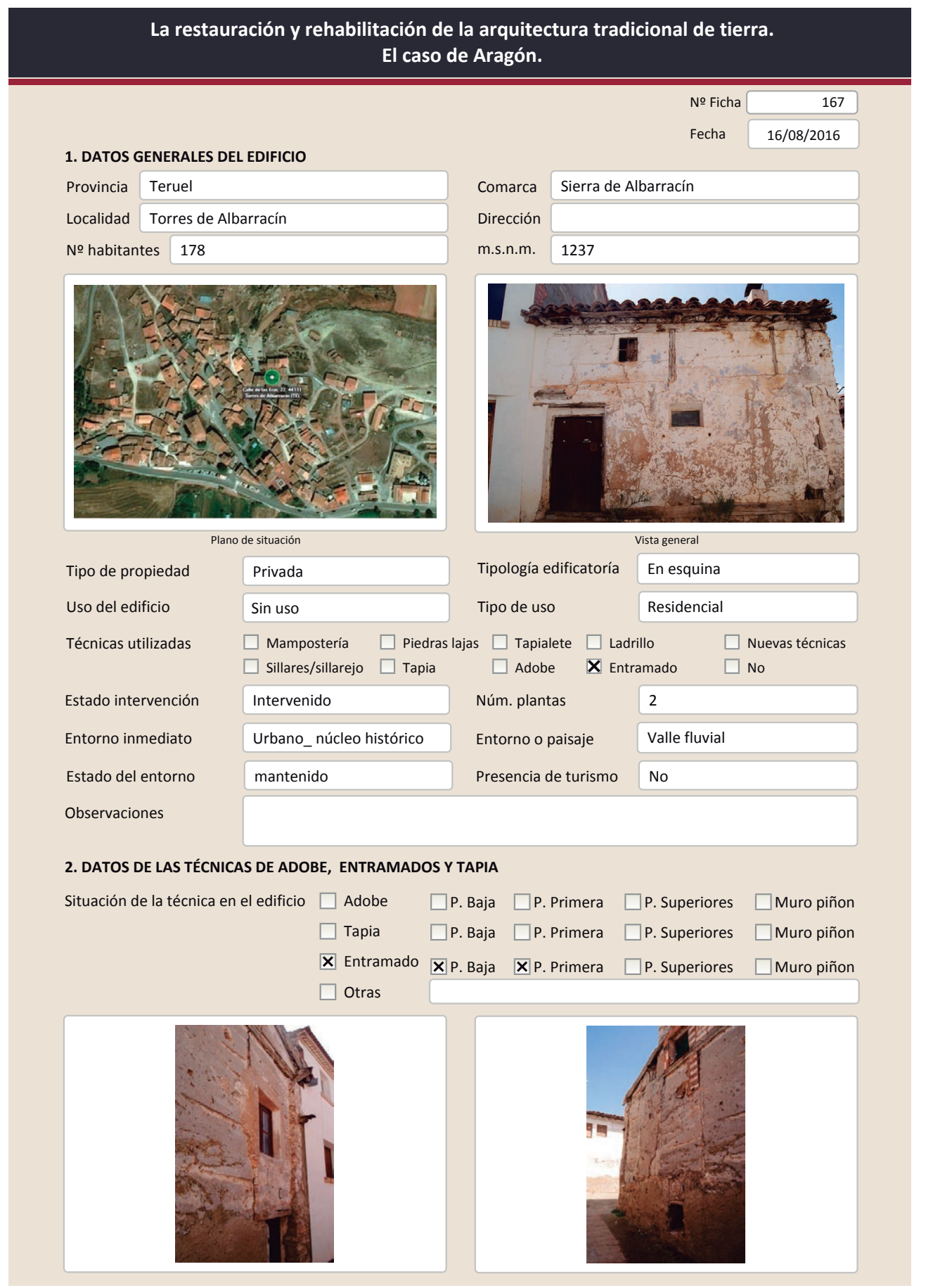

La restauración y rehabilitación de la arquitectura tradicional de tierra.

El caso de Aragón.

2.3. ENTRAMADOS

\begin{tabular}{|c|c|c|c|}
\hline Distancia entre montantes & $>120 \mathrm{~cm}$ & Elementos diagonales & No \\
\hline Altura de los montantes & $100-150 \mathrm{~cm}$ & Elementos horizontales intermedios & No \\
\hline Sección de los montantes & Escuadrada & Sección de las piezas horizontales & Escuadrada \\
\hline Dimensión de los montantes & $<10 \mathrm{~cm}$ & Dimensión de las piezas horizontales & $20-30 \mathrm{~cm}$ \\
\hline
\end{tabular}

Ténica de relleno del entramad
$\square$ Entre pantallas de madera
Pared de mano $\square$ Cañizo
$\square$ Adobe horizontal $\square$ Encestados

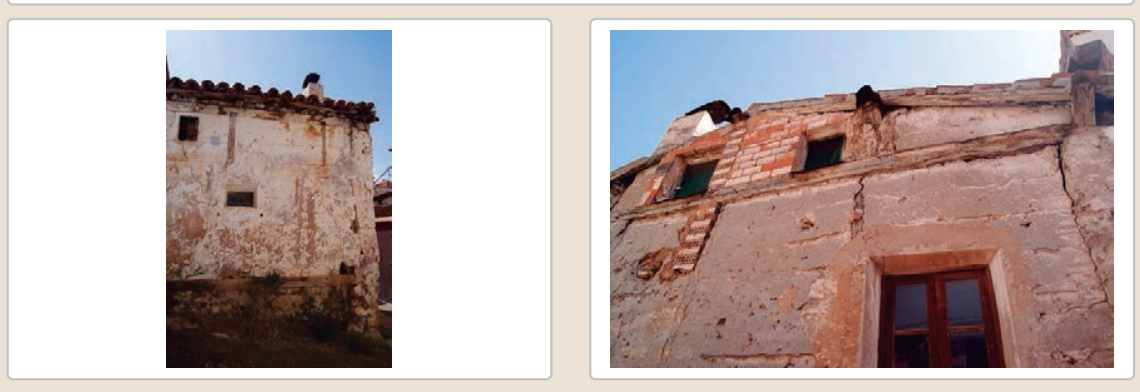
Lesiones $\quad$ XMuro $\square$ Zócalo $\mathbf{X}$ Revestimiento $\square$ Cubierta $\square$ Otro...
$\mathbf{X}$ Erosión del material $\quad \square$ Carcoma o termitas $\quad \mathbf{X}$ Grietas por falta de traba
$\square$ Erosion de las juntas $\quad \square$ Rotura de la madera $\quad \square$ Grietas por asentamientos
$\square$ Pérdida de sección $\square$ Pudrición de la madera $\square$ Colapso
$\square$ vegetación $\quad \square$ Deformación madera $\quad \square$ Por elementos impropios
\ Desconchados $\square$ Pudrición del relleno $\square$ Derivado de intervenciones
X Humedad por capilaridad $\quad \square$ Pérdida de verticalidad $\quad \square$ Otro...
$\square$ Humedades (manch/eflor) $\square$ Grietas por empuje de la cubierta

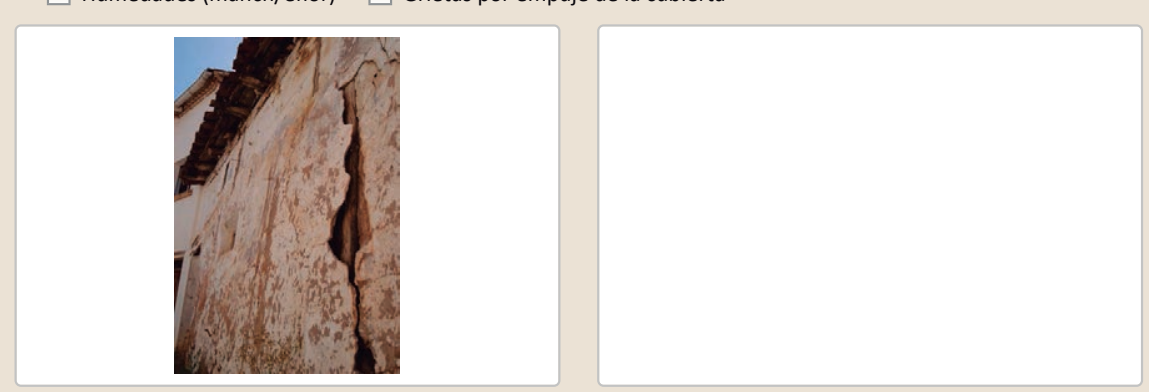

Observaciones 
La restauración y rehabilitación de la arquitectura tradicional de tierra. El caso de Aragón

\section{La restauración y rehabilitación de la arquitectura tradicional de tierra.}

\section{El caso de Aragón.}

3. DATOS DE LA INTERVENCIÓN

Intervención de:

$\square$ Mantenimiento $\square$ Rehabilitación parcia

$\square$ Restauración $\square$ Demolición X Reparación $\quad \square$ Rehabilitación integral $\quad \square$ Ampliación $\quad \square$ Otro...

Reflexión previa

Intervención espontanea

Observaciones

(n)

3.1. MUROS

Tipo de intervención $\quad \square$ Actualización $\quad \square$ Reintegración $\quad \square$ Demolición $\square$ Otro..

Intervenido

$\square$ Consolidación $\square$ Reconstrucción $\quad \mathbf{X}$ Sustitución

Tipo de material

\begin{tabular}{|l|l|l|}
\hline No tradicional & Tipo de técnica Diferente a la existente \\
\hline
\end{tabular}

Descripción

Sustitución de paños por muro de ladrillo hueco

3.2. ZÓCALO

Intervenido

Tipo de intervención

Actualización $\square$ Reintegración $\square$ Demolición $\square$ Otro..

$\square$ Consolidación X Reconstrucción $\square$ Sustitución

Tipo de material

No tradicional Tipo de técnica

Descripción

Revestimiento de cemento

3.3. REVESTIMIENTOS

\section{No intervenido}

Tipo de intervención

$\square$ Actualización $\square$ Reintegración $\square$ Demolición $\square$ Otro...

Tipo de material

Descripción

3.4. VANOS

$\square$ Consolidación $\square$ Reconstrucción $\square$ Sustitución

Tipo de intervención

No intervenido

Tipo de material

Descripción

3.5. CUBIERTA

Tipo de intervención

No intervenido

Tipo de intervencion

$\square$ Actualización

$\square$ Consolidación $\square$ Reconstrucción $\quad \square$ Sustitución

Tipo de técnica

Tipo de materia

Descripción

3.6. OTRAS

$\square$ Consolidación $\square$ Reconstrucción $\square$ sustitución

Tipo de técnica 


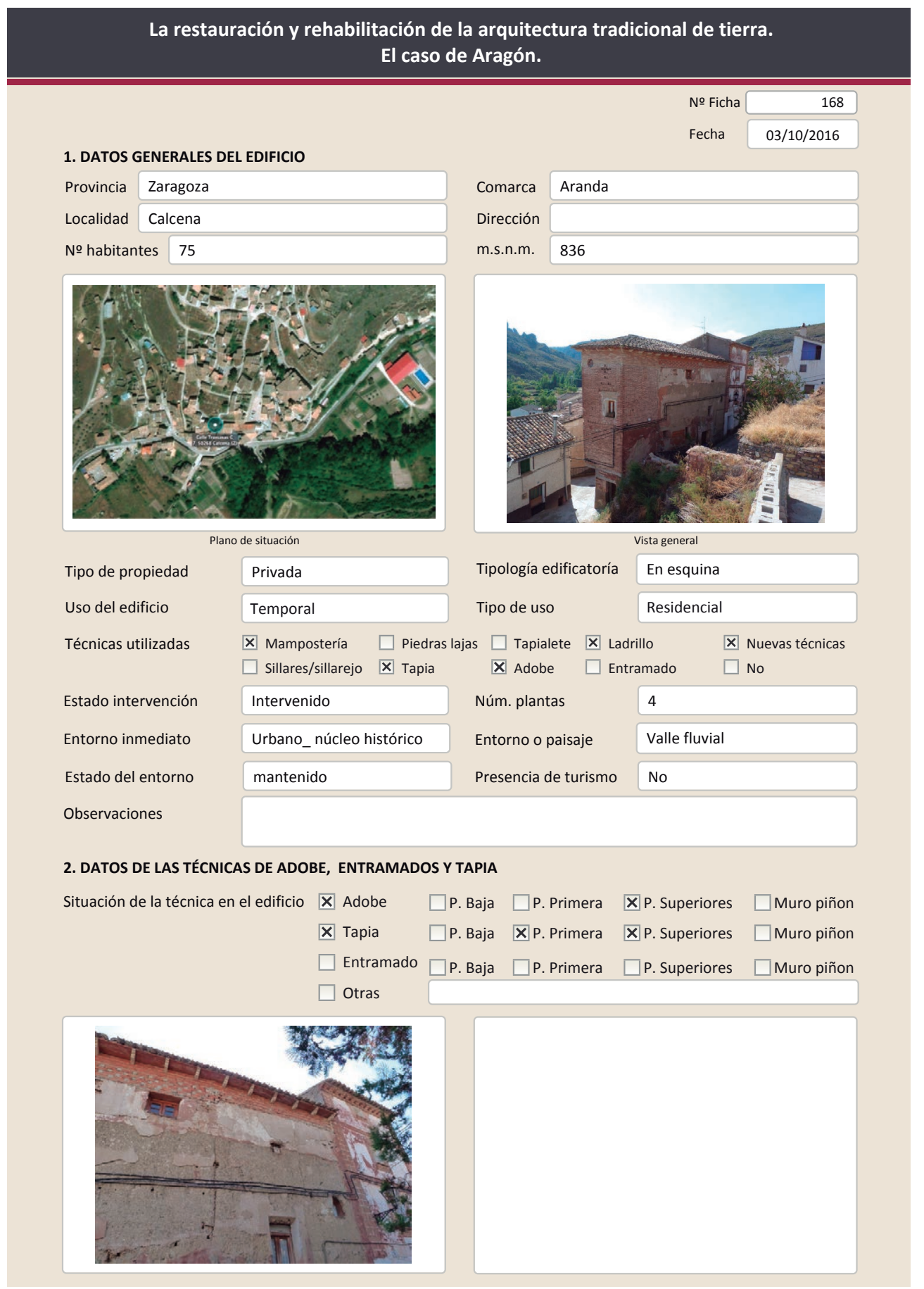

La restauración y rehabilitación de la arquitectura tradicional de tierra.

El caso de Aragón.

2.1. ADOBE

Dimensión de las piezas Dimensión del muro Aparejo del muro Función estructural

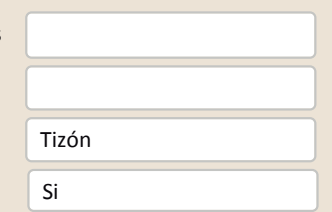
Color de las piezas

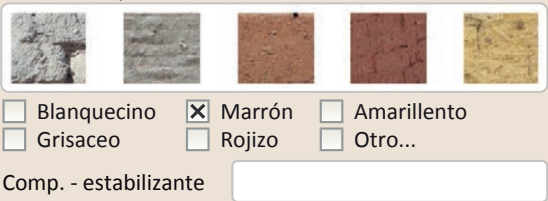
Variante constructiva/ tipo de fábrica

メ simple

$\square$ suplementada en juntas

$\square$ Mixta

$\square$ Como suplemento

Х Elementos de protección
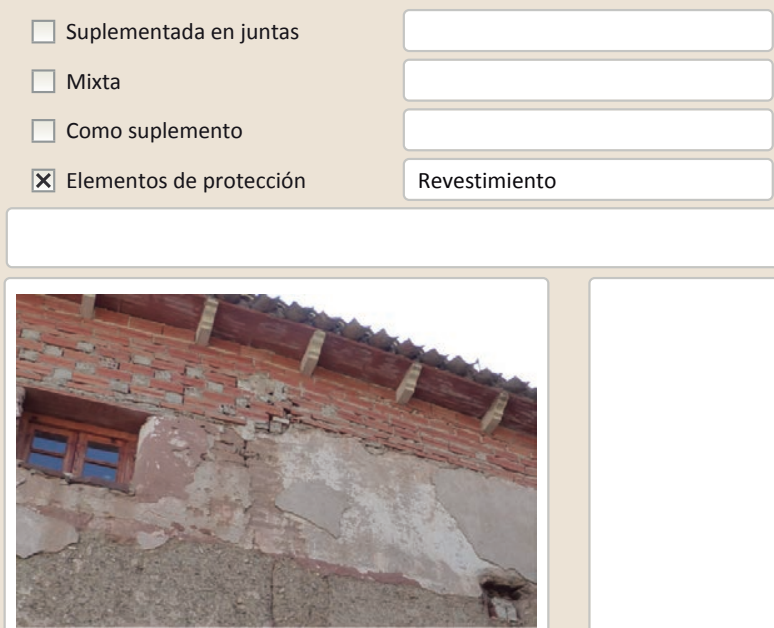

Lesiones ХMuro $\square$ Zócalo \ $\mathbf{\text { Revestimiento }}$

X Erosión del material $\square$ Humedad por capilaridad X Erosion de las juntas $\square$ Humedades (manch/eflo)

$\square$ Pérdida de sección $\square$ Pérdida de verticalidad

$\square$ Vegetación $\quad \square$ Grietas por empuje de la cubir $\square$ Grietas porfalta de traba

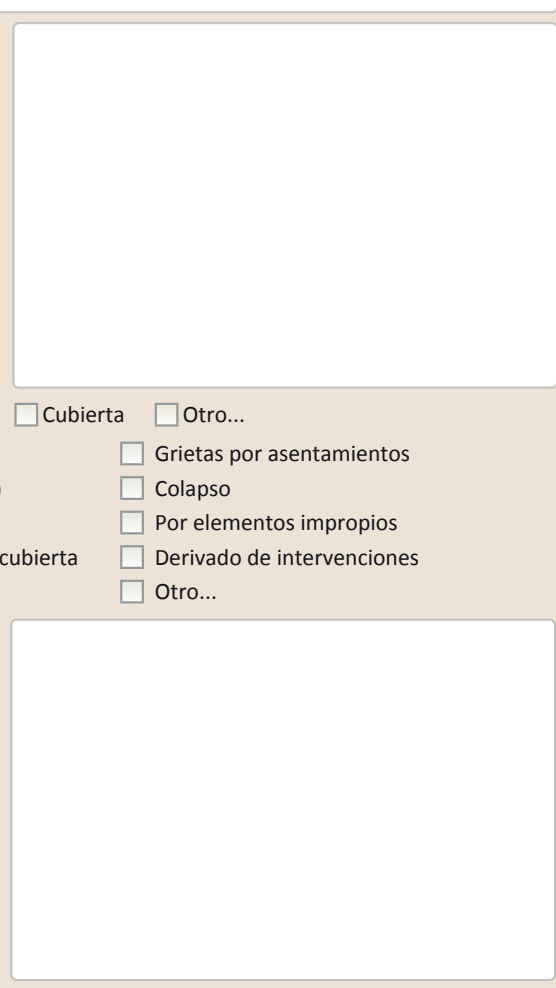

Observaciones 


\section{La restauración y rehabilitación de la arquitectura tradicional de tierra.} El caso de Aragón.

\subsection{TAPIA}

Ancho del muro

Dimensión tapiales

Tipo de aguja

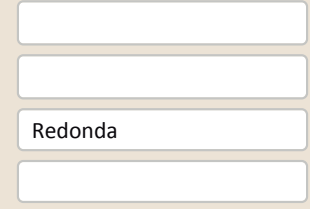

\section{Color de la tapia}

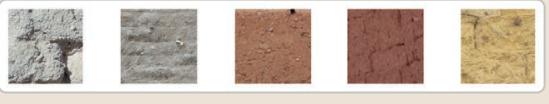

$\square$ Blanquecino $\quad \mathbf{X}$ Marrón $\square$ Amarillento $\square$ Grisaceo $\square$ Rojizo $\square$ Otro...

Variante constructiva

$\mathbf{x}$ Simple/homogen

$\square$ suplemento superficial

Simple / homogénea

$\square$ Suplemento en juntas

$\square$ Mixta

X Elementos de protección

Revestimiento
La restauración y rehabilitación de la arquitectura tradicional de tierra. El caso de Aragón.

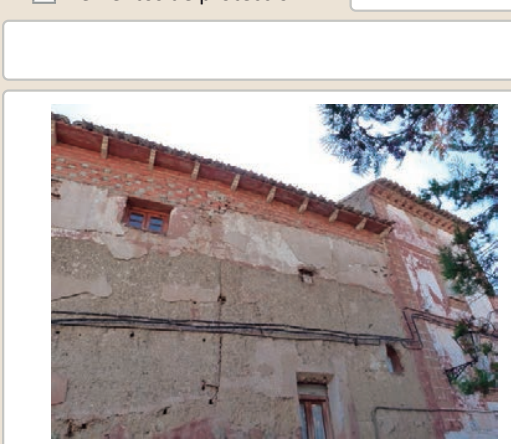

Lesiones ХMuro $\square$ Zócalo \ Xevestimiento $\square$ Cubierta $\square$ Otro...

$\mathbf{X}$ Erosión del material $\quad \mathbf{X}$ Humedad por capilaridad $\quad \square$ Grietas por asentamientos

$\square$ Erosion de las juntas $\square$ Humedades (manch/eflo) $\square$ Colapso

$\square$ Pérdida de sección $\square$ Pérdida de verticalidad $\quad \square$ Por elementos impropios

$\square$ Vegetación $\square$ Grietas por empuje de la cubierta $\square$ Derivado de intervenciones

X Desconchados $\quad \square$ Grietas porfalta de traba $\quad \square$ Otro...
3. DATOS DE LA INTERVENCIÓN

Intervención de: $\quad \square$ Mantenimiento $\quad \square$ Rehabilitación parcial $\quad \square$ Restauración $\square$ Demolición

Reflexión previa Intervención espontanea

Observaciones Existen intervenciones de forma aislada en distintos elementos del edificio. Existe una intencionalidad de intervención ya que en la esquina se ha utilizado ladrillo cara vista

3.1. MUROS

Tipo de intervención

Intervenido

Tipo de material

$\square$ Actualización $\quad \boldsymbol{X}$ Reintegración $\quad \square$ Demolición $\square$ Otro..

$\square$ Consolidación $\quad \mathbf{X}$ Reconstrucción $\square$ Sustitución

Descripción

No tradicional Tipo de técnica Diferente a la existente

Se han rellenado pares faltantes con ladrillo y se ha recrecido el muro aproximadamente un metro con ladrillo hueco.

3.2. ZÓCALO

Tipo de intervención

Intervenido

$\square$ Actualización $\square$ Reintegración $\square$ Demolición $\square$ Otro.

$\square$ Consolidación $\mathbf{X}$ Reconstrucción $\square$ Sustitución

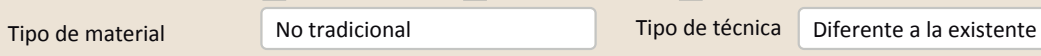

Descripción

Hormigón encofrado sobre la mampostería del zócalo

3.3. REVESTIMIENTOS

Tipo de intervención

No intervenido

Tipo de material

Descripción

3.4. VANOS

Tipo de intervención

Intervenido

Tipo de material

$\square$ Actualización $\quad \mathbf{X}$ Reintegración $\square$ Demolición $\square$ Otro...

$\square$ Consolidación $\square$ Reconstrucción $\quad \boldsymbol{X}$ Sustitución

\begin{tabular}{l|l|l|l|l} 
Tipo de material & No tradicional & Tipo de técnica & Diferente a la existente
\end{tabular}

Descripción Se han sustituido las carpinterías de muchos de los huecos. En algunos casos la carpintería es de distinta dimensión por lo que hay que adaptar el hueco

3.5. CUBIERTA

Tipo de intervención

Intervenido

$\square$ Actualización $\square$ Reintegración $\square$ Demolición $\square$ Otro

$\square$ Consolidación $\square$ Reconstrucción $\mathbf{X}$ Sustitución

Tipo de material

\begin{tabular}{l|l|l} 
No tradicional & Tipo de técnica & Diferente a la existente
\end{tabular}

Descripción

Nueva cubierta sobre el recrecido del muro. Se han utilizado materiales industriales para su configuración

3.6. OTRAS forjado intermedio (refuerzo de los forjados) 
La restauración y rehabilitación de la arquitectura tradicional de tierra.

$$
\text { El caso de Aragón. }
$$

3.7. REHABILITACIÓN ENERGÉTICA

$\square$ Fachada $\quad \square$ Vanos $\square$ Forjados $\square$ Cubierta

Observaciones

FOTOGRAFÍAS DE LA INTERVENCIÓN
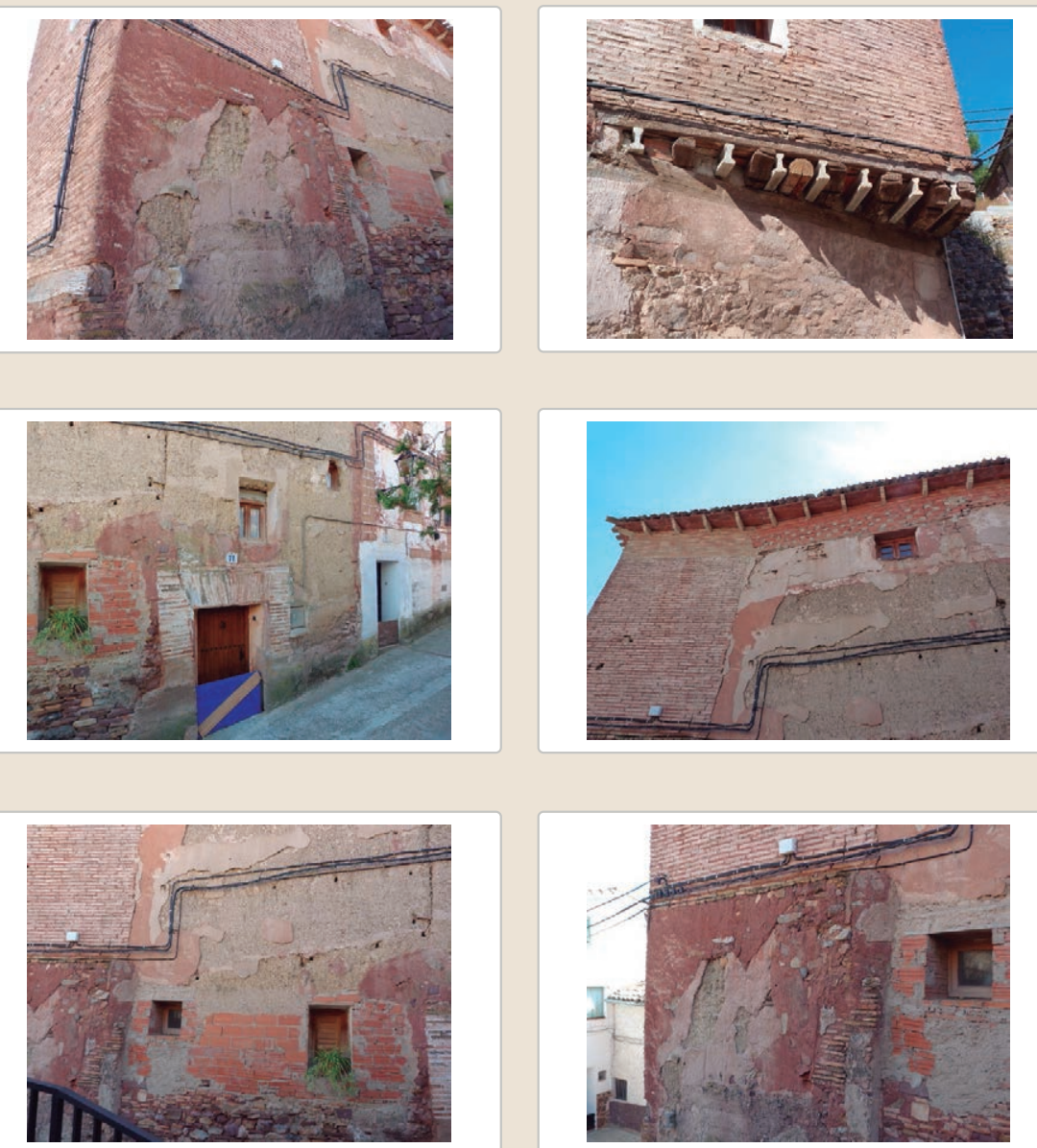


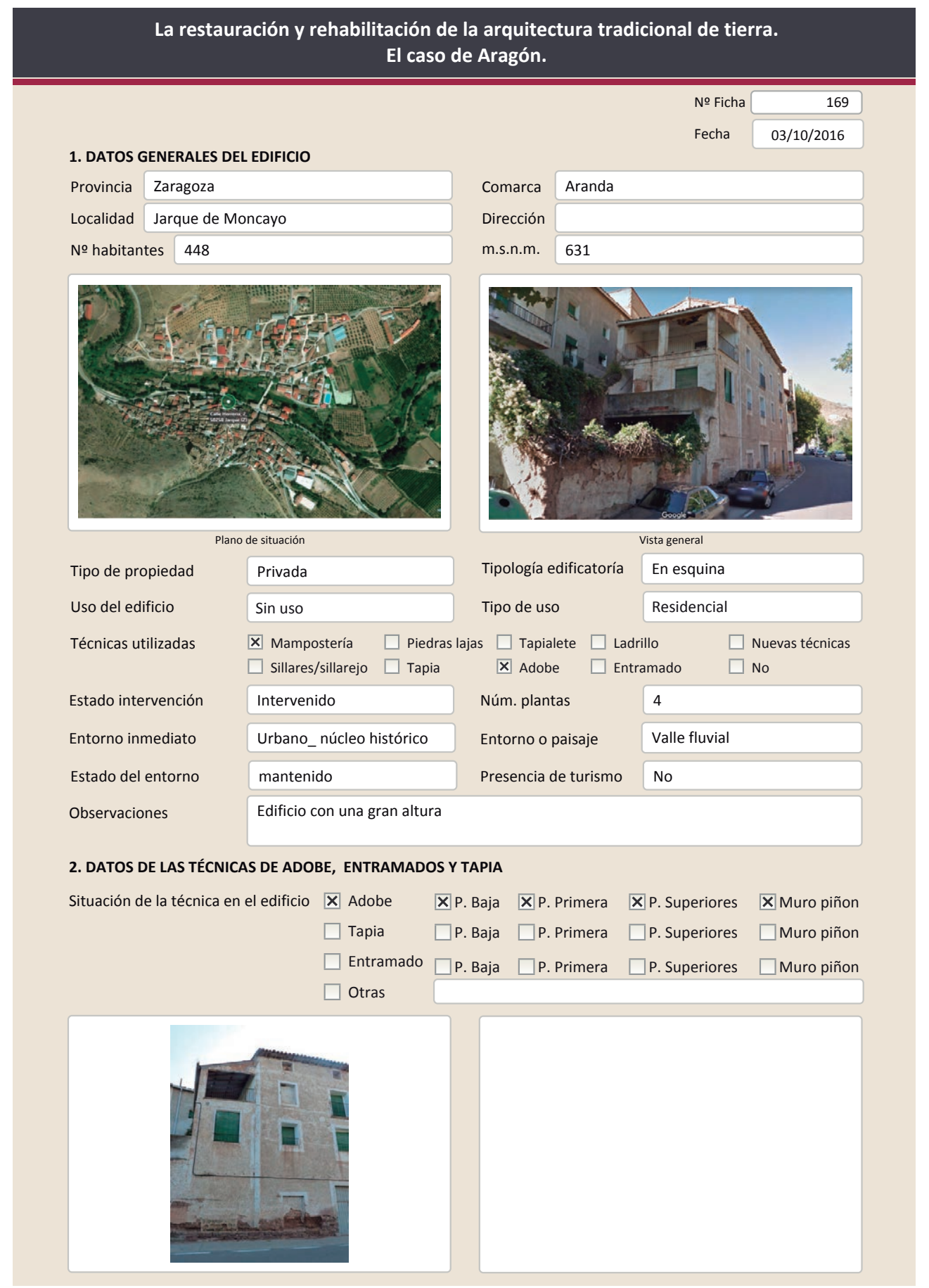

2.1. ADOBE

Dimensión de las piezas

Dimensión del muro

Aparejo del muro

Función estructural

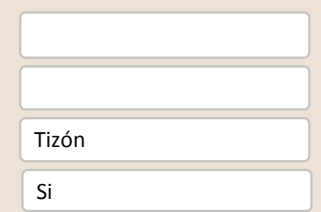

Color de las piezas

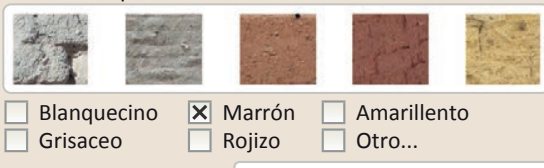

Rojizo $\square$ Otro.

Variante constructiva/ tipo de fábrica

区 Simple

$\square$ Suplementada en juntas

X Mixta

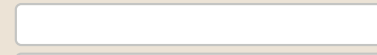

$\square$ Como suplemento

X Elementos de protección Revestimiento En esquinas

Piedra

No se aprecia la variante constructiva debido al revestimiento. En los desconchados no se aprecia mamposterí en todas las esquinas pero si en algunas de ellas

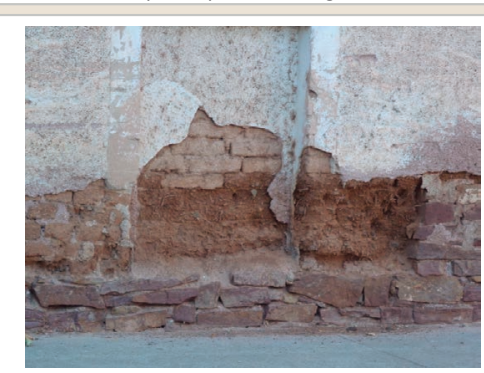

Lesiones $\quad \mathbf{X}$ Muro $\mathbf{X}$ Zócalo $\mathbf{X}$ Revestimiento $\mathbb{X}$ Erosión del material $\mathbf{X}$ Humedad por capilaridad $\square$ Erosion de las juntas $\mathbf{X}$ Humedades (manch/eflo) $\square$ Pérdida de sección $\square$ Pérdida de verticalidad

$\square$ Vegetación $\quad \square$ Grietas por empuje de la cubic $\mathbf{X}$ Desconchados $\square$ Grietas porfalta de traba

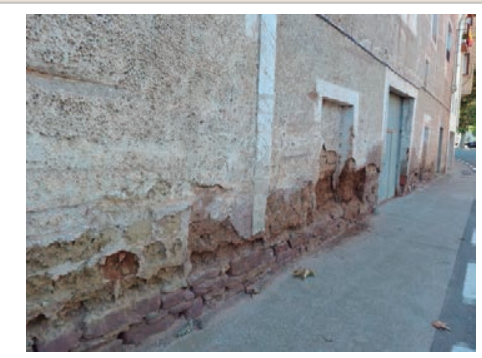

Observacione
Problemas serios por la humedad por capilaridad. También se observan pérdidas de tejas en la cubierta.

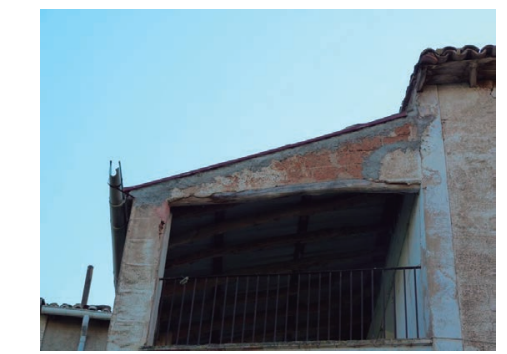

Cubierta $\square$ Otro...

$\square$ Grietas por asentamiento X Colapso

$\square$ Por elementos impropios

$\square$ Derivado de intervenciones $\square$ Otro...

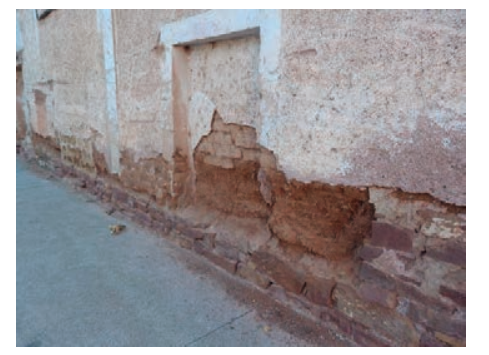




\section{La restauración y rehabilitación de la arquitectura tradicional de tierra.} El caso de Aragón.

3. DATOS DE LA INTERVENCIÓN

Intervención de:

$\square$ Mantenimiento $\square$ Rehabilitación parcial

$\square$ Restauración $\square$ Demolición

Reflexión previa X Reparación $\square$ Rehabilitación integra

$\square$ Ampliación $\square$ otro...

Reflexion previa

Intervención espontanea

(n)

3.1. MUROS
Tipo de intervención

\section{No intervenido}

$\square$ Actualización $\quad \square$ Reintegración $\quad \square$ Demolición $\quad \square$ Otro...
$\square$ Consolidación $\quad \square$ Reconstrucción $\quad \square$ Sustitución

Tipo de material

Descripción

3.2. ZÓCALO

Tipo de intervención

$\square$ Consolidación

Tipo de técnica

No intervenido

$\square$ Actualización $\square$ Reintegración $\square$ Demolición $\square$ Otro...

$\square$ Consolidación $\quad \square$ Reconstrucción $\square$ sustitución

Tipo de material

Descripción

3.3. REVESTIMIENTOS

Tipo de intervención

Tipo de material

Descripción

3.4. VANOS

Tipo de intervención

Tipo de material

Descripción

3.5. CUBIERTA

Tipo de intervención

Tipo de material

Descripción

3.6. OTRAS

$\square$ Actualización $\square$ Reintegración $\square$ Demolición $\square$ Otro...

$\square$ Consolidación $\quad \square$ Reconstrucción $\quad \square$ sustitución

Tipo de técnica

Intervenido

$\square$ Actualización $\square$ Reintegración $\square$ Demolición $\square$ Otro...

$\square$ Consolidación $\square$ Reconstrucción $\quad \boldsymbol{x}$ Sustitución

No tradicional Tipo de técnica Diferente a la existente

Sustitución de carpinterías y adaptación de los huecos a estas. Hueco de grandes dimensiones en planta baja

Intervenido

$\square$ Actualización $\square$ Reintegración $\square$ Demolición $\square$ Otro..
No tradicional
Tipo de técnica Diferente a la existente

Sustitución de parte de la cubierta por una chapa metálica
Adaptación del edificio y reparaciones puntuales

La restauración y rehabilitación de la arquitectura tradicional de tierra.

El caso de Aragón.

3.7. REHABILITACIÓN ENERGÉTICA $\quad \square$ Fachada $\square$ Vanos $\square$ Forjados $\square$ Cubierta

Observaciones

FOTOGRAFÍAS DE LA INTERVENCIÓN
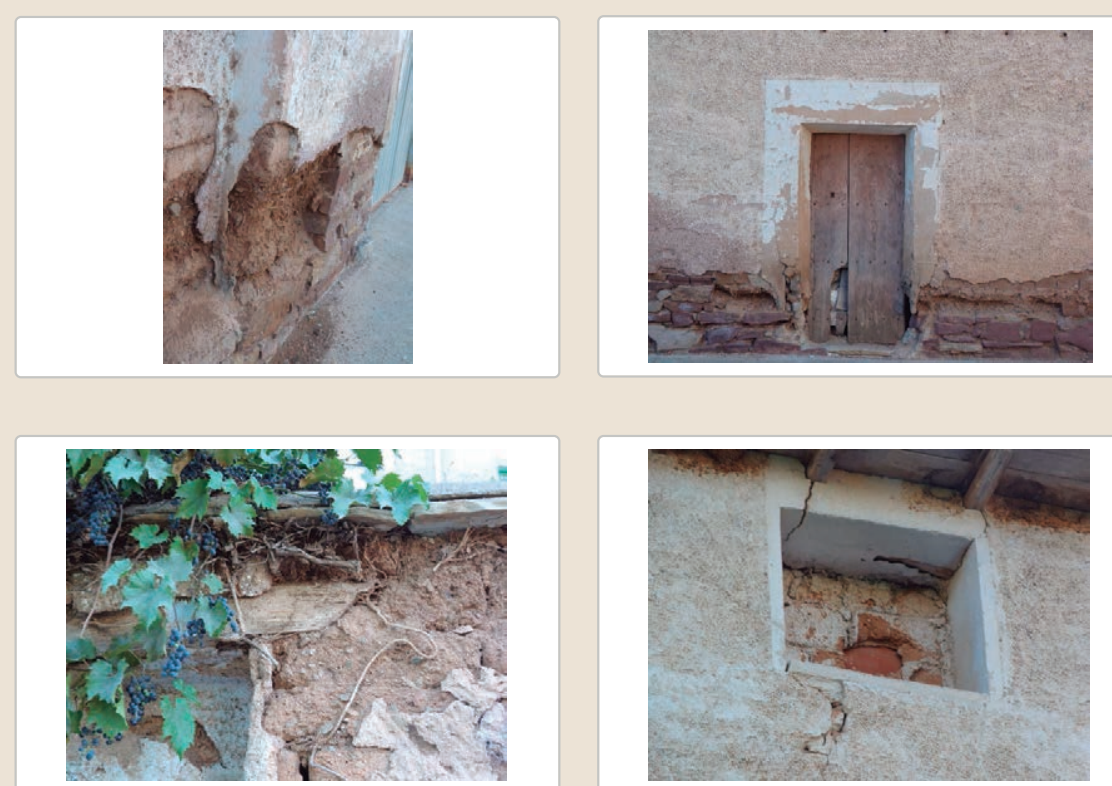

$\square$ Consolidación $\square$ Reconstrucción $\quad \boldsymbol{x}$ Sustitución
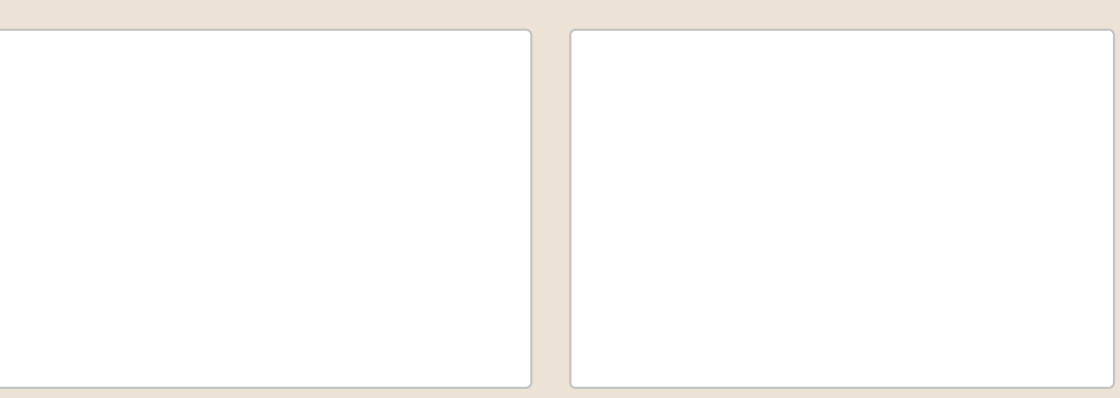


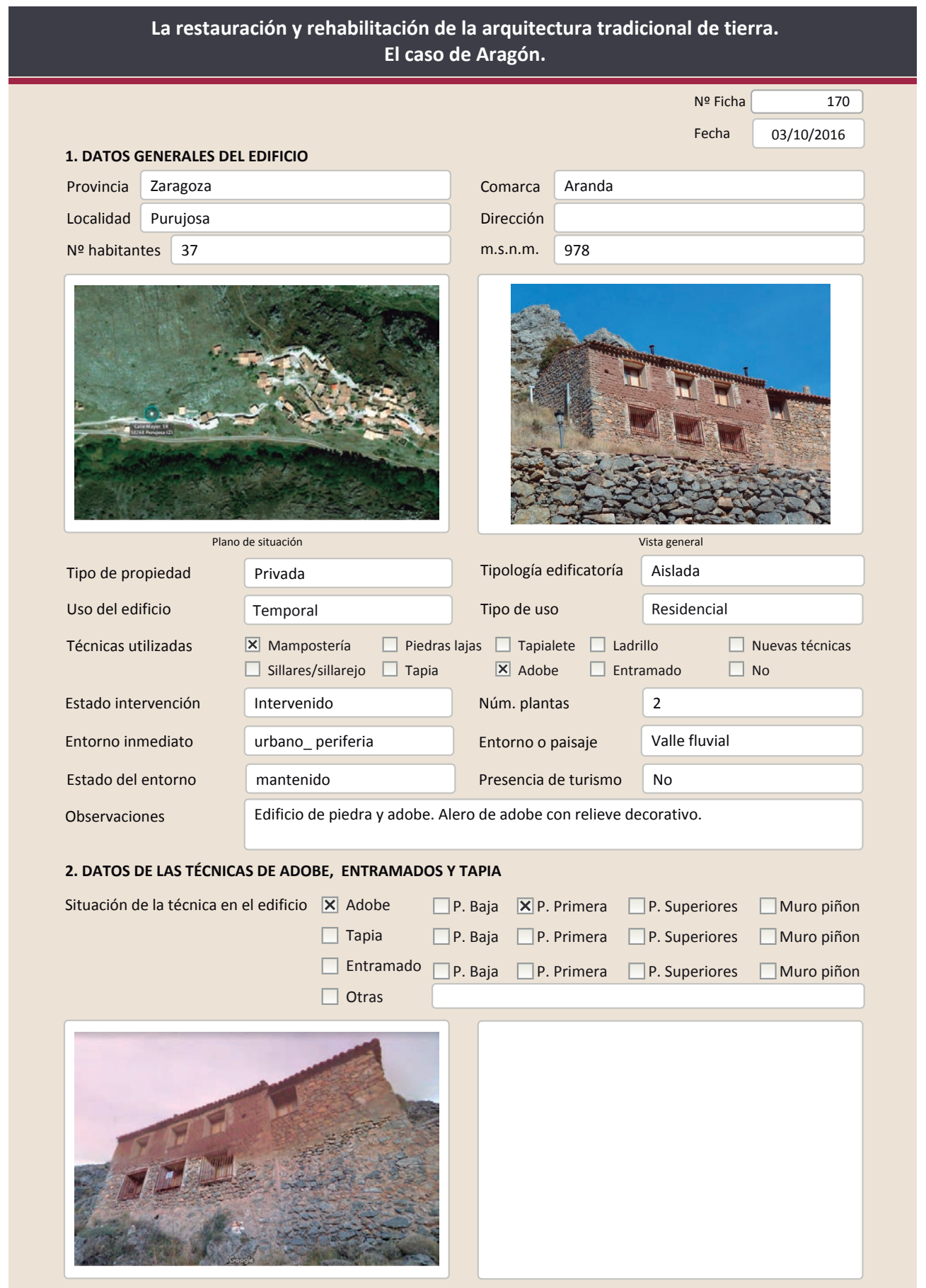

2.1. ADOBE

Dimensión de las piezas

Dimensión del muro

Aparejo del muro

Función estructural

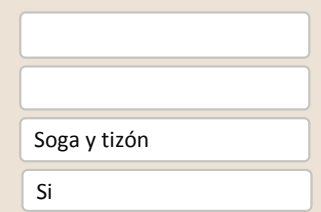

Color de las piezas

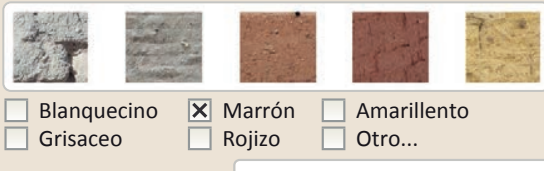

Grisaceo

Rojizo

Variante constructiva/ tipo de fábrica

$\square$ simple

$\square$ Suplementada en juntas

区 Mixta

En esquinas

Comp. - estabilizante

Mixto- En esquinas

$\square$ Elementos de protección

Existen dos tipos de adobe: los que conforman el muro, $y$ adobes tierra cemento que están en esquinas de la facha principal y de las jambas de los huecos (estos últimos cortados por la intervención)

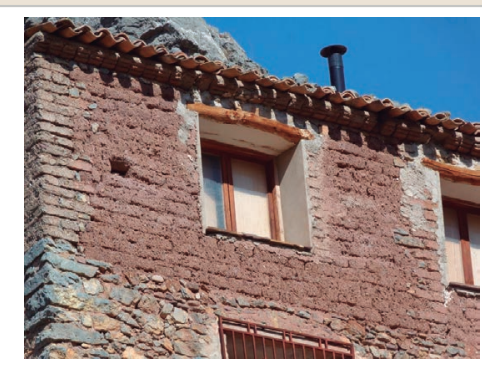

Lesiones $\quad$ XMuro $\square$ Zócalo $\square$ Revestimiento $\square$ Cubierta $\square$ otro...

X Erosión del material $\square$ Humedad por capilaridad $\quad \square$ Grietas por asentamiento X Erosion de las juntas $\square$ Humedades (manch/eflo) $\quad \square$ Colapso

$\square$ Pérdida de sección $\square$ Pérdida de verticalidad $\square$ Por elementos impropios

$\square$ Vegetación $\quad \square$ Grietas por empuje de la cubierta $\quad \square$ Derivado de intervenciones

$\square$ Desconchados $\square$ Grietas porfalta de traba $\quad \square$ Otro...
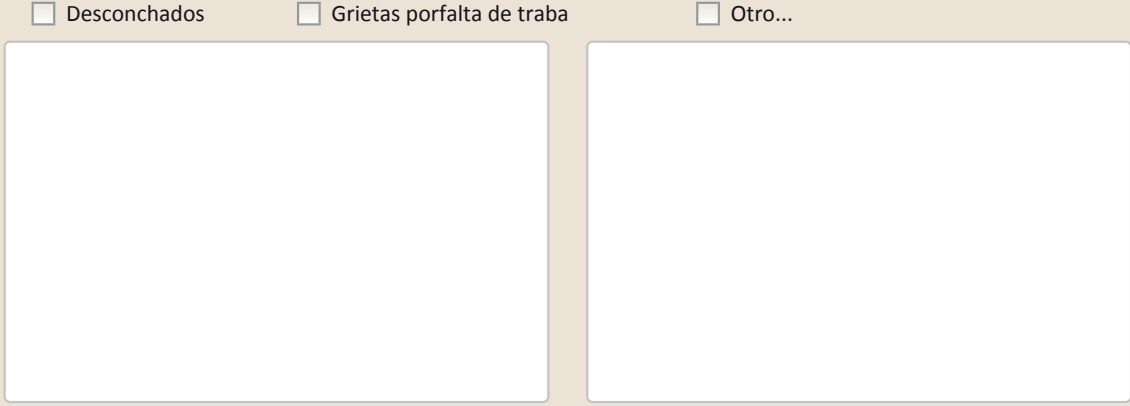

Observaciones 
La restauración y rehabilitación de la arquitectura tradicional de tierra.

El caso de Aragón.

3. DATOS DE LA INTERVENCIÓN

\begin{tabular}{llll} 
Intervención de: & $\square$ Mantenimiento $\quad \boldsymbol{X}$ Rehabilitación parcial $\quad \square$ Restauración $\quad \square$ Demolición \\
& $\square$ Reparación $\quad \square$ Rehabilitación integral $\quad \square$ Ampliación $\quad \square$ Otro... \\
\hline $\begin{array}{l}\text { Reflexión previa } \\
\text { Observaciones }\end{array}$ & Intervención planificada \\
\hline
\end{tabular}

\subsection{MUROS}

Tipo de intervención

No intervenid

Tipo de material

$\square$ Actualización $\square$ Reintegración $\square$ Demolición $\square$ Otro...

$\square$ Consolidación $\square$ Reconstrucción $\square$ sustitución

Descripción

3.2. ZÓCALO

No intervenido

Tipo de intervención

$\square$ Actualización

Tipo de material

Descripción

3.3. REVESTIMIENTOS

Tipo de intervención

\section{No aplica}

Tipo de material

Descripción Tipo de técnica

3.4. VANOS

Tipo de intervención

Intervenido

$\begin{array}{lll} & \square \text { Consolidación } \square \text { Reconstrucción } \square \text { Sustitución } \\ \text { Tipo de material } & \text { Tradicional diferente }\end{array}$

$\square$ Actualización $\quad \mathbf{X}$ Reintegración $\square$ Demolición $\square$ Otro...

Descripción Ampliación de los huecos. Se observa en los adobes cortaos de las jambas. Nuevas

carpinterías de madera y rejería. Se han conservado los dinteles de madera.

3.5. CUBIERTA

Tipo de intervención

No visible

Tipo de material

$\square$ Actualización $\square$ Reintegración $\quad \square$ Demolición $\square$ Otro.

$\square$ Consolidación $\square$ Reconstrucción $\square$ Sustitución

Descripción

$$
\text { Tipo de técnica }
$$

3.6. OTRAS 
La restauración y rehabilitación de la arquitectura tradicional de tierra. El caso de Aragón

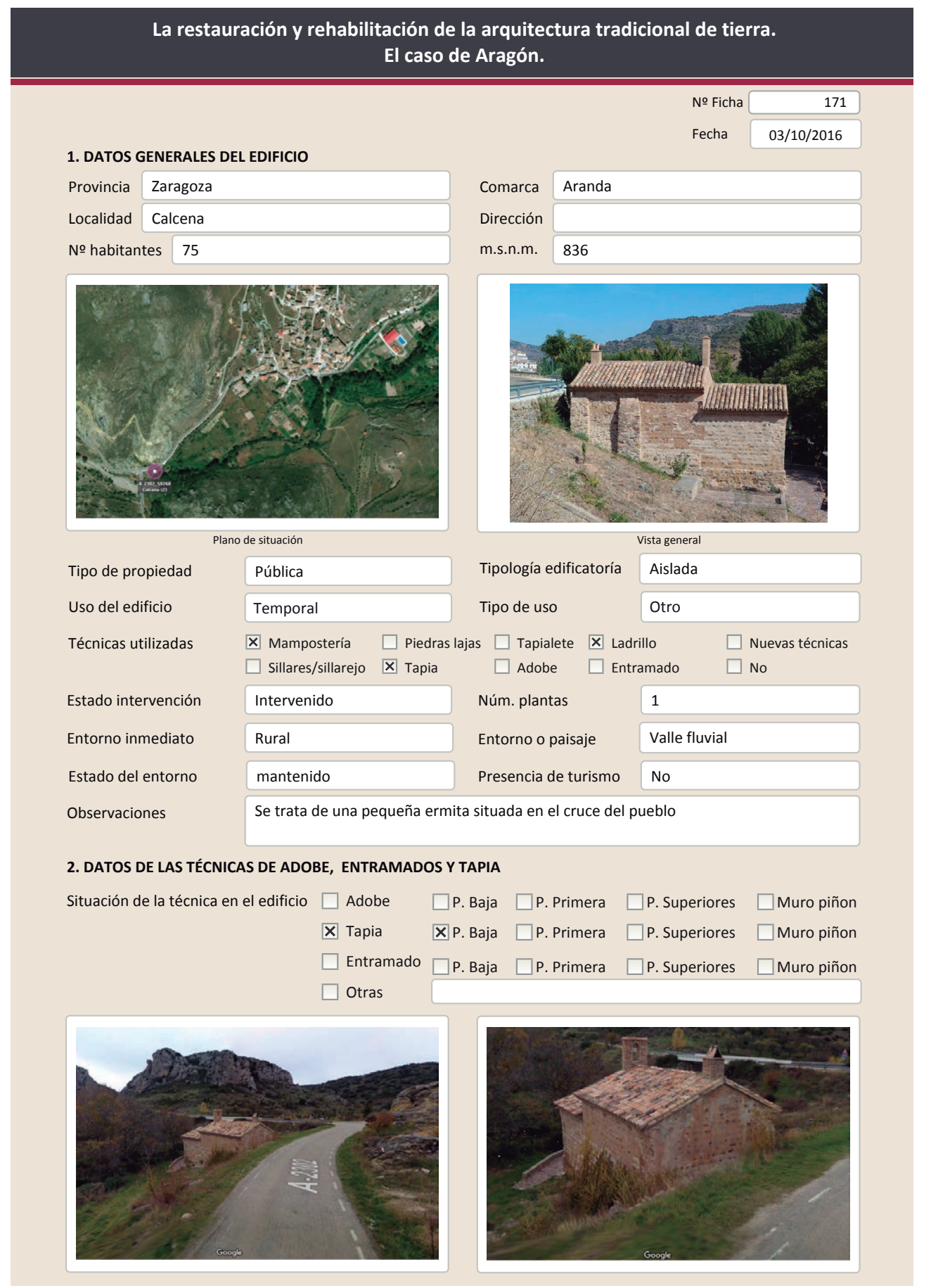

2.2. TAPIA

Ancho del muro

Dimensión tapiales

Tipo de aguja

№ agujas/cajón

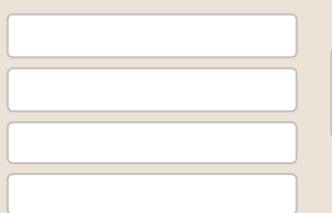

Color de la tapia

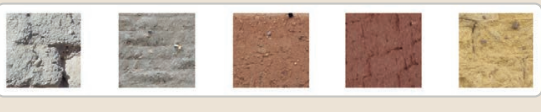

$\square$ Blanquecino $\square$ Marrón $\square$ Amarillento

$\square$ Blanquecino
$\square$ Grisaceo

$\square$ Simple / homogénea

$\mathbf{X}$ Suplemento superficial

$\square$ suplemento en juntas

$\square$ Mixta

$\square$ Elementos de protección
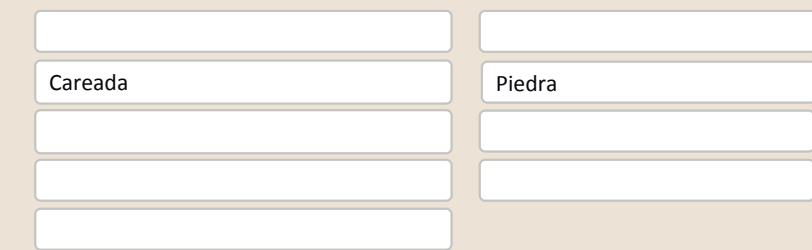

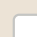

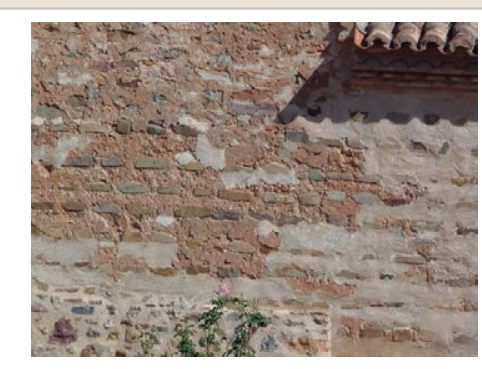

Lesiones $\square$ Muro $\mathbf{X}$ Zócalo $\square$ Revestimiento $\square$ Cubierta $\square$ Otro...

$\square$ Erosión del material $\quad \mathbf{X}$ Humedad por capilaridad $\quad \square$ Grietas por asentamientos

$\square$ Erosion de las juntas $\mathbf{X}$ Humedades (manch/eflo)

$\square$ Pérdida de sección $\quad \square$ Pérdida de verticalidad

$\square$ Vegetación $\square$ Grietas por empuje de la cubierta

$\square$ Desconchados

$\square$ Por elementos impropios

$\square$ Grietas porfalta de traba

$\square$ Derivadoc

Observaciones 


\section{La restauración y rehabilitación de la arquitectura tradicional de tierra.}

\section{El caso de Aragón.}

3. DATOS DE LA INTERVENCIÓN

\begin{tabular}{|c|c|c|c|c|}
\hline Intervención de: & $\begin{array}{l}\square \text { Mantenimiento } \\
\mathbf{X} \text { Reparación }\end{array}$ & $\begin{array}{l}\square \text { Rehabilitación parcial } \\
\square \text { Rehabilitación integral }\end{array}$ & $\begin{array}{l}\square \text { Restauración } \\
\square \text { Ampliación }\end{array}$ & $\begin{array}{l}\square \text { Demolición } \\
\square \text { Otro... }\end{array}$ \\
\hline Reflexión previa & \multicolumn{4}{|c|}{ Intervención planificada } \\
\hline 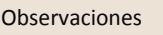 & & & & \\
\hline
\end{tabular}

\subsection{MUROS}

Tipo de intervención

Intervenido

Tipo de material

$\square$ Actualización $\quad$ X Reintegración $\square$ Demolición $\square$ Otro...

$\square$ Consolidación $\square$ Reconstrucción $\square$ sustitución

Descripción

\begin{tabular}{|l|l|l|l} 
No tradicional & Tipo de técnica Diferente a la existente \\
\hline
\end{tabular}

3.2. ZóCALO

Tipo de intervención

Reintegración de la costra de los muros con mortero

Tipo de material

Intervenido

$\square$ Actualización $\quad \mathbf{X}$ Reintegración $\square$ Demolición $\square$ Otro...

$\begin{array}{ll}\square \text { Actualización } & \mathbf{X} \text { Reintegración } \\ \square \text { Consolidación } & \square \text { Reconstrucción } \quad \square \text { Sustitución }\end{array}$

Descripción
No tradicional
Tipo de técnica Diferente a la existente

3.3. REVESTIMIENTOS

Reintegración de la mampostería del zócalo con gran cantidad de mortero

Tipo de intervención

\section{No aplica}

Tipo de material

$\square$ Actualización

$\square$ Reintegración $\square$ Demolición $\square$ Otro...

Tipo de materia

$\square$ Consolidación $\square$ Reconstrucción $\square$ Sustitución

Descripción

3.4. VANOS

No visible

Tipo de intervención

$\square$ Actualización $\square$ Reintegración $\square$ Demolición $\square$ Otro...

Tipo de material

Descripción

$\square$ Consolidación $\square$ Reconstrucción $\square$ sustitución

3.5. CUBIERTA

Tipo de intervención

Intervenido

$\square$ Actualizació

Tipo de técnica

Tipo de material

$\square$ Consolidación $\quad \square$ Reconstrucción $\quad \square$ Sustitución

Descripción

No tradicional Tipo de técnica Similar a la existente

Reintegración de la cubierta recuperando las tejas antiguas cogidas con mortero de cemento

3.6. OTRAS 


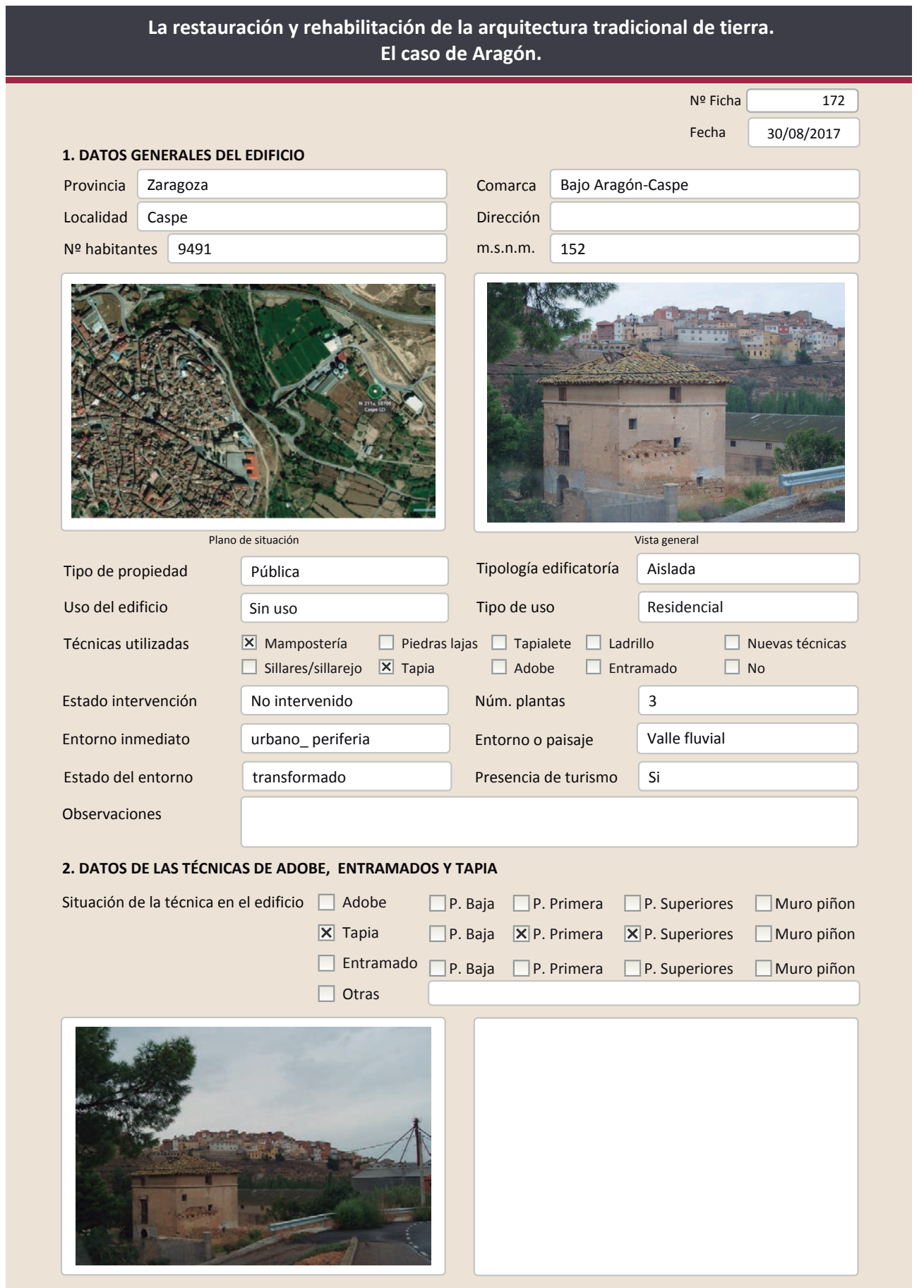

2.2. TAPIA

Ancho del muro

Dimensión tapiales

Tipo de aguja

№ agujas/cajón

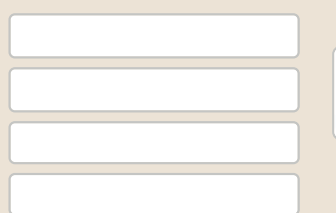

Color de la tapia

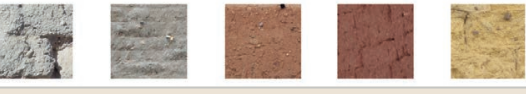

$\square$ Blanquecino $\mathbf{X}$ Marrón $\square$ Amarillento

Grisaceo $\square$ Rojizo $\square$ Otro...

Variante constructiva

$\square$ Simple / homogénea

X Suplemento superficial

$\square$ suplemento en juntas

X Mixta
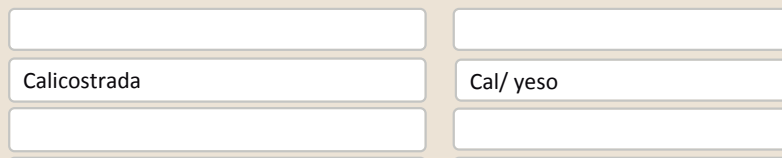

$\mathbf{X}$ Elementos de protección

En esquinas

Piedra

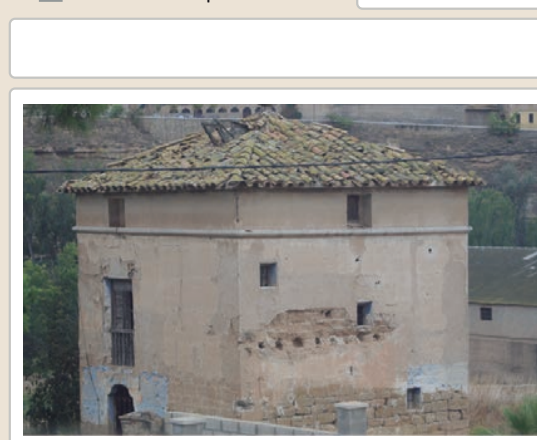

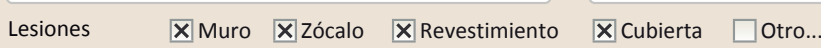

\ Erosión del material $\quad \mathbf{X}$ Humedad por capilaridad $\quad \square$ Grietas por asentamiento

$\square$ Erosion de las juntas $\square$ Humedades (manch/eflo)

X Pérdida de sección $\square$ Pérdida de verticalidad

$\square$ Vegetación $\square$ Grietas por empuje de la cubierta

$\mathbf{X}$ Desconchados

$\square$ Por elementos impropios

$\square$ Grietas porfalta de traba

$\square$ Otro... 


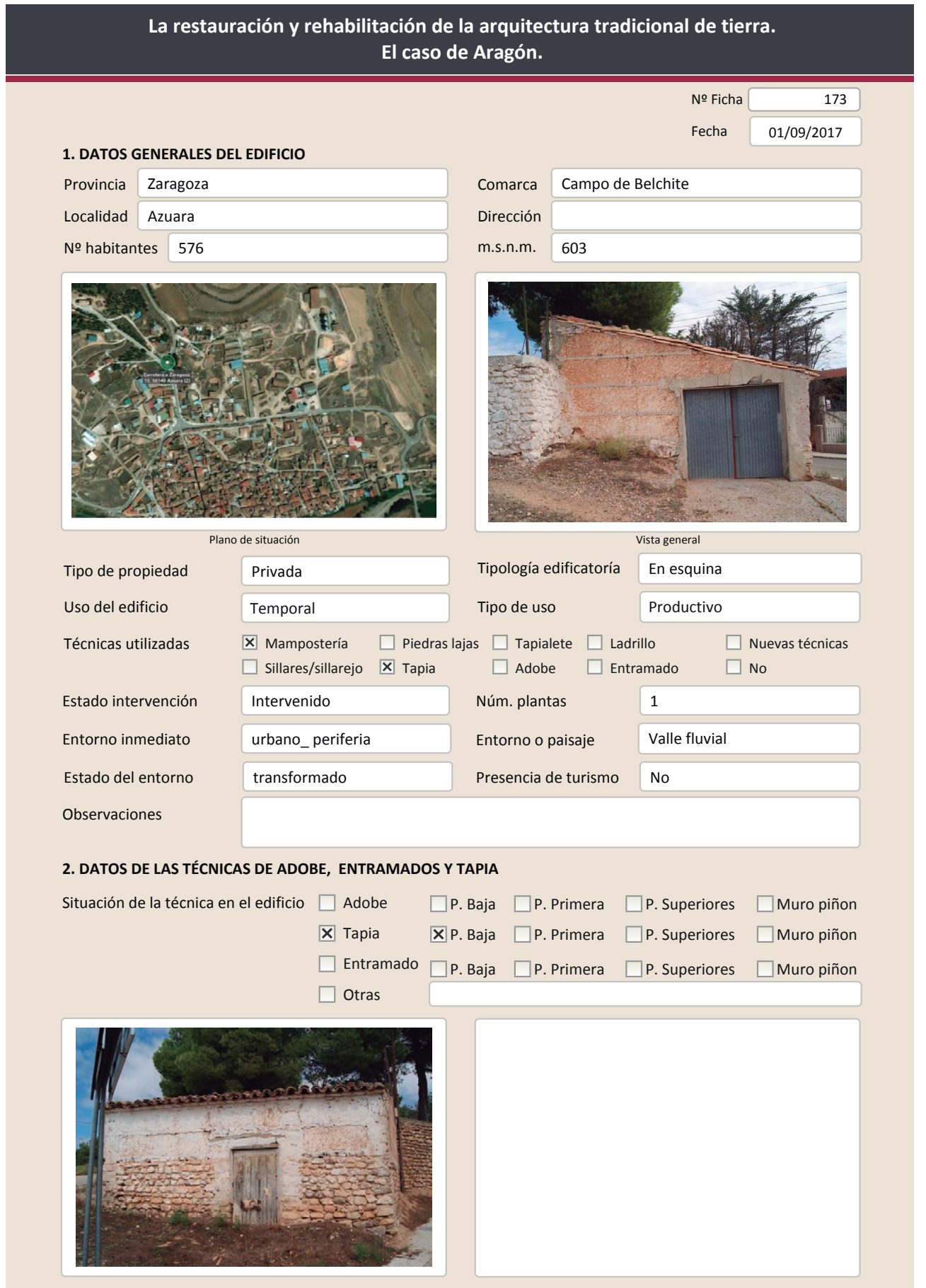

La restauración y rehabilitación de la arquitectura tradicional de tierra.

El caso de Aragón.

2.2. TAPIA

Ancho del muro

Dimensión tapiales

Tipo de aguja

Redond

№ agujas/cajón

3

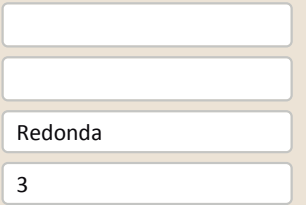

Color de la tapia

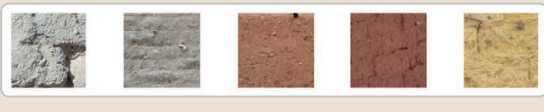

$\square$ Blanquecino $\quad \mathbf{X}$ Marrón $\square$ Amarillento

$\begin{array}{ll}\square \text { Blanquecino } & \mathbf{x} \text { Marrón } \\ \square \text { Grisaceo } & \square \text { Amajill } \\ & \square \text { Rojizo }\end{array}$

Variante constructiva

$\square$ Simple / homogénea

$\square$ suplemento superficial

$\boldsymbol{X}$ Suplemento en juntas

$\mathbf{X}$ Mixta
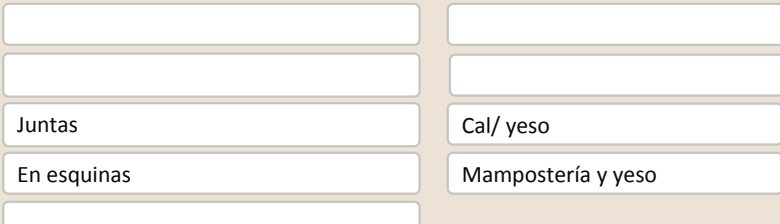

$\square$ Elementos de protección

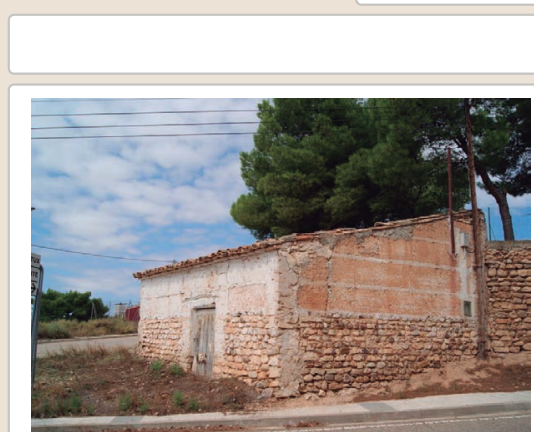

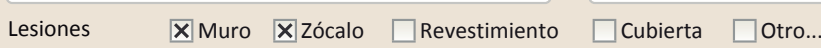

Х Erosión del material $\quad \mathbf{X}$ Humedad por capilaridad $\quad \square$ Grietas por asentamiento

$\square$ Erosion de las juntas $\square$ Humedades (manch/eflo) $\square$ Colapso

$\square$ Pérdida de sección $\quad \square$ Pérdida de verticalidad $\quad \square$ Por elementos impropios

$\square$ Vegetación $\quad$ X Grietas por empuje de la cubierta $\quad \square$ Derivado de intervenciones

$\square$ Desconchados $\square$ Grietas porfalta de traba $\quad \square$ Otro... 
La restauración y rehabilitación de la arquitectura tradicional de tierra. El caso de Aragón

\section{La restauración y rehabilitación de la arquitectura tradicional de tierra.}

\section{El caso de Aragón.}

3. DATOS DE LA INTERVENCIÓN

Intervención de:

$\square$ Mantenimiento $\quad \mathbf{X}$ Rehabilitación parcial

$\square$ Restauración $\square$ Demolición

Reflexión previa

$\square$ Reparación

$\square$ Rehabilitación integral $\square$ Ampliació

$\square$ Otro..

Observaciones

Intervención espontanea

3.1. MUROS

Tipo de intervención

No intervenido

Tipo de material

$\square$ Actualización $\square$ Reintegración $\square$ Demolición $\square$ Otro...

$\square$ Consolidación $\square$ Reconstrucción $\square$ Sustitución

Descripción

3.2. ZÓCALO

No intervenido

Tipo de intervención

$\square$ Actualización

Tipo de material

Descripción

3.3. REVESTIMIENTOS

Tipo de intervención

\section{No aplica}

Tipo de material

$\square$ Actualización

Tipo de técnica

Descripción

3.4. VANOS

Tipo de intervención

Intervenido

$\begin{array}{lll} & \square \text { Consolidación } \square \text { Reconstrucción } \boldsymbol{X} \text { Sustitución } \\ \text { Tipo de material } & \text { No tradicional } & \text { Tipo de técnica Di }\end{array}$

$\square$ Actualización $\square$ Reintegración $\square$ Demolición $\square$ Otro...

Descripción Incorporación de nuevo hueco de grandes dimensiones para el acceso de vehículos en el edificio

3.5. CUBIERTA

Tipo de intervención

Intervenido

Tipo de material

$\square$ Actualización $\quad$ X Reintegración $\square$ Demolición $\square$ Otro.

$\square$ Consolidación $\quad \square$ Reconstrucción $\square$ Sustitución

\begin{tabular}{|l|l|l|l|l} 
No tradicional & Tipo de técnica & Diferente a la existente \\
\hline
\end{tabular}

Descripción Pequeñas reparaciones en el muro bajo la cubierta. Algunas tejas cogidas con cemento

3.6. OTRAS Inserción de elementos varios en el edificio como cajas de luz utilizando cemento. 


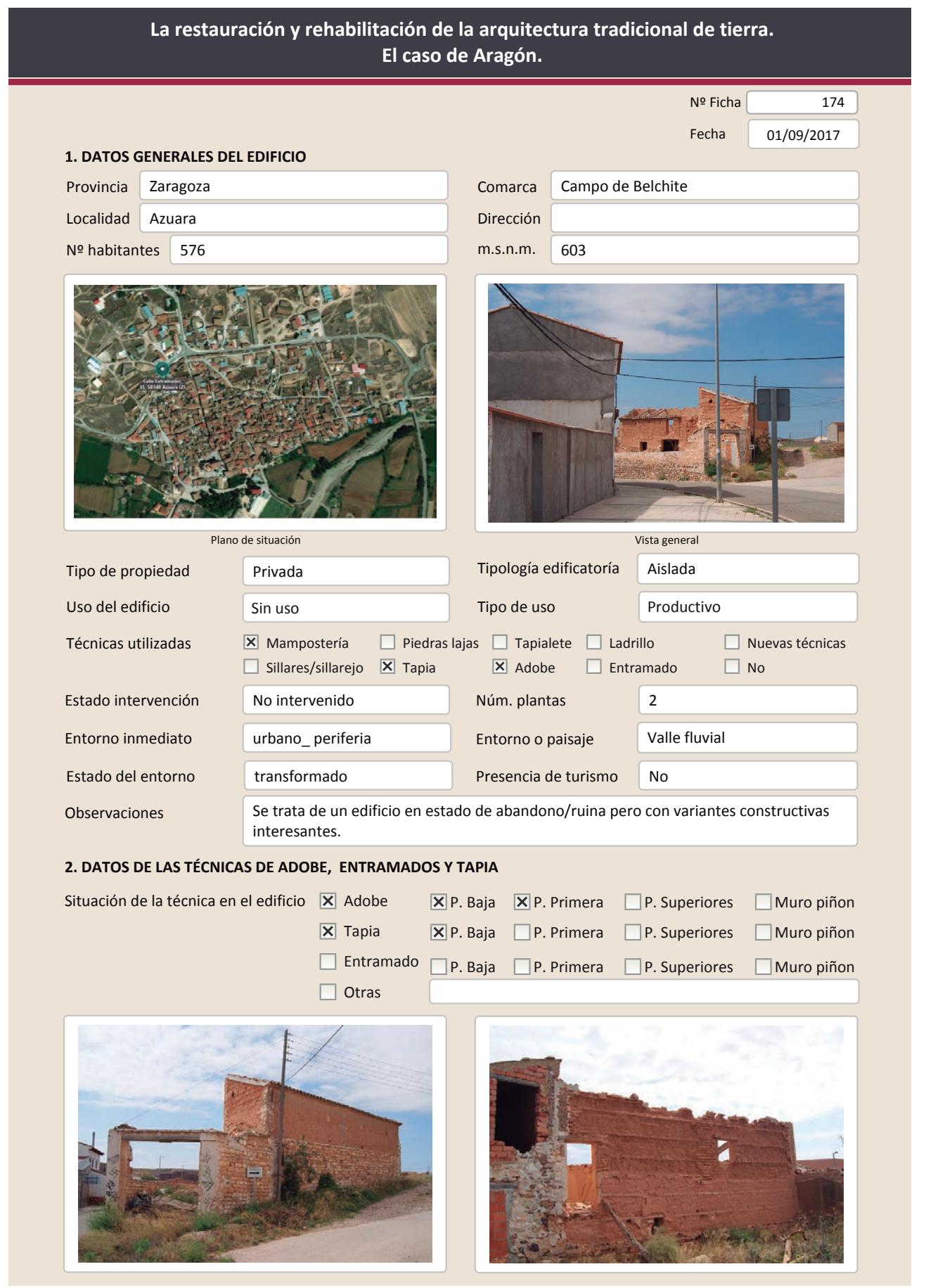

La restauración y rehabilitación de la arquitectura tradicional de tierra. El caso de Aragón.

2.1. ADOBE

Dimensión de las piezas Dimensión del muro Aparejo del muro Función estructural
Color de las piezas

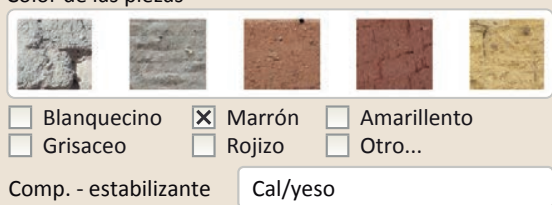

Variante constructiva/ tipo de fábrica

$\square$ Simple

$\square$ Suplementada en juntas

X Mixta

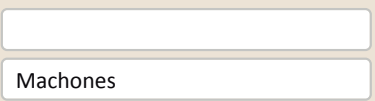

$\mathbf{X}$ Como suplemento

\section{Mixto- Machones}

X Elementos de protección

Revestimiento

Se trata de un muro de adobe suplementado con adobe. Este segundo se aprecia mayor cantidad de árido y algún tipo de conglomerante

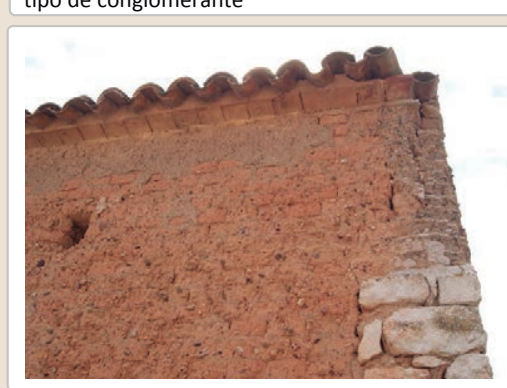

Lesiones \Muro $\square$ Zócalo $\square$ Revestimiento Xuro $\quad \square$ Zócalo $\quad \square$ Revestimiento
material $\quad \square$ Humedad por capilarida $\mathbf{X}$ Erosión del material $\square$ Humedad por capilaridad X Pérdida de sección $\square$ Pérdida de verticalidad

$\square$ Vegetación $\quad \square$ Grietas por empuje de la c

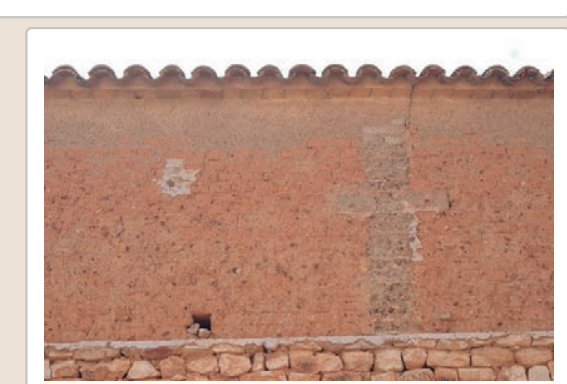

$\square$ Grietas por empuje de la

$\square$ Cubierta $\square$ Otro...

$\square$ Desconchados
$\square$ Grietas por a
$\square$ Colapso
$\square$ Por elementos impropios
$\square$ Derivado de intervenciones

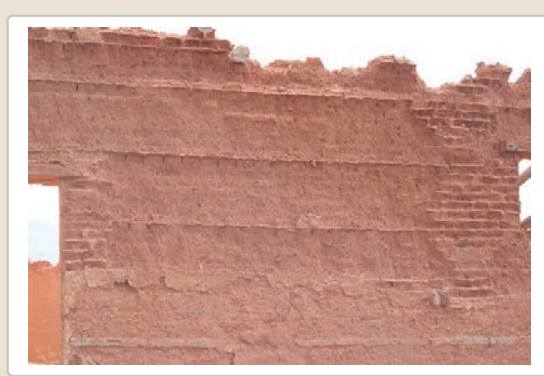
$\square$ Otro...

Erosión importante de todo el muro. En el muro lateral se aprecia como existe una junta de yeso cada 6 hiladas y como se han conformado una especie $d$ machones suplemento en esquinas utilizando yeso en las juntas de una zona en vertical 
La restauración y rehabilitación de la arquitectura tradicional de tierra. El caso de Aragón

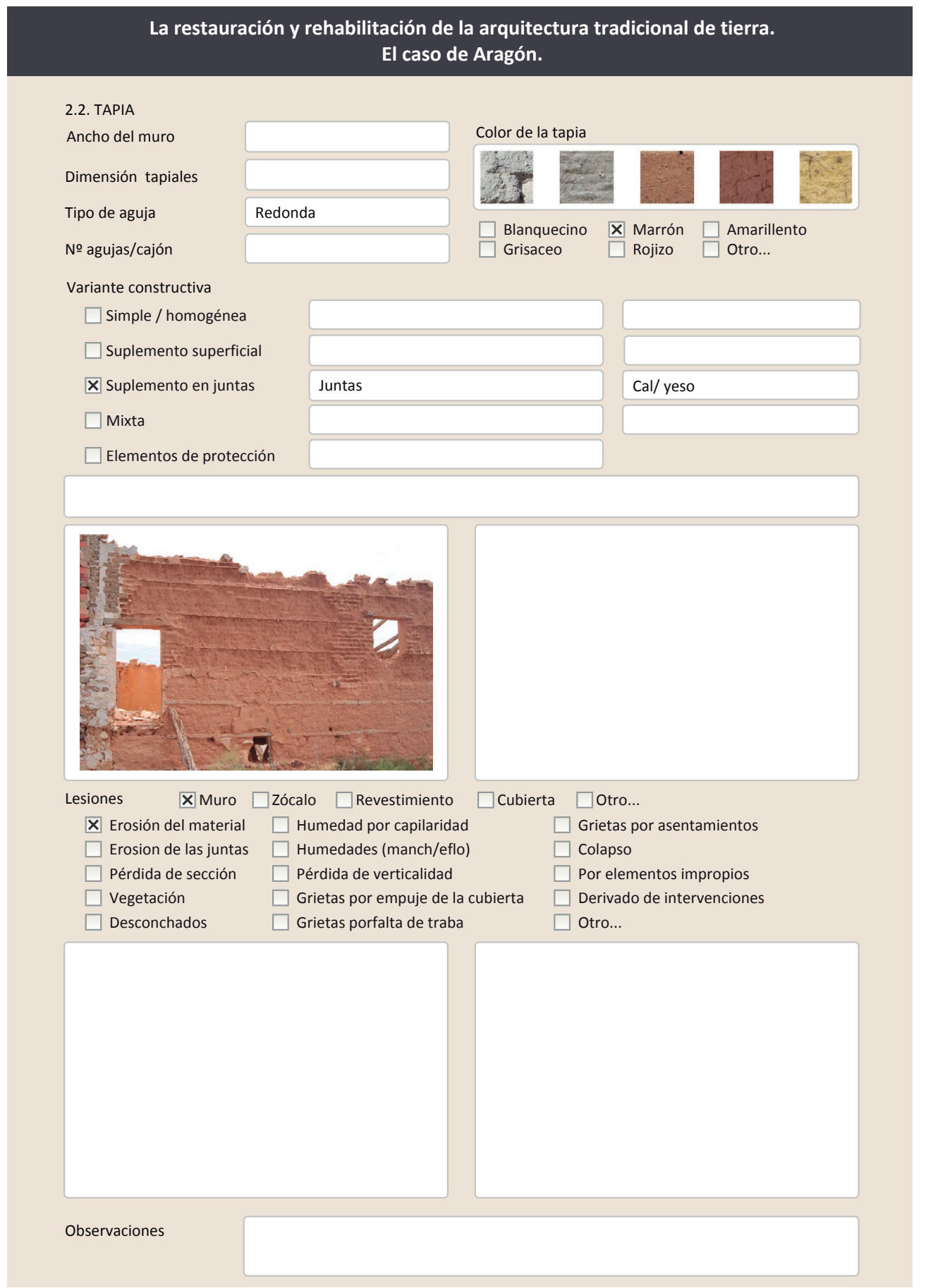

La restauración y rehabilitación de la arquitectura tradicional de tierra.

El caso de Aragón.

3.7. REHABILITACIÓN ENERGÉTICA $\square$ Fachada $\square$ Vanos $\square$ Forjados $\square$ Cubierta

Observaciones

FOTOGRAFíAS DE LA INTERVENCIÓN
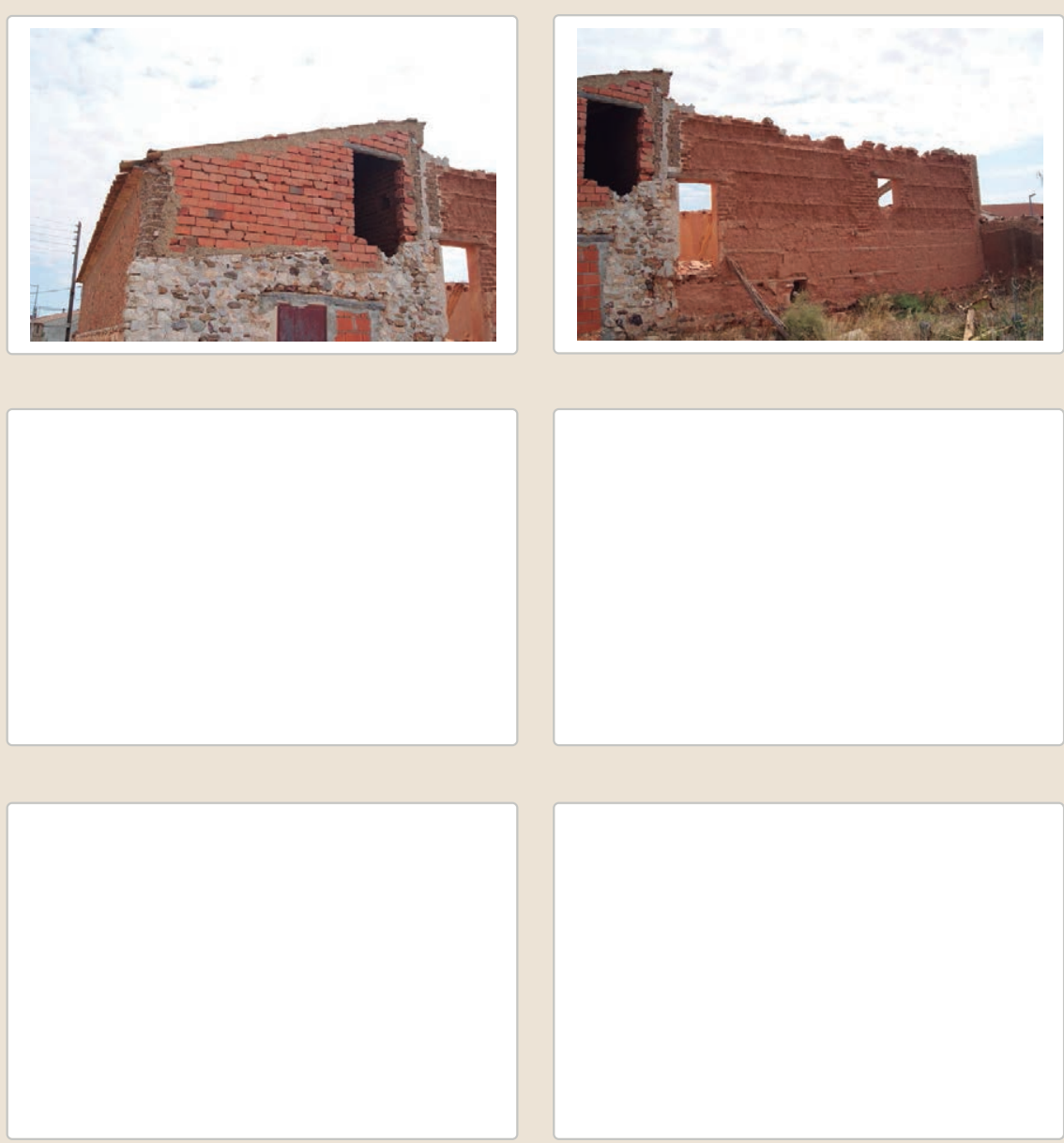


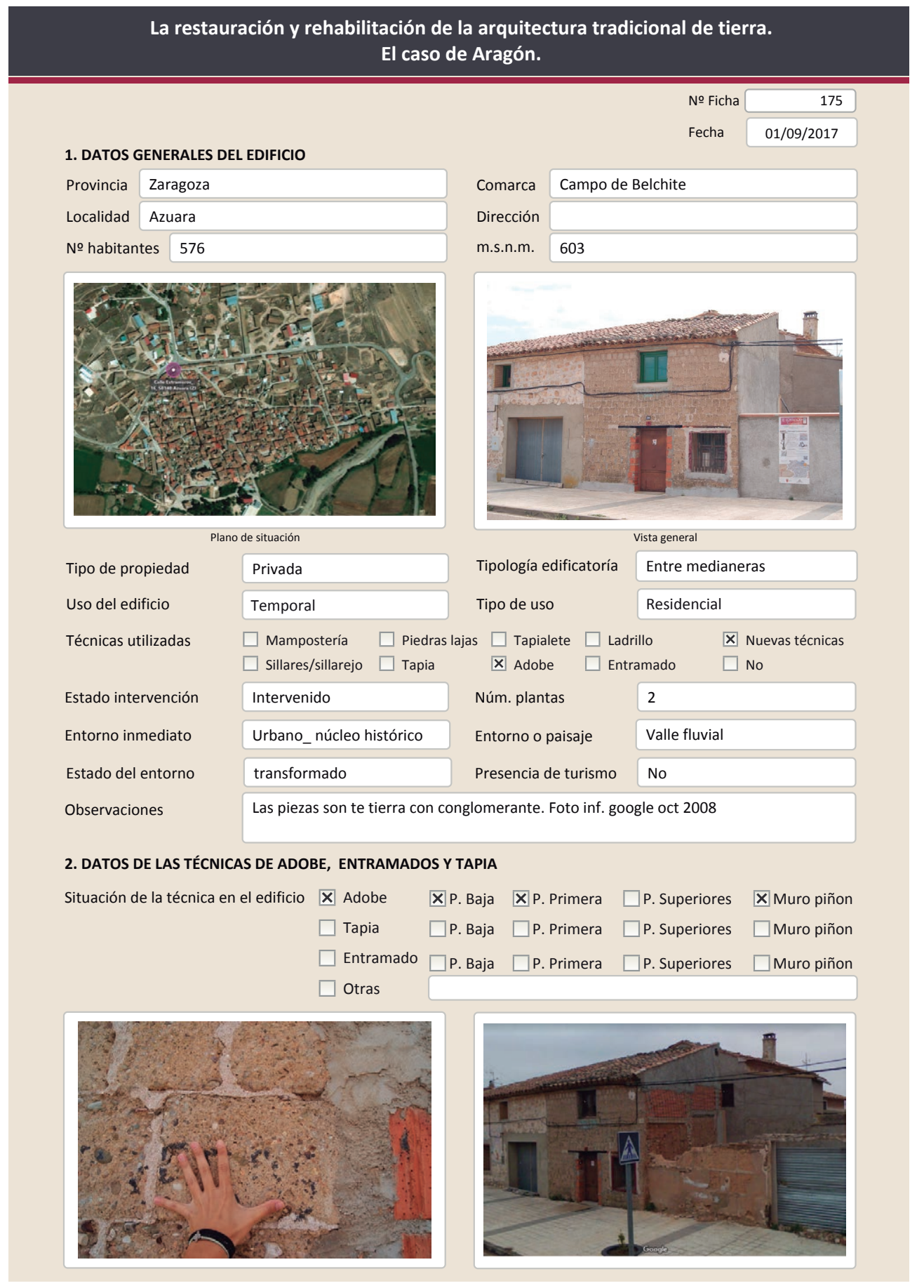

La restauración y rehabilitación de la arquitectura tradicional de tierra.

El caso de Aragón.

\begin{tabular}{l|l|} 
2.1. ADOBE & \\
Dimensión de las piezas & $24 \times 18,5 \times 18,5$ \\
\hline Dimensión del muro & $20-30 \mathrm{~cm}$ \\
\hline Aparejo del muro & Tizón \\
Función estructural & $\mathrm{Si}$
\end{tabular}

Variante constructiva/ tipo de fábrica

X Simple
$\mathbf{X}$ Suplementada en juntas
$\square$ Mixta
$\square$ Como suplemento
$\square$ Elementos de protección

Color de las piezas

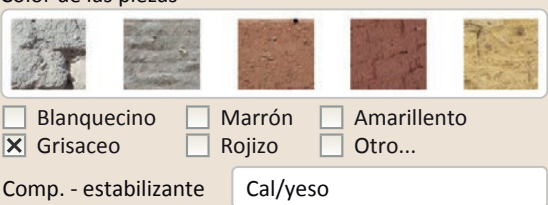

Comp. - estabilizante Cal/yeso

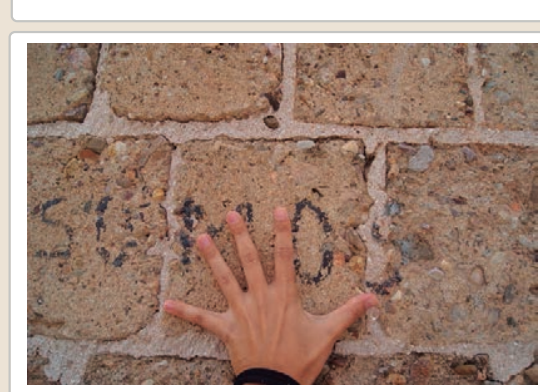

Lesiones $\quad \square$ Muro $\square$ Zócalo $\square$ Revestimiento $\square$ Erosion de las juntas $\square$ Humedades (manch/eflo) $\square$ Pérdida de sección $\square$ Pérdida de verticalidad

$\square$ Vegetación

$\square$ Desconchados $\square$ Grietas por empuje de la cubie

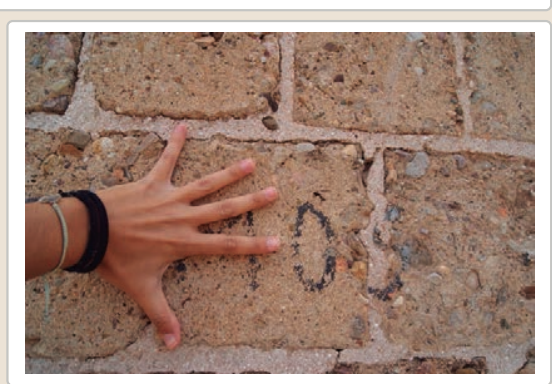

$\square$ Cubierta $\square$ Otro...

$\square$ Grietas por asentamientos $\square$ Colapso

$\square$ Por elementos impropios

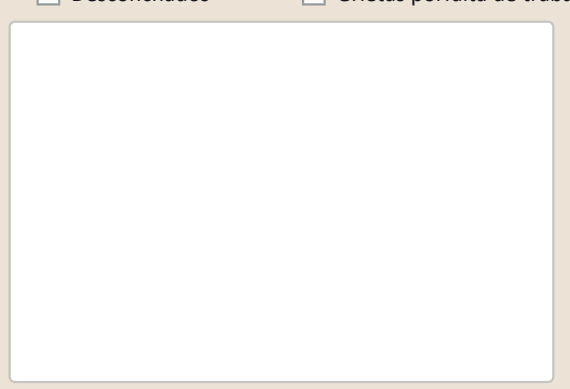

$\square$ Derivado de intervenciones $\square$ Otro...

Observaciones

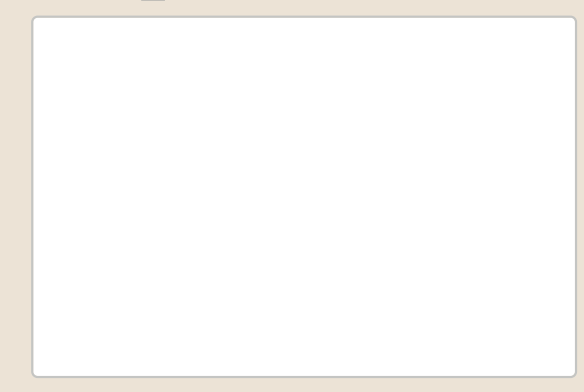




\section{La restauración y rehabilitación de la arquitectura tradicional de tierra.}

\section{El caso de Aragón.}

3. DATOS DE LA INTERVENCIÓN

Intervención de:

$\square$ Mantenimiento $\square$ Rehabilitación parcia

$\square$ Restauración $\square$ Demolición

Reflexión previa

X Reparación

$\square$ Rehabilitación integra

Ampliación

$\square$ Otro..

Observaciones

Intervención espontanea

3.1. MUROS

Tipo de intervención

Intervenido

Tipo de intervención

$\square$ Actualización $\quad \square$ Reintegración $\square$ Demolición $\square$ Otro...

$\square$ Consolidación $\square$ Reconstrucción $\quad \boldsymbol{X}$ Sustitución

Descripción

No tradicional Tipo de técnica Diferente a la existente

3.2. ZóCALO

Sustitución parcial del muro piñón por ladrillo hueco.

Tipo de intervención

Intervenido

Actualización $\square$ Reintegración $\quad \square$ Demolición $\square$ Otro...

$\square$ Consolidación $\quad \mathbf{X}$ Reconstrucción $\square$ sustitución

Tipo de material

Descripción

Tipo de técnica Diferente a la existente

3.3. REVESTIMIENTOS

Intervenido

Tipo de intervención

$\square$ Actualización $\square$ Reintegración $\square$ Demolición $\square$ Otro...

$\square$ Consolidación $\quad \mathbf{X}$ Reconstrucción $\square$ Sustitución

Tipo de material

Descripción

3.4. VANOS

Tipo de intervención

Nuevo revestimiento de cemento que cubre todo el muro piñón del edificio

Tipo de material

Intervenido

Descripción

$\square$ Actualización $\quad \boldsymbol{X}$ Reintegración $\square$ Demolición $\square$ Otro...

$\square$ Consolidación $\square$ Reconstrucción $\mathbf{X}$ Sustitución

No tradicional Tipo de técnica Diferente a la existente

3.5. CUBIERTA

Tipo de intervención

Reintegración del hueco de acceso utilizando ladrillo hueco en las jambas. Sustitución de carpinterías e inserción de rejas.

tervenido

Tipo de material

$\square$ Actualización $\quad \mathbf{X}$ Reintegración $\square$ Demolición $\square$ Otro.

$\square$ Consolidación $\quad \square$ Reconstrucción $\square$ Sustitución

Descripción

No tradicional Tipo de técnica Similar a la existente

Se ha reintegrado las tejas de cubierta. Ademas en el lateral se ha levantado la hilada lateral de tejas con un ladrillo para evitar que el agua deslice por el muro

3.6. OTRAS 


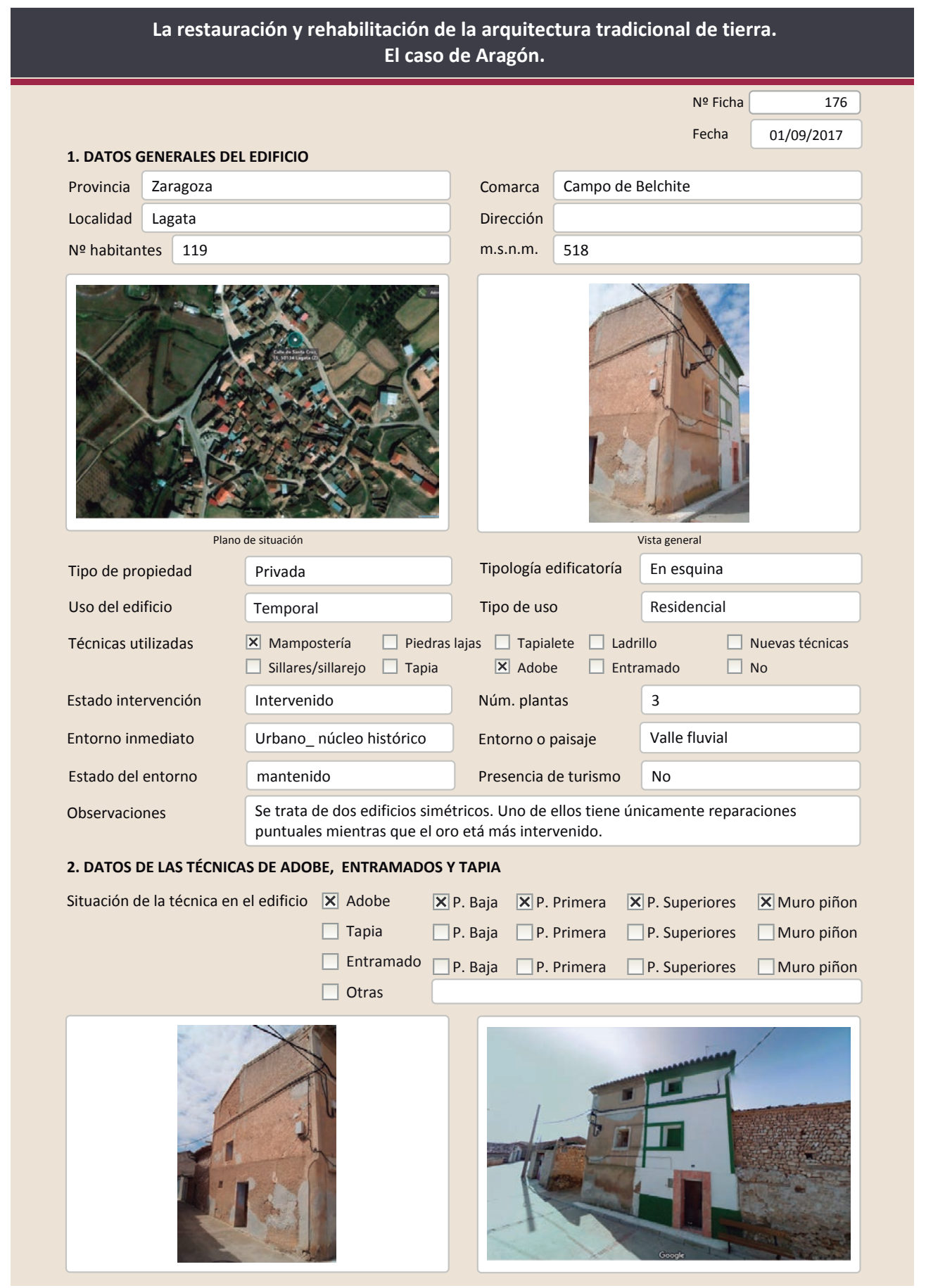

La restauración y rehabilitación de la arquitectura tradicional de tierra.

El caso de Aragón.

2.1. ADOBE

Dimensión de las piezas

Dimensión del muro

Aparejo del muro

Función estructural

Variante constructiva/ tipo de fábrica

X Simple

$\square$ Suplementada en juntas

$\square$ Mixta

$\square$ Como suplemento

$\mathbf{X}$ Elementos de protección

Revestimiento

Color de las piezas

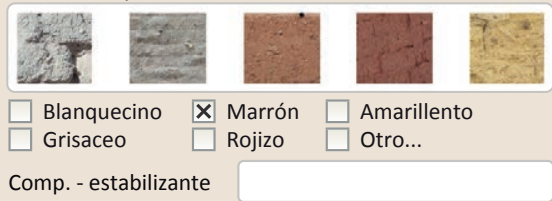

Comp. - estabilizante

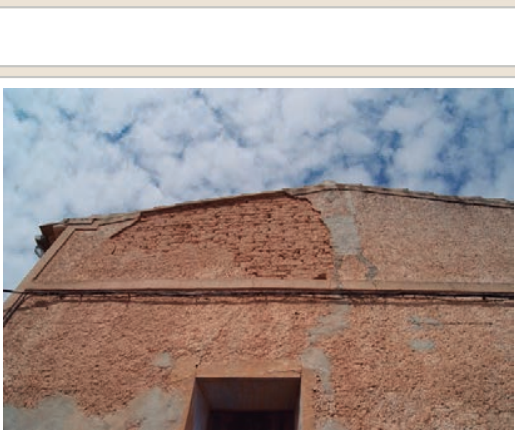

Lesiones ХMuro $\square$ Zócalo \ Xevestimiento $\square$ Cubierta $\square$ Otro...

X Erosión del material $\quad \square$ Humedad por capilaridad $\quad \square$ Grietas por asentamientos

$\square$ Erosion de las juntas $\square$ Humedades (manch/eflo) $\quad \square$ Colapso

$\square$ Pérdida de sección $\square$ Pérdida de verticalidad

X Desconchados

$\square$ Grietas por empuje de la cubie
$\square$ Grietas porfalta de traba

$\square$ Por elementos impropios

$\square$ Derivado de intervenciones

$\square$ Otro...

Observaciones 
La restauración y rehabilitación de la arquitectura tradicional de tierra. El caso de Aragón

\section{La restauración y rehabilitación de la arquitectura tradicional de tierra.}

\section{El caso de Aragón.}

3. DATOS DE LA INTERVENCIÓN

Intervención de:

$\square$ Mantenimiento $\mathbf{X}$ Rehabilitación parcial

$\square$ Restauración $\square$ Demolición

Reflexión previa

$\square$ Reparación

Rehabilitación integra

Ampliación

$\square$ Otro..

Observaciones

Intervención planificada

(n)

3.1. MUROS

Tipo de intervención

No visible

Tipo de material

$\square$ Actualización $\square$ Reintegración $\square$ Demolición $\square$ Otro...

$\square$ Consolidación $\square$ Reconstrucción $\square$ sustitución

Descripción

3.2. ZÓCALO

Tipo de intervención

Intervenido

Tipo de intervención

X Actualización $\square$ Reintegración $\square$ Demolición $\square$ Otro...

Tipo de material

No tradicional

Tipo de técnica

Descripción

Zócalo con cemento

3.3. REVESTIMIENTOS

\section{Intervenido}

Tipo de intervención

X Actualización $\square$ Reintegración $\square$ Demolición $\square$ Otro...

$\square$ Consolidación $\quad \mathbf{X}$ Reconstrucción $\square$ Sustitución

Tipo de material

Descripción

No tradicional Tipo de técnica Diferente a la existente

Nuevo revestimiento en todo el edificio y pintura blanca con elementos decorativos en

3.4. VANOS

Intervenido

Tipo de intervención

X Actualización $\mathbf{X}$ Reintegración $\square$ Demolición $\square$ Otro...

$\square$ Consolidación $\square$ Reconstrucción $\quad \mathbb{X}$ Sustitución

Tipo de material No tradicional Tipo de técnica Diferente a la existente

Descripción Integración de elementos decorativos (baldosas) alrededor de la puerta y sustitución de carpinterías.

3.5. CUBIERTA

Tipo de intervención $\square$ Actualización $\quad$ Reintegración $\square$ Demolición $\square$ Otro...

Intervenido

Tipo de material

$\square$ Consolidación $\square$ Reconstrucción $\square$ Sustitución

Descripción
No tradicional
Tipo de técnica Similar a la existente

3.6. OTRAS

Reintegración de los elementos de cubierta con cemento 


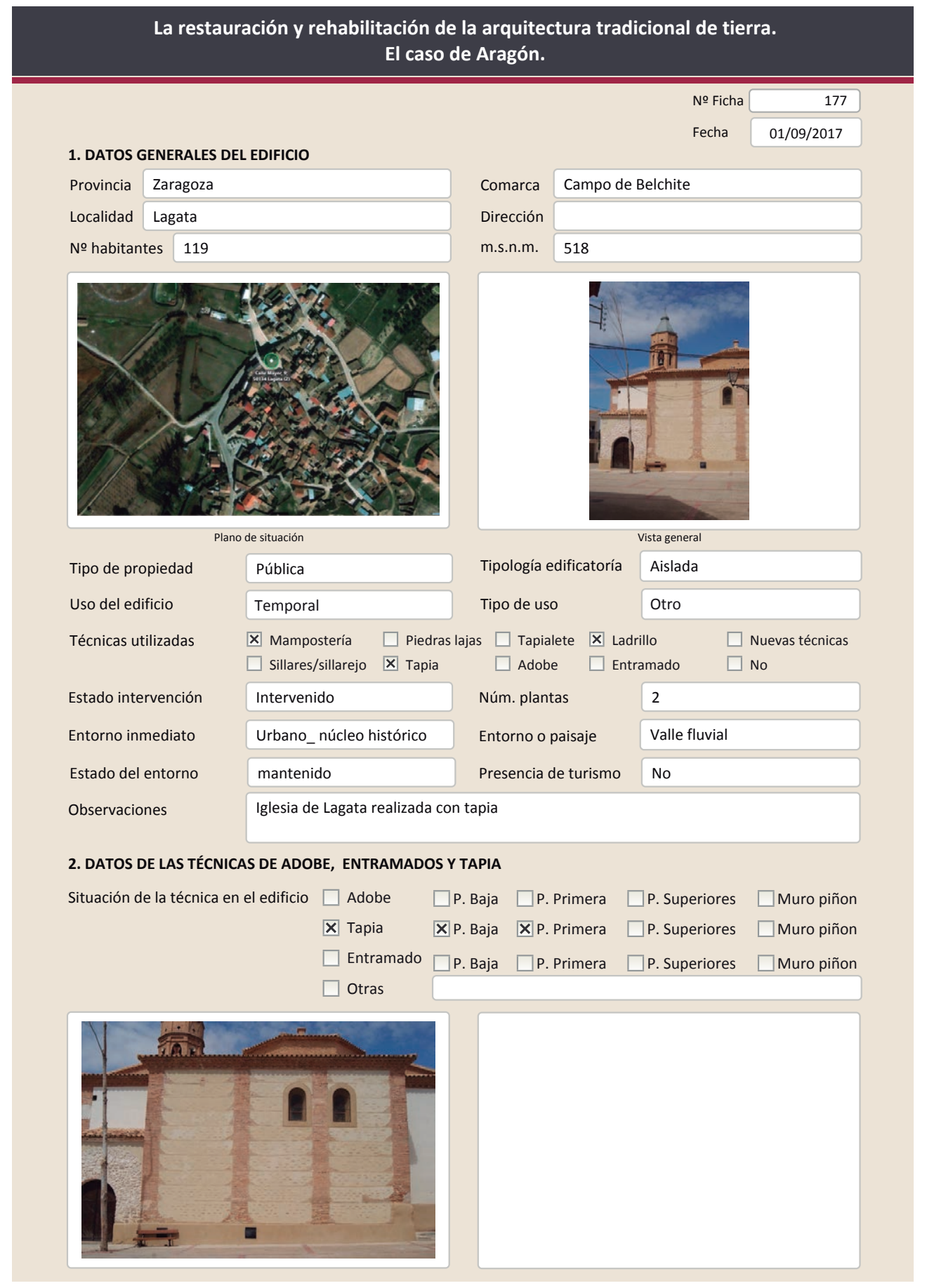

La restauración y rehabilitación de la arquitectura tradicional de tierra. El caso de Aragón.

\subsection{TAPIA}

Ancho del muro

Dimensión tapiales

Tipo de aguja

№ agujas/cajón

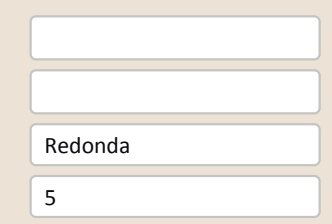

Color de la tapia

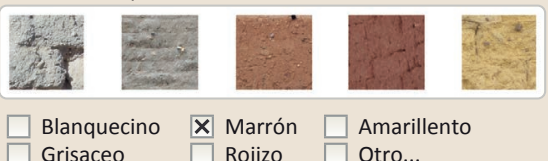

$\square$ Blanquecino $\quad \boldsymbol{X}$ Marrón $\square$ Amarillento

Variante constructiva

$\square$ Simple / homogénea

X Suplemento superficial

$\square$ suplemento en juntas

X Mixta

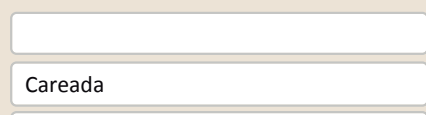

$\square$ Elementos de protección

Machones y verdugadas

Ladrillo

Careada con ladrillo y calicostrada

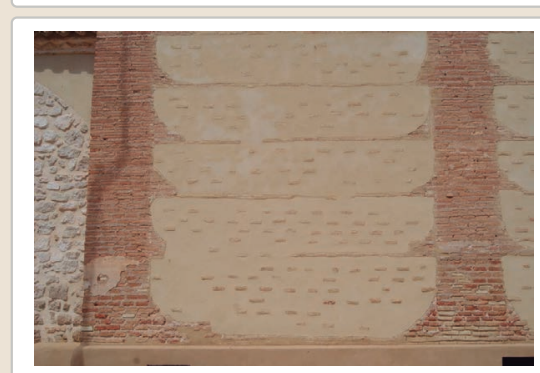

Lesiones $\square$ Muro $\square$ Zócalo $\square$ Revestimiento $\square$ Cubierta $\square$ otro...

$\square$ Erosión del material $\quad \square$ Humedad por capilaridad $\quad \square$ Grietas por asentamientos

$\square$ Erosion de las juntas $\square$ Humedades (manch/eflo)

$\square$ Pérdida de sección $\square$ Pérdida de verticalidad

$\square$ Vegetación $\square$ Grietas por empuje de la cubierta

$\square$ Desconch $\square$ Grietas por empuje de la cubic
$\square$ Grietas porfalta de traba

Colapso

$\square$ Desconchados

Por elementos impropios

$\square$ Derivado de intervenciones

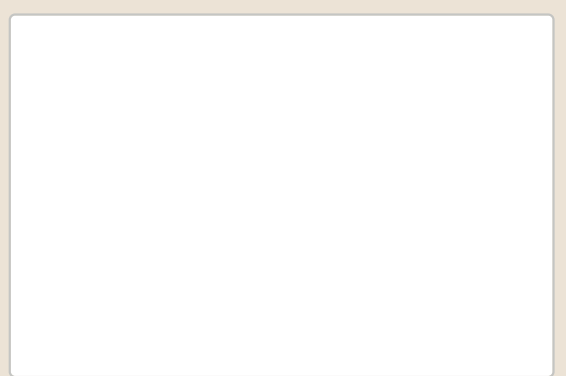

Observaciones 


\section{La restauración y rehabilitación de la arquitectura tradicional de tierra.}

\section{El caso de Aragón.}

3. DATOS DE LA INTERVENCIÓN

$\square$ Mantenimiento $\square$ Rehabilitación parcial

\ Restauración $\square$ Demolición

anción preva

$\square$ Reparación

$\square$ Rehabilitación integra

$\square$ Ampliación

$\square$ Otro...

Reflexión previa $\quad$ Intervención planificada

Observaciones Descripción completa de la obra: http://elcobijoarquitecturas.blogspot. jp/2014/06/restauracion-de-fachadas-iglesia.htm

3.1. MUROS
Tipo de intervención

Intervenido

Tipo de intervencion

$\square$ Actualización $\quad \boldsymbol{X}$ Reintegración $\square$ Demolición $\square$ Otro...

$\square$ Consolidación $\quad \square$ Reconstrucción $\square$ Sustitución

Descripción

Tradicional diferente

Tipo de técnica Diferente a la existente

3.2. ZÓCALO

Tipo de intervención

reintegración de la zona erosionadas de tapia

Intervenido

$\square$ Actualización $\square$ Reintegración $\square$ Demolición $\square$ Otro..

$\square$ Consolidación $\quad \mathbf{X}$ Reconstrucción $\square$ Sustitución

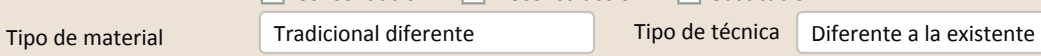

Descripción

3.3. REVESTIMIENTOS

Tipo de intervención

Eliminación del zócalo de cemento y construcción de uno nuevo con cal

\section{No aplica}

$\square$ Actualización $\quad \square$ Reintegración $\quad \square$ Demolición $\quad \square$ Otro...

$\square$ Consolidación $\square$ Reconstrucción $\square$ Sustitución

Tipo de técnica

Tipo de material

Descripción

3.4. VANOS

Tipo de intervención

No visible

Tipo de material

Descripción

3.5. CUBIERTA

Tipo de intervención

Tipo de material

Descripción

3.6. OTRAS

$\square$ Actualización $\square$ Reintegración $\square$ Demolición $\square$ Otro. $\square$ Consolidación $\square$ Reconstrucción $\square$ Sustitución Tipo de técnica
La restauración y rehabilitación de la arquitectura tradicional de tierra.

El caso de Aragón.

3.7. REHABILITACIÓN ENERGÉTICA $\quad \square$ Fachada $\square$ Vanos $\square$ Forjados $\square$ Cubierta

Observaciones

FOTOGRAFíAS DE LA INTERVENCIÓN
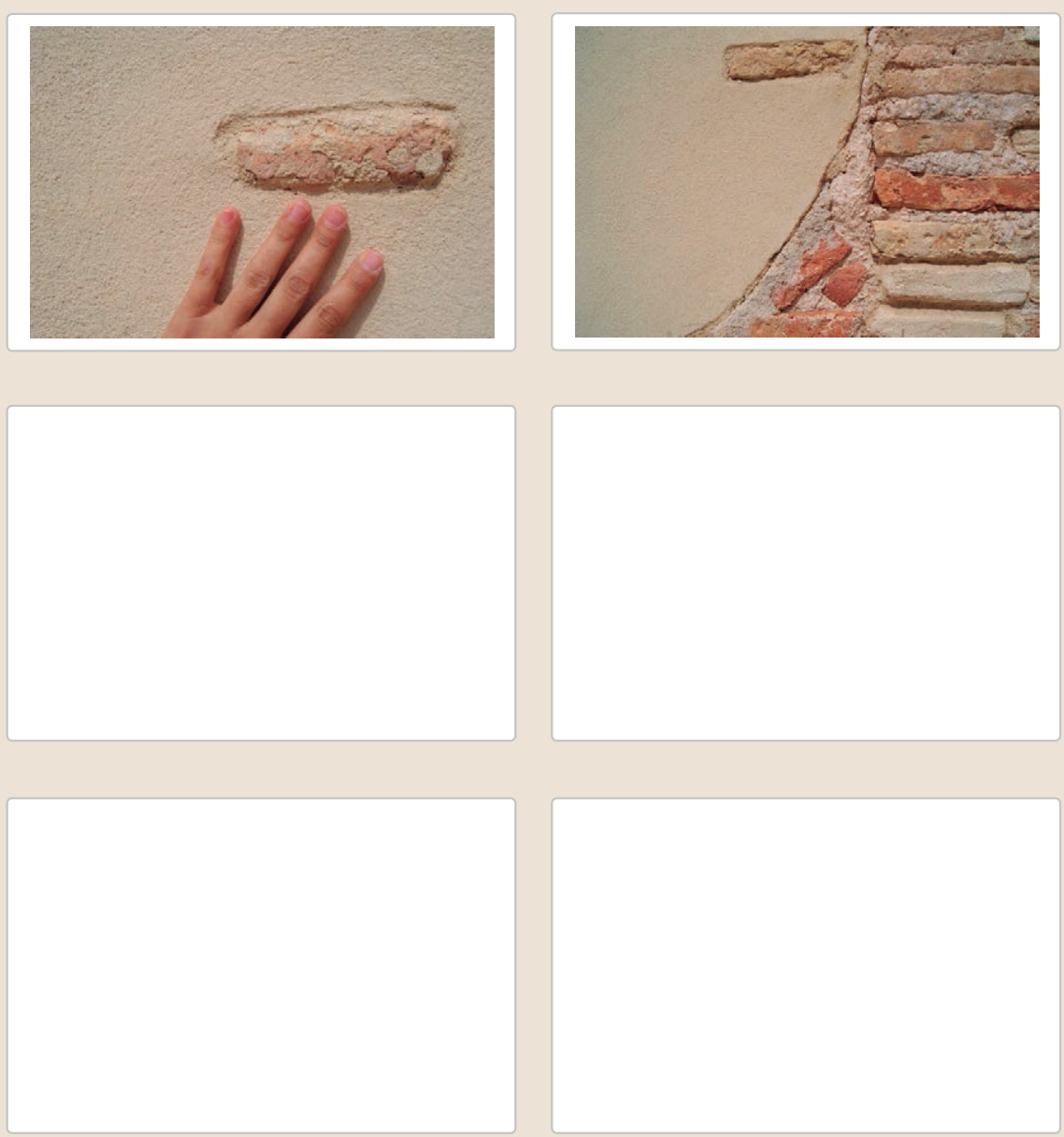
La restauración y rehabilitación de la arquitectura tradicional de tierra. El caso de Aragón.

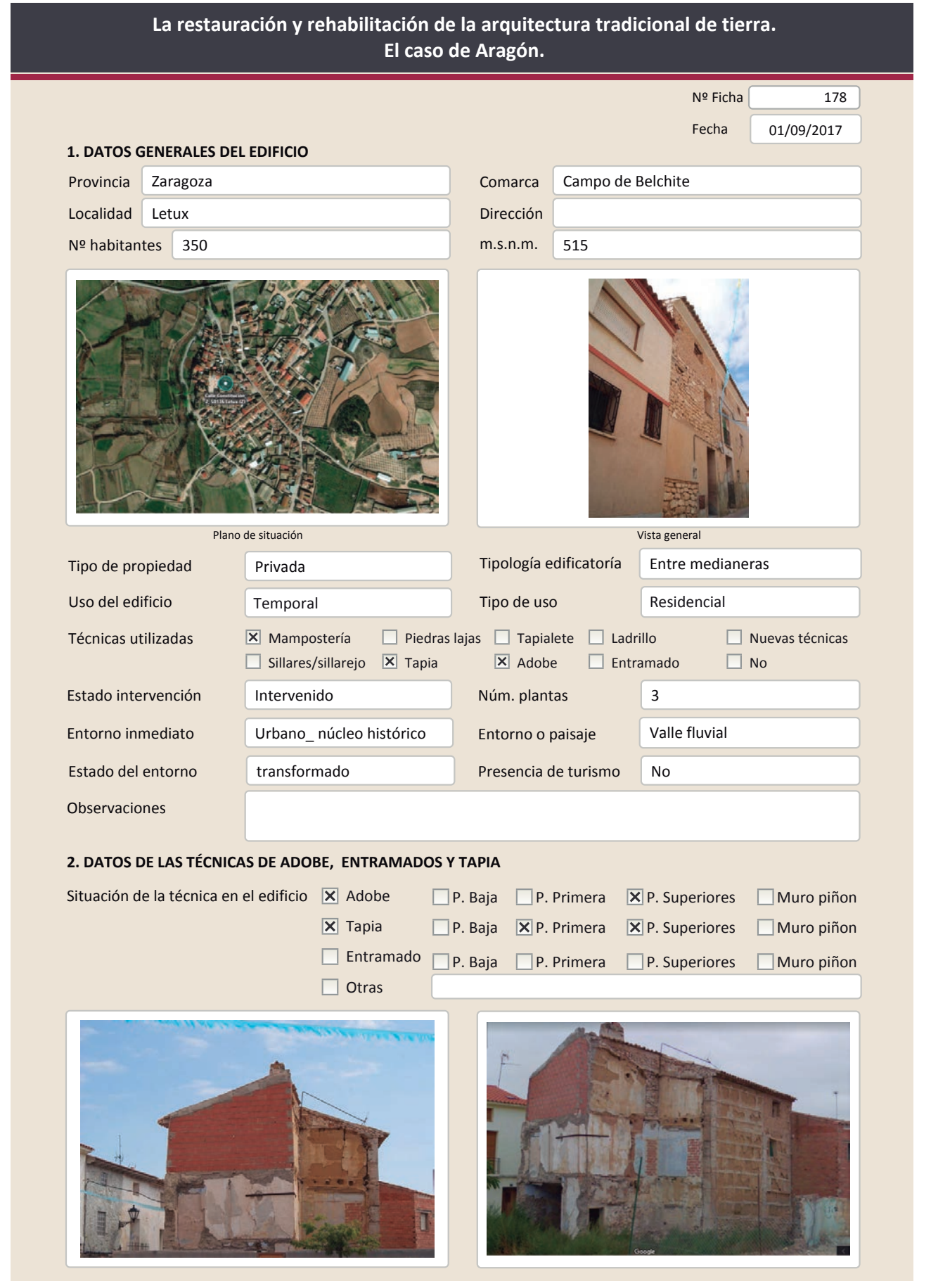

La restauración y rehabilitación de la arquitectura tradicional de tierra.

El caso de Aragón.
2.1. ADOBE

Dimensión de las piezas Dimensión del muro

Aparejo del muro

Función estructural
Color de las piezas

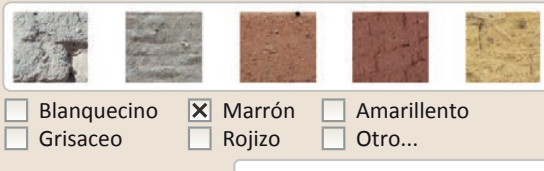

Comp. - estabilizante
Grisaceo $\square$ Rojizo $\square$ Otro..

Variante constructiva/ tipo de fábrica

メ simple

$\square$ suplementada en juntas

$\square$ Mixta

$\square$ Como suplemento

$\square$ Elementos de protección

Hay dos tipo de adobe diferente. Se distingue por la erosión de los mismos

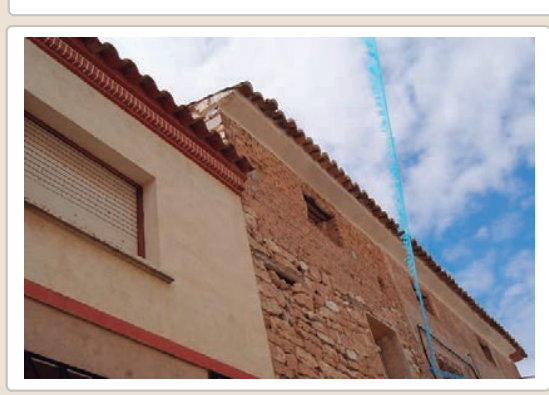

Lesiones $\quad \mathbf{X}$ Muro $\square$ Zócalo $\square$ Revestimiento $\square$ Cubierta $\square$ Otro...

区 Erosión del material $\quad \square$ Humedad por capilaridad $\quad \square$ Grietas por asentamiento

$\square$ Erosion de las juntas $\square$ Humedades (manch/eflo) $\quad \square$ Colapso

$\square$ Pérdida de sección $\square$ Pérdida de verticalidad $\square$ Por elementos impropios

$\square$ Vegetación $\quad \square$ Grietas por empuje de la cubierta $\quad \square$ Derivado de intervenciones

$\square$ Desconchados $\square$ Grietas porfalta de traba $\quad \square$ Otro...

Observaciones 


\section{La restauración y rehabilitación de la arquitectura tradicional de tierra.} El caso de Aragón.

\subsection{TAPIA}

Ancho del muro

Dimensión tapiales

Tipo de aguja

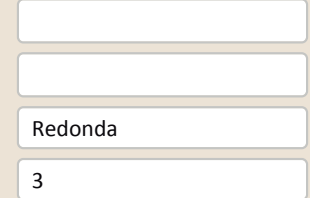

\section{Color de la tapia}

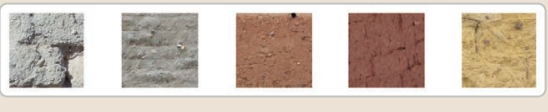

$\square$ Blanquecino $\quad$ X Marrón $\square$ Amarillento

$\square$ Grisaceo $\quad \square$ Rojizo $\square$ Otro...

Variante constructiva

$\square$ Simple / homogénea

$\square$ suplemento superficial

$\boldsymbol{X}$ Suplemento en juntas

X Mixta

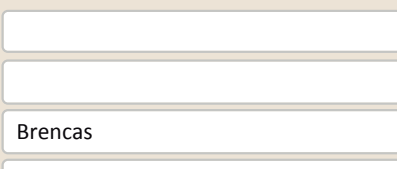

Machones

Revestimiento

$\mathbf{X}$ Elementos de protección

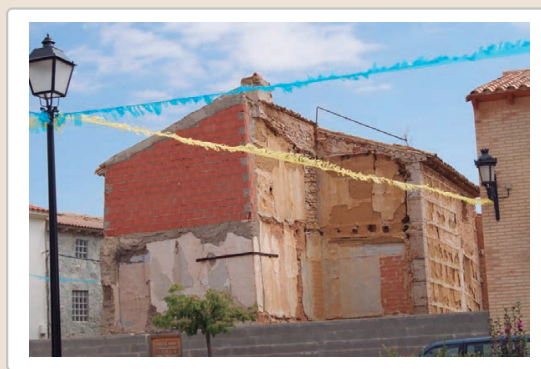

Lesiones $\quad$ XMuro $\square$ Zócalo $\quad$ X Revestimiento $\square$ Cubierta $\square$ otro...

X Erosión del material $\square$ Humedad por capilaridad $\quad \square$ Grietas por asentamientos

$\square$ Erosion de las juntas $\square$ Humedades (manch/eflo) $\quad \square$ Colapso

$\square$ Pérdida de sección $\square$ Pérdida de verticalidad $\square$ Por elementos impropios

$\square$ Vegetación $\quad \mathbf{X}$ Grietas por empuje de la cubierta $\square$ Derivado de intervenciones

X Desconchados

$\begin{array}{ll}X \text { Grietas por empuje de la cubierta } & \square \text { Derivadod } \\ \square \text { Grietas porfalta de traba } & \square \text { Otro... }\end{array}$

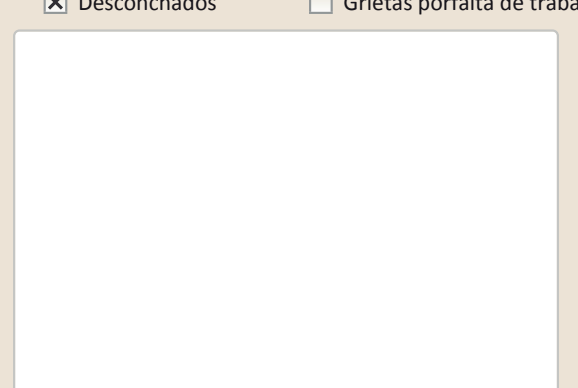

\section{$\mathrm{Cal} /$ yeso}

Mampostería y yeso

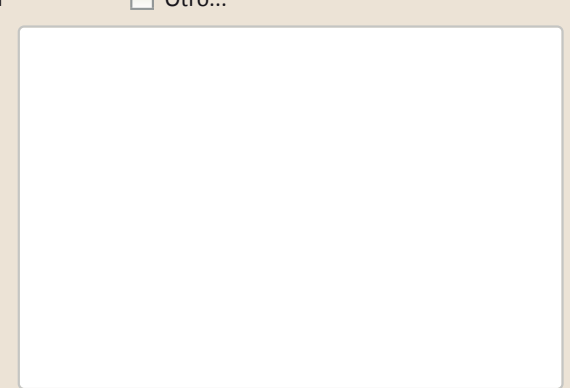

La restauración y rehabilitación de la arquitectura tradicional de tierra.

El caso de Aragón.

3. DATOS DE LA INTERVENCIÓN

Intervención de: $\quad \square$ Mantenimiento $\quad \square$ Rehabilitación parcial $\square$ Restauración

Reflexión previa Intervención espontanea

Observaciones

3.1. MUROS

Tipo de intervención

Tipo de material

Intervenido

$\square$ Actualización $\quad \square$ Reintegración $\quad \square$ Demolición $\quad \square$ Otro..

$\square$ Consolidación $\square$ Reconstrucción $\quad \mathbf{X}$ Sustitución

Descripción

Tipo de técnica Diferente a la existente

3.2. ZÓCALO

Sustitución parcial de muros por bloque de termoarcilla

Tipo de intervención

Intervenido

$\square$ Actualización $\square$ Reintegración $\square$ Demolición $\square$ Otro...

$\square$ Consolidación $\square$ Reconstrucción $\mathbf{x}$ Sustitución

Tipo de material No tradicional Tipo de técnica Similar a la existente

Descripción

Sustitución del revestimiento tradicional por mortero de cemento en la pare inferior del muro

3.3. REVESTIMIENTOS

Tipo de intervención

No intervenido

Tipo de material

Descripción

3.4. VANOS

Tipo de intervención

No intervenido

Tipo de material

$\square$ Actualización $\square$ Reintegración $\square$ Demolición $\square$ Otro...

$\square$ Consolidación $\quad \square$ Reconstrucción $\square$ Sustitución

Descripción

3.5. CUBIERTA

Tipo de intervención

Tipo de material

Intervenido

$\square$ Actualización $\quad \mathbf{X}$ Reintegración $\square$ Demolición $\square$ Otro.

$\square$ Consolidación $\quad \square$ Reconstrucción $\square$ sustitución

Descripción

No tradicional Tipo de técnica Diferente a la existente

reintegración de la cubierta recuperando las piezas y recolocadas con mortero de cemento

3.6. OTRAS 
La restauración y rehabilitación de la arquitectura tradicional de tierra. El caso de Aragón.

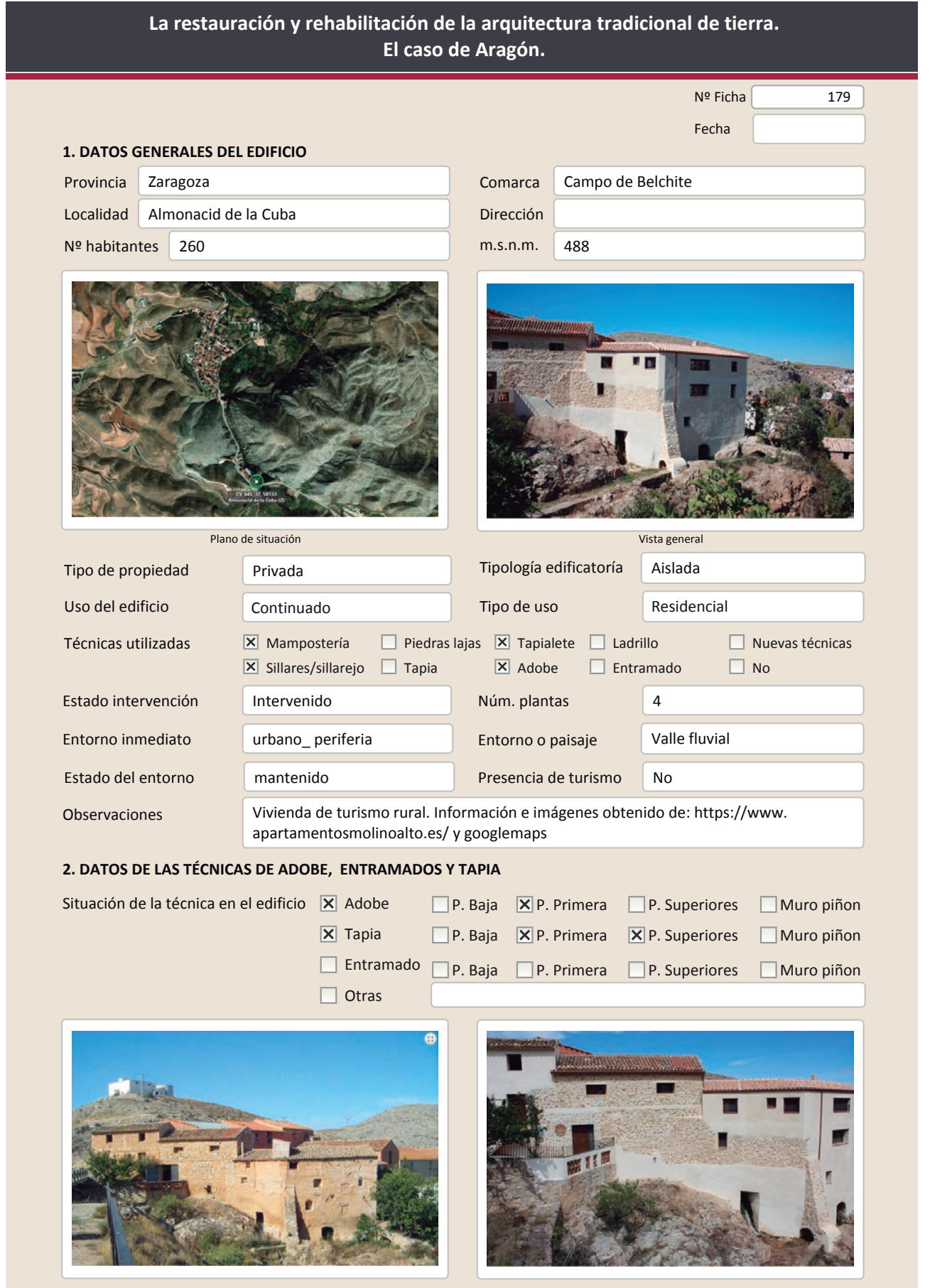

La restauración y rehabilitación de la arquitectura tradicional de tierra.
2.1. ADOBE

Dimensión de las piezas Dimensión del muro

Aparejo del muro

Función estructural

\section{El caso de Aragón.}

Color de las piezas

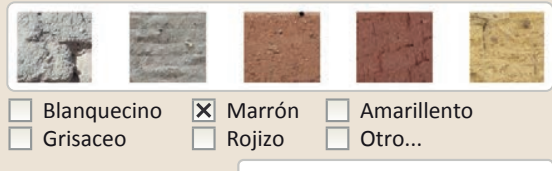

Comp. - estabilizante
Variante constructiva/ tipo de fábrica

$\square$ simple

$\square$ Suplementada en juntas

X Mixta

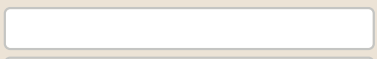

$\square$ Como suplemento

$\square$ Elementos de protección

Googlemaps. oct 2008

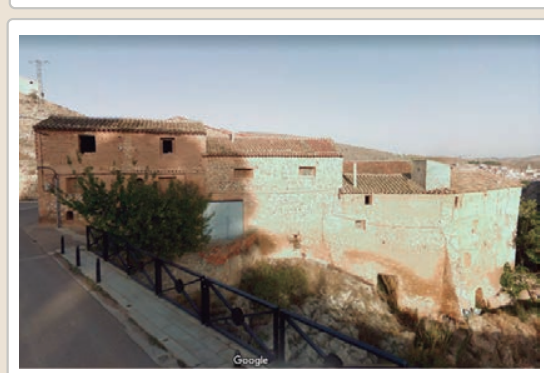

esiones

$\square$ Muro $\square$ Zócalo $\square$ Revestimiento $\square$ Cubierta $\square$ otro..

$\square$ Erosión del material $\quad \square$ Humedad por capilaridad $\quad \square$ Grietas por asentamientos $\square$ Erosion de las juntas $\square$ Humedades (manch/eflo) $\quad \square$ Colapso

$\square$ Pérdida de sección $\square$ Pérdida de verticalidad

$\square$ Vegetación $\quad \square$ Grietas por empuje de la cubierta

$\square$ Desconchados

$\square$ Gietas por empuje de la
$\square$ Grietas porfalta de traba
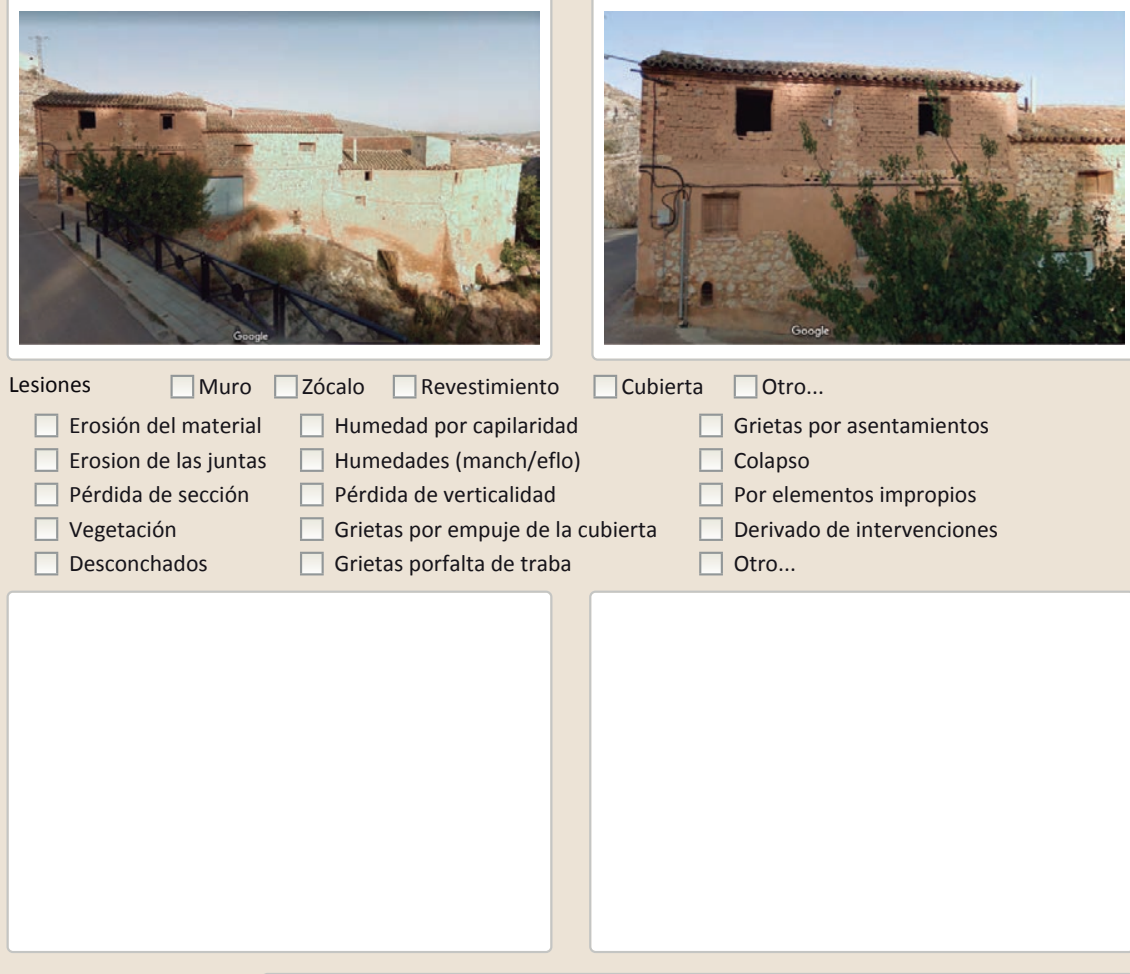

$\square$ Por elementos impropios

$\square$ Derivado de intervenciones $\square$ Otro...

Observaciones 


\section{La restauración y rehabilitación de la arquitectura tradicional de tierra.} El caso de Aragón.

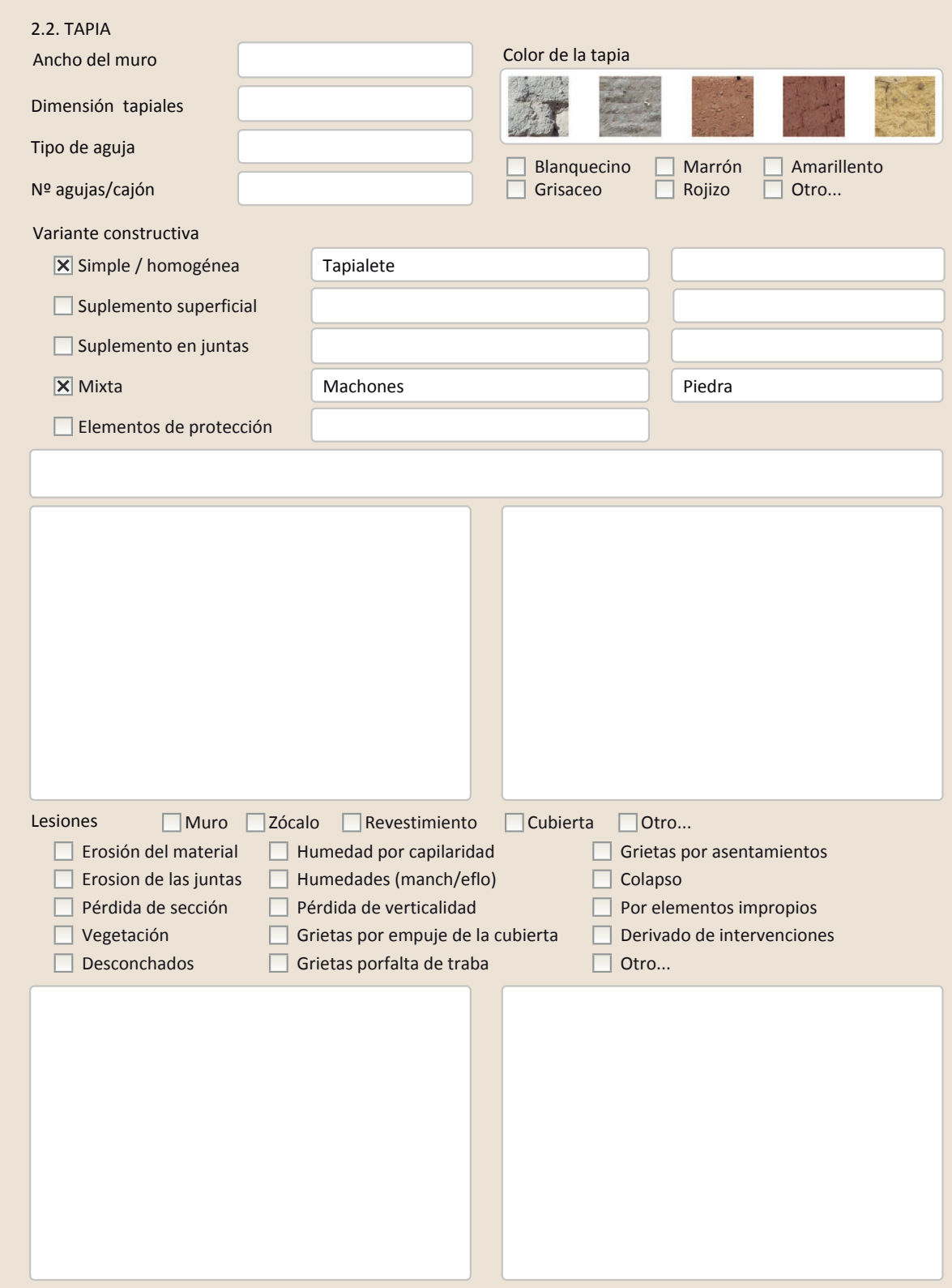

Observaciones
La restauración y rehabilitación de la arquitectura tradicional de tierra.

El caso de Aragón.

3. DATOS DE LA INTERVENCIÓN

Intervención de: $\quad \square$ Mantenimiento $\quad \square$ Rehabilitación parcial $\quad \square$ Restauración $\square$ Demolición

Reflexión previa Intervención planificada

Observaciones El molino ha sido transformado en viviendas de turismo rura

3.1. MUROS

Tipo de intervención

Intervenido

Tipo de material

$\square$ Actualización $\quad \mathbf{X}$ Reintegración $\square$ Demolición $\square$ Otro.

$\square$ Consolidación $\square$ Reconstrucción $\square$ sustitución

Descripción

No tradicional Tipo de técnica Similar a la existente

Reintegración de todos los muros de mampostería

3.2. ZÓCALO

Intervenido

Tipo de intervención

$\square$ Actualización $\quad \mathbf{X}$ Reintegración $\square$ Demolición $\square$ Otro...

$\square$ Consolidación $\square$ Reconstrucción $\square$ sustitución

\begin{tabular}{l|lll} 
Tipo de material No tradicional Tipo de técnica Similar a la existente &
\end{tabular}

Descripción

Reintegración de la mampostería

3.3. REVESTIMIENTOS

Tipo de intervención

Intervenido

Tipo de material

Descripción

3.4. VANOS

Tipo de intervención

Tipo de material

Descripción

3.5. CUBIERTA

Tipo de intervención

Tipo de material

Descripción

$\square$ Actualización $\quad \square$ Reintegración $\quad \square$ Demolición $\quad \square$ Otro...

$\square$ Consolidación $\mathbb{X}$ Reconstrucción $\square$ Sustitución

No tradicional Tipo de técnica Diferente a la existente

Nuevos revestimientos en todas las zonas donde la construcción no era de piedra.

Intervenido

$\square$ Actualización $\square$ Reintegración $\square$ Demolición $\square$ Otro.

$\square$ Consolidación $\mathbf{X}$ Reconstrucción $\mathbf{X}$ Sustitución

No tradicional Tipo de técnica Diferente a la existente

Todas las carpinterías han sido sustituidas. Nueva configuración de huecos, algunos han sido cegados y se han abierto nuevos

Intervenido

$\square$ Actualización $\square$ Reintegración $\square$ Demolición $\square$ Otro...

$\square$ Consolidación $\mathbf{X}$ Reconstrucción $\mathbf{X}$ Sustitución

No tradicional Tipo de técnica Diferente a la existente

En algunas áreas del edificio la cubierta se ha reconstruido con los elementos tradicionales y en otra zona se ha sustituido por completo

3.6. OTRAS 
La restauración y rehabilitación de la arquitectura tradicional de tierra.

$$
\text { El caso de Aragón. }
$$

3.7. REHABILITACIÓN ENERGÉTICA

Х Fachada $\mathbf{X}$ Vanos $\square$ Forjados $\mathbf{X}$ Cubierta

Observaciones

Puesto que la intervención es posterior a 2008 debe de cumplir el CTE y habrá sido modificado en muchos aspectos

FOTOGRAFíAS DE LA INTERVENCIÓN

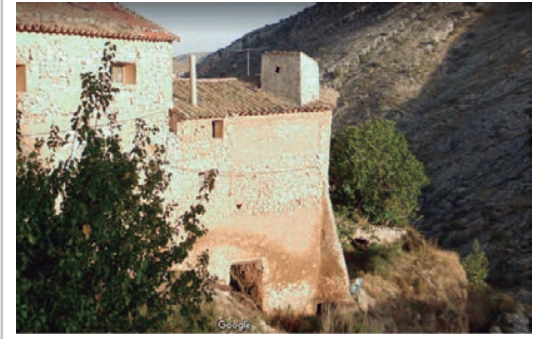

Google oct. 2008
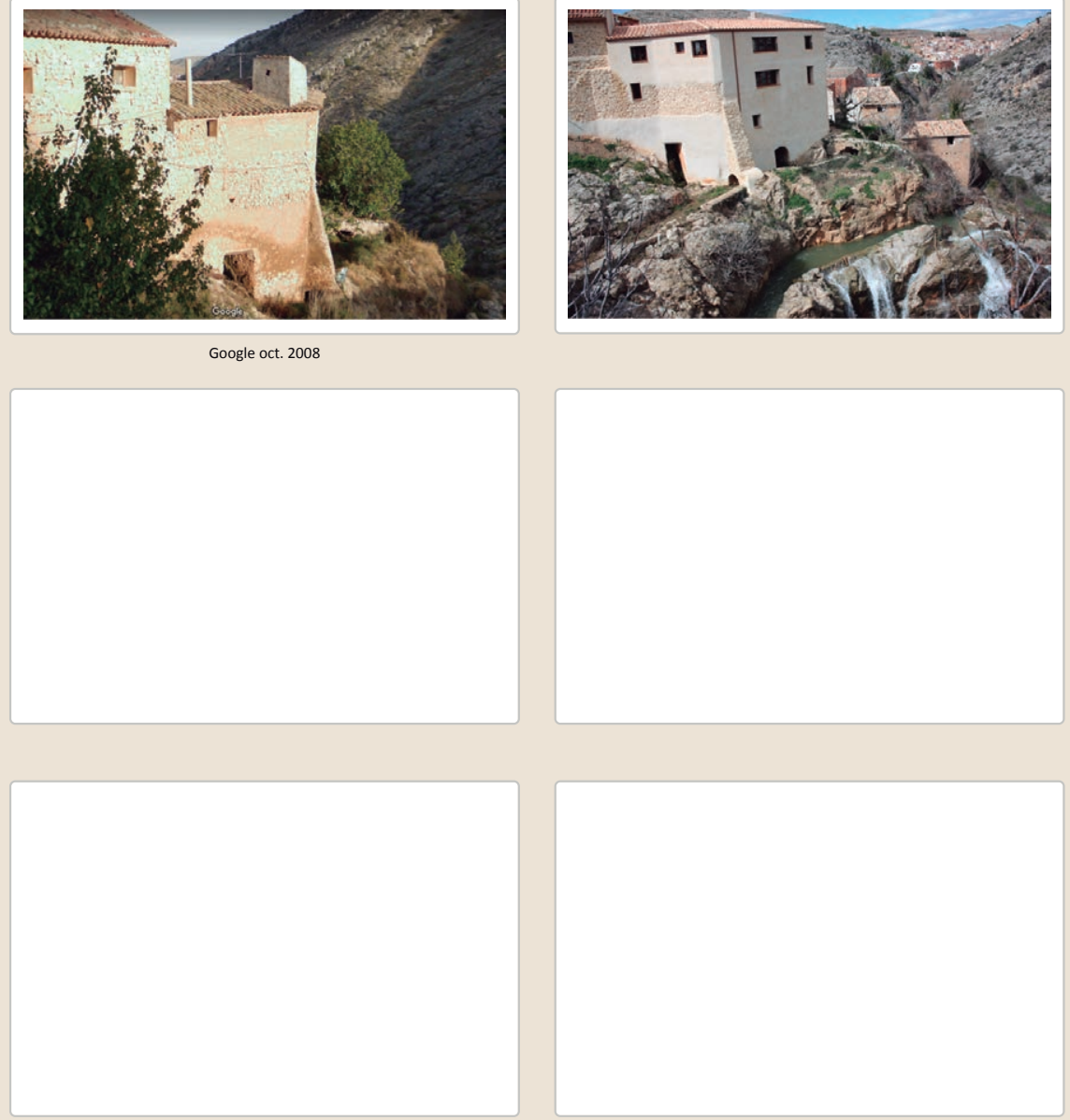


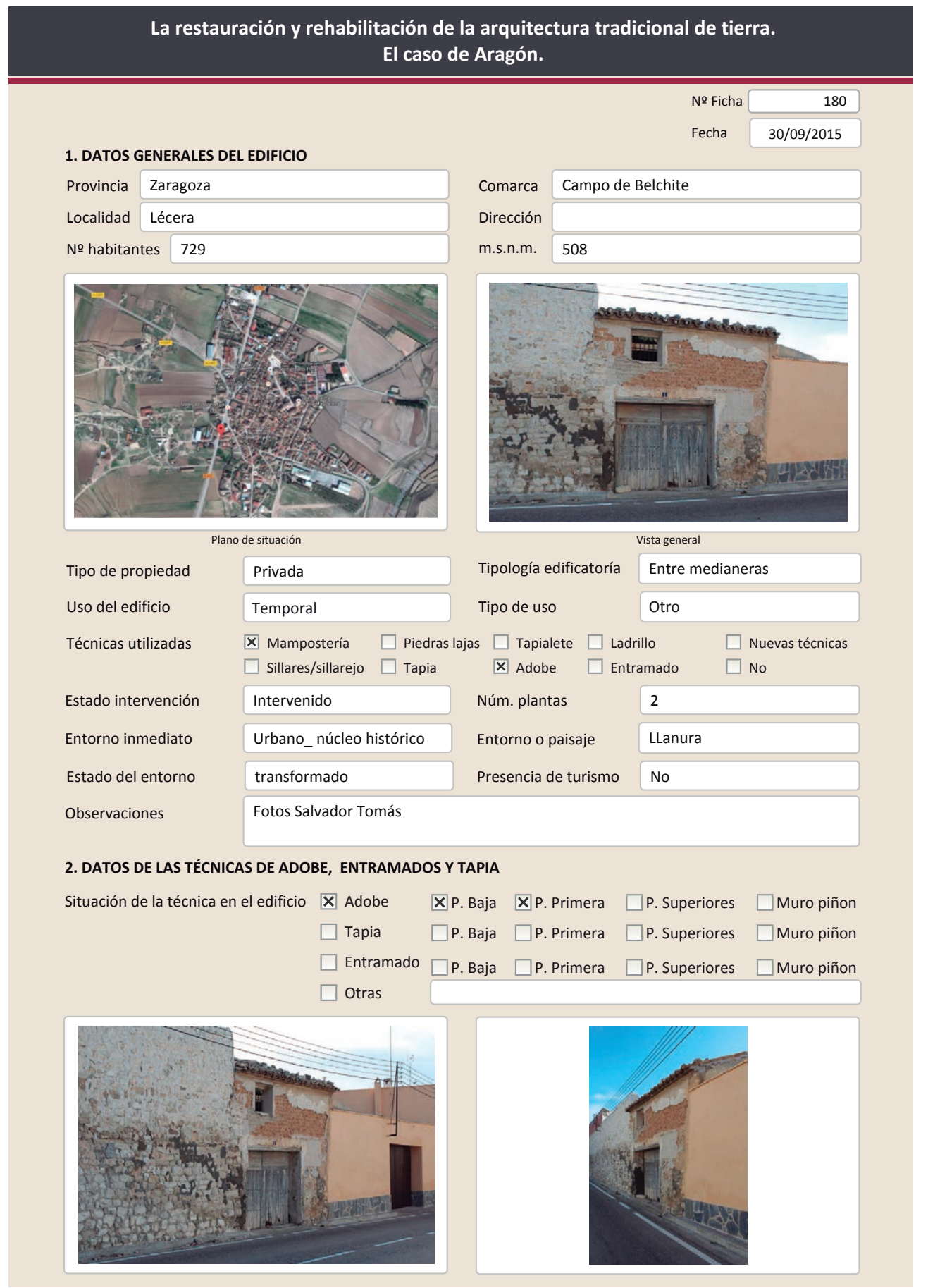

2.1. ADOBE

Dimensión de las piezas

Dimensión del muro

Aparejo del muro

Función estructural

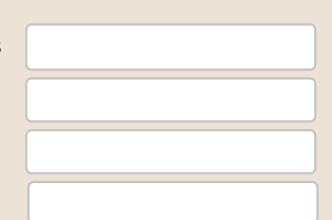

Color de las piezas

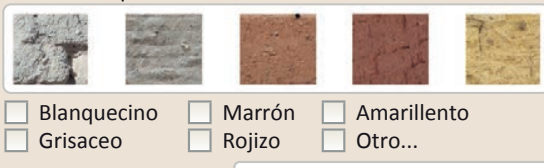

Comp. - estabilizante

Variante constructiva/ tipo de fábrica

Х Simple

$\square$ Suplementada en juntas

$\square$ Mixta

$\square$ Como suplemento

$\square$ Elementos de protección

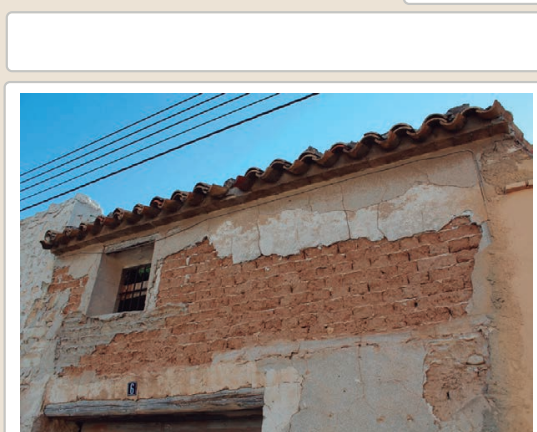

Lesiones $\mathbf{X}$ Muro $\mathbf{X}$ Zócalo $\mathbf{X}$ Revestimiento

$\mathbf{X}$ Erosión del material $\mathbf{X}$ Humedad por capilaridad $\square$ Erosion de las juntas $\square$ Humedades (manch/eflo)

X Pérdida de sección $\square$ Pérdida de verticalidad

$\square$ Vegetación $\quad \square$ Grietas por empuje de la c

X Desconchados

$\square$ Grietas porfalta de traba

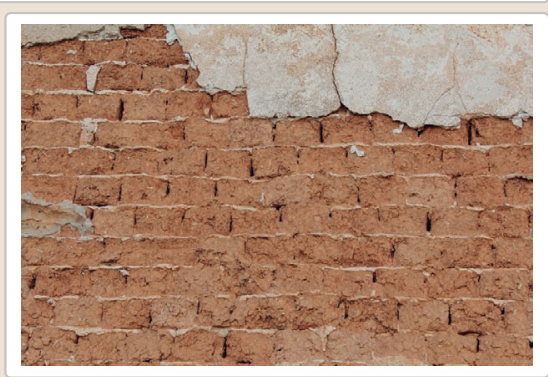

$\square$ Cubierta $\square$ Otro...

$\square$ Grietas por asentamiento

$\square$ Colapso

$\square$ Grietas porfalta de traba

$\square$ Derivado de intervenciones

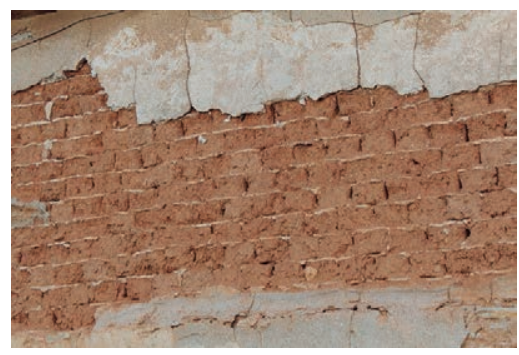

Observaciones 


\section{La restauración y rehabilitación de la arquitectura tradicional de tierra.}

\section{El caso de Aragón.}

3. DATOS DE LA INTERVENCIÓN

Intervención de:

$\square$ Mantenimiento $\square$ Rehabilitación parcial

$\square$ Restauración $\square$ Demolición X Reparación $\square$ Rehabilitación integral $\square$ Ampliación $\square$ Otro...

Reflexión previa Intervención espontanea

Observaciones Intervenciones de rejuntado y relleno volumétrico principalmente.

3.1. MUROS
Tipo de intervención

Intervenido

Tipo de intervención

$\square$ Actualización $\quad$ Reintegración $\square$ Demolición $\square$ Otro...

$\square$ Consolidación $\quad \square$ Reconstrucción $\square$ Sustitución

Descripción

No tradicional

Tipo de técnica Diferente a la existente

3.2. ZÓCALO

Tipo de intervención relleno de ceme

\section{Intervenido}

$\square$ Actualización $\quad \mathbf{X}$ Reintegración $\square$ Demolición $\square$ Otro...

$\square$ Consolidación $\square$ Reconstrucción $\square$ Sustitución

Tipo de material

No tradicional

Tipo de técnica

Diferente a la existente

Descripción

3.3. REVESTIMIENTOS

Tipo de intervención

Rejuntado con cemento de la mampostería.

\section{No intervenido}

$\square$ Actualización $\square$ Reintegración $\square$ Demolición $\square$ Otro...

$\square$ Consolidación $\square$ Reconstrucción $\square$ sustitución

Tipo de material

Descripción

3.4. VANOS

Tipo de intervención

No intervenido

$\square$ Actualización $\square$ Reintegración $\square$ Demolición $\square$ Otro...

Tipo de material

Descripción

3.5. CUBIERTA

Tipo de intervención

Tipo de material

Descripción

3.6. OTRAS

Tipo de técnica

$\square$ Actualización $\square$ Reintegración $\square$ Demolición $\square$ Otro. $\square$ Consolidación $\square$ Reconstrucción $\square$ Sustitución Tipo de técnica
La restauración y rehabilitación de la arquitectura tradicional de tierra.

El caso de Aragón.

3.7. REHABILITACIÓN ENERGÉTICA $\quad \square$ Fachada $\square$ Vanos $\square$ Forjados $\square$ Cubierta

Observaciones

FOTOGRAFÍAS DE LA INTERVENCIÓN
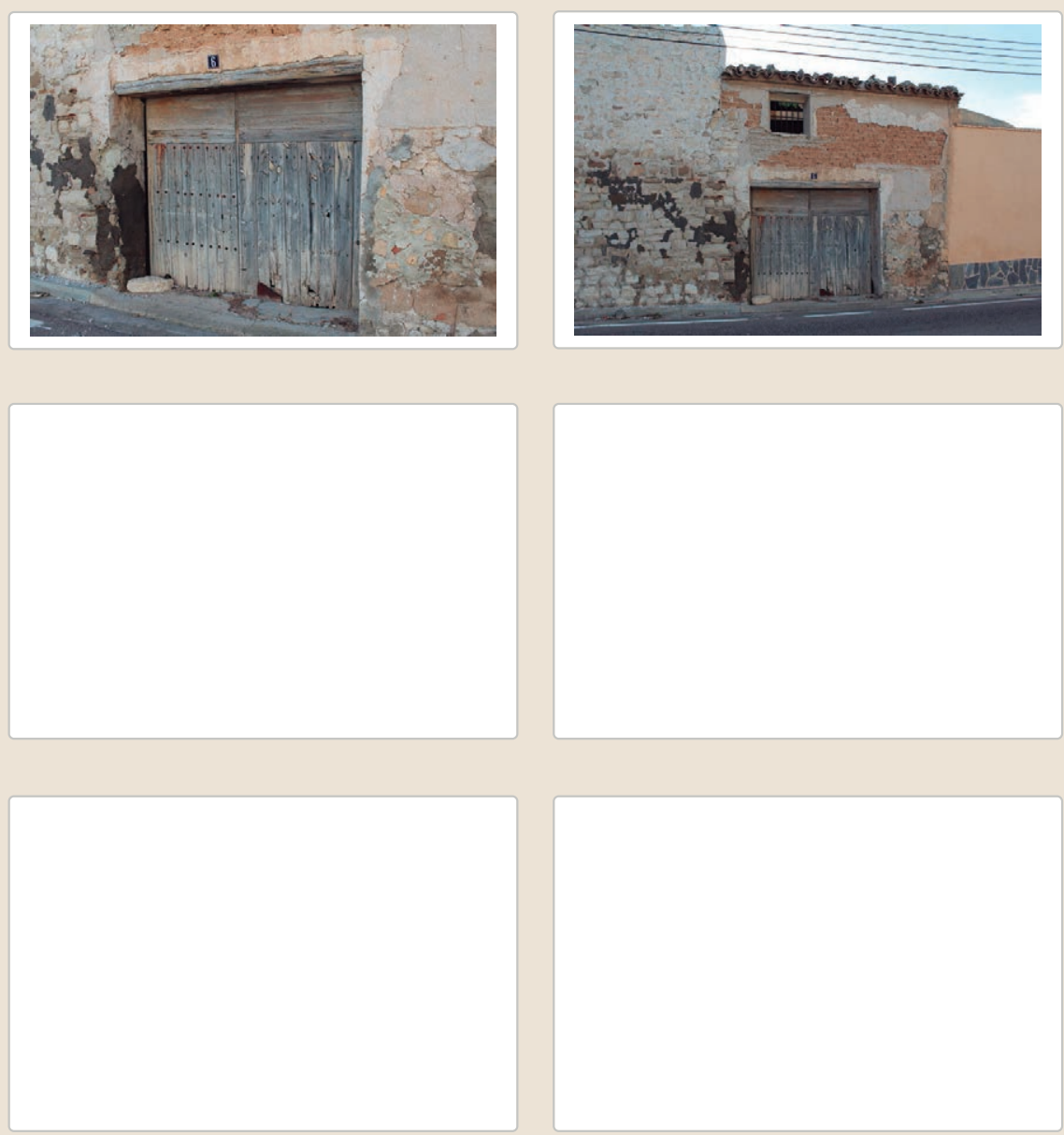


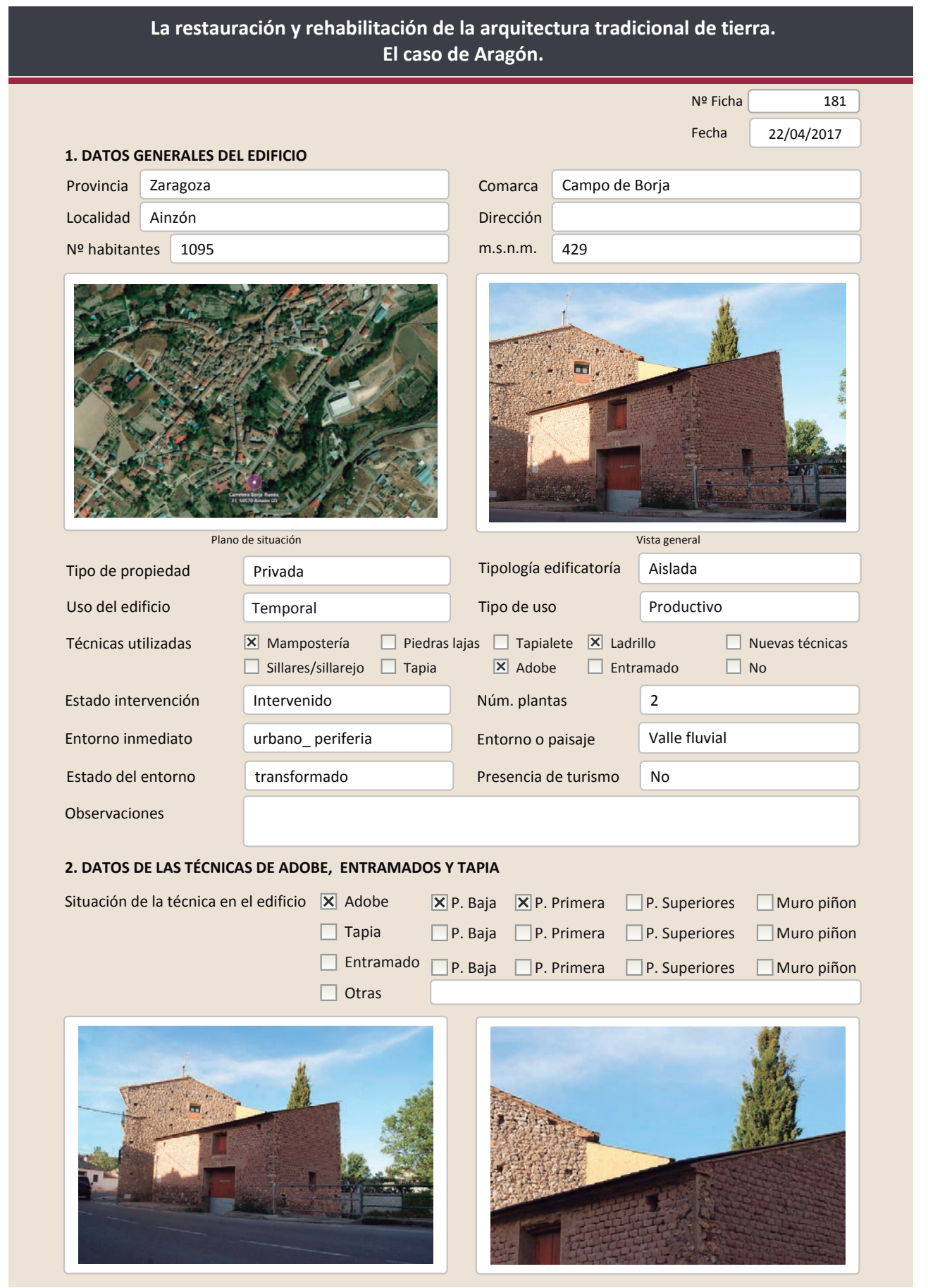

2.1. ADOBE

Dimensión de las piezas Dimensión del muro

Aparejo del muro

Función estructural

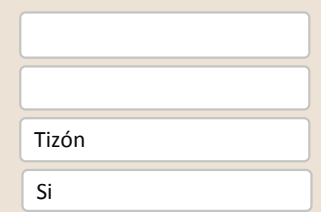

Color de las piezas

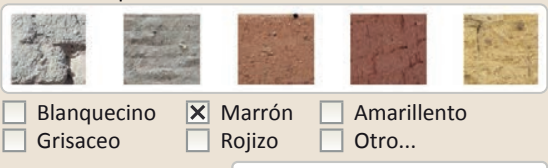

Comp. - estabilizante Aridos

Variante constructiva/ tipo de fábrica

$\square$ Simple

$\square$ Suplementada en juntas

区 Mixta

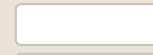

$\square$ Como suplemento

$\square$ Elementos de protección

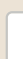

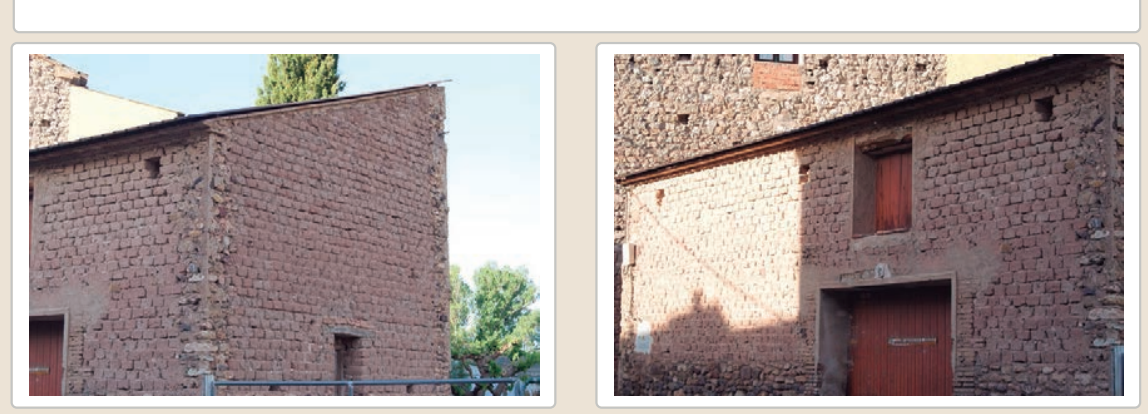

Lesiones $\quad \mathbf{X}$ Muro $\mathbf{X}$ Zócalo $\square$ Revestimiento $\square$ Cubierta $\square$ Otro...

区 Erosión del material $\mathbf{X}$ Humedad por capilaridad $\quad \square$ Grietas por asentamientos $\square$ Erosion de las juntas $\mathbf{X}$ Humedades (manch/eflo) $\square$ Colapso

$\square$ Pérdida de sección $\square$ Pérdida de verticalidad

$\square$ Vegetación $\quad \square$ Grietas por empuje de la cubierta

$\square$ Desconchados

$\square$ Grietas por empuje de la

$\square$ Por elementos impropios

$\square$ Derivado de intervenciones

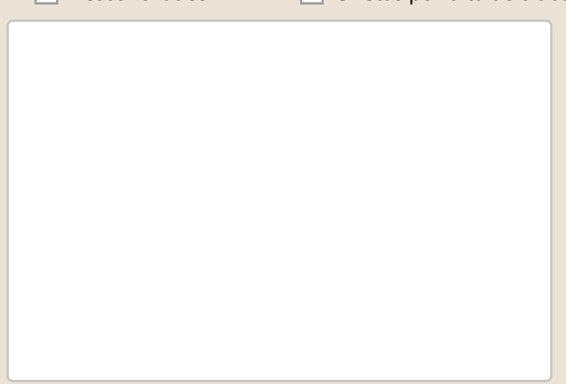
$\square$ Otro... 
La restauración y rehabilitación de la arquitectura tradicional de tierra.

El caso de Aragón.

3. DATOS DE LA INTERVENCIÓN

\begin{tabular}{|c|c|c|c|c|}
\hline Intervención de: & $\begin{array}{l}\square \text { Mantenimiento } \\
\mathbf{X} \text { Reparación }\end{array}$ & $\begin{array}{l}\square \text { Rehabilitación parcial } \\
\square \text { Rehabilitación integral }\end{array}$ & $\begin{array}{l}\square \text { Restauración } \\
\square \text { Ampliación }\end{array}$ & $\begin{array}{l}\square \text { Demolición } \\
\square \text { Otro... }\end{array}$ \\
\hline Reflexión previa & \multicolumn{4}{|c|}{ Intervención espontanea } \\
\hline 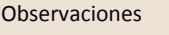 & & & & \\
\hline
\end{tabular}

\subsection{MUROS}

Tipo de intervención

No intervenido

Tipo de material

$\square$ Actualización $\square$ Reintegración $\square$ Demolición $\square$ Otro...

$\square$ Consolidación $\square$ Reconstrucción $\square$ Sustitución

Descripción

3.2. ZÓCALO

Tipo de intervención

No intervenido

Tipo de intervención

$\square$ Actualización

Descripción

3.3. REVESTIMIENTOS

Tipo de intervención

\section{No aplica}

Tipo de material

Descripción Tipo de técnica

3.4. VANOS

Tipo de intervención

$\square$ Consolidación

$\square$ Demolición

Tipo de material

Intervenido

$\mathbf{X}$ Actualización $\quad \mathbf{X}$ Reintegración $\square$ Demolición $\square$ Otro...

$\square$ Consolidación $\square$ Reconstrucción $\square$ Sustitución

Descripción

No tradicional

Tipo de técnica Diferente a la existente

3.5. CUBIERTA

Tipo de intervención

Reintegración de jambas y dintel con una capa gruesa de mortero de cemento

Intervenido

$\square$ Actualización $\square$ Reintegración $\square$ Demolición $\square$ Otro.

Tipo de material

$\square$ Consolidación $\square$ Reconstrucción $\quad \boldsymbol{X}$ Sustitución

Descripción

No tradicional Tipo de técnica Diferente a la existente

Sustitución de la cubierta tradicional por una cubierta de chapa

3.6. OTRAS 


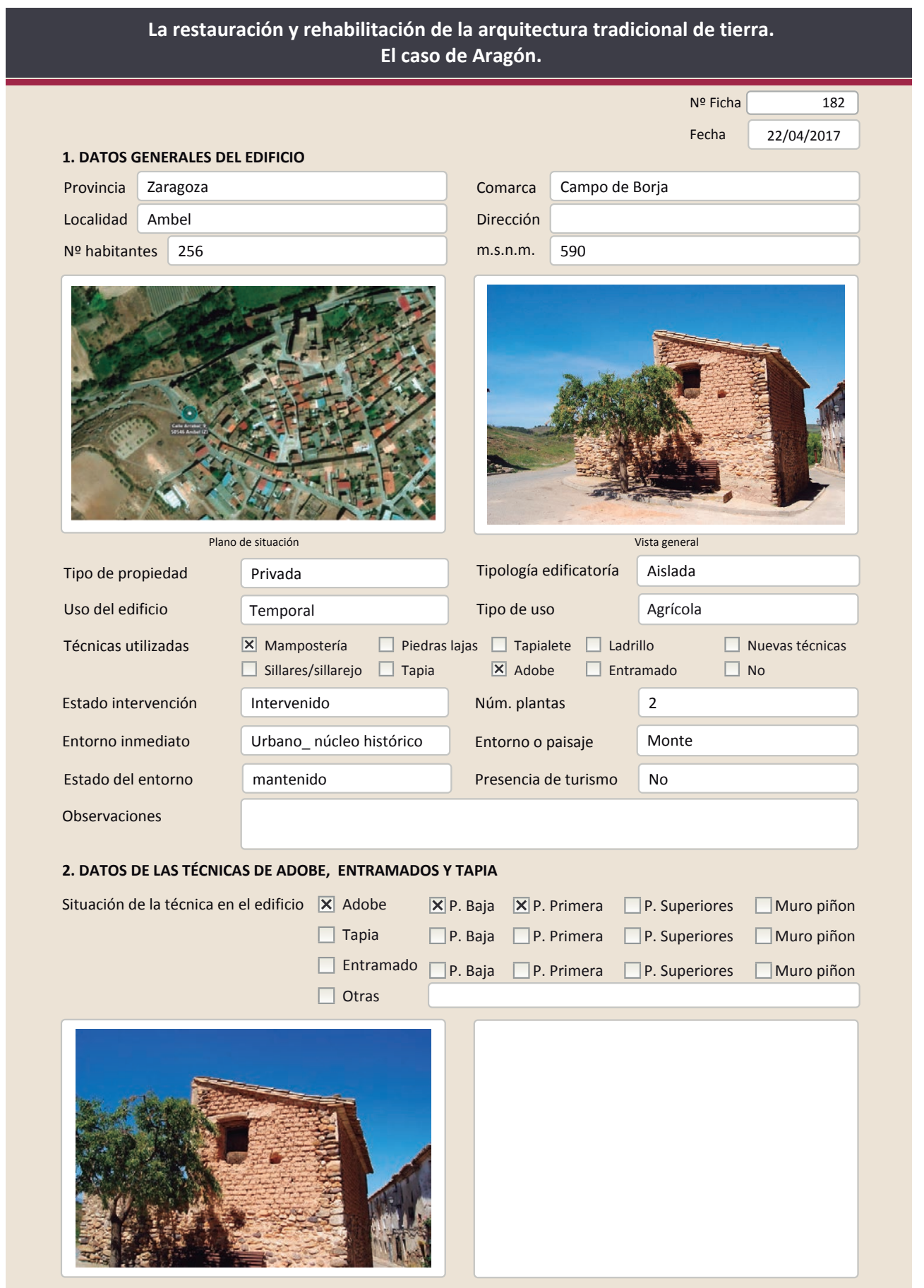

2.1. ADOBE

Dimensión de las piezas $41 \times 20 \times 9$

Dimensión del muro $40-50 \mathrm{~cm}$

Aparejo del muro Tizón

Función estructural

$\mathrm{Si}$

Variante constructiva/ tipo de fábrica

$\square$ simple

$\square$ Suplementada en juntas

X Mixta

$\square$ Como suplemento

$\square$ Elementos de protección

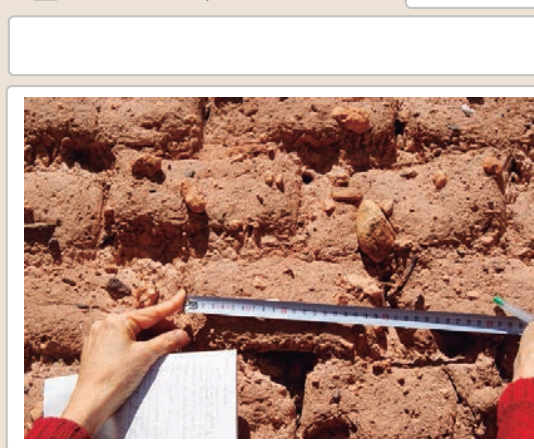

Lesiones $\quad \mathbf{X}$ Muro $\square$ Zócalo $\square$ Revestimiento X Erosión del material $\square$ Humedad por capilaridad $\mathbf{X}$ Erosion de las juntas $\square$ Humedades (manch/eflo) X Pérdida de sección $\square$ Pérdida de verticalidad

$\square$ Vegetación $\quad \square$ Grietas por empuje de la cub

$\square$ Desconchados $\quad \square$ Grietas porfalta de trab

$\square$ Grietas porfalta de traba

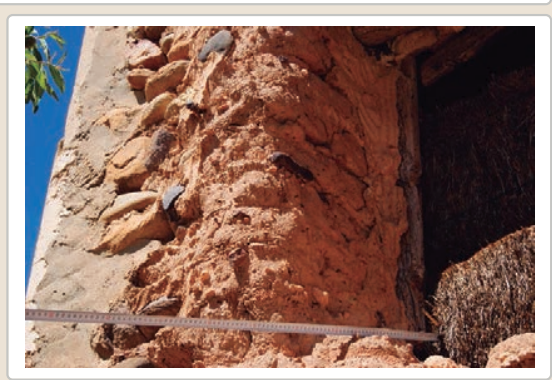

$\square$ Cubierta $\square$ Otro...

$\square$ Grietas por asentamientos $\square$ Colapso

$\square$ Por elementos impropios

$\square$ Derivado de intervenciones

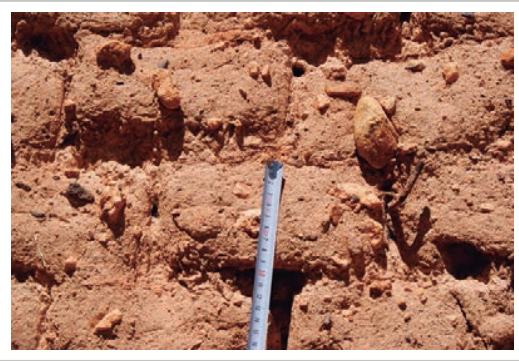

Observaciones 
La restauración y rehabilitación de la arquitectura tradicional de tierra.

El caso de Aragón.

3. DATOS DE LA INTERVENCIÓN

\begin{tabular}{llll|} 
Intervención de: & $\square$ Mantenimiento $\quad \square$ Rehabilitación parcial & $\square$ Restauración $\quad \square$ Demolición \\
Reflexión previa & $\mathbf{X}$ Reparación $\quad \square$ Rehabilitación integral $\quad \square$ Ampliación $\quad \square$ Otro... \\
\hline Observaciones & Intervención espontanea & \\
& & \\
& & \\
\end{tabular}

\subsection{MUROS}

Tipo de intervención

Intervenido

Tipo de material

$\square$ Actualización $\quad$ X Reintegración $\square$ Demolición $\square$ Otro...

$\square$ Consolidación $\square$ Reconstrucción $\square$ sustitución

Descripción

\begin{tabular}{l|l|l} 
No tradicional & Tipo de técnica Diferente a la existente
\end{tabular}

Descripción Rejuntado de la man
con cantos rodados.

3.2. ZÓCALO

Tipo de intervención

Intervenido

Tipo de material

$\square$ Actualización

Х Reintegración $\square$ Demolición $\square$ Otro...

$\square$ Consolidación $\square$ Reconstrucción $\square$ Sustitución

Descripción
(t)
Tipo de técnica Diferente a la existente

3.3. REVESTIMIENTOS

Reintegración parcial del zócalo con cemento

Tipo de intervención

\section{No aplica}

Tipo de material

$\square$ Actualización

$\square$ Reintegración $\square$ Demolición $\square$ Otro...

$\square$ Consolidación $\square$ Reconstrucción $\square$ Sustitución

Descripción

3.4. VANOS

No intervenido

Tipo de intervención

$\square$ Actualización $\square$ Reintegración $\square$ Demolición $\square$ Otro...

Tipo de material

$\square$ Consolidación $\square$ Reconstrucción $\square$ sustitución

Descripción

3.5. CUBIERTA

Tipo de intervención

No intervenido

Tipo de material

$\square$ Actualización $\quad \square$ Reintegración $\quad \square$ Demolición
$\square$ Consolidación $\quad \square$ Reconstrucción $\quad \square$ Sustitución

Tipo de técnica

Descripción

$$
\text { Tipo de técnica }
$$

3.6. OTRAS 


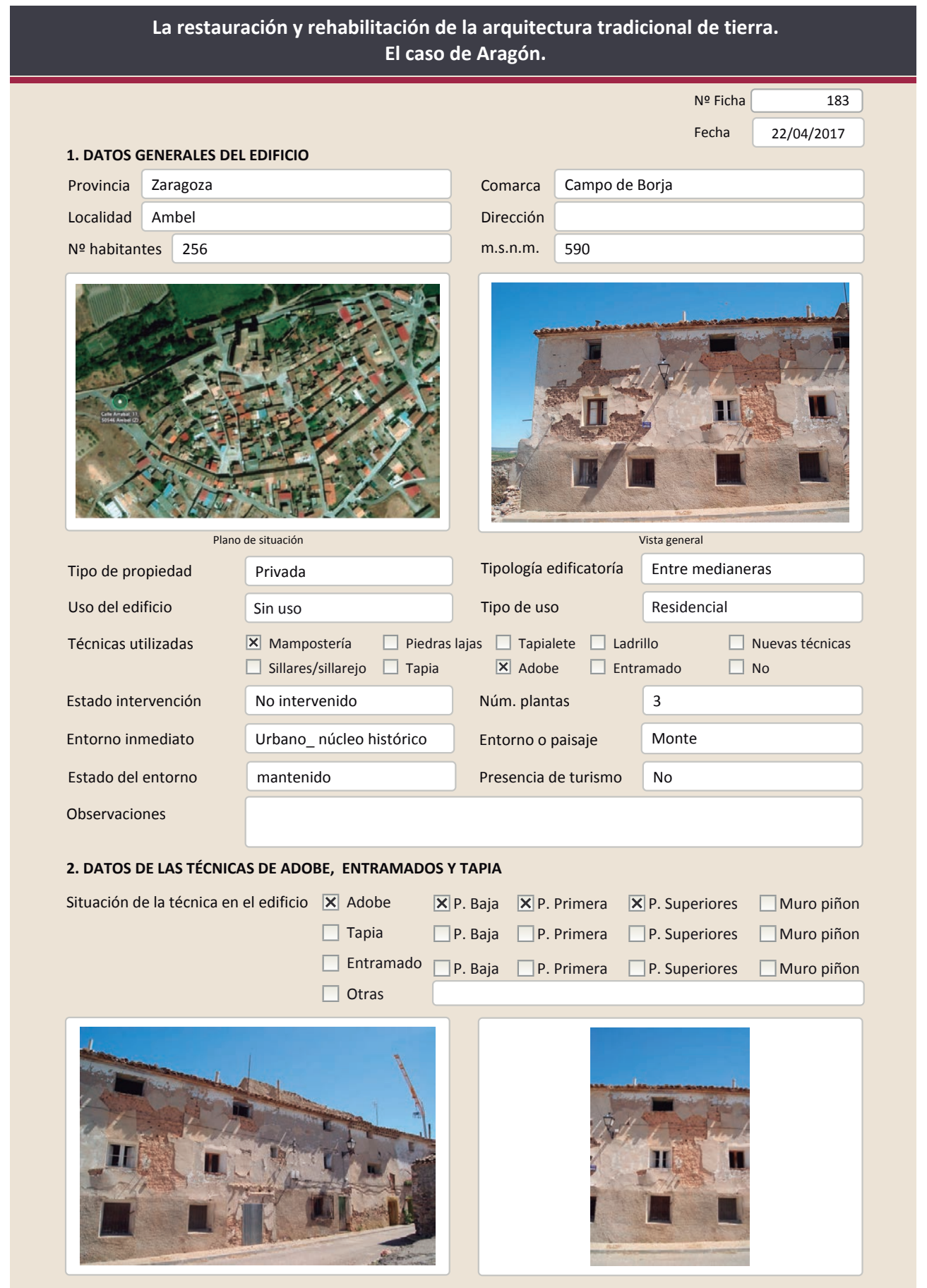

\begin{tabular}{l|l|} 
2.1. ADOBE & \\
Dimensión de las piezas & $33 \times 16 \times 8$ \\
\hline $\begin{array}{l}\text { Dimensión del muro } \\
\text { Aparejo del muro }\end{array}$ & $30-40 \mathrm{~cm}$ \\
\hline Función estructural & $\mathrm{Si}$ \\
\hline
\end{tabular}

Color de las piezas

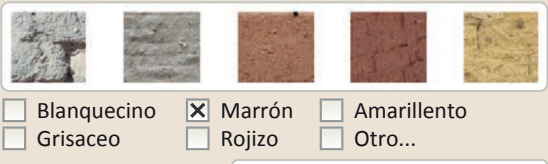

Función estructural

$\mathrm{Si}$

Variante constructiva/ tipo de fábrica

$\square$ Simple
$\mathbf{X}$ Suplementada en juntas
Horizontales
$\mathrm{Cal} /$ yeso
区 Mixta
En esquinas
Ladrillo

$\square$ Como suplemento

$\mathbf{X}$ Elementos de protección

Revestimiento

Hay adobe en los muros exteriores pero también en los tabiques del interior

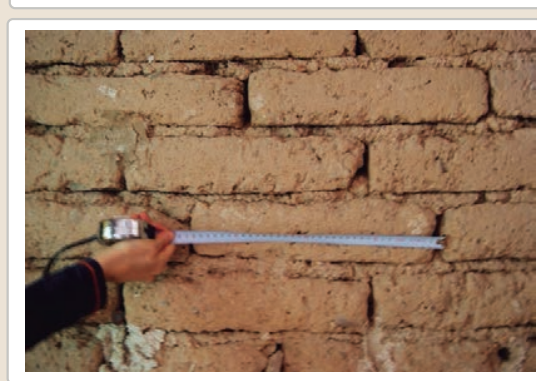

Lesiones

xMuro $\square$ Zócalo $x$ Revestimiento

$\mathbf{X}$ Erosión del material $\square$ Humedad por capilaridad

$\square$ Pérdida de sección $\quad \square$ Pérdida de verticalidad

$\square$ Vegetación $\quad \square$ Grietas por empuje de la cubic

X Desconchados

$\square$ Grietas porfalta de traba

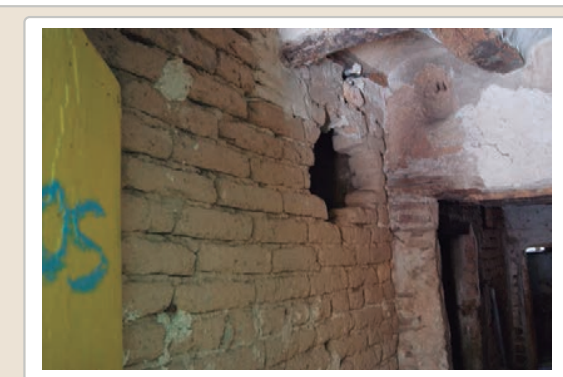

X Cubierta $\square$ Otro...

$\square$ Grietas por asentamientos

$\square$ Colapso

$\square$ Por elementos impropios

$\square$ Derivado de intervenciones

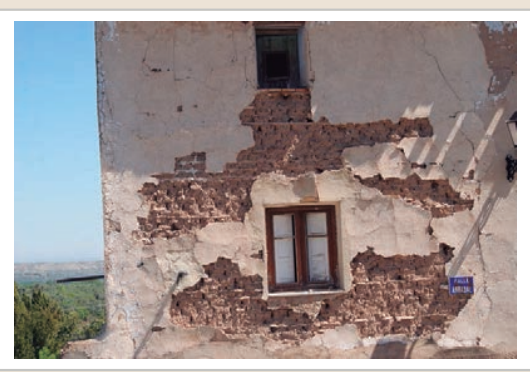

Observaciones 


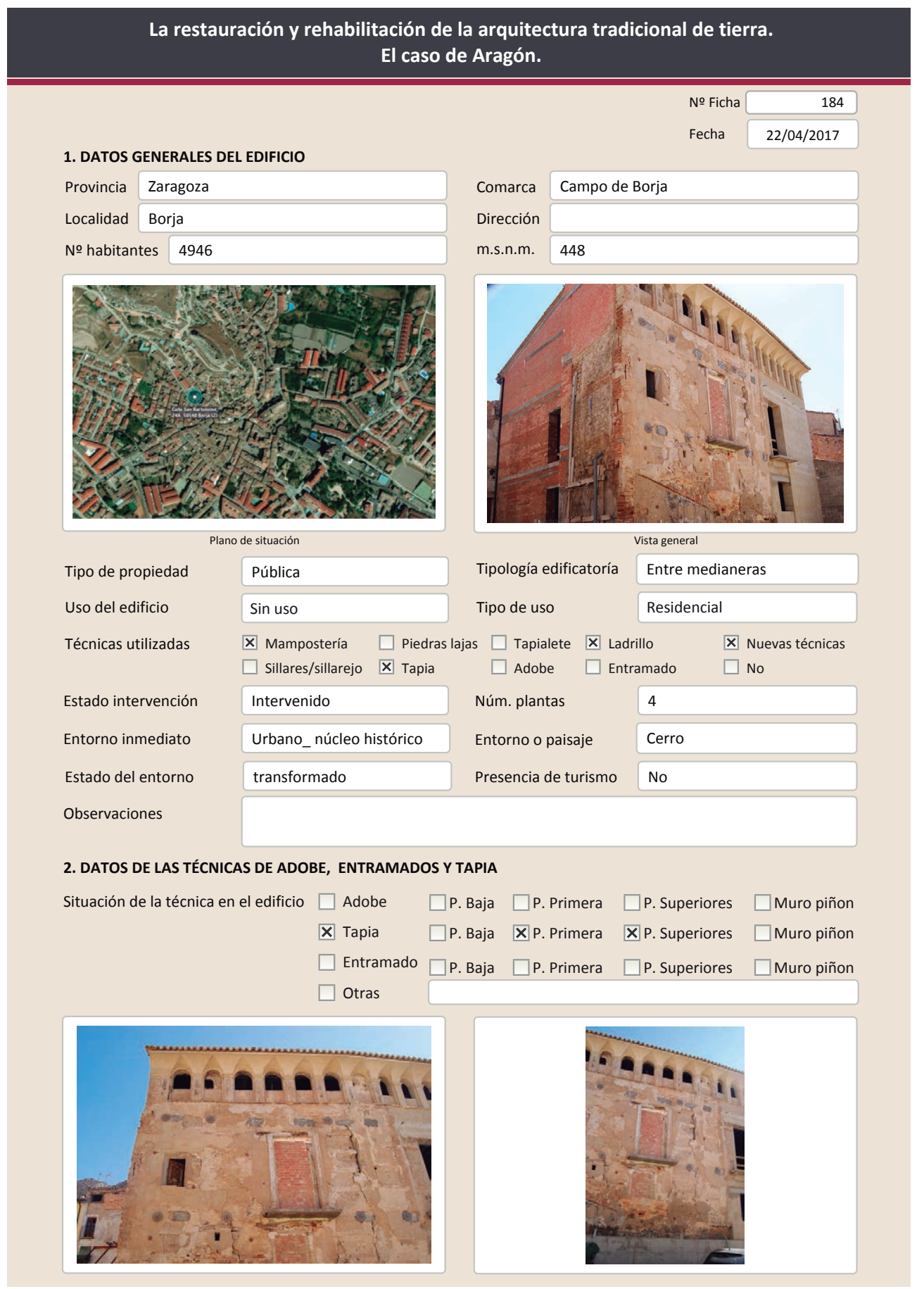

La restauración y rehabilitación de la arquitectura tradicional de tierra. El caso de Aragón.

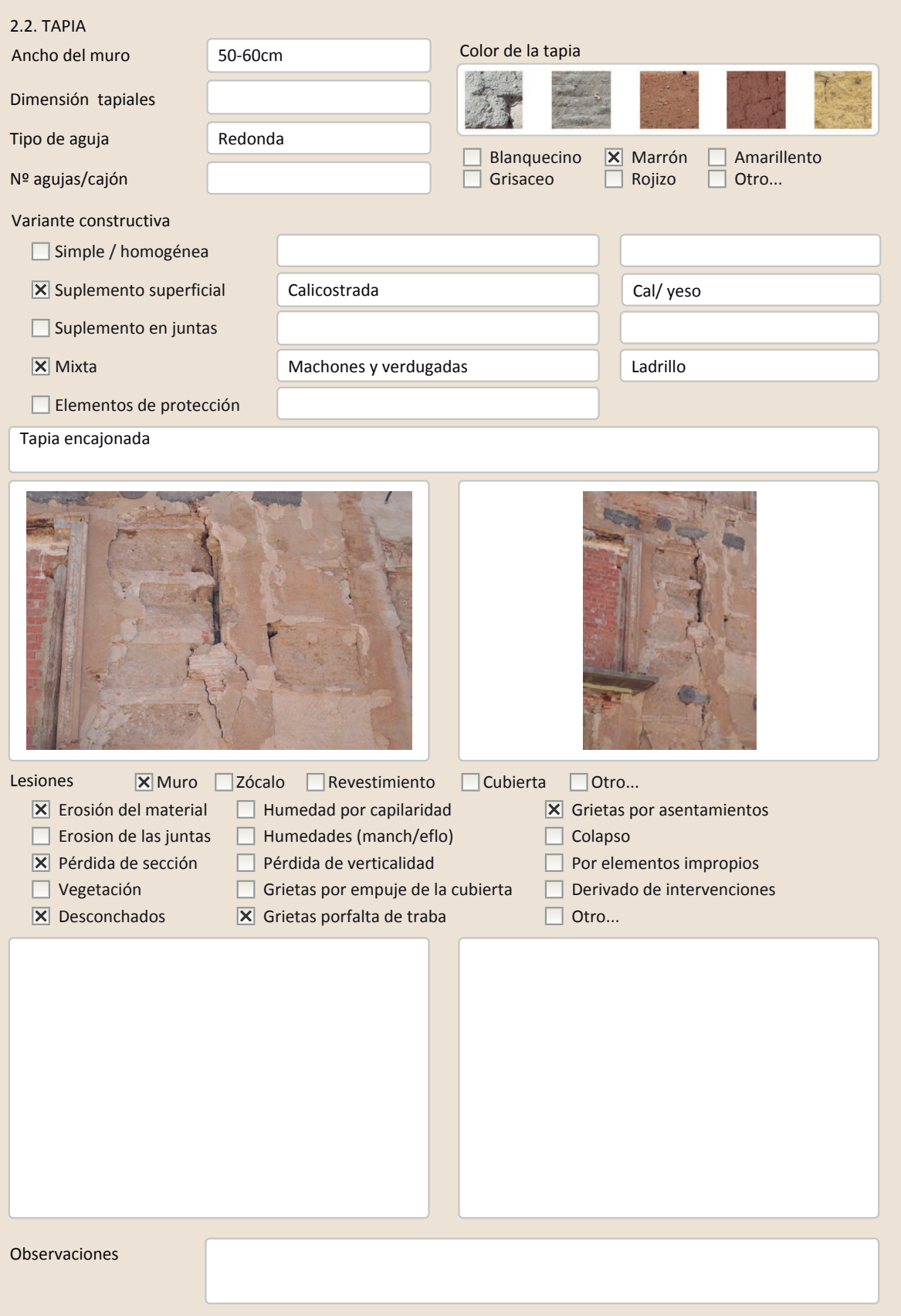




\section{La restauración y rehabilitación de la arquitectura tradicional de tierra.} El caso de Aragón.

3. DATOS DE LA INTERVENCIÓN

$\square$ Mantenimien

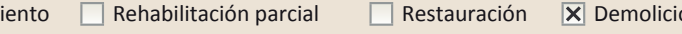

$\square$ Reparación $\quad$ X Rehabilitación integral $\square$ Ampliación $\square$ Otro...

Reflexión previa Intervención planificada

Observaciones Solo se ha conservado la fachada del edificio. Se ha vaciado y se ha construido de nuevo con estructura de hormigón armado

\subsection{MUROS Intervenido \\ Tipo de intervención \\ $\square$ Actualización $\quad \mathbf{X}$ Reintegración $\quad \boldsymbol{X}$ Demolición $\square$ Otro... \\ $\square$ Consolidación $\square$ Reconstrucción $\quad \boldsymbol{X}$ Sustitución}

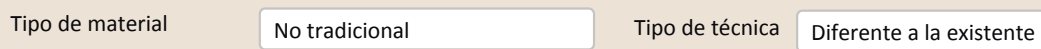

Descripción El muro tiene de todo tipo de intervenciones. Se han sustituido partes, otras se ha doblado el muro con ladrillo y también se ha atirantado a los nuevos forjados

3.2. ZÓCALO

Tipo de intervención

Intervenido

$\square$ Actualización $\square$ Reintegración $\square$ Demolición $\square$ Otro...

$\square$ Consolidación $\quad \mathbf{X}$ Reconstrucción $\square$ Sustitución

Tipo de material No tradicional Tipo de técnica Diferente a la existente

Descripción

3.3. REVESTIMIENTOS

Tipo de intervención

La base de la fachada conservada se ha reforzado con un muro de hormigón armado

Tipo de material

Descripción

3.4. VANOS

Tipo de intervención

Tipo de material

Descripción

3.5. CUBIERTA

Tipo de intervención

Tipo de material

Descripción

\section{No intervenido}

$\square$ Actualización $\square$ Reintegración $\square$ Demolición $\square$ Otro...

$\square$ Consolidación $\square$ Reconstrucción $\square$ sustitución

Tipo de técnica

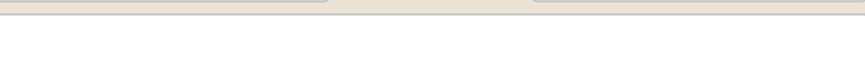

Intervenido

$\square$ Actualización $\square$ Reintegración $\square$ Demolición $\square$ Otro...

$\square$ Consolidación $\mathbf{X}$ Reconstrucción $\boldsymbol{X}$ Sustitución

No tradicional Tipo de técnica Diferente a la existente

Se han cegado huecos y se han abierto nuevo en las zonas de muro reconstruido

\section{Intervenido}

$\square$ Actualización $\square$ Reintegración $\square$ Demolición $\square$ Otro..

$\square$ Consolidación $\square$ Reconstrucción $\quad$ Sustitución
No tradiciona
Tipo de técnica Diferente a la existente

La restauración y rehabilitación de la arquitectura tradicional de tierra.

El caso de Aragón.

3.7. REHABILITACIÓN ENERGÉTICA $\quad \square$ Fachada $\square$ Vanos $\square$ Forjados $\square$ Cubierta

Observaciones

FOTOGRAFÍAS DE LA INTERVENCIÓN
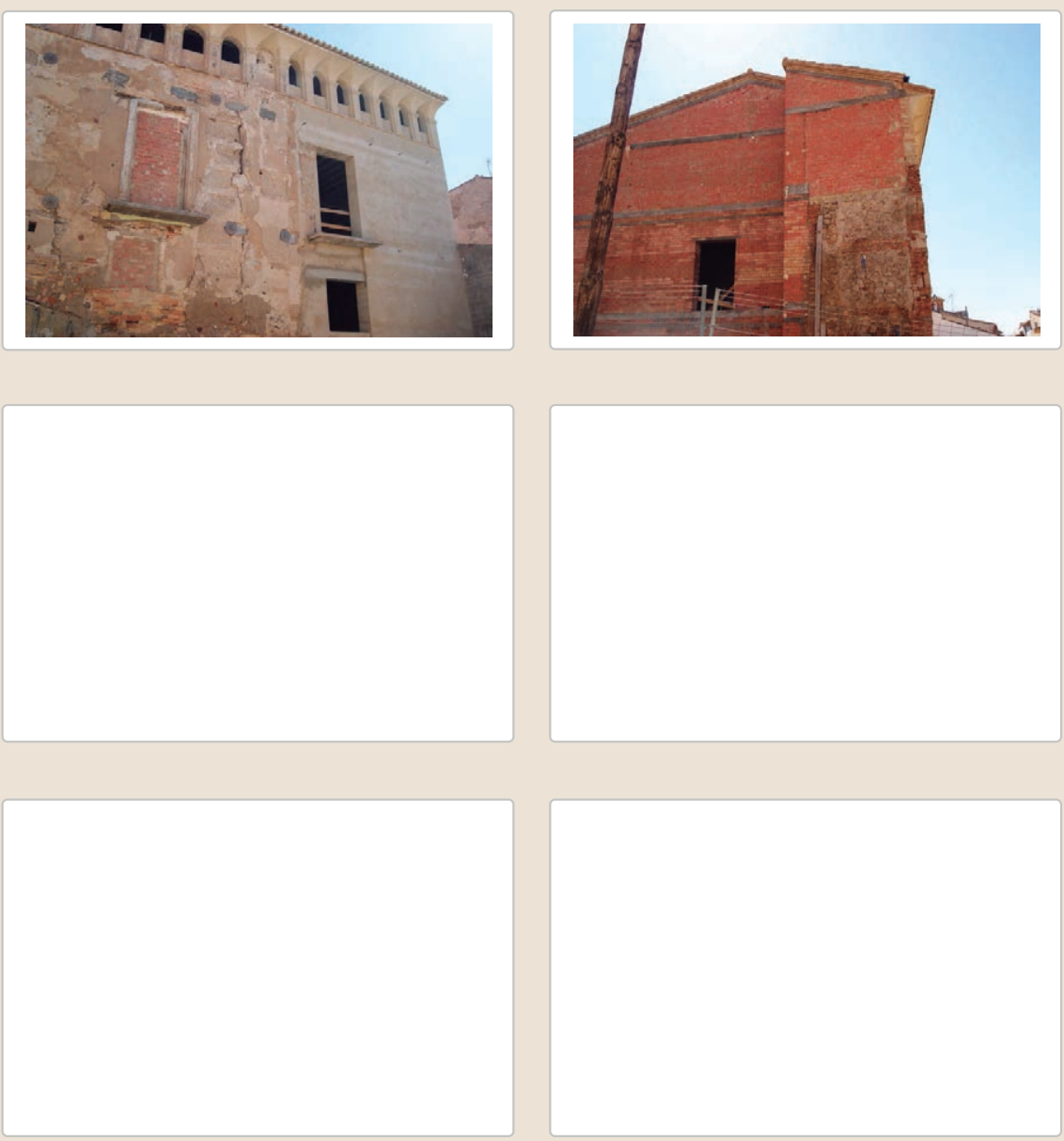

3.6. OTRAS 
La restauración y rehabilitación de la arquitectura tradicional de tierra. El caso de Aragón.

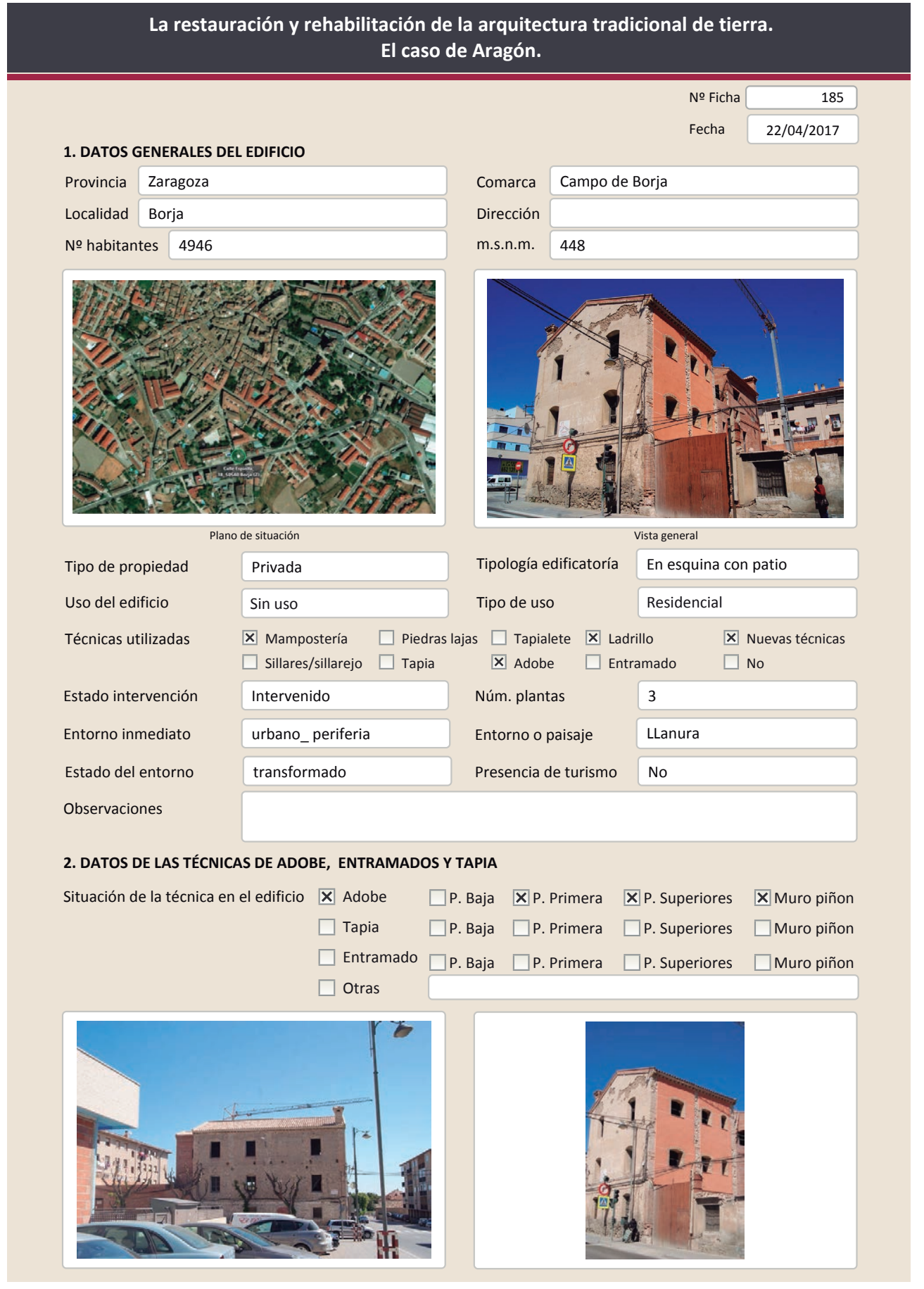

La restauración y rehabilitación de la arquitectura tradicional de tierra. El caso de Aragón.

\subsection{ADOBE}

Dimensión de las piezas

Dimensión del muro

Aparejo del muro

Función estructural

Variante constru

\section{$\square$ Simple}

Х Suplementada en juntas

X Mixta

$\square$ Como suplemento

Х Elementos de protección Machones de piedra y de ladrillo

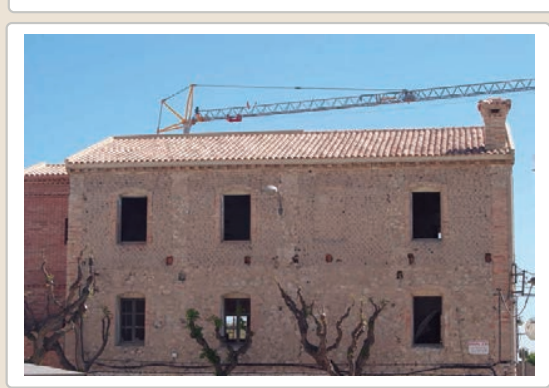

Lesiones $\square$ Muro $\square$ Zócalo $\square$ Revestimiento $\square$ Erosión del material $\square$ Humedad por capilaridad $\square$ Erosion de las juntas $\square$ Humedades (manch/eflo) $\square$ Pérdida de sección $\square$ Pérdida de verticalidad $\square$ Vegetación $\quad \square$ Grietas por empuje de la cubierta $\begin{array}{ll}\square \text { Vescotación } & \square \text { Grietas por empuje de la } \\ \square \text { Grietas porfalta de traba }\end{array}$
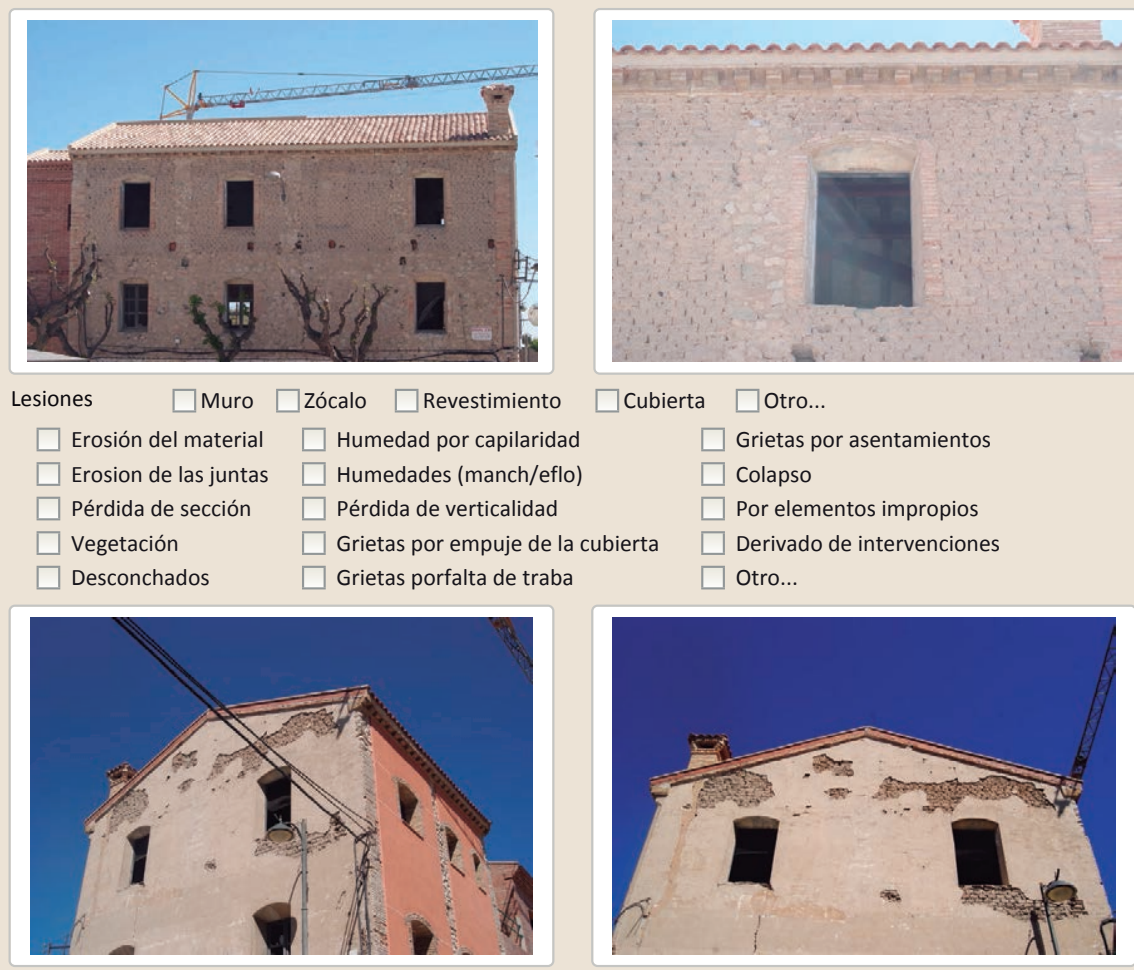

$\square$ Cubierta $\square$ Otro...

$\square$ Grietas por asentamiento $\square$ Colapso

$\square$ Por elementos impropios

$\square$ Derivado de intervenciones $\square$ Otro...

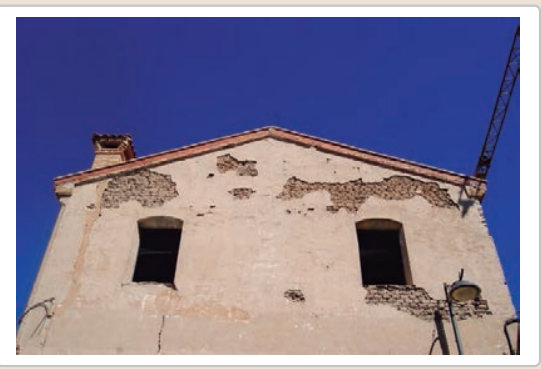

Observaciones 


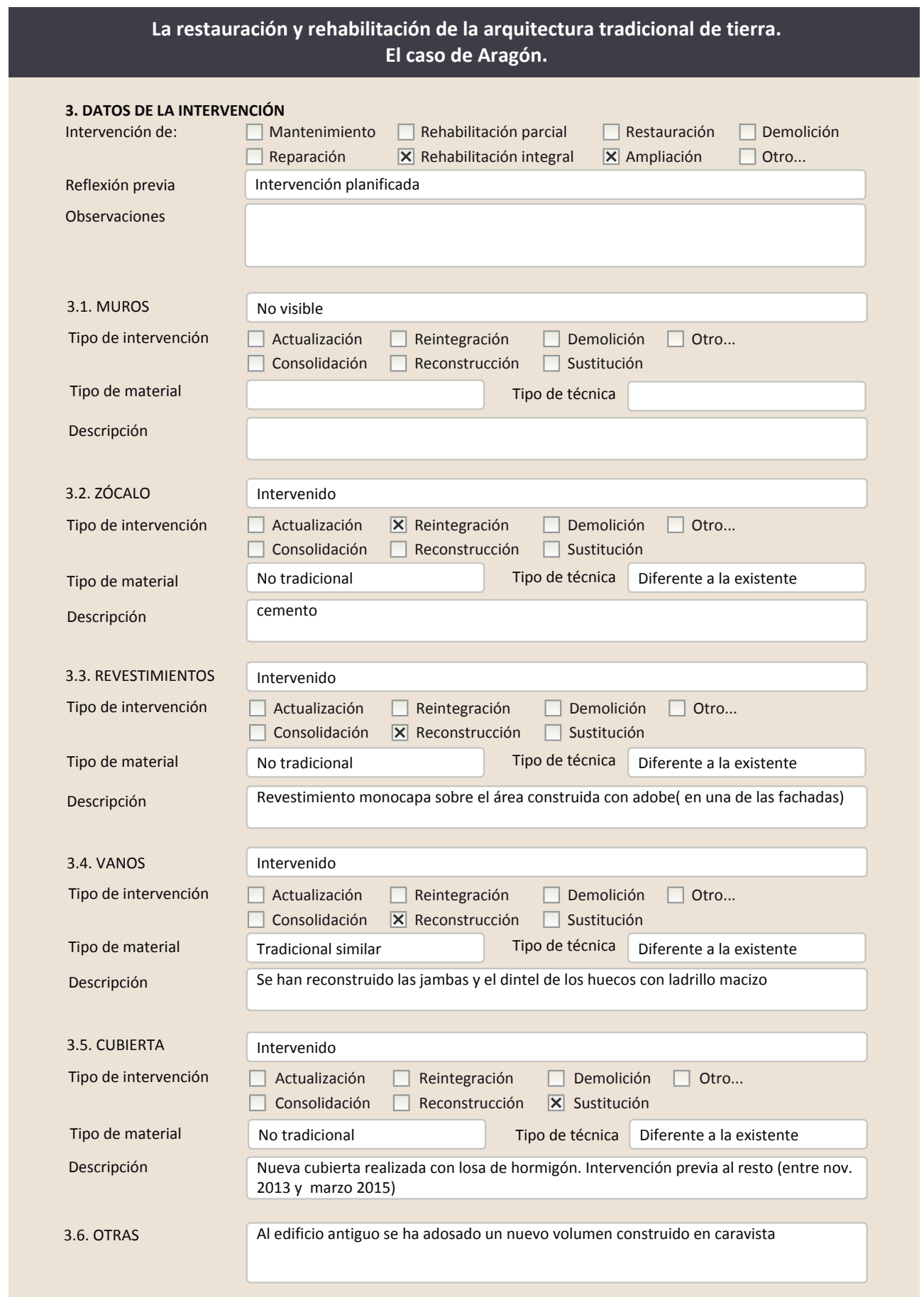

3.7. REHABILITACIÓN ENERGÉTICA \ Fachada $\square$ Vanos $\square$ Forjados $\boldsymbol{X}$ Cubierta Observaciones

FOTOGRAFÍAS DE LA INTERVENCIÓN
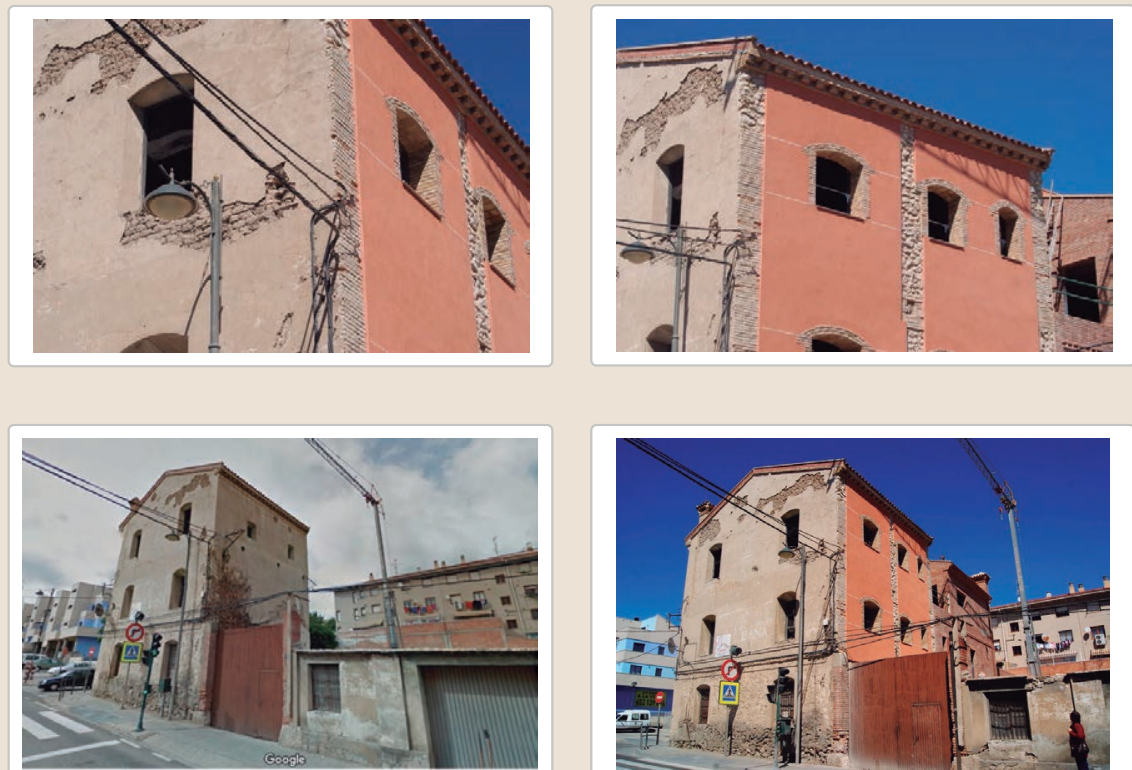

Google. Septiembre 2015

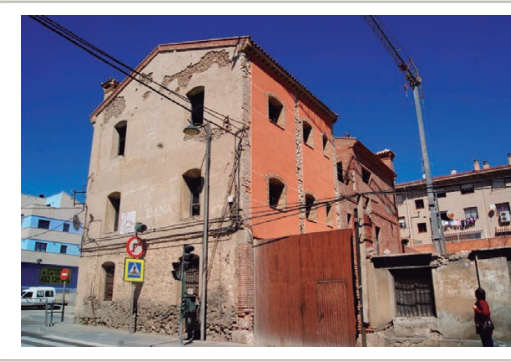

bril 2017
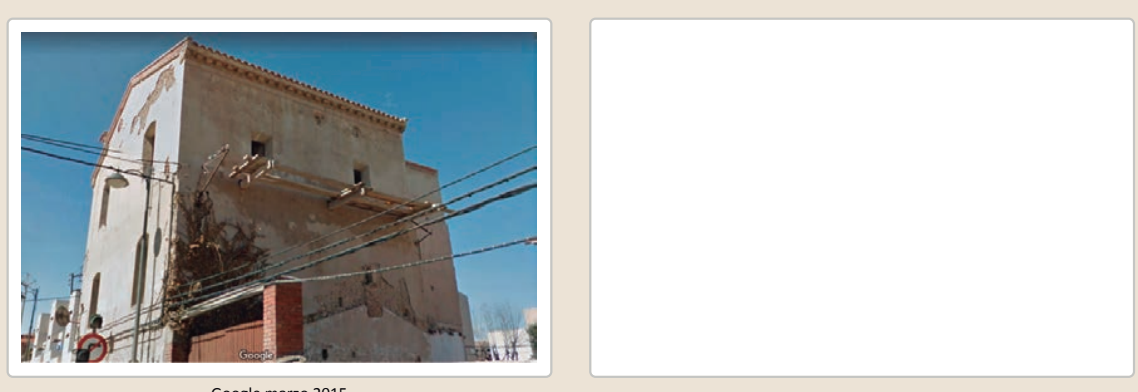


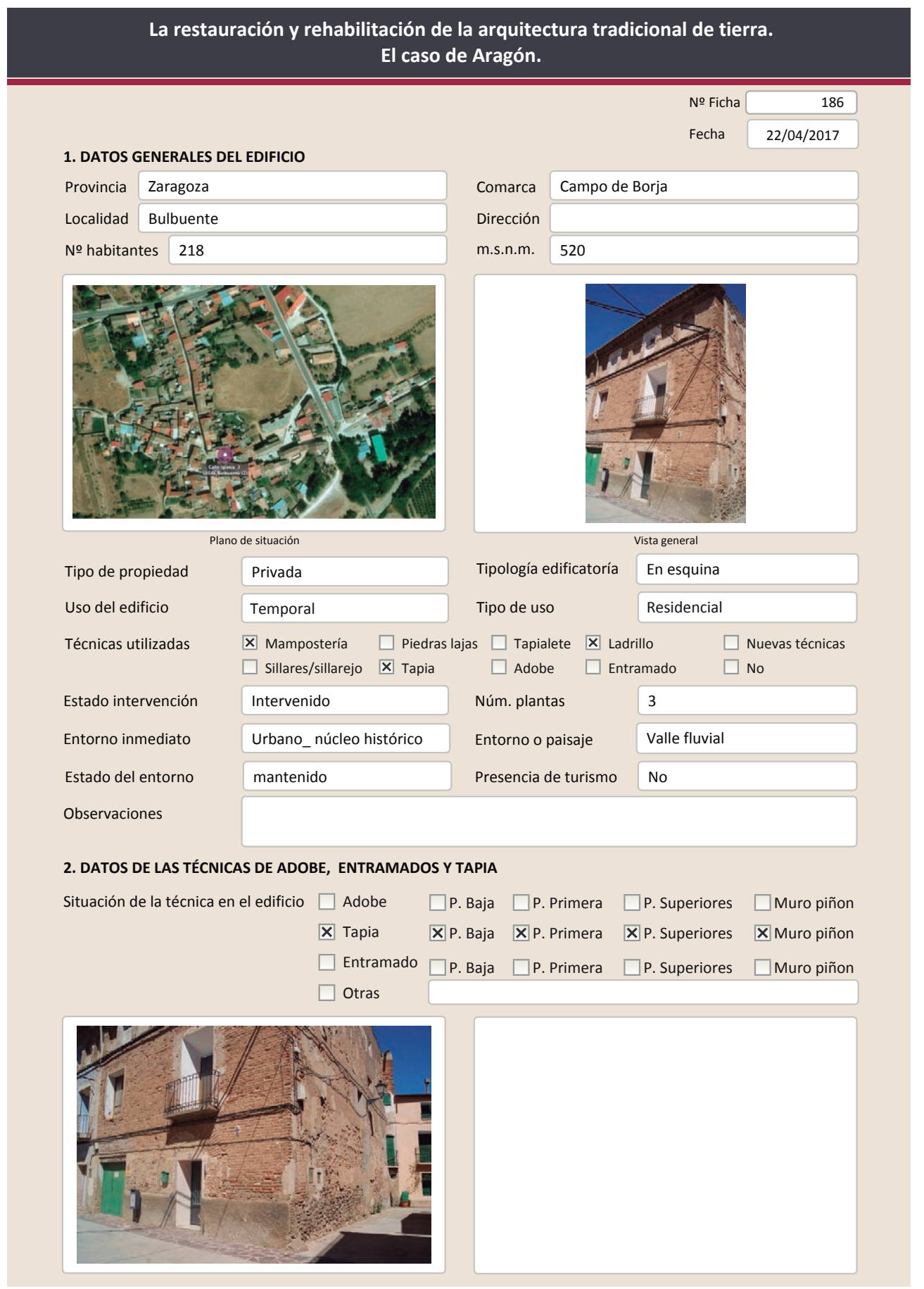

La restauración y rehabilitación de la arquitectura tradicional de tierra. El caso de Aragón.
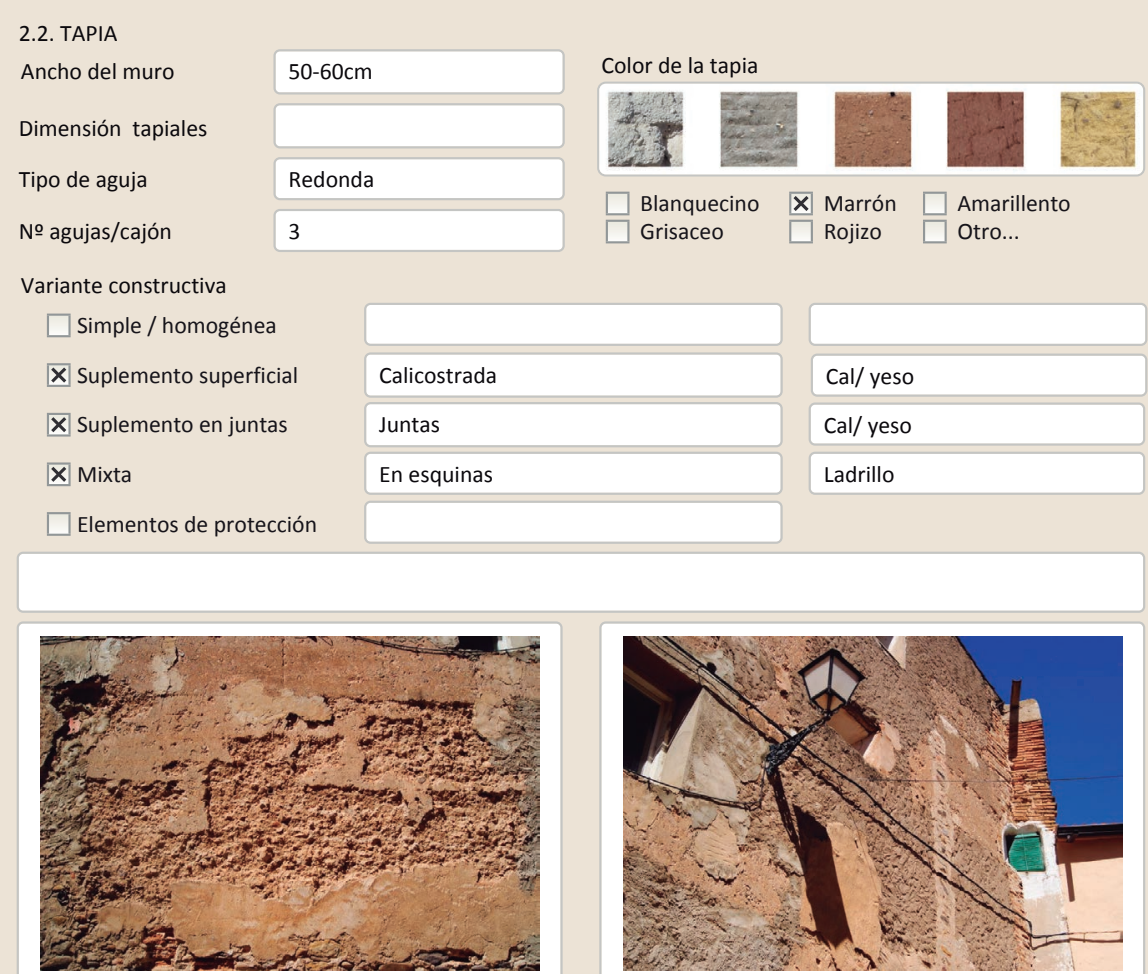

Lesiones ХMuro ХZŹcalo Х Revestimiento $\square$ Cubierta $\square$ Otro...

\ Erosión del material $\quad$ \ Humedad por capilaridad $\quad \square$ Grietas por asentamientos $\square$ Erosion de las juntas $\square$ Humedades (manch/eflo) X Pérdida de sección $\square$ Pérdida de verticalidad

$\square$ Vegetación

$\square$ Grietas por erticalidad

X Desconchados

$\square$ Grietas porfalta de traba

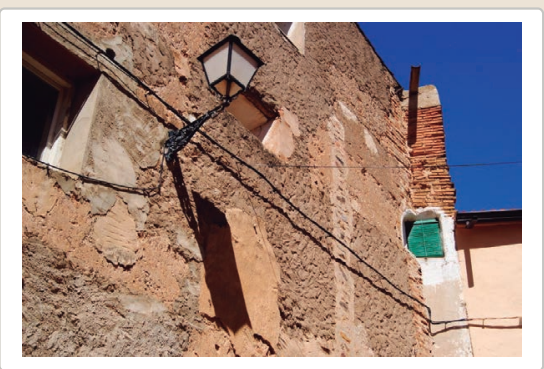

$\square$ Grietas por
$\square$ Colapso

$\square$ Por elementos impropios

$\square$ Derivado de intervenciones

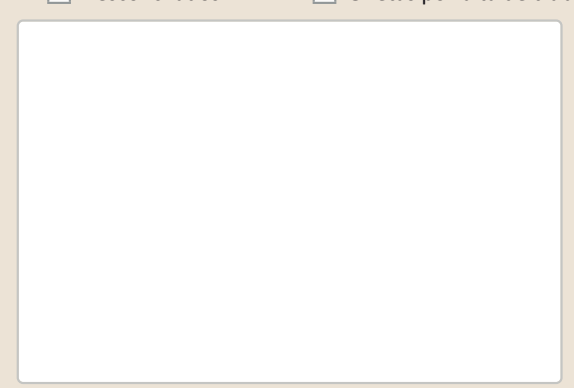

Observaciones 


\section{La restauración y rehabilitación de la arquitectura tradicional de tierra.}

\section{El caso de Aragón.}

3. DATOS DE LA INTERVENCIÓN

Intervención de:

$\square$ Mantenimiento $\square$ Rehabilitación parcia

$\square$ Restauración $\square$ Demolición

Reflexión previa

X Reparación

Rehabilitación integra

Ampliación

$\square$ Otro..

Observaciones

Intervención espontanea

3.1. MUROS

Tipo de intervención

Intervenido

Tipo de intervención

$\square$ Actualización $\quad$ Reintegración $\square$ Demolición $\square$ Otro...

$\square$ Consolidación $\square$ Reconstrucción $\square$ Sustitución

Descripción

No tradicional Tipo de técnica Diferente a la existente

3.2. ZóCALO

Tipo de intervención

Reintegraciones con cemento en la tapia

Tipo de material

Intervenido

X Actualización $\square$ Reintegración $\square$ Demolición $\square$ Otro...

$\square$ Consolidación $\quad \mathbf{X}$ Reconstrucción $\square$ Sustitución

Descripción

No tradicional Tipo de técnica Diferente a la existente

Zócalo de gotelé de cemento

3.3. REVESTIMIENTOS

\section{Intervenido}

Tipo de intervención

$\square$ Actualización $\square$ Reintegración $\square$ Demolición $\square$ Otro...

$\square$ Consolidación $\quad \mathbf{X}$ Reconstrucción $\square$ Sustitución

Tipo de material

Descripción

\subsection{VANOS}

Tipo de intervención

Nuevo revestimiento en algunas áreas donde se ha perdido la costra de la tapia

Tipo de material

Intervenido

Descripción

$\square$ Actualización $\quad \mathbf{X}$ Reintegración $\square$ Demolición $\square$ Otro...

$\square$ Consolidación $\square$ Reconstrucción $\quad$ Sustitución

3.5. CUBIERTA

Tipo de intervención

No tradicional

Tipo de técnica Diferente a la existente

Sustitución de las carpintería. Adaptación de los antiguos huecos a nuevas dimensiones

y proporciones

Intervenido

Tipo de material

$\square$ Actualización $\quad$ X Reintegración $\quad \square$ Demolición $\square$ Otro..

$\square$ Consolidación $\quad \square$ Reconstrucción $\square$ Sustitución

Descripción

No tradicional Tipo de técnica Similar a la existente

3.6. OTRAS 


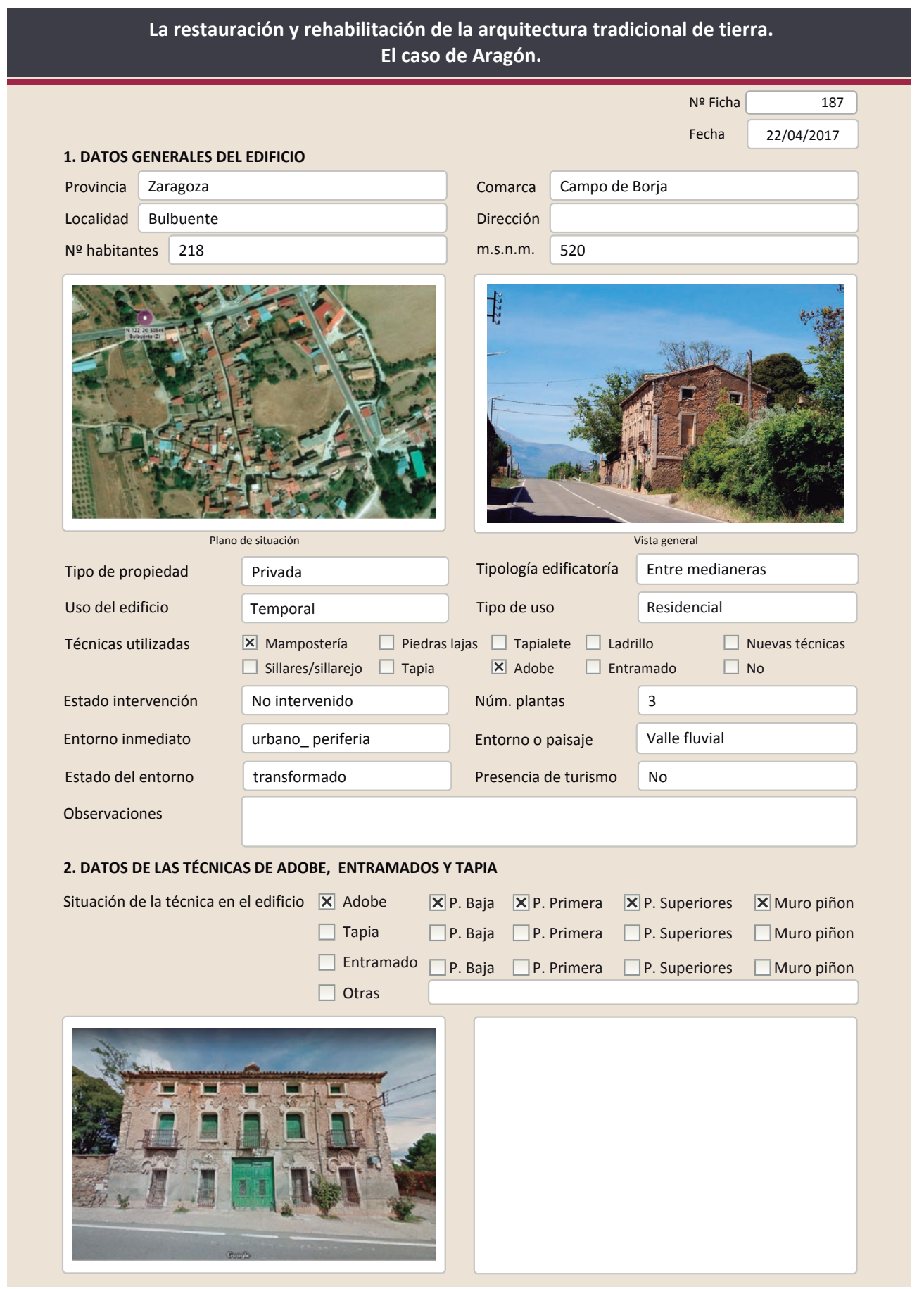

La restauración y rehabilitación de la arquitectura tradicional de tierra.

El caso de Aragón.

2.1. ADOBE

Dimensión de las piezas

Dimensión del muro

Aparejo del muro

Función estructural

iva/ tipo de fábrica

$\square$ Simple

$\square$ Suplementada en juntas

X Mixta

\section{Machones}

Color de las piezas

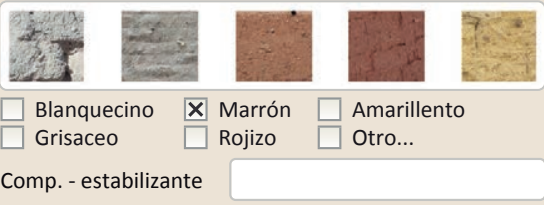

Comp. - estabilizante

$\square$ Como suplemento

$\mathbf{X}$ Elementos de protección

Revestimiento y elementos decorativos

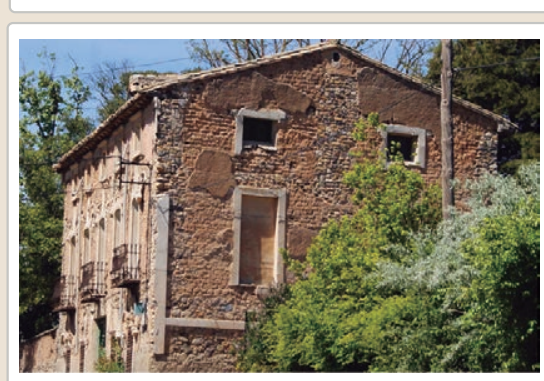

Lesiones $\quad \mathbf{X}$ Muro $\square$ Zócalo $\mathbf{X}$ Revestimiento $\square$ Cubierta $\square$ Otro...

区 Erosión del material $\square$ Humedad por capilaridad $\quad \square$ Grietas por asentamientos

$\square$ Erosion de las juntas $\square$ Humedades (manch/eflo) $\quad \square$ Colapso

$\square$ Pérdida de sección $\square$ Pérdida de verticalidad

$\square$ Vegetación $\quad \square$ Grietas por empuje de la cubie

$\square$ Por elementos impropios

$\mathbf{X}$ Desconchados

$\square$ Grietas porfalta de traba

Observaciones 


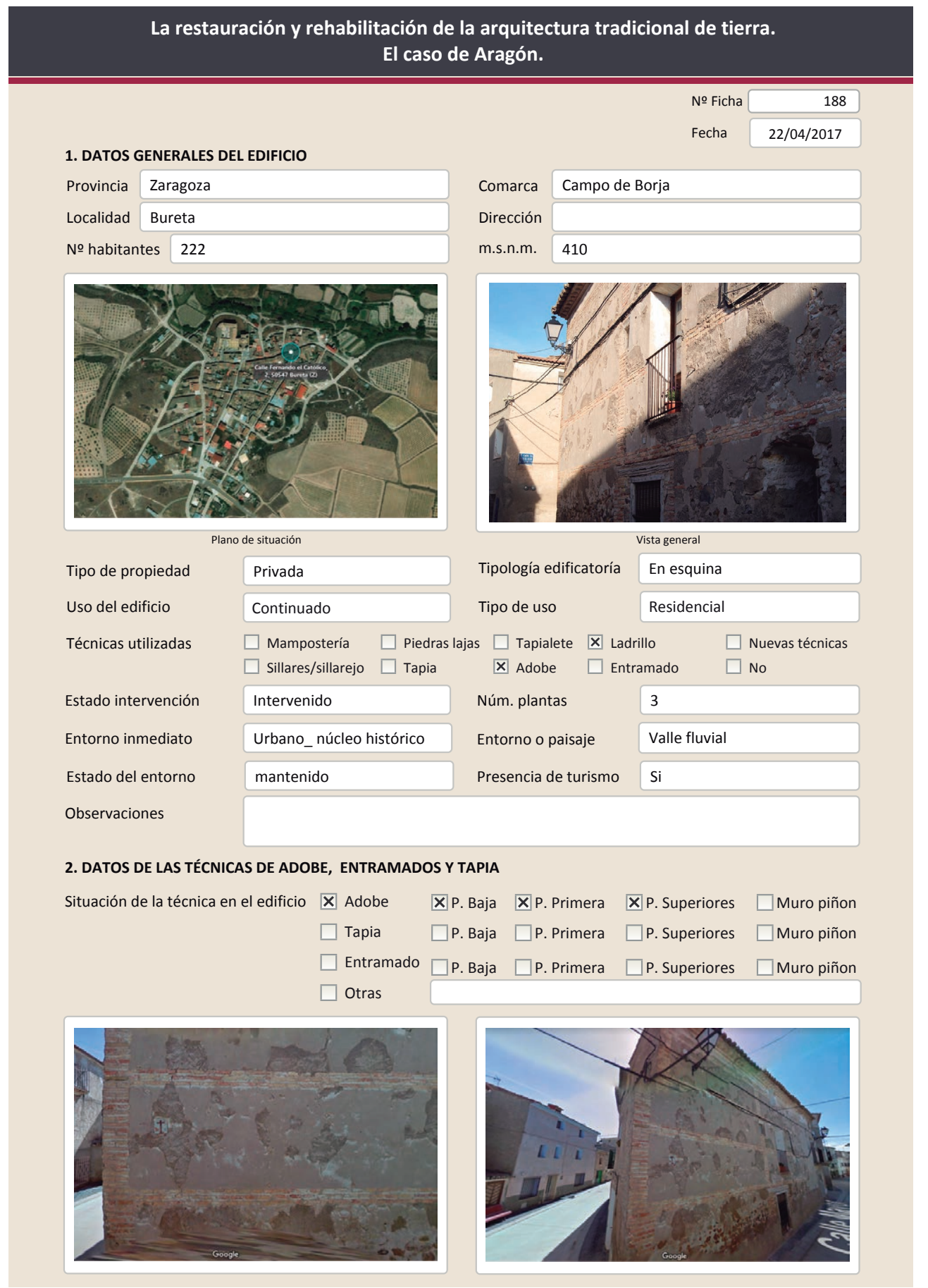

2.1. ADOBE

Dimensión de las piezas

Dimensión del muro

Aparejo del muro

Función estructural

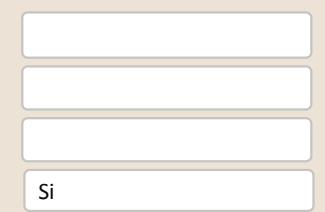

Color de las piezas

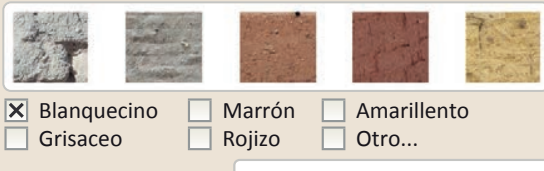

Rojizo Otro.

Comp. - estabilizante

Variante constructiva/ tipo de fábrica

$\square$ simple

$\square$ suplementada en juntas

区 Mixta

$\square$ Como suplemento

$\square$ Elementos de protección

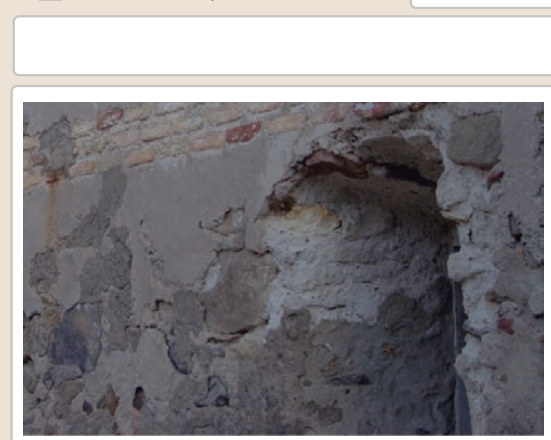

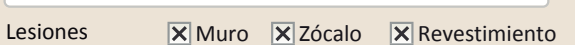

$\mathbf{X}$ Erosión del material $\quad \mathbf{X}$ Humedad por capilaridad

$\square$ Erosion de las juntas $\mathbf{X}$ Humedades (manch/eflo)

\ Pérdida de sección $\square$ Pérdida de verticalidad

$\square$ Vegetación

$\square$ Grietas por empuje de la cubir

X Desconchados

$\square$ Grietas porfalta de traba

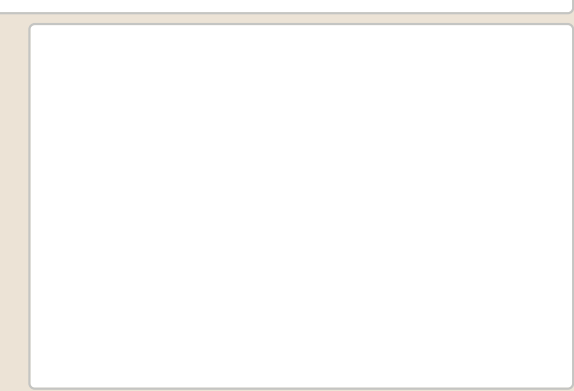

$\square$ Cubierta $\square$ otro...

$\square$ Grietas por asentamiento

$\square$ Colapso

$\square$ Por elementos impropios

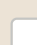

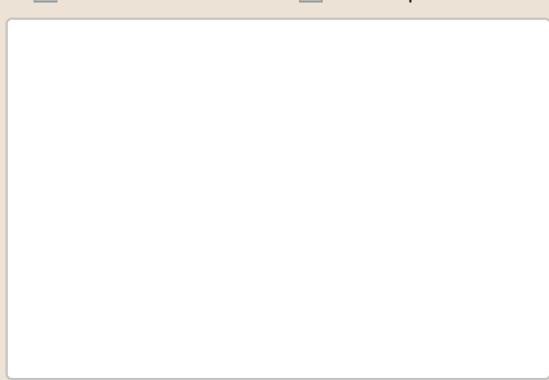

$\square$ Derivado de intervenciones $\square$ Otro...

Observaciones 


\section{La restauración y rehabilitación de la arquitectura tradicional de tierra.}

\section{El caso de Aragón.}

3. DATOS DE LA INTERVENCIÓN

Intervención de:

$\square$ Mantenimiento $\square$ Rehabilitación parcial $\square$ Restauración $\square$ Demolición \ Reparación $\square$ Rehabilitación integral $\square$ Ampliación $\square$ Otro...

Reflexión previa Intervención espontanea $\begin{array}{ll}\text { Observaciones } & \begin{array}{l}\text { Diferentes reparaciones separadas en el tiempo que consisten principalmente en } \\ \text { parcheados con cemento }\end{array}\end{array}$

\begin{tabular}{|c|c|c|c|c|}
\hline 3.1. MUROS & Intervenido & & & \\
\hline Tipo de intervención & $\begin{array}{l}\square \text { Actualización } \\
\square \text { Consolidación }\end{array}$ & \multicolumn{3}{|c|}{$\begin{array}{ll}\boldsymbol{x} \text { Reintegración } & \square \text { Demolición } \quad \square \text { Otro... } \\
\square \text { Reconstrucción } & \square \text { Sustitución }\end{array}$} \\
\hline Tipo de material & \multicolumn{2}{|l|}{ No tradicional } & ripo de técnica & Diferente a la existente \\
\hline Descripción & \multicolumn{4}{|c|}{ oquedades con mortero de cemento } \\
\hline 3.2. ZÓCALO & \multicolumn{4}{|l|}{ Intervenido } \\
\hline Tipo de intervención & $\begin{array}{l}\square \text { Actualización } \\
\square \text { Consolidación }\end{array}$ & $\begin{array}{l}\square \text { Reintegración } \\
\boldsymbol{X} \text { Reconstrucción }\end{array}$ & $\begin{array}{l}\square \text { Demolición } \\
\square \text { Sustitución }\end{array}$ & in $\square$ Otro... \\
\hline Tipo de material & \multicolumn{2}{|l|}{ No tradicional } & Tipo de técnica & Diferente a la existente \\
\hline Descripción & \multicolumn{4}{|c|}{ mortero de cemento } \\
\hline 3.3. REVESTIMIENTOS & \multicolumn{4}{|l|}{ Intervenido } \\
\hline Tipo de intervención & $\begin{array}{l}\square \text { Actualización } \\
\square \text { Consolidación }\end{array}$ & $\begin{array}{l}\square \text { Reintegración } \\
\boldsymbol{X} \text { Reconstrucción }\end{array}$ & $\begin{array}{l}\square \text { Demoliciór } \\
\square \text { Sustitución }\end{array}$ & on \\
\hline Tipo de material & \multicolumn{2}{|l|}{ No tradicional } & Tipo de técnica & Diferente a la existente \\
\hline Descripción & \multicolumn{4}{|c|}{ Reconstrucción completa del revestimiento con mortero de cemento } \\
\hline 3.4. VANOS & \multicolumn{4}{|l|}{ No intervenido } \\
\hline Tipo de intervención & $\begin{array}{l}\square \text { Actualización } \\
\square \text { Consolidación }\end{array}$ & $\begin{array}{l}\square \text { Reintegración } \\
\square \text { Reconstrucción }\end{array}$ & $\begin{array}{l}\square \text { Demolición } \\
\square \text { Sustitución }\end{array}$ & n $\square$ Otro... \\
\hline Tipo de material & \multicolumn{4}{|c|}{ Tipo de técnica } \\
\hline \multicolumn{5}{|l|}{ Descripción } \\
\hline 3.5. CUBIERTA & \multicolumn{4}{|l|}{ No visible } \\
\hline Tipo de intervención & $\begin{array}{l}\square \text { Actualización } \\
\square \text { Consolidación }\end{array}$ & $\begin{array}{l}\square \text { Reintegración } \\
\square \text { Reconstrucción }\end{array}$ & $\begin{array}{l}\square \text { Demolició } \\
\text { n } \square \text { Sustitució }\end{array}$ & ón $\square$ Otro... \\
\hline Tipo de material & \multicolumn{4}{|c|}{ Tipo de técnica } \\
\hline Des & & & & \\
\hline
\end{tabular}

3.6. OTRAS 


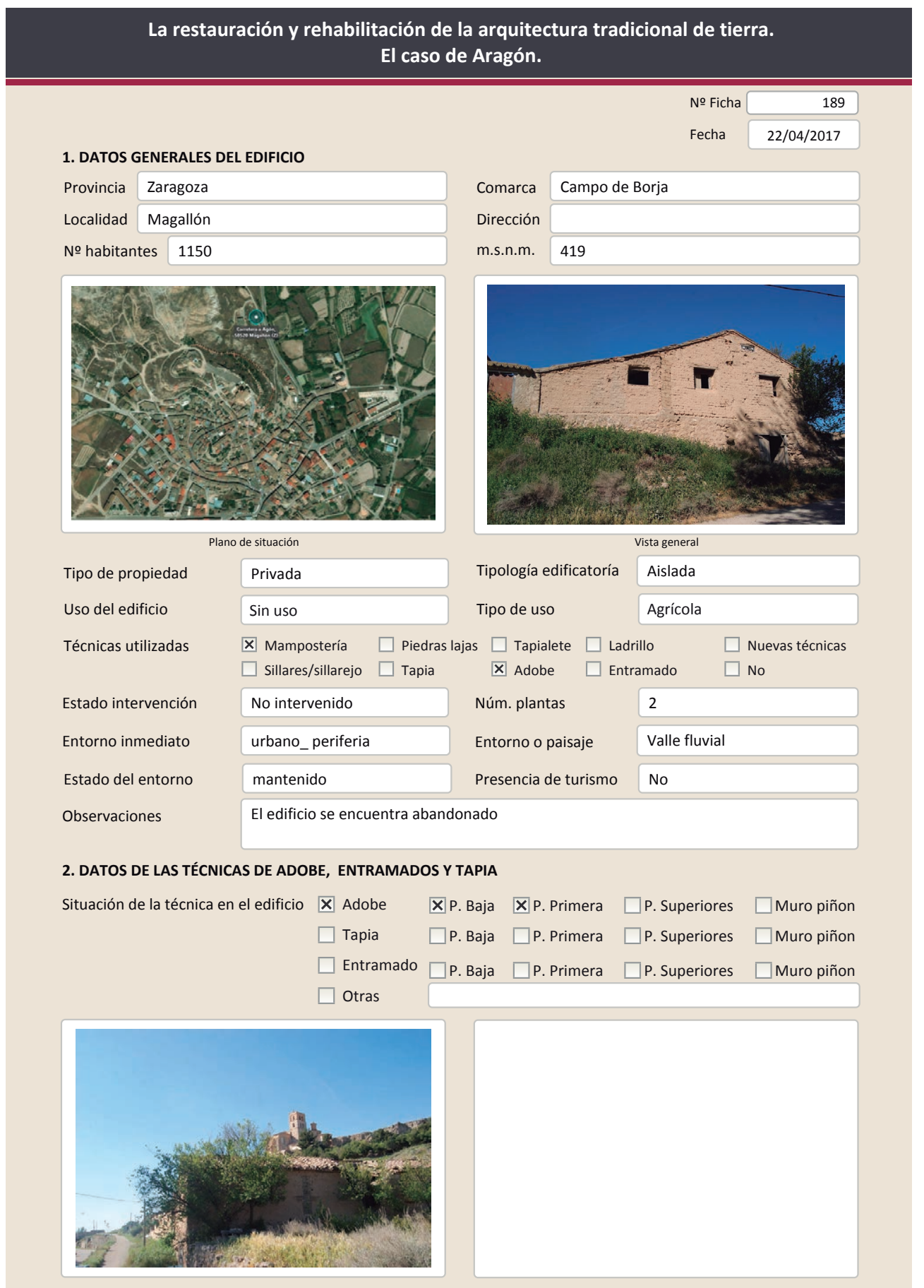

2.1. ADOBE

Dimensión de las piezas

Dimensión del muro

Aparejo del muro

Función estructural

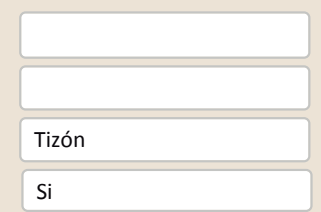

Color de las piezas

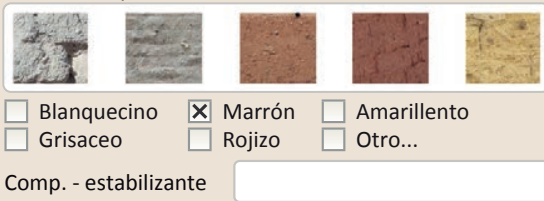

Variante constructiva/ tipo de fábrica

$\square$ Simple

$\square$ Suplementada en juntas

区 Mixta

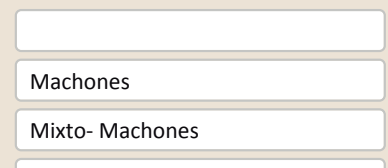

Adobe

$\mathbf{X}$ Como suplemento

$\square$ Elementos de protección

Dos tipos de adobe, el que conforma el muro y el que conforma los machones (bloque de tierra con conglomerante)

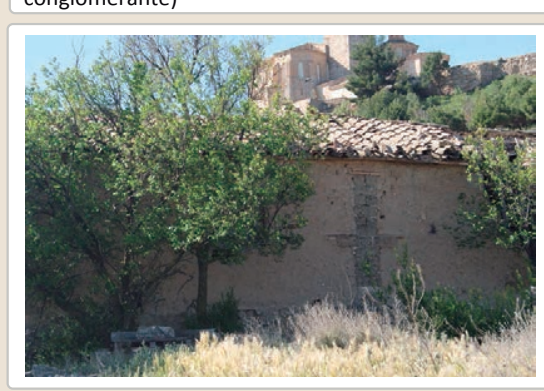

Lesiones $\quad$ Muro $\square$ Zócalo $\square$ Revestimiento

X Erosión del material $\square$ Humedad por capilaridad $\mathbf{X}$ Erosion de las juntas $\square$ Humedades (manch/eflo)

$\square$ Pérdida de sección $\quad \square$ Pérdida de verticalidad

$\square$ Vegetación $\quad \square$ Grietas por empuje de la cub

$\square$ Desconchado

$\square$ Grietas porfalta de traba

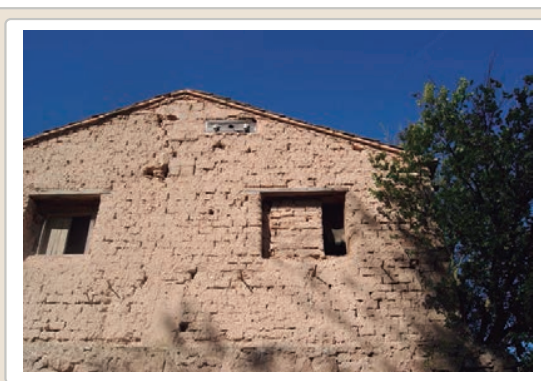

X Cubierta $\square$ Otro...

$\square$ Grietas por asentamiento $x$ Colapso

$\square$ Por elementos impropios

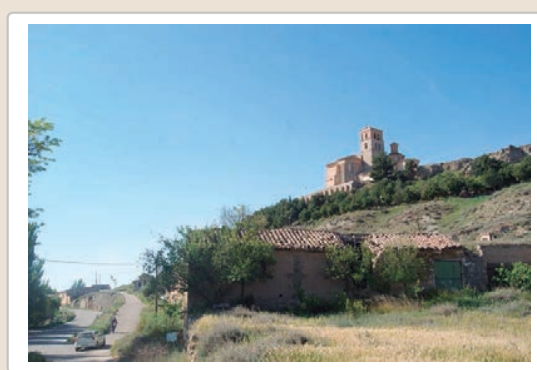

$\square$ Derivado

Observaciones 


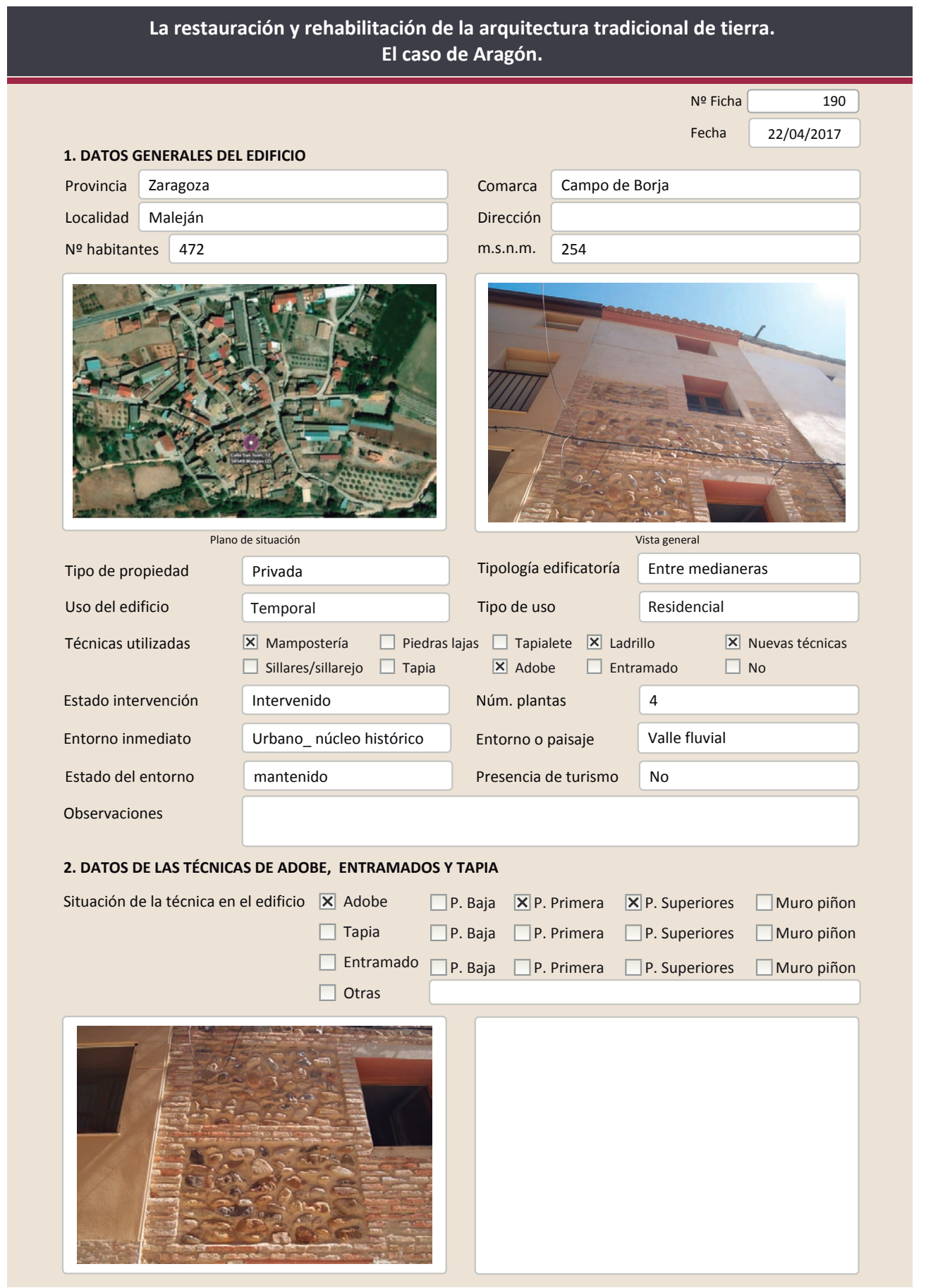

La restauración y rehabilitación de la arquitectura tradicional de tierra.

El caso de Aragón.

2.1. ADOBE

Dimensión de las piezas

Dimensión del muro

Aparejo del muro

Función estructural
Color de las piezas

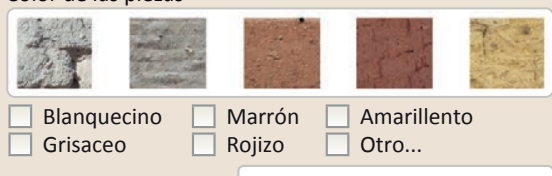

$\square$ Ro

Variante constructiva/ tipo de fábrica

$\square$ simple

$\square$ Suplementada en juntas

X Mixta

\section{Ladrillo}

$\square$ Como suplemento

$\mathbf{X}$ Elementos de protección

Piedra

No se aprecian los adobes pero esta variante se ha observado en otros ejemplos de la zona. Se realiza el encajonado de los adobes y luego se revisten con cantos rodados

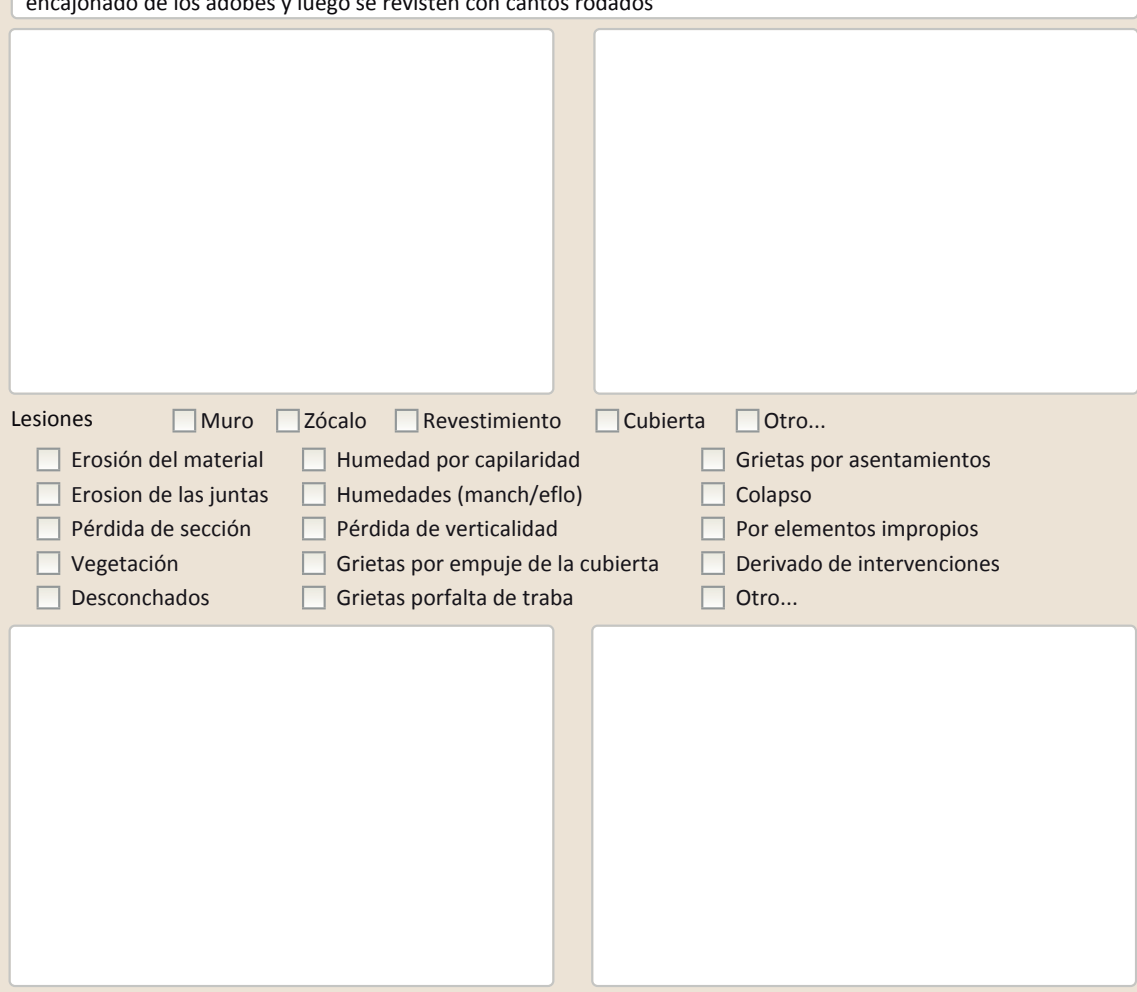

Observaciones 


\section{La restauración y rehabilitación de la arquitectura tradicional de tierra.}

\section{El caso de Aragón.}

3. DATOS DE LA INTERVENCIÓN

$\square$ Mantenimien

(a)

$\square$ Reparació

$\square$ Rehabilitación parcial

$\square$ Restauración

$\square$ Demolición

Intervención planificada

Observaciones

Interion planicada

3.1. MUROS
Tipo de intervención

Intervenido

Tipo de material

$\square$ Actualización $\quad \mathbf{X}$ Reintegración $\square$ Demolición $\square$ Otro...

$\square$ Consolidación $\quad \mathbf{X}$ Reconstrucción $\square$ Sustitución

Descripción

No tradicional

Tipo de técnica Similar a la existente

3.2. ZÓCALO

Tipo de intervención recrecido del edificio ( edificio de al lado visible)
redio

Tipo de material

Intervenido

$\square$ Actualización $\quad \mathbf{X}$ Reintegración $\quad \square$ Demolición $\square$ Otro...

$\square$ Consolidación $\square$ Reconstrucción $\square$ Sustitución

Descripción

3.3. REVESTIMIENTOS

Tipo de intervención

No tradicional

$$
\text { Tipo de técnica Diferente a la existente }
$$

\section{Intervenido}

$\square$ Actualización $\square$ Reintegración $\quad \square$ Demolición $\square$ Otro...

$\square$ Consolidación $\quad \mathbf{X}$ Reconstrucción $\square$ sustitución

Tipo de material

Descripción

3.4. VANOS

Tipo de intervención

No tradicional

Tipo de técnica Diferente a la existente

Aplicación de revestimiento en la zona superior del edificio (recrecido)

Tipo de material

Intervenido

Descripción

A Actualzación $\square$ Reintegración $\square$ Demolición $\square$ Otro...

$\square$ Consolidación $\square$ Reconstrucción $\quad$ X Sustitución

3.5. CUBIERTA

Tipo de intervención

No tradicional

Tipo de técnica Diferente a la existente

Sustitución de dintel y de carpintería

Intervenido

$\square$ Actualización $\square$ Reintegración $\square$ Demolición $\square$ Otro..

$\square$ Consolidación $\square$ Reconstrucción $\mathbf{x}$ Sustitución

Tipo de material

No tradicional

Tipo de técnica Diferente a la existente

Descripción

Nueva cubierta. Tejas nuevas. Parece estar conformada con una losa de hormigón
La restauración y rehabilitación de la arquitectura tradicional de tierra.

El caso de Aragón.

3.7. REHABILITACIÓN ENERGÉTICA $\square$ Fachada $\quad$ V Vanos $\square$ Forjados $\quad$ C Cubierta

Observaciones

FOTOGRAFíAS DE LA INTERVENCIÓN
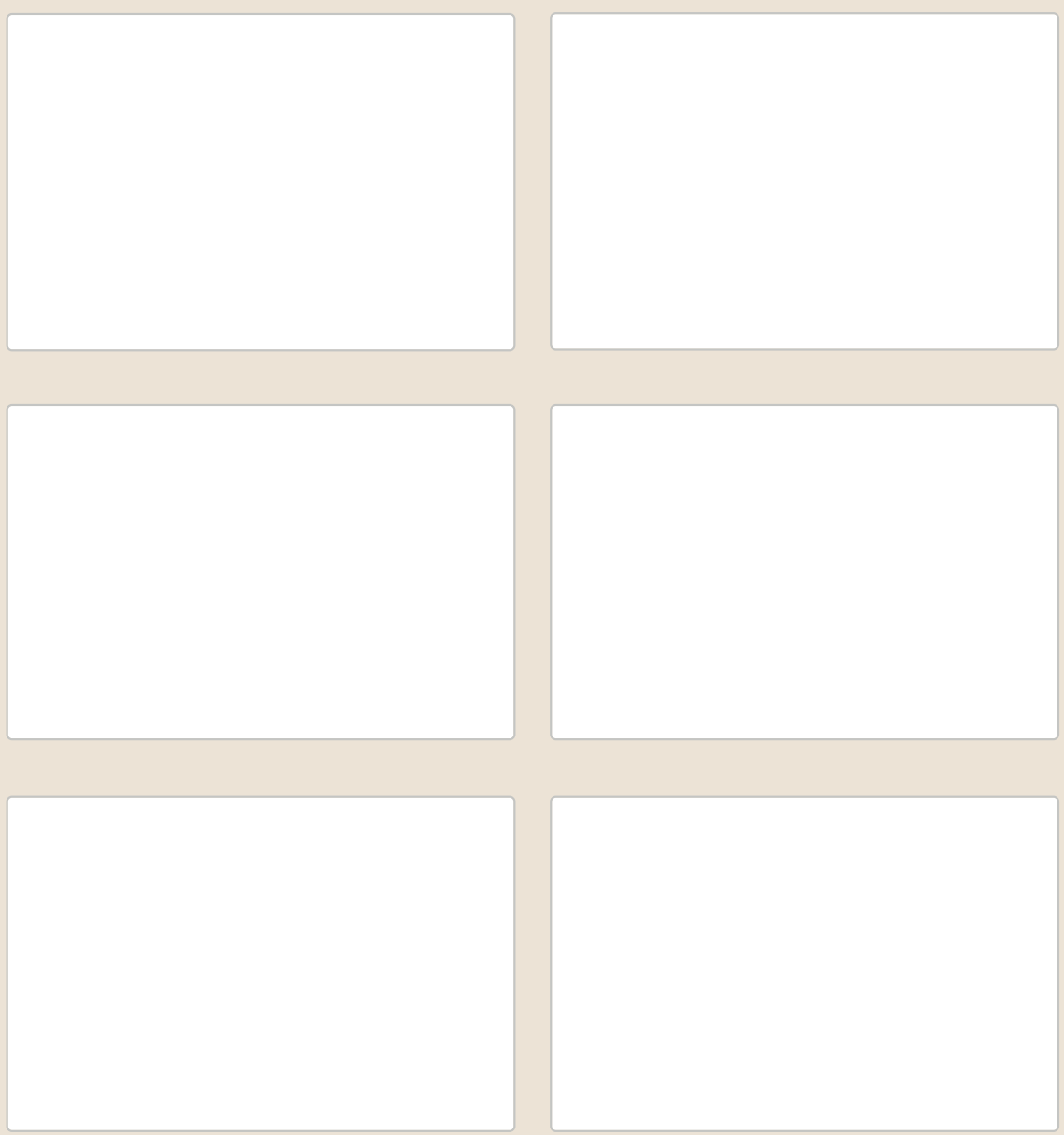

3.6. OTRAS 


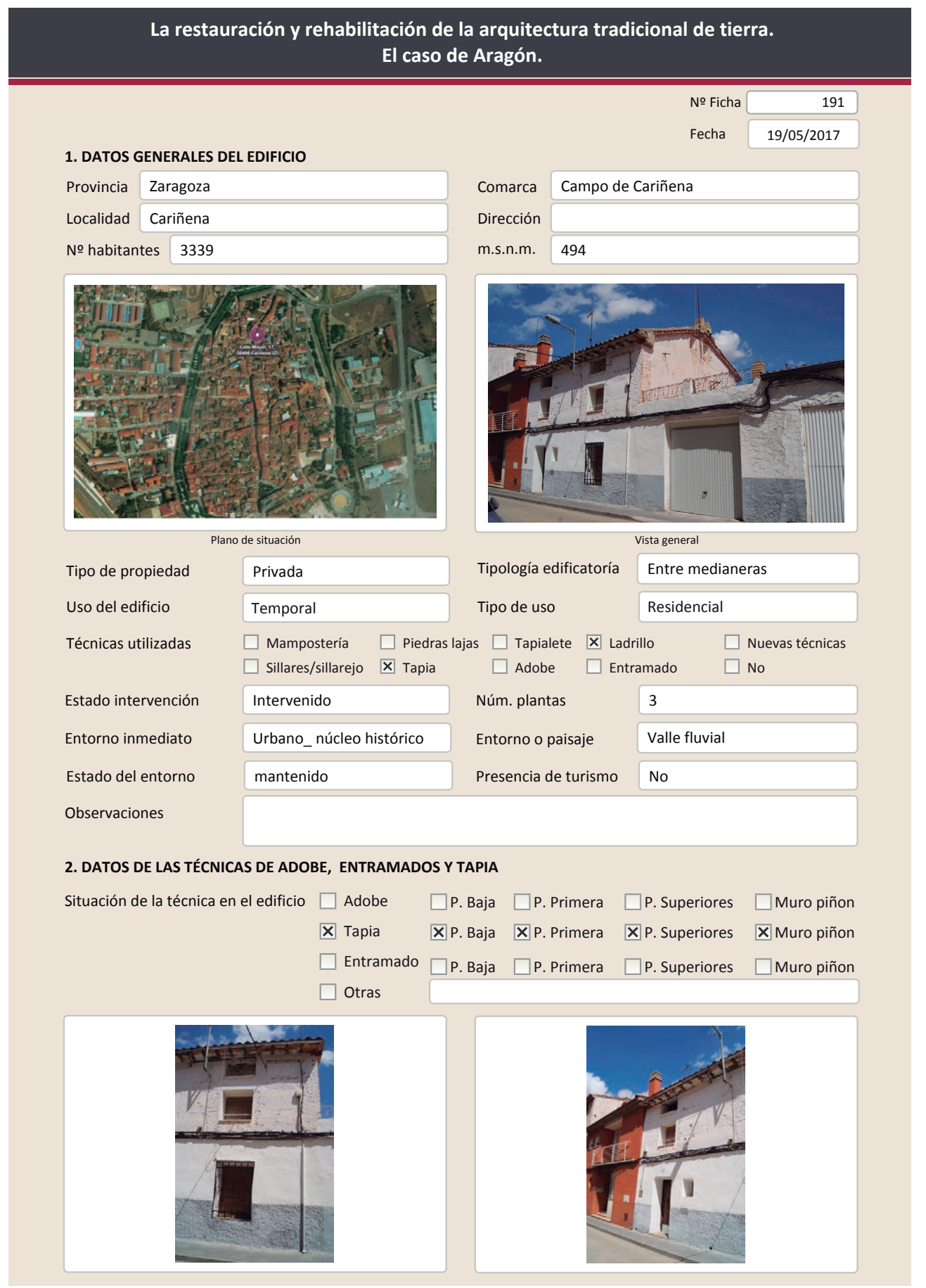

La restauración y rehabilitación de la arquitectura tradicional de tierra. El caso de Aragón.
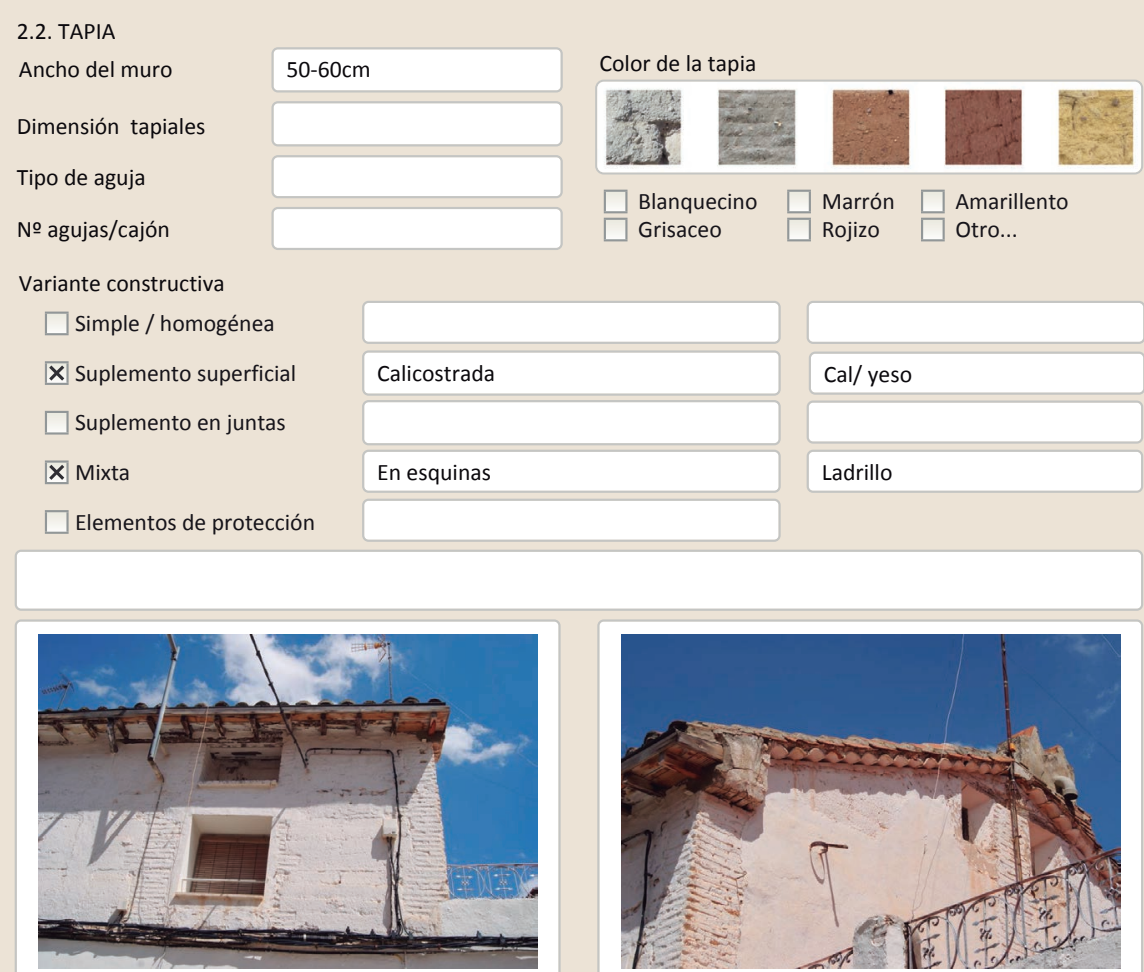

Lesiones $\square$ Muro $\square$ Zócalo $\square$ Revestimiento $\square$ Cubierta $\square$ otro...

$\square$ Erosión del material $\quad \square$ Humedad por capilaridad $\quad \square$ Grietas por asentamientos $\square$ Erosion de las juntas $\square$ Humedades (manch/eflo) $\square$ Colapso $\square$ Pérdida de sección $\quad \square$ Pérdida de verticalidad

$\square$ Vegetación

$\square$ Por elementos impropios

$\square$ Desconchados $\quad \square$ Grietas porfalta de traba

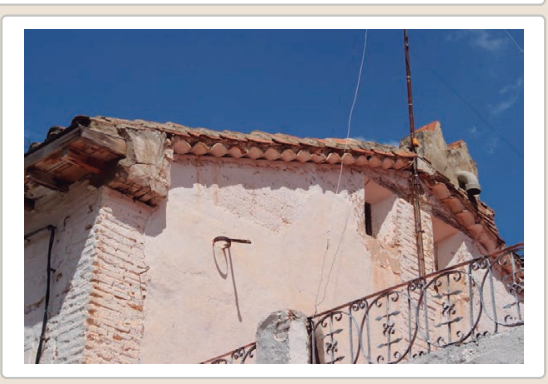

$\square$ Derivado

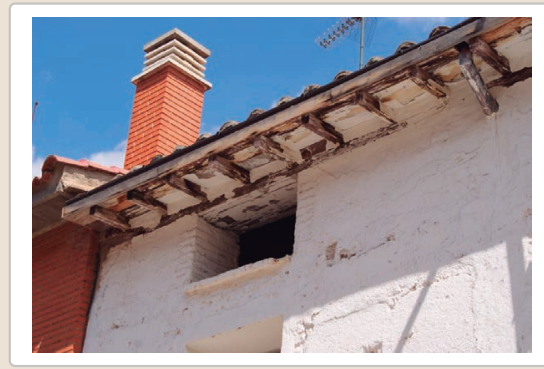

Observaciones 
La restauración y rehabilitación de la arquitectura tradicional de tierra. El caso de Aragón

\section{La restauración y rehabilitación de la arquitectura tradicional de tierra.}

\section{El caso de Aragón.}

3. DATOS DE LA INTERVENCIÓN

\begin{tabular}{llll} 
Intervención de: & $\square$ Mantenimiento $\quad \boldsymbol{X}$ Rehabilitación parcial & $\square$ Restauración & $\square$ Demolición \\
& $\square$ Reparación $\quad \square$ Rehabilitación integral & $\square$ Ampliación $\quad \square$ Otro... \\
\hline Reflexión previa & Intervención planificada & \\
Observaciones & &
\end{tabular}

3.1. MUROS

No intervenido

Tipo de intervención

$\square$ Actualización $\square$ Reintegración $\square$ Demolición $\square$ Otro...

$\square$ Consolidación $\square$ Reconstrucción $\square$ sustitución

Tipo de material

Descripción

3.2. ZÓCALO

Tipo de intervención

Intervenido

Tipo de intervención

Reión $\square$ Reintegración $\square$ Demolición $\square$ Otro.

Tipo de material

No tradicional Tipo de técnica Diferente a la existente

Tipo de técnica

Descripción

3.3. REVESTIMIENTOS

\section{Intervenido}

Tipo de intervención

X Actualización $\square$ Reintegración $\quad \square$ Demolición $\quad \square$ Otro..

$\square$ Consolidación $\quad \mathbf{X}$ Reconstrucción $\square$ Sustitución

Tipo de material

Descripción

3.4. VANOS

Tipo de intervención

$\square$ Actualización $\square$ Reintegración $\square$ Demolición $\square$ Otro...

Tipo de material

Descripción

$$
\text { Tipo de técnica }
$$

3.5. CUBIERTA

Tipo de intervención $\square$ Actualización $\quad \boldsymbol{X}$ Reintegración $\quad \square$ Demolición $\square$ Otro...

$$
\text { Los vanos del edificio no se han intervenido. En la construcción anexa si que se ha }
$$

sustituido la carpintería del hueco que ya era posterior probablemente.

Tipo de material

$\square$ Actualización $\quad$ Reintegración $\square$ Demolición $\square$ Otro..

$\square$ Consolidación $\quad \mathbf{X}$ Reconstrucción $\square$ Sustitución

Descripción

\begin{tabular}{|l|l|l|l} 
No tradicional Tipo de técnica & Similar a la existente
\end{tabular}

Reintegración de nuevos elementos de madera en el alero. reconstrucción de la cubierta con la técnica tradicional pero utilizando mortero de cemento

3.6. OTRAS 


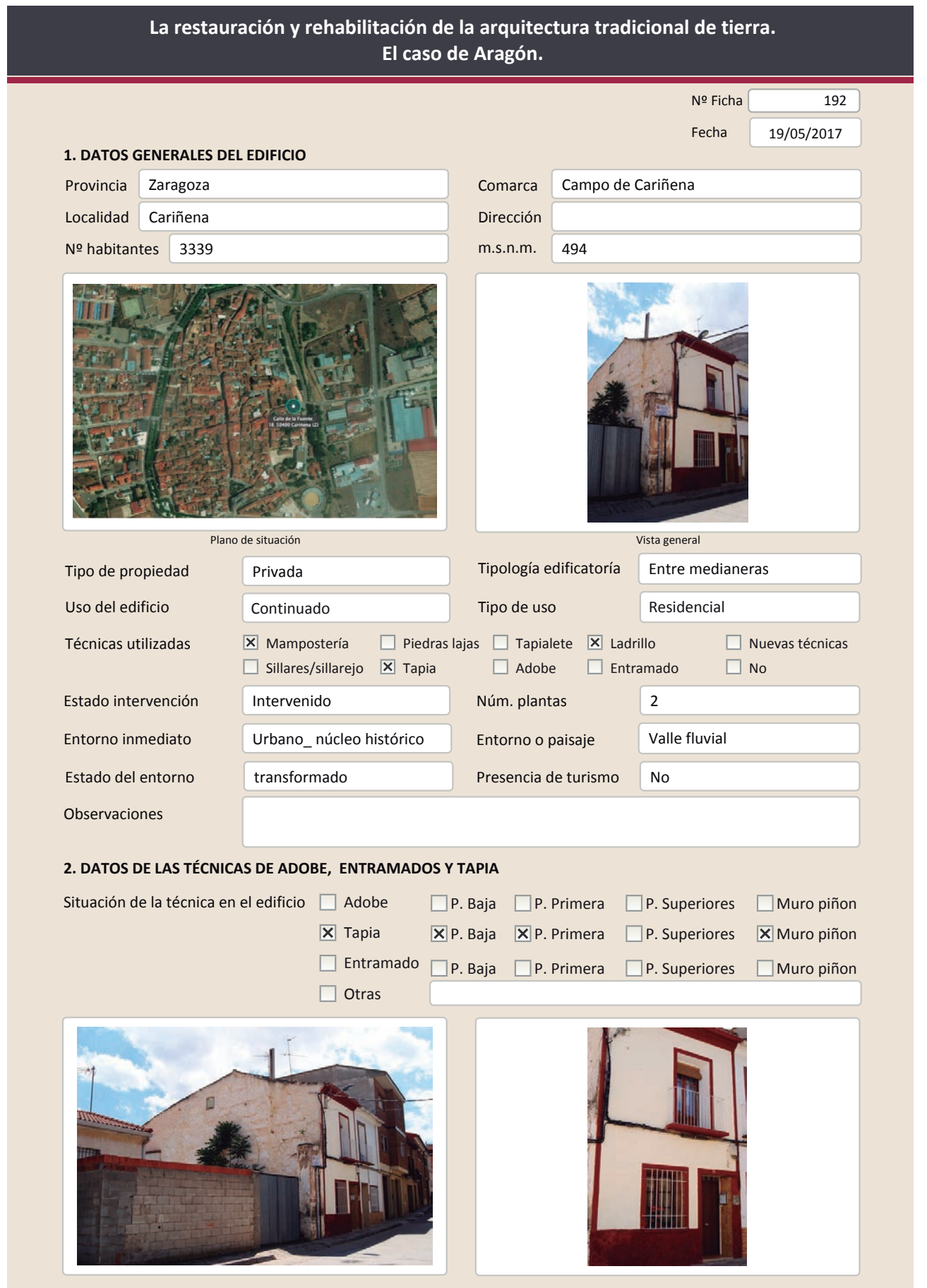

La restauración y rehabilitación de la arquitectura tradicional de tierra. El caso de Aragón.

\subsection{TAPIA \\ Ancho del muro \\ Dimensión tapiales \\ Tipo de aguja \\ № agujas/cajón \\ Variante constructiva
$\square$ Simple / homogénea
$\square$ suplemento superficial
$\square$ suplemento en juntas
X Mixta

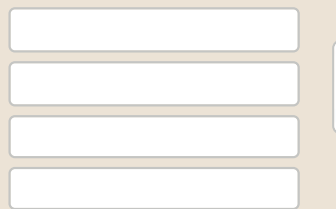

Color de la tapia
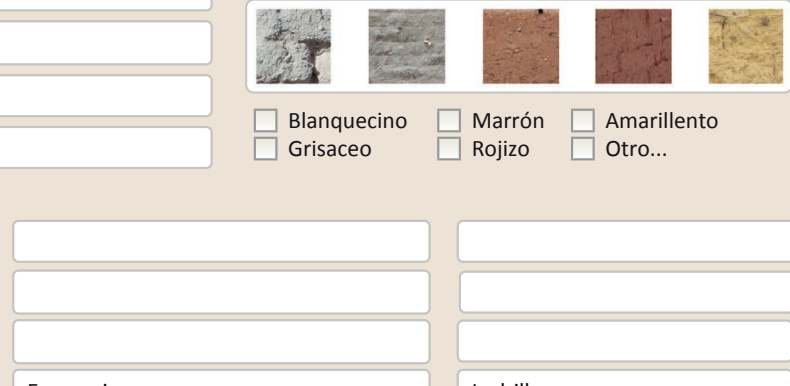

$\square$ Elementos de protección

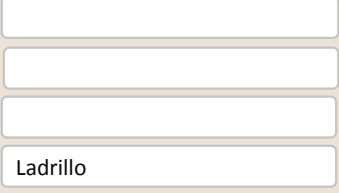

No se aprecia bien pero en el muro saliente de la esquina se aprecian ladrillo y esa es la tipología más común

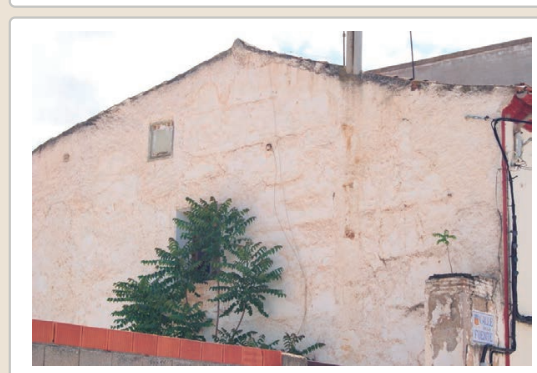

Lesiones $\square$ Muro ХZŹcalo $\square$ Revestimiento $\square$ Cubierta $\square$ otro...

$\square$ Erosión del material $\quad \mathbf{X}$ Humedad por capilaridad $\quad \square$ Grietas por asentamientos $\square$ Erosion de las juntas $\mathbf{X}$ Humedades (manch/eflo)

$\square$ Pérdida de sección $\quad \square$ Pérdida de verticalidad

Vegetación

$\square$ Desconchados

$\square$ Por elementos impropios

$\square$ Derivado de intervenciones
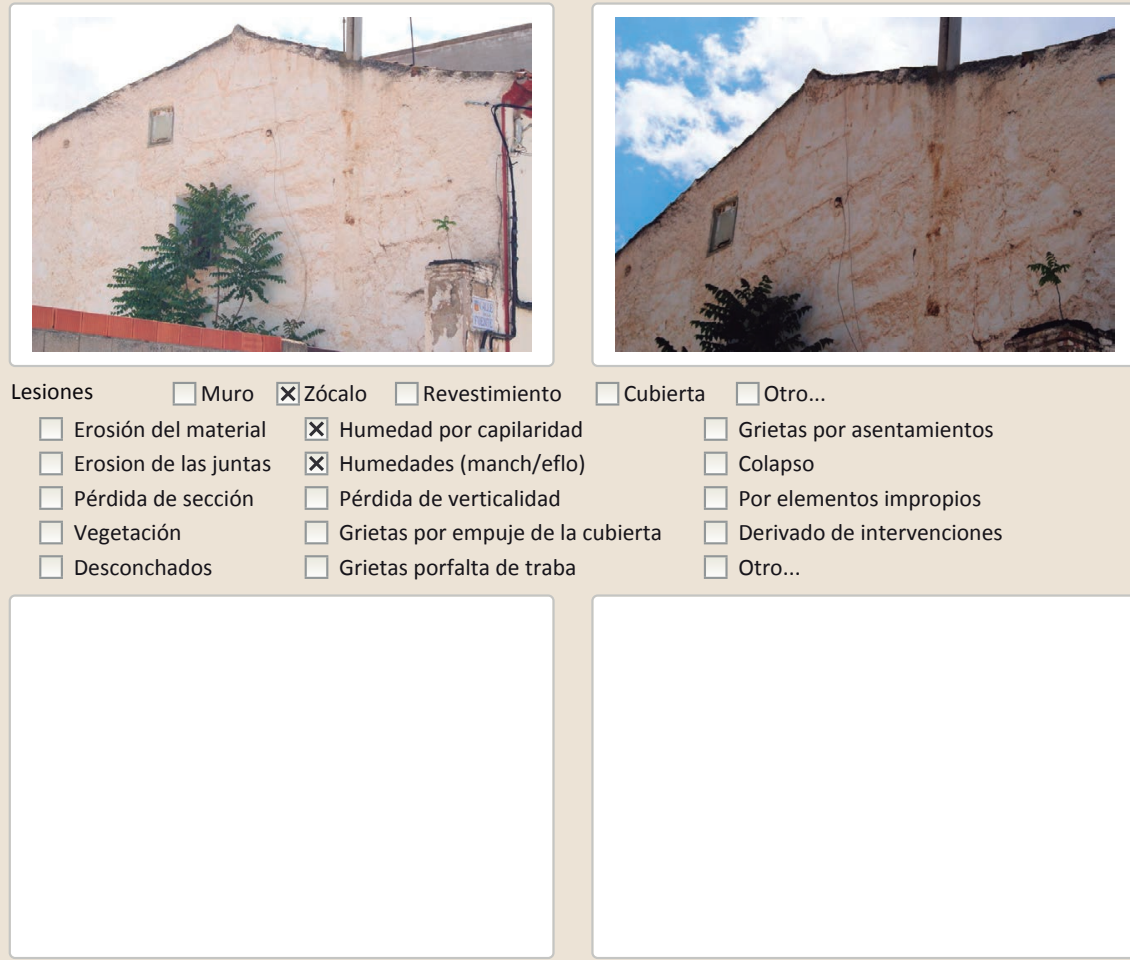

Observaciones 


\section{La restauración y rehabilitación de la arquitectura tradicional de tierra.}

\section{El caso de Aragón.}

3. DATOS DE LA INTERVENCIÓN

\begin{tabular}{llll|} 
Intervención de: & $\square$ Mantenimiento $\quad \boldsymbol{X}$ Rehabilitación parcial & $\square$ Restauración & $\square$ Demolición \\
& $\square$ Reparación $\quad \square$ Rehabilitación integral & $\square$ Ampliación $\quad \square$ Otro... \\
Reflexión previa & Intervención planificada & \\
Observaciones & & \\
& &
\end{tabular}

3.1. MUROS

Intervenido

Tipo de intervención

$\square$ Actualización $\quad \mathbf{X}$ Reintegración $\quad \square$ Demolición $\square$ Otro...

$\square$ Consolidación $\quad \square$ Reconstrucción $\square$ Sustitución

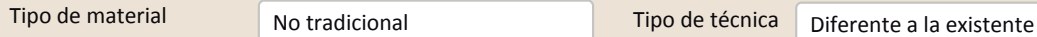

Descripción En el muro piñón se aprecian el relieve de intervenciones puntuales en distintos puntos

3.2. ZÓCALO

Tipo de intervención

Intervenido

Tipo de intervención

Actualización $\square$ Reintegración $\square$ Demolición $\square$ Otro...

$\square$ Consolidación $\quad \mathbf{X}$ Reconstrucción $\square$ Sustitución

Tipo de material

No tradicional Tipo de técnica Diferente a la existente

Descripción

Gotelé de cemento y pintura granate

3.3. REVESTIMIENTOS

Intervenido

Tipo de intervención

X Actualización $\square$ Reintegración $\quad \square$ Demolición $\square$ Otro...

$\square$ Consolidación $\quad \mathbf{X}$ Reconstrucción $\square$ Sustitución

Tipo de material

Tipo de técnica Diferente a la existente

Descripción

Nuevo revestimiento en la fachada principal y pintura blanca en todo el edificio.

Contorno de los huecos enmarcados con pintura granate

3.4. VANOS

Intervenido

Tipo de intervención $\square$ Actualización $\quad \mathbf{X}$ Reintegración $\square$ Demolición $\square$ Otro...

Tipo de material No tradicional Tipo de técnica Diferente a la existente

Descripción Reintegración del contorno de los huecos de plata baja con baldosa cerámica.

Sustitución de la puerta de acceso (las otras carpinterías se conservan)

3.5. CUBIERTA

Intervenido

Tipo de intervención

$\square$ Actualización $\quad \mathbf{X}$ Reintegración $\square$ Demolición $\square$ Otro

$\square$ Consolidación $\quad \mathbf{X}$ Reconstrucción $\square$ Sustitución

\begin{tabular}{l|l|l|l|l|l} 
Tipo de material & No tradicional de técnical Similar a la existente \\
\hline
\end{tabular}

Descripción Reconstrucción de la cubierta con teja curva cogida con cemento. Se ha incorporado una hilada de ladrillos en el canto de la cubierta ¿̇? y un canalón

3.6. OTRAS 


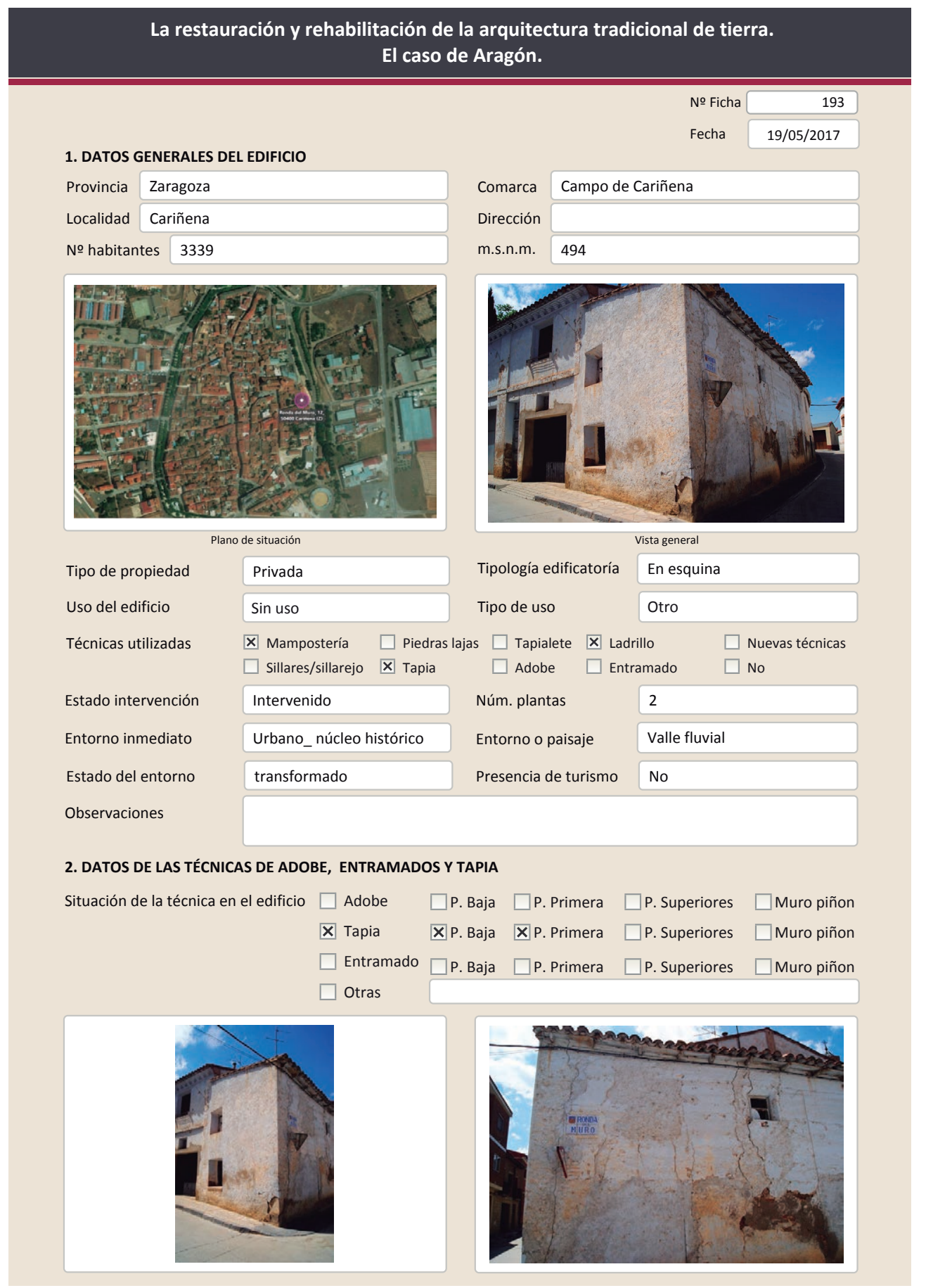

La restauración y rehabilitación de la arquitectura tradicional de tierra. El caso de Aragón.
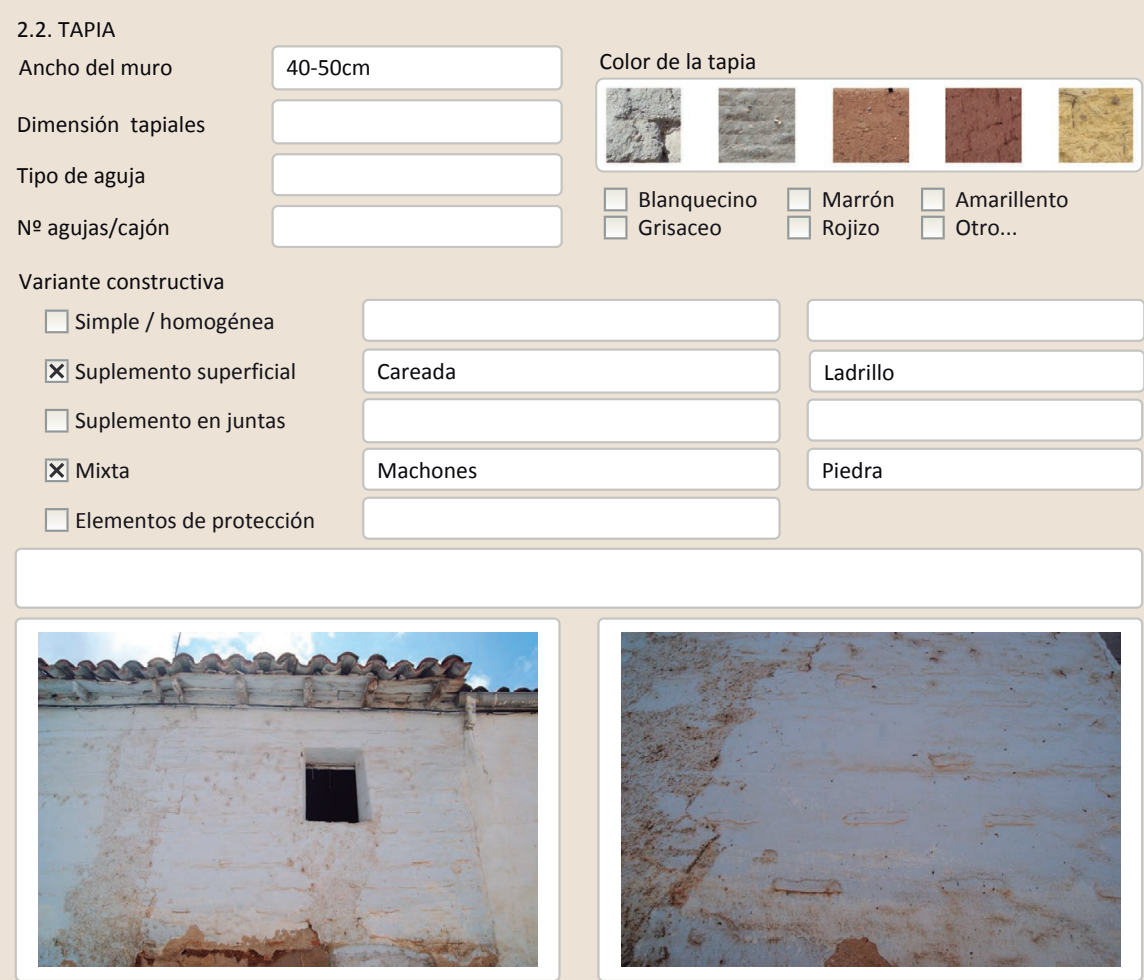

Lesiones $\mathbf{X}$ Muro $\mathbf{X}$ Zócalo $\mathbf{X}$ Revestimiento $\square$ Cubierta $\square$ Otro...

$\mathbb{X}$ Erosión del material $\mathbf{X}$ Humedad por capilaridad $\mathbf{X}$ Grietas por asentamientos $\square$ Erosion de las juntas $\mathbf{X}$ Humedades (manch/eflo) $\quad \square$ Colapso

$X$ Pérdida de sección $\square$ Pérdida de verticalidad

$\square$ Vegetación $\quad \square$ Grietas por empuje de la cubierta

Х Desconchados $\quad \square$ Grietas porfalta de traba

$\square$ Por elementos impropios

X Derivado de intervenciones
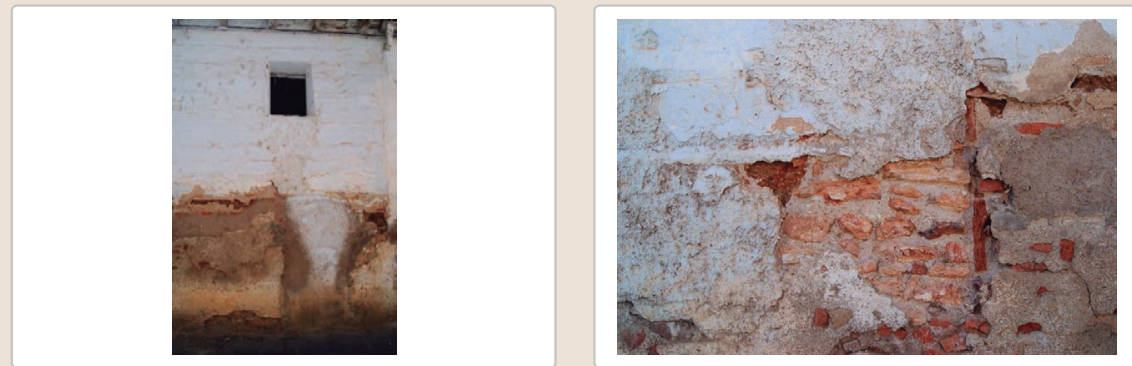

Observaciones

Las reparaciones en el zócalo con cemento están empeorando el estado de esta zona del edificio.

Existen mucha grietas por movimientos o por cargas puntuales de las viguetas en el 


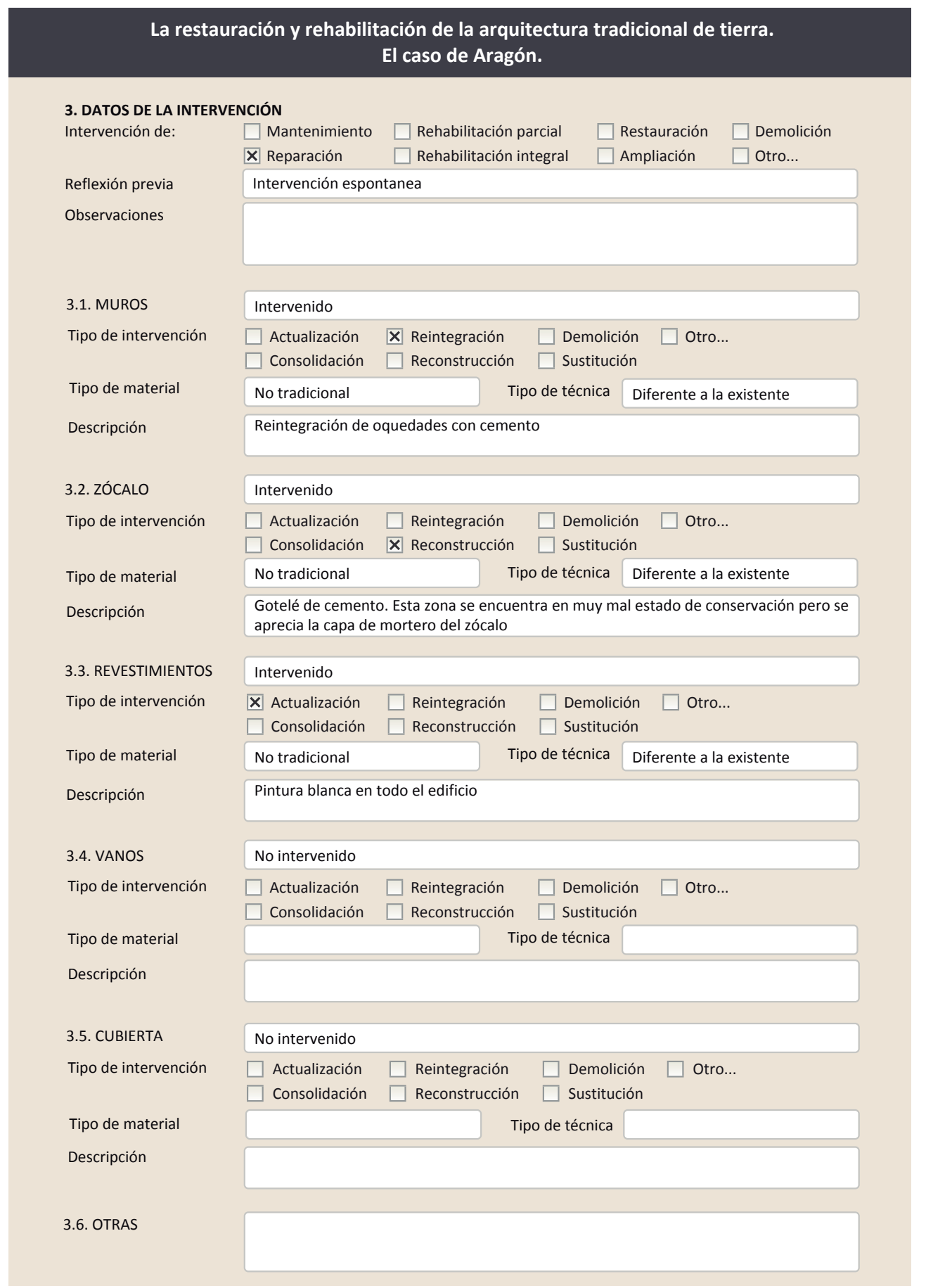

\subsection{REHABILITACIÓN ENERGÉTICA $\quad \square$ Fachada $\square$ Vanos $\square$ Forjados $\square$ Cubierta}

Observaciones

FOTOGRAFÍAS DE LA INTERVENCIÓN
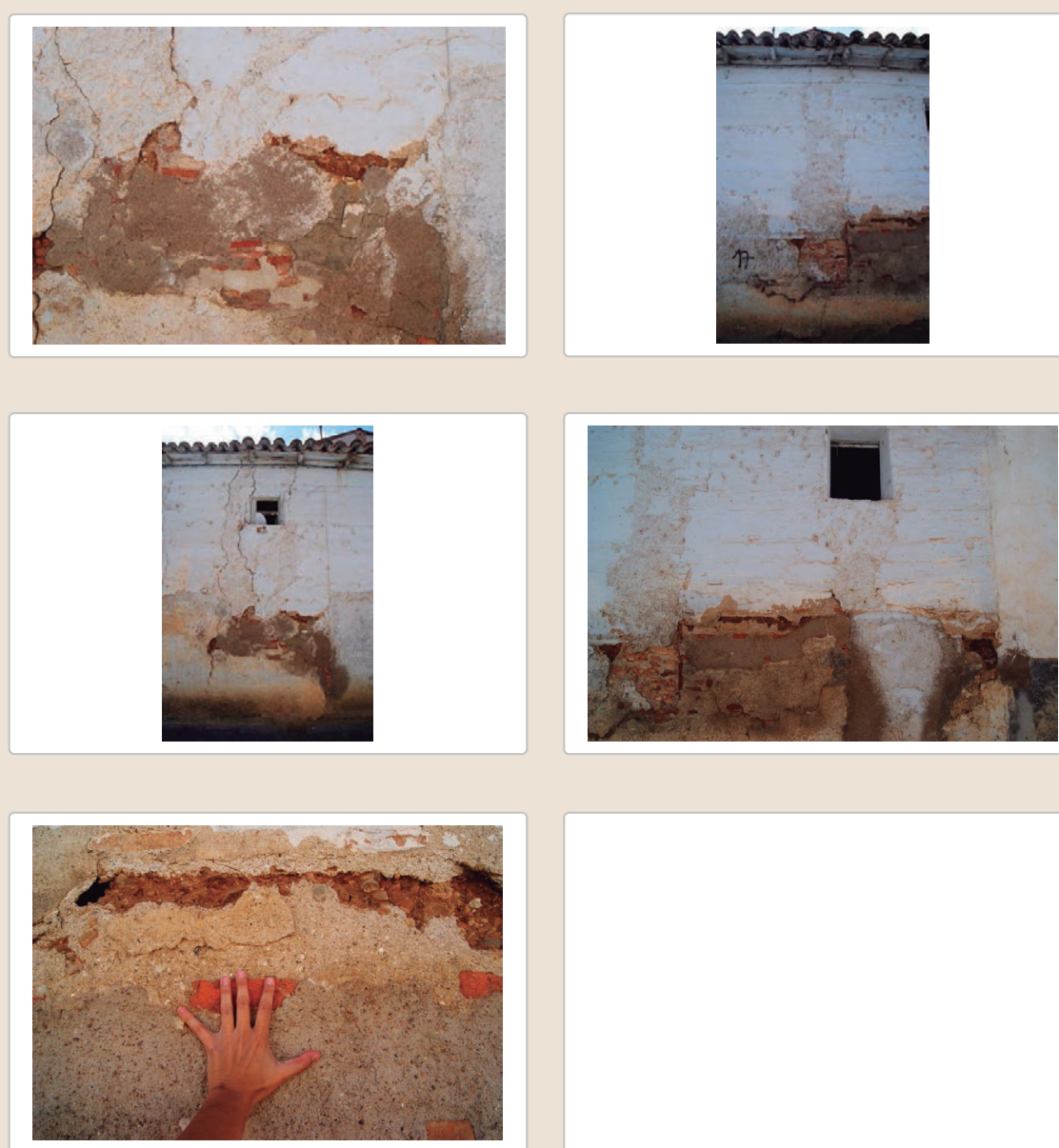


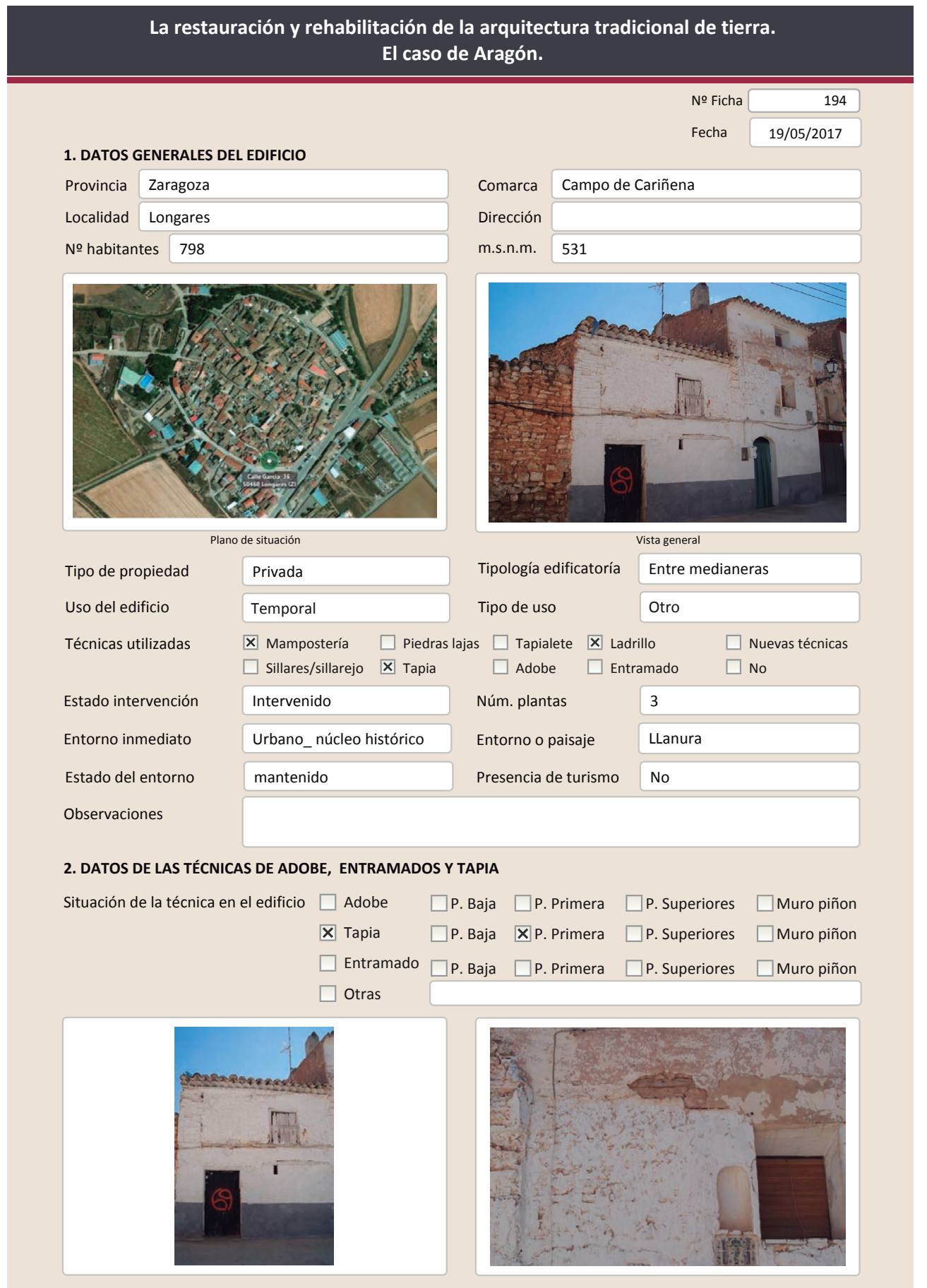

La restauración y rehabilitación de la arquitectura tradicional de tierra.

El caso de Aragón.

2.2. TAPIA

Ancho del muro

Dimensión tapiales

Tipo de aguja

№ agujas/cajón

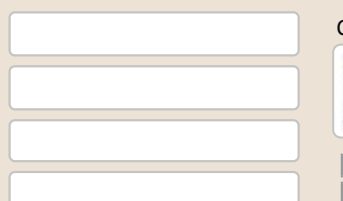

Color de la tapia

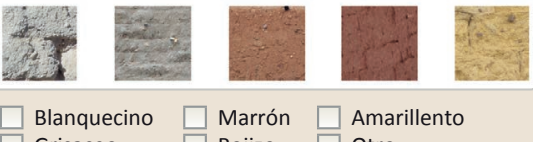

$\square$ Blanquecino $\square$ Marrón $\square$ Amarillento

$\square$ Grisaceo

Variante constructiva

\begin{abstract}
X Simple / homogénea
$\square$ suplemento superficial

$\square$ suplemento en juntas

X Mixta
\end{abstract}

Mampostería encofrada
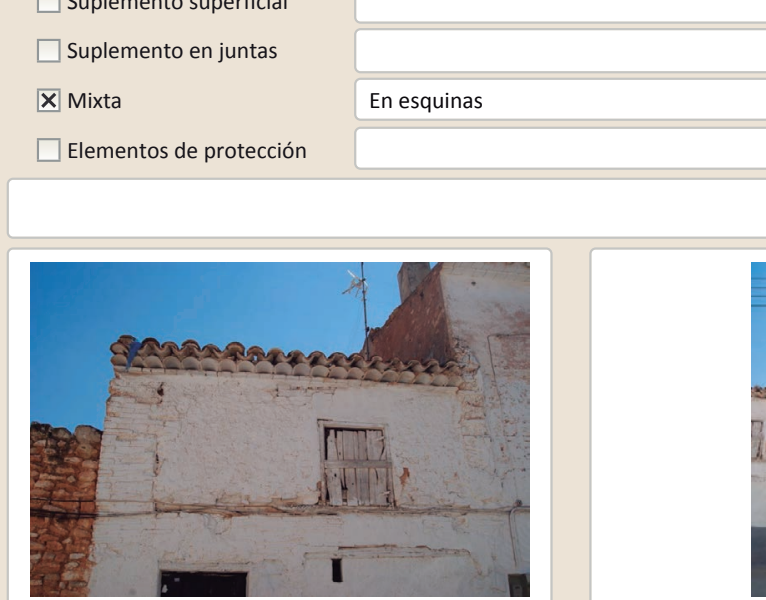

Lesiones $\quad$ X Muro $\square$ Zócalo $\square$ Revestimiento $\square$ Cubierta $\square$ Otro..

X Erosión del material $\quad \square$ Humedad por capilaridad $\quad \square$ Grietas por asentamientos $\square$ Erosion de las juntas $\square$ Humedades (manch/eflo)

$\square$ Pérdida de sección $\quad \square$ Pérdida de verticalidad

$\square$ Vegetación $\square$ Grietas por empuie de la cubietta

$\square$ Desconch

$\square$ Por elementos impropios

$\square$ Desconchados

$\square$ Grietas porfalta de traba

$\square$ Otro... 
La restauración y rehabilitación de la arquitectura tradicional de tierra. El caso de Aragón

\section{La restauración y rehabilitación de la arquitectura tradicional de tierra.}

\section{El caso de Aragón.}

3. DATOS DE LA INTERVENCIÓN

Intervención de:

$\square$ Mantenimiento $\square$ Rehabilitación parcia

$\square$ Restauración $\square$ Demolición X Reparación $\quad \square$ Rehabilitación integral $\quad \square$ Ampliación $\quad \square$ Otro...

Reflexión previa

Intervención espontanea

Observaciones

ing

3.1. MUROS

No intervenido

Tipo de intervención

$\square$ Actualización

$\square$ Consolidación $\square$ Reconstrucción $\square$ Sustitución

Tipo de material

Descripción

3.2. ZÓCALO

Tipo de intervención

\section{Intervenido}

X Actualización $\square$ Reintegración $\square$ Demolición $\square$ Otro..

$\square$ Consolidación $\quad \mathbf{X}$ Reconstrucción $\quad \square$ Sustitución

Tipo de material

No tradicional Tipo de técnica Diferente a la existente

Descripción

Cemento en toda la plana baja y pintura

3.3. REVESTIMIENTOS

\section{Intervenido}

Tipo de intervención

\ Actualización $\square$ Reintegración $\square$ Demolición $\square$ Otro...

Tipo de material

$\square$ Consolidación $\square$ Reconstrucción $\square$ sustitución

Tipo de mate

No tradicional

Tipo de técnica Diferente a la existente

3.4. VANOS

Pintura blanca en todo el edificio

Tipo de intervención

No intervenido

Tipo de material

$\square$ Actualización $\quad \square$ Reintegración $\quad \square$ Demolición $\quad \square$ Otro...
$\square$ Consolidación $\quad \square$ Reconstrucción $\quad \square$ sustitución

Tipo de materia
Descripción

(3.5. CUBERTA

3.5. CUBIERTA

Tipo de intervención

No intervenido

Tipo de material

$\square$ Actualización

$\square$ Consolidación $\quad \square$ Reconstrucción $\quad \square$ Sustitución

Tipo de técnica

Descripción

$$
\text { Tipo de técnica }
$$

3.6. OTRAS 


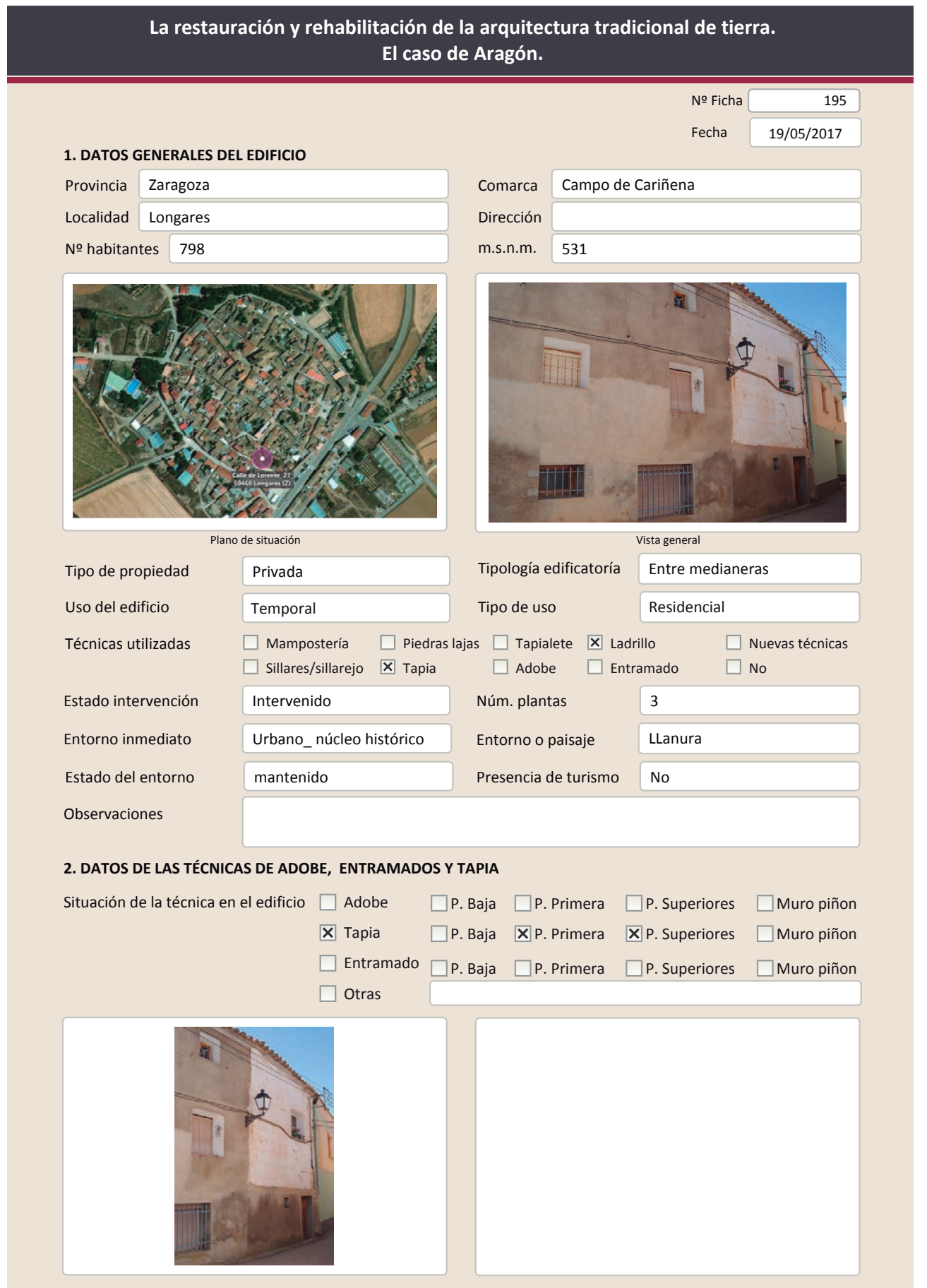

La restauración y rehabilitación de la arquitectura tradicional de tierra.

El caso de Aragón.

2.2. TAPIA

Ancho del muro

Dimensión tapiales

Tipo de aguja

№ agujas/cajón

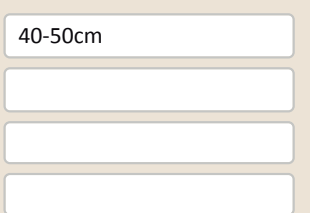

Color de la tapia

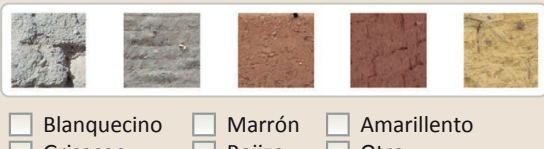

$\square$ Blanquecino $\quad \square$ Marrón $\quad \square$ Amarillento
$\square$ Grisaceo
Rojizo $\quad \square$ Otro...

Variante constructiv

$\square$ Simple / homogénea

$\mathbf{X}$ Suplemento superficial

$\square$ suplemento en juntas

区 Mixta
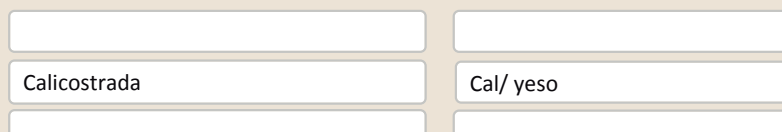

En esquinas

Ladrillo

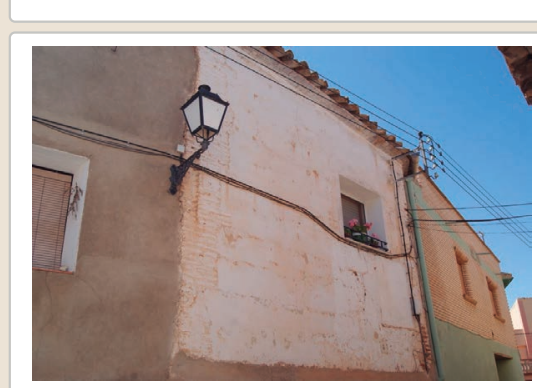

Lesiones $\quad \mathbf{X}$ Muro $\quad$ XZócalo $\square$ Revestimiento

$\mathbf{X}$ Erosión del material $\mathbf{X}$ Humedad por capilaridad

$\square$ Erosion de las juntas $\quad \mathbf{X}$ Humedades (manch/eflo)

$\square$ Pérdida de sección $\quad \square$ Pérdida de verticalidad

$\square$ Vegetación

Pérdida de verticalidad

$\square$ Desconchados

$\square$ Grietas porfalta de traba

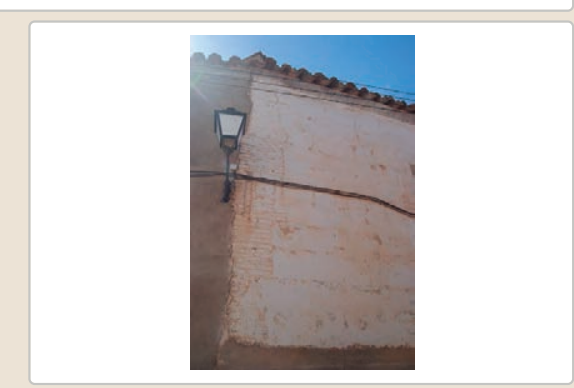

$\square$ Cubierta $\square$ otro...

$\square$ Grietas por asentamientos $\square$ Colapso

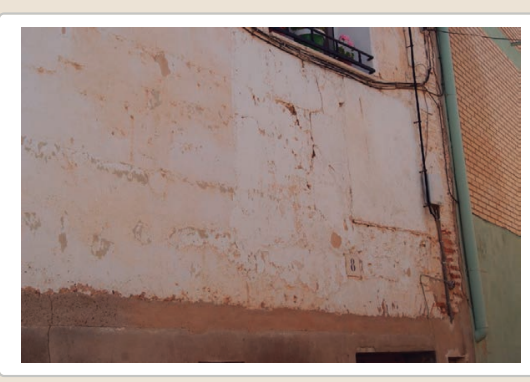

Por elementos impropios

$\square$ Derivado de intervenciones

Observaciones 
La restauración y rehabilitación de la arquitectura tradicional de tierra. El caso de Aragón

\section{La restauración y rehabilitación de la arquitectura tradicional de tierra.}

\section{El caso de Aragón.}

3. DATOS DE LA INTERVENCIÓN

Intervención de:

$\square$ Mantenimiento $\quad \mathbf{X}$ Rehabilitación parcial

$\square$ Restauración $\square$ Demolición

Reflexión previa

$\square$ Reparación

Rehabilitación integral $\square$ Ampliació

$\square$ Otro..

Reflexión previa

Intervención espontanea

(20)

3.1. MUROS

No intervenido

Tipo de intervención

$\square$ Actualización

$\square$ Consolidación $\square$ Reconstrucción $\square$ Sustitución

Tipo de material

Descripción

3.2. ZÓCALO

Tipo de intervención

Intervenido

Tipo de intervención

$\square$ Actualizació

Tipo de material

No tradicional

$\square$ Reintegración $\square$ Demolición

Tipo de técnica

Descripción

Tipo de técnica Diferente a la existente

3.3. REVESTIMIENTOS

Tipo de intervención

Intervenido

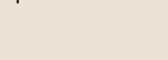

X Actualización

$\square$ Consolidación

$\square$ Reintegración $\square$ Demolición $\square$ Otro...

No tradicional

Descripción

Pintura blanca en las plantas superiores

3.4. VANOS

Intervenido

Tipo de intervención

$\square$ Actualización $\square$ Reintegración $\square$ Demolición $\square$ Otro..

$\square$ Consolidación $\square$ Reconstrucción $\quad \boldsymbol{X}$ Sustitución

Tipo de material

Tradicional diferente

Tipo de técnica Similar a la existente

Descripción Sustitución de carpinterías e incorporación de nuevos elementos como persianas y

mosquiteras

3.5. CUBIERTA

Tipo de intervención

Intervenido

Tipo de material

$\square$ Actualización $\square$ Reintegración $\quad \square$ Demolición $\square$ Otro..

$\square$ Consolidación $\square$ Reconstrucción $\mathbf{X}$ Sustitución

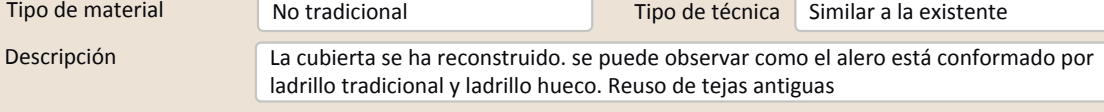

3.6. OTRAS 


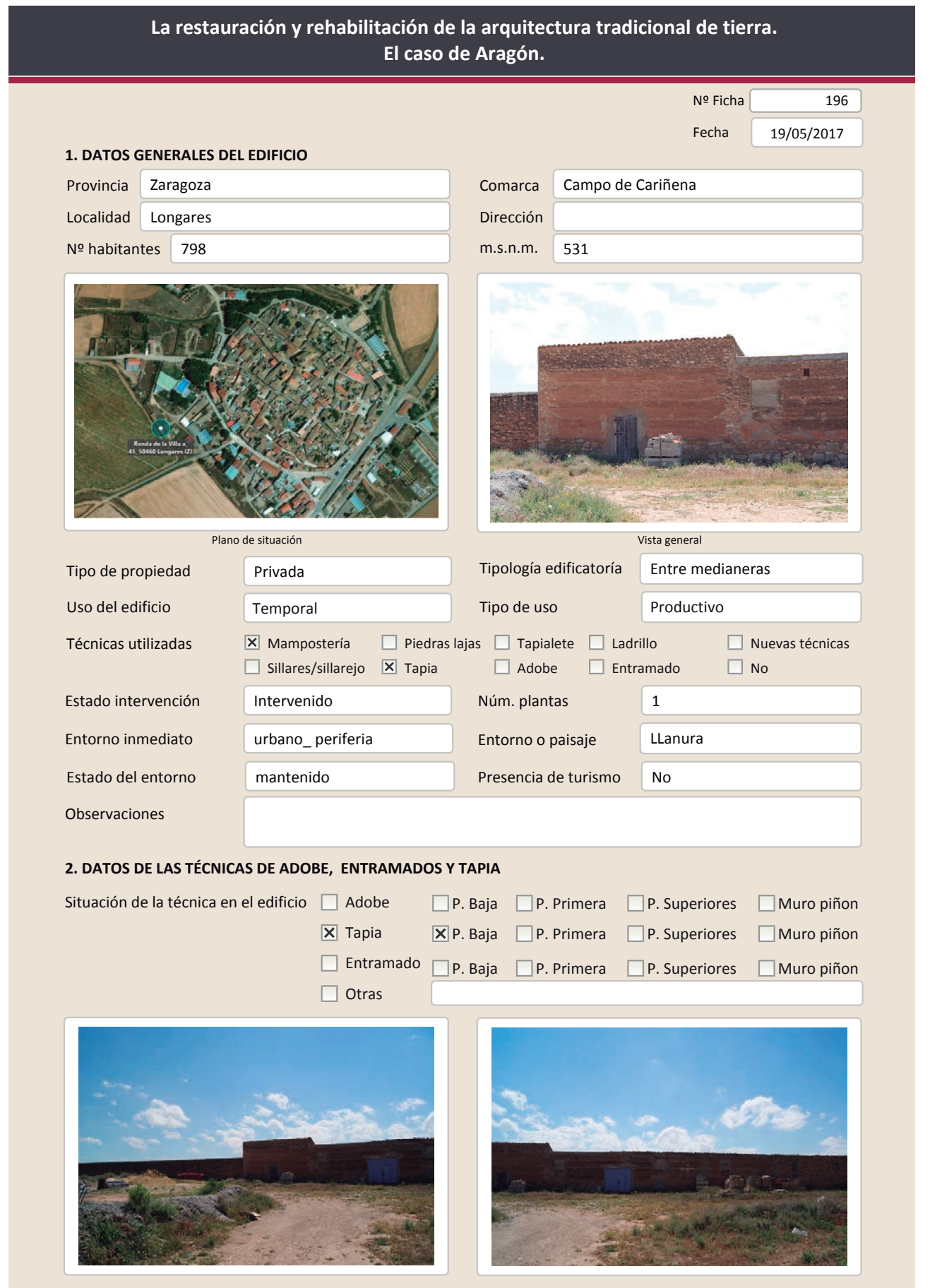

La restauración y rehabilitación de la arquitectura tradicional de tierra.

El caso de Aragón.

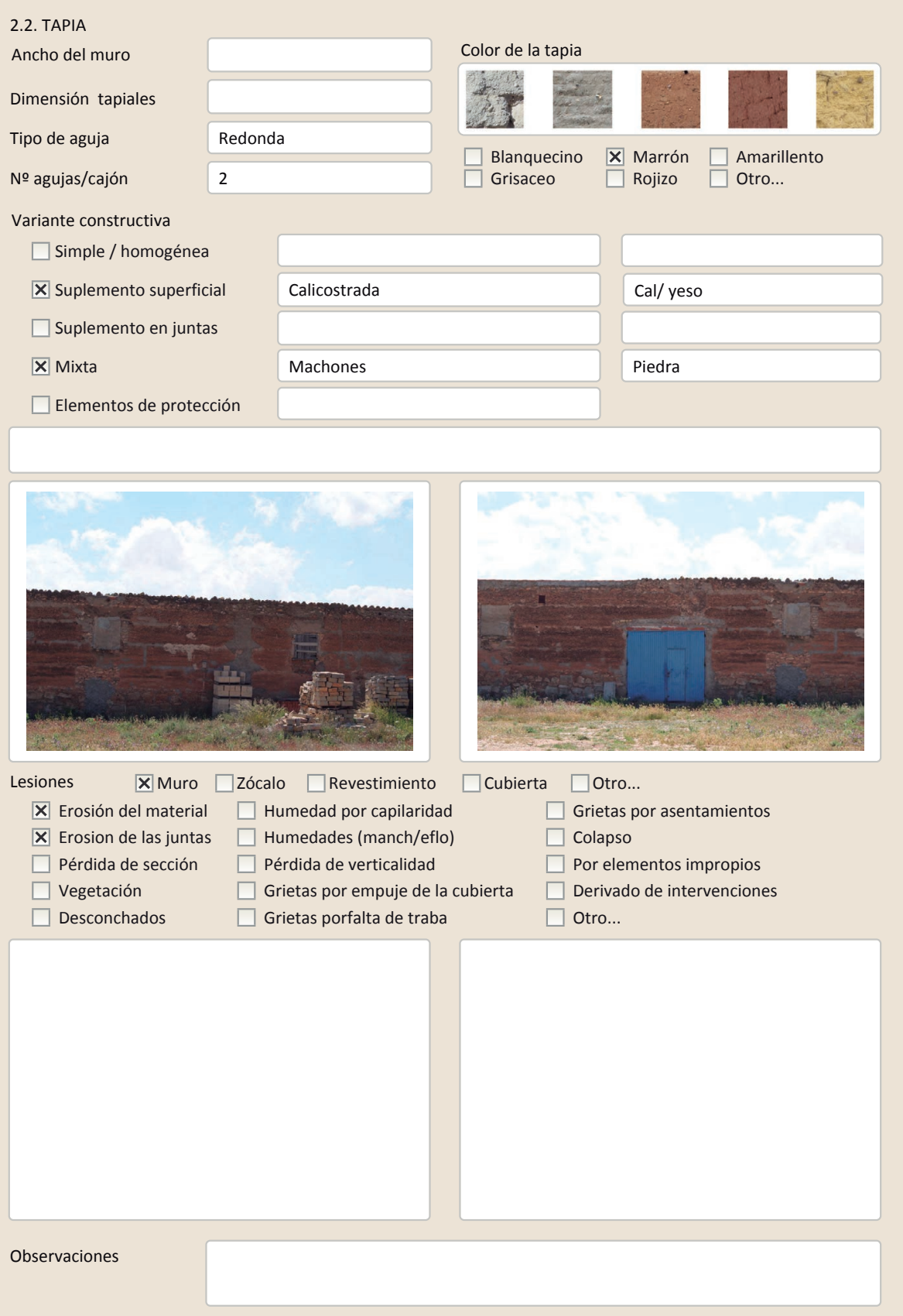


La restauración y rehabilitación de la arquitectura tradicional de tierra. El caso de Aragón

\section{La restauración y rehabilitación de la arquitectura tradicional de tierra.}

\section{El caso de Aragón.}

3. DATOS DE LA INTERVENCIÓN

Intervención de:

$\square$ Mantenimiento $\square$ Rehabilitación parcia

$\square$ Restauración $\square$ Demolición

Reflexión previa

X Reparación

$\square$ Rehabilitación integral $\square$ Ampliación

$\square$ Otro..

Reflexión previa

Intervención espontanea

3.1. MUROS

Tipo de intervención

Intervenido

Tipo de material

$\square$ Actualización $\quad$ Reintegración $\square$ Demolición $\square$ Otro..

$\square$ Consolidación $\square$ Reconstrucción $\square$ Sustitución

\begin{tabular}{l|l|l|l} 
No tradicional & Tipo de técnica & Diferente a la existente
\end{tabular} $\begin{array}{ll}\text { Descripción } & \begin{array}{l}\text { Reintegración de las juntas entre tapiales ya que esta zona era la más erosionada } \\ \text { (pequeñas oquedades) }\end{array}\end{array}$

3.2. ZÓCALO

No intervenido

Tipo de intervención

$\square$ Actualización

Tipo de material

$\square$ Consolidación $\square$ Reconstrucción $\square$ Sustitución

Descripción

3.3. REVESTIMIENTOS

\section{No intervenido}

Tipo de intervención

$\square$ Actualización $\square$ Reintegración $\square$ Demolición $\square$ Otro...

Tipo de material

Descripción

3.4. VANOS

Tipo de intervención

Consolidación

Reconstrucción $\square$ Sustitución

Tipo de material

Intervenido

Descripción

$\square$ Consolidación $\mathbf{x}$ Reconstrucción $\mathbf{x}$ Sustitución

\begin{tabular}{|l|l|l|l|l}
\hline No tradicional Tipo de técnica Diferente a la existente &
\end{tabular}

3.5. CUBIERTA

Intervenido

Tipo de intervención

$\square$ Actualización $\quad \square$ Reintegración $\quad \square$ Demolición $\square$ Otro.

$\square$ Consolidación $\quad \mathbf{X}$ Reconstrucción $\square$ Sustitución

Tipo de material

No tradicional

Tipo de técnica Diferente a la existente

Descripción

Reconstrucción parcial de un tramo de cubierta. e aprecia las tejas recolocadas en el canto del muro

3.6. OTRAS 


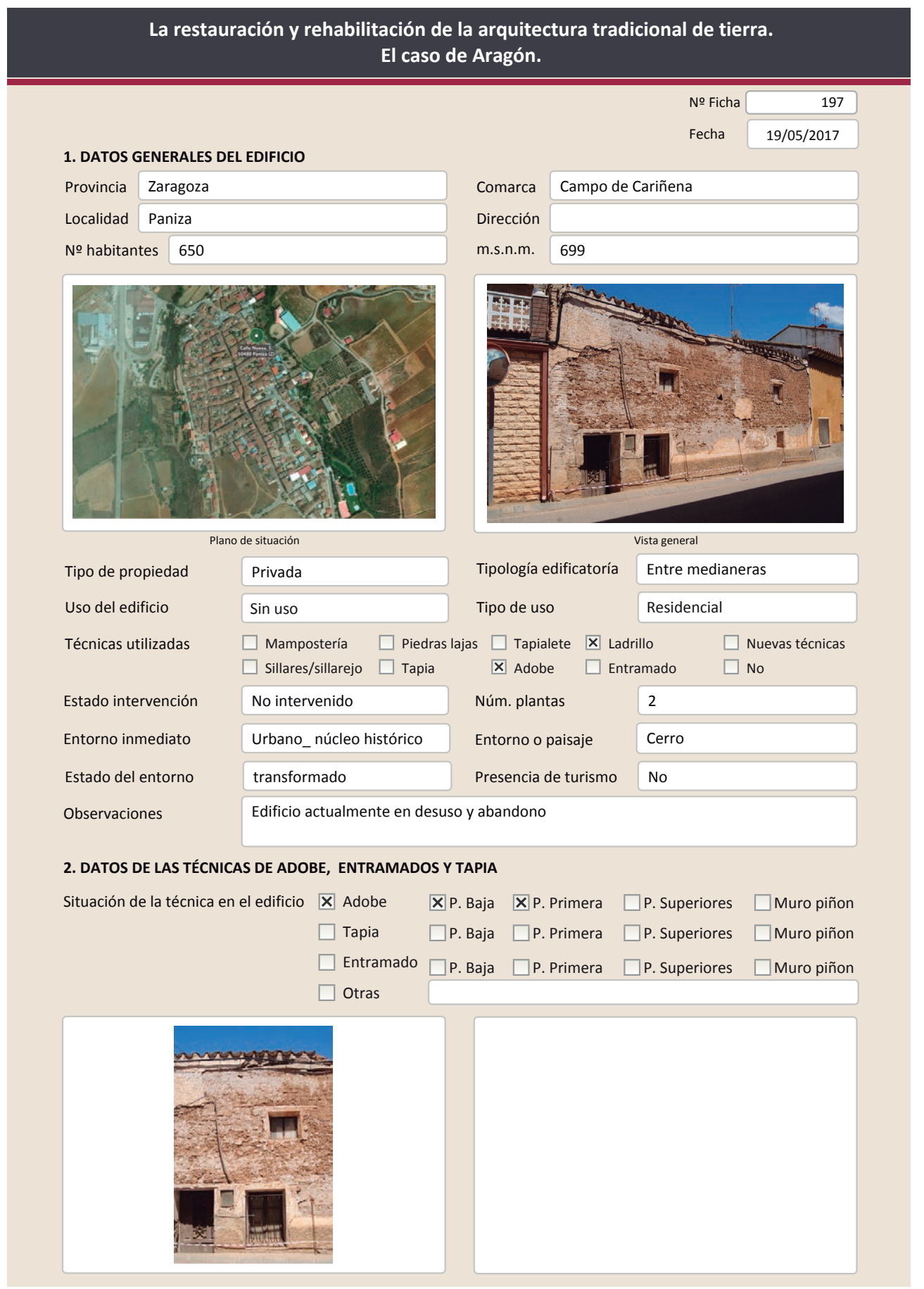

La restauración y rehabilitación de la arquitectura tradicional de tierra.

El caso de Aragón.

2.1. ADOBE

Dimensión de las piezas

Dimensión del muro

Aparejo del muro

Función estructural

Variante constructiva/ tipo de fábrica

$\square$ simple

$\square$ Suplementada en juntas

X Mixta

\section{Machones}

Color de las piezas

$\square$ Como suplemento

X Elementos de protección

Revestimiento

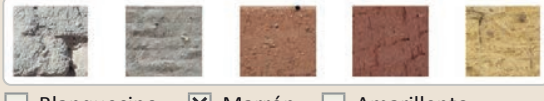

$\square$ Blanquecino $\mathbf{X}$ Marrón $\square$ Amarillento $\square$ Grisaceo $\quad \square$ Rojizo $\square$ Otro...

Comp. - estabilizante Aridos

\section{Revestimiento}

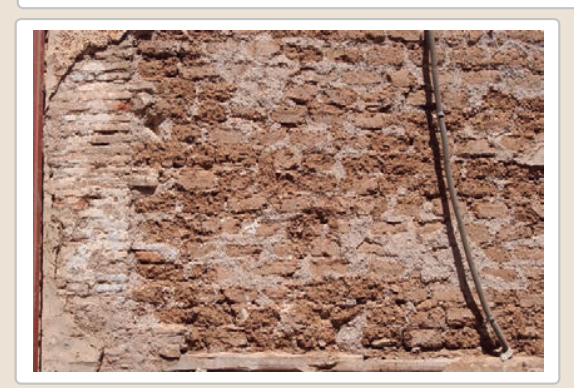

Lesiones $\quad$ Muro $\square$ Zócalo $\mathbf{X}$ Revestimiento

\ Erosión del material $\square$ Humedad por capilaridad

$\square$ Erosion de las juntas $\square$ Humedades (manch/eflo)

X Pérdida de sección $\square$ Pérdida de verticalidad

$\square$ Vegetación $\quad \square$ Grietas por empuje de la c

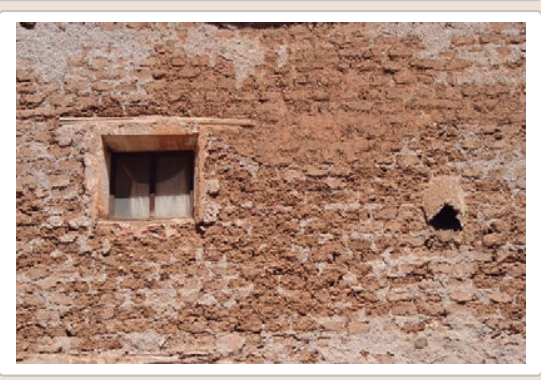

$\mathbf{X}$ Desconchados

$\square$ Grietas porfalta de traba

X Cubierta $\square$ Otro...

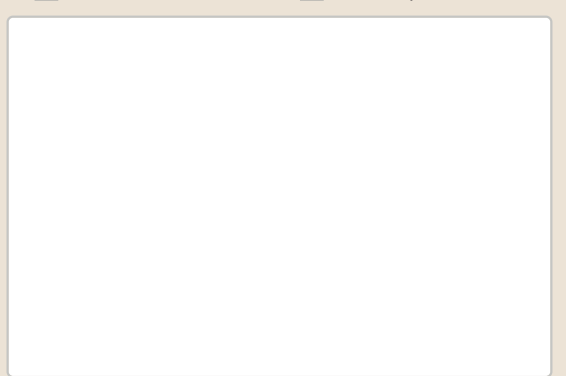

$\square$ Grietas por asentamiento

X Colapso

$\square$ Por elementos impropios

$\square$ Derivado de intervenciones

$\square$ Otro...

Observacione 
La restauración y rehabilitación de la arquitectura tradicional de tierra. El caso de Aragón

\section{La restauración y rehabilitación de la arquitectura tradicional de tierra.}

El caso de Aragón.
3.7. REHABILITACIÓN ENERGÉTICA

Observaciones

FOTOGRAFÍAS DE LA INTERVENCIÓN
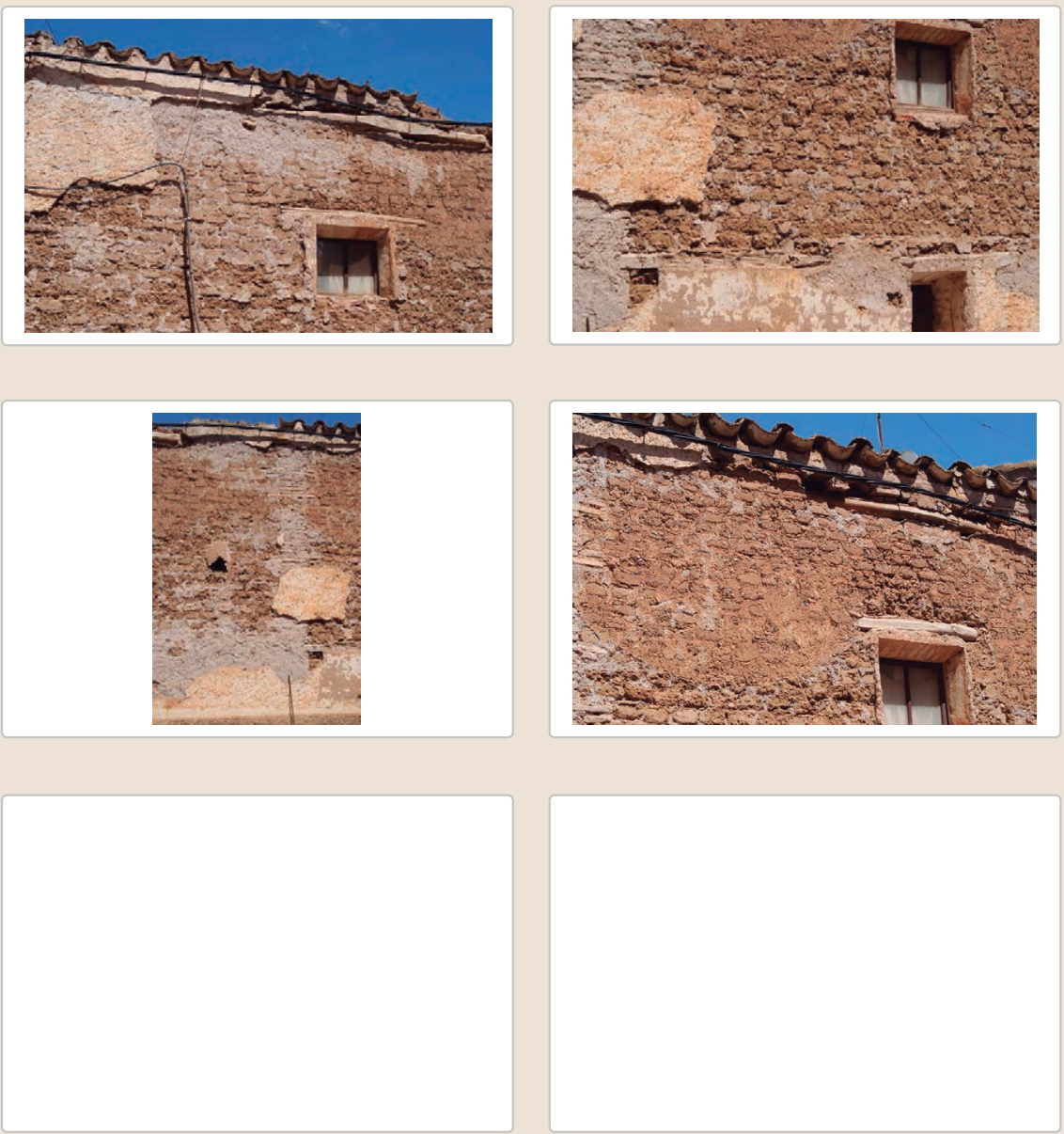


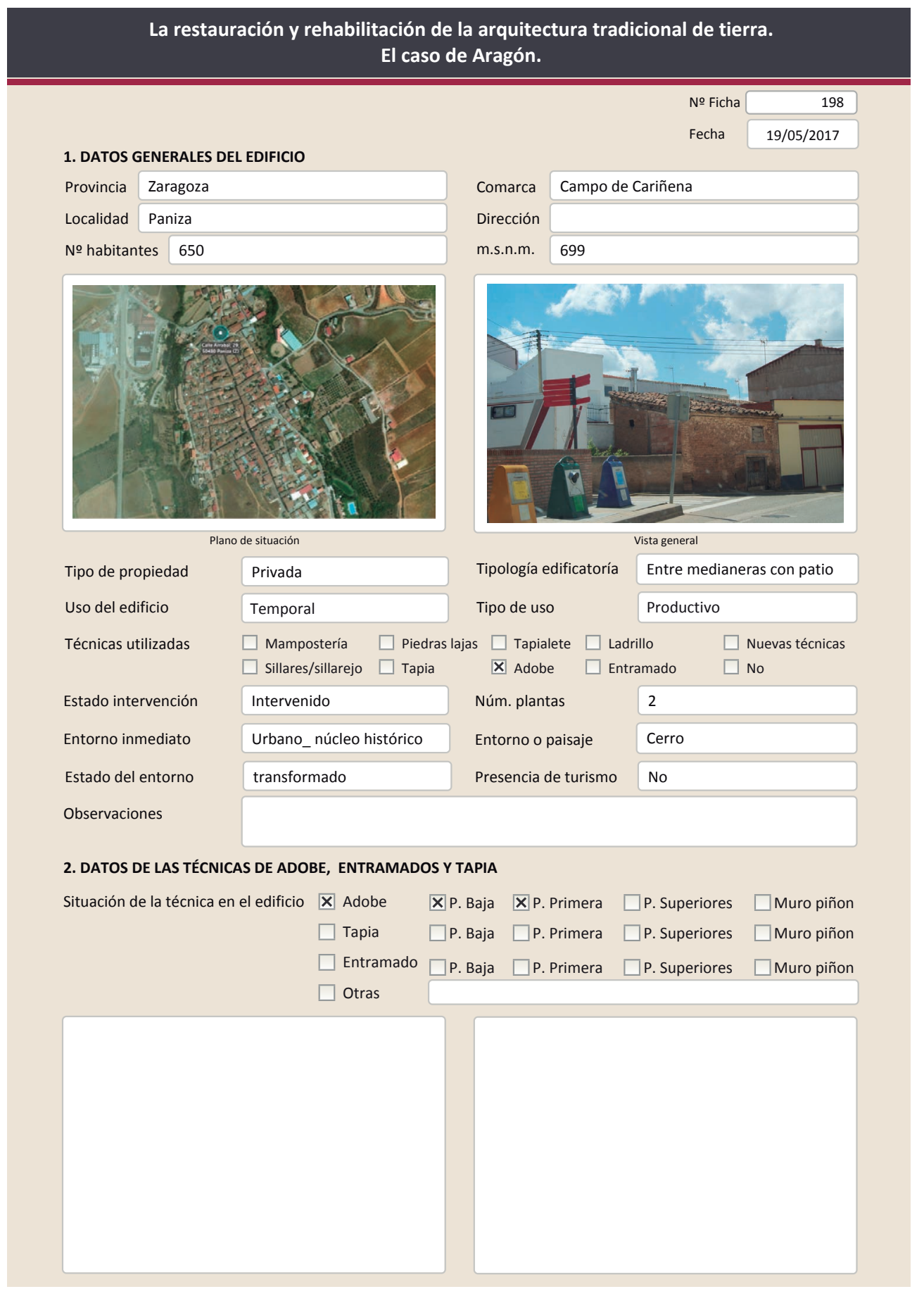

La restauración y rehabilitación de la arquitectura tradicional de tierra.

El caso de Aragón.

2.1. ADOBE

Dimensión de las piezas Dimensión del muro

Aparejo del muro

Función estructural

\begin{tabular}{|l|}
\hline $30-40 \mathrm{~cm}$ \\
\hline Tizón \\
\hline $\mathrm{Si}$ \\
\hline
\end{tabular}

Color de las piezas

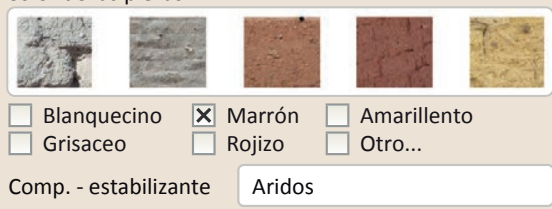

Variante constructiva/ tipo de fábrica

$\square$ simple

$\square$ Suplementada en juntas

X Mixta

En esquinas

Ladrillo

$\square$ Como suplemento

$\square$ Elementos de protección

Esquinas de ladrillo y un machón intermedio de madera en el muro piñón

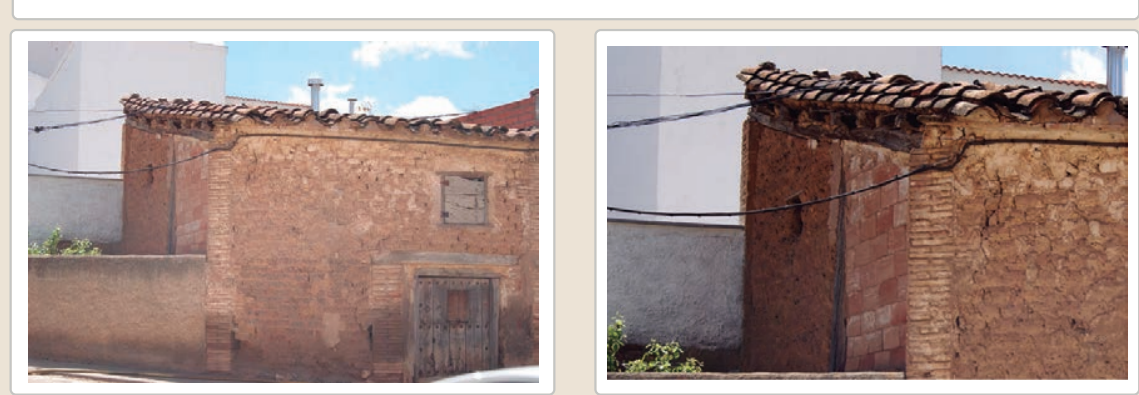

Lesiones $\quad \mathbf{X}$ Muro $\mathbf{X}$ Zócalo $\square$ Revestimiento $\square$ Cubierta $\square$ Otro...

\ Erosión del material $\quad \mathbf{X}$ Humedad por capilaridad $\quad \square$ Grietas por asentamientos $\square$ Erosion de las juntas $\mathbf{X}$ Humedades (manch/eflo) $\quad \square$ Colapso

X Pérdida de sección $\square$ Pérdida de verticalidad $\quad \square$ Por elementos impropios

$\square$ Vegetación $\quad \square$ Grietas por empuje de la cubierta $\square$ Derivado de intervenciones

$\square$ Desconchados $\quad \square$ Grietas porfalta de traba

$\square$ Derivado

Observaciones 
La restauración y rehabilitación de la arquitectura tradicional de tierra. El caso de Aragón

\section{La restauración y rehabilitación de la arquitectura tradicional de tierra.}

\section{El caso de Aragón.}

3. DATOS DE LA INTERVENCIÓN

Intervención de:

$\square$ Mantenimiento $\square$ Rehabilitación parcia

$\square$ Restauración $\square$ Demolición

Reflexión previa

X Reparación

$\square$ Rehabilitación integral $\square$ Ampliació

$\square$ Otro..

Reflexión previa
Observaciones

Intervención espontanea

3.1. MUROS

Tipo de intervención

Intervenido

Tipo de material

$\square$ Actualización $\square$ Reintegración $\square$ Demolición $\square$ Otro...

$\square$ Consolidación $\square$ Reconstrucción $\quad \square$ Sustitución

Descripción

\begin{tabular}{l|l|l} 
No tradicional & Tipo de técnica & Similar a la existente
\end{tabular}

Descripción

3.2. ZÓCALO

Tipo de intervención

No intervenido

Tipo de material

$\square$ Actualización

Descripción

3.3. REVESTIMIENTOS

Tipo de intervención

\section{No aplica}

Tipo de material

$\square$ Actualización $\square$ Reintegración $\square$ Demolición $\square$ Otro...

$\square$ Reintegración $\square$ Demolición Tipo de técnica

Descripción

3.4. VANOS

Tipo de intervención

No intervenido

Tipo de material

Descripción

Consolidación $\quad \square$ Reconstrucción $\quad \square$ Sustitución

3.5. CUBIERTA

Tipo de intervención

No intervenido

Tipo de intervención

$\square$ Actualización

$\square$ Consolidación $\square$ Reconstrucción $\quad \square$ Sustitución

Tipo de técnica

Tipo de materia

po de técnica

Descripción

3.6. OTRAS

$\square$ Consolidación $\square$ Reconstrucción $\square$ sustitución

Tipo de técnica 
La restauración y rehabilitación de la arquitectura tradicional de tierra. El caso de Aragón.

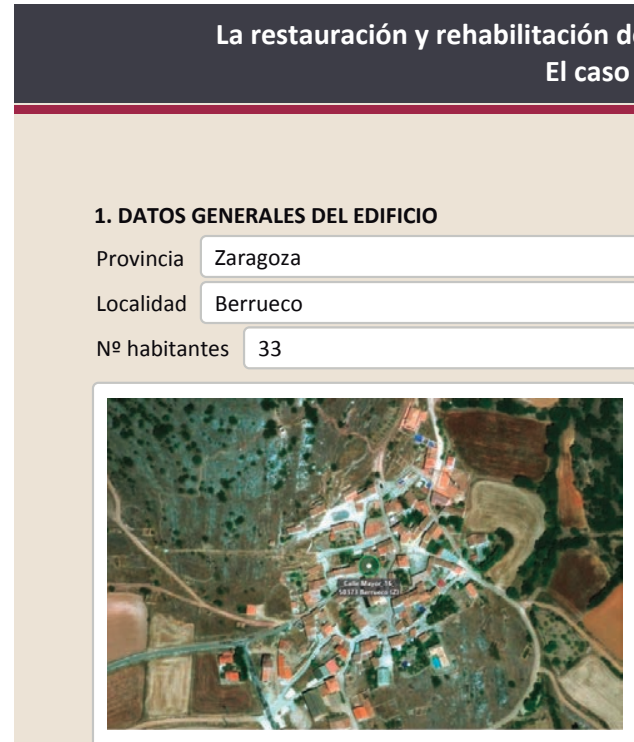

Plano de situación

Tipo de propiedad Privada

Uso del edificio Temporal

X Mampostería $\square$ Piedras lajas $\square$ Tapialete $\square$ Iadrillo $\square$ Nuevas técnicas

$$
\square \text { sillares/sillarejo } \mathbf{X} \text { Tapia }
$$

Estado intervención

Urbano_núcleo histórico

Entorno inmediato

Estado del entorno

mantenido

rato

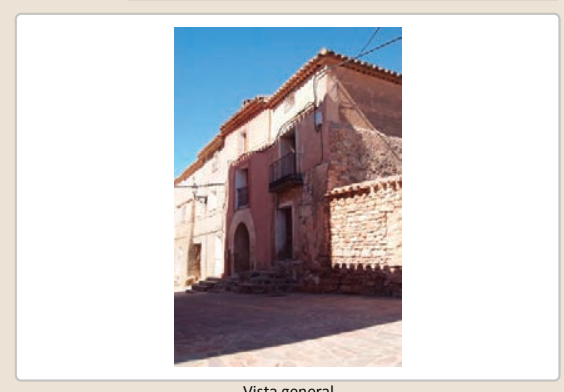
$\square$ sillares/sillarejo $\quad$ Tapia $\quad \square$ Adobe $\square$ Entramado $\quad \square$ No

№ Ficha $\quad 199$

Fecha $07 / 10 / 2017$

Comarca Campo de Daroca Dirección

m.s.n.m. 1098

Vista general

Tipología edificatoría Entre medianeras

Tipo de uso Residencial

$\square$ Adobe $\square$ Entramado $\square$ No

Núm. plantas 3

Entorno o paisaje

Presencia de turismo
Observaciones

\section{DATOS DE LAS TÉCNICAS DE ADOBE, ENTRAMADOS Y TAPIA}

Situación de la técnica en el edificio $\square$ Adobe $\quad \square$ P. Baja $\quad \square$ P. Primera $\quad \square$ P. Superiores $\square$ Muro piñon Х Tapia $\square$ P. Baja $\quad$ XP. Primera $\quad$ XP. Superiores $\square$ Muro piñon $\square$ Entramado $\square$ P. Baja $\square$ P. Primera $\square$ P. Superiores $\square$ Muro piñon $\square$ otras
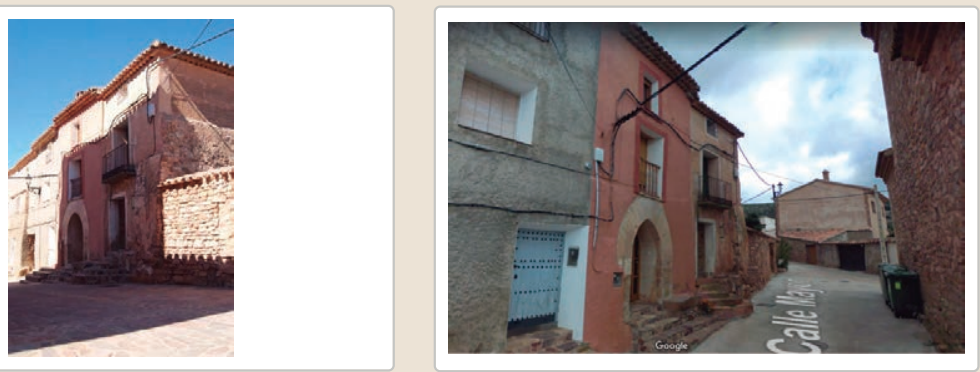

La restauración y rehabilitación de la arquitectura tradicional de tierra.

El caso de Aragón.

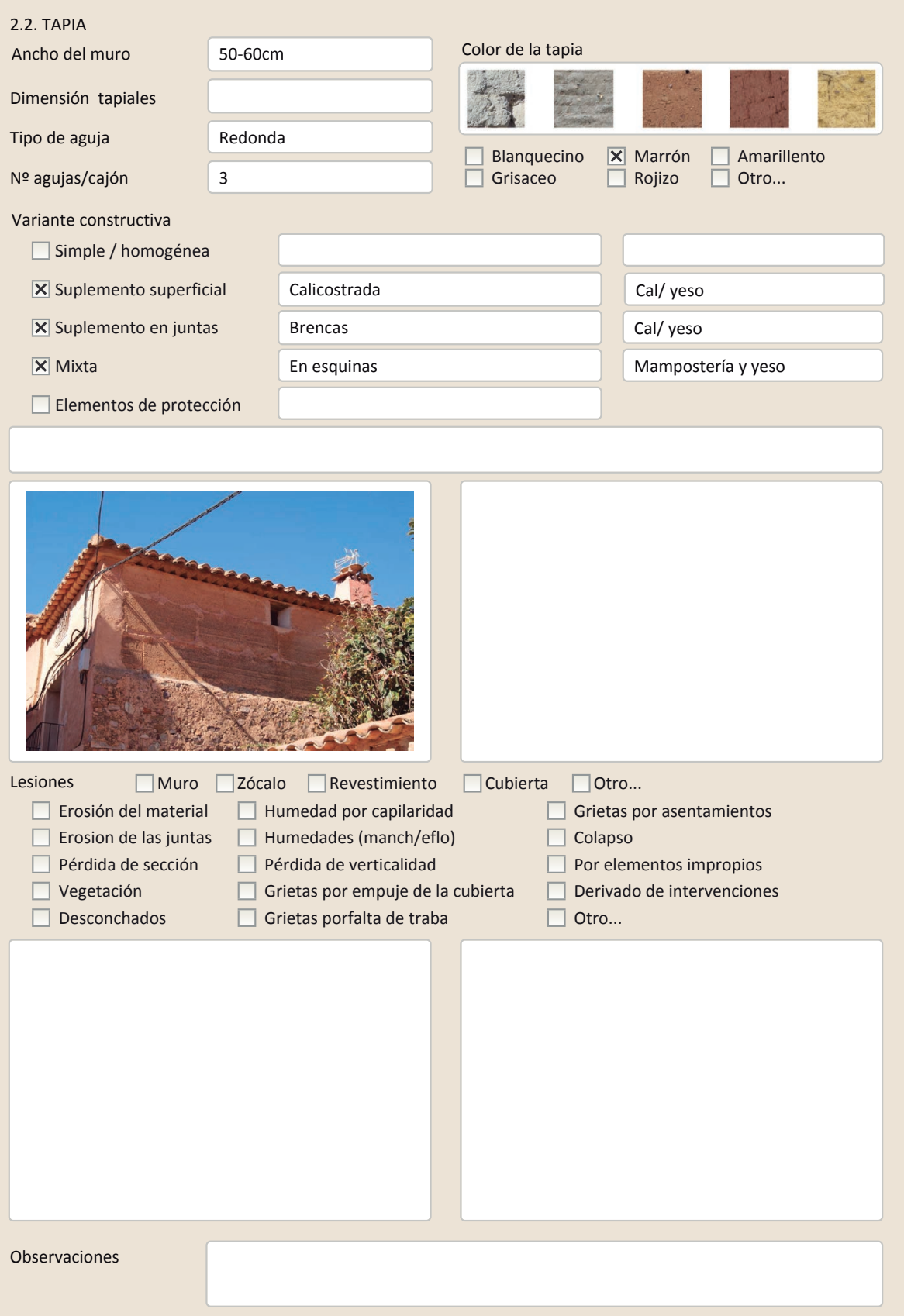

2.2. TAPIA

Tipo de aguja

\begin{tabular}{|l|}
\hline Redonda \\
\hline 3 \\
\hline
\end{tabular}

Blanquecino $\mathbf{X}$ Marrón $\square$ Amarillento

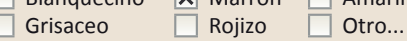

Calicostrada

X Mixta

En esquinas

$\mathrm{Cal} /$ yeso

Elementos de protección

Lesiones $\square$ Muro $\square$ Zócalo $\square$ Revestimiento $\square$ Cubierta $\square$ otro..

$\square$ Erosión del material $\quad \square$ Humedad por capilaridad $\quad \square$ Grietas por asentamientos

Dérdida de verticalidad

$\square$ Desconchados $\square$ Grietas porfalta de traba $\quad \square$ Otro.

Observaciones 


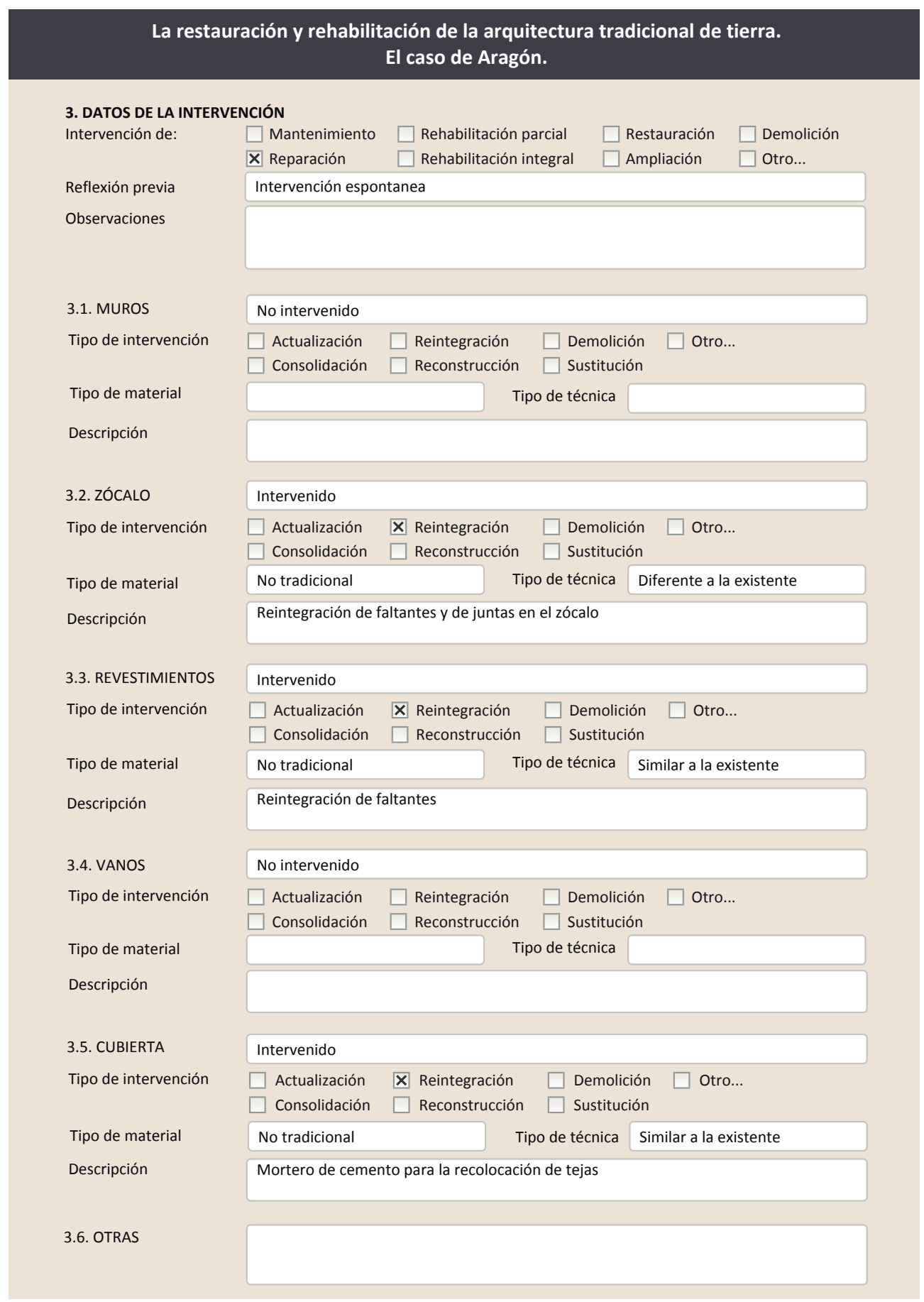

\subsection{REHABILITACIÓN ENERGÉTICA $\quad \square$ Fachada $\square$ Vanos $\square$ Forjados $\square$ Cubierta} Observaciones

FOTOGRAFÍAS DE LA INTERVENCIÓN

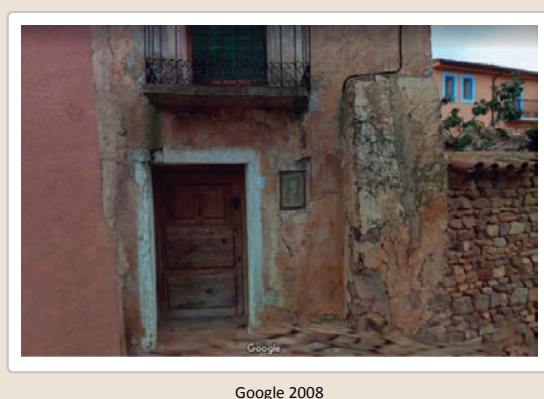

$$
\text { Google } 2008
$$

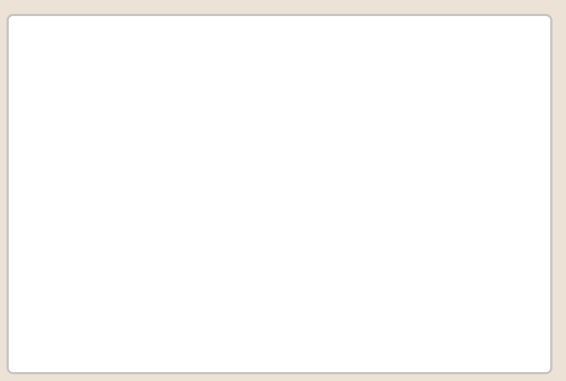

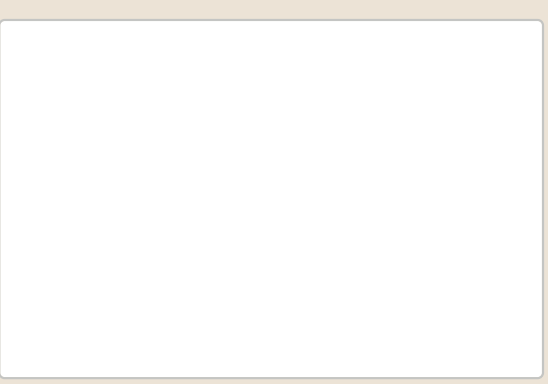
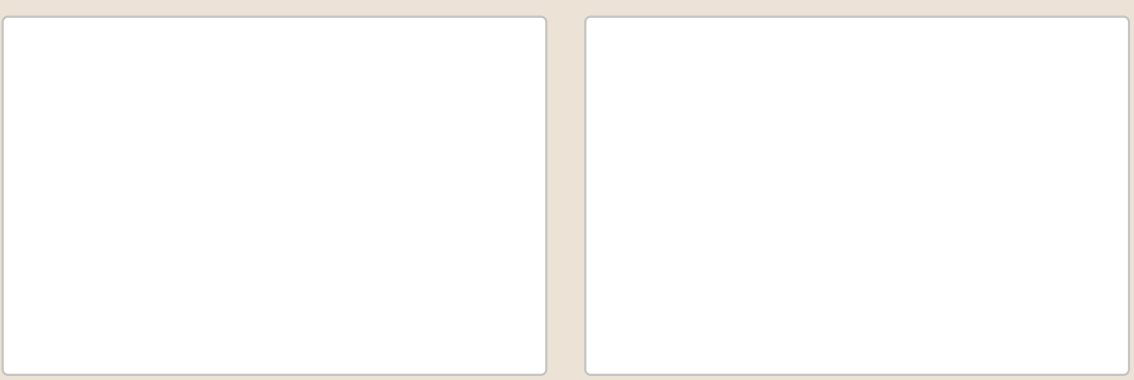


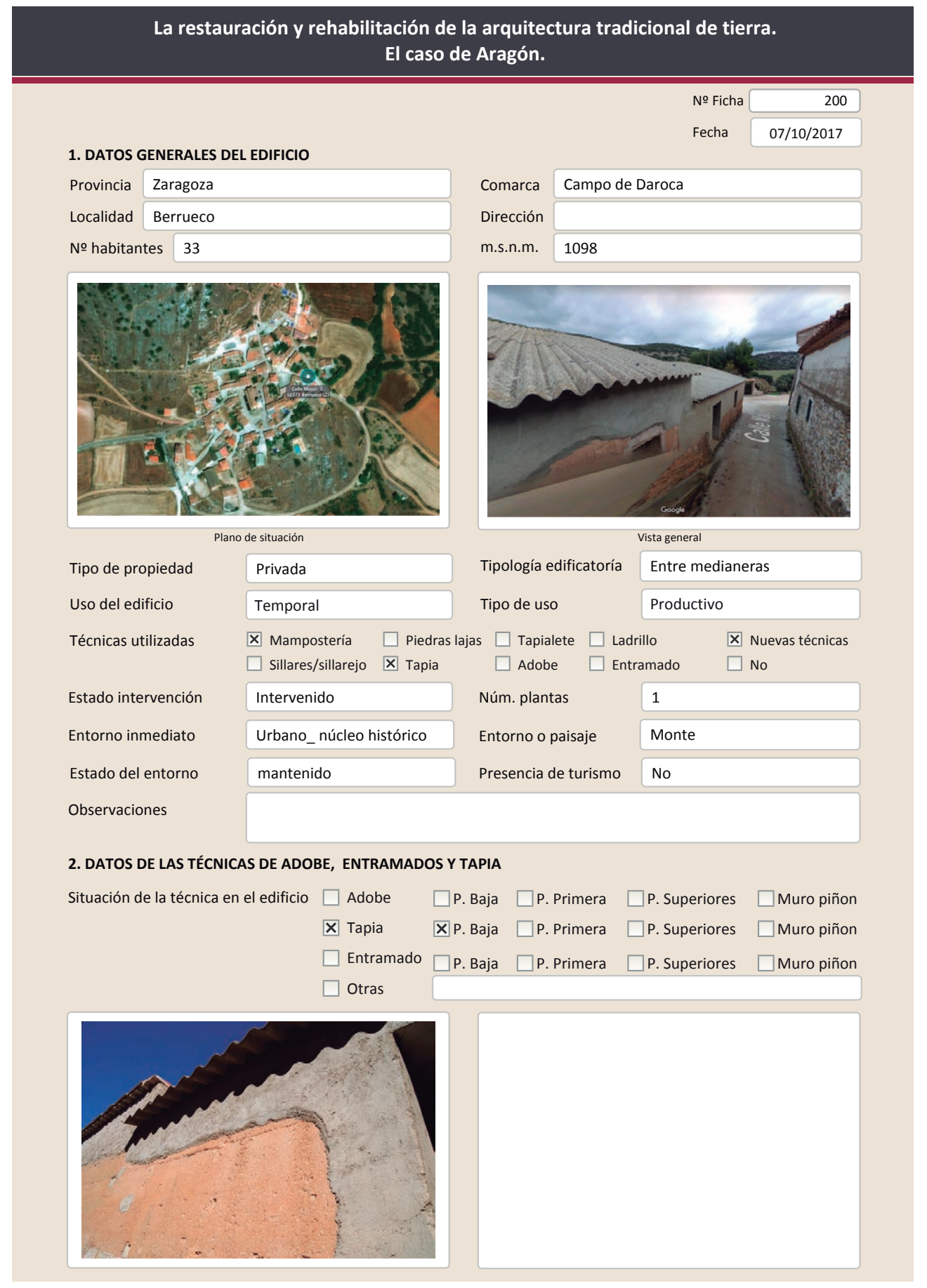

La restauración y rehabilitación de la arquitectura tradicional de tierra.

El caso de Aragón.

\subsection{TAPIA}

Ancho del muro

Dimensión tapiales

Tipo de aguja

№ agujas/cajón

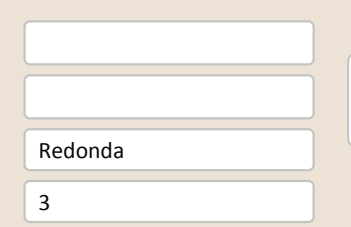

Color de la tapia

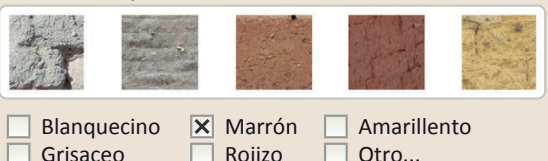

$\begin{array}{ll}\square \text { Blanquecino } & \boldsymbol{X} \text { Marrón } \\ \square \text { Grisaceo } & \square \text { Amarillento } \\ & \square \text { Rojizo } \quad \square \text { Otro... }\end{array}$

$\square$ Simple / homogénea

X Suplemento superficial

$\square$ suplemento en juntas

$\square$ Mixta

$\square$ Elementos de protección
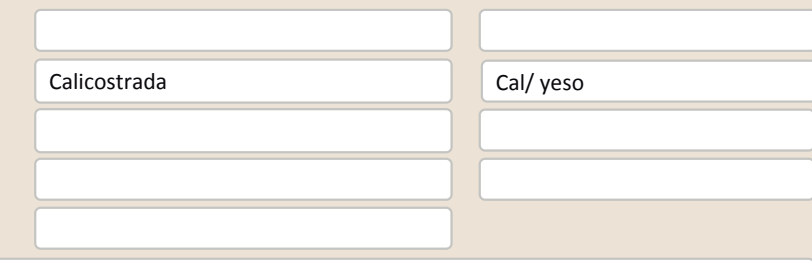

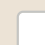

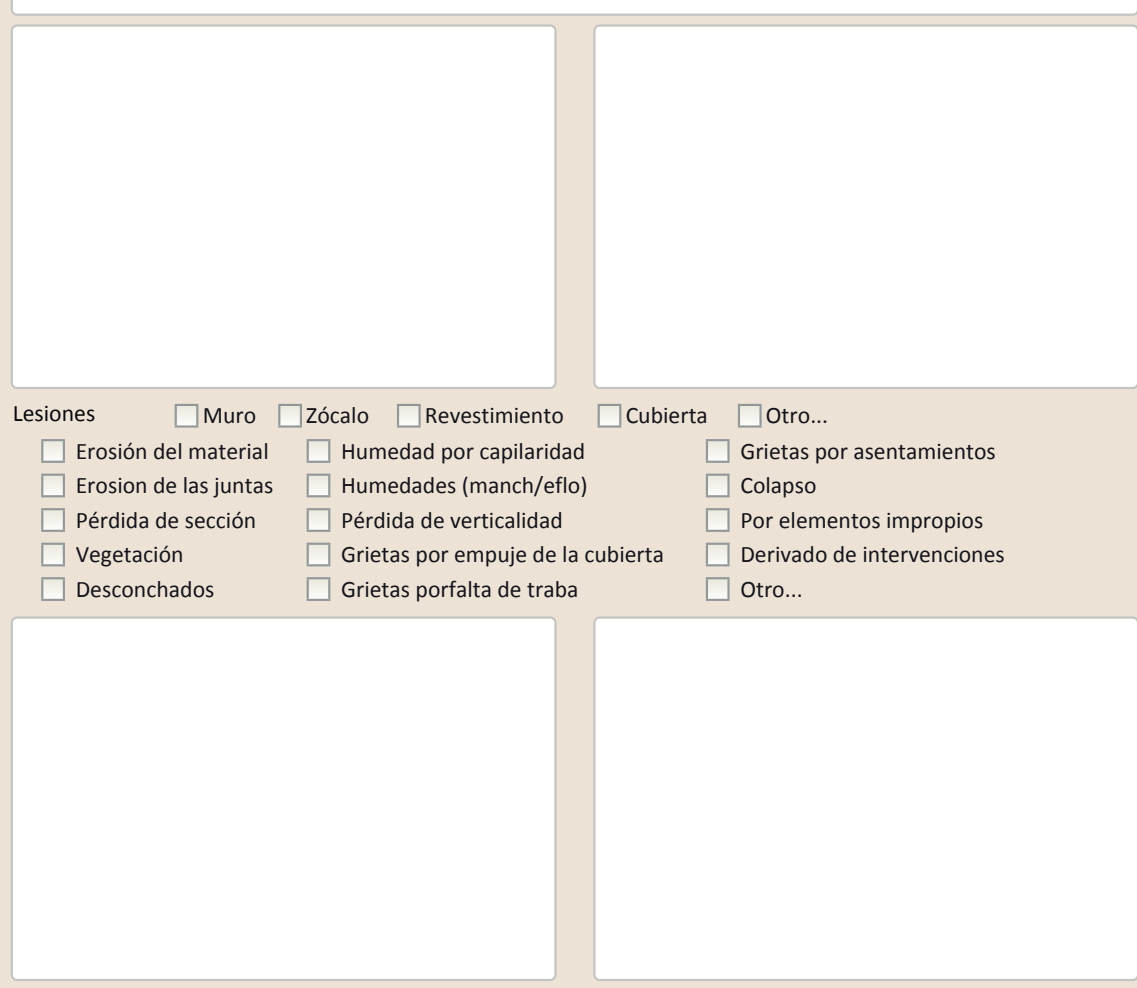

Observaciones 
La restauración y rehabilitación de la arquitectura tradicional de tierra. El caso de Aragón

\section{La restauración y rehabilitación de la arquitectura tradicional de tierra.}

\section{El caso de Aragón.}

3. DATOS DE LA INTERVENCIÓN

Intervención de:

$\square$ Mantenimiento $\square$ Rehabilitación parcia

$\square$ Restauración $\square$ Demolición X Reparación $\quad \square$ Rehabilitación integral $\quad \square$ Ampliación $\quad \square$ Otro...

Reflexión previa Intervención espontanea

Observaciones

3.1. MUROS

Intervenido

Tipo de intervención

$\square$ Actualización $\quad$ Reintegración $\square$ Demolición $\square$ Otro..

$\square$ Consolidación $\square$ Reconstrucción $\square$ sustitución

Tipo de material

\begin{tabular}{|l|l|l|l} 
No tradicional & Tipo de técnica Diferente a la existente
\end{tabular}

Descripción

Reintegración del área afectado por la cubierta y de otros puntos del muro

3.2. ZÓCALO

No intervenido

Tipo de intervención

$\square$ Actualización

Tipo de material

$\square$ Consolidación $\square$ Reconstrucción $\square$ sustitución

Descripción

3.3. REVESTIMIENTOS

Tipo de intervención

\section{No aplica}

Tipo de material

$\square$ Actualización $\square$ Reintegración $\square$ Demolición $\square$ Otro...

Tipo de materia

Descripción

3.4. VANOS

Tipo de intervención

No intervenido

Tipo de material

$\square$ Actualización $\quad \square$ Reintegración $\quad \square$ Demolición $\quad \square$ Otro...
$\square$ Consolidación $\quad \square$ Reconstrucción $\quad \square$ sustitución

Tipo de materia

3.5. CUBIERTA

Tipo de intervención

Intervenido

$\square$ Actualización $\square$ Reintegración $\square$ Demolición $\square$ Otro.

Tipo de material

$\square$ Consolidación $\square$ Reconstrucción $\quad \boldsymbol{X}$ Sustitución

Descripción

No tradicional Tipo de técnica Diferente a la existente

Sustitución de la cubierta por placas de fibrocemento

3.6. OTRAS 
La restauración y rehabilitación de la arquitectura tradicional de tierra. El caso de Aragón.

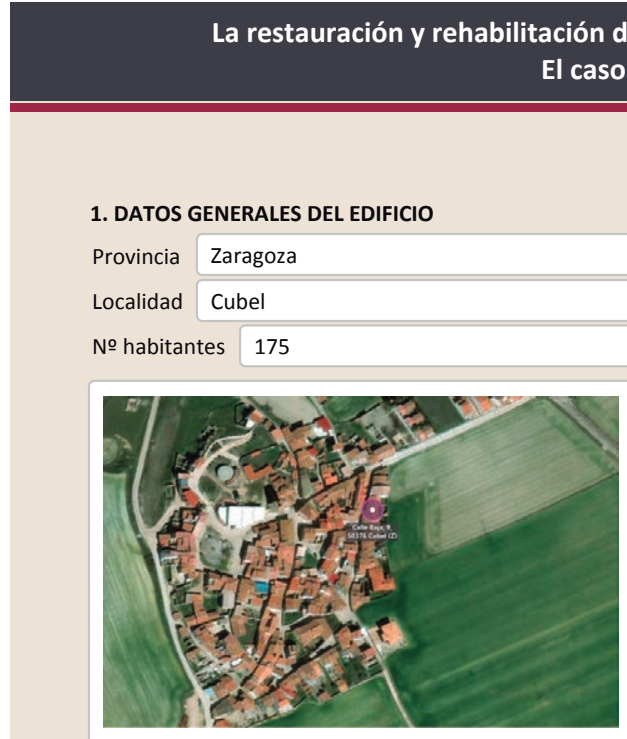

Plano de situación

Tipo de propiedad

Uso del edificio
№ Ficha

Fecha $07 / 10 / 2017$

Comarca Campo de Daroca

Dirección

m.s.n.m. 1108

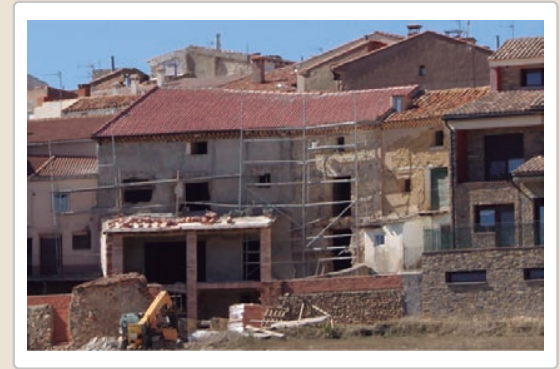

Vista general

Tipología edificatoría Entre medianeras

Sin uso Tipo de uso Residencial

Х Mampostería $\square$ Piedras lajas $\square$ Tapialete $\square$ Ladrillo $\quad$ N Nuevas técnicas $\square$ sillares/sillarejo $\square$ Tapia $\quad \mathbf{X}$ Adobe $\quad \square$ Entramado $\quad \square$ No

\begin{tabular}{l|l|l|l|l|l} 
Estado intervención Núm. plantas & Intervenido
\end{tabular}

Entorno inmediato Urbano_núcleo histórico Entorno o paisaje Monte

$\begin{array}{lll}\text { Estado del entorno } & \text { mantenido } & \text { Presencia de turismo No }\end{array}$

Observaciones El edificio estaba siendo intervenido en el momento de la toma de datos. Img inf.oct 2017 y google 2008

\section{DATOS DE LAS TÉCNICAS DE ADOBE, ENTRAMADOS Y TAPIA}

Situación de la técnica en el edificio $\mathbf{X}$ Adobe $\square$ P. Baja $\quad$ XP. Primera $\quad$ XP. Superiores $\square$ Muro piñon $\square$ Tapia $\square$ P. Baja $\square$ P. Primera $\square$ P. Superiores $\square$ Muro piñon $\square$ Entramado $\square$ P. Baja $\square$ P. Primera $\square$ P. Superiores $\square$ Muro piñon $\square$ Otras

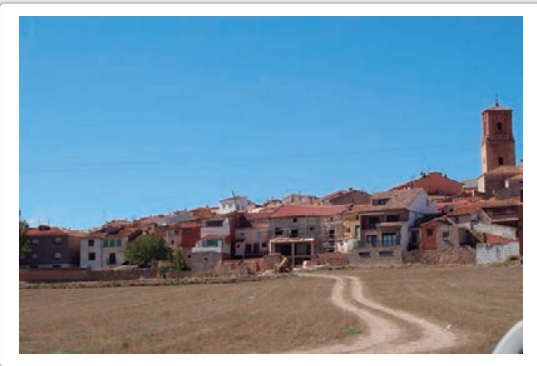

La restauración y rehabilitación de la arquitectura tradicional de tierra.

El caso de Aragón.
2.1. ADOBE

Dimensión de las piezas Dimensión del muro

Aparejo del muro

Función estructural

\begin{tabular}{|l|}
\hline \\
\hline $40-50 \mathrm{~cm}$ \\
\hline Tizón \\
\hline Si \\
\hline
\end{tabular}

Color de las piezas

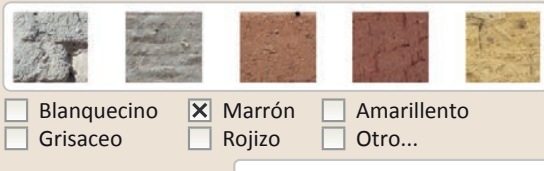

Comp. - estabilizante

Variante constructiva/ tipo de fábrica

メ simple

$\square$ suplementada en juntas

$\square$ Mixta

$\square$ Como suplemento

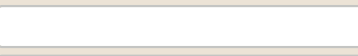

Revestimiento
$\mathbf{X}$ Elementos de protección

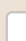

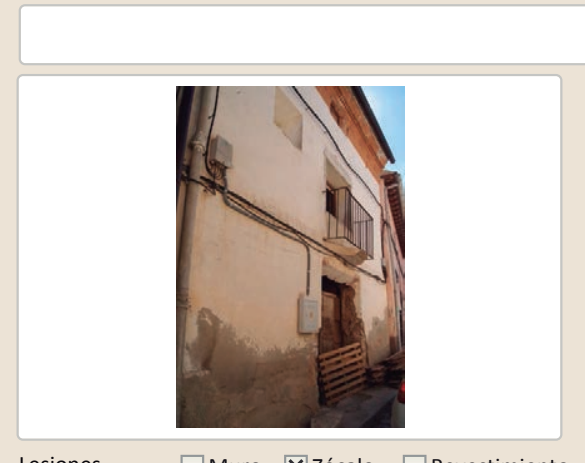

Lesiones $\square$ Muro $\quad \mathbf{X}$ Zócalo $\square$ Revestimiento

$\square$ Erosión del material $\quad \mathbf{X}$ Humedad por capilaridad

$\square$ Erosion de las juntas $\square$ Humedades (manch/eflo)

$\square$ Pérdida de sección $\square$ Pérdida de verticalidad

$\square$ Vegetación

$\square$ Grietas por empuje de la cubir $\square$ Grietas porfalta de traba

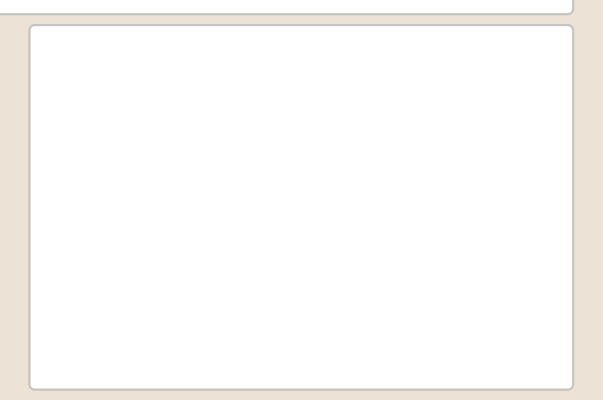

$\square$ Cubierta $\square$ otro...

$\square$ Colapso

$\square$ Desconchados

$\square$ Por elementos impropios

$\square$ Derivado de intervenciones

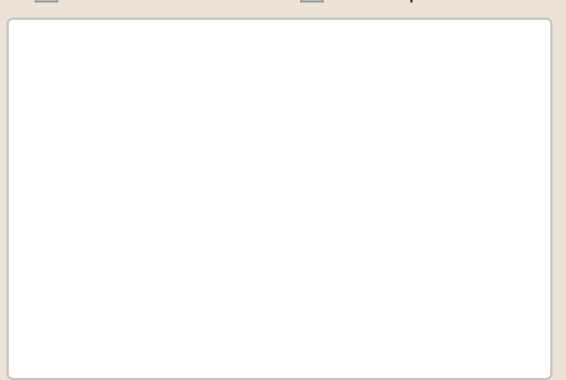

Observaciones 


\section{La restauración y rehabilitación de la arquitectura tradicional de tierra.}

\section{El caso de Aragón.}

3. DATOS DE LA INTERVENCIÓN

Mantenimien

Intervención de:

$\square$ Reparación

$\square$ Rehabilitación parcial

$\square$ Restauración $\square$ Demolición

Reflexión previa

Intervención planificada

Observaciones

(n)

3.1. MUROS
Tipo de intervención

Intervenido

Tipo de material

$\square$ Actualización $\quad \mathbf{X}$ Reintegración $\quad \square$ Demolición $\quad \square$ Otro...
$\square$ Consolidación $\quad \mathbf{X}$ Reconstrucción $\quad \square$ Sustitución

Descripción

X Reconstrucción $\square$ sustitución

D.2. zOCALO

Tipo de intervención

No tradicional

Tipo de técnica Diferente a la existente

Reintegración de faltantes . Construcción de nuevos elementos como el porche trasero.

Intervenido

$\square$ Actualización $\square$ Reintegración $\square$ Demolición $\square$ Otro...

$\square$ Consolidación $\quad \mathbf{X}$ Reconstrucción $\square$ Sustitución

Tipo de material

No tradicional

Tipo de técnica Diferente a la existente

Descripción

3.3. REVESTIMIENTOS

Tipo de intervención

Intervenido

$\square$ Actualización $\square$ Reintegración $\quad \square$ Demolición $\square$ Otro...

$\square$ Consolidación $\quad \mathbf{X}$ Reconstrucción $\square$ sustitución

Tipo de material

Descripción

No tradicional

Tipo de técnica Diferente a la existente

3.4. VANOS

Tipo de intervención

Revestimiento de cemento aplicado por el momento en la fachada trasera

Tipo de material

Intervenido

$\square$ Actualización $\quad \mathbf{X}$ Reintegración $\square$ Demolición $\square$ Otro...

Descripción

3.5. CUBIERTA

Tipo de intervención

Consolidación $\square$ Reconstrucción $\mathbf{x}$ Sustitución

\begin{tabular}{|l|l|l} 
No tradicional Tipo de técnica Diferente a la existente &
\end{tabular}

No se aprecian las intervenciones que se van a llevar a cabo

Intervenido

$\square$ Actualización $\square$ Reintegración $\square$ Demolición $\quad \square$ Otro..

$\square$ Consolidación $\square$ Reconstrucción $\quad \mathbb{\text { Sustitución }}$

Tipo de material

No tradicional

Tipo de técnica Diferente a la existente

Descripción$$
\text { Sus }
$$

3.6. OTRAS

Sustitución de los forjados. Las viguetas si que se han conservado y se han añadido elementos aislantes
La restauración y rehabilitación de la arquitectura tradicional de tierra.

El caso de Aragón.

3.7. REHABILITACIÓN ENERGÉTICA $\square$ Fachada $\square$ Vanos $\quad \mathbf{X}$ Forjados $\square$ Cubierta

Observaciones

FOTOGRAFÍAS DE LA INTERVENCIÓN
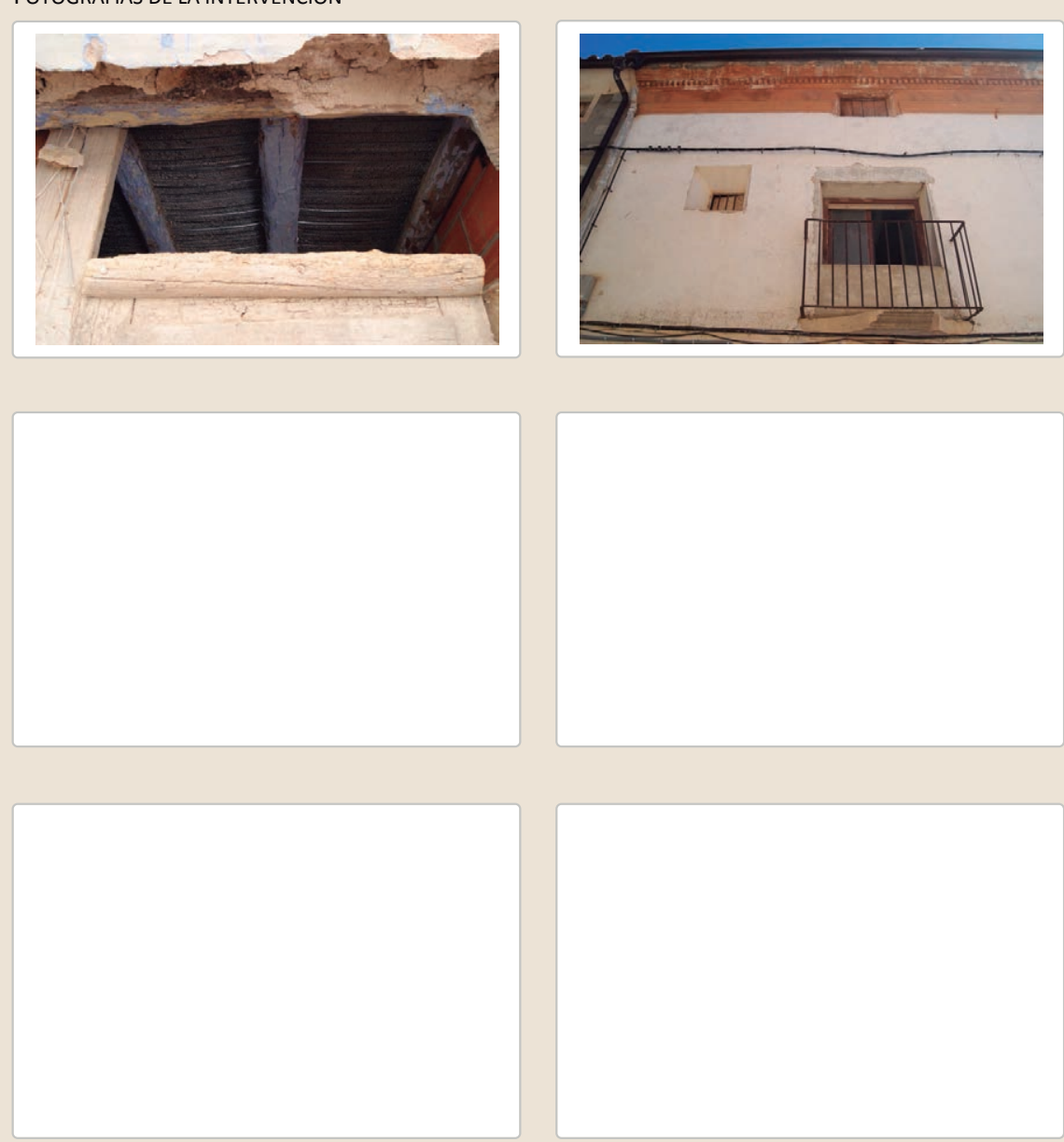


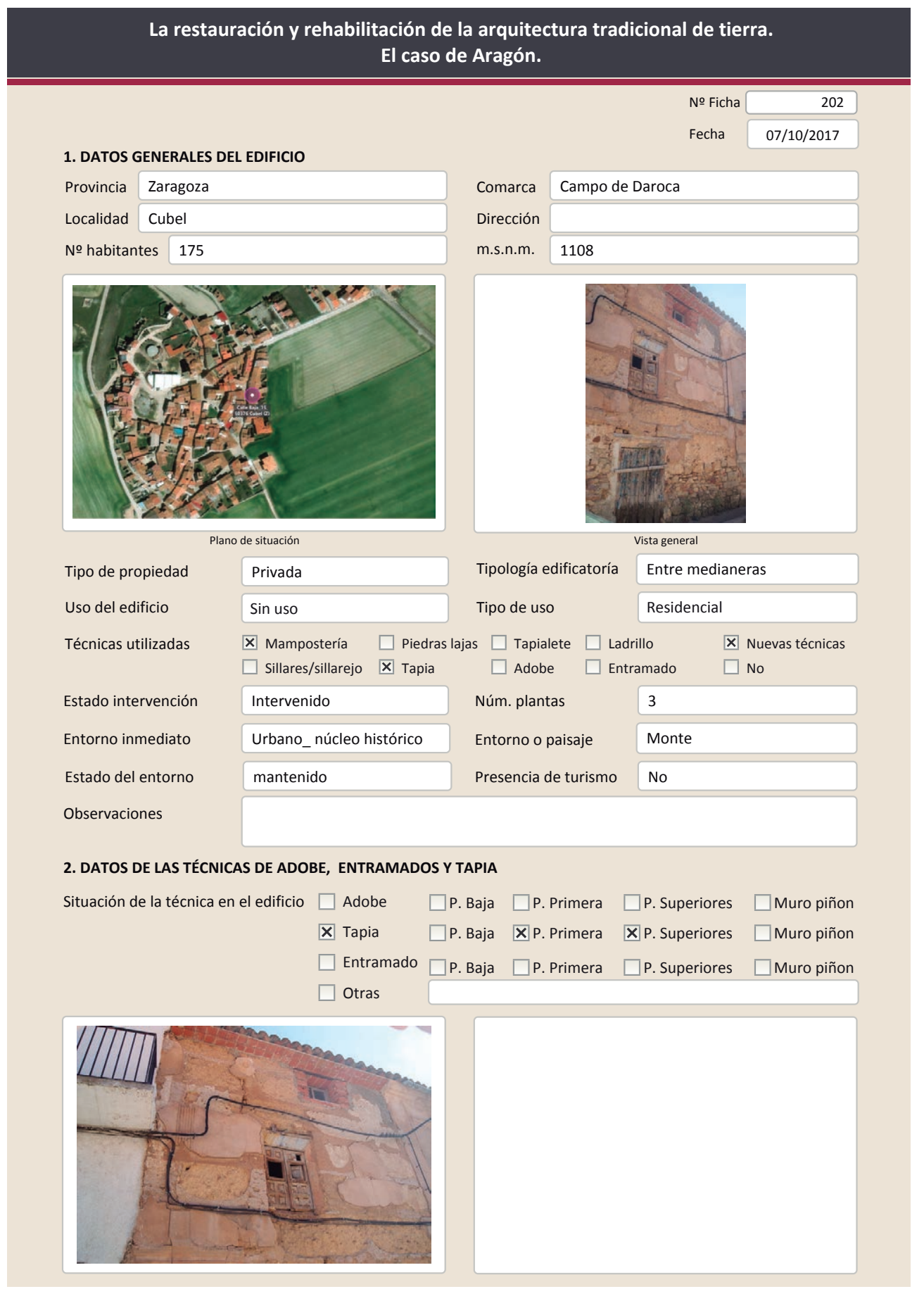

La restauración y rehabilitación de la arquitectura tradicional de tierra. El caso de Aragón.
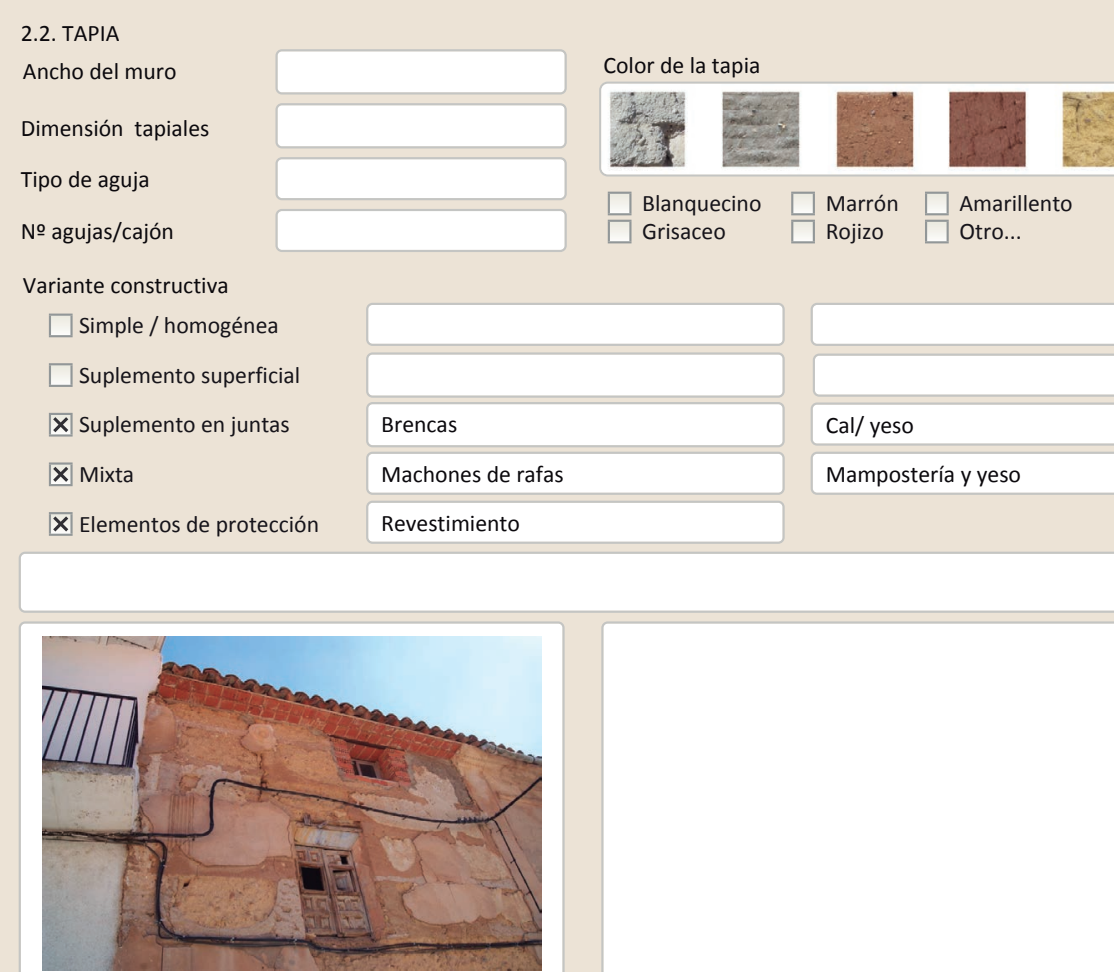

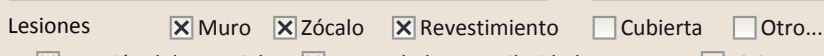
Х Erosión del material $\mathbf{X}$ Humedad por capilaridad $\quad \square$ Grietas por asentamientos $\square$ Erosion de las juntas $\mathbf{X}$ Humedades (manch/eflo) $\quad \square$ Colapso
$\square$ Pérdida de sección $\square$ Pérdida de verticalidad $\quad \square$ Por elementos impropios
$\square$ Vegetación
$\checkmark$ Por elementos impropios

$\mathbf{X}$ Desconchados $\square$ Grietas pofatta de traba

$\square$ Otro...

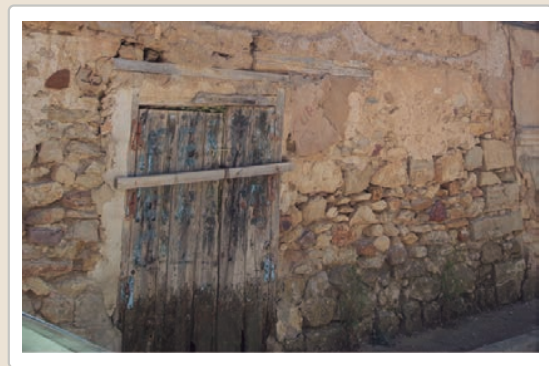

Observaciones 
La restauración y rehabilitación de la arquitectura tradicional de tierra. El caso de Aragón

\section{La restauración y rehabilitación de la arquitectura tradicional de tierra.}

\section{El caso de Aragón.}

3. DATOS DE LA INTERVENCIÓN

Intervención de:

$\square$ Mantenimiento $\square$ Rehabilitación parcia

$\square$ Restauración $\square$ Demolición

Reflexión previa

X Reparación

$\square$ Rehabilitación integral $\square$ Ampliación

$\square$ Otro..

Observaciones

Intervención espontanea

(n)

3.1. MUROS

No intervenido

Tipo de intervención

$\square$ Actualización $\square$ Reintegración $\square$ Demolición $\square$ Otro...

$\square$ Consolidación $\square$ Reconstrucción $\square$ Sustitución

Tipo de material

Descripción

3.2. ZÓCALO

Tipo de intervención

No intervenido

Tipo de material

$\square$ Actualización

Remolición $\square$ Otro...

Descripción

3.3. REVESTIMIENTOS

Tipo de intervención

No intervenido

$\square$ Actualización

Tipo de técnica

Tipo de material

Descripción

3.4. VANOS

Tipo de intervención

Intervenido

Tipo de material

$\square$ Actualización $\quad \boldsymbol{X}$ Reintegración $\quad \square$ Demolición $\quad \square$ Otro...
$\square$ Consolidación $\quad \square$ Reconstrucción $\quad \square$ Sustitución

Tipo de materia
Descripción

3.5. CUBIERTA

Tipo de intervención

No tradicional

Tipo de técnica Diferente a la existente

Reintegración de jambas y alfeizar del hueco bajo la cubierta con ladrillo hueco

Tipo de material

Intervenido

$\square$ Actualización $\square$ Reintegración $\square$ Demolición $\square$ Otro..

$\square$ Consolidación $\square$ Reconstrucción \ Sustitución

Descripción
No tradicional
Tipo de técnica Diferente a la existente

3.6. OTRAS

Nueva cubierta construida con elementos cerámicos y con ja tradicional curva 


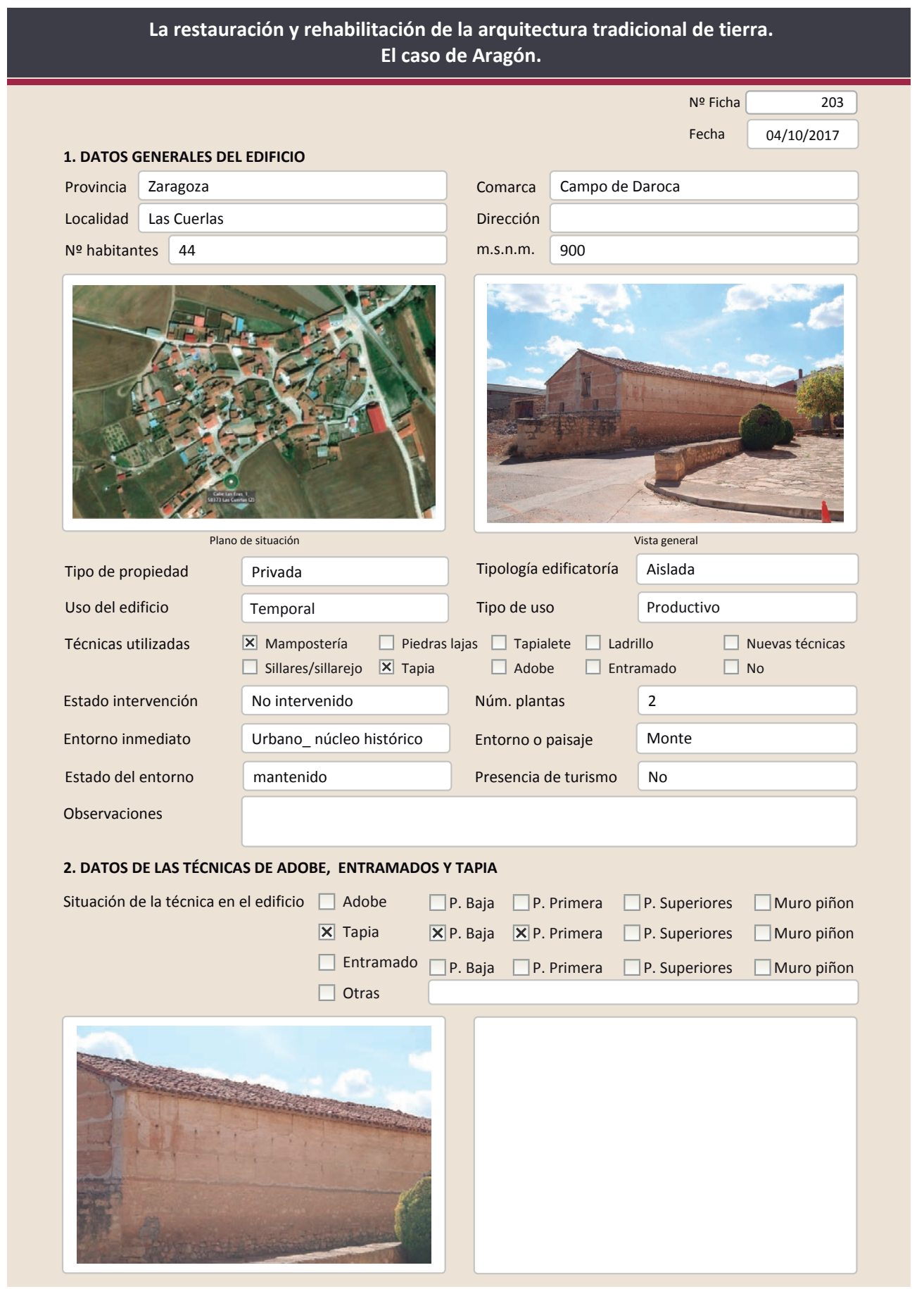

La restauración y rehabilitación de la arquitectura tradicional de tierra.

El caso de Aragón.

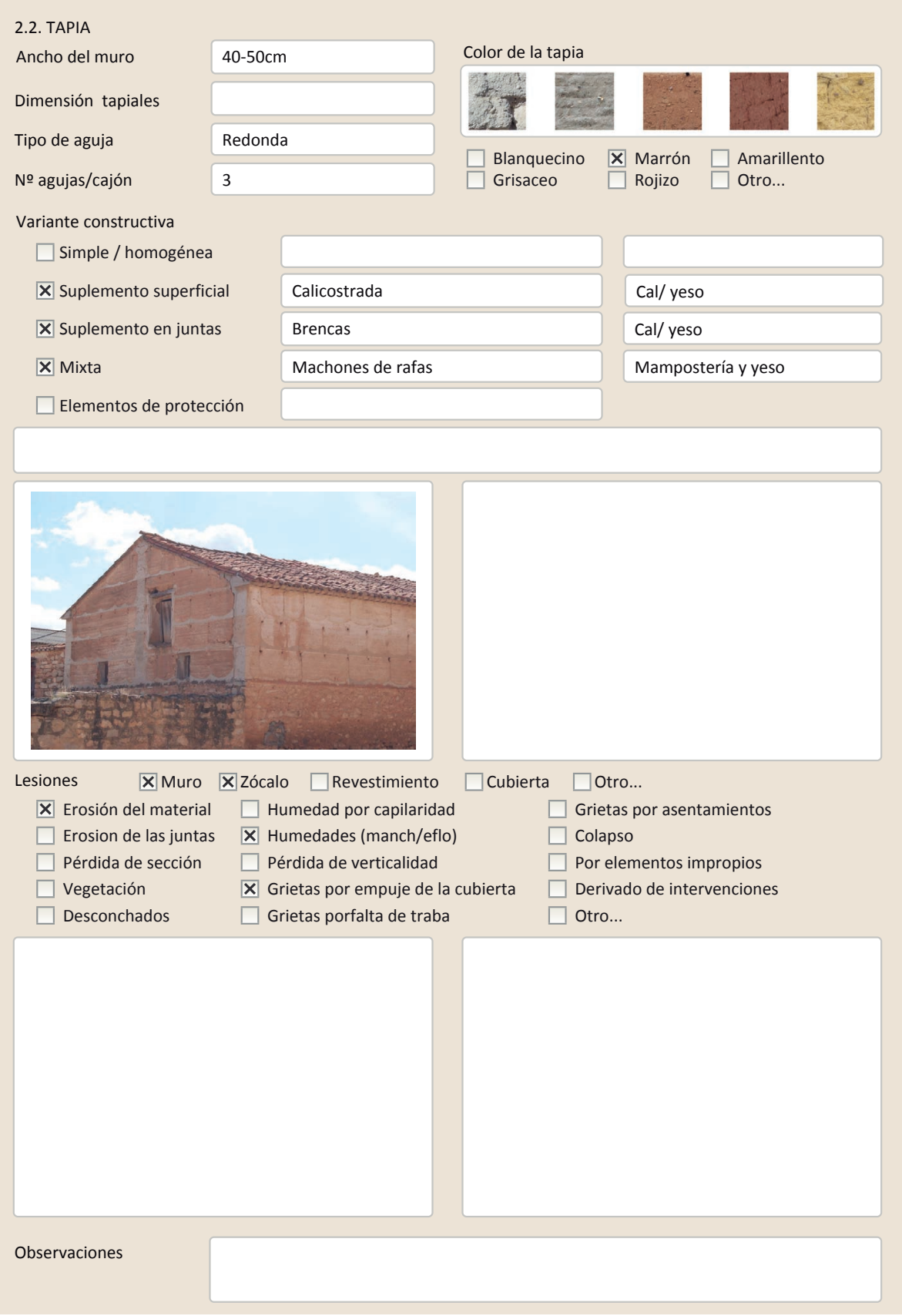


La restauración y rehabilitación de la arquitectura tradicional de tierra. El caso de Aragón

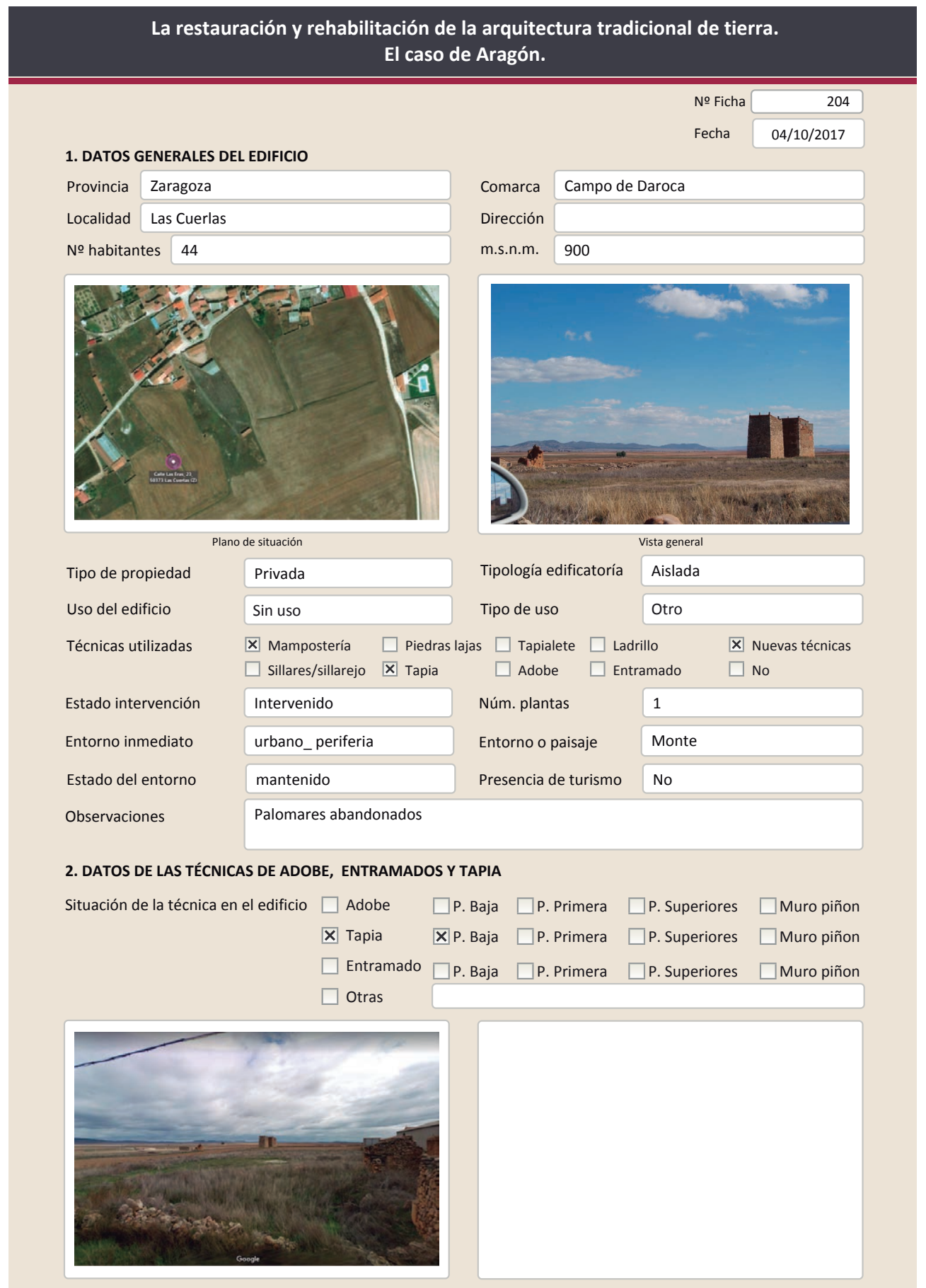

2.2. TAPIA

Ancho del muro

Dimensión tapiales

Tipo de aguja

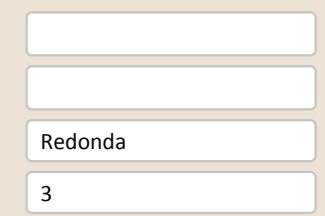

Color de la tapia

№ agujas/cajón

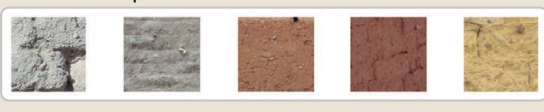

$\square$ Blanquecino $\quad \mathbf{X}$ Marrón $\square$ Amarillento

$\begin{array}{ll}\square \text { Blanquecino } & \mathbf{x} \text { Marrón } \\ \square \text { Grisaceo } & \square \text { Rojizo }\end{array}$

Variante constructiva

$\square$ Simple / homogénea

X Suplemento superficial

$\mathbf{X}$ Suplemento en juntas

$\mathbf{X}$ Mixta
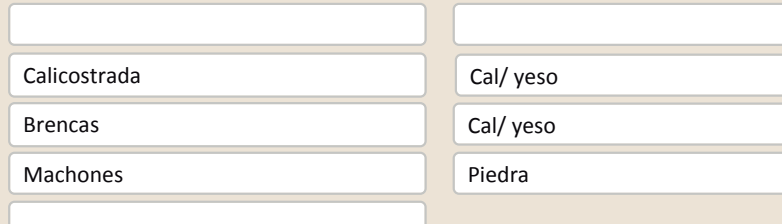

Elementos de protección

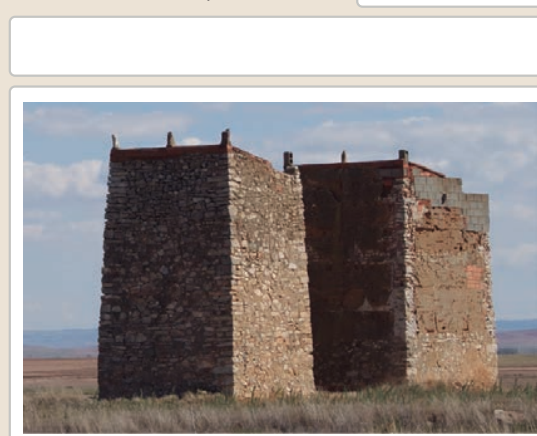

Lesiones ХMuro ХZŹcalo Х Revestimiento $\square$ Cubierta $\square$ Otro...

Х Erosión del material $\quad \square$ Humedad por capilaridad $\quad \square$ Grietas por asentamiento

X Pérdida de sección $\square$ Pérdida de verticalidad $\quad \square$ Por elementos impropios

$\square$ Vegetación $\quad \square$ Grietas por empuje de la cubierta $\square$ Derivado de intervenciones X Desconchados $\square$ Grietas porfalta de traba $\quad \square$ Otro... 
La restauración y rehabilitación de la arquitectura tradicional de tierra.

El caso de Aragón.

3. DATOS DE LA INTERVENCIÓN

\begin{tabular}{llll|} 
Intervención de: & $\square$ Mantenimiento $\quad \square$ Rehabilitación parcial & $\square$ Restauración $\quad \square$ Demolición \\
Reflexión previa & $\mathbf{X}$ Reparación $\quad \square$ Rehabilitación integral $\quad \square$ Ampliación $\quad \square$ Otro... \\
\hline Observaciones & Intervención espontanea & \\
& & \\
& & \\
\end{tabular}

\subsection{MUROS}

Tipo de intervención

Tipo de material

$\square$ Actualización $\quad \mathbf{X}$ Reintegración $\square$ Demolición $\square$ Otro...

$\square$ Consolidación $\quad \mathbf{X}$ Reconstrucción $\quad \square$ sustitución

Descripción

No tradicional Tipo de técnica Diferente a la existente

3.2. ZOCALO Reconstrucción parcial de la coronación de muro con blo

\subsection{ZÓCALO}

Tipo de intervención

No intervenido

Tipo de material

$\square$ Actualización

Descripción

3.3. REVESTIMIENTOS

Tipo de intervención

\section{No aplica}

Tipo de material

$\square$ Actualización $\quad \square$ Reintegración $\quad \square$ Demolición $\square$ Otro...

$\square$ Reintegración $\square$ Demolición

oque de hormigón prefabricado.

Consolidación $\quad \square$ Reconstrucción $\square$ Sustitución
Tipo de técnica

Descripción

3.4. VANOS

Tipo de intervención

No visible

Tipo de material

Descripción

Consolidación $\quad \square$ Reconstrucción $\quad \square$ Sustitución

3.5. CUBIERTA

Tipo de intervención

Intervenido

Tipo de intervención

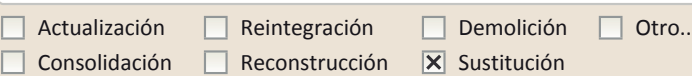

Tipo de material

No tradicional

Tipo de técnica Diferente a la existente

Descripción

La cubierta parece sustituida en ambos casos

3.6. OTRAS 


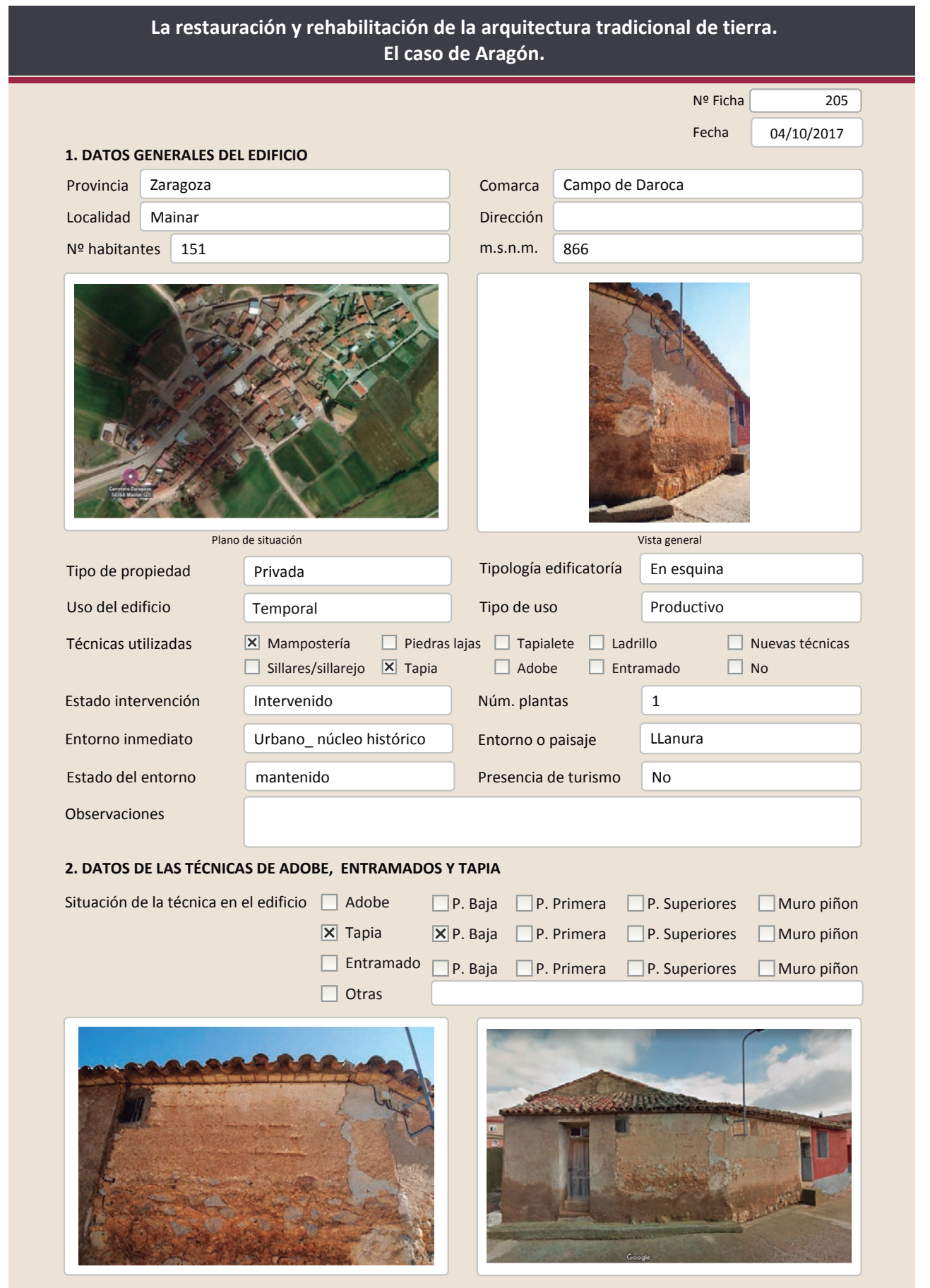

\subsection{TAPIA}

Ancho del muro

Dimensión tapiales

Tipo de aguja

\begin{tabular}{|l|}
\hline $60-70 \mathrm{~cm}$ \\
\hline \\
\hline Redonda \\
\hline 3 \\
\hline
\end{tabular}

Color de la tapia

№ agujas/cajón

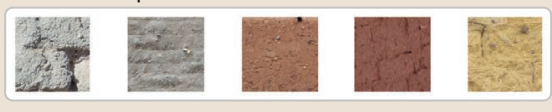

$\square$ Blanquecino $\mathbf{X}$ Marrón $\square$ Amarillento

$\begin{array}{ll}\square \text { Blanquecino } & \mathbf{x} \text { Marrón } \\ \square \text { Grisaceo } & \square \text { Amaril } \\ & \square \text { Rojizo }\end{array}$

Variante constructiva

$\square$ Simple / homogénea

$\mathbf{X}$ Suplemento superficial

$\square$ suplemento en juntas

$\square$ Mixta

$\square$ Elementos de protección
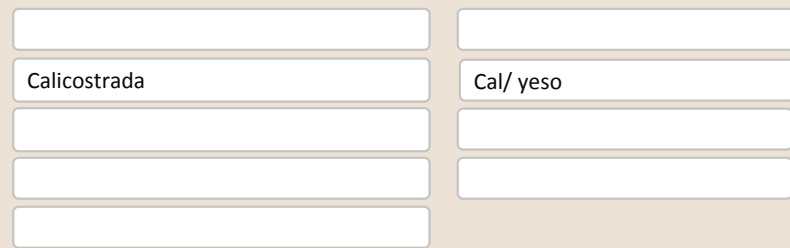

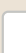

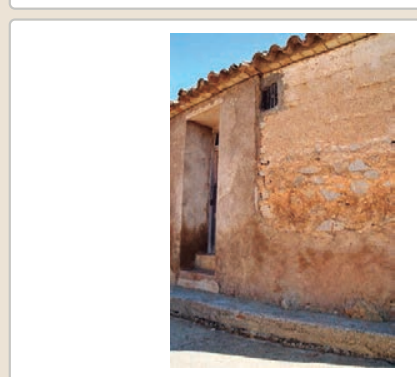

Lesiones $\quad \mathbf{X}$ Muro $\mathbf{X}$ Zócalo $\square$ Revestimiento

X Erosión del material $\mathbf{X}$ Humedad por capilaridad

$\square$ Erosion de las juntas $\mathbf{X}$ Humedades (manch/eflo)

$\square$ Pérdida de sección $\quad \square$ Pérdida de verticalidad

$\square$ Vegetación $\quad \square$ Grietas por empuje de la

$\square$ Desconchados $\quad \square$ Grietas porfalta de traba

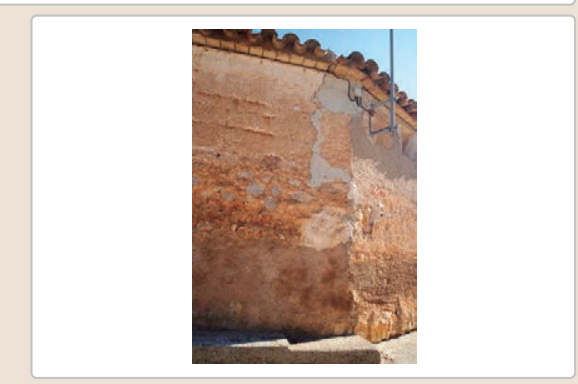

$\square$ Cubierta $\square$ Otro...

$\square$ Grietas por asentamientos

$\square$ Colapso

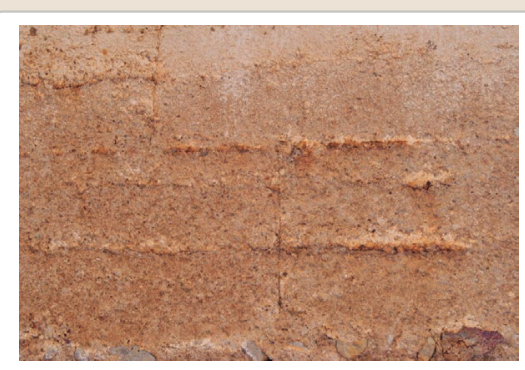

Observaciones 


\section{La restauración y rehabilitación de la arquitectura tradicional de tierra.}

\section{El caso de Aragón.}

3. DATOS DE LA INTERVENCIÓN

\begin{tabular}{|c|c|c|c|c|}
\hline Intervención de: & $\begin{array}{l}\square \text { Mantenimiento } \\
\mathbf{X} \text { Reparación }\end{array}$ & $\begin{array}{l}\square \text { Rehabilitación parcial } \\
\square \text { Rehabilitación integral }\end{array}$ & $\begin{array}{l}\square \text { Restauración } \\
\square \text { Ampliación }\end{array}$ & $\begin{array}{l}\square \text { Demolición } \\
\square \text { Otro... }\end{array}$ \\
\hline Reflexión previa & \multicolumn{4}{|c|}{ Intervención espontanea } \\
\hline erva & & & & \\
\hline
\end{tabular}

\subsection{MUROS}

Tipo de intervención

Intervenido

Tipo de material

$\square$ Actualización $\quad \mathbf{X}$ Reintegración $\quad \square$ Demolición $\square$ Otro...

$\square$ Consolidación $\square$ Reconstrucción $\square$ sustitución

Descripción

No tradicional Tipo de técnica Diferente a la existente

3.2. ZÓCALO

Tipo de intervención

Reintegración del faltantes con cemento

Tipo de material

Intervenido

$\square$ Actualización $\square$ Reintegración $\square$ Demolición $\square$ Otro...

$\square$ Actualización $\square$ Reintegración $\quad \square$ Demolición
$\square$ Consolidación $\quad \boldsymbol{X}$ Reconstrucción $\quad \square$ Sustitución

Descripción

No tradicional Tipo de técnica Diferente a la existente

3.3. REVESTIMIENTOS

Revestimiento en el zócalo (poco grosor)

Tipo de intervención

\section{No aplica}

Tipo de material

Descripción

$\square$ Actualización

$\square$ Reintegración $\square$ Demolición $\square$ Otro...

$\square$ Consolidación $\quad \square$ Reconstrucción $\square$ sustitución

3.4. VANOS

Tipo de intervención

Intervenido

Tipo de material

$\square$ Actualización $\square$ Reintegración $\square$ Demolición $\square$ Otro...

$\square$ Consolidación $\quad \mathbf{X}$ Reconstrucción $\square$ Sustitución

Descripción

No tradicional

Tipo de técnica Diferente a la existente

3.5. CUBIERTA

Tipo de intervención

Reconstrucción de los contornos de la puerta de acceso

Tipo de material

Intervenido

$\square$ Actualización $\square$ Reintegración $\square$ Demolición $\square$ Otro..

$\square$ Actualización $\quad \square$ Reintegración $\quad \square$ Demolición
$\square$ consolidación $\quad \boldsymbol{X}$ Reconstrucción $\quad \square$ Sustitución

Descripción
No tradicional
Tipo de técnica Similar a la existente

Reconstrucción de la cubierta con cemento. Se ha conservado el alero de rasillas y las tejas curvas

3.6. OTRAS 
La restauración y rehabilitación de la arquitectura tradicional de tierra. El caso de Aragón

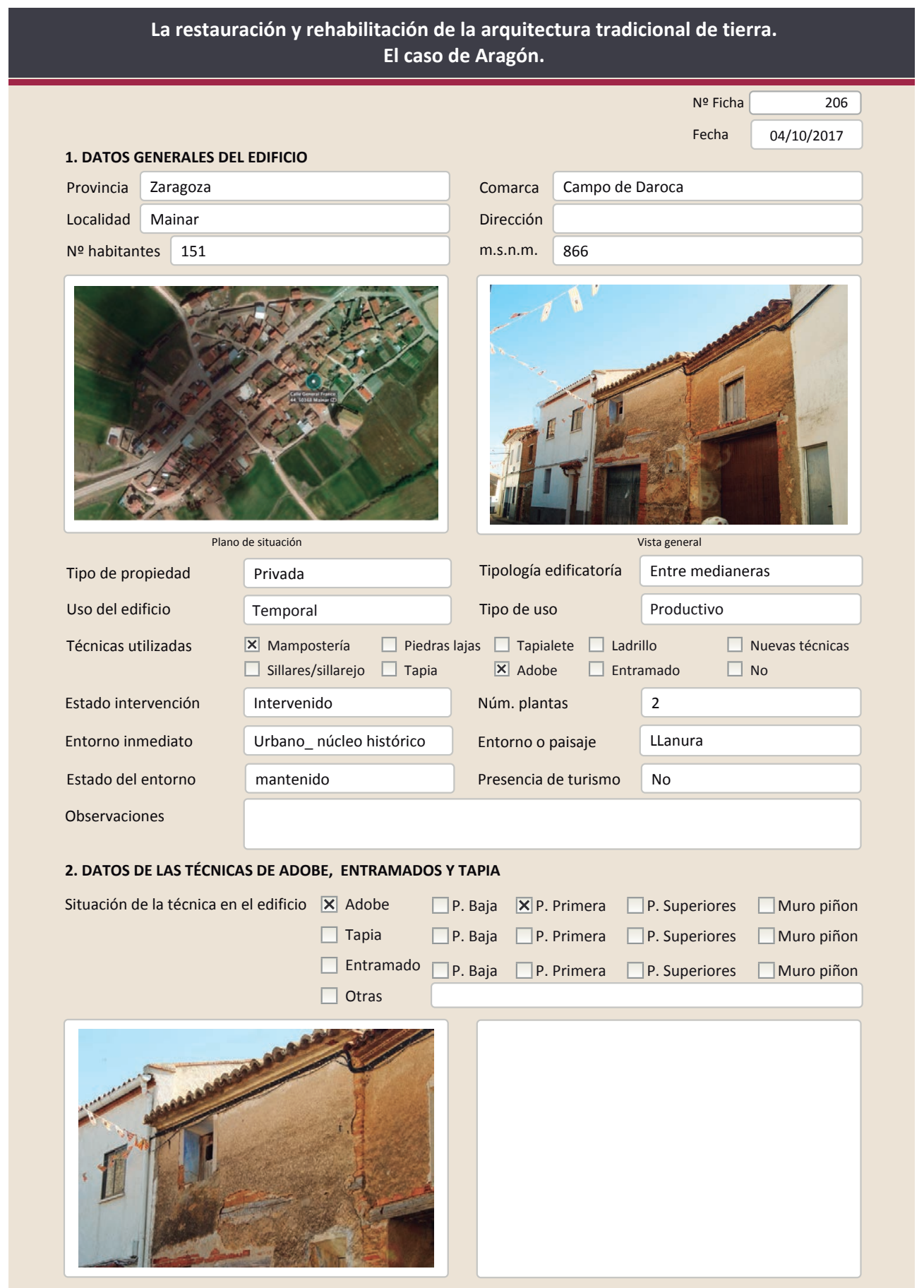

2.1. ADOBE

Dimensión de las piezas Dimensión del muro

Aparejo del muro

\begin{tabular}{|l|}
\hline \\
\hline $30-40 \mathrm{~cm}$ \\
\hline Tizón \\
\hline $\mathrm{Si}$ \\
\hline
\end{tabular}

Color de las piezas

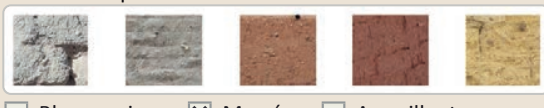

Blanquecino $\mathbf{X}$ Marrón $\square$ Amarillento $\square$ Grisaceo $\square$ Rojizo $\square$ Otro...

Función estructural

Comp. - estabilizante

Variante constructiva/ tipo de fábrica

$\square$ simple

$\square$ Suplementada en juntas

区 Mixta

En esquinas

Ladrillo

$\square$ Como suplemento

X Elementos de protección

Revestimiento

El muro de planta primera apoya sobre un durmiente de madera

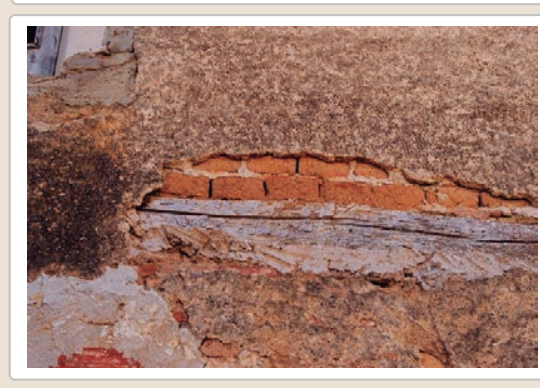

Lesiones $\square$ Muro ХZŹcalo $\mathbf{X}$ Revestimiento

$\square$ Erosión del material $\quad \mathbf{X}$ Humedad por capilaridad

$\square$ Erosion de las juntas $\mathbb{X}$ Humedades (manch/eflo)

$\square$ Pérdida de sección $\square$ Pérdida de verticalidad

$\square$ Vegetación

$\square$ Grietas por empuje de la

$\square$ Grietas porfalta de traba

$\square$ Cubierta $\square$ otro...

$\square$ Grietas por asentamiento

$\square$ Colapso

X Desconchados

$\square$ Por elementos impropios

$\square$ Derivado de intervenciones $\square$ Otro... 


\section{La restauración y rehabilitación de la arquitectura tradicional de tierra.}

\section{El caso de Aragón.}

3. DATOS DE LA INTERVENCIÓN

\begin{tabular}{|c|c|c|c|c|}
\hline Intervención de: & $\begin{array}{l}\square \text { Mantenimiento } \\
\boldsymbol{X} \text { Reparación }\end{array}$ & $\begin{array}{l}\square \text { Rehabilitación parcial } \\
\square \text { Rehabilitación integral }\end{array}$ & $\begin{array}{l}\square \text { Restauración } \\
\square \text { Ampliación }\end{array}$ & $\begin{array}{l}\square \text { Demolición } \\
\square \text { Otro... }\end{array}$ \\
\hline Reflexión previa & \multicolumn{4}{|c|}{ Intervención espontanea } \\
\hline Observaciones & & & & \\
\hline
\end{tabular}

\subsection{MUROS}

Tipo de intervención

Intervenido

Tipo de material

$\square$ Actualización $\quad$ X Reintegración $\square$ Demolición $\square$ Otro...

$\square$ Consolidación $\square$ Reconstrucción $\square$ Sustitución

Descripción

$\begin{array}{lll}\text { No tradicional } & \text { Tipo de técnica } & \text { Diferente a la existente }\end{array}$

3.2. ZóCALO

Reintegración de la perdida de sección sobre el hueco de planta baja con ladrillo hueco

Tipo de intervención

Intervenido

Tipo de material

$\square$ Actualización $\quad \mathbf{X}$ Reintegración $\quad \square$ Demolición $\square$ Otro...

$\begin{array}{ll}\square \text { Actualización } & \boldsymbol{X} \text { Reintegración } \\ \square \text { Consolidación } \quad \square \text { Reconstrucción } \quad \square \text { Sustitución }\end{array}$

Descripción

Tipo de técnica Diferente a la existente

3.3. REVESTIMIENTOS

Revestimiento de cemento. Se encuentra en mal estado

Tipo de intervención

No intervenido

Tipo de material

$\square$ Actualización $\quad \square$ Reintegración $\square$ Demolición $\square$ Otro...

Tipo de materia

$\square$ Consolidación $\square$ Reconstrucción $\square$ Sustitución

Descripción

3.4. VANOS

No intervenido

Tipo de intervención

$\square$ Actualización $\quad \square$ Reintegración $\quad \square$ Demolición $\quad \square$ Otro...
$\square$ Consolidación $\quad \square$ Reconstrucción $\quad \square$ Sustitución

Tipo de material

Descripción

3.5. CUBIERTA

Tipo de intervención

Intervenido

Tipo de material

$\square$ Actualización $\quad \boldsymbol{X}$ Reintegración $\quad \square$ Demolición $\quad \square$ Otro..

Descripción

No tradicional

$$
\text { Tipo de técnica }
$$

3.6. OTRAS

Reintegración de las tejas de cubierta con mortero de cemento 
La restauración y rehabilitación de la arquitectura tradicional de tierra. El caso de Aragón

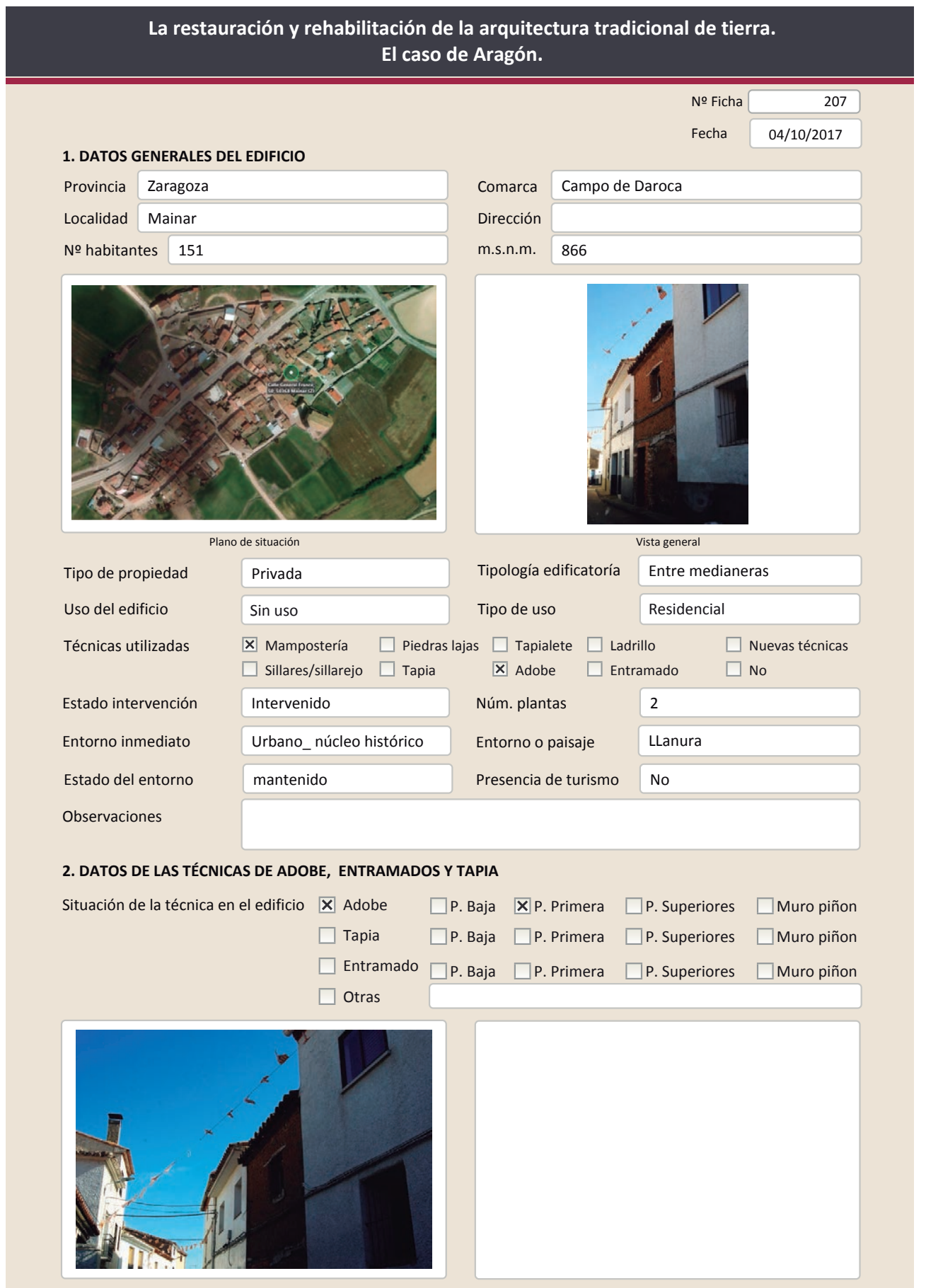

La restauración y rehabilitación de la arquitectura tradicional de tierra.

El caso de Aragón.

2.1. ADOBE

Dimensión de las piezas Dimensión del muro

Aparejo del muro

\begin{tabular}{|l|}
\hline \\
\hline $30-40 \mathrm{~cm}$ \\
\hline Tizón \\
\hline $\mathrm{Si}$ \\
\hline
\end{tabular}

Color de las piezas

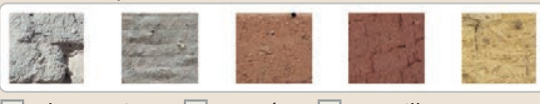

$\square$ Blanquecino $\mathbf{X}$ Marrón $\square$ Amarillento $\square$ Grisaceo $\square$ Rojizo $\square$ Otro.. Función estructural

Comp. - estabilizante Fibras vegetales

Variante constructiva/ tipo de fábrica

$\square$ Simple
X Suplementada en juntas
Horizontales
$\square$ Mixta
$\square$ Como suplemento
$\square$ Elementos de protección

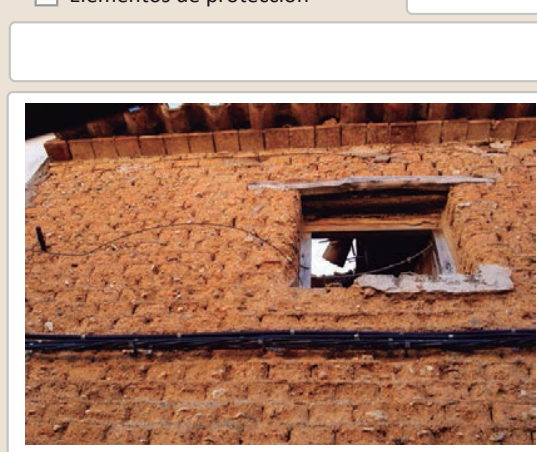

Lesiones $\quad \mathbf{X}$ Muro $\mathbf{X}$ Zócalo $\square$ Revestimiento

$\mathbf{X}$ Erosión del material $\mathbf{X}$ Humedad por capilaridad

$\square$ Erosion de las juntas $\mathbb{X}$ Humedades (manch/eflo)

X Pérdida de sección $\square$ Pérdida de verticalidad

$\square$ Vegetación $\quad \square$ Grietas por empuje de la cu $\square$ Grietas porfalta de traba

X Cubierta $\square$ Otro...

$\square$ Grietas por asentamientos

X Colapso

X Desconchado

$\square$ Derivado de intervenciones 


\section{La restauración y rehabilitación de la arquitectura tradicional de tierra.}

\section{El caso de Aragón.}

3. DATOS DE LA INTERVENCIÓN

Intervención de:

$\square$ Mantenimiento $\square$ Rehabilitación parcial

$\square$ Restauración $\square$ Demolición

Reflexión previa X Reparación Rehabilitación integra

$\square$ Ampliación $\square$ Otro...

Observaciones

Intervención espontanea

Observaciones

3.1. MUROS

Tipo de intervención

Tipo de material

Descripción

3.2. ZÓCALO

Tipo de intervención

Tipo de material

Descripción

3.3. REVESTIMIENTOS

Tipo de intervención

Tipo de material

Descripción

3.4. VANOS

Tipo de intervención

Tipo de material

Descripción

3.5. CUBIERTA

Tipo de intervención

Tipo de material

Descripción

3.6. OTRAS

Intervenido

$\square$ Actualización $\mathbf{X}$ Reintegración $\square$ Demolición $\square$ Otro..

$\square$ Consolidación $\square$ Reconstrucción $\square$ sustitución

No tradicional Tipo de técnica Diferente a la existente

Reintegración del zócalo con cemento

\section{No aplica}

$\square$ Actualización $\square$ Reintegración $\square$ Demolición $\square$ Otro...

$\square$ Consolidación $\square$ Reconstrucción $\square$ sustitución

Tipo de técnica

Intervenido

$\square$ Actualización $\quad \boldsymbol{X}$ Reintegración $\square$ Demolición $\square$ Otro...

$\square$ Consolidación $\mathbf{X}$ Reconstrucción $\mathbf{X}$ Sustitución

No tradicional Tipo de técnica Diferente a la existente

Se ha cegado un hueco. Otro hueco se ha sustituido la carpintería y reconstruido jambas y dintel con ladrillo hueco

No intervenido

$\square$ Actualización $\square$ Reintegración $\square$ Demolición $\quad \square$ Otro.. $\square$ Consolidación $\square$ Reconstrucción $\square$ Sustitución Tipo de técnica

\section{La restauración y rehabilitación de la arquitectura tradicional de tierra.}

El caso de Aragón.

3.7. REHABILITACIÓN ENERGÉTICA $\quad \square$ Fachada $\square$ Vanos $\square$ Forjados $\square$ Cubierta

Observaciones

FOTOGRAFÍAS DE LA INTERVENCIÓN
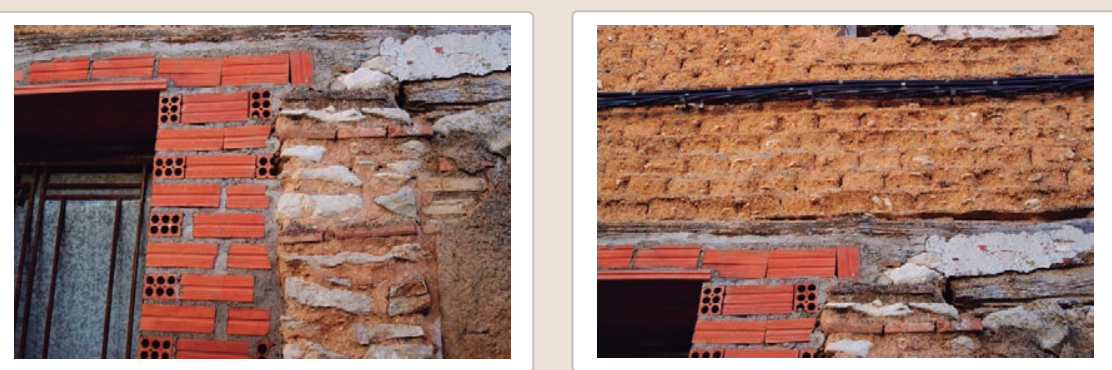

Tho de
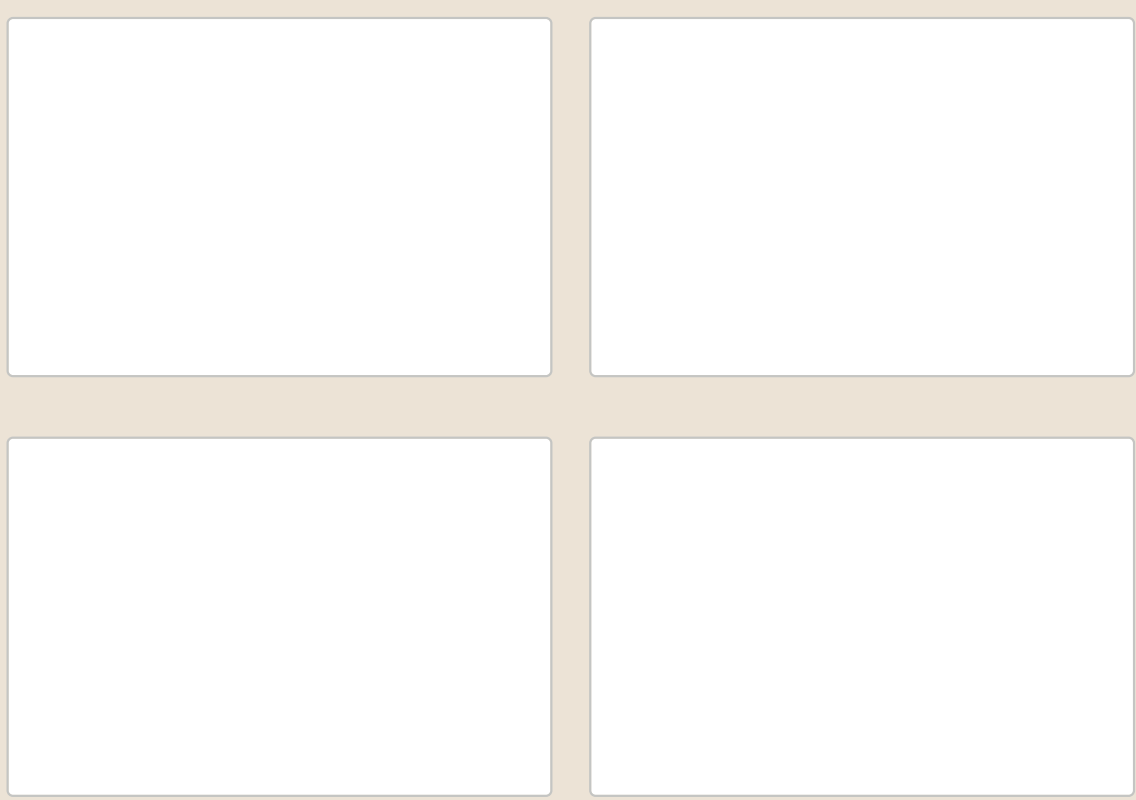


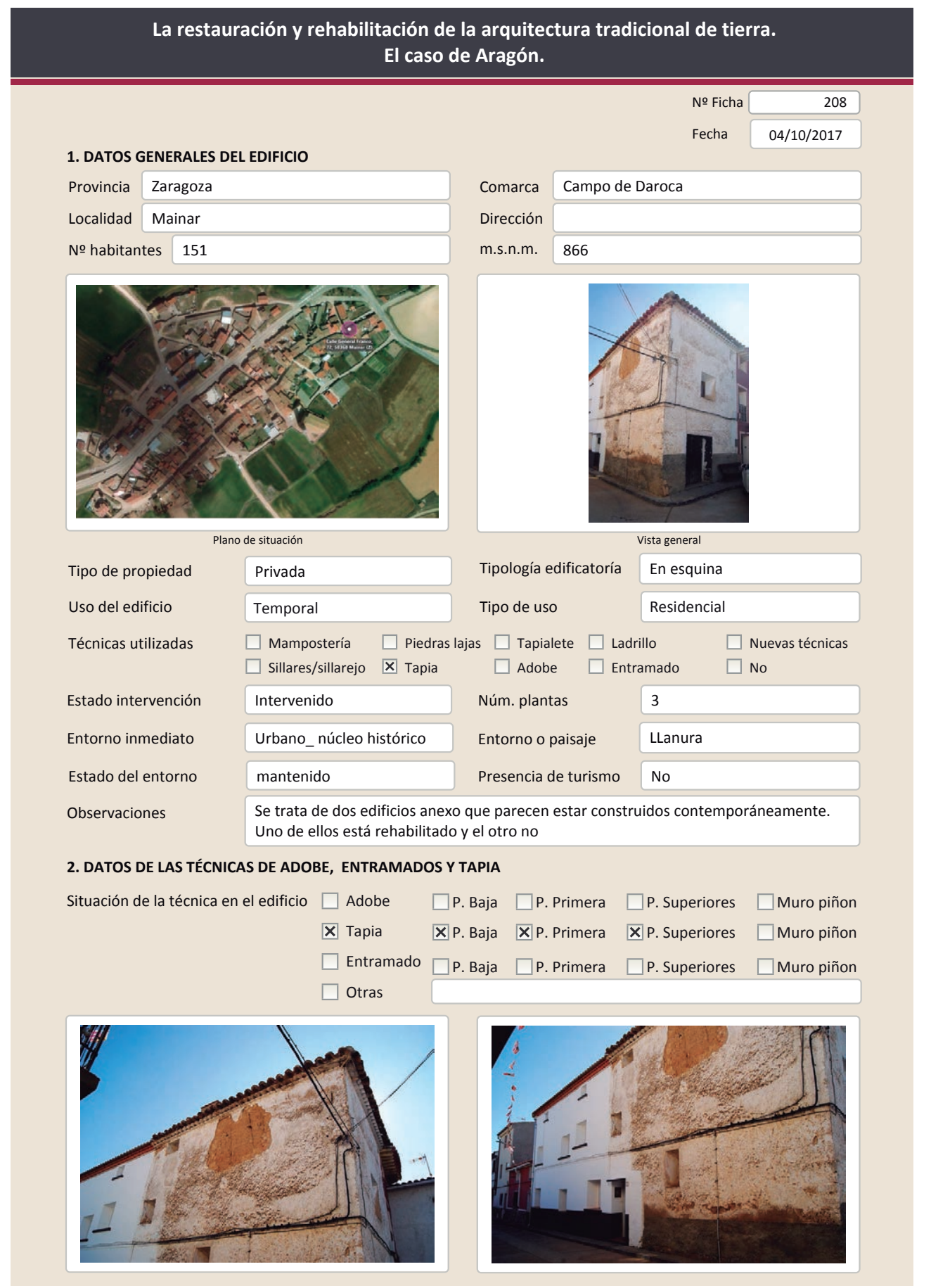

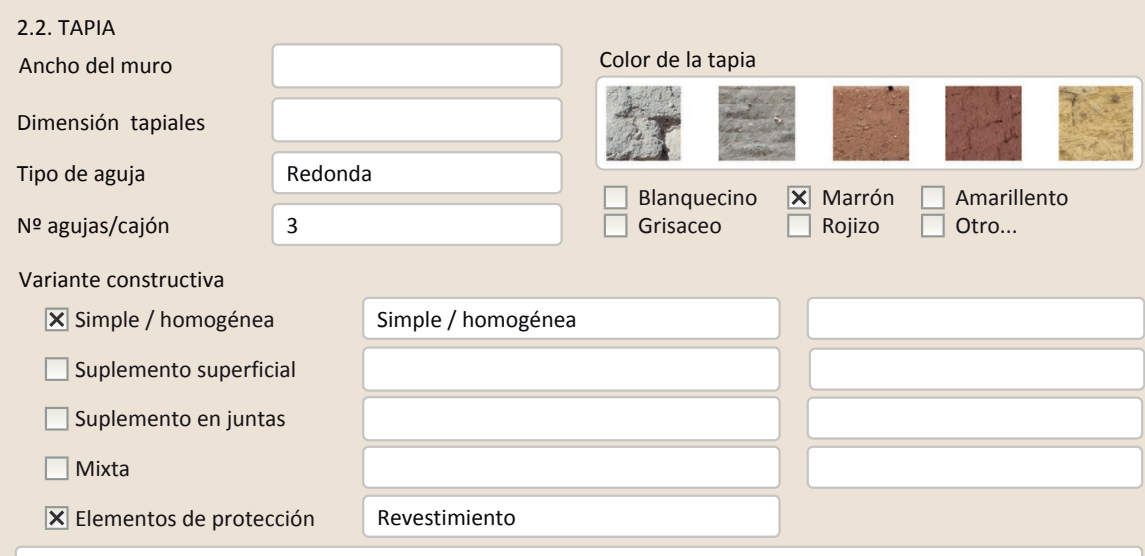

Revestimiento

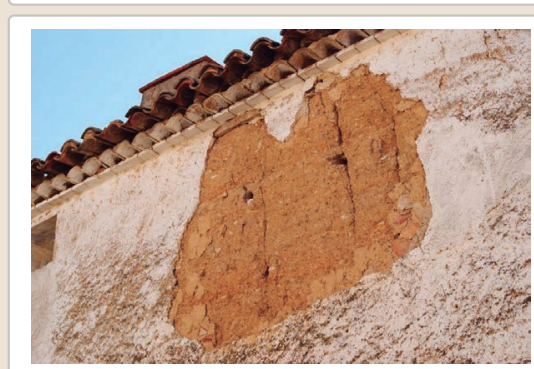

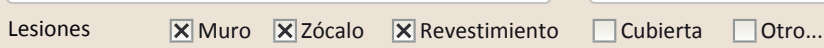

\ Erosión del material $\mathbf{X}$ Humedad por capilaridad $\quad \square$ Grietas por asentamientos $\square$ Erosion de las juntas $\mathbf{X}$ Humedades (manch/eflo)

$\square$ Pérdida de sección $\quad \square$ Pérdida de verticalidad

$\square$ Vegetación $\square$ Grietas por empuje de la cubieta

$x$ Desconchados

$\square$ Grietas porfalta de traba
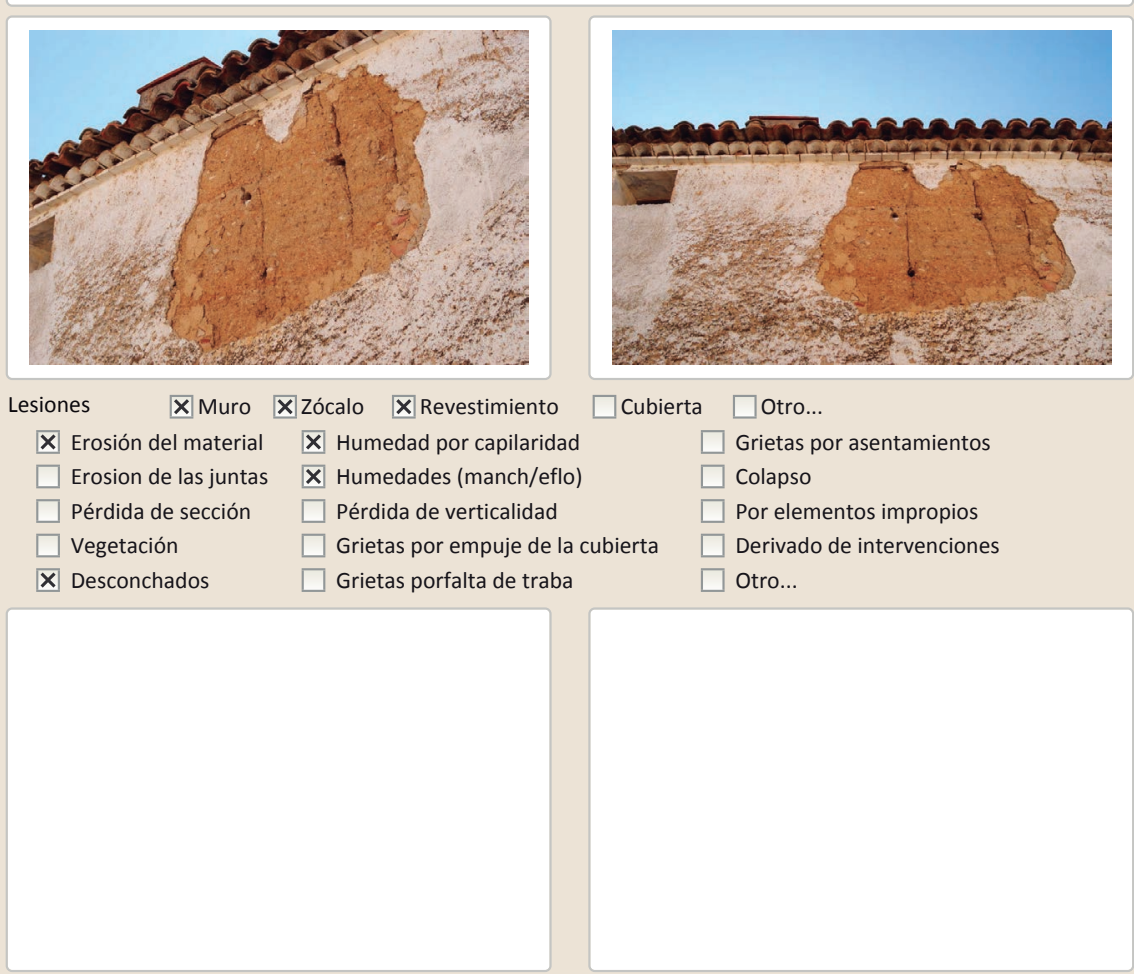

$\square$ Por elementos impropios

$\square$ Derivado de intervenciones $\square$ Otro... 


\section{La restauración y rehabilitación de la arquitectura tradicional de tierra.} El caso de Aragón.

3. DATOS DE LA INTERVENCIÓN

NCIÓN

La restauración y rehabilitación de la arquitectura tradicional de tierra.

El caso de Aragón.

3.7. REHABILITACIÓN ENERGÉTICA $\square$ Fachada $\square$ Vanos $\square$ Forjados $\square$ Cubierta

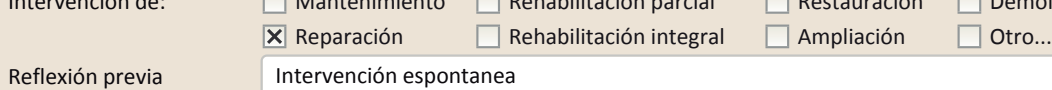

Observaciones

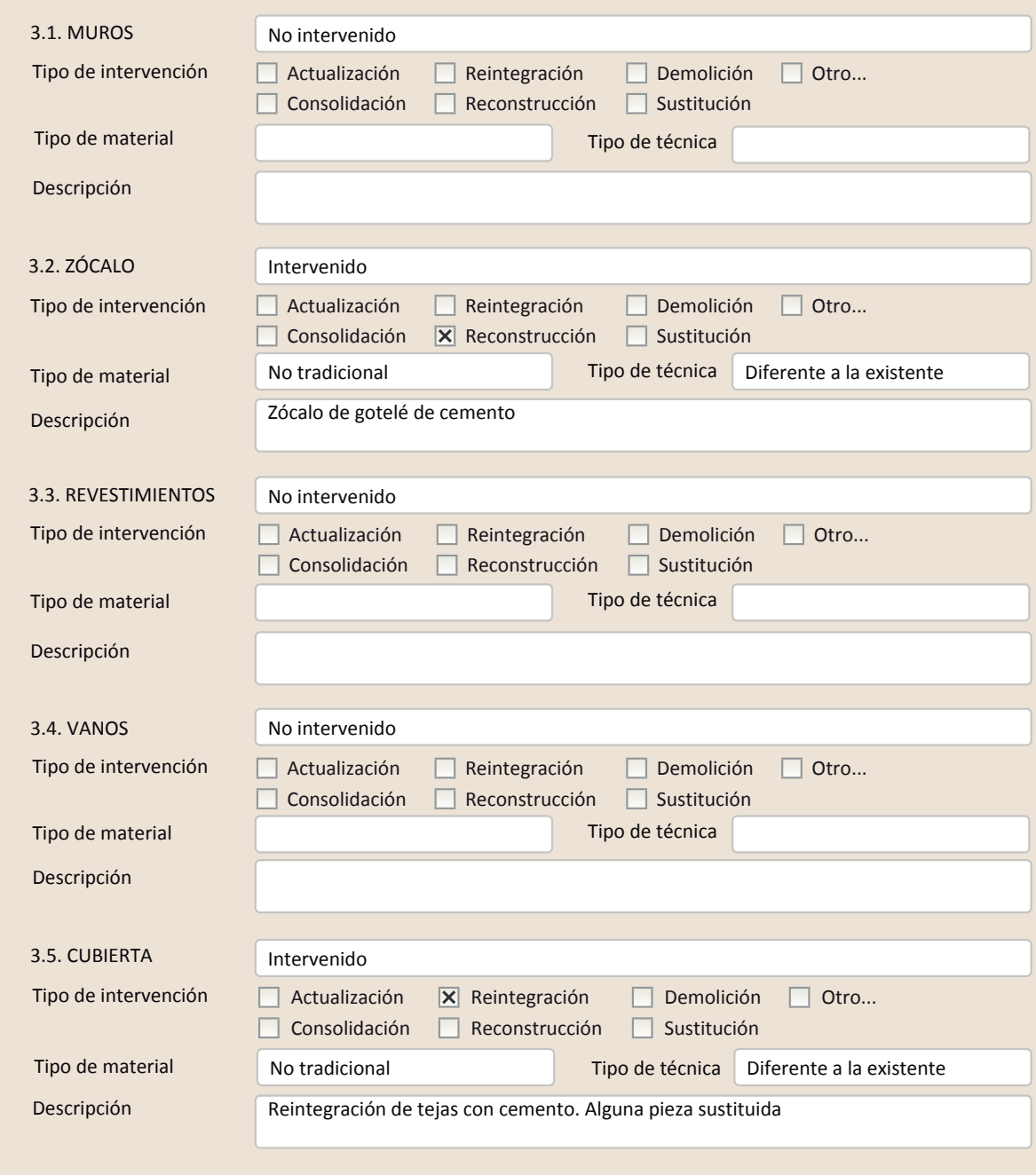

3.6. OTRAS

Observaciones

FOTOGRAFÍAS DE LA INTERVENCIÓN
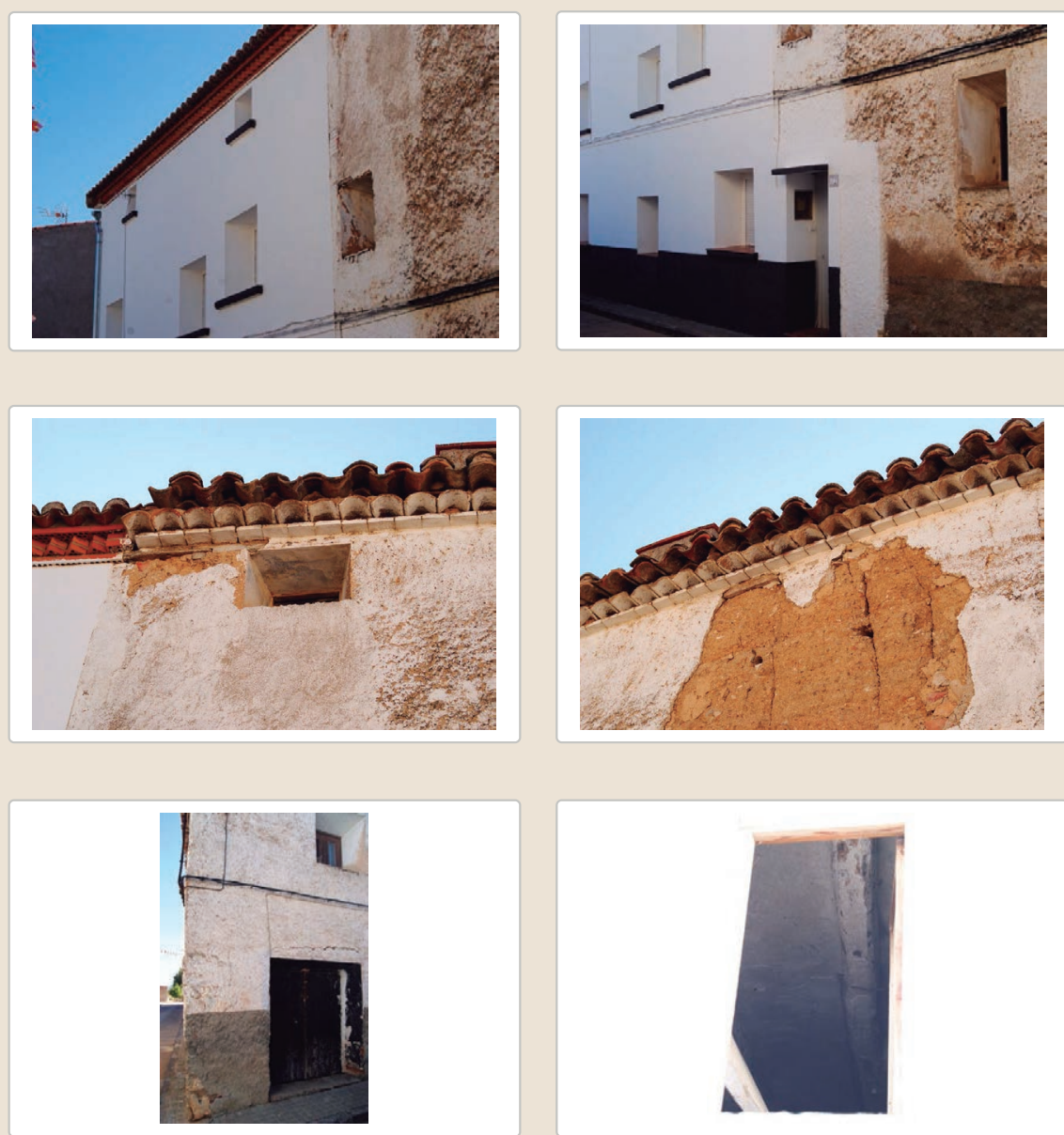


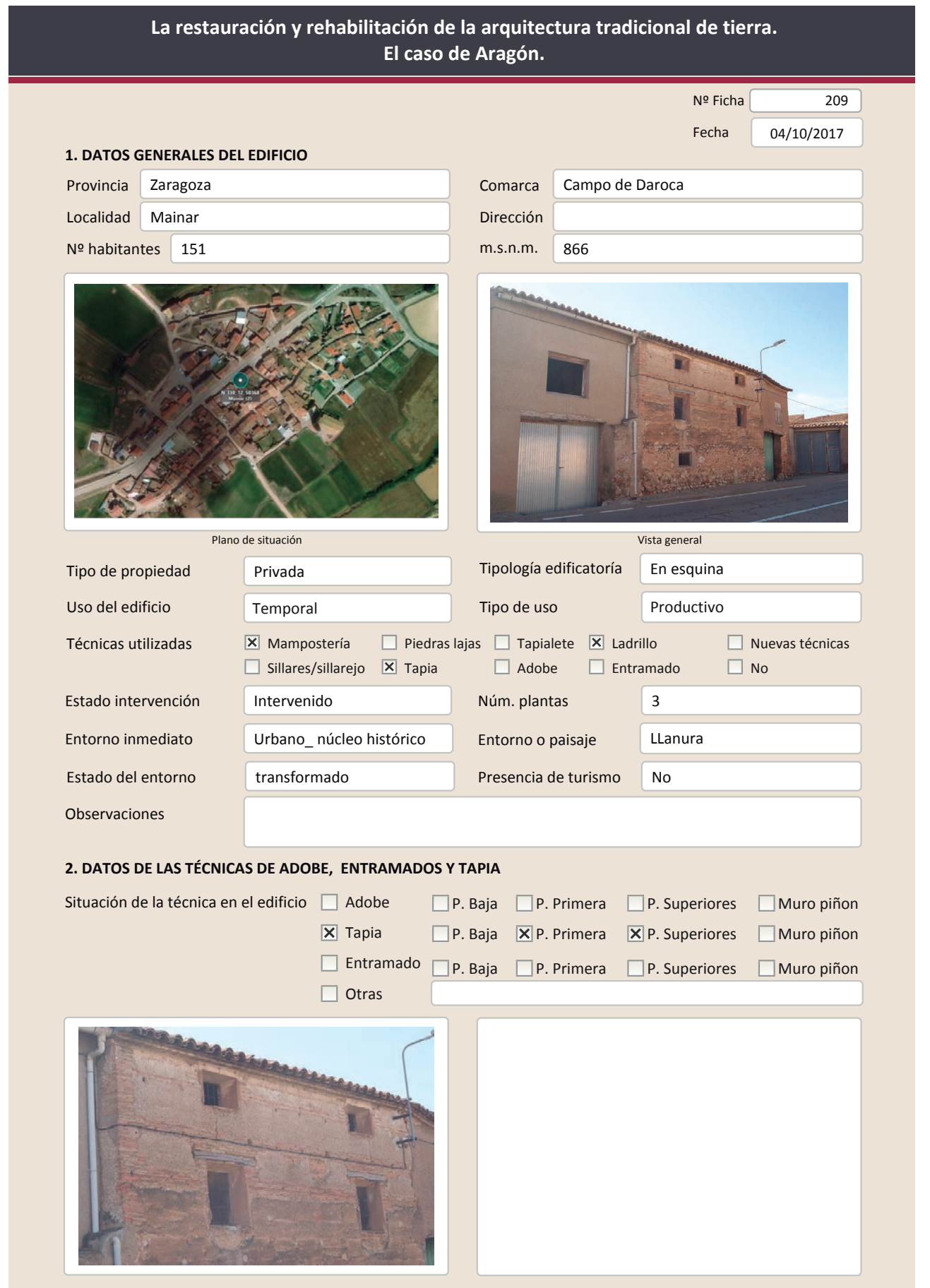

La restauración y rehabilitación de la arquitectura tradicional de tierra.

El caso de Aragón.

\subsection{TAPIA}

Ancho del muro

Dimensión tapiales

Tipo de aguja

№ agujas/cajón

Variante constructiva

$\square$ Simple/homogente

$\mathbf{x}$ Suplemento superficia

$\square$ suplemento en juntas

区 Mixta

$\square$ Elementos de protección

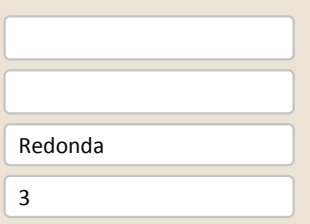

Color de la tapia

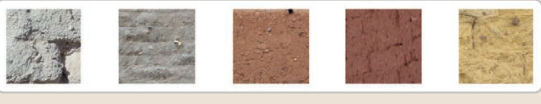

$\square$ Blanquecino $\quad \mathbf{X}$ Marrón $\square$ Amarillento

$\begin{array}{ll}\square \text { Blanquecino } & \mathbf{x} \text { Marrón } \\ \square \text { Grisaceo } & \square \text { Rojizo } \quad \square \text { Otro... }\end{array}$
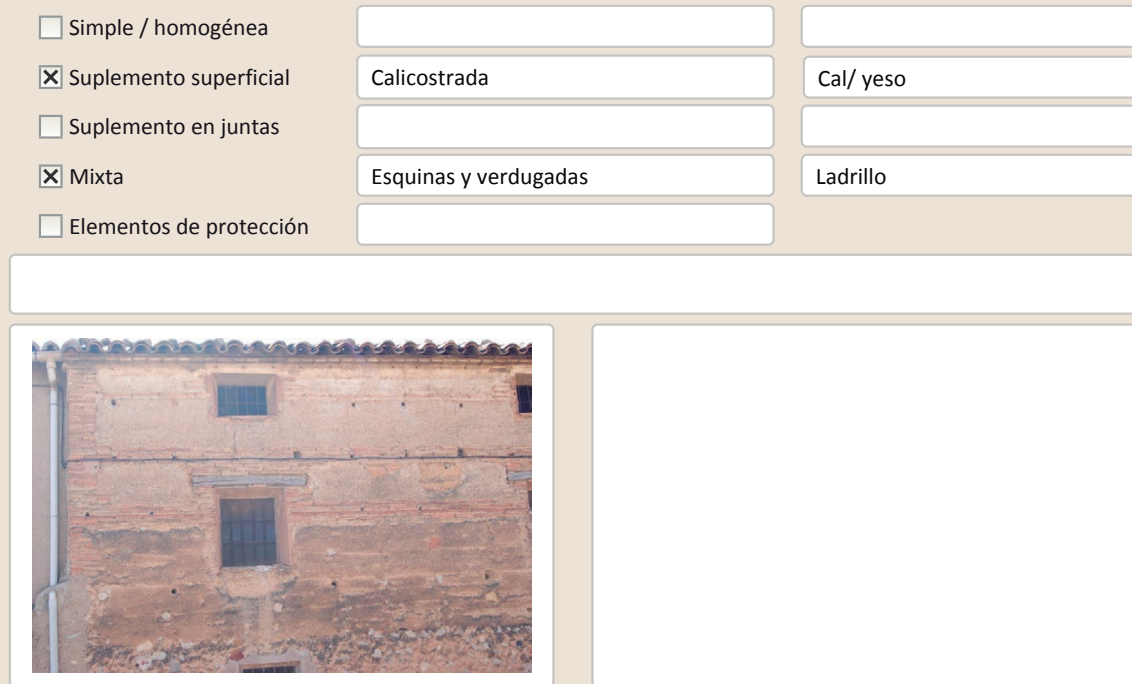

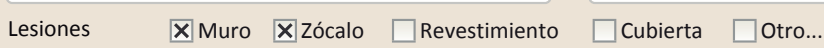

X Erosión del material $\quad$ X Humedad por capilaridad $\quad \square$ Grietas por asentamientos

$\square$ Erosion de las juntas $\mathbf{X}$ Humedades (manch/eflo)

$\square$ Pérdida de sección $\square$ Pérdida de verticalidad

$\square$ Colapso

$\square$ Vegetación $\quad \mathbf{X}$ Grietas por empuje de la cubierta

X Desconchados

$\square$ Grietas porfalta de traba

$\square$ Por elementos impropios

$\square$ Derivado de intervenciones

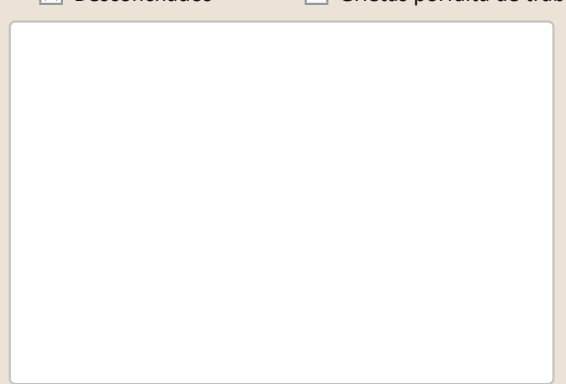

Observaciones 


\section{La restauración y rehabilitación de la arquitectura tradicional de tierra.}

\section{El caso de Aragón.}

3. DATOS DE LA INTERVENCIÓN

\begin{tabular}{|c|c|c|c|c|}
\hline Intervención de: & $\begin{array}{l}\square \text { Mantenimiento } \\
\mathbf{X} \text { Reparación }\end{array}$ & $\begin{array}{l}\square \text { Rehabilitación parcial } \\
\square \text { Rehabilitación integral }\end{array}$ & $\begin{array}{l}\square \text { Restauración } \\
\square \text { Ampliación }\end{array}$ & $\begin{array}{l}\square \text { Demolición } \\
\square \text { Otro... }\end{array}$ \\
\hline Reflexión previa & \multicolumn{4}{|c|}{ Intervención espontanea } \\
\hline erva & & & & \\
\hline
\end{tabular}

\subsection{MUROS}

Tipo de intervención

No intervenido

Tipo de material

$\square$ Actualización $\quad \square$ Reintegración $\square$ Demolición $\quad \square$ Otro...

$\square$ Consolidación $\square$ Reconstrucción $\square$ sustitución

Descripción

3.2. ZÓCALO

Tipo de intervención

No intervenido

Tipo de intervención

Descripción

3.3. REVESTIMIENTOS

Tipo de intervención

\section{Intervenido}

Tipo de material

$\square$ Actualización

Actualización $\square$ Reintegración $\square$ Demolición $\square$ Otro...

$\square$ Consolidación $\quad \square$ Reconstrucción $\square$ Sustitución

Descripción

$\square$ Consolidacion

$\square$ Reintegración $\square$ Demolición $\square$ Otro...

\Reconstrucción $\square$ Sustitución

3.4. VANOS

Tipo de intervención

Intervenido

Tipo de material

$\square$ Actualización $\quad \mathbf{X}$ Reintegración $\square$ Demolición $\square$ Otro...

Tipo de materia
Descripción

$\square$ Consolidación $\square$ Reconstrucción $\square$ Sustitución

3.5. CUBIERTA

Tipo de intervención

No tradicional

Tipo de técnica Diferente a la existente

Reintegración del contorno de varios huecos con cemento

Tipo de material

Intervenido

$\square$ Actualización $\quad \mathbf{X}$ Reintegración $\square$ Demolición $\square$ Otro...

$\begin{array}{ll}\square \text { Actualización } \quad \boldsymbol{X} \text { Reintegración } & \square \text { Demolición } \\ \square \text { consolidación } \quad \square \text { Reconstrucción } \quad \square \text { Sustitución }\end{array}$

Descripción
No tradicional
Tipo de técnica Similar a la existente

3.6. OTRAS 


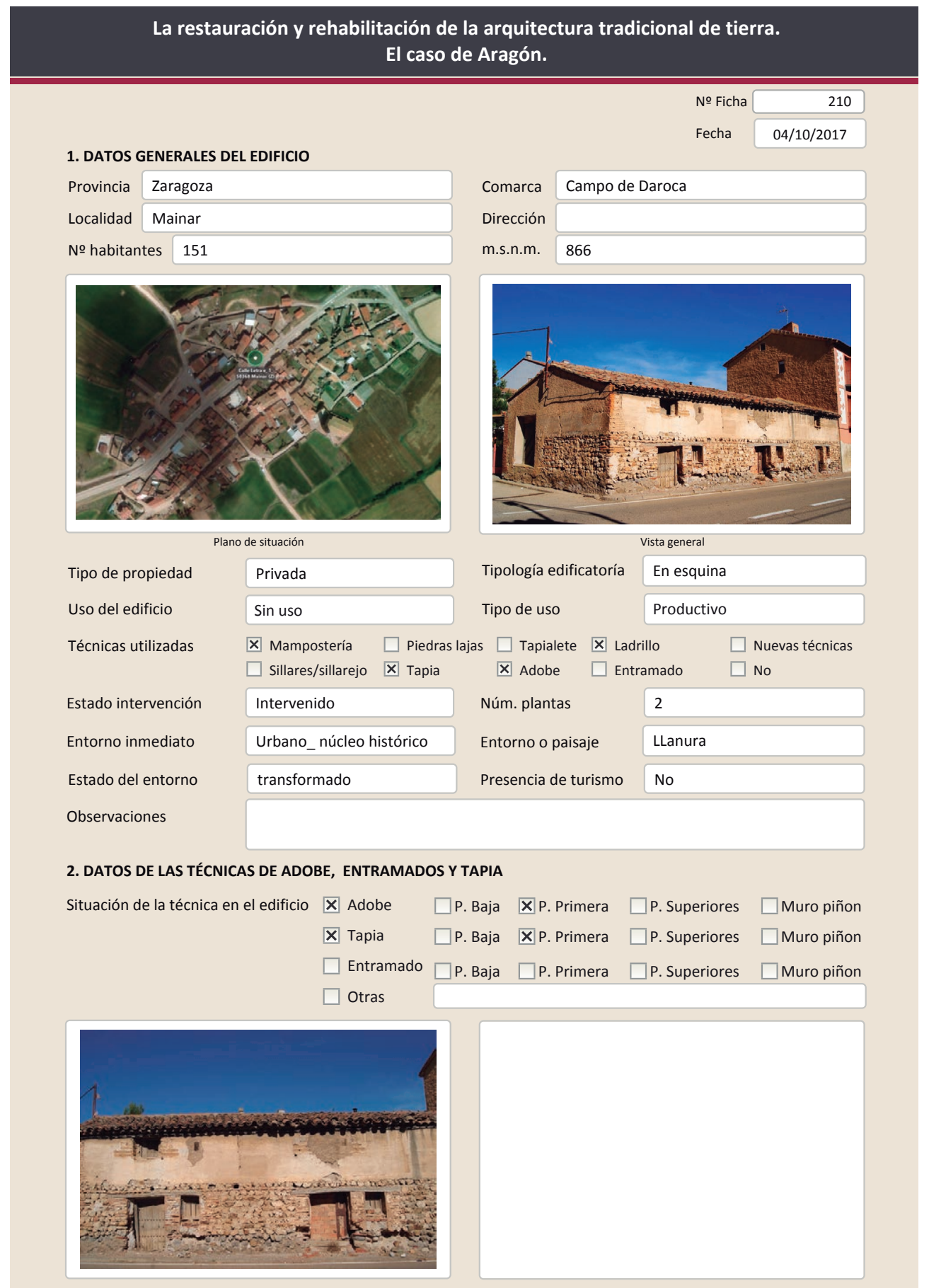

2.1. ADOBE

Dimensión de las piezas

Dimensión del muro

Aparejo del muro

Función estructural

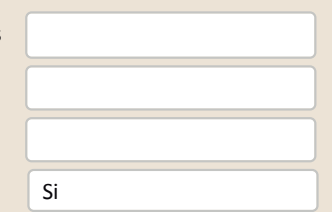

Color de las piezas

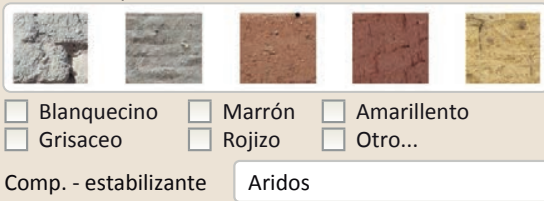

Variante constructiva/ tipo de fábrica

$\square$ Simple

$\square$ Suplementada en juntas

$\square$ Mixta

$\mathbf{X}$ Como suplemento

Mixto- En esquinas

$\square$ Elementos de protección

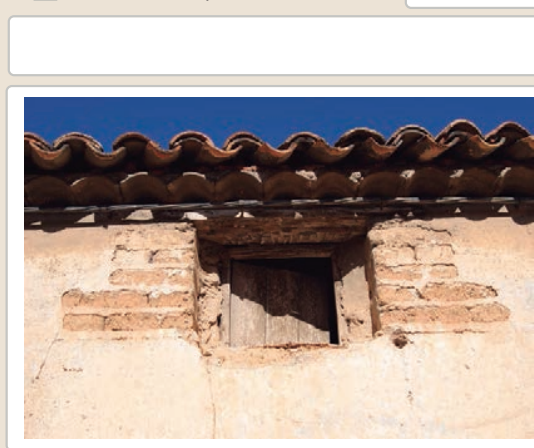

Lesiones \Muro $\square$ Zócalo $\square$ Revestimiento

X Erosión del material $\quad \square$ Humedad por capilaridad

$\square$ Erosion de las juntas $\square$ Humedades (manch/eflo)

$\square$ Pérdida de sección $\square$ Pérdida de verticalidad

$\square$ Vegetación $\quad \square$ Grietas por empuje de la cub

$\square$ Grietas porfalta de traba

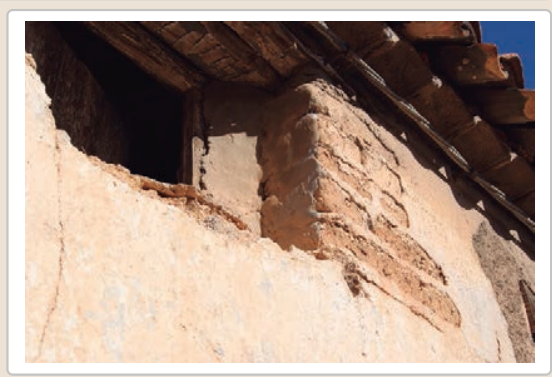

$\square$ Cubierta $\square$ Otro...

$\square$ Grietas por asentamiento

$\square$ Colapso

$\square$ Desconchados

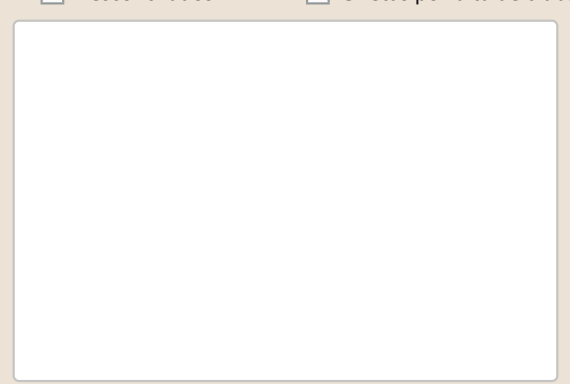

$\square$ Por elementos impropios

$\square$ Derivado de intervenciones $\square$ Otro... 


\section{La restauración y rehabilitación de la arquitectura tradicional de tierra.} El caso de Aragón.

\subsection{TAPIA}

Ancho del muro

Dimensión tapiales

Tipo de aguja

№ agujas/cajón

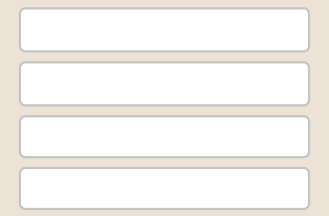

Color de la tapia

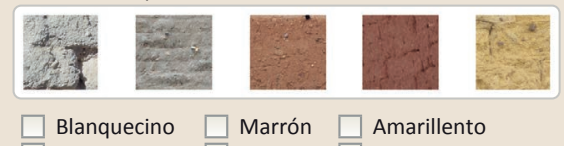
$\square$ Blanquecino $\quad \square$ Marrón $\quad \square$ Amarillento
$\square$ Grisaceo
Rojizo $\quad \square$ Otro...

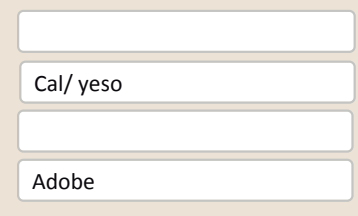

Variante constructiva
$\square$ Simple / homogéne

X Suplemento superficial

$\square$ Suplemento en juntas

X Mixta

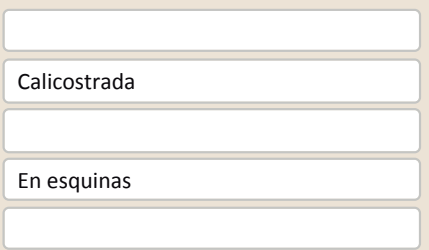

Adobe

\section{$\square$ Elementos de protección}

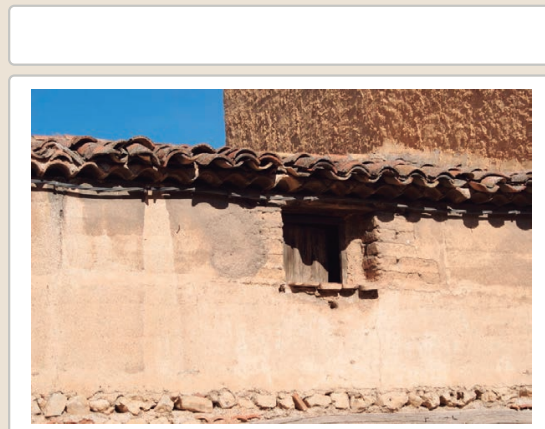

(5ises

XMuro XZócalo $\square$ Revestimiento

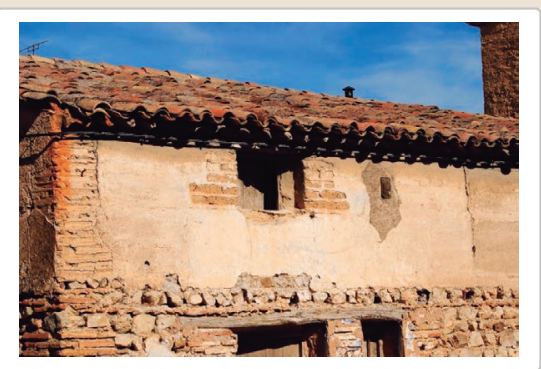

$\mathbf{X}$ Erosión del material $\mathbf{X}$ Humedad por capilaridad $\quad \square$ Grietas por asentamientos

$\square$ Erosion de las juntas $\mathbf{X}$ Humedades (manch/eflo)

$\square$ Colapso

Pérdida de sección $\square$ Pérdida de verticalidad

$\square$ Por elementos impropios

$\square$ Vegetación

$\square$ Grietas pelementos impropios

$\square$ Desconchados

$\square$ Grietas porfalta de traba

$\square$ Otro...

\section{La restauración y rehabilitación de la arquitectura tradicional de tierra.}

El caso de Aragón.

3. DATOS DE LA INTERVENCIÓN

reflexión

$\square$ Mantenimiento $\quad \square$ Rehabilitación parcial

$\square$ Restauración $\square$ Demolición

Reflexión previa Intervención espontanea

Observaciones

$\square$ Re

3.1. MUROS

Tipo de intervención

Tipo de material

Intervenido

$\square$ Actualización $\quad \mathbf{X}$ Reintegración $\square$ Demolición $\square$ Otro..

$\square$ Consolidación $\square$ Reconstrucción $\square$ sustitución

Descripción

\begin{tabular}{lll} 
No tradicional & Tipo de técnica Diferente a la existente \\
\hline
\end{tabular}

Pequeñas reintegraciones con mortero de cemento

3.2. ZÓCALO

Intervenido

Tipo de intervención

$\square$ Actualización $\quad \mathbf{x}$ Reintegración $\square$ Demolición $\square$ Otro.

$\square$ Consolidación $\square$ Reconstrucción $\square$ Sustitución

Tipo de material

No tradicional

Tipo de técnica Diferente a la existente

Descripción

Reintegración con cemento en la pare inferior que ha producido más degradaciones. Área en muy mal estado de conservación

3.3. REVESTIMIENTOS

Tipo de intervención

No aplica

Tipo de material

Descripción

3.4. VANOS

Tipo de intervención

Tipo de material

Descripción

$\square$ Consolidación $\quad \square$ Reconstrucción $\square$ Sustitución

Tipo de técnica

3.5. CUBIERTA

Tipo de intervención

Tipo de material

Descripción

3.6. OTRAS

Observaciones 
La restauración y rehabilitación de la arquitectura tradicional de tierra. El caso de Aragón

\section{La restauración y rehabilitación de la arquitectura tradicional de tierra.} El caso de Aragón.
3.7. REHABILITACIÓN ENERGÉTICA
$\square$ Fachad
$\square$ Vanos
$\square$ Forjados
$\square$ Cubierta

Observaciones

FOTOGRAFÍAS DE LA INTERVENCIÓN
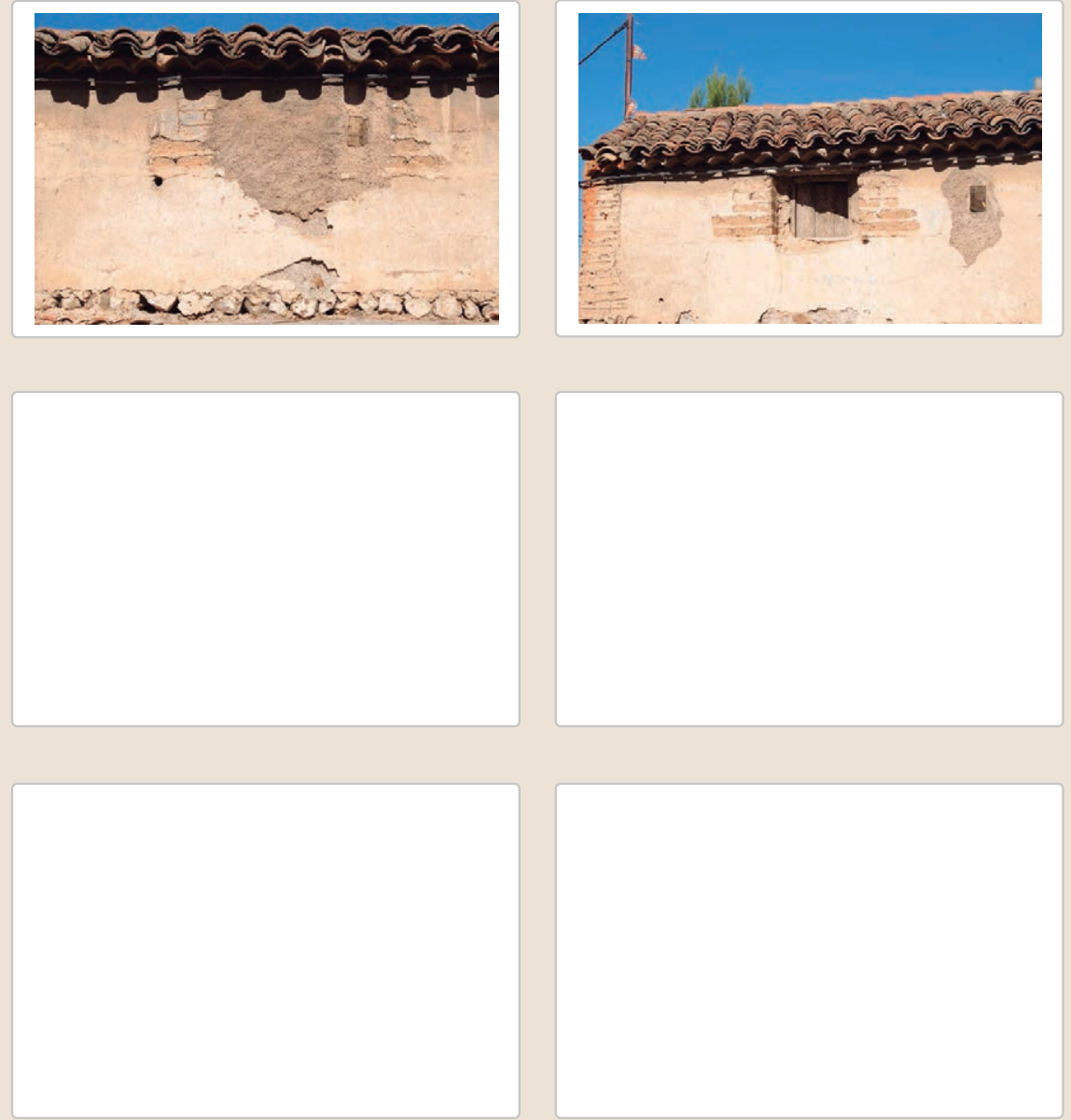
La restauración y rehabilitación de la arquitectura tradicional de tierra. El caso de Aragón.

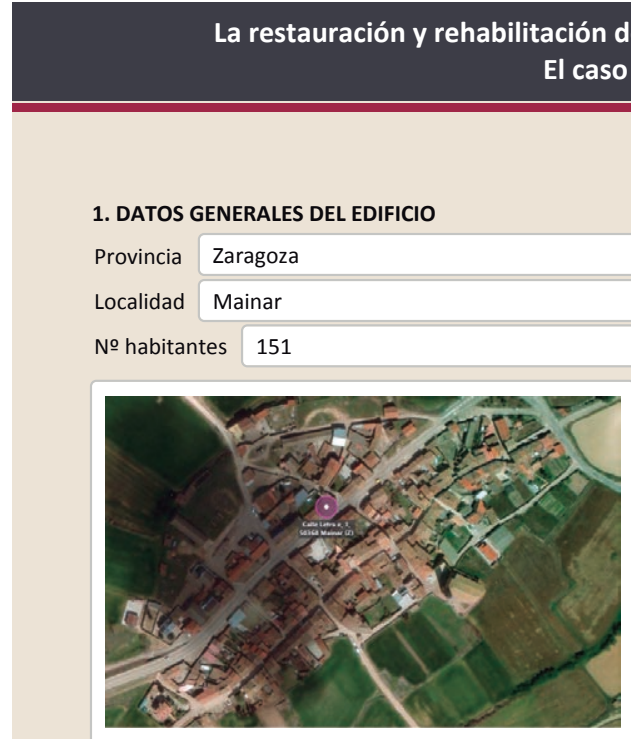

Plano de situación

Tipo de propiedad

Privada

Uso del edificio

Técnicas utilizadas

Temporal

X Mampostería $\square$ Piedras $\square$ sillares/sillarejo $\square$ Tapia

Intervenido

Urbano_núcleo histórico

Entorno inmediato

Estado del entorno

transformado

(n)

№ Ficha

211

Fecha $04 / 10 / 2017$

Comarca Campo de Daroca

Dirección

m.s.n.m. 866

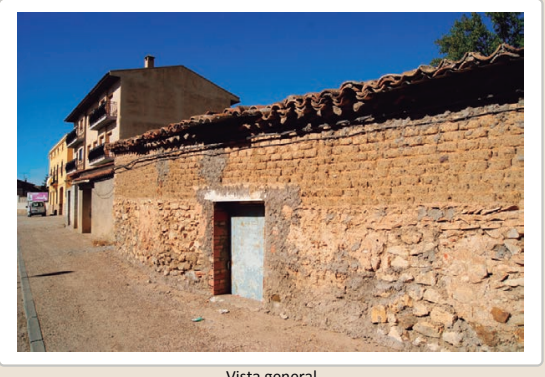

Tipología edificatoría Entre medianeras

Tipo de uso Productivo

$\square$ Tapialete $\square$ Ladrillo $\quad \square$ Nuevas técnicas X Adobe $\square$ Entramado $\quad \square$ No

Núm. plantas 1

Entorno o paisaje

Presencia de turismo
Observaciones

\section{DATOS DE LAS TÉCNICAS DE ADOBE, ENTRAMADOS Y TAPIA}

Situación de la técnica en el edificio $\mathbf{X}$ Adobe $\quad \mathbf{X}$ P. Baja $\square$ P. Primera $\square$ P. Superiores $\square$ Muro piñon $\square$ Tapia $\quad \square$ P. Baja $\square$ P. Primera $\square$ P. Superiores $\square$ Muro piñon $\square$ Entramado $\square$ P. Baja $\square$ P. Primera $\square$ P. Superiores $\square$ Muro piñon $\square$ otras
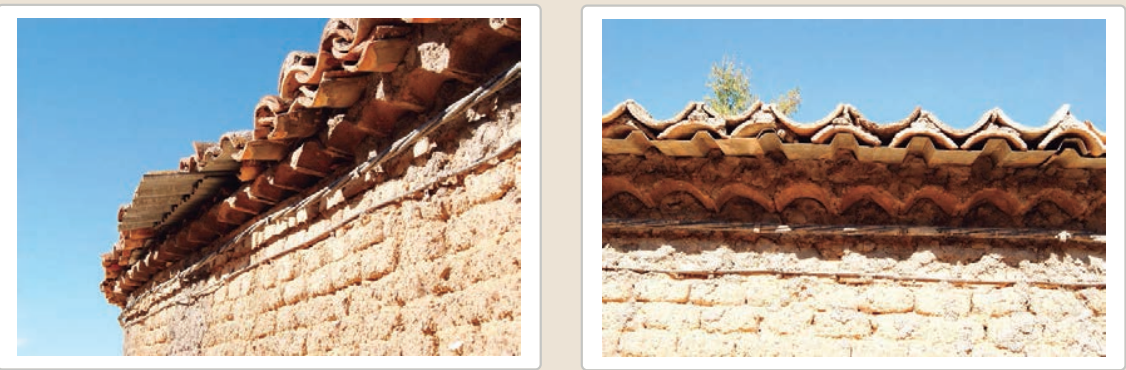

La restauración y rehabilitación de la arquitectura tradicional de tierra.

El caso de Aragón.

2.1. ADOBE

Dimensión de las piezas $\quad \mathrm{L} \times 18 \times 7$

Dimensión del muro $30-40 \mathrm{~cm}$

Aparejo del muro Tizón

Función estructural

$\mathrm{Si}$

\section{$\square$ Simple}

$\square$ Suplementada en juntas

X Mixta

$\square$ Como suplemento

$\square$ Elementos de protección

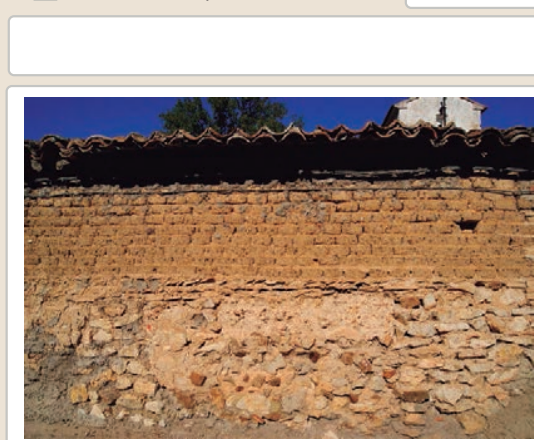

Lesiones $\square$ Muro $\square$ Zócalo $\square$ Revestimiento

$\square$ Erosión del material $\quad \square$ Humedad por capilaridad

$\square$ Erosion de las juntas $\square$ Humedades (manch/eflo)

$\square$ Pérdida de sección $\square$ Pérdida de verticalidad

$\square$ Vegetación $\quad \square$ Grietas por empuje de la c

$\square$ Desconchados

$\square$ Grietas porfalta de traba

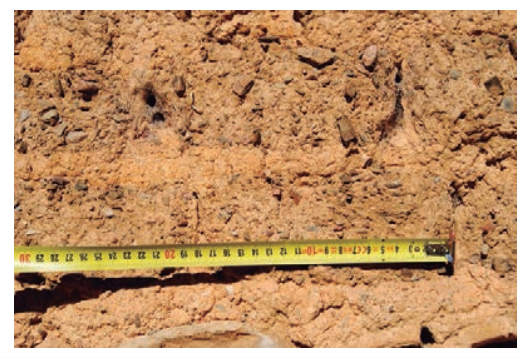

Observaciones
Color de las piezas

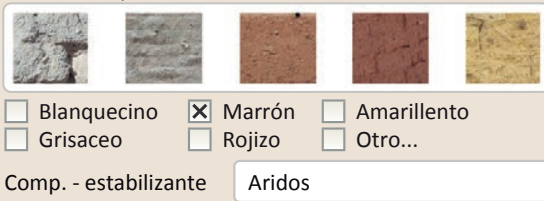

Comp. - estabilizante Aridos 


\section{La restauración y rehabilitación de la arquitectura tradicional de tierra.}

\section{El caso de Aragón.}

3. DATOS DE LA INTERVENCIÓN

Intervención de:

$\square$ Mantenimiento $\square$ Rehabilitación parcia

$\square$ Restauración $\square$ Demolición

Reflexión previa

X Reparación

Rehabilitación integra

Ampliación

$\square$ Otro..

Observaciones

Intervención espontanea

3.1. MUROS

Tipo de intervención

Intervenido

Tipo de intervención

$\square$ Actualización $\quad \boldsymbol{X}$ Reintegración $\square$ Demolición $\square$ Otro...

$\square$ Consolidación $\square$ Reconstrucción $\square$ Sustitución

Descripción

No tradicional Tipo de técnica Diferente a la existente

3.2. ZÓCALO

Tipo de intervención

Pellas de mortero en áreas donde los adobes están más degradados

Tipo de material

Intervenido

$\square$ Actualización \ Reintegración $\square$ Demolición $\square$ Otro...

$\begin{array}{ll}\square \text { Actualización } & \mathbf{X} \text { Reintegración } \\ \square \text { Consolidación } \quad \square \text { Reconstrucción } \quad \square \text { Sustitución }\end{array}$

Descripción
No tradicional
Tipo de técnica Diferente a la existente

3.3. REVESTIMIENTOS

Reintegración de la mampostería con pellas de mortero de cemento

Tipo de intervención

\section{No aplica}

Tipo de material

$\square$ Actualización

$\square$ Reintegración $\square$ Demolición $\square$ Otro...

$\square$ Consolidación $\square$ Reconstrucción $\square$ sustitución

Descripción

3.4. VANOS

Intervenido

Tipo de intervención

$\square$ Actualización $\square$ Reintegración $\square$ Demolición $\square$ Otro...

$\square$ Consolidación $\quad \boldsymbol{X}$ Reconstrucción $\mathbf{X}$ Sustitución

Tipo de material

No tradicional Tipo de técnica Diferente a la existente

Descripción

Reconstrucción del contorno del hueco y sustitución de la carpintería del hueco de

Reconso
acceso

3.5. CUBIERTA

Tipo de intervención

Intervenido

Tipo de material

$\square$ Actualización $\square$ Reintegración $\square$ Demolición $\square$ Otro..

$\square$ Consolidación $\quad$ Reconstrucción $\square$ Sustitución

\begin{tabular}{l|l|l|l|l} 
No tradicional & Tipo de técnica Diferente a la existente \\
\hline
\end{tabular}

Descripción

Reconstrucción de la cubierta en la que se ha incluido una chapa grecada bajo la cobertura de teja curva tradicional

3.6. OTRAS 


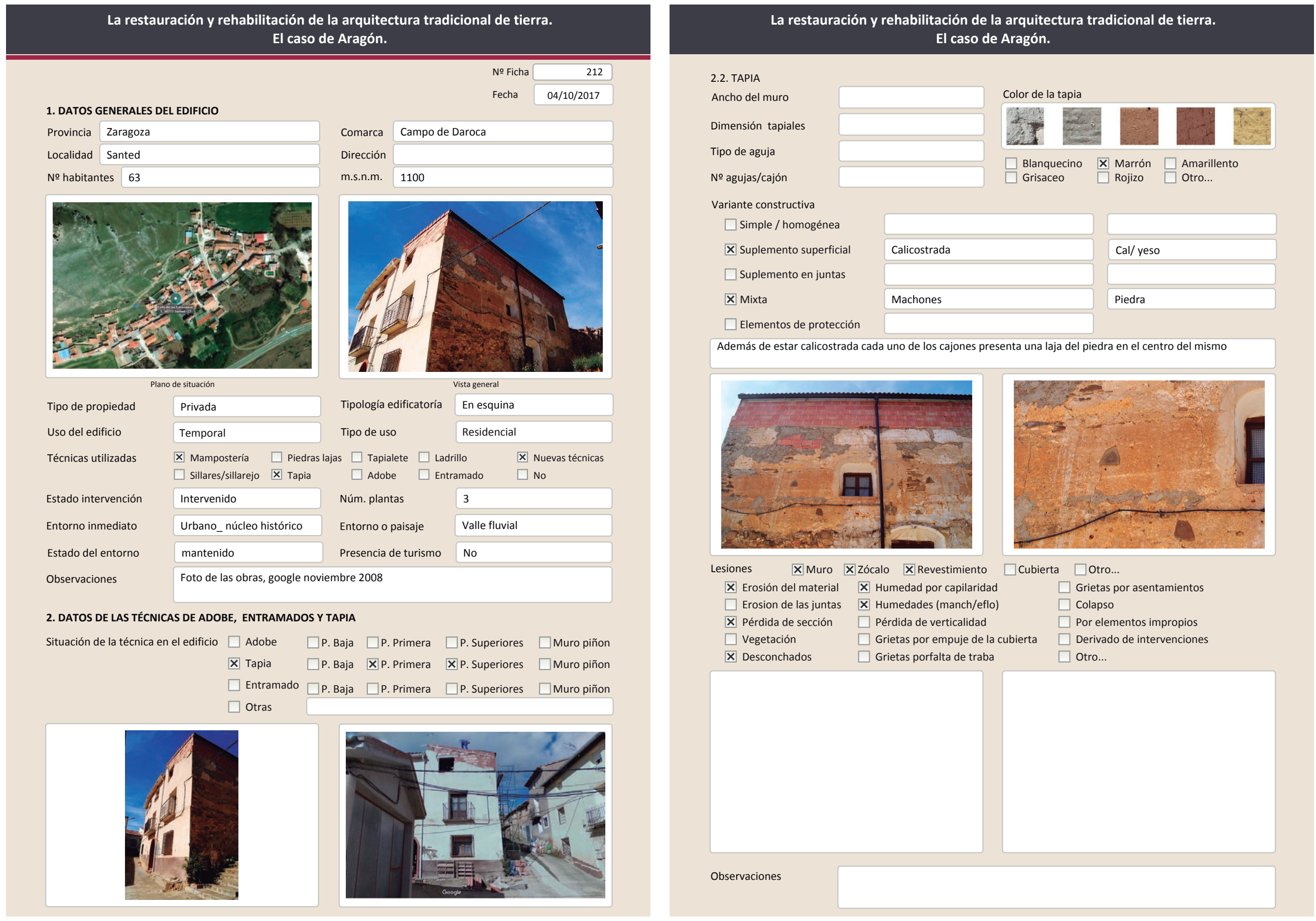




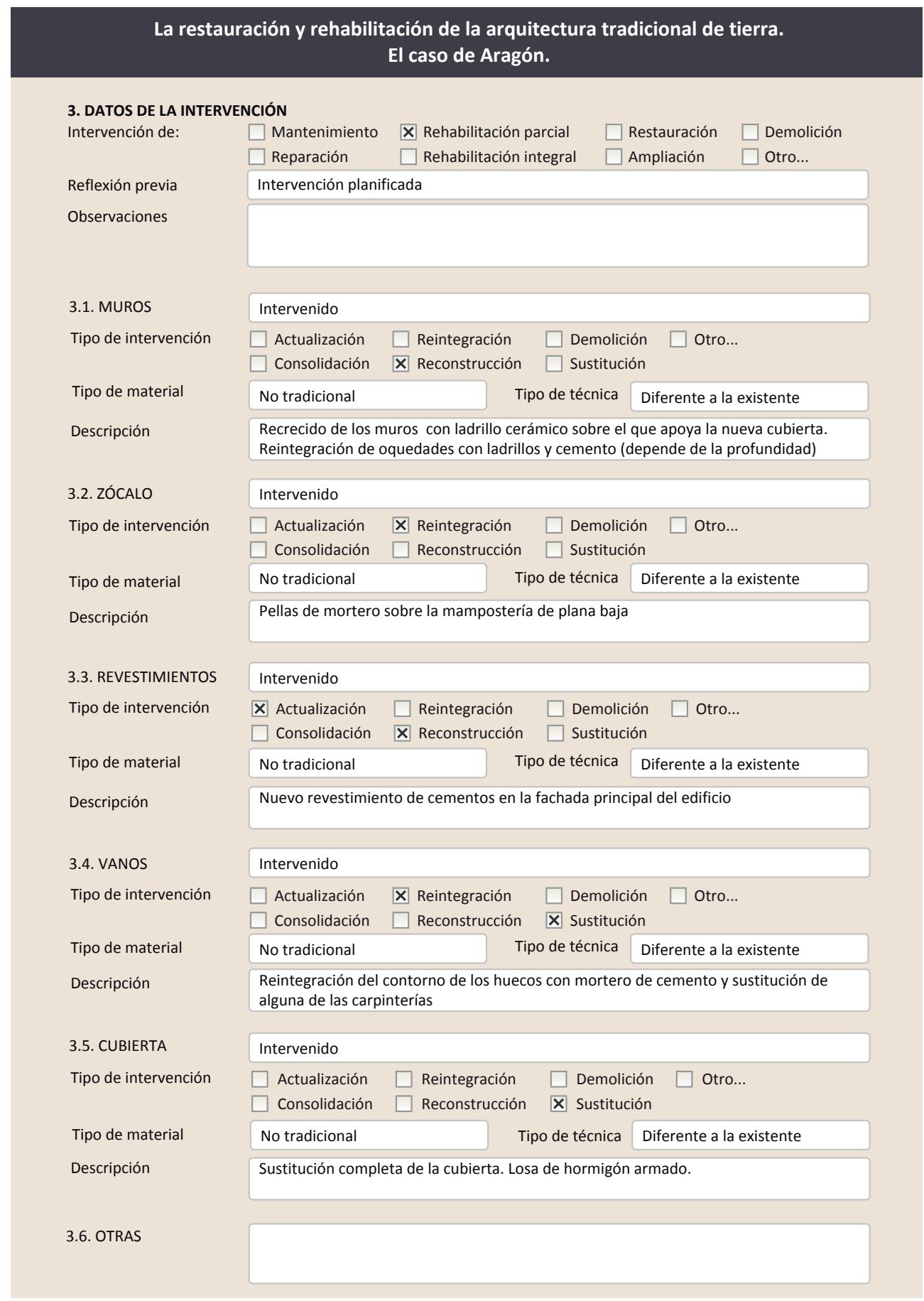

3.7. REHABILITACIÓN ENERGÉTICA $\quad \square$ Fachada $\square$ Vanos $\square$ Forjados $\square$ Cubierta Observaciones

FOTOGRAFÍAS DE LA INTERVENCIÓN
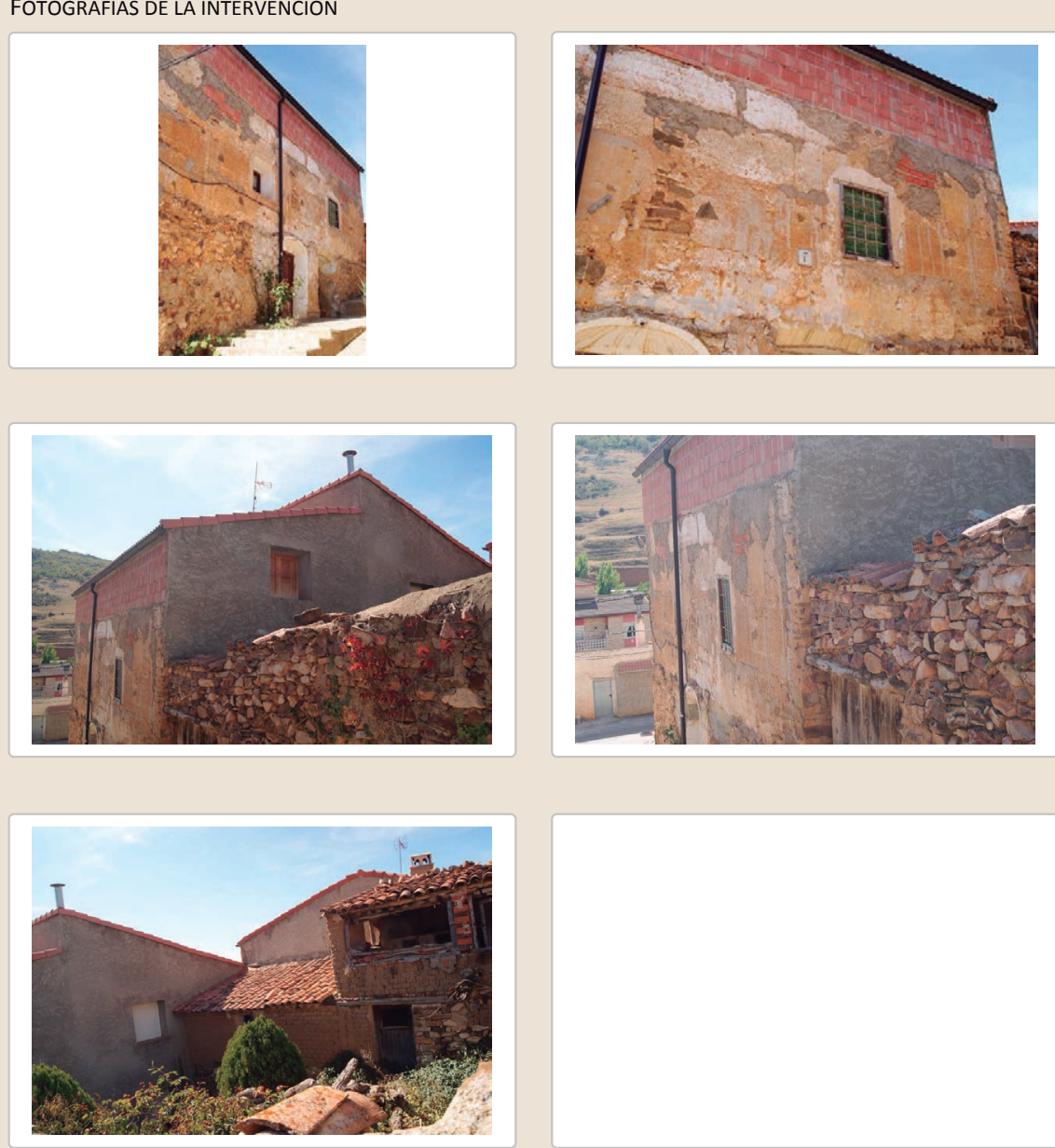
La restauración y rehabilitación de la arquitectura tradicional de tierra. El caso de Aragón.

№ Ficha

213

1. DATOS GENERALES DEL EDIFICIO

Provincia Zaragoza

Localidad Torralba de los Frailes

№ habitantes 88

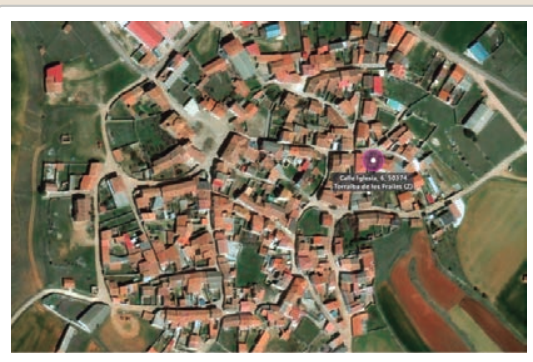

Plano de situación

Tipo de propiedad

Privada

Uso del edificio

Sin uso

$\times$ Mampostería $\quad \square$ Piedras lajas $\square$ Tapialete $\square$ Ladrillo $\quad \square$ Nuevas técnicas $\square$ sillares/sillarejo \ Tapia

Estado intervención

Urbano_núcleo histórico

Entorno inmediato

Estado del entorno

degradado

Edificio en ruinas. En el se pueden apreciar todas las técnicas constructivas utilizadas

Observaciones

m.s.n.m. 1095

Tipología edificatoría Entre medianeras

Tipo de uso Residencial

\ Adobe $\quad$ Entramado $\square$ No

Núm. plantas 2

Entorno o paisaje LLanura

Presencia de turismo No
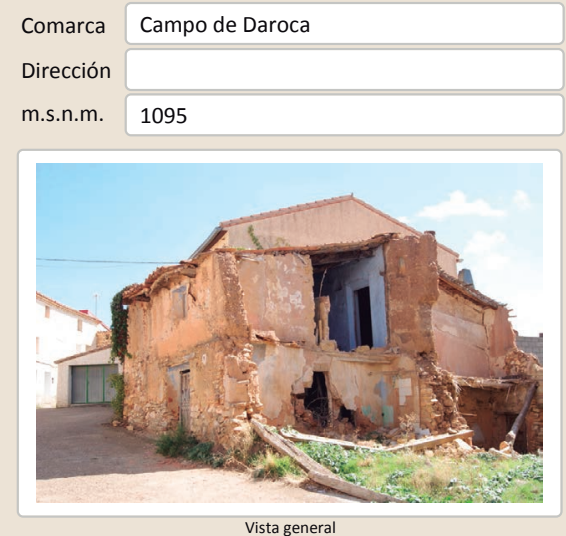

\section{DATOS DE LAS TÉCNICAS DE ADOBE, ENTRAMADOS Y TAPIA}

Situación de la técnica en el edificio $\mathbf{X}$ Adobe $\quad \mathbf{X}$ P. Baja $\quad \mathbf{X}$ P. Primera $\square$ P. Superiores $\square$ Muro piñon Х Tapia $\quad$ ХP. Baja $\quad$ XP. Primera $\square$ P. Superiores $\square$ Muro piñon $\mathbf{X}$ Entramado $\mathbf{X P}$. Baja $\mathbf{X}$ P. Primera $\square$ P. Superiores $\square$ Muro piñon $\square$ Otras

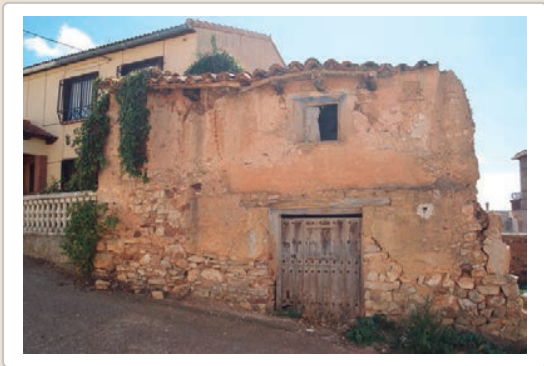

La restauración y rehabilitación de la arquitectura tradicional de tierra.

El caso de Aragón.

2.1. ADOBE

Dimensión de las piezas

Dimensión del muro

Aparejo del muro

Función estructural

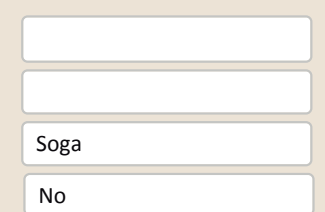

Color de las piezas

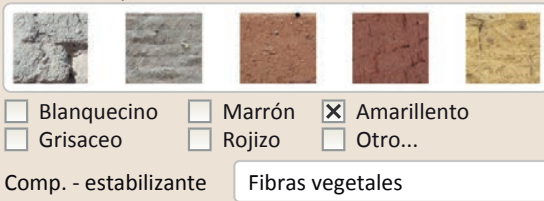

Variante constructiva/ tipo de fábrica

$\square$ Simple

$\square$ Suplementada en juntas

X Mixta

\section{Machones}

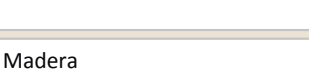

$\square$ Como suplemento

$\mathbf{X}$ Elementos de protección

Revestimiento

El adobe en ese edificio se encuentra en las pariciones interiores

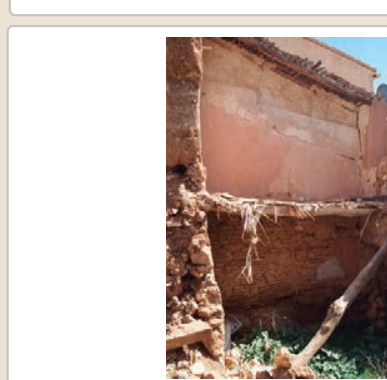

Lesiones

X Muro XZócalo $\mathbf{X}$ Revestimiento

$\mathbf{X}$ Erosión del material $\quad \mathbf{X}$ Humedad por capilaridad $\square$ Erosion de las juntas $\mathbf{X}$ Humedades (manch/eflo)

$\square$ Pérdida de sección $\quad \square$ Pérdida de verticalidad

$\square$ Vegetación $\quad \square$ Grietas por empuje de la c $\square$ Grietas porfalta de trab

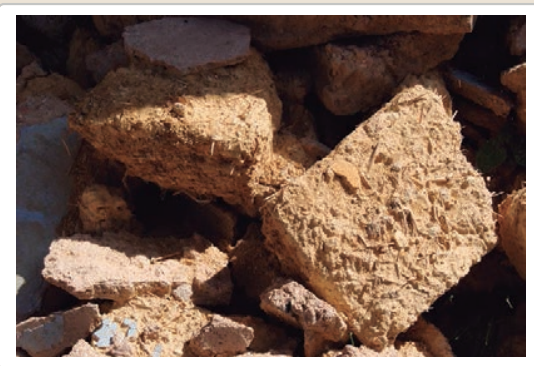

X Desconchados

$\square$

$\square$ Otro..

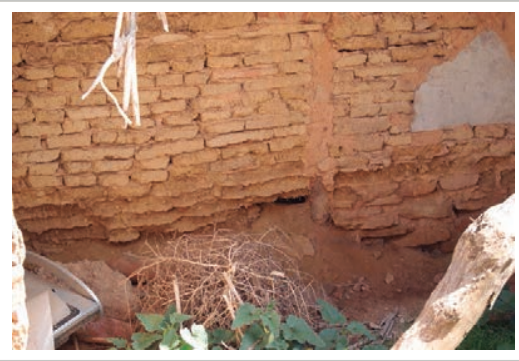

Observaciones $\square$ Grietas por asentamiento X Colapso

$\square$ Por elementos impropios

$\square$ Derivado de intervenciones

$\square$ Otro... 


\section{La restauración y rehabilitación de la arquitectura tradicional de tierra.} El caso de Aragón.

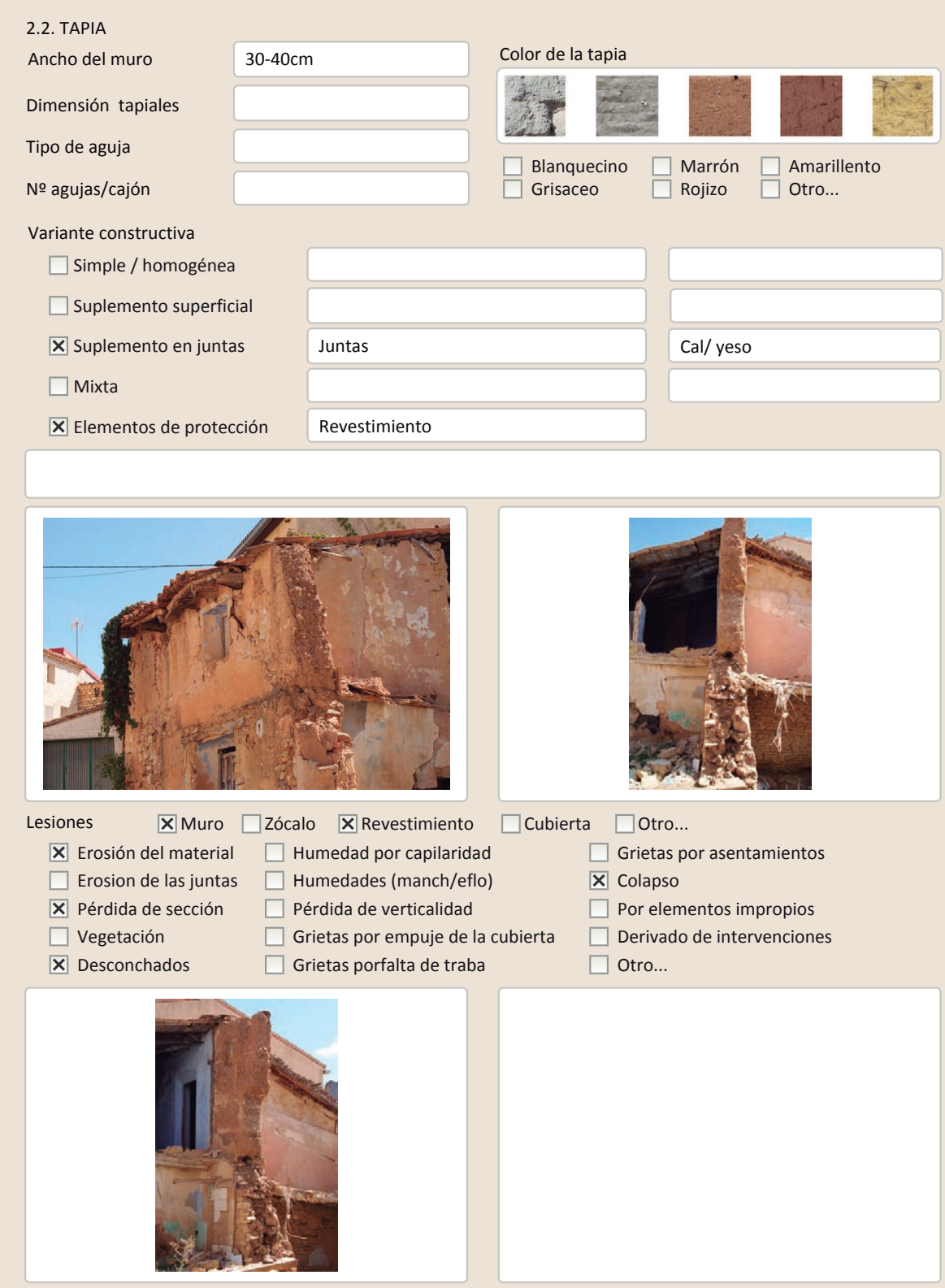

Observaciones
La restauración y rehabilitación de la arquitectura tradicional de tierra.

El caso de Aragón.

\subsection{ENTRAMADOS}

Altura de los montantes

Sección de los montantes

$<40 \mathrm{~cm}$

Elementos diagonales

Elementos horizontales intermedios No

Dimensión de los montantes $<10 \mathrm{~cm}$ Sección de las piezas horizontales Dimensión de las piezas horizontales $10-20 \mathrm{~cm}$ Tipo de relleno del entramado $\quad \square$ Monolítico $\mathbf{X}$ Piezas/fábrica $\quad \square$ Tejido

Técnica de relleno del entramado

$\square$ Entre pantallas de madera $\square$ Pared de mano $\square$ Cañizo

$\square$ Tierra y mampuestos $\quad \mathbf{X}$ Adobe horizontal $\square$ Encestados

$\square$ Tapialete $\quad \square$ Adobe aletorio $\square$ Otro..

\section{Adobe a panderete. La caja de escalera está configurada con esta técnica}
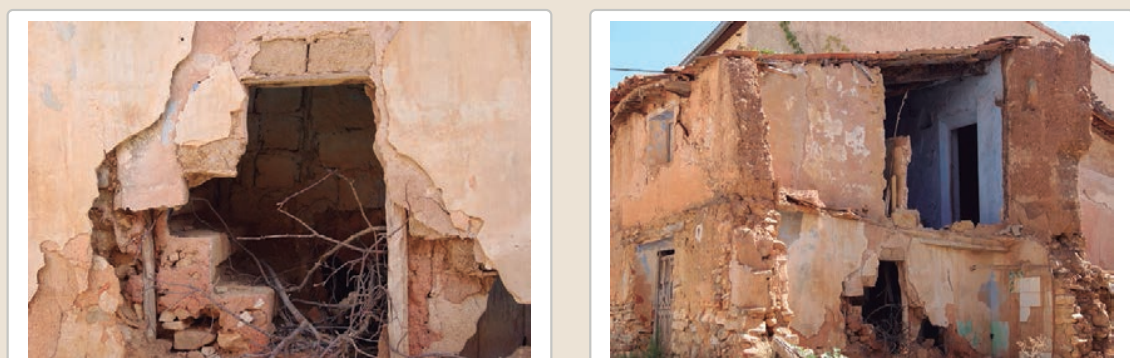

Lesiones $\quad$ Muro $\square$ Zócalo $\quad$ X Revestimiento $\square$ Cubierta $\square$ otro...

$\square$ Erosion de las juntas

$\square$ Carcoma o termitas

X Rotura de la madera

$\square$ Grietas por falta de traba

$\square$ Pérdida de sección

$\square$ Pudrición de la madera

$\square$ Gretas po

Vegetación

$\square$ Deformación madera

X Colapso

$\square$ Humedad por capilaridad $\square$ Pérdida de verticalidad

$\square$ Por elementos impropios

$\square$ Humedades (manch/eflor) $\square$ Grietas por empuje de la cubierta
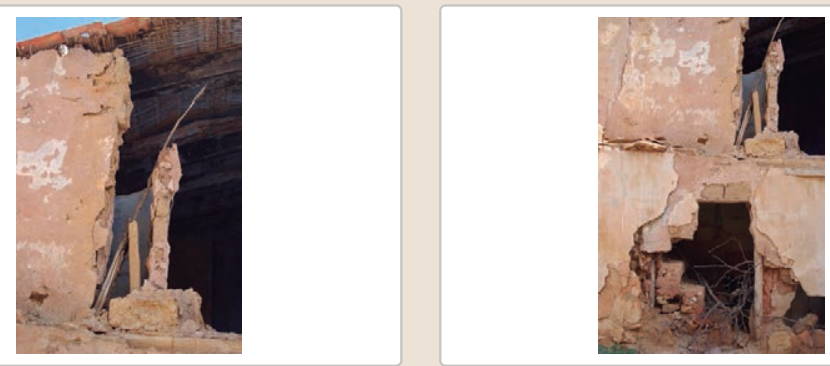

Observacione 


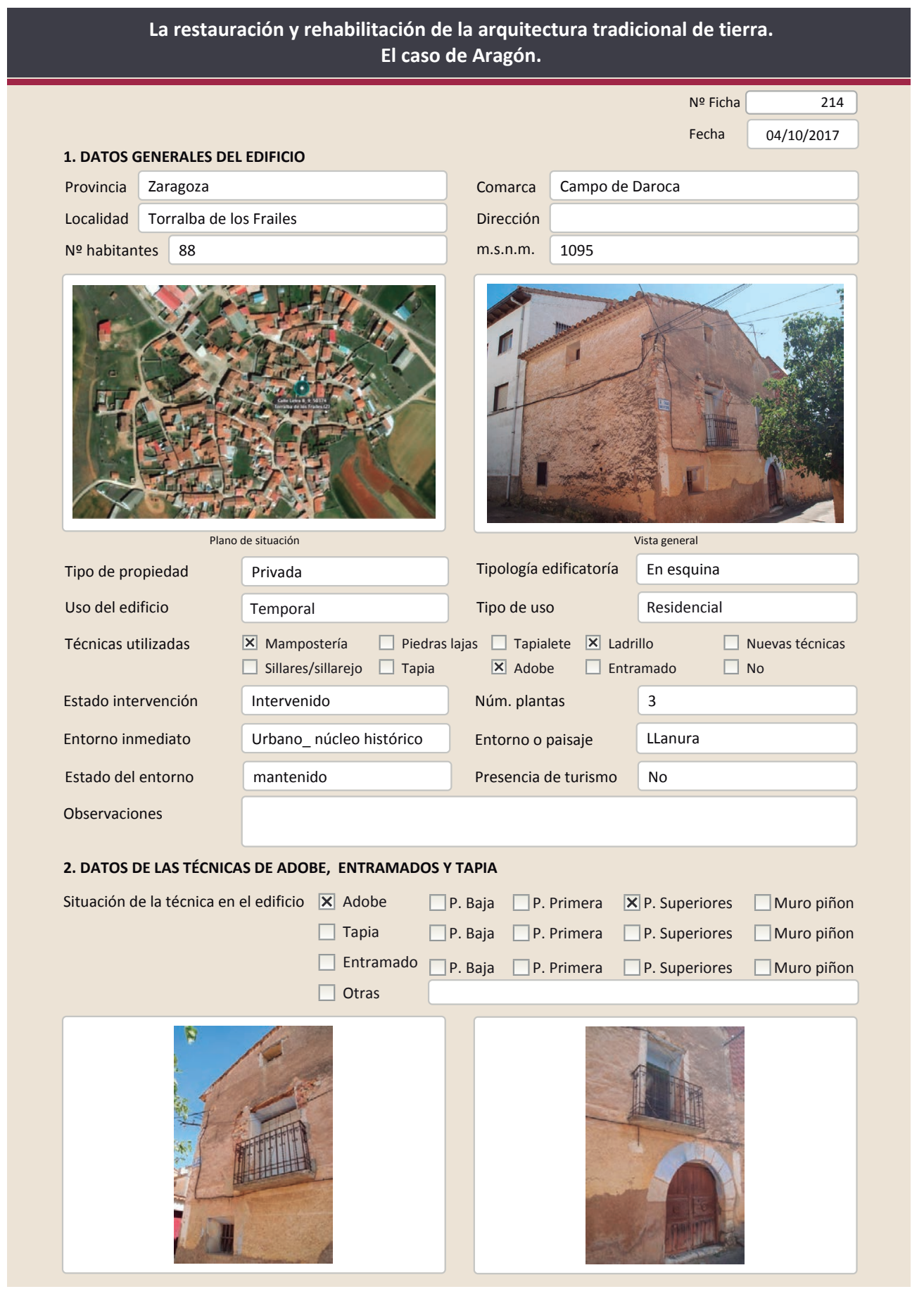

La restauración y rehabilitación de la arquitectura tradicional de tierra.

El caso de Aragón.

2.1. ADOBE

Dimensión de las piezas Dimensión del muro

Aparejo del muro

Función estructural

\begin{tabular}{|l|}
\hline $30-40 \mathrm{~cm}$ \\
\hline Tizón \\
\hline $\mathrm{Si}$ \\
\hline
\end{tabular}

Color de las piezas

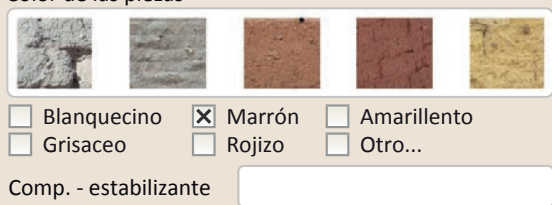

Variante constructiva/ tipo de fábrica

$\square$ simple

$\square$ Suplementada en juntas

X Mixta

En esquinas

Piedra

$\square$ Como suplemento

X Elementos de protección

Revestimiento

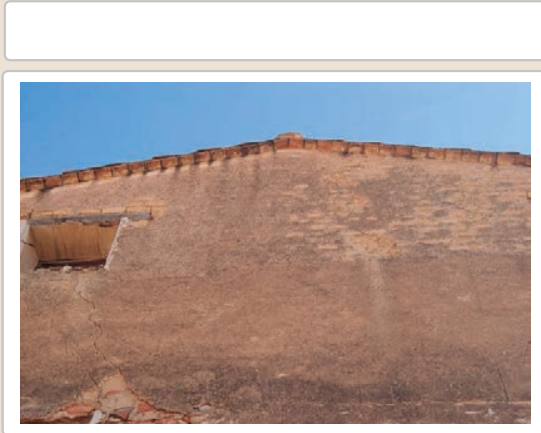

Lesiones ХMuro ХZŹcalo $\mathbf{X}$ Revestimiento

\ Erosión del material $\square$ Humedad por capilaridad

$\square$ Erosion de las juntas $\mathbf{X}$ Humedades (manch/eflo)

$\square$ Pérdida de sección $\square$ Pérdida de verticalidad

$\begin{array}{ll}\square \text { Vegetación } & \boldsymbol{X} \text { Grietas por empuje de la cub } \\ \square \text { Desconchados } & \square \text { Grietas porfalta de traba }\end{array}$

Cubierta $\square$ Otro...

$\square$ Grietas po

$\square$ Por elementos impropios

$\square$ Derivado
$\square$ Otro...

Observaciones 
La restauración y rehabilitación de la arquitectura tradicional de tierra. El caso de Aragón

\section{La restauración y rehabilitación de la arquitectura tradicional de tierra.}

\section{El caso de Aragón.}

3. DATOS DE LA INTERVENCIÓN

Intervención de:

$\square$ Mantenimiento $\square$ Rehabilitación parcial

$\square$ Restauración $\square$ Demolición

X Reparación $\square$ Rehabilitación integral $\mathbf{X}$ Ampliación $\square$ Otro...

Reflexión previa

Intervención espontanea

Observaciones

(n)

3.1. MUROS

Tipo de intervención $\quad \square$ Actualización $\quad \square$ Reintegración $\quad \square$ Demolición $\square$ Otro..

Intervenido

$\square$ Consolidación $\mathbb{X}$ Reconstrucción $\square$ Sustitución

Descripción

\begin{tabular}{|l|l|l|l|l}
\hline No tradicional & Tipo de técnica & Diferente a la existente \\
\hline
\end{tabular}

3.2. ZÓCALO

Reconstrucción de un volumen anexo al edificio con fábrica de ladrillo hueco

Tipo de intervención

Intervenido

Tipo de intervención

$\square$ Actualización $\quad \mathbf{X}$ Reintegración $\square$ Demolición $\square$ Otro...

$\square$ Consolidación $\quad \square$ Reconstrucción $\square$ Sustitución

Tipo de material

No tradicional

Tipo de técnica Similar a la existente

Descripción

nuevo revestimiento de cemento

3.3. REVESTIMIENTOS

No intervenido

Tipo de intervención

$\square$ Actualización $\square$ Reintegración $\quad \square$ Demolición $\square$ Otro...

Tipo de material

Descripción

3.4. VANOS

$\square$ Consolidación $\square$ Reconstrucción $\square$ Sustitución

Tipo de intervención

No intervenido

Tipo de material

Descripción

3.5. CUBIERTA

Tipo de intervención

Intervenido

Tipo de material

$\square$ Actualización $\quad \mathbf{X}$ Reintegración $\quad \square$ Demolición $\square$ Otro.

$\square$ Consolidación $\quad \square$ Reconstrucción $\square$ Sustitución

\begin{tabular}{ll|l} 
No tradicional & Tipo de técnica Diferente a la existente
\end{tabular}

Descripción Reintegración de los laterales de la cubierta con mortero de cemento

3.6. OTRAS 
La restauración y rehabilitación de la arquitectura tradicional de tierra. El caso de Aragón.

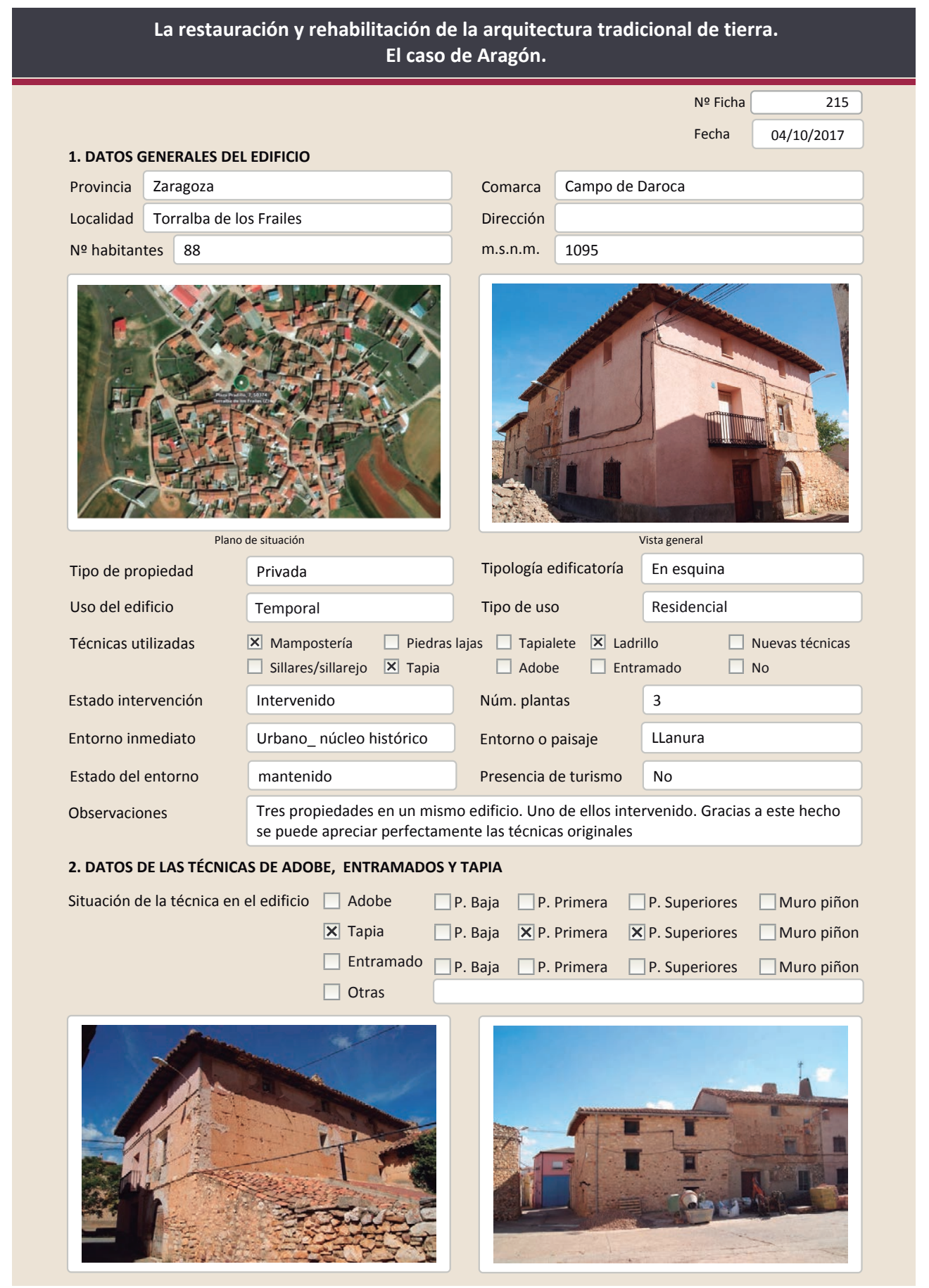

La restauración y rehabilitación de la arquitectura tradicional de tierra. El caso de Aragón.

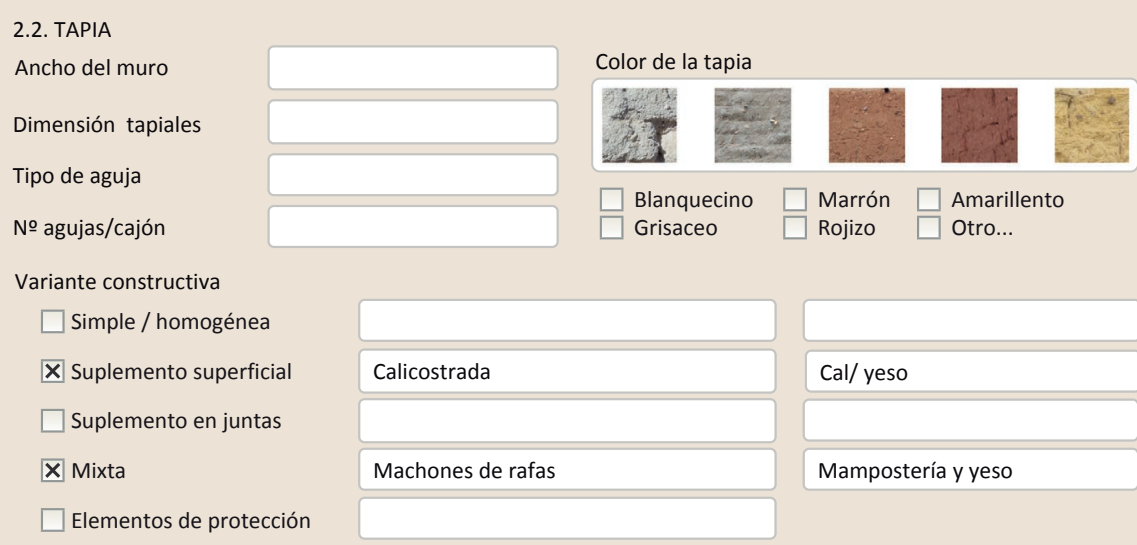

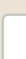

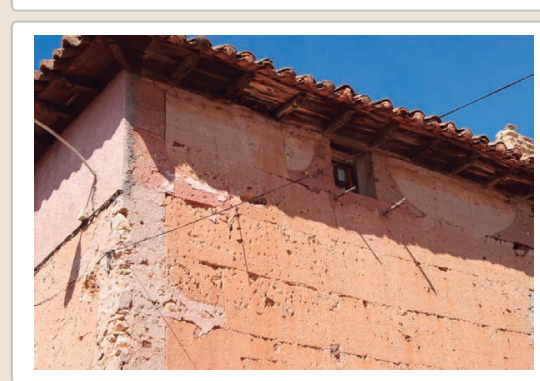

Lesiones ХMuro ХZŹcalo $\square$ Revestimiento $\mathbb{X}$ Erosión del material $\mathbf{X}$ Humedad por capilaridad $\square$ Erosion de las juntas $\mathbf{X}$ Humedades (manch/eflo) $\square$ Pérdida de sección $\quad \square$ Pérdida de verticalidad

$\square$ Vegetación

X Desconchados $\square$ Grietas por empuje de la cubierta

$\square$ Grietas porfalta de traba

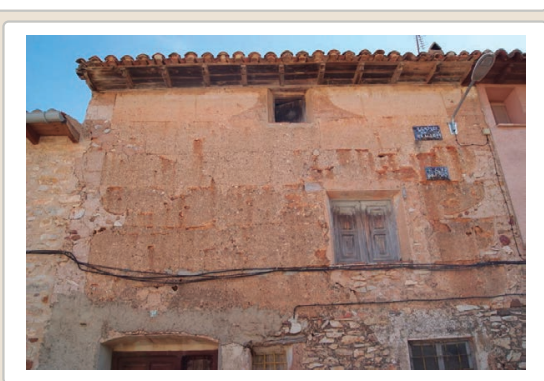

$\square$ Cubierta $\square$ Otro...

$\square$ Grietas por asentamiento $\square$ Colapso

$\square$ Por elementos impropios

$\square$ Derivado de intervenciones $\square$ Otro... 


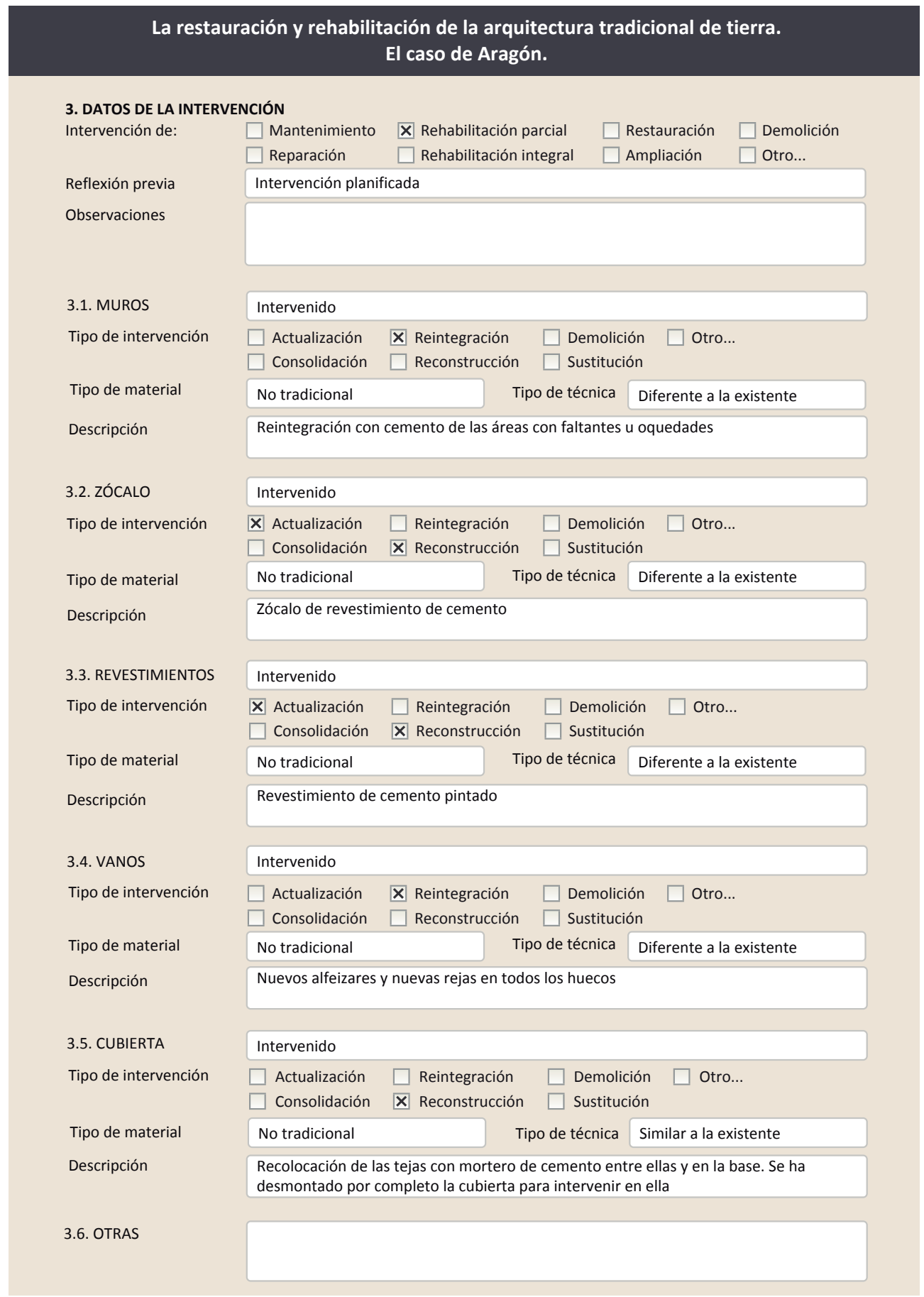

3.7. REHABILITACIÓN ENERGÉTICA $\quad \square$ Fachada $\square$ Vanos $\square$ Forjados $\square$ Cubierta Observaciones

FOTOGRAFÍAS DE LA INTERVENCIÓN
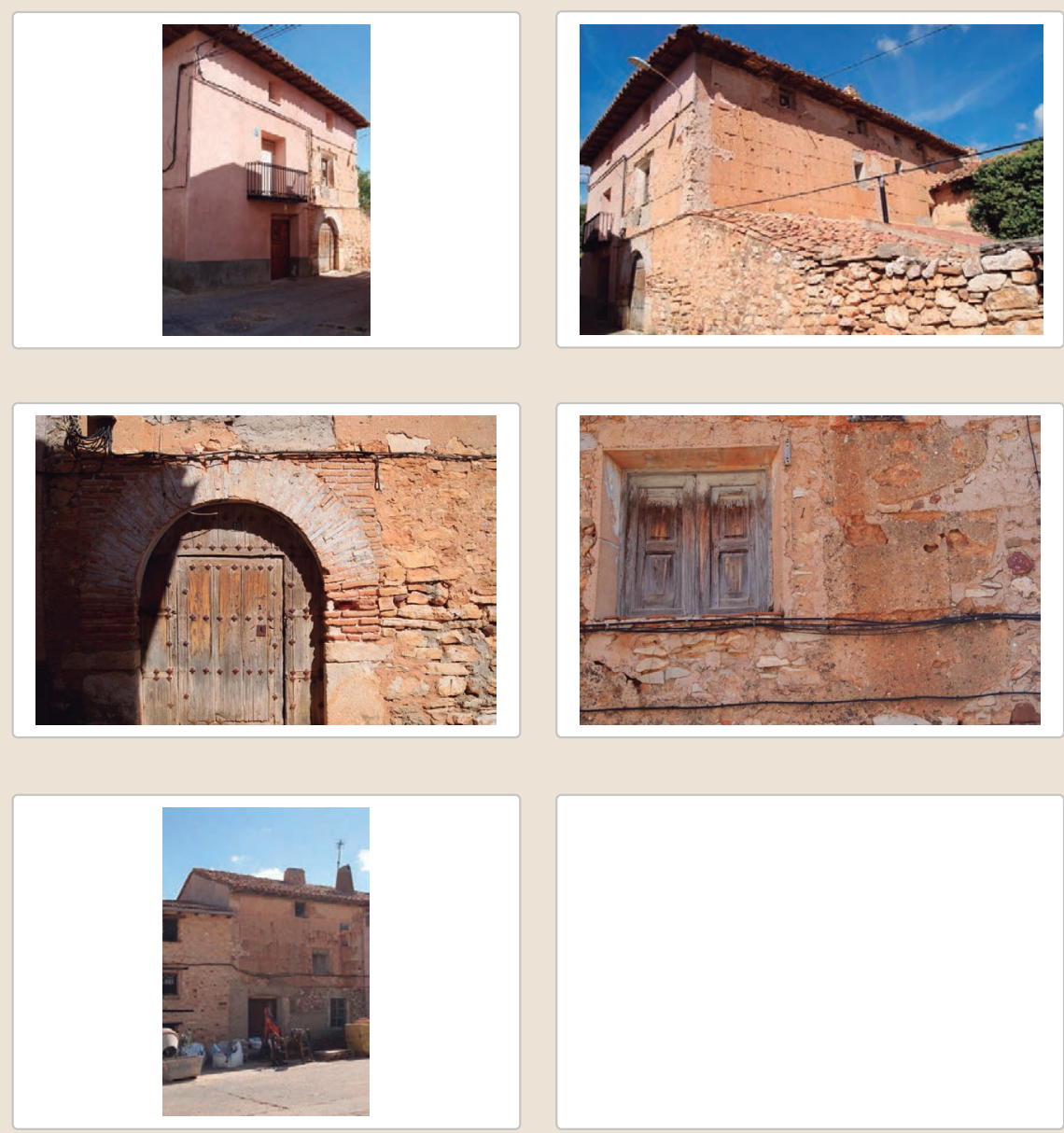
La restauración y rehabilitación de la arquitectura tradicional de tierra. El caso de Aragón.

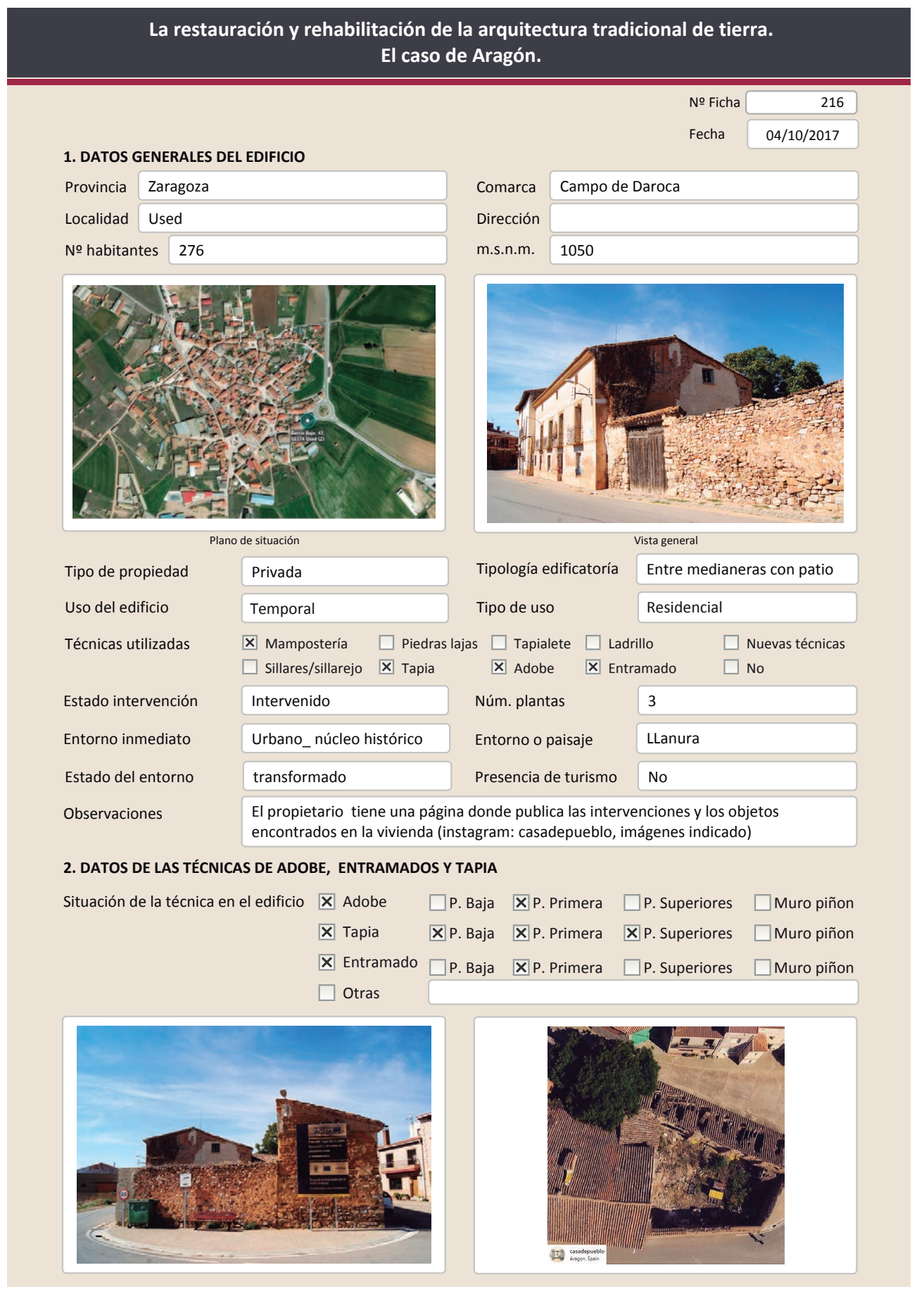

La restauración y rehabilitación de la arquitectura tradicional de tierra. El caso de Aragón.

2.1. ADOBE

Dimensión de las piezas Dimensión del muro Aparejo del muro Función estructural Variante constructiva/ tip

$\square$ simple

Х Suplementada en juntas

$\square$ Mixta

$\square$ Como suplemento

$\mathbf{X}$ Elementos de protección

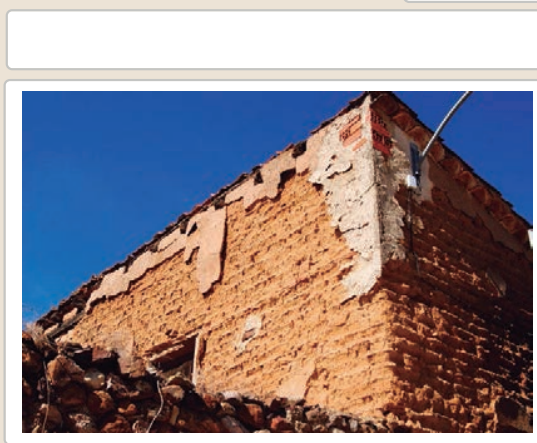

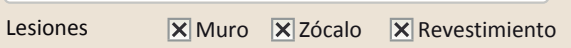
$\mathbf{X}$ Erosión del material $\mathbf{X}$ Humedad por capilaridad $\square$ Erosion de las juntas $\mathbf{X}$ Humedades (manch/eflo) \ Pérdida de sección $\square$ Pérdida de verticalidad

$\square$ Vegetación $\quad \square$ Grietas por empuje de la cubierta $\square$ Desconchados $\quad \square$ Grietas porfalta de traba
X
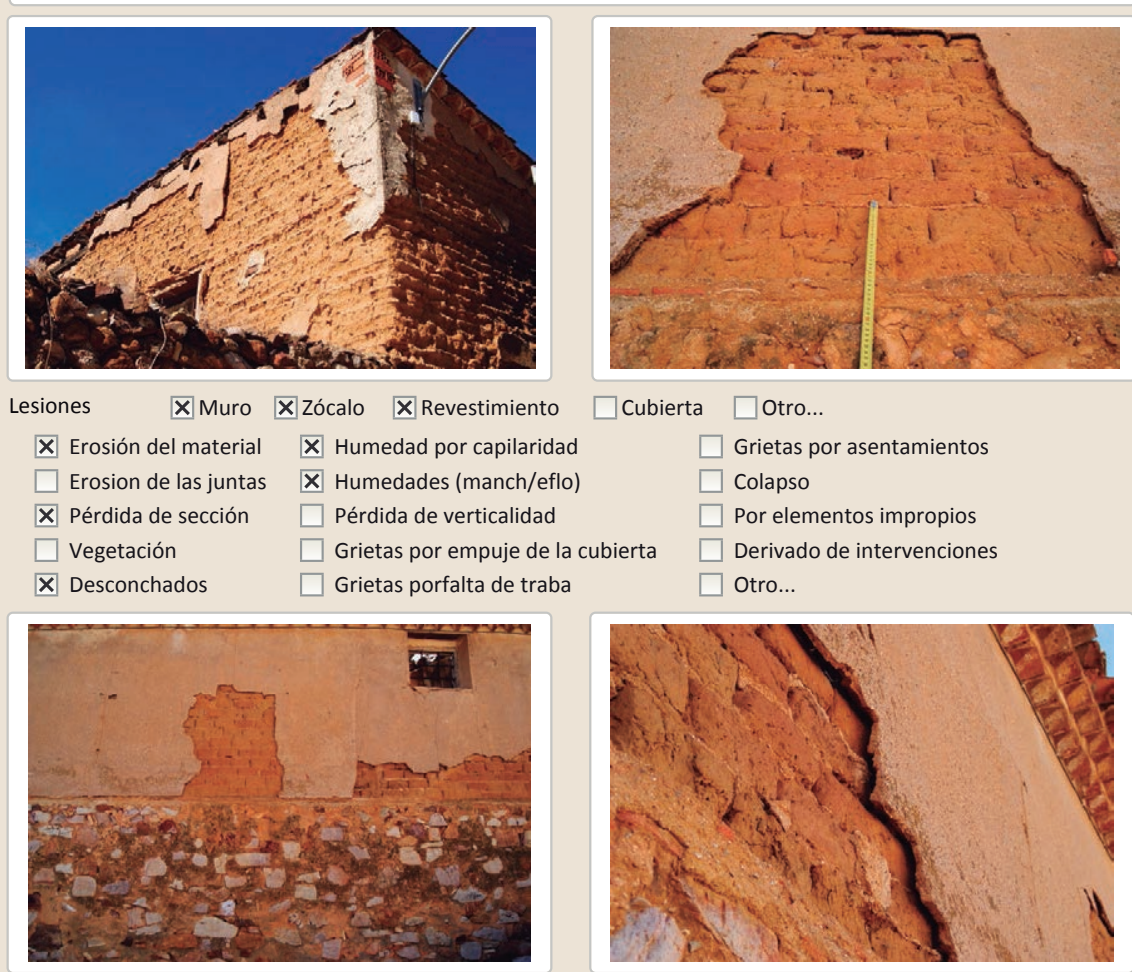

$\square$ Cubierta $\square$ Otro...

$\square$ Grietas por asentamientos

$\square$ Colapso

$\square$ Por elementos impropios

$\square$ Derivado de intervenciones $\square$ Otro...

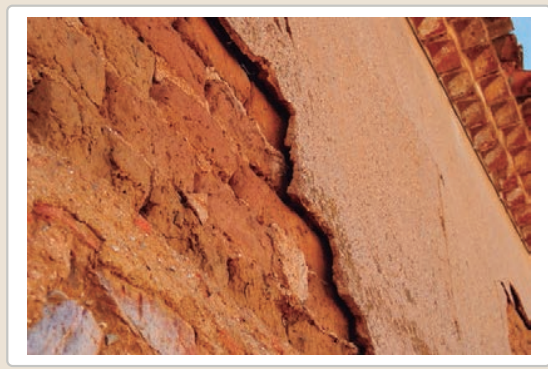

Observaciones El revestimiento se ha despegado por completo del muro de adobe 


\section{La restauración y rehabilitación de la arquitectura tradicional de tierra.} El caso de Aragón.

\subsection{TAPIA}

Ancho del muro

Dimensión tapiales

Tipo de aguja

№ agujas/cajón

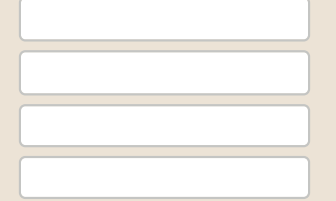

Color de la tapia

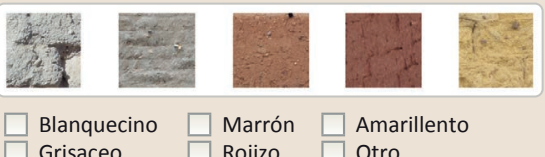

$\square$ Blanquecino $\square$ Marrón $\square$ Amarillento

Variante constructiva

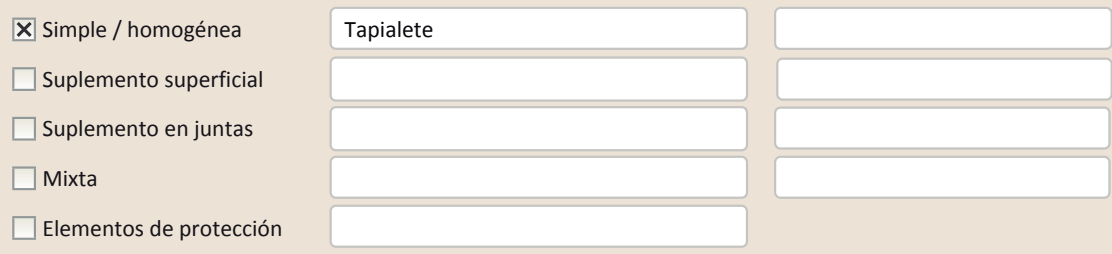

$\square$ Elementos de protección

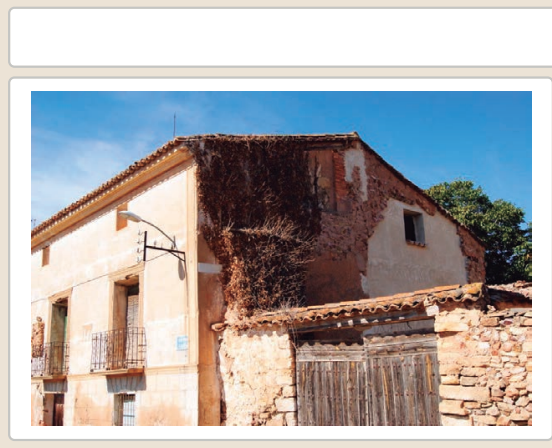

Lesiones $\quad$ XMuro $\square$ Zócalo $\square$ Revestimiento

$\square$ Erosión del material $\square$ Humedad por capilaridad

$\square$ Erosion de las juntas $\square$ Humedades (manch/eflo)

X Pérdida de sección $\square$ Pérdida de verticalidad

$\square$ Vegetación

$\square$ Grietas por empuje de la

$\square$ Desconchados

$\square$ Grietas porfalta de traba

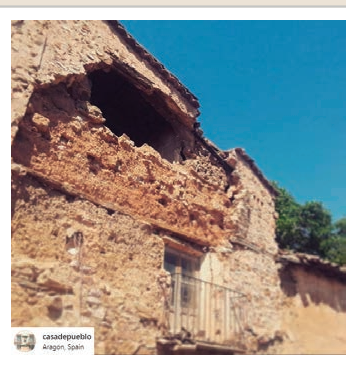

$\square$ Cubierta $\square$ Otro...

$\square$ Grietas por asentamiento

$x$ Colapso

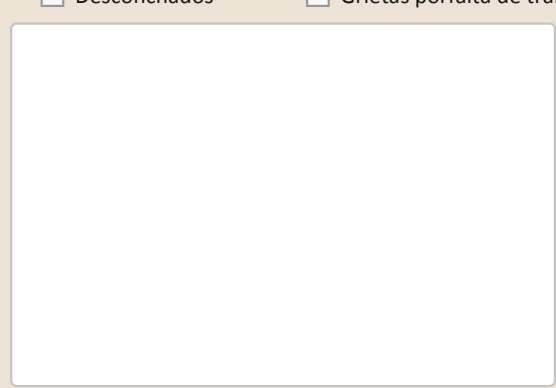

$\square$ Derivado de in

$\square$ Otro...

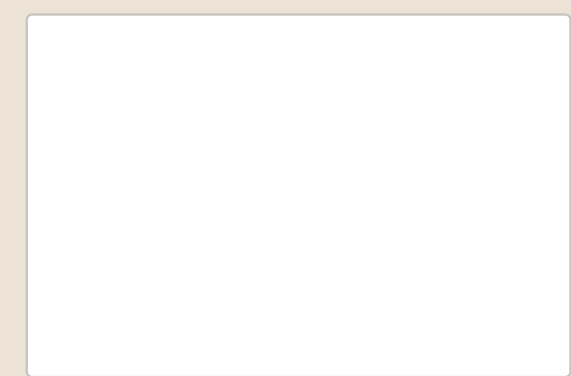

Observaciones

2.3. ENTRAMADOS

Distancia entre montantes

Altura de los montantes

\begin{tabular}{|l|}
$80-100 \mathrm{~cm}$ \\
$150-200 \mathrm{~cm}$ \\
\hline Escuadrada
\end{tabular}

Elementos diagonales

No

Sección de los montantes

Escuadrad

Elementos horizontales intermedios

Dimensión de los montantes

$10-20 \mathrm{~cm}$

Sección de las piezas horizontales

Escuadrada

Tipo de relleno del entramado

Técnica de relleno del entramado

$\begin{array}{ll}\square \text { Entre pantallas de madera } & \square \text { Pared de mano } \quad \square \text { Cañizo } \\ \square \text { Tierra y mampuestos } & \boldsymbol{X} \text { Adobe horizontal } \quad \square \text { Encestados }\end{array}$

$\square$ Tapialete

$\square$ Adobe aletorio $\quad \square$ Otro..

Entramado muy intervenido, mucha variedad de soluciones de relleno (lajas de piedra, ladrillo, adobe)
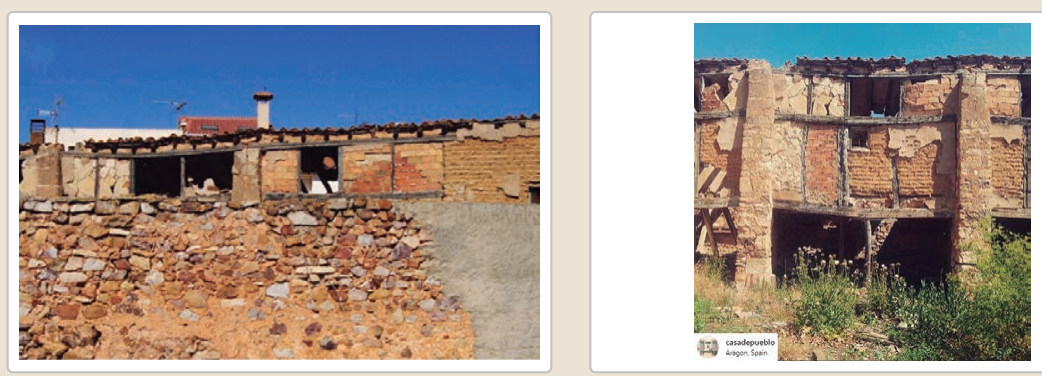

Lesiones

XMuro $\square$ Zócalo $\mathbf{X}$ Revestimiento

$\square$ Cubierta $\square$ Otro...

$\mathbf{X}$ Erosión del materi

$\square$ Carcoma o termitas

$\square$ Grietas por falta de traba

$\square$ Erosion de las juntas

X Pérdida de sección

$\square$ Rotura de la madera

$\square$ Vegetación

$\square$ Pudrición de la madera

$\square$ Colapso

X Desconchados

$\square$ Pudrición del relleno

$\square$ Por elementos impropios

$\square$ Humedad por capilaridad

$\square$ Pérdida de verticalidad

$\square$ Derivado de intervenciones

$\square$ Humedades (manch/eflor)

$\square$ Grietas por empuje de la cubierta

$\square$ Otro...
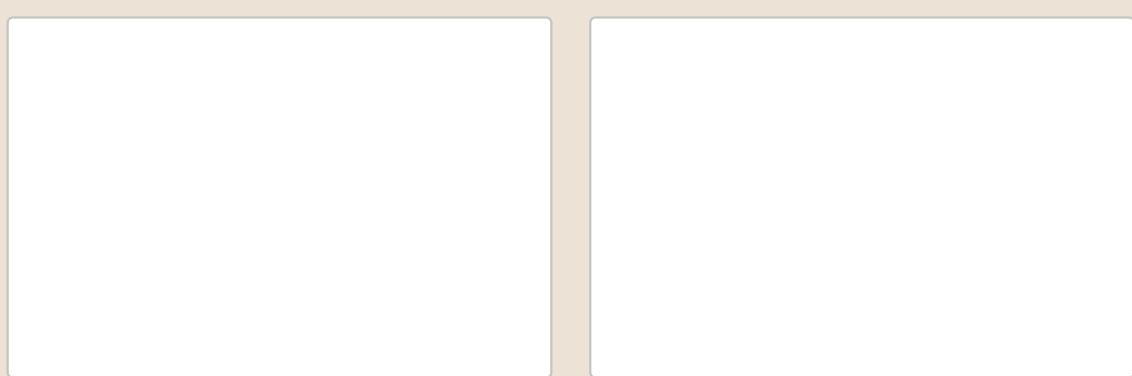

Observaciones

La madera tiene flechas importantes en algunos de los puntos 


\section{La restauración y rehabilitación de la arquitectura tradicional de tierra.} El caso de Aragón.

3. DATOS DE LA INTERVENCIÓN

Intervención de:

$\square$ Mantenimiento $\square$ Rehabilitación parcial

$\square$ Restauración $\square$ Demolición X Reparación $\quad \square$ Rehabilitación integral $\square$ Ampliación $\quad \square$ Otro...

Reflexión previa

Intervención planificada

Observaciones

Sustitución de cuarterones de adobe por ladrillo

3.1. MUROS

Tipo de intervención

Tipo de material

Descripción

3.2. ZÓCALO

Tipo de intervención

Tipo de material

Descripción

3.3. REVESTIMIENTOS

Tipo de intervención

Tipo de material

Descripción

3.4. VANOS

Tipo de intervención

Tipo de material

Descripción

3.5. CUBIERTA

Tipo de intervención

Tipo de material

Descripción

3.6. OTRAS

No intervenido

$\square$ Actualización $\square$ Reintegración $\square$ Demolición $\square$ Otro...

$\square$ Consolidación $\square$ Reconstrucción $\square$ Sustitución

No intervenido
$\square$ Actualización $\quad \square$ Reintegración $\quad \square$ Demolición $\square$ Otro...

$\square$ Consolidación $\quad \square$ Reconstrucción $\quad \square$ sustitución

Tipo de técnica

Tipo de técnica

No intervenido

$\square$ Actualización $\square$ Reintegración $\square$ Demolición $\square$ Otro.

$\square$ Consolidación $\square$ Reconstrucción $\square$ Sustitución Tipo de técnica
La restauración y rehabilitación de la arquitectura tradicional de tierra.

El caso de Aragón.

3.7. REHABILITACIÓN ENERGÉTICA $\quad \square$ Fachada $\square$ Vanos $\square$ Forjados $\square$ Cubierta

Observaciones

FOTOGRAFÍAS DE LA INTERVENCIÓN

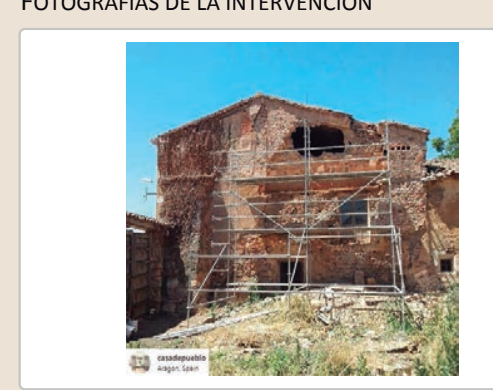

instagram: casadepueblo

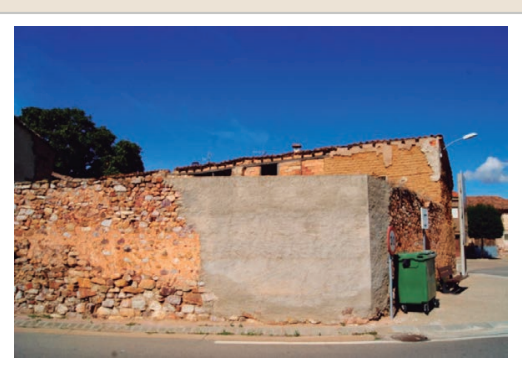

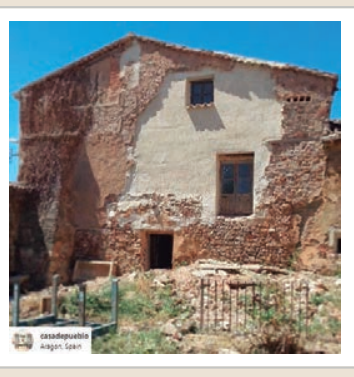

instagram: casadepueblo

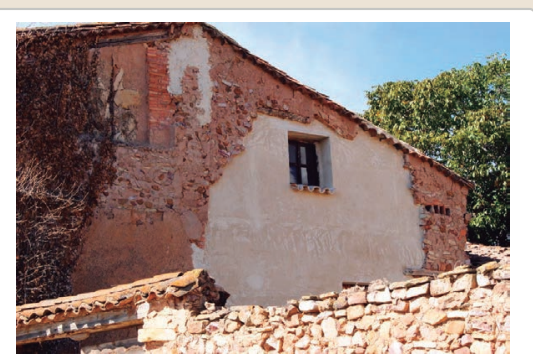

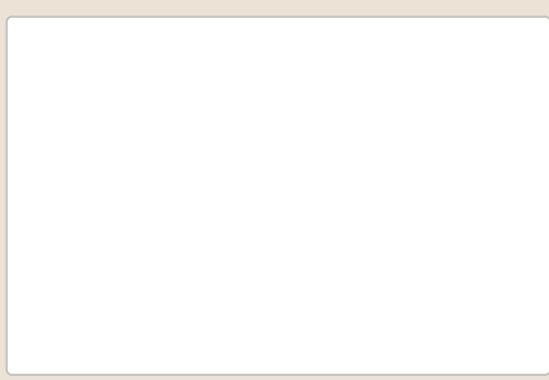

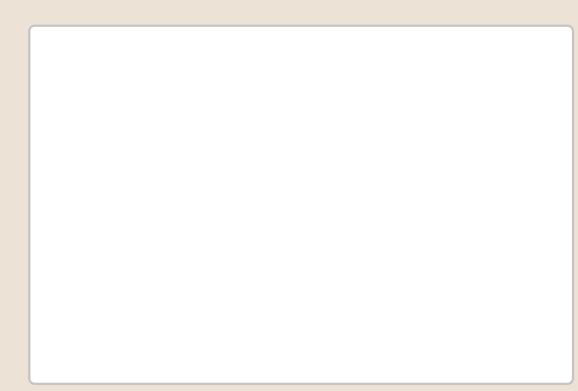




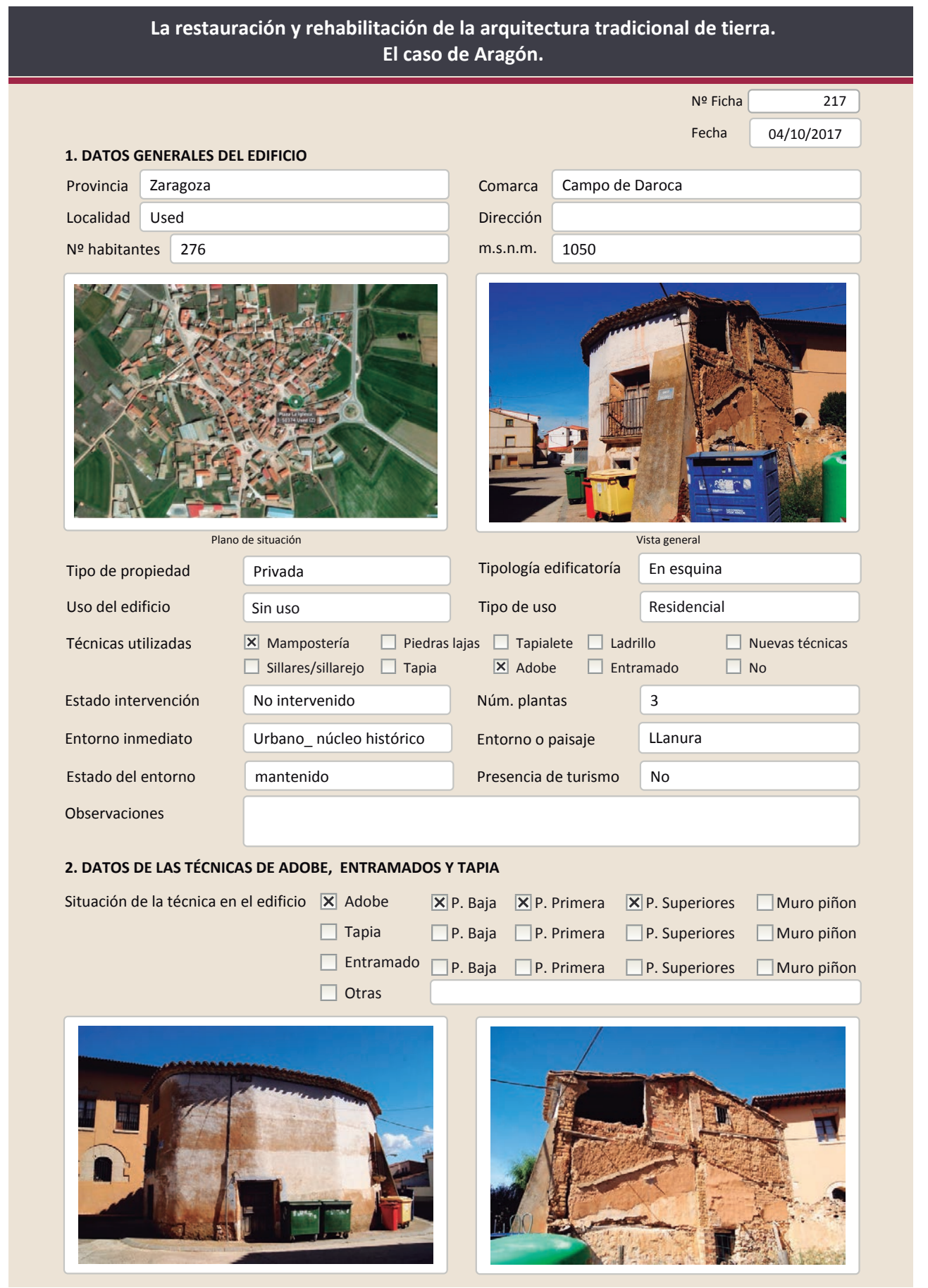

2.1. ADOBE

Dimensión de las piezas

Dimensión del muro

Aparejo del muro

Función estructural

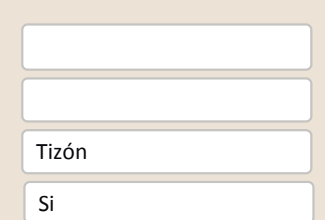

Color de las piezas

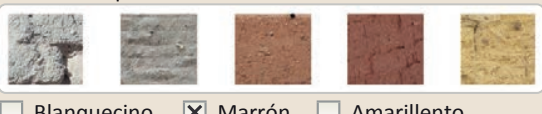

$\square$ Blanquecino $\mathbf{X}$ Marrón $\square$ Amarillento $\square$ Grisaceo $\square$ Rojizo $\square$ Otro..

Comp. - estabilizante $\mathbf{x}$ Simple

$\square$ suplementada en juntas

$\square$ Mixta

$\square$ Como suplemento

$\square$ Elementos de protección

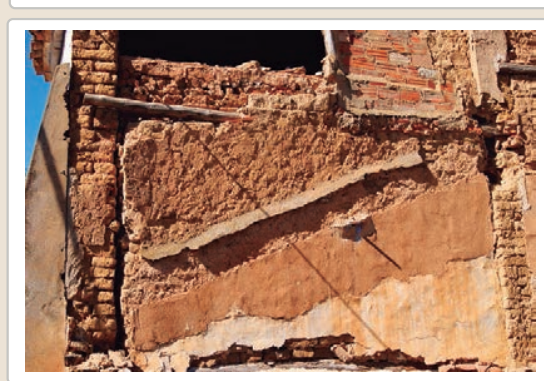

Lesiones XMuro $\square$ Zócalo X Revestimiento

X Erosión del material $\square$ Humedad por capilaridad $\square$ Erosion de las juntas $\square$ Humedades (manch/eflo)

$\square$ Pérdida de sección $\square$ Pérdida de verticalidad

$\square$ Vegetación $\quad \square$ Grietas por empuje de la cubie

X Desconchado $\square$ Grietas porfalta de traba

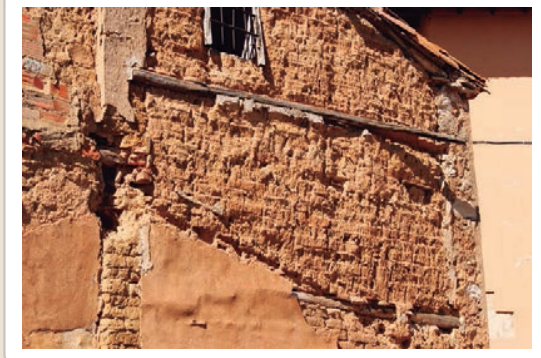

$\square$ Cubierta $\square$ otro...

$\square$ Grietas por asentamiento X Colapso

$\square$ Por elementos impropios

$\square$ Derivado de intervenciones $\square$ Otro... 


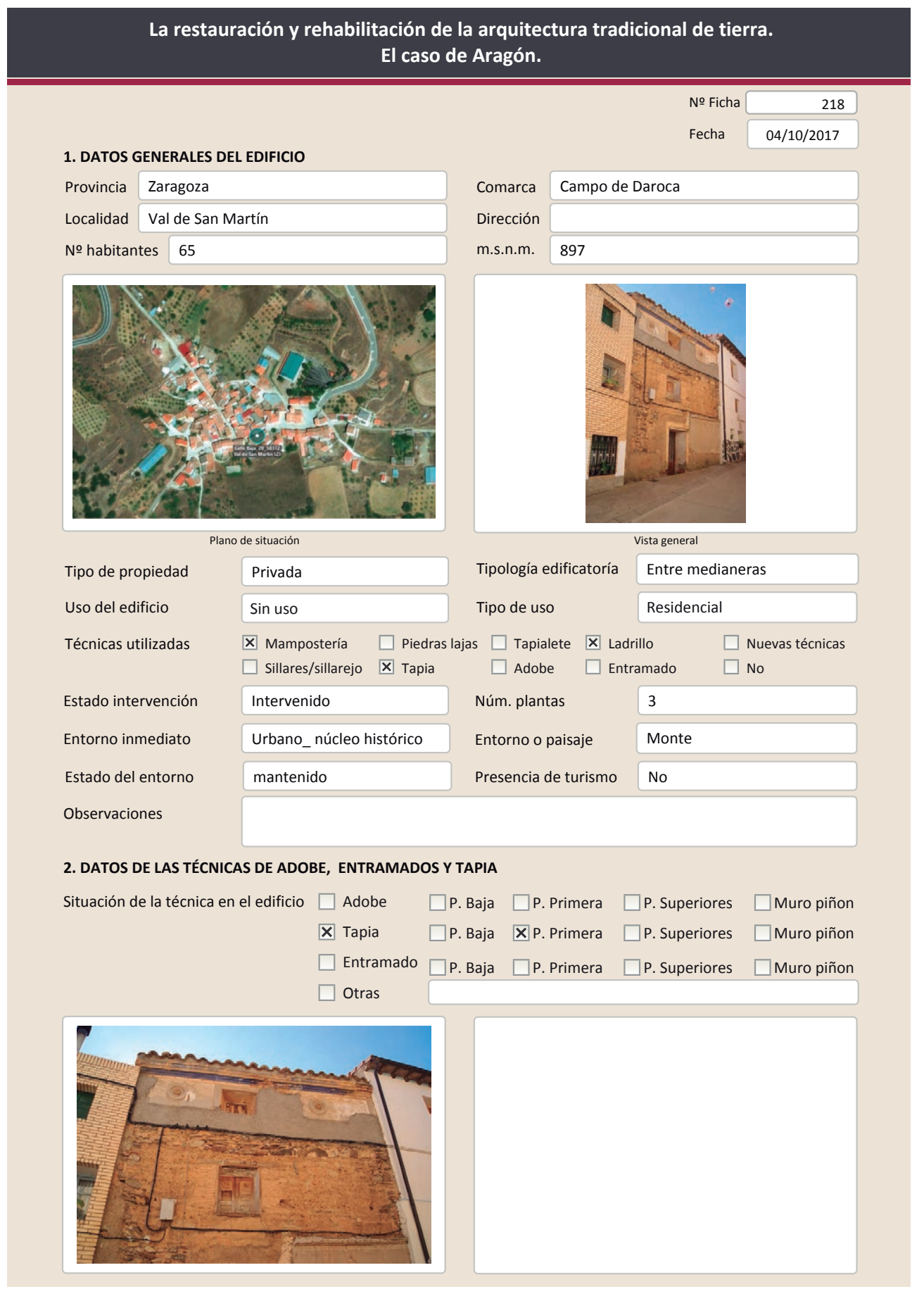

La restauración y rehabilitación de la arquitectura tradicional de tierra.

El caso de Aragón.

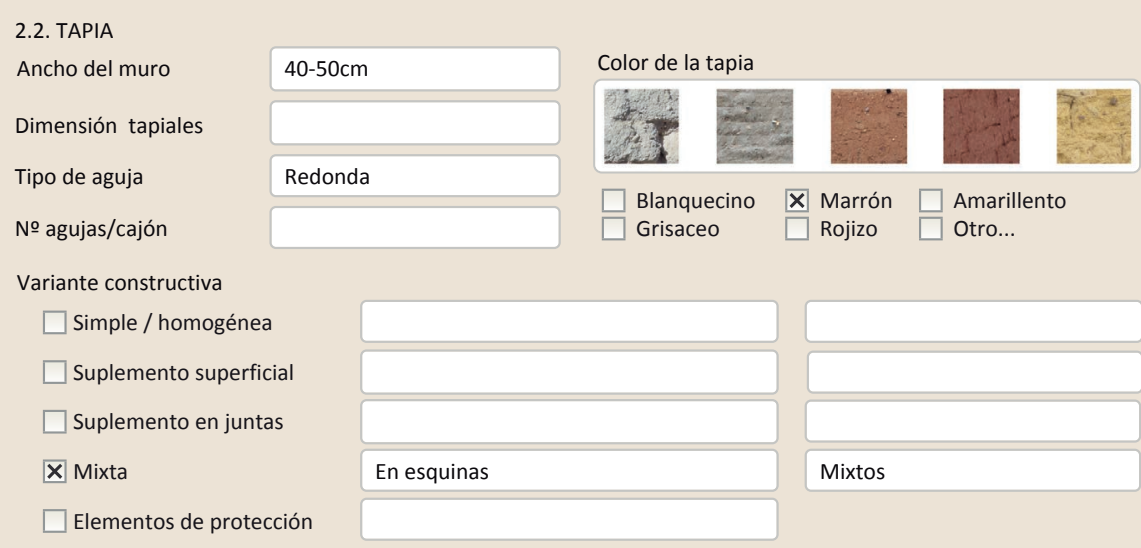

Esquinas del edificio con piedra y jambas de huecos con ladrillo

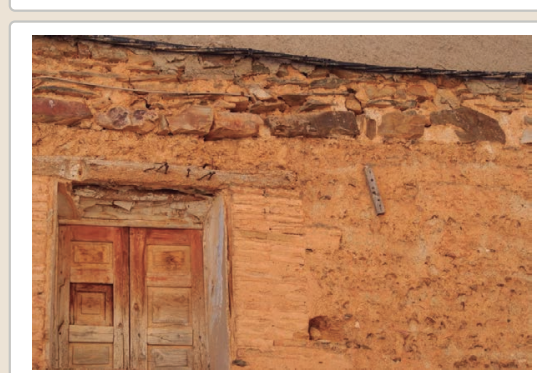

$\begin{array}{lll}\text { Lesiones } \mathbf{X} \text { Muro } \mathbf{X} \text { Zócalo } \square \text { Revestimiento } & \square \text { Cubierta } & \square \text { Otro... } \\ \mathbf{X} \text { Erosión del material } \quad \boldsymbol{X} \text { Humedad por capilaridad } & \square \text { Grietas por asentamientos } \\ \square \text { Erosion de las juntas } \quad \boldsymbol{X} \text { Humedades (manch/eflo) } & \square \text { Colapso } \\ \square \text { Pérdida de sección } \quad \square \text { Pérdida de verticalidad } & \square \text { Por elementos impropios } \\ \square \text { Vegetación } & \square \text { Grietas por empuje de la cubierta } & \square \text { Derivado de intervenciones } \\ \square \text { Desconchados } & \square \text { Grietas porfalta de traba } & \square \text { Otro... }\end{array}$

Observaciones 


\section{La restauración y rehabilitación de la arquitectura tradicional de tierra.}

\section{El caso de Aragón.}

3. DATOS DE LA INTERVENCIÓN

Intervención de:

$\square$ Mantenimiento $\square$ Rehabilitación parcia

$\square$ Restauración $\square$ Demolición

Reflexión previa

X Reparación

Rehabilitación integra

Ampliación

$\square$ Otro..

Reflexión previa

Intervención espontanea

(2)

3.1. MUROS

No intervenido

Tipo de intervención

$\square$ Actualización

$\square$ Consolidación $\square$ Reconstrucción $\square$ Sustitución

Tipo de material

Descripción

3.2. ZÓCALO

Tipo de intervención

Intervenido

Tipo de intervención

$\square$ Actualizació

Tipo de material

Descripción

Revestimiento de cemento

3.3. REVESTIMIENTOS

\section{Intervenido}

Tipo de intervención

$\square$ Actualización $\mathbf{X}$ Reintegración $\mathbf{X}$ Demolición $\square$ Otro...

Tipo de material

Descripción

Consolidación $\square$ Reconstrucción $\square$ sustitución

3.4. VANOS

Tipo de intervención

Se ha eliminado parte del revestimiento que tenía molduras y elementos decorativos y en la pare superior se ha reintegrado con cemento

Intervenido

Tipo de material

$\square$ Actualización $\quad \mathbf{X}$ Reintegración $\square$ Demolición $\square$ Otro...

$\square$ Consolidación $\square$ Reconstrucción $\mathbf{X}$ Sustitución

\begin{tabular}{|lll} 
No tradicional & Tipo de técnica & Diferente a la existente
\end{tabular}

Descripción Se ha reintegrado el contorno de la puerta de acceso con ladrillo hueco y se han sustituido la carpintería

3.5. CUBIERTA

Tipo de intervención

Intervenido

Tipo de material

$\square$ Actualización $\quad \square$ Reintegración $\quad \square$ Demolición $\square$ Otro..

$\square$ Consolidación $\quad$ Xeconstrucción $\square$ Sustitución

Descripción Se ha reconstruido la cubierta con teja curva y cemento pero su colocación es distinta ya que en el alero las tejas no vuelan a penas.

3.6. OTRAS 


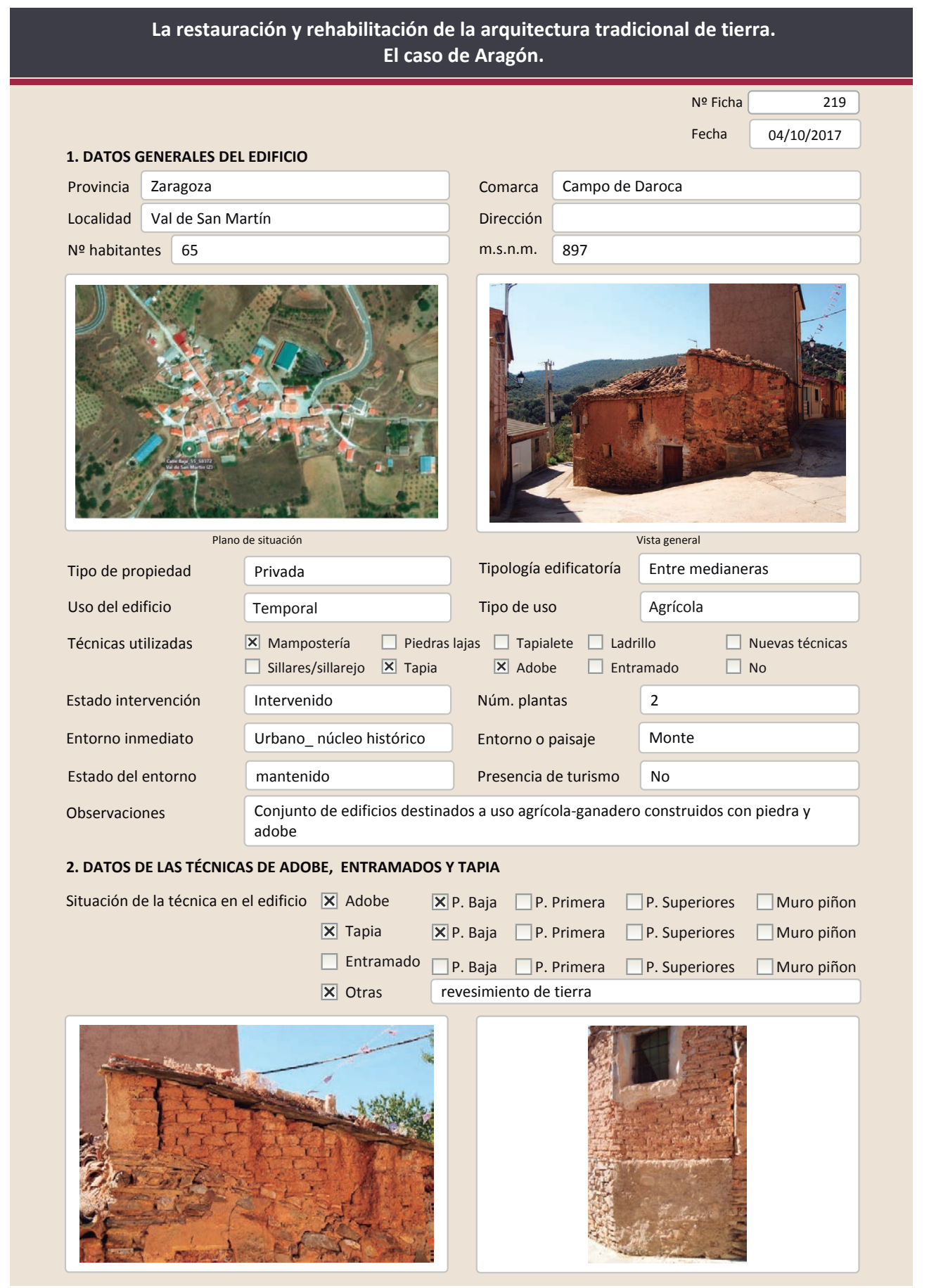

La restauración y rehabilitación de la arquitectura tradicional de tierra. El caso de Aragón.

2.1. ADOBE

Dimensión de las piezas Dimensión del muro

Aparejo del muro

Función estructural

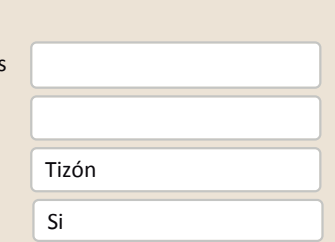

Color de las piezas

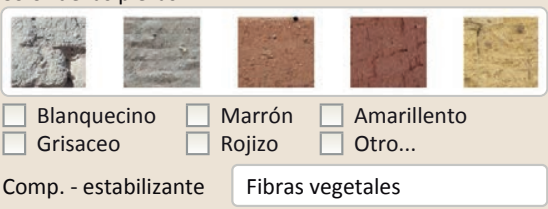

nstructiva/ tipo de fábrica

メ simple

$\square$ suplementada en juntas

$\square$ Mixta

$\square$ Como suplemento

$\square$ Elementos de protección

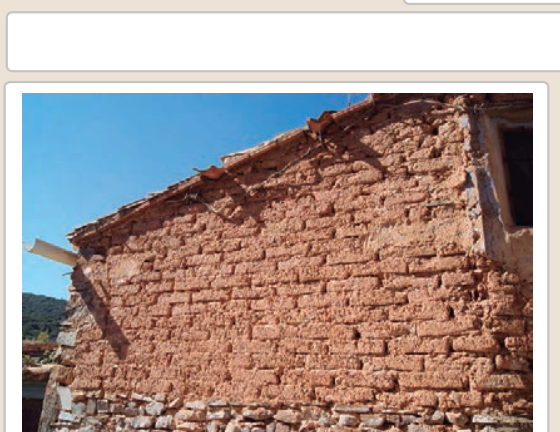

Lesiones $\mathbf{X}$ Muro $\square$ Zócalo $\square$ Revestimiento

X Erosión del material $\square$ Humedad por capilaridad X Erosion de las juntas $\square$ Humedades (manch/eflo)

$\square$ Pérdida de sección $\square$ Pérdida de verticalidad

$\square$ Vegetación X Grietas por empuje de la c

$\square$ Desconchados

$\square$ Grietas porfalta de traba

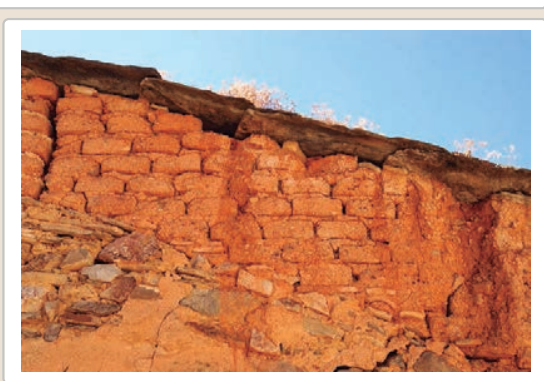

X Cubierta $\square$ otro...

$\square$ Grietas por

$\square$ Por elementos impropios

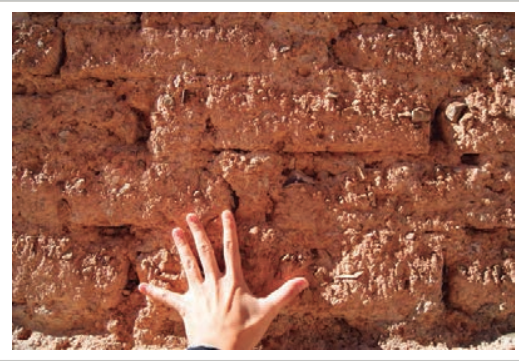

$\square$ Derivado

Observaciones 


\section{La restauración y rehabilitación de la arquitectura tradicional de tierra.} El caso de Aragón.

\subsection{TAPIA}

Ancho del muro

Dimensión tapiales

Tipo de aguja

№ agujas/cajón

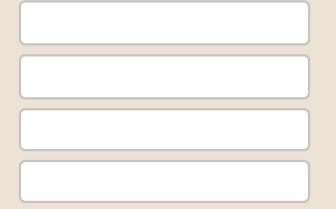

\section{Color de la tapia}

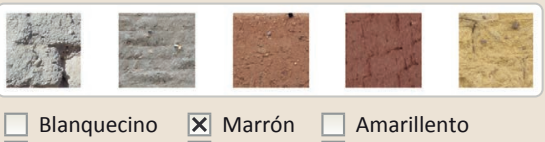

$\square$ Blanquecino $\quad \mathbf{X}$ Marrón $\square$ Amarillento $\square$ Grisaceo

Variante constructiva

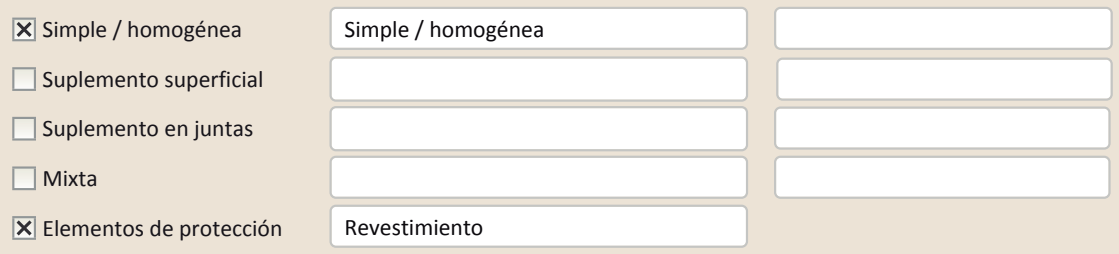

X Elementos de protección

Revestimiento

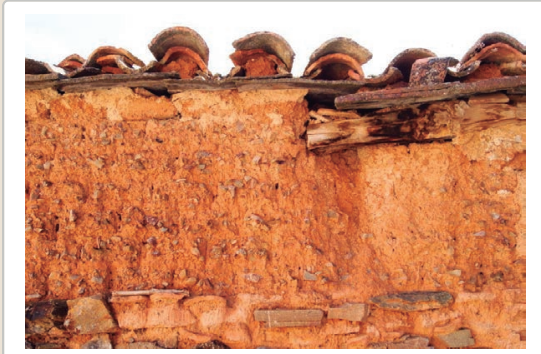

Lesiones ХMuro $\square$ Zócalo \ Xevestimiento \Cubierta $\square$ Otro...

$\begin{array}{lll}\mathbf{X} \text { Erosión del material } & \square \text { Humedad por capilaridad } & \square \text { Grietas por asentamientos } \\ \square \text { Erosion de las juntas } & \square \text { Humedades (manch/fflo) } & \mathbf{X} \text { Colapso } \\ \mathbf{X} \text { Pérdida de sección } & \square \text { Pérdida de verticalidad } & \square \text { Por elementos impropios } \\ \square \text { Vegetación } & \square \text { Grietas por empuje de la cubierta } & \square \text { Derivado de intervenciones }\end{array}$

X Pérdida de sección $\square$ Pérdida de verticalidad $\square$ Por elementos impropios

\ Desconchados $\square$ Grietas porfalta de traba $\quad \square$ Otro...
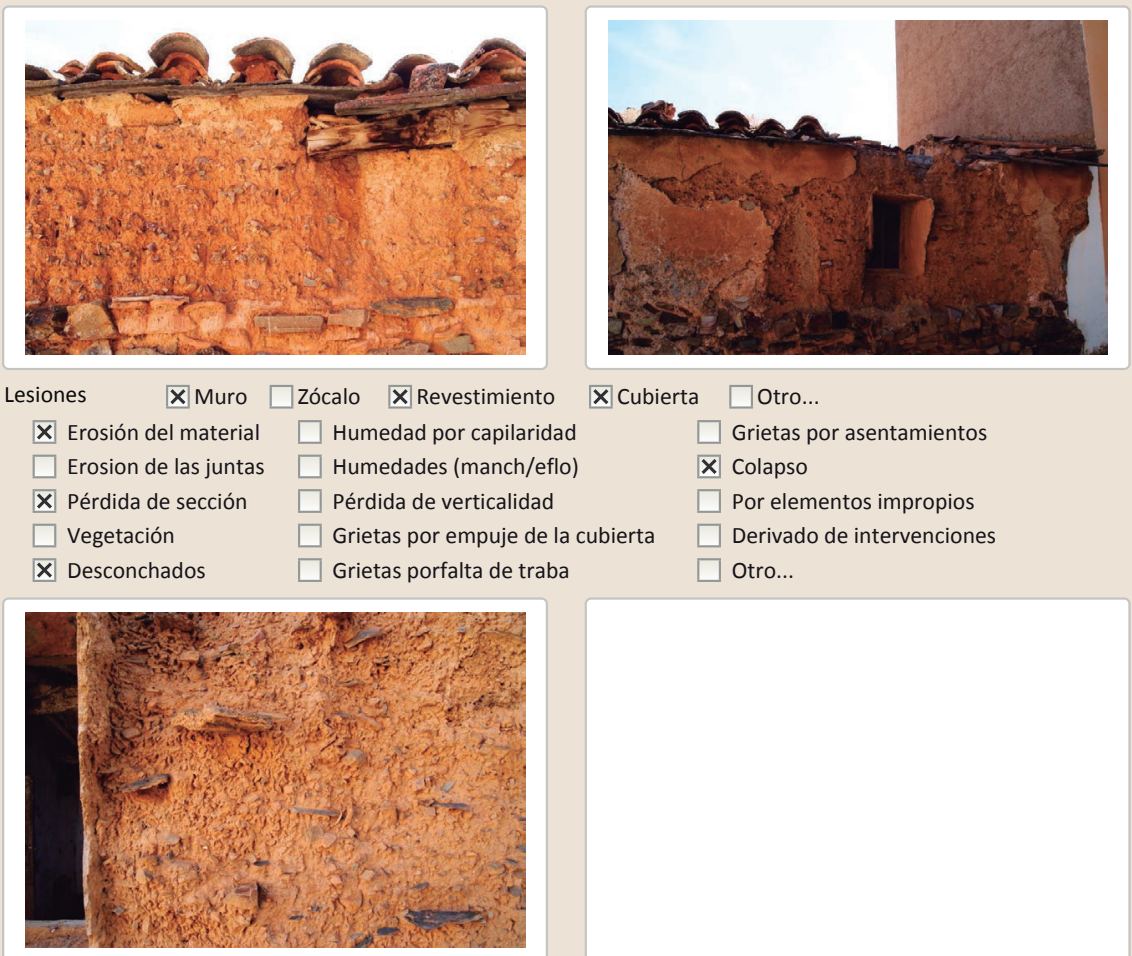

Observaciones

La restauración y rehabilitación de la arquitectura tradicional de tierra.

El caso de Aragón.

3. DATOS DE LA INTERVENCIÓN

Intervención de: $\quad \square$ Mantenimiento $\quad \square$ Rehabilitación parcial $\quad \square$ Restauración $\square$ Demolición

Reflexión previa Intervención espontanea

Observaciones

3.1. MUROS

Tipo de intervención

Tipo de material

Descripción

3.2. ZÓCALO

Tipo de intervención

Tipo de material

Descripción

3.3. REVESTIMIENTOS

Tipo de intervención

Tipo de material

Descripción

3.4. VANOS

Tipo de intervención

Tipo de material

Descripción

3.5. CUBIERTA

Tipo de intervención

Tipo de material

Descripción

3.6. OTRAS
Intervenido

$\square$ Actualización $\quad \mathbf{X}$ Reintegración $\square$ Demolición $\square$ Otro.

$\square$ Consolidación $\square$ Reconstrucción $\square$ Sustitución

\begin{tabular}{|l|l|l|l} 
No tradicional & Tipo de técnica Similar a la existente
\end{tabular}

Reintegración de la esquina del muro de adobe con ladrillo hueco

Intervenido

$\square$ Actualización $\quad \mathbf{X}$ Reintegración $\square$ Demolición $\square$ Otro..

$\square$ Consolidación $\square$ Reconstrucción $\square$ Sustitución

No tradicional Tipo de técnica Diferente a la existente

Reintegración de una pequeña área del zócalo

No intervenido

$\square$ Actualización $\square$ Reintegración $\square$ Demolición $\square$ Otro...

$\square$ Consolidación $\square$ Reconstrucción $\square$ sustitución$$
\text { Tipo de técnica }
$$

No intervenido

$\square$ Actualización $\square$ Reintegración $\square$ Demolición $\square$ Otro..

$\square$ Consolidación $\quad \square$ Reconstrucción $\square$ Sustitución

Tomento

\section{No intervenido}

$\square$ Actualización $\square$ Reintegración $\quad \square$ Demolición $\square$ Otro.

$\square$ Consolidación $\square$ Reconstrucción $\square$ Sustitución

Tipo de técnica 


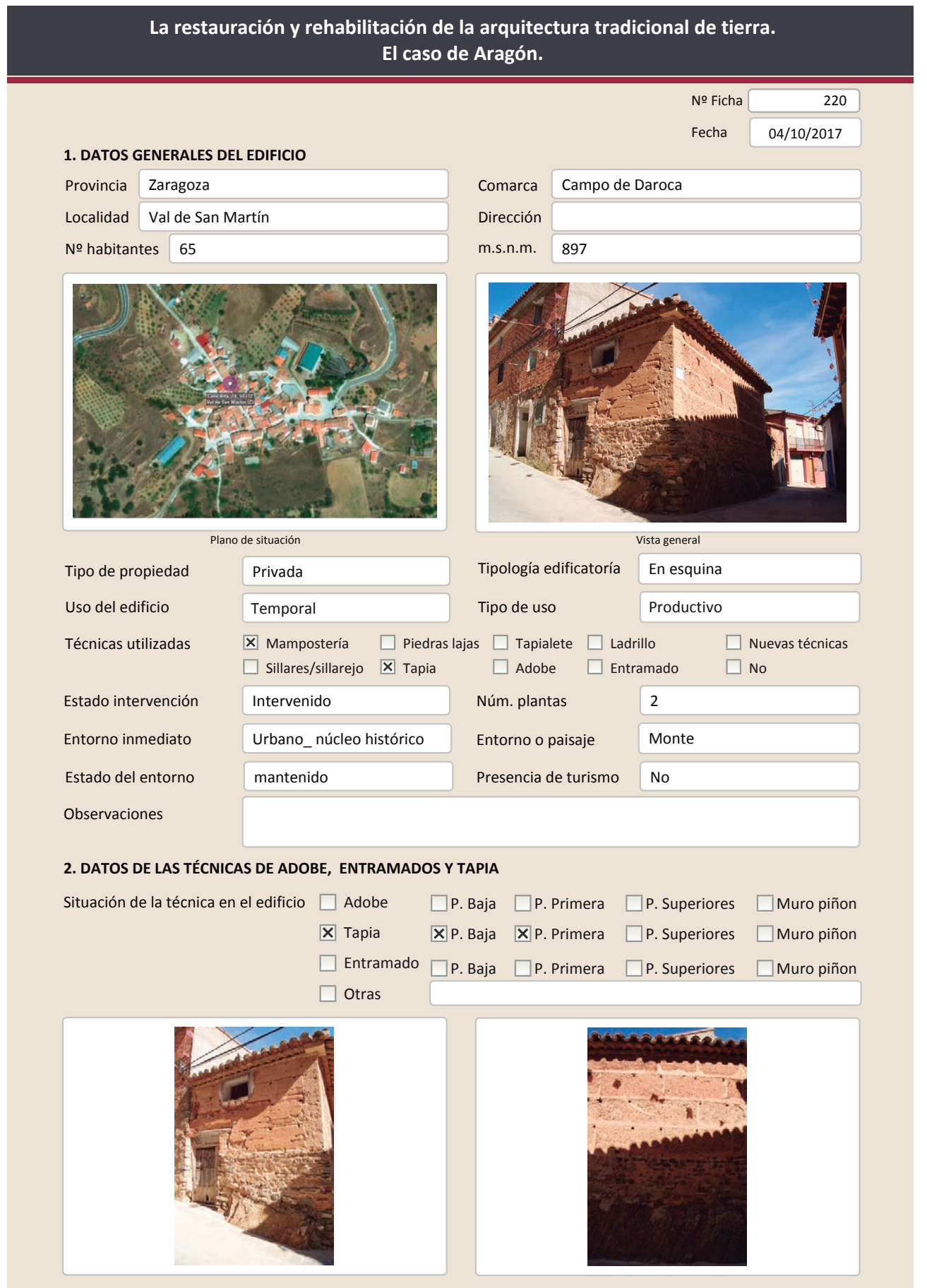

La restauración y rehabilitación de la arquitectura tradicional de tierra. El caso de Aragón.

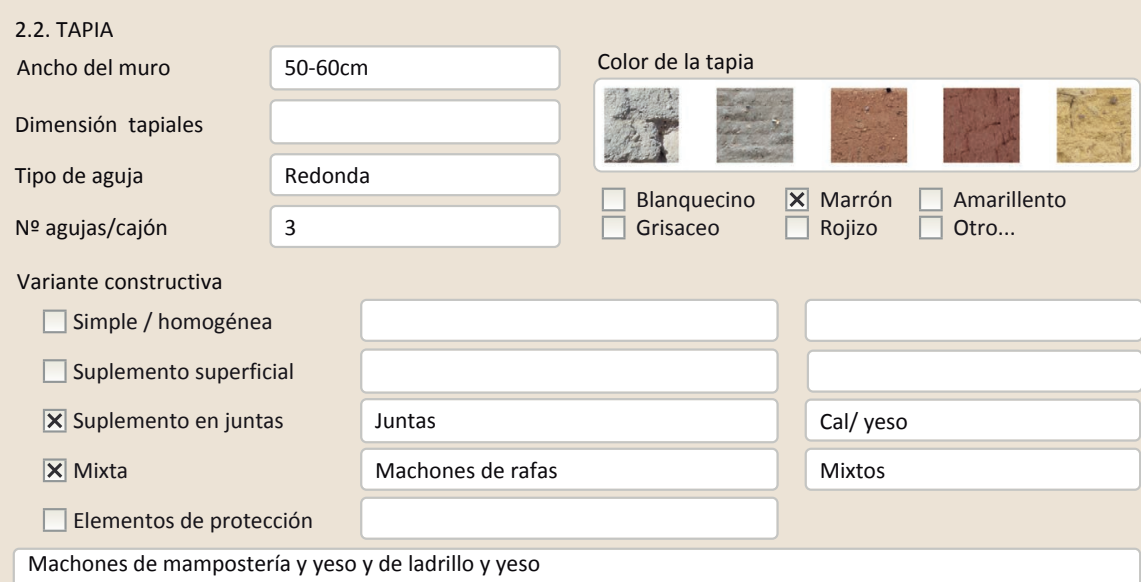

Machones de mampostería y yeso y de ladrillo y yeso

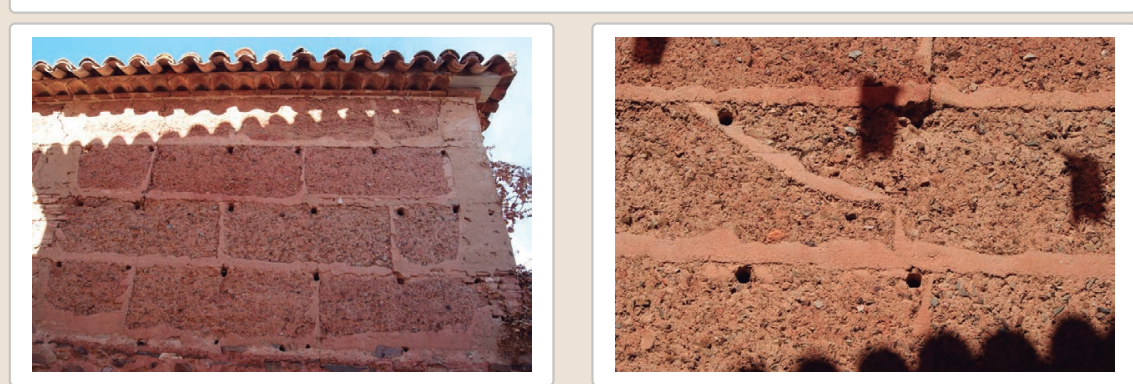

Lesiones $\square$ Muro $\square$ Zócalo $\square$ Revestimiento $\square$ Cubierta $\square$ otro...

$\square$ Erosión del material $\quad \square$ Humedad por capilaridad $\quad \square$ Grietas por asentamientos $\square$ Erosion de las juntas $\square$ Humedades (manch/eflo) $\quad \square$ Colapso

$\square$ Pérdida de sección $\square$ Pérdida de verticalidad $\quad \square$ Por elementos impropios

$\square$ Vegetación $\quad \square$ Grietas por empuje de la cubierta $\square$ Derivado de intervenciones

$\square$ Desconchados $\quad \square$ Grietas porfalta de traba $\quad \square$ Otro... 


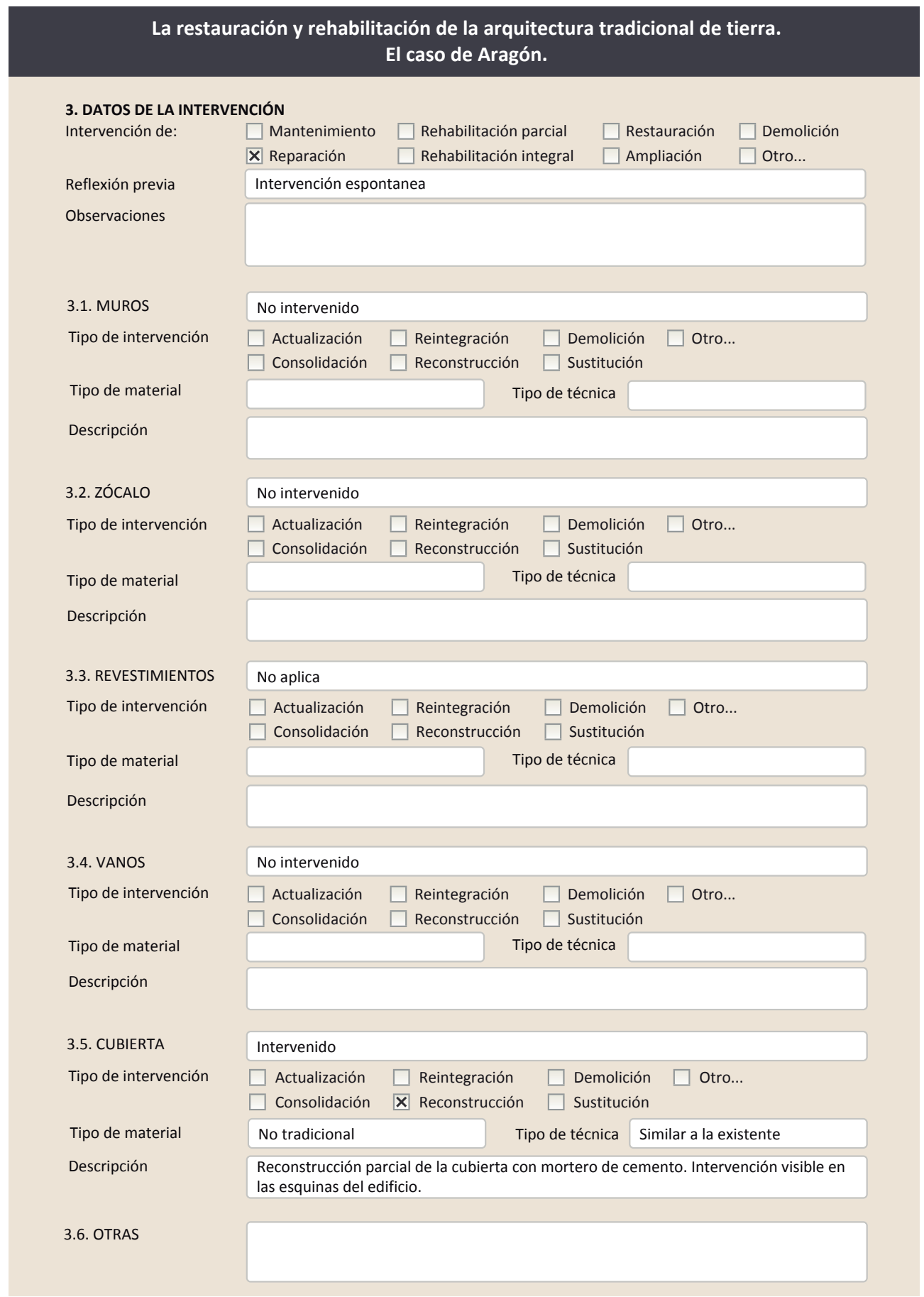

\subsection{REHABILITACIÓN ENERGÉTICA $\quad \square$ Fachada $\square$ Vanos $\square$ Forjados $\square$ Cubierta}

Observaciones

FOTOGRAFÍAS DE LA INTERVENCIÓN
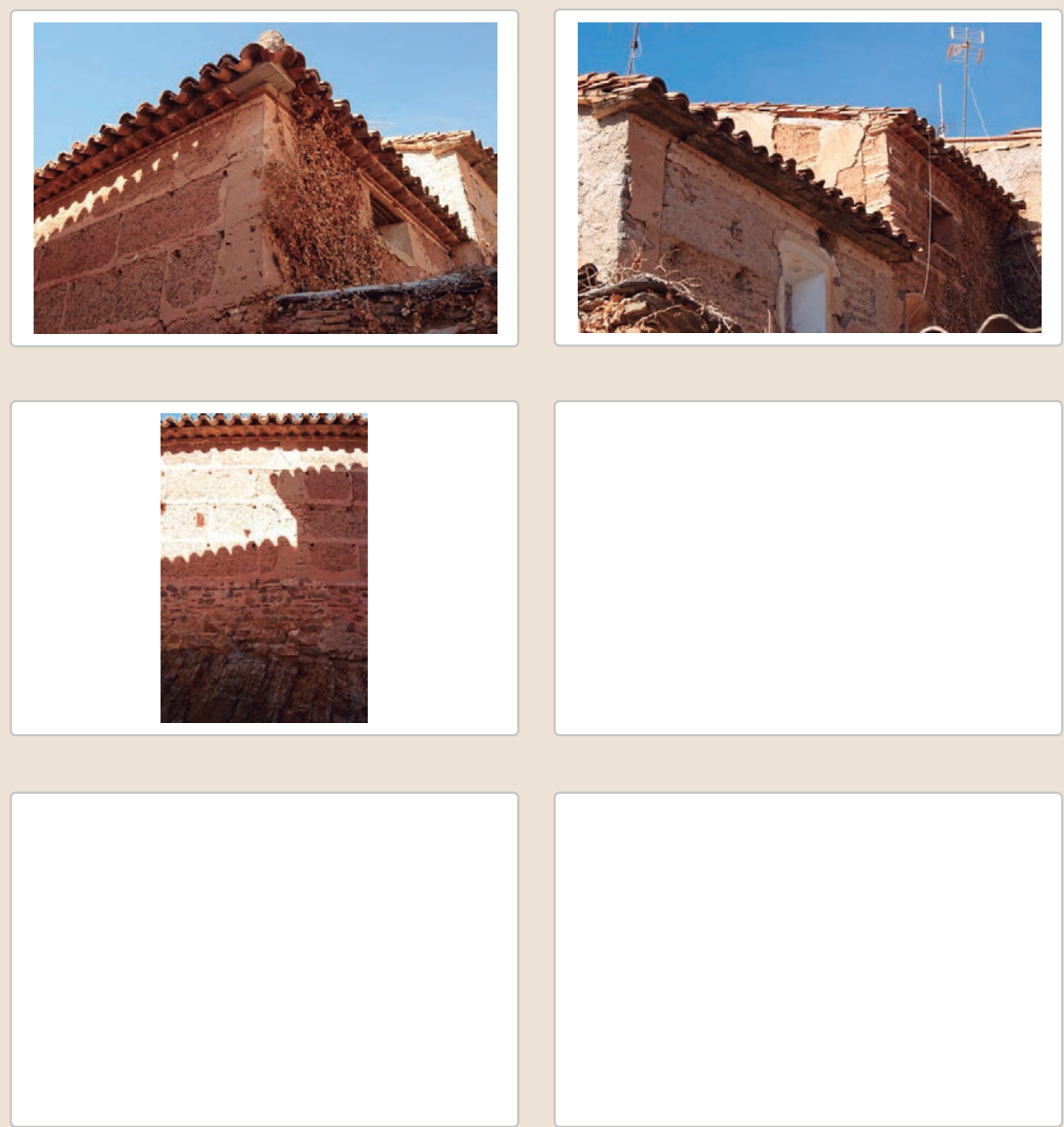


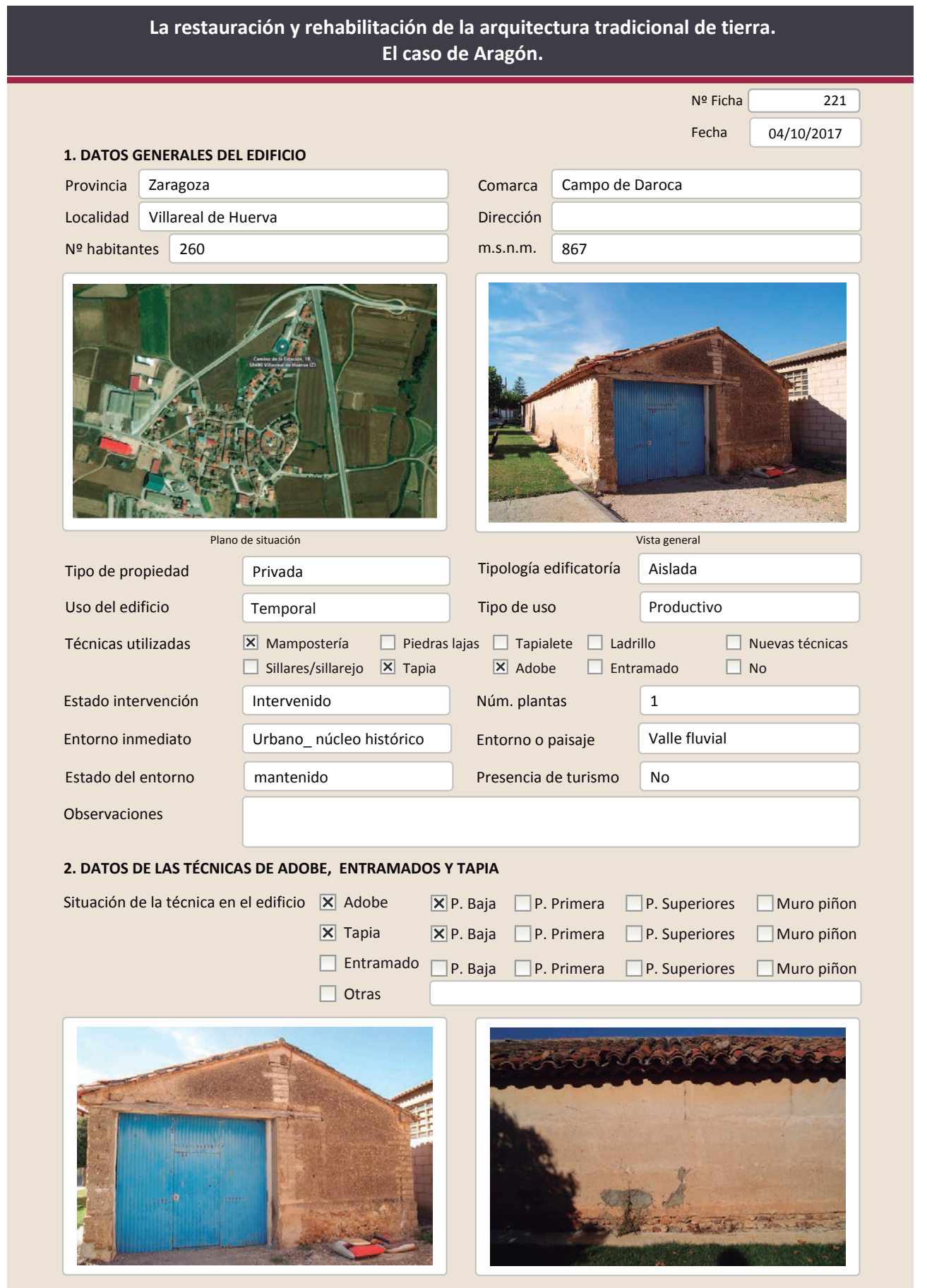

La restauración y rehabilitación de la arquitectura tradicional de tierra.

El caso de Aragón.

2.1. ADOBE

Dimensión de las piezas $35 \times 17 \times 10$

Dimensión del muro

Aparejo del muro

Tizón

Función estructural

$\mathrm{Si}$

Variante constructiva/ tipo de fábrica

$\square$ Simple

\begin{tabular}{l|l} 
X Suplementada en juntas & Horizontales \\
$\square$ Mixta & Mixto- En esquinas \\
\hline X Como suplemento
\end{tabular}

$\square$ Elementos de protección Bloque tierra-cemento

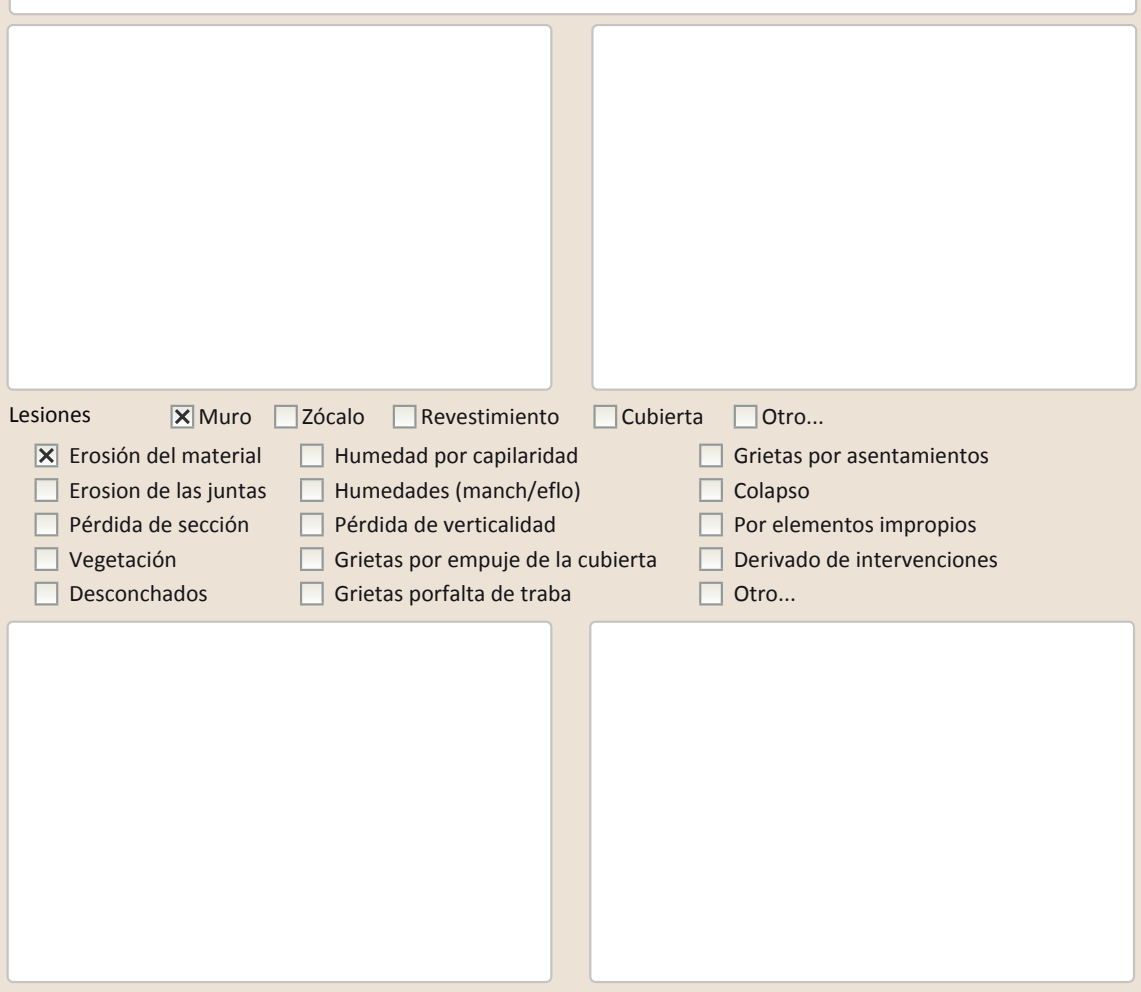

Observaciones
Color de las piezas

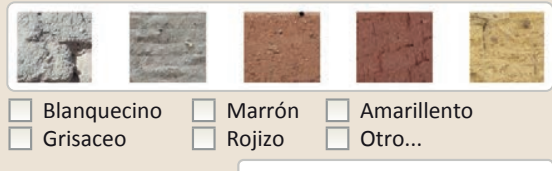

Rojizo Otro..

Comp. - estabilizante
$\mathrm{Cal} /$ yeso 


\section{La restauración y rehabilitación de la arquitectura tradicional de tierra.} El caso de Aragón.

\subsection{TAPIA}

Ancho del muro

Dimensión tapiales

Tipo de aguja

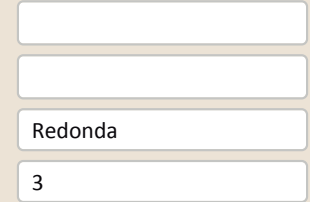

\section{Color de la tapia}

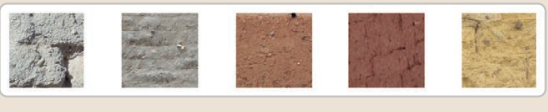

$\square$ Blanquecino $\square$ Marrón $\square$ Amarillento

$\square$ Grisaceo $\square$ Rojizo $\square$ Otro...

Variante constructiva

$\square$ Simple/homog

X Suplemento superficial

$\square$ suplemento en juntas

X Mixta

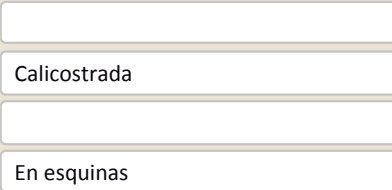

En esquinas

\begin{tabular}{|l|}
\hline Cal/ yeso \\
\hline Adobe \\
\hline
\end{tabular}

$\square$ Elementos de protección

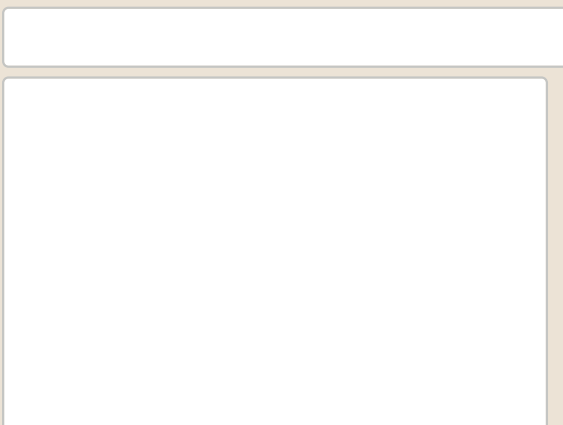

Lesiones $\quad$ XMuro $\square$ Zócalo $\square$ Revestimiento $\square$ Cubierta $\square$ Otro...

$\square$ Erosión del material $\quad \square$ Humedad por capilaridad $\quad \square$ Grietas por asentamientos

$\square$ Erosion de las juntas $\square$ Humedades (manch/eflo) $\quad \square$ Colapso

$\square$ Pérdida de sección $\square$ Pérdida de verticalidad $\quad \square$ Por elementos impropios

$\square$ Vegetación $\square$ Grietas por empuje de la cubierta $\square$ Derivado de intervencion

$\mathbf{X}$ Desconchados

$\square$ Grietas porfalta de traba $\quad \square$ Otro...

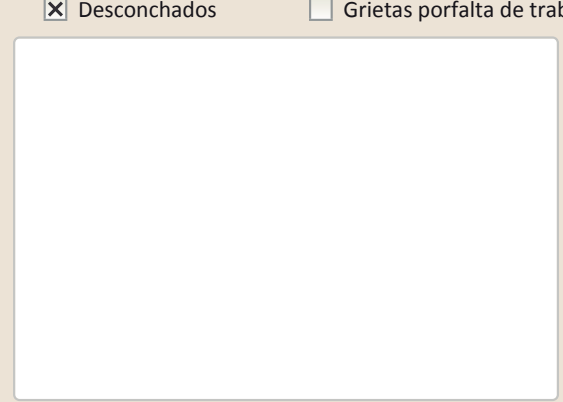

Observaciones
La restauración y rehabilitación de la arquitectura tradicional de tierra.

El caso de Aragón.

3. DATOS DE LA INTERVENCIÓN

Intervención de: $\square$ Mantenimiento $\square$ Rehabilitación parcial $\square$ Restauración $\square$ Demolición

Reflexión previa Intervención espontanea

Observaciones

3.1. MUROS

Tipo de intervención

Intervenido

Tipo de material

$\square$ Actualización $\quad \boldsymbol{X}$ Reintegración $\square$ Demolición $\square$ Otro..

$\square$ Consolidación $\quad \square$ Reconstrucción $\square$ Sustitución

Descripción

No tradicional Tipo de técnica Diferente a la existente

3.2. ZÓCALO

Reintegración de oquedades con cemento

Tipo de intervención

Tipo de material

Descripción

3.3. REVESTIMIENTOS

Tipo de intervención

\section{No aplica}

No intervenido

$\square$ Actualización $\square$ Reintegración $\square$ Demolición $\square$ Otro..

$\square$ Consolidación $\square$ Reconstrucción $\square$ Sustitución

Tipo de técnica

Tipo de material

Descripción

3.4. VANOS

Tipo de intervención

Intervenido

Tipo de material

$\square$ Actualización $\quad \square$ Reintegración $\quad \square$ Demolición $\square$ Otro..

$\square$ Consolidación $\square$ Reconstrucción $\quad \mathbf{X}$ Sustitución

\begin{tabular}{l|l|l|l|l} 
Tipo de material & No tradicional & Tipo de técnica & Diferente a la existente
\end{tabular}

Descripción

Sustitución de la puerta de acces

3.5. CUBIERTA

Tipo de intervención

Intervenido

$\square$ Actualización $\quad \mathbf{X}$ Reintegración $\quad \square$ Demolición $\square$ Otro

$\square$ consolidación $\square$ Reconstrucción $\square$ Sustitución

Tipo de material

No tradicional Tipo de técnica Similar a la existente

Descripción

Reintegración de nuevas tejas en cubierta eliminando las que están en mal estado

3.6. OTRAS 


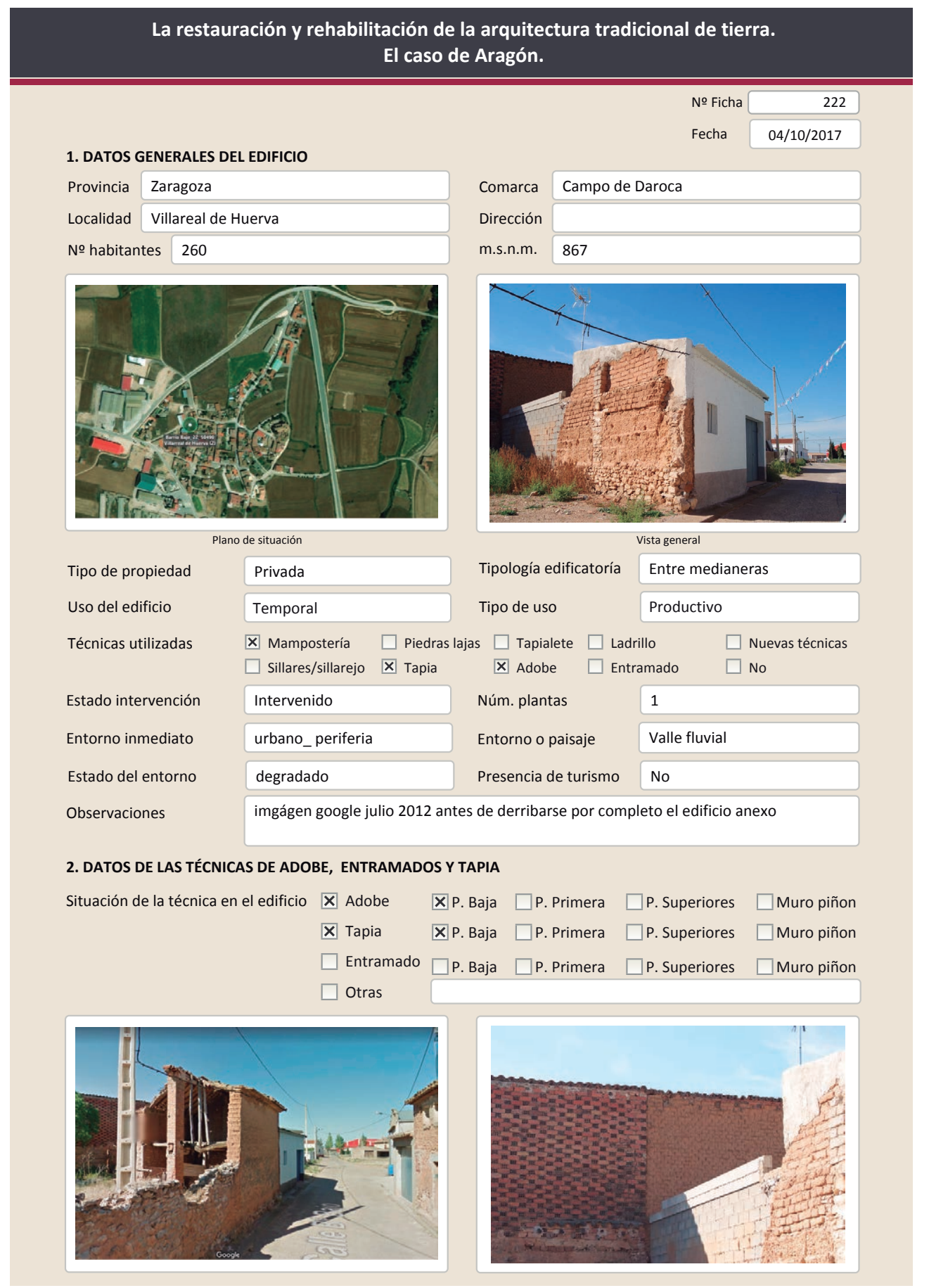

La restauración y rehabilitación de la arquitectura tradicional de tierra.

El caso de Aragón.

2.1. ADOBE

Dimensión de las piezas

Dimensión del muro

Aparejo del muro

Función estructural

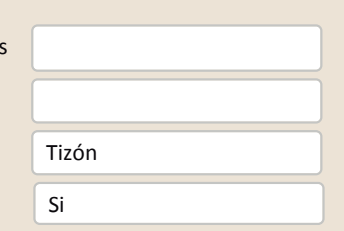

Color de las piezas

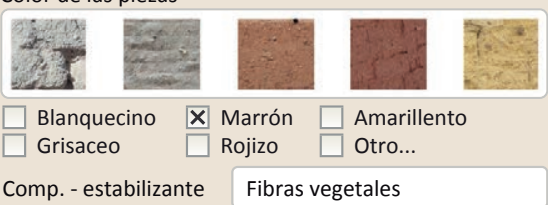

Variante constructiva/ tipo de fábrica

$\square$ Simple
X Suplementada en juntas
Horizontales
$\mathrm{Cal} /$ yeso
$\mathbb{x}$ Mixta
Machones
Mixtos

$\square$ Como suplemento

$\square$ Elementos de protección

machones de iedra $y$ adobe

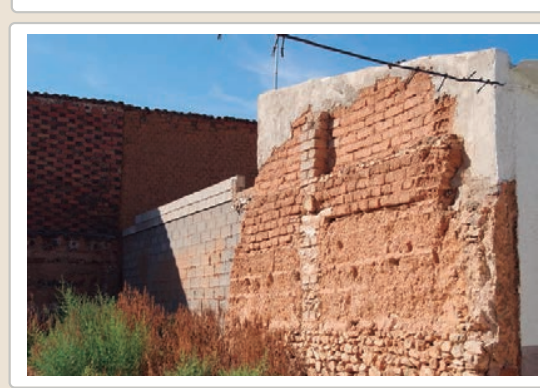

Lesiones $\quad \mathbf{X}$ Muro $\square$ Zócalo $\square$ Revestimiento

X Erosión del material $\square$ Humedad por capilaridad

$\square$ Erosion de las juntas $\square$ Humedades (manch/eflo)

$\square$ Pérdida de sección $\square$ Pérdida de verticalidad

$\square$ Vegetación

$\square$ Grietas por empuje de la

$\square$ Grietas porfalta de traba

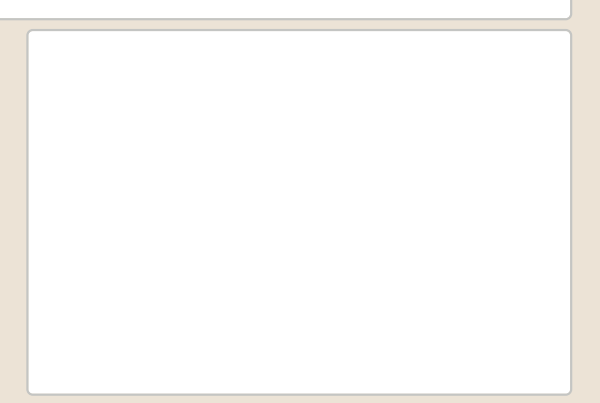

$\square$ Cubierta $\square$ otro...

$\square$ Grietas por asentamientos

$\square$ Colapso

$\square$ Desconchados

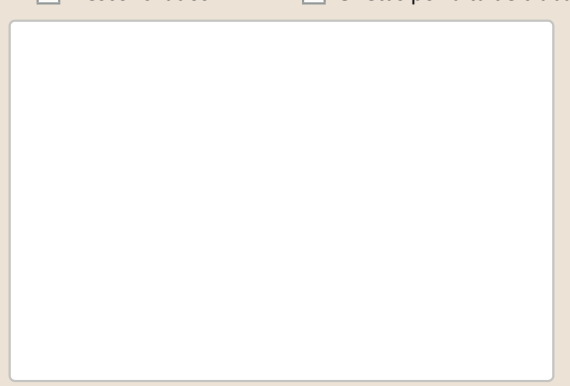

$\square$ Por elementos impropios

$\square$ Derivado de intervenciones $\square$ Otro... 


\section{La restauración y rehabilitación de la arquitectura tradicional de tierra.} El caso de Aragón.

\subsection{TAPIA}

Ancho del muro

Dimensión tapiales

Tipo de aguja

№ agujas/cajón

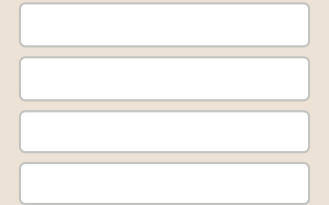

\section{Color de la tapia}

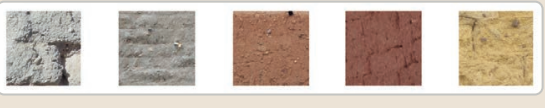

$\square$ Blanquecino $\mathbf{X}$ Marrón $\square$ Amarillento

$\checkmark$ Grisaceo $\square$ Rojizo $\square$ Otro...

Variante constructiva

$\square$ Simple / homogénea

$\square$ Suplemento superficial

$\mathbf{X}$ Suplemento en juntas

X Mixta
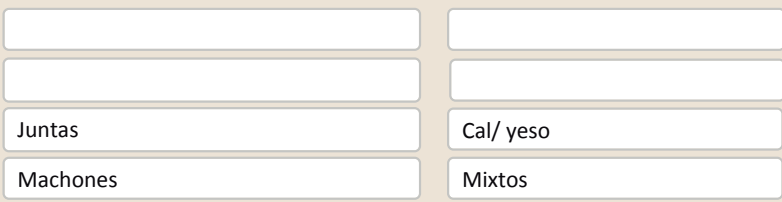

$\square$ Elementos de protección

Mixtos
La restauración y rehabilitación de la arquitectura tradicional de tierra.

El caso de Aragón.

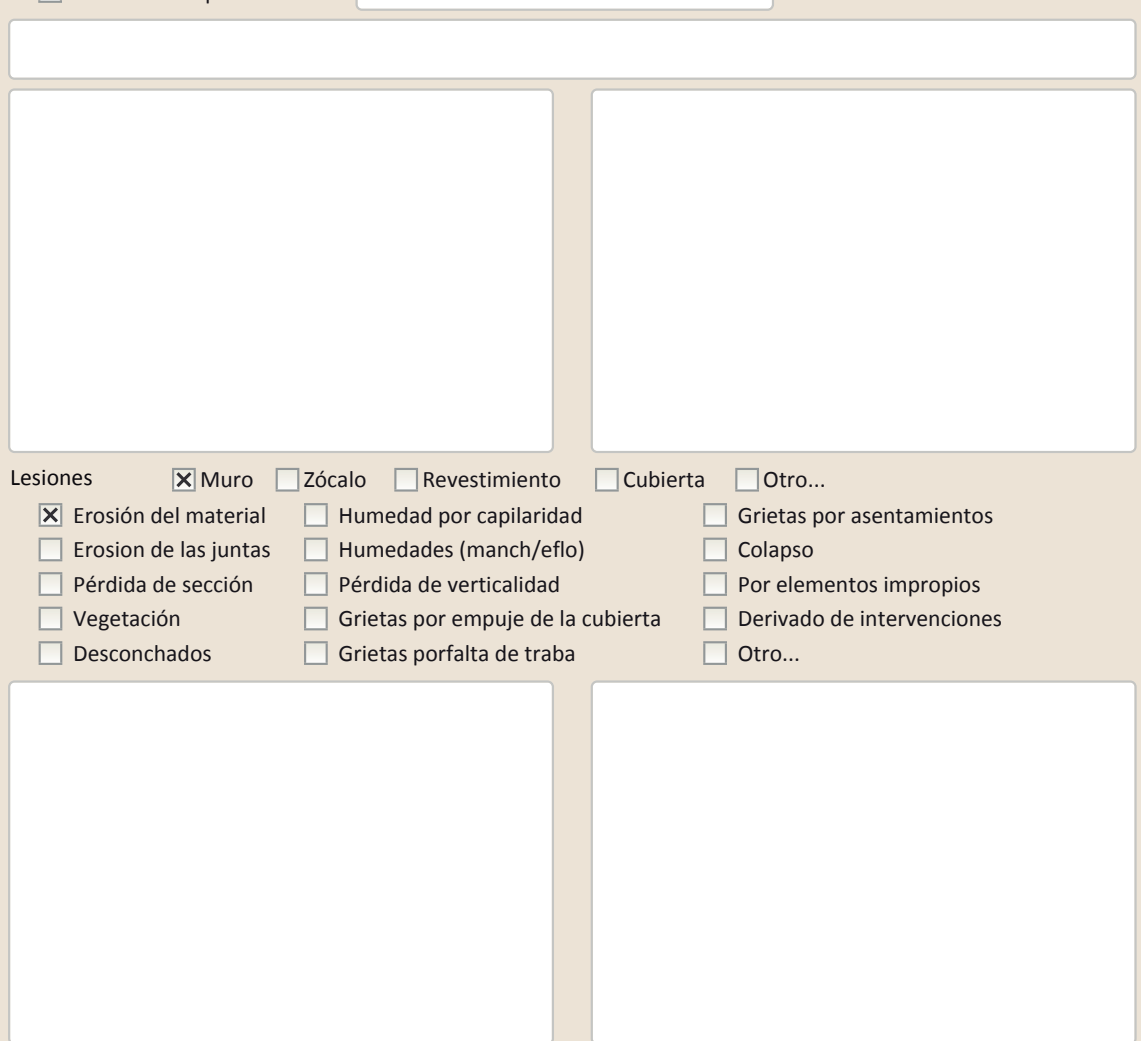

3. DATOS DE LA INTERVENCIÓN

Intervención de: $\square$ Mantenimiento $\quad \mathbf{X}$ Rehabilitación parcial $\square$ Restauración $\square$ Demolición

$\square$ Reparación $\quad \square$ Rehabilitación integral $\square$ Ampliación $\square$ Otro..

Reflexión previa Intervención espontanea

Observaciones

3.1. MUROS

Tipo de intervención

Tipo de material

Descripción

3.2. ZÓCALO

Tipo de intervención

Tipo de material

Descripción

3.3. REVESTIMIENTOS

Tipo de intervención

Tipo de material

Descripción

3.4. VANOS

Tipo de intervención

Tipo de material

Descripción

3.5. CUBIERTA

Tipo de intervención

Tipo de material

Descripción

3.6. OTRAS
Intervenido

$\square$ Actualización $\quad \square$ Reintegración $\quad \square$ Demolición $\quad \square$ Otro..

$\square$ Consolidación $\quad \mathbb{X}$ Reconstrucción $\quad \mathbb{X}$ Sustitución

No tradicional

Reconstrucción de la parte superior del muro medianero.

Sustitución del muro de cercado por bloque de hormigón

Intervenido

$\mathbf{X}$ Actualización $\square$ Reintegración $\square$ Demolición $\square$ Otro..

$\square$ Consolidación $\quad \mathbf{X}$ Reconstrucción $\square$ Sustitución

No tradicional Tipo de técnica Diferente a la existente

capa gruesa de cemento pinada de gris

Intervenido

X Actualización $\square$ Reintegración $\square$ Demolición $\square$ Otro..

$\square$ Consolidación $\quad \mathbf{X}$ Reconstrucción $\square$ Sustitución

No tradicional Tipo de técnica Diferente a la existente

Revestimiento de cemento en toda la fachada principal

Intervenido

$\square$ Actualización $\square$ Reintegración $\square$ Demolición $\square$ Otro.

$\square$ Consolidación $\square$ Reconstrucción $\quad \boldsymbol{X}$ Sustitución

\begin{tabular}{l|l|l} 
No tradicional & Tipo de técnica Diferente a la existente
\end{tabular}

Sustitución de carpinterías y ampliación del hueco de acceso

Intervenido

$\square$ Actualización $\quad \square$ Reintegración $\quad \square$ Demolición $\square$ Otro

$\square$ Consolidación $\square$ Reconstrucción $\mathbb{X}$ Sustitución
No tradicional
Tipo de técnica Diferente a la existente

Cubierta de ficrocemento 


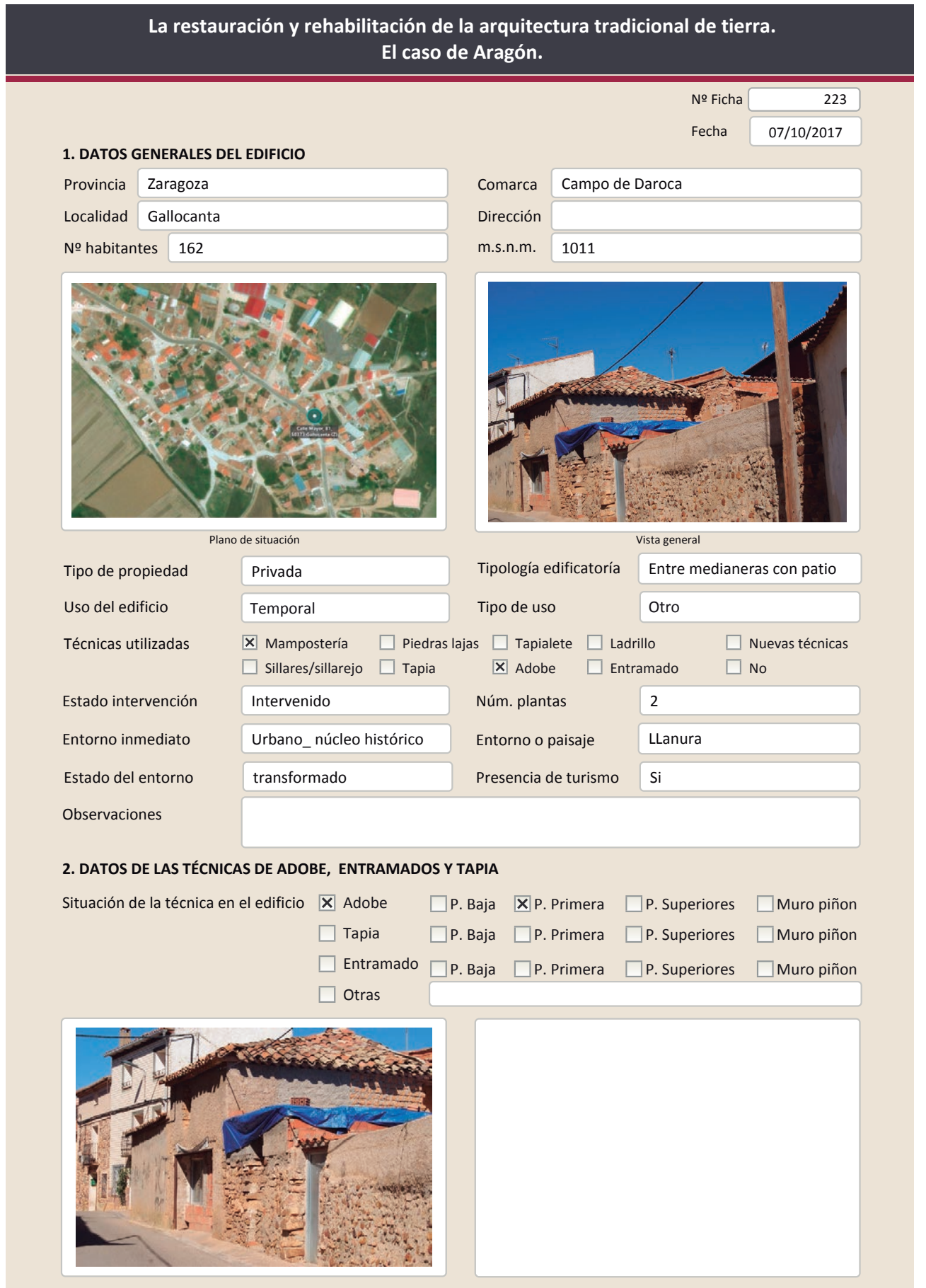

La restauración y rehabilitación de la arquitectura tradicional de tierra.

El caso de Aragón.

2.1. ADOBE

Dimensión de las piezas

Dimensión del muro

Aparejo del muro

Función estructural

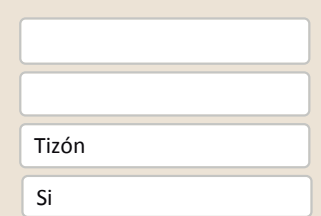

Color de las piezas

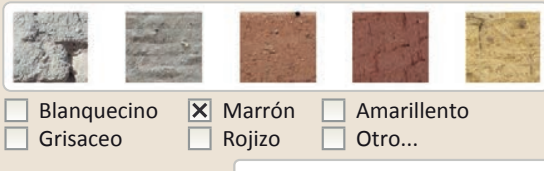

Comp. - estabilizante

Variante constructiva/tipo de fábrica

\ simple

$\square$ Suplementada en juntas

$\square$ Mixta

$\square$ Como suplemento

$\square$ Elementos de protección

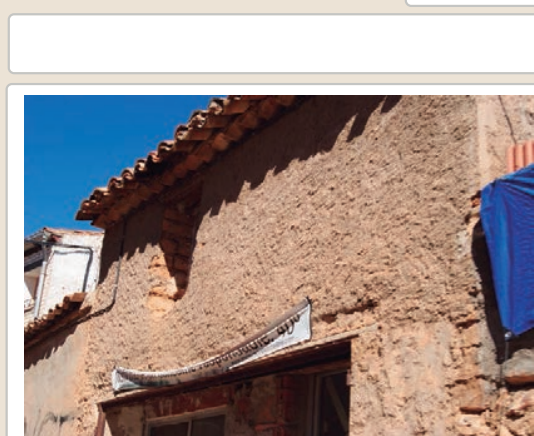

Lesiones

$\square$ Muro $\square$ zócalo

$\square$ Erosión del material $\quad \square$ Humedad por capilaridad

$\square$ Erosion de las juntas $\square$ Humedades (manch/eflo)

Pérdida de sección $\square$ Pérdida de verticalidad

$\square$ Vegetación

$\square$ Grietas por empuje de

$\square$ Grietas porfalta de traba

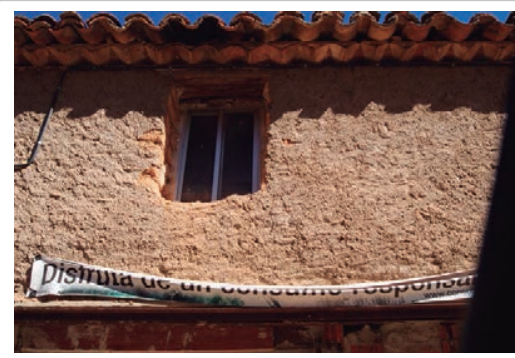

$\square$ Desconchados

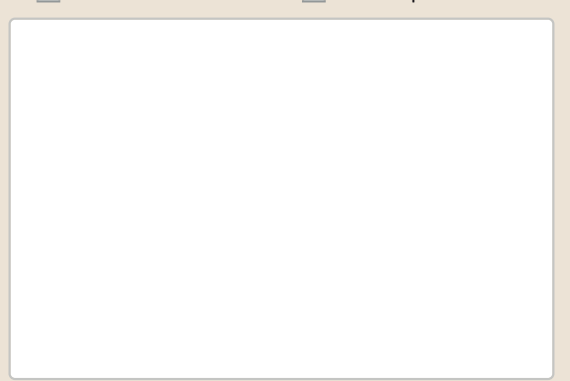

Observacione $\square$ Cubierta $\square$ otro...

$\square$ Grietas por asentamiento

$\square$ Colapso

$\square$ Por elementos impropios

$\square$ Derivado de intervenciones

$\square$ Otro... 
La restauración y rehabilitación de la arquitectura tradicional de tierra. El caso de Aragón

\section{La restauración y rehabilitación de la arquitectura tradicional de tierra.}

\section{El caso de Aragón.}

3. DATOS DE LA INTERVENCIÓN

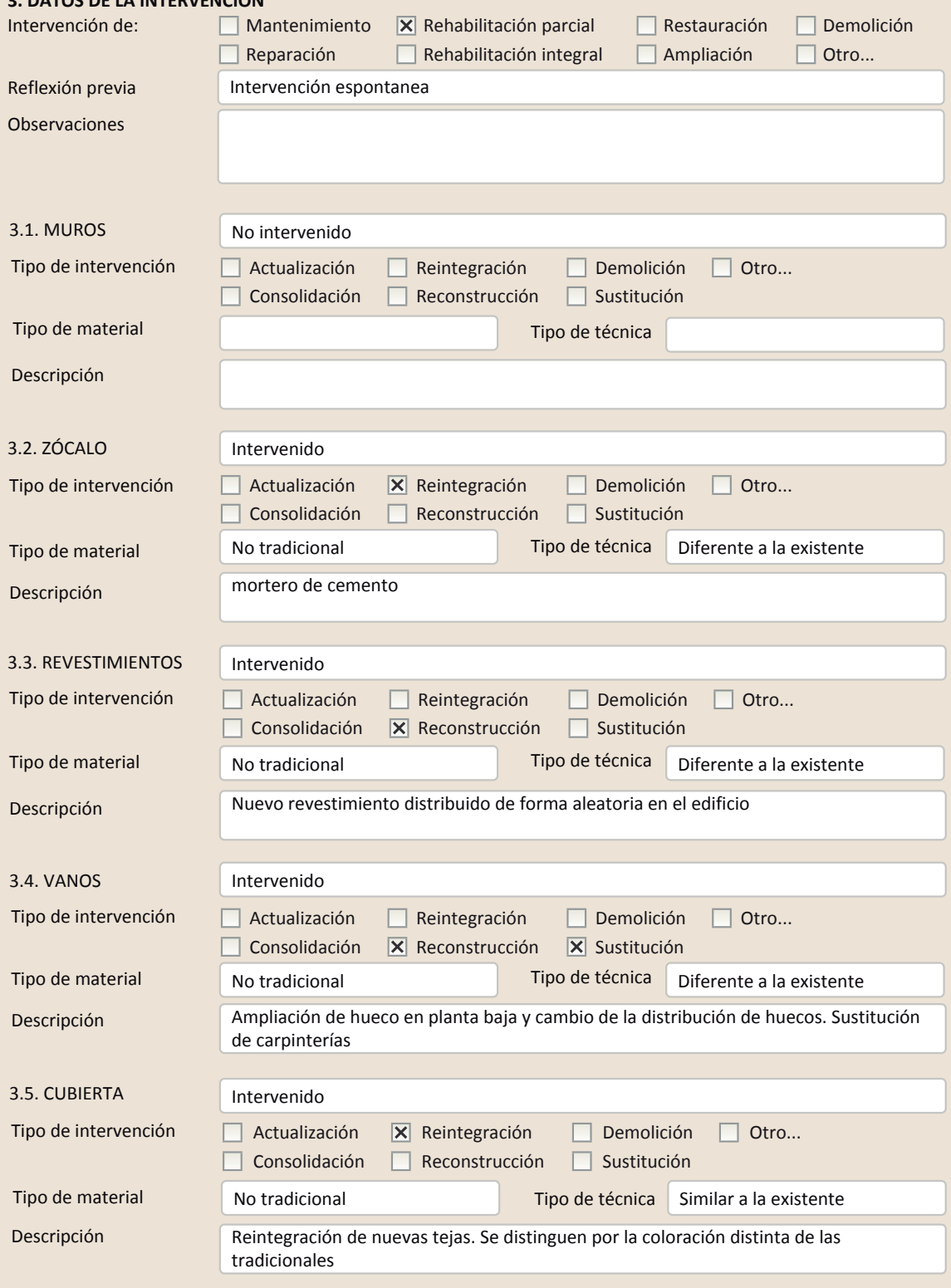

3.6. OTRAS 
La restauración y rehabilitación de la arquitectura tradicional de tierra. El caso de Aragón.

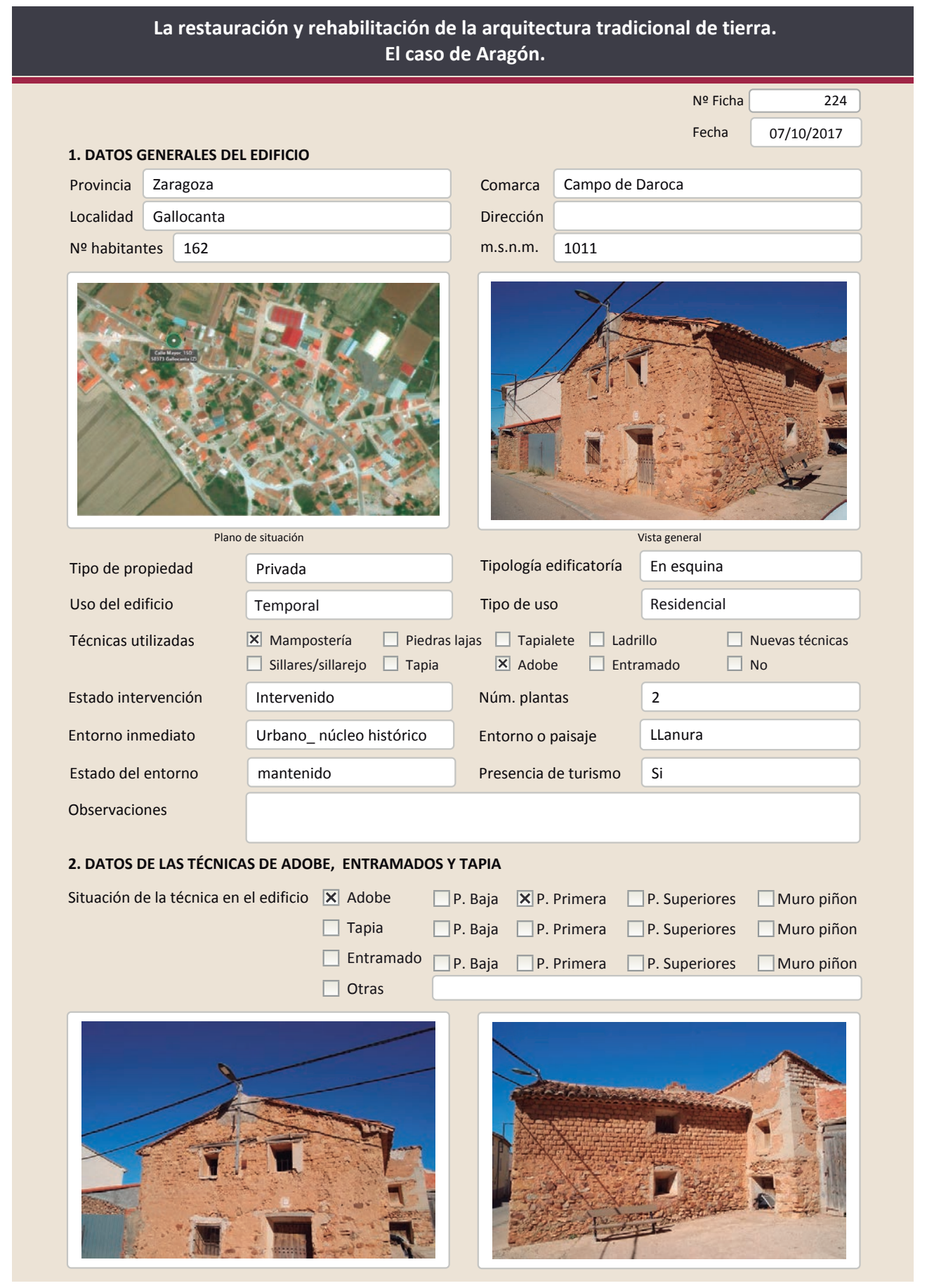

La restauración y rehabilitación de la arquitectura tradicional de tierra. El caso de Aragón.
2.1. ADOBE

Dimensión de las piezas Lx18×11

Dimensión del muro $30-40 \mathrm{~cm}$

Aparejo del muro Tizón

Función estructural

Si
Color de las piezas

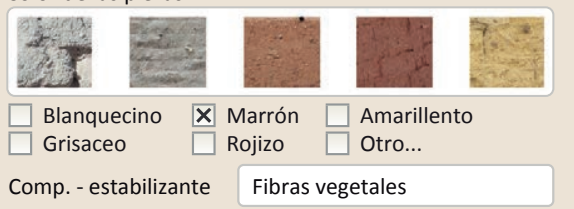

$\square$ Blanquecino $\mathbf{X}$ Marrón $\square$ Amarillento

Comp. - estabilizante Fibras vegetales

区 Simple

$\square$ suplementada en juntas

$\square$ Mixta

$\square$ Como suplemento

$\square$ Elementos de protección

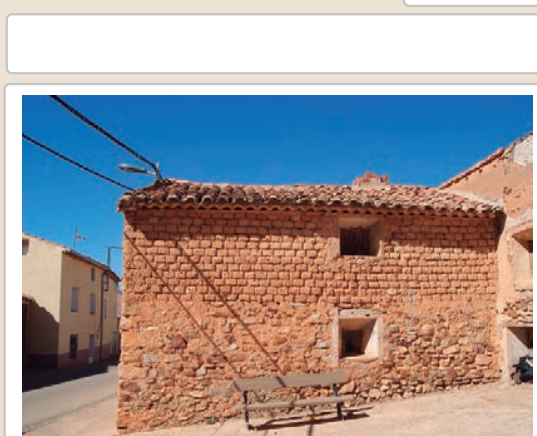

Lesiones $\quad \mathbf{M}$ Muro $\square$ Zócalo $\square$ Revestimiento

\ Erosión del material $\square$ Humedad por capilaridad

$\mathbf{X}$ Erosion de las juntas $\square$ Humedades (manch/eflo)

$\square$ Pérdida de sección $\quad \square$ Pérdida de verticalidad

$\square$ Vegetación $\quad \square$ Grietas por empuje de la cubiert

$\square$ Desconchados

$\square$ Grietas por empuje de

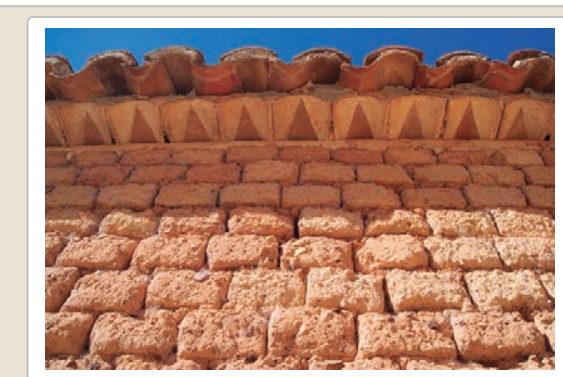

$\square$ Cubierta $\square$ Otro...

$\square$ Grietas por asentamiento

$\square$ Colapso

$\square$ Por elementos impropios

$\square$ Derivado de intervenciones

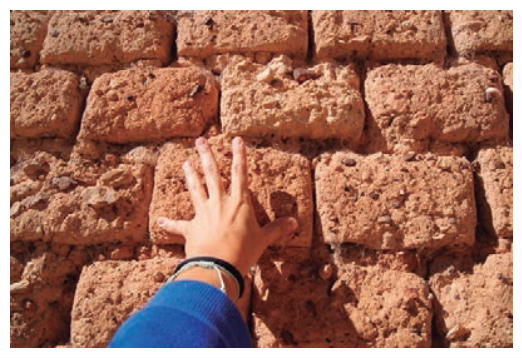

$\square$ Otro...

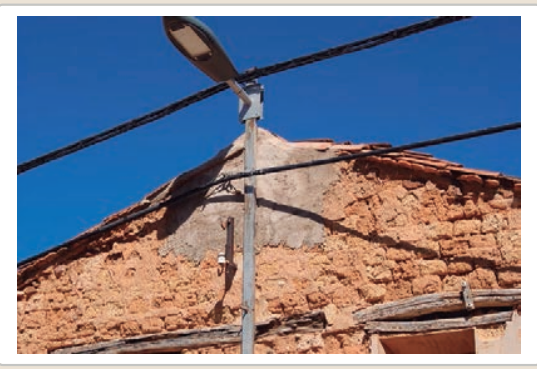

Observaciones 
La restauración y rehabilitación de la arquitectura tradicional de tierra. El caso de Aragón

\section{La restauración y rehabilitación de la arquitectura tradicional de tierra.}

\section{El caso de Aragón.}

3. DATOS DE LA INTERVENCIÓN

Intervención de:

$\square$ Mantenimiento $\square$ Rehabilitación parcia

$\square$ Restauración $\square$ Demolición

X Reparación $\quad \square$ Rehabilitación integral $\square$ Ampliación $\quad \square$ Otro...

Reflexión previa

Intervención espontanea

Observaciones

(n)

3.1. MUROS

No intervenido

Tipo de intervención

$\square$ Actualización $\square$ Reintegración $\square$ Demolición $\square$ Otro...

$\square$ Consolidación $\square$ Reconstrucción $\square$ Sustitución

Tipo de material

Descripción

3.2. ZÓCALO

No intervenido

Tipo de intervención

$\square$ Actualización

Tipo de material

Descripción

3.3. REVESTIMIENTOS

Tipo de intervención

\section{No aplica}

Tipo de material

$\square$ Actualización

Tipo de técnica

Descripción

3.4. VANOS

Tipo de intervención

No intervenido

Tipo de material

Descripción

3.5. CUBIERTA

Tipo de intervención

Intervenido

$\square$ Actualización $\quad \mathbf{X}$ Reintegración $\square$ Demolición $\square$ Otro.

Tipo de material

$\square$ Consolidación $\quad \square$ Reconstrucción $\square$ Sustitución

Descripción

\begin{tabular}{l|l} 
No tradicional & Tipo de técnica \\
\hline
\end{tabular}

Reintegración de la cumbrera de la cubierta con cemento. También se han recolocado con cemento las tejas próximas al alero

3.6. OTRAS 


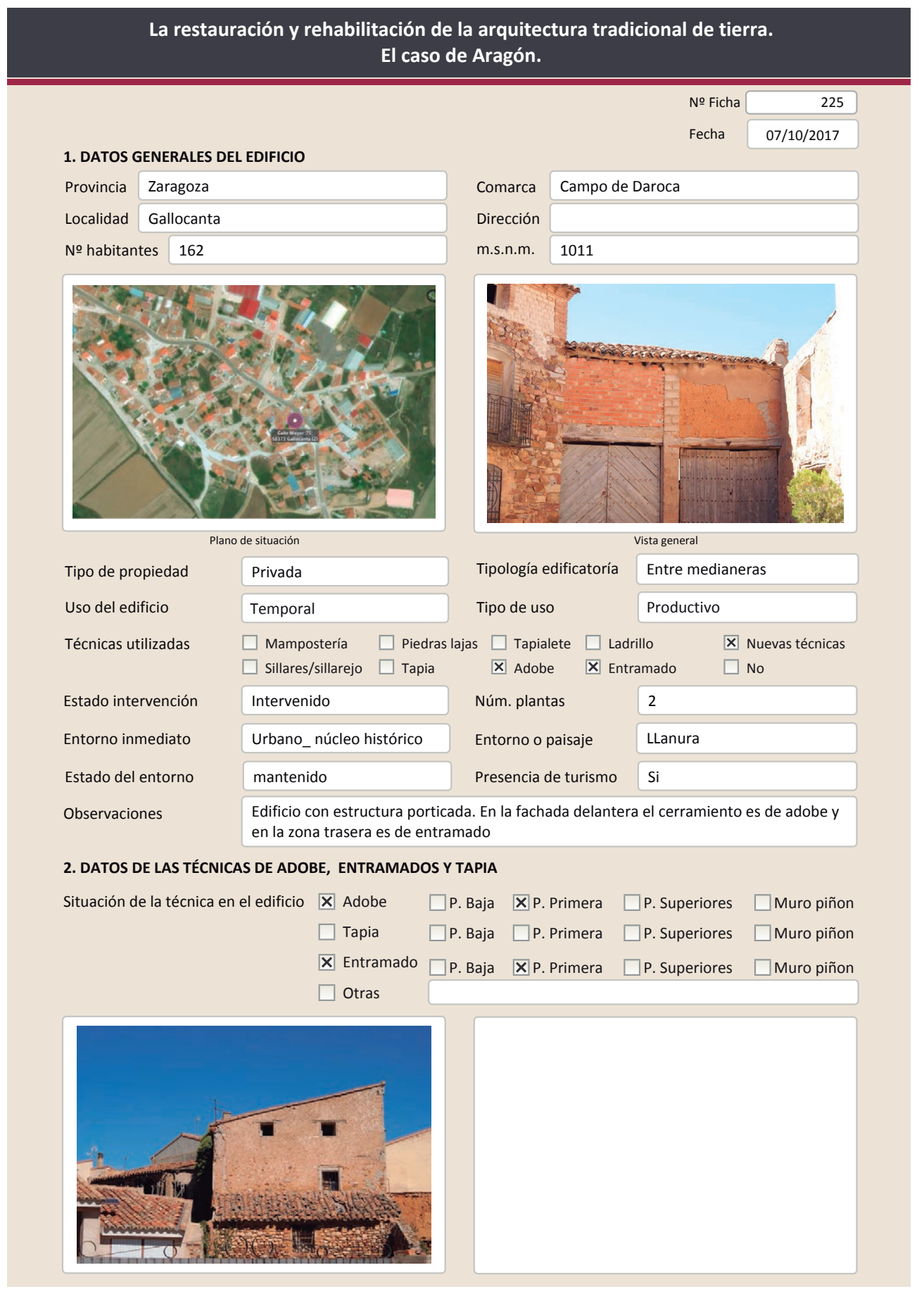

La restauración y rehabilitación de la arquitectura tradicional de tierra.

El caso de Aragón.

2.1. ADOBE

Dimensión de las piezas

Dimensión del muro

Aparejo del muro

Función estructural

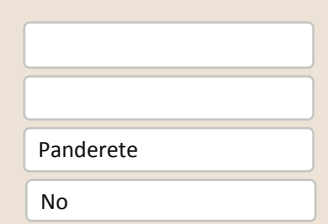

Color de las piezas

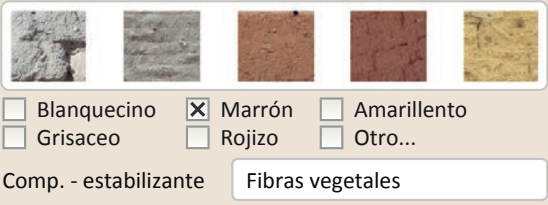

$\square$ simple

$\square$ Suplementada en juntas

区 Mixta

Machones

Adobe

$\mathbf{X}$ Como suplemento

Mixto- Machones

$\square$ Elementos de protección

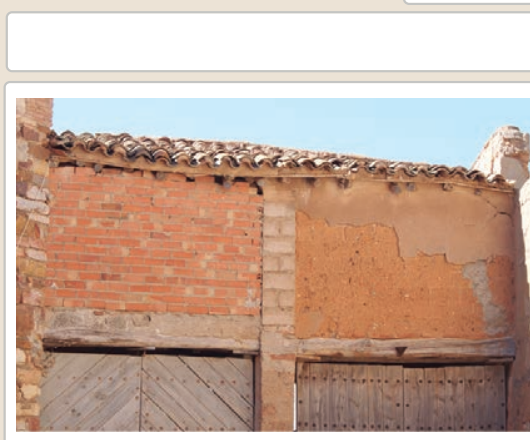

Lesiones $\quad \mathbf{X}$ Muro $\square$ Zócalo $\mathbf{X}$ Revestimiento

\ Erosión del material $\square$ Humedad por capilaridad

$\square$ Erosion de las juntas $\square$ Humedades (manch/eflo)

$\square$ Pérdida de sección $\square$ Pérdida de verticalidad

$\begin{array}{ll}\square \text { Vegetación } & \square \text { Grietas por empuje de la cubie } \\ \square \text { Desconchados } & \square \text { Grietas porfalta de traba }\end{array}$

$\square$ Cubierta $\square$ otro...

$\mathbf{X}$ Grietas por asentamiento

$\square$ Colapso

$\square$ Por elementos impropios

$\square$ Derivado de intervenciones $\square$ Otro...

Observaciones 


\section{La restauración y rehabilitación de la arquitectura tradicional de tierra.} El caso de Aragón.

\subsection{ENTRAMADOS}

Distancia entre montantes

Altura de los montantes

\begin{tabular}{|l|}
$40-60 \mathrm{~cm}$ \\
\hline $150-200 \mathrm{~cm}$ \\
\hline Rollizos
\end{tabular}

Elementos diagonales

Elementos horizontales intermedios

Sección de los montantes

Rollizos

Sección de las piezas horizontales

Dimensión de los montantes

Tipo de relleno del entramado

$\square$ Monolítico $\mathbf{X}$ Piezas/fábrica $\quad \mathbf{X}$ Tejido

Técnica de relleno del entramado
$\square$ Entre pantallas de madera
$\square$ Pared de mano $\quad \boldsymbol{X}$ Cañizo
$\square$ Tierra y mampuestos $\quad \mathbf{X}$ Adobe horizontal $\square$ Encestados
$\square$ Tapialete
$\square$ Adobe aletorio $\square$ Otro

Se aprecia dos tipo relleno, adobe a panderete y cañizo. El muro esta muy deteriorado por lo que la técnica no está clara

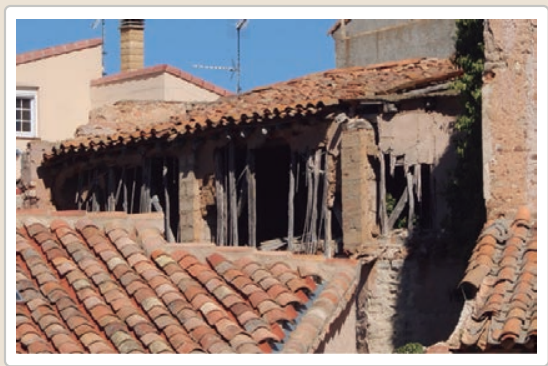

Lesiones \Muro $\square$ Zócalo $\square$ Revestimiento $\square$ Cubierta $\square$ Otro...
$\square$ Erosión del material
Carcoma o termitas
$\square$ Grietas por falta de traba
$\square$ Erosion de las juntas
$\square$ Rotura de la madera
$\square$ Pérdida de secir
$\square$ Pudrición de la mader
$\square$ Grietas por asentamiento
$\square$ Desconchados
Deformación madera
Pudrición del relleno
$\mathbf{X}$ Colapso
$\square$ Humedad por capilaridad
$\square$ Pérdida de verticalidad
$\square$ Por elementos impropios
Grietas por empuje de la cubierta
$\square$ Otro.

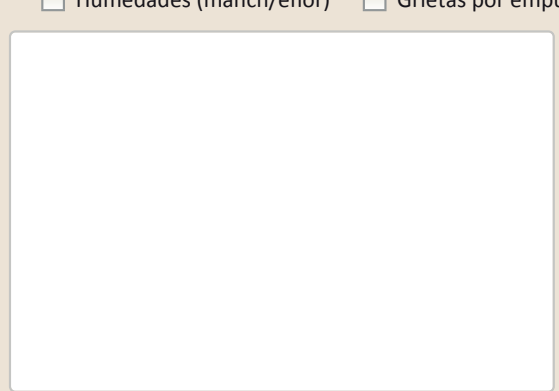

La restauración y rehabilitación de la arquitectura tradicional de tierra.

El caso de Aragón.
3. DATOS DE LA INTERVENCIÓN

refor

Reflexión previa

Observaciones

3.1. MUROS

Tipo de intervención

Tipo de material

Descripción

3.2. ZÓCALO

Tipo de intervención

Tipo de material

Descripción

3.3. REVESTIMIENTOS

Tipo de intervención

Tipo de material

Descripción

3.4. VANOS

Tipo de intervención

Tipo de material

Descripción

3.5. CUBIERTA

Tipo de intervención

Tipo de material

Descripción

3.6. OTRAS $\square$ Mantenimiento $\square$ Rehabilitación parcial $\quad \square$ Restauración $\square$ Demolición X Reparación $\square$ Rehabilitación integral $\square$ Ampliación $\square$ Otro...

Intervención espontanea
Intervenido
$\square$ Actualización $\quad \boldsymbol{X}$ Reintegración $\quad \square$ Demolición $\square$ Otro...
$\square$ Consolidación $\quad \square$ Reconstrucción $\quad \boldsymbol{X}$ Sustitución

No tradicional Tipo de técnica Similar a la existente

Sustitución de uno de los paños de adobe a panderete por ladrillo hueco. Reintegración de grieta con cemento

No intervenido

$\square$ Actualización $\quad \square$ Reintegración $\quad \square$ Demolición $\square$ Otro..

$\square$ Consolidación $\square$ Reconstrucción $\square$ sustitución

Tipo de técnica

\section{No intervenido}

$\square$ Actualización $\square$ Reintegración $\square$ Demolición $\square$ Otro...

$\square$ Consolidación $\square$ Reconstrucción $\quad \square$ Sustitución

Tipo de técnica

No intervenido

$\square$ Actualización $\square$ Reintegración $\square$ Demolición $\square$ Otro.

$\square$ Consolidación $\square$ Reconstrucción $\square$ Sustitución

Tipo de técnica

No intervenido

$\square$ Actualización $\square$ Reintegración $\square$ Demolición $\square$ Otro...

$\square$ Consolidación $\square$ Reconstrucción $\square$ Sustitución Tipo de técnica

Observaciones 


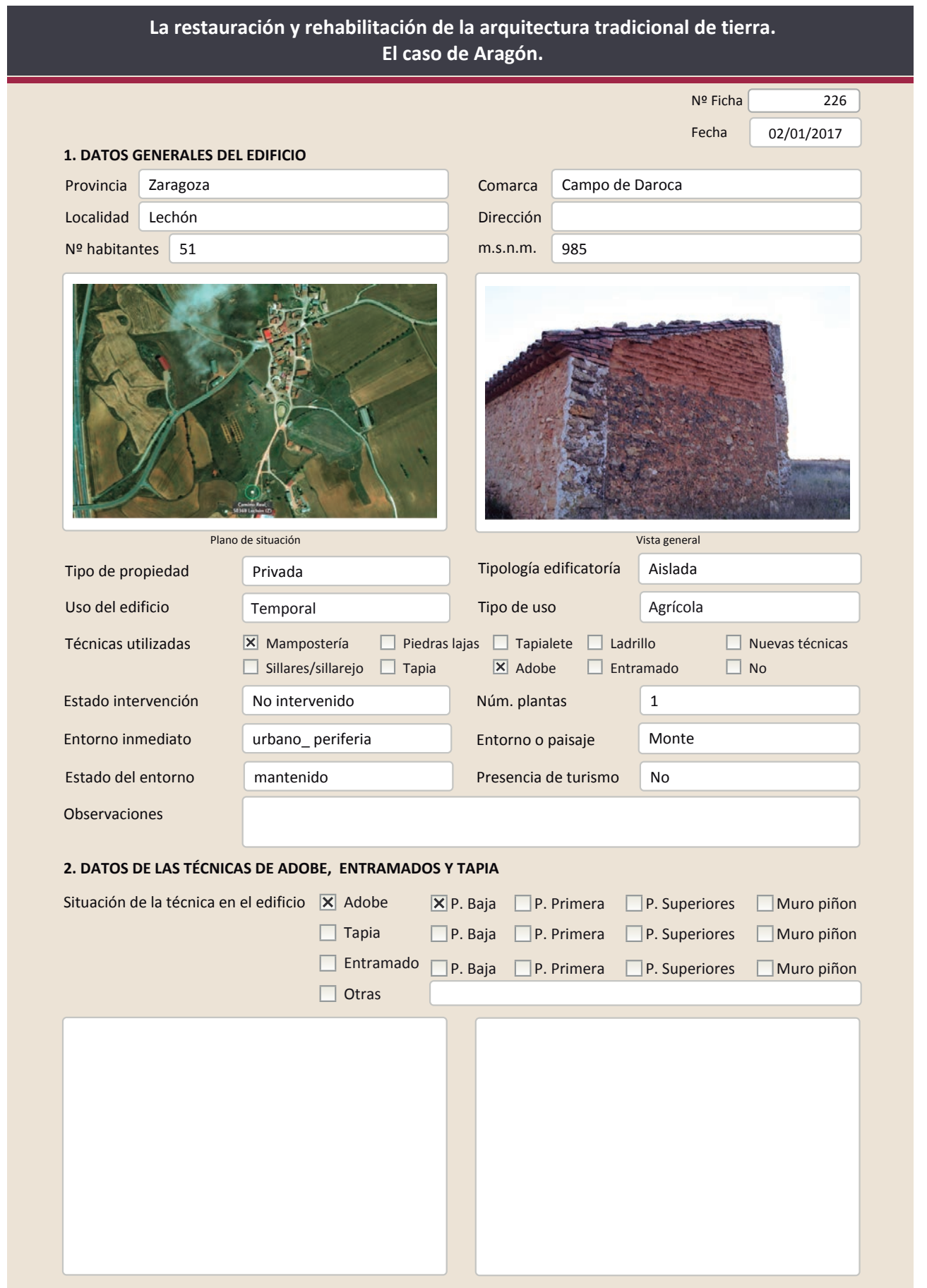

La restauración y rehabilitación de la arquitectura tradicional de tierra.

El caso de Aragón.

2.1. ADOBE

Dimensión de las piezas

Dimensión del muro

Aparejo del muro

Función estructural

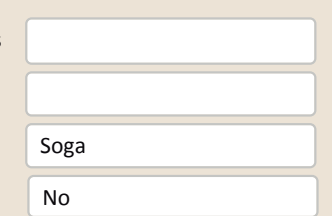

Color de las piezas

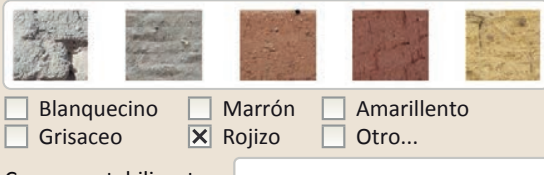

Comp. - estabilizante

Variante constructiva/ tipo de fábrica

$\square$ Simple
Х Suplementada en juntas
Horizontales
\ Mixta
En esquinas
$\square$ Como suplemento
$\square$ Elementos de protección

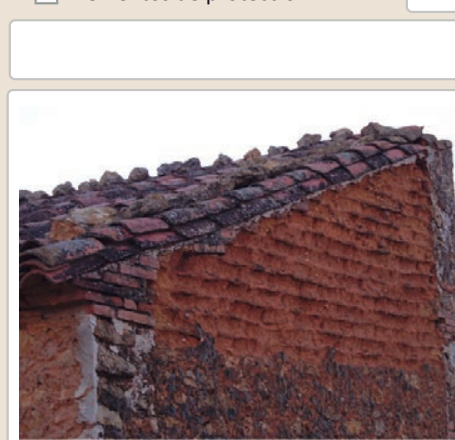

Lesiones

X Muro $\square$ Zócalo $\square$ Revestimiento

X Erosión del material $\square$ Humedad por capilaridad

$\square$ Erosion de las juntas $\square$ Humedades (manch/eflo)

X Pérdida de sección $\square$ Pérdida de verticalidad

$\square$ Vegetación $\quad \square$ Grietas por empuje de la cu $\square$ Grietas porfalta de traba

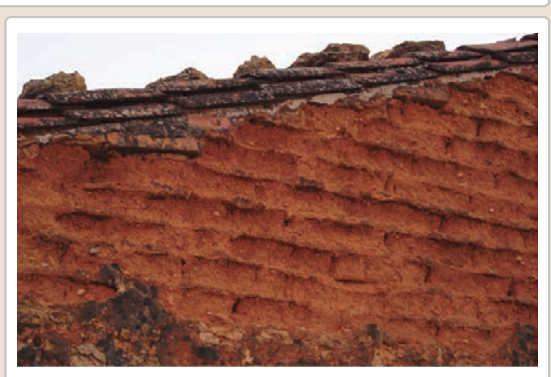

$\square$ Cubierta $\square$ Otro...

$\square$ Grietas por asentamientos

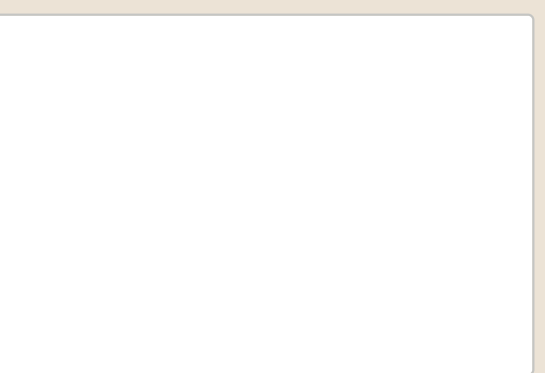

$\square$ Por elementos impropios

$\square$ Derivado de intervenciones $\square$ Otro... 


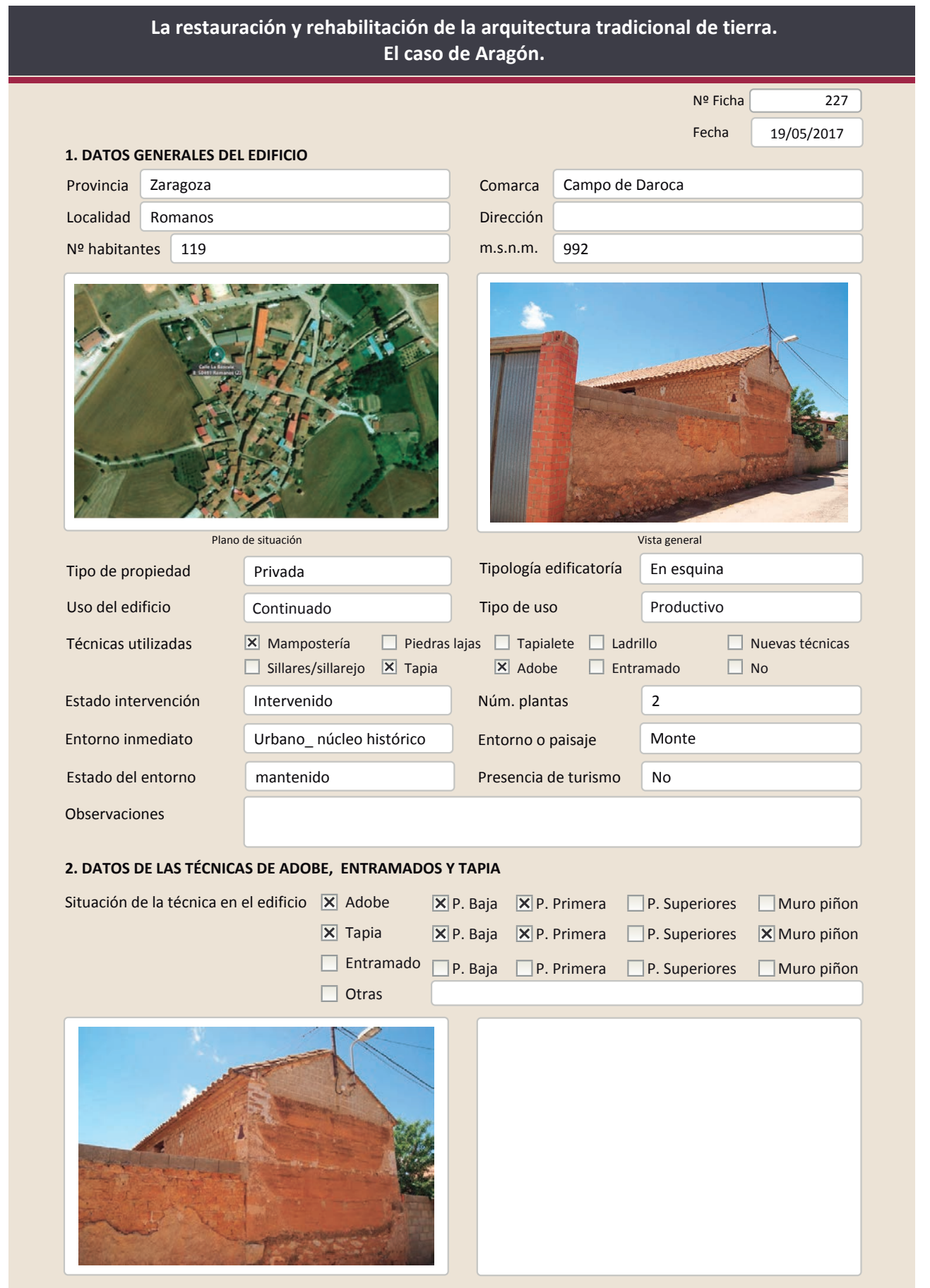

La restauración y rehabilitación de la arquitectura tradicional de tierra.

El caso de Aragón.
2.1. ADOBE

Dimensión de las piezas $\mathrm{L} \times 15 \times 12$

Dimensión del muro 30-40 cm

Función estructural

Variante constructiva/ tipo de fábrica

$\square$ simple

$\square$ Suplementada en juntas

区 Mixta

Color de las piezas

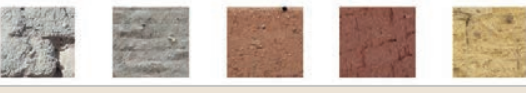

Blanquecino $\mathbf{X}$ Marrón $\square$ Amarillento $\square$ Grisaceo $\square$ Rojizo $\square$ Otro..

Comp. - estabilizante Fibras vegetales
Aparejo del muro Tizón
$\square$ Como suplemento

$\square$ Elementos de protección

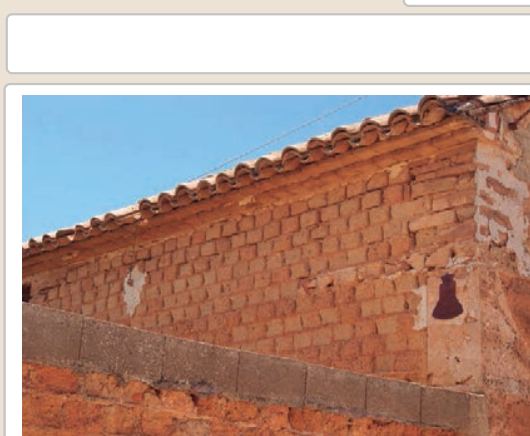

Lesiones $\mathbf{X}$ Muro $\mathbf{X}$ Zócalo $\mathbf{X}$ Revestimiento

X Erosión del material $\square$ Humedad por capilaridad

$\square$ Erosion de las juntas $\mathbf{X}$ Humedades (manch/eflo)

$\square$ Pérdida de sección $\square$ Pérdida de verticalidad

$\square$ Vegetación $\quad \square$ Grietas por empuje de la c $\square$ Grietas porfalta de traba

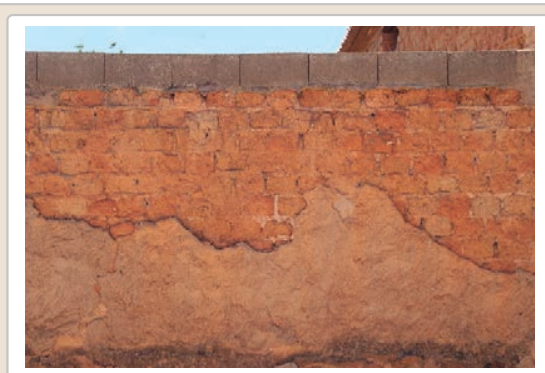

$\square$ Grietas porfalta de traba

Cubierta $\square$ Otro...

$\square$ Grietas por

X Desconchados

$\square$ Por elementos impropios

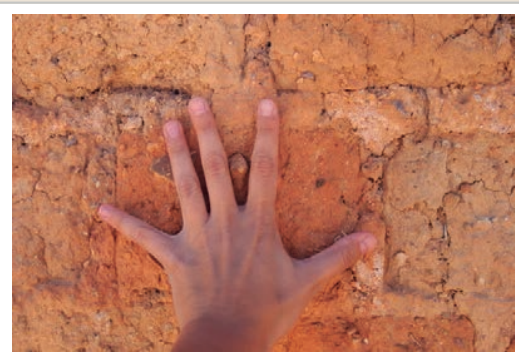

$\mathbf{X}$ Derivado
$\square$ Otro...

Observaciones

El revestimiento de cemento 


\section{La restauración y rehabilitación de la arquitectura tradicional de tierra.}

\section{El caso de Aragón.}

\subsection{TAPIA}

Ancho del muro

Dimensión tapiales

Tipo de aguja

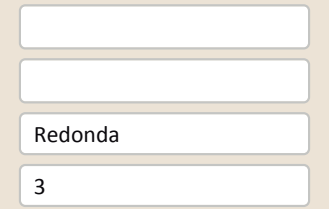

Color de la tapia

№ agujas/cajón

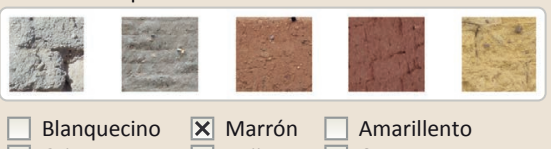
$\begin{array}{ll}\square \text { Blanquecino } & \boldsymbol{X} \text { Marrón } \\ \square \text { Grisaceo } & \square \text { Amarillento } \\ \text { Rojizo } & \square \text { Otro... }\end{array}$

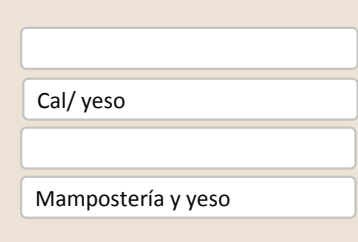

Variante constructiva

$\square$ Simple / homogénea

$\mathbf{X}$ Suplemento superficial

$\square$ Suplemento en juntas

X Mixta

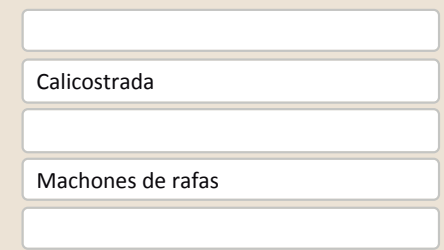

$\square$ Elementos de protección
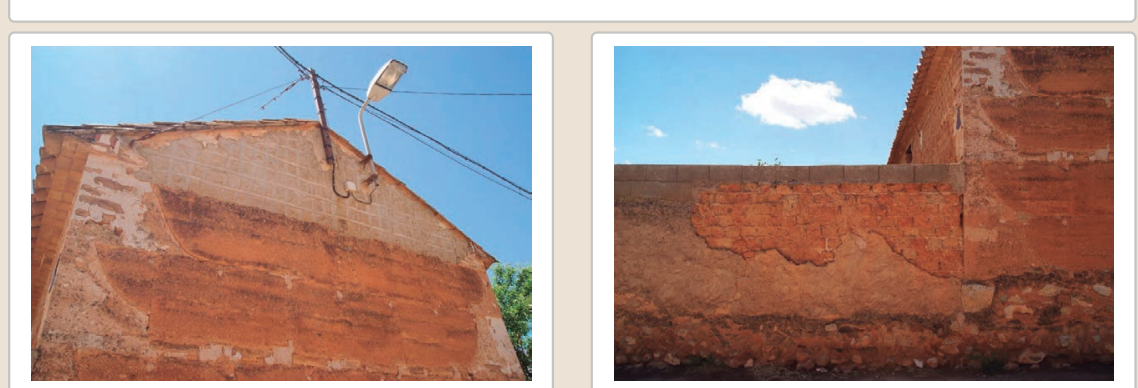

Lesiones ХMuro $\square$ Zócalo $\square$ Revestimiento $\square$ Cubierta $\square$ Otro...

$\mathbf{X}$ Erosión del material $\square$ Humedad por capilaridad $\quad \square$ Grietas por asentamientos

$\square$ Erosion de las juntas $\mathbf{X}$ Humedades (manch/eflo) $\quad \square$ Colapso

$\square$ Pérdida de sección $\square$ Pérdida de verticalidad $\quad \square$ Por elementos impropios

$\square$ Vegetación $\square$ Grietas por empuje de la cubierta $\square$ Derivado de intervenciones

$\square$ Desconchados $\quad \square$ Grietas porfalta de traba $\quad \square$ Otro...
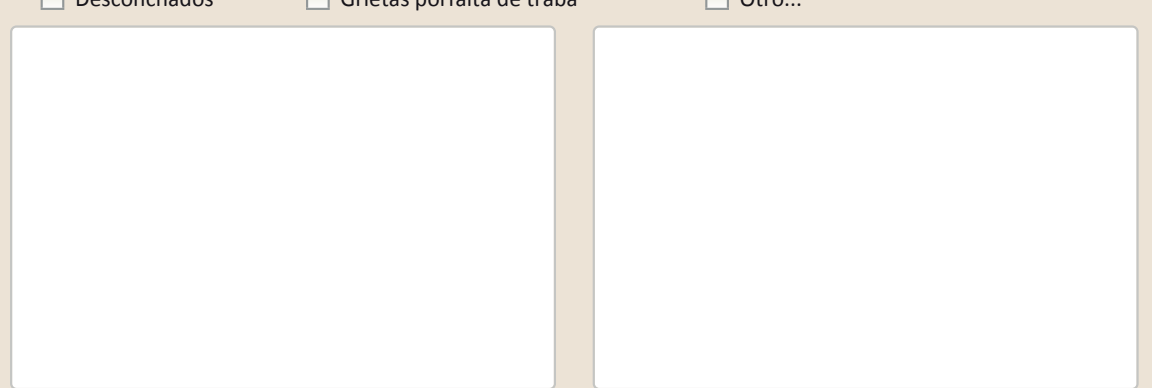

La restauración y rehabilitación de la arquitectura tradicional de tierra.

El caso de Aragón.

3. DATOS DE LA INTERVENCIÓN

Intervención de: $\quad \square$ Mantenimiento $\quad \square$ Rehabilitación parcial $\quad \square$ Restauración $\square$ Demolición

Reflexión previa Intervención espontanea

Observaciones

3.1. MUROS

Tipo de intervención

Tipo de material

Intervenido

Descripción

$\square$ Consolidación $\quad \mathbf{X}$ Reconstrucción $\square$ Sustitución prefabricado

3.2. ZÓCALO

Tipo de intervención

Intervenido

$\square$ Actualización $\quad \mathbf{x}$ Reintegración $\quad \square$ Demolición $\square$ Otro.

$\square$ Consolidación $\square$ Reconstrucción $\square$ Sustitución

\begin{tabular}{lll} 
Tipo de material No tradicional Tipo de técnica Diferente a la existente \\
\hline
\end{tabular}

Descripción

Reintegraciones con cemento

3.3. REVESTIMIENTOS

Tipo de intervención

Intervenido

Tipo de material

Descripción

3.4. VANOS

Tipo de intervención

Tipo de material

Descripción

3.5. CUBIERTA

Tipo de intervención

Tipo de material

Descripción

3.6. OTRAS $\square$ Actualización $\square$ Reintegración $\square$ Demolición $\square$ Otro...

$\square$ Consolidación $\mathbf{X}$ Reconstrucción $\square$ Sustitución

No tradicional Tipo de técnica Diferente a la existente

Revestimiento de cemento en el muro de cerca y en la pare superior del muro piñón

No intervenido

$\square$ Actualización $\square$ Reintegración $\square$ Demolición $\square$ Otro..

$\square$ Consolidación $\square$ Reconstrucción $\square$ Sustitución

Tipo de técnica

No intervenido

$\square$ Actualización $\square$ Reintegración $\square$ Demolición $\square$ Otro

$\square$ Consolidación $\square$ Reconstrucción $\square$ Sustitución Tipo de técnica

Observaciones 

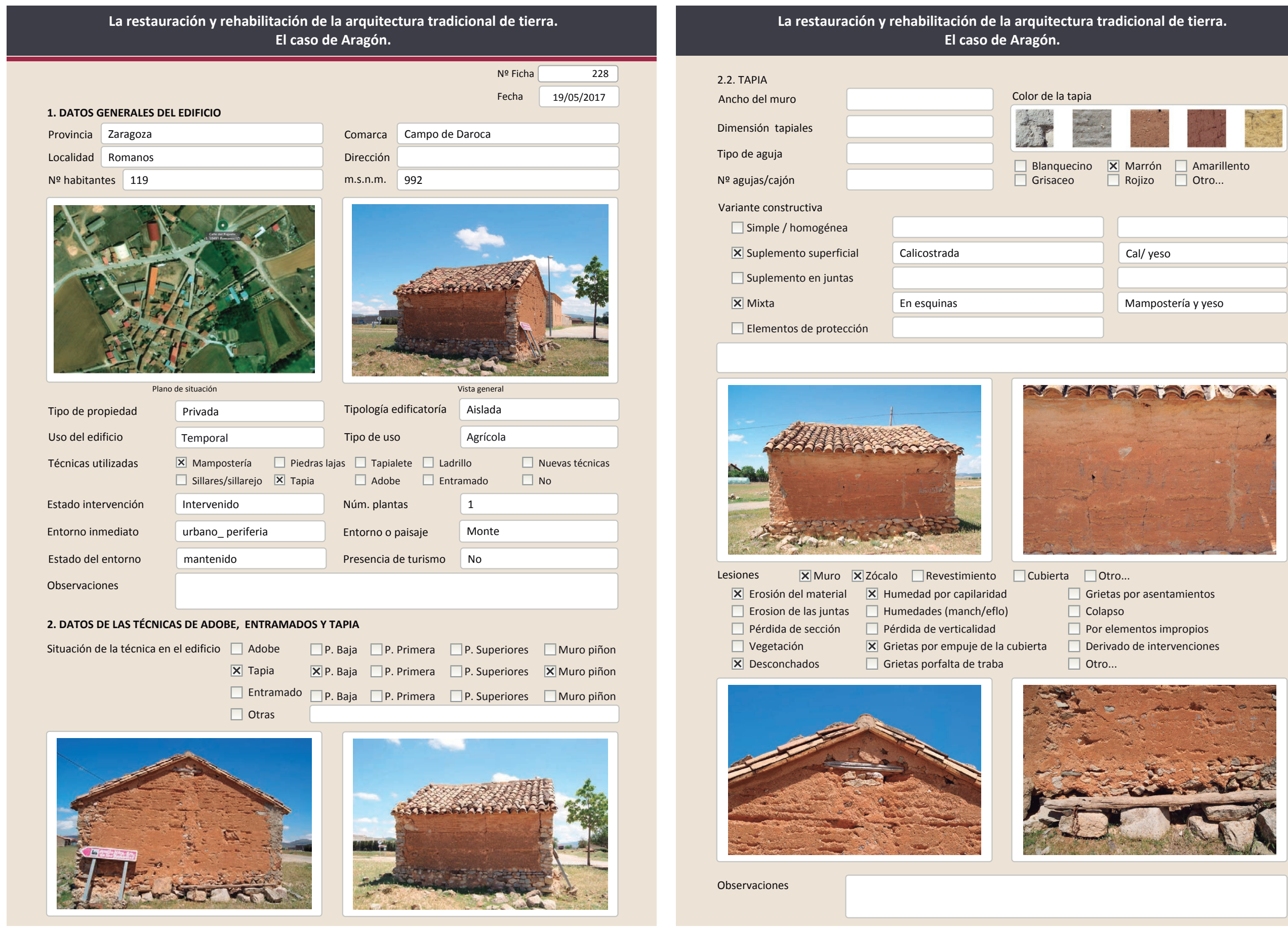

de protección

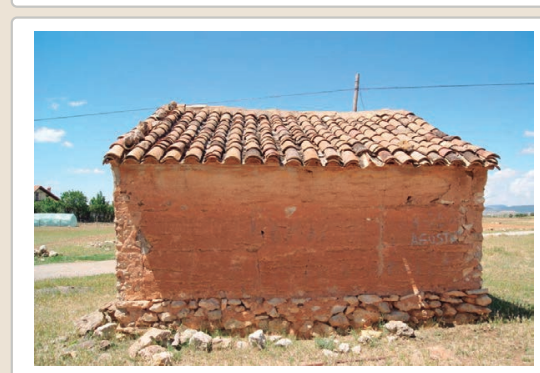

Lesiones $\quad$ XMuro $\boldsymbol{X}$ Zócalo $\square$ Revestimiento $\square$ Cubierta $\square$ otro...

$\begin{array}{lll}\mathbf{X} \text { Erosión del material } \quad \boldsymbol{X} \text { Humedad por capilaridad } & \square \text { Grietas por asentamientos } \\ \square \text { Erosion de las juntas } & \square \text { Humedades (manch/eflo) } & \square \text { Colapso } \\ \square \text { Pérdida de sección } & \square \text { Pérdida de verticalidad } & \square \text { Por elementos impropios } \\ \square \text { Vegetación } & \mathbf{X} \text { Grietas por empuje de la cubierta } & \square \text { Derivado de intervenciones }\end{array}$

$X$ Grietas por empuje de la

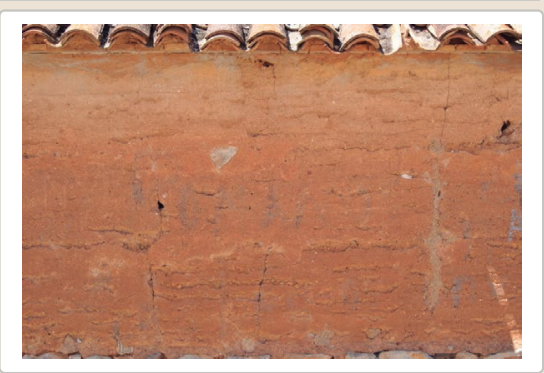

X Desconchados

$\square$ Derivadoc
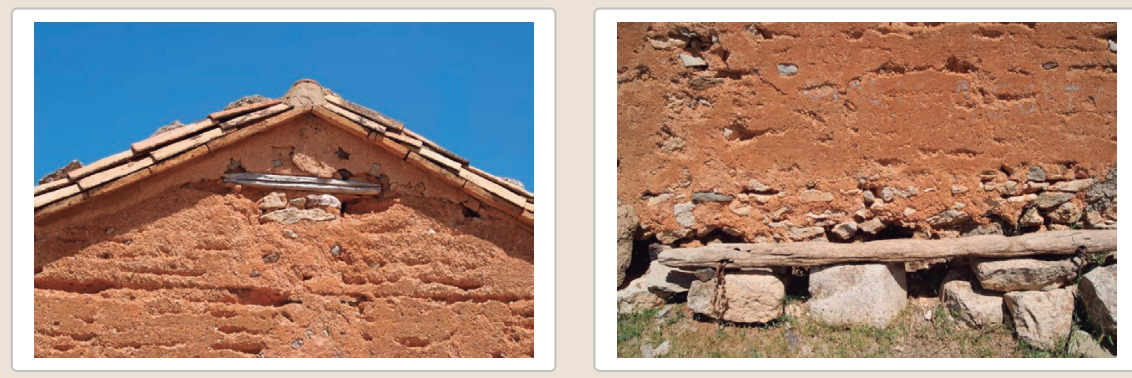

Observaciones 
La restauración y rehabilitación de la arquitectura tradicional de tierra. El caso de Aragón.

3. DATOS DE LA INTERVENCIÓN

Intervención de:

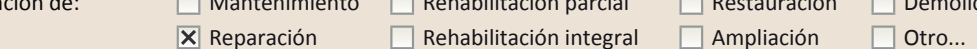

Reflexión previa Intervención espontane

Observaciones

3.1. MUROS Tipo de intervención Tipo de material

\section{Intervenido}

$\square$ Actualización $\quad$ Reintegración $\square$ Demolición $\square$ Otro...

$\square$ Consolidación $\square$ Reconstrucción $\square$ Sustitución

Descripción

No tradicional

Tipo de técnica Diferente a la existente

3.2. ZóCALO

Tipo de intervención desconchados con
hueco y cement

No intervenido

$\square$ Actualización $\square$ Reintegración $\square$ Demolición $\square$ Otro... $\square$ Consolidación $\quad \square$ Reconstrucción $\square$ Sustitución

Tipo de materia

Descripción

3.3. REVESTIMIENTOS

Tipo de intervención

Tipo de material

Descripción

3.4. VANOS

Tipo de intervención

Tipo de material

Descripción

3.5. CUBIERTA

Tipo de intervención

Tipo de material

Descripción

3.6. OTRAS
La restauración y rehabilitación de la arquitectura tradicional de tierra.

El caso de Aragón.

3.7. REHABILITACIÓN ENERGÉTICA $\quad \square$ Fachada $\square$ Vanos $\square$ Forjados $\square$ Cubierta

Observaciones

FOTOGRAFÍAS DE LA INTERVENCIÓN
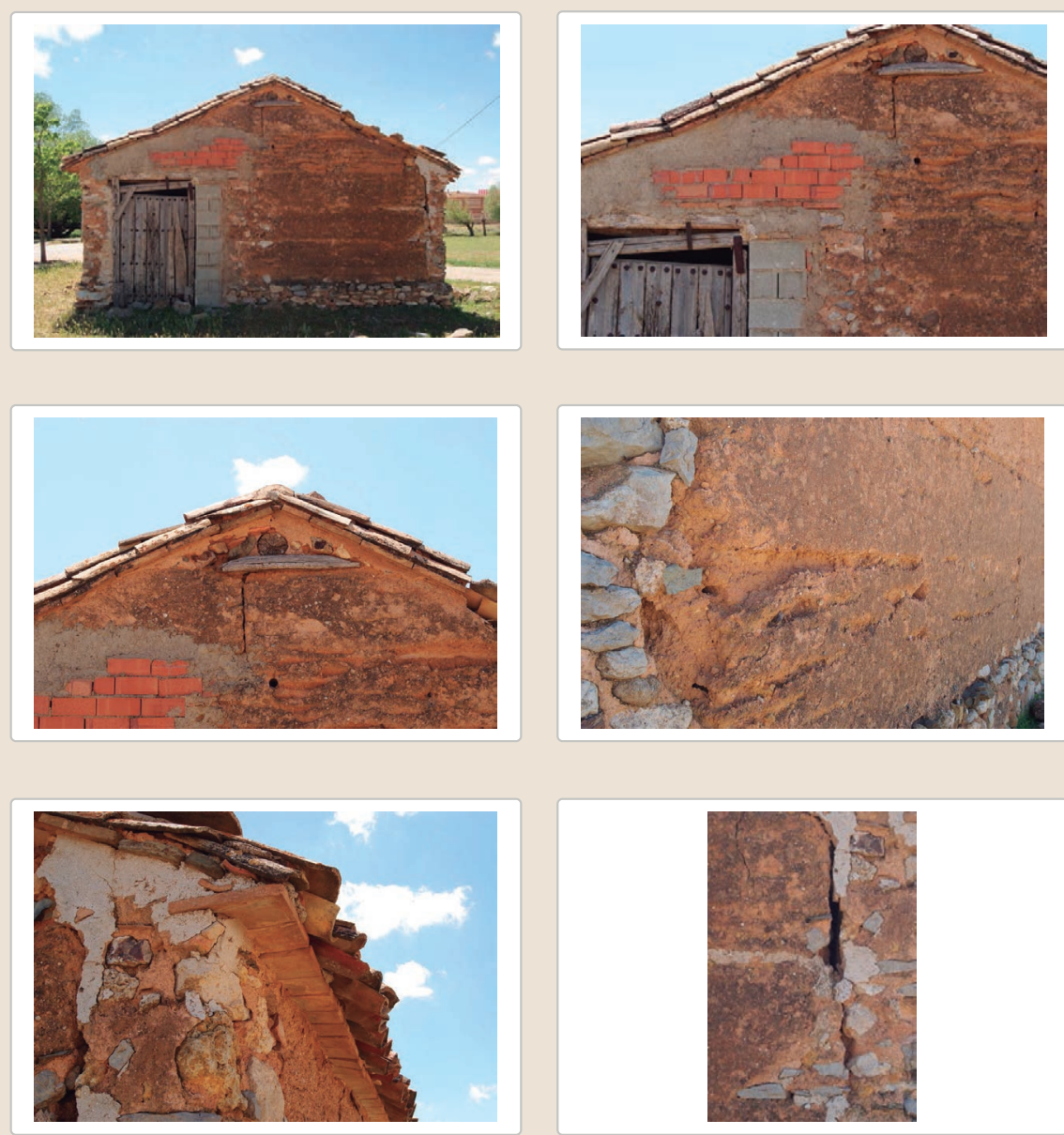


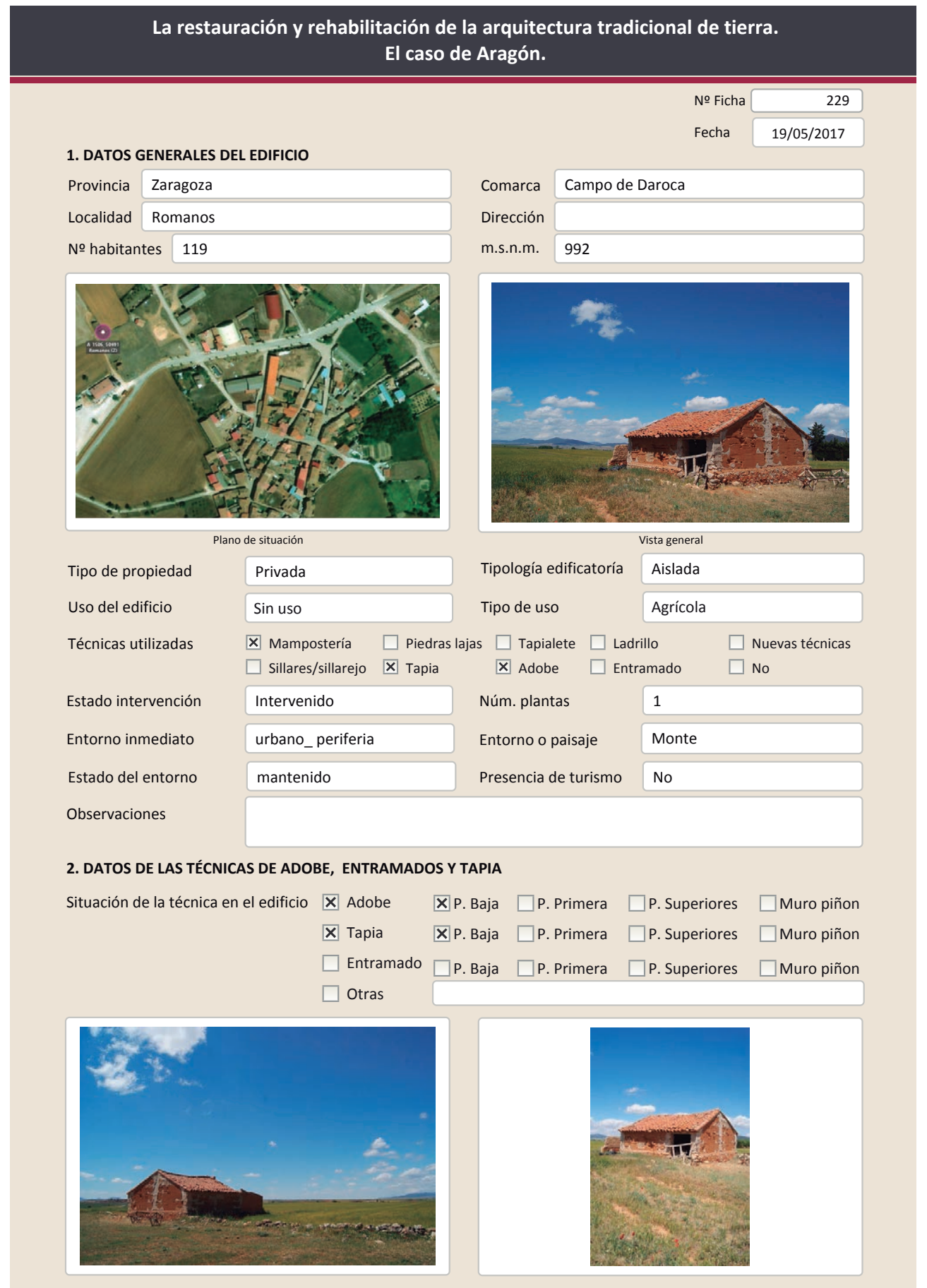

2.1. ADOBE

Dimensión de las piezas

Dimensión del muro

Aparejo del muro

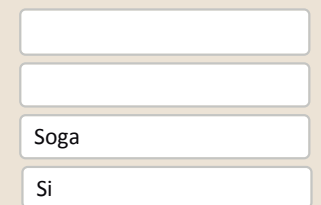

Color de las piezas

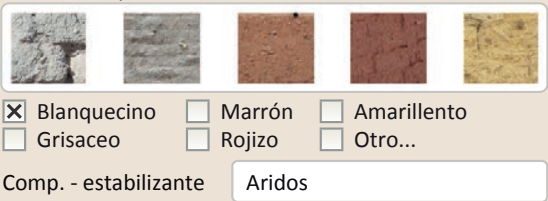

Función estructural

Comp. - estabilizante Aridos

Variante constructiva/ tipo de fábrica

Х Simple

$\square$ Suplementada en juntas

$\square$ Mixta

$\square$ Como suplemento

$\square$ Elementos de protección

muro de cercado

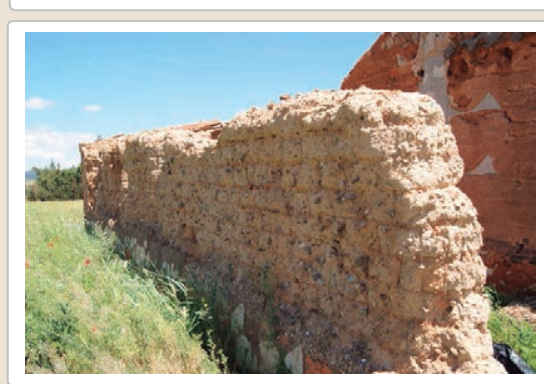

Lesiones $\quad \mathbf{X}$ Muro $\square$ Zócalo $\square$ Revestimiento

X Erosión del material $\square$ Humedad por capilaridad

$\square$ Erosion de las juntas $\square$ Humedades (manch/eflo)

$\mathbf{X}$ Pérdida de sección $\square$ Pérdida de verticalidad

$\square$ Vegetación $\quad \square$ Grietas por empuje de la

$\square$ Desconchados $\quad \square$ Grietas porfalta de traba

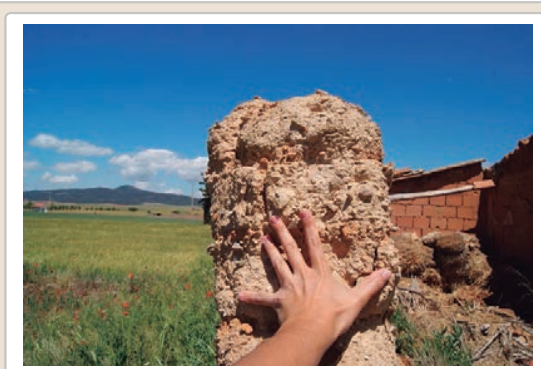

$\square$ Cubierta $\square$ otro...

$\square$ Grietas por asentamientos

$x$ Colapso

$\square$ Desconchados

$\square$ Por elementos impropios

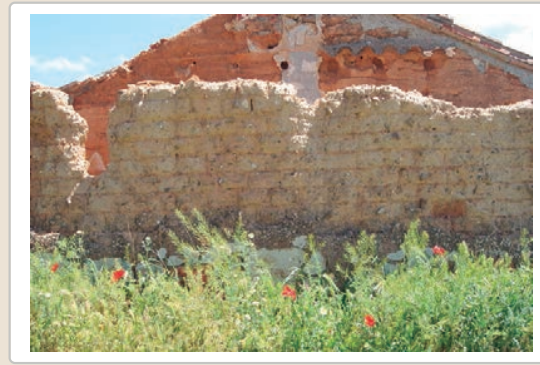

Observaciones 


\section{La restauración y rehabilitación de la arquitectura tradicional de tierra.} El caso de Aragón.

\subsection{TAPIA}

Ancho del muro

Dimensión tapiales

Tipo de aguja

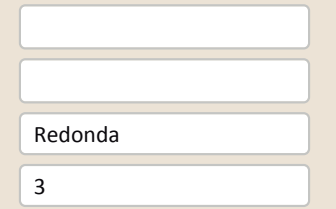

Color de la tapia

№ agujas/cajón

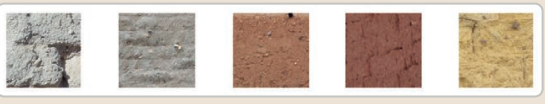

$\square$ Blanquecino $\square$ Marrón $\square$ Amarillento

$\square$ Grisaceo \ Rojizo $\square$ Otro...

Variante constructiva

$\square$ Simple / homogénea

X Suplemento superficial

$\square$ suplemento en juntas

X Mixta

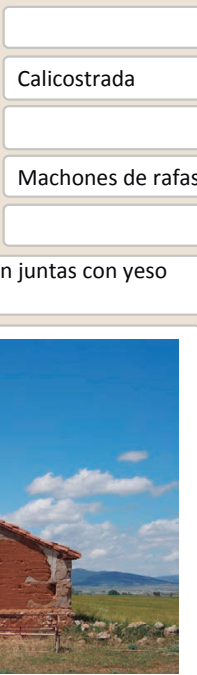

$\square$ Elementos de protección

En el interior esta suplementada en juntas con yeso

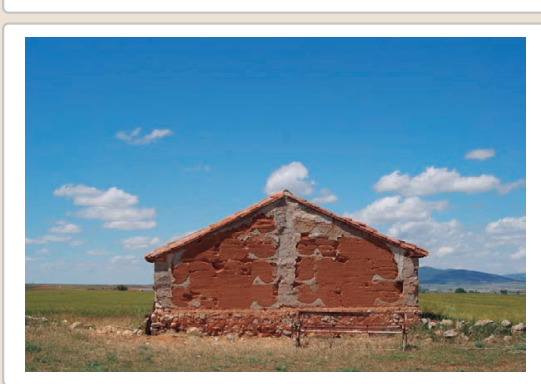

Lesiones $\quad \mathbf{X}$ Muro $\mathbf{X}$ Zócalo $\square$ Revestimiento

$\mathbf{X}$ Erosión del material $\mathbf{X}$ Humedad por capilaridad

$\square$ Erosion de las juntas $\square$ Humedades (manch/eflo)

X Pérdida de sección $\square$ Pérdida de verticalidad

$\square$ Vegetación $\quad \square$ Grietas por empuje de la

$\mathbf{X}$ Desconchados

$\square$ Grietas porfalta de traba
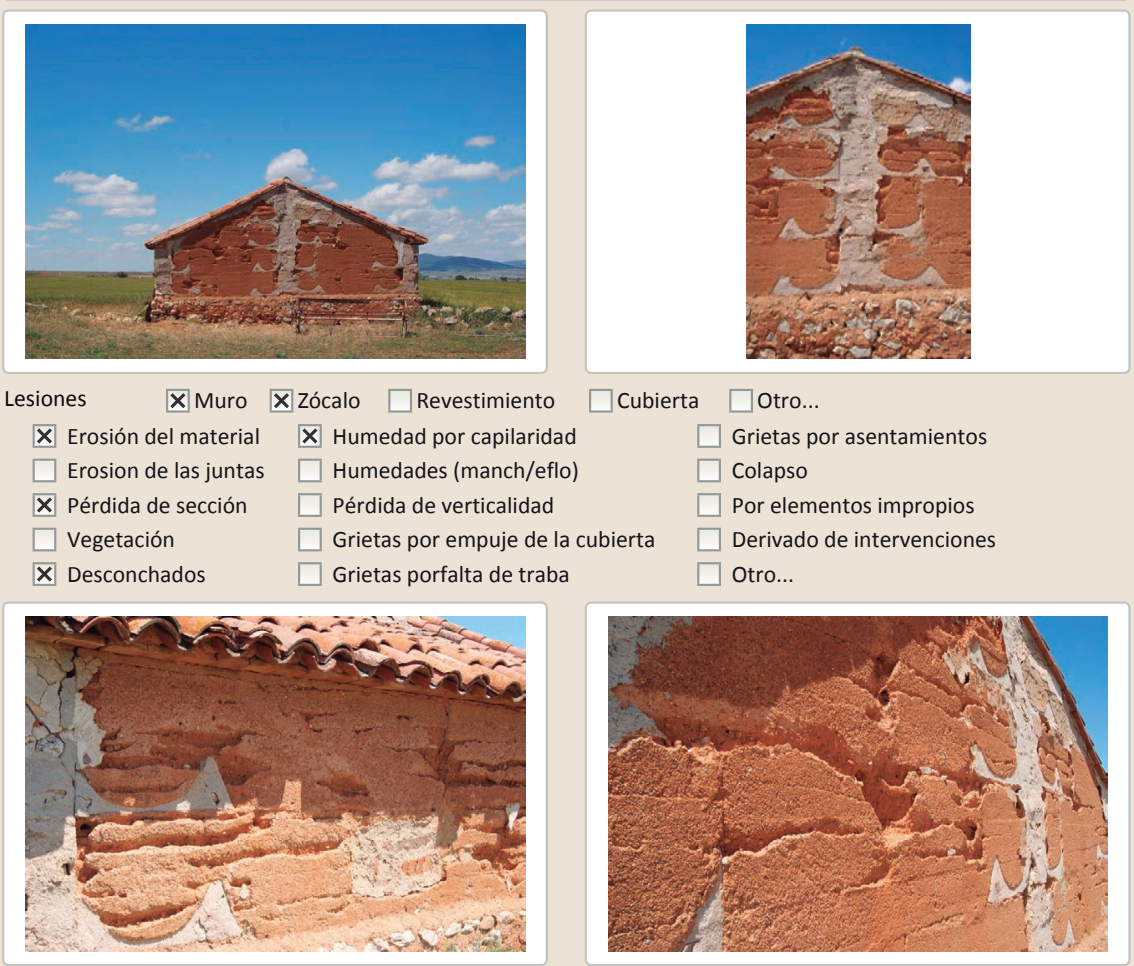

$\square$ Cubierta $\square$ Otro...

$\square$ Grietas por asentamientos

$\square$ Colapso

$\square$ Por elementos impropios

$\square$ Derivado de $\square$ Otro...

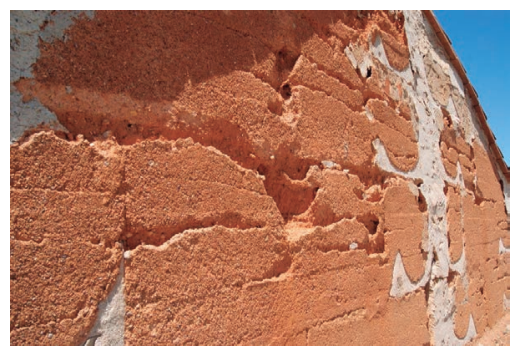

La restauración y rehabilitación de la arquitectura tradicional de tierra.

El caso de Aragón.

3. DATOS DE LA INTERVENCIÓN

Intervención de: $\quad \square$ Mantenimiento $\quad \square$ Rehabilitación parcial $\quad \square$ Restauración $\square$ Demolición

Reflexión previa Intervención espontanea

Observaciones

3.1. MUROS

Tipo de intervención

Tipo de material

Intervenido

$\square$ Actualización $\quad \mathbf{X}$ Reintegración $\square$ Demolición $\square$ Otro.

$\square$ Consolidación $\square$ Reconstrucción $\quad \mathbb{X}$ Sustitución

No tradicional Tipo de técnica Diferente a la existente

Descripción Reintegración con cemento y ladrillos.

Sustitución de un paño de muro por ladrillo

3.2. ZÓCALO

Tipo de intervención

Intervenido

$\square$ Actualización $\square$ Reintegración $\quad \square$ Demolición $\square$ Otro.

$\square$ Consolidación $\mathbf{X}$ Reconstrucción $\square$ Sustitución

\begin{tabular}{llll} 
Tipo de material No tradicional & Tipo de técnica Diferente a la existente \\
\hline
\end{tabular}

Descripción

Mortero de cemento

3.3. REVESTIMIENTOS

Tipo de intervención

No aplica

Tipo de material

Descripción

3.4. VANOS

Tipo de intervención

No intervenido

$\square$ Actualización $\square$ Reintegración $\square$ Demolición $\square$ Otro..

$\square$ Consolidación $\quad \square$ Reconstrucción $\square$ Sustitución

Tipo de material

Descripción

3.5. CUBIERTA

No intervenido

Tipo de intervención

$\square$ Actualización

$\square$ Consolidación $\square$ Reintegración $\square$ Demolición

$\square$ Consolidación $\square$ Reconstrucción $\square$ Sustitución

Tipo de material

Descripción Tipo de técnica

3.6. OTRAS

Observaciones 
La restauración y rehabilitación de la arquitectura tradicional de tierra. El caso de Aragón

\section{La restauración y rehabilitación de la arquitectura tradicional de tierra.}

El caso de Aragón.
3.7. REHABILITACIÓN ENERGÉTICA
$\square$ Fachada $\square$ Vanos $\square$ Forjados $\square$ Cubierta

Observaciones

FOTOGRAFÍAS DE LA INTERVENCIÓN
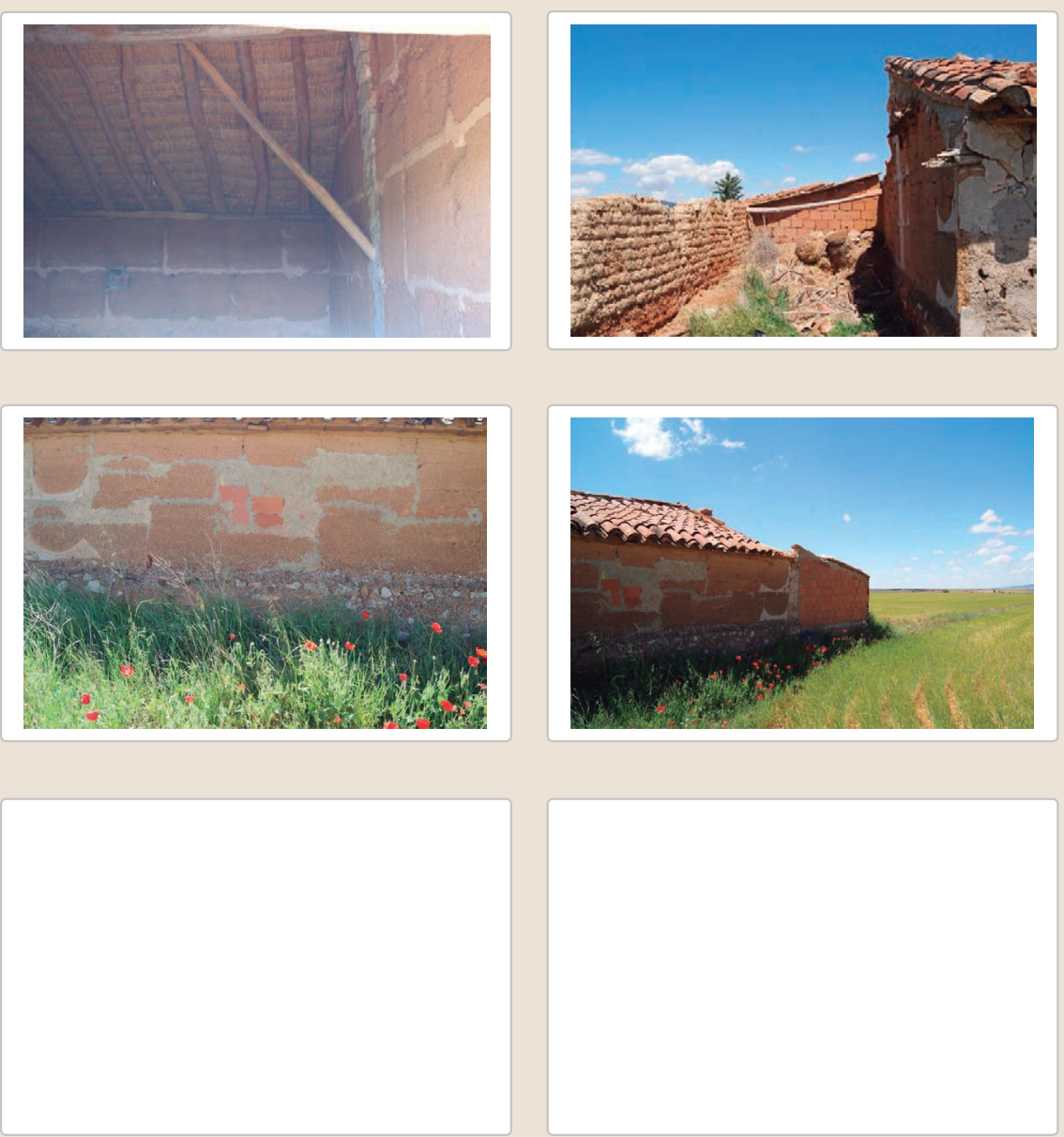
La restauración y rehabilitación de la arquitectura tradicional de tierra. El caso de Aragón.

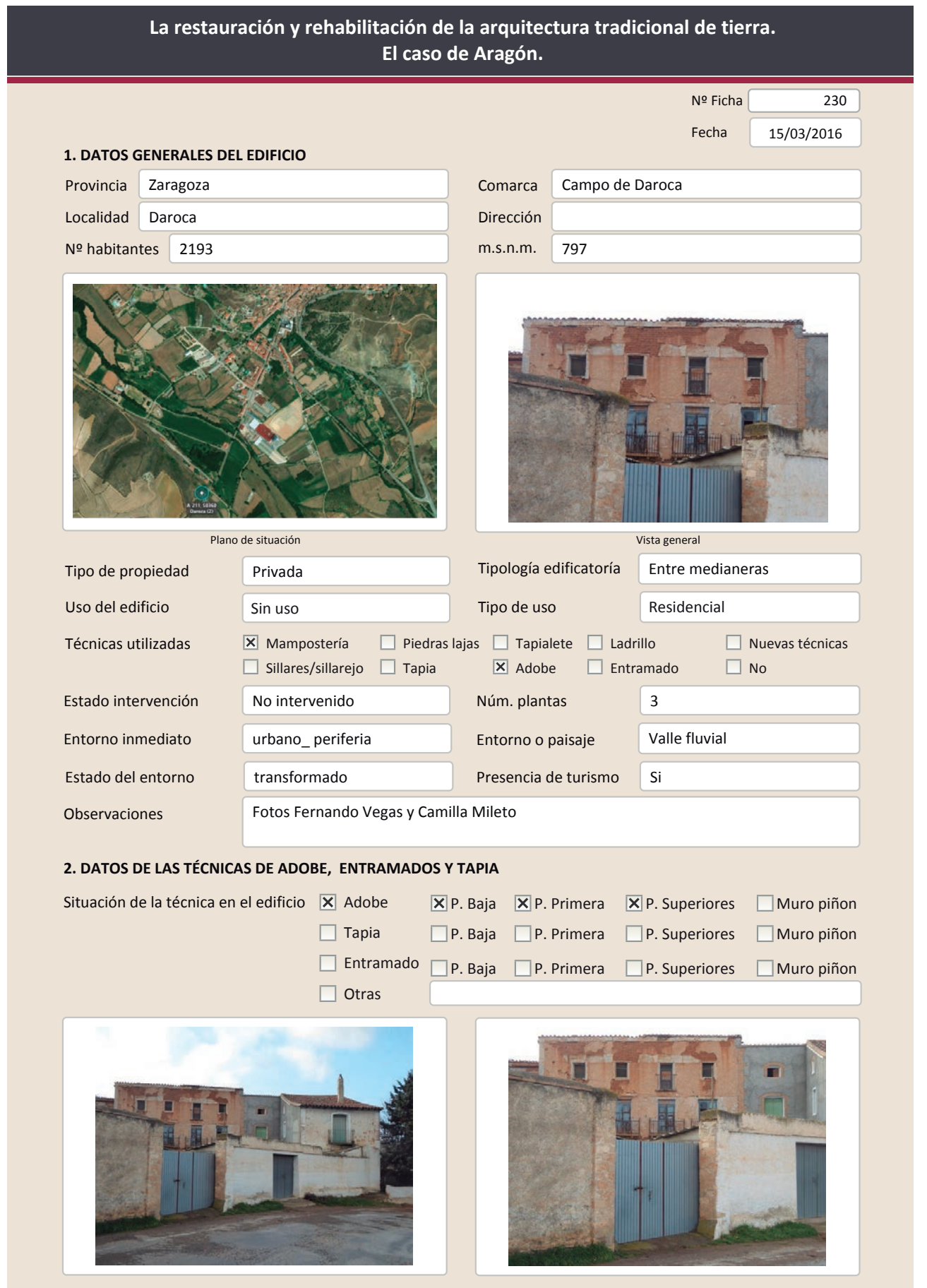

La restauración y rehabilitación de la arquitectura tradicional de tierra.

El caso de Aragón.
2.1. ADOBE

Dimensión de las piezas

Dimensión del muro

Aparejo del muro

Función estructural
Color de las piezas

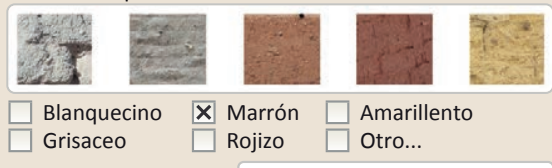

Grisaceo $\square$ Rojizo $\square$ Otro..

Comp. - estabilizante
Variante constructiva/ tipo de fábrica
$\square$ Simple

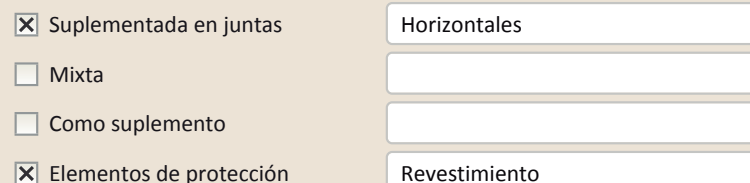
$\mathbf{X}$ Elementos de protección
Revestimiento

\section{$\mathrm{Cal} /$ yeso}

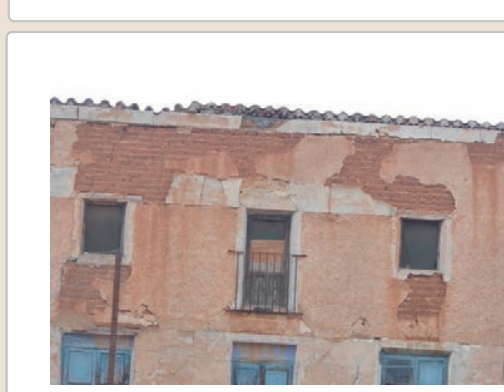

Lesiones $\quad \mathbf{X}$ Muro $\square$ Zócalo $\mathbf{X}$ Revestimiento

\ Erosión del material $\square$ Humedad por capilaridad

$\square$ Erosion de las juntas $\square$ Humedades (manch/eflo)

$\square$ Pérdida de sección $\square$ Pérdida de verticalidad

$\square$ Vegetación $\quad \square$ Grietas por empuje de la cub $\square$ Grietas porfalta de traba

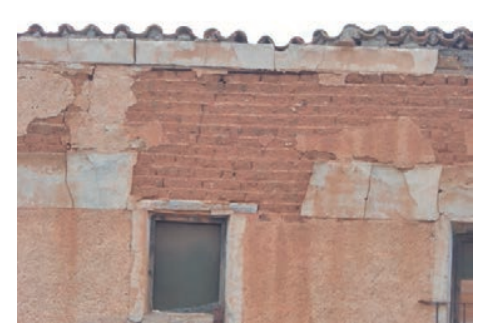

$\square$ Cubierta $\square$ Otro...

$\mathbf{X}$ Desconchados

$\square$ Grietas por asentamiento $\square$ Colapso

$\square$ Por elementos impropios

$\square$ Derivado de intervenciones

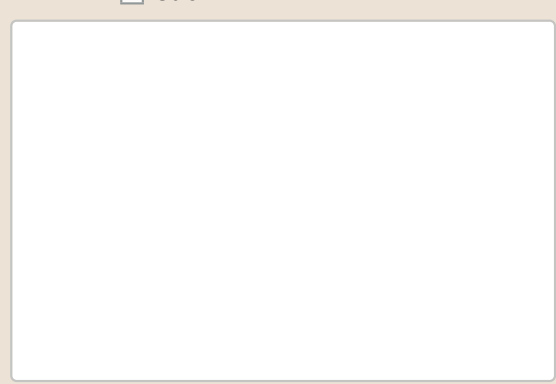

Observacione Pérdida de revestimientos. Lavado y agrietamiento de los muros. 


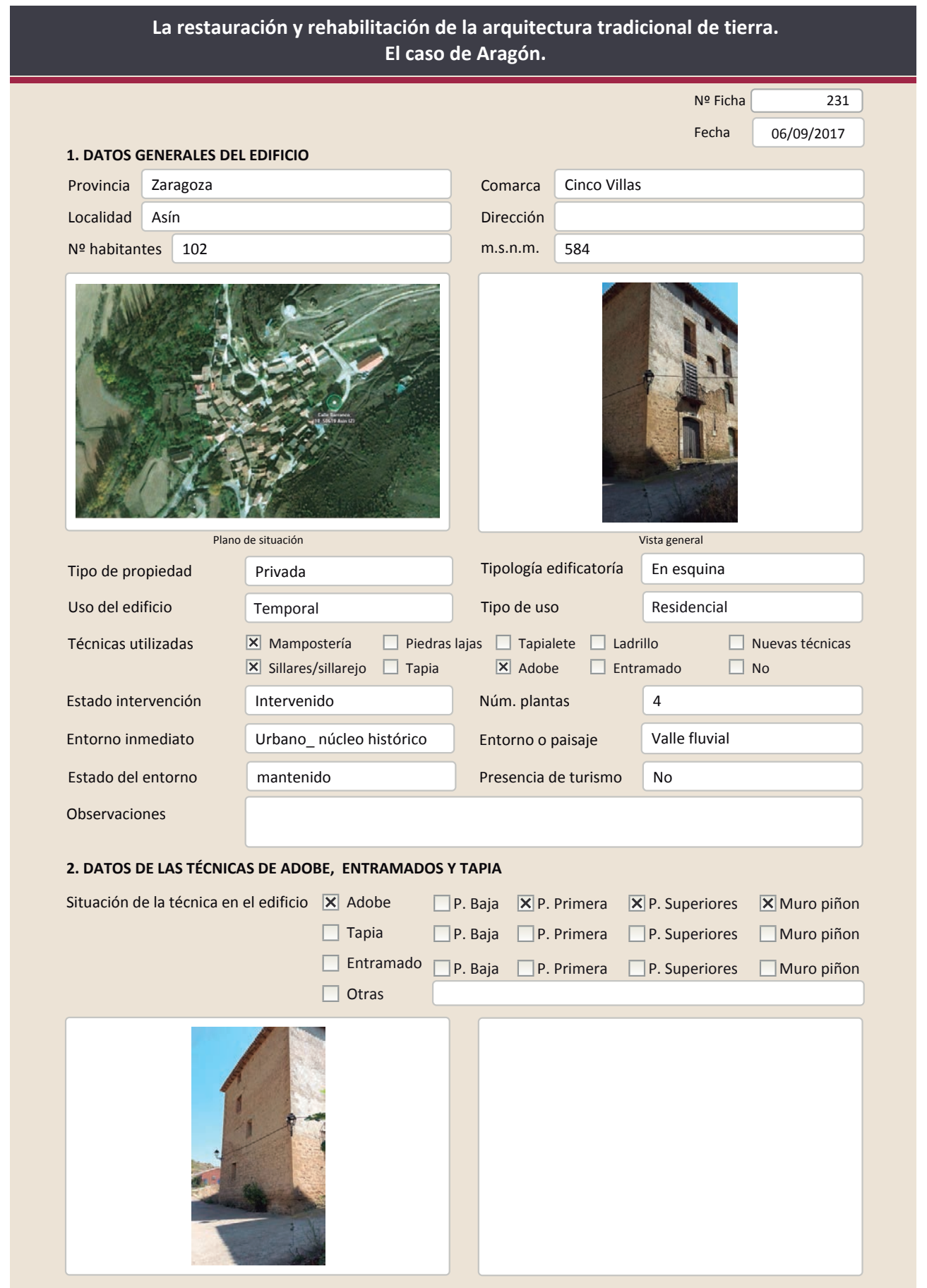

2.1. ADOBE

Dimensión de las piezas Dimensión del muro

Aparejo del muro

Función estructural

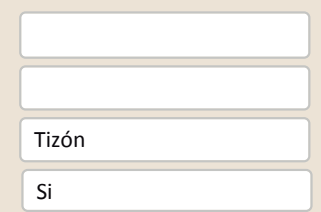

Color de las piezas

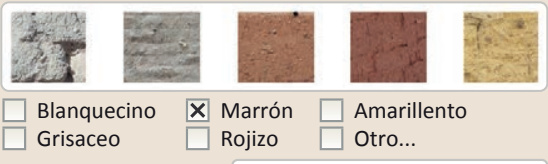

Grisaceo

$\square$ Rojizo $\square$ Otro..

Variante constructiva/ tipo de fábrica

$\square$ simple

$\square$ Suplementada en juntas

区 Mixta

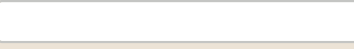

$\square$ Como suplemento

$\square$ Elementos de protección Esquinas de sillería

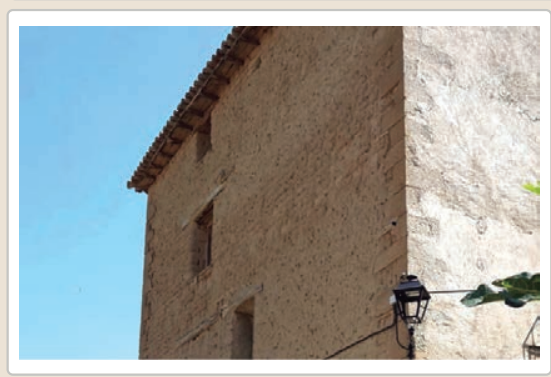

Lesiones $\mathbf{X}$ Muro $\mathbf{X}$ Zócalo $\mathbf{X}$ Revestimiento

$\mathbf{X}$ Erosión del material $\mathbf{X}$ Humedad por capilarida $\square$ Erosion de las juntas $\mathbf{X}$ Humedades (manch/eflo)

$\square$ Pérdida de sección $\square$ Pérdida de verticalidad

$\square$ Vegetación $\quad \square$ Grietas por empuje de la c $\square$ Grietas porfalta de traba

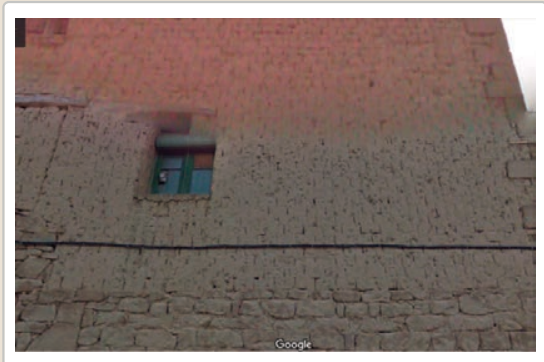

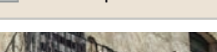

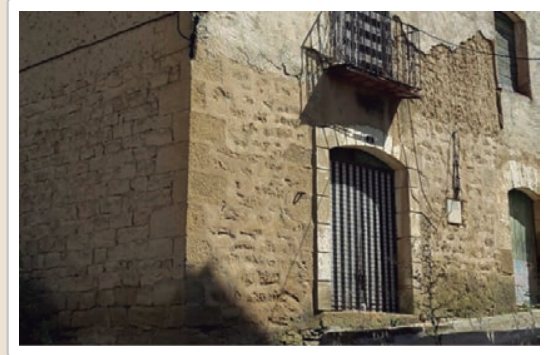

Observaciones 
La restauración y rehabilitación de la arquitectura tradicional de tierra.

El caso de Aragón.

3. DATOS DE LA INTERVENCIÓN

\begin{tabular}{|c|c|c|c|c|}
\hline Intervención de: & $\begin{array}{l}\square \text { Mantenimiento } \\
\mathbf{X} \text { Reparación }\end{array}$ & $\begin{array}{l}\square \text { Rehabilitación parcial } \\
\square \text { Rehabilitación integral }\end{array}$ & $\begin{array}{l}\square \text { Restauración } \\
\square \text { Ampliación }\end{array}$ & $\begin{array}{l}\square \text { Demolición } \\
\square \text { Otro... }\end{array}$ \\
\hline Reflexión previa & \multicolumn{4}{|c|}{ Intervención espontanea } \\
\hline Observacione & & & & \\
\hline
\end{tabular}

\subsection{MUROS}

Tipo de intervención

No intervenido

Tipo de material

$\square$ Actualización $\square$ Reintegración $\square$ Demolición $\square$ Otro...

$\square$ Consolidación $\square$ Reconstrucción $\square$ Sustitución

Descripción

3.2. ZÓCALO

Tipo de intervención

Intervenido

Tipo de intervención

$\square$ Actualizació

\Reintegración $\square$ Demolición $\square$ Otro...

Descripción

(adiciona

Tipo de técnica Diferente a la existente

3.3. REVESTIMIENTOS

Rejuntado de la mampostería con cemento. Junta muy ancha

Tipo de intervención

Intervenido

Tipo demateral

Reintegración $\square$ Demolición $\square$ Otro...

Tipo de material

X Reconstrucción $\square$ Sustitución

Descripción

Revestimiento del adobe de la fachada principal. Amplias áreas con desconchados

3.4. VANOS

No intervenido

Tipo de intervención

$\square$ Actualización $\square$ Reintegración $\square$ Demolición $\square$ Otro...

Tipo de material

$\square$ Consolidación $\square$ Reconstrucción $\square$ sustitución

Descripción

3.5. CUBIERTA

Tipo de intervención

No visible

Tipo de material

$\square$ Actualización $\square$ Reintegración $\square$ Demolición $\quad \square$ Otro..

Descripción

$$
\text { Tipo de técnica }
$$

3.6. OTRAS 


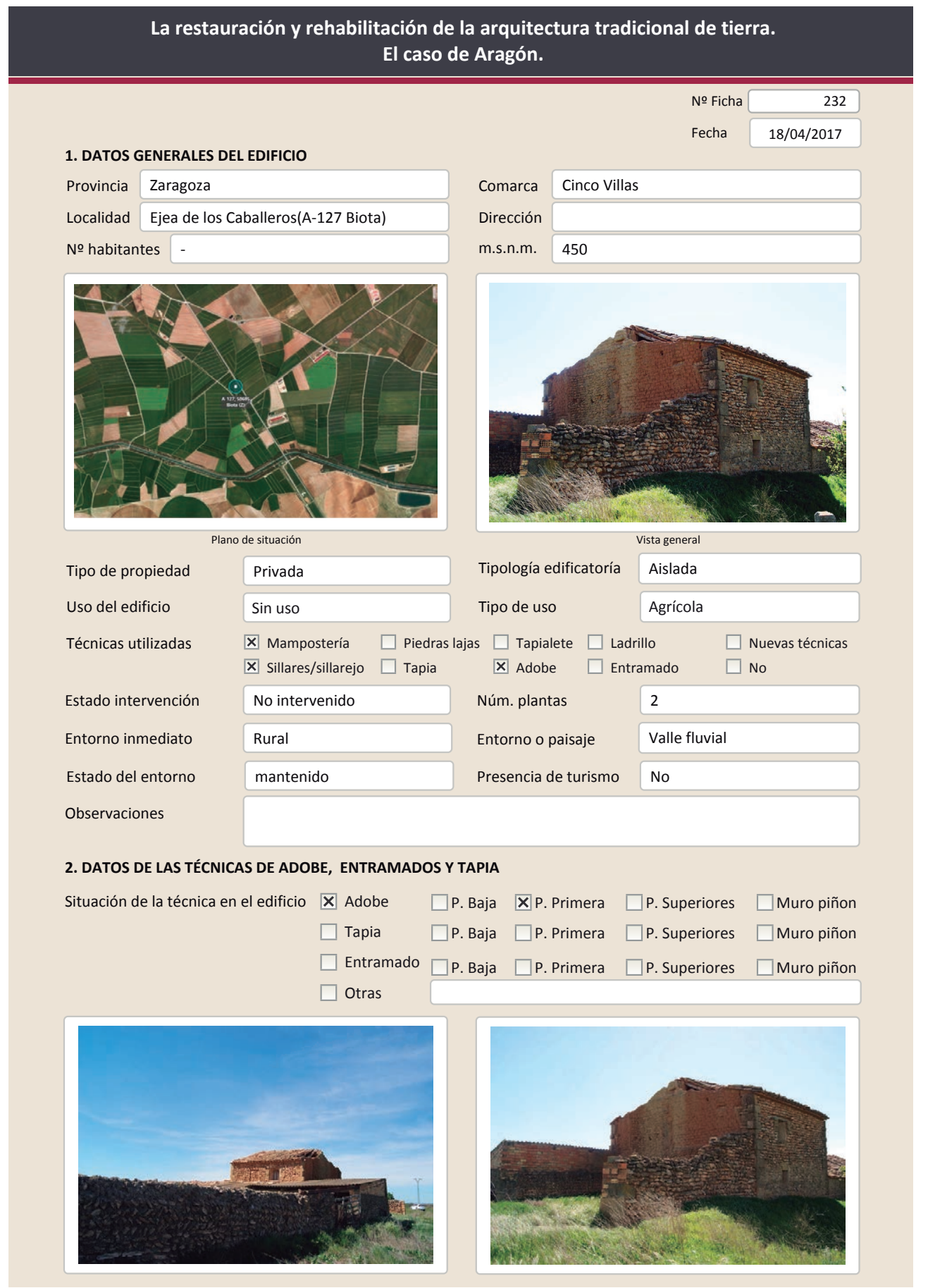

2.1. ADOBE

Dimensión de las piezas Dimensión del muro

Aparejo del muro

Función estructural

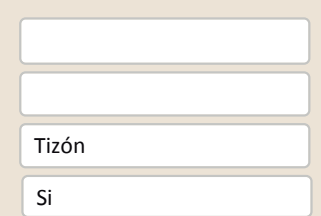

Color de las piezas

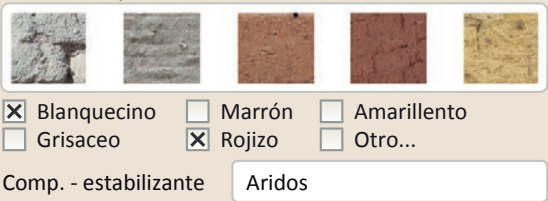

Variante constructiva/ tipo de fábrica

$\square$ Simple

$\square$ suplementada en juntas

区 Mixta

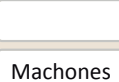

Comp. - estabilizante Aridos

$\square$ Como suplemento

$\square$ Elementos de protección

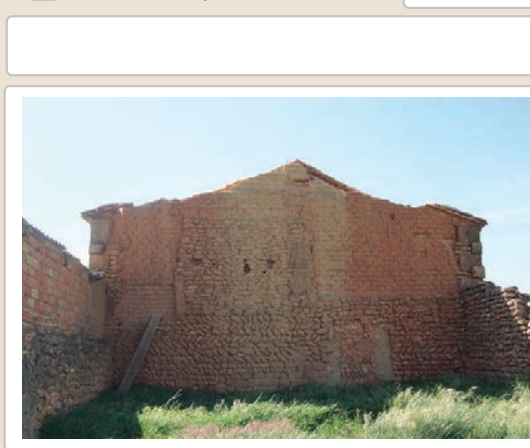

Lesiones \Muro $\square$ Zócalo $\square$ Revestimiento 区 Erosión del material $\square$ Humedad por capilaridad $\mathbf{X}$ Erosion de las juntas $\square$ Humedades (manch/eflo) X Pérdida de sección $\quad \square$ Pérdida de verticalidad

$\square$ Vegetación $\quad \square$ Grietas por empuje de la cubie $\square$ Desconchados $\quad \square$ Grietas porfalta de traba

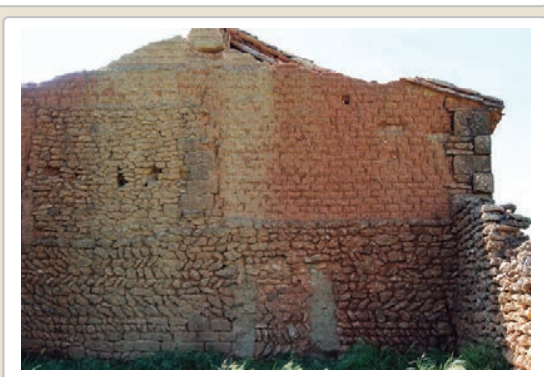

X Cubierta $\square$ Otro...

$\square$ Grietas por asentamiento $x$ Colapso

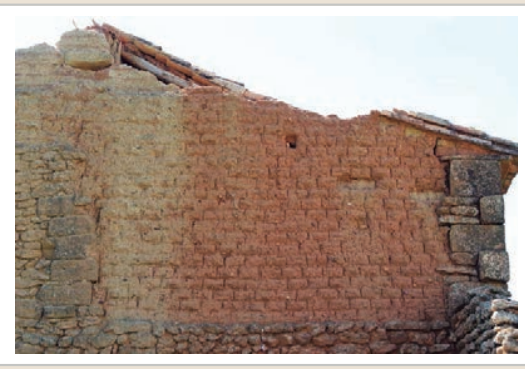

Por elementos impropios

$\square$ Derivado de intervenciones $\square$ Otro... 


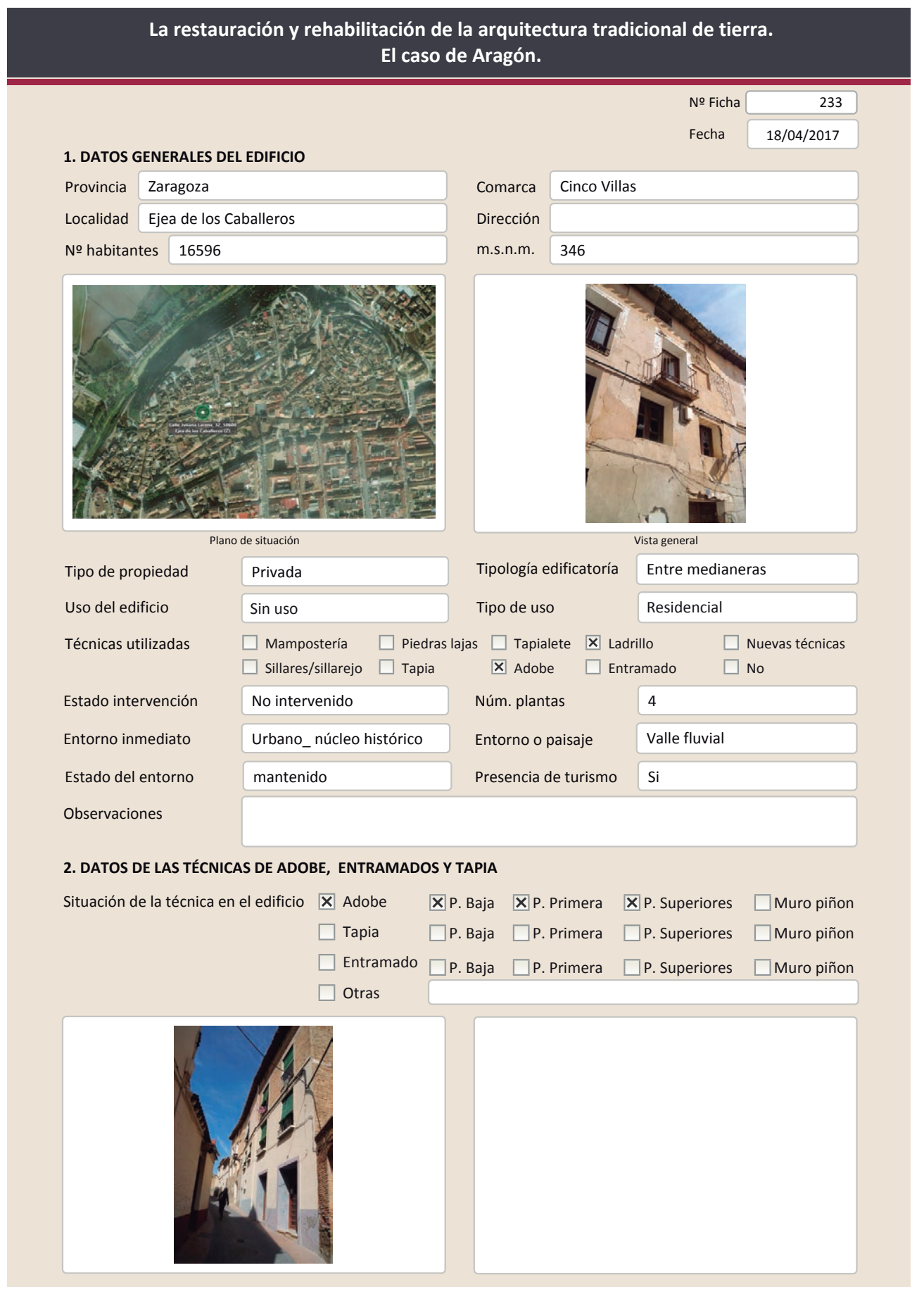

La restauración y rehabilitación de la arquitectura tradicional de tierra. El caso de Aragón.

\begin{tabular}{l|l|} 
2.1. ADOBE & \\
Dimensión de las piezas & $38 \times 18 \times 10$ \\
Dimensión del muro & $50-60 \mathrm{~cm}$ \\
Aparejo del muro & Soga \\
Función estructural & $\mathrm{Si}$
\end{tabular}

Función estructural

Variante constructiva/ tipo de fábrica

$\square$ Simple

$\square$ Suplementada en juntas

X Mixta

$\square$ Como suplemento

Х Elementos de protección El muro en planta baja mide $57 \mathrm{~cm}$

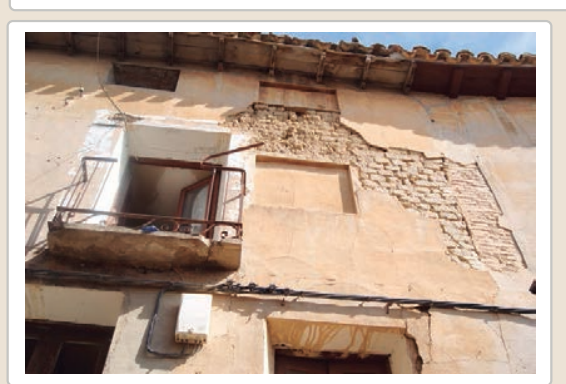

Lesiones ХMuro ХZŹcalo Х Revestimiento

$\mathbb{X}$ Erosión del material $\mathbf{X}$ Humedad por capilaridad $\square$ Erosion de las juntas $\square$ Humedades (manch/eflo)

$\square$ Pérdida de sección $\square$ Pérdida de verticalidad

$\square$ Vegetación $\quad \square$ Grietas por empuje de la

$\boldsymbol{X}$ Desconchados

$\square$ Grietas por empuje de la
$\square$ Grietas porfalta de traba

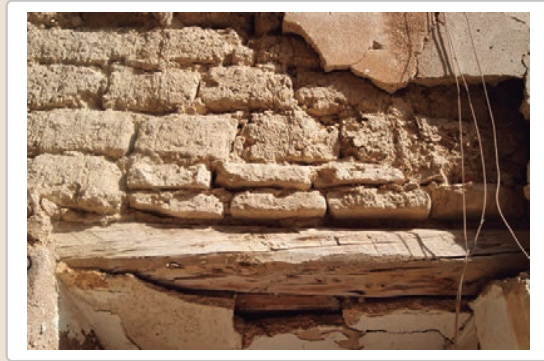

Color de las piezas

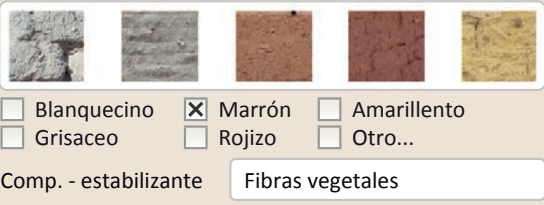

Comp. - estabilizante Fibras vegetales

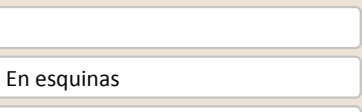

Ladrillo

Revestimiento

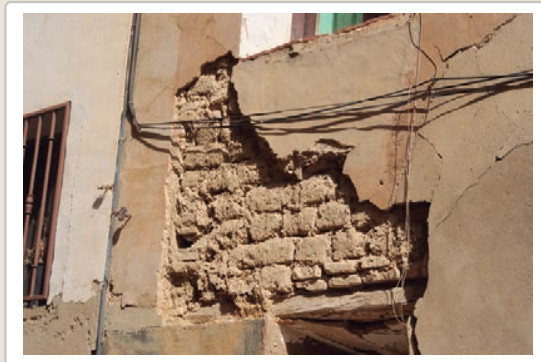

$\square$ Cubierta $\square$ Otro...

$\square$ Grietas por asentamientos

$\square$ Colapso

$\square$ Por elementos impropios

$\square$ Derivado de intervenciones

$\square$ Otro...

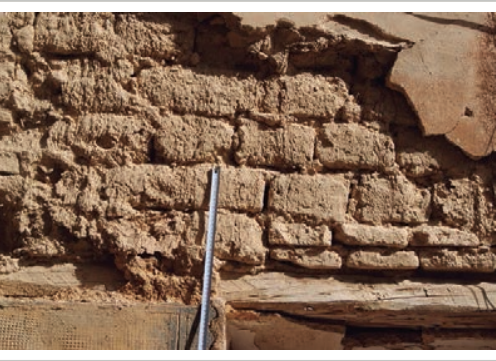




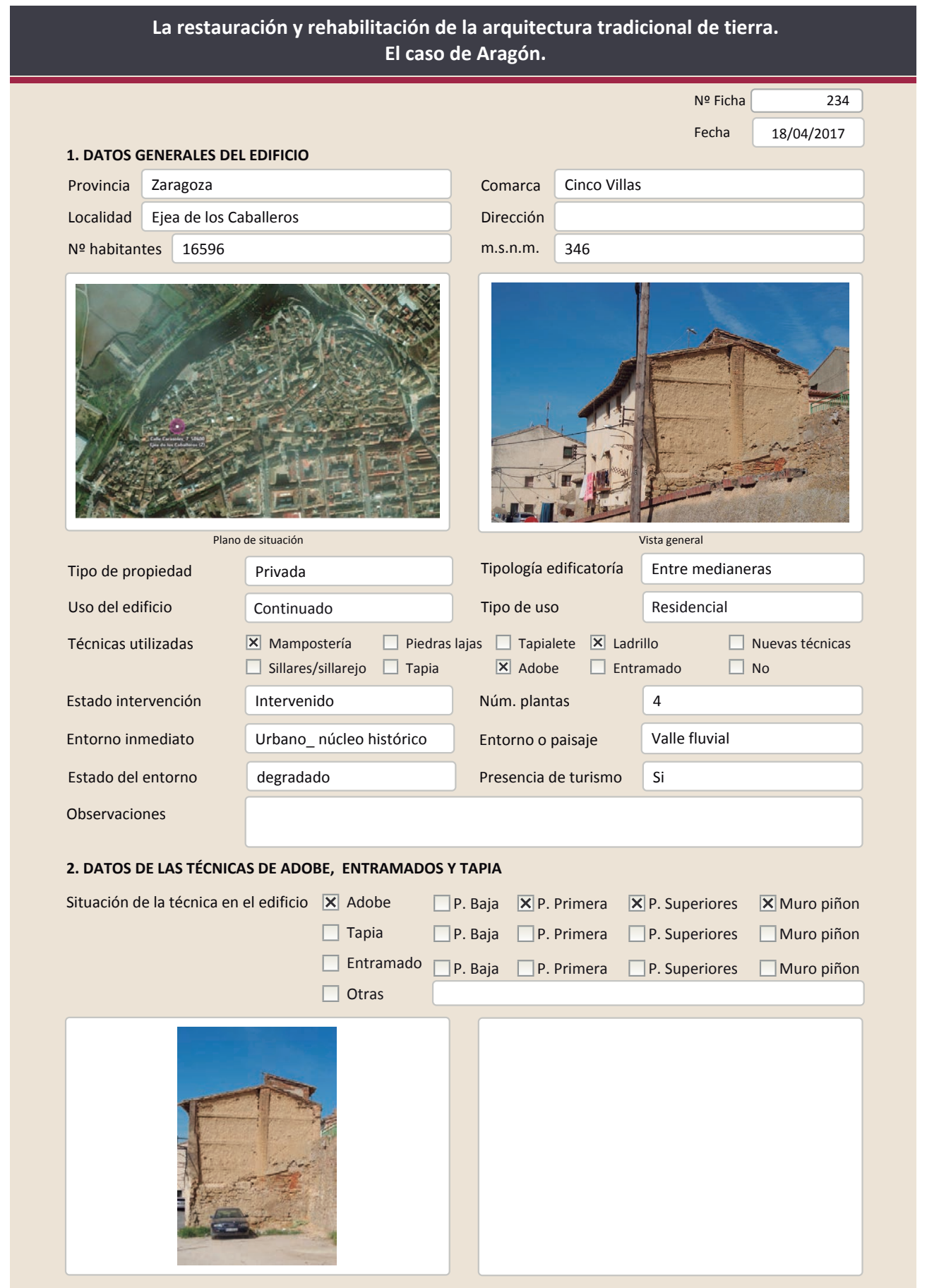

2.1. ADOBE

Dimensión de las piezas

Dimensión del muro

Aparejo del muro

Función estructural

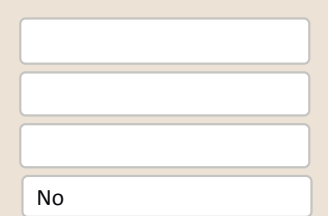

Color de las piezas

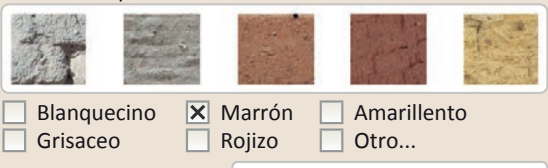

Variante constructiva/ tipo de fábrica

$\square$ simple

$\square$ Suplementada en juntas

区 Mixta

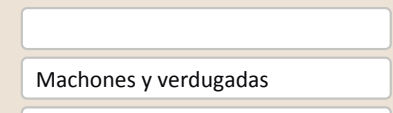

Ladrillo

$\square$ Como suplemento

$\square$ Elementos de protección

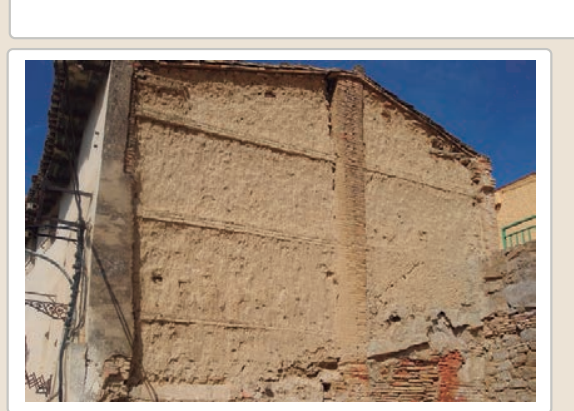

Lesiones $\mathbf{X}$ Muro $\mathbf{X}$ Zócalo $\mathbf{X}$ Revestimiento

$\mathbf{X}$ Erosión del material $\mathbf{X}$ Humedad por capilaridad $\square$ Erosion de las juntas $\mathbf{X}$ Humedades (manch/eflo)

$\boldsymbol{X}$ Pérdida de sección $\square$ Pérdida de verticalidad

$\square$ Vegetación $\quad \square$ Grietas por empuje de la

X Desconchados

$\square$ Grietas por empuje de la

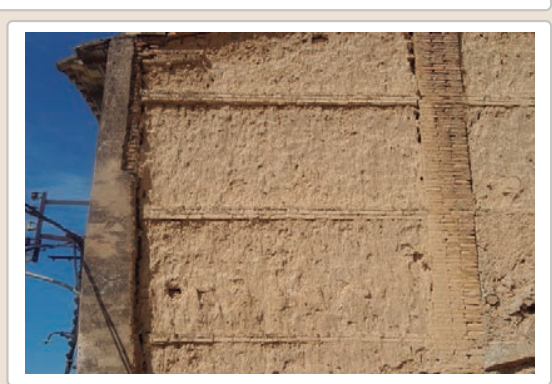

$\square$ Cubierta $\square$ Otro...

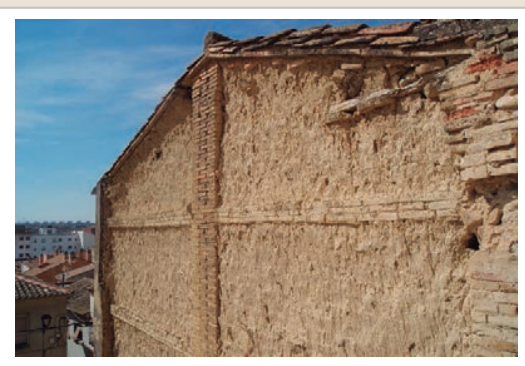

$\square$ Grietas por asentamientos

$\square$ Colapso

$\square$ Por elementos impropios

$\square$ Derivado de intervenciones $\square$ Otro...

Observaciones

La perdida de sección es importante en el muro

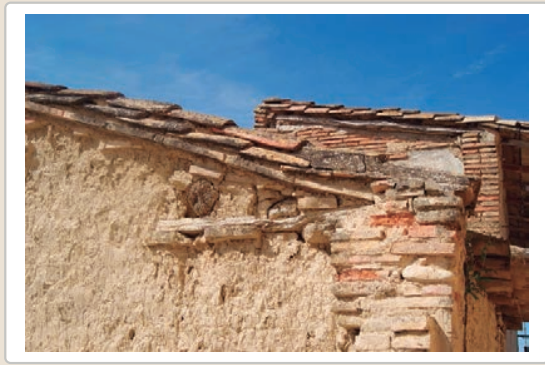


La restauración y rehabilitación de la arquitectura tradicional de tierra.

El caso de Aragón.

3. DATOS DE LA INTERVENCIÓN

\begin{tabular}{llll|} 
Intervención de: & $\square$ Mantenimiento $\quad \boldsymbol{X}$ Rehabilitación parcial & $\square$ Restauración & $\square$ Demolición \\
& $\square$ Reparación $\quad \square$ Rehabilitación integral & $\square$ Ampliación $\quad \square$ Otro... \\
Reflexión previa & Intervención espontanea & \\
Observaciones & & \\
& &
\end{tabular}

\subsection{MUROS}

Tipo de intervención

No intervenido

Tipo de material

$\square$ Actualización $\square$ Reintegración $\square$ Demolición $\square$ Otro...

$\square$ Consolidación $\square$ Reconstrucción $\square$ Sustitución

Descripción

3.2. ZÓCALO

Tipo de intervención

Intervenido

Tipo de material

X Actualización

ción $\square$ Reintegración $\square$ Demolición $\square$ Otro...

Descripción

No tradicional Tipo de técnica Diferente a la existente

3.3. REVESTIMIENTOS

Cemento

Tipo de intervención

\section{Intervenido}

X Actualización $\square$ Reintegración $\square$ Demolición $\square$ Otro...

Tipo de material

$\square$ Consolidación $\quad \mathbf{X}$ Reconstrucción $\square$ Sustitución

Descripción

Tipo de técnica Diferente a la existente

3.4. VANOS

Revestimiento de cemento y pintura blanca

Tipo de intervención

No intervenido

Tipo de material

$\square$ Actualización $\square$ Reintegración $\square$ Demolición $\square$ Otro...

Descripción

$\square$ Consolidación $\square$ Reconstrucción $\square$ Sustitución

3.5. CUBIERTA

Tipo de intervención

No intervenido

$\square$ Actualización $\square$ Reintegración $\square$ Demolición $\quad \square$ Otro..

Tipo de material

$\square$ Reconstrucción $\square$ Sustitución

Descripción

$$
\text { Tipo de técnica }
$$

3.6. OTRAS 


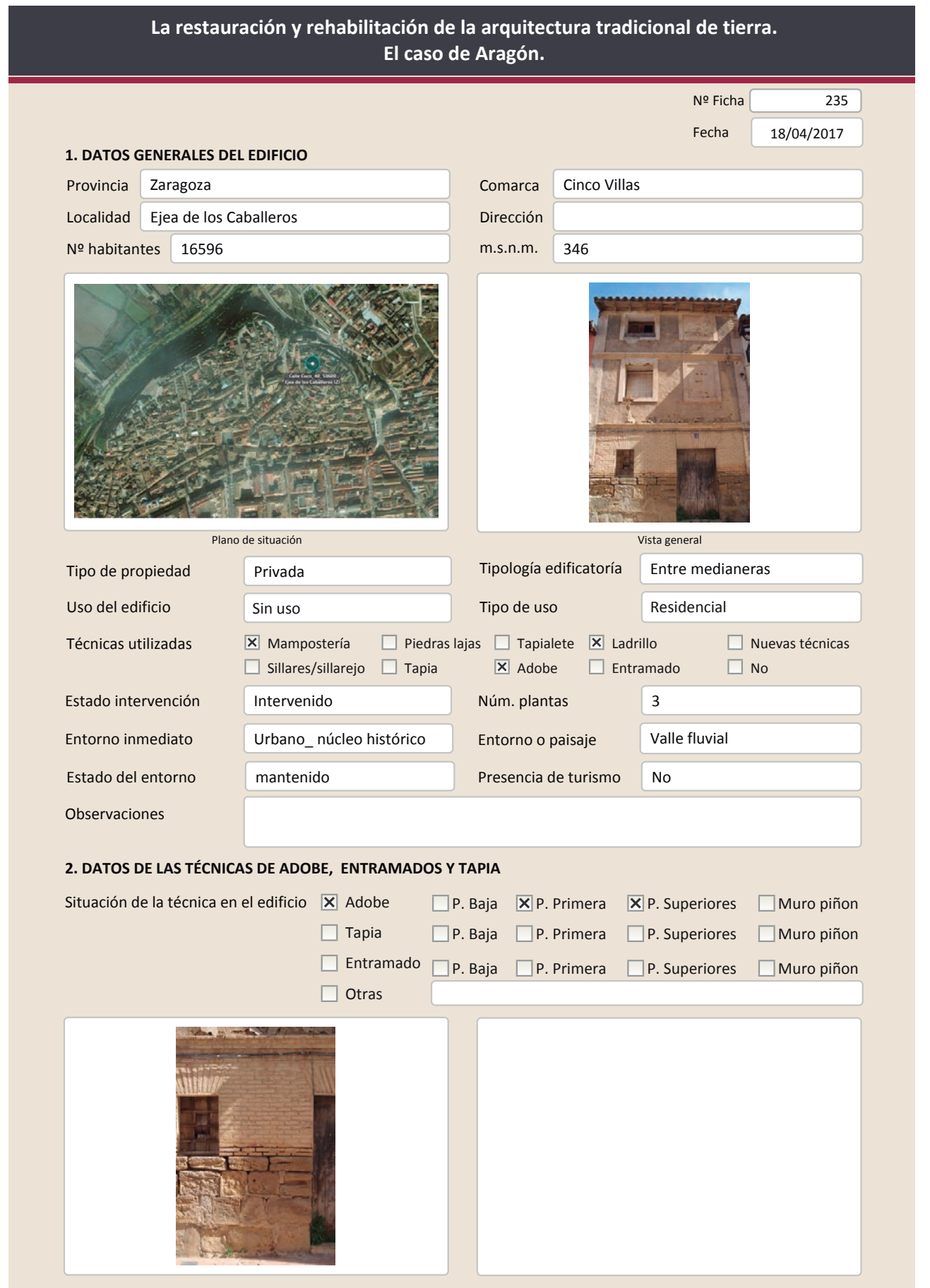

La restauración y rehabilitación de la arquitectura tradicional de tierra.

El caso de Aragón.

\subsection{ADOBE}

Dimensión de las piezas Dimensión del muro

Aparejo del muro

Función estructural

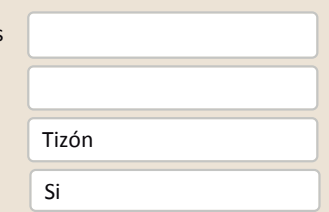

Color de las piezas

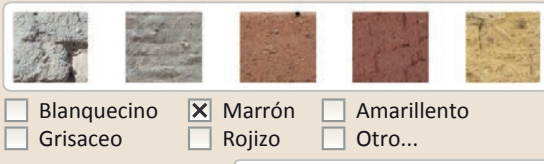

$\square$ Rojizo $\square$ Otro.

Comp. - estabilizante Fibras vegetales
Variante constructiva/ tipo de fábrica

$\square$ Simple

$\square$ Suplementada en juntas

区 Mixta

En esquinas

Ladrillo

$\square$ Como suplemento

$\mathbf{X}$ Elementos de protección

Revestimiento

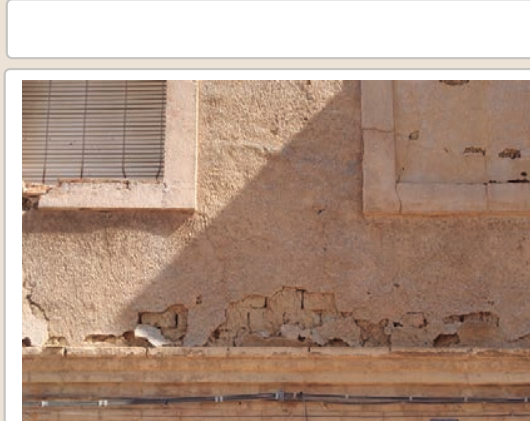

Lesiones $\square$ Muro $\mathbf{X}$ Zócalo $\mathbf{X}$ Revestimiento $\square$ Cubierta $\square$ Otro...

$\square$ Erosión del material $\quad \mathbf{X}$ Humedad por capilaridad $\quad \square$ Grietas por asentamientos

$\square$ Erosion de las juntas $\mathbf{X}$ Humedades (manch/eflo) $\quad \square$ Colapso

$\square$ Pérdida de sección $\square$ Pérdida de verticalidad $\square$ Por elementos impropios

$\square$ Vegetación $\quad \square$ Grietas por empuje de la cubierta $\square$ Derivado de intervenciones

Х Desconchados $\square$ Grietas porfalta de traba $\square$ Otro... 
La restauración y rehabilitación de la arquitectura tradicional de tierra.

El caso de Aragón.

3. DATOS DE LA INTERVENCIÓN

\begin{tabular}{l|lll|} 
Intervención de: & $\square$ Mantenimiento & $\square$ Rehabilitación parcial & $\square$ Restauración \\
& $\boldsymbol{x}$ Reparación & $\square$ Demolición \\
Reflexión previa & Intervención planificada & \\
Observacionen integral & $\square$ Ampliación $\quad \square$ Otro... \\
& &
\end{tabular}

\subsection{MUROS}

Tipo de intervención

No intervenido

Tipo de material

$\square$ Actualización $\square$ Reintegración $\square$ Demolición $\square$ Otro...

$\square$ Consolidación $\square$ Reconstrucción $\square$ sustitución

Descripción

3.2. ZÓCALO

Tipo de intervención

Intervenido

Tipo de intervención

$\square$ Actualización

× Reintegración $\square$ Demolición $\square$ Otro...

Descripción

3.3. REVESTIMIENTOS

Rejuntado de los sillares

Tipo de intervención

No intervenido

Tipo de materal

$\square$ Actualización Tipo de técnica

Descripción

3.4. VANOS

Reintegración $\square$ Demolición $\square$ Otro...

Tipo de técnica

Tipo de intervención

No intervenido

Tipo de material

Descripción

3.5. CUBIERTA

Tipo de intervención

Intervenido

$\square$ Actualización $\square$ Reintegración $\quad \square$ Demolición $\quad \square$ Otro...

Tipo de material

$\square$ Consolidación $\quad \mathbf{X}$ Reconstrucción $\square$ Sustitución

Descripción

$\begin{array}{lll}\text { No tradicional Tipo de técnica Similar a la existente } & \end{array}$

Reconstrucción de la cubierta con una base de mortero de cemento y teja curva ( piezas sustituidas)

3.6. OTRAS 


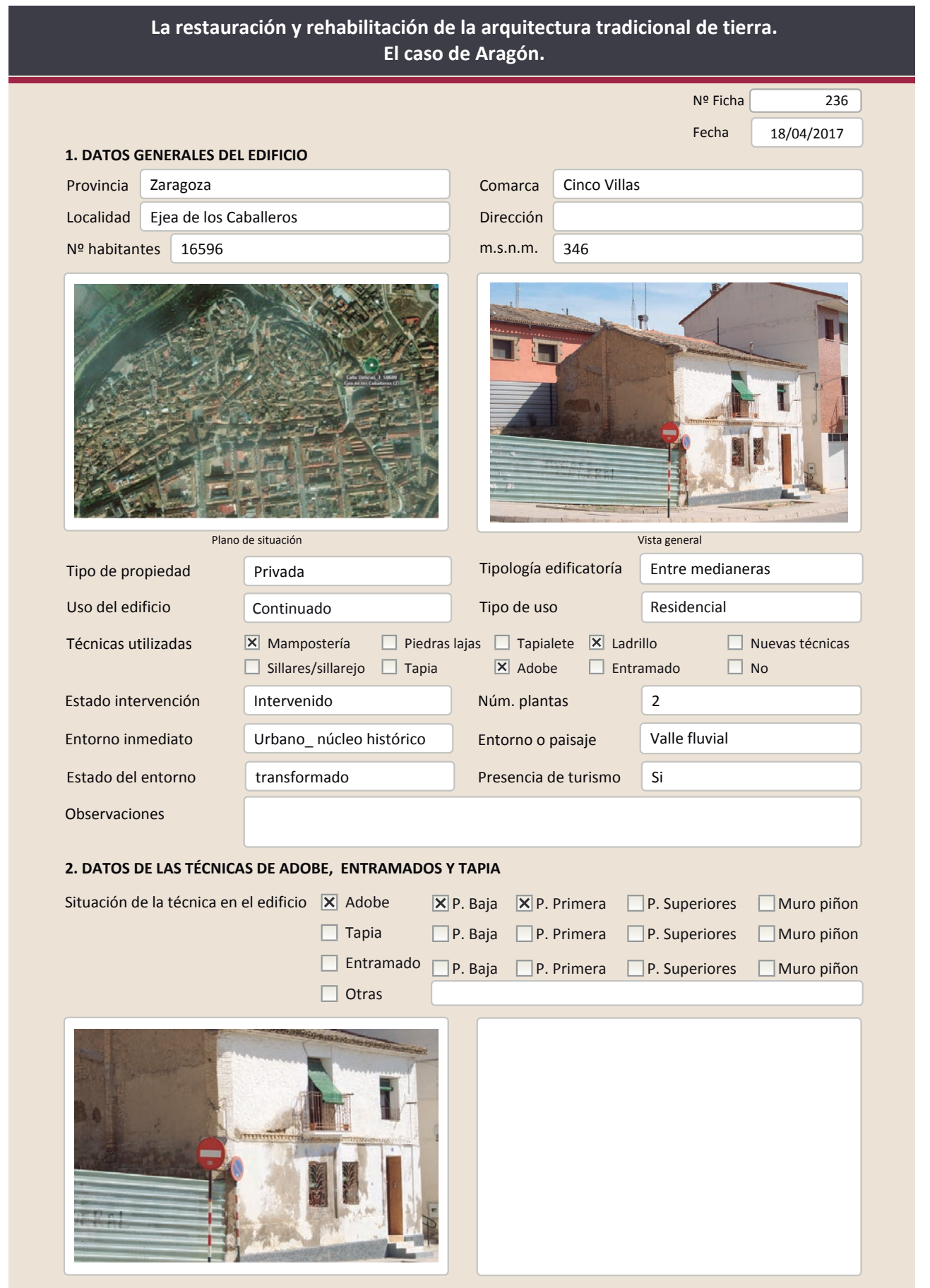

La restauración y rehabilitación de la arquitectura tradicional de tierra.

El caso de Aragón.

\subsection{ADOBE}

Dimensión de las piezas Dimensión del muro

Aparejo del muro

Función estructural

Variante constructiva/ tipo

$\square$ Simple

$\square$ Suplementada en juntas

区 Mixta

Machones

$\square$ Como suplemento

X Elementos de protección

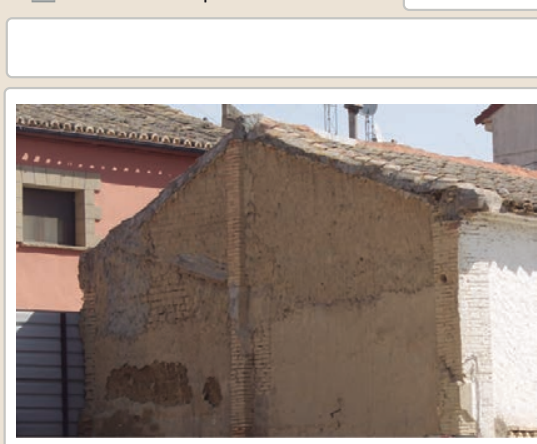

Color de las piezas

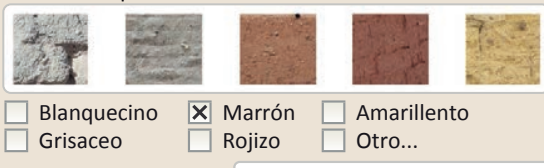

$\begin{array}{lll}\square \text { Blanquecino } & \underline{x} \text { Marrón } \square \text { Amaril } \\ \square \text { Grisaceo } & \square \text { Rojizo } \square \text { Otro... }\end{array}$

Comp. - estabilizante
Lesiones XMuro XZócalo X Revestimiento

$\mathbf{X}$ Erosión del material $\mathbf{X}$ Humedad por capilarida $\square$ Erosion de las juntas $\mathbf{X}$ Humedades (manch/eflo)

$\square$ Pérdida de sección $\quad \square$ Pérdida de verticalidad

$\square$ Vegetación

X Desconchados

$\square$ Grietas por empuje de la $\square$ Grietas porfalta de traba

$$
x
$$

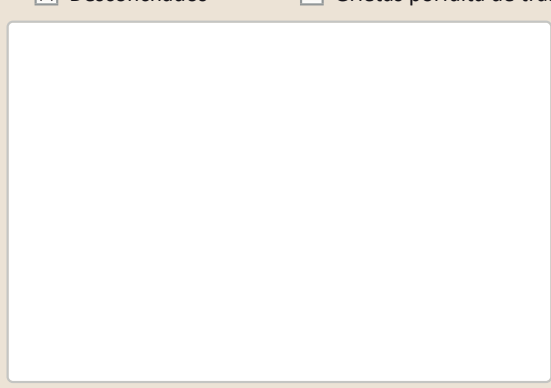

$\begin{aligned} \square \text { Cubierta } & \square \text { Otro... } \\ & \square \text { Grietas por asentamientos } \\ & \square \text { Colapso } \\ & \square \text { Por elementos impropios } \\ & \square \text { Derivado de intervenciones } \\ & \square \text { Otro... }\end{aligned}$

Observaciones 
La restauración y rehabilitación de la arquitectura tradicional de tierra.

\section{El caso de Aragón.}

3. DATOS DE LA INTERVENCIÓN

\begin{tabular}{|c|c|c|c|c|}
\hline Intervención de: & $\begin{array}{l}\square \text { Mantenimiento } \\
\mathbf{X} \text { Reparación }\end{array}$ & $\begin{array}{l}\square \text { Rehabilitación parcial } \\
\square \text { Rehabilitación integral }\end{array}$ & $\begin{array}{l}\square \text { Restauración } \\
\square \text { Ampliación }\end{array}$ & $\begin{array}{l}\square \text { Demolición } \\
\square \text { Otro... }\end{array}$ \\
\hline Reflexión previa & \multicolumn{4}{|c|}{ Intervención espontanea } \\
\hline Observ & & & & \\
\hline
\end{tabular}

3.1. MUROS

Intervenido

Tipo de intervención

$\square$ Actualización $\quad \mathbf{X}$ Reintegración $\square$ Demolición $\square$ Otro...

$\square$ Consolidación $\square$ Reconstrucción $\square$ Sustitución

Tipo de material

No tradicional Tipo de técnica Diferente a la existente

Descripción

pellas de mortero de cemento en algunas de las zonas más degradadas

3.2. ZÓCALO

Intervenido

Tipo de intervención

X Actualización

Tipo de material

$\square$ Consolidación $\mathbf{X}$ Reconstrucción $\square$ sustitución

Descripción

Gotelé de cemento pintado de azul. Intervención realizada sobre el zócalo anterior que Gotelé de cemento
tenía mayor altura

3.3. REVESTIMIENTOS

Intervenido

Tipo de intervención

X Actualización $\square$ Reintegración $\square$ Demolición $\square$ Otro...

Tipo de material

$\square$ Consolidación $\square$ Reconstrucción $\quad \mathbf{X}$ Sustitución

Descripción

No tradicional Tipo de técnica Diferente a la existente

Sustitución del revestimiento de planta baja por uno nuevo de cemento y pintura

3.4. VANOS

Tipo de intervención

Intervenido

Tipo de material

$\square$ Actualización $\quad \mathbf{X}$ Reintegración $\square$ Demolición $\square$ Otro...

$\square$ Consolidación $\quad \square$ Reconstrucción $\square$ Sustitución

Descripción

No tradicional

Tipo de técnica Diferente a la existente

3.5. CUBIERTA

Reintegración del contorno de la puerta con baldosas cerámicas

Tipo de intervención

Intervenido

Tipo de intervención

$\square$ Actualización $\quad \boldsymbol{X}$ Reintegración $\square$ Demolición $\square$ Otro..

Tipo de material

$\square$ Consolidación $\square$ Reconstrucción $\square$ Sustitución

Descripción

No tradicional

Tipo de técnica Similar a la existente

3.6. OTRAS

Reintegración de las tejas de cumbrera y de los laterales con cemento 


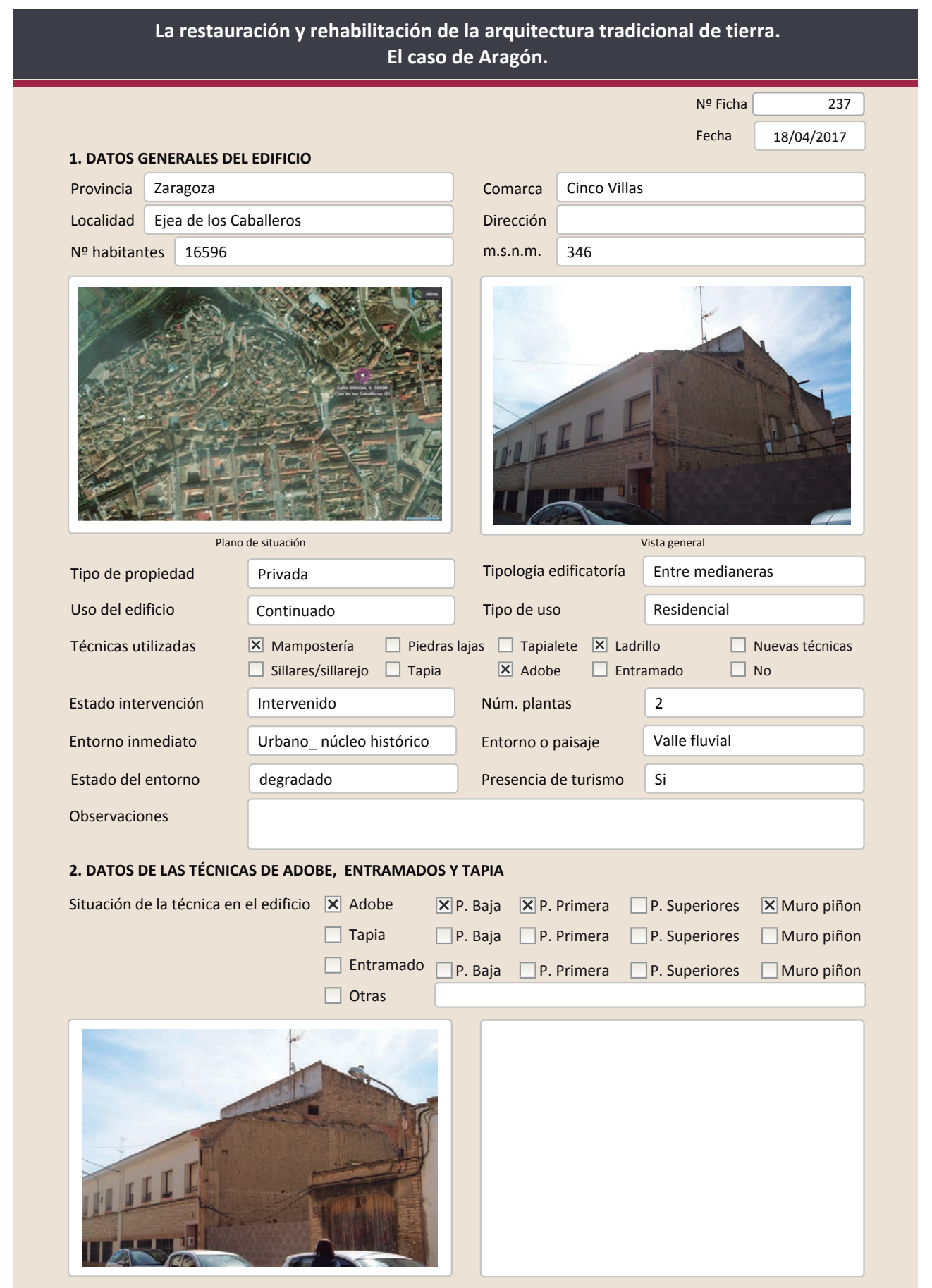

La restauración y rehabilitación de la arquitectura tradicional de tierra.
2.1. ADOBE

Dimensión de las piezas Dimensión del muro

Aparejo del muro

Función estructural

\section{El caso de Aragón.}

Color de las piezas

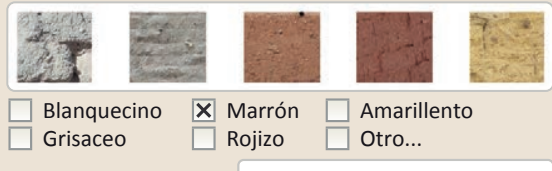

Comp. - estabilizante Fibras vegetales
Variante constructiva/ tipo de fábrica

$\square$ simple

$\square$ suplementada en juntas

区 Mixta

\section{Machones}

Ladrillo

$\square$ Como suplemento

$\square$ Elementos de protección

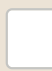

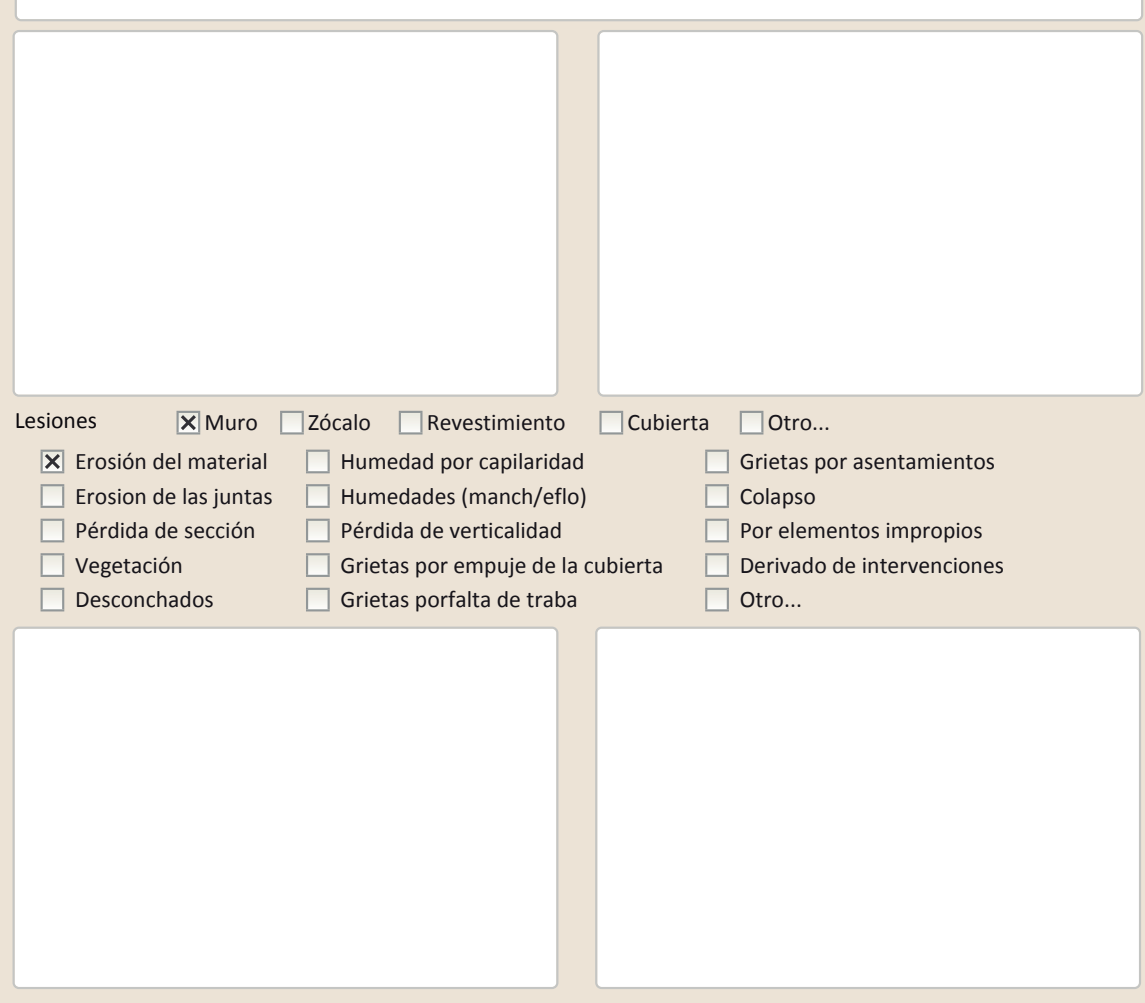

Observaciones 
La restauración y rehabilitación de la arquitectura tradicional de tierra.

\section{El caso de Aragón.}

3. DATOS DE LA INTERVENCIÓN

\begin{tabular}{llll|} 
Intervención de: & $\square$ Mantenimiento & $\square$ Rehabilitación parcial & $\square$ Restauración $\quad \square$ Demolición \\
Reflexión previa & $\square$ Reparación $\quad \boldsymbol{X}$ Rehabilitación integral & $\square$ Ampliación $\quad \square$ Otro... \\
Observaciones & Intervención planificada \\
& La fachada del edificio se h hactualizado por completo \\
& & \\
&
\end{tabular}

\subsection{MUROS}

Tipo de intervención

$$
\text { No visible }
$$

Tipo de material

$\square$ Actualización $\quad \square$ Reintegración $\quad \square$ Demolición $\square$ Otro... $\square$ Consolidación $\square$ Reconstrucción $\square$ Sustitución

Descripción

3.2. ZÓCALO

Tipo de intervención

Intervenido

Tipo de intervención

\ Actualizació

ión $\square$ Reintegración $\square$ Demolición $\square$ Otro...

Descripción

No tradicional Tipo de técnica Diferente a la existente

3.3. REVESTIMIENTOS

$$
\text { Tipo de técnica }
$$

\section{Tipo de intervención}

\section{Intervenido}

Tipo de material

$\square$ Reintegración $\square$ Demolición $\square$ Otro...

Tipo de materia

No tradicional

X Reconstrucción $\square$ Sustitución

Descripción

Revestimiento de cemento pintado de blanco y de aplacado de piedra

3.4. VANOS

Intervenido

Tipo de intervención

$\square$ Actualización $\square$ Reintegración $\square$ Demolición $\square$ Otro...

$\square$ Consolidación $\quad \mathbf{X}$ Reconstrucción $\square$ Sustitución

Tipo de material

No tradicional Tipo de técnica Diferente a la existente

Descripción la configuración de los huecos parece nueva. En planta baja se han añadido rejas en
todos los casos

3.5. CUBIERTA

$\begin{array}{ll}\text { Tipo de intervención } & \square \text { Actualización } \quad \square \text { Reintegración } \quad \square \text { Demolición } \quad \square \text { Otro... } \\ & \square \text { consolidación } \quad \square \text { Reconstrucción } \quad \boldsymbol{X} \text { Sustitución }\end{array}$

Intervenido

\begin{tabular}{lll} 
Tipo de material No tradicional Tipo de técnica Diferente a la existente \\
\hline
\end{tabular}

Descripción

Cubierta con nuevas tejas y configuración distintas.

3.6. OTRAS 


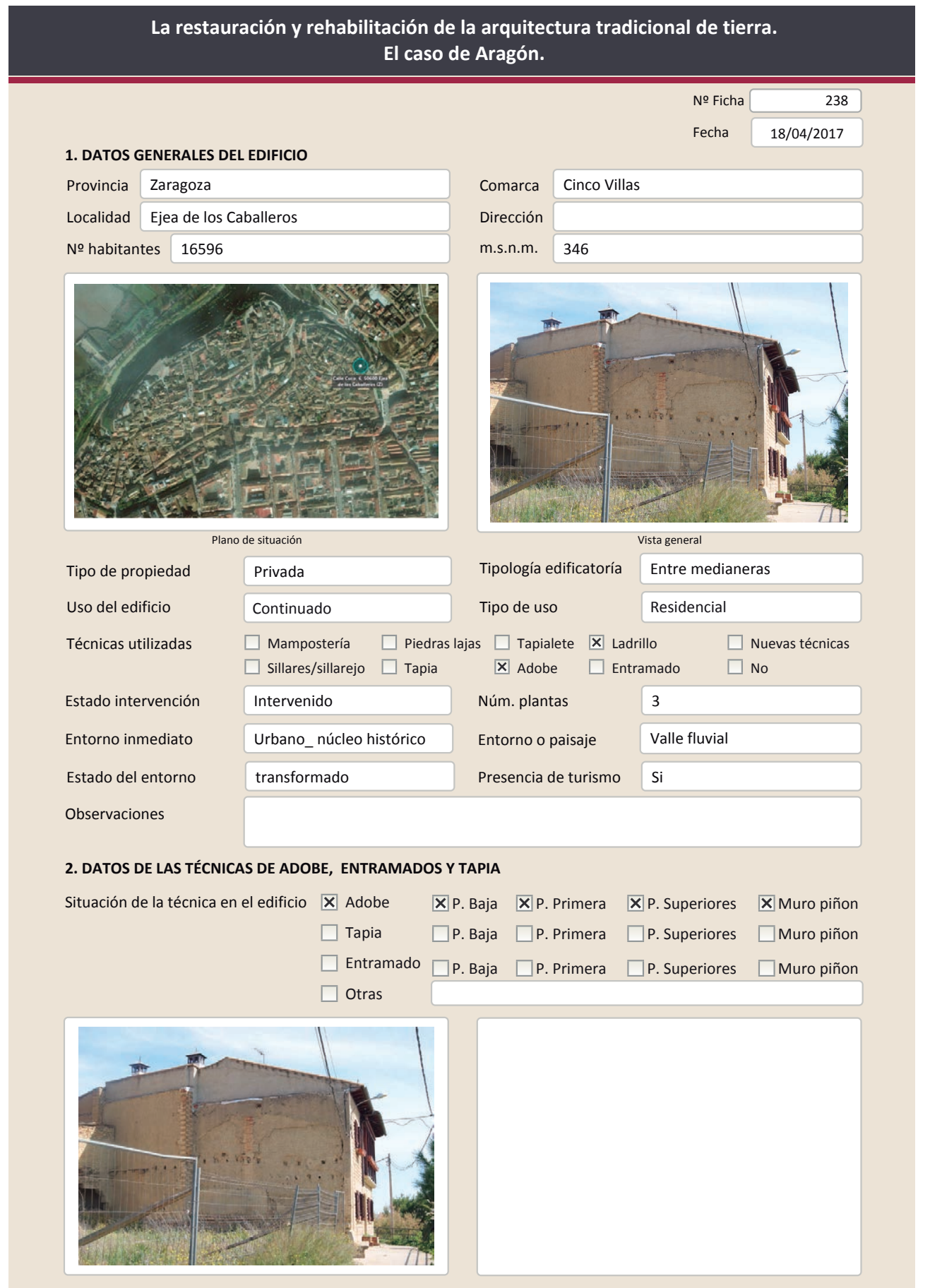

La restauración y rehabilitación de la arquitectura tradicional de tierra.
2.1. ADOBE

Dimensión de las piezas Dimensión del muro

Aparejo del muro

Función estructural

\section{El caso de Aragón.}

Color de las piezas

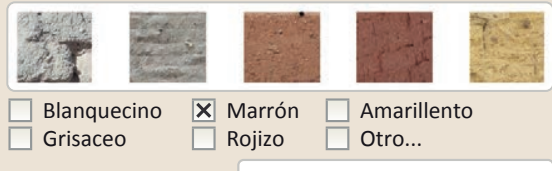

$\square$ Rojizo $\square$ Otro...

Variante constructiva/ tipo de fábrica

$\square$ Simple

$\square$ Suplementada en juntas

区 Mixta

\section{Machones}

Ladrillo

$\square$ Como suplemento

$\square$ Elementos de protección

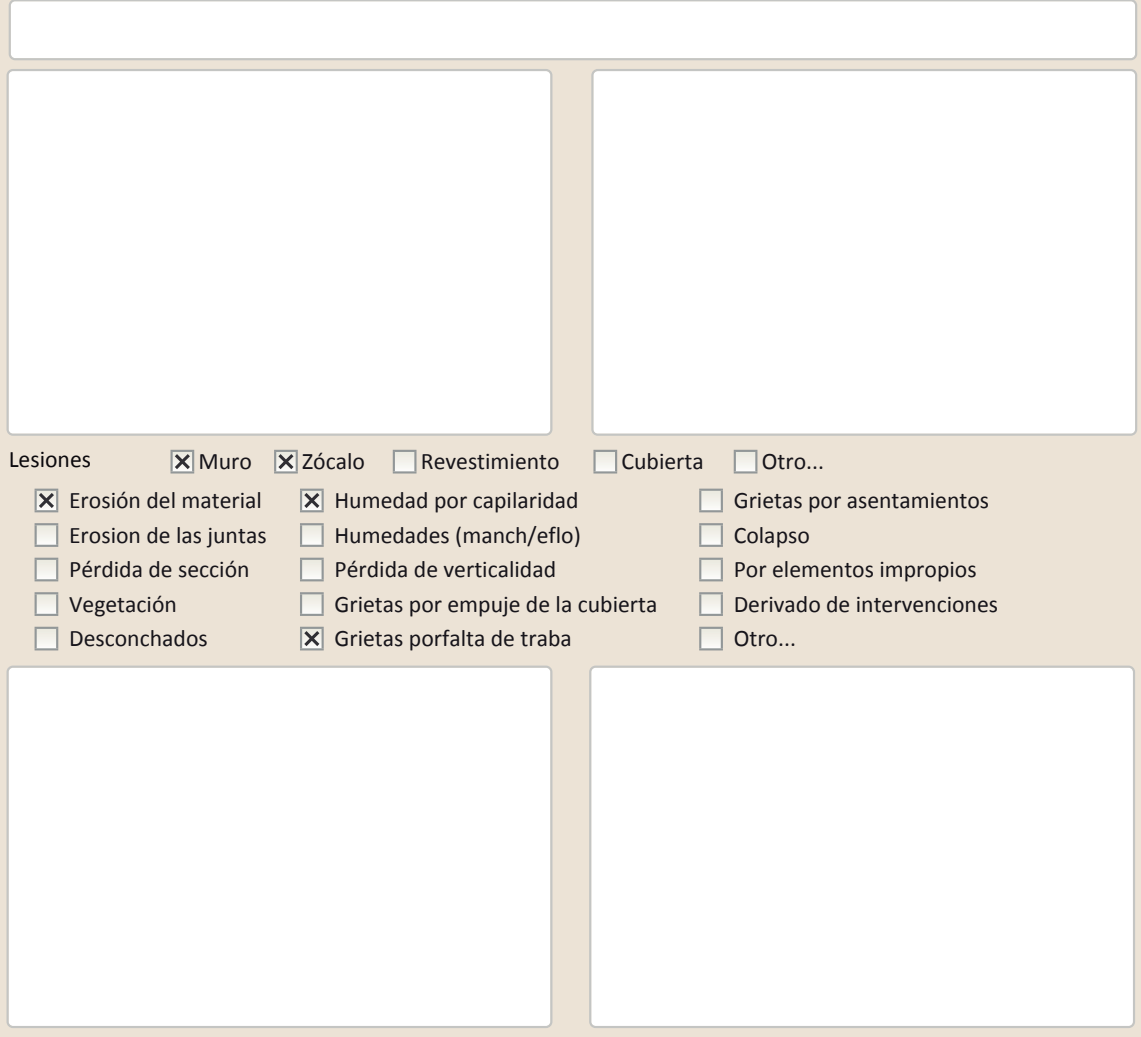

Observaciones 


\section{La restauración y rehabilitación de la arquitectura tradicional de tierra.}

\section{El caso de Aragón.}

3. DATOS DE LA INTERVENCIÓN

Intervención de:

$\square$ Mantenimie

Reflexión previa

$\square$ Reparació

$\square$ Rehabilitación parcial

$\square$ Restauración $\square$ Demolición

Intervención planificada

Observaciones

(2)

3.1. MUROS
Tipo de intervención

Intervenido

Tipo de material

\ Actualización $\square$ Reintegración $\square$ Demolición $\square$ Otro...

$\square$ Consolidación $\quad \mathbb{X}$ Reconstrucción $\quad \boldsymbol{X}$ Sustitución

Descripción

\begin{tabular}{|lr} 
No tradicional Tipo de técnica & Diferente a la existente \\
\hline Recrecido del muro piñón. Sustitución del muro de fachada por muro con piedra
\end{tabular} Recrecido del muro pin
ladrillo al exterior

3.2. ZóCALO
Tipo de intervención

Intervenido

Tipo de material

$\square$ Actualización

lización $\square$ Reintegración $\quad \square$ Demolición $\square$ otro...

$\square$ Consolidación $\mathbb{X}$ Reconstrucción $\square$ Sustitución

Descripción

Tipo de técnica Diferente a la existente

3.3. REVESTIMIENTOS

Tipo de intervención

Tipo de material

Descripción

3.4. VANOS

Tipo de intervención

Tipo de material

Descripción

3.5. CUBIERTA

Tipo de intervención

Tipo de material

Descripción

\section{No aplica}

$\square$ Actualización $\square$ Reintegración $\quad \square$ Demolición $\quad \square$ Otro...

$\square$ Consolidación $\square$ Reconstrucción $\quad \square$ sustitución

$$
\text { Tipo de técnica }
$$

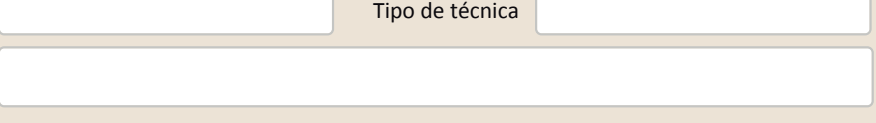

\section{Intervenido}

\ Actualización $\square$ Reintegración $\square$ Demolición $\square$ Otro...

$\square$ Consolidación $\square$ Reconstrucción $\quad \mathbf{X}$ Sustitución

No tradicional Tipo de técnica Diferente a la existente

Todos los huecos de fachada son nuevos

\section{Intervenido}

$\square$ Actualización $\square$ Reintegración $\square$ Demolición $\square$ Otro..

$\square$ Consolidación $\mathbf{x}$ Reconstrucción $\mathbf{x}$ Sustitución
No tradicional
Tipo de técnica Diferente a la existente

3.6. OTRAS

Nueva cubierta sobre el recrecido del muro
La restauración y rehabilitación de la arquitectura tradicional de tierra.

El caso de Aragón.

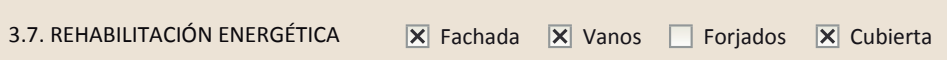

Observaciones

FOTOGRAFíAS DE LA INTERVENCIÓN
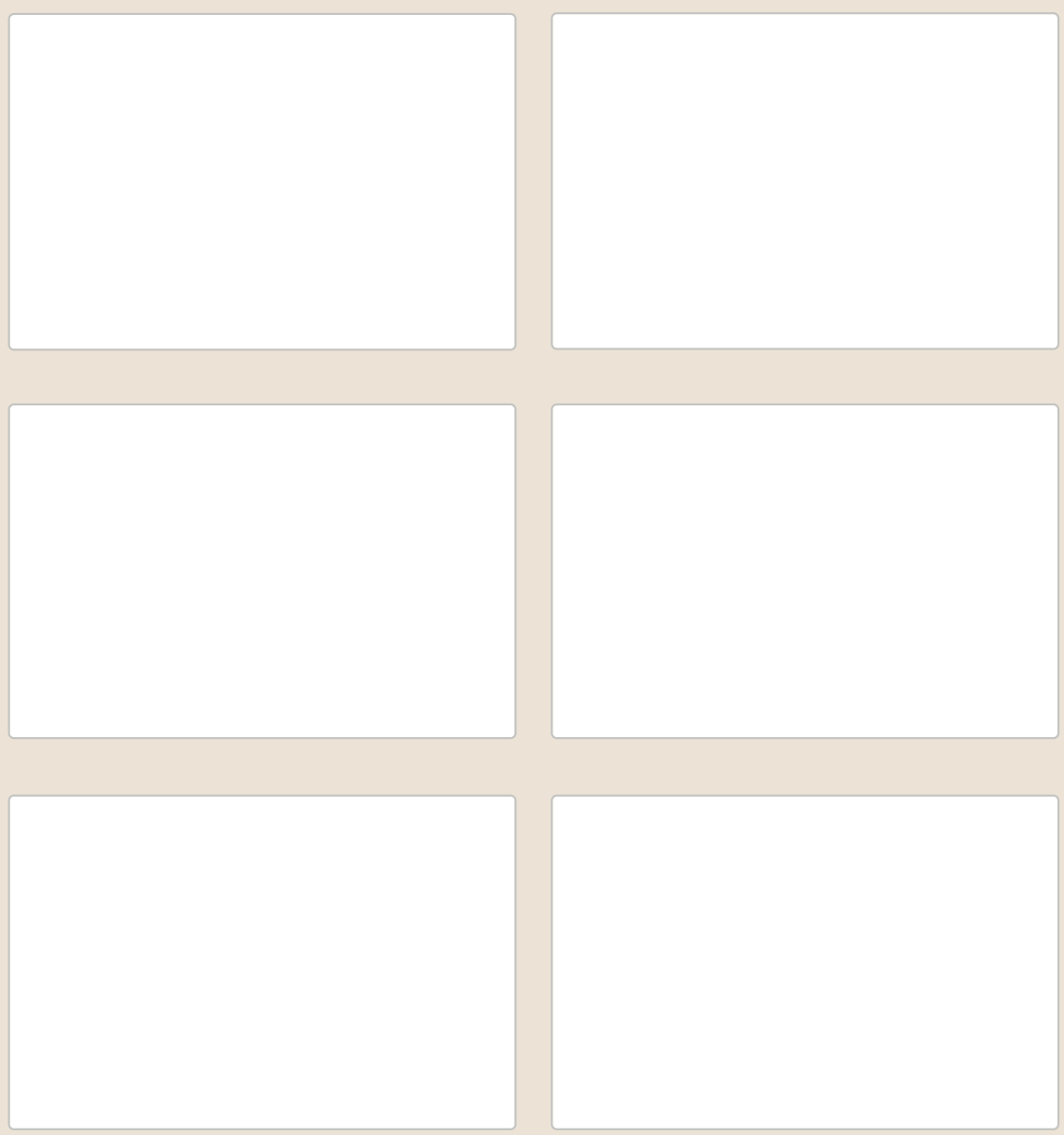


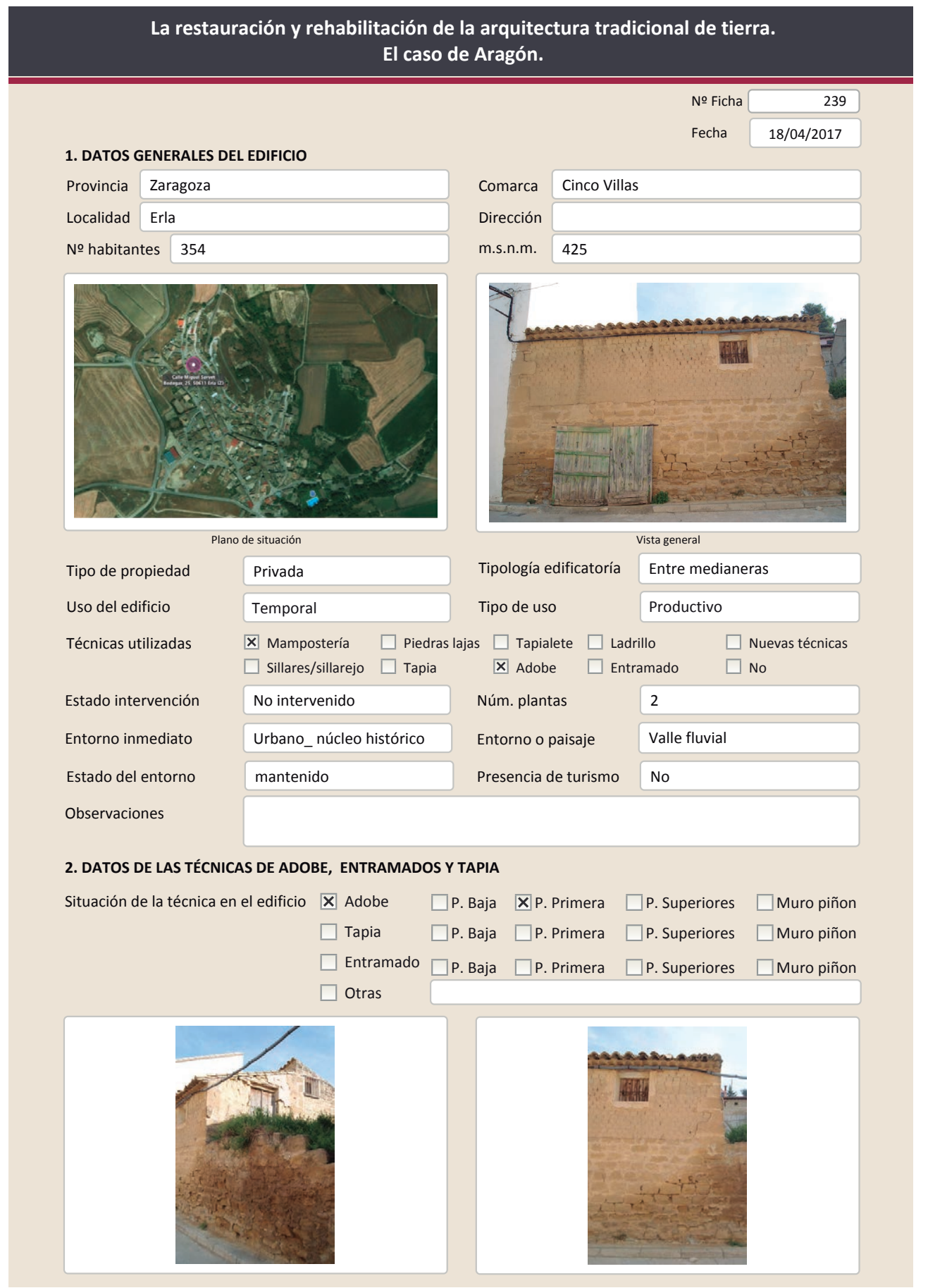

2.1. ADOBE

Dimensión de las piezas Dimensión del muro

Aparejo del muro

Función estructural

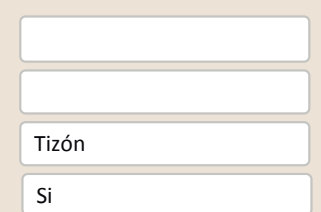

Color de las piezas

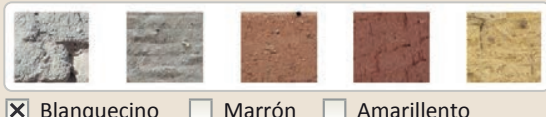

X Blanquecino $\square$ Marrón $\square$ Amarillento $\square$ Grisaceo $\square$ Rojizo $\square$ Otro...

Comp. - estabilizante

Variante constructiva/ tipo de fábrica

$\square$ simple

$\square$ Suplementada en juntas

区 Mixta

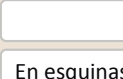

Piedra

$\square$ Como suplemento

$\square$ Elementos de protección

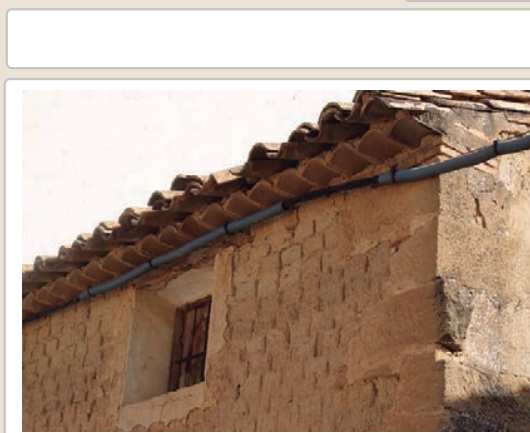

Lesiones $\mathbf{X}$ Muro XZŹcalo $\mathbf{X}$ Revestimiento

$\mathbf{X}$ Erosión del material $\mathbf{X}$ Humedad por capilaridad $\mathbf{X}$ Erosion de las juntas $\mathbf{X}$ Humedades (manch/eflo)

\ Pérdida de sección $\quad \square$ Pérdida de verticalidad

$\square$ Vegetación $\quad \square$ Grietas por empuje de la c

X Desconchados

$\square$ Grietas porfalta de traba

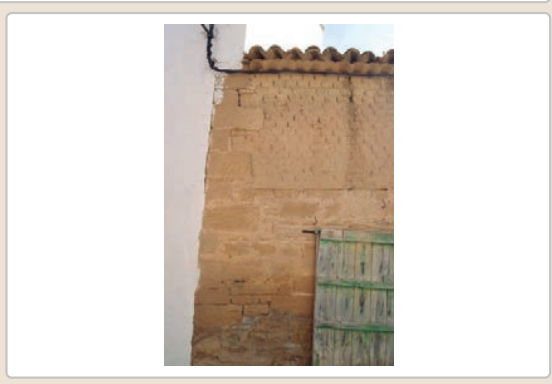

Cubierta $\square$ Otro...

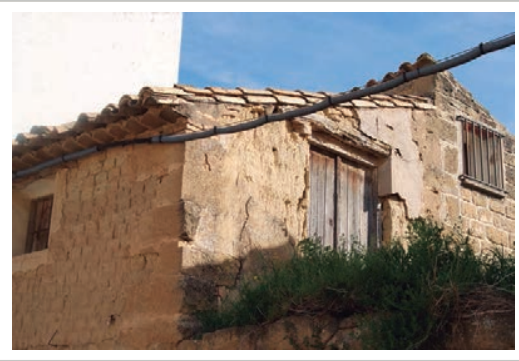

Observacione 


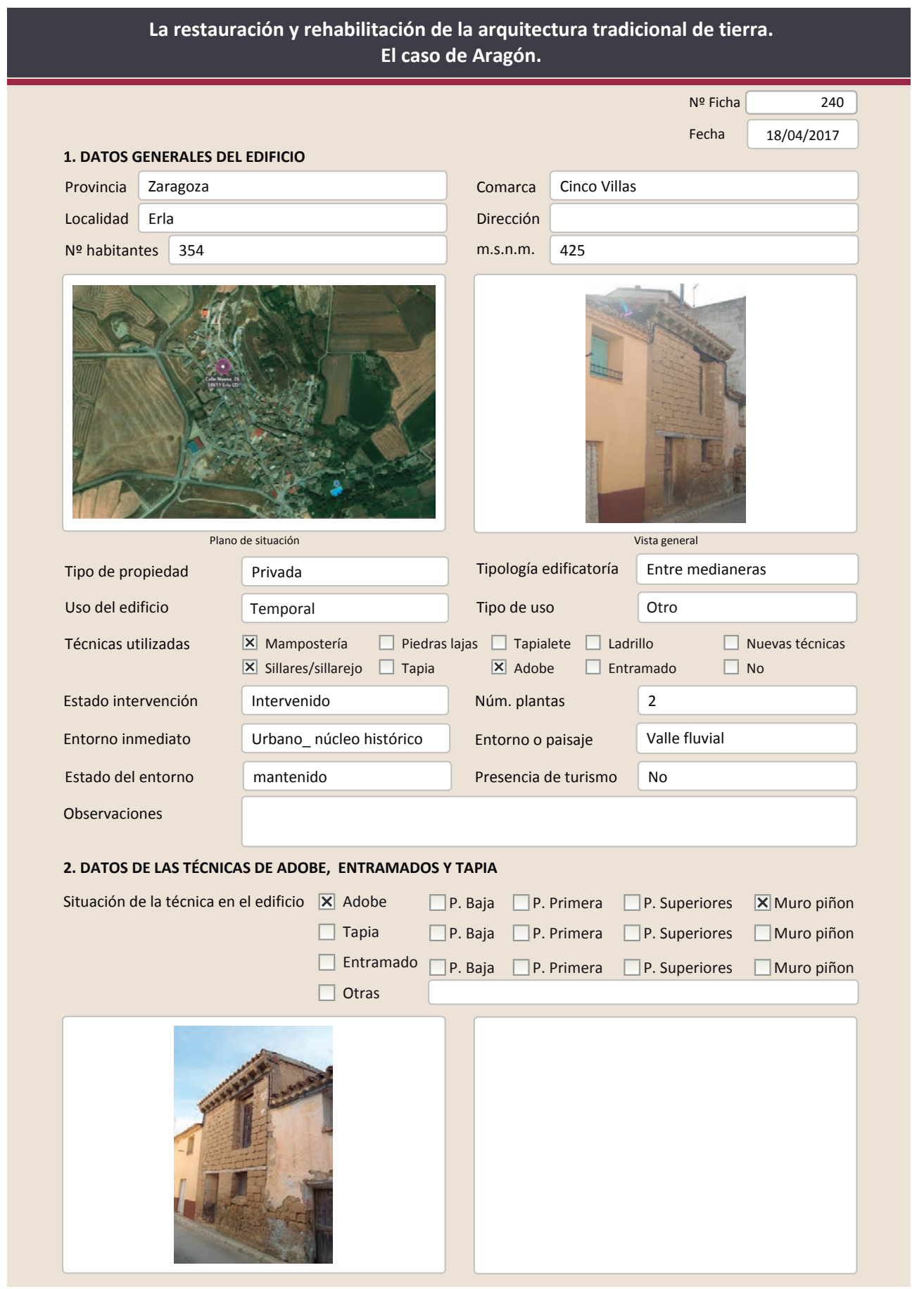

La restauración y rehabilitación de la arquitectura tradicional de tierra.

El caso de Aragón.

\subsection{ADOBE}

Dimensión de las piezas

Dimensión del muro

Aparejo del muro

Función estructural

Función estructu

Variante construc
$\square$ Simple

$\square$ Suplementada en juntas

区 Mixta

En esquinas

$\square$ Como suplemento

$\mathbf{X}$ Elementos de protección

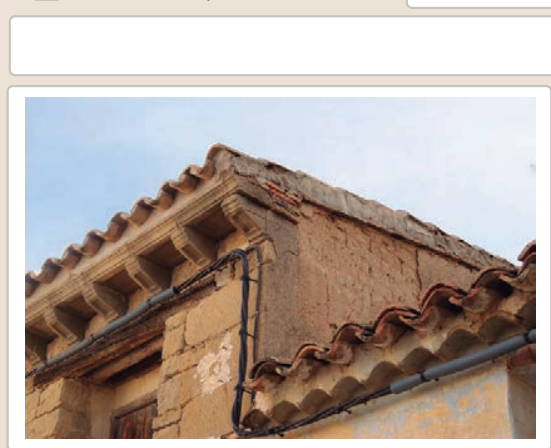

Lesiones $\quad \mathbf{X}$ Muro $\mathbf{X}$ Zócalo $\square$ Revestimiento

$\mathbf{X}$ Erosión del material $\quad \mathbf{X}$ Humedad por capilaridad

$\square$ Erosion de las juntas $\mathbf{X}$ Humedades (manch/eflo)

\ Pérdida de sección $\square$ Pérdida de verticalidad

$\square$ Vegetación $\quad \square$ Grietas por empuje de la cub

$\square$ Desconchados

$\square$ Grietas porfalta de traba
Color de las piezas

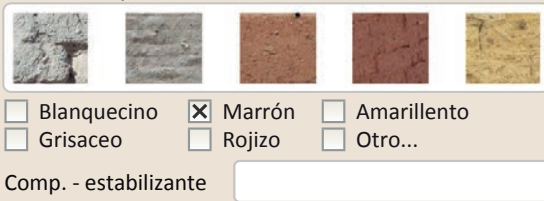

Comp. - estabilizante

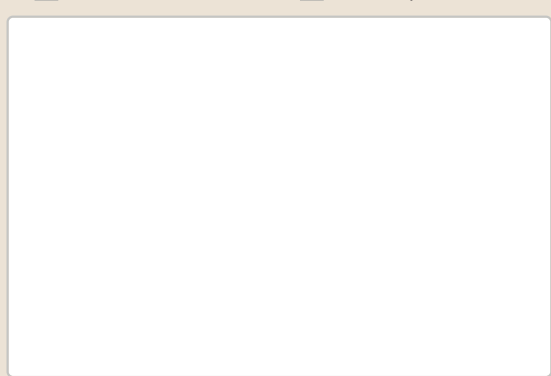

Observaciones 
La restauración y rehabilitación de la arquitectura tradicional de tierra. El caso de Aragón

\section{La restauración y rehabilitación de la arquitectura tradicional de tierra.}

\section{El caso de Aragón.}

3. DATOS DE LA INTERVENCIÓN

Intervención de:

$\square$ Mantenimiento $\square$ Rehabilitación parcia

$\square$ Restauración $\square$ Demolición

Reflexión previa

X Reparación

$\square$ Rehabilitación integra

Ampliación

$\square$ Otro..

Observaciones

Intervención espontanea

3.1. MUROS

No intervenido

Tipo de intervención

$\square$ Actualización

$\square$ Consolidación $\square$ Reconstrucción $\square$ Sustitución

Tipo de material

Descripción

3.2. ZÓCALO

Tipo de intervención

Intervenido

$\square$ Actualización

× Reintegración $\square$ Demolición $\square$ Otro...

Tipo de material

No tradicional

Reintegración $\square$ Demolición

Tipo de técnica

Descripción

Diferente a la existente

3.3. REVESTIMIENTOS

No intervenido

Tipo de intervención

$\square$ Actualización $\square$ Reintegración $\quad \square$ Demolición $\square$ Otro...

Tipo de material

Descripción

3.4. VANOS

$\square$ Consolidación $\square$ Reconstrucción $\square$ Sustitución

Tipo de intervención

No intervenido

Tipo de material

Descripción

3.5. CUBIERTA

Tipo de intervención

$\square$ Actualización $\quad \square$ Reintegración $\quad \square$ Demolición $\square$ Otro.

$\square$ Consolidación $\square$ Reconstrucción $\mathbf{X}$ Sustitución

Tipo de material

No tradicional

Tipo de técnica Diferente a la existente

Descripción

Sustitución de la cubierta. Se ha reconstruido sobre el antigua alero. Se aprecia un cano muy amplio (inserción de aislante o colocación de una capa de hormigón)

3.6. OTRAS 


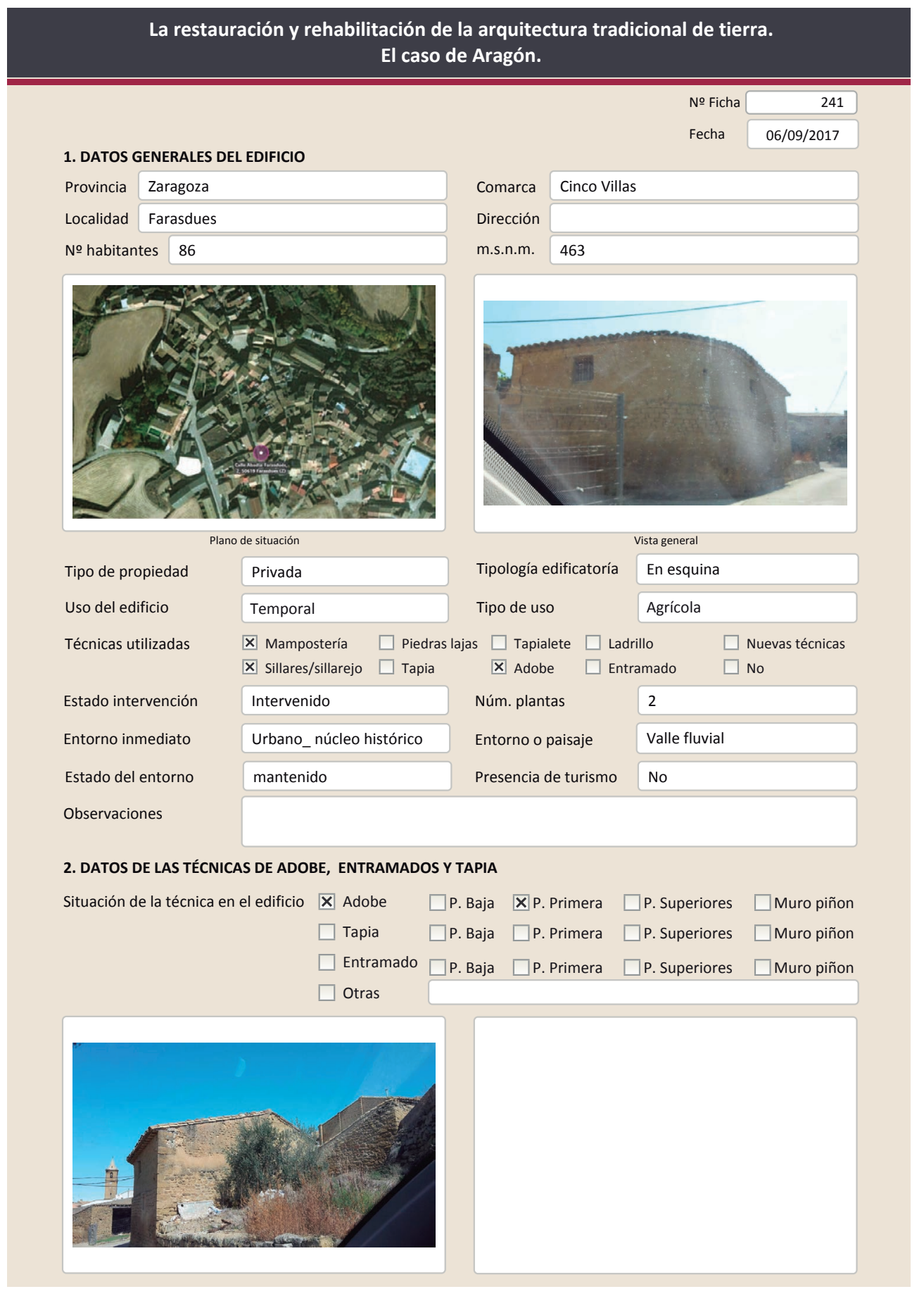

La restauración y rehabilitación de la arquitectura tradicional de tierra.

El caso de Aragón.

\subsection{ADOBE}

Dimensión de las piezas Dimensión del muro

Aparejo del muro

Función estructural

\begin{tabular}{|l|}
\hline \\
\hline $40-50 \mathrm{~cm}$ \\
\hline Tizón \\
\hline $\mathrm{Si}$ \\
\hline
\end{tabular}

Color de las piezas

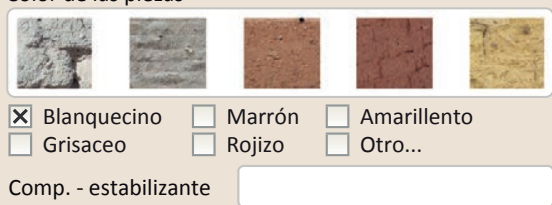

Variante constructiva/ tipo de fábrica

$\square$ Simple

$\square$ Suplementada en juntas

X Mixta

En esquinas

Piedra

$\square$ Como suplemento

$\mathbf{X}$ Elementos de protección

Revestimiento

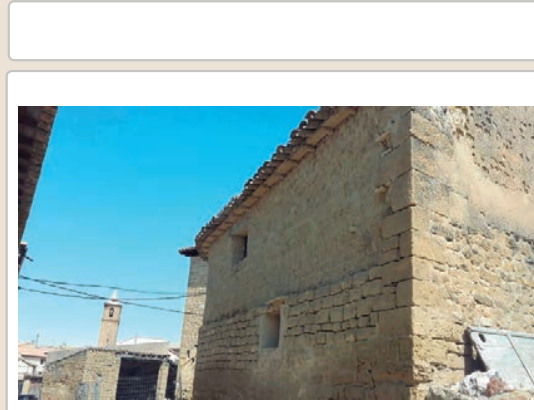

Lesiones

X Muro XZźcalo $\mathbf{X}$ Revestimiento

$\mathbf{X}$ Erosión del material $\mathbf{X}$ Humedad por capilaridad

$\square$ Erosion de las juntas $\mathbf{X}$ Humedades (manch/eflo)

X Pérdida de sección $\square$ Pérdida de verticalidad

$\square$ Vegetación $\quad \square$ Grietas por empuje de la c $\square$ Grietas porfalta de traba

$\square$ Cubierta $\square$ otro...

$\square$ Grietas por asentamiento

$\square$ Colapso

X Desconchado

$\square$ Por elementos impropios

$\square$ Derivado de intervenciones 
La restauración y rehabilitación de la arquitectura tradicional de tierra. El caso de Aragón

\section{La restauración y rehabilitación de la arquitectura tradicional de tierra.}

\section{El caso de Aragón.}

3. DATOS DE LA INTERVENCIÓN

Intervención de:

$\square$ Mantenimiento $\square$ Rehabilitación parcia

$\square$ Restauración $\square$ Demolición

Reflexión previa

X Reparación

$\square$ Rehabilitación integral $\square$ Ampliación

$\square$ Otro..

Reflexión previa

Intervención espontanea

(n)

3.1. MUROS

No intervenido

Tipo de intervención

$\square$ Actualización

$\square$ Consolidación $\square$ Reconstrucción $\square$ Sustitución

Tipo de material

Descripción

3.2. ZÓCALO

Tipo de intervención

Intervenido

$\square$ Actualización

Х Reintegración $\square$ Demolición $\square$ Otro...

Tipo de material

No tradicional

$x$ Reintegración
$\square$ Reconstrucción $\quad \square$ Sustitución

Descripción

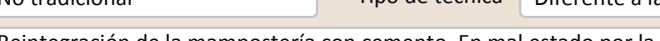

3.3. REVESTIMIENTOS

Intervenido

Tipo de intervención

$\square$ Actualización $\quad \boldsymbol{X}$ Reintegración $\square$ Demolición $\square$ Otro...

Tipo de material

No tradicional Tipo de técnica Diferente a la existente

Descripción

Reintegración de un área faltante de revestimiento en el muro piñón

3.4. VANOS

No intervenido

Tipo de intervención

$\square$ Actualización $\square$ Reintegración $\square$ Demolición $\square$ Otro...

Tipo de material

Descripción

3.5. CUBIERTA

Tipo de intervención

Tipo de material

Descripción

3.6. OTRAS

No intervenido

$\square$ Actualización

$\square$ Consolidación $\quad \square$ Reconstrucción $\quad \square$ Sustitución

Tipo de técnica

Tipo de técnica

rang




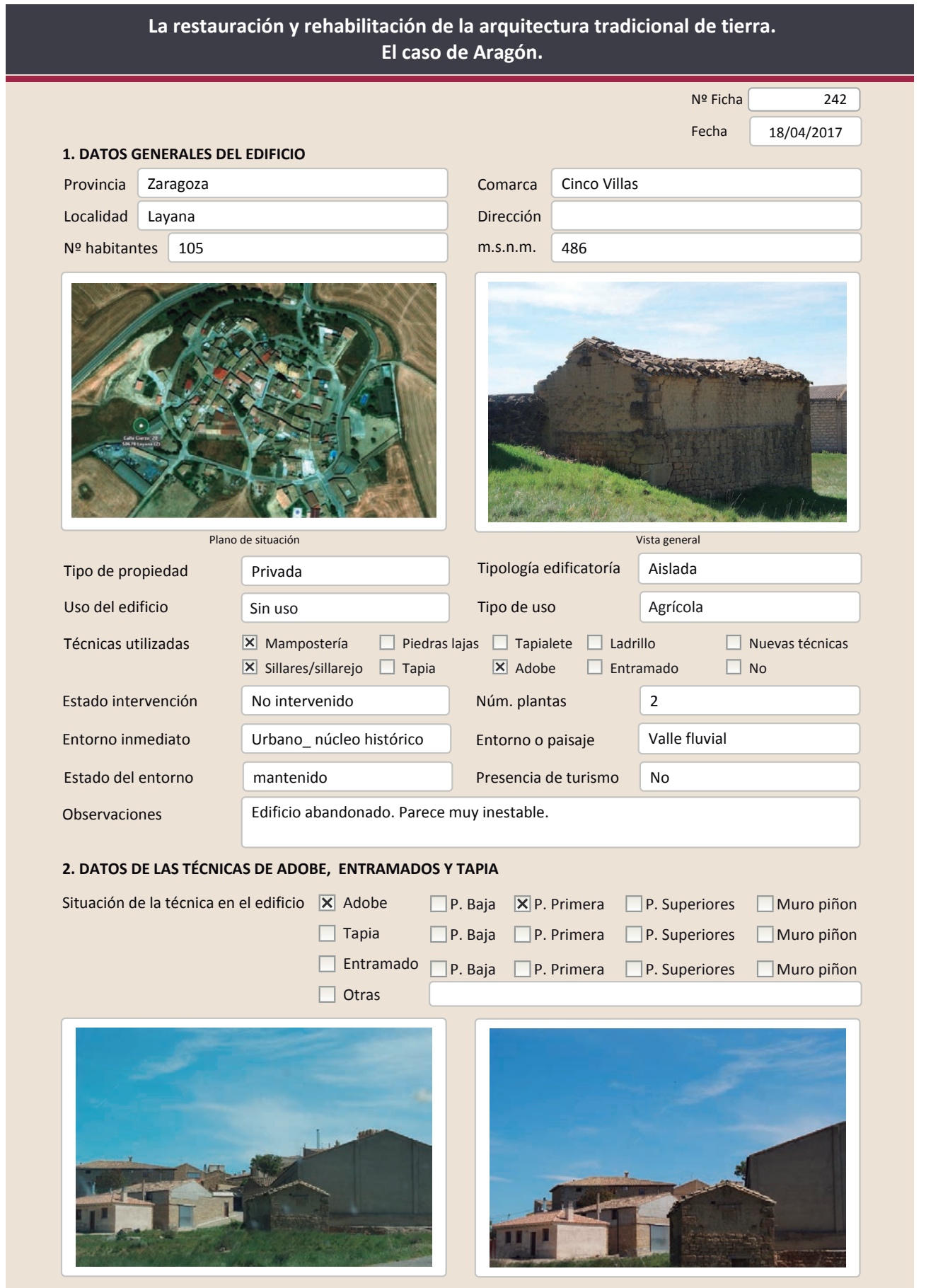

La restauración y rehabilitación de la arquitectura tradicional de tierra.

El caso de Aragón.

2.1. ADOBE

Dimensión de las piezas Dimensión del muro

Aparejo del muro

Función estructural

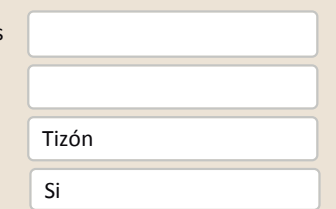

Color de las piezas

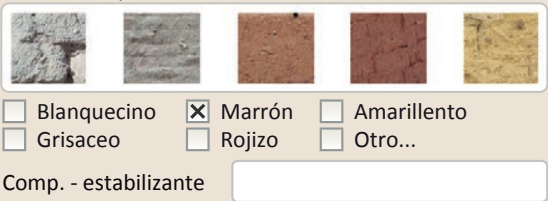

Variante constructiva/ tipo de fábrica

$\square$ simple

$\square$ suplementada en juntas

X Mixta

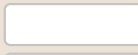

$\square$ Como suplemento

$\square$ Elementos de protección

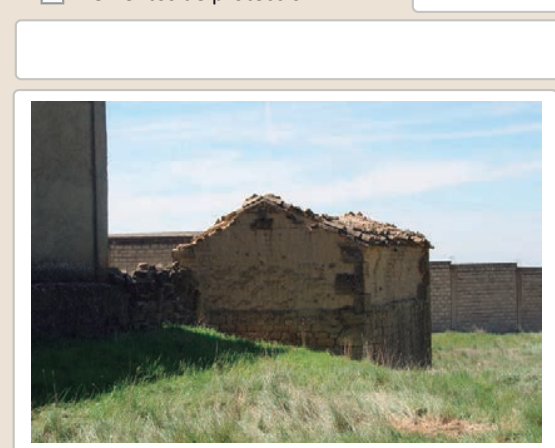

Lesiones \Muro $\square$ Zócalo $\square$ Revestimiento $\square$ Cubierta $\square$ otro...

区 Erosión del material $\quad \square$ Humedad por capilaridad $\quad \square$ Grietas por asentamiento $\mathbf{X}$ Erosion de las juntas $\square$ Humedades (manch/eflo) $\quad \square$ Colapso

$\mathbf{X}$ Pérdida de sección $\mathbf{X}$ Pérdida de verticalidad

$\square$ Vegetación $\quad \square$ Grietas por empuje de la c

$\square$ Por elementos impropios

$\square$ Desconchado

$\square$ Grietas porfalta de traba

$\square$ Derivado de intervenciones
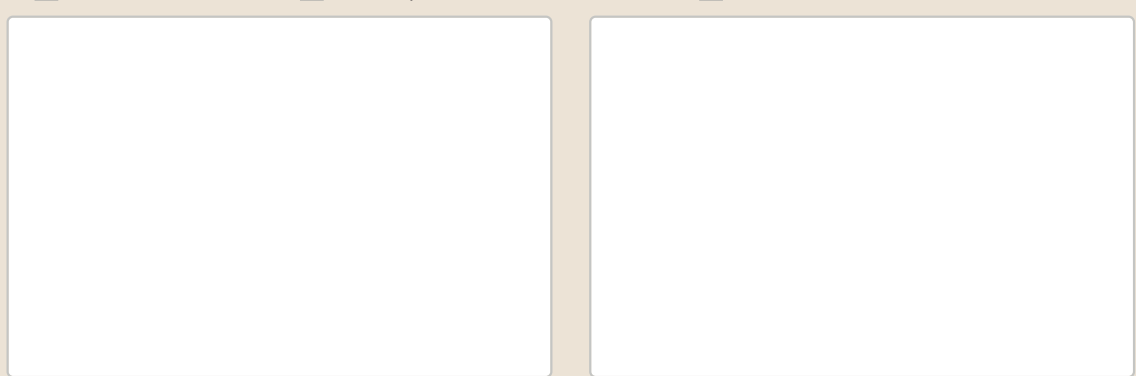

Observacione 
La restauración y rehabilitación de la arquitectura tradicional de tierra. El caso de Aragón

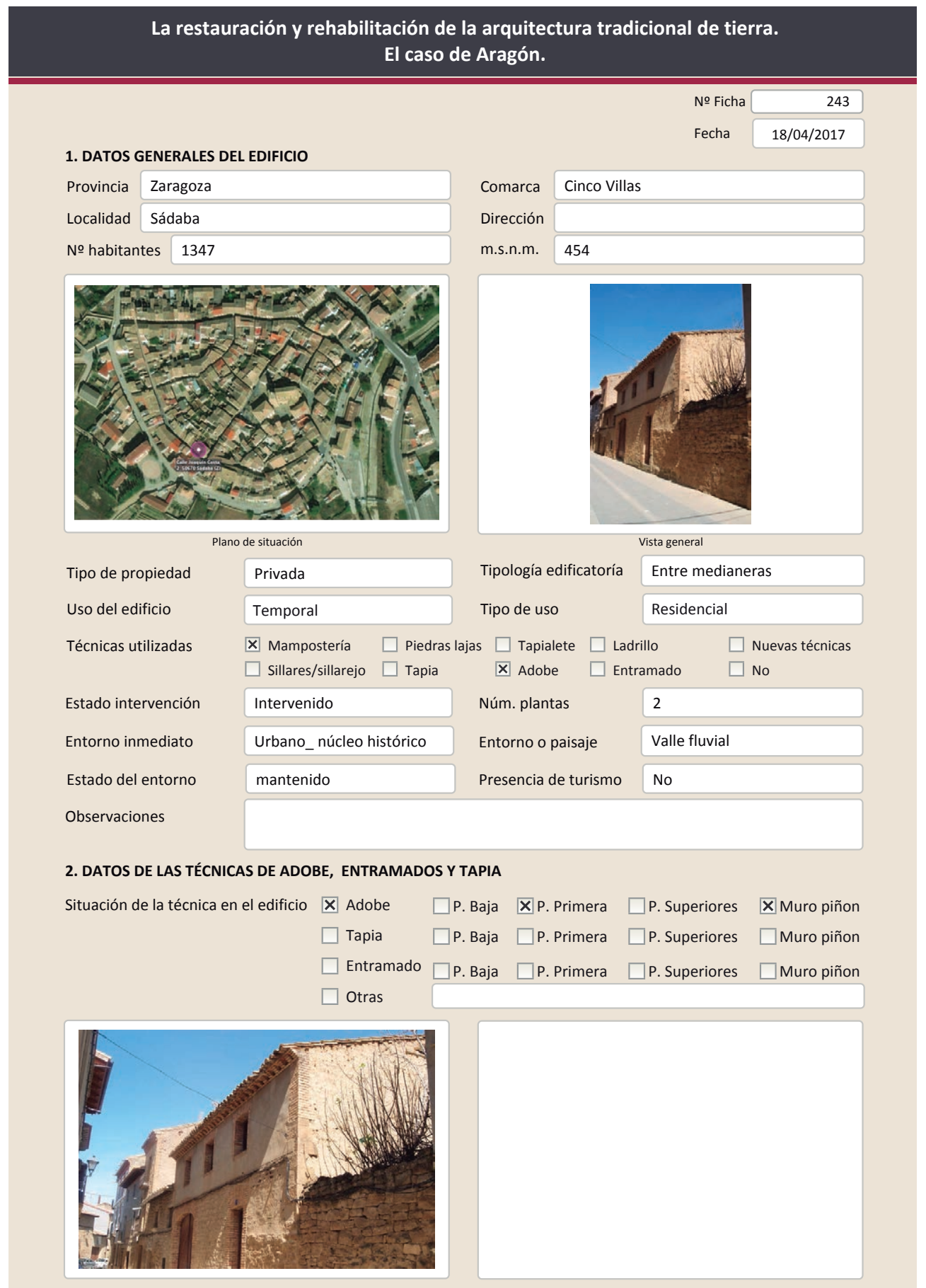

La restauración y rehabilitación de la arquitectura tradicional de tierra.

El caso de Aragón.

2.1. ADOBE

Dimensión de las piezas

Dimensión del muro

Aparejo del muro

Función estructural

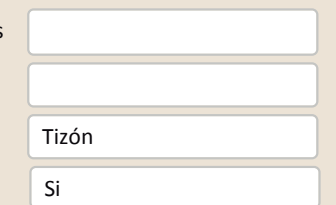

Color de las piezas

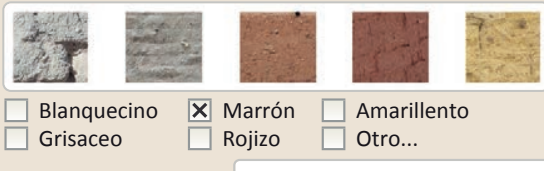

Grisaceo

Variante constructiva/ tipo de fábrica

$\square$ simple

$\square$ Suplementada en juntas

区 Mixta

En esquinas

Piedra

$\square$ Como suplemento

$\square$ Elementos de protección

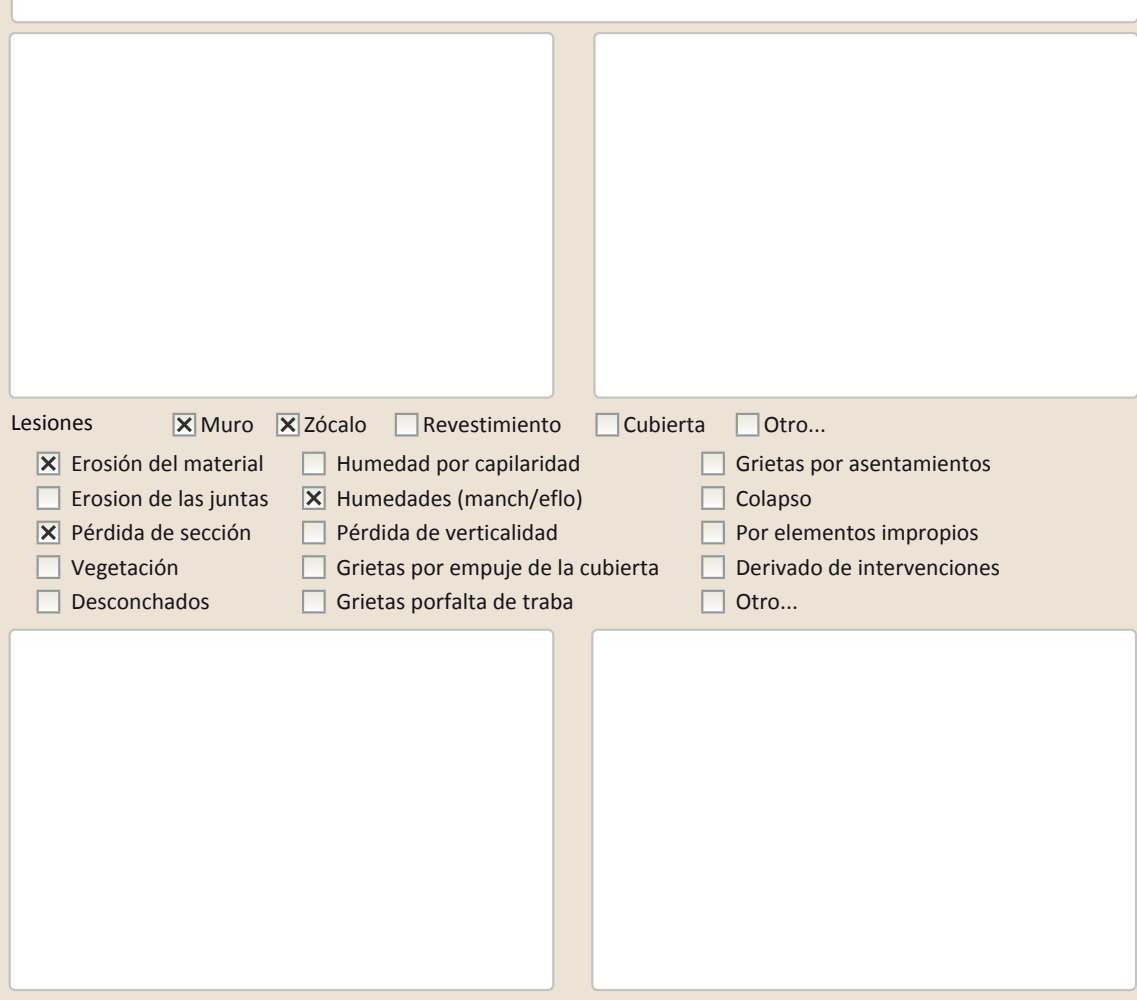

Observaciones 


\section{La restauración y rehabilitación de la arquitectura tradicional de tierra.}

\section{El caso de Aragón.}

\section{DATOS DE LA INTERVENCIÓN}

Intervención de:

$\square$ Mantenimiento $\mathbf{X}$ Rehabilitación parcial

$\square$ Restauración $\square$ Demolición

Reflexión previa

$\square$ Reparación

Rehabilitación integra

Ampliación

$\square$ Otro...

Observaciones

Intervención planificada

(2)

3.1. MUROS

No intervenido

Tipo de intervención

$\square$ Actualización

$\square$ Consolidación $\square$ Reconstrucción $\square$ Sustitución

Tipo de material

Descripción

3.2. ZÓCALO

Tipo de intervención

Intervenido

$\square$ Actualización

X Reintegración $\square$ Demolición $\square$ Otro...

Tipo de material

No tradicional

$\square$ Reconstrucción $\square$ Sustitución

Descripción

Reintegración de la mampostería del zócalo con junta ancha de cemento. Toda la plana baja es mamposería

3.3. REVESTIMIENTOS

Intervenido

Tipo de intervención

$\square$ Actualización $\square$ Reintegración $\square$ Demolición $\square$ Otro...

$\square$ Consolidación $\quad \mathbf{X}$ Reconstrucción $\square$ Sustitución

Tipo de material

Descripción

No tradicional Tipo de técnica Diferente a la existente

Revestimiento de cemento en toda la fachada principal sobre el muro de adobe

3.4. VANOS

Intervenido

Tipo de intervención $\square$ Actualización $\quad \boldsymbol{X}$ Reintegración $\square$ Demolición $\square$ Otro...

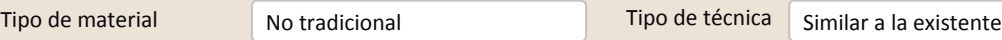

Descripción

3.5. CUBIERTA

Tipo de intervención

Intervenido

Tipo de material

$\square$ Actualización $\quad$ Xeintegración $\square$ Demolición $\square$ Otro.

$\square$ Consolidación $\square$ Reconstrucción $\square$ Sustitución

\begin{tabular}{|l|l|l|l|l} 
No tradicional & Tipo de técnica Similar a la existente
\end{tabular}

Descripción

Reintegración del alero colocando las tejas con mortero de cemento

3.6. OTRAS 


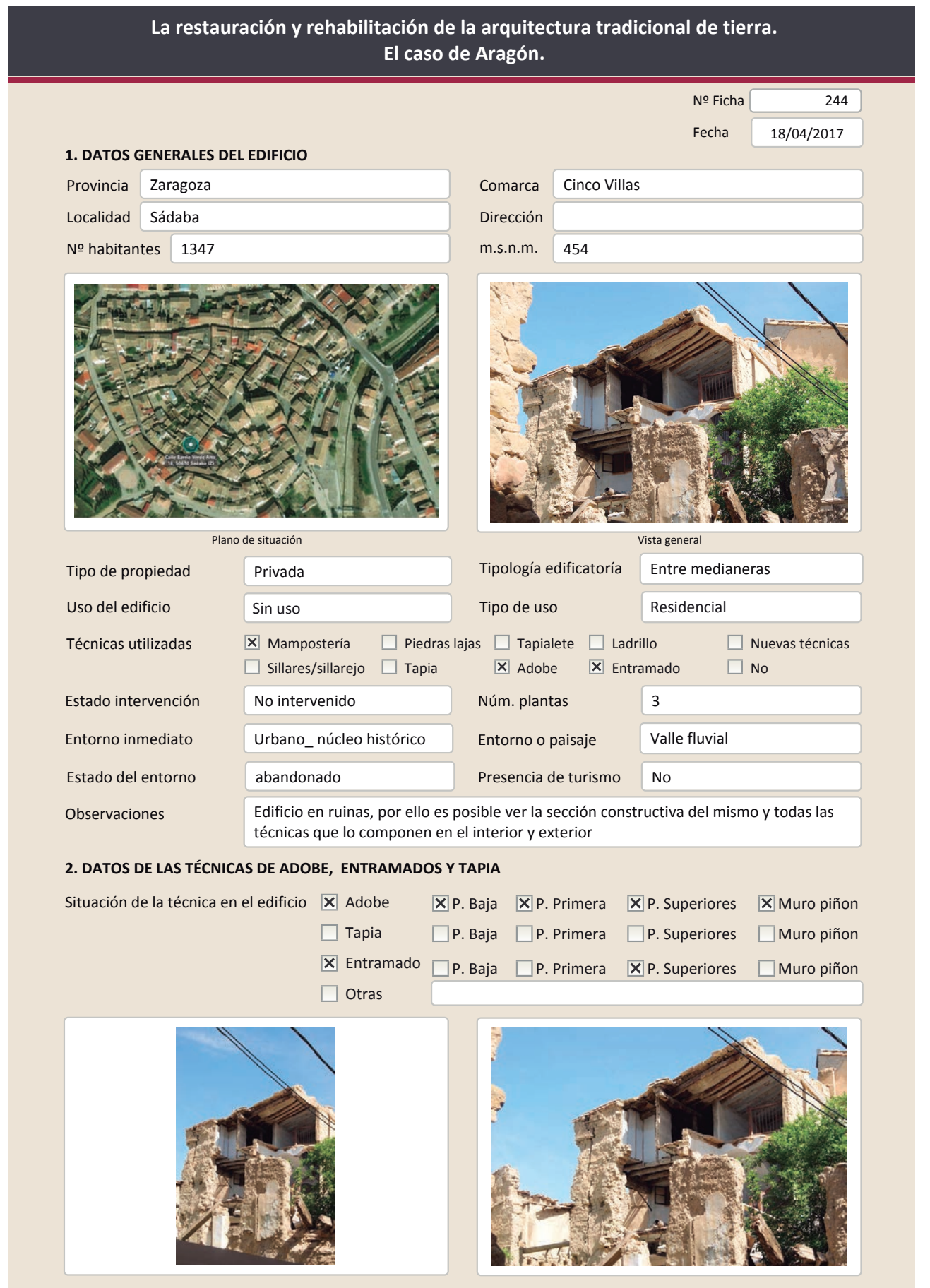

2.1. ADOBE

Dimensión de las piezas Dimensión del muro

Aparejo del muro

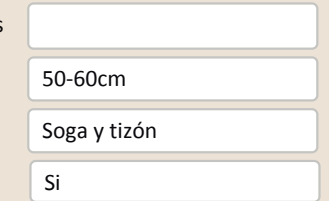

Color de las piezas

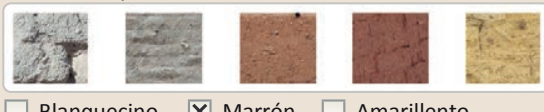

$\square$ Blanquecino $\mathbf{X}$ Marrón $\square$ Amarillento

Función estructural

$\mathrm{Si}$

Variante constructiva/ tipo de fábrica

X Simple

$\square$ Suplementada en juntas

$\square$ Mixta

$\square$ Como suplemento

$\square$ Elementos de protección

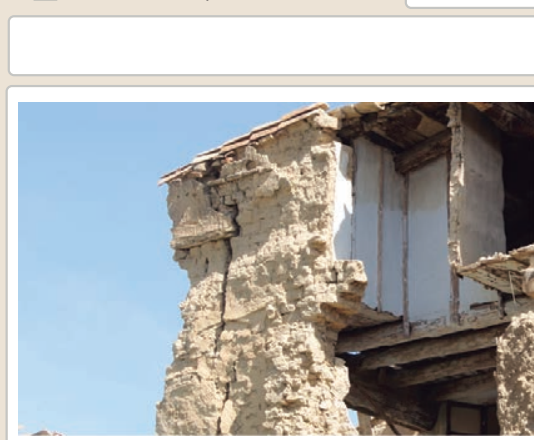

Lesiones $\quad \mathbf{X}$ Muro $\square$ Zócalo $\square$ Revestimiento $\mathbf{X}$ Cubierta $\square$ Otro...

X Erosión del material $\quad \square$ Humedad por capilaridad $\quad \square$ Grietas por asentamiento Х Erosion de las juntas $\square$ Humedades (manch/eflo) $\quad$ X Colapso

X Pérdida de sección $\quad \mathbf{X}$ Pérdida de verticalidad $\square$ Por elementos impropios

$\square$ Vegetación $\quad \square$ Grietas por empuje de la cubierta $\quad \square$ Derivado de intervenciones

$\square$ Desconchados $\square$ Grietas porfalta de traba $\quad \square$ Otro... 
La restauración y rehabilitación de la arquitectura tradicional de tierra.

\section{El caso de Aragón.}

2.3. ENTRAMADOS

\begin{tabular}{llll|} 
Distancia entre montantes & $60-80 \mathrm{~cm}$ & Elementos diagonales & No \\
\hline Altura de los montantes & $200-250 \mathrm{~cm}$ & Elementos horizontales intermedios & No \\
\hline Sección de los montantes & Rollizos & Sección de las piezas horizontales & Rollizos \\
\hline $\begin{array}{lll}\text { Dimensión de los montantes } \\
\text { Tipo de relleno del entramado }\end{array}$ & $10-20 \mathrm{~cm}$ & Dimensión de las piezas horizontales & $20-30 \mathrm{~cm}$ \\
\hline
\end{tabular}

Tipo de relleno del entramado

$\square$ Monolítico $\quad \mathbf{X}$ Piezas/fábrica $\square$ Tejido

Técnica de relleno del entramado

$\begin{array}{ll}\square \text { Entre pantallas de madera } & \square \text { Pared de mano } \quad \square \text { Cañizo } \\ \square \text { Tierra y mampuestos } \quad \mathbf{X} \text { Adobe horizontal } \quad \square \text { Encestados }\end{array}$

$\square$ Tapialete $\quad \square$ Adobe aletorio $\square$ Otro...

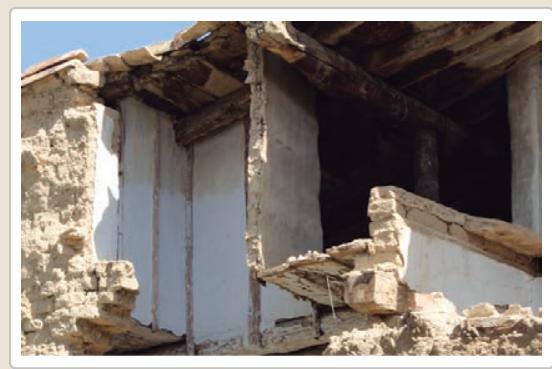

Lesion

XMuro $\square$ Zócalo $\square$ Revestimiento $\square$ Cubierta $\square$ Otro..
$\mathbf{X}$ Erosión del material
$\square$ Carcoma o termitas
$\square$ Grietas por falta de traba
$\square$ Grietas por asentamientos
$\square$ Erosion de las juntas
$\square$ Carcoma o termitas
$\square$ Rotura de la madera
$\square$ Pérdida de sección
$\square$ Pudrición de la madera
$\mathbf{X}$ Colapso
$\square$ Desconchados
$\square$ Deformación madera
$\square$ Por elementos impropios
$\square$ Humedad por capilaridad
$\square$ Pérdida de verticalidad
$\square$ Derivado de intervenciones
$\square$ Humedades (manch/eflor)
$\square$ Grietas por empuje de la cubierta
$\square$ Otro...
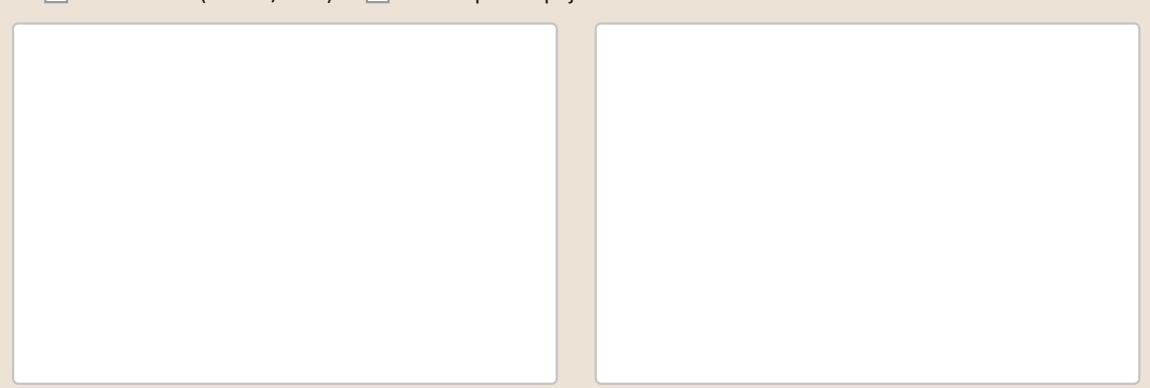

Observaciones 


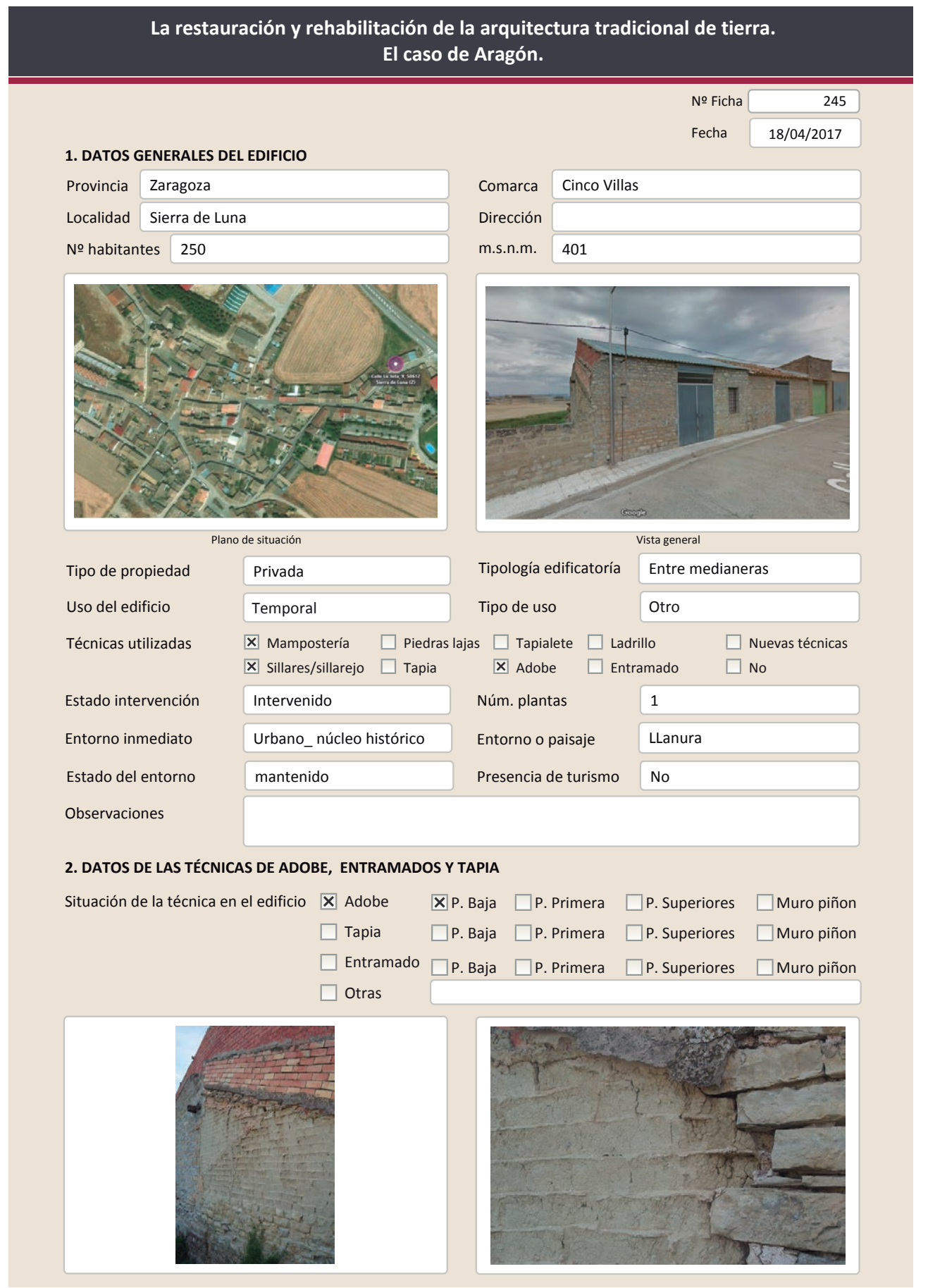

2.1. ADOBE

Dimensión de las piezas Dimensión del muro

Aparejo del muro
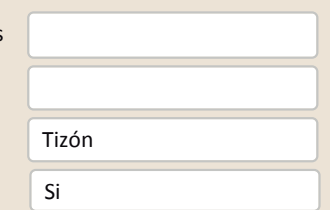

Color de las piezas

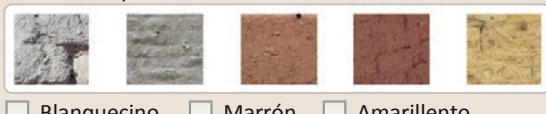

$\square$ Blanquecino $\square$ Marrón $\square$ Amarillento X Grisaceo $\square$ Rojizo $\square$ Otro..

Función estructural

Comp. - estabilizante Fibras vegetales

Variante constructiva/ tipo de fábrica

$\square$ Simple
X Suplementada en juntas
Horizontales
$\square$ Mixta
$\square$ Como suplemento
$\square$ Elementos de protección

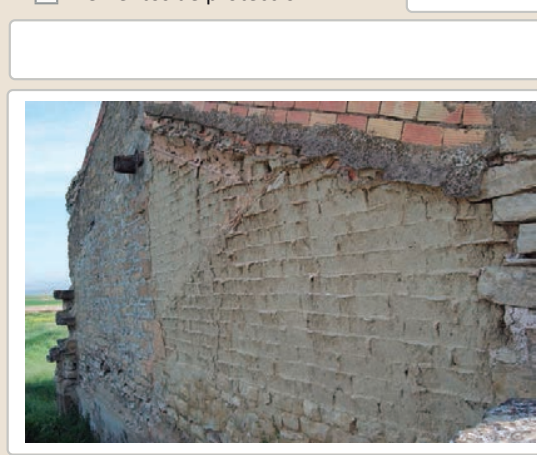

Lesiones $\quad \mathbf{M}$ Muro $\square$ Zócalo $\square$ Revestimiento

X Erosión del material $\square$ Humedad por capilaridad

$\square$ Erosion de las juntas $\square$ Humedades (manch/eflo)

X Pérdida de sección $\square$ Pérdida de verticalidad

$\square$ Vegetación

$\square$ Grietas por empuje de

$\square$ Desconchados

$\square$ Grietas porfalta de traba

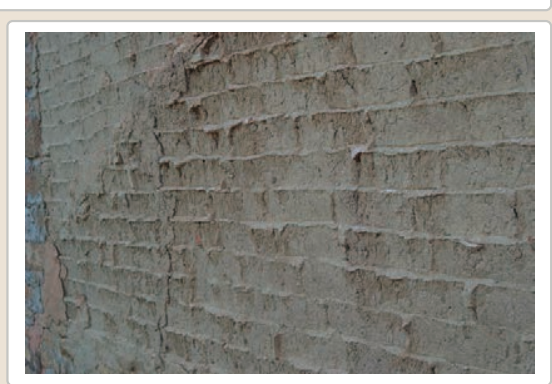

$\square$ Cubierta $\square$ Otro...
$\square$ Grietas por asentamientos
$\square$ Colapso
$\square$ Por elementos impropios

(1)

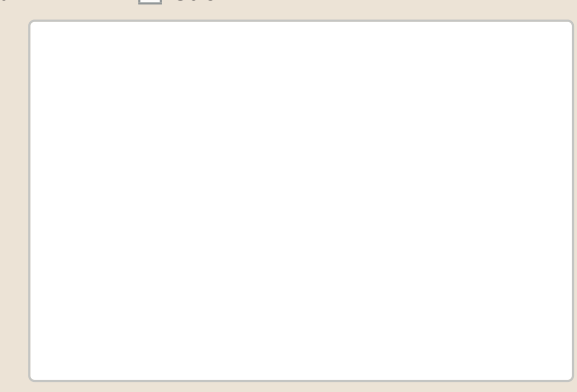

Observaciones 


\section{La restauración y rehabilitación de la arquitectura tradicional de tierra.}

\section{El caso de Aragón.}

\section{DATOS DE LA INTERVENCIÓN}

\begin{tabular}{llll|} 
Intervención de: & $\square$ Mantenimiento $\quad \boldsymbol{X}$ Rehabilitación parcial & $\square$ Restauración & $\square$ Demolición \\
& $\square$ Reparación $\quad \square$ Rehabilitación integral & $\square$ Ampliación $\quad \square$ Otro... \\
Reflexión previa & Intervención espontanea & \\
Observaciones &
\end{tabular}

\subsection{MUROS}

Tipo de intervención

Intervenido

Tipo de material

$\square$ Actualización $\quad \mathbf{X}$ Reintegración $\square$ Demolición $\square$ Otro...

$\square$ Consolidación $\quad \mathbf{X}$ Reconstrucción $\quad \square$ sustitución

Descripción

No tradicional Tipo de técnica Diferente a la existente

Descripción Rejuntado
hueco

\subsection{ZÓCALO}

Tipo de intervención

Intervenido

Tipo de material

$\square$ Actualizació

ón $\square$ Reintegración $\square$ Demolición $\square$ Otro...

Descripción

No tradicional

Encofrado de hormigón sobre el zócalo

3.3. REVESTIMIENTOS

\section{No aplica}

Tipo de intervención

$\square$ Actualización

Tipo de material

$\square$ Consolidación

$\square$ Reintegración $\square$ Demolición $\square$ Otro...

Descripción

3.4. VANOS

Intervenido

Tipo de intervención

$\square$ Actualización $\square$ Reintegración $\square$ Demolición $\square$ Otro...

Tipo de material

$\square$ Consolidación $\mathbf{X}$ Reconstrucción $\mathbf{X}$ Sustitución

Descripción

No tradicional

Tipo de técnica Diferente a la existente

3.5. CUBIERTA

Tipo de intervención

Nuevo hueco de acceso de mayores dimensiones. Carpintería sustituida

Tipo de material

Intervenido

$\square$ Actualización $\square$ Reintegración $\quad \square$ Demolición $\quad \square$ Otro...

$\square$ Actualización $\square$ Reintegración $\square$ Demolición

Descripción
No tradicional
Tipo de técnica Diferente a la existente

Nueva cubierta sobre el recrecido del muro

3.6. OTRAS 


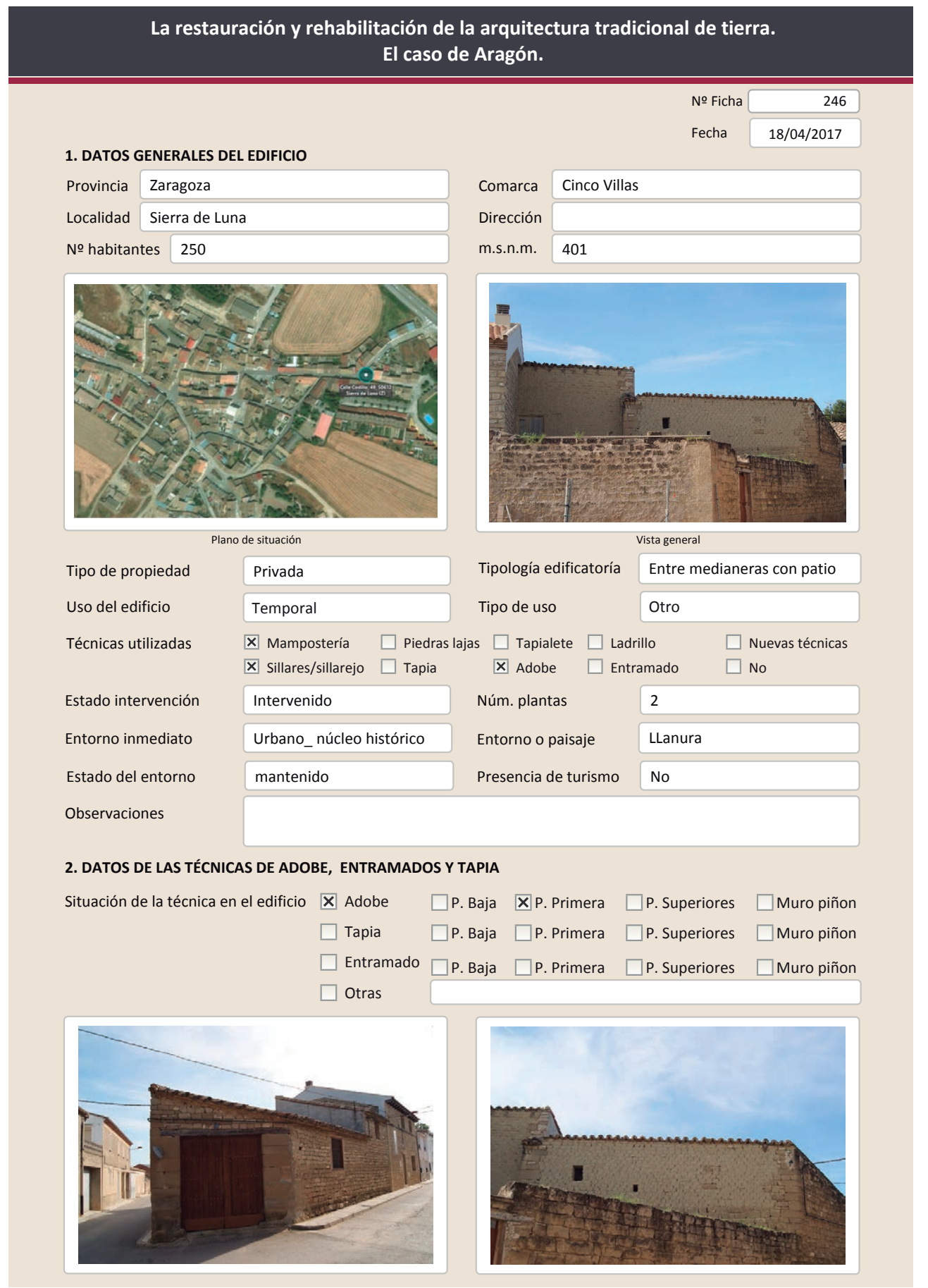

2.1. ADOBE

Dimensión de las piezas

Dimensión del muro

Aparejo del muro
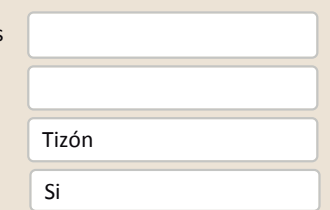

Color de las piezas

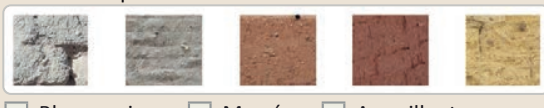

$\square$ Blanquecino $\square$ Marrón $\square$ Amarillento X Grisaceo $\square$ Rojizo $\square$ Otro..

Función estructural

Comp. - estabilizante Fibras vegetales

Variante constructiva/ tipo de fábrica

$\square$ Simple

区 Mixta

Horizontales

$\mathrm{Cal} /$ yeso

$\square$ Como suplemento

$\square$ Elementos de protección Uno de los muros es a soga y el otro a tizón

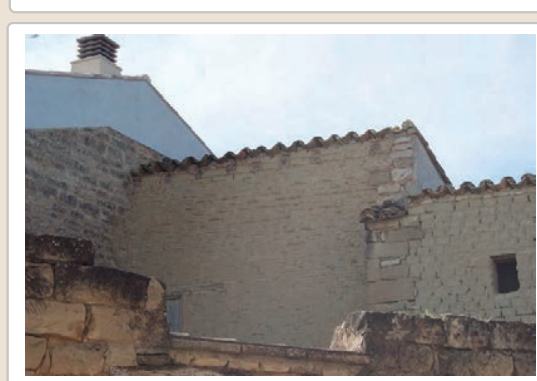

Lesiones $\quad \mathbf{X}$ Muro $\mathbf{X}$ Zócalo $\square$ Revestimiento

$\mathbf{X}$ Erosión del material $\mathbf{X}$ Humedad por capilaridad $\square$ Erosion de las juntas $\square$ Humedades (manch/eflo)

$\square$ Pérdida de sección $\square$ Pérdida de verticalidad

$\square$ Vegetación

$\square$ Desconchados

$\square$ Grietas por empuje de la
$\square$ Grietas porfalta de traba

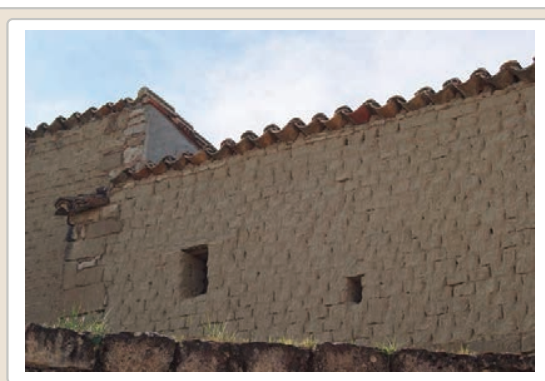

$\square$ Cubierta $\square$ otro...

$\square$ Grietas por asentamientos

$\square$ Colapso

$\square$ Por elementos impropios

$\square$ Derivado de intervenciones

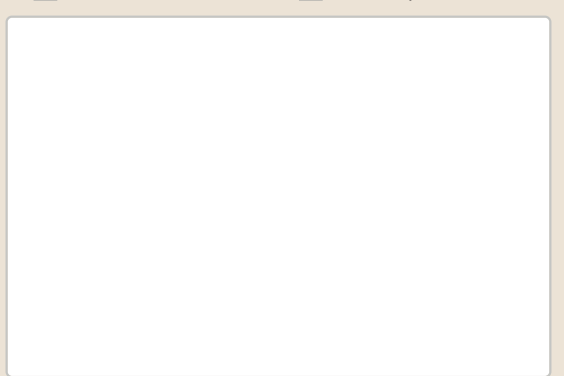


La restauración y rehabilitación de la arquitectura tradicional de tierra.

El caso de Aragón.

3. DATOS DE LA INTERVENCIÓN

\begin{tabular}{llll|} 
Intervención de: & $\square$ Mantenimiento $\quad \square$ Rehabilitación parcial & $\square$ Restauración $\quad \square$ Demolición \\
Reflexión previa & $\mathbf{X}$ Reparación $\quad \square$ Rehabilitación integral $\quad \square$ Ampliación $\quad \square$ Otro... \\
\hline Observaciones & Intervención espontanea & \\
& & \\
& & \\
\end{tabular}

\subsection{MUROS}

Tipo de intervención

Tipo de material

$\square$ Actualización $\quad \mathbf{X}$ Reintegración $\square$ Demolición $\square$ Otro...

$\square$ Consolidación $\square$ Reconstrucción $\square$ Sustitución

Descripción

No tradicional Tipo de técnica Diferente a la existente

3.2. ZÓCALO

Rejuntado de los muros de mampostería

Tipo de intervención

Intervenido

Tipo de intervención

$\square$ Actualización $\square$ Reintegración $\square$ Demolición $\square$ Otro...

$\square$ Consolidación $\quad \mathbf{X}$ Reconstrucción $\square$ sustitución

Descripción

3.3. REVESTIMIENTOS

Revestimiento de cemento

Tipo de intervención

\section{Intervenido}

$\square$ Actualización $\square$ Reintegración $\quad \square$ Demolición $\square$ Otro...

Tipo de material

$\square$ Consolidación $\quad \mathbf{x}$ Reconstrucción $\square$ Sustitución

Descripción

Revestimiento de cemento en uno de los muros piñón del edificio

3.4. VANOS

No intervenido

Tipo de intervención

$\square$ Actualización $\square$ Reintegración $\square$ Demolición $\square$ Otro...

Tipo de material

Descripción

$\square$ Consolidación $\square$ Reconstrucción $\square$ Sustitución

3.5. CUBIERTA

Tipo de intervención

No intervenido

$\square$ Actualización $\square$ Reintegración $\square$ Demolición $\quad \square$ Otro..

Tipo de material

$\square$ Reconstrucción $\square$ Sustitución

Descripción

$$
\text { Tipo de técnica }
$$

3.6. OTRAS 


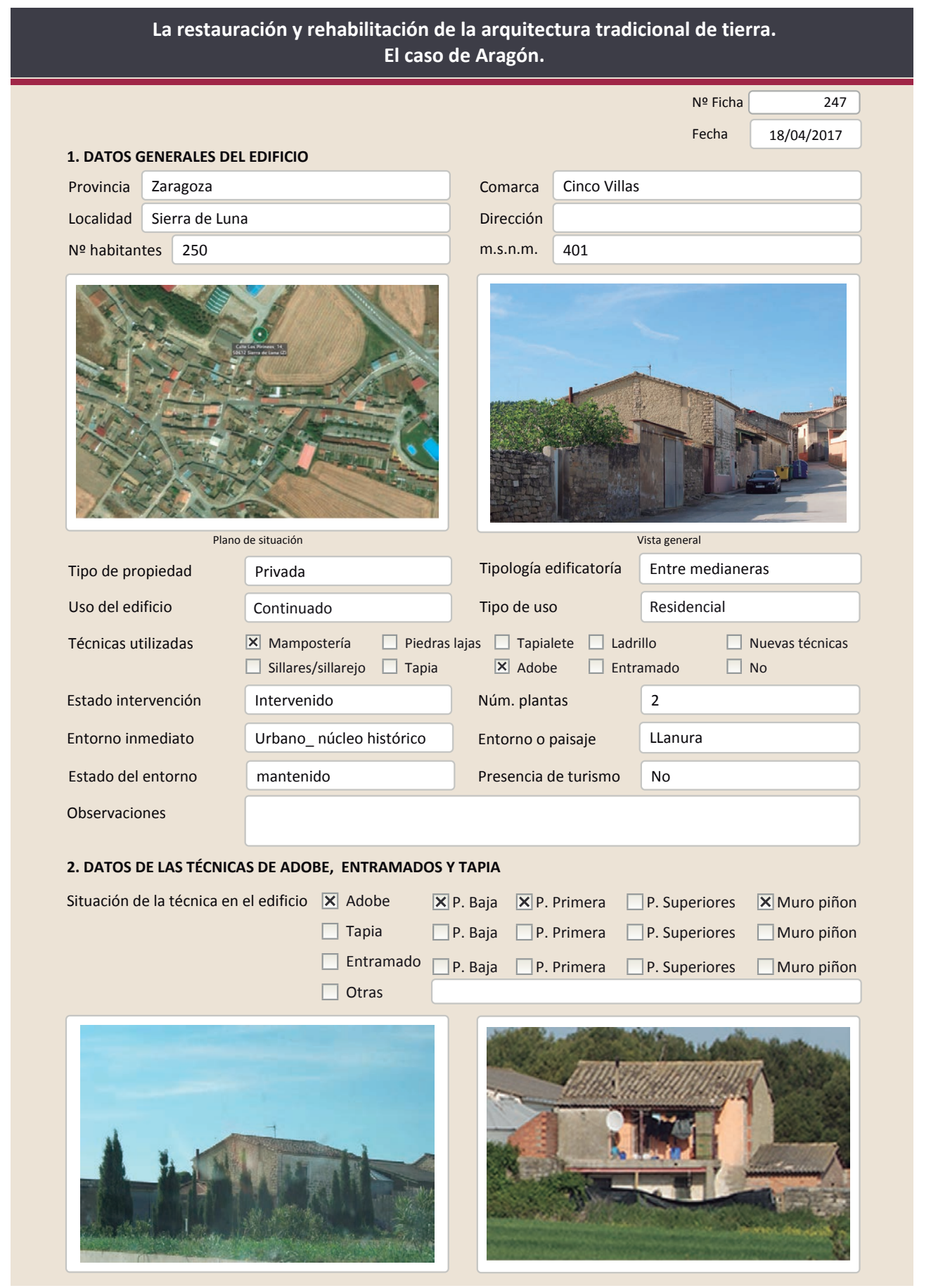

2.1. ADOBE

Dimensión de las piezas

Dimensión del muro

Aparejo del muro

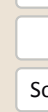

Función estructural

$\mathrm{Si}$

Variante constructiva/ tipo de fábrica

\section{$\square$ Simple}

X Suplementada en juntas
X Mixta
$\square$ Como suplemento
$\square$ Elementos de protección

$\square$ Elementos de protección

Color de las piezas

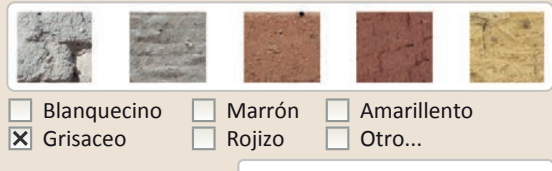

Comp. - estabilizante
Cal/yeso Piedra

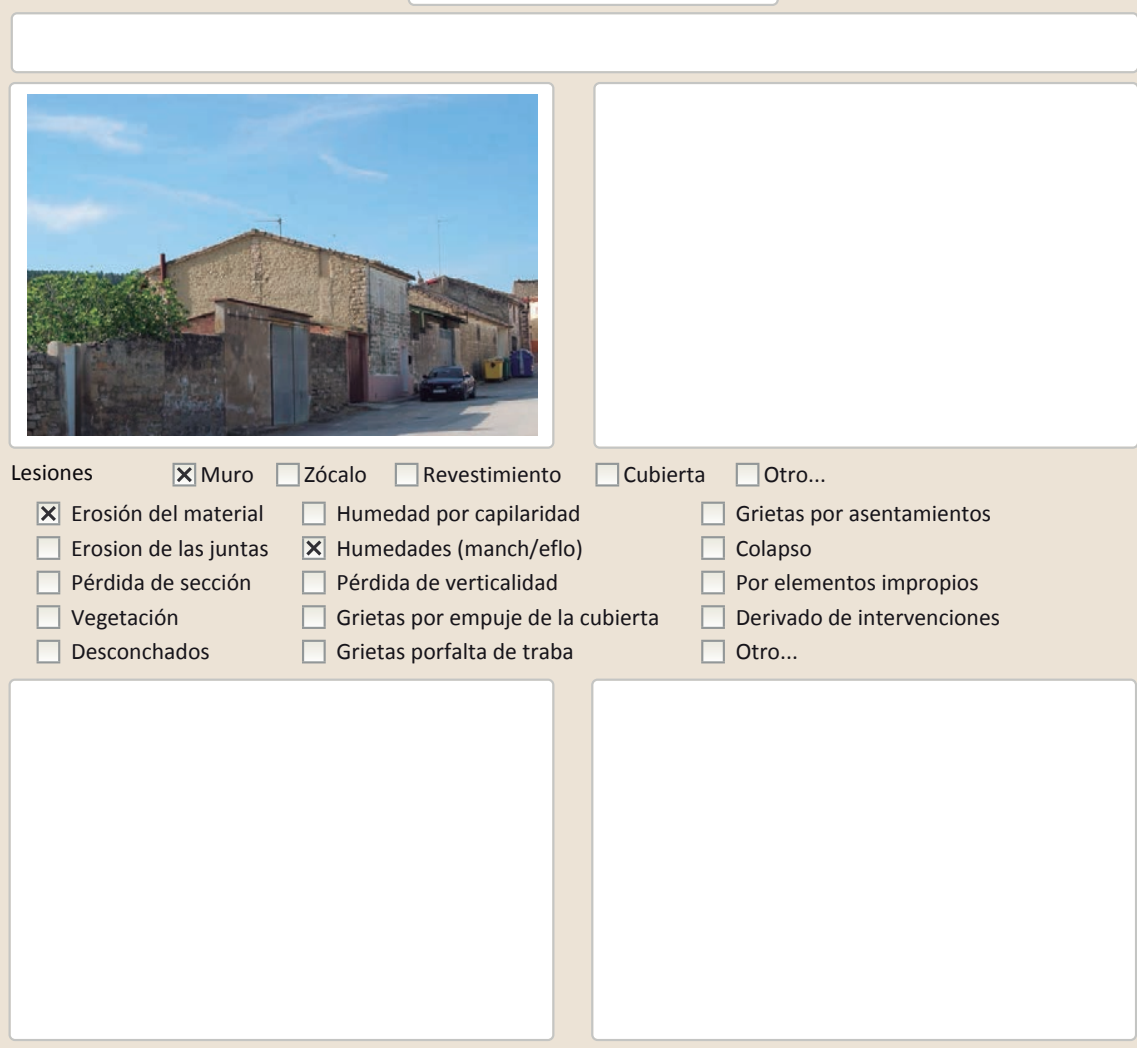

Observaciones

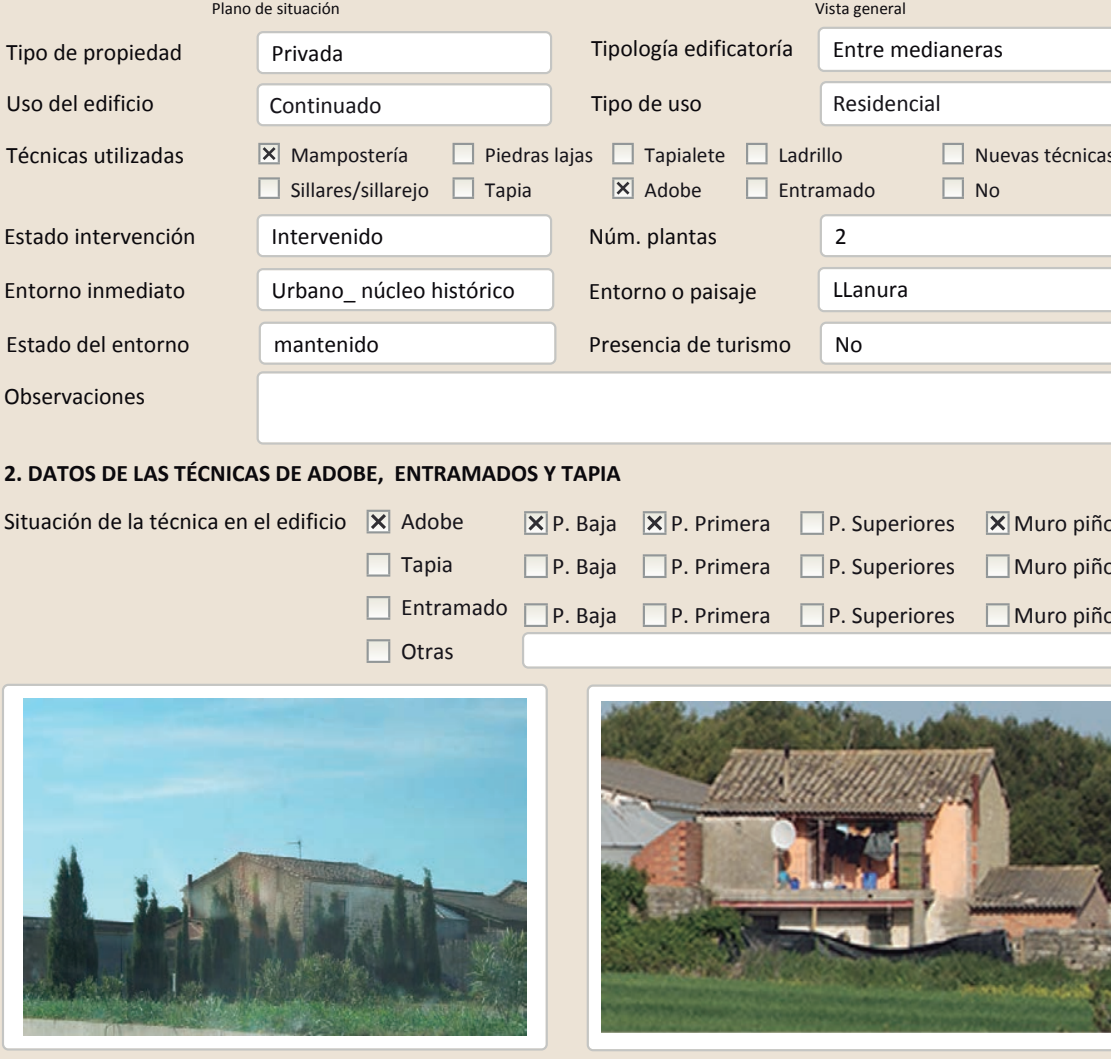




\section{La restauración y rehabilitación de la arquitectura tradicional de tierra.}

\section{El caso de Aragón.}

3. DATOS DE LA INTERVENCIÓN

.

$\square$ Restauración $\square$ Demolición

Reflexión previa

Intervención espontanea

Observaciones

3.1. MUROS

Tipo de intervención

Tipo de material

Descripción

3.2. ZÓCALO

Tipo de intervención

Tipo de material

Descripción

3.3. REVESTIMIENTOS

Tipo de intervención

Tipo de material

Descripción

3.4. VANOS

Tipo de intervención

Tipo de material

Descripción

3.5. CUBIERTA

Tipo de intervención

Tipo de material

Descripción

3.6. OTRAS

Actualización $\square$ Reintegración $\square$ Demolición $\square$ Otro...

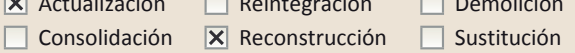

$\square$ Consolidación $\quad \boldsymbol{X}$ Reconstrucción $\square$ Sustitución
No tradicional Tipo de técnica Diferente a la existente

Revestimiento grueso de cemento pintado de rosa

\section{No aplica}

$\square$ Consolidación $\quad \square$ Reconstrucción $\square$ sustitución

Tipo de técnica

Intervenido

$\square$ Actualización $\quad$ X Reintegración $\square$ Demolición $\square$ Otro...

$\square$ Consolidación $\square$ Reconstrucción $\square$ Sustitución

\begin{tabular}{|l|l|l} 
No tradicional & Tipo de técnica Diferente a la existente
\end{tabular}

\section{No intervenido}

$\square$ Actualización $\square$ Reintegración $\quad \square$ Demolición $\square$ Otro..

$\square$ Consolidación $\square$ Reconstrucción $\square$ Sustitución Tipo de técnica

Se ha añadido un cuerpo de porche y terraza en la fachada trasera. $\square$ Mantenimiento $\quad \mathbf{X}$ Rehabilitación parcial

La restauración y rehabilitación de la arquitectura tradicional de tierra.

El caso de Aragón.

3.7. REHABILITACIÓN ENERGÉTICA $\quad \square$ Fachada $\square$ Vanos $\square$ Forjados $\square$ Cubierta

Observaciones

FOTOGRAFÍAS DE LA INTERVENCIÓN

$\square$ Actualización $\square$ Reintegración $\square$ Demolición $\square$ Otro...

the

Integración de cajas de persianas
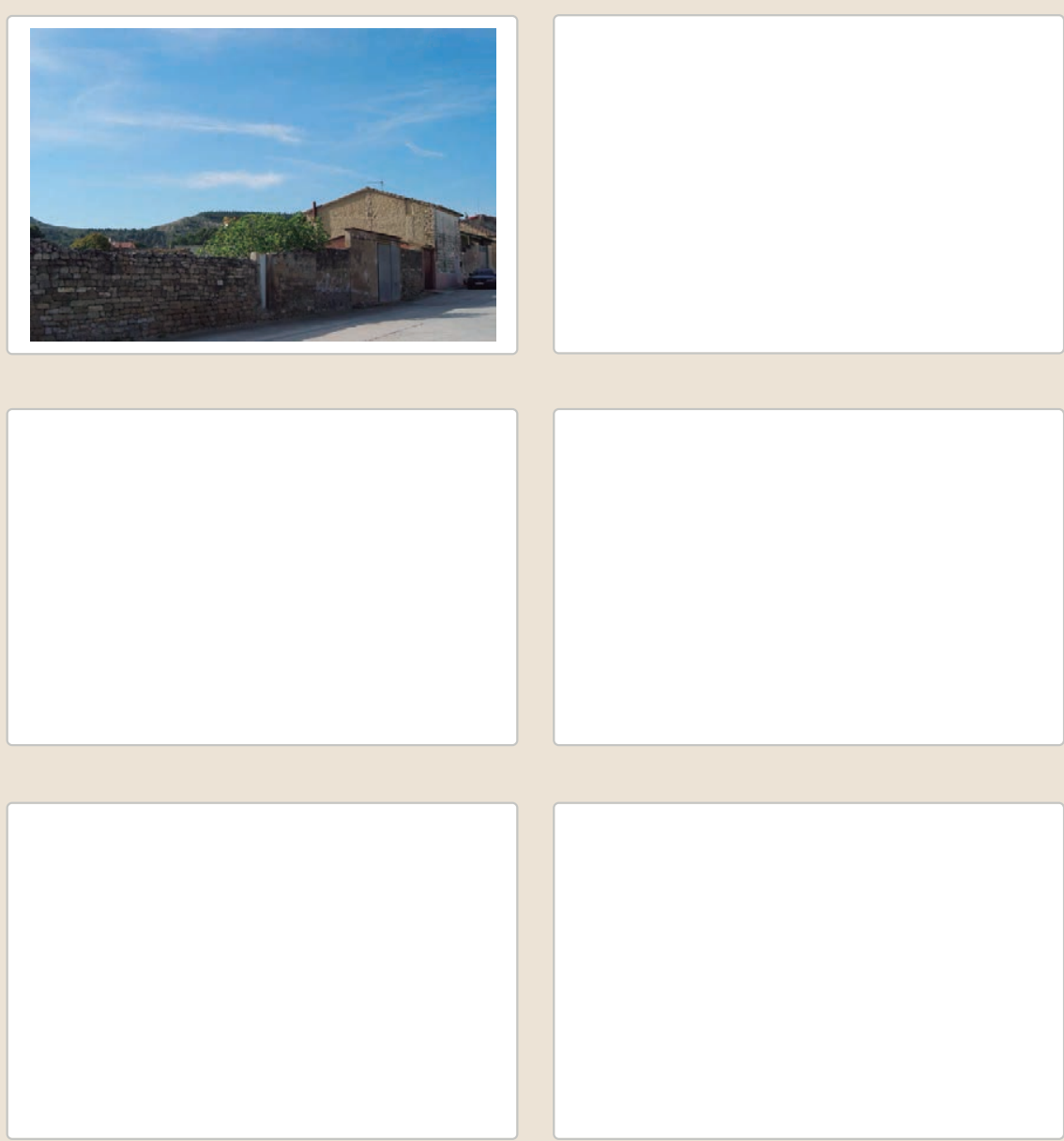
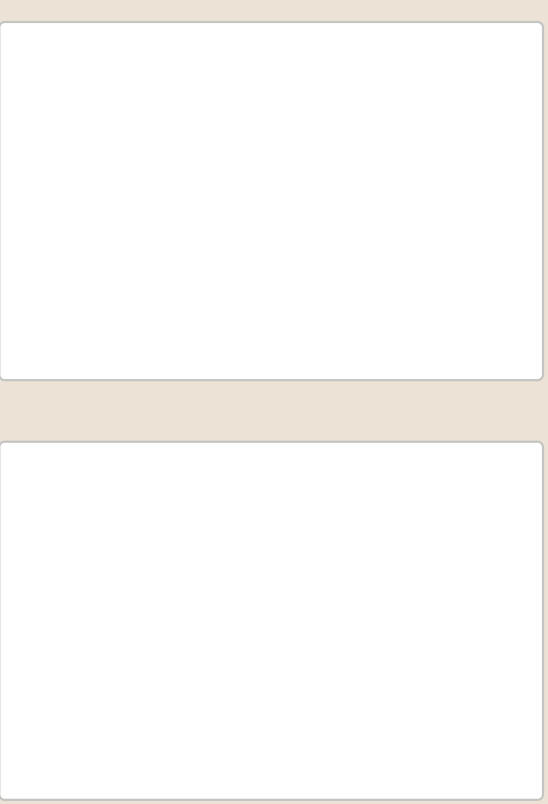
La restauración y rehabilitación de la arquitectura tradicional de tierra. El caso de Aragón

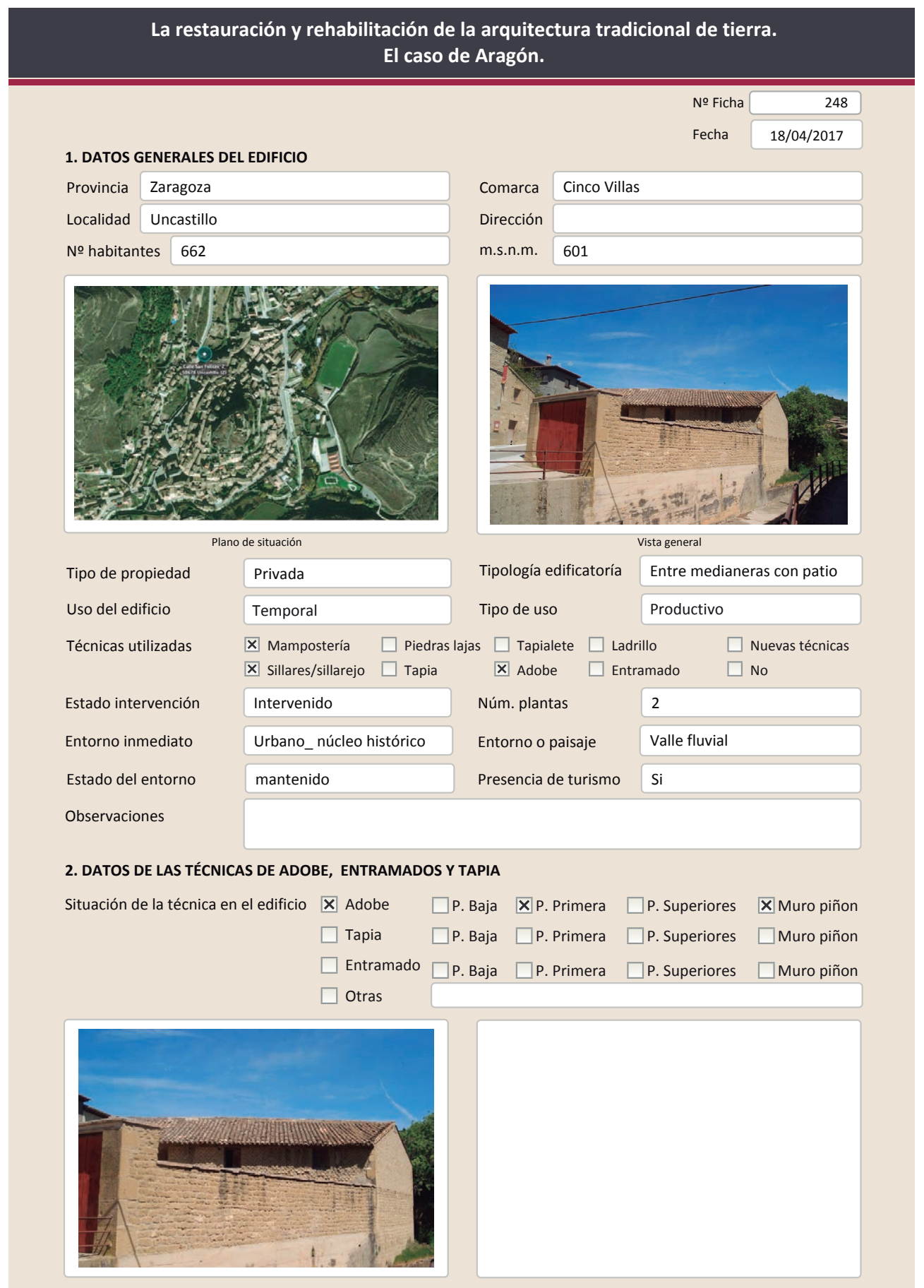

2.1. ADOBE

Dimensión de las piezas

Dimensión del muro

Aparejo del muro

Función estructural

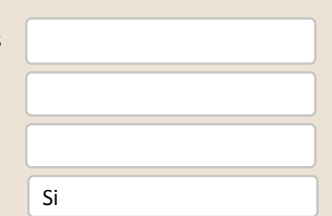

Color de las piezas

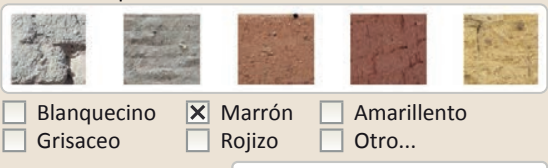

Rojizo $\square$ Otro.

Variante constructiva/ tipo de fábrica

$\square$ simple

$\square$ Suplementada en juntas

X Mixta

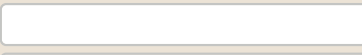

$\square$ Como suplemento

$\square$ Elementos de protección

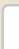
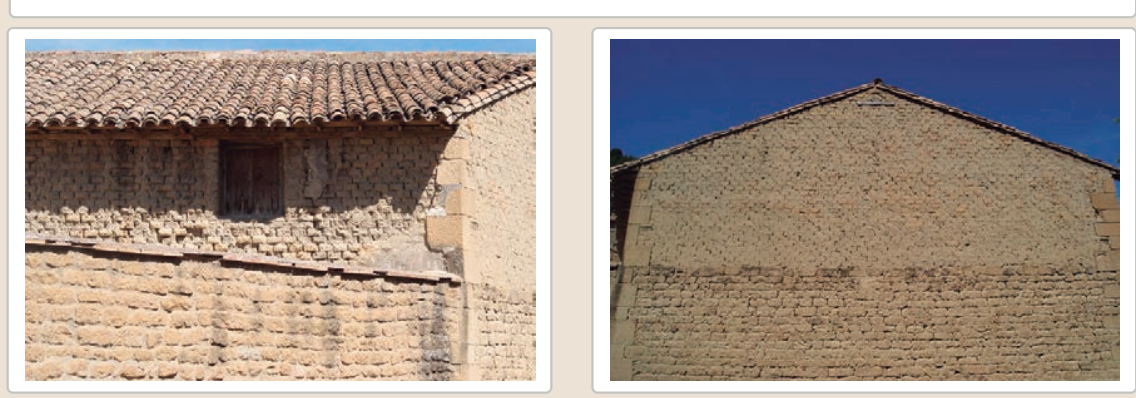

Lesiones \Muro $\square$ Zócalo $\square$ Revestimiento $\square$ Cubierta $\square$ Otro...

\ Erosión del material $\square$ Humedad por capilaridad $\quad \square$ Grietas por asentamientos $\square$ Erosion de las juntas $\square$ Humedades (manch/eflo) $\quad \square$ Colapso

$\square$ Pérdida de sección $\square$ Pérdida de verticalidad

$\square$ Colapso

$\square$ Vegetación

$\square$ Grietas por empuje de la cubir

$\square$ Desconchados $\square$ Grietas porfalta de traba

$\square$ Derivado
$\square$ Otro...

Observaciones 


\section{La restauración y rehabilitación de la arquitectura tradicional de tierra.}

\section{El caso de Aragón.}

3. DATOS DE LA INTERVENCIÓN

\begin{tabular}{|c|c|c|c|c|}
\hline Intervención de: & $\begin{array}{l}\square \text { Mantenimiento } \\
\mathbf{X} \text { Reparación }\end{array}$ & $\begin{array}{l}\square \text { Rehabilitación parcial } \\
\square \text { Rehabilitación integral }\end{array}$ & $\begin{array}{l}\square \text { Restauración } \\
\square \text { Ampliación }\end{array}$ & $\begin{array}{l}\square \text { Demolición } \\
\square \text { Otro... }\end{array}$ \\
\hline Reflexión previa & \multicolumn{4}{|c|}{ Intervención espontanea } \\
\hline erva & & & & \\
\hline
\end{tabular}

\subsection{MUROS}

Tipo de intervención

Intervenido

Tipo de material

$\square$ Actualización $\quad$ X Reintegración $\square$ Demolición $\square$ Otro...

$\square$ Consolidación $\square$ Reconstrucción $\square$ sustitución

Descripción

No tradicional Tipo de técnica Diferente a la existente

3.2. ZóCALO

Tipo de intervención

Reintegración de las zonas más degradadas con cemento

Tipo de material

Intervenido

$\square$ Actualización $\quad \square$ Reintegración $\quad \square$ Demolición $\square$ Otro...

$\square$ Actualización
$\square$ Consolidación $\quad \boldsymbol{X}$ Reintegración
Rectrucción $\quad \square$ Sustitución

Descripción
No tradicional
Tipo de técnica Diferente a la existente

3.3. REVESTIMIENTOS

En la zona del cana se ha encofrado con hormigón parte del muro

Tipo de intervención

\section{No aplica}

Tipo de material

$\square$ Actualización

$\square$ Reintegración $\square$ Demolición $\square$ Otro...

$\square$ Consolidación $\square$ Reconstrucción $\square$ Sustitución

Descripción

3.4. VANOS

Intervenido

Tipo de intervención

$\square$ Actualización $\square$ Reintegración $\square$ Demolición $\square$ Otro...

$\square$ Consolidación $\square$ Reconstrucción $\quad$ Sustitución

$\begin{array}{lll}\text { Tipo de material } & \text { No tradicional } & \text { Tipo de técnica } \\ \text { Sustifución del dintel de la a la existente } \\ \text { y pusta de acceso por una vigueta de hormigón prefabica }\end{array}$

Descripción Sustitución del dintel de la puerta de acceso por una vigueta de hormigón prefabricada y sustitución de la puerta de acceso

3.5. CUBIERTA

Tipo de intervención

Intervenido

Tipo de intervención

$\square$ Actualización $\quad \boldsymbol{X}$ Reintegración $\square$ Demolición $\square$ Otro..

Tipo de material

$\square$ Consolidación $\quad \square$ Reconstrucción $\square$ Sustitución

Descripción

No tradicional Tipo de técnica Similar a la existente

Reintegración de las tejas de cumbrera con mortero de cemento y algunas piezas sueltas

3.6. OTRAS 
La restauración y rehabilitación de la arquitectura tradicional de tierra. El caso de Aragón

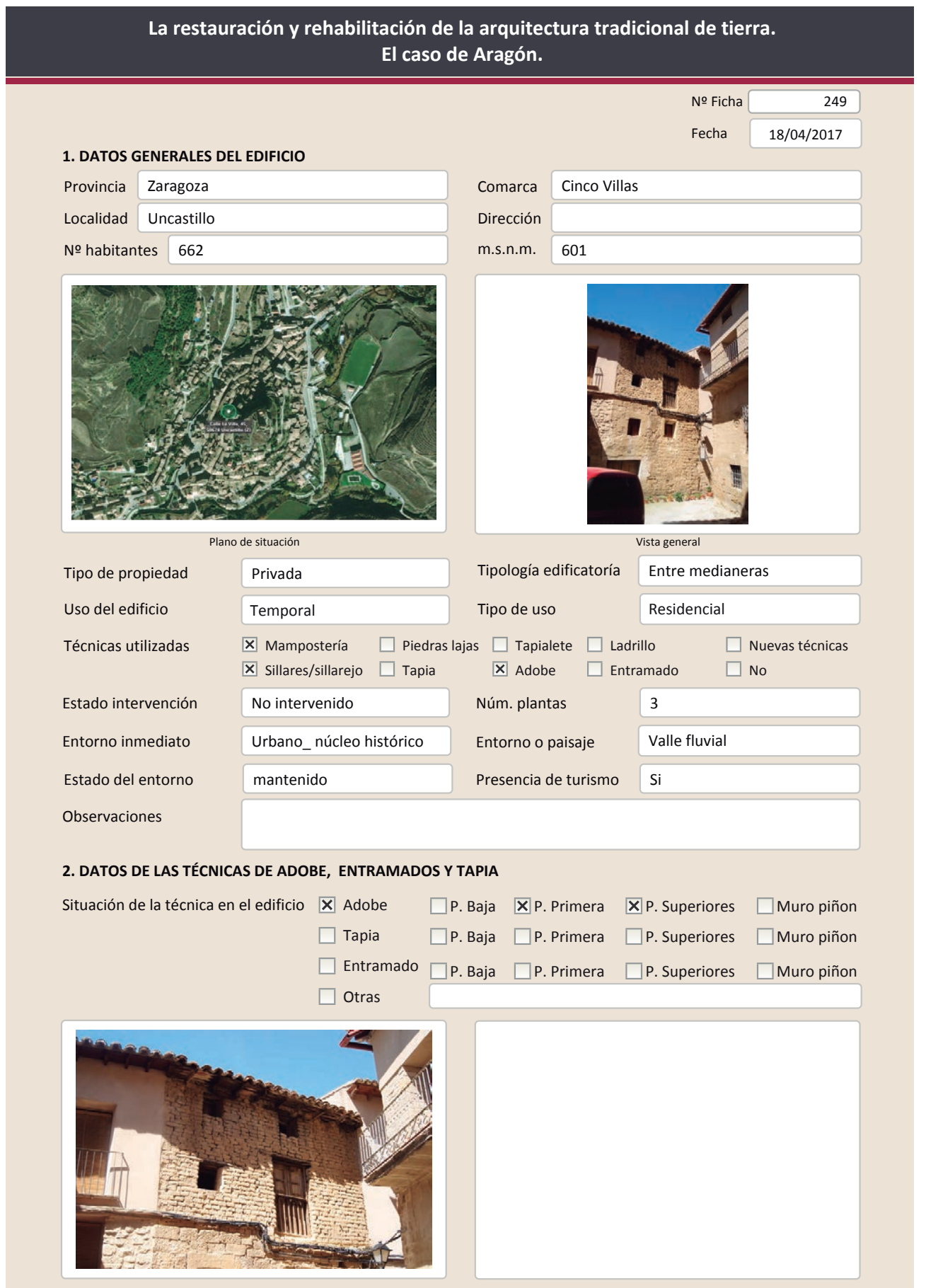

2.1. ADOBE

Dimensión de las piezas

Dimensión del muro

Aparejo del muro

Función estructural

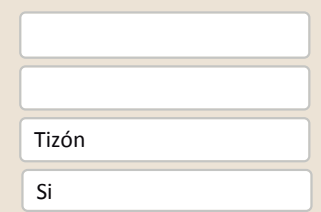

Color de las piezas

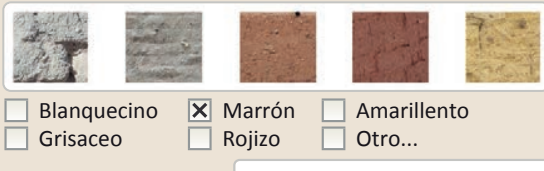

Variante constructiva/ tipo de fábrica

X Simple

$\square$ Suplementada en juntas

$\square$ Mixta

$\square$ Como suplemento

$\square$ Elementos de protección

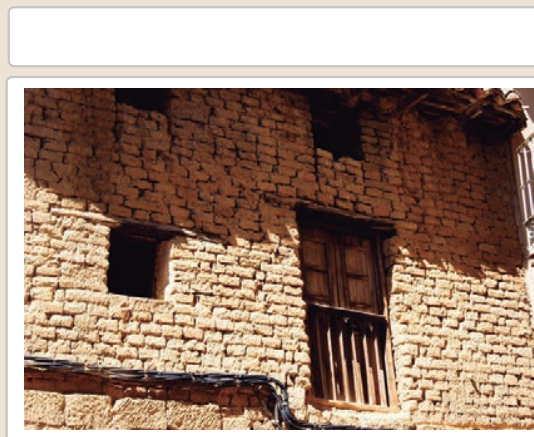

Lesiones $\mathbf{X M u r o ~} \square$ Zócalo $\square$ Revestimiento $\mathbf{X}$ Cubierta $\square$ otro...

区 Erosión del material $\quad \square$ Humedad por capilaridad $\quad \square$ Grietas por asentamientos $\square$ Erosion de las juntas $\mathbf{X}$ Humedades (manch/eflo) $\quad \square$ Colapso

X Pérdida de sección $\square$ Pérdida de verticalidad $\square$ Por elementos impropios

$\square$ Vegetación $\square$ Grietas por empuje de la cubierta $\square$ Derivado de intervenciones

$\square$ Desconchados

$\square$ Grietas porfalta de traba

$\square$ Derivado 


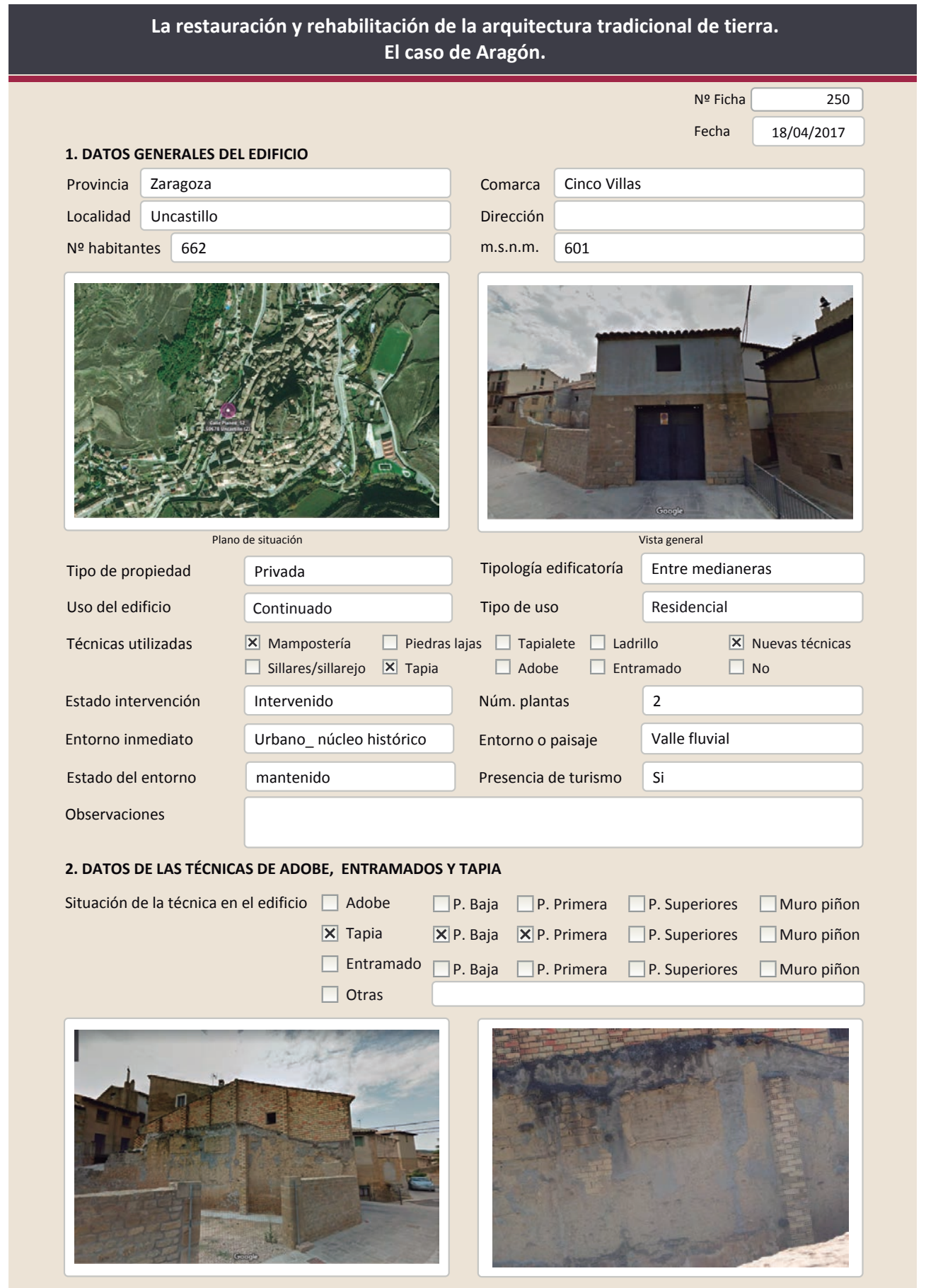

La restauración y rehabilitación de la arquitectura tradicional de tierra.

El caso de Aragón.

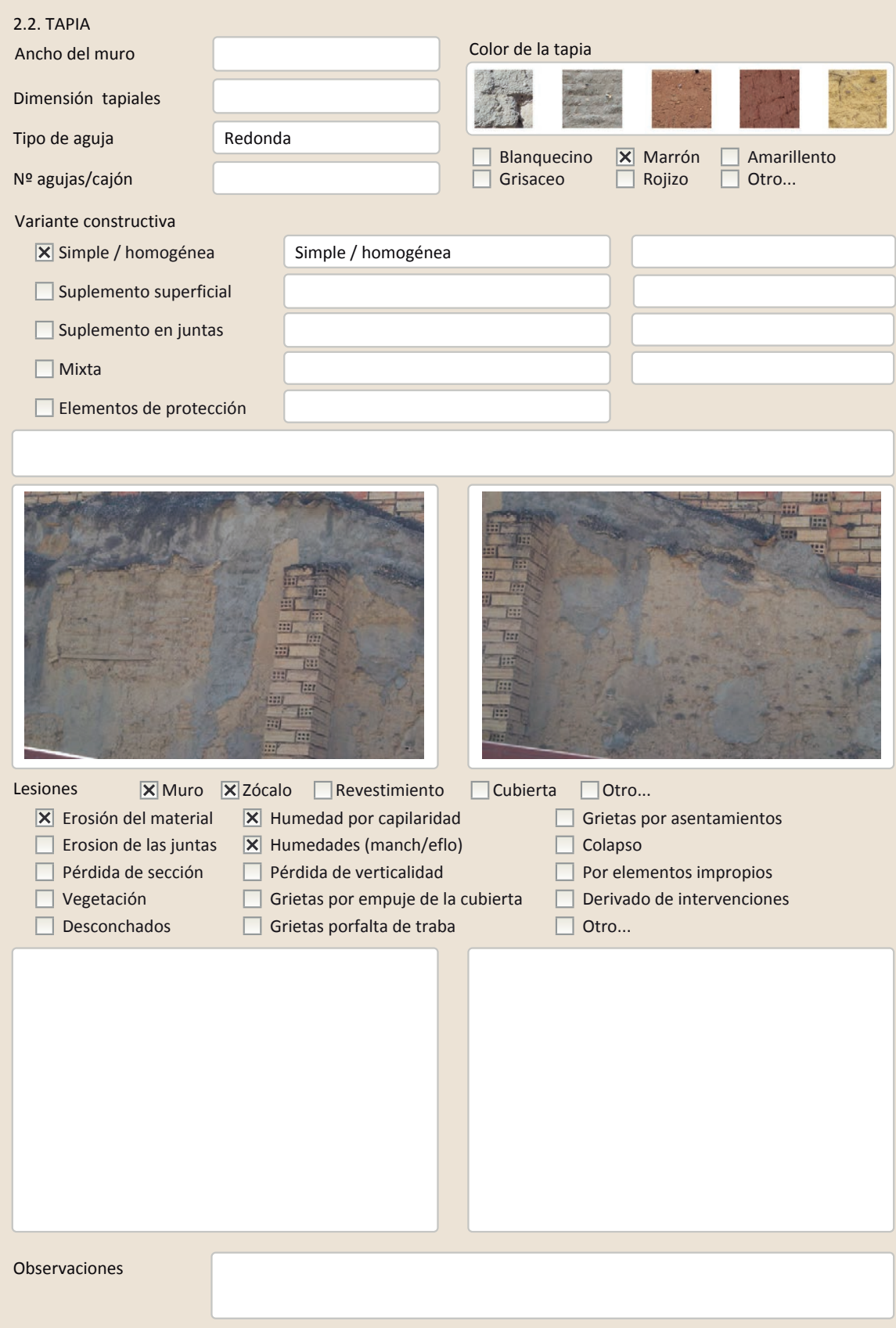


La restauración y rehabilitación de la arquitectura tradicional de tierra. El caso de Aragón

\section{La restauración y rehabilitación de la arquitectura tradicional de tierra.}

\section{El caso de Aragón.}

3. DATOS DE LA INTERVENCIÓN

Intervención de:

$\square$ Mantenimiento $\square$ Rehabilitación parcial

$\square$ Restauración $\quad \square$ Demolición

$\square$ Reparación $\quad \square$ Rehabilitación integral $\quad$ Ampliación $\square$ Otro...

Reflexión previa

Intervención planificada

Observaciones

Recrecido de una planta en el edificio

3.1. MUROS

Intervenido

Tipo de intervención

$\square$ Actualización $\square$ Reintegración $\square$ Demolición $\square$ Otro..

$\square$ Consolidación $\quad$ Xeconstrucción $\square$ Sustitución

Tipo de material

\begin{tabular}{l|l|l|l|l} 
No tradicional Tipo de técnica Diferente a la existente &
\end{tabular}

Descripción

Recrecido de una planta del muro con fábrica de ladrillo hueco

3.2. ZÓCALO

No intervenido

Tipo de intervención

$\square$ Actualización

Tipo de material

$\square$ Consolidación $\square$ Reconstrucción $\square$ Sustitución

Descripción

3.3. REVESTIMIENTOS

Tipo de intervención

\section{No aplica}

Tipo de material

$\square$ Actualización $\quad \square$ Reintegración $\quad \square$ Demolición
$\square$ consolidación $\quad \square$ Reconstrucción $\quad \square$ Sustitución

Tipo de materia

Descripción

3.4. VANOS

Tipo de intervención

Intervenido

Tipo de material

$\square$ Actualización $\quad \square$ Reintegración $\quad \square$ Demolición $\square$ Otro...

Descripción

$\square$ Consolidación $\square$ Reconstrucción $\mathbf{X}$ Sustitución

3.5. CUBIERTA

No tradicional

Tipo de técnica Diferente a la existente

Tipo de intervención

Intervenido

$\square$ Actualización $\quad \square$ Reintegración $\quad \square$ Demolición $\quad \square$ Otro...
$\square$ Consolidación $\quad \boldsymbol{X}$ Reconstrucción $\quad \square$ Sustitución

Tipo de material

No tradicional

Tipo de técnica Diferente a la existente

Descripción

Nueva cubierta

$$
\text { Tipo de técnica }
$$

3.6. OTRAS 


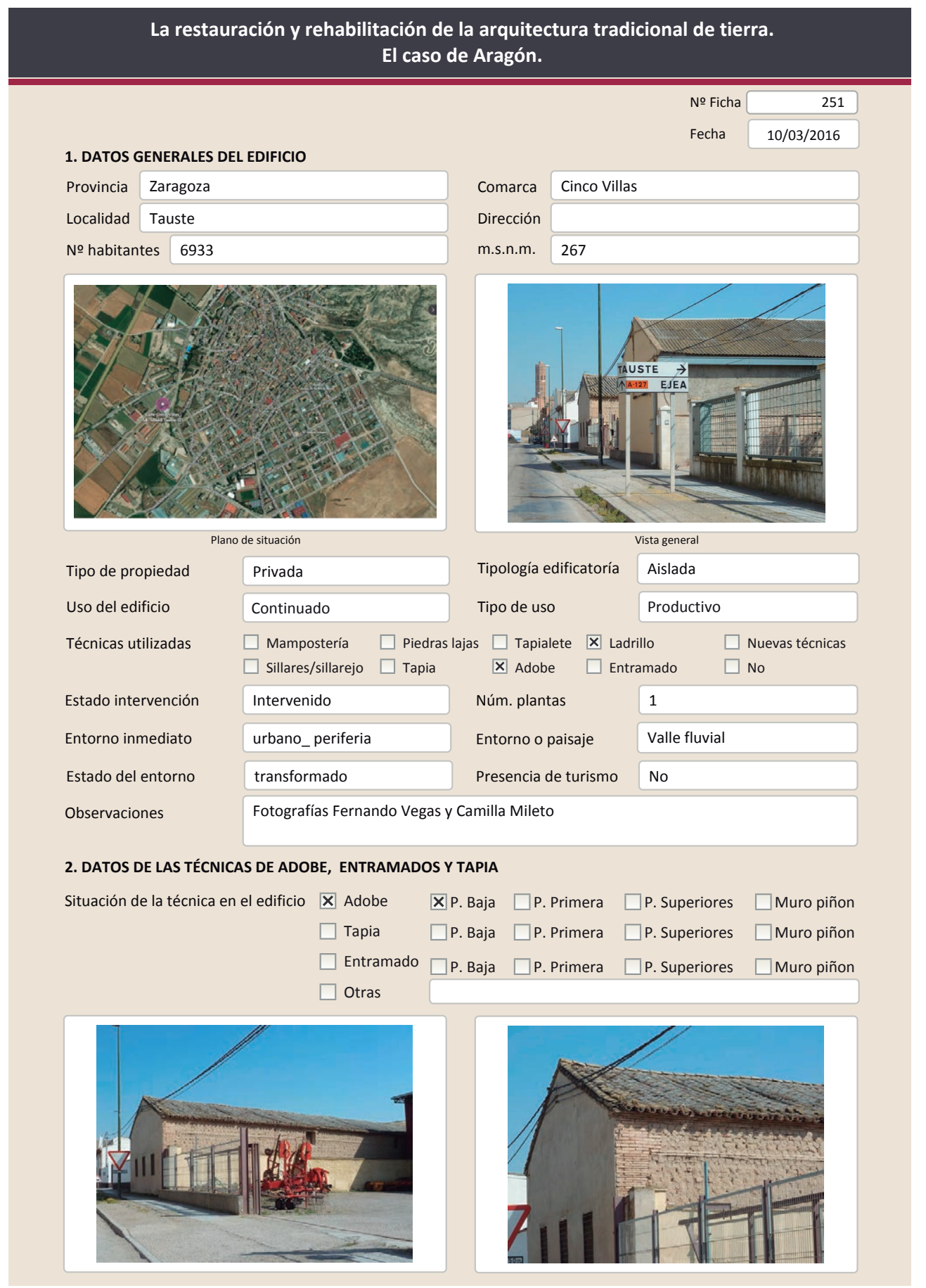

La restauración y rehabilitación de la arquitectura tradicional de tierra. El caso de Aragón.

\subsection{ADOBE \\ Dimensión de las piezas Dimensión del muro Aparejo del muro Función estructural \\ Variante constructiva/ tipo de fábrica
$\square$ Suplementada en juntas
X Mixta
$\square$ Como suplemento \\ $\square$ Simple \\ $\square$ Elementos de protección}

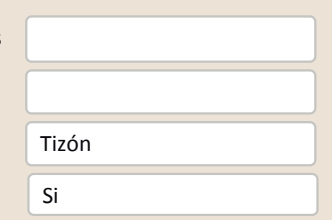
Color de las piezas
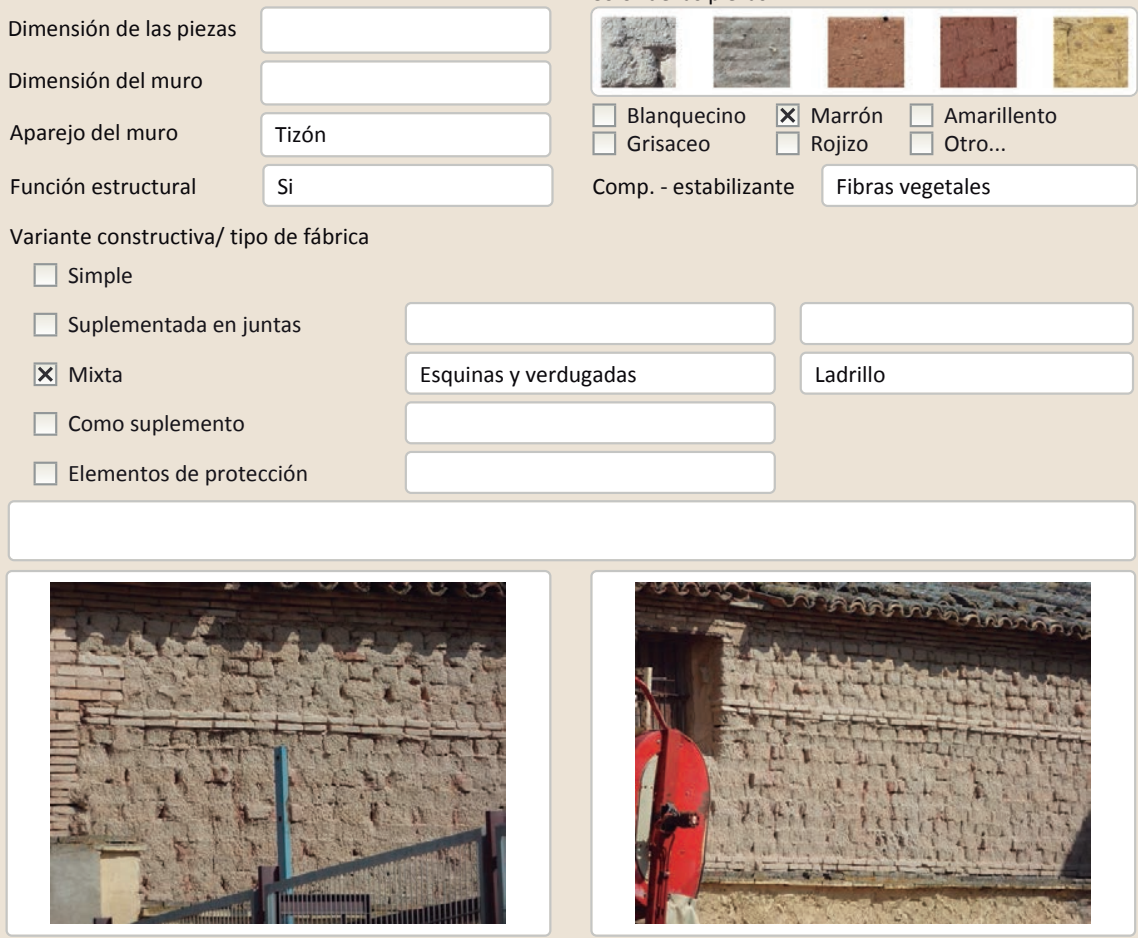

Lesiones $\quad \mathbf{X}$ Muro $\square$ Zócalo $\square$ Revestimiento

X Erosión del material $\square$ Humedad por capilaridad $\square$ Erosion de las juntas $\square$ Humedades (manch/eflo)

$\square$ Pérdida de sección $\square$ Pérdida de verticalidad

$\begin{array}{ll}\square \text { Vegetación } & \square \text { Grietas por empuje de la c } \\ \square \text { Desconchados } & \square \text { Grietas porfalta de traba }\end{array}$

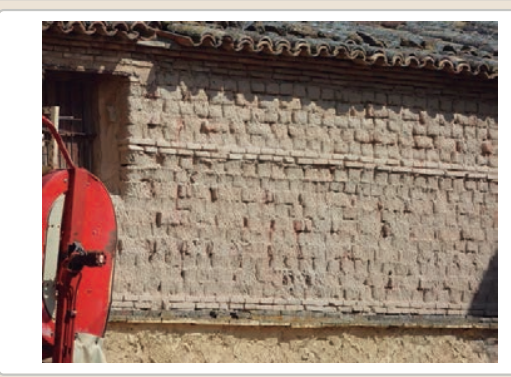

C Cubierta $\square$ Otro...
$\square$ Grietas por asentamiento
$\square$ Colapso
$\square$ Por elementos impropios
$\square$ Derivado de intervenciones

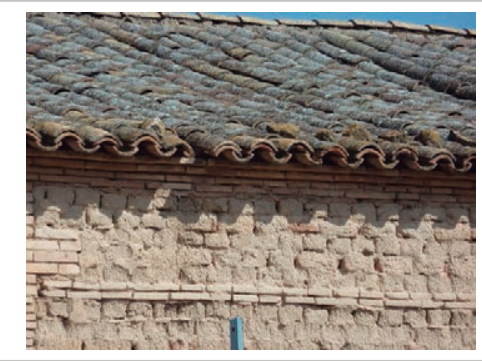

Observaciones 
La restauración y rehabilitación de la arquitectura tradicional de tierra. El caso de Aragón

\section{La restauración y rehabilitación de la arquitectura tradicional de tierra.}

\section{El caso de Aragón.}

3. DATOS DE LA INTERVENCIÓN

Intervención de:

$\square$ Mantenimiento $\square$ Rehabilitación parcia

$\square$ Restauración $\square$ Demolición

Reflexión previa

X Reparación

$\square$ Rehabilitación integral $\square$ Ampliación

$\square$ Otro..

Reflexión previa

Intervención espontanea

(n)

3.1. MUROS

No intervenido

Tipo de intervención

$\square$ Actualización $\square$ Reintegración $\square$ Demolición $\square$ Otro...

$\square$ Consolidación $\square$ Reconstrucción $\square$ sustitución

Tipo de material

Descripción

3.2. ZÓCALO

Tipo de intervención

Intervenido

Tipo de intervención

$\square$ Actualización $\quad \square$ Reintegración $\quad \square$ Demolición $\square$ Otro...

Tipo de material

$\square$ Consolidación $\quad \mathbf{X}$ Reconstrucción $\square$ Sustitución

Descripción

Zócalo alto de revestimiento de cemento

3.3. REVESTIMIENTOS

\section{Intervenido}

Tipo de intervención

$\square$ Actualización $\square$ Reintegración $\square$ Demolición $\square$ Otro...

Tipo de material

$\square$ Consolidación $\quad \mathbf{X}$ Reconstrucción $\square$ Sustitución

Descripción
No tradicional
Tipo de técnica Diferente a la existente

3.4. VANOS

Nuevo revestimiento de cemento en el muro piñón

Tipo de intervención

No intervenido

Tipo de material

$\square$ Actualización $\square$ Reintegración $\square$ Demolición $\square$ Otro...

Descripción

$\square$ Consolidación $\square$ Reconstrucción $\square$ Sustitución

3.5. CUBIERTA

Tipo de intervención

No intervenido

$\square$ Actualización $\square$ Reintegración $\quad \square$ Demolición $\square$ Otro.

Tipo de material

$\square$ Consolidación $\square$ Reconstrucción $\square$ Sustitución

Descripción

$$
\text { Tipo de técnica }
$$

3.6. OTRAS 


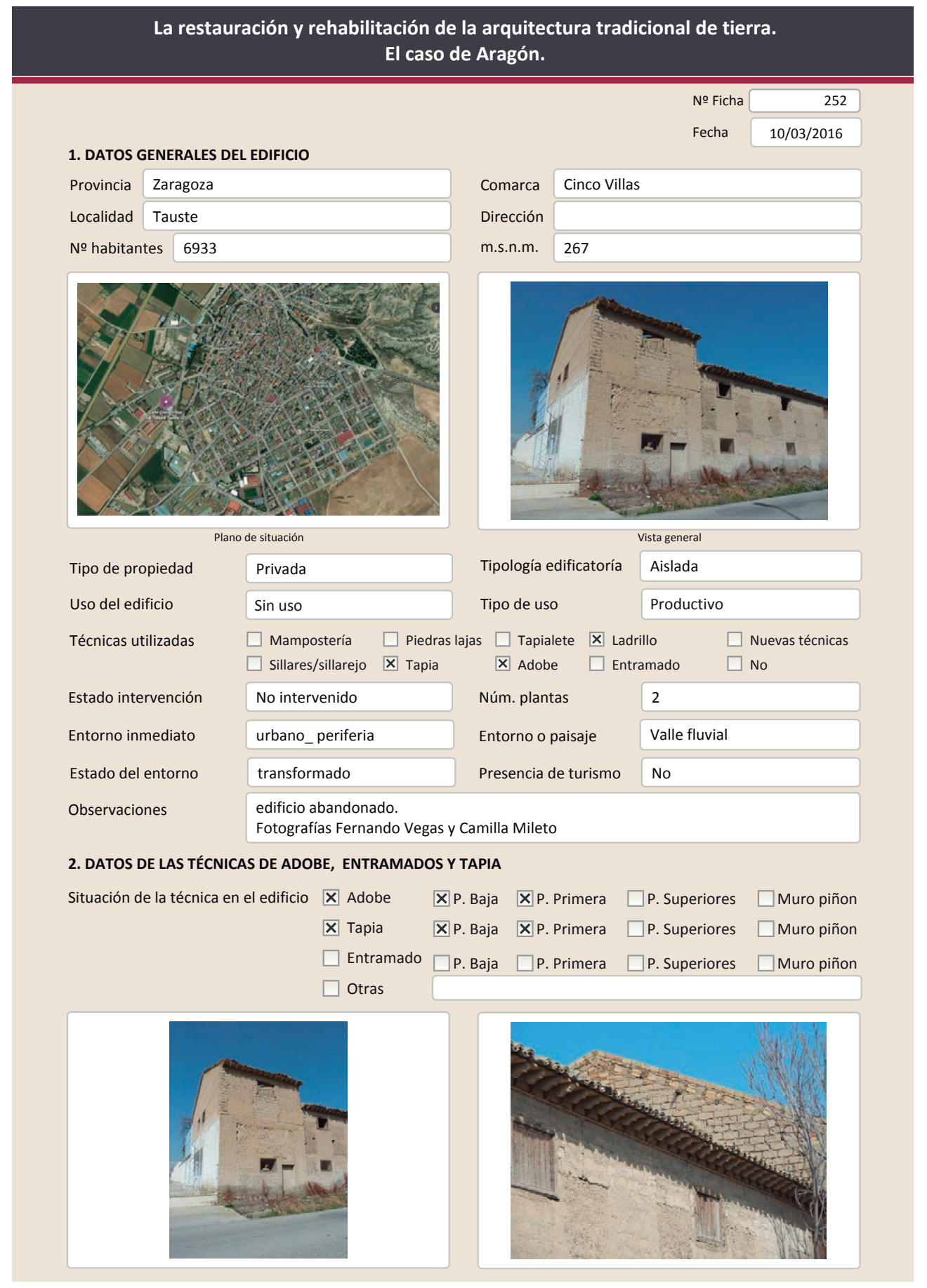

La restauración y rehabilitación de la arquitectura tradicional de tierra.

El caso de Aragón.

2.1. ADOBE

Dimensión de las piezas

Dimensión del muro

Aparejo del muro

Función estructural

Variante construc
$\square$ Simple

$\square$ Suplementada en juntas

$\square$ Mixta

X Como suplemento

$\square$ Elementos de protección

Bloque tierra cemento. Suplemento de muro de tapia

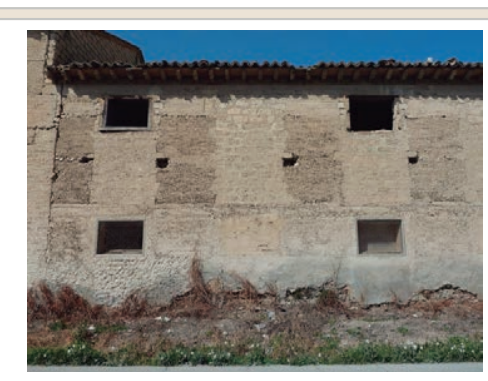

Lesiones $\square$ Muro $\square$ Zócalo $\mathbf{X}$ Revestimiento

$\square$ Erosión del material $\square$ Humedad por capilaridad

$\square$ Erosion de las juntas $\square$ Humedades (manch/eflo)

$\square$ Pérdida de sección $\square$ Pérdida de verticalidad

$\square$ Vegetación $\quad \square$ Grietas por empuje de la cubie

$\square$ Vegetacic

$\square$ Grietas por empuje de la cubie
$\square$ Grietas porfalta de traba

Color de las piezas

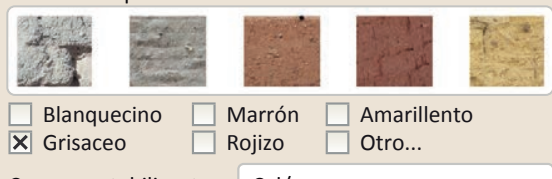

X Grisaceo $\square$ Rojizo $\square$ Otro..

Comp. - estabilizante Cal/yeso

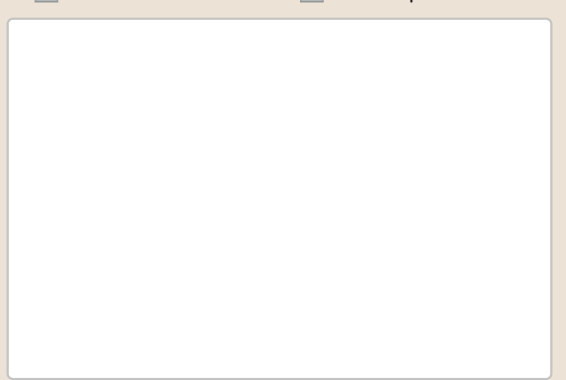

Observaciones

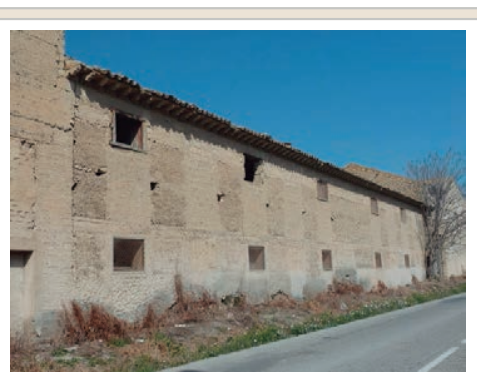

Cubierta $\square$ Otro...

$\square$ Grietas por asentamientos $\square$ Colapso

$\square$ Por elementos impropios

$\square$ Derivado de intervenciones $\square$ Otro... 
La restauración y rehabilitación de la arquitectura tradicional de tierra. El caso de Aragón

\section{La restauración y rehabilitación de la arquitectura tradicional de tierra.}

\section{El caso de Aragón.}

2.2. TAPIA
Ancho del muro

Dimensión tapiales

Tipo de aguja

№ agujas/cajón

Variante constructiva

$\square$ Simple / homogénea

X Suplemento superficial

$\square$ Suplemento en juntas

X Mixta

Machones

$\square$ Elementos de protección

Es posible que la tapia contenga cemento en su masa como las piezas de adobe

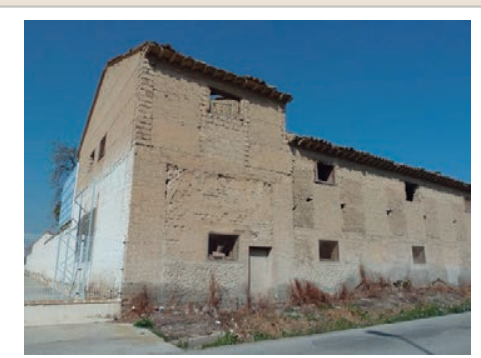

Lesiones $\square$ Muro $\square$ Zócalo $\square$ Revestimient

$\square$ Erosión del material $\square$ Humedad por capilaridad

$\square$ Erosion de las juntas $\square$ Humedades (manch/eflo)

$\square$ Pérdida de sección

$\square$ Pérdida de verticalidad

$\square$ Vegetación

$\square$ Grietas por empuje de la cubierta

Color de la tapia

$\square$ Desconchados

$\square$ Grietas porfalta de traba $\square$ Cubierta $\square$ Otro...

$\square$ Grietas por asentamientos

$\square$ Colapso

$\square$ Por elementos impropios

\section{Cal/yeso}

Adobe

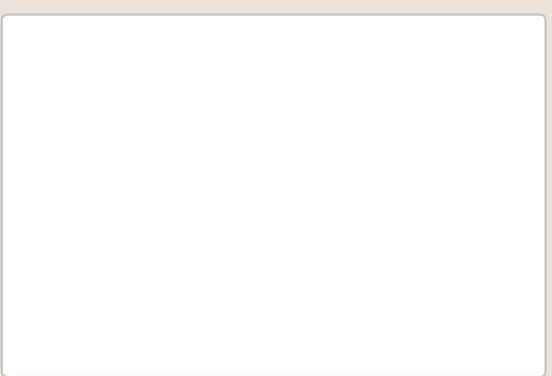

Observaciones 


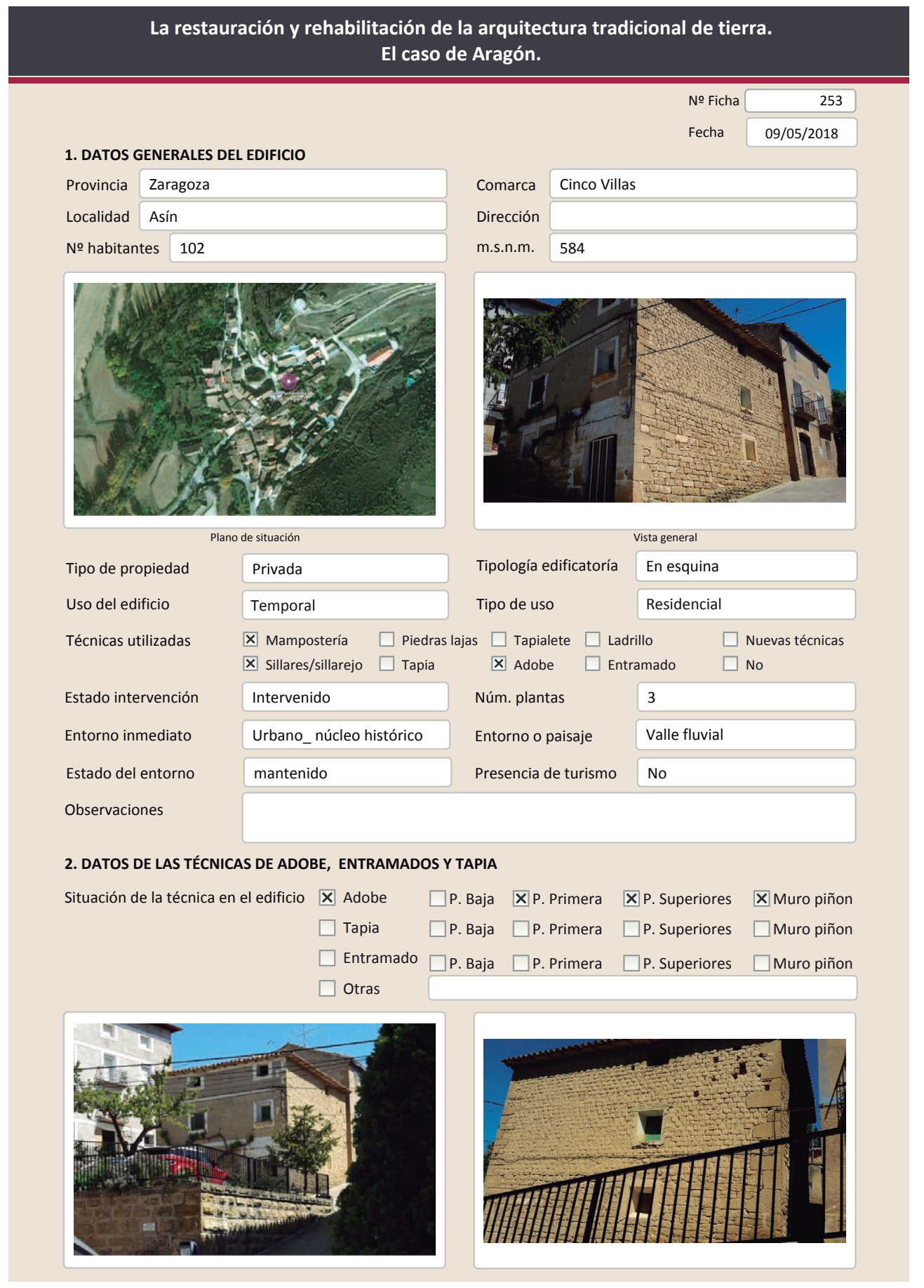

La restauración y rehabilitación de la arquitectura tradicional de tierra. El caso de Aragón.

2.1. ADOBE

Dimensión de las piezas Dimensión del muro

Aparejo del muro

Función estructural

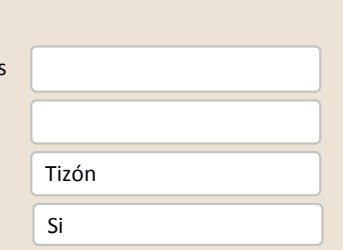

Color de las piezas

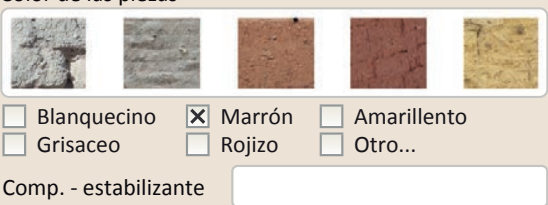

Variante constructiva/ tipo de fábrica

$\square$ simple

$\square$ Suplementada en juntas

X Mixta

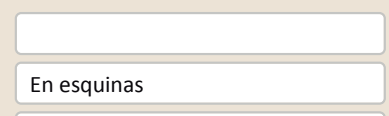

Piedr

$\square$ Como suplemento

\section{$\square$ Elementos de protección}

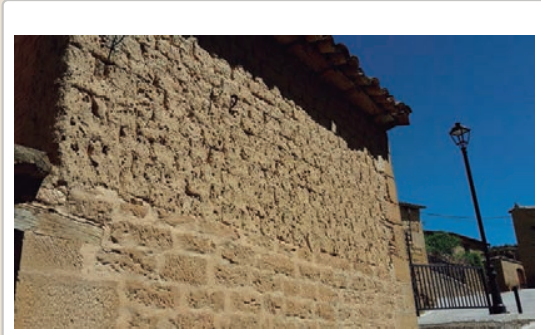

Lesiones ХMuro XZócalo X Revestimiento

$\mathbf{X}$ Erosión del material $\mathbf{X}$ Humedad por capilaridad

$\square$ Erosion de las juntas $\mathbf{X}$ Humedades (manch/eflo)

$\square$ Pérdida de sección $\square$ Pérdida de verticalidad

$\square$ Vegetación $\quad \square$ Grietas por empuje de la cubic

$\mathbf{X}$ Desconchados

$\square$ Grietas porfalta de traba

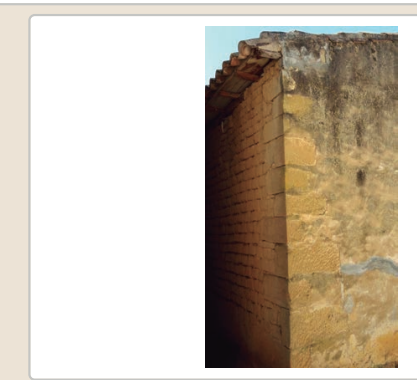

$\square$ Cubierta $\square$ otro...

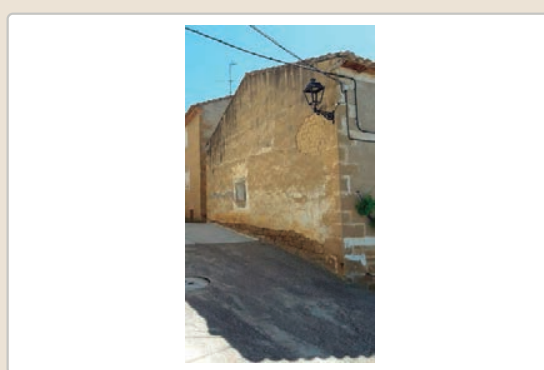

$\square$ Grietas por asentamiento

$\square$ Colapso

$\square$ Por elementos impropios

X Derivado de intervenciones $\square$ Otro...

Faltan algunas piezas en una de las fachadas

Desconchados del nuevo revestimiento de cemento, falta de adherencia material.

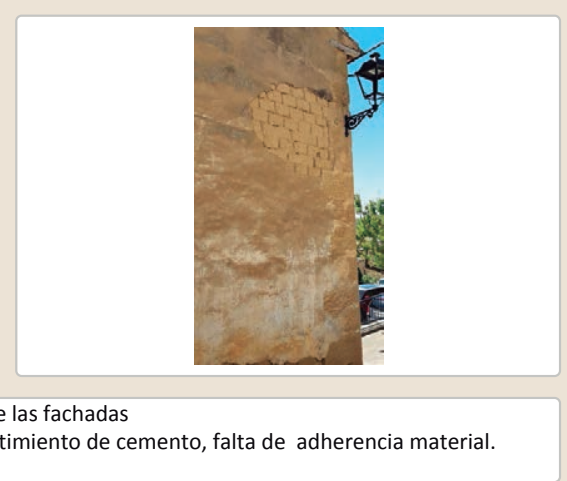




\section{La restauración y rehabilitación de la arquitectura tradicional de tierra.} El caso de Aragón.

3. DATOS DE LA INTERVENCIÓN

$\square$ Mantenimiento $\quad \mathbf{X}$ Rehabilitación parcia

$\square$ Restauración $\square$ Demolición

arion X Reparación $\square$ Rehabilitación integra

Ampliación $\square$ Otro...

Reflexión previa $\quad$ Intervención espontanea

Observaciones Intervención principalmente en los elementos exteriores

3.1. MUROS
Tipo de intervención

No intervenido

Tipo de material

Descripción

3.2. ZóCALO

Tipo de intervención

Tipo de material

Descripción

3.3. REVESTIMIENTOS

Tipo de intervención

Tipo de material

Descripción

3.4. VANOS

Tipo de intervención

Tipo de material

Descripción

3.5. CUBIERTA

Tipo de intervención

Tipo de material

Descripción

$\square$ Actualización

$\square$ Consolidación

$\square$ Reintegración

$\square$ Demolición

$\square$ sustitución

Intervenido

X Actualización $\quad \mathbf{x}$ Reintegración $\square$ Demolición $\square$ Otro...

$\square$ Consolidación $\quad \square$ Reconstrucción $\square$ Sustitución

No tradicional Tipo de técnica Diferente a la existente

Rejuntado de la mampostería con cemento

Intervenido

X Actualización $\square$ Reintegración $\square$ Demolición $\square$ Otro...

$\square$ Consolidación $\mathbf{X}$ Reconstrucción $\square$ Sustitución

No tradicional Tipo de técnica Diferente a la existente

Nuevo revestimiento sobre el adobe dejando la sillería de las esquinas vista. En la

fachada principal se ha pintado con distintos colores.

Intervenido

区 Actualización $\square$ Reintegración $\square$ Demolición $\square$ Otro...

$\square$ Consolidación $\square$ Reconstrucción $\square$ Sustitución

\begin{tabular}{|l|l|l} 
No tradicional & Tipo de técnica & Diferente a la existente
\end{tabular}

Pintura blanca en el contorno de los huecos de la fachada principal

Intervenido

$\square$ Actualización $\quad \mathbf{X}$ Reintegración $\square$ Demolición $\square$ Otro.

$\square$ Consolidación $\quad \square$ Reconstrucción $\quad \square$ Sustitución
No tradicional
Tipo de técnica Similar a la existente

Reintegración de las tejas cerámicas con cemento
La restauración y rehabilitación de la arquitectura tradicional de tierra.

El caso de Aragón.

3.7. REHABILITACIÓN ENERGÉTICA $\square$ Fachada $\square$ Vanos $\square$ Forjados $\square$ Cubierta

Observaciones

FOTOGRAFíAS DE LA INTERVENCIÓN
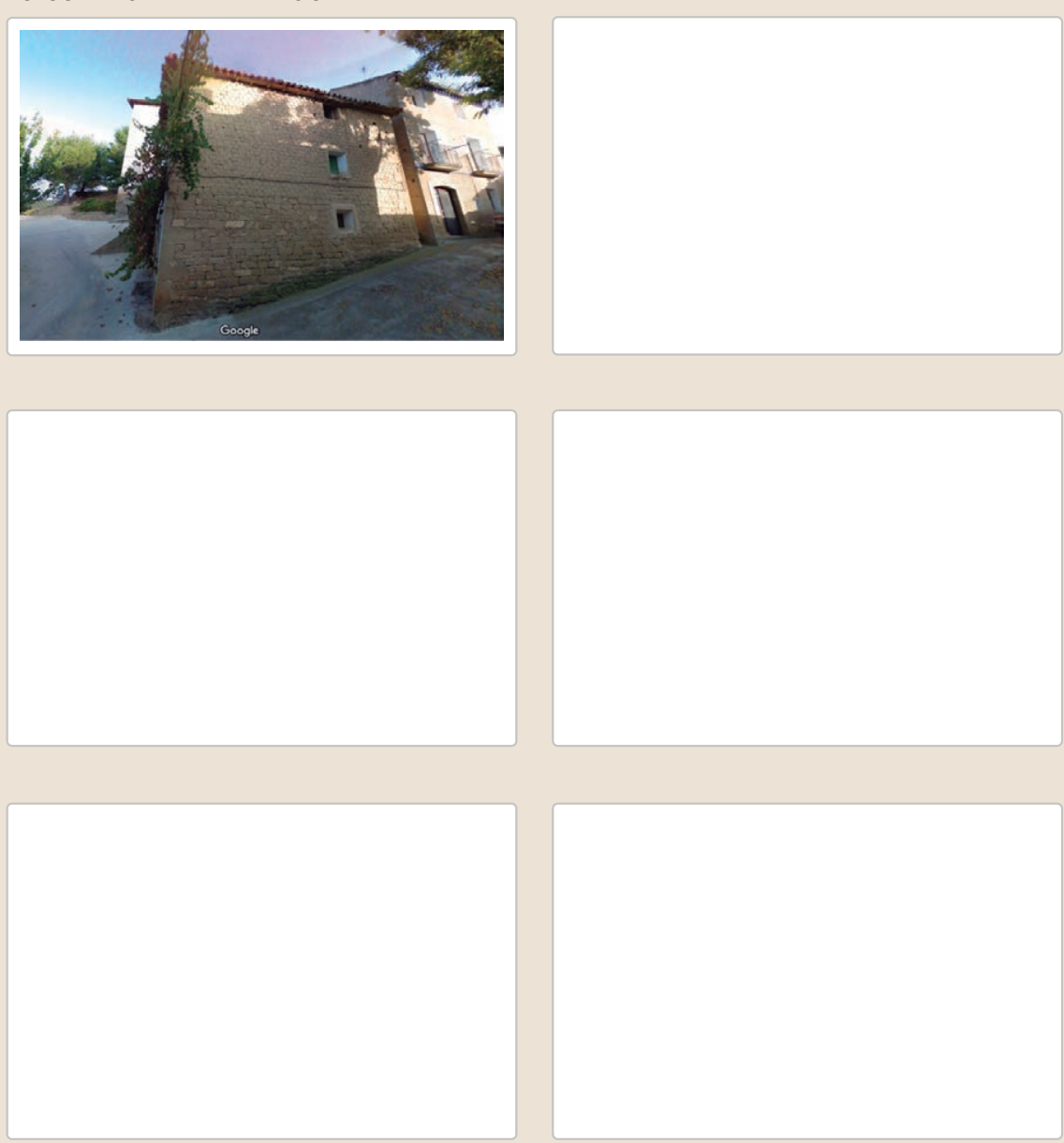

3.6. OTRAS 
La restauración y rehabilitación de la arquitectura tradicional de tierra. El caso de Aragón.

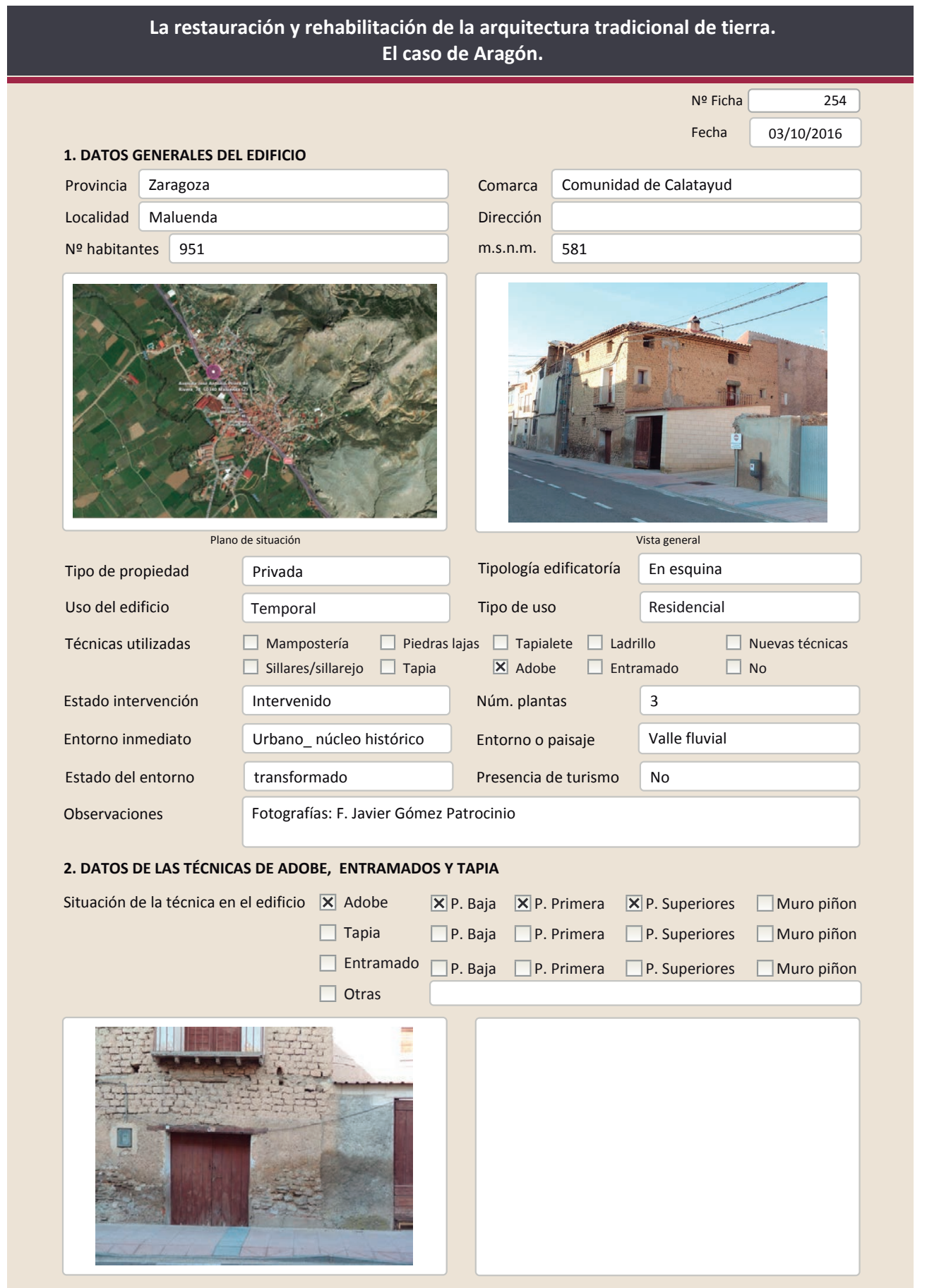

La restauración y rehabilitación de la arquitectura tradicional de tierra.

El caso de Aragón.

2.1. ADOBE

Dimensión de las piezas

Dimensión del muro

Aparejo del muro

Función estructural
Color de las piezas

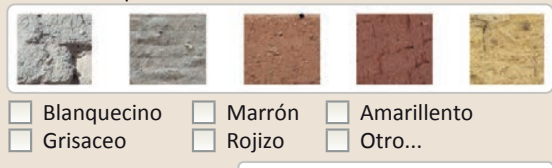

Grisaceo $\square$ Rojizo $\square$ Otro.

Comp. - estabilizante

Variante constructiva/ tipo de fábrica

X simple

$\square$ Suplementada en juntas

$\square$ Mixta

$\square$ Como suplemento

$\square$ Elementos de protección

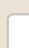

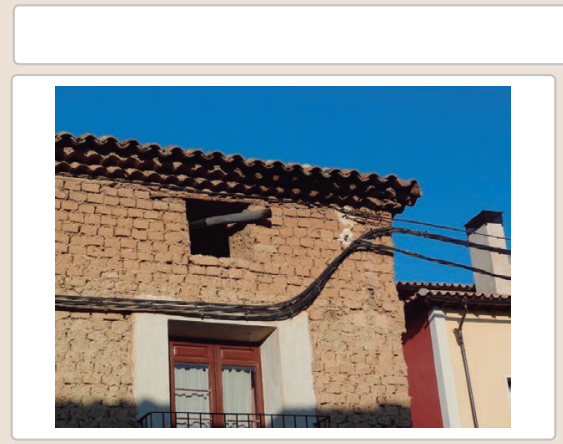

Lesiones $\quad \mathbf{X}$ Muro $\mathbf{X}$ Zócalo $\square$ Revestimiento

$\mathbf{X}$ Erosión del material $\mathbf{X}$ Humedad por capilaridad $\mathbf{X}$ Erosion de las juntas $\mathbf{X}$ Humedades (manch/eflo)

$\square$ Pérdida de sección $\square$ Pérdida de verticalidad

$\square$ Vegetación $\quad \square$ Grietas por empuje de la cubierta

$\square$ Grietas por empuje de la cubie
$\square$ Grietas porfalta de traba

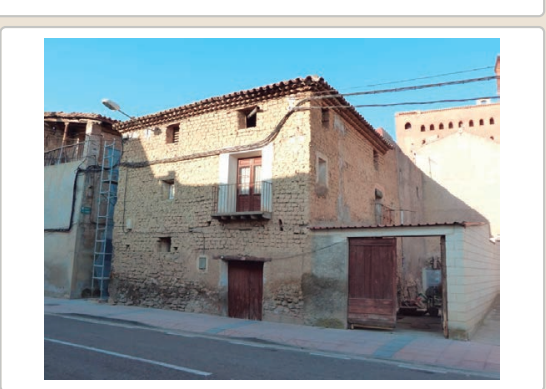

Cubierta $\square$ Otro...

$\square$ Grietas por asentamientos

$\square$ Colapso

$\square$ Por elementos impropios

$\square$ Derivado de intervenciones

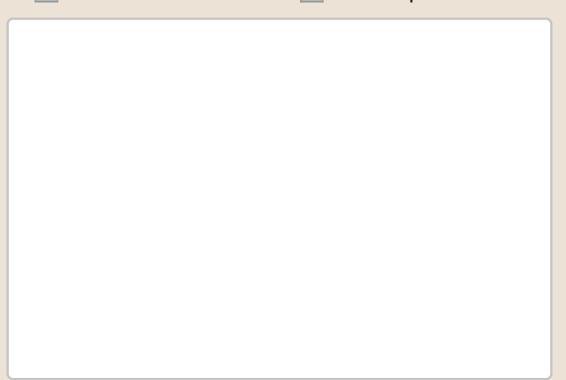
$\square$ Otro...

Observaciones 


\section{La restauración y rehabilitación de la arquitectura tradicional de tierra.} El caso de Aragón.

3. DATOS DE LA INTERVENCIÓN

$\square$ Mantenimiento $\square$ Rehabilitación parcial Xeparación $\square$ Rehabilitación integral X Ampliación $\square$ Otro...

Reflexión previa Intervención espontanea

Observaciones Construcción de un garaje en el corral anex

3.1. MUROS
Tipo de intervención

Intervenido

Tipo de material

$\square$ Actualización $\square$ Reintegración $\quad$ X Demolición $\square$ Otro...

$\square$ Consolidación $\quad \square$ Reconstrucción $\quad \square$ Sustitución

Descripción

No tradicional

Tipo de técnica Diferente a la existente

3.2. ZóCALO

Tipo de intervención

Roza en el muro rellenada con cemento.
Nuevos muros en la conformación del garaje anexo con bloque de cemento.

Intervenido

$\square$ Actualización $\quad \square$ Reintegración $\quad \square$ Demolición $\square$ Otro...

$\square$ Consolidación $\quad \mathbf{X}$ Reconstrucción $\square$ Sustitución

Tipo de material

Descripción

3.3. REVESTIMIENTOS

Tipo de intervención

No tradicional

Tipo de técnica Diferente a la existente

Revestimiento del zócalo de mampostería con cemento.

\section{Intervenido}

$\square$ Actualización $\square$ Reintegración $\square$ Demolición $\square$ Otro...

$\square$ Consolidación $\mathbf{X}$ Reconstrucción $\square$ Sustitución

Tipo de material

Descripción

No tradicional

Tipo de técnica Diferente a la existente

3.4. VANOS

Tipo de intervención

Revestimiento de cemento en la fachada lateral. El edificio se encuentra en obras en el momento de la toma de datos por lo que es posible que esta práctica se extienda a las

\section{Tipo de material}

Intervenido

Descripción

3.5. CUBIERTA

Tipo de intervención

Tipo de material

Descripción

Actualización $\quad \mathbf{X}$ Reintegración $\square$ Demolición $\square$ Otro...

$\square$ Consolidación $\quad \square$ Reconstrucción $\square$ Sustitución

No tradicional Tipo de técnica Similar a la existente

Revestimiento en jambas del primer piso que puede responder a la sustitución de piezas.

\section{Intervenido}

$\square$ Actualización $\quad \mathbf{X}$ Reintegración $\square$ Demolición $\square$ Otro..

$\square$ Consolidación $\square$ Reconstrucción $\square$ Sustitución
No tradicional
Tipo de técnica Similar a la existente

3.6. OTRAS
La restauración y rehabilitación de la arquitectura tradicional de tierra.

El caso de Aragón.

3.7. REHABILITACIÓN ENERGÉTICA $\quad \square$ Fachada $\square$ Vanos $\square$ Forjados $\square$ Cubierta

Observaciones

FOTOGRAFíAS DE LA INTERVENCIÓN
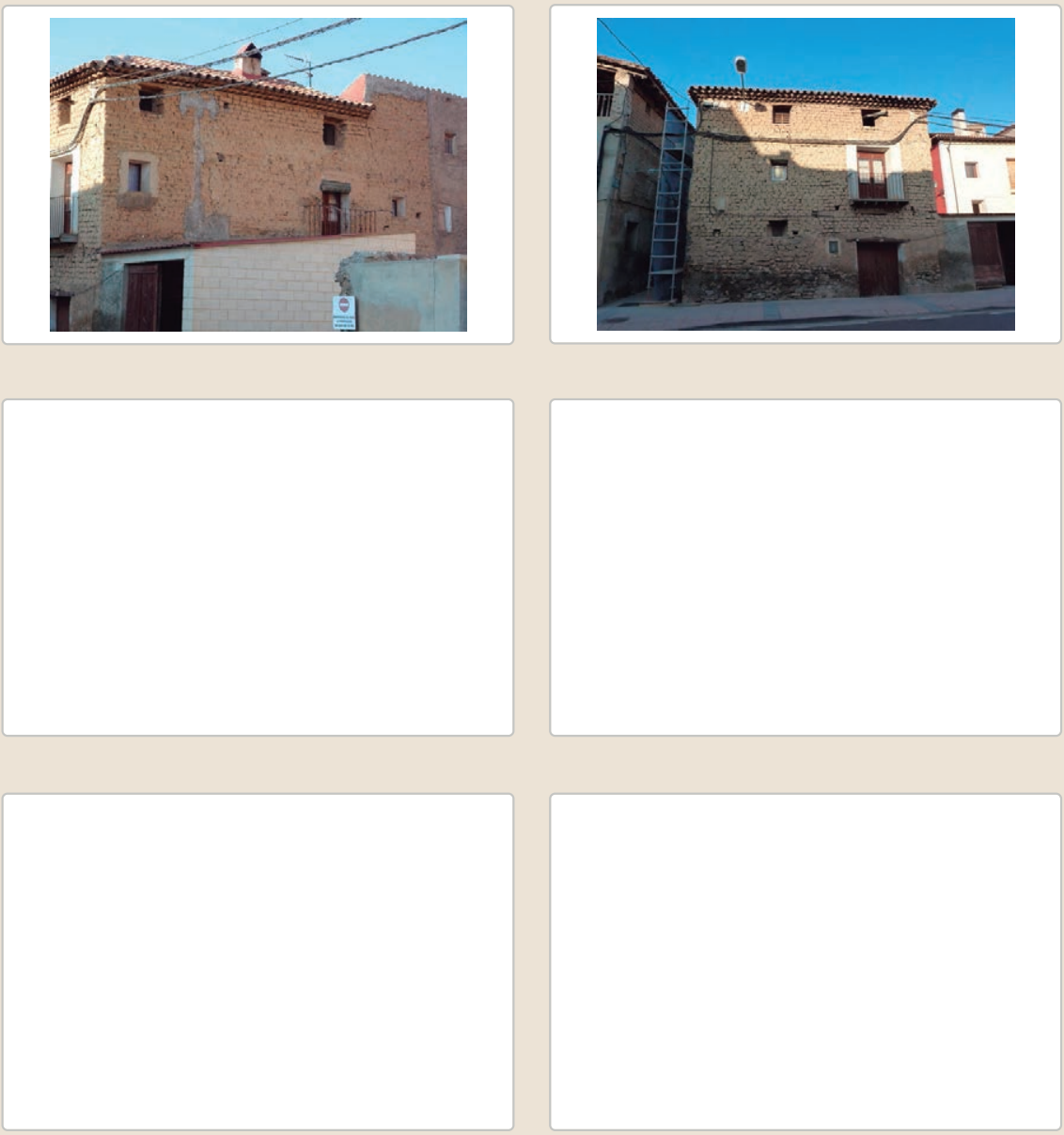


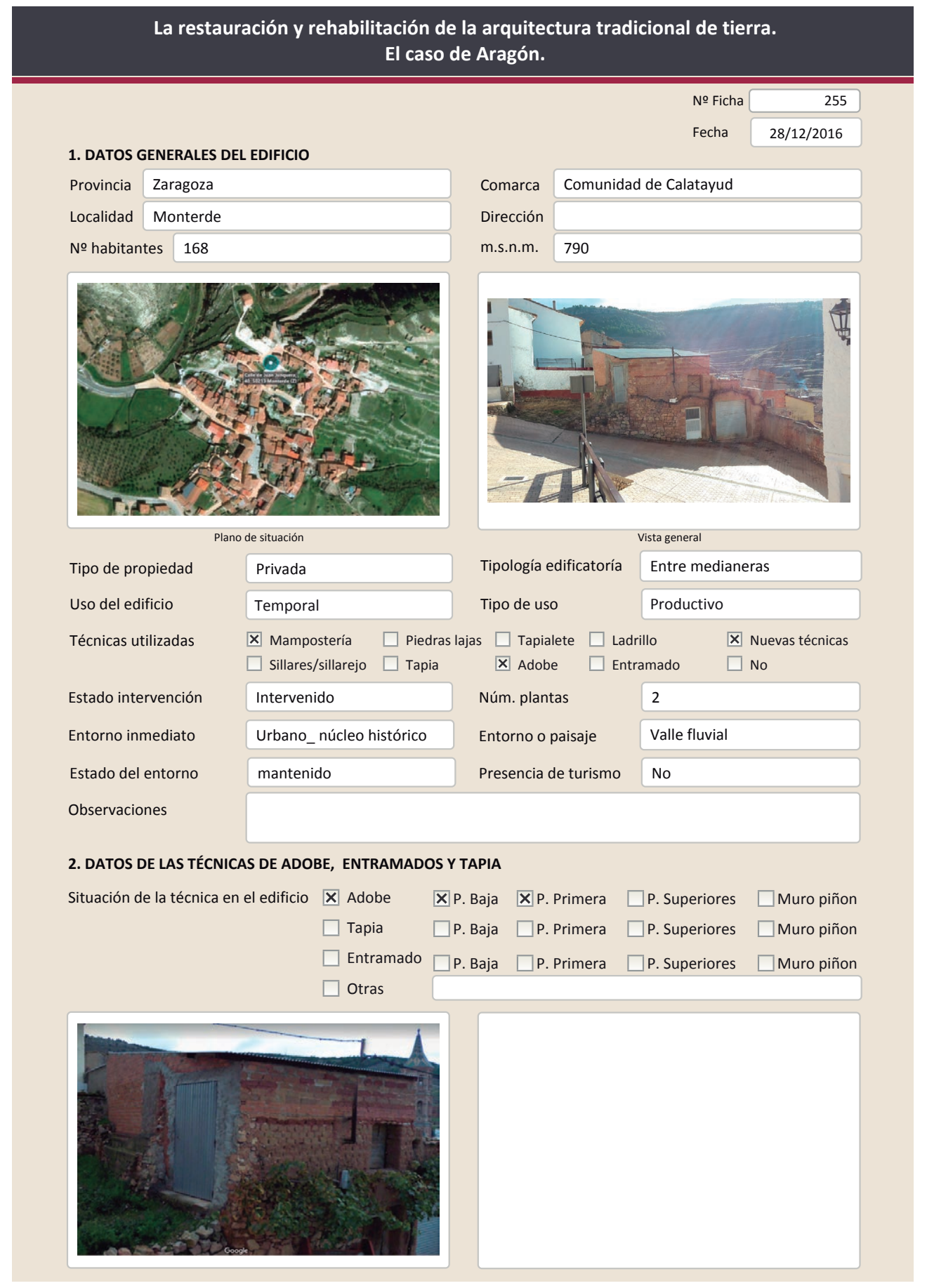

La restauración y rehabilitación de la arquitectura tradicional de tierra.

El caso de Aragón.
2.1. ADOBE
Dimensión de las piezas Dimensión del muro
Aparejo del muro
Función estructural
Variante constructiva/ tipo de fábrica
\ Simple
$\square$ suplementada en juntas
$\square$ Mixta
$\square$ Como suplemento
$\square$ Elementos de protección

\begin{tabular}{|l|}
\hline \\
\hline $30-40 \mathrm{~cm}$ \\
\hline Tizón \\
\hline $\mathrm{Si}$ \\
\hline
\end{tabular}

Color de las piezas

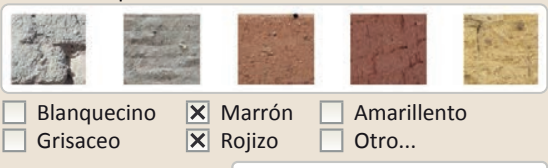

$X$ Rojizo $\square$ Otro...

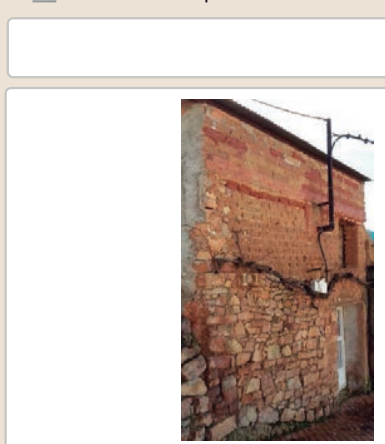
Lesiones $\quad$ Muro $\square$ Zócalo $\square$ Revestimiento $\square$ Cubierta $\square$ Otro...
区 Erosión del material $\square$ Humedad por capilaridad $\quad \square$ Grietas por asentamientos
$\square$ Erosion de las juntas $\square$ Humedades (manch/eflo) $\quad \square$ Colapso
$\square$ Pérdida de sección $\square$ Pérdida de verticalidad $\square$ Por elementos impropios
$\square$ Vegetación $\quad \square$ Grietas por empuje de la cubierta $\square$ Derivado de intervenciones
$\square$ Desconchados $\quad \square$ Grietas porfalta de traba $\quad \square$ Otro...




\section{La restauración y rehabilitación de la arquitectura tradicional de tierra.}

\section{El caso de Aragón.}

3. DATOS DE LA INTERVENCIÓN

Intervención de:

$\square$ Mantenimiento $\square$ Rehabilitación parcia

$\square$ Restauración $\square$ Demolición

Reflexión previa

X Reparación

Rehabilitación integra

Ampliación

$\square$ Otro..

Observaciones

Intervención espontanea

3.1. MUROS

Tipo de intervención

Intervenido

Tipo de material

$\square$ Actualización $\square$ Reintegración $\square$ Demolición $\square$ Otro...

$\square$ Consolidación $\quad$ Reconstrucción $\square$ Sustitución

Descripción

\begin{tabular}{|l|l|l|l|l} 
No tradicional & Tipo de técnica & Similar a la existente
\end{tabular}

3.2. ZóCALO

Reconstrucción del muro piñón con ladrillo y pequeño recrecido de todo el edificio

Tipo de intervención

Intervenido

Actualización $\times$ Reintegración $\square$ Demolición $\square$ Otro...

$\square$ Consolidación $\quad \square$ Reconstrucción $\square$ Sustitución

Tipo de material

No tradicional

Tipo de técnica Diferente a la existente

Descripción

El zócalo de la parte superior del edifico se ha reintegrado con hormigón

3.3. REVESTIMIENTOS

\section{No aplica}

Tipo de intervención

$\square$ Actualización $\square$ Reintegración $\square$ Demolición $\square$ Otro...

Tipo de material

Descripción

3.4. VANOS

Tipo de intervención

$\square$ Consolidación $\square$ Reconstrucción $\square$ Sustitución

Tipo de técnica

Tipo de material

Intervenido

Descripción

区 Reintegración $\square$ Demolición $\square$ Otro...

$\square$ Consolidación $\mathbf{X}$ Reconstrucción $\mathbf{X}$ Sustitución

3.5. CUBIERTA

No tradicional Tipo de técnica Diferente a la existente

Tipo de intervención

Reintegración de jambas de hueco de plana baja
superior del edificio. Sustitución de carpinterías

Tipo de intervención

Intervenido

$\begin{array}{lll}\text { Tipo de material } & \text { No tradicional } \\ \text { Descripción } & \text { Viguetas metálicas y cubierta de chapa ondulada }\end{array}$

$\square$ Actualización $\square$ Reintegración $\square$ Demolición $\square$ Otro..

$\square$ Consolidación $\square$ Reconstrucción $\quad$ S Sustitución

3.6. OTRAS

nica Diferente a la existente

Velas metalcas y cubieta dechapa ond 


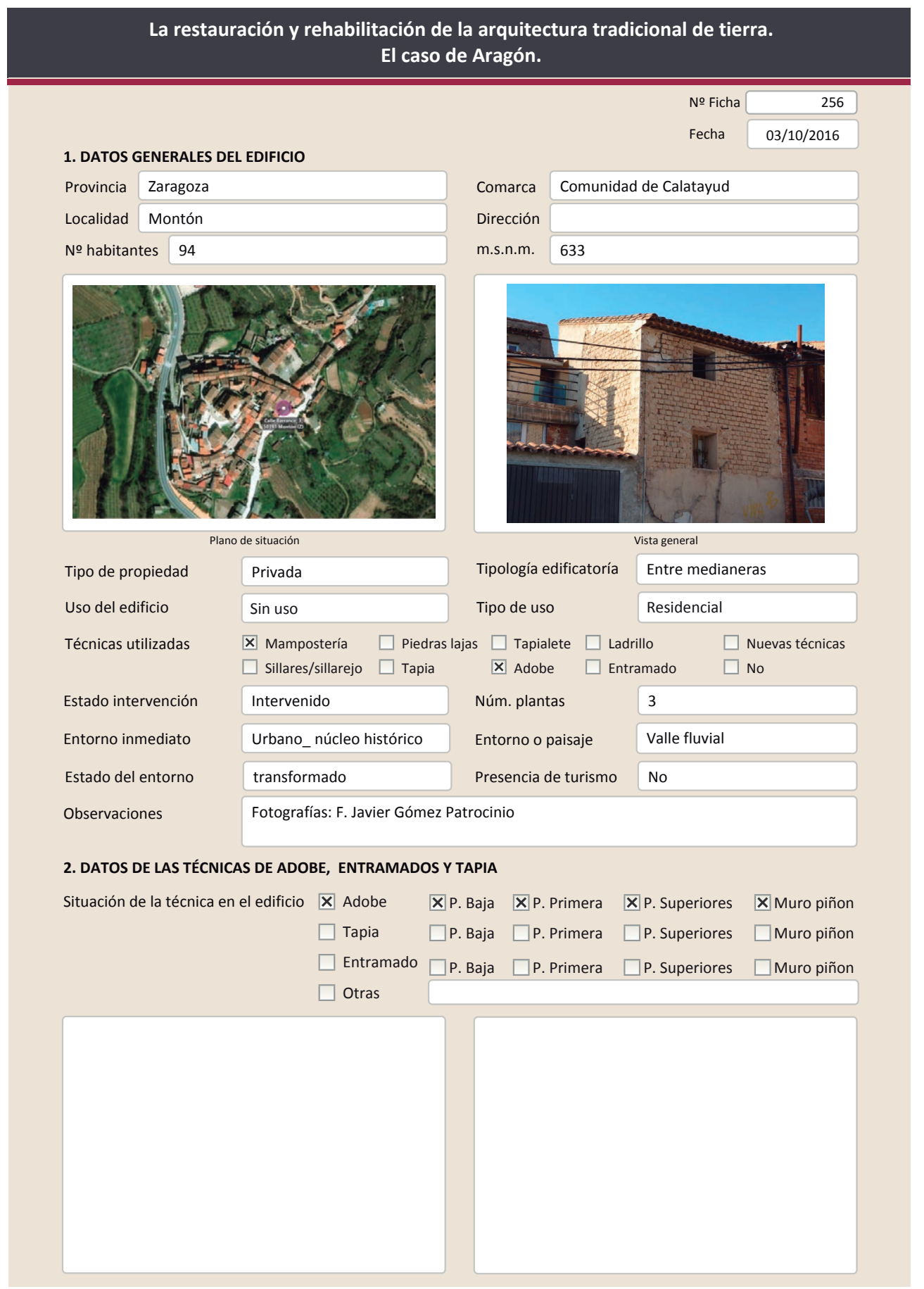

La restauración y rehabilitación de la arquitectura tradicional de tierra.

El caso de Aragón.
2.1. ADOBE
Dimensión de las piezas Dimensión del muro Aparejo del muro
Función estructural
メ Simple
$\square$ Suplementada en juntas
$\square$ Mixta
$\square$ Como suplemento
$\square$ Elementos de protección

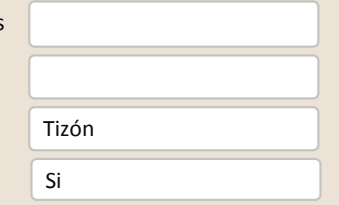
Color de las piezas

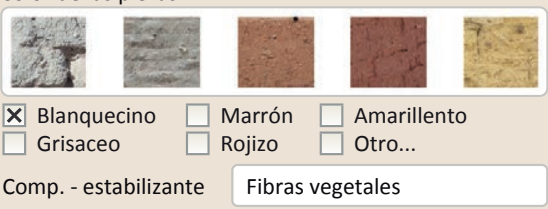

Comp. - estabilizante Fibras vegetales

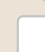

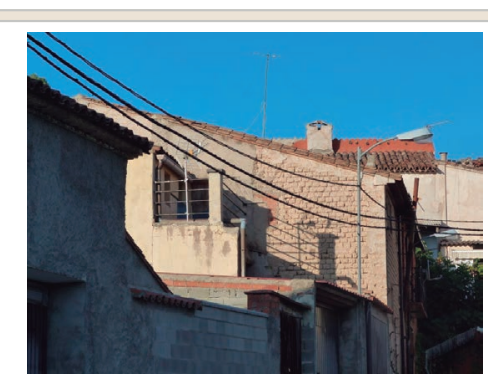

Lesiones $\quad$ Muro $\square$ Zócalo $\square$ Revestimiento $\square$ Cubierta $\square$ Otro...

区 Erosión del material $\square$ Humedad por capilaridad $\quad \square$ Grietas por asentamientos $\mathbf{X}$ Erosion de las juntas $\square$ Humedades (manch/eflo) $\square$ Colapso

$\square$ Pérdida de sección $\square$ Pérdida de verticalidad $\square$ Por elementos impropios

$\square$ Vegetación $\quad \square$ Grietas por empuje de la cubierta $\square$ Derivado de intervenciones

$\square$ Desconchados $\quad \square$ Grietas porfalta de traba $\quad \square$ Otro... 
La restauración y rehabilitación de la arquitectura tradicional de tierra. El caso de Aragón

\section{La restauración y rehabilitación de la arquitectura tradicional de tierra.}

\section{El caso de Aragón.}

3. DATOS DE LA INTERVENCIÓN

Intervención de:

$\square$ Mantenimiento $\square$ Rehabilitación parcia

$\square$ Restauración $\square$ Demolición X Reparación $\quad \square$ Rehabilitación integral $\quad \square$ Ampliación $\quad \square$ Otro...

Reflexión previa

Intervención espontanea

Observaciones

Inter

3.1. MUROS

No intervenido

Tipo de intervención

$\square$ Actualización

$\square$ Consolidación $\square$ Reconstrucción $\square$ Sustitución

Tipo de material

Descripción

3.2. ZÓCALO

Tipo de intervención

Intervenido

Tipo de intervención

$\square$ Actualizació

Descripción

No tradicion

Revestimiento de cemento

3.3. REVESTIMIENTOS

Intervenido

Tipo de intervención

$\square$ Actualización $\square$ Reintegración $\square$ Demolición $\square$ Otro...

$\square$ Consolidación $\mathbf{X}$ Reconstrucción $\square$ Sustitución

Tipo de material

Descripción

No tradicional

Tipo de técnica Diferente a la existente

3.4. VANOS

Revestimiento parcial en el muro piñón del edificio

Tipo de intervención

No intervenido

Tipo de material

$\square$ Actualización $\square$ Reintegración $\square$ Demolición $\quad \square$ Otro...

Descripción

$\square$ Consolidación $\square$ Reconstrucción $\square$ Sustitución

(3.5. CUBERTA

3.5. CUBIERTA

Tipo de intervención

No intervenido

Tipo de material

$\square$ Actualización

$\square$ Consolidación $\square$ Reconstrucción $\quad \square$ Sustitución

Tipo de técnica

Descripción

Tipo de técnica

3.6. OTRAS 
La restauración y rehabilitación de la arquitectura tradicional de tierra. El caso de Aragón.

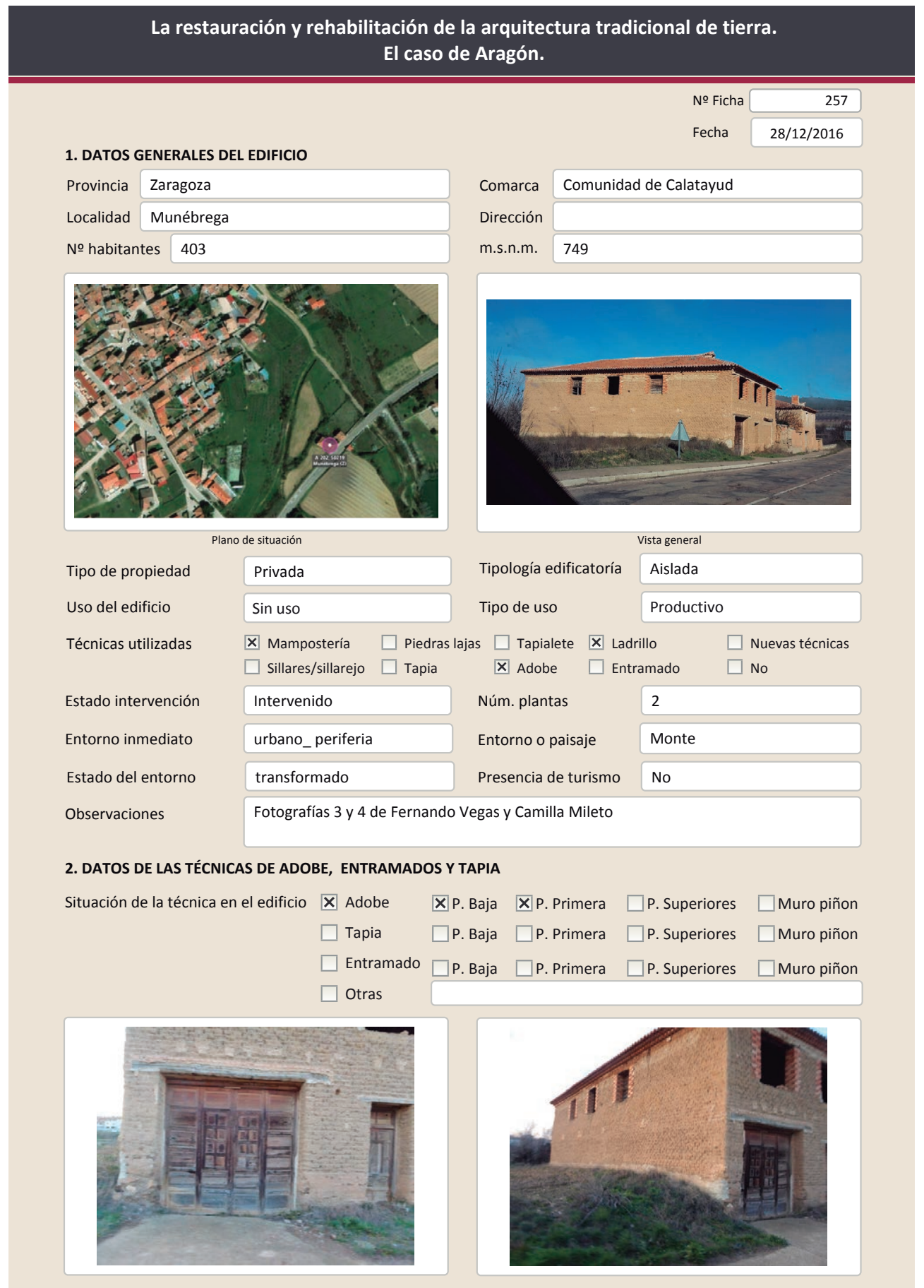

La restauración y rehabilitación de la arquitectura tradicional de tierra.

El caso de Aragón.
2.1. ADOBE

Dimensión de las piezas

Dimensión del muro

Aparejo del muro

Función estructural
Color de las piezas

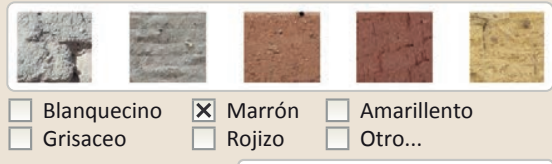

Rojizo $\square$ Otro..
Variante constructiva/ tipo de fábrica

X Simple

$\square$ Suplementada en juntas

$\square$ Mixta

$\square$ Como suplemento

$\square$ Elementos de protección
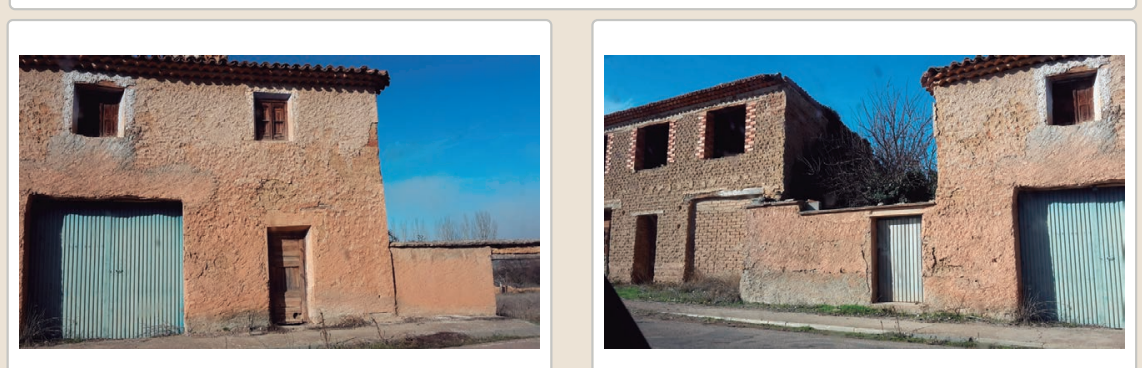

Lesiones $\mathbf{X}$ Muro $\square$ Zócalo $\square$ Revestimiento $\square$ Cubierta $\square$ Otro...

Х Erosión del material $\quad \square$ Humedad por capilaridad $\quad \square$ Grietas por asentamientos $\square$ Erosion de las juntas $\square$ Humedades (manch/eflo) $\quad \square$ Colapso

$\square$ Pérdida de sección $\square$ Pérdida de verticalidad

$\square$ Vegetación $\quad \square$ Grietas por empuje de la cubierta

$\square$ Por elementos impropios

$\square$ Desconchados

$\square$ Grietas porfalta de traba

$\square$ Derivado de intervenciones

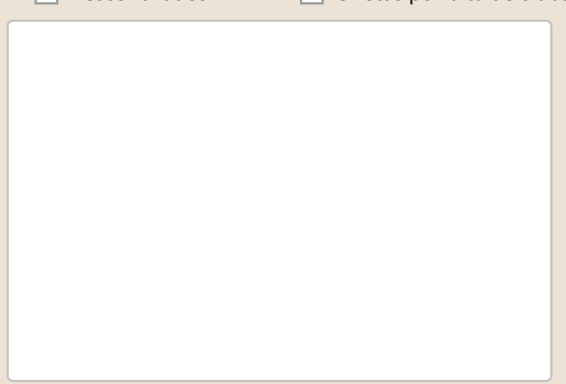

$\square$ Otro...

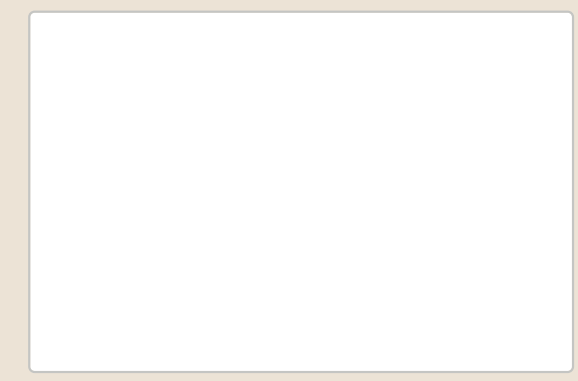

Observaciones 
La restauración y rehabilitación de la arquitectura tradicional de tierra. El caso de Aragón

\section{La restauración y rehabilitación de la arquitectura tradicional de tierra.}

\section{El caso de Aragón.}

3. DATOS DE LA INTERVENCIÓN

Intervención de:

$\square$ Mantenimiento $\square$ Rehabilitación parcia

$\square$ Restauración $\square$ Demolición X Reparación $\square$ Rehabilitación integral $\square$ Ampliación $\square$ Otro...

Reflexión previa

Intervención espontanea

Observaciones

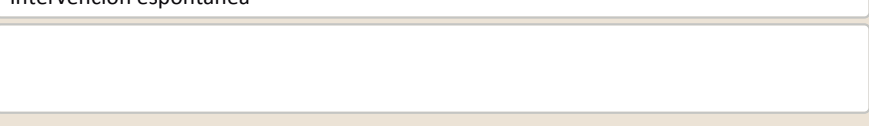

3.1. MUROS

No intervenido

Tipo de intervención

$\square$ Actualización $\square$ Reintegración $\square$ Demolición $\square$ Otro...

$\square$ Consolidación $\square$ Reconstrucción $\square$ Sustitución

Tipo de material

Descripción

3.2. ZÓCALO

Tipo de intervención

No intervenido

Tipo de material

Actualización $\square$ Reintegración $\square$ Demolición $\square$ Otro...

$\square$ Consolidación $\square$ Reconstrucción $\square$ Sustitución

Descripción

3.3. REVESTIMIENTOS

Tipo de intervención

\section{No aplica}

Tipo de material

Descripción Tipo de técnica

3.4. VANOS

Tipo de intervención

Intervenido

Tipo de material

$\square$ Actualización $\quad \mathbf{X}$ Reintegración $\quad \square$ Demolición $\square$ Otro...

Tipo de materia
Descripción

Consolidación $\square$ Reconstrucción $\square$ Sustitución

3.5. CUBIERTA

Tipo de intervención

No tradicional

Tipo de técnica Similar a la existente

Reintegración de las jambas de planta primera con ladrillo hueco

Tipo de intervención

Intervenido

Tipo de material

$\square$ Actualización $\quad \boldsymbol{X}$ Reintegración $\square$ Demolición $\square$ Otro.

Descripción

Descripción

No tradicional

Tipo de técnica Similar a la existente

3.6. OTRAS

Reintegración de cumbreras y alero con cemento 


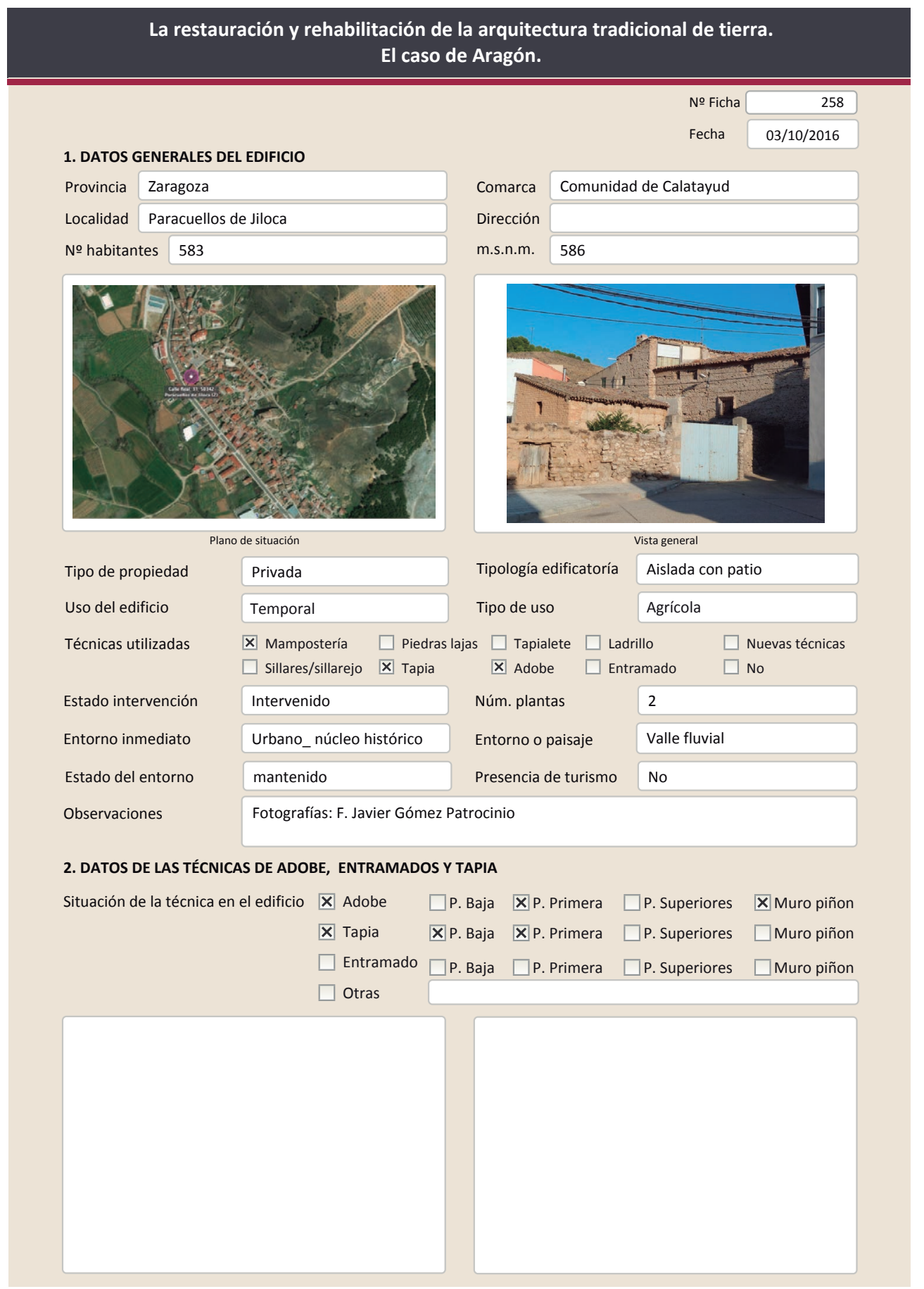

La restauración y rehabilitación de la arquitectura tradicional de tierra.

El caso de Aragón.

2.1. ADOBE

Dimensión de las piezas Dimensión del muro

Aparejo del muro

Función estructural

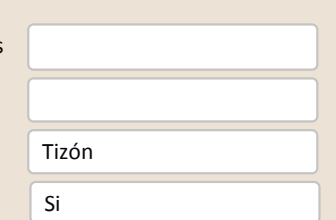

Color de las piezas

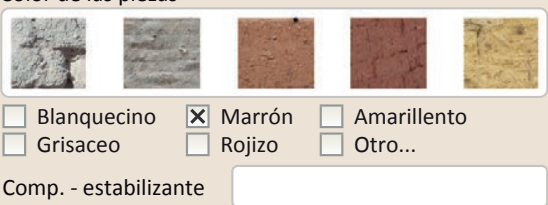

Variante constructiva/ tipo de fábrica

X simple
$\mathbf{X}$ Suplementada en juntas
Horizontales
$\mathrm{Cal} /$ yeso
$\square$ Mixta

$\square$ Como suplemento

$\square$ Elementos de protección

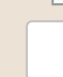

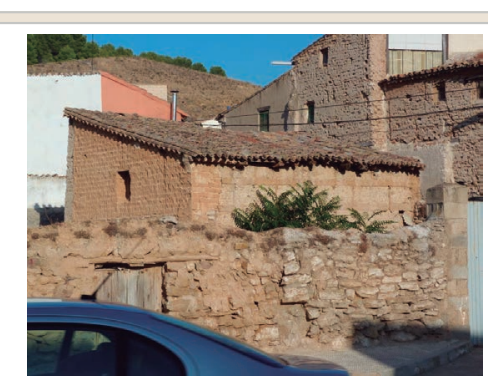

Lesiones $\quad$ Muro $\square$ Zócalo $\square$ Revestimiento

X Erosión del material $\square$ Humedad por capilaridad $\square$ Erosion de las juntas $\square$ Humedades (manch/eflo)

$\square$ Pérdida de sección $\square$ Pérdida de verticalidad

$\square$ Vegetación $\quad \square$ Grietas por empuje de la cubierta

$\square$ Desconchados

$\square$ Grietas por empuje de la
$\square$ Grietas porfalta de traba

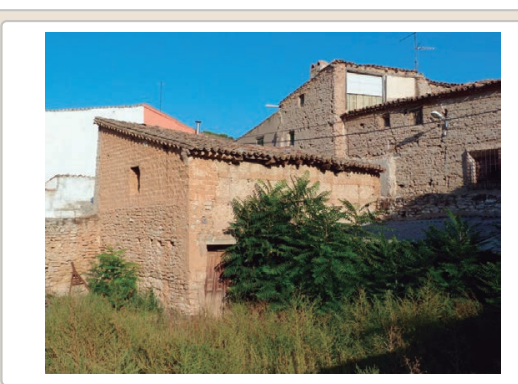

$\square$ Cubierta $\square$ Otro...
$\square$ Grietas p
$\square$ Colapso
$\square$ Por elementos impropios

$\square$ Derivado

Observaciones 


\section{La restauración y rehabilitación de la arquitectura tradicional de tierra.} El caso de Aragón.

\subsection{TAPIA}

Ancho del muro

Dimensión tapiales

Tipo de aguja

№ agujas/cajón

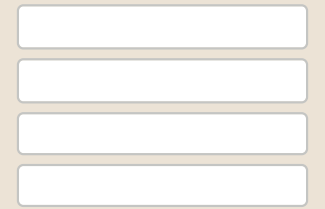

\section{Color de la tapia}

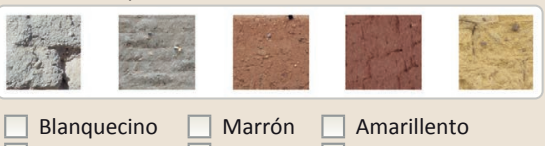

$\square$ Blanquecino $\square$ Marrón $\square$ Amarillento $\square$ Grisaceo

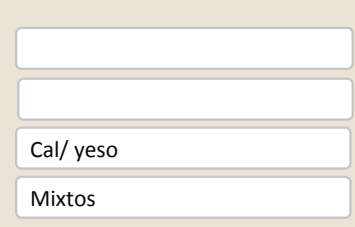

Variante constructiva

$\square$ Simple / homogénea

$\square$ suplemento superficial

$X$ Suplemento en juntas

X Mixta

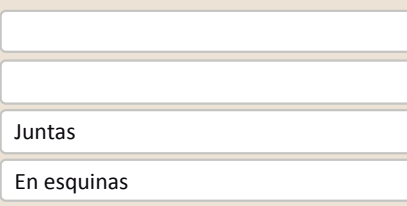

Mixto

$\square$ Elementos de protección

Una esquina es de adobe y la otra de mampostería y yeso

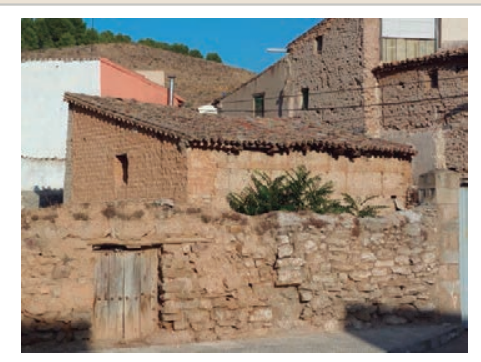

Lesiones $\square$ Muro $\square$ Zócalo $\square$ Revestimiento $\square$ Cubierta $\square$ otro...

$\square$ Erosión del material $\quad \square$ Humedad por capilaridad $\quad \square$ Grietas por asentamientos

$\square$ Erosion de las juntas $\square$ Humedades (manch/eflo) $\quad \square$ Colapso

$\square$ Pérdida de sección $\square$ Pérdida de verticalidad $\square$ Por elementos impropios

$\square$ Vegetación $\square$ Grietas por empuje de la cubierta $\square$ Derivado de intervencion

$\square$ Desconchados $\quad \square$ Grietas porfalta de traba $\quad \square$ Otro...
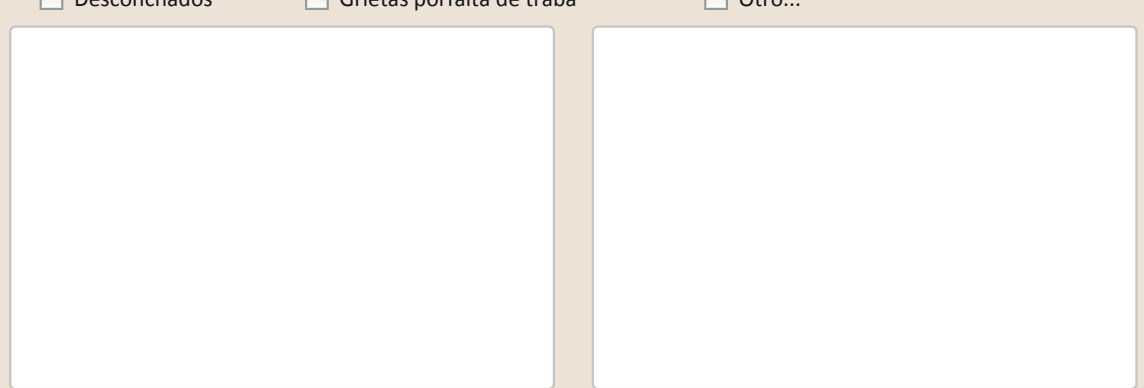

Observaciones
La restauración y rehabilitación de la arquitectura tradicional de tierra.

El caso de Aragón.

3. DATOS DE LA INTERVENCIÓN

Intervención de: $\quad \square$ Mantenimiento $\quad \square$ Rehabilitación parcial $\quad \square$ Restauración $\square$ Demolición

Reflexión previa Intervención espontanea

Observaciones

3.1. MUROS

Tipo de intervención

No intervenido

Tipo de material

$\square$ Actualización $\square$ Reintegración $\square$ Demolición $\square$ Otro..

$\square$ Consolidación $\square$ Reconstrucción $\square$ sustitución

Descripción

3.2. ZÓCALO

No intervenido

Tipo de intervención

Actualización $\square$ Reintegración $\square$ Demolición $\square$ Otro..

$\square$ Consolidación $\square$ Reconstrucción $\square$ Sustitución

Tipo de material

Descripción

3.3. REVESTIMIENTOS

Tipo de intervención

No aplica

Tipo de material

Descripción

3.4. VANOS

Tipo de intervención

Intervenido

Tipo de material

$\square$ Actualización $\square$ Reintegración $\square$ Demolición $\square$ Otro..

$\square$ Consolidación $\square$ Reconstrucción $\quad \mathbf{X}$ Sustitución

\begin{tabular}{l|l|l|l} 
Tipo de material & No tradicional & Tipo de técnica & Diferente a la existente
\end{tabular}

Descripción Sustitución del dintel de la puerta de planta baja por una vigueta de hormigón prefabricado

3.5. CUBIERTA

No intervenido

Tipo de intervención

$\square$ Actualización

Tipo de material

$\square$ Consolidación $\square$ Reconstrucción $\square$ sustitución

Descripción

Tipo de técnica 


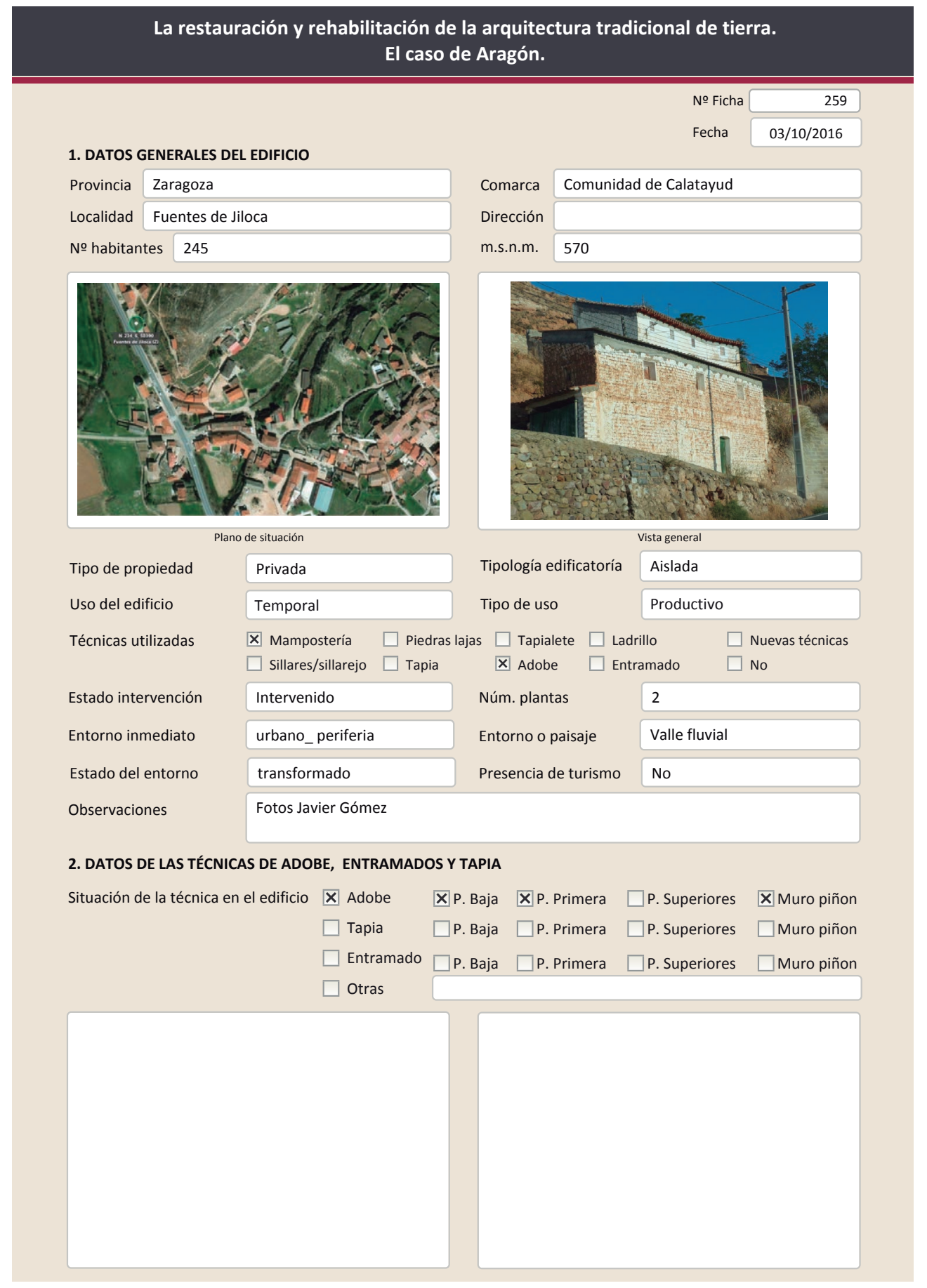

La restauración y rehabilitación de la arquitectura tradicional de tierra.

El caso de Aragón.
2.1. ADOBE
Dimensión de las piezas
Dimensión del muro
Aparejo del muro
Tizón
Función estructural
$\mathrm{Si}$
区 Simple
$\square$ Suplementada en juntas
$\square$ Mixta
$\square$ Como suplemento
$\square$ Elementos de protección
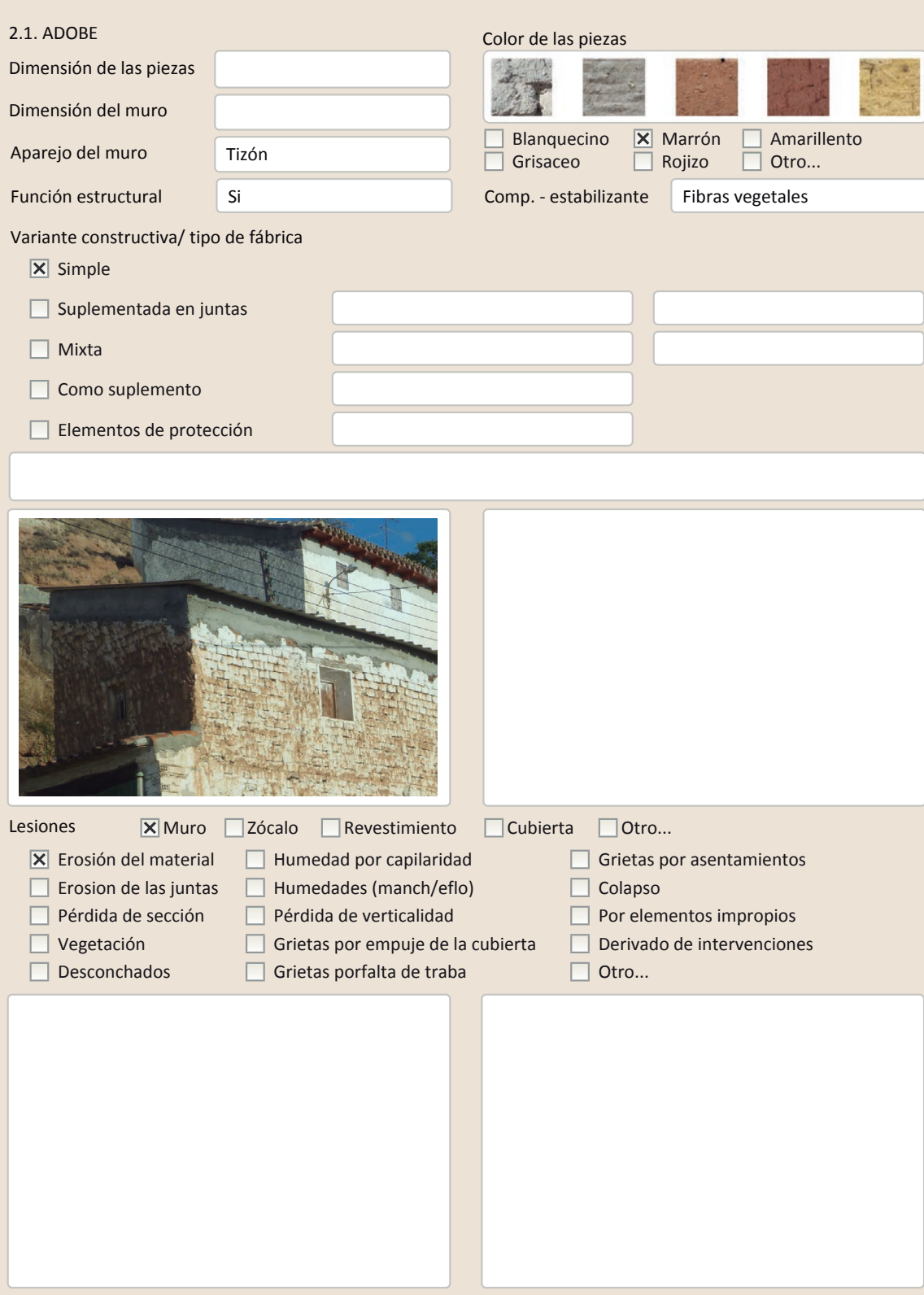

Observaciones 
La restauración y rehabilitación de la arquitectura tradicional de tierra. El caso de Aragón

\section{La restauración y rehabilitación de la arquitectura tradicional de tierra.}

\section{El caso de Aragón.}

3. DATOS DE LA INTERVENCIÓN

Intervención de:

$\square$ Mantenimiento $\quad \mathbf{X}$ Rehabilitación parcial

$\square$ Restauración $\square$ Demolición

Reflexión previa

$\square$ Reparación

$\square$ Rehabilitación integral $\square$ Ampliació

$\square$ Otro..

Observaciones

Intervención espontanea

3.1. MUROS

Tipo de intervención

Intervenido

Tipo de material

$\square$ Actualización $\square$ Reintegración $\square$ Demolición $\square$ Otro..

$\square$ Consolidación $\quad$ Xeconstrucción $\square$ Sustitución

\begin{tabular}{l|l|l|l|l|l} 
No tradicional & Tipo de técnica & Diferente a la existente
\end{tabular}

Descripción Recrecido del muro $(50 \mathrm{~cm}$ aprox) con revestimiento de cemento sobre el que apoya la nueva cubierta

3.2. ZÓCALO

No intervenido

Tipo de intervención

$\square$ Actualización

Tipo de material

$\square$ Consolidación $\square$ Reconstrucción $\square$ Sustitución

Descripción

3.3. REVESTIMIENTOS

Tipo de intervención

Intervenido

Tipo de material

X Actualización

$\square$ Consolidación

$\square$ Reintegración $\square$ Demolición $\square$ Otro...

No tradicional Tipo de técnica

Descripción

Pintura blanca o encalado

3.4. VANOS

Intervenido

Tipo de intervención $\quad \square$ Actualización $\square$ Reintegración $\quad \square$ Demolición $\square$ Otro...

$\begin{array}{lll} & \square \text { Consolidación } \quad \boldsymbol{X} \text { Reconstrucción } \square \text { Sustitución } \\ \text { Tipo de material } & \text { No tradicional } & \text { Tipo de técnica } \\ & \text { Referente a la existente }\end{array}$

Descripción Reconstrucción del hueco de acceso lateral con jambas de ladrillo y nuevo tejadillo

3.5. CUBIERTA

Tipo de intervención

Intervenido

Tipo de material

$\square$ Actualización $\square$ Reintegración $\square$ Demolición $\square$ Otro..

$\square$ Consolidación $\square$ Reconstrucción $\bigotimes$ Sustitución

\begin{tabular}{l|l|l|l|l|l} 
No tradicional & Tipo de técnica & Diferente a la existente \\
\hline
\end{tabular}

Descripción

Cubierta de chapa grecada

3.6. OTRAS 


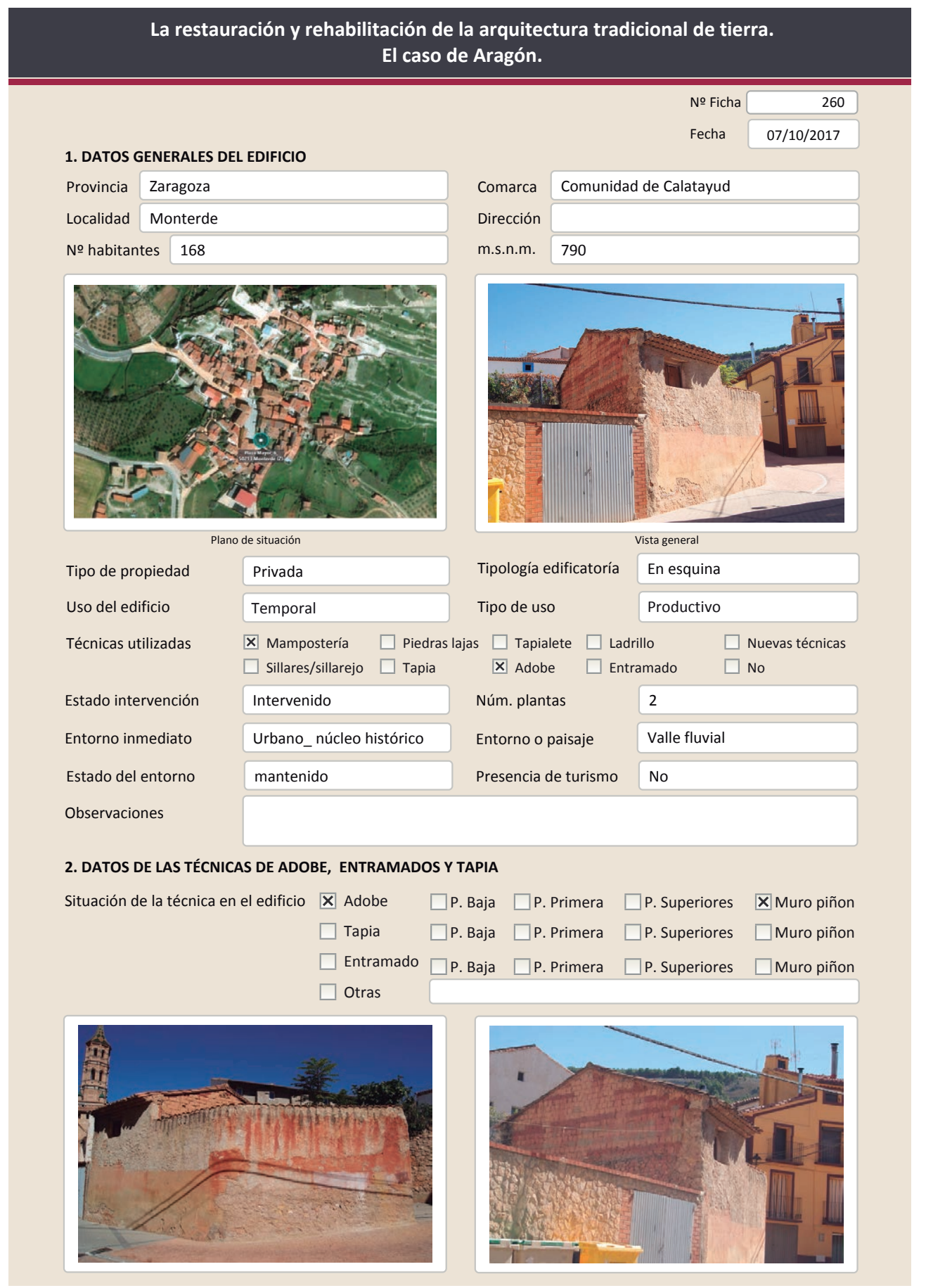

La restauración y rehabilitación de la arquitectura tradicional de tierra.

2.1. ADOBE

Dimensión de las piezas Dimensión del muro

Aparejo del muro

Función estructural

\section{El caso de Aragón.}

Color de las piezas

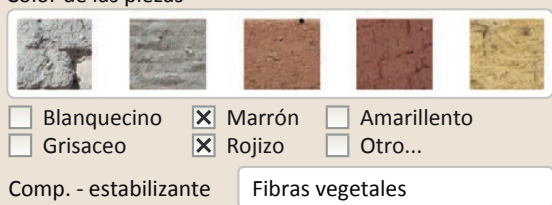

Comp. - estabilizante Fibras vegetales

Variante constructiva/ tipo de fábrica

$\square$ simple

$\square$ Suplementada en juntas

X Mixta

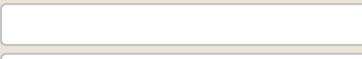

$\square$ Como suplemento

$\square$ Elementos de protección

Hay tres tipos de adobe distintos en el edificio.

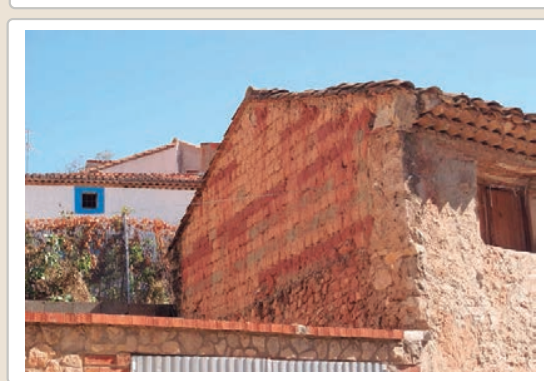

Lesiones X $\quad$ Muro XZócalo $\square$ Revestimiento

X Erosión del material $\quad \mathbf{X}$ Humedad por capilaridad $\square$ Erosion de las juntas $\mathbf{X}$ Humedades (manch/eflo)

$\square$ Pérdida de sección $\square$ Pérdida de verticalidad

$\square$ Vegetación $\quad \square$ Grietas por empuje de la c $\square$ Grietas porfalta de traba

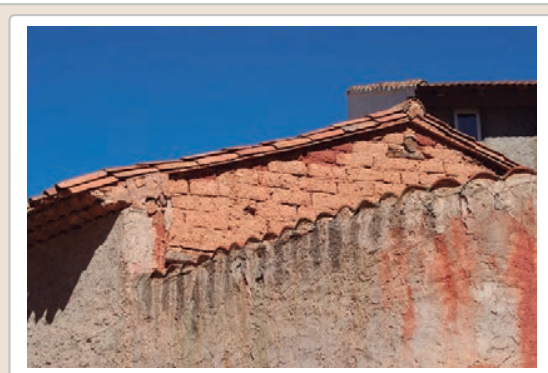

$\square$ Cubierta $\square$ otro...

$\square$ Desconchado

$\square$ Grietas por asentamientos

$\square$ Colapso

$\square$ Por elementos impropios

$\square$ Derivado de intervenciones

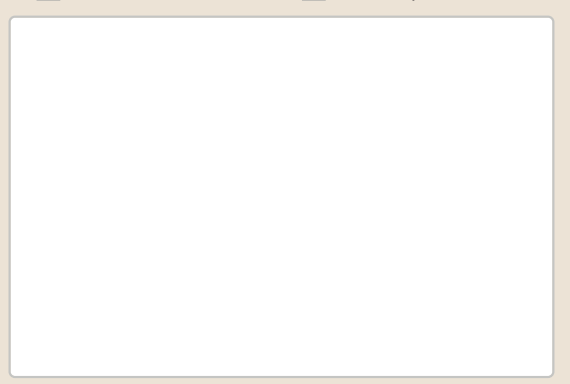
$\square$ Otro...

Observaciones 
La restauración y rehabilitación de la arquitectura tradicional de tierra. El caso de Aragón

\section{La restauración y rehabilitación de la arquitectura tradicional de tierra.}

\section{El caso de Aragón.}

3. DATOS DE LA INTERVENCIÓN

Intervención de:

$\square$ Mantenimiento $\square$ Rehabilitación parcia

$\square$ Restauración $\square$ Demolición

X Reparación $\square$ Rehabilitación integral $\square$ Ampliación $\square$ Otro...

Reflexión previa

Intervención espontanea

Observaciones

(n)

3.1. MUROS

No intervenido

Tipo de intervención

$\square$ Actualización $\square$ Reintegración $\square$ Demolición $\square$ Otro...

$\square$ Consolidación $\square$ Reconstrucción $\square$ Sustitución

Tipo de material

Descripción

3.2. ZÓCALO

Tipo de intervención

Intervenido

Tipo de intervención

$\square$ Actualizació

Tipo de material

Descripción

Revestimiento de cemento

3.3. REVESTIMIENTOS

Intervenido

Tipo de intervención

$\square$ Actualización $\square$ Reintegración $\square$ Demolición $\square$ Otro...

Tipo de material

$\square$ Consolidación $\quad \mathbf{X}$ Reconstrucción $\square$ Sustitución

Descripción

No tradicional Tipo de técnica Diferente a la existente

Revestimiento en la pare exterior del edificio que da a la calle

3.4. VANOS

No intervenido

Tipo de intervención $\square$ Actualización $\square$ Reintegración $\square$ Demolición $\square$ Otro...

Tipo de material $\quad \square$ Consolidación $\square$ Reconstrucción $\square$ sustitución

Descripción

3.5. CUBIERTA

Tipo de intervención

No intervenido

Tipo de material

$\square$ Actualización

$\square$ Consolidación $\square$ Reconstrucción $\quad \square$ Sustitución

Tipo de técnica

Descripción

Tipo de técnica

3.6. OTRAS 


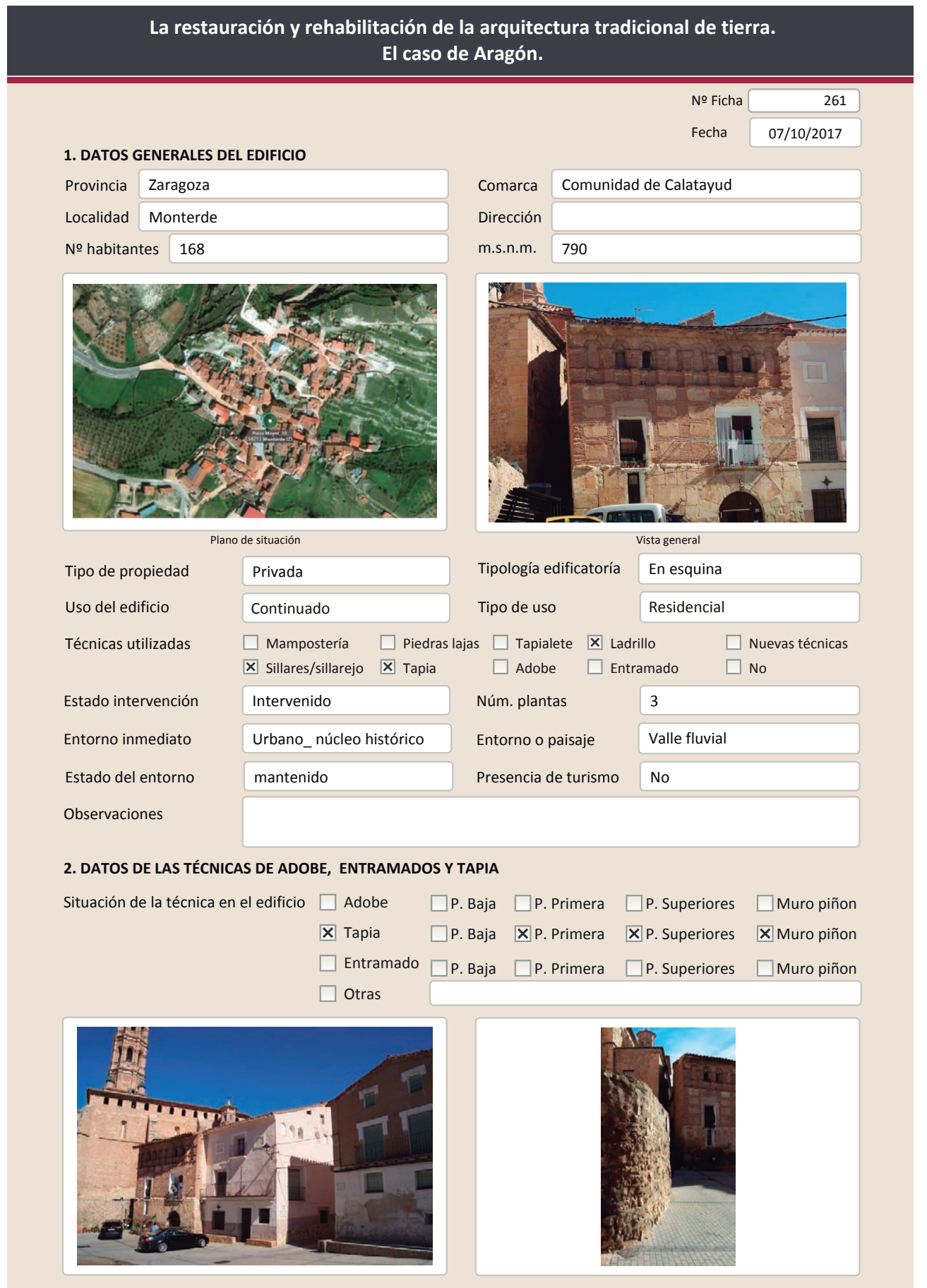

La restauración y rehabilitación de la arquitectura tradicional de tierra. El caso de Aragón.

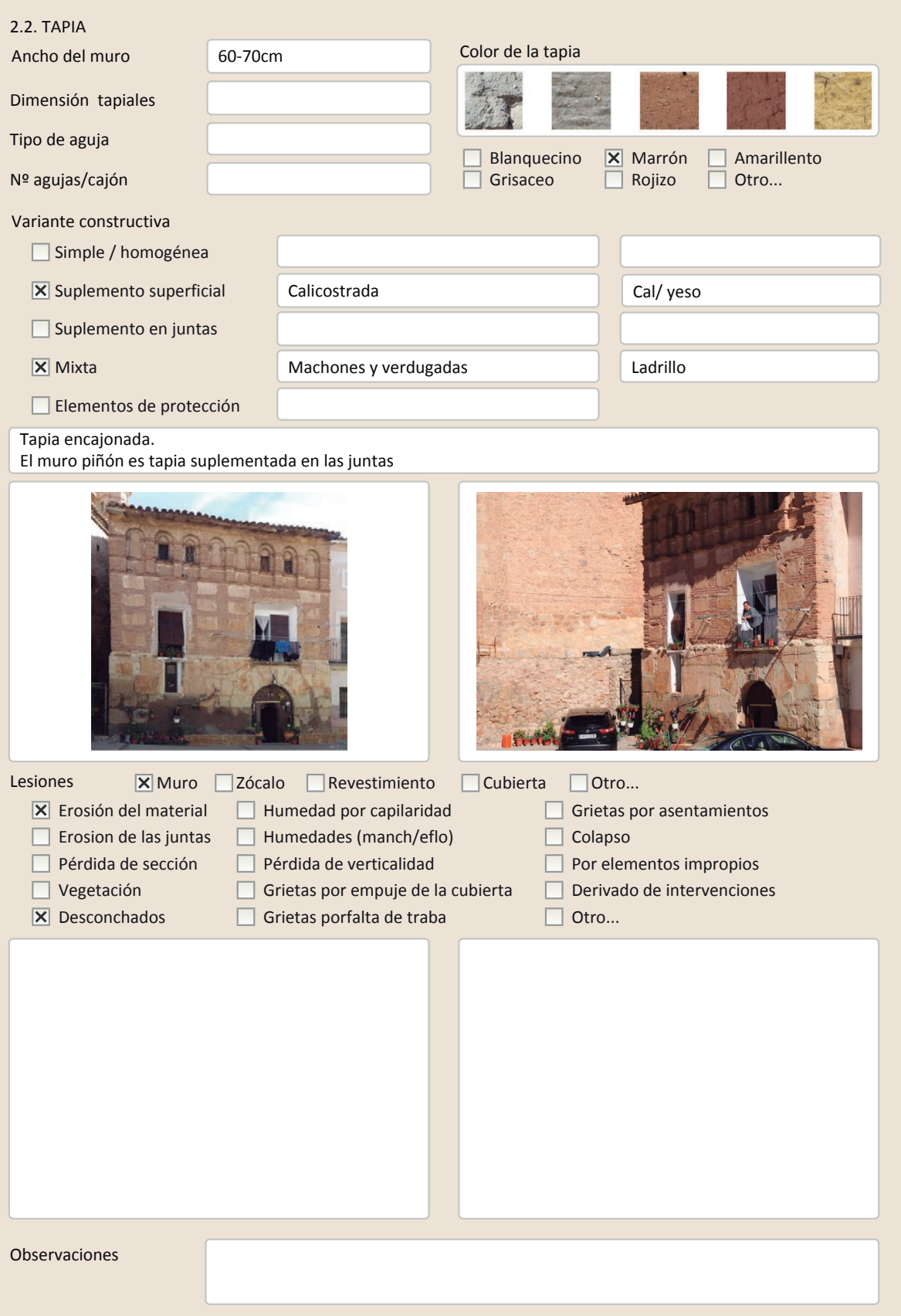


La restauración y rehabilitación de la arquitectura tradicional de tierra. El caso de Aragón

\section{La restauración y rehabilitación de la arquitectura tradicional de tierra.}

\section{El caso de Aragón.}

3. DATOS DE LA INTERVENCIÓN

Intervención de:

$\square$ Mantenimiento $\quad \mathbf{X}$ Rehabilitación parcial

$\square$ Restauración $\square$ Demolición

Reflexión previa

$\square$ Reparación

$\square$ Rehabilitación integral $\square$ Ampliació

$\square$ Otro..

Reflexión previa
Observaciones

Intervención espontanea

3.1. MUROS

Tipo de intervención

No intervenido

Tipo de material

$\square$ Actualización $\square$ Reintegración $\square$ Demolición $\square$ Otro...

$\square$ Consolidación $\square$ Reconstrucción $\square$ Sustitución

Descripción

3.2. ZÓCALO

No intervenido

Tipo de intervención

$\square$ Actualización

Tipo de material

Descripción

3.3. REVESTIMIENTOS

Tipo de intervención

\section{No aplica}

Tipo de material

$\square$ Actualización

Tipo de técnica

Descripción

3.4. VANOS

Tipo de intervención

Intervenido

$\square$ Actualización $\mathbf{X}$ Reintegración $\square$ Demolición $\square$ Otro...

$\square$ Consolidación $\quad \square$ Reconstrucción $\quad \boldsymbol{X}$ Sustitución

\begin{tabular}{l|l|l|l|l} 
Tipo de material & No tradicional & Tipo de técnica & Diferente a la existente
\end{tabular}

Descripción Sustitución de carpinterías. Reintegración de una nueva composición de huecos dentro del hueco original

3.5. CUBIERTA

Tipo de intervención

Intervenido

Tipo de material

$\square$ Actualización $\quad$ X Reintegración $\square$ Demolición $\square$ Otro.

$\square$ Consolidación $\quad \square$ Reconstrucción $\quad \square$ Sustitución

\begin{tabular}{|l|l|l|l|l|l|l|l}
\hline & Tipo de técnica & Diferente a la existente \\
\hline
\end{tabular}

Descripción

Pequeñas reintegraciones con gran cantidad de cemento

3.6. OTRAS 


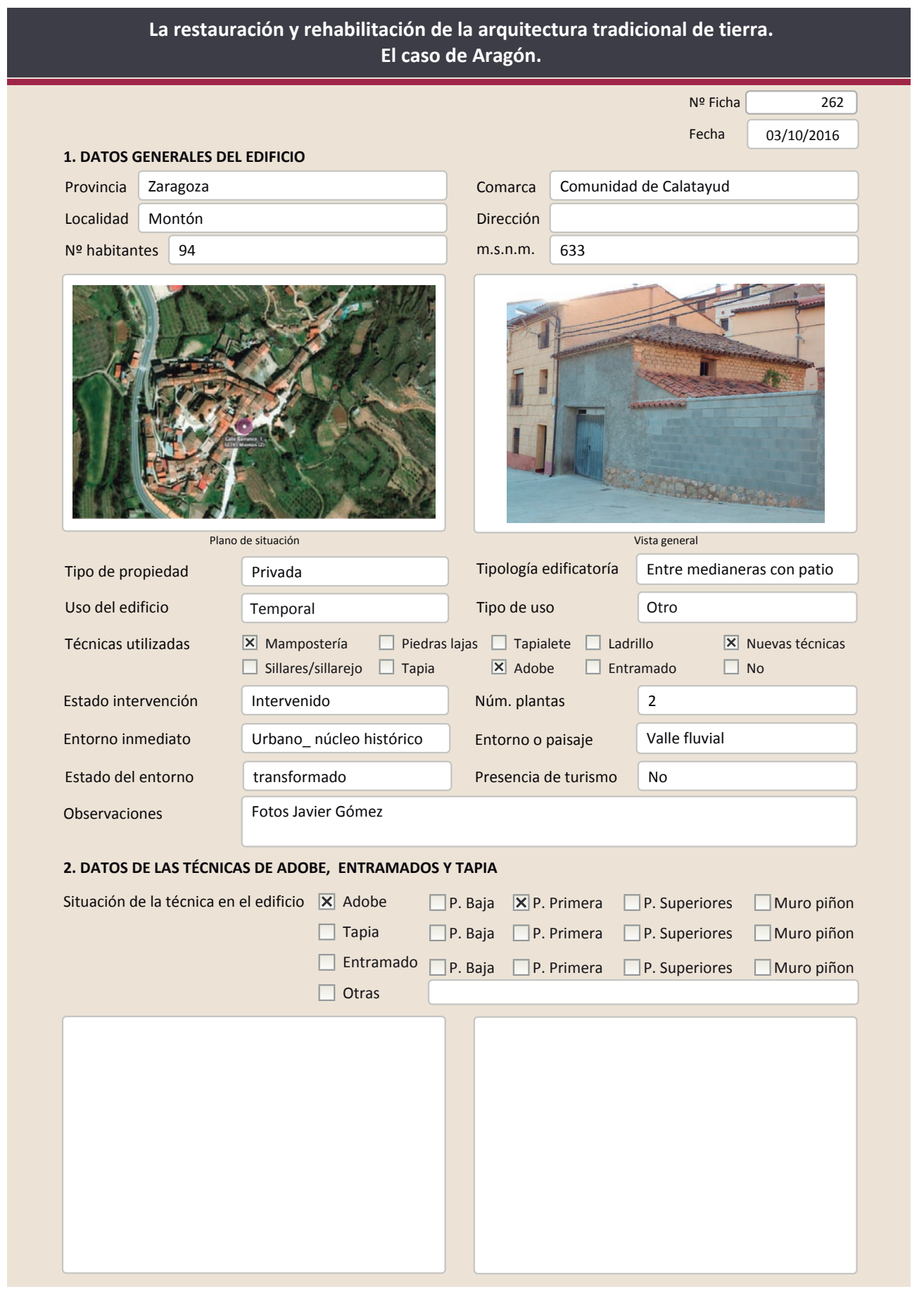

La restauración y rehabilitación de la arquitectura tradicional de tierra.

\subsection{ADOBE}

Dimensión de las piezas Dimensión del muro

Aparejo del muro

Función estructural

\section{El caso de Aragón.}

Color de las piezas

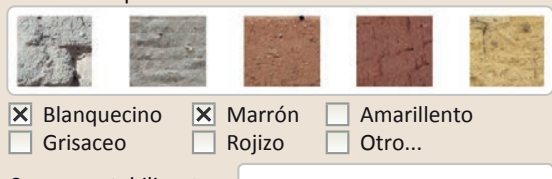

$\square$ Grisaceo $\square$ Rojizo $\square$ Otro..

Variante constructiva/ tipo de fábrica

\section{Simple}

$\square$ suplementada en juntas

$\square$ Mixta

$\square$ Como suplemento

$\square$ Elementos de protección

" tipos de adobe distintos

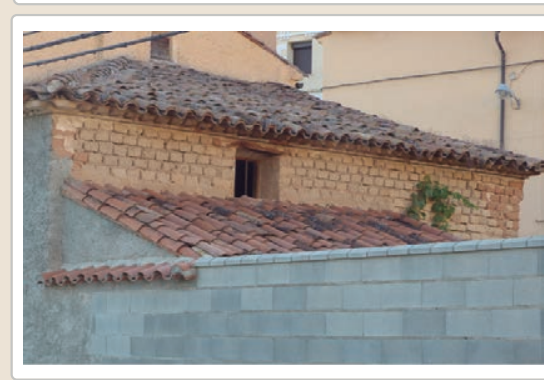

Lesiones $\square$ Muro $\square$ Zócalo $\square$ Revestimiento

$\square$ Erosión del material $\square$ Humedad por capilaridad

$\square$ Erosion de las juntas $\square$ Humedades (manch/eflo)

$\square$ Pérdida de sección $\square$ Pérdida de verticalidad

$\begin{array}{ll}\square \text { Vegetación } & \square \text { Grietas por empuje de la c } \\ \square \text { Desconchados } & \square \text { Grietas porfalta de traba }\end{array}$ $\square$ Grietas porfalta de traba

$\square$ Cubierta $\square$ otro...

$\square$ Grietas por asentamiento

$\square$ Colapso

$\square$ Por elementos impropios

$\square$ Derivado de intervenciones

$\square$ Otro...

Observaciones 


\section{La restauración y rehabilitación de la arquitectura tradicional de tierra.}

\section{El caso de Aragón.}

3. DATOS DE LA INTERVENCIÓN

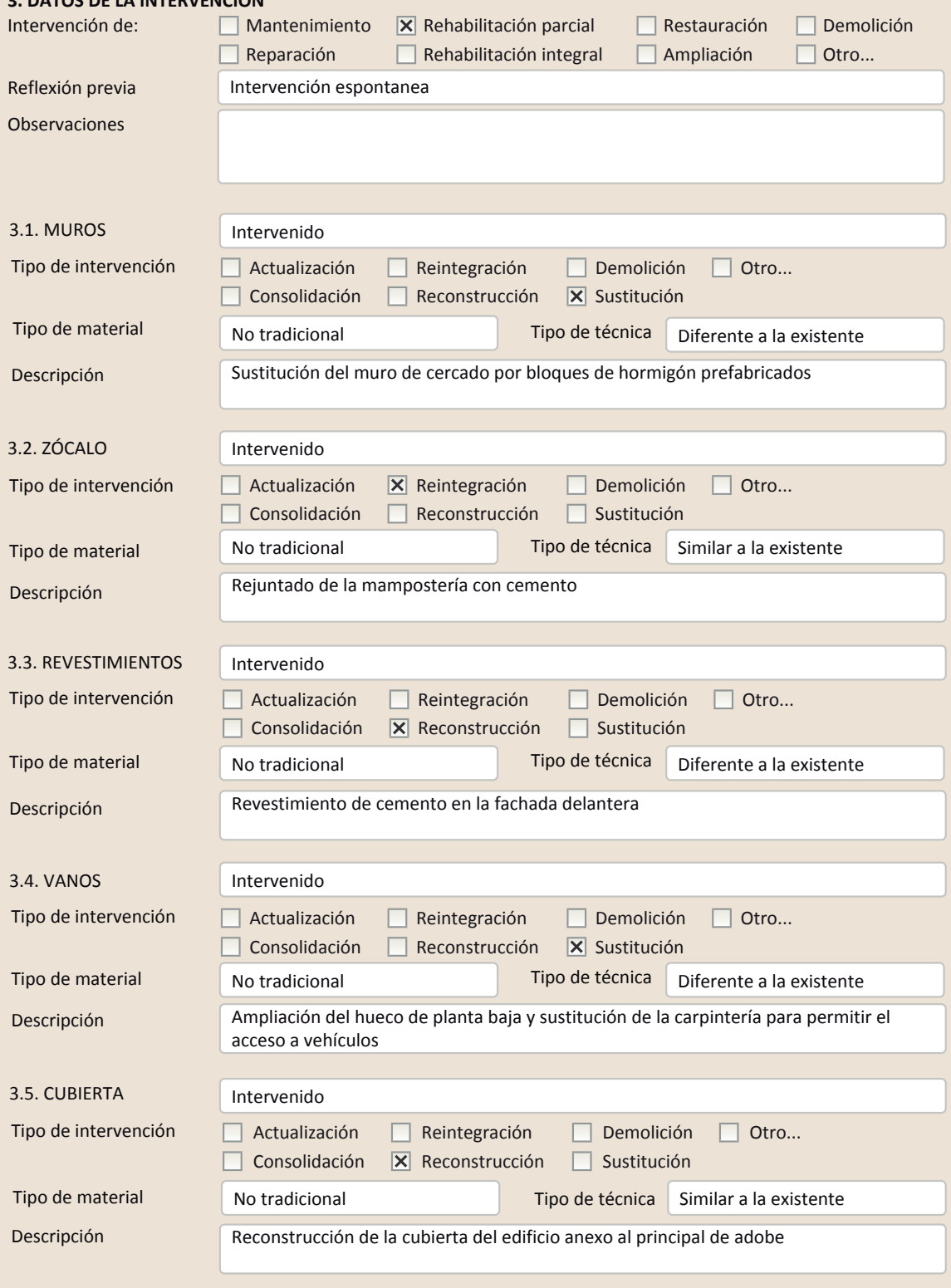

3.6. OTRAS 


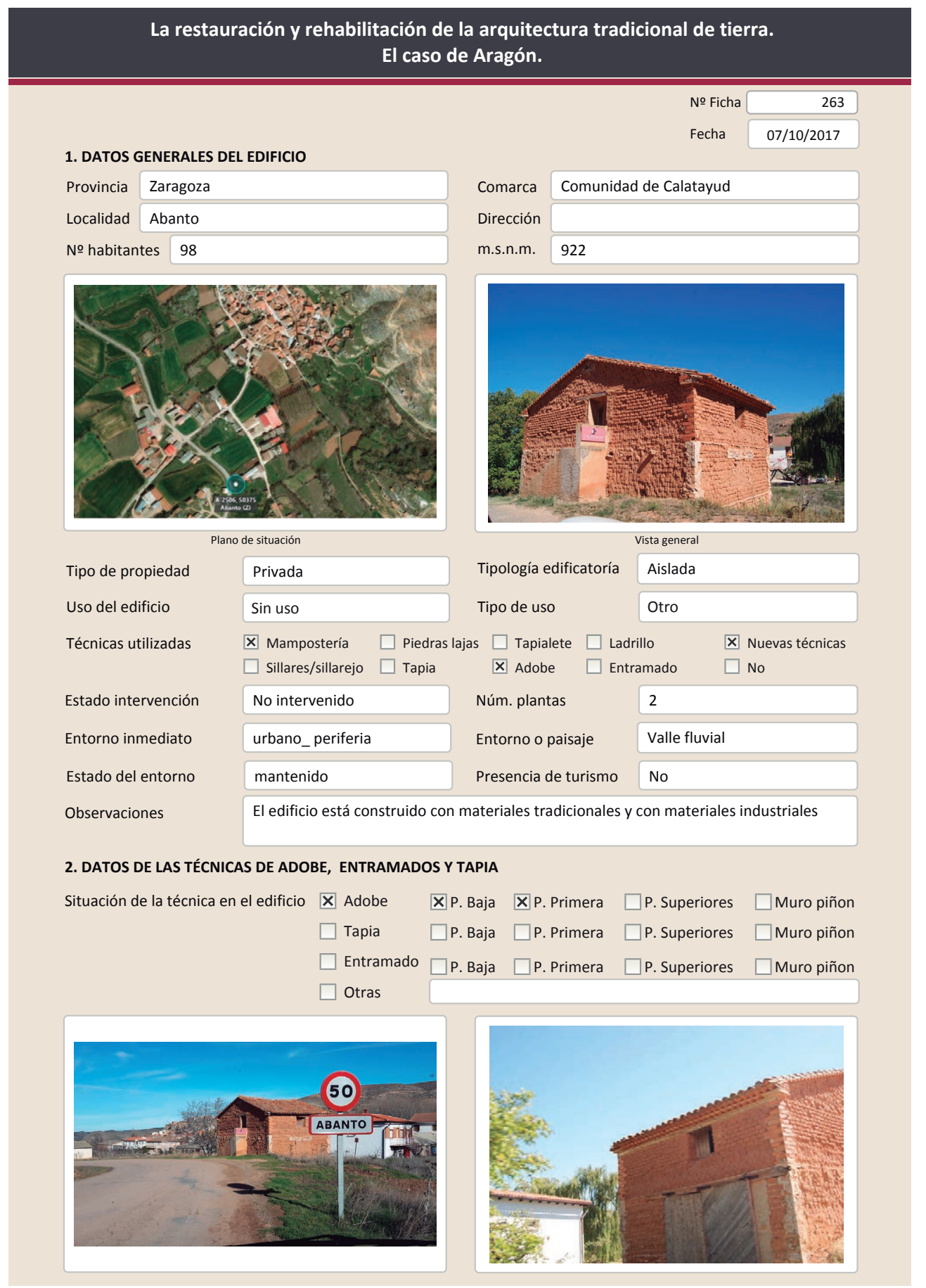

La restauración y rehabilitación de la arquitectura tradicional de tierra.

El caso de Aragón.

2.1. ADOBE

Dimensión de las piezas

Dimensión del muro

Aparejo del muro

Función estructural

Variante const
$\square$ Simple

$\square$ Suplementada en juntas

X Mixta

$\square$ Como suplemento

$\square$ Elementos de protección Ladrillos industriales en las esquinas

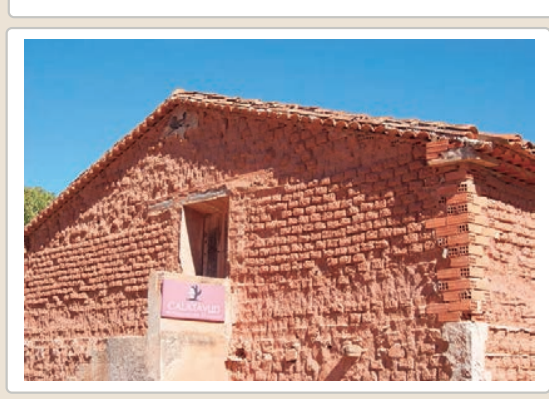

Lesiones $\quad \mathbf{X}$ Muro $\square$ Zócalo $\square$ Revestimiento

X Erosión del material $\square$ Humedad por capilaridad $\boldsymbol{X}$ Erosion de las juntas $\square$ Humedades (manch/eflo)

X Pérdida de sección $\square$ Pérdida de verticalidad

$\square$ Vegetación $\quad \square$ Grietas por empuje de la cubie $\begin{array}{ll}\square \text { Vegetación } & \square \text { Grietas por empuje de la cub } \\ \square \text { Desconchados } \quad \square \text { Grietas porfalta de traba }\end{array}$
Color de las piezas

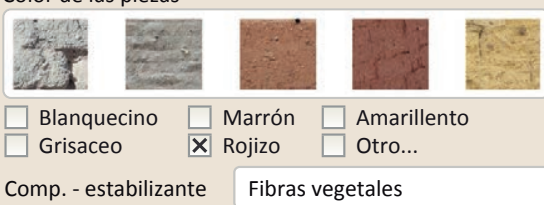

Comp. - estabilizante Fibras vegetales
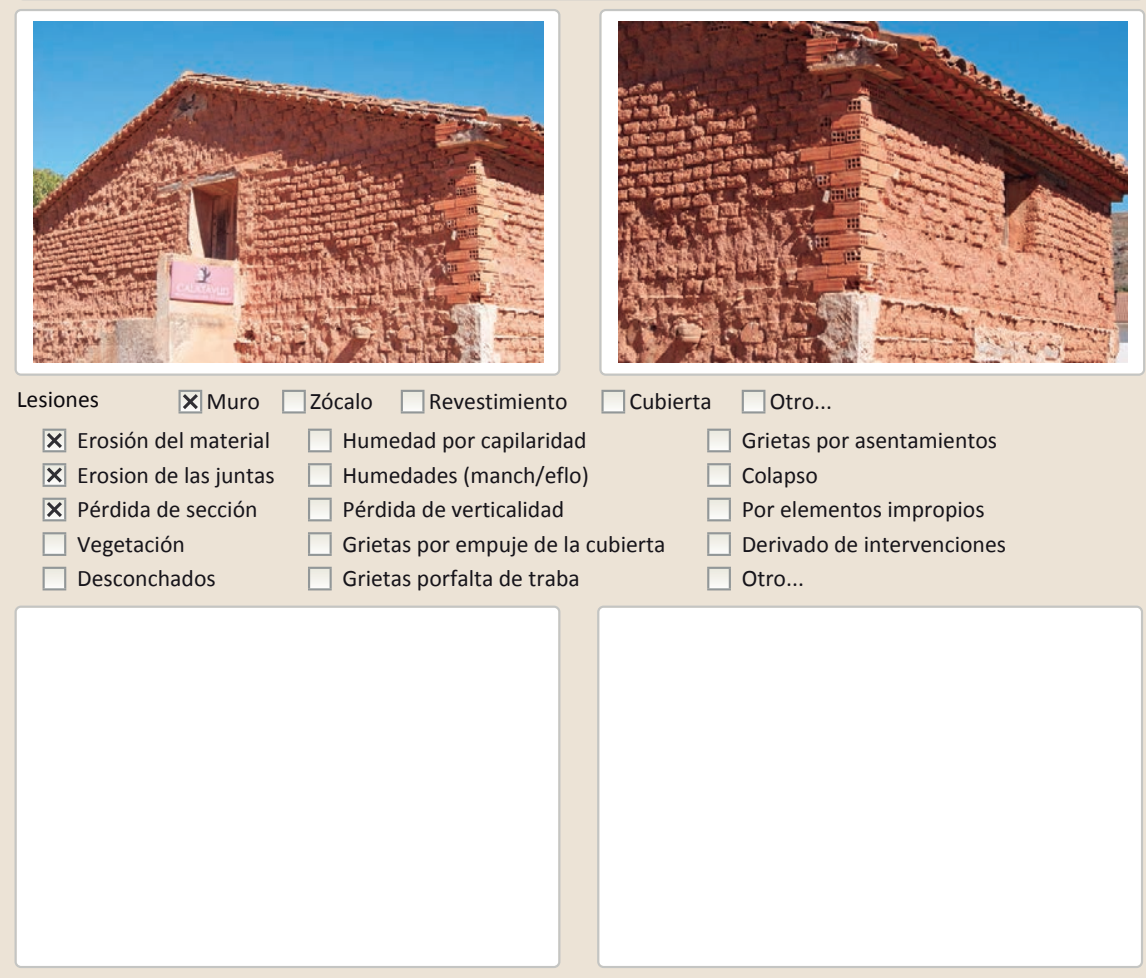

Cubierta $\square$ otro...

Observaciones

$\square$ Colapso

$\square$ Por elementos impropios

$\square$ Derivado de intervenciones $\square$ Derivadod 


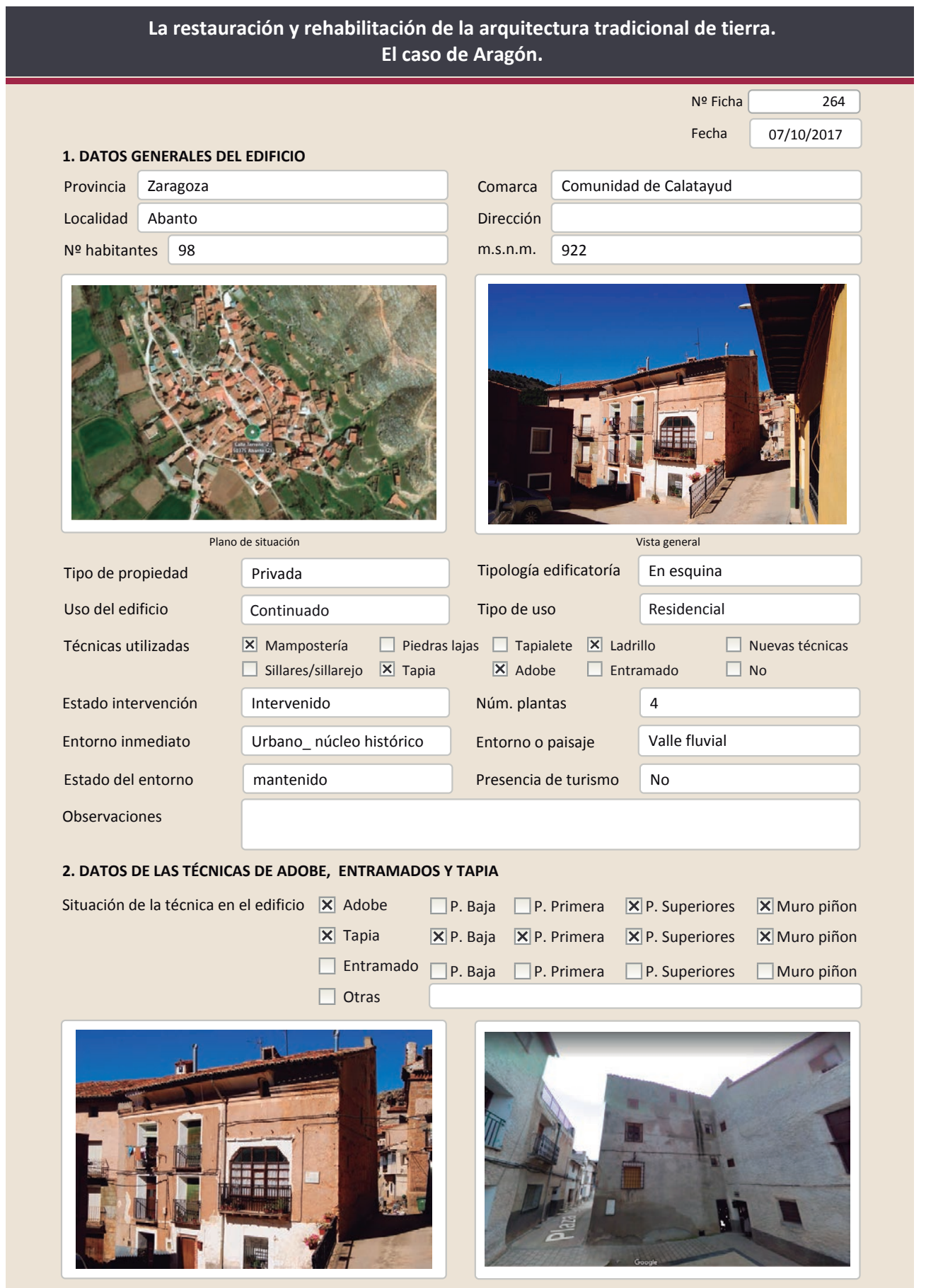

2.1. ADOBE

Dimensión de las piezas

Dimensión del muro

Aparejo del muro

Función estructural

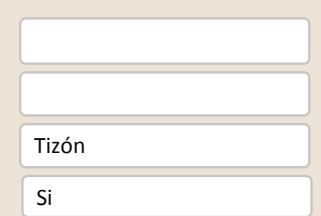

Color de las piezas

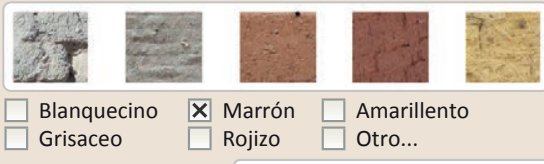

$\square$ Rojizo $\square$ Otro..

Comp. - estabilizante

Variante constructiva/ tipo de fábrica

$\square$ simple
$\boldsymbol{X}$ Suplementada en juntas
Horizontales
$\square$ Mixta
$\square$ Como suplemento
区 Elementos de protección
Revestimiento

$\mathrm{Cal} /$ yeso

No se aprecia bien por el revestimiento

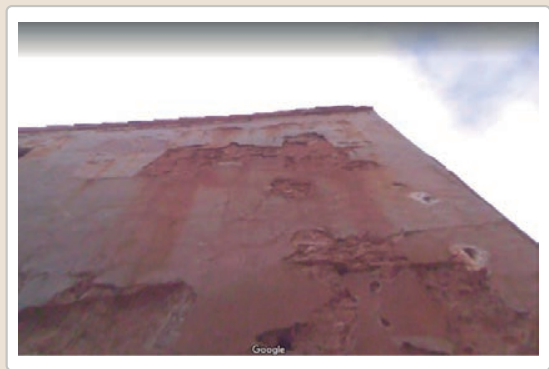

Lesiones XMuro XZócalo X Revestimiento

$\mathbf{X}$ Erosión del material $\mathbf{X}$ Humedad por capilaridad

$\square$ Erosion de las juntas $\square$ Humedades (manch/eflo)

$\square$ Pérdida de sección $\square$ Pérdida de verticalidad

$\square$ Vegetación $\quad \square$ Grietas por empuje de la cubic $\square$ Grietas porfalta de traba

$\square$ Cubierta $\square$ Otro...

$\square$ Grietas por asentamiento

$\square$ Colapso

$\mathbf{X}$ Desconchados

$\square$ Derivado de intervenciones

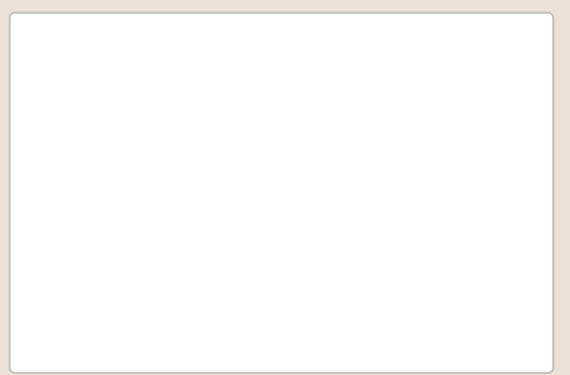

Observaciones 


\section{La restauración y rehabilitación de la arquitectura tradicional de tierra.}

\section{El caso de Aragón.}

\subsection{TAPIA}

Ancho del muro

Dimensión tapiales

Tipo de aguja

№ agujas/cajón

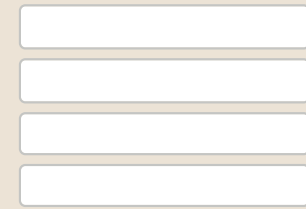

\section{Color de la tapia}

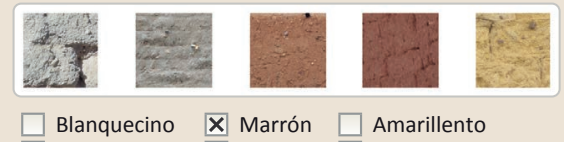
$\begin{array}{ll}\square \text { Blanquecino } & \mathbf{X} \text { Marrón } \\ \square \text { Grisaceo } & \square \text { Amarillento } \\ \text { Rojizo } & \square \text { Otro... }\end{array}$

Variante constructiva

$\square$ Simple / homogénea

X Suplemento superficial

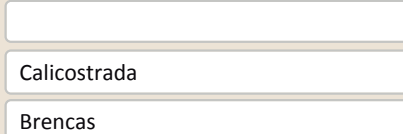

$\mathbf{X}$ Suplemento en juntas

$\square$ Mixta

$\square$ Elementos de protección
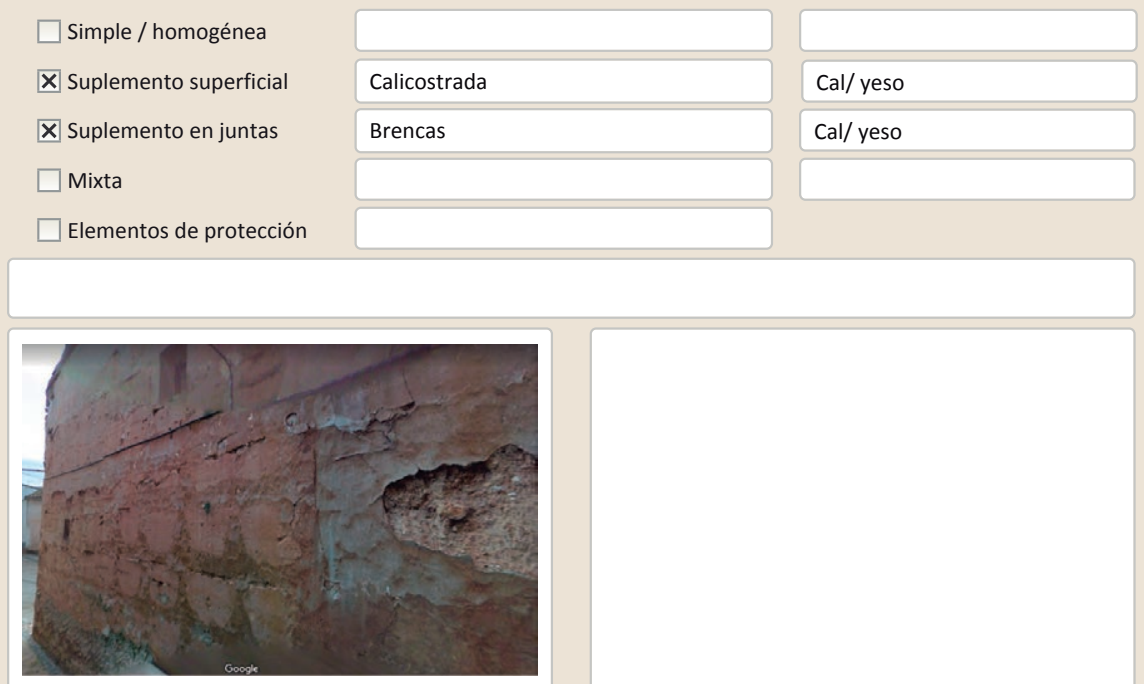

Lesiones ХMuro $\mathbf{X}$ Zócalo $\mathbf{X}$ Revestimiento $\square$ Cubierta $\square$ Otro...

X Erosión del material $\square$ Humedad por capilaridad $\quad \square$ Grietas por asentamientos

$\square$ Erosion de las juntas $\mathbf{X}$ Humedades (manch/eflo) $\quad \square$ Colapso

$\square$ Pérdida de sección $\square$ Pérdida de verticalidad $\square$ Por elementos impropios

$\square$ Vegetación $\quad \square$ Grietas por empuje de la cubierta $\square$ Derivado de intervenciones

X Desconchados $\square$ Grietas porfalta de traba $\quad \square$ Otro...

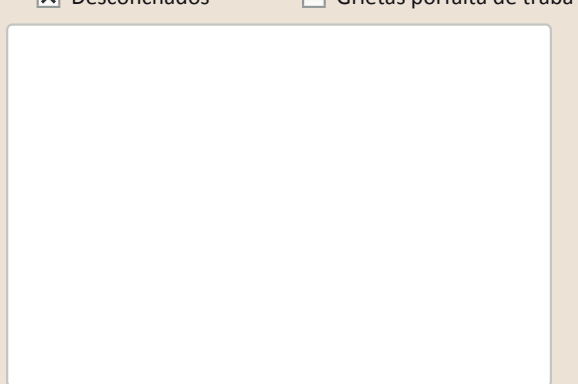

La restauración y rehabilitación de la arquitectura tradicional de tierra.

El caso de Aragón.

3. DATOS DE LA INTERVENCIÓN

Intervención de: $\square$ Mantenimiento $\quad \mathbf{X}$ Rehabilitación parcial $\square$ Restauración $\square$ Demolión

\ Reparación $\square$ Rehabilitación integral $\square$ Ampliación $\square$ Otro...

Reflexión previa Intervención espontanea

Observaciones

3.1. MUROS

Tipo de intervención

Tipo de material

Descripción

3.2. ZÓCALO

Tipo de intervención

Tipo de material

Descripción

3.3. REVESTIMIENTOS

Tipo de intervención

Tipo de material

Descripción

3.4. VANOS

Tipo de intervención

Tipo de material

Descripción

3.5. CUBIERTA

Tipo de intervención

Tipo de material

Descripción

No intervenido
$\square$ Actualización $\quad \square$ Reintegración $\quad \square$ Demolición $\quad \square$ Otro...
$\square$ Consolidación $\quad \square$ Reconstrucción $\quad \square$ Sustitución

$\square$ Consolidación $\square$ Reconstrucción $\square$ sustitución

Tipo de técnica

Intervenido

$\mathbf{X}$ Actualización $\square$ Reintegración $\quad \square$ Demolición $\square$ Otro.

$\square$ Consolidación $\quad \mathbf{X}$ Reconstrucción $\square$ Sustitución

No tradicional Tipo de técnica Diferente a la existente

Revestimiento de cemento dispuesto de forma aleatoria. Pintura en la fachada principal

Intervenido

$\square$ Actualización $\square$ Reintegración $\square$ Demolición $\square$ Otro...

$\square$ Consolidación $\quad \mathbf{X}$ Reconstrucción $\square$ Sustitución

No tradicional Tipo de técnica Diferente a la existente

Revestimiento de cemento en la fachada trasera del edificio.

Intervenido

$\square$ Actualización $\square$ Reintegración $\square$ Demolición $\square$ Otro..

$\square$ Consolidación $\square$ Reconstrucción $\mathbf{x}$ Sustitución

\begin{tabular}{l|l|l|l|l|l|l|l}
\hline No tradicional & Tipo de técnica & Diferente a la existente
\end{tabular}

Sustitución de carpinterías

Intervenido

$\square$ Actualización $\quad \mathbf{X}$ Reintegración $\quad \square$ Demolición $\square$ Otro

$\square$ Consolidación $\quad \square$ Reconstrucción $\square$ Sustitución
No tradicional
Tipo de técnica Similar a la existente

Reintegración de tejas con mortero de cemento

Observaciones

3.6. OTRAS 
La restauración y rehabilitación de la arquitectura tradicional de tierra. El caso de Aragón

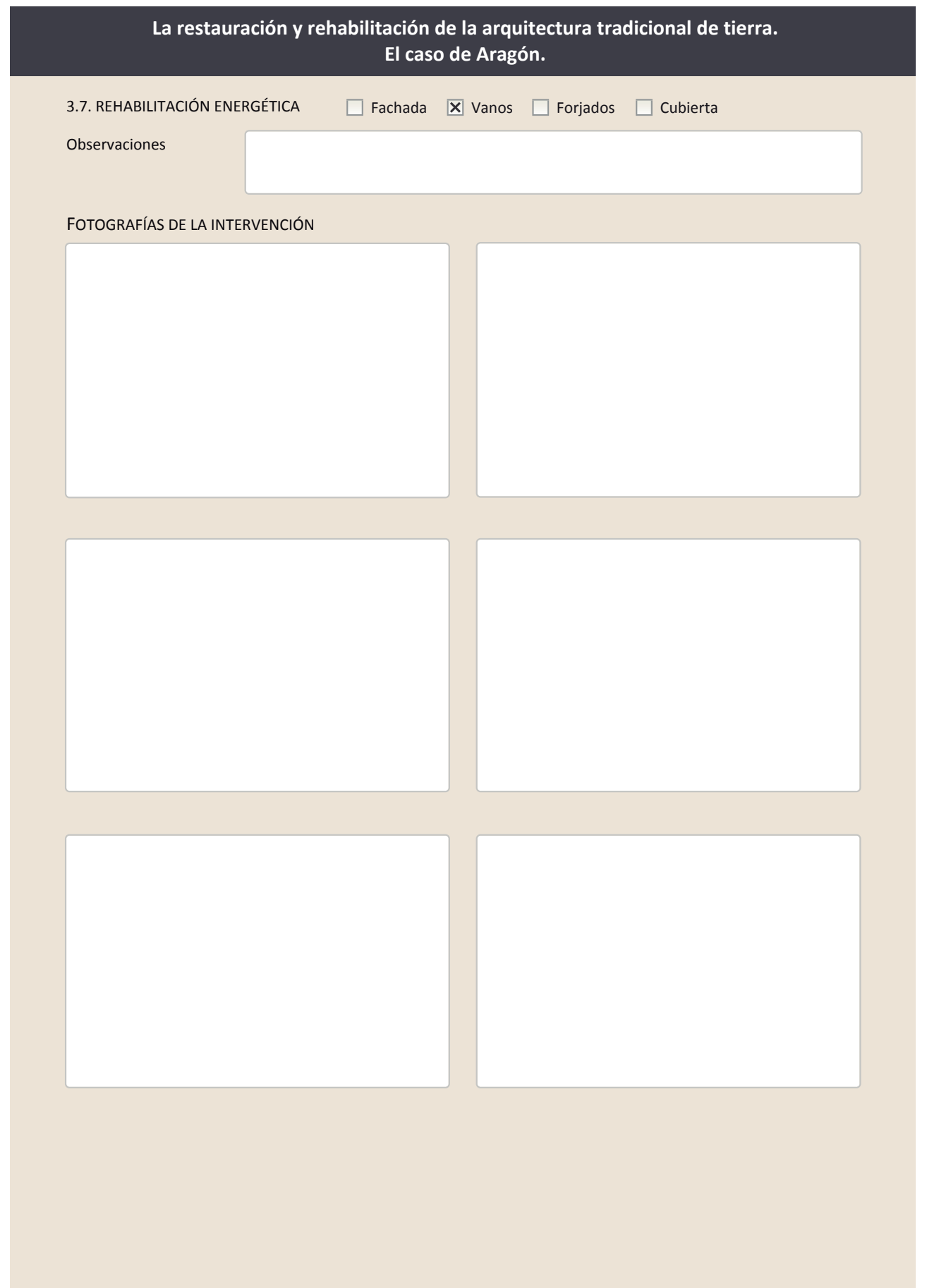

La restauración y rehabilitación de la arquitectura tradicional de tierra.

El caso de Aragón.

3.7. REHABILITACIÓN ENERGÉTICA $\square$ Fachada $\quad \boldsymbol{X}$ Vanos $\square$ Forjados $\square$ Cubierta

Observaciones

FOTOGRAFÍAS DE LA INTERVENCIÓN 


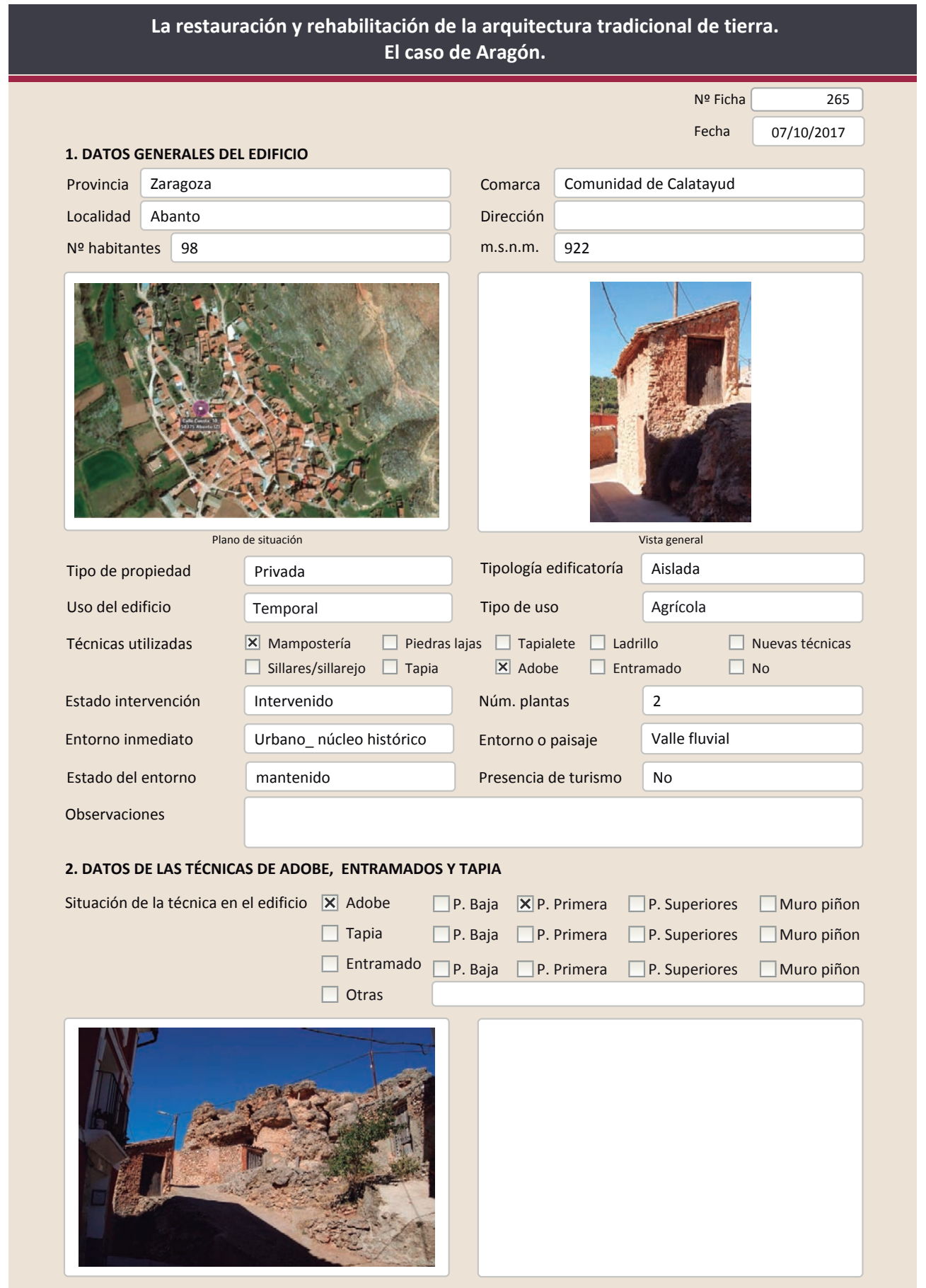

La restauración y rehabilitación de la arquitectura tradicional de tierra.

El caso de Aragón.

2.1. ADOBE

Dimensión de las piezas Dimensión del muro

Aparejo del muro

Función estructural

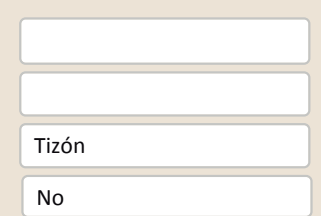

Color de las piezas

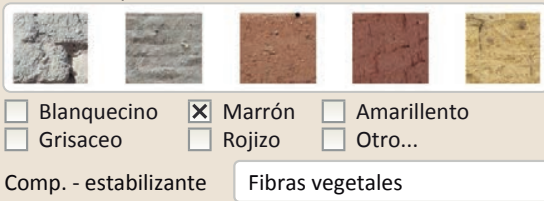

Variante constructiva/ tipo de fábrica

$\square$ Simple

$\square$ Suplementada en juntas

区 Mixta

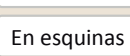

Piedra

$\square$ Como suplemento

$\square$ Elementos de protección

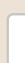

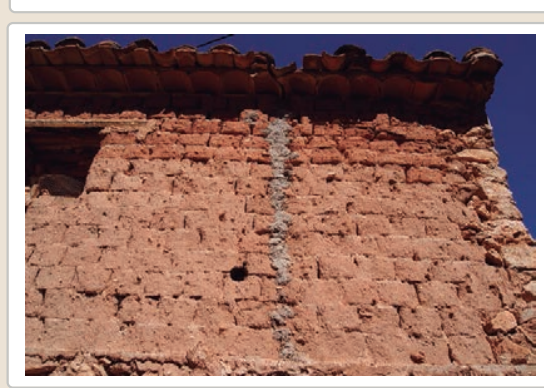

Lesiones X Muro $\square$ Zócalo $\square$ Revestimiento

X Erosión del material $\square$ Humedad por capilaridad $\mathbf{X}$ Erosion de las juntas $\square$ Humedades (manch/eflo)

$\square$ Pérdida de sección $\square$ Pérdida de verticalidad

$\square$ Vegetación $\quad \square$ Grietas por empuje de la c

$\square$ Desconchados

$\square$ Grietas porfalta de traba

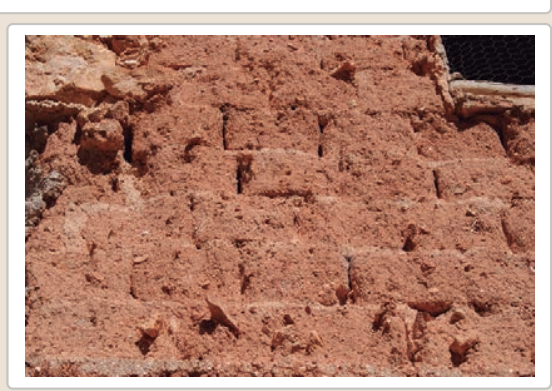

X Cubierta $\square$ Otro...
$\square$ Grietas por
$\square$ Colapso
$\square$ Por elementos impropios
$\square$ Derivado de intervenciones

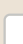

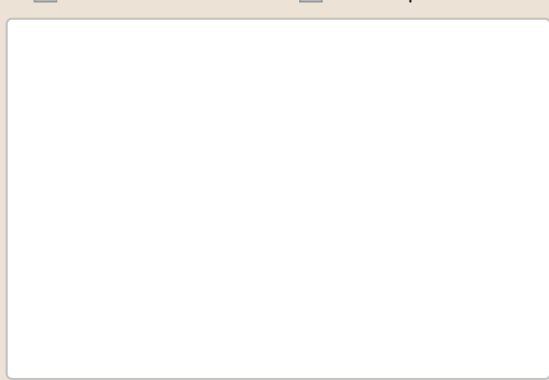

Observaciones 
La restauración y rehabilitación de la arquitectura tradicional de tierra. El caso de Aragón

\section{La restauración y rehabilitación de la arquitectura tradicional de tierra.}

\section{El caso de Aragón.}

3. DATOS DE LA INTERVENCIÓN

Intervención de:

$\square$ Mantenimiento $\square$ Rehabilitación parcia

$\square$ Restauración $\square$ Demolición

X Reparación $\square$ Rehabilitación integral $\square$ Ampliación $\square$ Otro...

Reflexión previa

Intervención espontanea

Observaciones

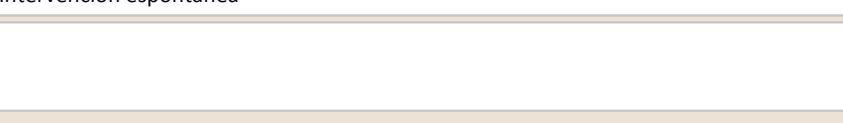

3.1. MUROS

Tipo de intervención

Intervenido

$\square$ Actualización $\quad \boldsymbol{X}$ Reintegración $\square$ Demolición $\square$ Otro...

$\square$ Consolidación $\square$ Reconstrucción $\square$ Sustitución

Tipo de material
No tradicional
Tipo de técnica Diferente a la existente

Descripción

Reintegración de oquedades con pellas de mortero de cemento

3.2. ZÓCALO

No intervenido

Tipo de intervención

$\square$ Actualización

Tipo de material

Descripción

3.3. REVESTIMIENTOS

Tipo de intervención

\section{No aplica}

Tipo de material

$\square$ Actualización

Reconstrucción $\square$ Sustitución

Descripción

3.4. VANOS

Tipo de intervención

No intervenido

Tipo de material

Descripción

3.5. CUBIERTA

Tipo de intervención

Intervenido

Tipo de intervención

$\square$ Actualización $\quad \boldsymbol{X}$ Reintegración $\square$ Demolición $\square$ Otro.

Tipo de material

$\square$ Consolidación $\square$ Reconstrucción $\square$ Sustitución

Descripción

No tradicional Tipo de técnica Similar a la existente

3.6. OTRAS

Reintegración de las tejas del lateral de la cubierta con cemento 
La restauración y rehabilitación de la arquitectura tradicional de tierra. El caso de Aragón.

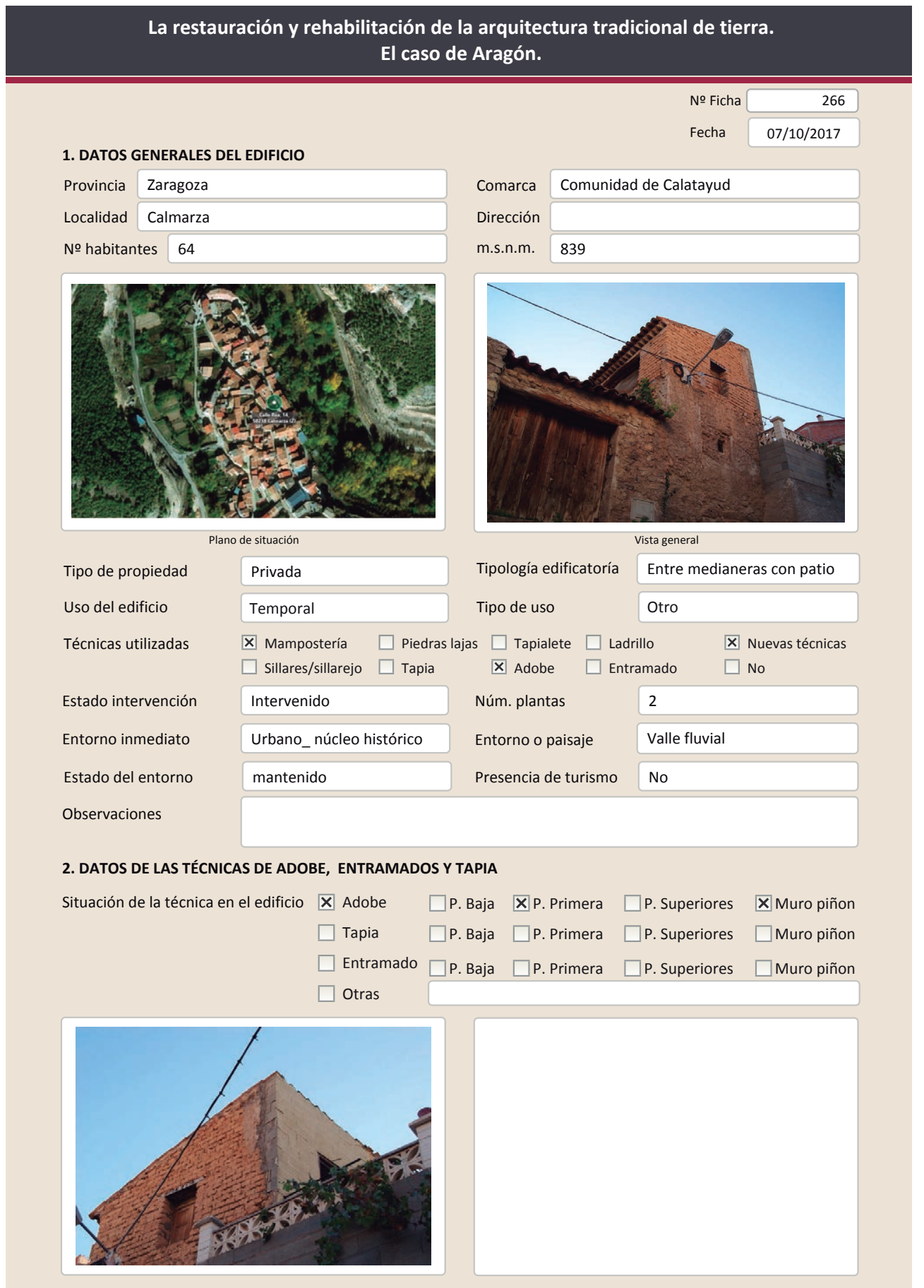

La restauración y rehabilitación de la arquitectura tradicional de tierra.

El caso de Aragón.
2.1. ADOBE

Dimensión de las piezas Dimensión del muro

Aparejo del muro

Función estructural inante constructiva/ tipo de fábrica

$\square$ Suplementada en juntas

$\square$ Mixta

$\square$ Como suplemento
Color de las piezas

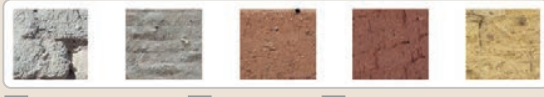

$\square$ Blanquecino $\mathbf{X}$ Marrón $\square$ Amarillento

$\square$ Grisaceo $\square$ Rojizo $\square$ Otro...

Comp. - estabilizante Aridos

\section{$\square$ Elementos de protección}

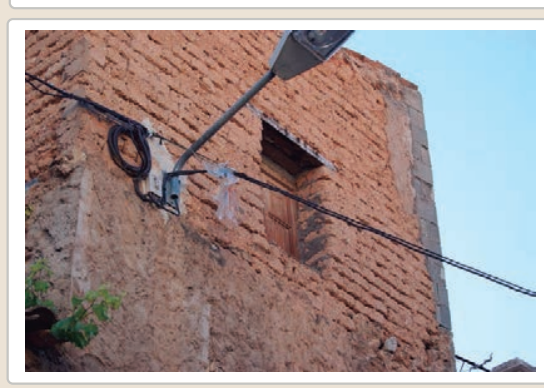

Lesiones $\quad \mathbf{X}$ Muro $\square$ Zócalo $\square$ Revestimiento $\square$ Cubierta $\square$ Otro...

\ Erosión del material $\quad \square$ Humedad por capilaridad $\quad \square$ Grietas por asentamientos

$\square$ Erosion de las juntas $\square$ Humedades (manch/eflo) $\quad \square$ Colapso

$\square$ Pérdida de sección $\quad \square$ Pérdida de verticalidad $\square$ Por elementos impropios

$\square$ Vegetación $\quad \square$ Grietas por empuje de la cubierta $\quad \square$ Derivado de intervenciones

$\square$ Desconchados $\square$ Grietas porfalta de traba $\quad \square$ Otro...

Observaciones 
La restauración y rehabilitación de la arquitectura tradicional de tierra. El caso de Aragón

\section{La restauración y rehabilitación de la arquitectura tradicional de tierra.}

\section{El caso de Aragón.}

3. DATOS DE LA INTERVENCIÓN

Intervención de:

$\square$ Mantenimiento $\square$ Rehabilitación parcia

$\square$ Restauración $\square$ Demolición

Reflexión previa

X Reparación

Rehabilitación integra

Ampliación

$\square$ Otro..

Observaciones

Intervención espontanea

3.1. MUROS

Tipo de intervención

Intervenido

Tipo de material

$\square$ Actualización $\quad \mathbf{X}$ Reintegración $\square$ Demolición $\square$ Otro...

$\square$ Consolidación $\quad \mathbf{X}$ Reconstrucción $\square$ Sustitución

Descripción

No tradicional Tipo de técnica Diferente a la existente

3.2. ZóCALO

Reconstrucción del muro trasero del edificio con bloque de hormigón prefabricado. Reintegración de oquedades con pellas de mortero de cemento

Tipo de intervención Intervenido

Tipo de material

$\square$ Actualización $\quad \square$ Reintegración $\quad \square$ Demolición $\quad \square$ Otro...

$\square$ Actualización $\square$ Reintegración $\quad \square$ Demolición
$\square$ Consolidación $\quad \mathbf{\text { Reconstrucción }} \quad \square$ Sustitución

Descripción
No tradicional
Tipo de técnica Diferente a la existente

3.3. REVESTIMIENTOS

Mortero de cemento en toda la superficie de la mampostería de planta baja

Tipo de intervención

\section{No aplica}

Tipo de material

$\square$ Actualización

$\square$ Reintegración $\square$ Demolición $\square$ Otro...

$\square$ Consolidación $\square$ Reconstrucción $\square$ sustitución

Descripción

3.4. VANOS

Tipo de intervención

No intervenido

Tipo de material

$\square$ Actualización $\quad \square$ Reintegración $\quad \square$ Demolición $\quad \square$ Otro...
$\square$ Consolidación $\quad \square$ Reconstrucción $\quad \square$ sustitución

Descripción

3.5. CUBIERTA

Tipo de intervención

Intervenido

Tipo de material

$\square$ Actualización $\quad \boldsymbol{X}$ Reintegración $\square$ Demolición $\square$ Otro..

Descripción
No tradicional
Tipo de técnica Similar a la existente

3.6. OTRAS

Reintegración del lateral de la cubierta

$$
\text { Tipo de técnica }
$$




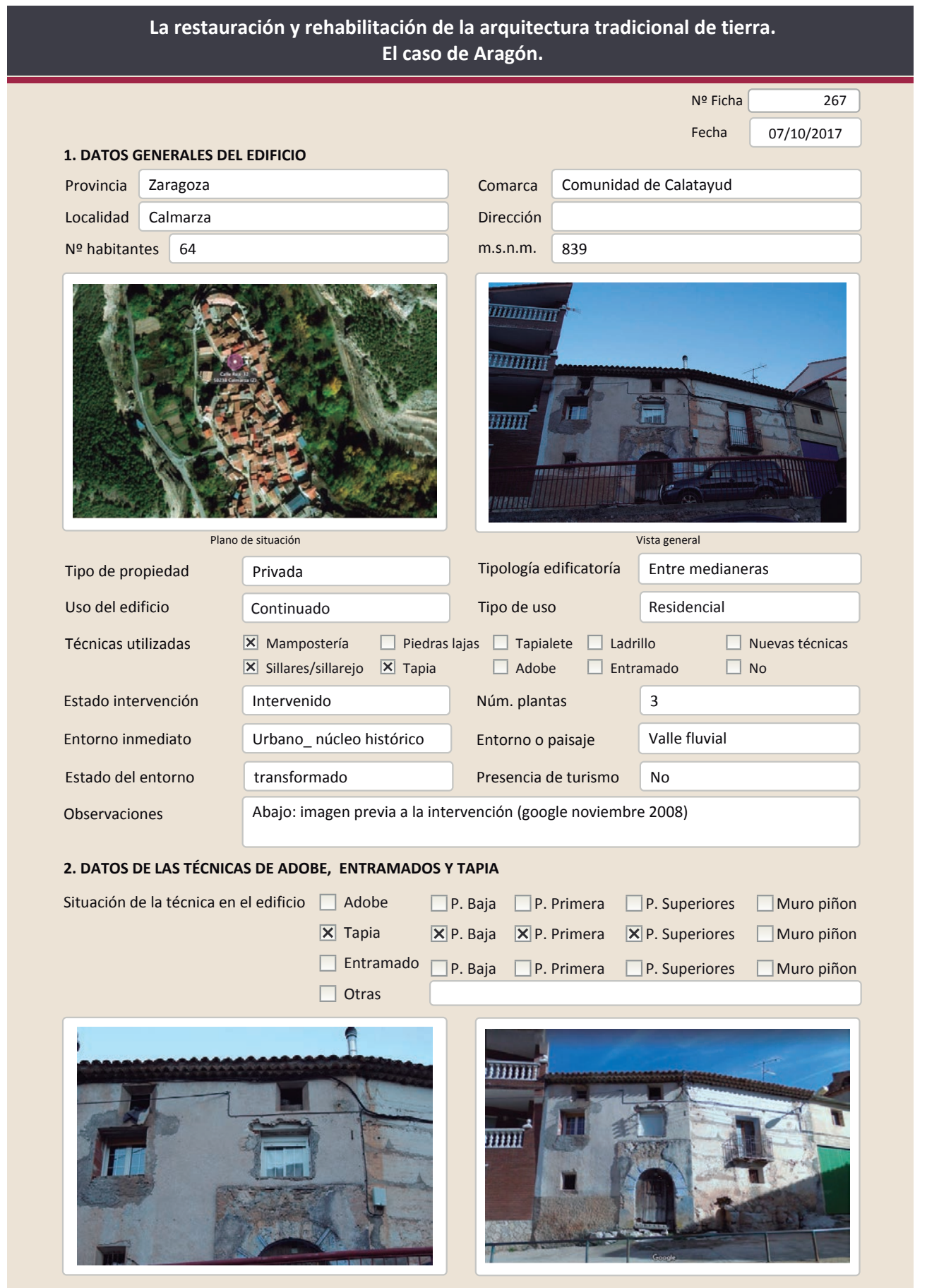

La restauración y rehabilitación de la arquitectura tradicional de tierra. El caso de Aragón.

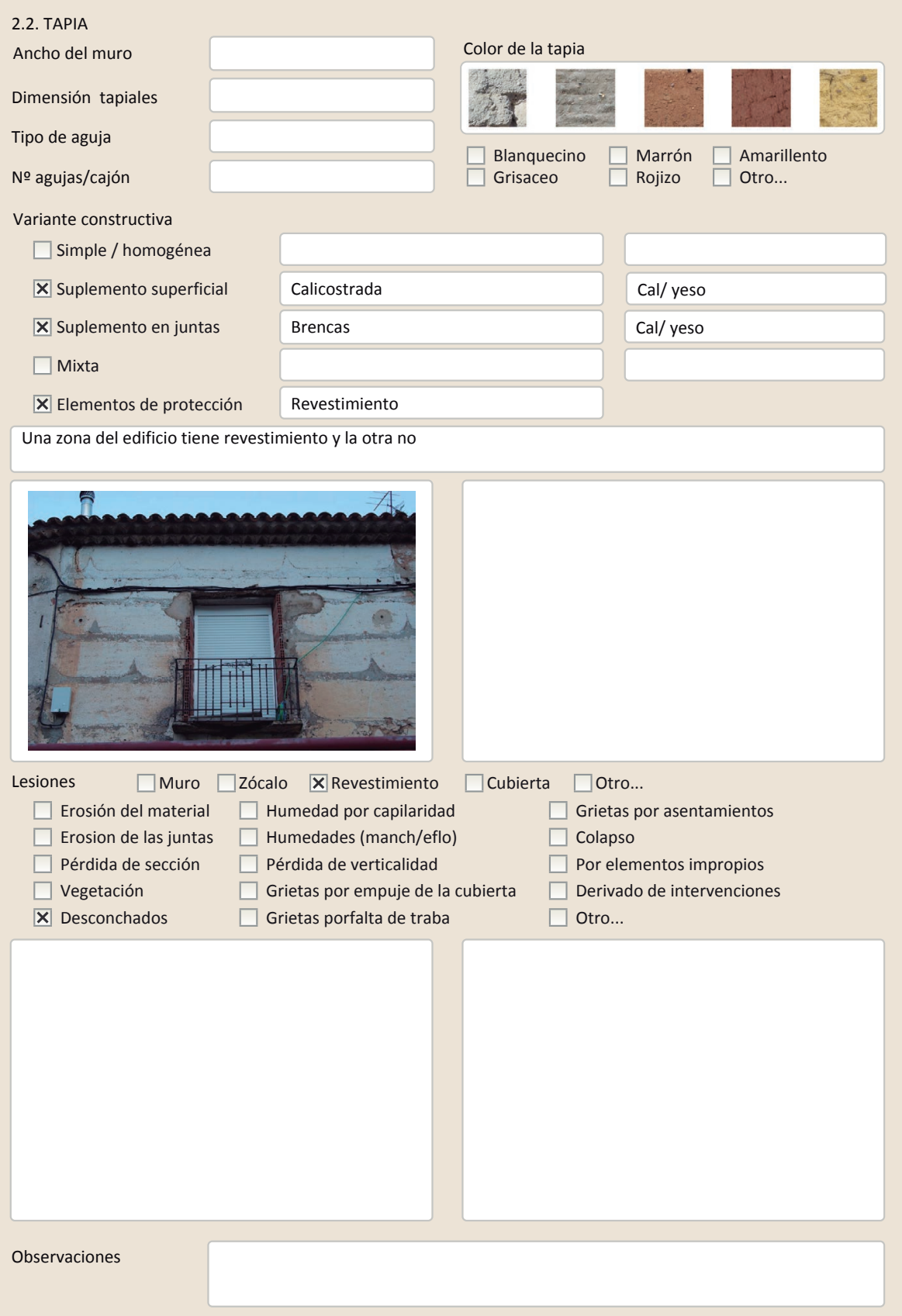




\section{La restauración y rehabilitación de la arquitectura tradicional de tierra.}

\section{El caso de Aragón.}

3. DATOS DE LA INTERVENCIÓN

Intervención de:

$\square$ Mantenimiento $\quad$ X Rehabilitación parcial

$\square$ Restauración $\square$ Demolición

Reflexión previa

Intervención planificada

Observaciones

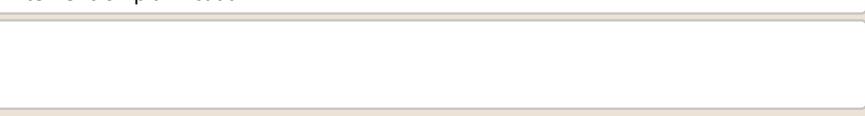

\subsection{MUROS}

Tipo de intervención

No intervenido

Tipo de material

Descripción

3.2. ZóCALO

Tipo de intervención

Tipo de material

Descripción

3.3. REVESTIMIENTOS

Tipo de intervención

Tipo de material

Descripción

3.4. VANOS

Tipo de intervención

Tipo de material

Descripción

3.5. CUBIERTA

Tipo de intervención

Tipo de material

Descripción

$\square$ Actualización $\square$ Reintegración $\square$ Demolición $\square$ Otro...

$\square$ Consolidación $\quad \square$ Reconstrucción $\square$ Sustitución

Tipo de técnica

Intervenido

$\square$ Actualización $\quad \square$ Reintegración $\square$ Demolición $\square$ Otro..

$\square$ Consolidación $\quad \mathbf{X}$ Reconstrucción $\square$ Sustitución

No tradicional Tipo de técnica Diferente a la existente

Revestimiento de cemento

No intervenido

$\square$ Actualización $\square$ Reintegración $\square$ Demolición $\square$ Otro...

$\square$ Consolidación $\square$ Reconstrucción $\square$ sustitución

Tipo de técnica

and

Intervenido

$\square$ Actualización $\square$ Reintegración $\square$ Demolición $\square$ Otro...

$\square$ Consolidación $\mathbf{X}$ Reconstrucción $\boldsymbol{X}$ Sustitución

No tradicional Tipo de técnica Diferente a la existente

Reconstrucción de huecos con nuevas dimensiones, regularización de jambas con

rasillas y sustitución de dinteles. Sustitución de las carpinterías + persianas

Intervenido

$\square$ Actualización $\quad \square$ Reintegración $\quad \square$ Demolición $\quad \square$ Otro.

$\square$ Consolidación $\mathbf{X}$ Reconstrucción $\square$ Sustitución

No tradicional Tipo de técnica Similar a la existente

Reconstrucción de la cubierta con teja curva. Se ha reconstruido por completo. EN el alero se puede observar un grosor de mortero de apoyo muy amplio, probablemente
La restauración y rehabilitación de la arquitectura tradicional de tierra.

El caso de Aragón.

3.7. REHABILITACIÓN ENERGÉTICA $\square$ Fachada $邓$ Vanos $\square$ Forjados $邓$ Cubierta

Observaciones

FOTOGRAFíAS DE LA INTERVENCIÓN
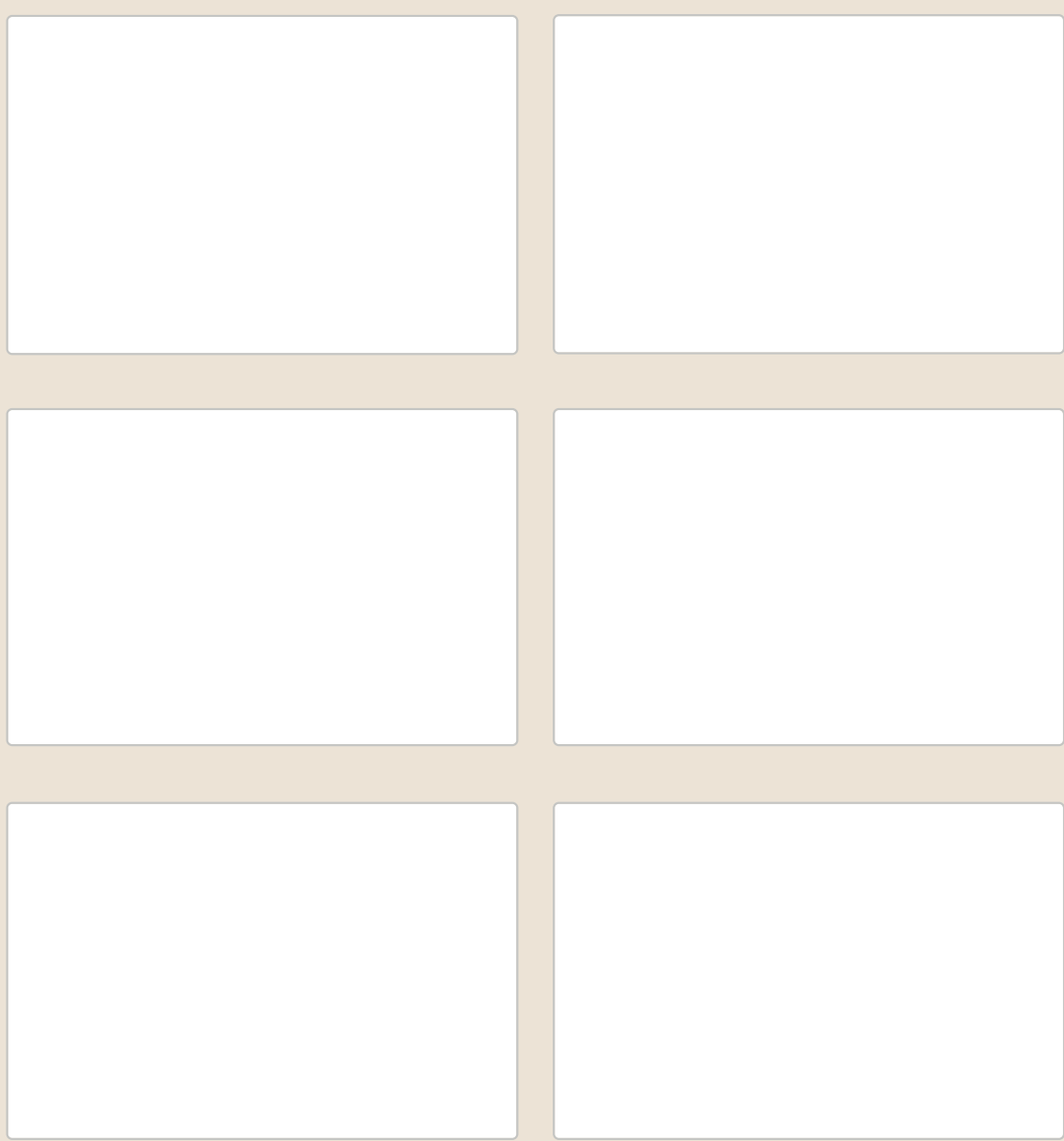

3.6. OTRAS 
La restauración y rehabilitación de la arquitectura tradicional de tierra. El caso de Aragón.

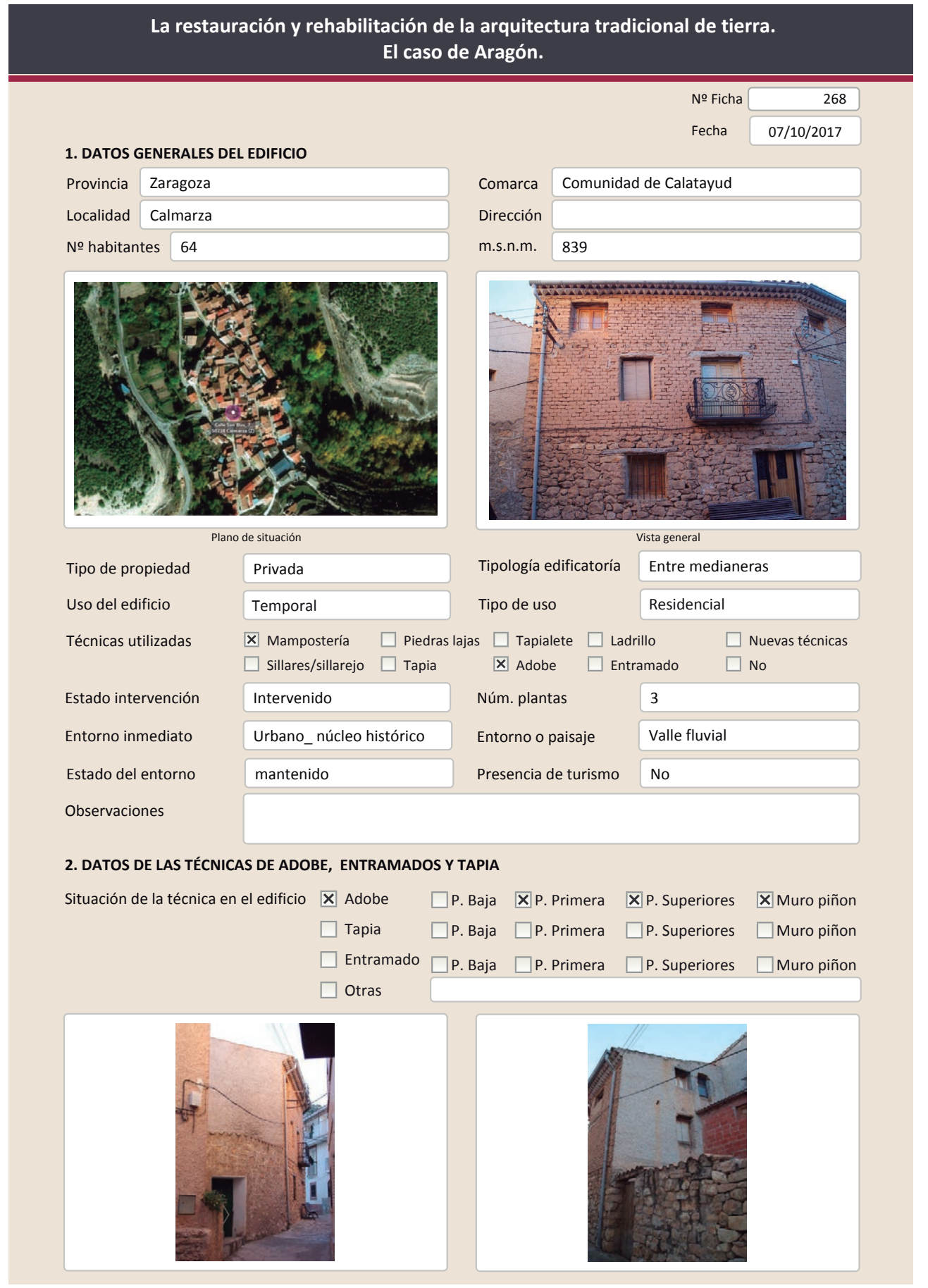

La restauración y rehabilitación de la arquitectura tradicional de tierra.

El caso de Aragón.

2.1. ADOBE

Dimensión de las piezas Dimensión del muro

Aparejo del muro

Función estructural

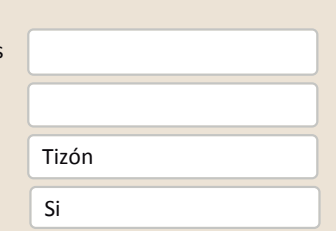

Color de las piezas

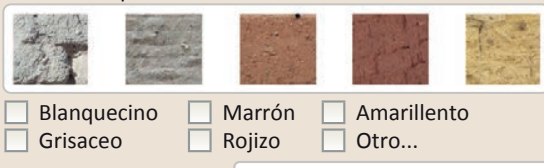

Rojizo $\square$ Otro..

Comp. - estabilizante Aridos

Variante constructiva/ tipo de fábrica

X Simple

$\square$ Suplementada en juntas

$\square$ Mixta

$\square$ Como suplemento

$\square$ Elementos de protección

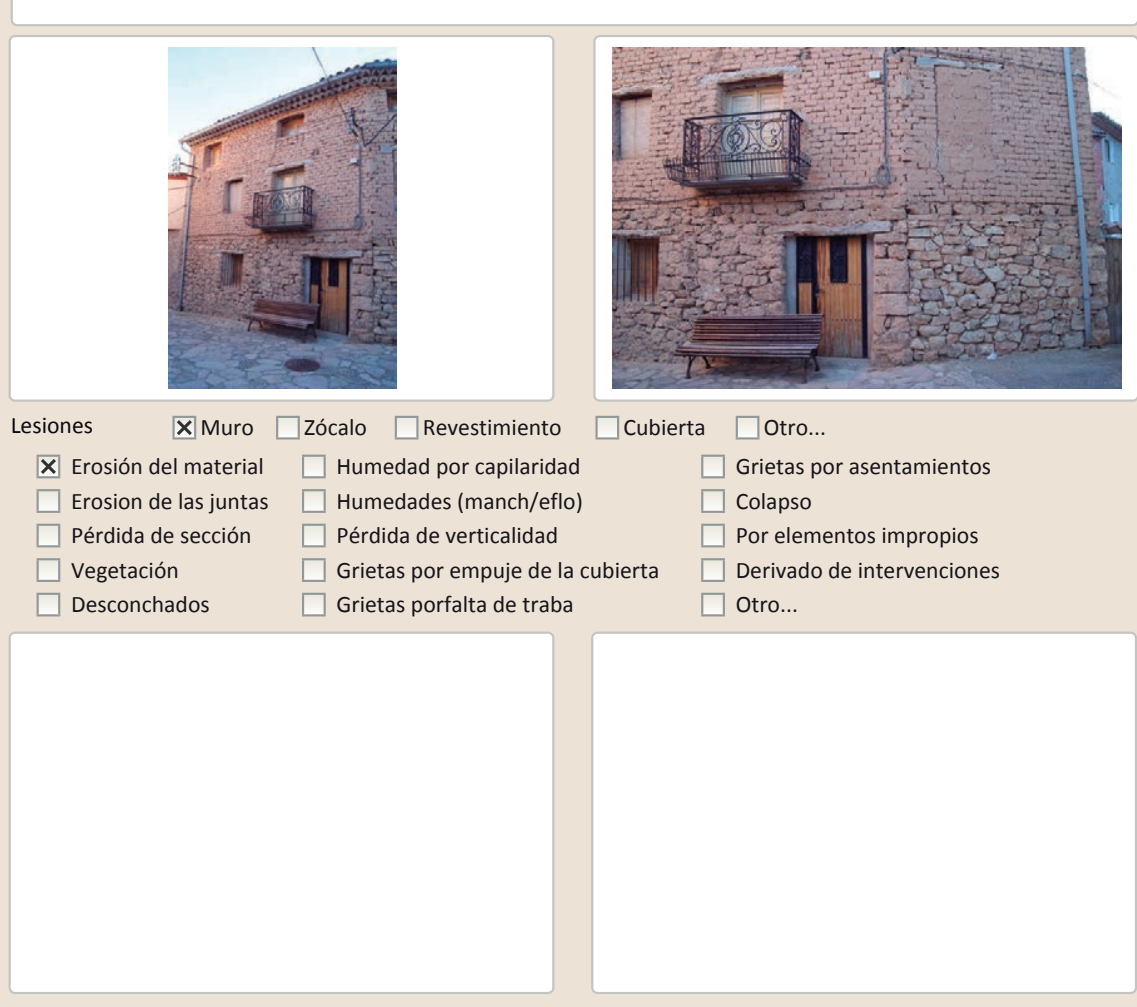

Observaciones 


\section{La restauración y rehabilitación de la arquitectura tradicional de tierra.}

\section{El caso de Aragón.}

3. DATOS DE LA INTERVENCIÓN

$\square$ Mantenimiento $\quad \mathbf{X}$ Rehabilitación parcia

$\square$ Restauración $\square$ Demolición

Rlexión previa

$\square$ Reparación

Rehabilitación integra

$\square$ Ampliación

$\square$ Otro...

Observaciones

Intervención planificada

3.1. MUROS

Tipo de intervención

No intervenido

Tipo de material

Descripción

3.2. ZÓCALO

Tipo de intervención

Tipo de material

Descripción

3.3. REVESTIMIENTOS

Tipo de intervención

Tipo de material

Descripción

3.4. VANOS

Tipo de intervención

Tipo de material

Descripción

3.5. CUBIERTA

Tipo de intervención

Tipo de material

Descripción

$\square$ Actualización $\quad \square$ Reintegración $\quad \square$ Demolición $\quad \square$ Otro...
$\square$ Consolidación $\quad \square$ Reconstrucción $\quad \square$ Sustitución

Tipo de técnica

Intervenido

$\square$ Actualización $\mathbf{X}$ Reintegración $\square$ Demolición $\square$ Otro...

$\square$ Consolidación $\square$ Reconstrucción $\square$ sustitución

No tradicional Tipo de técnica Diferente a la existente

Pellas de mortero

\section{Intervenido}

$\square$ Actualización $\square$ Reintegración $\quad \square$ Demolición $\square$ Otro...

$\square$ Consolidación $\quad \mathbf{X}$ Reconstrucción $\quad \square$ Sustitución

No tradicional Tipo de técnica Diferente a la existente

Revestimiento de cemento en las fachadas laterales del edificio

Intervenido

$\square$ Actualización $\quad$ X Reintegración $\square$ Demolición $\square$ Otro...

$\square$ Consolidación $\square$ Reconstrucción $\quad \boldsymbol{X}$ Sustitución

Tradicional diferente Tipo de técnica Similar a la existente

Sustitución de las carpinterías por unas nuevas de madera. Los huecos se han

reintegrado con ladrillo o bloque a las nuevas dimensiones de las mismas

Intervenido

$\square$ Actualización $\square$ Reintegración $\square$ Demolición $\square$ Otro..

$\square$ Consolidación $\quad$ X Reconstrucción $\square$ Sustitución
No tradicional
Tipo de técnica Similar a la existente

Reconstrucción con teja curva. Se aprecia una mayor sección de la cubierta por lo que probablemente se haya integrado aislante e impermeabilizante.
La restauración y rehabilitación de la arquitectura tradicional de tierra.

El caso de Aragón.

3.7. REHABILITACIÓN ENERGÉTICA $\square$ Fachada $\quad$ \ Vanos $\square$ Forjados $\mathbf{X}$ Cubierta

Observaciones

FOTOGRAFíAS DE LA INTERVENCIÓN
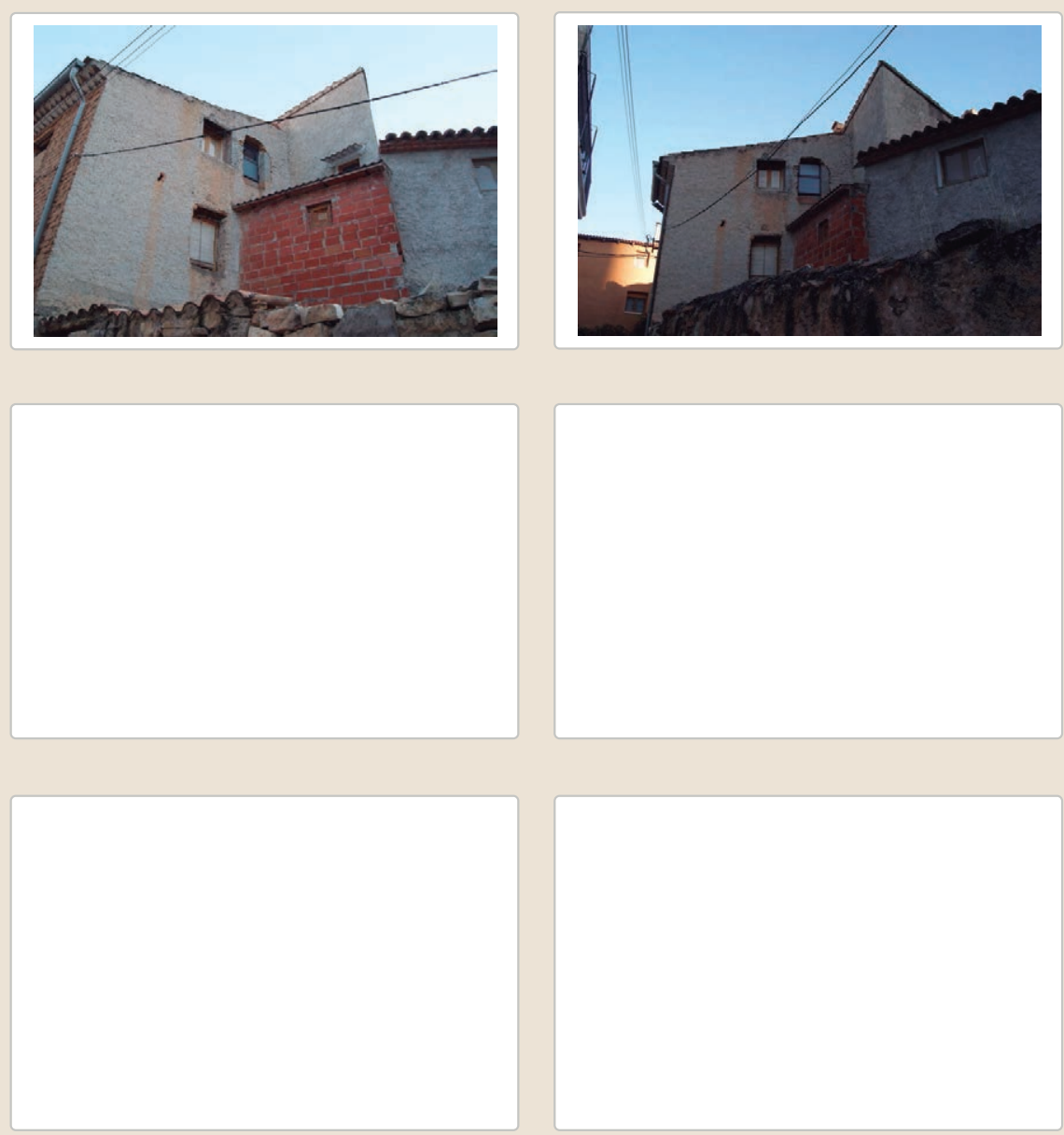

3.6. OTRAS 


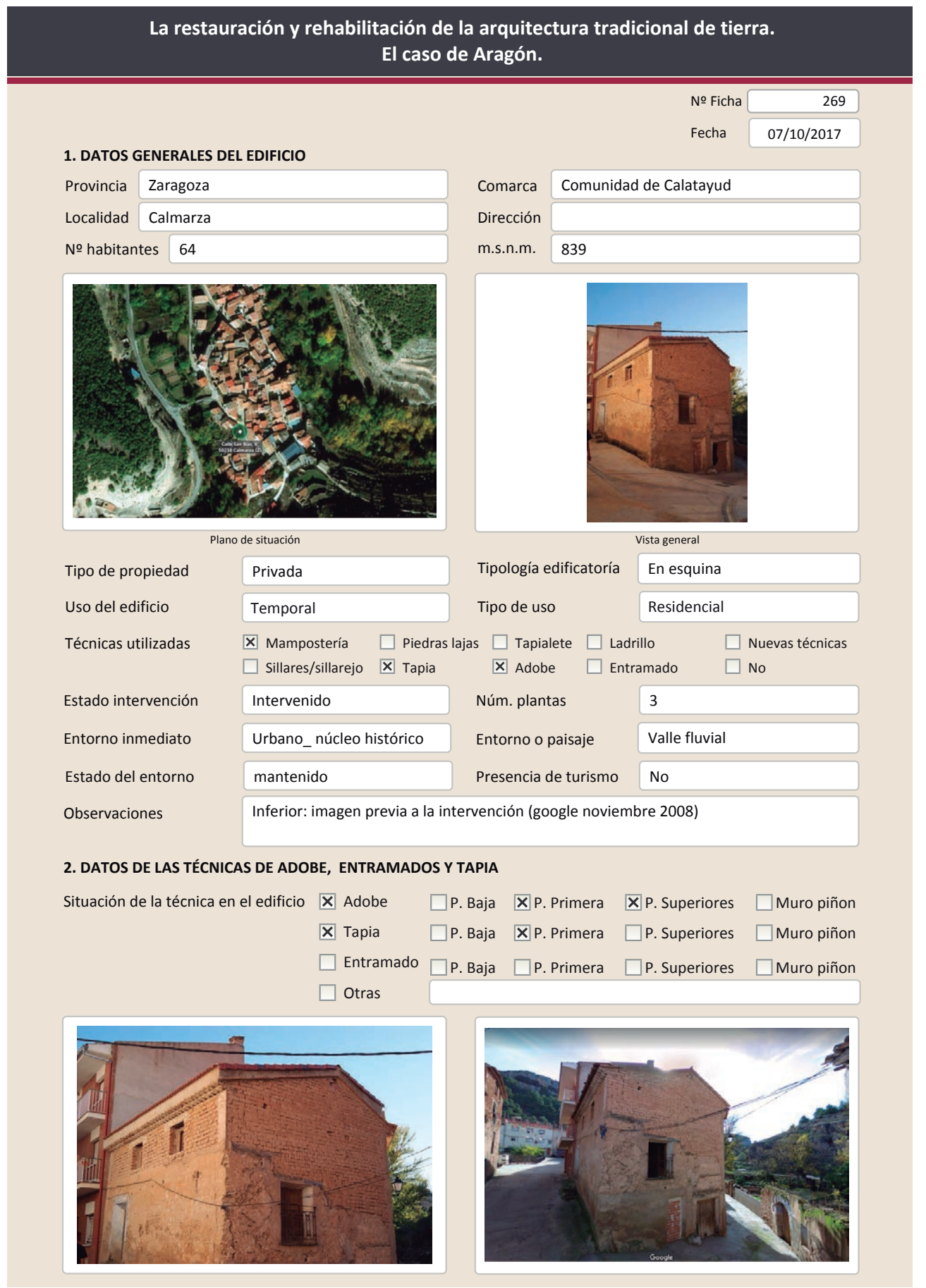

La restauración y rehabilitación de la arquitectura tradicional de tierra.

El caso de Aragón.

2.1. ADOBE

Dimensión de las piezas

Dimensión del muro

Aparejo del muro

Función estructural

\begin{tabular}{|l|}
\hline \\
\hline $30-40 \mathrm{~cm}$ \\
\hline Tizón \\
\hline $\mathrm{Si}$ \\
\hline
\end{tabular}

Color de las piezas

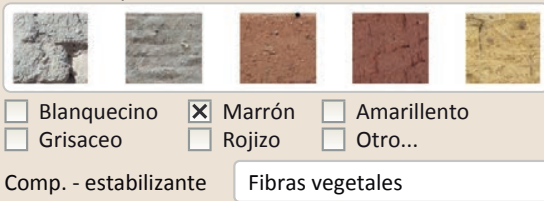

Variante constructiva/ tipo de fábrica

メ simple

$\square$ suplementada en juntas

$\square$ Mixta

$\square$ Como suplemento

$\square$ Elementos de protección

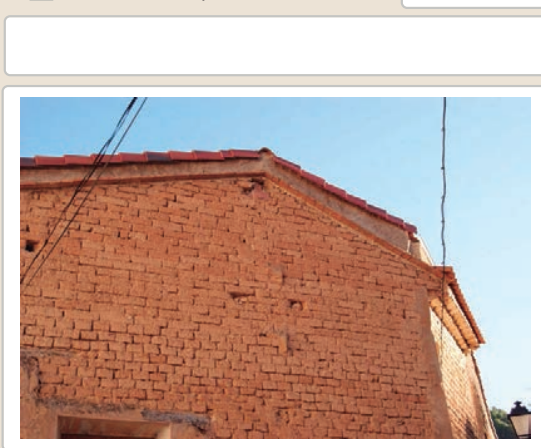

Lesiones Х Muro $\square$ Zócalo $\square$ Revestimiento

$\mathbf{X}$ Erosión del material $\square$ Humedad por capilaridad

$\square$ Erosion de las juntas $\square$ Humedades (manch/eflo)

$\square$ Pérdida de sección $\square$ Pérdida de verticalidad

$\square$ Vegetación

$\mathbf{X}$ Grietas por empuje de lacut $\square$ Grietas porfalta de traba

$\square$ Desconchados

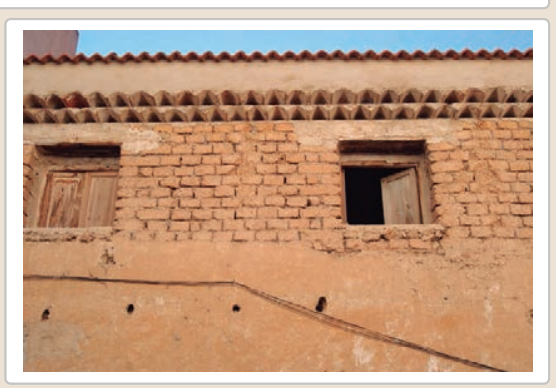

XCubierta $\square$ otro...

$\square$ Grietas por asentamientos

$\square$ Colapso

$\square$ Por elementos impropios

$\square$ Derivado de intervenciones

$\square$ Otro...

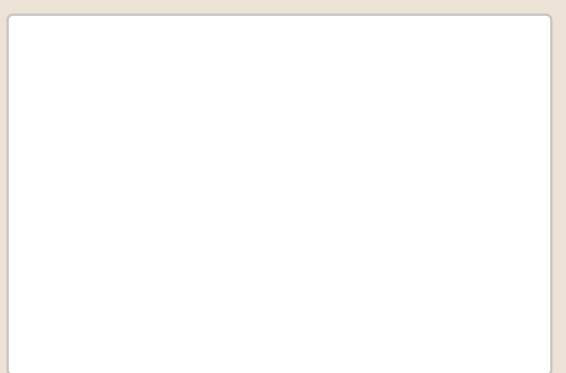

Observacione 


\section{La restauración y rehabilitación de la arquitectura tradicional de tierra.} El caso de Aragón.

\subsection{TAPIA}

Ancho del muro

Dimensión tapiales

Tipo de aguja

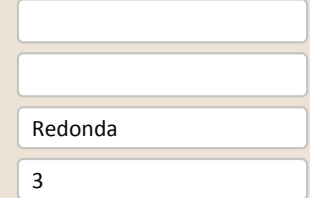

\section{Color de la tapia}

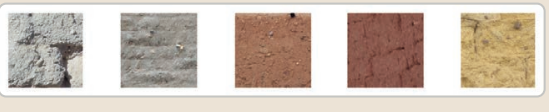

$\square$ Blanquecino $\quad \mathbf{X}$ Marrón $\square$ Amarillento $\square$ Grisaceo $\quad \square$ Rojizo $\square$ Otro...
Variante constructiva

$\square$ Simple / homogénea

X Suplemento superficial

$\square$ suplemento en juntas

$\square$ Mixta

$\square$ Elementos de protección

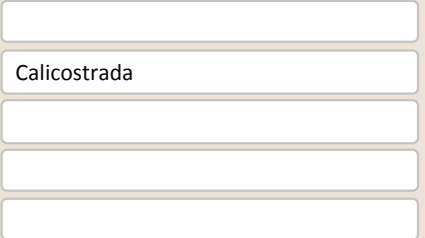

$\mathrm{Cal} /$ yeso

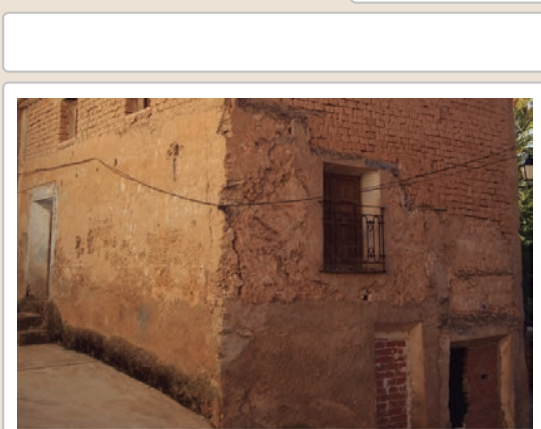

Lesiones \Muro ХZŹcalo $\square$ Revestimiento $\square$ Cubierta $\square$ Otro...

$\mathbf{X}$ Erosión del material $\quad \mathbf{X}$ Humedad por capilaridad $\quad \square$ Grietas por asentamientos

$\square$ Erosion de las juntas $\mathbf{X}$ Humedades (manch/eflo)

$\square$ Colapso

$\square$ Pérdida de sección $\square$ Pérdida de verticalidad

$\square$ Por elementos impropios

$\square$ Vegetación

$\square$ Grietas por empuje de la cubierta $\square$ Derivado de intervenciones

$\mathbf{X}$ Desconchados

$\square$ Grietas porfalta de traba

$\square$ Otro...
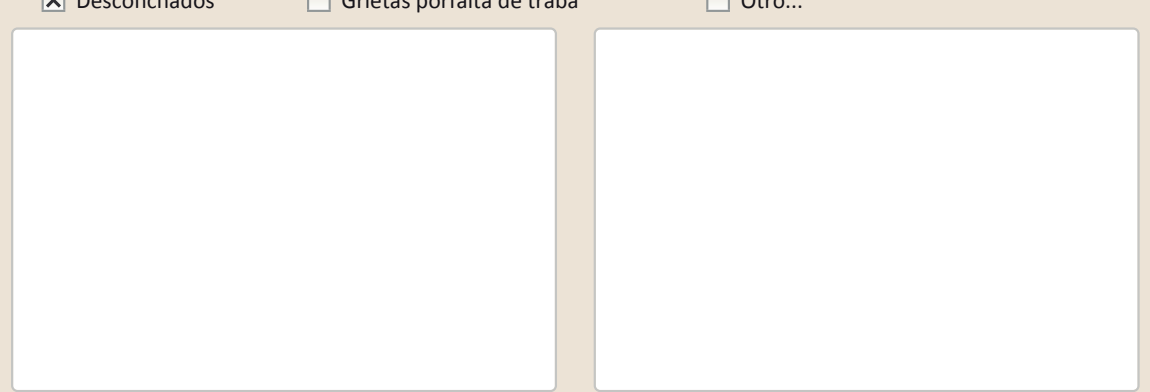

Observaciones

La restauración y rehabilitación de la arquitectura tradicional de tierra.

El caso de Aragón.

3. DATOS DE LA INTERVENCIÓN

Intervención de: $\quad \square$ Mantenimiento $\quad \square$ Rehabilitación parcial $\quad \square$ Restauración $\square$ Demolición

X Reparación $\square$ Rehabilitación integral $\square$ Ampliación $\square$ Otro...

Reflexión previa Intervención espontanea

Observaciones Intervención principalmente sobre la cubierta del edificio

3.1. MUROS

Tipo de intervención

No intervenido

Tipo de material

$\square$ Actualización $\quad \square$ Reintegración $\quad \square$ Demolición $\quad \square$ otro..

$\square$ Consolidación $\square$ Reconstrucción $\square$ sustitución

Descripción

3.2. ZÓCALO

Intervenido

Tipo de intervención

Actualización $\square$ Reintegración $\square$ Demolición $\square$ Otro.

$\square$ Consolidación $\quad \mathbf{X}$ Reconstrucción $\square$ Sustitución

\begin{tabular}{l|lll} 
Tipo de material No tradicional Tipo de técnical Diferente a la existente & \\
\hline
\end{tabular}

Descripción

Revestimiento de cemento

3.3. REVESTIMIENTOS

Tipo de intervención

No aplica

Tipo de material

Descripción

3.4. VANOS

Tipo de intervención

Intervenido

Tipo de material

$\square$ Actualización $\square$ Reintegración $\square$ Demolición $\square$ Otro..

$\square$ Consolidación $\quad \boldsymbol{X}$ Reconstrucción $\square$ Sustitución

Descripción

No tradicional

Tipo de técnica Diferente a la existente

3.5. CUBIERTA

Tipo de intervención

Tipo de material

Intervenido

$\square$ Actualización $\quad \square$ Reintegración $\quad \square$ Demolición $\quad \square$ otro

$\square$ consolidación $\square$ Reconstrucción $\quad$ \ Sustitución

Descripción

Tipo de técnica Diferente a la existente

Sustitución completa de la cubierta. Reconstrucción de la misma sobre una losa de hormigón de gran anchura. Tejas de características distintas a las tradicionales

3.6. OTRAS 
La restauración y rehabilitación de la arquitectura tradicional de tierra.

\section{El caso de Aragón.}

3.7. REHABILITACIÓN ENERGÉTICA $\square$ Fachada $\square$ Vanos $\square$ Forjados $\square$ Cubierta

Observaciones

FOTOGRAFÍAS DE LA INTERVENCIÓN
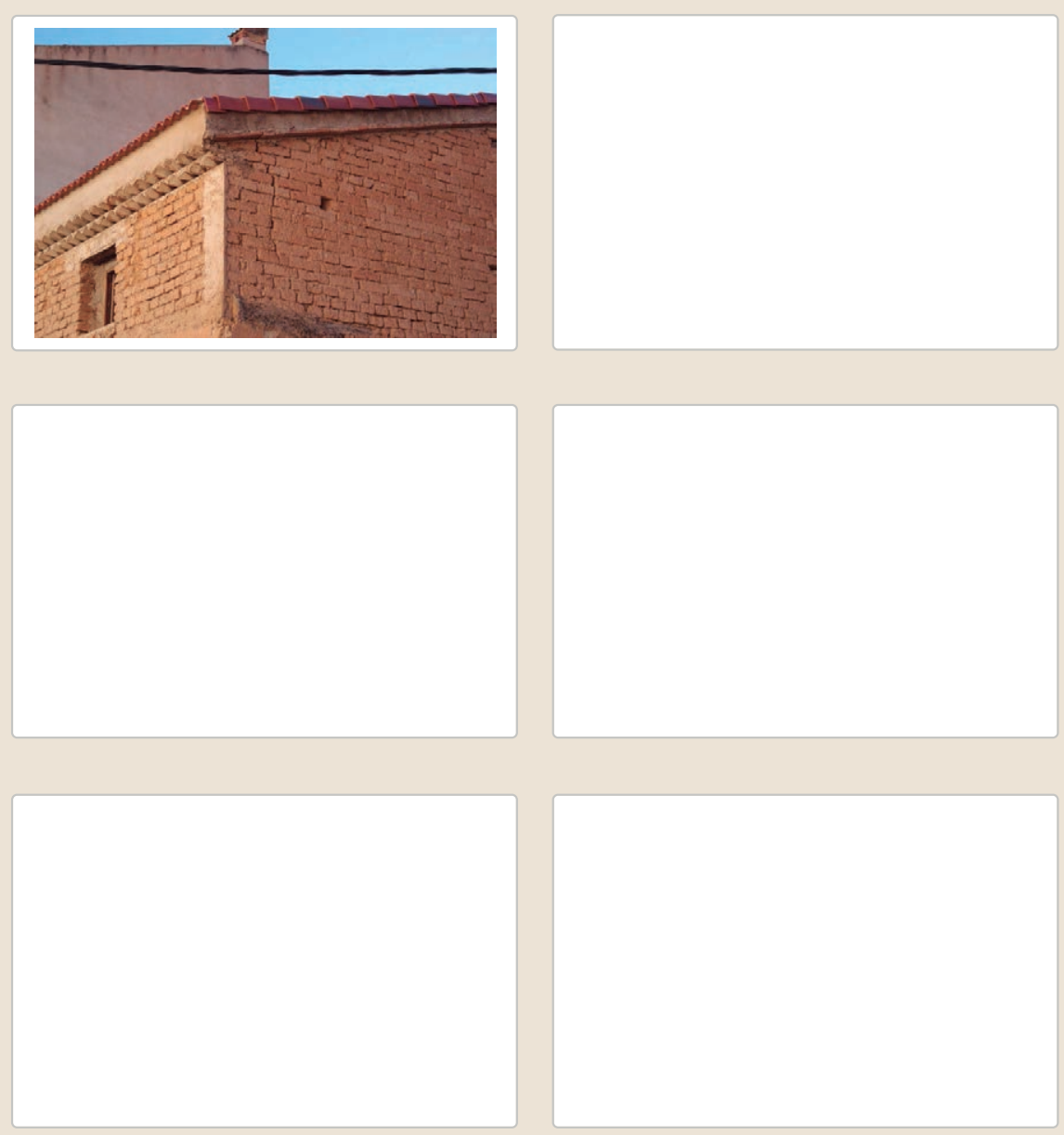


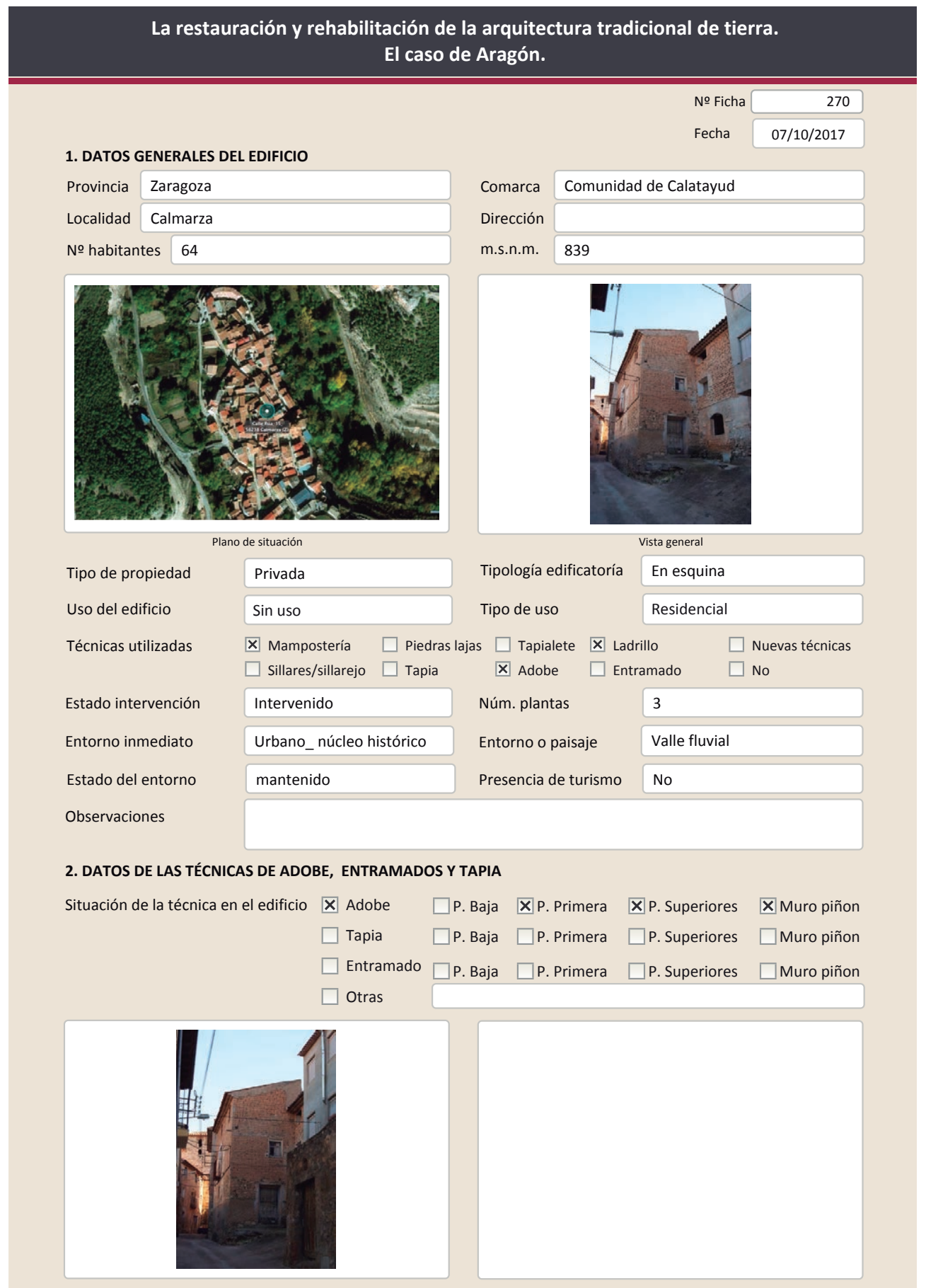

2.1. ADOBE

Dimensión de las piezas Dimensión del muro

Aparejo del muro

Función estructural

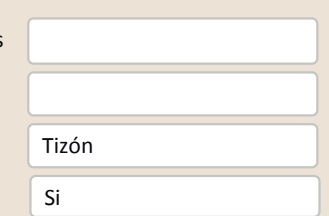

Color de las piezas

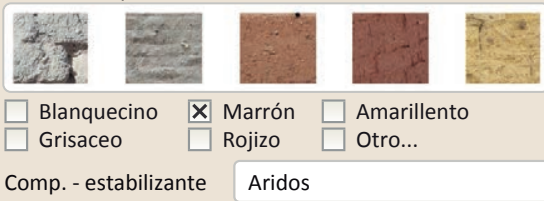

Variante constructiva/ tipo de fábrica

X Simple
$\mathbf{X}$ Suplementada en juntas
Horizontales
$\square$ Mixta
$\square$ Como suplemento
$\square$ Elementos de protección

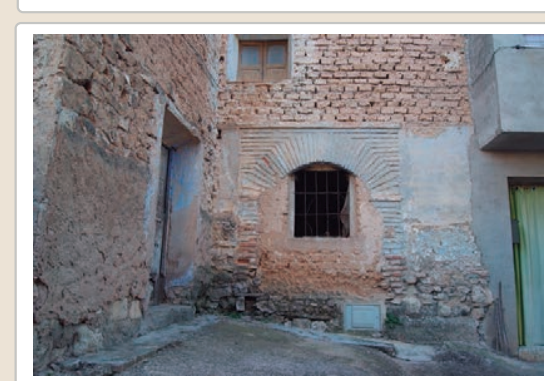

Lesiones ХMuro ХZócalo $\square$ Revestimiento

$\mathbf{X}$ Erosión del material $\mathbf{X}$ Humedad por capilaridad $\square$ Erosion de las juntas $\mathbf{X}$ Humedades (manch/eflo)

$\square$ Pérdida de sección $\square$ Pérdida de verticalidad

$\square$ Vegetación $\quad \square$ Grietas por empuje de la c

$\square$ Desconchados

$\square$ Grietas porfalta de traba

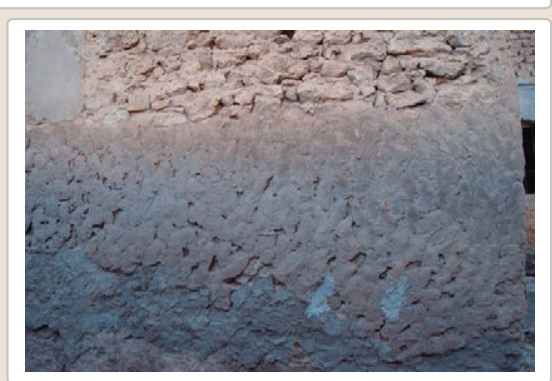

$\square$ Cubierta $\square$ otro...

$$
\begin{aligned}
& \square \text { Grietas por asentamientos } \\
& \square \text { Colapso } \\
& \square \text { Por elementos impropios } \\
& \square \text { Derivado de intervenciones }
\end{aligned}
$$

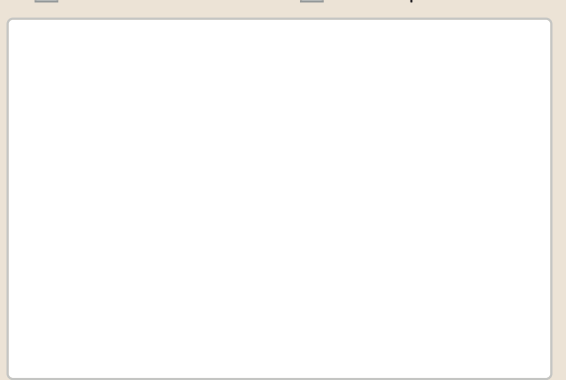

Observaciones 
La restauración y rehabilitación de la arquitectura tradicional de tierra.

El caso de Aragón.

3. DATOS DE LA INTERVENCIÓN

\begin{tabular}{|c|c|c|c|c|}
\hline Intervención de: & $\begin{array}{l}\square \text { Mantenimiento } \\
\text { Х Reparación }\end{array}$ & $\begin{array}{l}\square \text { Rehabilitación parcial } \\
\square \text { Rehabilitación integral }\end{array}$ & $\begin{array}{l}\square \text { Restauración } \\
\square \text { Ampliación }\end{array}$ & $\begin{array}{l}\square \text { Demolición } \\
\square \text { Otro... }\end{array}$ \\
\hline Reflexión previa & \multicolumn{4}{|c|}{ Intervención espontanea } \\
\hline erva & & & & \\
\hline
\end{tabular}

\subsection{MUROS}

Tipo de intervención

No intervenido

Tipo de material

$\square$ Actualización $\square$ Reintegración $\square$ Demolición $\square$ Otro...

$\square$ Consolidación $\square$ Reconstrucción $\square$ sustitución

Descripción

3.2. ZÓCALO

Tipo de intervención

Intervenido

Tipo de intervención

$\square$ Actualización $\square$ Reintegración $\square$ Demolición $\square$ Otro...

$\square$ Consolidación $\quad \mathbf{X}$ Reconstrucción $\square$ Sustitución

Descripción

No tradicional Tipo de técnica Diferente a la existente

3.3. REVESTIMIENTOS

Revestimiento de cemento

Tipo de intervención

No intervenido

Tipo de material

$\square$ Actualización $\square$ Reintegración $\quad \square$ Demolición $\square$ Otro...

Tipo de materia

$\square$ Consolidación $\square$ Reconstrucción $\square$ Sustitución

Descripción

3.4. VANOS

No intervenido

Tipo de intervención

$\square$ Actualización $\quad \square$ Reintegración $\quad \square$ Demolición $\quad \square$ Otro...
$\square$ Consolidación $\quad \square$ Reconstrucción $\quad \square$ Sustitución

Tipo de material

Descripción

3.5. CUBIERTA

Tipo de intervención

Intervenido

$\square$ Actualización $\quad$ X Reintegración $\quad \square$ Demolición $\square$ Otro.

Tipo de material

$\square$ Consolidación $\quad \square$ Reconstrucción $\square$ Sustitución

Descripción

\begin{tabular}{l|l|l|l|l} 
No tradicional Tipo de técnica Similar a la existente &
\end{tabular}

3.6. OTRAS Reintegración de los laterales de la cubierta. La hilera del lateral se ha recolocado para
evitar los desperfectos del muro 


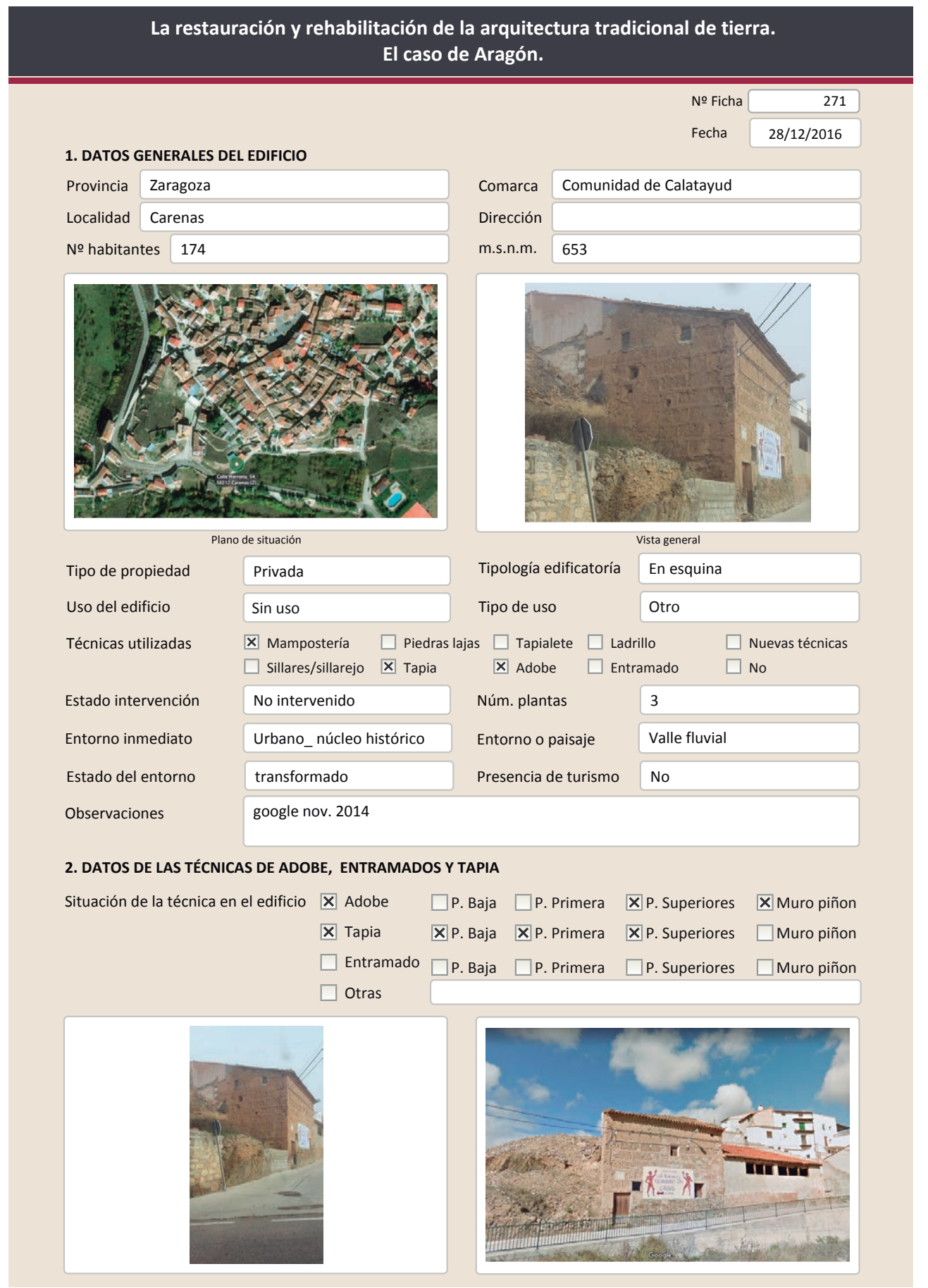

2.1. ADOBE

Dimensión de las piezas

Dimensión del muro

Aparejo del muro

Función estructural

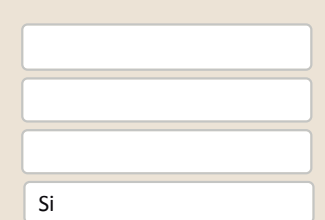

Color de las piezas

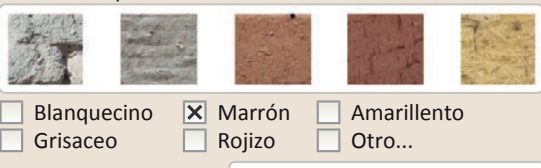

Rojizo

Variante constructiva/ tipo de fábrica

X Simple
$\mathbf{X}$ Suplementada en juntas
Horizontales
$\square$ Mixta
$\square$ Como suplemento
X Elementos de protección
Revestimiento

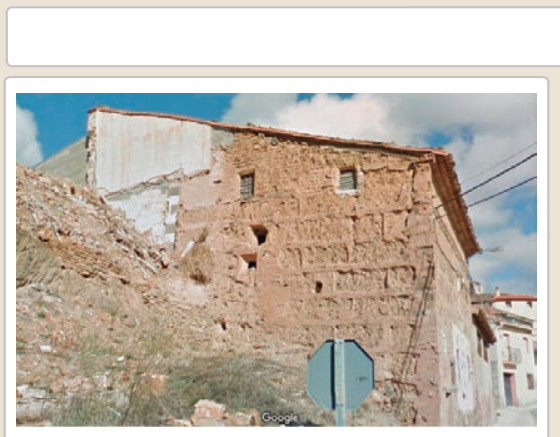

Lesiones ХMuro $\square$ Zócalo $\square$ Revestimiento

$\mathbf{X}$ Erosión del material $\quad \square$ Humedad por capilarida $\square$ Erosion de las juntas $\square$ Humedades (manch/eflo)

\ Pérdida de sección $\square$ Pérdida de verticalidad

$\square$ Vegetación $\quad \square$ Grietas por empuje de la c

$\square$ Grietas porfalta de traba

$\square$ Cubierta $\square$ otro...

$\square$ Grietas por asentamiento

$\square$ Colapso

$\square$ Desconchados

Por elementos impropios

$\square$ Derivado de intervenciones

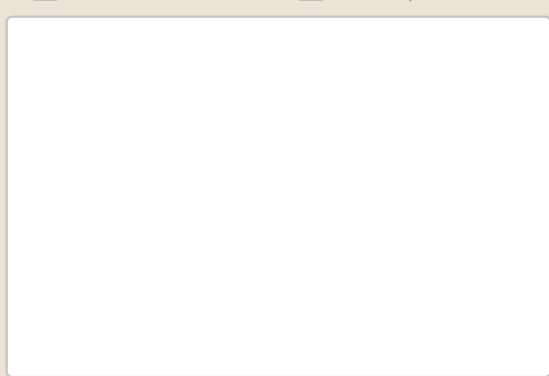

Observacione 
La restauración y rehabilitación de la arquitectura tradicional de tierra.

El caso de Aragón.
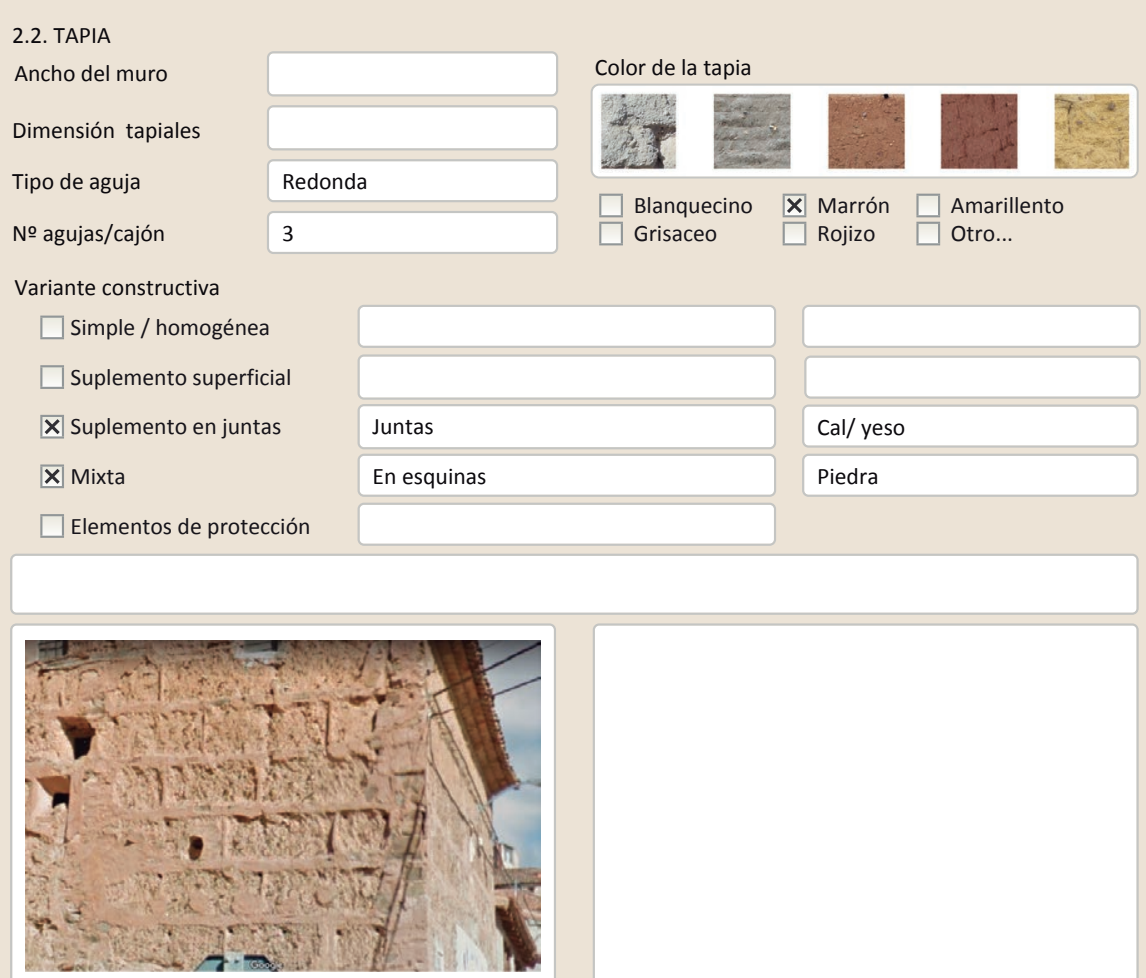

Lesiones $\quad \mathbf{X}$ Muro $\mathbf{X}$ Zócalo $\square$ Revestimiento $\square$ Cubierta $\square$ otro...

$\mathbf{X}$ Erosión del material $\mathbf{X}$ Humedad por capilaridad $\quad \square$ Grietas por asentamientos

$\square$ Erosion de las juntas $\square$ Humedades (manch/eflo)

$X$ Pérdida de sección $\square$ Pérdida de verticalidad

$\square$ Colapso

$\square$ Vegetación $\quad \square$ Grietas por empuje de la cubier

Por elementos impropios

$\square$ Desconchados

$\square$ Grietas porfalta de traba

$\square$ Otro...

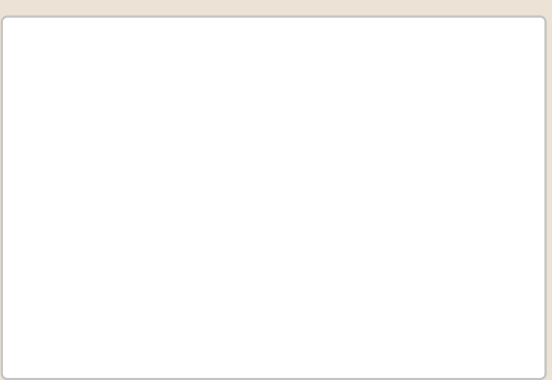




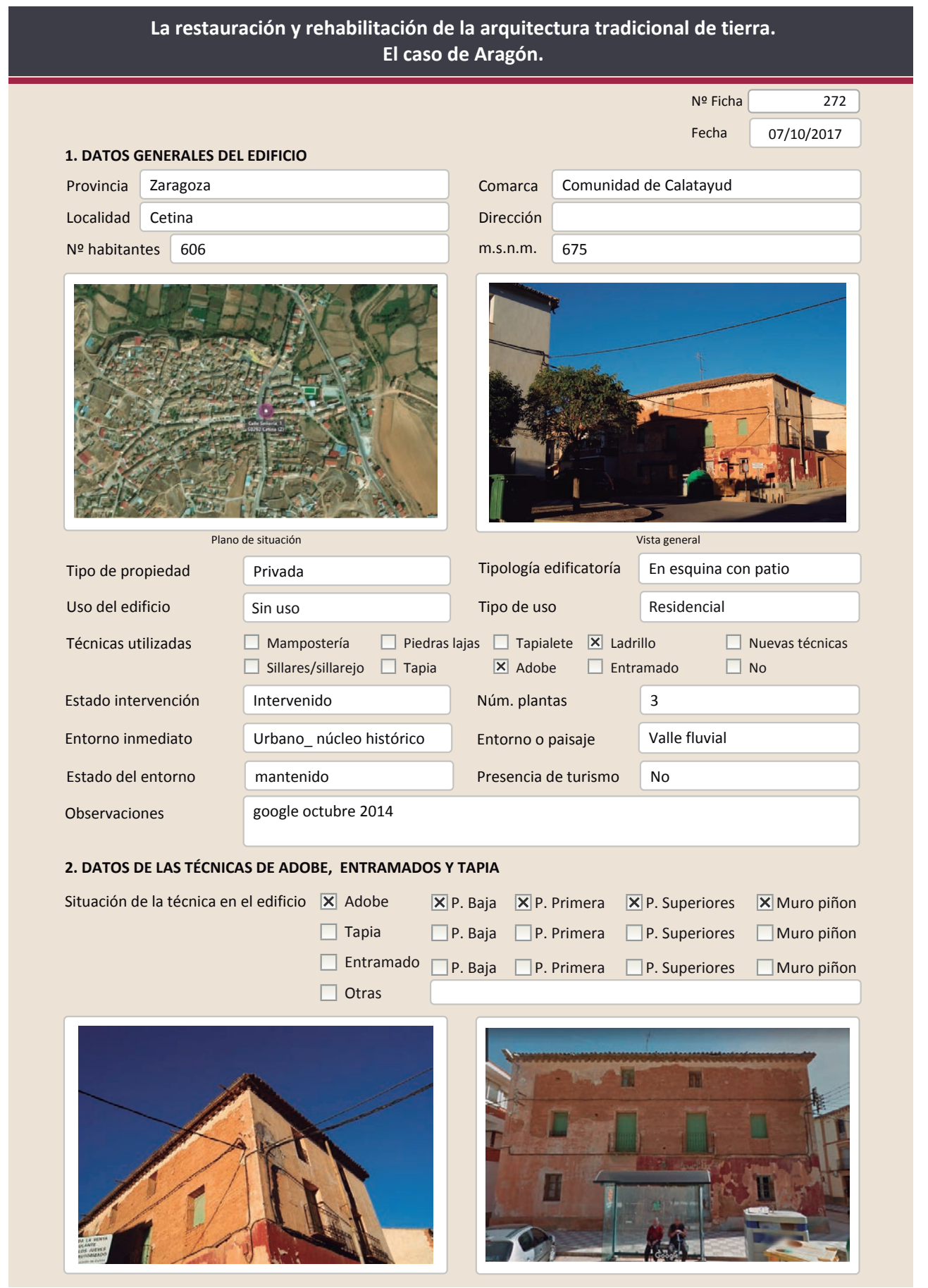

2.1. ADOBE

Dimensión de las piezas

Dimensión del muro

Aparejo del muro

Función estructural

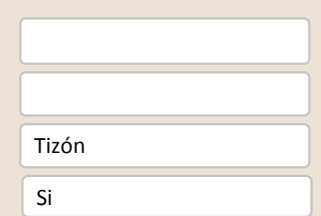

Color de las piezas

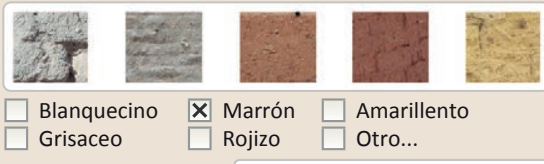

Grisaceo

Variante constructiva/ tipo de fábrica

$\square$ Simple

$\square$ Suplementada en juntas

区 Mixta

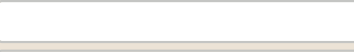

$\square$ Como suplemento

$\square$ Elementos de protección No en todas las esquinas hay ladrillo

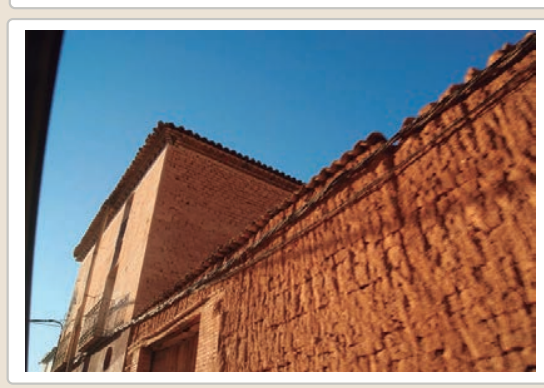

Lesiones Х Muro $\square$ Zócalo \ Revestimiento

$\mathbf{X}$ Erosión del material $\square$ Humedad por capilaridad $\square$ Erosion de las juntas $\square$ Humedades (manch/eflo)

$\square$ Pérdida de sección $\square$ Pérdida de verticalidad

$\square$ Vegetación

$\mathbf{X}$ Desconchados

$\square$ Grietas por empuje de la $\square$ Grietas porfalta de traba

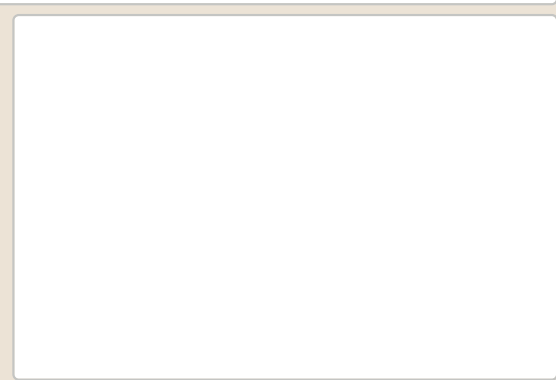

$\square$ Cubierta $\square$ Otro...

$\square$ Grietas por asentamiento

$\square$ Colapso

$\square$ Por elementos impropios

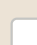

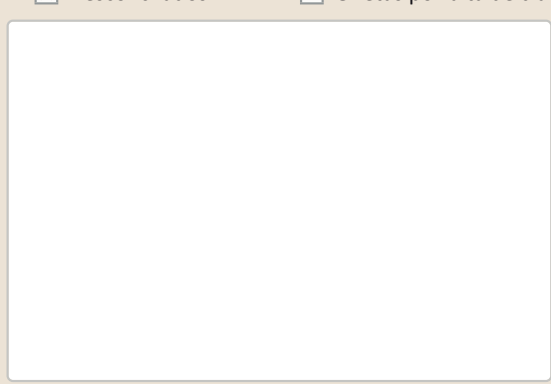

$\square$ Derivado de intervenciones $\square$ Otro... 
La restauración y rehabilitación de la arquitectura tradicional de tierra.

El caso de Aragón.

3. DATOS DE LA INTERVENCIÓN

Intervención de:

$\square$ Mantenimiento $\quad \boldsymbol{X}$ Rehabilitación parcia

$\square$ Restauración $\quad \square$ Demolición

Reflexión previa

X Reparación

Rehabilitación integra

Ampliación

$\square$ Otro..

Observaciones

Intervención espontanea

(2)

3.1. MUROS

Tipo de intervención

Intervenido

Tipo de material

$\square$ Actualización $\quad \boldsymbol{X}$ Reintegración $\quad \square$ Demolición $\square$ Otro...

$\square$ Consolidación $\quad \square$ Reconstrucción $\square$ Sustitución

Descripción

\begin{tabular}{l|l|l} 
No tradicional & Tipo de técnica & Diferente a la existente
\end{tabular}

3.2. ZÓCALO

Tipo de intervención

Cemento en una zona erosionada del muro

Tipo de material

Intervenido

X Actualización $\square$ Reintegración $\square$ Demolición $\square$ Otro...

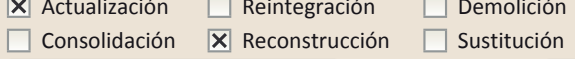

Descripción

No tradicional Tipo de técnica Diferente a la existente

Zócalo de cemento grueso

3.3. REVESTIMIENTOS

Intervenido

Tipo de intervención

X Actualización $\square$ Reintegración $\square$ Demolición $\square$ Otro...

Tipo de material

$\square$ Consolidación $\square$ Reconstrucción $\square$ Sustitución

Descripción

No tradicional

Tipo de técnica Diferente a la existente

3.4. VANOS

Pintura plástica roja en planta baja

Tipo de intervención

No intervenido

Tipo de material

$\square$ Actualización $\quad \square$ Reintegración $\quad \square$ Demolición $\quad \square$ Otro...
$\square$ Consolidación $\quad \square$ Reconstrucción $\quad \square$ sustitución

Tipo de materia
Descripción

3.5. CUBIERTA

Tipo de intervención

No intervenido

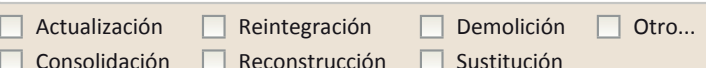

Tipo de material

$\square$ Reconstrucción $\square$ Sustitución

Descripción

Tipo de técnica

3.6. OTRAS 


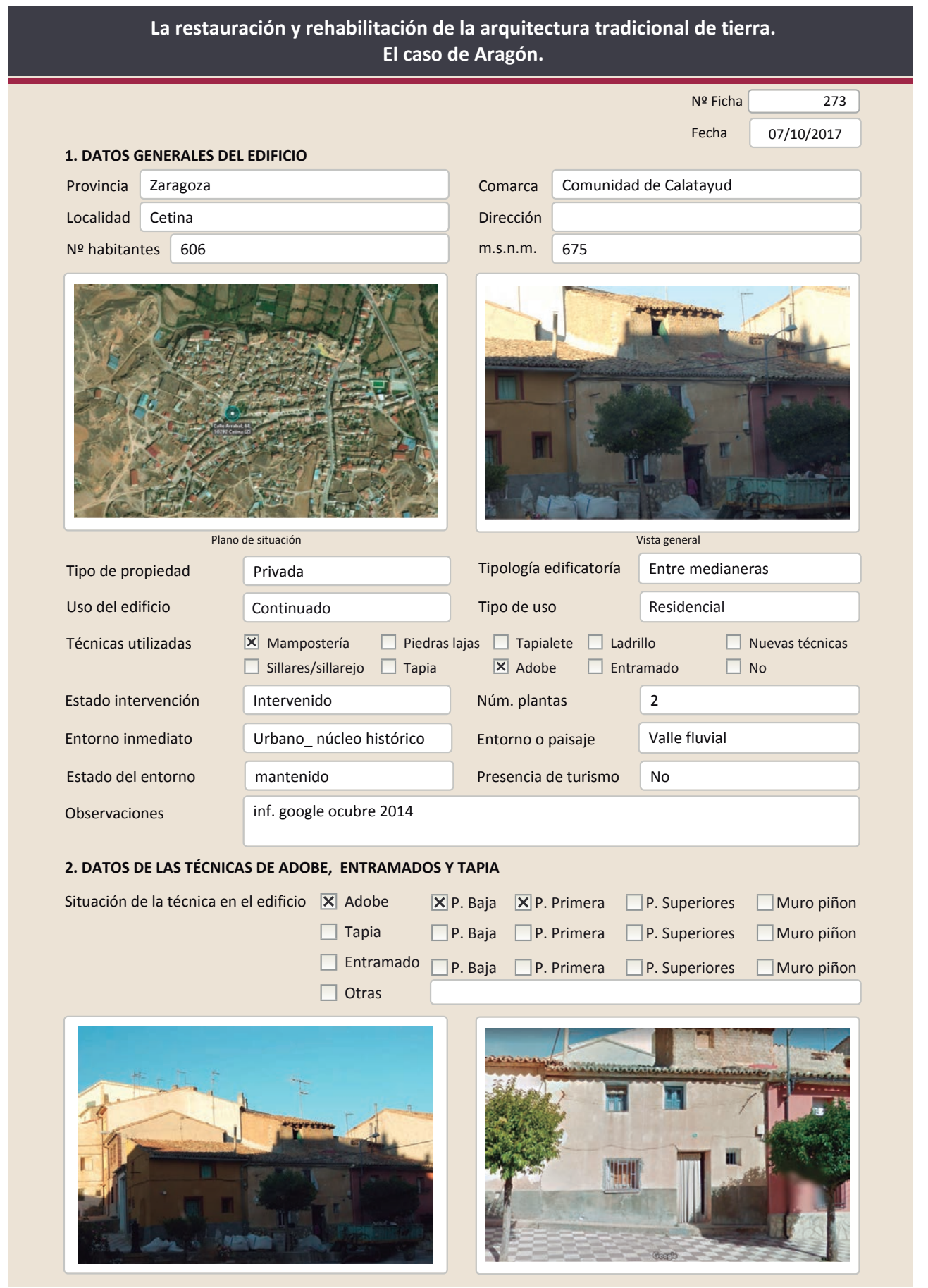

2.1. ADOBE

Dimensión de las piezas Dimensión del muro

Aparejo del muro

Función estructural

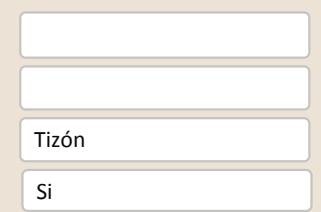

Color de las piezas

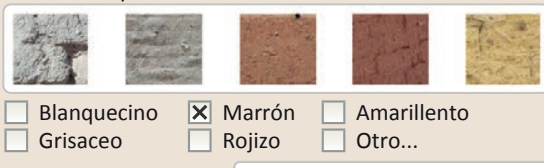

Grisaceo

Variante constructiva/ tipo de fábrica

区 Simple

$\square$ Suplementada en juntas

$\square$ Mixta

$\square$ Como suplemento

$\square$ Elementos de protección

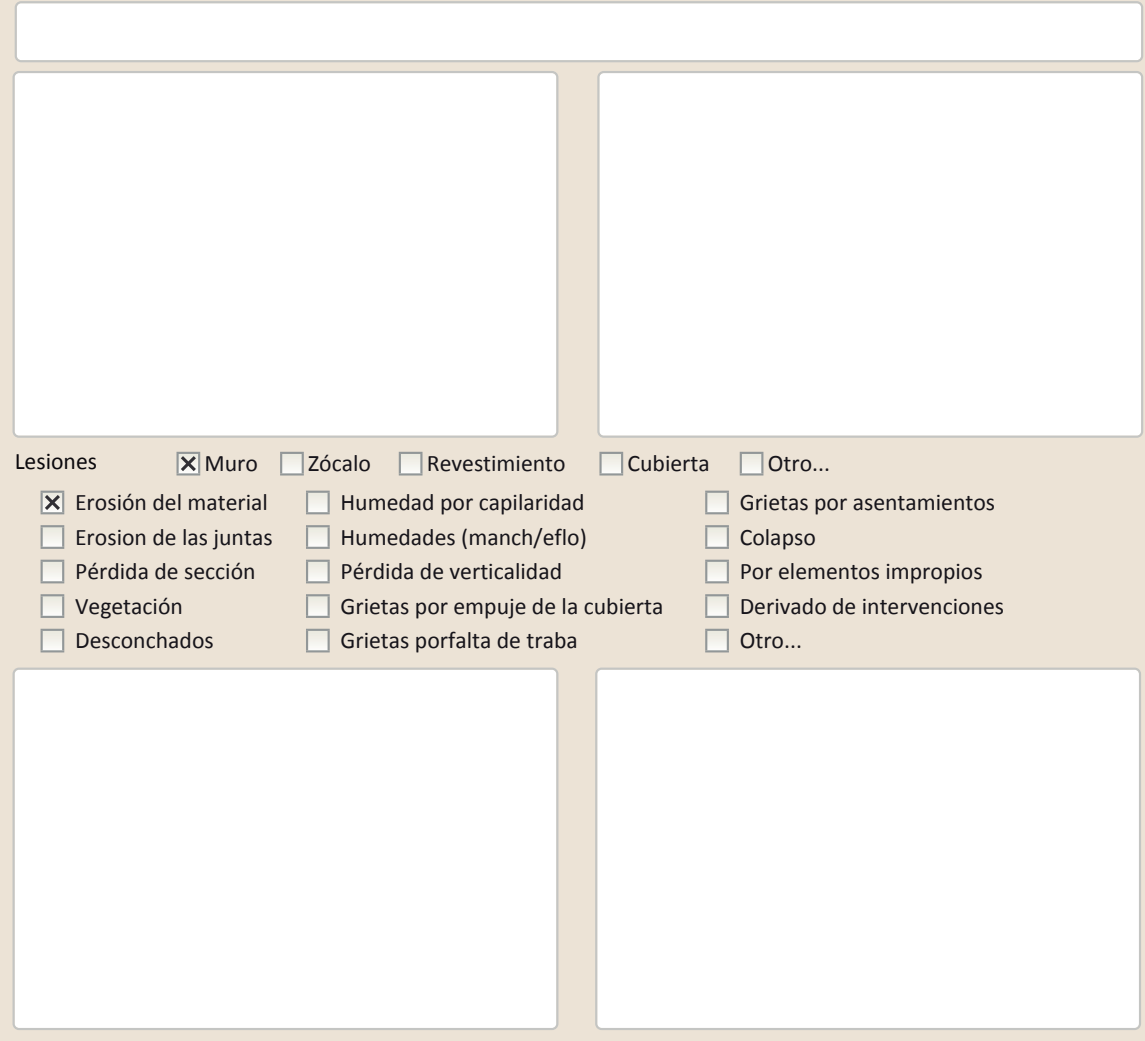

Observaciones 


\section{La restauración y rehabilitación de la arquitectura tradicional de tierra.}

\section{El caso de Aragón.}

3. DATOS DE LA INTERVENCIÓN

Intervencín LA

.

$\square$ Mantenimiento $\quad \mathbf{X}$ Rehabilitación parcial

$\square$ Restauración $\square$ Demolición

Reflexión previa

Intervención espontanea

Observaciones

3.1. MUROS
Tipo de intervención

Tipo de material

Descripción

3.2. ZóCALO

Tipo de intervención

Tipo de material

Descripción

3.3. REVESTIMIENTOS

Tipo de intervención

Tipo de material

Descripción

3.4. VANOS

Tipo de intervención

Tipo de material

Descripción

3.5. CUBIERTA

Tipo de intervención

Tipo de material

Descripción

3.6. OTRAS

No visible
$\square$ Actualización $\quad \square$ Reintegración $\quad \square$ Demolición $\quad \square$ Otro...
consolidación $\quad \square$ Reconstrucción $\quad \square$ Sustitución

$\square$ Consolidación $\quad \square$ Reconstrucción $\square$ Sustitución

\section{Intervenido}

メ Actualización $\square$ Reintegración $\quad \square$ Demolición $\square$ Otro...

$\square$ Consolidación $\quad \mathbf{X}$ Reconstrucción $\square$ Sustitución

No tradicional Tipo de técnica Diferente a la existente

Zócalo con lajas de piedra cogidas con cemento

\section{Intervenido}

X Actualización $\square$ Reintegración $\square$ Demolición $\square$ Otro...

$\square$ Consolidación $\quad \mathbf{X}$ Reconstrucción $\quad \square$ Sustitución

No tradicional Tipo de técnica Diferente a la existente

Revestimiento de cemento y pintura amarilla, La pare superior del edificio solo una

capa muy fina de revestimiento de cemento.

Intervenido

$\square$ Actualización $\quad \square$ Reintegración $\square$ Demolición $\square$ Otro...

$\square$ Consolidación $\square$ Reconstrucción $\mathbf{X}$ Sustitución

\section{No intervenido}

$\square$ Actualización $\square$ Reintegración $\quad \square$ Demolición $\square$ Otro..

$\square$ Consolidación $\square$ Reconstrucción $\square$ Sustitución Tipo de técnica
La restauración y rehabilitación de la arquitectura tradicional de tierra.

El caso de Aragón.

3.7. REHABILITACIÓN ENERGÉTICA $\square$ Fachada $\quad \boldsymbol{X}$ Vanos $\square$ Forjados $\square$ Cubierta

Observaciones

FOTOGRAFíAS DE LA INTERVENCIÓN

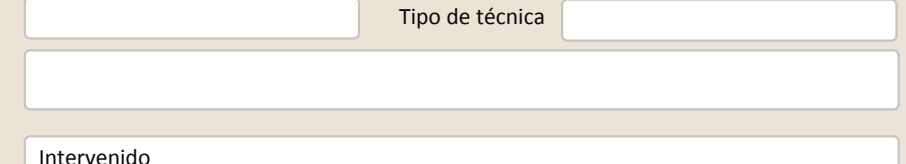
No tradicional
Tipo de técnica Diferente a la existente

Sustitución de las carpinerías
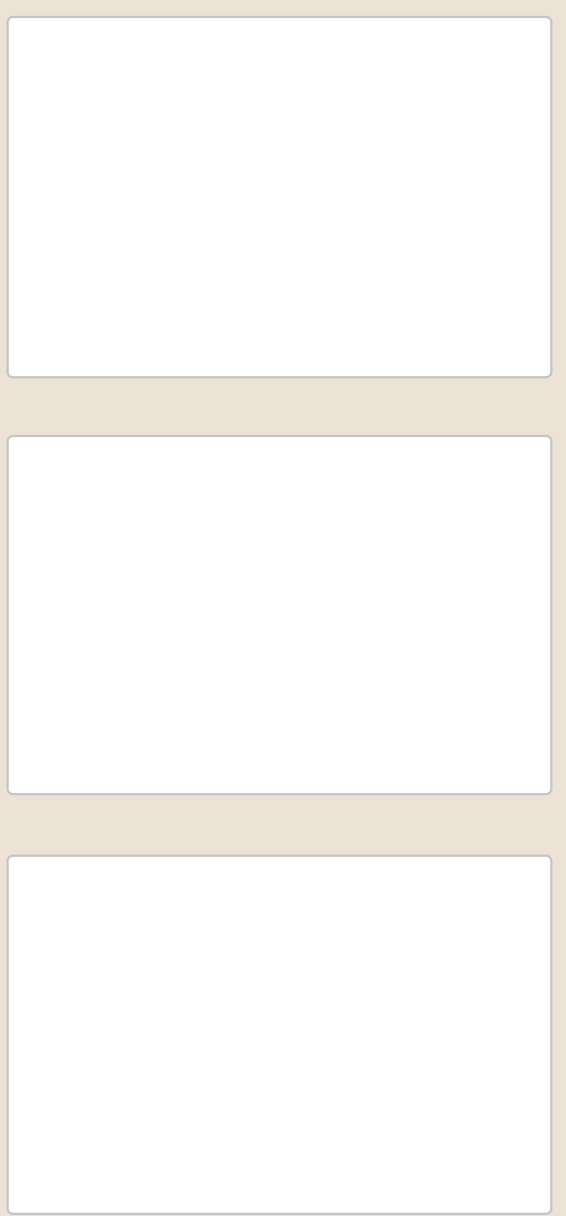
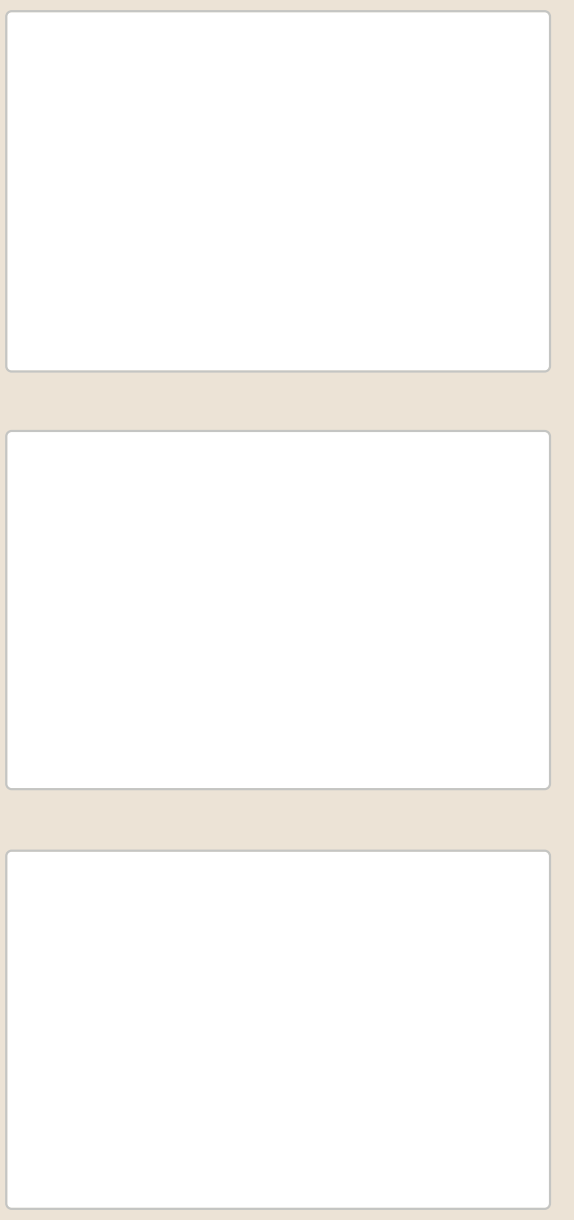
La restauración y rehabilitación de la arquitectura tradicional de tierra. El caso de Aragón

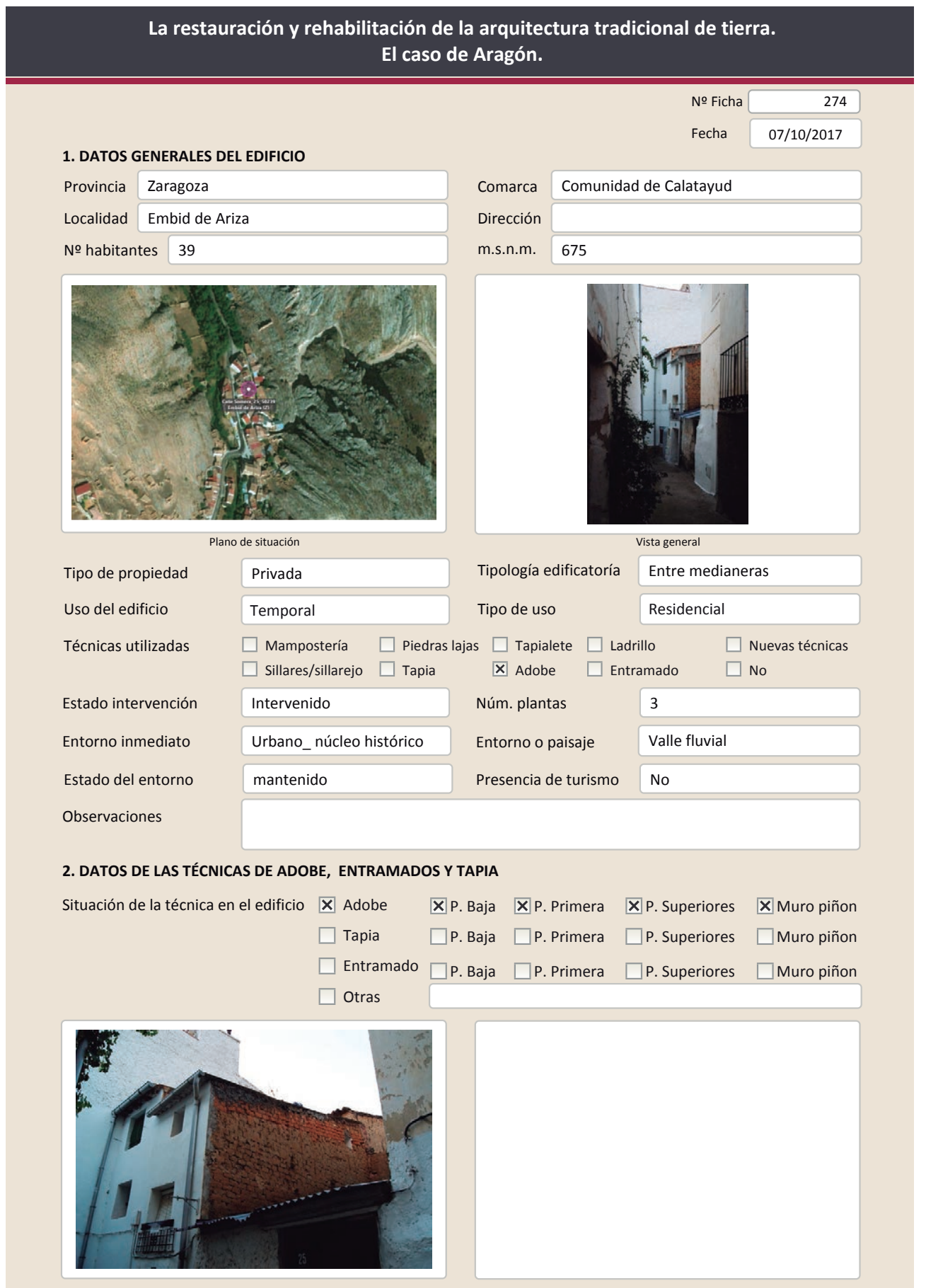

2.1. ADOBE

Dimensión de las piezas Dimensión del muro

Aparejo del muro

Función estructural

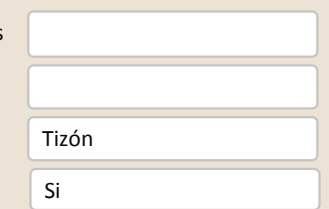

Color de las piezas

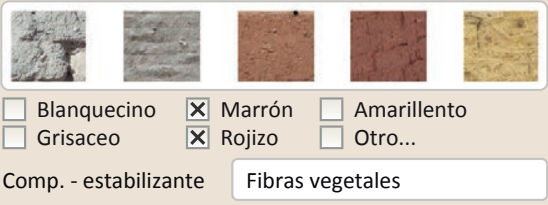

Variante constructiva/ tipo de fábrica

区 Simple

$\square$ Suplementada en juntas

$\square$ Mixta

$\square$ Como suplemento

$\square$ Elementos de protección Dos tipos de adobe diferentes

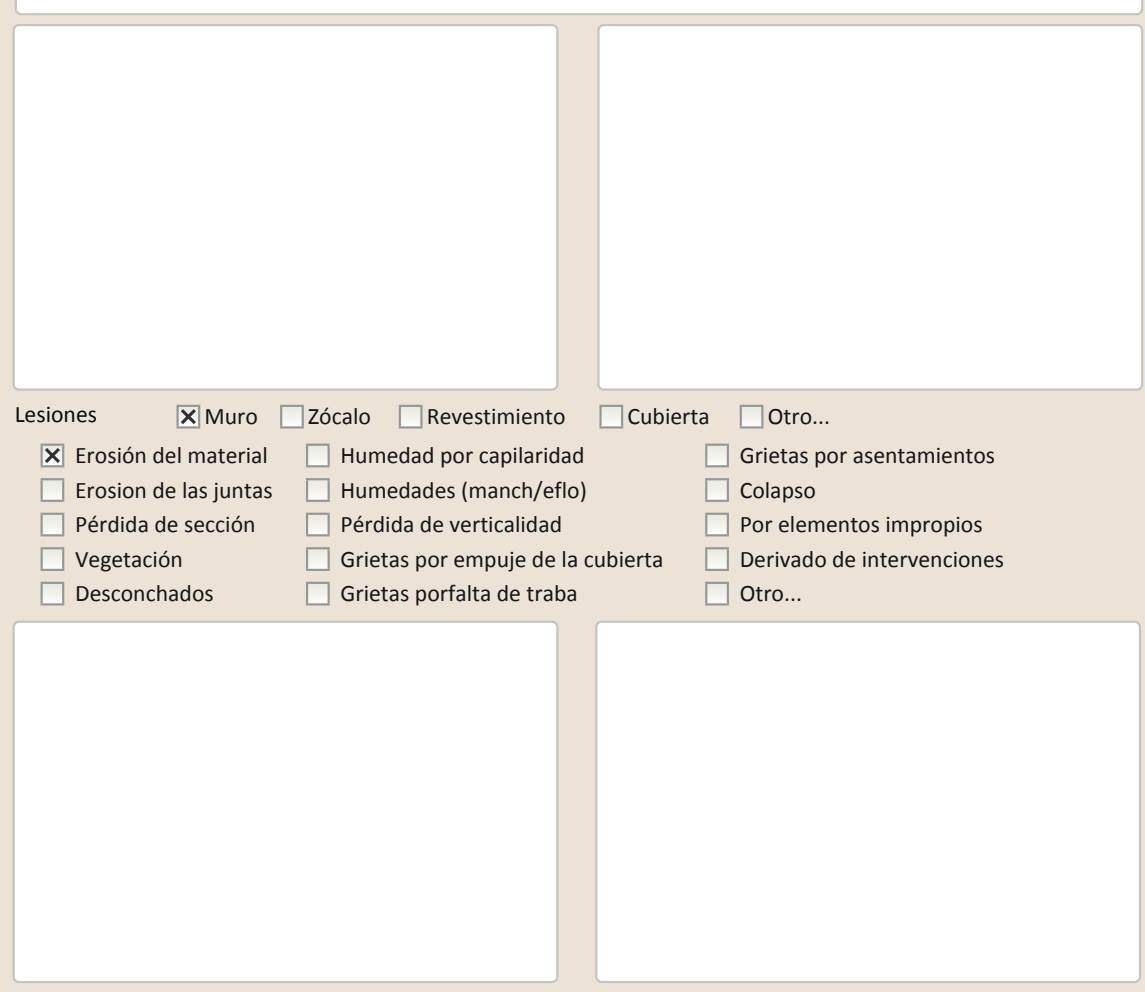

Observaciones 
La restauración y rehabilitación de la arquitectura tradicional de tierra.

\section{El caso de Aragón.}

3. DATOS DE LA INTERVENCIÓN

\begin{tabular}{|c|c|c|c|c|}
\hline Intervención de: & $\begin{array}{l}\square \text { Mantenimiento } \\
\text { Х Reparación }\end{array}$ & $\begin{array}{l}\square \text { Rehabilitación parcial } \\
\square \text { Rehabilitación integral }\end{array}$ & $\begin{array}{l}\square \text { Restauración } \\
\square \text { Ampliación }\end{array}$ & $\begin{array}{l}\square \text { Demolición } \\
\square \text { Otro... }\end{array}$ \\
\hline Reflexión previa & \multicolumn{4}{|c|}{ Intervención espontanea } \\
\hline erva & & & & \\
\hline
\end{tabular}

\subsection{MUROS}

Tipo de intervención

No intervenido

Tipo de material

$\square$ Actualización $\square$ Reintegración $\square$ Demolición $\square$ Otro... $\square$ Consolidación $\square$ Reconstrucción $\square$ Sustitución

Descripción

3.2. ZÓCALO

Tipo de intervención

\section{Intervenido}

X Actualizació

Tipo de material

Descripción

Tipo de técnica Diferente a la existente

3.3. REVESTIMIENTOS

\section{Intervenido}

Tipo de intervención

\ Actualización $\square$ Reintegración $\square$ Demolición $\square$ Otro...

Tipo de material

$\square$ Consolidación $\quad \mathbf{X}$ Reconstrucción $\square$ sustitución

Tipo de materia
Descripción

No tradicional

Tipo de técnica Diferente a la existente

3.4. VANOS

Fachada principal. Pintura blanca

Tipo de intervención

No visible

Tipo de material

$\square$ Actualización $\quad \square$ Reintegración $\quad \square$ Demolición $\quad \square$ Otro...
$\square$ Consolidación $\quad \square$ Reconstrucción $\quad \square$ sustitución

Descripción

3.5. CUBIERTA

Tipo de intervención

Intervenido

$\square$ Actualización $\square$ Reintegración $\square$ Demolición $\square$ Otro..

Tipo de material

$\square$ Consolidación $\square$ Reconstrucción $\quad \boldsymbol{X}$ Sustitución

Descripción

No tradicional Tipo de técnica Diferente a la existente

3.6. OTRAS 
La restauración y rehabilitación de la arquitectura tradicional de tierra. El caso de Aragón

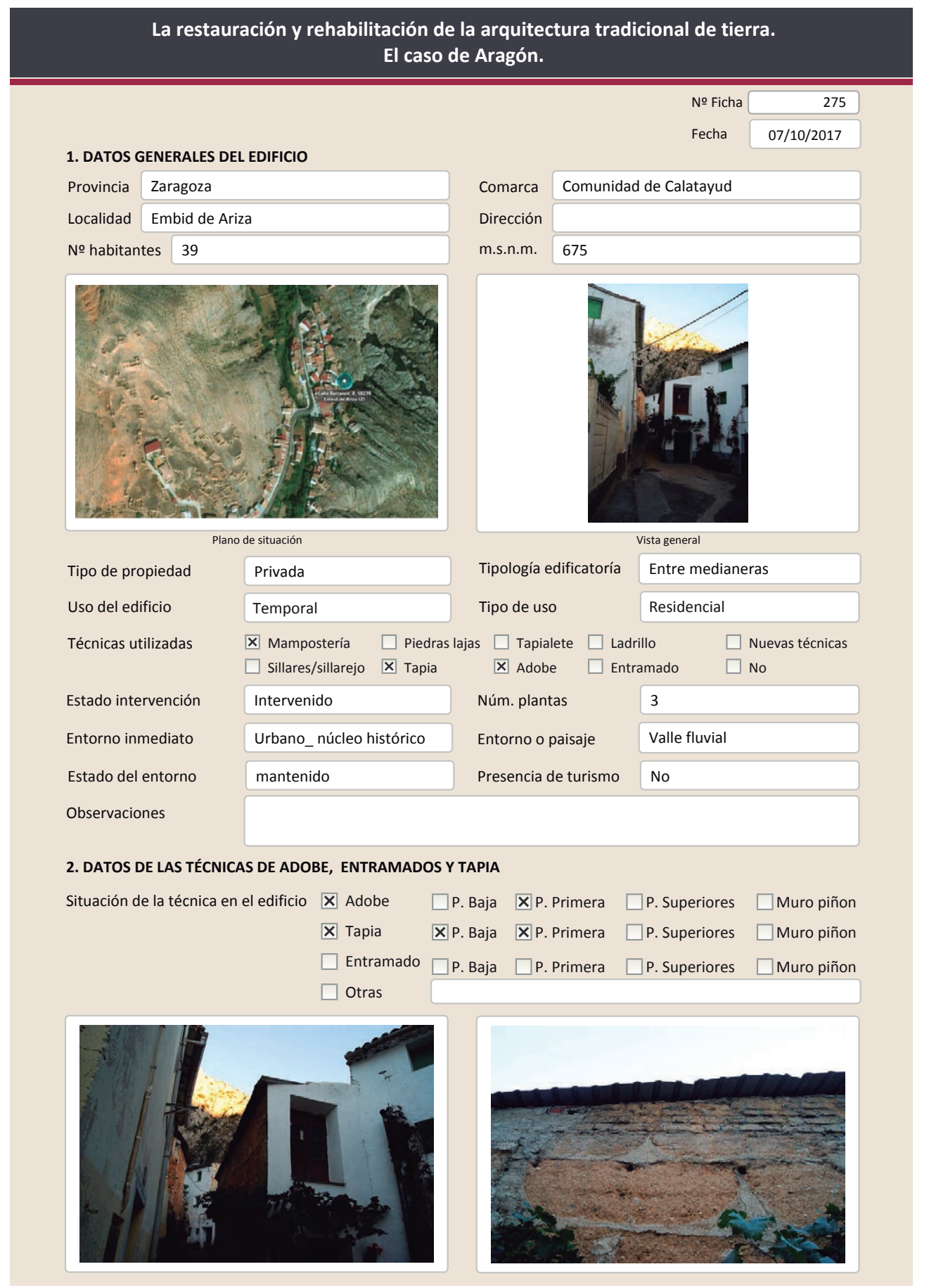

2.1. ADOBE

Dimensión de las piezas Dimensión del muro

Aparejo del muro

Función estructural

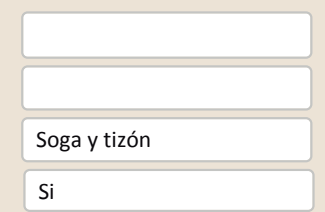

Color de las piezas

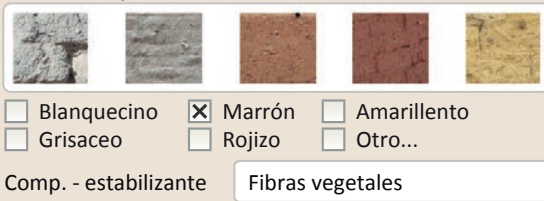

Variante constructiva/ tipo de fábrica

メ simple

$\square$ Suplementada en juntas

$\square$ Mixta

$\square$ Como suplemento

$\square$ Elementos de protección

Muro de adobe sobre el muro de tapia

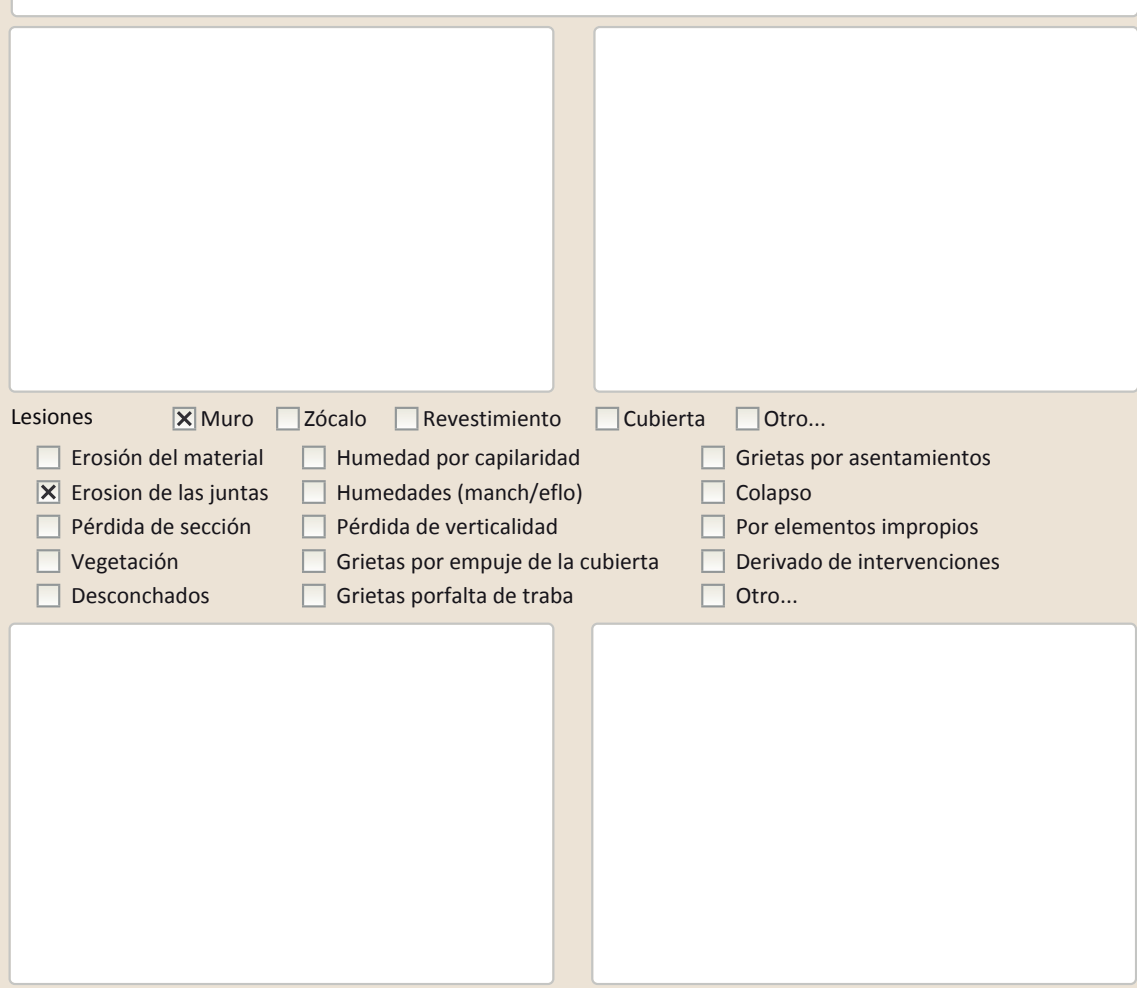

Observaciones 


\section{La restauración y rehabilitación de la arquitectura tradicional de tierra.}

\section{El caso de Aragón.}

\subsection{TAPIA}

Ancho del muro

Dimensión tapiales

Tipo de aguja

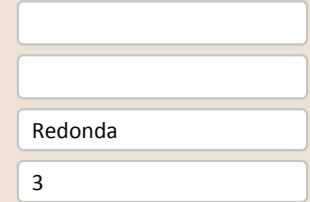

Color de la tapia

№ agujas/cajón

3

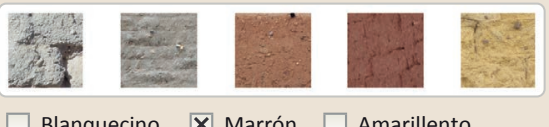

$\square$ Blanquecino $\quad \mathbf{X}$ Marrón $\square$ Amarillento $\square$ Grisaceo

$\square$ Rojizo $\square$ Otro...

Variante constructiva

$\square$ Simple / homogénea

$\square$ suplemento superficial

$X$ Suplemento en juntas

$\square$ Mixta

$\square$ Elementos de protección
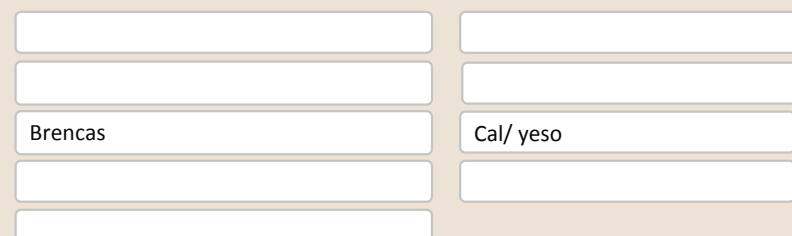

\section{Cal/ yeso}

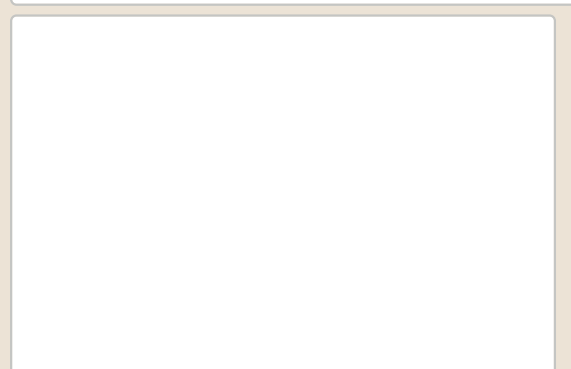

Lesiones $\quad$ Muro $\square$ Zócalo $\square$ Revestimiento $\square$ Cubierta $\square$ Otro...

\ Erosión del material $\quad \square$ Humedad por capilaridad $\quad \square$ Grietas por asentamientos

$\square$ Erosion de las juntas $\square$ Humedades (manch/eflo) $\quad \square$ Colapso

$\square$ Pérdida de sección $\square$ Pérdida de verticalidad $\square$ Por elementos impropios

$\square$ Vegetación $\square$ Grietas por empuje de la cubierta $\square$ Derivado de intervenciones

$\square$ Desconchados $\quad \square$ Grietas porfalta de traba $\quad \square$ Otro...
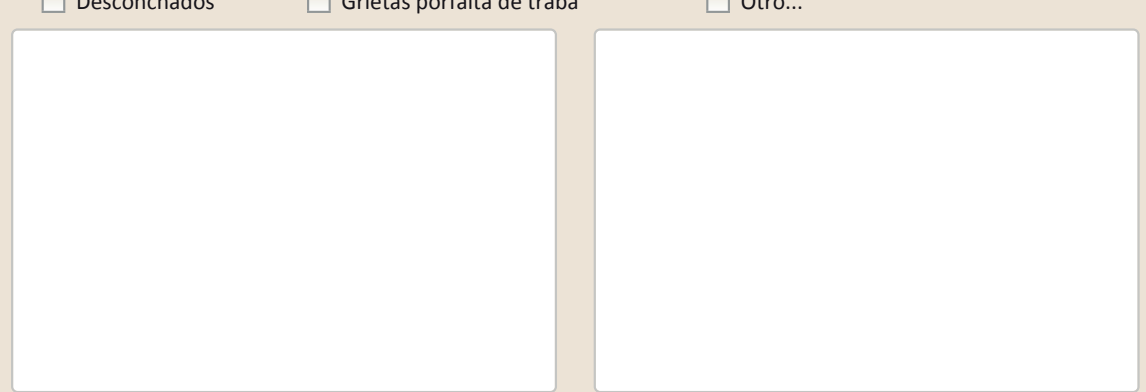

Observaciones
La restauración y rehabilitación de la arquitectura tradicional de tierra.

El caso de Aragón.

3. DATOS DE LA INTERVENCIÓN

Intervención de: $\quad \square$ Mantenimiento $\quad \mathbf{X}$ Rehabilitación parcial $\quad \square$ Restauración $\square$ Demolición

$\square$ Reparación $\quad \square$ Rehabilitación integral $\square$ Ampliación $\square$ Otro..

Reflexión previa Intervención espontanea

Observaciones

3.1. MUROS

Tipo de intervención

Intervenido

Tipo de material

$\square$ Actualización $\quad \square$ Reintegración $\quad \square$ Demolición $\quad \square$ Otro..

$\square$ Consolidación $\quad \mathbf{X}$ Reconstrucción $\square$ Sustitución

Descripción

No tradicional Tipo de técnica Diferente a la existente

3.2. ZóCALO

Reconstrucción parcial del muro con bloque de hormigón prefabricado y ladrillo hueco revestido con cemento.

Tipo de intervención $\quad \mathbf{X}$ Actualización $\square$ Reintegración $\square$ Demolición $\square$ Otro.

$\mathbf{X}$ Actualización $\square$ Reintegración $\square$ Demolición
$\square$ Consolidación $\quad \boldsymbol{X}$ Reconstrucción $\square$ Sustitución

Tipo de material

$\square$ Consolidación $\quad \mathbf{X}$ Reconstrucción $\square$ Sustitución

Descripción

Revestimiento de cemento pintado de azu

3.3. REVESTIMIENTOS

Tipo de intervención

Intervenido

X Actualización $\square$ Reintegración $\square$ Demolición $\square$ Otro...

Tipo de material

Consolidación $\mathbf{X}$ Reconstrucción $\square$ Sustitución

Descripción

3.4. VANOS

Tipo de intervención

No tradicional

Tipo de técnica Diferente a la existente

Revestimiento de cemento pintado de blanco

Tipo de material

No intervenido

$\square$ Actualización $\square$ Reintegración $\square$ Demolición $\square$ Otro..

$\square$ Consolidación $\quad \square$ Reconstrucción $\square$ Sustitución

Descripción

3.5. CUBIERTA

Tipo de intervención

Intervenido

$\square$ Actualización $\quad \square$ Reintegración $\quad \square$ Demolición $\quad \square$ Otro

$\square$ Consolidación $\square$ Reconstrucción $\mathbb{X}$ Sustitución

\begin{tabular}{l|lll} 
Tipo de material & No tradicional tipo de técnical Diferente a la existente
\end{tabular}

Descripción

Sustitución parcial de la cubierta por chapa grecada metálica

3.6. OTRAS 
La restauración y rehabilitación de la arquitectura tradicional de tierra. El caso de Aragón

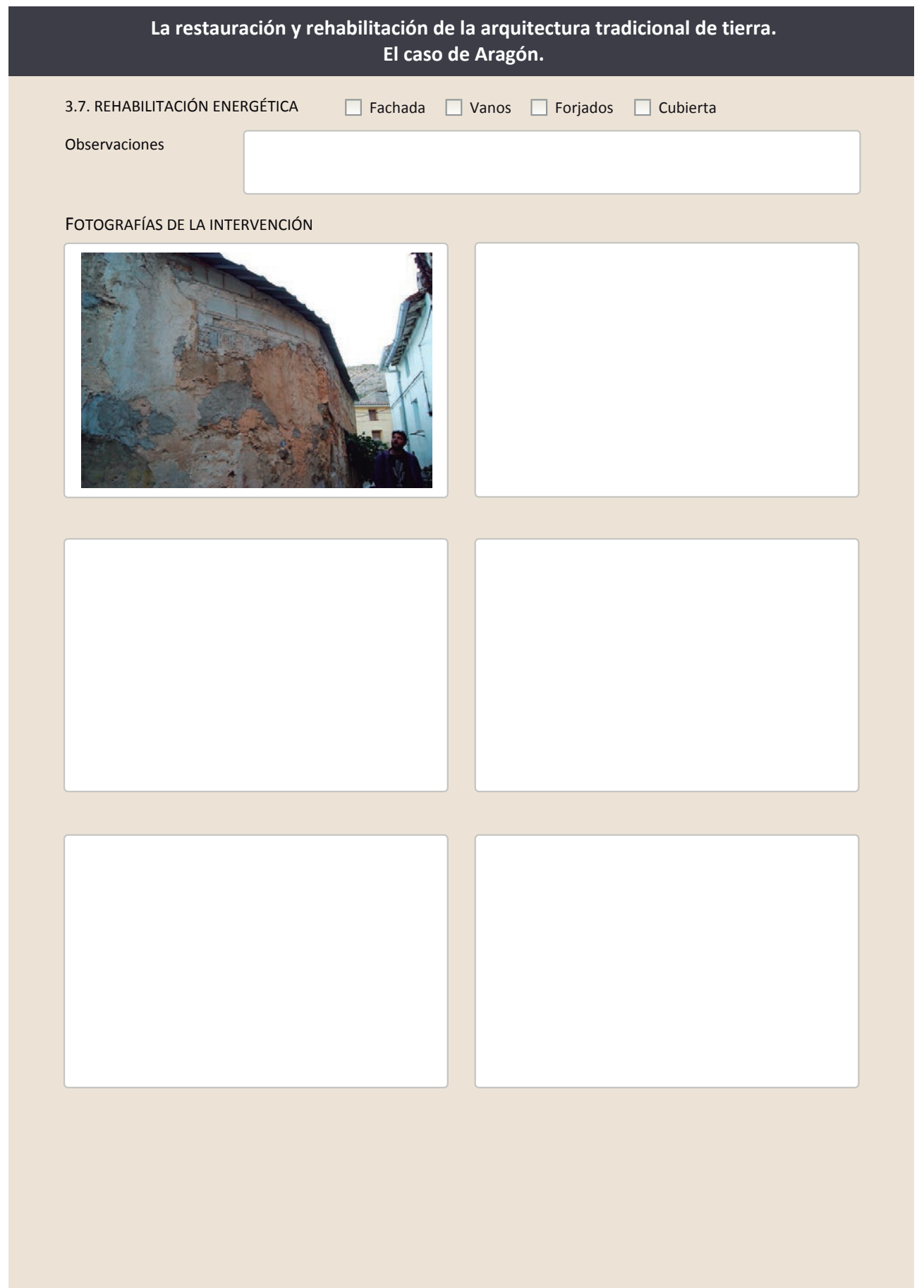

La restauración y rehabilitación de la arquitectura tradicional de tierra.

El caso de Aragón.

3.7. REHABILITACIÓN ENERGÉTICA $\square$ Fachada $\square$ Vanos $\square$ Forjados $\square$ Cubierta

Observaciones

FOTOGRAFÍAS DE LA INTERVENCIÓN 


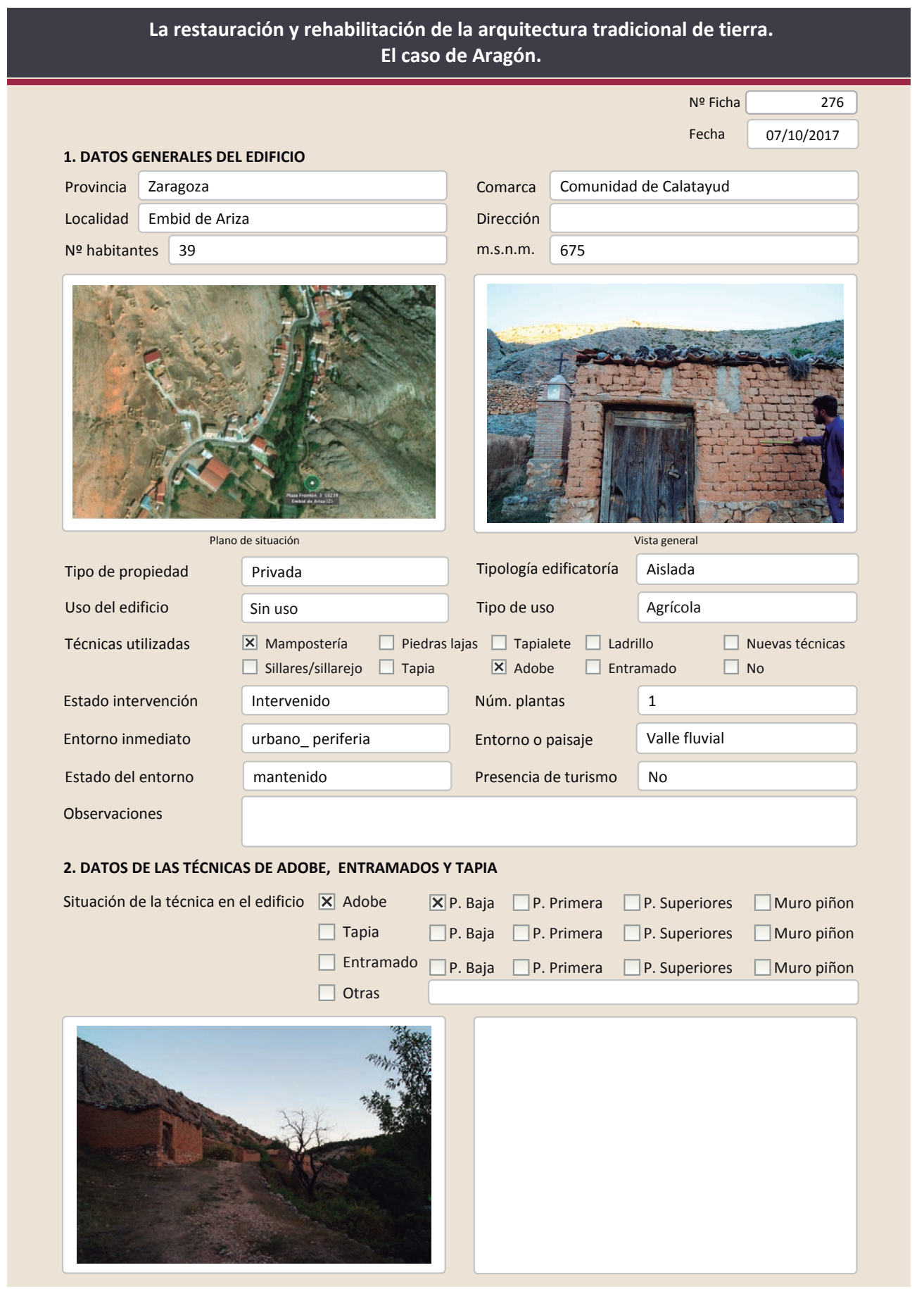

La restauración y rehabilitación de la arquitectura tradicional de tierra. El caso de Aragón.

\subsection{ADOBE \\ Dimensión de las piezas $37 \times 18 \times 9$ \\ Dimensión del muro $30-40 \mathrm{~cm}$ \\ Aparejo del muro Tizón \\ Función estructural \\ $\mathrm{Si}$ \\ Variante constructiva/ tipo de fábrica \\ X Simple \\ $\square$ Suplementada en juntas \\ $\square$ Mixta \\ $\square$ Como suplemento \\ $\square$ Elementos de protección \\ Dos tipos de adobe}

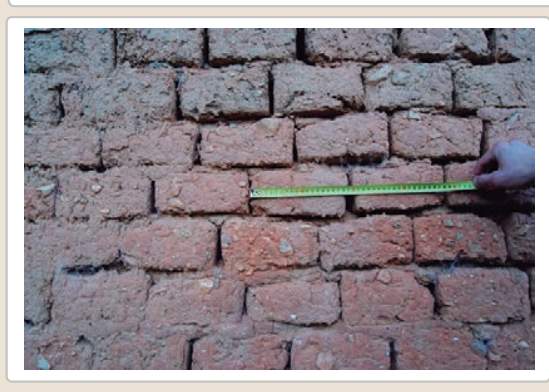

Lesiones $\quad$ XMuro $\square$ Zócalo $\square$ Revestimiento

X Erosión del material $\square$ Humedad por capilaridad $\mathbf{X}$ Erosion de las juntas $\square$ Humedades (manch/eflo)

$\square$ Pérdida de sección $\square$ Pérdida de verticalidad

$\square$ Vegetación $\quad \square$ Grietas por empuje de la cubierta

$\square$ Desconchados

$\square$ Grietas porfalta de traba

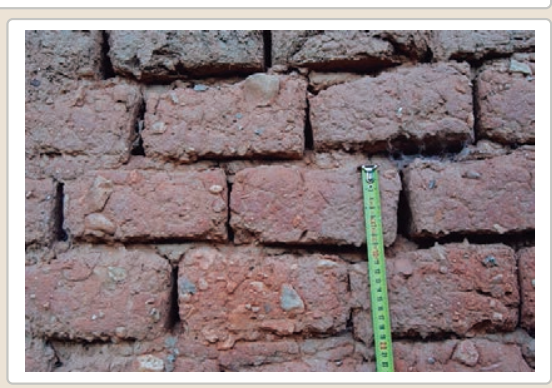

$\square$ Cubierta $\square$ otro...

$$
\begin{aligned}
& \square \text { Grietas por asentamientos } \\
& \square \text { Colapso } \\
& \square \text { Por elementos impropios } \\
& \square \text { Derivado de intervenciones }
\end{aligned}
$$

$\square$ Otro...

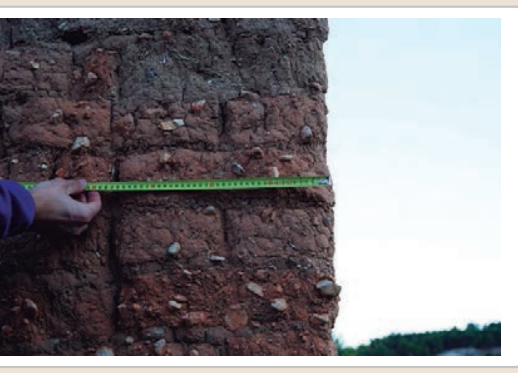

Observaciones

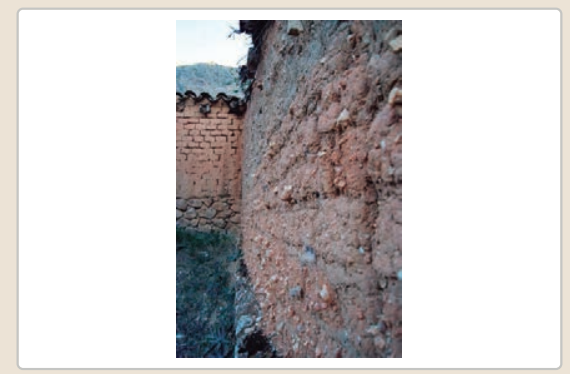

Color de las piezas

$\square$ Blanquecino $\mathbf{X}$ Marrón $\square$ Amarillento

Rojizo $\square$ Otro... 
La restauración y rehabilitación de la arquitectura tradicional de tierra. El caso de Aragón

\section{La restauración y rehabilitación de la arquitectura tradicional de tierra.}

\section{El caso de Aragón.}

3. DATOS DE LA INTERVENCIÓN

Intervención de:

$\square$ Mantenimiento $\square$ Rehabilitación parcia

$\square$ Restauración $\square$ Demolición Xeparación $\quad \square$ Rehabilitación integral $\quad \square$ Ampliación $\quad \square$ Otro...

Reflexión previa

Intervención espontanea

Observaciones

(n)

3.1. MUROS

Tipo de intervención

Intervenido

Tipo de intervención

$\square$ Actualización $\quad$ Reintegración $\square$ Demolición $\square$ Otro...

Tipo de material

$\square$ Sustitución

Descripción

No tradicional Tipo de técnica Diferente a la existente

3.2. ZÓCALO

Oquedades con pellas de mortero de cement

Tipo de intervención

No intervenido

Tipo de material

Actualización $\square$ Reintegración $\square$ Demolición $\square$ Otro...

$\square$ Consolidación $\quad \square$ Reconstrucción $\square$ Sustitución

Descripción

3.3. REVESTIMIENTOS

Tipo de intervención

No intervenido

$\square$ Actualización $\square$ Reintegración $\square$ Demolición $\square$ Otro...

Tipo de material

Descripción

3.4. VANOS

$\square$ Consolidación $\square$ Reconstrucción $\square$ Sustitución

Tipo de intervención

Tipo de material

Descripción

3.5. CUBIERTA

Tipo de intervención

No intervenido

Tipo de material

$\square$ Actualización

$\square$ Consolidación $\quad \square$ Reconstrucción $\quad \square$ Sustitución

Tipo de técnica

Descripción

$$
\text { Tipo de técnica }
$$

3.6. OTRAS 
La restauración y rehabilitación de la arquitectura tradicional de tierra. El caso de Aragón.

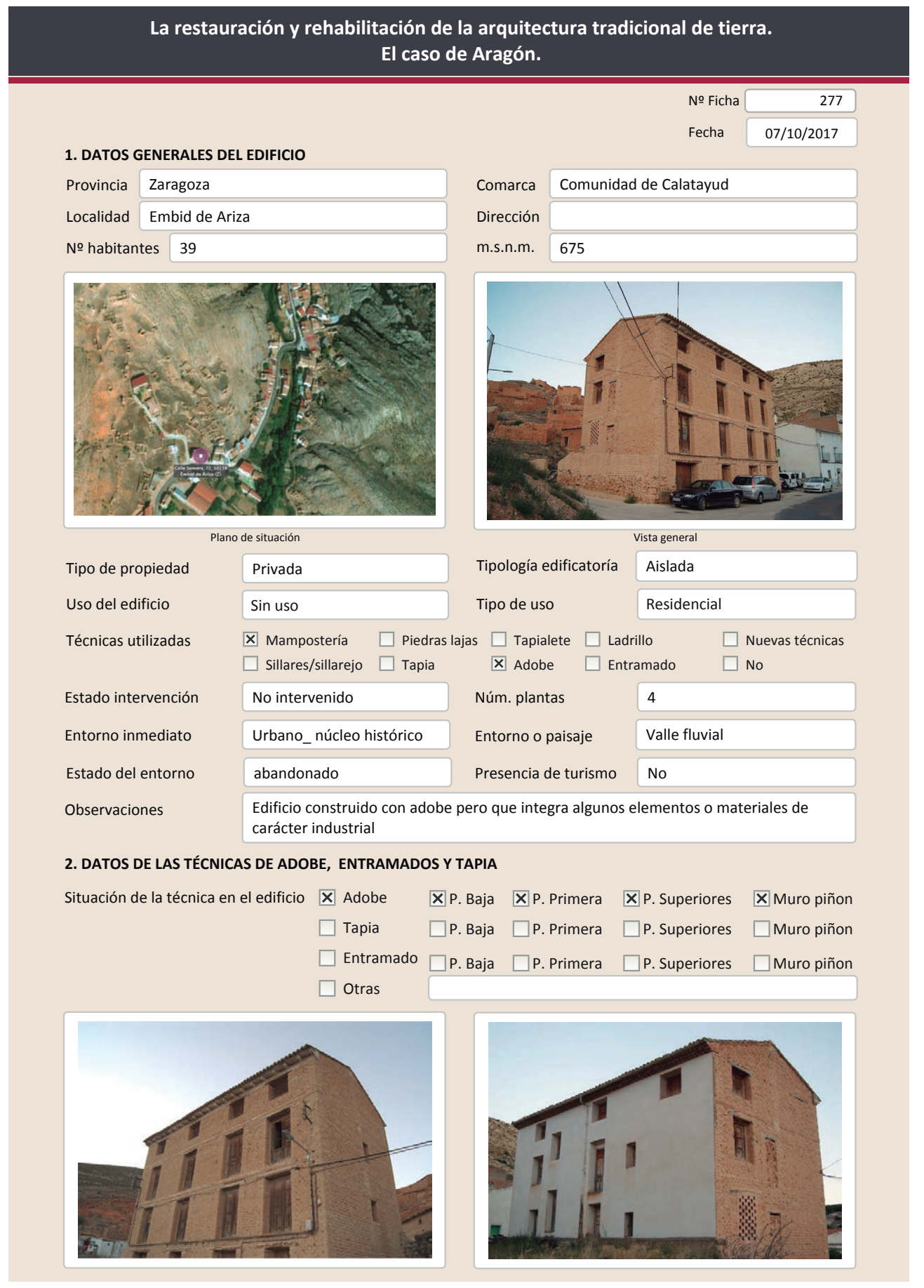

La restauración y rehabilitación de la arquitectura tradicional de tierra. El caso de Aragón.

2.1. ADOBE

Dimensión de las piezas $37 \times 18 \times 9$

Dimensión del muro

Aparejo del muro

Función estructural

Variante constr

$\square$ simple

X Suplementada en juntas

$\square$ Mixta

$\square$ Como suplemento

$\square$ Elementos de protección

Plana baja muro de un pie y medio, en plantas superiores un pie

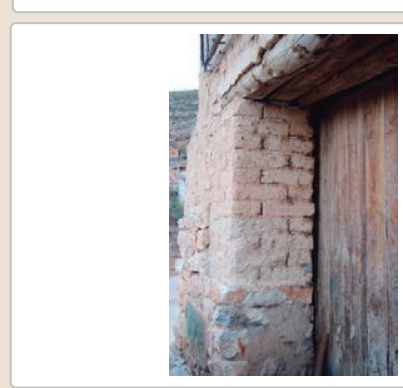

Lesiones

$\square$ Muro $\square$ Zócalo $\square$ Revestimiento

$\square$ Erosión del material $\quad \square$ Humedad por capilaridad $\square$ Erosion de las juntas $\square$ Humedades (manch/eflo)

$\square$ Pérdida de sección $\square$ Pérdida de verticalidad

$\begin{array}{ll}\square \text { Vegetación } & \square \text { Grietas por empuje de la cu } \\ \square \text { Desconchados } & \square \text { Grietas porfalta de traba }\end{array}$

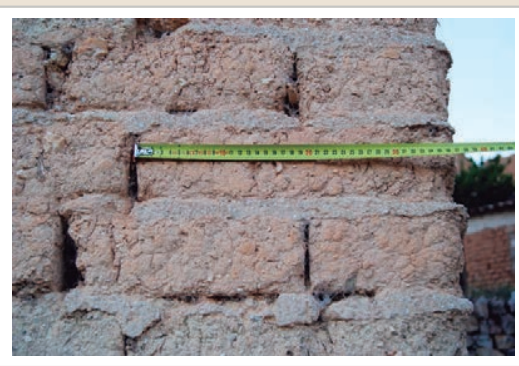

Observaciones

No presenta lesiones
Color de las piezas

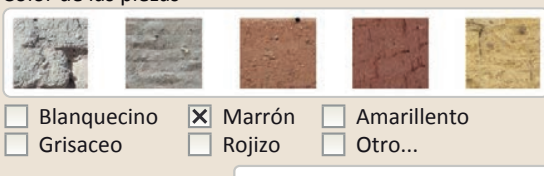

Grisaceo $\square$ Rojizo $\square$ Otro...

Comp. - estabilizante

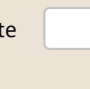


La restauración y rehabilitación de la arquitectura tradicional de tierra. El caso de Aragón

\section{La restauración y rehabilitación de la arquitectura tradicional de tierra.}

El caso de Aragón.

3.7. REHABILITACIÓN ENERGÉTICA $\square$ Fachada $\square$ Vanos $\square$ Forjados $\square$ Cubierta

Observaciones

FOTOGRAFÍAS DE LA INTERVENCIÓN
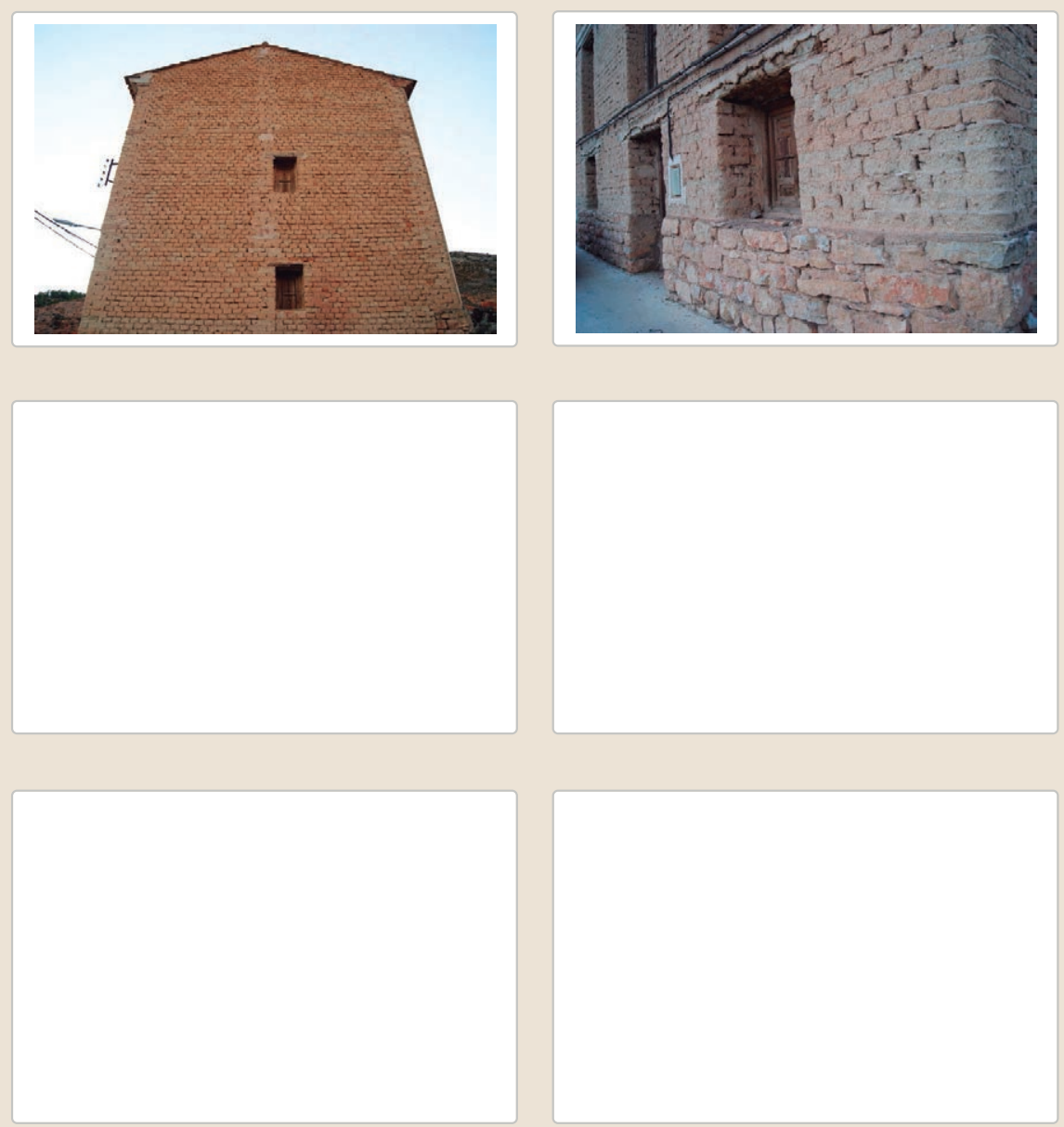


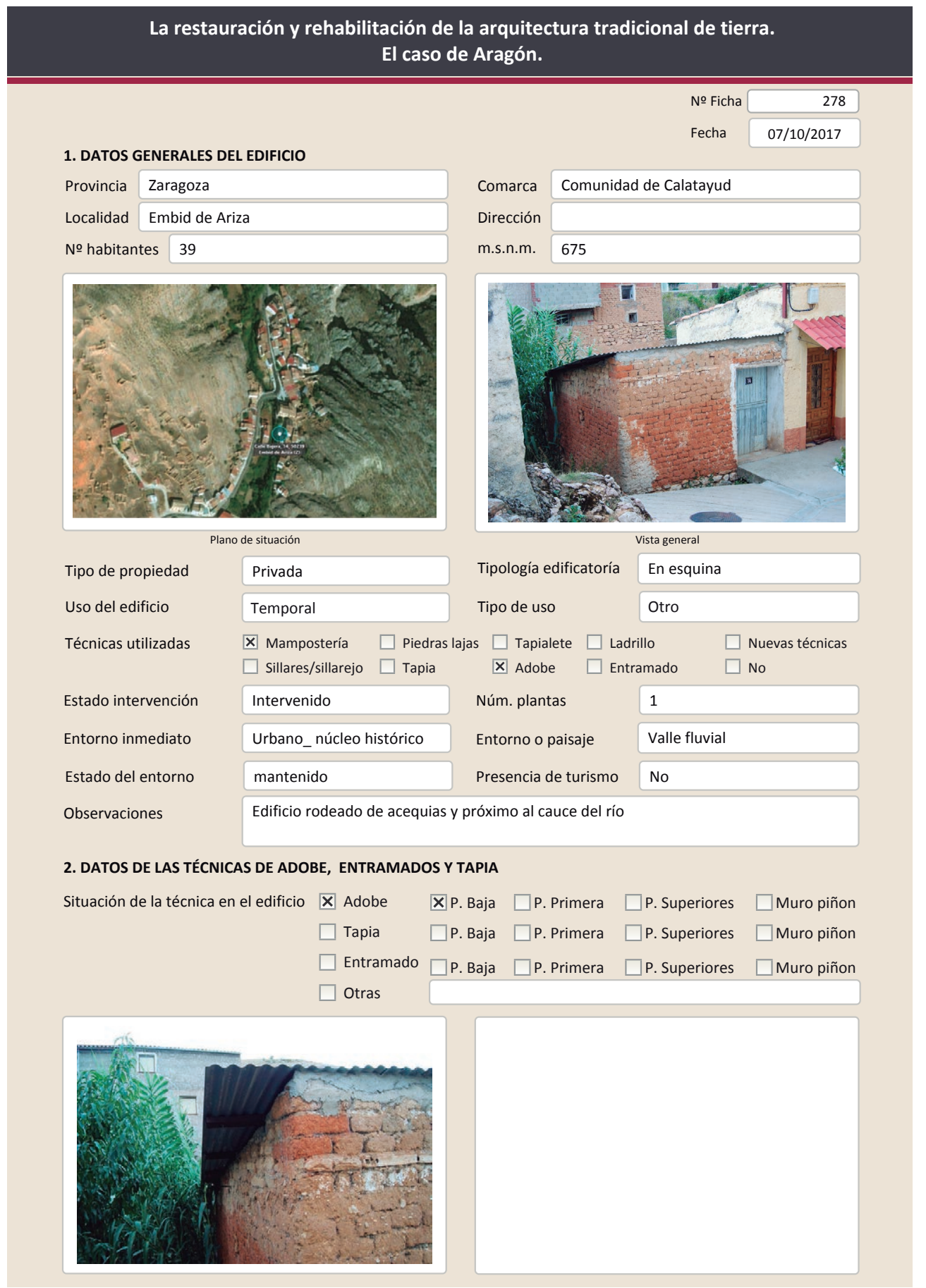

La restauración y rehabilitación de la arquitectura tradicional de tierra.

2.1. ADOBE

Dimensión de las piezas Dimensión del muro

Función estructural
Aparejo del muro

\section{El caso de Aragón.}

Variante constructiva/ tipo de fábica

区 Simple

$\square$ Suplementada en juntas

$\square$ Mixta

$\square$ Como suplemento

$\square$ Elementos de protección

Dos tipos de adobes distintos

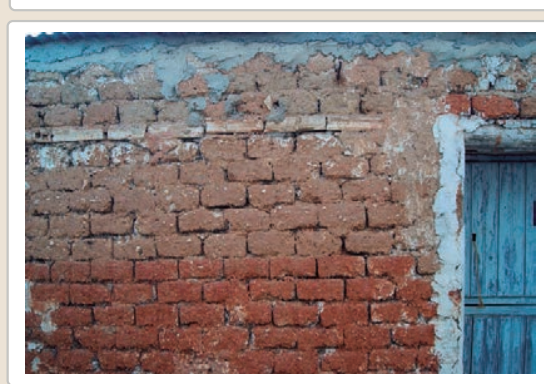

Lesiones \Muro $\square$ Zócalo $\square$ Revestimiento $\square$ Cubierta $\square$ Otro...

$\square$ Erosión del material $\quad \square$ Humedad por capilaridad $\quad \square$ Grietas por asentamientos

X Erosion de las juntas $\square$ Humedades (manch/eflo) $\square$ Colapso

$\square$ Pérdida de sección $\square$ Pérdida de verticalidad $\square$ Por elementos impropios

$\square$ Vegetación $\quad \square$ Grietas por empuje de la cubierta $\square$ Derivado de intervenciones

$\square$ Desconchados $\quad \square$ Grietas porfalta de traba $\quad \square$ Otro...

Observaciones 
La restauración y rehabilitación de la arquitectura tradicional de tierra. El caso de Aragón

\section{La restauración y rehabilitación de la arquitectura tradicional de tierra.}

\section{El caso de Aragón.}

3. DATOS DE LA INTERVENCIÓN

Intervención de:

$\square$ Mantenimiento $\square$ Rehabilitación parcia

$\square$ Restauración $\square$ Demolición

Reflexión previa

X Reparación

$\square$ Rehabilitación integral $\square$ Ampliación

$\square$ Otro..

Reflexión previa

Intervención espontanea

(n)

3.1. MUROS

No intervenido

Tipo de intervención

$\square$ Actualización $\square$ Reintegración $\square$ Demolición $\square$ Otro...

$\square$ Consolidación $\square$ Reconstrucción $\square$ Sustitución

Tipo de material

Descripción

3.2. ZÓCALO

Tipo de intervención

No intervenido

Tipo de material

$\square$ Actualización

Demolición $\square$ Otro...

Descripción

3.3. REVESTIMIENTOS

Tipo de intervención

\section{No aplica}

Tipo de material

Descripción

Tipo de técnica

3.4. VANOS

Tipo de intervención

Intervenido

Tipo de material

$\square$ Actualización $\quad \mathbf{X}$ Reintegración $\quad \square$ Demolición $\square$ Otro...

$\square$ Consolidación $\square$ Reconstrucción $\square$ sustitución

Descripción

No tradicional

Tipo de técnica Diferente a la existente

3.5. CUBIERTA

Tipo de intervención

Reintegración de las jambas de la puerta con mortero

Tipo de material

Intervenido

$\square$ Actualización $\square$ Reintegración $\square$ Demolición $\square$ Otro.

$\square$ Consolidación $\square$ Reconstrucción $\bigotimes$ Sustitución

\begin{tabular}{l|l|l|l|l} 
No tradicional & Tipo de técnica Diferente a la existente \\
\hline
\end{tabular}

Descripción

Sustitución de la cubierta por una con viguetas de tubo metálico cuadrado y chapa ondulada.

3.6. OTRAS 


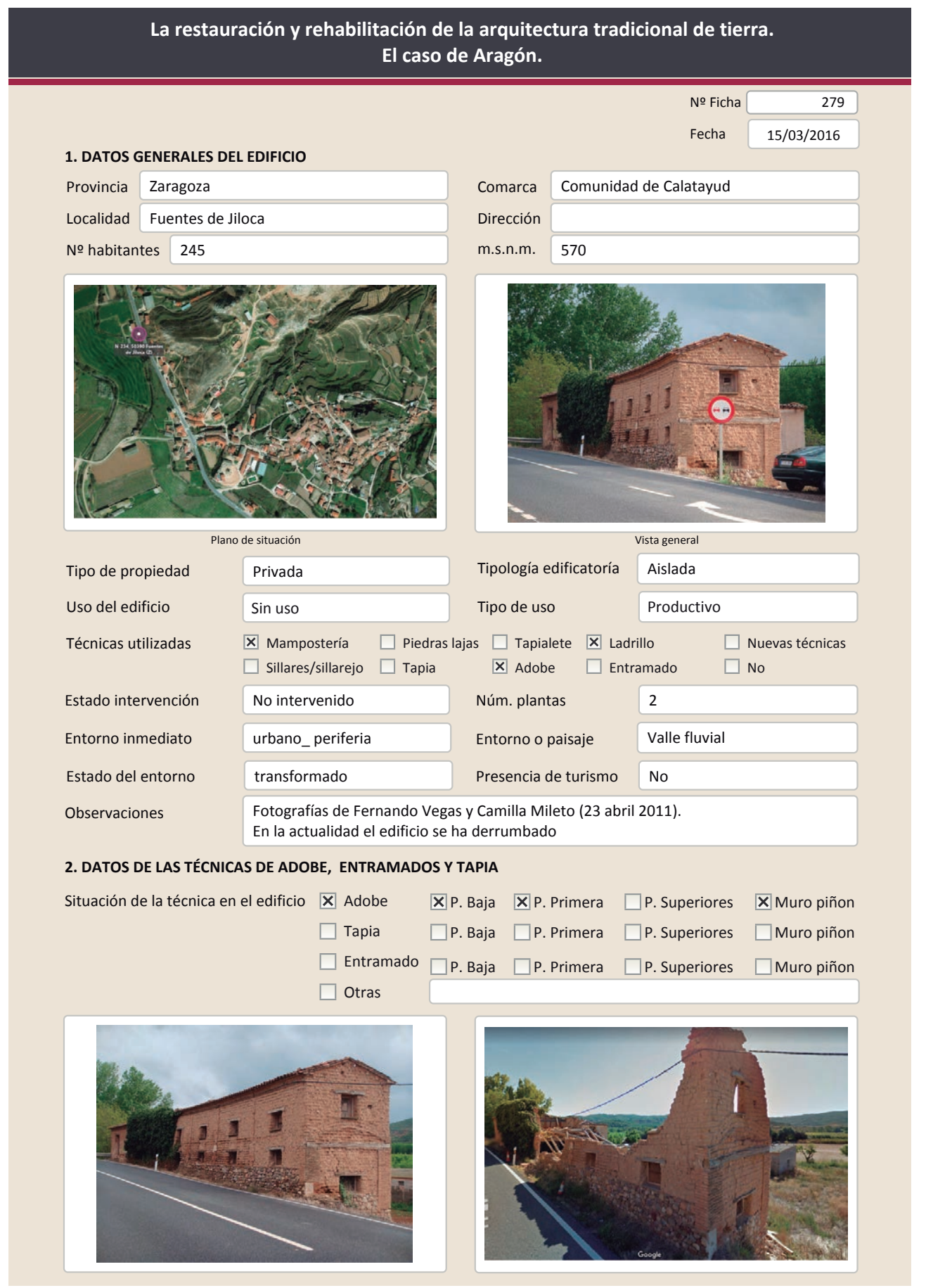

La restauración y rehabilitación de la arquitectura tradicional de tierra. El caso de Aragón.

2.1. ADOBE

Dimensión de las piezas

Dimensión del muro

Aparejo del muro

Función estructural

Variante constructiva/ tipo de fábrica

$\square$ Simple

X Suplementada en juntas

X Mixta

$\square$ Como suplemento

$\square$ Elementos de protección

\section{-}

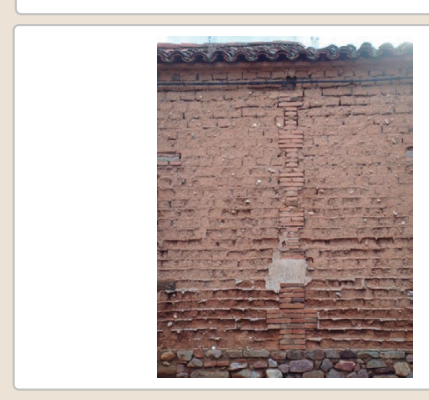

Lesiones

ХMuro ХZócalo $\square$ Revestimiento

$\mathbf{X}$ Erosión del material $\mathbf{X}$ Humedad por capilaridad $\square$ Erosion de las juntas $\square$ Humedades (manch/eflo)

Х Pérdida de sección $\quad \square$ Pérdida de verticalidad

$\square$ Vegetación $\quad \square$ Grietas por empuje de la cubie

$\square$ Desconchados

$\square$ Grietas porfalta de traba

Color de las piezas

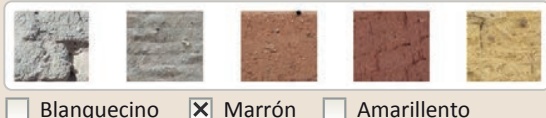

$\square$ Blanquecino $\mathbf{X}$ Marrón $\square$ Amarillento

$\square$ Grisaceo $\square$ Rojizo $\square$ Otro...

Comp. - estabilizante Fibras vegetales

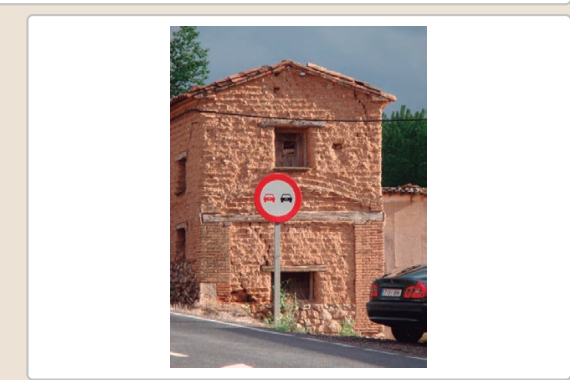

$\square$ Cubierta $\square$ Otro...

$\square$ Grietas por asentamientos

$\square$ Colapso

$\square$ Por elementos impropios

$\square$ Derivado de intervenciones

$\square$ Otro...

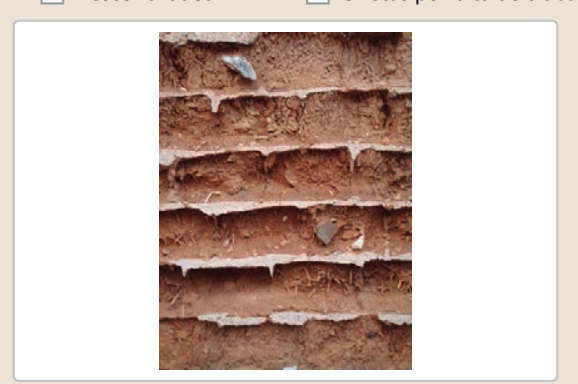

Observaciones

Se aprecian perfectamente las juntas de yeso del muro

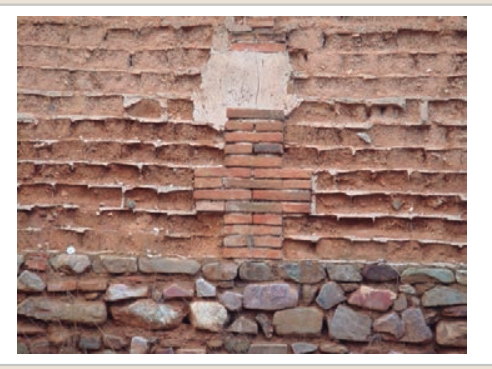




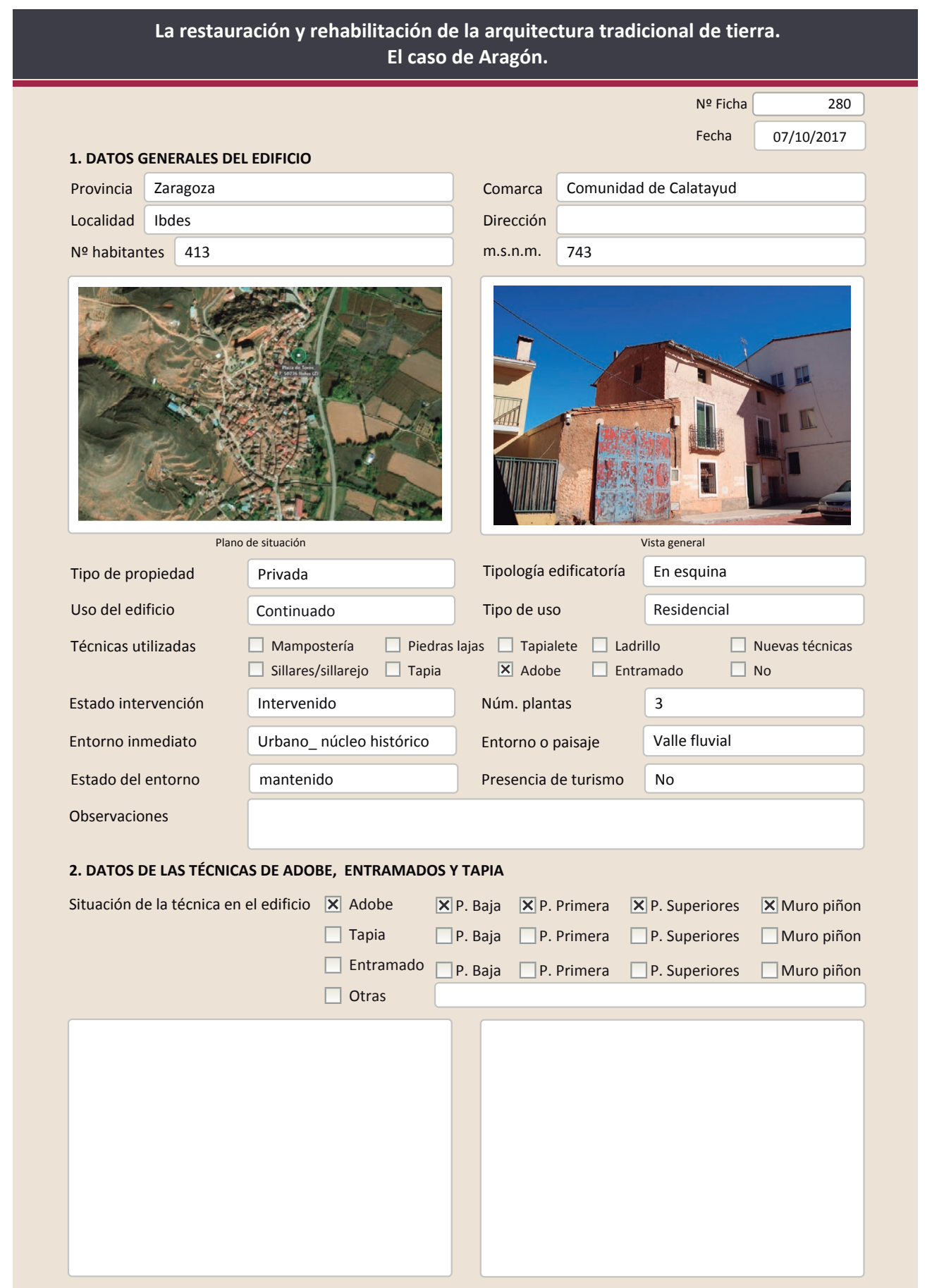

La restauración y rehabilitación de la arquitectura tradicional de tierra.
2.1. ADOBE

Dimensión de las piezas Dimensión del muro

Aparejo del muro

Función estructural

\section{El caso de Aragón.}

Color de las piezas

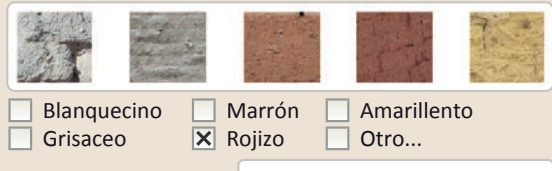

$\begin{array}{lll}\square \text { Blanquecino } & \square \text { Marrón } \square \text { Amarillentc } \\ \square \text { Grisaceo } & \mathbb{X} & \text { Rojizo } \square \text { Otro... }\end{array}$

Comp. - estabilizante
Variante constructiva/ tipo de fábrica

X simple

$\square$ Suplementada en juntas

$\square$ Mixta

$\square$ Como suplemento

$\mathbf{X}$ Elementos de protección

Revestimiento

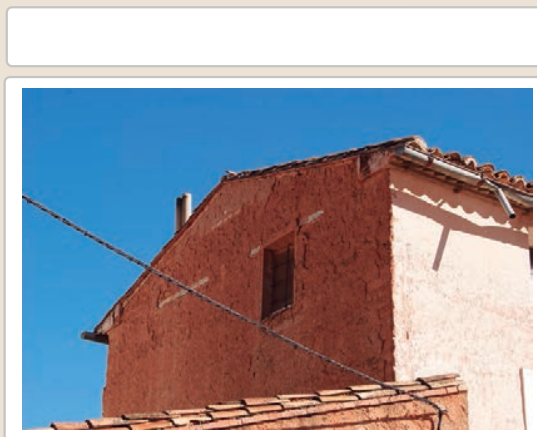

Lesiones $\quad$ Muro $\square$ Zócalo $\mathbf{X}$ Revestimiento

$\mathbf{X}$ Erosión del material $\square$ Humedad por capilaridad $\square$ Cubierta $\square$ otro...

$\square$ Erosion de las juntas $\square$ Humedades (manch/eflo) $\square$ Colapso

$\square$ Pérdida de sección $\square$ Pérdida de verticalidad

$\square$ Por elementos impropios

$\square$ Vegetación

$\square$ Grietas por empuje de la

X Desconchados

$\square$ Grietas porfalta de traba

$\square$ Otro...

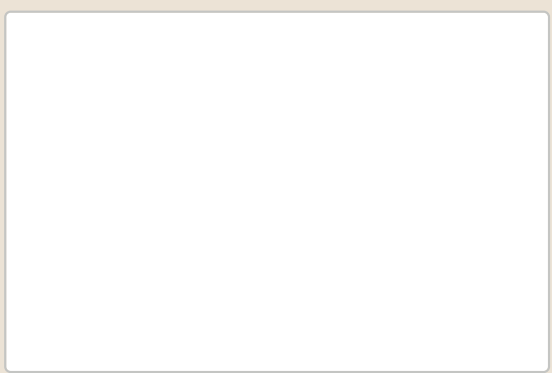

Observaciones

El revestimiento del muro piñón se encuentra en muy mal estado de conservación 


\section{La restauración y rehabilitación de la arquitectura tradicional de tierra.}

\section{El caso de Aragón.}

3. DATOS DE LA INTERVENCIÓN

Intervención de:

$\square$ Mantenimiento $\quad$ Rehabilitación parcial

$\square$ Restauración $\square$ Demolición

Reflexión previa

$\square$ Reparación

$\square$ Rehabilitación integra

$\square$ Ampliación

$\square$ Otro...

Observaciones

Intervención planificada

\subsection{MUROS \\ Tipo de intervención}

Tipo de material

Descripción

3.2. ZÓCALO

Tipo de intervención

Tipo de material

Descripción

3.3. REVESTIMIENTOS

Tipo de intervención

Tipo de material

Descripción

3.4. VANOS

Tipo de intervención

Tipo de material

Descripción

3.5. CUBIERTA

Tipo de intervención

Tipo de material

Descripción

\section{No intervenido}

$\square$ Actualización $\square$ Reintegración $\square$ Demolición $\square$ Otro...

$\square$ Consolidación $\quad \square$ Reconstrucción $\quad \square$ Sustitución

Tipo de técnica $\square$

\section{Intervenido}

邓 Actualización $\square$ Reintegración $\quad \square$ Demolición $\square$ Otro...

$\square$ Consolidación $\quad$ X Reconstrucción $\square$ Sustitución

No tradicional Tipo de técnica Diferente a la existente

Capa gruesa de cemento

\section{Intervenido}

区 Actualización $\square$ Reintegración $\square$ Demolición $\square$ Otro...

$\square$ Consolidación $\mathbf{X}$ Reconstrucción $\square$ Sustitución

No tradicional Tipo de técnica Diferente a la existente

Revestimiento en la fachada principal pintado de blanco

\section{Intervenido}

\ Actualización $\square$ Reintegración $\square$ Demolición $\square$ Otro...

$\square$ Consolidación $\quad \mathbf{X}$ Reconstrucción $\square$ Sustitución

\begin{tabular}{l|l|l} 
No tradicional & Tipo de técnica Diferente a la existente
\end{tabular}

Contorno de huecos con revestimiento saliente y pintura blanca. Doble carpintería en

\section{Intervenido}

$\square$ Actualización $\quad \boldsymbol{X}$ Reintegración $\square$ Demolición $\square$ Otro..

$\square$ Consolidación $\square$ Reconstrucción $\square$ Sustitución
No tradicional
Tipo de técnica Similar a la existente

3.6. OTRAS

Reintegración de tejas con mortero de cemento los huecos de plana primera.

La restauración y rehabilitación de la arquitectura tradicional de tierra.

El caso de Aragón.

3.7. REHABILITACIÓN ENERGÉTICA $\square$ Fachada $\quad \boldsymbol{X}$ Vanos $\square$ Forjados $\square$ Cubierta

Observaciones

FOTOGRAFíAS DE LA INTERVENCIÓN
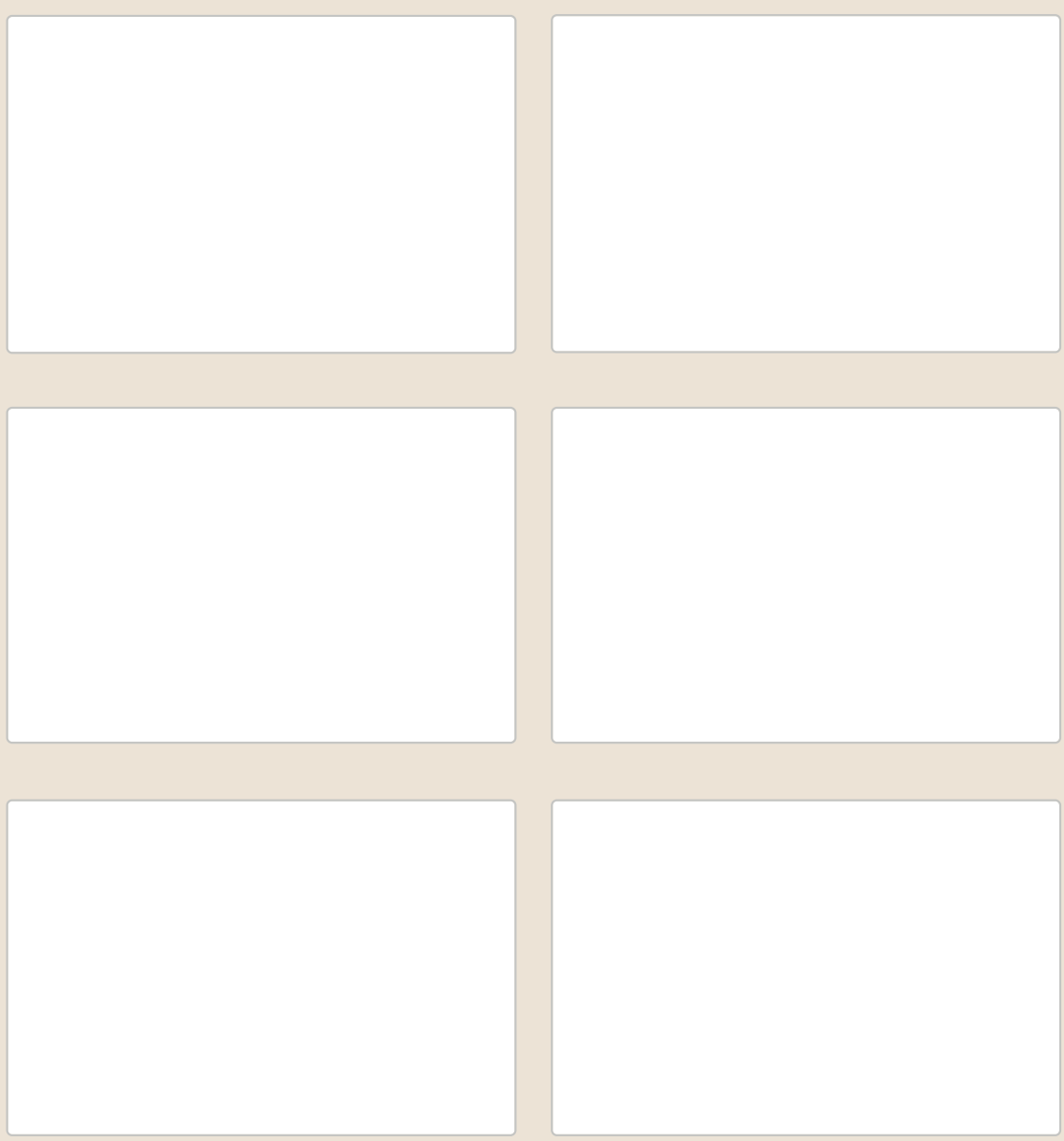


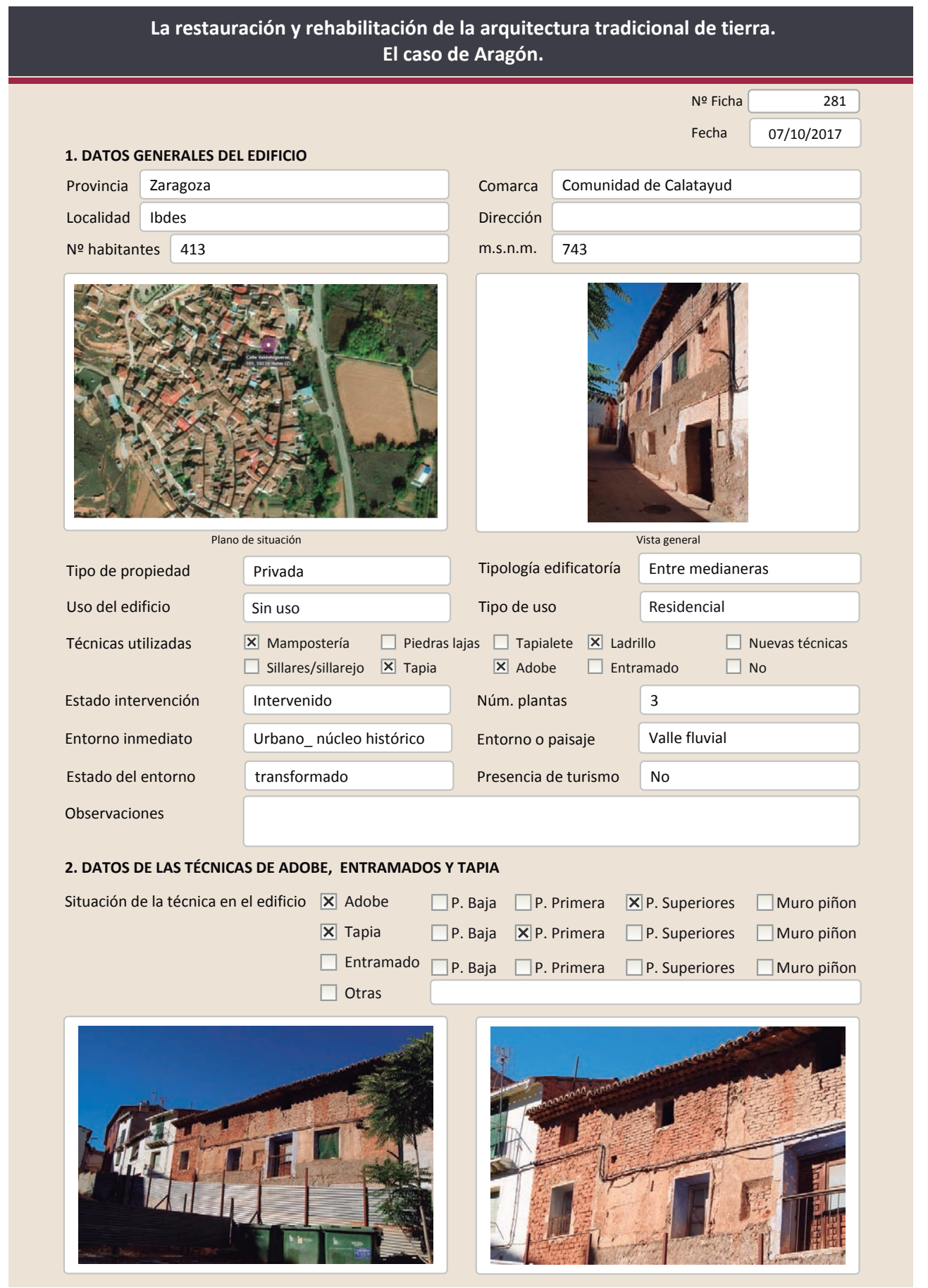

2.1. ADOBE

Dimensión de las piezas

Dimensión del muro

Aparejo del muro

Función estructural

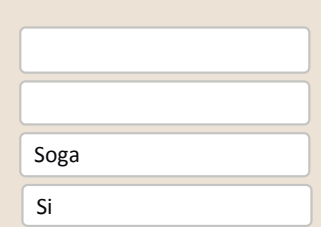

Color de las piezas

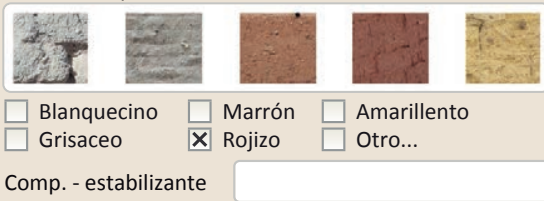

Variante constructiva/ tipo de fábrica

$\square$ simple

$\square$ Suplementada en juntas

X Mixta

\section{Machones}

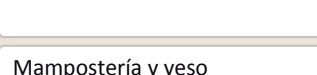

$\square$ Como suplemento

$\square$ Elementos de protección

Los adobes son muy finos. Se puede ver la comparación con los del edificio anexo

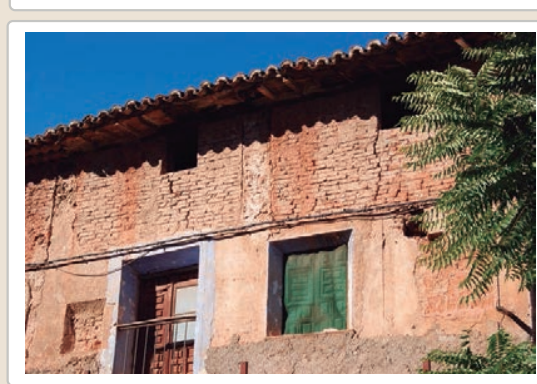

Lesiones $\quad \mathbf{X}$ Muro $\square$ Zócalo $\square$ Revestimiento

$\square$ Erosión del material $\square$ Humedad por capilaridad $\square$ Erosion de las juntas $\square$ Humedades (manch/eflo)

$\square$ Pérdida de sección $\square$ Pérdida de verticalidad

$\square$ Vegetación

$\square$ Grietas por empuje de $\square$ Grietas porfalta de traba

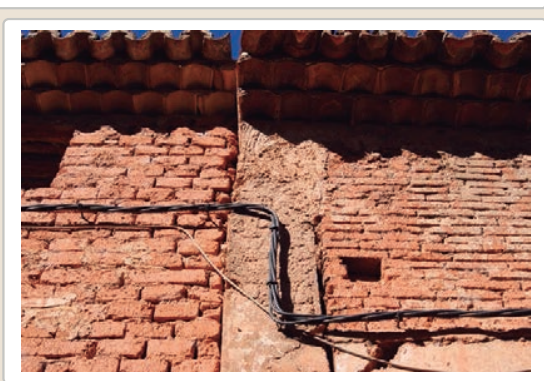

$\square$ Cubierta $\square$ otro...

$\square$ Grietas por asentamientos $\square$ Colapso

$\square$ Desconchados

$\square$ Por elementos impropios

$\square$ Derivado de intervenciones

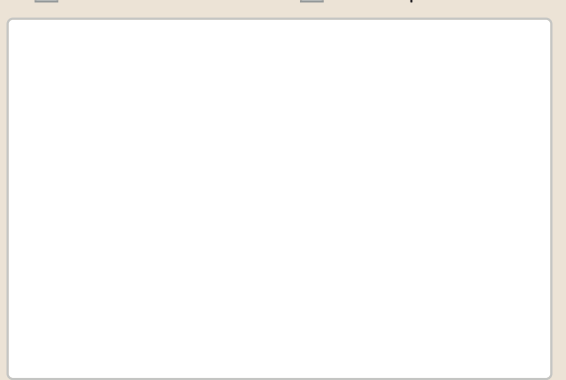

$\square$ Otro... 


\section{La restauración y rehabilitación de la arquitectura tradicional de tierra.}

\section{El caso de Aragón.}

\subsection{TAPIA}

Ancho del muro

Dimensión tapiales

Tipo de aguja

№ agujas/cajón

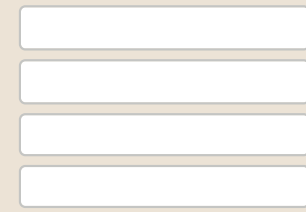

\section{Color de la tapia}

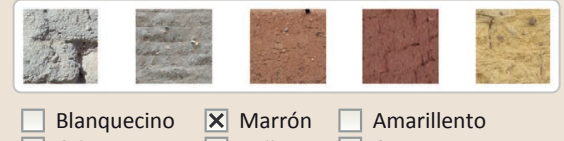
$\begin{array}{ll}\square \text { Blanquecino } & \boldsymbol{X} \text { Marrón } \\ \square \text { Grisaceo } & \square \text { Rojizo } \quad \square \text { Otroillento }\end{array}$

Variante constructiva

$\square$ Simple / homogénea

X Suplemento superficial

$\square$ suplemento en juntas

X Mixta

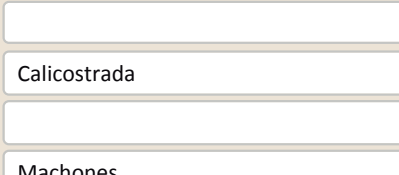

Machones

Cal/ yeso

$\square$ Elementos de protección

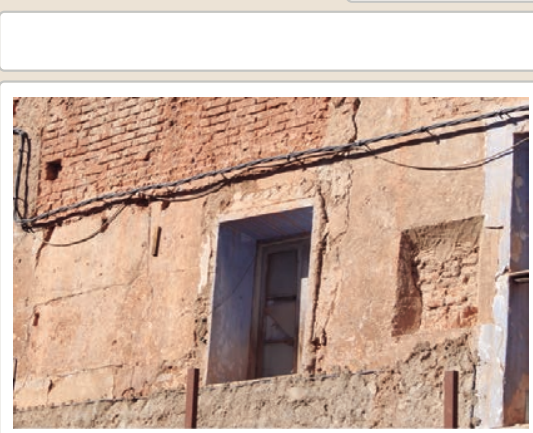

Lesiones $\square$ Muro $\square$ Zócalo $\square$ Revestimiento $\square$ Cubierta $\square$ otro...

$\square$ Erosión del material $\quad \square$ Humedad por capilaridad $\quad \square$ Grietas por asentamientos

$\square$ Erosion de las juntas $\square$ Humedades (manch/eflo) $\square$ Colapso

$\square$ Pérdida de sección $\square$ Pérdida de verticalidad $\square$ Por elementos impropios

$\square$ Vegetación $\square$ Grietas por empuje de la cubierta $\square$ Derivado de intervenciones

$\square$ Desconchados $\quad \square$ Grietas porfalta de traba $\quad \square$ Otro...

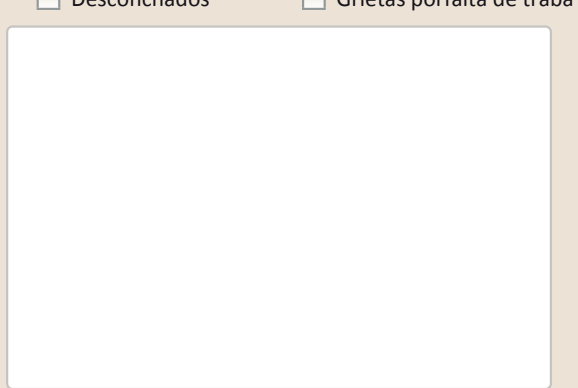

Observaciones
La restauración y rehabilitación de la arquitectura tradicional de tierra.

El caso de Aragón.

3. DATOS DE LA INTERVENCIÓN

Intervención de: $\quad \square$ Mantenimiento $\quad \square$ Rehabilitación parcial $\quad \square$ Restauración $\square$ Demolición

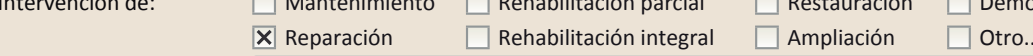

Reflexión previa Intervención espontanea

Observaciones

3.1. MUROS

Tipo de intervención

Tipo de material

Descripción

3.2. ZÓCALO

Tipo de intervención

Tipo de material

Descripción

3.3. REVESTIMIENTOS

Tipo de intervención

Tipo de material

Descripción

3.4. VANOS

Tipo de intervención

Tipo de material

Descripción

3.5. CUBIERTA

Tipo de intervención

Tipo de material

Descripción

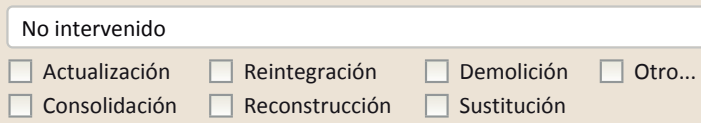

$\square$ Consolidación $\quad \square$ Reconstrucción $\square$ sustitución

Tipo de técnica

Intervenido

$\square$ Actualización $\square$ Reintegración $\square$ Demolición $\square$ Otro...

$\square$ Consolidación $\quad \mathbf{X}$ Reconstrucción $\square$ Sustitución

No tradicional Tipo de técnica Diferente a la existente

Cemento

No aplica

$\square$ Actualización $\square$ Reintegración $\square$ Demolición $\square$ Otro..

$\square$ Consolidación $\square$ Reconstrucción $\square$ sustitución

Tipo de técnica

3.6. OTRAS
No intervenido

$\square$ Actualización $\square$ Reintegración $\square$ Demolición $\square$ Otro..

$\square$ Consolidación $\square$ Reconstrucción $\quad \square$ Sustitución

Tipo de técnica

Intervenido

$\square$ Actualización $\quad \mathbf{X}$ Reintegración $\square$ Demolición $\square$ Otro

$\square$ Consolidación $\quad \square$ Reconstrucción $\square$ Sustitución
No tradicional
Tipo de técnica Similar a la existente

Reintegración de las tejas del alero con cemento 


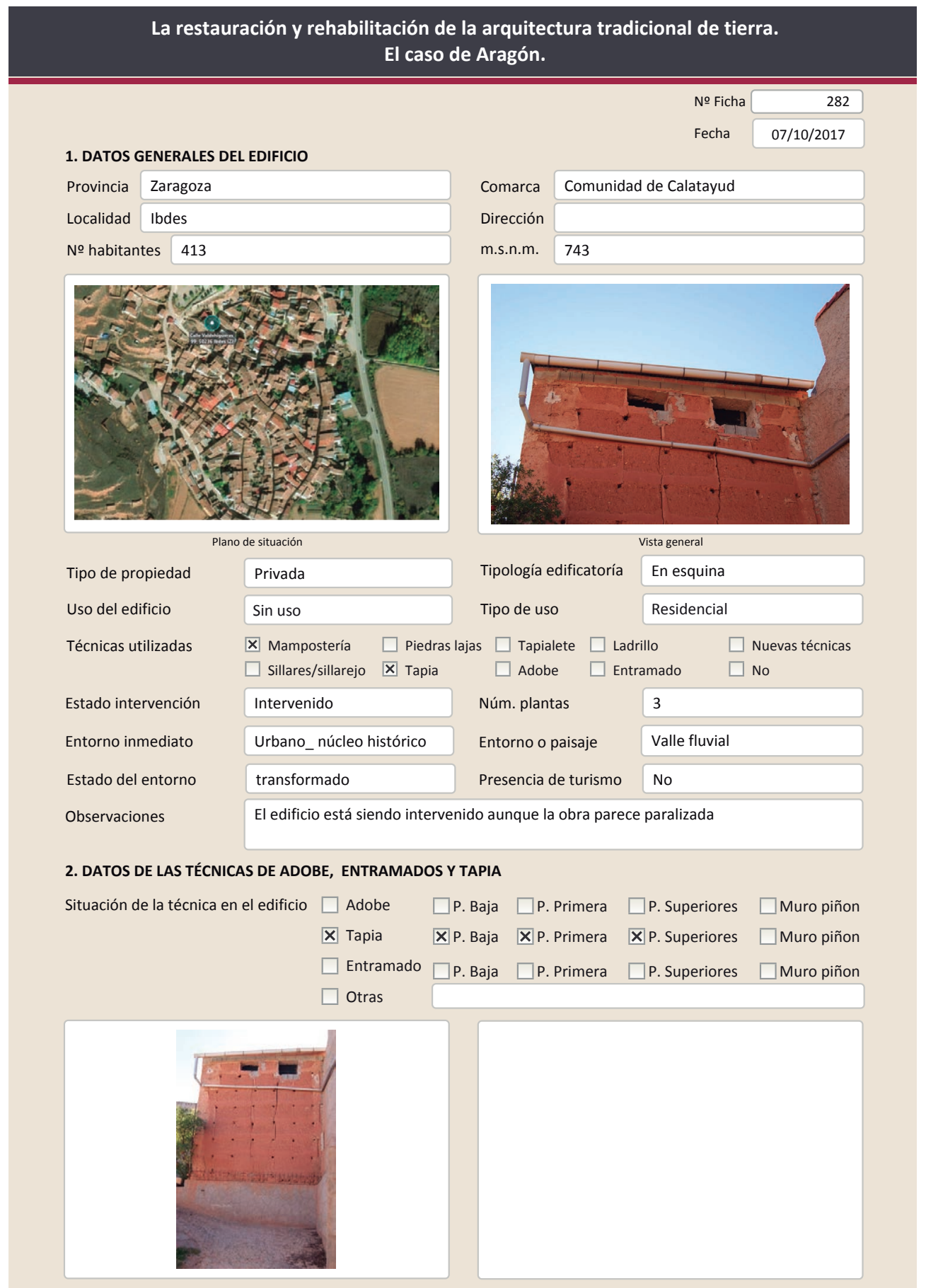

2.2. TAPIA

Ancho del muro

Dimensión tapiales

Tipo de aguja

\begin{tabular}{|l|}
\hline \\
\hline $150 \times 70$ aprox \\
\hline Redonda \\
\hline 3 \\
\hline
\end{tabular}

Color de la tapia

№ agujas/cajón

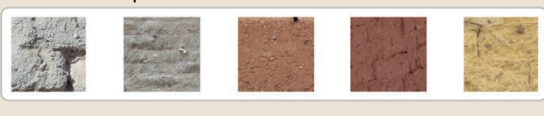

$\square$ Blanquecino $\square$ Marrón $\square$ Amarillento

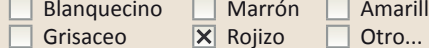

Variante constructiva

$\square$ Simple / homogénea

$\square$ suplemento superficial

$X$ Suplemento en juntas

区 Mixta

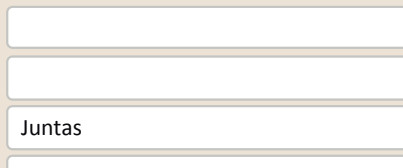

$\square$ Elementos de protección

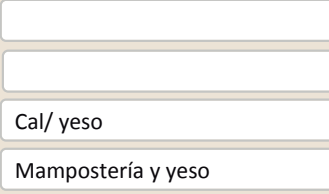

Mampostería y yeso

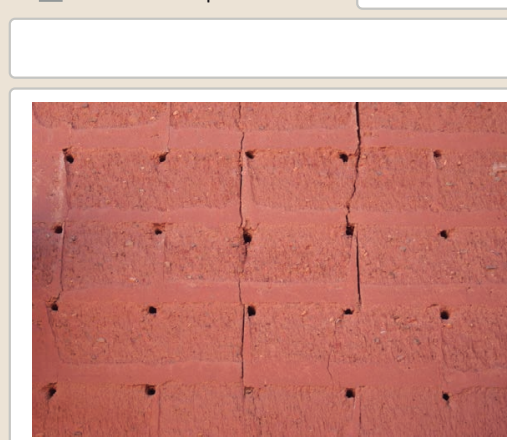

Lesiones $\quad$ XMuro $\square$ Zócalo $\square$ Revestimiento $\square$ Cubierta $\square$ otro...

\ Erosión del material $\square$ Humedad por capilaridad $\quad \mathbf{X}$ Grietas por asentamientos $\square$ Erosion de las juntas $\square$ Humedades (manch/eflo)

X Pérdida de sección $\square$ Pérdida de verticalidad

$\square$ Vegetación $\square$ Grietas por empuje de la cubierta

$\square$ Desconchados

$\square$ Grietas porfalta de traba
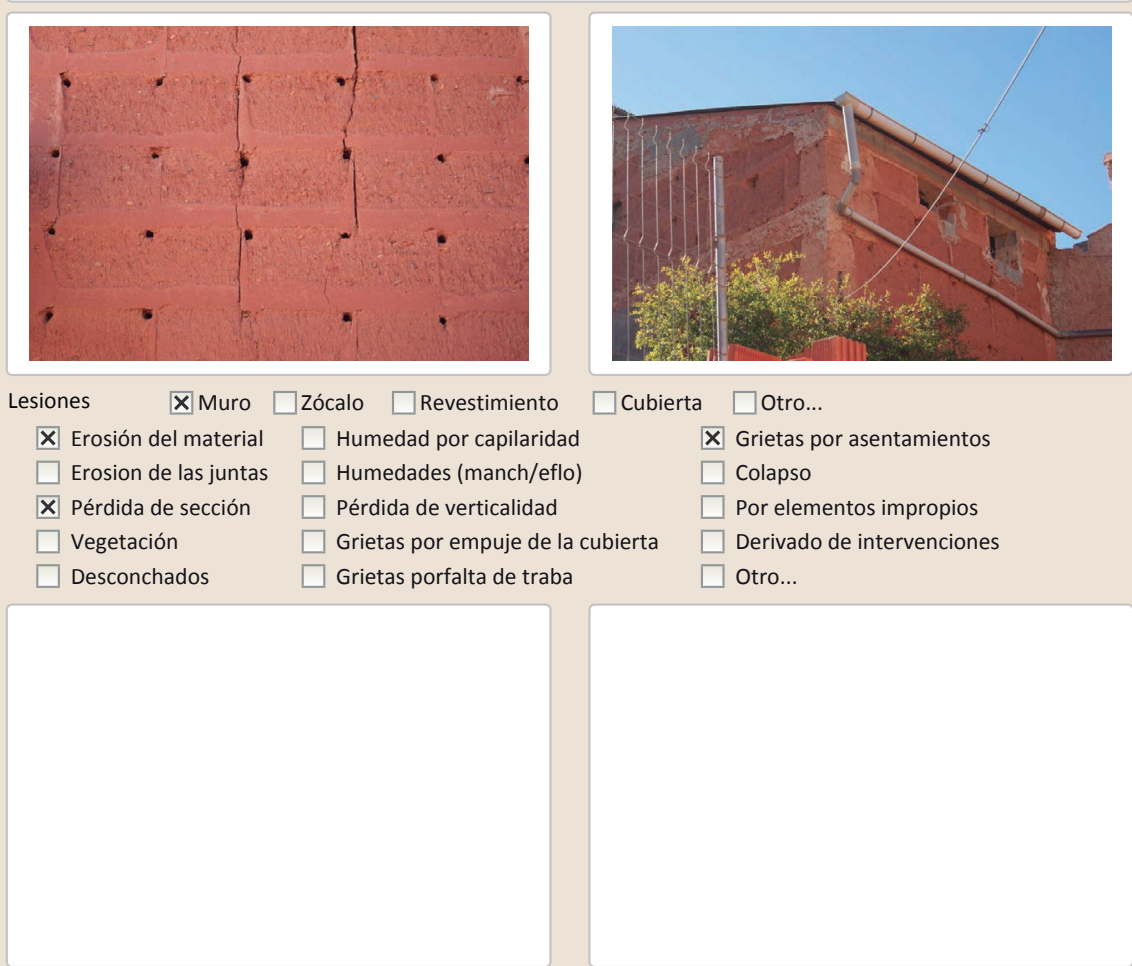

Observaciones 


\section{La restauración y rehabilitación de la arquitectura tradicional de tierra.}

\section{El caso de Aragón.}

3. DATOS DE LA INTERVENCIÓN

\begin{tabular}{|c|c|c|c|c|}
\hline Intervención de: & $\begin{array}{l}\square \text { Mantenimiento } \\
\square \text { Reparación }\end{array}$ & $\begin{array}{l}\square \text { Rehabilitación parcial } \\
\boldsymbol{X} \text { Rehabilitación integral }\end{array}$ & $\begin{array}{l}\square \text { Restauración } \\
\square \text { Ampliación }\end{array}$ & $\begin{array}{l}\square \text { Demolición } \\
\square \text { Otro... }\end{array}$ \\
\hline Reflexión previa & \multicolumn{4}{|c|}{ Intervención planificada } \\
\hline Observaciones & & & & \\
\hline
\end{tabular}

\subsection{MUROS}

Tipo de intervención

Intervenido

Tipo de material

$\square$ Actualización $\quad \square$ Reintegración $\quad \square$ Demolición $\square$ Otro...

$\square$ Consolidación $\quad$ Reconstrucción $\square$ Sustitución

Descripción

\begin{tabular}{|l|l|l|l|l} 
No tradicional & Tipo de técnica & Diferente a la existente
\end{tabular}

3.2. ZÓCALO

Tipo de intervención

Pequeño recrecido del muro en la pare superior

Tipo de material

Intervenido

$\square$ Actualización $\square$ Reintegración $\square$ Demolición $\mathbf{X}$ Otro...

$\square$ Consolidación $\quad \mathbf{X}$ Reconstrucción $\square$ Sustitución

Descripción
No tradicional
Tipo de técnica Diferente a la existente

3.3. REVESTIMIENTOS

Se ha Realizado un muro de contención a la altura del zócalo (probablemente para evitar movimientos en el terreno)

Tipo de intervención

No aplica

Tipo de material

$\square$ Actualización $\square$ Reintegración $\quad \square$ Demolición $\square$ Otro...

Tipo de materia

$\square$ Consolidación $\square$ Reconstrucción $\square$ Sustitución

Descripción

3.4. VANOS

No intervenido

Tipo de intervención

$\square$ Actualización $\quad \square$ Reintegración $\quad \square$ Demolición $\quad \square$ Otro...
$\square$ Consolidación $\quad \square$ Reconstrucción $\quad \square$ Sustitución

Tipo de material

Descripción

3.5. CUBIERTA

Tipo de intervención

Intervenido

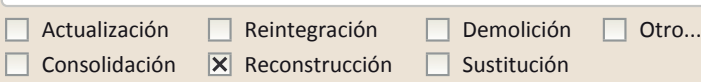

Tipo de material

No tradicional

Tipo de técnica

Descripción

Chapa metálica Tipo de técnica Diferente a la existente

3.6. OTRAS 


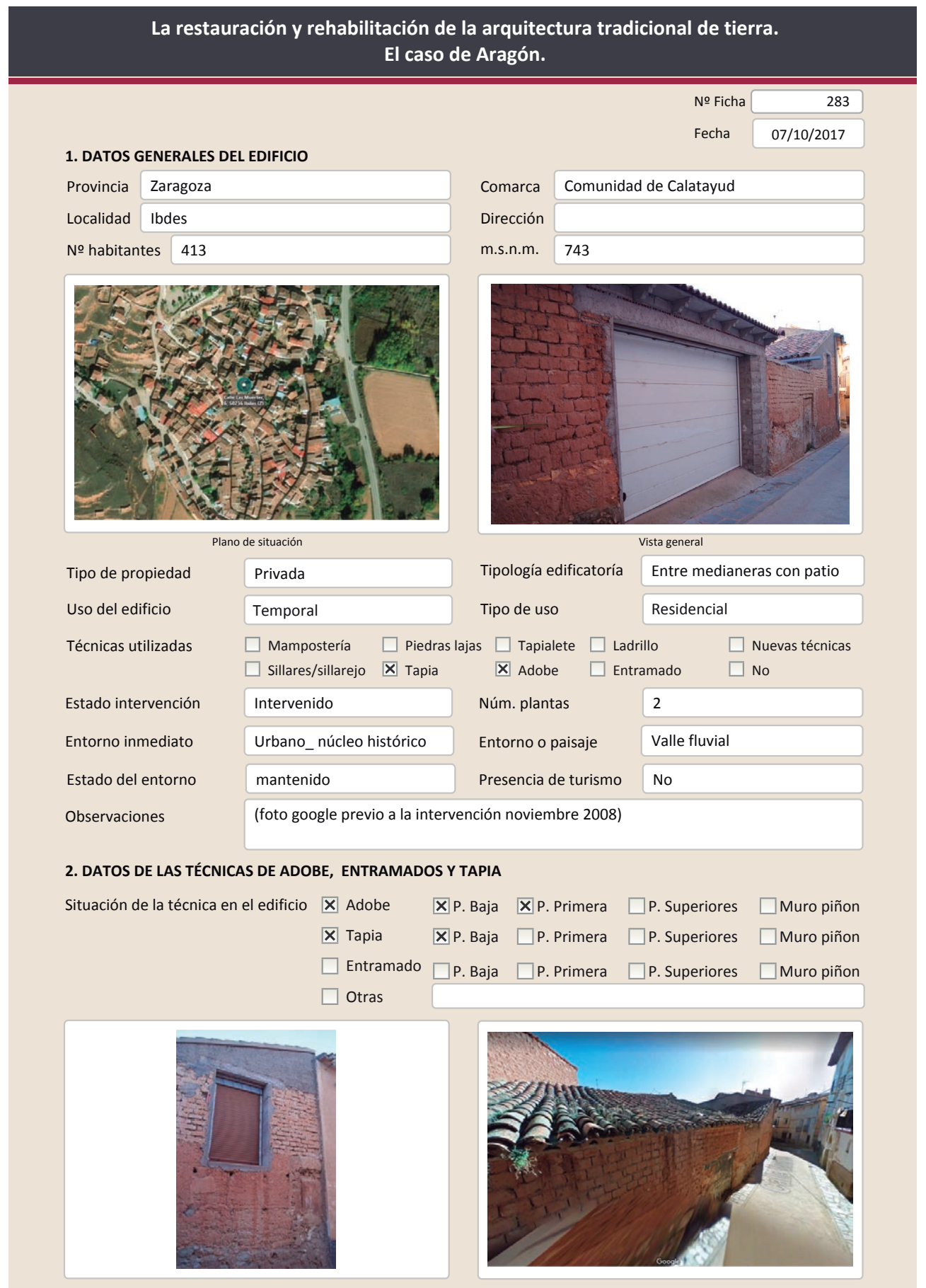

\subsection{ADOBE \\ Dimensión de las piezas $19 \times 10$ \\ Dimensión del muro 40-50 cm \\ Aparejo del muro Tizón \\ Función estructural \\ Si \\ Variante constructiva/ tipo de fábrica
$\square$ Suplementada en juntas
$\square$ Mixta
$\square$ Como suplemento \\ メ Simple \\ $\square$ Elementos de protección}

\section{-}
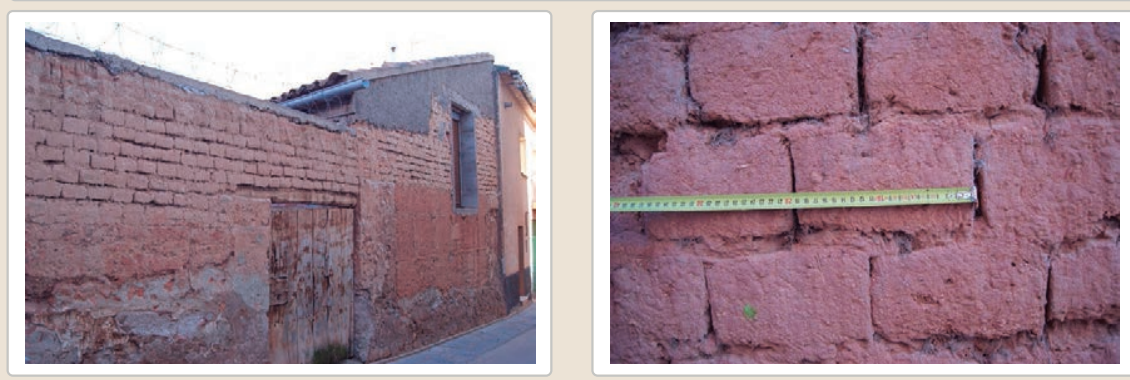

Lesiones $\quad$ MMuro $\square$ Zócalo $\square$ Revestimiento $\square$ Cubierta $\square$ otro...

$\begin{array}{lll}\mathbf{X} \text { Erosión del material } & \square \text { Humedad por capilaridad } & \square \text { Grietas por asentamientos } \\ \square \text { Erosion de las juntas } & \square \text { Humedades (manch/eflo) } & \square \text { Colapso } \\ \square \text { Pérdida de sección } & \square \text { Pérdida de verticalidad } & \square \text { Por elementos impropios } \\ \square \text { Vegetación } & \square \text { Grietas por empuje de la cubierta } & \square \text { Derivado de intervenciones }\end{array}$

$\square$ Desconchados $\quad \square$ Grietas porfalta de traba $\quad \square$ Otro...
Fibras vegetales

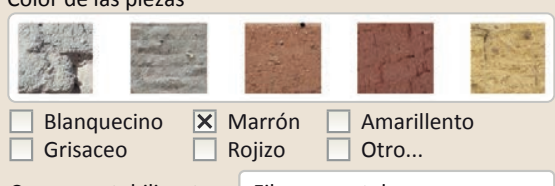

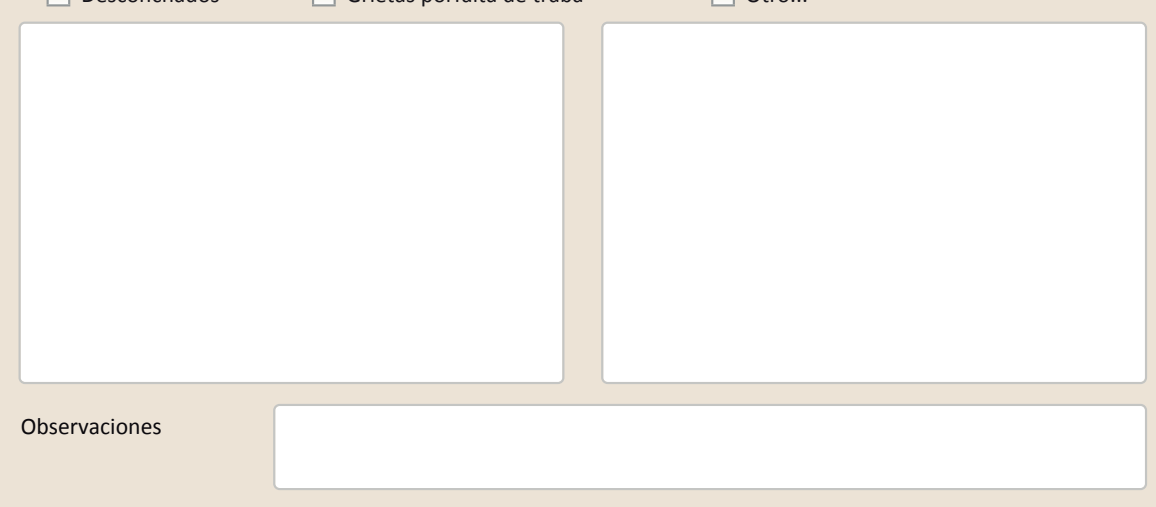




\section{La restauración y rehabilitación de la arquitectura tradicional de tierra.}

\section{El caso de Aragón.}

\subsection{TAPIA}

Ancho del muro

Dimensión tapiales

Tipo de aguja

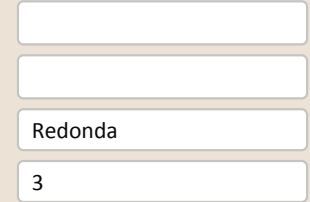

\section{Color de la tapia}

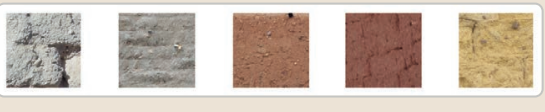

$\square$ Blanquecino $\square$ Marrón $\square$ Amarillento

$\square$ Grisaceo $\quad \mathbf{X}$ Rojizo $\square$ Otro...

Variante constructiva

$\square$ Simple / homogénea

$\square$ suplemento superficial

$X$ Suplemento en juntas

$\square$ Mixta

$\square$ Elementos de protección
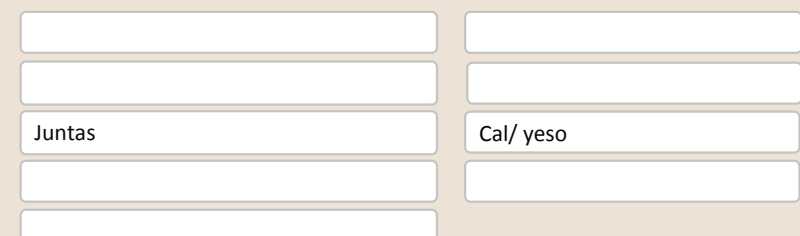

\section{Cal/ yeso}

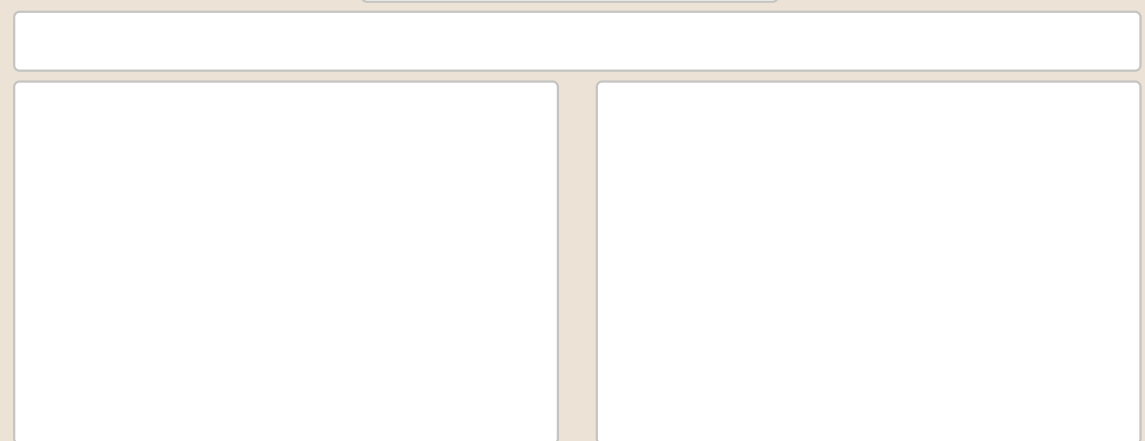

Lesiones \Muro $\square$ Zócalo $\square$ Revestimiento $\square$ Cubierta $\square$ Otro...

X Erosión del material $\square$ Humedad por capilaridad $\quad \square$ Grietas por asentamientos

$\square$ Erosion de las juntas $\square$ Humedades (manch/eflo) $\quad \square$ Colapso

$\square$ Pérdida de sección $\square$ Pérdida de verticalidad $\square$ Por elementos impropios

$\square$ Vegetación $\quad \square$ Grietas por empuje de la cubierta $\square$ Derivado de intervenciones

$\square$ Desconchados $\quad \square$ Grietas porfalta de traba $\quad \square$ Otro...

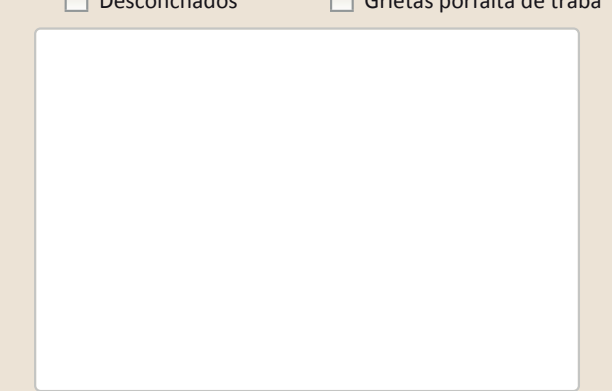

$+2$

Observaciones

La restauración y rehabilitación de la arquitectura tradicional de tierra.

El caso de Aragón.

3. DATOS DE LA INTERVENCIÓN

Intervención de: $\quad \square$ Mantenimiento $\square$ Rehabilitación parcial $\square$ Restauración $\square$ Demolicón

$\square$ Reparación $\quad \mathbf{X}$ Rehabilitación integral $\square$ Ampliación $\quad \square$ Otro...

Reflexión previa Intervención planificada

Observaciones

3.1. MUROS

Tipo de intervención

Tipo de material

Intervenido

Descripción Nueva coronación en el muro de cercado

$\square$ Consolidación $\square$ Reconstrucción $\square$ sustitución

3.2. ZÓCALO

Intervenido

$\begin{array}{ll}\text { Tipo de intervención } & \square \text { Actualización } \quad \square \text { Reintegración } \quad \square \text { Demolición } \quad \square \text { Otro... } \\ & \square \text { Consolidación } \quad \text { × Reconstrucción } \quad \square \text { Sustitución }\end{array}$

Tipo de material No tradicional Tipo de técnica Diferente a la existente

Descripción

Revestimiento parcial de cemento

3.3. REVESTIMIENTOS

Tipo de intervención $\quad \square$ Actualización $\square$ Reintegración $\quad \square$ Demolición $\square$ Otro...

$\square$ Consolidación $\mathbf{X}$ Reconstrucción $\square$ Sustitución

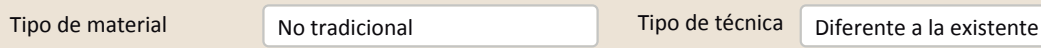

Descripción Revestimiento de cemento bajo la nueva cubierta

3.4. VANOS

Tipo de intervención

Intervenido

$\square$ Actualización $\square$ Reintegración $\square$ Demolición $\square$ Otro...

Tipo de material $\square$ Consolidación $\square$ Reconstrucción $\quad \mathbf{X}$ Sustitución

Descripción Nuevos huecos con dintel de hormigón, reintegración de jambas y sustitución de las carpinterías

3.5. CUBIERTA

Tipo de intervención

Intervenido

X Actualización $\square$ Reintegración $\square$ Demolición $\square$ Otro...

$\square$ Consolidación $\square$ Reconstrucción $\quad \mathbf{X}$ Sustitución

\begin{tabular}{l|lll} 
Tipo de material & No tradicional dipo décnical Diferente a la existente
\end{tabular}

Descripción

Sustitución de las cubiertas. Incluyen elemento de imitación a la madera del alero 
La restauración y rehabilitación de la arquitectura tradicional de tierra. El caso de Aragón

\section{La restauración y rehabilitación de la arquitectura tradicional de tierra.}

El caso de Aragón.
3.7. REHABILITACIÓN ENERGÉTICA
$\square$ Fachada $\square$ Vanos $\square$ Forjados $\square$ Cubierta

Observaciones

FOTOGRAFÍAS DE LA INTERVENCIÓN
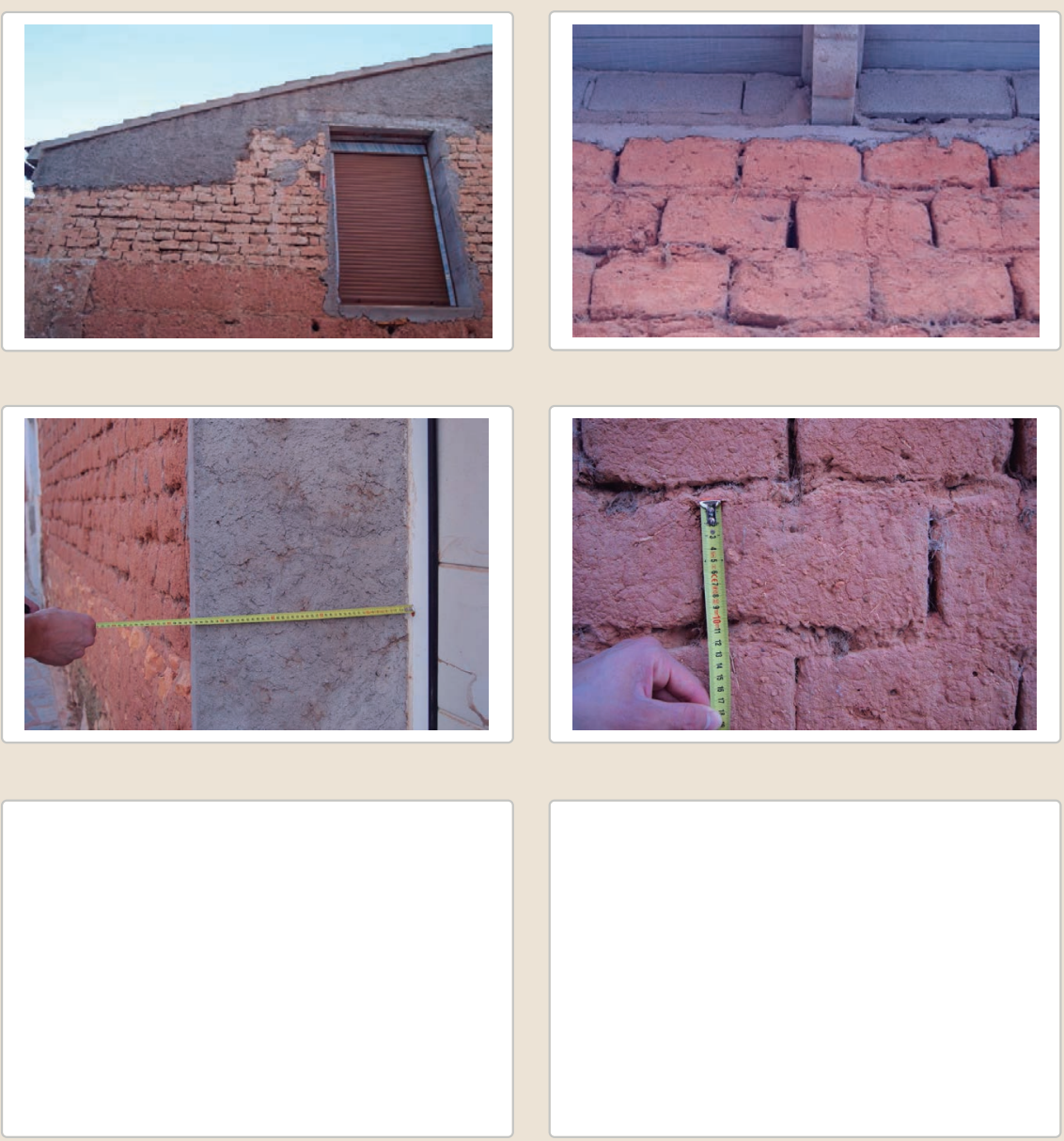
La restauración y rehabilitación de la arquitectura tradicional de tierra. El caso de Aragón.

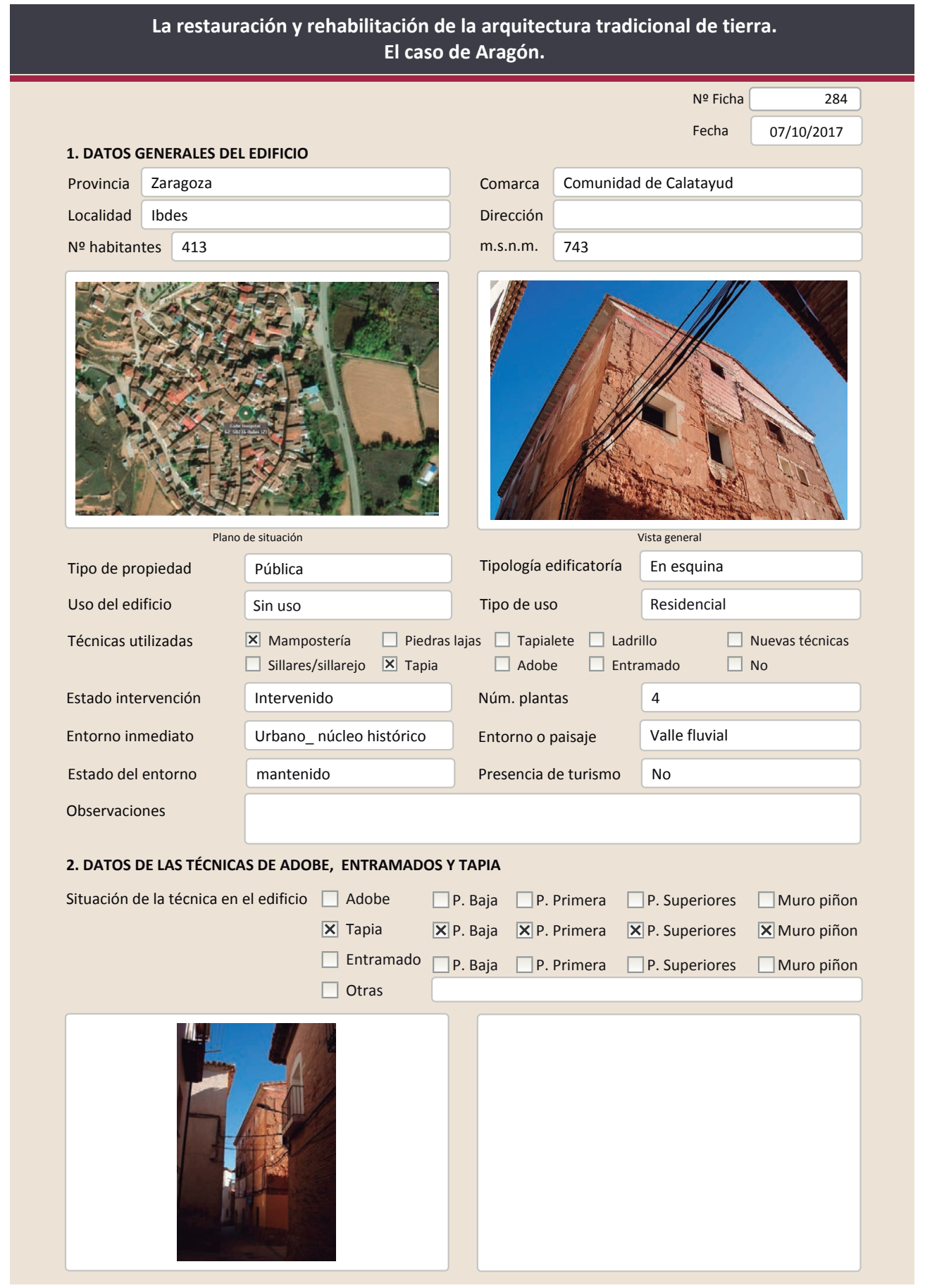

La restauración y rehabilitación de la arquitectura tradicional de tierra. El caso de Aragón.

\subsection{TAPIA}

Ancho del muro

Dimensión tapiales

Tipo de aguja

№ agujas/cajón

Variante constructiva

$\square$ Simple / homogénea

$\mathbf{X}$ Suplemento superficial

X Suplemento en juntas

$\square$ Mixta

X Elementos de protección

\section{Revestimiento con elementos decorativos que se encuentra muy deteriorado}

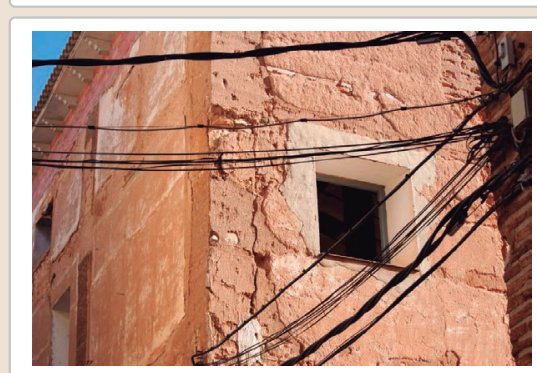

Lesiones \Muro $\square$ Zócalo $\mathbf{X}$ Revestimiento $\square$ Cubierta $\square$ Otro...

X Erosión del material $\quad \square$ Humedad por capilaridad $\quad \square$ Grietas por asentamiento $\square$ Erosion de las juntas $\square$ Humedades (manch/eflo)

$\square$ Pérdida de sección $\quad \square$ Pérdida de verticalidad

$\square$ Vegetación

$\square$ Por elementos impropios

X Desconchados

$\square$ Grietas por empuje de la

$\square$ Otro... 


\section{La restauración y rehabilitación de la arquitectura tradicional de tierra.}

\section{El caso de Aragón.}

3. DATOS DE LA INTERVENCIÓN

$\square$ Mantenimiento $\square$ Rehabilitación parcial $\square$ Restauración $\quad \square$ Demolición $\square$ Reparación $\quad$ Rehabilitación integral $\square$ Ampliación $\quad \square$ Otro...

Reflexión previa Intervención planificada

$\begin{array}{lll}\text { Observaciones } & \text { Intervención subvencionada por la DGA y elayuntamiento de Ibdes con } 50000 \text { euros }\end{array}$

3.1. MUROS

Tipo de intervención

Tipo de material

Intervenido

$\square$ Actualización $\square$ Reintegración $\square$ Demolición $\square$ Otro...

$\square$ Consolidación $\quad \mathbf{X}$ Reconstrucción $\square$ Sustitución

Descripción

Tipo de técnica Diferente a la existente

3.2. ZÓCALO

Tipo de intervención

Recrecido del muro con fábrica de ladrillo hueco

Intervenido

X Actualización $\square$ Reintegración $\square$ Demolición $\square$ Otro...

$\square$ Consolidación $\quad \mathbf{X}$ Reconstrucción $\square$ Sustitución

\begin{tabular}{llll} 
Tipo de material No tradicional Tipo de técnica & Diferente a la existente \\
\hline
\end{tabular}

Descripción

3.3. REVESTIMIENTOS

Tipo de intervención

Zócalo de lajas de piedra

\section{Intervenido}

X Actualización $\square$ Reintegración $\square$ Demolición $\square$ Otro...

$\square$ Consolidación $\square$ Reconstrucción $\square$ Sustitución

Tipo de material

Descripción

3.4. VANOS

Tipo de intervención

No tradicional

Tipo de técnica Diferente a la existente

Pintura en planta baja

Tipo de material

Descripción

3.5. CUBIERTA

Tipo de intervención

\section{Intervenido}

No intervenido

$\square$ Actualización $\quad \square$ Reintegración $\square$ Demolición $\square$ Otro...

$\square$ Consolidación $\quad \square$ Reconstrucción $\square$ Sustitución

Tipo de material

$\square$ Actualización

$\square$ Consolidación

$\square$ Reintegració

Tipo de técnica

Descripción

o tradiciona

Cubierta de hormigón con bovedilla de poletestica Diferente a la existente

3.6. OTRAS
La restauración y rehabilitación de la arquitectura tradicional de tierra.

El caso de Aragón.

3.7. REHABILITACIÓN ENERGÉTICA $\square$ Fachada $\square$ Vanos $\square$ Forjados $\quad$ C Cubierta

Observaciones

FOTOGRAFíAS DE LA INTERVENCIÓN
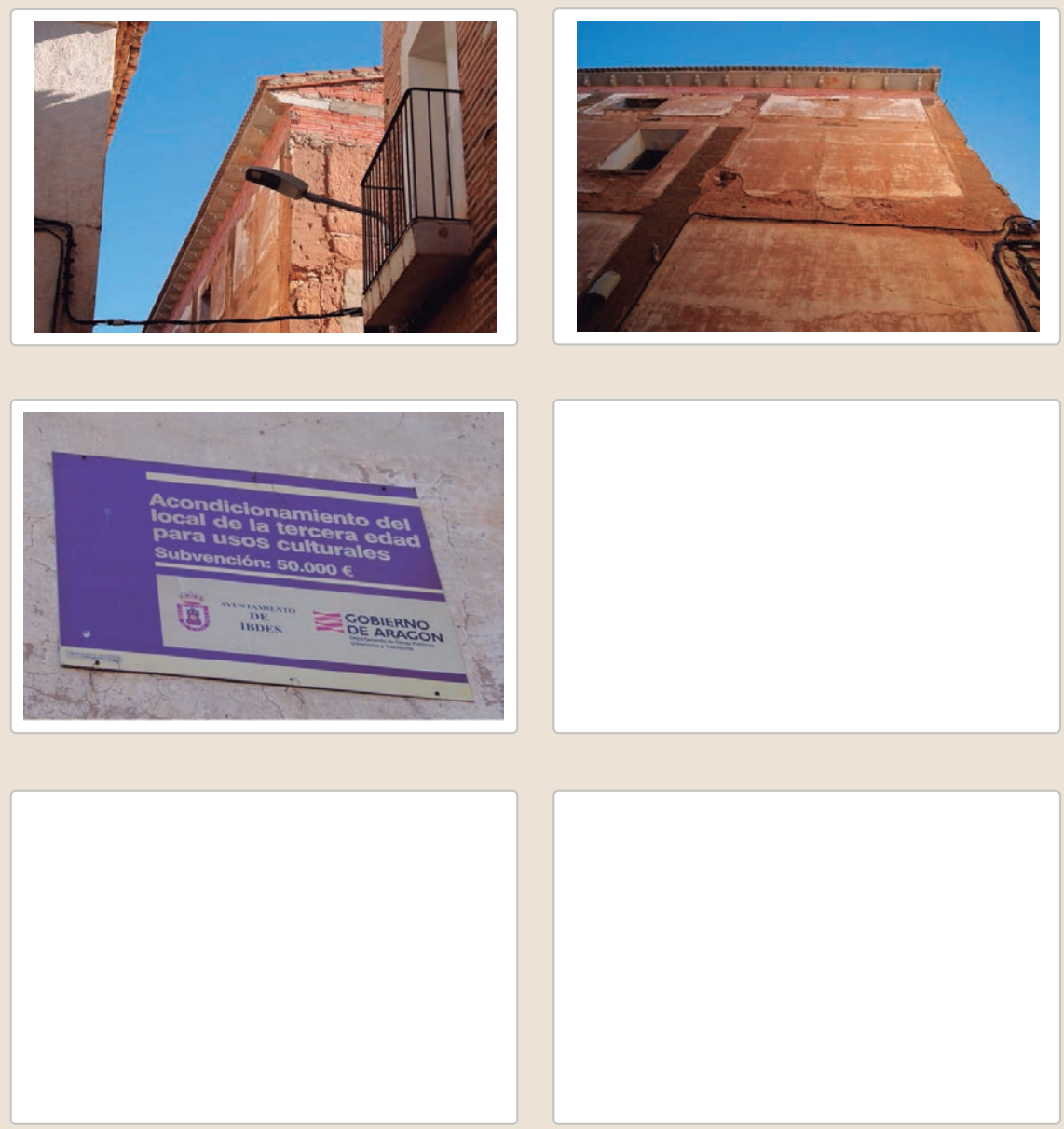


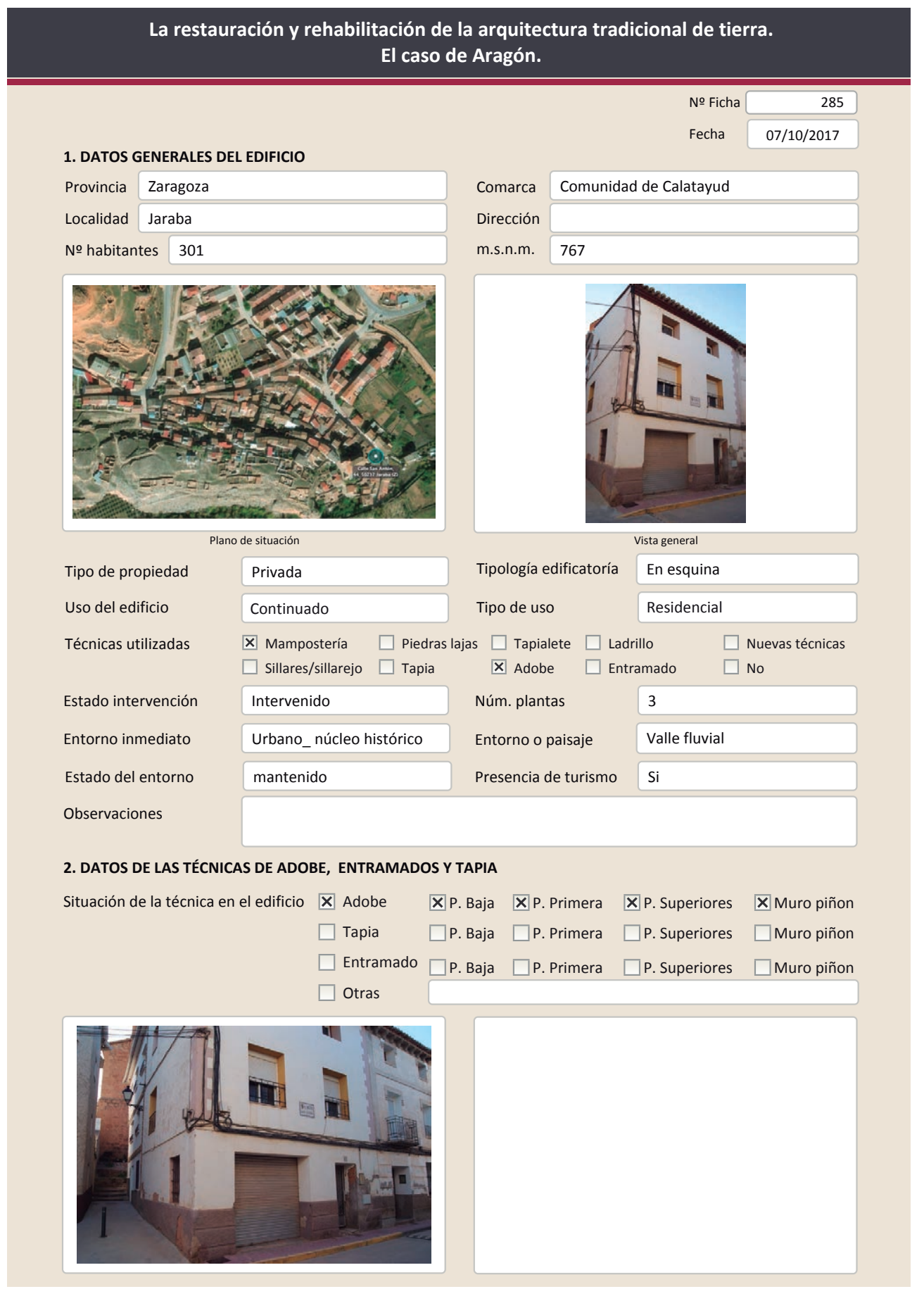

La restauración y rehabilitación de la arquitectura tradicional de tierra.

El caso de Aragón.

2.1. ADOBE

Dimensión de las piezas

Dimensión del muro

Aparejo del muro

Función estructural
Color de las piezas

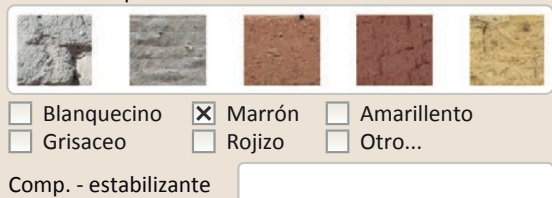

constructiva/ tipo de fábrica

メ simple

$\square$ Suplementada en juntas

$\square$ Mixta

$\square$ Como suplemento

$\square$ Elementos de protección

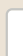

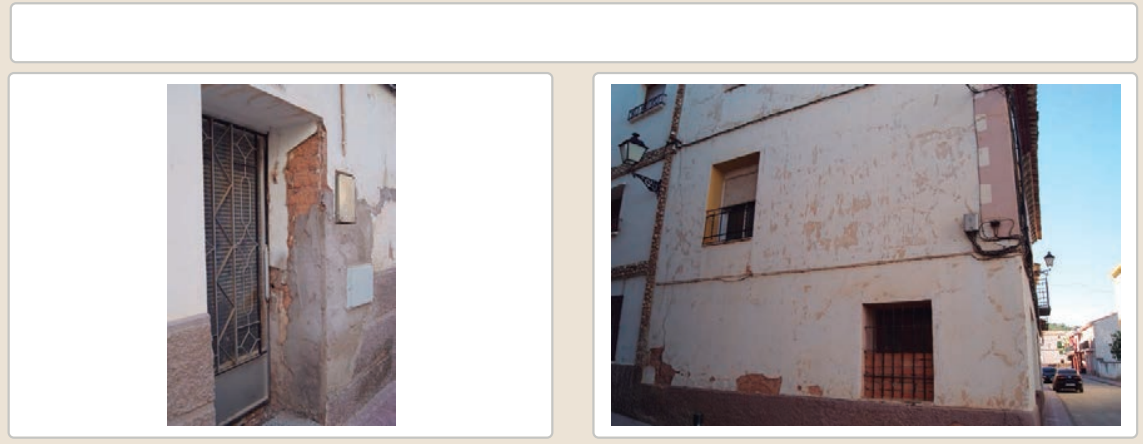

Lesiones

$\square$ Muro $\square$ Zócalo $\mathbf{X}$ Revestimiento

$\square$ Cubierta $\square$ otro...

$\square$ Erosión del material $\quad \square$ Humedad por capilaridad $\quad \square$ Grietas por asentamientos

$\square$ Erosion de las juntas $\square$ Humedades (manch/eflo) $\quad \square$ Colapso

$\square$ Pérdida de sección $\square$ Pérdida de verticalidad $\square$ Por elementos impropios

$\square$ Vegetación $\square$ Grietas por empuje de la cubierta $\square$ Derivado de intervenciones

\ Desconchados $\quad \square$ Grietas porfalta de traba

$\square$ Derivadod
$\square$ Otro...

Observaciones 


\section{La restauración y rehabilitación de la arquitectura tradicional de tierra.}

\section{El caso de Aragón.}

3. DATOS DE LA INTERVENCIÓN

$\square$ Mantenimien

Intervención de:

$\square$ Reparación

$\square$ Rehabilitación parcial

$\square$ Restauración $\square$ Demolición

Reflexión previa

Intervención planificada

Observaciones

(n)

3.1. MUROS
Tipo de intervención

\section{No visible}

Tipo de material

$\square$ Actualización

$\square$ Consolidació

$\square$ Reintegración

$\square$ Demolición

de técnica

Descripción

3.2. ZÓCALO

Tipo de intervención

\section{Intervenido}

X Actualización $\square$ Reintegración $\square$ Demolición $\square$ Otro...

$\square$ Consolidación $\quad \mathbf{X}$ Reconstrucción $\square$ Sustitución

Tipo de material

No tradicional

Tipo de técnica Diferente a la existente

Descripción

3.3. REVESTIMIENTOS

Tipo de intervención

Intervenido

X Actualización $\square$ Reintegración $\square$ Demolición $\square$ Otro...

$\square$ Consolidación $\quad \mathbf{X}$ Reconstrucción $\square$ Sustitución

Tipo de material

Descripción

3.4. VANOS

Tipo de intervención

No tradicional

Tipo de técnica Diferente a la existente

Revestimiento de cemento pintado de blanco con fingido de sillares en la esquina

\begin{tabular}{l|lll} 
Tipo de material Tipo de técnica & No tradicional & Tifente a la existente \\
\hline
\end{tabular}

Intervenido

$\square$ Actualización $\square$ Reintegración $\square$ Demolición $\square$ Otro...

$\square$ Consolidación $\mathbf{X}$ Reconstrucción $\mathbf{X}$ Sustitución

Descripción Sustitución de las carpinterías e incorporación de persianas. Los dinteles parecen intervenidos. Ampliación del hueco en planta baja

3.5. CUBIERTA

Tipo de intervención

Intervenido

$\square$ Actualización $\quad$ X Reintegración $\square$ Demolición $\square$ Otro..

$\square$ Consolidación $\quad \square$ Reconstrucción $\square$ Sustitución

Tipo de material

No tradicional

Tipo de técnica Diferente a la existente

Descripción

Reintegración de las tejas con cemento. Por la forma del alero (parece ladrillo hueco) es posible que la cubierta por completo haya sido reconstruida
La restauración y rehabilitación de la arquitectura tradicional de tierra.

El caso de Aragón.

3.7. REHABILITACIÓN ENERGÉTICA $\quad \square$ Fachada $\square$ Vanos $\square$ Forjados $\square$ Cubierta

Observaciones

FOTOGRAFÍAS DE LA INTERVENCIÓN
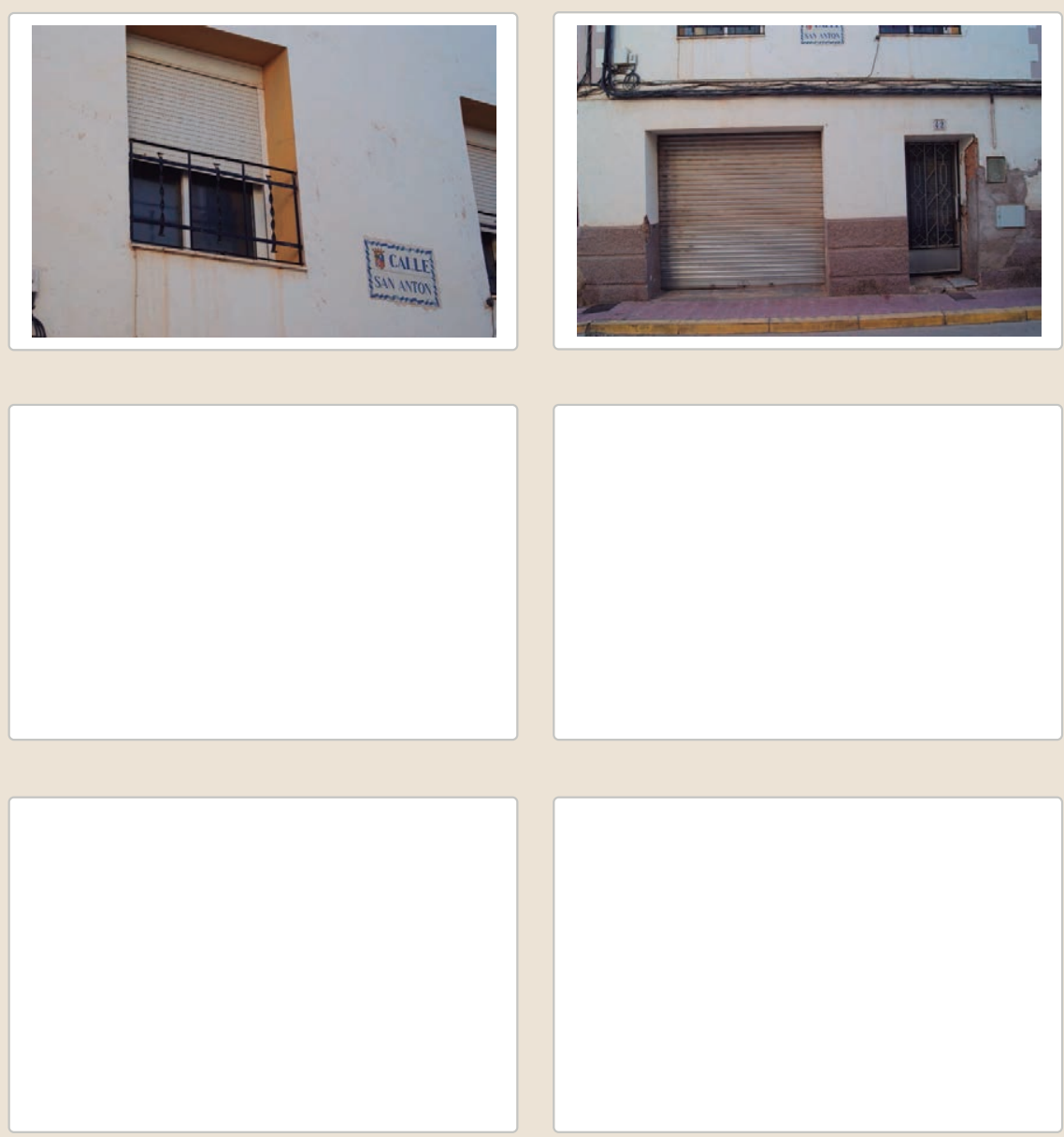

3.6. OTRAS 


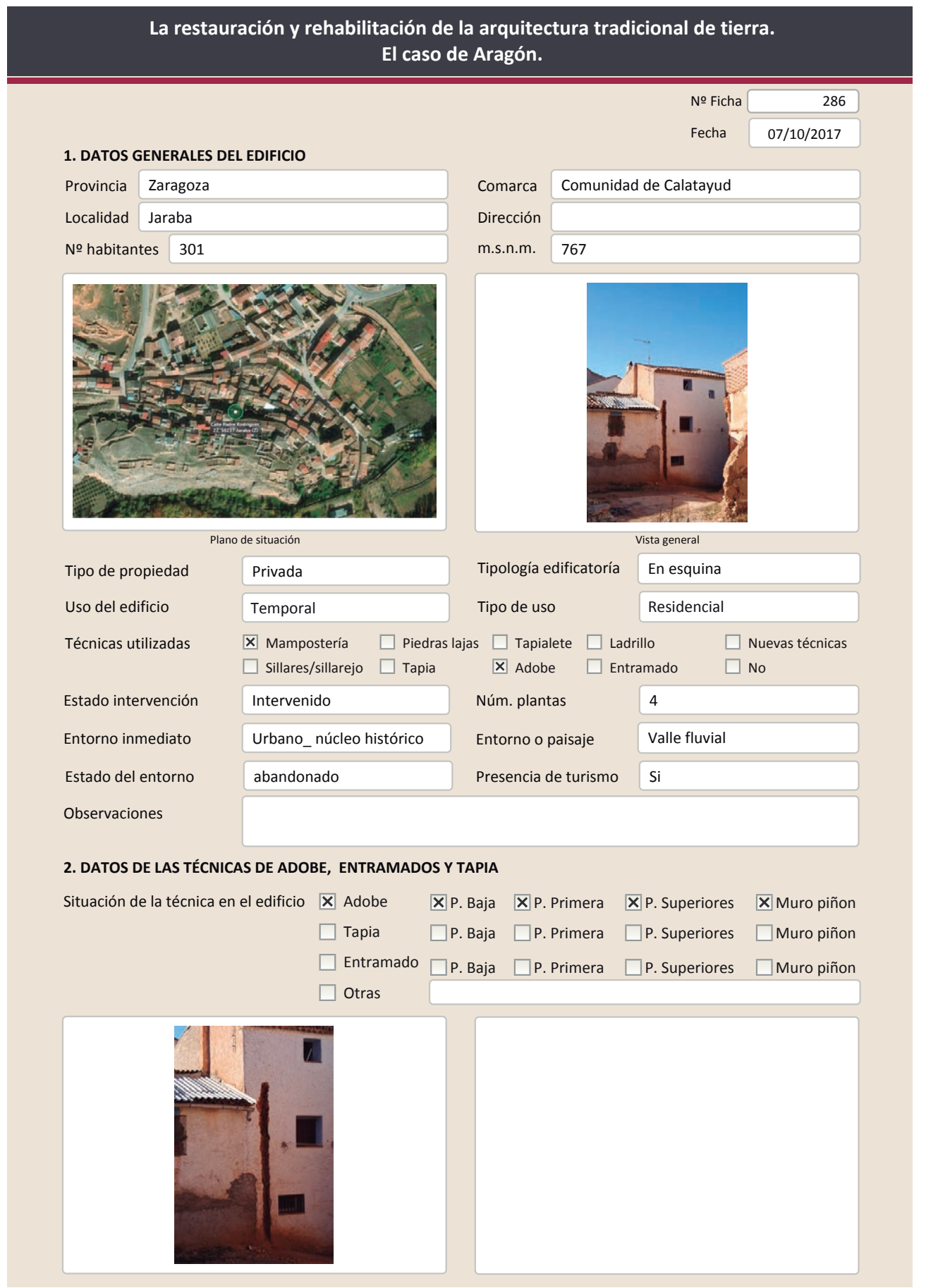

La restauración y rehabilitación de la arquitectura tradicional de tierra.

2.1. ADOBE

Dimensión de las piezas

Dimensión del muro

Aparejo del muro

Función estructural

\section{El caso de Aragón.}

Color de las piezas

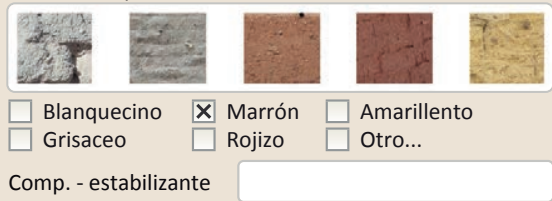

Comp. - estabilizante

Variante constructiva/ tipo de fábrica

$\square$ Simple
X Suplementada en juntas
Horizontales
$\square$ Mixta
$\square$ Como suplemento
$\square$ Elementos de protección

$\mathrm{Cal} /$ yeso

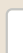

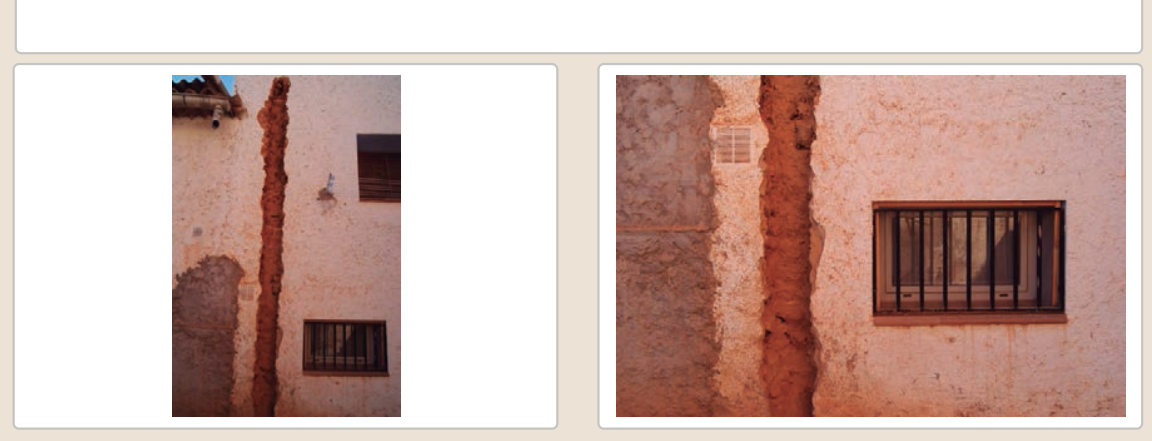

Lesiones

$\square$ Muro $\square$ Zócalo $\square$ Revestimiento

X Cubierta $\square$ Otro...

$\begin{array}{lll}\square \text { Erosión del material } & \square \text { Humedad por capilaridad } & \square \text { Grietas por asentamientos } \\ \square \text { Erosion de las juntas } & \square \text { Humedades (manch/eflo) } & \boldsymbol{X} \text { Colapso } \\ \square \text { Pérdida de sección } & \square \text { Pérdida de verticalidad } & \square \text { Por elementos impropios } \\ \square \text { Vegetación } & \square \text { Grietas por empuje de la cubierta } & \square \text { Derivado de intervenciones }\end{array}$

$\square$ Pérdida de sección $\square$ Pérdida de verticalidad $\square$ Por elementos impropios

$\square$ Desconchados $\quad \square$ Grietas porfalta de traba $\quad \square$ Otro... 


\section{La restauración y rehabilitación de la arquitectura tradicional de tierra.}

\section{El caso de Aragón.}

3. DATOS DE LA INTERVENCIÓN

Intervención de:

$\square$ Mantenimiento $\quad \times$ Rehabilitación parcial

$\square$ Restauración $\square$ Demolición

Reflexión previa

Intervención espontanea

Observaciones

(n)

3.1. MUROS
Tipo de intervención

Intervenido

Tipo de material

$\square$ Actualización

$\square$ Consolidación

$\square$ Reintegración

X Demolición

No tradicional

Descripción

Intervenido

3.2. ZÓCALO

Tipo de intervención

$\square$ Actualizacion

$\square$ Consolidació

$\square$ Reintegración $\quad \square$ Demolición $\quad \square$ Otro...

Tipo de material

ado de forma aleatoria

3.3. REVESTIMIENTOS

Tipo de intervención

Intervenido

X Actualización $\square$ Reintegración $\quad \square$ Demolición $\square$ Otro..

$\square$ Consolidación $\mathbf{X}$ Reconstrucción $\square$ Sustitución

Tipo de material

Descripción

3.4. VANOS

No tradicional

Tipo de técnica Diferente a la existente

Revestimiento de cemento en todo el edificio

Tipo de intervención

Intervenido

Tipo de material

$\square$ Actualización

$\square$ Consolidación

$\square$ Reintegración

$\square$ Demolición $\square$ Otro...

No tradicional

Descripción

Sustitución de carpinterías

3.5. CUBIERTA

Tipo de intervención

Intervenido

$\square$ Actualización $\mathbf{X}$ Reintegración $\square$ Demolición $\square$ Otro..

$\square$ Consolidación $\quad \mathbf{X}$ Reconstrucción $\square$ Sustitución

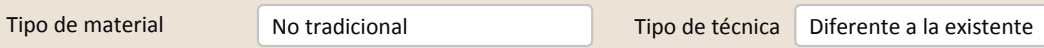

Descripción

Reconstrucción de la cubierta del cuerpo principal con teja curva nueva y cemento. El

cuerpo de menor altura tiene placas prefabricadas onduladas cubriendo el tejado
La restauración y rehabilitación de la arquitectura tradicional de tierra.

El caso de Aragón.

3.7. REHABILITACIÓN ENERGÉTICA $\square$ Fachada $\quad$ \Vanos $\square$ Forjados $\square$ Cubierta

Observaciones

FOTOGRAFíAS DE LA INTERVENCIÓN
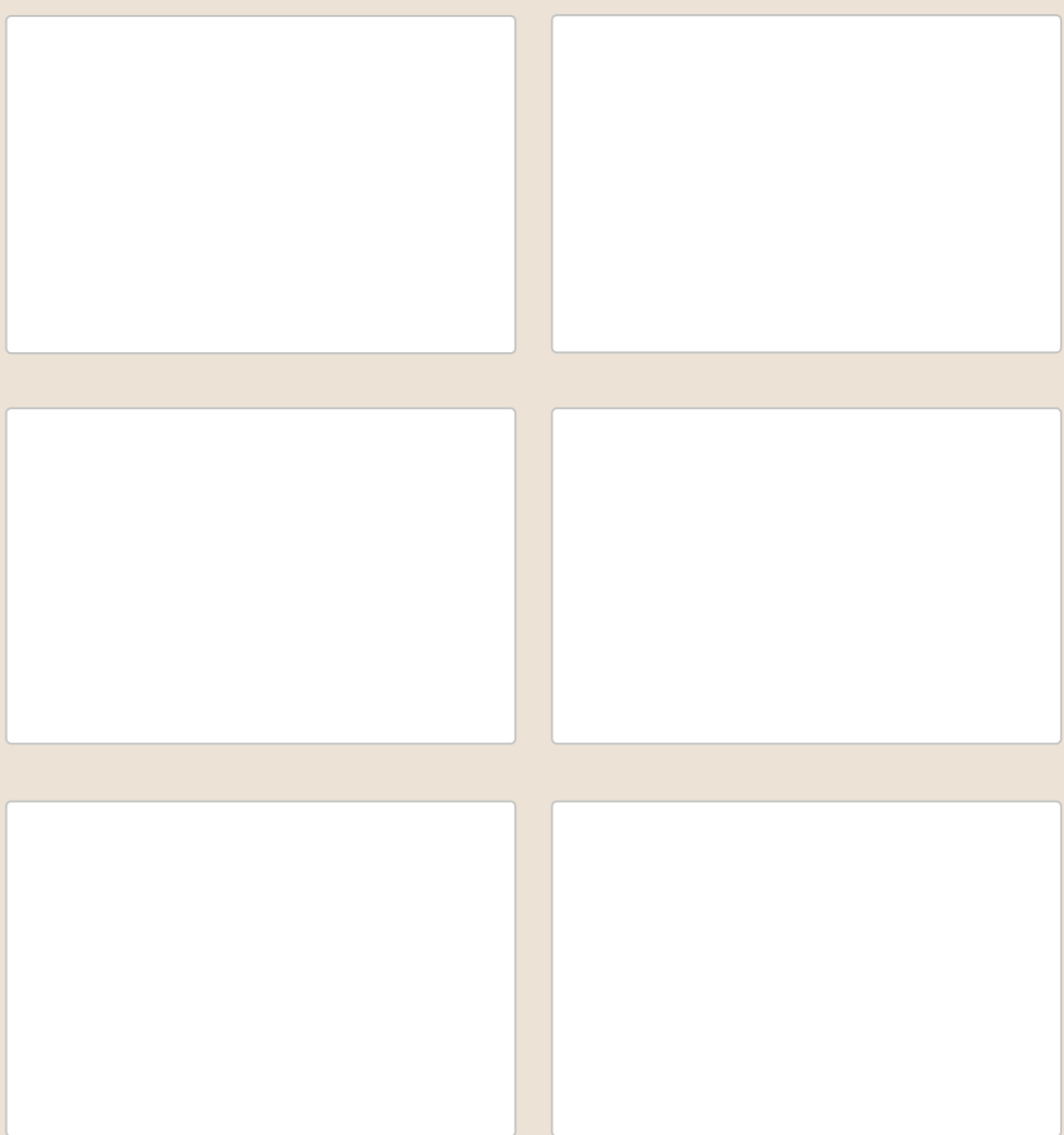

3.6. OTRAS 


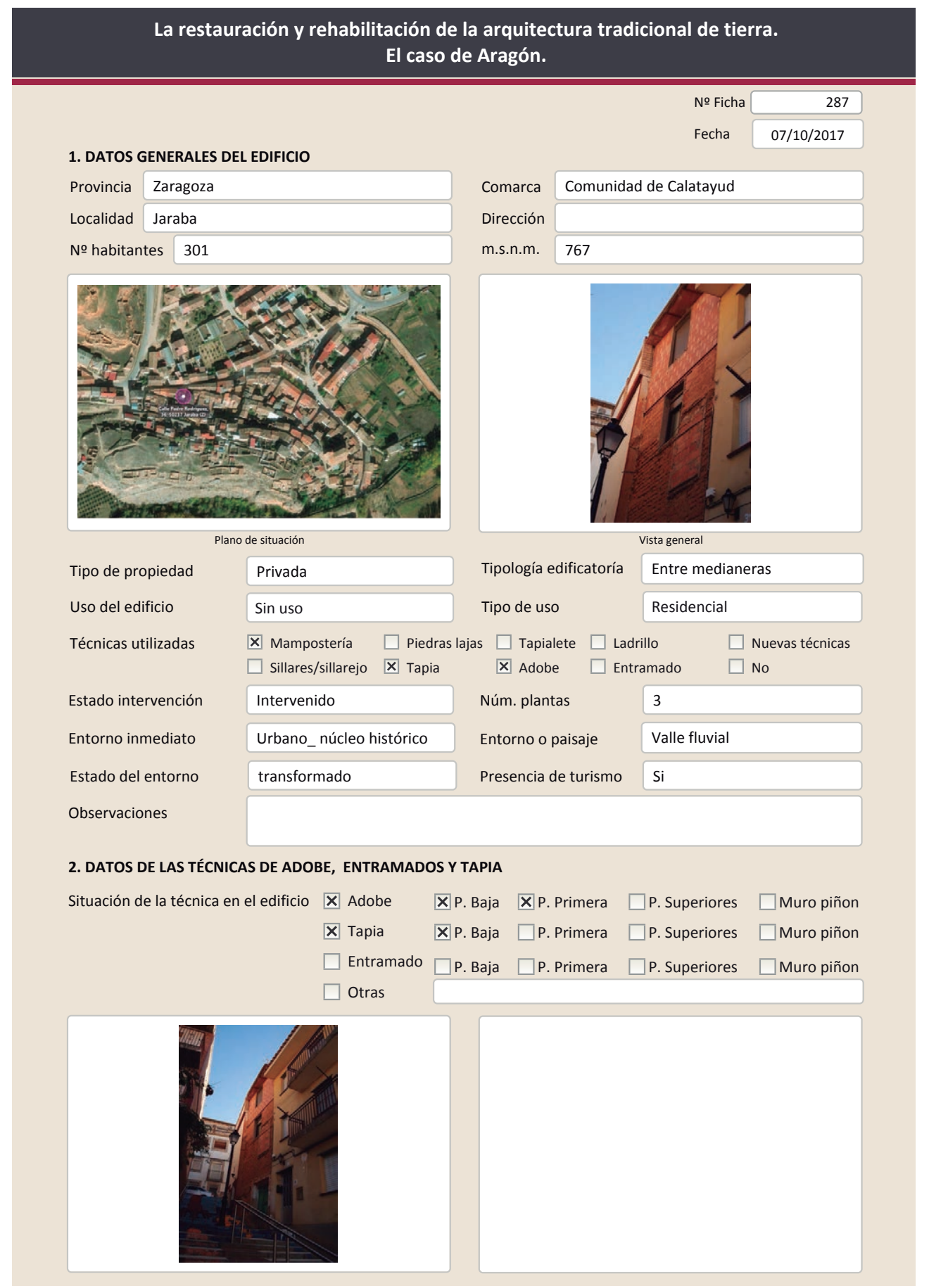

La restauración y rehabilitación de la arquitectura tradicional de tierra.

El caso de Aragón.

\subsection{ADOBE}

Dimensión de las piezas Dimensión del muro Aparejo del muro Función estructural Variante constructiva/ tipo de fábrica

X simple

$\square$ Suplementada en juntas

$\square$ Mixta

$\square$ Como suplemento

$\square$ Elementos de protección

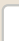

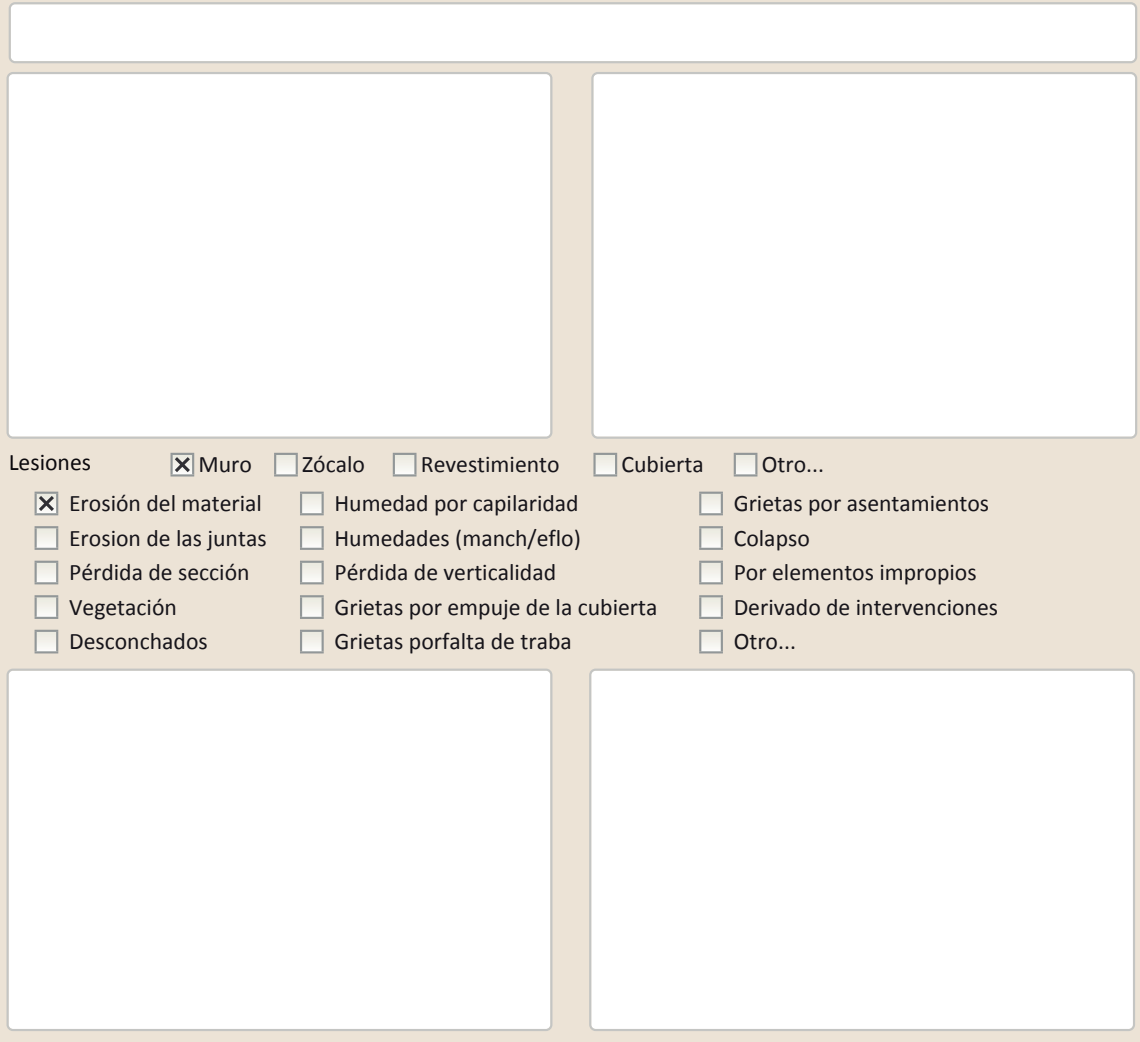

Observaciones

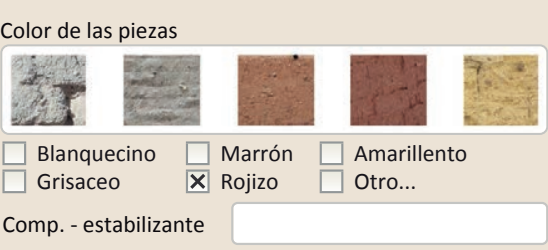

Comp. - estabilizante 


\section{La restauración y rehabilitación de la arquitectura tradicional de tierra.} El caso de Aragón.

\subsection{TAPIA}

Ancho del muro

Dimensión tapiales

Tipo de aguja

№ agujas/cajón

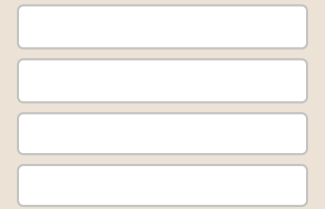

\section{Color de la tapia}

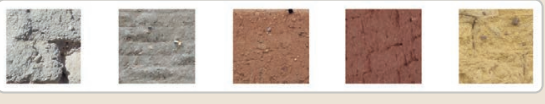

$\square$ Blanquecino $\square$ Marrón $\square$ Amarillento

$\square$ Grisaceo

Variante constructiva
X Simple / homogénea
$\square$ suplemento superficial
$\square$ Suplemento en juntas
$\square$ Mixta

Simple / homogénea

$\square$ Elementos de protección

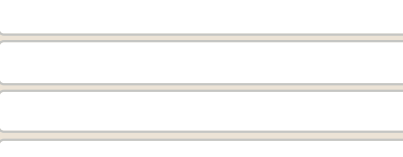

Solo una pequeña superficie en planta baja está hecha con tapia

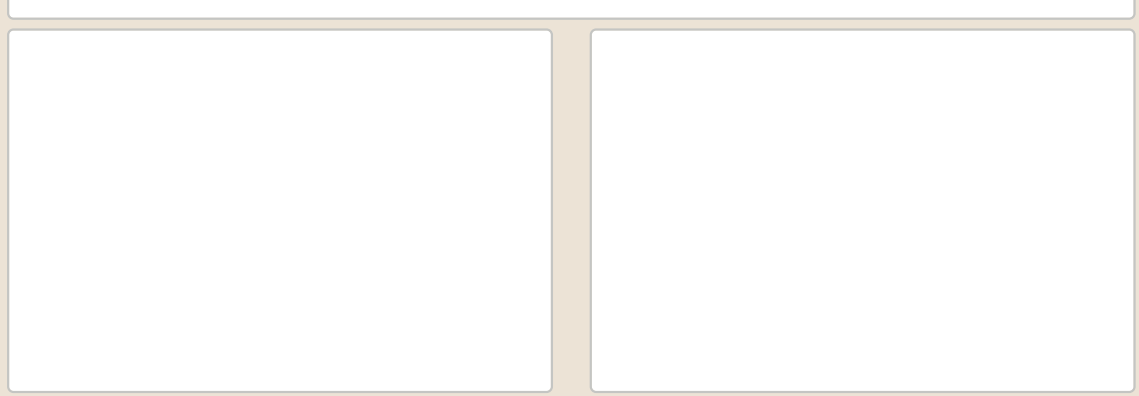

Lesiones $\mathbf{X}$ Muro $\mathbf{X}$ Zócalo $\square$ Revestimiento $\square$ Cubierta $\square$ otro...

X Erosión del material $\quad \mathbf{X}$ Humedad por capilaridad $\quad \square$ Grietas por asentamientos

$\square$ Erosion de las juntas $\quad \square$ Humedades (manch/eflo) $\quad \square$ Colapso

X Pérdida de sección $\square$ Pérdida de verticalidad $\quad \square$ Por elementos impropios

$\square$ Vegetación $\square$ Grietas por empuje de la cubierta $\square$ Derivado de intervencion

$\square$ Desconchados

$\begin{array}{ll}\square \text { Grietas por empuje de la cubierta } & \square \text { Derivadod } \\ \square \text { Grietas porfalta de traba } & \square \text { Otro... }\end{array}$

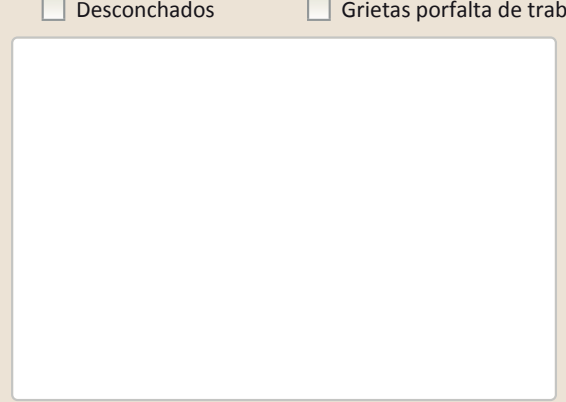

Observaciones

La restauración y rehabilitación de la arquitectura tradicional de tierra.

El caso de Aragón.

3. DATOS DE LA INTERVENCIÓN

Intervención de: $\quad \square$ Mantenimiento $\square$ Rehabilitación parcial $\square$ Restauración $\square$ Demolción

$\square$ Reparación $\quad \square$ Rehabilitación integral $\quad$ X Ampliación $\quad \square$ Otro..

Reflexión previa Intervención planificada

Observaciones

3.1. MUROS

Tipo de intervención

Tipo de material

Intervenido

$\square$ Actualización $\quad \square$ Reintegración $\quad \square$ Demolición $\quad \square$ otro.

$\square$ Consolidación $\quad$ X Reconstrucción $\square$ Sustitución

Descripción

No tradicional Tipo de técnica Diferente a la existente

3.2. ZÓCALO

Recrecido de una plana del edificio sobre el muro de adobe

Tipo de intervención

No intervenido

Reintegración $\quad \square$ Demolición $\quad \square$ Otro...

$\square$ Consolidación $\square$ Reconstrucción $\square$ Sustitución

Tipo de material

Descripción

3.3. REVESTIMIENTOS

Tipo de intervención

No aplica

Tipo de material

Descripción

3.4. VANOS

Tipo de intervención

Intervenido

Tipo de material

$\square$ Actualización $\quad \square$ Reintegración $\quad \square$ Demolición $\square$ Otro..

$\square$ Consolidación $\mathbf{X}$ Reconstrucción $\mathbf{X}$ Sustitución

\begin{tabular}{l|l|l|l} 
& No tradicional & Tipo de técnica & Diferente a la existente
\end{tabular}

Descripción

Cegado del hueco existente y construcción de un nuevo hueco centrado. Nuevas carpinerías.

3.5. CUBIERTA

Intervenido

Tipo de intervención

$\square$ Actualización $\square$ Reintegración $\square$ Demolición $\square$ Otro

$\square$ Consolidación $\square$ Reconstrucción $\quad$ \ Sustitución

\begin{tabular}{l|lll} 
Tipo de material & No tradicional & Tipo de técnica & Diferente a la existente
\end{tabular}

Descripción

Nueva cubierta con estructura metálica sobre bardos

3.6. OTRAS 
La restauración y rehabilitación de la arquitectura tradicional de tierra.

\section{El caso de Aragón.}

3.7. REHABILITACIÓN ENERGÉTICA

$\square$ Fachada $\quad \mathbf{X}$ Vanos $\square$ Forjados $\mathbf{X}$ Cubierta

Observaciones

FOTOGRAFÍAS DE LA INTERVENCIÓN
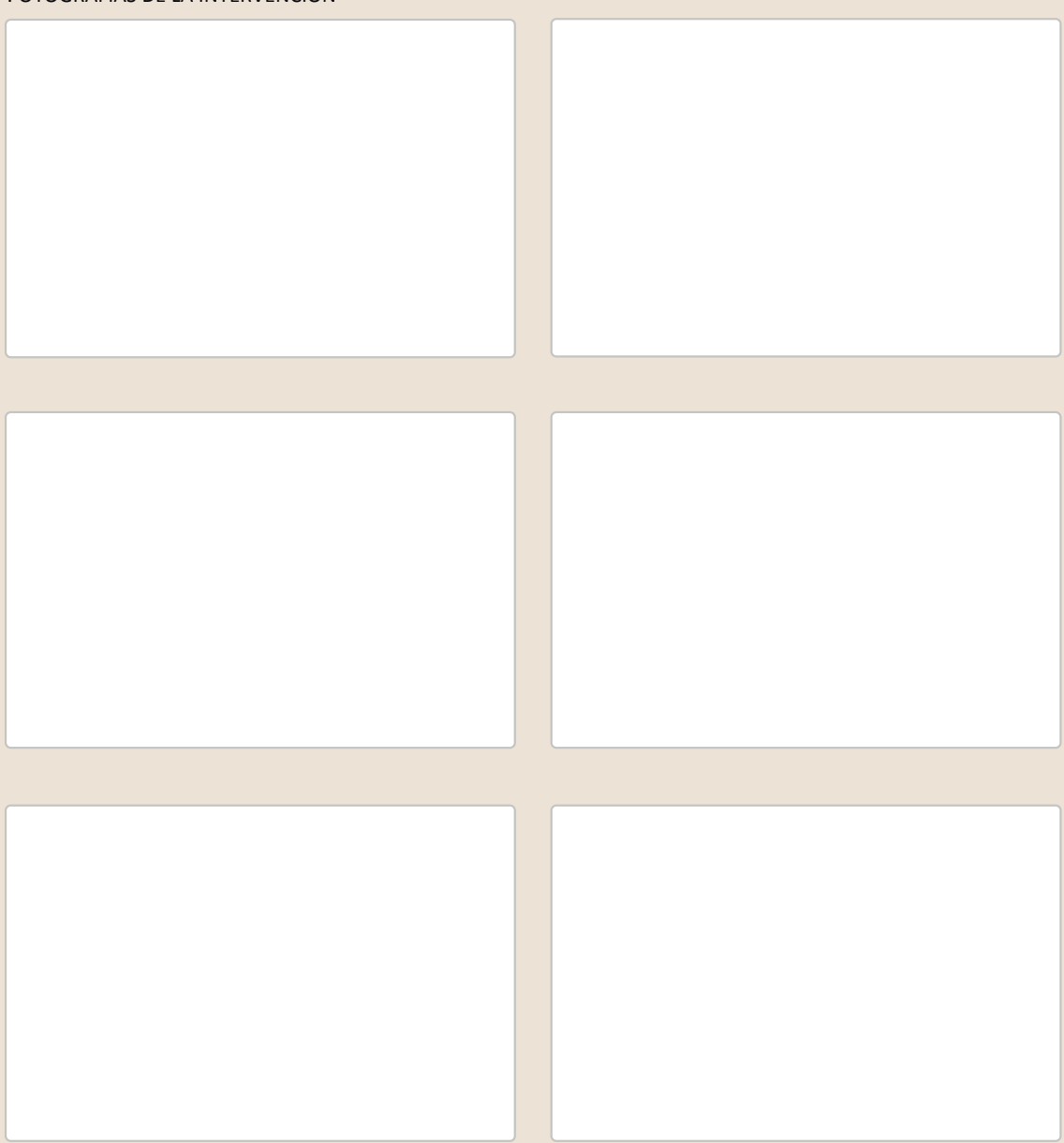
La restauración y rehabilitación de la arquitectura tradicional de tierra. El caso de Aragón

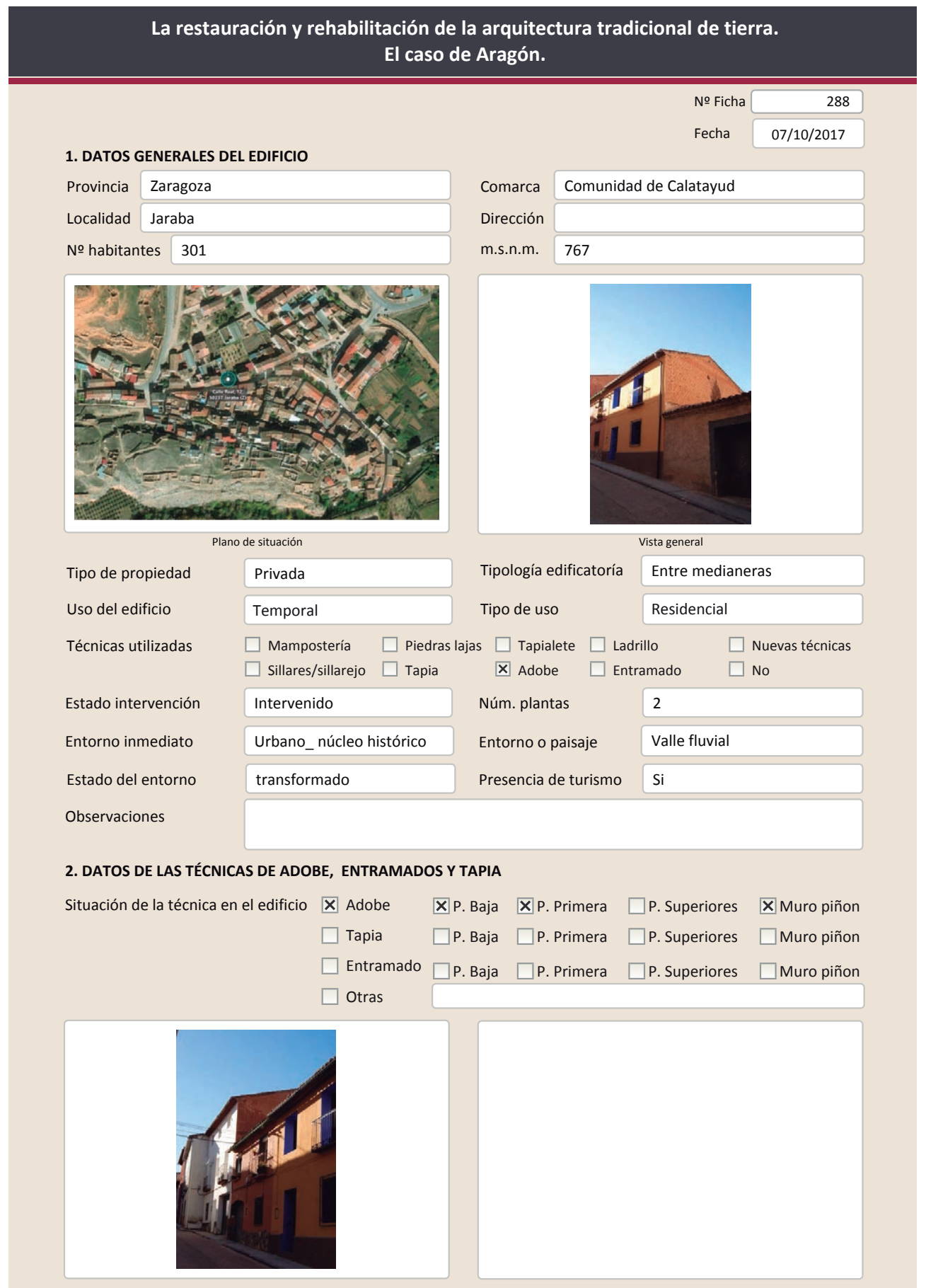

2.1. ADOBE

Dimensión de las piezas Dimensión del muro

Aparejo del muro

Función estructural

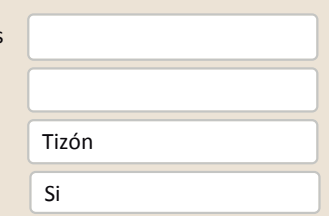

Color de las piezas

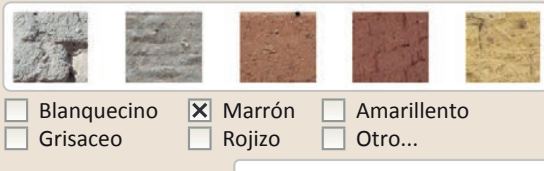

Grisaceo

Variante constructiva/ tipo de fábrica

区 Simple

$\square$ Suplementada en juntas

$\square$ Mixta

$\square$ Como suplemento

$\square$ Elementos de protección

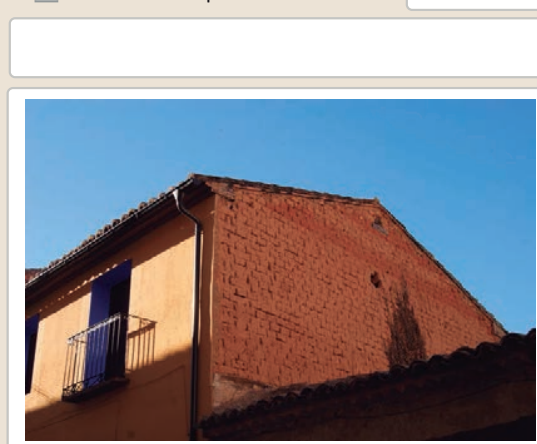

Lesiones X Muro $\square$ Zócalo $\square$ Revestimiento

X Erosión del material $\square$ Humedad por capilaridad

$\square$ Erosion de las juntas $\square$ Humedades (manch/eflo)

$\square$ Pérdida de sección $\square$ Pérdida de verticalidad

$\square$ Vegetación $\quad \square$ Grietas por empuje de la c $\square$ Grietas porfalta de traba

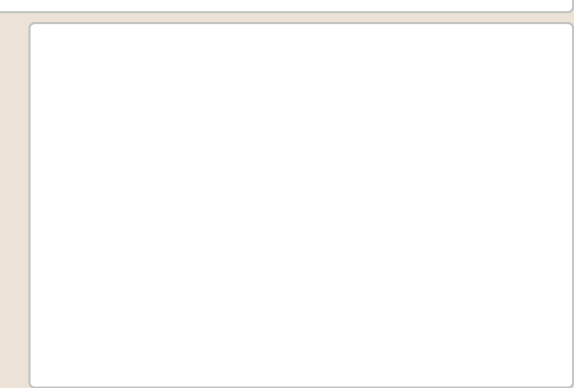

$\square$ Desconchados

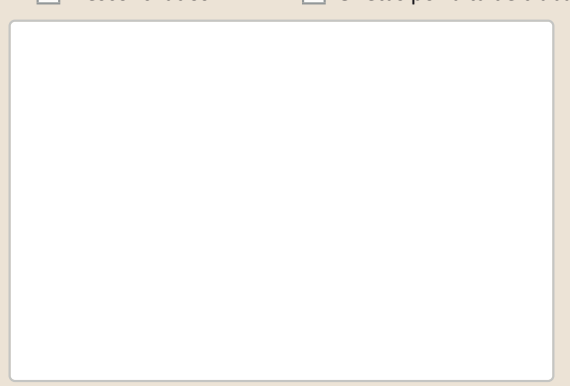

$\square$ Cubierta $\square$ Otro...

$\square$ Grietas por asentamiento

$\square$ Colapso

$\square$ Por elementos impropios

$\square$ Derivado de intervenciones $\square$ Otro... 


\section{La restauración y rehabilitación de la arquitectura tradicional de tierra.}

\section{El caso de Aragón.}

3. DATOS DE LA INTERVENCIÓN

.

$\square$ Mantenimiento $\quad \mathbf{X}$ Rehabilitación parcial

$\square$ Restauración $\square$ Demolición

$\square$ Reparación

$\square$ Rehabilitación integr

$\square$ Ampliación

$\square$ Otro...

Reflexión previ
Observaciones

Intervención planificada

\subsection{MUROS}

Tipo de intervención

Tipo de material

Descripción

3.2. ZÓCALO

Tipo de intervención

Tipo de material

Descripción

3.3. REVESTIMIENTOS

Tipo de intervención

Tipo de material

Descripción

3.4. VANOS

Tipo de intervención

Tipo de material

Descripción

3.5. CUBIERTA

Tipo de intervención

Tipo de material

Descripción

\section{No visible}

$\square$ Actualización $\quad \square$ Reintegración $\quad \square$ Demolición $\square$ Otro...

$\square$ Consolidación $\square$ Reconstrucción $\square$ Sustitución

$$
\text { Tipo de técnica }
$$

\section{Intervenido}

メ Actualización $\square$ Reintegración $\square$ Demolición $\square$ Otro..

$\square$ Consolidación $\quad$ X Reconstrucción $\square$ Sustitución

No tradicional Tipo de técnica Diferente a la existente

Revestimiento grueso de cemento pintado de gris

\section{Intervenido}

X Actualización $\square$ Reintegración $\quad \square$ Demolición $\square$ Otro...

$\square$ Consolidación $\quad \mathbf{X}$ Reconstrucción $\square$ sustitución
No tradicional
Tipo de técnica
Diferente a la existente

Cemento y pintura amarilla

Intervenido

Х Actualización $\quad \boldsymbol{X}$ Reintegración $\square$ Demolición $\square$ Otro...

$\square$ Consolidación $\square$ Reconstrucción $\mathbf{X}$ Sustitución

\begin{tabular}{|l|l|l|l} 
No tradicional Tipo de técnica Diferente a la existente &
\end{tabular}

Reintegración de los huecos y pintura azul. Sustitución de las carpinterías e

incorporación de persianas

Intervenido

$\square$ Actualización $\quad \boldsymbol{X}$ Reintegración $\square$ Demolición $\square$ Otro..

$\square$ Consolidación $\quad \square$ Reconstrucción $\square$ Sustitución

No tradicional Tipo de técnica Similar a la existente

Reintegración de las tejas con cemento
La restauración y rehabilitación de la arquitectura tradicional de tierra.

El caso de Aragón.

3.7. REHABILITACIÓN ENERGÉTICA $\square$ Fachada $\quad$ Vanos $\square$ Forjados $\square$ Cubierta

Observaciones

FOTOGRAFíAS DE LA INTERVENCIÓN
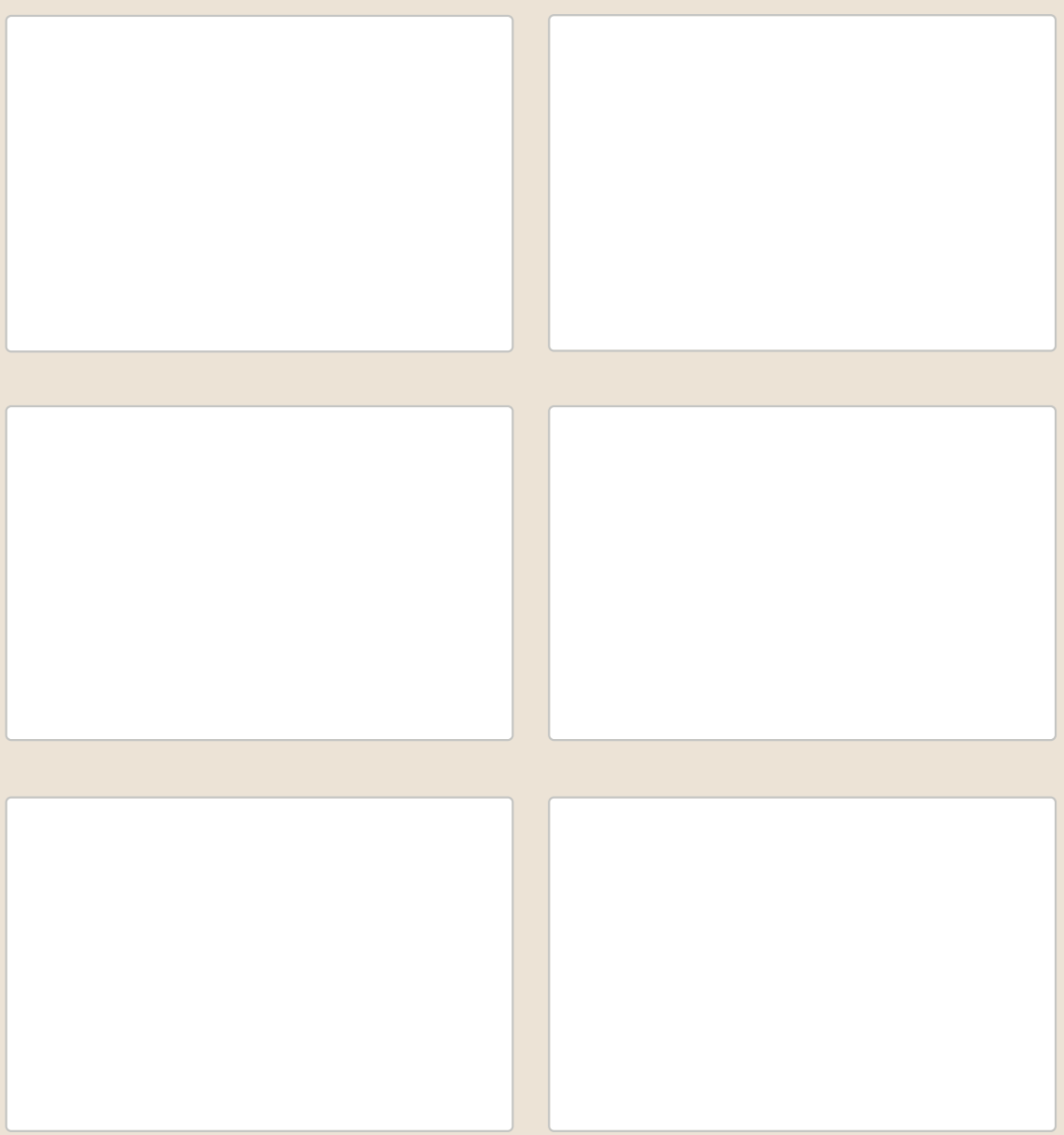

3.6. OTRAS 
La restauración y rehabilitación de la arquitectura tradicional de tierra. El caso de Aragón

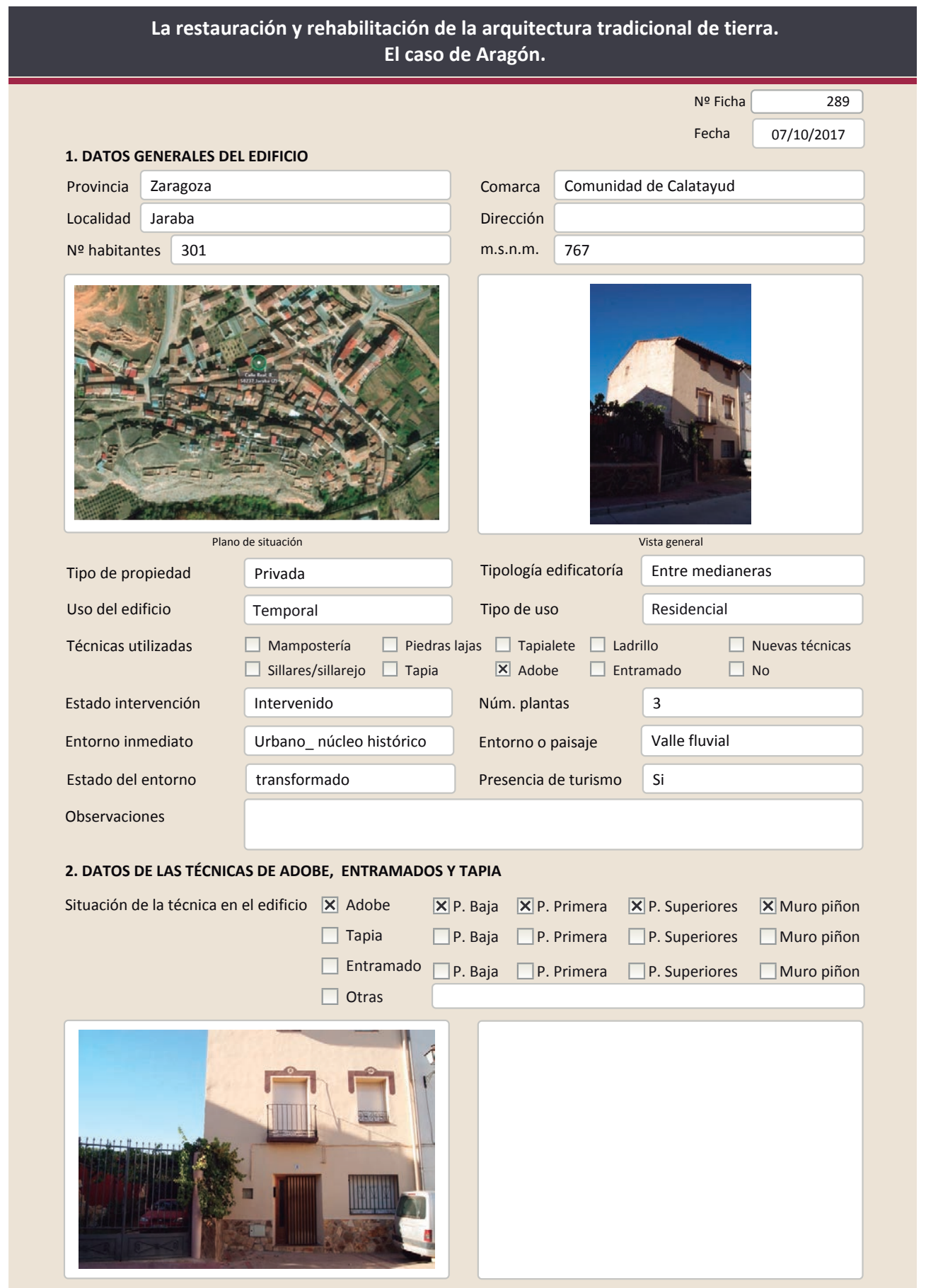

2.1. ADOBE

Dimensión de las piezas Dimensión del muro

Aparejo del muro

Función estructural

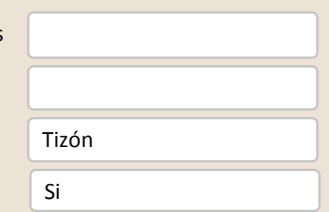

Color de las piezas

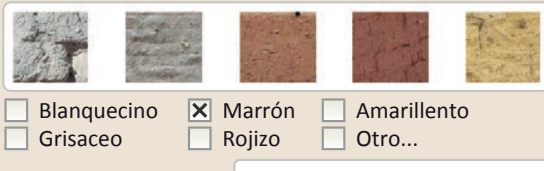

Grisaceo

Variante constructiva/ tipo de fábrica

区 Simple

$\square$ Suplementada en juntas

$\square$ Mixta

$\square$ Como suplemento

$\square$ Elementos de protección

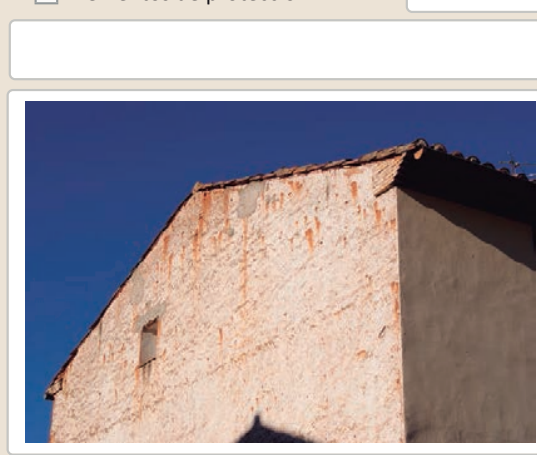

Lesiones $\quad \mathbf{X}$ Muro $\square$ Zócalo $\square$ Revestimiento

$\mathbf{X}$ Erosión del material $\square$ Humedad por capilaridad

$\square$ Erosion de las juntas $\square$ Humedades (manch/eflo)

$\square$ Pérdida de sección

$\square$ Pérdida de verticalidad

$\square$ Grietas por asentamiento

$\square$ Vegetación

$\square$ Grietas por empuje de la cubir

$\square$ Colapso

$\begin{array}{lll}\square \text { Vegetación } & \square \text { Grietas por empuje de la cubierta } & \square \text { Derivado } \\ \square \text { Desconchados } & \square \text { Grietas porfalta de traba } & \square \text { Otro... }\end{array}$

$\square$ Desconchados $\square$ Grietas porfalta de traba $\quad \square$ Otro...

$\square$ Por elementos impropios

$\square$ Derivado de intervenciones 
La restauración y rehabilitación de la arquitectura tradicional de tierra.

\section{El caso de Aragón.}

3. DATOS DE LA INTERVENCIÓN

$\begin{array}{llll}\text { Intervención de: } & \square \text { Mantenimiento } \quad \square \text { Rehabilitación parcial } & \square \text { Restauración } & \square \text { Demolición } \\ & \square \text { Reparación } \quad \boldsymbol{X} \text { Rehabilitación integral } & \square \text { Ampliación } \quad \square \text { Otro... } \\ \text { Reflexión previa } & \text { Intervención planificada } & \\ \text { Observaciones } & & \\ & & \end{array}$

\subsection{MUROS}

Tipo de intervención

No visible

Tipo de material

$\square$ Actualización $\square$ Reintegración $\square$ Demolición $\square$ Otro... $\square$ Consolidación $\square$ Reconstrucción $\square$ sustitución

Descripción

3.2. ZÓCALO

Tipo de intervención

Intervenido

Tipo de intervención

\ Actualización $\square$ Reintegración $\square$ Demolición $\square$ Otro...

$\square$ Consolidación $\quad \mathbf{X}$ Reconstrucción $\square$ sustitución

Descripción

Zócalo con lajas de piedra

3.3. REVESTIMIENTOS

\section{Intervenido}

Tipo de intervención

X Actualización $\square$ Reintegración $\square$ Demolición $\square$ Otro...

$\square$ Consolidación $\quad \mathbb{X}$ Reconstrucción $\square$ sustitución

Tipo de material

Descripción

No tradicional

Tipo de técnica Diferente a la existente

revestimien
los huecos

3.4. VANOS

Intervenido

Tipo de intervención $\square$ Actualización $\quad \boldsymbol{X}$ Reintegración $\square$ Demolición $\square$ Otro...

\begin{tabular}{l|l|l|l|} 
Tipo de material & No tradicional & Tipo de técnica & Diferente a la existente \\
\hline
\end{tabular}

Descripción Reintegración del contorno de los huecos y sustitución de carpinterías + persianas+ rejería

3.5. CUBIERTA

$\begin{array}{ll}\text { Tipo de intervención } & \square \text { Actualización } \quad \boldsymbol{X} \text { Reintegración } \quad \square \text { Demolición } \quad \square \text { Otro... } \\ & \square \text { consolidación } \quad \square \text { Reconstrucción } \quad \square \text { Sustitución }\end{array}$

Intervenido

\begin{tabular}{l|lll} 
Tipo de material To tradicional & Tipo de técnica Similar a la existente \\
\hline
\end{tabular}

Descripción

Reintegración de tejas con cementor

3.6. OTRAS 


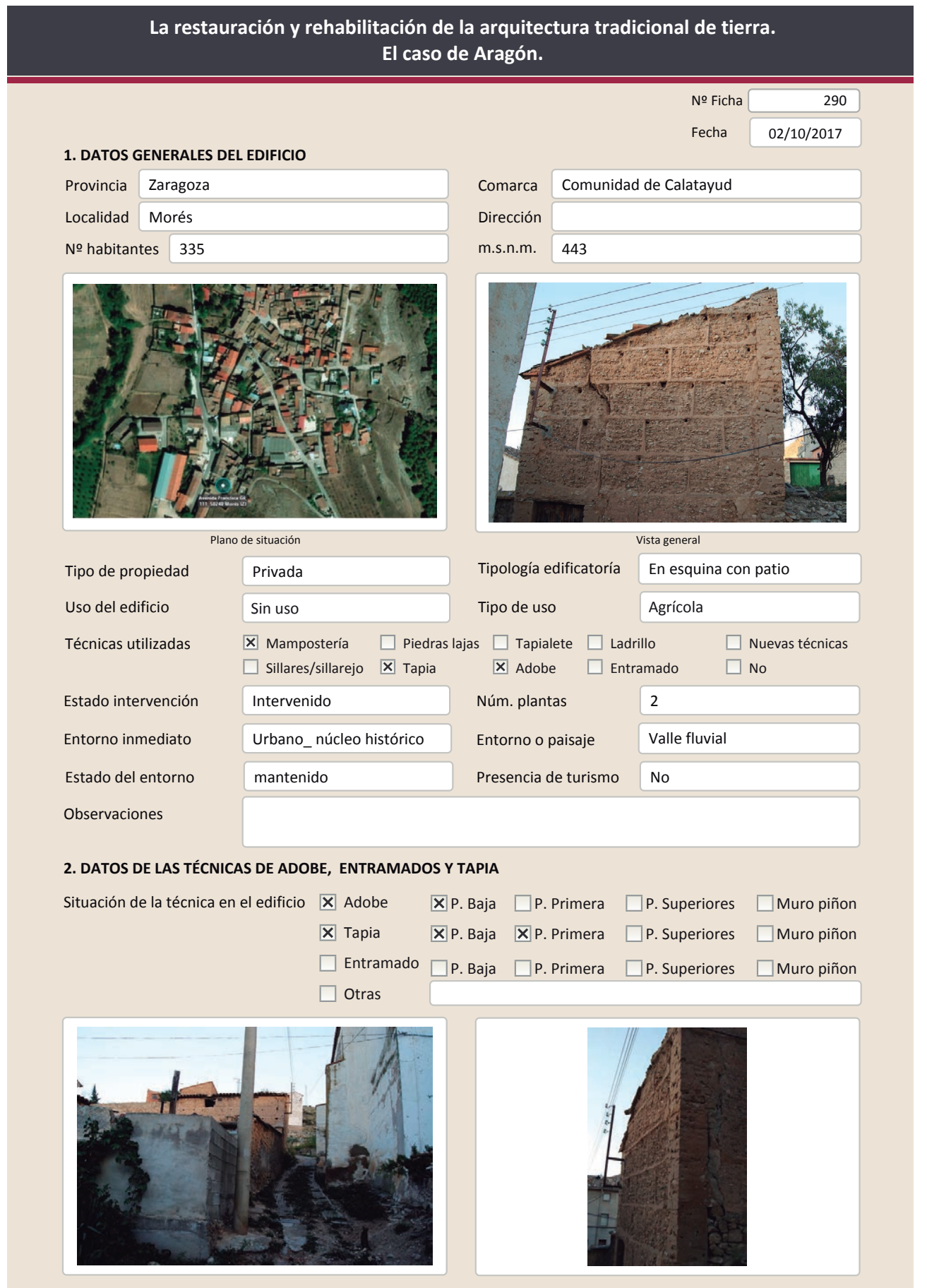

2.1. ADOBE

Dimensión de las piezas Dimensión del muro

Aparejo del muro

Función estructural

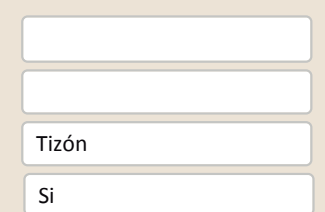

Color de las piezas

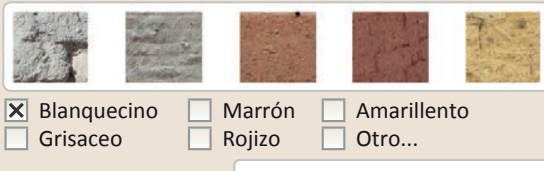

$\square$ Rojizo $\square$ Otro...

Comp. - estabilizante Aridos

Xiante constructiva/ tipo de fábrica

$\mathbf{X}$ Simple

$\square$ Suplementada en juntas

$\square$ Mixta

$\square$ Como suplemento

$\square$ Elementos de protección

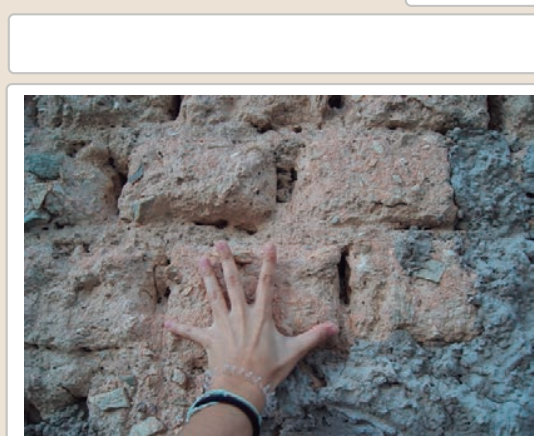

Lesiones ХMuro ХZŹcalo $\square$ Revestimiento $\square$ Cubierta $\square$ Otro...

Х Erosión del material $\quad \mathbf{X}$ Humedad por capilaridad $\quad \square$ Grietas por asentamientos $\square$ Erosion de las juntas $\square$ Humedades (manch/eflo) $\quad \square$ Colapso

X Pérdida de sección $\square$ Pérdida de verticalidad $\square$ Por elementos impropios

$\square$ Vegetación $\quad \square$ Grietas por empuje de la cubierta $\quad \square$ Derivado de intervenciones

$\square$ Desconchados $\square$ Grietas porfalta de traba $\quad \square$ Otro...

Observacione 


\section{La restauración y rehabilitación de la arquitectura tradicional de tierra.} El caso de Aragón.
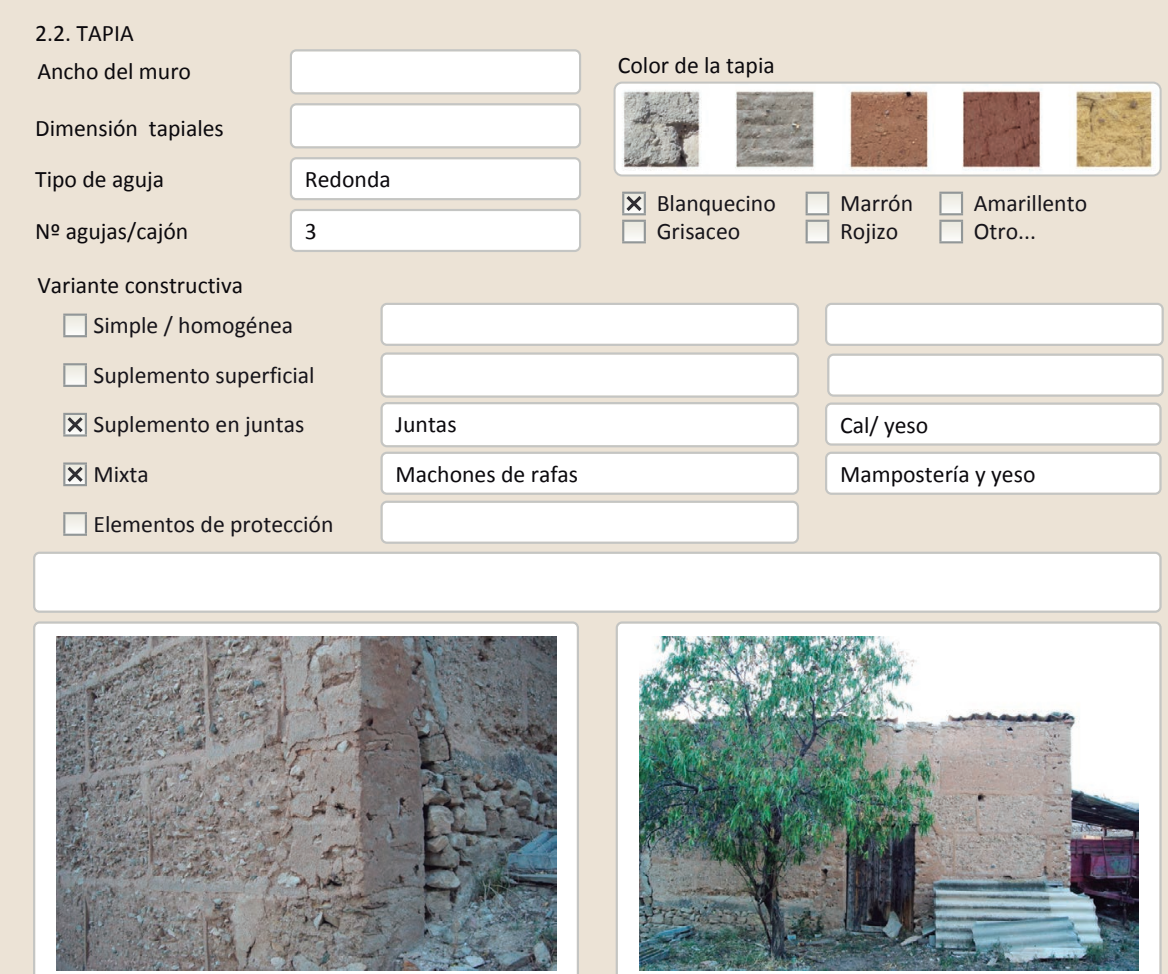

Lesiones $\quad \mathbf{X}$ Muro $\mathbf{X}$ Zócalo $\square$ Revestimiento $\square$ Cubierta $\square$ otro...

$\begin{array}{lll}\boldsymbol{X} \text { Erosión del material } & \boldsymbol{X} \text { Humedad por capilaridad } & \square \text { Grietas por asentamientos } \\ \square \text { Erosion de las juntas } & \square \text { Humedades (manch/eflo) } & \square \text { Colapso } \\ \square \text { Pérdida de sección } & \square \text { Pérdida de verticalidad } & \square \text { Por elementos impropios } \\ \square \text { Vegetación } & \square \text { Grietas por empuje de la cubierta } & \square \text { Derivado de intervenciones }\end{array}$

$\square$ Pérdida de sección $\square$ Pérdida de verticalidad

$\square$ Desconchados $\quad \square$ Grietas porfalta de traba
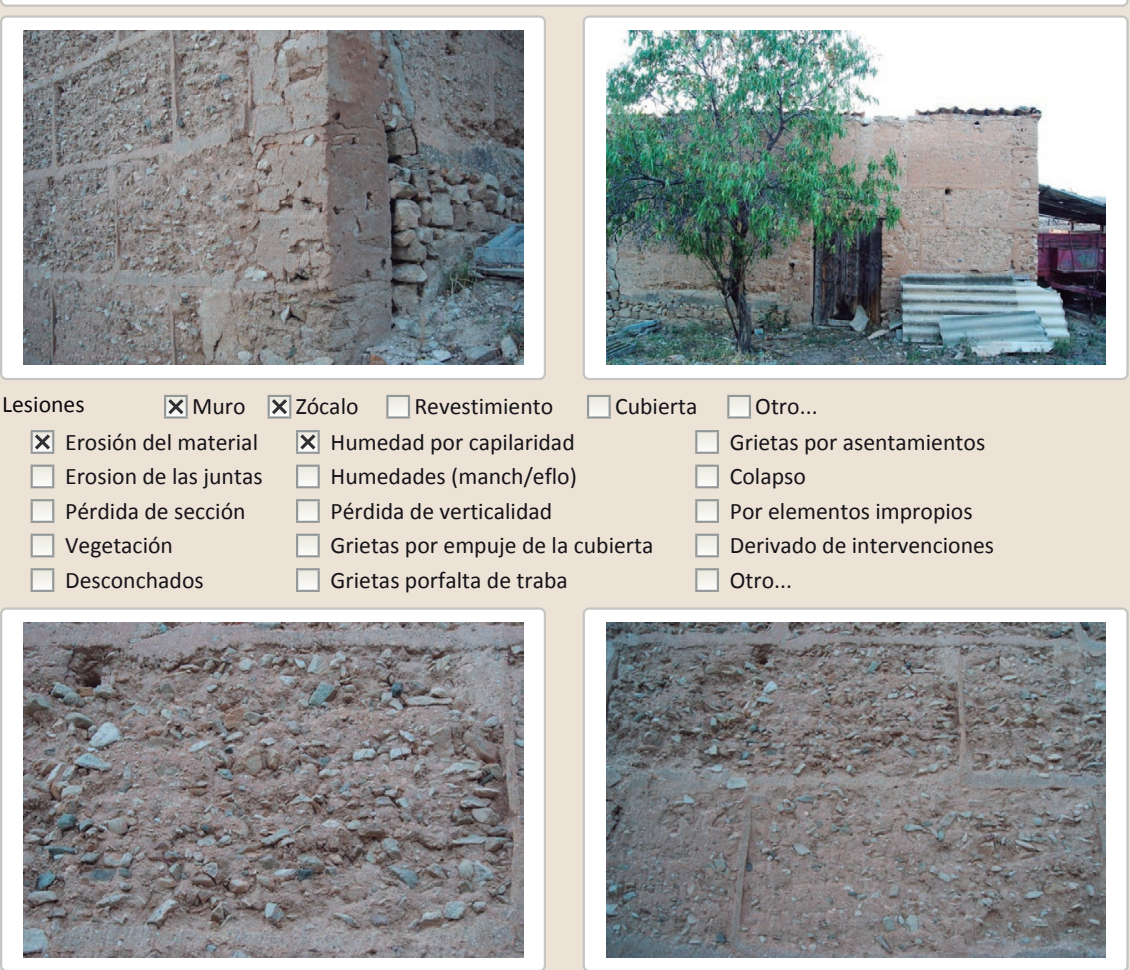

$\square$ Otro...

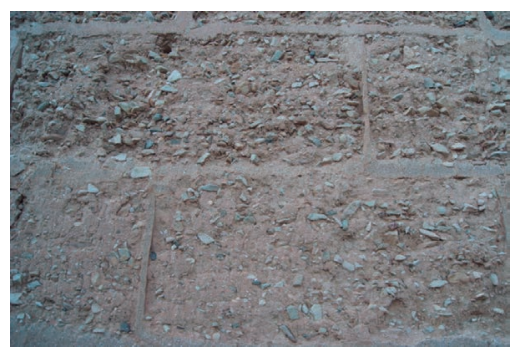

Observaciones
La restauración y rehabilitación de la arquitectura tradicional de tierra.

El caso de Aragón.

3. DATOS DE LA INTERVENCIÓN

Intervención de: $\quad \square$ Mantenimiento $\quad \square$ Rehabilitación parcial $\quad \square$ Restauración $\square$ Demolición

Reflexión previa Intervención espontanea

Observaciones

Intervención espontanea

3.1. MUROS

Tipo de intervención

Tipo de material

Intervenido

$\square$ Actualización $\quad \mathbf{X}$ Reintegración $\square$ Demolición $\square$ Otro..

$\square$ Consolidación $\square$ Reconstrucción $\square$ sustitución

Descripción

No tradicional Tipo de técnica Diferente a la existente

3.2. ZÓCALO

Pellas de mortero en las zonas más degradadas del muro de adobe

Tipo de intervención $\square$ Actualización $\quad \mathbf{X}$ Reintegración $\square$ Demolición $\square$ Otro..

$\square$ Actualización $\quad \boldsymbol{X}$ Reintegración $\quad \square$ Demolición
$\square$ Consolidación $\quad \square$ Reconstrucción $\quad \square$ Sustitución

Tipo de material

Descripción

Mortero de cemento

3.3. REVESTIMIENTOS

Tipo de intervención

\section{No aplica}

$\square$ Actualización $\square$ Reintegración $\square$ Demolición $\square$ Otro...

$\square$ Consolidación $\square$ Reconstrucción $\square$ sustitución

Tipo de material

Descripción

3.4. VANOS

Tipo de intervención

No intervenido

Tipo de material

$\square$ Actualización $\quad \square$ Reintegración $\square$ Demolición $\square$ Otro...

$\square$ Consolidación $\square$ Reconstrucción $\square$ Sustitución

Descripción

$$
\text { Tipo de técnica }
$$

3.5. CUBIERTA

No intervenido

Tipo de intervención

$\square$ Actualización $\quad \square$ Reintegración $\quad \square$ Demolición
$\square$ Consolidación $\quad \square$ Reconstrucción $\quad \square$ Sustitución

Tipo de material

Descripción

$$
\text { Tipo de técnica }
$$

3.6. OTRAS 


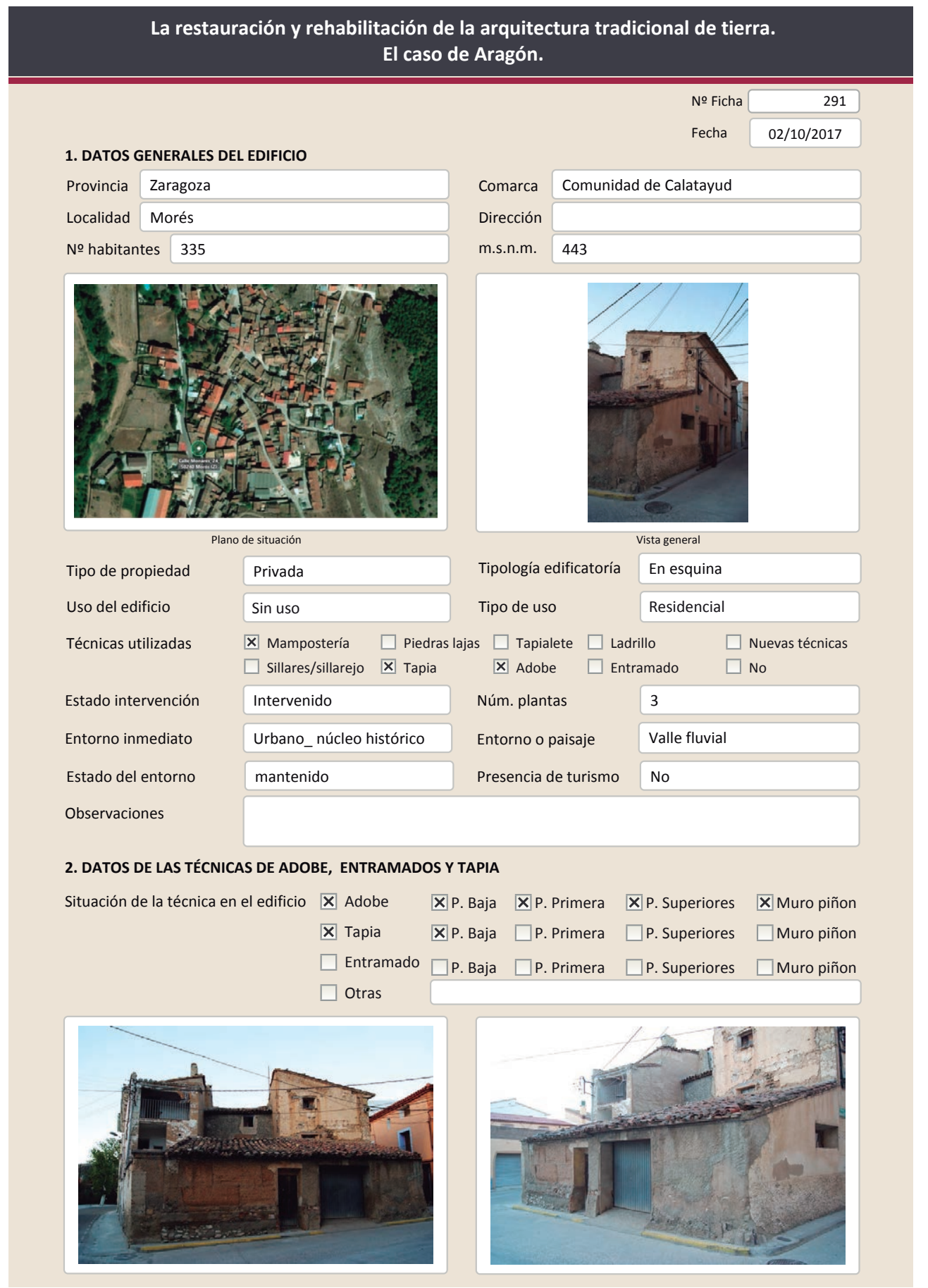

2.1. ADOBE

Dimensión de las piezas

Dimensión del muro

Aparejo del muro

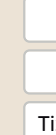

Función estructural
Color de las piezas

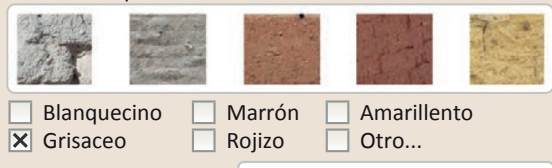

x Grisaceo $\square$ Rojizo $\square$ Omaril

Comp. - estabilizante

Variante constructiva/ tipo de fábrica
$\square$ Simple
区 Suplementada en juntas
Verticales $\mathrm{y}$ horizontales
区 Mixta
En esquinas
$\square$ Como suplemento
$\square$ Elementos de protección

$\mathrm{Cal} /$ yeso

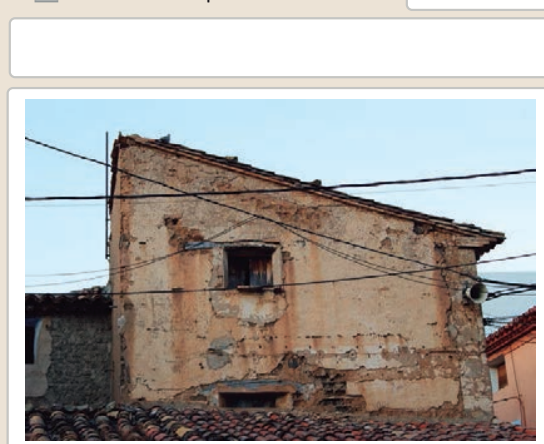

Lesiones $\mathbf{X}$ Muro $\mathbf{X}$ Zócalo $\mathbf{X}$ Revestimiento

$\mathbf{X}$ Erosión del material $\mathbf{X}$ Humedad por capilaridad

$\square$ Erosion de las juntas $\mathbf{X}$ Humedades (manch/eflo)

X Pérdida de sección $\square$ Pérdida de verticalidad

$\begin{array}{ll}\square \text { Vegetación } & \square \text { Grietas por empuje de la c } \\ \square \text { Desconchados } & \square \text { Grietas porfalta de traba }\end{array}$

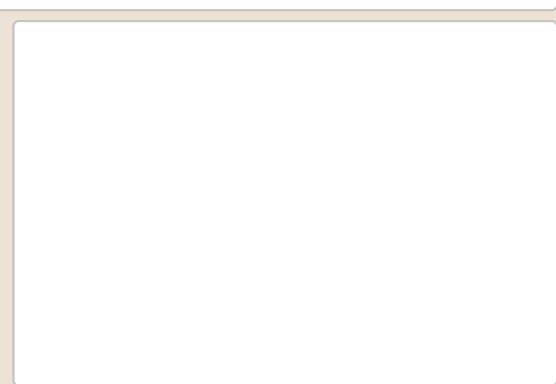

$\begin{aligned} \square \text { Cubierta } & \square \text { otro... } \\ & \square \text { Grietas por asentamientos } \\ & \square \text { Colapso } \\ & \square \text { Por elementos impropios } \\ & \square \text { Derivado de intervenciones } \\ & \square \text { Otro... }\end{aligned}$

Observaciones 
La restauración y rehabilitación de la arquitectura tradicional de tierra. El caso de Aragón.
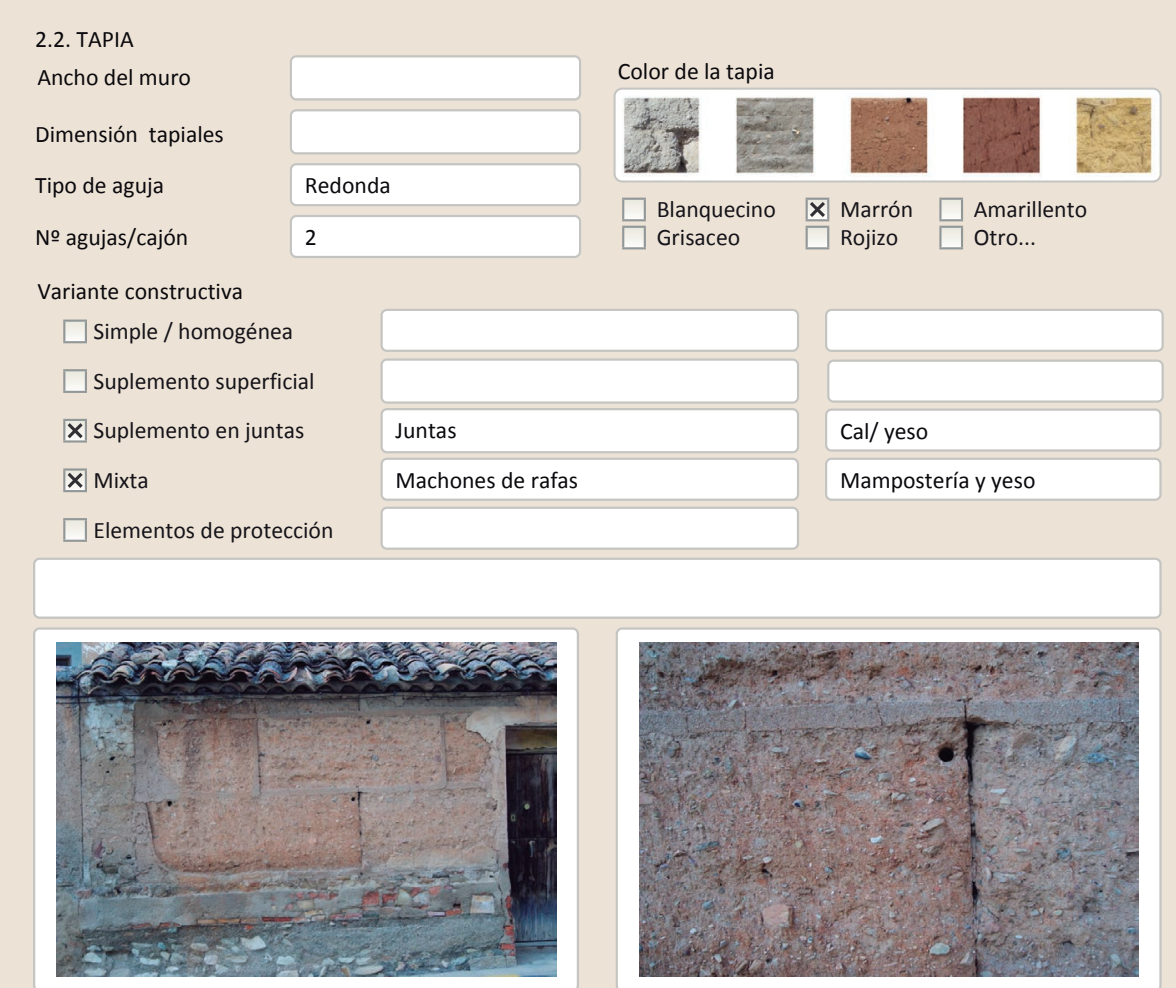

Lesiones \Muro XZócalo $\square$ Revestimiento $\square$ Cubierta $\square$ Otro...
$\mathbf{X}$ Erosión del material $\mathbf{X}$ Humedad por capilaridad
$\square$ Grietas po
$\square$ Erosion de las juntas $\mathbf{X}$ Humedades (manch/eflo)
$\square$ Pérdida de sección $\quad \square$ Pérdida de verticalidad
$\square$ Colapso
$\square$ Por elementos impropios
$\square$ Derivado de intevencions

$\begin{array}{ll}\square \text { Vegetación } & \square \text { Grietas por empuje de la } \\ \square \text { Desconchados } \quad \square \text { Grietas porfalta de traba }\end{array}$

$\square$ Otro...
La restauración y rehabilitación de la arquitectura tradicional de tierra.

El caso de Aragón.

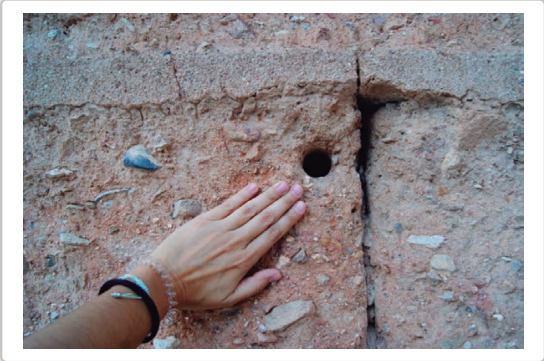

3. DATOS DE LA INTERVENCIÓN

Intervención de: $\quad \square$ Mantenimiento $\square$ Rehabilitación parcial $\square$ Restauración $\square$ Q $\square$ Demolicón X Reparación $\quad \square$ Rehabilitación integral $\quad \square$ Ampliación $\quad \square$ Otro...

Reflexión previa Intervención espontanea

Observaciones

Intervención espontanea

3.1. MUROS

Tipo de intervención

Tipo de material

Descripción

3.2. ZÓCALO

Tipo de intervención

Tipo de material

Descripción

3.3. REVESTIMIENTOS

Tipo de intervención

Tipo de material

Descripción

3.4. VANOS

Tipo de intervención

Tipo de material

Descripción

3.5. CUBIERTA

Tipo de intervención

Tipo de material

Descripción

3.6. OTRAS

\section{Intervenido}

$\square$ Actualización $\quad \mathbf{X}$ Reintegración $\square$ Demolición $\square$ Otro..

$\square$ Consolidación $\quad \square$ Reconstrucción $\square$ sustitución

\begin{tabular}{l|l|l|l|l} 
No tradicional & Tipo de técnica Diferente a la existente
\end{tabular}

pellas de mortero en las zona degradadas

Intervenido

$\square$ Actualización $\square$ Reintegración $\square$ Demolición $\square$ Otro.

$\square$ Consolidación $\quad \mathbf{X}$ Reconstrucción $\square$ Sustitución

No tradicional Tipo de técnica Diferente a la existente

Zócalo de ladrillo hueco revestido con mortero de cemento

Intervenido

$\square$ Actualización $\square$ Reintegración $\square$ Demolición $\square$ Otro...

$\square$ Consolidación $\quad \mathbf{X}$ Reconstrucción $\square$ Sustitución

No tradicional Tipo de técnica Diferente a la existente

Revestimiento parcial con cemento en la planta baja del edificio

Intervenido

$\square$ Actualización $\square$ Reintegración $\square$ Demolición $\square$ Otro..

$\square$ Consolidación $\mathbf{x}$ Reconstrucción $\mathbf{x}$ Sustitución

\begin{tabular}{l|l|l} 
No tradicional & Tipo de técnica & Diferente a la existente
\end{tabular}

Ampliación del hueco en planta baja para permitir el acceso a vehículos y sustitución de la carpitnerí

No intervenido

$\square$ Actualización $\square$ Reintegración $\quad \square$ Demolición $\square$ Otro

$\square$ consolidación $\square$ Reconstrucción $\square$ Sustitución Tipo de técnica

Observaciones 


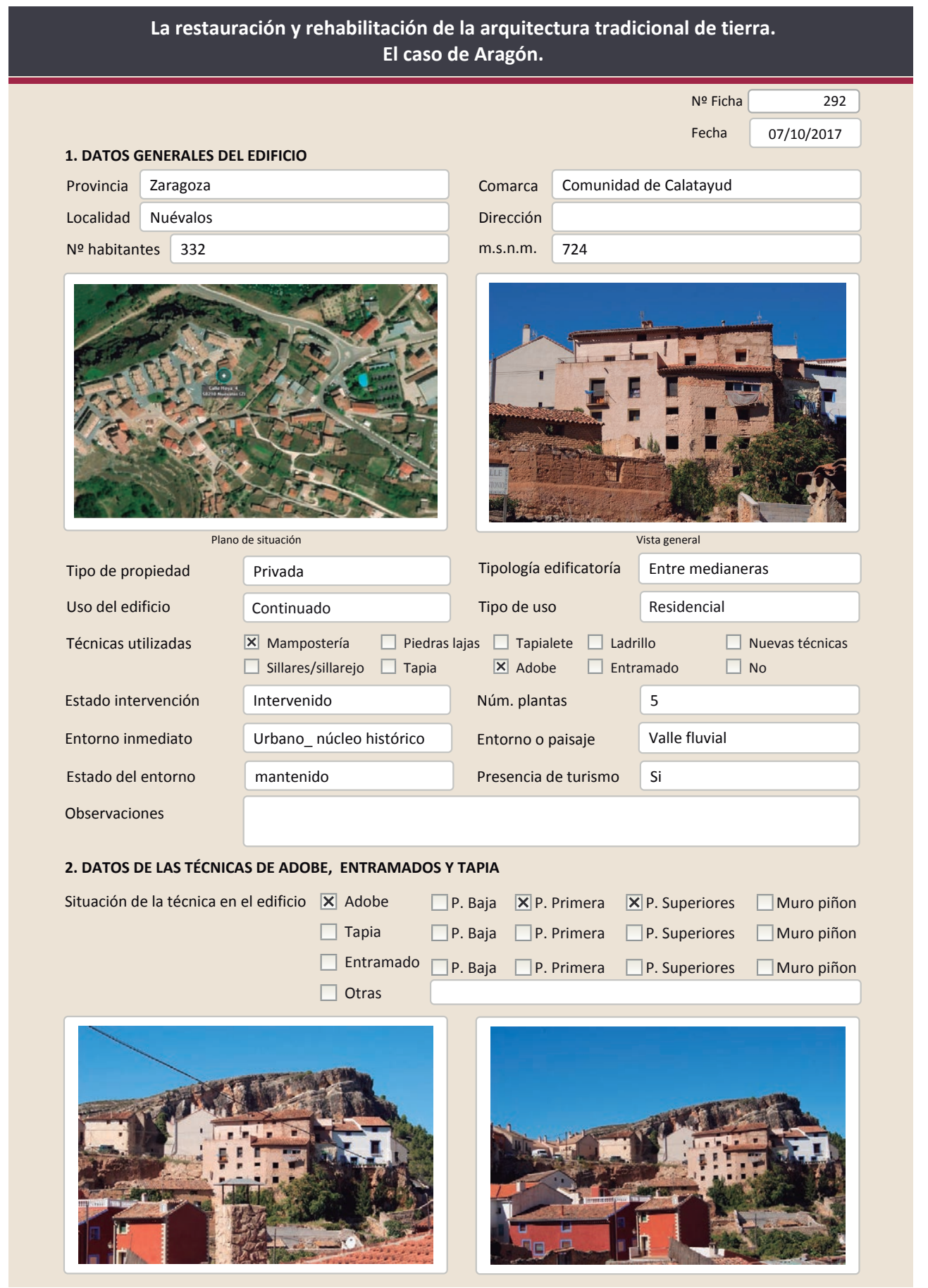

2.1. ADOBE

Dimensión de las piezas Dimensión del muro

Aparejo del muro

Función estructural

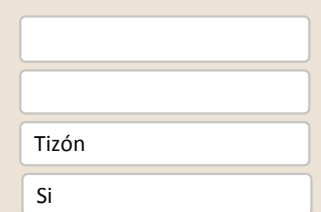

Color de las piezas

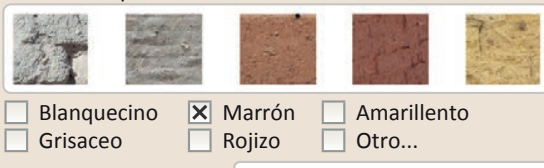

Comp. - estabilizante

Variante constructiva/ tipo de fábrica

$\square$ Simple

$\square$ Suplementada en juntas

区 Mixta

En esquina

Piedra

$\square$ Como suplemento

$\square$ Elementos de protección

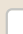

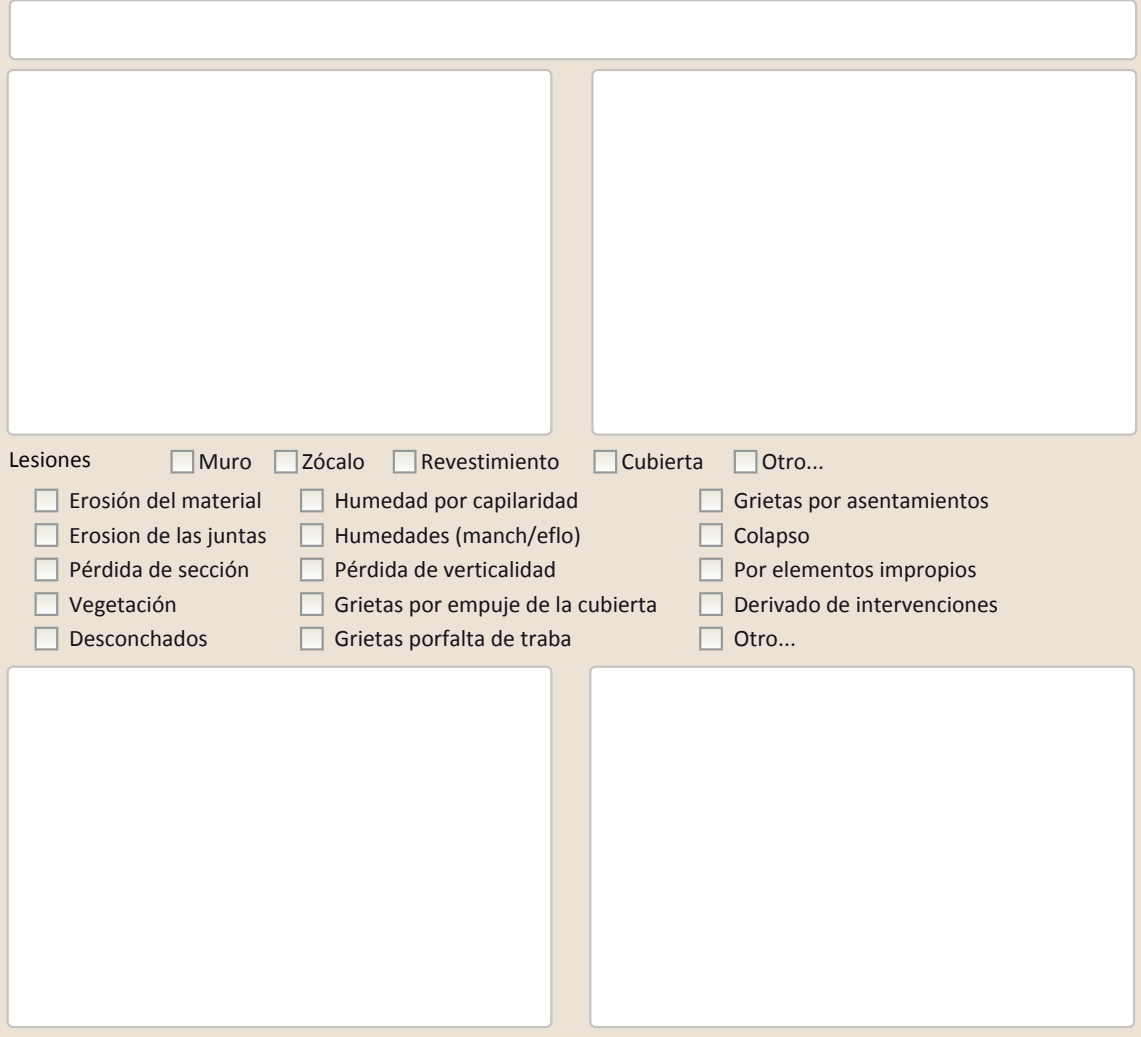

Observaciones 


\section{La restauración y rehabilitación de la arquitectura tradicional de tierra.}

\section{El caso de Aragón.}

3. DATOS DE LA INTERVENCIÓN

Intervención de:

$\square$ Mantenimie

Reflexión previa

$\square$ Reparación

$\square$ Rehabilitación parcial

$\square$ Restauración $\square$ Demolición

Intervención planificada

Observaciones

(2)

3.1. MUROS
Tipo de intervención

Intervenido

Tipo de material

$\square$ Actualización $\square$ Reintegración $\quad \square$ Demolición $\square$ Otro...

$\square$ Consolidación $\quad \mathbb{\text { Reconstrucción }} \square$ Sustitución

Descripción

No tradicional

Tipo de técnica Diferente a la existente

3.2. ZÓCALO Recrecido de los muros en planta cuarta para conformar la cubierta plana - terraza

Tipo de intervención

Tipo de material

Descripción

3.3. REVESTIMIENTOS

Tipo de intervención

Tipo de material

Descripción

3.4. VANOS

Tipo de intervención

Tipo de material

Descripción

3.5. CUBIERTA

Tipo de intervención

Tipo de material

Descripción

\section{No visible}

$\square$ Actualización $\square$ Reintegración $\square$ Demolición $\square$ Otro...

$\square$ consolidación $\quad \square$ Reconstrucción $\quad \square$ Sustitución

\section{Intervenido}

X Actualización $\square$ Reintegración $\square$ Demolición $\square$ Otro...

$\square$ Consolidación $\quad \mathbf{X}$ Reconstrucción $\square$ Sustitución

No tradicional Tipo de técnica Diferente a la existente

Revestimiento con tonalidades que buscan la integración en el entorno

\section{Intervenido}

$\square$ Actualización $\square$ Reintegración $\square$ Demolición $\square$ Otro...

$\square$ Consolidación $\square$ Reconstrucción $\quad$ X Sustitución

No tradicional Tipo de técnica Diferente a la existente

Sustitución de carpinterías

\section{Intervenido}

$\square$ Actualización $\quad \boldsymbol{X}$ Reintegración $\square$ Demolición $\quad \square$ Otro...

$\square$ Consolidación $\square$ Reconstrucción $\quad \mathbf{x}$ Sustitución

No tradicional Tipo de técnica Diferente a la existente

Sustitución de parte de la cubierta por una cubierta plana y reintegración de la zona superior de cubierta con cemento
La restauración y rehabilitación de la arquitectura tradicional de tierra.

El caso de Aragón.

3.7. REHABILITACIÓN ENERGÉTICA $\square$ Fachada $\quad$ V Vanos $\square$ Forjados $\square$ Cubierta

Observaciones

FOTOGRAFíAS DE LA INTERVENCIÓN
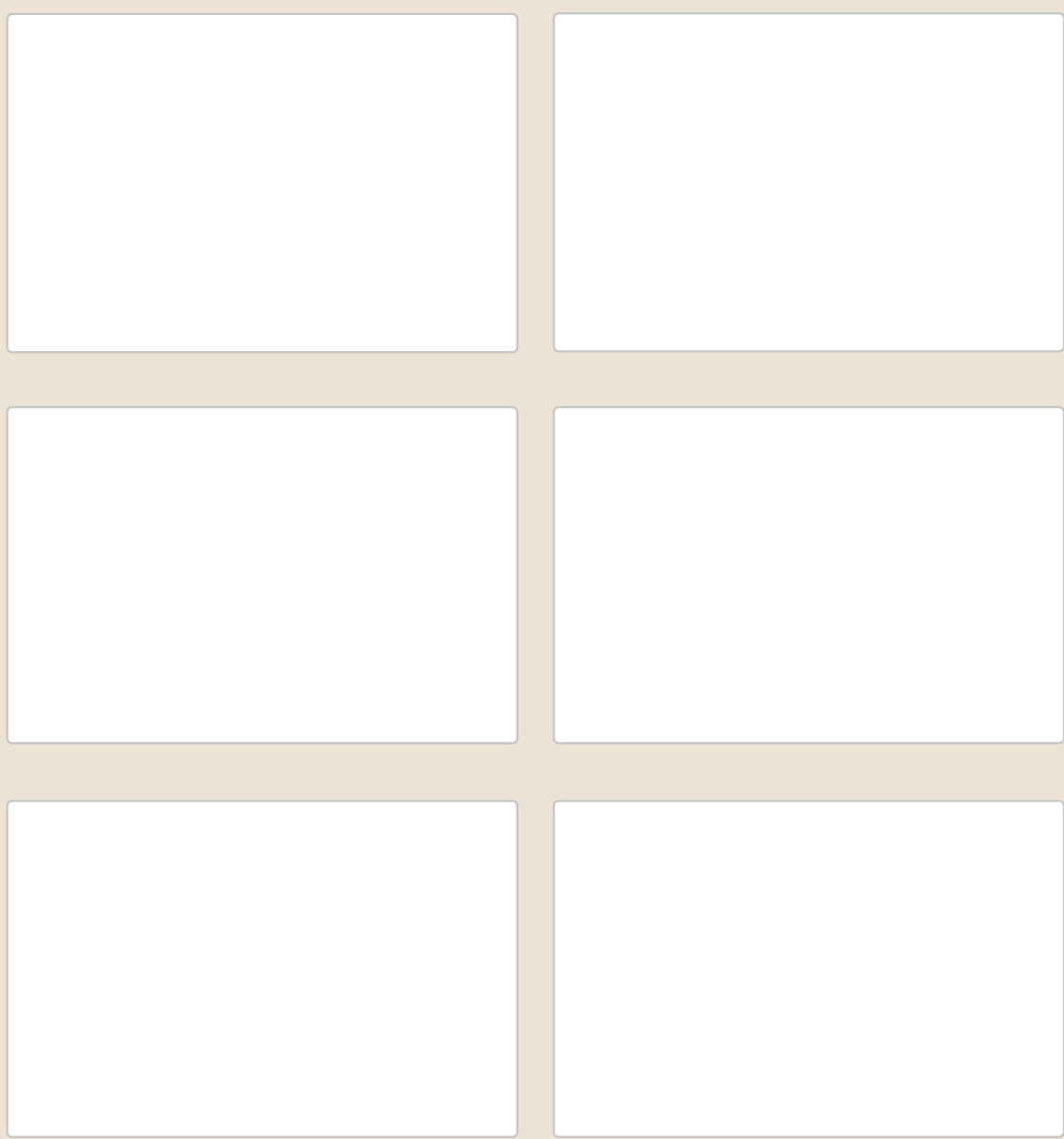
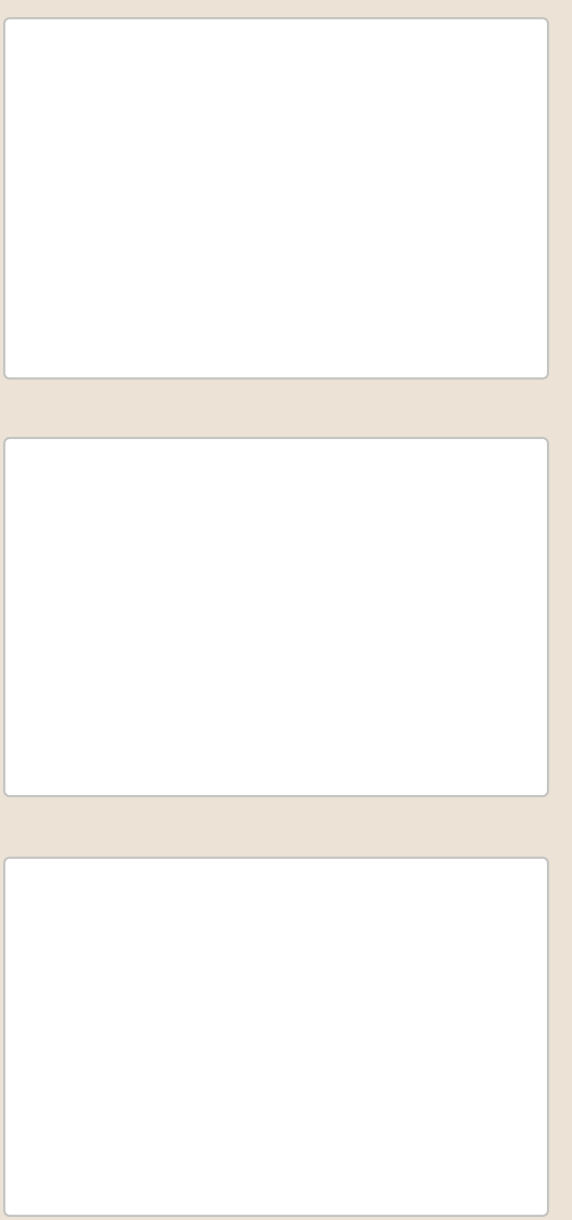

3.6. OTRAS 


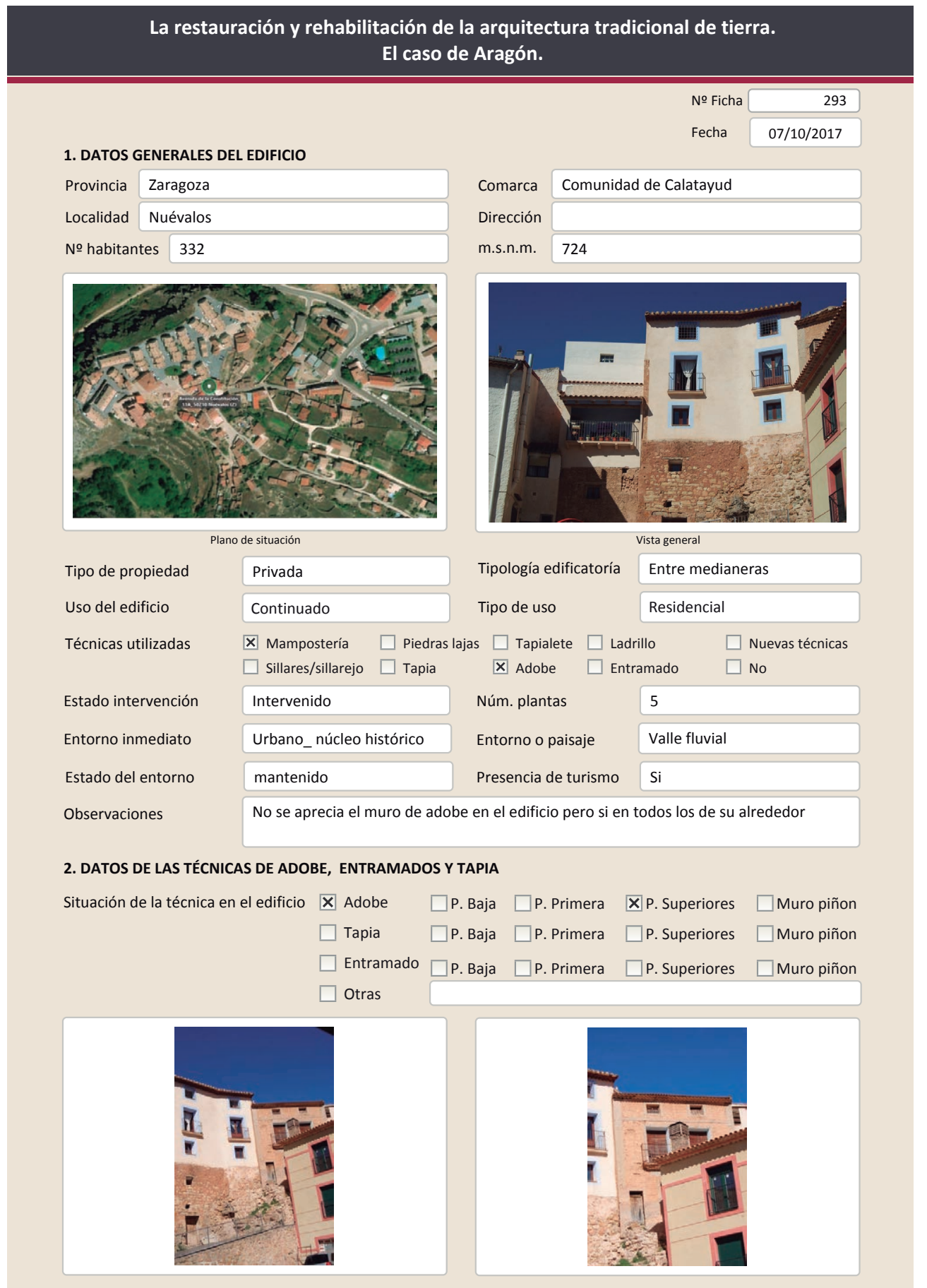

2.1. ADOBE

Dimensión de las piezas Dimensión del muro

Aparejo del muro

Función estructural

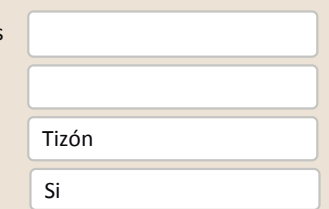

Color de las piezas

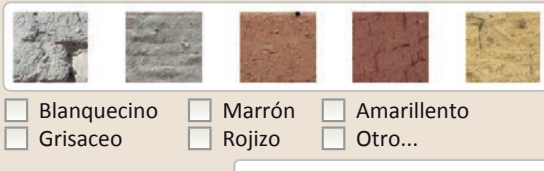

Grisaceo

$\square$ Rojizo $\square$ Otro..

Variante constructiva/ tipo de fábrica

$\square$ simple

$\square$ Suplementada en juntas

$\square$ Mixta

$\square$ Como suplemento

$\square$ Elementos de protección

Observaciones 


\section{La restauración y rehabilitación de la arquitectura tradicional de tierra.}

\section{El caso de Aragón.}

3. DATOS DE LA INTERVENCIÓN

Intervención de:

$\square$ Mantenimie

Reflexión previa

Rehabilitación parcial 区 Rehabilitación integral

Intervención planificada

Observaciones

Intervención planificada

3.1. MUROS
Tipo de intervención

No visible

Tipo de material

Descripción

3.2. ZÓCALO

Tipo de intervención

Tipo de material

Descripción

3.3. REVESTIMIENTOS

Tipo de intervención

Tipo de material

Descripción

3.4. VANOS

Tipo de intervención

Tipo de material

Descripción

3.5. CUBIERTA

Tipo de intervención

Tipo de material

Descripción

$\square$ Actualización $\square$ Reintegración $\square$ Demolición $\square$ Otro...

$\square$ Consolidación $\square$ Reconstrucción $\square$ sustitución

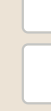

No intervenido

$\square$ Actualización $\quad \square$ Reintegración $\quad \square$ Demolición $\square$ Otro...

$\square$ consolidación $\quad \square$ Reconstrucción $\square$ Sustitución

\section{Intervenido}

X Actualización $\square$ Reintegración $\square$ Demolición $\square$ Otro...

$\square$ Consolidación $\quad \mathbf{X}$ Reconstrucción $\square$ sustitución

No tradicional Tipo de técnica Diferente a la existente

Nuevo revestimiento pintado de beige y contorno azul en los huecos

Intervenido

$\square$ Actualización $\quad \boldsymbol{X}$ Reintegración $\square$ Demolición $\square$ Otro...

$\square$ Consolidación $\square$ Reconstrucción $\mathbf{X}$ Sustitución

No tradicional Tipo de técnica Diferente a la existente

Reintegración del contorno de los huecos y sustitución de todas las carpinterías

\section{Intervenido}

$\square$ Actualización $\square$ Reintegración $\square$ Demolición $\square$ Otro...

$\square$ Consolidación $\quad$ Xeconstrucción $\square$ Sustitución

3.6. OTRAS

Reconstrucción de la cubierta con los elementos tradicionales y cemento
La restauración y rehabilitación de la arquitectura tradicional de tierra.

El caso de Aragón.

3.7. REHABILITACIÓN ENERGÉTICA $\square$ Fachada $\quad \boldsymbol{X}$ Vanos $\square$ Forjados $\mathbf{X}$ Cubierta

Observaciones

FOTOGRAFÍAS DE LA INTERVENCIÓN
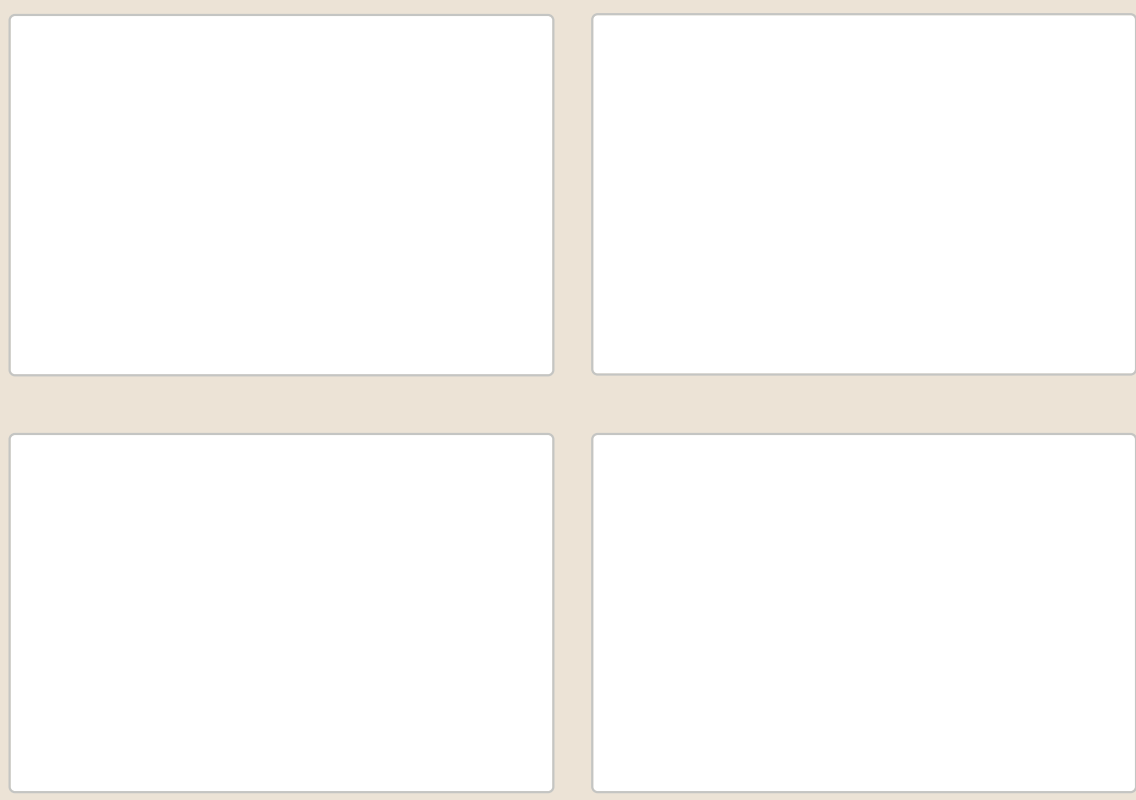


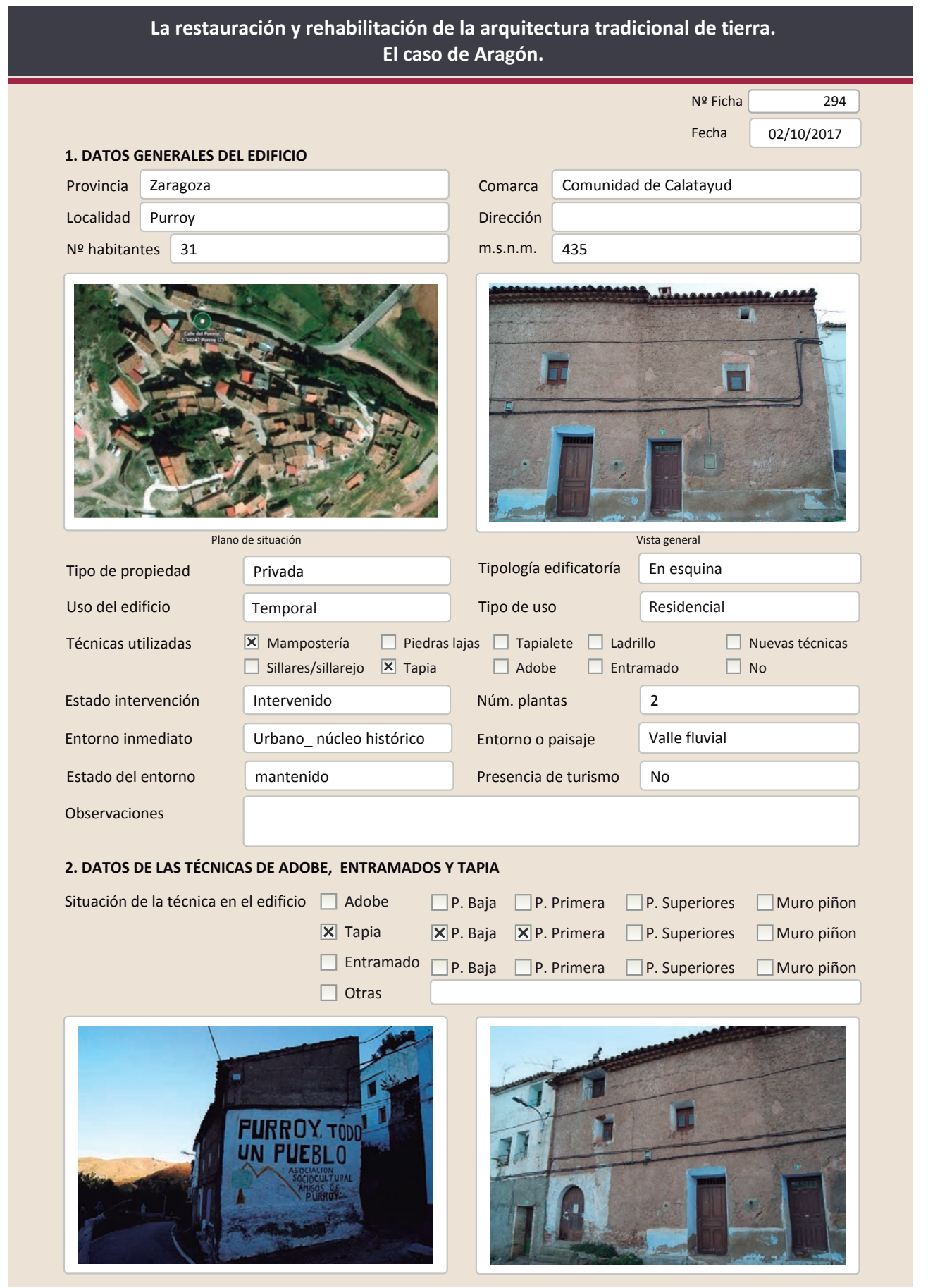

2.2. TAPIA

Ancho del muro

Dimensión tapiales

Tipo de aguja

№ agujas/cajón

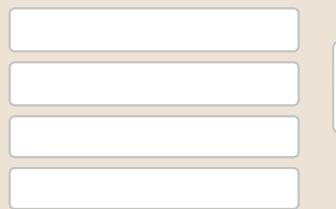

Color de la tapia

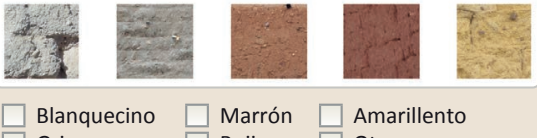

$\square$ Blanquecino $\square$ Marrón $\square$ Amarillento

Variante constructiva

$\square$ Simple / homogénea

$\mathbf{X}$ Suplemento superficial

Х Suplemento en juntas

X Mixta

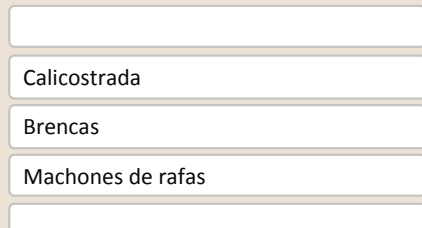

Cal/ yeso

$\mathrm{Cal} /$ yeso

Mampostería y yeso

$\square$ Elementos de protección

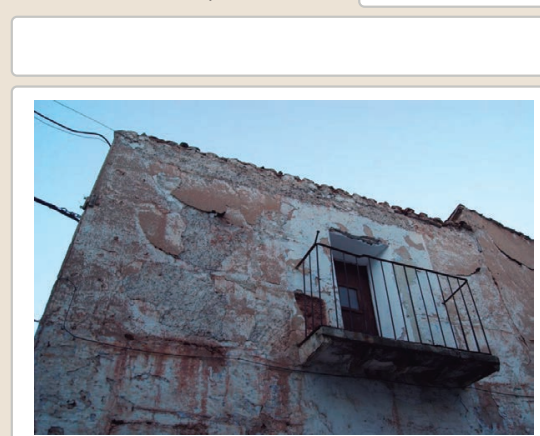

Lesiones ХMuro XZócalo X Revestimiento

$\mathbf{X}$ Erosión del material $\mathbf{X}$ Humedad por capilaridad $\square$ Erosion de las juntas $\mathbf{X}$ Humedades (manch/eflo)

$\square$ Pérdida de sección $\quad \square$ Pérdida de verticalidad

$\square$ Vegetación

X Desconchados

$\square$ Grietas porfalta de trab

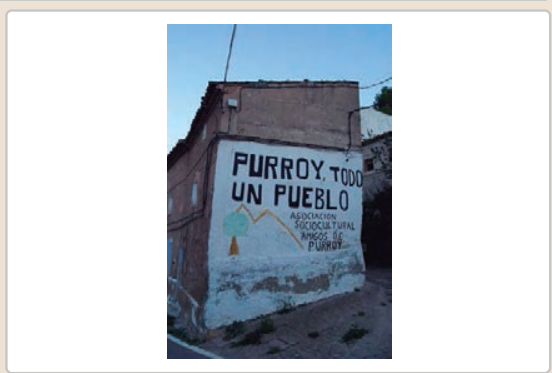

$\square$ Cubierta $\square$ Otro...

Grietas por asentamiento $\square$ Colapso

$\square$ Por elementos impropios

Yrome

|

$\square$ Otro...
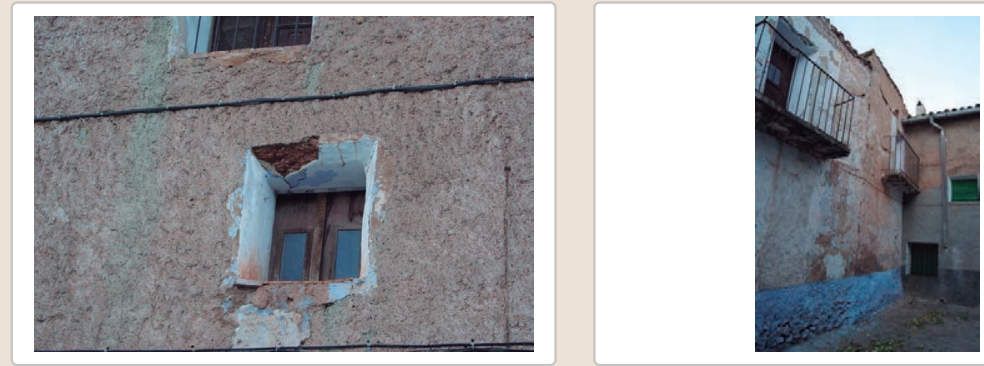

Observaciones 
La restauración y rehabilitación de la arquitectura tradicional de tierra.

El caso de Aragón.

3. DATOS DE LA INTERVENCIÓN

\begin{tabular}{llll|} 
Intervención de: & $\square$ Mantenimiento $\quad \square$ Rehabilitación parcial & $\square$ Restauración $\quad \square$ Demolición \\
Reflexión previa & $\mathbf{X}$ Reparación $\quad \square$ Rehabilitación integral $\quad \square$ Ampliación $\quad \square$ Otro... \\
\hline Observaciones & Intervención espontanea & \\
& & \\
& & \\
\end{tabular}

\subsection{MUROS}

Tipo de intervención

No visible

Tipo de material

$\square$ Actualización $\square$ Reintegración $\square$ Demolición $\square$ Otro... $\square$ Consolidación $\square$ Reconstrucción $\square$ sustitución

Descripción

3.2. ZÓCALO

Tipo de intervención

Intervenido

Tipo de material

X Actualizació

Descripción

Tipo de técnica Diferente a la existente

3.3. REVESTIMIENTOS

Zocalo con capa gruesa de mortero de cemento

Tipo de intervención

Intervenido

Tipo dematenta

X Actualización

$\square$ Reintegración $\square$ Demolición $\square$ Otro...

Tipo de materia

No tradicional

$\mathbf{X}$ Reconstrucción $\square$ Sustitución

Descripción

revestimiento de cemento rugoso en la fachada delantera

3.4. VANOS

No intervenido

Tipo de intervención

$\square$ Actualización $\square$ Reintegración $\square$ Demolición $\square$ Otro...

Tipo de material

Descripción

$\square$ Consolidación $\quad \square$ Reconstrucción $\square$ sustitución

3.5. CUBIERTA

Tipo de intervención

No intervenido

Actualización $\quad \square$ Reintegración $\quad \square$ Demolición $\quad \square$ Otro.

Tipo de material

$\square$ Consolidación $\square$ Reconstrucción $\square$ Sustitución

Descripción

Tipo de técnica

3.6. OTRAS 


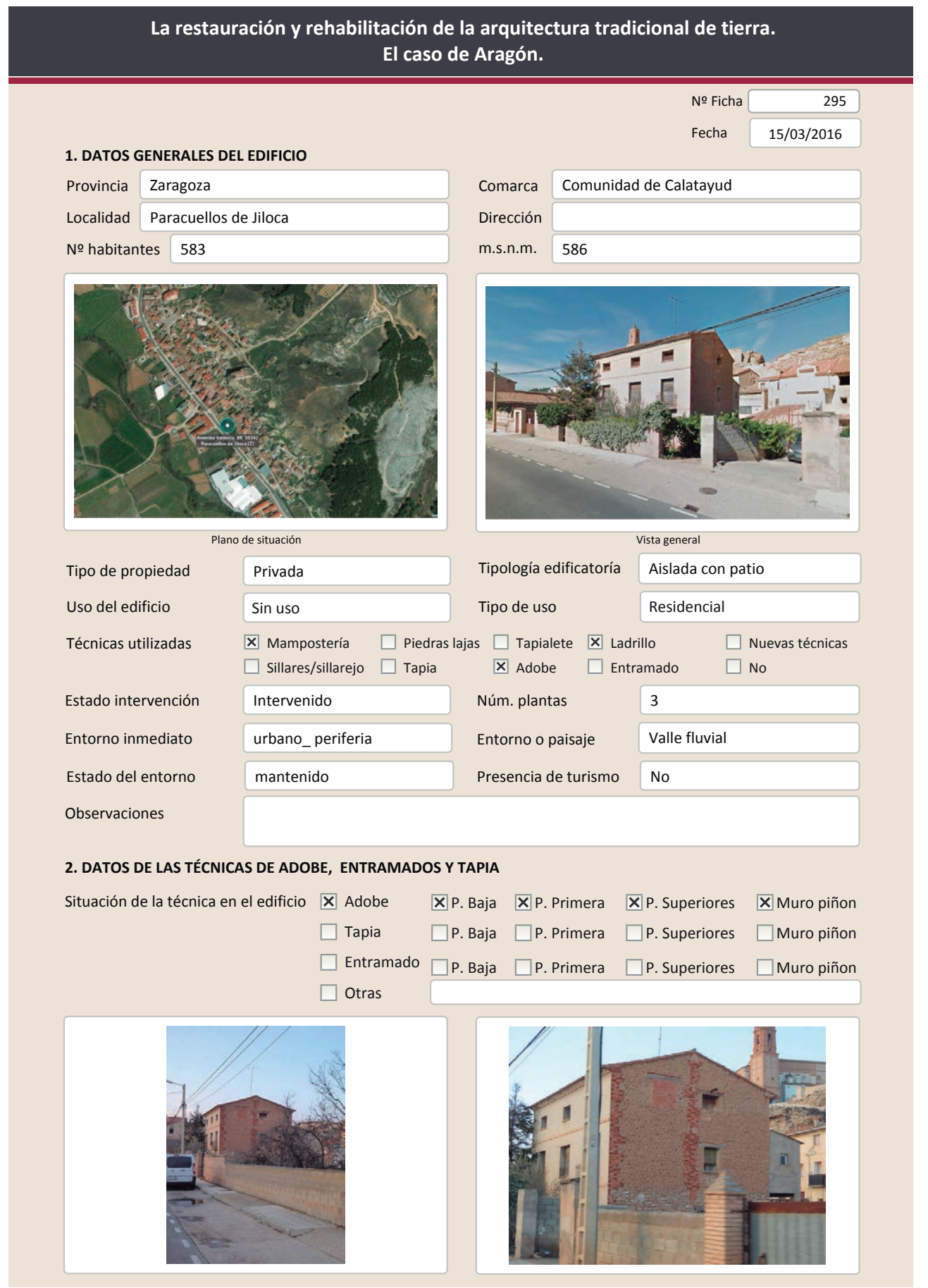

2.1. ADOBE

Dimensión de las piezas Dimensión del muro

Aparejo del muro

Función estructural

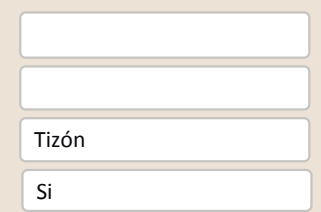

Color de las piezas

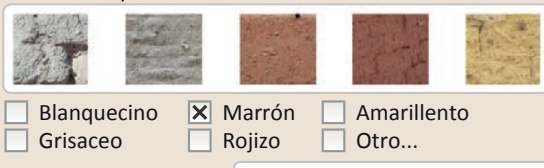

Rojizo $\square$ Otro...

Variante constructiva/ tipo de fábrica

$\square$ Simple

$\square$ Suplementada en juntas

区 Mixta

\section{Machones}

Comp. - estabilizante Fibras vegetales

$\square$ Como suplemento

$\square$ Elementos de protección

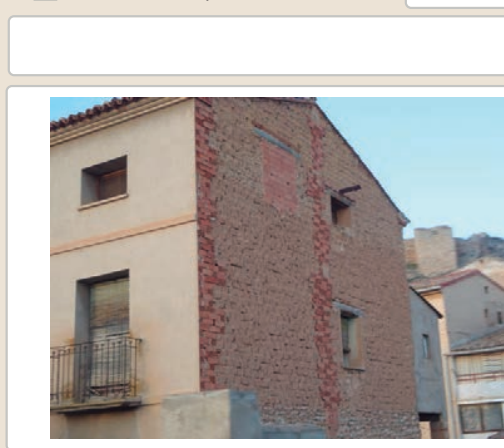

Lesiones $\quad \mathbf{X}$ Muro $\square$ Zócalo $\square$ Revestimiento

X Erosión del material $\quad \square$ Humedad por capilaridad $\mathbf{X}$ Erosion de las juntas $\square$ Humedades (manch/eflo)

$\square$ Pérdida de sección $\quad \square$ Pérdida de verticalidad

$\square$ Vegetación $\quad \square$ Grietas por empuje de la c $\square$ Grietas porfalta de traba

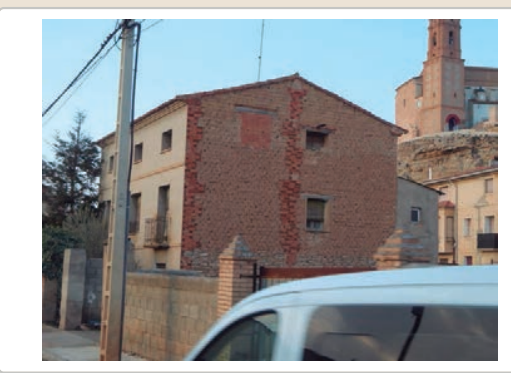

$\square$ Cubierta $\square$ Otro...

$\square$ Desconchado

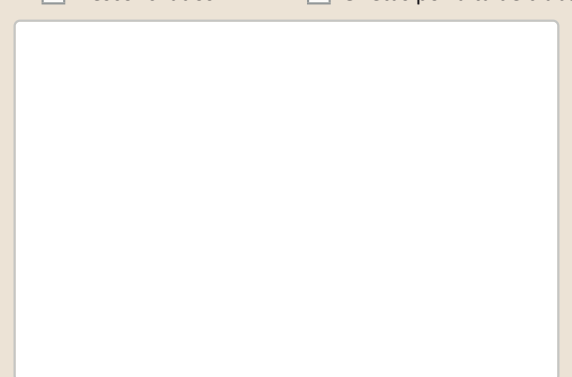

$\square$ Grietas por asentamientos $\square$ Colapso

$\square$ Por elementos impropios

$\square$ Derivado de intervenciones $\square$ Otro... 


\section{El caso de Aragón.}

3. DATOS DE LA INTERVENCIÓN

\begin{tabular}{|c|c|c|c|c|}
\hline Intervención de: & $\begin{array}{l}\square \text { Mantenimiento } \\
\mathbf{X} \text { Reparación }\end{array}$ & $\begin{array}{l}\square \text { Rehabilitación parcial } \\
\square \text { Rehabilitación integral }\end{array}$ & $\begin{array}{l}\square \text { Restauración } \\
\square \text { Ampliación }\end{array}$ & $\begin{array}{l}\square \text { Demolición } \\
\square \text { Otro... }\end{array}$ \\
\hline Reflexión previa & \multicolumn{4}{|c|}{ Intervención planificada } \\
\hline 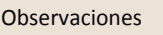 & & & & \\
\hline
\end{tabular}

\subsection{MUROS}

Tipo de intervención

Intervenido

Tipo de material

$\square$ Actualización $\square$ Reintegración $\square$ Demolición $\square$ Otro...

$\square$ Consolidación $\square$ Reconstrucción $\mathbf{X}$ Sustitución

Descripción

\begin{tabular}{l|l|l|l|l} 
No tradicional & Tipo de técnica & Similar a la existente
\end{tabular}

3.2. ZOCALO

Sustitución de piezas para conformar dos machones con ladrillo. Estos no tienen una
verticalidad clara lo que ayuda a pensar que se ha realizado a posteriori

3.2. ZÓCALO

Tipo de intervención

No visible

Tipo de material

$\square$ Actualización $\quad \square$ Reintegración $\quad \square$ Demolición $\quad \square$ Otro...

$\square$ Consolidación $\square$ Reconstrucción $\square$ sustitución

Descripción

3.3. REVESTIMIENTOS

Tipo de intervención

Intervenido

Tipo de material

X Actualización

Tipo de material

$\square$ Consolidación

Tipo de técnica

Descripción

Revestimiento de la fachada principal

3.4. VANOS

Intervenido

Tipo de intervención

$\square$ Actualización $\quad \square$ Reintegración $\quad \square$ Demolición $\square$ Otro...

Tipo de material

$\square$ Consolidación $\square$ Reconstrucción $\quad \boldsymbol{x}$ Sustitución

Descripción

No tradicional

Tipo de técnica Diferente a la existente

3.5. CUBIERTA

Tipo de intervención

No visible

Tipo de intervención

$\square$ Actualización $\square$ Reintegración $\square$ Demolición $\square$ Otro...

Tipo de mate

$\square$ Reconstrucción $\square$ Sustitución

Descripción

Tipo de técnica

3.6. OTRAS 


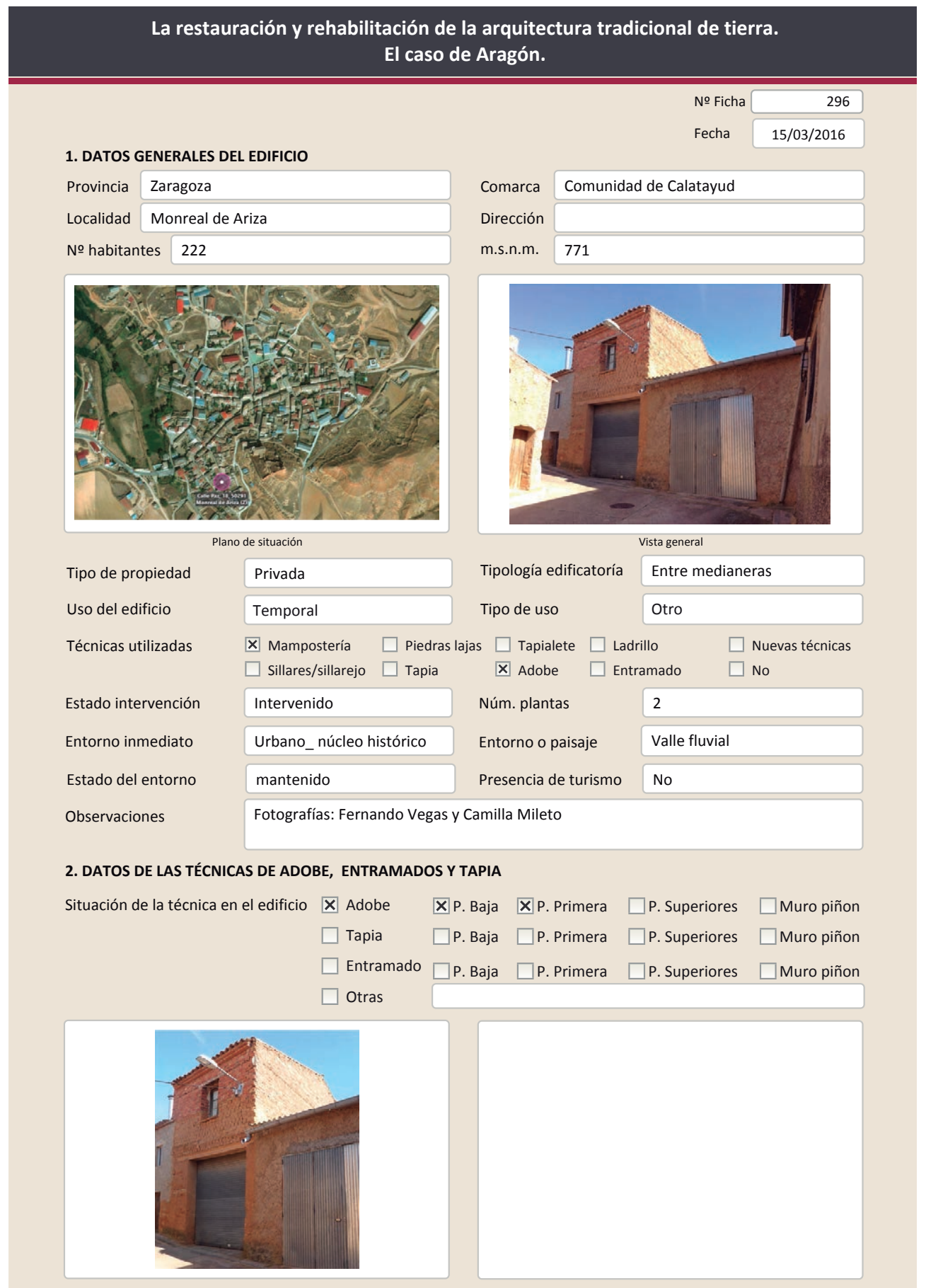

2.1. ADOBE

Dimensión de las piezas Dimensión del muro

Aparejo del muro

Función estructural

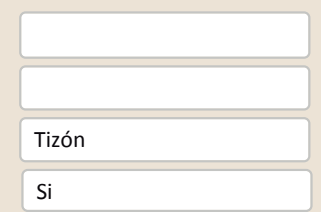

Color de las piezas

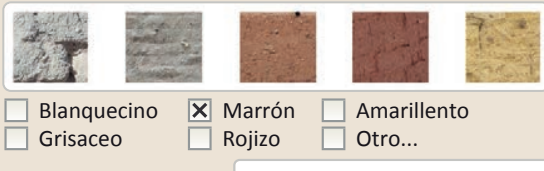

Variante constructiva/ tipo de fábrica

$\mathbf{X}$ Simple

$\square$ Suplementada en juntas

$\square$ Mixta

$\square$ Como suplemento

$\square$ Elementos de protección

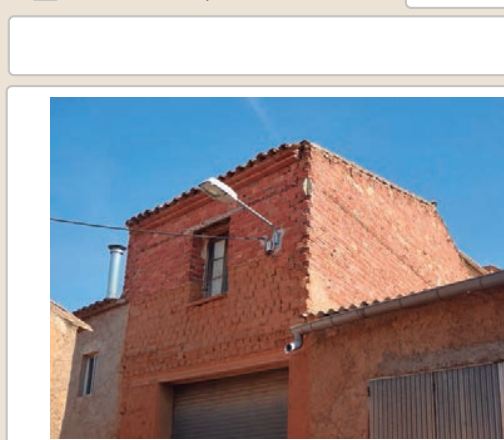

Lesiones X Muro XZZócalo $\square$ Revestimiento

$\mathbf{X}$ Erosión del material $\mathbf{X}$ Humedad por capilaridad $\mathbf{X}$ Erosion de las juntas $\mathbf{X}$ Humedades (manch/eflo)

X Pérdida de sección $\square$ Pérdida de verticalidad

$\square$ Vegetación $\quad \square$ Grietas por empuje de la cu

$\square$ Grietas por empuje de la cubierta
$\square$ Grietas porfalta de traba

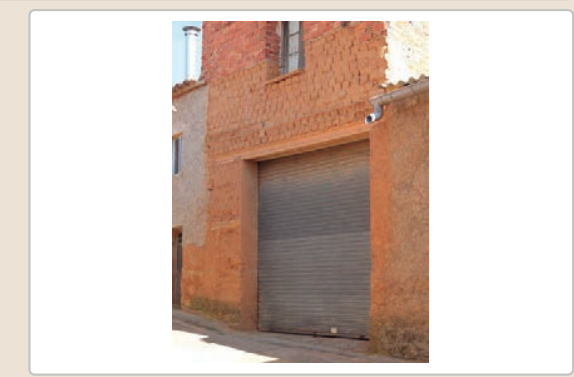

$\square$ Cubierta $\square$ Otro...

$\square$ Grietas por asentamiento

$\square$ Desconchado

Colapso

$\square$ Por elementos impropios

$\square$ Derivado de intervenciones

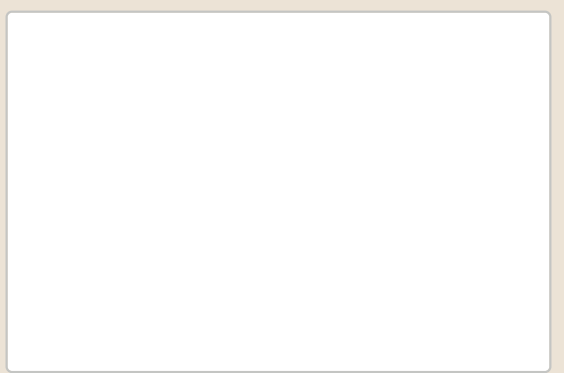

Observaciones 


\section{La restauración y rehabilitación de la arquitectura tradicional de tierra.}

\section{El caso de Aragón.}

3. DATOS DE LA INTERVENCIÓN

$\begin{array}{llll}\text { Intervención de: } & \square \text { Mantenimiento } \quad \boldsymbol{X} \text { Rehabilitación parcial } & \square \text { Restauración } & \square \text { Demolición } \\ & \square \text { Reparación } & \square \text { Rehabilitación integral } & \square \text { Ampliación } \quad \square \text { Otro... } \\ \text { Reflexión previa } & \text { Intervención espontanea } & \\ \text { Observaciones } & & & \\ & & & \\ & & \end{array}$

\subsection{MUROS}

Tipo de intervención

Intervenido

Tipo de material

$\square$ Actualización $\quad \square$ Reintegración $\quad \square$ Demolición $\square$ Otro...

$\square$ Consolidación $\quad \mathbf{X}$ Reconstrucción $\square$ Sustitución

Descripción

No tradicional Tipo de técnica Similar a la existente

3.2. ZÓCALO

Tipo de intervención

Recrecido de la fábrica con ladrillo

Tipo de material

Intervenido

$\square$ Actualización $\square$ Reintegración $\quad \square$ Demolición $\square$ Otro...

$\square$ Actualización
$\square$ Consolidación $\quad \boldsymbol{X}$ Reintegracionstrucción $\quad \square$ Sustitución

Descripción
No tradicional
Tipo de técnica Diferente a la existente

3.3. REVESTIMIENTOS

Nueva capa de cemento sobre la mampostería.

Tipo de intervención

\section{No aplica}

Tipo de material

$\square$ Actualización

$\square$ Reintegración $\square$ Demolición $\square$ Otro...

$\square$ Consolidación $\square$ Reconstrucción $\square$ Sustitución

Descripción

3.4. VANOS

Intervenido

Tipo de intervención

$\square$ Actualización $\square$ Reintegración $\square$ Demolición $\square$ Otro...

$\square$ Consolidación $\square$ Reconstrucción $\quad \boldsymbol{X}$ Sustitución

Tipo de material

No tradicional Tipo de técnica Diferente a la existente

Descripción

Ampliación del hueco. Nuevo dintel con vigueta prefabricada de hormigón y carpinterías metálicas.

3.5. CUBIERTA

Intervenido

Tipo de intervención

$\square$ Actualización $\square$ Reintegración $\quad \boldsymbol{X}$ Demolición $\square$ Otro..

Tipo de material

$\square$ Consolidación $\square$ Reconstrucción $\mathbf{x}$ Sustitución

Descripción

No tradicional Tipo de técnica Diferente a la existente

Sustitución completa de la cubierta (posible reutilización de tejas)

3.6. OTRAS 


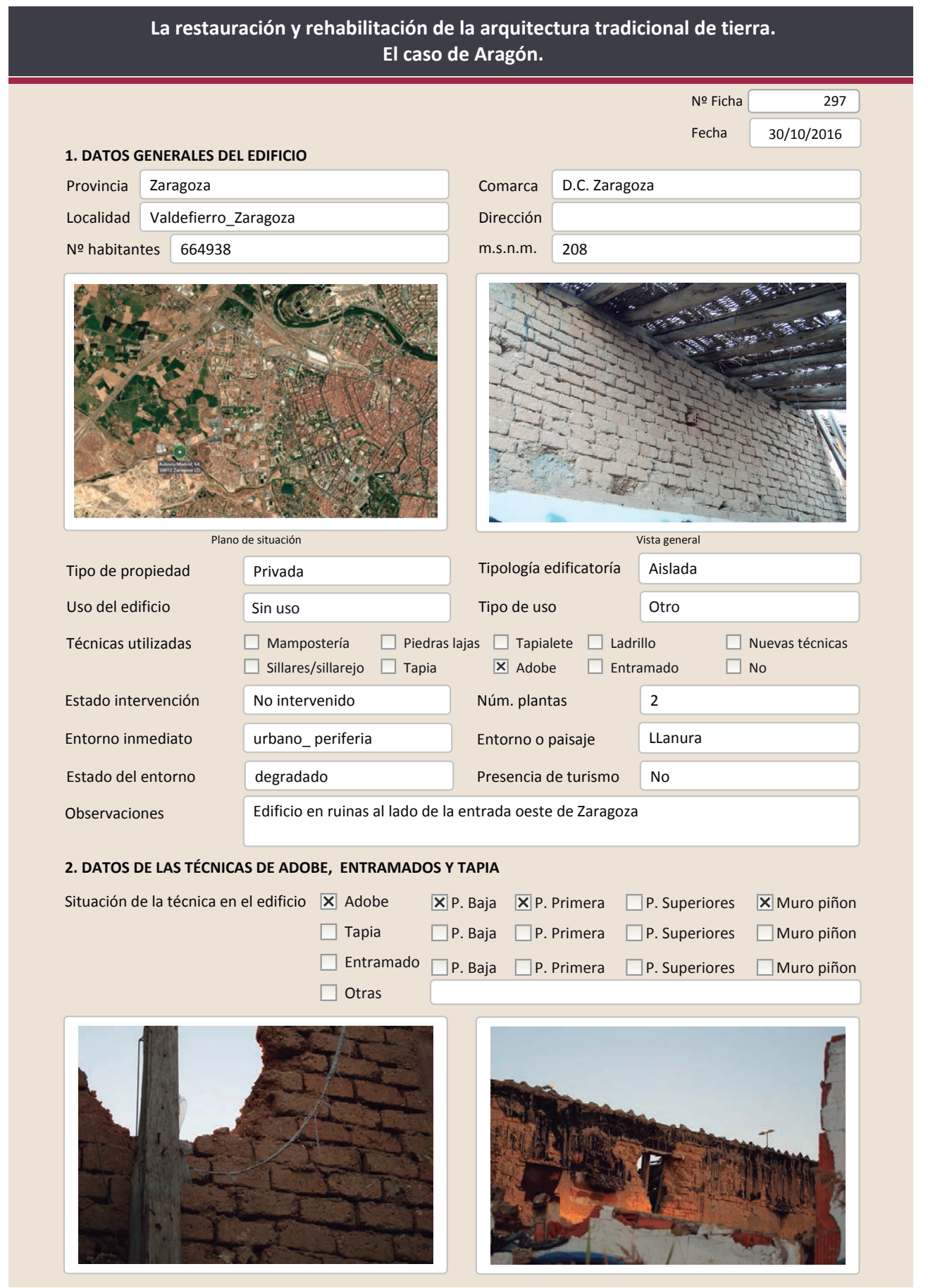

\subsection{ADOBE \\ Dimensión de las piezas $41 \times 20 \times 9$ \\ Dimensión del muro 40-50 cm \\ Aparejo del muro Tizón \\ Función estructural \\ $\mathrm{Si}$ \\ Xe fábrica \\ X Simple \\ $\square$ Suplementada en juntas \\ $\square$ Mixta \\ $\square$ Como suplemento \\ $\square$ Elementos de protección}

Color de las piezas

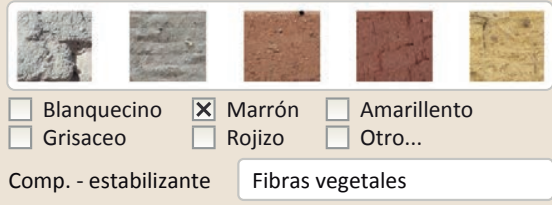

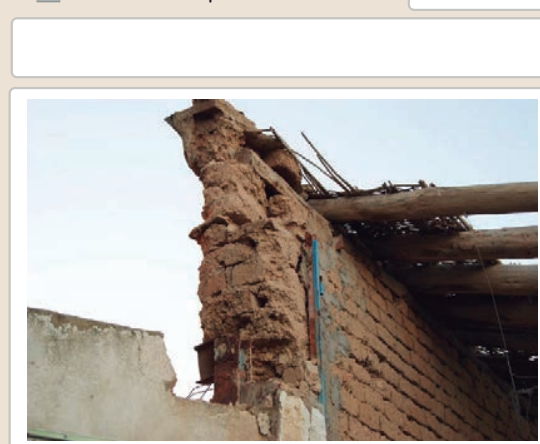

Lesiones $\quad \mathbf{X}$ Muro $\square$ Zócalo $\square$ Revestimiento X Erosión del material $\square$ Humedad por capilaridad $\square$ Erosion de las juntas $\square$ Humedades (manch/eflo) \ Pérdida de sección $\quad \square$ Pérdida de verticalidad

$\square$ Vegetación $\quad \square$ Grietas por empuje de la cubierta

$\square$ Desconchados

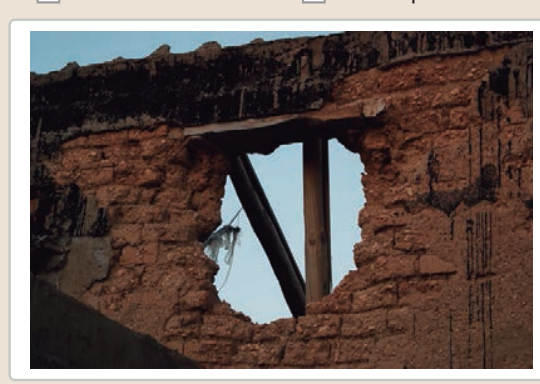

Observaciones

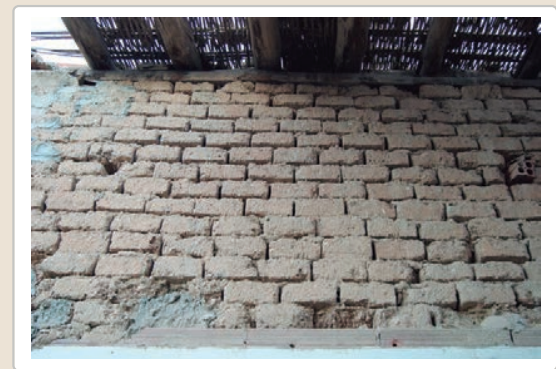

$\square$ Cubierta $\square$ otro...

$\square$ Grietas por asentamiento X Colapso

$\square$ Por elementos impropios

$\square$ Derivado de intervenciones $\square$ Otro... 
La restauración y rehabilitación de la arquitectura tradicional de tierra. El caso de Aragón.

3.7. REHABILITACIÓN ENERGÉTICA $\square$ Fachada $\square$ Vanos $\square$ Forjados $\square$ Cubierta

Observaciones

FOTOGRAFÍAS DE LA INTERVENCIÓN
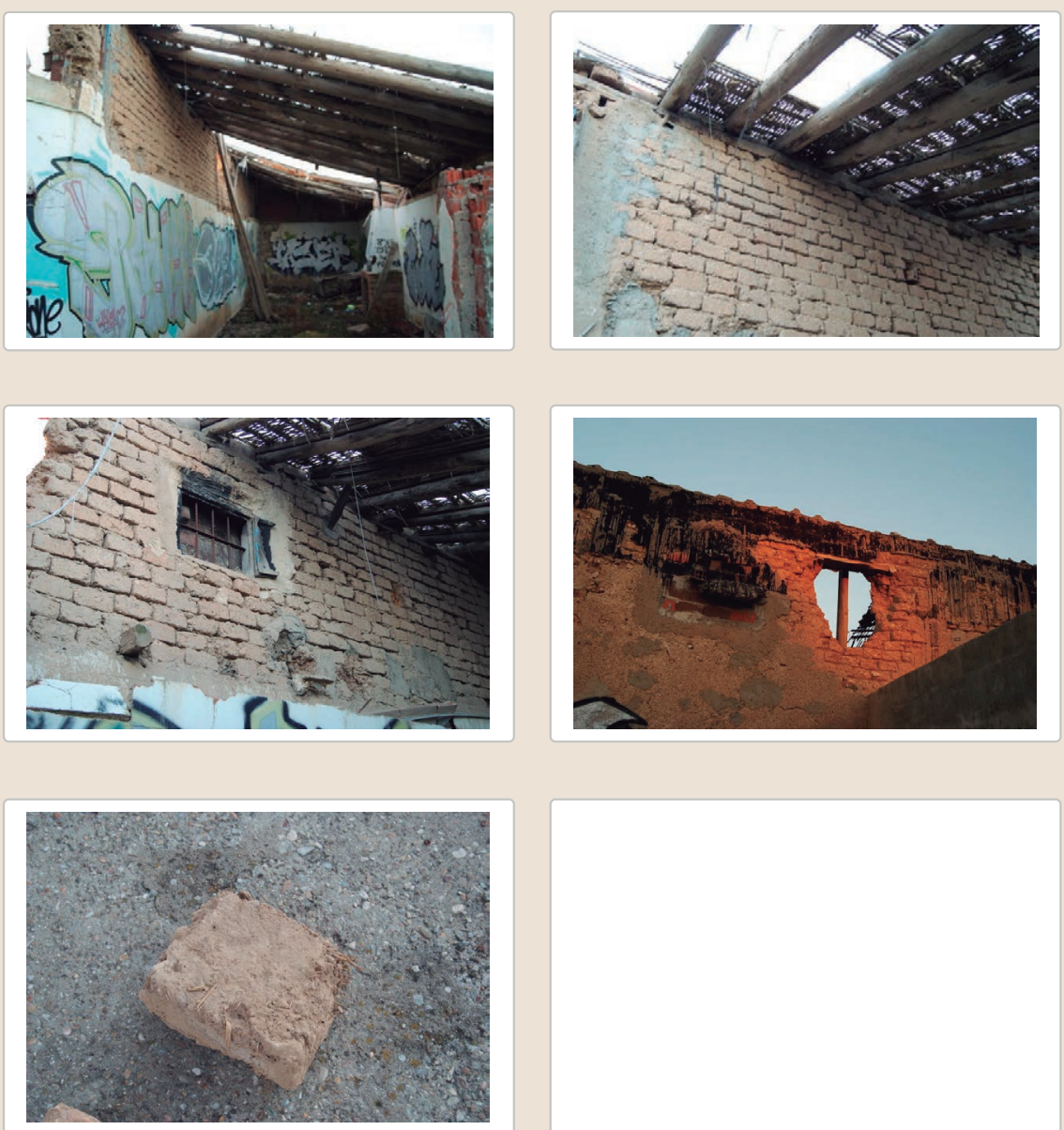

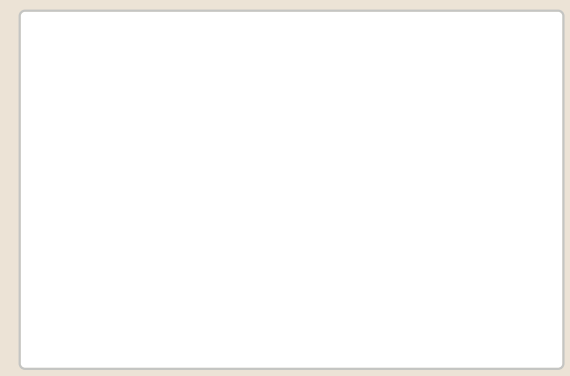




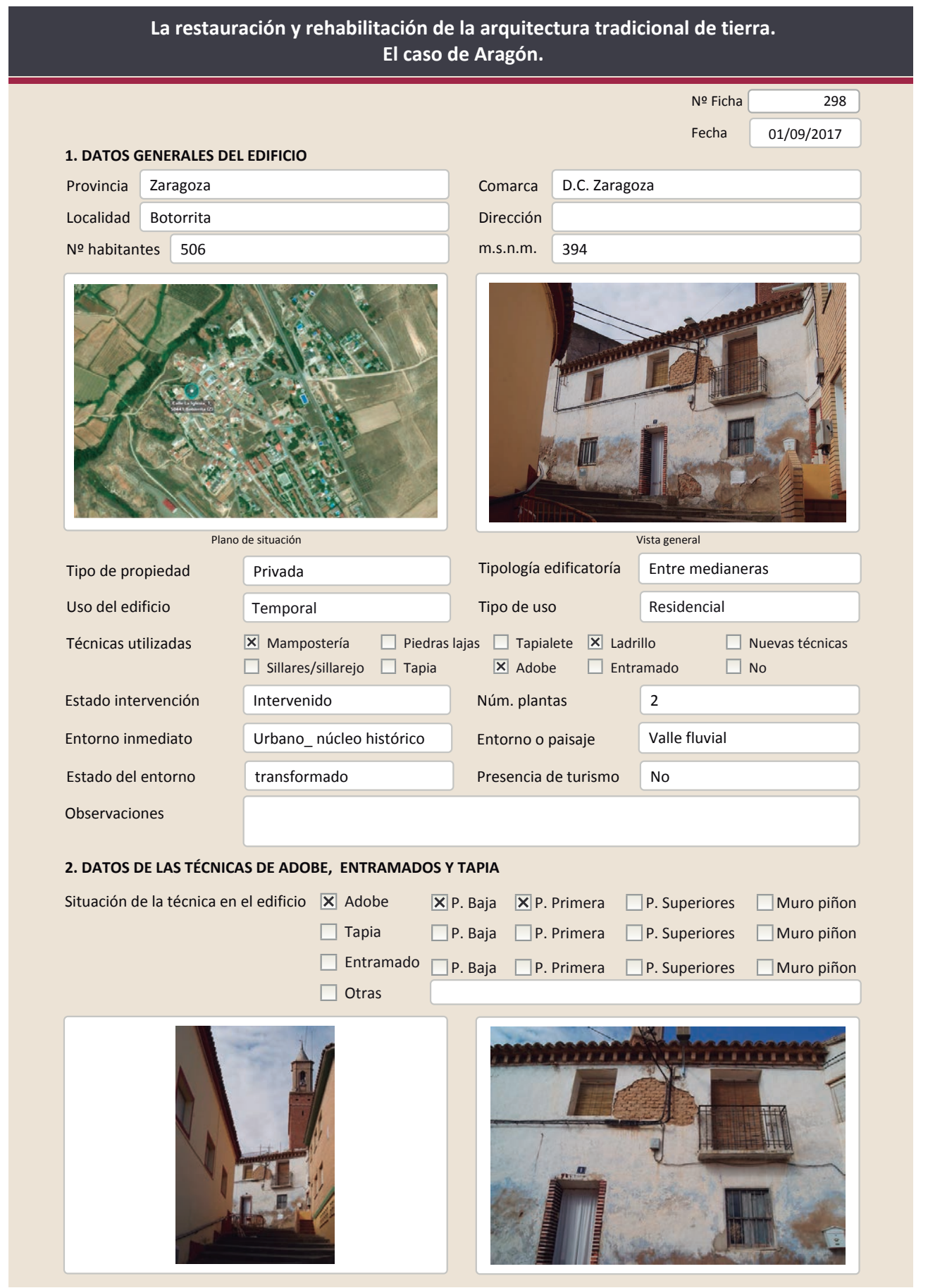

2.1. ADOBE

Dimensión de las piezas

Dimensión del muro

Aparejo del muro

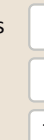

Función estructural

$$
\text { Tizón }
$$$$
\mathrm{Si}
$$

Variante constructiva/ tipo de fábrica

X Simple

$\square$ Suplementada en juntas

$\square$ Mixta

$\square$ Como suplemento

$\square$ Elementos de protección

Hay adobes en la formación del alero de la cubierta

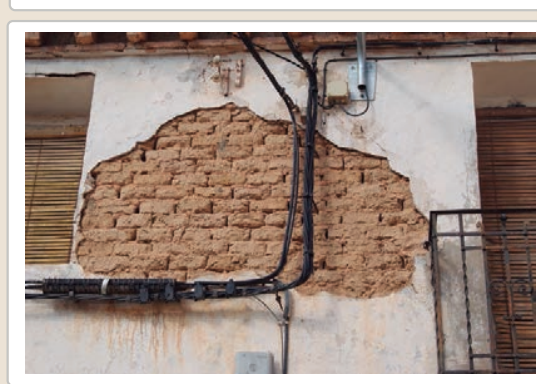

Lesiones $\quad \square$ Muro $\mathbf{X}$ Zócalo $\mathbf{X}$ Revestimiento

$\square$ Erosión del material $\quad \mathbf{X}$ Humedad por capilaridad

$\square$ Erosion de las juntas $\mathbf{X}$ Humedades (manch/eflo)

$\square$ Pérdida de sección $\square$ Pérdida de verticalidad

$\square$ Vegetación $\quad \square$ Grietas por empuje de la cubie

\ Desconchados $\quad \square$ Grietas porfalta de traba

Color de las piezas

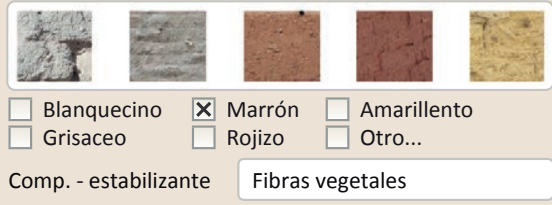

Comp. - estabilizante Fibras vegetales

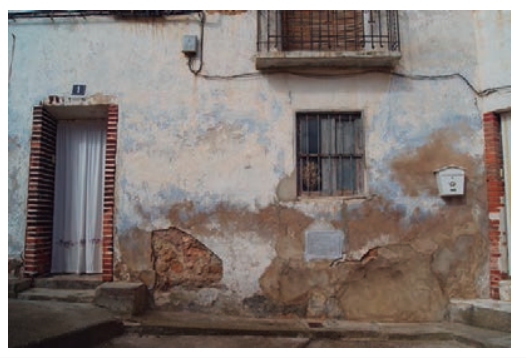

Observaciones

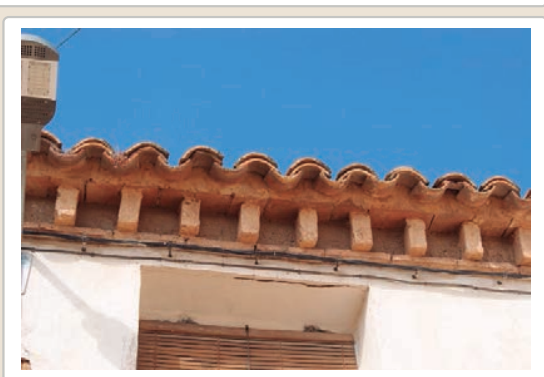

$\square$ Cubierta $\square$ Otro...

$\square$ Grietas por asentamientos $\square$ Colapso

$\square$ Por elementos impropios

$\square$ Derivado de intervenciones $\square$ Otro... 


\section{La restauración y rehabilitación de la arquitectura tradicional de tierra.}

\section{El caso de Aragón.}

\section{DATOS DE LA INTERVENCIÓN}

$\begin{array}{llll}\text { Intervención de: } & \square \text { Mantenimiento } \quad \boldsymbol{X} \text { Rehabilitación parcial } & \square \text { Restauración } & \square \text { Demolición } \\ & \square \text { Reparación } \quad \square \text { Rehabilitación integral } & \square \text { Ampliación } \quad \square \text { Otro... } \\ \text { Reflexión previa } & \text { Intervención planificada } & \\ \text { Observaciones } & & & \\ & & & \\ & & \end{array}$

\subsection{MUROS}

Tipo de intervención

No intervenido

Tipo de material

$\square$ Actualización $\square$ Reintegración $\quad \square$ Demolición $\quad \square$ Otro... $\square$ Consolidación $\square$ Reconstrucción $\square$ sustitución

Descripción

3.2. ZÓCALO

Tipo de intervención

Intervenido

$\square$ Actualizació

Tipo de material

Descripción

Tipo de técnica Diferente a la existente

3.3. REVESTIMIENTOS

Reconstrucción del zócalo con mortero de cemento

\section{Tipo de intervención}

\section{Intervenido}

Tipo de material

X Actualización

$\square$ Reintegración $\square$ Demolición $\square$ Otro...

Tipo de materia

No tradicional

X Reconstrucción $\square$ Sustitución

Descripción

Revestimiento de cemento pintado de blanco

3.4. VANOS

Intervenido

Tipo de intervención

$\square$ Actualización $\square$ Reintegración $\square$ Demolición $\square$ Otro...

$\square$ Consolidación $\mathbf{X}$ Reconstrucción $\mathbf{X}$ Sustitución

\begin{tabular}{lll} 
Tipo de material No tradicional Tipo de técnica Diferente a la existente \\
\hline
\end{tabular}

Descripción reconstrucción de las jambas de la puerta con ladrillo. Sustitución de algunas de las carpinerías

3.5. CUBIERTA

Tipo de intervención $\quad \square$ Actualización $\quad \square$ Reintegración $\quad \square$ Demolición $\square$ Otro...

Intervenido

Tipo de material

$\square$ Consolidación $\quad \boldsymbol{X}$ Reconstrucción $\square$ Sustitución

Descripción

No tradicional Tipo de técnica Similar a la existente

3.6. OTRAS \begin{tabular}{l}
$\begin{array}{l}\text { Reconstrucción de la cubierta con tejas curvas y cemento sobre el alero de ladrillo y } \\
\text { adobe }\end{array}$ \\
\hline
\end{tabular} 


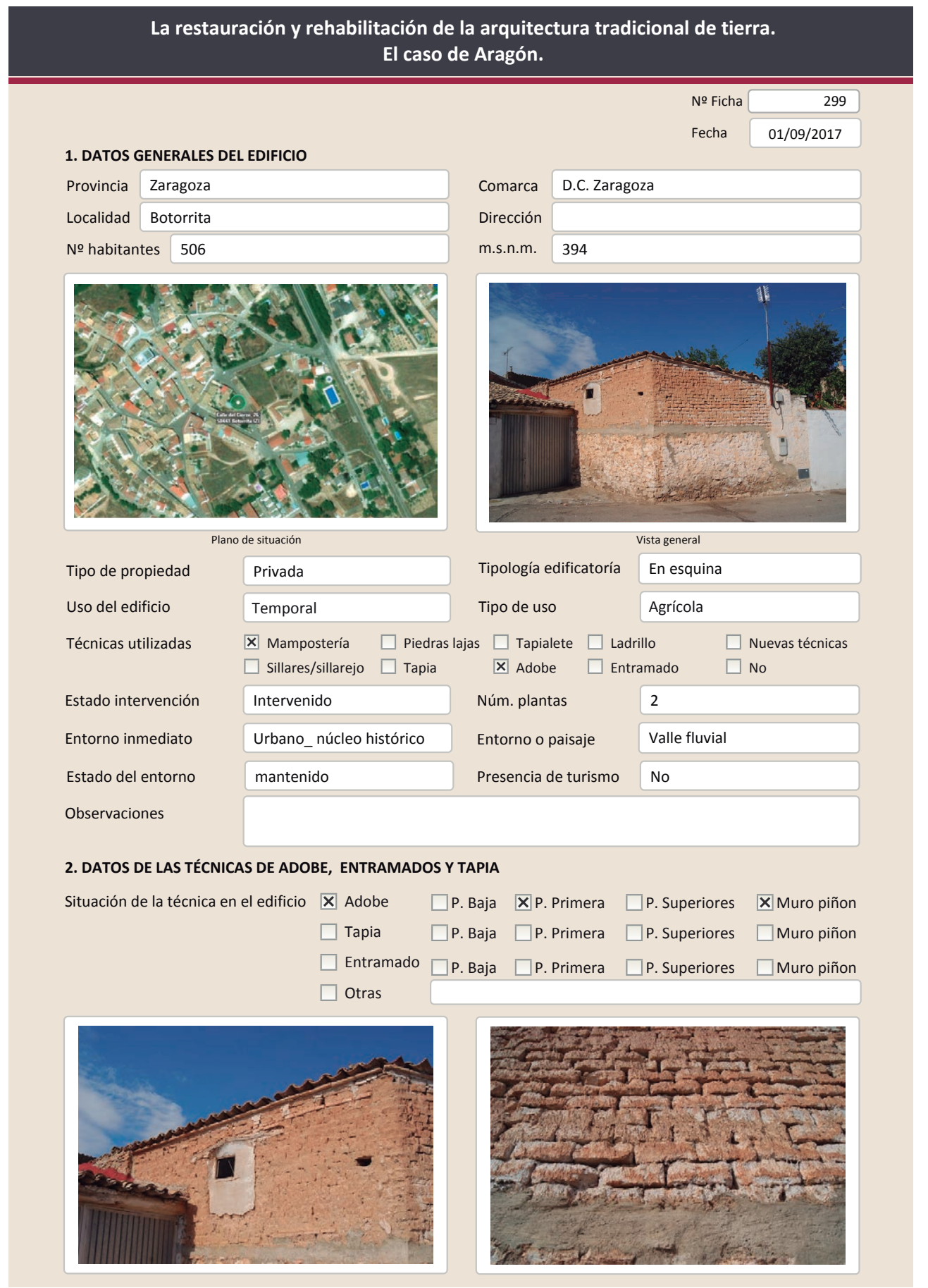

2.1. ADOBE

Dimensión de las piezas

Dimensión del muro

Aparejo del muro

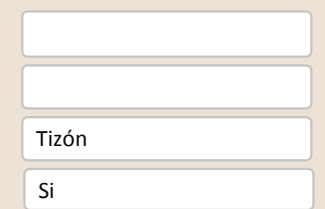

Color de las piezas

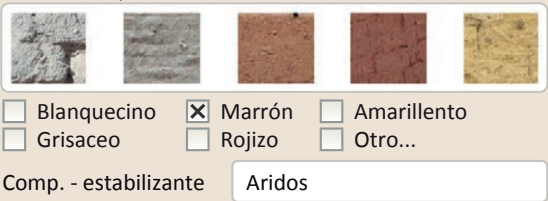

Función estructural

Comp. - estabilizante Aridos

Variante constructiva/ tipo de fábrica

Х Simple

$\square$ suplementada en juntas

$\square$ Mixta

$\square$ Como suplemento

$\square$ Elementos de protección

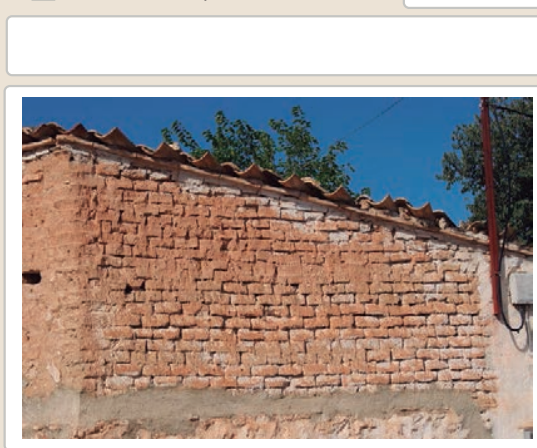

Lesiones X Muro XZZócalo $\square$ Revestimiento

$\mathbf{X}$ Erosión del material $\mathbf{X}$ Humedad por capilaridad $\mathbf{X}$ Erosion de las juntas $\mathbf{X}$ Humedades (manch/eflo)

$\square$ Pérdida de sección $\square$ Pérdida de verticalidad

$\square$ Vegetación $\quad \square$ Grietas por empuje de la cube

$\square$ Desconchados

$\square$ Grietas porfalta de traba

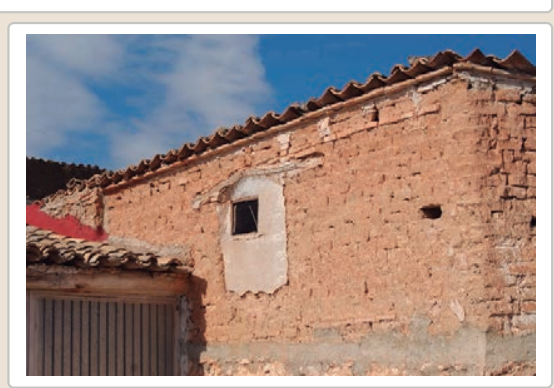

$\square$ Cubierta $\square$ otro...

Grietas por asentamientos

$\square$ Colapso

$\square$ Por elementos impropios

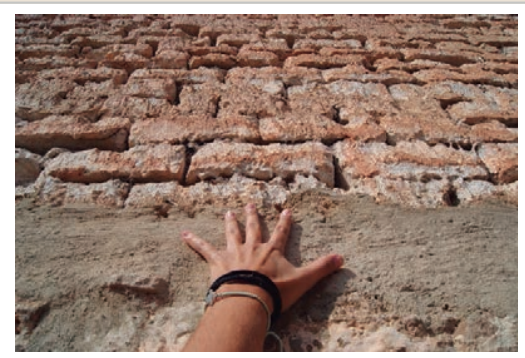

$\square$ Derivado de intervenciones $\square$ Otro... 
La restauración y rehabilitación de la arquitectura tradicional de tierra.

El caso de Aragón.

3. DATOS DE LA INTERVENCIÓN

\begin{tabular}{llll|} 
Intervención de: & $\square$ Mantenimiento $\quad \square$ Rehabilitación parcial & $\square$ Restauración $\quad \square$ Demolición \\
Reflexión previa & $\mathbf{X}$ Reparación $\quad \square$ Rehabilitación integral $\quad \square$ Ampliación $\quad \square$ Otro... \\
\hline Observaciones & Intervención espontanea & \\
& & \\
& & \\
\end{tabular}

\subsection{MUROS}

Tipo de intervención

Intervenido

Tipo de material

$\square$ Actualización $\quad$ X Reintegración $\square$ Demolición $\square$ Otro...

$\square$ Consolidación $\square$ Reconstrucción $\square$ Sustitución

Descripción

No tradicional Tipo de técnica Diferente a la existente

3.2. ZóCALO

Tipo de intervención

Roza realizada entre el adobe y la mampostería cubierta con cemento

Tipo de material

Intervenido

X Actualización $\square$ Reintegración $\square$ Demolición $\square$ Otro...

$x$ Actualización $\square$ Reintegración
$\square$ Consolidación $\quad \square$ Reconstrucción $\quad \square$ Sustitución

Descripción

No tradicional Tipo de técnica Diferente a la existente

3.3. REVESTIMIENTOS

Zócalo con pintura blanca

Tipo de intervención

\section{No aplica}

Tipo de material

Descripción

$\square$ Actualización

$\square$ Reintegración $\square$ Demolición $\square$ Otro...

$\square$ Consolidación $\square$ Reconstrucción $\square$ Sustitución

3.4. VANOS

No intervenido

Tipo de intervención

$\square$ Actualización $\quad \square$ Reintegración $\quad \square$ Demolición $\quad \square$ Otro...
$\square$ Consolidación $\quad \square$ Reconstrucción $\quad \square$ Sustitución

Tipo de material

Descripción

3.5. CUBIERTA

Tipo de intervención

No intervenido

$\square$ Actualización $\quad \square$ Reintegración $\square$ Demolición $\square$ Otro.

Tipo de material

$\square$ Consolidación $\square$ Reconstrucción $\square$ Sustitución

Descripción

$$
\text { Tipo de técnica }
$$

3.6. OTRAS 


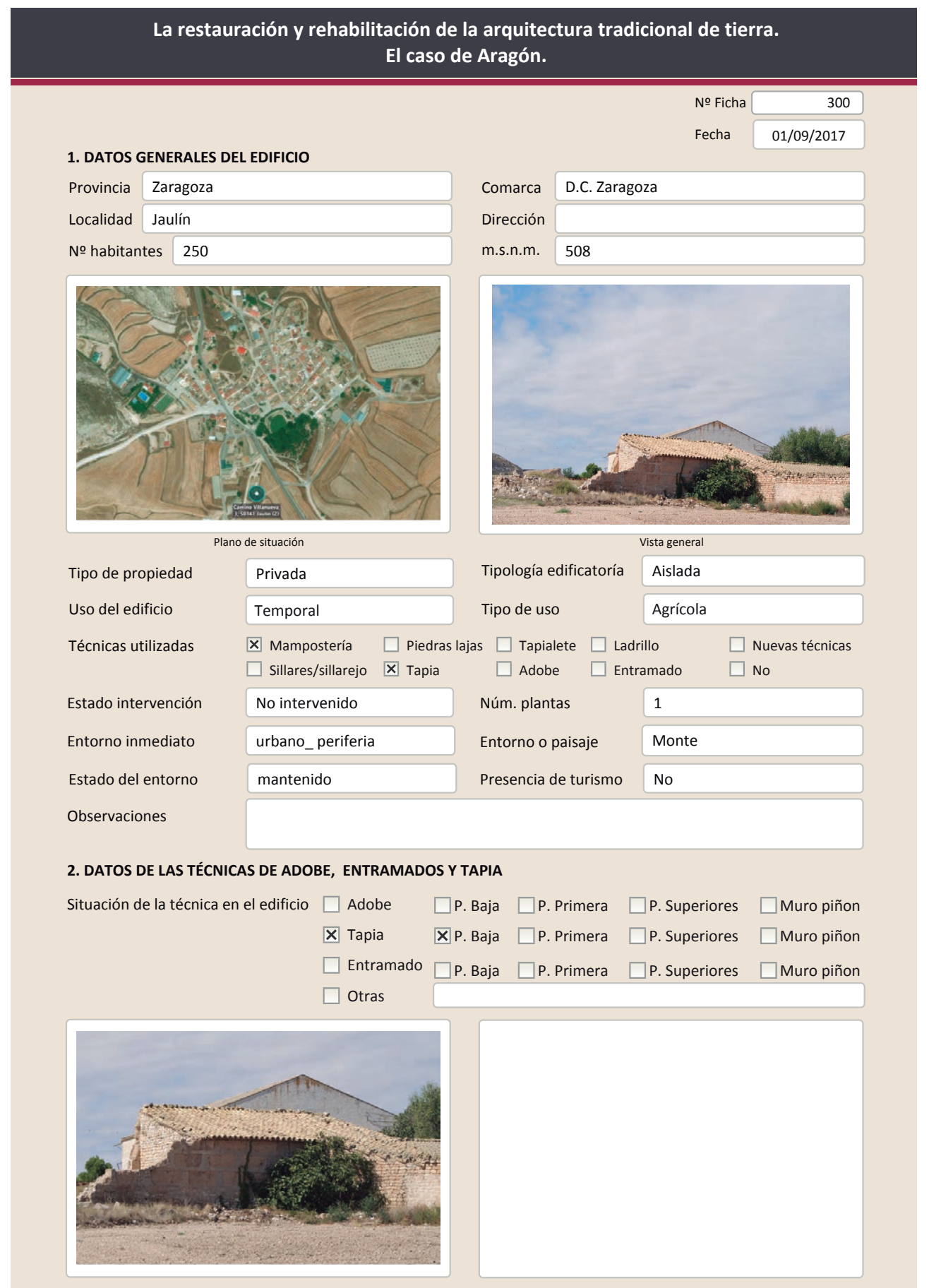

La restauración y rehabilitación de la arquitectura tradicional de tierra. El caso de Aragón.

\subsection{TAPIA}

Ancho del muro

Dimensión tapiales

Tipo de aguja

№ agujas/cajón

Variante constructiva

$\square$ simple / homogen

$\square$ suplemento superficial

X Suplemento en juntas

$\square$ Mixta

$\square$ Elementos de protección

\begin{tabular}{|l|}
\hline $50-60 \mathrm{~cm}$ \\
\hline \\
\hline Redonda \\
\hline 3 \\
\hline
\end{tabular}

Color de la tapia

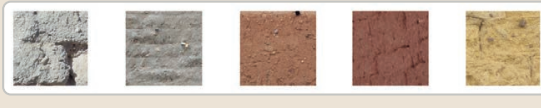

$\square$ Blanquecino $\quad \mathbf{X}$ Marrón $\square$ Amarillento $\begin{array}{ll}\square \text { Blanquecino } \quad \mathbf{X} \text { Marrón } \quad \square \text { Amarill } \\ \square \text { Grisaceo } & \square \text { Rojizo } \quad \square \text { Otro... }\end{array}$
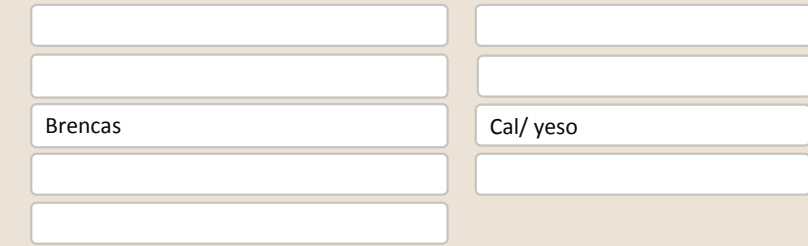

Las brencas y las juntas horizontales son muy anchas

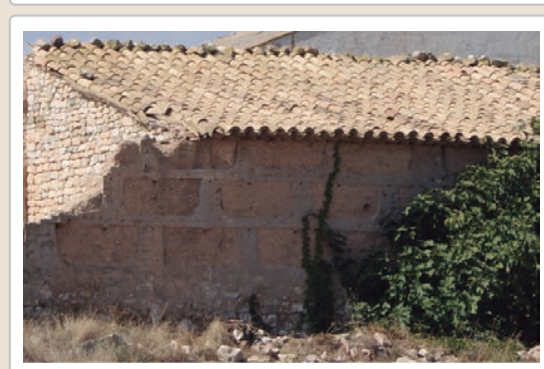

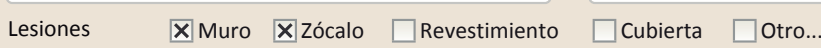

Х Erosión del material $\mathbf{X}$ Humedad por capilaridad $\quad \square$ Grietas por asentamientos $\square$ Erosion de las juntas $\square$ Humedades (manch/eflo) $\quad \square$ Colapso

X Pérdida de sección $\square$ Pérdida de verticalidad $\quad \square$ Por elementos impropios

$\square$ Vegetación $\quad \square$ Grietas por empuje de la cubierta $\quad \square$ Derivado de intervenciones

$\square$ Desconchados

$\square$ Grietas por empuje de la cubierta $\quad \square$ Derivadta de traba $\quad \square$ Otro...
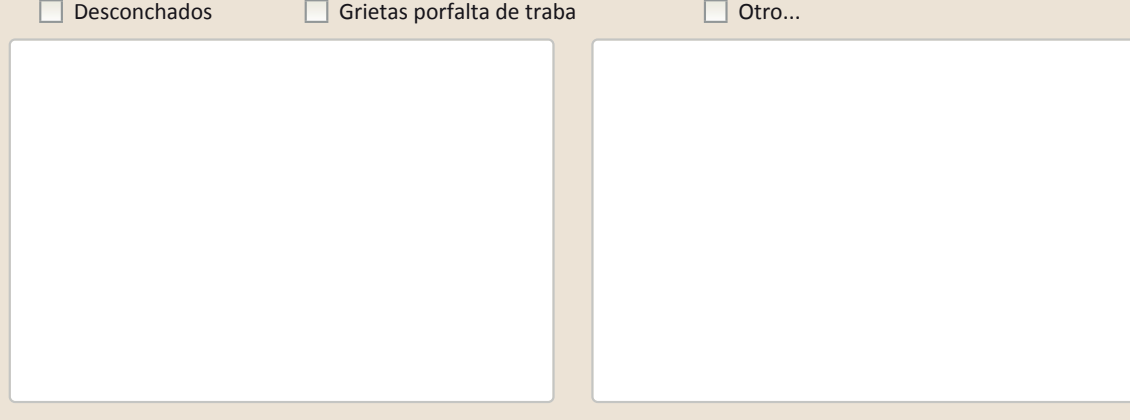


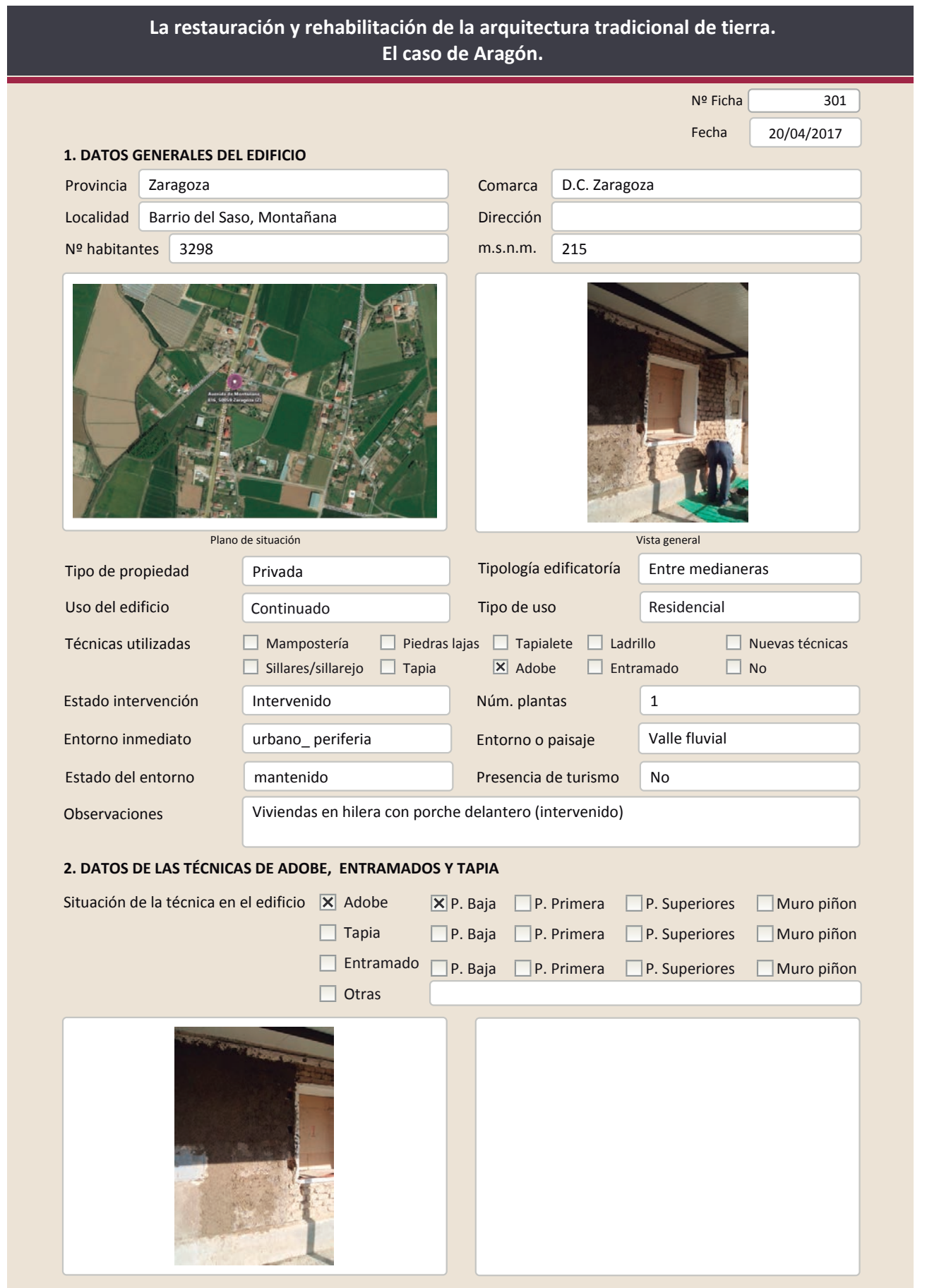

La restauración y rehabilitación de la arquitectura tradicional de tierra.

El caso de Aragón.

2.1. ADOBE

Dimensión de las piezas Dimensión del muro

Aparejo del muro

Función estructural

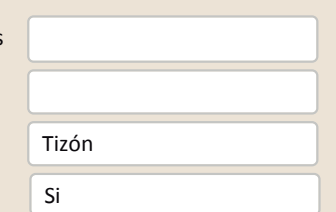

Color de las piezas

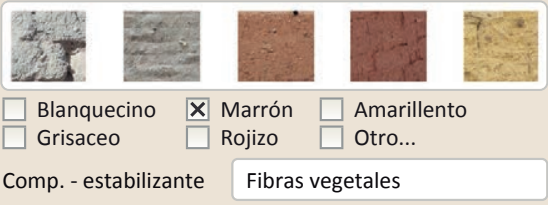

Variante constructiva/ tipo de fábrica

区 Simple

$\square$ Suplementada en juntas

$\square$ Mixta

$\square$ Como suplemento

$\square$ Elementos de protección

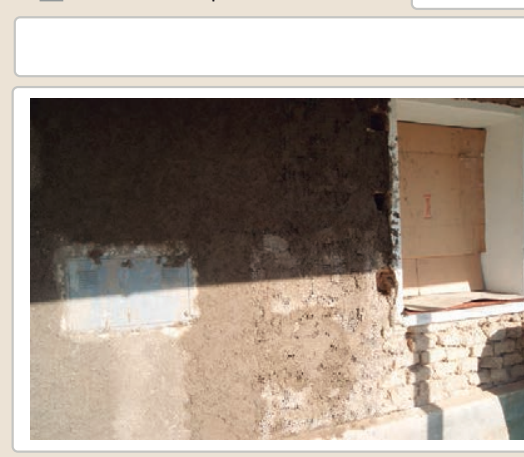

Lesiones $\square$ Muro $\square$ Zócalo $\square$ Revestimiento $\square$ Cubierta $\square$ otro.

$\square$ Erosión del material $\quad \square$ Humedad por capilaridad $\quad \square$ Grietas por asentamientos $\square$ Erosion de las juntas $\square$ Humedades (manch/eflo) $\quad \square$ Colapso

$\square$ Pérdida de sección $\square$ Pérdida de verticalidad

$\square$ Vegetación $\quad \square$ Grietas por empuje de la cubierta

$\square$ Desconchados

$\square$ Grietas por empuje de

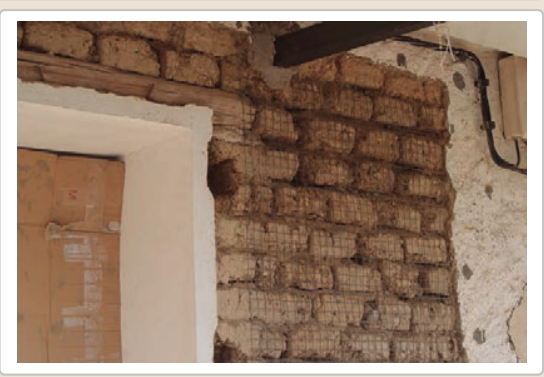$$
\square \text { Grietas porfalta de tra }
$$

Observaciones 


\section{La restauración y rehabilitación de la arquitectura tradicional de tierra.}

\section{El caso de Aragón.}

3. DATOS DE LA INTERVENCIÓN

$\square$ Mantenimiento $\quad \mathbf{X}$ Rehabilitación parcia

$\square$ Restauración $\square$ Demolición

Reflexión previa

$\square$ Reparación

Rehabilitación integra

Ampliación

$\square$ Otro...

Observaciones

Intervención espontanea

\subsection{MUROS}

Tipo de intervención

No intervenido

Tipo de material

Descripción

3.2. ZÓCALO

Tipo de intervención

Tipo de material

Descripción

3.3. REVESTIMIENTOS

Tipo de intervención

Tipo de material

Descripción

3.4. VANOS

Tipo de intervención

Tipo de material

Descripción

3.5. CUBIERTA

Tipo de intervención

Tipo de material

Descripción

$\square$ Consolidación $\square$ Reconstrucción $\square$ Sustitución

Tipo de técnica

\section{Intervenido}

$\square$ Actualización $\square$ Reintegración $\square$ Demolición $\square$ Otro..

$\square$ Consolidación $\quad \mathbf{X}$ Reconstrucción $\square$ Sustitución

No tradicional Tipo de técnica Diferente a la existente

Revestimiento grueso de cemento en la parte baja del muro

\section{Intervenido}

$\square$ Actualización $\square$ Reintegración $\square$ Demolición $\square$ Otro...

$\square$ Consolidación $\mathbf{X}$ Reconstrucción $\square$ sustitución
No tradicional
Tipo de técnica Diferente a la existente

Nuevo revestimiento con malla metálica

Intervenido

$\square$ Actualización $\square$ Reintegración $\square$ Demolición $\square$ Otro...

$\square$ Consolidación $\mathbf{X}$ Reconstrucción $\square$ Sustitución

No tradicional Tipo de técnica Diferente a la existente

Reconstrucción del contorno de los huecos

\section{Intervenido}

$\square$ Actualización $\quad \square$ Reintegración $\quad \square$ Demolición $\quad \square$ Otro..

$\square$ Consolidación $\mathbf{X}$ Reconstrucción $\square$ Sustitución

Nuevo porche de en la entrada
La restauración y rehabilitación de la arquitectura tradicional de tierra.

El caso de Aragón.

3.7. REHABILITACIÓN ENERGÉTICA $\quad \square$ Fachada $\square$ Vanos $\square$ Forjados $\square$ Cubierta

Observaciones

FOTOGRAFíAS DE LA INTERVENCIÓN

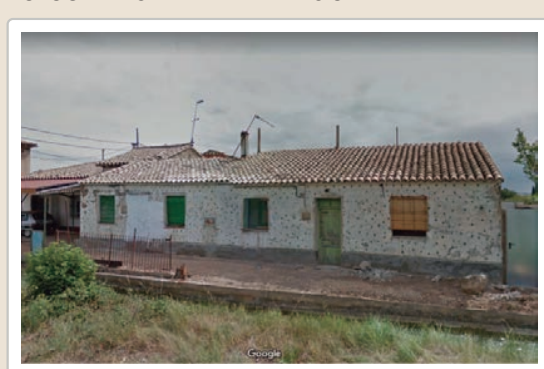

Google. Agosto 2014
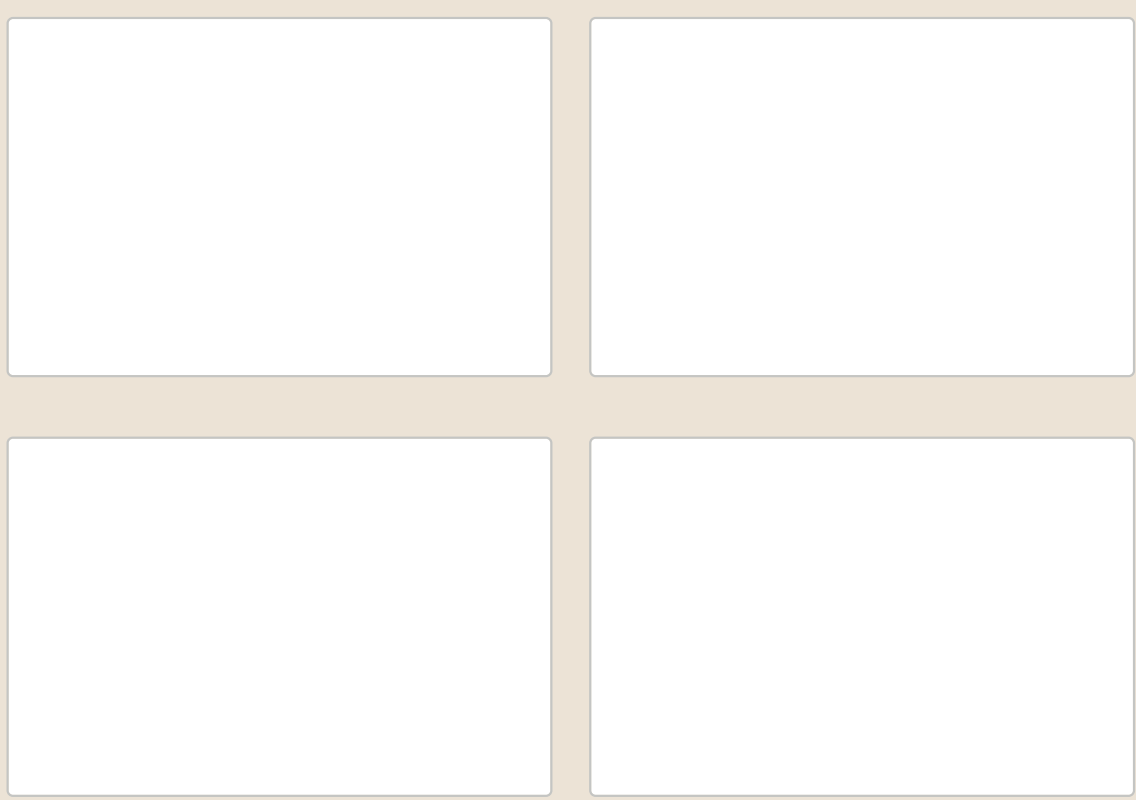

3.6. OTRAS 


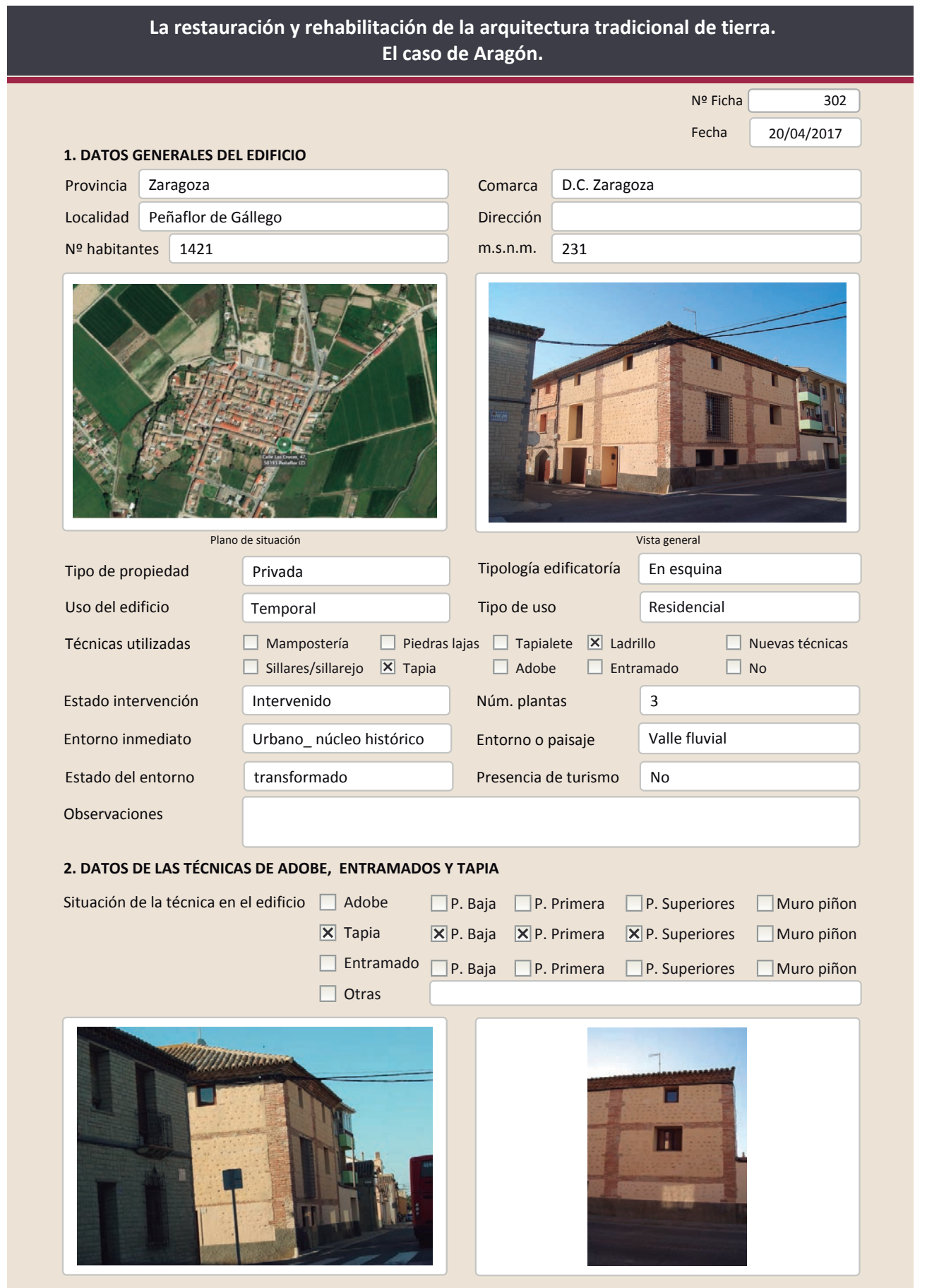

La restauración y rehabilitación de la arquitectura tradicional de tierra. El caso de Aragón.

2.2. TAPIA

Ancho del muro

Dimensión tapiales

Tipo de aguja

№ agujas/cajón

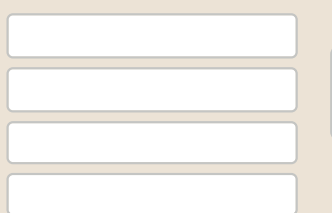

Color de la tapia

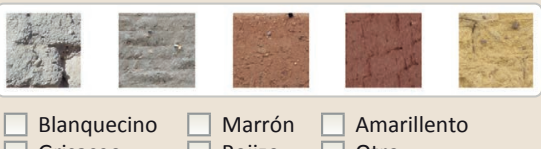

$\square$ Blanquecino $\square$ Marrón $\square$ Amarillento

Variante constructiva

$\square$ Simple / homogénea

X Suplemento superficial

$\square$ suplemento en juntas

Х Mixta
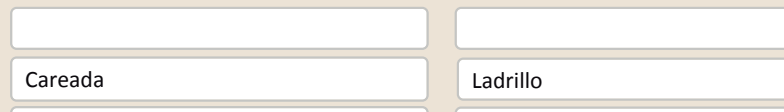

Ladrillo

Machones y verdugadas

Ladrillo

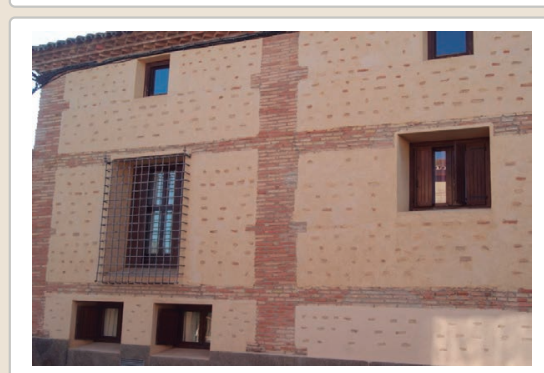

Lesiones $\square$ Muro $\square$ Zócalo $\square$ Revestimiento $\square$ Erosión del material $\quad \square$ Humedad por capilaridad $\square$ Erosion de las juntas $\square$ Humedades (manch/eflo) $\square$ Pérdida de sección $\quad \square$ Pérdida de verticalidad

$\square$ Vegetación

$\square$ Desconchados

$\square$ Grietas por empuje de la

$\square$ Por elementos impropios

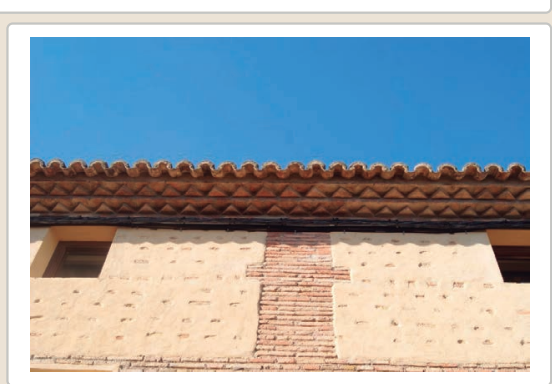

$\square$ Cubierta $\square$ Otro..

$\square$ Grietas por asentamientos

Colapso

Dor elementos impropios $\square$ Otro... 


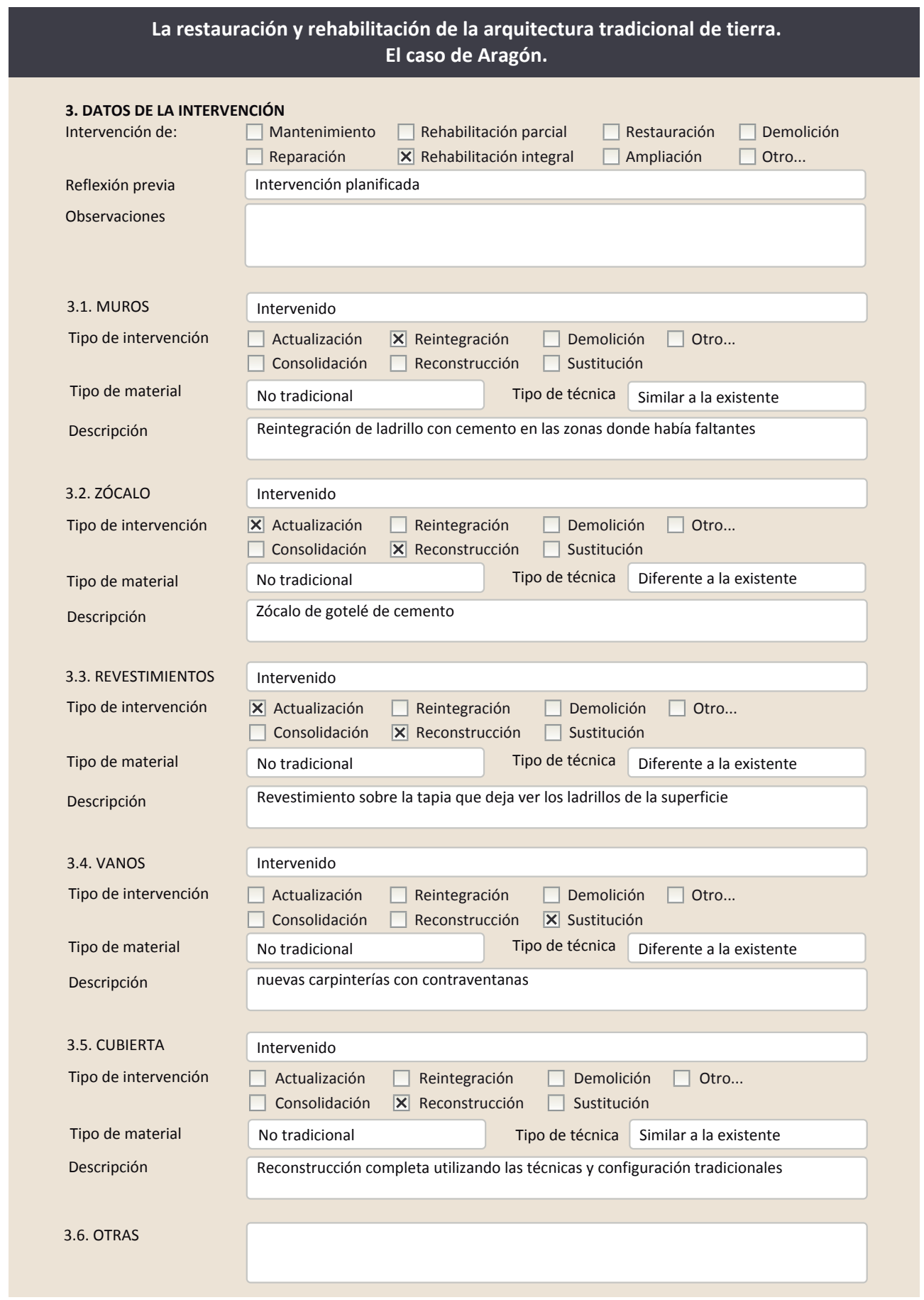

3.7. REHABILITACIÓN ENERGÉTICA $\square$ Fachada $\boldsymbol{\bigotimes}$ Vanos $\square$ Forjados $\boldsymbol{X}$ Cubierta

Observaciones

FOTOGRAFíAS DE LA INTERVENCIÓN
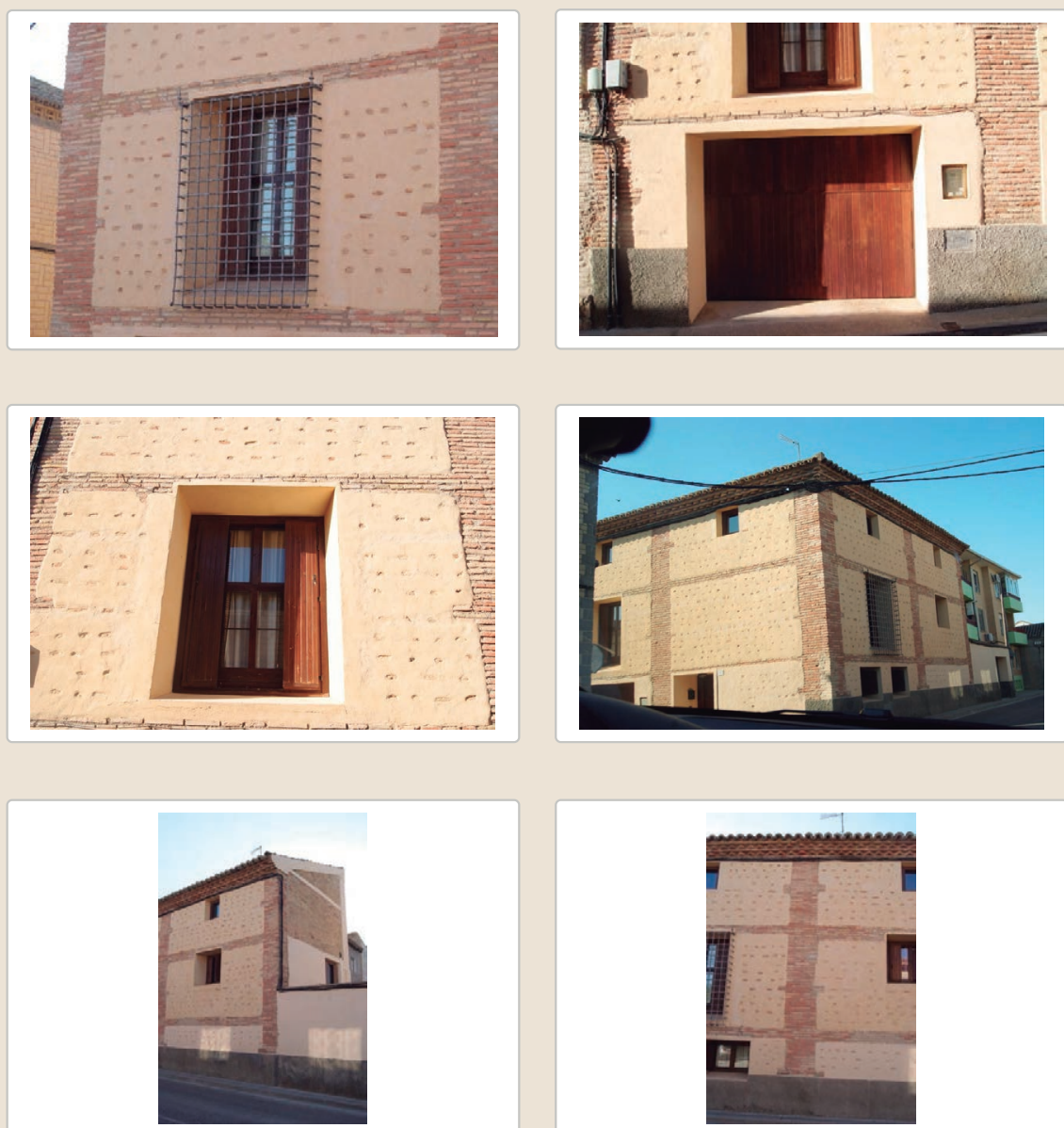


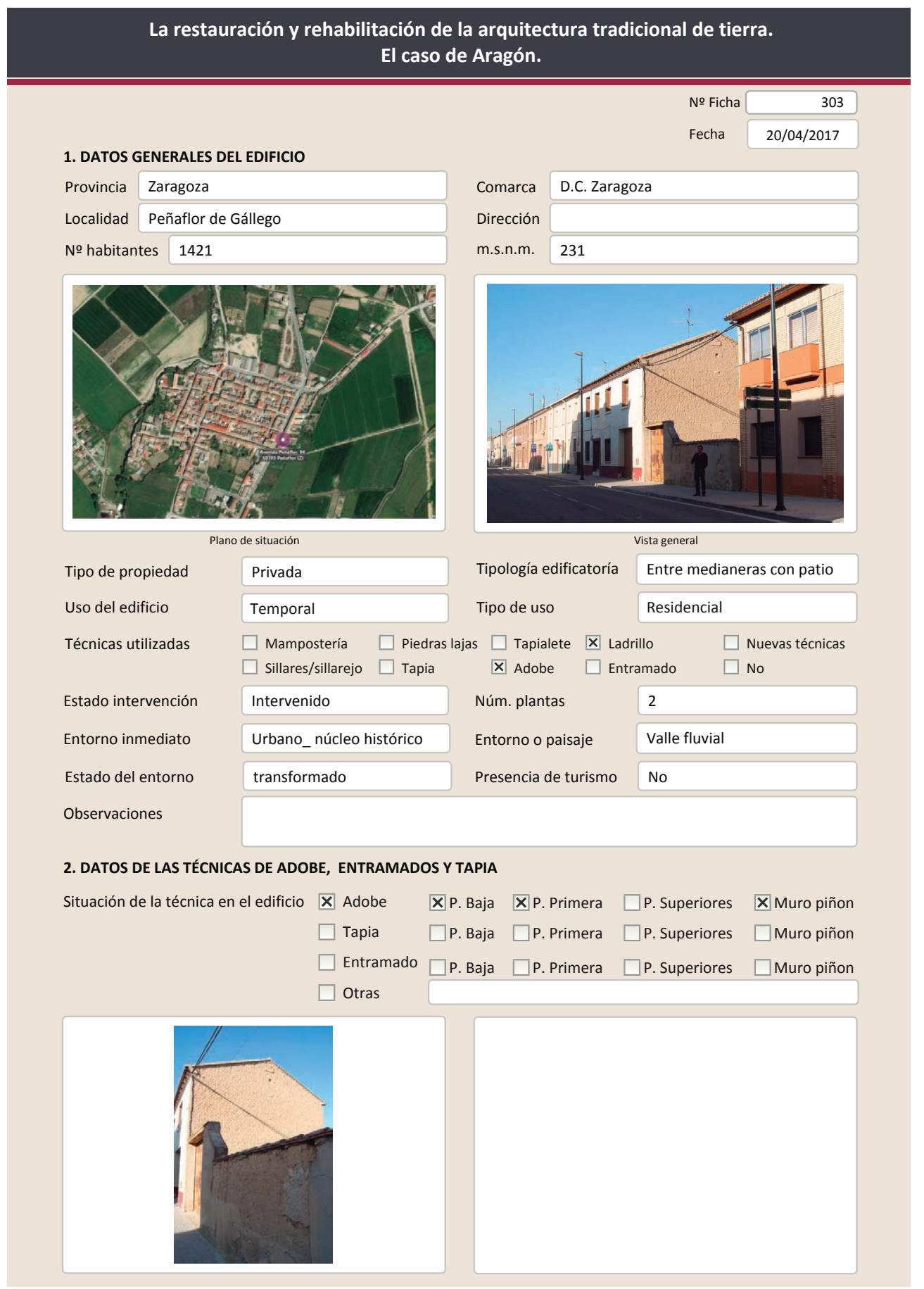

La restauración y rehabilitación de la arquitectura tradicional de tierra.

El caso de Aragón.

2.1. ADOBE

Dimensión de las piezas Dimensión del muro Aparejo del muro Función estructural
Color de las piezas

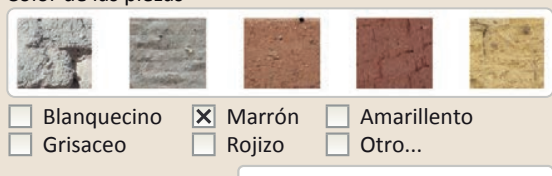

Rojizo $\square$ Otro.

Variante constructiva/ tipo de fábrica

メ simple

$\square$ Suplementada en juntas

$\square$ Mixta

$\square$ Como suplemento

$\mathbf{X}$ Elementos de protección

\section{Revestimiento}

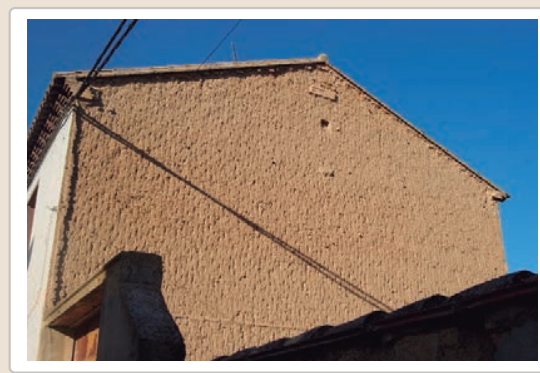

Lesiones $\quad \mathbf{X}$ Muro $\square$ Zócalo $\square$ Revestimiento

\ Erosión del material $\square$ Humedad por capilaridad

X Erosion de las juntas $\square$ Humedades (manch/eflo)

$\square$ Pérdida de sección $\square$ Pérdida de verticalidad

$\square$ Vegetación $\quad \square$ Grietas por empuje de la cubie

$\square$ Desconchados

$\square$ Grietas por empuje de la
$\square$ Grietas porfalta de traba

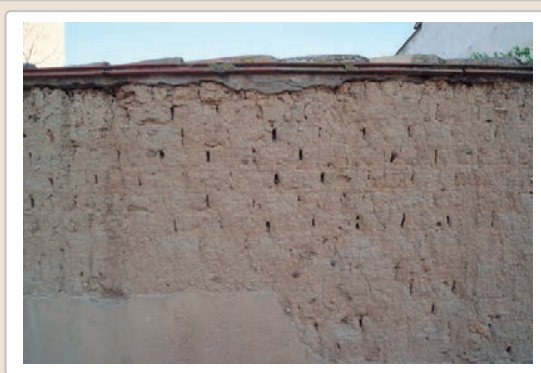

$\square$ Cubierta $\square$ Otro...

$\square$ Grietas por asentamiento

$\square$ Colapso

$\square$ Por elementos impropios$$
\text { - }
$$

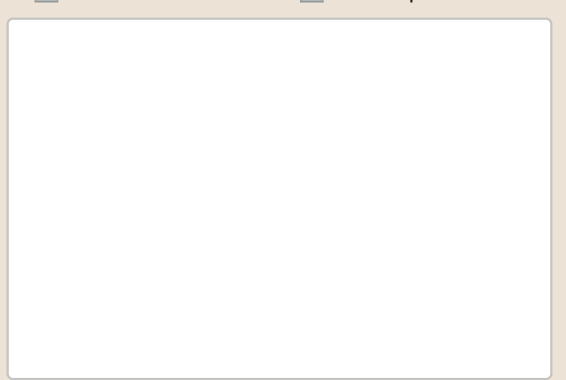

$\square$ Derivado de intervenciones

$\square$ Otro... 
La restauración y rehabilitación de la arquitectura tradicional de tierra. El caso de Aragón

\section{La restauración y rehabilitación de la arquitectura tradicional de tierra.}

\section{El caso de Aragón.}

3. DATOS DE LA INTERVENCIÓN

Intervención de:

$\square$ Mantenimiento $\square$ Rehabilitación parcia

$\square$ Restauración $\square$ Demolición X Reparación $\square$ Rehabilitación integral $\square$ Ampliación $\square$ Otro...

Reflexión previa Intervención espontanea

Observaciones

3.1. MUROS

No intervenido

Tipo de intervención

$\square$ Actualización $\square$ Reintegración $\square$ Demolición $\square$ Otro...

$\square$ Consolidación $\square$ Reconstrucción $\square$ Sustitución

Tipo de material

Descripción

3.2. ZÓCALO

Tipo de intervención

\section{Intervenido}

X Actualización $\square$ Reintegración $\square$ Demolición $\square$ Otro...

$\boldsymbol{X}$ Actualización
$\square$ Consolidación $\quad \boldsymbol{X}$ Reintegración
Retrucción $\quad \square$ Sustitución

Tipo de material

No tradicional Tipo de técnica

Descripción

revestimiento de gran grosor pintado de rojo

3.3. REVESTIMIENTOS

\section{Intervenido}

Tipo de intervención

\ Actualización $\square$ Reintegración $\square$ Demolición $\square$ Otro...

Tipo de material

$\square$ Consolidación $\square$ Reconstrucción $\square$ sustitución

Descripción

No tradicional Tipo de técnica Similar a la existente

3.4. VANOS

Pintura blanca en la fachada principa

Tipo de intervención

No intervenido

Tipo de material

Descripción

$\square$ Actualización $\square$ Reintegración $\square$ Demolición $\square$ Otro...

$\square$ Consolidación $\quad \square$ Reconstrucción $\quad \square$ Sustitución

3.5. CUBIERTA

Tipo de intervención

Intervenido

$\square$ Actualización $\quad \boldsymbol{X}$ Reintegración $\square$ Demolición $\square$ Otro.

Tipo de material

$\square$ Consolidación $\quad \square$ Reconstrucción $\square$ Sustitución

Descripción

No tradicional Tipo de técnica Similar a la existente

recolocación de tejas con mortero de cemento

3.6. OTRAS 


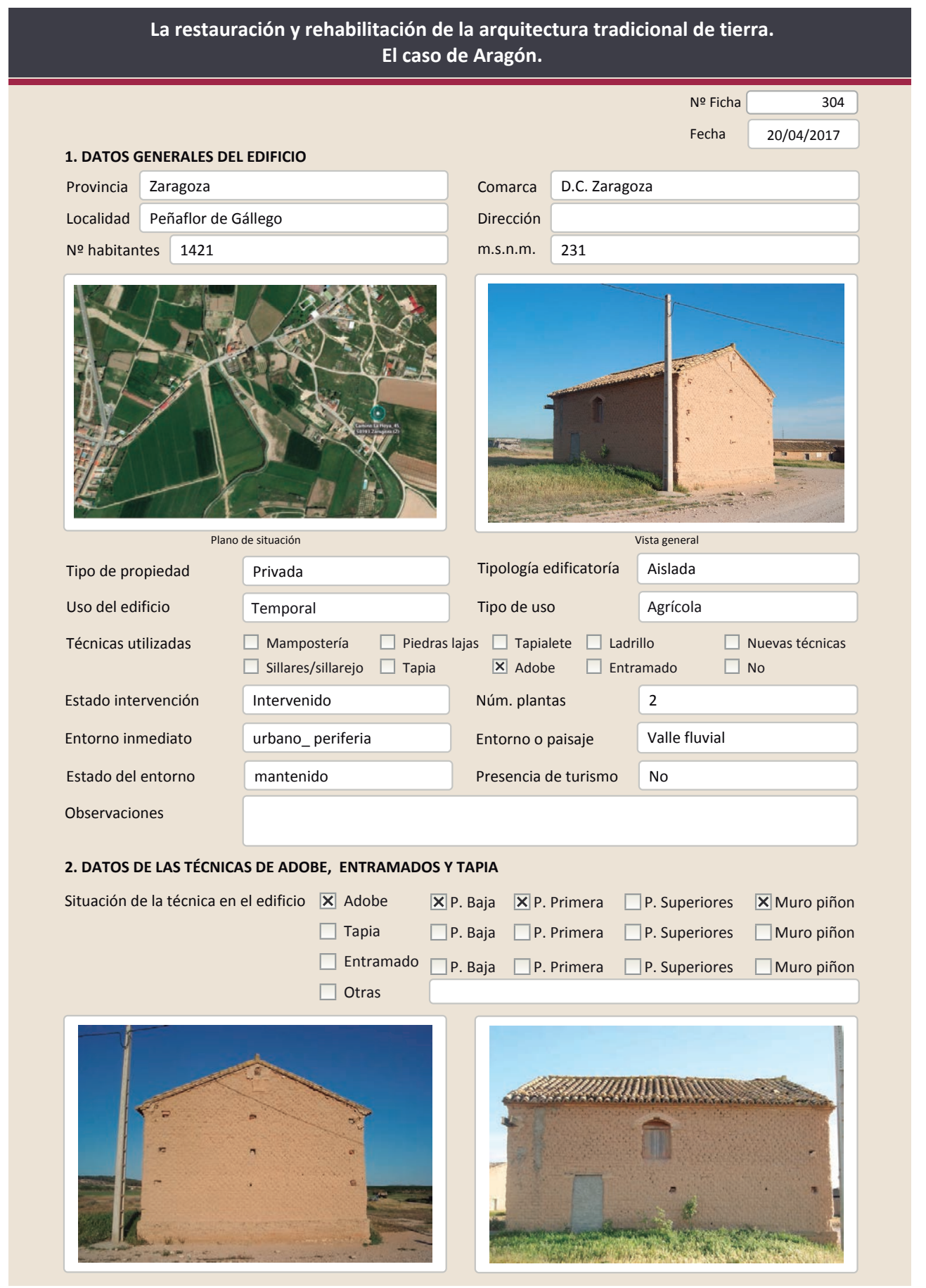

La restauración y rehabilitación de la arquitectura tradicional de tierra.

El caso de Aragón.

2.1. ADOBE

Dimensión de las piezas

Dimensión del muro

Aparejo del muro

Función estructural

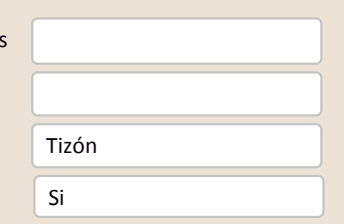

Color de las piezas

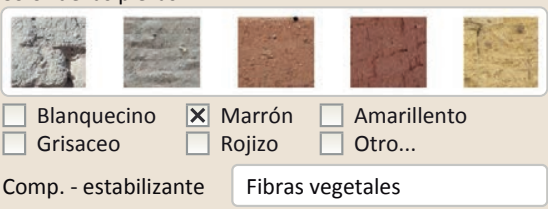

X Simple

$\square$ Suplementada en juntas

$\square$ Mixta

$\square$ Como suplemento

$\square$ Elementos de protección

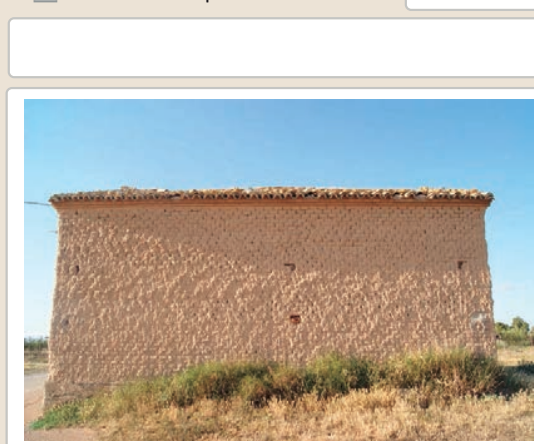

Lesiones XMuro $\square$ Zócalo $\square$ Revestimiento

X Erosión del material $\square$ Humedad por capilaridad X Erosion de las juntas $\square$ Humedades (manch/eflo)

X Pérdida de sección $\square$ Pérdida de verticalidad

$\square$ Vegetación $\quad \square$ Grietas por empuje de la c

$\square$ Desconchados

$\square$ Grietas por empuje de la cubie

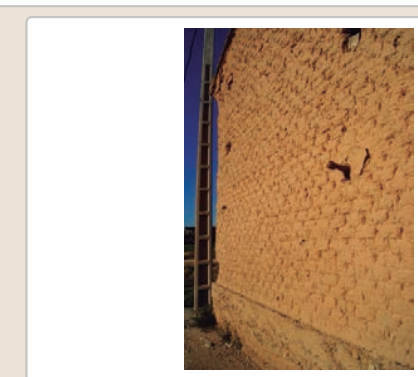

$\square$ Cubierta $\square$ otro...

$\square$ Grietas por asentamientos $\square$ Colapso

$\square$ Desconchados $\square$ Grietas porfalta de

$\square$ Por elementos impropios

$\square$ Derivado de intervenciones $\square$ Otro...

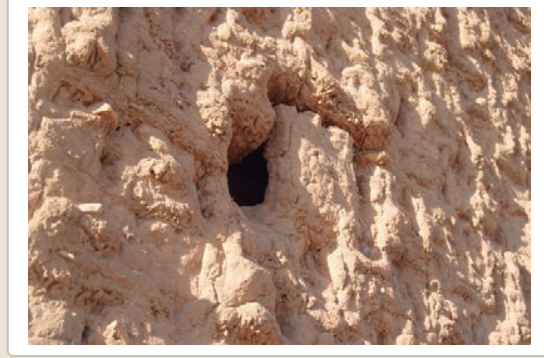

Observaciones 


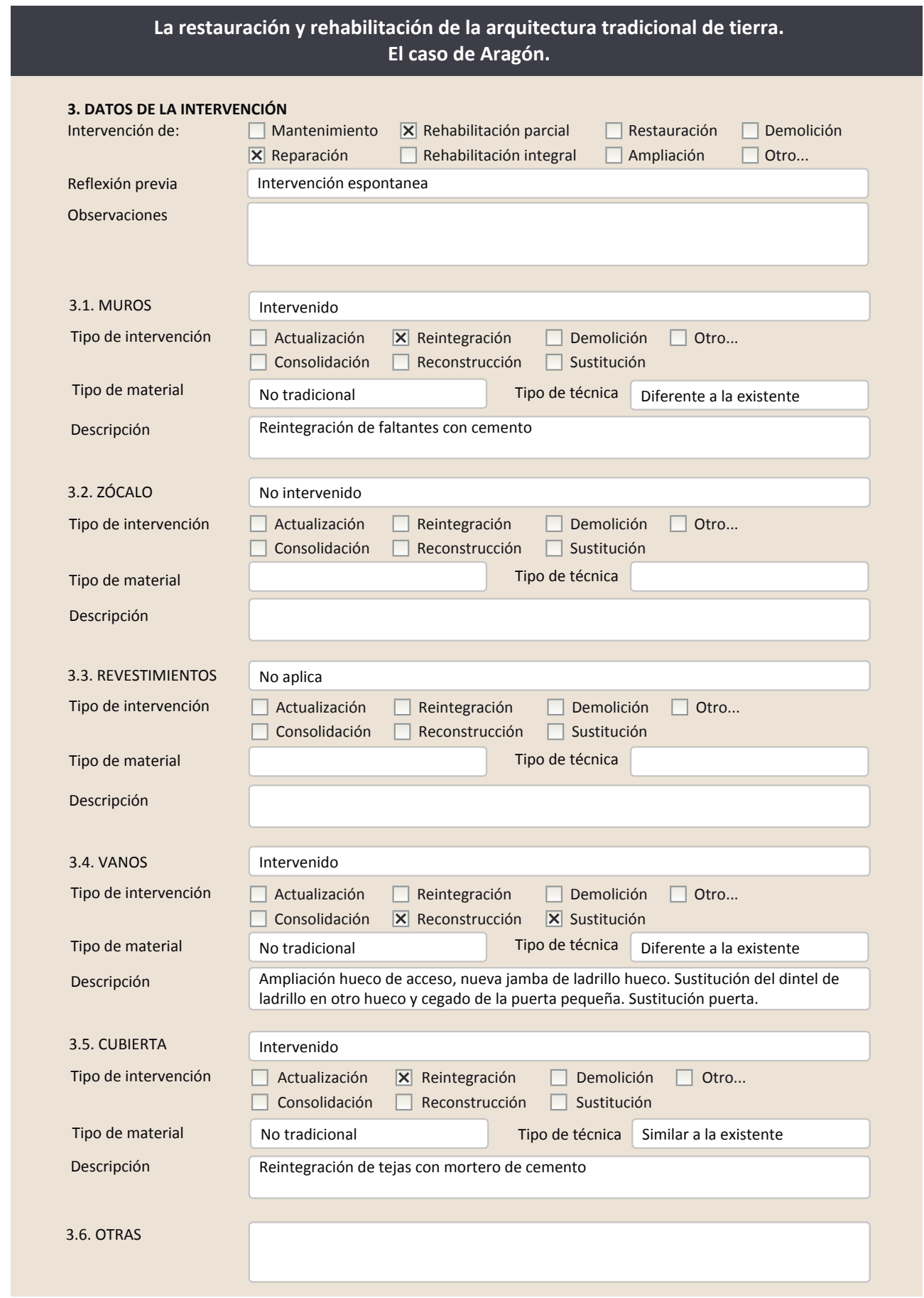

3.7. REHABILITACIÓN ENERGÉTICA $\square$ Fachada $\square$ Vanos $\square$ Forjados $\square$ Cubierta

Observaciones

FOTOGRAFÍAS DE LA INTERVENCIÓN
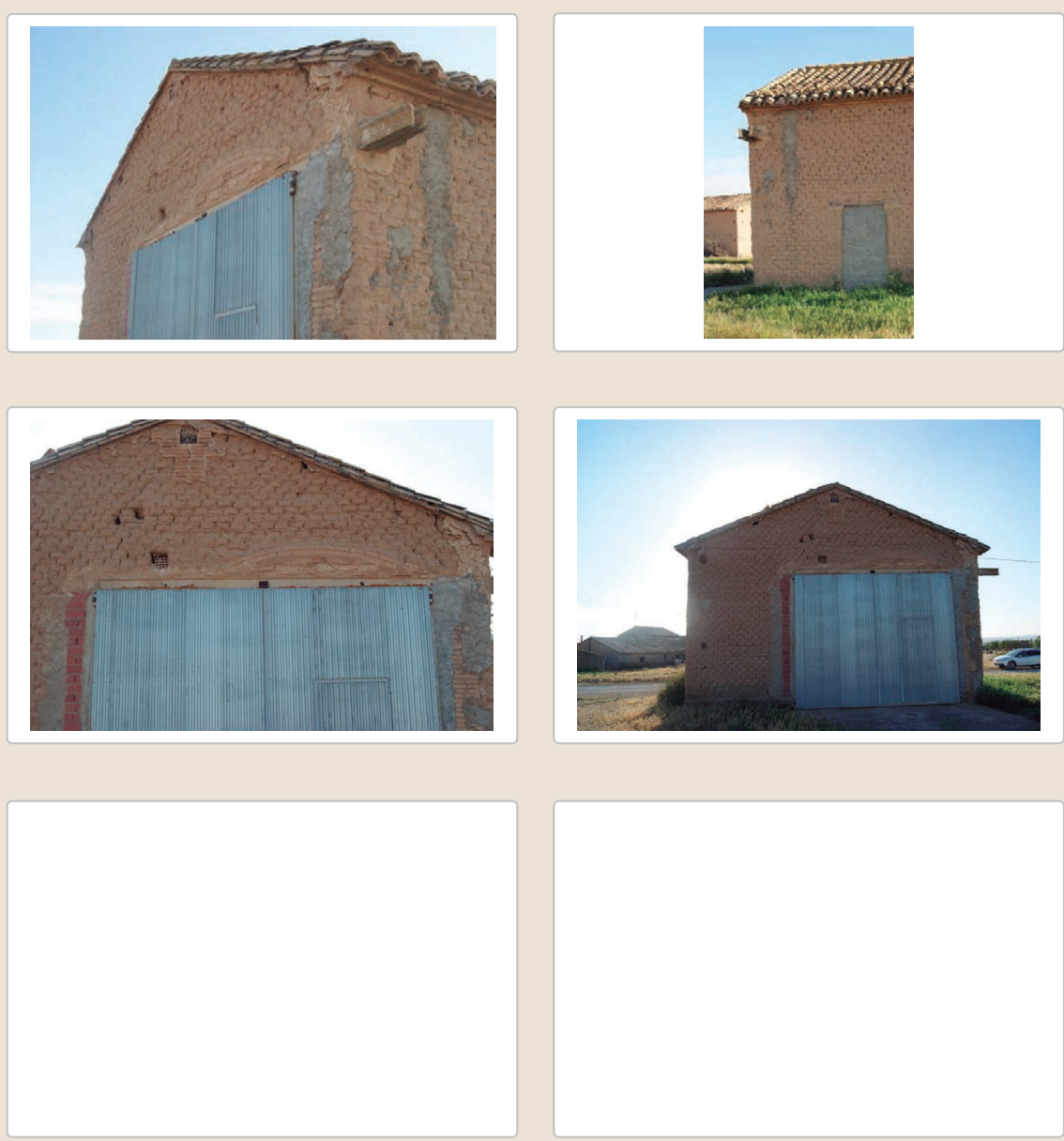


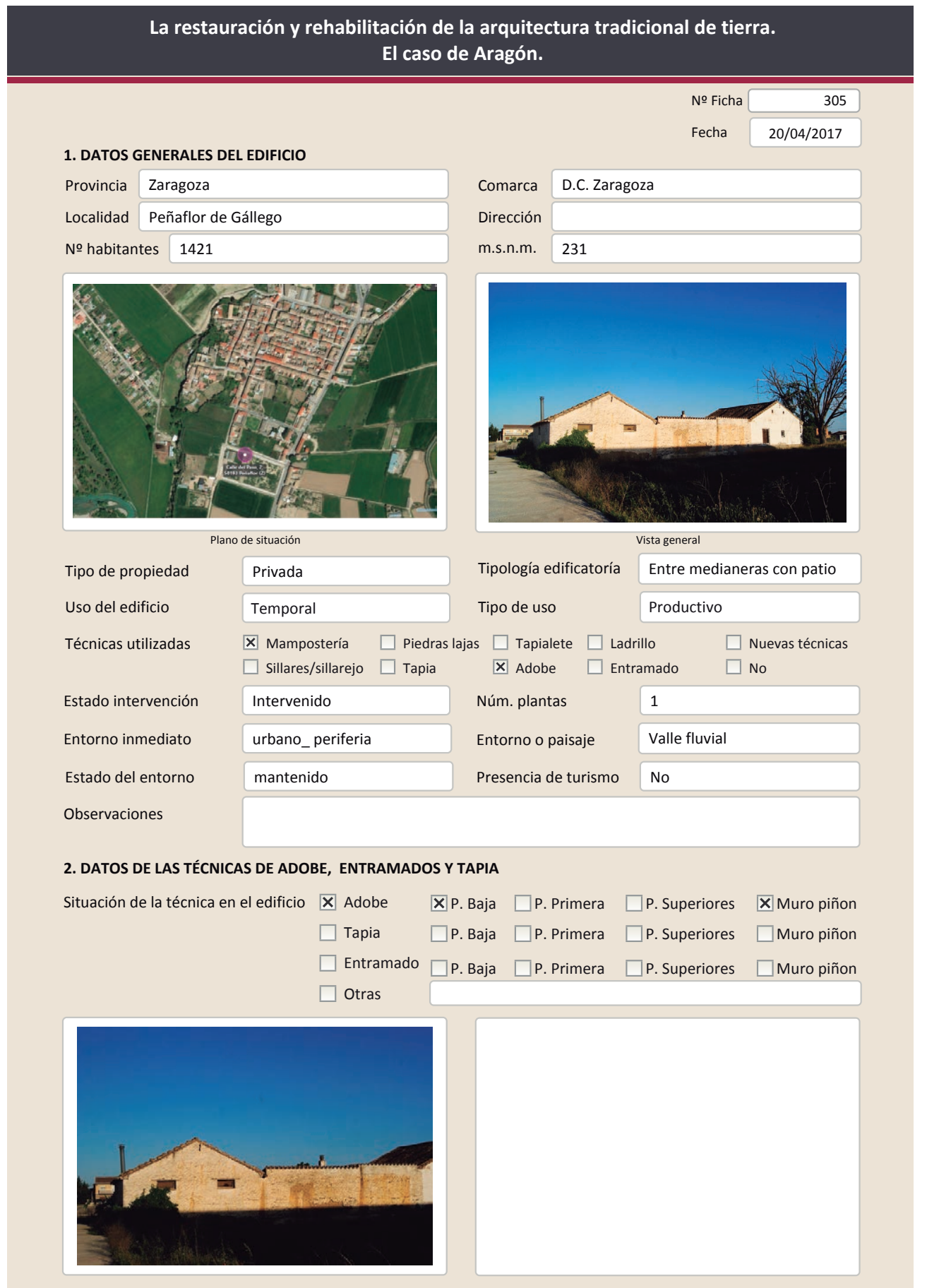

La restauración y rehabilitación de la arquitectura tradicional de tierra.

El caso de Aragón.

2.1. ADOBE

Dimensión de las piezas

Dimensión del muro

Aparejo del muro

Función estructural

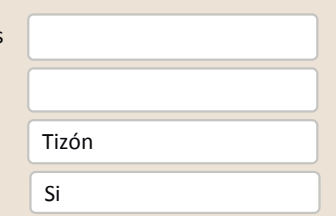

Color de las piezas

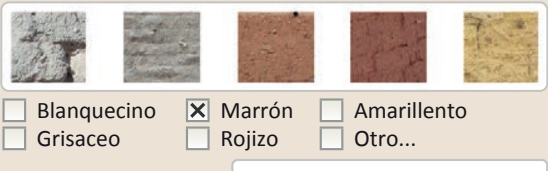

Variante constructiva/ tipo de fábrica

X Simple

$\square$ suplementada en juntas

$\square$ Mixta

$\square$ Como suplemento

$\square$ Elementos de protección

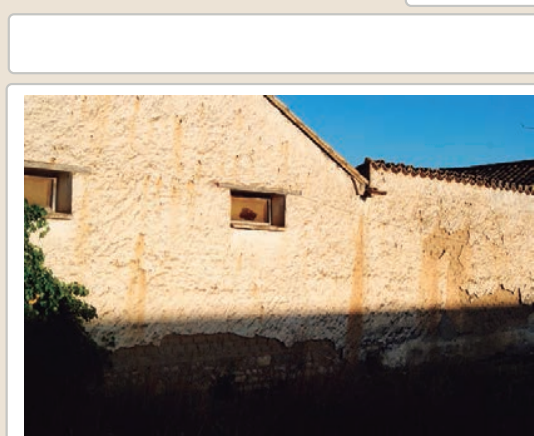

Lesiones $\square$ Muro $\square$ Zócalo $\mathbf{X}$ Revestimiento

区 Erosión del material $\square$ Humedad por capilaridad

$\square$ Erosion de las juntas $\square$ Humedades (manch/eflo)

$\square$ Pérdida de sección $\square$ Pérdida de verticalidad

$\square$ Vegetación $\quad \square$ Grietas por empuje de la c

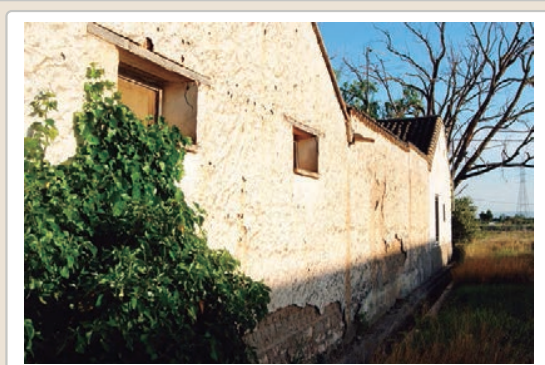

$\square$ Grietas porfalta de traba

Cubierta $\square$ Otro...

$\square$ Grietas por asentamientos

$\square$ Colapso

X Por elementos impropios

$\begin{aligned} & \\ \square & \text { Derivado } \\ & \text { Otro... }\end{aligned}$ 
La restauración y rehabilitación de la arquitectura tradicional de tierra. El caso de Aragón

\section{La restauración y rehabilitación de la arquitectura tradicional de tierra.}

\section{El caso de Aragón.}

3. DATOS DE LA INTERVENCIÓN

Intervención de:

$\square$ Mantenimiento $\quad \mathbf{X}$ Rehabilitación parcial

$\square$ Restauración $\square$ Demolición

Reflexión previa

$\square$ Reparación

Rehabilitación integral $\square$ Ampliació

$\square$ Otro..

Reflexión previa

Intervención espontanea

(n)

3.1. MUROS

No intervenido

Tipo de intervención

$\square$ Actualización $\square$ Reintegración $\square$ Demolición $\square$ Otro...

$\square$ Consolidación $\square$ Reconstrucción $\square$ Sustitución

Tipo de material

Descripción

3.2. ZÓCALO

No intervenido

Tipo de intervención

$\square$ Actualización

Tipo de material

Descripción

3.3. REVESTIMIENTOS

Tipo de intervención

\section{Intervenido}

X Actualización $\square$ Reintegración $\square$ Demolición $\square$ Otro...

$\square$ Consolidación $\mathbf{X}$ Reconstrucción $\square$ Sustitución

Tipo de material

Descripción

No tradicional Tipo de técnica Diferente a la existente

Cemento con pintura blanca. Esta intervención esta muy degradada por la

3.4. VANOS

Intervenido

Tipo de intervención $\square$ Actualización $\quad \mathbf{X}$ Reintegración $\quad \square$ Demolición $\square$ Otro...

\begin{tabular}{l|l|l|l|l|l|l}
\hline Tipo de material & No tradicional & Tipo de técnica & Diferente a la existente \\
\hline
\end{tabular}

Descripción

Alféizares de cemento

3.5. CUBIERTA

Tipo de intervención

No intervenido

Tipo de material

$\square$ Actualización $\square$ Reintegración $\quad \square$ Demolición $\square$ Otro...

Descripción

Tipo de técnica

3.6. OTRAS 


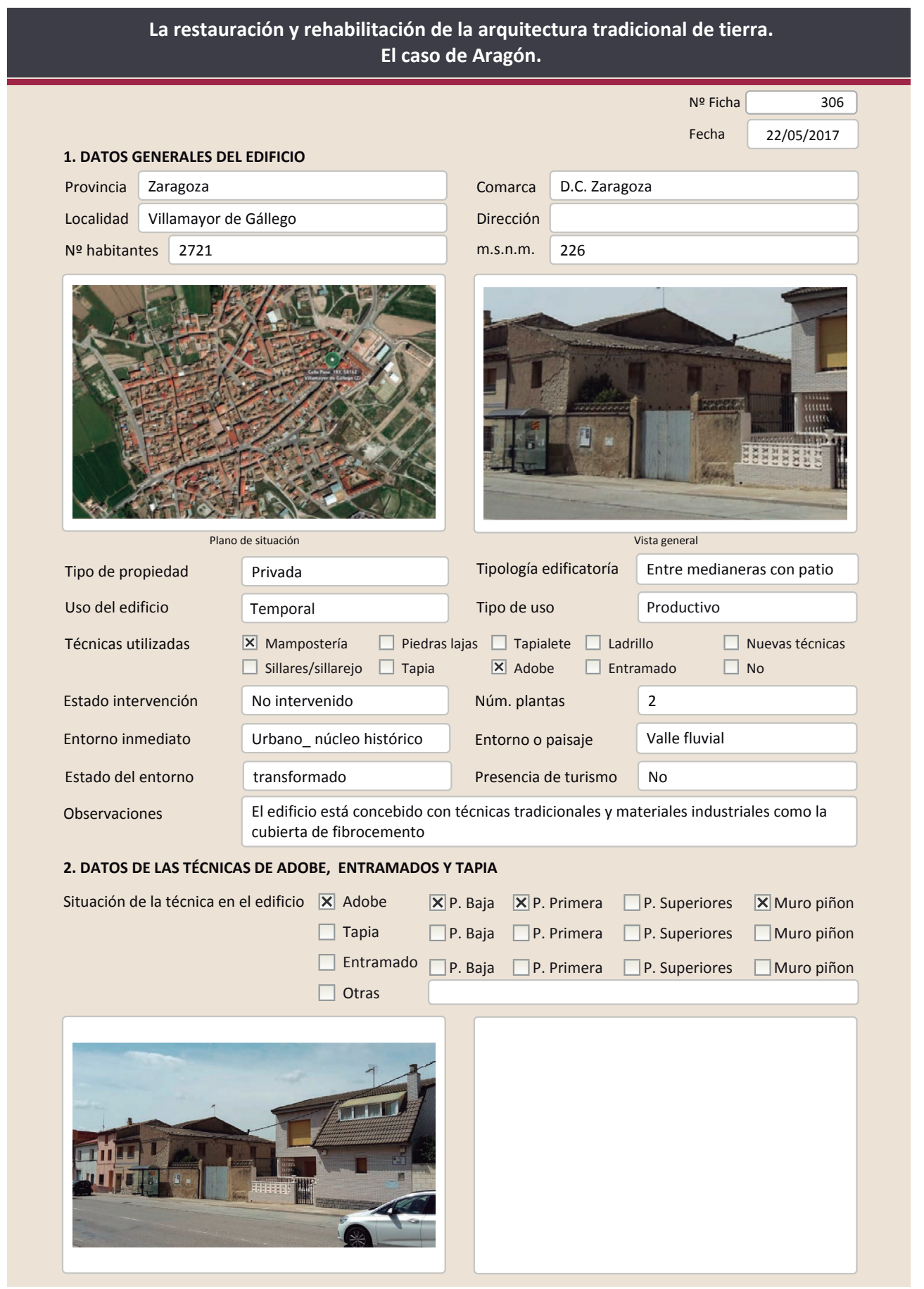

La restauración y rehabilitación de la arquitectura tradicional de tierra.

2.1. ADOBE

Dimensión de las piezas Dimensión del muro

Aparejo del muro

Función estructural

\section{El caso de Aragón.}
メ Simple
$\square$ Suplementada en juntas
$\square$ Mixta
$\square$ Como suplemento
$\square$ Elementos de protección
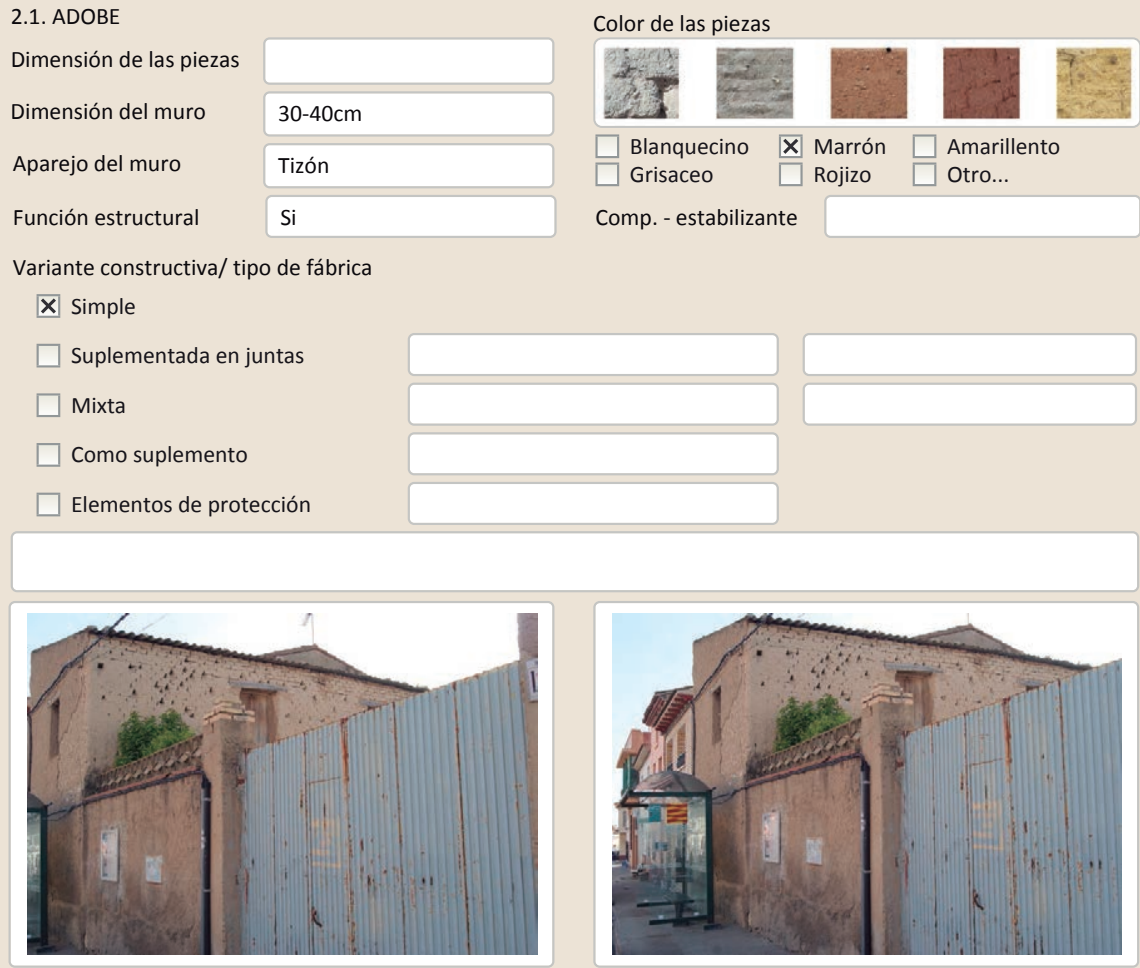

Comp. - estabilizante

fábrica

iones

X Muro XZócalo X Revestimiento

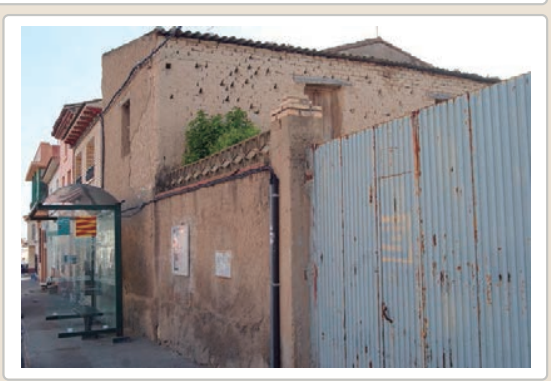

$\mathbf{X}$ Erosión del material $\mathbf{X}$ Humedad por capilaridad

$\square$ Cubierta $\square$ otro...
$\mathbf{X}$ Pérdida de sección
$X$ Humedades (manch/eflo)
$\square$ Pérdida de verticalidad
$\square$ Colapso
$\square$ Por elementos impropios

$\square$ Grietas por asentamiento

$\square$ Vegetación $\quad \square$ Grietas por empuje de la cubic

X Desconchados

$\square$ Grietas porfalta de traba

$\square$ Derivado

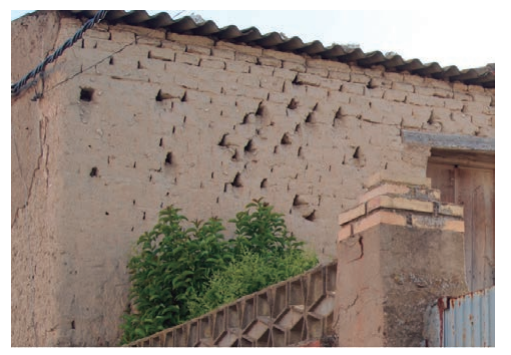

Observaciones

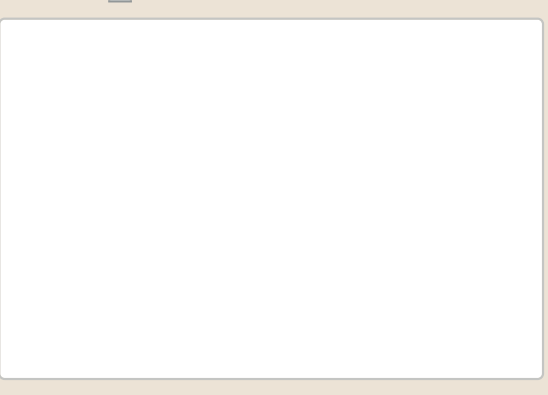

Degradación del muro que presenta oquedades con forma triangular. 


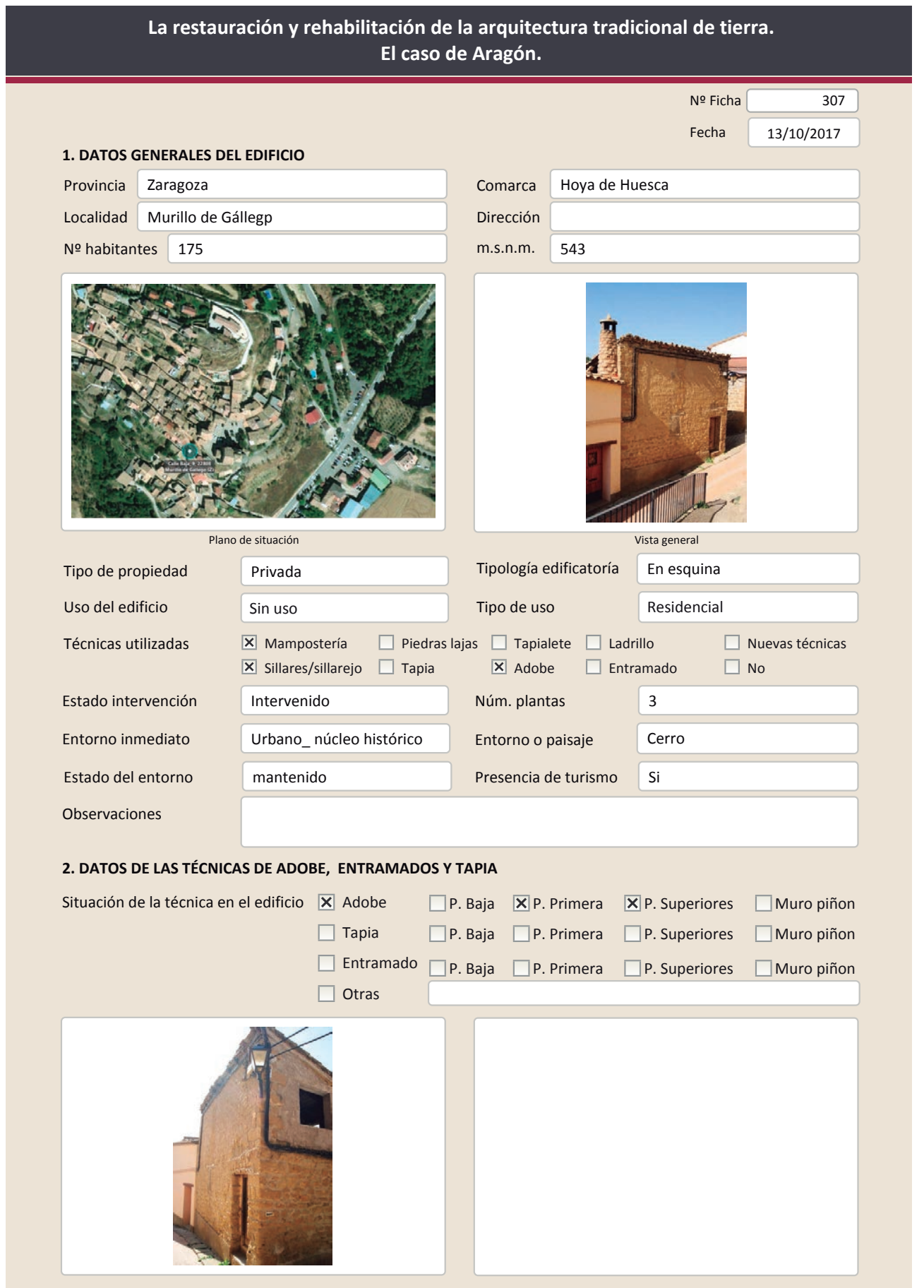

2.1. ADOBE

Dimensión de las piezas $\quad \mathrm{L} \times 16,5 \times 8,5$

Dimensión del muro $30-40 \mathrm{~cm}$

Aparejo del muro Tizón

Función estructural

$\mathrm{Si}$
Color de las piezas

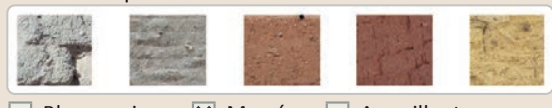

Blanquecino $\mathbf{x}$ Marrón $\square$ Amarillento $\square$ Grisaceo $\square$ Rojizo $\square$ Otro..

Comp. - estabilizante

Variante constructiva/ tipo de fábrica

$\square$ Simple

$\square$ Suplementada en juntas

X Mixta

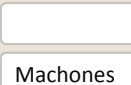

\section{Piedra}

$\square$ Como suplemento

$\square$ Elementos de protección

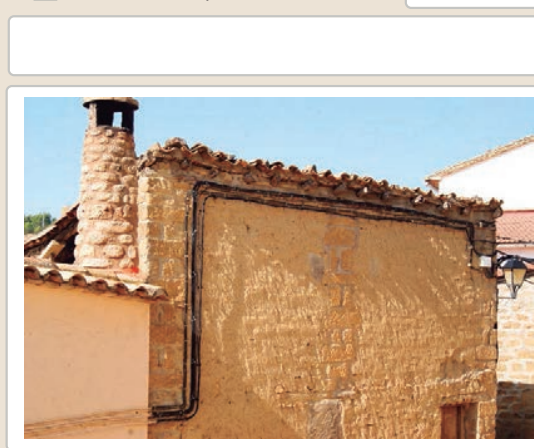

Lesiones ХMuro $\square$ Zócalo $\square$ Revestimiento

X Erosión del material $\square$ Humedad por capilaridad

X Erosion de las juntas $\square$ Humedades (manch/eflo)

$\square$ Pérdida de sección $\quad \square$ Pérdida de verticalidad

Por elementos impropios

$\square$ Vegetación $\square$ Grietas por empuje de la cubie

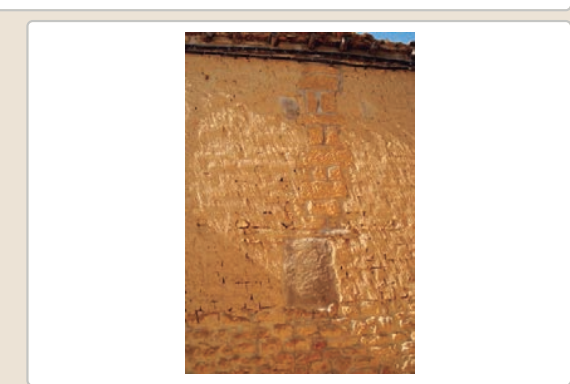

$\square$ Desconchados

$\square$ Grietas porfalta de trab

$\square$ Cubierta $\square$ otro...

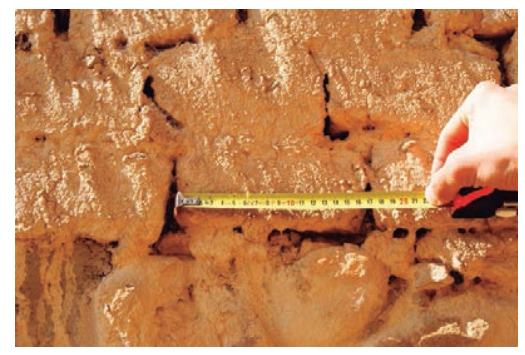

$\square$ Derivado de intervenciones

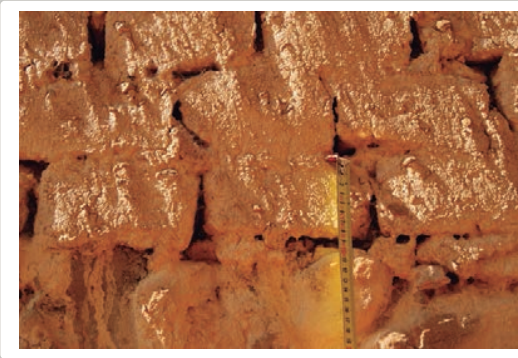

Observaciones 


\section{La restauración y rehabilitación de la arquitectura tradicional de tierra.} El caso de Aragón.

3. DATOS DE LA INTERVENCIÓN

Intervención de:

$\square$ Mantenimien

La restauración y rehabilitación de la arquitectura tradicional de tierra.

El caso de Aragón.

\begin{tabular}{l|l|l|} 
Intervención de: & Mantenimiento $\quad \square$ Rehabilitación parcial $\quad \square$ Restauración $\quad \square$ Demolición \\
& $\square$ Reparación $\quad \boldsymbol{X}$ Rehabilitación integral $\quad \square$ Ampliación $\quad \square$ Otro... \\
Reflexión previa & Intervención planificada \\
Observaciones & La intervención está en proceso y ha quedado paralizada a mitad \\
& &
\end{tabular}

3.1. MUROS
Tipo de intervención

Intervenido

Tipo de material

$\square$ Actualización $\quad \boldsymbol{X}$ Reintegración $\square$ Demolición $\square$ Otro...

$\square$ Consolidación $\square$ Reconstrucción $\square$ Sustitución

Descripción

No tradicional Tipo de técnica Diferente a la existente

\subsection{ZÓCALO}

Tipo de intervención Reintegración

Tipo de material

\section{Intervenido}

$\square$ Actualización $\quad \mathbf{X}$ Reintegración $\quad \square$ Demolición $\square$ Otro...

$\square$ Consolidación $\quad \mathbf{X}$ Reconstrucción $\square$ Sustitución

Descripción

3.3. REVESTIMIENTOS

Tipo de intervención

No tradicional

Tipo de técnica Diferente a la existente

Rejuntado de la mampostería y nuevo revestimiento de cemento.

\section{Intervenido}

$\square$ Actualización $\quad \square$ Reintegración $\quad \square$ Demolición $\quad \square$ Otro...

Tipo de material

Descripción

Consolidación $\mathbf{X}$ Reconstrucción $\square$ Sustitución

3.4. VANOS

Tipo de intervención

Tipo de técnica Diferente a la existente

Revestimiento con cemento en las fachadas lateral y delantera

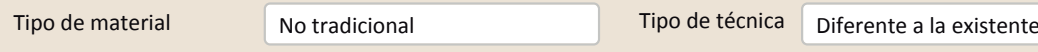

Intervenido

$\square$ Actualización $\square$ Reintegración $\square$ Demolición $\square$ Otro...

$\square$ Consolidación $\mathbf{X}$ Reconstrucción $\square$ Sustitución

Descripción Nueva configuración de los huecos. EL dintel se ha sustituido por prefabricado de hormigón

3.5. CUBIERTA

Tipo de intervención

Intervenido

$\square$ Actualización

$\square$ Consolidación

区 Reintegració

$\square$ Otro...

Tipo de material

No tradicional

Descripción

Fijación de las tejas existentes con cemento

\subsection{REHABILITACIÓN ENERGÉTICA $\quad \square$ Fachada $\square$ Vanos $\square$ Forjados $\square$ Cubierta}

Observaciones

FOTOGRAFíAS DE LA INTERVENCIÓN
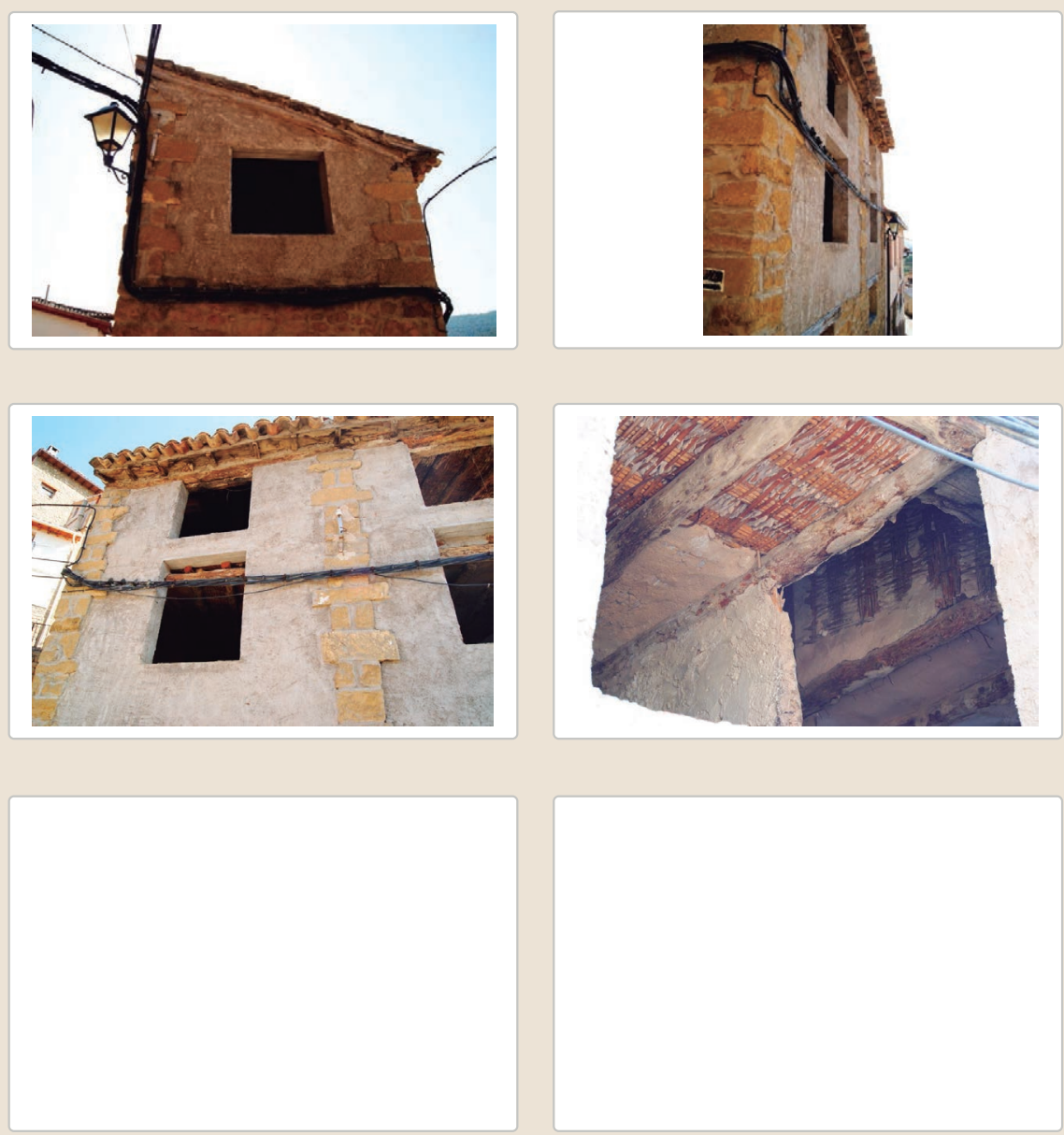

3.6. OTRAS 


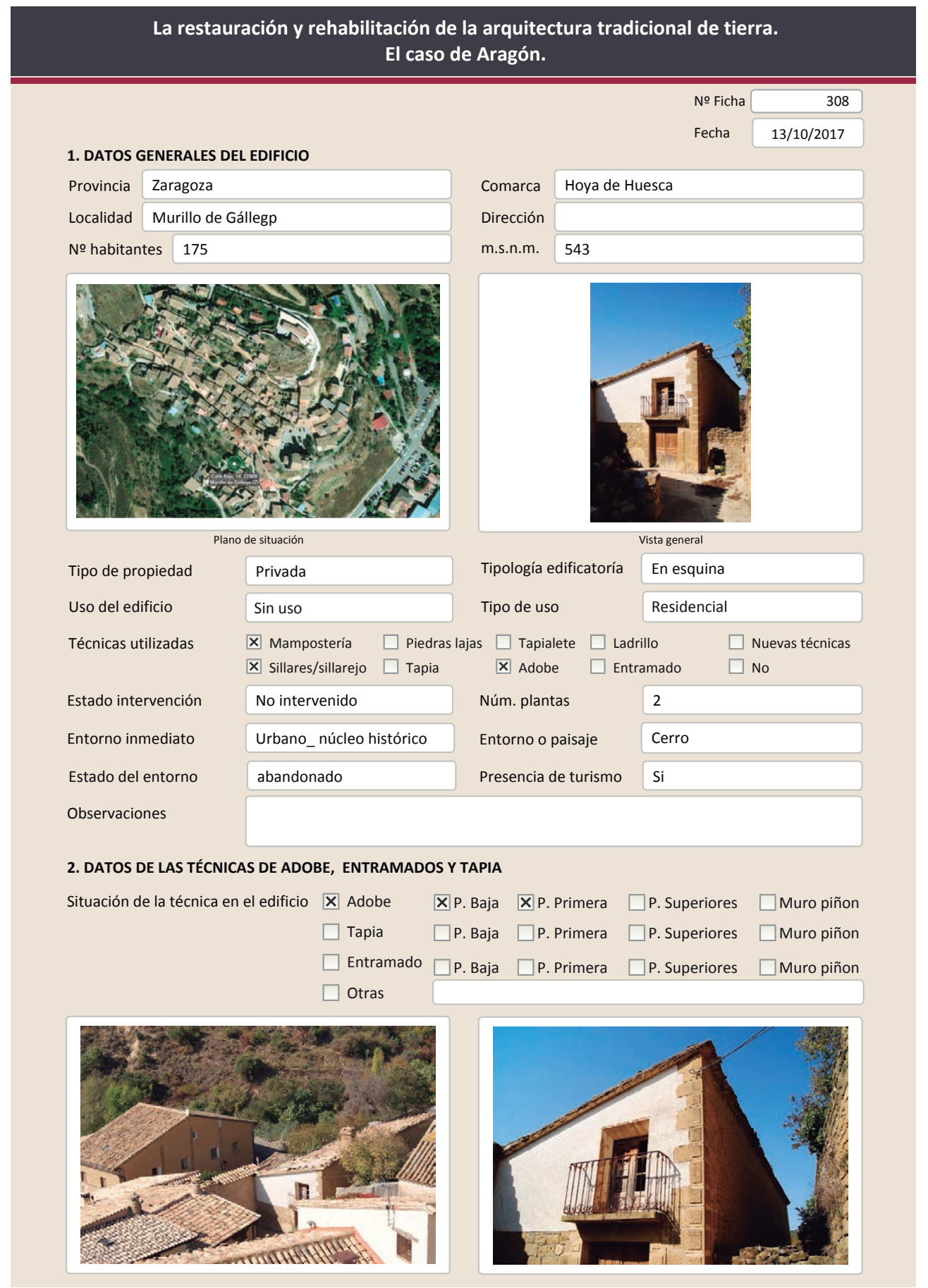

2.1. ADOBE

Dimensión de las piezas Dimensión del muro

Aparejo del muro

Función estructural

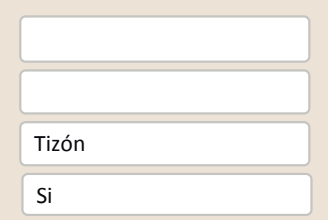

Color de las piezas

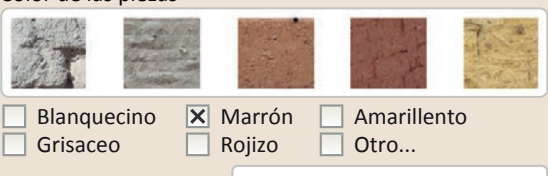

Comp. - estabilizante

Variante constructiva/ tipo de fábrica

$\square$ simple

$\square$ suplementada en juntas

区 Mixta
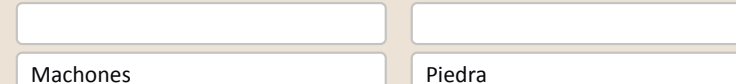

$\square$ Como suplemento

$\square$ Elementos de protección

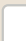

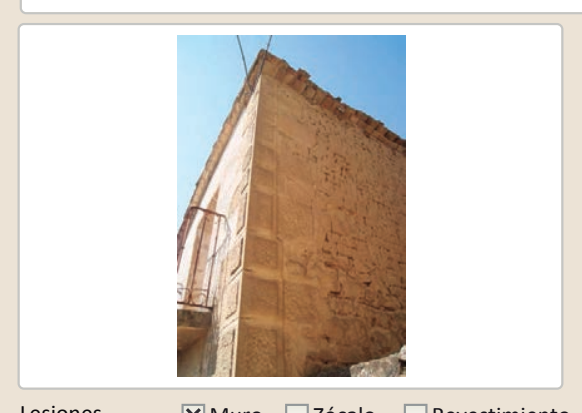

Lesiones \Muro $\square$ Zócalo $\square$ Revestimiento

区 Erosión del material $\square$ Humedad por capilaridad

$\square$ Erosion de las juntas $\square$ Humedades (manch/eflo)

$\square$ Pérdida de sección $\square$ Pérdida de verticalidad

$\square$ Vegetación $\quad \square$ Grietas por empuje de la

$\square$ Grietas porfalta de traba

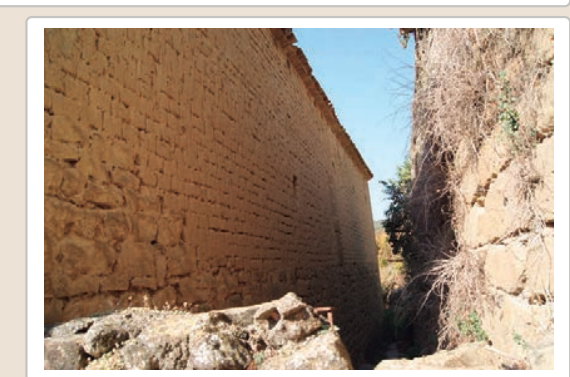

$\square$ Cubierta $\square$ Otro...

$\square$ Desconchados $\square$ Grietas porfalta de traba

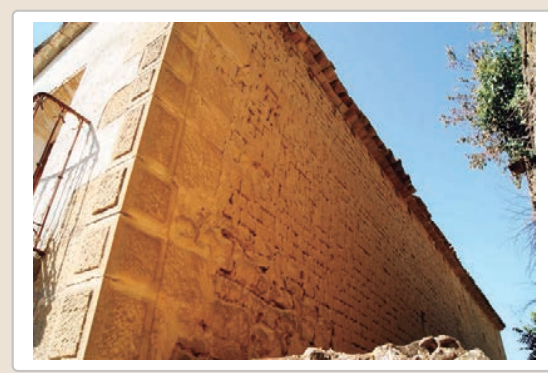

Observaciones 


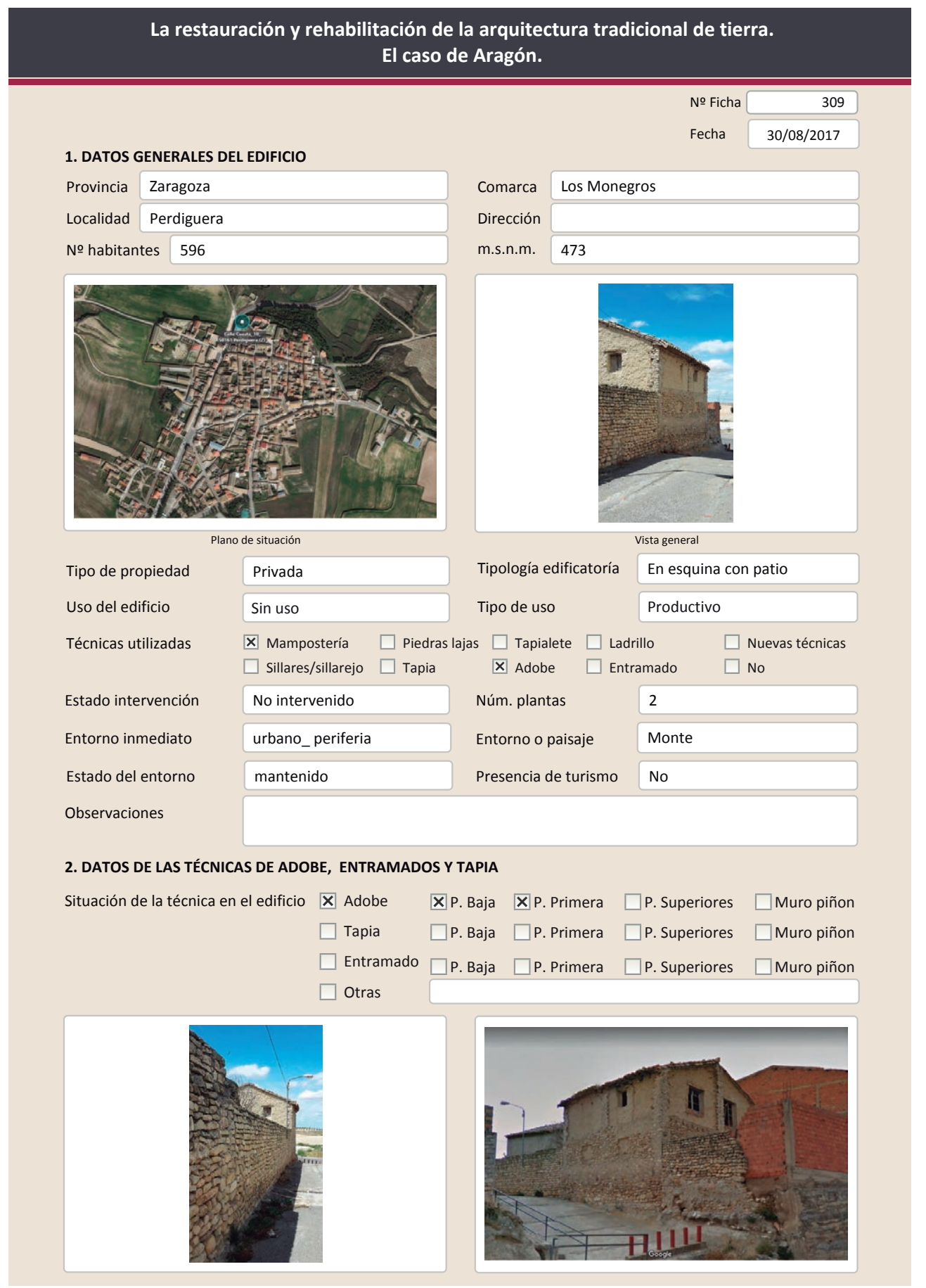

La restauración y rehabilitación de la arquitectura tradicional de tierra.

El caso de Aragón.

2.1. ADOBE

Dimensión de las piezas Dimensión del muro Aparejo del muro Función estructural
Color de las piezas

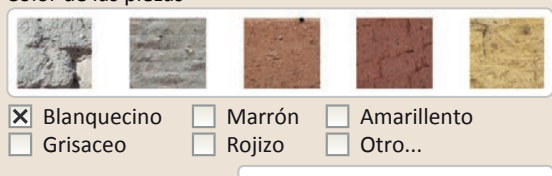

Grisaceo

ante

Variante constructiva/ tipo de fábrica

\section{$\square$ Simple}

$\square$ Suplementada en juntas

X Mixta

\section{Machones}

Mampostería y yeso

$\square$ Como suplemento

$\square$ Elementos de protección

Los pilares no son encofrados como en la mayoría de los casos localizados.

Hay dos tipos de adobe que se distinguen claramente en el nivel de deterioro

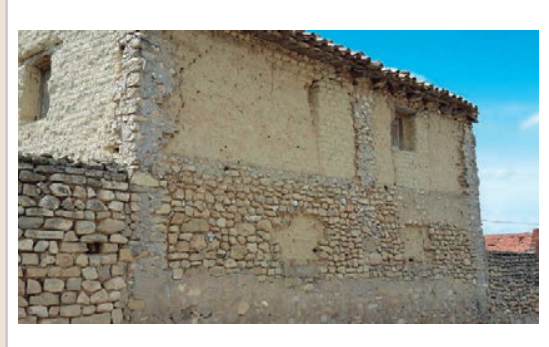

Lesiones $\quad \mathbf{X}$ Muro $\square$ Zócalo $\square$ Revestimiento $\mathbf{X}$ Cubierta $\square$ Otro...

区 Erosión del material $\quad \square$ Humedad por capilaridad $\quad \square$ Grietas por asentamientos

$\mathbf{X}$ Erosion de las juntas $\square$ Humedades (manch/eflo) $\square$ Colapso

X Pérdida de sección $\square$ Pérdida de verticalidad $\square$ Por elementos impropios

$\square$ Vegetación $\quad \square$ Grietas por empuje de la cubierta $\square$ Derivado de intervenciones

$\square$ Desconchados

$\begin{array}{ll}\square \text { Grietas por empuje de la cubierta } & \square \text { Derivadod } \\ \square \text { Grietas porfalta de traba } & \square \text { Otro... }\end{array}$

Observaciones 


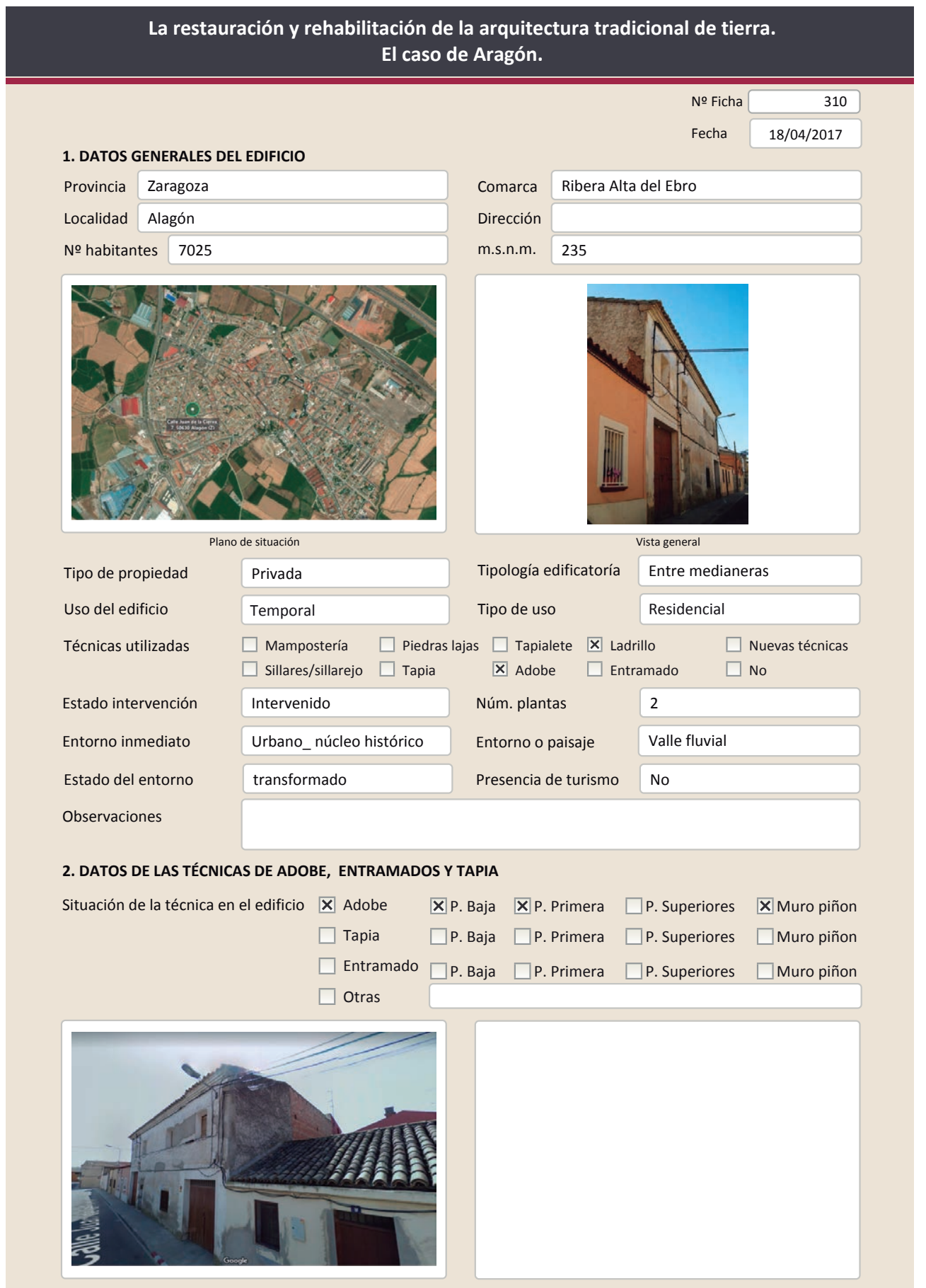

2.1. ADOBE

Dimensión de las piezas Dimensión del muro

Aparejo del muro

Función estructural

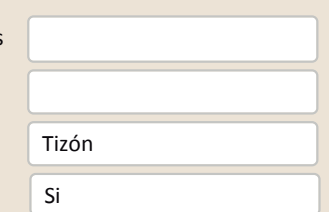

Color de las piezas

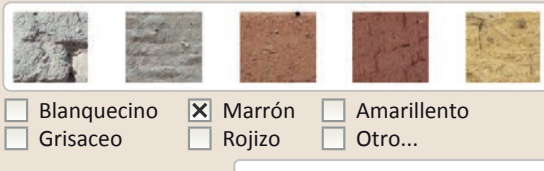

Grisaceo

Variante constructiva/ tipo de fábrica

区 Simple

$\square$ Suplementada en juntas

$\square$ Mixta

$\square$ Como suplemento

X Elementos de protección

Revestimiento

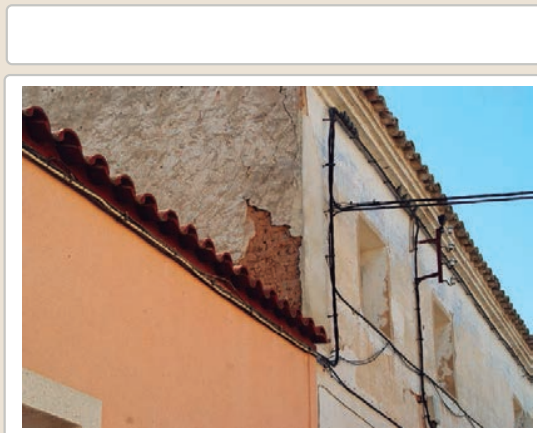

Lesiones $\square$ Muro $\mathbf{X}$ Zócalo $\mathbf{X}$ Revestimiento

$\square$ Erosión del material $\quad \mathbf{X}$ Humedad por capilaridad

$\square$ Erosion de las juntas $\quad \mathbf{X}$ Humedades (manch/eflo)

$\square$ Pérdida de sección $\square$ Pérdida de verticalidad

$\square$ Vegetación

$X$ Grietas por empuje de la $\square$ Grietas porfalta de traba

$\square$ Cubierta $\square$ otro...

$\square$ Grietas por asentamiento

$\square$ Colapso

$\mathbf{X}$ Desconchados

$\square$ Por elementos impropios

$\square$ Derivado de intervenciones 


\section{La restauración y rehabilitación de la arquitectura tradicional de tierra.}

\section{El caso de Aragón.}

3. DATOS DE LA INTERVENCIÓN

\begin{tabular}{|c|c|c|c|c|}
\hline Intervención de: & $\begin{array}{l}\square \text { Mantenimiento } \\
\text { Х Reparación }\end{array}$ & $\begin{array}{l}\square \text { Rehabilitación parcial } \\
\square \text { Rehabilitación integral }\end{array}$ & $\begin{array}{l}\square \text { Restauración } \\
\text { X Ampliación }\end{array}$ & $\begin{array}{l}\square \text { Demolición } \\
\square \text { Otro... }\end{array}$ \\
\hline Reflexión previa & \multicolumn{4}{|c|}{ Intervención espontanea } \\
\hline erva & & & & \\
\hline
\end{tabular}

\subsection{MUROS}

Tipo de intervención

Intervenido

Tipo de material

$\square$ Actualización $\quad \square$ Reintegración $\quad \square$ Demolición $\square$ Otro...

$\square$ Consolidación $\quad$ Reconstrucción $\square$ Sustitución

Descripción

Tipo de técnica Similar a la existente

3.2. ZÓCALO

Tipo de intervención

Ampliación del edificio por la parte trasera con fábrica de ladrillo

Tipo de material

Intervenido

$\square$ Actualización $\quad \mathbf{X}$ Reintegración $\square$ Demolición $\square$ Otro...

$\square$ Consolidación $\quad \square$ Reconstrucción $\quad \square$ Sustitución

Descripción

No tradicional Tipo de técnica Diferente a la existente

3.3. REVESTIMIENTOS

Cemento

Tipo de intervención

Intervenido

Tipo de material

$\square$ Actualización $\quad \boldsymbol{X}$ Reintegración $\quad \square$ Demolición $\square$ Otro...

$\square$ Consolidación $\quad \square$ Reconstrucción $\square$ Sustitución

Descripción

No tradicional Tipo de técnica Similar a la existente

3.4. VANOS

Reintegración de faltantes en el revestimiento con mortero de cemento

Tipo de intervención

Intervenido

Tipo de material

$\square$ Actualización $\quad \square$ Reintegración $\quad \square$ Demolición $\square$ Otro...

$\square$ Consolidación $\quad \boldsymbol{X}$ Reconstrucción $\mathbf{X}$ Sustitución

Descripción

No tradicional

Tipo de técnica Diferente a la existente

Ampliación de los huecos de plana baja y sustitución de sus carpinterías

correspondientes

3.5. CUBIERTA

Tipo de intervención

Intervenido

Tipo de intervención

$\square$ Actualización $\quad \boldsymbol{X}$ Reintegración $\quad \square$ Demolición $\square$ Otro..

Tipo de material

$\square$ Consolidación $\quad \square$ Reconstrucción $\square$ Sustitución

Descripción

No tradicional

Tipo de técnica Similar a la existente

3.6. OTRAS 


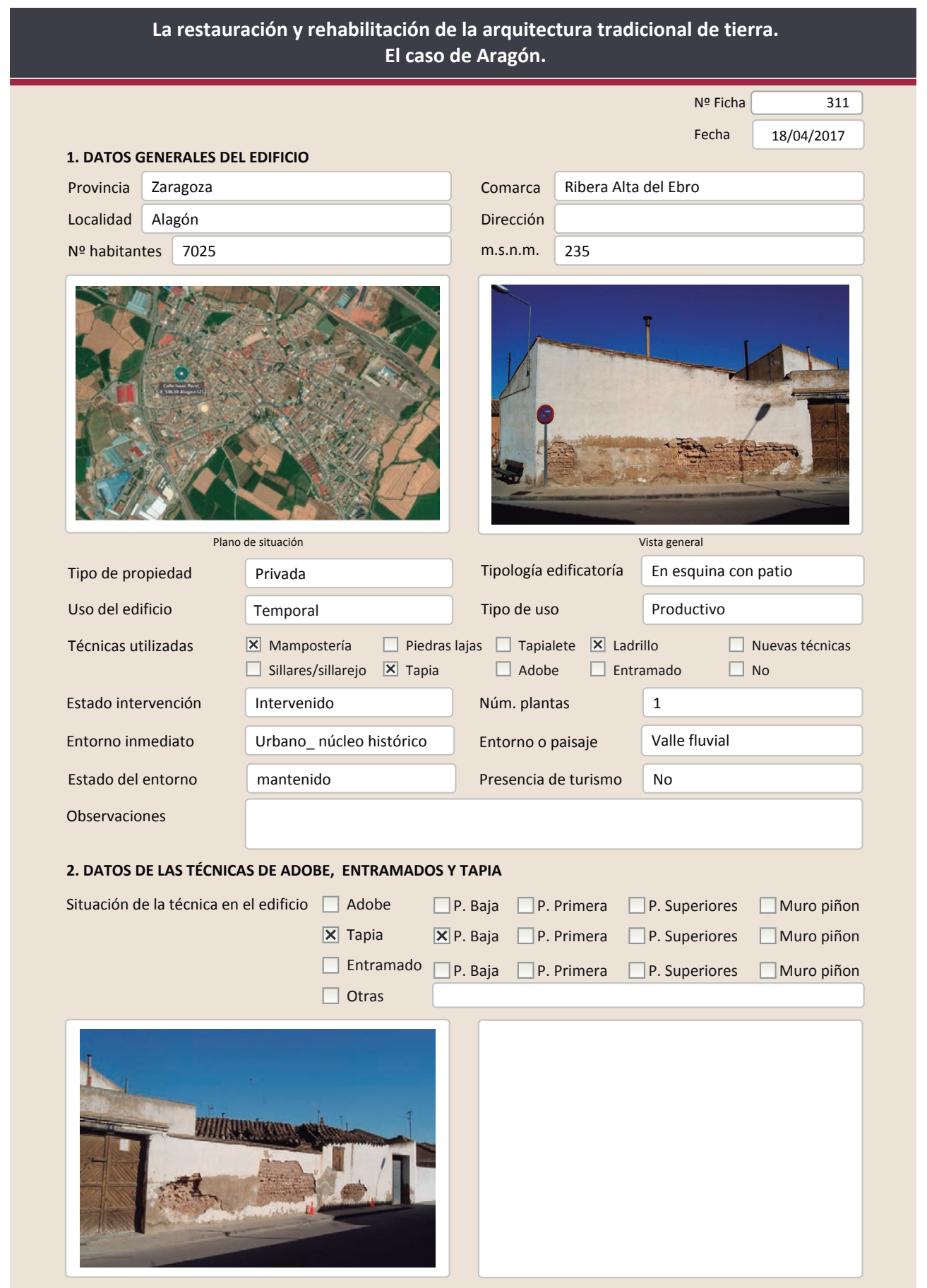

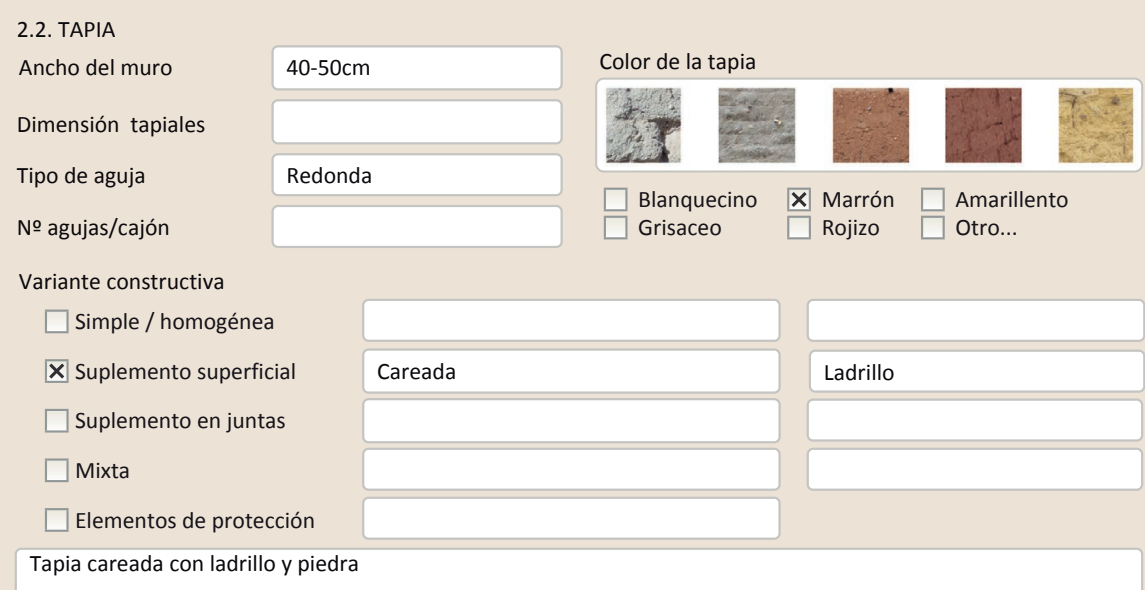

Tapia careada con ladrillo y piedra

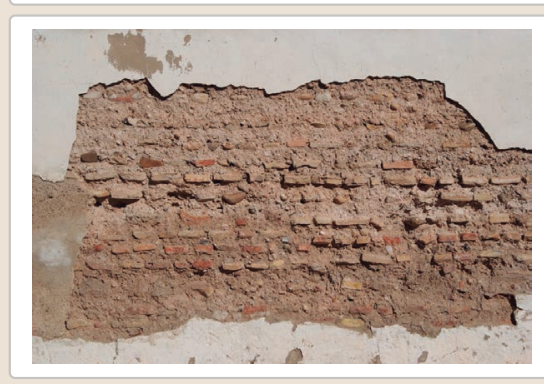

Lesiones ХMuro $\square$ Zócalo $\mathbf{X}$ Revestimiento $\square$ Cubierta $\square$ Otro...

\ Erosión del material $\quad \square$ Humedad por capilaridad $\quad \square$ Grietas por asentamientos $\square$ Erosion de las juntas $\square$ Humedades (manch/eflo) $\quad \square$ Colapso

X Pérdida de sección $\square$ Pérdida de verticalidad $\quad \square$ Por elementos impropios

$\square$ Vegetación $\square$ Perivado de inteverion

X Desconchados $\quad \square$ Grietas porfalta de traba

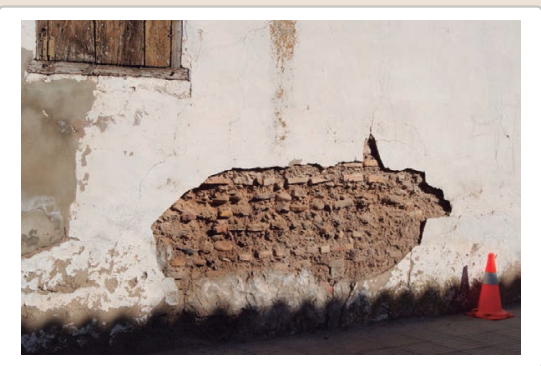

$\square$ Deriva
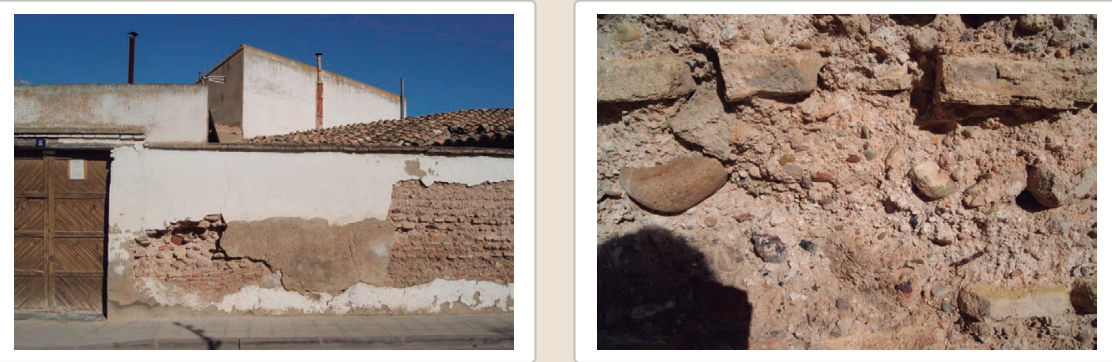

Observaciones 


\section{La restauración y rehabilitación de la arquitectura tradicional de tierra.}

\section{El caso de Aragón.}

3. DATOS DE LA INTERVENCIÓN

Intervención de:

$\square$ Mantenimiento $\square$ Rehabilitación parcial

$\square$ Restauración $\square$ Demolición

Reflexión previa X Reparación $\square$ Rehabilitación integra

$\square$ Ampliación $\square$ Otro...

Observaciones

Intervención espontanea

(n)

3.1. MUROS

Tipo de intervención

No intervenido

Tipo de material

Descripción

3.2. ZÓCALO

Tipo de intervención

Tipo de material

Descripción

3.3. REVESTIMIENTOS

Tipo de intervención

Tipo de material

Descripción

3.4. VANOS

Tipo de intervención

Tipo de material

Descripción

3.5. CUBIERTA

Tipo de intervención

Tipo de material

Descripción

3.6. OTRAS

Intervenido

$\square$ Actualización $\mathbf{X}$ Reintegración $\square$ Demolición $\square$ Otro...

$\square$ Consolidación $\square$ Reconstrucción $\square$ sustitución

No tradicional Tipo de técnica Diferente a la existente

Reintegraciones con cemento en el zócalo

\section{Intervenido}

$\square$ Actualización $\quad$ X Reintegración $\square$ Demolición $\square$ Otro...

$\square$ Consolidación $\quad \square$ Reconstrucción $\quad \square$ Sustitución

No tradicional Tipo de técnica Similar a la existente

Reintegración de zonas faltantes en el revestimiento

Intervenido

$\square$ Consolidación $\square$ Reconstrucción $\mathbf{x}$ Sustitución

No tradicional Tipo de técnica Diferente a la existente de azul

No intervenido

$\square$ Actualización $\square$ Reintegración $\square$ Demolición $\quad \square$ Otro..

$\square$ Consolidación $\square$ Reconstrucción $\square$ Sustitución Tipo de técnica
La restauración y rehabilitación de la arquitectura tradicional de tierra.

El caso de Aragón.

3.7. REHABILITACIÓN ENERGÉTICA $\quad \square$ Fachada $\square$ Vanos $\square$ Forjados $\square$ Cubierta

Observaciones

FOTOGRAFÍAS DE LA INTERVENCIÓN
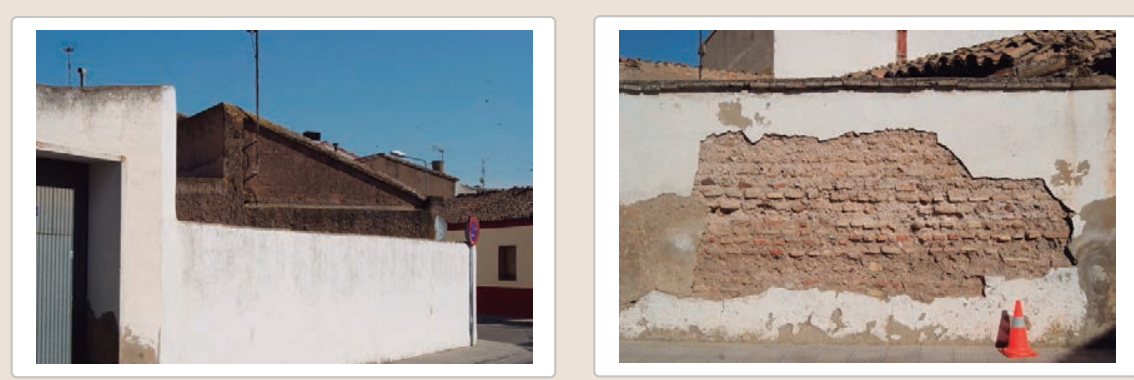

$\square$ Actualización $\square$ Reintegración $\square$ Demolición $\square$ Otro...

Ampliación y sustitución de una de los huecos de acceso. Carpintería metálica pintada
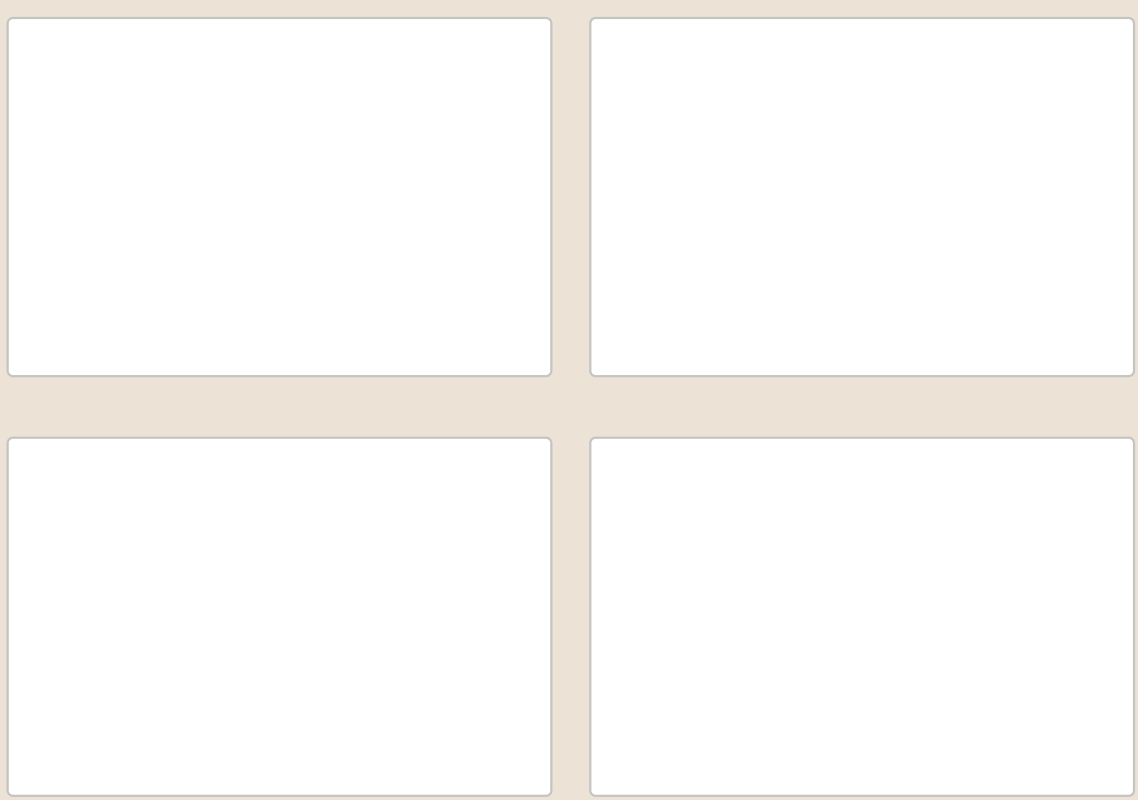


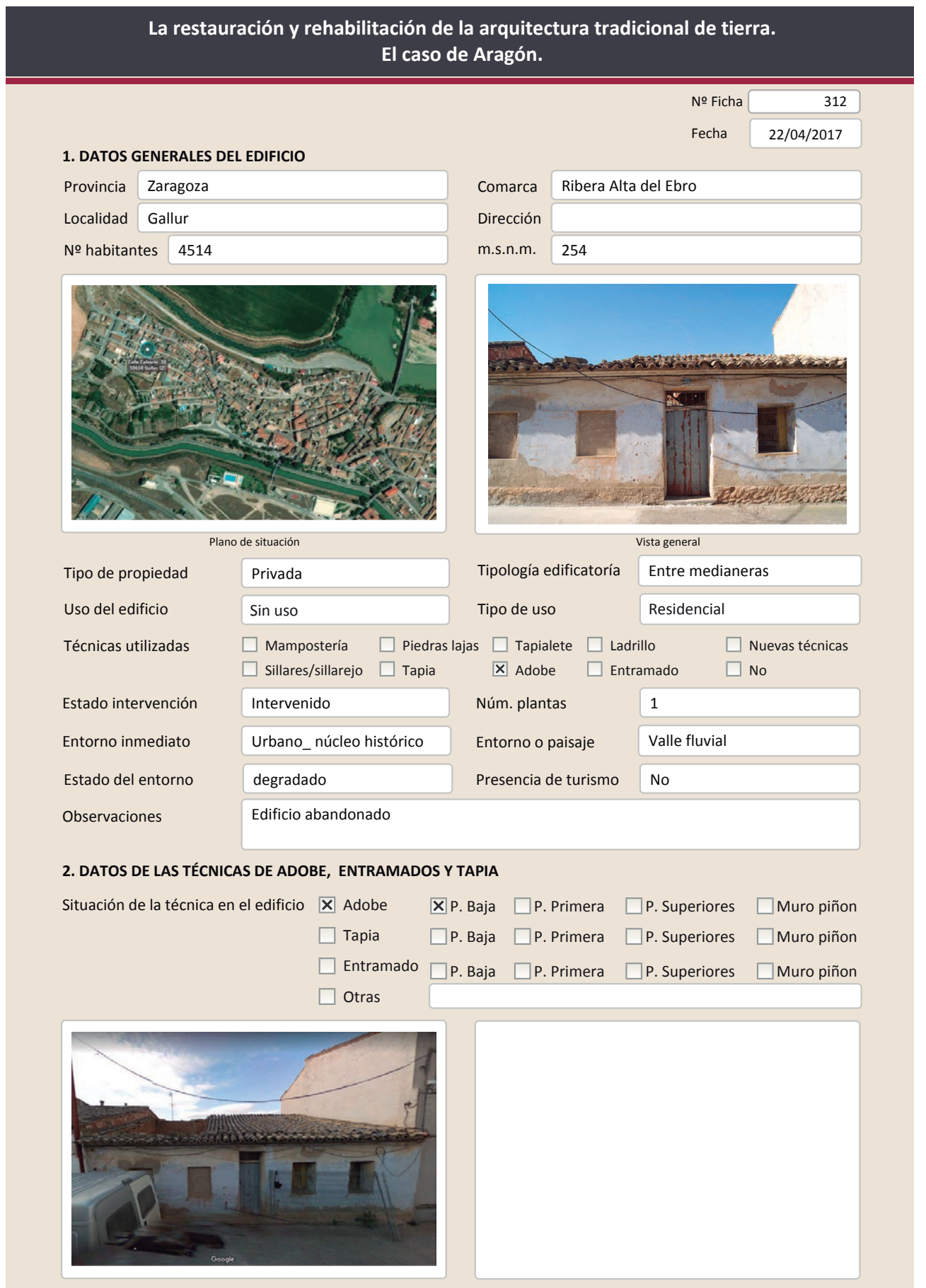

2.1. ADOBE

Dimensión de las piezas

Dimensión del muro

Aparejo del muro

Función estructural

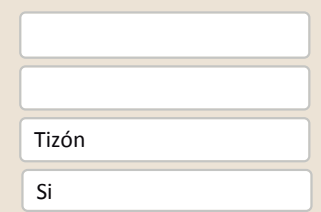

Color de las piezas

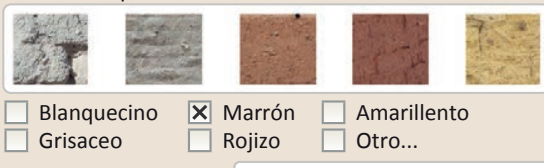

$\square$ Rojizo $\square$ Otro..

Variante constructiva/ tipo de fábrica

区 Simple

$\square$ Suplementada en juntas

$\square$ Mixta

$\square$ Como suplemento

$\square$ Elementos de protección

\section{are}

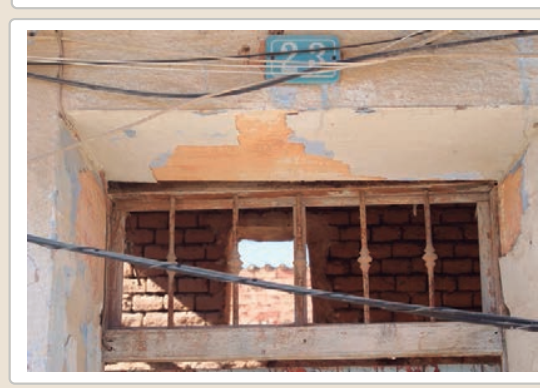

Lesiones $\square$ Muro ХZŹcalo $\mathbf{X}$ Revestimiento

$\square$ Erosión del material $\quad \mathbf{X}$ Humedad por capilaridad

$\square$ Erosion de las juntas $\square$ Humedades (manch/eflo)

$\square$ Pérdida de sección $\square$ Pérdida de verticalidad

$\begin{array}{ll}\square \text { Vegetación } & \square \text { Grietas por empuje de la cub } \\ \square \text { Desconchados } & \square \text { Grietas porfalta de traba }\end{array}$

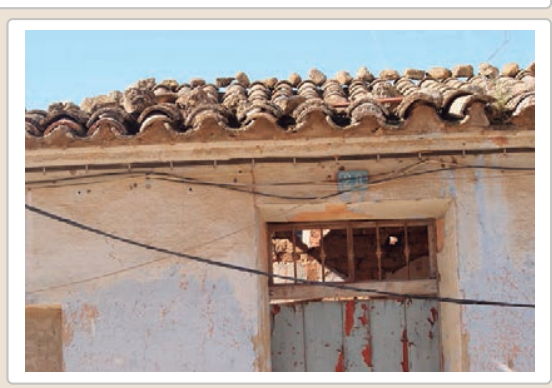

XCubierta $\square$ Otro...

$\square$ Grietas por asentamiento

X Colapso

$\square$ Por elementos impropios

$\square$ Derivado de intervenciones $\square$ Otro... 
La restauración y rehabilitación de la arquitectura tradicional de tierra.

El caso de Aragón.

3. DATOS DE LA INTERVENCIÓN

\begin{tabular}{|c|c|c|c|c|}
\hline Intervención de: & $\begin{array}{l}\square \text { Mantenimiento } \\
\mathbf{X} \text { Reparación }\end{array}$ & $\begin{array}{l}\square \text { Rehabilitación parcial } \\
\square \text { Rehabilitación integral }\end{array}$ & $\begin{array}{l}\square \text { Restauración } \\
\square \text { Ampliación }\end{array}$ & $\begin{array}{l}\square \text { Demolición } \\
\square \text { Otro... }\end{array}$ \\
\hline Reflexión previa & \multicolumn{4}{|c|}{ Intervención espontanea } \\
\hline 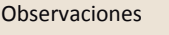 & & & & \\
\hline
\end{tabular}

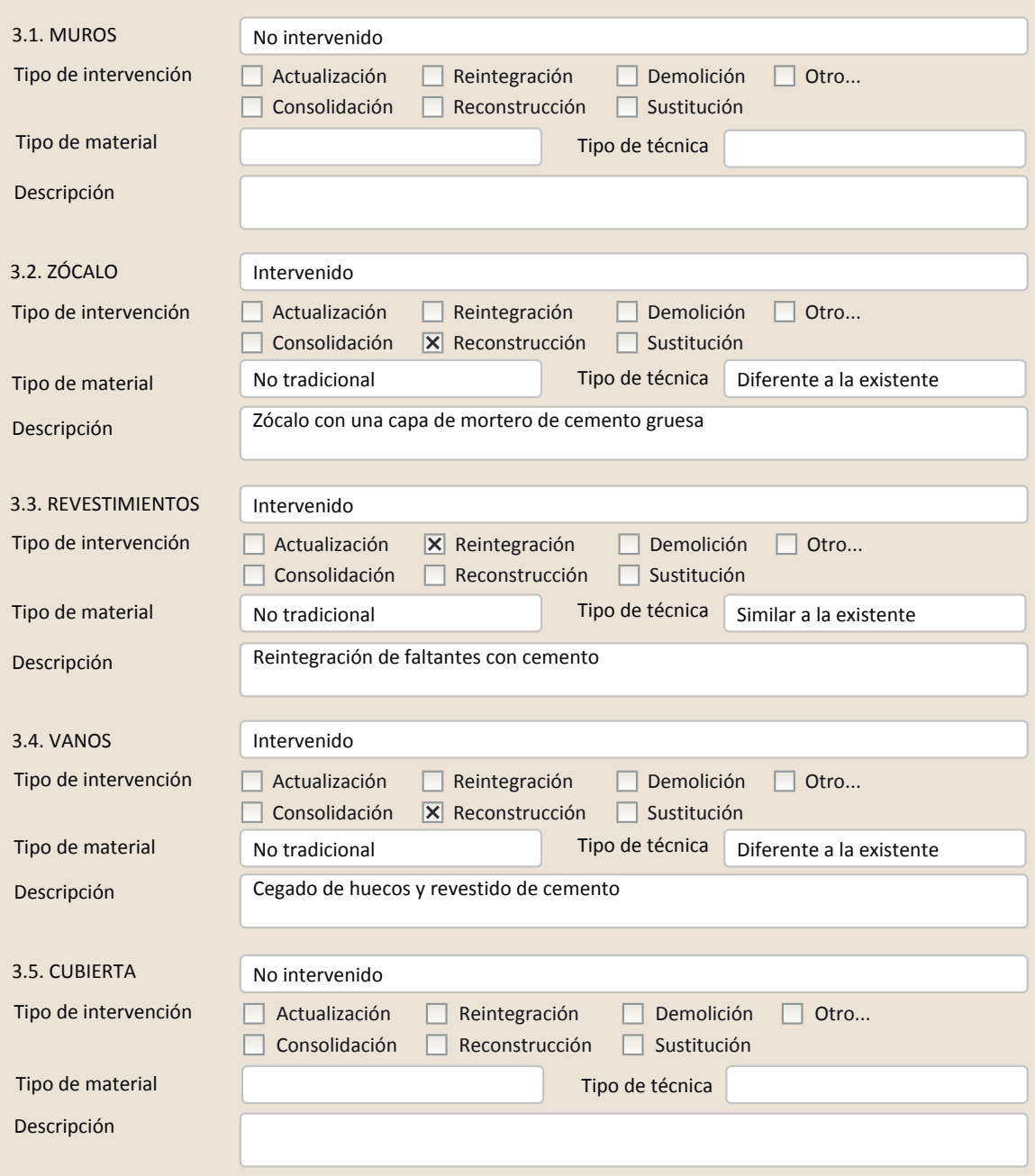

3.6. OTRAS 


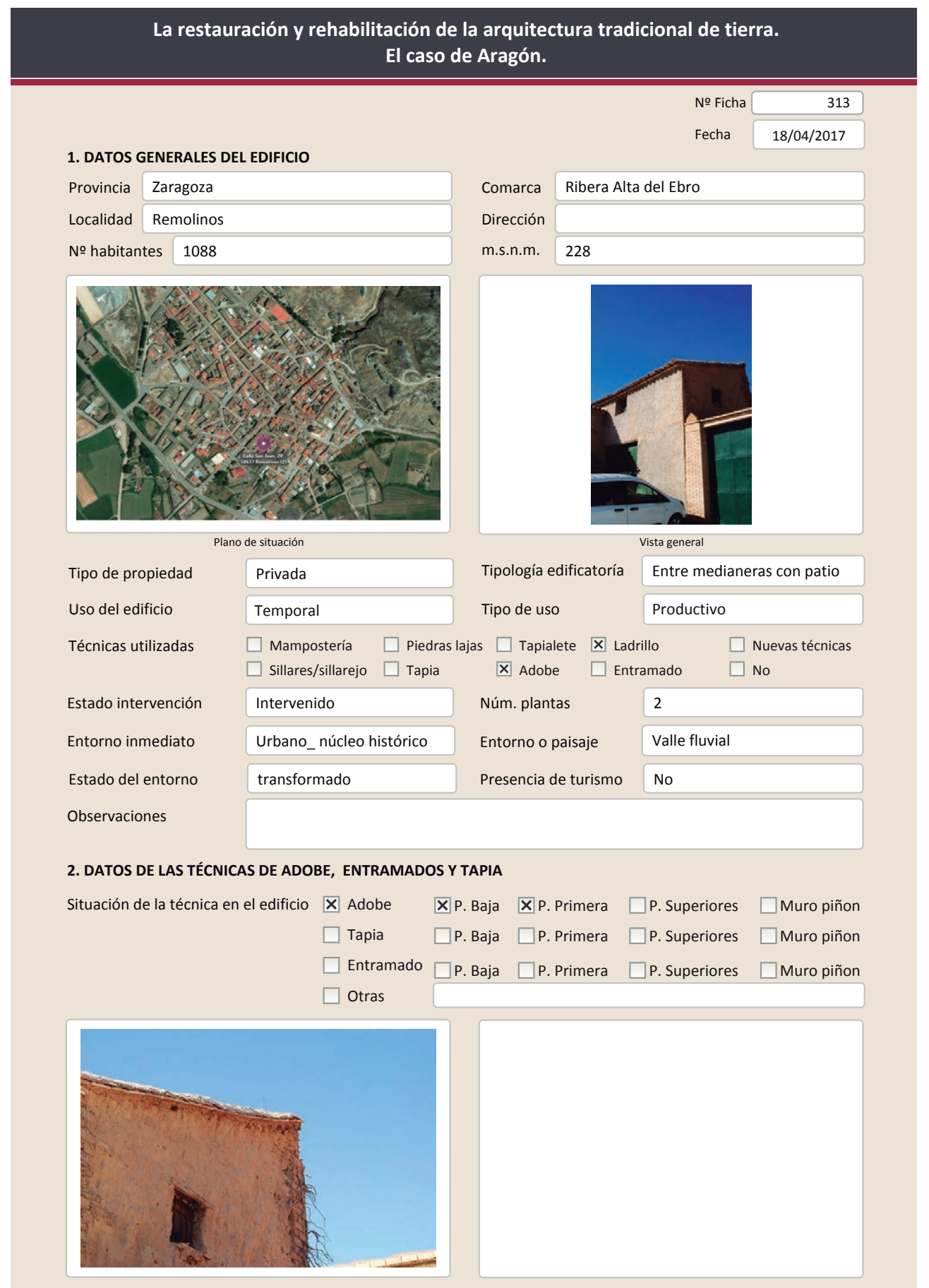

La restauración y rehabilitación de la arquitectura tradicional de tierra.
2.1. ADOBE

Dimensión de las piezas Dimensión del muro

Aparejo del muro

Función estructural

\section{El caso de Aragón.}

Variante constructiva/ tipo de fábrica

$\square$ Simple

$\square$ Suplementada en juntas

X Mixta

$\mathbf{X}$ Como suplemento

Mixto- En esquinas

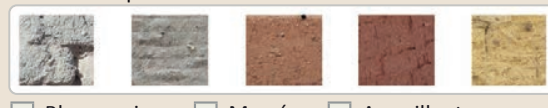

$\square$ Blanquecino $\square$ Marrón $\square$ Amarillento $\square$ Grisaceo $\square$ Rojizo $\square$ Otro...

Comp. - estabilizante $\square$ Elementos de protección Bloques tierra cemento en las esquinas

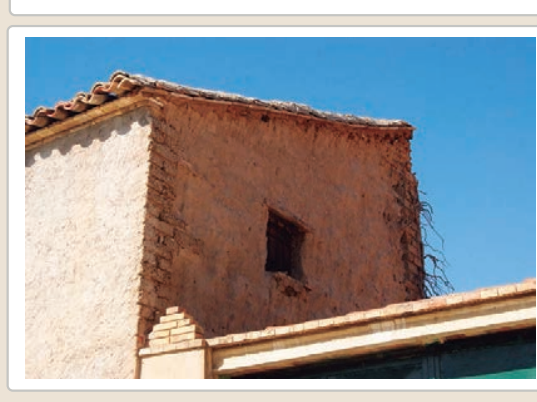

Lesiones $\quad \mathbf{X}$ Muro $\square$ Zócalo $\square$ Revestimiento $\mathbf{X}$ Erosión del material $\square$ Humedad por capilaridad $\mathbf{X}$ Erosion de las juntas $\square$ Humedades (manch/eflo) X Pérdida de sección $\square$ Pérdida de verticalidad $\square$ Cubierta $\square$ Otro...

$\square$ Vegetación $\quad \square$ Grietas por empuje de la cubierta $\square$ Derivado de intervenciones $\square$ Desconchados $\square$ Grietas porfalta de traba $\quad \square$ Otro...

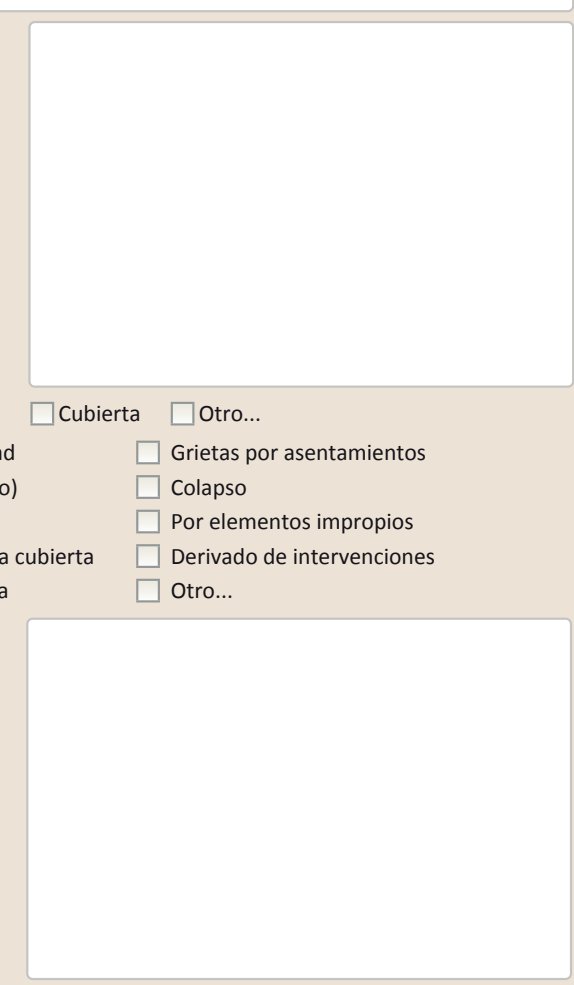

Observaciones 


\section{La restauración y rehabilitación de la arquitectura tradicional de tierra.}

\section{El caso de Aragón.}

\section{DATOS DE LA INTERVENCIÓN}

Intervención de:

$\square$ Mantenimiento $\quad \mathbf{X}$ Rehabilitación parcial

$\square$ Restauración $\square$ Demolición

Reflexión previa

$\square$ Reparación

Rehabilitación integra

Ampliación

$\square$ Otro...

Observaciones

Intervención espontanea

(2)

3.1. MUROS

No intervenido

Tipo de intervención

$\square$ Actualización

$\square$ Consolidación $\square$ Reconstrucción $\square$ Sustitución

Tipo de material

Descripción

3.2. ZÓCALO

Tipo de intervención

Intervenido

$\square$ Actualizació

$\square$ Reintegración $\square$ Demolición $\square$ Otro..

Tipo de material

Descripción

Tipo de técnica Diferente a la existente

3.3. REVESTIMIENTOS
Tipo de intervención

Revestimiento de cemento

Intervenido

Tpo dematental

Tipo de material

Descripción

No tradicional

$\square$ Reintegración $\square$ Demolición $\square$ Otro...

X Reconstrucción $\square$ Sustitución

3.4. VANOS

Nuevo revestimiento de cemento en la fachada principal

Tipo de intervención

No intervenido

Tipo de material

$\square$ Actualización $\quad \square$ Reintegración $\quad \square$ Demolición $\quad \square$ Otro...
$\square$ Consolidación $\quad \square$ Reconstrucción $\quad \square$ Sustitución

Descripción

3.5. CUBIERTA

Tipo de intervención

Intervenido

$\square$ Actualización $\quad \boldsymbol{X}$ Reintegración $\quad \square$ Demolición $\quad \square$ Otro...
$\square$ Consolidación $\quad \square$ Reconstrucción $\quad \square$ Sustitución

Tipo de material

No tradicional

Tipo de técnica Similar a la existente

Descripción

Reintegración de las tejas laterales de la cubierta con mortero de cemento

3.6. OTRAS 
La restauración y rehabilitación de la arquitectura tradicional de tierra. El caso de Aragón

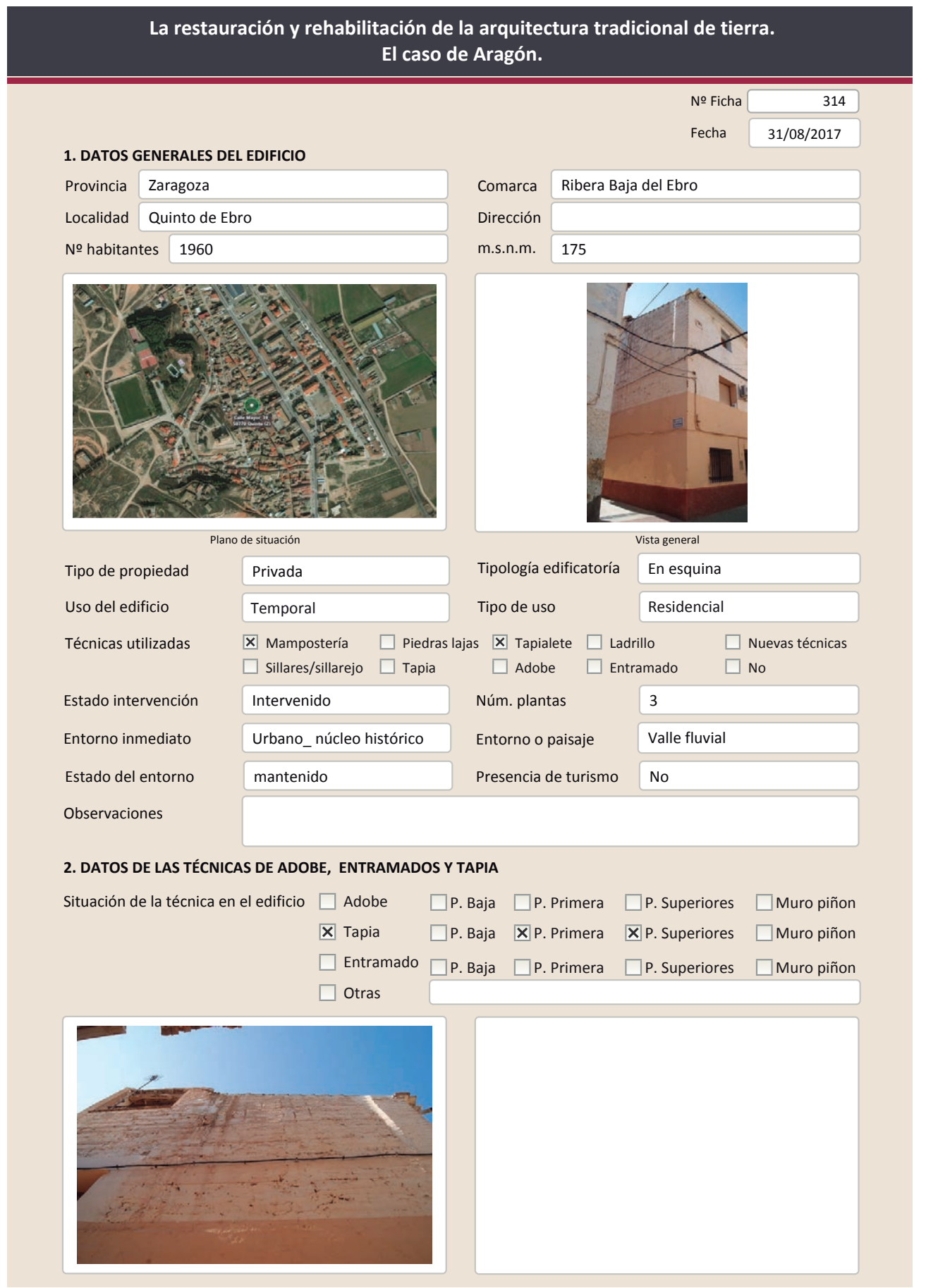

2.2. TAPIA

Ancho del muro

Dimensión tapiales

Tipo de aguja

№ agujas/cajón

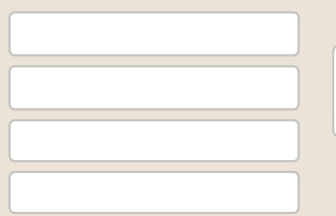

Color de la tapia

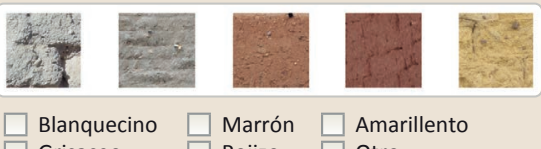

$\square$ Blanquecino $\square$ Marrón $\square$ Amarillento

$\square$ Grisaceo$$
\square \text { Rojico } \square \text { otro... }
$$

Variante constructiva

\begin{abstract}
X Simple / homogénea
$\square$ Suplemento superficial

$\square$ suplemento en juntas

区 Mixta
\end{abstract}

Tapialete

$\square$ Elementos de protección
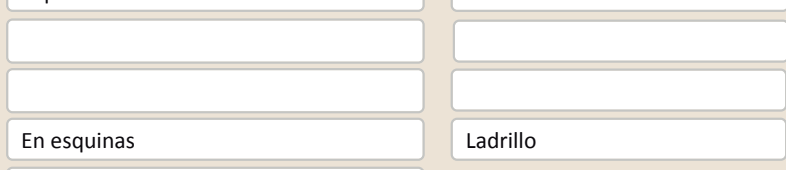

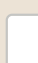

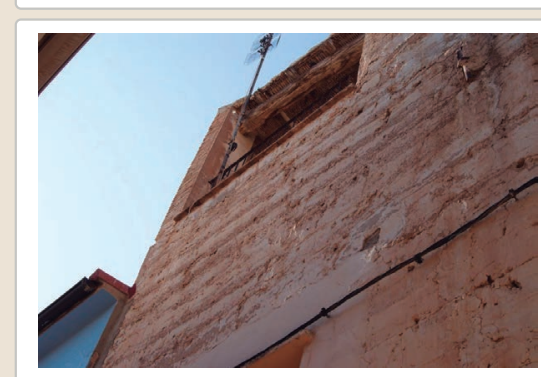

Lesiones $\square$ Muro $\square$ Zócalo $\square$ Revestimiento $\square$ Cubierta $\square$ otro...

$\square$ Erosión del material $\quad \square$ Humedad por capilaridad $\quad \square$ Grietas por asentamiento $\square$ Erosion de las juntas $\square$ Humedades (manch/eflo) $\square$ Pérdida de sección $\square$ Pérdida de verticalidad

$\square$ Vegetación $\quad \square$ Grietas por empuje de la cubierta

$\square$ Desconchados $\quad \square$ Grietas porfalta de traba

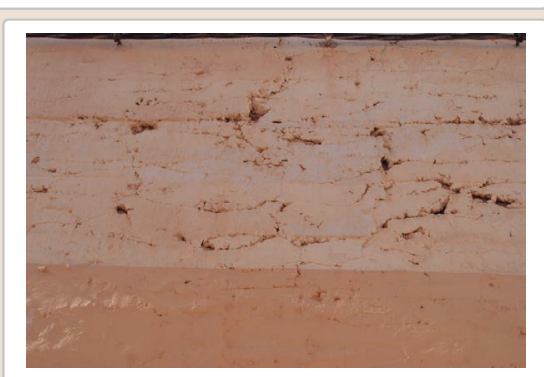

$\square$ Colapso

$\square$ Por elementos impropios

$\square$ Derivado de intervenciones $\square$ Otro...

Observaciones 
La restauración y rehabilitación de la arquitectura tradicional de tierra.

El caso de Aragón.

3. DATOS DE LA INTERVENCIÓN

\begin{tabular}{llll|} 
Intervención de: & $\square$ Mantenimiento $\quad \boldsymbol{X}$ Rehabilitación parcial & $\square$ Restauración & $\square$ Demolición \\
& $\square$ Reparación $\quad \square$ Rehabilitación integral & $\square$ Ampliación $\quad \square$ Otro... \\
Reflexión previa & Intervención espontanea & \\
Observaciones & & \\
& &
\end{tabular}

\subsection{MUROS}

Tipo de intervención

No intervenido

Tipo de material

$\square$ Actualización $\square$ Reintegración $\square$ Demolición $\square$ Otro...

$\square$ Consolidación $\square$ Reconstrucción $\square$ Sustitución

Descripción

3.2. ZÓCALO

Tipo de intervención

Intervenido

Tipo de intervención

$\square$ Actualizació

Reión $\quad \square$ Reintegración $\quad \square$ Demolición $\quad \square$ Otro...

Descripción

3.3. REVESTIMIENTOS

Gotelé con cemento

Tipo de intervención

\section{No aplica}

Tipo de material

Descripción Tipo de técnica

3.4. VANOS

Tipo de intervención

\section{Intervenido}

Tipo de material
Descripción

$\square$ Actualización $\square$ Reintegración $\square$ Demolición $\square$ Otro...

Consolidación $\square$ Reconstrucción $\quad$ X Sustitución

3.5. CUBIERTA

Tipo de intervención

No tradicional

Tipo de técnica Diferente a la existente

Sustitución de carpinterías

Tipo de material

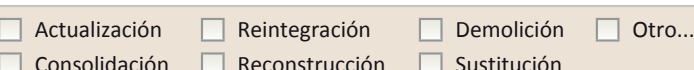

Descripción

$\square$ Consolidación $\square$ Reconstrucción $\square$ Sustitución

Tipo de técnica

3.6. OTRAS 


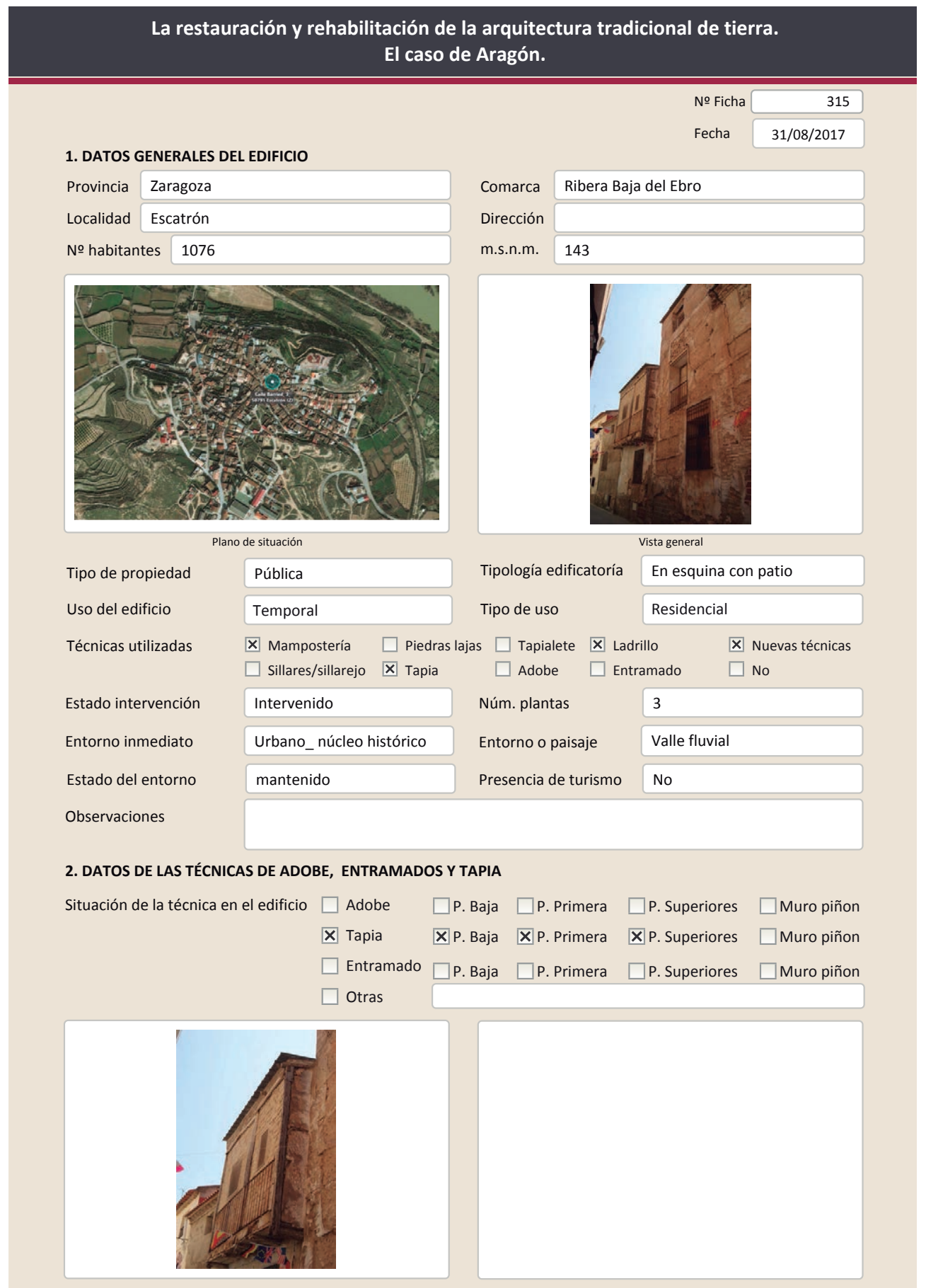

2.2. TAPIA

Ancho del muro

Dimensión tapiales

Tipo de aguja

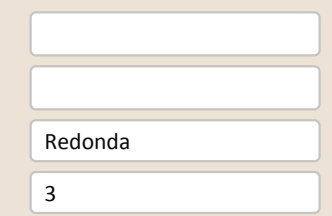

Color de la tapia

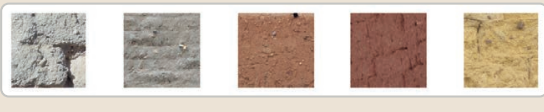

$\square$ Blanquecino $\mathbf{X}$ Marrón $\square$ Amarillento

№ agujas/cajón

Grisaceo

$X$ Marrón $\square$ Amarillento
$\square$ Rojizo $\square$ Otro...

Variante constructiva

$\square$ Simple / homogénea

$\square$ suplemento superficial

$\boldsymbol{X}$ Suplemento en juntas

区 Mixta

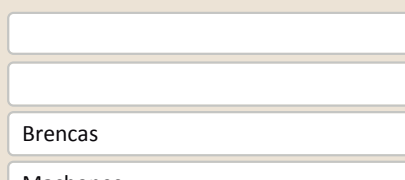

$\square$ Elementos de protección

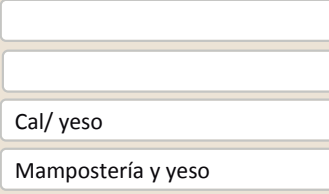

Mampostería y yeso

$$
\text { (1) }
$$

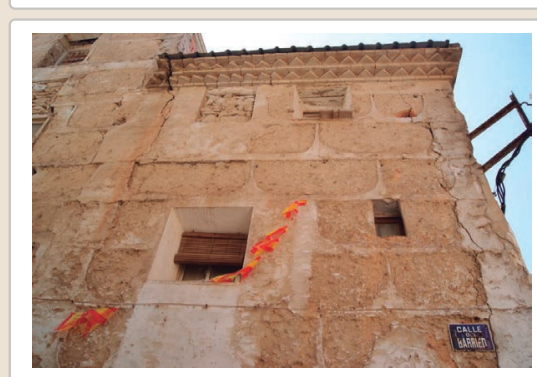

Lesiones \Muro $\square$ Zócalo $\square$ Revestimiento $\square$ Cubierta $\square$ Otro...

Х Erosión del material $\quad \square$ Humedad por capilaridad $\quad \square$ Grietas por asentamientos $\square$ Erosion de las juntas $\square$ Humedades (manch/eflo)

X Pérdida de sección $\square$ Pérdida de verticalidad

$\square$ Vegetación $\quad \square$ Grietas por empuje de la cubierta

$\square$ Desconchados

$\mathbf{X}$ Grietas porfalta de traba

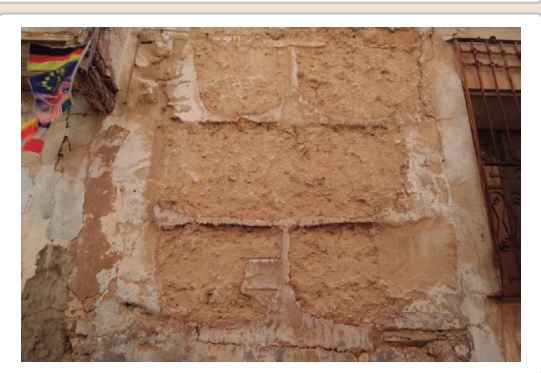

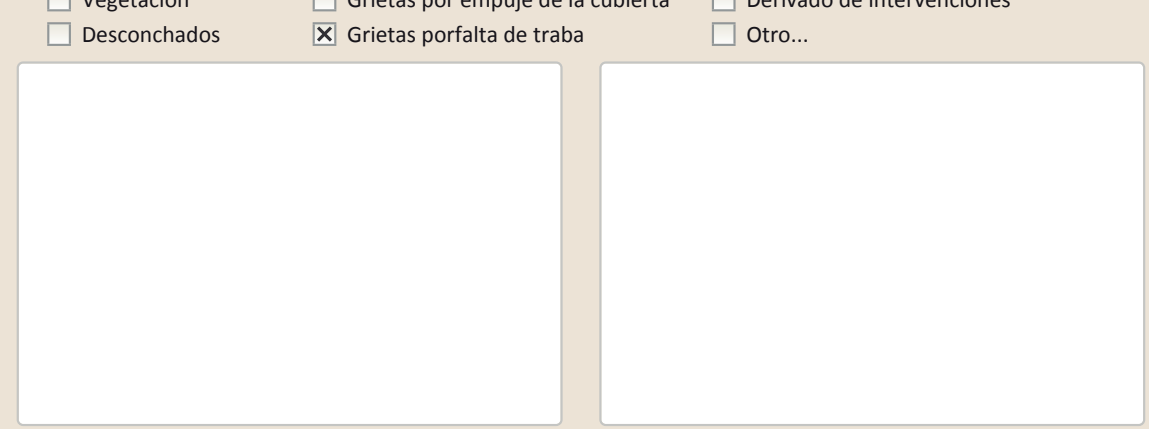

Observaciones 


\section{La restauración y rehabilitación de la arquitectura tradicional de tierra.}

\section{El caso de Aragón.}

3. DATOS DE LA INTERVENCIÓN

\begin{tabular}{|c|c|c|c|c|}
\hline Intervención de: & $\begin{array}{l}\square \text { Mantenimiento } \\
\mathbf{X} \text { Reparación }\end{array}$ & $\begin{array}{l}\square \text { Rehabilitación parcial } \\
\square \text { Rehabilitación integral }\end{array}$ & $\begin{array}{l}\square \text { Restauración } \\
\square \text { Ampliación }\end{array}$ & $\begin{array}{l}\square \text { Demolición } \\
\square \text { Otro... }\end{array}$ \\
\hline Reflexión previa & \multicolumn{4}{|c|}{ Intervención espontanea } \\
\hline erva & & & & \\
\hline
\end{tabular}

\subsection{MUROS}

Tipo de intervención

No intervenido

Tipo de material

$\square$ Actualización $\square$ Reintegración $\quad \square$ Demolición $\quad \square$ Otro... $\square$ Consolidación $\square$ Reconstrucción $\square$ sustitución

Descripción

3.2. ZÓCALO

Tipo de intervención

Intervenido

$\square$ Actualización

メ Reintegración $\square$ Demolición $\square$ Otro...

Tipo de material

Descripción

3.3. REVESTIMIENTOS

Cemento y ladrillo cerámico

Tipo de intervención

\section{No aplica}

$\checkmark$ Actualización Tipo de técnica

Tipo de material

Descripción

3.4. VANOS

Tipo de intervención

\section{Intervenido}

Tipo de material
Descripción

$\square$ Actualización $\square$ Reintegración $\square$ Demolición $\square$ Otro...

Consolidación $\square$ Reconstrucción $\boldsymbol{X}$ Sustitución

3.5. CUBIERTA

Tipo de intervención

No tradicional

Tipo de técnica Diferente a la existente

Sustitución parcial de las carpinterías por otras de aluminio

Tipo de intervención

Intervenido

$\square$ Actualización $\quad \square$ Reintegración $\quad \square$ Demolición $\quad \square$ Otro...

Descripción

$\square$ Consolidación $\square$ Reconstrucción $\quad \boldsymbol{X}$ Sustitución

Descripción

No tradicional Tipo de técnica Diferente a la existente

3.6. OTRAS

minación de las tejas y colocación de una chapa metálica 


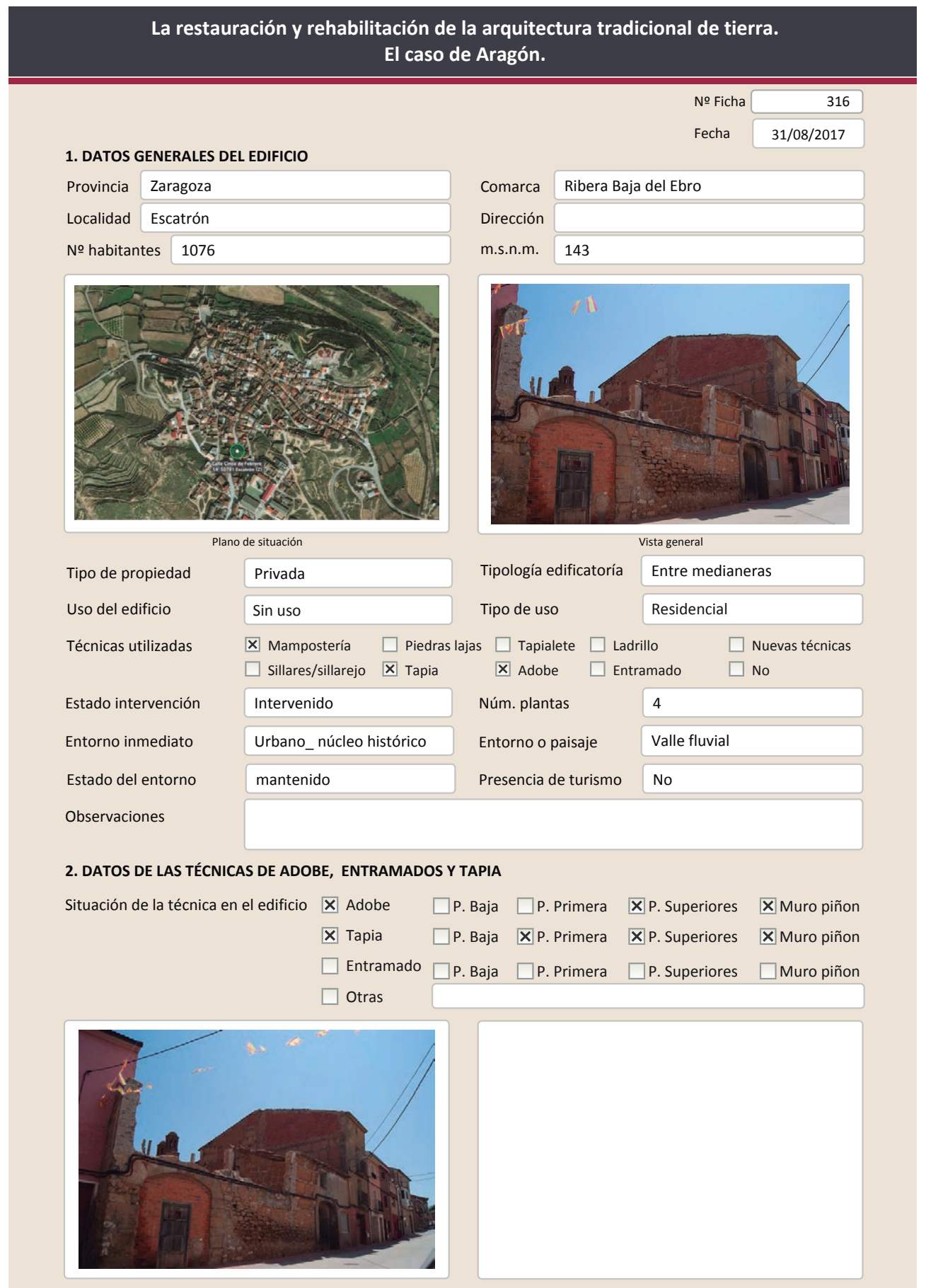

2.1. ADOBE

Dimensión de las piezas Dimensión del muro

Aparejo del muro

Función estructural

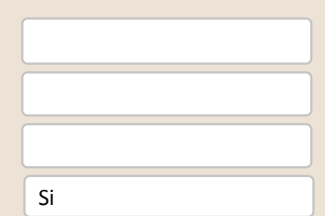

Color de las piezas

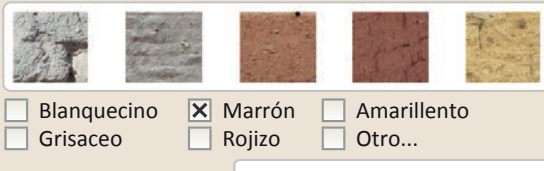

Rojizo $\square$ Otro..

Variante constructiva/ tipo de fábrica

$\square$ simple

$\square$ Suplementada en juntas

区 Mixta

\section{Machones}

Comp. - estabilizante

$\square$ Como suplemento

$\square$ Elementos de protección

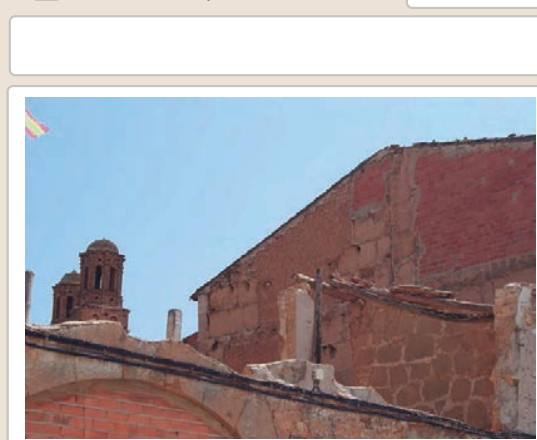

Lesiones $\quad \mathbf{X}$ Muro $\square$ Zócalo $\square$ Revestimiento $\square$ Cubierta $\square$ Otro...

X Erosión del material $\quad \square$ Humedad por capilaridad $\quad \square$ Grietas por asentamientos

$\square$ Erosion de las juntas $\square$ Humedades (manch/eflo) $\quad \square$ Colapso

$\square$ Pérdida de sección $\square$ Pérdida de verticalidad

$\square$ Por elementos impropios

$\square$ Vegetación

$\square$ Grietas por empuje de la cubir

$\square$ Derivado de intervenciones

$\square$ Desconchados

$\square$ Grietas porfalta de traba

Observacione 


\section{La restauración y rehabilitación de la arquitectura tradicional de tierra.}

\section{El caso de Aragón.}

\subsection{TAPIA}

Ancho del muro

Dimensión tapiales

Tipo de aguja

№ agujas/cajón

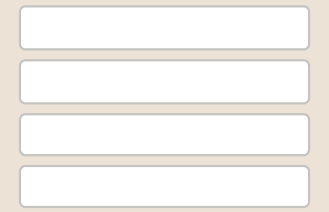

\section{Color de la tapia}

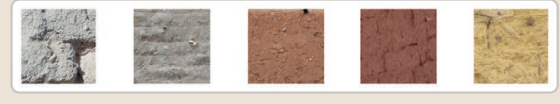

$\square$ Blanquecino $\quad \mathbf{X}$ Marrón $\square$ Amarillento $\square$ Grisaceo

Variante constructiva

$\square$ Simple / homogénea

$\square$ Suplemento superficial

$\mathbf{X}$ Suplemento en juntas

X Mixta

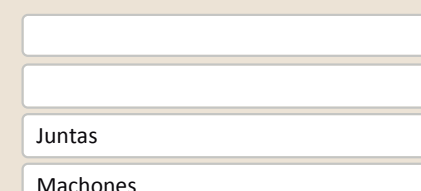

Machones

\section{Cal/ yeso}

$\square$ Elementos de protección

Mampostería y yeso

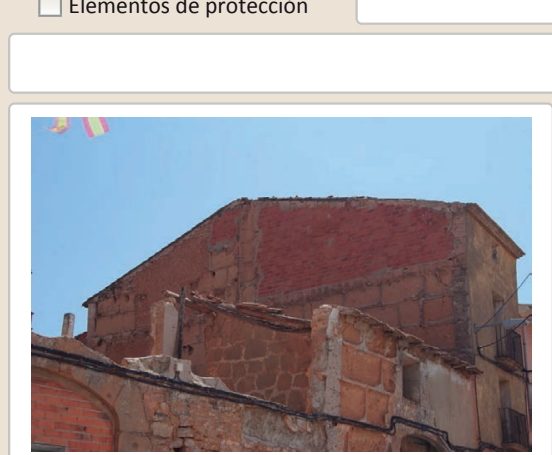

Lesiones $\quad$ Muro $\square$ Zócalo $\square$ Revestimiento $\square$ Cubierta $\square$ Otro...

区 Erosión del material $\quad \square$ Humedad por capilaridad $\quad \square$ Grietas por asentamientos

$\square$ Erosion de las juntas $\square$ Humedades (manch/eflo) $\quad \square$ Colapso

X Pérdida de sección $\square$ Pérdida de verticalidad $\square$ Por elementos impropios

$\square$ Vegetación $\quad$ Grietas por empuje de la cubierta $\square$ Perivado de intervencios

$\square$ Desconchados $\quad \square$ Grietas porfalta de traba $\quad \square$ Otro...
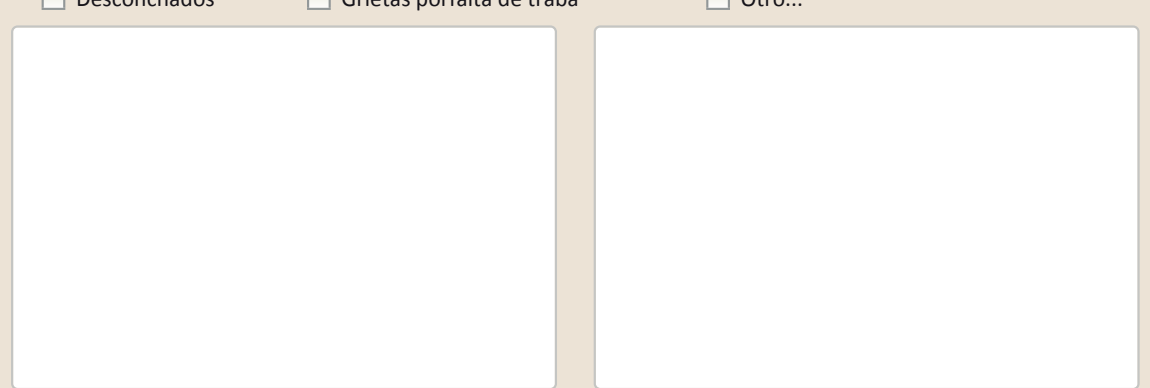

Observaciones

La restauración y rehabilitación de la arquitectura tradicional de tierra.

El caso de Aragón.

3. DATOS DE LA INTERVENCIÓN

Intervención de: $\quad \square$ Mantenimiento $\quad \square$ Rehabilitación parcial $\quad \square$ Restauración $\square$ Demolición

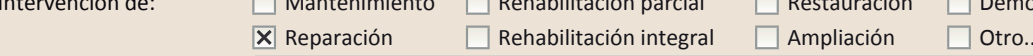

Reflexión previa Intervención espontanea

Observaciones

3.1. MUROS

Tipo de intervención

Tipo de material

Intervenido

$\square$ Actualización $\square$ Reintegración $\square$ Demolición $\square$ Otro..

$\square$ Consolidación $\mathbf{X}$ Reconstrucción $\mathbf{X}$ Sustitución

Descripción

No tradicional Tipo de técnica Diferente a la existente

3.2. ZOCALO

Reconstrucción de parte de los muros de forma aleatoria con fábrica de ladrillo

3.2. ZÓCALO
Tipo de intervención
Tipo de material
Descripción

Intervenido

$\square$ Actualización $\square$ Reintegración $\square$ Demolición $\square$ Otro...

$\square$ Actualización $\square$ Reintegración $\square$ Demolición

$\square$ Consolidación $\quad$ Xeconstrucción $\square$ Sustitución

Descripción

Revestimiento de cemento pinado

3.3. REVESTIMIENTOS

Tipo de intervención

Intervenido

Tipo de material

$\square$ Actualización

$\square$ Consolidación

$\square$ Reintegración $\square$ Demolición $\square$ Otro...

Descripción Revestimiento en la fachada principal

3.4. VANOS

Tipo de intervención

Intervenido

Tipo de material

$\square$ Actualización $\square$ Reintegración $\square$ Demolición $\square$ Otro...

$\square$ Consolidación $\square$ Reconstrucción $\quad \boldsymbol{x}$ Sustitución

Descripción

No tradicional

Tipo de técnica Diferente a la existente

3.5. CUBIERTA

Cegado de huecos

Tipo de intervención

No intervenido

$\square$ Actualización $\square$ Reintegración $\square$ Demolición $\square$ Otro...

$\square$ Consolidación $\square$ Reconstrucción $\square$ sustitución

Tipo de material

Descripción

$$
\text { Tipo de técnica }
$$

3.6. OTRAS 
La restauración y rehabilitación de la arquitectura tradicional de tierra. El caso de Aragón

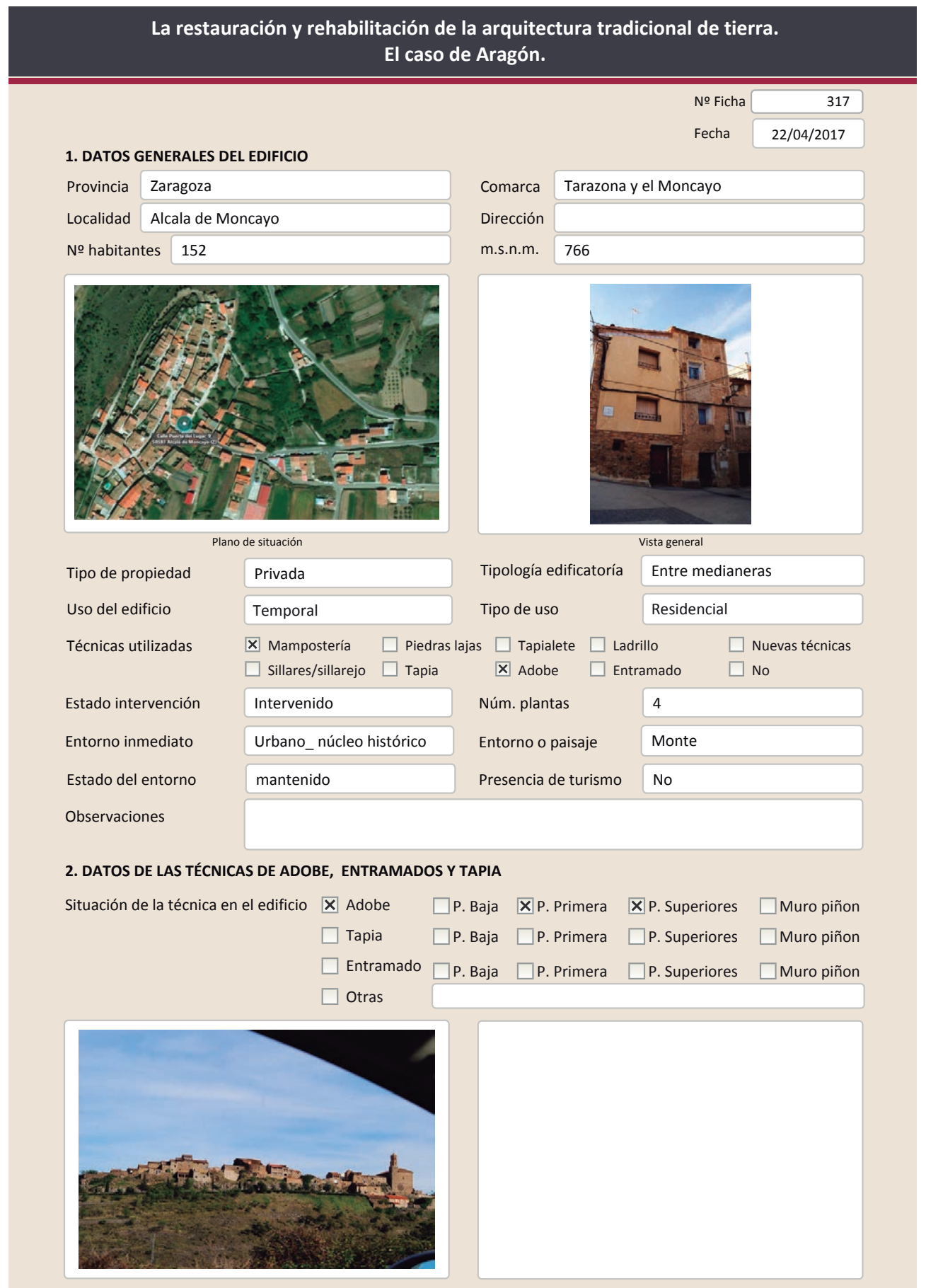

2.1. ADOBE

Dimensión de las piezas Dimensión del muro

Aparejo del muro

Función estructural

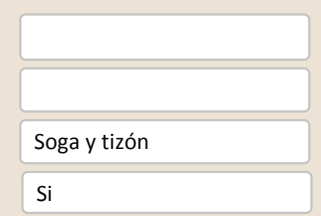

Color de las piezas

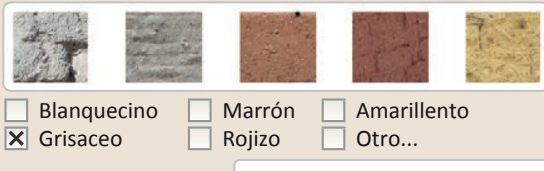

Comp. - estabilizante

Variante constructiva/ tipo de fábrica

$\square$ Simple

$\square$ Suplementada en juntas

区 Mixta

En esquinas

Piedra

$\square$ Como suplemento

$\mathbf{X}$ Elementos de protección

Revestimiento

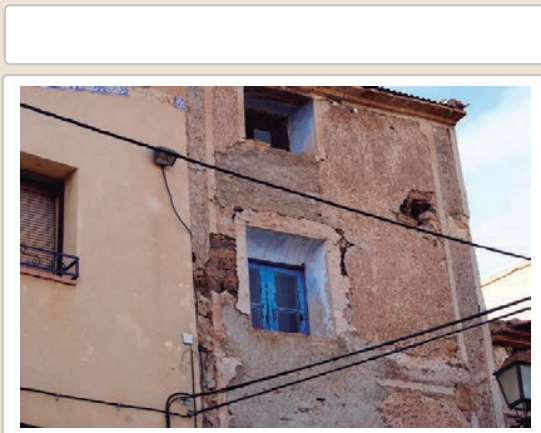

Lesiones ХMuro ХZócalo Х Revestimiento

$\mathbf{X}$ Erosión del material $\quad \mathbf{X}$ Humedad por capilaridad

$\square$ Erosion de las juntas $\mathbf{X}$ Humedades (manch/eflo)

$\square$ Pérdida de sección $\quad \square$ Pérdida de verticalidad

$\square$ Vegetación $\quad \square$ Grietas por empuje de la c $\square$ Grietas porfalta de traba

$\square$ Cubierta $\square$ Otro...

$\square$ Grietas por asentamiento

$\square$ Colapso

$\mathbf{X}$ Desconchados

$\square$ Por elementos impropios

$\square$ Derivado de intervenciones 


\section{La restauración y rehabilitación de la arquitectura tradicional de tierra.}

\section{El caso de Aragón.}

3. DATOS DE LA INTERVENCIÓN

\begin{tabular}{|c|c|c|c|c|}
\hline Intervención de: & $\begin{array}{l}\square \text { Mantenimiento } \\
\text { Х Reparación }\end{array}$ & $\begin{array}{l}\square \text { Rehabilitación parcial } \\
\square \text { Rehabilitación integral }\end{array}$ & $\begin{array}{l}\square \text { Restauración } \\
\square \text { Ampliación }\end{array}$ & $\begin{array}{l}\square \text { Demolición } \\
\square \text { Otro... }\end{array}$ \\
\hline Reflexión previa & \multicolumn{4}{|c|}{ Intervención espontanea } \\
\hline erva & & & & \\
\hline
\end{tabular}

\subsection{MUROS}

Tipo de intervención

No intervenido

Tipo de material

$\square$ Actualización $\square$ Reintegración $\square$ Demolición $\square$ Otro... $\square$ Consolidación $\square$ Reconstrucción $\square$ sustitución

Descripción

3.2. ZÓCALO

Tipo de intervención

Intervenido

$\square$ Actualización

メ Reintegración $\square$ Demolición $\square$ Otro...

Tipo de material

No tradicional

Tipo de técnica

Descripción

Tipo de técnica Diferente a la existente

3.3. REVESTIMIENTOS

Intervenido

Tipo de intervención

$\square$ Actualización $\quad \boldsymbol{X}$ Reintegración $\square$ Demolición $\square$ Otro...

Tipo de material

$\square$ Consolidación $\square$ Reconstrucción $\square$ Sustitución

Descripción

No tradicional Tipo de técnica Similar a la existente

3.4. VANOS

Nuevo revestimiento en las áreas donde este se había perdido

Tipo de intervención

No intervenido

Tipo de material

$\square$ Actualización $\quad \square$ Reintegración $\quad \square$ Demolición $\quad \square$ Otro...
$\square$ Consolidación $\quad \square$ Reconstrucción $\quad \square$ sustitución

Descripción

3.5. CUBIERTA

Tipo de intervención

Intervenido

$\square$ Actualización $\quad \square$ Reintegración $\square$ Demolición $\square$ Otro.

Tipo de material

$\square$ Consolidación $\square$ Reconstrucción $\quad \boldsymbol{X}$ Sustitución Sustitución de la cubiestas de laterales
tejas

3.6. OTRAS 


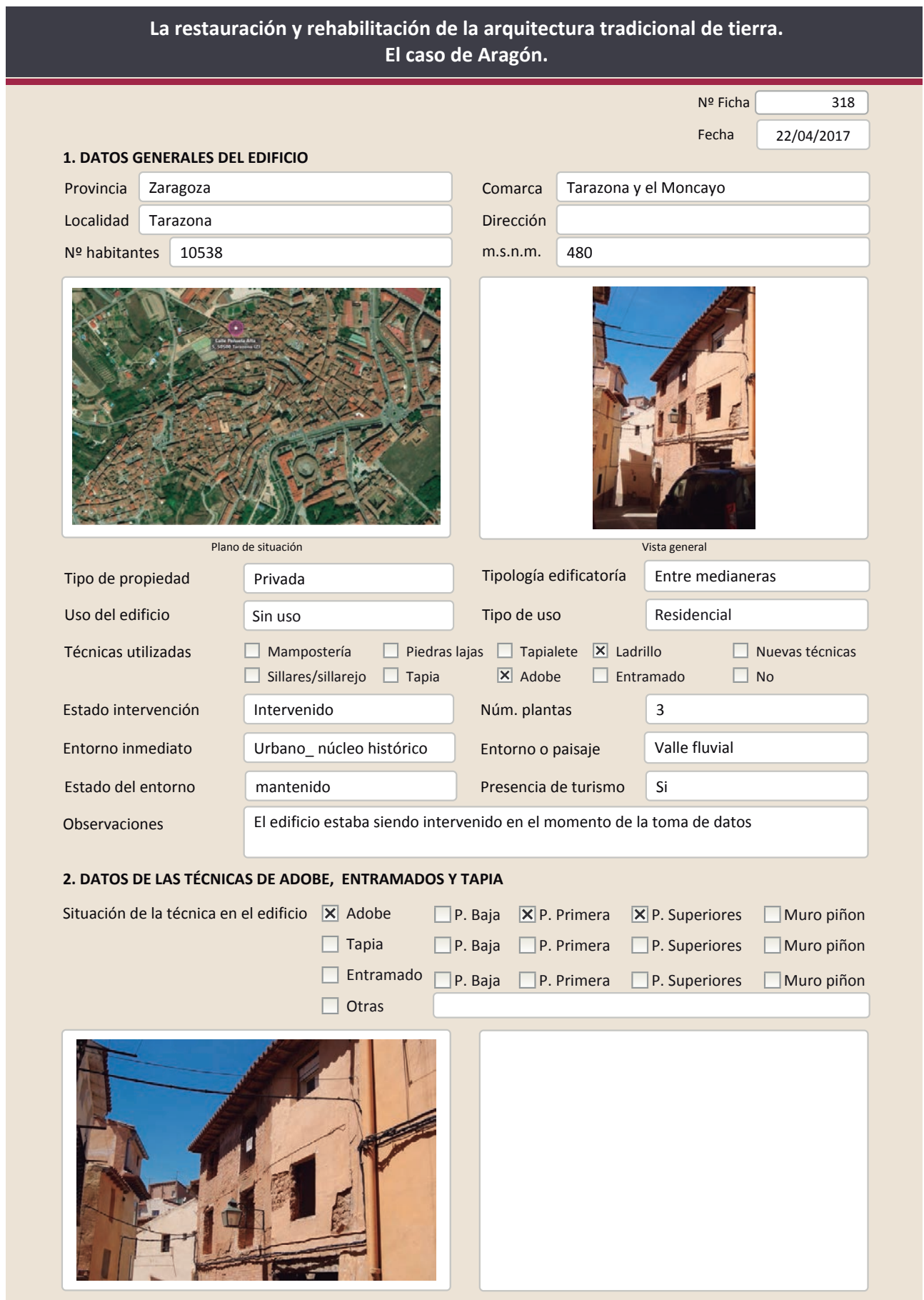

2.1. ADOBE

Dimensión de las piezas Dimensión del muro

Aparejo del muro

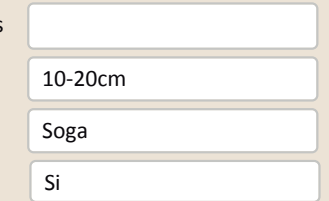

Color de las piezas

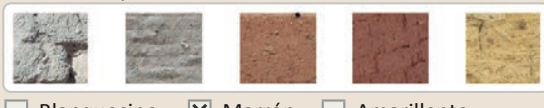

$\square$ Blanquecino $\mathbf{X}$ Marrón $\square$ Amarillento

Función estructural

Grisaceo

$\square$ Rojizo $\square$ Otro...

Variante constructiva/ tipo de fábrica

Х Simple

$\square$ suplementada en juntas

$\square$ Mixta

$\square$ Como suplemento

$\square$ Elementos de protección Muro de muy poco espesor

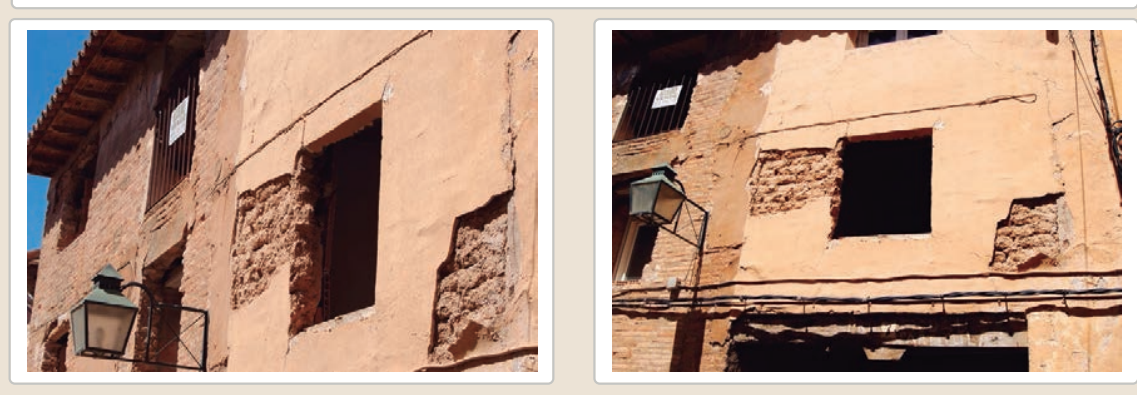

Lesiones ХMMro $\square$ Zócalo $\mathbf{X}$ Revestimiento $\square$ Cubierta $\square$ Otro...

X Erosión del material $\quad \square$ Humedad por capilaridad $\quad \square$ Grietas por asentamientos $\square$ Erosion de las juntas $\square$ Humedades (manch/eflo) $\quad \square$ Colapso

X Pérdida de sección $\square$ Pérdida de verticalidad $\square$ Por elementos impropios

$\square$ Desconchados $\square$ Grietas porfalta de traba $\quad \square$ Otro.. 


\section{La restauración y rehabilitación de la arquitectura tradicional de tierra.}

\section{El caso de Aragón.}

3. DATOS DE LA INTERVENCIÓN

Intervención de:

$\square$ Mantenimie

\begin{abstract}
Reflexión previa
\end{abstract}
$\square$ Reparación

$\square$ Rehabilitación parcial

$\square$ Restauración $\square$ Demolición

Intervención planificada

Observaciones

(2)

3.1. MUROS
Tipo de intervención

Intervenido

Tipo de material

$\square$ Actualización $\square$ Reintegración $\quad \square$ Demolición $\square$ Otro...

$\square$ Consolidación $\quad \mathbb{\text { Reconstrucción }} \square$ Sustitución

Descripción

No tradicional

Tipo de técnica Diferente a la existente

3.2. ZÓCALO

Doblado de los muros por el interior con ladrillo

Tipo de intervención

Tipo de material

Descripción

3.3. REVESTIMIENTOS

Tipo de intervención

Tipo de material

Descripción

3.4. VANOS

Tipo de intervención

Tipo de material

Descripción

3.5. CUBIERTA

Tipo de intervención

Tipo de material

Descripción

\section{No intervenido}

$\square$ Actualización $\quad \square$ Reintegración $\quad \square$ Demolición $\square$ Otro...

$\square$ consolidación $\quad \square$ Reconstrucción $\quad \square$ Sustitución

\section{No intervenido}

$\square$ Actualización $\square$ Reintegración $\square$ Demolición $\square$ Otro...

$\square$ Consolidación $\quad \square$ Reconstrucción $\quad \square$ sustitución

Tipo de técnica

raterido

\section{Intervenido}

$\square$ Actualización $\square$ Reintegración $\quad \boldsymbol{X}$ Demolición $\square$ Otro...

$\square$ Consolidación $\mathbf{X}$ Reconstrucción $\mathbf{X}$ Sustitución

No tradicional Tipo de técnica Diferente a la existente Incorporación de carpinterías nuevas de PVC blancas sobre el muro de doblado interior
(en la plana superior)

\section{Intervenido}

$\square$ Actualización $\quad \square$ Reintegración $\quad \square$ Demolición $\quad \square$ Otro...

$\square$ Consolidación $\quad$ Reconstrucción $\square$ Sustitución
No tradicional
Tipo de técnica Similar a la existente

Reconstrucción de la cubierta utilizando teja curva cogida con cemento. Incorporación de elementos requeridos por la normativa actual
La restauración y rehabilitación de la arquitectura tradicional de tierra.

El caso de Aragón.

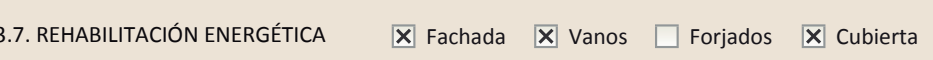

Observaciones

FOTOGRAFíAS DE LA INTERVENCIÓN
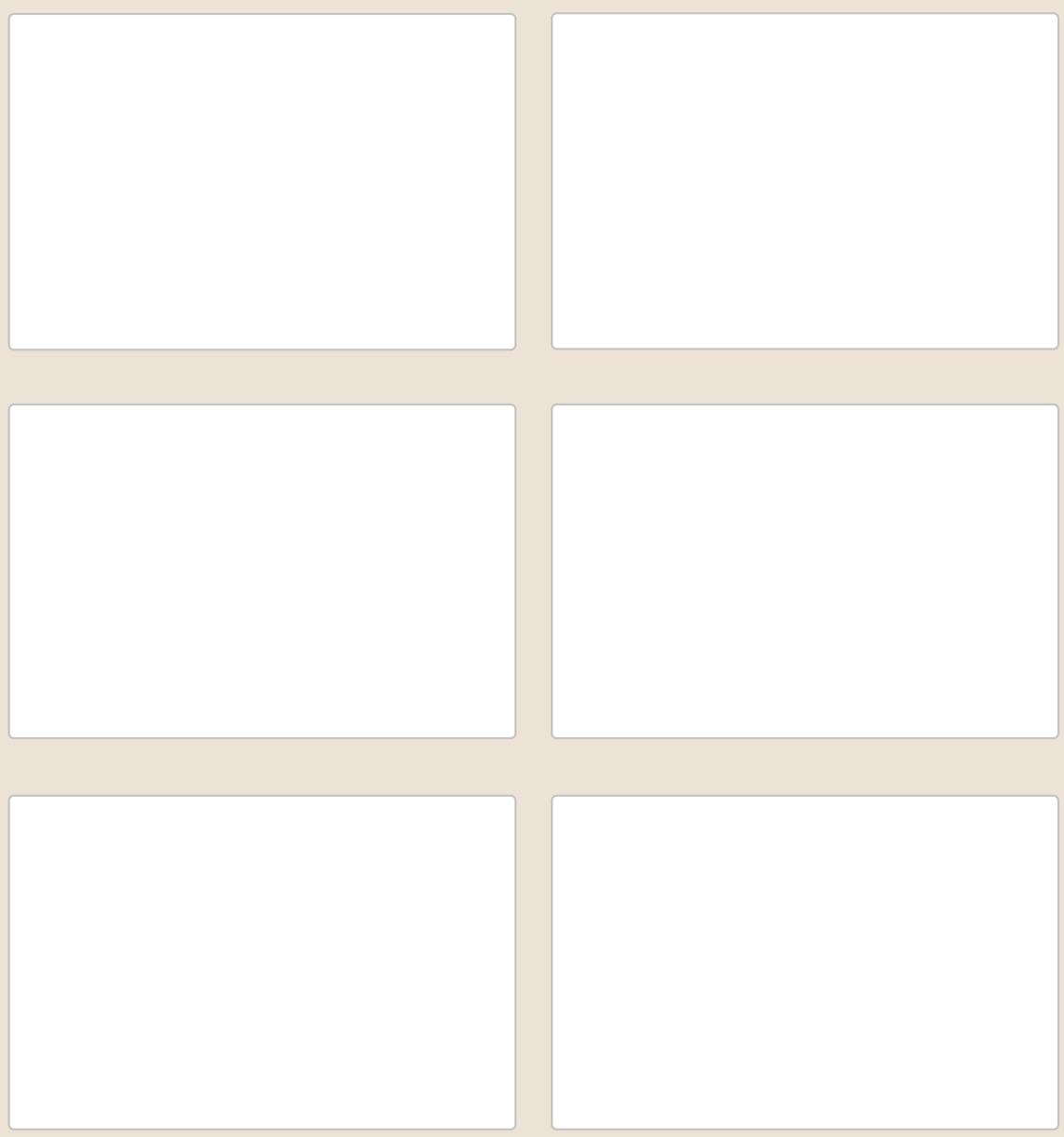

3.6. OTRAS 


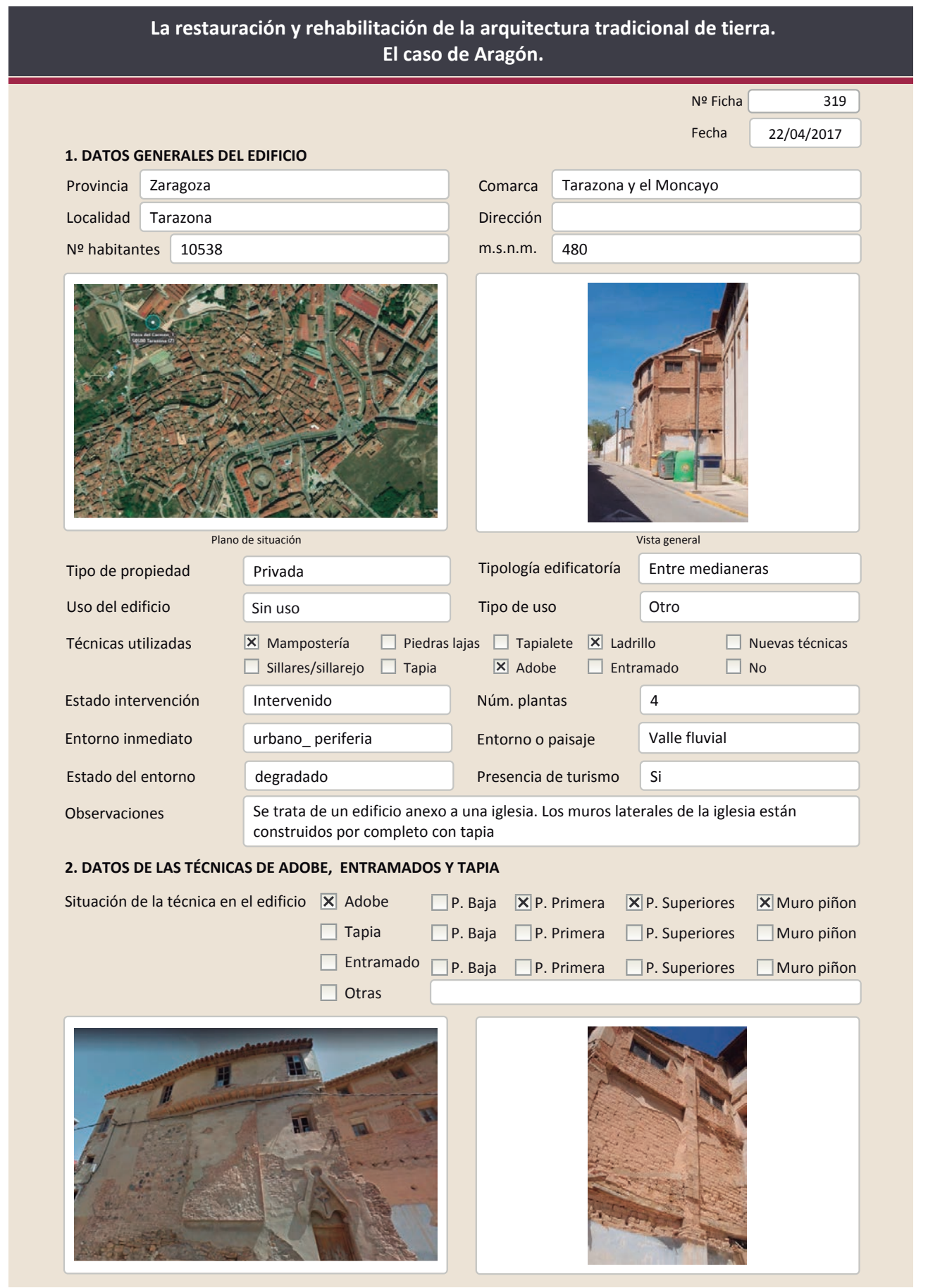

2.1. ADOBE

Dimensión de las piezas

Dimensión del muro

Aparejo del muro

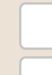

Función estructural

$$
\text { Soga }
$$

Variante constructiva/ tipo de fábrica
$\square$ Simple
$\square$ Suplementada en juntas
X Mixta

\section{Machones}

Color de las piezas

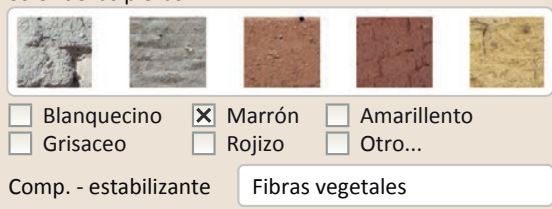

Comp. - estabilizante Fibras vegetes

$\square$ Como suplemento

$\square$ Elementos de protección

El adobe se encuentra el el muro piñón y sobre un voladizo de la fachada principal

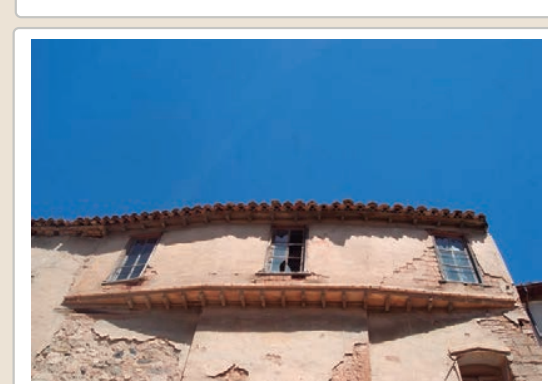

Lesiones X Muro $\square$ Zócalo $\mathbf{X}$ Revestimiento

$\mathbf{X}$ Erosión del material $\square$ Humedad por capilaridad $\square$ Erosion de las juntas $\square$ Humedades (manch/eflo)

$\square$ Pérdida de sección $\square$ Pérdida de verticalidad

$\square$ Vegetación $\quad \square$ Grietas por empuje de la cubie

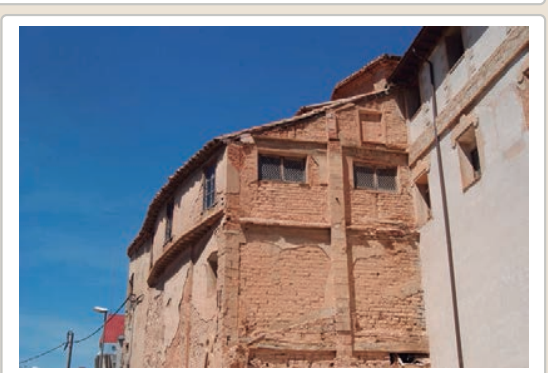

$\square$ Grietas porfalta de traba

$\square$ Cubierta $\square$ Otro...

$\square$ Grietas por asentamientos
$\square$ Colapso
$\square$ Por elementos impropios
$\square$ Derivado de intervenciones


La restauración y rehabilitación de la arquitectura tradicional de tierra.

El caso de Aragón.

3. DATOS DE LA INTERVENCIÓN

\begin{tabular}{llll|} 
Intervención de: & $\square$ Mantenimiento $\quad \square$ Rehabilitación parcial $\quad \square$ Restauración $\quad \square$ Demolición \\
Reflexión previa & $\boldsymbol{X}$ Reparación $\quad \square$ Rehabilitación integral $\quad \square$ Ampliación $\quad \square$ Otro... \\
\hline Observaciones & Intervención espontanea & \\
& Se ha intervenido únicamente en la cubierta del edificio \\
& &
\end{tabular}

\subsection{MUROS}

Tipo de intervención

No intervenido

Tipo de material

$\square$ Actualización $\square$ Reintegración $\square$ Demolición $\square$ Otro...

$\square$ Consolidación $\square$ Reconstrucción $\square$ Sustitución

Descripción

3.2. ZÓCALO

Tipo de intervención

No intervenido

Tipo de intervención

$\square$ Actualización

Descripción

3.3. REVESTIMIENTOS

Tipo de intervención

\section{No intervenido}

$\square$ Actualización Tipo de técnica

Tipo de material

Descripción

3.4. VANOS

Tipo de intervención

No intervenido

Tipo de material

$\square$ Actualización $\quad \square$ Reintegración $\quad \square$ Demolición $\quad \square$ Otro...
$\square$ Consolidación $\quad \square$ Reconstrucción $\quad \square$ sustitución

Descripción

Descripción

3.5. CUBIERTA

Tipo de intervención

Intervenido

Tipo de material

$\square$ Actualización $\quad \square$ Reintegración $\quad \square$ Demolición $\square$ Otro..

$\square$ Consolidación $\quad$ Reconstrucción $\square$ Sustitución

Descripción

No tradicional Tipo de técnica Similar a la existente

Reconstrucción de la cubierta con teja curva e incorporando una lámina grecada entre estas y la superficie de apoyo

3.6. OTRAS 
La restauración y rehabilitación de la arquitectura tradicional de tierra. El caso de Aragón

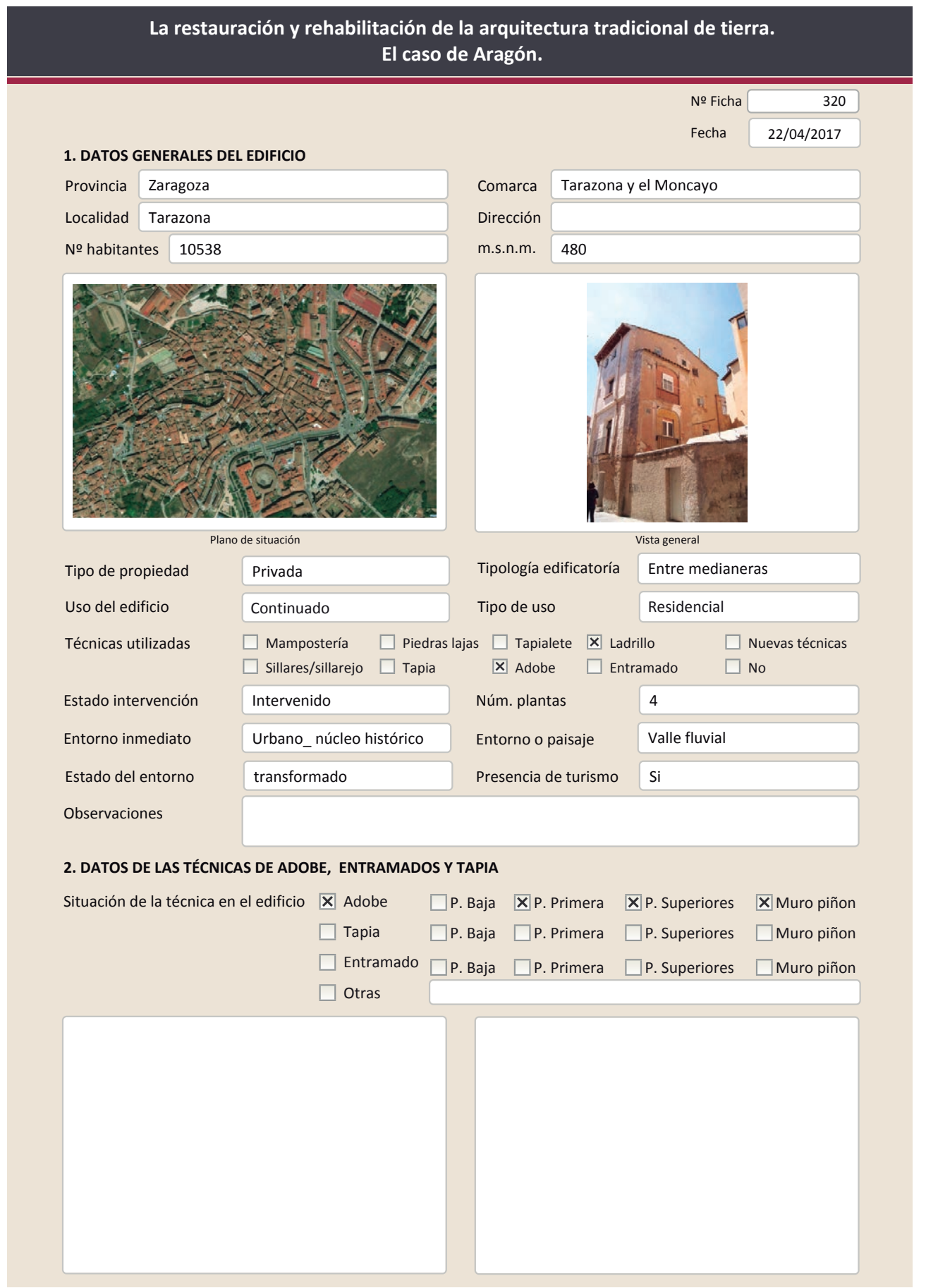

2.1. ADOBE

Dimensión de las piezas

Dimensión del muro

Aparejo del muro

Función estructural

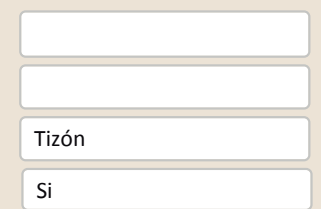

Color de las piezas

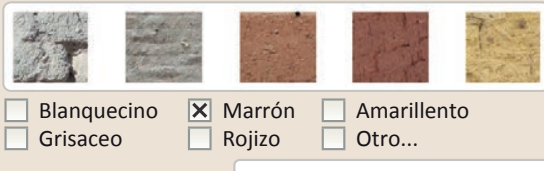

Grisaceo

Rojizo

Variante constructiva/ tipo de fábrica

$\square$ Simple

$\square$ Suplementada en juntas

X Mixta

\section{Machones}

Comp. - estabilizante

$\square$ Como suplemento

$\mathbf{X}$ Elementos de protección

Revestimiento

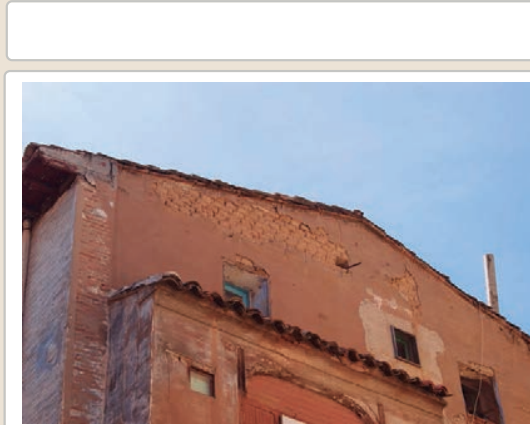

Lesiones $\mathbf{X}$ Muro $\square$ Zócalo $\mathbf{X}$ Revestimiento $\square$ Cubierta $\square$ otro...

区 Erosión del material $\quad \square$ Humedad por capilaridad $\quad \square$ Grietas por asentamientos

$\square$ Erosion de las juntas $\square$ Humedades (manch/eflo) $\quad \square$ Colapso

$\square$ Pérdida de sección $\square$ Pérdida de verticalidad $\square$ Por elementos impropios

$\square$ Vegetación $\quad \square$ Grietas por empuje de la cubierta $\square$ Derivado de intervenciones

X Desconchados

$\square$ Grietas porfalta de traba

$\square$ Otro... 


\section{La restauración y rehabilitación de la arquitectura tradicional de tierra.}

\section{El caso de Aragón.}

3. DATOS DE LA INTERVENCIÓN

.

$\square$ Restauración $\square$ Demolición

Reflexión previa

Intervención espontanea

Observaciones

3.1. MUROS

Tipo de intervención

Tipo de material

Descripción

3.2. ZÓCALO

Tipo de intervención

Tipo de material

Descripción

3.3. REVESTIMIENTOS

Tipo de intervención

Tipo de material

Descripción

3.4. VANOS

Tipo de intervención

Tipo de material

Descripción

3.5. CUBIERTA

Tipo de intervención

Tipo de material

Descripción

3.6. OTRAS

No intervenido
$\square$ Actualización $\quad \square$ Reintegración $\quad \square$ Demolición $\quad \square$ Otro...
$\square$ Consolidación $\quad \square$ Reconstrucción $\quad \square$ Sustitución

$\square$ Consolidación $\quad \square$ Reconstrucción $\square$ Sustitución

Intervenido

X Actualización $\square$ Reintegración $\square$ Demolición $\square$ Otro...

$\square$ Consolidación $\quad$ X Reconstrucción $\square$ Sustitución

No tradicional Tipo de técnica Diferente a la existente

gotelé de cemento pintado de gris

\section{No intervenido}

$\square$ Actualización $\square$ Reintegración $\square$ Demolición $\square$ Otro...

$\square$ Consolidación $\quad \square$ Reconstrucción $\square$ sustitución

Tipo de técnica

Intervenido

$\square$ Actualización $\quad \boldsymbol{X}$ Reintegración $\square$ Demolición $\square$ Otro...

$\square$ Consolidación $\square$ Reconstrucción $\quad \boldsymbol{X}$ Sustitución

No tradicional Tipo de técnica Diferente a la existente

Sustitución de carpinterías incorporación de persianas y adaptación de algunos de los

Sustitución de carpinterias incorporación de persian
huecos a las nuevas dimensiones de las carpinterías

Intervenido

$\square$ Actualización $\square$ Reintegración $\square$ Demolición $\square$ Otro..

$\square$ Consolidación $\quad$ Xeconstrucción $\square$ Sustitución

No tradicional Tipo de técnica Similar a la existente

Reconstrucción de la carpintería con teja curva y cemento $\square$ Mantenimiento $\quad \mathbf{X}$ Rehabilitación parcial

La restauración y rehabilitación de la arquitectura tradicional de tierra.

El caso de Aragón.

3.7. REHABILITACIÓN ENERGÉTICA $\square$ Fachada $\quad \boldsymbol{X}$ Vanos $\square$ Forjados $\square$ Cubierta

Observaciones

FOTOGRAFíAS DE LA INTERVENCIÓN

Tipo de técnica $\square$

trong
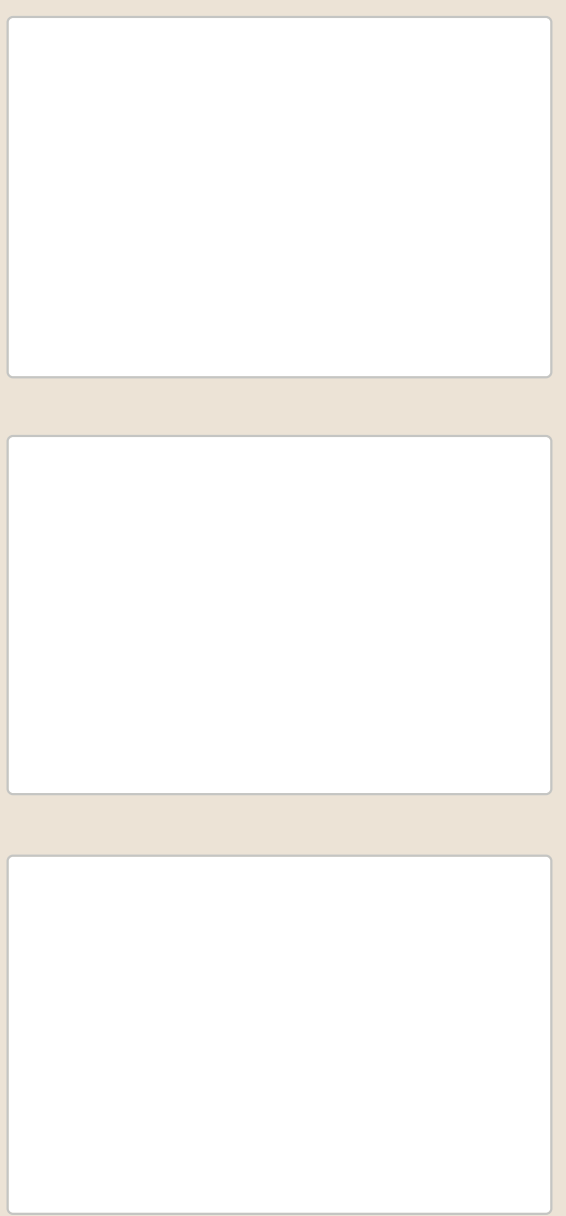
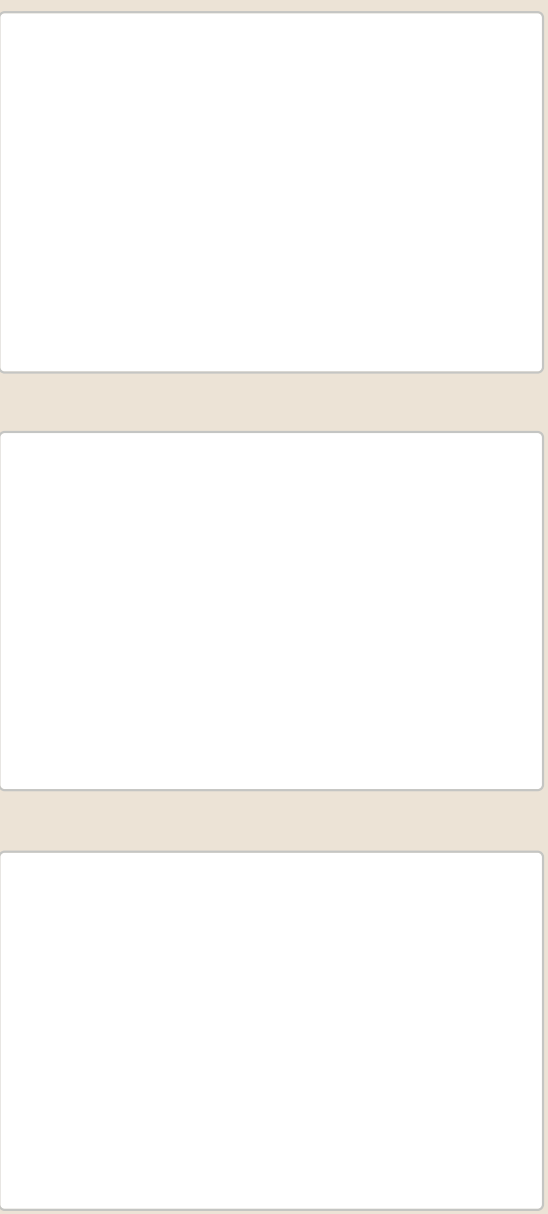


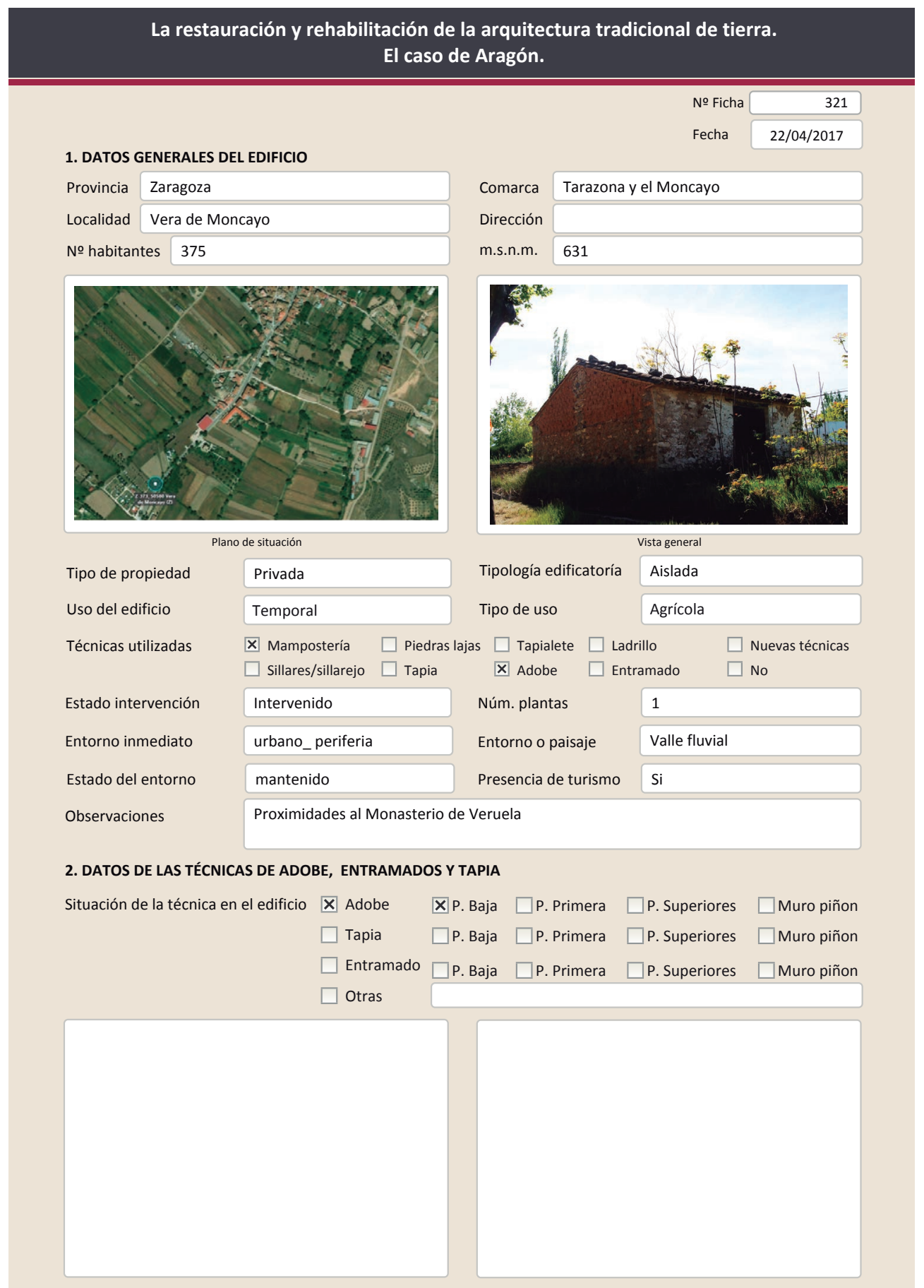

2.1. ADOBE

Dimensión de las piezas Dimensión del muro

Aparejo del muro

Función estructural

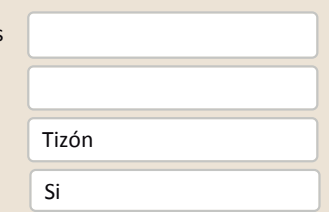

Color de las piezas

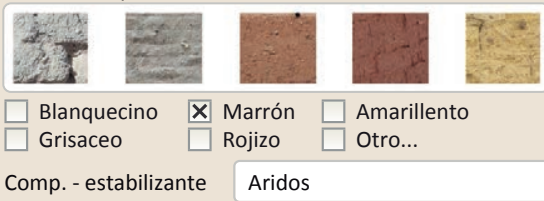

Variante constructiva/ tipo de fábrica

$\square$ Simple

$\square$ Suplementada en juntas

区 Mixta

\section{Machones}

Piedra

$\square$ Como suplemento

$\square$ Elementos de protección

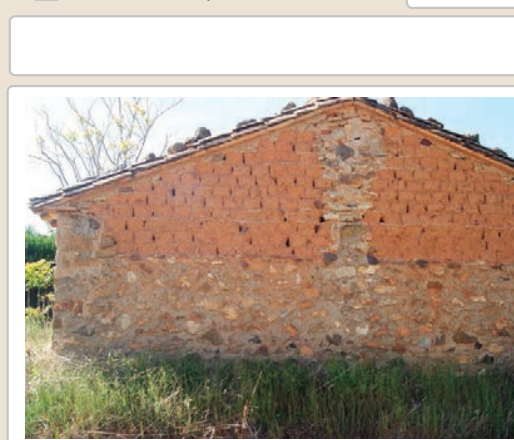

Lesiones X XMuro $\square$ Zócalo $\square$ Revestimiento

Х Erosión del material $\square$ Humedad por capilaridad $\square$ Erosion de las juntas $\square$ Humedades (manch/eflo)

$\square$ Pérdida de sección

$\square$ Pérdida de verticalidad

$\square$ Vegetación

$\square$ Desconchados

$\square$ Grietas por empuje de la $\square$ Grietas porfalta de traba

$\square$ Cubierta $\square$ Otro...

$\square$ Grietas por asentamiento

$\square$ Colapso

$\square$ Por elementos impropios$$
\square \text { Gietas porato dro }
$$

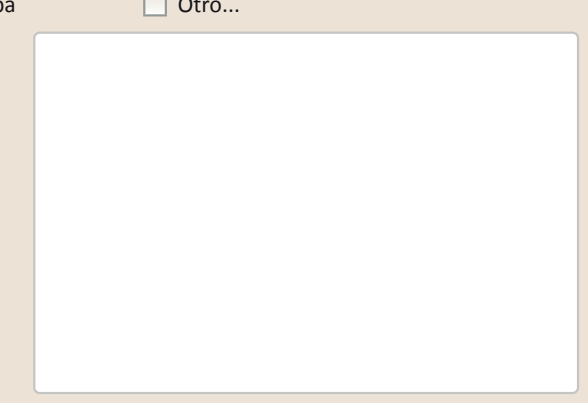

Observaciones 
La restauración y rehabilitación de la arquitectura tradicional de tierra.

El caso de Aragón.

3. DATOS DE LA INTERVENCIÓN

\begin{tabular}{llll|} 
Intervención de: & $\square$ Mantenimiento $\quad \square$ Rehabilitación parcial & $\square$ Restauración $\quad \square$ Demolición \\
Reflexión previa & $\mathbf{X}$ Reparación $\quad \square$ Rehabilitación integral $\quad \square$ Ampliación $\quad \square$ Otro... \\
\hline Observaciones & Intervención espontanea & \\
& & \\
& & \\
&
\end{tabular}

\subsection{MUROS}

Tipo de intervención

Intervenido

Tipo de material

$\square$ Actualización $\quad$ X Reintegración $\square$ Demolición $\square$ Otro...

$\square$ Consolidación $\square$ Reconstrucción $\square$ Sustitución

Descripción

No tradicional Tipo de técnica Similar a la existente

3.2. ZÓCALO

Rejuntado de mampostería y pintura blanca

Tipo de intervención

Intervenido

Tipo de material

$\square$ Actualización $\quad \mathbf{X}$ Reintegración $\square$ Demolición $\square$ Otro...

$\begin{array}{ll}\square \text { Actualización } \quad \boldsymbol{x} \text { Reintegración } & \square \text { Demolición } \\ \square \text { Consolidación } \quad \square \text { Reconstrucción } \quad \square \text { Sustitución }\end{array}$

Descripción

No tradicional Tipo de técnica Similar a la existente

3.3. REVESTIMIENTOS

Rejuntado de mampostería

Tipo de intervención

\section{No aplica}

Tipo de material

Descripción

$\square$ Reintegración $\square$ Demolición $\square$ Otro...

$\square$ Consolidación $\square$ Reconstrucción $\square$ sustitución

3.4. VANOS

No intervenido

Tipo de intervención

$\square$ Actualización $\quad \square$ Reintegración $\quad \square$ Demolición $\quad \square$ Otro...
$\square$ Consolidación $\quad \square$ Reconstrucción $\quad \square$ Sustitución

Tipo de material

Descripción

3.5. CUBIERTA

Tipo de intervención

No intervenido

$\square$ Actualización $\square$ Reintegración $\square$ Demolición $\quad \square$ Otro...

Tipo de material

$\square$ Reconstrucción $\square$ Sustitución

Descripción

$$
\text { Tipo de técnica }
$$

3.6. OTRAS 


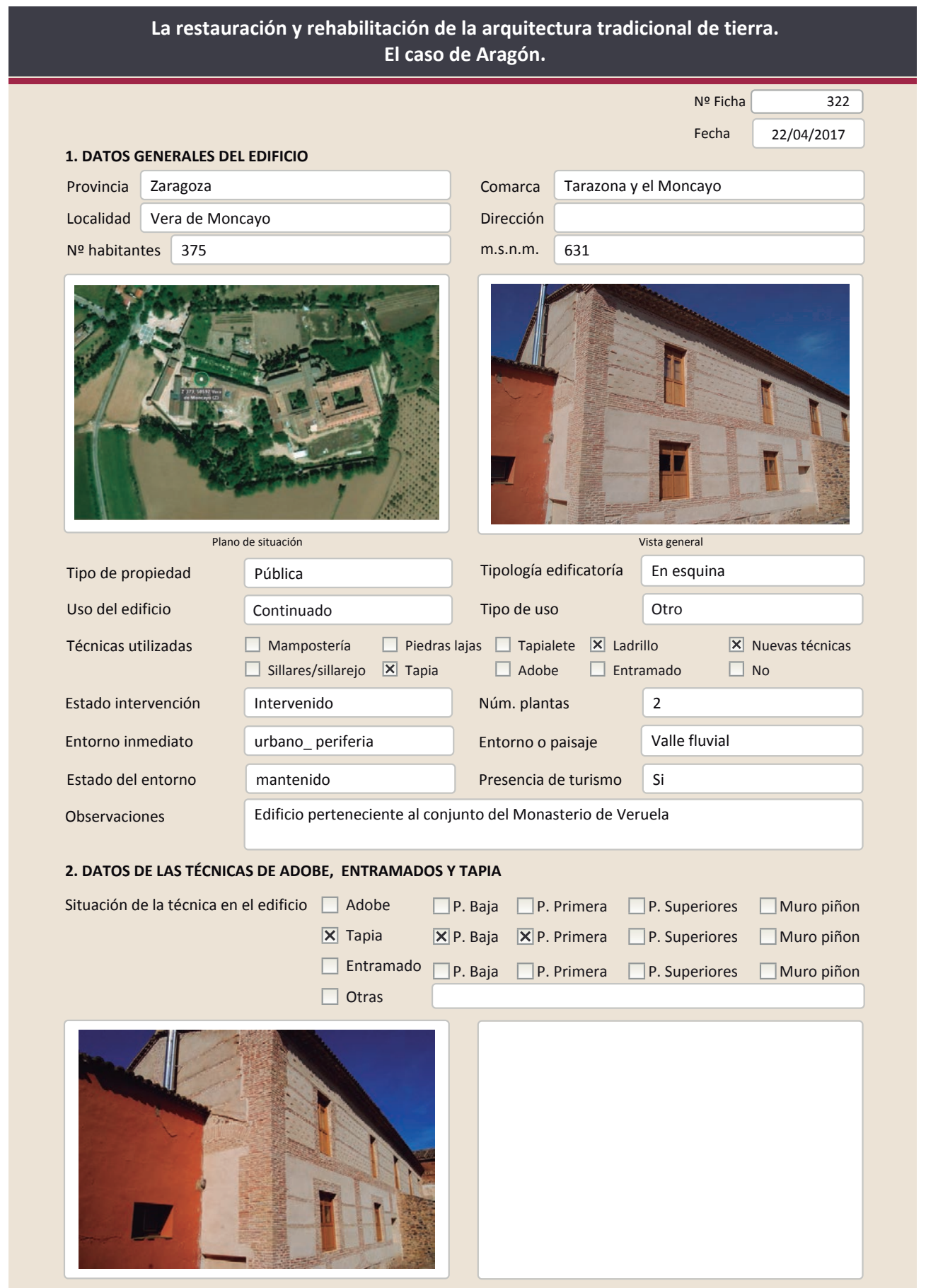

2.2. TAPIA

Ancho del muro

Dimensión tapiales

Tipo de aguja

№ agujas/cajón

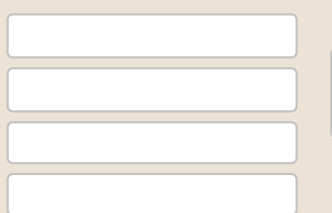

Color de la tapia

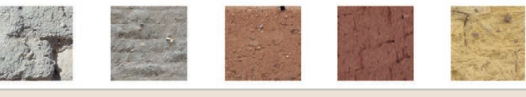

$\square$ Blanquecino $\square$ Marrón $\square$ Amarillento

$\square$ Grisaceo

Rojizo $\square$ Otro...

Variante constructiva

$\square$ Simple / homogénea

X Suplemento superficial

$\square$ Suplemento en juntas

区 Mixta

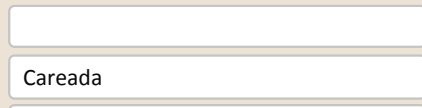

$\square$ Elementos de protección

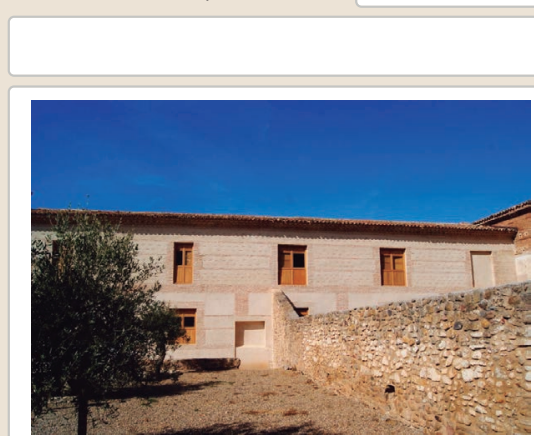

Lesiones $\square$ Muro ХZŹcalo $\square$ Revestimiento $\square$ Cubierta $\square$ otro...

$\square$ Erosión del material $\quad \mathbf{X}$ Humedad por capilaridad $\quad \square$ Grietas por asentamiento

$\square$ Erosion de las juntas $\square$ Humedades (manch/eflo)

$\square$ Pérdida de sección $\quad \square$ Pérdida de verticalidad

$\square$ Vegetación $\square$ Grietas por empuje de la cubie

$\square$ Desconchado

$\square$ Por elementos impropios

$\square$ Grietas porfalta de traba

$\square$ Derivado

Observaciones 


\section{La restauración y rehabilitación de la arquitectura tradicional de tierra.}

\section{El caso de Aragón.}

3. DATOS DE LA INTERVENCIÓN

Intervención de:

$\square$ Mantenimiento

\begin{abstract}
Reflexión previa
\end{abstract}
$\square$ Reparación

$\square$ Rehabilitación parcial

$\square$ Restauración $\square$ Demolición

Intervención planificada

Observaciones

(2)

3.1. MUROS
Tipo de intervención

Intervenido

Tipo de material

\ Actualización $\quad \boldsymbol{X}$ Reintegración $\quad \square$ Demolición $\square$ Otro...

$\square$ Consolidación $\square$ Reconstrucción $\square$ Sustitución

Descripción

No tradicional

Tipo de técnica

3.2. zócALO

Tipo de intervención

Rejuntado del muro de ladrillo.

\section{Intervenido}

$\square$ Actualización $\quad \square$ Reintegración $\quad \square$ Demolición $\quad \square$ otro...

$\square$ Consolidación $\quad \mathbf{X}$ Reconstrucción $\square$ Sustitución

Tipo de material

No tradicional Tipo de técnica Diferente a la existente

Descripción

3.3. REVESTIMIENTOS

Tipo de intervención

revestimiento de cemento

\section{Intervenido}

$\square$ Actualización $\square$ Reintegración $\square$ Demolición $\square$ Otro...

$\square$ Consolidación $\quad \boldsymbol{X}$ Reconstrucción $\quad \square$ sustitución

Tipo de material

Descripción

3.4. VANOS

Tipo de intervención

No tradicional

Tipo de técnica Diferente a la existente

Revestimiento de cemento sobre los cajones de tapia dejando ver los ladrillos de la

$$
\text { superficie }
$$

Tipo de material
Descripción

Intervenido

$\square$ Actualización $\square$ Reintegración $\square$ Demolición $\square$ Otro...

$\square$ Consolidación $\square$ Reconstrucción $\quad$ X Sustitución

Descripción

3.5. CUBIERTA

Tipo de intervención

No tradicional

Sustitución de las carpinterías

\section{Intervenido}

$\square$ Actualización $\quad \square$ Reintegración $\quad \square$ Demolición $\quad \square$ Otro... $\square$ Consolidación $\quad \mathbf{X}$ Reconstrucción $\quad \square$ Sustitución

Tipo de material

No tradicional

Tipo de técnica Similar a la existente

Descripción

Reconstrucción de la cubierta. Se ha conservado el alero y se ha recolocado todo con cemento ( probablemente se han incorporado aislantes e impermabilizantes)
La restauración y rehabilitación de la arquitectura tradicional de tierra.

El caso de Aragón.

3.7. REHABILITACIÓN ENERGÉTICA $\square$ Fachada $\bigotimes$ Vanos $\square$ Forjados $邓$ Cubierta

Observaciones Al ser un edificio público probablemente también se hayan intervenido fachada y forjado para cumplir la normativa

FOTOGRAFíAS DE LA INTERVENCIÓN
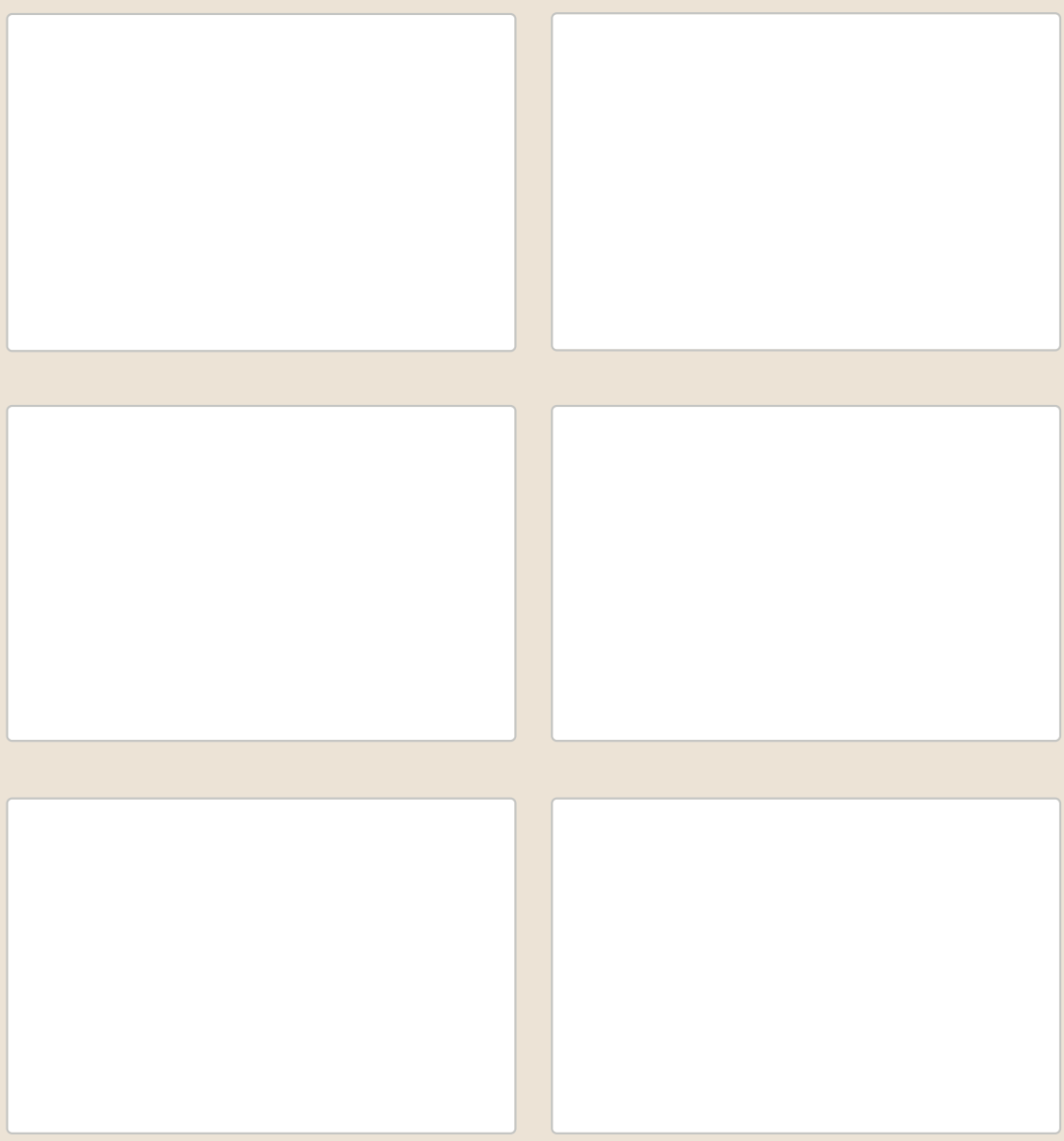

3.6. OTRAS 


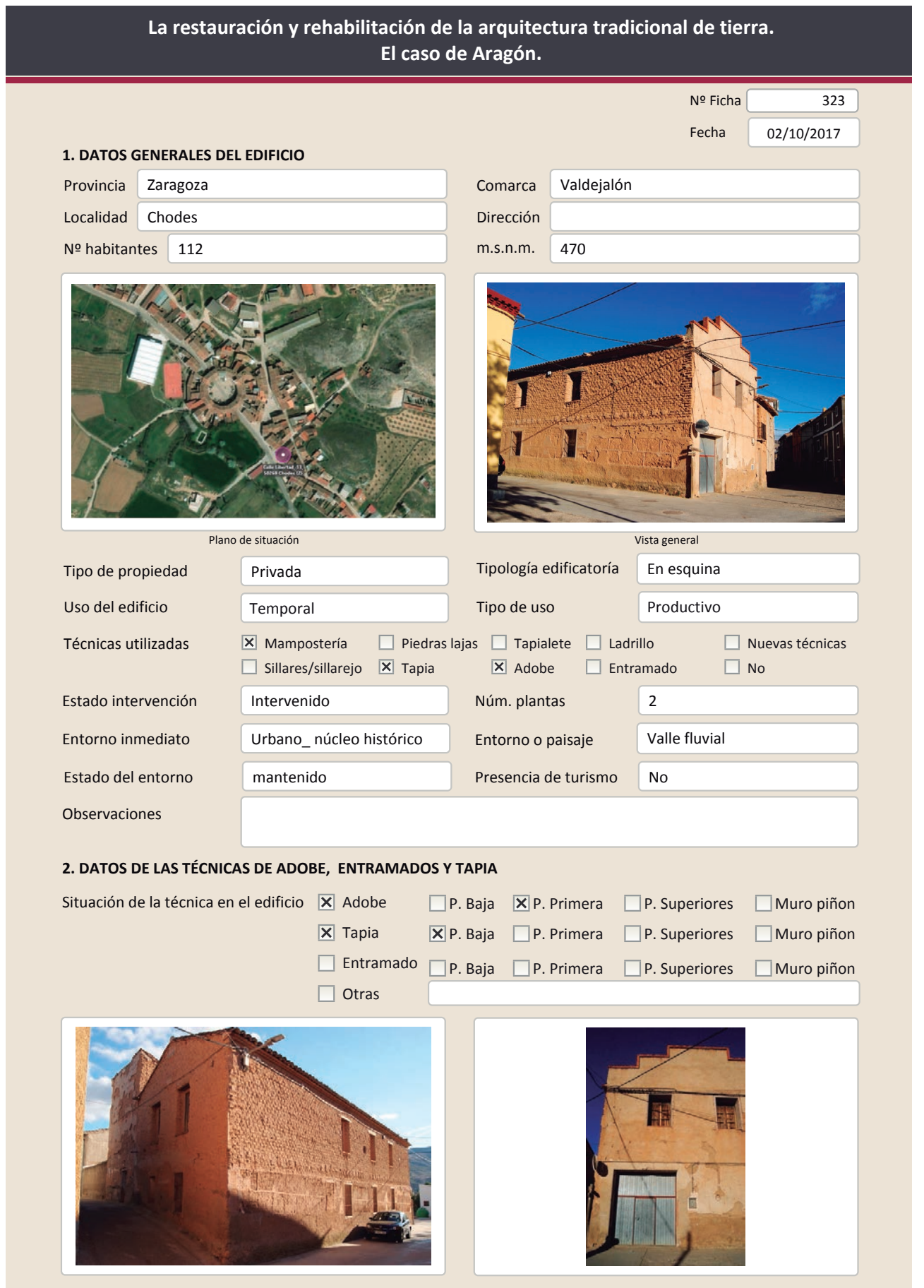

2.1. ADOBE

Dimensión de las piezas Dimensión del muro

Aparejo del muro

Función estructural

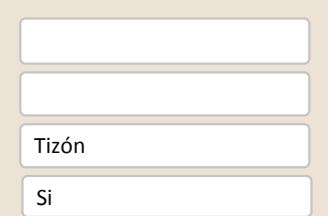

Color de las piezas

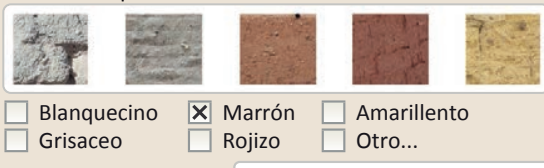

Variante constructiva/ tipo de fábrica

X Simple

$\square$ Mixta

$\square$ Como suplemento

$\square$ Elementos de protección

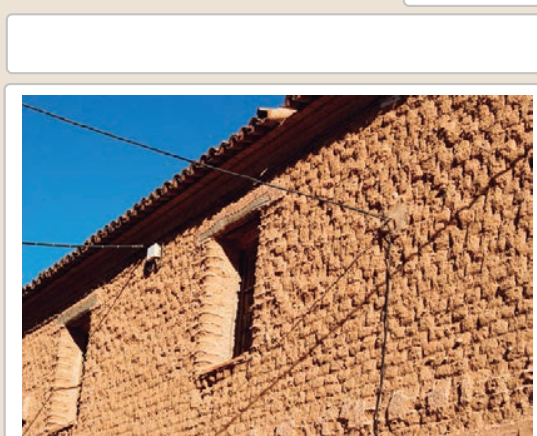

Lesiones ХMuro $\square$ Zócalo $\square$ Revestimiento

X Erosión del material $\square$ Humedad por capilaridad $\square$ Erosion de las juntas $\square$ Humedades (manch/eflo)

Х Pérdida de sección $\square$ Pérdida de verticalidad

$\square$ Vegetación

$\square$ Grietas por empuje de la

$\square$ Desconchados $\square$ Grietas porfalta de traba

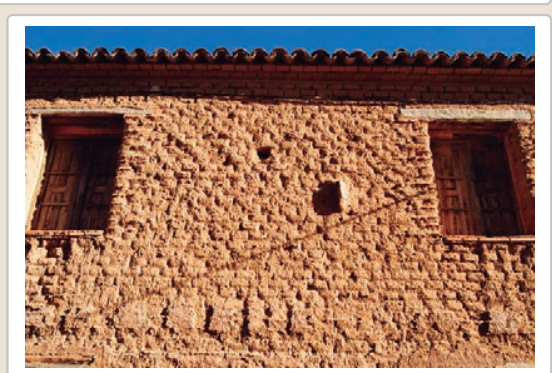

$\square$ Cubierta $\square$ Otro...

$$
\begin{aligned}
& \square \text { Grietas por asentamientos } \\
& \square \text { Colapso } \\
& \square \text { Por elementos impropios } \\
& \square \text { Derivado de intervenciones }
\end{aligned}
$$

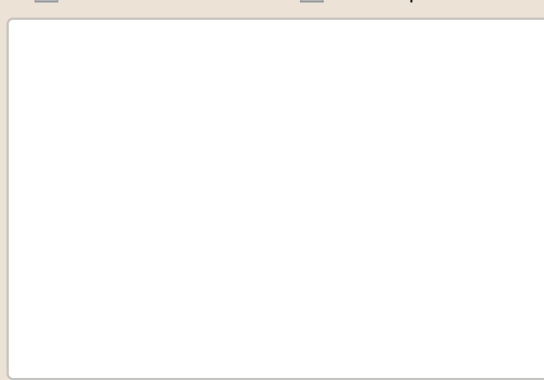

Observaciones 


\section{La restauración y rehabilitación de la arquitectura tradicional de tierra.} El caso de Aragón.

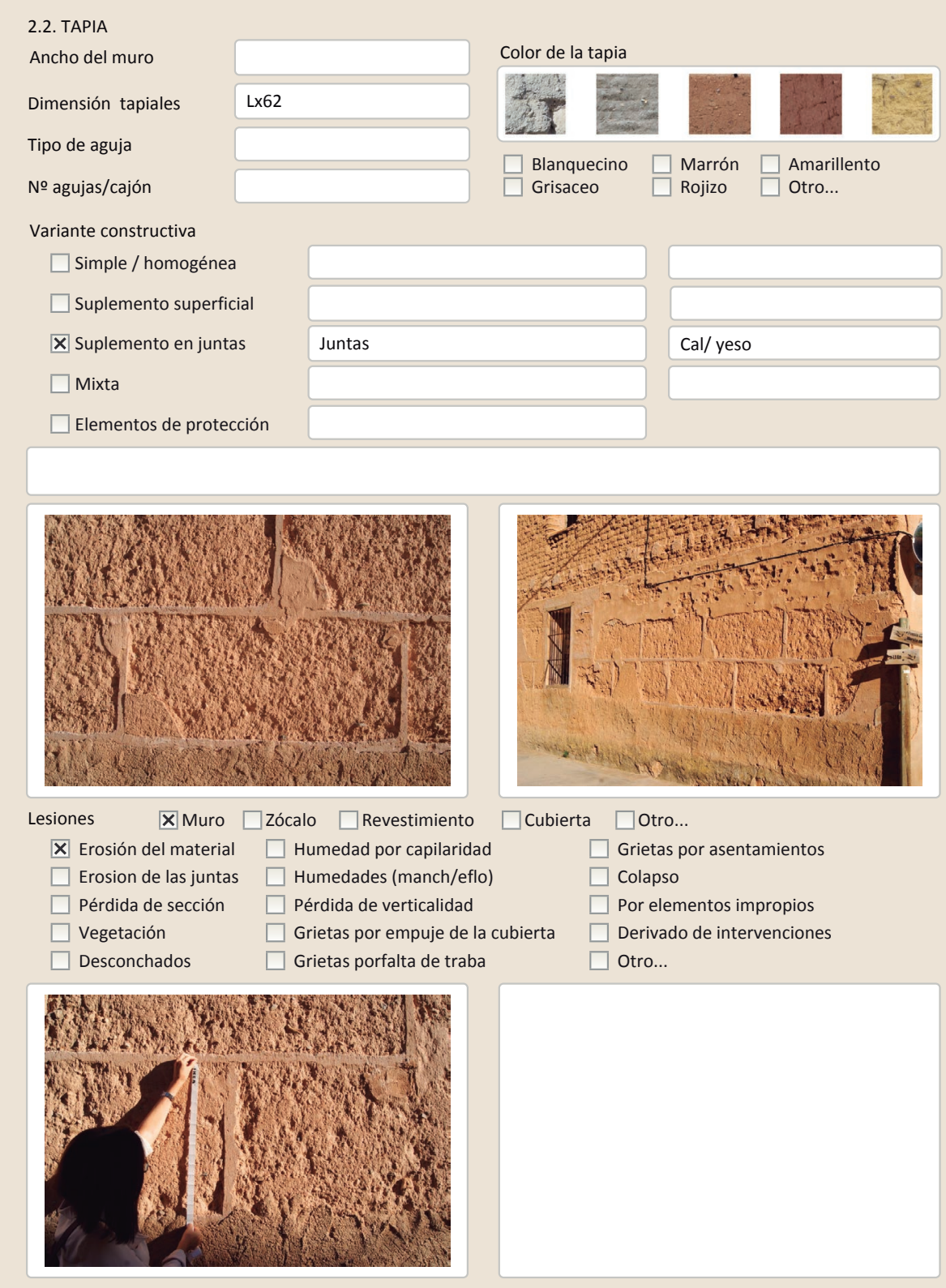

Observaciones
La restauración y rehabilitación de la arquitectura tradicional de tierra.

El caso de Aragón.

3. DATOS DE LA INTERVENCIÓN

Intervención de:

Reflexión previa Intervención espontanea

Observaciones

3.1. MUROS

No intervenido

Tipo de intervención

$\square$ Actualización $\quad \square$ Reintegración $\quad \square$ Demolición $\quad \square$ Otro...

$\square$ Consolidación $\square$ Reconstrucción $\square$ sustitución

Tipo de material

Descripción

3.2. ZÓCALO

Tipo de intervención

Tipo de material

Intervenido

$\square$ Actualización $\quad \square$ Reintegración $\quad \square$ Demolición $\quad \square$ Otro...

$\square$ Consolidación $\quad$ X Reconstrucción $\square$ Sustitución

Descripción

Tipo de técnica Diferente a la existente

3.3. REVESTIMIENTOS

Zócalo con revestimiento de cemento

Tipo de intervención

No aplica

Tipo de material

Descripción

3.4. VANOS

Tipo de intervención

Tipo de material

Descripción

$\square$ Actualización $\quad \square$ Reintegración $\quad \square$ Demolición $\quad \square$ Otro...

$\square$ Consolidación $\quad \square$ Reconstrucción $\quad \square$ Sustitución

$$
\text { Tipo de técnica }
$$

3.5. CUBIERTA

Tipo de intervención

Tipo de material

Descripción

3.6. OTRAS
Intervenido

$\square$ Actualización $\square$ Reintegración $\square$ Demolición $\square$ Otro..

$\square$ Consolidación $\mathbf{x}$ Reconstrucción $\mathbf{x}$ Sustitución

\begin{tabular}{l|l|l|l|l} 
No tradicional Tipo de técnica Diferente a la existente &
\end{tabular}

Ampliación del hueco y sustitución de la puerta de acceso

No intervenido

$\square$ Actualización $\quad \square$ Reintegración $\quad \square$ Demolición $\quad \square$ Otro

$\square$ Consolidación $\square$ Reconstrucción $\square$ Sustitución Tipo de técnica 
La restauración y rehabilitación de la arquitectura tradicional de tierra. El caso de Aragón

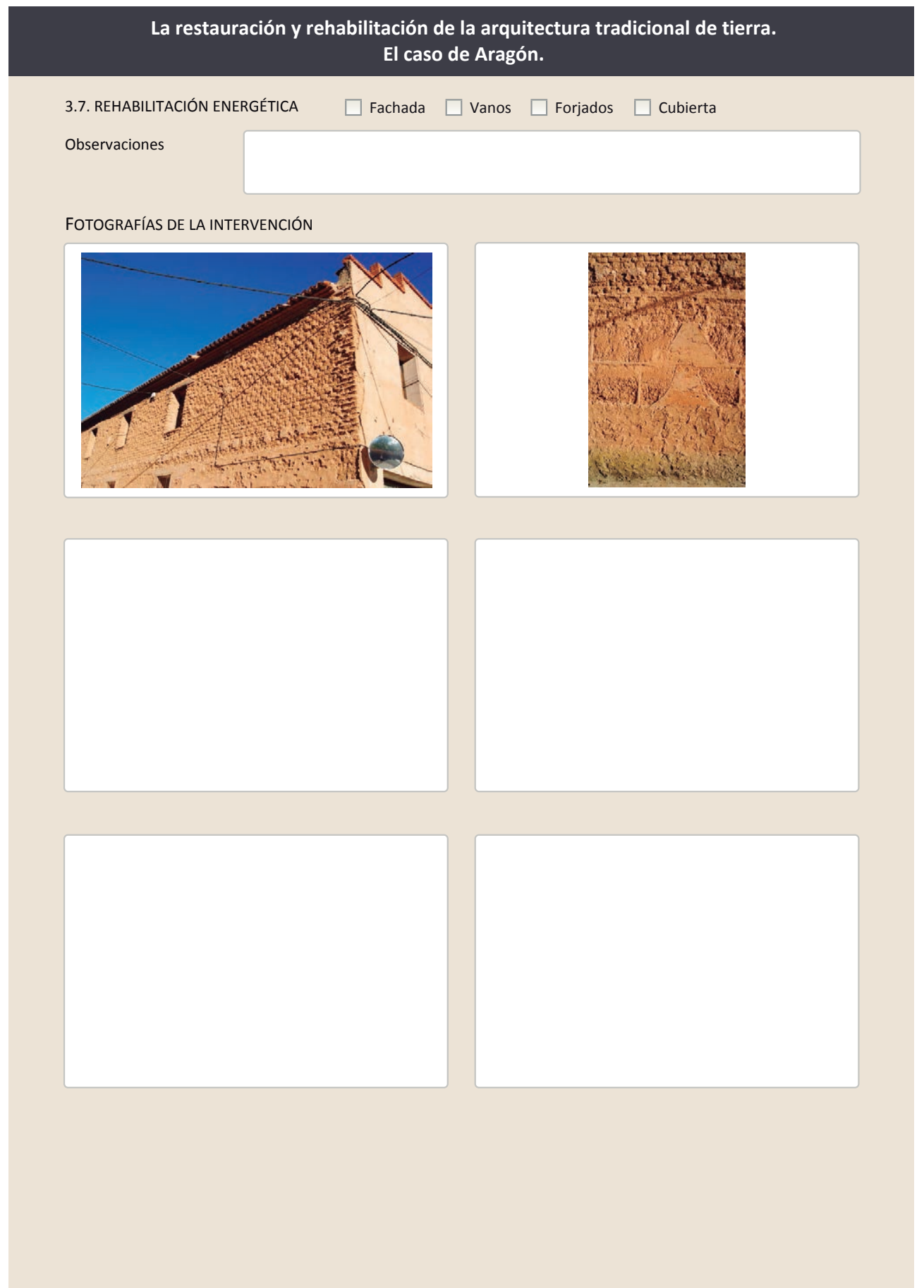

La restauración y rehabilitación de la arquitectura tradicional de tierra.

El caso de Aragón.

3.7. REHABILITACIÓN ENERGÉTICA $\square$ Fachada $\square$ Vanos $\square$ Forjados $\square$ Cubierta

Observaciones

FOTOGRAFÍAS DE LA INTERVENCIÓN 


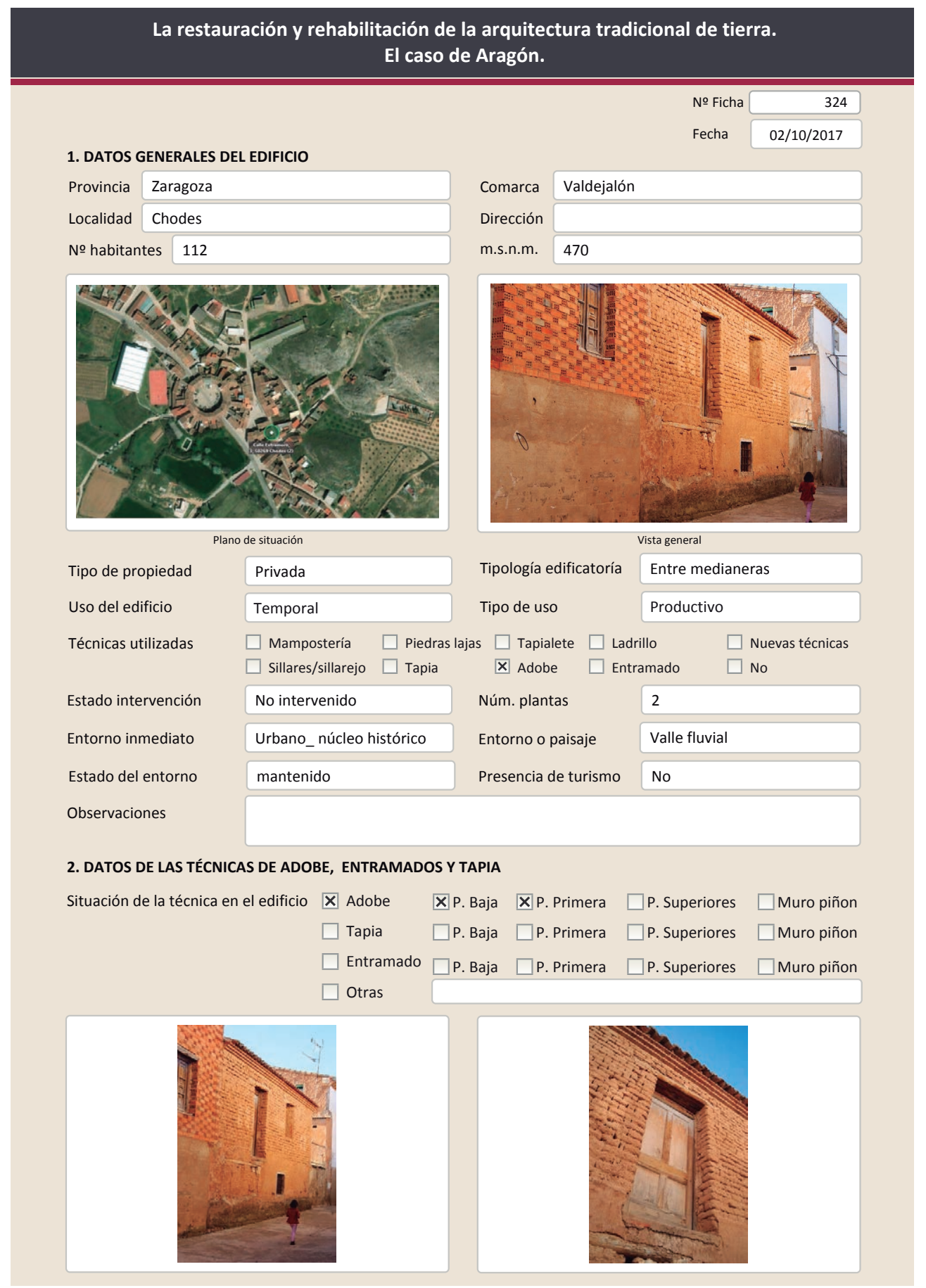

La restauración y rehabilitación de la arquitectura tradicional de tierra. El caso de Aragón.

\subsection{ADOBE \\ Dimensión de las piezas $\mathrm{L} \times 20,5 \times 9$ \\ Dimensión del muro $30-40 \mathrm{~cm}$ \\ Aparejo del muro Tizón \\ Función estructural \\ $\mathrm{Si}$ \\ Variante constructiva/ tipo de fábrica
$\square$ Suplementada en juntas
$\square$ Mixta
$\square$ Como suplemento
$\square$ Elementos de protección \\ \ Simple}

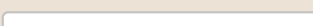

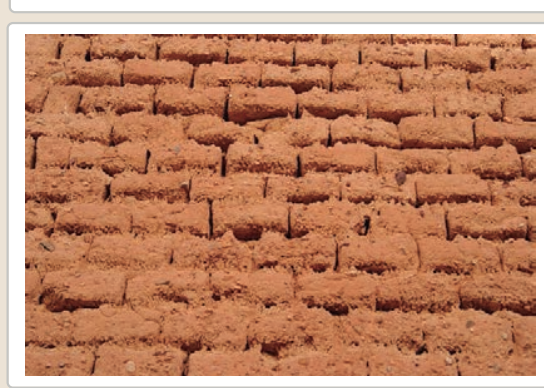

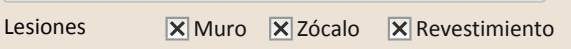

$\mathbf{X}$ Erosión del material $\mathbf{X}$ Humedad por capilaridad

$\square$ Erosion de las juntas $\mathbf{X}$ Humedades (manch/eflo)

$\square$ Pérdida de sección $\quad \square$ Pérdida de verticalidad

$\begin{array}{ll}\square \text { Vegetación } & \square \text { Grietas por empuje de la cubie } \\ \boldsymbol{X} \text { Desconchados } & \square \text { Grietas porfalta de traba }\end{array}$

Color de las piezas

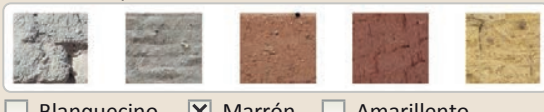

$\square$ Blanquecino $\mathbf{X}$ Marrón $\square$ Amarillento $\square$ Grisaceo $\square$ Rojizo $\square$ Otro...

Comp. - estabilizante Fibras vegetales

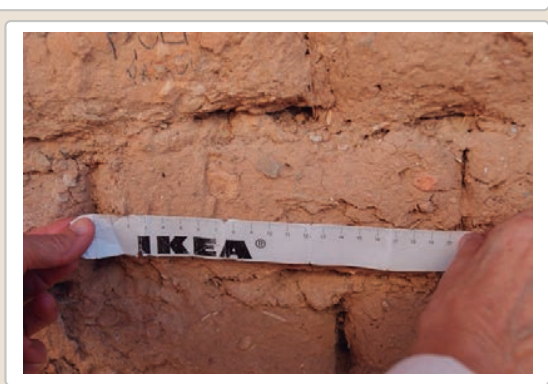

$\square$ Cubierta $\square$ otro...

$\square$ Grietas por asentamiento $\square$ Colapso

$\square$ Por elementos impropios

$\square$ Derivado de intervenciones $\square$ Otro...

Observaciones 

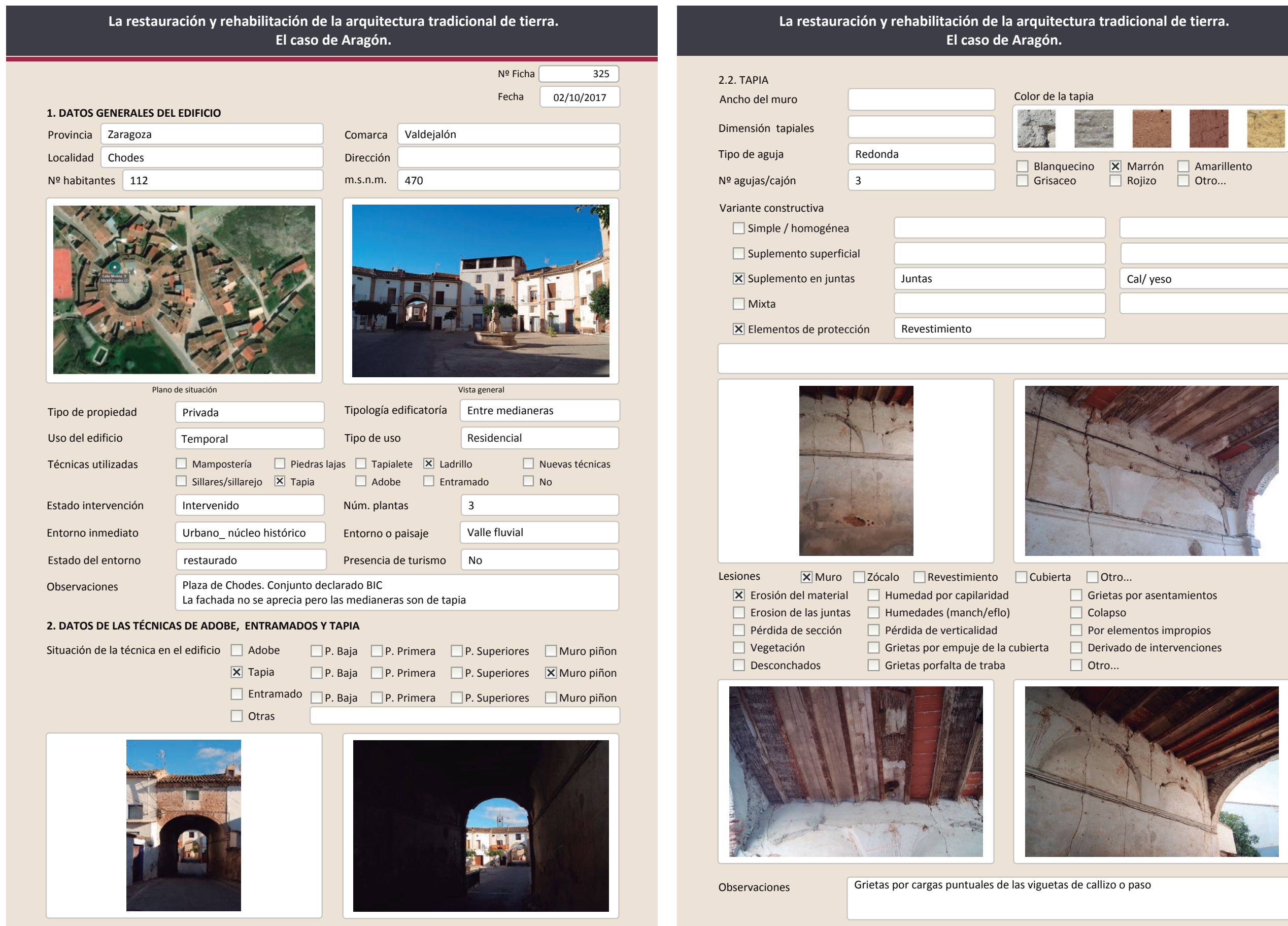

\section{$x$}
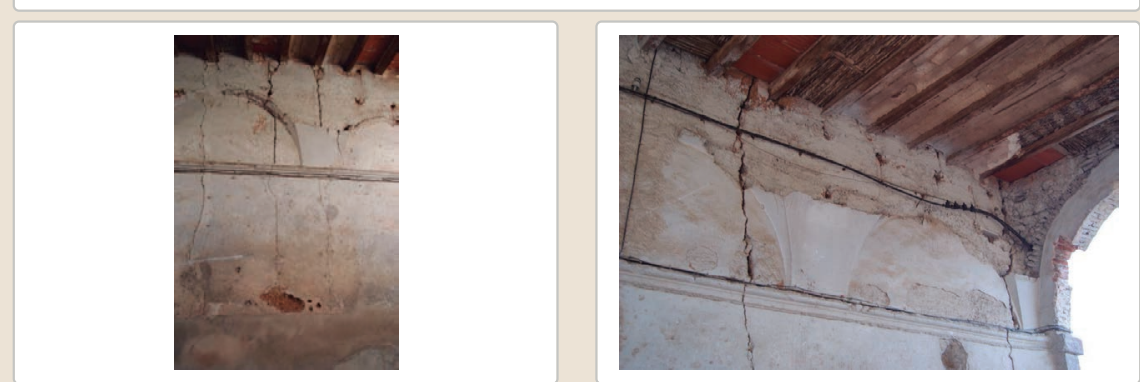

Lesiones $\quad$ Muro $\square$ Zócalo $\square$ Revestimiento $\square$ Cubierta $\square$ otro...

X Erosión del material $\quad \square$ Humedad por capilaridad $\quad \square$ Grietas por asentamientos $\square$ Erosion de las juntas $\square$ Humedades (manch/eflo) $\square$ Pérdida de sección $\quad \square$ Pérdida de verticalidad

$\square$ Vegetación $\quad \square$ Grietas por empuje de la cubierta $\square$ Colapso $\square$ Grietas porfalta de traba

$\square$ Por elementos impropios $\square$ Desconchados

$\square$ Otro...
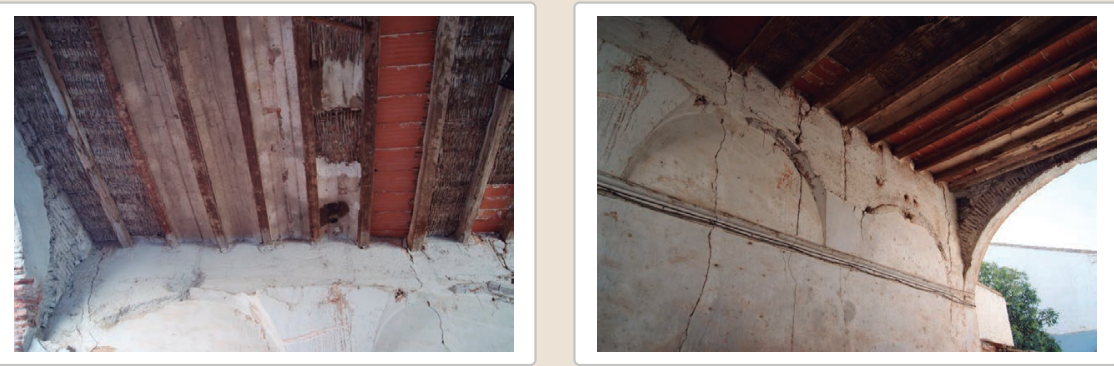

Observaciones Grietas por cargas puntuales de las viguetas de callizo o paso 


\section{La restauración y rehabilitación de la arquitectura tradicional de tierra.}

\section{El caso de Aragón.}

3. DATOS DE LA INTERVENCIÓN

\begin{tabular}{|c|c|c|c|c|}
\hline Intervención de: & $\begin{array}{l}\square \text { Mantenimiento } \\
\square \text { Reparación }\end{array}$ & $\begin{array}{l}\square \text { Rehabilitación parcial } \\
\boldsymbol{X} \text { Rehabilitación integral }\end{array}$ & $\begin{array}{l}\mathbf{X} \text { Restauración } \\
\square \text { Ampliación }\end{array}$ & $\begin{array}{l}\square \text { Demolición } \\
\square \text { Otro... }\end{array}$ \\
\hline Reflexión previa & \multicolumn{4}{|c|}{ Intervención planificada } \\
\hline Observaciones & \multicolumn{4}{|c|}{ Toda la plaza ha sido restaurada y sus viviendas rahabilitadas } \\
\hline
\end{tabular}

\subsection{MUROS}

Tipo de intervención

$$
\text { No visible }
$$

Tipo de material

$\square$ Actualización $\quad \square$ Reintegración $\quad \square$ Demolición $\square$ Otro... $\square$ Consolidación $\square$ Reconstrucción $\square$ sustitución

Descripción

3.2. ZÓCALO

Tipo de intervención

Intervenido

Tipo de intervención

X Actualización

$\square$ Consolidación

$\square$ Reintegración $\square$ Demolición $\square$ Otro...

Descripción

Tipo de técnica Similar a la existente

3.3. REVESTIMIENTOS

Pintura blanca

Tipo de intervención

\section{Intervenido}

Tipo de material

$\square$ Consolidación

Tipo de técnica

Descripción

3.4. VANOS

Tipo de intervención

Revestimiento de cemento probablemente y pintura blanca

Intervenido

Tipo de material

$\square$ Actualización $\quad \boldsymbol{X}$ Reintegración $\square$ Demolición $\square$ Otro...

$\square$ Consolidación $\square$ Reconstrucción $\quad$ \ Sustitución

Descripción

No tradicional

Tipo de técnica Diferente a la existente

Reintegración de ladrillos en las jambas de la puerta y sustitución de alguna de las carpinterías

3.5. CUBIERTA

Tipo de intervención

Intervenido

Tipo de intervención

$\square$ Actualización $\quad$ X Reintegración $\quad \square$ Demolición $\square$ Otro.

Tipo de material

$\square$ Consolidación $\square$ Reconstrucción $\square$ Sustitución

Descripción

No tradicional

Tipo de técnica Similar a la existente

3.6. OTRAS 


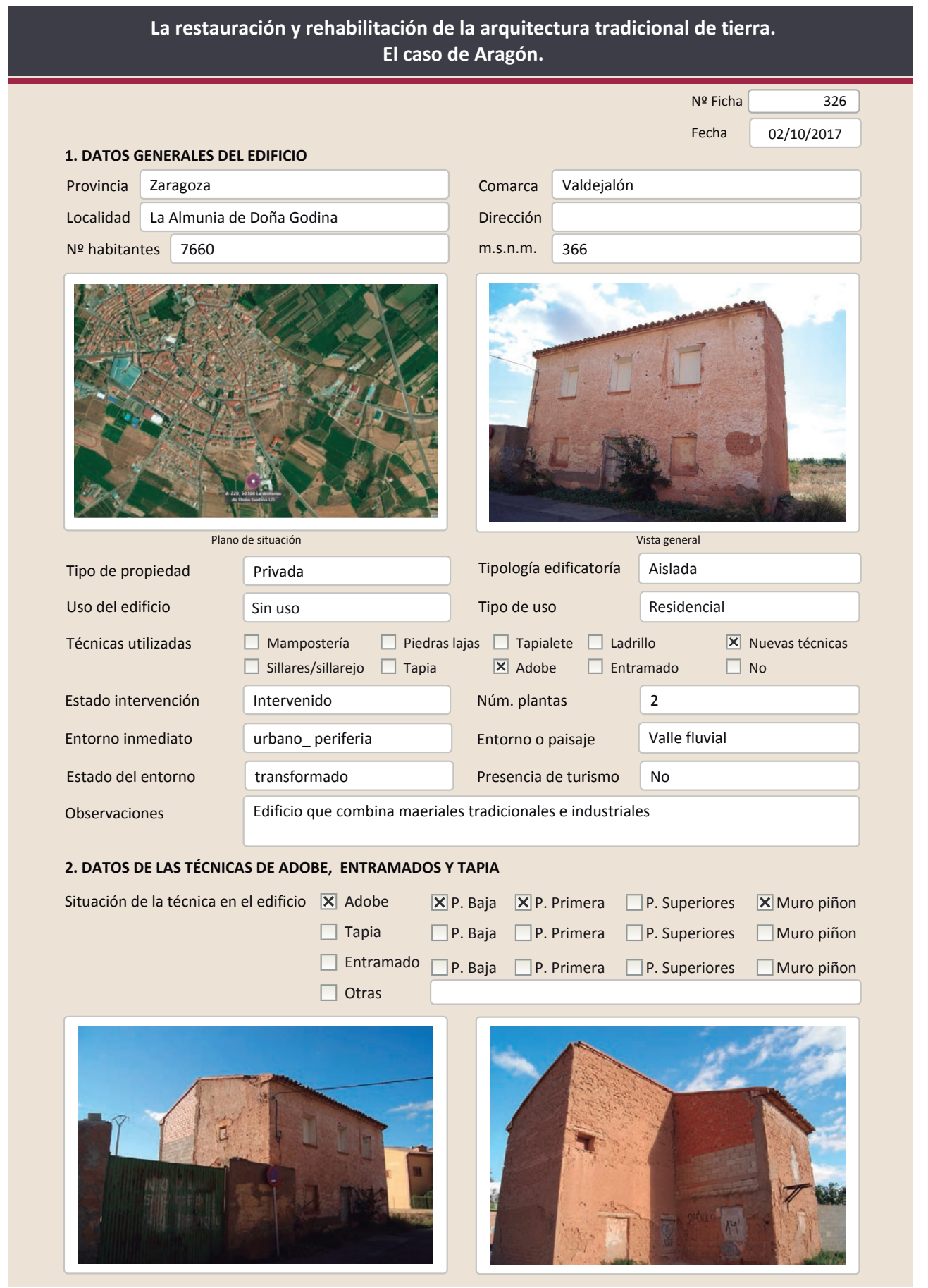

2.1. ADOBE

Dimensión de las piezas

Dimensión del muro

Aparejo del muro

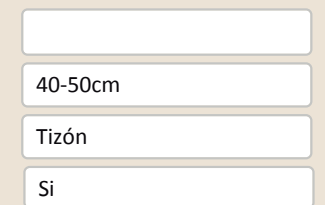

Color de las piezas

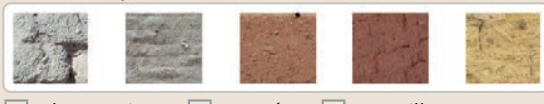

Blanquecino $\mathbf{X}$ Marrón $\square$ Amarillento $\square$ Grisaceo $\square$ Rojizo $\square$ Otro...

Función estructural

Comp. - estabilizante Fibras vegetales

Variante constructiva/ tipo de fábrica

Х Simple

$\square$ Suplementada en juntas

$\square$ Mixta

$\square$ Como suplemento

$\square$ Elementos de protección

Adobe en muro piñón a soga (no estructural)
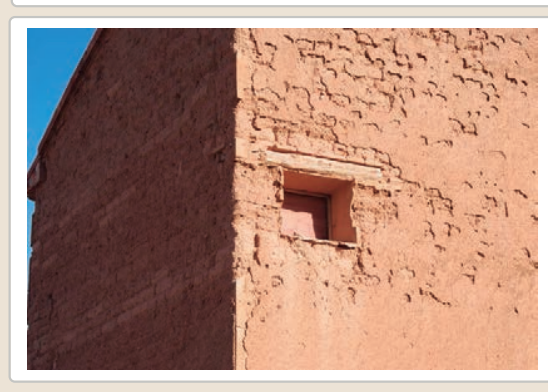

Lesiones $\quad \mathbf{X}$ Muro $\square$ Zócalo $\mathbf{X}$ Revestimiento

$\mathbf{X}$ Erosión del material $\quad \square$ Humedad por capilarida $\square$ Erosion de las juntas $\square$ Humedades (manch/eflo)

Х Pérdida de sección $\quad \square$ Pérdida de verticalidad

$\square$ Vegetación $\quad \square$ Grietas por empuje de la cubie $\square$ Grietas porfalta de traba

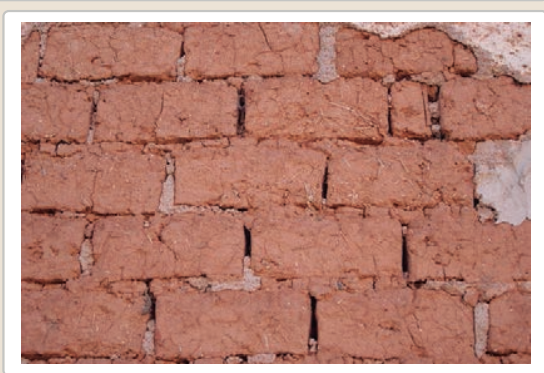

$\square$ Cubierta $\square$ Otro...

$\square$ Grietas por asentamiento

$\square$ Colapso

$\mathbf{X}$ Desconchados

$\square$ Por elementos impropios

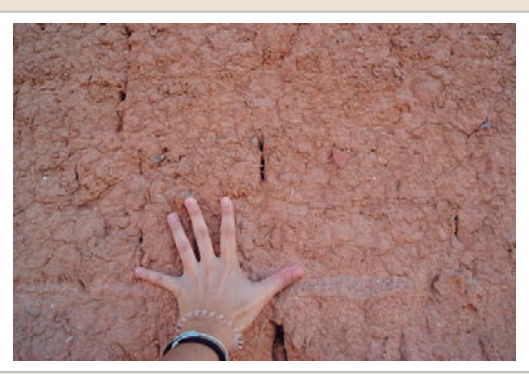

$\square$ Derivadod
$\square$ Otro...

Observacione 


\section{La restauración y rehabilitación de la arquitectura tradicional de tierra.}

\section{El caso de Aragón.}

3. DATOS DE LA INTERVENCIÓN

Intervención de:

$\square$ Mantenimiento $\square$ Rehabilitación parcial

$\square$ Restauración $\square$ Demolición

Reflexión previa X Reparación $\square$ Rehabilitación integra

$\square$ Ampliación $\square$ Otro...

Reflexion previa

Intervención espontanea

Observaciones

3.1. MUROS

Tipo de intervención

Tipo de material

Descripción

3.2. ZÓCALO

Tipo de intervención

Tipo de material

Descripción

3.3. REVESTIMIENTOS

Tipo de intervención

Tipo de material

Descripción

3.4. VANOS

Tipo de intervención

Tipo de material

Descripción

3.5. CUBIERTA

Tipo de intervención

Tipo de material

Descripción

3.6. OTRAS

$\square$ Actualización $\square$ Reintegración $\square$ Demolición $\square$ Otro...

$\square$ Consolidación $\square$ Reconstrucción $\square$ sustitución

Tipo de técnica

Intervenido

$\square$ Consolidación $\quad \square$ Reconstrucción $\square$ Sustitución

\begin{tabular}{|l|l|l} 
No tradicional & Tipo de técnica Diferente a la existente
\end{tabular}

Cegado de los huecos

\section{No intervenido}

$\square$ Actualización $\square$ Reintegración $\square$ Demolición $\square$ Otro..

$\square$ Consolidación $\square$ Reconstrucción $\square$ Sustitución Tipo de técnica
La restauración y rehabilitación de la arquitectura tradicional de tierra.

El caso de Aragón.

3.7. REHABILITACIÓN ENERGÉTICA $\quad \square$ Fachada $\square$ Vanos $\square$ Forjados $\square$ Cubierta

Observaciones

FOTOGRAFÍAS DE LA INTERVENCIÓN
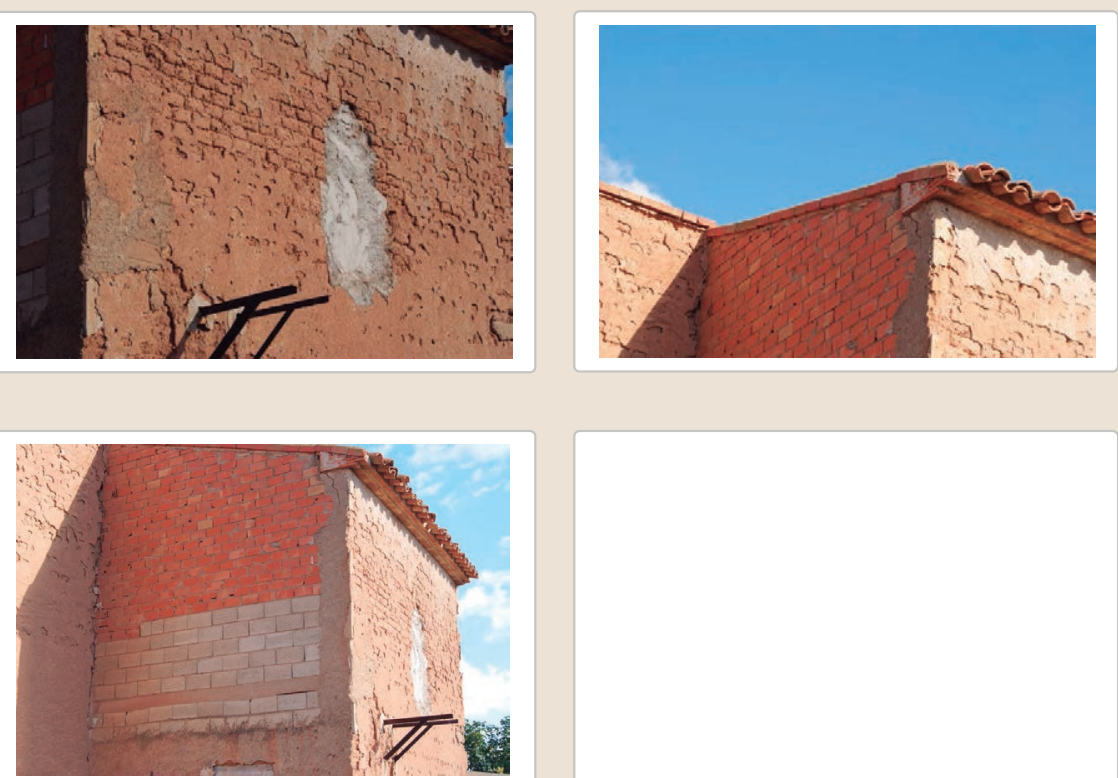

$\square$ Actualización $\quad$ X Reintegración $\square$ Demolición $\square$ Otro...
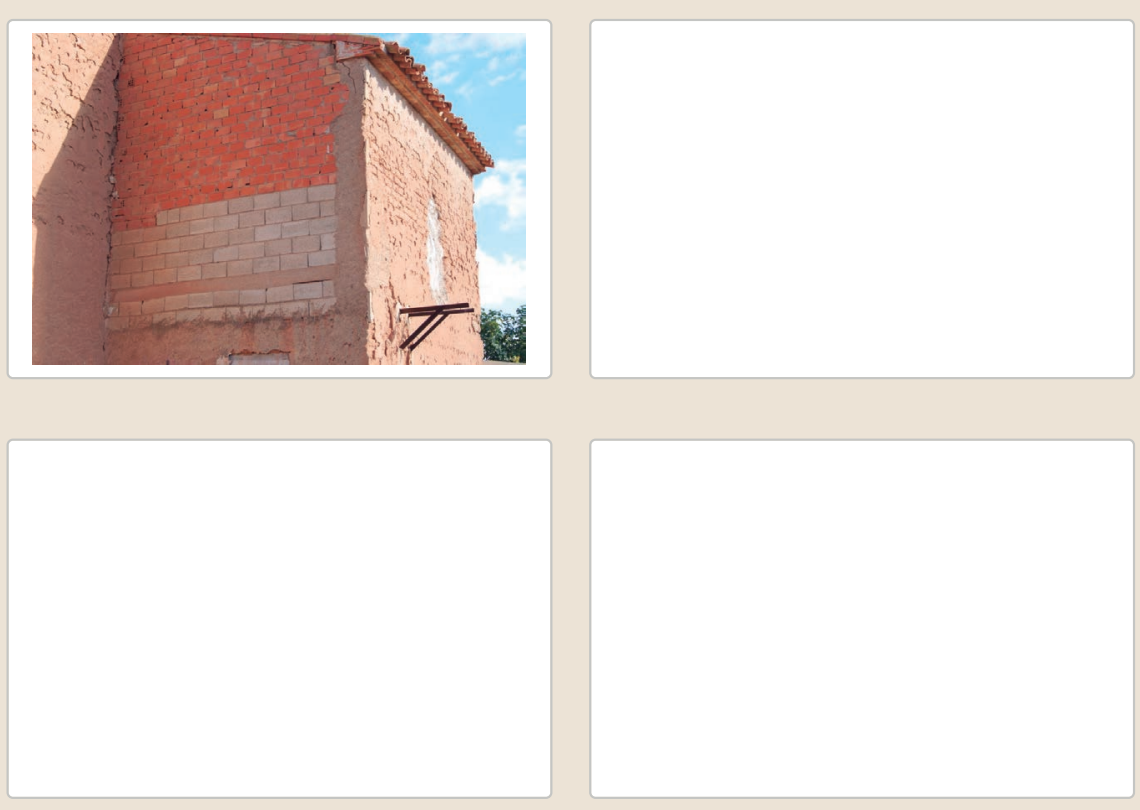


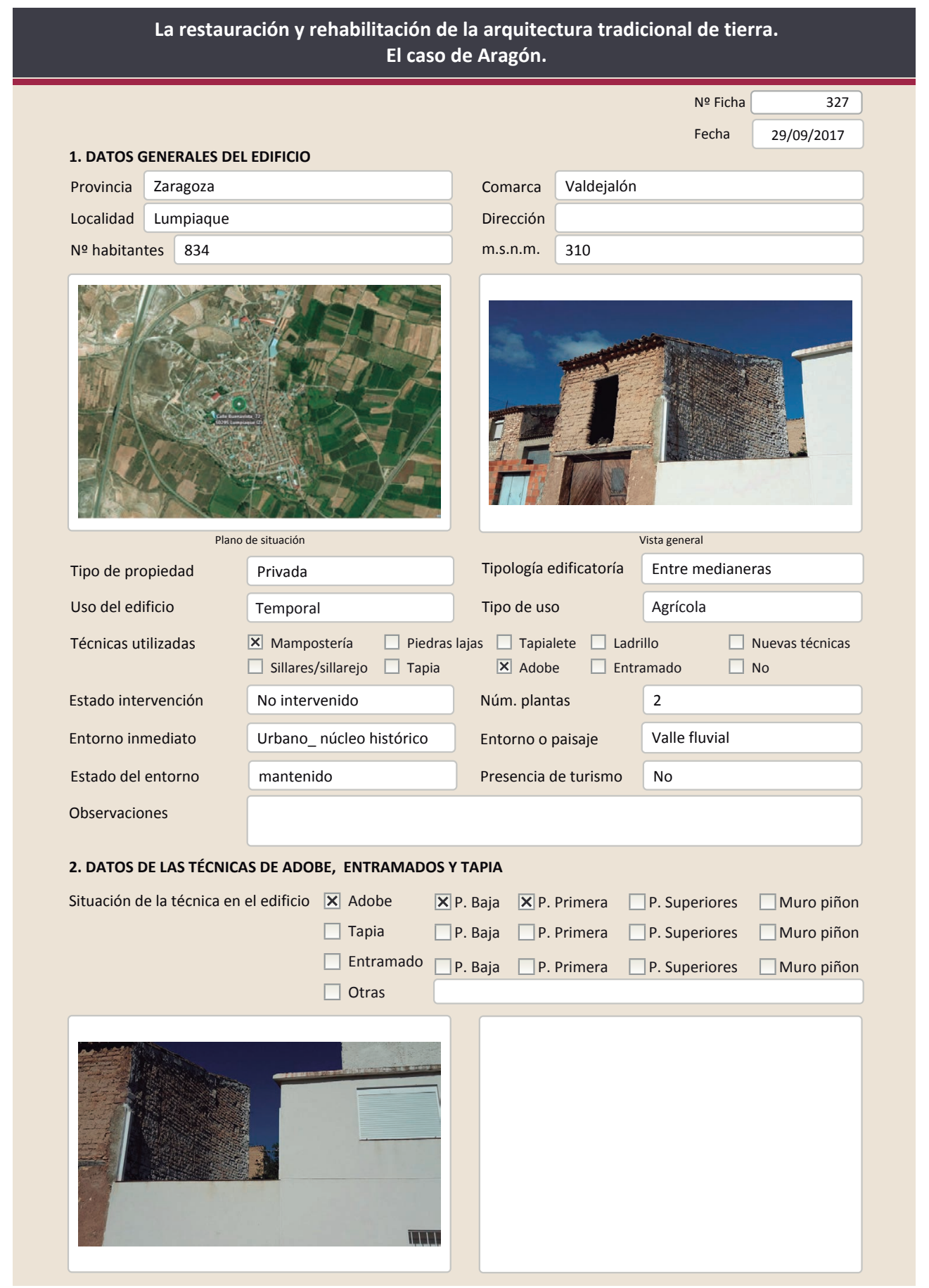

2.1. ADOBE

Dimensión de las piezas Dimensión del muro

Aparejo del muro

\begin{tabular}{|l|}
\hline \\
\hline So-20cm \\
\hline Si
\end{tabular}

Color de las piezas

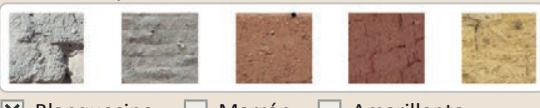

X Blanquecino $\square$ Marrón $\square$ Amarillento $\square$ Grisaceo $\square$ Rojizo $\square$ Otro... Función estructural

Variante constructiva/ tipo de fábrica
X Simple
$\square$ Suplementada en juntas
$\square$ Mixta
$\square$ Como suplemento
$\square$ Elementos de protección

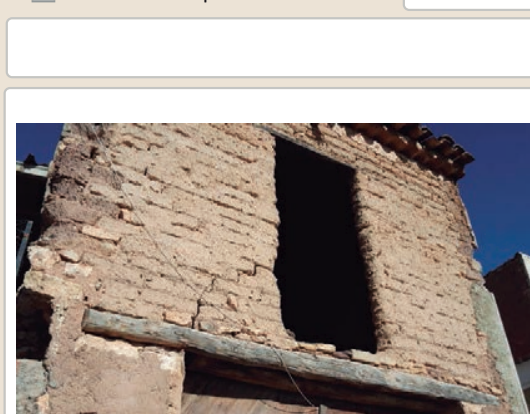

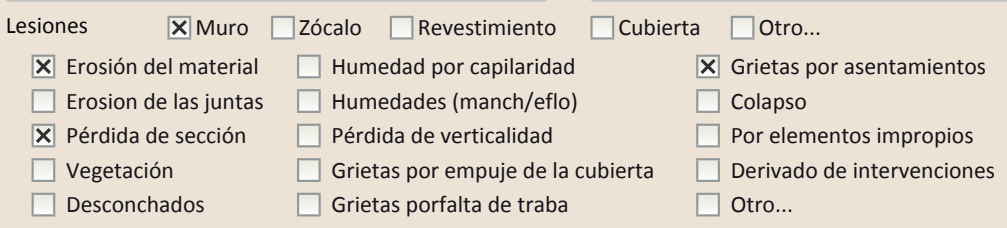

Observaciones 


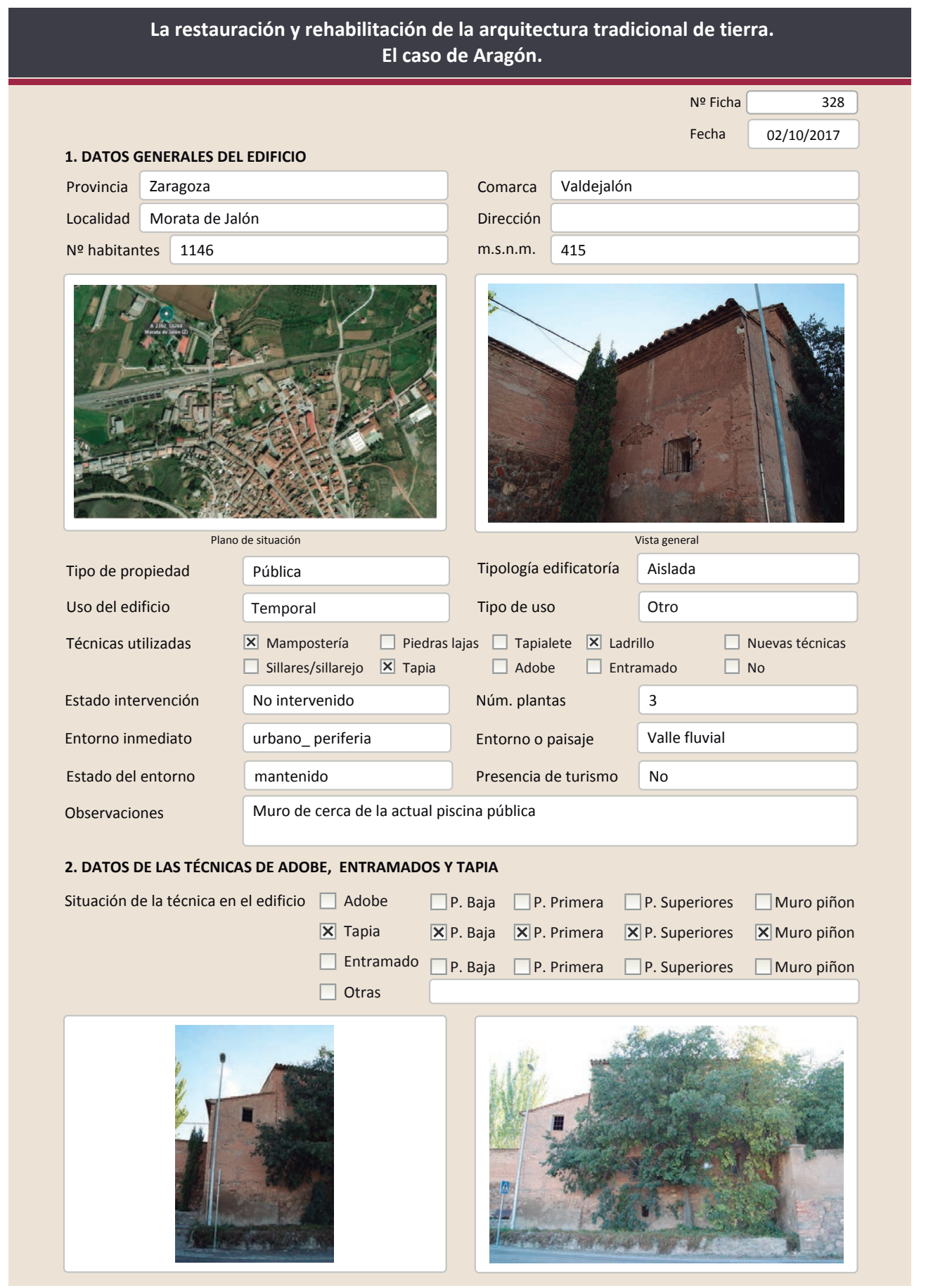

La restauración y rehabilitación de la arquitectura tradicional de tierra. El caso de Aragón.

\subsection{TAPIA}

Ancho del muro

Dimensión tapiales

Tipo de aguja

Redonda

№ agujas/cajón

Variante constructiva

$\square$ Simple / homogénea

X Suplemento superficial

Х Suplemento en juntas

区 Mixta

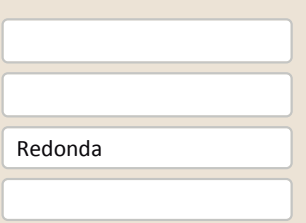

Color de la tapia

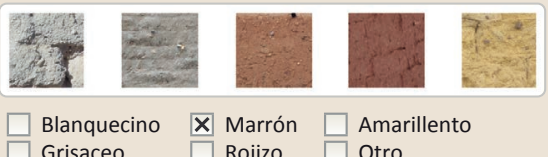

$\begin{array}{ll}\square \text { Blanquecino } & \boldsymbol{x} \text { Marrón } \\ \square \text { Grisaceo } & \square \text { Amarillento } \\ \text { Rojizo } & \square \text { Otro... }\end{array}$

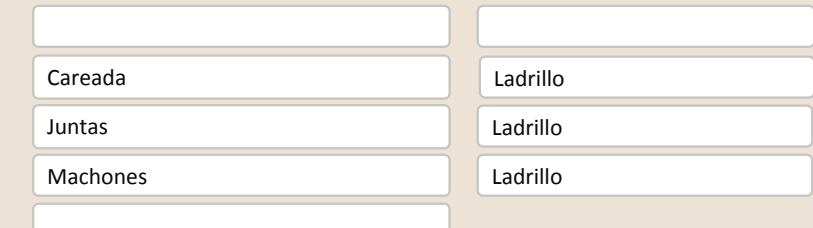

Elementos de protección

Una de las zonas es calicostrada en vez de careada

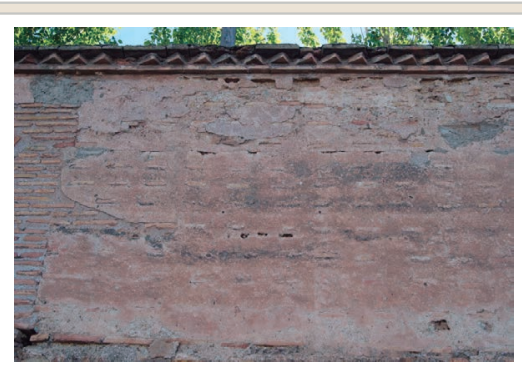

Lesiones $\quad \mathbf{X}$ Muro $\square$ Zócalo $\mathbf{X}$ Revestimiento $\square$ Cubierta $\square$ otro...

X Erosión del material $\quad \square$ Humedad por capilaridad $\quad \square$ Grietas por asentamiento $\square$ Erosion de las juntas $\square$ Humedades (manch/eflo)

$\square$ Pérdida de sección $\quad \square$ Pérdida de verticalidad

$\square$ Vegetación $\square$ Grietas por empuje de la cubierta

X Desconchados

$\square$ Grietas porfalta de trab
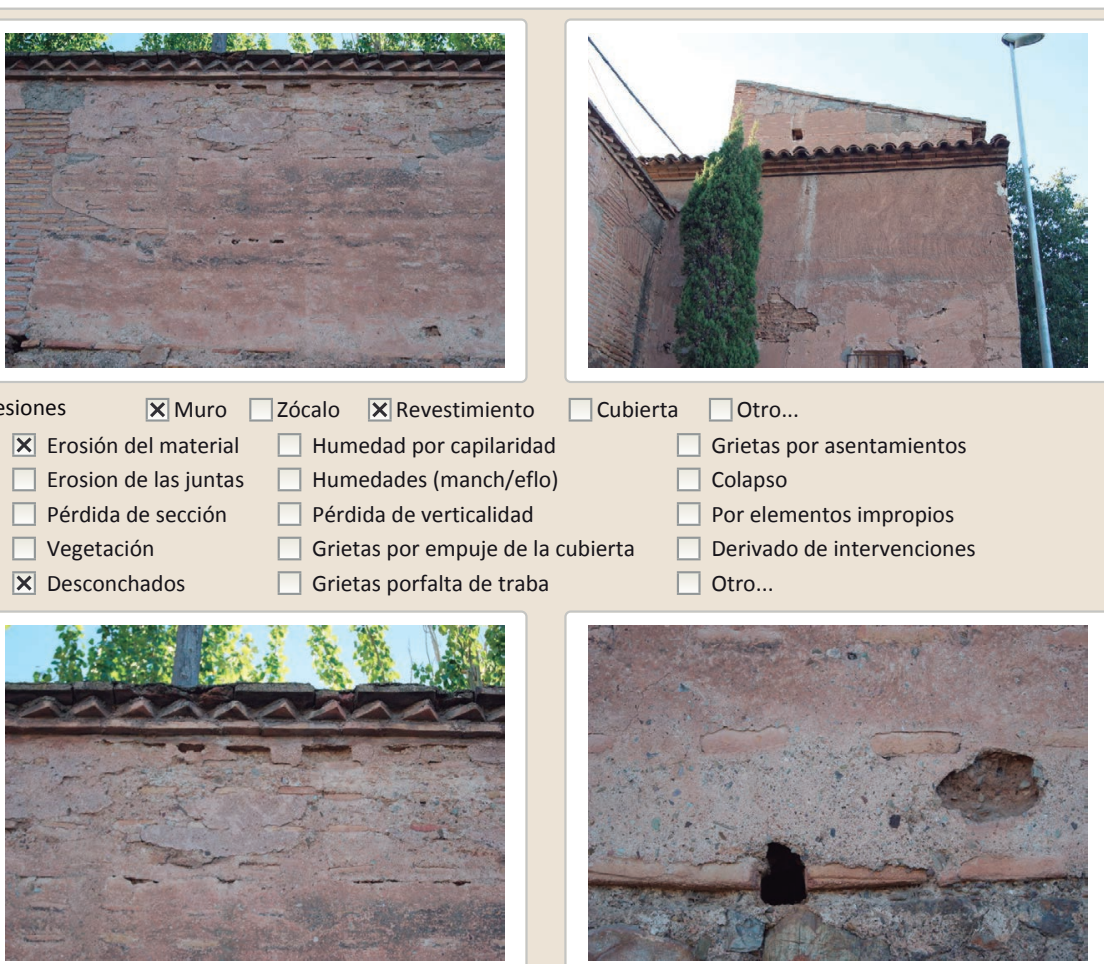

$\square$ Por elementos impropios

$\square$ Derivado de intervenciones $\square$ Otro...

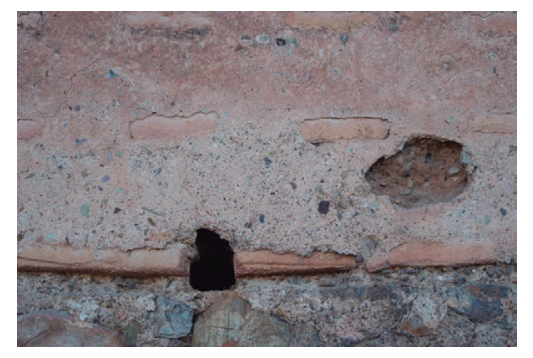

Observaciones 


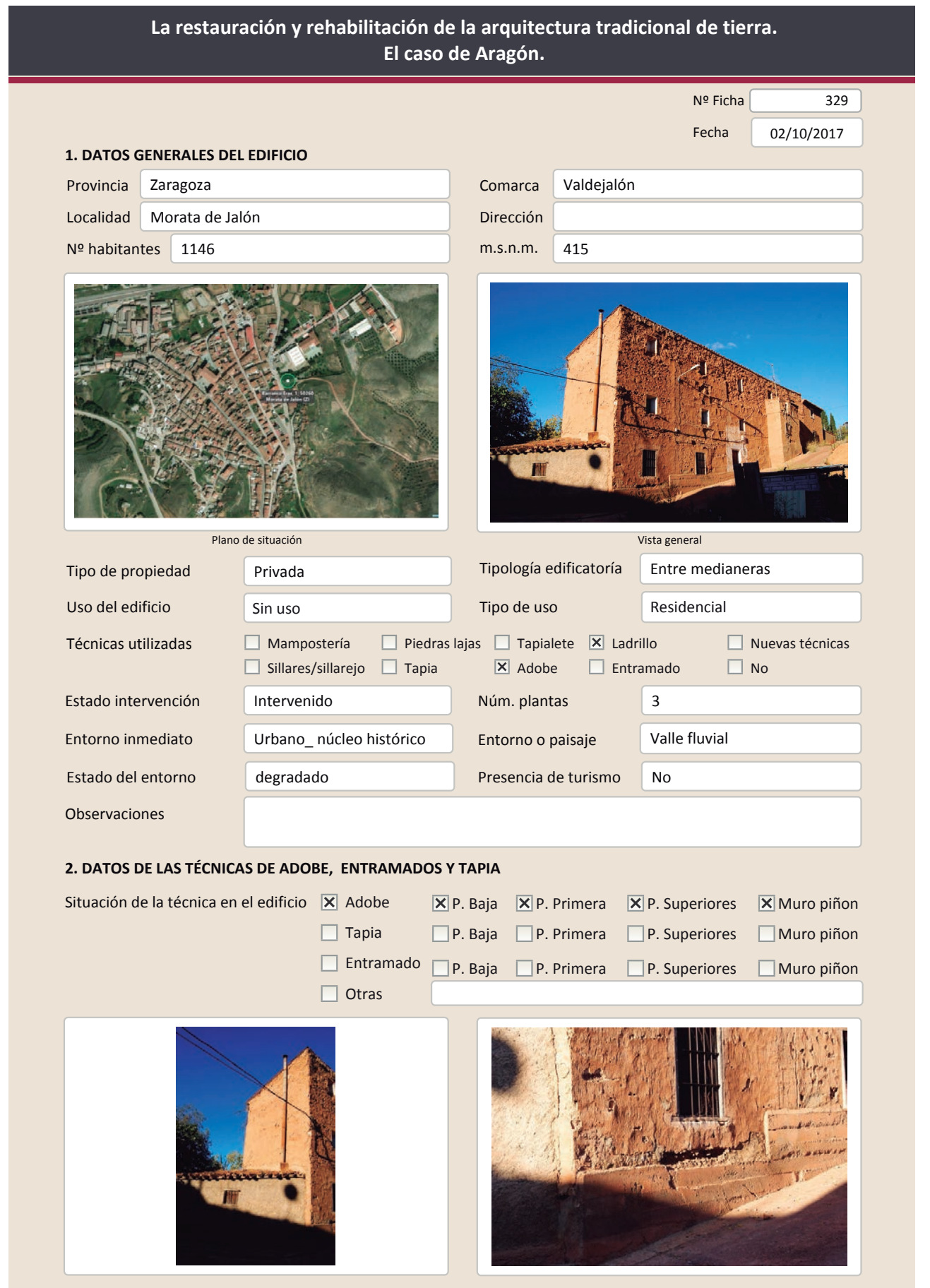

2.1. ADOBE

Dimensión de las piezas

Dimensión del muro

Aparejo del muro

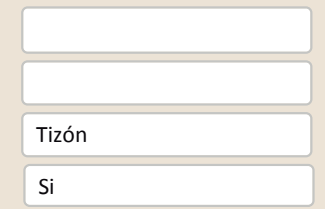

Color de las piezas

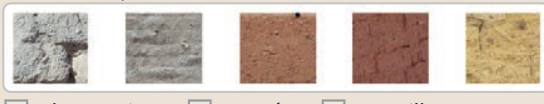

$\square$ Blanquecino $\mathbf{X}$ Marrón $\square$ Amarillento $\square$ Grisaceo $\square$ Rojizo $\square$ Otro..

Función estructural

Comp. - estabilizante Fibras vegetales

Variante constructiva/ tipo de fábrica

$\square$ simple
$\mathbf{X}$ Suplementada en juntas
$\square$ Mixta
$\square$ Como suplemento
Х Elementos de protección
Verticales $\mathrm{y}$ horizontales
Revestimiento

$\mathrm{Cal} /$ yeso

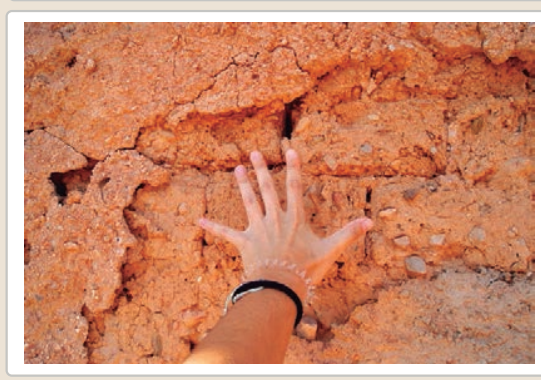

Lesiones $\quad \mathbf{X}$ Muro $\mathbf{X}$ Zócalo $\mathbf{X}$ Revestimiento

$\mathbf{X}$ Erosión del material $\mathbf{X}$ Humedad por capilaridad

$\square$ Erosion de las juntas $\mathbf{X}$ Humedades (manch/eflo)

$\square$ Pérdida de sección $\quad \square$ Pérdida de verticalidad

$\begin{array}{ll}\square \text { Vegetación } & \square \text { Grietas por empuje de la cubie } \\ \boldsymbol{X} \text { Desconchados } & \square \text { Grietas porfalta de traba }\end{array}$
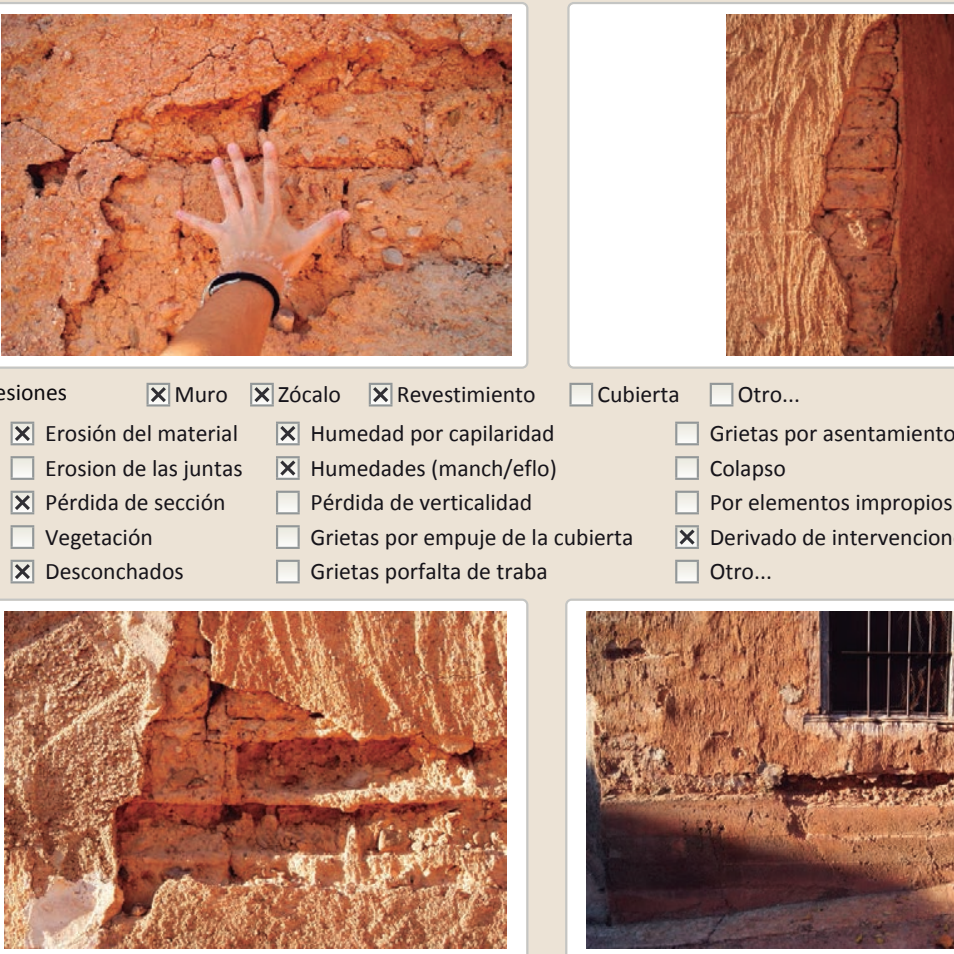

$\square$ otro

$\square$ Grietas por asentamiento

$\square$ Colapso

$\square$ Por elementos impropios

$\boldsymbol{X}$ Derivado de intervenciones $\square$ Otro...

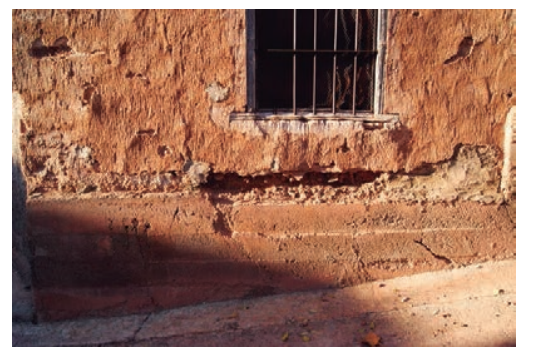

Observaciones Ascensión de la hum
zócalo de hormigón 


\section{La restauración y rehabilitación de la arquitectura tradicional de tierra.}

\section{El caso de Aragón.}

3. DATOS DE LA INTERVENCIÓN

NCIÓN

$\begin{array}{llll} & \text { Mantenimiento } & \text { Rehabilitación parcial } & \square \text { Restauración } \\ \text { Reflexión previa } & \text { Reparación } & \text { Demolición } \\ \text { Observaciones } & \text { Intervención espontanea } & \\ & & \end{array}$

\begin{tabular}{|c|c|c|c|c|}
\hline 3.1. MUROS & No intervenido & & & \\
\hline Tipo de intervención & $\begin{array}{l}\square \text { Actualización } \\
\square \text { Consolidación }\end{array}$ & $\begin{array}{l}\square \text { Reintegración } \\
\square \text { Reconstrucción }\end{array}$ & $\begin{array}{l}\square \text { Demolición } \\
\square \text { Sustitución }\end{array}$ & $\square$ Otro... \\
\hline Tipo de material & \multicolumn{4}{|c|}{ Tipo de técnica } \\
\hline \multicolumn{5}{|l|}{ Descripción } \\
\hline 3.2. ZÓCALO & \multicolumn{4}{|l|}{ Intervenido } \\
\hline Tipo de intervención & $\begin{array}{l}\square \text { Actualización } \\
\square \text { Consolidación }\end{array}$ & \multicolumn{3}{|c|}{$\begin{array}{l}\square \text { Reintegración } \quad \square \text { Demolición } \\
\boldsymbol{X} \text { Reconstrucción } \quad \square \text { Sustitución }\end{array}$} \\
\hline Tipo de material & \multicolumn{2}{|l|}{ No tradicional } & oo de técnica & Diferente a la existente \\
\hline Descripción & \multicolumn{4}{|l|}{ Hormigón } \\
\hline 3.3. REVESTIMIENTOS & \multicolumn{4}{|l|}{ Intervenido } \\
\hline Tipo de intervención & $\begin{array}{l}\square \text { Actualización } \\
\square \text { Consolidación }\end{array}$ & $\begin{array}{l}\square \text { Reintegración } \\
\boldsymbol{X} \text { Reconstrucción }\end{array}$ & $\begin{array}{l}\square \text { Demolición } \\
\square \text { Sustitución }\end{array}$ & $\square$ Otro... \\
\hline Tipo de material & No tradicional & & oo de técnica $S$ & Similar a la existente \\
\hline Descripción & \multicolumn{4}{|c|}{ Reconstrucción de parte del revestimiento con cemento } \\
\hline 3.4. VANOS & \multicolumn{4}{|l|}{ No intervenido } \\
\hline Tipo de intervención & $\begin{array}{l}\square \text { Actualización } \\
\square \text { Consolidación }\end{array}$ & $\begin{array}{l}\square \text { Reintegración } \\
\square \text { Reconstrucción }\end{array}$ & $\begin{array}{l}\square \text { Demolición } \\
\square \text { Sustitución }\end{array}$ & $\square$ Otro... \\
\hline Tipo de material & \multicolumn{4}{|c|}{ Tipo de técnica } \\
\hline \multicolumn{5}{|l|}{ Descripción } \\
\hline 3.5. CUBIERTA & \multicolumn{4}{|l|}{ No intervenido } \\
\hline Tipo de intervención & $\begin{array}{l}\square \text { Actualización } \\
\square \text { Consolidación }\end{array}$ & $\begin{array}{l}\square \text { Reintegración } \\
\square \text { Reconstrucción }\end{array}$ & $\begin{array}{l}\square \text { Demolició } \\
\square \text { Sustitució }\end{array}$ & $n$ \\
\hline Tipo de material & \multicolumn{4}{|c|}{ Tipo de técnica } \\
\hline & & & & \\
\hline
\end{tabular}

3.6. OTRAS
La restauración y rehabilitación de la arquitectura tradicional de tierra.

El caso de Aragón.

3.7. REHABILITACIÓN ENERGÉTICA $\quad \square$ Fachada $\square$ Vanos $\square$ Forjados $\square$ Cubierta

Observaciones

FOTOGRAFíAS DE LA INTERVENCIÓN
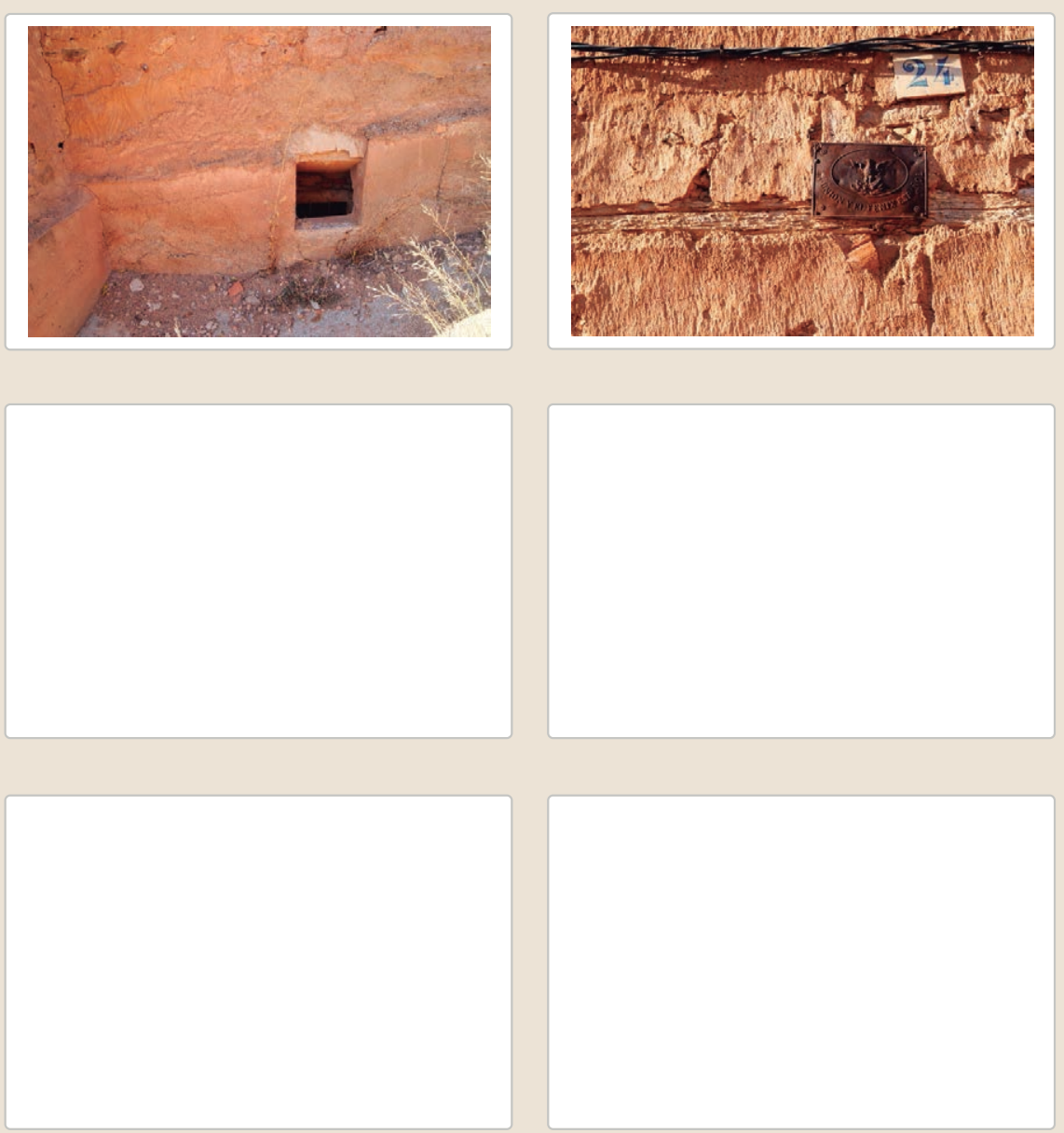


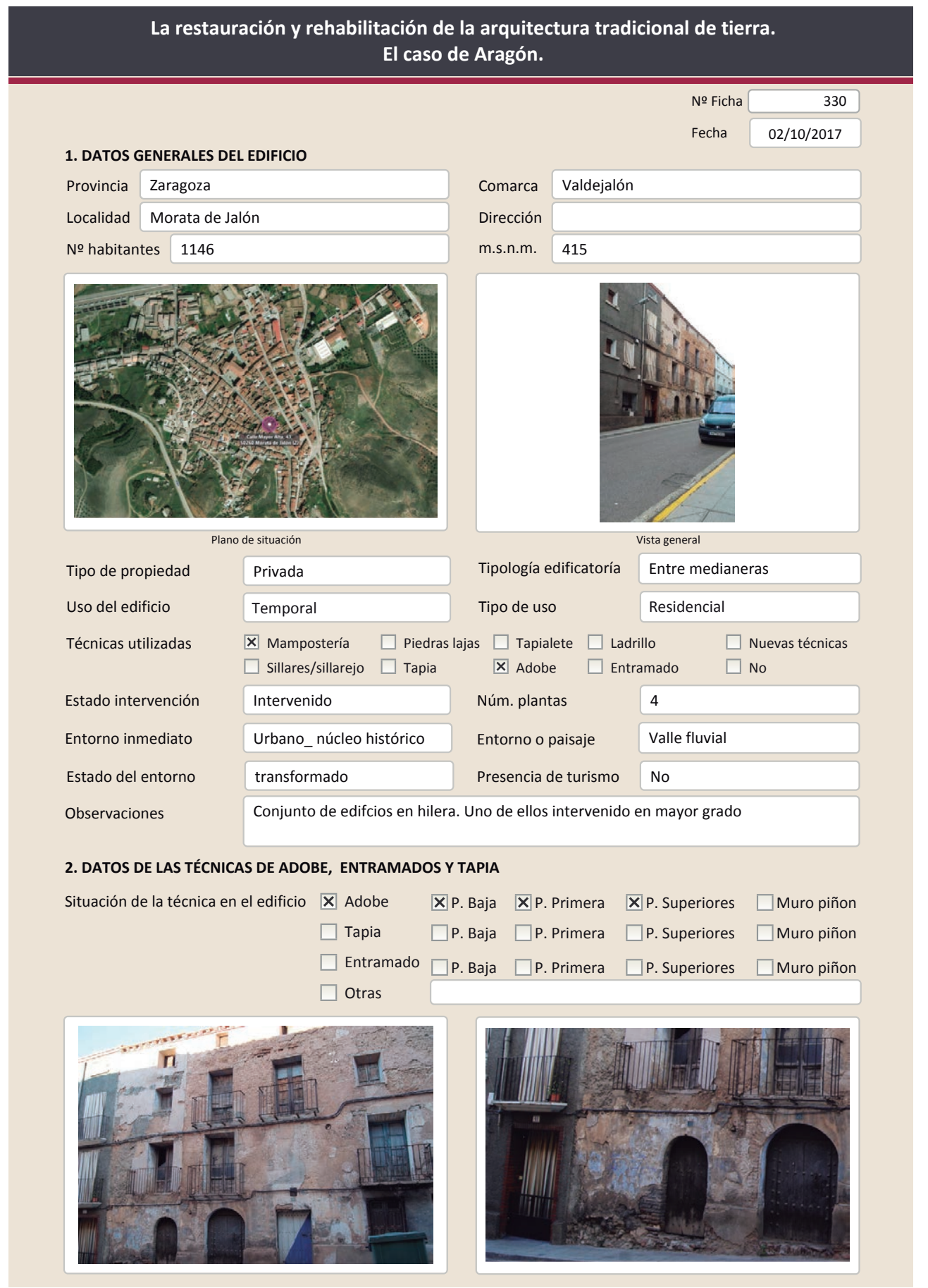

2.1. ADOBE

Dimensión de las piezas Dimensión del muro

Aparejo del muro

Función estructural

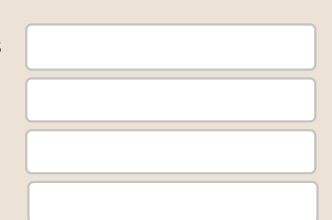

Color de las piezas

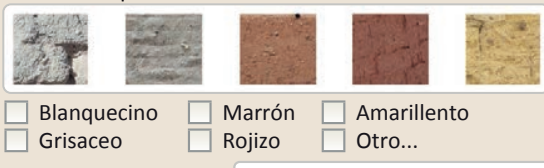

Comp. - estabilizante

Variante constructiva/ tipo de fábrica

$\square$ Simple
X Suplementada en juntas
Horizontales
$\mathrm{Cal} /$ yeso
$\square$ Mixta
$\square$ Como suplemento
X Elementos de protección
Revestimiento

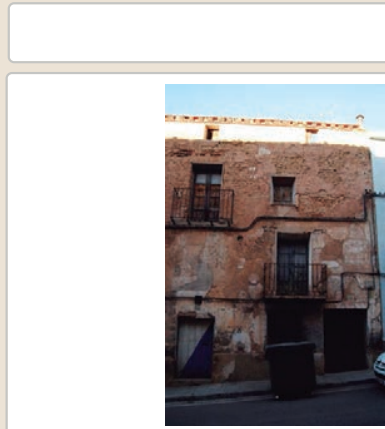

Lesiones

XMuro Xzócalo

$\mathbf{X}$ Erosion delmaterial $\mathbf{X}$ Humedad por capilaridad

$\square$ Cubierta $\square$ Otro...

$\square$ Erosion de las juntas $\square$ Humedades (manch/eflo) $\square$ Colapso

$\square$ Pérdida de sección $\square$ Pérdida de verticalidad

$\square$ Vegetación

$\square$ Grietas por empuje de la

$\square$ Por elementos impropios

$\square$ Desconchados

$\square$ Grietas porfalta de traba

$\square$ Derivadod
$\square$ Otro...

Observacione 


\section{La restauración y rehabilitación de la arquitectura tradicional de tierra.}

\section{El caso de Aragón.}

3. DATOS DE LA INTERVENCIÓN

Intervención de:

$\square$ Mantenimie

Reflexión previa

$\square$ Reparació

$\square$ Rehabilitación parcial

$\square$ Restauración $\square$ Demolición

Intervención planificada

Observaciones

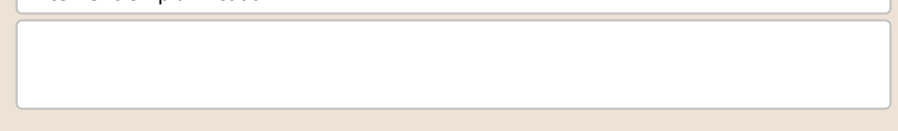

3.1. MUROS
Tipo de intervención

\section{No visible}

Tipo de material

Descripción

3.2. ZÓCALO

Tipo de intervención

Tipo de material

Descripción

3.3. REVESTIMIENTOS

Tipo de intervención

Tipo de material

Descripción

3.4. VANOS

Tipo de intervención

Tipo de material

Descripción

3.5. CUBIERTA

Tipo de intervención

Tipo de material

Descripción

$\square$ Actualización $\quad \square$ Reintegración $\quad \square$ Demolición $\quad \square$ Otro...
$\square$ Consolidación $\quad \square$ Reconstrucción $\quad \square$ Sustitución

Intervenido

$\square$ Actualización $\square$ Reintegración $\square$ Demolición $\square$ Otro...

$\square$ Consolidación $\quad \mathbf{X}$ Reconstrucción $\square$ Sustitución

No tradicional Tipo de técnica Diferente a la existente

Capa gruesa de cemento

\section{Intervenido}

$\square$ Actualización $\square$ Reintegración $\quad \square$ Demolición $\square$ Otro...

$\square$ Consolidación $\quad \mathbf{X}$ Reconstrucción $\square$ sustitución

No tradicional Tipo de técnica Diferente a la existente

Nuevo revestimiento pintado de gris en todo el edificio

\section{Intervenido}

$\square$ Consolidación $\square$ Reconstrucción $\quad \boldsymbol{X}$ Sustitución

No tradicional Tipo de técnica Diferente a la existente Reintegración de jambas y dintel de la puerta con ladrillo. Sustitución de carpinterías e
incorporación de cajas de persianas

Intervenido

$\square$ Actualización $\quad \square$ Reintegración $\square$ Demolición $\quad \square$ Otro...

$\square$ Consolidación $\square$ Reconstrucción $\mathbf{X}$ Sustitución
No tradicional
Tipo de técnica Diferente a la existente

3.6. OTRAS

El alero y la cubierta han sido sustituido y reconstruidos $\square$ Actualización $\quad \boldsymbol{X}$ Reintegración $\square$ Demolición $\square$ Otro...

La restauración y rehabilitación de la arquitectura tradicional de tierra.

El caso de Aragón.

3.7. REHABILITACIÓN ENERGÉTICA $\square$ Fachada $\quad \boldsymbol{X}$ Vanos $\square$ Forjados $\square$ Cubierta

Observaciones

FOTOGRAFíAS DE LA INTERVENCIÓN
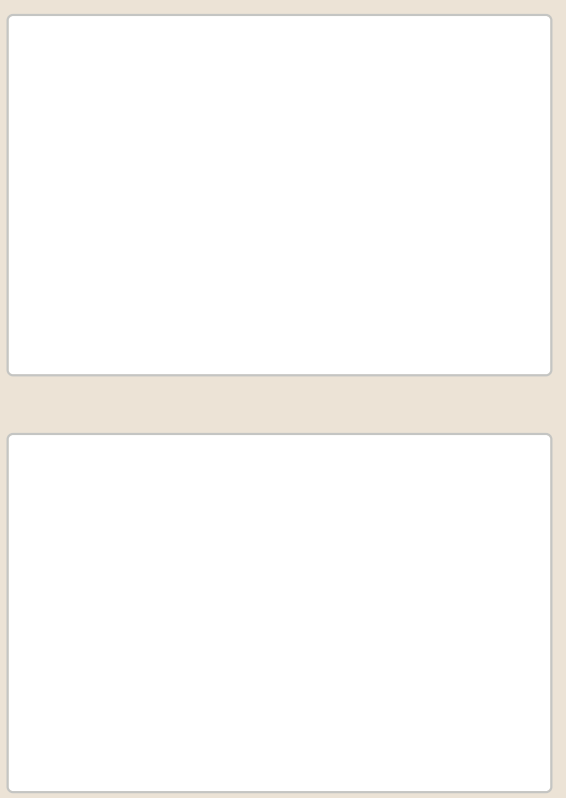
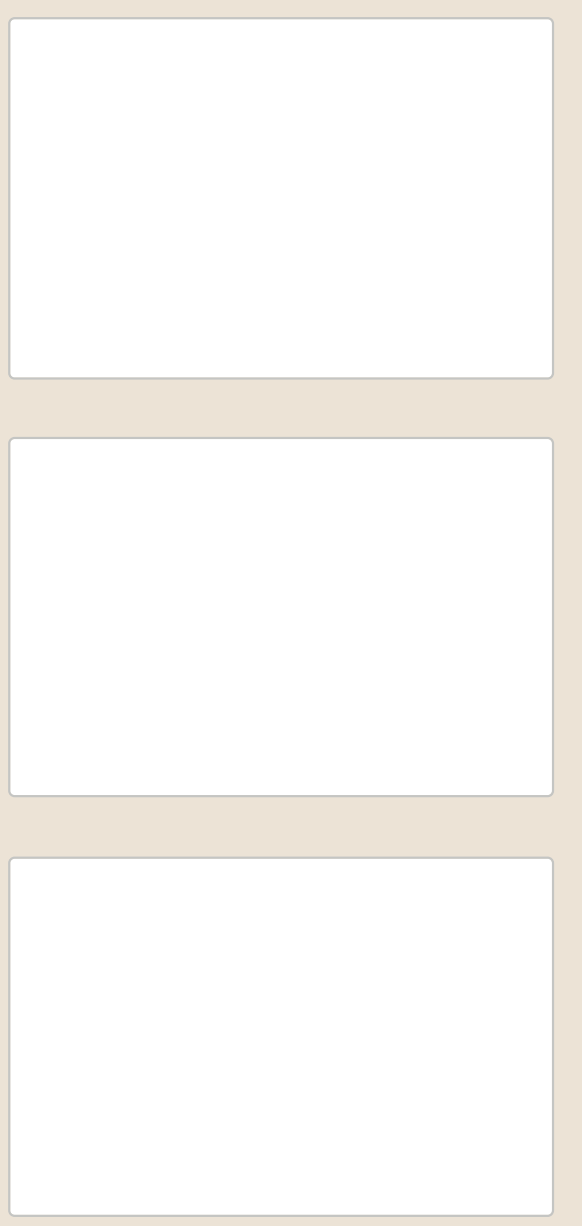


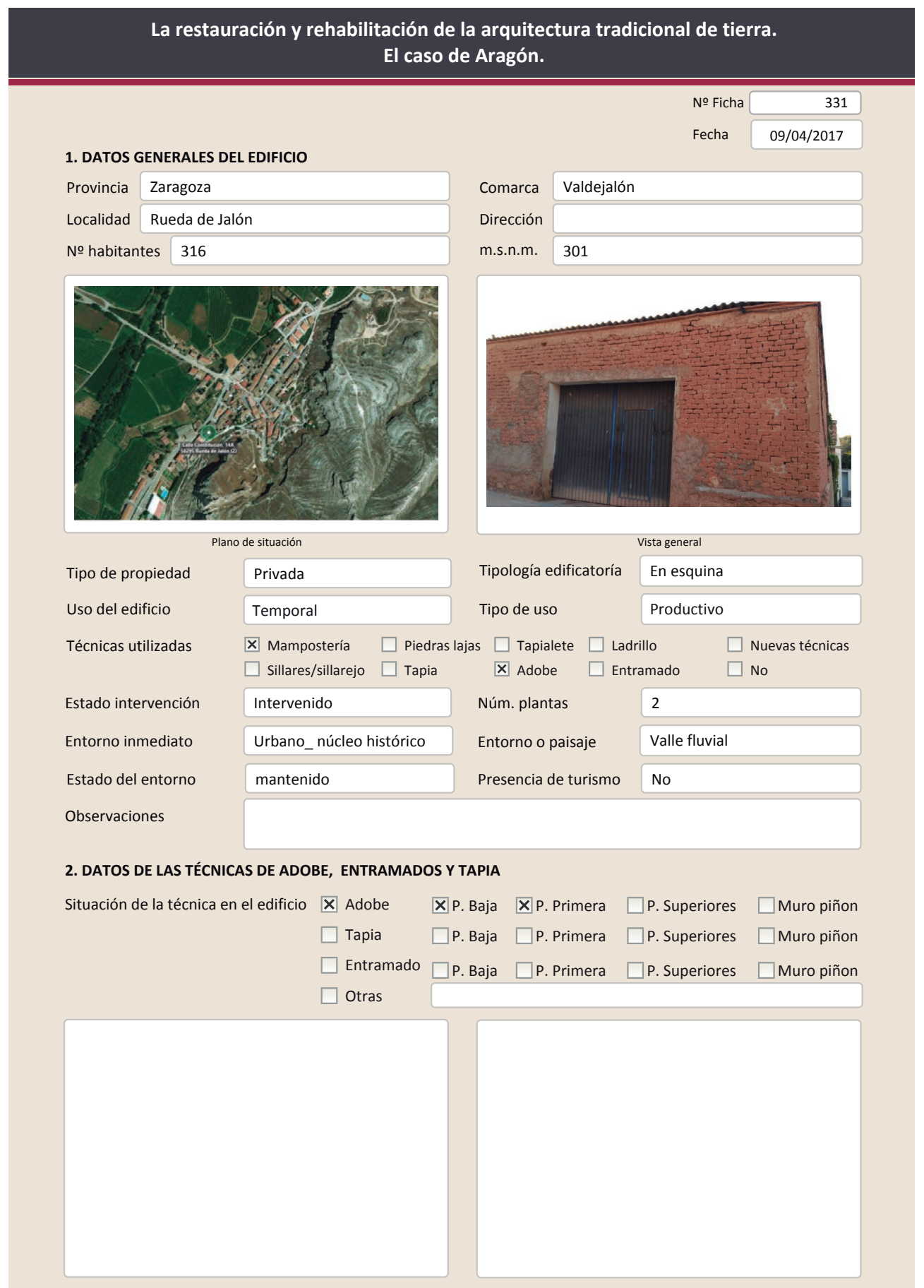

2.1. ADOBE

Dimensión de las piezas Dimensión del muro

Aparejo del muro

Función estructural

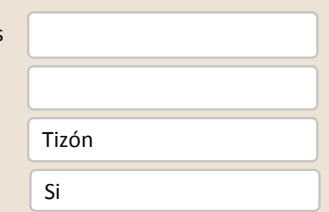

Color de las piezas

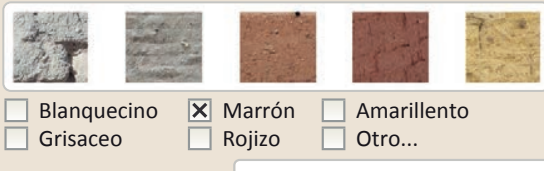

Variante constructiva/ tipo de fábrica

$\mathbf{X}$ Simple

$\square$ Suplementada en juntas

$\square$ Mixta

$\square$ Como suplemento

$\square$ Elementos de protección

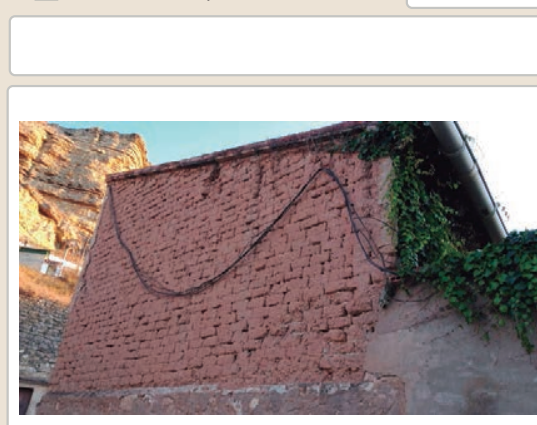

Lesiones $\quad \mathbf{X}$ Muro $\mathbf{X}$ Zócalo $\square$ Revestimiento

\ Erosión del material $\mathbf{X}$ Humedad por capilaridad

$\square$ Erosion de las juntas $\square$ Humedades (manch/eflo)

$\square$ Pérdida de sección $\square$ Pérdida de verticalidad

$\square$ Vegetación $\quad \square$ Grietas por empuje de la c $\square$ Grietas porfalta de traba

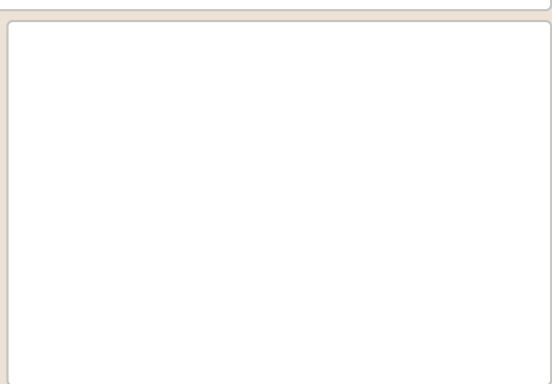

$\square$ Cubierta $\square$ otro...

$\square$ Grietas por asentamientos

$\square$ Colapso

$\square$ Desconchados

$\square$ Por elementos impropios

$\square$ Derivado de intervenciones 


\section{La restauración y rehabilitación de la arquitectura tradicional de tierra.}

\section{El caso de Aragón.}

3. DATOS DE LA INTERVENCIÓN

\begin{tabular}{l|lll|} 
Intervención de: & $\square$ Mantenimiento & $\boldsymbol{X}$ Rehabilitación parcial & $\square$ Restauración \\
& $\mathbf{X}$ Reparación & $\square$ Demolición \\
Reflexión previa & Intervención espontanea & \\
Observaciones & & \\
& & \\
& & \\
\end{tabular}

\subsection{MUROS}

Tipo de intervención

Intervenido

Tipo de material

$\square$ Actualización $\quad \mathbf{X}$ Reintegración $\square$ Demolición $\square$ Otro...

$\square$ Consolidación $\square$ Reconstrucción $\square$ sustitución

Descripción

\begin{tabular}{ll|l} 
No tradicional Tipo de técnica Diferente a la existente &
\end{tabular}

3.2. ZÓCALO

Tipo de intervención

Pequeñas reintegraciones en zonas faltantes

Tipo de material

Intervenido

$\square$ Actualización $\quad \square$ Reintegración $\quad \square$ Demolición $\square$ Otro...

$\square$ Consolidación $\quad \mathbf{X}$ Reconstrucción $\square$ Sustitución

Descripción

No tradicional Tipo de técnica Diferente a la existente

3.3. REVESTIMIENTOS

Capa gruesa de cemento

Tipo de intervención

\section{No aplica}

Tipo de material

Descripción

$\square$ Reintegración $\square$ Demolición $\square$ Otro...

$\square$ Consolidación $\square$ Reconstrucción $\quad \square$ Sustitución

3.4. VANOS

Tipo de intervención

Intervenido

Tipo de material

$\square$ Actualización $\square$ Reintegración $\square$ Demolición $\square$ Otro...

Tipo de materia
Descripción

$\square$ Consolidación $\mathbf{X}$ Reconstrucción $\boldsymbol{X}$ Sustitución

3.5. CUBIERTA

Tipo de intervención

No tradicional

Tipo de técnica Diferente a la existente

Ampliación del hueco de acceso y sustitución de la carpintería

Tipo de material

Intervenido

$\square$ Actualización $\square$ Reintegración $\square$ Demolición $\square$ Otro..

$\square$ Consolidación $\square$ Reconstrucción $\quad$ X Sustitución

Descripción

No tradicional

Tipo de técnica Diferente a la existente

3.6. OTRAS 


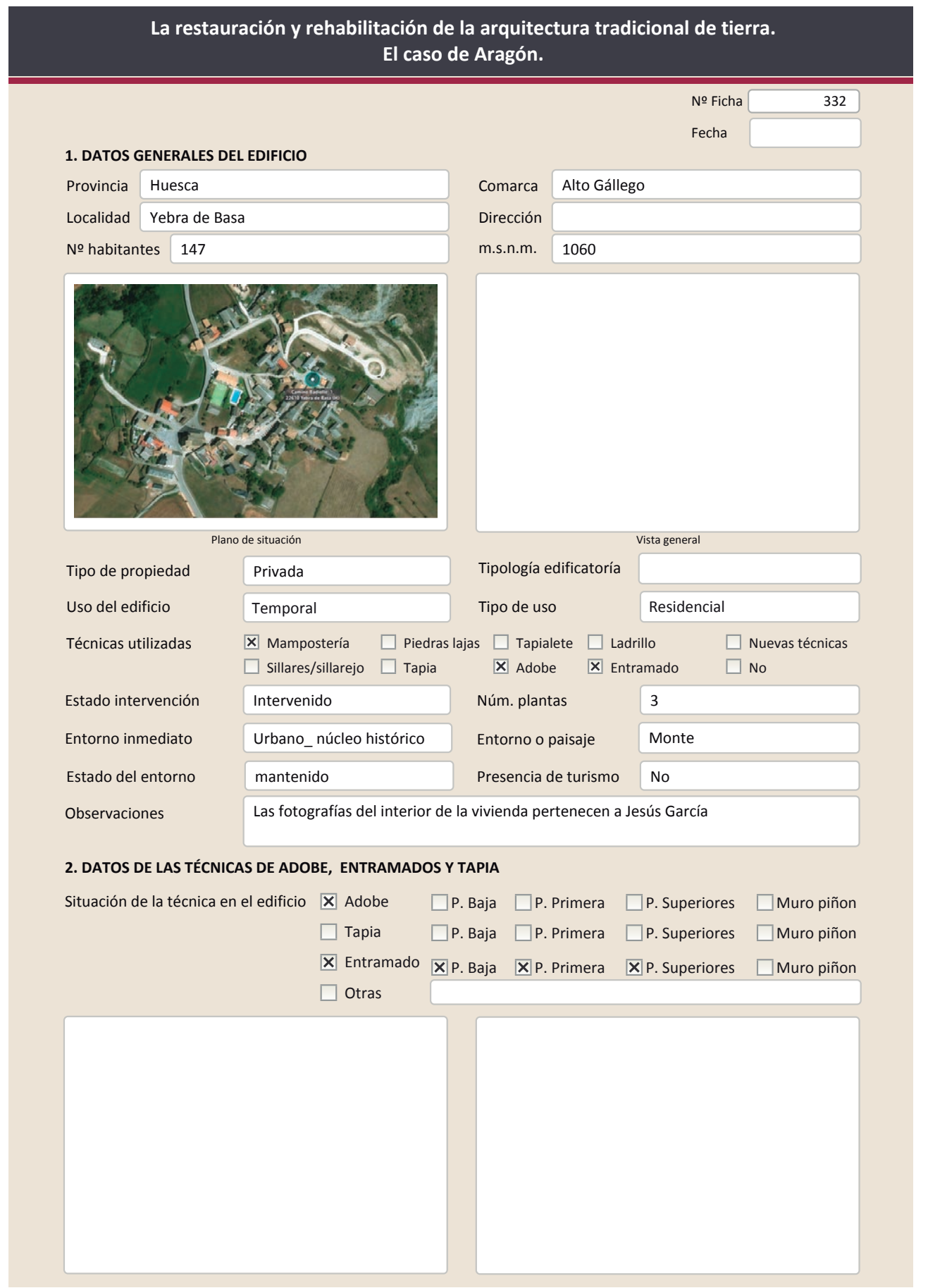

2.1. ADOBE

Dimensión de las piezas Dimensión del muro

Aparejo del muro

Función estructural

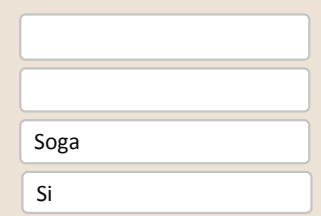

Color de las piezas

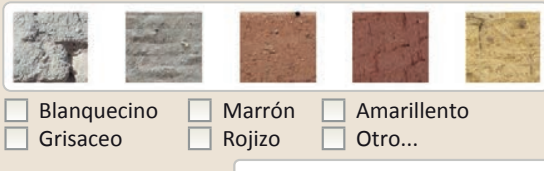

Grisaceo

$\square$ Rojizo $\square$ Otro...

Variante constructiva/ tipo de fábrica

Х Simple

$\square$ Suplementada en juntas

$\square$ Mixta

$\square$ Como suplemento

$\square$ Elementos de protección Se trata del tiro de la chimenea.

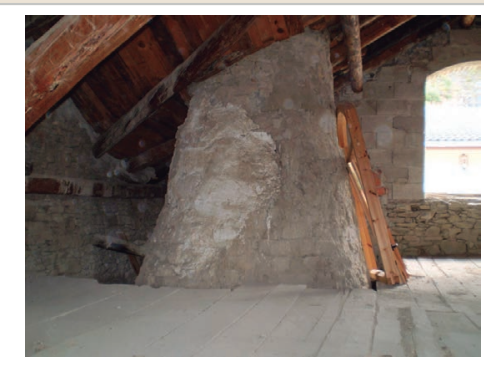

Lesiones $\quad \mathbf{X}$ Muro $\square$ Zócalo $\square$ Revestimiento

X Erosión del material $\square$ Humedad por capilaridad $\square$ Erosion de las juntas $\square$ Humedades (manch/eflo)

$\square$ Pérdida de sección $\square$ Pérdida de verticalidad

$\square$ Vegetación $\quad \square$ Grietas por empuje de la cubie $\square$ Grietas porfalta de trab

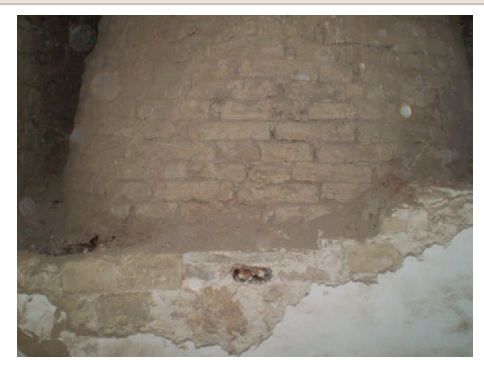

Cubierta $\square$ Otro...

$\square$ Grietas por asentamiento

$\square$ Colapso

$\square$ Desconchados

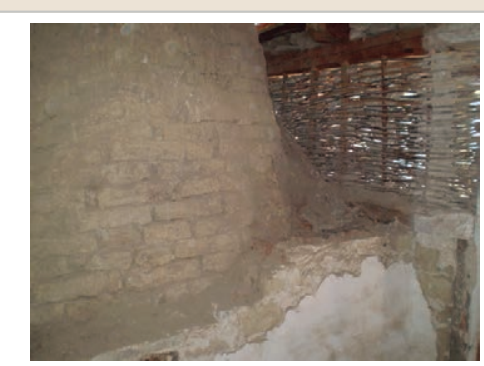

Observacione 


\section{La restauración y rehabilitación de la arquitectura tradicional de tierra.}

\section{El caso de Aragón.}

\subsection{ENTRAMADOS}

\begin{tabular}{|c|c|c|c|}
\hline Distancia entre montantes & $40-60 \mathrm{~cm}$ & Elementos diagonales & No \\
\hline Altura de los montantes & $<100 \mathrm{~cm}$ & Elementos horizontales intermedios & $\mathrm{Si}$ \\
\hline Sección de los montantes & Escuadrada & Sección de las piezas horizontales & Escuadrada \\
\hline Dimensión de los montantes & $10-20 \mathrm{~cm}$ & Dimensión de las piezas horizontales & $20-30 \mathrm{~cm}$ \\
\hline Tipo de relleno del entramado & $\square$ Monolítico $\mathbf{x}$ & | Piezas/fábrica $\quad$ X Tejido & \\
\hline \multicolumn{4}{|l|}{ Técnica de relleno del entramado } \\
\hline$\square$ Entre pantallas de madera & $\square$ Pared de mano & $\square$ Cañizo & \\
\hline$\square$ Tierra y mampuestos & $\mathbf{X}$ Adobe horizontal & $\mathbf{X}$ Encestados & \\
\hline$\square$ Tapialete & $\square$ Adobe aletorio & $\square$ Otro... & \\
\hline
\end{tabular}

permite machiembrar las piezas con los montantes para evitar movimientos.

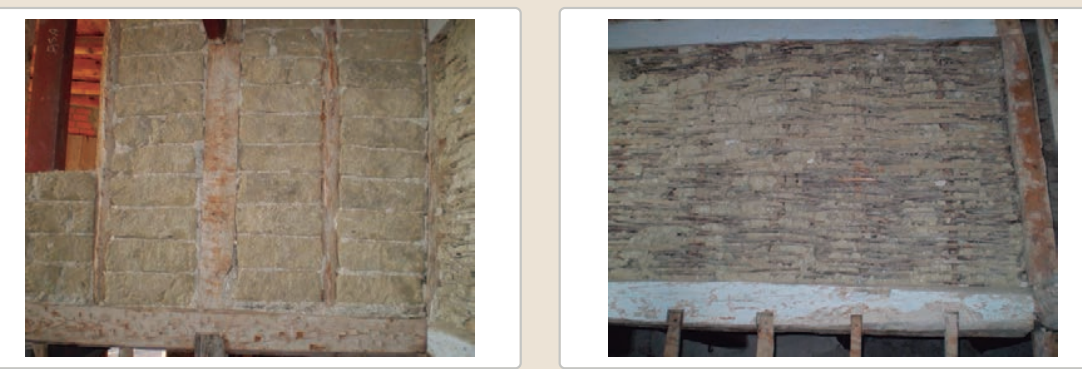

Lesiones

$\square$ Muro $\square$ Zócalo $\square$ Revestimiento $\square$ Cubierta $\square$ otro.
$\square$ Erosión del material
$\square$ Carcoma o termitas
$\square$ Erosion de las juntas
$\square$ Rotura de la madera
$\square$ Pudrición de la madera
$\square$ Vegetación
$\square$ Deformación madera
$\square$ Desconchados
$\square$ Pudrición del relleno
$\square$ Humedad por capilaridad
Pérdida de verticalidad
$\square$ Grietas por falta de traba
$\square$ Grietas por asentamientos
$\square$ Colapso
$\square$ Por elementos impropios
$\square$ Grietas por empuje de la cubierta
$\square$ Otro...
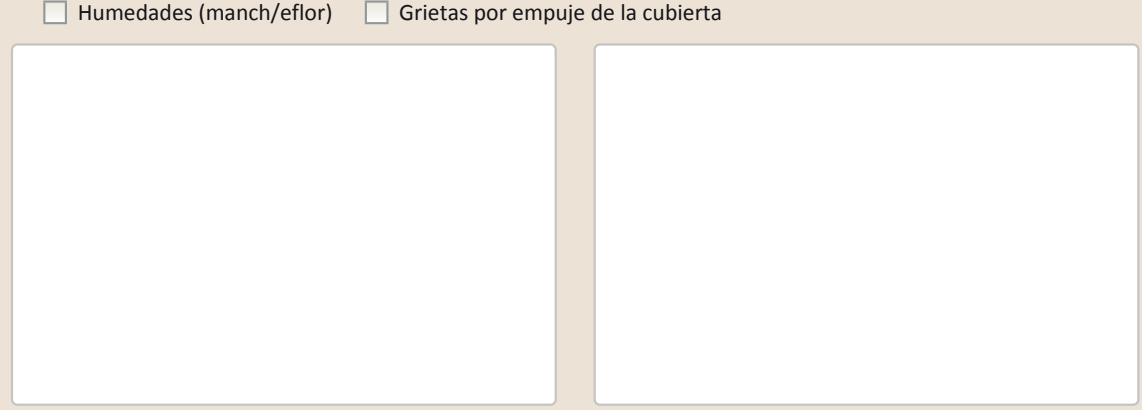

Observaciones

No presenta patologías. Todos los tabiques se encontraban revestidos

La restauración y rehabilitación de la arquitectura tradicional de tierra.

El caso de Aragón.

3. DATOS DE LA INTERVENCIÓN

Intervención de: $\quad \square$ Mantenimiento $\square$ Rehabilitación parcial $\square$ Restauración $\quad$ X Demolición

Reflexión previa Intervención planificada

Observaciones

Intervención planificada

3.1. MUROS

Tipo de intervención

Intervenido

Tipo de material

$\square$ Actualización $\square$ Reintegración $\quad$ Demolición $\square$ Otro..

$\square$ Consolidación $\square$ Reconstrucción $\mathbf{X}$ Sustitución

\begin{tabular}{|l|l|l|l|l} 
Tradicional diferente & Tipo de técnica Diferente a la existente \\
\hline
\end{tabular}

Descripción

Muros_Eliminación de los adobes y reconstrucción Chimenea: mantenido

3.2. ZÓCALO No aplica

Tipo de intervención

Tipo de material

$\square$ Actualización $\square$ Reintegración $\quad \square$ Demolición $\square$ Otro...

$\square$ Consolidación $\square$ Reconstrucción $\square$ sustitución

Descripción

3.3. REVESTIMIENTOS

Tipo de intervención

Intervenido

Tipo de material

$\square$ Actualización $\square$ Reintegración $\square$ Demolición $\square$ Otro...

Descripción Revestimiento con cal en el tiro de la chimenea. Suplementos de tierra donde era necesario

3.4. VANOS

Tipo de intervención

Intervenido

Tipo de material

$\square$ Actualización $\square$ Reintegración $\square$ Demolición $\square$ Otro...

$\square$ Consolidación $\square$ Reconstrucción $\mathbf{x}$ Sustitución

\begin{tabular}{l|l|l|l|l} 
Tradicional diferente & Tipo de técnica & Similar a la existente
\end{tabular}

Descripción

Sustitución de las carpinterías por otras de madera

3.5. CUBIERTA

Tipo de intervención

Intervenido

$\square$ Actualización $\square$ Reintegración $\square$ Demolición $\square$ Otro

$\square$ Consolidación $\mathbf{X}$ Reconstrucción $\square$ Sustitución

Tipo de material

Tradicional similar Tipo de técnica Similar a la existente

Descripción

Reconstrucción de la cubierta con lajas de piedra

3.6. OTRAS 


\section{La restauración y rehabilitación de la arquitectura tradicional de tierra.} El caso de Aragón.
3.7. REHABILITACIÓN ENERGÉTICA
$\square$ Fachada $\square$ Vanos $\square$ forjados $\square$ Cubierta

Observaciones

FOTOGRAFÍAS DE LA INTERVENCIÓN
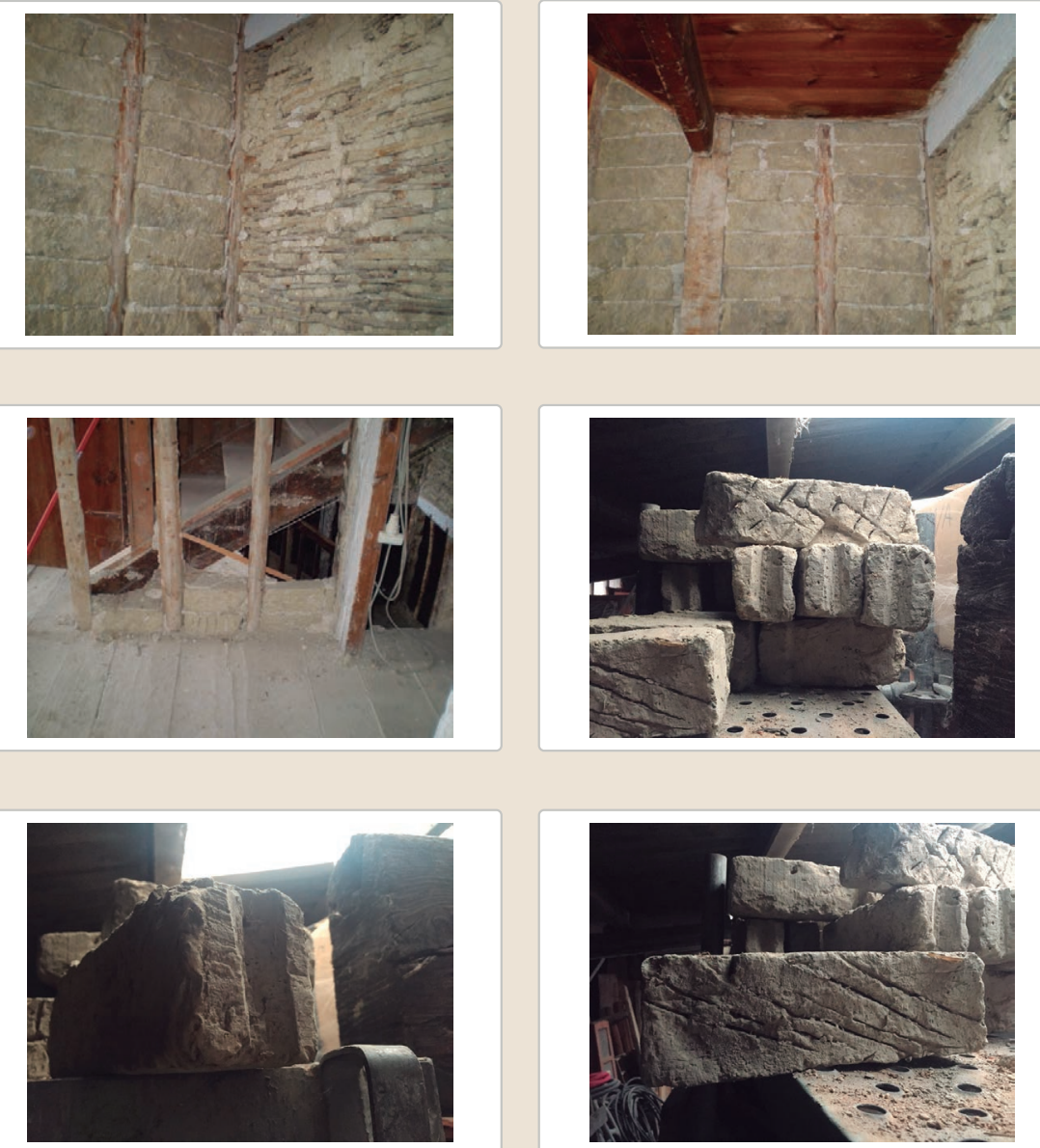


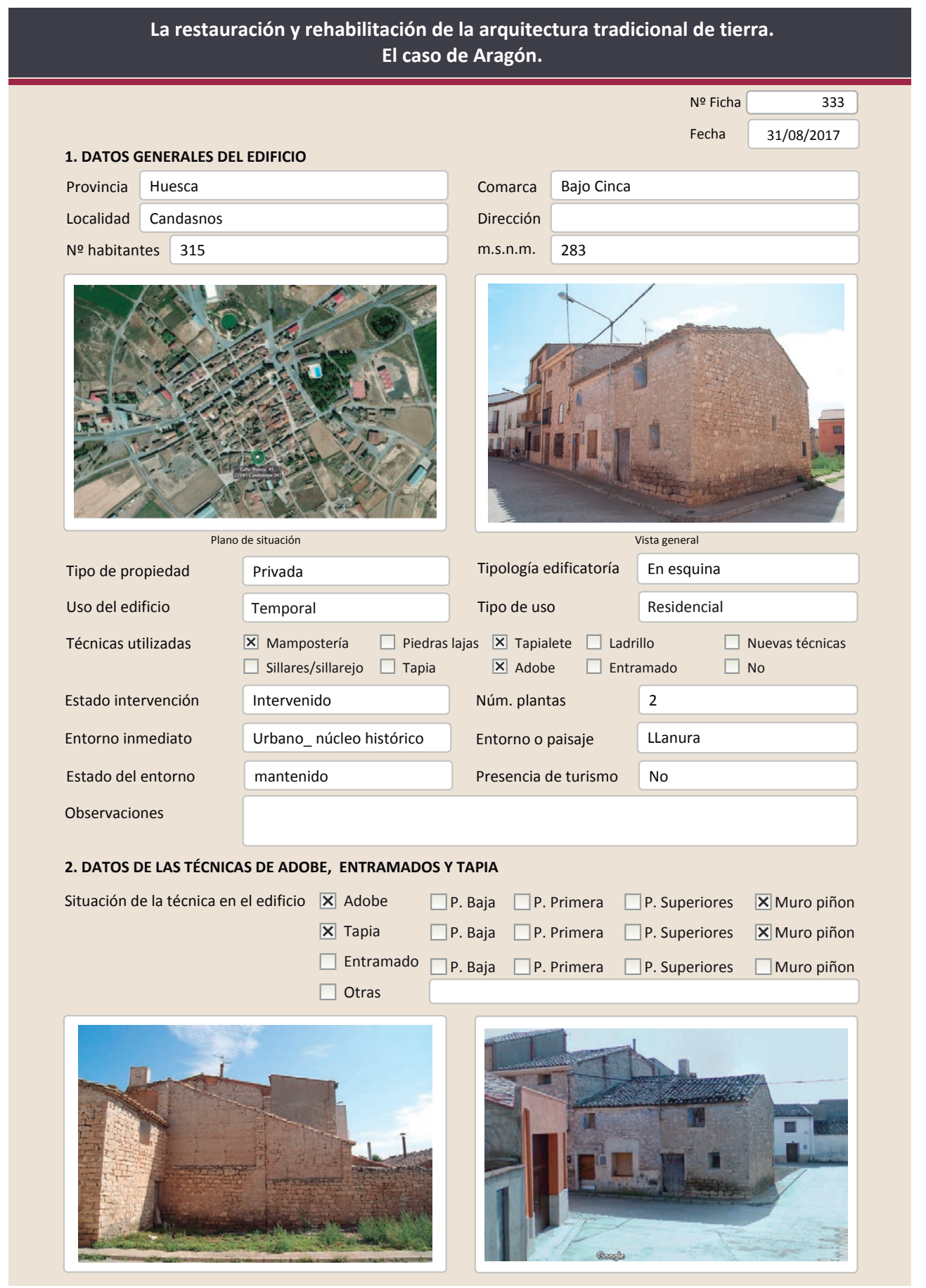

La restauración y rehabilitación de la arquitectura tradicional de tierra.

2.1. ADOBE

Dimensión de las piezas Dimensión del muro

Aparejo del muro

Función estructural

\section{El caso de Aragón.}

Color de las piezas

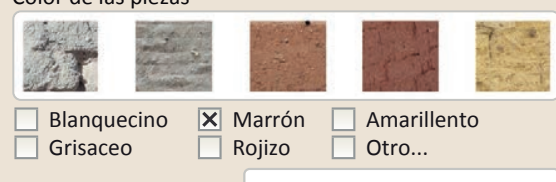

Grisaceo $\square$ Rojizo $\square$ Otro...

Variante constructiva/ tipo de fábrica

$\square$ Simple

$\square$ Suplementada en juntas

X Mixta

Machones

$\square$ Como suplemento

$\mathbf{X}$ Elementos de protección

Revesting to

Piedra

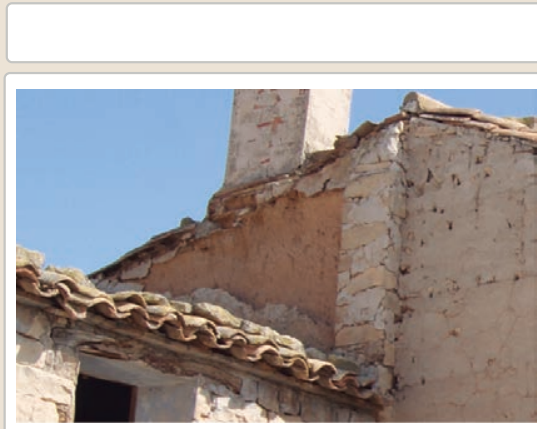

Lesiones $\mathbf{X}$ Muro $\mathbf{X}$ Zócalo $\mathbf{X}$ Revestimiento

\ Erosión del material $\mathbf{X}$ Humedad por capilaridad $\square$ Erosion de las juntas $\square$ Humedades (manch/eflo)

X Pérdida de sección $\square$ Pérdida de verticalidad

$\begin{array}{ll}\square \text { Vegetación } & \square \text { Grietas por empuje de la cube } \\ \text { Х Desconchados } & \square \text { Grietas porfalta de traba }\end{array}$

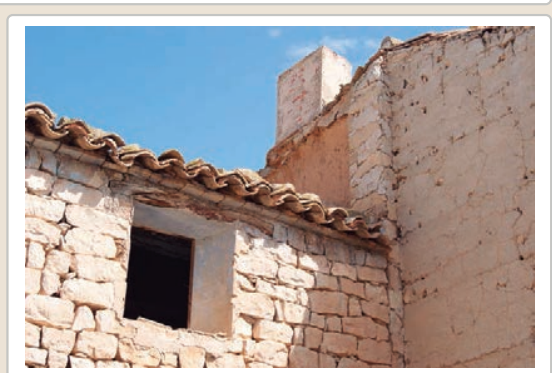

$\square$ Cubierta $\square$ Otro...

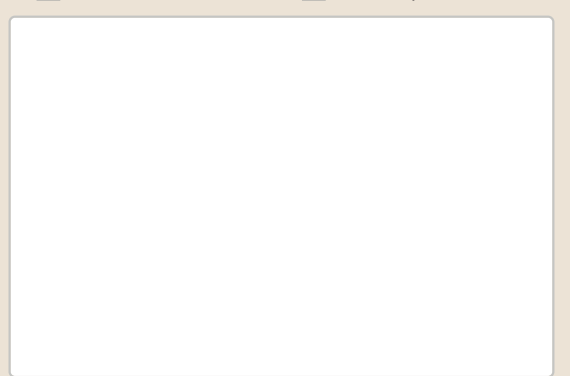

$\square$ Grietas por asentamiento

$\square$ Colapso

$\square$ Por elementos impropios

$\square$ Derivado de intervenciones

Observaciones 


\section{La restauración y rehabilitación de la arquitectura tradicional de tierra.} El caso de Aragón.

\subsection{TAPIA}

Ancho del muro

Dimensión tapiales

Tipo de aguja

№ agujas/cajón

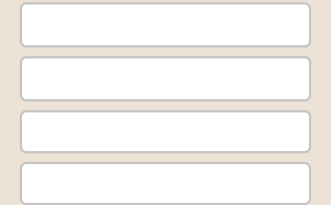

\section{Color de la tapia}

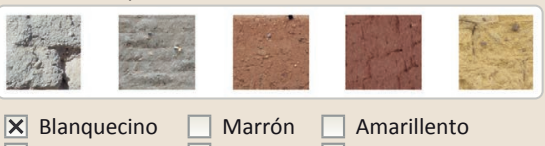
$\mathbf{X}$ Blanquecino $\square$ Marrón $\square$ Amarillento
$\square$ Grisaceo

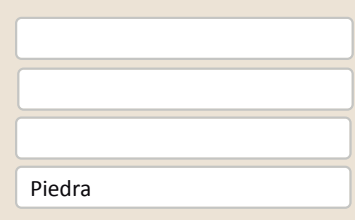

\section{Machones}

$\square$ Elementos de protección

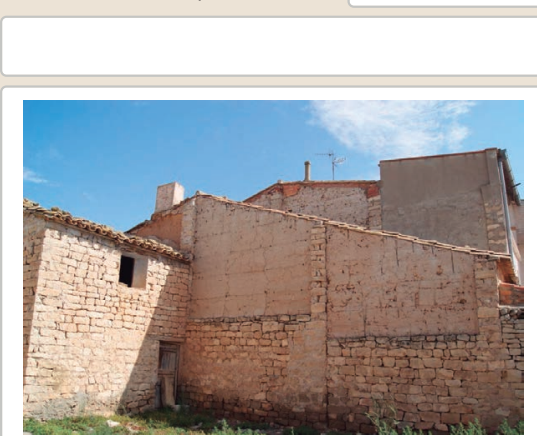

Lesiones ХMuro XZŹcalo $\square$ Revestimiento

$\mathbf{X}$ Erosión del material $\mathbf{X}$ Humedad por capilaridad

$\square$ Cubierta $\square$ otro..

$\square$ Erosion de las juntas $\square$ Humedades (manch/eflo)

$\square$ Pérdida de sección $\square$ Pérdida de verticalidad

$\square$ Grietas por asentamiento

$\square$ Vegetación

$\square$ Grietas por empuje de la

$\square$ Desconchados

$\square$ Grietas porfalta de traba

$\square$ Colapso

$\square$ Por elementos impropios

$\square$ Derivado de intervenciones

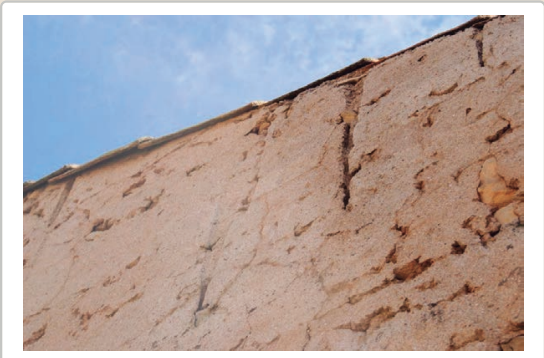

$\square$ Otro...

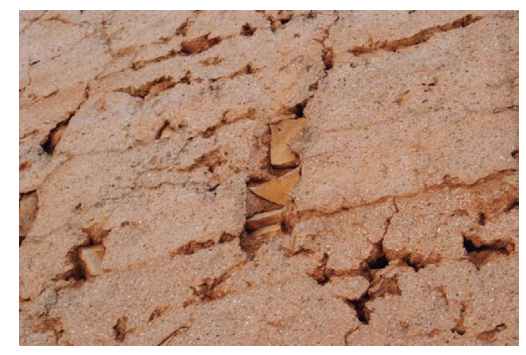

Observaciones
La restauración y rehabilitación de la arquitectura tradicional de tierra.

El caso de Aragón.

3. DATOS DE LA INTERVENCIÓN

Intervención de: $\quad \square$ Mantenimiento $\quad \mathbf{X}$ Rehabilitación parcial $\quad \square$ Restauración $\square$ Demolición

$\square$ Reparación $\square$ Rehabilitación integral $\square$ Ampliación $\square$ Otro..

Reflexión previa Intervención espontanea

Observaciones

3.1. MUROS

Tipo de intervención

No intervenido

Tipo de material

Descripción

3.2. ZÓCALO

Tipo de intervención

Tipo de material

Descripción

3.3. REVESTIMIENTOS

Tipo de intervención

Tipo de material

Descripción

3.4. VANOS

Tipo de intervención

Intervenido

Tipo de material

$\square$ Actualización $\quad \square$ Reintegración $\square$ Demolición $\square$ Otro..

$\square$ Consolidación $\square$ Reconstrucción $\mathbf{x}$ Sustitución

\begin{tabular}{|l|l|l|l} 
Tradicional diferente & Tipo de técnica & Diferente a la existente
\end{tabular}

Descripción

Sustitución de carpinterías. Inserción de cajas de persianas

3.5. CUBIERTA

No intervenido

Tipo de intervención

$\square$ Actualización

Remolición $\square$ Otro.

Tipo de material

Descripción

3.6. OTRAS 
La restauración y rehabilitación de la arquitectura tradicional de tierra.

\section{El caso de Aragón.}

3.7. REHABILITACIÓN ENERGÉTICA $\quad \square$ Fachada $\square$ Vanos $\square$ Forjados $\square$ Cubierta

Observaciones

FOTOGRAFÍAS DE LA INTERVENCIÓN
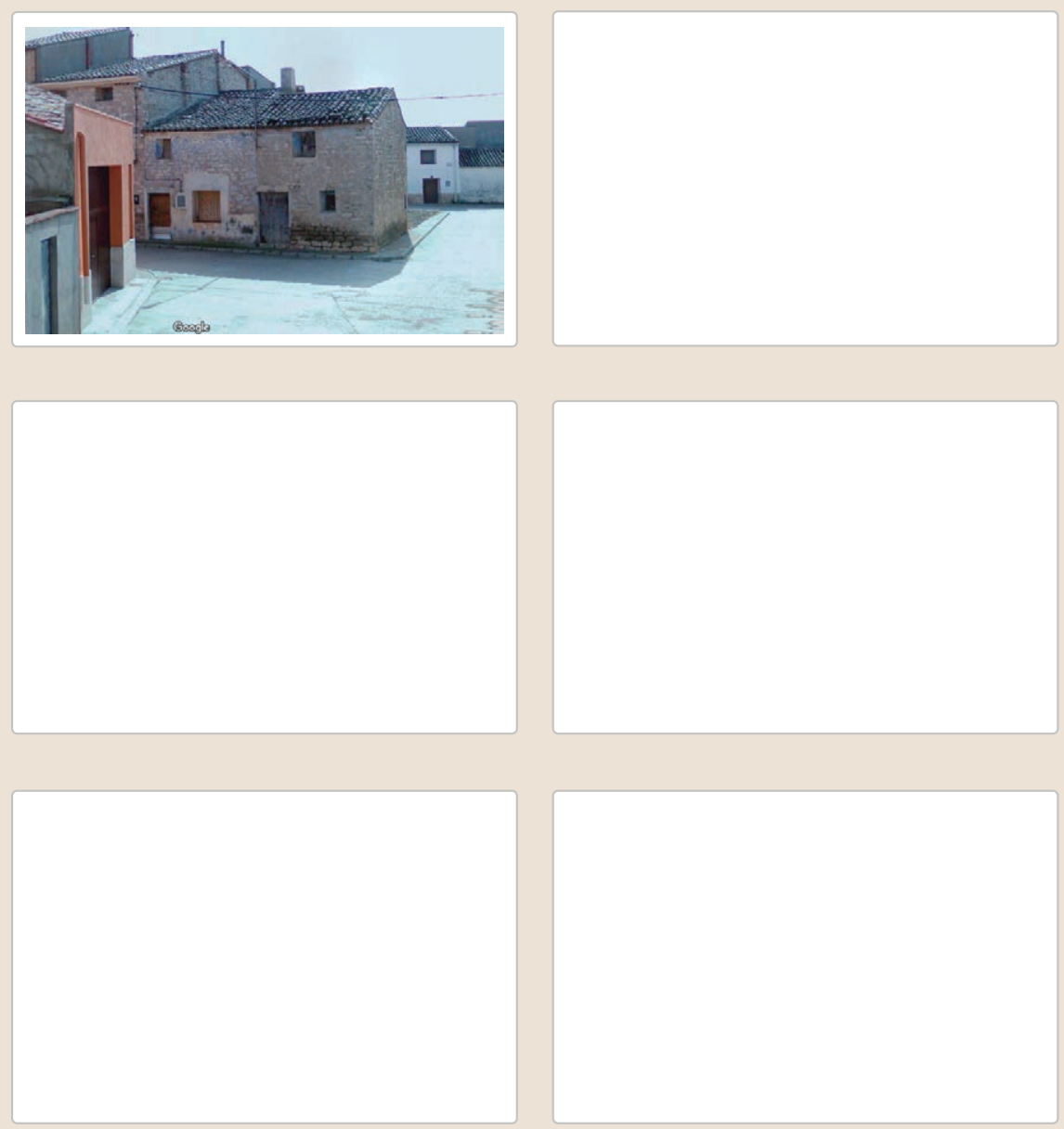


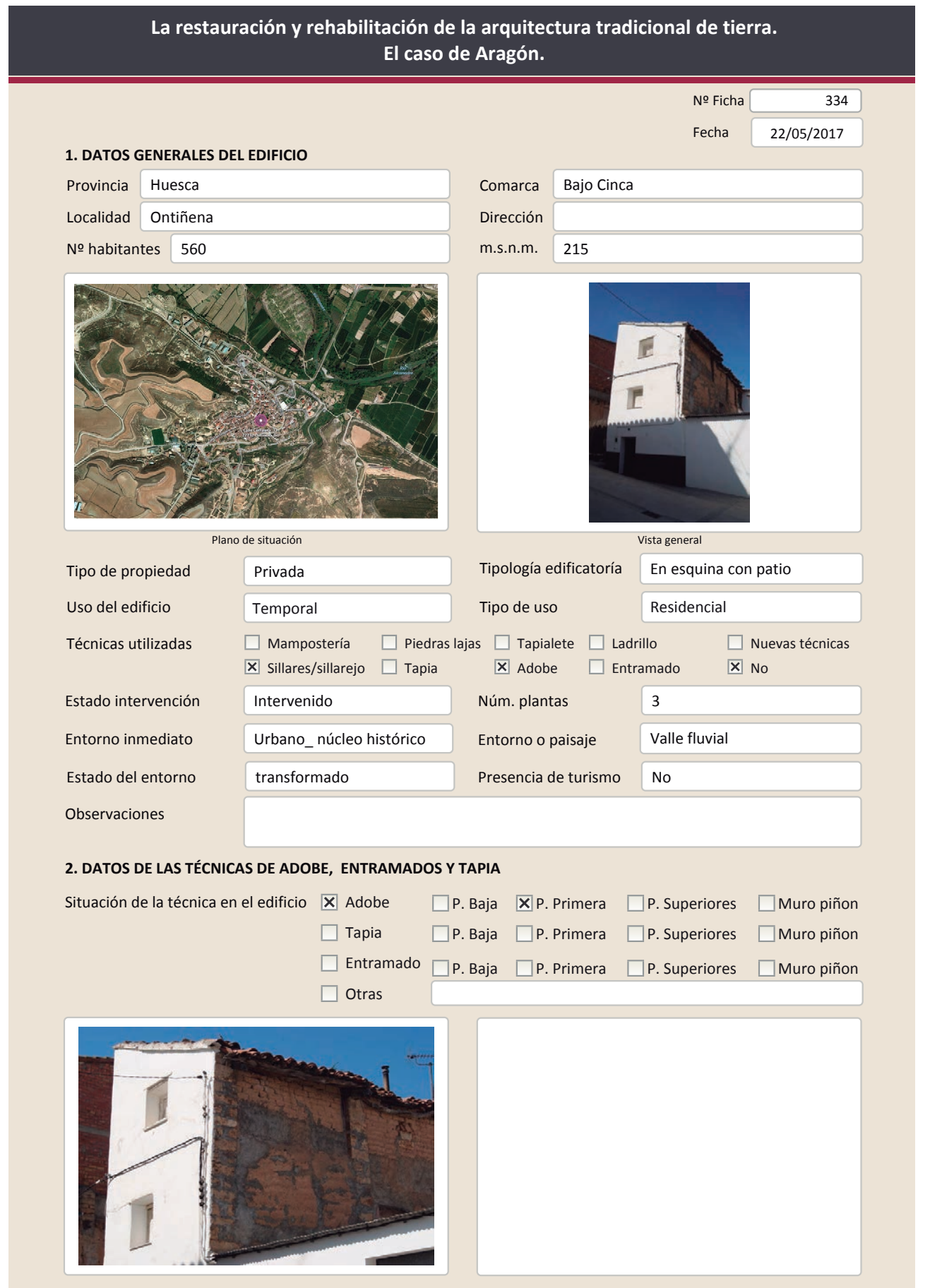

2.1. ADOBE

Dimensión de las piezas Dimensión del muro

Aparejo del muro

Función estructural

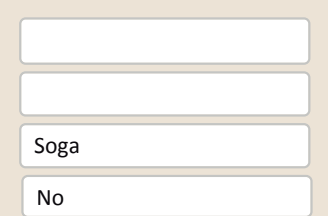

Color de las piezas

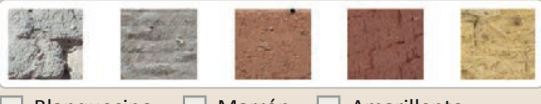

$\square$ Blanquecino $\square$ Marrón $\square$ Amarillento $\square$ Grisaceo $\square$ Rojizo $\square$ Otro..

Comp. - estabilizante

Variante constructiva/ tipo de fábrica
$\square$ Simple
$\mathbf{X}$ Suplementada en juntas
Horizontales
$\mathrm{Cal} /$ yeso
区 Mixta
Machones
Piedra
$\square$ Como suplemento
$\square$ Elementos de protección

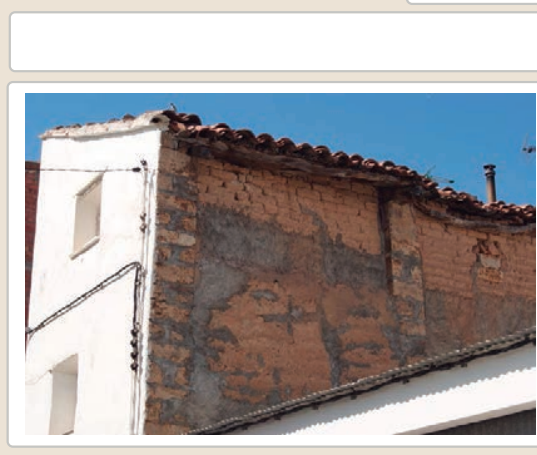

Lesiones \Muro $\square$ Zócalo $\square$ Revestimiento $\square$ Cubierta $\square$ otro...

区 Erosión del material $\square$ Humedad por capilaridad $\quad \square$ Grietas por asentamientos

$\square$ Erosion de las juntas $\square$ Humedades (manch/eflo) $\square$ Colapso

$\square$ Pérdida de sección $\square$ Pérdida de verticalidad $\square$ Por elementos impropios

$\square$ Vegetación $\quad \square$ Grietas por empuje de la cubierta $\square$ Derivado de intervenciones

$\square$ Desconchados $\square$ Grietas porfalta de traba $\quad \square$ Otro...
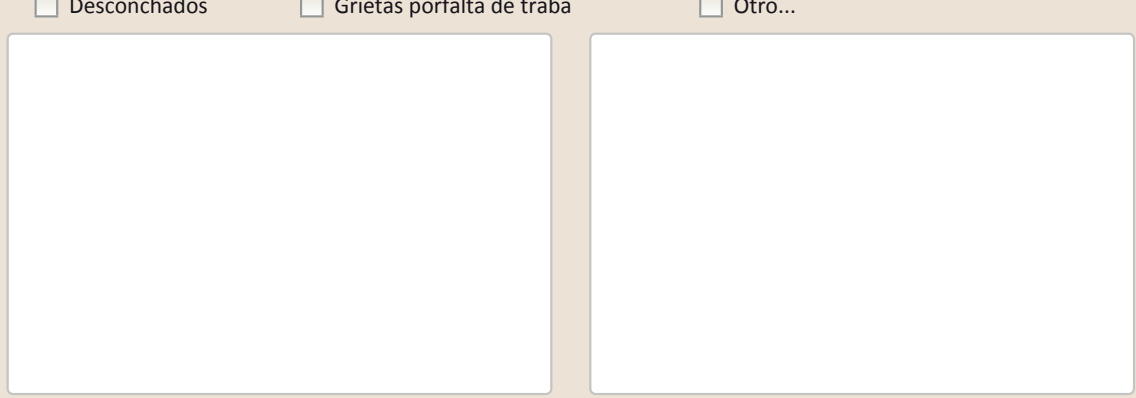

Observaciones 


\section{La restauración y rehabilitación de la arquitectura tradicional de tierra.}

\section{El caso de Aragón.}

3. DATOS DE LA INTERVENCIÓN

Intervención de: $\quad X$ Mantenimiento

Reflexión previa

$\square$ Restauración $\square$ Demolición

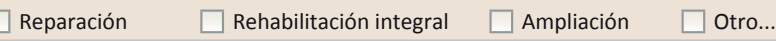

Observaciones

Intervención espontanea

3.1. MUROS
Tipo de intervención

Intervenido

Tipo de intervención

$\square$ Actualización

$\square$ Consolidación

X Reintegración

$\square$ Demolición

$\square$ Sustitución

Descripción

Rejuntado del muros de adobe con cemento.

3.2. ZÓCALO

Tipo de intervención

Intervenido

X Actualización $\square$ Reintegración $\square$ Demolición $\square$ Otro...

$\square$ Consolidación $\quad \mathbf{X}$ Reconstrucción $\square$ Sustitución

No tradicional Tipo de técnica Diferente a la existente

Tipo de material

Descripción

3.3. REVESTIMIENTOS

Tipo de intervención

Revestimiento de cemento con gotelé y pintura marrón

\section{Intervenido}

X Actualización $\square$ Reintegración $\quad \square$ Demolición $\square$ Otro...

$\square$ Consolidación $\quad \mathbf{X}$ Reconstrucción $\square$ sustitución

Tipo de material

Descripción

3.4. VANOS

Tipo de intervención

No tradicional

Tipo de técnica Similar a la existente

Nuevo revestimiento y pintura en la fachada principal.

No intervenido

$\square$ Actualización $\square$ Reintegración $\square$ Demolición $\square$ Otro...

$\square$ Consolidación $\quad \square$ Reconstrucción $\square$ Sustitución

Tipo de material

Descripción

3.5. CUBIERTA

Tipo de intervención

\section{Intervenido}

$\square$ Actualización $\quad \mathbf{X}$ Reintegración $\square$ Demolición $\square$ Otro. $\square$ Consolidación $\quad \square$ Reconstrucción $\square$ Sustitución

Tipo de material

No tradicional

Tipo de técnica Similar a la existente

Descripción

Reintegración de las tejas con cemento, o al menos los laterales de la cubierta
La restauración y rehabilitación de la arquitectura tradicional de tierra.

El caso de Aragón.

3.7. REHABILITACIÓN ENERGÉTICA $\quad \square$ Fachada $\square$ Vanos $\square$ Forjados $\square$ Cubierta

Observaciones

FOTOGRAFÍAS DE LA INTERVENCIÓN
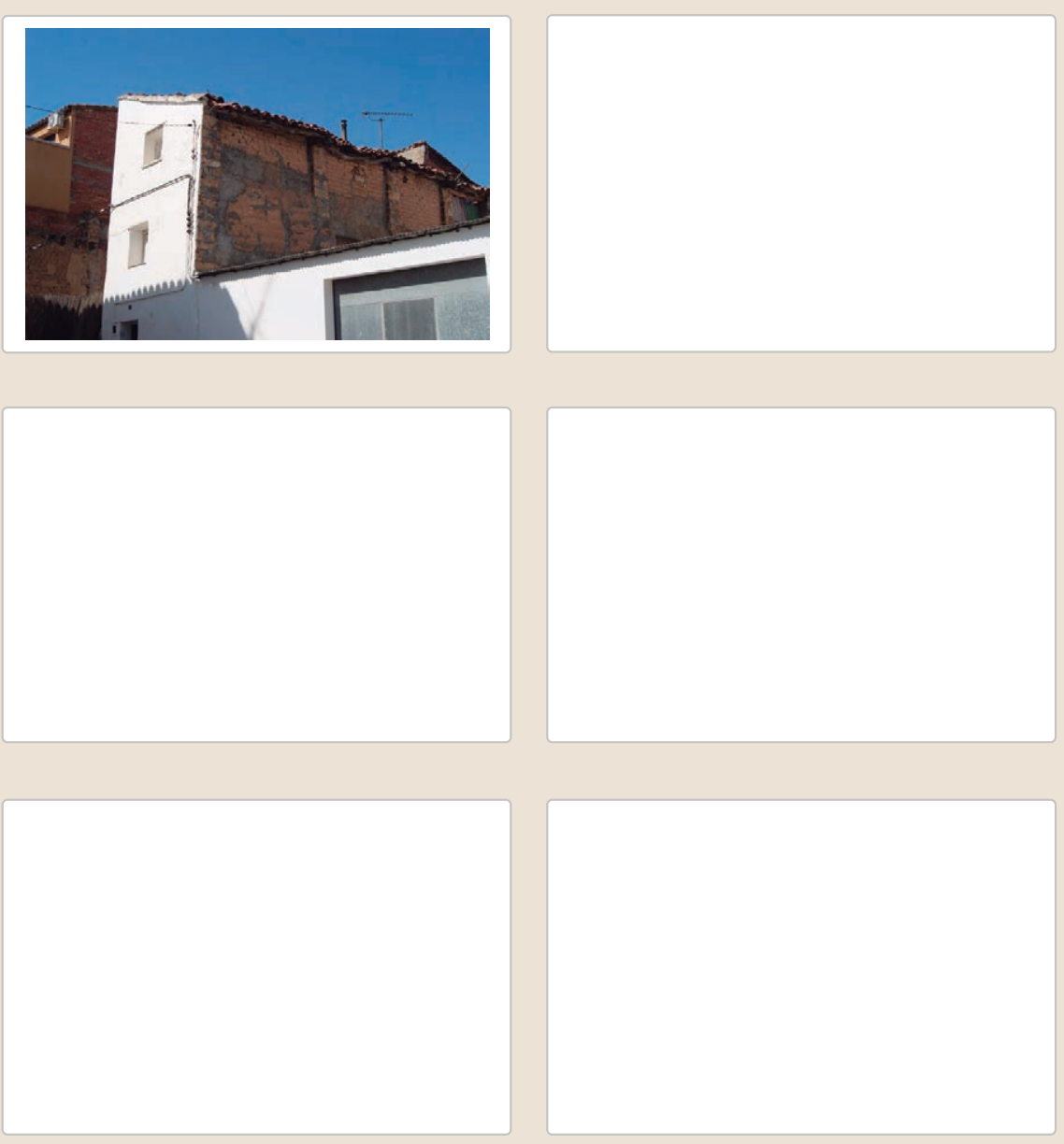

3.6. OTRAS 


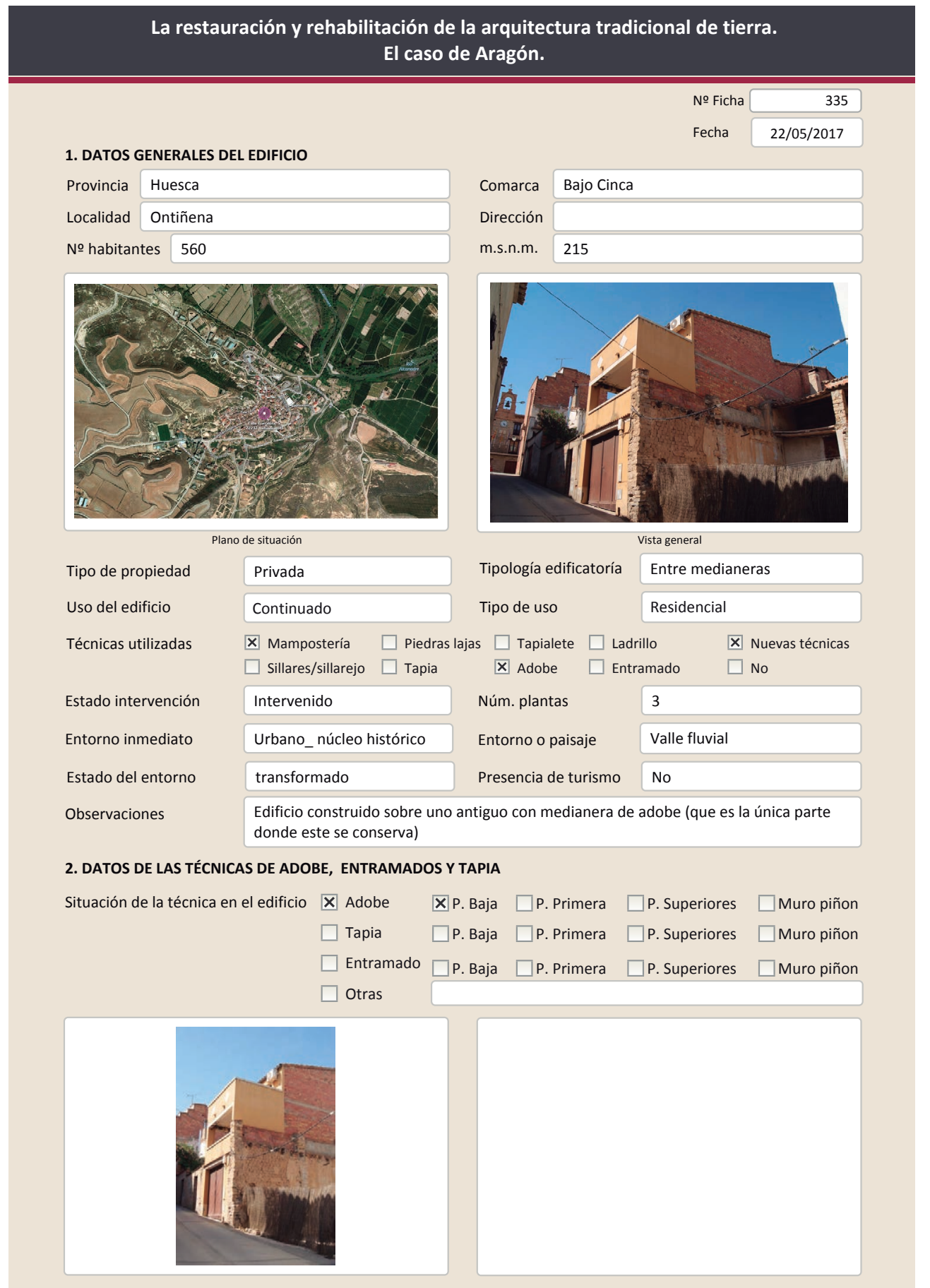

La restauración y rehabilitación de la arquitectura tradicional de tierra.

El caso de Aragón.
2.1. ADOBE

Dimensión de las piezas Dimensión del muro

Aparejo del muro

Función estructural

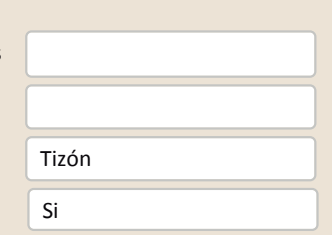

Color de las piezas

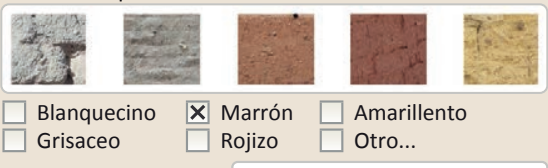

Comp. - estabilizante
Variante constructiva/ tipo de fábrica

$\square$ Simple

$\square$ Suplementada en juntas

X Mixta

\section{Machones}

Piedra

$\square$ Como suplemento

$\square$ Elementos de protección

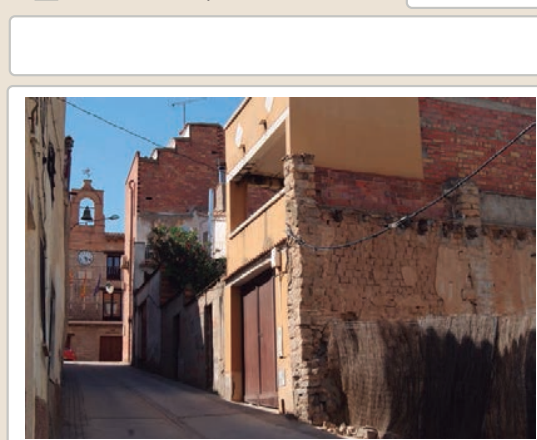

Lesiones $\quad$ XMuro $\square$ Zócalo $\mathbf{X}$ Revestimiento $\square$ Cubierta $\square$ otro...

区 Erosión del material $\square$ Humedad por capilaridad $\quad \square$ Grietas por asentamientos $\boldsymbol{X}$ Erosion de las juntas $\quad \square$ Humedades (manch/eflo) $\quad \square$ Colapso

$\square$ Pérdida de sección $\square$ Pérdida de verticalidad

X Desconchados

$\square$ Grietas por empuje de la

$\square$ Por elementos impropios

$\square$ Derivado de intervenciones 


\section{El caso de Aragón.}

3. DATOS DE LA INTERVENCIÓN

\begin{tabular}{|c|c|c|c|c|}
\hline Intervención de: & $\begin{array}{l}\square \text { Mantenimiento } \\
\square \text { Reparación }\end{array}$ & $\begin{array}{l}\square \text { Rehabilitación parcial } \\
\mathbf{X} \text { Rehabilitación integral }\end{array}$ & $\begin{array}{l}\square \text { Restauración } \\
\text { X Ampliación }\end{array}$ & $\begin{array}{l}\square \text { Demolición } \\
\square \text { Otro... }\end{array}$ \\
\hline Reflexión previa & \multicolumn{4}{|c|}{ Intervención planificada } \\
\hline Observaciones & \multicolumn{4}{|c|}{$\begin{array}{l}\text { Se ha construido la nueva vivienda sobre la base de pilares de piedra y cerramiento de } \\
\text { adobe. }\end{array}$} \\
\hline
\end{tabular}

\subsection{MUROS}

Tipo de intervención

Intervenido

Tipo de material

$\square$ Actualización $\square$ Reintegración $\quad$ X Demolición $\square$ Otro...

$\square$ Consolidación $\square$ Reconstrucción $\square$ sustitución

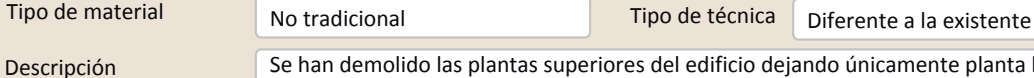
ha construido sobre este dos plantas con fábrica de ladrillo

3.2. ZÓCALO

Tipo de intervención Intervenido

Tipo de material

$\square$ Actualización $\square$ Reintegración $\square$ Demolición $\square$ Otro...

$\square$ Actualización $\square$ Reintegración
$\square$ Consolidación $\quad \square$ Reconstrucción $\quad \square$ Sustitución

Descripción
No tradicional
Tipo de técnica Diferente a la existente

3.3. REVESTIMIENTOS

Reconstrucción del zócalo con cemento que se ha degradado con la humedad

Tipo de intervención

Intervenido

Tipo de material

$\square$ Actualización $\square$ Reintegración $\quad \square$ Demolición $\square$ Otro...

$\square$ Consolidación $\quad \mathbf{X}$ Reconstrucción $\square$ Sustitución

Tipo de material
Descripción

No tradicional

Tipo de técnica Diferente a la existente

3.4. VANOS

Revestimiento con monocapa amarillo

Tipo de intervención

Intervenido

Tipo de material

$\square$ Actualización $\quad \square$ Reintegración $\quad \square$ Demolición $\square$ Otro...

$\square$ Consolidación $\square$ Reconstrucción $\quad \boldsymbol{X}$ Sustitución

Descripción

No tradicional

Tipo de técnica Diferente a la existente

3.5. CUBIERTA

Tipo de intervención

El acceso principal es una puerta de garaje, sustitución de la anterior

Tipo de material

Intervenido

$\square$ Actualización $\quad \square$ Reintegración $\quad \square$ Demolición $\quad \square$ Otro...

$\square$ Consolidación $\square$ Reconstrucción $\quad \mathbf{X}$ Sustitución

\begin{tabular}{l|l|l|l|l} 
No tradicional & Tipo de técnica Diferente a la existente
\end{tabular}

Descripción

Cubierta plana en la fachada y cubierta a dos aguas nueva en la zona posterior

3.6. OTRAS 


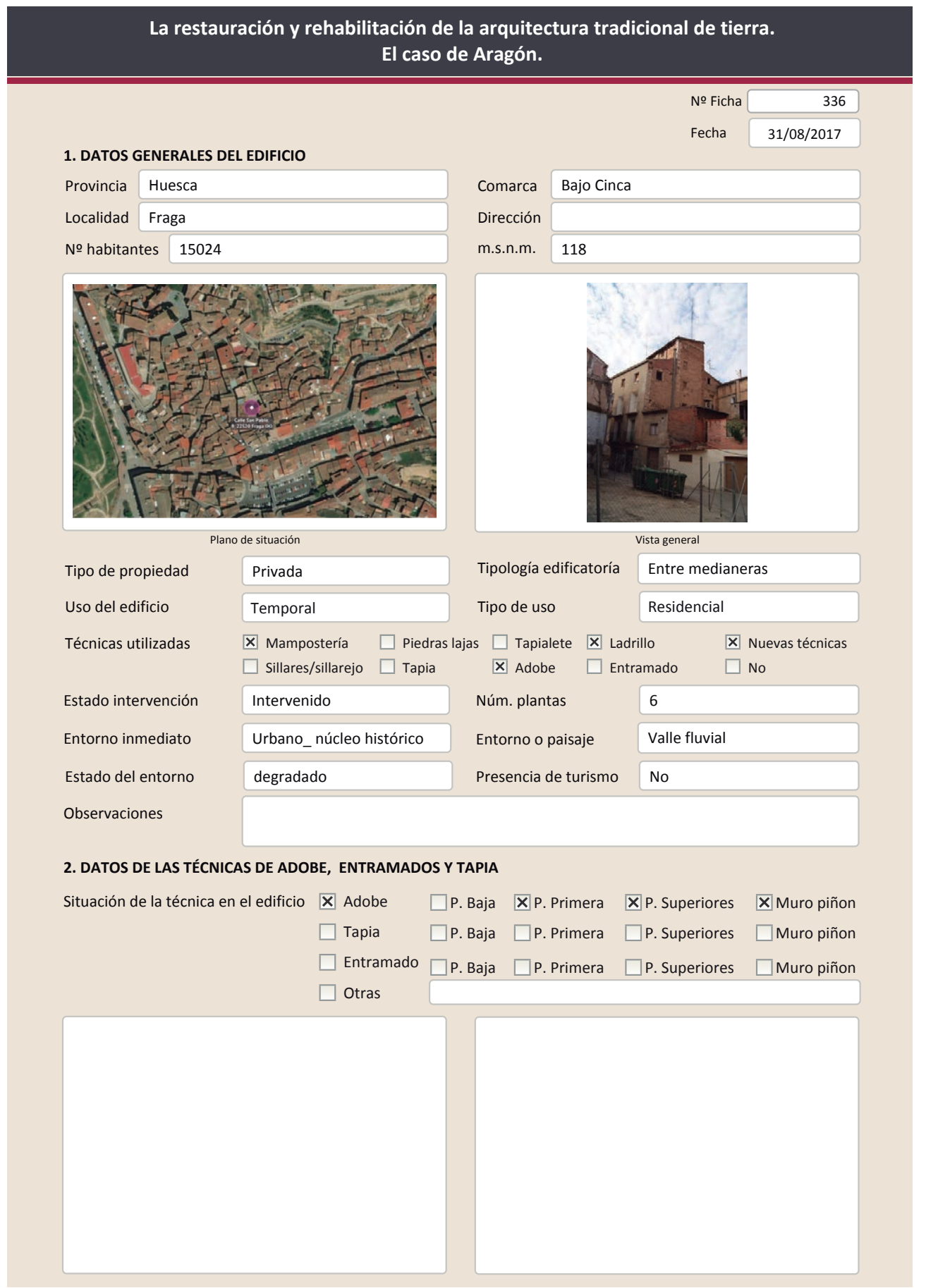

2.1. ADOBE

Dimensión de las piezas

Dimensión del muro

Aparejo del muro

Función estructural

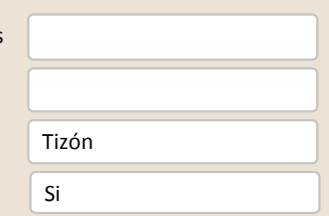

Color de las piezas

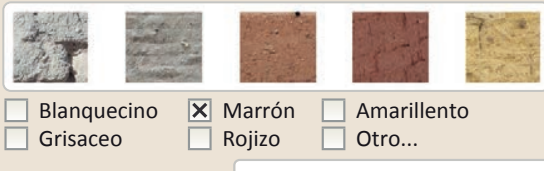

Grisaceo

Rojizo

Variante constructiva/ tipo de fábrica

$\square$ Simple

$\square$ Suplementada en juntas

区 Mixta

\section{Machones}

Comp. - estabilizante

$\square$ Como suplemento

$\mathbf{X}$ Elementos de protección

Machones de piedra y de ladrillo.

Existen también dos tipos de adobe distintos. Los de la última planta parecen tener fibras

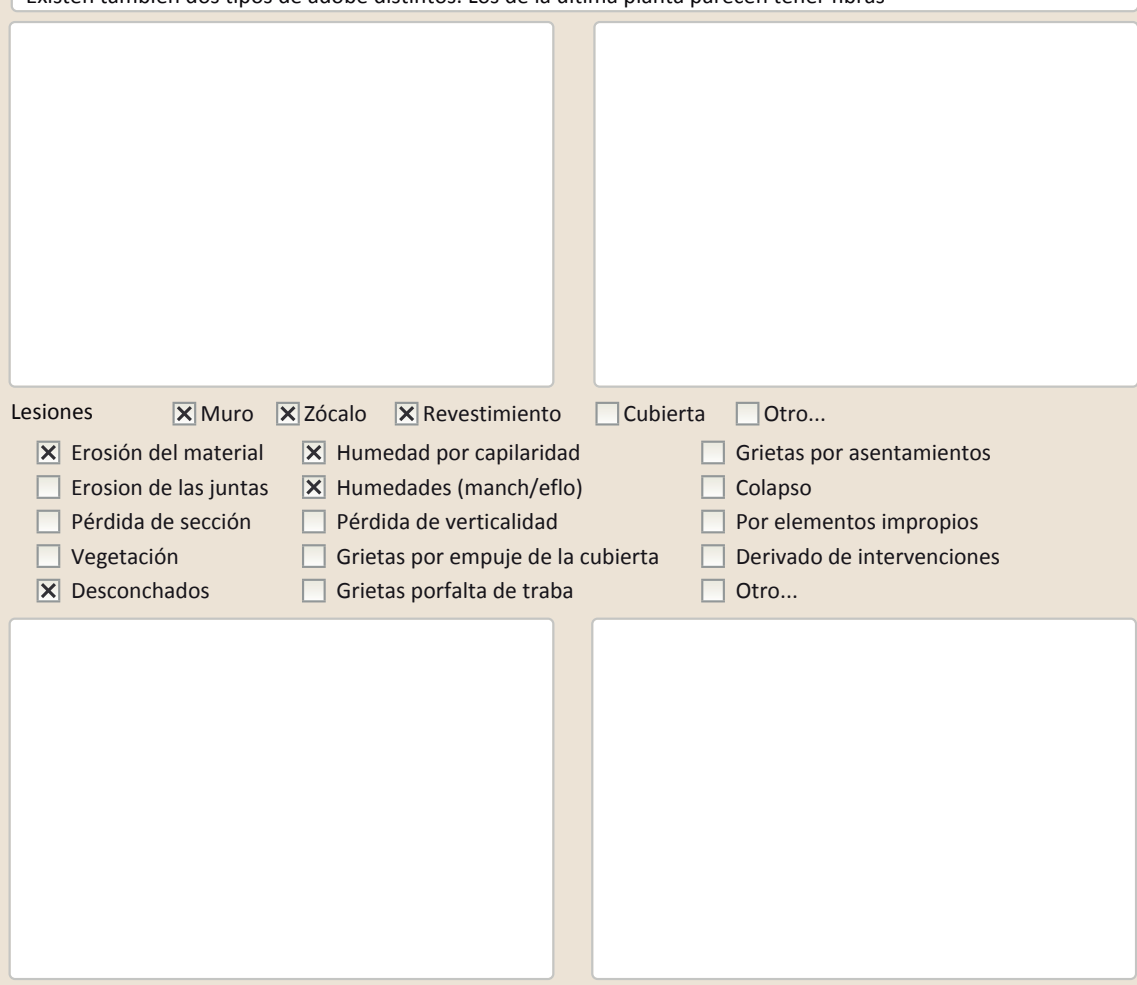

Observaciones 
La restauración y rehabilitación de la arquitectura tradicional de tierra.

El caso de Aragón.

3. DATOS DE LA INTERVENCIÓN

Intervención de:

$\square$ Mantenimiento $\square$ Rehabilitación parcial

$\square$ Restauración $\square$ Demolición X Reparación $\square$ Rehabilitación integral $\square$ Ampliación $\square$ Otro...

Reflexión previa

Intervención espontanea

Observaciones

3.1. MUROS

Tipo de intervención

Tipo de material

Descripción

3.2. ZÓCALO

Tipo de intervención

Tipo de material

Descripción

3.3. REVESTIMIENTOS

Tipo de intervención

Tipo de material

Descripción

3.4. VANOS

Tipo de intervención

Tipo de material

Descripción

3.5. CUBIERTA

Tipo de intervención

Tipo de material

Descripción

Intervenido

$\square$ Actualización $\quad \square$ Reintegración $\quad \square$ Demolición $\square$ Otro...

$\square$ Consolidación $\square$ Reconstrucción $\mathbf{X}$ Sustitución

No tradicional Tipo de técnica Similar a la existente

Sustitución de parte del muro piñón de adobe por fábrica de ladrillo

Intervenido

$\square$ Actualización $\square$ Reintegración $\square$ Demolición $\square$ Otro..

$\square$ Consolidación $\quad \mathbf{X}$ Reconstrucción $\square$ Sustitución
No tradicional
Tipo de técnica Diferente a la existente

Reconstrucción del zócalo con un revestimiento de cemento pintado. Actualmente

tiene machas de humedad

Intervenido

$\square$ Actualización $\square$ Reintegración $\square$ Demolición $\square$ Otro..

$\square$ Consolidación $\quad \boldsymbol{X}$ Reconstrucción $\square$ sustitución

No tradicional Tipo de técnica Diferente a la existente

Nuevo revestimiento de cemento en toda la fachada principal del edificio.

Intervenido

$\square$ Actualización $\square$ Reintegración $\square$ Demolición $\square$ Otro...

$\square$ Consolidación $\square$ Reconstrucción $\quad \boldsymbol{X}$ Sustitución

\begin{tabular}{l|l|l} 
No tradicional & Tipo de técnica Diferente a la existente
\end{tabular}

Sustitución de la puerta de acceso por una de aluminio con vidrio

Intervenido

$\square$ Actualización $\quad \mathbf{X}$ Reintegración $\square$ Demolición $\square$ Otro.

$\square$ Consolidación $\square$ Reconstrucción $\square$ Sustitución

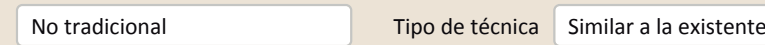

Reintegración de la cubierta con cemento e incorporación de canaleras

3.6. OTRAS 


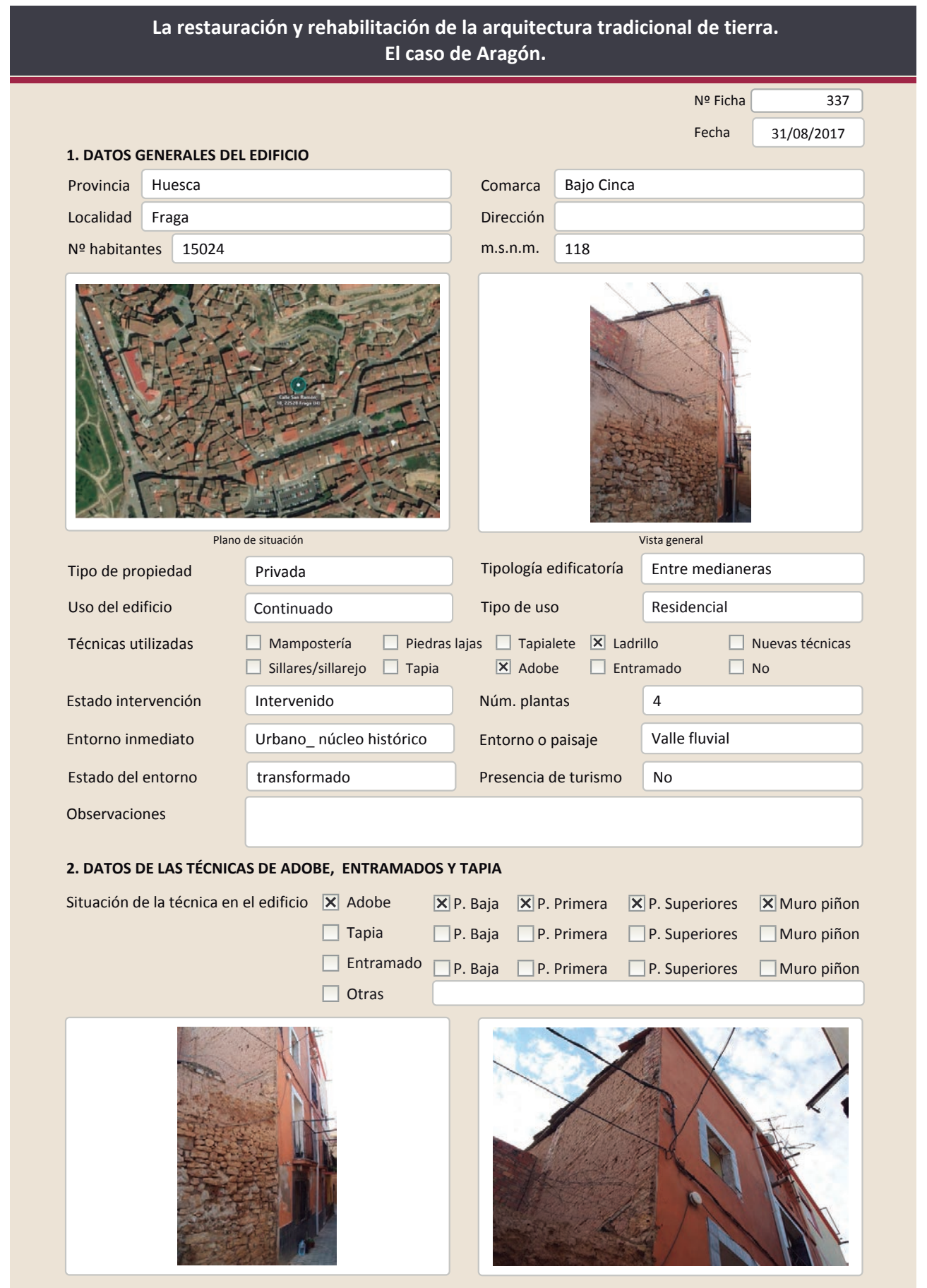

2.1. ADOBE

Dimensión de las piezas

Dimensión del muro

Aparejo del muro

\begin{tabular}{|l|}
\hline \\
\hline $20-30 \mathrm{~cm}$ \\
\hline Soga \\
\hline $\mathrm{Si}$ \\
\hline
\end{tabular}

Color de las piezas

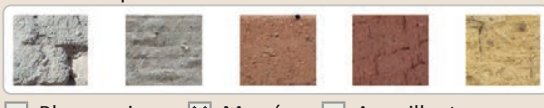

$\square$ Blanquecino $\mathbf{X}$ Marrón $\square$ Amarillento $\square$ Grisaceo $\square$ Rojizo $\square$ Otro...

Función estructural

Comp. - estabilizante

Variante constructiva/ tipo de fábrica

$\square$ simple

$\square$ Suplementada en juntas

X Mixta

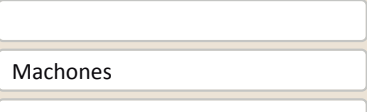

Adobe

X Como suplemento

Mixto- Machones

$\square$ Elementos de protección

Edificio con machones conformados con rasillas cerámicas y adobe por hiladas intercaladas
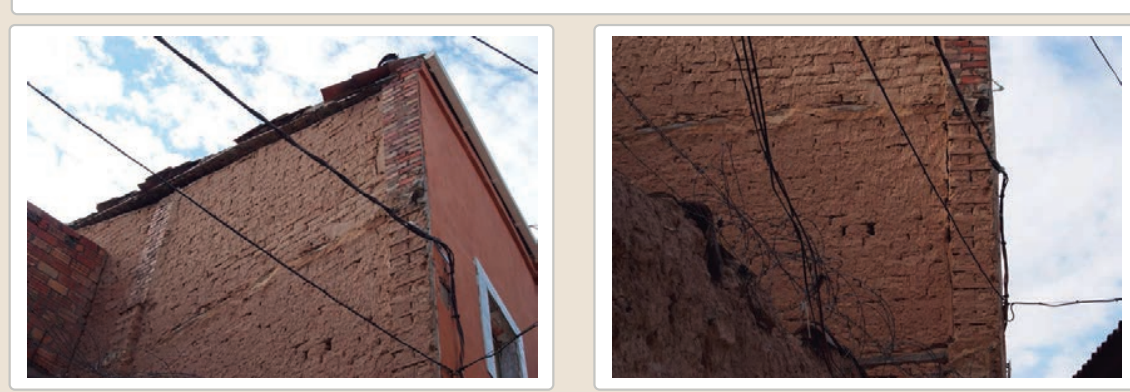

Lesiones \Muro ХZŹcalo $\square$ Revestimiento $\square$ Cubierta $\square$ Otro...

$\mathbf{X}$ Erosión del material $\quad \mathbf{X}$ Humedad por capilaridad $\quad \square$ Grietas por asentamientos $\mathbf{X}$ Erosion de las juntas $\mathbf{X}$ Humedades (manch/eflo) $\square$ Colapso

$\square$ Pérdida de sección $\square$ Pérdida de verticalidad

$\square$ Por elementos impropios

$\square$ Vegetación

$\square$ Grietas por empuje de la

$\square$ Derivado de intervenciones

$\square$ Desconchados

$\square$ Grietas porfalta de traba $\square$ Otro... 


\section{La restauración y rehabilitación de la arquitectura tradicional de tierra.}

\section{El caso de Aragón.}

3. DATOS DE LA INTERVENCIÓN

\begin{tabular}{|c|c|c|c|c|}
\hline Intervención de: & $\begin{array}{l}\square \text { Mantenimiento } \\
\square \text { Reparación }\end{array}$ & $\begin{array}{l}\text { X Rehabilitación parcial } \\
\square \text { Rehabilitación integral }\end{array}$ & $\begin{array}{l}\square \text { Restauración } \\
\square \text { Ampliación }\end{array}$ & $\begin{array}{l}\square \text { Demolición } \\
\square \text { Otro... }\end{array}$ \\
\hline Reflexión previa & \multicolumn{4}{|c|}{ Intervención planificada } \\
\hline Observaciones & \multicolumn{4}{|c|}{ Se ha rehabilitado la fachada principal } \\
\hline
\end{tabular}

\subsection{MUROS}

Tipo de intervención

No intervenido

Tipo de material

$\square$ Actualización $\square$ Reintegración $\square$ Demolición $\square$ Otro... $\square$ Consolidación $\square$ Reconstrucción $\square$ Sustitución

Descripción

3.2. ZÓCALO

Tipo de intervención

Intervenido

Tipo de intervención

X Actualización

Reión $\square$ Reintegración $\square$ Demolición $\square$ Otro...

Descripción

No tradicional Tipo de técnica Diferente a la existente

3.3. REVESTIMIENTOS

cemento

3.3. REVESTIMIENTOS
Tipo de intervención

Intervenido

Tipo de material

$\square$ Actualización $\square$ Reintegración $\quad \square$ Demolición $\square$ Otro...

$\square$ Consolidación $\quad \mathbf{X}$ Reconstrucción $\square$ Sustitución

Descripción

No tradicional

Tipo de técnica Similar a la existente

3.4. VANOS

Tipo de intervención

cemento y pintura

Tipo de material

Intervenido

区 Actualización $\square$ Reintegración $\square$ Demolición $\square$ Otro...

$\square$ Consolidación $\quad \square$ Reconstrucción $\square$ sustitución

Descripción

No tradicional

Tipo de técnica Diferente a la existente

3.5. CUBIERTA

Tipo de intervención

Se ha colocado baldosas cerámicas recercando los huecos

Tipo de intervención

Intervenido

Tipo de material

$\square$ Actualización $\quad \mathbf{X}$ Reintegración $\square$ Demolición $\square$ Otro.

Descripción

No tradicional

$\square$ Reconstrucción $\square$ Sustitución

Tipo de técnica Similar a la existente

3.6. OTRAS

Reintegración de elementos con cemento 


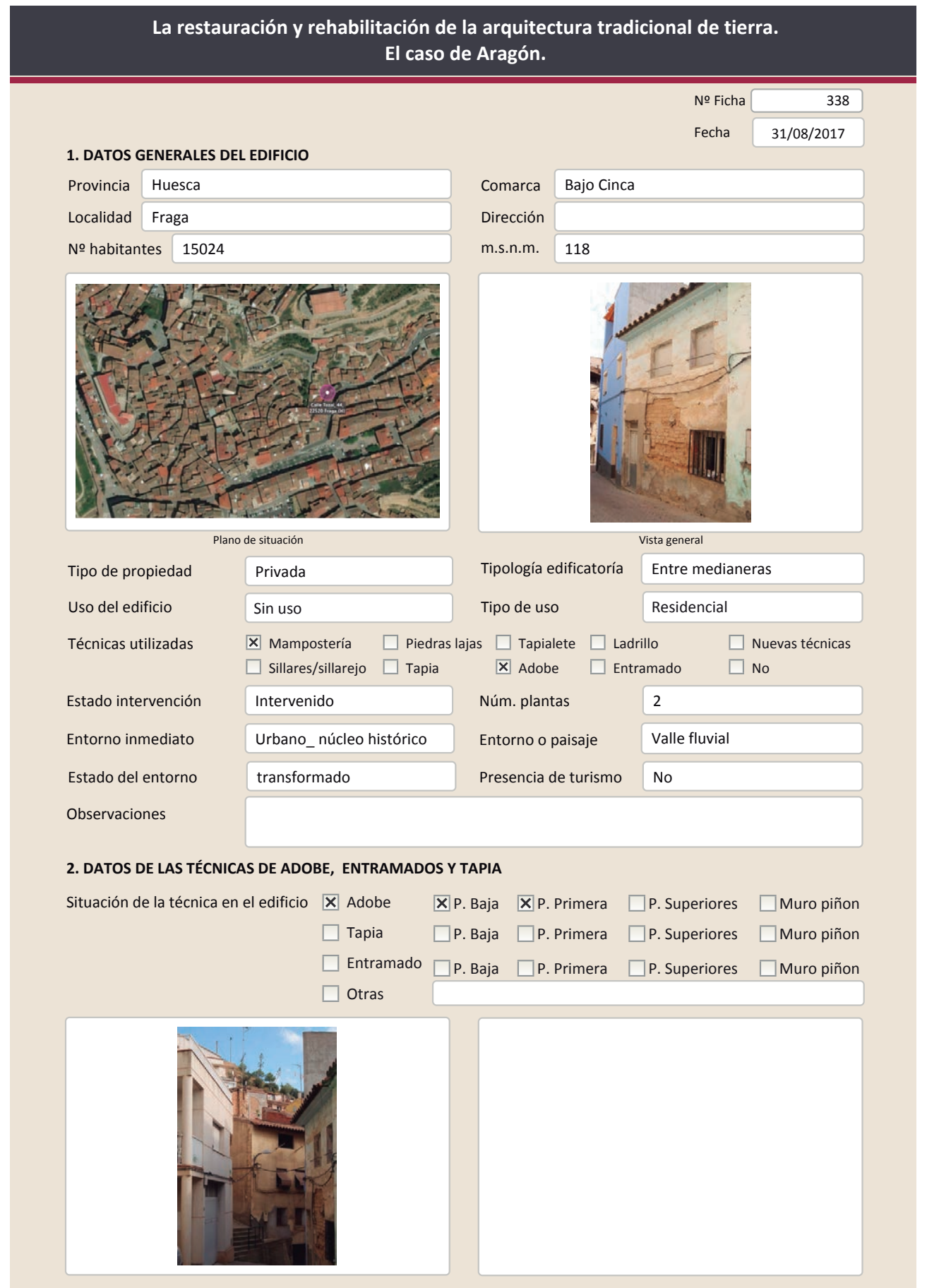

2.1. ADOBE

Dimensión de las piezas Dimensión del muro

Aparejo del muro

\begin{tabular}{|l|}
\hline \\
\hline $30-40 \mathrm{~cm}$ \\
\hline Tizón \\
\hline $\mathrm{Si}$ \\
\hline
\end{tabular}

Color de las piezas

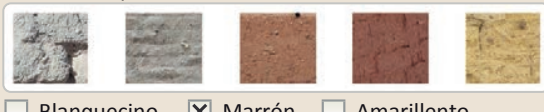

$\square$ Blanquecino $\mathbf{X}$ Marrón $\square$ Amarillento $\square$ Grisaceo $\square$ Rojizo $\square$ Otro...

Función estructural

Comp. - estabilizante

Variante constructiva/ tipo de fábrica

$\square$ Simple
$\boldsymbol{X}$ Suplementada en juntas
Verticales y horizontales
$\square$ Mixta
$\square$ Como suplemento
$\mathbf{X}$ Elementos de protección

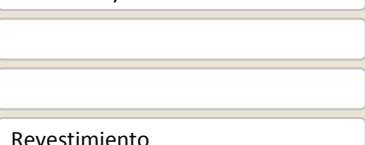
Revestimiento

$\mathrm{Cal} /$ yeso

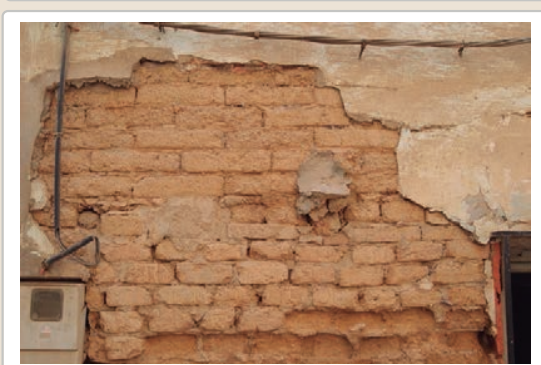

Lesiones X $\quad$ Muro $\mathbf{X}$ Zócalo $\mathbf{X}$ Revestimiento $\mathbf{X}$ Erosión del material $\mathbf{X}$ Humedad por capilaridad $\mathbf{X}$ Erosion de las juntas $\mathbf{X}$ Humedades (manch/eflo) \ Pérdida de sección $\quad \square$ Pérdida de verticalidad

$\square$ Vegetación $\square$ Vesconchados $\quad \square$ Grietas porfalta de traba
X

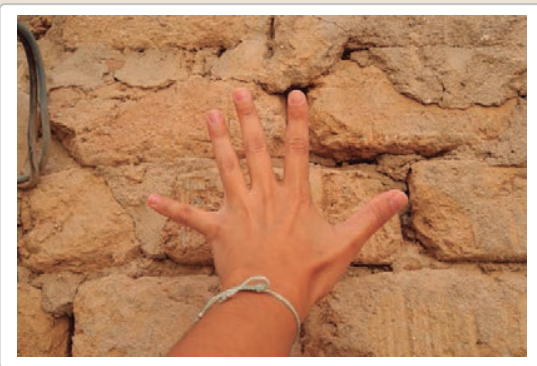

$\square$ Cubierta $\square$ Otro...

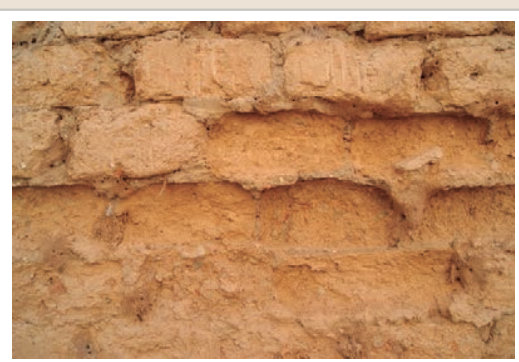

Observaciones La colocación de un zócalo de cemento ha producido que la humedad ascienda I punto inmediatamente superior a este. 


\section{La restauración y rehabilitación de la arquitectura tradicional de tierra.}

\section{El caso de Aragón.}

3. DATOS DE LA INTERVENCIÓN

\begin{tabular}{|c|c|c|c|c|}
\hline Intervención de: & $\begin{array}{l}\square \text { Mantenimiento } \\
\mathbf{X} \text { Reparación }\end{array}$ & $\begin{array}{l}\square \text { Rehabilitación parcial } \\
\square \text { Rehabilitación integral }\end{array}$ & $\begin{array}{l}\square \text { Restauración } \\
\square \text { Ampliación }\end{array}$ & $\begin{array}{l}\square \text { Demolición } \\
\square \text { Otro... }\end{array}$ \\
\hline Reflexión previa & \multicolumn{4}{|c|}{ Intervención espontanea } \\
\hline erva & & & & \\
\hline
\end{tabular}

\subsection{MUROS}

Tipo de intervención

No intervenido

Tipo de material

$\square$ Actualización $\square$ Reintegración $\square$ Demolición $\square$ Otro... $\square$ Consolidación $\square$ Reconstrucción $\square$ sustitución

Descripción

3.2. ZÓCALO

Tipo de intervención

Intervenido

$\square$ Actualizació

Tipo de material

Descripción

3.3. REVESTIMIENTOS

Zócalo con mortero de cemento

Tipo de intervención

No intervenido

Tipodenaterat

$\square$ Actualización $\quad \square$ Reintegración $\quad \square$ Demolición
$\square$ Consolidación $\quad \square$ Reconstrucción $\quad \square$ Sustitución

$\square$ Reintegración $\square$ Demolición $\square$ Otro...

Tipo de material

Descripción

3.4. VANOS

Tipo de intervención

Tipo de material

Intervenido

Descripción

$\square$ Actualización $\quad \mathbf{X}$ Reintegración $\square$ Demolición $\square$ Otro...

$\square$ Consolidación $\quad \square$ Reconstrucción $\square$ sustitución

3.5. CUBIERTA

\begin{tabular}{|l|l|l} 
No tradicional & Tipo de técnica & Diferente a la existente
\end{tabular}

Tipo de intervención

Integración de rejas en ventanas con ladrillo hueco
jambas y dintel de la puerta de acceso. Cemento

Tipo de material

No visible

Descripción

$\square$ Actualización $\square$ Reintegración $\square$ Demolición $\square$ Otro.

$\square$ Consolidación $\square$ Reconstrucción $\square$ Sustitución

$$
\text { Tipo de técnica }
$$

No es visible de forma segur aunque si que parece reconstruida con elementos tradicionales

3.6. OTRAS 


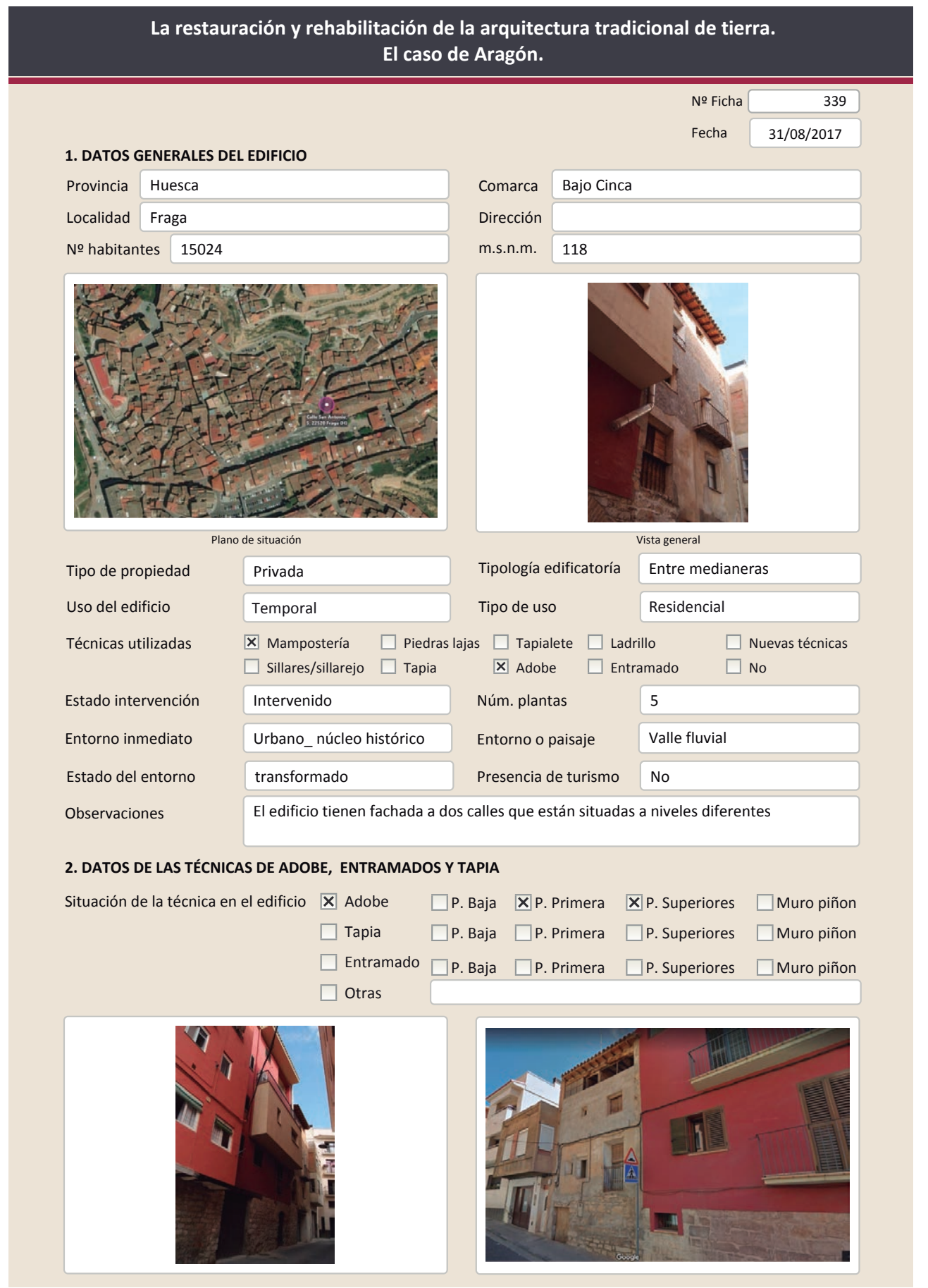

2.1. ADOBE

Dimensión de las piezas Dimensión del muro

Aparejo del muro

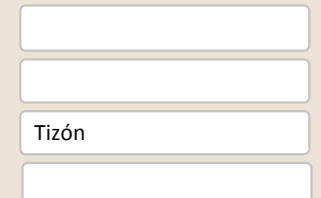

Color de las piezas

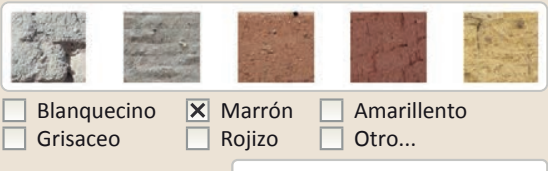

Función estructural

Variante constructiva/ tipo de fábrica

$\square$ Simple

$\square$ Suplementada en juntas

区 Mixta

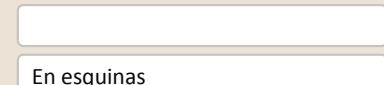

$\square$ Como suplemento

Х Elementos de protección

Revestimiento

Ladrillo revestimiento parcialmente perdido

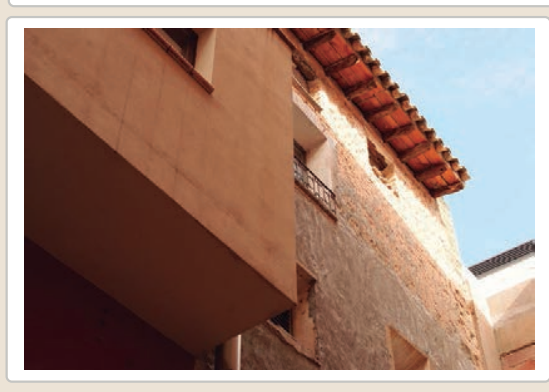

Lesiones $\quad \mathbf{X}$ Muro $\square$ Zócalo $\square$ Revestimiento $\square$ Cubierta $\square$ otro...

X Erosión del material $\quad \square$ Humedad por capilaridad $\quad \square$ Grietas por asentamientos $\square$ Erosion de las juntas $\square$ Humedades (manch/eflo) $\quad \square$ Colapso

$\square$ Pérdida de sección $\square$ Pérdida de verticalidad

$\square$ Por elementos impropios

$\square$ Vegetación

$\square$ Grietas por empuje de la cubierta $\quad \square$ Derivado de intervenciones

$\square$ Desconchados $\square$ Grietas porfalta de traba

$\square$ Derivado
$\square$ Otro...

Observacione 
La restauración y rehabilitación de la arquitectura tradicional de tierra.

\section{El caso de Aragón.}

3. DATOS DE LA INTERVENCIÓN

\begin{tabular}{|c|c|c|c|c|}
\hline Intervención de: & $\begin{array}{l}\square \text { Mantenimiento } \\
\square \text { Reparación }\end{array}$ & $\begin{array}{l}\text { X Rehabilitación parcial } \\
\square \text { Rehabilitación integral }\end{array}$ & $\begin{array}{l}\square \text { Restauración } \\
\square \text { Ampliación }\end{array}$ & $\begin{array}{l}\square \text { Demolición } \\
\square \text { Otro... }\end{array}$ \\
\hline Reflexión previa & \multicolumn{4}{|c|}{ Intervención planificada } \\
\hline Observaciones & \multicolumn{4}{|c|}{ Conjunto de intervenciones independientes unas de otras } \\
\hline
\end{tabular}

3.1. MUROS

Intervenido

Tipo de intervención

$\square$ Actualización $\quad$ X Reintegración $\square$ Demolición $\square$ Otro..

Tipo de material

$\square$ Consolidación $\square$ Reconstrucción $\square$ sustitución

Descripción

No tradicional $\quad$ Tipo de técnica Diferente a la existente

3.2. ZÓCALO

Reintegración del muro de adobe en la zona superior con pellas de mortero de cemento

Tipo de intervención

Intervenido

Tipo de material

$\square$ Actualización $\quad \mathbf{X}$ Reintegración $\quad \square$ Demolición $\quad \square$ Otro...

$\begin{array}{ll}\square \text { Actualización } & \boldsymbol{x} \text { Reintegración } \\ \square \text { Consolidación } \quad \square \text { Reconstrucción } \quad \square \text { Sustitución }\end{array}$

Descripción

3.3. REVESTIMIENTOS

Rejuntado de la mampostería del zócalo

Tipo de intervención

Intervenido

Tipo de material

$\square$ Reintegración $\square$ Demolición $\square$ Otro...

Tipo de materia

No tradicional

$\mathbf{X}$ Reconstrucción $\square$ Sustitución

Descripción

Reconstrucción parcial del revestimiento

3.4. VANOS

Intervenido

Tipo de intervención

$\square$ Actualización $\square$ Reintegración $\square$ Demolición $\square$ Otro...

$\square$ Consolidación $\square$ Reconstrucción $\quad \boldsymbol{X}$ Sustitución

Tipo de material

No tradicional Tipo de técnica Diferente a la existente

Descripción

Sustitución del vano principal de la calle inferior. Ampliación del mismo y colocación de un perfil metálico como dintel del mismo. Nueva carpinería.

3.5. CUBIERTA Intervenido

Tipo de intervención

$\square$ Actualización $\quad \boldsymbol{X}$ Reintegración $\square$ Demolición $\square$ Otro..

Tipo de material

$\square$ Consolidación $\quad \square$ Reconstrucción $\square$ Sustitución

Descripción

Tipo de técnica Similar a la existente

3.6. OTRAS

Reintegración de la cubierta con cemento 


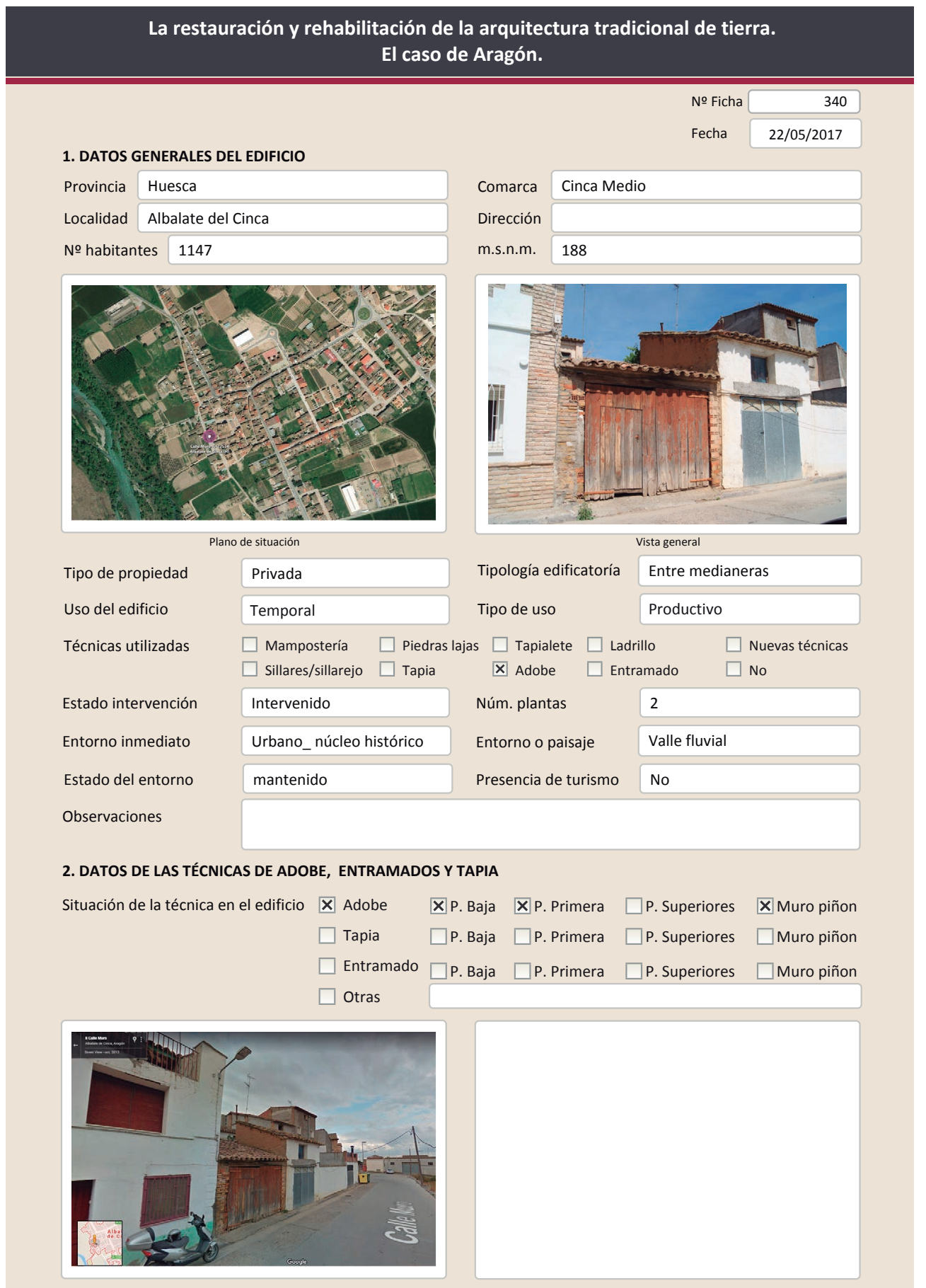

2.1. ADOBE

Dimensión de las piezas Dimensión del muro

Aparejo del muro

\begin{tabular}{|l|}
\hline \\
\hline $30-40 \mathrm{~cm}$ \\
\hline Tizón \\
\hline $\mathrm{Si}$ \\
\hline
\end{tabular}

Color de las piezas

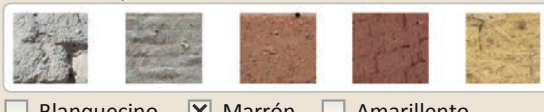

$\square$ Blanquecino $\mathbf{X}$ Marrón $\square$ Amarillento $\square$ Grisaceo $\square$ Rojizo $\square$ Otro...

Función estructural

Comp. - estabilizante

Variante constructiva/ tipo de fábrica

$\square$ Simple
$\boldsymbol{X}$ Suplementada en juntas
Verticales $\mathrm{y}$ horizontales
$\square$ Mixta
$\square$ Como suplemento
$\square$ Elementos de protección

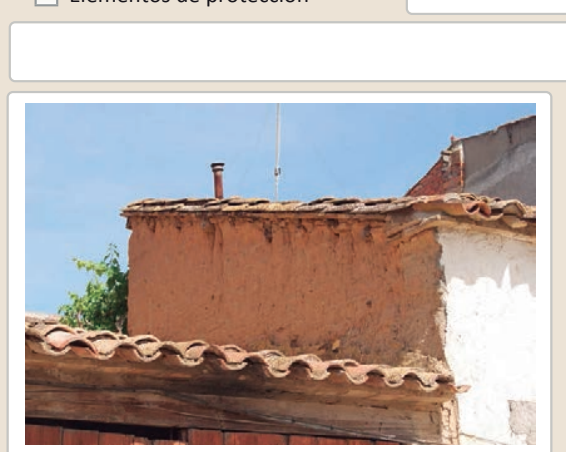

Lesiones $\square$ Muro $\square$ Zócalo $\square$ Revestimiento

X Erosión del material $\quad \square$ Humedad por capilaridad $\square$ Erosion de las juntas $\square$ Humedades (manch/eflo)

$\square$ Pérdida de sección $\square$ Pérdida de verticalidad

$\square$ Vegetación $\quad \square$ Grietas por empuje de la cub

$\square$ Desconchados

$\square$ Grietas por empuje de la

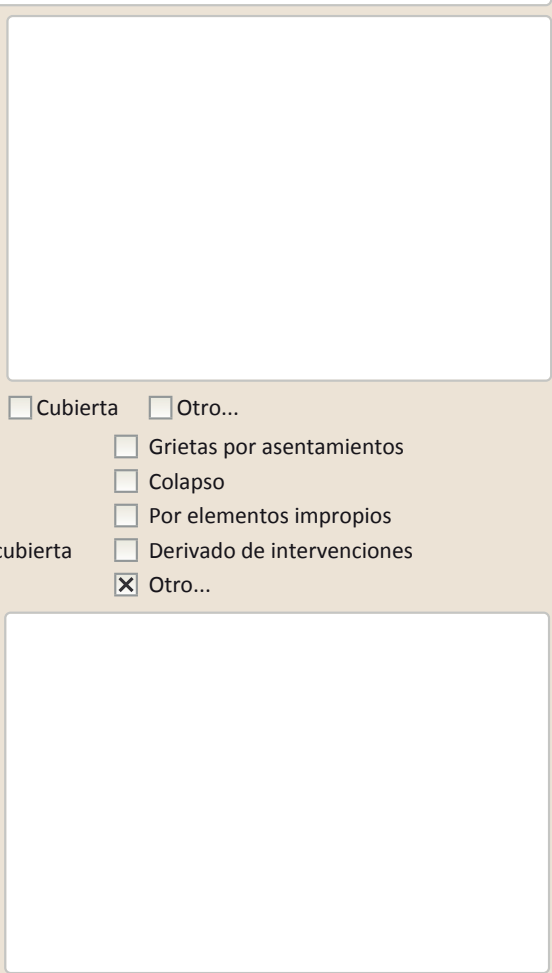

Observaciones 


\section{La restauración y rehabilitación de la arquitectura tradicional de tierra.}

\section{El caso de Aragón.}

3. DATOS DE LA INTERVENCIÓN

Intervención de:

$\square$ Mantenimiento $\quad \mathbf{X}$ Rehabilitación parcial

$\square$ Restauración $\square$ Demolición

Reflexión previa

$\square$ Reparación

Rehabilitación integra

$\square$ Ampliación

$\square$ Otro...

Observaciones

Cambio de dintel y puerta principal de acceso.

3.1. MUROS
Tipo de intervención

No intervenido

$\square$ Actualización

$\square$ Consolidació

$\square$ Reintegració

$\square$ Demolición

de técnica

Tipo de material

Descripción

3.2. ZÓCALO

Tipo de intervención

Tipo de material

Descripción

3.3. REVESTIMIENTOS

Tipo de intervención

Tipo de material

Descripción

3.4. VANOS

Tipo de intervención

Tipo de material

Descripción

3.5. CUBIERTA

Tipo de intervención

Tipo de material

Descripción

Intervenido

$\square$ Actualización $\quad \square$ Reintegración $\quad \square$ Demolición $\quad \square$ Otro...

$\square$ Consolidación $\quad \mathbf{X}$ Reconstrucción $\square$ Sustitución

No tradicional Tipo de técnica Diferente a la existente

revestimiento de cemento

\section{Intervenido}

X Actualización $\quad \square$ Reintegración $\quad \square$ Demolición $\square$ Otro...

$\square$ Consolidación $\quad \mathbf{X}$ Reconstrucción $\square$ sustitución

No tradicional Tipo de técnica Similar a la existente

Nuevo revestimiento de cemento en fachada con pintura plástica blanca. Se puede apreciar en la arista con la fachada lateral

Intervenido

$\square$ Actualización $\square$ Reintegración $\square$ Demolición $\square$ Otro...

$\square$ Consolidación $\square$ Reconstrucción $\quad \boldsymbol{x}$ Sustitución

No tradicional Tipo de técnica Diferente a la existente

Nuevo dintel de hormigón revestido de cemento en la puerta de acceso. Actualmente la puerta es metálica aunque presumiblemente sería de madera.

Intervenido

$\square$ Actualización $\quad \boldsymbol{X}$ Reintegración $\square$ Demolición $\square$ Otro..

$\square$ Consolidación $\quad \square$ Reconstrucción $\square$ Sustitución
No tradicional
Tipo de técnica Similar a la existente

3.6. OTRAS

Reintegración de algunas de las tejas con mortero de cemento
La restauración y rehabilitación de la arquitectura tradicional de tierra.

El caso de Aragón.

3.7. REHABILITACIÓN ENERGÉTICA $\quad \square$ Fachada $\square$ Vanos $\square$ Forjados $\square$ Cubierta

Observaciones

FOTOGRAFÍAS DE LA INTERVENCIÓN
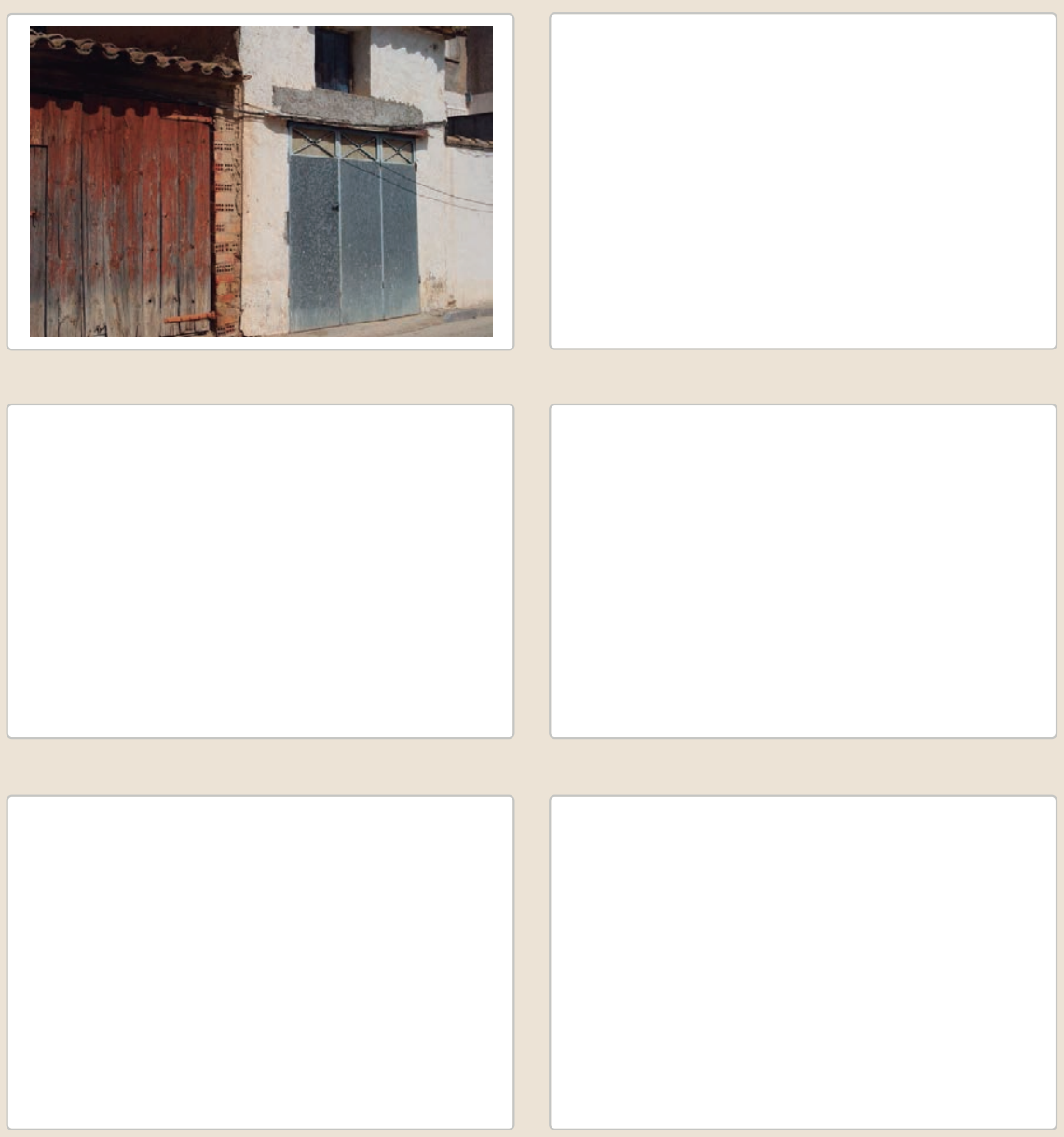


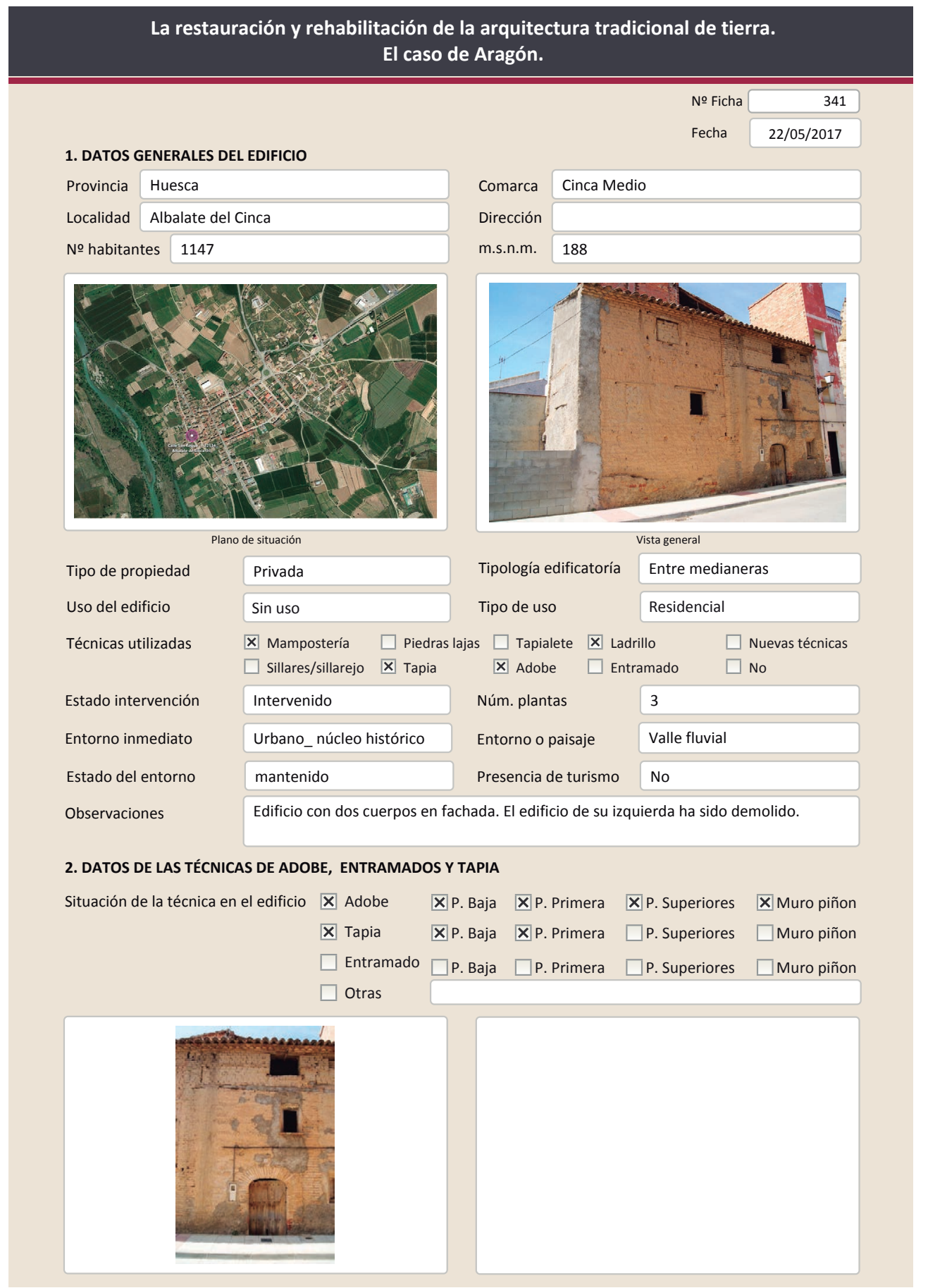

\begin{tabular}{l|l|} 
2.1. ADOBE & \\
Dimensión de las piezas & $18 \times \dot{\imath} ? \times 10$ \\
\hline $\begin{array}{l}\text { Dimensión del muro } \\
\text { Aparejo del muro }\end{array}$ & $30-40 \mathrm{~cm}$ \\
\hline Función estructural & $\mathrm{Si}$ \\
\hline
\end{tabular}

Función estructural $\mathrm{Si}$

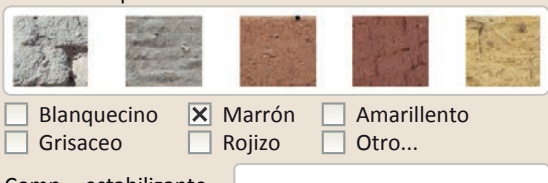

Comp. - estabilizante

Variante constructiva/ tipo de fábrica

$\square$ Simple

$\square$ Suplementada en juntas

X Mixta

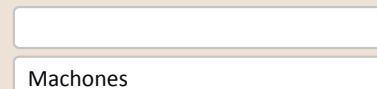

$\square$ Como suplemento

$\square$ Elementos de protección

En la parte superior derecha hay una verdugada de dos hiladas de ladrillo

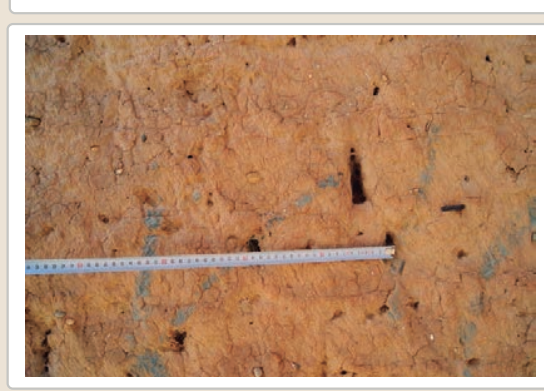

Lesiones ХMuro ХZŹcalo $\square$ Revestimiento

$\mathbf{X}$ Erosión del material $\mathbf{X}$ Humedad por capilaridad X Erosion de las juntas $\square$ Humedades (manch/eflo) X Pérdida de sección $\quad \square$ Pérdida de verticalidad

$\square$ Vegetación $\quad \square$ Grietas por empuje de la cu

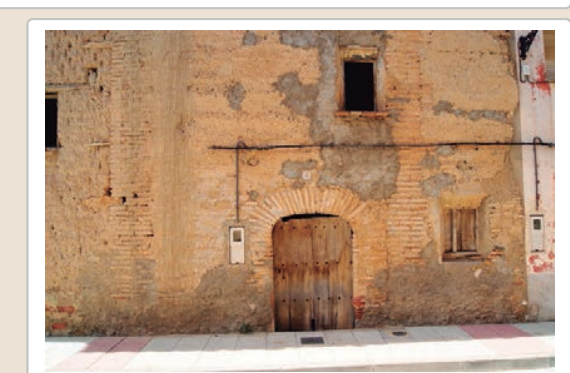

$\square$ Grietas porfalta de traba

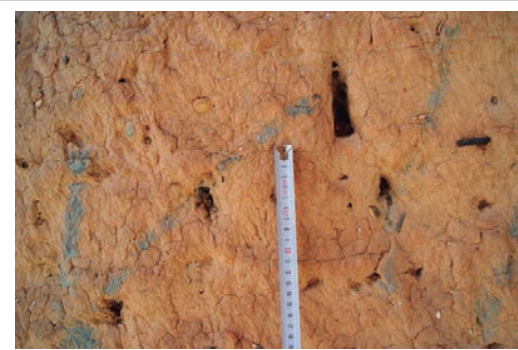

X Cubierta $\square$ Otro...

$\square$ Grietas por asentamiento

$\square$ Colapso

$\square$ Por elementos impropios

$\mathbf{X}$ Derivado de intervenciones X Otro...

Observaciones 


\section{La restauración y rehabilitación de la arquitectura tradicional de tierra.}

\section{El caso de Aragón.}

\subsection{TAPIA}

Ancho del muro

$$
40-50 \mathrm{~cm}
$$

Color de la tapia

Dimensión tapiales

Tipo de aguja

№ agujas/cajón
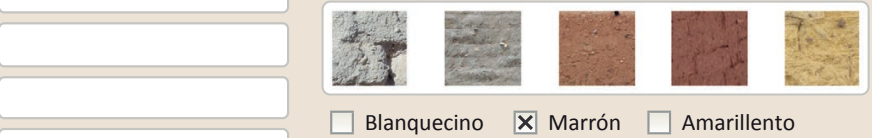

$\square$ Blanquecino $\mathbf{X}$ Marrón $\square$ Amarillento $\square$ Grisaceo

Rojizo $\square$ Otro...

Variante constructiva

$\square$ Simple / homogénea

$\mathbf{X}$ Suplemento superficial

$\square$ suplemento en juntas

X Mixta

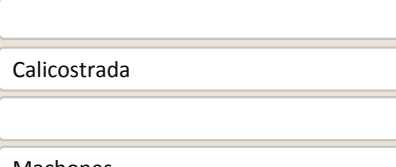

Machones

\begin{tabular}{l}
\hline Cal/ yeso \\
\hline Ladrillo
\end{tabular}

$\square$ Elementos de protección

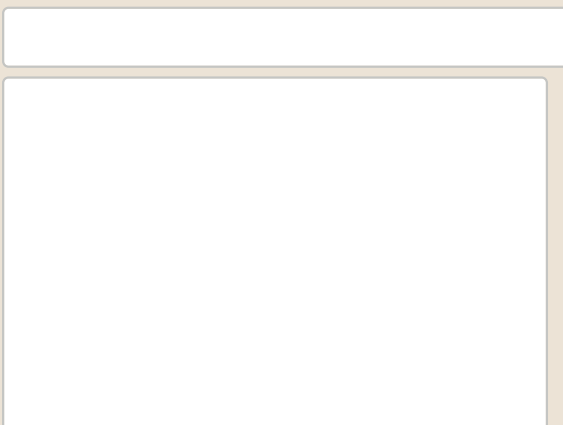

Lesiones \Muro $\square$ Zócalo $\square$ Revestimiento $\square$ Cubierta $\square$ Otro...

区 Erosión del material $\square$ Humedad por capilaridad $\quad \square$ Grietas por asentamientos

$\square$ Erosion de las juntas $\square$ Humedades (manch/eflo) $\quad \square$ Colapso

$\square$ Pérdida de sección $\square$ Pérdida de verticalidad $\square$ Por elementos impropios

$\square$ vegetación $\quad \square$ Grietas por empuje de la cubierta $\square$ Derivado de intervenciones

$\square$ Desconchados $\square$ Grietas porfalta de traba $\quad$ X Otro...
La restauración y rehabilitación de la arquitectura tradicional de tierra.

El caso de Aragón.
3. DATOS DE LA INTERVENCIÓN

Reflexión previa

Observaciones

X Reparación $\quad \square$ Rehabilitación integral $\square$ Ampliación $\quad \square$ Otro...

3.1. MUROS

Tipo de intervención

Tipo de material

Descripción

3.2. ZÓCALO

Tipo de intervención

Tipo de material

Descripción

3.3. REVESTIMIENTOS

Tipo de intervención

Tipo de material

Descripción

3.4. VANOS

Tipo de intervención

Tipo de material

Descripción

3.5. CUBIERTA

Tipo de intervención

Tipo de material

Descripción

3.6. OTRAS

\section{Intervenido}

$\square$ Actualización $\quad$ X Reintegración $\quad \square$ Demolición $\square$ Otro...

$\square$ Consolidación $\quad \square$ Reconstrucción $\square$ Sustitución

\begin{tabular}{|l|l|l|} 
No tradicional & Tipo de técnica & Diferente a la existente
\end{tabular}

Rejuntado de muros con cemento

Intervenido

$\square$ Actualización $\times$ Reintegración $\square$ Demolición $\square$ Otro.

$\square$ Consolidación $\square$ Reconstrucción $\square$ Sustitución

No tradicional Tipo de técnica Diferente a la existente

Reintegración del muro de adobe con cemento y ladrillo hueco en la pare inferior del edificio donde se había perdido parte de la sección

Intervenido

$\square$ Actualización $\quad \square$ Reintegración $\quad \square$ Demolición $\square$ Otro..

$\square$ Consolidación $\quad \mathbf{X}$ Reconstrucción $\square$ Sustitución

No tradicional Tipo de técnica Diferente a la existente

Revestimiento de cemento en el muro piñón. Es posible que no existiera revestimiento en esa zona antes de la actual intervención

No intervenido

$\square$ Actualización $\square$ Reintegración $\square$ Demolición $\square$ Otro..

$\square$ Consolidación $\quad \square$ Reconstrucción $\square$ Sustitución

Huecos cegados con adobe, algunos de ellos desde la construcción del edificio.

Intervenido

$\square$ Actualización $\quad \mathbf{X}$ Reintegración $\square$ Demolición $\square$ Otro

$\square$ Consolidación $\quad \square$ Reconstrucción $\square$ Sustitución

No tradicional Tipo de técnica Similar a la existente

Reintegración de uno de los lados de la cubierta utilizando mortero de cemento y conservando los elementos tradicionales 
La restauración y rehabilitación de la arquitectura tradicional de tierra. El caso de Aragón

\section{La restauración y rehabilitación de la arquitectura tradicional de tierra.} El caso de Aragón.
3.7. REHABILITACIÓN ENERGÉTICA
$\square$ Fachada $\square$ Vanos $\square$ forjados $\square$ Cubierta

Observaciones

FOTOGRAFÍAS DE LA INTERVENCIÓN
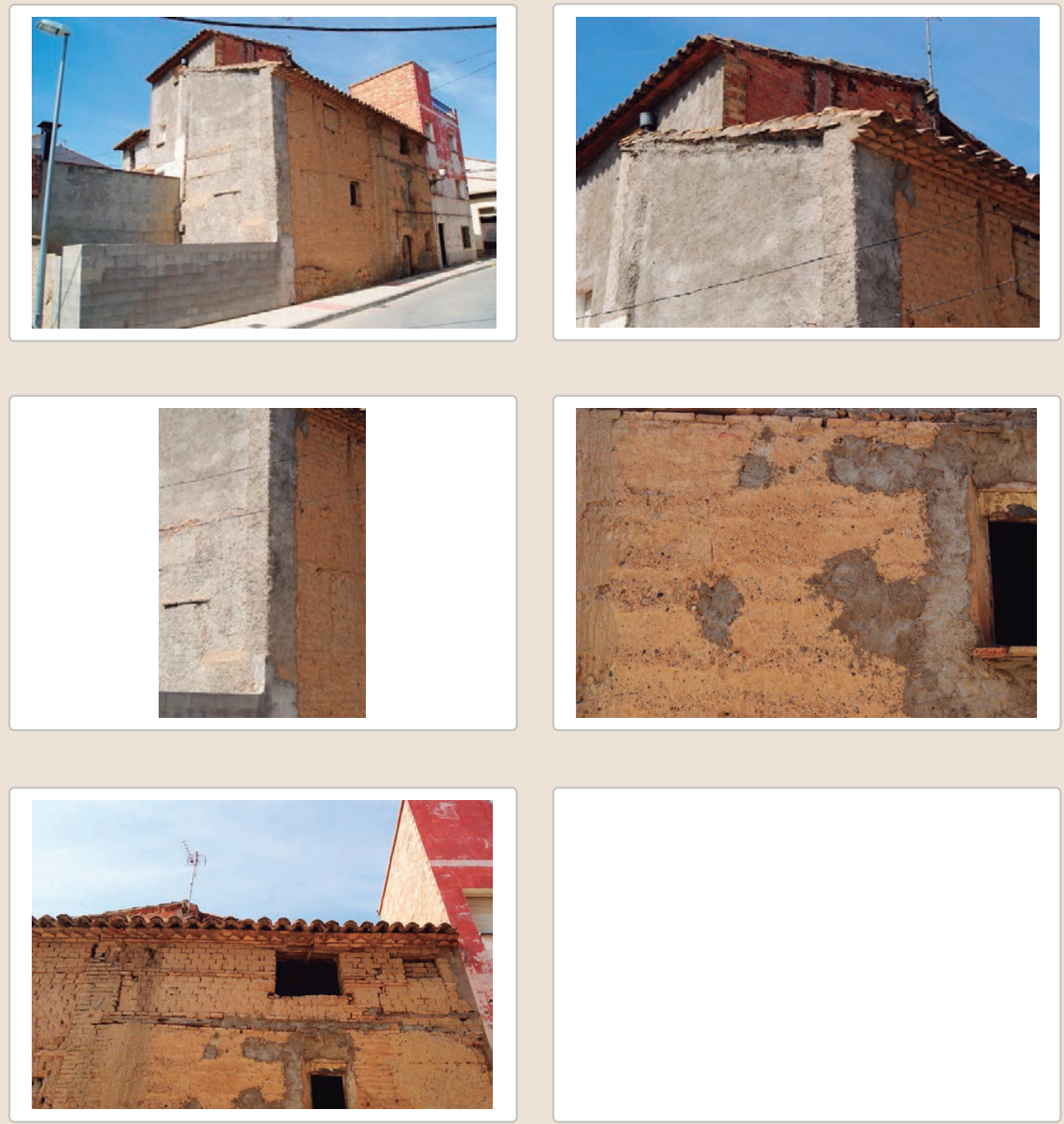


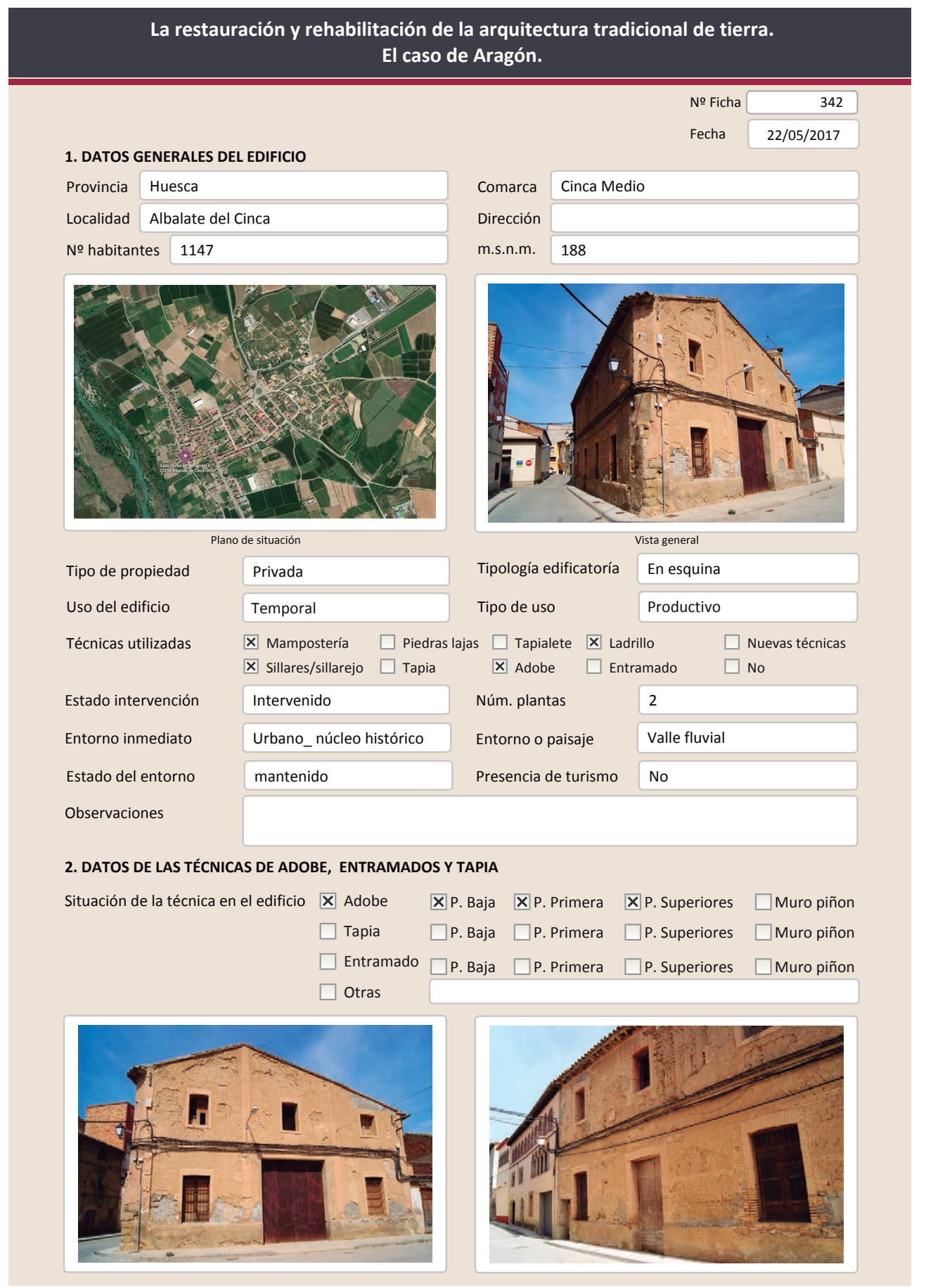

La restauración y rehabilitación de la arquitectura tradicional de tierra. El caso de Aragón.

\begin{tabular}{l|l|} 
2.1. ADOBE & \\
Dimensión de las piezas & $18 \times \dot{e} ? \times 10$ \\
Dimensión del muro & $30-40 \mathrm{~cm}$ \\
\hline Aparejo del muro & Tizón \\
Función estructural & $\mathrm{Si}$
\end{tabular}

Función estructural

Variante constructiva/ tipo de fábrica

$\square$ Simple

$\square$ Suplementada en juntas

X Mixta

$\square$ Como suplemento

X Elementos de protección

Machones y verdugadas de forma aleatoria. No conforman una retícula regular

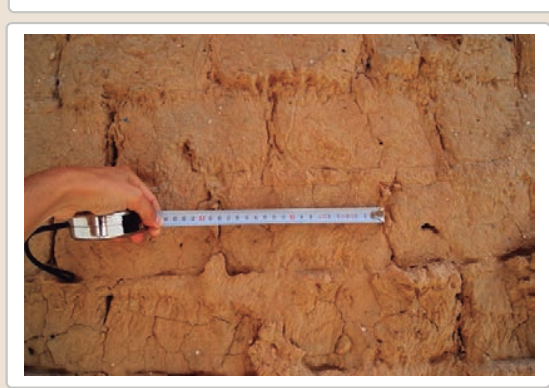

Lesiones ХMuro ХZócalo Х Revestimiento

$\mathbf{X}$ Erosión del material $\mathbf{X}$ Humedad por capilaridad $\mathbf{X}$ Erosion de las juntas $\square$ Humedades (manch/eflo)

$\square$ Pérdida de sección $\square$ Pérdida de verticalidad

$\square$ Vegetación $\quad \square$ Grietas por empuje de la cubier

$\mathbf{X}$ Desconchados

$\square$ Grietas porfalta de traba

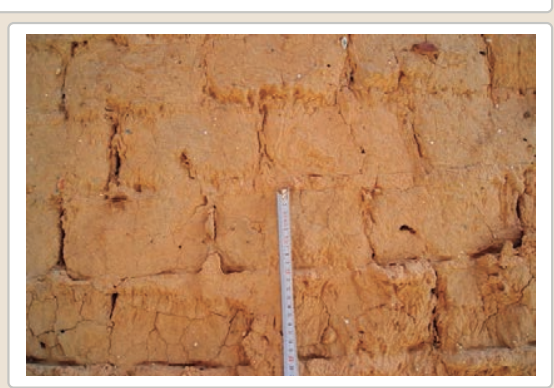

$\square$ Cubierta $\square$ otro...

$\square$ Grietas por asentamientos

$\square$ Colapso

$\square$ Por elementos impropios

$\square$ Derivado de intervenciones

$$
\text { (x) }
$$
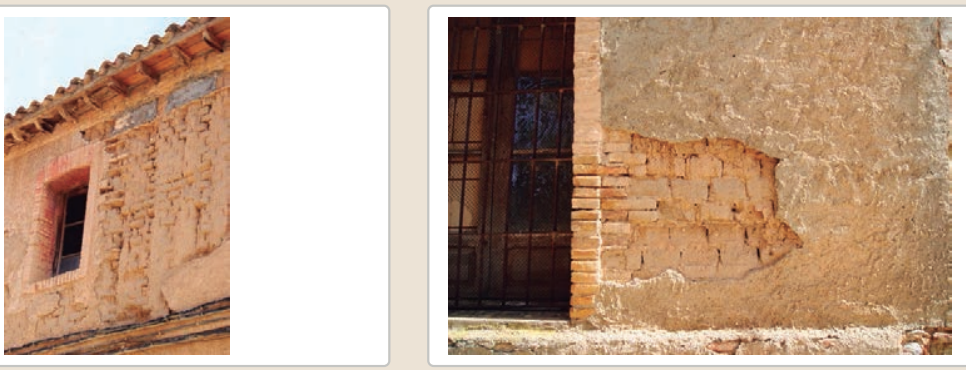

Observaciones

El edificio presenta varias lesiones, principalmente por acción del agua. Estos

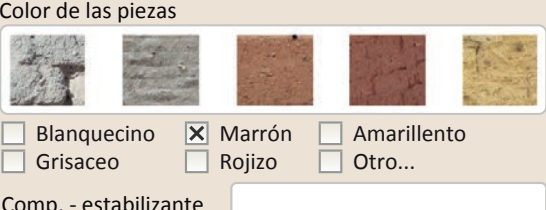
problemas, sin embargo, no tienen un carácter estructural grave.

$$
\text { . }
$$




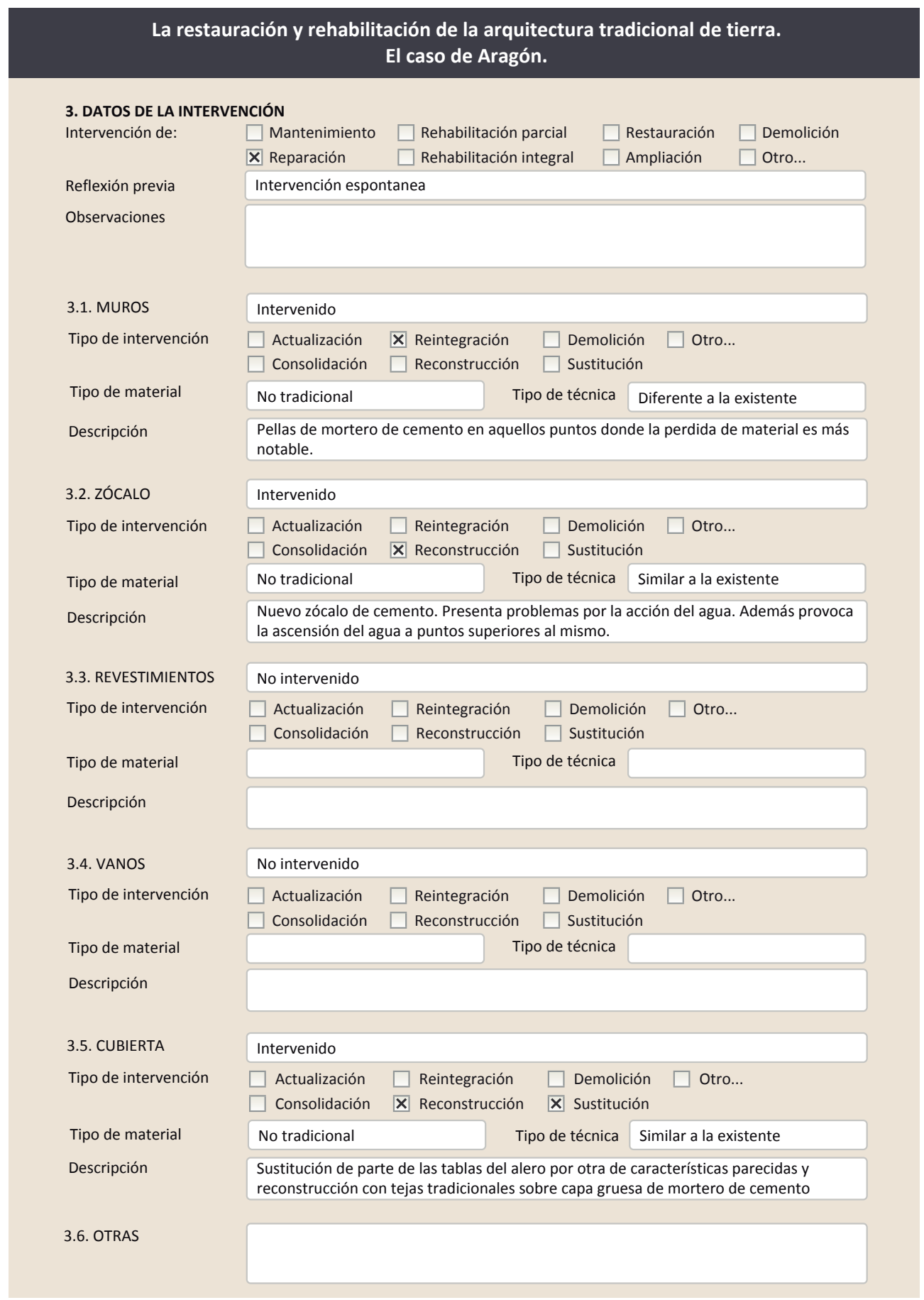

3.7. REHABILITACIÓN ENERGÉTICA $\square$ Fachada $\square$ Vanos $\square$ Forjados $\square$ Cubierta

Observaciones

FOTOGRAFÍAS DE LA INTERVENCIÓN
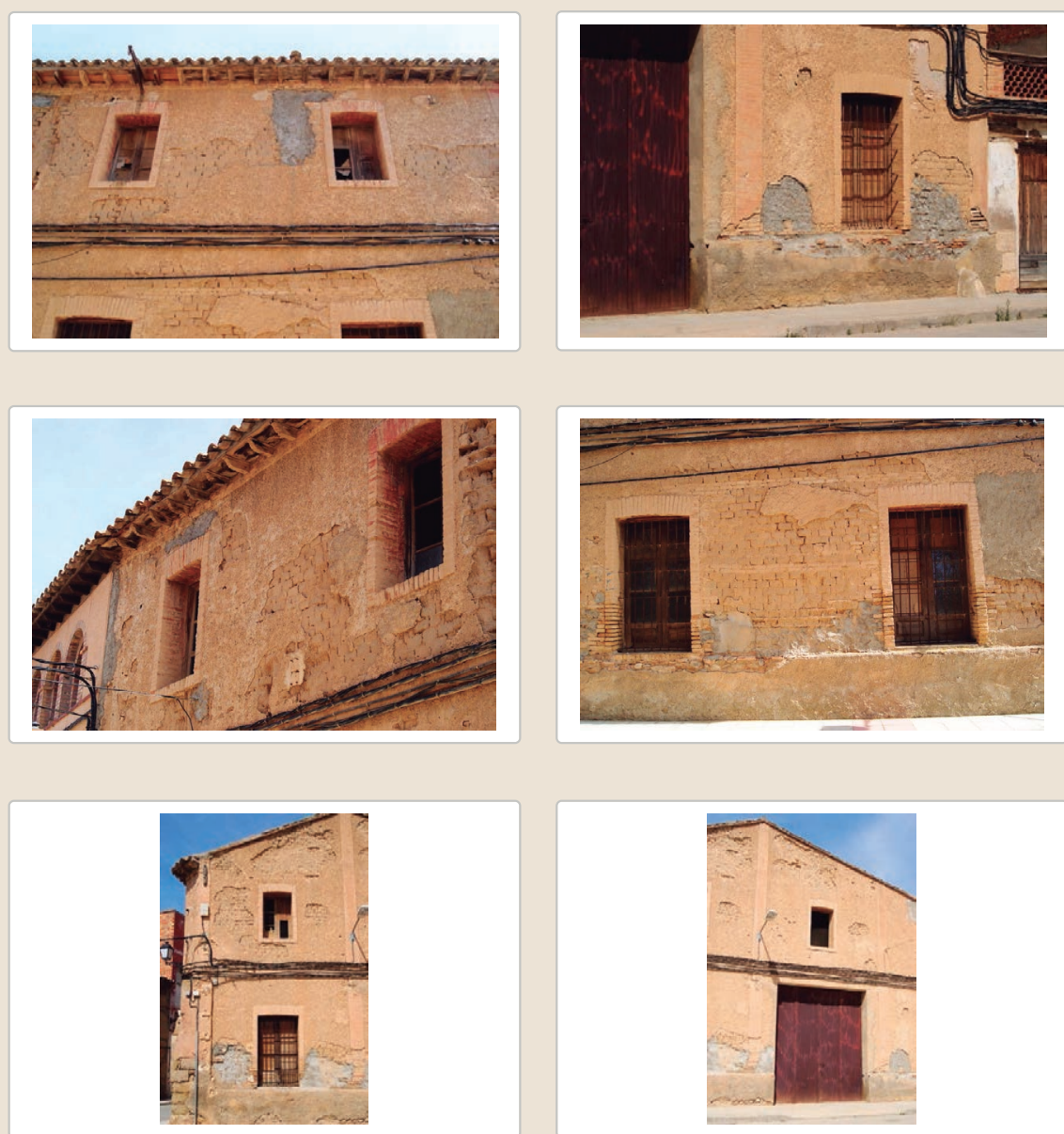


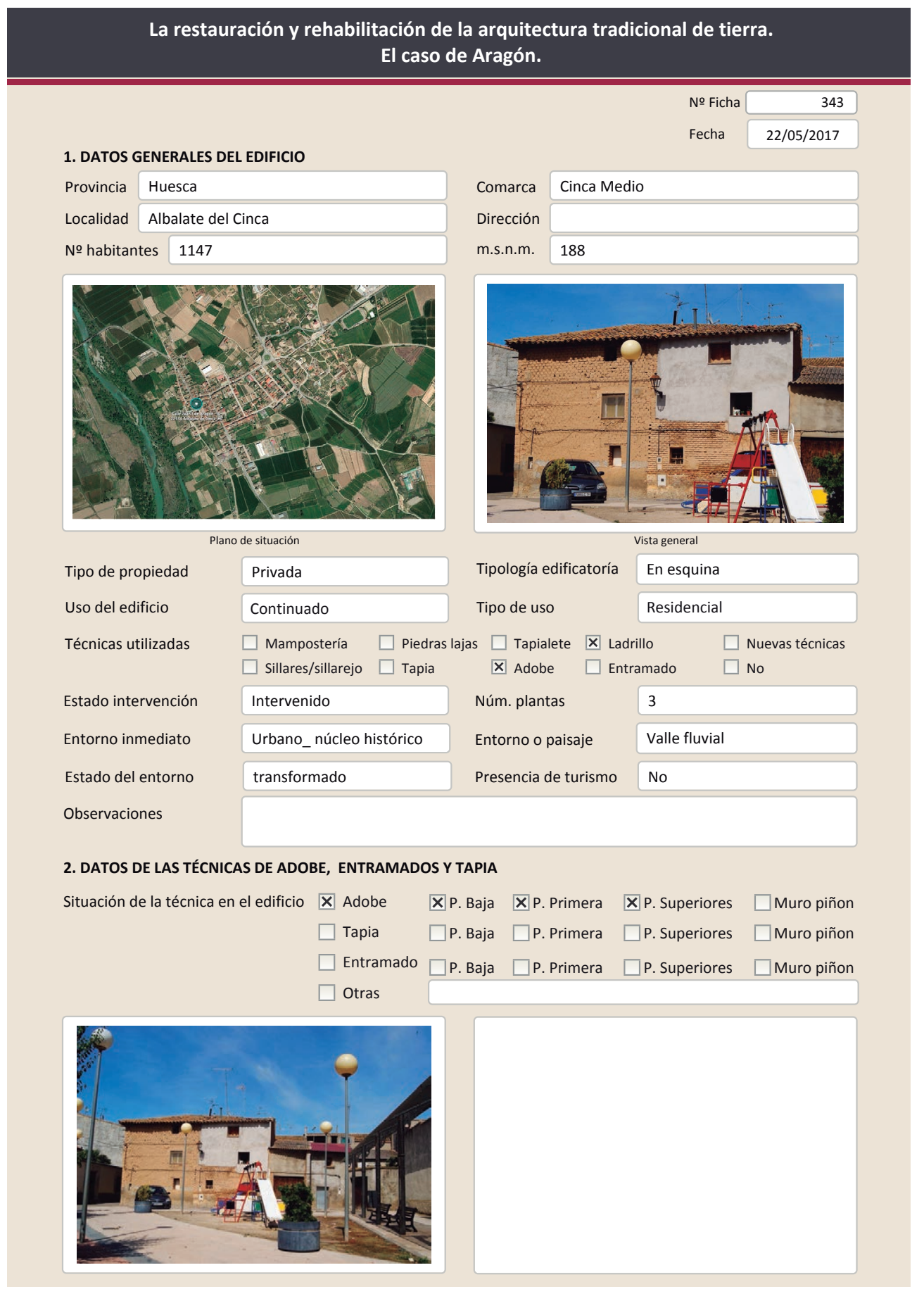

La restauración y rehabilitación de la arquitectura tradicional de tierra.

El caso de Aragón.

\begin{tabular}{ll} 
2.1. ADOBE \\
Dimensión de las piezas \\
Dimensión del muro \\
Aparejo del muro & \\
Función estructural & Tizón \\
\hline
\end{tabular}

Color de las piezas

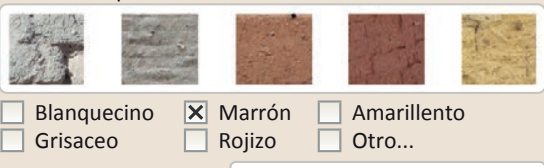

Variante constructiva/ tipo de fábrica
$\square$ Simple
$\square$ Suplementada en juntas
区 Mixta
$\square$ Como suplemento
$\square$ Elementos de protección

Esquinas y verdugadas

Comp. - estabilizante

Rojizo

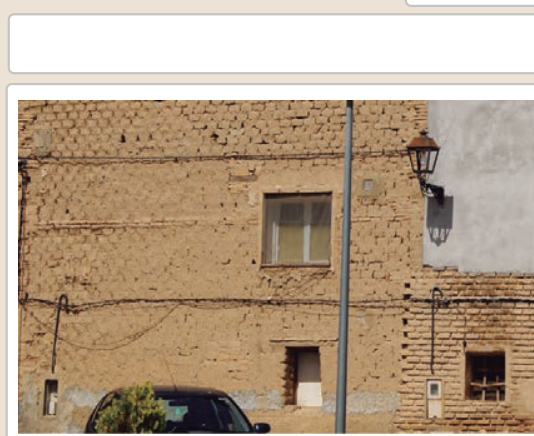

Lesiones $\quad \mathbf{X}$ Muro $\mathbf{X}$ Zócalo $\square$ Revestimiento

$\mathbf{X}$ Erosión del material $\mathbf{X}$ Humedad por capilaridad $\mathbf{X}$ Erosion de las juntas $\square$ Humedades (manch/eflo)

$\square$ Pérdida de sección $\square$ Pérdida de verticalidad

$\square$ Vegetación $\quad \square$ Grietas por empuje de la c $\square$ Grietas porfalta de traba

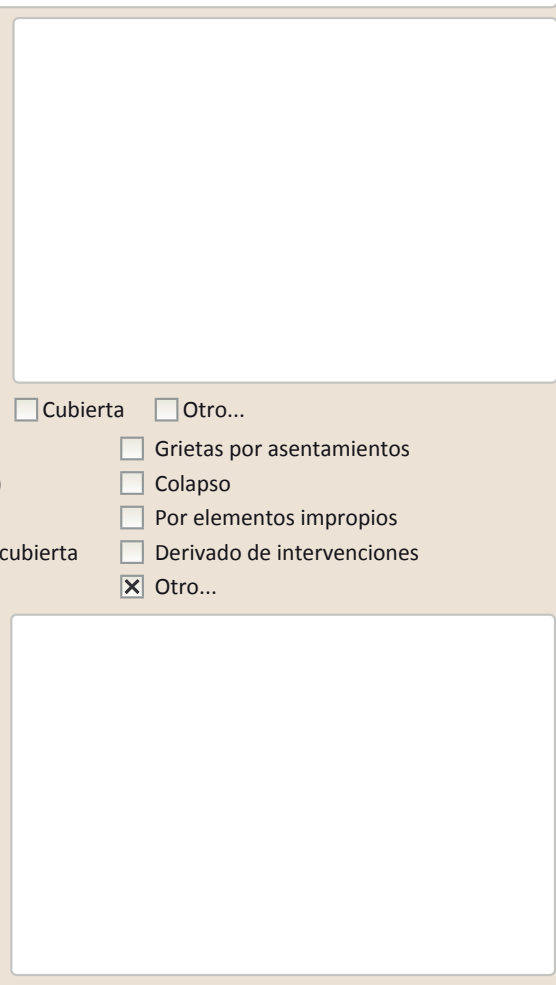

Observaciones 
La restauración y rehabilitación de la arquitectura tradicional de tierra. El caso de Aragón

\section{La restauración y rehabilitación de la arquitectura tradicional de tierra.}

\section{El caso de Aragón.}

3. DATOS DE LA INTERVENCIÓN

Intervención de:

$\square$ Mantenimiento $\square$ Rehabilitación parcia

$\square$ Restauración $\square$ Demolición $x$ Reparación $\square$ Rehabilitación integral $\square$ Ampliación $\quad \square$ Otro...

Reflexión previa Intervención espontanea

Observaciones Nuevo revestimiento de parte del muro de adobe.

\subsection{MUROS}

Tipo de intervención

No intervenido

Tipo de material

$\square$ Actualización $\square$ Reintegración $\square$ Demolición $\square$ Otro...

$\square$ Consolidación $\square$ Reconstrucción $\square$ Sustitución

Descripción

3.2. ZÓCALO

Tipo de intervención

Intervenido

$\square$ Actualizació

$\square$ Reintegración $\square$ Demolición $\square$ Otro...

Tipo de material

Descripción

Nuevo rejuntado de ladrillo de la parte inferior del muro / nuevo revestimiento en esta zona.

3.3. REVESTIMIENTOS

Intervenido

Tipo de intervención

$\square$ Actualización $\square$ Reintegración $\quad \square$ Demolición $\square$ Otro...

$\square$ Consolidación $\quad \mathbf{X}$ Reconstrucción $\square$ Sustitución

Tipo de material

Descripción
No tradicional
Tipo de técnica Similar a la existente

3.4. VANOS

Revestimiento de cemento parcial sobre el muro de adobe.

Tipo de intervención

No intervenido

Tipo de material

$\square$ Actualización $\square$ Reintegración $\square$ Demolición $\square$ Otro...

Descripción

$\square$ Consolidación $\square$ Reconstrucción $\square$ Sustitución

3.5. CUBIERTA

Tipo de intervención

No intervenido

$\square$ Actualización

$\square$ Consolidación $\square$ Reconstrucción $\square$ Sustitución

Tipo de material

Tipo de técnica

Descripción

Tipo de técnica

3.6. OTRAS 


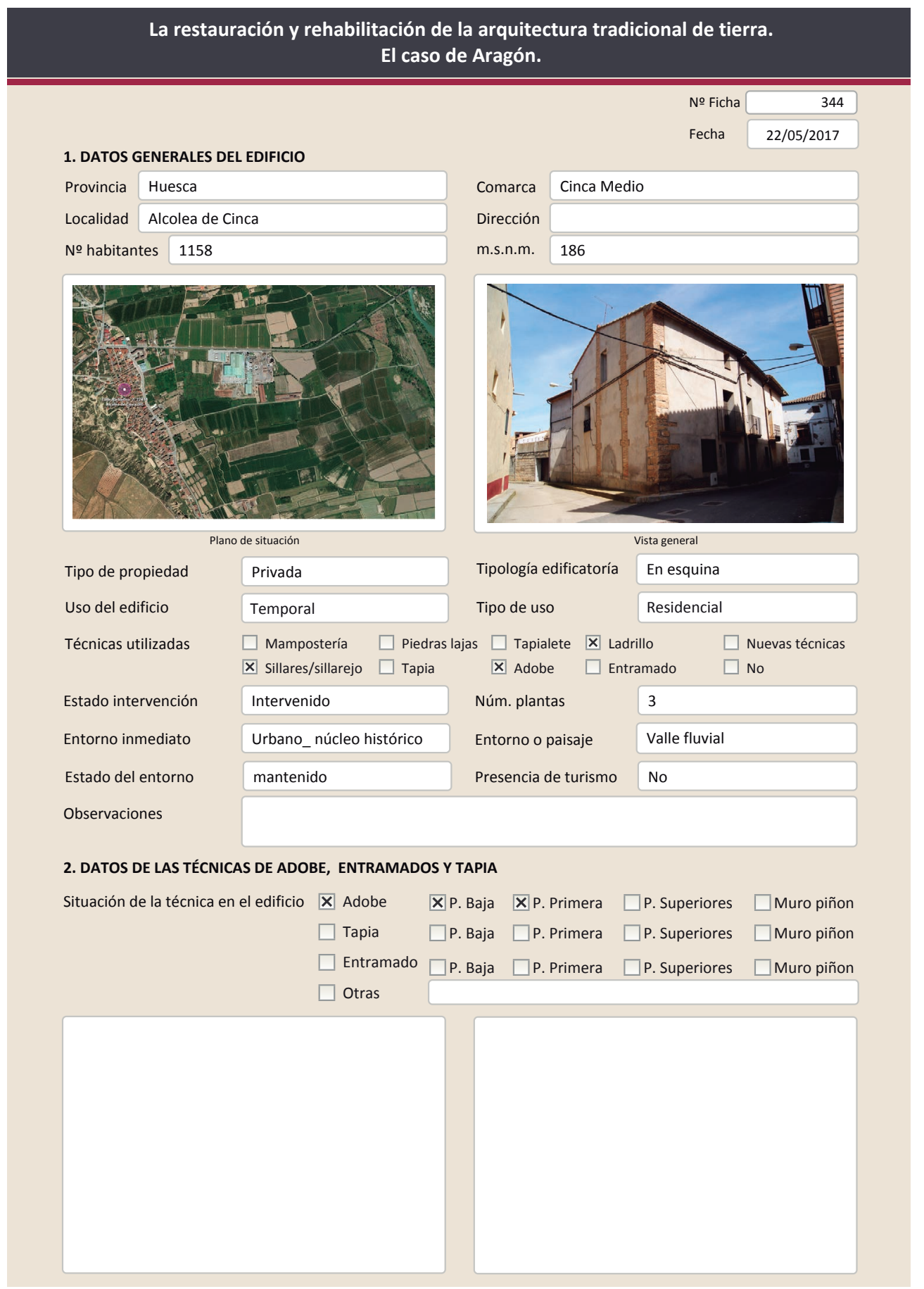

La restauración y rehabilitación de la arquitectura tradicional de tierra.

El caso de Aragón.

2.1. ADOBE

Dimensión de las piezas

Dimensión del muro

Aparejo del muro

Función estructural

constructiva/ tipo de fábrica

$\square$ simple

$\square$ Suplementada en juntas

X Mixta

\section{Machones}

Color de las piezas

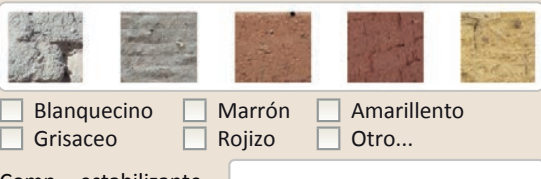

Comp. - estabilizante

$\square$ Como suplemento

$\square$ Elementos de protección

No se pueden ver los adobes por el nuevo revestimiento pero presumiblemente el edificio es de este material ya que existen otros ejemplos como este en la localidad

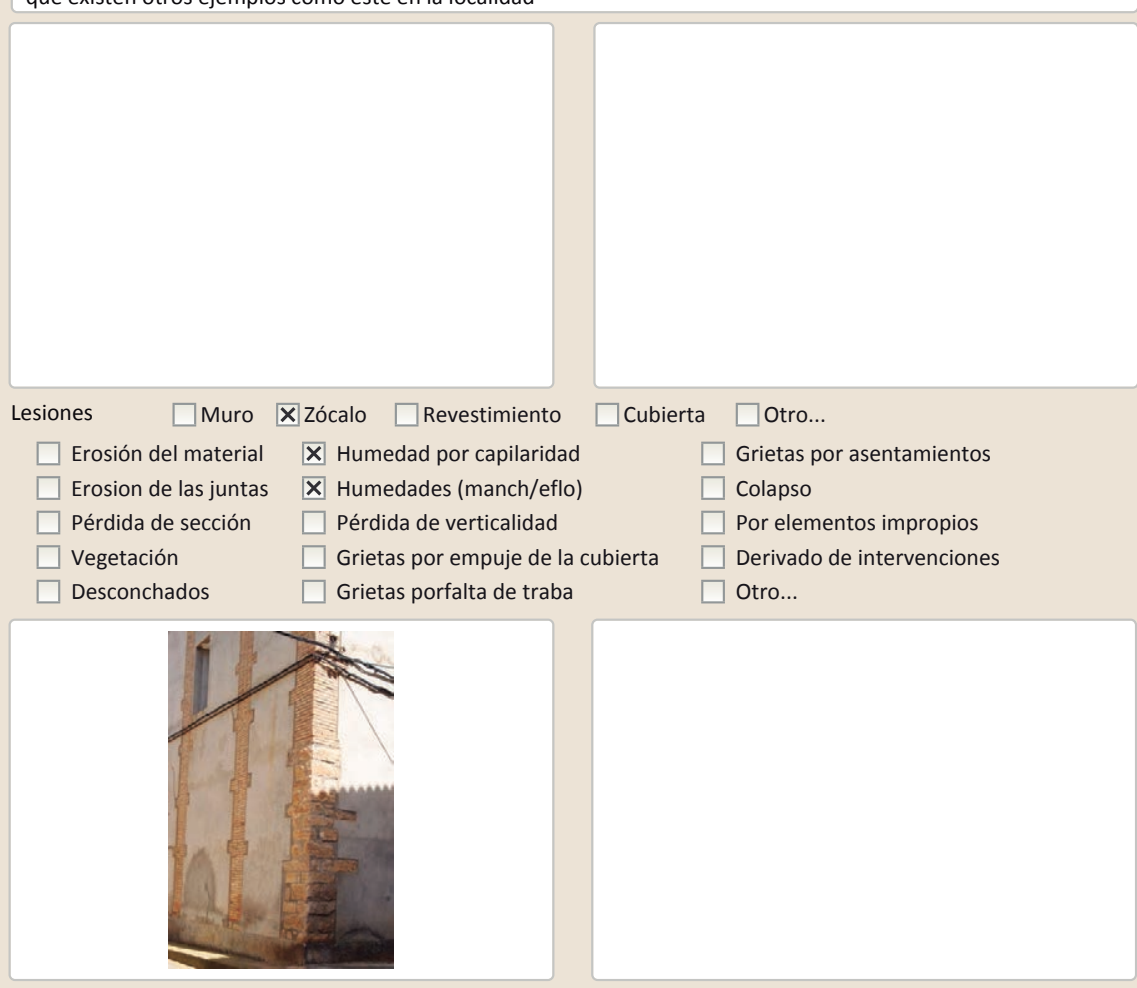

Observaciones 


\section{La restauración y rehabilitación de la arquitectura tradicional de tierra.}

\section{El caso de Aragón.}

3. DATOS DE LA INTERVENCIÓN

$\square$ Mantenimien

Reparación $\square$ Rehabilitación parcial $\square$ Restauración $\square$ Demolición

$\begin{array}{lll} & \square \text { Reparación } \quad \text { Rehabilitación integral } \square \text { Ampliación } \square \text { Otro... } \\ \text { Reflexión previa } & \text { Intervención planificada }\end{array}$

Observaciones Restauración de los paramentos de tierra del edificio, de forma planificada aunque los materiales utilizados no son los idóneos.

3.1. MUROS
Tipo de intervención

Intervenido

Tipo de material

$\square$ Actualización $\square$ Reintegración $\square$ Demolición $\square$ Otro...

$\square$ Consolidación $\quad \mathbf{X}$ Reconstrucción $\square$ Sustitución

\begin{tabular}{|l|l|l|} 
No tradicional & Tipo de técnica & Diferente a la existente \\
\hline
\end{tabular}

Descripción Toda la zona no construida con tierra se ha revestido. Construcción presumiblemente en tierra aunque no es apreciable.

3.2. ZÓCALO

Tipo de intervención

Intervenido

$\square$ Actualización $\square$ Reintegración $\square$ Demolición $\square$ Otro...

$\square$ Consolidación $\quad$ X Reconstrucción $\square$ Sustitución

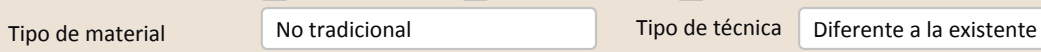

Descripción

3.3. REVESTIMIENTOS

Tipo de intervención

El zócalo anterior a la última intervención es visible. También es de cemento.

\section{Intervenido}

$\square$ Actualización $\square$ Reintegración $\square$ Demolición $\square$ Otro...

$\square$ Consolidación $\quad \mathbf{X}$ Reconstrucción $\square$ Sustitución

Tipo de material

Descripción

3.4. VANOS

Tipo de intervención

Tipo de material

No tradicional

Tipo de técnica Diferente a la existente

Revestimiento completo de la superficie de muro construida con tierra.

Descripción

3.5. CUBIERTA

Tipo de intervención

Tipo de material

Descripción

Intervenido

$\square$ Actualización $\square$ Reintegración $\square$ Demolición $\square$ Otro...

X Consolidación $\square$ Reconstrucción $\mathbf{X}$ Sustitución

\begin{tabular}{l|l|l} 
No tradicional & Tipo de técnica Diferente a la existente
\end{tabular}

Se ha regularizado todos los huecos. Sustitución parcial de carpinterías

Intervenido

$\square$ Actualización $\square$ Reintegración $\square$ Demolición $\square$ Otro.

$\square$ Consolidación $\quad \mathbf{X}$ Reconstrucción $\square$ Sustitución

No tradicional Tipo de técnica Similar a la existente

Reconstrucción de la cubierta con teja cerámica curva. Probablemente se hayan integrado aislante e impermeablilizante.
La restauración y rehabilitación de la arquitectura tradicional de tierra.

El caso de Aragón.

3.7. REHABILITACIÓN ENERGÉTICA $\quad \square$ Fachada $\square$ Vanos $\square$ Forjados $\square$ Cubierta

Observaciones

FOTOGRAFíAS DE LA INTERVENCIÓN
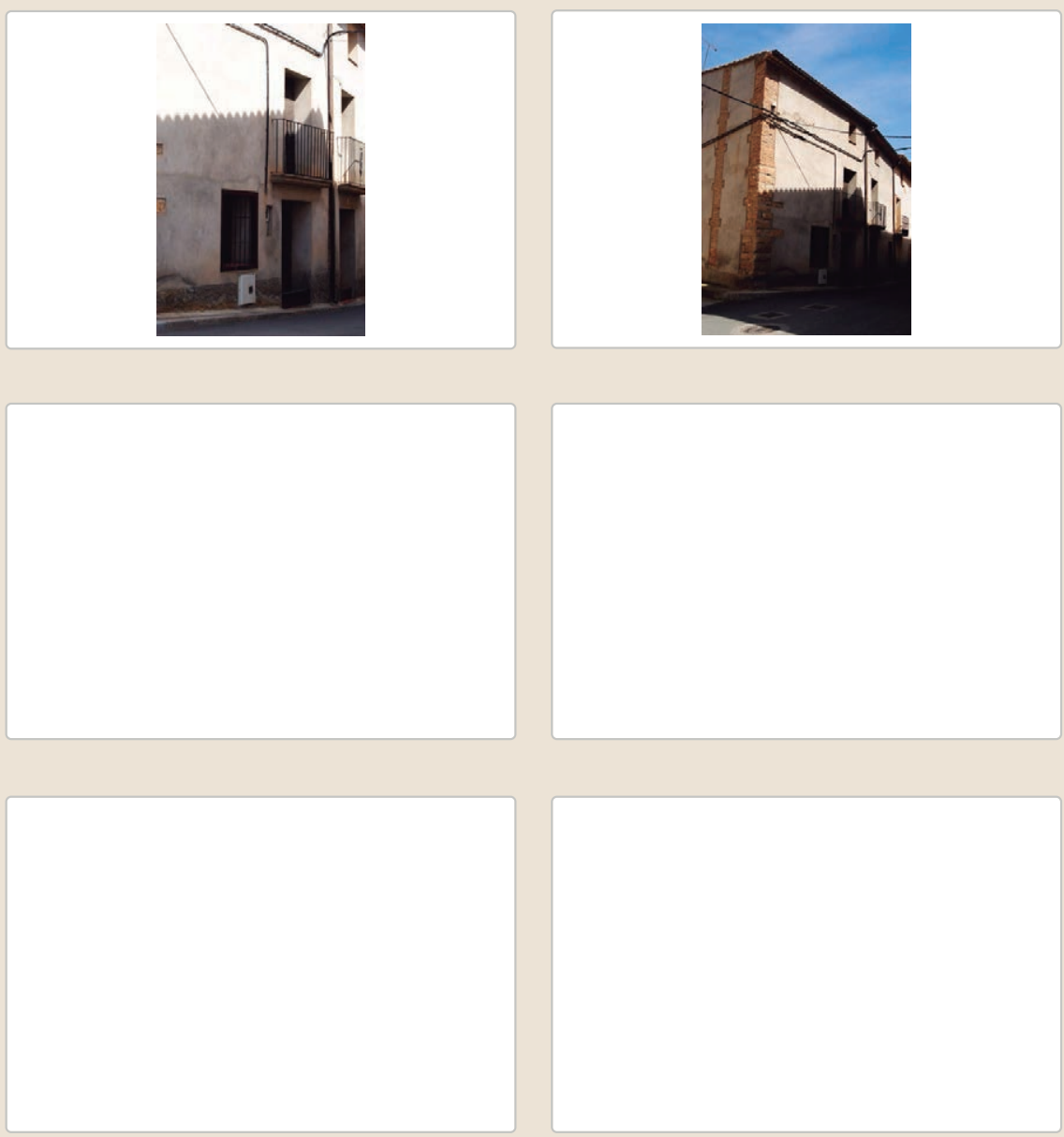

3.6. OTRAS 
La restauración y rehabilitación de la arquitectura tradicional de tierra. El caso de Aragón.

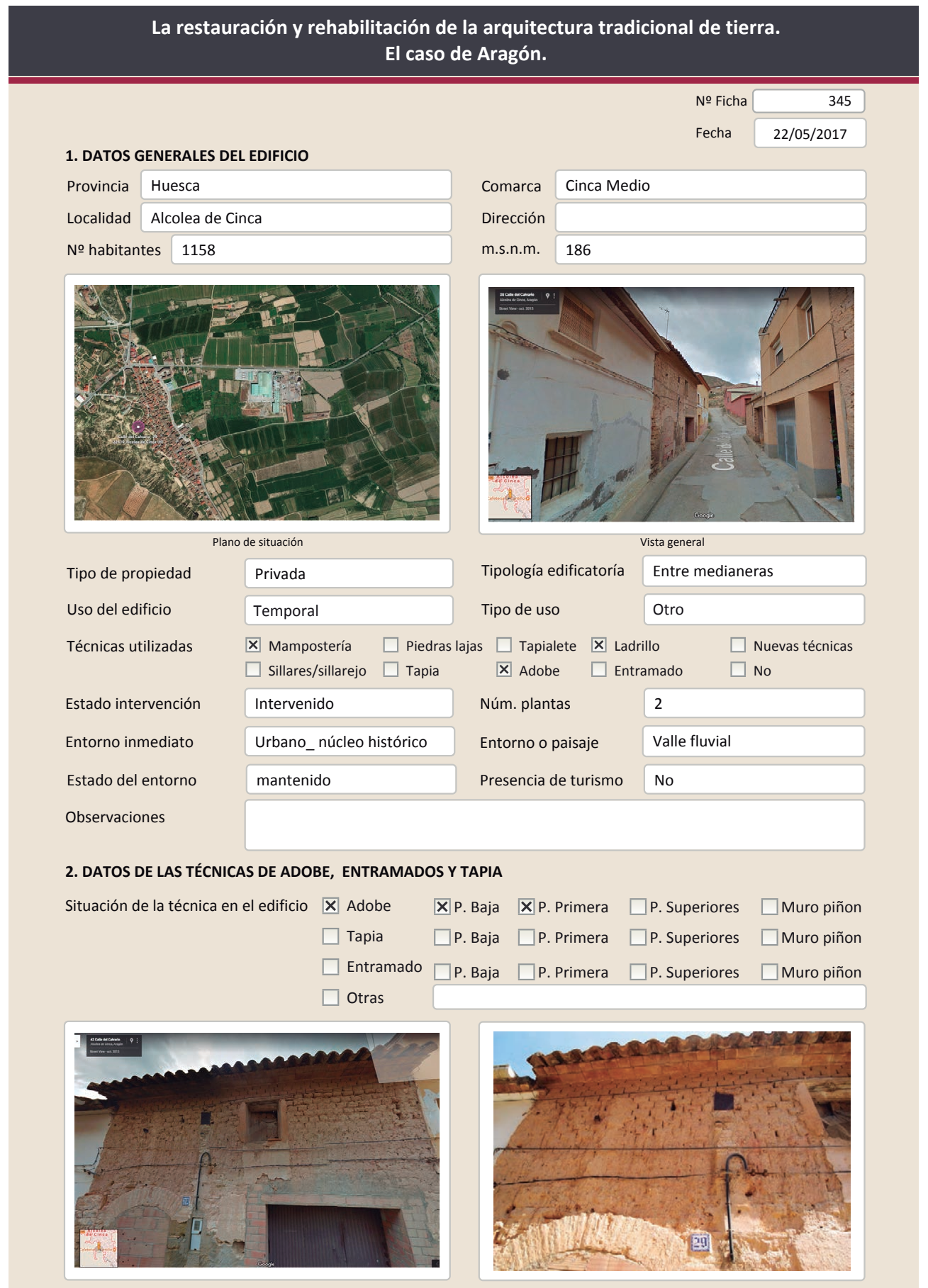

La restauración y rehabilitación de la arquitectura tradicional de tierra. El caso de Aragón.
2.1. ADOBE

Dimensión de las piezas

Dimensión del muro

Aparejo del muro

Función estructural

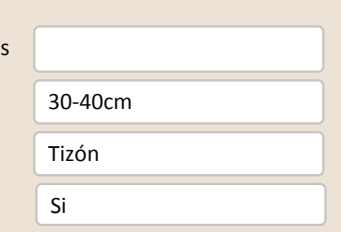

Color de las piezas

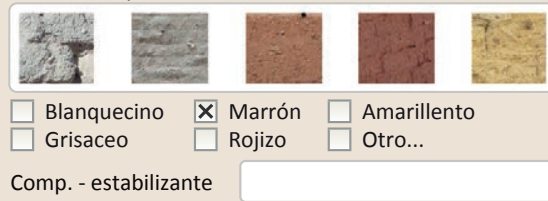

Comp. - estabilizante
$\square$ Suplementada en juntas
$\square$ Mixta
$\square$ Como suplemento
$\square$ Elementos de protección

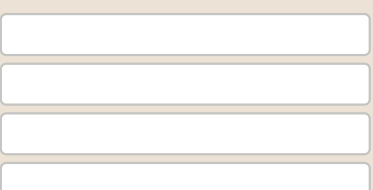

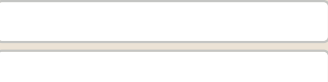

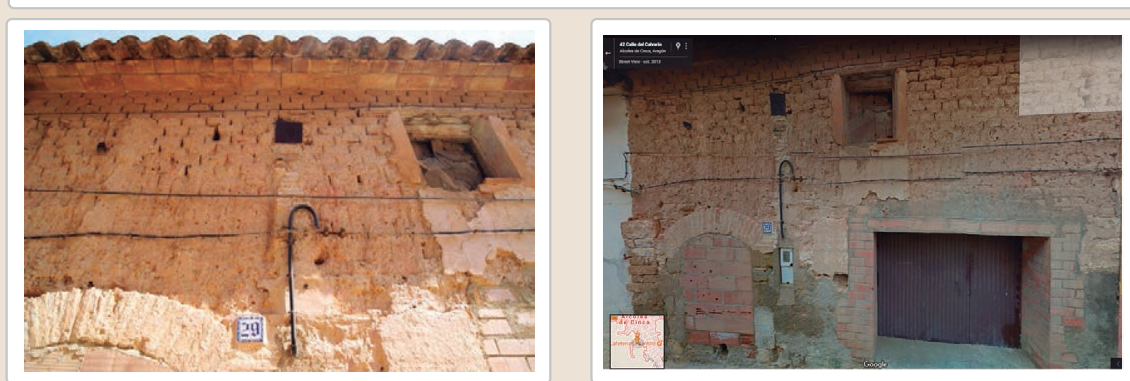

Lesiones ХMuro \Zócalo $\square$ Revestimiento $\square$ Cubierta $\square$ otro...

\ Erosión del material $\quad \mathbf{X}$ Humedad por capilaridad $\quad \square$ Grietas por asentamientos $\boldsymbol{X}$ Erosion de las juntas $\mathbf{X}$ Humedades (manch/eflo) $\square$ Colapso

X Pérdida de sección $\square$ Pérdida de verticalidad $\square$ Por elementos impropios

$\square$ Vegetación $\quad \square$ Grietas por empuje de la cubierta $\quad \square$ Derivado de intervenciones

X Desconchados $\square$ Grietas porfalta de traba $\quad \square$ Otro

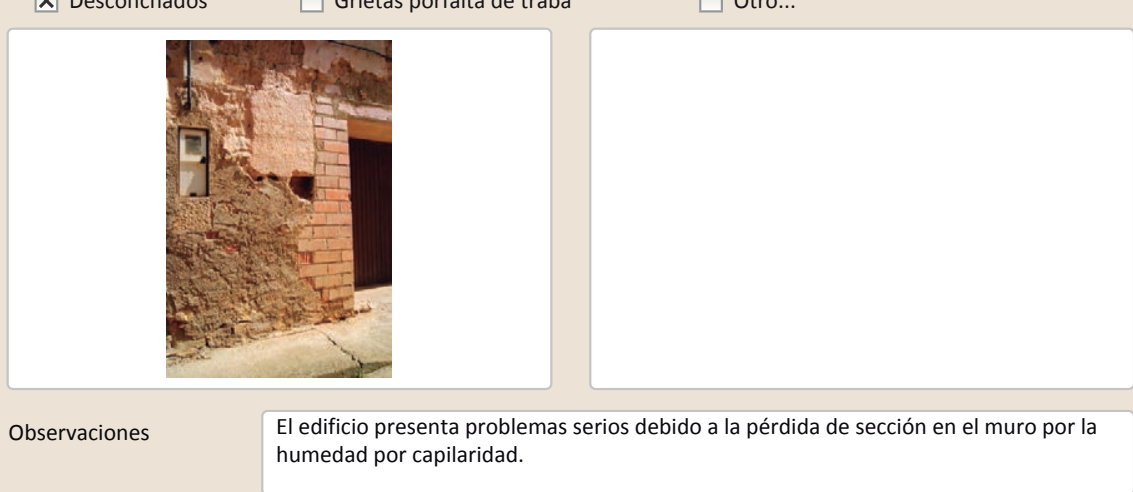




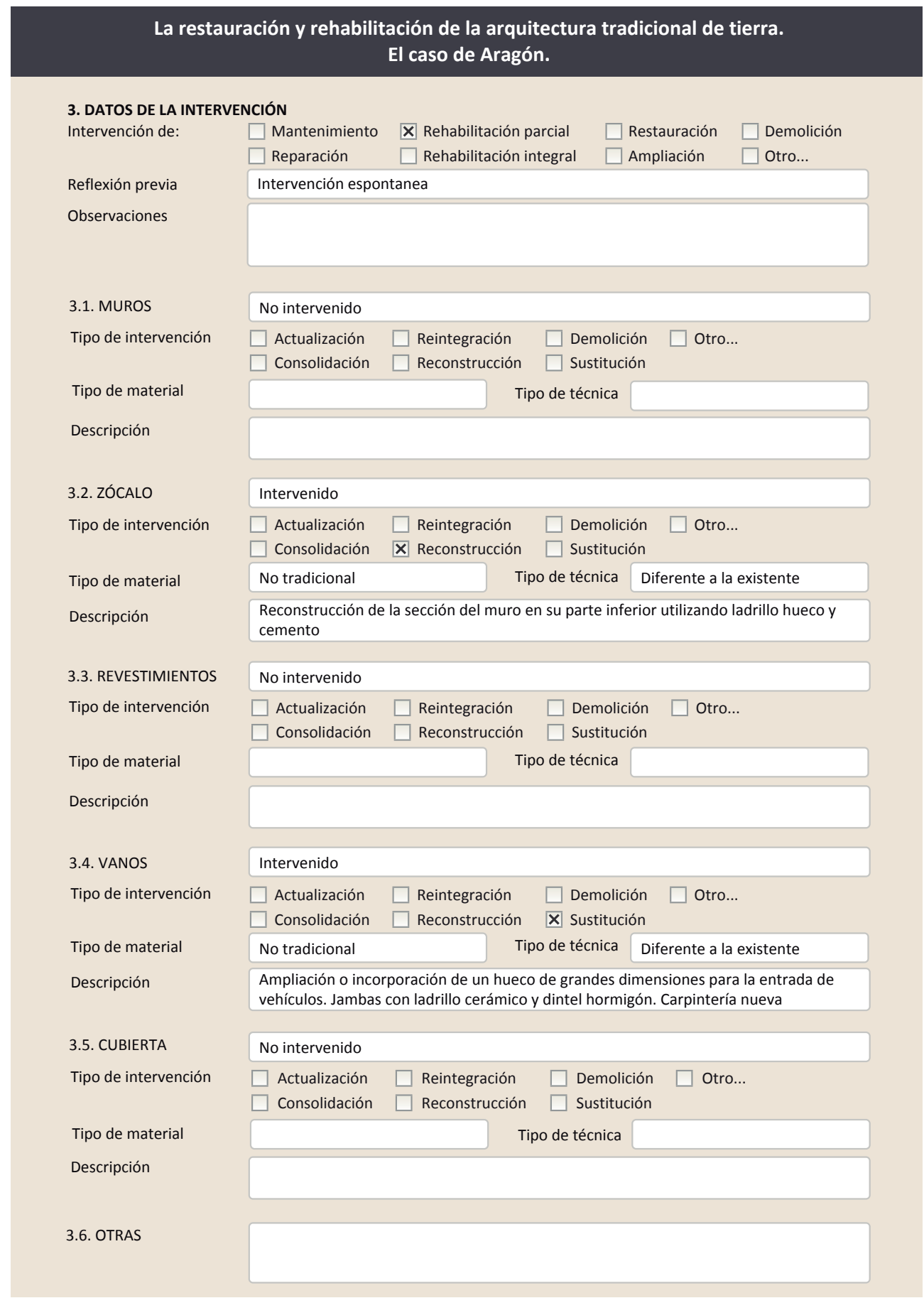

3.7. REHABILITACIÓN ENERGÉTICA $\square$ Fachada $\square$ Vanos $\square$ Forjados $\square$ Cubierta

Observaciones

FOTOGRAFÍAS DE LA INTERVENCIÓN
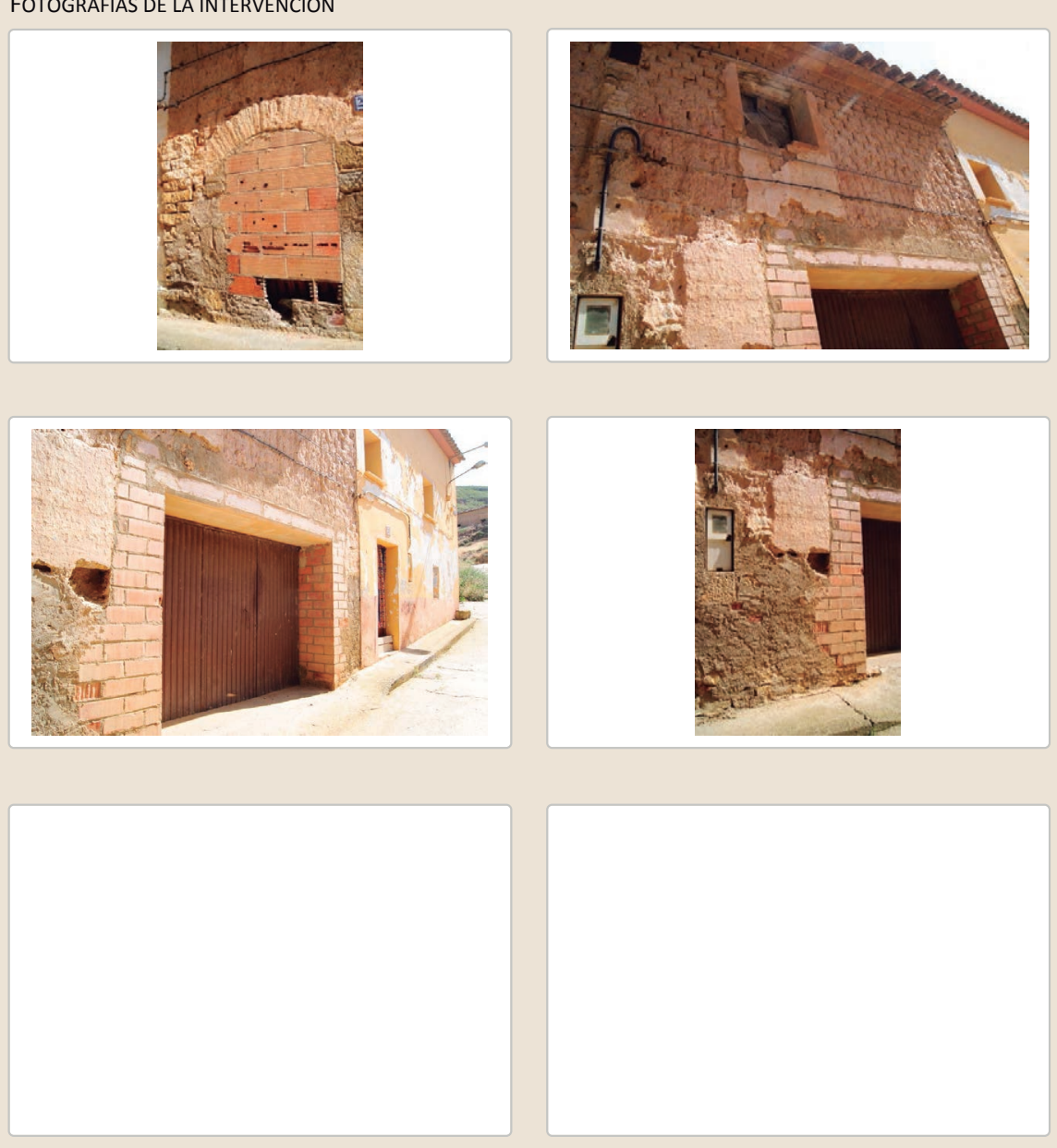


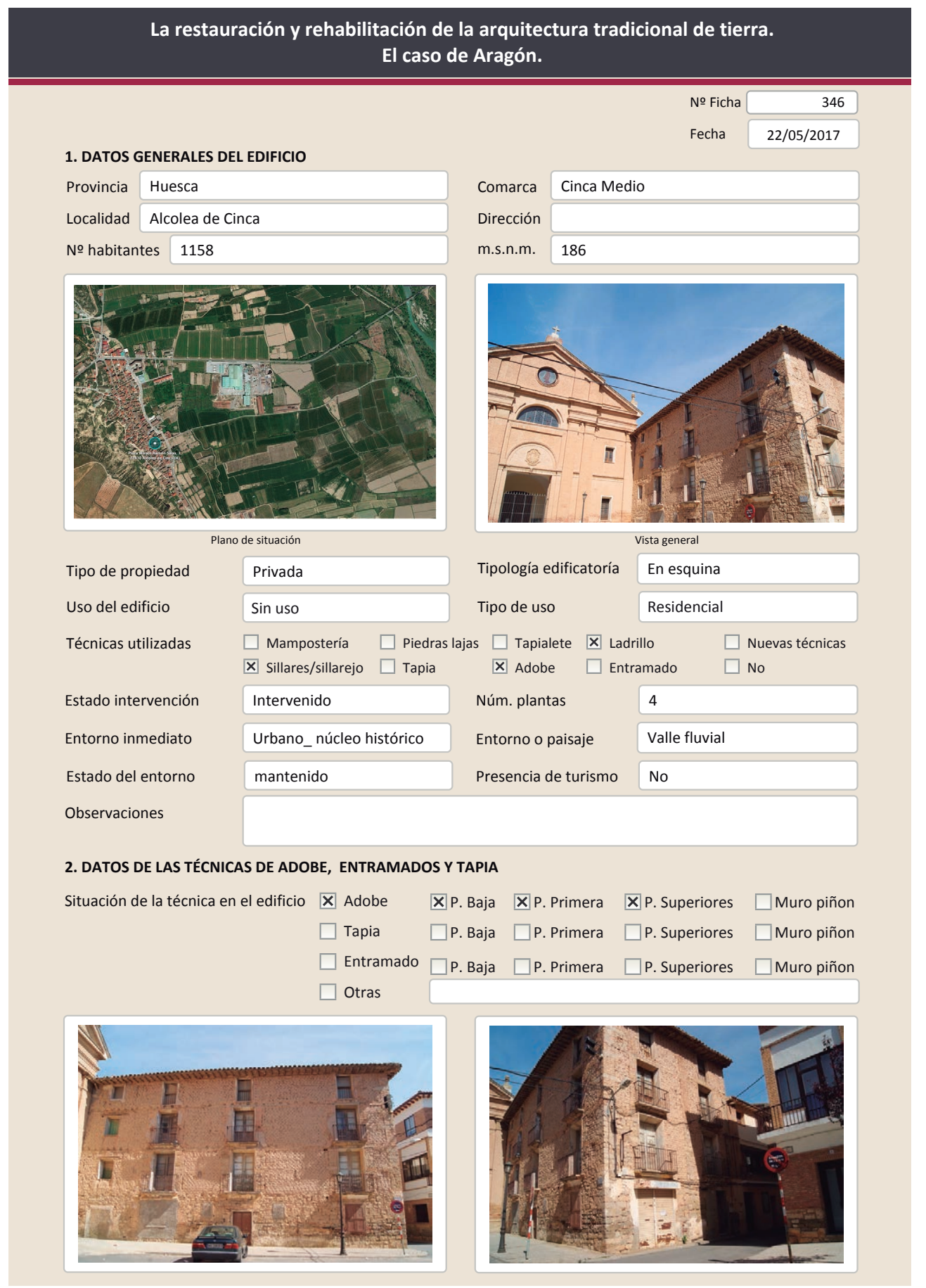

La restauración y rehabilitación de la arquitectura tradicional de tierra. El caso de Aragón.

2.1. ADOBE

Dimensión de las piezas

Dimensión del muro

Aparejo del muro

Función estructural

$\square$ Simple

$\square$ Suplementada en juntas

X Mixta

\section{En esquinas}

Color de las piezas

$\square$ Como suplemento

$\square$ Elementos de protección

Ladrillo y piedra. Durmiente de madera en cada plana para el poyo de los forjados y que además arriostran el edificio. Tenia revestimiento pero se ha perdido o lo han picado

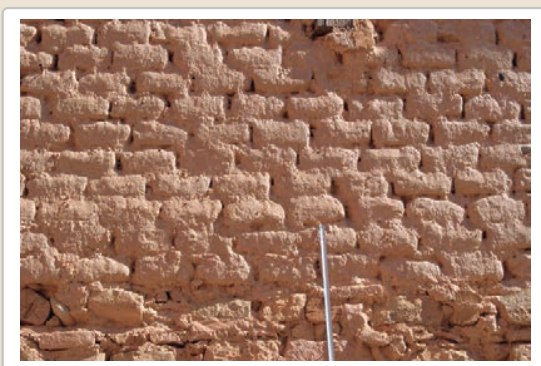

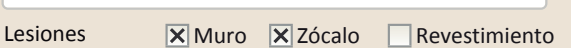
$\mathbf{X}$ Erosión del material $\mathbf{X}$ Humedad por capilaridad $\mathbf{X}$ Erosion de las juntas $\mathbf{X}$ Humedades (manch/eflo) $\square$ Pérdida de sección $\square$ Pérdida de verticalidad

$\square$ Vegetación $\quad \square$ Grietas por empuje de la cubie

$\square$ Desconchados $\quad \square$ Grietas porfalta de traba

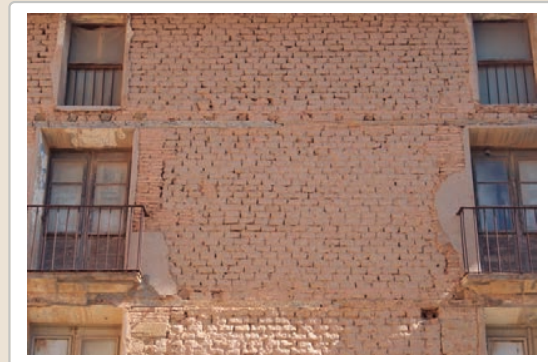

$\square$ Cubierta $\square$ otro...

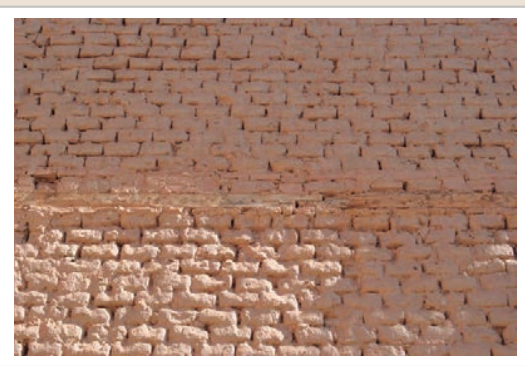

Observaciones

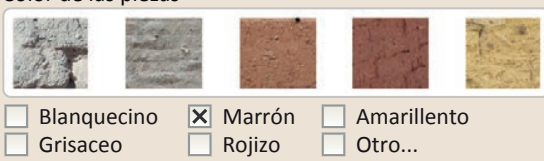

Comp. - estabilizante
$\square$ Colapso
$\square$ Por elementos impropios
$\square$ Otro... 


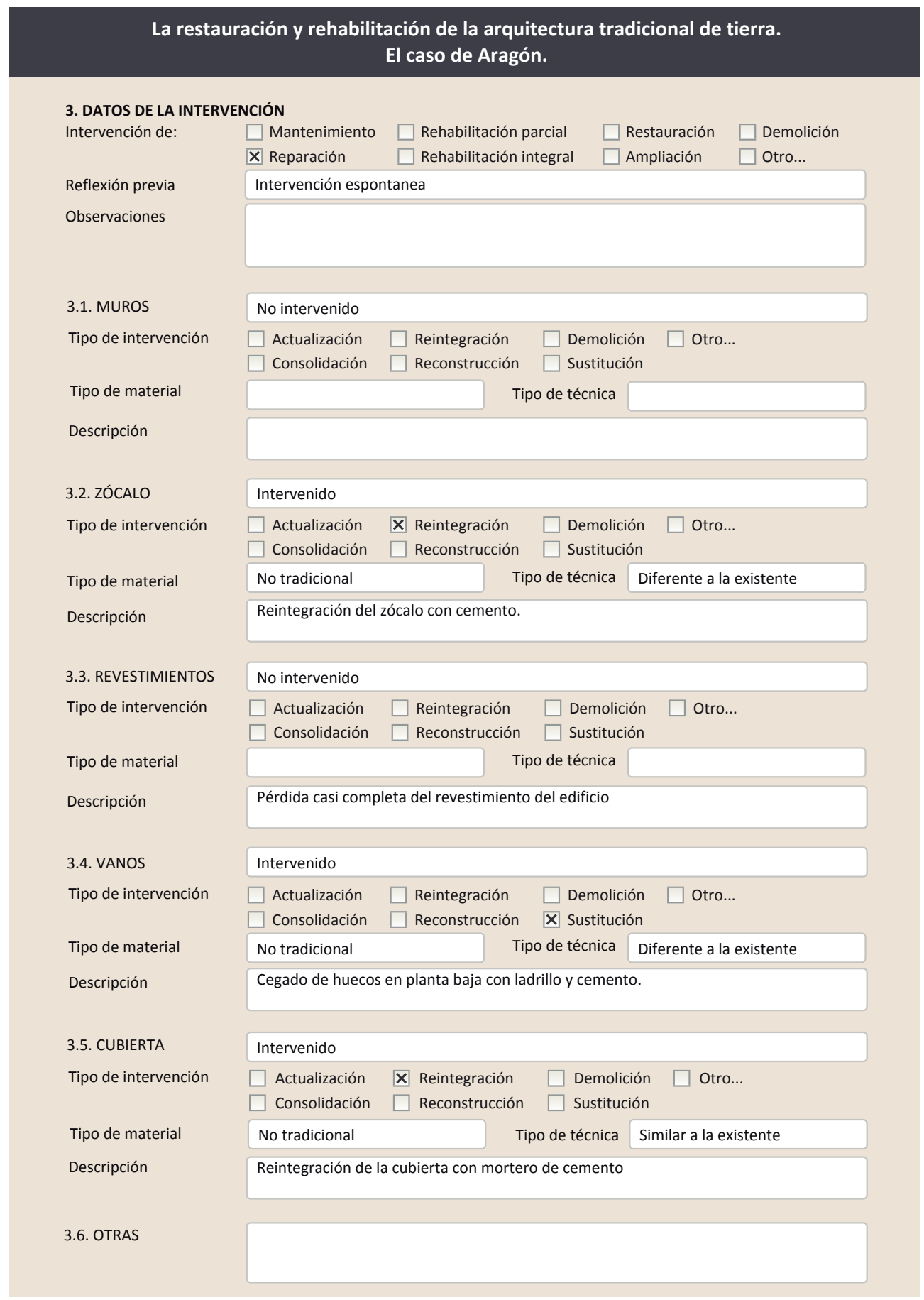

3.7. REHABILITACIÓN ENERGÉTICA $\quad \square$ Fachada $\square$ Vanos $\square$ Forjados $\square$ Cubierta Observaciones

FOTOGRAFíAS DE LA INTERVENCIÓN
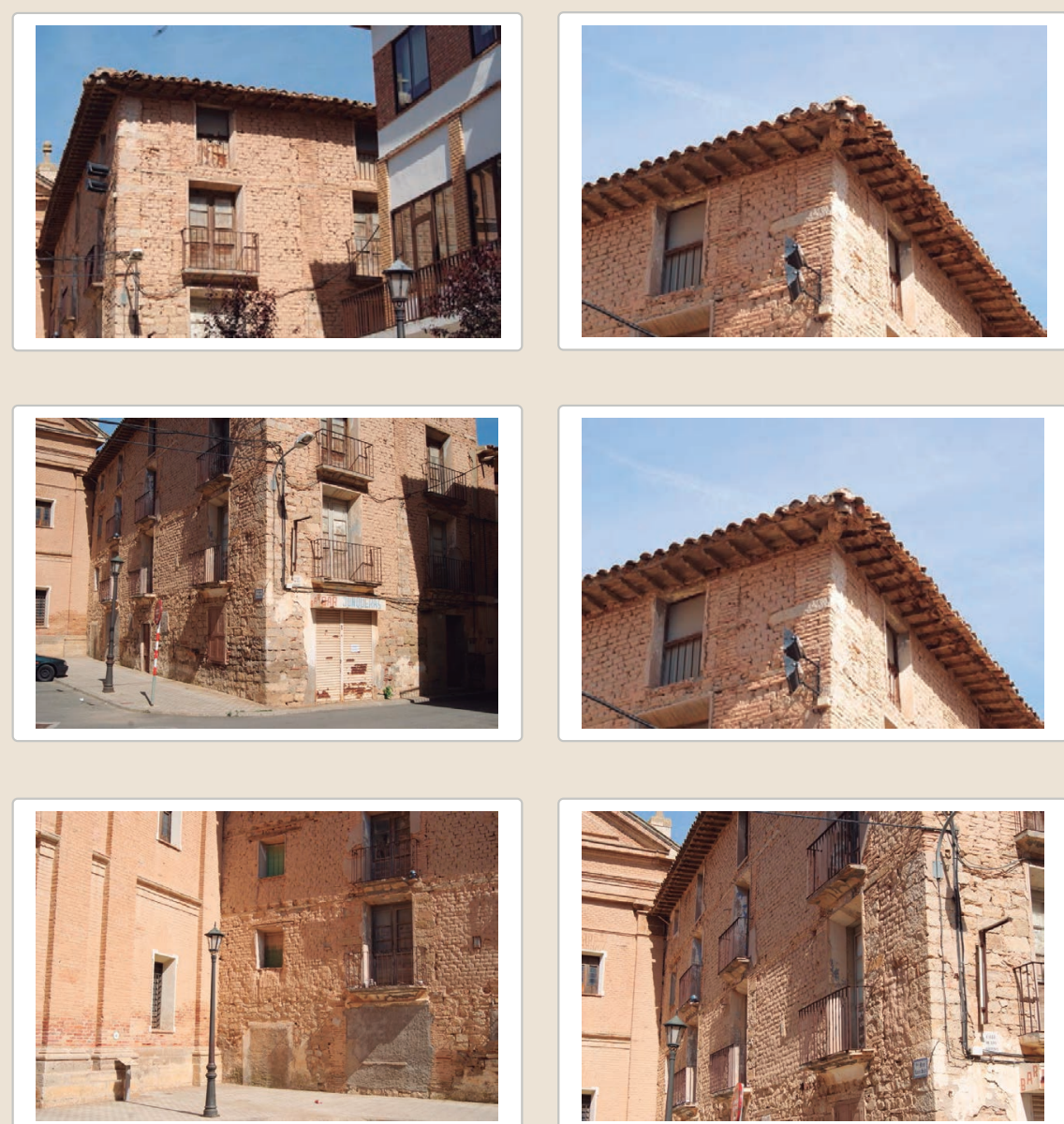


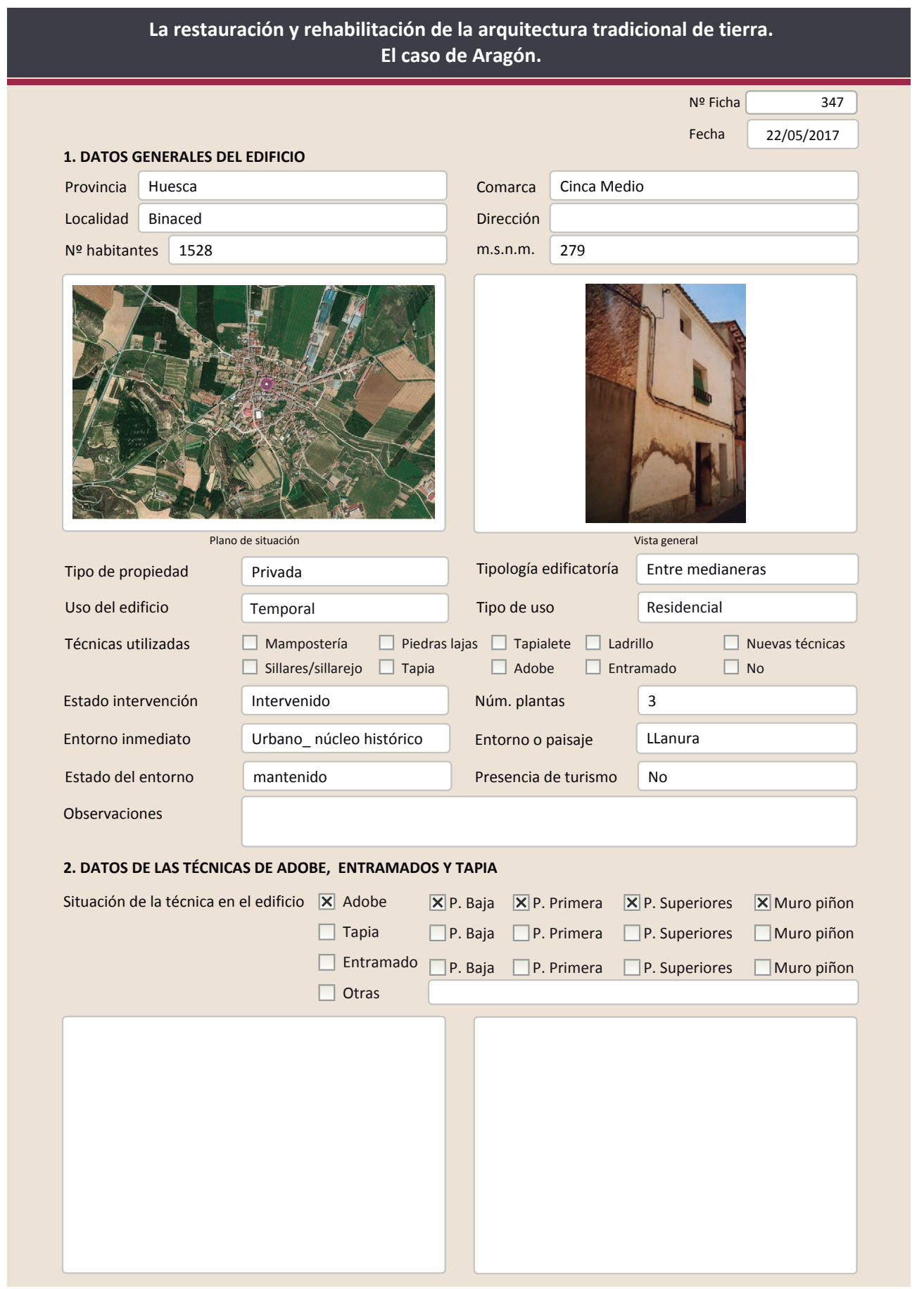

La restauración y rehabilitación de la arquitectura tradicional de tierra.

El caso de Aragón.

2.1. ADOBE

Dimensión de las piezas Dimensión del muro Aparejo del muro Función estructural
Color de las piezas

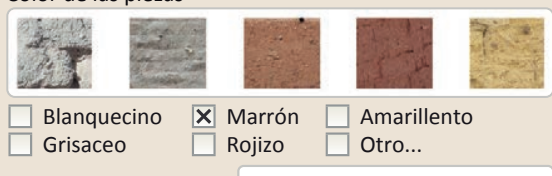

Grisaceo

ante

Comp. - estabilizante

Variante constructiva/ tipo de fábrica

\section{$\square$ Simple}

$\square$ Suplementada en juntas

X Mixta

\section{Machones}

$\square$ Como suplemento

$\mathbf{X}$ Elementos de protección

Revestimiento

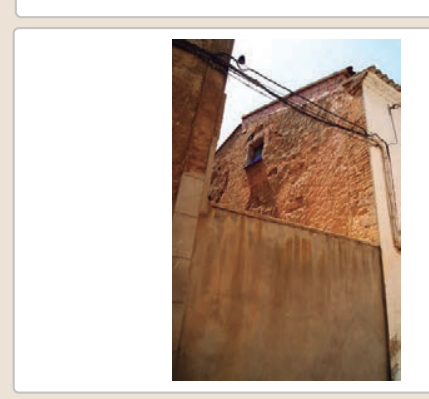

Lesiones

$\mathbf{X}$ Erosión del material $\mathbf{X}$ Humedad por capilaridad

$\square$ Erosion de las juntas $\mathbf{X}$ Humedades (manch/eflo)

$\square$ Pérdida de sección $\square$ Pérdida de verticalidad

$\square$ Vegetación

\ Desconchados

$\square$ Grietas por empuje de lacubala

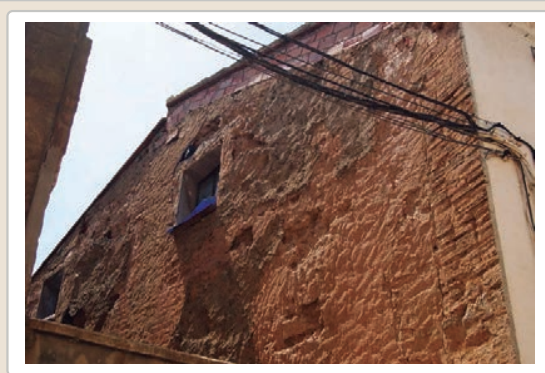

$\square$ Cubierta $\square$ Otro...

$\square$ Grietas por asentamiento

$\square$ Colapso

$\square$ Por elementos impropios

X Derivado de intervenciones $\square$ Otro...
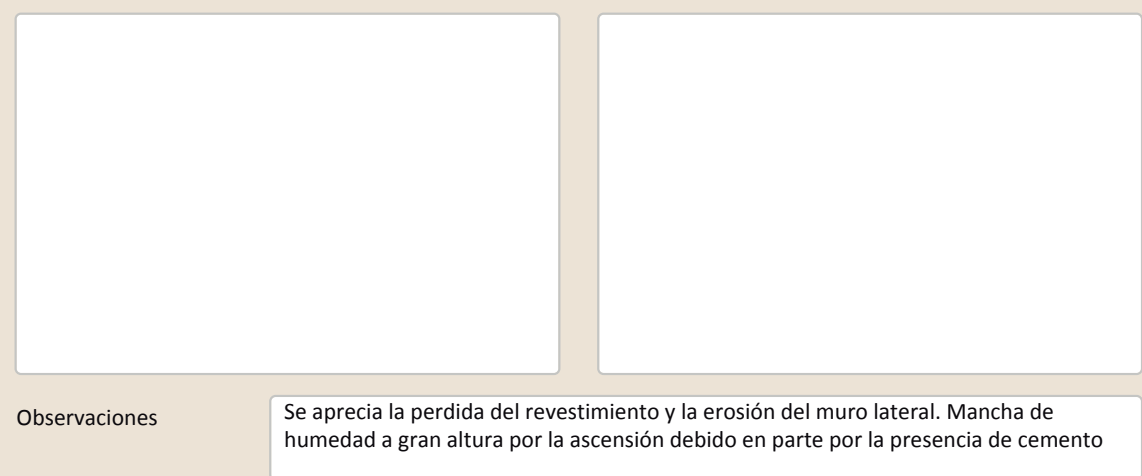


\section{La restauración y rehabilitación de la arquitectura tradicional de tierra.} El caso de Aragón.

3. DATOS DE LA INTERVENCIÓN

$\square$ Mantenimiento

Reflexión previa

X Reparación

$\square$ Rehabilitación parcial

$\square$ Restauración $\square$ Demolición

Intervención planificada

Observaciones

inter

3.1. MUROS
Tipo de intervención

Intervenido

Tipo de material

$\square$ Actualización $\quad \boldsymbol{X}$ Reintegración $\quad \square$ Demolición $\quad \square$ Otro...
$\square$ Consolidación $\quad \mathbf{X}$ Reconstrucción $\quad \square$ Sustitución

Descripción Tipo de técnica Diferente a la existente

3.2. ZóCALO

Tipo de intervención

Reintegración

\section{Intervenido}

メ Actualización $\square$ Reintegración $\square$ Demolición $\square$ Otro...

$\square$ Consolidación $\quad \mathbf{X}$ Reconstrucción $\square$ Sustitución

Tipo de material

No tradicional

Tipo de técnica Diferente a la existente

Descripción

3.3. REVESTIMIENTOS

Tipo de intervención

Zócalo con gotelé de cemento. Se ve la humedad que sube hasta una altura de $2 \mathrm{~m}$ aprox.

Intervenido

X Actualización $\square$ Reintegración $\square$ Demolición $\square$ Otro...

$\square$ Consolidación $\quad \boldsymbol{X}$ Reconstrucción $\square$ Sustitución

Tipo de material

Descripción

3.4. VANOS

Tipo de intervención

No tradicional

Tipo de técnica Similar a la existente

Revestimiento de fachada nuevo. cemento pintado de blanco

Intervenido

$\begin{array}{lll} & \square \text { Consolidación } \square \text { Reconstrucción } \square \text { Sustitución } \\ \text { Tipo de material } & \text { No tradicional } & \text { Tipo de técnica S }\end{array}$

$\square$ Actualización $\quad \mathbf{X}$ Reintegración $\square$ Demolición $\square$ Otro...

Descripción Consolidación de los huecos en la fachada lateral. Se aprecia ladrillo hueco y cemento. Sustitución parcial de las carpinterías

3.5. CUBIERTA

Tipo de intervención

Intervenido

$\square$ Actualización $\square$ Reintegración $\square$ Demolición $\square$ Otro...

$\square$ Consolidación $\square$ Reconstrucción $\quad$ Sustitución

Tipo de material

No tradicional

Tipo de técnica Diferente a la existente

Descripción

Se ha levantado la cubierta parcialmente utilizando ladrillo hueco colocado en dirección a la pendiente. El alero se conserva a la altura original
La restauración y rehabilitación de la arquitectura tradicional de tierra.

El caso de Aragón.

3.7. REHABILITACIÓN ENERGÉTICA $\quad \square$ Fachada $\square$ Vanos $\square$ Forjados $\square$ Cubierta

Observaciones

FOTOGRAFíAS DE LA INTERVENCIÓN
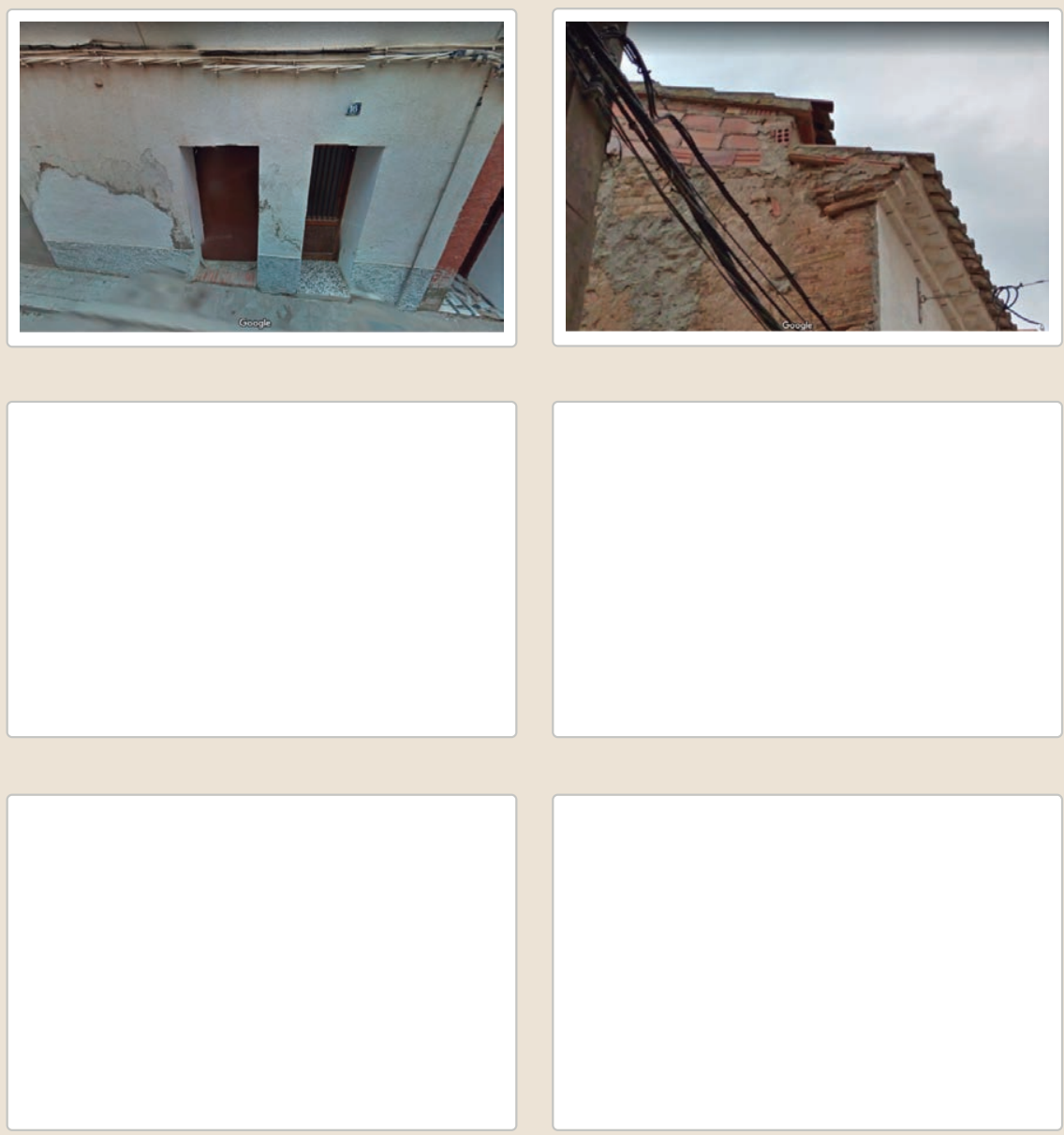

3.6. OTRAS 


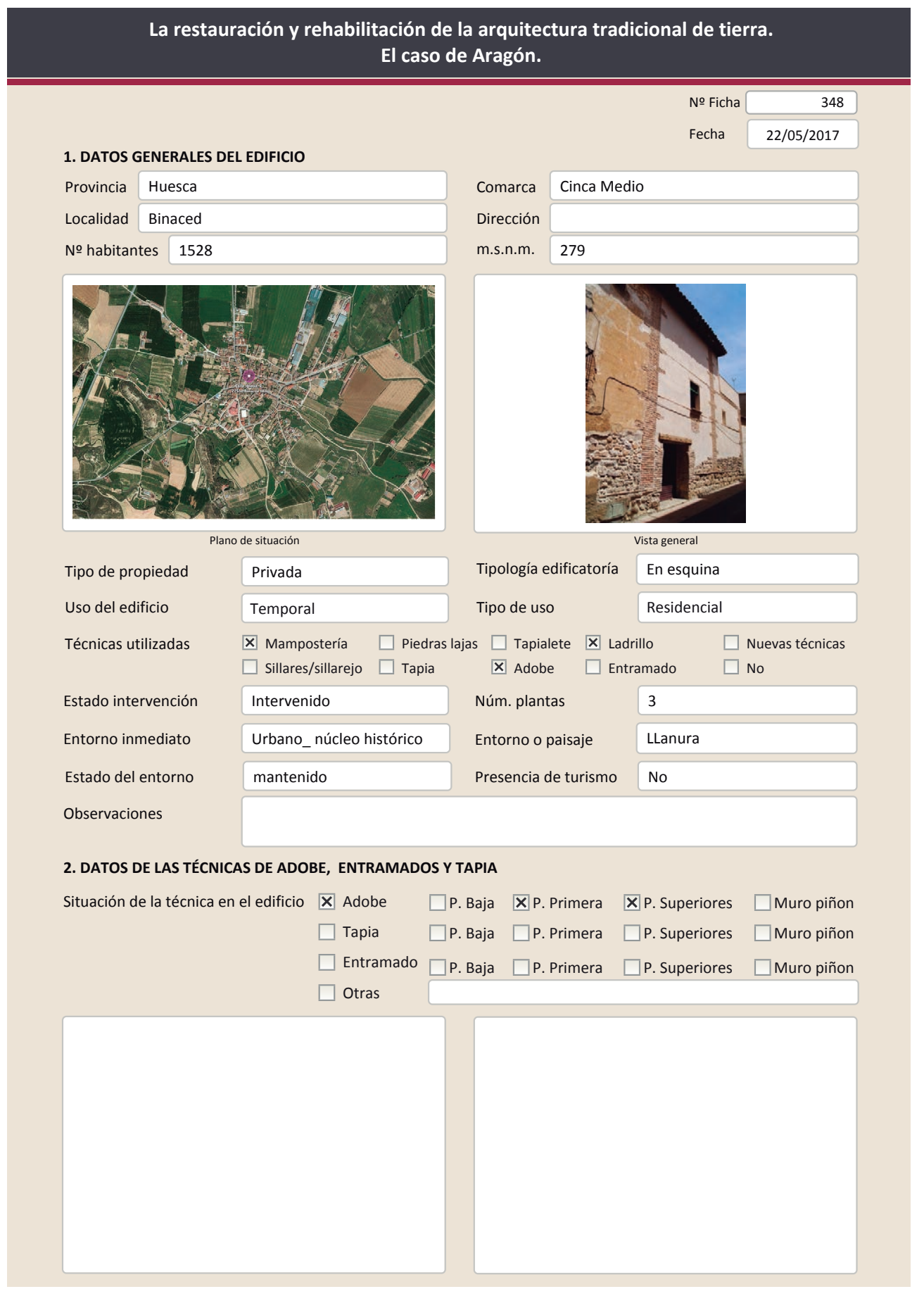

La restauración y rehabilitación de la arquitectura tradicional de tierra.

El caso de Aragón.

\subsection{ADOBE}

Dimensión de las piezas

Dimensión del muro

Aparejo del muro

Función estructural

Variante constructiva/ tipo de fábrica

$\square$ Simple

$\square$ Suplementada en juntas

\ Mixta

Machones

Color de las piezas

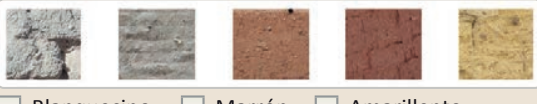

$\square$ Blanquecino $\square$ Marrón $\square$ Amarillento

$\square$ Grisaceo $\square$ Rojizo $\square$ Otro...

Comp. - estabilizante

$\square$ Como suplemento

$\square$ Elementos de protección

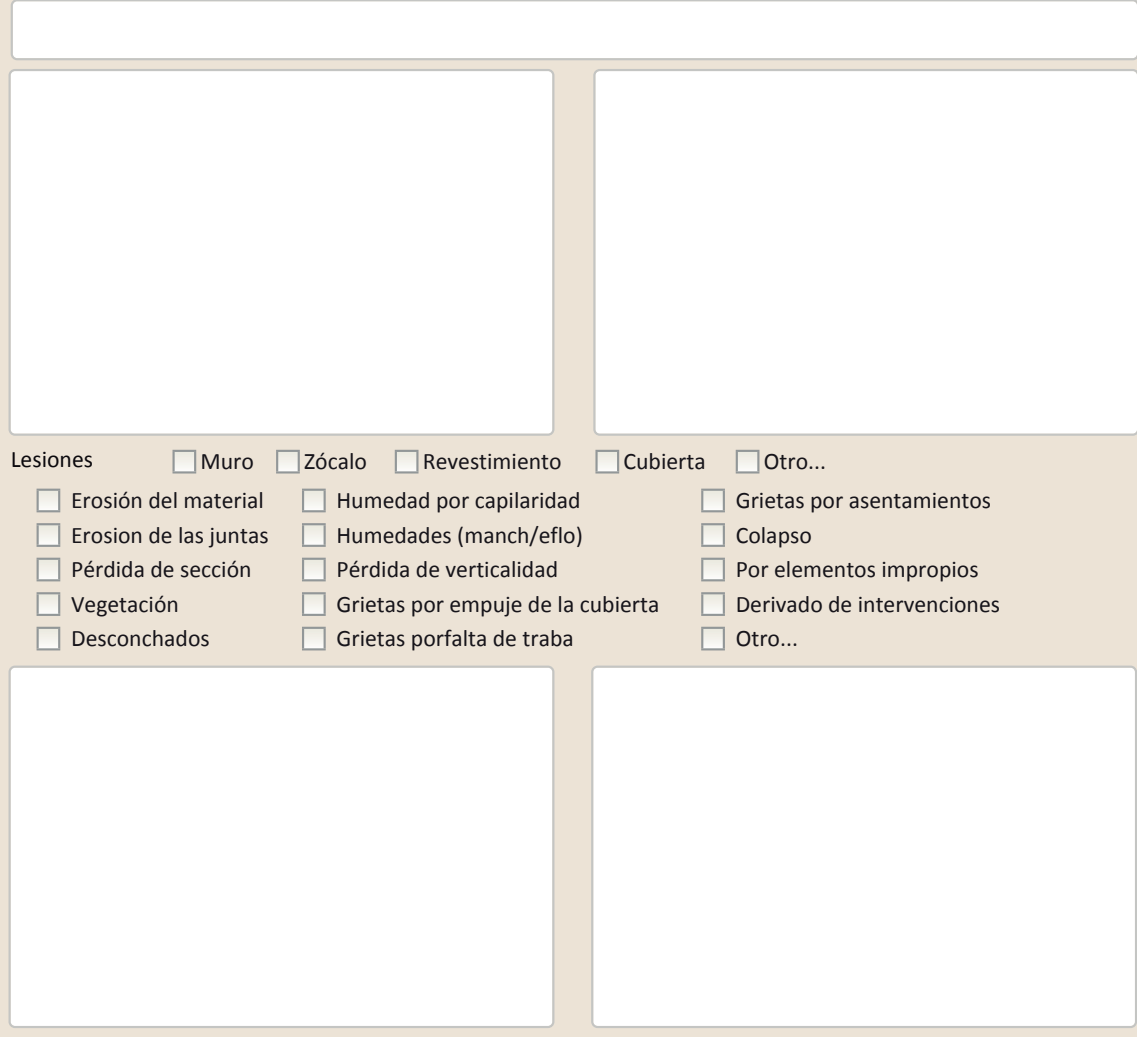

Observaciones 


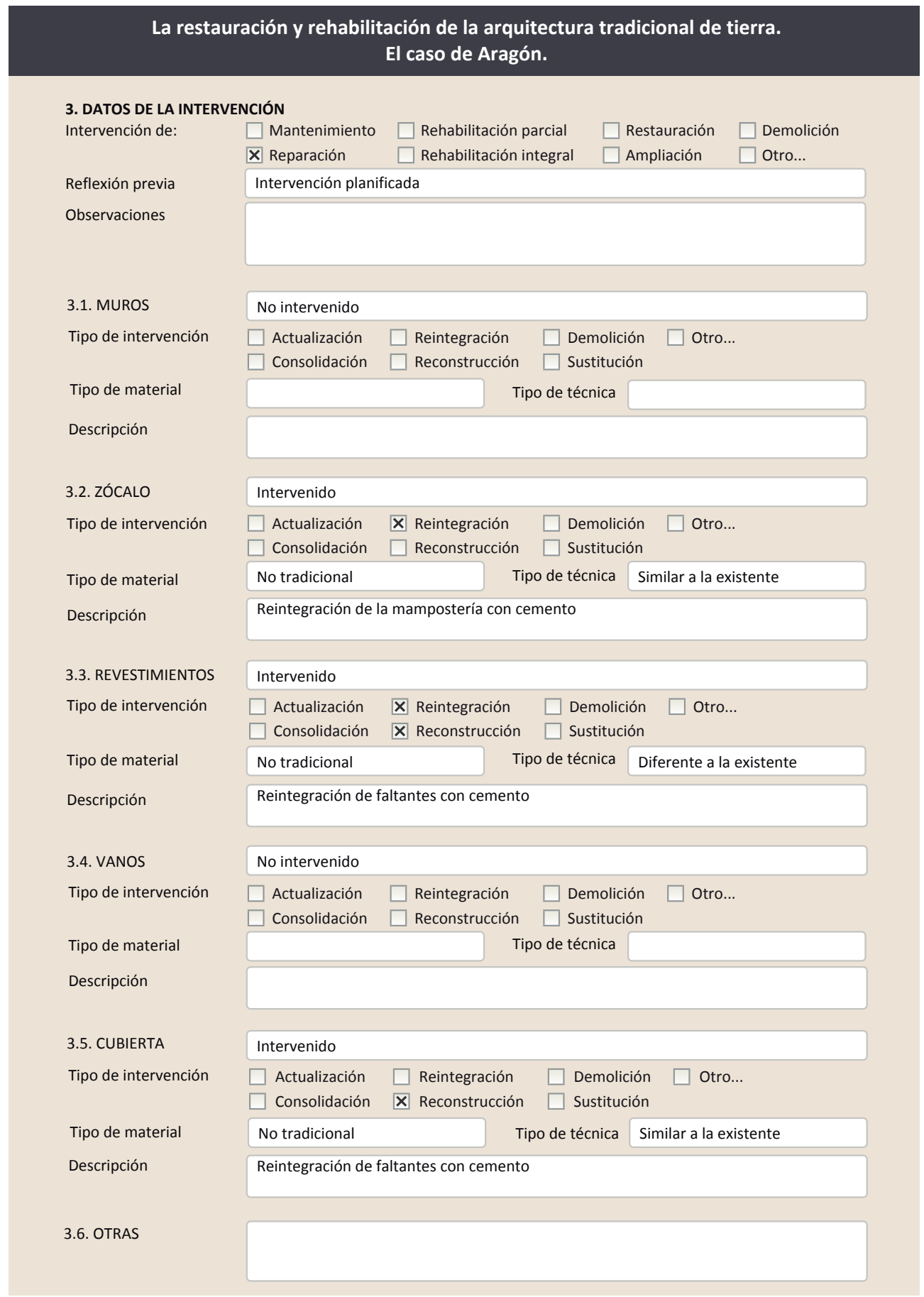

3.7. REHABILITACIÓN ENERGÉTICA $\quad \square$ Fachada $\square$ Vanos $\square$ Forjados $\square$ Cubierta Observaciones

FOTOGRAFÍAS DE LA INTERVENCIÓN
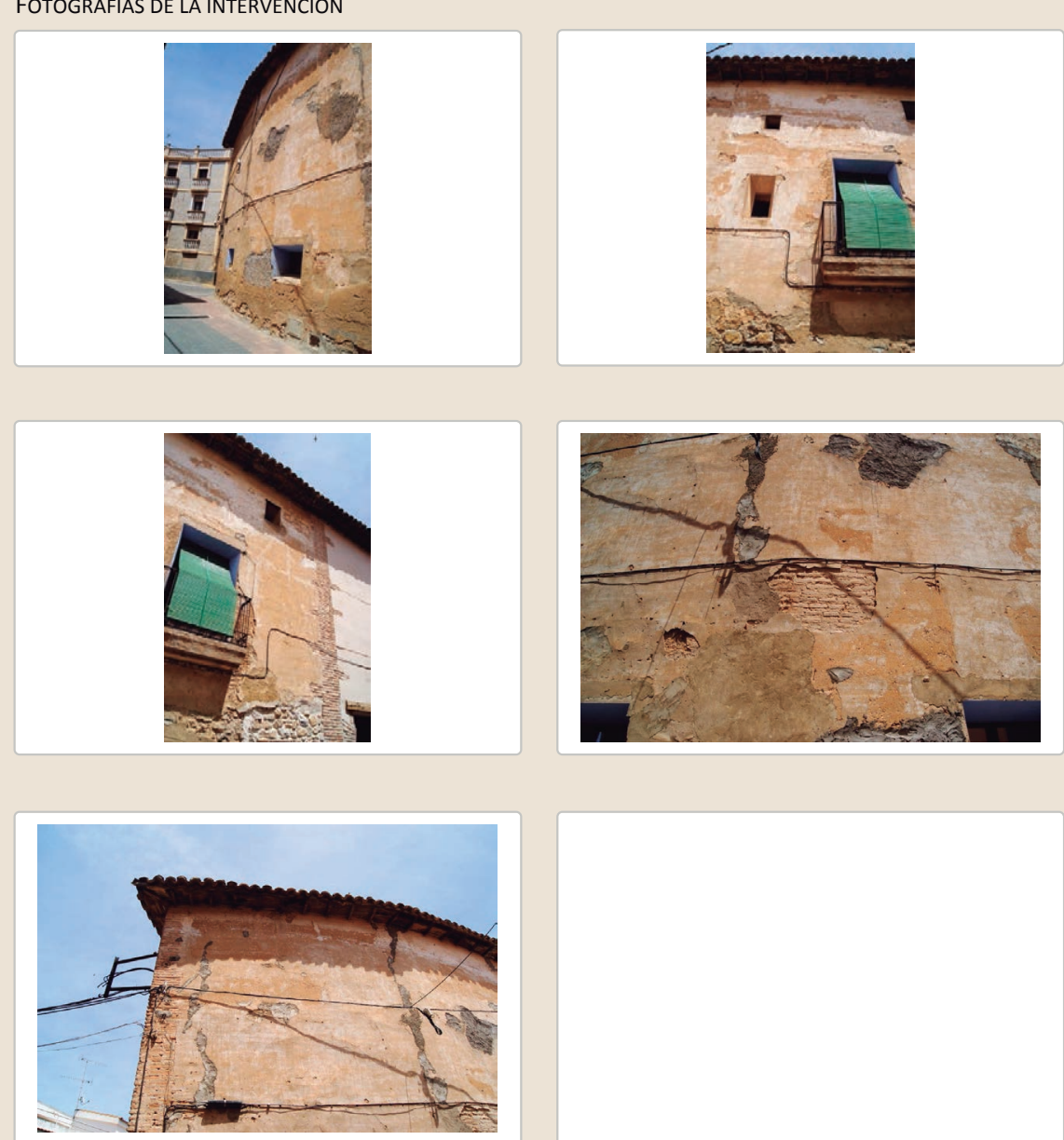


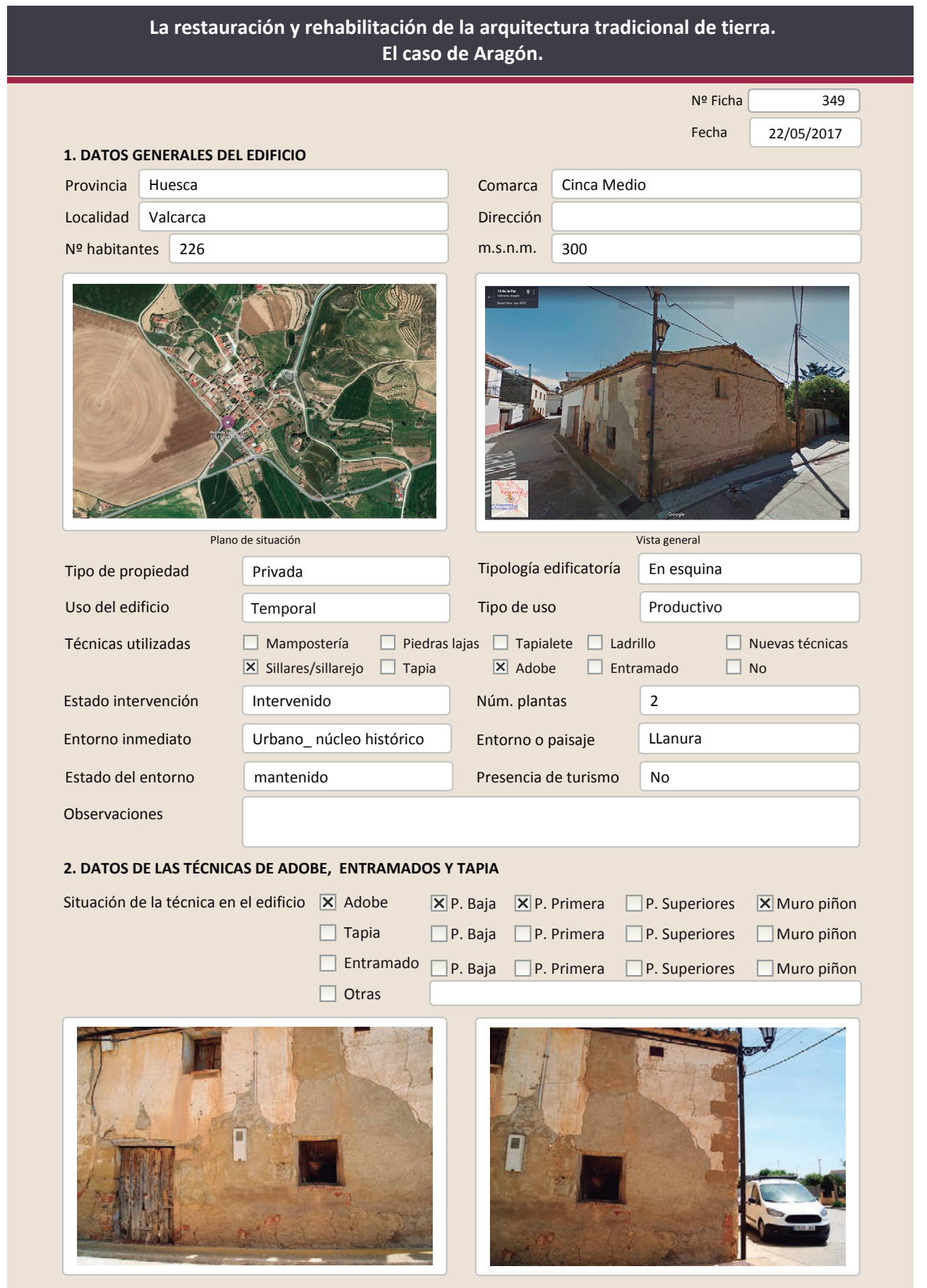

La restauración y rehabilitación de la arquitectura tradicional de tierra.

El caso de Aragón.

2.1. ADOBE

Dimensión de las piezas

Dimensión del muro

Aparejo del muro

Función estructural

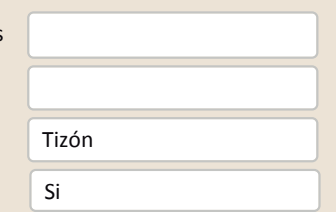

Color de las piezas

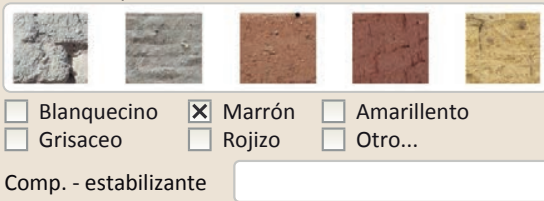

Variante constructiva/ tipo de fábrica

$\square$ Simple

$\square$ Suplementada en juntas

区 Mixta

En esquinas

Piedra

$\square$ Como suplemento

$\mathbf{X}$ Elementos de protección

Revestimiento

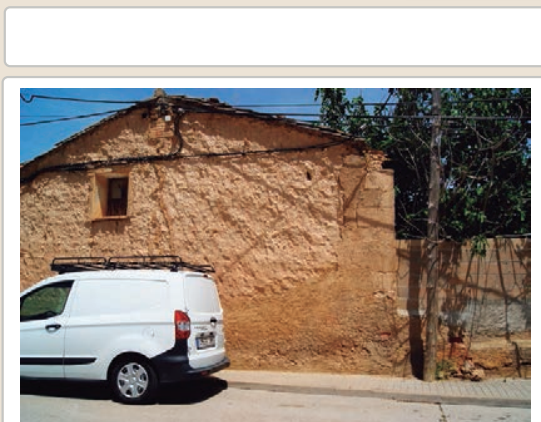

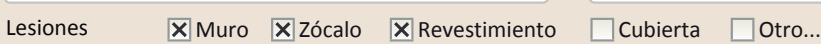

$\mathbf{X}$ Erosión del material $\mathbf{X}$ Humedad por capilaridad $\quad \square$ Grietas por asentamientos $\mathbf{X}$ Erosion de las juntas $\mathbf{X}$ Humedades (manch/eflo) $\square$ Colapso

X Pérdida de sección $\square$ Pérdida de verticalidad $\square$ Por elementos impropios

$\square$ Vegetación $\quad \square$ Grietas por empuje de la cubierta $\square$ Derivado de intervenciones

$\mathbf{X}$ Desconchados

$\square$ Grietas porfalta de traba

$\square$ Otro...

Observaciones 
La restauración y rehabilitación de la arquitectura tradicional de tierra. El caso de Aragón

\section{La restauración y rehabilitación de la arquitectura tradicional de tierra.}

\section{El caso de Aragón.}

3. DATOS DE LA INTERVENCIÓN

Intervención de:

X Mantenimiento $\square$ Rehabilitación parcial

$\square$ Restauración $\square$ Demolición $\square$ Reparación $\square$ Rehabilitación integral $\square$ Ampliación $\quad \square$ Otro...

Reflexión previa Intervención espontanea

Observaciones

3.1. MUROS

No intervenido

Tipo de intervención

$\square$ Actualización

$\square$ Consolidación $\square$ Reconstrucción $\quad \square$ Sustitución

Tipo de material

Descripción

3.2. ZÓCALO

Tipo de intervención

Intervenido

$\square$ Actualización

区 Reintegración $\square$ Demolición $\square$ Otro...

Tipo de material

No tradicional

Tipo de técnica Diferente a la existente

Descripción

Reintegración del zócalo con ladrillo hueco y cemento debido a que se había perdido una sección importante

3.3. REVESTIMIENTOS

Intervenido

Tipo de intervención

$\square$ Actualización $\quad$ X Reintegración $\square$ Demolición $\square$ Otro...

$\square$ Consolidación $\square$ Reconstrucción $\square$ Sustitución

Tipo de material

Descripción
No tradicional
Tipo de técnica Similar a la existente

3.4. VANOS

reintegración de las partes faltantes con cemento

Tipo de intervención

No intervenido

Tipo de material

$\square$ Actualización $\square$ Reintegración $\square$ Demolición $\square$ Otro...

Descripción

$\square$ Consolidación $\quad \square$ Reconstrucción $\square$ Sustitución

3.5. CUBIERTA

Tipo de intervención

No intervenido

$\square$ Actualización $\square$ Reintegración $\quad \square$ Demolición $\square$ Otro.

Tipo de material

$\square$ Consolidación $\square$ Reconstrucción $\square$ Sustitución

Descripción

$$
\text { Tipo de técnica }
$$

3.6. OTRAS 


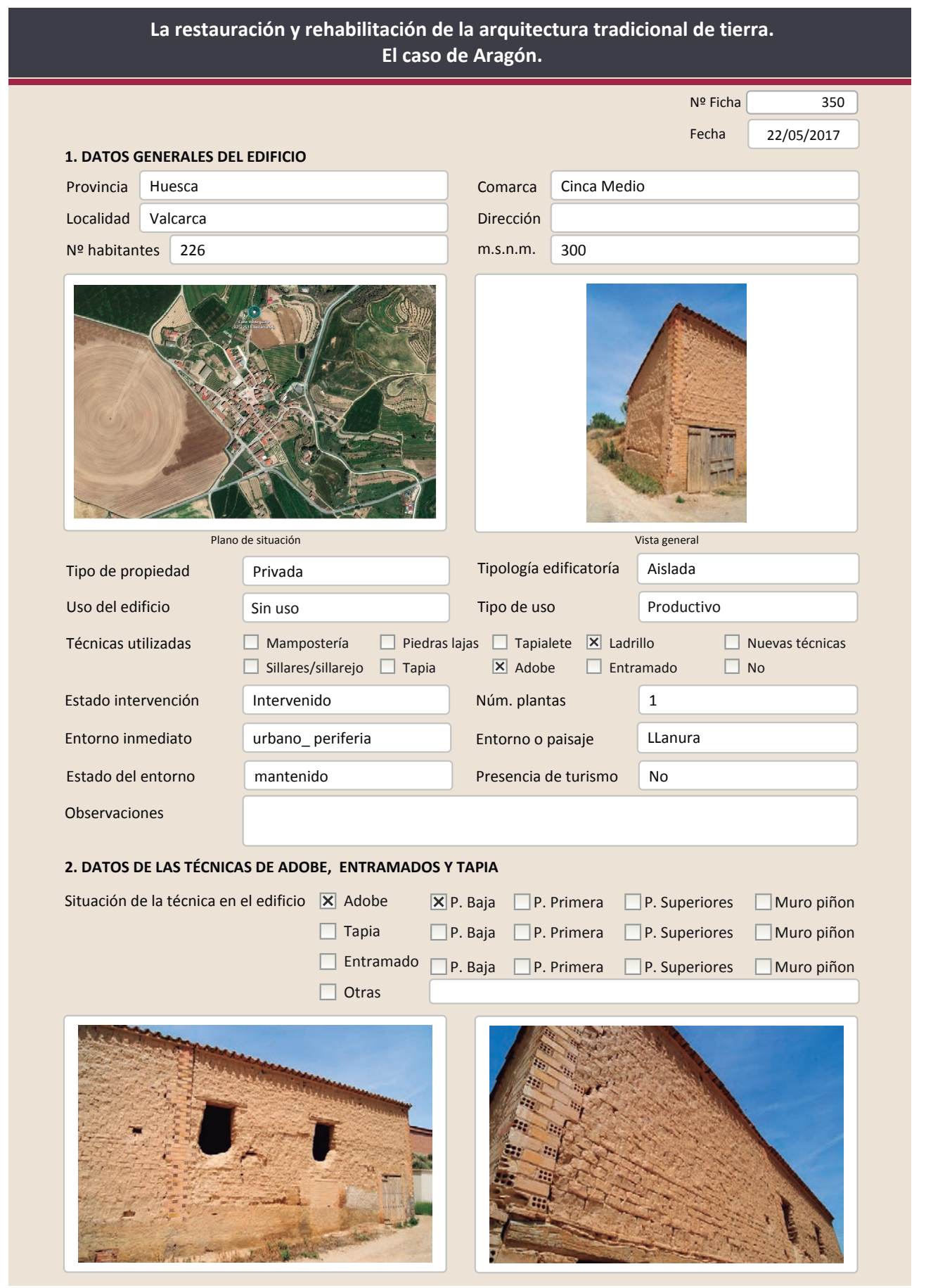

La restauración y rehabilitación de la arquitectura tradicional de tierra. El caso de Aragón.

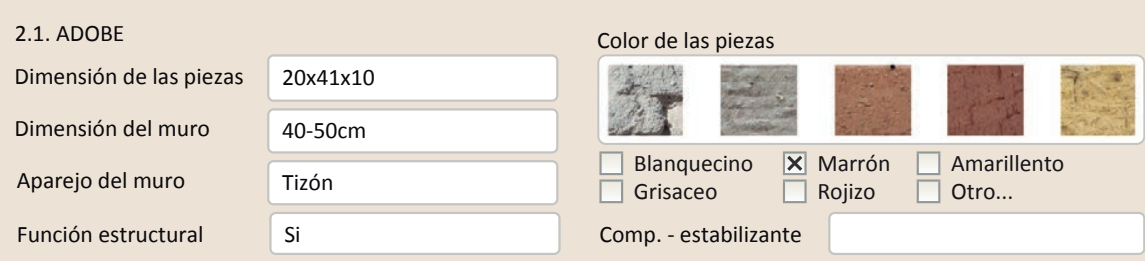

Función estructural

Comp. - estabilizante

Variante constructiva/ tipo de fábrica
$\square$ simple
$\square$ Suplementada en juntas
区 Mixta
$\square$ Como suplemento
$\square$ Elementos de protección
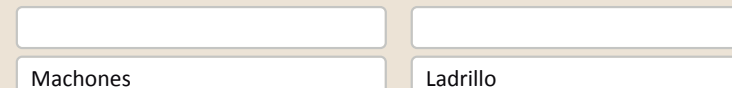

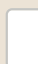

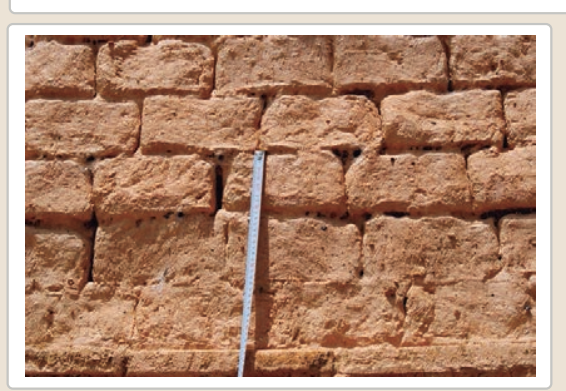

Lesiones $\quad \mathbf{X}$ Muro $\mathbf{X}$ Zócalo $\square$ Revestimiento

$\mathbf{X}$ Erosión del material $\mathbf{X}$ Humedad por capilaridad $\mathbf{X}$ Erosion de las juntas $\square$ Humedades (manch/eflo)

$\square$ Pérdida de sección $\square$ Pérdida de verticalidad

$\begin{array}{ll}\square \text { Vegetación } & \square \text { Grietas por empuje de la c } \\ \square \text { Desconchados } \quad \square \text { Grietas porfalta de traba }\end{array}$

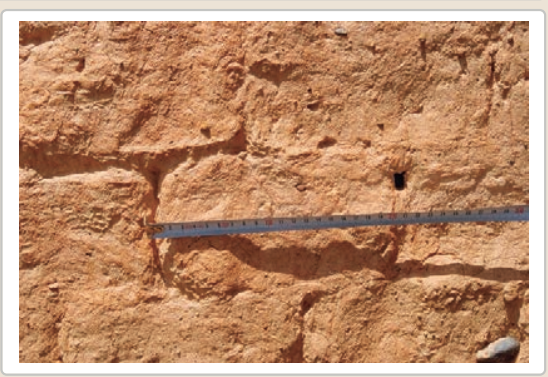

$\square$ Cubierta $\square$ Otro...

$$
\begin{aligned}
& \square \text { Grietas por asentamientos } \\
& \square \text { Colapso } \\
& \square \text { Por elementos impropios } \\
& \text { X Derivado de intervenciones }
\end{aligned}
$$
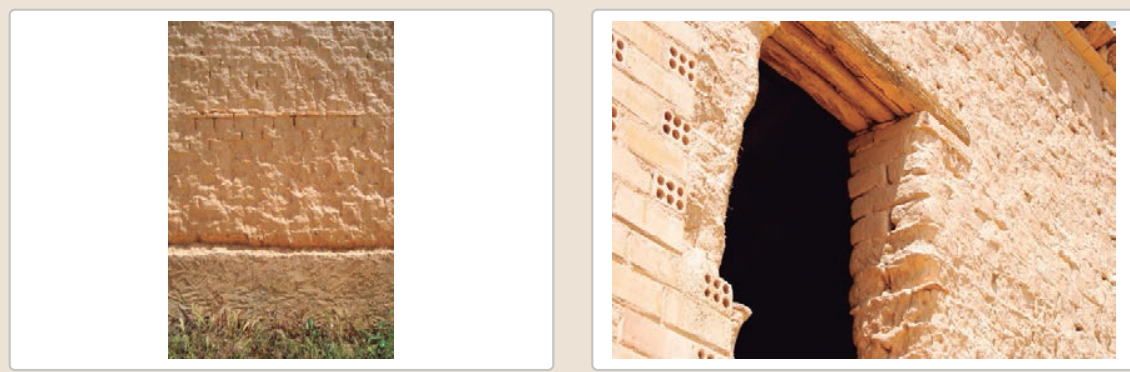

Observaciones 


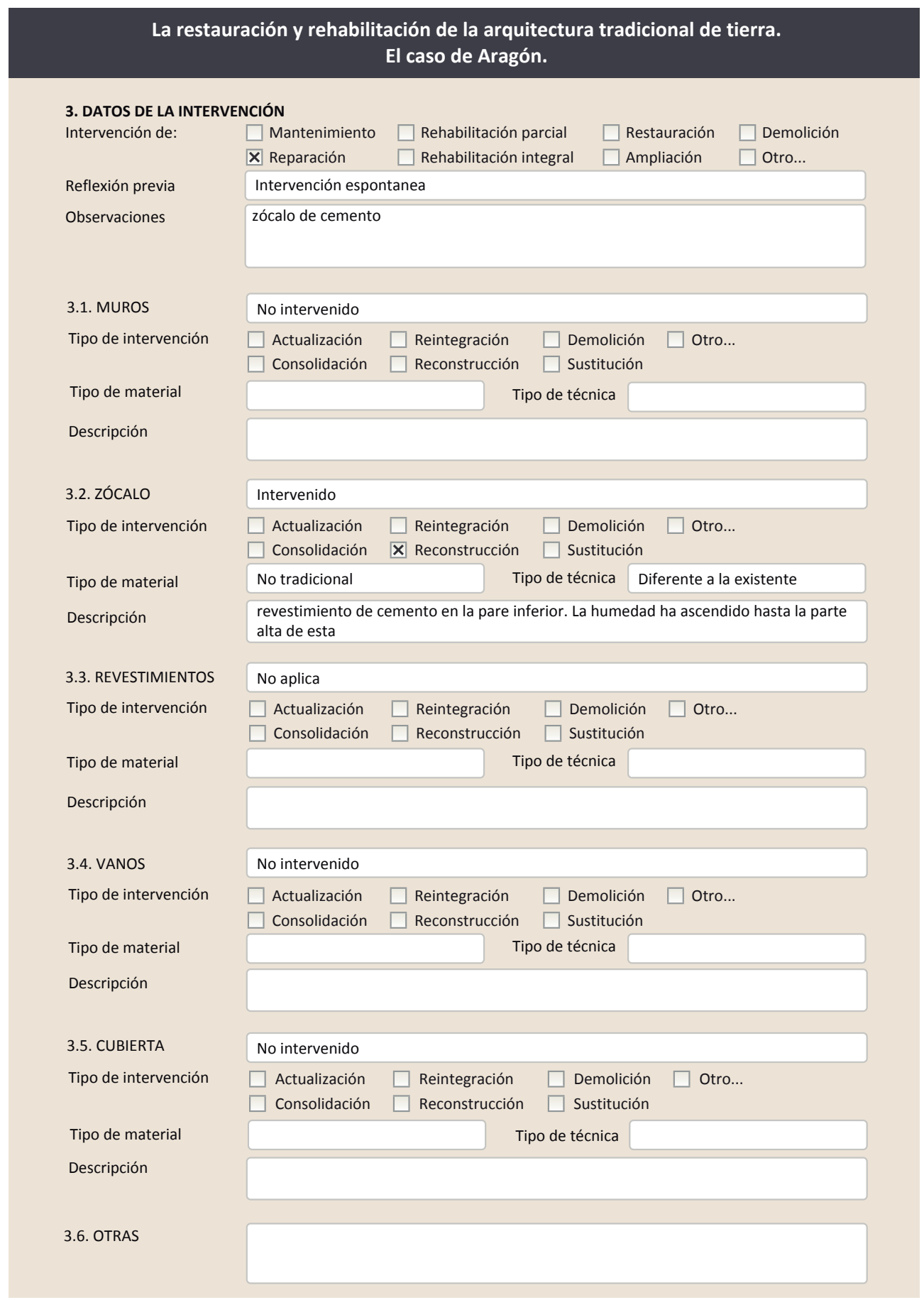

3.7. REHABILITACIÓN ENERGÉTICA $\square$ Fachada $\square$ Vanos $\square$ Forjados $\square$ Cubierta

Observaciones

FOTOGRAFíAS DE LA INTERVENCIÓN
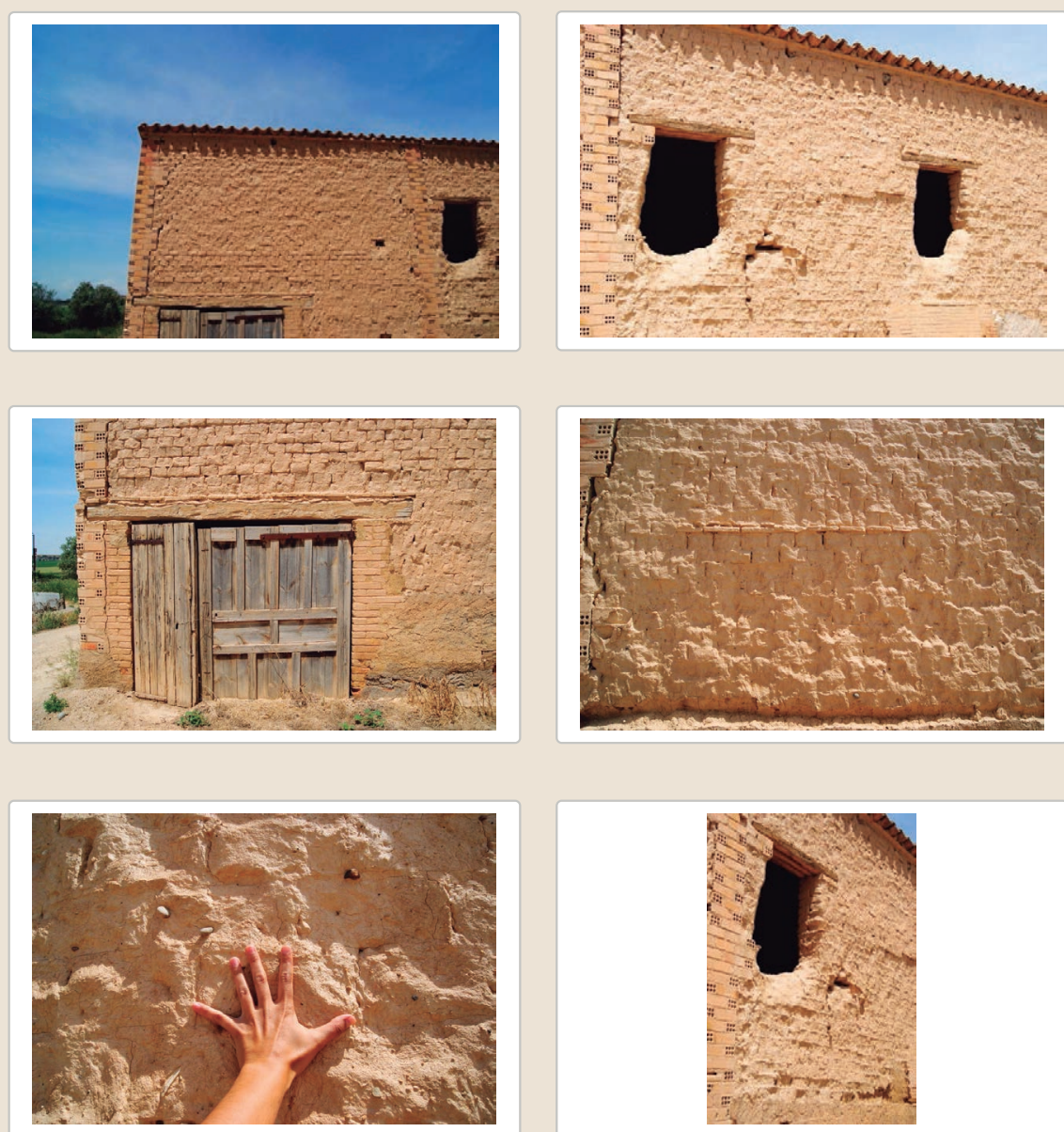


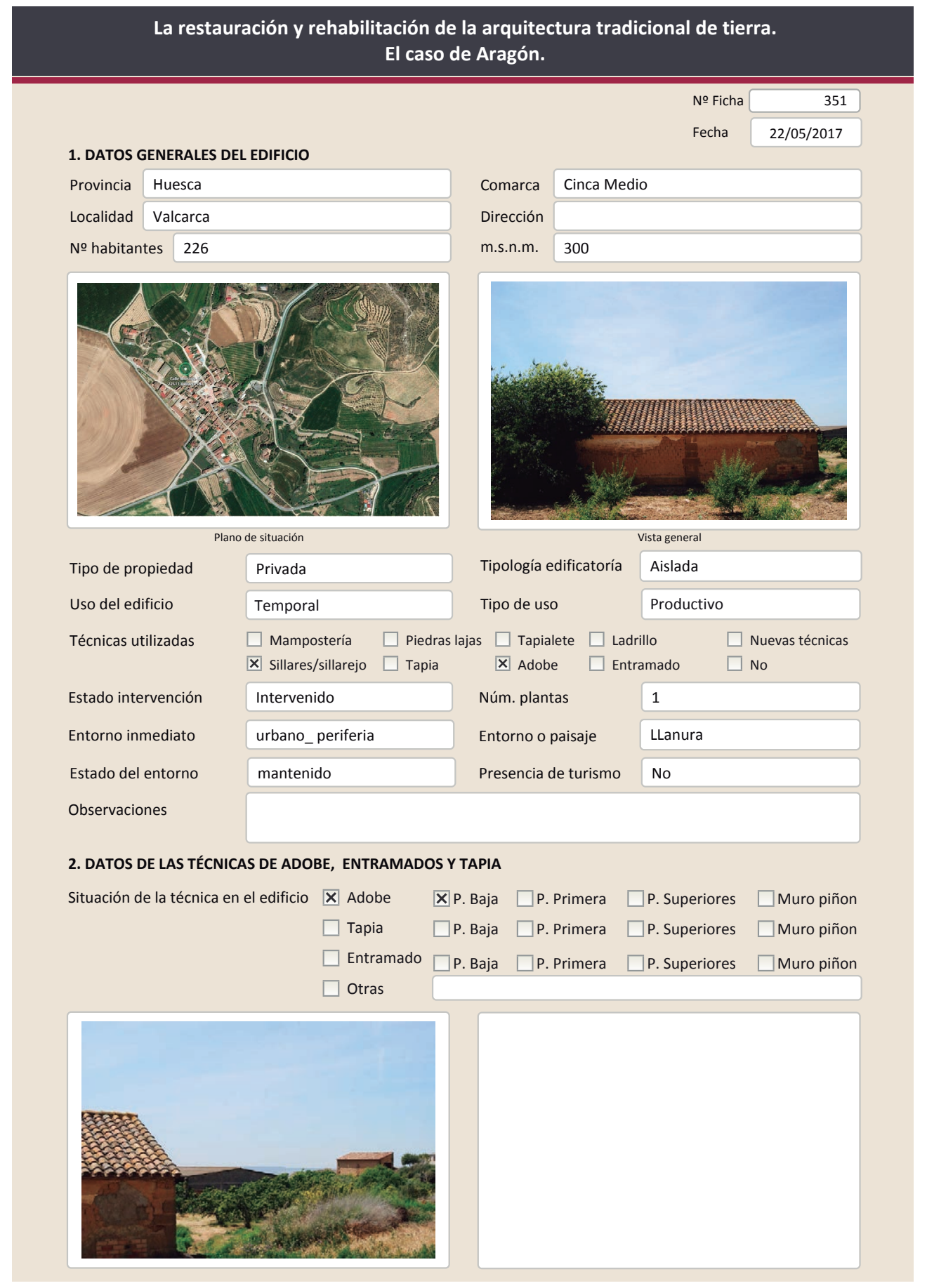

La restauración y rehabilitación de la arquitectura tradicional de tierra.

\subsection{ADOBE}

Dimensión de las piezas Dimensión del muro

Aparejo del muro

Función estructural

\section{El caso de Aragón.}

Color de las piezas

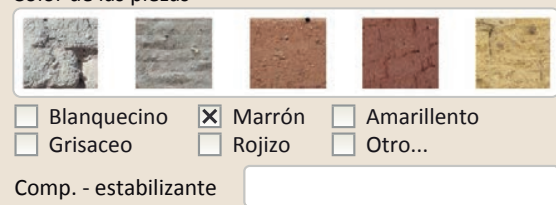

Variante constructiva/ tipo de fábrica

$\square$ Simple

$\square$ Suplementada en juntas

メ Mixta

\section{Machones}

Piedra

$\square$ Como suplemento

$\square$ Elementos de protección

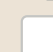

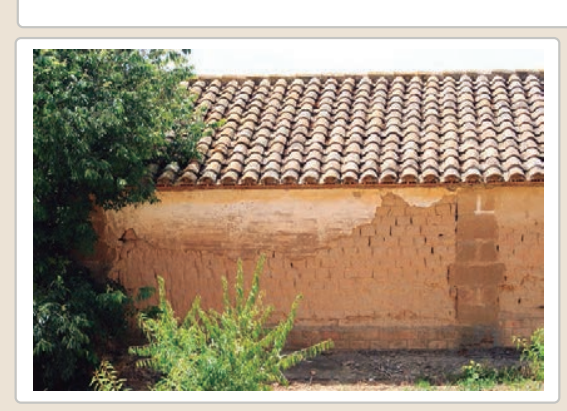

Lesiones $\mathbf{X}$ Muro $\mathbf{X}$ Zócalo $\mathbf{X}$ Revestimiento $\square$ Cubierta $\square$ otro...

区 Erosión del material $\quad \mathbf{X}$ Humedad por capilaridad $\quad \square$ Grietas por asentamientos $\boldsymbol{X}$ Erosion de las juntas $\square$ Humedades (manch/eflo) $\quad \square$ Colapso

X Pérdida de sección $\square$ Pérdida de verticalidad $\square$ Por elementos impropios

$\square$ Vegetación $\square$ Grietas por empuje de la cubierta $\square$ Derivado de intervenciones

区 Desconchados $\square$ Grietas porfalta de traba $\square$ Otro...

Observaciones 


\section{La restauración y rehabilitación de la arquitectura tradicional de tierra.}

\section{El caso de Aragón.}

3. DATOS DE LA INTERVENCIÓN

$\mathbf{X}$ Mantenimiento $\square$ Rehabilitación parcia

$\square$ Restauración $\square$ Demolición

(1)

X Reparación

Rehabilitación integra

Ampliación

$\square$ Otro...

Observaciones

Intervención espontanea

\subsection{MUROS}

Tipo de intervención

No intervenido

Tipo de material

Descripción

3.2. ZÓCALO

Tipo de intervención

Tipo de material

Descripción

3.3. REVESTIMIENTOS

Tipo de intervención

Tipo de material

Descripción

3.4. VANOS

Tipo de intervención

Tipo de material

Descripción

3.5. CUBIERTA

Tipo de intervención

Tipo de material

Descripción

3.6. OTRAS

Intervenido

$\square$ Actualización $\quad \mathbf{X}$ Reintegración $\square$ Demolición $\square$ Otro...

$\square$ Consolidación $\square$ Reconstrucción $\square$ Sustitución

No tradicional Tipo de técnica Diferente a la existente

Reintegración con cemento y ladrillo rellenando la sección perdida

\section{Intervenido}

$\square$ Actualización $\quad \boldsymbol{X}$ Reintegración $\square$ Demolición $\square$ Otro...

$\square$ Consolidación $\quad \square$ Reconstrucción $\quad \square$ Sustitución

No tradicional Tipo de técnica Diferente a la existente

Zonas con nuevo revestimiento de forma aleatoria

\section{No intervenido}

$\square$ Actualización $\square$ Reintegración $\square$ Demolición $\square$ Otro...

$\square$ Consolidación $\square$ Reconstrucción $\square$ Sustitución

$$
\text { Tipo de técnica }
$$

\section{No intervenido}

$\square$ Actualización $\square$ Reintegración $\square$ Demolición $\square$ Otro.

$\square$ Consolidación $\square$ Reconstrucción $\square$ Sustitución Tipo de técnica
La restauración y rehabilitación de la arquitectura tradicional de tierra.

El caso de Aragón.

3.7. REHABILITACIÓN ENERGÉTICA $\quad \square$ Fachada $\square$ Vanos $\square$ Forjados $\square$ Cubierta

Observaciones

FOTOGRAFíAS DE LA INTERVENCIÓN
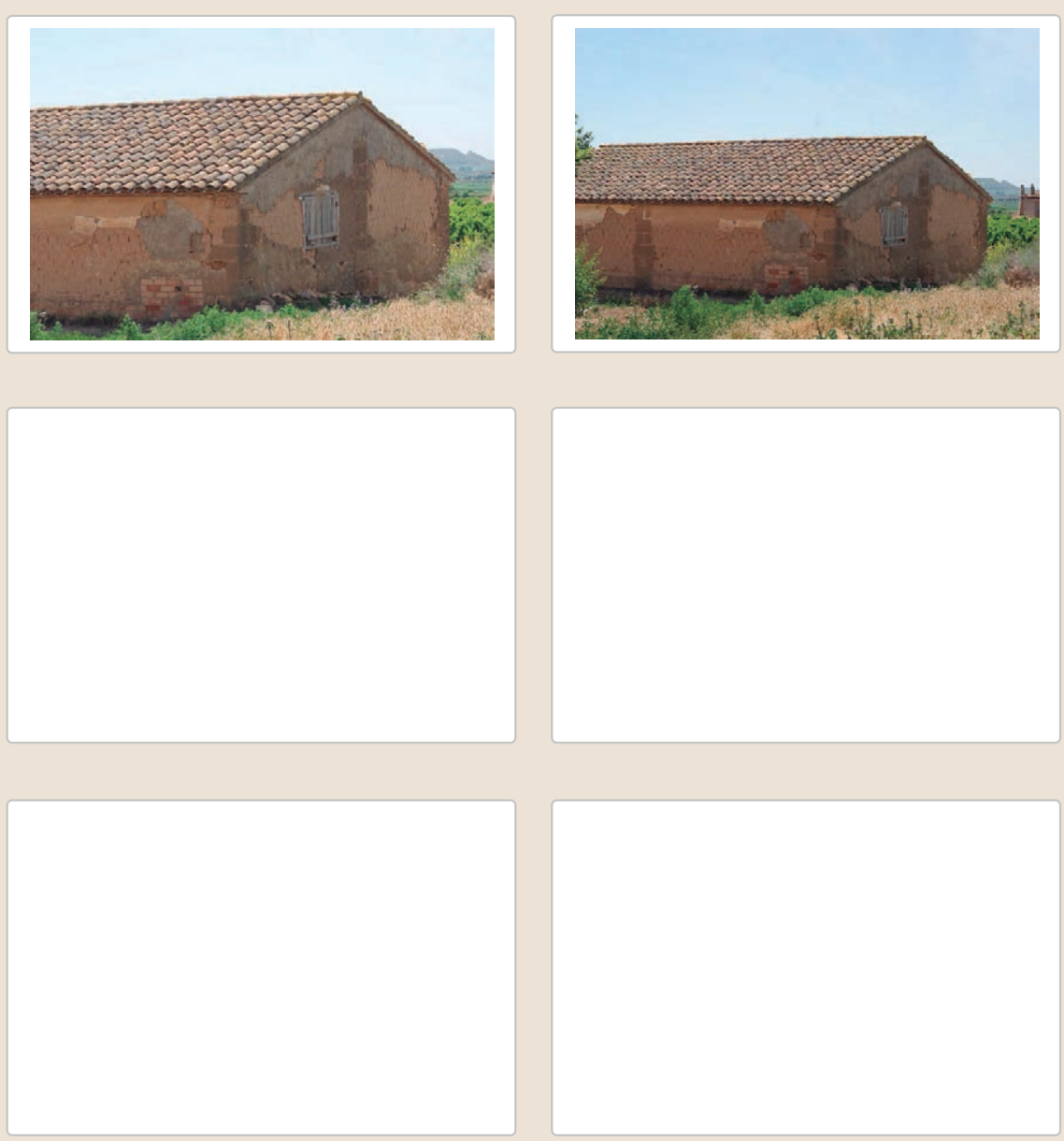


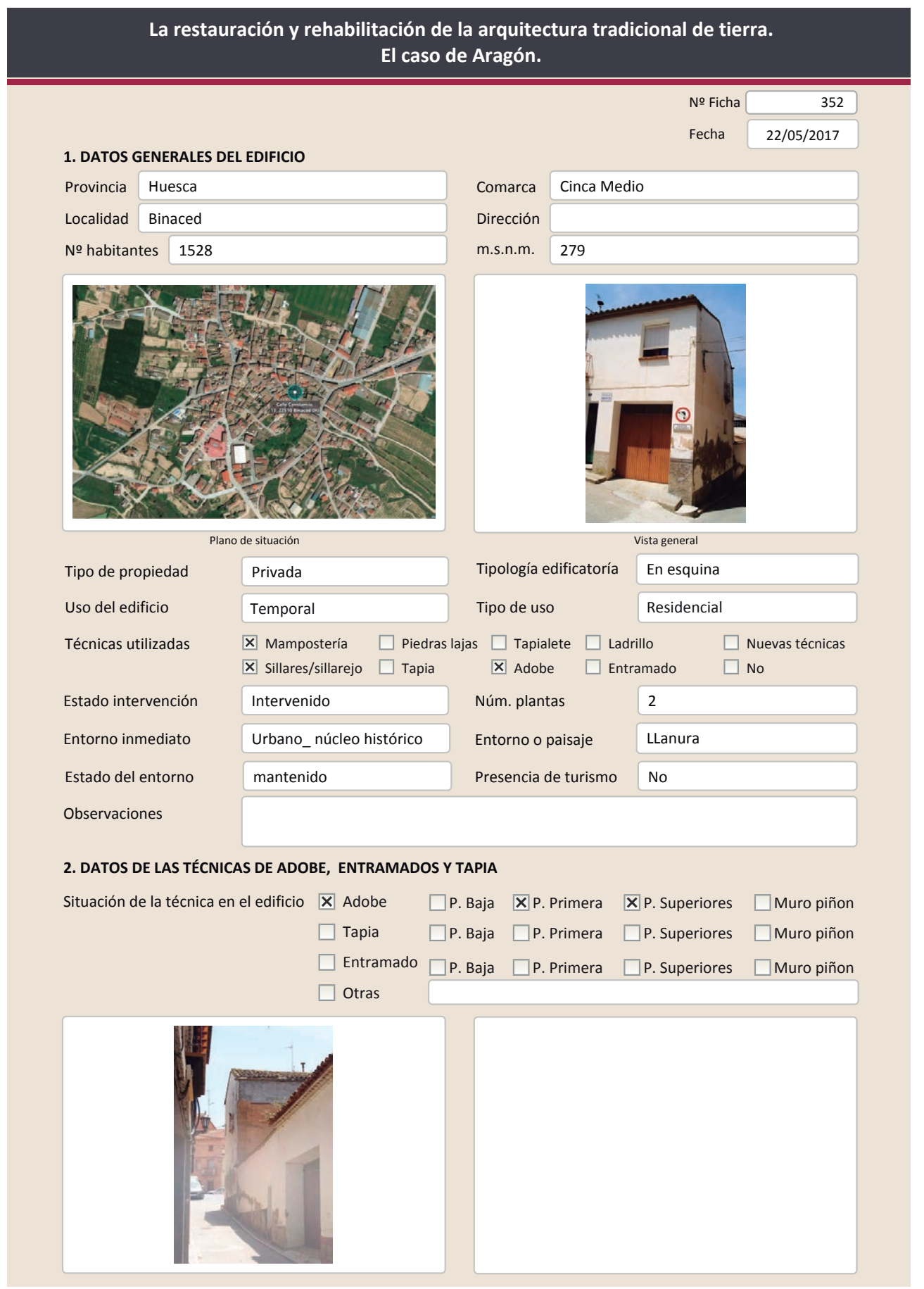

La restauración y rehabilitación de la arquitectura tradicional de tierra.

El caso de Aragón.

\subsection{ADOBE}

Dimensión de las piezas

Dimensión del muro

Aparejo del muro

Función estructural

Variante constructiva/ tipo de fábrica
Color de las piezas

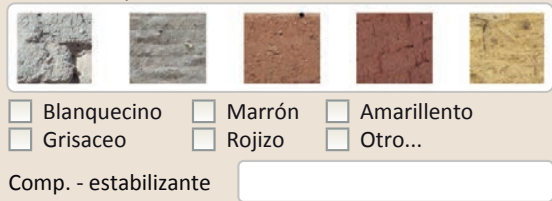

Comp. - estabilizante
$\square$ Simple
$\square$ Suplementada en juntas
区 Mixta

\section{Machones}
$\square$ Como suplemento
X Elementos de protección
Revestimiento

Piedra

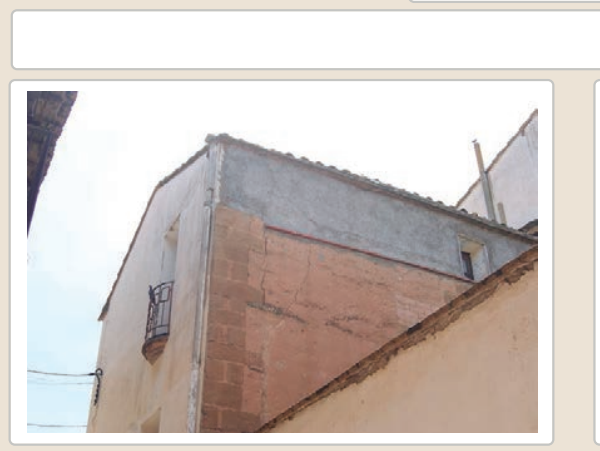
Lesiones
$\square$ Muro XZócalo $\square$ Revestimiento
$\begin{array}{lll}\square \text { Erosión del material } \quad \boldsymbol{X} \text { Humedad por capilaridad } & \square \text { Grietas por } \\ \square \text { Erosion de las juntas } & \square \text { Humedades (manch/eflo) } & \square \text { Colapso }\end{array}$
$\square$ Cubierta $\square$ otro...
$\square$ Pérdida de sección $\square$ Pérdida de verticalidad
$\square$ Colapso
$\square$ Vegetación
$\square$ Grietas por empuje de la cub
$\square$ Por elementos impropios
$\square$ Desconchados
$\square$ Grietas porfalta de traba
$\square$ Derivado
$\square$ Otro...

Observacione 
La restauración y rehabilitación de la arquitectura tradicional de tierra. El caso de Aragón

\section{La restauración y rehabilitación de la arquitectura tradicional de tierra.}

\section{El caso de Aragón.}

3. DATOS DE LA INTERVENCIÓN

Intervención de:

$\square$ Mantenimiento $\quad \boldsymbol{X}$ Rehabilitación parcial $\square$ Restauración $\square$ Demolición

$\square$ Reparación $\quad \square$ Rehabilitación integral $\quad \square$ Ampliación $\quad \square$ Otro...

Reflexión previa Intervención planificada

Observaciones podría ser que el edificio haya sido recrecido (visible en la parte trasera)

3.1. MUROS

No visible

Tipo de intervención

$\square$ Actualización $\quad \square$ Reintegración $\quad \square$ Demolición $\square$ Otro...

$\square$ Consolidación $\square$ Reconstrucción $\square$ Sustitución

Tipo de material

Descripción

3.2. ZÓCALO

Tipo de intervención

Intervenido

Tipo de intervención

Х Actualizació

Tipo de material

No tradicional Tipo de técnica Diferente a la existente

Tipo de técnica

Descripción

3.3. REVESTIMIENTOS

\section{Intervenido}

Tipo de intervención

X Actualización $\square$ Reintegración $\square$ Demolición $\square$ Otro...

$\square$ Consolidación $\quad \boldsymbol{X}$ Reconstrucción $\square$ Sustitución

Tipo de material

Descripción

3.4. VANOS

Intervenido

Tipo de intervención

$\square$ Actualización $\quad \mathbf{X}$ Reintegración $\square$ Demolición $\square$ Otro...

$\square$ Consolidación $\square$ Reconstrucción $\quad \boldsymbol{X}$ Sustitución

\begin{tabular}{l|l|l|l|l|l|l|l} 
Tipo de material & No tradicional de técnica & Diferente a la existente \\
\hline
\end{tabular}

Descripción Sustitución de carpinterías. Ampliación del hueco de planta baja para acceso de vehículos

3.5. CUBIERTA

Intervenido

Tipo de intervención

$\square$ Actualización $\square$ Reintegración $\square$ Demolición $\square$ Otro.

Tipo de material

$\square$ Consolidación $\square$ Reconstrucción $\quad \boldsymbol{X}$ Sustitución

Descripción

La cubierta parece reconstruida

Tipo de técnica Similar a la existente

3.6. OTRAS 
La restauración y rehabilitación de la arquitectura tradicional de tierra. El caso de Aragón.

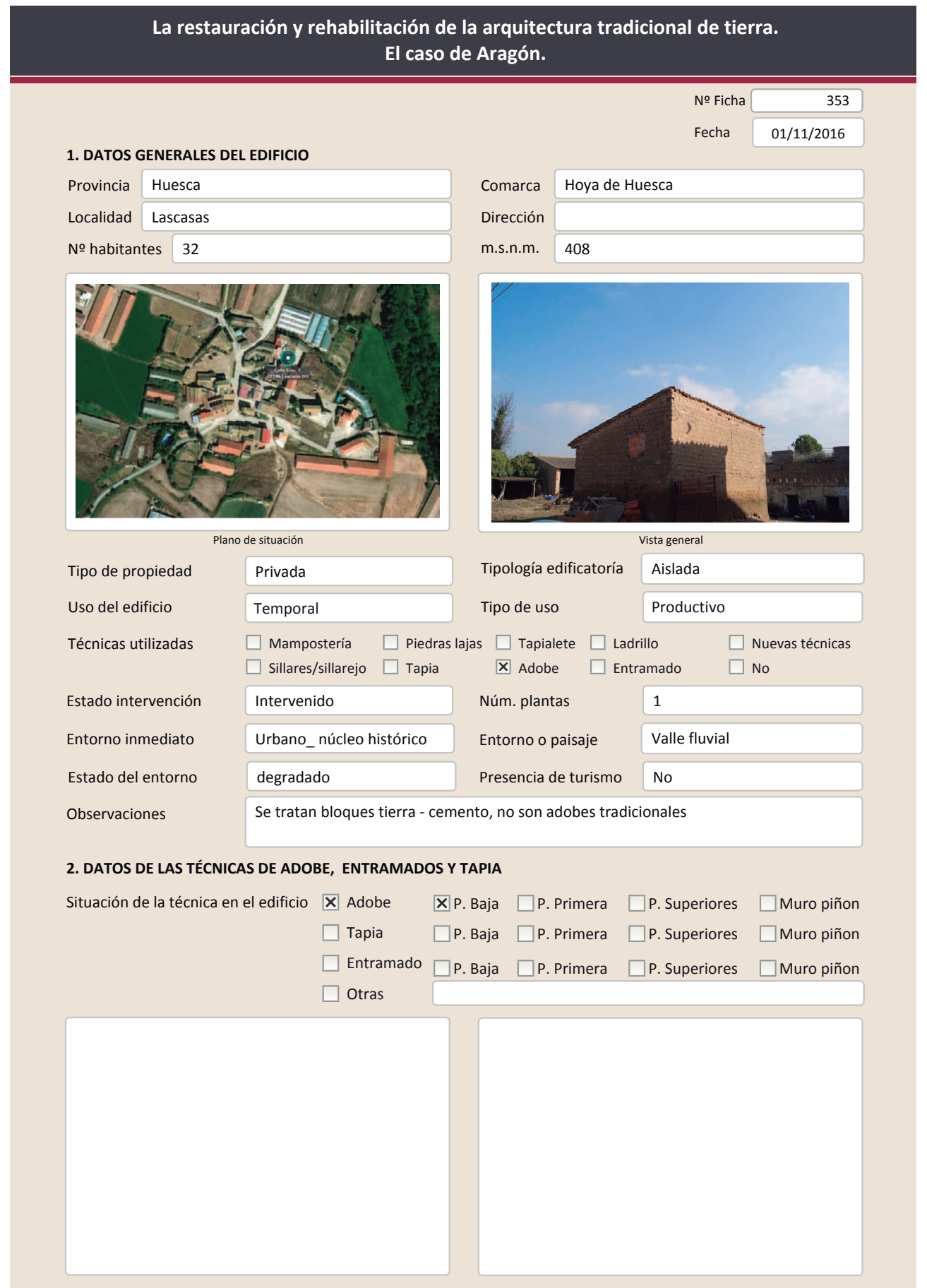

La restauración y rehabilitación de la arquitectura tradicional de tierra.

El caso de Aragón.
2.1. ADOBE

Dimensión de las piezas Dimensión del muro

Aparejo del muro

Función estructural
Color de las piezas

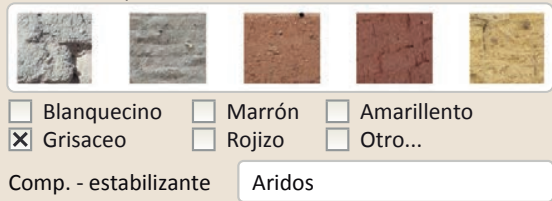

Variante constructiva/ tipo de fábrica

Х Simple

$\square$ suplementada en juntas

$\square$ Mixta

$\square$ Como suplemento

$\square$ Elementos de protección

Bloques tierra cemento

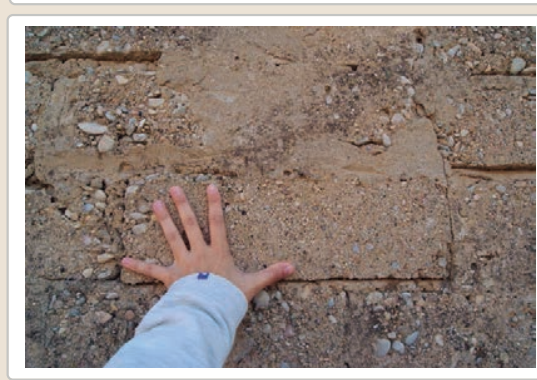

Lesiones $\quad \mathbf{X}$ Muro $\square$ Zócalo $\square$ Revestimiento $\mathbf{X}$ Muro $\square$ Zócalo $\square$ Revestimiento
material $\quad \mathbf{X}$ Humedad por capilarida $\square$ Erosión del material $\quad \mathbf{X}$ Humedad por capilaridad $\square$ Pérdida de sección $\square$ Pérdida de verticalidad

$\square$ Vegetación $\quad \square$ Grietas por empuje de la cubie

$\begin{array}{ll}\square \text { Vegetación } & \boldsymbol{X} \text { Grietas por empuje de la } \\ \square \text { Desconchados } & \square \text { Grietas porfalta de traba }\end{array}$

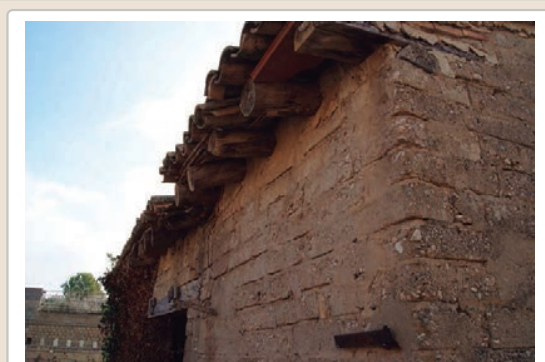

X Cubierta $\square$ Otro...

$\square$ Grietas por asentamiento X Colapso

$\square$ Por elementos impropios

$\square$ Derivado de intervenciones

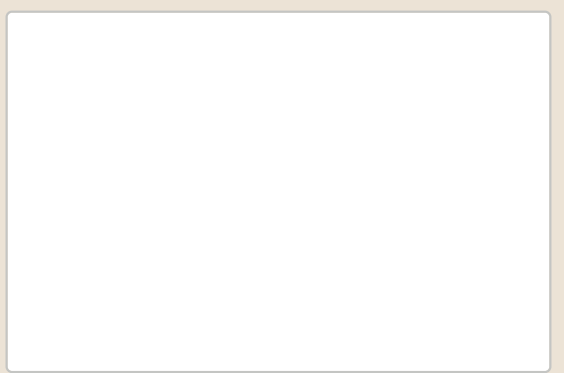
X Otro... 


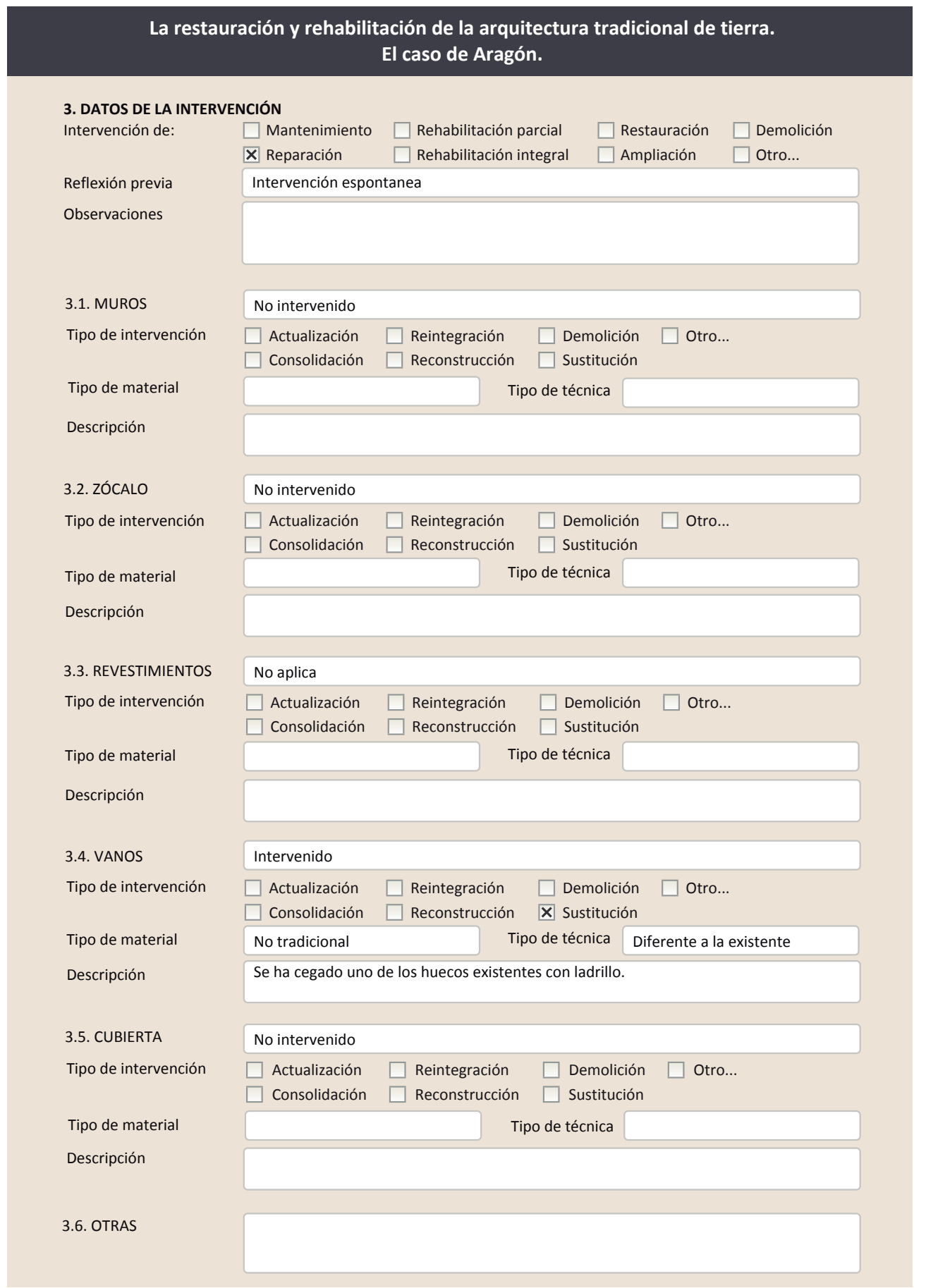

\subsection{REHABILITACIÓN ENERGÉTICA $\quad \square$ Fachada $\square$ Vanos $\square$ Forjados $\square$ Cubierta}

Observaciones

FOTOGRAFíAS DE LA INTERVENCIÓN
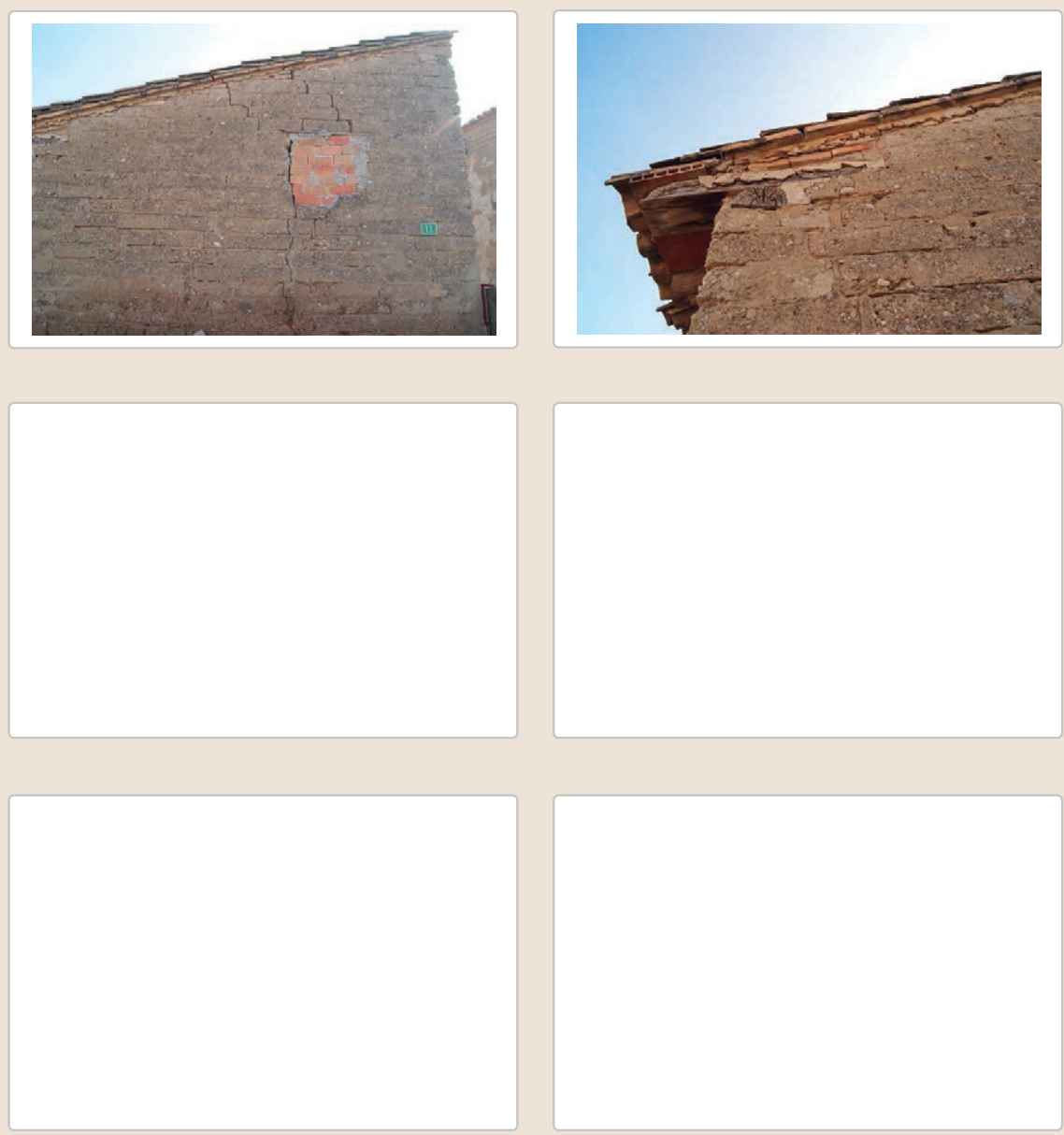


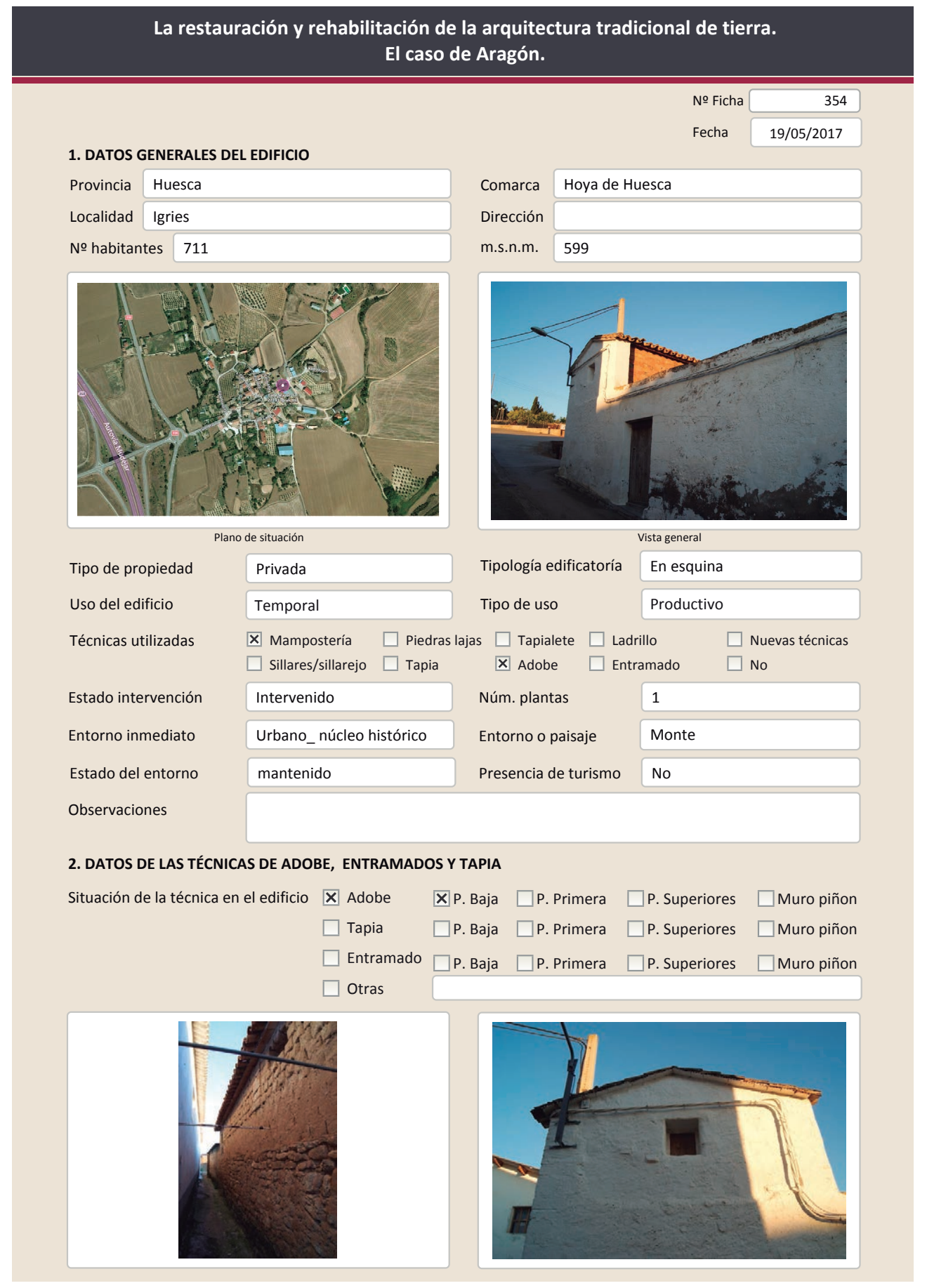

La restauración y rehabilitación de la arquitectura tradicional de tierra. El caso de Aragón.

2.1. ADOBE

Dimensión de las piezas Lx19×16

Dimensión del muro $30-40 \mathrm{~cm}$

Aparejo del muro Tizón

Función estructural

Si
Color de las piezas

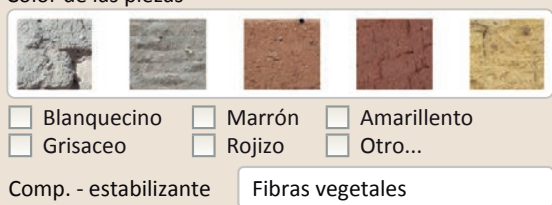

Comp. - estabilizante Fibras vegtales

Variante constructiva/ tipo de fábrica

$\square$ simple

$\square$ Suplementada en juntas

X Mixta

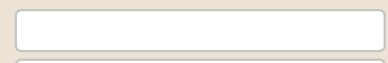

$\square$ Como suplemento

$\square$ Elementos de protección

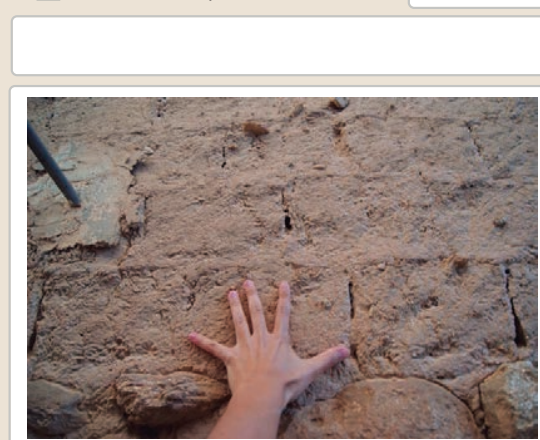

Lesiones $\quad \mathbf{X}$ Muro $\mathbf{X}$ Zócalo $\square$ Revestimiento

X Erosión del material $\quad \mathbf{X}$ Humedad por capilaridad $\square$ Erosion de las juntas $\square$ Humedades (manch/eflo)

$\square$ Pérdida de sección $\square$ Pérdida de verticalidad

$\square$ Vegetación $\quad \square$ Grietas por empuje de la cubie

$\square$ Desconchados

$\square$ Grietas porfalta de traba

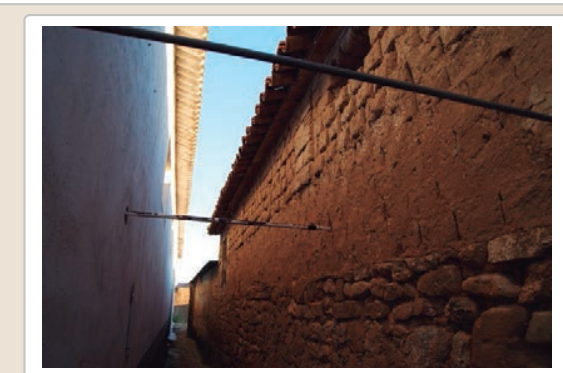

$\square$ Cubierta $\square$ Otro...

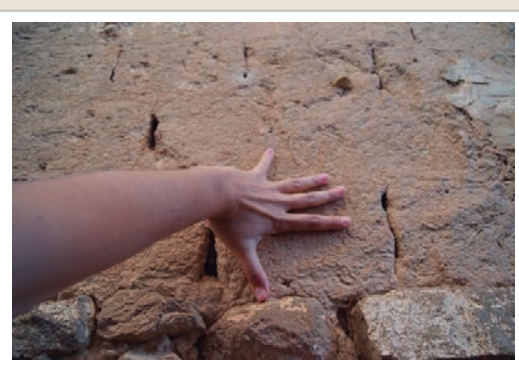

Observaciones $\square$ Grietas por asentamientos

$\square$ Colapso

\section{Piedra}

$\square$ Por elementos impropios

$\square$ Derivado de intervenciones $\square$ Otro... 


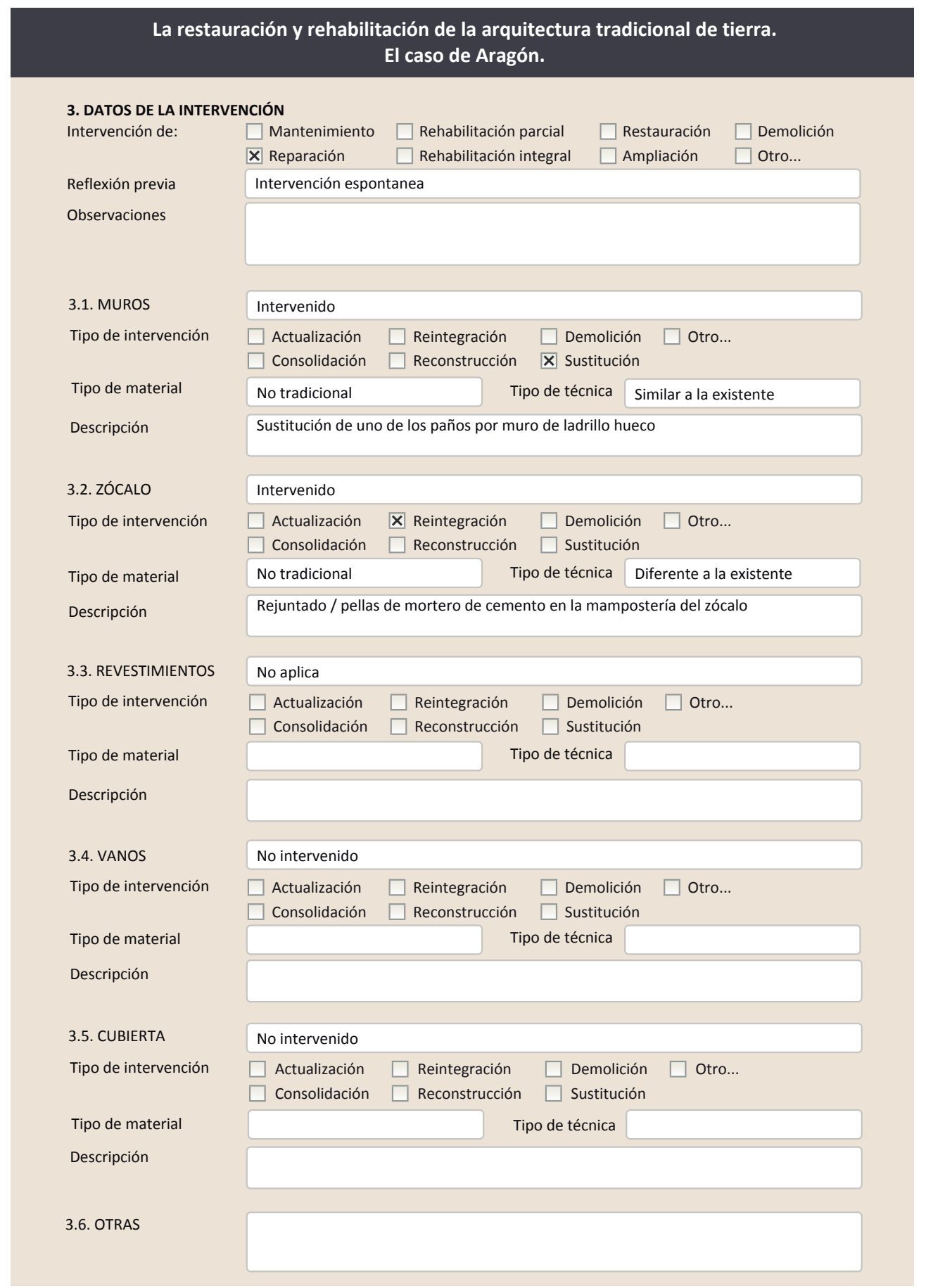

3.7. REHABILITACIÓN ENERGÉTICA $\quad \square$ Fachada $\square$ Vanos $\square$ Forjados $\square$ Cubierta Observaciones

FOTOGRAFíAS DE LA INTERVENCIÓN
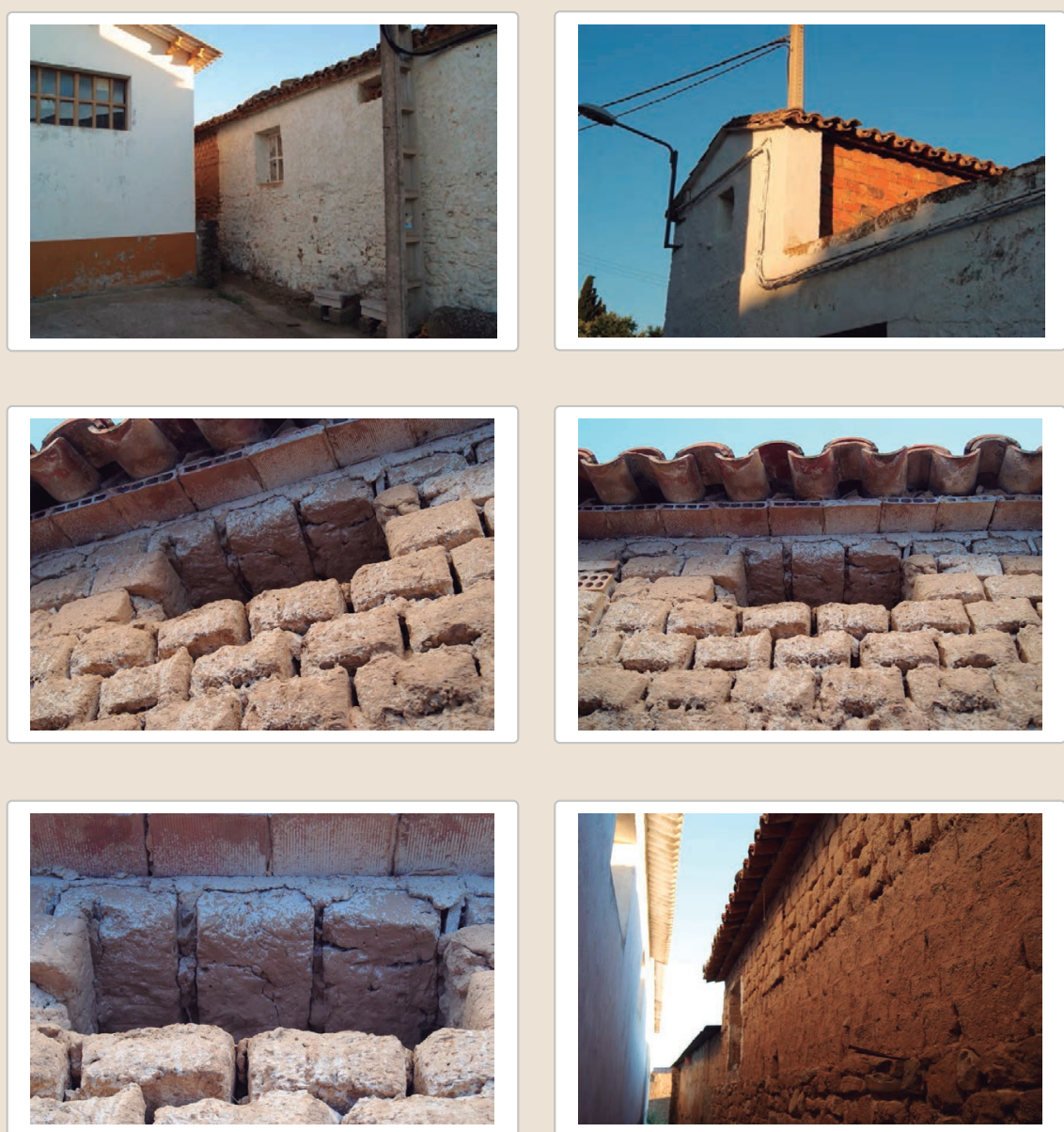


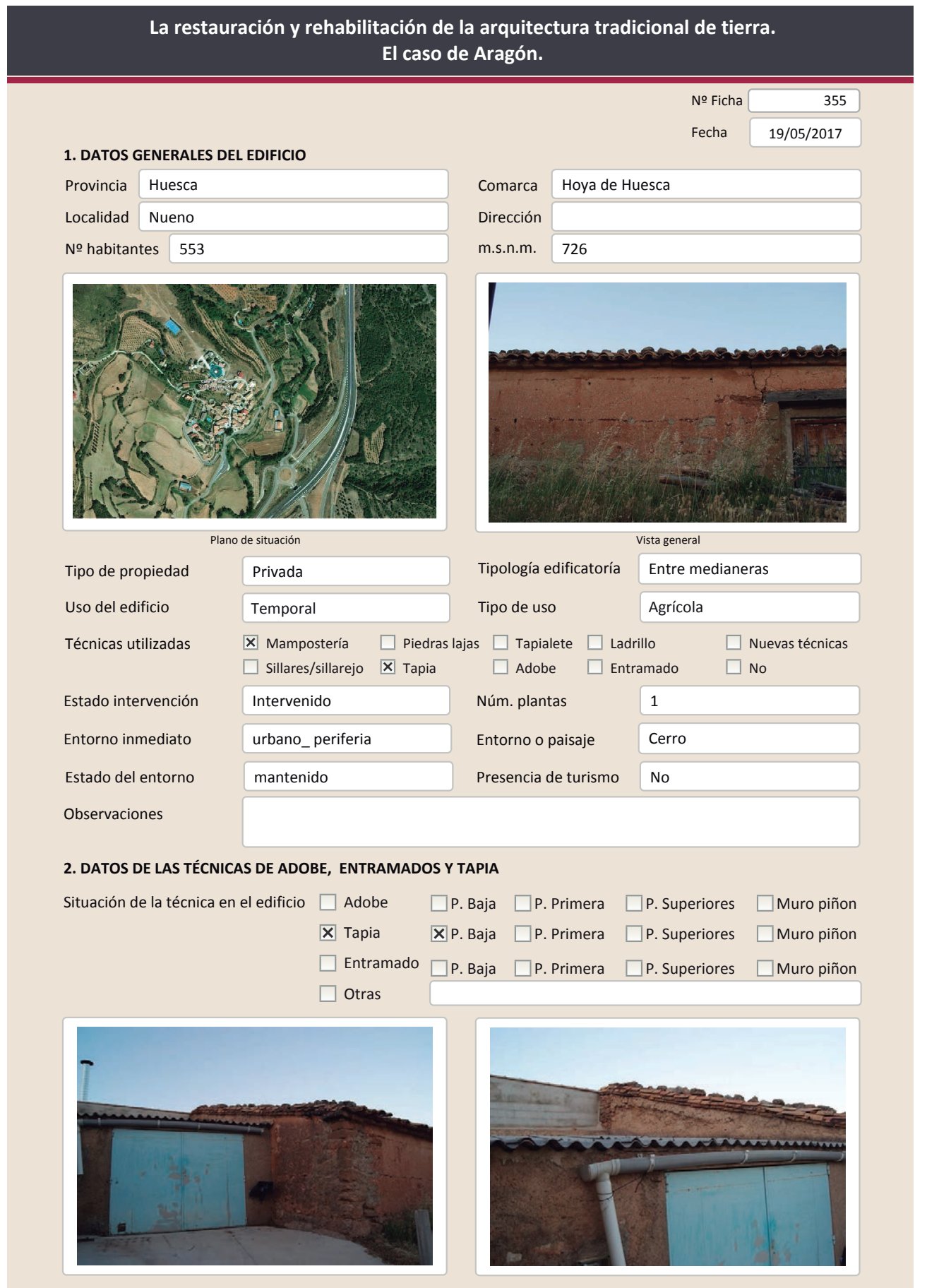

La restauración y rehabilitación de la arquitectura tradicional de tierra. El caso de Aragón.

2.2. TAPIA

Ancho del muro

Dimensión tapiales

Tipo de aguja

№ agujas/cajón

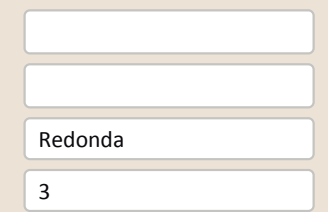

Color de la tapia

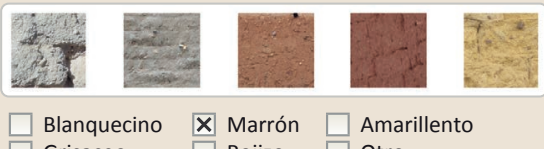

$\square$ Blanquecino $\quad \mathbf{X}$ Marrón $\square$ Amarillento

Variante constructiva

$\square$ Simple / homogénea

X Suplemento superficial

$\square$ suplemento en juntas

X Mixta
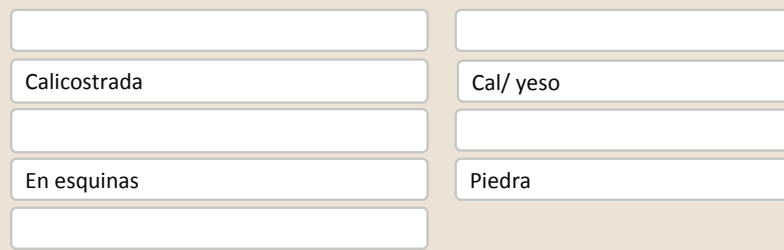

Elementos de protección

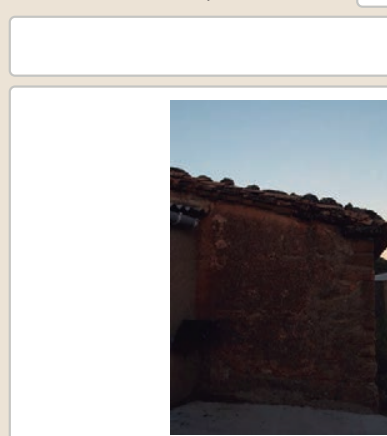

Lesiones

XMuro XZócalo $\square$ Revestimiento

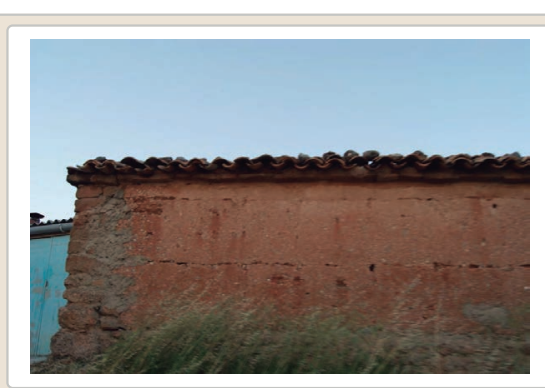

$X$ Erosion de las juntas $\square$ Humedades (manch/eflo)

$\square$ Pérdida de sección $\square$ Pérdida de verticalidad

$\square$ Vegetación

$\square$ Desconchados

$\mathbf{X}$ Grietas porfalta de trab

$\square$ Grietas por

$\square$ Por elementos impropios

$\square$ Derivado

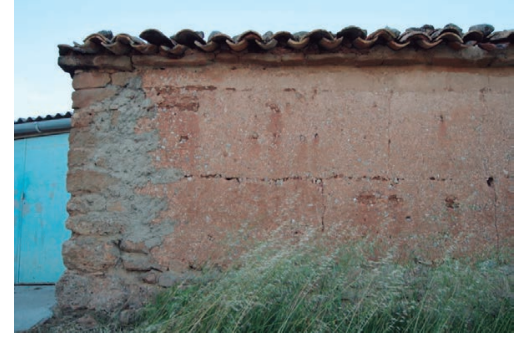

Observaciones 
La restauración y rehabilitación de la arquitectura tradicional de tierra. El caso de Aragón

\section{La restauración y rehabilitación de la arquitectura tradicional de tierra.}

\section{El caso de Aragón.}

3. DATOS DE LA INTERVENCIÓN

Intervención de:

$\square$ Mantenimiento $\square$ Rehabilitación parcia

$\square$ Restauración $\square$ Demolición X Reparación $\quad \square$ Rehabilitación integral $\quad \square$ Ampliación $\quad \square$ Otro...

Reflexión previa Intervención espontanea

Observaciones

3.1. MUROS

Intervenido

Tipo de intervención

$\square$ Actualización $\quad \boldsymbol{X}$ Reintegración $\square$ Demolición $\square$ Otro...

$\square$ Consolidación $\square$ Reconstrucción $\square$ sustitución

Tipo de material

\begin{tabular}{l|l} 
No tradicional & Tipo de técnica Diferente a la existente
\end{tabular}

Descripción

Reintegración de grietas con cemento. Unión entre la mampostería y la tapia

3.2. ZÓCALO

Intervenido

Tipo de intervención

Actualización $\quad \mathbf{x}$ Reintegración $\square$ Demolición $\square$ Otro..

$\square$ Consolidación $\quad \square$ Reconstrucción $\quad \square$ Sustitución
$\square$ Cotión

Tipo de material

No tradicional Tipo de técnica Diferente a la existente

Descripción

Pellas de mortero

3.3. REVESTIMIENTOS

Tipo de intervención

\section{No aplica}

Tipo de material

$\square$ Actualización $\quad \square$ Reintegración $\quad \square$ Demolición
$\square$ consolidación $\quad \square$ Reconstrucción $\quad \square$ Sustitución

Tipo de materia

Descripción

3.4. VANOS

Tipo de intervención

Intervenido

Tipo de material

$\square$ Actualización $\square$ Reintegración $\square$ Demolición $\square$ Otro...

Descripción

No tradicional

Tipo de técnica Diferente a la existente

3.5. CUBIERTA

Tipo de intervención

No intervenido

$\square$ Actualización $\square$ Reintegración $\quad \square$ Demolición $\square$ Otro.

Tipo de material

$\square$ Consolidación $\square$ Reconstrucción $\quad \square$ sustitución

Descripción

Tipo de técnica

3.6. OTRAS 


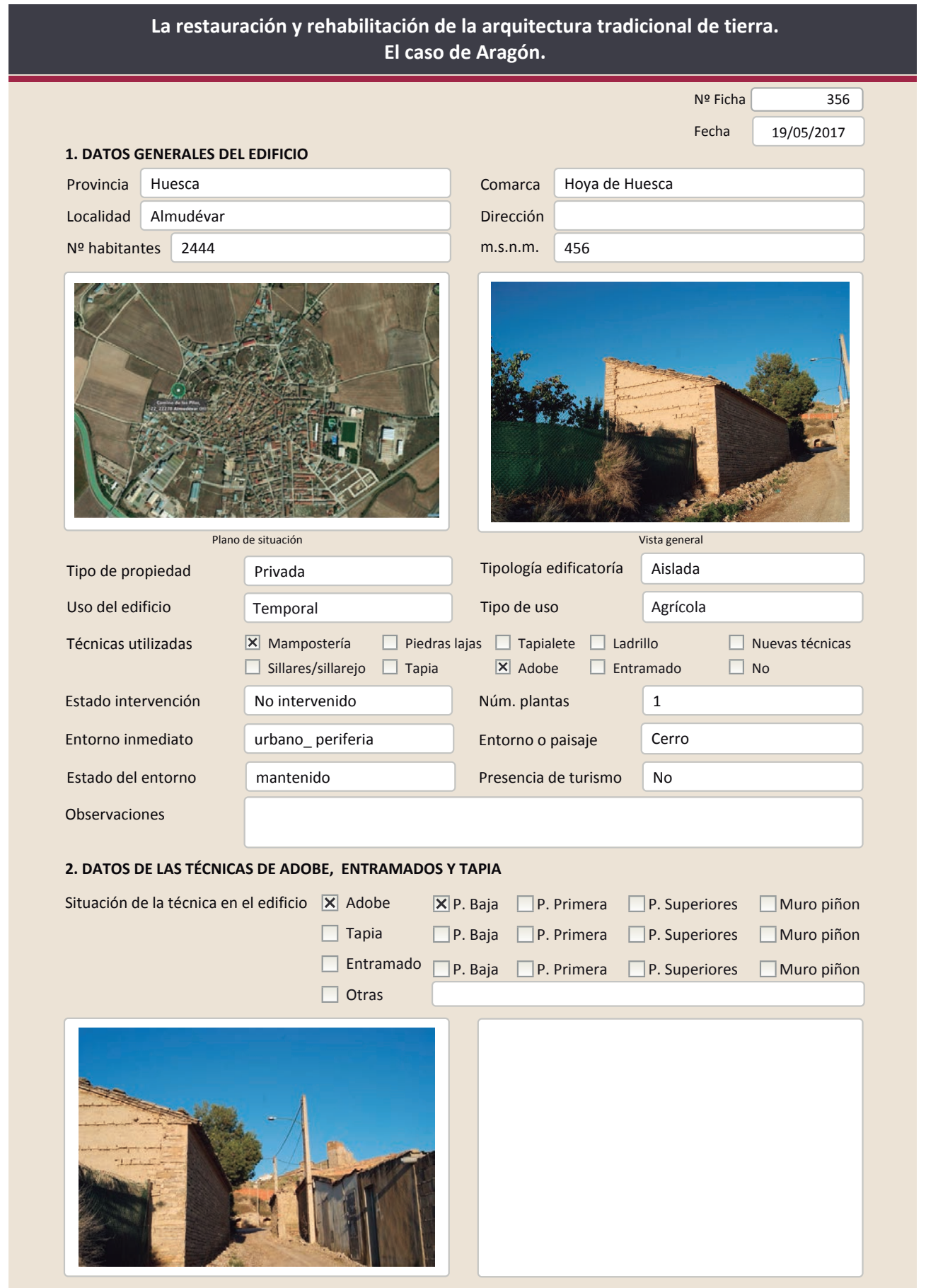

La restauración y rehabilitación de la arquitectura tradicional de tierra.

El caso de Aragón.

2.1. ADOBE

Dimensión de las piezas

Dimensión del muro

Aparejo del muro

Función estructural

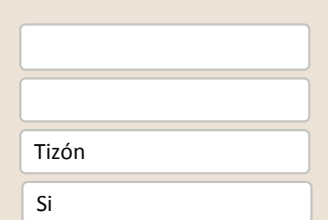

Color de las piezas

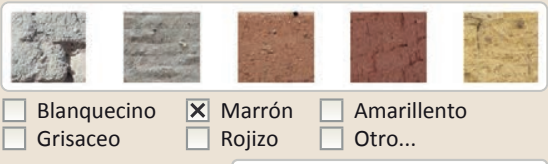

Variante constructiva/ tipo de fábrica

$\square$ simple
Х Suplementada en juntas
Horizontales
$\mathrm{Cal} /$ yeso
$\mathbf{X}$ Mixta
En esquinas
Piedra

$\square$ Como suplemento

$\square$ Elementos de protección

Suplemento en una junta cada 4 o 5 hiladas de adobe

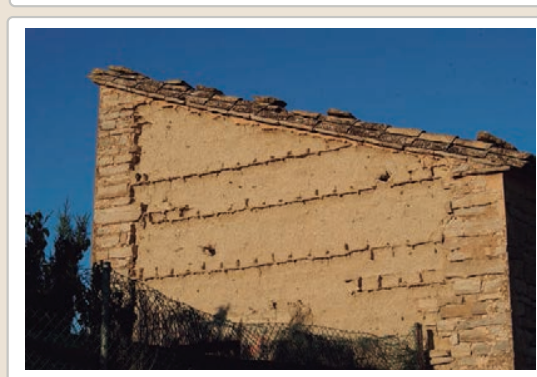

Lesiones $\quad \mathbf{X}$ Muro $\square$ Zócalo $\square$ Revestimiento $\mathbf{X}$ Erosión del material $\square$ Humedad por capilaridad $\mathbf{X}$ Erosion de las juntas $\square$ Humedades (manch/eflo) Х Pérdida de sección $\quad \square$ Pérdida de verticalidad

$\begin{array}{ll}\square \text { Vegetación } & \square \text { Grietas por empuje de la } \\ \square \text { Desconchados } & \square \text { Grietas porfalta de traba }\end{array}$

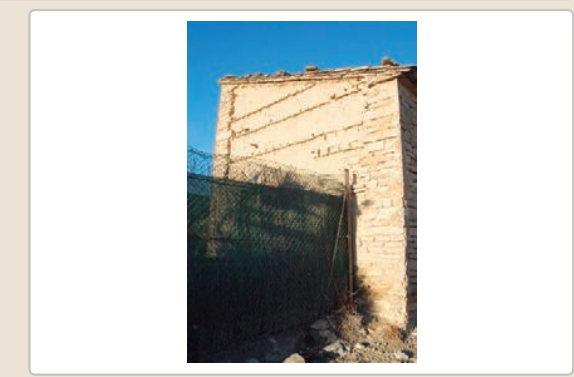

$\square$ Cubierta $\square$ otro...

$$
\begin{aligned}
& \square \text { Grietas por asentamientos } \\
& \square \text { Colapso } \\
& \square \text { Por elementos impropios } \\
& \square \text { Derivado de intervenciones }
\end{aligned}
$$

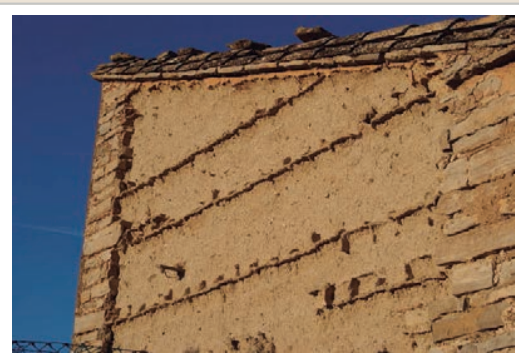

Observaciones 


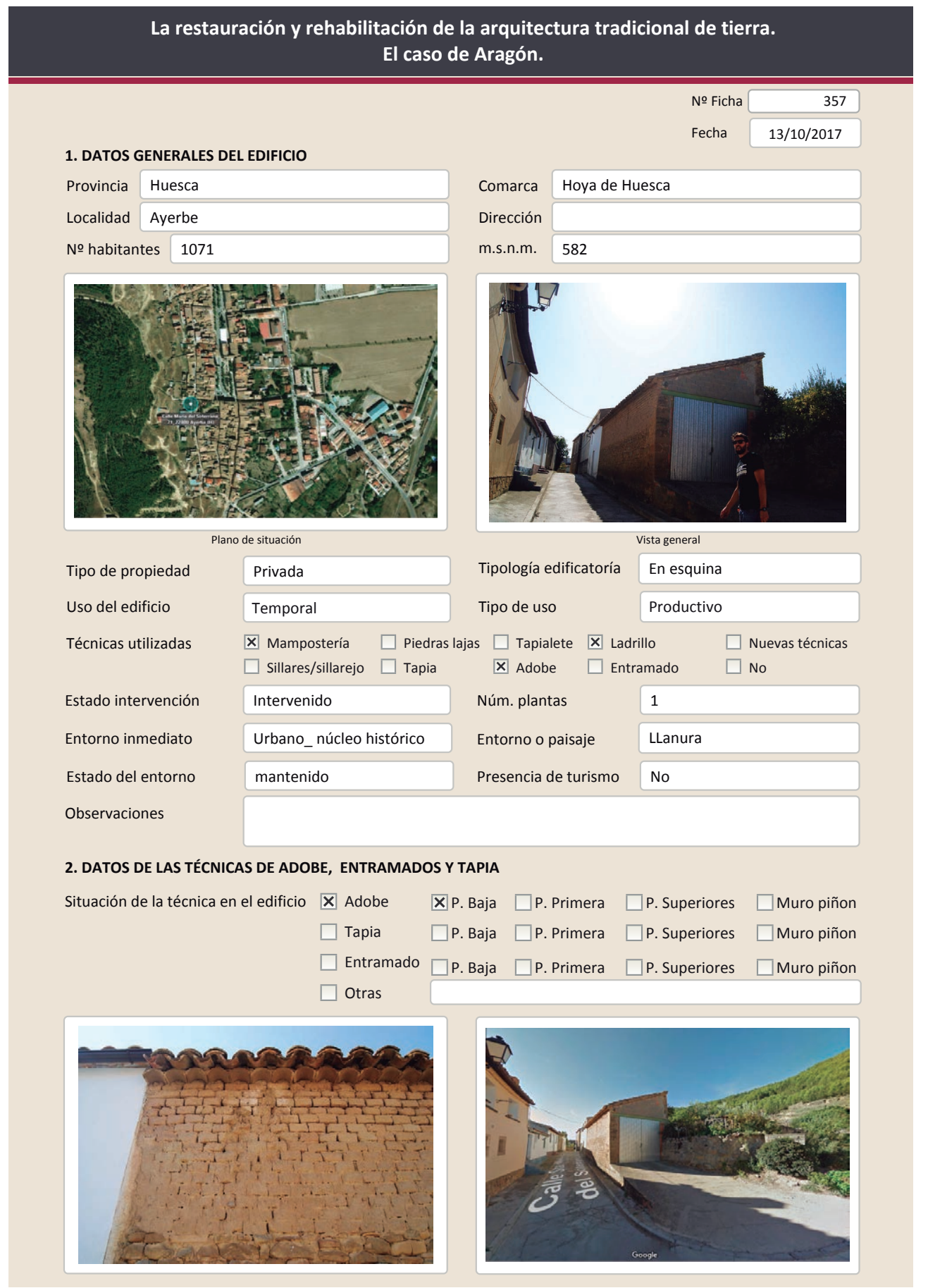

2.1. ADOBE

Dimensión de las piezas $\quad \mathrm{L} \times 18 \times 10$

Dimensión del muro $30-40 \mathrm{~cm}$

Aparejo del muro Tizón

Función estructural

$\mathrm{Si}$

Variante constructiva/ tipo de fábrica

$\square$ Simple

$\square$ Suplementada en juntas

X Mixta

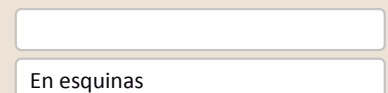

$\square$ Como suplemento

$\square$ Elementos de protección Machón de mampostería y ladrillo

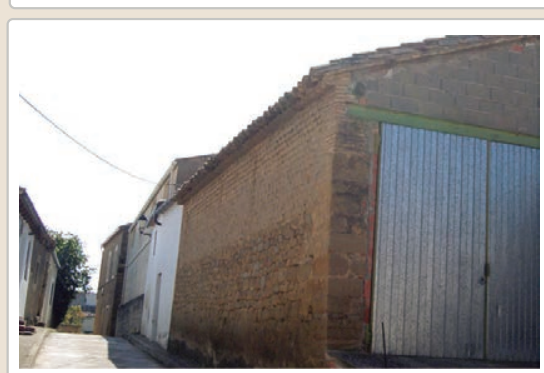

Lesiones

X Muro XZócalo $\square$ Revestimiento

$\mathbf{X}$ Erosión del material $\quad \mathbf{X}$ Humedad por capilaridad $\mathbf{X}$ Erosion de las juntas $\square$ Humedades (manch/eflo) $\square$ Pérdida de sección $\square$ Pérdida de verticalidad

$\square$ Vegetación $\quad \square$ Grietas por empuje de la c

$\square$ Desconchados

$\square$ Grietas porfalta de traba

Color de las piezas
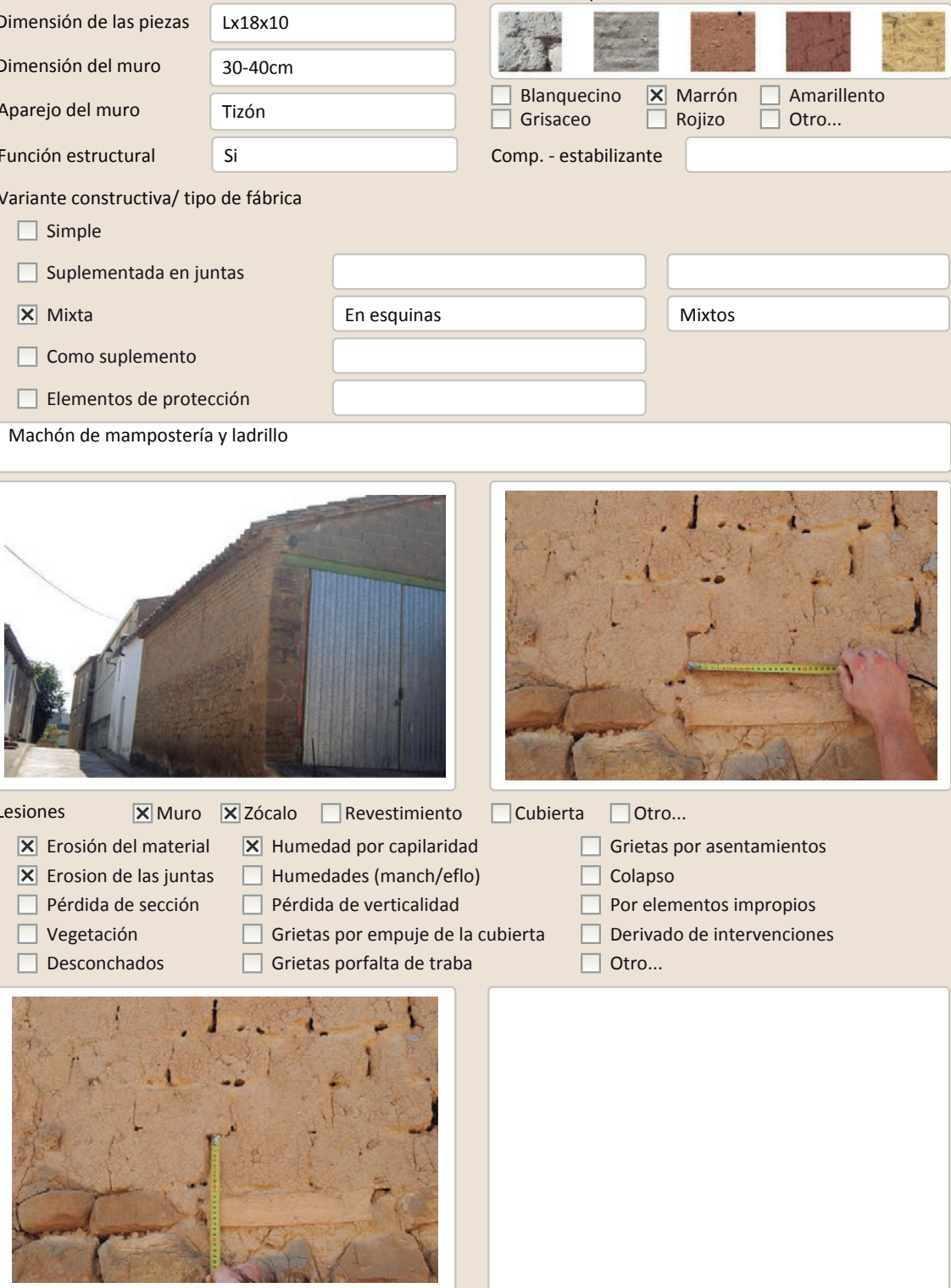

Observaciones

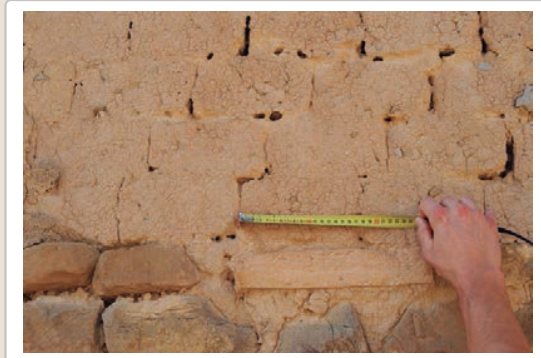

$\square$ Cubierta $\square$ Otro...

$\square$ Grietas por asentamiento

$\square$ Colapso

$\square$ Por elementos impropios

$\square$ Derivado de intervenciones

$\square$ Otro... 


\section{La restauración y rehabilitación de la arquitectura tradicional de tierra.}

\section{El caso de Aragón.}

\section{DATOS DE LA INTERVENCIÓN}

Intervención de:

$\square$ Mantenimiento $\quad \mathbf{X}$ Rehabilitación parcial

$\square$ Restauración $\square$ Demolición

Reflexión previa

$\square$ Reparación

Rehabilitación integra

Ampliación

$\square$ Otro...

Observaciones

Intervención espontanea

(2)

3.1. MUROS

Intervenido

Tipo de intervención

$\square$ Actualización $\square$ Reintegración $\square$ Demolición $\square$ Otro...

$\square$ Consolidación $\square$ Reconstrucción $\quad$ X Sustitución

Tipo de material

\begin{tabular}{l|l|l|l|l} 
No tradicional & Tipo de técnica Diferente a la existente
\end{tabular}

Descripción

sustitución parcial del muro en el área sobre la ampliación del hueco (muro piñón)

3.2. ZÓCALO

Intervenido

Tipo de intervención

Actualización $\square$ Reintegración $\square$ Demolición $\square$ Otro...

Tipo de material

$\square$ Actualización $\quad \square$ Reintegración $\quad \square$ Demolición
$\square$ Consolidación $\quad \mathbf{X}$ Reconstrucción $\quad \square$ Sustitución

Descripción

\begin{tabular}{|lll}
\hline No tradicional Tipo de técnica Diferente a la existente \\
\hline
\end{tabular}

3.3. REVESTIMIENTOS

Revestimiento con cemento

3.3. REVESTIMIENTOS
Tipo de intervención

\section{No aplica}

Tipo de material

Descripción

$\square$ Actualización

$\square$ Reintegración $\square$ Demolición $\square$ Otro...

Consolidación $\square$ Reconstrucción $\square$ Sustitución

3.4. VANOS

Intervenido

Tipo de intervención

$\square$ Actualización $\square$ Reintegración $\square$ Demolición $\square$ Otro...

Tipo de material

$\square$ consolidación $\square$ Reconstrucción $\boldsymbol{X}$ Sustitución

Descripción

No tradicional

Tipo de técnica Diferente a la existente

3.5. CUBIERTA

Tipo de intervención

No intervenido

$\square$ Actualización $\square$ Reintegración $\square$ Demolición $\square$ Otro...

Tipo de material

$\square$ Reconstrucción $\square$ Sustitución

Descripción

$$
\text { Tipo de técnica }
$$

3.6. OTRAS 


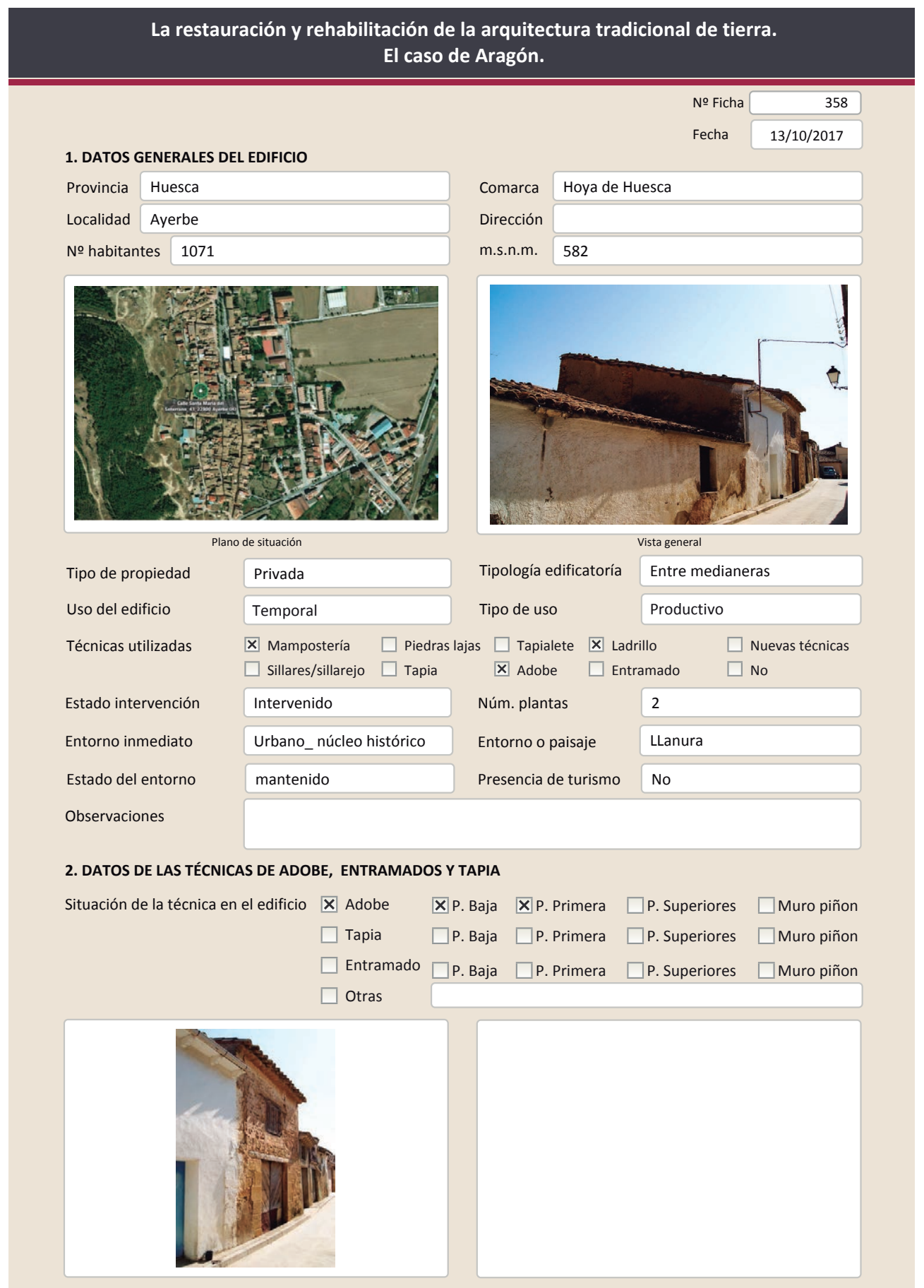

2.1. ADOBE

Dimensión de las piezas

Dimensión del muro

Aparejo del muro

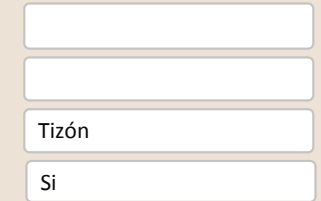

Color de las piezas

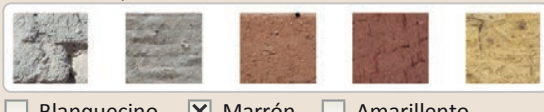

Blanquecino $\mathbf{X}$ Marrón $\square$ Amarillento $\square$ Grisaceo $\square$ Rojizo $\square$ Otro...

Función estructural

Comp. - estabilizante

Variante constructiva/ tipo de fábrica

$\square$ simple

$\square$ Suplementada en juntas

区 Mixta

\section{Machones}

Mixtos

$\square$ Como suplemento

$\mathbf{X}$ Elementos de protección

Revestimiento

Machón de fachada de piedra. Machones del muro piñón de ladrillo

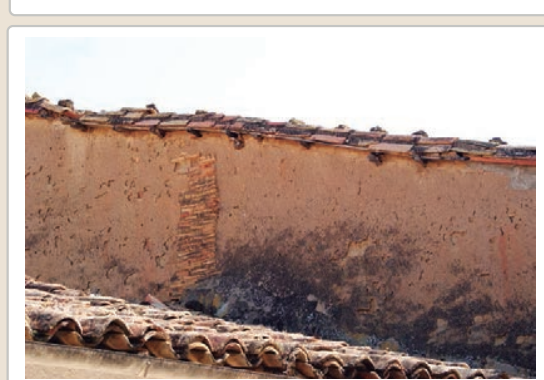

Lesiones $\mathbf{X}$ Muro $\mathbf{X}$ Zócalo $\mathbf{X}$ Revestimiento

$\square$ Erosión del material $\square$ Humedad por capilaridad

$\square$ Erosion de las juntas $\mathbf{X}$ Humedades (manch/eflo)

$\square$ Pérdida de sección $\square$ Pérdida de verticalidad

$\square$ Vegetación $\quad \square$ Grietas por empuje de la cubie

$\square$ Grietas por empuje de la cubierta
$\square$ Grietas porfalta de traba

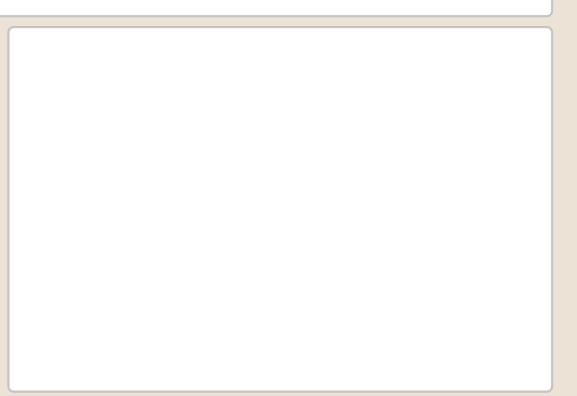

X Cubierta $\square$ Otro...

X Desconchados

$\square$ Grietas

$\square$ Por elementos impropios

$\square$ Derivado de intervenciones 


\section{La restauración y rehabilitación de la arquitectura tradicional de tierra.}

\section{El caso de Aragón.}

3. DATOS DE LA INTERVENCIÓN

tervención de:

$\square$ Mantenimiento $\square$ Rehabilitación parcial

$\square$ Restauración $\square$ Demolición X Reparación $\square$ Rehabilitación integral $\square$ Ampliación $\square$ Otro...

Observaciones

Intervención espontanea

Observaciones

3.1. MUROS

Tipo de intervención

Tipo de material

Descripción

3.2. ZóCALO

Tipo de intervención

Tipo de material

Descripción

3.3. REVESTIMIENTOS

Tipo de intervención

Tipo de material

Descripción

3.4. VANOS

Tipo de intervención

Tipo de material

Descripción

3.5. CUBIERTA

Tipo de intervención

Tipo de material

Descripción

No intervenido

$\square$ Actualización $\quad \square$ Reintegración $\quad \square$ Demolición $\quad \square$ Otro...
$\square$ Consolidación $\quad \square$ Reconstrucción $\quad \square$ Sustitución

Intervenido

X Actualización $\square$ Reintegración $\square$ Demolición $\square$ Otro...

$\square$ Consolidación $\quad \mathbf{X}$ Reconstrucción $\square$ Sustitución

No tradicional Tipo de técnica Diferente a la existente

Revestido de cemento

Intervenido

X Actualización $\square$ Reintegración $\quad \square$ Demolición $\square$ Otro...

$\square$ Consolidación $\mathbf{X}$ Reconstrucción $\square$ Sustitución

No tradicional Tipo de técnica Diferente a la existente

Revestimiento de cemento con pintura blanca en la fachada principal

Intervenido

$\square$ Actualización $\square$ Reintegración $\square$ Demolición $\square$ Otro...

$\square$ Consolidación $\square$ Reconstrucción $\quad \boldsymbol{x}$ Sustitución

\begin{tabular}{|l|l|l|l|l} 
No tradicional & Tipo de técnica Diferente a la existente
\end{tabular}

Sustitución de la puerta de acceso

Intervenido

$\square$ Actualización $\square$ Reintegración $\quad \square$ Demolición $\square$ Otro..

$\square$ Consolidación $\quad \boldsymbol{X}$ Reconstrucción $\square$ Sustitución

No tradicional Tipo de técnica Diferente a la existente

Sustitución del alero y de parte de las piezas de apoyo de la cubierta. Elementos prefabricados de hormigón y bardos. Retejado con la teja antigua
La restauración y rehabilitación de la arquitectura tradicional de tierra.

El caso de Aragón.

3.7. REHABILITACIÓN ENERGÉTICA $\quad \square$ Fachada $\square$ Vanos $\square$ Forjados $\square$ Cubierta

Observaciones

FOTOGRAFÍAS DE LA INTERVENCIÓN
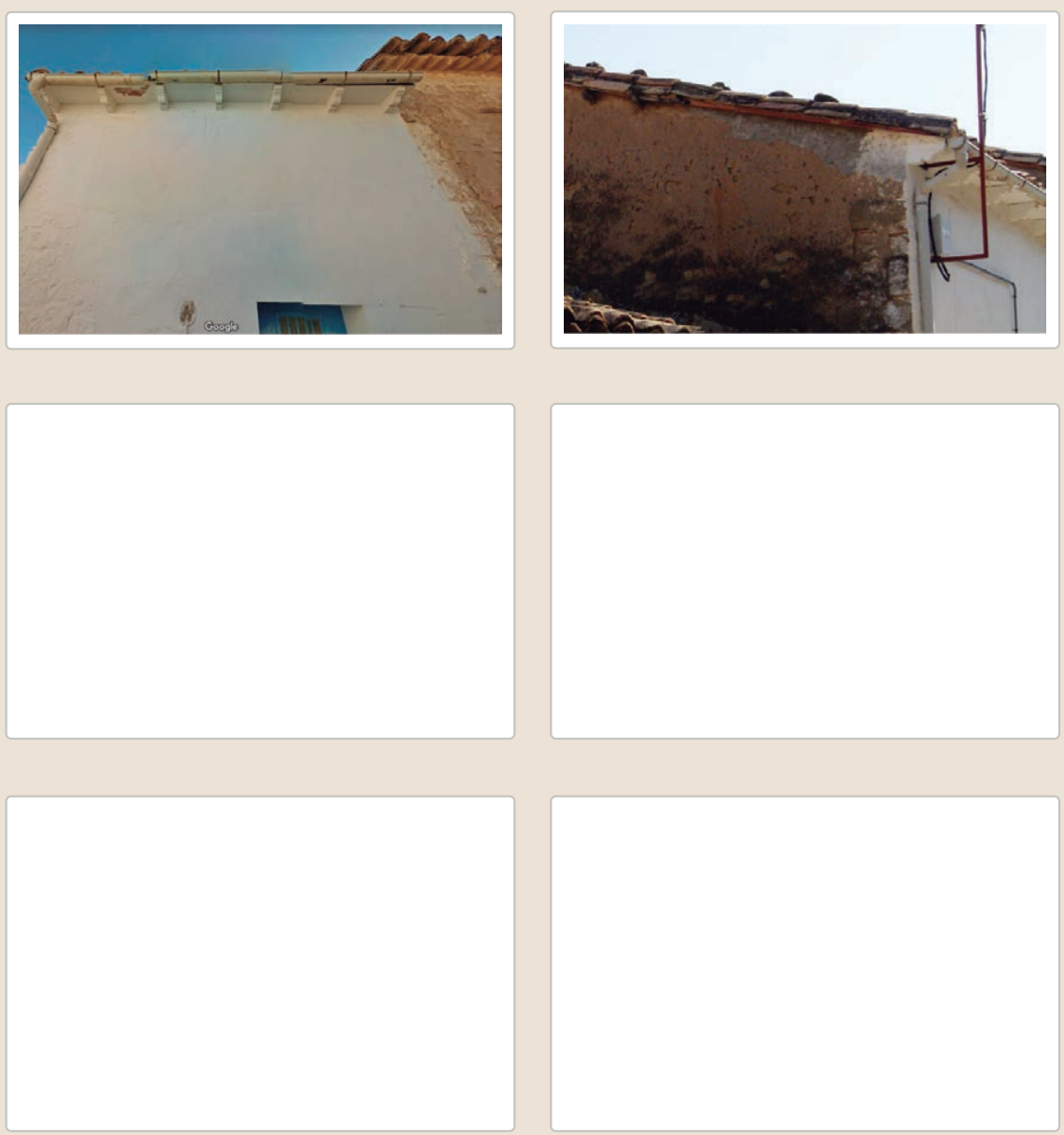

3.6. OTRAS 

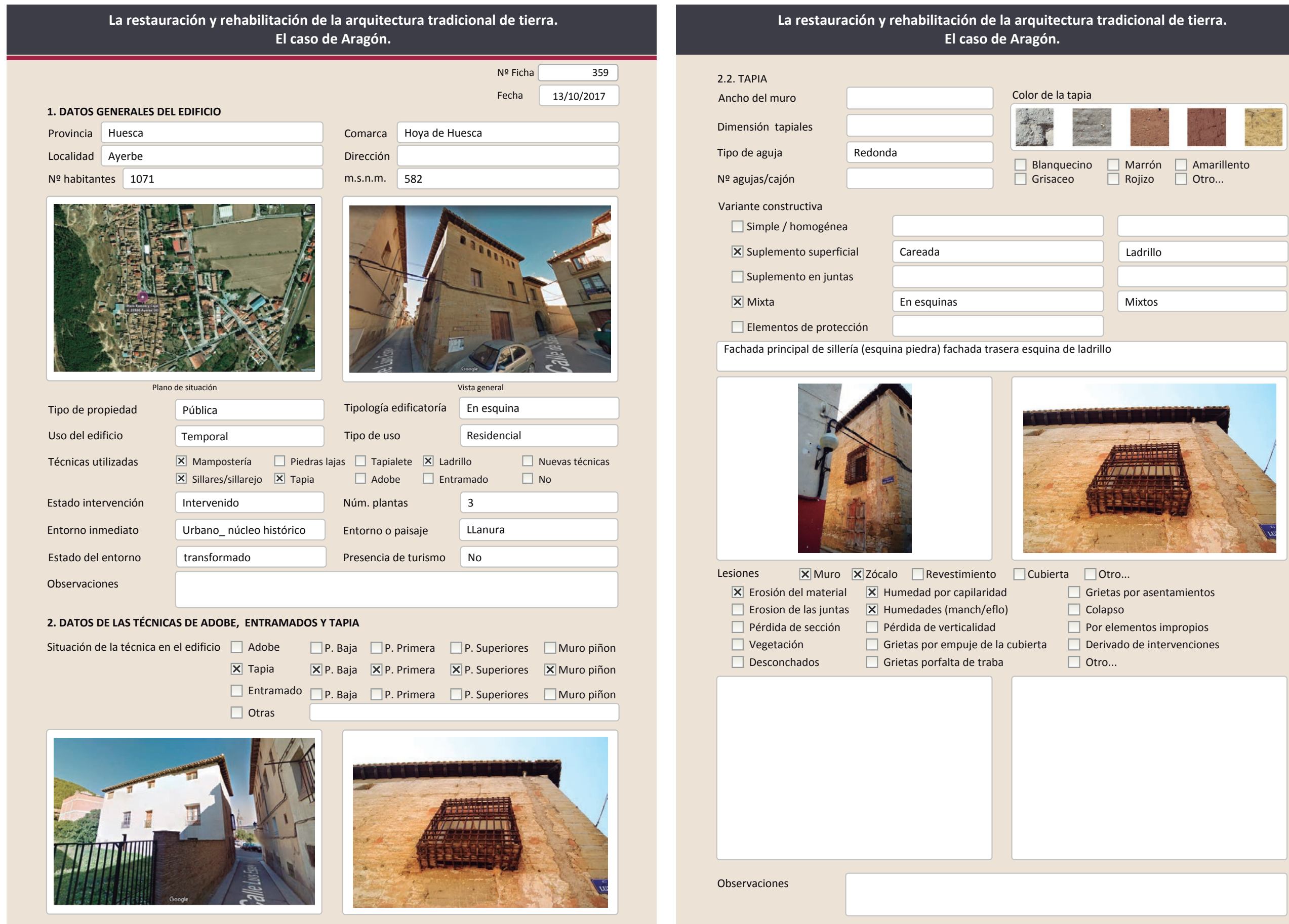

$\square$ Elementos de protección

Fachada principal de sillería (esquina piedra) fachada trasera esquina de ladrillo

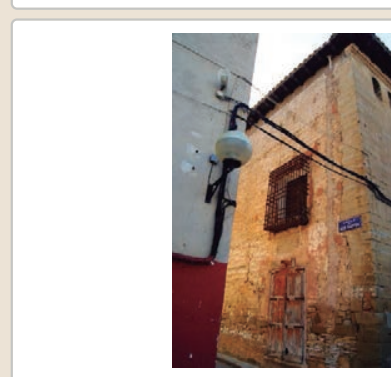

Lesiones

X Muro ХZócalo $\square$ Revestimiento

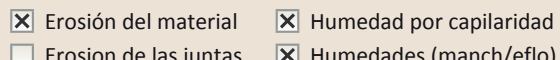

$\square$ Erosion de las juntas $\mathbf{X}$ Humedades (manch/e

$\square$ Vegetación $-\square$ Grietas por empuje de la cubierta

$\square$ Desconchados

$\square$ Grietas porfalta de traba

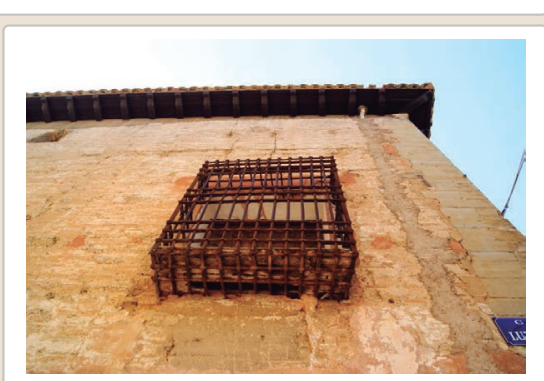

Cubierta $\square$ Otro...

$\square$ Grietas por asentamientos

$\square$ Colapso

$\square$ Por elementos impropios

$\square$ Derivado de intervenciones $\square$ Otro... 


\section{La restauración y rehabilitación de la arquitectura tradicional de tierra.}

\section{El caso de Aragón.}

\section{DATOS DE LA INTERVENCIÓN}

Intervención de:

$\square$ Mantenimiento $\quad \mathbf{X}$ Rehabilitación parcial

$\square$ Restauración $\square$ Demolición

Reflexión previa

$\square$ Reparación

Rehabilitación integra

Ampliación

$\square$ Otro...

Observaciones

Intervención planificada

(2)

3.1. MUROS

Tipo de intervención

Intervenido

Tipo de material

$\square$ Actualización $\quad \boldsymbol{X}$ Reintegración $\quad \boldsymbol{X}$ Demolición $\square$ Otro...

$\square$ Consolidación $\quad \square$ Reconstrucción $\quad \square$ Sustitución

Descripción

No tradicional Tipo de técnica Diferente a la existente

3.2. ZóCALO

Inserción de elementos realizando rozas en el muro de tapia

Tipo de intervención

No intervenido

Tipo de material

No intervenido

$\square$ Actualización $\square$ Reintegración $\quad \square$ Demolición $\square$ Otro...

$\square$ Consolidación $\square$ Reconstrucción $\square$ Sustitución

Descripción

3.3. REVESTIMIENTOS

Tipo de intervención

\section{No aplica}

Tipo de material

Descripción

$\square$ Consolidación $\square$ Reconstrucción $\square$ Sustitución

3.4. VANOS

No intervenido

Tipo de intervención

$\square$ Actualización $\quad \square$ Reintegración $\quad \square$ Demolición $\quad \square$ Otro...
$\square$ Consolidación $\quad \square$ Reconstrucción $\quad \square$ Sustitución

Tipo de material

Descripción

3.5. CUBIERTA

Tipo de intervención

Intervenido

$\square$ Actualización $\quad \square$ Reintegración $\quad \square$ Demolición $\quad \square$ Otro...
$\square$ Consolidación $\quad \boldsymbol{x}$ Reconstrucción $\quad \square$ Sustitución

Tipo de material

Descripción

No tradicional Tipo de técnica Diferente a la existente

Reconstrucción de la cubierta. Se ha conservado el alero de madera pero se ha

levantado por completo utilizando cemento para su recolocación

3.6. OTRAS 
La restauración y rehabilitación de la arquitectura tradicional de tierra. El caso de Aragón

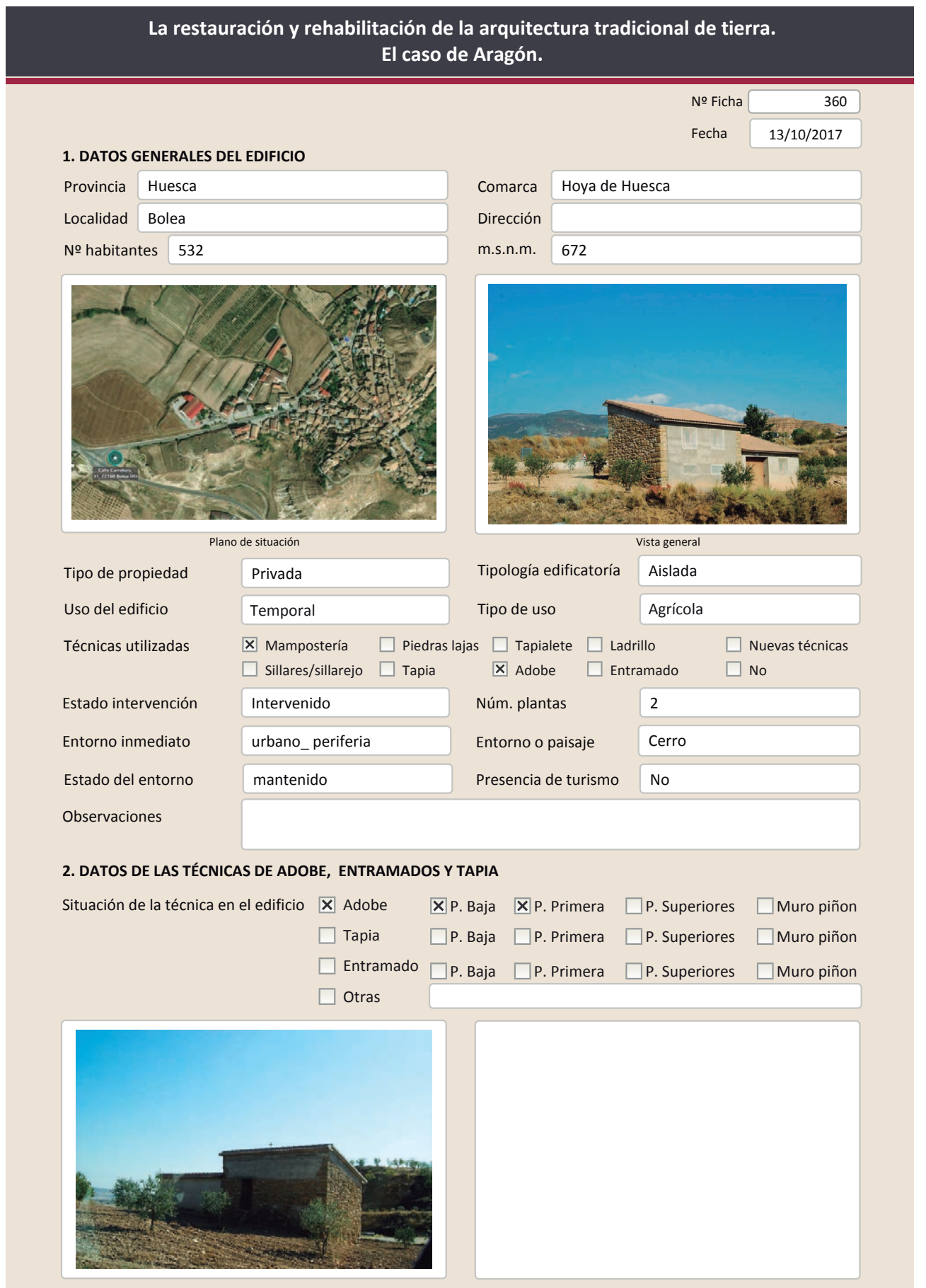

2.1. ADOBE

Dimensión de las piezas Dimensión del muro

Aparejo del muro

Función estructural

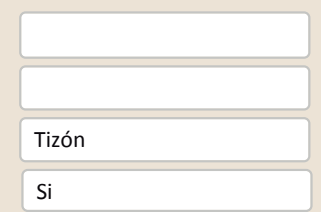

Color de las piezas

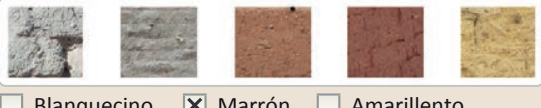

$\square$ Blanquecino $\mathbf{X}$ Marrón $\square$ Amarillento $\square$ Grisaceo $\square$ Rojizo $\square$ Otro..

Comp. - estabilizante

Variante constructiva/ tipo de fábrica
$\square$ Simple
$\mathbf{X}$ Suplementada en juntas
$\mathbf{X}$ Mixta
Horizontales
$\mathrm{Cal} /$ yeso
$\square$ Como suplemento
$\square$ Elementos de protección

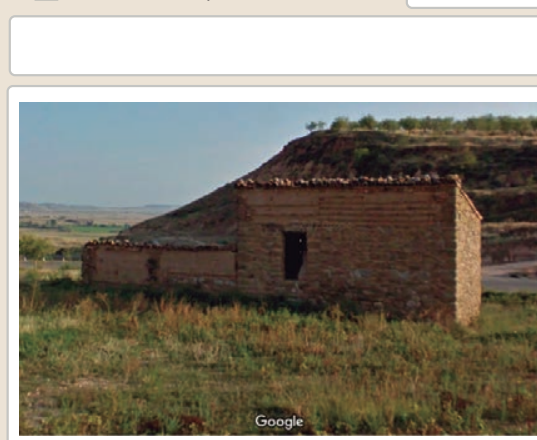

Lesiones $\quad \mathbf{X}$ Muro $\square$ Zócalo $\square$ Revestimiento $\mathbf{X}$ Cubierta $\square$ otro...

区 Erosión del material $\square$ Humedad por capilaridad $\quad \square$ Grietas por asentamientos X Erosion de las juntas $\square$ Humedades (manch/eflo) $\quad \square$ Colapso

X Pérdida de sección $\square$ Pérdida de verticalidad $\quad \square$ Por elementos impropios

$\square$ Vegetación $\quad \square$ Grietas por empuje de la cubierta $\square$ Derivado de intervenciones

$\square$ Desconchados $\square$ Grietas porfalta de traba $\quad \square$ Otro... 


\section{La restauración y rehabilitación de la arquitectura tradicional de tierra.} El caso de Aragón.

3. DATOS DE LA INTERVENCIÓN

ENCIÓN

\begin{tabular}{|c|c|c|c|c|}
\hline merverion ae. & $\begin{array}{l}\square \text { Mantenimiento } \\
\square \text { Reparación }\end{array}$ & $\begin{array}{l}\text { Rehabilitación parcial } \\
\text { Х Rehabilitación integral }\end{array}$ & $\begin{array}{l}\text { Restauración } \\
\text { Х Ampliación }\end{array}$ & $\begin{array}{l}X \text { Demolición } \\
\square \text { Otro... }\end{array}$ \\
\hline Reflexión previa & \multicolumn{4}{|c|}{ Intervención planificada } \\
\hline Observaciones & $\begin{array}{l}\text { el edificio de meno } \\
\text { reconstruido de nu }\end{array}$ & $\begin{array}{l}\text { limensión anexo se ha mc } \\
\text { o. }\end{array}$ & do por comp & se h \\
\hline
\end{tabular}

\subsection{MUROS}

Tipo de intervención

Tipo de material

Descripción

3.2. ZÓCALO

Tipo de intervención

Tipo de material

Descripción

3.3. REVESTIMIENTOS

Tipo de intervención

Tipo de material

Descripción

3.4. VANOS
Tipo de intervención

Tipo de material

Descripción

3.5. CUBIERTA

Tipo de intervención

Tipo de material

Descripción

Intervenido

$\square$ Actualización $\quad$ X Reintegración $\square$ Demolición $\square$ Otro...

$\square$ Consolidación $\quad \square$ Reconstrucción $\square$ sustitución

No tradicional Tipo de técnica Diferente a la existente

Reintegración de las juntas del muro de mampostería y relleno del la perdida de sección del muro de adobe

Intervenido

$\square$ Actualización $\quad \boldsymbol{X}$ Reintegración $\quad \square$ Demolición $\square$ Otro...

$\square$ Consolidación $\quad \square$ Reconstrucción $\square$ Sustitución

No tradicional Tipo de técnica Similar a la existente

Rejuntado de la mampostería

\section{Intervenido}

$\square$ Actualización $\quad \square$ Reintegración $\quad \square$ Demolición $\quad \square$ Otro...

$\square$ Consolidación $\mathbf{X}$ Reconstrucción $\square$ Sustitución

No tradicional Tipo de técnica Diferente a la existente

Todo el área de muros de tierra ha sido revestida con una capa gruesa de cemento

Intervenido

$\square$ Actualización $\square$ Reintegración $\square$ Demolición $\square$ Otro...

$\square$ Consolidación $\square$ Reconstrucción $\quad$ X Sustitución

No tradicional Tipo de técnica Diferente a la existente

Nuevos huecos que responde a nuevo diseño o a ampliación de otro existentes. Nuevas carpinterías. Se ha puesto tela para evitar el acceso de insectos

Intervenido

$\square$ Actualización $\square$ Reintegración $\square$ Demolición $\square$ Otro..

$\square$ Consolidación $\square$ Reconstrucción $\quad \mathbf{x}$ Sustitución

No tradicional Tipo de técnica Diferente a la existente

3.6. OTRAS Nueva cubierta de hormigón armado sobre un zuncho de hormigón que arriostra todo
el muro

El caso de Aragón.

3.7. REHABILITACIÓN ENERGÉTICA $\square$ Fachada $\quad \mathbf{X}$ Vanos $\square$ Forjados $\mathbf{X}$ Cubierta

Observaciones

FOTOGRAFíAS DE LA INTERVENCIÓN
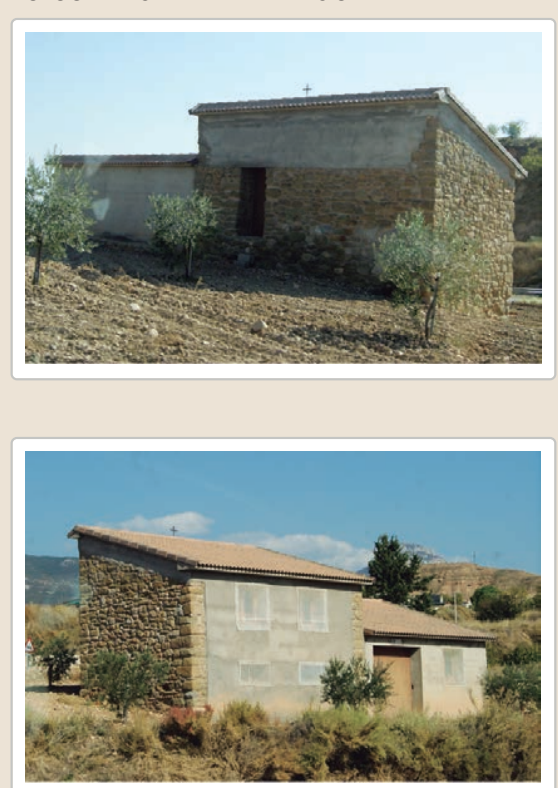

google sept 2009

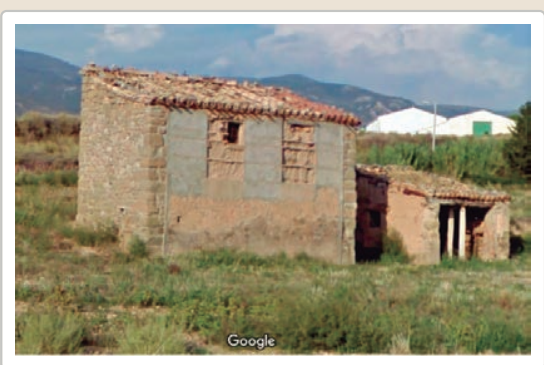

google sept 2009

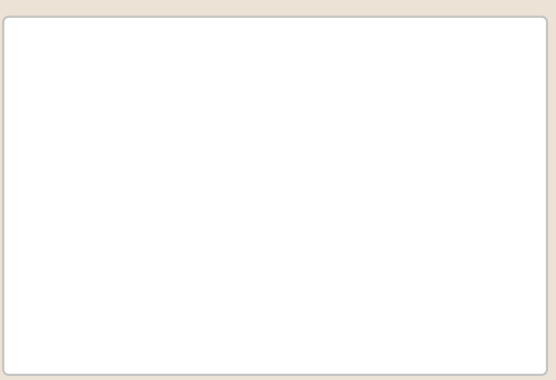




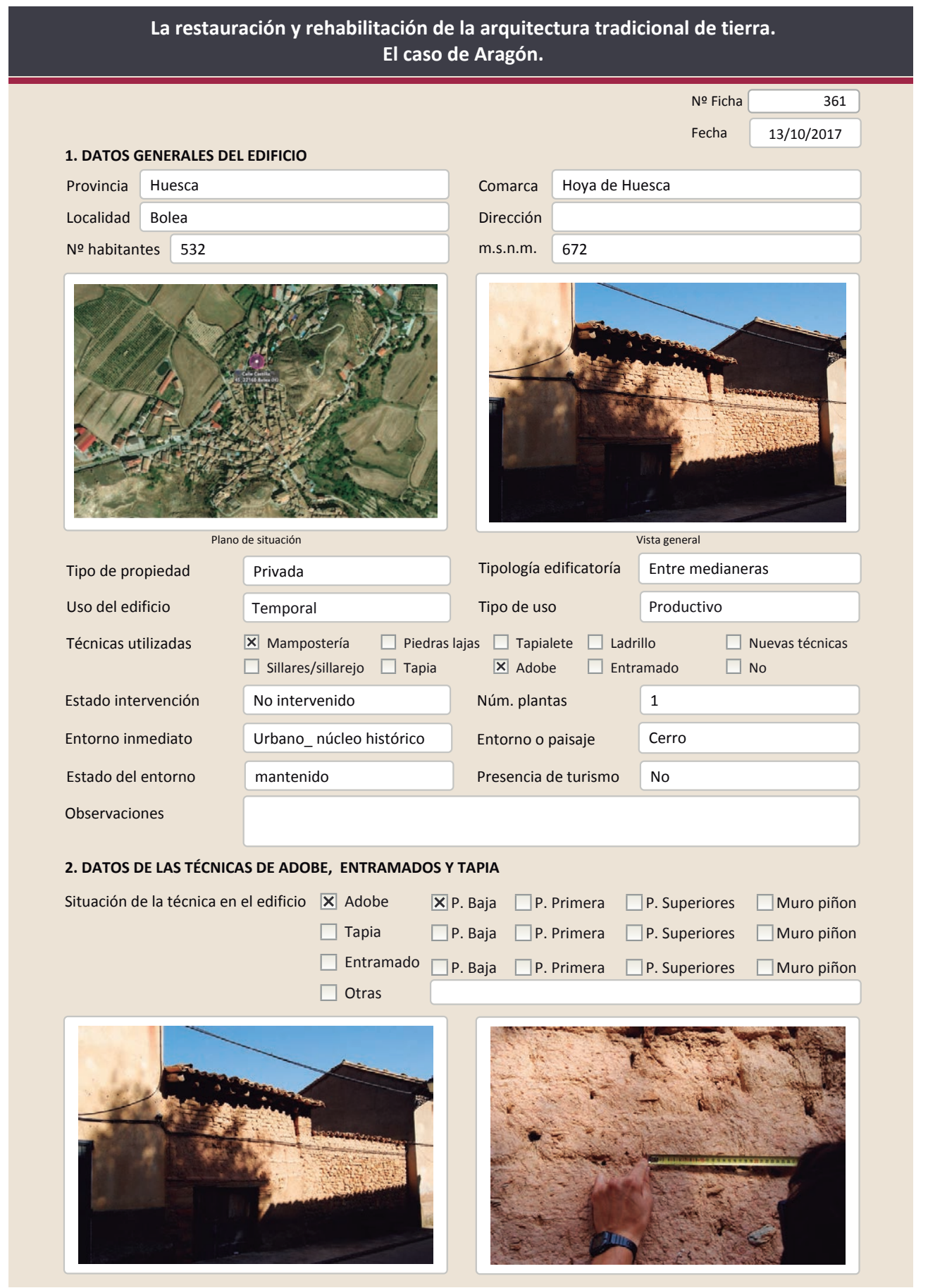

\subsection{ADOBE \\ Dimensión de las piezas $135 \times 17 \times 9,5$ \\ Dimensión del muro $30-40 \mathrm{~cm}$ \\ Aparejo del muro Tizón \\ Función estructural \\ $\mathrm{Si}$ \\ Variante constructiva/tipo de fábrica
$\square$ Simple
$\square$ suplementada en juntas
X Mixta
$\square$ Como suplemento \\ $\square$ Elementos de protección}

En esquinas

Color de las piezas

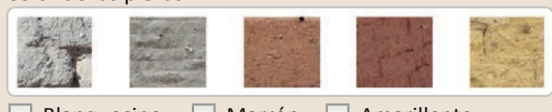

$\square$ Blanquecino $\square$ Marrón $\square$ Amarillento $\square$ Grisaceo $\square$ Rojizo $\square$ Otro...

Comp. - estabilizante Fibras vegetales

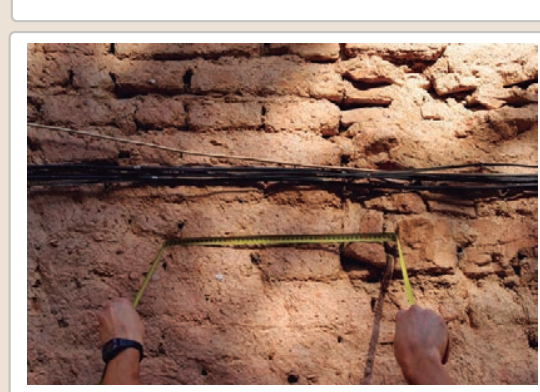

Lesiones $\quad \mathbf{X}$ Muro $\mathbf{X}$ Zócalo $\square$ Revestimiento

$\mathbf{X}$ Erosión del material $\mathbf{X}$ Humedad por capilaridad $\mathbf{X}$ Erosion de las juntas $\square$ Humedades (manch/eflo) Х Pérdida de sección $\quad \square$ Pérdida de verticalidad

$\square$ Vegetación $\quad \square$ Grietas por empuje de la c

$\square$ Desconchados

$\square$ Grietas porfalta de traba

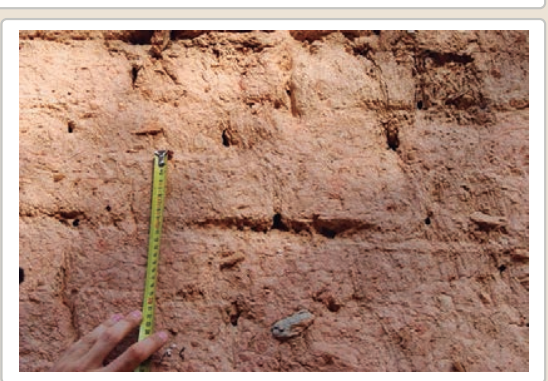

$\square$ Cubierta $\square$ Otro...

$\square$ Grietas por asentamiento $\square$ Colapso

$\square$ Por elementos impropios

$\square$ Derivado de intervenciones $\square$ Otro... 
La restauración y rehabilitación de la arquitectura tradicional de tierra. El caso de Aragón.

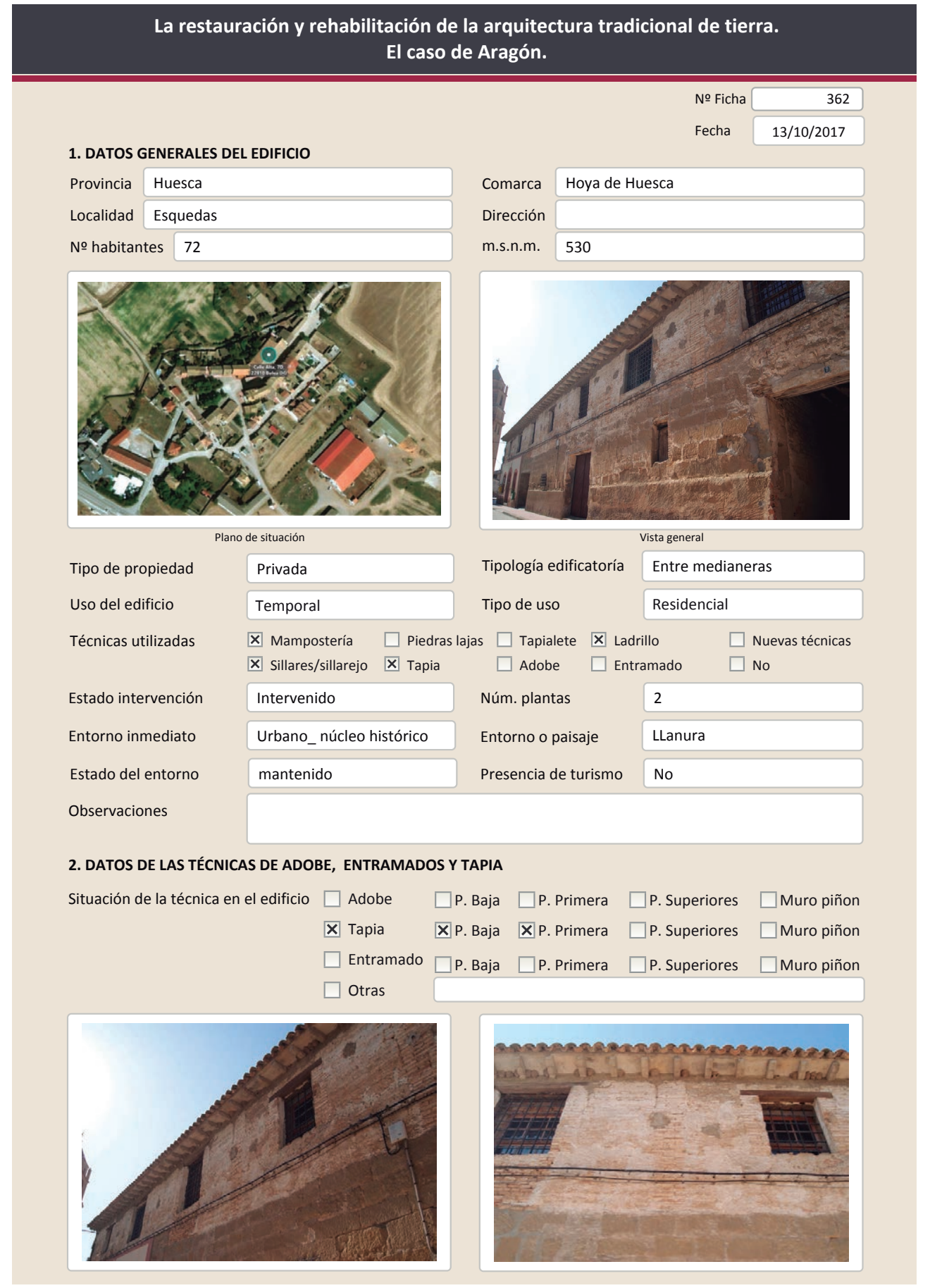

La restauración y rehabilitación de la arquitectura tradicional de tierra. El caso de Aragón.

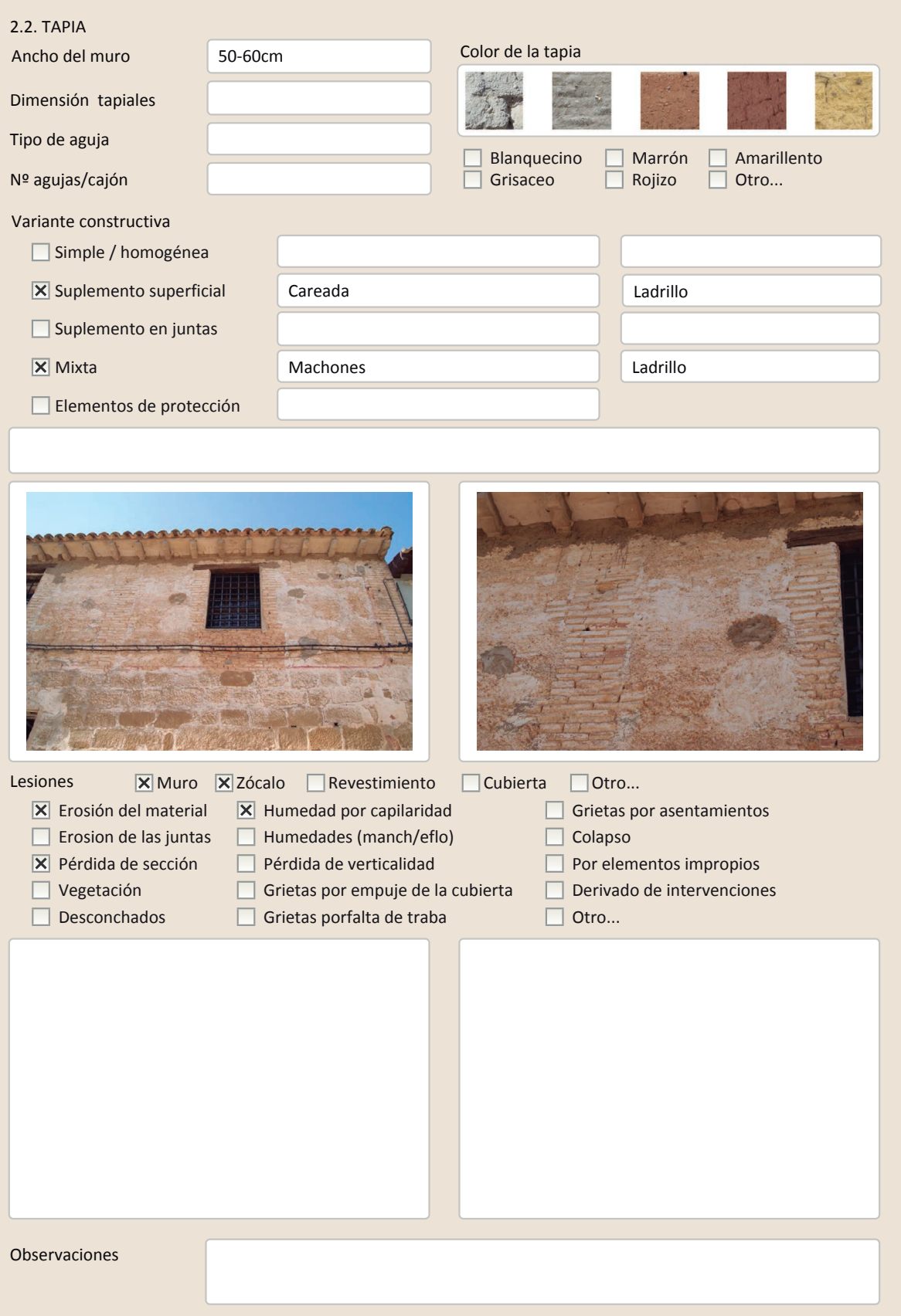

Ancho del muro

Dimensión tapiales

Tipo de aguja

№ agujas/cajón

$\mathbf{X}$ Mixta

$\square$ Marrón $\square$ Amarillento 


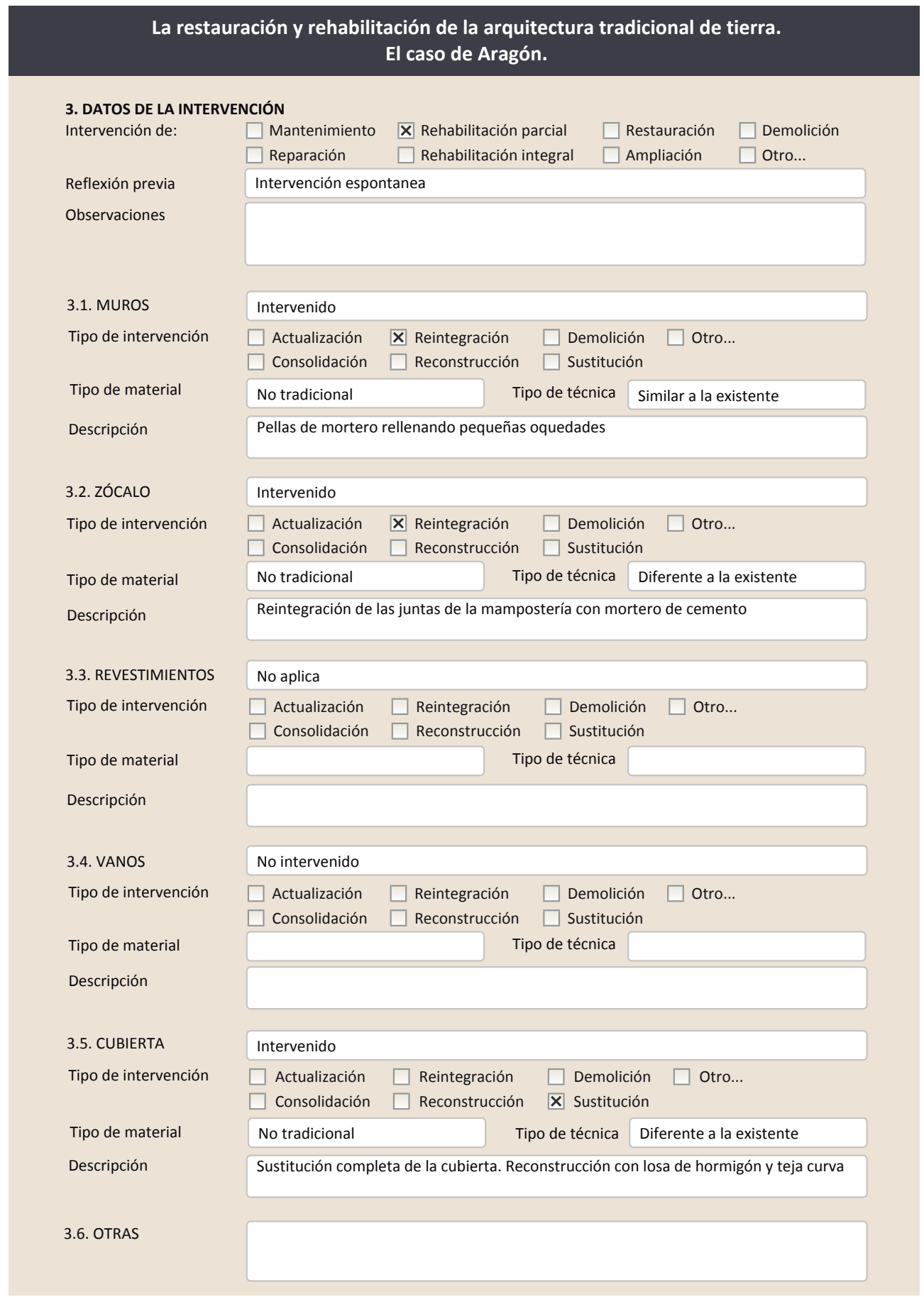

\subsection{REHABILITACIÓN ENERGÉTICA $\square$ Fachada $\square$ Vanos $\square$ Forjados $\quad$ X Cubierta}

Observaciones

FOTOGRAFíAS DE LA INTERVENCIÓN
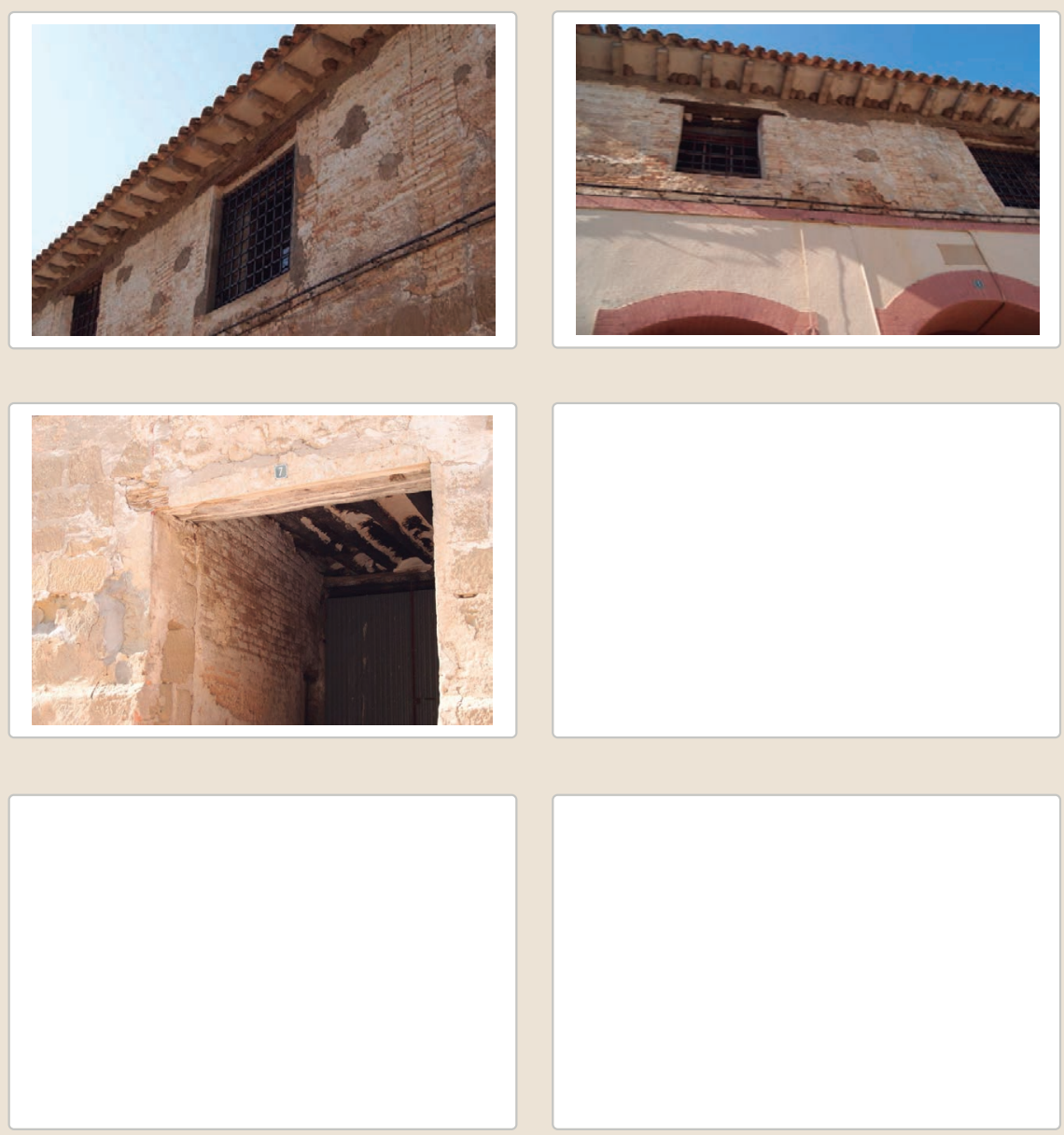


\section{La restauración y rehabilitación de la arquitectura tradicional de tierra.} El caso de Aragón.

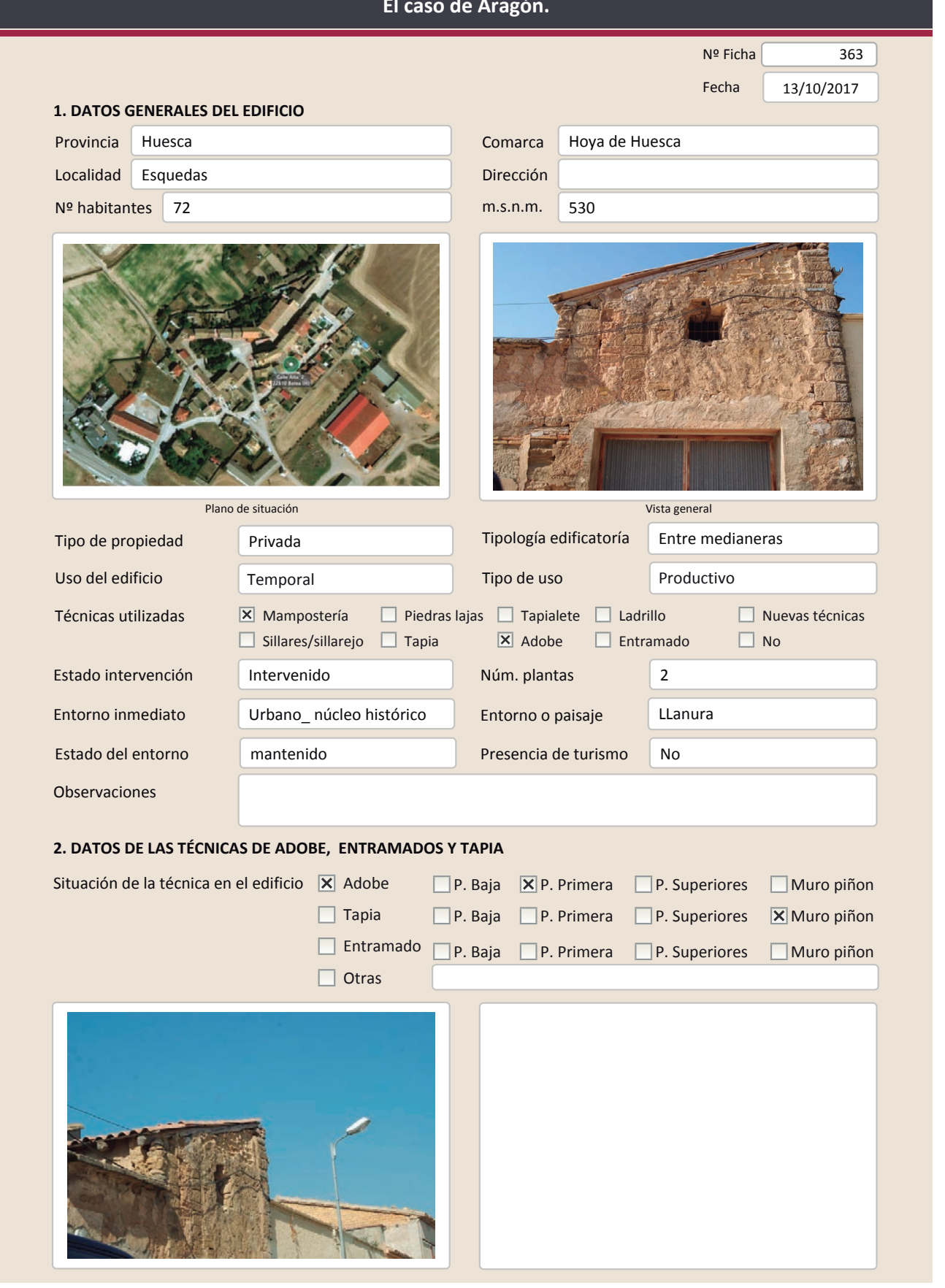

La restauración y rehabilitación de la arquitectura tradicional de tierra.

El caso de Aragón.
2.1. ADOBE

Dimensión de las piezas Dimensión del muro

Aparejo del muro

Función estructural
Color de las piezas

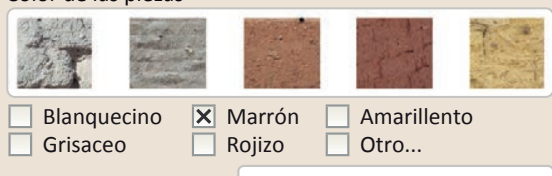

$\square$ Grisaceo $\square$ Rojizo $\square$ Otro...
Variante constructiva/ tipo de fábrica

$\square$ Simple

$\square$ Suplementada en juntas

X Mixta

\section{Machones}

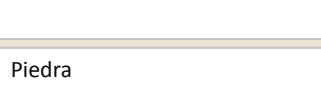

$\square$ Como suplemento

Х Elementos de protección Revestimiento de tierra

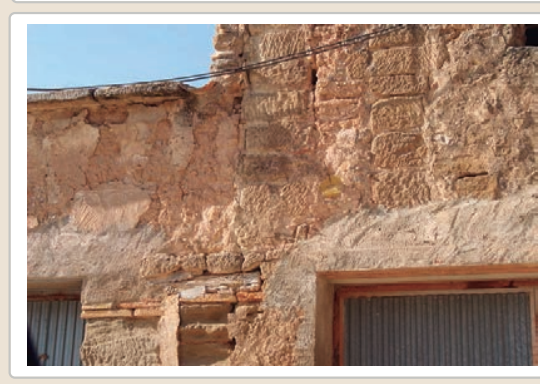

Lesiones ХMuro ХZócalo Х Revestimiento $\mathbb{X}$ Erosión del material $\mathbf{X}$ Humedad por capilaridad $\boldsymbol{X}$ Erosion de las juntas $\square$ Humedades (manch/eflo) X Pérdida de sección $\square$ Pérdida de verticalidad

$\begin{array}{ll}\square \text { Vegetación } & \square \text { Grietas por empuje de la c } \\ \text { Х Desconchados } & \square \text { Grietas porfalta de traba }\end{array}$

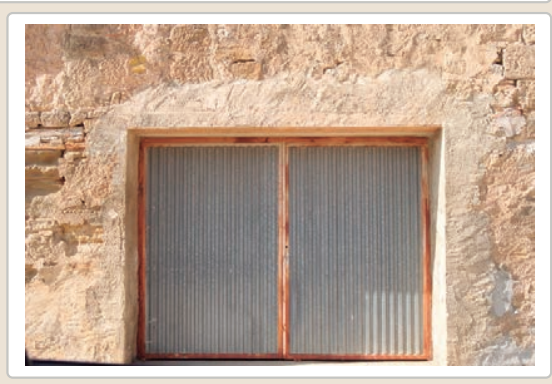

$\square$ Cubierta $\square$ Otro...

$\square$ Grietas por asentamientos $\square$ Colapso

X Desconchados $\square$ Grietas porfalta de traba

$\square$ Por elementos impropios

$\square$ Derivado de intervenciones $\square$ Otro...

Observaciones 
La restauración y rehabilitación de la arquitectura tradicional de tierra. El caso de Aragón

\section{La restauración y rehabilitación de la arquitectura tradicional de tierra.}

\section{El caso de Aragón.}

3. DATOS DE LA INTERVENCIÓN

Intervención de:

Mantenimiento $\quad \mathbf{X}$ Rehabilitación parcial

$\square$ Restauración $\square$ Demolición

Reflexión previa

$\square$ Reparación

$\square$ Rehabilitación integral $\square$ Ampliació

$\square$ Otro..

Reflexión previa
Observaciones

Intervención espontanea

3.1. MUROS

Tipo de intervención

No intervenido

Tipo de material

$\square$ Actualización $\square$ Reintegración $\square$ Demolición $\square$ Otro...

$\square$ Consolidación $\square$ Reconstrucción $\square$ Sustitución

Descripción

3.2. ZÓCALO

Tipo de intervención

Intervenido

Tipo de intervención

$\square$ Actualización

X Reintegración $\square$ Demolición $\square$ Otro..

Tipo de material

No tradicional

Tipo de técnica

Descripción

Tipo de técnica Diferente a la existente

3.3. REVESTIMIENTOS

\section{No aplica}

Tipo de intervención

$\square$ Actualización

obre la mamposterí

Tipo de material

Descripción

3.4. VANOS

Tipo de intervención

Reintegración $\square$ Demolición $\square$ Otro...

Consolidación $\square$ Reconstrucción $\square$ Sustitución

Tipo de técnica

Tipo de material

Intervenido

No tradicional Tipo de técnica Diferente a la existente
Sustitución del hueco de acceso. Ampliación de las dimensiones y sustitución de

carpintería

3.5. CUBIERTA

Intervenido

Tipo de intervención

$\square$ Actualización $\quad \square$ Reintegración $\square$ Demolición $\square$ Otro.

$\square$ Consolidación $\square$ Reconstrucción $\bigotimes$ Sustitución

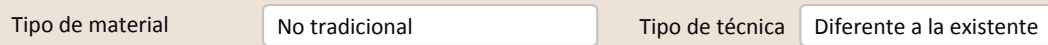

Descripción Sustitución de la cubierta de tejas por elementos prefabricados con fingido de tejas curvas

3.6. OTRAS 
La restauración y rehabilitación de la arquitectura tradicional de tierra. El caso de Aragón.

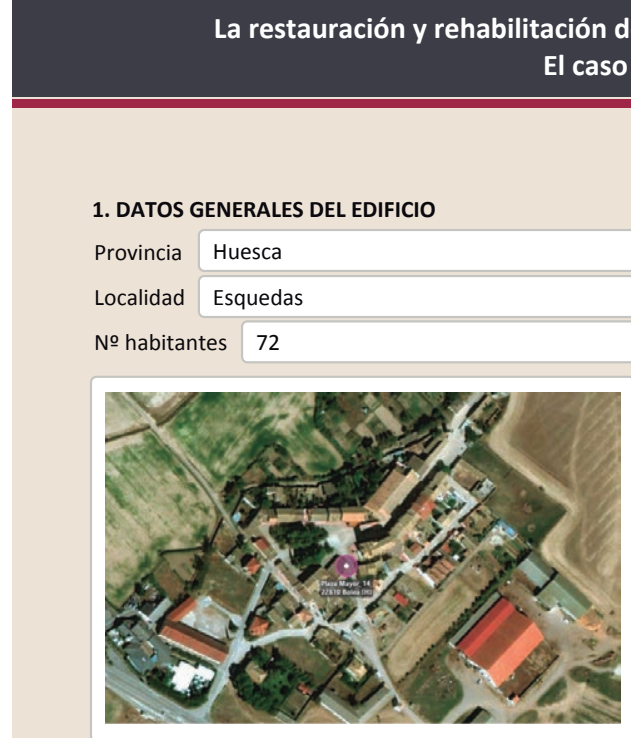

Plano de situación

Tipo de propiedad

Privada

Uso del edificio

Continuado

\ Mampostería $\quad \square$ Piedras lajas $\square$ Tapialete $\square$ Ladrillo $\quad \square$ Nuevas técnicas $\square$ sillares/sillarejo $\mathbf{X}$ Tapia

Intervenido

Urbano_núcleo histórico

Estado intervención

mantenido

(n)

Fecha $13 / 10 / 2017$

Comarca Hoya de Huesca

Dirección

m.s.n.m. 530

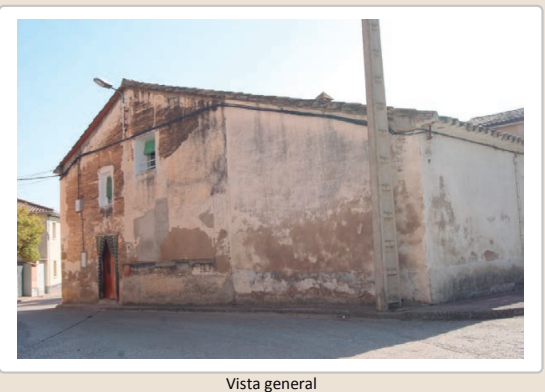

Tipología edificatoría

Tipo de uso - Residencia

$\square$ Adobe $\quad \square$ Entramado $\quad \square$ No

Núm. plantas 2

Entorno o paisaje LLanur

Presencia de turismo

№ Ficha $\quad 364$

Observaciones

\section{DATOS DE LAS TÉCNICAS DE ADOBE, ENTRAMADOS Y TAPIA}

Situación de la técnica en el edificio $\square$ Adobe $\quad \square$ P. Baja $\square$ P. Primera $\square$ P. Superiores $\square$ Muro piñon Х Tapia $\quad$ XP. Baja $\quad$ XP. Primera $\square$ P. Superiores $\square$ Muro piñon

$\square$ Entramado $\square$ P. Baja $\square$ P. Primera $\square$ P. Superiores $\square$ Muro piñon $\square$ Otras

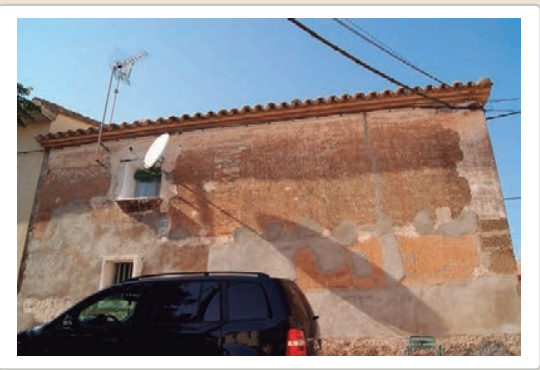

La restauración y rehabilitación de la arquitectura tradicional de tierra.

El caso de Aragón.
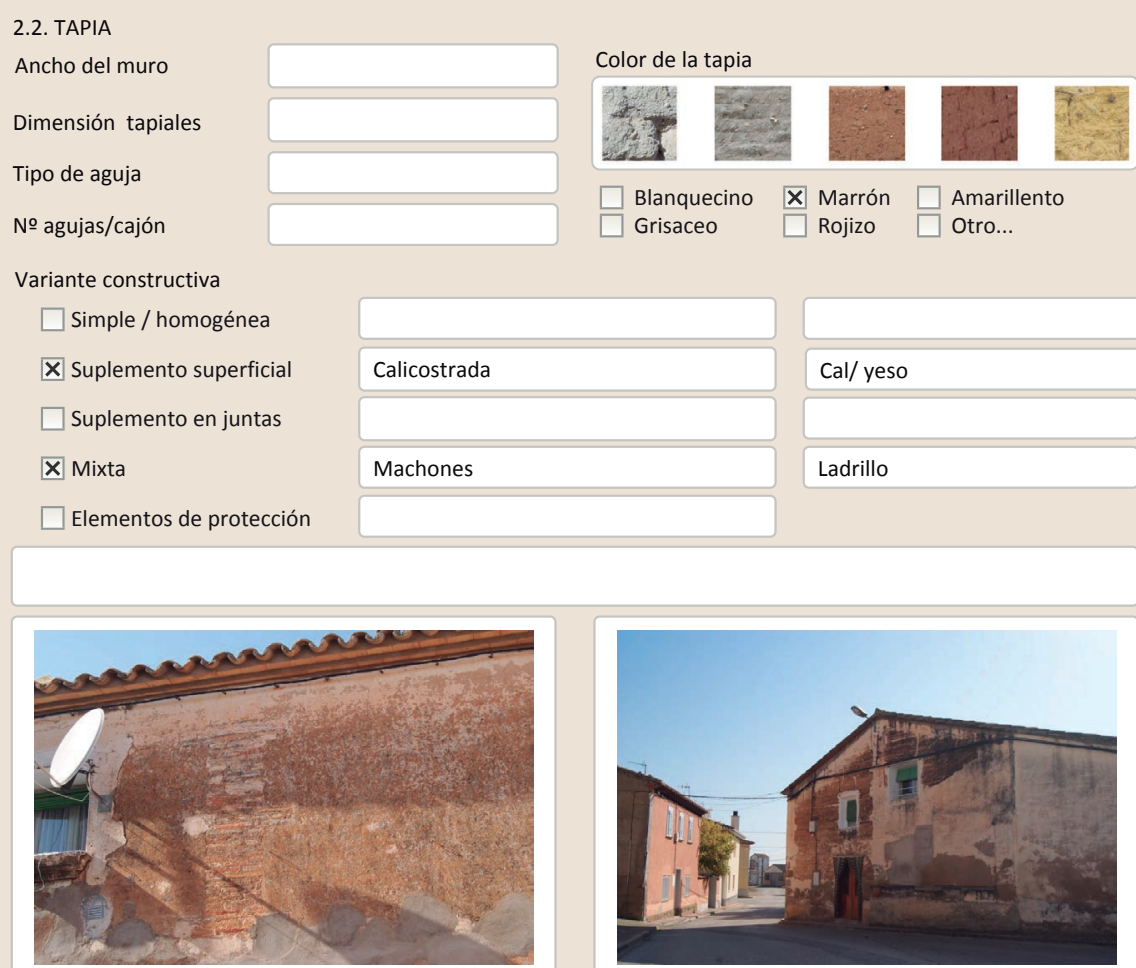

Lesiones $\quad$ XMuro $\boldsymbol{X}$ Zócalo $\square$ Revestimiento $\square$ Cubierta $\square$ Otro...

\ Erosión del material $\quad \mathbf{X}$ Humedad por capilaridad $\quad \square$ Grietas por asentamiento $\square$ Erosion de las juntas $\square$ Humedades (manch/eflo)

$\square$ Pérdida de sección $\square$ Pérdida de verticalidad

$\square$ Vegetación $\square$ Grietas por empuje de la cubierta

$\mathbf{X}$ Desconchados

$\square$ Grietas porfalta de traba
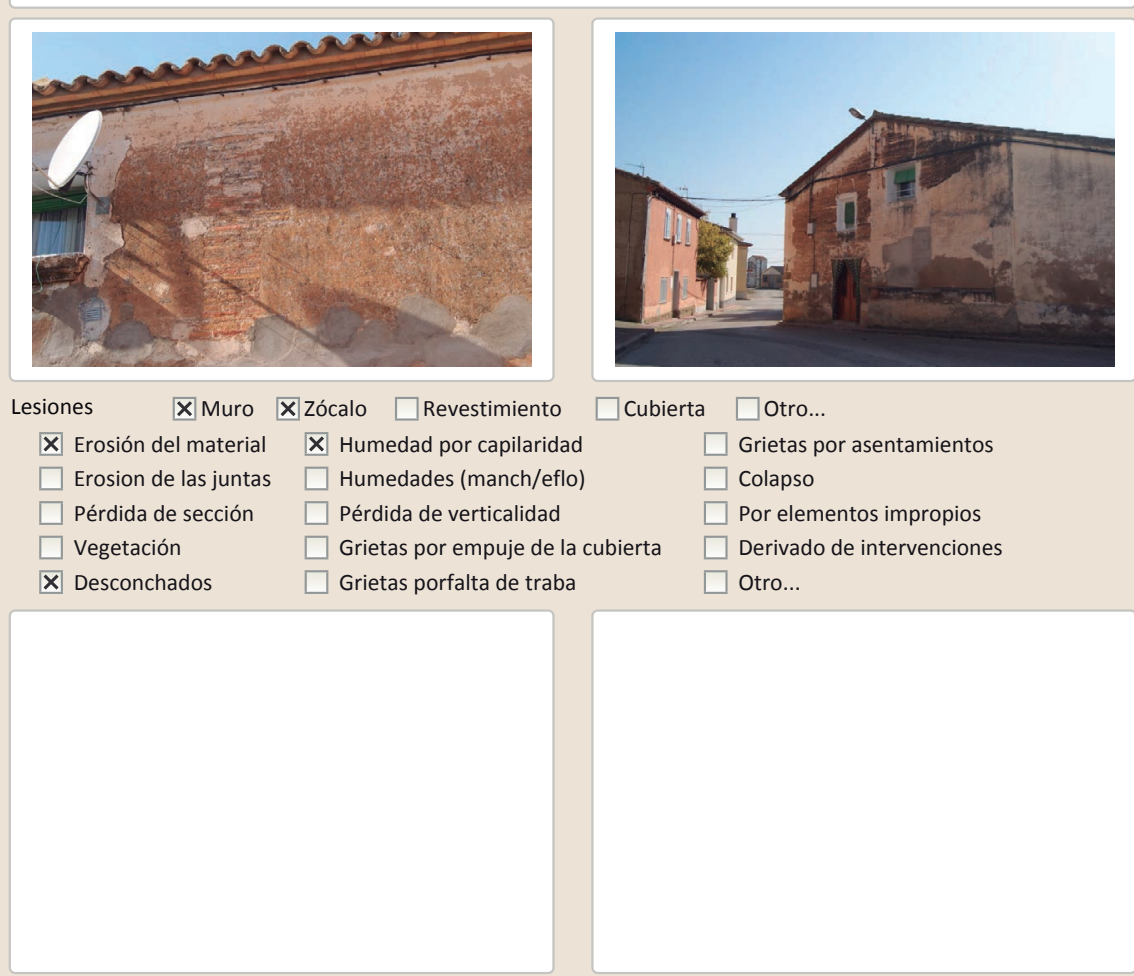

$\square$ Por elementos impropios

$\square$ Derivado de intervenciones 


\section{La restauración y rehabilitación de la arquitectura tradicional de tierra.}

\section{El caso de Aragón.}

3. DATOS DE LA INTERVENCIÓN

Intervención de:

$\square$ Mantenimiento $\square$ Rehabilitación parcia

$\square$ Restauración $\square$ Demolición

Reflexión previa

X Reparación

Rehabilitación integra

Ampliación

$\square$ Otro..

Observaciones

Intervención espontanea

3.1. MUROS

Tipo de intervención

Intervenido

Tipo de intervención

$\square$ Actualización $\quad$ Reintegración $\square$ Demolición $\square$ Otro...

$\square$ Consolidación $\square$ Reconstrucción $\square$ Sustitución

Descripción

No tradicional Tipo de técnica Diferente a la existente

3.2. ZóCALO

Pellas de mortero de cemento en las áreas con faltantes

\section{Tipo de intervención}

Intervenido

$\square$ Actualizació

Reintegración $\square$ Demolición $\quad \square$ Otro...

Tipo de material

Descripción

\section{Revestimiento de cemento}

3.3. REVESTIMIENTOS

\section{Intervenido}

Tipo de intervención

$\square$ Actualización $\quad \boldsymbol{X}$ Reintegración $\square$ Demolición $\square$ Otro...

Tipo de material

$\square$ Consolidación $\mathbf{X}$ Reconstrucción $\square$ sustitución

Descripción
No tradicional
Tipo de técnica Diferente a la existente

Reintegraciones

3.4. VANOS

Intervenido

Tipo de intervención $\quad \square$ Actualización $\square$ Reintegración $\quad \square$ Demolición $\square$ Otro...

\begin{tabular}{l|ll} 
& $\square$ Consolidación $\square$ Reconstrucción $\boldsymbol{X}$ Sustitución \\
Tipo de material & No tradicional & Tipo de técnica \\
Diferente a la existente
\end{tabular}

Descripción Sustitución de la carpintería de la puerta de acceso. Se trataba de un arco cerámico y actualmente es una puerta rectangular.

3.5. CUBIERTA

Tipo de intervención

Intervenido

Tipo de material

$\square$ Actualización $\square$ Reintegración $\square$ Demolición $\square$ Otro..

$\square$ Consolidación $\square$ Reconstrucción $\mathbf{X}$ Sustitución

Descripción

No tradicional Tipo de técnica Diferente a la existente

Sustitución de una de las aguas de la cubierta. Se ha vuelto a construir con bardos y teja curva

3.6. OTRAS 


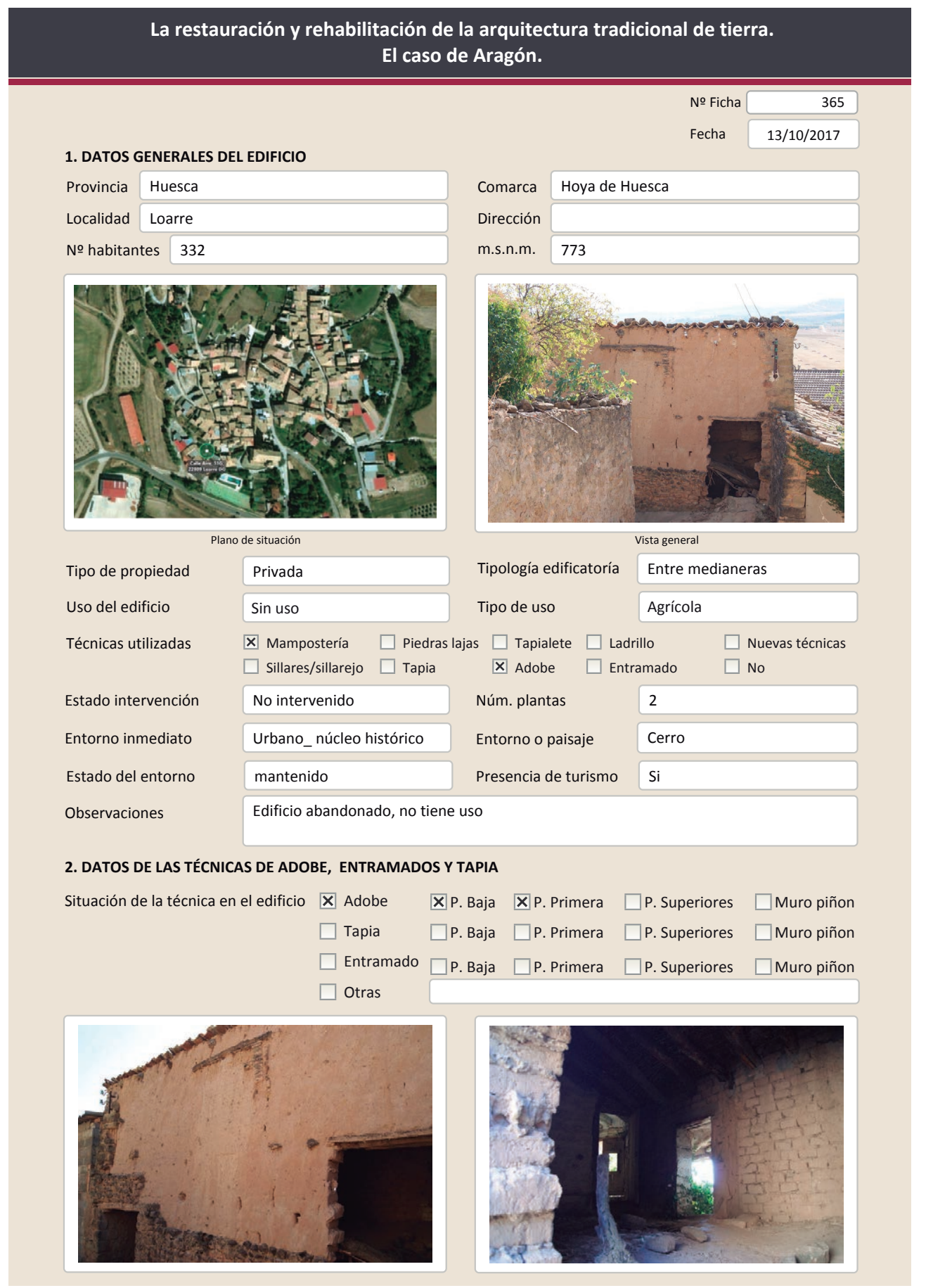

La restauración y rehabilitación de la arquitectura tradicional de tierra.

El caso de Aragón.

2.1. ADOBE

Dimensión de las piezas

Dimensión del muro

Aparejo del muro

Función estructural

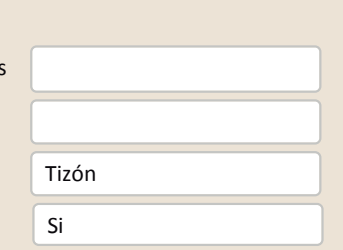

Color de las piezas

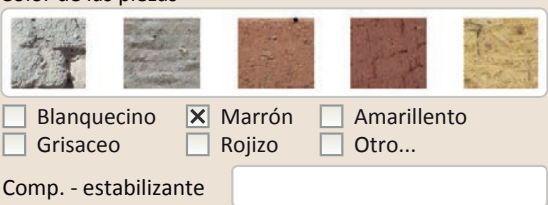

ante constructiva/ tipo de fábrica

$\square$ simple

$\square$ Suplementada en juntas

X Mixta

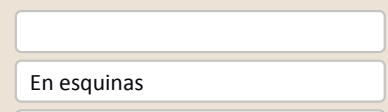

Piedr

$\square$ Como suplemento

$\square$ Elementos de protección

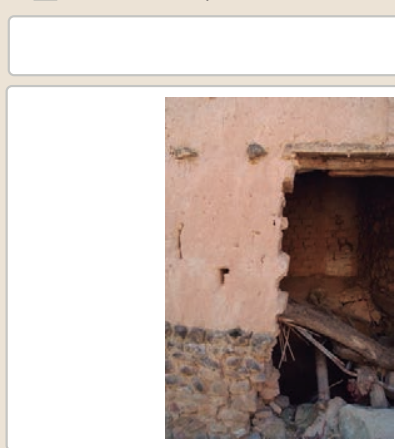

Lesiones

X Muro XZzócalo $\square$ Revestimiento

\ Erosión del material $\mathbf{X}$ Humedad por capilaridad $\mathbf{X}$ Erosion de las juntas $\square$ Humedades (manch/eflo)

X Pérdida de sección $\quad \square$ Pérdida de verticalidad

$\square$ Vegetación $\quad \square$ Grietas por empuje de la cu

$\square$ Desconchados

$\square$ Grietas porfalta de trab

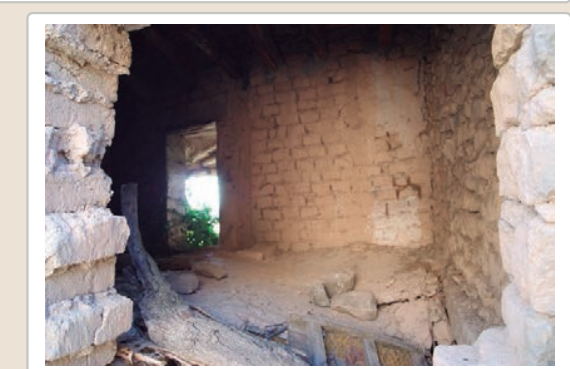

$\square$ Cubierta $\square$ Otro...

$\square$ Grietas por asentamientos

$\square$ Colapso

$\square$ Por elementos impropios

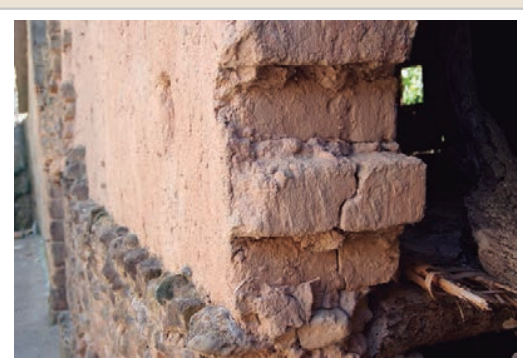

$\square$ Derivado de intervenciones X Otro...

Observaciones 


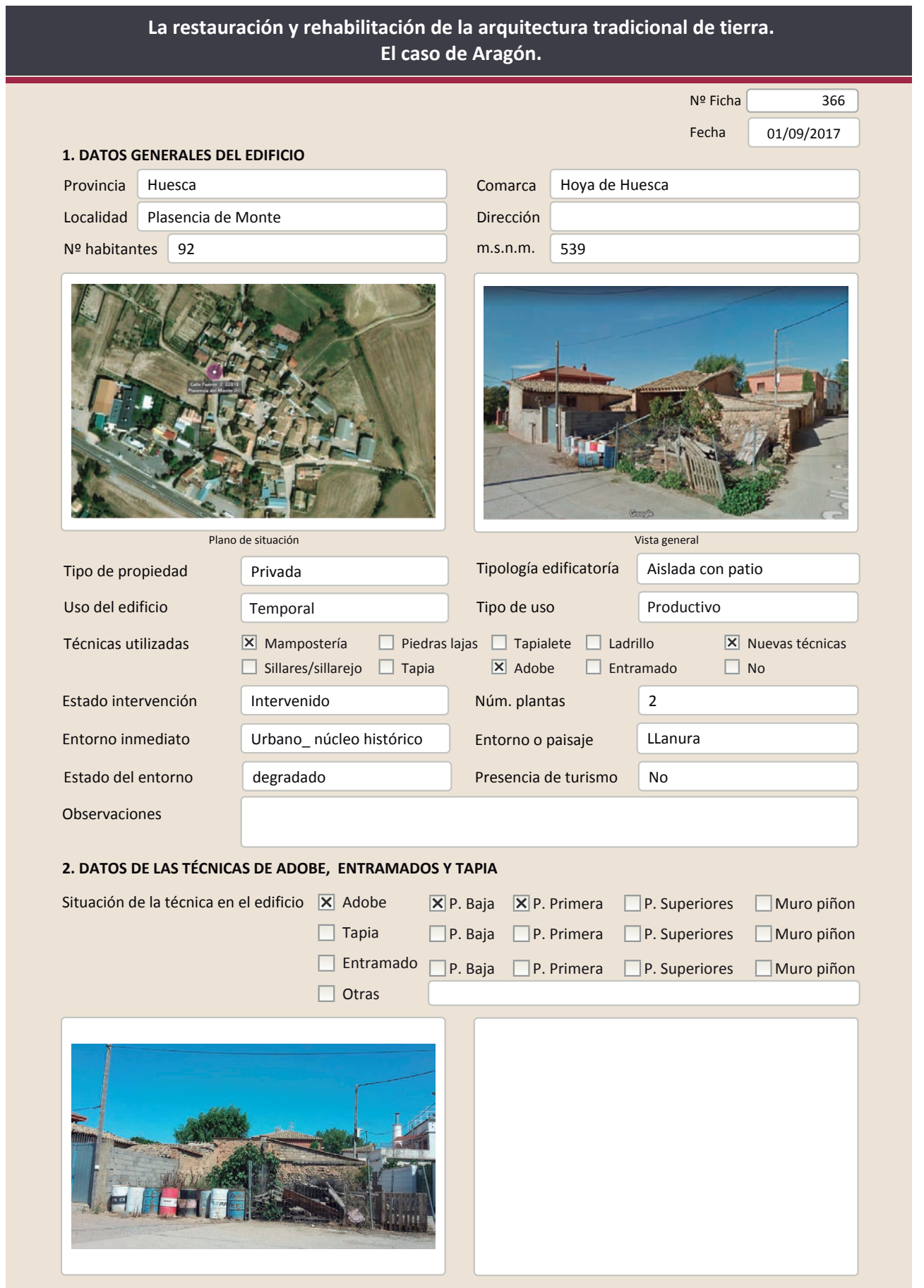

2.1. ADOBE

Dimensión de las piezas Dimensión del muro

Aparejo del muro

Función estructural

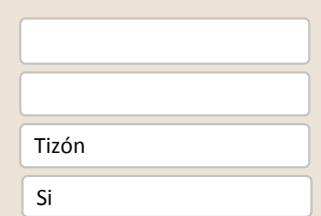

Color de las piezas

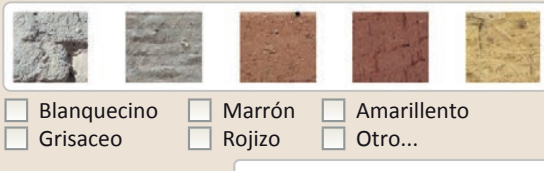

Grisaceo

ante

Variante constructiva/ tipo de fábrica

$\square$ Simple

$\square$ Suplementada en juntas

区 Mixta

\section{Machones}

$\square$ Como suplemento

$\square$ Elementos de protección

El edificio esta suplementado con machones de madera

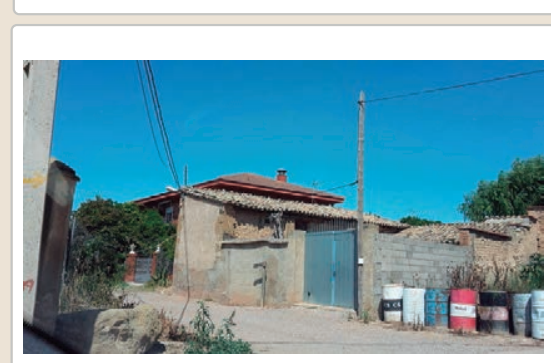

Lesiones X Muro XZzócalo $\square$ Revestimiento

$\mathbf{X}$ Erosión del material $\mathbf{X}$ Humedad por capilaridad

$\square$ Erosion de las juntas $\square$ Humedades (manch/eflo)

$\square$ Pérdida de sección $\square$ Pérdida de verticalidad

$\square$ Vegetación

$\square$ Grietas por empuje de la $\square$ Grietas porfalta de traba

Comp. - estabilizante
Ladrillo

arrón $\square$ Amarill
$\square$ Otro...

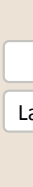

rillo $\square$ Desconchados
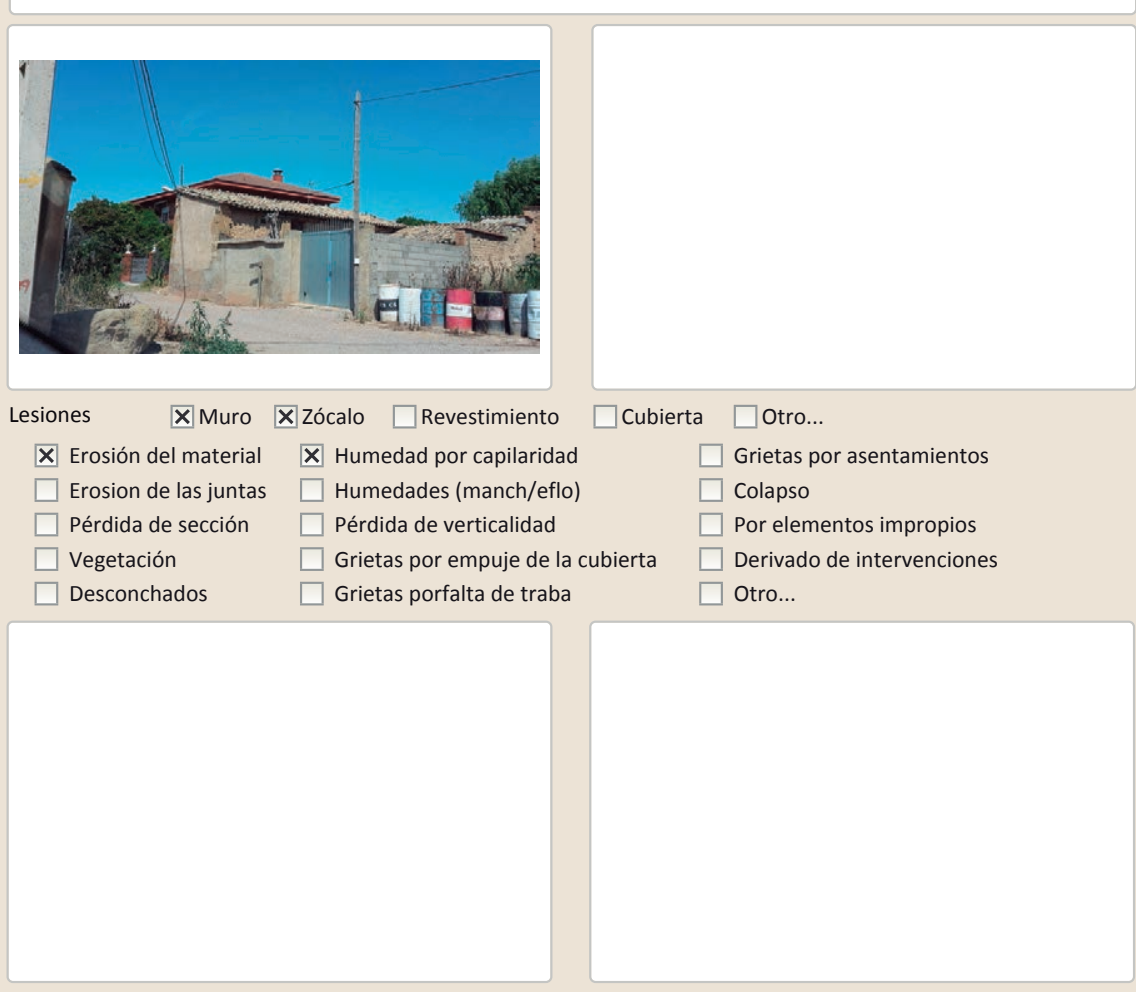

Observaciones 


\section{La restauración y rehabilitación de la arquitectura tradicional de tierra.}

\section{El caso de Aragón.}

3. DATOS DE LA INTERVENCIÓN

\begin{tabular}{|c|c|c|c|c|}
\hline Intervención de: & $\begin{array}{l}\square \text { Mantenimiento } \\
\mathbf{X} \text { Reparación }\end{array}$ & $\begin{array}{l}\square \text { Rehabilitación parcial } \\
\square \text { Rehabilitación integral }\end{array}$ & $\begin{array}{l}\square \text { Restauración } \\
\square \text { Ampliación }\end{array}$ & $\begin{array}{l}\square \text { Demolición } \\
\square \text { Otro... }\end{array}$ \\
\hline Reflexión previa & \multicolumn{4}{|c|}{ Intervención espontanea } \\
\hline erva & & & & \\
\hline
\end{tabular}

\subsection{MUROS}

Tipo de intervención

Intervenido

Tipo de material

$\square$ Actualización $\quad$ X Reintegración $\square$ Demolición $\square$ Otro...

$\square$ Consolidación $\square$ Reconstrucción $\quad$ \ Sustitución

$\begin{array}{llll}\text { Tipo de material } & \text { No tradicional } & \text { Tipo de técnica } & \text { Diferente a la existente } \\ \text { Descripción } & \text { Sustitución de un tramo de muro por bloque de hormigón prefabricado. Nueva }\end{array}$ coronación en todo el muro de cercado

3.2. ZÓCALO

Tipo de intervención Intervenido

Tipo de intervención

$\square$ Actualización $\square$ Reintegración $\square$ Demolición $\square$ Otro...

Descripción

\begin{tabular}{|l|l|l|l}
\hline Tipo de técnica & Diferente a la existente
\end{tabular}

3.3. REVESTIMIENTOS

Revestimiento de cemento

Tipo de intervención

\section{Intervenido}

Tipo dematenta

$\square$ Reintegración $\quad \square$ Demolición $\square$ Otro...

Tipo de materia

No tradicional

X Reconstrucción $\square$ Sustitución

Descripción

Nuevo revestimiento de cemento en gran parte de los muros

3.4. VANOS

Intervenido

Tipo de intervención

$\square$ Actualización $\square$ Reintegración $\square$ Demolición $\square$ Otro...

Tipo de material

$\square$ Consolidación $\square$ Reconstrucción $\mathbf{X}$ Sustitución

Descripción

No tradicional

Tipo de técnica Diferente a la existente

3.5. CUBIERTA

Tipo de intervención

No intervenido

$\square$ Actualización

$\square$ Consolidación $\quad \square$ Reconstrucción $\quad \square$ Sustitución

Tipo de material

Descripción

Tipo de técnica

3.6. OTRAS 


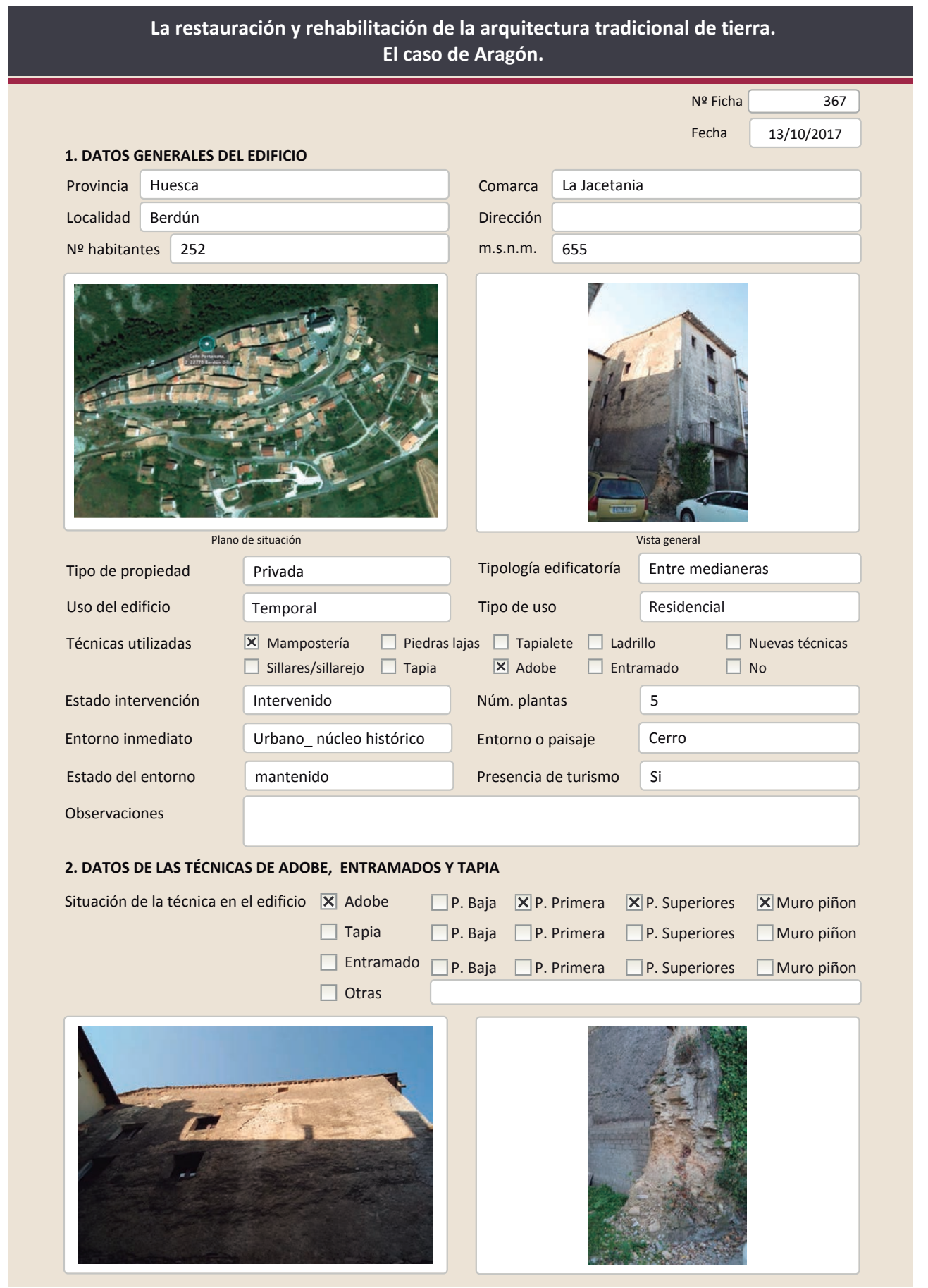

2.1. ADOBE

Dimensión de las piezas Dimensión del muro

Aparejo del muro

Función estructural

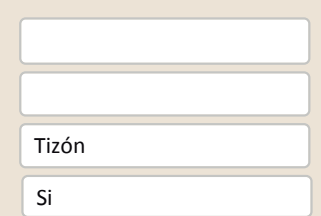

Color de las piezas

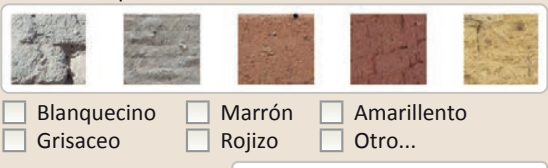

Grisaceo

ante

Variante constructiva/ tipo de fábrica

$\square$ simple

$\square$ suplementada en juntas

X Mixta

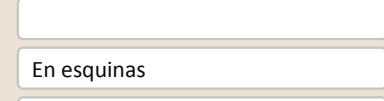

Piedra

$\square$ Como suplemento

$\square$ Elementos de protección

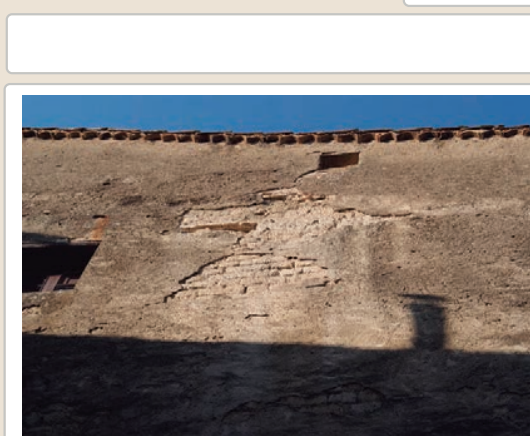

Lesiones $\mathbf{X}$ Muro $\mathbf{X}$ Zócalo $\mathbf{X}$ Revestimiento $\mathbf{X}$ Muro $\mathbf{X}$ Zócalo $\mathbf{X}$ Revestimiento
material $\quad \mathbf{X}$ Humedad por capilarida $\mathbf{X}$ Erosión del material $\mathbf{X}$ Humedad por caplaridad $\square$ Pérdida de sección $\square$ Pérdida de verticalidad

$\square$ Vegetación

$\mathbf{X}$ Desconchados

$\square$ Grietas por empuje de la

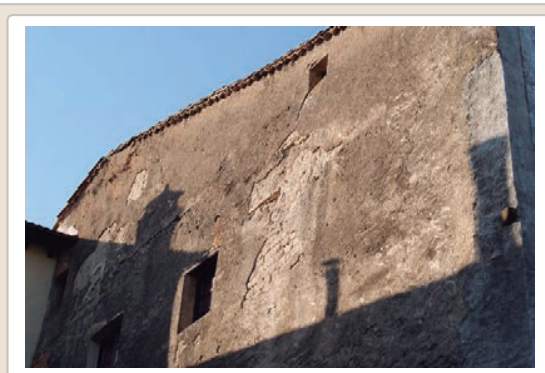

Cubierta $\square$ Otro...

$\square$ Grietas por asentamiento

$\square$ Colapso

$\square$ Por elementos impropios

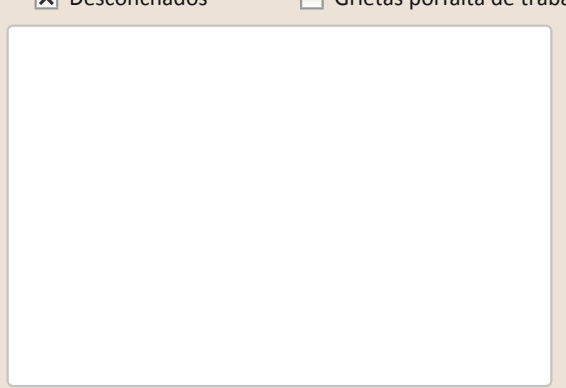

$\square$ Derivado de intervenciones

$\square$ Otro...

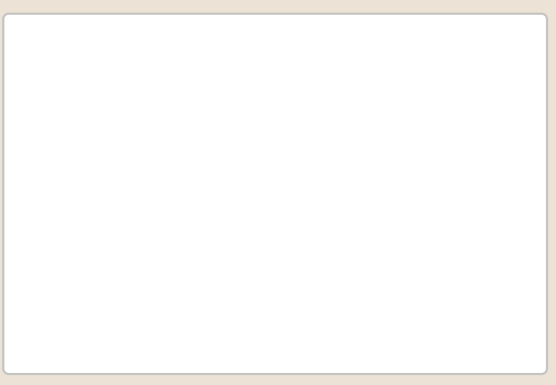

Observaciones 


\section{La restauración y rehabilitación de la arquitectura tradicional de tierra.}

\section{El caso de Aragón.}

3. DATOS DE LA INTERVENCIÓN

Intervención de:

$\square$ Restauración $\square$ Demolición

Reflexión previa X Reparación Rehabilitación integra

$\square$ Ampliación $\square$ Otro...

Observaciones

Intervención espontanea

Observaciones

3.1. MUROS

Tipo de intervención

Tipo de material

Descripción

3.2. ZÓCALO

Tipo de intervención

Tipo de material

Descripción

3.3. REVESTIMIENTOS

Tipo de intervención

Tipo de material

Descripción

3.4. VANOS

Tipo de intervención

Tipo de material

Descripción

3.5. CUBIERTA

Tipo de intervención

Tipo de material

Descripción

3.6. OTRAS

No intervenido
$\square$ Actualización $\quad \square$ Reintegración $\quad \square$ Demolición $\quad \square$ Otro...
$\square$ Consolidación $\quad \square$ Reconstrucción $\quad \square$ Sustitución

$\square$ Consolidación $\quad \square$ Reconstrucción $\square$ Sustitución

Intervenido

$\square$ Actualización $\square$ Reintegración $\square$ Demolición $\square$ Otro...

$\square$ Consolidación $\quad \mathbf{X}$ Reconstrucción $\square$ Sustitución

No tradicional Tipo de técnica Diferente a la existente

Reconstrucción de parte del zócalo con bloque de hormigón prefabricado

\section{Intervenido}

$\square$ Actualización $\quad \mathbf{X}$ Reintegración $\quad \square$ Demolición $\square$ Otro...

No tradicional Tipo de técnica Diferente a la existente planta. Reintegración de la esquina del edificio con cemento

No intervenido

$\square$ Actualización $\square$ Reintegración $\square$ Demolición $\square$ Otro...

$\square$ Consolidación $\quad \square$ Reconstrucción $\square$ sustitución

No intervenido

$\square$ Actualización $\square$ Reintegración $\square$ Demolición $\quad \square$ Otro.. $\square$ Consolidación $\square$ Reconstrucción $\square$ Sustitución Tipo de técnica $\square$ Mantenimiento $\square$ Rehabilitación parcial

La restauración y rehabilitación de la arquitectura tradicional de tierra.

El caso de Aragón.

3.7. REHABILITACIÓN ENERGÉTICA $\quad \square$ Fachada $\square$ Vanos $\square$ Forjados $\square$ Cubierta

Observaciones

FOTOGRAFÍAS DE LA INTERVENCIÓN

Tipo de técnica $\square$

$\square$ Consolidación $\mathbf{X}$ Reconstrucción $\square$ sustitución

Nuevo revestimiento de cemento sobre el área con mampostería hasta casi la segunda

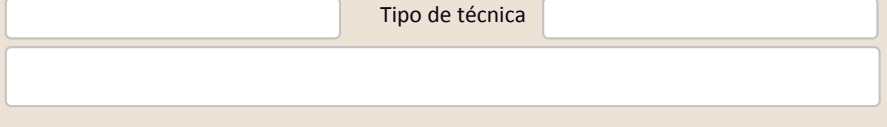
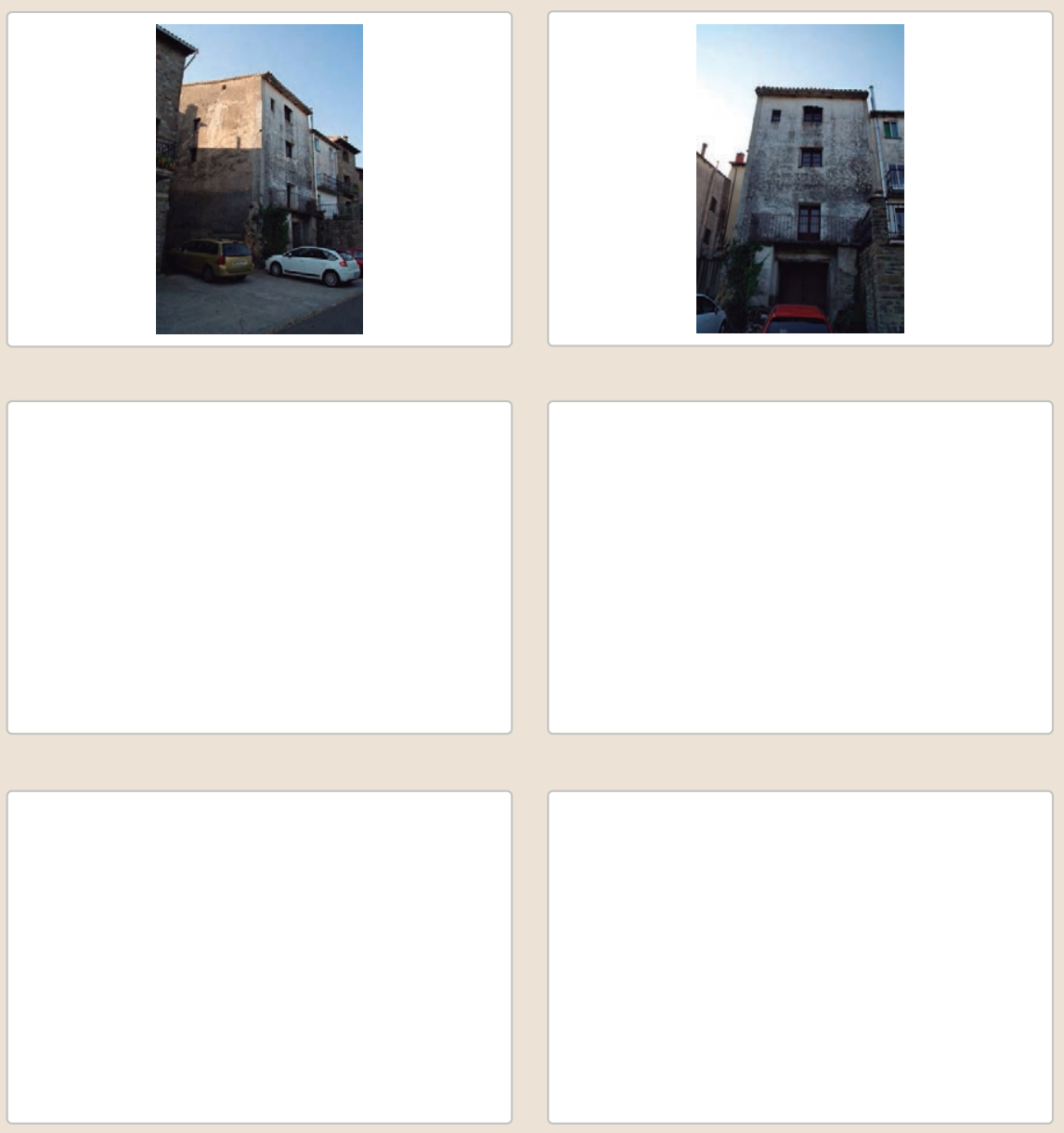


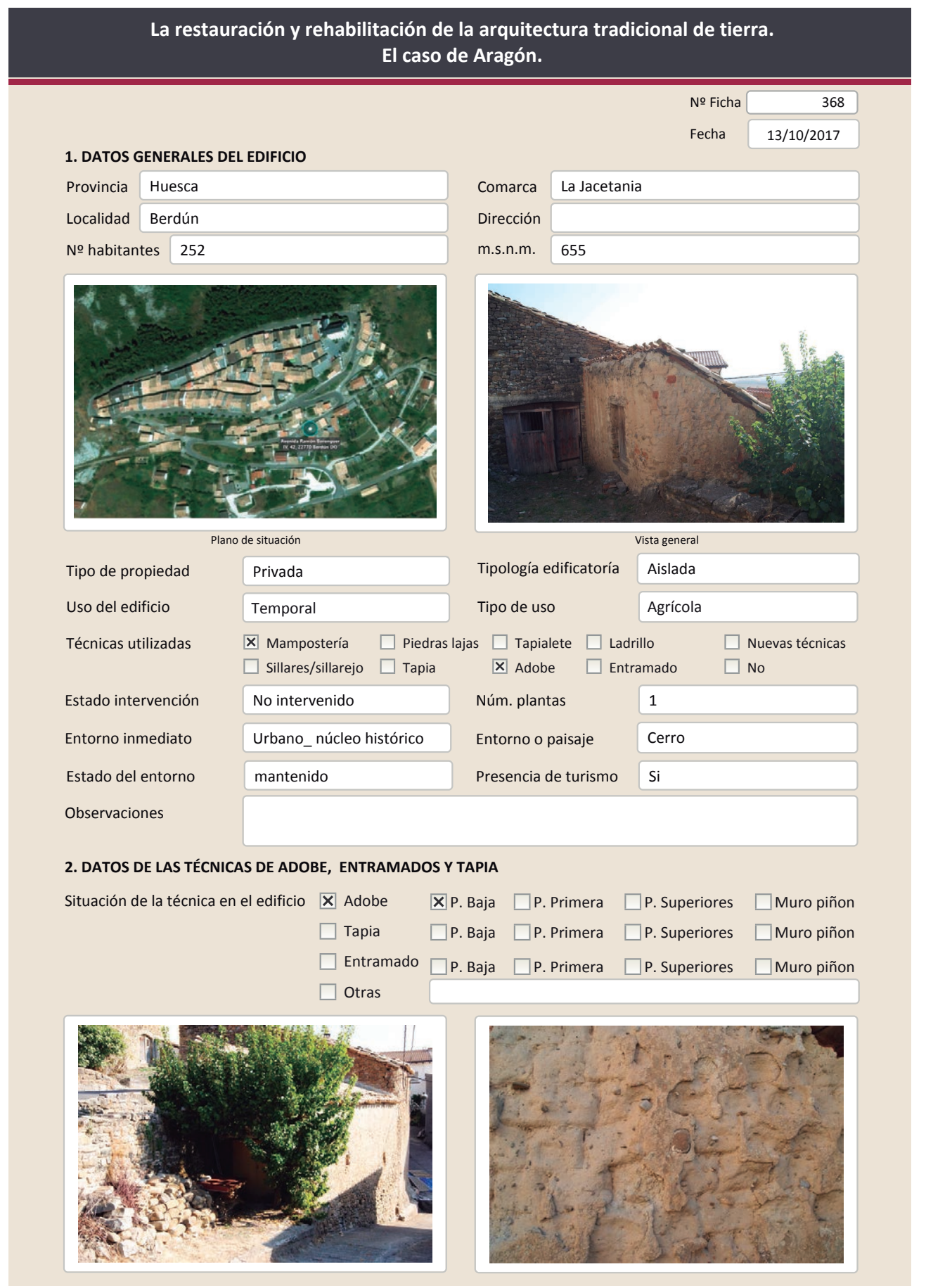

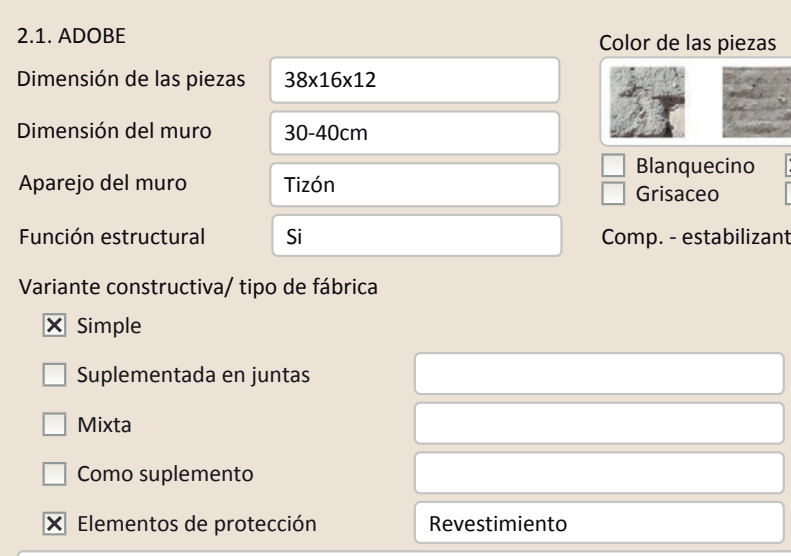

X Elementos de protección
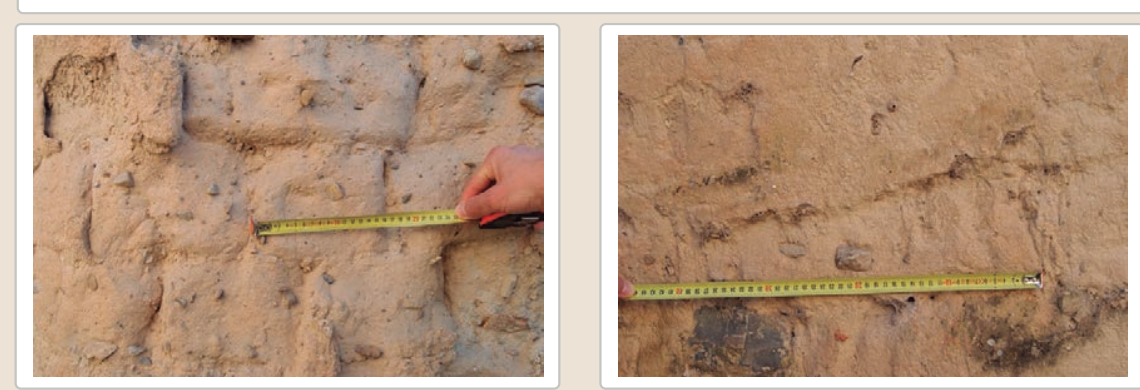

Lesiones $\quad \mathbf{X}$ Muro $\square$ Zócalo $\mathbf{X}$ Revestimiento

$\mathbf{X}$ Erosión del material $\quad \square$ Humedad por capilarida $\mathbf{X}$ Erosion de las juntas $\square$ Humedades (manch/eflo)

X Pérdida de sección $\square$ Pérdida de verticalidad

$\begin{array}{ll}\square \text { Vegetación } & \square \text { Grietas por empuje de la cubic } \\ \square \text { Desconchados } \quad \square \text { Grietas porfalta de traba }\end{array}$
(c)
$\square$ Grietas por asentamiento
$\square$ Colapso
$\square$ Por elementos impropios
$\square$ Derivado de intervenciones

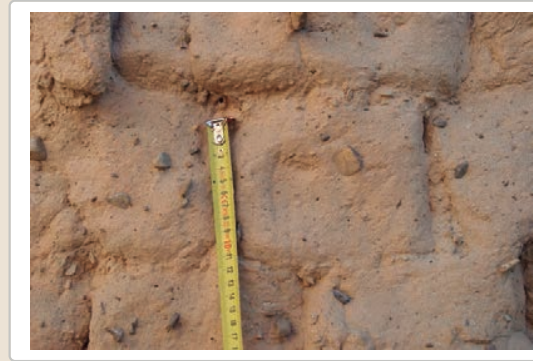

Observaciones 
La restauración y rehabilitación de la arquitectura tradicional de tierra. El caso de Aragón.

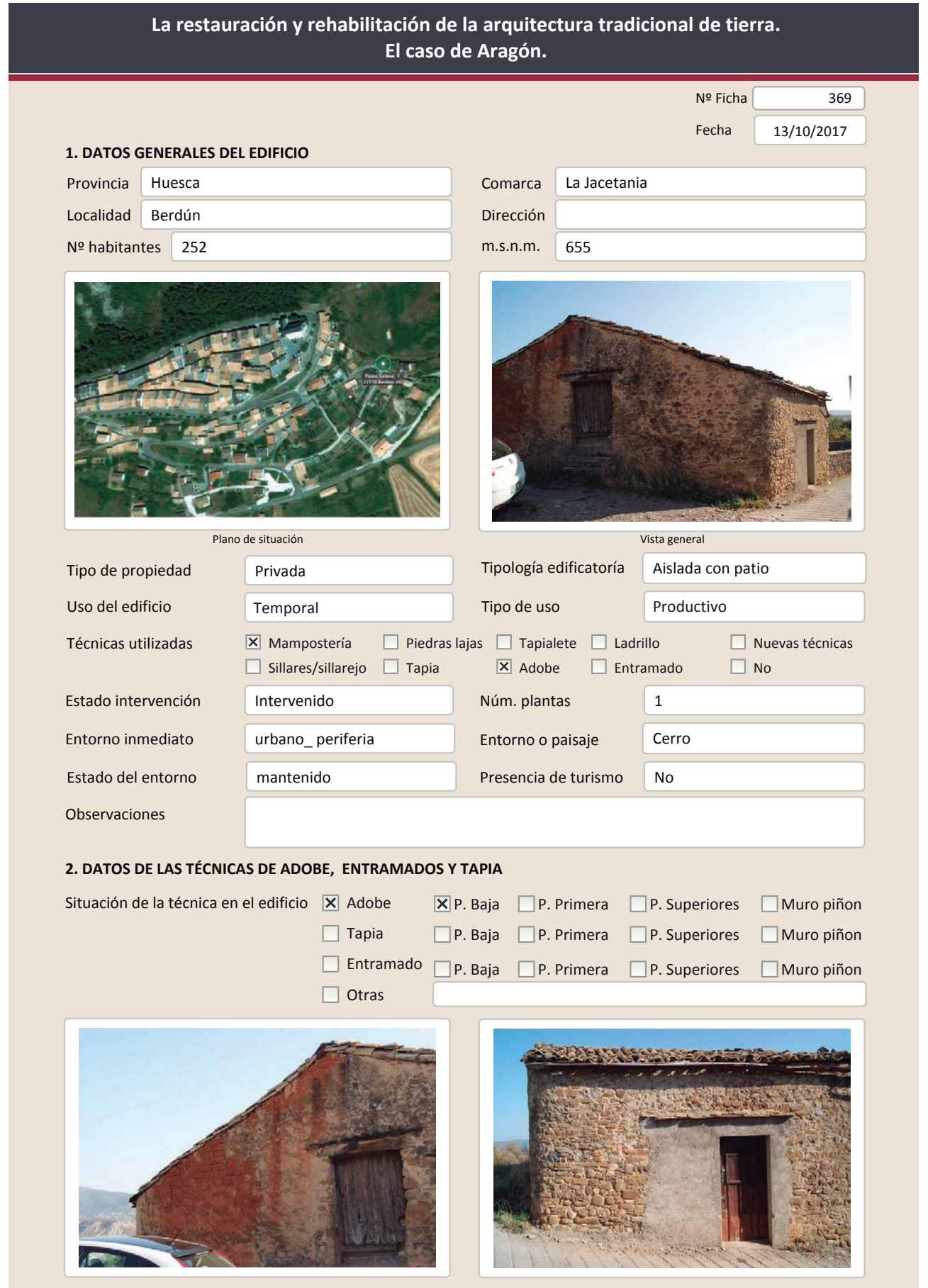

La restauración y rehabilitación de la arquitectura tradicional de tierra.
2.1. ADOBE

Dimensión de las piezas

Dimensión del muro

Aparejo del muro

Función estructural

\section{El caso de Aragón.}

Color de las piezas

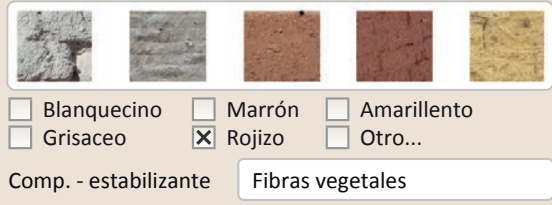

Variante constructiva/ tipo de fábrica

Х Simple

$\square$ suplementada en juntas

$\square$ Mixta

$\square$ Como suplemento

$\square$ Elementos de protección

En el edificio predomina la piedra. El adobe aparece de forma parcial sobre ese material.

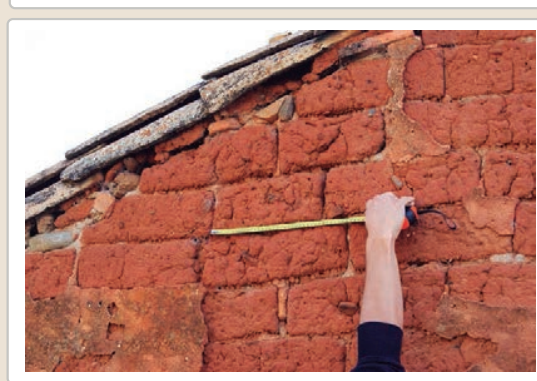

Lesiones $\quad \mathbf{X}$ Muro $\square$ Zócalo $\square$ Revestimiento X Erosión del material $\square$ Humedad por capilaridad X Erosion de las juntas $\square$ Humedades (manch/eflo) $\square$ Pérdida de sección $\square$ Pérdida de verticalidad

$\square$ Vegetación $\quad \square$ Grietas por empuje de la cubie $\square$ Desconchados $\quad \square$ Grietas porfalta de traba

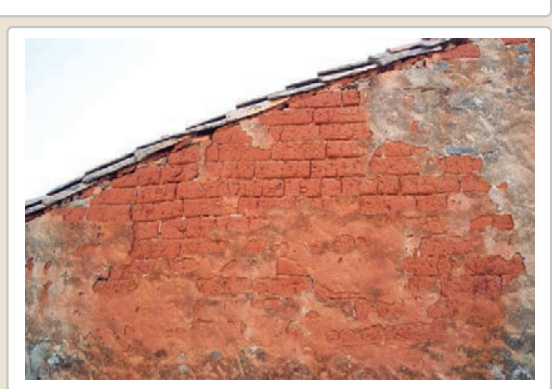

$\square$ Cubierta $\square$ otro...

$\square$ Grietas por asentamiento $\square$ Colapso

$\square$ Por elementos impropios

$\square$ Derivado de intervenciones $\square$ Otro...

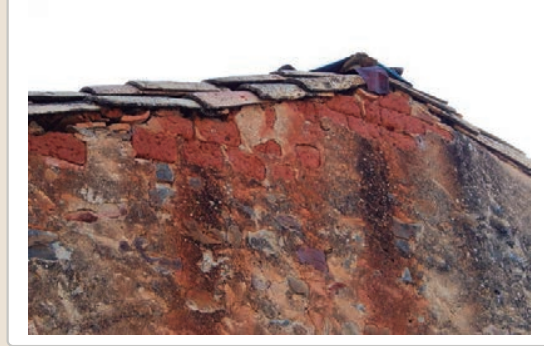

Observaciones 
La restauración y rehabilitación de la arquitectura tradicional de tierra. El caso de Aragón

\section{La restauración y rehabilitación de la arquitectura tradicional de tierra.}

\section{El caso de Aragón.}

3. DATOS DE LA INTERVENCIÓN

Intervención de:

$\square$ Mantenimiento $\quad \mathbf{X}$ Rehabilitación parcial

$\square$ Restauración $\square$ Demolición

Reflexión previa

$\square$ Reparación

$\square$ Rehabilitación integral $\square$ Ampliación

$\square$ Otro..

Reflexión previa

Intervención espontanea

(20)

3.1. MUROS

No intervenido

Tipo de intervención

$\square$ Actualización $\square$ Reintegración $\square$ Demolición $\square$ Otro...

$\square$ Consolidación $\square$ Reconstrucción $\square$ Sustitución

Tipo de material

Descripción

3.2. ZÓCALO

No intervenido

Tipo de intervención

$\square$ Actualización

Tipo de material

Descripción

3.3. REVESTIMIENTOS

Tipo de intervención

No intervenido

Tipo de material

$\square$ Actualización

Tipo de técnica

Descripción

3.4. VANOS

Tipo de intervención

\section{Intervenido}

Tipo de material

$\square$ Actualización $\quad \boldsymbol{X}$ Reintegración $\square$ Demolición $\square$ Otro...

Tipo de materia
Descripción

Consolidación $\square$ Reconstrucción $\square$ sustitución

3.5. CUBIERTA

Tipo de intervención

No tradicional

Tipo de técnica Diferente a la existente

Reintegración del hueco reduciéndolo al tamaño de la nueva carpintería

Tipo de material

No intervenido

$\square$ Actualización $\square$ Reintegración $\square$ Demolición $\square$ Otro.

$\square$ Consolidación $\square$ Reconstrucción $\square$ Sustitución

Descripción

$$
\text { Tipo de técnica }
$$

3.6. OTRAS 
La restauración y rehabilitación de la arquitectura tradicional de tierra. El caso de Aragón.

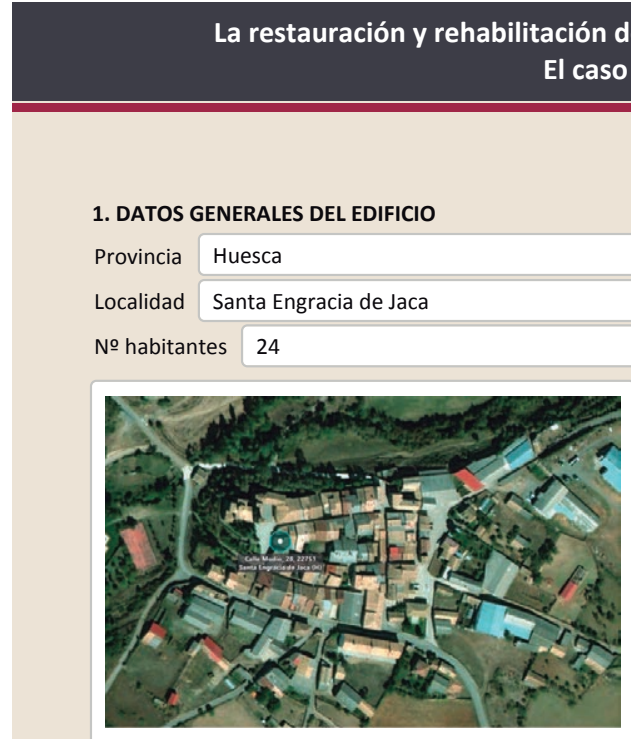

Plano de situación

Tipo de propiedad

Privada

Uso del edificio

Técnicas utilizadas

\section{C}
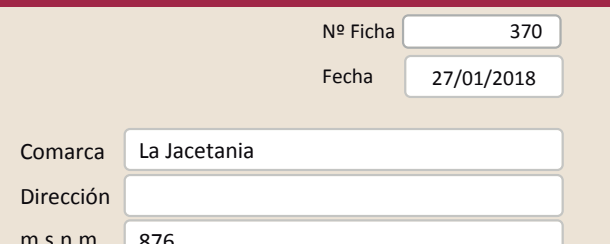

m.s.n.m. 876

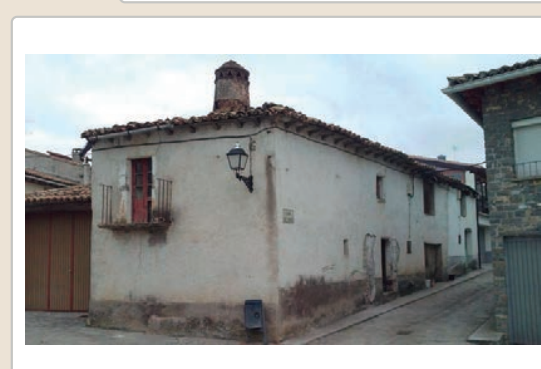

Vista general

Tipo de uso Residencial

X Mampostería $\square$ Piedras lajas $\square$ Tapialete $\square$ Ladrillo $\quad \square$ Nuevas técnicas \ sillares/sillarejo $\square$ Tapia $\quad \square$ Adobe $\quad \mathbf{\text { Entramado }} \quad \square$ No

\begin{tabular}{llll} 
Estado intervención No intervenido plantas & Nún \\
\hline
\end{tabular}

Entorno inmediato Urbano_núcleo histórico Entorno o paisaje LLanura

Estado del entorno mantenido Presencia de turismo No

\begin{tabular}{lll} 
Observaciones & Fotografías de Pedro Bel \\
\hline
\end{tabular}

\section{DATOS DE LAS TÉCNICAS DE ADOBE, ENTRAMADOS Y TAPIA}

Situación de la técnica en el edificio $\square$ Adobe $\quad \square$ P. Baja $\quad \square$ P. Primera $\quad \square$ P. Superiores $\square$ Muro piñon $\square$ Tapia $\square$ P. Baja $\square$ P. Primera $\square$ P. Superiores $\square$ Muro piñon Х Entramado ХP. Baja $\quad$ XP. Primera $\square$ P. Superiores $\square$ Muro piñon $\square$ Otras
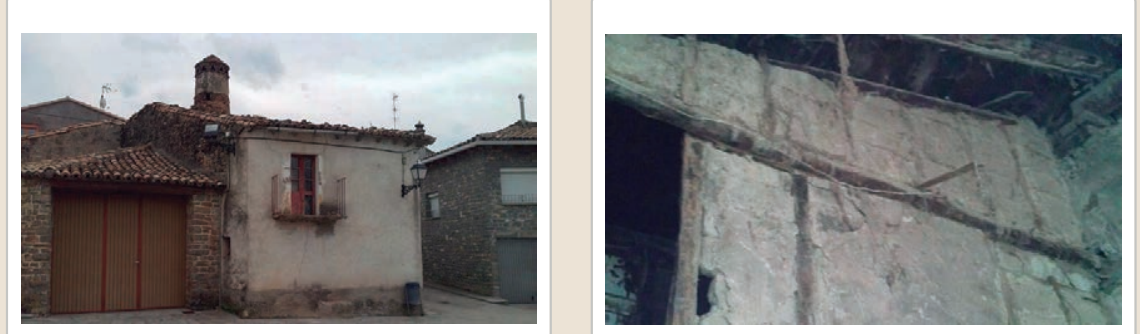

La restauración y rehabilitación de la arquitectura tradicional de tierra.

El caso de Aragón.

\subsection{ENTRAMADOS}

Altura de los montantes

$<40 \mathrm{~cm}$
$150-200 \mathrm{~cm}$

Elementos diagonales

Elementos horizontales intermedios

Sección de los montantes Escuadrada

Dimensión de los montantes $10-20 \mathrm{~cm}$

Tipo de relleno del entramado

Técnica de relleno del entramado

$\square$ Entre pantallas de madera $\quad \square$ Pared de mano $\quad \square$ Cañizo

$\square$ Tierra y mampuestos $\quad \boldsymbol{X}$ Adobe horizontal $\square$ Encestados

$\square$ Tapialete

$\square$ Adobe aletorio $\quad \square$ Otro..

Entramado con adobe utilizado en las divisiones interiores del edificio

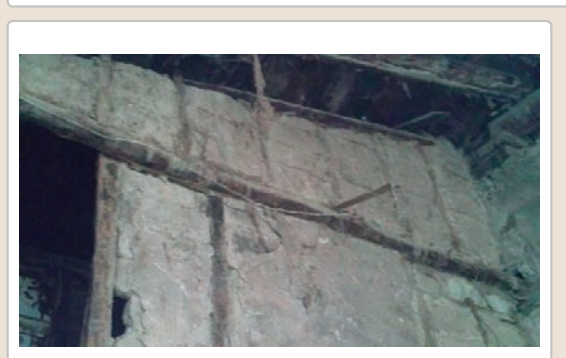

Lesio

$\begin{array}{lll}\text { Lesiones } \quad \boldsymbol{X} \text { Muro } \square \text { Zócalo } & \square \text { Revestimiento } \\ \mathbf{X} \text { Erosión del material } & \square \text { Cubierta } & \square \text { Otro... } \\ \mathbf{X} \text { Erosion de las juntas } & \square \text { Rotura de la madera } & \square \text { Grietas por falta de traba } \\ \square \text { Pérdida de sección } & \square \text { Pudrición de la madera } & \square \text { Grietas por asentamientos } \\ \square \text { Vegetación } & \square \text { Deformación madera } & \square \text { Por elementos impropios } \\ \square \text { Desconchados } & \square \text { Pudrición del relleno } & \square \text { Derivado de intervenciones } \\ \square \text { Humedad por capilaridad } & \square \text { Pérdida de verticalidad } & \square \text { Otro... } \\ \square \text { Humedades (manch/eflor) } & \square \text { Grietas por empuje de la cubierta } & \end{array}$

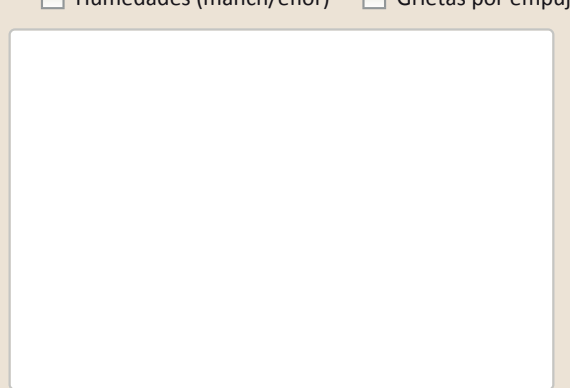

Observaciones

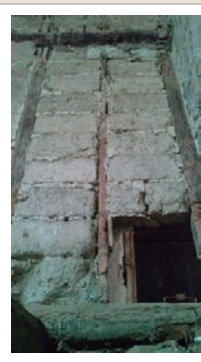


La restauración y rehabilitación de la arquitectura tradicional de tierra. El caso de Aragón

\section{La restauración y rehabilitación de la arquitectura tradicional de tierra.} El caso de Aragón.
3.7. REHABILITACIÓN ENERGÉTICA
$\square$ Fachada $\square$ Vanos $\square$ Forjados $\square$ Cubierta

Observaciones

FOTOGRAFÍAS DE LA INTERVENCIÓN
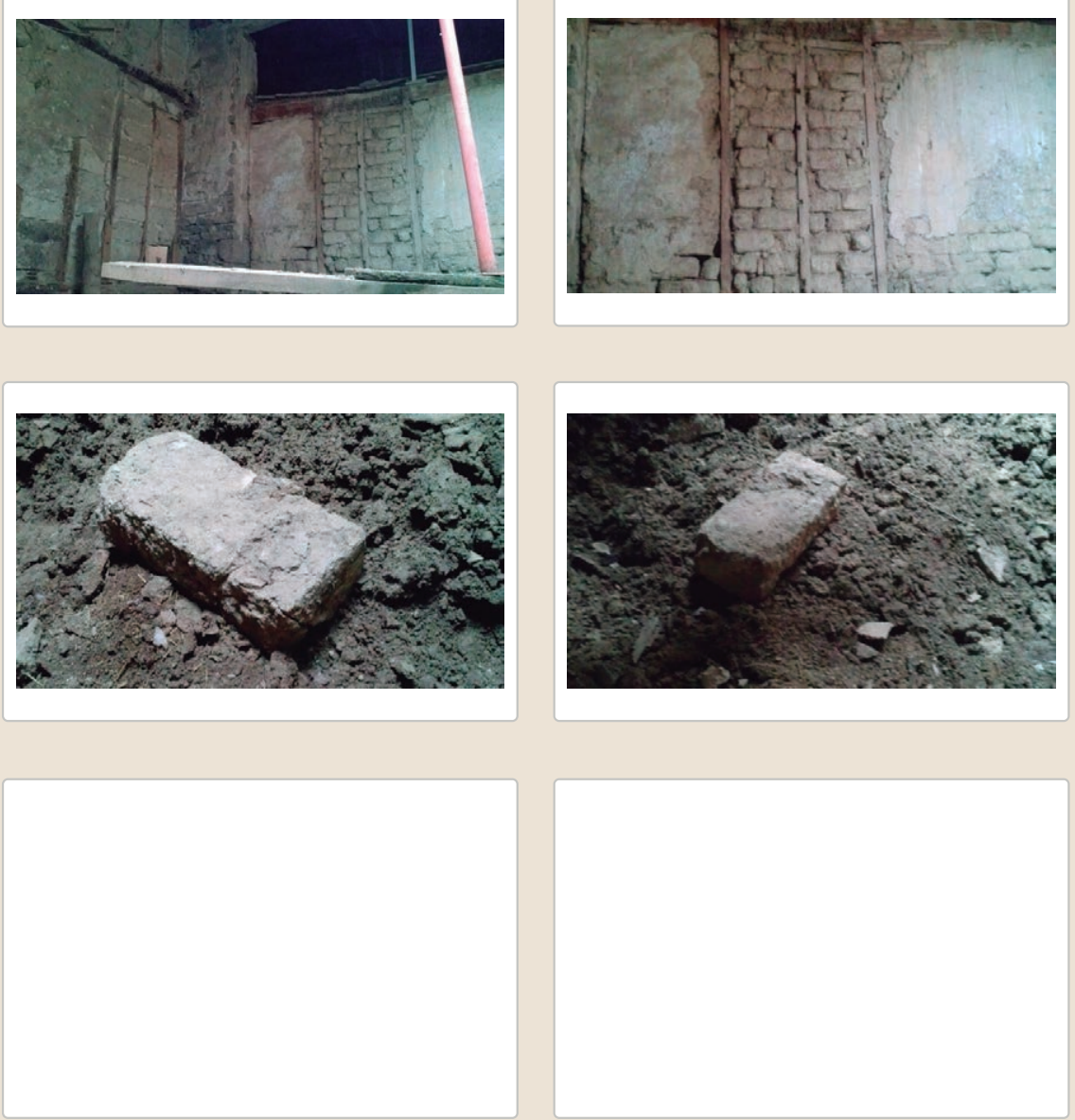


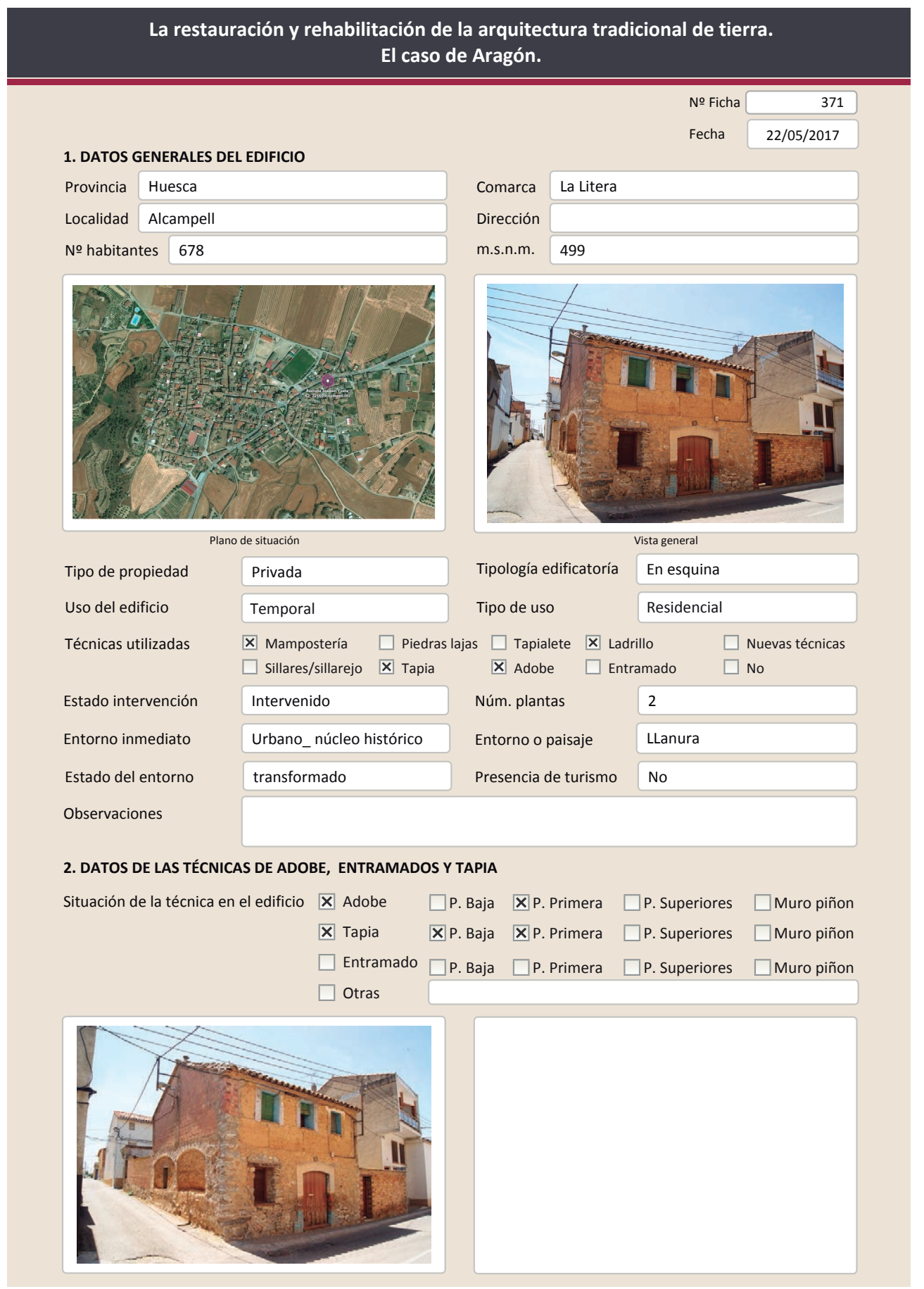

La restauración y rehabilitación de la arquitectura tradicional de tierra.

El caso de Aragón.

\subsection{ADOBE}

Dimensión de las piezas Dimensión del muro Aparejo del muro Función estructural
Color de las piezas

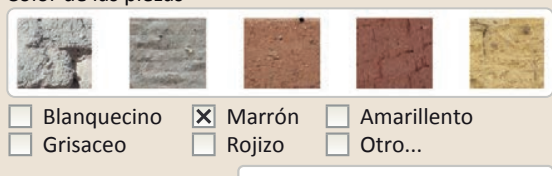

$\begin{array}{ll}\square \text { Blanquecino } & \boldsymbol{X} \text { Marrón } \\ \square \text { Grisaceo } & \square \text { Amarillen } \\ \text { Rojizo } & \square \text { Otro... }\end{array}$

Comp. - estabilizante

Variante constructiva/ tipo de fábrica

メ simple

$\square$ suplementada en juntas

$\square$ Mixta

$\square$ Como suplemento

$\square$ Elementos de protección

La presencia de adobes es mínima en este edificio

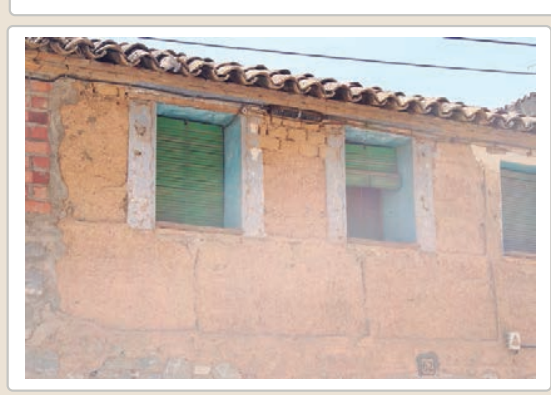

Lesiones \Muro $\square$ Zócalo $\square$ Revestimiento

Х Erosión del material $\square$ Humedad por capilaridad

$\boldsymbol{X}$ Erosion de las juntas $\square$ Humedades (manch/eflo)

$\square$ Cubierta $\square$ otro...

$\square$ Pérdida de sección $\square$ Pérdida de verticalidad

por asentamientos

$\square$ Vegetación

$\square$ Grietas por empuje de la

Colapso

$\square$ Desetación $\quad \square$ Grietas por empujes de la cubes $\quad \square$ Grietas porfalta de traba

Por elementos impropios
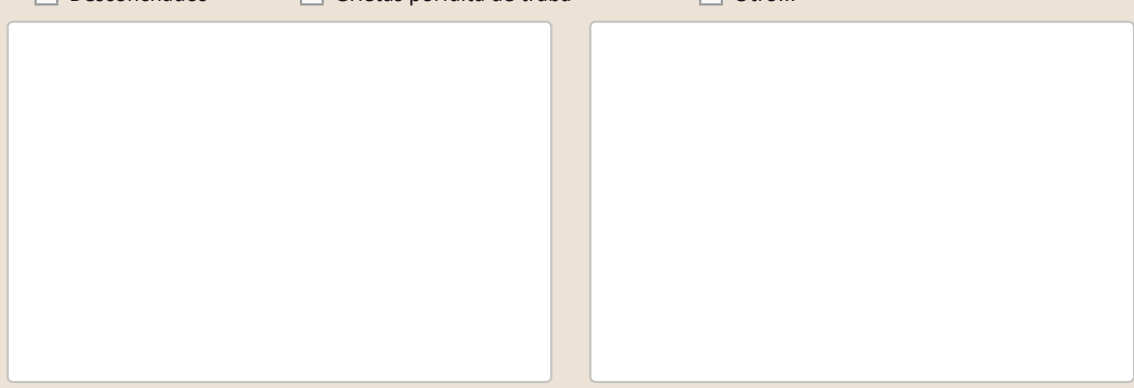

Observaciones

El adobe se encuentra únicamente entro dos huecos bajo cubierta. 


\section{La restauración y rehabilitación de la arquitectura tradicional de tierra.} El caso de Aragón.

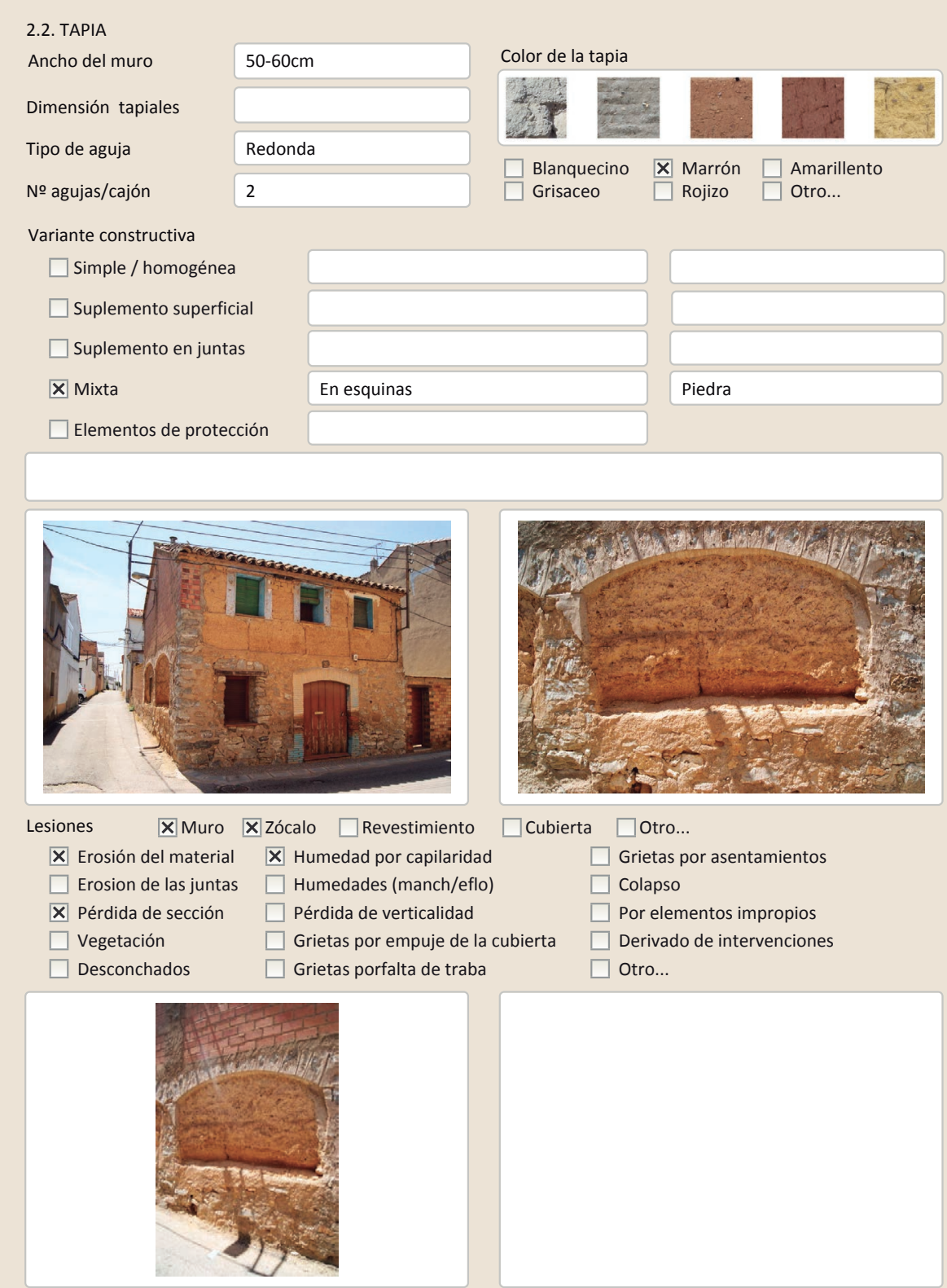

Observaciones
La restauración y rehabilitación de la arquitectura tradicional de tierra. El caso de Aragón.

3. DATOS DE LA INTERVENCIÓN

Intervención de: $\quad \square$ Mantenimiento $\quad \square$ Rehabilitación parcial $\quad \square$ Restauración $\square$ Demolición

\Reparación $\square$ Rehabilitación integral $\square$ Ampliación $\square$ Otro...

Reflexión previa Intervención espontanea

Observaciones

3.1. MUROS

Tipo de intervención

Tipo de material

Intervenido

$\square$ Actualización $\quad$ X Reintegración $\square$ Demolición $\square$ Otro..

$\square$ Consolidación $\square$ Reconstrucción $\mathbf{X}$ Sustitución

Descripción

No tradicional Tipo de técnica Diferente a la existente

Sustitución del muro piñón por fábrica de ladrillo. Reintegraciones con cemento

3.2. ZÓCALO

Intervenido

Tipo de intervención $\square$ Actualización $\mathbf{X}$ Reintegración $\square$ Demolición $\square$ Otro...

$\square$ Consolidación $\quad \square$ Reconstrucción $\square$ sustitución

\begin{tabular}{llll} 
Tipo de material & No tradicional & Tipo de técnica Diferente a la existente \\
\hline
\end{tabular}

Descripción

Rejuntado de la mampostería del zócalo con gran cantidad de cemento

3.3. REVESTIMIENTOS

Tipo de intervención

\section{No aplica}

$\square$ Actualización $\quad \square$ Reintegración $\quad \square$ Demolición $\square$ Otro.

$\square$ Consolidación $\square$ Reconstrucción $\square$ Sustitución

Tipo de material

Descripción

3.4. VANOS

Tipo de intervención

No intervenido

$\square$ Actualización $\square$ Reintegración $\square$ Demolición $\square$ Otro..

$\square$ Consolidación $\quad \square$ Reconstrucción $\square$ Sustitución

Tipo de material

Descripción

3.5. CUBIERTA

Tipo de intervención

Tipo de material

Intervenido

$\square$ Actualización $\mathbf{X}$ Reintegración $\square$ Demolición $\square$ Otro

$\square$ Consolidación $\square$ Reconstrucción $\square$ Sustitución

Descripción

No tradiciona

Tipo de técnica Similar a la existente

Reintegración de tejas con cemento ( lateral de la cubierta)

3.6. OTRAS 
La restauración y rehabilitación de la arquitectura tradicional de tierra.

El caso de Aragón.

3.7. REHABILITACIÓN ENERGÉTICA

$\square$ Fachada $\square$ Vanos $\square$ Forjados $\square$ Cubierta

Observaciones

FOTOGRAFÍAS DE LA INTERVENCIÓN
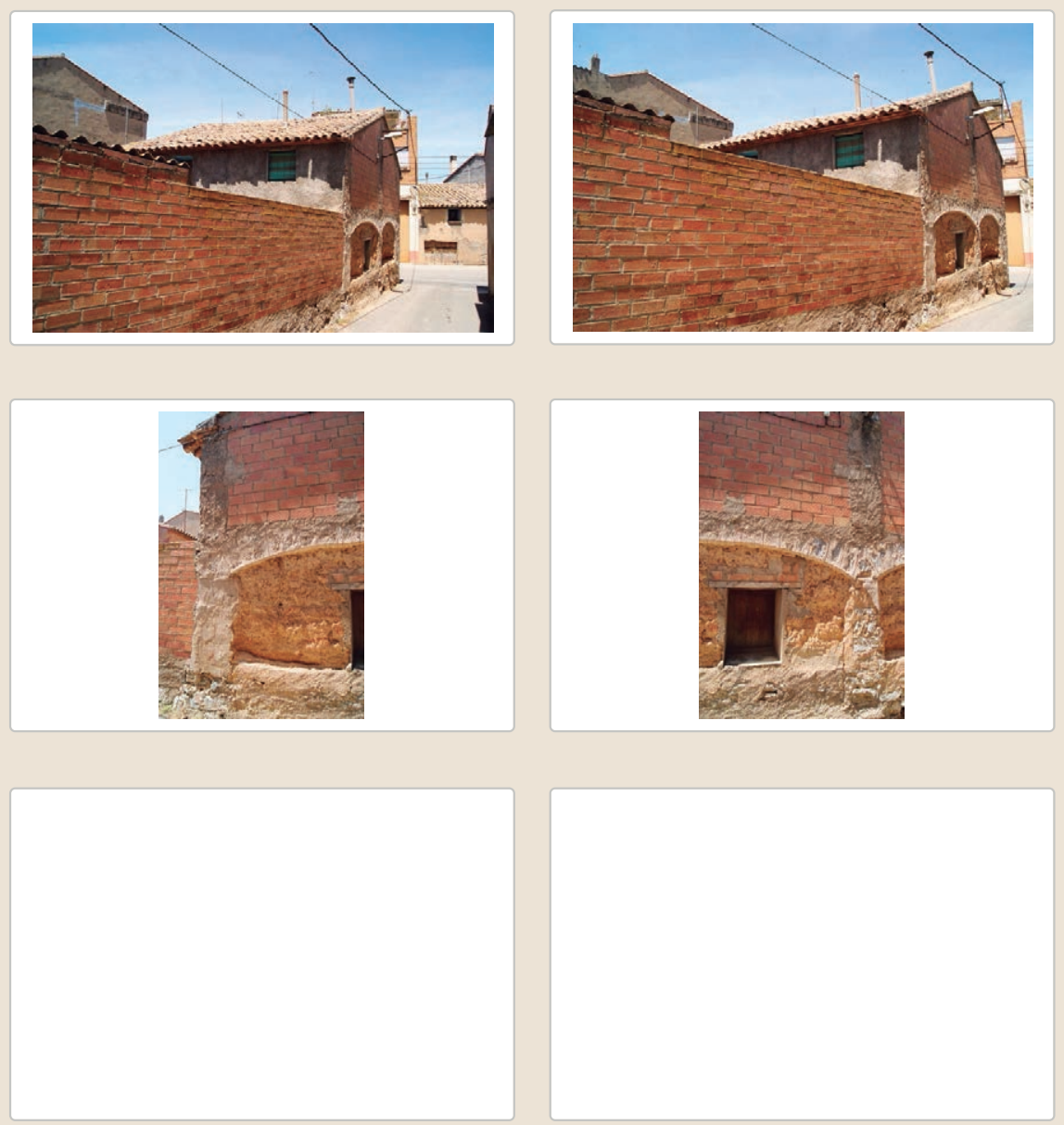

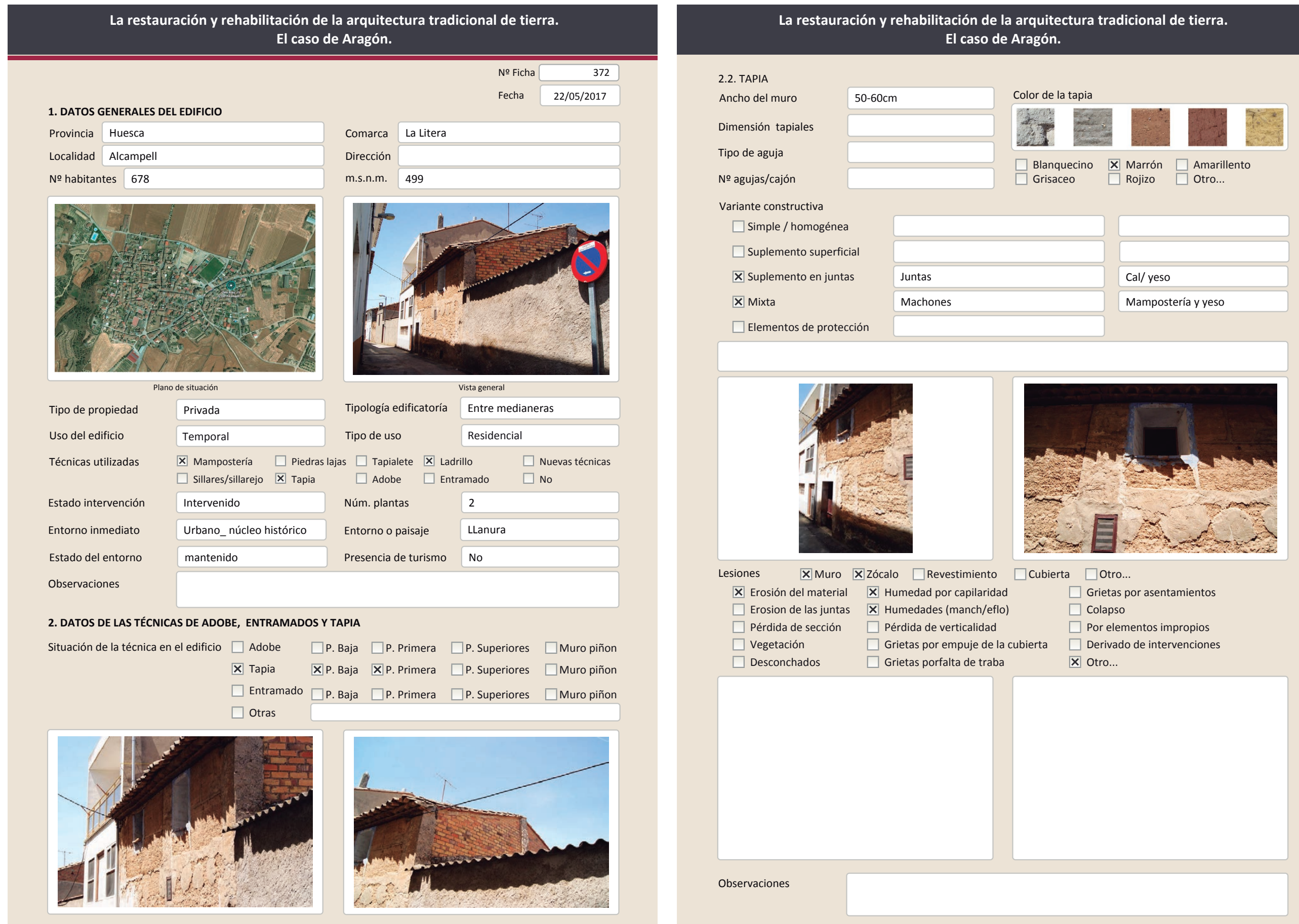
La restauración y rehabilitación de la arquitectura tradicional de tierra.

El caso de Aragón.

3. DATOS DE LA INTERVENCIÓN

\begin{tabular}{llll|} 
Intervención de: & $\square$ Mantenimiento $\quad \square$ Rehabilitación parcial & $\square$ Restauración $\quad \square$ Demolición \\
Reflexión previa & $\mathbf{X}$ Reparación $\quad \square$ Rehabilitación integral $\quad \square$ Ampliación $\quad \square$ Otro... \\
\hline Observaciones & Intervención espontanea & \\
& & \\
& & \\
\end{tabular}

\subsection{MUROS}

Tipo de intervención

Tipo de material

$\square$ Actualización $\square$ Reintegración $\square$ Demolición $\square$ Otro...

$\square$ Consolidación $\square$ Reconstrucción $\quad$ X Sustitución

Descripción

No tradicional Tipo de técnica Diferente a la existente

3.2. ZóCALO

Sustitución del muro piñón por fábrica de ladrillo hueco

Tipo de intervención

Intervenido

Actualización $\square$ Reintegración $\square$ Demolición $\square$ Otro..

$\square$ Consolidación $\quad \mathbf{X}$ Reconstrucción $\square$ Sustitución

Tipo de material

Descripción

Diferente a la existente

3.3. REVESTIMIENTOS

Tipo de intervención

\section{No aplica}

Tipo de material

$\square$ Actualización $\quad \square$ Reintegración $\quad \square$ Demolición
$\square$ Consolidación $\quad \square$ Reconstrucción $\quad \square$ Sustitución

gran espesor en al zócalo

Descripción

3.4. VANOS

Tipo de intervención

No intervenido

Tipo de material

Descripción

3.5. CUBIERTA

Tipo de intervención

No intervenido

Tipo de intervención

$\square$ Actualización

$\square$ Consolidación $\quad \square$ Reconstrucción $\quad \square$ Sustitución

Tipo de material

Tipo de técnica

Descripción

3.6. OTRAS 


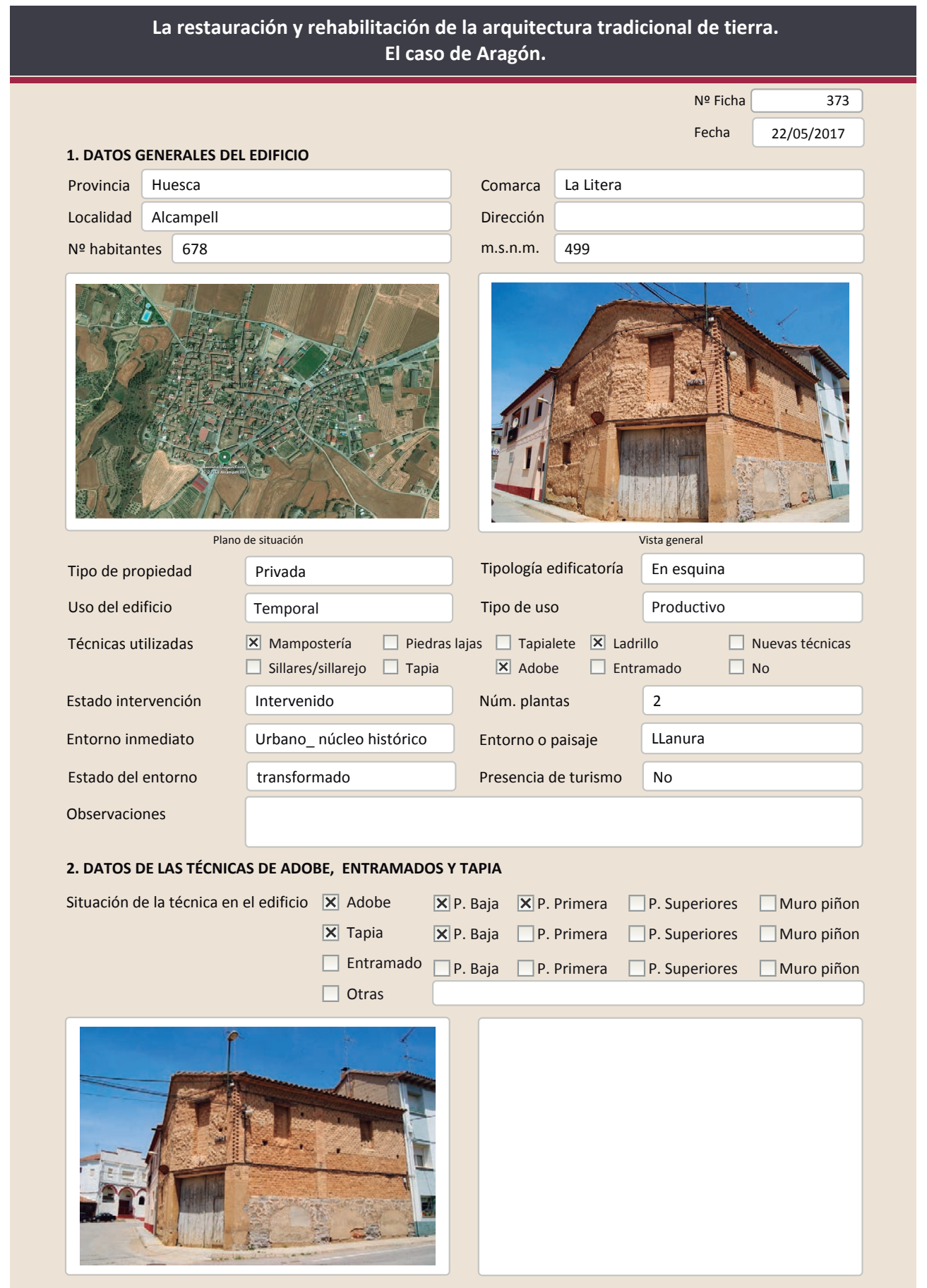

2.1. ADOBE

Dimensión de las piezas

Dimensión del muro

Aparejo del muro

Función estructural

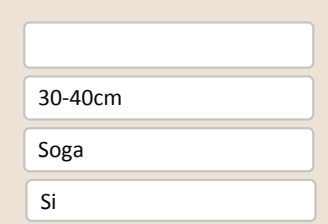

Color de las piezas

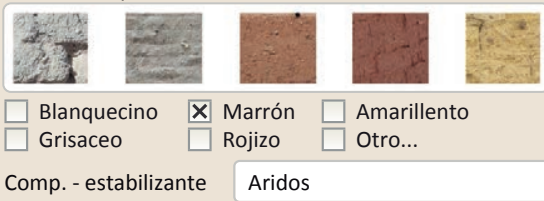

Variante constructiva/ tipo de fábrica

$\square$ Simple

$\square$ Suplementada en juntas

区 Mixta

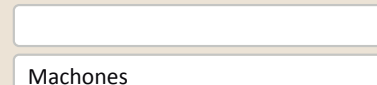

$\square$ Como suplemento

X Elementos de protección Revestimiento

Existía un revestimiento en toda la fachada del que hora solo se aprecian algunas muestras en la zona bajo el alero

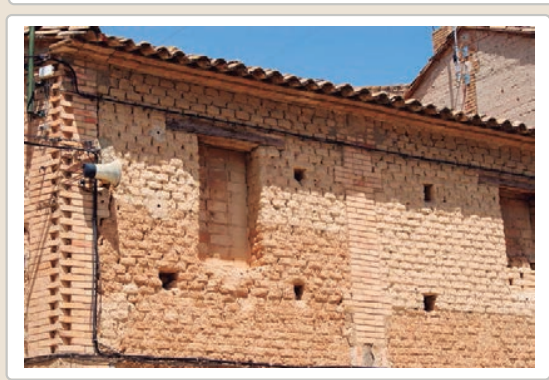

Lesiones X Muro XZzócalo $\square$ Revestimiento $\mathbf{X}$ Erosión del material $\mathbf{X}$ Humedad por capilarida $\mathbf{X}$ Erosion de las juntas $\mathbf{X}$ Humedades (manch/eflo) \ Pérdida de sección $\square$ Pérdida de verticalidad

$\square$ Vegetación $\quad \square$ Grietas por empuje de la cubie $\square$ Desconchados $\mathbf{X}$ Grietas porfalta de traba

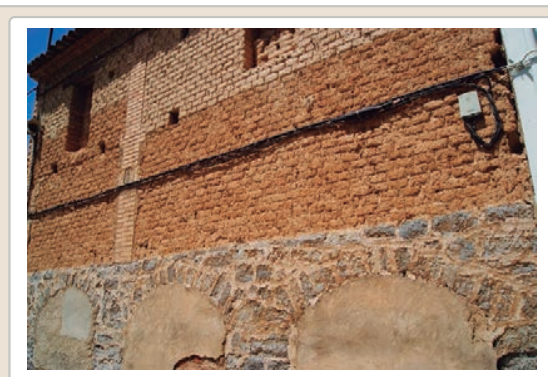

$\square$ Cubierta $\square$ Otro...

$\square$ Grietas por asentamientos $\square$ Colapso

$\square$ Por elementos impropios $\boldsymbol{x}$ Derivado de intervenciones

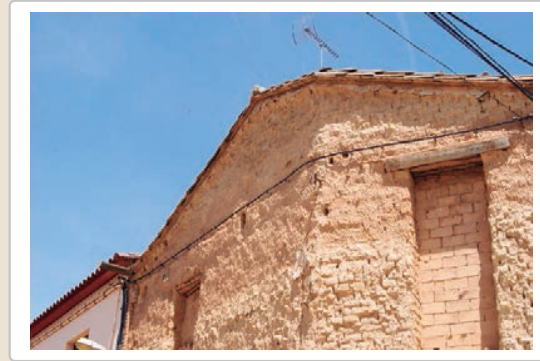
$\square$ Otro...

Observaciones 


\section{La restauración y rehabilitación de la arquitectura tradicional de tierra.}

\section{El caso de Aragón.}

\subsection{TAPIA}

Ancho del muro

Dimensión tapiales

Tipo de aguja

№ agujas/cajón

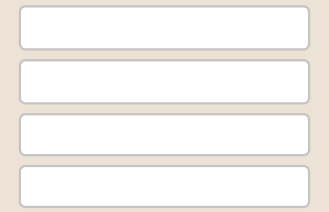

\section{Color de la tapia}

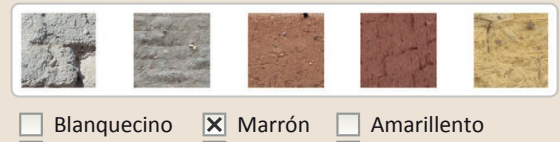

$\square$ Blanquecino $\quad \boldsymbol{X}$ Marrón $\square$ Amarillento $\square$ Grisaceo

Variante constructiva

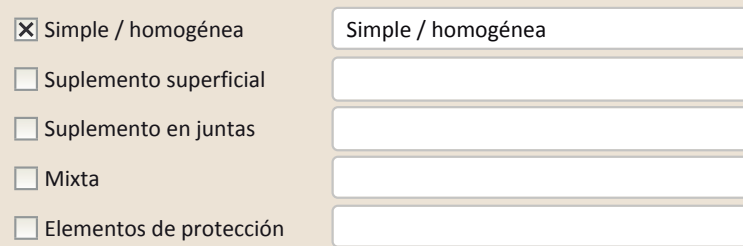

$\square$ Elementos de protección

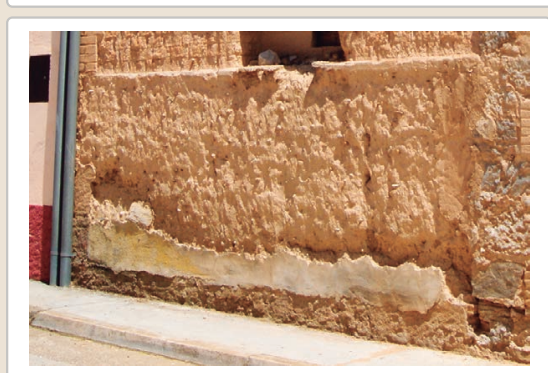

Lesiones $\square$ Muro $\mathbf{X}$ Zócalo $\square$ Revestimiento $\square$ Cubierta $\square$ otro...

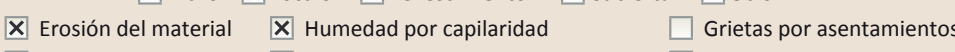

$\square$ Erosion de las juntas $\square$ Humedades (manch/eflo) $\quad \square$ Colapso

X Pérdida de sección $\square$ Pérdida de verticalidad $\square$ Por elementos impropios

$\square$ Vegetación $\square$ Grietas por empuje de la cubierta $\mathbf{X}$ Derivado de intervenciones

$\square$ Desconchados $\quad \square$ Grietas porfalta de traba $\quad \square$ Otro...
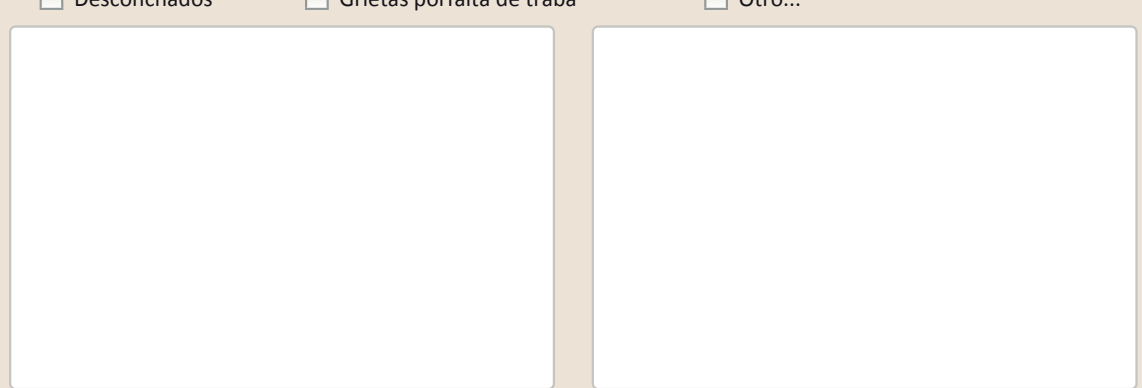

Observaciones

La restauración y rehabilitación de la arquitectura tradicional de tierra.

El caso de Aragón.

3. DATOS DE LA INTERVENCIÓN

Intervención de: $\quad \mathbf{X}$ Mantenimiento $\square$ Rehabilitación parcial $\square$ Restauración $\square$ - $\square$ Remolión

$\square$ Reparación $\quad \square$ Rehabilitación integral $\quad \square$ Ampliación $\quad \square$ Otro...

Reflexión previa Intervención espontanea

Observaciones

3.1. MUROS

Tipo de intervención

No intervenido

Tipo de material

$\square$ Actualización $\square$ Reintegración $\square$ Demolición $\square$ Otro..

$\square$ Consolidación $\quad \square$ Reconstrucción $\square$ sustitución

Descripción

3.2. ZÓCALO

Intervenido

$\begin{array}{ll}\text { Tipo de intervención } & \square \text { Actualización } \quad \boldsymbol{X} \text { Reintegración } \quad \square \text { Demolición } \quad \square \text { Otro... } \\ & \square \text { Consolidación } \quad \square \text { Reconstrucción } \quad \square \text { Sustitución }\end{array}$

Tipo de material

Descripción

3.3. REVESTIMIENTOS

Uso de cemento en la parte baja del muro de tierra y en el rejuntado de la mampostería

Tipo de intervención

No intervenido

$\square$ Actualización $\square$ Reintegración $\square$ Demolición $\square$ Otro...

$\square$ Consolidación $\quad \square$ Reconstrucción $\quad \square$ Sustitución

Tipo de material

Descripción

3.4. VANOS

Tipo de intervención

Intervenido

Tipo de material

$\square$ Actualización $\quad \mathbf{X}$ Reintegración $\square$ Demolición $\quad \mathbf{X}$ Otro...

Tipo de material
Descripción

Consolidación $\square$ Reconstrucción $\square$ Sustitución

3.5. CUBIERTA

\begin{tabular}{l|l|l} 
No tradicional & Tipo de técnica & Diferente a la existente
\end{tabular}

Se han reintegrado las jambas del hueco principal. Además el resto de huecos se han cegado utilizando ladrillo cerámica.

Tipo de intervención

No intervenido

$\square$ Actualización $\quad \square$ Reintegración $\quad \square$ Demolición $\quad \square$ Otro...

$\square$ Consolidación $\square$ Reconstrucción $\square$ Sustitución

Tipo de material

Descripción

$$
\text { Tipo de técnica }
$$

3.6. OTRAS 


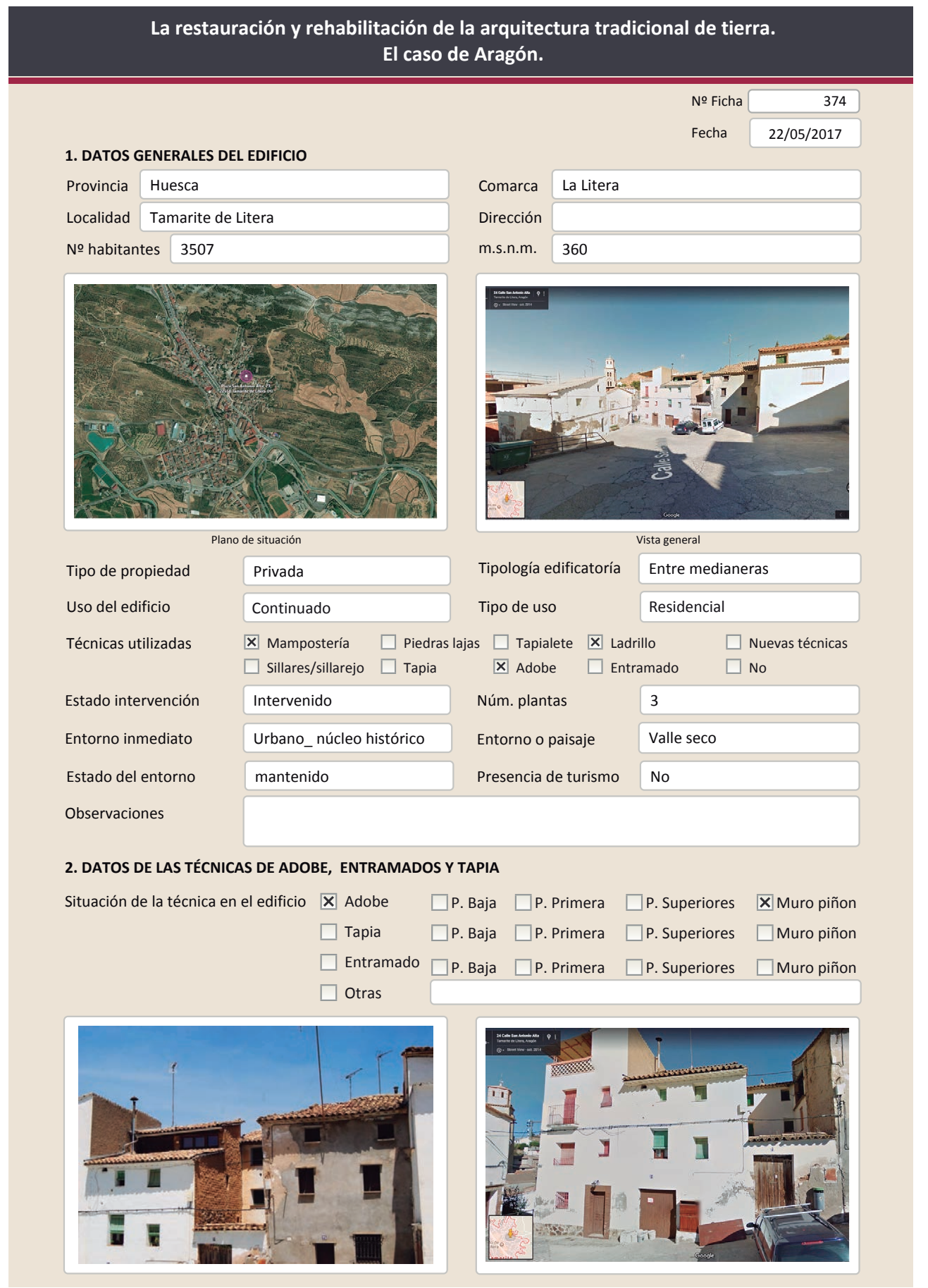

2.1. ADOBE

Dimensión de las piezas Dimensión del muro

Aparejo del muro

Función estructural

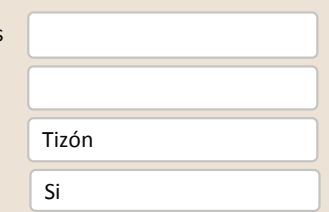

Color de las piezas

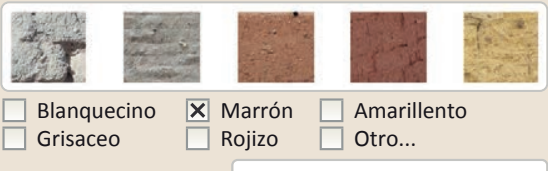

Grisaceo

Variante constructiva/ tipo de fábrica

$\square$ Simple

$\square$ Suplementada en juntas

X Mixta

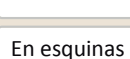

Ladrillo

$\square$ Como suplemento

$\square$ Elementos de protección
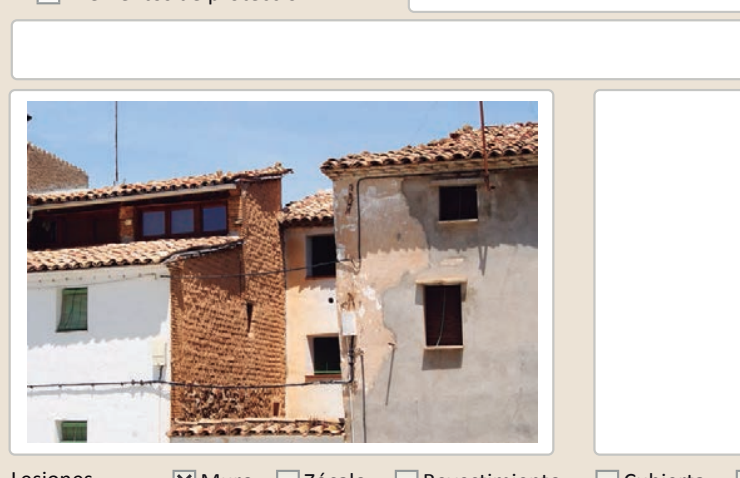

Lesiones ХMuro $\square$ Zócalo $\square$ Revestimiento

Х Erosión del material $\square$ Humedad por capilaridad $\square$ Erosion de las juntas $\square$ Humedades (manch/eflo)

$\square$ Pérdida de sección $\square$ Pérdida de verticalidad

$\square$ Vegetación $\quad \square$ Grietas por empuje de la cub $\square$ Grietas porfalta de traba

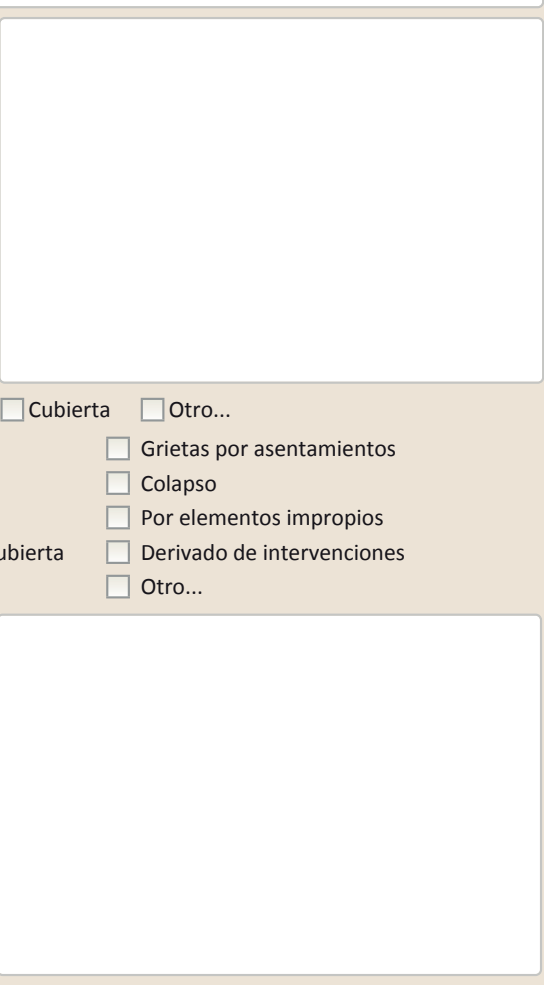

Observaciones 


\section{La restauración y rehabilitación de la arquitectura tradicional de tierra.}

\section{El caso de Aragón.}

3. DATOS DE LA INTERVENCIÓN

Intervención de:

M Rehabilitación parcial

$\square$ Restauración $\square$ Demolición

Reflexión previa

$\square$ Reparación

Ampliación

$\square$ Otro...

Observaciones

Nuevo revestimiento en la fachada principal y pintura plástica

3.1. MUROS
Tipo de intervención

Tipo de material

Descripción

3.2. ZÓCALO

Tipo de intervención

Tipo de material

Descripción

3.3. REVESTIMIENTOS

Tipo de intervención

Tipo de material

Descripción

3.4. VANOS

Tipo de intervención

Tipo de material

Descripción

3.5. CUBIERTA

Tipo de intervención

Tipo de material

Descripción

No intervenido

$\square$ Actualización $\square$ Reintegración $\quad \square$ Demolición $\square$ Otro...

$\square$ Consolidación $\square$ Reconstrucción $\square$ Sustitución

$$
\text { Tipo de técnica }
$$

Intervenido

X Actualización $\square$ Reintegración $\square$ Demolición $\square$ Otro...

$\square$ Consolidación $\quad \mathbf{X}$ Reconstrucción $\square$ Sustitución

No tradicional Tipo de técnica Diferente a la existente

revestimiento de cemento continuo con el resto del muro

\section{Intervenido}

X Actualización $\square$ Reintegración $\quad \square$ Demolición $\square$ Otro...

$\square$ Consolidación $\mathbf{X}$ Reconstrucción $\square$ Sustitución

No tradicional Tipo de técnica Diferente a la existente

Revestimiento de cemento y pintura blanca en la fachada principal

Intervenido

$\square$ Actualización $\square$ Reintegración $\square$ Demolición $\square$ Otro...

$\square$ Consolidación $\square$ Reconstrucción $\mathbf{X}$ Sustitución

No tradicional Tipo de técnica Similar a la existente

Nuevas carpinterías con imitación a madera

\section{Intervenido}

$\square$ Actualización $\quad \mathbf{X}$ Reintegración $\square$ Demolición $\square$ Otro.

$\square$ Consolidación $\square$ Reconstrucción $\square$ Sustitución

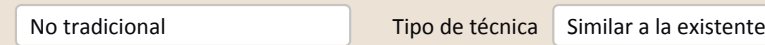

3.6. OTRAS

Se ha insertado una lamina impermebilizante y se han recolocado las tejas antiguas.
La restauración y rehabilitación de la arquitectura tradicional de tierra.

El caso de Aragón.
3.7. REHABILITACIÓN ENERGÉTICA $\square$ Fachada $\quad$ \ Vanos $\square$ Forjados $\bigotimes$ Cubierta

Observaciones

Sustitución carpinterías

FOTOGRAFÍAS DE LA INTERVENCIÓN
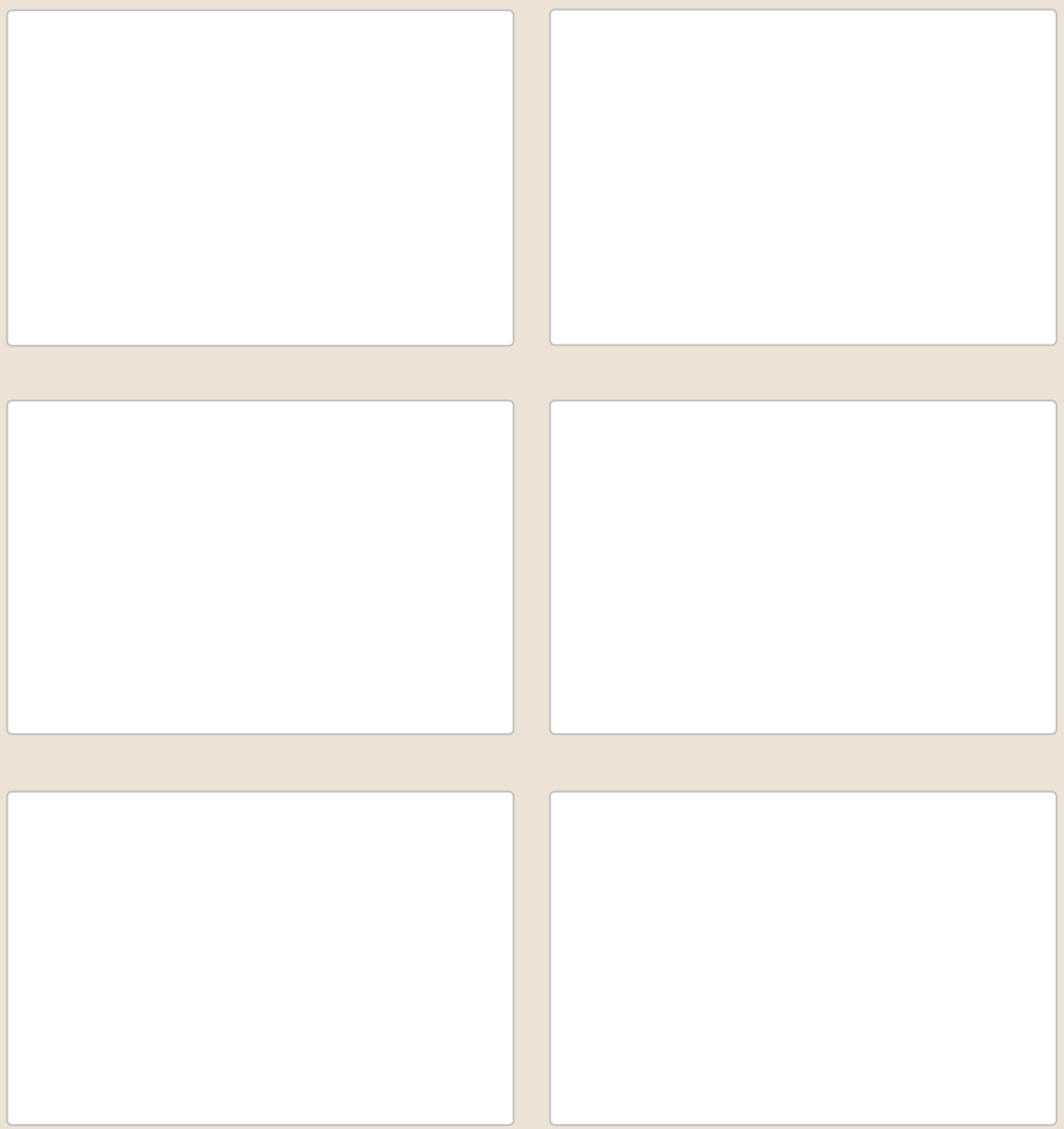


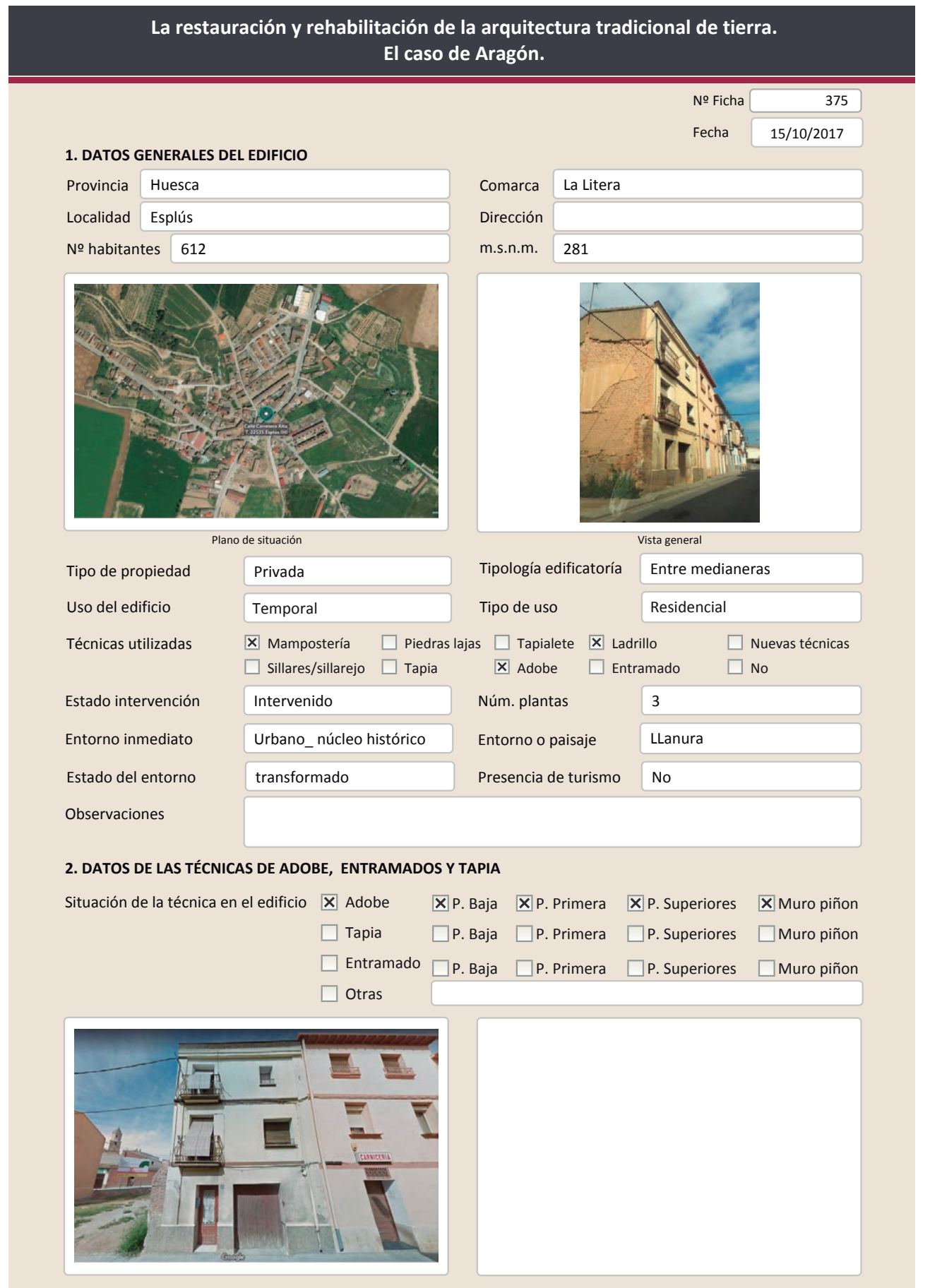

La restauración y rehabilitación de la arquitectura tradicional de tierra.
2.1. ADOBE

Dimensión de las piezas

Dimensión del muro

Aparejo del muro

Función estructural

\section{El caso de Aragón.}

Color de las piezas

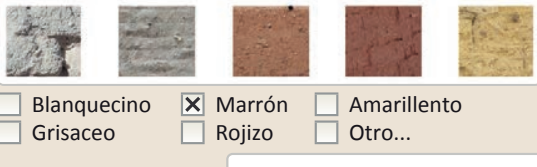

Variante constructiva/ tipo de fábrica

$\square$ simple

$\square$ Suplementada en juntas

区 Mixta

\section{Machones}

Ladrillo

$\mathbf{X}$ Como suplemento

Mixto- Machones

Х Elementos de protección Revestimiento

Perdida casi total del revestimiento del muro piñón

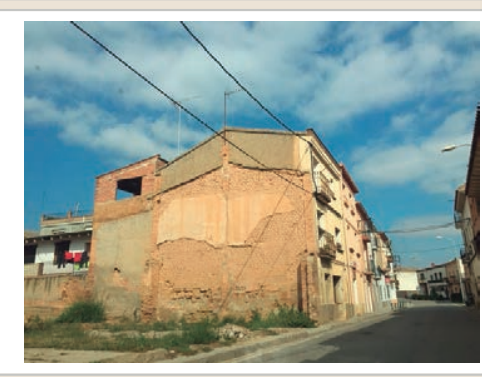

Lesiones $\quad \mathbf{X}$ Muro $\mathbf{X}$ Zócalo $\mathbf{X}$ Revestimiento $\square$ Cubierta $\square$ Otro...

X Erosión del material $\mathbf{X}$ Humedad por capilaridad $\quad \square$ Grietas por asentamientos $\mathbf{X}$ Erosion de las juntas $\mathbf{X}$ Humedades (manch/eflo) $\square$ Colapso

$\square$ Pérdida de sección $\square$ Pérdida de verticalidad $\square$ Por elementos impropios

$\square$ Vegetación $\square$ Grietas por empuje de la cubierta $\square$ Derivado de intervenciones

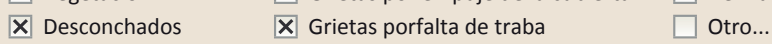




\section{La restauración y rehabilitación de la arquitectura tradicional de tierra.}

\section{El caso de Aragón.}

\section{DATOS DE LA INTERVENCIÓN}

Intervención de:

$\square$ Mantenimiento $\mathbf{X}$ Rehabilitación parcial

$\square$ Restauración $\square$ Demolición

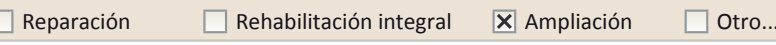

Reflexión previa Intervención espontanea

Observaciones Se ha añadido un volumen en la parte trasera. La fachada se desconoce si es una actualización posterior o es contemporáneo al edificio.

\begin{tabular}{|c|c|c|c|c|}
\hline 3.1. MUROS & No intervenido & & & \\
\hline Tipo de intervención & $\begin{array}{l}\square \text { Actualización } \\
\square \text { Consolidación }\end{array}$ & $\begin{array}{l}\square \text { Reintegración } \\
\square \text { Reconstrucción }\end{array}$ & $\begin{array}{l}\square \text { Demolición } \\
\square \text { Sustitución }\end{array}$ & in $\square$ Otro... \\
\hline Tipo de material & \multicolumn{4}{|c|}{ Tipo de técnica } \\
\hline \multicolumn{5}{|l|}{ Descripción } \\
\hline 3.2. ZÓCALO & \multicolumn{4}{|l|}{ Intervenido } \\
\hline Tipo de intervención & $\begin{array}{l}\mathbf{X} \text { Actualización } \\
\square \text { Consolidación }\end{array}$ & \multicolumn{3}{|c|}{$\begin{array}{l}\boldsymbol{X} \text { Reintegración } \quad \square \text { Demolición } \quad \square \text { Otro... } \\
\square \text { Reconstrucción } \quad \square \text { Sustitución }\end{array}$} \\
\hline Tipo de material & No tradicional & $\mathrm{Ti}$ & o de técnica & Diferente a la existente \\
\hline Descripción & \multicolumn{4}{|c|}{ Rejuntado con cemento en la mampostería. Gotelé en la fachada principal } \\
\hline 3.3. REVESTIMIENTOS & \multicolumn{4}{|l|}{ No intervenido } \\
\hline Tipo de intervención & $\begin{array}{l}\square \text { Actualización } \\
\square \text { Consolidación }\end{array}$ & $\begin{array}{l}\square \text { Reintegración } \\
\square \text { Reconstrucción }\end{array}$ & $\begin{array}{l}\square \text { Demolición } \\
\square \text { Sustitución }\end{array}$ & on \\
\hline Tipo de material & \multicolumn{4}{|c|}{ Tipo de técnica } \\
\hline \multicolumn{5}{|l|}{ Descripción } \\
\hline 3.4. VANOS & No intervenido & & & \\
\hline Tipo de intervención & $\begin{array}{l}\square \text { Actualización } \\
\square \text { Consolidación }\end{array}$ & $\begin{array}{l}\square \text { Reintegración } \\
\square \text { Reconstrucción }\end{array}$ & $\begin{array}{l}\square \text { Demolición } \\
\square \text { Sustitución }\end{array}$ & n $\square$ Otro... \\
\hline Tipo de material & \multicolumn{4}{|c|}{ Tipo de técnica } \\
\hline \multicolumn{5}{|l|}{ Descripción } \\
\hline 3.5. CUBIERTA & No intervenido & & & \\
\hline Tipo de intervención & $\begin{array}{l}\square \text { Actualización } \\
\square \text { Consolidación }\end{array}$ & $\begin{array}{l}\square \text { Reintegración } \\
\square \text { Reconstrucción }\end{array}$ & $\begin{array}{l}\square \text { Demolició } \\
\square \text { Sustituciór }\end{array}$ & ón $\square$ Otro... \\
\hline Tipo de material & \multicolumn{4}{|c|}{ Tipo de técnica } \\
\hline Des & & & & \\
\hline
\end{tabular}

3.6. OTRAS 


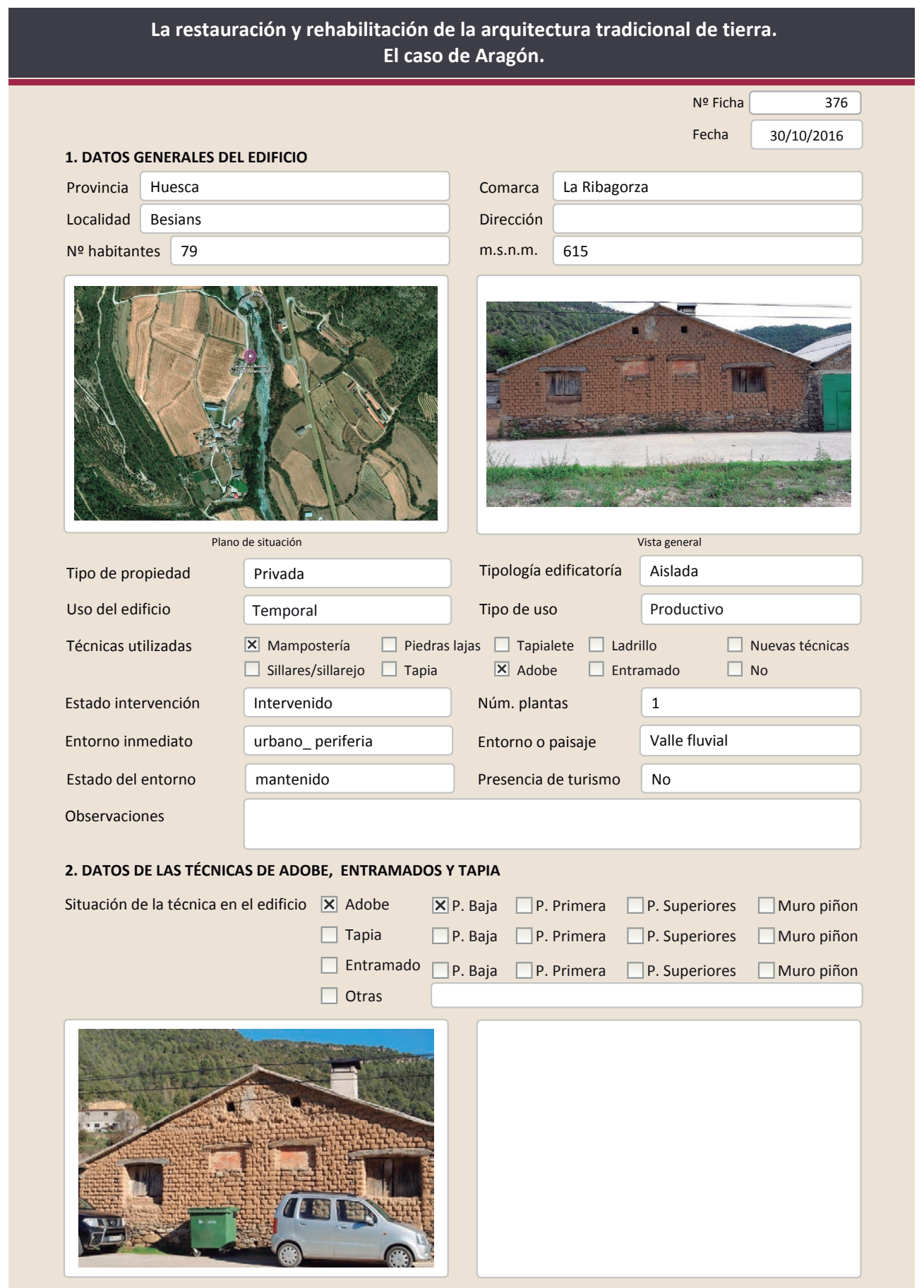

2.1. ADOBE

Dimensión de las piezas $43 \times 21 \times 12$

Dimensión del muro $40-50 \mathrm{~cm}$

Aparejo del muro Tizón

Función estructural

$\mathrm{Si}$

Variante constructiva/ tipo de fábrica

メ simple

$\square$ Suplementada en juntas

$\square$ Mixta

$\square$ Como suplemento

$\square$ Elementos de protección

Para configurar el aparejo en las esquinas se han insertado en la fábrica cantos rodados de forma que no es necesario cortar ninguna pieza

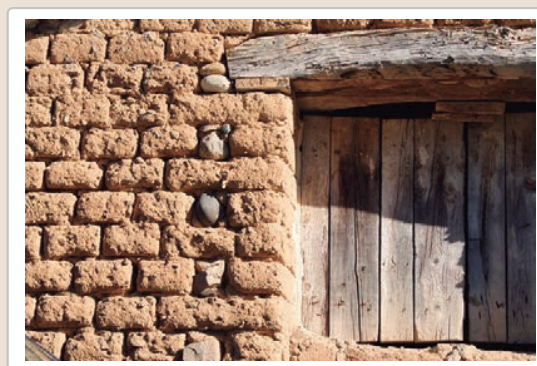

Lesiones $\quad \mathbf{X}$ Muro $\square$ Zócalo $\square$ Revestimiento

$\mathbf{X}$ Erosión del material $\square$ Humedad por capilaridad X Erosion de las juntas $\square$ Humedades (manch/eflo)

$\square$ Pérdida de sección $\square$ Pérdida de verticalidad

$\square$ Vegetación $\quad \square$ Grietas por empuje de la c

$\square$ Desconchados

$\square$ Grietas porfalta de traba

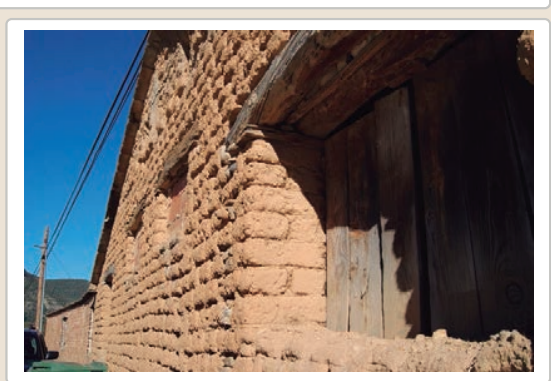

$\square$ Cubierta $\square$ Otro...

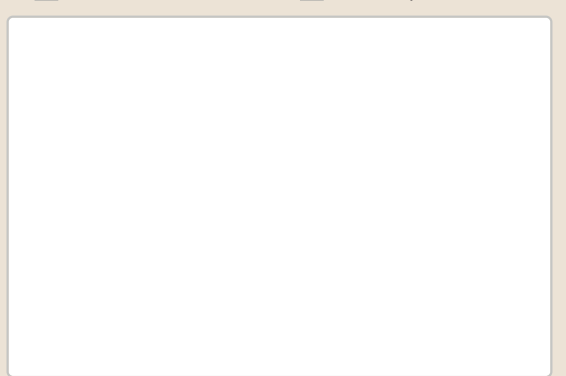

Color de las piezas

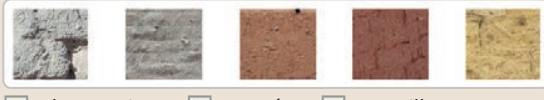

$\square$ Blanquecino $\mathbf{X}$ Marrón $\square$ Amarillento

Grisaceo $\square$ Rojizo $\square$ Otro.

Comp. - estabilizante Aridos

Observaciones 
La restauración y rehabilitación de la arquitectura tradicional de tierra. El caso de Aragón.

3. DATOS DE LA INTERVENCIÓN

$\square$ Mantenimiento $\square$ Rehabilitación parcial $\quad \square$ Restauración $\square$ Demolición X Reparación $\square$ Rehabilitación integral $\square$ Ampliación $\square$ Otro...

Reflexión previa Intervención espontanea

Observaciones La cubierta del edificio ha sido sustituida, acción que no afecta al muro ya que se conservan las piezas de piedra que conforman el alero sobre las que se ha vertido cemento y se ha colocado paneles de fibrocemento.

3.1. MUROS
Tipo de intervención

Intervenido

Tipo de intervencion

$\square$ Actualización $\quad \mathbf{X}$ Reintegración $\square$ Demolición $\square$ Otro...

$\square$ Consolidación $\quad \square$ Reconstrucción $\square$ Sustitución

Descripción

No tradicional

Tipo de técnica Diferente a la existente

3.2. ZóCALO

Tipo de intervención pequeños reju

Tipo de material

No intervenido

$\square$ Actualización $\square$ Reintegración $\square$ Demolición $\square$ Otro...

$\square$ Consolidación $\quad \square$ Reconstrucción $\quad \square$ Sustitución

Descripción

3.3. REVESTIMIENTOS

Tipo de intervención

Tipo de material

Descripción

3.4. VANOS

Tipo de intervención

Tipo de material

Descripción

3.5. CUBIERTA

Tipo de intervención

Tipo de material

Descripción

Intervenido

$\square$ Actualización $\square$ Reintegración $\square$ Demolición $\square$ Otro. $\square$ Consolidación $\square$ Reconstrucción $\quad \mathbf{x}$ Sustitución Tipo de técnica

\section{No aplica}

$\square$ Actualización $\quad \square$ Reintegración $\quad \square$ Demolición $\quad \square$ Otro...

$\square$ Consolidación $\quad \square$ Reconstrucción $\quad \square$ Sustitución

Tipo de técnica

No intervenido

$\square$ Actualización $\square$ Reintegración $\square$ Demolición $\square$ Otro...

$\square$ Consolidación $\quad \square$ Reconstrucción $\quad \square$ Sustitución

$$
\text { Tipo de técnica }
$$

Sustitución de la cubierta por una capa de mortero de cemento y chapa de fibrocemento sobre las losas antiguas
La restauración y rehabilitación de la arquitectura tradicional de tierra.

El caso de Aragón.

3.7. REHABILITACIÓN ENERGÉTICA $\quad \square$ Fachada $\square$ Vanos $\square$ Forjados $\square$ Cubierta

Observaciones

FOTOGRAFíAS DE LA INTERVENCIÓN
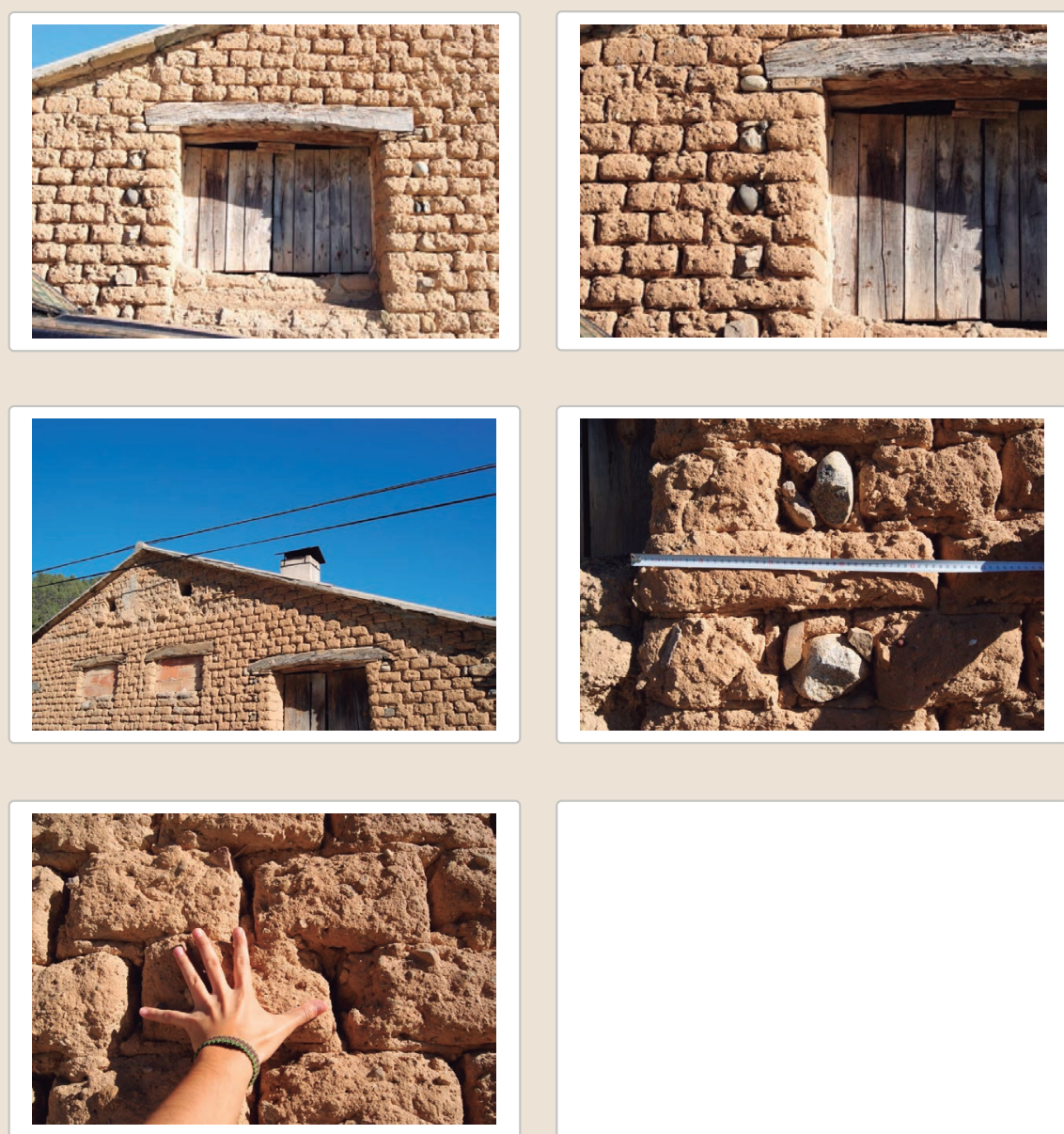

3.6. OTRAS 


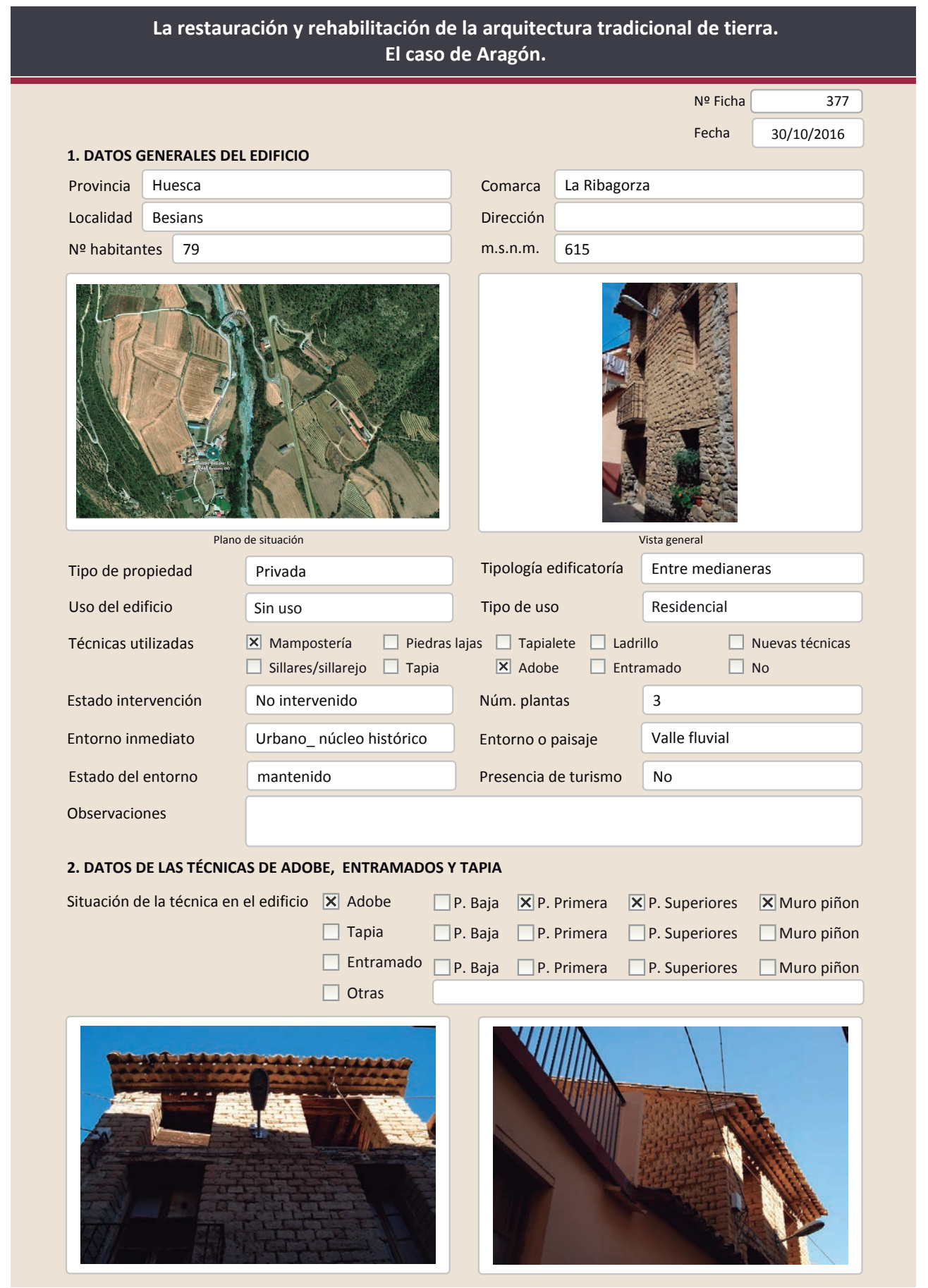

\subsection{ADOBE \\ Dimensión de las piezas Dimensión del muro \\ Aparejo del muro Función estructural \\ Variante constructiva/ tipo de fábrica \\ メ simple \\ $\square$ Suplementada en juntas \\ $\square$ Mixta \\ $\square$ Como suplemento \\ $\square$ Elementos de protección}

\begin{tabular}{|l|}
\hline \\
\hline $40-50 \mathrm{~cm}$ \\
\hline Tizón \\
\hline $\mathrm{Si}$ \\
\hline
\end{tabular}

Color de las piezas

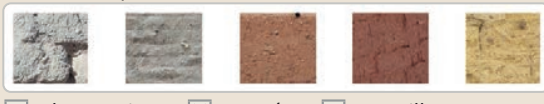

$\square$ Blanquecino $\mathbf{X}$ Marrón $\square$ Amarillento $\square$ Grisaceo $\square$ Rojizo $\square$ Otro... Comp. - estabilizante Aridos

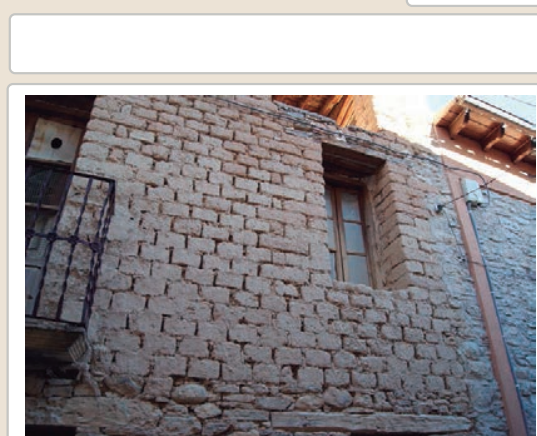

Lesiones \Muro $\square$ Zócalo $\square$ Revestimiento Х Erosión del material $\square$ Humedad por capilaridad $\square$ Erosion de las juntas $\square$ Humedades (manch/eflo) $\square$ Pérdida de sección $\square$ Pérdida de verticalidad
$\square$ Vegetación
$\square$ Grietas por empuje de la

$\square$ Desconchados $\square$ Grietas porfalta de traba

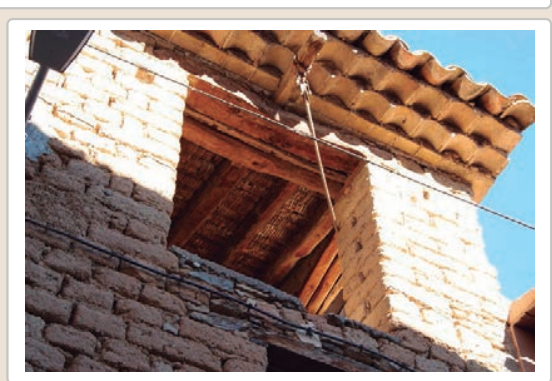

$\square$ Cubierta $\square$ otro...

$$
\begin{aligned}
& \square \text { Grietas por asentamientos } \\
& \square \text { Colapso } \\
& \square \text { Por elementos impropios } \\
& \square \text { Derivado de intervenciones }
\end{aligned}
$$

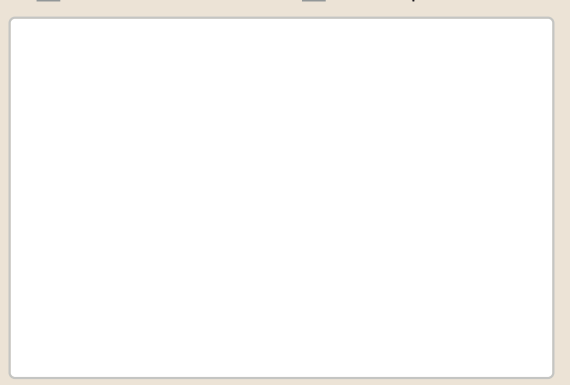
$\square$ Otro... 


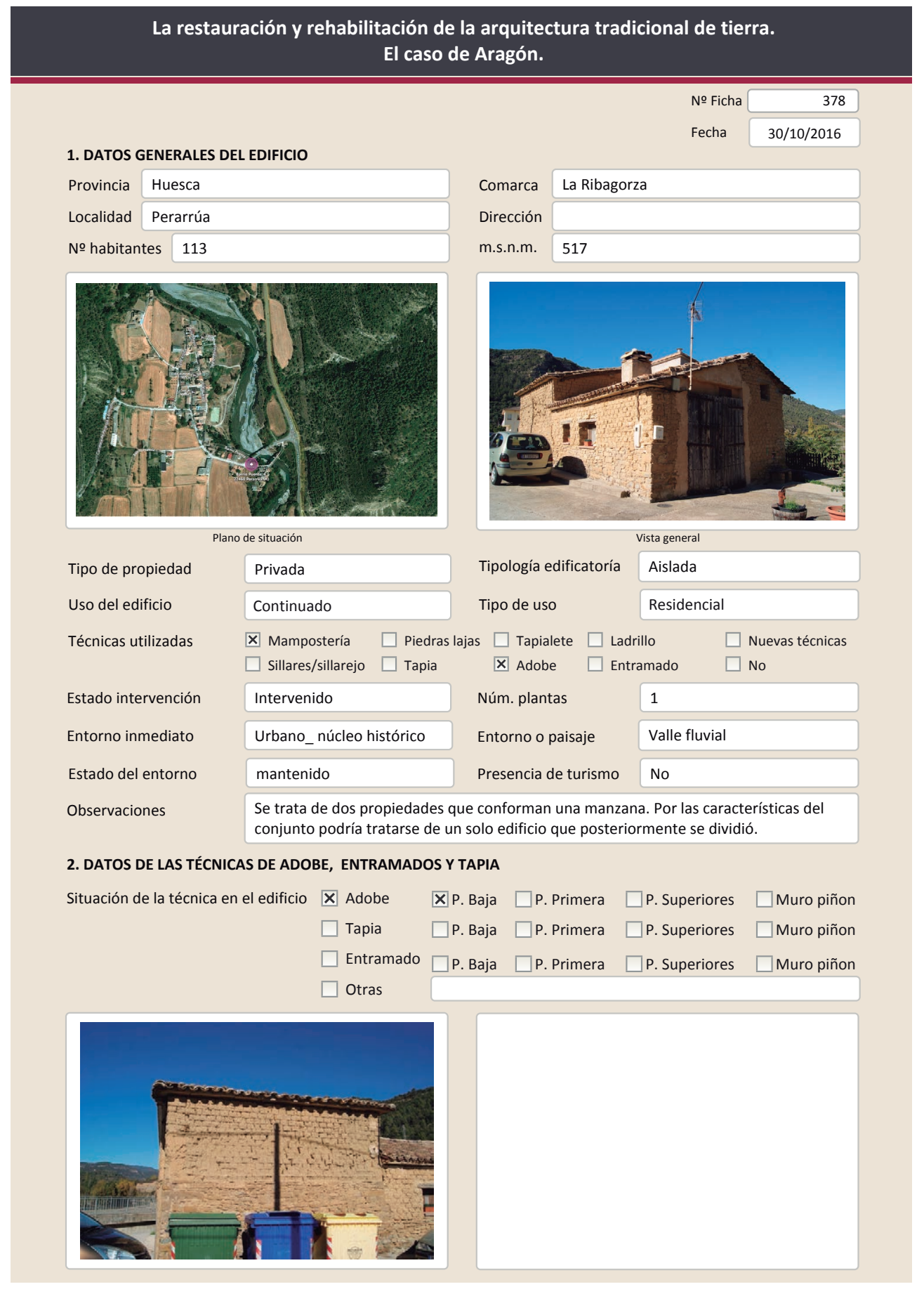

La restauración y rehabilitación de la arquitectura tradicional de tierra.

El caso de Aragón.

\subsection{ADOBE \\ Dimensión de las piezas $19 \times 39 \times 11$ \\ Dimensión del muro 30-40 cm \\ Aparejo del muro Tizón \\ Función estructural \\ $\mathrm{Si}$ \\ Variante constructiva/ tipo de fábrica \\ X Simple \\ $\square$ Suplementada en juntas \\ $\square$ Mixta \\ $\square$ Como suplemento \\ $\square$ Elementos de protección}

Color de las piezas

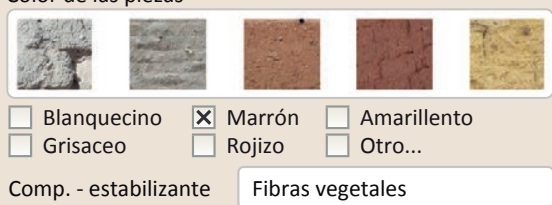

En una de las esquinas hay piezas cerámicas insertadas en las juntas del aparejo, probablemente porque quedaba una junta muy gruesa en esa zona

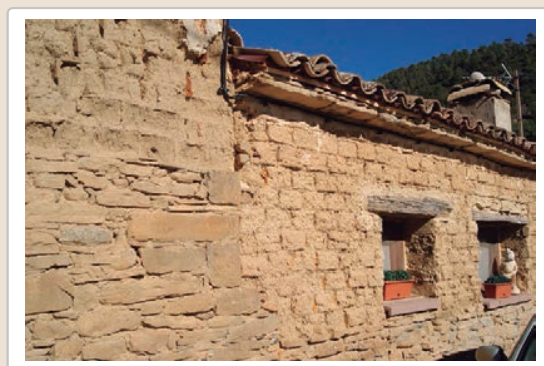

Lesiones $\quad \mathbf{X}$ Muro $\mathbf{X}$ Zócalo $\square$ Revestimiento

$\mathbf{X}$ Erosión del material $\mathbf{X}$ Humedad por capilarida $\square$ Erosion de las juntas $\square$ Humedades (manch/eflo)

$\square$ Pérdida de sección $\square$ Pérdida de verticalidad

$\square$ Vegetación $\quad \square$ Grietas por empuje de la

$\square$ Desconchados $\quad \square$ Grietas porfalta de traba

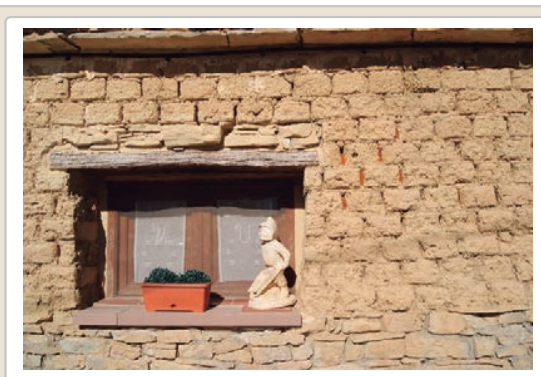

$\square$ Cubierta $\square$ Otro...

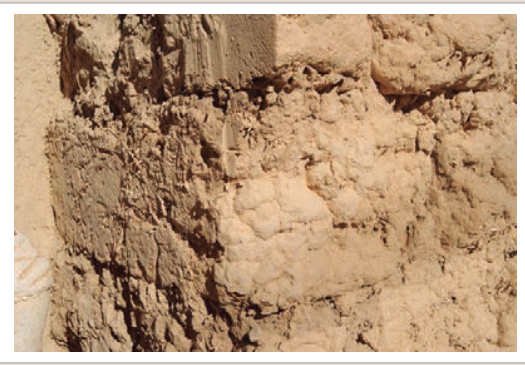

Observaciones 


\section{La restauración y rehabilitación de la arquitectura tradicional de tierra.} El caso de Aragón.

3. DATOS DE LA INTERVENCIÓN

Mantenimiento $\square$ Rehabilitación parcial $\quad \square$ Restauración $\quad \square$ Demolición X Reparación $\quad \square$ Rehabilitación integral $\quad \square$ Ampliación $\quad \square$ Otro...

Reflexión previa Intervención espontanea

Observaciones Intervención de la cubierta sin afectar al muro de adobe ya que conserva las lajas que conforman el alero, y que lo protegen.

\subsection{MUROS}

Tipo de intervención

Tipo de material

Intervenido

$\square$ Actualización $\quad$ X Reintegración $\square$ Demolición $\square$ Otro..

$\square$ Consolidación $\quad \square$ Reconstrucción $\square$ Sustitución

Descripción

3.2. ZÓCALO

Tipo de intervención

No tradicional

Tipo de técnica Diferente a la existente

Relleno de poliestireno entre las juntas de los adobes.

Intervenido

$\square$ Actualización $\quad \mathbf{x}$ Reintegración $\square$ Demolición $\square$ Otro..

$\square$ Consolidación $\quad \square$ Reconstrucción $\quad \square$ Sustitución

Tipo de material No tradicional Tipo de técnica Similar a la existente

Descripción

3.3. REVESTIMIENTOS

Tipo de intervención

Tipo de material

Descripción

3.4. VANOS

Tipo de intervención

Tipo de material

rejuntado parcial de cemento del zócalo de mampostería

No aplica

$\square$ Actualización $\square$ Reintegración $\quad \square$ Demolición $\square$ Otro...

$\square$ Consolidación $\square$ Reconstrucción $\square$ sustitución de la intervención en dintel y jambas. Cambio de las carpinterías y el alféizar de las

3.5. CUBIERTA

Tipo de intervención

Intervenido

$\square$ Actualización $\quad \square$ Reintegración $\quad \square$ Demolición $\quad \square$ Otro.

$\square$ Consolidación $\quad \mathbf{X}$ Reconstrucción $\square$ Sustitución

Tipo de material

No tradicional

Tipo de técnica Similar a la existente

Descripción

Se ha reconstruido la cubierta con los elementos tradicionales pero se ha insertado aislante y una lámina impermablizante cogido con poliestileno.
La restauración y rehabilitación de la arquitectura tradicional de tierra. El caso de Aragón.

3.7. REHABILITACIÓN ENERGÉTICA $\square$ Fachada $\quad$ \ Vanos $\square$ Forjados $\quad$ C Cubierta Observaciones

FOTOGRAFÍAS DE LA INTERVENCIÓN
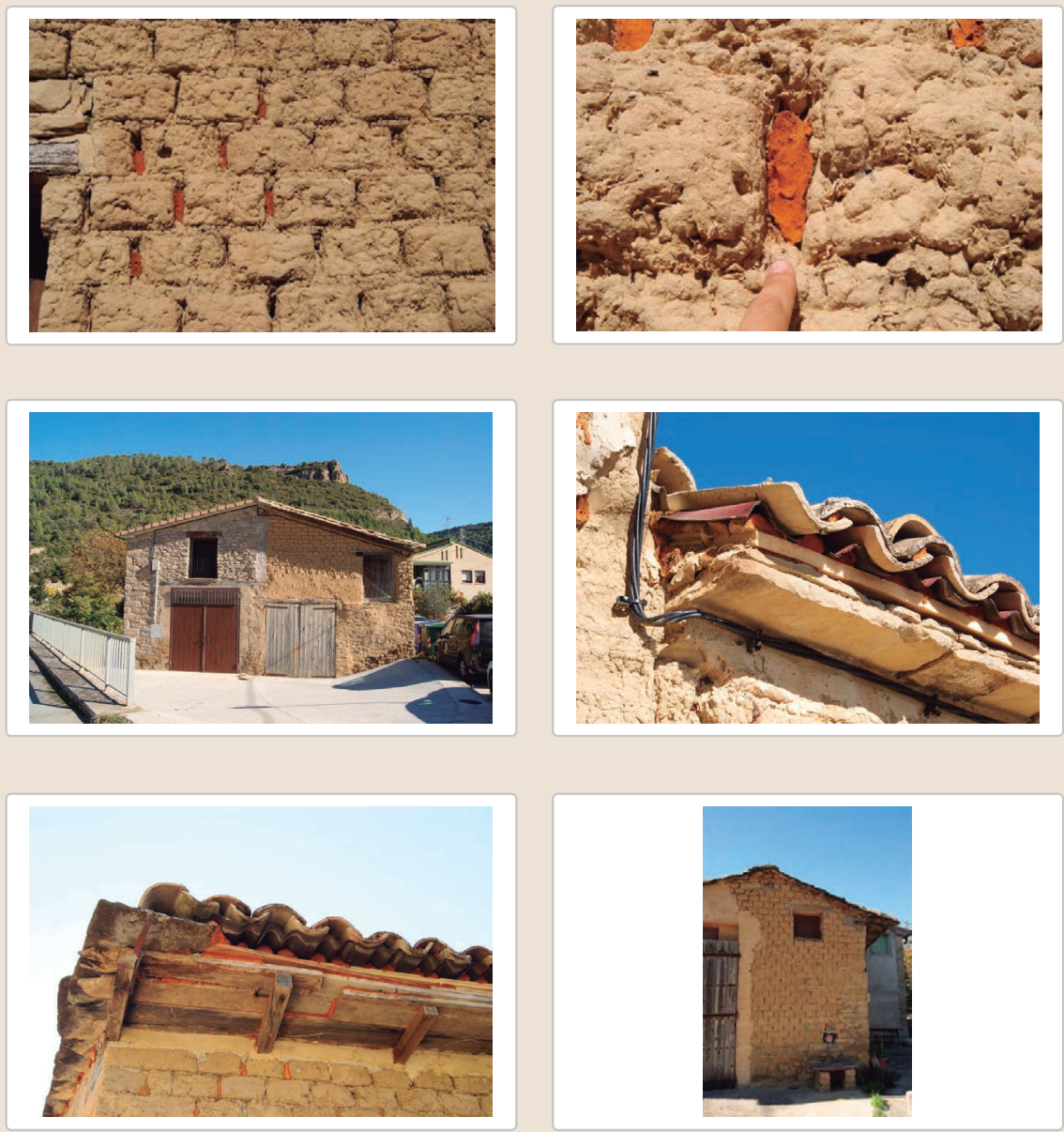

3.6. OTRAS 


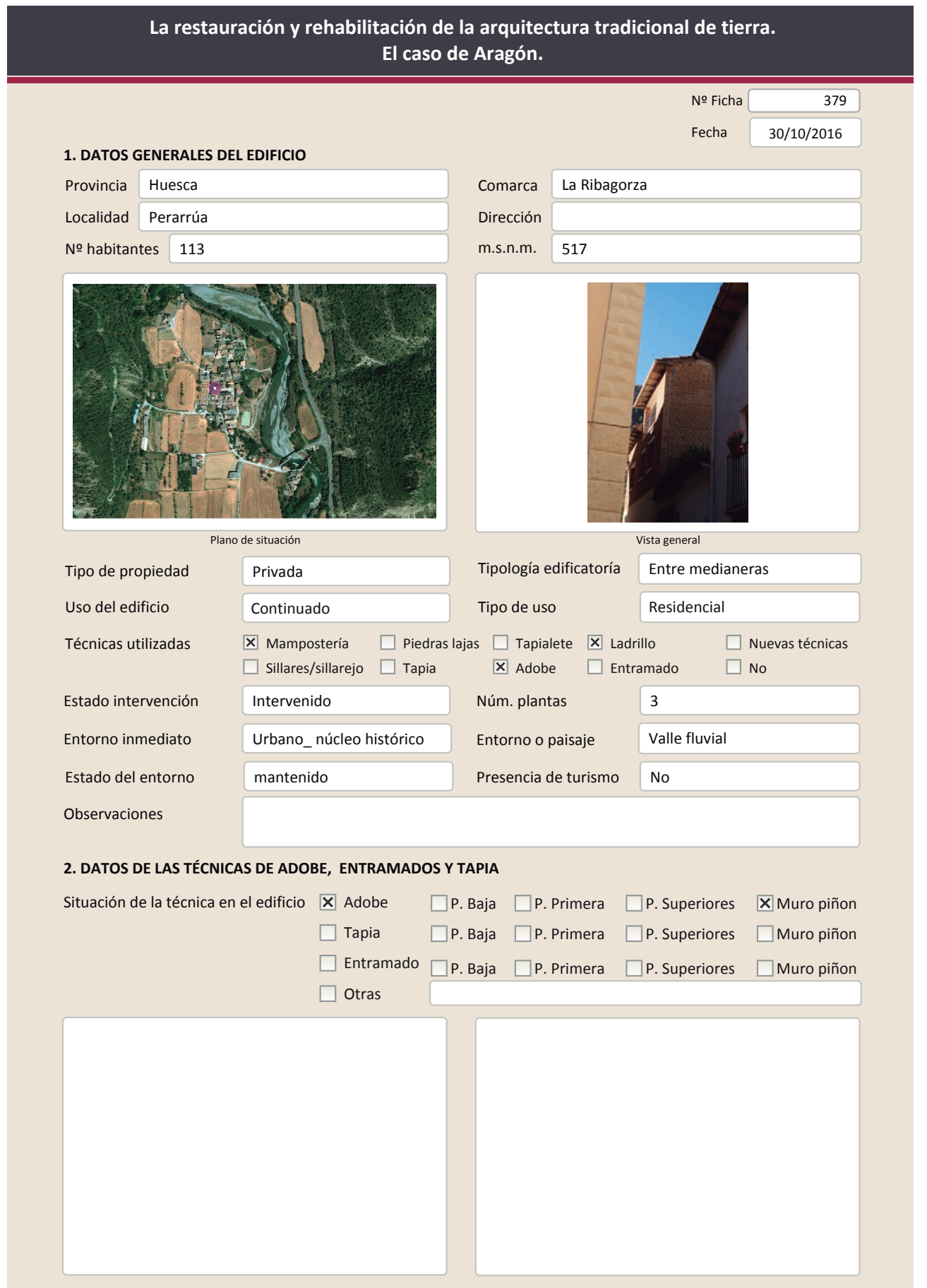

La restauración y rehabilitación de la arquitectura tradicional de tierra.

El caso de Aragón.

\subsection{ADOBE \\ Dimensión de las piezas Dimensión del muro \\ Aparejo del muro \\ Función estructural Tizón \\ $\mathrm{Si}$ \\ Variante constructiva/ tipo de fábrica
$\mathbf{X}$ Simple
$\square$ Suplementada en juntas
$\square$ Mixta
$\square$ Como suplemento
$\square$ Elementos de protección

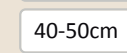

Color de las piezas

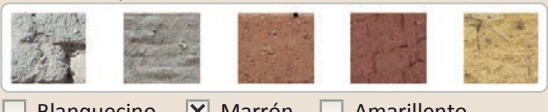

$\square$ Blanquecino $\mathbf{X}$ Marrón $\square$ Amarillento $\square$ Grisaceo $\square$ Rojizo $\square$ Otro...

Comp. - estabilizante

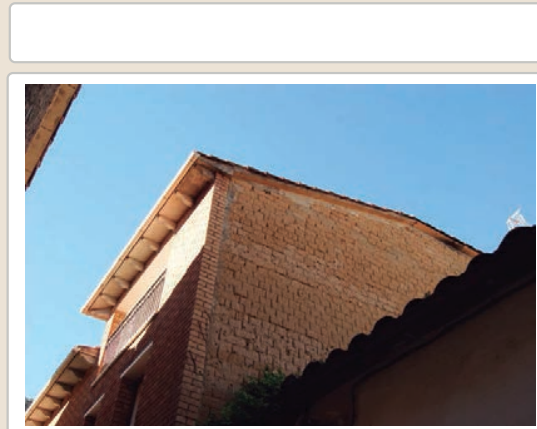

Lesiones \Muro $\square$ Zócalo $\square$ Revestimiento

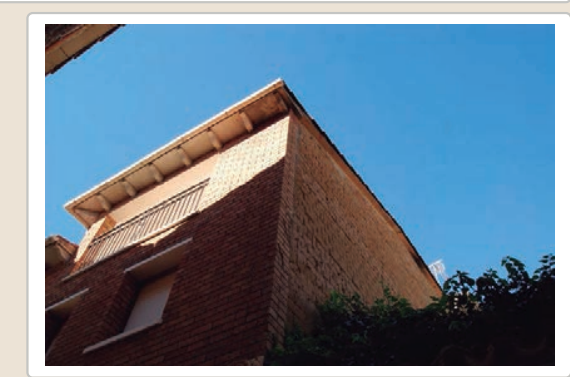

Cubierta $\square$ otro...
X Erosión del material $\square$ Humedad por capilaridad
$\square$ Erosion de las juntas
$\square$ Humedades (manch/eflo)
Grietas por asentamientos
$\square$ Pérdida de seción
1] Pérdida de verticalidad
$\square$ Colapso
$\square$ Vegetación
$\square$ Grietas por empuje de la cubic
$\square$ Por elementos impropios
$\square$ Desconchados
$\square$ Grietas porfalta de traba
$\square$ Derivado de intervenciones $\square$ Otro...

Observaciones 


\section{La restauración y rehabilitación de la arquitectura tradicional de tierra.}

\section{El caso de Aragón.}

3. DATOS DE LA INTERVENCIÓN

$\square$ Rehabilitación parcial

$\square$ Restauración $\square$ Demolición $\square$ Reparación $\quad \mathbf{X}$ Rehabilitación integral $\square$ Ampliación $\quad \square$ Otro...

Reflexión previa Intervención planificada

Observaciones En la intervención la fachada principal se ha revestido completamente por ladrillo nuevo

3.1. MUROS
Tipo de intervención

Intervenido

Tipo de material

$\square$ Actualizacion

$\square$ Consolidación

$\square$ Reintegració

$\square$ Demolición

No tradicional Tipo de técnica Diferente a la existente

Descripción

Fachada sustituida / revestida con muro de ladrillo.

3.2. ZÓCALO

\section{No aplica}

Tipo de intervención

$\square$ Actualizació

$\square$ Reintegración $\quad \square$ Demolición $\square$ Otro...

$\square$ Consolidación $\square$ Reconstrucción $\square$ Sustitución

Tipo de material

Descripción

3.3. REVESTIMIENTOS

Tipo de intervención

Tipo de material

Descripción

3.4. VANOS

Tipo de intervención

Tipo de material

Descripción

3.5. CUBIERTA

Tipo de intervención

Tipo de material

Descripción

\section{No aplica}

$\square$ Actualización $\square$ Reintegración $\quad \square$ Demolición $\square$ Otro...

$\square$ Consolidación $\square$ Reconstrucción $\square$ sustitución

Tipo de técnica

Intervenido

$\square$ Actualización $\square$ Reintegración $\square$ Demolición $\square$ Otro...

$\square$ Consolidación $\square$ Reconstrucción $\quad \boldsymbol{X}$ Sustitución

\begin{tabular}{l|l|l} 
No tradicional & Tipo de técnica Diferente a la existente
\end{tabular}

Sustitución de huecos ya que toda su fachada ha cambiado. Nuevo hueco de balcón retranqueado incorporado en esta fachada.

Intervenido

$\square$ Actualización $\quad \square$ Reintegración $\quad \square$ Demolición $\quad \square$ Otro... $\square$ Consolidación $\square$ Reconstrucción $\quad \boldsymbol{\otimes}$ Sustitución
No tradicional
Tipo de técnica Diferente a la existente

3.6. OTRAS

Sustitución completa de la cubierta. Se han utilizado bardos de apoyo y cemento para su configuración. Presumiblemente se ha incorporado aislante e imperm.

the

La restauración y rehabilitación de la arquitectura tradicional de tierra.

El caso de Aragón.

3.7. REHABILITACIÓN ENERGÉTICA $\square$ Fachada $\square$ Vanos $\square$ Forjados $\quad$ X Cubierta

Observaciones

FOTOGRAFíAS DE LA INTERVENCIÓN 


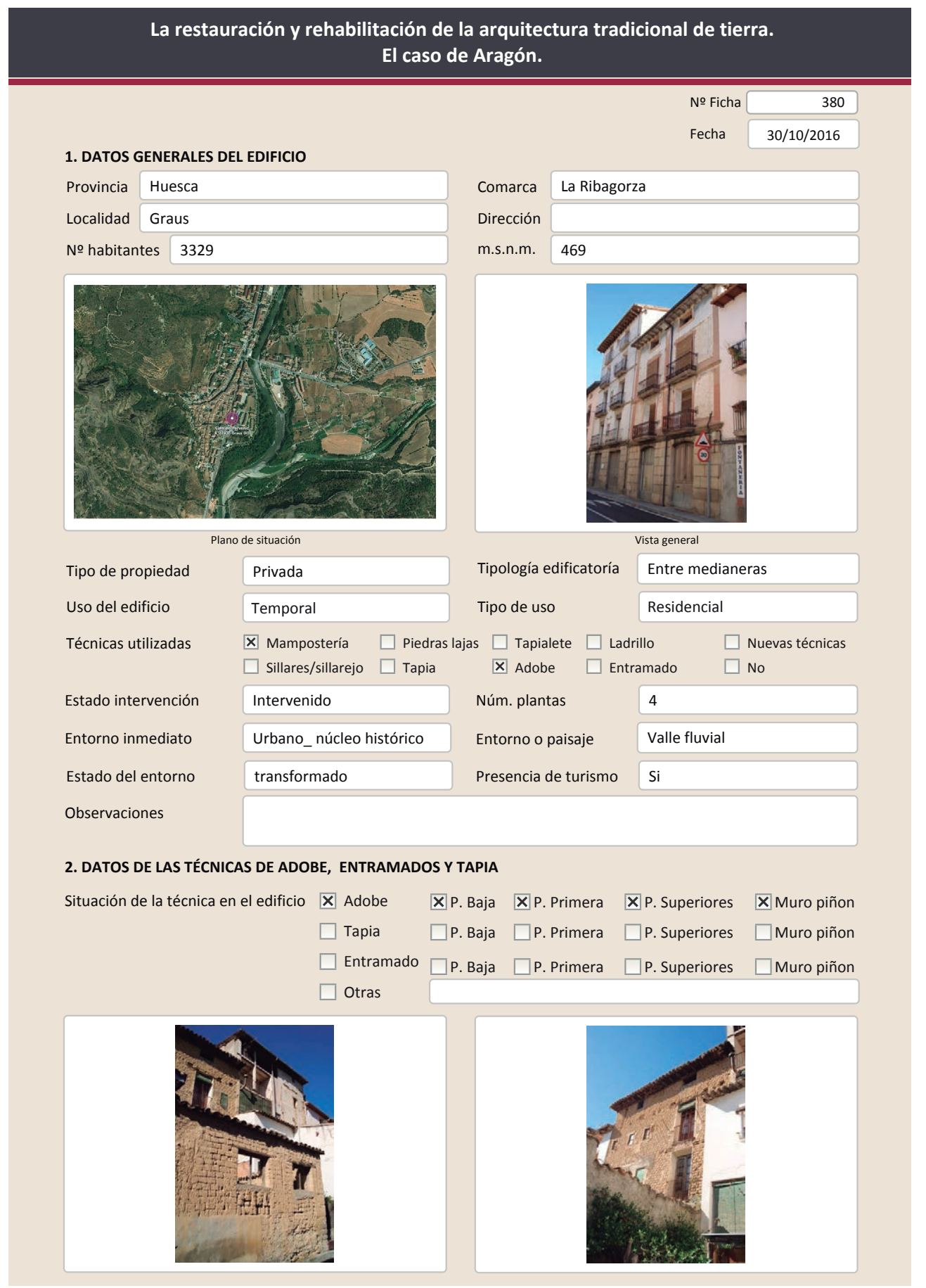

La restauración y rehabilitación de la arquitectura tradicional de tierra. El caso de Aragón.

\subsection{ADOBE \\ Dimensión de las piezas $20 \times 35 \times 12$ \\ Dimensión del muro $30-40 \mathrm{~cm}$ \\ Aparejo del muro Tizón \\ Función estructural \\ $\mathrm{Si}$ \\ Variante constructiva/ tipo de fábrica \\ X Simple \\ $\square$ Suplementada en juntas \\ $\square$ Mixta \\ $\square$ Como suplemento \\ $\square$ Elementos de protección}

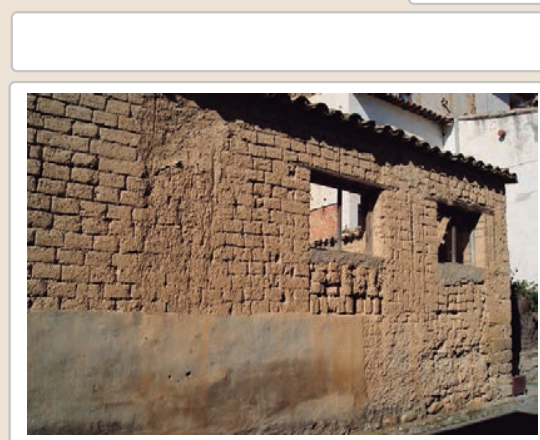

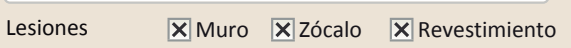

$\mathbf{X}$ Erosión del material $\mathbf{X}$ Humedad por capilaridad

$\square$ Erosion de las juntas $\mathbf{X}$ Humedades (manch/eflo)

X Pérdida de sección $\square$ Pérdida de verticalidad

$\square$ Vegetación $\quad \square$ Grietas por empuje de la cubie

X Desconchados

$\square$ Grietas porfalta de traba

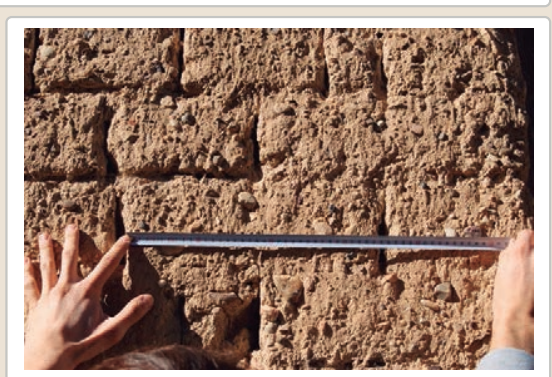

Cubierta $\square$ Otro...

$$
\begin{aligned}
& \square \text { Grietas por asentamientos } \\
& \boldsymbol{X} \text { Colapso } \\
& \square \text { Por elementos impropios } \\
& \square \text { Derivado de intervenciones }
\end{aligned}
$$

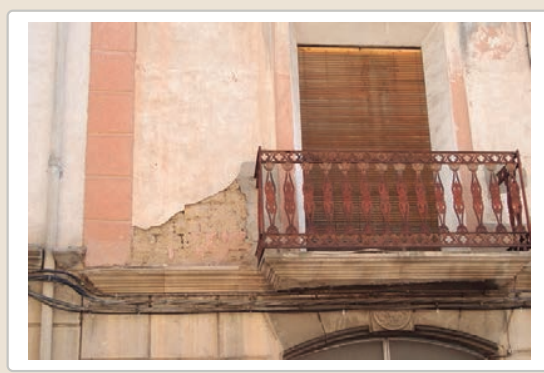

Observaciones

Parte delantera revestida, parte trasera del edificio sin revestir. Existen agujeros en la cubierta por los que entra el agua lavando el muro produciendo una pérdida de sección importante 


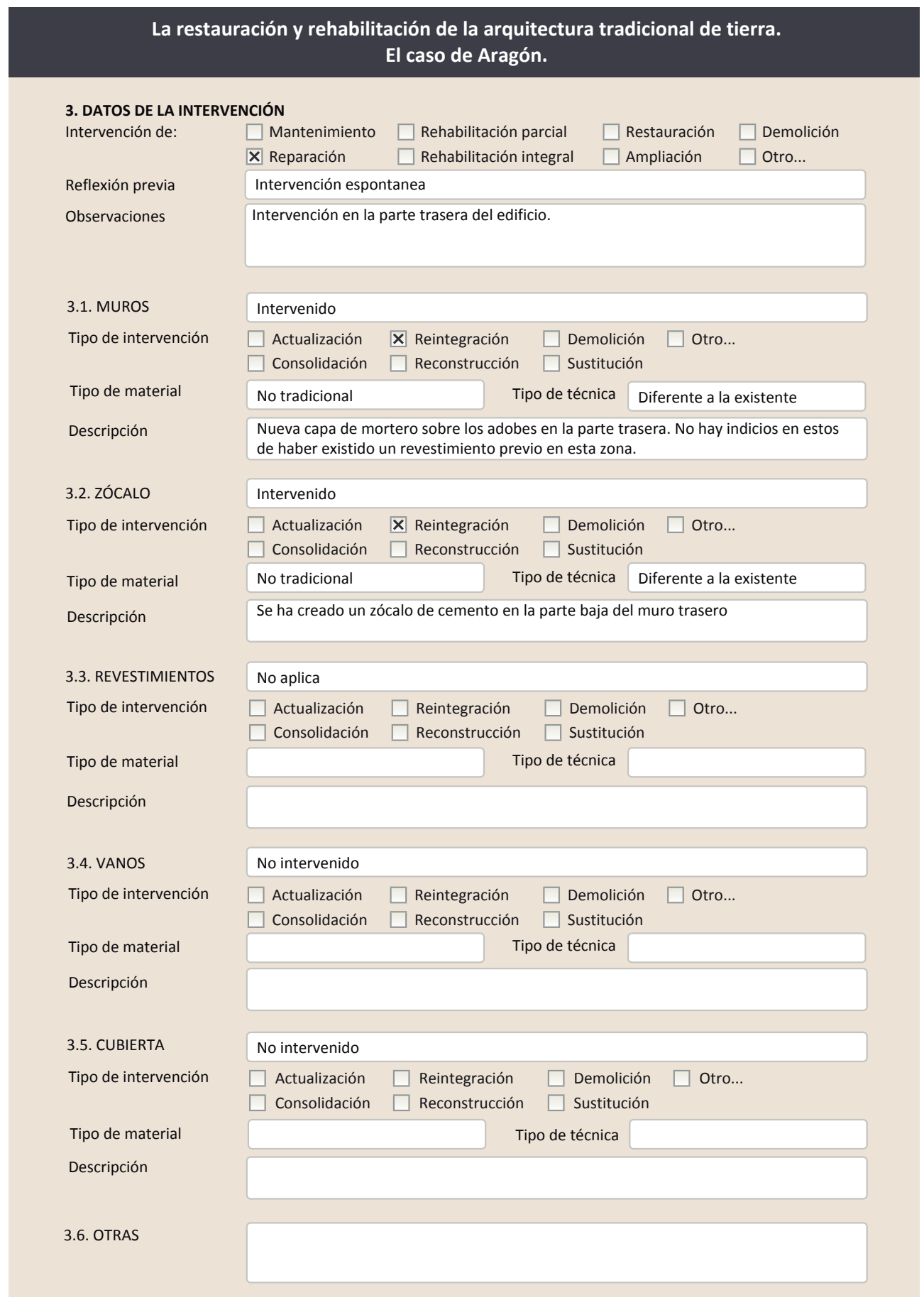

3.7. REHABILITACIÓN ENERGÉTICA $\quad \square$ Fachada $\square$ Vanos $\square$ Forjados $\square$ Cubierta Observaciones

FOTOGRAFíAS DE LA INTERVENCIÓN
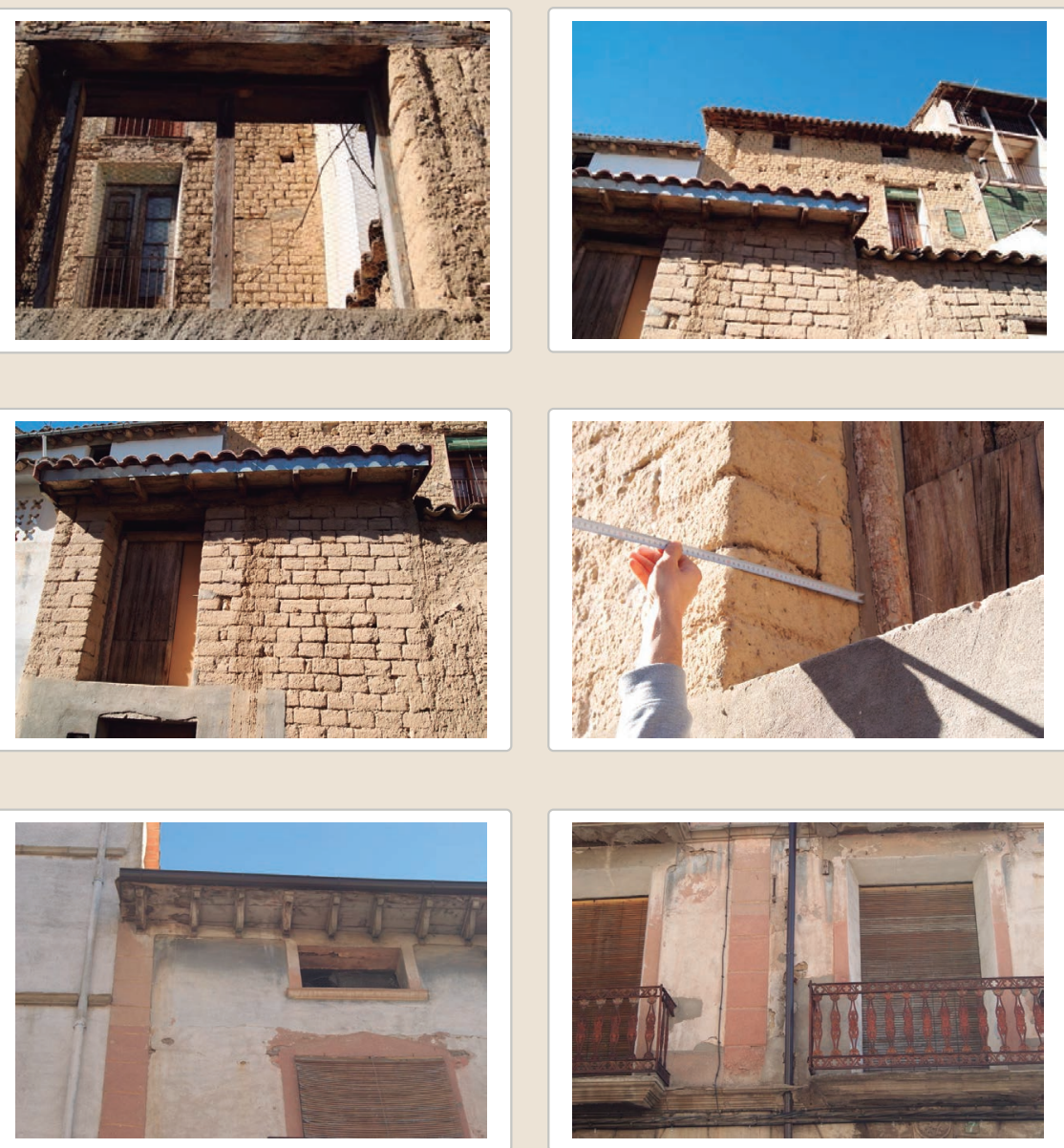
La restauración y rehabilitación de la arquitectura tradicional de tierra. El caso de Aragón.

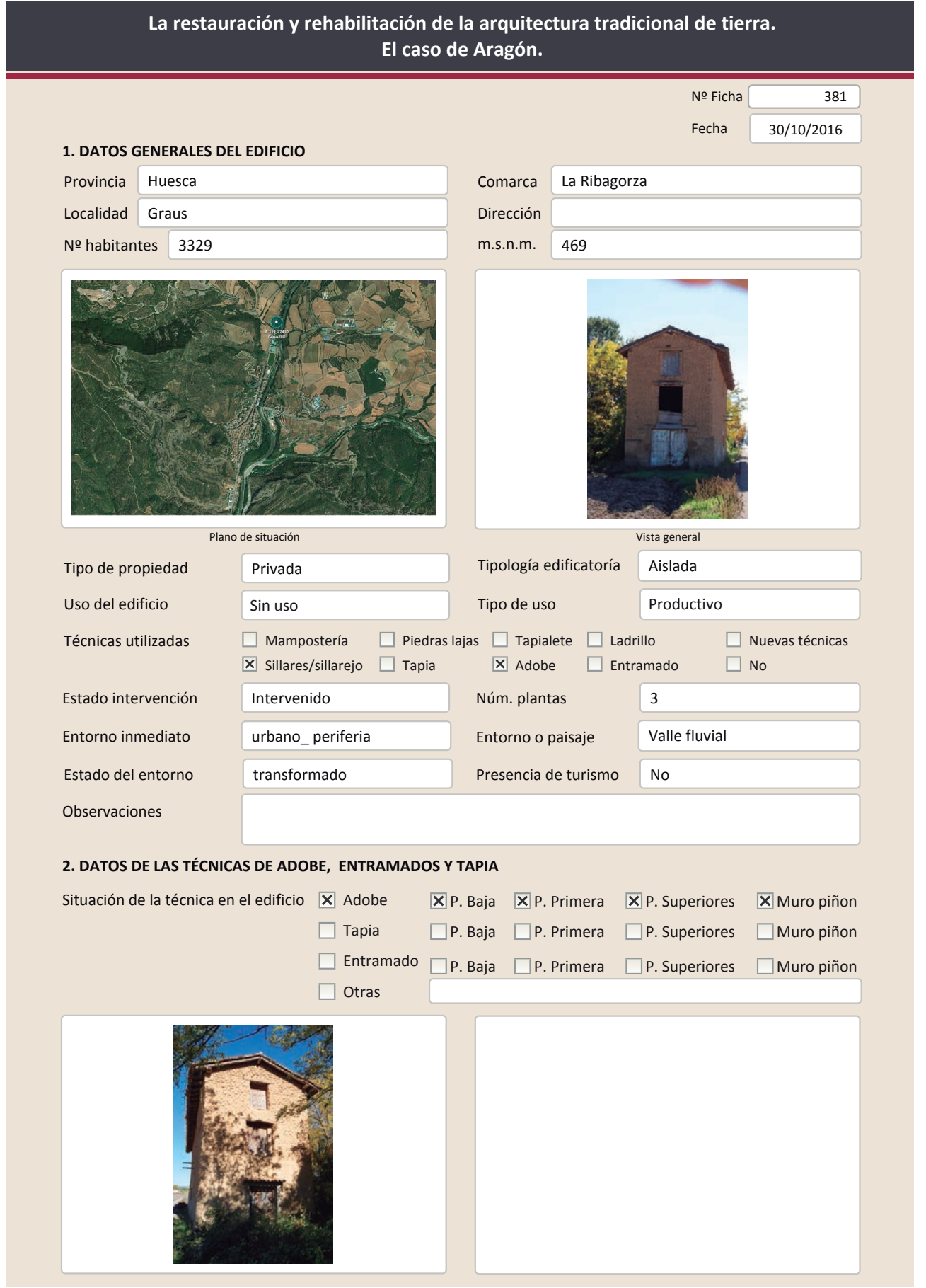

La restauración y rehabilitación de la arquitectura tradicional de tierra.

El caso de Aragón.
2.1. ADOBE

Dimensión de las piezas Dimensión del muro

Aparejo del muro

Función estructural
Color de las piezas

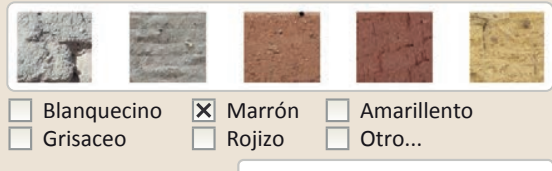

$\square$ Rojizo $\square$ Otro...

Comp. - estabilizante Aridos
Variante constructiva/ tipo de fábrica

X Simple

$\square$ Suplementada en juntas

$\square$ Mixta

$\square$ Como suplemento

$\square$ Elementos de protección

Tabiques de adobe en el interior con aparejo a soga.

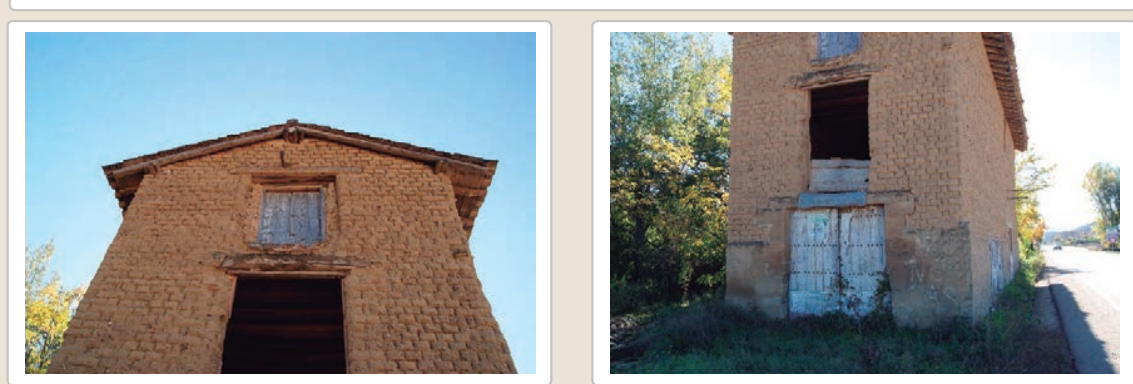

Lesiones $\quad \mathbf{X}$ Muro $\square$ Zócalo $\square$ Revestimiento $\square$ Cubierta $\square$ Otro...

X Erosión del material $\quad \square$ Humedad por capilaridad $\quad \square$ Grietas por asentamientos $\square$ Erosion de las juntas $\square$ Humedades (manch/eflo) $\quad \square$ Colapso

$\square$ Pérdida de sección $\square$ Pérdida de verticalidad $\quad \square$ Por elementos impropios

$\square$ Vegetación $\quad \square$ Grietas por empuje de la cubierta $\quad \square$ Derivado de intervenciones

$\square$ Desconchados $\square$ Grietas porfalta de traba $\quad$ Х Otro... 


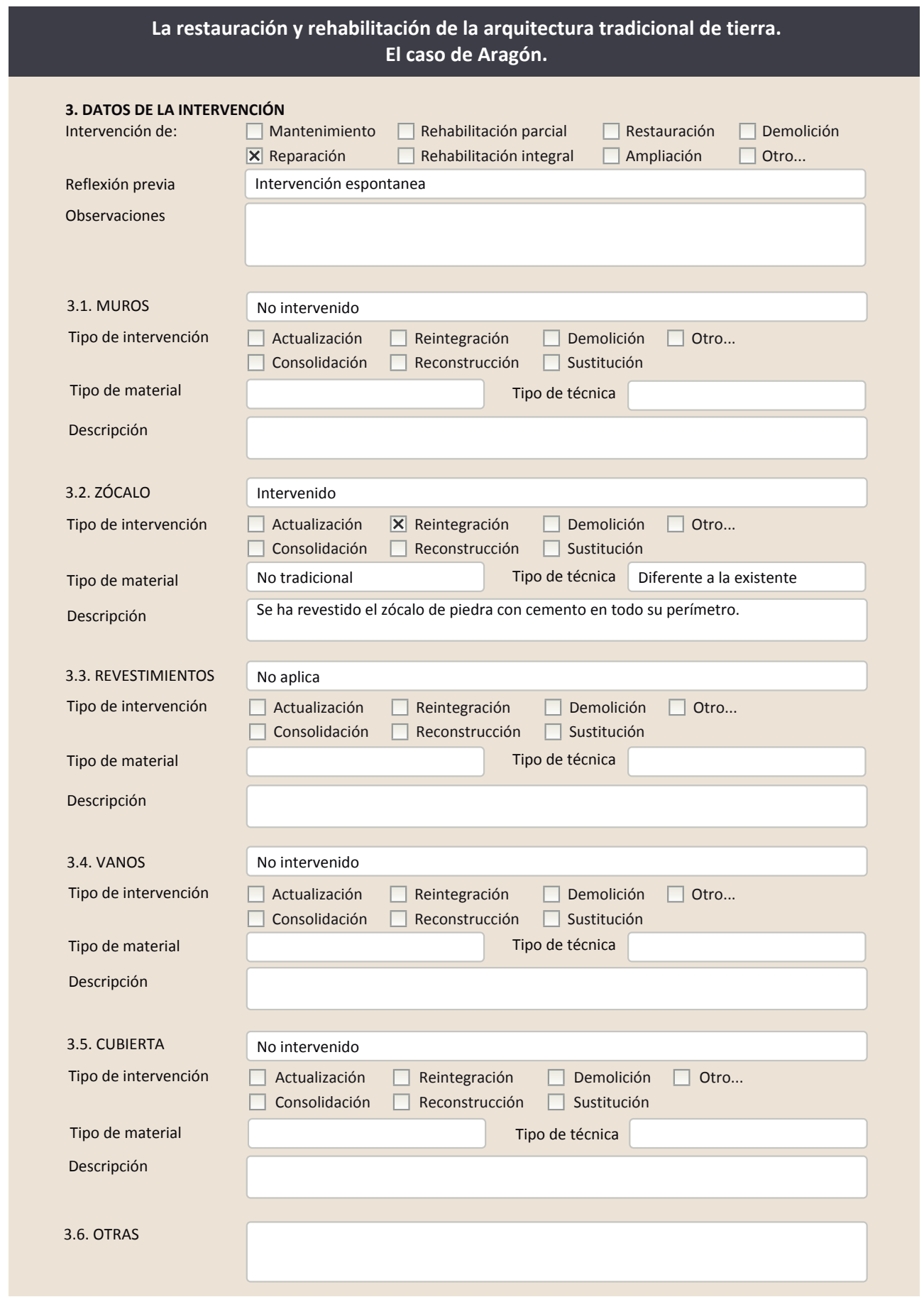

\subsection{REHABILITACIÓN ENERGÉTICA $\quad \square$ Fachada $\square$ Vanos $\square$ Forjados $\square$ Cubierta}

Observaciones

FOTOGRAFÍAS DE LA INTERVENCIÓN
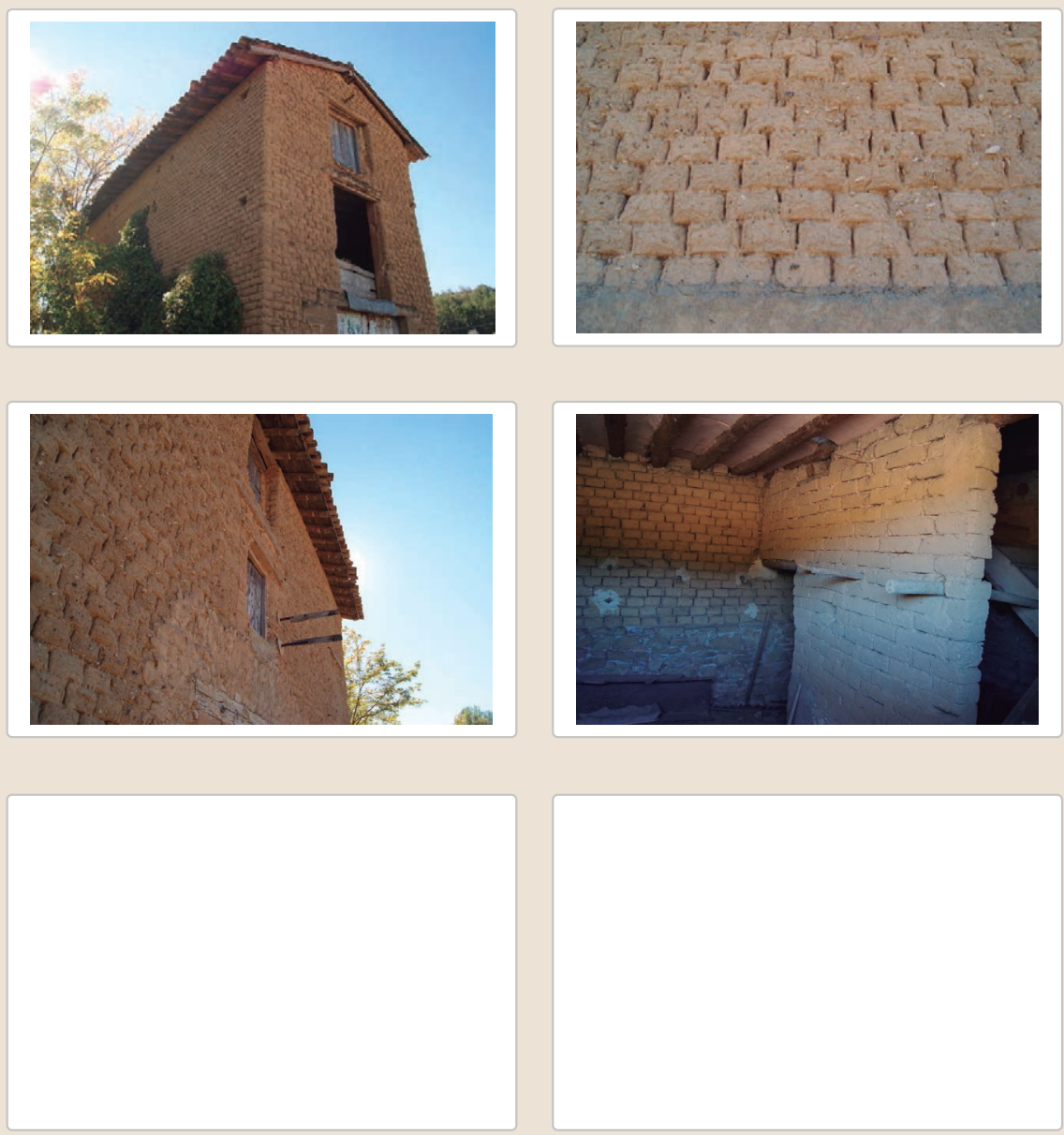


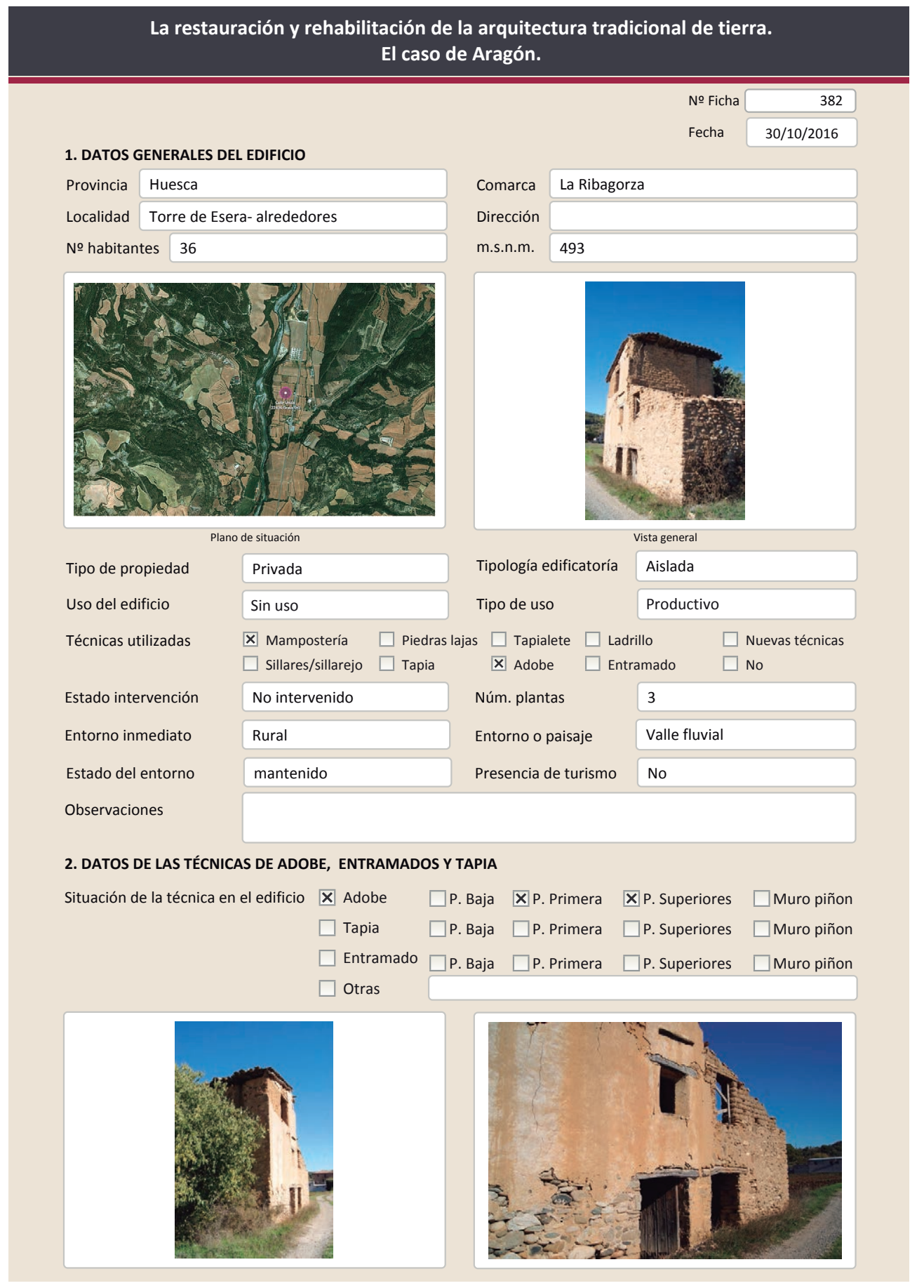

La restauración y rehabilitación de la arquitectura tradicional de tierra. El caso de Aragón.

\subsection{ADOBE \\ Dimensión de las piezas $24 \times 41 \times 12$ \\ Dimensión del muro $30-40 \mathrm{~cm}$ \\ Aparejo del muro Soga \\ Función estructural \\ Si \\ Variante constructiva/ tipo de fábrica \\ X Simple \\ $\square$ Suplementada en juntas \\ $\square$ Mixta \\ $\square$ Como suplemento \\ $\square$ Elementos de protección}

El aparejo varía en función de la localización en el edificio. Predomina a soga

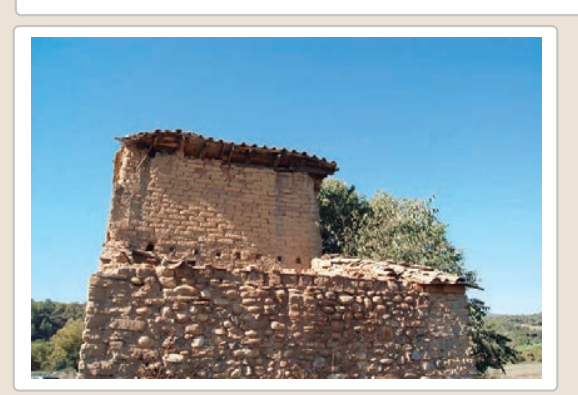

Lesiones $\square$ Muro $\square$ Zócalo $\square$ Revestimiento

Х Erosión del material $\square$ Humedad por capilaridad $\square$ Erosion de las juntas $\square$ Humedades (manch/eflo)

$\square$ Pérdida de sección $\square$ Pérdida de verticalidad

$\square$ Vegetación $\square$ Grietas por empuje de la cube

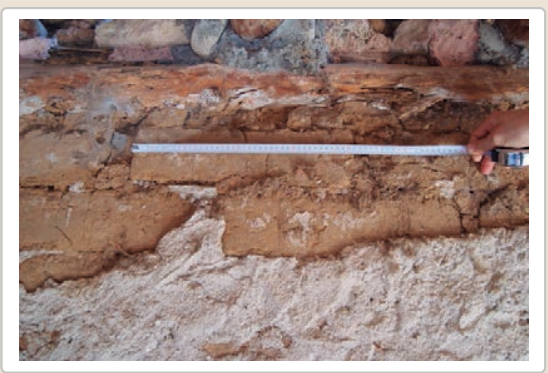

$\square$ Cubierta $\square$ Otro...

Color de las piezas

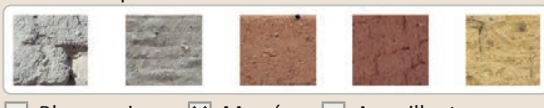

$\square$ Blanquecino $\mathbf{X}$ Marrón $\square$ Amarillento

Grisaceo $\square$ Rojizo $\square$ Otro...

Comp. - estabilizante Fibras vegetales $\square$ Grietas porfalta de traba
$\square$ Grietas por a
$\square$ Por elementos impropios
$\square$ Derivado de intervenciones
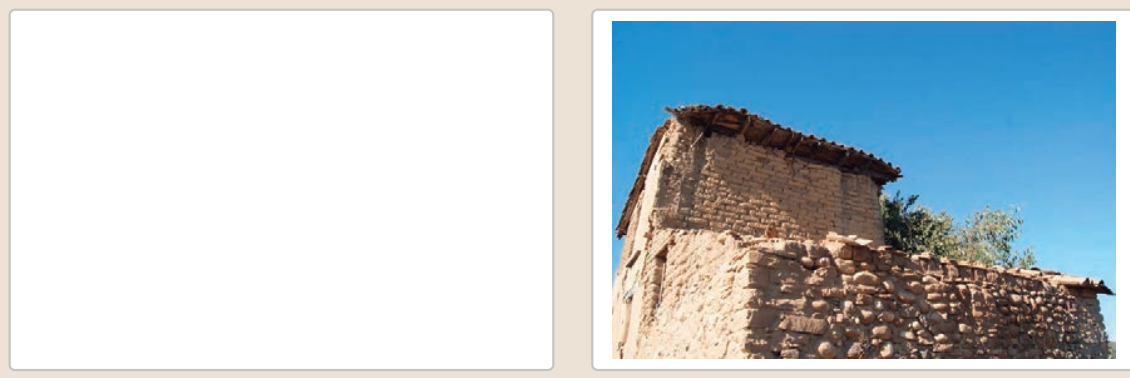

Observaciones El edificio se encuentra en muy mal estado. parte de sus forjado y cubierta se encuentran caídos. 


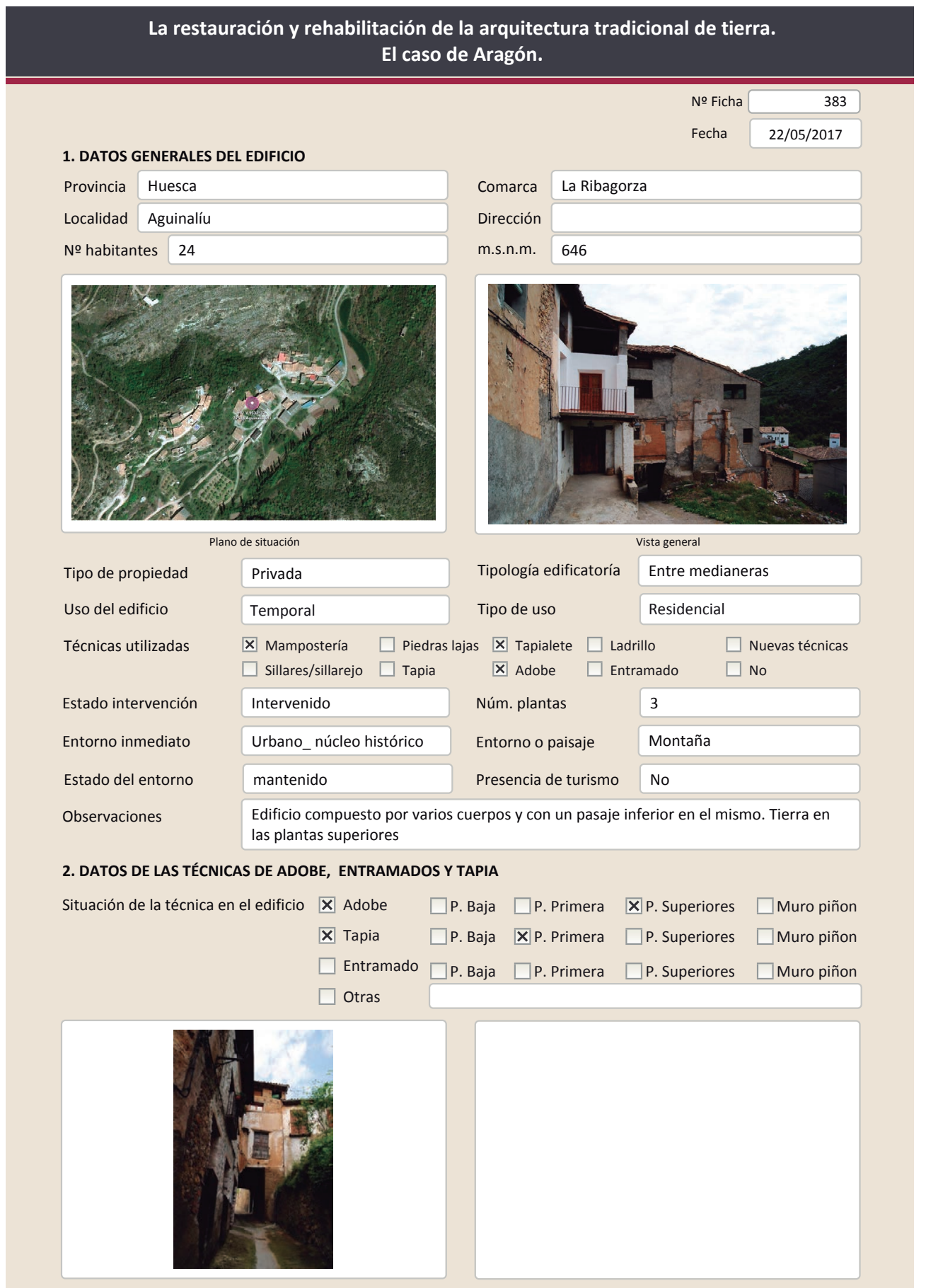

2.1. ADOBE

Dimensión de las piezas Dimensión del muro

Aparejo del muro

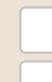

Función estructural

$$
\text { Soga }
$$

No
Color de las piezas

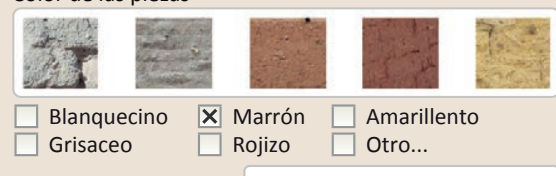

Comp. - estabilizante

Variante constructiva/ tipo de fábrica

$\square$ Simple
Х Suplementada en juntas
Verticales
$\mathrm{Cal} /$ yeso
$\square$ Mixta

$\square$ Como suplemento

$\square$ Elementos de protección

Hay aparejos a soga y aparejos a panderete (en la zona superior del pasaje)

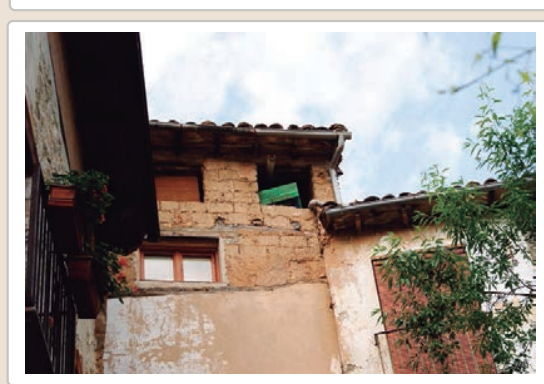

Lesiones $\quad \mathbf{X}$ Muro $\square$ Zócalo $\square$ Revestimiento

X Erosión del material $\square$ Humedad por capilaridad $\square$ Erosion de las juntas $\square$ Humedades (manch/eflo)

$\square$ Pérdida de sección

$\square$ Vegetación

$\square$ Desconchados

$\square$ Pérdida de verticalidad

$\square$ Grietas por empuje de la cubierta $\square$ Grietas porfalta de traba

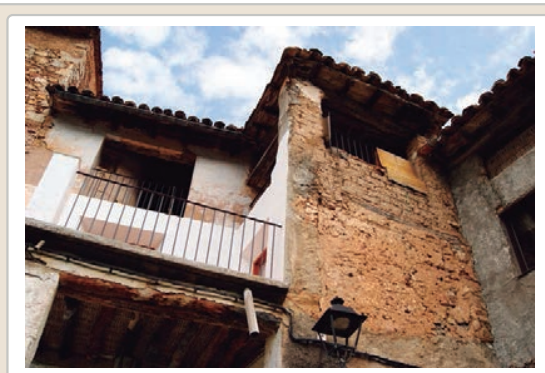

$\square$ Cubierta $\square$ Otro...
$\square$ Grietas por
$\square$ Por elementos impropios
$\square$ Deriva

$\square$ Otro... 


\section{La restauración y rehabilitación de la arquitectura tradicional de tierra.} El caso de Aragón.

\subsection{TAPIA}

Ancho del muro

Dimensión tapiales

Tipo de aguja

№ agujas/cajón

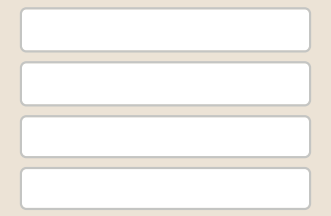

Color de la tapia

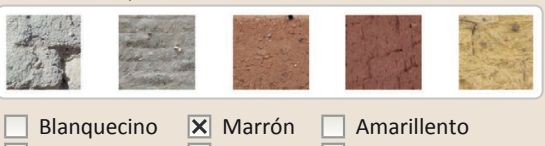

$\square$ Blanquecino $\mathbf{X}$ Marrón $\square$ Amarillento
Grisaceo

Variante constructiva

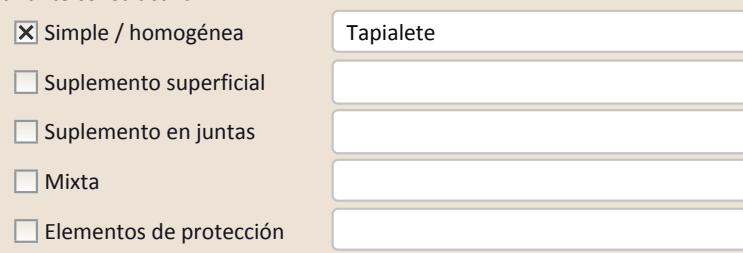

$\square$ Elementos de protección
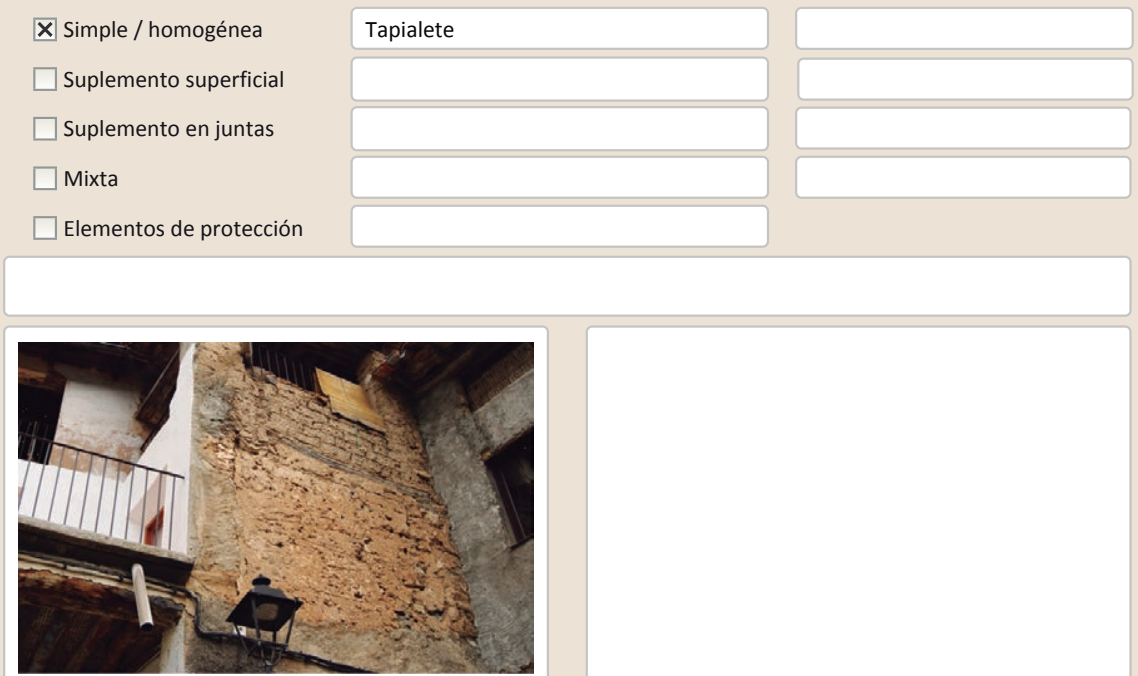

Lesiones $\square$ Muro $\square$ Zócalo $\square$ Revestimiento $\square$ Cubierta $\square$ otro...

$\square$ Erosión del material $\quad \square$ Humedad por capilaridad $\quad \square$ Grietas por asentamientos

$\square$ Erosion de las juntas $\square$ Humedades (manch/eflo) $\quad \square$ Colapso

$\square$ Pérdida de sección $\square$ Pérdida de verticalidad $\square$ Por elementos impropios

$\square$ Vegetación $\square$ Grietas por empuje de la cubierta $\square$ Derivado de intervenciones

$\square$ Desconchados $\quad \square$ Grietas porfalta de traba $\quad \square$ Otro...
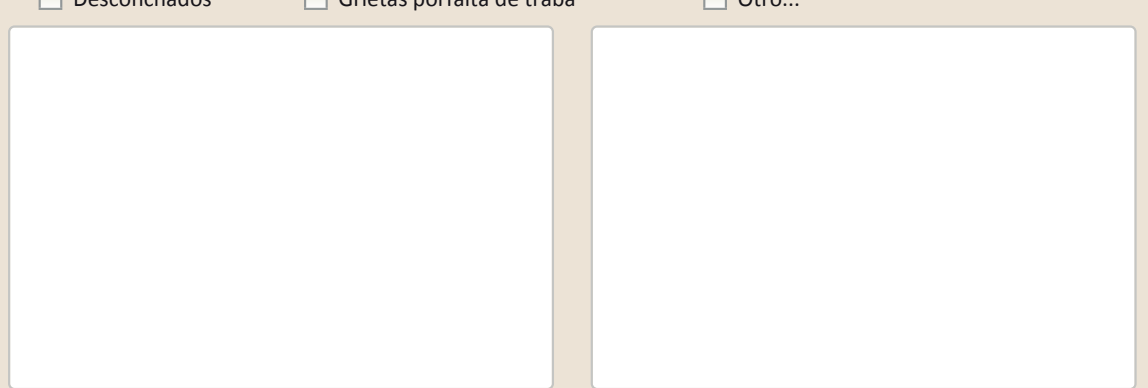

Observaciones
La restauración y rehabilitación de la arquitectura tradicional de tierra.

El caso de Aragón.

3. DATOS DE LA INTERVENCIÓN

Intervención de: $\quad \square$ Mantenimiento $\quad \mathbf{X}$ Rehabilitación parcial $\square$ Restauración $\square$ Demolición

Reflexión previa Intervención planificada

Observaciones Intervención parcial, no en todo el edificio. La parte más intervenida es la próxima al acceso.

3.1. MUROS

\section{No visible}

Tipo de intervención

$\square$ Actualización $\quad \square$ Reintegración $\quad \square$ Demolición $\square$ Otro...

$\square$ Consolidación $\square$ Reconstrucción $\square$ sustitución

Tipo de material

Descripción

3.2. ZÓCALO

Intervenido

$\begin{array}{ll}\text { Tipo de intervención } & \square \text { Actualización } \quad \square \text { Reintegración } \quad \square \text { Demolición } \quad \square \text { Otro... } \\ & \square \text { Consolidación } \quad \boldsymbol{X} \text { Reconstrucción } \quad \square \text { Sustitución }\end{array}$

\begin{tabular}{llll} 
Tipo de material No tradicional Tipo de técnica Diferente a la existente & \\
\hline
\end{tabular}

Descripción

Mortero de cemento

3.3. REVESTIMIENTOS

Tipo de intervención

Intervenido

Tipo de material

Actualización $\quad \boldsymbol{X}$ Reintegración $\square$ Demolición $\square$ Otro...

Descripción Nuevo revestimiento y reintegración de faltantes en la mayor parte del edificio. Pintura blanca en la fachada principal

3.4. VANOS

Tipo de intervención

Intervenido

\begin{tabular}{llll} 
Tipo de material Tradicional diferente & Tipo de técnica Diferente a la existente \\
\hline
\end{tabular}

$\square$ Actualización $\square$ Reintegración $\square$ Demolición $\square$ Otro...

$\square$ Consolidación $\square$ Reconstrucción $\quad \boldsymbol{x}$ Sustitución

Descripción

Sustitución de gran parte de las carpinterías por otras nuevas de madera.

3.5. CUBIERTA

\section{No intervenido}

Tipo de intervención

$\square$ Actualización

$\square$ Consolidación

$\square$ Reintegración $\square$ Demolición $\square$ Otro...

Tipo de material

Descripción

3.6. OTRAS 


\section{La restauración y rehabilitación de la arquitectura tradicional de tierra.} El caso de Aragón.

3.7. REHABILITACIÓN ENERGÉTICA $\square$ Fachada $\quad \mathbf{X}$ Vanos $\square$ Forjados $\square$ Cubierta

Observaciones

FOTOGRAFÍAS DE LA INTERVENCIÓN
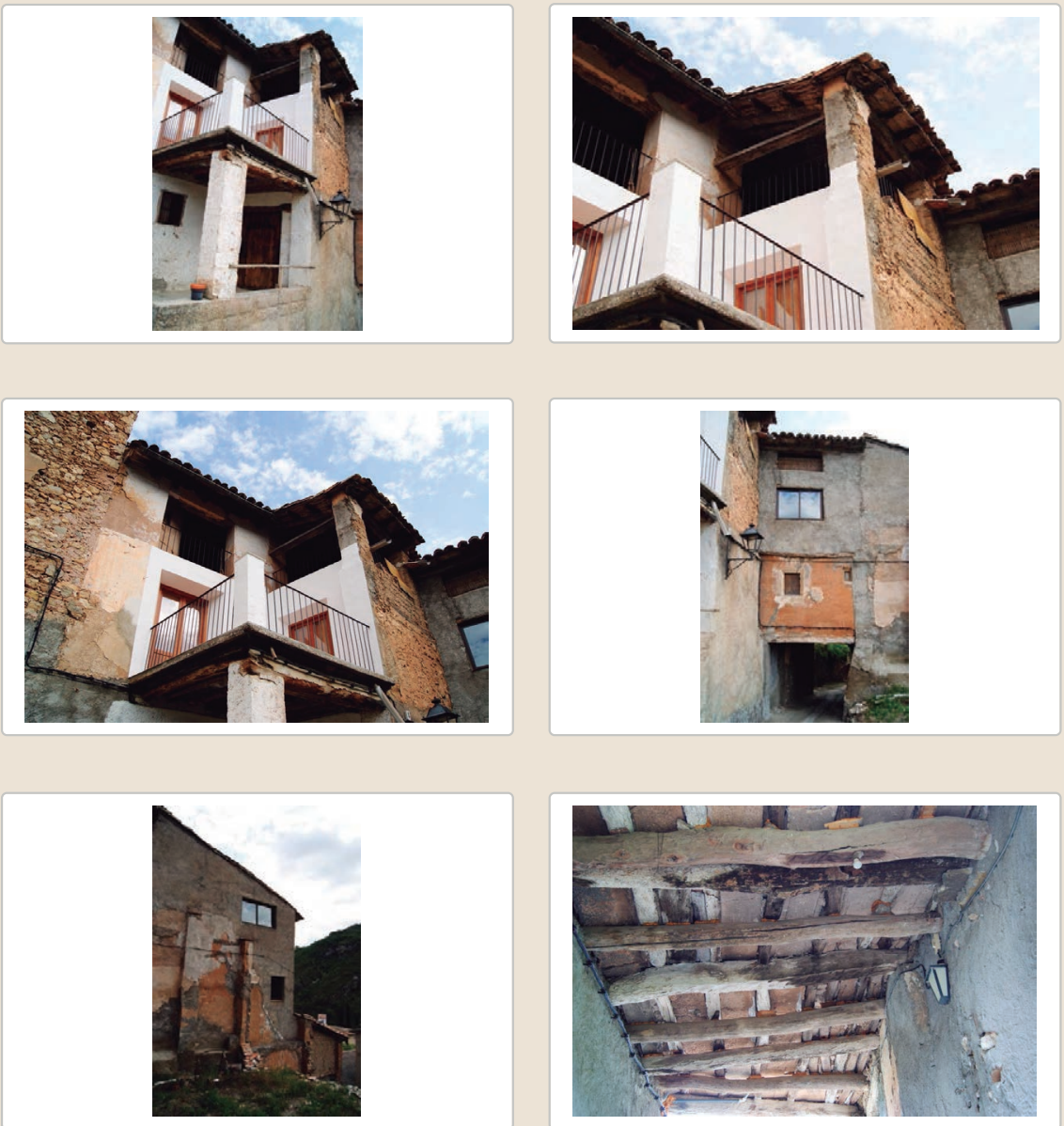


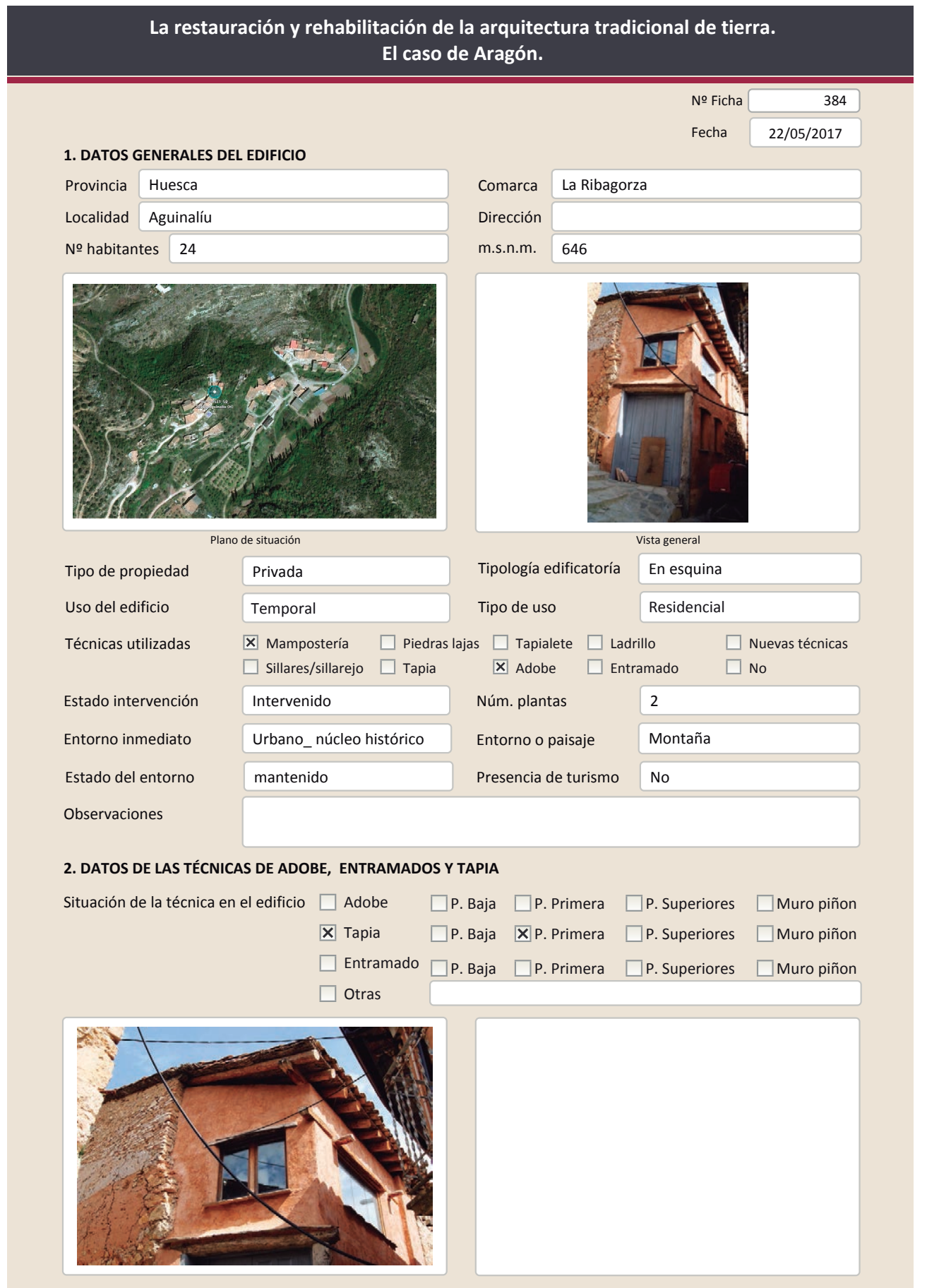

La restauración y rehabilitación de la arquitectura tradicional de tierra. El caso de Aragón.

2.2. TAPIA

Ancho del muro

Dimensión tapiales

Tipo de aguja

№ agujas/cajón

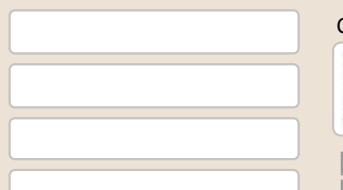

Color de la tapia

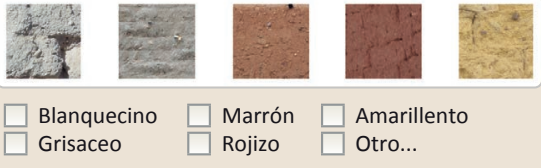

Variante constructiva

$$
\begin{aligned}
& \text { X Simple / homogénea } \\
& \square \text { Suplemento superficial } \\
& \square \text { Suplemento en juntas } \\
& \square \text { Mixta }
\end{aligned}
$$

$\square$ Elementos de protección
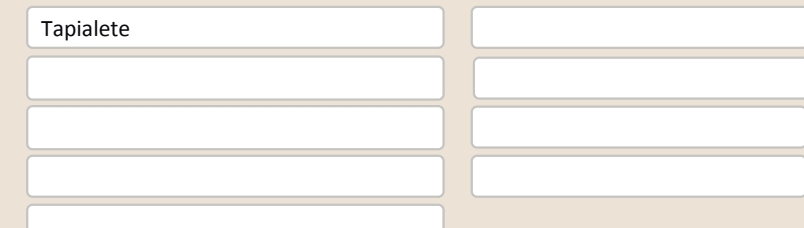

Parte del muro sin intevenir, al igual que la mayoría de los edificios de la localidad, está construido con tapialete. El muro intervenido tiene un nuevo revestimiento.

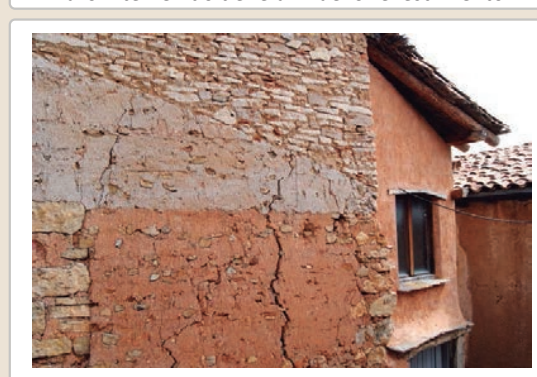

Lesiones $\quad$ Muro $\square$ Zócalo $\square$ Revestimiento $\square$ Cubierta $\square$ Otro...

$\square$ Erosión del material $\square$ Humedad por capilaridad $\quad$ X Grietas por asentamientos $\square$ Erosion de las juntas $\square$ Humedades (manch/eflo)

$\square$ Pérdida de sección $\quad \square$ Pérdida de verticalidad

$\square$ Vegetación $\quad \square$ Grietas por empuje de la cubierta

$\square$ Desconchados

X Grietas porfalta de traba
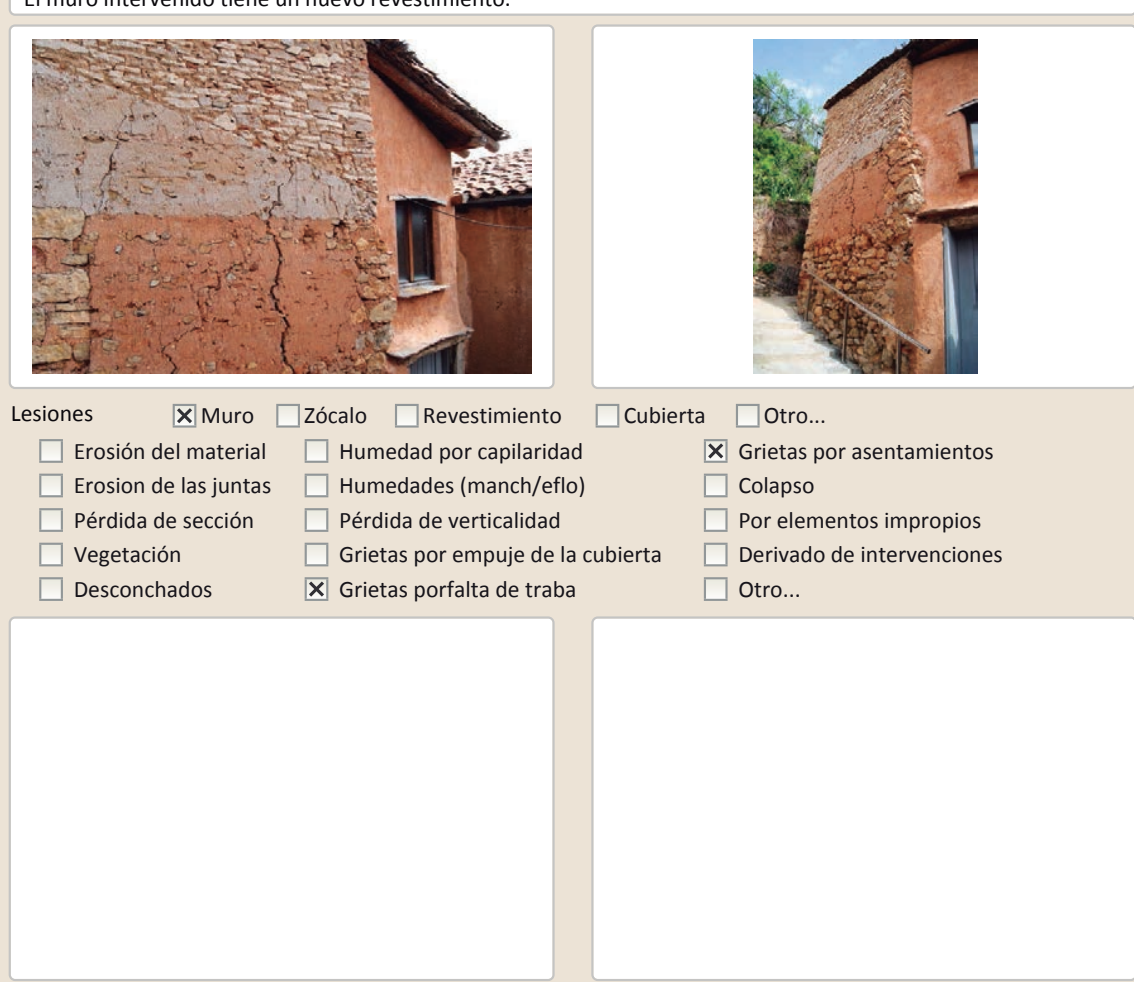

Observaciones 


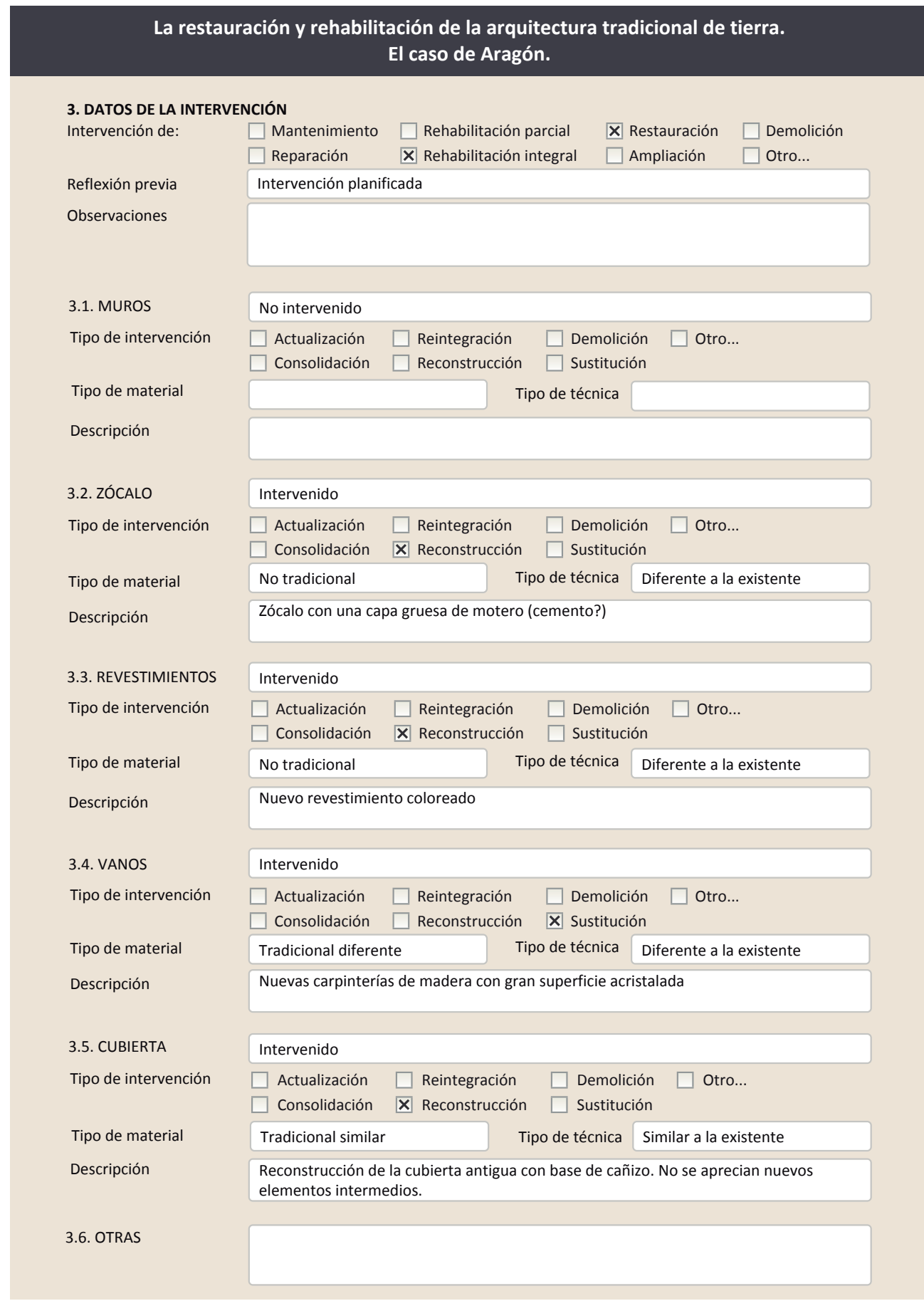

3.7. REHABILITACIÓN ENERGÉTICA $\quad \square$ Fachada $\square$ Vanos $\square$ Forjados $\square$ Cubierta Observaciones

FOTOGRAFíAS DE LA INTERVENCIÓN
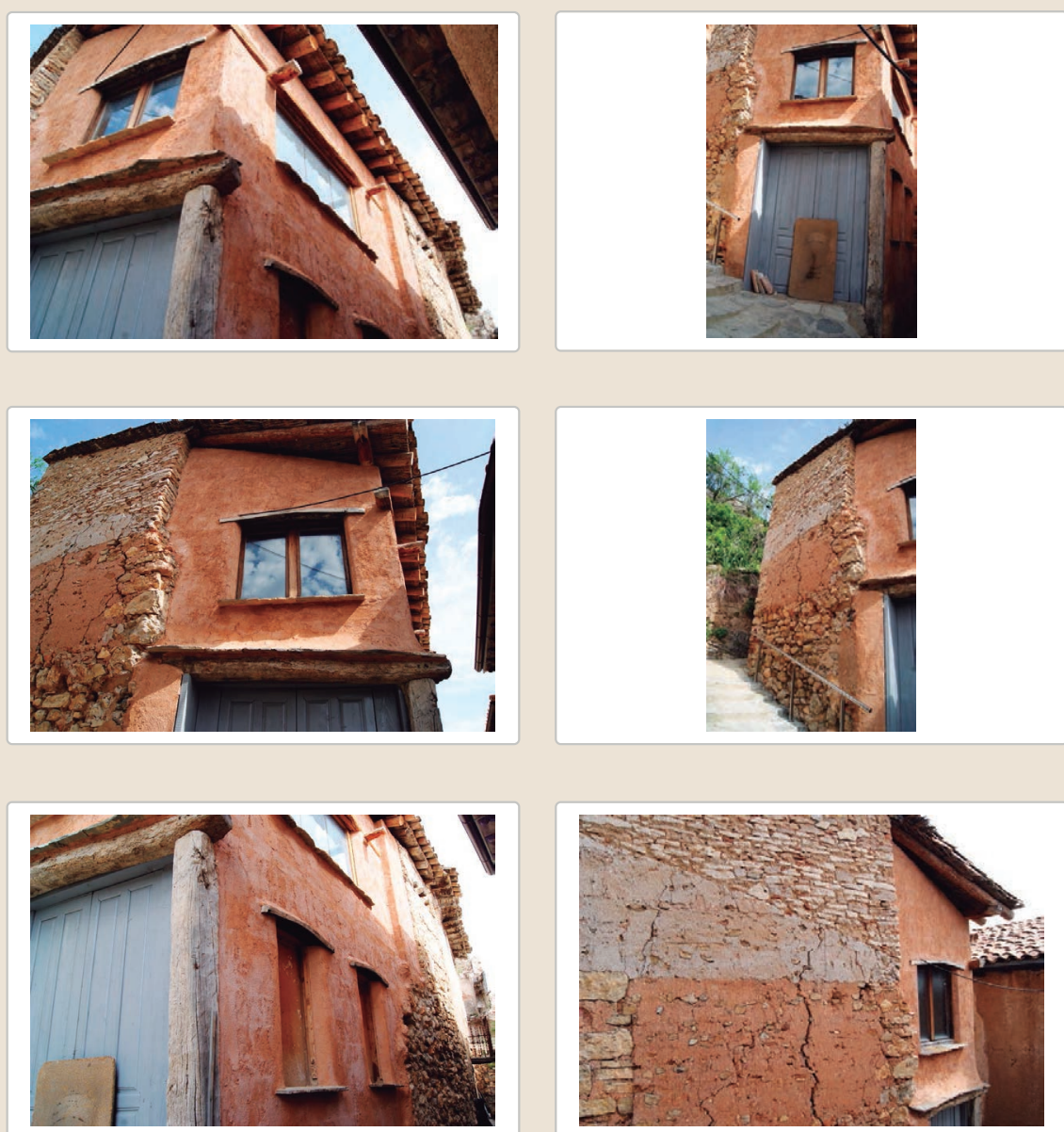


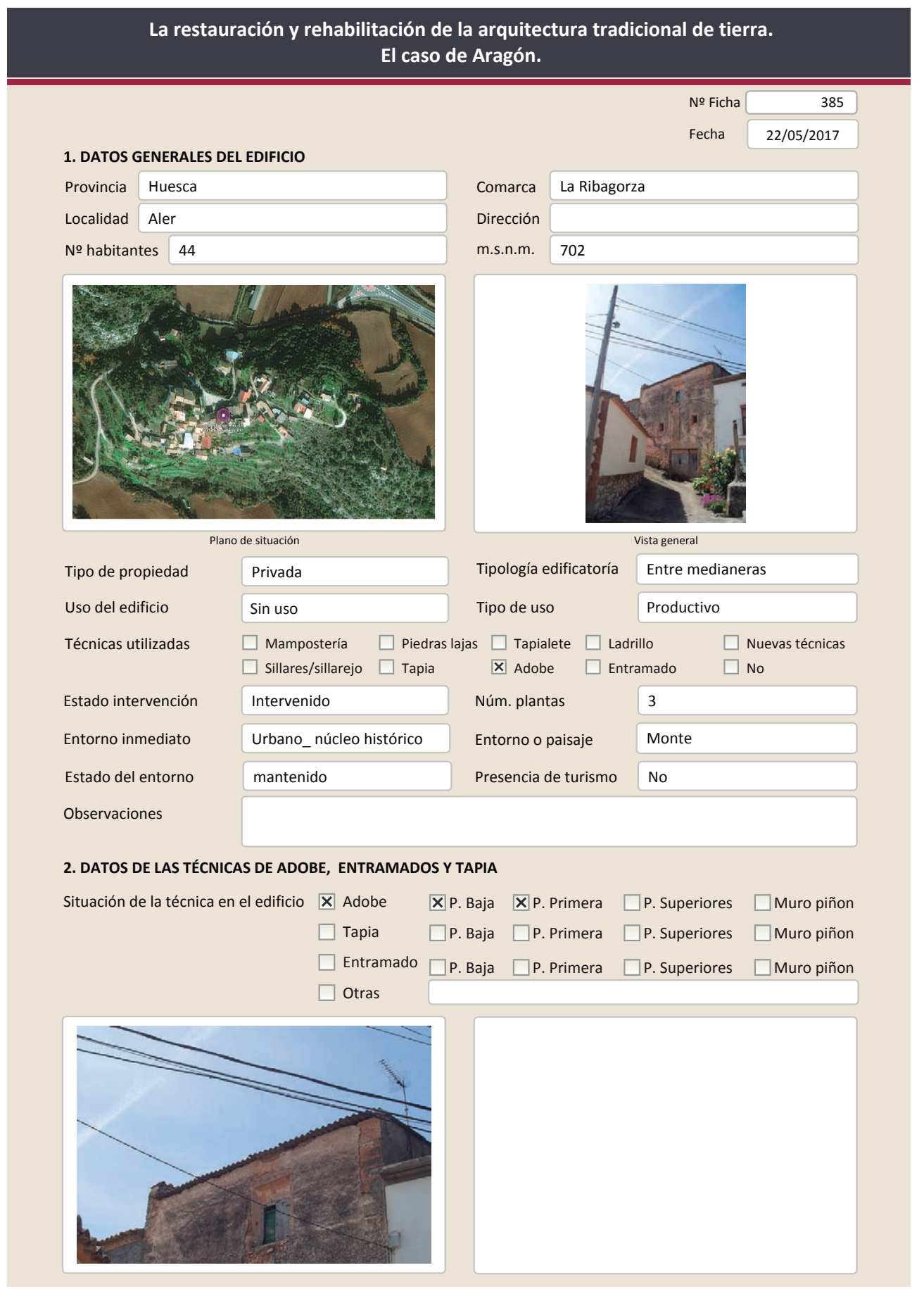

La restauración y rehabilitación de la arquitectura tradicional de tierra.

\subsection{ADOBE}

Dimensión de las piezas Dimensión del muro

Aparejo del muro

Función estructural

\section{El caso de Aragón.}

Color de las piezas

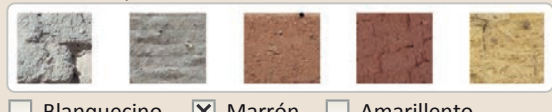

Blanquecino $\mathbf{X}$ Marrón $\square$ Amarillento $\square$ Grisaceo $\square$ Rojizo $\square$ Otro...

Comp. - estabilizante

Variante constructiva/ tipo de fábrica

$\square$ simple
X Suplementada en juntas
Horizontales
Tejas
区 Mixta
En esquinas
Piedra
$\square$ Como suplemento
$\mathbf{X}$ Elementos de protección
Revestimiento

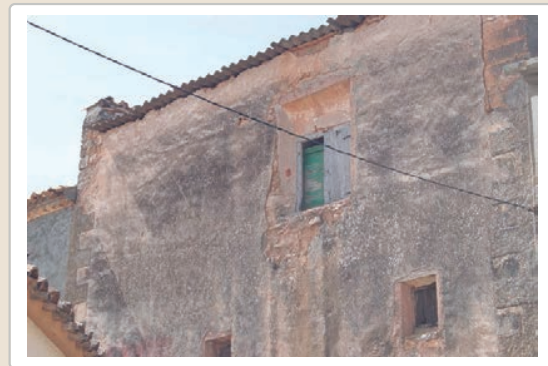

Lesiones $\quad \mathbf{X}$ Muro $\square$ Zócalo $\mathbf{X}$ Revestimiento

$\mathbf{X}$ Muro $\square$ Zócalo $\quad \mathbf{X}$ Revestimiento
material $\quad \square$ Humedad por capilarida

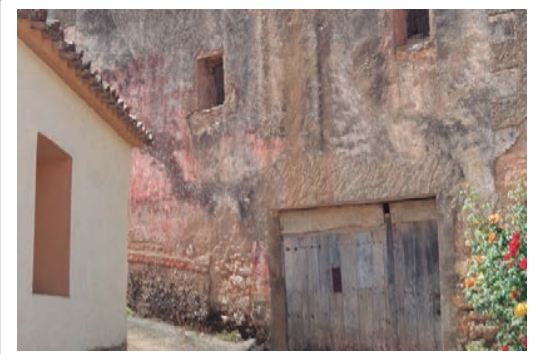

X Erosión del material $\square$ Humedad por capilaridad

$\square$ Cubierta $\square$ otro...

$\square$ Erosion de las juntas $\square$ Humedades (manch/eflo) $\square$ Colapso

X Pérdida de sección $\square$ Pérdida de verticalidad

$\square$ Por elementos impropios

$\square$ Vegetación

$\square$ Grietas por empuje de la cubir

Х Desconchados

$\square$ Grietas porfalta de traba

$\square$ Derivado
$\square$ Otro...

Observacione 
La restauración y rehabilitación de la arquitectura tradicional de tierra. El caso de Aragón

\section{La restauración y rehabilitación de la arquitectura tradicional de tierra.}

\section{El caso de Aragón.}

3. DATOS DE LA INTERVENCIÓN

Intervención de:

$\square$ Mantenimiento $\square$ Rehabilitación parcia

$\square$ Restauración $\square$ Demolición X Reparación $\quad \square$ Rehabilitación integral $\quad \square$ Ampliación $\quad \square$ Otro...

Reflexión previa

Intervención espontanea

Observaciones

(n)

3.1. MUROS

No intervenido

Tipo de intervención

$\square$ Actualización $\square$ Reintegración $\square$ Demolición $\square$ Otro...

$\square$ Consolidación $\square$ Reconstrucción $\square$ Sustitución

Tipo de material

Descripción

3.2. ZÓCALO

Tipo de intervención

Intervenido

$\square$ Actualización $\square$ Reintegración $\square$ Demolición $\square$ Otro...

Tipo de material

$\square$ Consolidación $\quad \mathbf{X}$ Reconstrucción $\square$ Sustitución

Descripción

Tipo de técnica Diferente a la existente

3.3. REVESTIMIENTOS

Zócalo de gotelé de cemento

Tipo de intervención

No intervenido

Actualización

$\square$ Reintegración $\square$ Demolición $\square$ Otro...

Consolidación $\quad \square$ Reconstrucción $\square$ Sustitución

Tipo de material

Descripción

3.4. VANOS

No intervenido

Tipo de intervención

$\square$ Actualización $\square$ Reintegración $\square$ Demolición $\square$ Otro...

Tipo de material

Descripción

3.5. CUBIERTA

Tipo de intervención

Intervenido

Tipo de material

$\square$ Actualización $\square$ Reintegración $\square$ Demolición $\square$ Otro.

$\square$ Consolidación $\square$ Reconstrucción $\quad \mathbf{X}$ Sustitución

Descripción

Sustitución por fibrocemento

Tipo de técnica Diferente a la existente

3.6. OTRAS 


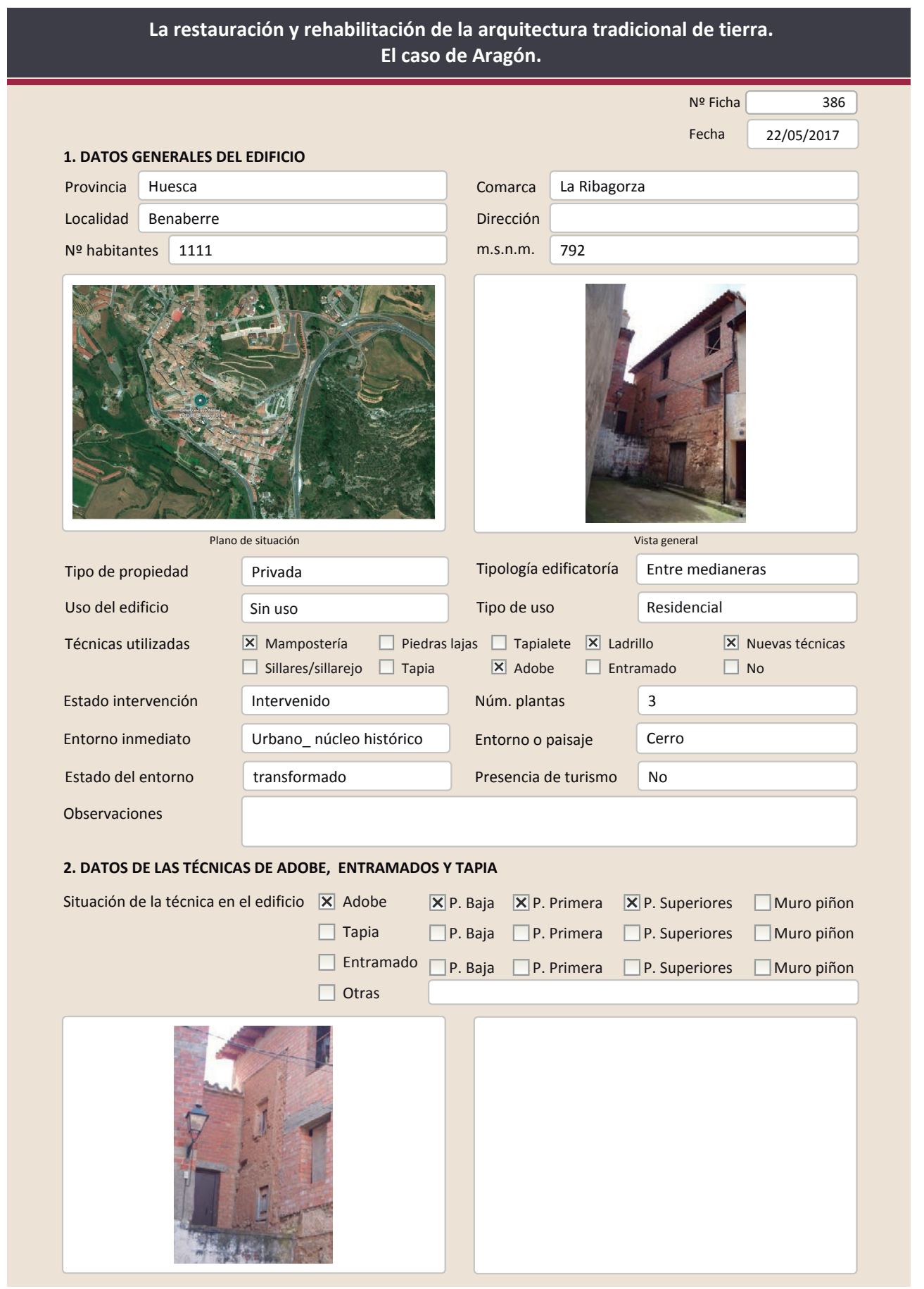

La restauración y rehabilitación de la arquitectura tradicional de tierra.

El caso de Aragón.

2.1. ADOBE

Dimensión de las piezas Dimensión del muro Aparejo del muro Función estructural
Color de las piezas

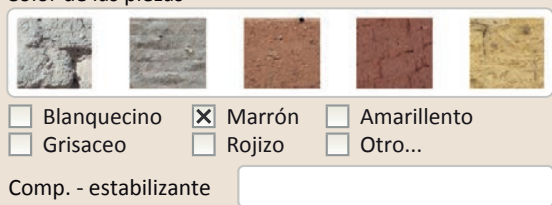

Comp. - estabilizante

Variante constructiva/ tipo de fábrica

$\square$ Simple
$\mathbf{X}$ Suplementada en juntas
Horizontales
$\square$ Mixta
$\square$ Como suplemento
$\square$ Elementos de protección

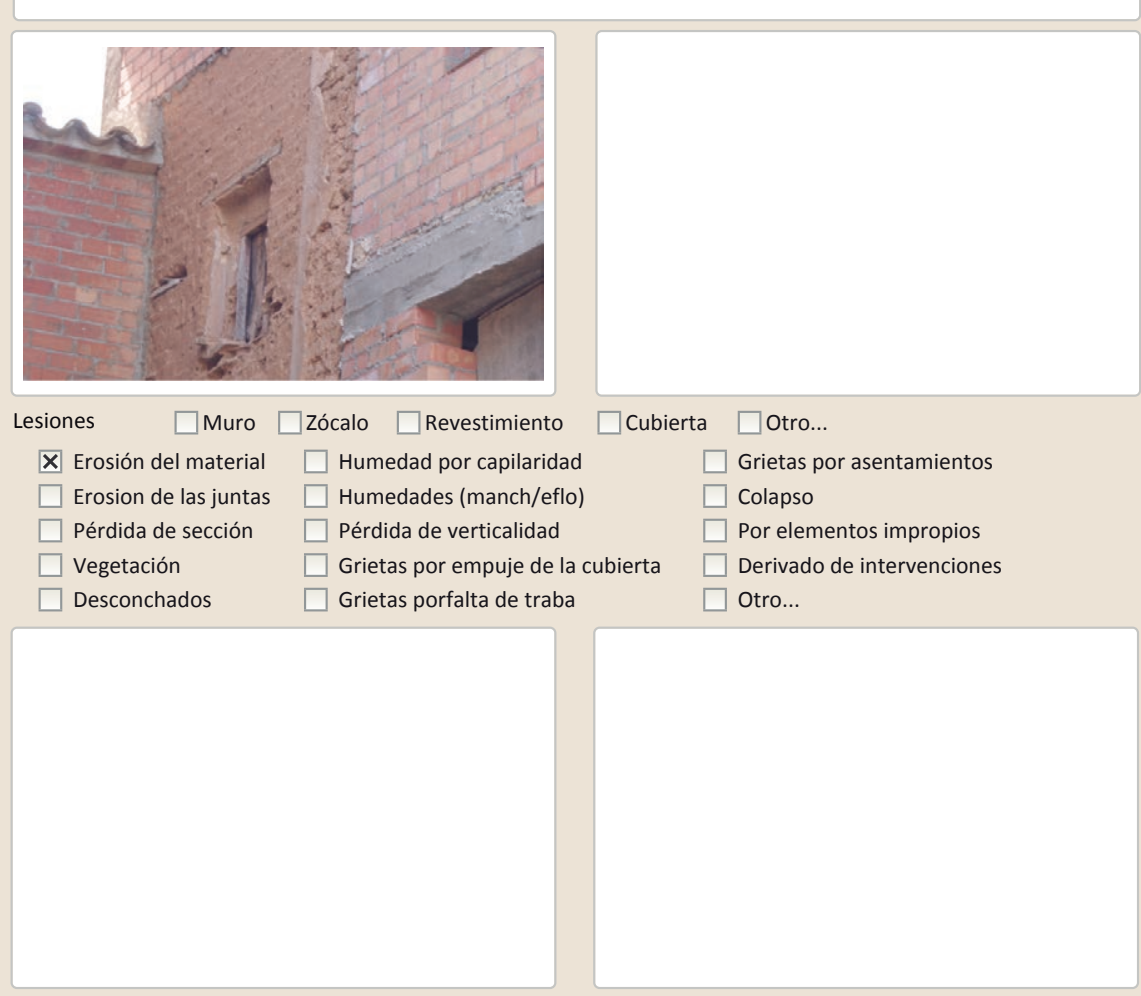

Observaciones 
La restauración y rehabilitación de la arquitectura tradicional de tierra. El caso de Aragón

\section{La restauración y rehabilitación de la arquitectura tradicional de tierra.}

\section{El caso de Aragón.}

3. DATOS DE LA INTERVENCIÓN

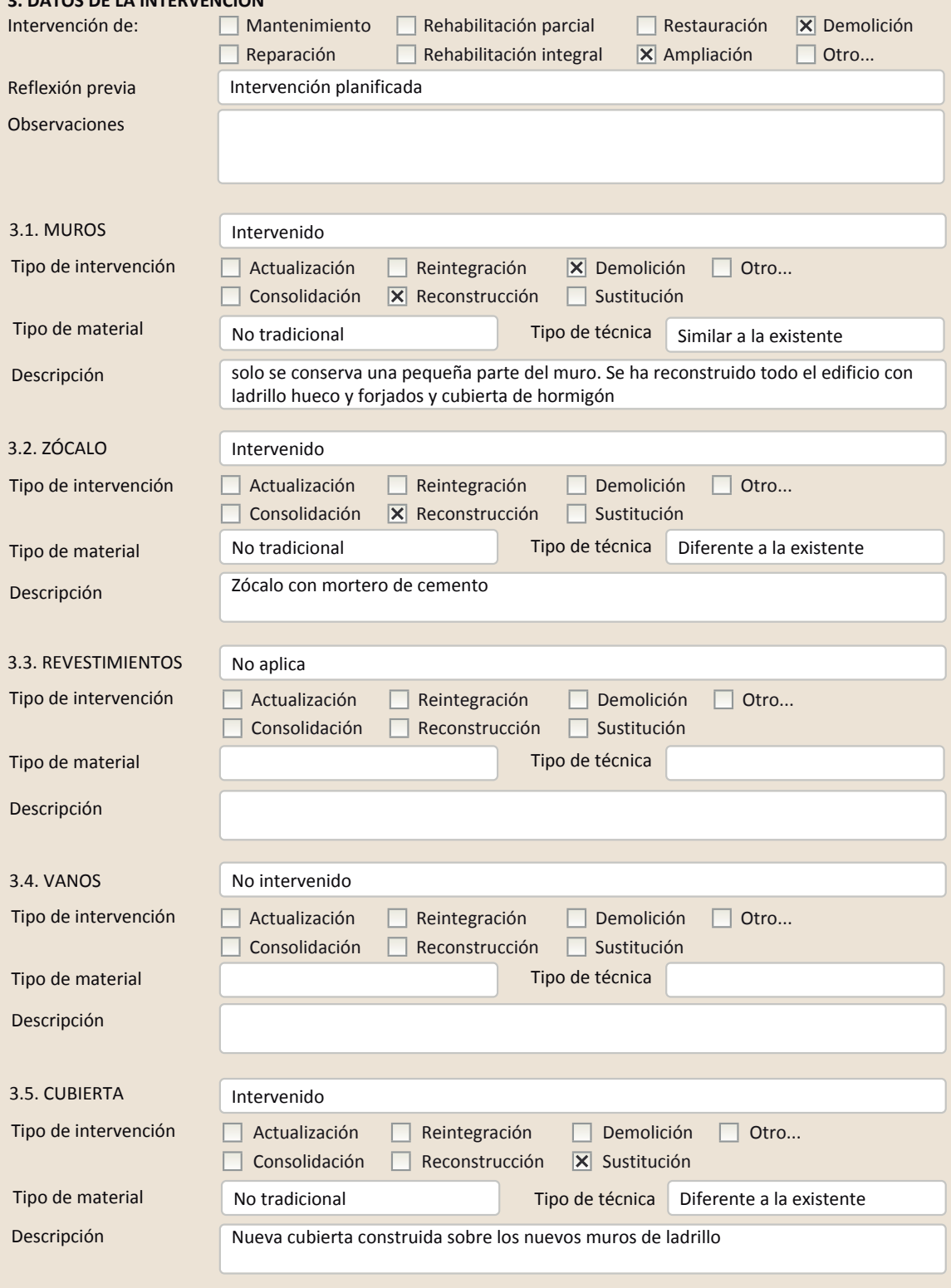

3.6. OTRAS 


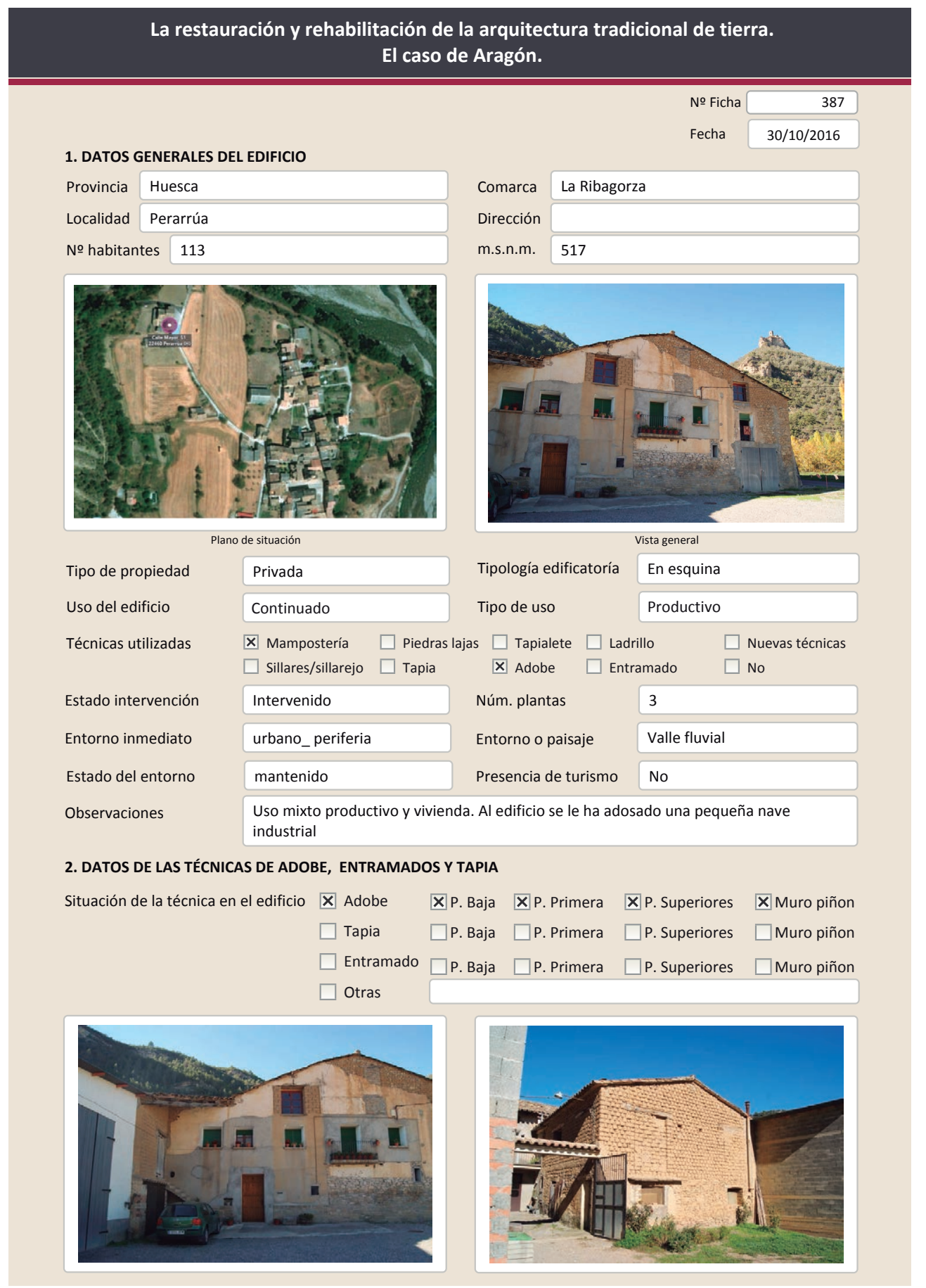

La restauración y rehabilitación de la arquitectura tradicional de tierra. El caso de Aragón.

\subsection{ADOBE \\ Dimensión de las piezas $40 \times 18 \times 14,5$ \\ Dimensión del muro $40-50 \mathrm{~cm}$ \\ Aparejo del muro Tizón \\ Función estructural \\ $\mathrm{Si}$ \\ Variante constructiva/ tipo de fábrica \\ X Simple \\ $\square$ Suplementada en juntas \\ $\square$ Mixta \\ $\square$ Como suplemento}

El caso

$\square$ Elementos de protección

Contiene fibras vegetales y áridos. La parte trasera del edificio esta compuesta por varios materiales dispuestos de forma aleatoria. Adobe visible en la zona superior.

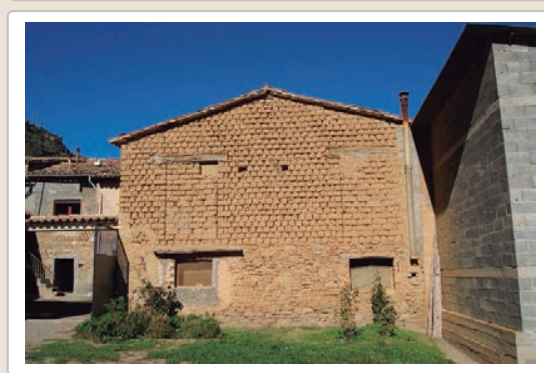

Lesiones $\quad \mathbf{X}$ Muro $\square$ Zócalo $\square$ Revestimiento X Erosión del material $\square$ Humedad por capilaridad X Erosion de las juntas $\square$ Humedades (manch/eflo) $\square$ Pérdida de sección $\square$ Pérdida de verticalidad

$\begin{array}{ll}\square \text { Vegetación } & \square \text { Grietas por empuje de lacub } \\ \square \text { Desconchados } \quad \square \text { Grietas porfalta de traba }\end{array}$

Color de las piezas

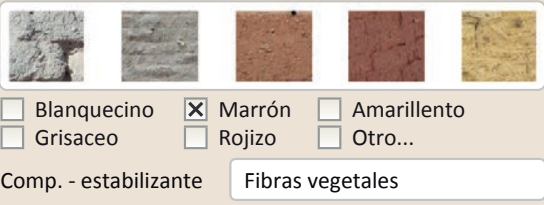

Comp. - estabilizante Fibras vegetales
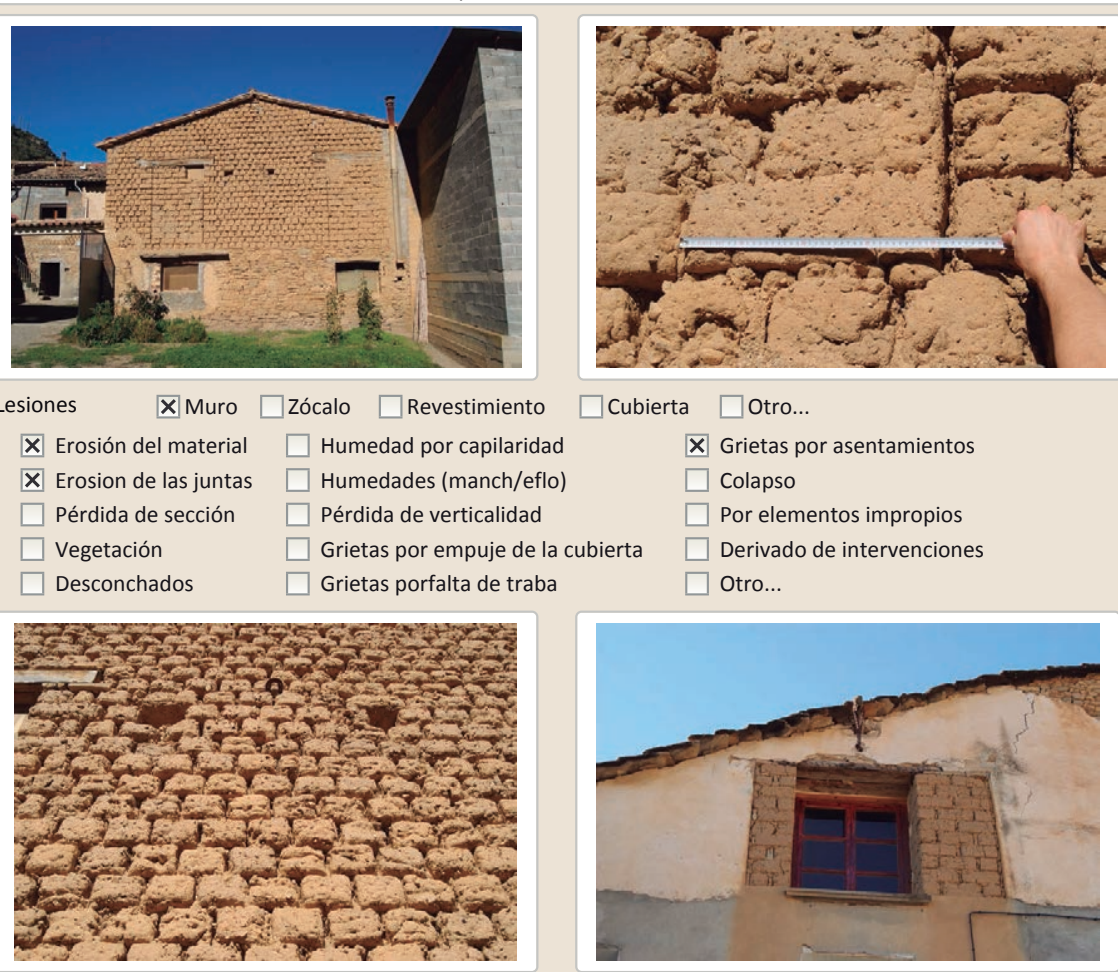

$\square$ Cubierta $\square$ otro...

$\mathbf{X}$ Grietas por asentamientos

$\square$ Colapso

$\square$ Por elementos impropios

$\square$ Derivado de intervenciones $\square$ Otro...

Observaciones

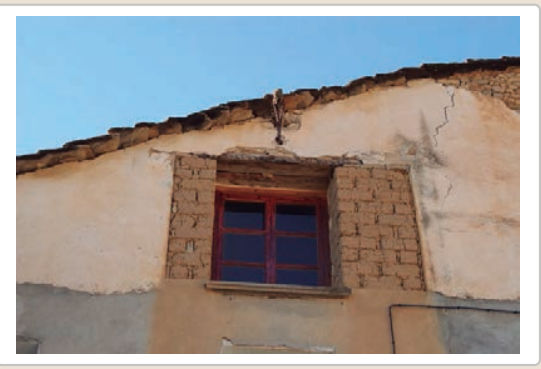




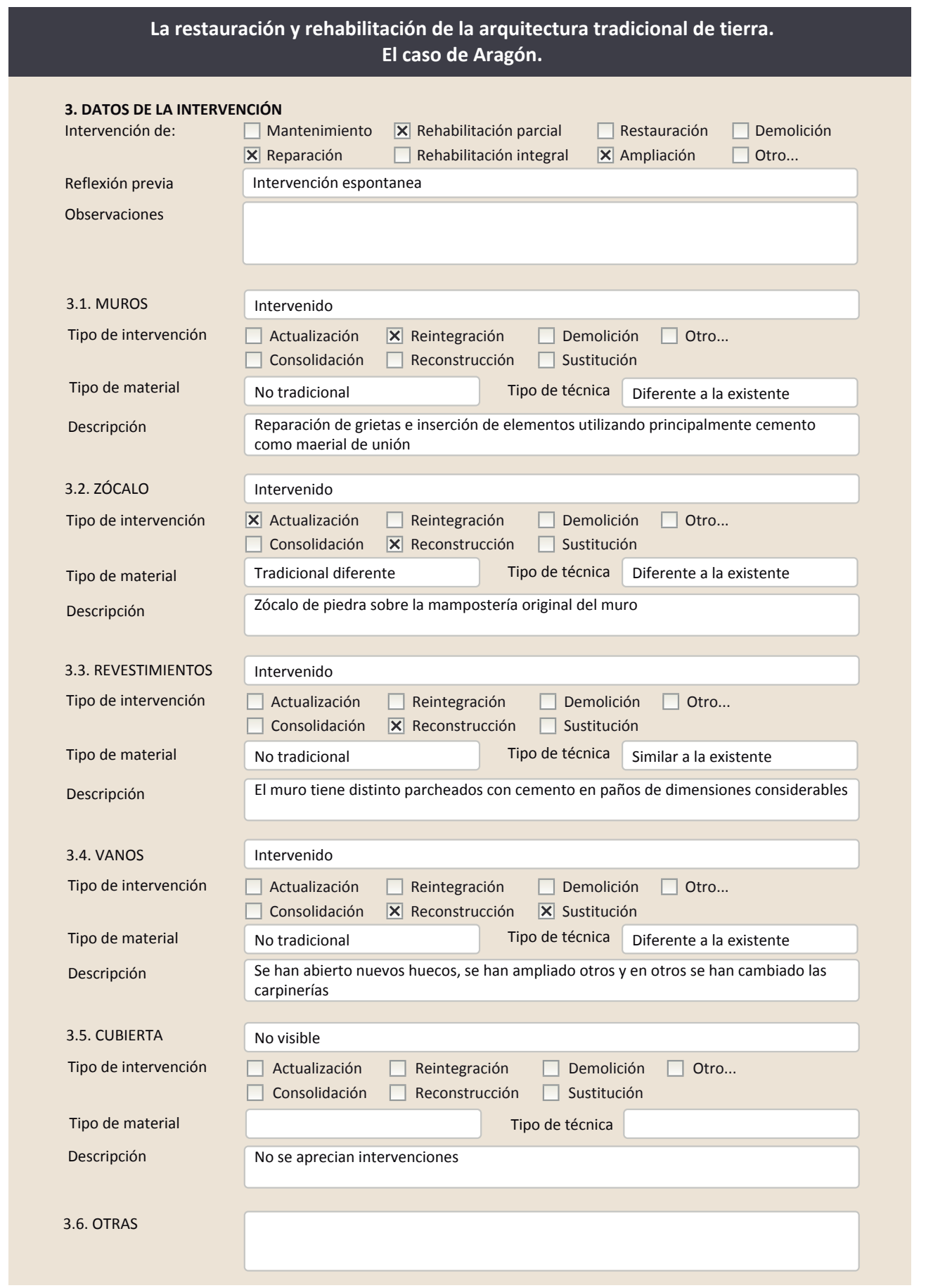

3.7. REHABILITACIÓN ENERGÉTICA $\square$ Fachada $\square$ Vanos $\square$ Forjados $\square$ Cubierta

Observaciones

FOTOGRAFíAS DE LA INTERVENCIÓN
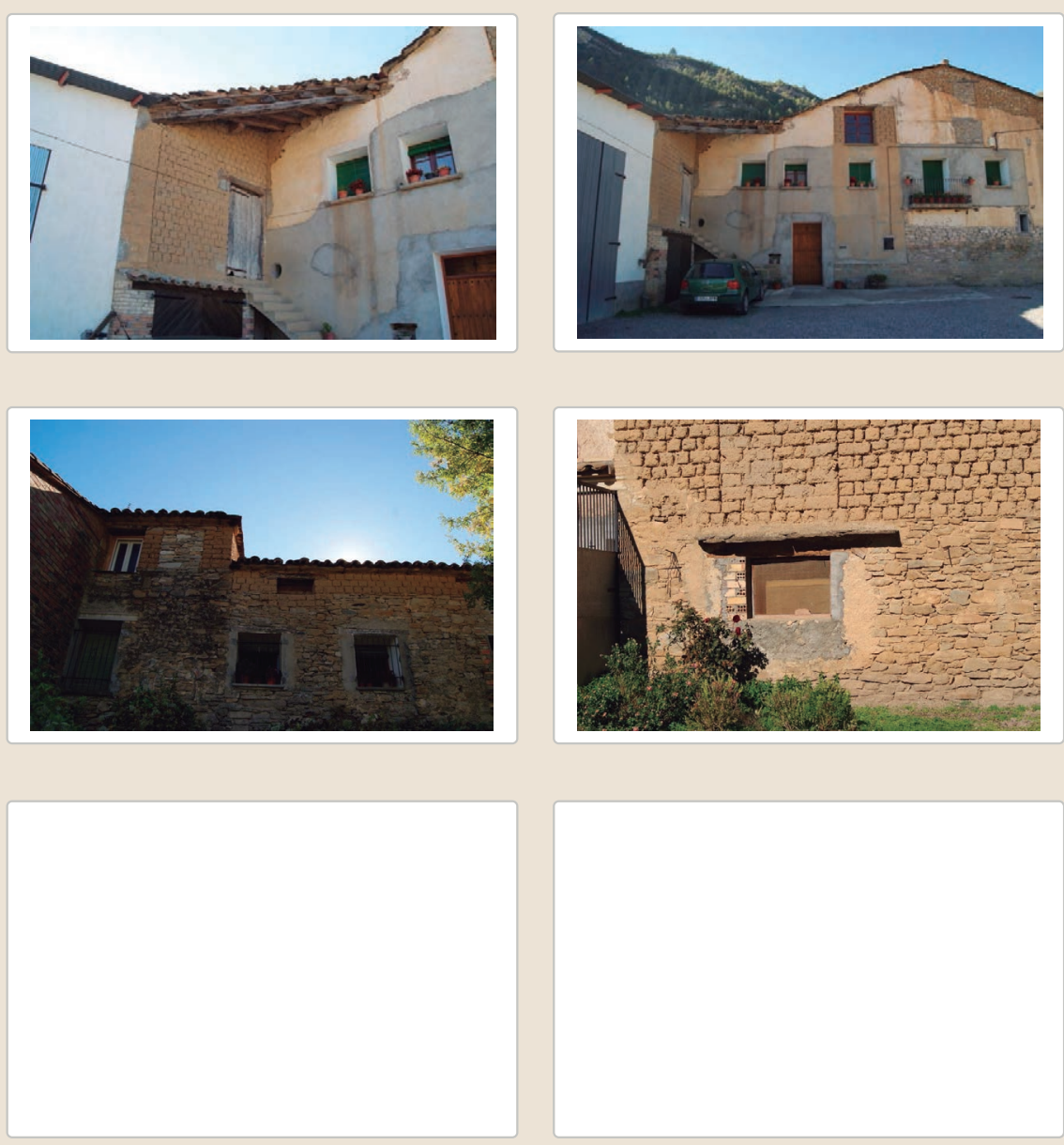


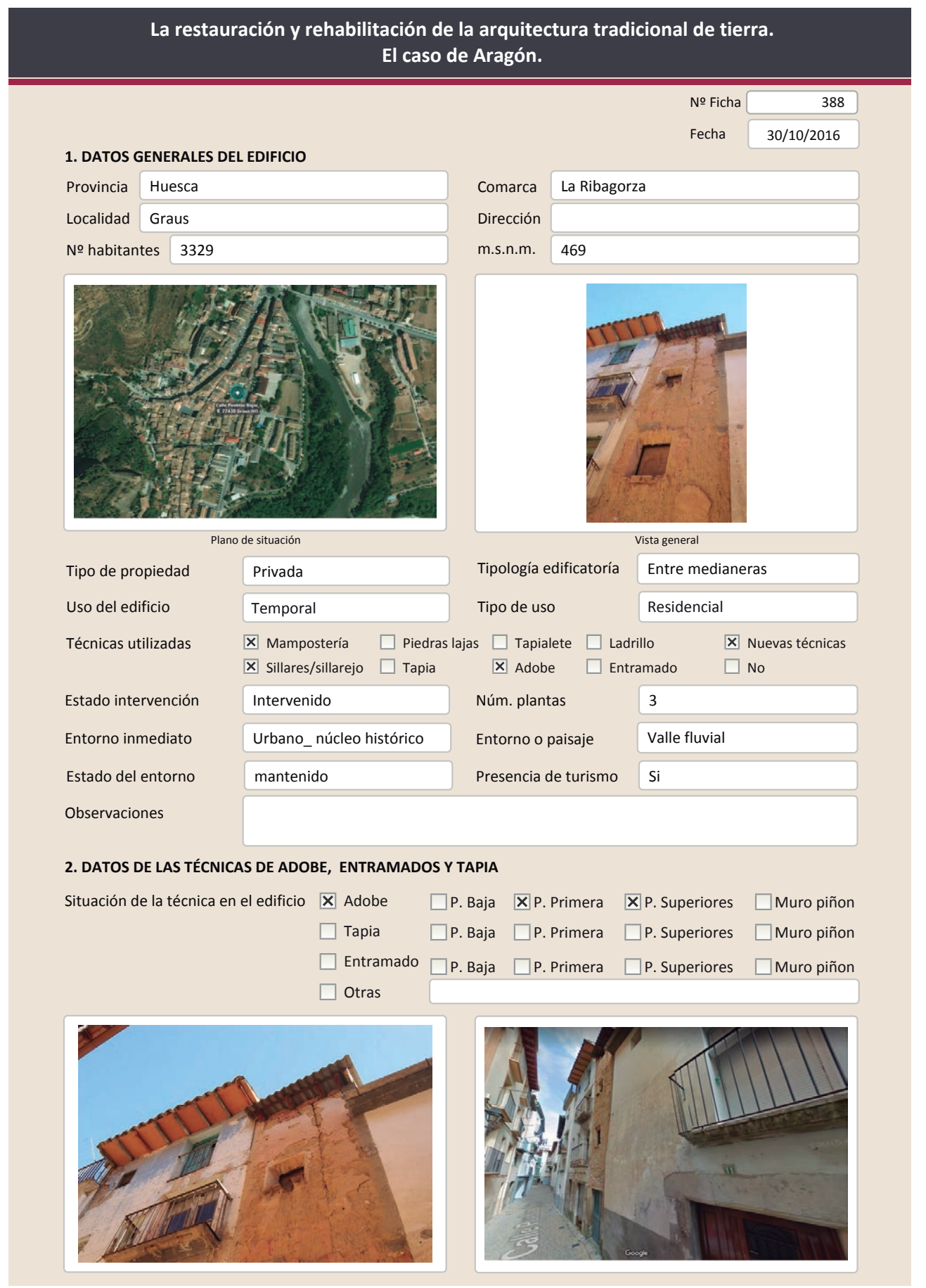

La restauración y rehabilitación de la arquitectura tradicional de tierra.

El caso de Aragón.

2.1. ADOBE

Dimensión de las piezas

Dimensión del muro

Aparejo del muro

Función estructural

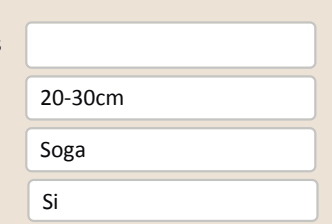

Color de las piezas

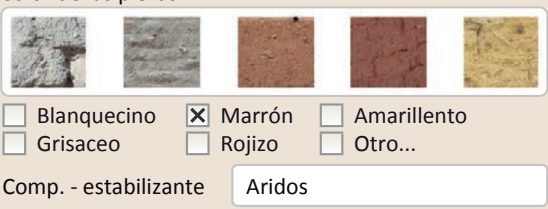

constructiva/ tipo de fábrica

メ simple

$\square$ suplementada en juntas

$\square$ Mixta

$\square$ Como suplemento

Х Elementos de protección

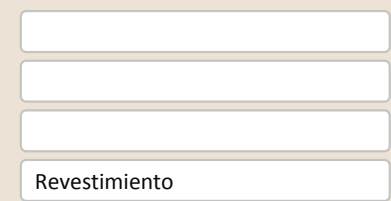

\section{Xesting}

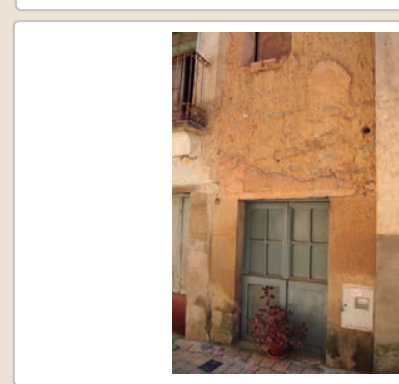

Lesiones

X Muro XZócalo Х Revestimiento

$\mathbf{X}$ Erosión del material $\mathbf{X}$ Humedad por capilaridad

$\mathbf{X}$ Erosion de las juntas $\mathbf{X}$ Humedades (manch/eflo)

$\triangle$ Pérdida de sección $\square$ Pérdida de verticalidad

$\begin{array}{ll}\square \text { Vegetación } & \square \text { Grietas por empuje de la c } \\ \mathbb{X} \text { Desconchados } & \boldsymbol{X} \text { Grietas porfalta de traba }\end{array}$

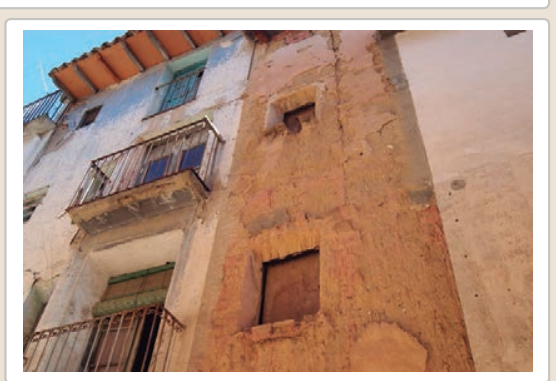

X Cubierta $\square$ Otro...

$\square$ Grietas por asentamiento

$\square$ Colapso

$\square$ Por elementos impropios

$\square$ Derivado de intervenciones

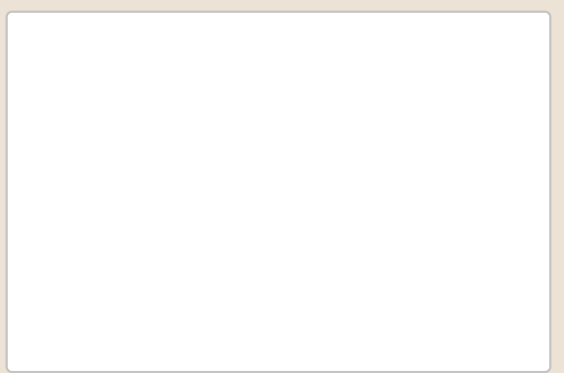

Observaciones 
La restauración y rehabilitación de la arquitectura tradicional de tierra. El caso de Aragón

\section{La restauración y rehabilitación de la arquitectura tradicional de tierra.}

\section{El caso de Aragón.}

3. DATOS DE LA INTERVENCIÓN

Intervención de:

$\square$ Mantenimiento $\square$ Rehabilitación parcia

$\square$ Restauración $\square$ Demolición X Reparación $\square$ Rehabilitación integral $\square$ Ampliación $\square$ Otro...

Reflexión previa Intervención espontanea

Observaciones

3.1. MUROS

Intervenido

Tipo de intervención

$\square$ Actualización $\quad \boldsymbol{X}$ Reintegración $\square$ Demolición $\square$ Otro...

$\square$ Consolidación $\square$ Reconstrucción $\square$ Sustitución

Tipo de material \begin{tabular}{l|l|l} 
No tradicional Tipo de técnica Diferente a la existente &
\end{tabular}

Descripción Reintegración de la zona superior del muro con ladrillo hueco.

3.2. ZÓCALO

Tipo de intervención Intervenido

Actualización $\quad \mathbf{X}$ Reintegración $\square$ Demolición $\square$ Otro...

Tipo de material

$\square$ Consolidación $\square$ Reconstrucción $\square$ sustitución

Descripción

3.3. REVESTIMIENTOS

Reintegración de la zona faltante de los sillares con cemento

Tipo de intervención

No intervenido

Actualización

$\square$ Reintegración $\square$ Demolición $\square$ Otro...

Tipo de material

Descripción

3.4. VANOS

$\square$ Consolidación $\quad \square$ Reconstrucción $\square$ Sustitución

Tipo de intervención

Tipo de material

Descripción

3.5. CUBIERTA

Tipo de intervención

Intervenido

Tipo de material

$\square$ Actualización $\square$ Reintegración $\quad \square$ Demolición $\quad \square$ Otro.

$\square$ Consolidación $\square$ Reconstrucción $\quad$ X Sustitución

\begin{tabular}{l|l|l|l|l|l|l} 
Nipo de técnica & Diferente a la existente
\end{tabular}

Descripción

Cubierta de chapa metálica sobre rollizos de madera

3.6. OTRAS 
La restauración y rehabilitación de la arquitectura tradicional de tierra. El caso de Aragón.

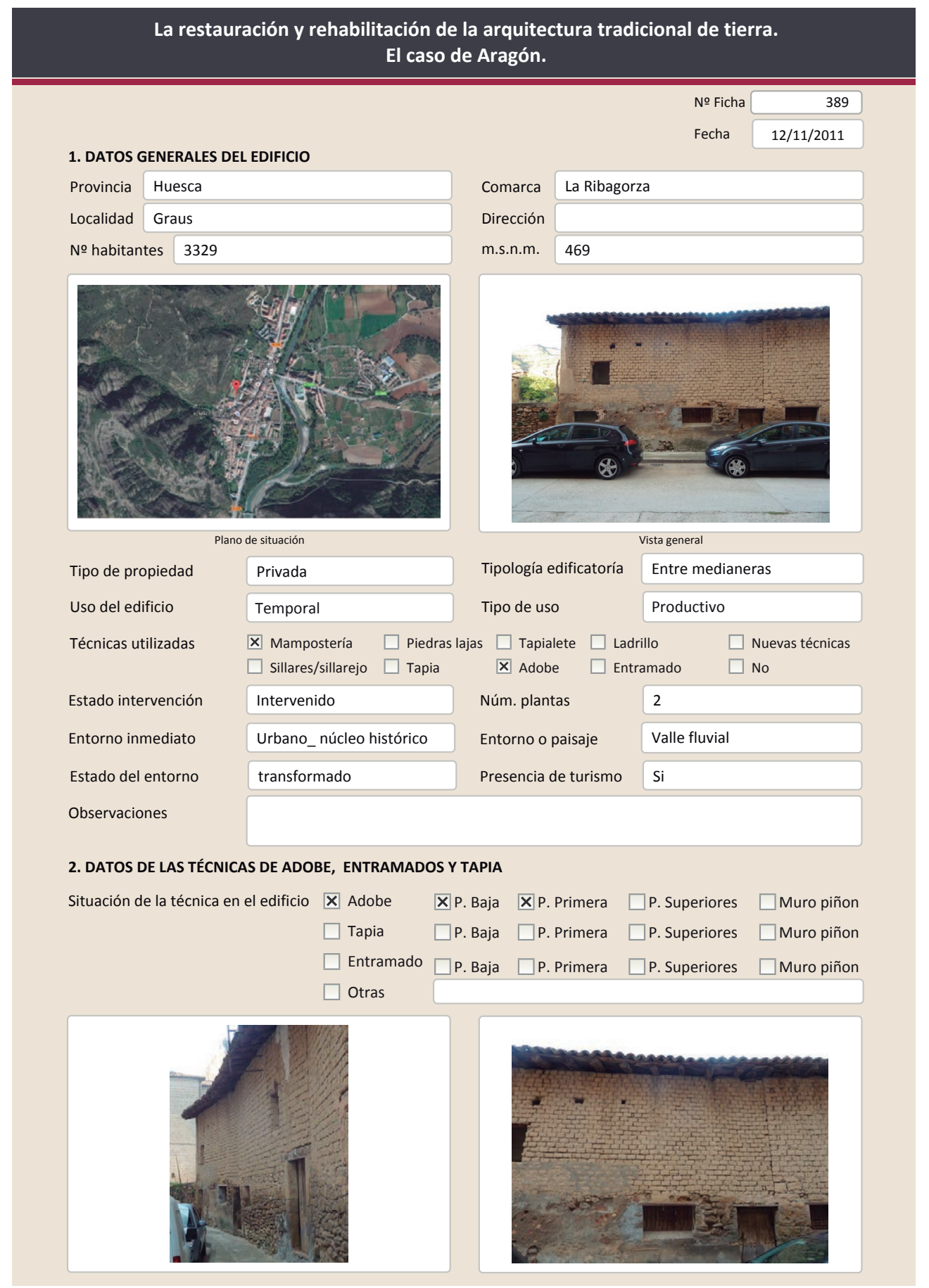

La restauración y rehabilitación de la arquitectura tradicional de tierra.

El caso de Aragón.

2.1. ADOBE

Dimensión de las piezas Dimensión del muro

Aparejo del muro

Función estructural
Color de las piezas

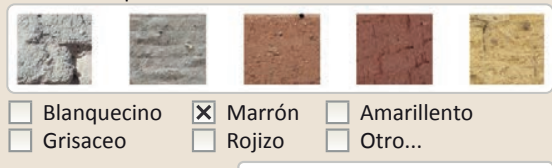

Grisaceo $\square$ Rojizo $\square$ Otro..

Variante constructiva/ tipo de fábrica

X Simple

$\square$ Suplementada en juntas

$\square$ Mixta

$\square$ Como suplemento

$\square$ Elementos de protección

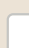

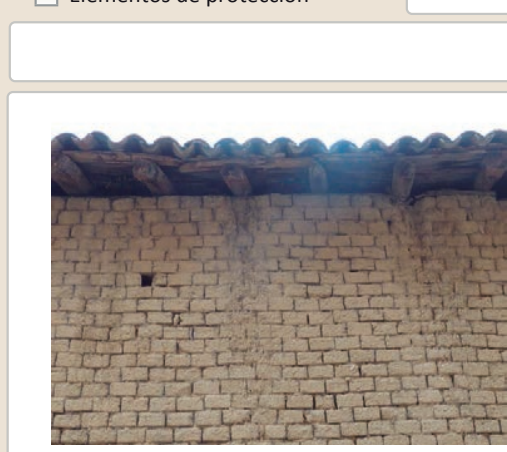

Lesiones $\quad \mathbf{X}$ Muro $\mathbf{X}$ Zócalo $\square$ Revestimiento

X Erosión del material $\mathbf{X}$ Humedad por capilaridad $\square$ Erosion de las juntas $\mathbf{X}$ Humedades (manch/eflo)

$\square$ Pérdida de sección $\square$ Pérdida de verticalidad

$\square$ Vegetación $\quad \square$ Grietas por empuje de la cubie

$\square$ Desconchados

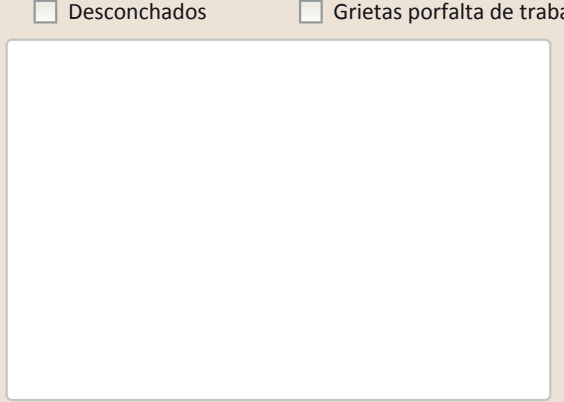

Observaciones

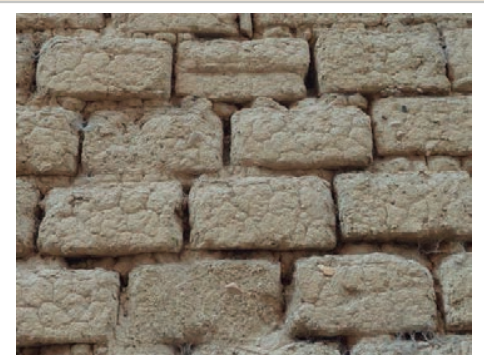

$\square$ Cubierta $\square$ Otro...

$\square$ Grietas por asentamiento $\square$ Colapso

$\square$ Por elementos impropios

$\boldsymbol{X}$ Derivado de intervenciones $\square$ Otro... 


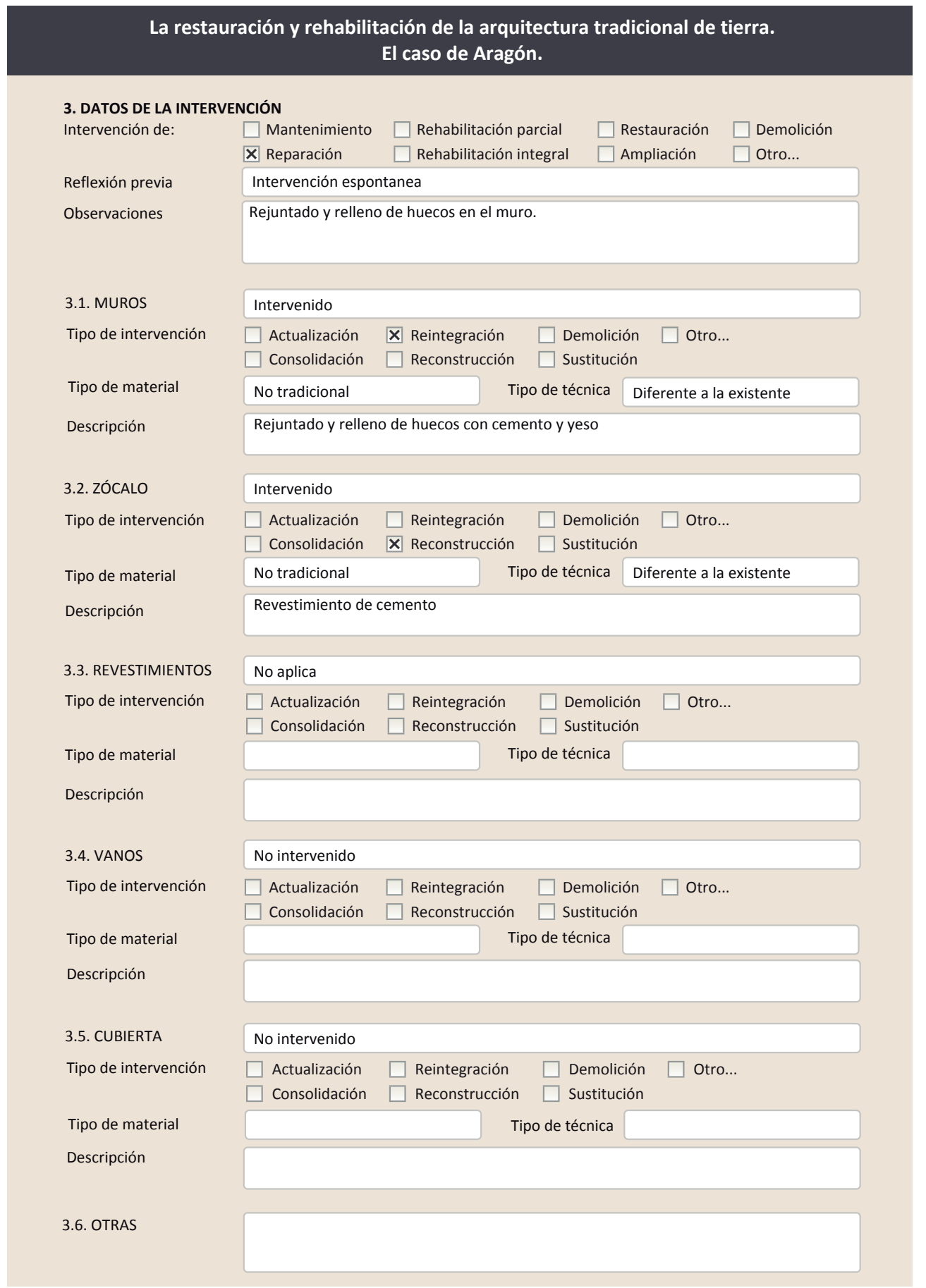

3.7. REHABILITACIÓN ENERGÉTICA $\square$ Fachada $\square$ Vanos $\square$ Forjados $\square$ Cubierta

Observaciones

FOTOGRAFÍAS DE LA INTERVENCIÓN
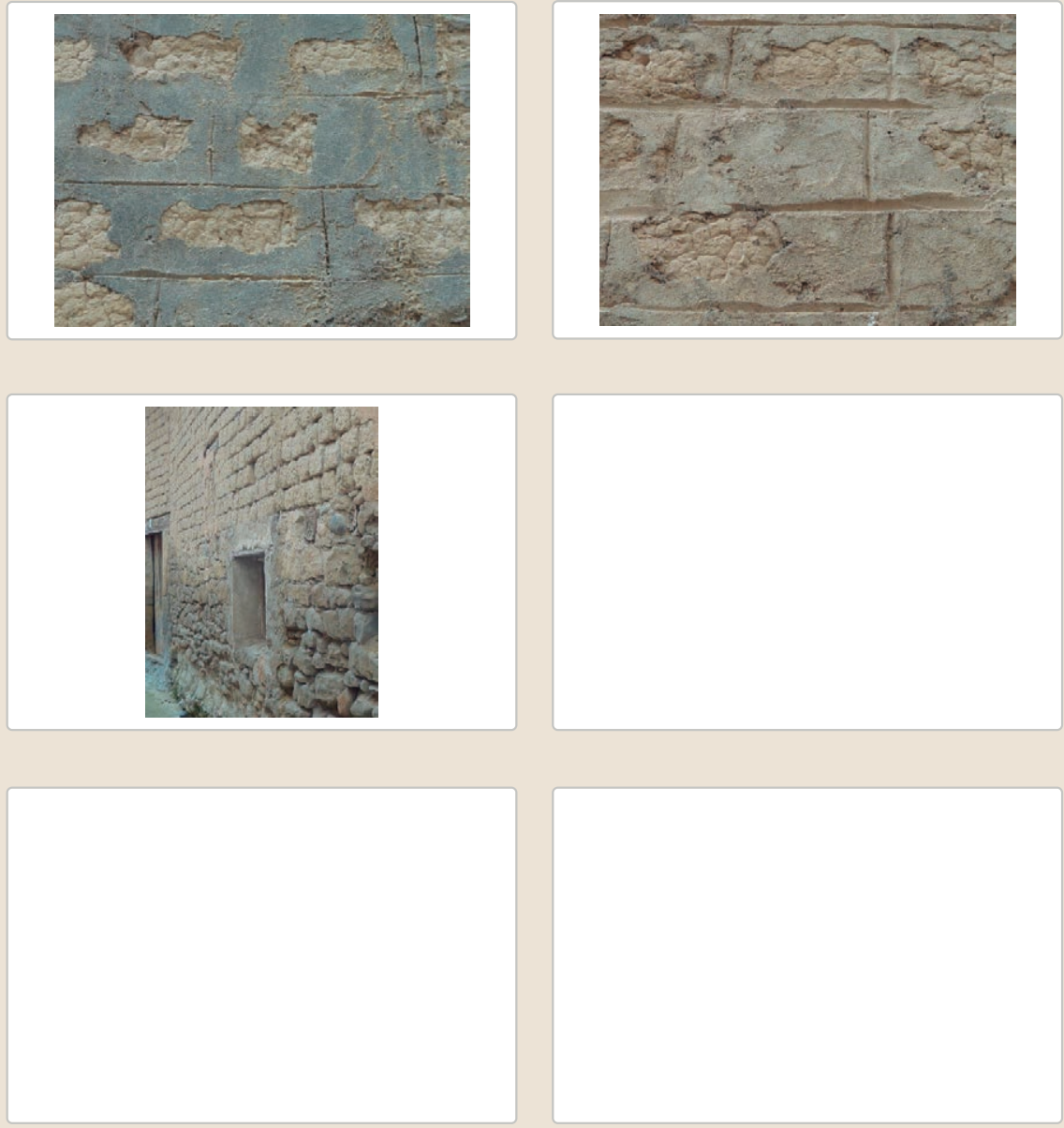


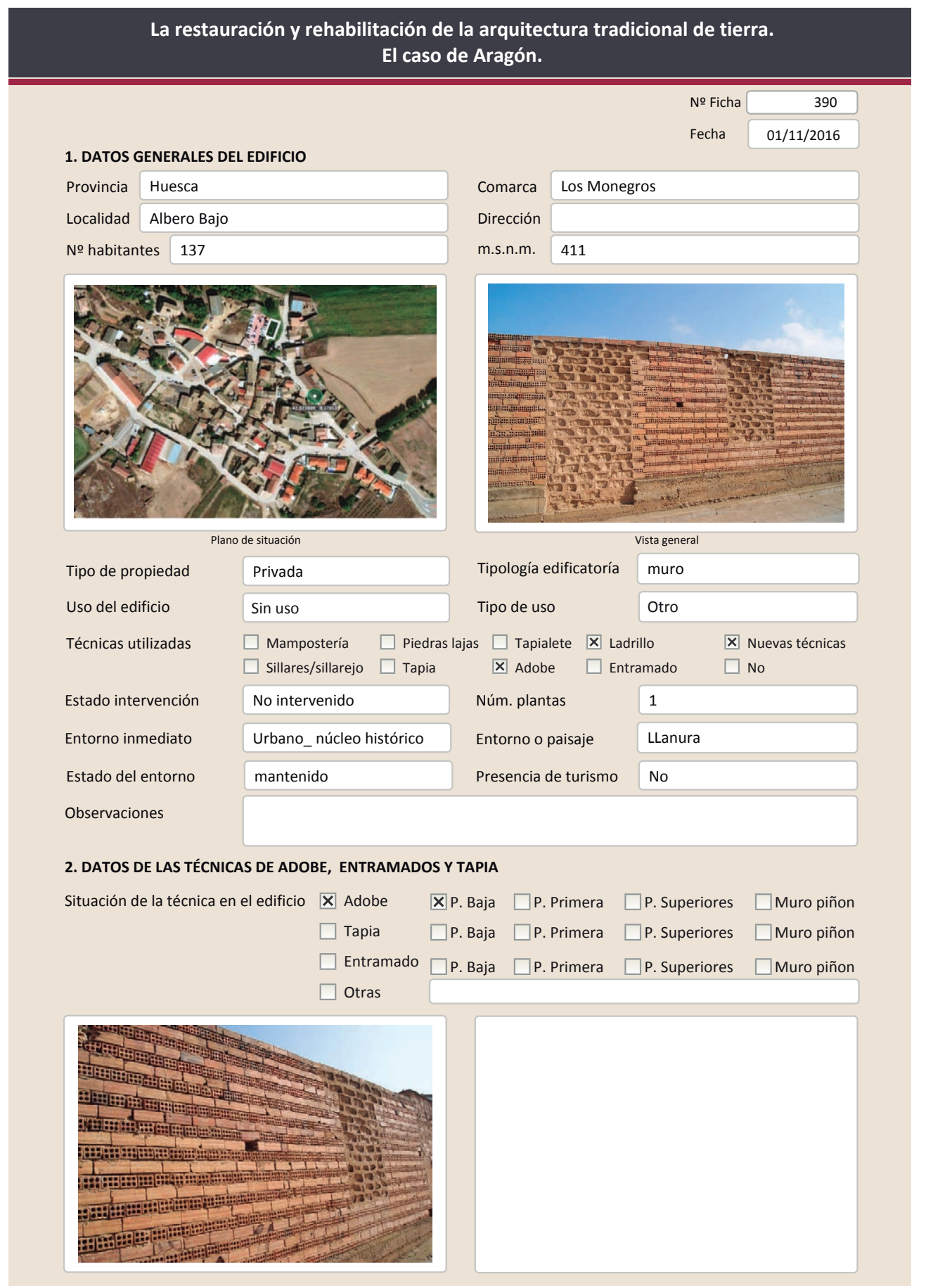

La restauración y rehabilitación de la arquitectura tradicional de tierra. El caso de Aragón.

2.1. ADOBE

Dimensión de las piezas

Dimensión del muro

Aparejo del muro

Función estructural

Variante constructiva/ tipo de fábrica

$\square$ simple

$\square$ Suplementada en juntas

X Mixta

\section{Machones}

Color de las piezas

$\square$ Como suplemento

$\square$ Elementos de protección

Adobe con mucha arcilla. <muro compuesto de adobe y ladrillo

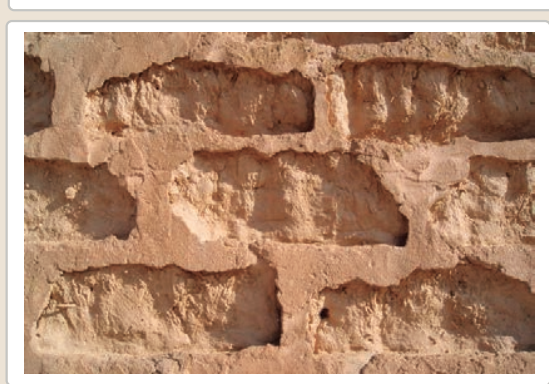

Lesiones $\quad \mathbf{X}$ Muro $\mathbf{X}$ Zócalo $\square$ Revestimiento

$\mathbf{X}$ Erosión del material $\mathbf{X}$ Humedad por capilaridad $\square$ Erosion de las juntas $\square$ Humedades (manch/eflo)

X Pérdida de sección $\square$ Pérdida de verticalidad

$\begin{array}{ll}\square \text { Vegetación } & \square \text { Grietas por empuje de la cuble } \\ \square \text { Desconchados } & \square \text { Grietas porfalta de traba }\end{array}$

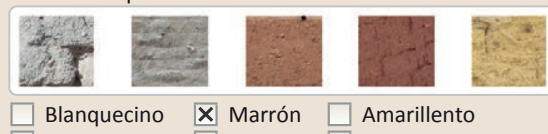

$\square$ Blanquecino $\mathbf{X}$ Marrón $\square$ Amarillento

Comp. - estabilizante

$\square$ Cubierta $\square$ otro...

$\square$ Grietas por asentamiento

$\mathbf{X}$ Colapso

$\square$ Por elementos impropios

$\square$ Derivado de intervenciones

$\square$ Otro...

$\square \mathrm{G}$

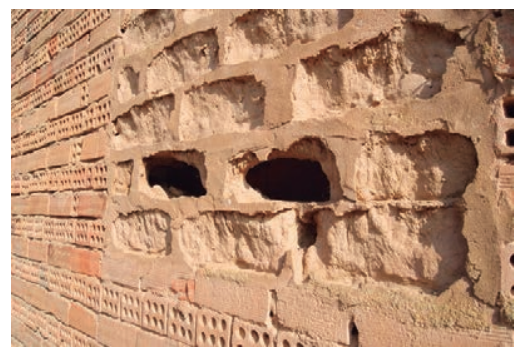

Observaciones

Perdida completa de algunas de las piezas

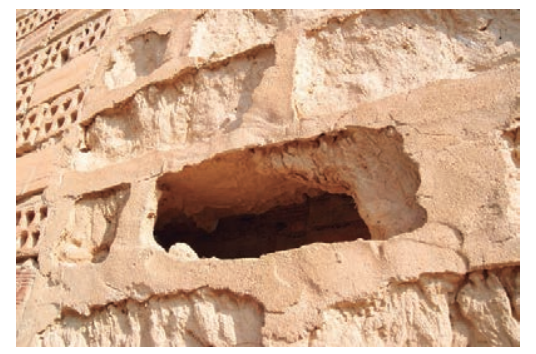




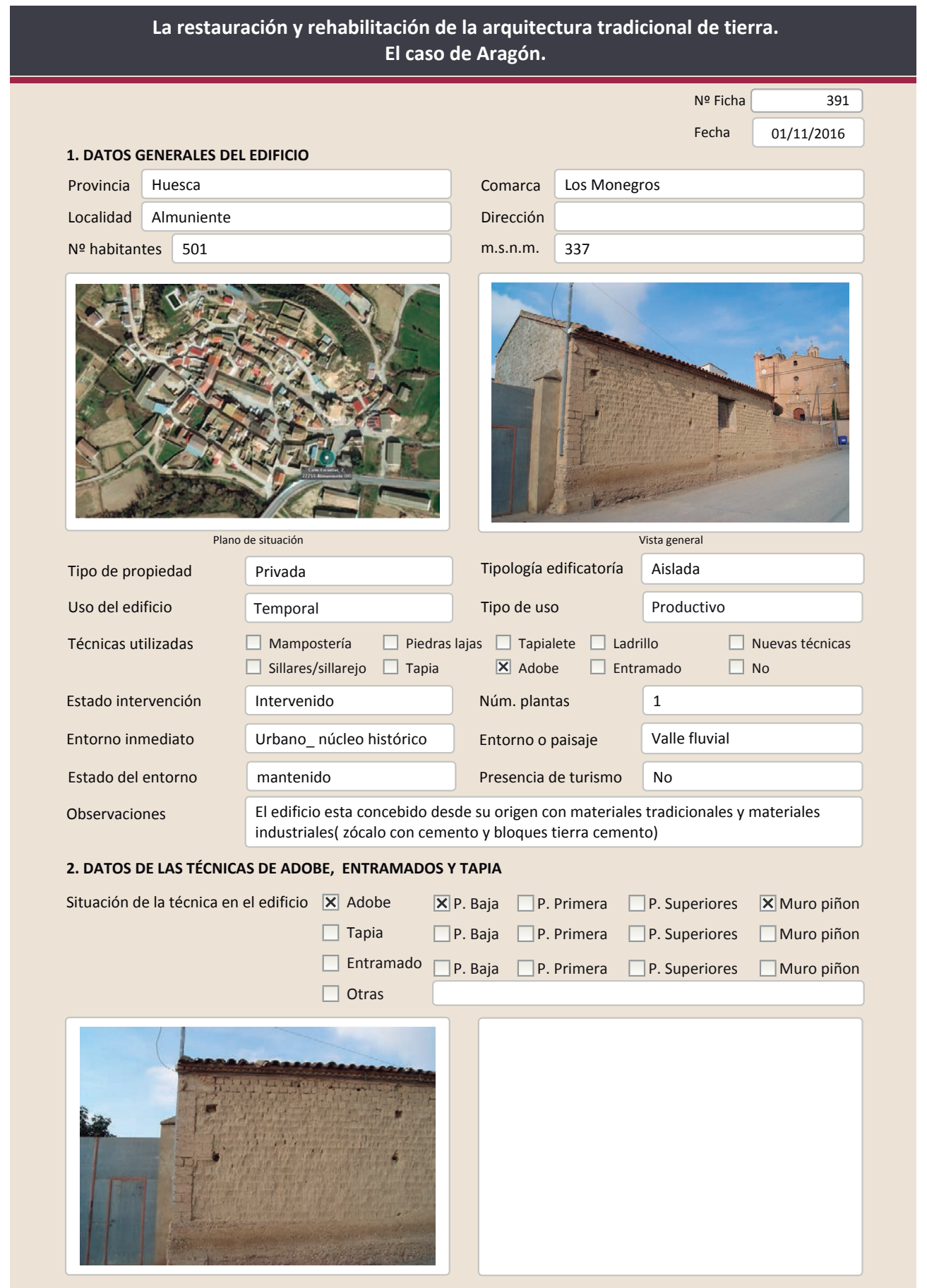

2.1. ADOBE

Dimensión de las piezas $38 \times 18 \times 14$

Dimensión del muro $30-40 \mathrm{~cm}$

Aparejo del muro Tizón

Función estructural

$\mathrm{Si}$

Variante constructiva/ tipo de fábrica

$\square$ Simple

$\square$ Suplementada en juntas

X Mixta

Machones

$\mathbf{X}$ Como suplemento

Mixto- Machones

$\square$ Elementos de protección

Existen dos tipos de adobes en el edificio: adobe tradicional y bloque tierra cemento Los otros $38 \times 18 \times 16$

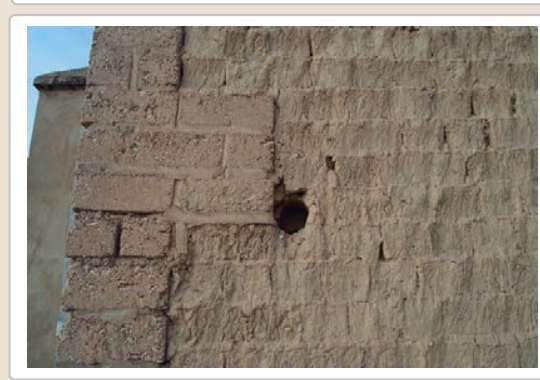

Lesiones ХMuro ХZŹcalo $\square$ Revestimiento

\ Erosión del material $\mathbf{X}$ Humedad por capilaridad

$\square$ Erosion de las juntas $\square$ Humedades (manch/eflo)

$\square$ Pérdida de sección $\square$ Pérdida de verticalidad

$\square$ Vegetación $\quad \square$ Grietas por empuje de la c

$\square$ Desconchado

$\square$ Grietas porfalta de trab

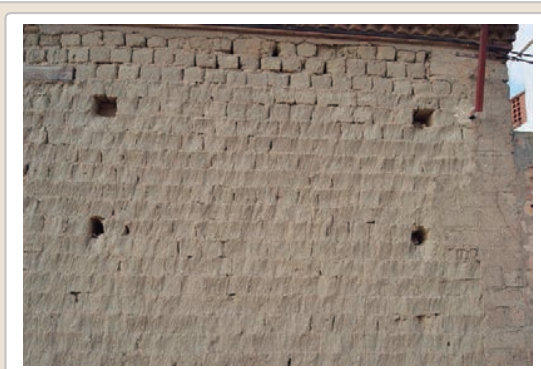

$\square$ Cubierta $\square$ otro...

$\square$ Grietas por asentamientos

$\square$ Colaps

$\square$ Por elementos impropios

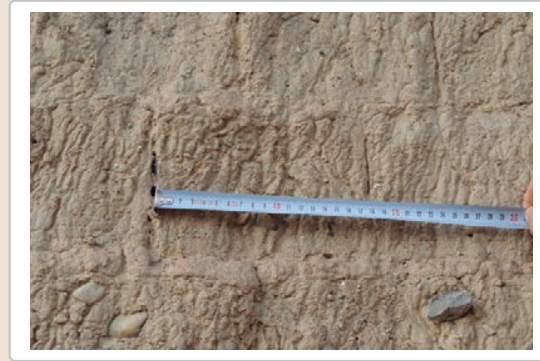

$\square$ Derivado
$\square$ Otro...

Observaciones 


\section{La restauración y rehabilitación de la arquitectura tradicional de tierra.}

\section{El caso de Aragón.}

3. DATOS DE LA INTERVENCIÓN

Intervención de:

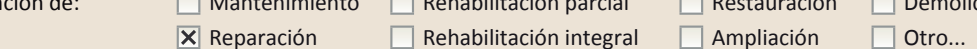

Reflexión previa Intervención espontanea

Observaciones

\subsection{MUROS} Tipo de intervención

Tipo de material

Descripción

3.2. ZÓCALO

Tipo de intervención

Tipo de material

Descripción

3.3. REVESTIMIENTOS

Tipo de intervención

Tipo de material

Descripción

3.4. VANOS

Tipo de intervención

Tipo de material

Descripción

3.5. CUBIERTA

Tipo de intervención

Tipo de material

Descripción

3.6. OTRAS

\section{No intervenido}

$\square$ Actualización $\square$ Reintegración $\square$ Demolición $\square$ Otro..

$\square$ Consolidación $\quad \square$ Reconstrucción $\square$ Sustitución

$\square$ Actualización $\quad \square$ Reintegración $\quad \square$ Demolición $\square$ Otro...

$\square$ Consolidación $\square$ Reconstrucción $\square$ sustitución

Tipo de técnica
La restauración y rehabilitación de la arquitectura tradicional de tierra.

El caso de Aragón.

Observaciones

FOTOGRAFÍAS DE LA INTERVENCIÓN
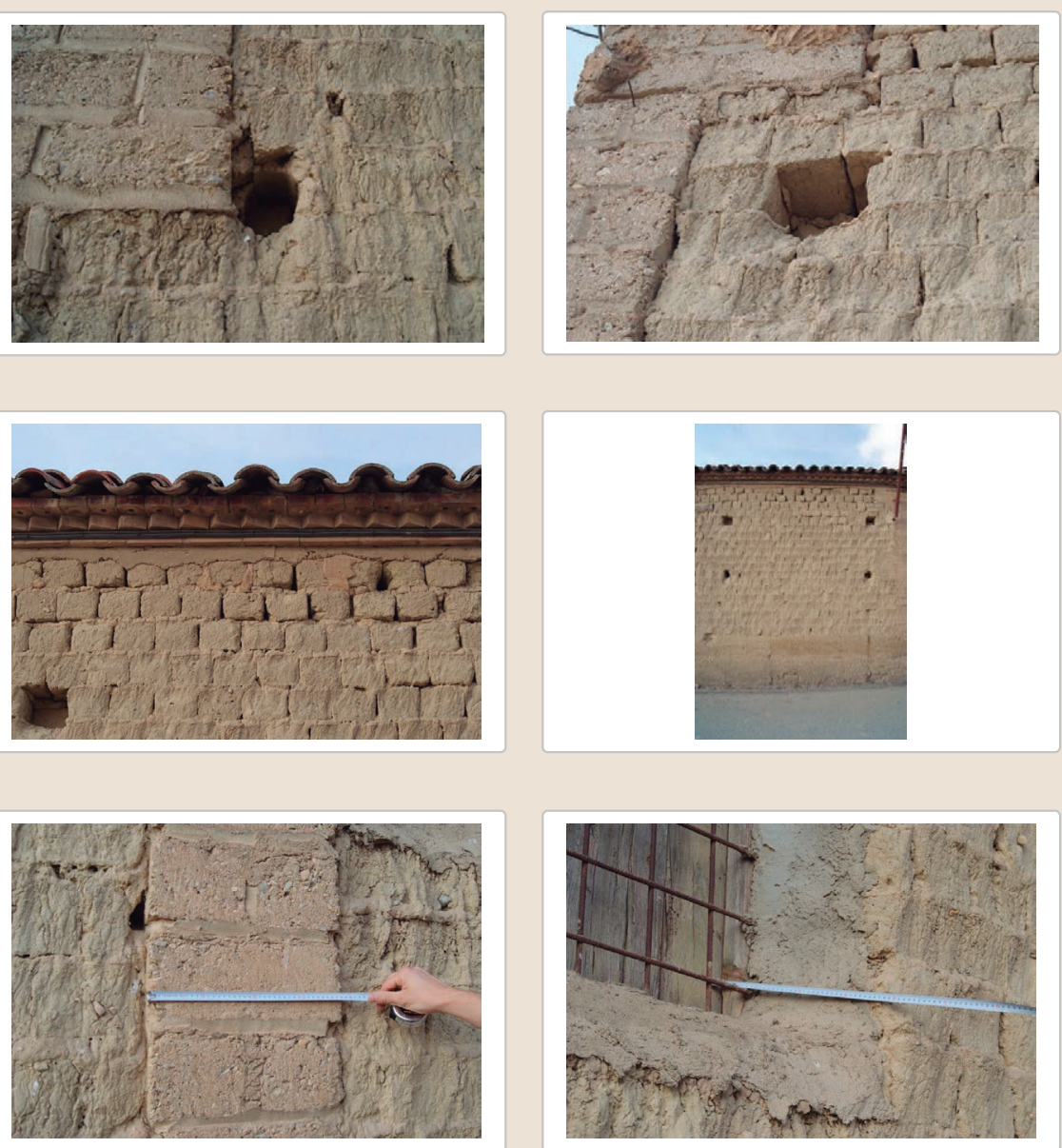


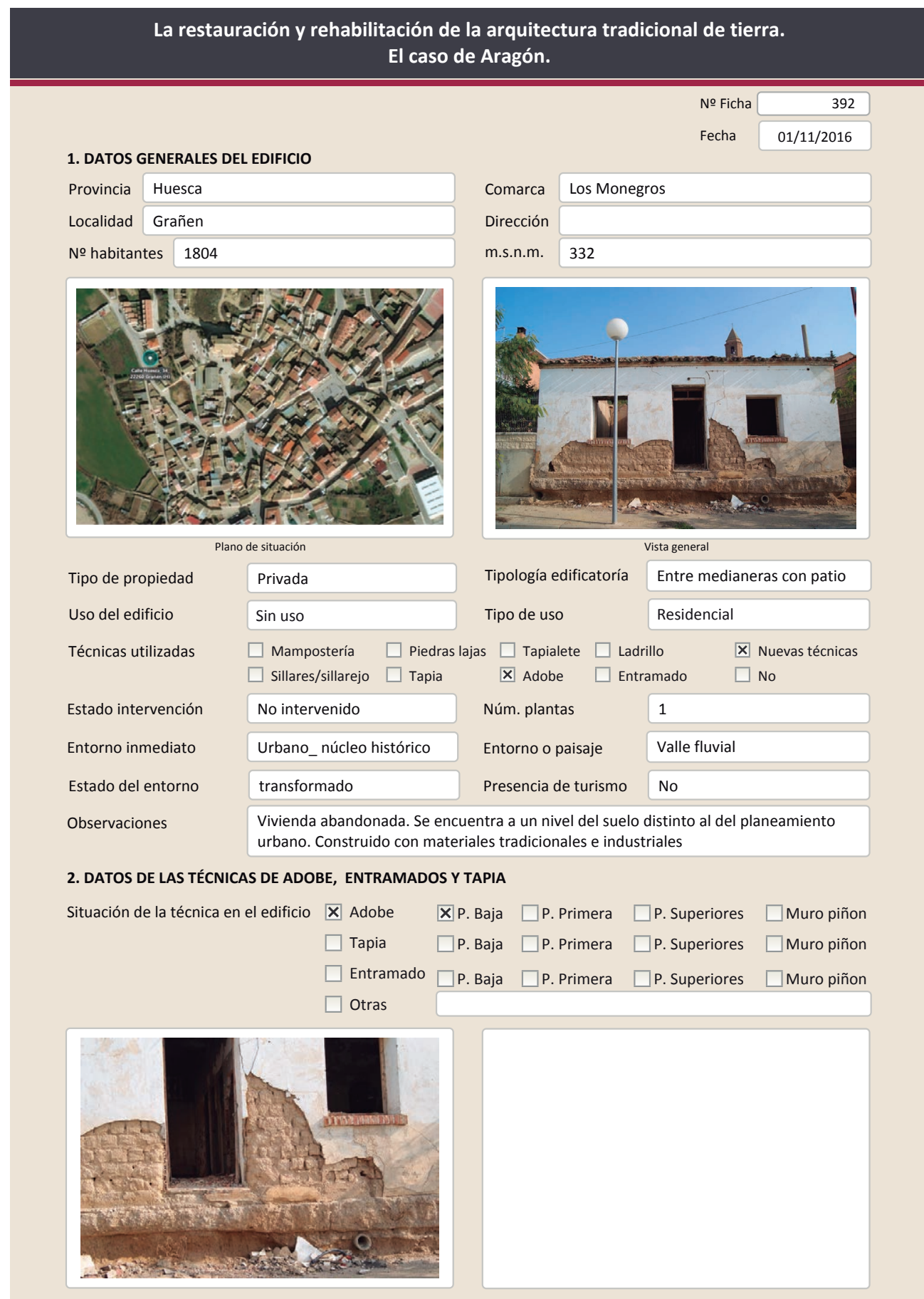

2.1. ADOBE

Dimensión de las piezas $35 \times 16,5 \times 14$

Dimensión del muro

Aparejo del muro

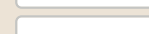

Función estructural

Tizón

$\mathrm{Si}$

tructiva/ tipo de fábrica

メ simple

$\square$ Suplementada en juntas

$\square$ Mixta

$\square$ Como suplemento

X Elementos de protección
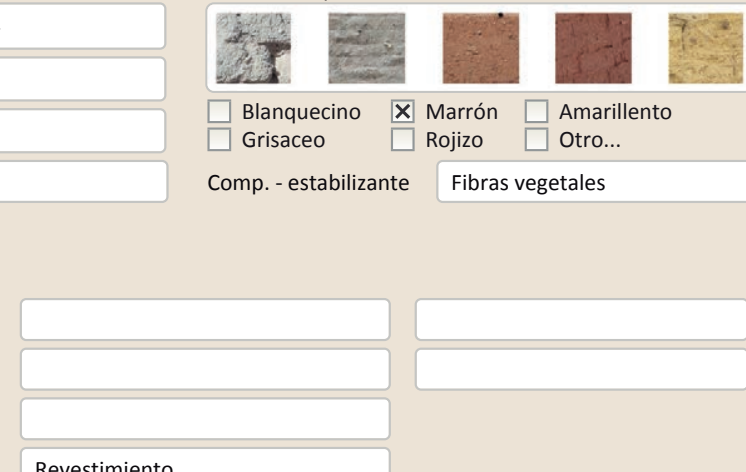

$\square$ Blanquecino $\mathbf{X}$ Marrón $\square$ Amarillento $\square$ Grisaceo $\square$ Rojizo $\square$ Otro...

Comp. - estabilizante Fibras vegetales

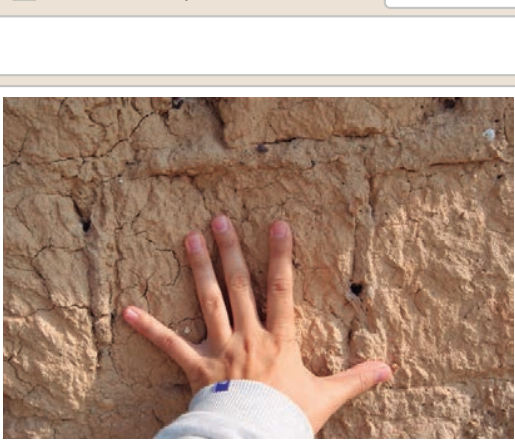

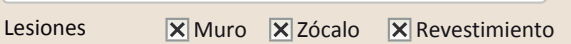
$\mathbb{X}$ Erosión del material $\mathbf{X}$ Humedad por capilaridad $\mathbf{X}$ Erosion de las juntas $\mathbf{X}$ Humedades (manch/eflo) \ Pérdida de sección $\square$ Pérdida de verticalidad

$\square$ Vegetación $\quad \square$ Grietas por empuje de la cube \ Desconchados

$\square$ Grietas porfalta de traba
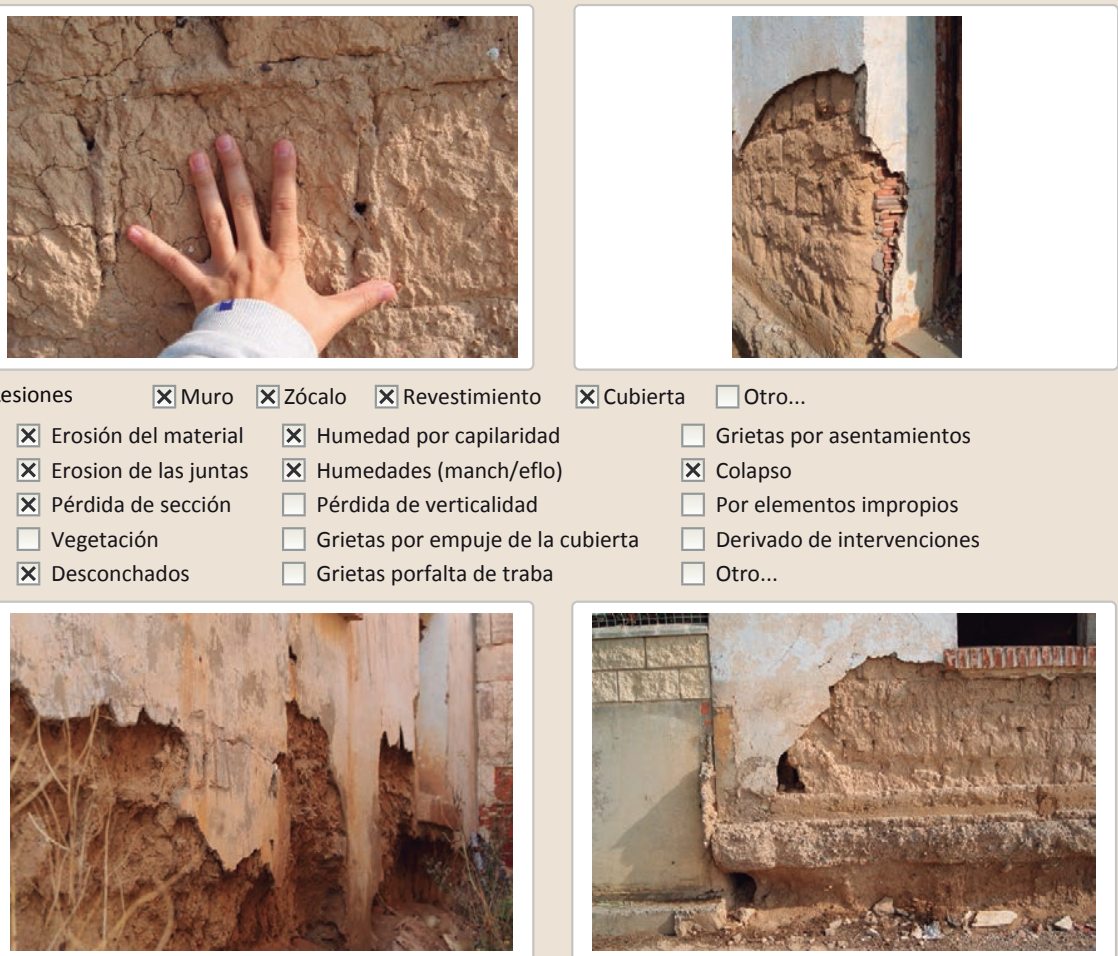

X Cubierta $\square$ Otro...

$\square$ Grietas por asentamiento $\mathbf{X}$ Colapso

$\square$ Por elementos impropios

$\square$ Derivado de intervenciones $\square$ Otro...

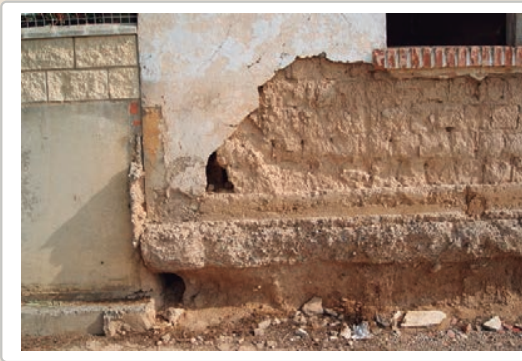

Observaciones El edificio se encuentra abandonado por lo que presenta problemas y derrumbes en muchos puntos 
La restauración y rehabilitación de la arquitectura tradicional de tierra.

$$
\text { El caso de Aragón. }
$$

3.7. REHABILITACIÓN ENERGÉTICA

$\square$ Fachada $\square$ Vanos $\square$ Forjados $\square$ Cubierta

Observaciones

FOTOGRAFÍAS DE LA INTERVENCIÓN
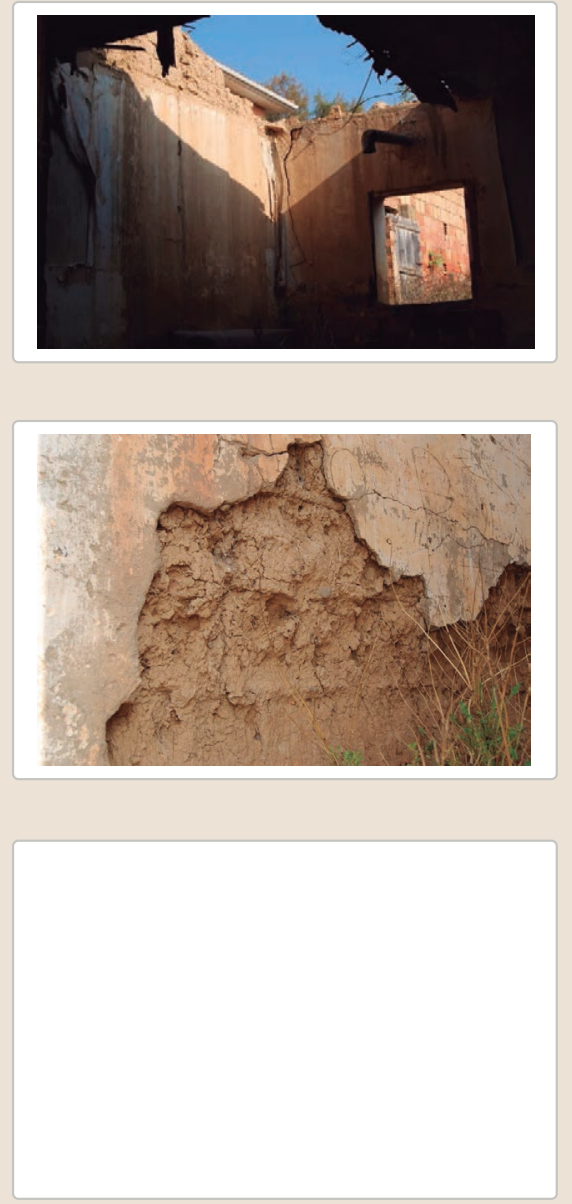
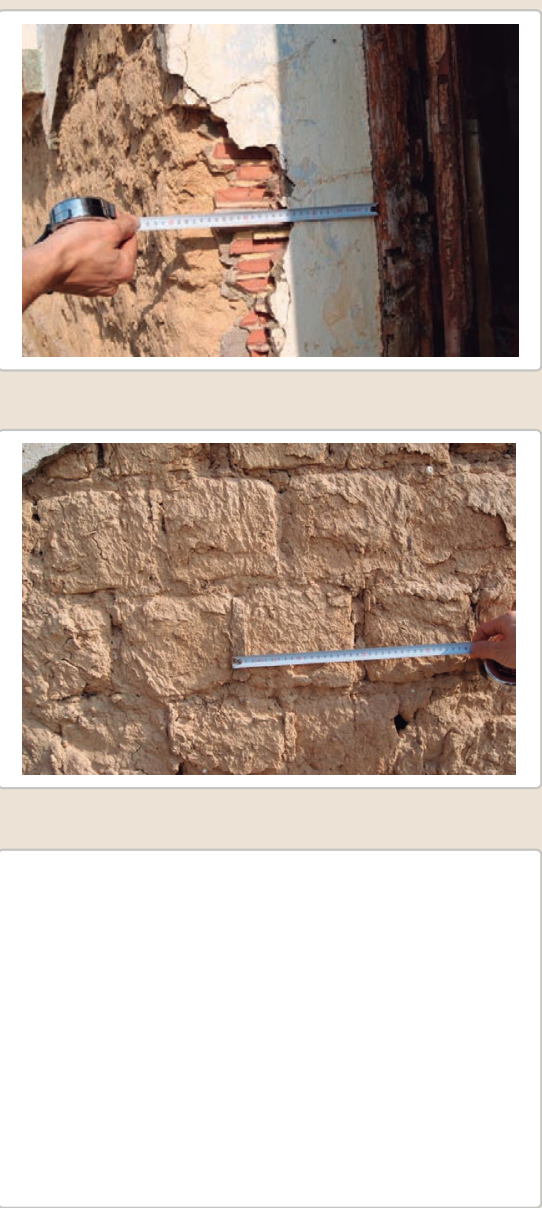


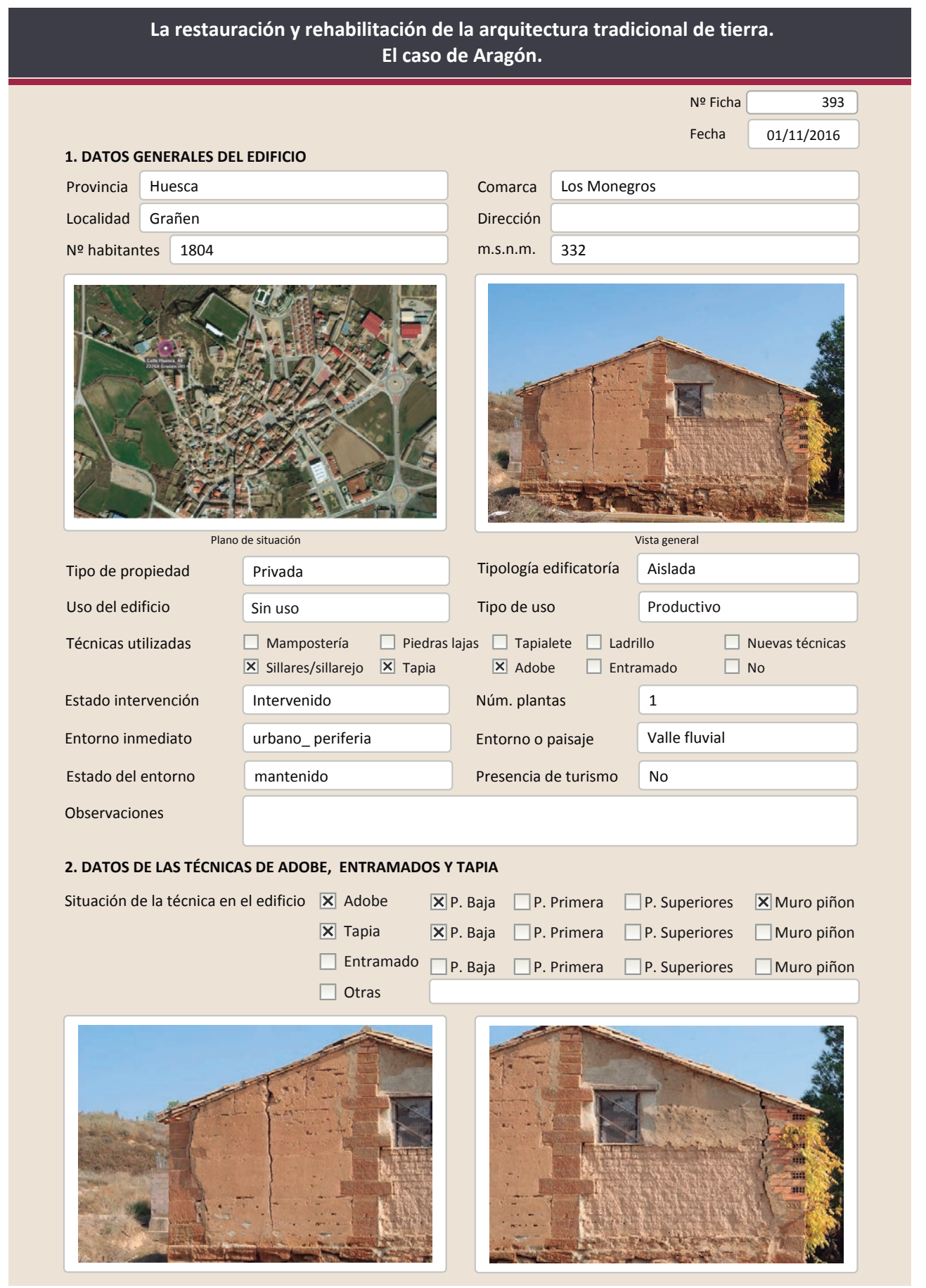

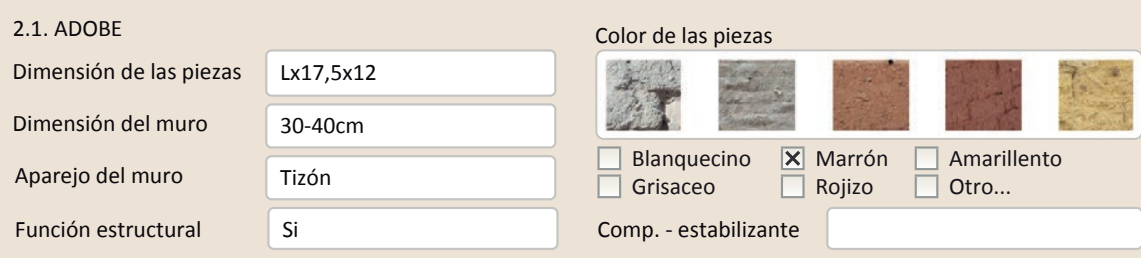

Función estructural $\mathrm{Si}$

Variante constructiva/ tipo de fábrica

$\square$ simple

$\square$ suplementada en juntas

X Mixta
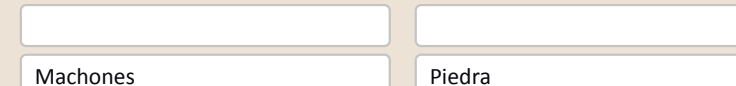

$\square$ Como suplemento

$\square$ Elementos de protección

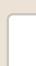

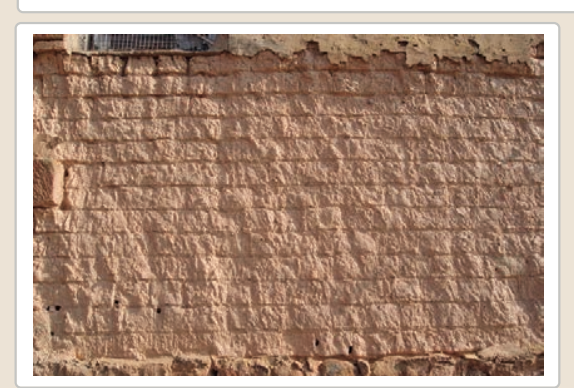

Lesiones ХMuro ХZócalo $\square$ Revestimiento $\mathbf{X}$ Erosión del material $\mathbf{X}$ Humedad por capilaridad $\mathbf{X}$ Erosion de las juntas $\square$ Humedades (manch/eflo) X Pérdida de sección $\quad \square$ Pérdida de verticalidad

$\square$ Vegetación $\quad \mathbf{X}$ Grietas por empuje de la cubie $\square$ Desconchados

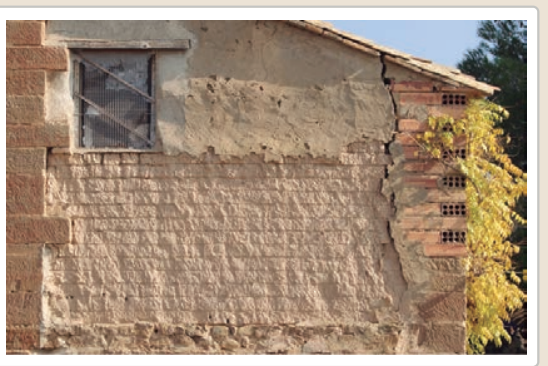

Observaciones
Todas las intervenciones realizadas con cemento se encuentran en un nivel alto de deterioro

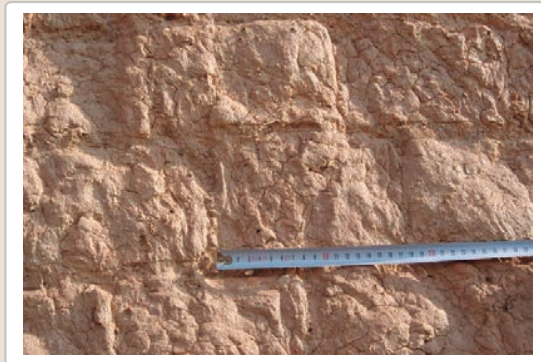

Cubierta $\square$ Otro..

$$
\begin{aligned}
& \square \text { Grietas por asentamientos } \\
& \square \text { Colapso } \\
& \square \text { Por elementos impropios } \\
& \mathbf{X} \text { Derivado de intervenciones }
\end{aligned}
$$
$\square$ Otro... 


\section{La restauración y rehabilitación de la arquitectura tradicional de tierra.} El caso de Aragón.

\subsection{TAPIA}

Ancho del muro

Dimensión tapiales

Tipo de aguja

№ agujas/cajón

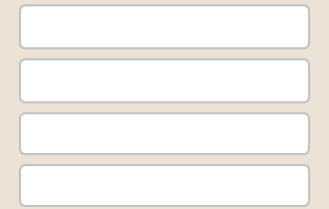

Color de la tapia

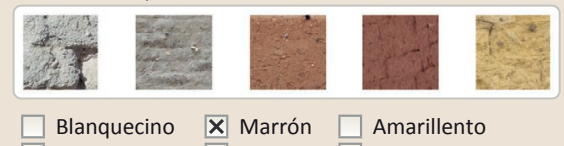
$\begin{array}{ll}\square \text { Blanquecino } & \boldsymbol{X} \text { Marrón } \\ \square \text { Grisaceo } & \square \text { Amarillento } \\ \text { Rojizo } & \square \text { Otro... }\end{array}$

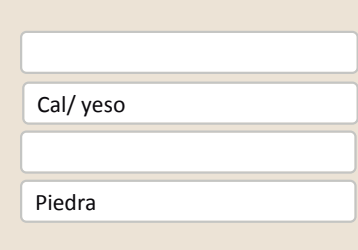

Variante constructiva

$\square$ Simple / homogénea

$\mathbf{X}$ Suplemento superficial

$\square$ Suplemento en juntas

X Mixta

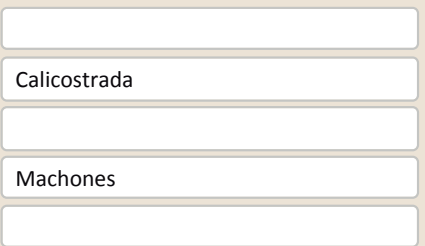

$\square$ Elementos de protección

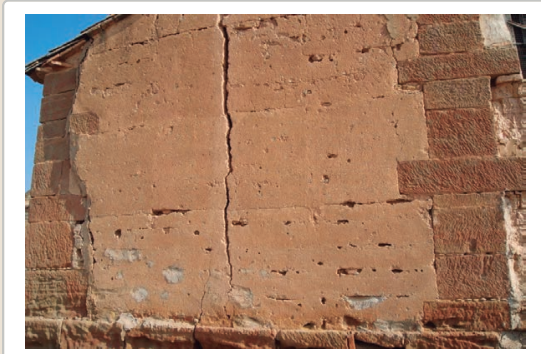

Lesiones

XMuro XZócalo $\square$ Revestimiento XCubierta $\square$ otro.

X Erosión del material $\quad \mathbf{X}$ Humedad por capilaridad $\quad \square$ Grietas por asentamientos

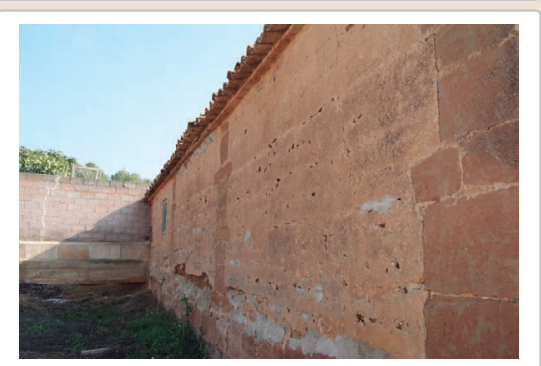

$\square$ Erosion de las juntas $\square$ Humedades (manch/eflo)

$\square$ Colapso

$X$ Pérdida de sección $\square$ Pérdida de verticalidad

$\square$ Por elementos impropios

$\square$ Vegetación

X Grietas por empuje de la

X Derivado de

$\mathbf{X}$ Desconchados

$\square$ Grietas porfalta de traba

$\square$ Otro..
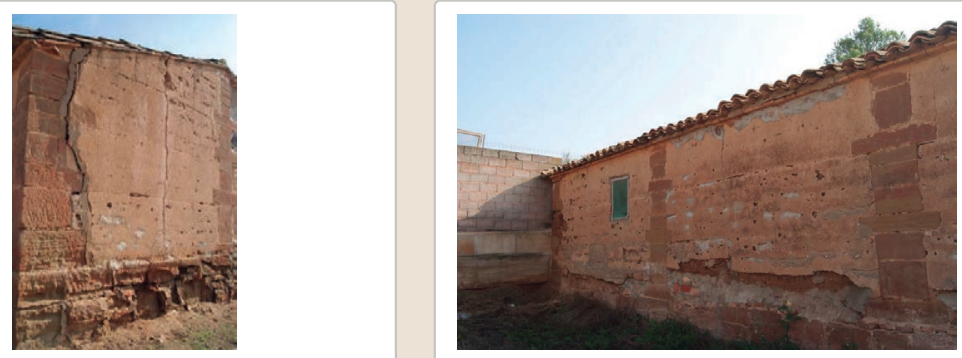

Observaciones
La restauración y rehabilitación de la arquitectura tradicional de tierra.

El caso de Aragón.

3. DATOS DE LA INTERVENCIÓN

Intervención de: $\quad \square$ Mantenimiento $\quad \square$ Rehabilitación parcial $\quad \square$ Restauración $\square$ Demolición

区 Reparación $\square$ Rehabilitación integral $\square$ Ampliación $\square$ Otro...

Reflexión previa Intervención espontanea

Observaciones Se ha intervenido sobre los problemas existentes pero simplemente intentando ocultarlos con cemento y no resolviéndolos

3.1. MUROS

Tipo de intervención

Intervenido

Tipo de material

$\square$ Actualización $\quad \boldsymbol{X}$ Reintegración $\quad \square$ Demolición $\square$ Otro..

$\square$ Consolidación $\square$ Reconstrucción $\quad \mathbb{X}$ Sustitución

Descripción

No tradicional Tipo de técnica Diferente a la existente

Descripción

Reintegración de oquedades y grietas con cemento. Sustitución parcial de un machón
de piedra por ladrillos.

3.2. ZÓCALO edra por ladrillos.

Tipo de intervención $\square$ Actualización $\mathbf{x}$ Reintegración $\square$ Demolición $\square$ Otro..

$\square$ Consolidación $\quad \square$ Reconstrucción $\square$ sustitución

\begin{tabular}{l|lll} 
Tipo de material & No tradicional & Tipo de técnica Diferente a la existente \\
\hline
\end{tabular}

Descripción

Reintegración con cemento

3.3. REVESTIMIENTOS

Tipo de intervención

Intervenido

\begin{tabular}{l|lll} 
Tipo de material To tradicional Tipo de técnica & Diferente a la existente
\end{tabular}

$\square$ Actualización $\quad \square$ Reintegración $\quad \square$ Demolición $\quad \square$ Otro...

Descripción

3.4. VANOS

Tipo de intervención

Revestimiento en el área construida con adobes. Más de la mitad de este revestimiento ya se ha desprendido.

Tipo de material

No intervenido

Descripción

$\square$ Consolidación $\quad \square$ Reconstrucción $\square$ Sustitución

3.5. CUBIERTA

Tipo de intervención

Tipo de material

Intervenido

$\square$ Actualización $\quad \mathbf{X}$ Reintegración $\quad \square$ Demolición $\square$ otro

$\square$ Consolidación $\square$ Reconstrucción $\square$ Sustitución

Descripción

No tradicional Tipo de técnica Similar a la existente

Reintegración parcial de las tejas con gran cantidad de cemento

3.6. OTRAS 
La restauración y rehabilitación de la arquitectura tradicional de tierra. El caso de Aragón

\section{La restauración y rehabilitación de la arquitectura tradicional de tierra.}

El caso de Aragón.

3.7. REHABILITACIÓN ENERGÉTICA $\square$ Fachada $\square$ Vanos $\square$ Forjados $\square$ Cubierta

Observaciones

FOTOGRAFÍAS DE LA INTERVENCIÓN
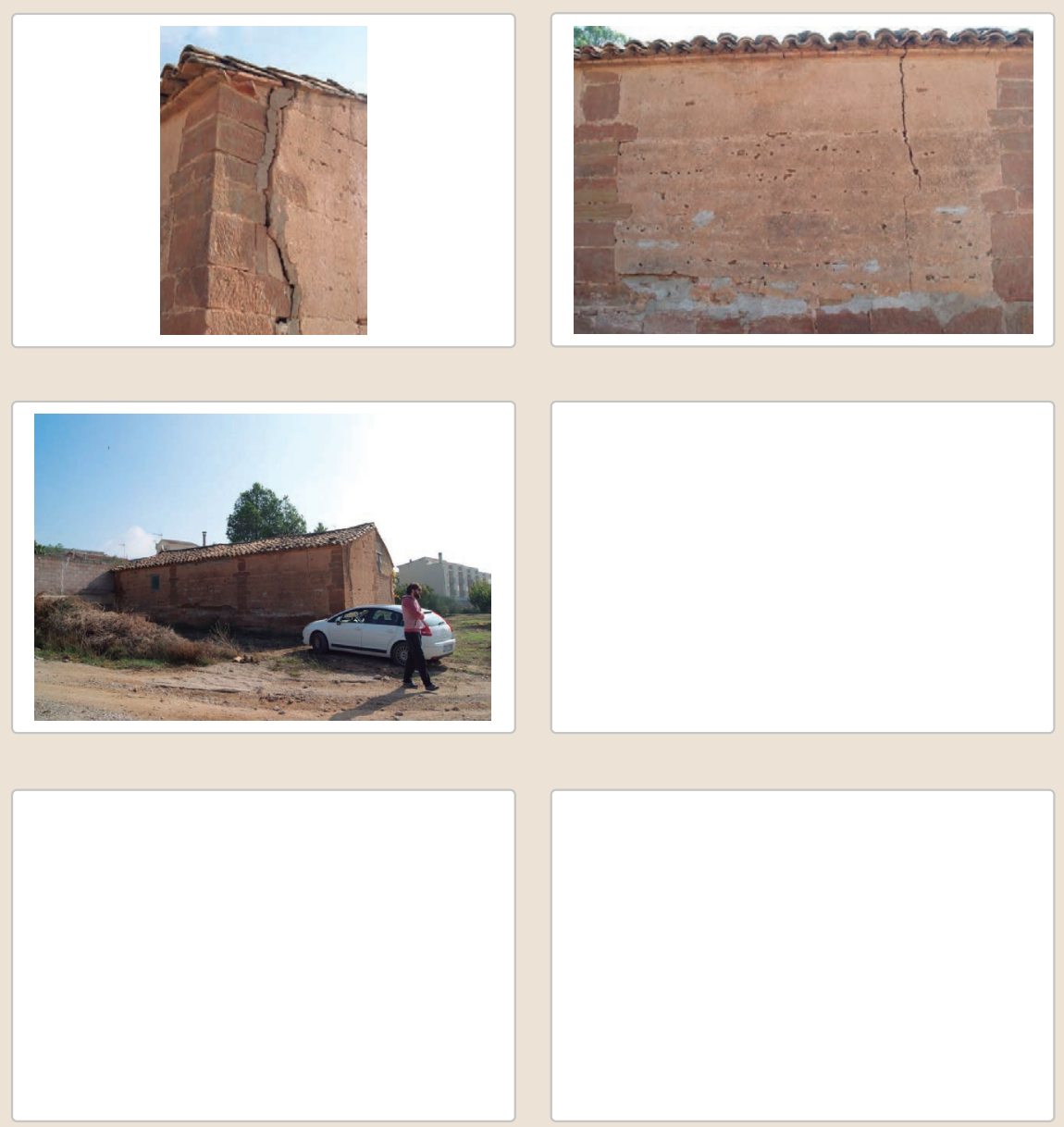


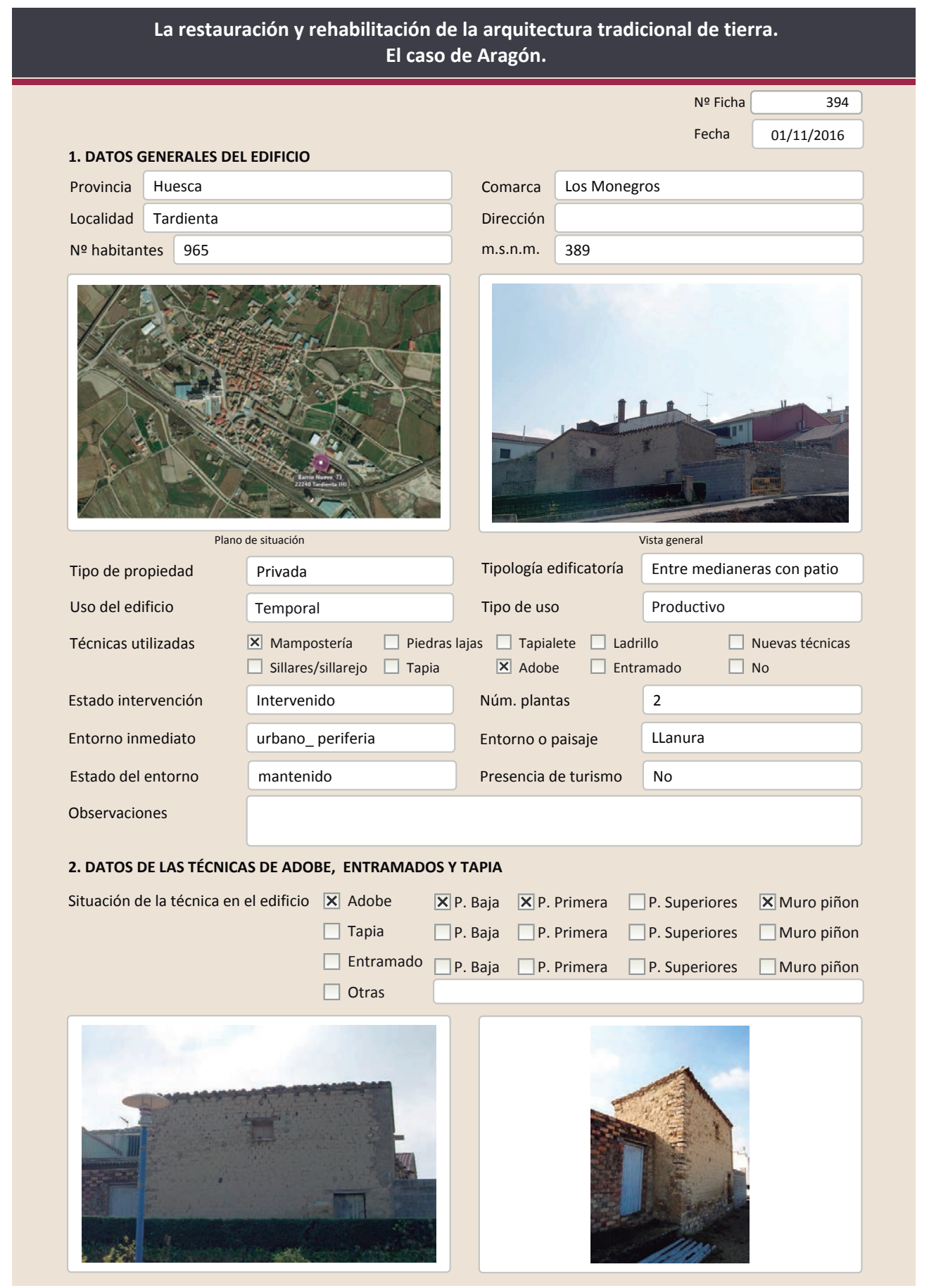

La restauración y rehabilitación de la arquitectura tradicional de tierra.

El caso de Aragón.

\begin{tabular}{l|l|} 
2.1. ADOBE & \\
Dimensión de las piezas & $38,5 \times 18 \times 11$ \\
\hline $\begin{array}{l}\text { Dimensión del muro } \\
\text { Aparejo del muro }\end{array}$ & $30-40 \mathrm{~cm}$ \\
\hline Función estructural & $\mathrm{Si}$
\end{tabular}

Función estructural

Variante constructiva/ tipo de fábrica
$\square$ simple
$\square$ Suplementada en juntas
区 Mixta
$\square$ Como suplemento
$\square$ Elementos de protección

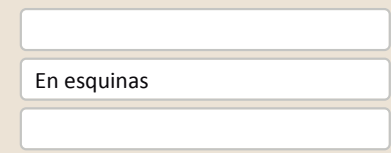

Color de las piezas

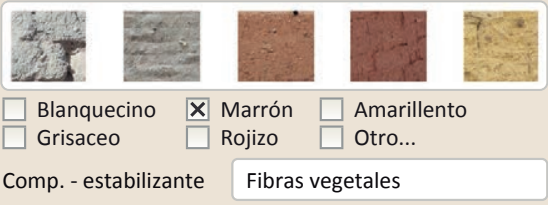

Comp. - estabilizante Fibras vege

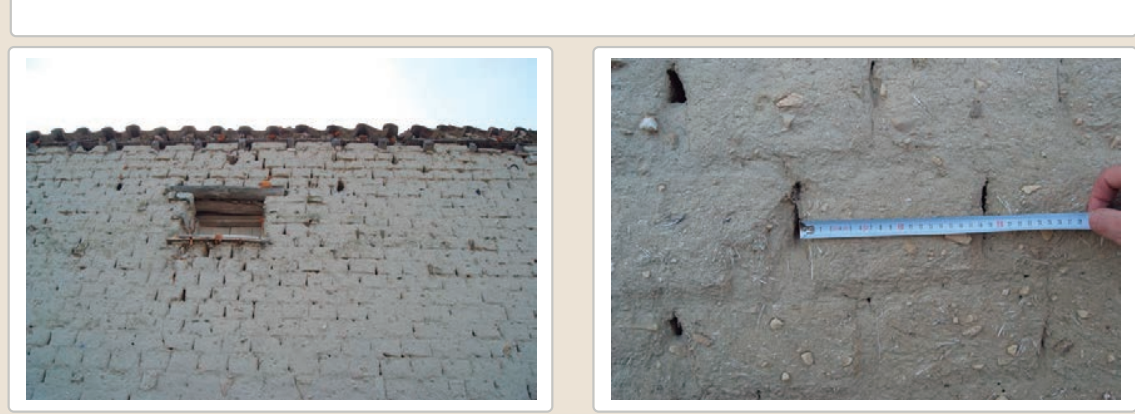

Lesiones $\quad \mathbf{X}$ Muro $\mathbf{X}$ Zócalo $\square$ Revestimiento $\square$ Cubierta $\square$ otro...

区 Erosión del material $\mathbf{X}$ Humedad por capilaridad $\quad \square$ Grietas por asentamientos $\mathbf{X}$ Erosion de las juntas $\mathbf{X}$ Humedades (manch/eflo) $\quad \square$ Colapso

X Pérdida de sección $\square$ Pérdida de verticalidad $\square$ Por elementos impropios

$\square$ Vegetación $\quad \square$ Grietas por empuje de la cubierta $\square$ Derivado de intervenciones

$\square$ Desconchados $\quad \square$ Grietas porfalta de traba

$\square$ Otro...
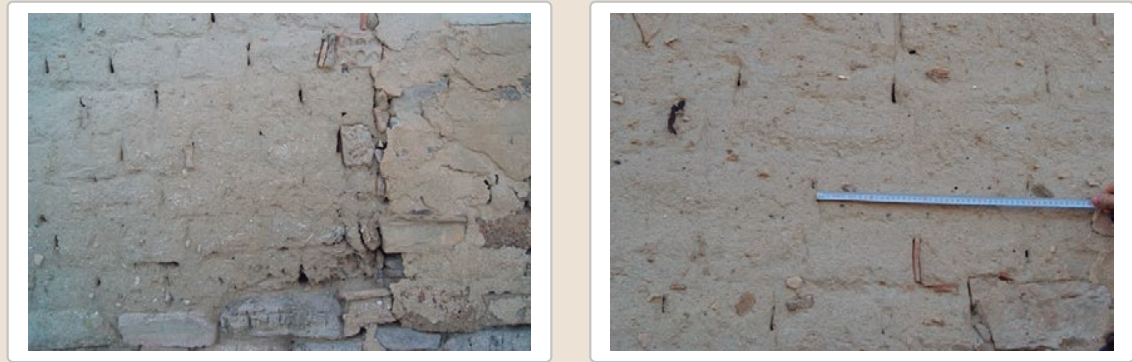

Observaciones 


\section{La restauración y rehabilitación de la arquitectura tradicional de tierra.} El caso de Aragón.

3. DATOS DE LA INTERVENCIÓN

Mantenimiento $\square$ Rehabilitación parcial $\quad \square$ Restauración $\quad \square$ Demolición X Reparación $\square$ Rehabilitación integral $\square$ Ampliación $\quad \square$ Otro...

Reflexión previa Intervención espontanea

Observaciones Reparación de uno de los laterales y reconstrucción de la cubiert

\subsection{MUROS}

Tipo de intervención

Tipo de material

Descripción

3.2. ZÓCALO

Tipo de intervención

Tipo de material

Descripción

3.3. REVESTIMIENTOS

Tipo de intervención

Tipo de material

Descripción

3.4. VANOS

Tipo de intervención

Tipo de material

Descripción

3.5. CUBIERTA

Tipo de intervención

Tipo de material

Descripción

3.6. OTRAS

\section{No intervenido}

$\square$ Actualización $\square$ Reintegración $\square$ Demolición $\square$ Otro.

$\square$ Consolidación $\quad \square$ Reconstrucción $\square$ Sustitución

$\square$ Actualización $\quad$ X Reintegración $\square$ Demolición $\square$ Otro..

$\square$ Consolidación $\square$ Reconstrucción $\square$ Sustitución

No tradicional Tipo de técnica Diferente a la existente

$\square$ Consolidación $\square$ Reconstrucción $\square$ Sustitución $\square$ Actualización $\square$ Reintegración $\square$ Demolición $\square$ Otro.

$\square$ Consolidación $\quad \mathbf{X}$ Reconstrucción $\square$ Sustitución

Reconstrucción de la cubierta con teja plana nueva colocada con poliestileno sobre el cañizo original

$\square$ Actualización $\square$ Reintegración $\square$ Demolición $\square$ Otro...

$\square$ Consolidación $\mathbb{X}$ Reconstrucción $\square$ Sustitución

No intervenido

Consolidación $\square$ Reconstrucción $\square$ Sustitución$$
\text { Tipo de técnica }
$$

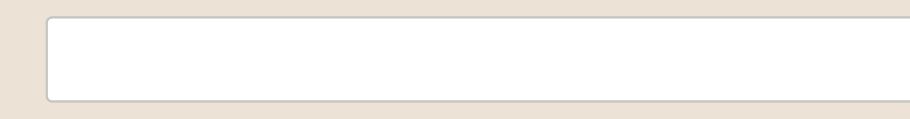

La restauración y rehabilitación de la arquitectura tradicional de tierra.

El caso de Aragón.

3.7. REHABILITACIÓN ENERGÉTICA $\square$ Fachada $\square$ Vanos $\square$ Forjados $\square$ Cubierta

Observaciones

FOTOGRAFíAS DE LA INTERVENCIÓN
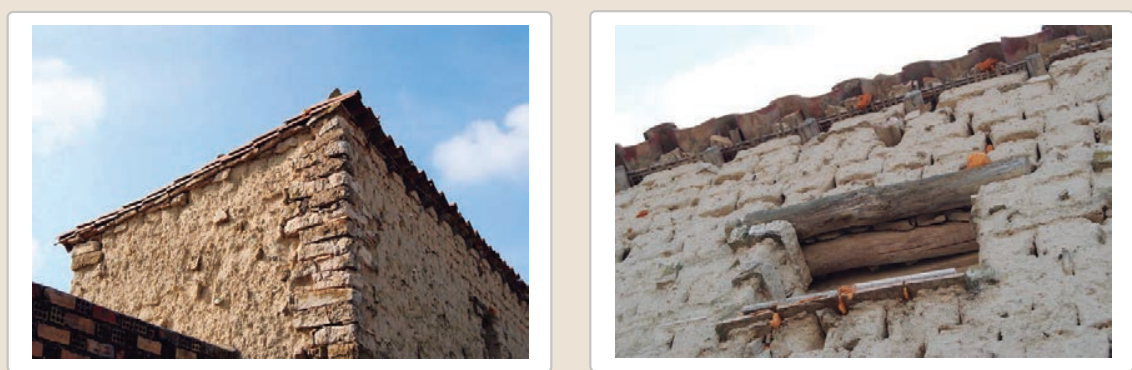
Reintegración de oquedades con poliestileno. Reintegración de la mampostería de una
de las esquinas con cemento
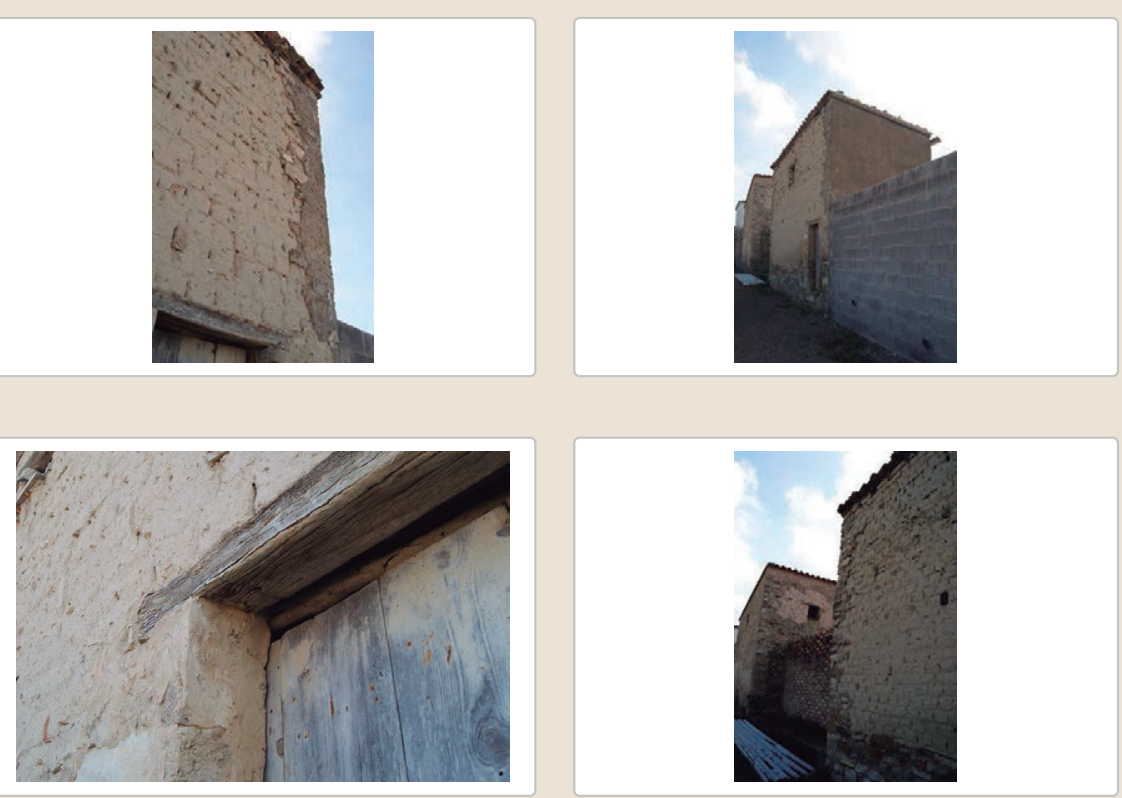

Revestimiento de cemento en una de las fachadas 
La restauración y rehabilitación de la arquitectura tradicional de tierra. El caso de Aragón.

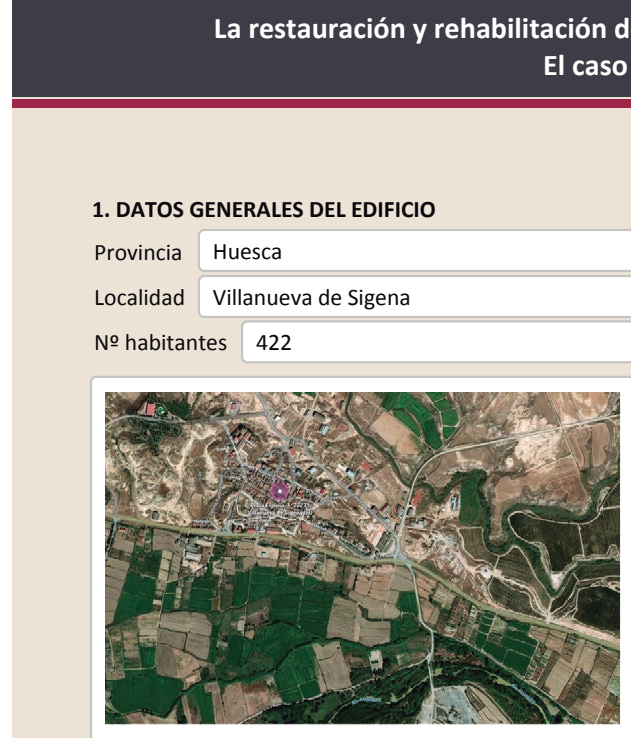

Plano de situación

Tipo de propiedad Privada

Uso del edificio Temporal

$\square$ Mampostería $\square$ Piedras lajas $\square$ Tapialete $\mathbf{X}$ Ladrillo $\square$ Nuevas técnicas $\square$ sillares/sillarejo $\mathbf{X}$ Tapia

Intervenido

Urbano_núcleo histórico

Estado intervención

mantenido

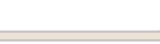

\section{D}

Fecha $22 / 05 / 2017$

Comarca Los Monegros

Dirección

m.s.n.m. 231

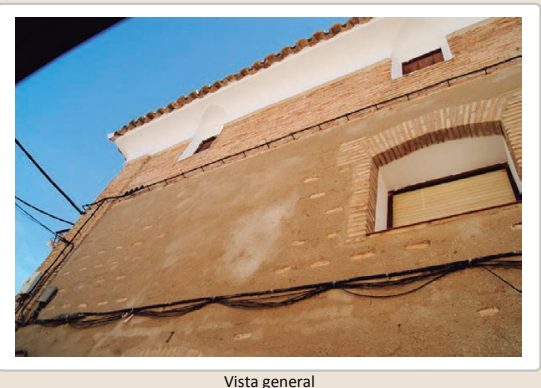

Tipología edificatoría En esquina

Tipo de uso Residencial

$\square$ Adobe $\square$ Entramado $\square$ No

Núm. plantas 3

Entorno o paisaje

Presencia de turismo

Valle fluvial

No

Observaciones

\section{DATOS DE LAS TÉCNICAS DE ADOBE, ENTRAMADOS Y TAPIA}

Situación de la técnica en el edificio $\square$ Adobe $\quad \square$ P. Baja $\quad \square$ P. Primera $\quad \square$ P. Superiores $\square$ Muro piñon

Х Tapia $\quad$ ХP. Baja $\quad$ XP. Primera $\square$ P. Superiores $\square$ Muro piñon

$\square$ Entramado $\square$ P. Baja $\square$ P. Primera $\square$ P. Superiores $\square$ Muro piñon

$\square$ Otras
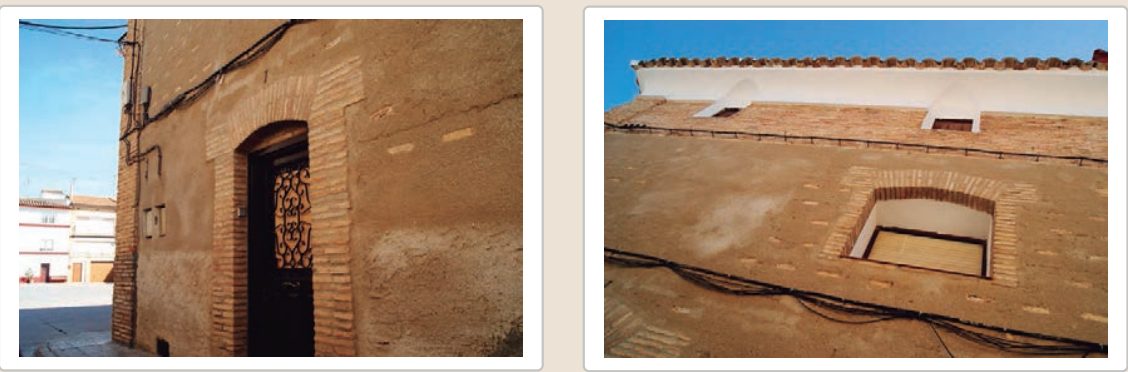

La restauración y rehabilitación de la arquitectura tradicional de tierra.

El caso de Aragón.

\subsection{TAPIA}

Ancho del muro

Dimensión tapiales

Tipo de aguja

№ agujas/cajón

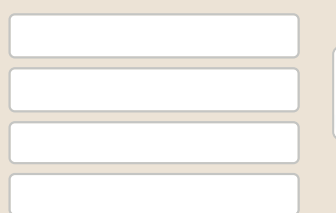

Color de la tapia

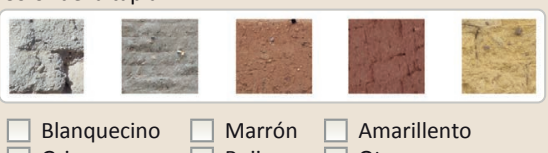

$\square$ Blanquecino $\square$ Marrón $\square$ Amarillento
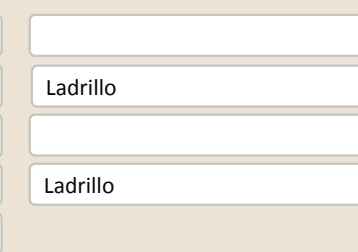

$\square$ Elementos de protección
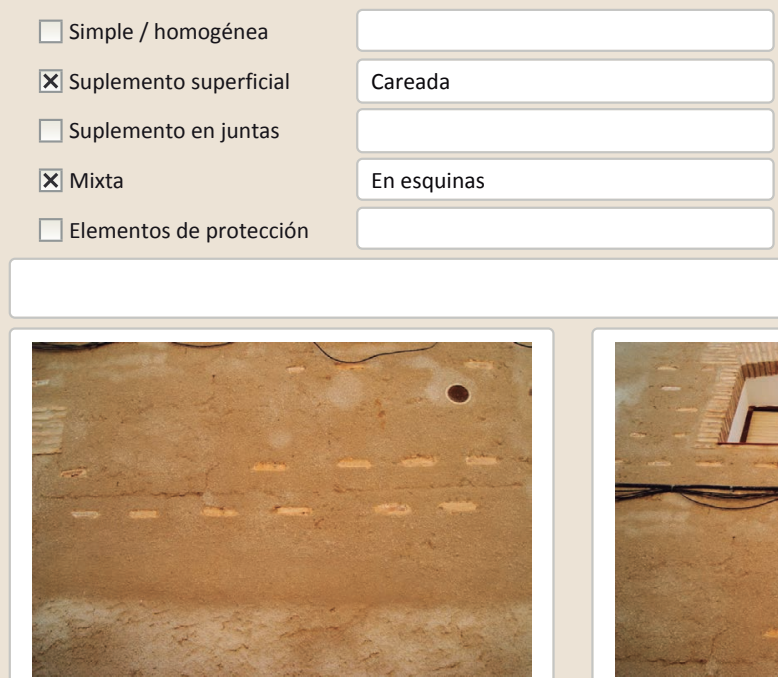

Lesiones $\square$ Muro $\mathbf{X}$ Zócalo $\square$ Revestimiento $\square$ Cubierta $\square$ Otro...

$\square$ Erosión del material $\quad \mathbf{X}$ Humedad por capilaridad $\quad \square$ Grietas por asentamientos

$\square$ Erosion de las juntas $\mathbf{X}$ Humedades (manch/eflo)

$\square$ Pérdida de sección $\square$ Pérdida de verticalidad

$\square$ Vegetación $\square$ Grietas por empuje de la cubieta

$\square$ Vesconion

$\square$ Grietas por empuje de la cubic
$\square$ Grietas porfalta de traba

$\square$ Desconchados

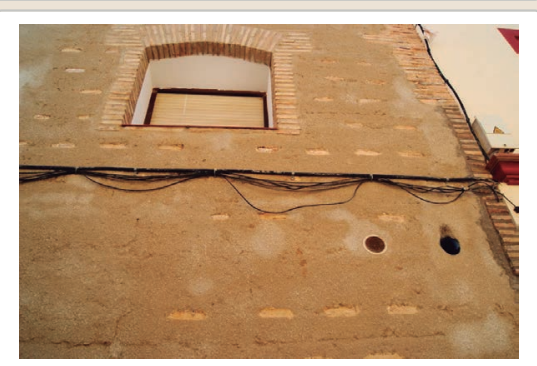

$\square$ Por elementos impropios

$\square$ Derivado de intervenciones $\mathbf{X}$ Otro... 
La restauración y rehabilitación de la arquitectura tradicional de tierra. El caso de Aragón

\section{La restauración y rehabilitación de la arquitectura tradicional de tierra.}

\section{El caso de Aragón.}

3. DATOS DE LA INTERVENCIÓN

Intervención de:

$\square$ Mantenimiento $\mathbf{X}$ Rehabilitación parcia

$\square$ Restauración $\square$ Demolición

Reflexión previa

X Reparación

Rehabilitación integra

Ampliación

$\square$ Otro..

Observaciones

Intervención planificada

3.1. MUROS

No visible

Tipo de intervención

$\square$ Actualización $\quad \square$ Reintegración $\quad \square$ Demolición $\square$ Otro...

$\square$ Consolidación $\square$ Reconstrucción $\square$ sustitución

Tipo de material

Descripción

3.2. ZÓCALO

Tipo de intervención

Intervenido

Tipo de intervención

$\square$ Actualizació

Tipo de material

Descripción

Tipo de técnica Diferente a la existente

3.3. REVESTIMIENTOS

revestimiento de cemento

Tipo de intervención

Intervenido

$\square$ Actualización

Tipo de material

$\square$ Consolidación

$\square$ Reintegración $\square$ Demolición $\square$ Otro...

No tradicional

X Reconstrucción $\square$ Sustitución

Descripción

Diferente a la existente

3.4. VANOS

Intervenido

Tipo de intervención

$\square$ Actualización $\square$ Reintegración $\square$ Demolición $\square$ Otro...

$\square$ Consolidación $\square$ Reconstrucción $\quad \boldsymbol{x}$ Sustitución

Tipo de material

Tradicional diferente Tipo de técnica Diferente a la existente

Descripción

El recercado de los huecos con ladrillo parece nuevo. Incorporación de persianas en los huecos

3.5. CUBIERTA

Intervenido

Tipo de intervención

$\square$ Actualización $\square$ Reintegración $\quad \square$ Demolición $\square$ Otro.

Tipo de material

$\square$ Consolidación $\quad \mathbf{X}$ Reconstrucción $\square$ Sustitución

Descripción

No tradicional

Tipo de técnica Diferente a la existente

3.6. OTRAS 
La restauración y rehabilitación de la arquitectura tradicional de tierra. El caso de Aragón.

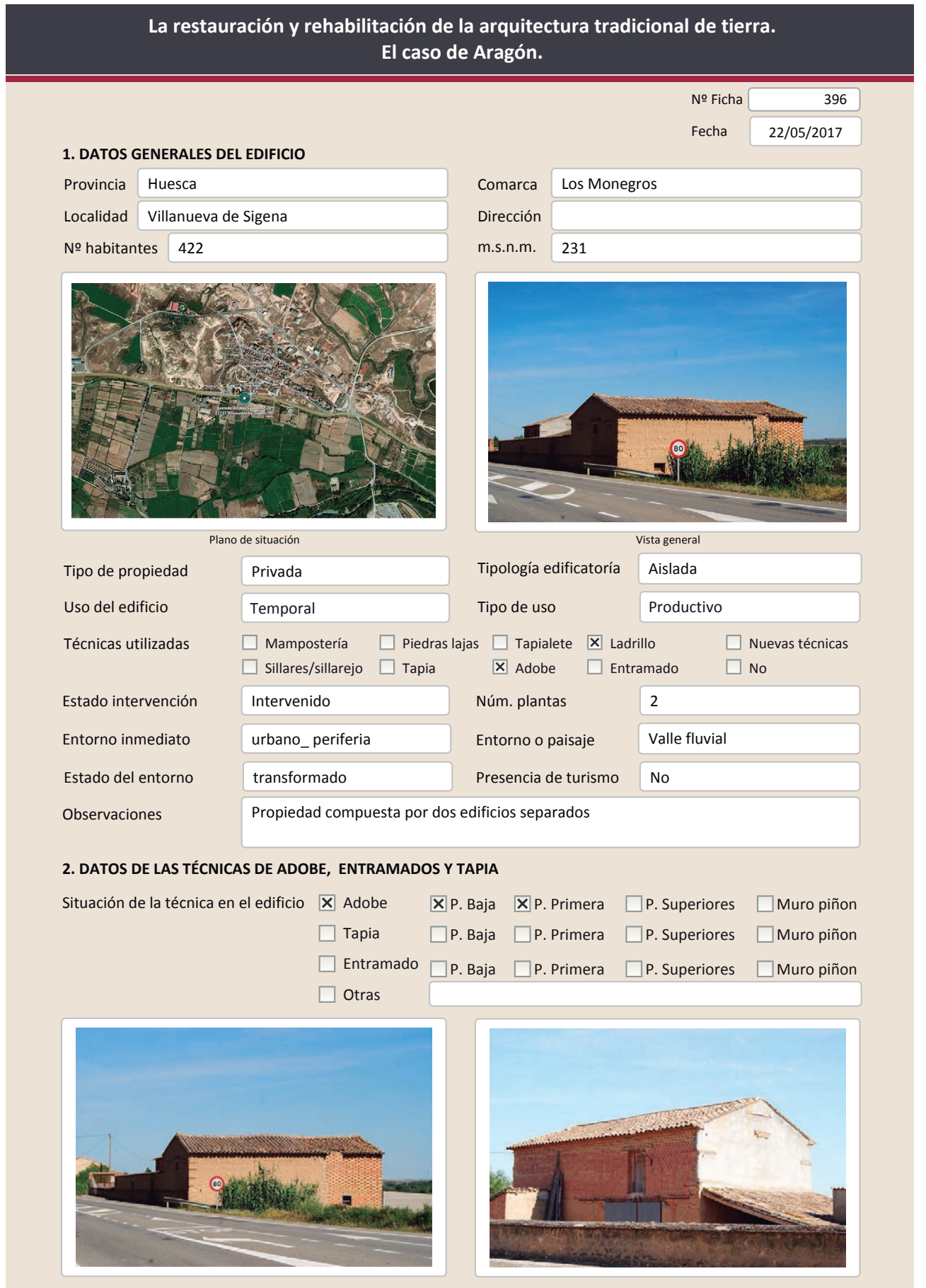

La restauración y rehabilitación de la arquitectura tradicional de tierra.

El caso de Aragón.

2.1. ADOBE

Dimensión de las piezas

Dimensión del muro

Aparejo del muro

Función estructural

$\square$ Suplementada en juntas

X Mixta

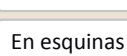

Color de las piezas

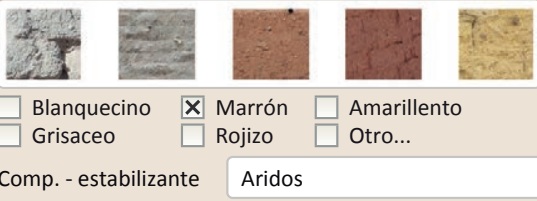

Comp. - estabilizante Aridos

$\square$ Como suplemento

$\square$ Elementos de protección

Las esquinas se han suplementado con tres hiladas de rasillas cada 304 hiladas de adobe

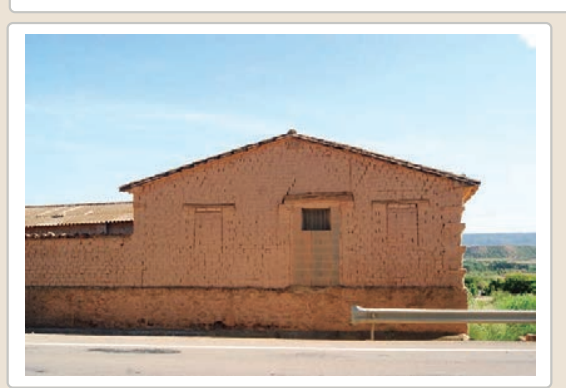

Lesiones X Muro XZócalo $\square$ Revestimiento

$\mathbf{X}$ Erosión del material $\mathbf{X}$ Humedad por capilaridad X Erosion de las juntas $\square$ Humedades (manch/eflo) \ Pérdida de sección $\quad \square$ Pérdida de verticalidad

$\square$ Vegetación $\quad \square$ Grietas por empuje de la cubic

$\square$ Desconchados

$\square$ Grietas porfalta de traba

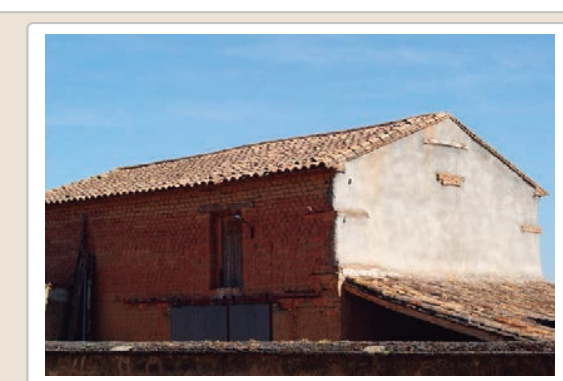

X Cubierta $\square$ otro...

$\square$ Grietas por asentamientos

X Colapso

$\square$ Por elementos impropios

$\square$ Derivado
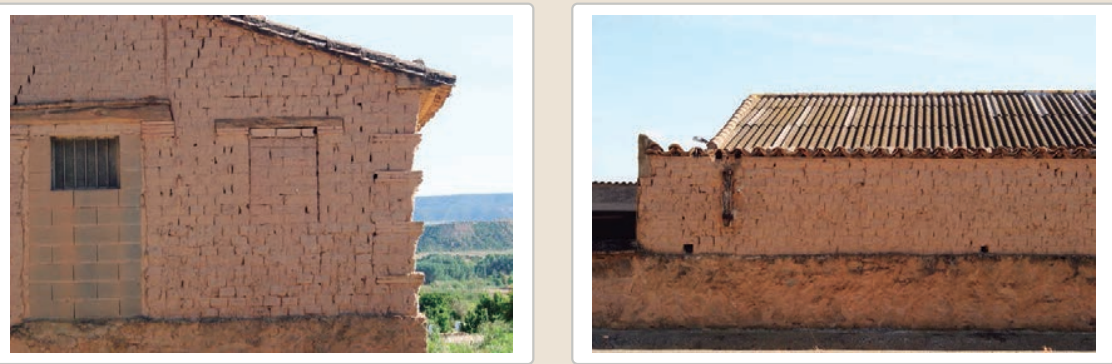

Observaciones 


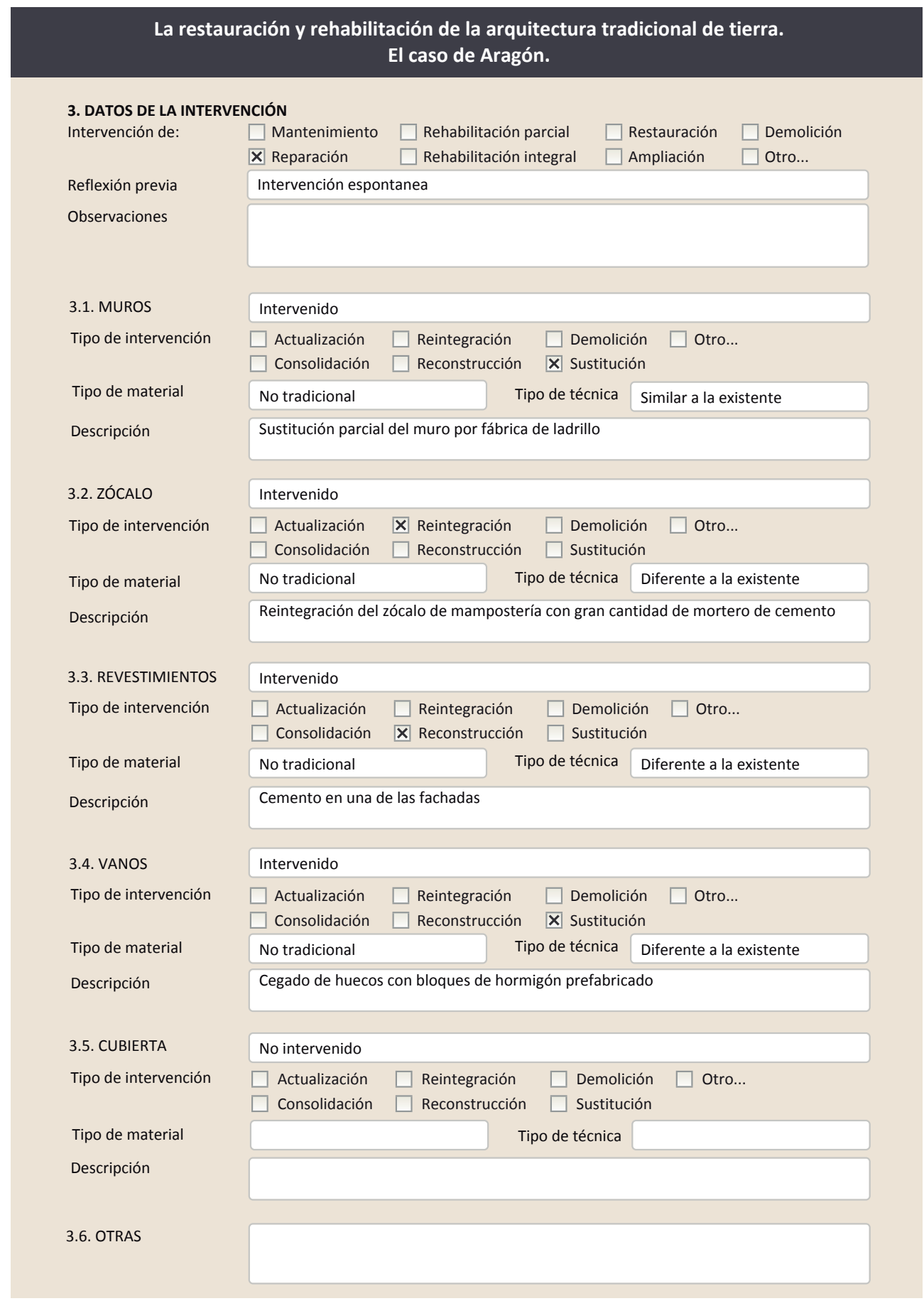

\subsection{REHABILITACIÓN ENERGÉTICA $\quad \square$ Fachada $\square$ Vanos $\square$ Forjados $\square$ Cubierta}

Observaciones

FOTOGRAFíAS DE LA INTERVENCIÓN
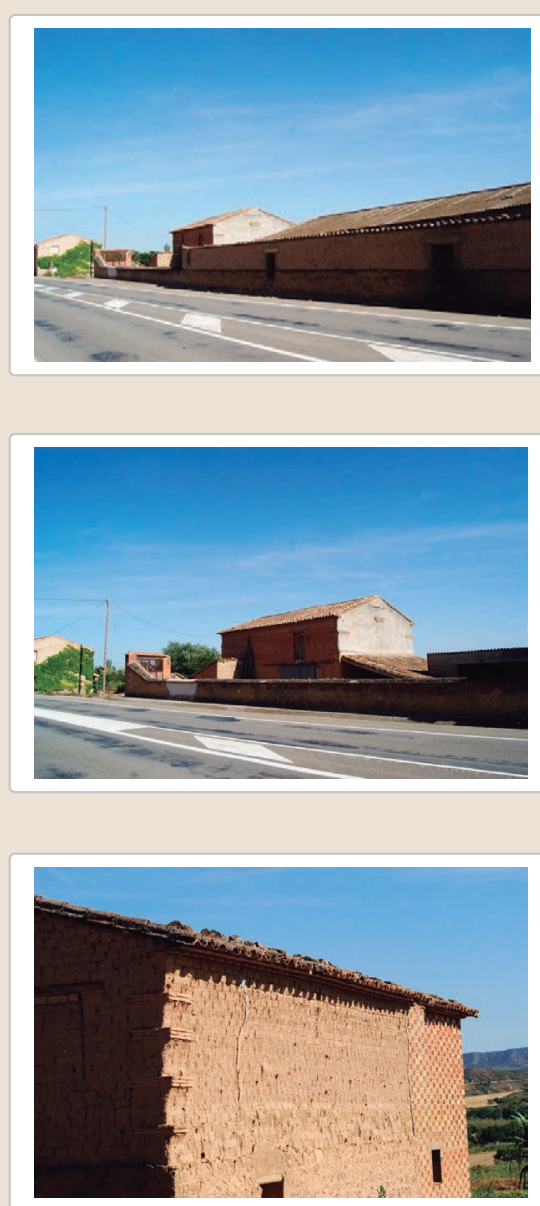
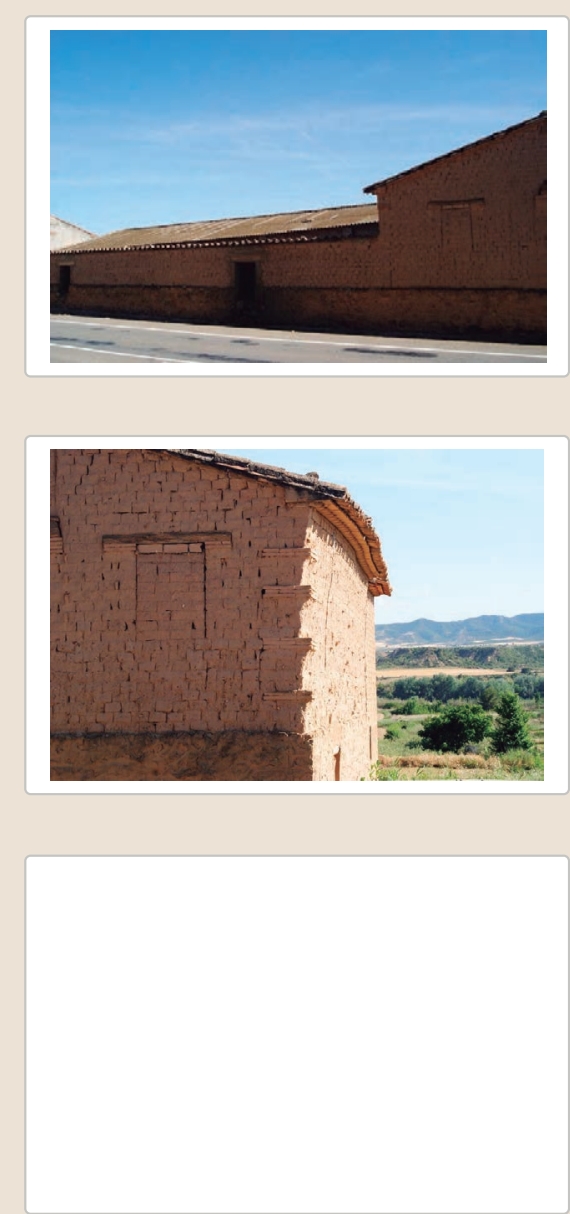


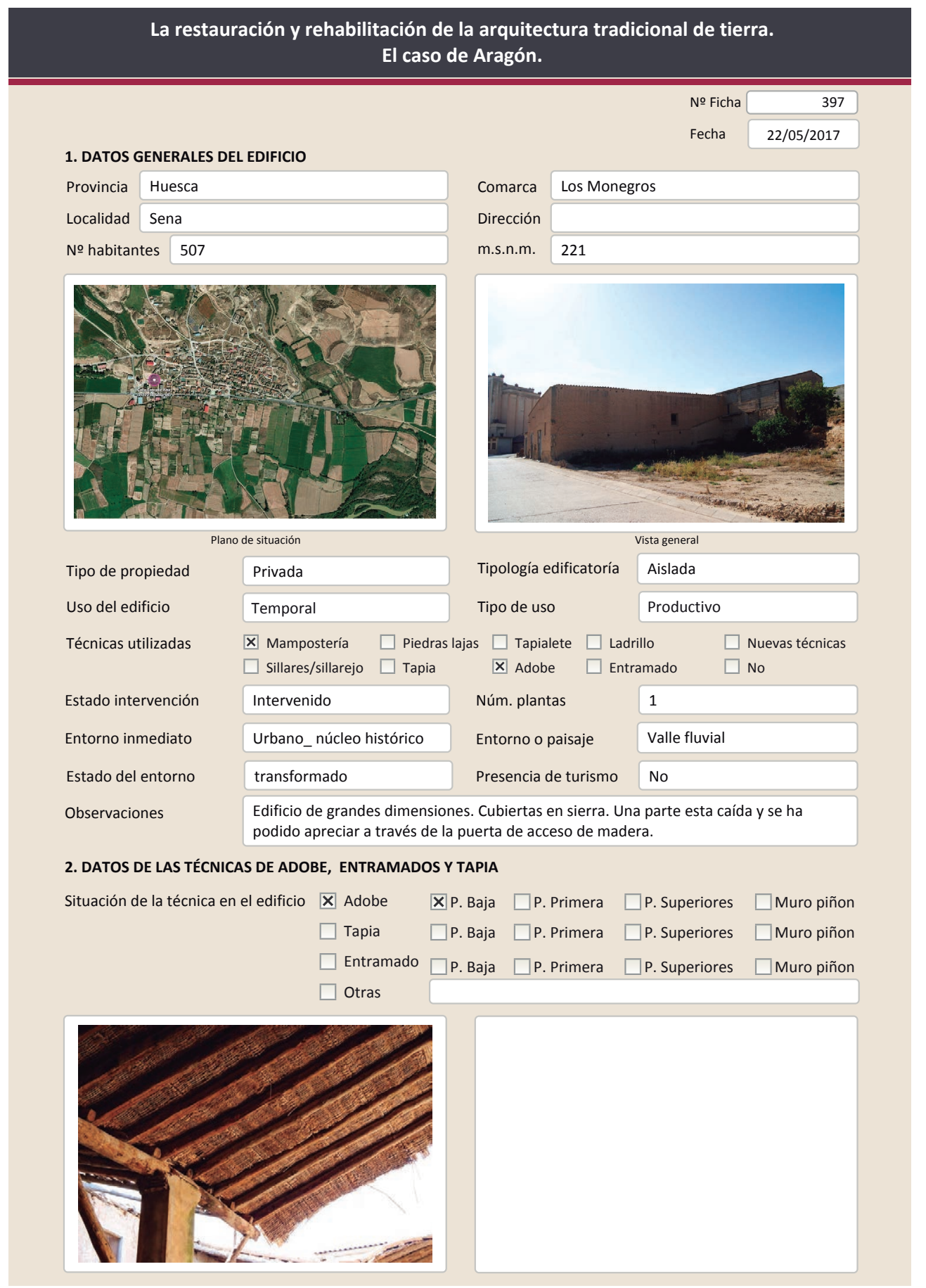

La restauración y rehabilitación de la arquitectura tradicional de tierra.

El caso de Aragón.

\subsection{ADOBE}

Dimensión de las piezas

Dimensión del muro

Aparejo del muro

Función estructural

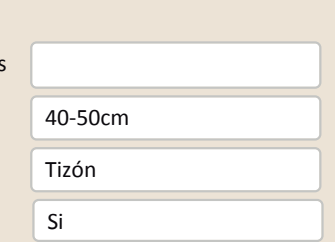

Color de las piezas

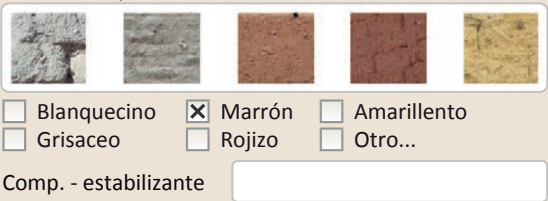

X Simple

$\square$ Suplementada en juntas

$\square$ Mixta

$\square$ Como suplemento

Х Elementos de protección
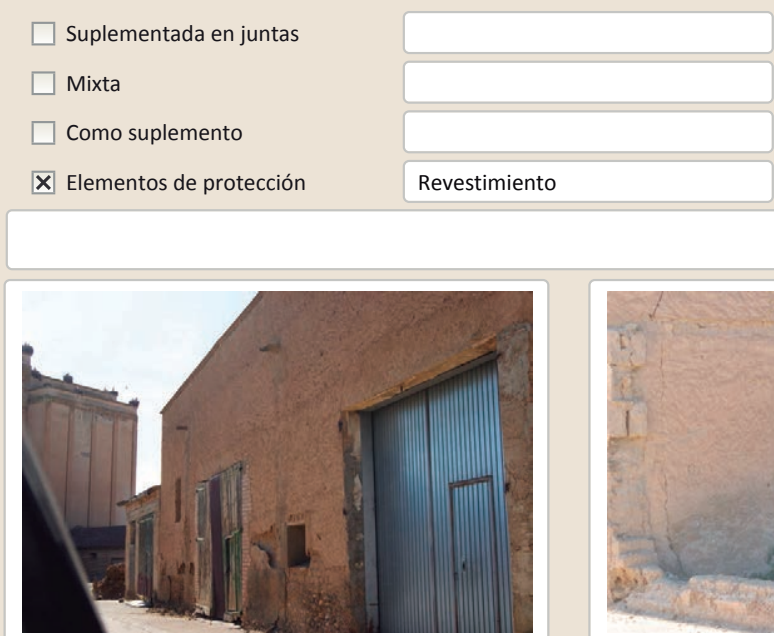

Lesiones

X Muro XZźcalo $\square$ Revestimiento

$\mathbf{X}$ Erosión del material $\mathbf{X}$ Humedad por capilaridad $\square$ Erosion de las juntas $\square$ Humedades (manch/eflo)

$\square$ Pérdida de sección $\square$ Pérdida de verticalidad

$\square$ Vegetación $\quad \square$ Grietas por empuje de la c

X Desconchados

$\square$ Grietas porfalta de traba

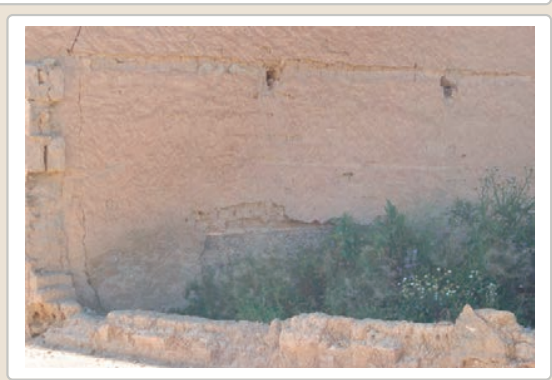

$\square$ Cubierta $\square$ otro...

$\square$ Grietas por asentamiento

$\square$ Colapso

$\square$ Por elementos impropios

$\square$ Derivado de intervenciones

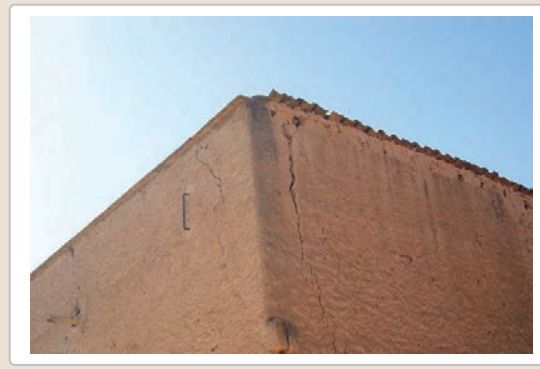
$\mathbf{X}$ Otro...

Observaciones

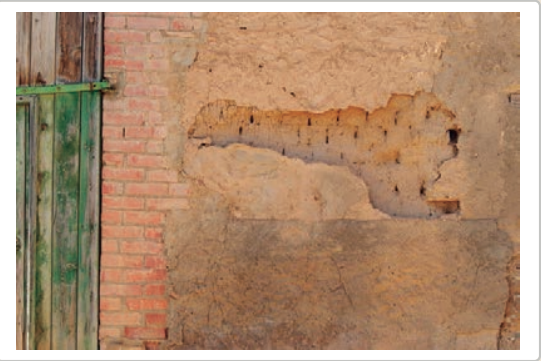


La restauración y rehabilitación de la arquitectura tradicional de tierra. El caso de Aragón

\section{La restauración y rehabilitación de la arquitectura tradicional de tierra.}

\section{El caso de Aragón.}

3. DATOS DE LA INTERVENCIÓN

Intervención de:

$\square$ Mantenimiento $\square$ Rehabilitación parcia

$\square$ Restauración $\square$ Demolición

Reflexión previa

Х Reparación

$\square$ Rehabilitación integra

Ampliación

$\square$ Otro...

Reflexión previa

Intervención espontanea

(20)

3.1. MUROS

No intervenido

Tipo de intervención

$\square$ Actualización $\square$ Reintegración $\square$ Demolición $\square$ Otro...

$\square$ Consolidación $\square$ Reconstrucción $\square$ Sustitución

Tipo de material

Descripción

3.2. ZÓCALO

Tipo de intervención

Intervenido

Tipo de intervención

$\square$ Actualizació

Tipo de material

Descripción

Dipo de técnica Diferente a la existente

3.3. REVESTIMIENTOS

No intervenido

Tipo de intervención

$\square$ Actualización $\square$ Reintegración $\square$ Demolición $\square$ Otro...

Tipo de material

Descripción

3.4. VANOS

Tipo de intervención

$\square$ Consolidación

Reconstrucción $\square$ Sustitución

Tipo de técnica

Tipo de material

Intervenido

Descripción

$\square$ Actualización $\square$ Reintegración $\square$ Demolición $\square$ Otro..

$\square$ Consolidación $\mathbf{X}$ Reconstrucción $\square$ Sustitución

No tradicional Tipo de técnica Similar a la existente

3.5. CUBIERTA

Reconstrucción de las jambas de una de las puertas con ladrillo y sustitución de una de las puertas por una metálica.

Tipo de intervención

No intervenido

Tipo de intervención

$\square$ Actualización $\square$ Reintegración $\square$ Demolición $\quad \square$ Otro...

Tipo de material

$\square$ Reconstrucción $\square$ Sustitución

Descripción

Tipo de técnica

3.6. OTRAS 


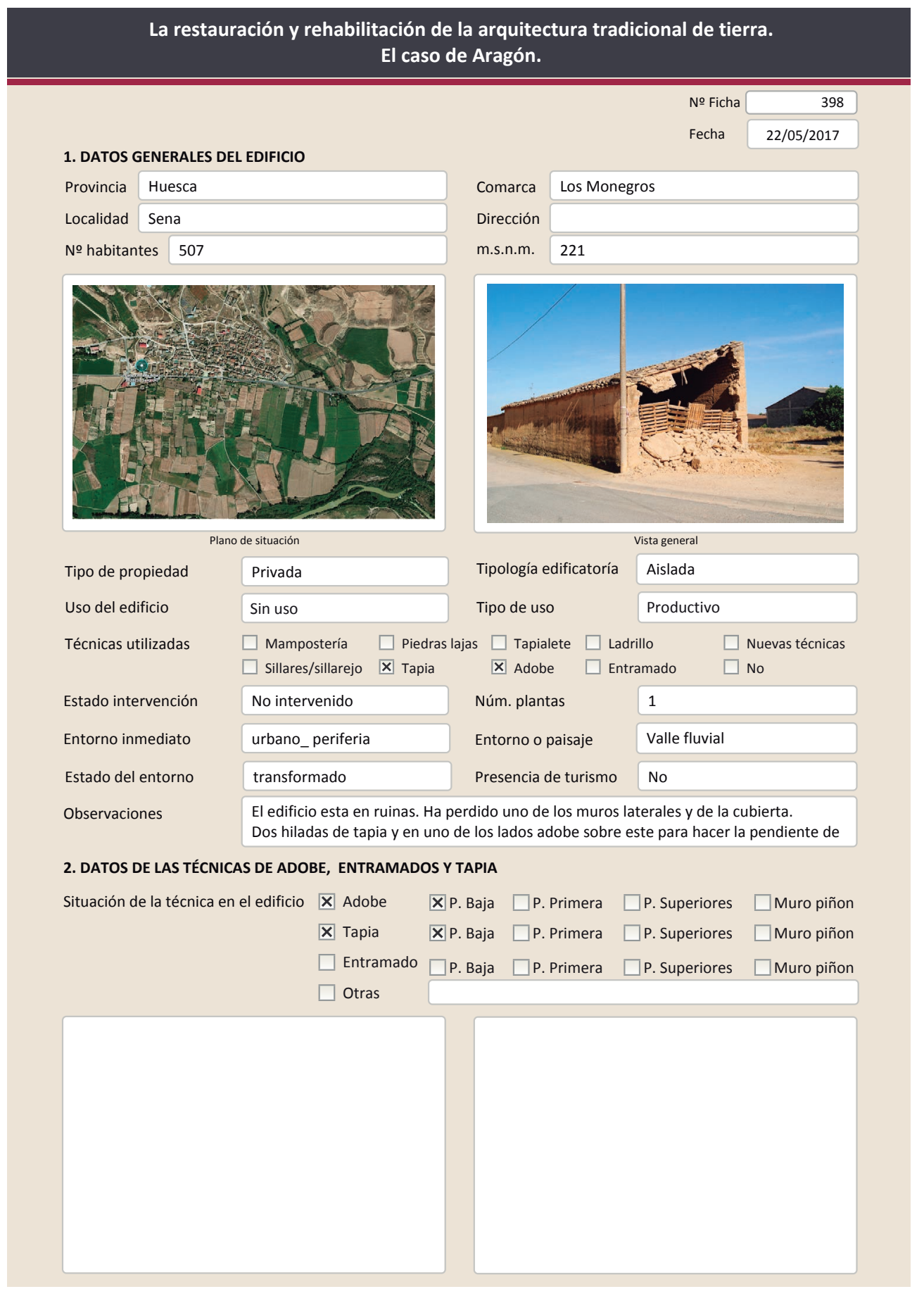

La restauración y rehabilitación de la arquitectura tradicional de tierra.

El caso de Aragón.

\subsection{ADOBE \\ Dimensión de las piezas Dimensión del muro \\ Aparejo del muro $40-50 \mathrm{~cm}$ Función estructural Tizón \\ Variante constructiva/ tipo de fábrica \\ 区 Simple \\ $\square$ Suplementada en juntas \\ $\square$ Mixta \\ $\square$ Como suplemento \\ $\square$ Elementos de protección}

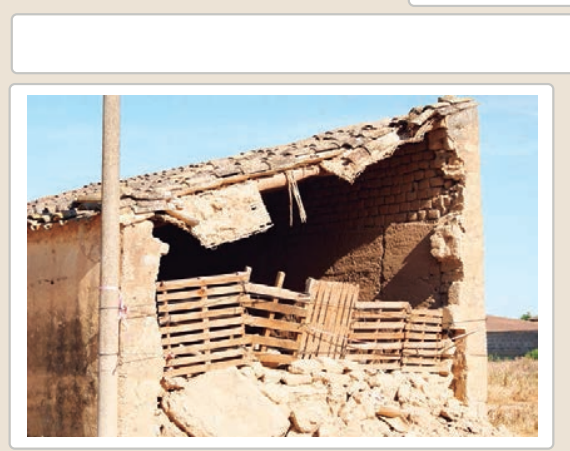

Lesiones

X Muro $\square$ Zócalo $\square$ Revestimiento

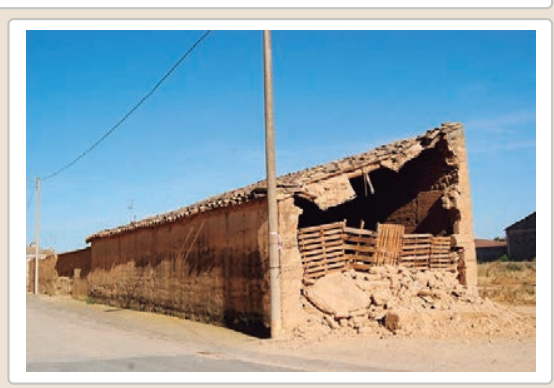

\ Erosión del material $\square$ Humedad por capilaridad $\square$ Erosion de las juntas $\square$ Humedades (manch/eflo)

$\square$ Pérdida de sección $\square$ Pérdida de verticalidad

$\square$ Vegetación $\quad \square$ Grietas por empuje de la c

$\square$ Desconchados

$\square$ Grietas porfalta de traba

Color de las piezas

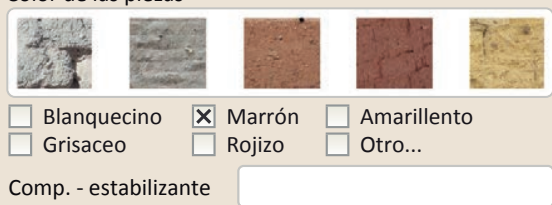

Comp. - estabilizante

$\square$ Derivado de intervenciones
$\square$ Otro...

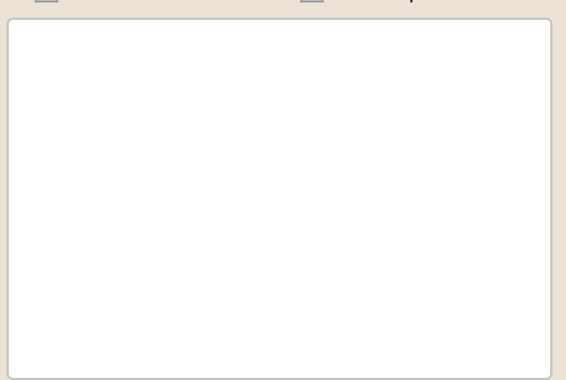

Observaciones 
La restauración y rehabilitación de la arquitectura tradicional de tierra. El caso de Aragón

\section{La restauración y rehabilitación de la arquitectura tradicional de tierra.}

\section{El caso de Aragón.}

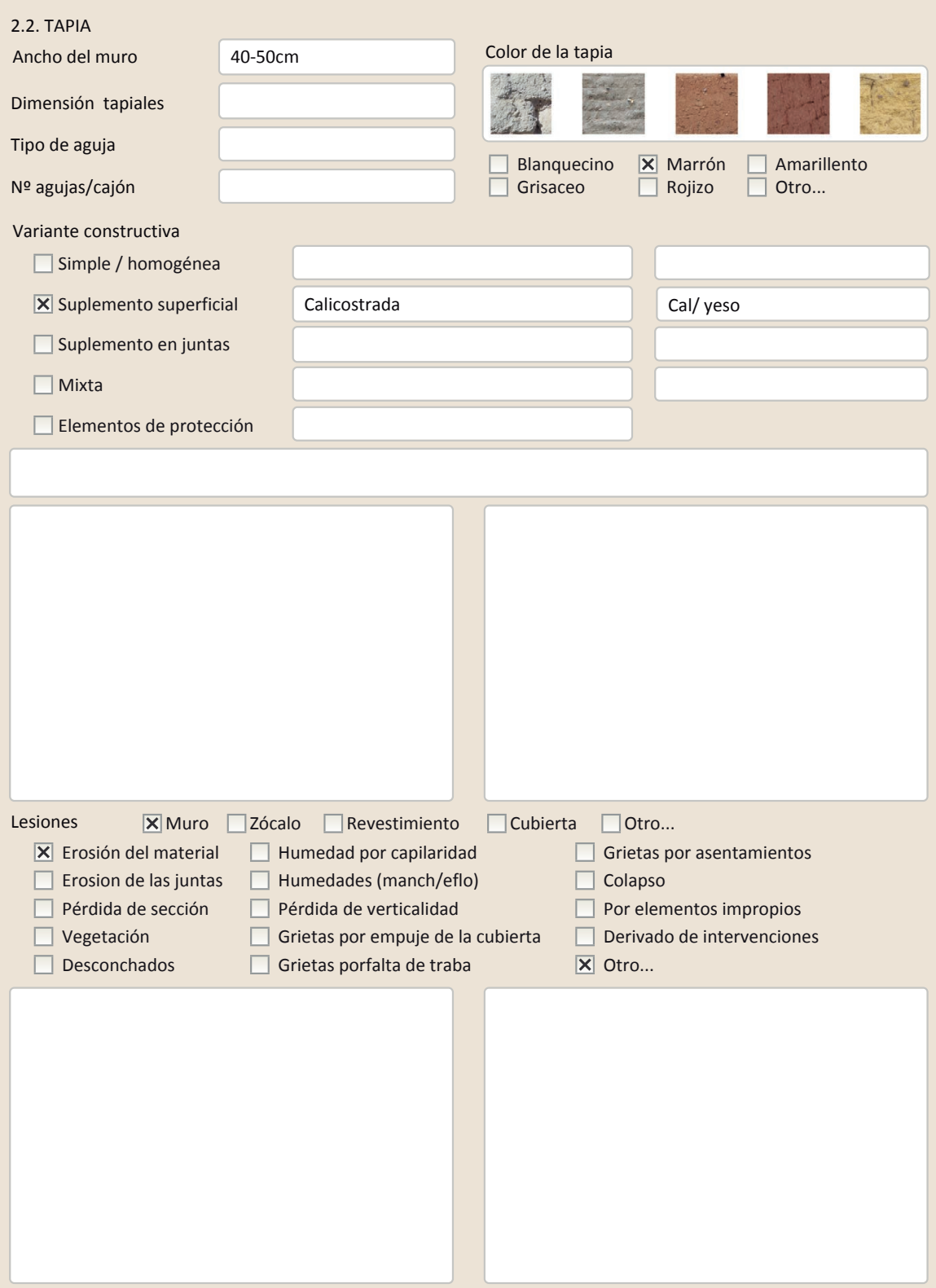

Observaciones 


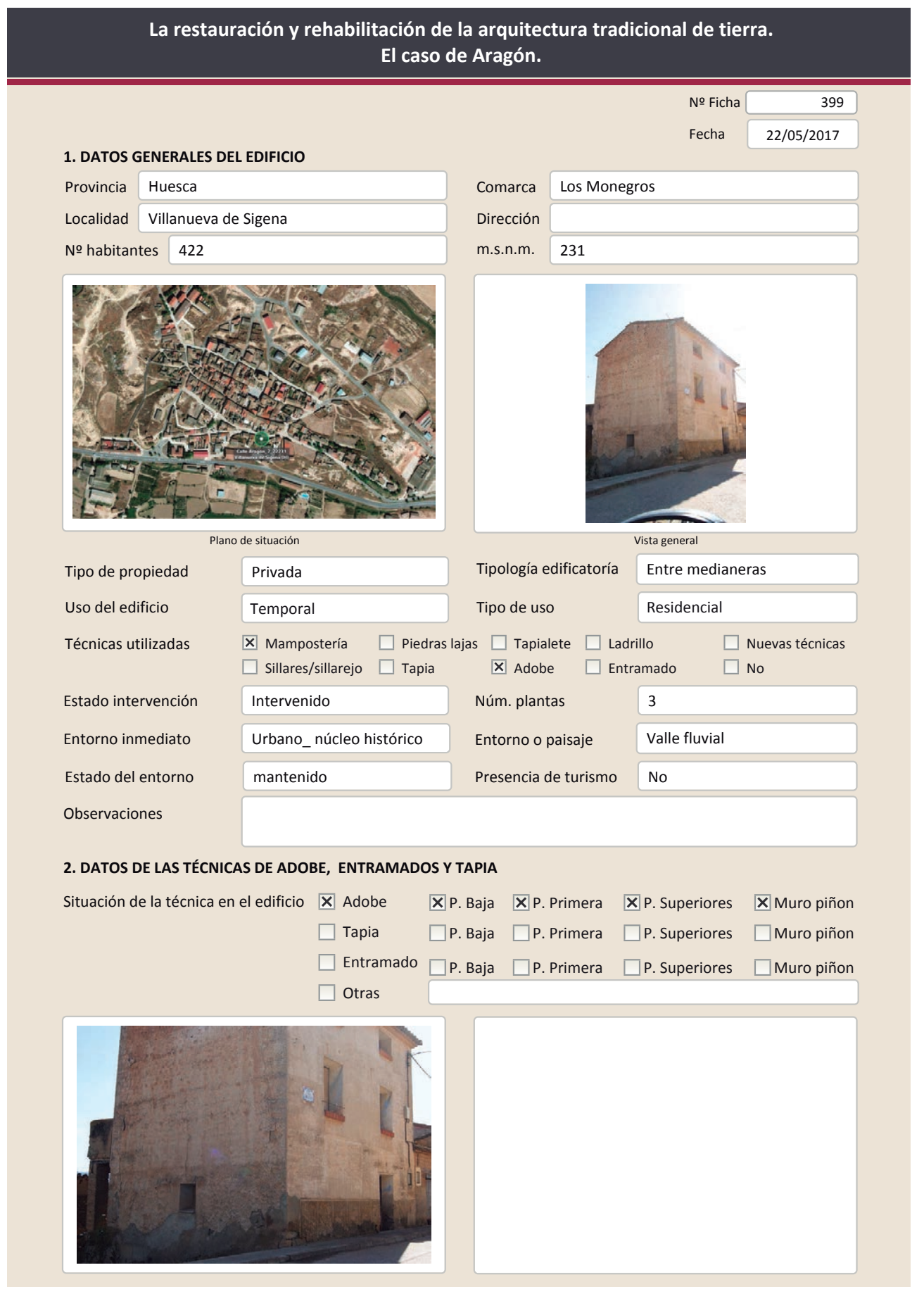

La restauración y rehabilitación de la arquitectura tradicional de tierra.

El caso de Aragón.

\subsection{ADOBE}

Dimensión de las piezas Dimensión del muro Aparejo del muro Función estructural Si

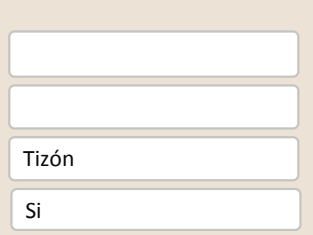
Color de las piezas

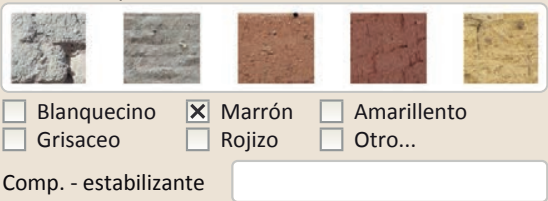

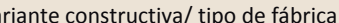

$\square$ simple

$\square$ Suplementada en juntas

区 Mixta

En esquinas

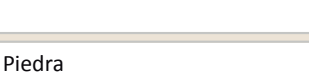

$\square$ Como suplemento

X Elementos de protección

Revestimiento

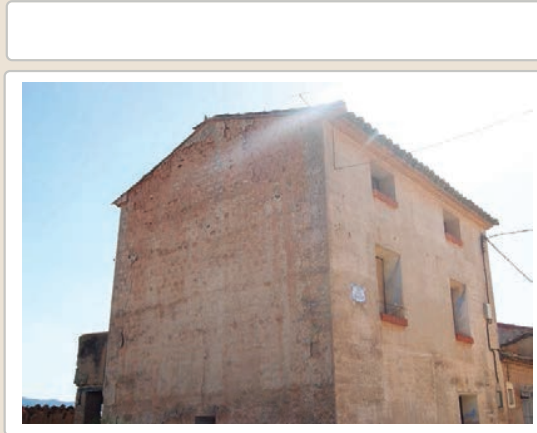

Lesiones ХMuro ХZŹcalo $\mathbf{X}$ Revestimiento $\mathbf{X}$ Erosión del material $\mathbf{X}$ Humedad por capilaridad $\square$ Erosion de las juntas $\square$ Humedades (manch/eflo)

$\square$ Pérdida de sección $\quad \square$ Pérdida de verticalidad

$\square$ Vegetación

X Desconchados $\square$ Grietas por empuje de la cubie
$\square$ Grietas porfalta de traba

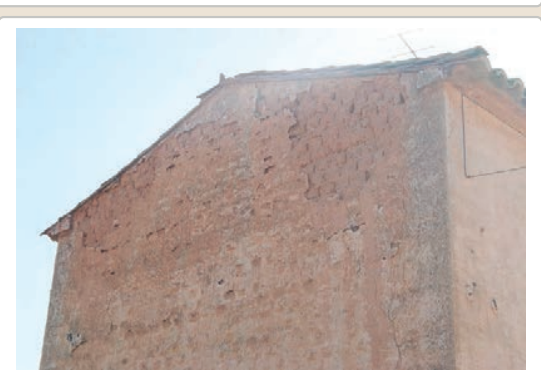

$\square$ Cubierta $\square$ otro...

$\square$ Grietas por asentamientos $\square$ Colapso

$\square$ Por elementos impropios

$\square$ Derivado de intervenciones $\square$ Otro... 
La restauración y rehabilitación de la arquitectura tradicional de tierra. El caso de Aragón

\section{La restauración y rehabilitación de la arquitectura tradicional de tierra.}

\section{El caso de Aragón.}

3. DATOS DE LA INTERVENCIÓN

Intervención de:

$\square$ Mantenimiento $\square$ Rehabilitación parcia

$\square$ Restauración $\square$ Demolición

Reflexión previa

X Reparación

$\square$ Rehabilitación integral $\square$ Ampliación

$\square$ Otro..

Reflexión previa

Intervención espontanea

(n)

3.1. MUROS

No intervenido

Tipo de intervención

$\square$ Actualización $\square$ Reintegración $\square$ Demolición $\square$ Otro...

$\square$ Consolidación $\square$ Reconstrucción $\square$ sustitución

Tipo de material

Descripción

3.2. ZÓCALO

Tipo de intervención

Intervenido

Actualización $邓$ Reintegración $\square$ Demolición $\square$ Otro...

Tipo de material

$\square$ Consolidación $\quad \mathbf{X}$ Reconstrucción $\square$ Sustitución

Descripción

Reintegración de partes faltantes con cemento. En la parte baja se ha reconstruid parte

con bloques de hormigón prefabricado.

3.3. REVESTIMIENTOS

No intervenido

Tipo de intervención

Actualización

$\square$ Reintegración $\square$ Demolición $\square$ Otro...

Consolidación $\square$ Reconstrucción $\square$ Sustitución

Tipo de material

Descripción

3.4. VANOS

No intervenido

Tipo de intervención

$\square$ Actualización $\square$ Reintegración $\square$ Demolición $\square$ Otro...

Tipo de material

Descripción

$\square$ Consolidación $\quad \square$ Reconstrucción $\square$ Sustitución

3.5. CUBIERTA

Tipo de intervención

No intervenido

Tipo de material

$\square$ Actualización

$\square$ Consolidación $\quad \square$ Reconstrucción $\quad \square$ Sustitución

Descripción

Tipo de técnica

3.6. OTRAS

$$
\text { Tipo de técnica }
$$


La restauración y rehabilitación de la arquitectura tradicional de tierra. El caso de Aragón.

La restauración y rehabilitación de la arquitectura tradicional de tierra. El caso de Aragón.

2.1. ADOBE

Dimensión de las piezas

1. DATOS GENERALES DEL EDIFICIO

Provincia Huesca

Localidad Grañen

№ habitantes 1804

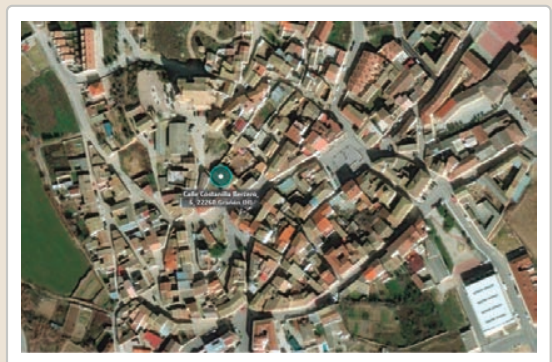

Plano de situación

Tipo de propiedad

Privada

Uso del edificio

Técnicas utilizadas

Temporal

ostería $\square$ Piedras $\square$ Sillares/sillarejo $\square$ Tapia

Intervenido

Urbano_núcleo histórico

Entorno inmediato

Estado del entorno

mantenido

Observaciones

\section{DATOS DE LAS TÉCNICAS DE ADOBE, ENTRAMADOS Y TAPIA}

Situación de la técnica en el edificio $\mathbf{X}$ Adobe $\square$ P. Baja $\quad$ XP. Primera $\quad$ XP. Superiores $\square$ Muro piñon $\square$ Tapia $\square$ P. Baja $\square$ P. Primera $\square$ P. Superiores $\square$ Muro piñon

$\square$ Entramado $\square$ P. Baja $\square$ P. Primera $\square$ P. Superiores $\square$ Muro piñon

$\square$ Otras
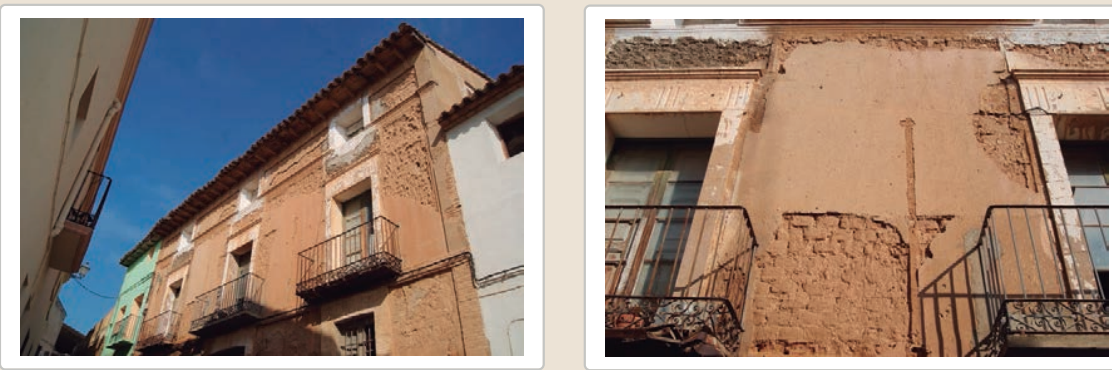

Comarca Los Monegros

Dirección

m.s.n.m. 332

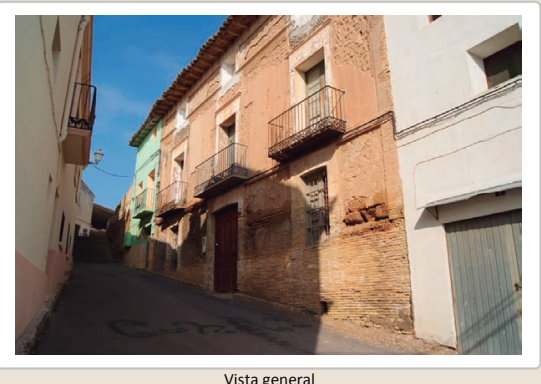

Tipología edificatoría Entre medianeras

Tipo de uso Residencial

Tapialete $\square$ Ladrillo $\quad \square$ Nuevas técnicas

Núm. plantas 1

Entorno o paisaje Valle fluvial

Presencia de turismo

No

Dimensión del muro

Aparejo del muro

Función estructural

$\square$ simple

$\square$ Suplementada en juntas

X Mixta

Como suplemento

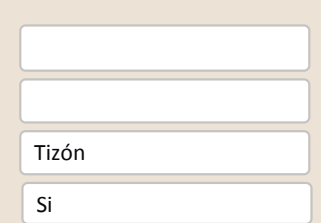

Color de las piezas

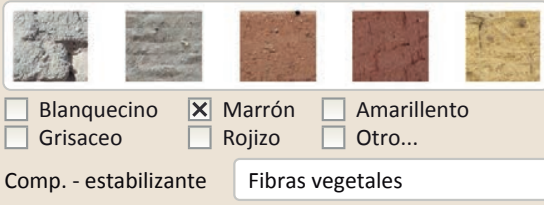

Variante constructiva/ tipo de fábrica

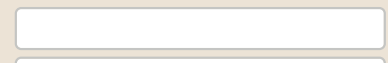

X Elementos de protección Planta baja de ladrillo y piedra

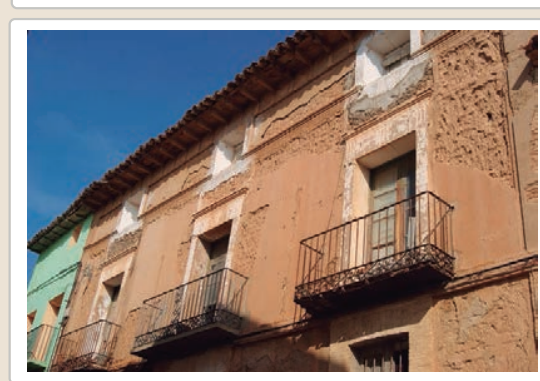

$\mathbf{X}$ Muro XZócalo $\mathbf{X}$ Revestimiento $\quad \mathbf{X}$ Humedad por capilaridad X Erosion de las juntas $\mathbf{X}$ Humedades (manch/eflo)

$x$ Pérdida de sección $\square$ Pérdida de verticalidad

$\square$ Vegetación $\quad \square$ Grietas por empuje de la c $\square$ Grietas porfalta de traba

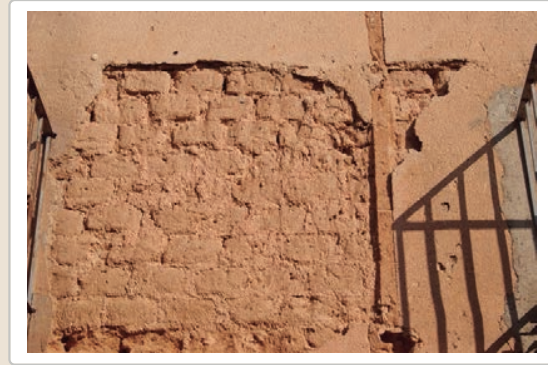

X Cubierta $\square$ Otro...

$\square$ Grietas por asentamiento X Colapso

$\square$ Por elementos impropios

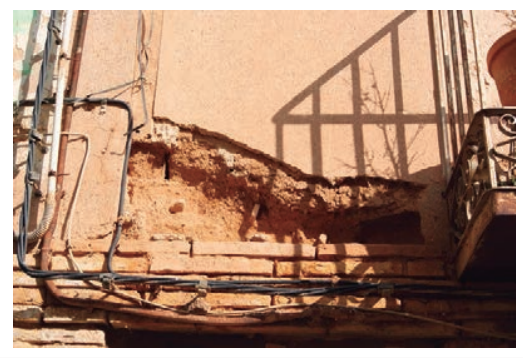

$\square$ Derivado de intervenciones $\square$ Otro...

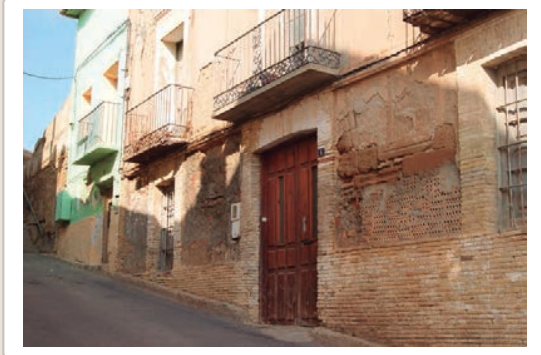

Observaciones perdido y se encuentra en muy mal estado de conservación 


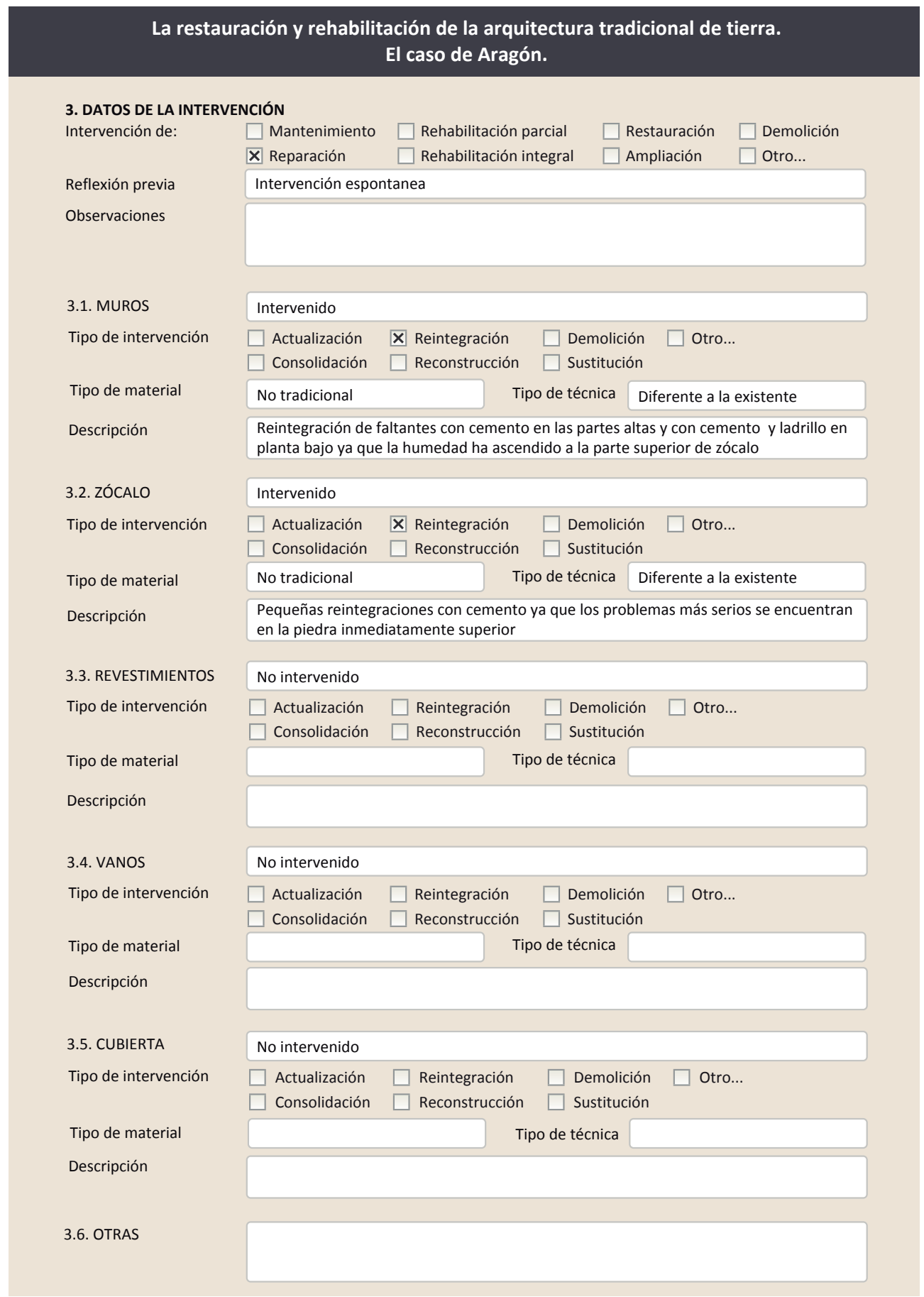

3.7. REHABILITACIÓN ENERGÉTICA $\square$ Fachada $\square$ Vanos $\square$ Forjados $\square$ Cubierta

Observaciones

FOTOGRAFÍAS DE LA INTERVENCIÓN
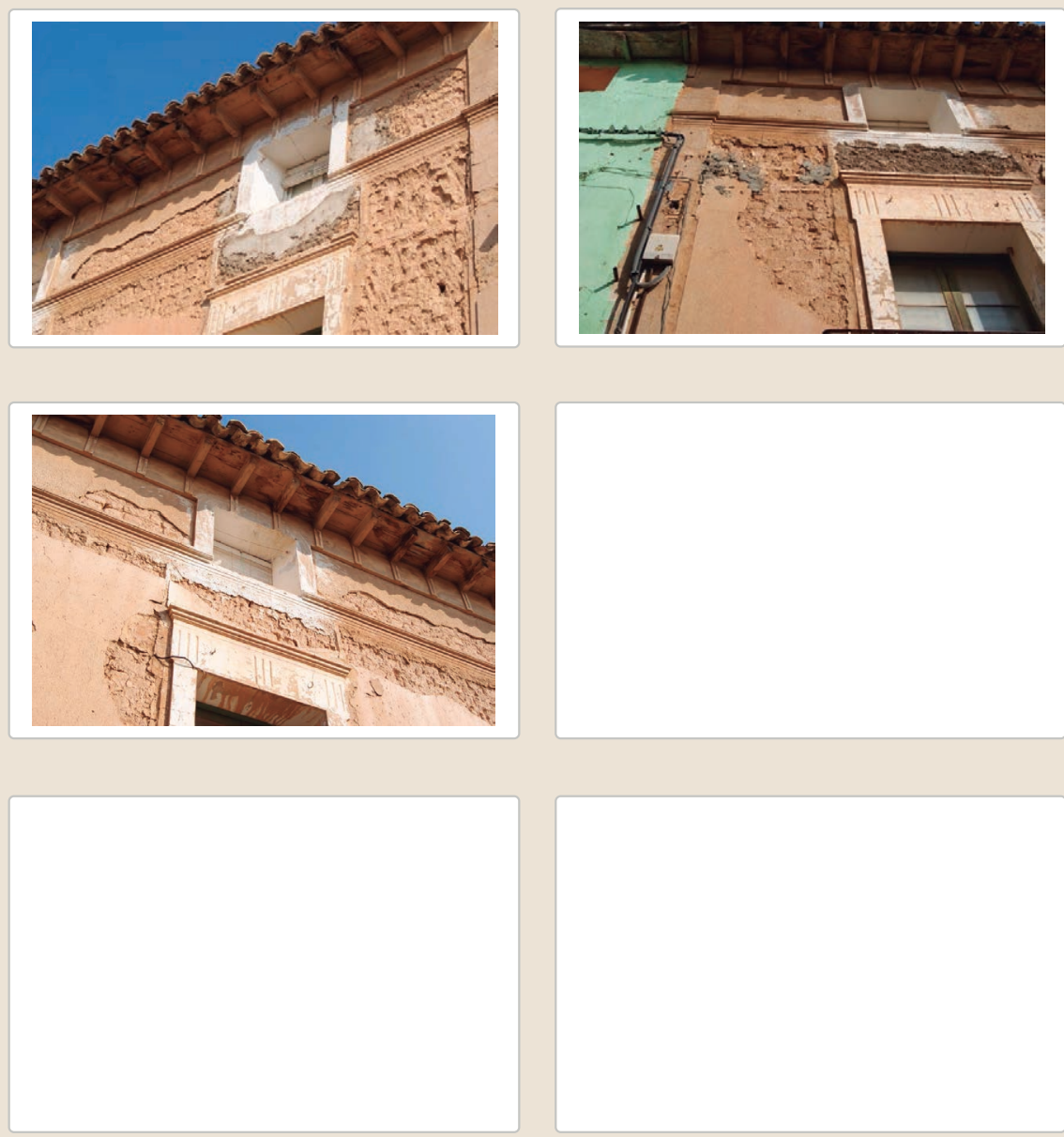


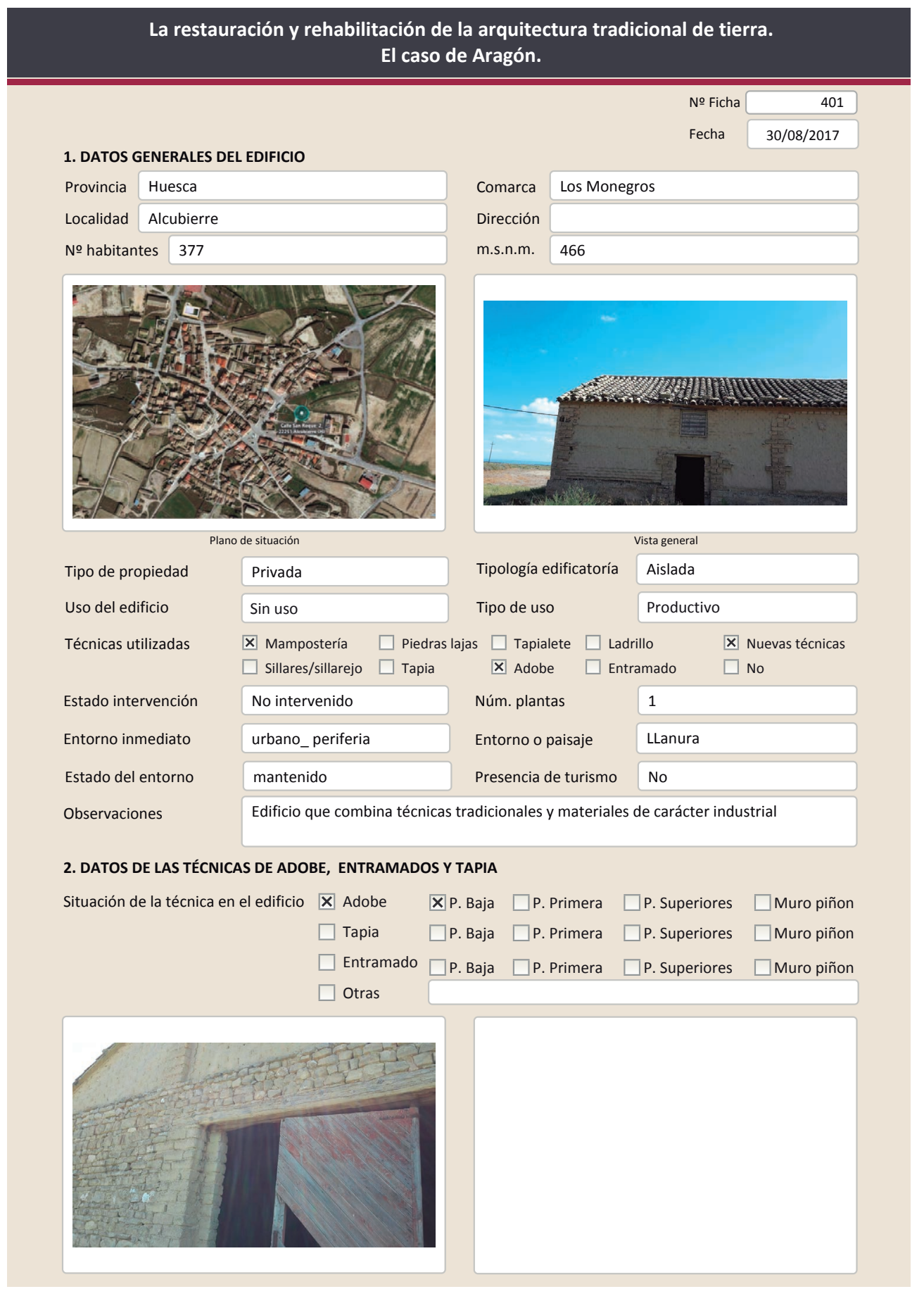

La restauración y rehabilitación de la arquitectura tradicional de tierra.

El caso de Aragón.

2.1. ADOBE

Dimensión de las piezas

Dimensión del muro

Aparejo del muro

Función estructural

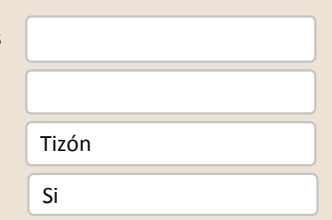

Color de las piezas

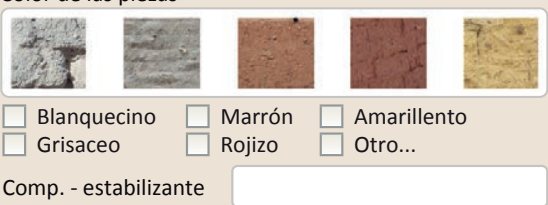

Variante constructiva/ tipo de fábrica

$\square$ Simple

$\square$ Suplementada en juntas

X Mixta

\section{Machones}

Mixto- Machones

$\mathbf{X}$ Como suplemento

$\square$ Elementos de protección

Bloques de tierra cemento en los machones. EL muro piñón es casi por completo de piedra. Solo en una pequeña zona se observan juntas suplementadas con conglomerante

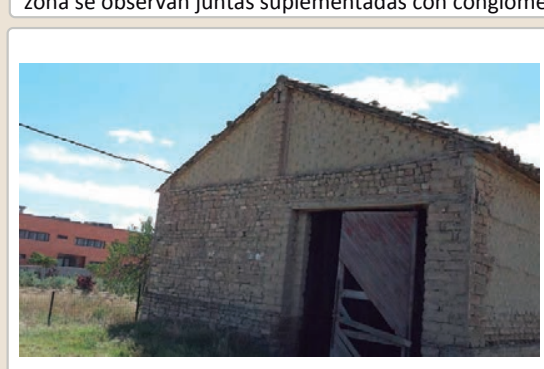

Lesiones $\quad \mathbf{X}$ Muro $\mathbf{X}$ Zócalo $\square$ Revestimiento $\square$ Cubierta $\square$ Otro...

区 Erosión del material $\mathbf{X}$ Humedad por capilaridad $\quad \square$ Grietas por asentamientos

$\square$ Erosion de las juntas $\square$ Humedades (manch/eflo) $\quad \square$ Colapso

X Pérdida de sección $\square$ Pérdida de verticalidad $\square$ Por elementos impropios

$\square$ Vegetación $\quad \square$ Grietas por empuje de la cubierta $\square$ Derivado de intervenciones

X Desconchados

$\square$ Grietas por empuje de la cubic

$\square$ Otro...

Observacione 
La restauración y rehabilitación de la arquitectura tradicional de tierra. El caso de Aragón

\section{La restauración y rehabilitación de la arquitectura tradicional de tierra.}

\section{El caso de Aragón.}

\section{DATOS DE LA INTERVENCIÓN}

Intervención de:

$\square$ Mantenimien

$\square$ Rehabilitación parcia

$\square$ Restauración $\square$ Demolición

$\square$ Reparación $\square$ Rehabilitación integral $\square$ Ampliación $\quad \square$ Otro...

Reflexión previa

Observaciones

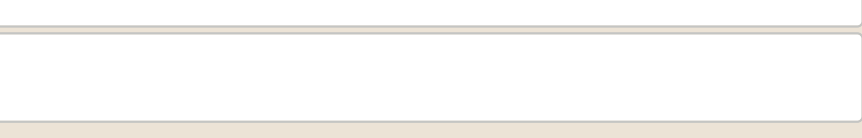

3.1. MUROS

Tipo de intervención

Tipo de material

$\square$ Actualización $\square$ Reintegración $\square$ Demolición $\square$ Otro...

$\square$ Consolidación $\square$ Reconstrucción $\square$ sustitución

Descripción

3.2. ZÓCALO

Tipo de intervención

Tipo de material

Descripción

3.3. REVESTIMIENTOS

Tipo de intervención

Tipo de material

Descripción

3.4. VANOS

Tipo de intervención

Tipo de material

Descripción

3.5. CUBIERTA

Tipo de intervención

Tipo de material

$\square$ Actualización $\square$ Reintegración $\square$ Demolición $\square$ Otro

$\square$ Consolidación $\square$ Reconstrucción $\square$ Sustitución

Descripción

$\square$ Actualización $\quad \square$ Reintegración $\quad \square$ Demolición $\square$ Otro...

$\square$ Consolidación $\quad \square$ Reconstrucción $\quad \square$ Sustitución

Tipo de técnica

\section{$\square$ Actualización $\square$ Reintegración $\square$ Demolición $\square$ Otro...}

$\square$ Consolidación $\square$ Reconstrucción $\square$ Sustitución

Tipo de técnica

3.6. OTRAS Tipo de técnica 


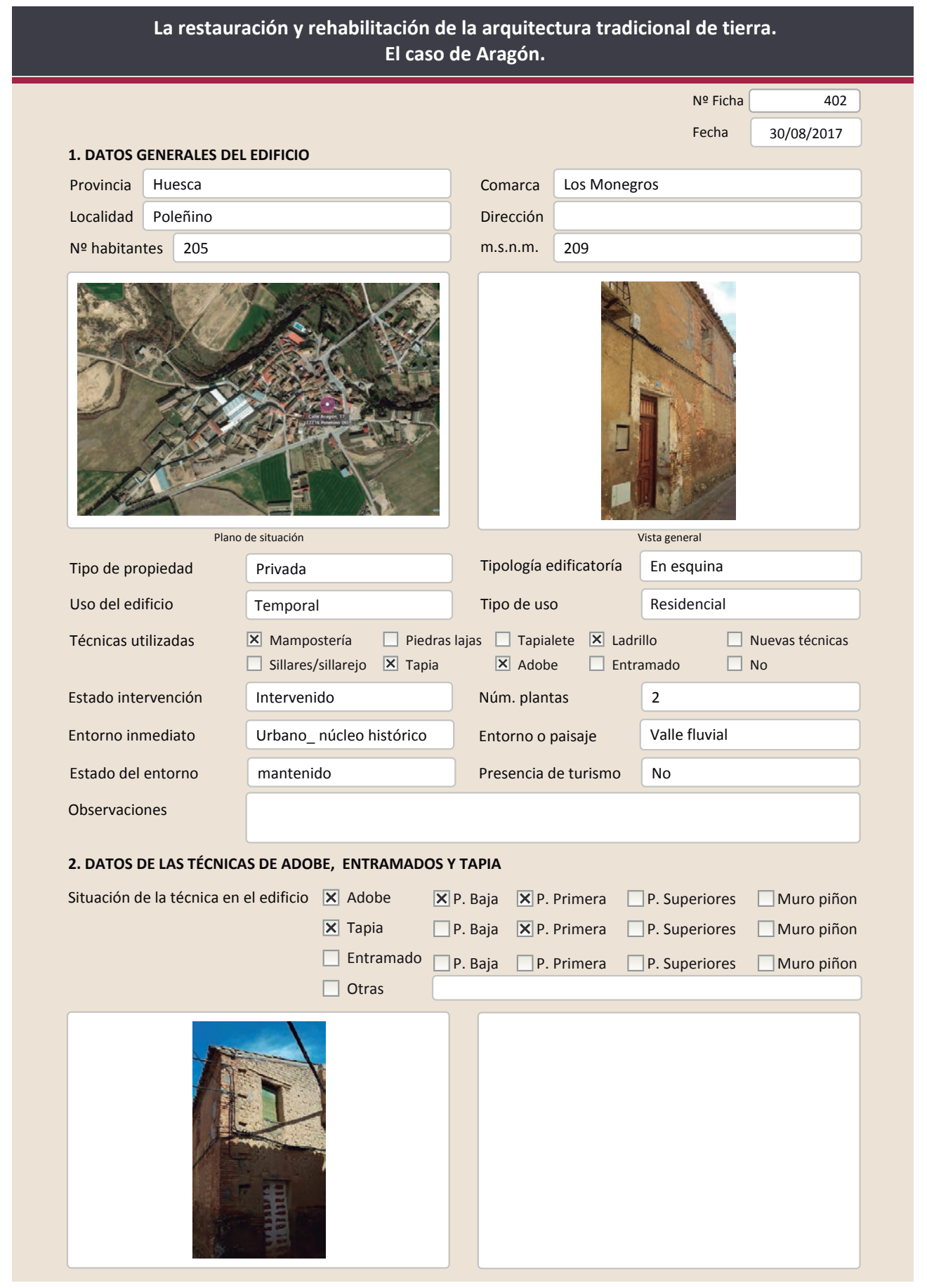

La restauración y rehabilitación de la arquitectura tradicional de tierra.

El caso de Aragón.

\subsection{ADOBE}

Dimensión de las piezas Dimensión del muro Aparejo del muro Función estructural

\begin{tabular}{|l|}
\hline \\
\hline Tizón \\
\hline Si \\
\hline
\end{tabular}
Color de las piezas Danquecino $\square$ Marrón $\square$ Amarillento
$\square$ Blajo
$\square$ Grisaceo $\square$ Rojizo $\square$ Otro...
Comp. - estabilizante Variante constructiva/ tipo de fábrica

$\square$ simple

$\square$ Suplementada en juntas

X Mixta Machones Ladrillo

$\square$ Como suplemento

$\square$ Elementos de protección

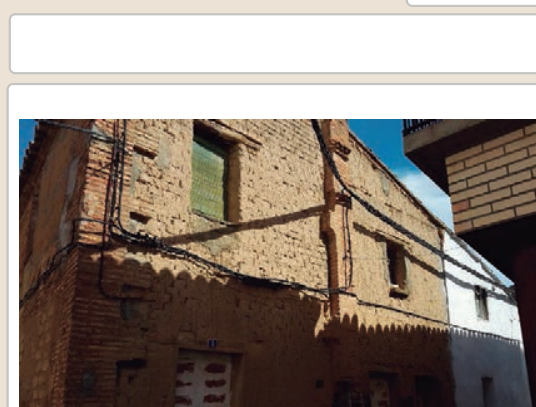

$$
\begin{aligned}
& \text { Lesiones } \square \text { Muro } \square \text { Zócalo } \square \text { Revestimiento } \square \text { Cubierta } \square \text { otro... } \\
& \square \text { Erosión del material } \quad \square \text { Humedad por capilaridad } \quad \square \text { Grietas por asentamientos } \\
& \square \text { Erosion de las juntas } \square \text { Humedades (manch/eflo) } \quad \square \text { Colapso } \\
& \square \text { Pérdida de sección } \square \text { Pérdida de verticalidad } \quad \square \text { Por elementos impropios } \\
& \square \text { Vegetación } \quad \square \text { Grietas por empuje de la cubierta } \square \text { Derivado de intervenciones } \\
& \square \text { Desconchados } \square \text { Grietas porfalta de traba } \quad \square \text { Otro... }
\end{aligned}
$$




\section{La restauración y rehabilitación de la arquitectura tradicional de tierra.} El caso de Aragón.

\subsection{TAPIA}

Ancho del muro

Dimensión tapiales

Tipo de aguja

№ agujas/cajón

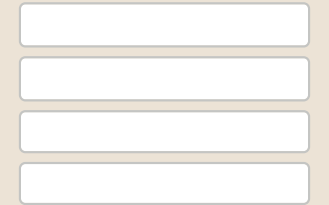

\section{Color de la tapia}

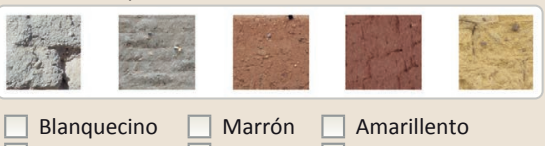

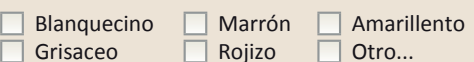

\begin{tabular}{|l|}
\hline \\
\hline Cal/ yeso \\
\hline Ladrillo \\
\hline
\end{tabular}

Variante constructiva

$\square$ Simple / homogénea

$\mathbf{X}$ Suplemento superficial

$\square$ Suplemento en juntas

X Mixta

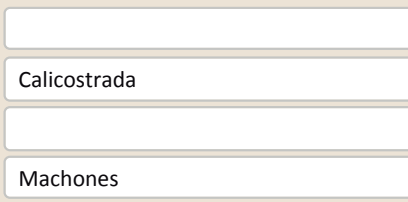

Machones

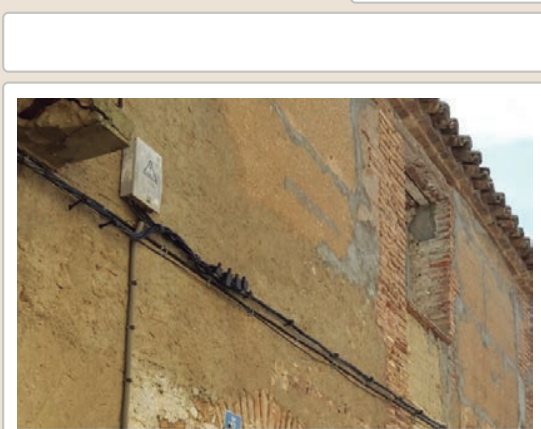

Lesiones $\square$ Muro $\square$ Zócalo $\square$ Revestimiento $\square$ Cubierta $\square$ otro...

$\square$ Erosión del material $\quad \square$ Humedad por capilaridad $\quad \square$ Grietas por asentamientos

$\square$ Erosion de las juntas $\square$ Humedades (manch/eflo) $\quad \square$ Colapso

$\square$ Pérdida de sección $\square$ Pérdida de verticalidad $\square$ Por elementos impropios

$\square$ Vegetación $\square$ Grietas por empuje de la cubierta $\square$ Derivado de intervenciones

$\square$ Desconchados $\quad \square$ Grietas porfalta de traba $\quad \square$ Otro...
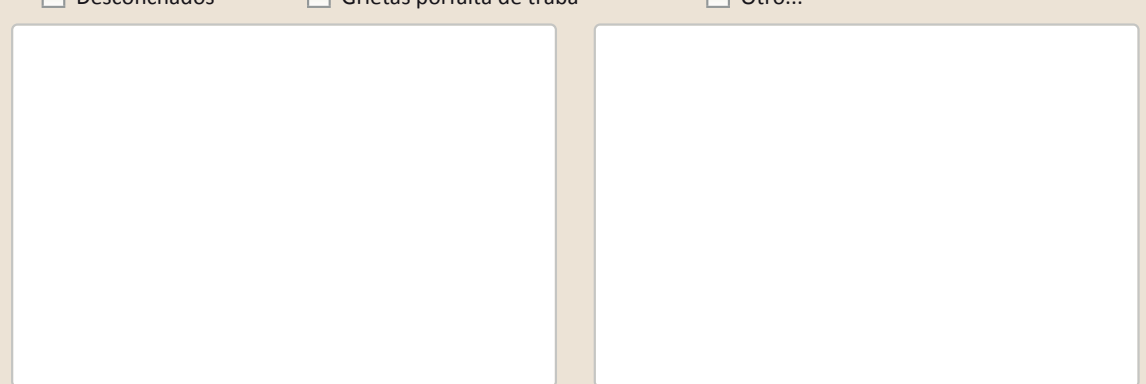

Observaciones

La restauración y rehabilitación de la arquitectura tradicional de tierra.

El caso de Aragón.

3. DATOS DE LA INTERVENCIÓN

Intervención de: $\quad \square$ Mantenimiento $\quad \square$ Rehabilitación parcial $\quad \square$ Restauración $\square$ Demolición

X Reparación $\square$ Rehabilitación integral $\square$ Ampliación $\square$ Otro..

Reflexión previa Intervención espontanea

Observaciones

3.1. MUROS

Tipo de intervención

Tipo de material

Descripción

3.2. ZÓCALO

Tipo de intervención

Tipo de material

Descripción

3.3. REVESTIMIENTOS

Tipo de intervención

Tipo de material

Descripción

3.4. VANOS

Tipo de intervención

Tipo de material

Descripción

3.5. CUBIERTA

Tipo de intervención

Tipo de material

Descripción

3.6. OTRAS

\section{Intervenido}

$\square$ Actualización $\quad \mathbf{X}$ Reintegración $\square$ Demolición $\square$ Otro...

$\square$ Consolidación $\quad \square$ Reconstrucción $\square$ Sustitución

\begin{tabular}{|l|l|l|}
\hline No tradicional & Tipo de técnica & Diferente a la existente
\end{tabular}

Faltantes con cemento

Intervenido

$\square$ Actualización $\square$ Reintegración $\square$ Demolición $\square$ Otro.

$\square$ Consolidación $\quad \mathbf{X}$ Reconstrucción $\square$ Sustitución

No tradicional Tipo de técnica Diferente a la existente

Revestimiento de cemento sobre la mampostería y ladrillos del zócalo preexistente

\section{No aplica}

$\square$ Actualización $\square$ Reintegración $\quad \square$ Demolición $\quad \square$ Otro...

$\square$ Consolidación $\square$ Reconstrucción $\square$ Sustitución

Tipo de técnica

Intervenido

$\square$ Actualización $\square$ Reintegración $\square$ Demolición $\square$ Otro..

$\square$ Consolidación $\square$ Reconstrucción $\quad \mathbf{X}$ Sustitución

\begin{tabular}{l|l|l|l|l} 
No tradicional & Tipo de técnica Diferente a la existente
\end{tabular}

Cegado de huecos con ladrillo

Intervenido

$\square$ Actualización $\quad \mathbf{X}$ Reintegración $\square$ Demolición $\square$ Otro

$\square$ Consolidación $\quad \square$ Reconstrucción $\square$ Sustitución

No tradicional Tipo de técnica Diferente a la existente

Reintegración de los laterales de la cubierta con gran cantidad de mortero de cemento 


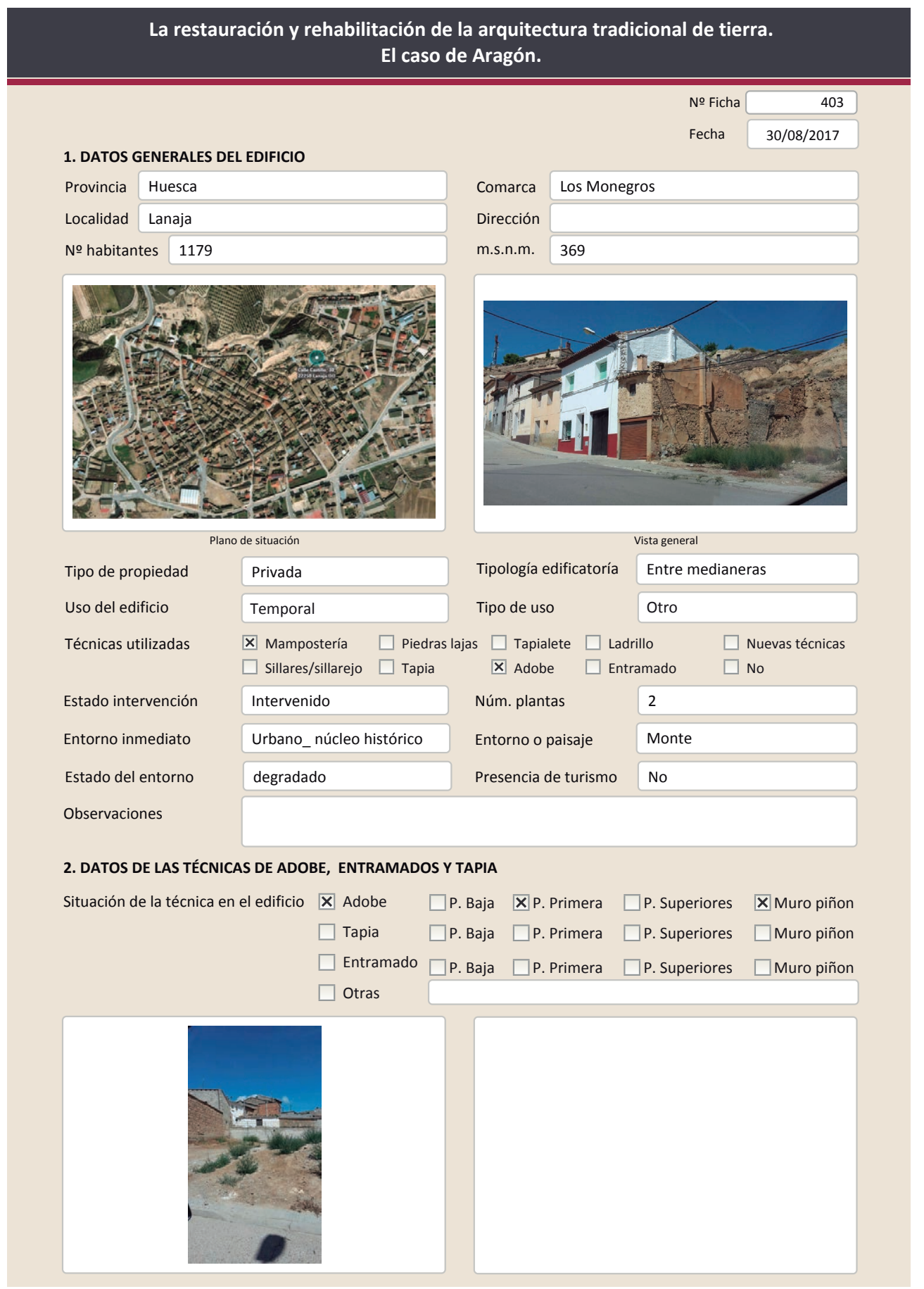

La restauración y rehabilitación de la arquitectura tradicional de tierra.

El caso de Aragón.

\subsection{ADOBE}

Dimensión de las piezas Dimensión del muro Aparejo del muro Función estructural
Color de las piezas

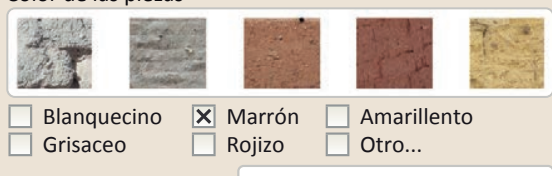

$\square$ Grisaceo

Rojizo $\square$ Otro...

Variante constructiva/ tipo de fábrica

$\square$ simple

X Suplementada en juntas

Verticales $\mathrm{y}$ horizontales

区 Mixta

\section{Machones}

$\mathrm{Cal} /$ yeso

$\square$ Como suplemento

Х Elementos de protección

Revestimiento

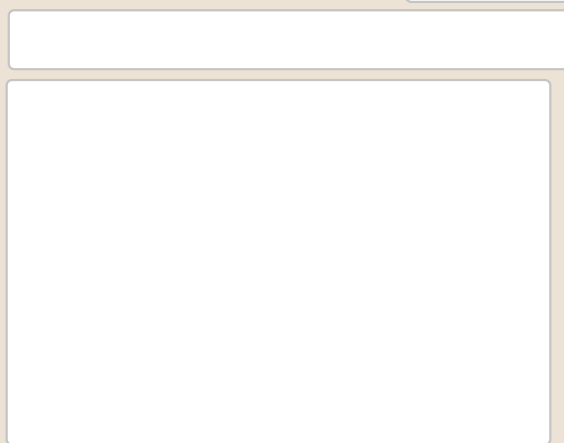

Lesiones ХMuro XZócalo X Revestimiento

$\mathbf{X}$ Erosión del material $\mathbf{X}$ Humedad por capilaridad

$\square$ Erosion de las juntas $\mathbf{X}$ Humedades (manch/eflo)

$\square$ Pérdida de sección $\square$ Pérdida de verticalidad

$\begin{array}{ll}\square \text { Vegetación } & \square \text { Grietas por empuje de la cubi } \\ \square \text { Desconchados } & \square \text { Grietas porfalta de traba }\end{array}$

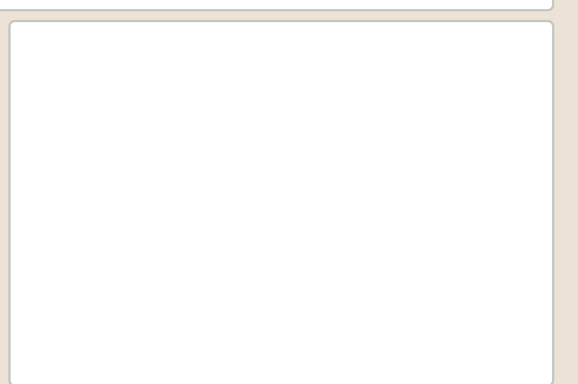

Cubierta $\square$ otro...

$\square$ Grietas por asentamientos

$\square$ Colapso

$\square$ Por elementos impropios

$\square$ Derivado de intervenciones

$\square$ Otro

Observaciones 
La restauración y rehabilitación de la arquitectura tradicional de tierra. El caso de Aragón

\section{La restauración y rehabilitación de la arquitectura tradicional de tierra.}

\section{El caso de Aragón.}

3. DATOS DE LA INTERVENCIÓN

Intervención de:

$\square$ Mantenimiento $\mathbf{X}$ Rehabilitación parcia

$\square$ Restauración $\square$ Demolición

Reflexión previa

$\square$ Reparación

Rehabilitación integra

Ampliación

$\square$ Otro..

Observaciones

Intervención espontanea

3.1. MUROS

No intervenido

Tipo de intervención

$\square$ Actualización $\square$ Reintegración $\square$ Demolición $\square$ Otro...

$\square$ Consolidación $\square$ Reconstrucción $\square$ Sustitución

Tipo de material

Descripción

3.2. ZÓCALO

Tipo de intervención

Intervenido

Tipo de intervención

$\square$ Actualización

邓 Reintegración $\square$ Demolición $\square$ Otro...

Tipo de material

\begin{tabular}{|l|l|l|l|l|l} 
No tradicional Tipo de técnica & Diferente a la existente \\
\hline Reintegración con pellas de mortero de cemento
\end{tabular}

Tipo de técnica

Descripción

3.3. REVESTIMIENTOS

No intervenido

Tipo de intervención

$\square$ Actualización $\square$ Reintegración $\square$ Demolición $\square$ Otro...

Tipo de material

Descripción

3.4. VANOS

Tipo de intervención

$\square$ Consolidación $\square$ Reconstrucción $\square$ Sustitución

Tipo de material

Intervenido

Descripción

$\square$ Actualización $\square$ Reintegración $\square$ Demolición $\square$ Otro...

$\square$ Consolidación $\mathbf{X}$ Reconstrucción $\mathbf{X}$ Sustitución

No tradicional Tipo de técnica Diferente a la existente

3.5. CUBIERTA

Tipo de intervención

Sustitución del vano de acceso por un hueco de
con puerta metálica y dintel de perfil metálico

Tipo de intervención

No intervenido

Tipo de material

$\square$ Actualización

$\square$ Consolidación $\quad \square$ Reconstrucción $\quad \square$ Sustitución

Descripción

Tipo de técnica

3.6. OTRAS 


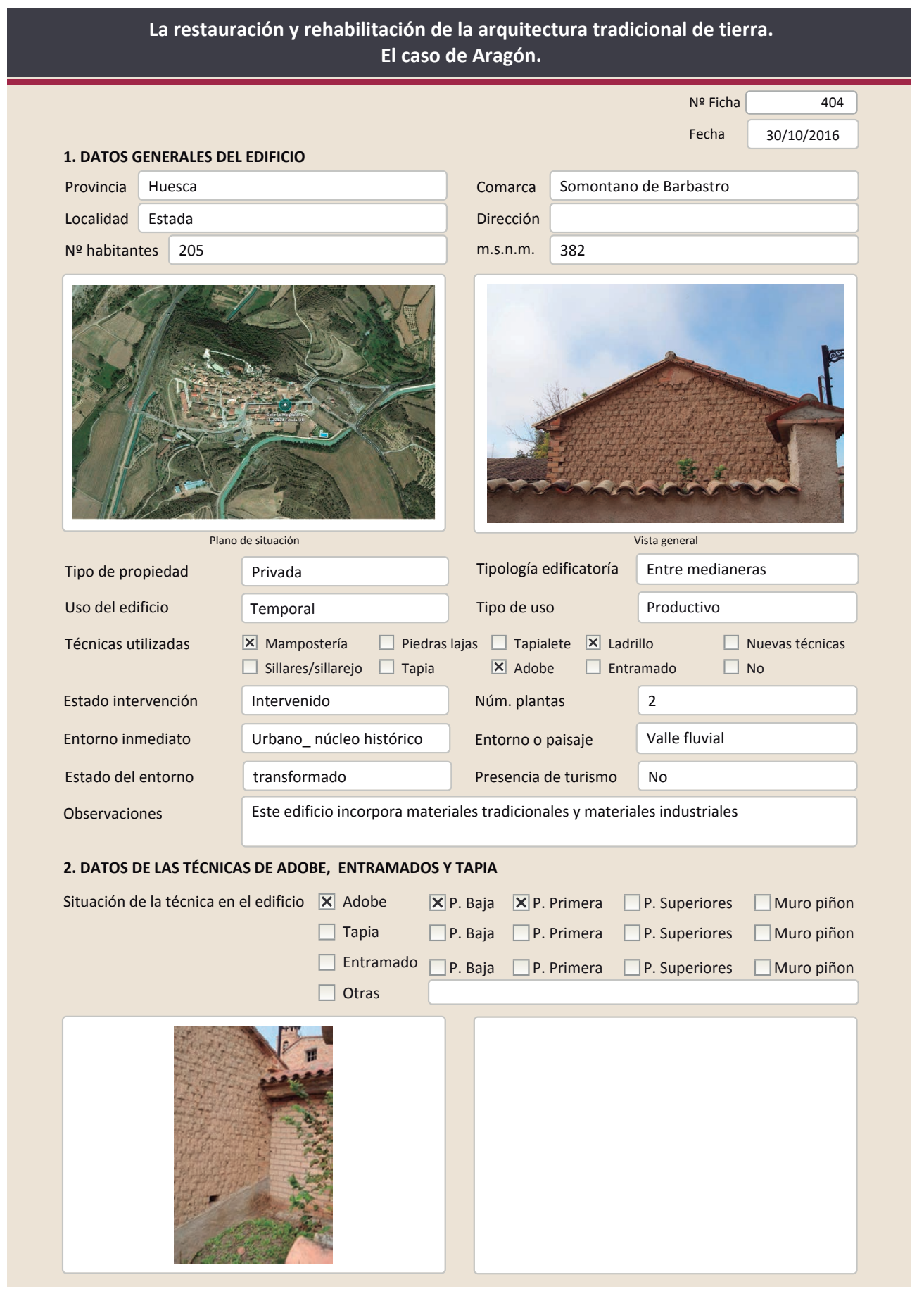

La restauración y rehabilitación de la arquitectura tradicional de tierra.

El caso de Aragón.

2.1. ADOBE

Dimensión de las piezas Dimensión del muro

Aparejo del muro

Función estructural

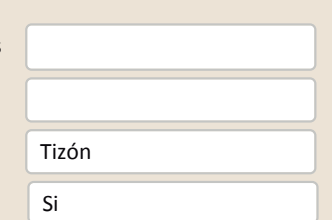

Color de las piezas

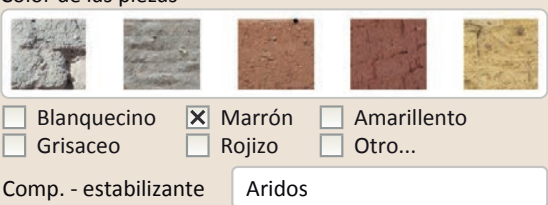

Variante constructiva/ tipo de fábrica

$\square$ Simple

$\square$ Suplementada en juntas

X Mixta
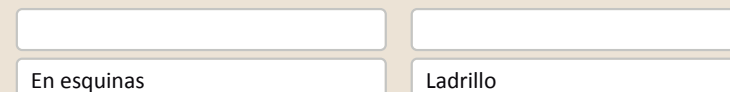

$\square$ Como suplemento

$\square$ Elementos de protección

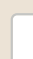

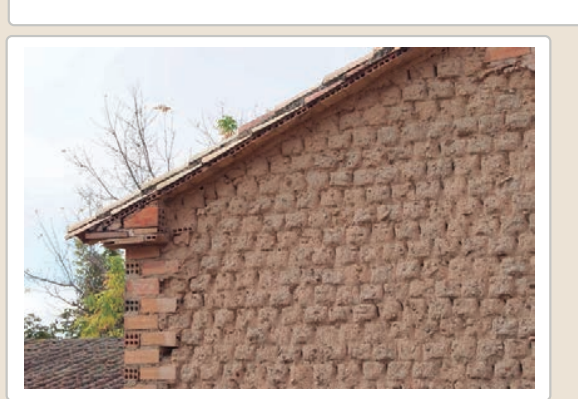

Lesiones $\quad \mathbf{X}$ Muro $\square$ Zócalo $\mathbf{X}$ Revestimiento

$\mathbf{X}$ Erosión del material $\mathbf{X}$ Humedad por capilaridad $\mathbf{X}$ Erosion de las juntas $\square$ Humedades (manch/eflo)

$\square$ Pérdida de sección $\square$ Pérdida de verticalidad

$\square$ Vegetación

$\square$ Vegetación
$\square$ Desconchados

$\square$ Grietas por empuje de la cubie

$\square$ Grietas porfalta de traba

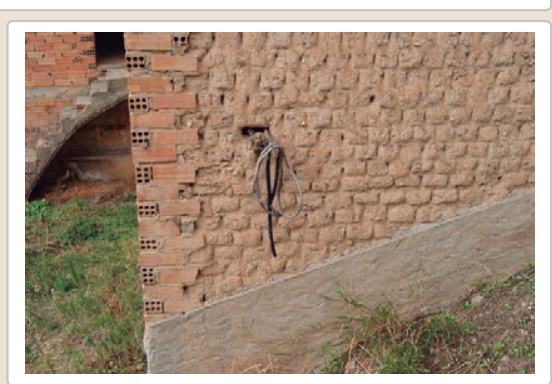

$\square$ Cubierta $\square$ Otro...

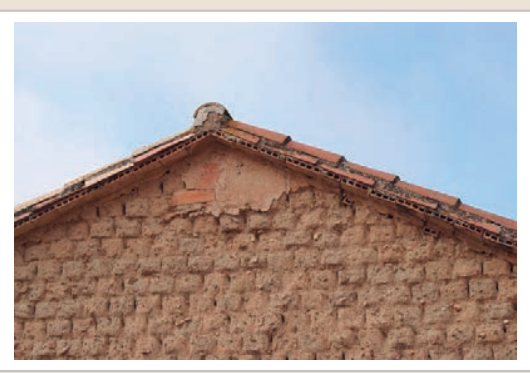

Observaciones 
La restauración y rehabilitación de la arquitectura tradicional de tierra. El caso de Aragón

\section{La restauración y rehabilitación de la arquitectura tradicional de tierra.}

\section{El caso de Aragón.}

3. DATOS DE LA INTERVENCIÓN

Intervención de:

$\square$ Mantenimiento $\square$ Rehabilitación parcial

$\square$ Restauración $\square$ Demolición

Reflexión previa

X Reparación

$\square$ Rehabilitación integra

Ampliación

$\square$ Otro...

Reflexión previa

Intervención espontanea

(20)

3.1. MUROS

No intervenido

Tipo de intervención

$\square$ Actualización

$\square$ Consolidación $\square$ Reconstrucción $\square$ Sustitución

Tipo de material

Descripción

3.2. ZÓCALO

Tipo de intervención

Intervenido

Tipo de intervención

$\square$ Actualización

Reintegración $\square$ Demolición $\square$ Otro...

Tipo de material

No tradicional

Х Reconstrucción $\square$ Sustitución

Descripción

Diferente a la existente

humedad por capilaridad.

3.3. REVESTIMIENTOS

Intervenido

Tipo de intervención

$\square$ Actualización $\square$ Reintegración $\quad \square$ Demolición $\square$ Otro...

$\square$ Consolidación $\quad \mathbf{X}$ Reconstrucción $\square$ sustitución

Tipo de material

Descripción

No tradicional

Tipo de técnica Diferente a la existente

3.4. VANOS

Tipo de intervención

Nuevo revestimiento en el muro de cercado exterior.

Tipo de material

Intervenido

Descripción

Reintegración $\quad \square$ Demolición $\square$ Otro..

$\square$ Consolidación $\square$ Reconstrucción $\quad \boldsymbol{x}$ Sustitución

No tradicional Tipo de técnica Diferente a la existente

3.5. CUBIERTA

Tipo de intervención

Intervenido

Tipo de intervención

$\square$ Actualización $\square$ Reintegración $\square$ Demolición $\quad \square$ Otro.

Tipo de material

$\square$ Consolidación $\square$ Reconstrucción $\quad \boldsymbol{X}$ Sustitución

Descripción

No tradicional Tipo de técnica Similar a la existente

3.6. OTRAS

Sustitución de la cubierta- coronación del muro de cercado exterior 


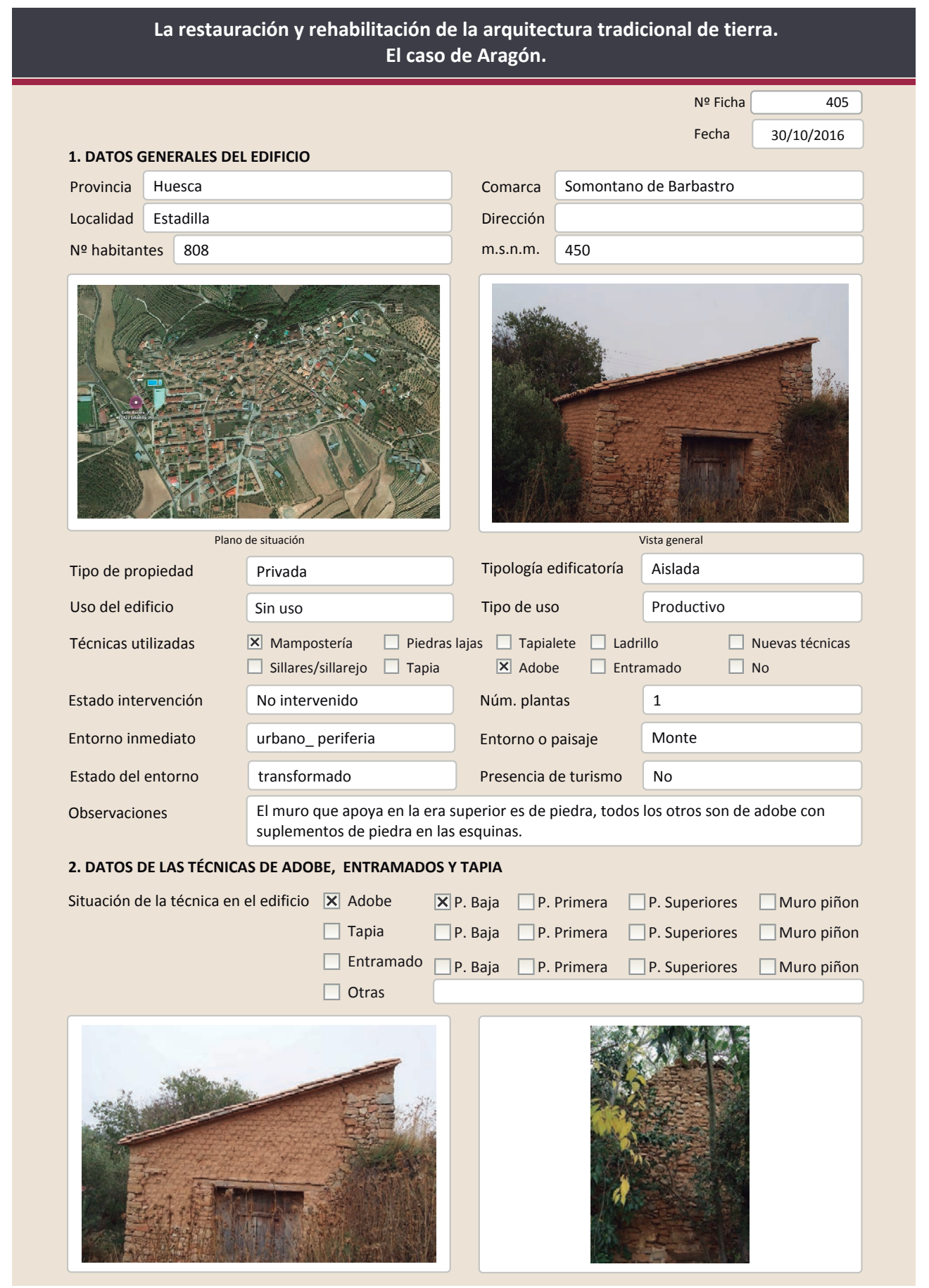

La restauración y rehabilitación de la arquitectura tradicional de tierra. El caso de Aragón.

2.1. ADOBE

Dimensión de las piezas Dimensión del muro

Aparejo del muro

Función estructural

iva/ tipo de fábrica

$\square$ Simple

$\square$ Suplementada en juntas

X Mixta

$\square$ Como suplemento

$\square$ Elementos de protección

\section{प Elemesto proteción}

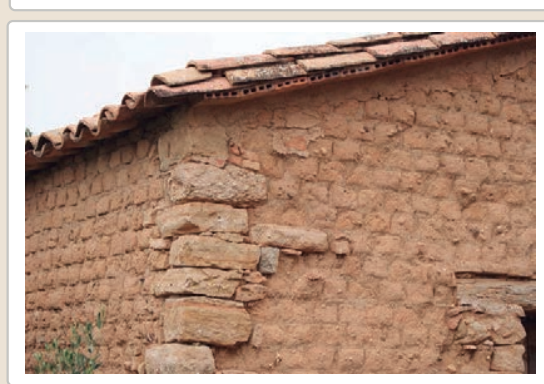

Lesiones $\quad$ XMuro $\square$ Zócalo $\square$ Revestimiento X Erosión del material $\square$ Humedad por capilaridad $\mathbf{X}$ Erosion de las juntas $\square$ Humedades (manch/eflo) Х Pérdida de sección $\square$ Pérdida de verticalidad

$\square$ Vegetación $\quad \square$ Grietas por empuje de la c $\square$ Desconchados $\square$ Grietas porfalta de traba

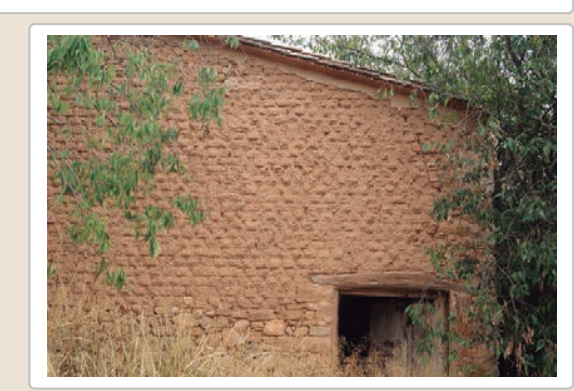

$\square$ Cubierta $\square$ Otro...

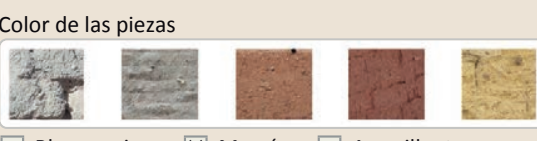

$\square$ Blanquecino $\quad \mathbf{X}$ Marrón $\square$ Amarillento $\square$ Grisaceo $\quad \square$ Rojizo $\square$ Otro... Comp. - estabilizante Fibras vegetales

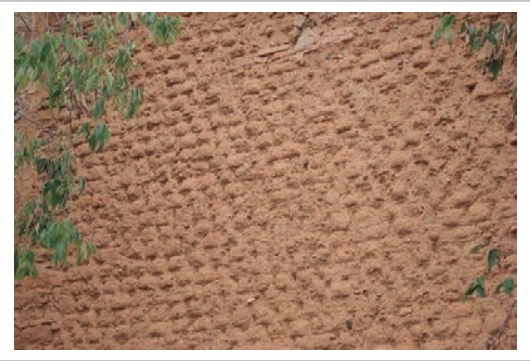

$\square$ Grietas por asentamientos $\square$ Colapso

$\square$ Por elementos impropios

$\square$ Derivado de intervenciones $\square$ Otro...

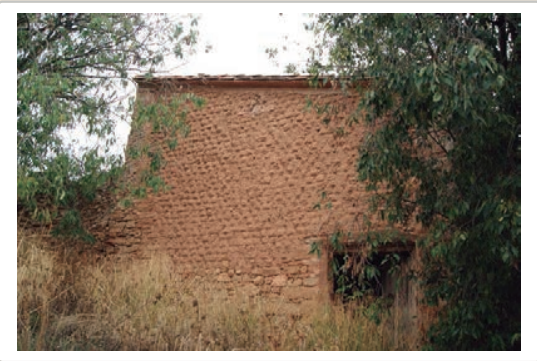

Observaciones 


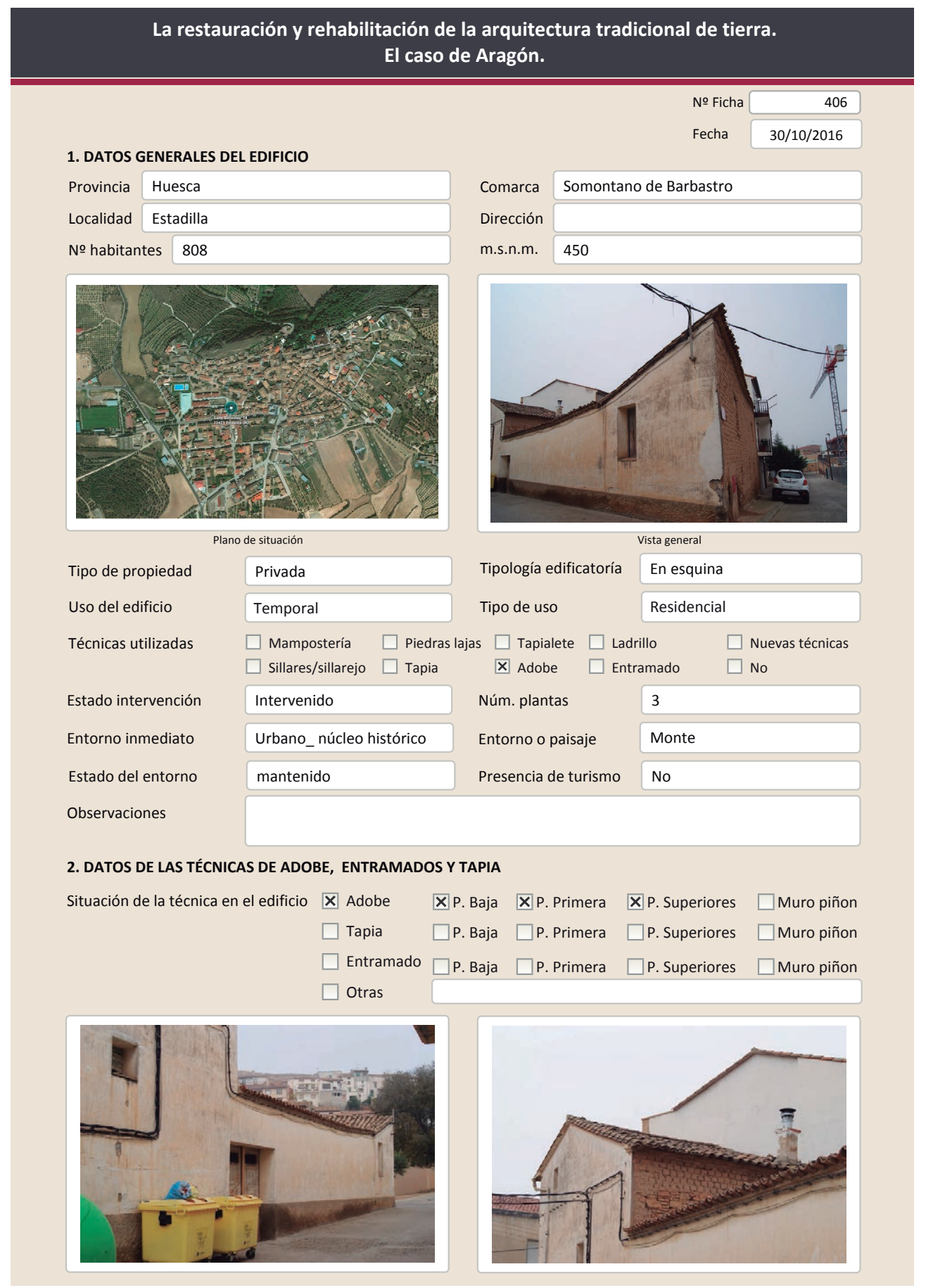

\subsection{ADOBE \\ Dimensión de las piezas $20 \times 37 \times 11$ \\ Dimensión del muro $30-40 \mathrm{~cm}$ \\ Aparejo del muro Tizón \\ Función estructural \\ $\mathrm{Si}$
\ Simple
$\square$ Suplementada en juntas
$\square$ Mixta
$\square$ Como suplemento
$\square$ Elementos de protección

Color de las piezas

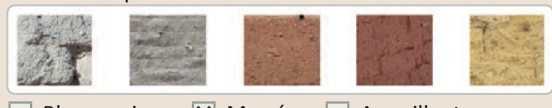

$\square$ Blanquecino $\mathbf{X}$ Marrón $\square$ Amarillento $\square$ Grisaceo $\square$ Rojizo $\square$ Otro...

Comp. - estabilizante Aridos

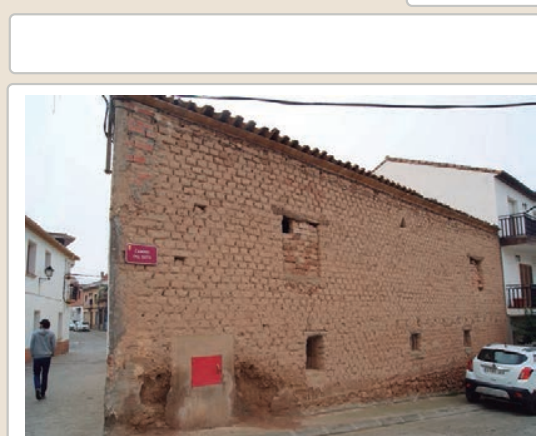

Lesiones $\quad \mathbf{X}$ Muro $\mathbf{X}$ Zócalo $\square$ Revestimiento X Erosión del material $\mathbf{X}$ Humedad por capilaridad $\mathbf{X}$ Erosion de las juntas $\mathbf{X}$ Humedades (manch/eflo) \ Pérdida de sección $\square$ Pérdida de verticalidad

$\square$ Vegetación

$\square$ Desconchados

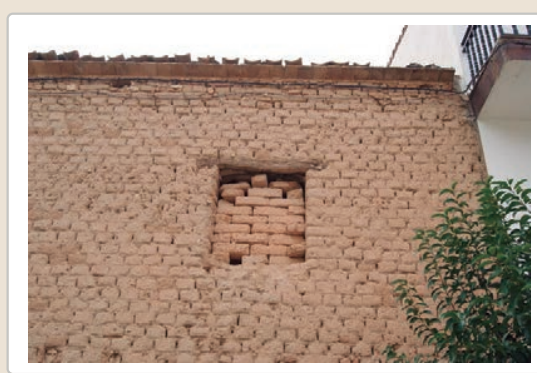

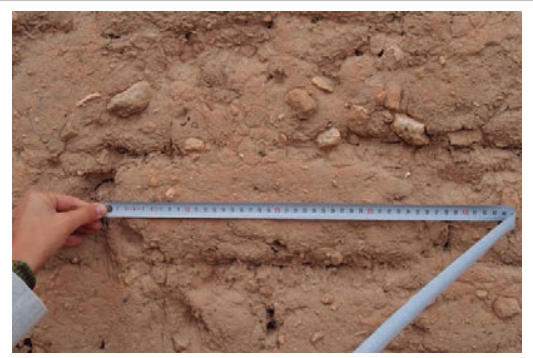

$\square$ Cubierta $\square$ otro... X Grietas por asentamientos $\square$ Colapso

$\square$ Por elementos impropios $\boldsymbol{X}$ Derivado de intervenciones $\square$ Otro...

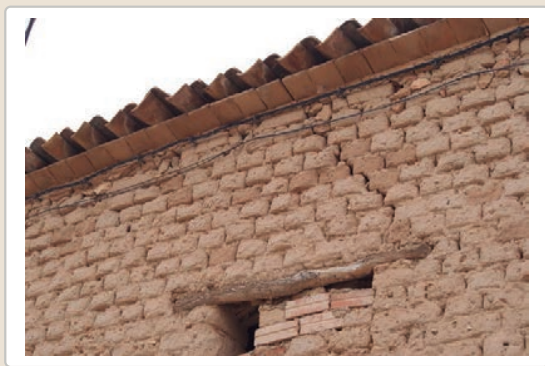

presenta distintas patologías. Es notable la perdida de material que esta sufriendo el muro en la parte inferior del mismo junto a un elemento añadido que es probablemente un registro de aguas con una fuga. 
La restauración y rehabilitación de la arquitectura tradicional de tierra. El caso de Aragón.

3. DATOS DE LA INTERVENCIÓN

Intervención de:

$\square$ Mantenimiento $\square$ Rehabilitación parcial X Reparación $\square$ Rehabilitación integr

$\square$ Restauración $\square$ Demolición Intervención espontanea

Reflexión previa

Observaciones

Intervenido

3.1. MUROS Tipo de intervención

Tipo de material

Descripción

3.2. ZÓCALO

Tipo de intervención

Tipo de material

Descripción

3.3. REVESTIMIENTOS

Tipo de intervención

Tipo de material

Descripción

3.4. VANOS

Tipo de intervención

Tipo de material

Descripción

3.5. CUBIERTA

Tipo de intervención

Tipo de material

Descripción

No intervenido

$\square$ Actualización

$\square$ Consolidación

$\square$ Reintegración $\square$ Demolición $\square$ Sustitución

La cubierta tiene ladrillo hueco de base pero probablemente sean de origen del edificio.
La restauración y rehabilitación de la arquitectura tradicional de tierra.

El caso de Aragón.

3.7. REHABILITACIÓN ENERGÉTICA $\quad \square$ Fachada $\square$ Vanos $\square$ Forjados $\square$ Cubierta

Observaciones

FOTOGRAFíAS DE LA INTERVENCIÓN
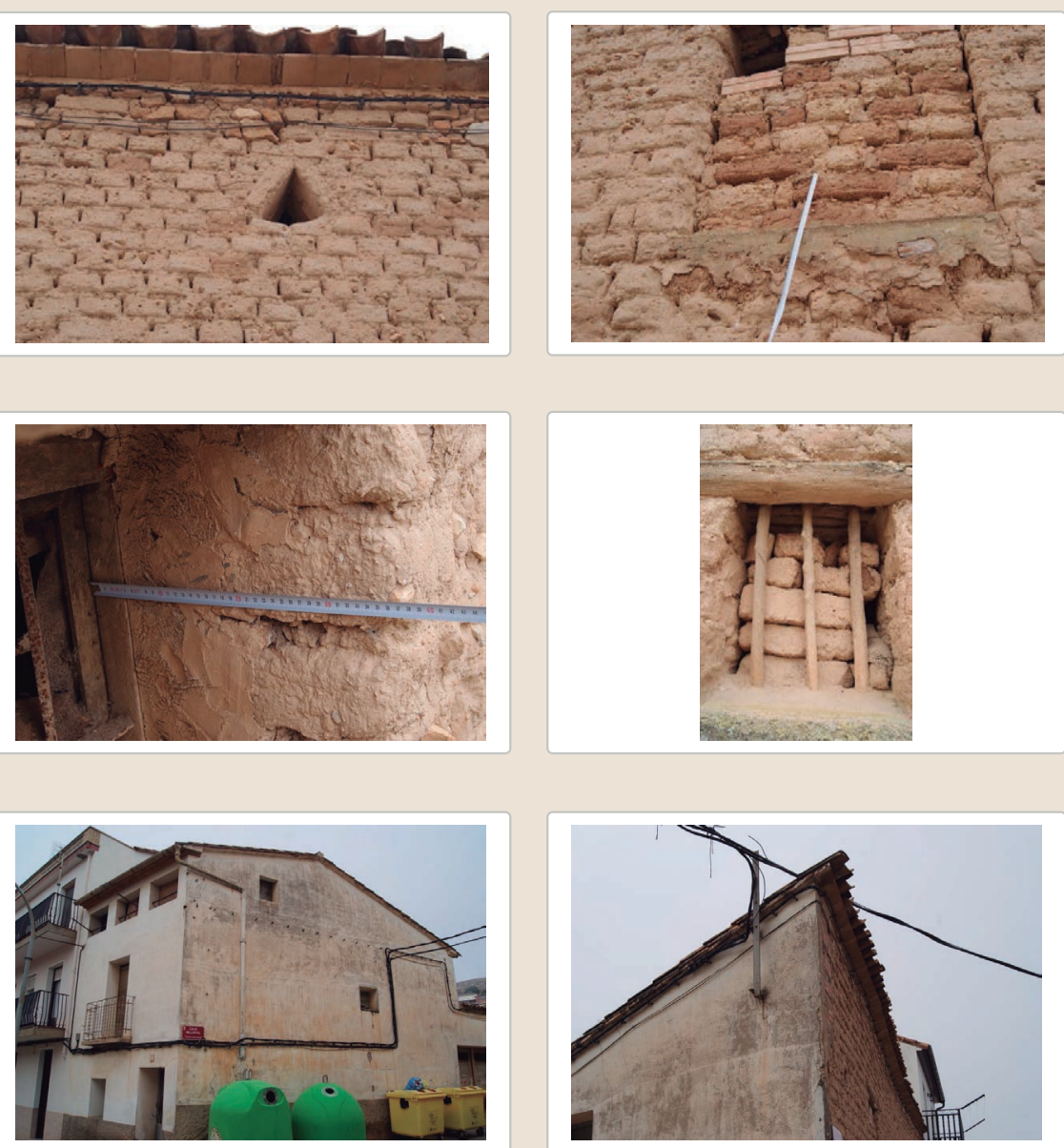

3.6. OTRAS 


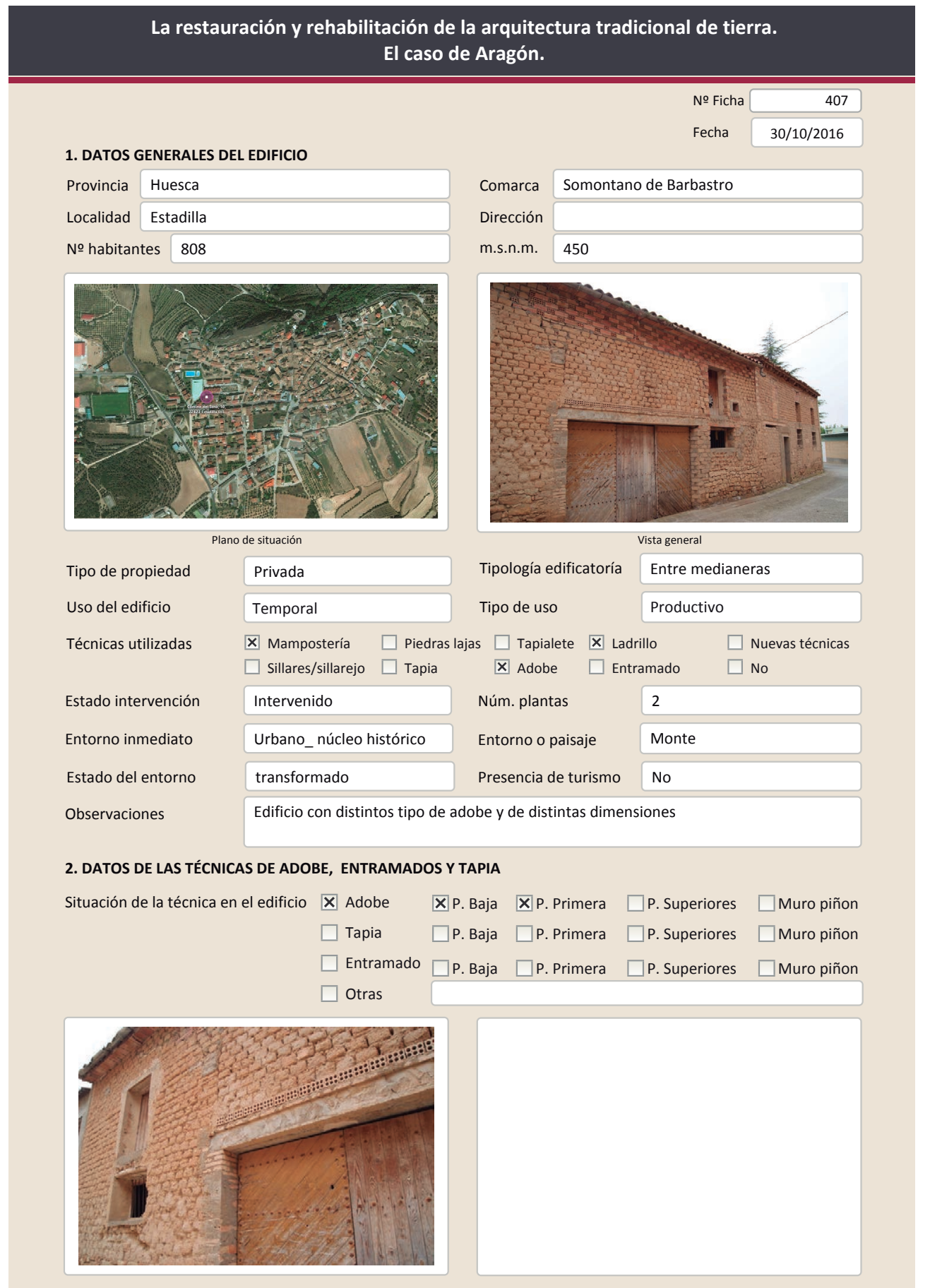

La restauración y rehabilitación de la arquitectura tradicional de tierra.

El caso de Aragón.

2.1. ADOBE

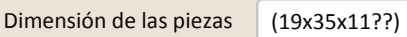

Dimensión del muro $30-40 \mathrm{~cm}$

Aparejo del muro Tizón

Función estructural

Variante constructiva/ tip

$\square$ Suplementada en juntas

$\square$ Mixta

$\square$ Como suplemento

$\square$ Elementos de protección

Distintos tipos de adobe dentro del mismo edificio

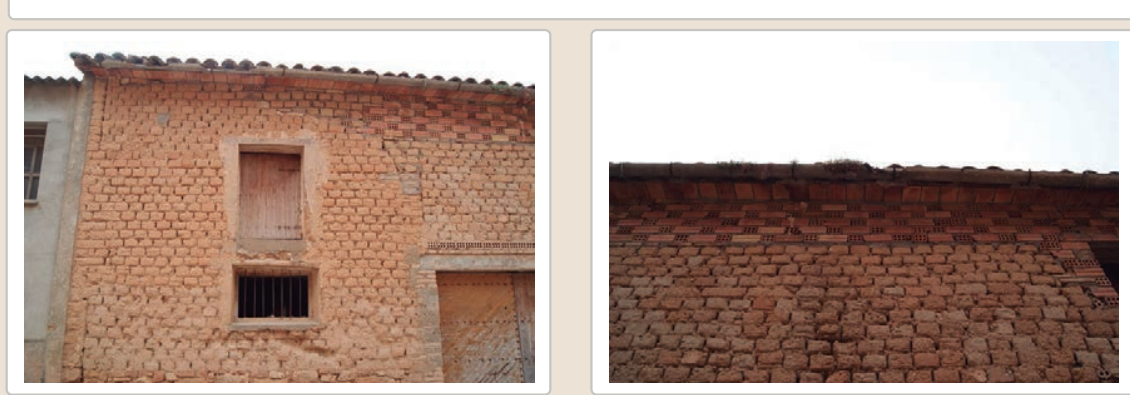

Lesiones ХMuro \Zócalo $\square$ Revestimiento $\square$ Cubierta $\square$ otro...

Х Erosión del material $\quad \mathbf{X}$ Humedad por capilaridad $\quad \square$ Grietas por asentamientos $\boldsymbol{X}$ Erosion de las juntas $\square$ Humedades (manch/eflo) $\square$ Colapso

$\square$ Pérdida de sección $\quad \square$ Pérdida de verticalidad

$\square$ Vegetación $\quad \square$ Grietas por empuje de la cubie

$\square$ Por elementos impropios

$\square$ Desconchados

$\square$ Grietas porfalta de traba

$\square$ Derivado de intervenciones

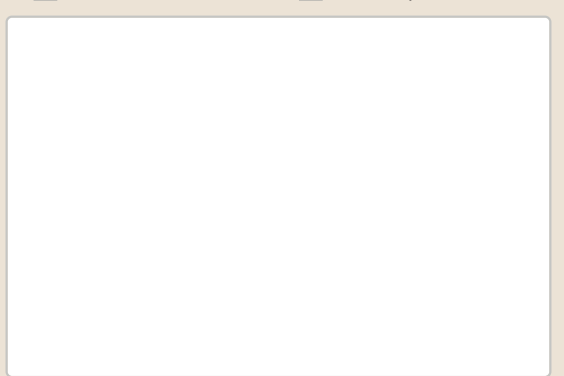
$\begin{array}{ll}\text { Observaciones } & \begin{array}{l}\text { Hay distintos tipos de adobe en el edificio, con composición, dimensiones y colores } \\ \text { diferentes }\end{array}\end{array}$ 


\section{La restauración y rehabilitación de la arquitectura tradicional de tierra.}

\section{El caso de Aragón.}

3. DATOS DE LA INTERVENCIÓN

Intervención de:

Mantenimiento $邓$ Rehabilitación parcial

$\square$ Restauración $\square$ Demolición

Reflexión previa

$\square$ Reparación

Rehabilitación integra

$\square$ Ampliación

$\square$ otro...

Observaciones

Intervención espontanea

3.1. MUROS

Tipo de intervención

Tipo de material

Descripción

3.2. ZÓCALO

Tipo de intervención

Tipo de material

Descripción

3.3. REVESTIMIENTOS

Tipo de intervención

Tipo de material

Descripción

3.4. VANOS

Tipo de intervención

Tipo de material

Descripción

3.5. CUBIERTA

Tipo de intervención

Tipo de material

Descripción

3.6. OTRAS

$\square$ Actualización $\square$ Reintegración $\square$ Demolición $\square$ Otro...

$\square$ Consolidación $\quad \square$ Reconstrucción $\square$ sustitución

Tipo de técnica

Intervenido

$\square$ Actualización $\quad \boldsymbol{X}$ Reintegración $\square$ Demolición $\square$ Otro...

$\square$ Consolidación $\mathbf{X}$ Reconstrucción $\square$ Sustitución

Reintegración de las jambas y dintel de los huecos de ventana y reconstrucción del

Reintegración de las jambas y dintel de los huecos de ventana y reconstrucción
hueco de acceso principal con nuevo dintel y jambas de viguetas de hormigón.

Intervenido

$\square$ Consolidación $\quad \mathbf{X}$ Reconstrucción $\square$ Sustitución

\begin{tabular}{|l|l|l|l|l}
\hline No tradicional Tipo de técnica Similar a la existente \\
\hline
\end{tabular}

Nueva cubierta de bardos cerámicos

Nueva cubierta de bardos cerámicos
La restauración y rehabilitación de la arquitectura tradicional de tierra.

El caso de Aragón.

3.7. REHABILITACIÓN ENERGÉTICA $\quad \square$ Fachada $\square$ Vanos $\square$ Forjados $\square$ Cubierta

Observaciones

FOTOGRAFíAS DE LA INTERVENCIÓN
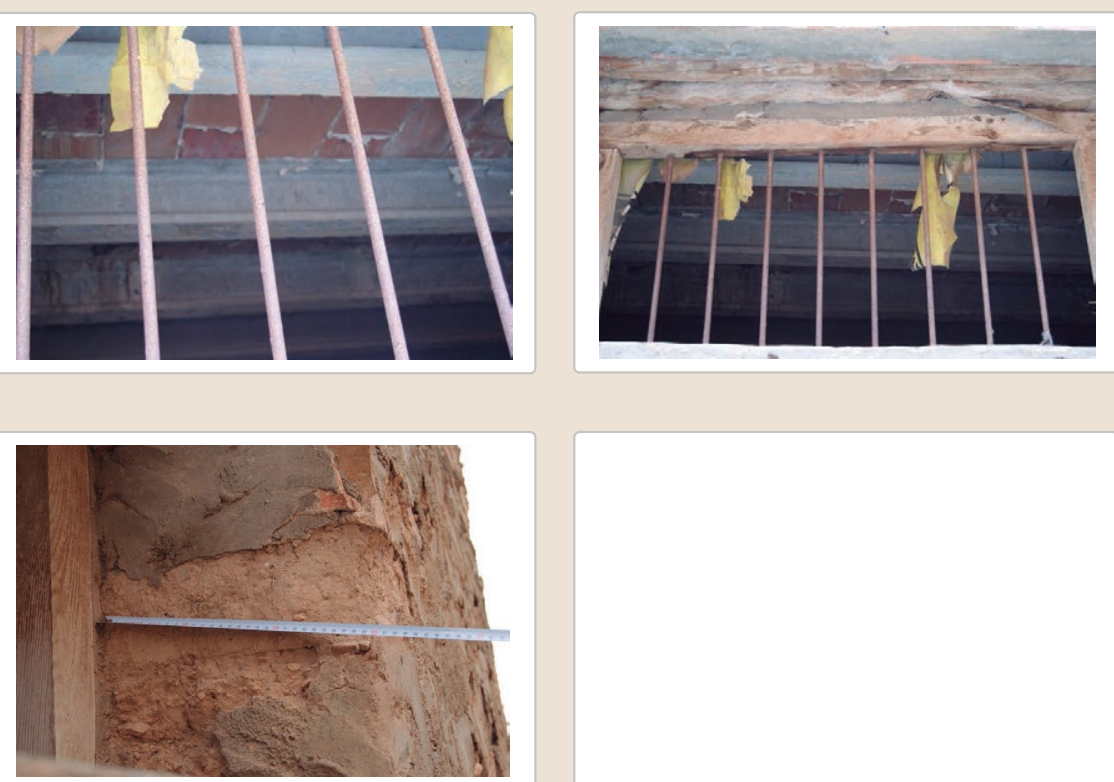

No tradicional Tipo de técnica Diferente a la existente

$\square$ Actualización $\square$ Reintegración $\square$ Demolición $\square$ Otro..
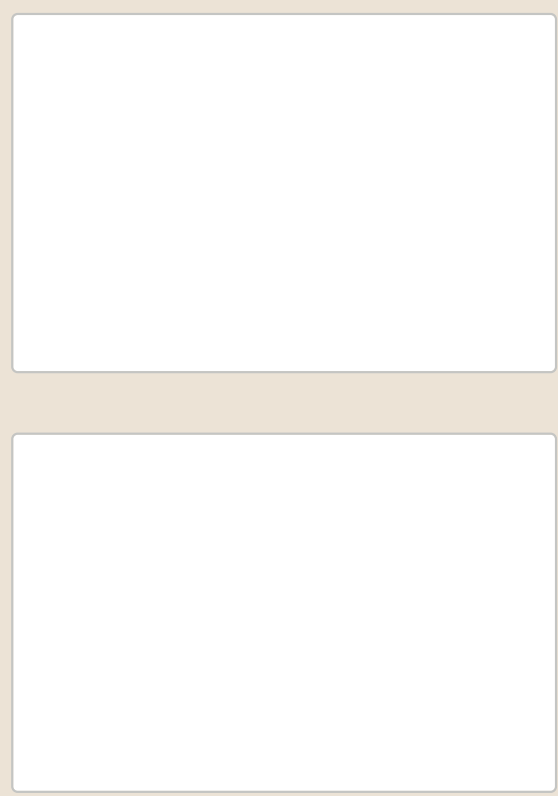


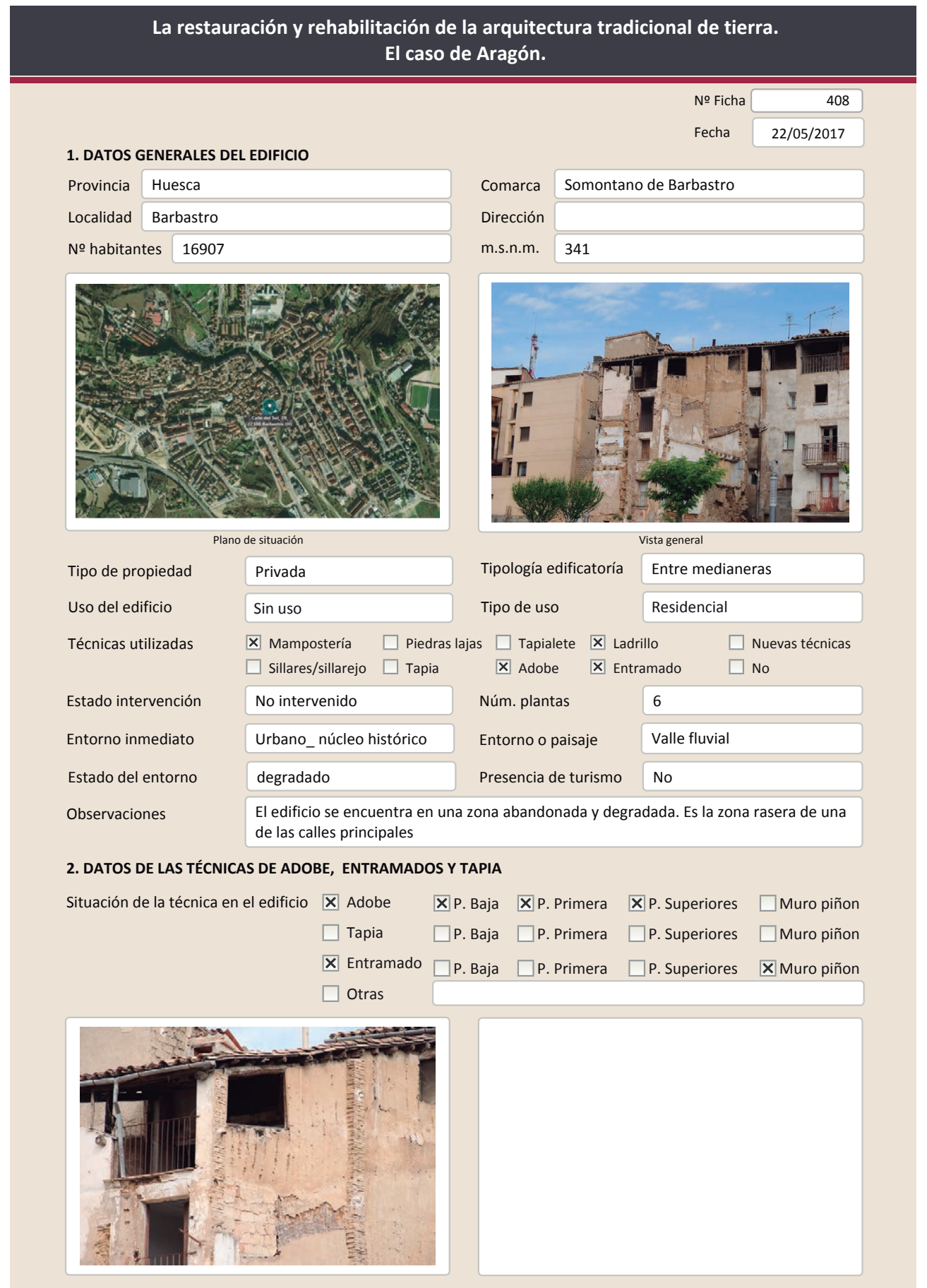

2.1. ADOBE

Dimensión de las piezas

Dimensión del muro

Aparejo del muro

Función estructural

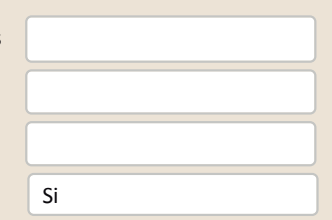

Color de las piezas

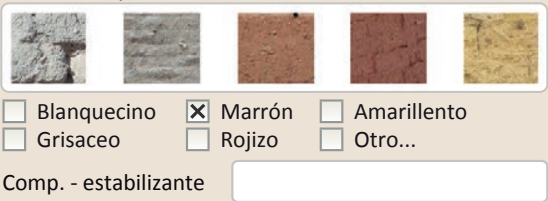

Variante constructiva/ tipo de fábrica

$\square$ Simple
X Suplementada en juntas
Verticales $\mathrm{y}$ horizontales
X Mixta
Machones
$\square$ Como suplemento

Cal/ yeso

$\square$ Elementos de protección

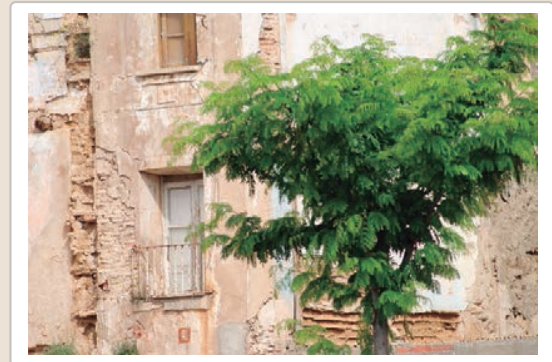

$\square$ Cubierta $\square$ otro.

Lesiones $\mathbf{X}$ Muro $\mathbf{X}$ Zócalo $\mathbf{X}$ Revestimiento

$\mathbf{X}$ Erosión del material $\quad \mathbf{X}$ Humedad por capilaridad $\square$ Erosion de las juntas $\square$ Humedades (manch/eflo) Х Pérdida de sección $\quad \square$ Pérdida de verticalidad $\begin{array}{ll}\square \text { Vegetación } & \square \text { Grietas por empuje de la c } \\ \text { メ Desconchados } & \square \text { Grietas porfalta de traba }\end{array}$ $\square$ Grietas por asentamientos
$\square$ Colapso
$\square$ Por elementos impropios
$\square$ Derivado de intervencione $\square$ Otro...

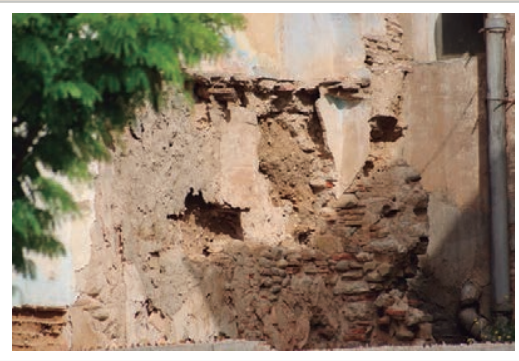

Observaciones 
La restauración y rehabilitación de la arquitectura tradicional de tierra.

El caso de Aragón.

\subsection{ENTRAMADOS}

Distancia entre montantes

Altura de los montantes

Sección de los montantes

Dimensión de los montantes

Tipo de relleno del entramado

Técnica de relleno del entramado

$\square$ Entre pantallas de madera
$\square$ Tierra y mampuestos

$\square$ Tapialete

\section{$\square$ Pared de mano $\quad \mathbf{X}$ Cañizo \\ $\square$ Adobe horizontal $\square$ Encestados \\ $\square$ Adobe aletorio $\square$ Otro.}

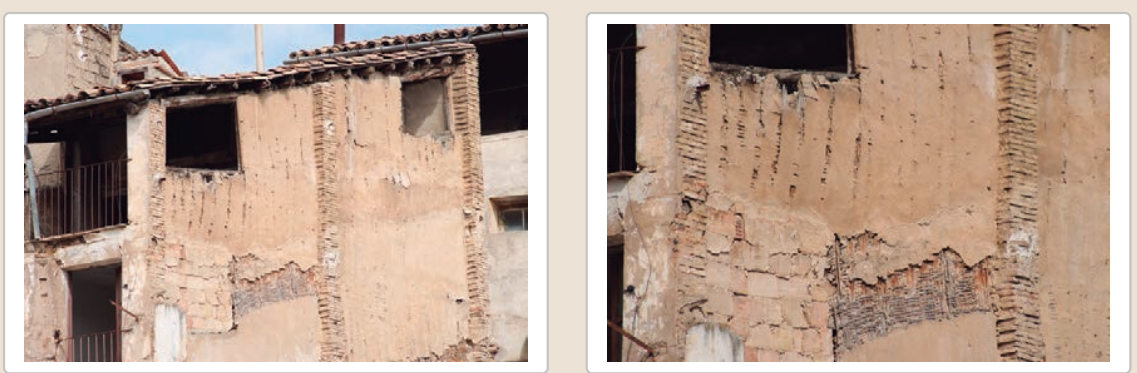

Lesiones

$\square$ Erosion de las juntas

$\square$ Pérdida de sección

$\square$ Vegetación

X Desconchados

Carcoma o termitas

$\square$ Rotura de la madera

$\square$ Pudrición de la madera

$\square$ Deformación madera

X Pudrición del relleno

Elementos diagonales

Eementos horizontales intermedios

Sección de las piezas horizontales

mensión de las piezas horizontales

Humedad por capilaridad - $\mathbf{X}$ Pérdida de verticalidad

$\square$ Grietas por empuje de la cubierta $\square$ Grietas por falta de traba

Grietas por asentamientos

$\square$ Colapso

$\square$ Por elementos impropios

$\square$ Derivado de intervenciones

$\square$ Otro...
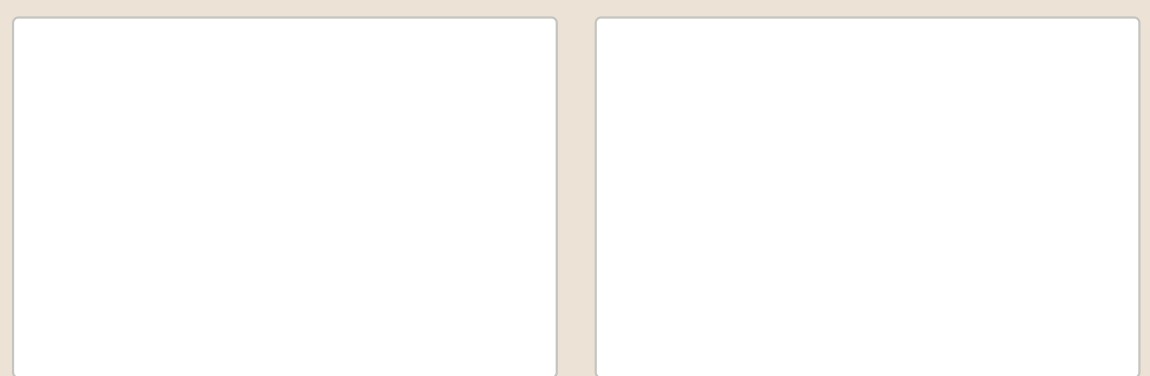


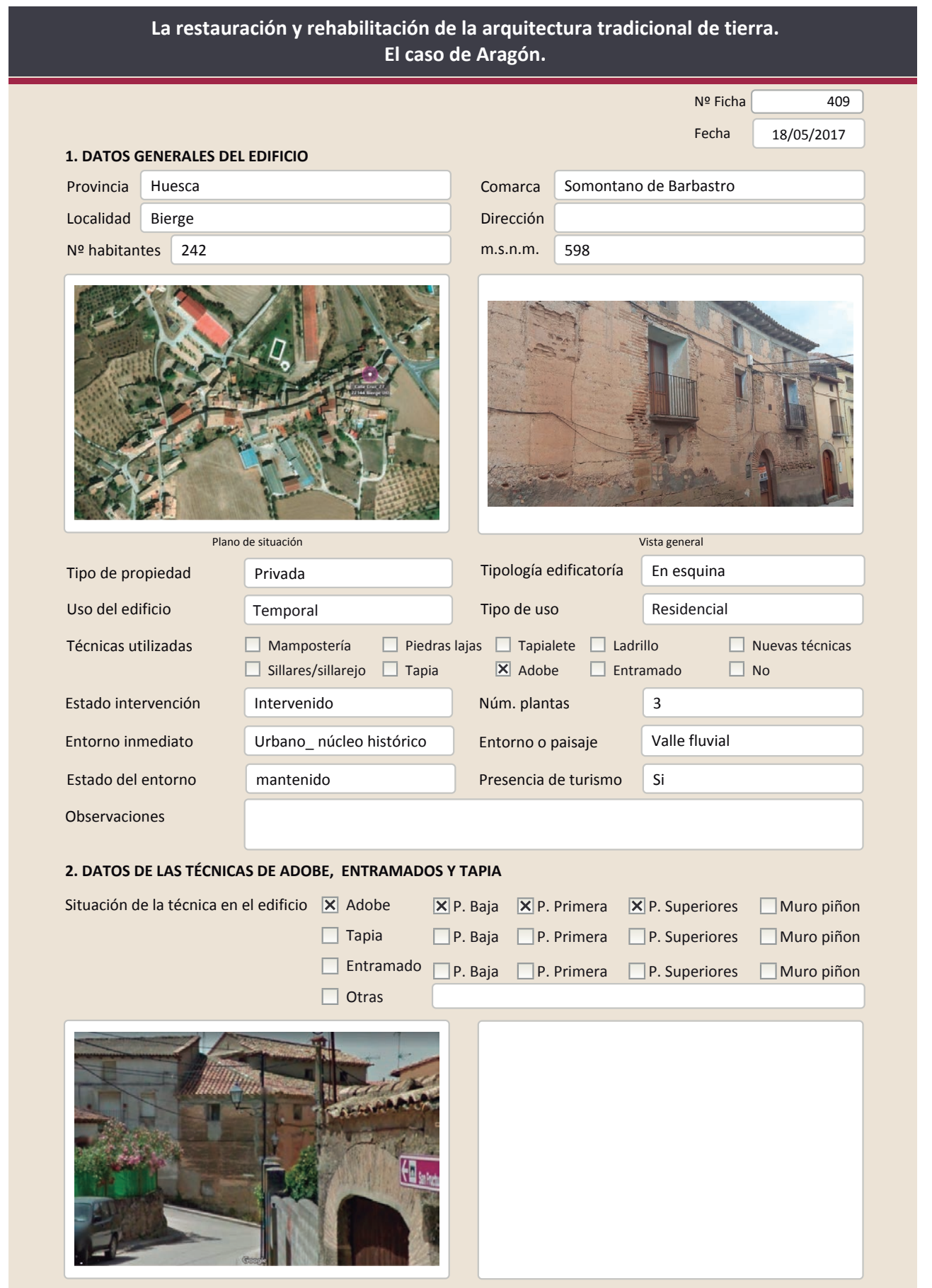

La restauración y rehabilitación de la arquitectura tradicional de tierra.

El caso de Aragón.
2.1. ADOBE

Dimensión de las piezas

Dimensión del muro

Aparejo del muro

Función estructural

Variante constructiva/ tipo de fábrica

$\square$ Suplementada en juntas

区 Mixta

\section{Machones}

Color de las piezas

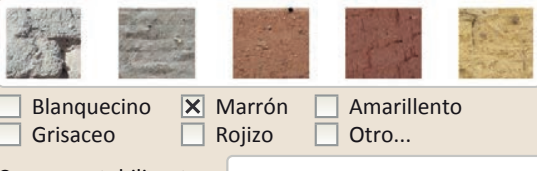

$\begin{array}{lll}\square \text { Blanquecino } & \mathbf{x} \text { Marrón } \square \text { Amarill } \\ \square \text { Grisaceo } & \square \text { Rojizo } \square \text { Otro... }\end{array}$

Comp. - estabilizante $\square$ Como suplemento

X Elementos de protección

Revestimiento

Los adobes están revestidos de forma que parece que la técnica constructiva sea la tapia

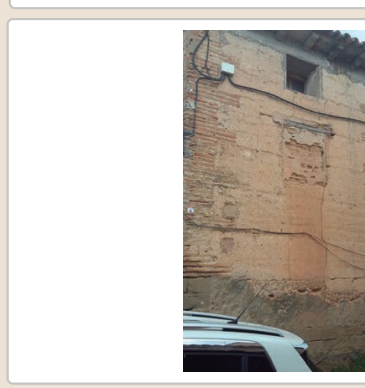

Lesiones $\mathbf{X}$ Muro XZŹcalo $\mathbf{X}$ Revestimiento

$\mathbf{X}$ Erosión del material $\mathbf{X}$ Humedad por capilarida

$\square$ Cubierta $\square$ otro...

$\square$ Erosion de las juntas $\square$ Humedades (manch/eflo) $\square$ Colapso

$\square$ Pérdida de sección $\square$ Pérdida de verticalidad

X Desconchados

$\begin{array}{ll}\square \text { Grietas por empuje de la cubierta } & \square \text { Deriva } \\ \square \text { Grietas porfalta de traba } & \square \text { Otro... }\end{array}$

Por elementos impropios

Observacione 


\section{La restauración y rehabilitación de la arquitectura tradicional de tierra.}

\section{El caso de Aragón.}

3. DATOS DE LA INTERVENCIÓN

\begin{tabular}{l|lll|} 
Intervención de: & $\square$ Mantenimiento $\quad \boldsymbol{X}$ Rehabilitación parcial & $\square$ Restauración & $\square$ Demolición \\
& $\boldsymbol{X}$ Reparación & $\square$ Rehabilitación integral & $\square$ Ampliación \\
Reflexión previa & Intervención planificada & \\
Observaciones & & \\
& & \\
& &
\end{tabular}

\subsection{MUROS}

Tipo de intervención

Intervenido

Tipo de material

$\square$ Actualización $\quad$ X Reintegración $\square$ Demolición $\square$ Otro...

$\square$ Consolidación $\square$ Reconstrucción $\square$ sustitución

Descripción

\begin{tabular}{ll} 
No tradicional Tipo de técnica & Diferente a la existente \\
\hline Reintegración con cemento de las zonas con erosión más profunda
\end{tabular}

3.2. ZÓCALO

Tipo de intervención

Intervenido

$\square$ Actualización

\Reintegración $\square$ Demolición $\square$ Otro...

Tipo de material

$\square$ Consolidación $\quad \square$ Reconstrucción $\square$ Sustitución

Descripción

No tradicional Tipo de técnica Diferente a la existente

3.3. REVESTIMIENTOS

Revestimiento de cemento sobre la sillería del zócalo

Tipo de intervención

Intervenido

Tipo de material

$\square$ Actualización $\quad \boldsymbol{X}$ Reintegración $\quad \square$ Demolición $\square$ Otro...

$\square$ Consolidación $\quad \square$ Reconstrucción $\square$ Sustitución

Descripción

No tradicional Tipo de técnica Diferente a la existente

3.4. VANOS

Reintegración del revestimiento con pequeñas pellas donde existen faltantes

Tipo de intervención

Intervenido

Tipo de material

$\square$ Actualización $\quad \square$ Reintegración $\quad \square$ Demolición $\square$ Otro...

$\square$ Consolidación $\square$ Reconstrucción $\quad$ \ Sustitución

\begin{tabular}{|l|l|l|l|l}
\hline & No tradicional & Tipo de técnica & Diferente a la existente
\end{tabular}

Descripción Se han cegado varios huecos con cemento. Se desconoce si estos estaban cegados con

anterioridad

3.5. CUBIERTA

$\begin{array}{ll}\text { Tipo de intervención } & \square \text { Actualización } \quad \square \text { Reintegración } \quad \square \text { Demolición } \quad \square \text { Otro... } \\ & \square \text { consolidación } \quad \square \text { Reconstrucción } \quad \text { X Sustitución }\end{array}$

Intervenido

Tipo de material

No tradicional Tipo de técnica Diferente a la existente

Descripción

Nueva cubierta de losa de hormigón sobre un zuncho de hormigón armado realizado en la coronación del muro

3.6. OTRAS 


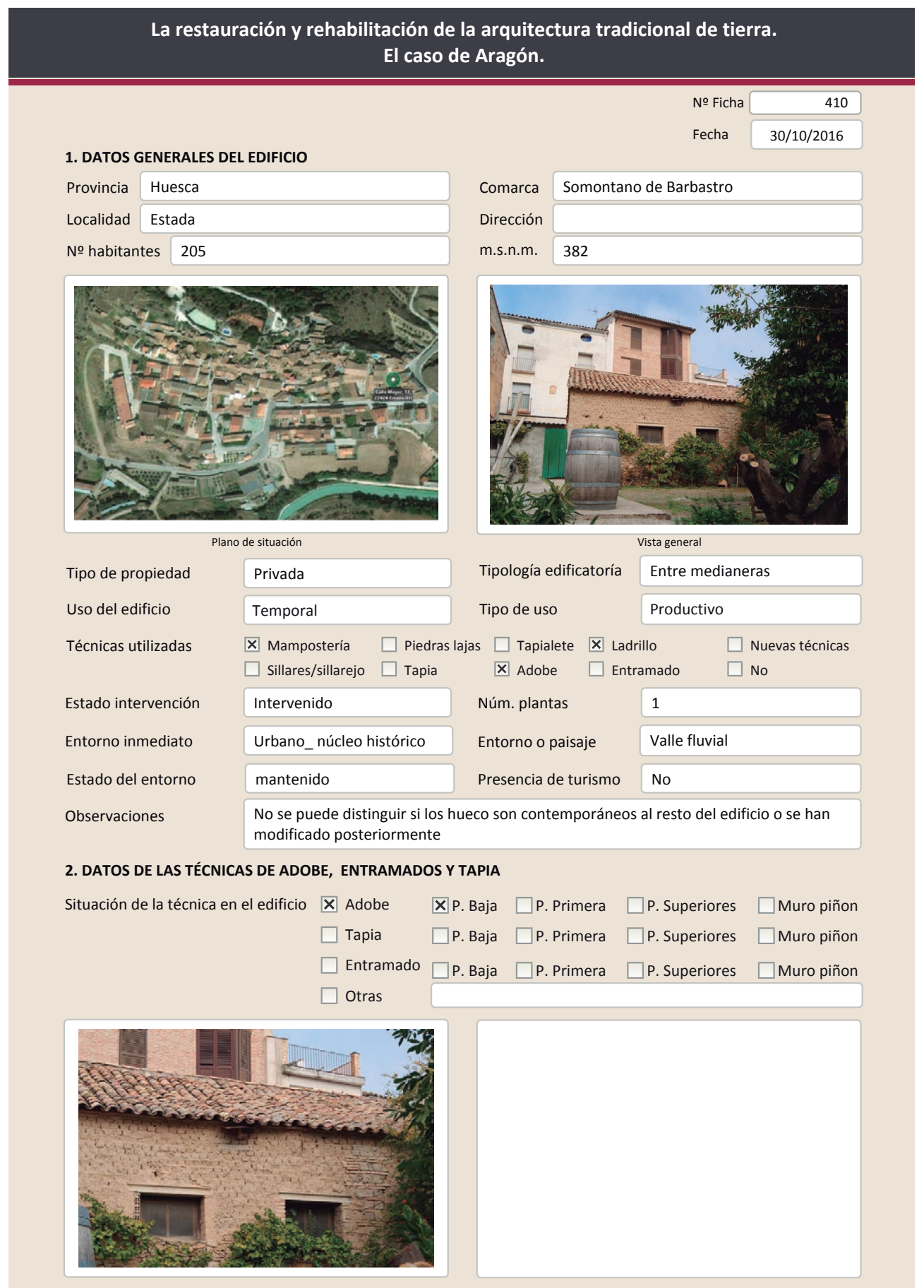

2.1. ADOBE

Dimensión de las piezas Dimensión del muro

Aparejo del muro

Función estructural

\begin{tabular}{|l|}
\hline \\
\hline $30-40 \mathrm{~cm}$ \\
\hline Tizón \\
\hline $\mathrm{Si}$ \\
\hline
\end{tabular}

Color de las piezas

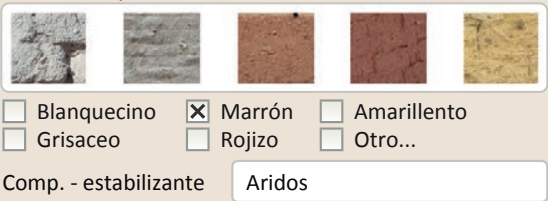

Variante constructiva/ tipo de fábrica

$\square$ simple

$\square$ Suplementada en juntas

区 Mixta

Machones

Mixtos

$\mathbf{X}$ Como suplemento

Mixto- Machones

$\square$ Elementos de protección

Machones de adobe (piezas tierra cemento) y rasillas

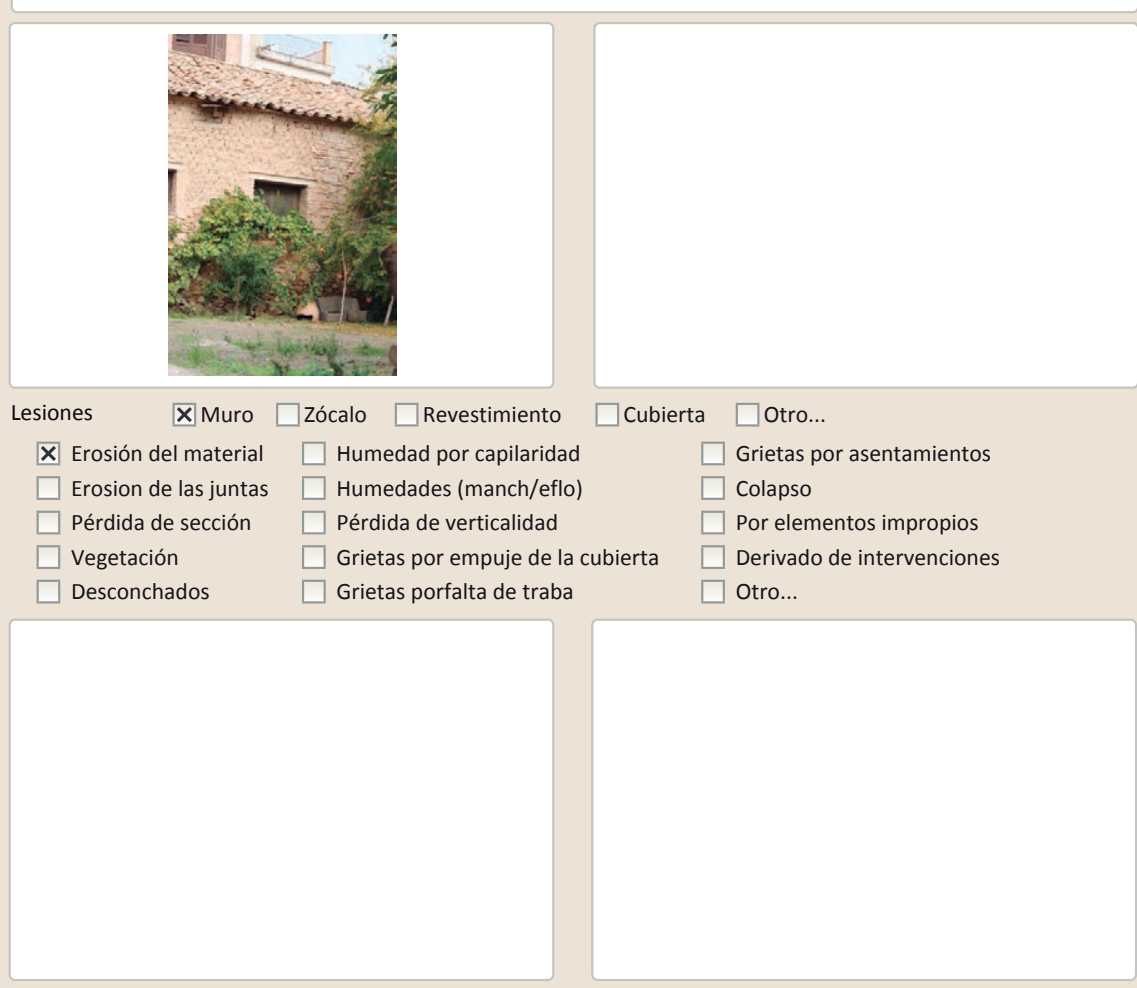

Observaciones 
La restauración y rehabilitación de la arquitectura tradicional de tierra.

El caso de Aragón.

3. DATOS DE LA INTERVENCIÓN

$\begin{array}{llll}\text { Intervención de: } & \square \text { Mantenimiento } \quad \boldsymbol{X} \text { Rehabilitación parcial } & \square \text { Restauración } & \square \text { Demolición } \\ & \square \text { Reparación } & \square \text { Rehabilitación integral } & \square \text { Ampliación } \quad \square \text { Otro... } \\ \text { Reflexión previa } & \text { Intervención espontanea } & \\ \text { Observaciones } & & \\ & & \end{array}$

3.1. MUROS

No intervenido

Tipo de intervención

$\square$ Actualización $\square$ Reintegración $\square$ Demolición $\square$ Otro...

Tipo de material

$\square$ Consolidación $\square$ Reconstrucción $\square$ sustitución

Descripción

3.2. ZÓCALO

No intervenido

Tipo de intervención

$\square$ Actualización

Tipo de material

Descripción

3.3. REVESTIMIENTOS

Tipo de intervención

\section{No aplica}

Tipo de material

Descripción Tipo de técnica

3.4. VANOS

Tipo de intervención

\section{Intervenido}

Tipo de material

$\square$ Actualización $\square$ Reintegración $\square$ Demolición $\square$ Otro...

$\square$ Consolidación $\square$ Reconstrucción $\quad \boldsymbol{X}$ Sustitución

Descripción

No tradicional

Tipo de técnica Diferente a la existente

3.5. CUBIERTA

Tipo de intervención

No intervenido

$\square$ Actualización $\square$ Reintegración $\square$ Demolición $\quad \square$ Otro...

Tipo de material

$\square$ Reconstrucción $\square$ Sustitución

Descripción

$$
\text { Tipo de técnica }
$$

3.6. OTRAS 


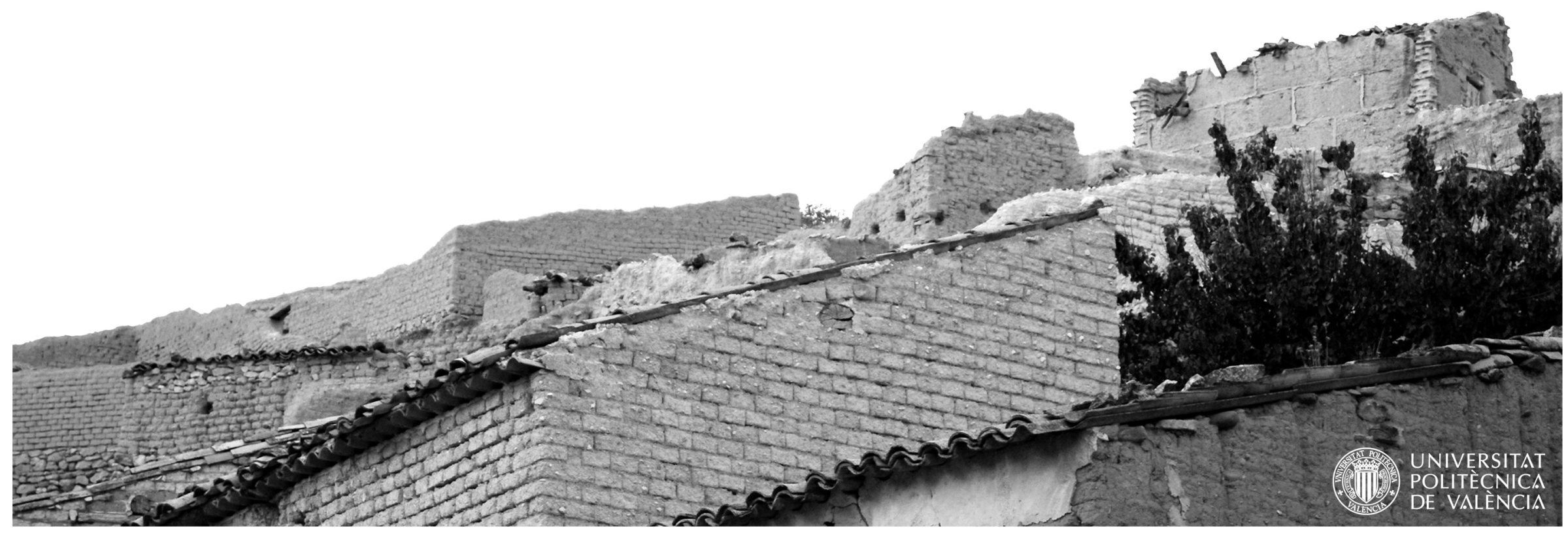

